\title{
Archeological Investigations at the Lang Pasture Site (41AN38) in the Upper Neches River Basin of East Texas
}

Timothy K. Perttula

Heritage Research Center, Stephen F. Austin State University

David B. Kelley

Coastal Environments, Inc.

Robert A. Ricklis

Follow this and additional works at: https://scholarworks.sfasu.edu/ita

Part of the American Material Culture Commons, Archaeological Anthropology Commons, Environmental Studies Commons, Other American Studies Commons, Other Arts and Humanities Commons, Other History of Art, Architecture, and Archaeology Commons, and the United States History Commons

Tell us how this article helped you.

This Article is brought to you for free and open access by the Center for Regional Heritage Research at SFA ScholarWorks. It has been accepted for inclusion in Index of Texas Archaeology: Open Access Gray Literature from the Lone Star State by an authorized editor of SFA ScholarWorks. For more information, please contact cdsscholarworks@sfasu.edu. 


\section{Archeological Investigations at the Lang Pasture Site (41AN38) in the Upper Neches River Basin of East Texas}

\section{Licensing Statement}

This is a work for hire produced for the Texas Department of Transportation (TxDOT), which owns all rights, title, and interest in and to all data and other information developed for this project under its contract with the report producer. The report may be cited and brief passages from this publication may be reproduced without permission provided that credit is given to TxDOT and the firm that produced it. Permission to reprint an entire chapter, section, figures or tables must be obtained in advance from the Supervisor of the Archeological Studies Branch, Environmental Affairs Division, Texas Department of Transportation, 125 East 11th Street, Austin, Texas, 78701.

\section{Creative Commons License}

(c) (1) (9)

This work is licensed under a Creative Commons Attribution-NonCommercial 4.0 International License 


\title{
ARCHEOLOGICAL INVESTIGATIONS AT THE LANG PASTURE SITE (41AN38) IN THE UPPER NECHES RIVER BASIN OF EAST TEXAS
}

\author{
Assembled and Edited by \\ Timothy K. Perttula, David B. Kelley, and Robert A. Ricklis \\ Waldo Troell, Principal Investigator \\ With Contributions by
}

Bruce M. Albert, Mark D. Bateman, Robert Cast, Phil Dering, James Feathers, Jeffrey R. Ferguson, Michael D. Glascock, Bobby Gonzalez, Donald G. Hunter, David B. Kelley, Bo Nelson, Timothy K. Perttula, Robert A. Ricklis, and Diane E. Wilson

With Appendix: TEST EXCAVATIONS AT 41AN159

By

Jon C. Lohse, Timothy K. Perttula, and Robert A. Ricklis

(THC Antiquities Permit No. 3333)

David B. Kelley, Principal Investigator

(THC Antiquities Permit No. 4040)

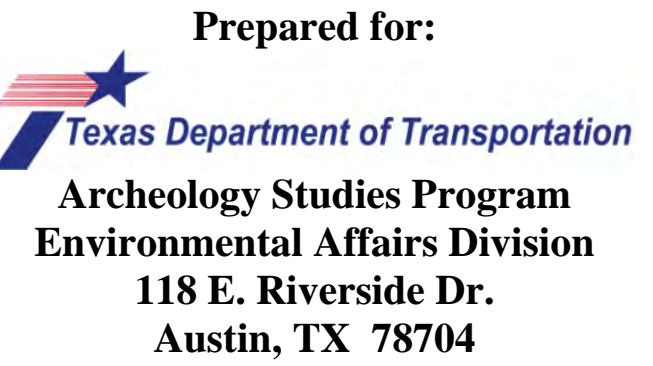

Prepared by:

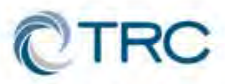

Austin, Texas

Contract No. 579XXSA003

Report 129

Technical Report No. 174202 



\section{Copyright (C) 2011 \\ Texas Department of Transportation (TxDOT)}

This is a work for hire produced for the Texas Department of Transportation (TxDOT), which owns all rights, title, and interest in and to all data and other information developed for this project under Contract 579XXSA003. Brief passages from this publication may be reproduced without permission provided that credit is given to TxDOT and TRC Environmental Corporation. Permission to reprint an entire chapter, section, figures or tables must be obtained in advance from the Supervisor of the Archeological Studies Program, Environmental Affairs Division, Texas Department of Transportation, 125 East $11^{\text {th }}$ Street, Austin, Texas, 78701. Copies of this publication have been deposited with the Texas State Library in compliance with the State Depository Requirement.

\section{Printed by Ginny’s Printing}

published by:

Archeological Studies Program

Environmental Affairs Division

Texas Department of Transportation

Scott Pletka, Ph.D., Supervisor

Archeological Studies Program Report No. 129

A. McGraw, Series Editor

and

TRC Environmental Corporation

Technical Report No. 174202

ISBN \# 1-930788-97-5 



\section{ABSTRACT AND MANAGEMENT SUMMARY}

Archeological testing at the Lang Pasture site (41AN38) and nearby Site 41AN159, was carried out in 2004 by a team of archeologists from Coastal Environments, Inc. and Archeological \& Environmental Consultants, LLC, working under Texas Antiquities Permit No. 3333. Based on these efforts, it was determined that the Lang Pasture site had considerable research potential, as it contained remains of prehistoric Caddo domestic habitation and associated burial features. 41AN159 was found to have been seriously disturbed by historic agricultural activities, and to thus have no significant research potential. Data recovery investigations were recommended for the Lang Pasture Site in anticipation of planned widening of State Highway 155, within the right-of-way of which a significant portion of the site was located.

The data recovery work sponsored by the Texas Department of Transportation and completed in 2006 by a team from Coastal Environments, Inc. and Archeological \& Environmental Consultants, LLC at the Lang Pasture site (41AN38) was carried out under Texas Antiquities Permit No. 4040. This work obtained a wealth of new archeological, bioarchaeological, and paleoenvironmental information about the lives and practices of prehistoric ancestors of the Caddo Indian peoples. This multidisciplinary work has cast a new light on the character and pace of native history of the Caddo in the East Texas region.

The data recovery investigations have been particularly important in advancing the field of Caddo archeology in several different respects: (1) work completed in $14^{\text {th }}$ to early $15^{\text {th }}$ century A.D. domestic habitation contexts resulted in the identification of a well-defined series of features from prehistoric Caddo houses, specialized structures (i.e., granaries or ramadas/arbors), and ancillary outdoor activity areas, such that the character of a rural domestic Caddo household in much of East Texas (or at least the Neches-Angelina River basins) has come into better focus; (2) the exposure and excavation of a Caddo family cemeteryand the attempt to determine the regional context for changes in Caddo diet and health-has contributed to an understanding of the bioarcheological character of the Caddo people in the upper Neches River basin that is unparalleled anywhere in the larger Caddo archeological area. The bioarcheological information on diet, health, and pathologies obtained during the course of the Lang Pasture site work provides a sweeping view of more than 800 years of Caddo life that will be relevant to understanding different Caddo peoples and groups in other parts of the Caddo world; (3) the Lang Pasture archeological and bioarcheological investigations were done in consultation with the Caddo Nation of Oklahoma. That consultation has allowed the Caddo peoples to keep abreast of the bioarcheological approach and findings, and to provide their perspectives on the meaning of the findings from these investigations. This is a first for the field of Caddo archeology, and it is a step in the right direction of making room for the Caddo peoples to be full partners in future Caddo archeological and bioarcheological investigations in their traditional homelands. Robert Cast and Bobby Gonzalez of the Caddo Nation have offered their impressions of this work and of the overall project, and these are included in the final chapter of this report; and (4) finally, the identification of the family cemetery at the Lang Pasture site-as well as the associated funerary offerings placed in each of the gravesallowed for the regional consideration of Caddo mortuary practices based on a study of a number of upper Neches River basin Caddo cemeteries. Additionally, the study of the style, manufacture, and function of 
mortuary ceramic vessels in the region permitted the first examination of issues of style and stylistic change, social identity, and changes in culinary traditions as possible manifestations of changes in ceramic practice that occurred among Caddo groups living in the upper Neches River valley of East Texas between the $14^{\text {th }}$ to $17^{\text {th }}$ centuries A.D. The mortuary ceramics from upper Neches River basin Caddo sites illustrate broad continuities in ceramic practice, particularly in terms of vessel decoration and vessel form, but also demonstrate patterns in technical choices that are very different than what is documented in domestic Caddo ceramic assemblages of the same age and made by the same social group of potters. The ceramic-practice data from both domestic and mortuary contexts has been employed to posit the existence of a distinctive upper Neches Caddo ceramic tradition.
A report on archeological testing at nearby Site 41AN159 is included as an appendix to this report. The senior author of this report, Jon C. Lohse, served as Project Archeologist, and Robert Ricklis and Timothy Perttula were Co-Principal Investigators.

The non-mortuary portion of the collection from 41AN38, as well as artifacts recovered during testing at nearby 41AN159, along with associated field and laboratory records, are permanently curated at the Texas Archeological Research Laboratory, The University of Texas at Austin. Human remains from burials, and associated funerary offerings, are being repatriated to the Caddo Nation of Oklahoma (Binger, Oklahoma). 


\section{TABLE OF CONTENTS}

PAGE

ABSTRACT AND MANAGEMENT SUMMARY ......................................................................

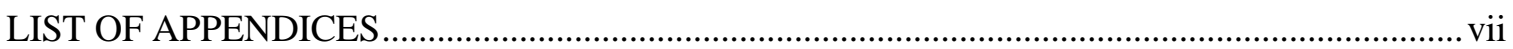

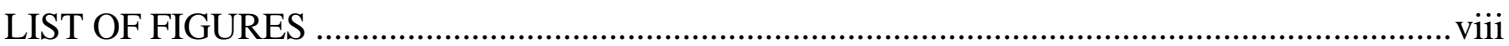

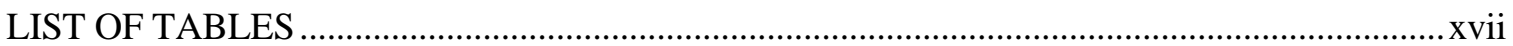

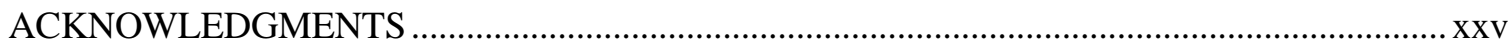

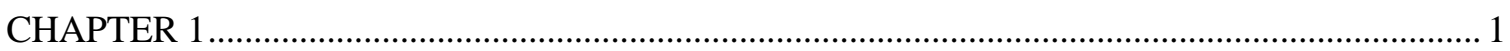

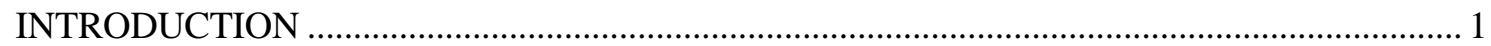

1.1 The Highway Modification Project ….................................................... 1

1.2 Contents of the Report ..................................................................... 8

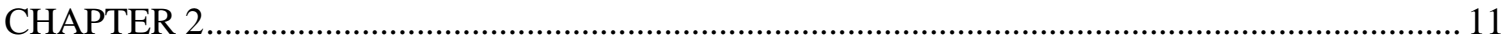

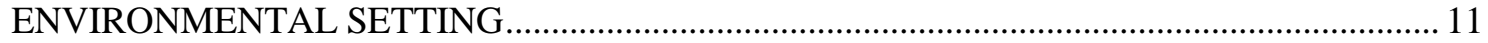

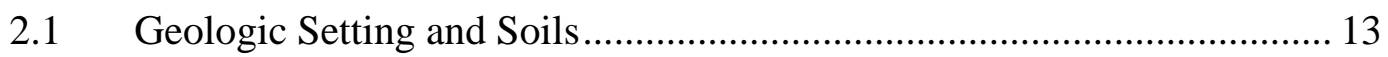

$2.2 \quad$ Holocene Environmental Change ......................................................... 15

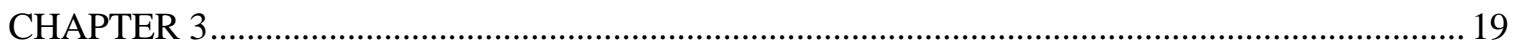

SUMMARY OF EAST TEXAS NATIVE AMERICAN CULTURE HISTORY ....................... 19

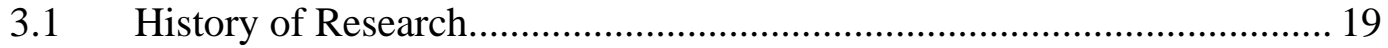

3.1.1 Paleoindian and Archaic Periods........................................................... 21

3.1.2 Woodland Period........................................................................ 24

3.1.3 Formative-Early-and Middle Caddo Periods .................................... 27

3.1.4 The Late Caddo Period....................................................................... 31

3.1.5 Historic Caddo............................................................................ 32

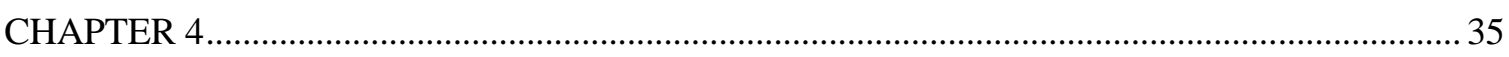

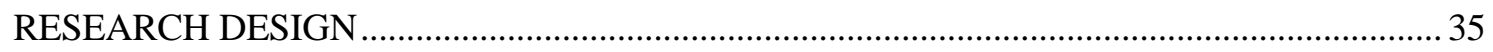

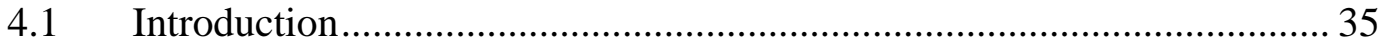

4.2 Local Caddo Research Context............................................................. 35

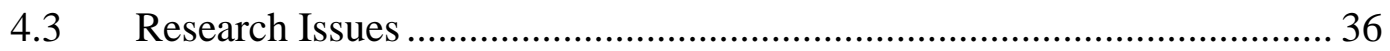

4.4 Cultural Chronology ........................................................................... 36

4.5 Caddo Settlement Systems and Households ............................................ 39

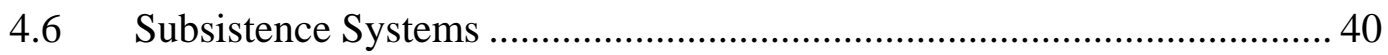

4.7 Local and Extra-Local Trade and Exchange........................................... 42

4.8 Material Culture of the Frankston Phase Caddo Peoples.......................... 45

4.9 The Health and Diet of the Caddo at the Lang Pasture site ...................... 53

4.10 Frankston Phase Mortuary Practices.................................................... 57

4.11 Paleoenvironmental Conditions and Human Adaptation.......................... 60 


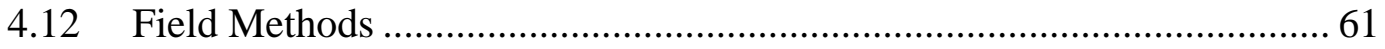

4.13 Laboratory Methods and Analysis ............................................................ 63

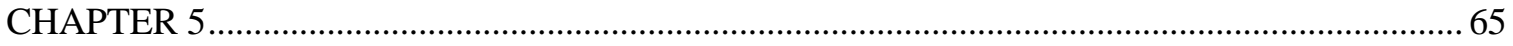

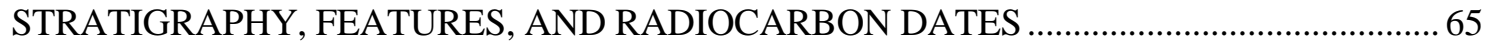

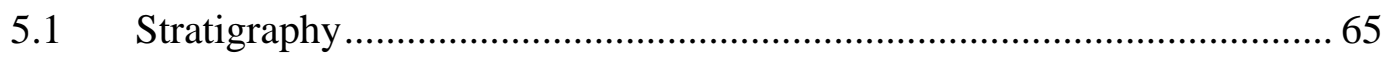

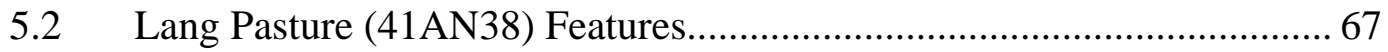

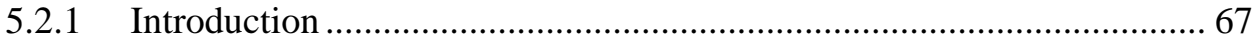

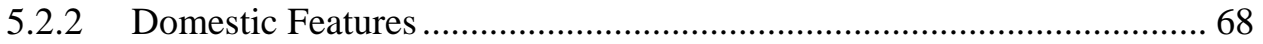

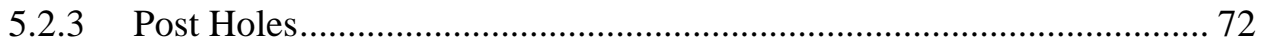

5.2.4 Small and Large Pits ........................................................................ 85

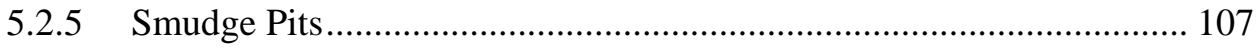

5.2.6 Outdoor Hearth................................................................................ 107

5.2.7 Fire-Cracked Rock Concentration ........................................................ 111

5.2.8 Fire-Cracked Rock Distribution ........................................................ 111

5.3 Radiocarbon Dates from the Lang Pasture Site (41AN38) and other Upper Neches River Basin Caddo Sites................................................... 135

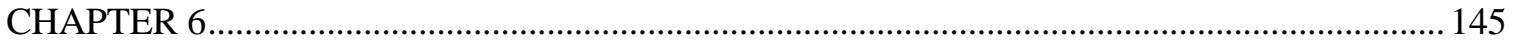

THE CERAMIC ARTIFACTS FROM THE LANG PASTURE SITE (41AN38) AND THE PLACE OF THE SITE WITHIN AN UPPER NECHES RIVER BASIN CADDO

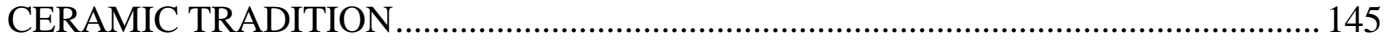

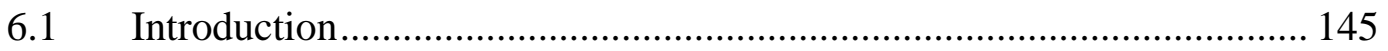

6.2 Organization of the Chapter ................................................................. 146

6.3 Methods of Analysis of the Vessel Sherds ……................................... 148

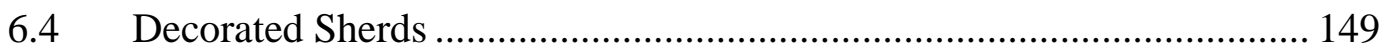

6.5 Assemblage Definition at the Lang Pasture Site Based on Decorated

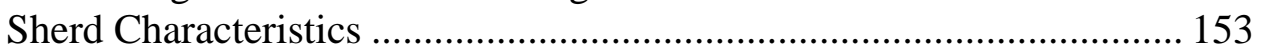

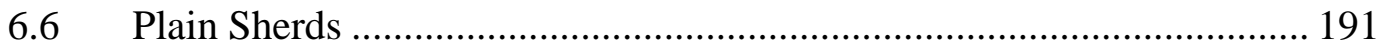

6.7 Rim and Lip Forms for Decorated and Plain Vessels............................... 200

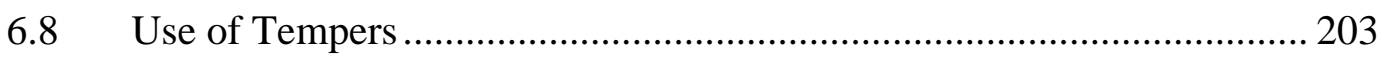

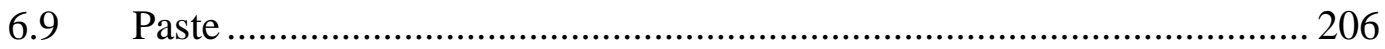

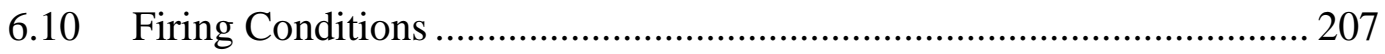

6.11 Pipe Sherds........................................................................................ 211

6.12 Other Ceramic Objects from the Lang Pasture Site (41AN38) .............. 217

6.13 Methods of Study of Upper Neches River Basin Caddo Vessels ............ 219

6.14 Vessels from Mortuary Contexts at the Lang Pasture Site (41AN38).... 223

6.15 Vessels from Selected Upper Neches River Basin Caddo Sites .............. 229

6.16 Intra-regional Comparisons ............................................................... 286

6.17 Conclusions: Upper Neches River Basin Caddo Pottery Traditions and

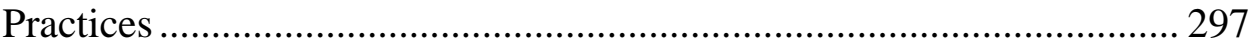


CHAPTER 7 321

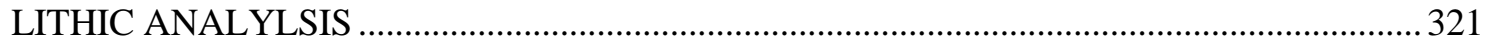

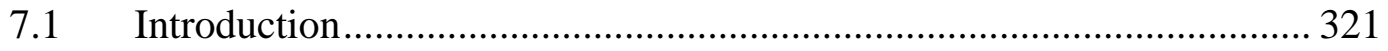

7.2 Artifact Descriptions ......................................................................... 321

7.3 Diagnostic Artifact Analysis............................................................ 332

7.4 Summary and Conclusions ............................................................. 346

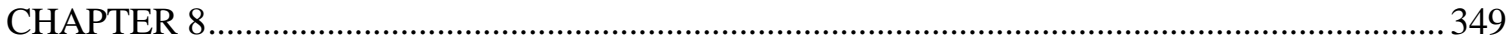

PLANT REMAINS FROM THE LANG PASTURE SITE (41AN38), ANDERSON COUNTY, TEXAS, AND THE CHARACTER OF CADDO AGRICULTURE IN

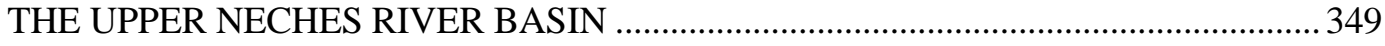

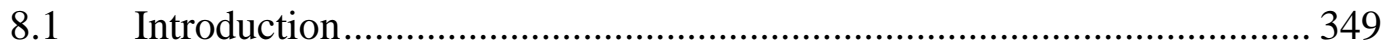

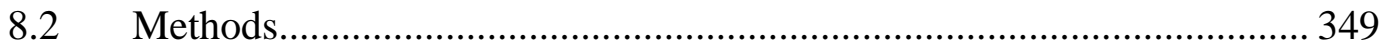

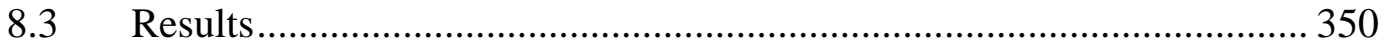

8.4 Summary of the Plant Remains from the Lang Pasture Site................... 357

8.5 Prehistoric Caddo Agriculture in East Texas .......................................... 358

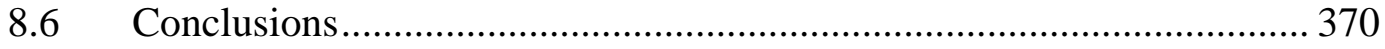

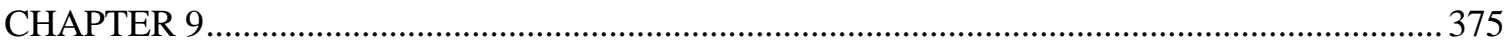

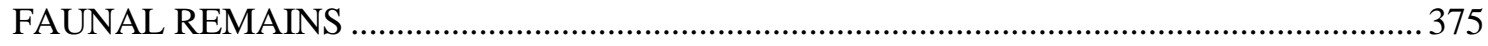

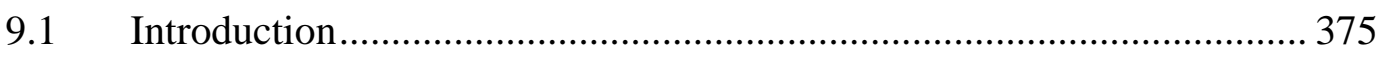

9.2 Previous Research in the Region ................................................... 375

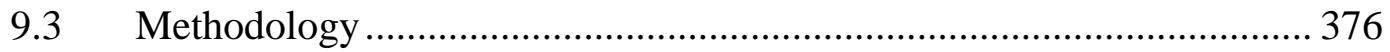

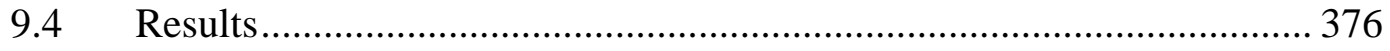

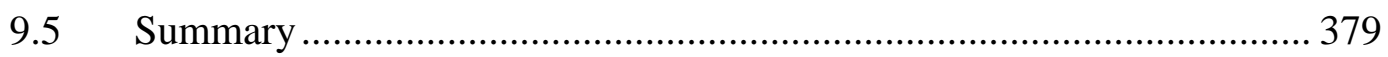

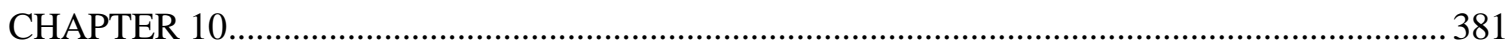

ANALYSIS OF HUMAN REMAINS FROM THE LANG PASTURE SITE............................381

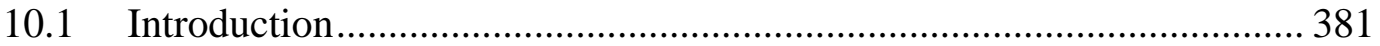

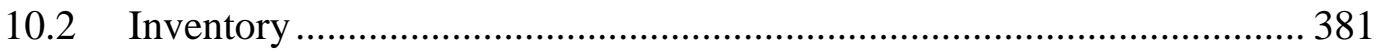

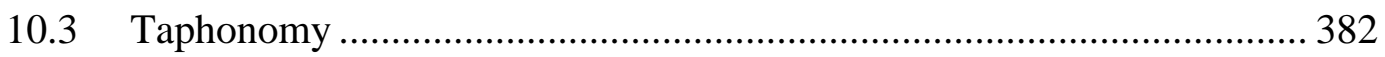

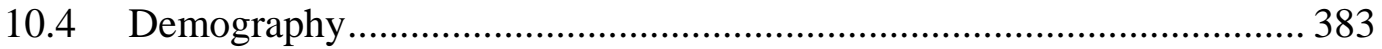

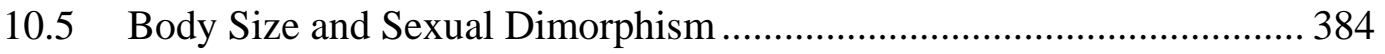

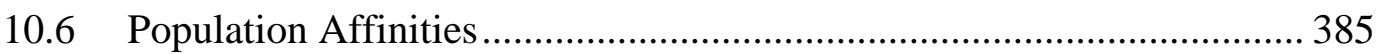

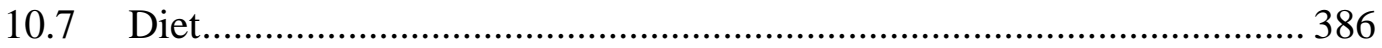

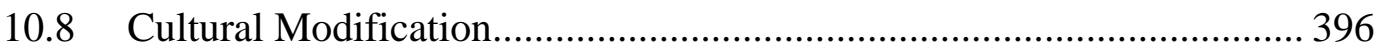

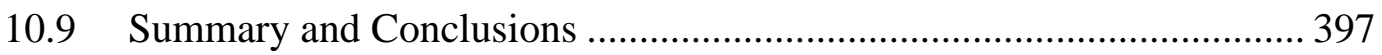

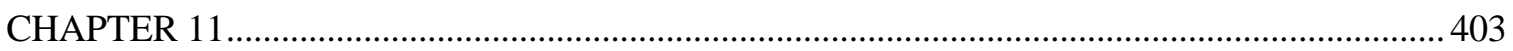

CADDO MORTUARY PRACTICES IN THE UPPER NECHES RIVER BASIN IN EAST TEXAS 


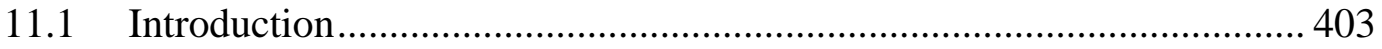

11.2 Perspective on Mortuary Practices........................................................... 404

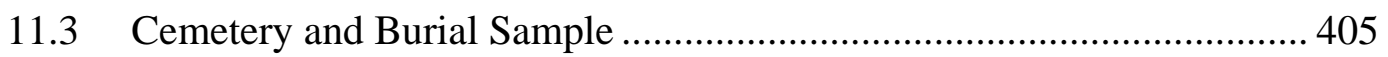

11.4 Mortuary Rituals and Burial Features..................................................... 409

11.5 Regional Comparisons in Mortuary Practices ......................................... 427

11.6 Summary and Concluding Comments .................................................... 431

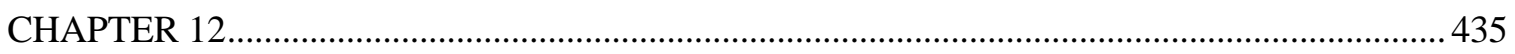

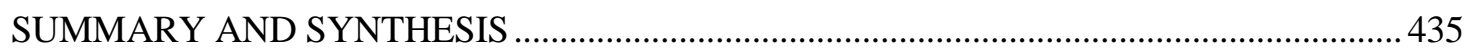

12.1 Summary Statement, Site Setting, and Archeological Components at the Lang Pasture Site ................................................................................ 435

12.2 Discussion of Research Design Issues ................................................... 437

12.3 The Caddo Nation Perspective on the Analysis of Human Remains from the Lang Pasture site (41AN38)...................................................... 456

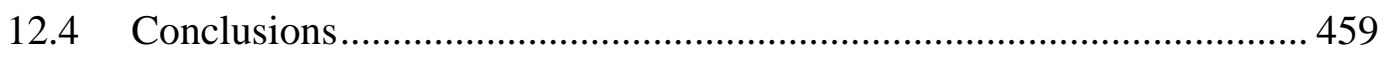

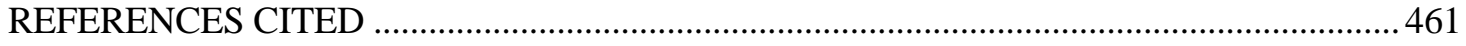




\section{LIST OF APPENDICES}

PAGE

APPENDIX A 497

MIDDLE TO LATE HOLOCENE PALYNOLOGY OF VIBRA-CORES FROM 41AN38 AND CADDO CREEK 497

APPENDIX B 559

QUARTZ OPTICAL DATING OF SEDIMENT SAMPLES FROM 41AN38.......................... 559

APPENDIX C 579

LUMINESCENCE DATING OF CERAMICS FROM THE LANG PASTURE SITE .............579

APPENDIX D 591

INSTRUMENTAL NEUTRON ACTIVATION ANALYSIS OF CADDO POTTERY FROM TEN SITES IN EASTERN TEXAS 591

APPENDIX E. 613

TEST EXCAVATIONS AT 41AN159 613

APPENDIX F. 637

DETAILED CERAMIC DATA, LANG PASTURE SITE (41AN38) AND OTHER CADDO SITES IN THE UPPER NECHES DRAINAGE BASIN 637

Appendix F.1 Detailed Data, Decorated Sherds 639

Appendix F.2 Detailed Analysis of Plain Body Sherds from 41AN38 657

Appendix F.3 Detailed Analysis of Base Sherds from 41AN38 668

Appendix F.4 Vessel Recordation Forms for 41AN38. 671 Appendix F.5 Vessel Documentation, Caddo Sites in Anderson and Cherokee

Counties, Texas, in the upper Neches River Basin 703

Appendix F.6 Database of Ceramic Vessels from the Upper Neches River Basin 982

APPENDIX G 989

CERAMIC ARTIFACTS FROM THE LANG PASTURE SITE, TABLES FOR CHAPTER 6. 989

APPENDIX H 1043

ANALYSIS OF HUMAN REMAINS, TABLES FOR CHAPTER 10 1043 APPENDIX I 1131

INNA RESULTS ON A NATURAL CLAY SAMPLE FROM 41AN38 1131 


\section{LIST OF FIGURES}

PAGE

Figure 1-1. Map Showing the Location of the Lang Pasture Site................................... 2

Figure 1-2. General Map Showing the Data Recovery Excavation Area ......................... 4

Figure 1-3. View of the Northern Half of the Lang Pasture Site .................................... 5

Figure 1-4. Location of 2004 Test Excavations at the Lang Pasture .............................. 6

Figure 2-1. Map Showing Physiographic Zones in East Texas .................................... 12

Figure 3-1. Late Caddo and Historic Caddo Sites and Cemeteries in the Upper Neches River Basin...................................................................................... 20

Figure 5-1. Profile of the North Wall of N175 E198-199........................................... 66

Figure 5-2. Photograph of the North Wall of Unit N175 E-198-199............................ 66

Figure 5-3. West Wall Profile between N190 E198 and N194 E198 ............................ 68

Figure 5-4. Fold-out Map of the Features within the Excavated Area. ........................... 69

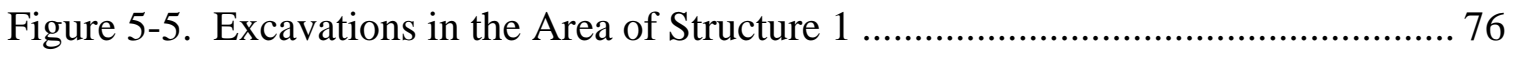

Figure 5-6. Plan of Features Associated with Structure 1 and Ramada......................... 77

Figure 5-7. Profiles of Select Structure 1 Post Holes. ................................................. 79

Figure 5-8. Feature 48, a Post Hole, in Plan and Profile, Looking West....................... 79

Figure 5-9. Plan of Features Associated with Structure 2 ........................................ 81

Figure 5-10. Profiles of Select Structure 2 Post Holes. ............................................. 82

Figure 5-11. Profiles of Select Post Holes in the Ramada (Structure 3)........................ 83

Figure 5-12. Post Holes Exposed at 35 cmbs under Feature 36. .................................. 84

Figure 5-13. Feature 74 Post Hole Exposed under Feature 25, Looking East................. 84

Figure 5-14. Features Associated with Outdoor Work/Activity Area ........................... 87

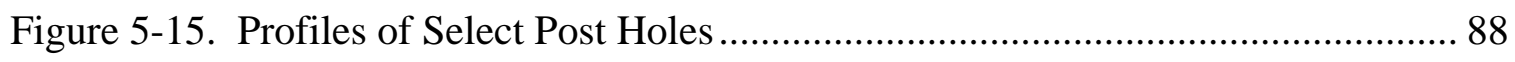


Figure 5-16. Plan and Profile of Feature 14, Outside Structure 2................................. 88

Figure 5-17. Photograph of Feature 2 ............................................................... 90

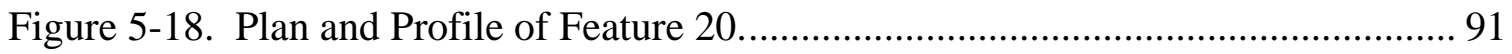

Figure 5-19. Plan and Profile of Feature 29......................................................... 91

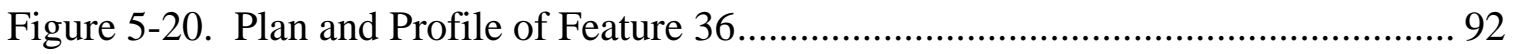

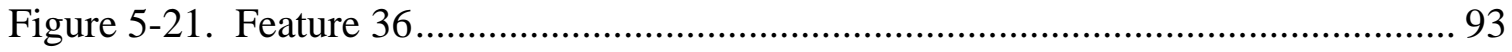

Figure 5-22. Feature 36 with the Organically-Enriched Fill Removed ......................... 94

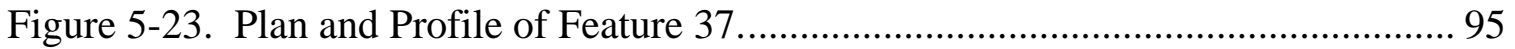

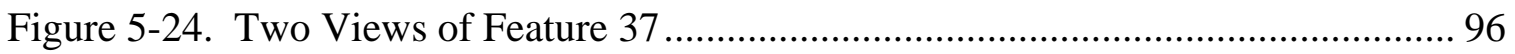

Figure 5-25. Plan and Profile of Feature 57............................................................ 97

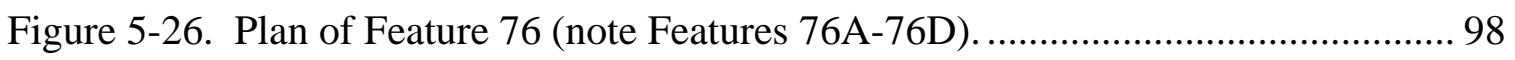

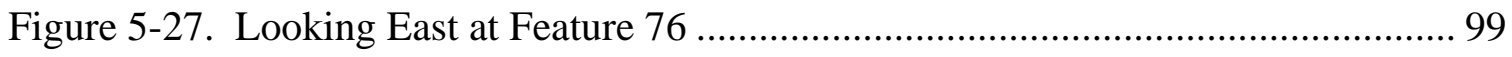

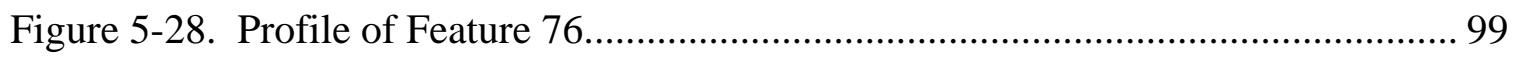

Figure 5-29. Relationship of Feature 76 and Feature 76A in Profile........................... 101

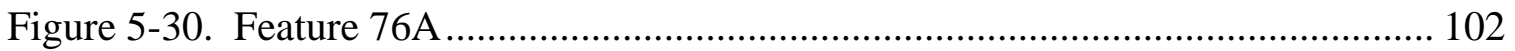

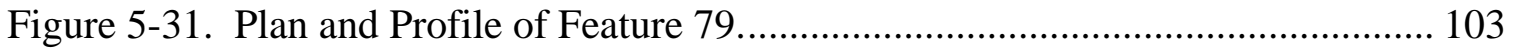

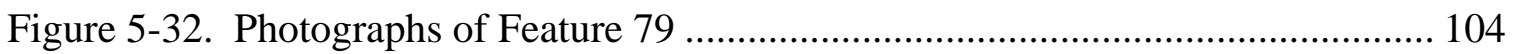

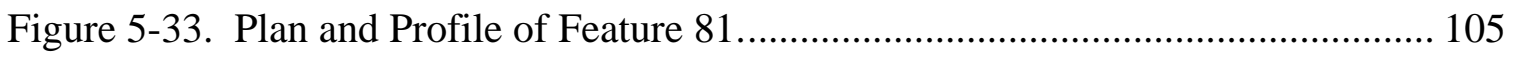

Figure 5-34. Plan and Profile of Feature 82......................................................... 105

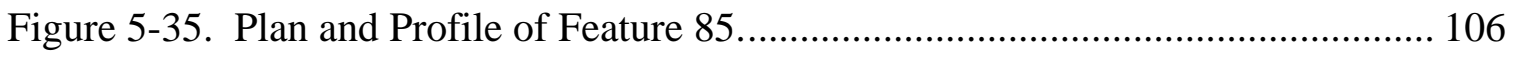

Figure 5-36. Looking South at Feature 85 in Plan View.......................................... 106

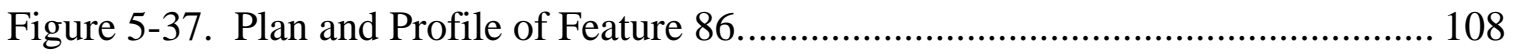

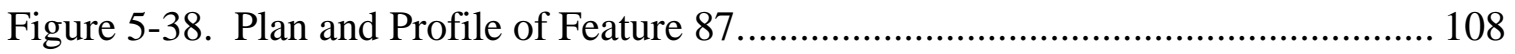

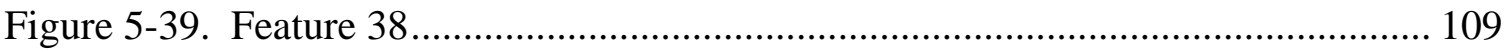

Figure 5-40. Plan and Profile of Feature 41.......................................................... 110 
Figure 5-41. Looking West at Feature 41 in Plan View............................................... 110

Figure 5-42. Plan and Profile of Feature 25............................................................. 112

Figure 5-43. Plan of Feature 25, Looking West........................................................... 112

Figure 5-44. Close-up Views of Feature 25................................................................... 113

Figure 5-45. Plan of Feature 35. ............................................................................ 114

Figure 5-46. Feature 35, Looking East. ......................................................................... 114

Figure 5-47. Spatial Distribution of Fire-Cracked Rock at the Lang Pasture Site. ....... 115

Figure 5-48. Plan of an Idealized Caddo Household in a Rural Community Setting.... 117

Figure 5-49. Spatial Distribution of Decorated Ceramic Sherds. ..................................... 119

Figure 5-50. Spatial Distribution of Plain Body and Base Sherds.................................. 120

Figure 5-51. Spatial Distribution of Plain Rim Sherds.................................................. 121

Figure 5-52. Spatial Distribution of Pipe Sherds........................................................... 123

Figure 5-53. Plan of Features 88, 91, 92, 93, and 94.................................................... 124

Figure 5-54. Views of Feature 8 During Excavations ....................................................... 125

Figure 5-55. Feature 76B Looking East..................................................................... 127

Figure 5-56. View of Feature 76D, Looking East. …………………………………..... 127

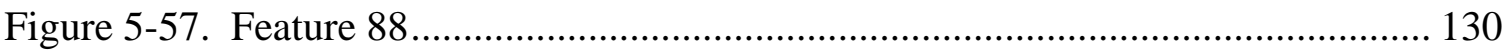

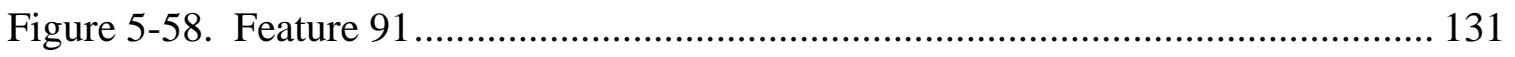

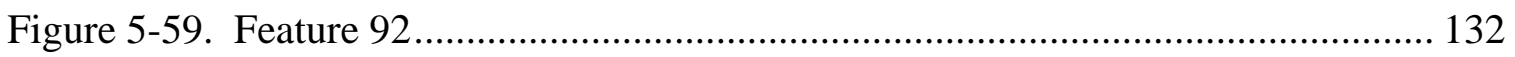

Figure 5-60. Plan View of Feature 93....................................................................... 133

Figure 5-61. Feature 94 ............................................................................................. 134

Figure 5-62. Looking Southeast at Feature 93 and Feature 94 ...................................... 136

Figure 5-63. Plots of 2 Sigma Calibrated Radiocarbon Age Ranges............................... 140

Figure 6-1. Upper Neches River Basin and Caddo Sites Mentioned in the Text. ......... 147

Figure 6-2. Differences in the Proportion of Decorative Methods on Vessel Sherds.... 154 
Figure 6-3. Brushed and Engraved Sherds from the Northern Area............................. 163

Figure 6-4. Decorated Sherds from the Lang Pasture Area ....................................... 163

Figure 6-5. Various Decorated Sherds Recovered in the Test Excavations ................. 165

Figure 6-6. Incised-Punctated and Incised Sherds from the Northern Site Area........... 169

Figure 6-7. Selected Decorative Elements on Utility Wares .................................... 169

Figure 6-8. Selected Decorative Elements on Utility Wares ...................................... 170

Figure 6-9. Punctated and Engraved Sherds from the Southern Area .......................... 172

Figure 6-10. Punctated Sherds from the Northern Area ........................................... 173

Figure 6-11. Engraved, Lip Notched, and Fingernail Punctated Sherds ...................... 174

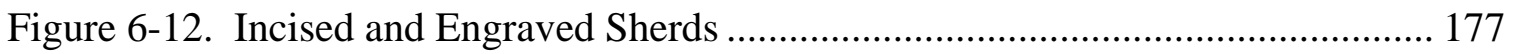

Figure 6-13. Selected Decorative Elements and Motifs in the Engraved Fine Wares... 182

Figure 6-14. Selected Decorative Elements and Motifs in the Engraved Fine Wares... 183

Figure 6-15. Poynor Engraved Rims ................................................................ 184

Figure 6-16. Engraved Bottle and Carinated Bowl Sherds ....................................... 188

Figure 6-17. Plain Rims from the Lang Pasture Site ................................................ 197

Figure 6-18. Range in Orifice Diameter in Rims from the Southern and Northern Ceramic Component/Areas. ............................................................. 201

Figure 6-19. Known Distribution of Caddo Sites with Pinkware Vessels and Vessel

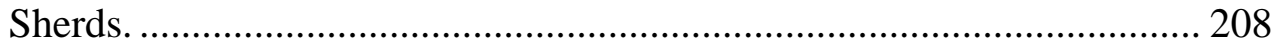

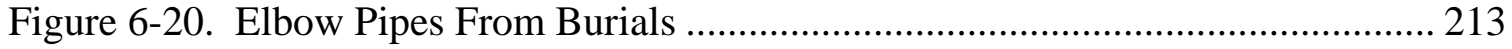

Figure 6-21. Elbow Pipe Sherds from the Southern Area ........................................ 213

Figure 6-22. Variety B Elbow Pipes from Scrape E ................................................ 214

Figure 6-23. Elbow Pipe Varieties A-F in the Upper Neches River Basin................... 216

Figure 6-24. Elbow Pipes from the Upper Neches River Basin ................................ 217

Figure 6-25. Potsherds with Perforations (spindle whorls). ..................................... 219 
Figure 6-26. Clay Pendant. .................................................................................. 220

Figure 6-27. Upper Neches River Basin Caddo Vessel Forms........................................ 221

Figure 6-28. Carinated Bowls from the Lang Pasture Site ………………………….... 225

Figure 6-29. Local Varieties (No. 1-5) of Poynor Engraved .......................................... 226

Figure 6-30. Compound Bowls.................................................................................. 226

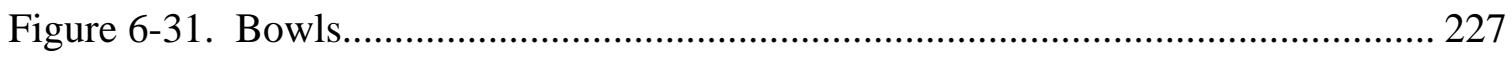

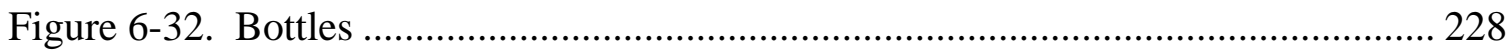

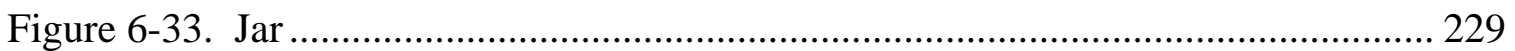

Figure 6-34. Unique Vessels with Suspension Holes ...................................................... 230

Figure 6-35. Orifice Diameter and Volume of Different Vessel Forms .......................... 231

Figure 6-36. Carinated Bowls and Compound Bowls ................................................... 232

Figure 6-37. Bowls................................................................................................ 232

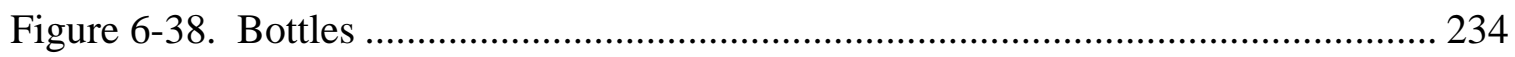

Figure 6-39. Jars.................................................................................................. 235

Figure 6-40. Orifice Diameter and Volume of Different Vessel Forms at the Mrs. J. M.

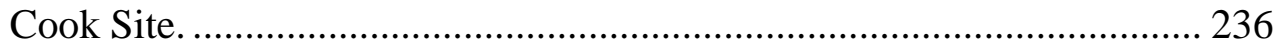

Figure 6-41. Vessels from the J. M. Cook Site............................................................ 237

Figure 6-42. Orifice Diameter and Volume of Different Vessel Forms at the J. M. Cook

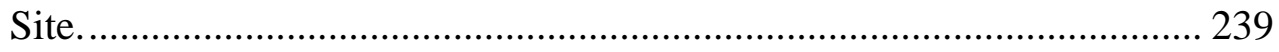

Figure 6-43. Carinated Bowls and Bowls .................................................................. 240

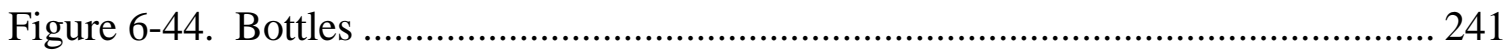

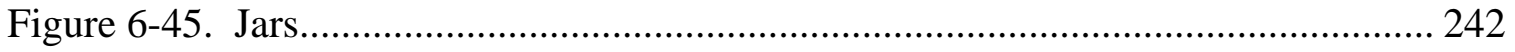

Figure 6-46. Orifice Diameter and Volume of Different Vessel Forms at the Fred McKee

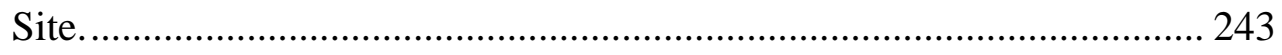

Figure 6-47. Carinated Bowls and Bowls .................................................................. 244

Figure 6-48. Hume Engraved or Hume Plain Bottles .................................................... 245 
Figure 6-49. Killough Pinched Jars 247

Figure 6-50. Orifice Diameter and Volume of Different Vessel Forms 248

Figure 6-51. Carinated Bowls

Figure 6-52. Effigy Bowls 251

Figure 6-53. Bottles 252

Figure 6-54. Jars 254

Figure 6-55. Selected Vessels 255

Figure 6-56. Orifice Diameter and Volume of Different Vessel Forms 256

Figure 6-57. Carinated Bowls and Bowls 258

Figure 6-58. Bottles and Effigy Bowls 260

Figure 6-59. Jars 260

Figure 6-60. Orifice Diameter and Volume of Different Vessel Forms at the E. W. Henry Site. 261

Figure 6-61. Carinated Bowls 262

Figure 6-62. Bottles 264

Figure 6-63. Orifice Diameter and Volume of Different Vessel Forms at the R. J. Fair Site. 265

Figure 6-64. Defined Varieties of Poynor Engraved ................................................. 267

Figure 6-65. Regional Varieties A-T of Poynor Engraved ........................................ 269

Figure 6-66. Defined Varieties of Patton Engraved and Hume Engraved..................... 270

Figure 6-67. Distribution of Hood Engraved Effigy Vessels ..................................... 272

Figure 6-68. Orifice Diameters and Volume (in liters) of Mortuary Vessels ................ 276

Figure 6-69. Comparison of the Decorated Sherds from the Lake Palestine Sites........ 288

Figure 6-70. The Distribution of Sites with Unassigned INAA Samples..................... 296

Figure 6-71. Late Caddo Ceramic Traditions in East Texas...................................... 299 
Figure 6-72. Area of the Upper Neches River Basin with Sites Showing the Closest Similarity to the Lang Pasture Site....

Figure 7-1. Selected Arrow Points from 41AN38 .................................................. 322

Figure 7-2. Selected Arrow Points and Other Lithic Artifacts Recovered .................... 324

Figure 7-3. Selected Points from the Lang Pasture Site ........................................... 327

Figure 7-4. Selected Points from the Lang Pasture Site ............................................ 330

Figure 7-5. Selected Ground-Stone Artifacts from the Lang Pasture Site.................... 332

Figure 7-6. Two Views of a Fragment of the Bit Section of a Ground-Stone Celt. ...... 333

Figure 7-7. Distributions of Typed and Unclassified Arrow Points within the Excavated Area.

Figure 7-8. Distributions of Dart Points within the Excavations..... 337

Figure 7-9. Distributions of Miscellaneous Lithic Tools. 339

Figure 11-1. Cemetery and Domestic Sites in the Vicinity ..... 406

Figure 11-2. Plan of the Caddo Cemetery at the E. W. Henry Site (41CE17). 411

Figure 11-3. Plan of the Caddo Cemetery at the Mrs. J. M. Cook Site (41AN1). 411

Figure 11-4. The Caddo Cemetery at the Mrs. J. W. Blackburn Site (41CE4). 412

Figure 11-5. Plan of the Caddo Cemetery at the R. J. Fair Site (41CE25).

Figure 11-6. The Allen Phase Caddo Cemetery at the Richard Patton Site (41AN26). 413

Figure 11-7. Plan of the Large Cemetery at the Jim Allen Site (41CE12). 413

Figure 11-8. The Placement of the Large Cemetery at the Jim Allen Site 426

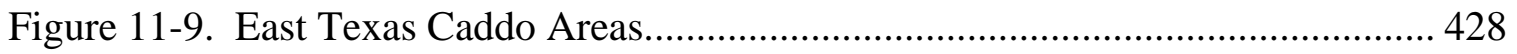

Figure 11-10. Plan of the Cemetery at the Deshazo Site ......................................... 430

Figure B-1. Examples of Single Grain OSL Data for Sample Shfd07148 ................... 564

Figure B-2. Results of Dose Recovery Test on Shfd07147 ..................................... 565

Figure B-3. Examples of Combined Probability Density Functions .......................... 567 
Figure B-4. The Relationship between Zero Dose Grains and Depth .......................... 568

Figure B-5. Showing the Age Depth Relationship with Single Grain OSL Ages ........ 572

Figure D-1. Bivariate Plot of Chromium and Dysprosium Base-10 Logged

Concentrations

Figure D-2. Bivariate Plot of Hafnium and Magnesium Base-10 Logged

Concentrations

Figure D-3. Bivariate Plot of Sodium and Chromium Base-10 Logged

Concentrations

Figure D-4. Bivariate Plot of Chromium and Tantalum Base-10 Logged

Concentrations

Figure D-5. Bivariate Plot of Chromium and Titanium Base-10 Logged

Concentrations

Figure D-6. Bivariate Plot of Chromium and Scandium Base-10 Logged

Concentrations

Figure D-7. Bivariate Plot of Chromium and Potassium Base-10 Logged

Concentrations

Figure D-8. Bivariate Plot of Arsenic and Chromium Base-10 Logged

Concentrations

Figure D-9. Biplot of Canonical Discriminant Functions One and Two

Figure D-10. Biplot of Canonical Discriminant Functions One and Two

Figure D-11. Bivariate Plot of Arsenic and Chromium Base-10 Logged

Concentrations

Figure E-1. Location of Project Area with Respect to Physiographic Provinces .......... 616

Figure E-2. Location of Project Area in Relation to Important River Drainages.......... 617

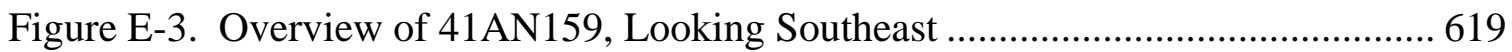

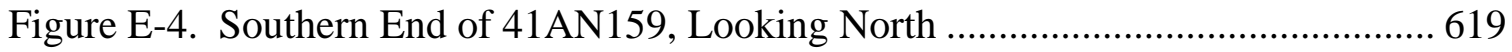

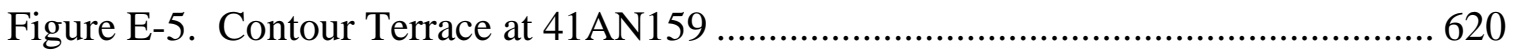

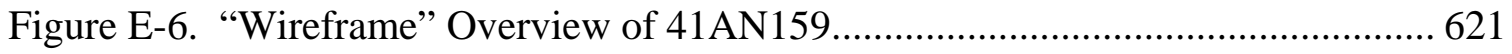

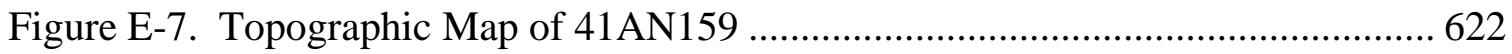

CTRC Technical Report No. 174202 
Figure E-8. Profiles of N99E105, South Wall (left) and N99E105, West Wall (Right) Unit.

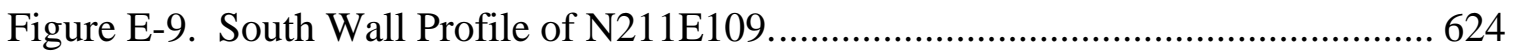

Figure E-10. Profiles of N11E103, East Wall (Top) and N203E109, North Wall (Bottom). 625

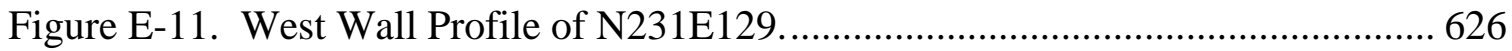

Figure E-12. Projectile Points and Fragments, By Lot Number, ................................. 629

Figure E-13. Non-Diagnostic Chipped Stone Tools Recovered from 41AN159. ......... 630 


\section{LIST OF TABLES}

PAGE

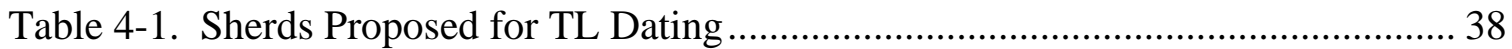

Table 4-2. Flotation Samples Proposed for Macrobotanical Analysis . ........................ 41

Table 4-3. Sherds from the Lang Pasture Site Recommended for INAA...................... 43

Table 4-4. Sherds from Sites at TARL Recommended for INAA................................ 46

Table 4-5. Comparative Sherd Assemblage Data from Lake Palestine Caddo Sites....... 48

Table 4-6. Caddo Vessels at TARL Proposed for Analysis.......................................... 51

Table 4-7. Vessels Proposed for Examination from Collections at TARL..................... 52

Table 4-8. Sherd Collections at TARL Proposed for Analysis....................................... 52

Table 4-9. Caddo Sites in the Neches River Basin with Human Remains ...................... 56

Table 4-10. Caddo Sites in the Upper Neches River Basin with Excavated Burials....... 59

Table 4-11. Pollen Samples Proposed for Analysis from Cores Collected .................... 60

Table 4-12. Radiocarbon Samples Proposed for Analysis.......................................... 60

Table 5-1. Feature Inventory from the Lang Pasture Site (41AN38). .......................... 71

Table 5-2. Numbers of Artifacts of Various Classes Associated with Features .............. 73

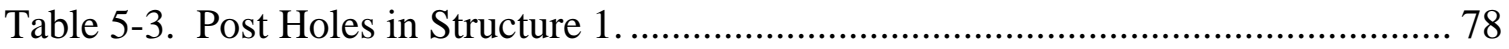

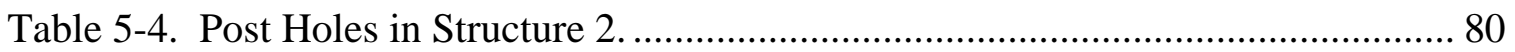

Table 5-5. Post Holes from Ramada (Structure 3) near Structure 1............................. 83

Table 5-6. Post Holes from Other Contexts at the Lang Pasture Site............................ 86

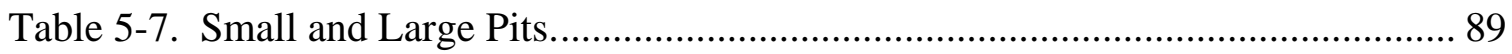

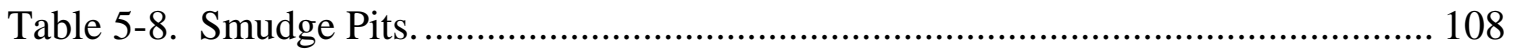

Table 5-9. Burial Features at the Lang Pasture Site.................................................. 124

Table 5-10. Radiocarbon Dates from the Lang Pasture Site....................................... 137 
Table 5-11. Radiocarbon Dates from Other Upper Neches River Basin Caddo Sites... 139

Table 6-1. Decorated Sherds from the Lang Pasture Site (41AN38). (This table may be found in Appendix G on the CD in the back cover of this report.) ............. 150

Table 6-2. Decorated Sherds from Lang Pasture (41AN38) Features.......................... 151

Table 6-3. Frequency of Decorated Utility Ware and Fine Ware Sherds ...................... 155

Table 6-4. Other Differences in the Ceramics ....................................................... 157

Table 6-5. TL Samples and TL Dates from the Lang Pasture Site.............................. 159

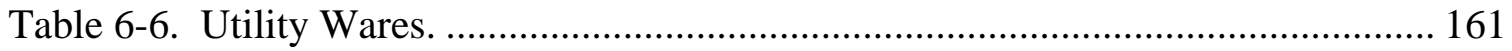

Table 6-7. Brushed Sherds from the Southern and Northern Areas .............................. 162

Table 6-8. Brushed-Punctated Decorative Elements. ............................................. 164

Table 6-9. Brushed-Incised Sherds. ........................................................................ 166

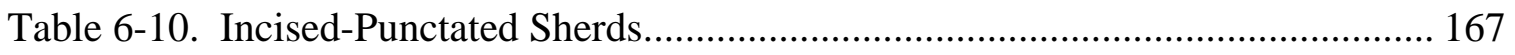

Table 6-11. Tool and Fingernail Punctated Sherds................................................ 171

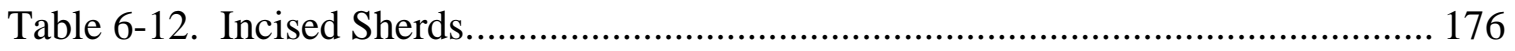

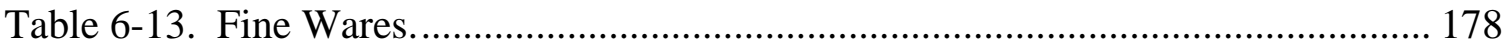

Table 6-14. Engraved Carinated Bowl and Bowl Fine Wares..................................... 178

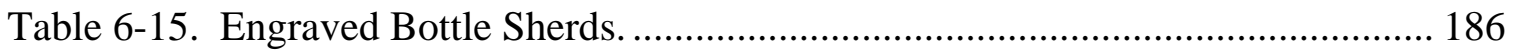

Table 6-16. Use of Pigments on Fine Ware Vessels................................................. 190

Table 6-17. Provenience of the Plain Sherds from the Data Recovery Investigations at the Lang Pasture site. (this table may be found in Appendix G on the compact disk in the back cover of this report)....................................... 191

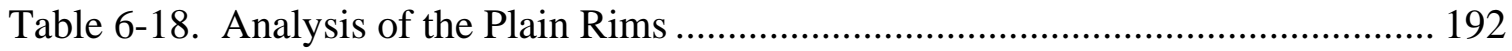

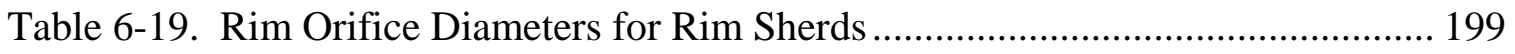

Table 6-20. Proportions of Vessel Size Classes......................................................... 202

Table 6-21. Rim and Lip Forms, Southern and Northern Ceramic Component/Areas. 202

Table 6-22. Trends and Differences in Rim and Lip Form...................................... 204 
Table 6-23. Tempers Used in the Manufacture of Ceramic Vessels 204

Table 6-24. Trends and Differences in the Use of Temper. 205

Table 6-25. Sandy Paste Sherds by Ware and Site Area. 207

Table 6-26. Pinkware Vessels in the Upper Neches River Basin. 209

Table 6-27. Firing Conditions by Site Area and Ceramic Ware. 210

Table 6-28. Distribution of Plain Sandy Paste Pottery Sherds. 211

Table 6-29. Pipe Sherds from the Lang Pasture Site (41AN38). 212

Table 6-30. Other Ceramic Objects from the Lang Pasture Site (41AN38). 218

Table 6-31. Vessel Forms in Selected Upper Neches River Basin Mortuary Assemblages.

Table 6-32. Tempers Documented in Mortuary Vessels. 277

Table 6-33. Firing Conditions Observed in Prehistoric Caddo Mortuary Vessels 279

Table 6-34. Use of Pigments on Mortuary Vessels 280

Table 6-35. Ceramic Vessel Database from the Upper Neches River Valley 282

Table 6-36. Seriation of Engraved Ceramics in Frankston and Allen Phase Sites 283

Table 6-37. Temporal Sequence of Poynor Engraved Varieties and Other Engraved Fine Wares. 285

Table 6-38. Decorated Sherd Assemblages from Lake Palestine 289

Table 6-39. Summary Characteristics of Vessel Sherd Assemblages 290

Table 6-40. Principal Decorative Elements, by Area 308

Table 7-1. Metric Data on Typed Arrow Points from the Lang Pasture Site. 323

Table 7-2. Metric Data on Typed Points from the Lang Pasture Site. 328

Table 7-3. List of Definitions for Kinds of Debitage from the Lang Pasture Site. 340

Table 7-4. Quantities and Percentages of Lithic Materials from Features 341

Table 8-1. Ubiquity and Total Weight of Plant Taxa Identified in the Flotation Samples. 351 
Table 8-2. Plant Materials from Light and Heavy Fractions .................................... 352

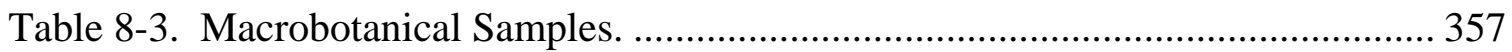

Table 8-4. Plant Foods and Other Plants Grown and Cultivated by the Caddo............. 359

Table 8-5. Ubiquity Values of Selected Plant Resources from Caddo Sites in Northeastern Texas and Northwestern Louisiana........................................................ 361

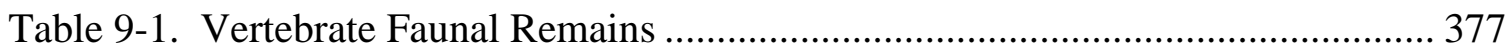

Tables 10-1 through 10-24 may be found in Appendix H, located on the compact disk inserted into the back cover of this report. .........................................401

Table 11-1. Upper Neches River Basin Caddo Cemetery Sites................................... 407

Table 11-2. Proportions of Various Kinds of Mortuary Offerings .............................. 417

Table 11-3. Summary Comparison of the Kinds and Proportions of Funerary Offerings .420

Table 11-4. Mean No. of Funerary Offerings per Burial.......................................... 421

Table 11-5. Differences in the Kind and Proportion of Funerary Offerings ................ 423

Table A-1. Caddo Creek Core 1 (with 30-cm compression after vibra-coring)............ 501

Table A-2. Caddo Creek Core 2 (with 20 cm compression after vibra-coring). ........... 501

Table A-3. Caddo Creek Core 3 (with 30 cm compression after vibra-coring) ............ 502

Table A-4. Pollen Core AMS Dates. ......................................................................... 503

Table A-5. Pollen Core Sedimentation Rates and Chronometry................................. 504

Table A-6. Cores 1 - 2, Pollen Concentration Values................................................ 506

Table A-7. Core 3, Pollen Concentration Values. ...................................................... 507

Table A-8. Correlation of Pollen Assemblage Zones in Cores 1-3. ............................ 516

Table A-9. Caddo Creek Cores 1/3, Comparison of Coeval Relative Pollen

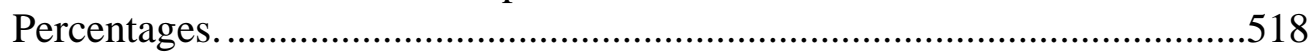

Table A-10. Caddo Creek Core 1, Absolute Pollen Counts. ....................................... 524 
Table A-11. Caddo Creek Core 1, Relative Pollen Percentages...................................... 528

Table A-12. 41AN38 Seep Core 2, Absolute Pollen Counts.......................................... 531

Table A-13. 41AN38 Seep Core 2, Relative Pollen Percentages. ................................... 536

Table A-14. Caddo Creek Core 3, Absolute Pollen Counts. .......................................... 538

Table A-15. Caddo Creek Core 3, Relative Pollen Percentages....................................... 547

Table B-1. Sample Descriptive Data. .............................................................................. 562

Table B-2. Summary of Results - Dosimetry Related Data. ........................................... 563

Table B-3. Summary of Single Grain OSL De Results ................................................... 566

Table B-4. Summary of Palaeodoses (De) from Components Identified within

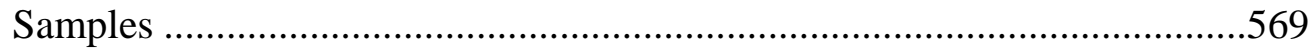

Table B-5. Ages Calculated from All Components Identified Within Samples............ 570

Table B-6. Final Ages Based on Dominant De Component as Identified within Samples..............................................................................570

Table C-1. Sample Characteristics............................................................................... 581

Table C-2. Sherd Radioactivity ............................................................................... 582

Table C-3. Sediment Radioactivity...................................................................... 583

Table C-4. Equivalent Dose and b-Value................................................................... 585

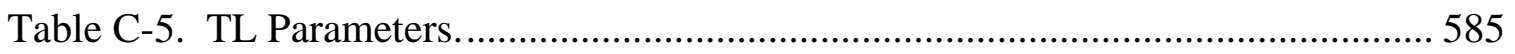

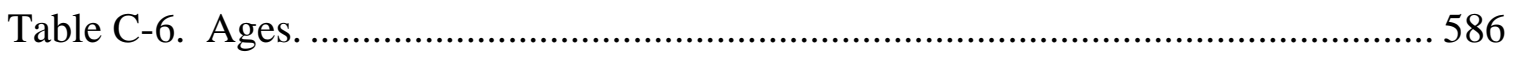

Table D-1. Chemical Group Assignments and Descriptive Data for the Pottery Samples.

Table D-2. Probabilities of Group Membership Based on a Mahalanobis Distance Calculation for Each of the Sherds. Those assigned to a group are highlighted in bold type.

Table E-1. Total Artifact Recovery from Shovel Tests at 41AN159.

Table E-2. Artifact Recovery by Unit-Level from 41AN159. The total lithic counts refer to debitage recoveries. 
Table E-3. Projectile Points and Point Fragments from 41AN159................................. 629

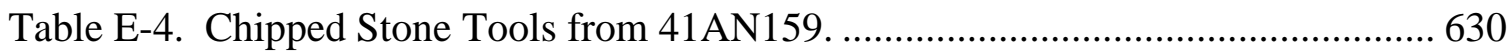

Table E-5. Distribution of Sherds at 41AN159......................................................... 631

Table E-6. Comparative Sherd Assemblage Data from Lake Palestine Caddo Sites.... 632

Table 6-1. Decorated Sherds from the Lang Pasture Site (41AN38). ............................ 991

Table 6-17. Provenience of the Plain Sherds from the Data Recovery Investigations at the Lang Pasture Site. .....................................................1015

Table 10-1. Inventory from the Lang Pasture Site, Burial Features with Skeletal

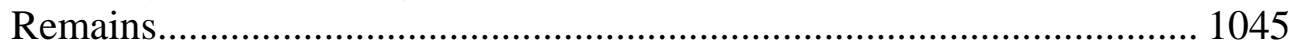

Table 10-2. Inventory from Area Scrapings from the Lang Pasture Site. .................... 1047

Table 10-3. Skeletal Inventory from Selected Caddo Sites ........................................... 1048

Table 10-4. Completeness of Skeletons and Preservation Scores for Burials

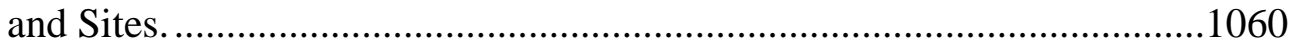

Table 10-5. Age and Sex of Individuals from the Upper Neches River Basin............. 1062

Table 10-6. Sex Ratios from Various Caddo Archaeological Samples......................... 1066

Table 10-7. Cranial Masurements for Adults from the Upper Neches River Basin.... 1067

Table 10-8. Adult Postcranial Measurements................................................................. 1069

Table 10-9. Subadult Cranial Measurements in Millimeters........................................ 1070

Table 10-10. Dental Measurements in Millimeters on Permanent Dentition............... 1071

Table 10-11. Dental Measurements in Millimeters on Deciduous Dentition............... 1106

Table 10-12. Sexual Dimorphism in the Tibia............................................................. 1109

Table 10-13. Cranial Nonmetric Traits................................................................... 1110

Table 10-14. Postcranial Nonmetric Traits................................................................ 1114

Table 10-15. Dental Nonmetric Traits.......................................................................... 1117

Table 10-16. Dental Wear Scores following Scott (1979) for Molars and Smith (1984) for Premolars, Canines and Incisors. 
Table 10-17. Dental Wear Scores following Scott (1979) for Molars and Smith (1984) for Premolars, Canines and Incisors.

Table 10-18. Average Wear Scores, Adults (>19 yrs. of age) from Caddo Sites in Texas.

Table 10-19. Caries Rates for Sites in the Upper Neches River Basin.

Table 10-20. Summary of Adult Dental Data from the Upper Neches River Basin. .. 1126

Table 10-21. Stable Isotope Results from the Lang Pasture Site and the Upper Neches River Basin Population.

Table 10-22. Mean Isotope Values Through Time.

Table 10-23. Frequency of Enamel Hypoplasia in the Upper Neches River Basin..... 1130

Table 10-24. Cranial Modeling Styles in the Upper Neches River Basin Where Observations Were Possible.

Table I-1. INAA Results on a Natural Clay Sample 


\section{ACKNOWLEDGMENTS}

The data recovery work at the Lang Pasture site was carried out by Coastal Environments, Inc (CEI) under a contract with the Texas Department of Transportation (TxDOT). Archeological \& Environmental Consultants, LLC (AEC) teamed with CEI as a subcontractor, and played a crucial role in both the field work and subsequent analyses. The CEI team was under the overall supervision of David Kelley, and the field work was directed by Jennifer Kelly. CEI field crew members were Bruce M. Albert, Lindsay Flood, and David Teague. Timothy K. Perttula led the AEC team, and Bo Nelson, Mark Walters, Anthony Clay Newton, and Chris Kugler of AEC participated in the field work. Phil Dering and Diane Wilson provided their expertise in the analysis of the plant remains and human remains recovered from the Lang Pasture site. Laboratory work was carried out at CEI's Corpus Christi office by Jennifer Kelly and Madeleine-Sophie Ricklis. Laura Nightengale and Dr. Darrell Creel at Texas Archeological Research Laboratory, The University of Texas at Austin, went out of their way to facilitate our analysis of vessel, vessel sherd, and pipe sherds in their collection from upper Neches River basin Caddo sites. They made office space available to us for collectiondocumentation efforts, and office space to Diane Wilson for her analysis of the remains from Lang Pasture as well as a suite of Caddo sites in the upper Neches in their burial collections.

Dr. James Abbott, Dr, Scott Pletka, Dr. Nancy Kenmotsu,, Dr. Lain Ellis, Dr. Owen Lindauer, Waldo Troell, Dennis Price, and Jay Tullos (Tyler District) served as liaisons between TxDOT and the archeological contractors throughout the duration of the project, and their role as facilitators is much appreciated. Dr. Abbott also coordinated with TRC in providing draft chapters of the report for editing and formatting, and in making the collections from the site available for TRC's use in addressing several questions that arose in our readings of the draft chapters, and for making a number of additional artifact photographs for inclusion in the text.

The Caddo Nation of Oklahoma, as the descendants of the people who lived at the Lang Pasture site and in the surrounding region of East Texas, were involved in this project from the beginning. Representatives of the Cultural Preservation Department at the Nation, Robert Cast and Bobby Gonzalez, have contributed a set of comments on their impressions of the project for the Caddo Nation that are included in the final chapter of this report. Their participation and input is very much valued and appreciated. We also want to thank them for their consultation efforts regarding the excavation and treatment of the burial features from the site.

Robert A. Ricklis

TRC Environmental Corporation

Timothy K. Perttula

Archeological \& Environmental

Consultants, LLC

March 2011 


\section{CHAPTER 1}

\section{INTRODUCTION}

Timothy K. Perttula and David B. Kelley

This report summarizes the archeological findings from 2006 data recovery excavations at the Lang Pasture (41AN38) site along the State Highway (SH) 155 right-of-way in Anderson County, Texas (Figure 1-1). This work was performed by Coastal Environments, Inc. and Archeological \& Environmental Consultants, LLC, under contract to the Texas Department of Transportation (TxDOT). David B. Kelley (Coastal Environments, Inc.) served as Principle Investigator during the data recovery work. TxDOT proposes to expand SH 155 from two to four lanes, and this expansion will destroy that portion of the Lang Pasture site that exists in the right-of-way.

The data recovery excavations were extensive, and resulted in the discovery and documentation of numerous features, including habitation deposits, and burial features in a small cemetery, from prehistoric Caddo occupations preserved in the right-ofway (Figures 1-2 and 1-3). The site itself is much larger than the existing right-of-way (cf. Perttula et al. 2007), and it is clear that the Lang Pasture site has a spatially substantial prehistoric Caddo habitation area. The excavations also documented Archaic and Woodland period archeological remains here.

The non-mortuary artifacts and ecofacts from the Lang Pasture site and 41AN159 are curated at the Texas Archeological Research Laboratory, The University of Texas at Austin. Mortuary material (human remains and associated/unassociated funerary offerings) are to be repatriated to the Caddo
Nation of Oklahoma, headquartered at Binger, Oklahoma.

\subsection{THE HIGHWAY MODIFICATION PROJECT}

This highway modification project is located in northeastern Anderson County, south of Frankston to Pert. The project limits are from FM 19 in Frankston to FM 2267 in Pert. The project area is nine miles in length. The highway improvements will follow the existing alignment. The project will reconstruct the existing two-lane roadway without shoulders as a four-lane divided road highway with a depressed median.

State Highway 155 consists of four lanes from the City of Tyler, south to the Henderson County Line and from FM 2267 to the City of Palestine. This project will aid in moving traffic more safely from FM 19 in Frankston through FM 2267 in Pert. State Highway 155 has been completed to widen from a two-lane to a four-lane from the Henderson County Line to FM 19.

The typical proposed $\mathrm{SH}$ section is to consist of four travel lanes with a depressed median. The four travel lanes will be 12 feet each with two inside shoulders four feet each and two outside shoulders 10 feet each. The crossovers will each be 40 feet wide and the depressed median will be 76 feet wide. At each crossover there will be a left turn lane that will be 12 feet in width. A total of 149.729 acres of right-of-way were purchased from the mid- to late 1970s through 1981. 


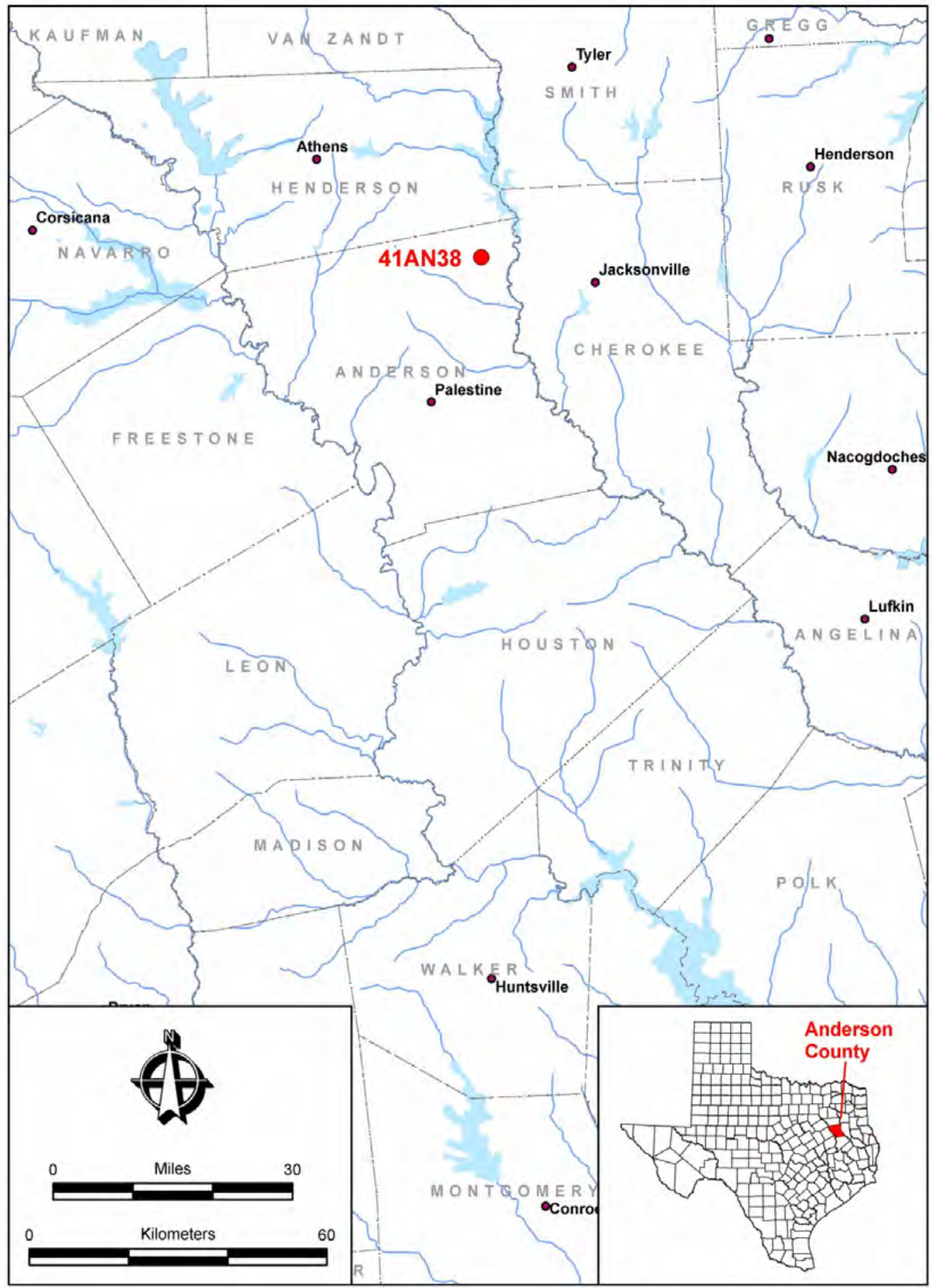

Figure 1-1. Map Showing the Location of the Lang Pasture Site (41AN38) in Anderson County, Texas.

The proposed widening will tie into the current SH 155 south of Frankston as a fivelane rural, then separate out into a four-lane divided with depressed median to connect with the current four-lane divided depressed median just south of Pert. The ultimate 
development of this four-lane divided highway will impact 164.22 acres.

\section{Previous Investigations at 41AN38}

The Lang Pasture site was originally recorded by TXDOT archeologists in 1983 during shovel testing of the SH 155 right-of-way (Campbell 2003:53). The site covered an upland ridge and toe slope about $200 \mathrm{~m}$ from Caney Branch, a small tributary to Caddo Creek, itself a tributary to the Neches River. The Neches River lies ca. $8 \mathrm{~km}$ to the east of the site.

Hicks \& Company, Inc. archeologists returned to the site during more comprehensive survey investigations of the SH 155 right-of-way in early 2003, and excavated eight shovel tests along the right-of-way, documenting that the Lang Pasture archeological deposits covered ca. $800 \mathrm{~m}^{2}$ on the western side of SH 155 (Campbell 2003:Figure 6.16). These shovel tests contained Caddo ceramic sherds, lithic debris, and a piece of fire-cracked rock. A possible post hole feature, with flecks or charcoal and oxidized soil, was identified between $47-53 \mathrm{~cm}$ bs in one of the shovel tests (Campbell 2003:56 and Figure 6.17). Campbell (2003:57) concluded that the Lang Pasture site was a prehistoric Caddo habitation site with the "potential to contain significant intact subsurface deposits within the right of way." 


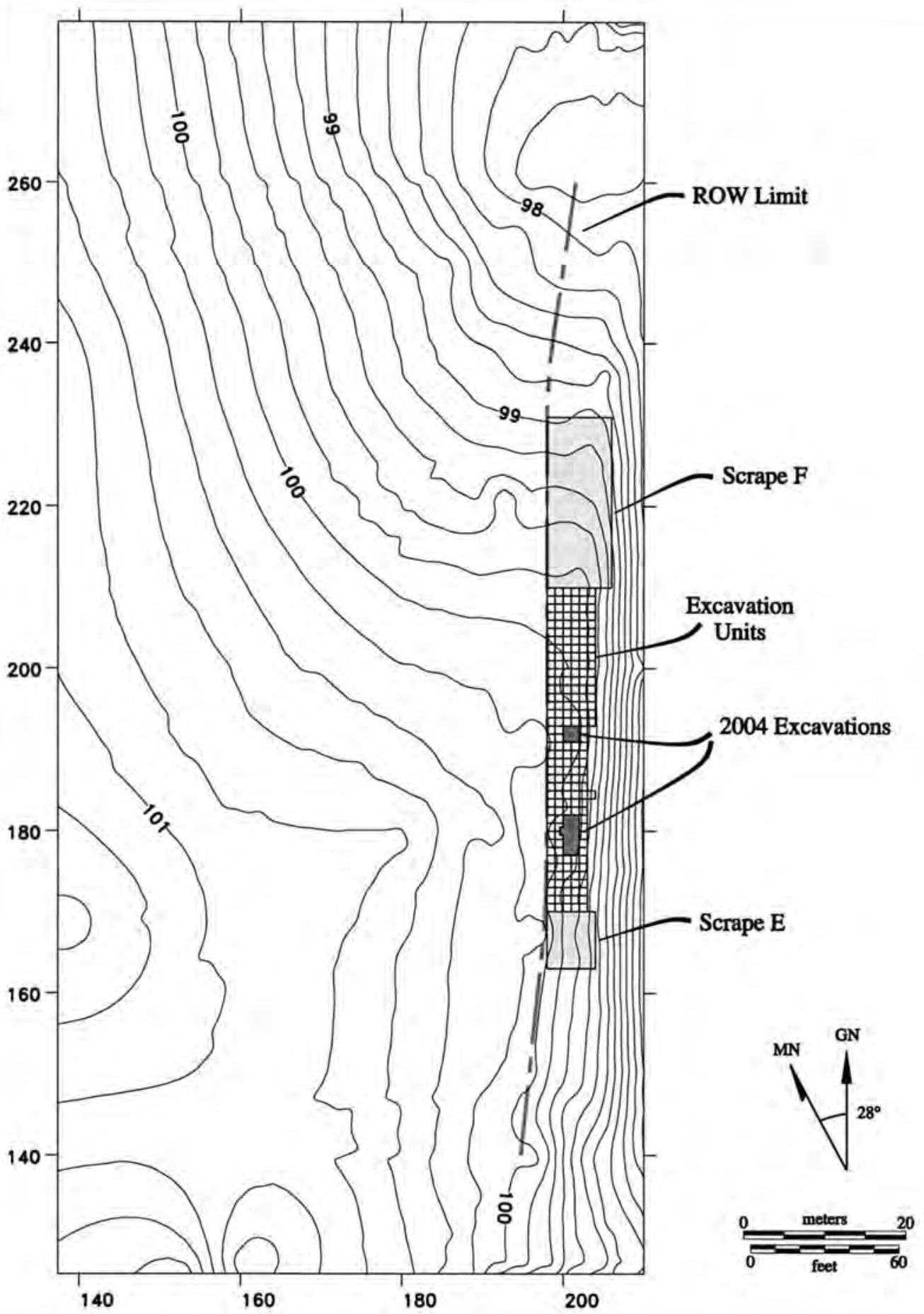

Figure 1-2. General Map Showing the Data Recovery Excavation Area at the Lang Pasture Site (41AN38). 


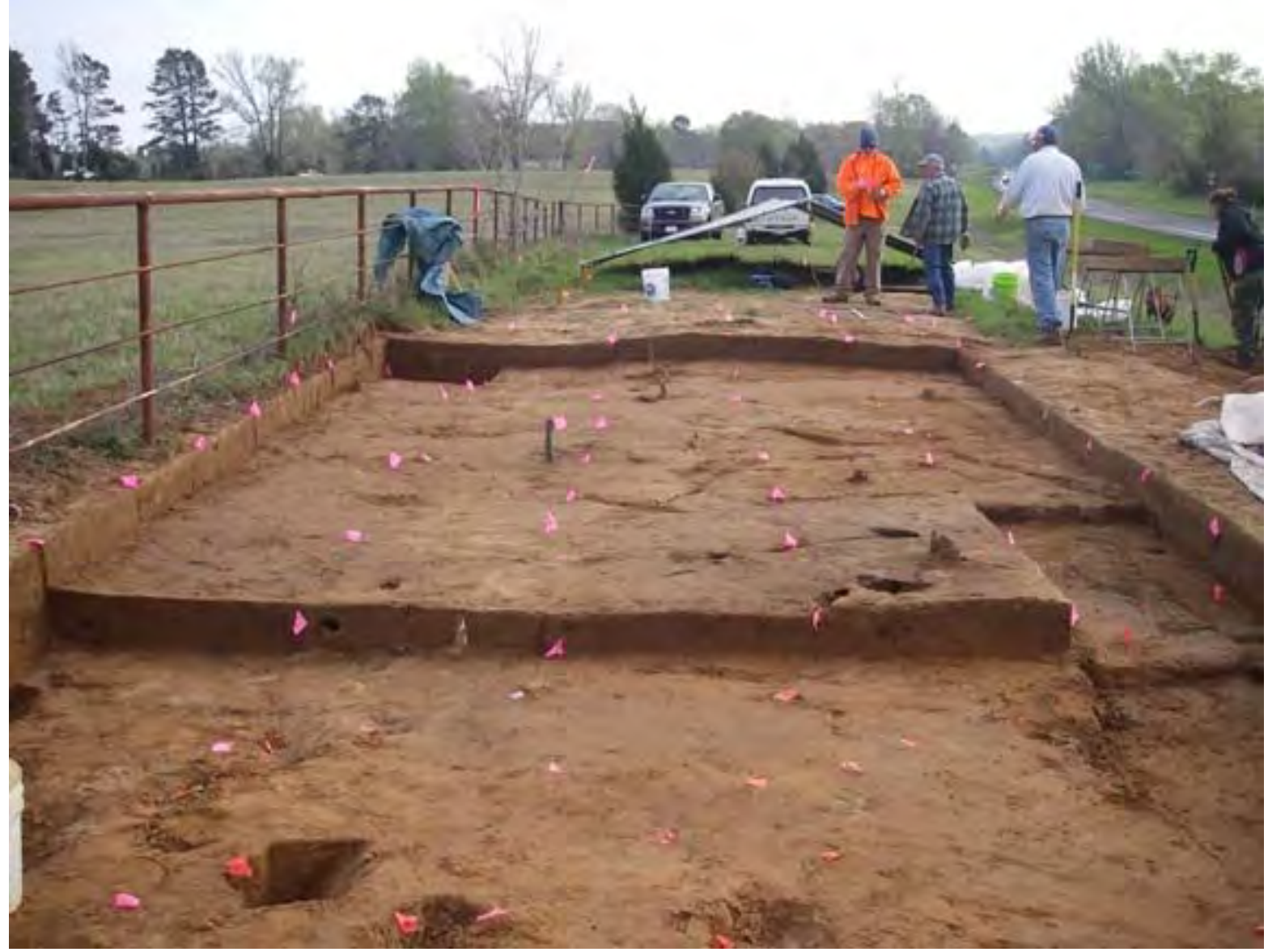

Figure 1-3. View of the Northern Half of the Lang Pasture Site (41AN38) during the Excavations.

Furthermore, Campbell (2003:57) recommended that the site be evaluated through test excavations to determine if it contains significant archeological deposits that would warrant inclusion in the National Register of Historic Places.

In January and February 2004, Coastal Environments, Inc. returned to the Lang Pasture site to complete archeological test excavations since TxDOT had determined that it could not avoid or protect the site within the SH 155 expanded right-of-way. During that work, an additional 20 shovel tests were excavated at the site, along with $14 \mathrm{~m}^{2}$ of hand-excavated units, and four small scrape areas were excavated using a box blade mounted on a tractor (Figure 1-4, see Lohse 2004:Figure 2.7).

Intact prehistoric Caddo archeological deposits about $30 \mathrm{~cm}$ in average thickness (Lohse 2004:25) were recognized over a ca. $400 \mathrm{~m}^{2}$ area of the existing SH 155 right-ofway. There were moderate densities of ceramic sherds (36 per $\mathrm{m}^{2}$ ) and lithic debris (35 per $\mathrm{m}^{2}$ ), with lesser amounts of chipped and ground stone tools $\left(0.7\right.$ per $\mathrm{m}^{2}$, primarily consisting of arrow point fragments) and clay pipe sherds $\left(0.2\right.$ per $\left.\mathrm{m}^{2}\right)$. 


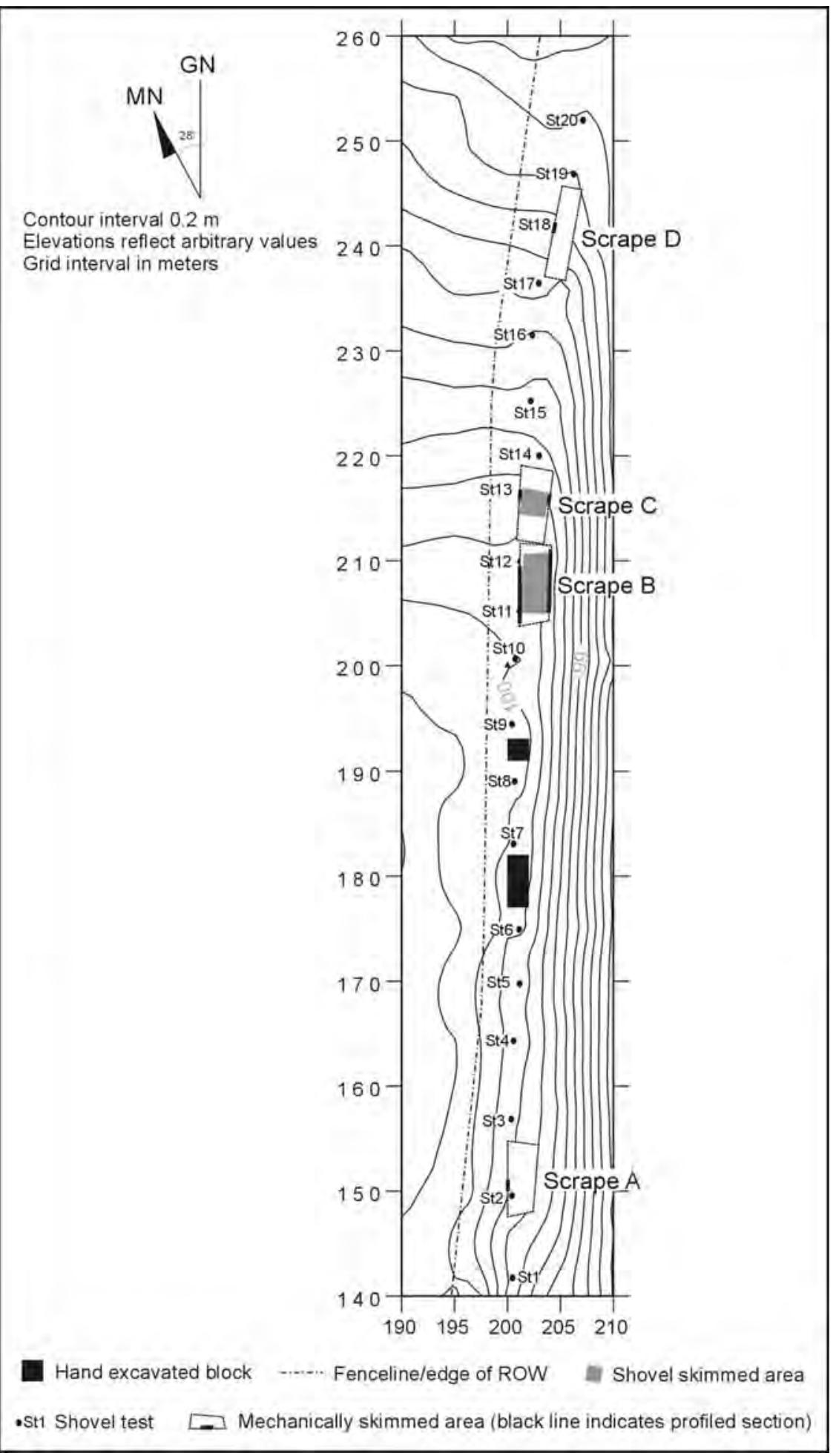

Figure 1-4. Location of 2004 Test Excavations at the Lang Pasture Site (from Lohse 2004: Figure 2.7). 
These deposits included several post hole and pit features in a hand-excavated block in one part of the site that appeared to be related to at least one Caddo structure (Lohse 2004:Table 3.2). Although the pattern of post holes did not show a clear outline in the small block excavation, the association of post and small pit features, as well as the highest densities of artifacts on the site, suggest that the post and pit features are part of a domestic structure in this area. A single extended burial with associated funerary objects was found about $25 \mathrm{~m}$ from the concentration of post holes and pits.

The domestic habitation features were generally exposed between ca. 30-50 cm bs, and were marked by darker sediments (with charcoal flecking) that contrasted with the yellowish-brown E-horizon sediments into which they had been dug. Charred plant remains were preserved (i.e., mainly wood charcoal and hickory nutshell, but other plant taxa as well), but animal bone was absent (Lohse 2004:61).

The one Caddo burial was that of an adult (sex or age undetermined, as the human remains had not been studied by a bioarcheologist at that time) in supine position with the head at the eastern end of the grave, facing west. According to Lohse (2004:22): “[b]one preservation was very poor, and only certain elements remained. These included pieces of long bones, patella fragments, and cranial material." Associated funerary objects included seven ceramic vessels (Lohse 2004:Figures 3.16 to 3.22) and an elbow pipe. Three of the vessels were decorated: a Poynor Engraved carinated bowl, a Maydelle Incised jar, and a red-slipped carinated bowl. The Poynor Engraved and Maydelle Incised vessels are commonly recovered on Frankston phase sites, and Poynor Engraved is the principal fine ware found on Late Caddo (ca. A.D. 1400 and after) sites in the upper Neches River basin (see Anderson et al. 1974; Gilmore 1983). The other four vessels were plain, among them a small bottle, a bowl with a thickened and scalloped rim/lip, and two carinated bowls. The pipe had an L-shaped angle between the bowl and the stem (Lohse 2004:Figure 3.23), a form more often seen in ca. A.D. 1350-1450 Caddo sites in the region (see Rogers and Perttula 2004) than the typical $\mathrm{V}$-shaped elbow pipes found in post-A.D. 1450 Frankston phase sites.

One radiocarbon sample was obtained on charred hickory nutshells from a pit feature (Feature 2). It returned a 2-sigma calibrated age range of A.D. 1030-1290 (Lohse 2004: Table 3.9). A second radiocarbon date was also obtained on a charred organic residue sample from the exterior surface of the Maydelle Incised jar in the burial feature. This sample yielded a 2-sigma calibrated age range of $\mathrm{AD}$ 780-1000 (UGA 14841). Finally, a modern calibrated age (A.D. 1650-1960) was obtained on a sample of wood charcoal from Feature 1 (a post hole), and the wood charcoal in the radiocarbon sample appears to have been intrusive into the post hole. Since none of the dates overlapped at 2 sigma, one possibility suggested by the radiocarbon samples was that the Lang Pasture site was occupied on more than one occasion by Caddo peoples, first in the Formative Caddo period (ca. A.D. 800-1000), then in the Early Caddo period (ca. A.D. 1000-1200) and the initial part of the Middle Caddo period (ca. A.D. 1200-1400), and then perhaps sometime after A.D. 1650. This scenario now seems unlikely (see Chapter 5, discussion of C14 dates), although the radiocarbon dates (except the one dating to modern times) cannot be excluded out of hand, particularly given the abysmal state of radiocarbon dating of prehistoric Caddo sites in the upper Neches River basin, but their interpretation must be based on the range of diagnostic artifacts (primarily decorated ceramic sherds and vessels) considered to be associated with the feature being dated.

A column of Oxidizable Carbon Ratio (OCR) dates was also obtained from the block of hand-excavated units (N179 E200, west wall) in the domestic area of the site. The OCR dates on pedogenic events in the column suggested that the Caddo occupation at the 
Lang Pasture site began as early as ca. A.D. 1300-1336 and ended ca. A.D. 1365-1400. Within that span of time, the occupation may have lasted as little as 30 years to as much as 100 years. The OCR dates are several hundred years later than two of the calibrated radiocarbon dates from the Lang Pasture site, and it was considered possible that they related not to the age of the Caddo occupation, but to a time of pedogenic instability postdating the occupation itself.

Finally, the initial analysis of the decorated ceramic sherds, the elbow pipe, and the vessels from the burial at the Lang Pasture site suggested that the Caddo occupation took place during the earlier part of the Frankston phase, probably between ca. A.D. 1400-1450. The "ceramics from habitation and mortuary contexts are from a single prehistoric Caddo component" (Perttula 2004a:42). These conclusions were based on the vessel seriation proposed by Kleinschmidt (1982) for Late Caddo cemeteries and habitation sites in the upper Neches River valley, the distinctive and temporally significant shape of the elbow pipe (Perttula 2004a:44), and the provisional seriation of decorated sherd assemblages from nearby Lake Palestine Caddo sites, which were acknowledged by Anderson et al. (1974; see also Gilmore 1983) to have been occupied during the Frankston phase (Perttula 2004a:Table 3.8).

Ricklis and Perttula (2004:61) concluded that "an intact Caddo component containing abundant artifacts and intact features is traversed by the highway ROW at 41AN38." They also noted that the existence of contemporaneous domestic and mortuary areas (as assessed from decorated ceramic similarities between the two) indicated that the site retains evidence of the "synchronic use of intra-site space," meaning that archeological information on prehistoric Caddo household and community planning should be preserved at the site. Finally, because the site contains lithic and ceramic artifacts from what appeared from all the available evidence to be a single, isolable component, there is a "high potential for investigating aspects of technology and style that are directly relevant to important research questions such as cultural chronology (e.g., ceramic stylistic change through time) and the technoeconomic dimensions of activities that were carried out at a prehistoric Caddo settlement” (Ricklis and Perttula 2004:62). Because of these characteristics, as well as its contextual integrity, the Lang Pasture site (41AN38) was considered eligible for inclusion in the NRHP under criterion $\mathrm{D}$, and it also warranted designation as a State Archeological Landmark. Ricklis and Perttula (2004:62) also recommended that "full data recovery efforts be carried out at the site, unless avoidance is possible during planned road construction.”

\subsection{Contents OF the Report}

Following this introductory chapter, Chapter 2 presents a summary of the environmental setting-both modern and Holocene-for the broader East Texas area as well as the upper Neches River basin. Chapter 3 is a summary of the Native American culture history in these same regional and basin-specific locales within East Texas. Chapter 4 is the final version of the data recovery research design developed and implemented for the work at the Lang Pasture site.

Chapter 5 includes two main parts: (a) a discussion of the stratigraphy of the archeological deposits at the Lang Pasture site, and (b) a detailed discussion of the character of the domestic and burial features uncovered during the data recovery excavations. This chapter also contains a section that considers the results of the radiocarbon analysis of charred plant remain samples from domestic feature contexts as well as radiocarbon dates on preserved human remains from several of the burial features. A more detailed consideration of the Caddo burial features is also presented in Chapter 11, as part of a specific consideration of the character of Upper Neches River basin Caddo mortuary practices for the period between ca. A.D. 1300-1700. 
Chapter 6 presents the detailed analysis of the recovered ceramic artifacts from the Lang Pasture site, including thousands of plain and decorated sherds from utility ware and fine ware vessels found in domestic contexts, as well as a few pipe sherds and other miscellaneous clay artifacts, along with the ceramic vessels placed as funerary offerings in the excavated burial features at the site. To better understand the spatial, social, and temporal context of the domestic and mortuary ceramics from the Lang Pasture site, this chapter also discusses and compares the kinds of ceramics found in other generally contemporaneous Caddo sites in the Upper Neches River Basin, and defines a basinspecific pottery tradition.

The lithic artifacts from the Lang Pasture site excavations are discussed in Chapter 7. The focus of the lithic analysis is the diagnostic artifacts found in the data recovery workespecially the arrow points and dart points of different types - to characterize the temporal, functional, and technological characteristics of the tool assemblages, as well as the analysis of the lithic debitage from selected cultural features.

Chapter 8 begins with the presentation of the results of the analysis of the preserved plant remains from cultural features at the Lang Pasture site, these remains having primarily been obtained through the flotation of feature fill. The plant remains are dominated by hickory nutshells, maize, and oak and pine wood charcoal; the ubiquity of maize suggests it was an important crop. The second part of Chapter 8 discusses our current understanding of the nature of prehistoric Caddo agriculture in East Texas, and compares paleobotanical findings from Woodland and prehistoric Caddo sites in the region to the paleobotanical assemblage from the Lang Pasture site.

The analysis of the poorly-preserved animal bones from the Lang Pasture site data recovery excavations are summarized in Chapter 9. They provide only limited insights into Caddo subsistence during the occupation, other than that various mammals, especially white-tailed deer, were procured by Caddo hunters to supplement the diet.

Diane E. Wilson summarizes the results of the analysis of human remains from the burial features at the Lang Pasture site in Chapter 10, focusing on determinations of the age and sex of the deceased individuals, skeletal pathologies and evidence of infections, evidence of nutritional stress, and the presence and frequency of caries. Also discussed are the results of stable carbon and nitrogen isotope analysis of these burial features and the implications of these analyses for determinations of the Caddo diet at the time the Lang Pasture site was occupied. This information is enhanced by a broader comparative discussion of the analysis of human remains from a sample of Early Caddo to Historic Caddo burial features in the Upper Neches River Basin.

In Chapter 11, Timothy K. Perttula summarizes the salient characteristics of Caddo mortuary practices at the Lang Pasture site. He also discusses available information from other Caddo burials in the Upper Neches region in order to place the Lang Pasture findings within the regional context of Caddo mortuary practices.

The concluding chapter (Chapter 12) synthesizes the archeological and paleoenvironmental findings from the various analyses that have been completed as part of the study of the Lang Pasture site, particularly in light of the research issues and problems posed in the research design. This chapter also includes a section by representatives of the Caddo Nation of Oklahoma that provides their perspective on the analyses of the human remains from Caddo burials at the site.

There are also a number of appendices that accompany the technical report. Appendix A, by Bruce M. Albert, presents the palynological and paleoenvironmental findings from three cores taken along Caddo Creek in the vicinity of the Lang Pasture site. Appendix B (Mark D. Bateman) and Appendix C (James Feathers) present the results of quartz optical 
dating of sediments, and luminescence dating of more than 20 Caddo ceramic sherds, respectively, from the Lang Pasture site. Appendix D (Jeffrey R. Ferguson and Michael D. Glascock) is the report on the instrumental neutron activation analysis (INAA) of 100 sherds from Upper Neches River basin Caddo sites. This study examined 50 sherds from the Lang Pasture site, and 50 sherds from nine contemporaneous Caddo sites in the basin. Appendix E (Jon Lohse, Timothy Perttula and Robert Ricklis), describes test excavations at 41AN159, a Caddo and pre-Caddo site located within the highway ROW south of the Lang Pasture site.

Appendix F contains several sub-appendices that present data on ceramics from the Lang Pasture site as well as from other Caddo sites in the Upper Neches Drainage Basin. Appendix $G$ contains some of the tables for Chapter 6, which have been placed on the compact disk due to their great length.
Appendix $\mathrm{H}$ contains the data tables for Chapter 10 (D. Wilson's bioarchaeological analyses), and Appendix I presents the findings from a chemical analysis of a raw clay sample extracted from the ground at 41AN38.

Completed vessel recordation forms for the whole vessels from the Lang Pasture site are included in Appendix F.3, and Appendix F.4 includes vessel recordation forms for 274 Caddo vessels at the Texas Archeological Research Laboratory at The University of Texas from other sites in Anderson and Cherokee counties in the upper Neches River Basin. Appendix F.5 is the Upper Neches River Basin ceramic vessel database compiled during the course of the project and studied for comparison with the mortuary vessel assemblage from the Lang Pasture site. Files containing photographs of the ceramic vessels described in Appendices F.3 and F.4 are included on the same compact disk inserted in the back cover. 


\section{CHAPTER 2}

\section{ENVIRONMENTAL SETTING}

The Lang Pasture site (41AN38) is located in the Pineywoods of East Texas, in the West Gulf Coastal Plain, and in the Neches River basin. It is situated on an upland ridge and toe slope (ca. 390 feet amsl) about $200 \mathrm{~m}$ northwest of Caney Branch. At the time of the archeological data recovery investigations the site area was primarily grass-covered, with several small trees along the SH 155 right-ofway fence (see Figure 1-3).

Within the broad region of the state that encompasses East Texas, there are three main biotic communities or physiographic zones: the Oak Woods and Prairies or Post Oak Savanna, the Blackland Prairie, and the Pineywoods (Diamond et al. 1987; Schmidly 2002) or the Southeastern Deciduous and Evergreen Forest (see Brown et al. 1998) (Figure 2-1). The site is within the boundaries of the modern Pineywoods, with the easternmost extent of the Post Oak Savanna cutting across the middle of Anderson County, Texas, as well as the headwater areas of the Neches River itself (see Figure 2-1), about 15 miles $(25 \mathrm{~km})$ from the site. The Blackland Prairie is approximately 30-50 miles (48-80 $\mathrm{km}$ ) west of the Lang Pasture site, well within reach of Caddo hunters over a 2-3 day trek.

The Pineywoods cover large parts of East Texas (Figure 2-1), have medium-tall to tall broadleaf deciduous forests in more mesic habitats, and shortleaf and loblolly pines are common on upland fine sandy loam soils with adequate moisture. Small areas of tall grass prairie may be present in both communities throughout the region (e.g., Jordan 1981:Figure 4.1), and this may be particularly the case in more xeric sandy lands. Bottomland communities along the major river and creek drainages contain a diverse hardwood and swamp forest (including cypress, tupelo, and sweet gum), with natural levees and alluvial terraces, point bar deposits, old stream channels, oxbow lakes, and backwater swamps. A less diverse bottomland hardwood community is present along the smaller creeks and their tributaries. The Red, Sulphur, Big Cypress, Sabine, Neches, Angelina, and Trinity rivers flow east and southeast through the Pineywoods (see Figure 2-1), but only the Angelina River and its tributaries originate in the Pineywoods.

The Post Oak Savanna or Oak Woods and Prairies is a narrow $(60-80 \mathrm{~km})$ southwestnortheast trending woodland belt that marks an ecotone or natural transition zone between the more xeric Blackland Prairie to the west and the more mesic Pineywoods to the east (see Figure 2-1). The Red, Sulphur, Big Cypress, Sabine, Neches, and Trinity rivers cut through the Post Oak Savanna, with the Big Cypress and Neches stream basins originating in this physiographic zone. The woodlands in the Post Oak Savanna consist of medium-tall to tall broadleaf deciduous forests, including several species of oak, as well as hickory and pecan. 


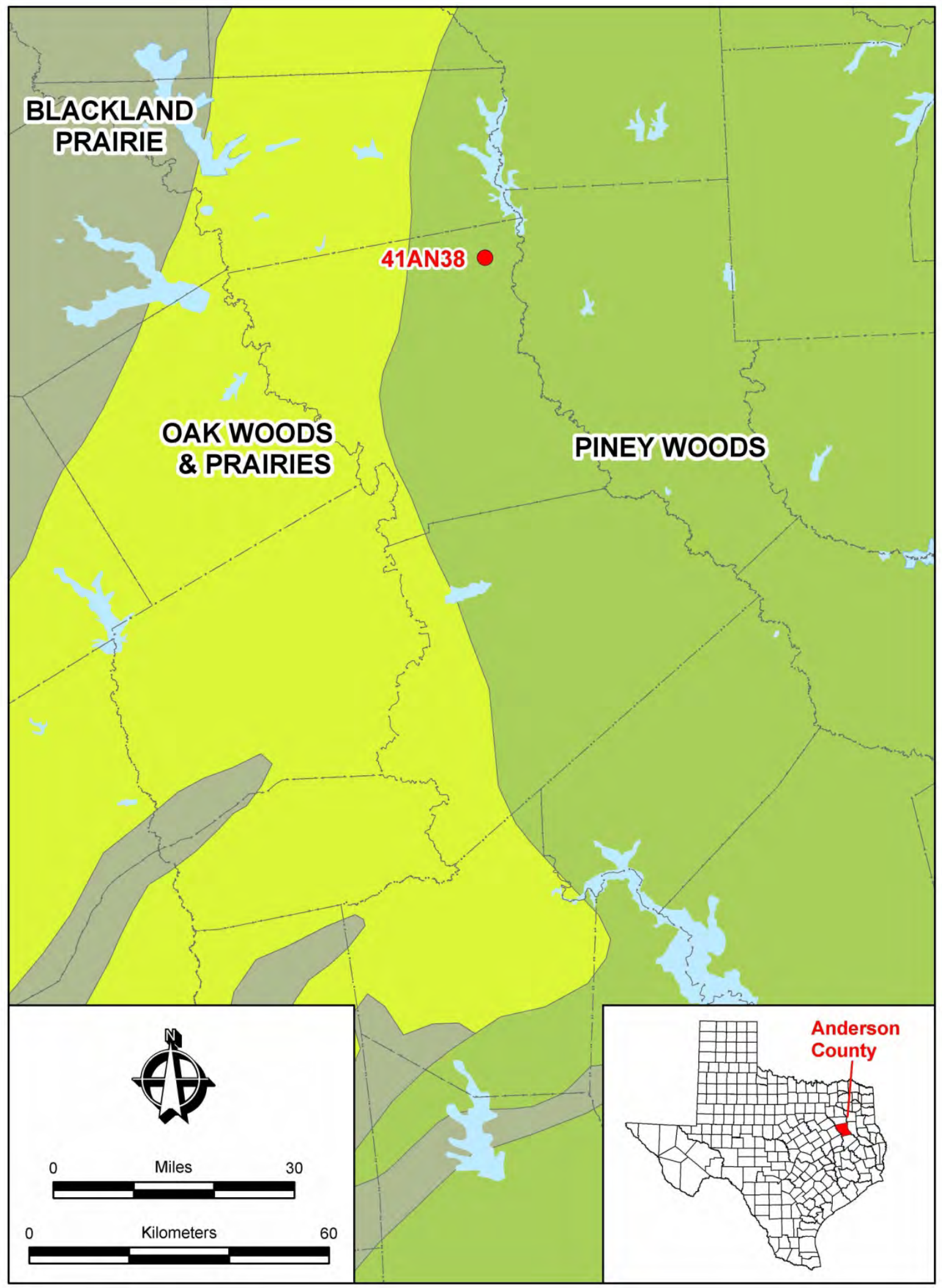

Figure 2-1. Map Showing Physiographic Zones in East Texas, and the General Location of the Lang Pasture Site (41AN38). 
The Blackland Prairie is a zone of tall grass prairie, with little bluestem and Indiangrass, along with a riparian deciduous forest of oak, hickory, and other tree species, along major streams (such as the Trinity and Sulphur rivers) and their tributaries. The headwaters of the Sulphur, Sabine, and Trinity rivers originate in the Blackland Prairie (see Figure 2-1).

The climate of the East Texas region is humid, with a mean annual precipitation in modern times of at least 100-125 cm across the region as a whole; according to Coffee (1975:89), mean precipitation in Anderson County in modern times is ca. $102 \mathrm{~cm}$ a year. Periods of maximum rainfall occur in the spring and fall seasons. The growing season in Anderson County is about 260 days, with the last freeze occurring in March and the first freeze in late November. Droughts are also not uncommon in the modern era, and dendrochronological analyses of tree rings for the last 1000 years suggest there were numerous wet and dry spells during that time (Stahle and Cleaveland 1994, 1995), including several lengthy droughts.

Based on mid-19 ${ }^{\text {th }}$ century General Land Office records from various parts of East Texas, in the uplands in both the Pineywoods and Post Oak Savannah, especially in settings with very deep and well-drained sandy soils, the overstory consisted of a mixture of pine and oaks, including blue oak, blackjack oak, post oak, and red oak. Some portion of these landform-soils settings (probably with deep sandy sediments) in the Pineywoods probably also had pure stands of pine. In the eastern and southern parts of the region, much of the steeply sloping uplands in the Pineywoods had pines or pine-oak overstories, as would southern and steeper upland slopes. However, northern and more gently sloping valley landforms appear to have been dominated by oaks.

In upland settings with thinner sandy sediments that are not as well-drained, the overstory in both the Post Oak Savannah and Pineywoods probably consisted of a variety of oaks (post oak, red oak, blackjack oak, bluejack oak, and chinquapin oak) and hickory. Abundant nut mast would have been available in these upland habitats on an annual basis. On landforms with deep and welldrained loamy fine sand, such as more mesic lower valley slopes, toe slopes, and elevated alluvial landforms, the vegetational overstory in mid-19th century times across the region had red oak and post oak trees, along with other hardwoods that tolerate periodic flooding.

\subsection{Geologic Setting ANd Solls}

East Texas is part of the Gulf Coastal Plain physiographic province. The province is comprised of Mesozoic and Cenozoic sediments that filled the East Texas basin with sediments of marine, delta, and river origins, including sandstone and mudstone, along a receding coastline. These deposits dip and become progressively younger towards the present Texas coastline.

Principal geologic formations from north to south in East Texas include the Austin, Eagle Ford, Woodbine, Navaroo, and Taylor groups (Cretaceous period); Wilcox and Midway groups (Paleocene period); Jackson and Claiborne groups (Eocene period); the Catahoula Formation (Oligocene period); Fleming and Oakville formations (Miocene period); and the Willis Formation (Pliocene period). All the major streams and most of their principal tributaries have Quaternary alluvium (Bureau of Economic Geology 1992). The Eocene Queen City Sand, Sparta Sand, and Weches formations (Bureau of Economic Geology 1965) form the underlying bedrock materials in the vicinity of the Lang Pasture site). The Queen City Sand has thick fine-grained quartz sand, beds of clay, lenses of glauconite, and beds and concretions of clay and ironstone (i.e., hematite and ferruginous sandstone).

These geologic formations in the Gulf Coastal Plain are poor in lithic raw materials (Banks 1990:Figure 2.1). Only the Pisgah Ridge chert in the Trinity River basin, Manning fused 
glass in the Manning Formation (part of the Jackson group of Eocene age), and various cherts and quartzites in the Catahoula Formation are in "geological formations that contain in situ rocks suitable for the manufacture of stone tools” (Banks 1990:49). There are also upland stream gravels (or Uvalde gravels) that are cobble to pebblesized that are relatively widely-spread in parts of East Texas, especially in the Trinity and Sulphur River basins (Banks 1990:56-57), and to a limited extent in the Neches River basin (see Anderson et al. 1974). However, high quality and large knappable cobbles of chert, novaculite, and quartzite are present in the Red River gravels in the northeastern part of East Texas, and these are derived from chertbearing formations in the Ouachita Mountains of southeastern Oklahoma (Banks 1990: Figure 1.20).

The diverse geological setting of East Texas is matched by the diversity in soils found in the region. Blackland Prairie clay soils are confined to the Cretaceous Navarro, Taylor, Austin, Eagle Ford, and Woodbine groups, with their limestone and marl bedrocks. The sandstones and mudstones that characterize the Paleocene, Eocene, Oligocene, Miocene, and Pliocene groups and associated formations have led to the development of sandy and sandy loam sediments (sometimes of considerable thickness) across the remainder of the region-including in uplands, alluvial landforms, and floodplains - in the Post Oak Savanna and Pineywoods. These sandy soils are generally acidic in nature, and bone and shell tend not to be well-preserved on archeological sites in these regions; bone and shell are poorly preserved at the Lang Pasture site.

Erosion due to intensive cultivation practices over the last 150 years in the Blackland Prairie has led to the aggradation of black clay soils in the floodplains of the Sulphur and Sabine rivers, but otherwise sandy and sandy loam deposits (including natural levees and point bars) are characteristic of other East Texas river and creek floodplains; back swamp areas on the larger streams tend to have fine clay sediments. Timber harvesting in the Pineywoods and Post Oak Savannah over the same time period has led to significant erosion across much of the uplands, and the colluvial deposition of sandy sediments along lower upland slopes and in alluvial settings. Less eroded areas in the uplands (depending upon the parent material) may have sand deposits more than 1-2 $\mathrm{m}$ in thickness.

The Caney Branch and Caddo Creek valleys are moderately dissected, with 100-150 feet of relief from the creek floodplain to the crest of their sandy, gravelly, and/or rocky upland landforms. The Caney Branch valley has a narrow floodplain with alluvial deposits, but the floodplain widens at its confluence with Caddo Creek, a few miles to the northeast. The broader floodplain of this Neches River tributary also has a few small knolls or natural rises in the floodplain. Water is also available in several springs in the vicinity of the Lang Pasture site.

Soils along the Caney Branch and Caddo Creek valleys include fine sandy loam and clayey soils along the floodplain and fine sandy loam and loamy fine sandy loams in the uplands (Coffee 1975). The area is part of the sandy and loamy soils of the Fuquay-KirvinDarco association, which formed in the interbedded sands and clays of the Queen City Sand, and under a pine-hardwood forest.

The soils at the Lang Pasture site are classified as Fuquay loamy fine sand, $3-8 \%$ slope. A typical pedon of this soil is a ca. $76 \mathrm{~cm}$ thick loamy fine sand A-horizon overlying a ca. 160 $\mathrm{cm}$ thick B-horizon sandy clay loam with plinthite inclusions. The C-horizon includes zones of sandy clay loam and clay (Coffee 1975:18-19). It is likely a desirable soil for agricultural purposes, having deep sediments that are easy to work with simple nonmechanized tools.

In general, other upland soils formed under a pine-hardwood forest along Caney Branch and Caddo Creek consist of fine sandy loam and loamy fine sand sediments of varying thickness (due in part to modern erosion, but 
ranging from ca. $20 \mathrm{~cm}$ to more than $1 \mathrm{~m}$ in thickness) overlying a red clay subsoil. These range in slope from $0-20 \%$. These upland soils include the Darco-Kirvin-Tenaha soils, Elrose fine sandy loam, 1-3\% series, the Kirvin-Sacul association, LaRue loamy fine sand, 1-3\%, Pelham loamy fine sand (formed under a hardwood forest, probably post oak flats, see Coffee 1975:33), Trawick fine sandy loam, 28\% and 8-20\% slope, and Trawick-Bub soils.

In the floodplain of both Caney Branch and Caddo Creek, the principal alluvial soil series are Hannahatchee fine sandy loam, Thenas fine sandy loam, and Robinsonville fine sandy loam (Coffee 1975). In narrower floodplain areas along tributary streams, these alluvial soils are subject to occasional or frequent overflows from flooding. The poorly drained Nahatche clay loam occurs along the larger Caddo Creek, but not along Caney Branch.

Several of the soils in the vicinity of the Lang Pasture site likely had some potential for prehistoric Caddo agricultural purposes, although it is difficult to gauge which soils these might have been because of the absence of proxy measures of soil quality and productivity for Caddo farmers as opposed to modern intensive agriculturists (see discussion in Rogers and Perttula 2004:9-10). As an indication of the potential for soils for prehistoric agricultural pursuits, the following soils in the vicinity of the Lang Pasture appear to be amenable for the cultivation of maize, based on modern assessments of their suitability for cultivation and their known productivity in terms of corn production (Coffee 1975:48-49 and Table 2): Fuquay loamy fine sand; Darco fine sand; Elrose fine sandy loam; LaRue loamy fine sand; and Trawick fine sandy loam. Large tracts of land to the immediate south and west of the Lang Pasture site, on the west side of Caney Branch, are mapped as having several of these soils, especially the Fuquay, Elrose, LaRue, and Trawick soil series (Coffee 1975: Sheet 11), and Caddo fields may have been located there during the Frankston phase occupation. The fine sandy loam floodplain soils east of the site may also have had agricultural fields, as they could be readily worked with hand tools, and they are rich in organics. However, they would have been subject to flooding during the winter and early spring, limiting the planting of crops, especially the first corn crop (e.g., Swanton 1942:129).

\subsection{HOLOCENE ENVIRONMENTAL ChANGE}

The climate in East Texas has changed dramatically over time, which has affected the biodiversity and carrying capacity of the region. This in turn likely influenced the adaptations of Native American groups that lived in this broad region, especially as they became more dependent upon cultivated plants in what is a risky and occasionally droughtprone environment. A review of the paleoenvironmental record is appropriate to provide the context for the discussion of the culture history of Native Americans that follows in Chapter 3.

Pollen data from Ferndale Bog (Holloway 1994) in the Ouachita Mountains of southeastern Oklahoma, and from several bogs in Central Texas (Bousman 1998), indicate that the Late Pleistocene climate (ca. 11,00014,000 years ago) was cool and dry, and probably supported a grassland steppe. By 11,000 years ago, as the climate became warmer and wetter, oak woodlands or oak savanna habitats would likely have been present throughout much of eastern Texas (and north into Oklahoma). These woodlands were maintained for several thousand years: perhaps until 7500 years ago, although Bousman (1998:Figure 4) notes a period of open, grassland vegetation in Central Texas between 9500-8750 B.P. The Ferndale Bog pollen diagram (see Ferring 1994:Figure 4.5) also points to a more open and grassy setting, based on decreasing oak pollen and a lower pollen influx between ca. 8000-9200 years ago. Whether such a setting characterized East Texas at that time is not known.

Between ca. 7500-5000/4500 years ago, the Middle Holocene climate was quite warm and dry, and Ferring (1995:24) suggests this was a 
period of significant reduction in available biomass for Native American hunter-gatherers in the region. In the Ferndale Bog area of southeastern Oklahoma, the vegetation was an oak-hickory-pine woodland, while farther to the south and west in Central Texas, grasslands were dominant. Bousman's (1998:210) palynological analyses led him to conclude that the grass cover was greatestand the climate the driest-between 55004500 B.P., while Ferring (1995:24) places the very dry and warm episode between ca. 65005000 B.P.

The Late Holocene period after ca. 4500 years ago appears to have been one of fluctuating climates-moist or dry cycles-that were generally wetter than during the preceding Middle Holocene period, and more like modern climatic conditions. Ferring and Yates (1996:Figure 7.5) propose that there were wetter years between ca. 5000-2000 B.P. and after 1000 B.P., with a drier cycle between 1000-2000 years ago when grassier conditions prevailed. With these climatic and rainfall conditions, oak-hickory-pine woodlands were probably the principal vegetation in upland habitats in much of the East Texas lands (as they are today), with a well-developed riverine forest in the floodplain settings.

Supporting the drier and warmer cycle in the middle portion of the Late Holocene, the Ferndale Bog pollen record indicates that the peak in pine pollen was between ca. 800-1800 B.P. (Holloway 1994:Table I.2), while Bousman (1998:207) notes one grass spike or peak in the Weakly Bog in Central Texas that dates about 1500-1600 years, with another between 400-500 B.P. Stable carbon and oxygen isotopes from mussel shells along Denton Creek in North Texas, however, point to a warm/dry peak at ca. 2850 B.P., and then again after 1500 B.P. (Brown 1998:164). Stable carbon isotope values from humate samples in the Cooper Lake area of the upper Sulphur River basin in Northeast Texas have C4-enriched peaks (i.e., higher $\mathrm{C} 4$ grasses in the biomass) around 2000 B.P. and 4000 B.P. (see Perttula 1999:Figure 2-4).
For the last 1000 years or more, dendrochronological records (from cypress trees and logs) are the most accurate and temporally sensitive data available on Late Holocene environmental change (e.g., Stahle 1996). Fortunately, recent dendrochronological research in Texas, Arkansas, and Louisiana, as well as the Southeast and Midwest U.S., by Stahle and Cleaveland (1988, 1992, 1993, 1994, 1995) and Benson et al. (2007) has compiled significant new information on subtle but changing climatic and rainfall conditions and trends for the general Trans-Mississippi South region, of which East Texas is a part (see Schambach 2002:Figure 5.1).

Droughts are not uncommon in the region in modern times, and dendrochronological analysis suggests there were numerous wet and dry spells between ca. A.D. 1000-1700, just as there were between 5000-1000 years ago. Some of the worse droughts may have occurred around A.D. 1555, 1570, 1595, and 1670, and the period between A.D. 1549-1577 had been suggested to have had the worse droughts in the past 450 years (Stahle et al. 1985), at least in parts of the mid-continent. Another severe droughty period appears to have taken place between about A.D. 14401475.

More detailed dendrochronological analyses from bald cypress tree-ring chronologies on spring rainfall between A.D. 1002-1988 from Big Cypress State Park in northwestern Louisiana indicate the wettest years were between A.D. 1053-1057, 1168-1176, 11781180, 1265-1268, 1323-1328, 1553-1555, 1584-1586, 1718-1719, 1797-1800, 18101812 , and 1866-1873; the very wettest years in prehistoric times were about a decade from 1168-1176 and 1178-1180. These years would likely have been optimal growing years for prehistoric and early historic Caddo agricultural groups, assuming a correlation between crop production and spring precipitation values (cf. Anderson et al. 1995:265). The wetter rainfall conditions would also likely have led to an increase in the extent of swamp and wetland habitats in the 
major stream basins, and a concomitant expansion in the carrying capacity of woodland plants and animals in the area. In historic times-after ca. A.D. 1650-the wettest intervals occurred between 1797-1815 and 1866-1876.

Conversely, the driest years in prehistoric and early historic times in East Texas-between A.D. 1014-1016, 1215-1217, 1444-1447, 1455-1460, 1529-1533, 1653-1655, 16971699, 1841-1846, and 1855-1860 - may well have led to stressed food supplies, as well as the ability of Caddo groups to produce sufficient food reserves from the cultivation of tropical cultigens, and the success of any maize harvests during these extended periods. The drier periods did not influence the character of Caddo settlement systems, which remained dispersed throughout the prehistoric and early historic periods, but it did influence their distribution across the landscape, as Caddo agricultural populations began to concentrate in the Pineywoods and along certain major streams (i.e., the Red, the lower Sulphur, the middle Sabine, and certain parts of the the Neches-Angelina river basins).

The very dry years between A.D. 1444 and 1460 correlate well with the grass spike/drier episode noted by Bousman (1998) from the Weakly Bog pollen record. These more significant droughts probably also affected the constancy of flow in the numerous upland springs in the area, as well as the volume of flow in the major and minor stream basins. This in turn would have influenced the relative quantity of animal and plant foods in floodplain and upland forested habitats. The very droughty years between 1841-1846 correlate closely with the final abandonment of East Texas by the Caddo. Stahle and Cleaveland's (1988) drought reconstruction for North Texas indicates that three of the driest years between 1698-1980 occurred in 1855, 1857, 1859, and 1855 was the driest year in that 282 year record.

For the period of wet and dry spells from ca. A.D. 1000-1650, the wetter years $(>1400$ standard ring width indices [sri]) were more than two times as frequent as the driest and droughty $(<560$ sri) years (see Perttula 1999:Figure 2-5). After ca. A.D. 1430, the wetter years occurred less often, some 55 percent less between A.D. 1600-1700 than in the ca. A.D. 1200-1400 period. In historic times, the two wettest but also equitable intervals were between 1792-1826 and 18611890 , with the wetter years eight times more common than the very dry and droughty years. Conversely, in the period between 1827-1861, the very dry and droughty years outnumbered the very wet years by a ratio of 9:1. These very different paleoenvironmental conditions over long periods of time may have played an important role in East Texas in human adaptations. These conditions may also have influenced changes to the landscape brought about by significant erosion (and the transportation of sandy sediments), stream down-cutting, and the formation, preservation, or degradation of landforms that contain, or once contained, traces of human occupation. 


\title{
CHAPTER 3
}

\section{SUMMARY OF EAST TEXAS NATIVE AMERICAN CULTURE HISTORY}

\author{
Timothy K. Perttula
}

This chapter considers the diverse character of the prehistoric and Caddo archeological record in East Texas, particularly from the Red River south to the confluence of the Neches and Angelina rivers. First, we discuss the history of archeological research in East Texas, then review what is known about the prehistory and early history of east Texas, beginning with the Paleoindian period. A principal focus of the summary of Native American culture history is the post-ca. A.D. 850 Caddo settlement of East Texas, in particular the ca. post-A.D. 1300-1450 Middle to Late Caddo settlement of the Neches River basin, since the principal occupation of the Lang Pasture site took place during this temporal interval.

\subsection{HISTORY OF RESEARCH}

Archeological research in Northeast Texas has a lengthy history that has been thoroughly discussed by several authors, particularly Story (1990), Thurmond (1990), Guy (1990), and Perttula (1992). Substantial archeological investigations began with the Philadelphia Academy of Natural Sciences expedition in 1912 along the Red River-mostly in northwestern Louisiana and southwestern Arkansas (Schambach 1983; Kelley 1997)_ but Clarence B. Moore (1912) did record several important Caddo mound sites, and conducted excavations at the Moore/Higginbotham site (3MI3/30), located a few miles east of the Texas state line (Kelley and Coxe 1998; Weinstein et al. 2003).

Much of our knowledge of the prehistoric use of the region is primarily based on the 1930s excavations by The University of Texas at Austin of aboriginal sites and cemeteries (e.g., Pearce 1932; Jackson 1933, 1934) throughout the region, very notably in the upper Neches River basin (Figure 3-1), and then extensive late 1930s-early 1940s Works Progress Administration investigations at the George C. Davis, Hatchel, Mitchell, and Yarbrough sites (Guy 1990; see also Newell and Krieger 1949; Johnson 1962; Creel 1996) in Cherokee, Bowie, and Van Zandt counties, respectively. Since then, most of the information about the Paleoindian, Archaic, Woodland, and Caddoan archeological record in East Texas comes from a disparate range of privately-funded archeological research, including: (1) avocational archeological investigations and Texas Archeological Society field schools (see Corbin and Hart 1998; Jelks 1967; Middlebrook 1994, 1997; Perttula et al. 2001; Turner and Smith 2003), and (2) University of Texas at Austin (Fields 1979; Story 1981, 1982, 1995, 1997) and Stephen F. Austin State University field schools in archeology (see Corbin and Hart 1998). There has also been extensive professional archeological work in a number of state and federally-funded or permitted reservoirs in the Sabine, Sulphur, Neches, Angelina, and Big Cypress drainage basins (see Anderson et al. 1974; Bruseth and Perttula 1981; Duffield 1963; Fields et al. 1997; Jelks 1965; Jensen 1968; McClurkan et al. 1966; Thurmond 1990; Woodall 1969), archeological survey investigations on the National Forests in East Texas (see Sherman et al. 1999), as well as in considerable archeological work in large surface lignite mines (e.g., Galan et al. 1997; Kotter et al. 1993; Perttula et al. 1998; Rogers et al. 2001; Rogers and Perttula 2004), and on TxDOTsponsored archeological projects (see Cliff and Perttula 2002; Cliff et al. 2004; Lohse 2005; Ricklis, ed., 2004; Rogers et al. 2003). Ahr 
(1999) has reported on Texas Department of Transportation investigations of a probable
Late Caddo site (41CE326) exposed along the US 69 right-of-way.

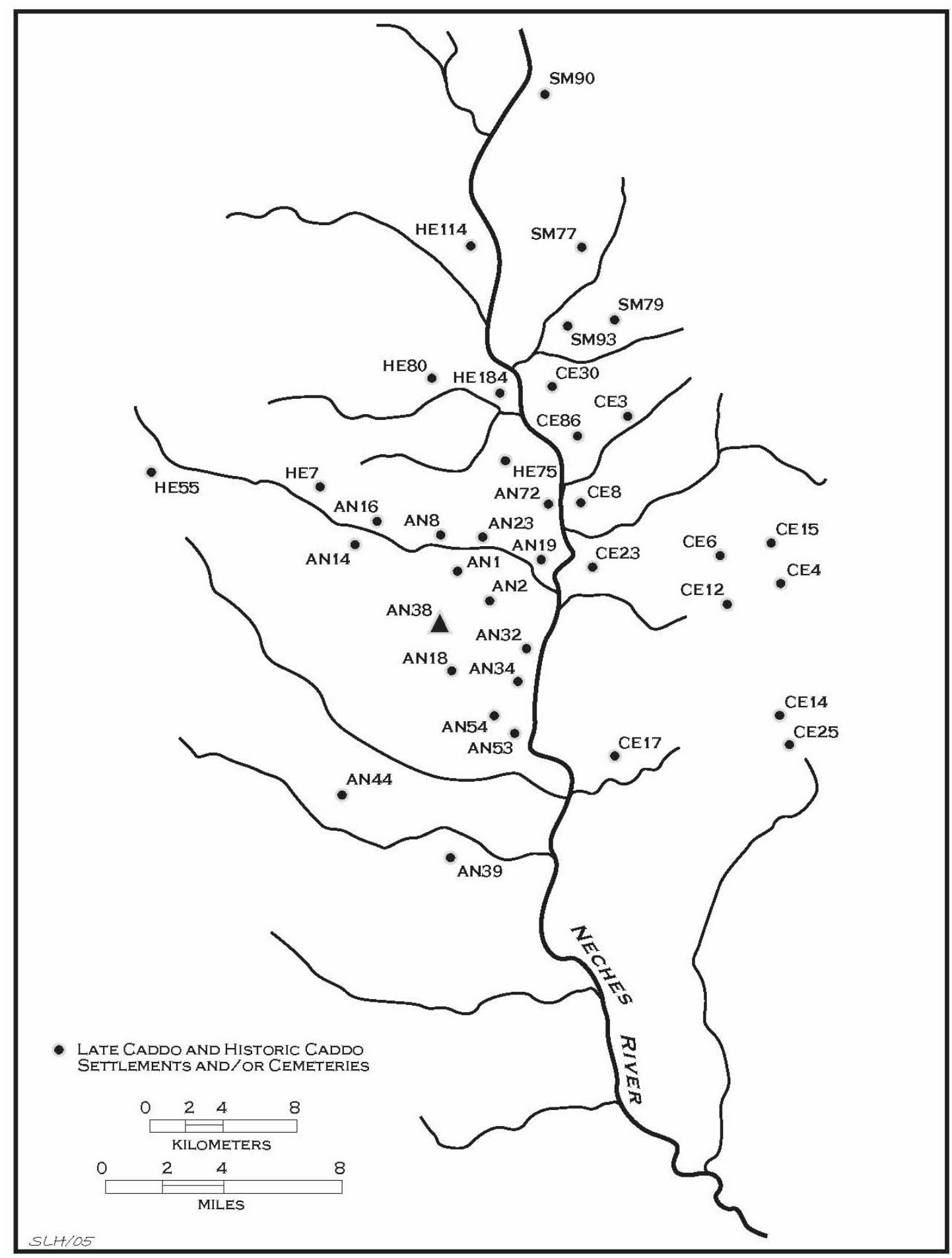

Figure 3-1. Late Caddo and Historic Caddo Sites and Cemeteries in the Upper Neches River Basin. 


\subsubsection{Paleoindian and Archaic Periods}

For the period prior to about $7000-8000$ years before the present (B.P.), extended perhaps to as long as ca. 13,000 years B.P. (Waters and Stafford 2007), the East Texas archeological record primarily consists of surficial, mixed, or isolated finds of diagnostic projectile points (cf. Bousman et al. 2004; Johnson 1989; Story 1990), based on comparisons with well-dated and stratified sites to the east and west of the region (see Anderson et al. 1996:15). At the Forrest Murphey site (41MR62), for example, Clovis, Plainview, Dalton, and other lanceolate projectile point forms and tools were found in several discrete concentrations on a high terrace above Big Cypress Creek; faunal remains from extinct elephants were also recovered in apparent association (Story 1990), which is rather rare. The Delta Bone Quarry 5 (41DT86) on the North Sulphur river had a buried hearth and an antler tool (Slaughter and Hoover 1965), and charcoal from the hearth has calibrated intercepts ranging between 10,560-10,794 years B.P. (Bousman et al. 2004:Table 2.1), broadly contemporaneous with Folsom and Dalton complexes in the region.

Undoubtedly other discrete archeological components are present in the region, such as the buried Finley Fan site occupied as early as 6400 years B.P. (Gadus et al. 1992) and the spatially discrete Late Paleoindian John Pearce site in the Red River basin in northwestern Louisiana (Webb et al. 1971), but they have proven to be quite difficult to define and recognize. For example, a provocative but poorly known Paleoindian site has been reported by avocational archeologists in deep sand deposits on the Neches River where it had been exposed by Lake Palestine shoreline erosion. Thirty-five Paleoindian lanceolates, primarily Dalton and Scottsbluff forms, projectile point preforms, drills, scrapers, and channel flakes have been found there, with most of the tools manufactured on cherts from the Edwards Plateau of Central Texas and Ouachita Mountains cherts and quartzites (Perttula 1989). The site also contains a
Folsom, two channel flakes, and a Folsom preform of Alibates agatized dolomite. In another case, McCrocklin (1994 personal communication) has documented Dalton and early side-notched (Big Sandy?) points, knives, scrapers, bone tools (antler flakers), and cut bone (some fossilized) from blue clay deposits buried in a Red River gravel bar north of Shreveport, Louisiana. An extensive buried Early to Middle Archaic settlement is present at the Conly site along Loggy Bayou in the Red River basin in northwestern Louisiana (Girard 2000).

Paleoindian materials have been recovered at a number of archeological sites in the Post Oak Savanna and Pineywoods of East Texas (Bousman et al. 2004:Table 2.2 and Figures 2.45, 2.46e, h-i). The early Paleoindian (ca. 13,000-10,500 years B.P., based on calibrated dates and age estimates) archeological materials include Clovis and Folsom fluted lanceolate points, commonly manufactured on high-quality non-local lithic raw materials, along with scraping tools (Story 1990:Table 44). According to Bever and Meltzer (2007:Table 1), only one Clovis point has been documented from Anderson County, Texas, but overall, the density of Clovis points and sites is high in East Texas (Bever and Meltzer 2007:74, 77).

Unfluted lanceolates-usually resharpened and beveled-dominate the Late Paleoindian period (ca. 10,500-9500 years B.P.) material culture record in the region, including Dalton (Johnson 1989:Figure 7; Wyckoff and Bartlett 1995), San Patrice, and Scottsbluff points which concentrate in Northeast Texas and locales to the east (e.g., Saunders and Allen 1997:Figure 2), as well as early side-notched points and Albany beveled bifaces or knives (see Webb et al. 1971; Johnson 1989:Figure 13), Quince-style scrapers, end and side scrapers, denticulates, burins, and bifacial adzes. San Patrice projectile points and associated tools are typically manufactured on local raw materials (Saunders and Allen 1997:3; Webb et al. 1971). One unrecorded Paleoindian and Early Archaic site in Gregg County, Texas, contains an abundance of large 
early side-notched points made from novaculite, along with a Dalton point of Ouachita Mountains chert and a single San Patrice lanceolate on a local raw material (Perttula 2004b:Figure 13.4).

The distributions of Paleoindian artifacts within the region suggest that these early occupations were principally situated within the valleys of major stream basins (see Thurmond 1990:Table 53 and 54; Anderson 1996a), as well as resource-rich areas like the Ouachita Mountains escarpment (Anderson 1996b:Figure 3.2). It appears that Paleoindian foraging groups occupied small camps and had an unspecialized hunting tool kit.

Anderson (1996b) postulated that the initial and most intensive Paleoindian settlement of the Southeast (which would include East Texas) took place in the resource-rich valleys of the Mississippi River and its principal tributaries. From there, Paleoindian groups settled throughout the wooded Southeast and East, with concentrations at 250-400 km intervals, indicating the scale of movement of these highly mobile foragers. The relatively sparse Paleoindian archeological record, in conjunction with the dispersion of artifacts on many landforms and different settings within the region, seems to indicate that the Paleoindian groups were very mobile hunters and gatherers rather than specialized hunters of extinct megafaunal species (Fields and Tomka 1993:82). Johnson (1989) also suggests that some of the Paleoindian archeological remains (Plainview and Scottsbluff projectile points, and Cody knives) from the region are a result of Plains Late Paleoindian (ca. 10,000-9,000 years B.P.) groups that moved into parts of East Texas, during periods when grassland habitat spread eastward, to exploit the plains resources (such as bison) found there.

Archeological data from the Yarbrough site (41VN6) on the upper Sabine River were employed by Johnson (1962) to first bring chronological and cultural order to the diverse Archaic (ca. 9500 to 2500 years B.P.) archeological record found in Northeast
Texas. Of particular import were Johnson's (1962:208) temporal divisions of the Archaic based on projectile point sequences, and the introduction of plain ceramics at the end of the Archaic. Story (1990:Figure 32) and Thurmond (1990:Table 8) provide the most current (although still poorly dated with supporting radiocarbon assays) chronological classifications of Archaic-age dart points, with straight and expanding stem forms characteristic of the Early and Middle Archaic periods and the contracting stem darts particularly diagnostic of the Late Archaic (and much of the Woodland period as well).

Recent paleoenvironmental research (see Chapter 2) suggests that much of the Archaic period, particularly the period between ca. 8000-4000 years B.P., was drier than today, with apparent reductions in biomass as well as the local expansion of prairie habitats along the western margins of the region. Nevertheless, drier conditions and changing vegetation conditions "clearly did not preclude occupations” (Ferring 1995:33) during these periods. While the archeological data are still rather limited, it appears that group mobility remained high for these hunting-gathering foragers (who utilized hardwood nuts, deer, shellfish, turtles, and small mammals) during the Early Archaic (ca. 9500-8000 years B.P.), and group territories were large and poorly defined, with most sites conforming to what Thurmond (1990:41) called "heavy" and "limited-use" areas; that is, repeated and recurrent occupations by small groups. Anderson (1996a) suggests that such Archaic groups had highly mobile foraging adaptations along the Red River, the central Sabine River, and in interior uplands away from major drainages, with expedient lithic technologies. Most sites of this age were briefly used, although this may be a product of differential site preservation, but tended to concentrate in the larger drainages within the region.

By the Middle Archaic period (ca. 8000-5000 years B.P.), fairly substantial and extensive occupations are recognized within the major basins in the region, with a rather limited use of smaller tributaries and headwater areas. 
Components of this period are open camps dominated by hunting tools (including the distinctive blade notched Evans point) and generalized cutting/scraping tools, debris, ground stone tools, and cores.

Burned rock features (possible hearths, ovens, and cooking pits?) and burned rock concentrations are present in dated Middle Archaic contexts at a few sites in the Sulphur River drainage (see Gadus et al. 1992; Cliff et al. 1996), suggesting that an important activity was the cooking and processing of plant foods, but mainly by small groups for short-term use (Fields et al. 1997:90). A single burned rock feature at the Unionville site (41CS151) has a calibrated date of 4040-4161 B.C. (Cliff et al. 1996). Lithic raw material data from a possible Middle Archaic assemblage at Lake Fork Reservoir in the upper Sabine River basin indicates that the exchange of non-local materials (particularly finished tools) was common place (Perttula 1984), although "patterns in raw material use were not uniform across Northeast Texas" (Fields and Tomka 1993:92), and in general, the use of non-local raw materials was not common. At Cooper Lake in Archaic contexts, the non-local lithics that are present primarily originated to the north in the Red River basin (Fields et al. 1997). Mound complexes of Middle Archaic age in northern Louisiana at this time also suggest the development of more complex hunter-gatherer societies in the TransMississippi South (see Saunders et al. 1997; Saunders and Allen 1997).

Late Archaic sites (ca. 5000-2500 years B.P.) are widely distributed in the Pineywoods and Post Oak Savanna, occurring along the major streams, near springs, on spring-fed branches, upland ridges, and on tributary drainages of all sizes. In fact, the distribution of Late Archaic sites suggests these groups moderately to extensively ranged over and exploited almost every part of the region, and in particular, Anderson (1996a) notes major concentrations of Late Archaic sites along the Red and Little Rivers in southwest Arkansas and northwest Louisiana, as well as in the Ouachita Mountains. Aboriginal populations continued a generalized foraging adaptation, combined with apparent population growth. There are only a few well-dated Late Archaic period components known in the region, however.

Some Late Archaic occupations in riverine settings contain earthen middens (e.g., the Yarbrough site along the Sabine River), but generally, sites of this age contain burned rock features and/or concentrations of burned rocks, as well as small pits. The Late Archaic occupation in Area $\mathrm{C}$ at the Unionville site (41CS151) had a buried anthrosol or occupational surface that had been darkened or stained by cultural activities, while within the anthrosol were two clusters of burned rock features (Cliff et al. 1996). Large pits and rock hearths in a Late Archaic component at the Herman Bellew site (41RK222) have calibrated dates that range from 380-1590 B.C. (Rogers et al. 2001). At the Mockingbird site (41TT550) in the Big Cypress Creek drainage, the Late Archaic component (dated between 2360-2780 years B.P.) contained scattered burned rocks and low amounts of stone tools and projectile points, suggesting it was used only as a temporary encampment or "limited use" area. Many other Late Archaic sites or components are known where burned rocks from hearth construction and use was relatively abundant, along with projectile points, bifacial and flake tools, and flake debris. In cases where there was an extensive use of burned rock features, this suggests that the cooking and bulk processing of plant foods in ovens and pits was important to some Late Archaic populations in the region.

These settlement data are compatible with higher population densities, limited group mobility but a wide dispersion of camp and foraging areas, the possible establishment of definable territorial ranges, and a welldeveloped foraging economy based on the hunting and gathering of local food resources. No paleobotanical evidence is available that indicates the Late Archaic populations here cultivated native plant species (i.e., such as sumpweed, sunflower, and chenopod), as was the case by the first millennium B.C. in many parts of Eastern North America (Fritz 
1994:25-27). Nutshells and a few fragments of prairie turnip (Psoralea sp.) are documented in Late Archaic components at the Unionville site (Cliff et al. 1996) along the lower Sulphur River, and at Cooper Reservoir sites (Fields et al. 1997). The high use of local lithic raw materials during the Late Archaic speaks to a more confined inter-regional interaction at this time (Fields and Tomka 1993; Perttula and Bruseth 1995). By contrast, in the Mississippi River basin of northern Louisiana, Late Archaic sites are marked by extensive quantities of non-local lithic raw materials, particularly novaculite and Ozark cherts (Saunders and Allen 1997:19).

\subsubsection{Woodland Period}

The Woodland period (ca. 2500 to ca. 11501100 years B.P.) in much of the region, particularly from the Sabine and Sulphur rivers to the Red River, may be recognized primarily by plain and relatively thick ceramic bowls and "flowerpot" shaped jars, doublebitted axe heads, the smaller and thinner Gary projectile points, and later in the period by corner-notched arrow points (Schambach 1998, 2001; Thurmond 1990). North of the Sulphur River and in contiguous areas in southwestern Arkansas, northwestern Louisiana, and southeastern Oklahoma, such Woodland cultures have been called Fourche Maline by Schambach (1998, 2001).

In several instances, Lower Mississippi Valley (LMV) related ceramics (such as Tchefuncte Stamped, Churupa Incised, Marksville Incised, Chevalier Stamped, and Marksville Stamped) occur with some frequency in earlier and later Woodland period components (Story 1990:246; Rogers et al. 2001). These ceramics may be trade items that evidence contact and interaction between Trans-Mississippi South Native Americans and groups in the LMV, or were ceramics whose stylistic decorative attributes were borrowed by local potters (see Schambach 1982, 1998; Perttula and Bruseth 1995).

At Woodland period sites along the Red River in southwestern Arkansas and Northeast
Texas, ceramics used for cooking and food serving are abundant, and comprise a significant proportion of the artifact assemblages, while in many other Woodland period sites in much of Northeast Texas (particularly between the Sulphur and Sabine rivers, but also characteristic of Woodland period sites in the Neches/Angelina river basins), the use of ceramics was not as prevalent. This suggests regional differences in Woodland period food processing (i.e., boiling of foods in vessels to make them palatable and a change from stone to wooden food preparation tools) and dietary habits (i.e., an increased consumption of carbohydraterich foods, possibly including some amounts of maize). It is probable that there were also differences in sedentism between Woodland populations across the region, based on strong correlations between sedentism and pottery making.

Later LMV Coles Creek period ceramics (and expanding stem arrow points similar to the Colbert and Friley types) are present in notable quantities in several sites along the Sabine River and the Red River, particularly at James Pace in a context dated between ca. 1300-1000 years B.P. (Girard 1994), and at the generally contemporaneous Ray site (41LR135) (Bruseth 1998). Similar ceramics occur in stratified contexts at the Crenshaw (3MI6) and Mounds Plantation (16CD12) sites in burial mound features (Schambach 1997; Webb and McKinney 1975), and this is also the period when larger villages and multiple mound centers begin to be constructed on the major streams (e.g., the Red and Sabine rivers) in the Trans-Mississippi South.

To the south of the Sabine River, but concentrated in the Neches-Angelina and Attoyac drainage basins, Woodland period sites contain plain sandy paste ceramics (Goose Creek Plain, var. unspecified) of the Mossy Grove tradition (Story 1990:Figure 39; Ricklis 2004:Figure 6.7) as well as decorated ceramics with LMV affiliations. Woodland period components account for at least 25-50 percent of the known prehistoric archeological sites in the Angelina-Neches confluence area 
and points west (Martin et al. 1995:Table 2; Perttula et al. 1993), and represent the campsites and habitation locales of seasonal foraging-gathering and hunting adaptations. Aboriginal pottery was adopted and used by Mossy Grove groups for the cooking and processing of plant and animal foods by about 2000 years B.P., and by 1250-1350 years B.P., if not earlier, the Mossy Grove populations were using a variety of stemmed arrow points for hunting.

Changes in the density and placement of Woodland period sites across the landscapeparticularly focusing on sandy interfluvesled Corbin (1998:114-115) to suggest that horticulture may have been introduced in the Neches-Angelina river basins during the Woodland period. Another alternative posited by Corbin (1998:115) to account for the number and distribution of Woodland period sites in that part of East Texas may "have been tied to...moving closer to a significant plant food source (i.e., plants that were restricted to valley margins and/or the floodplain) whose use was facilitated by processing via cooking in ceramic vessels." Settlement data from the McGee Bend area at the confluence of the Angelina and Attoyac rivers indicates that middens and occupational components are present in Woodland period contexts that range from 0.5-8 acres in size (Duffield 1963; Jelks 1965).

Woodland period groups were still primarily hunter-gatherers who lived in increasingly larger groups and resided for longer periods of time at certain sites. The fact that some of these latter sites have relatively substantial midden deposits (particularly along the Red River and in the upper Sulphur River basin, see Schambach 1982; Fields et al. 1997), and some evidence for structures (probably daubed pole and thatch structures), suggest more intensive occupations and a decreased residential mobility, and higher population densities, but the degree of permanence is still less than that seen in the subsequent long-term Caddo settlement of East Texas (Perttula et al. 1993:99). Schambach (1983:5) suggests that Woodland (or Fourche Maline) period settlements along the Great Bend of the Red River included "small to medium sized villages of from 1 to 4 ha."

On the basis of the available paleobotanical information, Woodland period groups may have cultivated squash (see McGregor 1997), and used native seeds and tubers/roots, as well as a variety of woodland and aquatic animal resources, particularly white-tailed deer. At the Resch site, the rather extensive midden deposits contained only burned rock features (probably used for the cooking and baking of plant foods) and dense quantities of charred nutshells and poorly preserved animal bones (Webb et al. 1969). The presence of chipped stone axes and hoe-shaped tools in Woodland occupations suggests that some horticultural practices (perhaps the use of colonizing weedy annuals) and forest clearance may have begun. Stable isotope analyses of human remains of some 25+ Late Archaic, Fourche Maline, and Formative Caddo-Early Caddo period samples indicate that maize was not a major part of the diet of Woodland period groups (see Rose et al. 1998). The examination of skeletal pathologies in Woodland period contexts from the Red River area and East Texas indicates low levels of infection, but high levels of degenerative diseases relative to subsequent Caddo populations (Rose et al. 1998:Table 64). These data further support the idea that Woodland period populations were primarily hunter-gatherers with a nutritionally adequate diet, who probably lived across the region in relatively low population densities, but whose life style was characterized by chronic stress (on the joints) and heavy work loads (Rose et al. 1998:121). Maize is also poorly represented in the archeological record before ca. $1250-1050$ years B.P.

In much of East Texas, Woodland period sites are not very common, perhaps because most of the area was not heavily settled during this time (e.g., Story 1990:310). One of the few well-studied Woodland period components in the Sabine River drainage is at the Herman Bellew site (41RK222), where the component dates between ca. 2450-1265 years B.P. (Rogers et al. 2001), and had rock 
concentrations as well as small and large pits, contracting stemmed dart points, and a small amount of mainly plain ceramics as well as LMV ceramic sherds. By contrast, settlements of this period are common throughout the Sulphur (see Fields et al. 1997) and NechesAngelina river basins (Corbin 1998).

No Woodland period burial mounds have been documented north of the Sabine River in the Pineywoods and Post Oak Savanna, although they have been found in bluff top and alluvial valley settings on the Red River in northwestern Louisiana and southwestern Arkansas (Schambach 1982, 1997; Webb 1984), and on the Angelina, Neches, and Sabine rivers in deep East Texas (Story 1990:310; see also Jelks 1965 and Jensen 1968). Associated with the construction and use of mounds in the Woodland period was the procurement and dispersal of costly nonlocal raw materials and artifacts, including cherts, copper, and LMV ceramic vessels that were included as grave goods or caches in the burial mounds.

The two or three mounds at James Pace (16DS268) on the Sabine River did not, however, apparently serve as platforms for burials or structures, or as caps for these features, and their functional significance is undetermined (Girard 1994:15). The appearance of burial mounds (and mounds covering crematoria) in the broader region does suggest that more complexly organized local groups did develop during the Woodland period in these localities (cf. Schambach 1996, 1997).

In non-mound contexts, there is also evidence of mortuary or ritual practices in the Woodland period. The Hurricane Hill site on the South Sulphur river contained a small cemetery on a prominent hill that dates between cal A.D. 59-449 (Perttula 1999), and the Mahaffey site on the Kiamichi River in southeastern Oklahoma also had a large cemetery with flexed and semi-flexed burials without grave goods (Perino and Bennett 1978). Later Woodland period cemeteries with 9-21+ burials-dating after ca. 1450-1750 years B.P.- - have also been identified at sites such as Snipes (41CP8; Jelks 1961) in the lower Sulphur River basin, and several sites in southwestern Arkansas (Schambach 1982). These later shallow extended burials contained an occasional whole vessel, boat stone, celt, or chipped biface. The vessels include flower-pot shaped Williams Plain and Coles Creek Incised types (see Jelks 1961:Plate 4). The Crenshaw site also had many late Woodland period extended burials in village midden contexts (the large village is estimated to cover $8 \mathrm{ha}$ ), and these also contained ceramic vessels as funerary objects (Schambach 1982:152).

Comparable burial cremation practices at the Hurricane Hill site in the upper Sulphur River basin and the contemporaneous Johnny Ford site (3LA5), an early Fourche Maline village (ca. 2150-1650 years B.P.) in the Great Bend area of the Red River valley, suggests the existence of similar belief systems among aboriginal Woodland period groups in the Red and Sulphur river basins. Schambach (1996:36) describes the burials at Johnny Ford as occurring in a "cremation cemetery," and he further suggests that everyone in the village may have been cremated (adults and children were also cremated at Hurricane Hill), using bluff edge crematoria at mound sites (Schambach 1997:57).

The identification of formally bounded cemeteries at a number of Woodland period habitation sites in the Trans-Mississippi South (see Rose et al. 1999) is consistent with the existence and settlement of distinctive social groups (based on kinship and/or residence) of affiliated individuals at sites and various locales during that time. It appears that children and adults were buried together in these cemeteries, suggesting that these Woodland populations had an egalitarian social organization within local settlements and communities. At its broadest scope, the establishment of cemeteries clearly correlates with an increasing sedentism in the western Gulf Coastal Plain of East Texas after ca. 2150 years B.P. 


\subsubsection{Formative-Early-and Middle Caddo Periods}

There is an abundance of archeological information available on the Formative (ca. 1150-950 years B.P.), Early (ca. 950-750 years B.P.), and Middle (ca. 750-550 years B.P.) Caddo period occupations of the Pineywoods and Post Oak Savanna of East Texas. First, Caddo archeological sites of these ages are quite common, and about 80 percent of the +500 radiocarbon dates available from Northeast Texas archeological sites pertain to occupations at prehistoric and protohistoric Caddo sites. The largest number of dates fall in the Middle Caddo period, followed by the Early Caddo period. Using calibrated ages and age mid-points of 1-sigma calibrated age ranges, the largest number of Caddo radiocarbon dates fall within the AD 1201-1300 interval (or 749-650 years B.P.) (Perttula 1998). While the number of dates in this period is probably inflated to some degree by the extensive series of dates from the George C. Davis site (see Story 1997, 2000), it does appear to be the case that Middle Caddo period occupations are rather commonplace throughout much of East Texas (Middlebrook and Perttula 1997), supporting the broad findings of the radiocarbon dates from the region.

Caddo sites of Formative to Middle Caddo period age are situated primarily on elevated landforms (alluvial terraces and rises, natural levees, and upland edges) adjacent to the major streams, as well as along minor tributaries and spring-fed branches. Proximity to arable sandy loam soils were preferred for settlement locations, presumably because of good drainage for habitation, and for cultivation purposes. The majority of these Caddo sites are permanent settlements with evidence of the structures, including posts, pits, and features marking their residency, along with cemeteries and graves where the dead were buried; the middens where the animal and plant food refuse was discarded amidst broken stone tools and pottery vessels; and the material remains of tools and ceramics used in the procurement and processing of the bountiful resources of the region. They represent the settlements of Caddo communities and sociopolitical entities, and the civic-ceremonial centers that were their focus (Perttula 1993:125).

The distribution of Caddo settlements across the landscape suggests that all habitats were used to some extent, either intensively as locations for the sedentary communities and farmsteads (that may have been occupied for single or multiple generations), or periodically by groups in logistical camps where specific natural resources could be procured by the Caddo in bulk. Along the Red River, and probably on the other large streams or rivers in the region, a particular focus of settlement was along natural levees in recently abandoned meander belts, and these habitats "served as an ideal context for a dispersed community" in a major floodplain landscape (Girard 1997:156).

The most common types of Caddo settlements in the region during these periods of time appear to be small year-round hamlets and farmsteads with circular to rectangular structures (Bruseth 1998; Bruseth and Perttula 1981; Cliff 1997; Middlebrook 1994, 1997; Rogers and Perttula 2004; Thurmond 1990). These settlements sometimes occur in association with small household cemeteries (see Goldschmidt 1935; Middlebrook and Perttula 1997), and occasionally with a larger cemetery ( $>10$ burials).

Larger communities (covering more than 10 acres) have also been recognized that occur in association with mound centers (such as the large settlements at George C. Davis [41CE19], Hale [41TT12], Boxed Springs [41UR30], and Hudnall-Pirtle [41RK4; see Bruseth 1991; Bruseth and Perttula 2006]). These mound centers have extensive habitation areas, plazas, and spatially restricted temple and burial mound locales. Shaft burials of high status individuals have been documented in mound contexts at the George C. Davis site (Story 1997, 1998, 2000) and a few other mound centers (such as Washington Square [41NA49)], Boxed Springs, and Sanders [41LR2]; see Corbin and 
Hart 1998; Hamilton 1997), and they also occur in non-mound contexts at several sites along the Red River during Formative Caddo period times (see Bruseth 1998).

Certainly the most thoroughly studied Formative and Early Caddo period site in the region is the George C. Davis site, a large village and mound center on the Neches River, downstream from the Lang Pasture site project area. Recent remote sensing investigations indicate that there are more than 100 structures in the village areas around the three mounds on site (Creel et al. 2005). Calibrated radiocarbon dates from village contexts establish that the site was occupied beginning by the mid-ninth century A.D., and then was continuously settled to the end of the 13th century A.D. (Story 2000). A large number of structures were built on, and adjacent to, Mound A, and the extensive structure rebuilding there indicates the area was preferred for settlement by the Caddo. Calibrated dates from a few contexts suggest that the site was inhabited to some degree as late as ca. 600 years B.P. (see Story 1997). There were three mounds at the Davis site, including Mound A (a flat-topped platform), Mound C (burial mound) built over a large pre-mound burial pit in the latter part of the Formative Caddo period and containing an estimated 25-30 elite burial pits, and Mound B (a second flat-topped platform) constructed about 750 years B.P. or slightly earlier (Story 1997, 1998).

One of the more significant Caddo sites investigated recently in the Pineywoods, the Oak Hill Village (41RK214), estimated to date between ca. 500-800 years B.P., has at least 42 circular and rectangular structures. Some of the structures had been rebuilt and some overlapped earlier structures, particularly at the northwestern end of the ridge and plaza, and they were arranged over the 3.5 acre village in a circular pattern around a central plaza area (Rogers and Perttula 2004; Perttula and Rogers 2007). Several small structures on the eastern side of the plaza have been identified as possible granaries for the storage of harvested corn. A small mound (covering a burned circular structure) is at the north end of the site, and several midden deposits have been identified that appear to be associated with individual structures. Two large circular structures have extended entranceways that pointed towards the plaza, and their special form and orientation suggests they are probably public buildings used by the Oak Hill Village community for special purposes. Ceramic analyses and radiocarbon dating indicate these structures were built after ca. 600 years B.P. during the extensive Late Village (Rogers and Perttula 2004).

Another important Middle Caddo period site is Tyson (41SY92) in the Attoyac River basin, dating between cal A.D. 1336-1490. This settlement contains evidence for structures and cooking and storage pit features, has extensive midden deposits and well-preserved plant and animal remains, and a small cemetery of children. Middlebrook (1994, 1997) suggests that the Tyson site represents the residence of a caddi or chiefly elite.

One of the calibrated dates from the Tyson site was on mussel shell included as grave goods with Feature 14, the burial of a 3- to 4-yr-old child accompanied by many grave goods (Middlebrook 1994:16). Among the burial offerings were eight ceramic vessels near the head and feet of the child, two large paired deer antlers over the child's head (perhaps as part of a head dress), carved shell inlays near the head, two carved bone ear spools, 32 Olivella shell beads, three columnella beads from a necklace, a turtle rattle, a cache of mussel shell, smoothed stones, two pitted stones, a cache of six deer ulna awls and two beaver teeth, and a cache of lithic pebble cores, flakes, preforms, and a notched shell point (Middlebrook 1994:16).

These Formative-Middle Caddo groups seem to have been horticulturists, cultivating maize and squash, along with several kinds of native seeds (Perttula and Bruseth 1983), gathered nuts and tubers/storage roots, and were proficient hunters of deer, fish, and many other animal species. The available paleobotanical and bioarcheological evidence 
(including stable carbon isotopes on human remains) from East Texas (and elsewhere in the Caddoan area, including the upper Neches River basin; see Rose et al. 1998) does not indicate, however, that Caddo groups became dependent upon maize and other domesticated crops until after about 650 years B.P.; by ca. 500 years B.P., maize likely comprised more than 50 percent of the diet (see Burnett 1990; Perttula 1996; Rose et al. 1998). Certain prehistoric groups that lived in the Trinity River basin in north central and east central Texas (outside of East Texas) and interacted with the Caddo living in the upper Neches River basin, also cultivated plants, but these plants appear "to have been incorporated into an existing subsistence system at a supplemental level . . . growing of crops...simply offered another source of foodstuffs” (Gadus et al. 2002:141).

Both temple and burial mounds were built by these Pineywoods Caddo groups. The larger sites are important civic-ceremonial centers containing multiple mounds and associated villages, and these generally date after ca. 1050 years B.P.. The multiple mound centers are rather evenly spaced along the Red River, Sabine River, and Big Cypress Bayou, and those that are contemporaneous may represent hierarchical systems of an "integrated ... regional network of interaction and redistribution" (Thurmond 1990:234). The Jamestown (eight mounds and village), Boxed Springs (four mounds, village, and large cemetery), and Hudnall-Pirtle (eight mounds and 60 acre village) multiple mound centers appear to represent the apex of postulated local Early-Middle Caddoan networks in the Sabine River basin. The McKenzie (41WD55) site in the middle Sabine River drainage has a single sub-structural mound that dates between cal A.D. 1298-1470 (see Granberry 1995), and there are contemporaneous mounds covering structures with extended entranceways at the Redwine (41SM193) and Bryan Hardy (41SM55) sites (see Walters et al. 1998; Walters and Haskins 2000). The Middle Caddo occupation at Redwine also included an extensive midden deposit, hearth and pit features and a small cemetery with extended supine burials.

The distribution, number, and spacing of mound centers, particularly the sites with multiple mounds, in East Texas and adjoining parts of southwestern Arkansas and northwestern Louisiana clearly indicates that the Caddo peoples who built and used these mounds were integrated into societies of considerable socio-political complexity. The premier mound centers in the NechesAngelina river basins include George C. Davis and Washington Square (Story 1997; Corbin and Hart 1998). The Washington Square mound complex is well-dated, with pooled radiocarbon dates on charcoal, hardwood nutshells, and charred corn range between cal AD 1268 and 1302 (Corbin and Hart 1998:74 and Table 4); the overall range of the calibrated dates from the site suggest it was occupied by the Caddo between ca. 700-500 years B.P. Extensive excavations documented a circular structure under Mound 1/2, an assortment of pits and post holes in nonmound contexts, and several large burial pits in a mortuary mound (the Reavely-House Mound). No clear evidence for on-site permanent Caddo habitation was identified at Washington Square, although an interesting assortment of large sherd-filled pits (representing many vessels) were encountered in one area between Mound 1/2 and the mortuary mound (see Corbin and Hart 1998:Figure 14). These may represent deposits from public feasting activities led by the Caddo elite (e.g., Scott and Jackson 1998) that used the Washington Square mound site as a ceremonial center in the 13th and 14th centuries A.D.

The radiocarbon dating of the Washington Square and George C. Davis sites hints at the possibility that the Washington Square Mound center began to flourish about the time (after ca. 700 years B.P.) the George C. Davis site was diminishing in power and social authority. This suggests that the Caddo community that built and used the Washington Square Mound site-more advantageously located eastward at the nexus of north-south (later to be known 
as the Caddo trace) and east-west (later known as the Camino Real) aboriginal trailsachieved pre-eminence at the expense of the long-lasting polity on the Neches River. The George C. Davis site was abandoned by the early 14th century A.D.

The Formative, Early, and Middle Caddo period groups possessed a rich material culture. Well-made, corner-notched, and rectangular-stemmed arrow points were common, along with siltstone and greenstone celts, perforators and borers, large Gahagan bifaces, and a variety of more expedient stone tools (unifacial flake scraping and cutting implements). Long-stemmed Red River (Hoffman 1967) and cigar-shaped ceramic pipes were made by the Caddo at this time, as were ceramic ear spools and figurines (see Newell and Krieger 1949).

The most distinctive material culture item of the Caddo groups living in East Texas were the ceramics they made for cooking, storage, and serving needs. The styles and forms of ceramics found on sites in the region hint at the variety, temporal span, and geographic extent of a number of prehistoric Caddo groups spread across the landscape. The diversity in decoration and shape in Caddo ceramics is substantial, both in the utility ware jars and bowls, as well as in the fine ware bottles, carinated bowls, and compound vessels. A diverse and distinctive ceramic assemblage characterizes the Caddo ceramics from the region. Ceramics are quite common in domestic contexts on habitation sites across the region and also occur as grave goods in mortuary contexts.

The Caddo made ceramics in a wide variety of vessel shapes, and with an abundance of wellcrafted and executed body and rim designs and surface treatments. There is an impressive diversity of vessel forms among the Caddo fine wares. This includes carinated bowls, deep compound bowls, double and triple vessels (joined bowls and bottles [Suhm and Jelks 1962:Plates 38k, 51e, 59d]), bottles, ollas, zoomorphic and anthropomorphic effigy bowls and bottles, ladles, platters, peaked jars, gourd and box-shaped bowls, and chalices. From the archeological contexts in which Caddo ceramics have been found, as well as inferences about their manufacture and use, it is evident that ceramics were important to the prehistoric Caddo in: the cooking and serving of foods and beverages, in the storage of foodstuffs, as personal possessions, as beautiful works of art and craftsmanship (i.e., some vessels were clearly made to never be used in domestic contexts), and as social identifiers; that is, certain shared and distinctive stylistic motifs and decorative patterns marked closely related communities and constituent groups.

The Caddo made both fine wares (with very finely crushed temper), bottles and many bowls, and utility wares (some of the simple bowls, as well as the jars that were made in a variety of sizes). Almost without exception, Caddo ceramics were tempered with grog (crushed sherds) or bone, although burned and crushed shells were used as temper after ca. 650 years B.P. among most of the Red River Caddo groups and on later Caddo sites in the lower and upper Sulphur River basin; grogtempered pottery was the norm throughout the upper Neches River basin, especially during the Late and Historic Caddo periods (Perttula 2007). After adding the temper to the clay, the kneaded clay was formed into clay coils that were added to flat disk bases to form the vessel, and the coils were apparently smoothed with a round river pebble to create the finished vessel form. Decorations and slips were added before, as well as after, baking in an open fire, and commonly the vessels were then burnished and polished; red ochre and white kaolinite clay pigments were often added to or painted on to the decorations on bottles and carinated bowls. These kinds of ceramics were designed to serve different purposes within Caddo communities and family groups-from that of a cooking pot to the mortuary function of a ceremonial beaker-and this is reflected in differences in paste, surface treatment, firing methods, decoration, and vessel form between the two wares. 
Other types of ceramic artifacts manufactured by prehistoric Caddo groups include ceramic ear spools and disks, figurines, and a variety of pipe forms (Jackson 1933:71). The earliest types of Caddo clay pipes were plain, tubular and cigar-shaped forms, followed by the longstem "Red River" pipes (Hoffman 1967) with burnished and polished stems and bowls; rectangular platform pipes and some elbow pipe forms have also been recovered in Caddo sites dating before 750 years B.P. (see Bruseth and Perttula 1981; Rogers and Perttula 2004:Figure 120). The later Caddo pipe forms in Northeast Texas are biconical and elbow pipe forms with small bowls $(<25 \mathrm{~mm})$ and small stem diameters $(<25 \mathrm{~mm})$ (see Jackson 1933:Plates 16-18).

\subsubsection{The Late Caddo Period}

Late Caddo period settlements in much of the Pineywoods and Post Oak Savanna of East Texas have been termed rural Caddo community systems (Perttula 1992:96) because they were distributed along secondary streams, were widely dispersed, and because they consisted primarily of functionally comparable farmsteads and hamlets. Similar kinds of rural communities occur throughout much of the Caddoan area (Story 1982, 1990; Jeter et al. 1989).

Only a small number of Late Caddo period mounds are known in the region, ranging from one to four small mounds per site, and they are unlike the types of mound complexes typically constructed in the major river valleys at this time (Story 1990). Pineywoods mounds were substructural mounds; no pyramidal platform or burial mounds are known for this time period. Substructural mounds are generally restricted to mounds that cap a burned circular structure that was constructed on the ground surface or in a small, shallow pit. In at least two instances, the mounds contained sequent structures, but the "structures originated at higher levels in the mound[s] due to occupational accumulations of soil and ash, and not the result of any deliberate capping" (Thurmond 1990:168).
The larger Caddo "towns" were distributed along the major stream valleys, such as the Red, Ouachita, and Little rivers. These communities were hierarchically arranged with: civic-ceremonial centers (those with platform and burial mounds), associated "towns" of linear but dispersed farmstead compounds with several structures, bark- or brush-covered shelters and storage platforms (Schambach 1983:7-8), hamlets, farmsteads, and specialized processing and/or procurement locales (such as salt-making sites, see Early 1993).

The later Caddo fine wares are stylistically diverse, and there are very specific differences in vessel shapes, designs, and decorative attributes between Caddo ceramics in individual drainages, or even within specific smaller segments of river and creek basins (e.g., Thurmond 1990; Perttula et al. 1998). This diversity can be reasonably interpreted to be representative of specific Caddo social groups. In historic Caddo times, ceramic vessel forms and decorations are considerably more homogeneous across much of the Caddoan area, suggesting extensive intraregional contact between contemporaneous Caddo groups (Perttula 1992:154 and Table 14).

In the upper Neches River basin, Late Caddoan period archeological sites have been included in the Frankston phase culturaltaxonomic unit. Frankston phase Caddo sites are clearly ancestral to the Allen phase, an historic Caddo cultural-taxonomic unit, and sites of the Allen phase have been definitively associated with one or more of the nine or more East Texas Hasinai Caddo ethnically and linguistically affiliated groups (cf. Rogers and Sabo 2004; Swanton 1942).

\section{Frankston Phase}

The Frankston phase is comprised of farmsteads, hamlets, and small villages in the Neches and Angelina river basins that date from ca. 300-550 years B.P. Only a single Frankston phase mound is known, the A.C. Saunders site (41AN19; see Jackson 1936; 
Kleinschmidt 1982) near the Neches River, and only a few miles upstream along the river from the Lang Pasture site. This small mound (2.2 m in height and $26 \times 33 \mathrm{~m}$ in length and width) had thick ash beds and fill zones, and probably represents a Caddo fire temple used by the social and political elite of one Frankston phase "affiliated groups" (Story and Creel 1982:36 and Figure 8). South of the mound a short distance was a large midden deposit that capped an important (public?) circular structure, based on its impressive size $(14 \times 13 \mathrm{~m})$ and several large interior hearths. The structure was built and dismantled in the 16th century (e.g., Kleinschmidt 1982:240 seriation of Frankston phase ceramics), then capped by the midden deposits (Kleinschmidt 1982:46). The midden deposits contained an abundance of Caddo artifacts from apparent residential settlement, including an estimated 1291 ceramic vessel sections (dominated by Poynor Engraved bowls, Bullard Brushed and Maydelle Incised jars, and LaRue Neck Banded jars), elbow pipes, Perdiz arrow points, stone drills, mussel shell digging tools, an assortment of bone tools (awls, needles, and beamers), and shell columnella beads.

Other Frankston phase sites are represented by small residential settlements in dispersed agricultural communities, with small family and/or community cemeteries not used for long periods of time (see Anderson 1972; Anderson et al. 1974; Johnson 1961; Shafer 1981). Anderson (1972:163) notes that the concentration of Frankston phase sites in one section of the upper Neches River basin comprise "base settlement clusters [with middens, burials, and structures, likely representing permanent settlements] on streamside flats with fertile soils in the...uplands. Other site types include scattered sherds, gathering stations in which pitted stones are found with a few sherds, and small campsites.” The Omer and Otis Hood cemetery with 20 burials (Kleinschmidt 1982) is one of the larger known Frankston phase cemeteries. Many others have less than 10 individuals (Kleinschmidt 1982:214), laid out individually in extended supine position, with a variety of grave goods (principally ceramic vessels). In at least one instance, a Frankston phase cemetery in the upper Neches River basin in Smith County, Texas, contains the burial of socially elite individuals in a family and/or village cemetery context. This particular burial was in a 12 foot wide pit, and had three individuals. Among the funerary objects placed with the multiple burial were 21 pottery vessels, a ground stone celt, and a large chipped biface (Jowell knife); baskets or matting were apparently also present in the grave (Anderson 1972:139-140).

\subsubsection{Historic Caddo}

New assessments of the route of the de SotoMoscoso 1542-1543 entrada through East Texas (Bruseth 1992; Hudson 1997; Kenmotsu et al. 1993; Schambach 1989; Thurmond 1990) indicate that the Spanish entrada encountered several different groups of Caddo peoples from the Red River south to the Nacogdoches area, although the exact route remains to be determined. Hudson (1997:Map 8) suggests that once the entrada entered Texas-probably in the vicinity of Texarkana-that the Spaniards and their Caddo guides were traveling along a definite aboriginal trail that extended from the Red River southwest into East Texas. The Caddo guides did what they could to delude the Spaniards, leading them away from the trails and known villages, and the guides paid for these acts when Moscoso discovered he was being misled (Hudson 1997:368).

From Nondacao in the Sabine River basin, which was a prosperous Caddo community where "one could find plenty of corn" (Hudson 1997:365), Moscoso and his men visited Soacatino, possibly in the upper Neches River basin, where corn was scarce, before reaching Guasco on the Neches River, probably near the Caddo trail crossing (now known as the Camino Real) by the George C. Davis site. The Caddo people in Guasco had plenty of corn as well as turquoise and shawls of cotton obtained in trade with Southwestern groups. Hearing of reports by the Caddo of other Spaniards in the area, the entrada moved south or southeast to the Caddo provinces of 
Naquiscoza and Nazacahoz. Hudson (1997:369-370) and Kenmotsu et al. (1993:Illustration 24 and 25) both agree that these Caddo provinces were in the Angelina River basin in the vicinity of the modern community of Nacogdoches. The entrada penetrated no farther south or east, but did move west to the River of Daycao, probably the modern Brazos River (Hudson 1997:Map 8).

It is possible that European diseases were introduced to the Caddo groups living in the East Texas Pineywoods by members of the de Soto-Moscoso entrada (Perttula 1992:27-28), but there is no evidence of this currently available in the archeological or bioarcheological records to substantiate this hypothesis. While it is suspected that the abandonment of certain parts of the Pineywoods in the early to late 17th century as seen in the archeological record may be a product of population loss, much more archeological investigations at well-dated sites is warranted to substantiate disease as the primary contributing factor. However, by the late 17th century, Caddo groups in East Texas had been exposed to European epidemic diseases (Derrick and Wilson 2001; Ewers 1973; Perttula 1992, 1996), which led eventually to substantial depopulation (probably 75-90 percent or more) among these Pineywoods groups by the early part of the 19th century.

In historic times, the archeology of the East Texas Caddo groups living south and west of the Sabine River is associated with the Allen phase, dated from ca. 150-300 years B.P. or later: "The Allen phase is believed to have developed out of the Frankston phase, and more importantly, to have shared the same form of organization, kinds of inter-group interaction, and settlement patterns" (Story and Creel 1982:34). The groups who, during the Allen phase. occupied the Neches and Angelina river basins were direct ancestors of the Hasinai tribes who were living in or near the Spanish missions established in the region between ca. 1691-1772, and they continued to maintain residence there until the 1830s.
Story and Creel (1982:32) suggest that the Frankston and Allen phase populations were organized in a "weakly hierarchical structure" analogous to the Hasinai confederacy (see Swanton 1942). Allen phase components are found in the Neches and Angelina river basins in Cherokee, Anderson, Houston, Rusk, and Nacogdoches counties (see Cole 1975; Kenmotsu 1992; Perttula and Nelson 2006, 2007; Story 1982, 1995), and usually contain small amounts of European trade goods found in village and burial contexts. Caddo domestic remains at these settlements included a variety of decorated and plain ceramic fine wares (principally Patton Engraved) and utility wares, usually bone-tempered and with brushed vessel bodies, triangular and stemmed arrow points, elbow pipes (plain and decorated), ground stone tools, and bone tools. These Caddo groups were successful agriculturists.

Excavations at the Deshazo site (41NA13), the best studied Allen phase settlement (Story 1982, 1995), indicates it was a small centralized hamlet of an affiliated group with a series of circular structures and an associated household or family cemetery. Most sites were apparently occupied for only short periods of time, perhaps an average of 20 to 40 years, based on an analysis of structure rebuilding episodes at the Deshazo site (Good 1982:6769).

While a single farmstead may have only included one or two structures, Caddo communities were apparently composed of many farmsteads spread out over a considerable distance. In 1687, in the community of Nabedache Caddo (one of the Hasinai groups) on San Pedro Creek in Houston County, Henri Joutel noted:

we took the path to the village where the Indians conducted us to the chief's hut which was a long league's distance from the entrance to the village. On the way, we passed several huts that were grouped in hamlets; there were seven or eight of them, each with twelve to fifteen huts 
together with space between each other and fields around the huts (Foster 1998:206).

Morfi (1935:87) further commented (based on earlier missionary reports) that in 1716, the Nacogdoche Indians were "divided into 22 rancherias...which spread for a distance of 10 leagues from South to North.”

Individual Hasinai Caddo families lived in their farmsteads, several of which have been archeologically investigated in Nacogdoches County (Story 1982, 1995; Kenmotsu 1992), and a number of farmsteads were organized into rancherias spread out over about 15 to 30 leagues (about 40 to 80 miles). Each rancheria was separated from the others by unoccupied lands (see Foster 1998:208) and hunting territory.
There are other clusters of historic Caddo archeological sites in East Texas. Among these are a series of probable early $18^{\text {th }}$ century Nasoni Caddo sites on the lower Sulphur River (Dickinson 1941; Harris et al. 1980; Lewis 1987), along a known trade portage. Late $18^{\text {th }}$ to early $19^{\text {th }}$ century Nadaco or Anadarko Caddo sites have been reported along the Sabine River in the Potters Creek area, along trail crossings of this stream (Jones 1968; Clark and Ivey 1974). Along the Red River in Bowie County, there are archeological remains of Nasoni Caddo and other Kadohadacho tribes that lived in the area until the late 1780s (Miroir et al. 1973; Gilmore 1986; Wedel 1978); the French built a trading post in the early $18^{\text {th }}$ century at the main Nasoni village, probably the Roseborough Lake site (41BW5). In the upper Sabine River basin and the Tyler District, the Gilbert and Pearson sites (Duffield and Jelks 1961; Jelks 1967) were occupied primarily in the mid- to late $18^{\text {th }}$ centuries, apparently by Caddo groups that were heavily involved in the fur trade (Perttula 1992:173, 256). 


\section{CHAPTER 4}

\section{RESEARCH DESIGN}

Timothy K. Perttula, David B. Kelley, Diane E. Wilson, and Bruce M. Albert

\subsection{INTRODUCTION}

The primary focus of the research is on prehistoric Caddo households and settlement systems in this part of the upper Neches River basin. This is based on (1) the kinds of archeological deposits that the site contained; and (2) important research issues for prehistoric Caddo sites in this part of East Texas (see Kenmotsu and Perttula 1993:121146) that are relevant for the Lang Pasture site (41AN38) investigations. This research design was written prior to initiation of data recovery work at the site, and was intemded to serve as a guide for that work.

\subsection{Local CAddo Research CONTEXT}

The Lang Pasture site is situated in a part of the upper Neches River valley that is known as one of the principal areas settled by prehistoric and historic Caddo groups that are identified archeologically as the Frankston (ca. A.D. 1400-1650) and Allen (ca. A.D. 16501750) phases (see Story and Creel 1982:29-32; Kleinschmidt 1982). Earlier Caddo occupations are not as well known in this area, but small habitation sites predating A.D. 1400 have been identified by Anderson et al. (1974) and Kleinschmidt (1982). The 2004 testing work at the Lang Pasture site suggested to us that the site was occupied during the early part of the Frankston phase (Lohse 2004:42-44), perhaps from ca. A.D. 1400-1450, although the chronological context of the Caddo occupation needed better resolution.
Much of the previous archeological work on Caddo sites on the upper Neches was done in the 1930s and focused almost exclusively on the excavation of cemeteries (see Guy 1990:Table 3; see also Campbell 1936; Cole 1975). One such nearby cemetery in the Caney Branch Creek valley is the Mrs. J. M. Cook site (41AN1) (see Figure 3-1), although there are a number of important known Caddo cemetery and habitation sites that we think are generally contemporaneous with the Lang Pasture site in this part of the upper Neches River valley.

The present site is located on an upland toe slope overlooking the Caney Branch Creek valley. Caney Branch Creek is a small tributary to the Neches River, and joins with it about $10 \mathrm{~km}$ downstream from the site (see Figure 3-1). Major excavations were also conducted in the early 1930s at the A. C. Saunders (41AN19) mound center (Jackson 1936; Kleinschmidt 1982) (see Figure 3-1) built and used during much of the Frankston phase according to Kleinschmidt (1982)—but there was a dearth of work done in habitation deposits (other than occasionally trenching a trash midden deposit). Story (2000:13) has noted that "none of the [Frankston phase] sites...has been extensively investigated nor well dated and much of the information comes from excavations made in the early and middle 1930s.”

In more recent times, archeological work in this part of the upper Neches River basin has taken place at or near Lake Palestine, a few miles to the north of the Lang Pasture site, where a number of primarily Late Caddo 
Frankston phase sites have been investigated (Anderson et al. 1974; Cliff et al. 2004; Gilmore 1983; Shafer 1981) (see Figure 3-1). Here too, however, the work was not specifically directed towards identifying and studying habitation features or the layout of Caddo settlements/households, and it was primarily successful only in the identification of trash midden deposits and their contents, or in salvaging the contents of a disturbed Late Caddo burial (i.e., Shafer 1981).

On Caddo habitation sites, "most excavations have been too limited to permit accurate characterization of the settlement size and structure, and sometimes even its history of use" (Story 1990:334). While there have been more extensive archeological investigations of Caddo habitation sites more recently in some parts of northeastern Texas (but not including the upper Neches River basin), the fact remains that our understanding of the basic character of prehistoric and early historic Caddo households, settlements, and communities is still poor. This is as true for Caddo habitation sites in the upper part of the Neches River basin as it is in any part of northeastern Texas, and points out where the basic importance of the investigations at the Lang Pasture site lay.

\subsection{RESEARCH ISSUES}

The development of the research issues guiding the Lang Pasture site archeological data recovery was shaped by several factors. First was a preliminary set of issues identified by Ricklis and Perttula (2004:62-63) in the interim report on the test excavations. These focused on intra-site planning and use of activity spaces; the range of non-structural features (including the placement of human burials at the site), and chronology (including establishing the duration of occupation and the age range of the prehistoric Caddo component). We also took into consideration comments and suggestions offered by TxDOT during their review of the interim report. Another important factor was the results of the data recovery excavations, summarized in an interim report submitted to TxDOT (Kelley et al. 2004). Finally, we incorporated relevant parts of the broad research problems framed by Kenmotsu and Perttula (1993:136-141) in the Historic Context "The Development of Agriculture in Northeast Texas before A.D. 1600" for the Northeast Texas archeological region preservation plan.

\subsection{Cultural Chronology}

A few radiocarbon and Oxidizable Carbon Ratio (OCR) dates had already been obtained from the site, but the results were contradictory with each other, as well as with the independent chronological estimates obtained from the examination of the decorated ceramic sherds, vessels, and pipes. We hoped to clarify this situation during the data recovery excavations by using multiple dating techniques on samples from carefully selected contexts.

The general research question concerned establishing the age of the occupations at the site. To answer this question we proposed to submit samples of ceramics and charred plant remains from undisturbed feature contexts for radiocarbon (charred plant remains and ceramics), and thermoluminescence (ceramics) dating. Up to 60 samples were to be submitted for radiocarbon dating analysis. In most cases these were to be composed of either charred hickory nutshells or charred corn cupules from the flotation of feature fill at Lang Pasture. Depending upon the context of recovery and the inferred association, 5-10 of the radiocarbon samples could be directly on sherds themselves.

Based on the initial analyses of the ceramics and lithics there were suggestions of time depth within the Caddo occupation in both data sets, and in the case of the ceramics the temporal differences seemed to correlate with the two house structures identified in the rightof-way. By carefully selecting radiocarbon and thermoluminescence samples from features associated with these structures we hoped to be able to determine their age and to address the question of the duration of the Caddo occupation of the site. This intensive 
dating effort could contribute to a better understanding of the cultural chronology of the local region. This is because few sites have any number of absolute dates or have been thoroughly investigated (see Kleinschmidt 1982; Story 1990, 2000; Story and Creel 1982).

In the absence or near absence of datable charred organic materials from certain contexts at the Lang Pasture site, the thermoluminescence (TL) dating of ceramic sherds is important in establishing the absolute age of the Caddo occupation or occupations at the site. In order to insure that TL dates were obtained on diagnostic ceramic sherds, the samples we proposed for TL dating were all decorated sherds. Decorated sherds are the most temporally diagnostic because they can be associated with specific styles of ceramic vessel decoration that are known or suspected to have both chronological and social/community significance.

The samples we proposed for TL dating analysis consist of 23 sherds, including five engraved fine wares and 18 sherds from decorated utility wares. The relative proportion of fine wares to utility wares in the TL sample was $22 \%$ and $78 \%$, respectively, virtually identical to the proportions of such wares (23\% and $77 \%$, respectively) in the larger decorated sherd assemblage from Lang Pasture (Kelley et al. 2006: Table 3-2). Consequently, there would be no obvious selection biases in the TL sample proposed for TL dating from the Lang Pasture site, as no one ware was favored in the selection sample over another; the consequences of employing TL dating on both high and low-fired ceramics are unknown at this point (James Feathers, personal communication, 2010).

The sherd samples we proposed for TL dating are listed below (Table 4-1). The kinds of decorated sherds represented in the proposed
TL sample were consistent with the range of decorative methods and elements found in the over 2400 decorated sherds examined for the preparation of the Lang Pasture site interim report.

Because the majority of the proposed TL sample available from the Lang Pasture site investigations came from archeological deposits associated with Structure 2 in the southern part of the block excavations $(n=19)$, compared to only four TL samples from the Structure 1 area, the TL dating of sherds would not be sufficient by itself to establish the age of features and archeological deposits across the entirety of the block excavations. Fortunately there were available dateable materials from features in both the northern and southern parts of the Lang Pasture site block excavation to provide an independent means of chronological information on the age of the prehistoric Caddo occupation, and we could also rely on the diagnostic decorated ceramic vessel sherds from 21 different features (Kelley et al. 2006:Table 3-3) to link TL dates on similar styles of decorated sherds as well as radiocarbon dates from some of these features containing more than 300 diagnostic decorated vessel sherds.

As a further aid to establishing the age of the deposits at the Lang Pasture site, we proposed to submit samples of sediment from the site for Optically Stimulated Luminescence (OSL) dating. This dating technique is applicable to quartz and feldspar-rich sediments that are otherwise often not dateable. Like thermoluminescence it involves exposing a sample to light or heat and measuring the amount of light emitted, which is proportional to the total amount of radiation that had accumulated since the sample was last exposed to heat. An age can then be calculated by dividing the total accumulated dose by an estimated annual dose. Analyses can be run on multiple or single quartz grains. 
Table 4-1. Sherds Proposed for TL Dating from the Lang Pasture Site.

\section{Fine wares}

\begin{tabular}{lll} 
No. & Provenience & Apparent decoration (based on limited examination) \\
\hline 1. & N196 E198, 21 cm & parallel engraved lines, bottle \\
2. & N199 E202, 40 cm & Poynor Engraved carinated bowl rim \\
3. & N177 E198, 19 cm & Poynor Engraved panel \\
4. & N175 E200, 28 cm & $\begin{array}{l}\text { Poynor Engraved carinated bowl, with brushing on body } \\
\text { 5. }\end{array}$ \\
N174 E198, 44 cm & diagonal engraved lines on rim
\end{tabular}

\section{Utility wares}

No. Provenience

6. N176 E199, $24 \mathrm{~cm}$

7. N175 E202, $30 \mathrm{~cm}$

8. N181 E199, $28 \mathrm{~cm}$

9. N176 E199, $27 \mathrm{~cm}$

10. N180 E202, $28 \mathrm{~cm}$

11. N180 E202, $17 \mathrm{~cm}$

12. N172 E199, $22 \mathrm{~cm}$

13. N179 E202, $26 \mathrm{~cm}$

14. N183 E202, $41 \mathrm{~cm}$

15. N181 E198, $21 \mathrm{~cm}$

16. N174 E200, $27 \mathrm{~cm}$

17. N178 E198, $32 \mathrm{~cm}$

18. N195 E199, $24 \mathrm{~cm}$

19. N197 E202, F.25

20. N178 E199, $21 \mathrm{~cm}$

21. N180 E199, $32 \mathrm{~cm}$

22. N180 E199, $38 \mathrm{~cm}$

23. N183 E198, $29 \mathrm{~cm}$

\author{
Apparent decoration (based on a limited examination) \\ parallel brushed \\ curvilinear and opposed incised lines \\ diagonal incised rim \\ parallel brushed; pinkware (a distinctive fired clay source \\ noted in preliminary inspection of vessel sherds) \\ Killough Pinched \\ opposed brushed \\ tool punctated rows \\ overlapping brushed \\ parallel brushed \\ overlapping brushed \\ parallel brushed \\ straight incised line \\ cross-hatched incised lines \\ diagonal brushed rim \\ overlapping brushed \\ incised panels \\ parallel brushed \\ parallel brushed
}

We proposed to submit 27 samples from the Lang Pasture site for single grain OSL analysis by the Sheffield Centre for International Drylands Research at the University of Sheffield, England. The samples were collected at $5 \mathrm{~cm}$ intervals from two columns. One of the columns was located at N197.5 E198 near the northernmost structure identified at the site. The other column was located in the burial area at N215.5 E198. By dating closely spaced samples from these two areas of the site it might be possible to determine if the sediments in both areas were deposited at the time of the prehistoric Caddo occupation, helping to determine if the Caddo structural remains and burial features are contemporaneous. The results of the single grain OSL dating, particularly if the dates were anomalously old or young or did not occur in stratigraphic sequence, should also allow an assessment of the extent of any natural disturbance (i.e., bioturbation) of the archeological deposits at the site. These results in turn might have implications for the research potential of certain archeological materials not recovered from feature contexts at the site, particularly considerations of the horizontal and vertical patterning of materials in the prehistoric Caddo component at the Lang Pasture site. 


\subsection{Caddo SetTlement Systems AND HOUSEHOLDS}

In a comprehensive review of prehistoric and historic Caddo archeology in 1990, Dee Ann Story (1990:336) noted, "the most fundamental building blocks of the Caddoan settlement system - the household and community-are poorly understood." She attributed this to the limited scale of most excavations of Caddo habitation sites (Story 1990:334).

Our research attempted to address two questions: what was the internal organization of the Caddo settlement at the Lang Pasture site, and how did it differ from that of other settlements in this region or other parts of the Caddoan Area? The first question was examined by developing functional interpretations of the features identified based on morphology, artifact content, and ethnohistoric and historic information available on Hasinai Caddo groups living in the Neches River basin in the seventeenth and eighteenth centuries (see Foster 1998; Swanton 1942). If the chronometric and artifact data indicated that there was measurable time depth within the Caddo occupation, then we would also search for indications of change through time in the organization of the settlement.

In order to address the second question, the data from the Lang Pasture site were compared to that from other sites in the upper Neches River basin and elsewhere in the Caddoan archeological area. Our efforts in this regard were enhanced by the examination of available settlement-level information from contemporaneous sites in the Texas Archeological Research Laboratory files (see Figure 3-1), along with excavated Frankston phase and earlier Caddo sites at or near Lake Palestine (Anderson et al. 1974).

Archeological investigations in the past in the upper Neches River basin have focused on the identification and excavation of Caddo burial sites and cemeteries (Jackson 1931, 1933a; Pearce and Woolsey 1935; Woolsey 1935a-n).
All that work was done in the 1930s. More recently, but still more than 30 years ago, excavations at a number of Late Caddo Frankston phase habitation sites at Lake Palestine (the Debro, William Sherman, Forest Drive, Halbert, Woldert, Ferguson, and Tomato Patch sites) focused on the excavations of midden deposits (Anderson et al. 1974), but unfortunately that research effort was based on the incorrect impression that midden deposits at these sites represented the remains of structures, when in fact the midden deposits were concentrated areas of trash and domestic refuse (see Jackson 1933a). Consequently, no substantive information was obtained from the Lake Palestine sites on structures or the kinds of activities that may have taken place outside of and around the structures themselves.

The 1930s excavations by the University of Texas-while focusing on Caddo cemeteries-often did note the location and general size of habitation deposits and/or midden deposits found on these same sites relative to cemetery settings. Middens tended to range between 25-600 $\mathrm{m}^{2}$ in size, suggesting considerable variation in the length and intensity of the Caddo occupations, as well as the size of the various settlements. Excavations at the midden at the Emma Owens site (41AN21) encountered a large and deep pit (more than $1 \mathrm{~m}$ in diameter and depth) along the edge of the midden (Cole 1975) that on first glance sounds very much like several of the large pit features at the Lang Pasture site. We can only speculate about the settlement organizational meaning of these midden deposits since none were systematically or carefully excavated, if they were examined at all. Presently, other than at the Lang Pasture site, we do not know the spatial relationship between domestic structures, middens, and cemeteries on upper Neches River basin Caddo sites.

The somewhat sketchy information from the University of Texas work at least provides an indication that prehistoric Caddo cemeteries in the upper Neches River basin occur in association with habitation deposits, although 
they might be separated by several hundred meters from each other. In most cases where information is available from the 1930s investigations, cemetery areas tend to be situated between a water source and the habitation areas, as at Lang Pasture. Their direction from the habitation areas runs the gamut from north to south and east to west, but habitation areas tend to be located north of cemeteries on Allen phase sites (Cole 1975), while earlier Frankston phase habitation areas were established south, southwest, and west of cemeteries, again as at Lang Pasture, although this is not always the case (cf. Shafer 1981). This geographic landscape patterning in the placement of cemetery and habitation areas may have significance to the prehistoric Caddo communities living in the upper Neches River basin with respect to their cosmology, mortuary ritual and its symbolic meaning, and Caddo views on directionality, life, and death (Kay and Sabo 2006:32-33).

It is very difficult, consequently, to compare the organization of the prehistoric Caddo settlement at the Lang Pasture site (i.e., circular structures, ramadas or work platforms outside structures, large pits, cemetery, and midden deposits) with generally contemporaneous Caddo sites in the upper Neches River basin because habitation deposits have never been the focus of previous investigations, or if they were, the excavation effort was misguided (cf. Anderson et al. 1974). The only documented Caddo structure in the upper Neches River basin is a $14 \mathrm{~m}$ diameter circular structure at the A.C. Saunders site (41AN19), but its large size and location under a deliberately constructed mound (albeit constructed with midden deposits) indicates it was not a domestic habitation structure like Structures 1 and 2 at Lang Pasture. Recent remote sensing work carried out at the A. C. Saunders site by the Texas Archeological Research Laboratory, The University of Texas at Austin may contain relevant archeological information on settlement organization around the mounds at this site, although this information has not been published to date.
For this reason we turned our attention to related (culturally, but not necessarily temporally) Caddo sites in the NechesAngelina River basin to determine how the site organization of the Lang Pasture site (or at least that part of the site within the boundaries of the SH 155 right-of-way) compared with other generally contemporaneous East Texas Caddo groups. Specifically, the welldocumented plan of circular structures (some overlapping and repeatedly rebuilt), open plaza area, and communal midden at the Deshazo site (41NA27) is relevant (Story and Creel 1982), as are structural features and village planning data from the Late Village at the Oak Hill Village site in Rusk County, Texas (Perttula and Rogers 2007), where occupation ended at ca. A.D. 1450. The spatial layout and relationship of structures, middens, and cemeteries-as well as outdoor working areas-are known from recent archeological and remote sensing work at Lake Naconiche in the Attoyac Bayou basin on three sites (41NA231, 41NA235, and 41NA242) that were occupied during the fourteenth and fifteenth centuries (Perttula [ed.] 2008a).

\subsection{Subsistence SyStems}

The sample of macrobotanical remains recovered during the data recovery excavations at the Lang Pasture site was relatively small, but the material recovered in flotation samples from features appeared to be well preserved and could therefore provide important data on Caddoan plant utilization in this region. The research questions that could be addressed were, how important was plant food production in the Caddo subsistence strategy at Lang Pasture, and how did this strategy compare to that of contemporary sites in this region or other regions? The ubiquity and density of plant remains in feature flotation samples provided one measure of plant food utilization. Features were selected for analysis on the basis of a range of factors, including the presence of charred plant material in the flotation sample, the volume of the feature and flotation sample, and the presence of diagnostic artifacts or dateable material from the feature. A list of samples 
proposed for analysis is presented in Table 42.

In order to address the second question the data on subsistence from the Lang Pasture site were compared to that from previously excavated Caddo sites in this region or other parts of the Caddoan area. Presently there are limited data on floral remains from late Caddo sites in the upper Neches River basin, other than the recovery of some incidental charcoal and nutshells. One notable exception is site 41CE354 (Perttula and Nelson 2007), located a few miles northeast of Lang Pasture on Flat Creek, a tributary to the Neches River.
Its well-preserved floral assemblage, recovered in flotation and fine-screen samples, included maize, beans, hickory nuts, black walnut, goosefoot/pigweed seeds, and legume seeds (Perttula and Nelson 2007). This Caddo habitation site dates after ca. A.D. 1650. By this time, the Caddo peoples living in the upper Neches River basin depended upon cultivated plants in their diet, but also supplemented that diet with hardwood mast and wild seeds. How much earlier such a subsistence strategy had evolved among the Caddo can be addressed with recovered plant remains from the Lang Pasture site and stable carbon isotope analyses from the Lang Pasture and other nearby Caddo cemetery sites.

Table 4-2. Flotation Samples Proposed for Macrobotanical Analysis .

\begin{tabular}{|c|c|c|}
\hline Sample No. & Feature No. & Provenience \\
\hline $1210-1211$ & 20 & N193-194 E203 (30-40cm) \\
\hline $1212-1213$ & 20 & N193-194 E203 (50-60cm) \\
\hline $1230-1231$ & 25 & N197 E201 (20-25cm) \\
\hline $1232-1233$ & 25 & N197 E201 (25-30cm) \\
\hline $1234-1235$ & 25 & N197 E201 (30-35cm) \\
\hline $1236-1237$ & 25 & N197 E201 (35-40cm) \\
\hline 1238 & 25 & N197 E201 S1/2 (40-45cm) \\
\hline $1239-1240$ & 25 & N197 E201 S1/2 (45-50cm) \\
\hline $1275-1276$ & 36 & N195 E201 $(25-35 \mathrm{~cm})$ \\
\hline $1277-1278$ & 36 & N195 E200 (25-35cm) \\
\hline $1279-1280$ & 36 & N195 E201 (35-40cm) \\
\hline $1293-1294$ & 41 & N186 E198 (30-40cm) \\
\hline $1295-1296$ & 41 & N186 E198 (40-44cm) \\
\hline $1369-1370$ & 76 & N197 E202 (30-60cm) \\
\hline $1371-1372$ & 76 & N197 E202 (70-80cm) \\
\hline $1373-1374$ & 76 & N197 E202 (80-90cm) \\
\hline $1375-1376$ & 76 & N197 E202 (90-100cm) \\
\hline $1377-1378$ & $76 \mathrm{~A}$ & N197 E203 \\
\hline $1379-1380$ & $76 A$ & N198 E203 (60-70cm) \\
\hline $1387-1388$ & 79 & N198 E198 (40-50cm) \\
\hline $1389-1390$ & 79 & N198 E198 W1/2 (50-60cm) \\
\hline $1391-1392$ & 79 & N198 E198 W1/2 $(60-70 \mathrm{~cm})$ \\
\hline $1393-1394$ & 79 & N198 E198 W1/2 (70-80cm) \\
\hline $1395-1396$ & 79 & N198 E198 $(80-90 \mathrm{~cm})$ \\
\hline $1427-1428$ & 86 & N208 E198 N1/2 (40-50cm) \\
\hline $1429-1430$ & 86 & N208 E198 N1/2 (50-60cm) \\
\hline $1431-1432$ & 86 & N208 E198 N1/2 (60-70cm) \\
\hline $433-1434$ & 86 & N208 E198 N1/2 (70-80cm) \\
\hline $1435-1436$ & 86 & N208 E198 N1/2 (80-90cm1) \\
\hline
\end{tabular}


Other possibilities for comparative data for the plant remains from the Lang Pasture site include several Late Caddo Titus phase assemblages in the Cypress Creek basin recently summarized by Dering (2005), and the Middle Caddo Oak Hill Village assemblage also analyzed by Dering (2004).

The samples of vertebrate and invertebrate faunal remains recovered in the data recovery excavations were small and poorly preserved. They were of limited use for addressing questions of faunal exploitation at the site.

\subsection{LOCAL AND EXTRA-LOCAL TRADE AND EXCHANGE}

Our research attempted to address two related questions concerning trade during the Caddo occupation at the Lang Pasture site: What goods were obtained through trade, and how was trade organized? The first question was examined through a combination of instrumental neutron activation analysis (INAA) of Caddo ceramics at Lang Pasture, and identification and quantification of nonlocal lithic raw materials and other exotic goods that may be preserved. The latter analysis focused on temporally diagnostic artifacts or samples of debitage from features that could be associated with the Caddo occupation through the presence of diagnostic artifacts or radiometric dates.

INAA studies of Caddo sherds from temporally reliable archeological contexts throughout northeastern Texas, have provided useful information on assessing the compositional diversity of different ceramic assemblages, determining if compositional groups are associated with specific vessel forms and decorative elements, and establishing if the ceramic compositional variation at sites changed over time, and thus reflect differing ceramic resource exploitation strategies or vessel movement patterns (Neff and Glascock 2000; Descantes et al. 2003; Perttula 2002). At least 10 ceramic chemical groups have recently (as of 2007) been defined through INAA from more than 100 sites throughout East Texas and surrounding parts of the Caddoan archeological area, including the Smith chemical group in the upper Neches and Angelina River basins (i.e., parts of Anderson, Cherokee, and Smith counties).

If the instrumental neutron activation analysis (INAA) of ceramic vessel sherds from the Lang Pasture site and other generally contemporaneous prehistoric Caddo sites in the upper Neches River basin were successful in identifying distinct chemical composition groups in ceramic vessel sherds selected for analysis, then we would have for the first time a quantifiable measure of the amount of nonlocal ceramic vessels (and some indication of their manufacturing source area) that occur in Frankston phase Caddo sites in this part of East Texas. We recognized that the INAA study of upper Neches River Caddo ceramic vessel sherds was a pilot effort because no INAA has been conducted on any upper Neches River basin Caddo sites (although more than 900 sherds have been subjected to INAA in East Texas since the mid-1990s), but INAA results obtained to date (cf. Perttula 2002:Figure 5.2) have successfully identified several distinct Caddo ceramic chemical groups in the region. The differences in the geographic distribution of these Caddo ceramic chemical groups-combined with stylistic analyses of the decorated Caddo vessel sherds subjected to INAA-have permitted the identification of the compositional nature of locally made vs. nonlocally made ceramic wares. The Lang Pasture INAA analyses would extend those findings to the upper Neches River basin for the first time.

In selecting 50 sherds from the Lang Pasture site for INAA, several considerations were paramount: (1) that the sherd was large enough to identify decorative elements on them, whether they were fine wares (i.e., engraved and red-slipped vessel sherds) or utility wares (i.e., wet-paste decorated sherds and plain ware rims); (2) that both fine wares, utility wares, and plain wares were sampled for INAA so we will be able to assess the amounts of possible non-local ceramic vessel sherds among each of the three ceramic wares at the site; and (3) the sherds selected for 
INAA come from the areas of Structures 1 and 2 and the various pit features outside of the structures.

We also selected sherds for INAA in proportion to the frequency of decorated sherds across the northern and southern parts of the sites (and presumably associated with Structures 1 and 2), the frequency of decorated sherds from features, and the frequency of plain rim sherds. A list of sherds proposed for INAA is presented in Table 4-3.

Table 4-3. Sherds from the Lang Pasture Site Recommended for INAA.

\begin{tabular}{|c|c|c|c|}
\hline Sample No. & Sherd Type & Provenience & Decoration \\
\hline AN38-1 & body & N196 E198, lv. 1 & $3+$ fingernail punctated rows \\
\hline AN38-2 & body & N196 E201, lv. 2 & parallel brushed \\
\hline AN38-3 & body & N195 E202, lv. 3 & $\begin{array}{l}\text { zoned-paneled incised lines with tool punctated- } \\
\text { filled zones }\end{array}$ \\
\hline AN38-4 & body & N191 E202, lv. 1 & $\begin{array}{l}\text { horizontal engraved with triangular } \\
\text { elements; cf. Poynor Engraved, carinated bowl }\end{array}$ \\
\hline AN38-5 & body & N192 E198, lv. 3 & parallel brushed \\
\hline AN38-6 & body & N190 E202, lv. 3 & $\begin{array}{l}\text { hatched and oval paneled engraved, cf. Poynor } \\
\text { Engraved }\end{array}$ \\
\hline AN38-7 & body & N190 E201, lv. 3 & parallel incised lines, widely-spaced \\
\hline AN38-8 & body & N190 E199, lv. 2 & large tool punctate \\
\hline AN38-9 & body & N190 E199, lv. 3 & $\begin{array}{l}\text { parallel brushed, with fingernail punctates within } \\
\text { brushing }\end{array}$ \\
\hline AN38-10 & body & N195 E199, lv. 4 & horizontal and diagonal engraved lines \\
\hline AN38-11 & body & N195 E200, lv. 2 & cross-hatched incised lines \\
\hline AN38-12 & rim & N196 E201, lv. 4 & plain \\
\hline AN38-13 & rim & N195 E201, lv. 3 & plain \\
\hline AN38-14 & body & N193 E198, F.66 & parallel brushed \\
\hline AN38-15 & body & N215 E203, F. 88 & parallel brushed \\
\hline AN38-16 & body & N197/198 E202, F.76 & broad horizontal and diagonal incised lines \\
\hline AN38-17 & body & N198 E202, F. 76 & $\begin{array}{l}\text { diagonal lines and excised triangles, carinated } \\
\text { bowl, cf. Poynor Engraved, except incised }\end{array}$ \\
\hline AN38-18 & body & N198 E203, F.76 & fingernail punctated body \\
\hline AN38-19 & body & N198 E199, F. 79 & parallel incised with tool punctated zones \\
\hline AN38-20 & body & N195 E201, lv. 3 & $\begin{array}{l}\text { horizontal engraved lines and hatched } \\
\text { triangular element; Poynor Engraved; bottle }\end{array}$ \\
\hline AN38-21 & body & N194 E203, lv. 4 & cross-hatched incised lines \\
\hline AN38-22 & body & N194 E201, lv. 2 & opposed engraved element \\
\hline AN38-23 & body & N194 E200, lv. 2 & $\begin{array}{l}\text { parallel brushed-incised with tool punctated row } \\
\text { through the brushing }\end{array}$ \\
\hline AN38-24 & body & N193 E199, lv. 2 & parallel brushing, cf. Bullard Brushed \\
\hline AN38-25 & body & N193 E198, lv. 3 & $\begin{array}{l}\text { vertical brushed with tool punctated row within } \\
\text { the brushing }\end{array}$ \\
\hline AN38-26 & body & N193 E198, lv. 4 & 2 widely-spaced tool punctated rows \\
\hline AN38-27 & body & N193 E201, lv. 2 & $\begin{array}{l}\text { horizontal and hatched triangular engraved; cf. } \\
\text { Poynor Engraved; carinated bowl }\end{array}$ \\
\hline AN38-28 & body & N193 E203, lv. 5 & opposed tool punctates \\
\hline AN38-29 & body & N193 E202, lv. 3 & hatched engraved ladders; bottle \\
\hline AN38-30 & body & N180 E198, lv. 1 & opposed incised panels \\
\hline AN38-31 & body & N180 E199, lv. 3 & vertical brushed and tool punctated row \\
\hline AN38-32 & body & N176 E199, lv. 3 & parallel brushed \\
\hline
\end{tabular}


Table 4-3, continued

\begin{tabular}{|c|c|c|c|}
\hline Sample No. & Sherd Type & Provenience & Decoration \\
\hline AN38-33 & body & N176 E198, lv. 3 & exterior red-slipped; bottle \\
\hline AN38-34 & body & N176 E199, lv. 2 & single tool punctate \\
\hline AN38-35 & body & N176 E199, lv. 4 & $\begin{array}{l}\text { engraved triangles and ovals; cf. Poynor } \\
\text { Engraved; bottle }\end{array}$ \\
\hline AN38-36 & body & N177 E198, lv. 4 & overlapping brushed \\
\hline AN38-37 & body & N178 E202, lv. 1 & parallel brushing \\
\hline AN38-38 & body & N178 E198, lv. 5 & $3+$ fingernail punctated rows \\
\hline AN38-39 & body & N178 E199, lv. 5 & opposed incised lines \\
\hline AN38-40 & body & N181 E199, lv. 1 & closely-spaced curvilinear engraved lines; bowl \\
\hline AN38-41 & body & N181 E198, lv. 4 & parallel brushed \\
\hline AN38-42 & body & N181 E202, lv. 4 & parallel brushed-incised \\
\hline AN38-43 & body & N183 E201, lv. 5 & $\begin{array}{l}\text { curvilinear engraved and zone of small circular } \\
\text { punctates }\end{array}$ \\
\hline AN38-44 & rim & N183 E201, lv. 3 & opposed incised lines \\
\hline AN38-45 & body & N175 E199, lv. 1 & single broad curvilinear engraved line \\
\hline AN38-46 & body & N175 E202, lv. 2 & $3+$ tool punctated rows \\
\hline AN38-47 & body & N175 E200, lv. 3 & parallel brushed \\
\hline AN38-48 & body & N184 E200, lv. 1 & parallel brushed \\
\hline AN38-49 & body & N184 E198, lv. 4 & widely-spaced curvilinear engraved lines; bottle \\
\hline AN38-50 & body & N182 E202, lv. 5 & opposed incised lines \\
\hline
\end{tabular}

We also wanted to be able to compare the chemical compositional group profiles between the Structure 1 and Structure 2 ceramic vessel sherds. Thus, of the proposed INAA sample of decorated ceramic sherds not from features ( $n=44$ sherds), 23 of them were from Structure 1 (N190-196 E198-199) and spatially archeological deposits around it, while the remaining 21 INAA sherds are from Structure 2 (N175-184 E198-200) and spatially associated archeological deposits.

To provide a broader regional context for understanding the occurrence of INAAdefined and chemically distinct ceramic wares at the Lang Pasture site, we submitted another 50 sherds for INAA from nearby and generally contemporaneous (based on earlier examinations of TARL records on known sites and associated ceramic vessel and vessel sherd collections) Caddo sites in the upper Neches River basin (see Figure 3-1). There are 10 sites in the TARL collections that have decorated sherd collections from domestic contexts on ca. A.D. 1400 and later Caddo sites in the general area of the Lang Pasture site (41AN1,
41AN2, 41AN8, 41AN14, 41AN23, 41AN32, 41CE3, 41CE4, 41CE8, and 41CE17). It is from that sample of more than 530 decorated sherds from these 10 sites that we selected additional INAA samples to develop a broader regional chemical profile of Caddo ceramic vessel sherds found in habitation contexts.

To help in developing the selection of additional INAA samples for this project from sites in the TARL collection, it was necessary to physically examine the sherd collections (albeit quickly) to make sure that suitable samples of decorated Caddo vessel sherds actually existed from these nearby sites. We were interested in examining the chemical composition of both fine wares and the range of utility wares known to be present on ca. A.D. 1400 Caddo sites in the upper Neches River basin to provide a window on the extent and direction of exchange that may have existed at that time, so we focused on assembling a proposed INAA sample from the TARL collections that have both engraved fine wares as well as incised, brushed, pinched, tool punctated, brushed-punctated, 
brushed-appliqued, brushed-incised, and neckbanded utility wares. The same kinds of stylistically diverse fine wares and utility wares are present at 41AN38, and were selected for INAA.

We proposed to do INAA on decorated sherds (both fine wares, $n=20$, and utility wares, $n=30$ ) from nine of the 10 TARL sites listed above, and we excluded 41AN2 because it did not have suitably large or stylistically diagnostic decorated sherds in the small collection available at TARL. The list of 50 decorated sherds submitted for INAA from TARL sites is provided in Table 4-4.

The second question-concerning how the trade was organized - was addressed through the use of models derived from ethnohistoric information on trade among the Caddo and ethnographic data on exchange in primitive societies. Specifically we attempted to distinguish between reciprocal exchange and redistribution by examining the types of goods being exchanged and their distribution within the site. Ethnographic data summarized by Pires-Ferreira and Flannery (1976) suggest that under conditions of reciprocity there is considerable variability in the distribution of non-local utilitarian commodities, such as lithic raw materials, between households. However, if the exchange is being controlled by a chiefly authority, there should be more uniformity in the distribution of utilitarian commodities, but marked variability in the distribution of non-utilitarian or exotic goods. The data from the features associated with the two households at the Lang Pasture site would be compared to the expectations derived from these models.

\subsection{MATERIAL CULTURE OF THE FRANKSTON PHASE CADDO PEOPLES}

The available data from what are identified as Frankston phase occupations in the upper Neches River basin suggest that there was considerable variability in the ceramic assemblages in this region. The causes of this diversity, whether temporal, cultural, or functional, are not presently clear, and this constituted one of the research questions that we proposed to address using the artifact data from the Lang Pasture site. In order to examine this question a series of comparisons were made with archeological data from other prehistoric Caddo occupations in the region that are thought to be generally contemporaneous with the Lang Pasture occupation(s). Temporal control was provided by using the available chronometric and stratigraphic information to order the assemblages. Functional variability was limited by only comparing domestic assemblages with other domestic assemblages and mortuary assemblages with other mortuary assemblages. Since the Lang Pasture site has both kinds of assemblages, this allowed a broader examination of the material culture in use by the Caddo residents of the site. Finally, contemporary assemblages (established through independent measures) from different localities within the region were compared with one another to determine if intra-regional cultural differences are a significant factor in explaining the diversity. 
Table 4-4. Sherds from Sites at TARL Recommended for INAA.

Site No.

41AN1

41AN1

41CE17

41CE17

41AN14

41AN14

41AN14

41CE8

41CE8

41CE8

41CE8

41CE8

41CE8

41AN32

41AN32

41AN32

41AN32

41AN32

41AN32

41AN8

41AN8

41AN8

41AN8

41AN8

41AN8

41AN8

41AN8

41CE3

41CE3

41CE3

41CE3

41CE3

41CE3

41AN23

41AN23

41AN23

41AN23

41AN23

41AN23

41AN23

41AN23

41AN23

41CE4

41CE4

41CE4

41CE4

41CE4

41CE4

41CE4

41CE4
Sherd Type Type of Decoration Technique

body

body

rim

body

body

body

body

rim

rim

body

body

rim

body

body

body

body

body

rim

body

body

body

rim

body

rim

rim

body

body

body

body

body

body

body

rim

body

rim

body

body

body

body

body

body

rim

rim

rim

body

body

body

body

body

body parallel incised lines

Poynor Engraved

Patton Engraved

Maydelle Incised

parallel brushed

Killough Pinched

parallel brushed

tool punctated rows

horizontal brushed

cross-hatched engraved panel

parallel brushed-tool punctated row

Poynor Engraved

Poynor Engraved

Poynor Engraved

Poynor Engraved

broad engraved line

parallel brushed-tool punctated

horizontal brushed with appliqued node

parallel brushed

parallel brushed

parallel brushed

horizontal brushed

opposed brushed

Poynor Engraved

Poynor Engraved

Killough Pinched

parallel brushed

parallel brushed/pinkware

parallel brushed-tool punctated

parallel brushed-opposed. incised

parallel brushed

parallel brushed

LaRue Neck Banded

Poynor Engraved

engraved hatched ladder

Poynor Engraved

Poynor Engraved

parallel brushed

parallel brushed

parallel brushed

Poynor Engraved

Poynor Engraved

Patton Engraved

opposed engraved lines

Poynor Engraved

parallel brushed/pinkware

overlapping brushed/pinkware

parallel brushed

overlapping brushed

Poynor Engraved 
The ceramic sherds, lithic tools, lithic debris, and other domestic artifacts in the Late Caddo component could contribute new and important archeological information on the stylistic, technological, and functional character of an artifact assemblage on a prehistoric Caddo residential settlement (Kenmotsu and Perttula 1993:SU 8, Technological Change and SU 9, Material Culture). So too could the funerary objects placed as offerings with the burials of Caddo adults and children. These remains were the means by which plant and animal resources were procured, processed, cooked, and stored, and as an integrated assemblage express the underlying nature of Caddo adaptations to the prehistoric environments of the upper Neches River basin. From these sorts of data, answers were sought in the analysis about how the Caddo peoples at the Lang Pasture site processed and cooked wild and domesticated plant foods and an assortment of animal foods, and how the ceramic vessels were actually used. Furthermore, the funerary offerings represent, in a symbolic and material sense, the items used by that individual in life, as well as goods needed to accompany the deceased on their journey to the other world.

The distinctive ceramics here, with many brushed sherds from apparent cooking vessels, also share stylistic similarities with other prehistoric Caddo settlements in northeastern Texas (as do the arrow points), all dating after ca. A.D. 1200. In combination with INAA analysis of clay pastes, the detailed examination of ceramic decorative motifs and vessel forms (cf. Kleinschmidt 1982:97-192) could shed considerable light on the nature of interaction with contemporaneous Caddo groups in the local and broader region, because it is quite probable that variations in vessel forms and design combinations "are evident within drainage segments and likely represent maps of distinct sociopolitical groups” (Early 2000:127). We are looking for temporal and spatial patterning in the kinds and frequencies of vessel forms and decorations in the local area.
Ceramics were the most abundant kind of artifact recovered during the archeological investigations at the Lang Pasture site, and our study of the material culture of Frankston phase Caddo peoples focused on this class of manufactured goods. The analysis of the ceramic artifacts, as well as our efforts to place the Caddo occupations at the Lang Pasture site in time as well as space (i.e., its relationship to other sites in the local community and to other communities), profited by specific stylistic and technological comparisons (i.e., decorative elements and motifs, use of certain kinds of tempering agents, methods of firing, etc.) that were made with Late Caddo sherd and vessel assemblages at Lake Palestine and other local upper Neches River basin sites (see Figure 3-1 and Kleinschmidt 1982:213-228).

These comparisons of the composition of upper Neches River basin Caddo decorated sherd assemblages — and the temporal orderings and cultural affiliations they imply-are based on the percentage of brushed sherds in the decorated sherd sample, the percentage of bone temper in the assemblages, the percentage of wet-paste decorations other than brushing (i.e., incised, punctated, appliqued, neck-banded, etc.), the plain/decorated sherd ratio (P/DR), and the brushed sherd/wet paste decorated sherd ratio (Table 4-5). From these comparisons, five different groups of assemblages were defined in a seriation of the Lake Palestine sites. These groups seem to reflect temporal changes due to the high frequency of Late Caddo Frankston phase decorated types, such as Poynor Engraved, Maydelle Incised, Bullard Brushed, Hume Engraved, and engraved effigy vessels, that are found in the Groups I-III sites-which includes the Lang Pasture site-and the occurrence of Early and Middle Caddo types such as Canton Incised, Dunkin Incised, Holly Fine Engraved, and Pennington PunctatedIncised in the Group IV and V Lake Palestine sites (see Anderson et al. 1974; Gilmore 1983); no Sanders phase pottery types (i.e., Sanders Engraved, Monkstown Fingernail Impressed, Maxey Noded Redware) were recovered in the Lake Palestine sites. 
Table 4-5. Comparative Sherd Assemblage Data from Lake Palestine Caddo Sites Compared to the Lang Pasture Site (41AN38).

\begin{tabular}{|c|c|c|c|c|c|c|}
\hline Site & $\begin{array}{l}\text { To. of Dec. } \\
\text { Sherds }\end{array}$ & \%Brushed & $\begin{array}{l}\text { \%bone- } \\
\text { temper }\end{array}$ & $\begin{array}{l}\text { \%Wet-paste } \\
\text { decorations }\end{array}$ & P/DR & $\begin{array}{l}\text { Brushed/Wet } \\
\text { paste ratio }\end{array}$ \\
\hline \multicolumn{7}{|l|}{$\overline{\text { GROUP I }}$} \\
\hline Debro & 311 & 80.0 & $?$ & 10.3 & 0.14 & 7.75 \\
\hline William Sherman & 525 & 75.8 & $?$ & 16.2 & 0.44 & 4.68 \\
\hline \multicolumn{7}{|l|}{ GROUP II } \\
\hline Forest Drive & 1693 & 68.6 & $?$ & 21.9 & 0.56 & 3.12 \\
\hline Halbert & 1757 & 65.8 & 2.6 & 26.3 & 0.70 & 2.51 \\
\hline Woldert & 1730 & 62.7 & 0.0 & 28.8 & 0.72 & 2.19 \\
\hline Ferguson & 4116 & 60.8 & $<1.0$ & 27.9 & 0.61 & 2.17 \\
\hline \multicolumn{7}{|l|}{ GROUP III } \\
\hline Tomato Patch & 912 & 49.2 & $?$ & 41.7 & 1.50 & 1.21 \\
\hline 41AN38 & 223 & 46.6 & 6.7 & 40.0 & 1.98 & 1.17 \\
\hline Mitchell, De & 54 & 32.1 & 0.0 & 33.3 & 1.37 & 1.50 \\
\hline \multicolumn{7}{|l|}{ GROUP IV } \\
\hline White Mule & 1404 & 18.5 & 1.5 & 63.7 & 2.61 & 0.29 \\
\hline 41HE139 & 40 & 17.5 & 8.1 & 65.0 & 2.51 & 0.33 \\
\hline \multicolumn{7}{|l|}{ GROUP V } \\
\hline Mitchell, A-C & 56 & 1.3 & 12.0 & 65.7 & 1.71 & 0.03 \\
\hline
\end{tabular}

Furthermore, it has been shown in several other ceramic studies in northeastern Texas that the proportion of brushed sherds in decorated sherd assemblages steadily increases through time, beginning after ca. A.D. 1250 (and after the principal Early Caddo occupation at the George C. Davis site), and by the late seventeenth and eighteenth centuries Caddo sites are known in the Neches and Angelina river basins (including Deshazo) where brushed sherds account for 50-90 percent of the decorated pottery.

If the sherd assemblage data from the Lake Palestine sites have chronological significance, and we suspect they do, then it is possible to seriate the decorated ceramic sherd assemblage from areas within the Lang Pasture site, and we can then independently establish their chronology and intra-site temporal relationships through radiocarbon and TL dating. Furthermore, Kleinschmidt's
(1982:Table 19) seriation of Frankston and Allen phase vessel assemblages from mortuary contexts can be refined and reworked using the vessels from mortuary contexts at the Lang Pasture site if we are able to establish through absolute dating the age of the burials at the site. This particular seriation, with three temporal groupings of Frankston phase sites with burials, is based on differences in (a) the proportions of Poynor Engraved varieties, Patton Engraved, engraved effigy vessels, Maydelle Incised, La Rue Neck Banded, and Bullard Brushed, (b) differences in the relative frequencies of common vessel forms in Poynor and Patton Engraved vessels (Kleinschmidt 1982:Figure 24), as well as (c) the occurrence of European trade goods.

The Lang Pasture ceramics were made by prehistoric Caddo peoples that lived in communities in this part of the upper Neches River basin that shared a common tradition or practice of ceramic manufacture, use, and 
decorative styles. To understand the place of the Lang Pasture Caddo settlement in the local community, as well as the scope of the local community (i.e., constituent and affiliated groups), an aspect of our proposed study of the ceramics from the site included detailed comparisons (cf. Campbell 1936; Cole 1975; Kleinschmidt 1982) of decorative motifs and vessel forms in the collections of fine wares and utility wares from other nearby and broadly contemporaneous Caddo sites in the upper Neches River basin (see Figure 3-1).

The sites shown in Figure 3-1 are those that have collections of whole vessels from mortuary contexts as well as quantities of decorated sherds from midden contexts. The collections at TARL that will be most relevant for mortuary comparisons of material culture include Mrs. J. M. Cook (41AN1, 35 vessels); J. M. Cook (41AN2, 17 vessels); E. W. Henry (41CE17, 31 vessels); R. J. Fair (41CE25, 27 vessels); Mrs. J. W. Blackburn (41CE4, 25 vessels), Fred McKee (41AN32, 21 vessels), and Omer and Otis Hood site (41CE14, 119 vessels). TARL collections of sherds from Caddo middens in the local area include the $\mathrm{E}$. W. Henry (41CE17), R. J. Fair (41CE25), J. M. Snow (41CE8), Mrs. J. W. Blackburn (41CE4), Solon Stanley (41CE3), Fred McKee (41AN32), Omer and Otis Hood (41CE14), Stephens Farm (41AN16), and Isabel-Gene Donnell (41AN14) sites.

As part of documenting the material culture of the Caddo inhabitants living at the Lang Pasture site, and characterizing the diversity in domestic and mortuary ceramic assemblages in existence around ca. A.D. 1400-1450, the following tasks were proposed for completion:

1. All vessels $(n=31)$ recovered from the 2006 excavations at the Lang Pasture site will be analyzed and photographed. A Vessel
Recordation form will be completed for each vessel; an example of the form is included below. This will include Vessels 1-7 (Feature 8); Vessel 1-2 (Feature 76B; Vessel 1, Feature 76C; Vessel 1, Feature 76D; Vessel 1-2 (Feature 88); Vessel 1-2 (Feature 91); Vessel 1-2 (Feature 92); Vessel 1-9 (Feature 93); and Vessel 15 (Feature 94). The vessel recordation form includes attributes that address the morphological, technological/functional, and stylistic character of the prehistoric Caddo pottery vessels from the Lang Pasture burials. This information can be readily compared to other Caddo pottery vessel assemblages from sites in the upper Neches River basin as well as Caddo pottery vessel assemblages analyzed by Prewitt \& Associates, the Caddo Nation of Oklahoma, and Archeological \& Environmental Consultants, LLC from contemporaneous Caddo sites in other parts of East Texas.

2. Photographic images of each of the vessels would be obtained as part of the comparative analysis of upper Neches River basin Caddo ceramic vessel assemblages. Images of the elbow pipes from burials at the Lang Pasture site would also be obtained during the analysis effort to be able to make stylistic and morphological comparisons between clay pipes found on contemporaneous Caddo sites in the upper Neches River basin. 
FEATURE:

\section{Vessel Recordation Form, Lang Pasture Site (41AN38) Collection}

VESSEL NO.:

NON-PLASTICS:

VESSEL FORM:

CORE COLOR:

INTERIOR SURFACE COLOR:

EXTERIOR SURFACE COLOR:

WALL THICKNESS:

INTERIOR SURFACE TREATMENT:

EXTERIOR SURFACE TREATMENT:

HEIGHT:

ORIFICE DIAMETER:

DIAMETER AT BOTTOM OF RIM OR NECK:

BASE DIAMETER:

ESTIMATED VOLUME:

DECORATION:

TYPE:

3. We proposed to examine a total of 284 prehistoric Caddo ceramic vessels in the Texas Archeological Research Laboratory at The University of Austin (Table 4-6). A Vessel Recordation form would be completed for each of these vessels. They include all the vessels from the following sites located near to the Lang Pasture site which are judged relevant from previous research and limited examination of the available records at TARL during the test excavation phase of the Lang Pasture site project:

4. Photographic images were also obtained of all the vessels listed in Table 4-6, along with any examples of clay pipes from these sites. Two to four images were taken of each vessel to capture the vessel form and decorative motif (if the vessel is decorated). 
Table 4-6. Caddo Vessels at TARL Proposed for Analysis.

\begin{tabular}{llc}
\hline Site & No. of Vessels \\
\hline 41AN1 & 33 \\
41AN2 & 17 \\
41AN32 & 23 \\
41CE4 & 24 \\
41CE14 & 118 \\
41CE17 & 35 \\
41CE25 & 27 \\
41HE7 & 2 \\
41HE55 & 2 \\
41HE75 & 3 \\
\hline
\end{tabular}

5. To further the comparison of the diversity in Frankston phase ceramic vessel assemblages in the upper Neches River basin, we proposed to examine TARL and Archeological \& Environmental Consultants, LLC file records for the further compilation of records, vessel drawings, and photographs for another 284 vessels from 25 generally contemporaneous Caddo sites in the upper Neches River basin (Table 4-7). These would provide comparative information for use in the analysis of the Lang Pasture site vessels and the detailed analysis completed on 284 other vessels at TARL. For further comparative studies of prehistoric Caddo vessels and decorative styles in the upper Neches River basin, we also drew upon the previous analyses of whole vessels completed by T. N. Campbell in 1936 ( $n=311$ vessels from seven sites in Anderson and Cherokee counties) and Ulrich Kleinschmidt's 1982 analysis of 561 whole vessels from sites in Anderson, Cherokee, Henderson, and Smith counties in the upper Neches River basin.
6. Another aspect of the analysis of Frankston phase material culture employing ceramic wares was to examine decorated sherd collections from TARL. These collections came from 10 sites in Anderson and Cherokee counties in the upper Neches River basin, near to the Lang Pasture site (Table 4-8). These sherds are from habitation deposits rather than from mortuary contexts, thereby facilitating comparisons with the more than 2300 decorated sherds from habitation deposits at Lang Pasture. Generally these sites are believed to be contemporaneous with the Lang Pasture site because they contain (from an examination of TARL site records) brushed sherds and Poynor Engraved sherds; both kinds of decorated pottery that are well represented in the decorated ceramic vessel sherds from the Lang Pasture site. A total of 539 sherds and 10 decorated pipes/pipe sherds were proposed for comparative analysis as part of this effort. 
Table 4-7. Vessels Proposed for Examination from Collections at TARL.

\begin{tabular}{lc}
\hline Site No./Name & No. of Vessels \\
\hline Buddy Jones Collection/Smith Co. & 19 \\
41AN8 & 5 \\
41AN14 & 14 \\
41AN16 & 2 \\
41AN18 & 2 \\
41AN23 & 1 \\
41AN34 & 21 \\
41AN39 & 9 \\
41AN44 & 12 \\
41AN53 & 4 \\
41CE3 & 21 \\
41CE6 & 8 \\
41CE8 & 1 \\
41CE12 & 58 \\
41CE15 & 3 \\
41CE23 & 8 \\
41HE7 & 8 \\
41HE55 & 4 \\
41HE75 & 9 \\
41HE114 & 21 \\
41SM77 & 39 \\
41SM93 & 14 \\
41SM355 & 1 \\
\hline
\end{tabular}

Table 4-8. Sherd Collections at TARL Proposed for Analysis.

Site No.

41AN1

$41 \mathrm{AN} 2$

41AN8

41AN14

41AN23

41AN32

41CE3

$41 \mathrm{CE} 4$

41CE8

41CE17

41CE25
No. of Analyzed Sherds

68

42

108

12

35

55

60

75

81

3
Pipes/Pipe Sherds

Totals

539

10 
The analysis consisted of sorting decorated rim and body sherds by decorative technique (i.e., brushing, incising, engraving) and decorative element (i.e., cross-hatched incised; negative engraved ovals; horizontal brushing on the rim) (see Chapter 6, this volume), and making sketches of distinctive decorative motifs for detailed comparisons. Also noted in the analysis of these sherds from domestic Caddo contexts were the number of decorated sherds tempered with bone, as the use of bone in the upper Neches River basin may have both temporal and social group significance.

The goal was to determine which sites-or groups of Caddo sites-had the highest degree of sharing of material culture (particularly decorative motifs and certain distinctive vessel shapes) with the Lang Pasture site. The extent of sharing of material culture would provide a measure of local social/kinship ties and the intensity of social group interactions.

The chipped stone tools, the ground stone tools, and the lithic debris recovered at the Lang Pasture site represent the discarded remains of tool manufacture, maintenance, and use activities, but whether they are the product of one or multiple Caddo occupations was not clear. The clustering (or absence of clustering) of the radiocarbon and TL dating of features and ceramic sherds in archeological deposits was used to establish if there was a single Caddo component present at the Lang Pasture site. If the absolute dates indicated that there were multiple Caddo components, an effort would be made to sort the diagnostic lithic artifacts into different assemblages for comparison of tool use and raw material use.

The samples of tools and debris appear to be small, but this seems to be a typical situation in northeastern Texas Late Caddo residential settlements, where Caddo groups apparently relied heavily on wooden and bone tools for many activities. Other contributing factors that may account for the low density of lithic artifacts include the limited amount of naturally occurring knappable stone in this part of the upper Neches River basin, and the technological organization of the Caddo peoples living at the site (i.e., the production of arrow points and flake tools). The sample sizes of tools and debris should allow ready inter-site comparisons between Lang Pasture and other contemporaneous sites in the kinds of tools made and used during the Late Caddo occupation, particularly the proportions of expedient vs. formal tools (cf. Tomka 2001). Furthermore, the lithic debris sample should be sufficient to characterize the manufacturing and tool refurbishing/maintenance activities that occurred there, as well as establish differences in the relative proportions of local vs. non-local lithic raw materials in the tools and debris in this component.

\subsection{The Health AND Diet of the CADDo at the LANG PASTURE SITE}

The physical anthropological study of the skeletal remains from the burials recovered during the test excavations and data recovery at the Lang Pasture site focused on the noninvasive identification of skeletal pathologies, degenerative diseases and infections, and evidence of nutritional stress in children and adults, along with the presence and frequency of caries. This research attempted to address a variety of questions about the Caddo group living at the Lang Pasture site, including: (a) was their diet nutritionally adequate, (b) what were local and regional population densities at the time, and how common were infectious diseases, (c) how heavy were their work loads, and (d) whether there were episodes of chronic stress that can be related to work load and lifestyle (see Rose et al. 1998:121).

Given the possible Late Caddo age (ca. A.D. 1400-1450) of burials from the Lang Pasture site, it is significant that infectious disease rates in the Caddo archeological area appear to have increased after ca. A.D. 1200 in most regions then remained relatively stable through the seventeenth century. In Caddo populations along the Red and Ouachita rivers where intensive maize-based agricultural economies had developed, a significant increase in infections occurred only after A.D. 1400 (Perttula 1996:321). This apparent 
association between intensive maize consumption and infectious disease rates is likely a product of higher population densities in these agricultural economies (Rose et al. 1998). If such an association should be present in a burial population at Lang Pasture in Late Caddo times, this would constitute compelling evidence (together with other archeological evidence) for the development of agricultural economies in this part of northeastern Texas.

With the study of the human remains from the Lang Pasture site burials, we can also examine demography, nutrition, and stress in conjunction with the archeological study of subsistence, settlement, and social status patterns evidenced at the site. Specifically, we proposed to evaluate the hypothesis that the population from the Lang Pasture site had a diet with a relatively low dependency on maize and that they also had a low rate of infectious disease. Very little is known about the bioculture of the Frankston phase Caddo peoples. Without access to local and regional information on Caddo health and diet, attempts to properly interpret the bioarcheological information from Lang Pasture would be hindered.

The Neches River drainage basin represents the westernmost part of the prehistoric Caddo traditional homeland in Texas. This region appears to be biologically and environmentally distinct. It lies mostly in what Burnett (1990) refers to as the Pine Forest. Non-metric data on teeth do suggest that the southern Caddo form a distinct and homogenous biological population (Lee 1999).

What is most apparent about the Neches River basin in general, and the Frankston phase in particular, is that it is poorly documented from a bioarcheological perspective. The bestknown site in the region is the Early Caddo period George C. Davis site (41CE19), located some miles downstream on the Neches River from Lang Pasture, a mound center with a village area and numerous poorly preserved burials. In Burnett's (1990) synthesis of the region, although small in the number of burials known and studied, and also poorly preserved, she suggested two bio-cultural factors that contrast with other Caddo data on health and diet. She noted a low rate of infection in contrast to Wilson's (1998) findings for the Caddo archeological area as a whole. Of the four adults in Burnett's (1990) synthesis from the Neches River basin, none exhibited adult stress in the form of osteoarthritis. Information on childhood stress was absent.

In contrast to the Caddo archeological area as a whole, Burnett (1990) also suggested a lack of dependence by the Caddo on maize in the Neches River basin, despite its presence in archeological features. Stable isotope data would help elucidate this inconsistency and we proposed that this should be performed on any additional human remains in burials encountered at the Lang Pasture site as well as other related sites in the upper Neches River basin.

We proposed to develop a bioarcheological understanding of the prehistoric Caddo human remains from the Lang Pasture site. We used a population approach that incorporated an array of skeletal evidence into a regional archeological framework to better understand how the human remains from the burials at Lang Pasture can contribute to our understanding of the Frankston phase and prehistoric Caddo culture at its southern periphery. First, the human remains recovered from the Lang Pasture site were analyzed in accordance with bioarcheological standards (cf. Buikstra and Ubelaker 1994) that allow for comparison with other sets of Caddo burials and human remains. Second, regional comparisons of the skeletal materials from other nearby Caddo sites of various ages with those from Lang Pasture maximized the interpretive potential of the burials from this site by creating a broad set of information comprising materials from sites within the Neches River basin, and specifically from Frankston phase sites as well as earlier and later Caddo groups historically related to them. And third, by looking at the health and diet of the Frankston phase Caddo peoples specifically, and placing the findings from 
Lang Pasture in its regional context, both geographic and temporal means for studying the bio-cultural processes of Caddo diet and health at the Lang Pasture site were possible.

We had four specific goals for the bioarcheological analysis of the human remains from burials at the Lang Pasture site. They included: (1) identifying the human remains at the site. These data would be collected and recorded on standardized data sheets (see Buikstra and Ubelaker 1994); (2) evaluating and synthesizing comparable information from other broadly contemporaneous Caddo sites in the region. To maximize the amount of information available about the health and diet of the Caddo peoples that lived at the Lang Pasture site, its context needed to be determined in relation to other Frankston phase and Neches River Caddo sites. Accepted standardized analysis criteria were applied to human remains not yet published and housed at the Texas Archeological Research Laboratory (TARL); (3) testing Burnett's (1990) assertions that the Neches River Caddo had little infectious disease and ate less maize than other Caddo populations; and (4) summarizing our findings in the final published report on the data recovery investigations at the Lang Pasture site.

The first objective of the study of human skeletal remains from the Lang Pasture site was to provide comparable information for researchers and the Caddo Nation of Oklahoma to utilize for other studies or other purposes. One problem with past bioarcheological reports on the prehistoric Caddo people is the lack of comparability of collected information sets. For this reason, since the mid-1990s bioarcheological information has been collected in a uniform manner so as to allow comparison with other sites. The remains recovered were examined following modern, standard osteological techniques outlined in Buikstra and Ubelaker (1994). The information gained from the burial(s) was recorded on standard osteological data forms developed to facilitate site collection comparison. The data reported on these forms provided the information used for analyses of this material in the second and third objectives listed earlier in this section.

The second objective was to overcome the difficulty created by the small number of burials represented at the Lang Pasture site by incorporating the new information from it with skeletal materials from 12 Caddo sites representing approximately 46 individuals housed at TARL (Table 4-9). Although the general age of these burial samples was known, we also selected five samples for radiocarbon dating to further refine the temporal context of these Caddo burials relative to the probable Frankston phase Caddo occupation at Lang Pasture. Together, this information provided a context for the bio-culture of the Lang Pasture site in terms of other Frankston phase sites and earlier and later Neches River basin Caddo sites. Without this broader synthesis, the information obtained from the study of the Lang Pasture burials and human remains would be difficult to use for meaningful interpretations about the Caddo people's health, nutrition, and demographics. Bioarcheological information previously collected using standard methodologies outlined above was used in this analysis. When such data was not available, we proposed to gather new information about the human remains in the TARL collections.

The third objective would be accomplished by using published information from Angelina and Sabine River basin Caddo populations (cf. Burnett 1990; Lee 1999) to compare distinct populations in these areas with the Neches River Caddo. The analysis of new information on Neches River basin skeletal remains, and the synthesis of published information, would address issues concerning the state of preservation of the remains, the demographic structure of the population, the body size and sexual dimorphism of the prehistoric Caddo population that resided in the Neches River drainage, an evaluation of the population's diet and health, and an assessment of their biological affinity to other populations within the southern Caddo area of Texas. 
Table 4-9. Caddo Sites in the Neches River Basin with Human Remains (Collections are at TARL).

Early to Middle Caddo period sites $(\mathrm{n}=12)$

41AN56 $(\mathrm{n}=1)$

41CE19 $(\mathrm{n}=10)$

41CE290 $(n=1)$

Late Caddo period sites (Frankston phase) $(\mathrm{n}=19)$

41AN34 (n=1)

41AN54 $(\mathrm{n}=4)$

41CE3 $(n=2)$

41CE4 $(\mathrm{n}=5)$

41CE15 $(\mathrm{n}=2)$

41CE17 $(n=5)$

Historic Caddo period sites (Allen phase) $(\mathrm{n}=15)$

41AN21 (n=1)

41CE6 $(\mathrm{n}=2)$

41CE12 $(\mathrm{n}=12)$

Establishing an inventory of the individuals in both the site and regional assemblages of Caddo burials and human remains was a prerequisite to osteological analysis. It served as a description of the remains that were present and was useful in the assessment of their preservation; mortuary patterns; bioturbation and other postmortem disturbances; excavation conditions and techniques; and soil conditions. Part of the inventory process was the investigation of taphonomy because it was essential to understand the processes of destruction and dispersal of bones, as well as an assessment of the role of humans as agents causing the modification, destruction, and dispersal of human skeletal remains at archeological sites. Demographic analysis looks at the sex and age profile of a population and is useful in determining their overall fitness and adaptation to specific environments as well as cultural patterns of gendered behaviors.

Stature and robusticity are known to be under genetic control to some degree; but it is also known that stature and body size are strongly influenced by the quantity and quality of a particular diet as well as the health of the individual. The collection of non-metric data on teeth and bone would aid reconstruction of genetic relationships within the region and allow comparisons with other locations outside the Neches river basin (e.g., Lee 1999).

In addition to studying the subsistence strategies of the Caddo peoples that lived at the Lang Pasture site from preserved animal and plant remains, in certain circumstances, stable carbon and nitrogen isotope analyses of human remains were requested to more accurately determine the dietary composition of the prehistoric Caddo groups living at Lang Pasture. Such analyses would be able to establish whether they had non-maize consuming diets, diets with low levels of maize consumption, or they had diets where maize was the principal source of carbohydrates and protein (see discussion by Hart 1999:169). They would also help to establish when cultigens were adopted, or at least were intensively used, as well as the rate of adoption of maize agriculture in the region (see Perttula 2005:Figure 11-20). Radiocarbon dates directly on maize samples from northeastern Texas Caddo sites are dated as 
early as A.D. 783-1021 (Rogers and Perttula 2004:Table 95), but most of the samples date after A.D. 1200. Two Late Caddo sites near Lake Palestine have calibrated 2 sigma age ranges on maize samples of A.D. 1390-1480 (41HE139) and A.D. 1440-1640 (41HE343) (Cliff et al. 2004: Tables 14 and 19).

The diet of any population is a reflection of cultural and natural environments. A maizeintensive diet is one aspect of Caddo diets that was not seen among their hunter-gatherer predecessors. As a hallmark of Caddo culture, it was important to detail the relative contribution of maize to the diet of Frankston phase individuals that lived at the Lang Pasture site. It was also important to test Burnett's (1990) finding of a low maize diet in the upper Neches River basin. To assess diet, most bioarcheological studies focus on dental remains and/or stable isotope analysis. Cariogenesis, dental attrition, antemortem tooth loss, and abscessing primarily reflect diet and food processing strategies. Throughout the Americas increased reliance on maize has been correlated with increased dental caries. Stable isotope analysis has long been used to examine trophic levels of organisms and specific dietary contributions from maize, legumes, and proteins. Combined with dental evidence, stable isotope analysis can flesh out significant parts of the Frankston phase diet not reflected in teeth alone. This study proposed to perform stable isotope analysis on individuals of the known Caddo archeological burial population available for study at TARL (see Table 4-9), thus making it possible to determine if maize was equally important in the southern Caddo diet as it was in the diets of other Caddo populations.

Paleopathology examines the rate of infectious disease, trauma, congenital disorders, and childhood and adult stress in a population. We examined the human remains for evidence of infectious disease, which is often an indicator of population aggregation. Trauma can be the result of violence or accident. Childhood mortality and physiological stress is often used as an indicator of a culture's overall adaptive success. We considered each of these factors to assess the overall health of the Lang Pasture population in comparison to other Caddo groups that were living in the Neches River basin at about the same time.

In summary, the proposed bioarcheological analyses would establish the basis for interpretation of the Lang Pasture site human remains that would be critical to an overall understanding of the prehistoric Caddo occupation of the site. The study was a threepart process: information collection, evaluation and synthesis, and comparison. The preservation of information for future researchers and the Caddo Nation of Oklahoma required the collection of bioarcheological data in accordance with established standards (Buikstra and Ubelaker 1994). To enhance the information that could be collected from the small number of burials at Lang Pasture, regional information on Caddo populations from the Neches River drainage basin was key to properly interpreting the cultural and archeological significance of the Lang Pasture human remains. This information was then compared geographically and temporally with other Caddo sites in the region to understand how the Lang Pasture site fit into its regional context. This study would test the hypothesis that the Caddo population from the site had a diet with a relatively low dependency on maize and had a low rate of infectious disease.

\subsection{FRANKSTON PHASE MORTUARY PRACTICES}

The mortuary features from the Lang Pasture site had the potential to contribute important information on the social differences that existed among this prehistoric Caddo population. The specific research question to be addressed was whether the burials from the site provided evidence of social differences that may have existed within or between sites in the region. The examination of the complexity of mortuary behaviors (i.e., the energy invested in the mortuary rituals, the amounts of grave goods placed with the dead, the kinds of grave goods placed with the dead, and the locale where the dead were buried) 
can contribute new information on the mortuary treatment of Caddo agricultural communities in Late Caddo times. This examination would be made even stronger by turning our attention to the size and organization of other generally contemporaneous Caddo cemeteries in the upper Neches River basin (see Story and Creel 1982:33), and building on the basic conclusions from current mortuary information that Caddo groups here lived in "habitation sites [that] were usually not occupied for long periods of time...the population associated with any one settlement was relatively small... and most statuses were not ranked” (Story and Creel 1982:33).

One topic to be examined concerned whether individual interments could be associated with specific households at the Lang Pasture site. This would be done by determining the placement of the individuals relative to households, or by establishing through radiocarbon and TL dating a specific chronological relationship. The kinds of funerary objects associated with the interments and the energy invested in burial (i.e., shaft tombs versus individual extended grave pits) would provide the information to examine the organization of the cemetery by status or rank. So too would the sex and age of the individuals, and the boundaries and orientation of formal cemetery areas, provide information on Caddo burial practices.

Mortuary data from prehistoric Caddo sites in the upper Neches River basin is relatively abundant and competently documented, and well suited for comparative analyses with the burials from the small cemetery at the Lang Pasture site. The vast majority of the available mortuary data derives from University of Texas excavations in the 1930s (Jackson 1931, 1933b; Pearce and Woolsey 1935; Woolsey 1935a-n; see also Cole 1975:337-357; Kleinschmidt 1982). More limited Caddo mortuary data are available from the Attaway site (41HE114; Shafer 1981) and Vanderpool (41SM77).

These mortuary data are sufficient to determine the following: (1) the location of cemeteries within sites and in relationship to habitation areas and sources of water; (2) the age of many of the burials, and perhaps the sex as well (employing the results of the present analysis of human remains in the TARL collections from the upper Neches River basin); (3) the kind and quantity of grave goods placed in most of the burials, including information on the placement of any goods of non-local origin; and (4) the orientation and internal arrangement of burials within cemeteries. From these data, combined with comparable mortuary data obtained from the analysis of the Lang Pasture site burials, we hoped to be able to evaluate the hypothesis posed by Story and Creel (1982:33) that upper Neches River basin Caddo populations living in this area around and after ca. A.D. 1400 did not have a social hierarchical character, when contemporaneous Caddo groups to the north (among Titus and McCurtain phase groups) or east (Texarkana and Belcher phase Caddo groups living on the Red River) did.

There were 31 roughly contemporaneous prehistoric Caddo cemeteries in the upper Neches River basin that were the focus of our investigation of the character of Caddo mortuary practices (Table 4-10). Documentation on these cemeteries was available in the records at TARL as well as Cole (1975), Kleinschmidt (1982), and Shafer (1981). 
Table 4-10. Caddo Sites in the Upper Neches River Basin with Excavated Burials (Collections are at TARL).

\section{Site No.}

$41 \mathrm{AN} 1$

41AN2

41AN8

$41 \mathrm{AN} 13$

41AN14

41AN16

41AN18

41AN21

41AN23

41AN26

41AN32

41AN34

41AN39

41AN44

41AN53

41CE3

41CE4

41CE6

41CE8

41CE12

41CE14

41CE15

41CE17

41CE23

41CE25

41HE7

41HE55

41HE75

41HE114

41SM77

41SM93
Site Name

Mrs. Cook

J. M. Cook

Cecil

Jowell

Donnell

Stephenson Farm

Beard

Emma Owens

Rose Daniels

Patton

McKee

Freeman

E. E. Daly

Tucker

Ballard

Stanley

Blackburn

Hackney

Cecil

Allen

Omer and Otis Hood

Reagor

Henry

John Bragg

Fair

A. S. Mann/Riley

L. B. Miller

DeRossett Farm/Watkins

Attaway

Vanderpool
No. of Reported Burials

6

3

$3+$

$2+$

2

1

1

1

1

3

4

4

1

$3+$

2

3

5

2

$1+$

18

22

2

11

2

11

1

1

2

2

2

$3-4$
From this information, we could examine the question of whether there was a social hierarchical character to the households within the settlement and the larger community, by comparisons with other Late Caddo family cemeteries with similar information in the upper Neches River basin (see Cole 1975; Kleinschmidt 1982; Shafer 1981; Story and Creel 1982, and reports on file at TARL written in the 1930s), as well as with elite burials in Caddo mound centers (i.e., the George C. Davis site, see Story 2000) or lesser centers. The detailed examination of ceramic styles and engraved rim motifs on the vessels placed as funerary objects would also provide information to establish if the social affiliations of the household(s) at the site related to geographically distinct sociopolitical groups. 


\subsection{PALEOENVIRONMENTAL CONDITIONS AND HUMAN ADAPTATION}

A final research issue concerned the character of the environment in the vicinity of the Lang Pasture site at the time of the Caddo occupation and the human impact on that environment due to forest clearance, burning, and the planting of agricultural fields. The question to be addressed is, to what extent did the Caddo population of the Lang Pasture site and the surrounding region affect the vegetation patterns? Did the agricultural practices of the Caddo degrade the local and regional environmental setting?

Palynological analysis of sediment cores can provide information on the makeup of the local vegetation, and in conjunction with radiocarbon dating, can be used to assess change in vegetation patterns through time. This would provide a baseline of paleoenvironmental data for better understanding Caddo subsistence strategies and dietary patterns reconstructed from other data, and it could serve as a measure of the impact of the Caddo on their environment.
Current models of Caddo settlement systems in the upper Neches River basin suggest that most of the population was dispersed in small farmsteads or hamlets. If that interpretation is correct, then Caddo impact on the vegetation in the vicinity of these settlements and the cumulative impact of the regional population may have been very limited. The proposed pollen analyses would evaluate this question by comparing percentages of arboreal and ruderal or weed pollen levels before and during the Caddo occupation of the Lang Pasture site.

Three vibracores were collected during the archeological fieldwork: Cores 1 and 3 was from Caddo Creek about $1.6 \mathrm{~km}$ north of the site and Core 2 came from a spring-fed drainage adjacent to the site. We proposed to analyze 42 pollen samples from the three cores, focusing on the period prior to and during the Caddo occupation (Table 4-11). We also proposed to submit 14 radiocarbon samples for analysis. These would be submitted in a phased approach, with an initial group of seven followed later by a second group whose location would depend on the results of the first group (Table 4-12).

Table 4-11. Pollen Samples Proposed for Analysis from Cores Collected in the Vicinity of the Lang Pasture Site.

\begin{tabular}{ll}
\hline Core No. & Sample Depths $(\mathrm{cm})$ \\
1 & $10,30,85,130,150,240,270,280$ \\
2 & $0,2,3,5,6,7,10,14,18,23,26,27$ \\
3 & $0,10,20,30,40,55,65,75,105,115,125,160,165,170,175,180,190$, \\
& $200,210,220,230,240$
\end{tabular}

Table 4-12. Radiocarbon Samples Proposed for Analysis from Cores Collected in the Vicinity of the Lang Pasture Site.

\begin{tabular}{ll}
\hline Core No. & Sample Depths (cm) \\
1 & 150 \\
2 & $0,25,35$ \\
3 & $85,185,225$ \\
\hline
\end{tabular}




\subsection{FieLd METHODS}

The hand excavations at 41AN38 were to consist of contiguous sets of $1 \times 1 \mathrm{~m}$ units in a large block excavation approximately 160 square meters in size. The block excavations would be of an appropriate size in the remaining undisturbed parts of the site in the SH 155 right-of-way to insure sufficient horizontal and vertical coverage of the core of the site to uncover features and associated artifact concentrations, and to obtain representative samples of the artifact classes and plant and animal remains known to be present.

The block and units were to be laid out to be oriented to grid north (see Lohse 2004:Figure 3.24), paralleling the SH 155 right-of-way fence, and the units will be excavated with flat shovels and trowels using a combination of natural and arbitrary $10 \mathrm{~cm}$ levels within sediment zones (if such are readily recognizable). The levels would conform to the slope of the modern ground surface and conform to the sediment zones recognized in the deposits. The sediment matrix will be screened through 1/4-inch hardware cloth to recover buried archeological materials, including macro-plant remains. Using balks, the units were to be excavated in sequence to consistent depths through the sediment zones, or to the bottom of sediment zones, to broadly expose any artifact concentrations and features that may be present at the same depths. Only after the units in the block were brought to similar depths, and unit/block floors troweled and artifacts/features mapped, would the units again be excavated to the next level or sediment contact zone.

The units were to be assigned unique numbers in consecutive order by block and site, and information on their artifact content, the densities of gravels and natural concretions, the sediments, modern and cultural disturbances, and the location (and top and/or bottom elevations) of any artifact concentrations will be noted on unit level forms for each level in the $1 \times 1 \mathrm{~m}$ units. The floor of each unit in the blocks were to be cleaned and troweled at the base of each level to determine if cultural disturbances are present, and also to map modern disturbances and/or any in situ artifacts. The handexcavated units in the block were to be excavated to approximately $40 \mathrm{~cm}$ bs by shovel and trowel, and then screened through 1/4-inch wire mesh, then shovel skimmed to at least $50 \mathrm{~cm}$ bs. At these depths, sufficient color and textural contrasts existed in the sediments to ensure recognition of features in plan view. Below this depth (see Table 3), the artifact densities were so low (less than 12 percent of the sherds, 20 percent of the lithic debris, and 10 percent of the lithic tools) that it would not be practical to recover them in a controlled manner. Moreover, these artifacts likely had been displaced by bioturbation and other disturbance processes, thus no longer having any contextual integrity.

Fine-screen samples (1/32-inch hardware cloth) could be obtained in $40 \times 40 \mathrm{~cm}$ columns in selected $1 \times 1 \mathrm{~m}$ units (and selected 5 or $10 \mathrm{~cm}$ levels within those units) only if midden deposits with concentrations of artifacts, fauna, and plant remains were identified in the excavations. These would be employed to more systematically retrieve micro-artifactual remains such as charred hickory nutshells, burned clay and daub, pipe sherds, as well as smaller faunal elements.

Plan views were to be drawn at the bottom of each arbitrary level, and concentrations of artifacts, features, or disturbances were to be plotted by depth and plan when they were encountered. Profile views were to be drawn of at least one wall of the block units at the conclusion of the excavations. The profiles would be drawn to delineate different soil zones in the sediments, and would accompany descriptions obtained on the character of the sediments (i.e., texture, color, inclusions, disturbances) in the profiles. The zones were considered to be any regular or irregular layer of sediments that can be characterized as distinct from surrounding sediments by some particular property or content (such as texture, compactness, color, etc.). Additional profiles 
would be obtained from the standing balks and outer block walls. Soil samples from sediment zones would be obtained for more detailed analysis of particle size, organic matter, and organic carbon from each zone.

When features were identified in the hand excavations, they would be carefully troweled to accurately define them in plan or profile views, and for mapping purposes. After each feature was drawn and assigned a unique number (beginning with Fea. 12, since Fea. 111 have already been assigned by Lohse [2004] in the test excavations) and recorded on a Feature Record form, its depth below surface was to be established, and the surrounding sediments and possible feature fill described. The feature would be cross-sectioned along north-south or east-west axes to determine if the stain or disturbance was of cultural origin rather than a root, tree stump, or a modern disturbance. If the profile indicated that the stain or disturbance was of apparent cultural origin (i.e., the stain has a rounded or flat bottom with regularly defined walls; the stain contains midden deposits, charcoal or bone flecking, etc.), the profile of the feature would be drawn, and then the cultural fill would be removed from the feature for flotation analysis and/or fine-screening (depending upon the volume of the feature). In most cases, approximately 50 percent of the feature matrix was to be screened through 1/16-inch fine screen, with the remaining fill saved for flotation processing, or for other special samples. As mentioned above, special samples were to include bulk sediments for flotation and fine screening, and smaller samples of feature sediments were to be employed for phytolith analyses (if warranted by enhanced preservation conditions of specific features), or for the collection of charcoal or other organic materials for macrobotanical identifications and possible radiocarbon dating. If charred plant remains were visible during feature excavation, samples for radiocarbon analysis were to be taken from the feature fill at that time, and if there were distinct zones of fill, or concentrations of carbon-rich sediments in the feature, then separate samples for radiocarbon dating or other analyses would be obtained.

With respect to field methods in the two heavy machine-scraped areas, the scraping was to remove the sandy sediments in $2-3 \mathrm{~cm}$ thick levels until just above the clay B-horizon, or until possible features or stains were exposed. These excavations were to be continually monitored by a team of two archeologists, who periodically would use a flat shovel and trowel to examine possible stains, soil discolorations, and cultural disturbances that were exposed during the initial scraping. These possible cultural features were to be marked with a pin flag for further investigations, at which point the heavy machinery would be moved over to continue scraping an adjacent area until it was at the same depth, or slightly lower, to maintain a generally flat surface across the entire scraped area. When the general depth at which possible cultural features were present was established, the blade on the heavy machinery will be slowly lowered to the scraped area, then drawn back across the excavations, removing about $1 \mathrm{~cm}$ of soil at a time, to create a cleaned and flat excavation surface that could be quickly shoveled and troweled in the final identification of features.

The investigated areas were to be cleaned with a flat shovel and trowel at least twice under different visibility conditions to ensure that possible feature stains were confidently identified. Cross-sections of the soil discolorations were to be employed to determine if the stain was of natural or cultural origin. Cultural features identified in the heavy machinery scraping work would be assigned a unique number and recorded on a Feature Record Form, and then mapped using a Total Data Station or other mapping equipment. The recording, profiling, sampling, and excavation of these features was to proceed in the same manner as described above for the features encountered in the $1 \times 1 \mathrm{~m}$ block units. 


\subsection{LABORATORY METHODS AND ANALYSIS}

The recovered archeological materials were to be initially processed in a field laboratory established near the project area. These materials were to be washed, dried, and catalogued by provenience, and the matrix from selected feature samples would either be fine-screened or subjected to flotation at the field laboratory to recover micro-botanical and faunal remains. The initial sorting of materials into broad classes of artifacts (i.e., ceramics, lithics, bone, charred plant remains, etc.) was also to be accomplished in the field laboratory, while the detailed analysis of the ceramics and lithic artifacts was to be conducted in the offices of Coastal Environments, Inc., or Archeological \& Environmental Consultants, LLC. Faunal, paleobotanical, and physical anthropological analyses were to be completed by Coastal Environments, Inc., and project consultants.

Based on artifact densities from the $1 \mathrm{x} 1 \mathrm{~m}$ units in the test excavations at 41AN38, and the size of the proposed data recovery effort, the following artifact sample size from the 1/4-inch matrix was expected from the block excavation work: approximately 5100 potsherds, 34 ceramic pipe sherds, 80 chipped and ground stone tools, and 5000 pieces of lithic debris. Almost 33 percent of the sherds would be decorated (based on the plain to decorated ratio of 1.98 from the test excavations), suggesting that about 1700 decorated sherds would be recovered from the block units, not including ones found in features. The sample of decorated and plain sherds would be large enough to obtain a representative sample of the kinds and varieties of decorated and plain vessel sherds in a Late Caddo ceramic assemblage in the upper Neches River basin, and also sufficient to obtain a reliable plain-to-decorated sherd ratio for comparison with other nearby prehistoric Caddo sites, (see Table 1).

The ceramic analysis from 41AN38 was to be conducted by Dr. Perttula and was to emphasize the acquisition of information on the stylistic and technological character of the prehistoric Caddo ceramic assemblage. The principal research issues included first refining the age and intra-site chronological relationships of the ceramics at the site, followed by establishing the occupational history of the site as reconstructed from ceramic stylistic analyses (particularly decorative elements and motifs), and determining structure-feature relationships through time. These same stylistic analyses were to be employed to answer broader questions of the social and cultural affiliation of the Late Caddo groups in the upper Neches River basin, through stylistic and vessel morphological comparisons with collections from other broadly contemporaneous Caddo sites in the local area (see Figure 1). These include TARL collections of sherds and whole vessels (see Campbell 1936) from the bestknown Caddo sites in the local area, building on the comparative analyses already completed by Campbell (1936), Gilmore (1983), and Kleinschmidt (1982): the Mrs. J. M. Cook (41AN1), J. M. Cook Farm (41AN2), Fred McKee (41AN32), Mrs. J. W. Blackburn (41CE4), J. M. Snow (41CE8), Omer and Otis Hood (41CE14), E. W. Henry (41CE17), and R. J. Fair (41CE25) sites, and whole vessels from 41SM77 in the Buddy Calvin Jones collection (see Figure 1). We were also concerned with determining the character and frequency of the utility ware vessel forms in any prehistoric Caddo households and components at the site, and how their composition at the assemblage level may be related to (and influenced by) the postulated intensification of maize consumption by Late Caddo groups in northeastern Texas (see Study Unit 9 in Kenmotsu and Perttula 1993:140).

The stylistic analysis of the 41AN38 ceramics was to focus on the definition of recognizable decorative elements in the fine wares (i.e., the engraved and red-slipped vessels, including carinated bowls and bottles) and utility wares (i.e., the coarse-paste decorated vessels), usually cooking or storage jars and simple bowls. These wares are known to have been made and used differently, based on 
functional, technological, and stylistic analyses on numerous Caddo sherd assemblages in the region. The ceramic analysis was to be completed in conjunction with formal and technological analyses of any vessels and vessel sections (from macroscopic analyses of sherd cross-sections), as well as a sample of the plain rim sherds and decorated sherds, emphasizing paste characteristics, nonplastic inclusions, surface treatments, and firing environments of the decorated and plain sherd assemblages.

The analysis of the lithic artifacts was to focus on the identification of the range of chipped and ground stone tools in the lithic assemblage, with two purposes: (1) to characterize stylistic, functional, and morphological attributes of the tools for documenting local and regional affiliations of the Caddo populations living at the site; and (2) to determine intra-site differences in tool use and discard, particularly activities that may have occurred inside of house structures as opposed to tool use in extra-mural work areas. Of particular importance would be the compositional recognition of the frequency of formal vs. expedient tools, the abundance of cores and bifacial tools, heavy woodworking tools (i.e., celts and chipped axes) or other ground stone tools, and the kinds of knapping debris, as these attributes will help characterize the lithic technological organization of the sedentary Caddo groups living at 41AN38.

Another area of analytical importance was the identification of lithic raw material use in the tools and debris from the site. While it would not be possible to carry out surveys to determine the kinds of lithic raw materials available in local, district, and regional sources in the upper Neches River basin, we did plan on collecting samples of knappable raw material from any gravel exposures or outcrops in the vicinity of 41AN38.
We would also attempt to enlist the volunteer assistance of local avocational archeologists who may know of lithic raw material sources in this part of Anderson County. Also useful would be any tested cobbles and cores with substantial amounts of cortex remaining on them that might be in the lithic assemblage, as it was likely (taken in conjunction with measurements of cobble or pebble size and information from known source areas) that these chipped lithics were probably gathered and initially reduced from local or regional sources (i.e., within $50 \mathrm{~km}$ of the sites).

Previous investigations of northeastern Texas Caddo sites have demonstrated long-term trends in the procurement and use of local vs. non-local raw materials (including Red River gravel sources well to the north and Edwards Formation chert more than $100 \mathrm{~km}$ to the west), but our understanding of lithic raw material use in ca. A.D. 1400-1450 Caddo contexts remains poorly developed in the upper Neches River basin. Based on comparisons with the occurrence of non-local ceramics in other northeastern Texas archeological contexts, one possibility to be investigated with the 41AN38 lithic assemblage was that the use of non-local lithics was substantial in Caddo times (as assessed in the tools and the debris from tool manufacture), as Caddo groups preferred finegrained cryptocrystalline materials (especially chert and novaculite) for the manufacture of arrow points and a variety of flake tools. 


\section{CHAPTER 5}

\section{STRATIGRAPHY, FEATURES, AND RADIOCARBON DATES}

Timothy K. Perttula

\subsection{Stratigraphy}

The stratigraphy of the archeological deposits at the Lang Pasture site (41AN38) is quite straightforward, although because of their loamy fine sand texture, they are bioturbated (in some cases severely) by insects, roots, and burrowing animals. The sediments represent a moderately developed soil (e.g., Holliday 2004:27) formed under forest conditions (Vogel 2002:Figure 1, bottom).

Four primary sediment zones, with clear boundaries between zones (cf. Vogel 2002:25) are defined within the block and scrape excavations (Figures 5-1 and 5-2):

Zone I, an Ap or plow zone horizon. Where this zone is present across the block, which is in most of the excavated area, it is a dark yellowishbrown (10YR4/4) loamy fine sand that is between $13-20 \mathrm{~cm}$ in thickness;

Zone II, an A-horizon that is ca. 20-25 $\mathrm{cm}$ in thickness. It is also a dark yellowish-brown (10YR3/4 to 10YR4/6) loamy fine sand with charcoal flecks and small amounts of concretions and gravels; many of the cultural features documented at the Lang Pasture site were first detected in this zone;

Zone III is a yellowish-red (5YR5/8) to yellowish-brown (10YR5/8) loamy fine sand E-horizon, with charcoal flecks; small gravels and concretions are more abundant than in Zone II, including hematite and limonite concretions. On the crest of the upland landform, Zone III is ca. $45 \mathrm{~cm}$ thick; and

Zone IV is a B-horizon sandy clay of strong brown (7.5YR4/6), yellowishred (5YR5/8), or red $(2.5 \mathrm{YR} 4 / 6)$ color. On the crest of the landform, the top of the B-horizon is not exposed until ca. 75 to $82 \mathrm{~cm}$ bs; in some cases in the block excavations, the B-horizon is not reached until more than $90 \mathrm{~cm}$ bs (i.e., N179 E200, N190 E198, and N193 E198). Off the crest of the landform - at the northern and southern ends of the block and scrape excavations - the top of the Bhorizon clay is much shallower (20 $\mathrm{cm}$ bs in Scrape D, $32 \mathrm{~cm}$ bs in Scrape A, and $49 \mathrm{~cm}$ in Scrape E), with a redder and more oxidized color, indicating the existence of a strongly developed soil along the landform margins (e.g., Holliday 2004:27). At the far northern end of the excavations (N214 E198), the B-horizon clay is intermixed with a ferruginous sandstone-rich gravel deposit.

Also recognized in one part of the block excavations-namely between N190.2 E198 and N196 E198-is a spatially discrete sediment zone that has been designated as Zone IIA (Figure 5-3). 


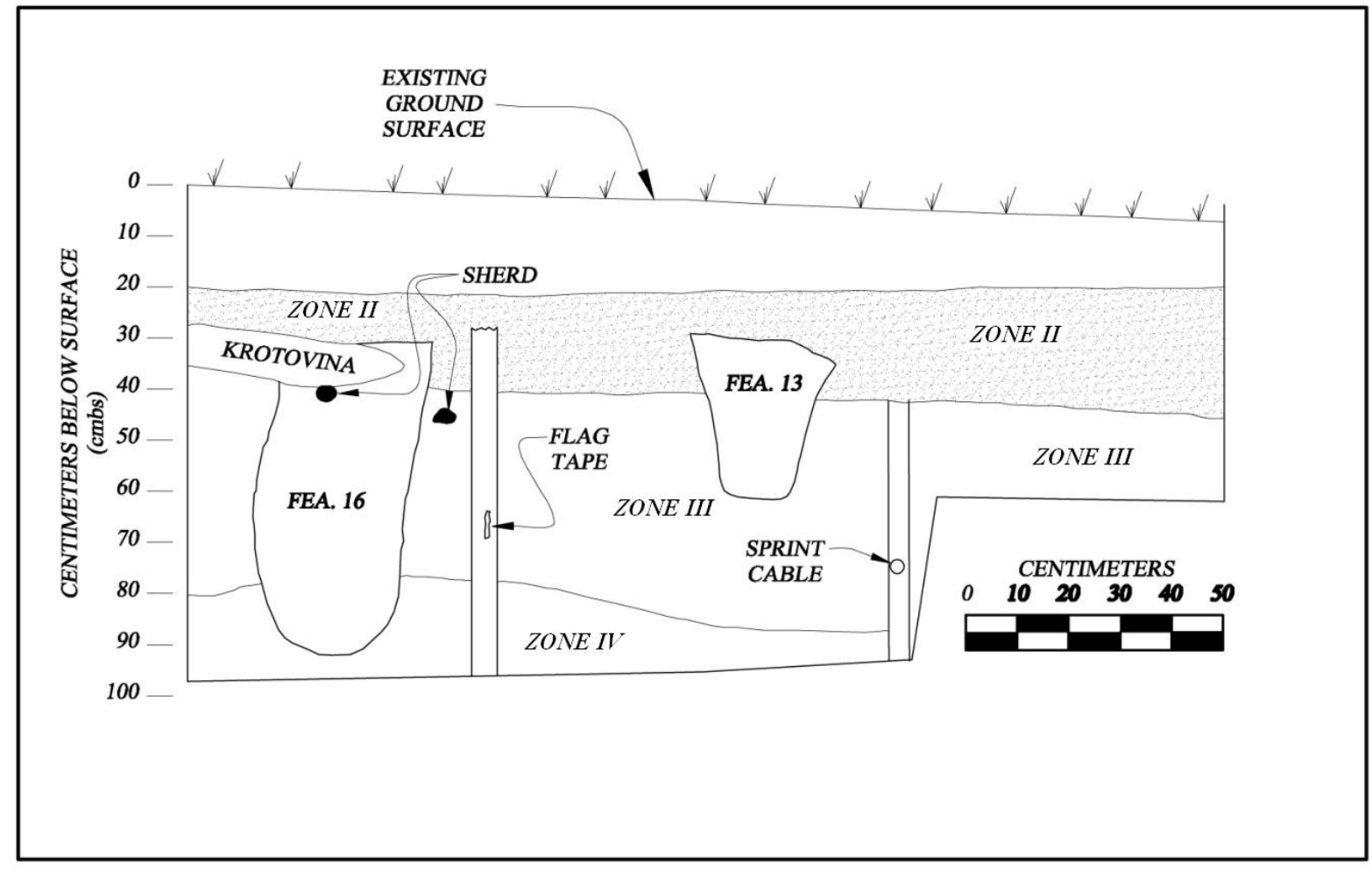

Figure 5-1. Profile of the North Wall of N175 E198-199.

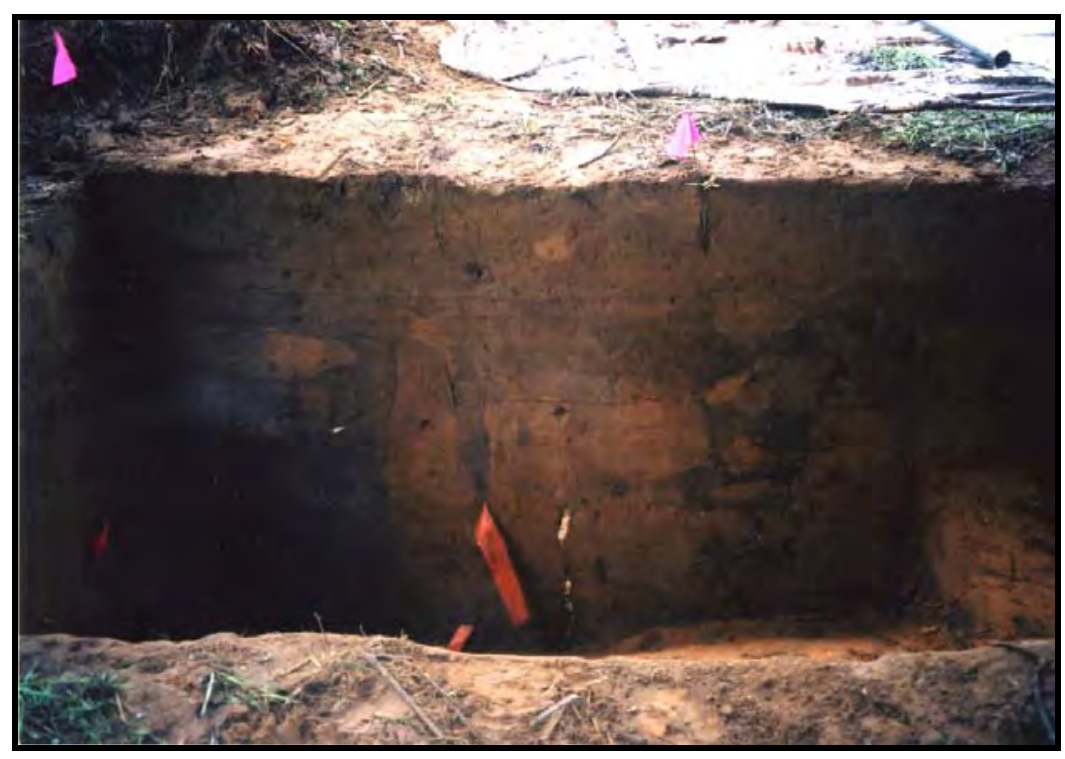

Figure 5-2. Photograph of the North Wall of Unit N175 E-198-199 near the Southern End of the Block Excavations; Features 13 and 16 are visible in the profile, along with the top of the Zone IV clay. 
This zone abruptly merges with the dark yellowish-brown loamy fine sand deposits that characterize Zone II, except they are dark brown (10YR3/3) in color, with some charcoal flecking presumably because of an increased organic content from prehistoric habitation activities; the zone thickens from south to north, from 20 to $31 \mathrm{~cm}$ in thickness. As the spatial distribution of Zone IIA appears to coincide rather precisely with the location of Structure 1 , a $14^{\text {th }}$ to $15^{\text {th }}$ century A.D. Caddo house, it is likely an anthrosol as defined by Holliday (2004:26-27). That is, it is the result of physical and chemical changes or alterations caused by human activity.

OSL dates from two columns in the northern part of the site (see Bateman, Appendix 2, this volume) may suggest that the sandy loam sediments on the upland landform were slowly aggrading-probably by aeolian deposition given the unlikelihood that floods along the nearby Caney Branch Creek could have deposited any alluvium on this landform.

An alternate explanation is that the OSL dates, although in stratigraphic order by depth, are more likely to be the product of bioturbation processes throughout the course of the Holocene (James Abott, 2010 personal communication), from what was essentially a stable surface long before the principal Caddo occupation took place at the Lang Pasture site.

The earliest OSL dates of $6390 \pm 320$ B.P (4440 B.C.) and $7980 \pm 410$ B.P. (6030 B.C.) from loamy fine sand deposits above the $\mathrm{B}$ horizon clay could indicate that the loamy fine sand sediments began to accumulate in the Middle Archaic period, a notably drier climatic interval in the region (see Chapter 2, this volume), or represent biosedimentation of old sand deposits across the site at those depths. On the crest of the upland landform (OSL column N197.5 E198), sediments may have been accumulated to a thickness of 65 cm by about 1000 years ago, or were already in place long before any prehistoric occupation. A second OSL column at N215.5 E198, along the northern slopes of the landform, documents about $55 \mathrm{~cm}$ of loamy fine sand sediments that may have accumulated until ca. 920 years ago, if not more recently, although the possibility remains that the OSL dates simply reflect bioturbation of sediments that have no archeological relevance. In general, the upland landform, however, was apparently a stable surface well before the time of the principal prehistoric Caddo occupation of the Lang Pasture site, which appears to have begun in the mid- $14^{\text {th }}$ century A.D. and lasted until the mid- $15^{\text {th }}$ century.

\subsection{LANG PASTURE (41AN38) FEATURES}

Timothy K. Perttula and Bo Nelson

\subsubsection{Introduction}

Including the features identified and/or investigated in the test excavations $(n=12)$ at the Lang Pasture site (41AN38) (see Lohse 2004), a total of 97 cultural features were excavated in the TXDOT right-of-way at the site during the course of both test excavations and the data recovery work (Figure 5-4). They include post holes $(n=65)$, pits of various sizes and probable functions $(\mathrm{n}=21)$, an outdoor hearth $(\mathrm{n}=1)$, a fire-cracked rock concentration $(\mathrm{n}=1)$, and a number of prehistoric Caddo Indian burial features $(\mathrm{n}=9)$ (Table 5-1).

The cultural features at the Lang Pasture site are not randomly distributed across the rightof-way-as will be discussed in more detail below. Rather, they are concentrated in four different parts of the block excavations. These include the areas in and near the two structures (Structures 1 and 2), marking the walls of the structures as well as outdoor activity areas, a cluster of three pits and one burial (Feature 8) north of Structure 1, and a group of five burials at the far northern end of the site. 


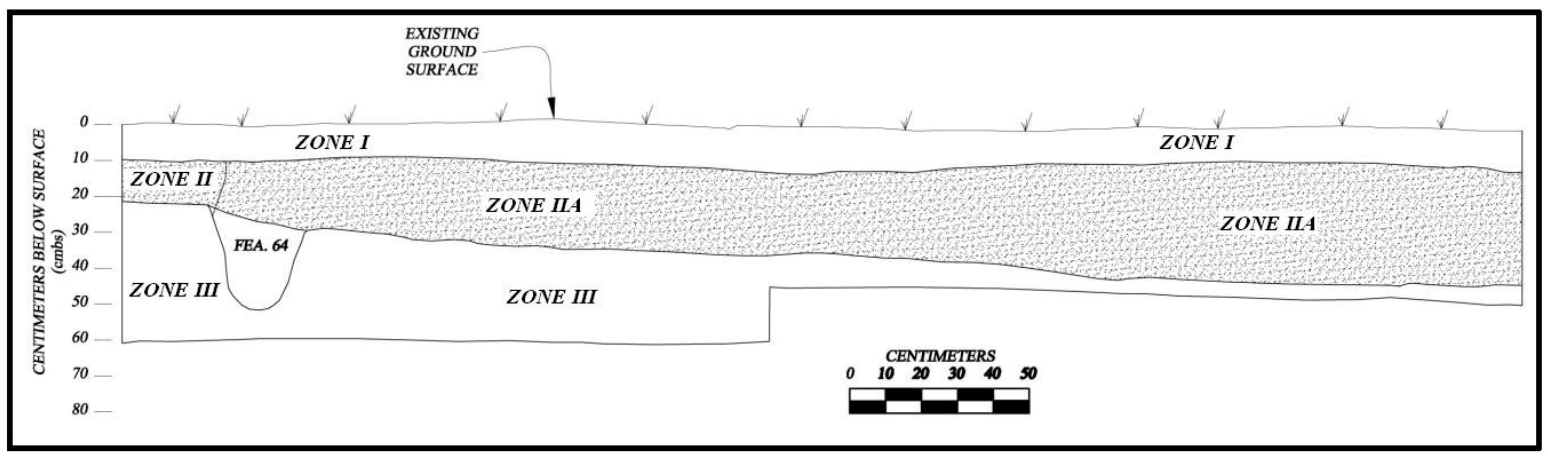

Figure 5-3. West Wall Profile between N190 E198 and N194 E198, Showing Relationship of Zone II and Zone IIA Sediments.

Most of the features were detected either near the base of the Zone II deposits, or at the Zone II-Zone III contact (see above). The lighter yellow and brown color of the Zone III sediments provided an excellent soil contrast by which to detect darker post holes and pits that originated near the modern ground surface, but penetrated into Zone III and, in some cases, also penetrated the Zone IV Bhorizon clay deposits.

\subsubsection{Domestic Features}

Domestic features documented at the Lang Pasture site include features associated with at least one prehistoric Caddo domestic settlement or household area. These features include post holes, small and large pits, smudge pits, an outdoor hearth, and a concentration of fire-cracked rock. Most of the features contain some refuse, primarily ceramic sherds, lithic debris, charred plant remains and charcoal, as well as burned and unburned animal bone (Table 5-2), but by far the largest amounts of discarded artifacts are in several large pits (Fea. 76, 76A, and 79) north and northeast of Structure 1, as well as a pit feature (Feature 36) associated with (or situated under?) a ramada/elevated platform by Structure 1, and an outdoor hearth (Feature 25) just north of the ramada/elevated platform. Post holes and smudge pits tend not to have many artifacts in their feature fills, only charcoal-staining that allowed them to be recognized in plan and cross-section profile views during the excavations.

The spatial arrangements of the various features can be seen in the fold-out map, Figure 5-4. 


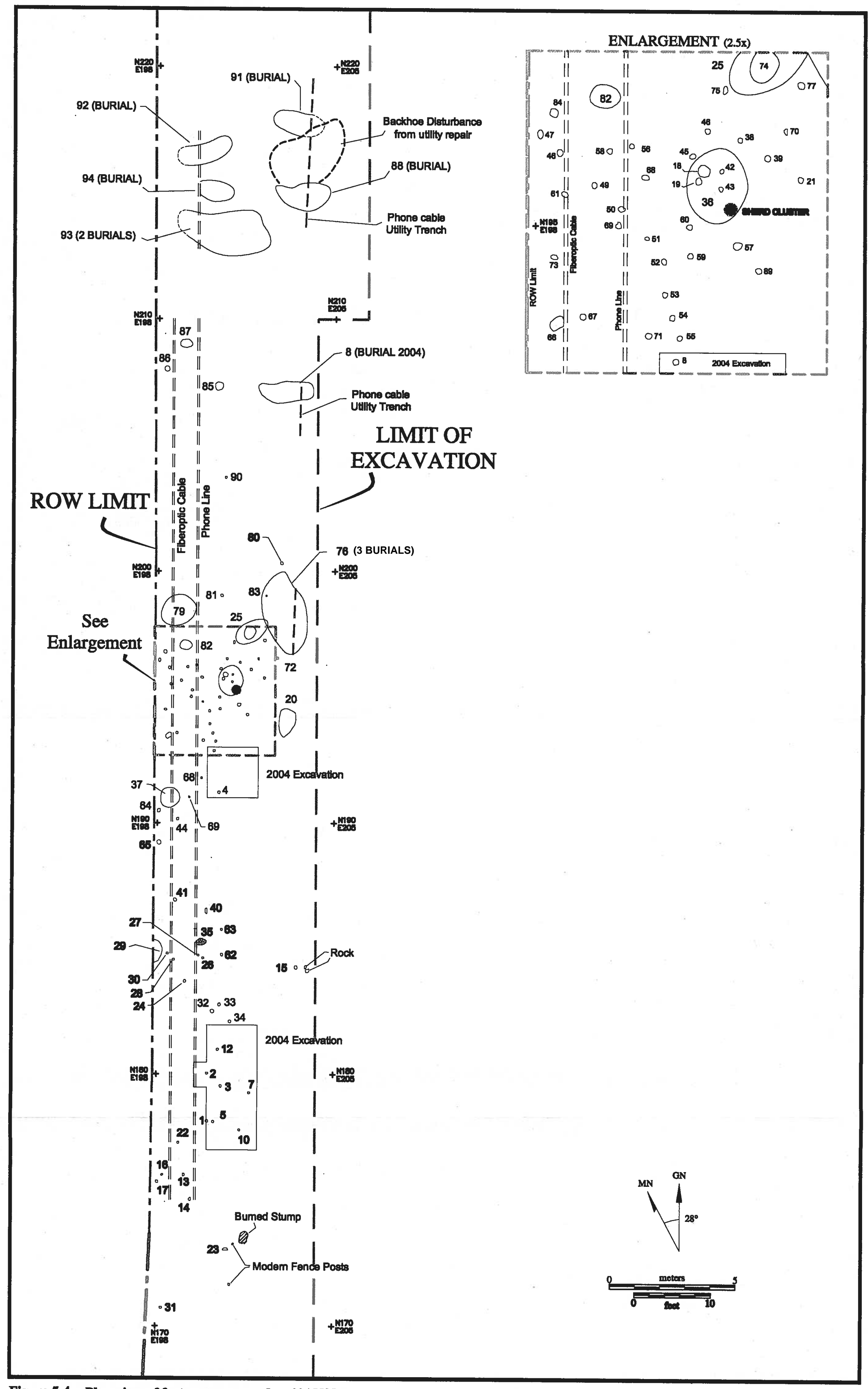

Figure 5-4. Plan view of features excavated at 41AN38. 
Table 5-1. Feature Inventory from the Lang Pasture Site (41AN38).

Feature No. Probable Function

\section{Test Excavations}

$\begin{array}{ll}\text { Fea. } 1 & \text { large posthole } \\ \text { Fea. } 2 & \text { small pit } \\ \text { Fea. } 3 & \text { post hole } \\ \text { Fea. } 4 & \text { post hole } \\ \text { Fea. } 5 & \text { post hole } \\ \text { Fea. } 6 & \text { post hole } \\ \text { Fea. } 7 & \text { post hole } \\ \text { Fea. } 8 & \text { burial } \\ \text { Fea. } 9 & \text { pit } \\ \text { Fea. } 10 & \text { post hole } \\ \text { Fea. } 11 & \text { post hole } \\ \text { Fea. } 12 & \text { post hole }\end{array}$

\section{Data Recovery}

Fea. 13

Fea. 14

Fea. 15

Fea. 16

Fea. 17

Fea. 18

Fea. 19

Fea. 20

Fea. 21

Fea. 22

Fea. 24

Fea. 25

Fea. 26

Fea. 27

Fea. 28

Fea. 29

Fea. 30

Fea. 31

Fea. 32

Fea. 33

Fea. 35

Fea. 36

Fea. 37

Fea. 38

Fea. 39

Fea. 40

Fea. 41

Fea. 42

Fea. 43

Fea. 44

Fea. 45

Fea. 46

Fea. 47

Fea. 48 post hole

post hole

post hole

post hole

post hole

post hole

post hole

pit

smudge pit

post hole

post hole

hearth

post hole

large post hole

post hole

pit

post hole

post hole

post hole

post hole

fire-cracked rock concentration

smudge pit or hearth

pit

smudge pit or posthole

post hole

pit

smudge pit

post hole

post hole

post hole

small pit

post hole

post hole

post hole
Feature No. Probable Function

Fea. 49 post hole

Fea. 50 post hole

Fea. 51 post hole

Fea. 52 post hole

Fea. 53 post hole

Fea. 54 post hole

Fea. 55 post hole

Fea. 56 post hole

Fea. 57 post hole

Fea. 58 post hole

Fea. 59 pit

Fea. 60

Fea. 61

Fea. 64

Fea. 65

Fea. 66

Fea. 67

Fea. 68

Fea. 69

Fea. 70

Fea. 71

Fea. 72

Fea. 73

Fea. 74

Fea. 75

Fea. 76

Fea. 76A

Fea. 76B

Fea. 76C

Fea. 76D

Fea. 77

Fea. 78

Fea. 79

Fea. 80

Fea. 81

Fea. 82

Fea. 83

Fea. 84

Fea. 85

Fea. 86

Fea. 87

Fea. 88

Fea. 89

Fea. 90

Fea. 91

Fea. 92

Fea. 93

Fea. 94 pit

post hole

post hole

post hole

post hole

post hole

post hole

post hole

post hole

post hole

post hole

post hole

post hole

post hole, beneath Fea. 25

post hole

large pit

pit within larger Fea. 76

burial

burial

burial

post hole

post hole

large pit

smudge pit

large post hole

pit

post hole

small pit

pit

pit

pit

burial

post hole

post hole

burial

burial

burial burial (2 individuals) 


\subsubsection{Post Holes}

There are a total of 17 post holes associated with the construction of Structure 1 (Figures 5-5 and 5-6; Table 5-3); these probably represent slightly less than half of all the wall posts that were used to construct this $6.8-\mathrm{m}$ diameter circular structure, with the remainder to be found on private property across the ROW fence. The exterior wall arc is welldefined across its northern and eastern halves, but became much more nebulous along the southern part of the arc; Feature 67 and Feature 73 may represent roof support posts (Figure 5-6). Despite protests of poor exposure and sandy soil conditions that limit the identifiability of post hole stains, this is a common archeological phenomena on Caddo sites where prehistoric structures were built on sandy landforms, and there is little midden deposition on the site, and thus post hole stains do not strongly contrast with the background soil matrix.
Most of the post holes in Structure 1 are circular in shape, with gently sloping sides and rounded bottoms (Figure 5-7), although two (Features 48 and 55) had flat bottoms (Figure $5-8)$, as if the posts placed in them had squared-off ends. It is probably likely that a number of the posts had deliberately charred ends, so as to forestall as much as possible the degradation of the ends of the posts from rotting. No paleobotanical samples from the Structure 1 post holes were analyzed, but based on the results of paleobotanical analyses from Structure 2 and other contexts at the site-as well as other Caddo sites with pole structures (see Rogers and Perttula 2004; Perttula and Sherman 2008)—both pine and oak wood were used for wall posts. 


\begin{tabular}{|c|c|c|c|c|c|c|c|c|c|c|c|c|c|c|c|c|c|c|}
\hline $\begin{array}{c}\text { Feature } \\
\text { No. }\end{array}$ & $\begin{array}{c}\text { Decorated } \\
\text { Ceramics } \\
\end{array}$ & $\begin{array}{c}\text { Plain } \\
\text { Ceramics } \\
\end{array}$ & Lithics & Charcoal & Bone & Concretions & $\begin{array}{c}\text { Nut } \\
\text { Shells } \\
\end{array}$ & Shells & FCR & Daub & $\begin{array}{c}\text { Ground } \\
\text { Stone } \\
\text { Tool } \\
\end{array}$ & Glass & $\begin{array}{l}\text { Arrow } \\
\text { Points } \\
\end{array}$ & $\begin{array}{c}\text { Baked } \\
\text { Clay } \\
\end{array}$ & Celts & Bifaces & $\begin{array}{c}\text { Dart } \\
\text { Points } \\
\end{array}$ & $\begin{array}{r}\text { Pipe } \\
\text { Stems } \\
\end{array}$ \\
\hline 13 & & 1 & 20 & 11 & 9 & 6 & & & & & & & & & & & & \\
\hline 14 & & 1 & 8 & 1 & & 6 & & & & & & & & & & & & \\
\hline 15 & & & 8 & & & 14 & & & & & & & & & & & & \\
\hline 16 & 2 & 3 & 18 & 28 & 23 & & & & & & & & & & & & & \\
\hline 17 & 1 & 1 & 4 & & & & & & & & & & & & & & & \\
\hline 18 & & & & $3 \mathrm{~g}$ & 17 & & & & & & & & & & & & & \\
\hline 19 & & & 2 & $9 \mathrm{~g}$ & & & & & & & & & & & & & & \\
\hline 20 & & 8 & 54 & 28 & 28 & & & & & & & & & & & & & \\
\hline 21 & & & 4 & 4 & & & & & & & & & & & & & & \\
\hline 22 & 2 & 3 & 3 & & & & 2 & & & & & & & & & & & \\
\hline 23 & & & 9 & & 9 & & & & & & & & & & & & & \\
\hline 24 & . & & 8 & & 3 & & 1 & & & & & & & & & & & \\
\hline 25 & 3 & 21 & 96 & 116 & 388 & & 10 & 27 & & & & & & & & & & \\
\hline 26 & & 1 & 6 & 3 & 5 & & & & & & & & & & & & & \\
\hline 27 & & & & & 6 & & & & & & & & & & & & & \\
\hline 28 & & & 5 & 17 & 30 & & & & & & & & & & & & & \\
\hline 29 & & & 13 & $190.14 \mathrm{~g}$ & 5 & & & & & & & & & & & & & \\
\hline 30 & & & 5 & 9 & & & & & & & & & & & & & & \\
\hline 31 & & & & 9 & & & & & & & & & & & & & & \\
\hline 32 & & & 1 & & & & & & & & & & & & & & & \\
\hline 34 & & & 2 & & & & & & & & & & & & & & & \\
\hline 35 & & & 2 & 3 & & & & & & & & & & & & & & \\
\hline 36 & 3 & 9 & 87 & 14 & 102 & & & 3 & & & & & & & & & & \\
\hline 37 & & 5 & 39 & 10 & 18 & & 6 & & & & & & & & & & & \\
\hline 38 & & & & $41 \mathrm{~g}$ & 1 & & & & & & & & & & & & & \\
\hline
\end{tabular}


Table 5-2, continued.

\begin{tabular}{|c|c|c|c|c|c|c|c|c|c|c|c|c|c|c|c|c|c|c|}
\hline $\begin{array}{l}\text { Fea. } \\
\text { No. }\end{array}$ & $\begin{array}{l}\text { Decorated } \\
\text { Ceramics } \\
\end{array}$ & $\begin{array}{c}\text { Plain } \\
\text { Ceramics } \\
\end{array}$ & Lithics & Charcoal & Bone & Concretions & $\begin{array}{c}\text { Nut } \\
\text { Shells } \\
\end{array}$ & Shells & FCR & Daub & $\begin{array}{c}\text { Ground } \\
\text { Stone } \\
\text { tool } \\
\end{array}$ & Glass & $\begin{array}{l}\text { Arrow } \\
\text { Points } \\
\end{array}$ & $\begin{array}{c}\text { Baked } \\
\text { Clay } \\
\end{array}$ & Celts & Bifaces & $\begin{array}{l}\text { Dart } \\
\text { Points } \\
\end{array}$ & $\begin{array}{l}\text { Pipe } \\
\text { Stems } \\
\end{array}$ \\
\hline 39 & 3 & 1 & & 11 & 1 & & & & & & & & & & & & & \\
\hline 40 & & & 5 & 3 & & & & & & & & & & & & & & \\
\hline 41 & & 1 & 6 & $50 \mathrm{~g}$ & 3 & & & & & & & & & & & & & \\
\hline 42 & & & & $35 \mathrm{~g}$ & 1 & & & & & & & & & & & & & \\
\hline 43 & & & 3 & 15 & & & & & & & & & & & & & & \\
\hline 44 & & & 17 & 19 & 4 & & & & & & & & & & & & & \\
\hline 45 & & & 7 & 22 & 20 & & & & & & & & & & & & & \\
\hline 46 & & 1 & 4 & 4 & 9 & & & & & & & & & & & & & \\
\hline 47 & & & & 20 & & & & & & & & & & & & & & \\
\hline 48 & & & 1 & $16.7 \mathrm{~g}$ & 2 & & & & & & & & & & & & & \\
\hline 49 & & & & 5 & & & & & & & & & & & & & & \\
\hline 50 & & 1 & 3 & & & & & & & & & & & & & & & \\
\hline 51 & & & 6 & 10 & 3 & & & & & & & & & & & & & \\
\hline 52 & & & 2 & 31 & & & & & & & & & & & & & & \\
\hline 53 & & & 2 & & & & & & & & & & & & & & & \\
\hline 54 & & 1 & & & & & 9 & & & & & & & & & & & \\
\hline 55 & & & & 5 & & & & & & & & & & & & & & \\
\hline 56 & & & 2 & & & & & & & & & & & & & & & \\
\hline 57 & 2 & 2 & 13 & 30 & 1 & & & & & & & & & & & & & \\
\hline 58 & & & & 6 & & & & & & & & & & & & & & \\
\hline 59 & & & 1 & & 2 & & & & & & & & & & & & & \\
\hline 60 & & 2 & 2 & 13 & & & & & & & & & & & & & & \\
\hline 61 & & & 4 & 6 & 3 & & & & & & & & & & & & & \\
\hline 62 & & 1 & & 2 & 2 & & & & & & & & & & & & & \\
\hline 63 & & 1 & 1 & 3 & 1 & & & & & & & & & & & & & \\
\hline
\end{tabular}


Table 5-2, continued.

\begin{tabular}{|c|c|c|c|c|c|c|c|c|c|c|c|c|c|c|c|c|c|c|}
\hline $\begin{array}{l}\text { Fea. } \\
\text { No. }\end{array}$ & $\begin{array}{l}\text { Decorated } \\
\text { Ceramics }\end{array}$ & $\begin{array}{c}\text { Plain } \\
\text { Ceramics }\end{array}$ & Lithics & Charcoal & Bone & Concretions & $\begin{array}{l}\text { Nut } \\
\text { Shells }\end{array}$ & Shells & FCR & Daub & $\begin{array}{l}\text { Ground } \\
\text { Stone } \\
\text { tools }\end{array}$ & Glass & $\begin{array}{l}\text { Arrow } \\
\text { Points }\end{array}$ & $\begin{array}{c}\text { Baked } \\
\text { Clay }\end{array}$ & Celts & Bifaces & $\begin{array}{c}\text { Dart } \\
\text { Points }\end{array}$ & $\begin{array}{l}\text { Pipe } \\
\text { Stems } \\
\end{array}$ \\
\hline 66 & & 9 & 13 & $10.68 \mathrm{~g}$ & 7 & & & & & 2 & & & & & & & & \\
\hline 68 & & & 1 & 5 & & & & & & & & & & & & & & \\
\hline 69 & & 1 & & 7 & & & & & & & & & & & & & & \\
\hline 70 & & & & 6 & & & & & & & & & & & & & & \\
\hline 71 & & & 1 & 4 & & & & & & & & & & & & & & \\
\hline 72 & & & & $30.0 \mathrm{~g}$ & 2 & & & & & 2 & & & & & & & & \\
\hline 73 & & & & & 2 & & & & & & & & & & & & & \\
\hline 74 & 1 & 4 & 10 & 5 & 45 & & & 6 & & & & & & & & & & \\
\hline 75 & & & 3 & 15 & 7 & & & & & 1 & & & & & & & & \\
\hline 76 & 164 & 288 & 224 & 145 & 153 & & 46 & & & & 1 & 1 & 5 & 1 & 1 & & 2 & 1 \\
\hline $76 \mathrm{~A}$ & 33 & 92 & 61 & 54 & 89 & & 1 & & & & & & & & & & & \\
\hline $76 \mathrm{~B}$ & 24 & 39 & 20 & 29 & 4 & & 1 & & & & & & & & & 1 & & \\
\hline 76B\&C & 3 & 3 & & & & & & & & & & & & & & & & \\
\hline 78 & & & 2 & 14 & 3 & & & & & & & & & & & & & \\
\hline 79 & 45 & 140 & 181 & 80 & 131 & & 2 & & & 2 & 1 & & & & & & & \\
\hline 80 & & & 4 & $79 \mathrm{~g}$ & 5 & & & & & & & & & & & & & \\
\hline 81 & 2 & 1 & 12 & 17 & 56 & & & & & & & & & & & & & \\
\hline 82 & 1 & & 31 & 10 & 10 & & & & & & & & & & & & & \\
\hline 84 & 3 & 4 & 10 & $20 \mathrm{~g}$ & 5 & & & & & & & & & & & & & \\
\hline 85 & 1 & 1 & 26 & 67 & 7 & & & & & & & & & & & & 1 & \\
\hline 86 & & & 17 & $170 \mathrm{~g}$ & 7 & & & & & & & & & & & & & \\
\hline 87 & & 1 & 10 & 12 & & & & & & & & & & & & & & \\
\hline 89 & & 1 & 1 & 2 & & & & & & & & & & & & & & \\
\hline 90 & & 2 & & & & & & & & & & & & & & & & \\
\hline 94 & & & 1 & $104 g$ & & & & & & & & & & & & & & \\
\hline
\end{tabular}



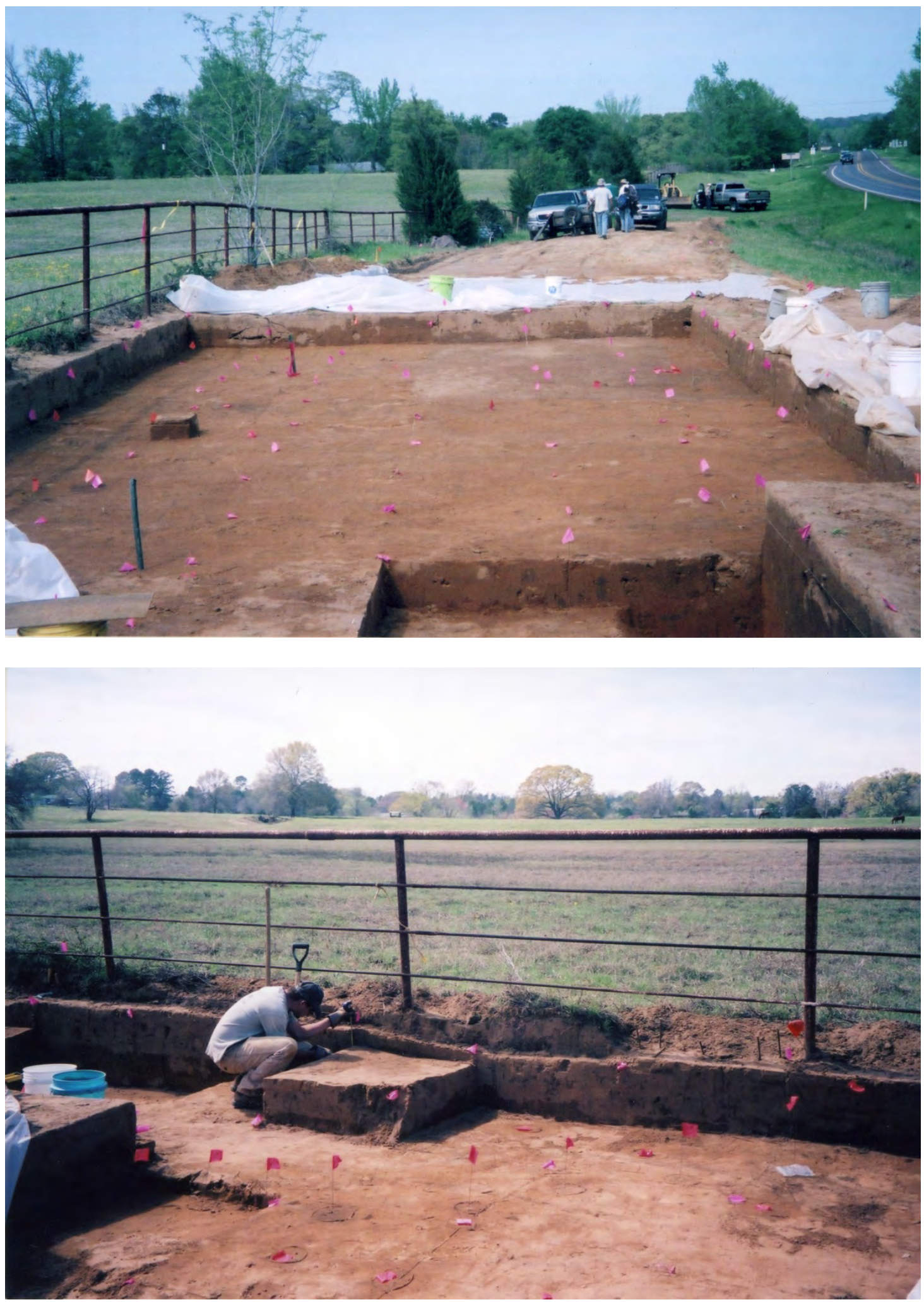

Figure 5-5. Excavations in the Area of Structure 1: a, looking north; b, looking west. Pin flags mark post hole locations. 


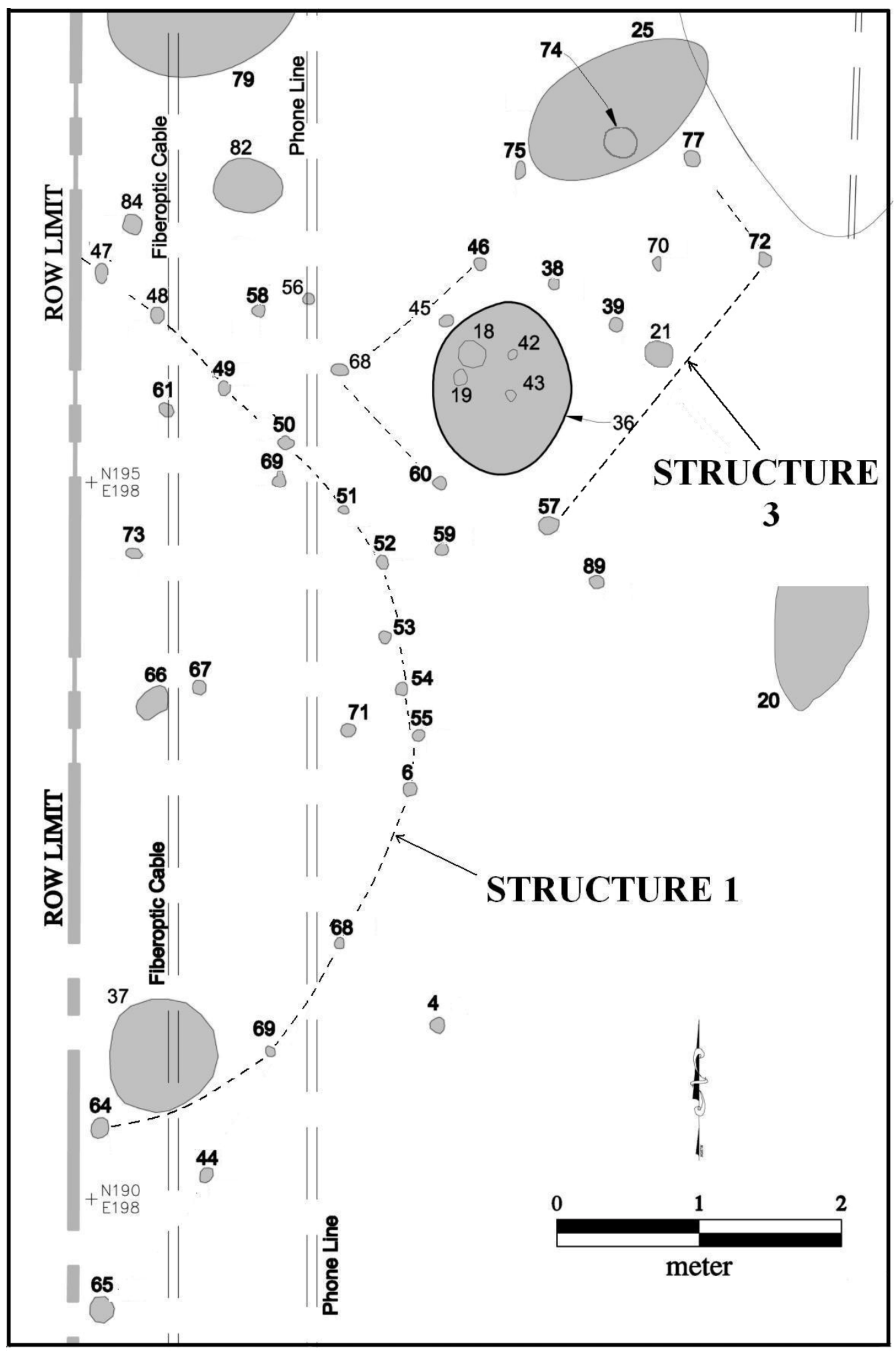

Figure 5-6. Plan of Features Associated with Structure 1 and Ramada (Structure 3) in the Northern Block Excavations at the Lang Pasture Site. 
Table 5-3. Post Holes in Structure 1.

\begin{tabular}{llc}
\hline Fea. No. & $\begin{array}{c}\text { Dimensions } \\
(\mathbf{L} \times \mathbf{~ W} \text {, in cm) }\end{array}$ & $\begin{array}{c}\text { Depth } \\
\text { (cm bs) }\end{array}$ \\
\hline 6 & $20 \times 22$ & $30-58$ \\
47 & $22 \times 22$ & $31-48$ \\
48 & $19 \times 19$ & $40-50$ \\
49 & $18 \times 18$ & $40-53$ \\
50 & $18 \times 18$ & $40-50$ \\
51 & $15 \times 15$ & $40-52$ \\
52 & $20 \times 20$ & $40-58$ \\
53 & $18 \times 18$ & $40-59$ \\
54 & $14 \times 14$ & $50-66$ \\
55 & $20 \times 20$ & $50-71$ \\
61 & $21 \times 21$ & $40-50$ \\
64 & $20 \times 20$ & $32-55$ \\
$66 *$ & $25 \times 25$ & $60-136$ \\
67 & $19 \times 19$ & $33-68$ \\
68 & $17 \times 17$ & $40-60$ \\
69 & $20 \times 20$ & $40-57$ \\
71 & $16 \times 16$ & $40-49$ \\
73 & $15 \times 15$ & $40-70$ \\
\hline
\end{tabular}

*probably a tap root, and not included in the discussion that follows

The Structure 1 post holes have a mean diameter of $18.47 \pm 1.97 \mathrm{~cm}$ (Coefficient of Variation $\left.^{1}[\mathrm{CV}]=10.66\right)$, and a range of 14 $22 \mathrm{~cm}$ (see Table 5-3). The posts themselves were probably about $10 \mathrm{~cm}$ in diameter. The mean bottom depth of the Structure 1 post holes was $57.3 \pm 6.7 \mathrm{~cm}(\mathrm{CV}=11.69)$; they were not set in holes dug into the underlying B-horizon clay, but only in holes that reached into the E-horizon sediments. The $\mathrm{CV}$ values in the size and depth of the post holes from Structure 1 indicate that this structure had the least variability in post hole size or in the depth to which they were set. Other than the post holes from the Structure 3 ramada, the post holes from Structure 1 were set the shallowest of the clusters of post holes associated with

${ }^{1}$ The Coefficient of Variation is determined by dividing the sample standard deviation by the sample mean, and multiplying the result by 100 .
Structure 2 or the post holes found outside of, but in proximity to, Structures 1 and 2 .

Only limited amounts of artifacts ended up in the Structure 1 post holes, including lithics $(n=23)$, ceramic sherds $(n=3)$, animal bone $(n=10)$, and charred plant remains $(\mathrm{n}=102$, plus $16.7 \mathrm{~g}$ of charred remains from Feature 48) (Table 5-2). The low density of artifacts indicates that no artifacts were deliberately set in the post holes before the structure was erected, and this low density also suggests that little trash or midden soils were allowed to accumulate on the floor of Structure 1, where they could more easily become incorporated into post hole fill. Both Structure 2 and Structure 3 post holes had significantly higher densities of artifacts in their fill (see below). 


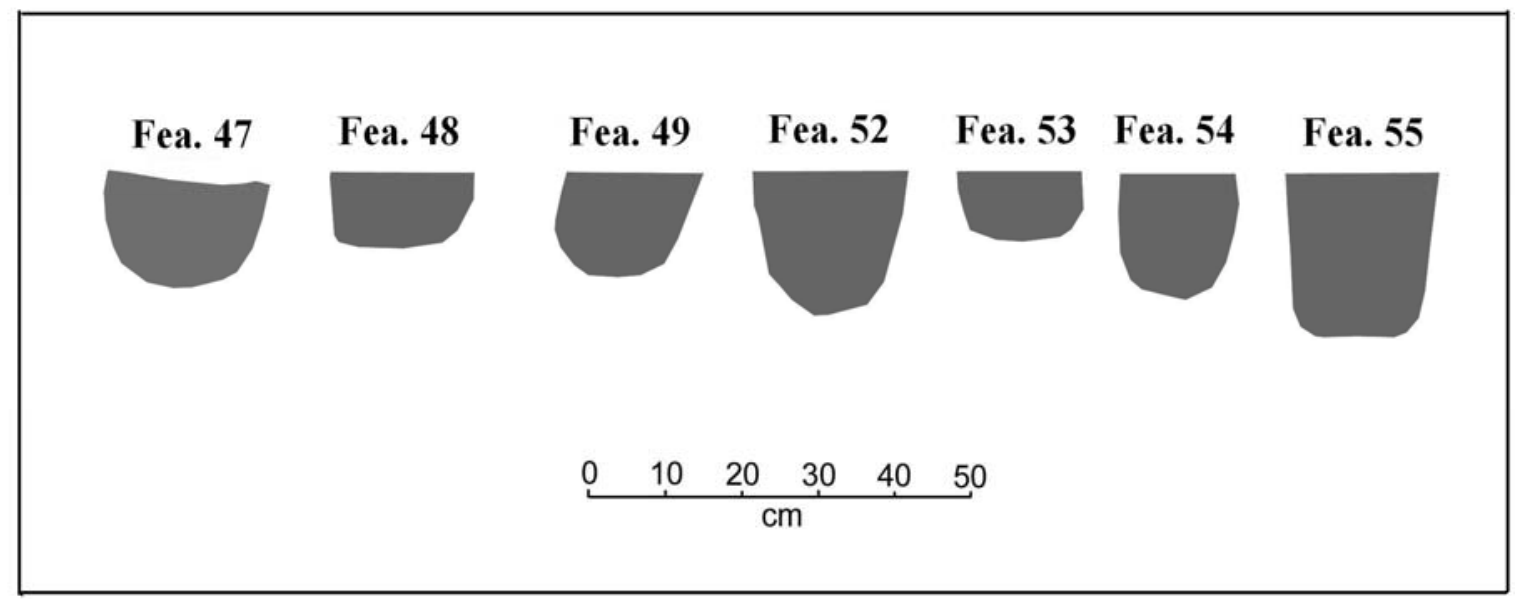

Figure 5-7. Profiles of Select Structure 1 Post Holes.

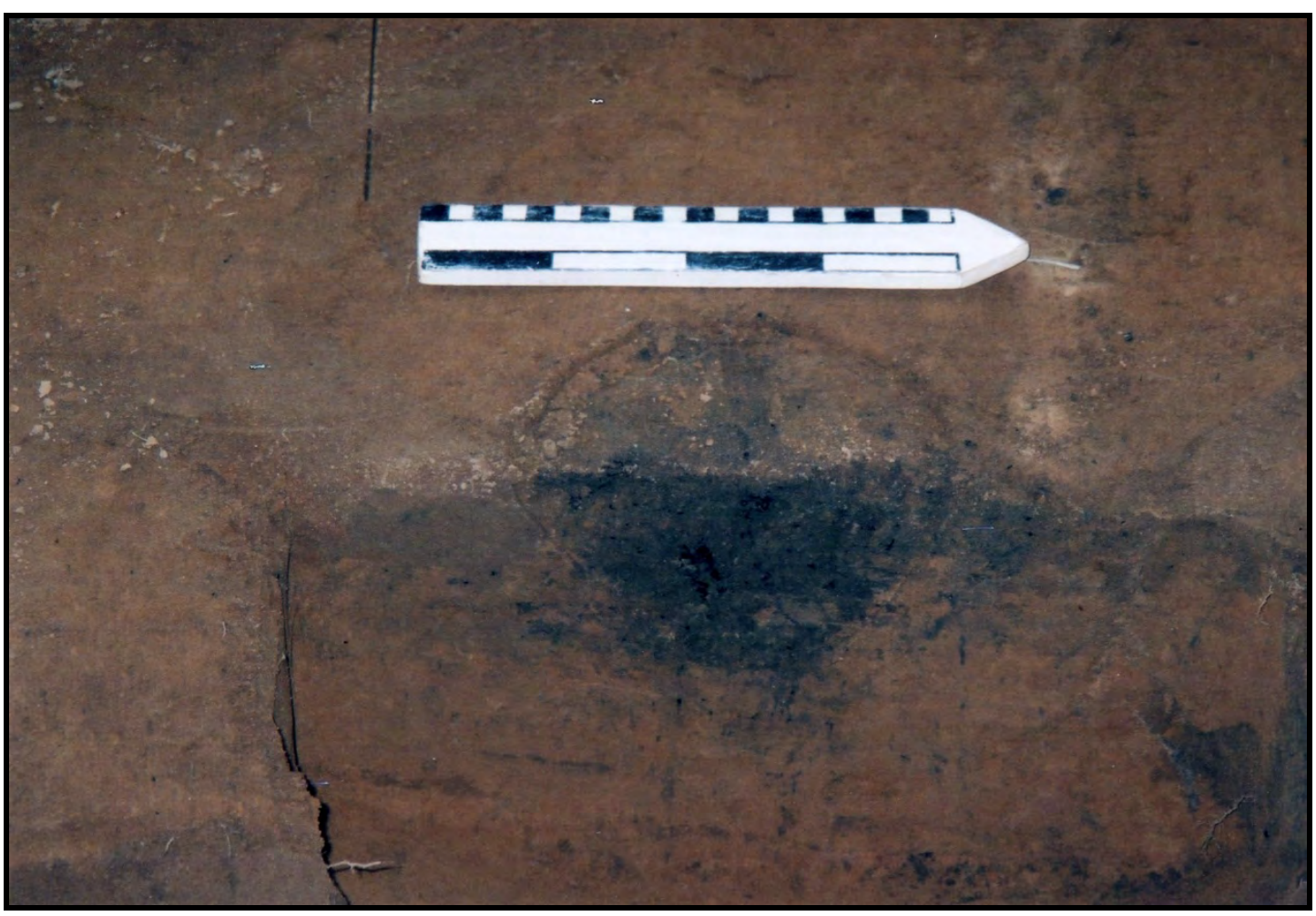

Figure 5-8. Feature 48, a Post Hole, in Plan and Profile, Looking West.

Thirteen post holes are part of the construction of Structure 2 (Table 5-4 and Figures 5-9 and 5-10). Only about one-third of this structure is represented in the TxDOT block excavations, based on its estimated diameter of $9.0 \mathrm{~m}$.
The Structure 2 posts were widely set (see Figure 5-9), much more so than with the construction of Structure 1, except in two instances (Features 1/5 and Features 32/33) where post holes were very close to one another. These latter double set of posts likely represent replacement posts from instances of wall repair where one post had 
rotted at the ground surface and needed to be replaced. There are no obvious roof supports in the exposed portion of the structure.

The posts were also on average larger in Structure 2 than they were in Structure 1, which seems consistent with the overall differences in size of the two structures (i.e., Structure 2 is $32 \%$ larger in diameter than Structure 1, and presumably needed larger poles to form the taller peaked roof). The Structure 2 post holes are $22.53 \pm 4.88 \mathrm{~cm}$ in diameter $(\mathrm{CV}=21.66)$, with a range of $12-35$ $\mathrm{cm}$. The wide range in post hole diameter size, based on the $\mathrm{CV}$ value, is notable, suggesting little selectivity in choosing poles of certain diameters for structure construction. The Structure 2 post holes are set deeper in the ground than were the post holes from Structure 1, with a mean bottom depth of $67.6 \pm 12.4 \mathrm{~cm}(\mathrm{CV}=18.34)$. Again, the CV value for the post holes in Structure 2 is considerable, pointing to the somewhat haphazard construction efforts (i.e., posts of widely-ranging size put in holes with widely ranging depths) seemingly put into the erection of Structure 2

Lithic artifacts $(\mathrm{n}=64)$ and animal bone $(n=65)$ were relatively common inclusions in the fill of the Structure 2 post holes, along with ceramic sherds $(n=13)$ and charred plant remains $(n=68)$ (see Table 5-2). Including only the post holes that contain artifacts, the density of incidental artifacts is almost three times as high in Structure 2 (mean=26.3) as it is in Structure 1 (mean=9.9). The artifact density in Structure 3 is intermediate, with a mean value per post hole of 16.6.

Table 5-4. Post Holes in Structure 2.

\begin{tabular}{cccc}
\hline Fea. No. & $\begin{array}{c}\text { Dimensions } \\
(\mathbf{L} \times \mathbf{x} \text { W, in cm) }\end{array}$ & $\begin{array}{c}\text { Depth } \\
(\mathbf{c m} \text { bs) }\end{array}$ & Comments \\
\hline 1 & $35 \times 35$ & $38-90$ & $\begin{array}{c}\text { C14 date }(2 \text { sigma): } \\
\text { A.D. 1650-1960 }\end{array}$ \\
3 & $20 \times 14$ & $?-58$ & \\
5 & $12 \times 10$ & $?-54$ & \\
12 & $30 \times 31$ & $?-62$ & \\
13 & $25 \times 21$ & $29-57$ & \\
16 & $29 \times 29$ & $29-90$ & C14 date (2 sigma): \\
& & & AD 880-1020 \\
17 & $17 \times 17$ & $50-66$ & \\
22 & $23 \times 23$ & $40-54$ & \\
24 & $20 \times 20$ & $35-59$ & \\
28 & $22 \times 22$ & $40-50$ & \\
30 & $15 \times 15$ & $45-84$ & \\
32 & $24 \times 24$ & $65-80$ & \\
33 & $20 \times 20$ & $65-75$ & \\
\hline
\end{tabular}




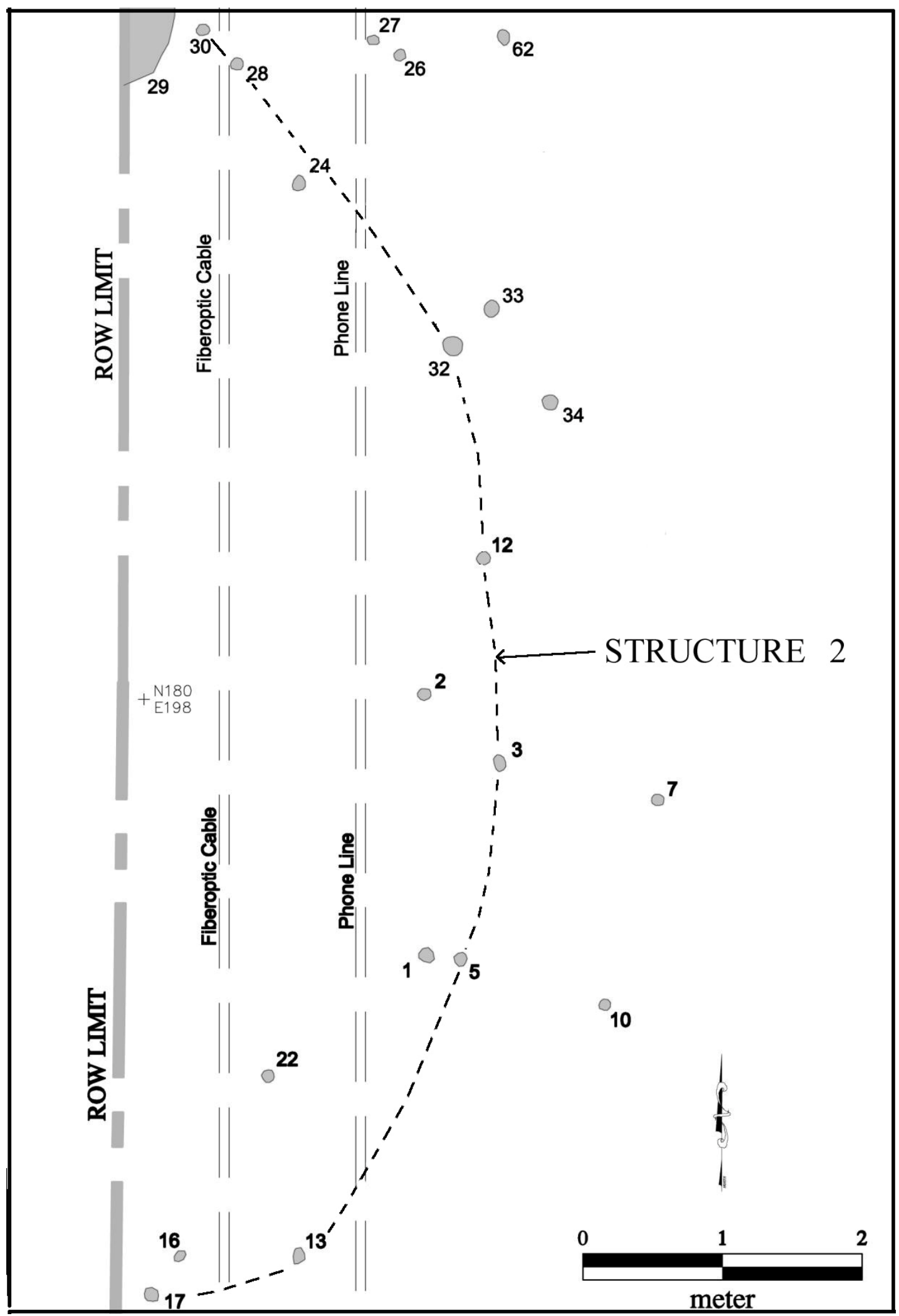

Figure 5-9. Plan of Features Associated with Structure 2 in the Southern Block Excavations. 


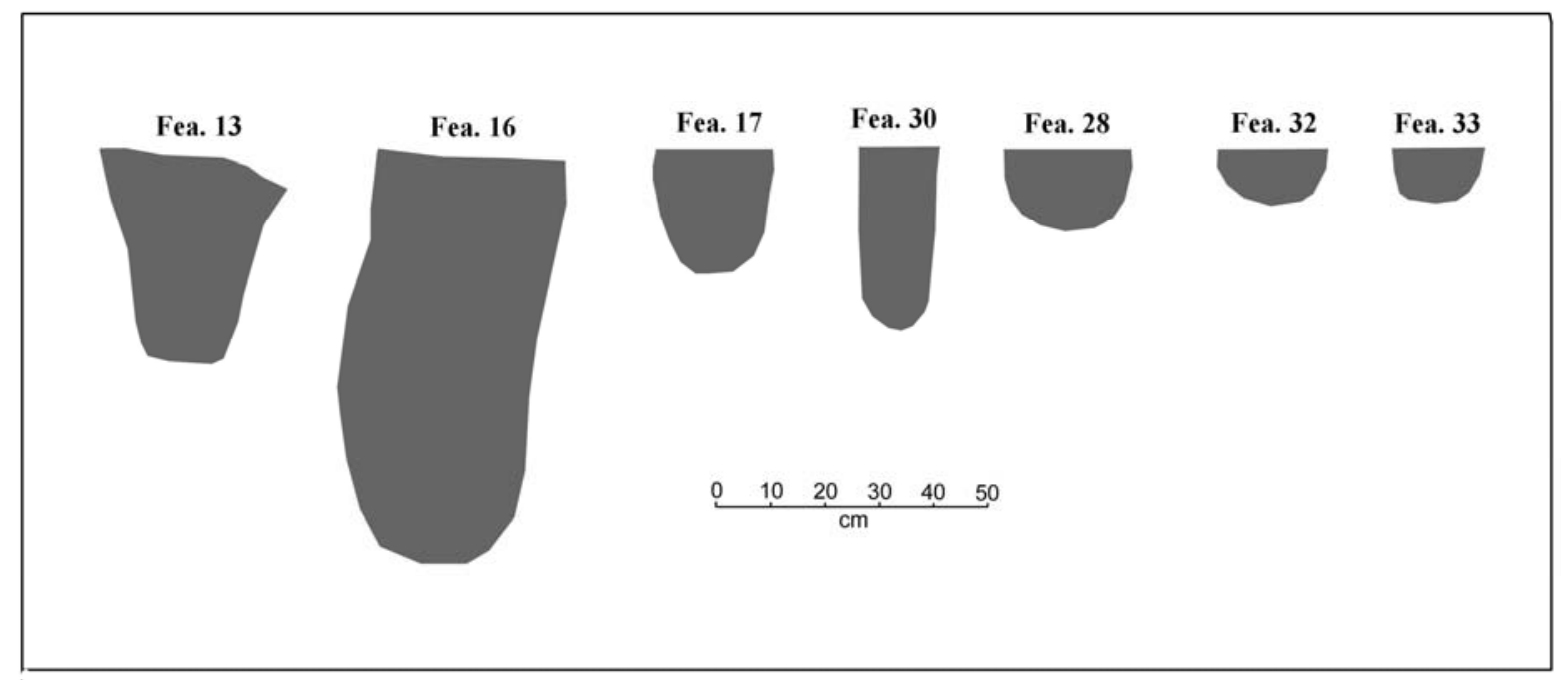

Figure 5-10. Profiles of Select Structure 2 Post Holes.

Fifteen post holes form a ca. 2 x 4 m rectangle about 1-3 m east-northeast of Structure 1 (see Figure 5-6 above). These posts, some of which are fairly shallow (Table 5-5), are presumed to represent the construction of a ramada or elevated work platform in the vicinity of the Structure 1 domestic residence, and placed squarely amidst outdoor work activities signaled by high densities of ceramic sherds in the same area as well as various outdoor features, including a hearth (Feature 25), a cooking pit (Feature 36), and smudge pits.

The post holes in the Structure 3 ramada have gently tapering sides and both rounded and flat bottoms (Figure 5-11). Flat-bottomed posts comprise $33 \%$ of the post holes in this structure, compared to only $12 \%$ in Structure 1 and $15 \%$ in Structure 2 . $\mathrm{T}$ he Structure 3 post holes are smaller than those associated with either Structure 1 or 2, with a mean diameter of $17.6 \pm 3.76 \mathrm{~cm}(\mathrm{CV}=21.36)$, with a range of $10-23 \mathrm{~cm}$. The posts were also generally set shallowly in the ground, with a mean bottom depth of $54.8 \pm 9.39 \mathrm{~cm}(\mathrm{CV}=17.13)$. The two deepest posts (Features 72 and 77) are along the eastern wall of Structure 3, and the Feature 78 post may mark one of the corners of the platform. Feature 89, also atypically deeply set, may mark the southwestern corner of the elevated platform.
Five of the post holes associated with Structure 3 (see Table 5-5) apparently cut through and postdate a large cooking pit (Feature 36) and an outdoor hearth (Feature 25) (Figures 5-12 and 5-13). The four that protrude into Feature 36 are relatively small in size and shallowly set, more so than many of the other Structure 3 post holes, but nevertheless the intersection of post holes through Feature 36 indicates that the ramada or outdoor work elevated platform postdates at least the use of this cooking pit in the outdoor activity area associated with Structure 1 .

Although the Feature 74 post hole was not exposed until near the bottom of the Feature 25 hearth (see discussion below), it must have bisected the hearth from top to bottom, as it cut through a pocket of ash at the very top of the hearth deposits. Therefore, the Feature 74 post hole postdates the earlier outdoor hearth situated along the northern edge of the Structure 3 ramada.

Other ramadas or work platforms have been identified on prehistoric Caddo sites along the Red River in southwestern Arkansas and northwestern Louisiana (Kelley 1997: Figure 20; Trubowitz 1984:91-92), and at two contemporaneous Caddo sites (41NA231 and 41TT653) in East Texas (Perttula ed., 2008a; Perttula and Sherman 2008). These tend to be 
about $3 \mathrm{~m}$ on a side and roughly square in shape, and are situated amidst outdoor work areas and areas of midden deposits. At the McLelland site (Kelley 1997:32) the ramada had larger post holes (ca. $25 \mathrm{~cm}$ in diameter) at its corners, but this was not the case at the
Tallow Grove site (41NA231). Most of the post holes in the ramada at Tallow Grove ranged from $18-22 \mathrm{~cm}$ in diameter, comparable to those from Structure 3 at the Lang Pasture site.

Table 5-5. Post Holes from Ramada (Structure 3) near Structure 1.

\begin{tabular}{lll}
\hline Fea. No. & $\begin{array}{c}\text { Dimensions } \\
\text { (L x W, in cm) }\end{array}$ & $\begin{array}{c}\text { Depth } \\
\text { (cm bs) }\end{array}$ \\
\hline $18^{*}$ & $21 \times 21$ & $35-39$ \\
$19^{*}$ & $10 \times 10$ & $35-40$ \\
39 & $22 \times 22$ & $40-51$ \\
$42^{*}$ & $10 \times 12$ & $35-43$ \\
$43^{*}$ & $14 \times 14$ & $35-47$ \\
46 & $13 \times 13$ & $40-46$ \\
59 & $23 \times 23$ & $40-50$ \\
60 & $15 \times 15$ & $40-52$ \\
70 & $19 \times 19$ & $40-57$ \\
72 & $20 \times 20$ & $50-82$ \\
$74^{* *}$ & $16 \times 16$ & $35-64$ \\
75 & $15 \times 15$ & $50-63$ \\
77 & $21 \times 21$ & $40-55$ \\
78 & $22 \times 22$ & $40-74$ \\
89 & $21 \times 21$ & $40-62$ \\
\hline
\end{tabular}

*post holes post date Fea. 36, which they protrude through

**exposed beneath Fea. 25

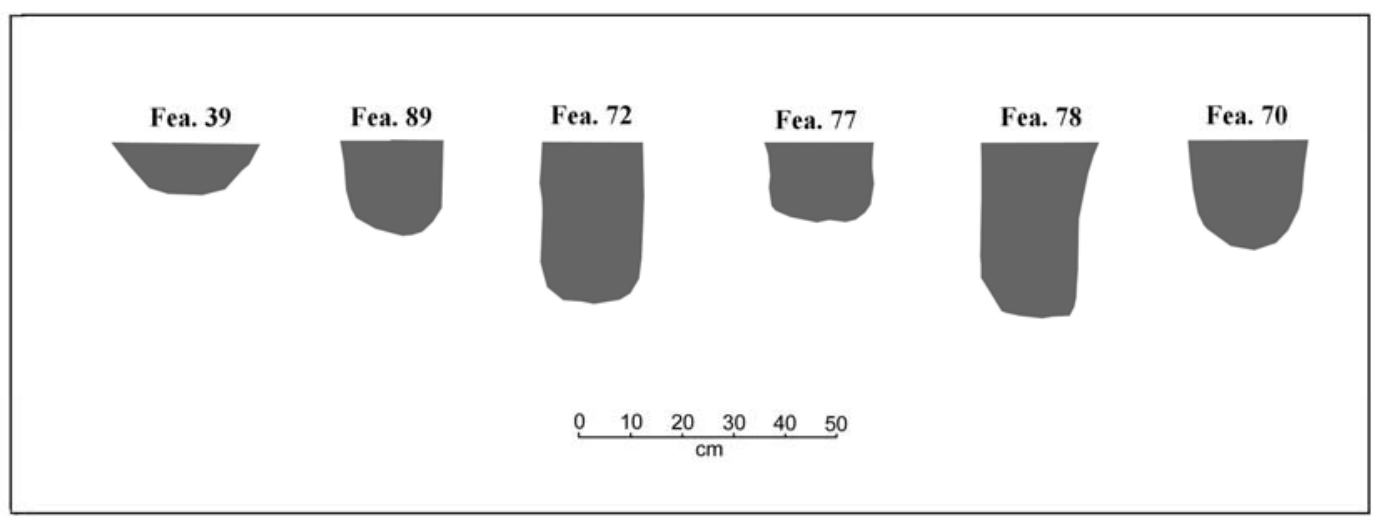

Figure 5-11. Profiles of Select Post Holes in the Ramada (Structure 3). 


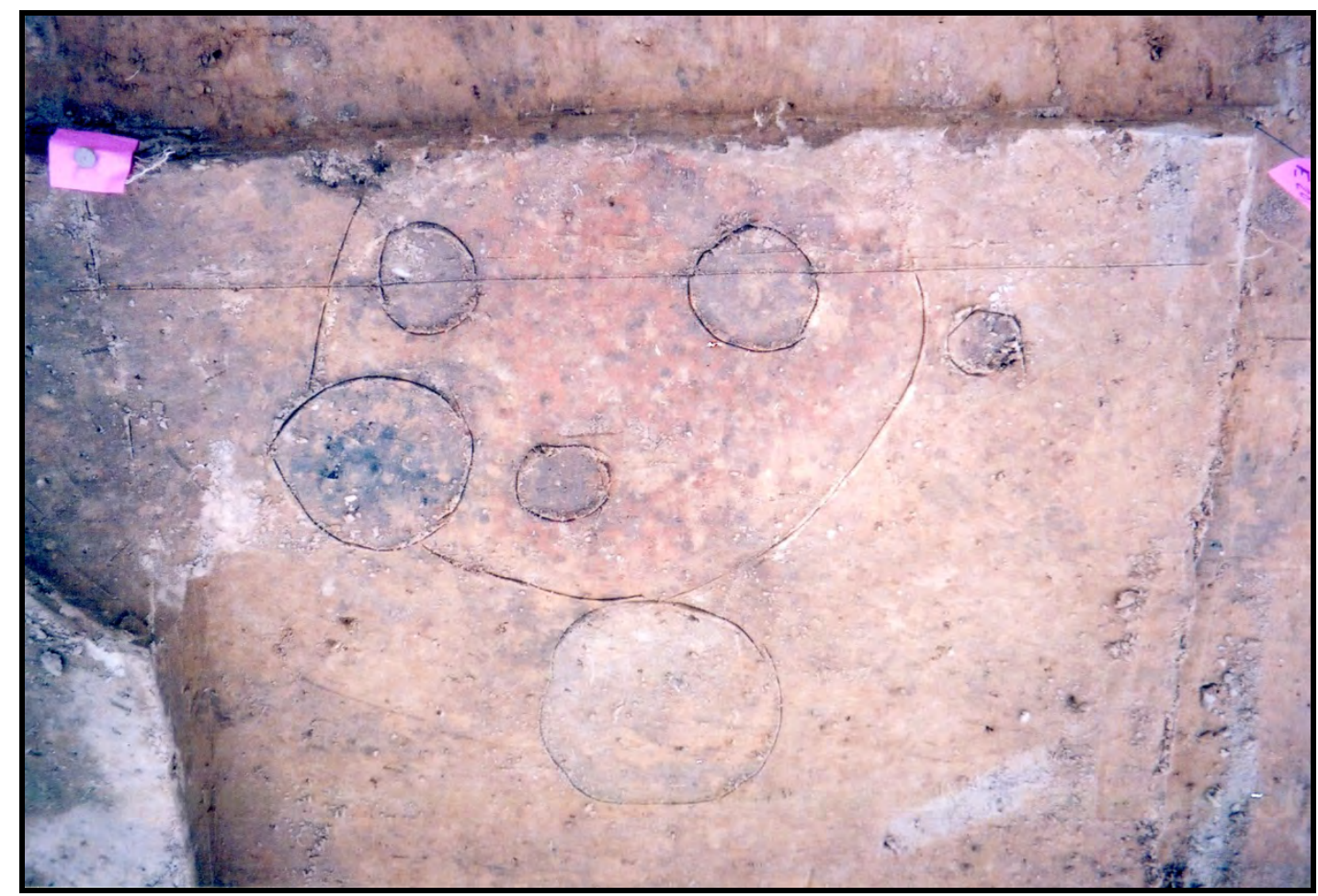

Figure 5-12. Post Holes Exposed at $35 \mathrm{cmbs}$ under Feature 36.

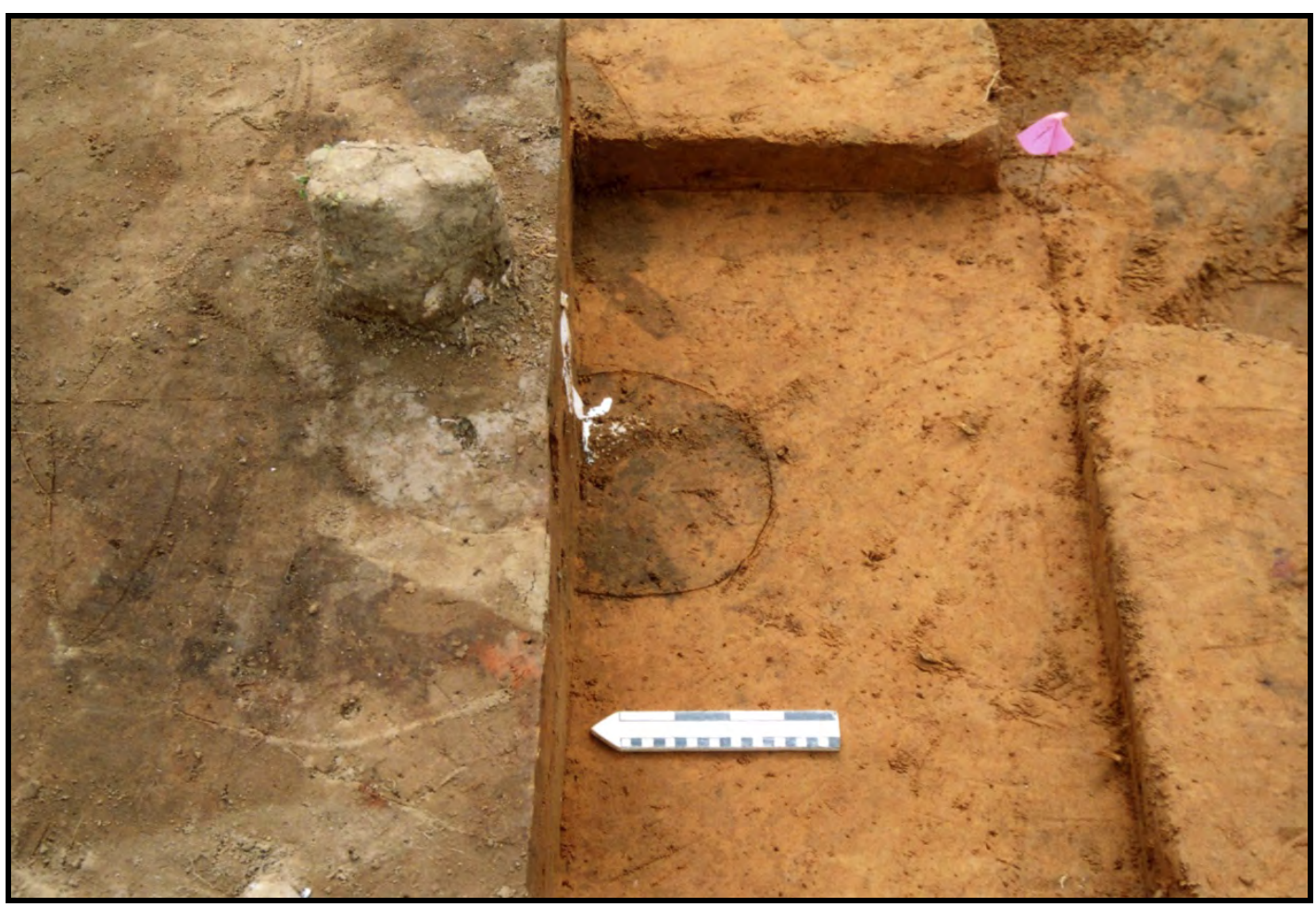

Figure 5-13. Feature 74 Post Hole Exposed under Feature 25, Looking East. 
A number of other post holes $(n=18)$ were identified and excavated from other contexts at the Lang Pasture site (Table 5-6). These include nine outside of, but in proximity to, Structure 2, among them several in an outdoor activity area 1-3 $\mathrm{m}$ north of Structure 2 (Figures 5-14 and 5-15). These form no coherent patterns, but may represent evidence for the construction and use of racks, screens, or wood supports to suspend cooking vessels above cooking fires.

The post holes in extra-mural settings are basically the same size as the posts used in the construction of both Structures 1 and 2, and most have gently sloping sides and rounded bottoms (Figure 5-15). It is interesting to note that the post holes found outside Structure 1, at $19.0 \pm 4.8 \mathrm{~cm}(\mathrm{CV}=25.26)$ in mean diameter and with a mean bottom depth of $58.5 \pm 9.0$ $\mathrm{cm}(\mathrm{CV}=15.38)$, are approximately the same size and depth as those post holes associated with Structure 1, while those found in extramural contexts outside Structure 2 have comparable post hole sizes $(23.6 \pm 3.29 \mathrm{~cm}$, $\mathrm{CV}=13.94)$ and depths $(64.1 \pm 13.83 \mathrm{~cm}$, $\mathrm{CV}=21.58$ ) as do Structure 2. The deliberate selection of larger poles associated with Structure 2 and its surrounding outdoor activity areas raises the possibility that timbers available for construction at the time of the Structure 2 occupation were naturally larger, and that by the time of the Structure 1 occupation (which presumably came slightly later), the larger timber had been culled, at least to the extent where it affected timber selection choices in the construction of Structure 1 and its associated Structure 3.

\subsubsection{Small and Large Pits}

There are 18 small and large pits at the Lang Pasture site (Table 5-7). Only three of the pits are within the two structures: Features 2 and 29 in Structure 2 and Feature 37 in Structure 1 . The others are in two outdoor activity area clusters, one north and northeast of Structure 1 and the other, but smaller, pit cluster about 11 $\mathrm{m}$ north of Structure 1 and west of the Feature 8 burial.

The larger and deeper pits (i.e., Features 20, $29,76 \mathrm{~A}$, and 79 ) were probably used for the storage of plant foods because of their considerable apparent volume and the nature of their fills. When they were no longer suitable as storage facilities, they were abandoned and filled in with sediments and discarded trash. Feature 76, the largest pit (see Table 5-7), is a special case among the Lang Pasture site pit features, in that while it was certainly large enough to store considerable amounts of plant foods, its primary use appears to have been for the emplacement of a series of burials rather than food storage. The larger pits typically have a dark brown fill, but with little evidence of stratification, discrete fill zones, or oxidized/fired areas, negating their use as earth ovens. Two of the pitsFeatures 76A and Feature 79-are more than large enough to have held 25 or more bushels (ca. $600 \mathrm{~kg}$ ) of plant foods. If that plant food was maize, that would be sufficient to meet the caloric needs for a year of a single nuclear family where maize comprised more than 55\% of the diet (Schroeder 1999: Table 5). 
Table 5-6. Post Holes from Other Contexts at the Lang Pasture Site.

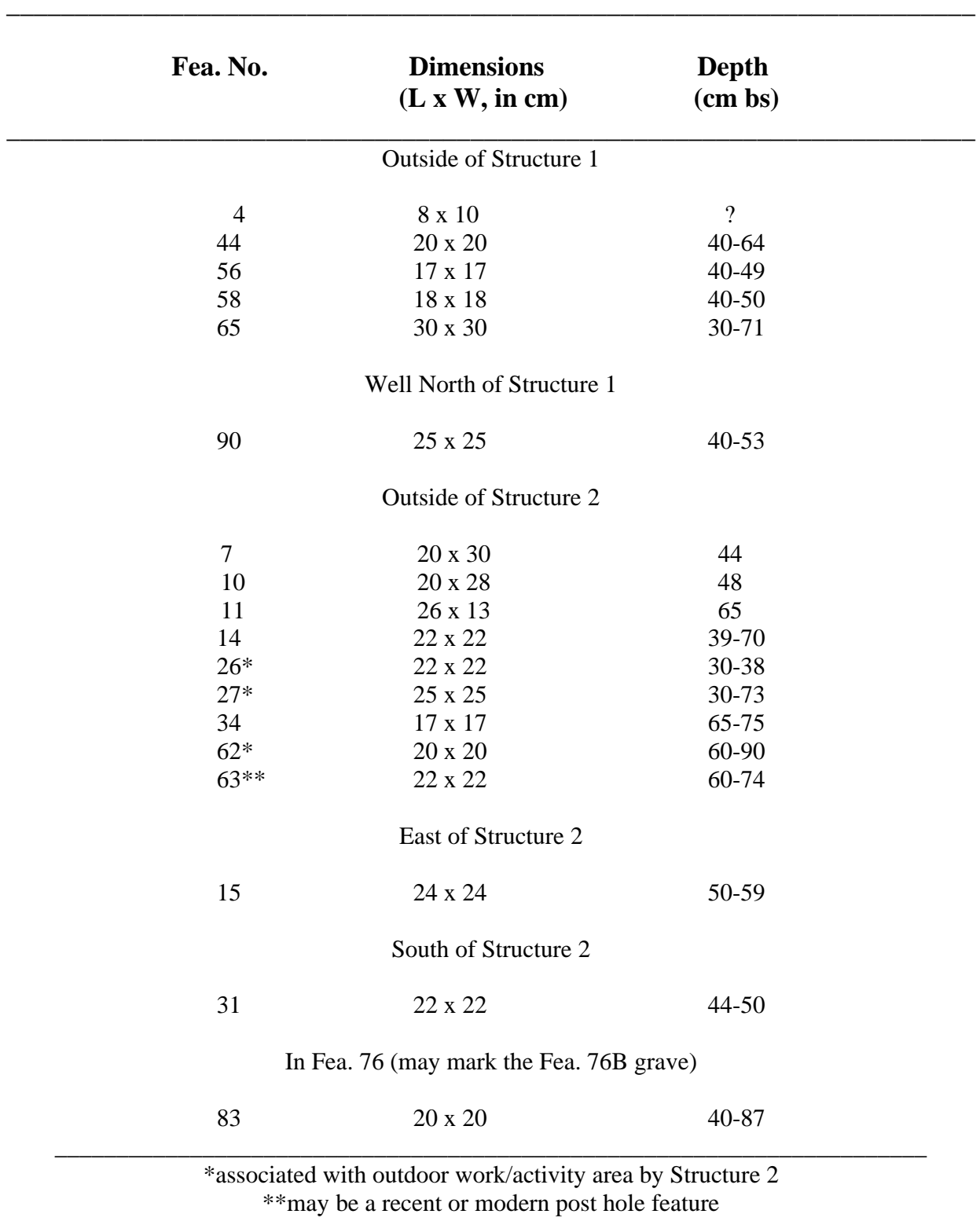

Such large pits were probably used for only a few years. Wall slumping and erosion would have been a problem in storage pit maintenance in the sandy soils at the Lang Pasture site, as would the deterioration and continual replacement of grass or canecovered walls and floors of the pits since none were lined with clay. When a storage pit was abandoned, a new storage pit was likely dug nearby.
The smaller pits (less than ca. $80 \mathrm{~cm}$ in diameter and relatively shallow in depth) could have held between ca. 1-6 bushels of plant foods. It is doubtful these pits were used for any large scale storage of plant foods, except perhaps for those at the larger end of the volume scale (i.e., Feature 37) that could have held $75 \mathrm{~kg}$ of food stuffs. The primary function of these smaller pits is uncertain. 


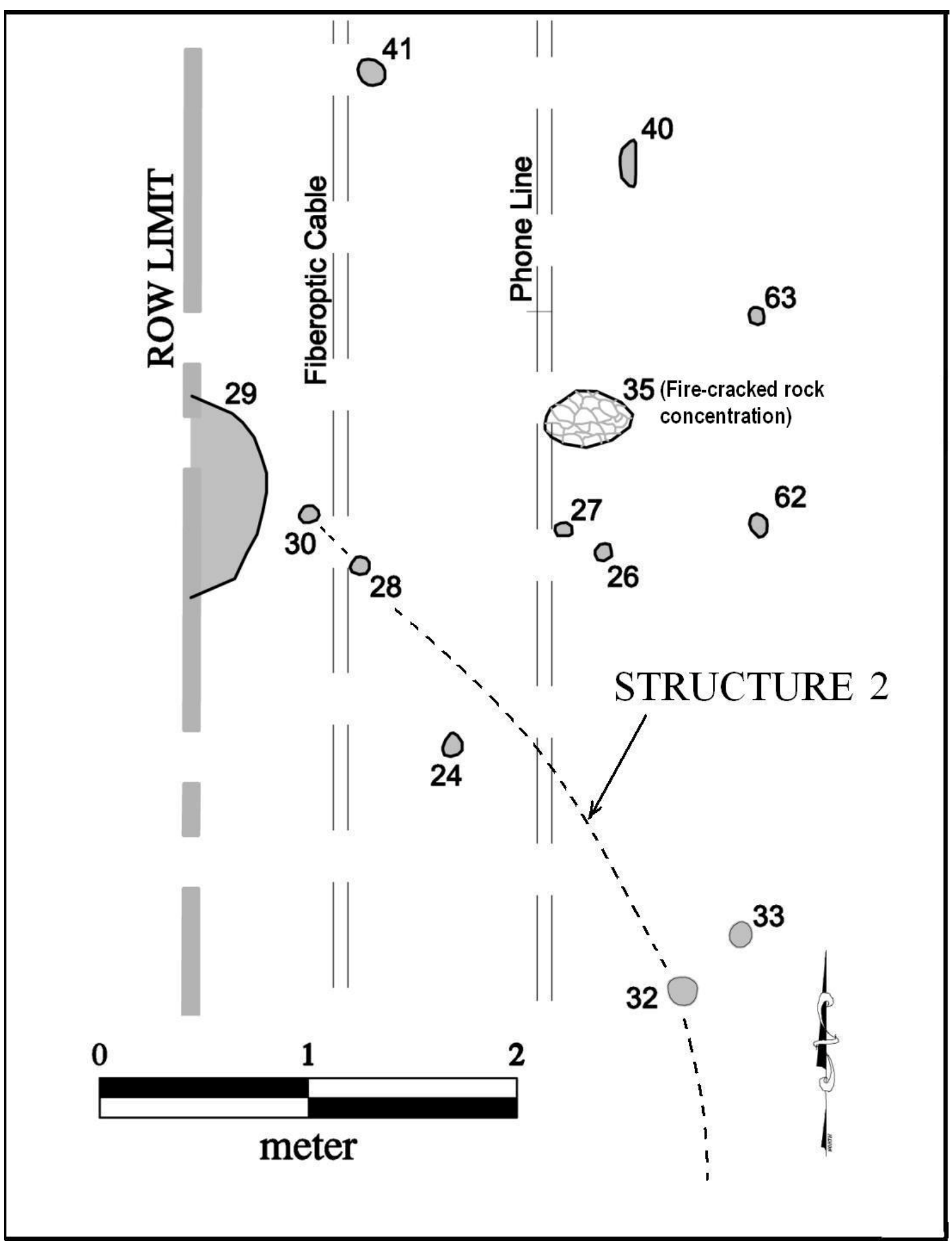

Figure 5-14. Features Associated with Outdoor Work/Activity Area Near Structure 2.

Only one of these pits (Feature 36) has evidence of in situ heating, such as oxidized soil or heat-baked floors or walls, perhaps from use as a cooking pit, but the matrix of these pit features often contain charcoal, bone, and a smattering of artifacts that had been discarded in the small pits (see Table 5-2). 


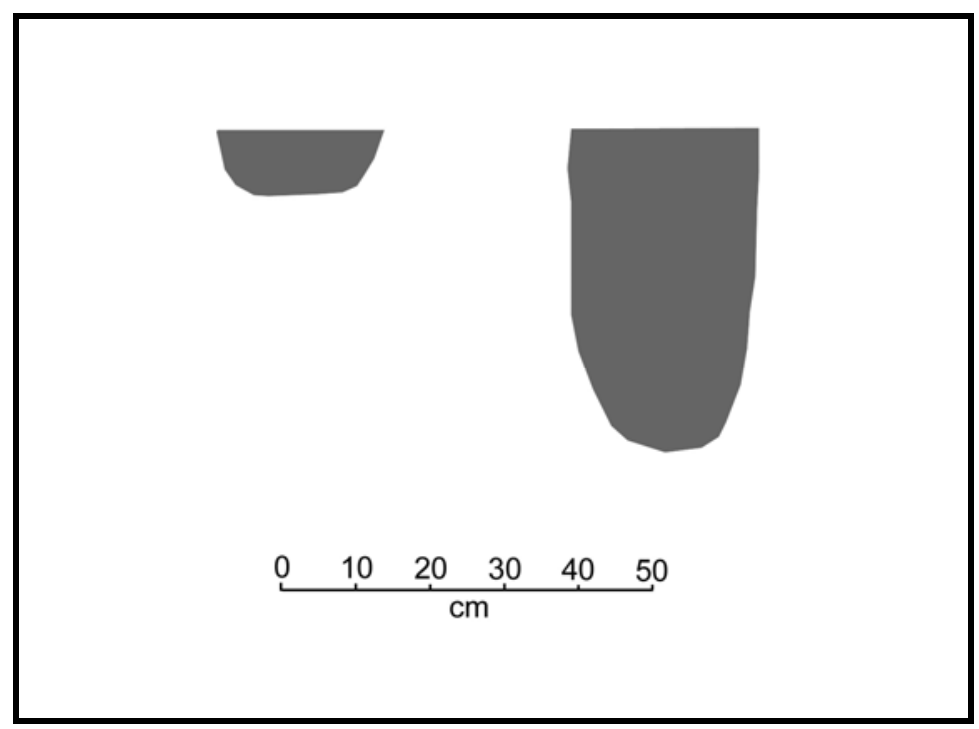

Figure 5-15. Profiles of Select Post Holes from the Outdoor Work/Activity Area near Structure 2.

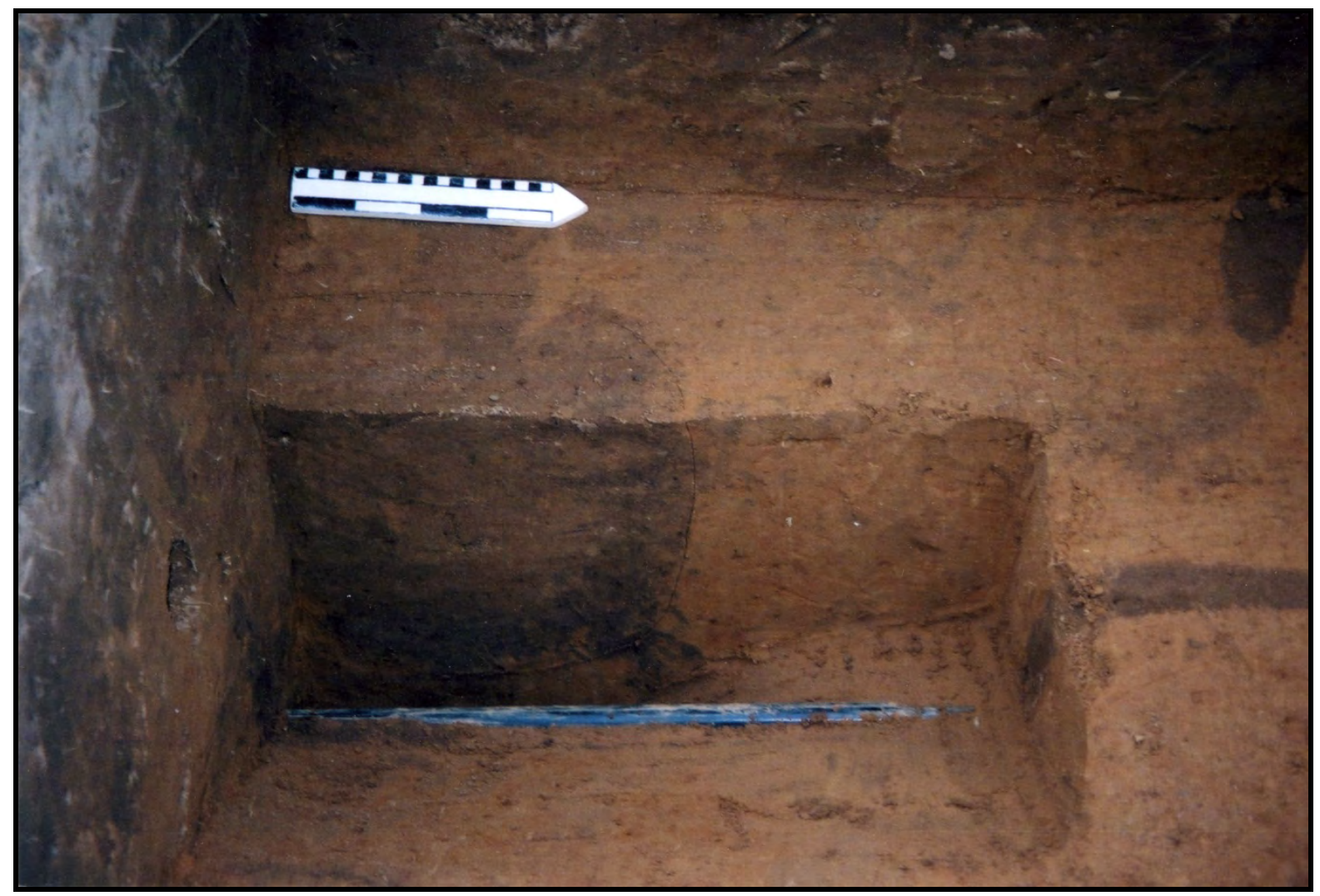

Figure 5-16. Plan and Profile of Feature 14, Outside Structure 2. 
Table 5-7. Small and Large Pits.

\begin{tabular}{|c|c|c|c|}
\hline Feature No. & $\begin{array}{l}\text { Dimensions } \\
(\mathrm{L} \times \mathrm{W} \text {, in } \mathrm{cm})\end{array}$ & $\begin{array}{l}\text { Depth } \\
\text { (cm bs) }\end{array}$ & Comments \\
\hline 2 & $25 \times 42$ & $33-68$ & C14 Date (2 sigma): AD1030-1290 \\
\hline 9 & $40+$ & & \\
\hline 20 & $132 \times 70$ & $34-56$ & $\begin{array}{l}\text { C14 Dates (2 sigma): AD 1290-1420 } \\
\text { and AD 1450-1650 }\end{array}$ \\
\hline 29 & $104 \times 29+$ & $39-65$ & C14 Date (2 sigma): AD 660-780 \\
\hline 36 & $115 \times 100$ & $25-38$ & $\begin{array}{l}\text { C14 Dates (2 sigma): AD 1300-1450 } \\
\text { and AD 1400-1450 }\end{array}$ \\
\hline 37 & $83 \times 73$ & $38-56$ & C14 Date (2 sigma): AD 1400-1450 \\
\hline 40 & $38+$ & $40-52$ & \\
\hline 45 & $34+$ & $35-46$ & C14 Date (2 sigma): AD 1260-1390 \\
\hline 57 & $28 \times 28$ & $40-70$ & \\
\hline 76 & $360 \times 210$ & $40-135$ & $\begin{array}{l}\text { C14 Dates (2 sigma): AD 1300-1430 } \\
\text { and AD 1300-1430, AD 1670-1950 }\end{array}$ \\
\hline $76 \mathrm{~A}$ & 107 x 90 & $30-135$ & C14 Date (2 sigma): AD 1050-1260 \\
\hline 79 & $118 \times 148$ & $40-94$ & $\begin{array}{l}\text { C14 Dates (2 sigma): AD 570-660 } \\
\text { and AD 1260-1390 }\end{array}$ \\
\hline 81 & $35 \times 35$ & $40-80$ & \\
\hline 82 & $56 \times 60$ & $40-80$ & C14 Date (2 sigma): 1040-840 BC \\
\hline 84 & $33 \times 37$ & $40-70$ & C14 Date (2 sigma): AD 1410-1470 \\
\hline 85 & $65 \times 60$ & $40-57$ & C14 Date (2 sigma): AD 1290-1420 \\
\hline 86 & $62 \times 58$ & $40-86$ & $\begin{array}{l}\text { C14 Dates (2 sigma): AD 70-330 and } \\
\text { AD 680-890 }\end{array}$ \\
\hline 87 & $70 \times 73$ & $40-54$ & \\
\hline
\end{tabular}

Feature $2\left(0.037 \mathrm{~m}^{3}\right.$ in estimated volume, enough to hold one bushel of food stuffs) is an oval-shaped pit with rounded sides and a rounded bottom (Figures 5-18). Its matrix is a very dark grayish-brown (10YR 3/2) sandy loam. The fill also contained small pieces of burned bone and charcoal.

Feature 9 was a poorly defined stain at least 20 $\mathrm{x} 40 \mathrm{~cm}$ in size that was identified during the test excavations at the Lang Pasture site (see Lohse 2004:Table 3.2). It had a brown (7.5YR $4 / 3$ ) sandy loam fill, but no charcoal or bone flecks or other artifacts were noted to occur in association with it. Further excavations in the 2006 block around the 2004 test units did not encounter the other edges of this nebulous pit, and it may simply represent a lightly stained patch of soil in an outdoor activity area east of Structure 2, rather than a discrete and deliberately excavated pit feature.
Feature 20 is a moderate-sized pit $\left(0.203 \mathrm{~m}^{3}\right.$, a volume large enough to hold 5.8 bushels of maize) about $3 \mathrm{~m}$ east of Structure 1 (Figure 519). The pit contained a modicum of artifacts and food refuse (see Table 5-2). The fill of the pit was a dark brown (10YR 3/3) loamy fine sand with charcoal flecking, particularly near the center of the feature in profile.

Feature 29 is a large pit situated within Structure 2, near the northern post hole wall arc. It is exposed in profile along the western edge of the block and TxDOT right-of-way, and thus its total shape and size is unknown; the exposed portion in the block suggests it is ca. $104 \mathrm{~cm}$ in diameter. The pit appears to be circular and basin-shaped, with sloping sides and a gently rounded base (Figure 5-20); a considerable quantity of charred plant remains were recovered from the feature fill (see Table 5-2). 
If the estimate of this feature's diameter is reasonably accurate, Feature 29 had a volume of $0.281 \mathrm{~m}^{3}$, sufficient to hold approximately 8 bushels of plant foods. This pit may have been a supplemental storage feature (since it could only have provided about $35 \%$ of a nuclear family's annual supply of maize), one placed within the walls of a structure to protect certain plant foods that might otherwise be damaged or destroyed if they had been placed in more vulnerable and accessible outdoor storage facilities.
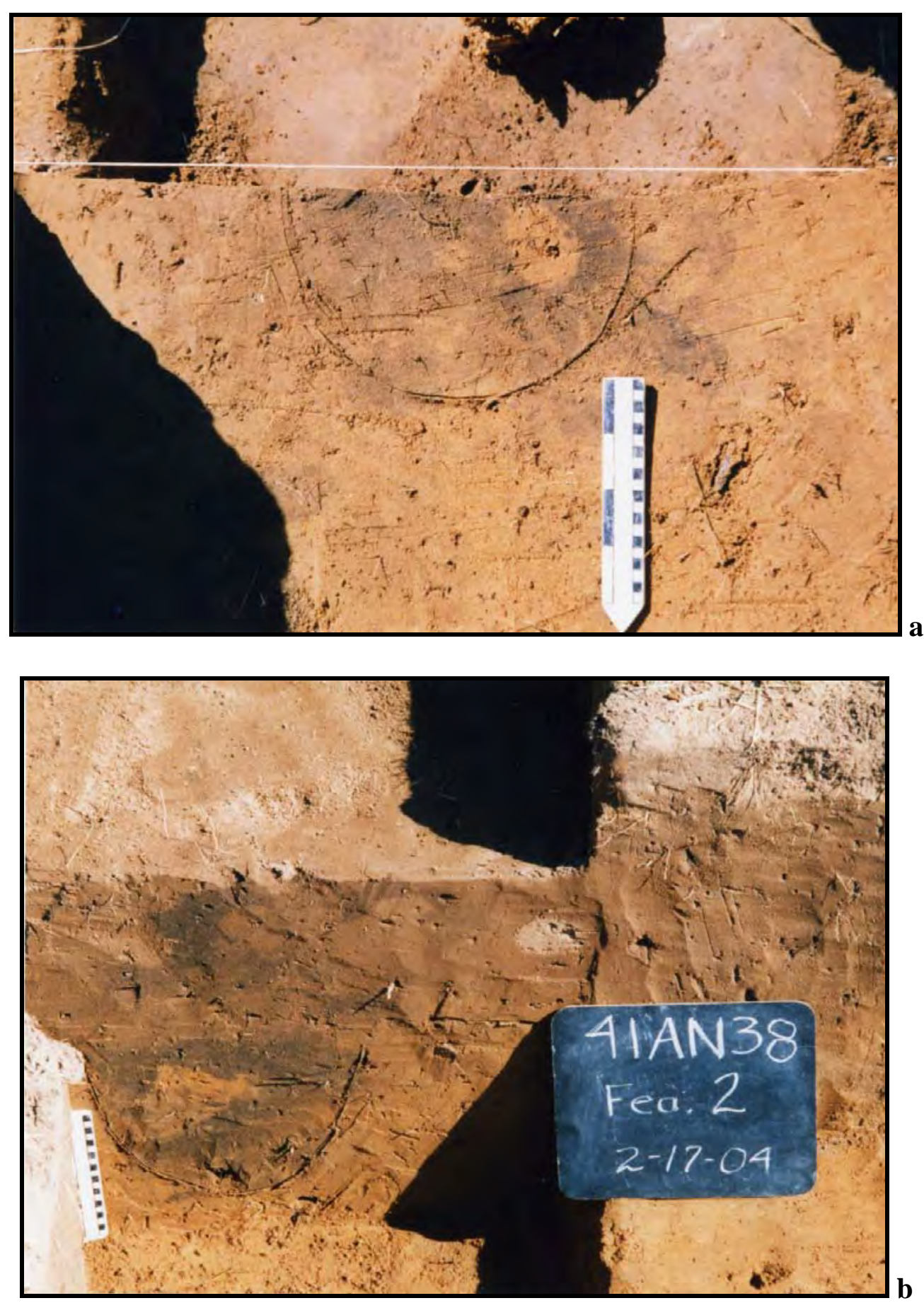

Figure 5-17. Photograph of Feature 2: $a$, Looking South in Plan; $b$, looking north in profile. 


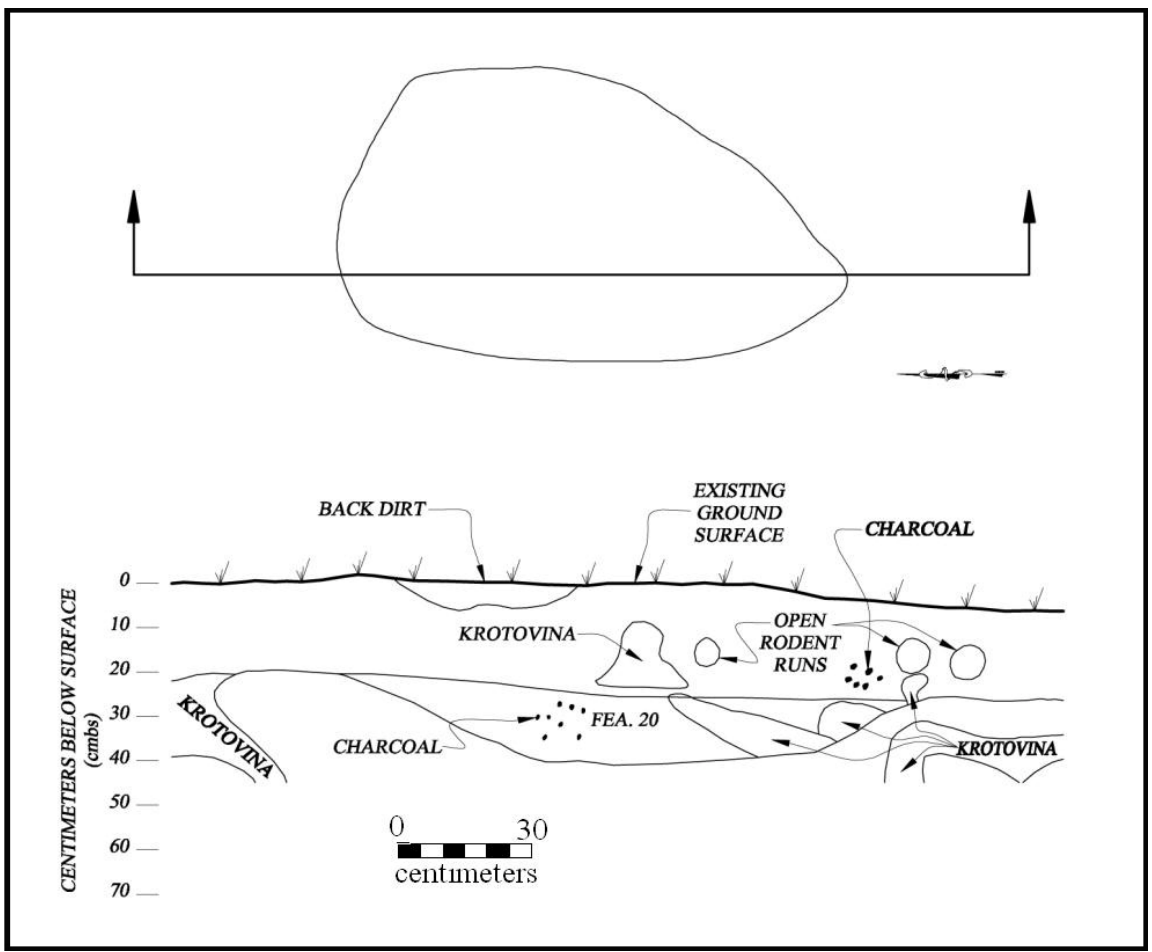

Figure 5-18. Plan and Profile of Feature 20.

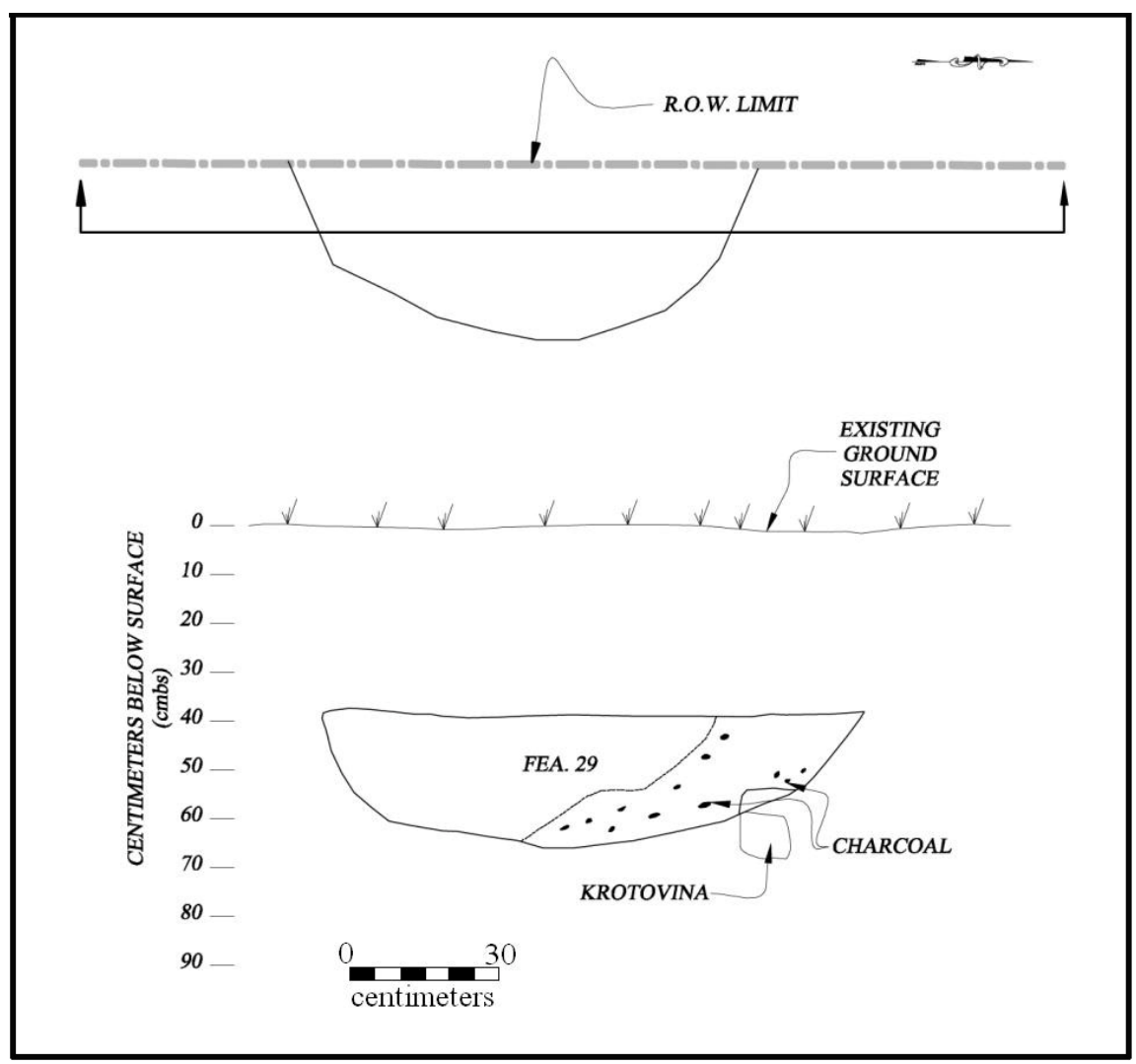

Figure 5-19. Plan and Profile of Feature 29. 


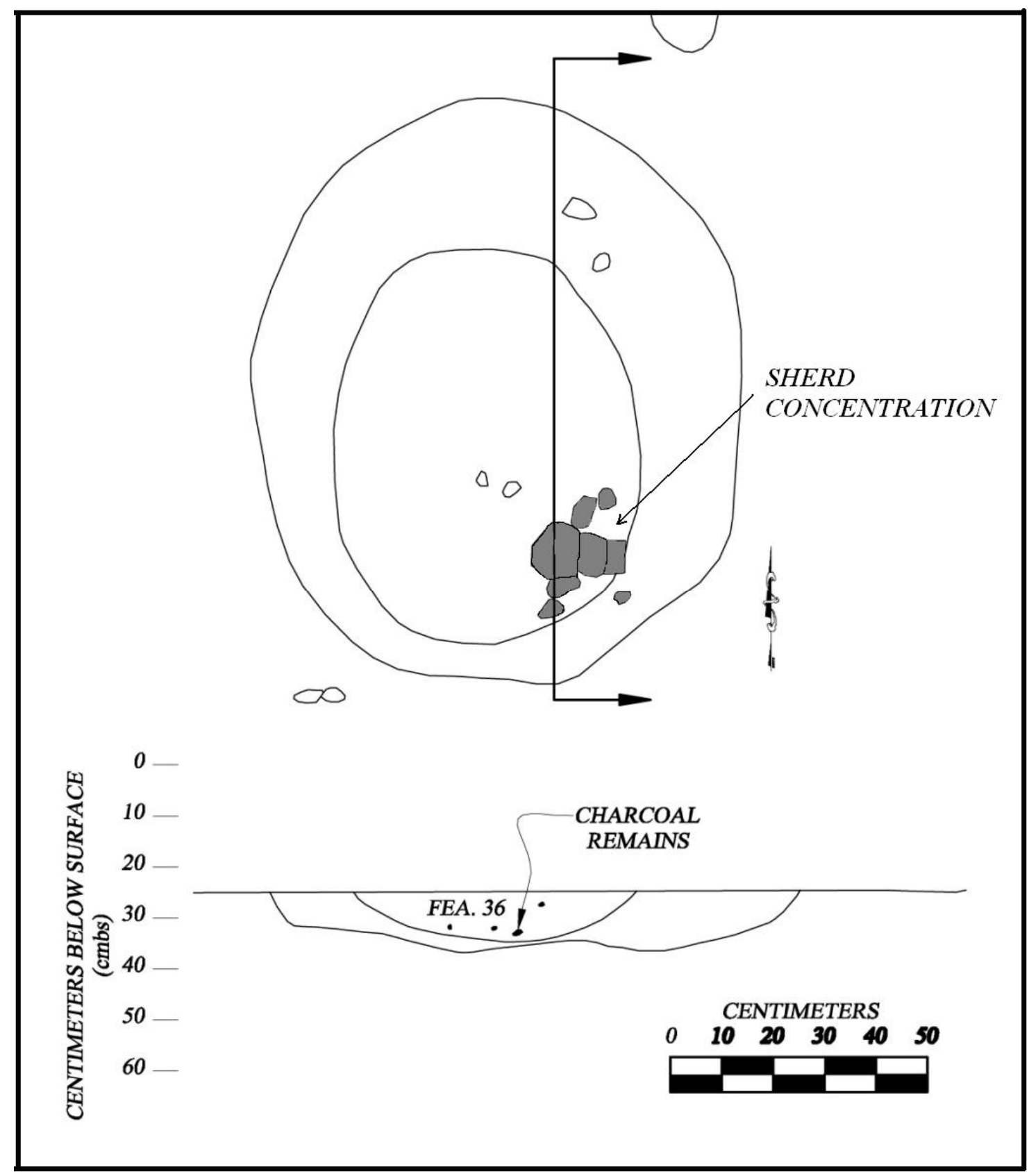

Figure 5-20. Plan and Profile of Feature 36. Note Sherd Concentration in Southeastern Part of the Feature.

Feature 36 is probably an outdoor cooking pit. It is oval-shaped, with a flat bottom and gently sloping side walls (Figures 5-21 and 5-22b). Pit fill consisted of a dark brown (10YR 3/3) to very dark brown (10YR 2/2) loamy fine sand with charcoal flecking along the margins of the pit, with a concentrated area of black (10YR 2/1) charcoal-stained fill in the central part of the pit. A cluster of sherds from a broken plain vessel were found at the top of these feature deposits (Figure 5-22a). Other remains recovered in the pit fill included other sherds, lithics, charred plant remains, animal bone, and a few fragments of mussel shell (see Table 5-2). 

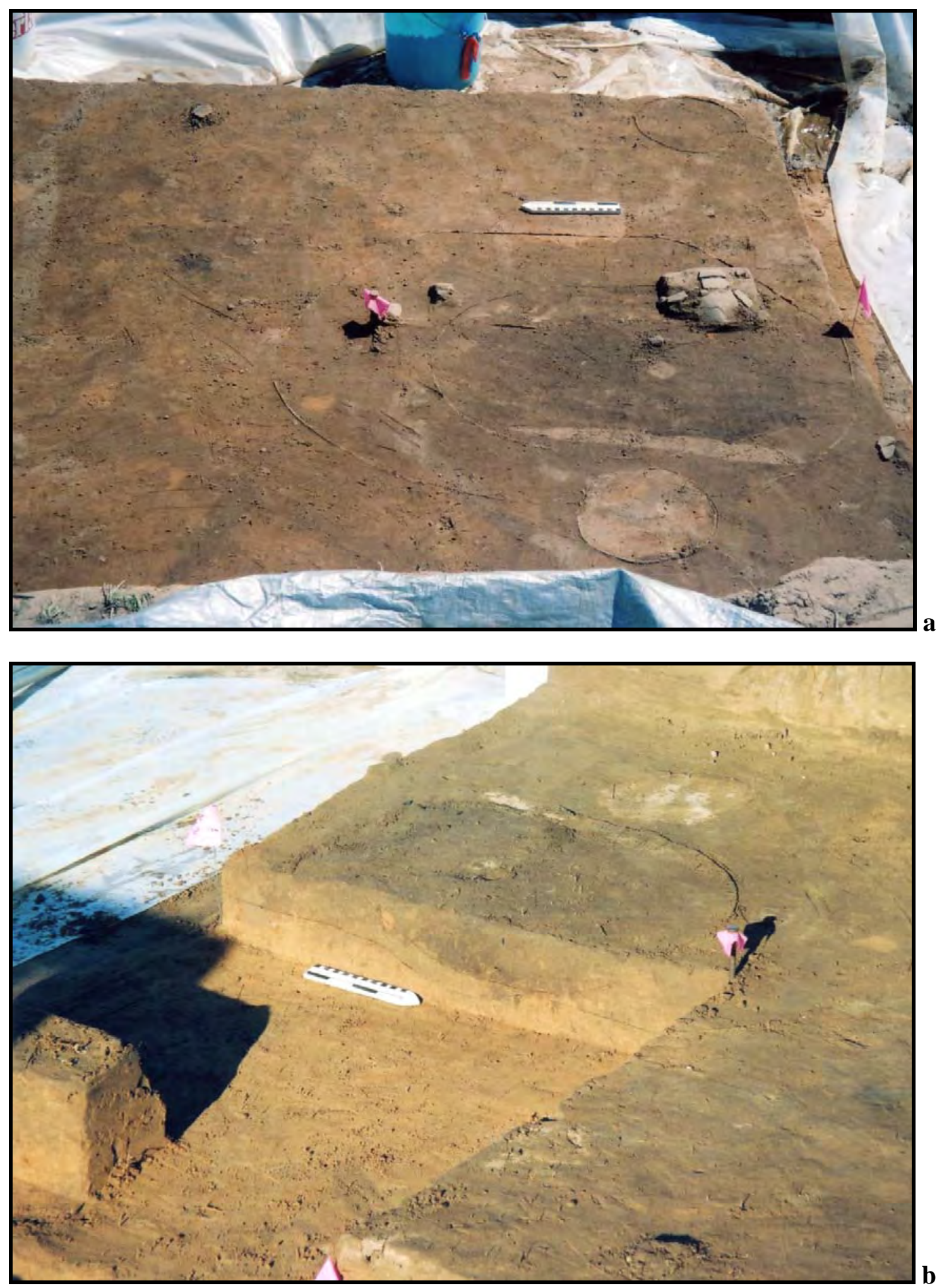

Figure 5-21. Feature 36: $a$, in Plan, with Sherd Concentration, Looking East; b, in Profile, Looking West. 

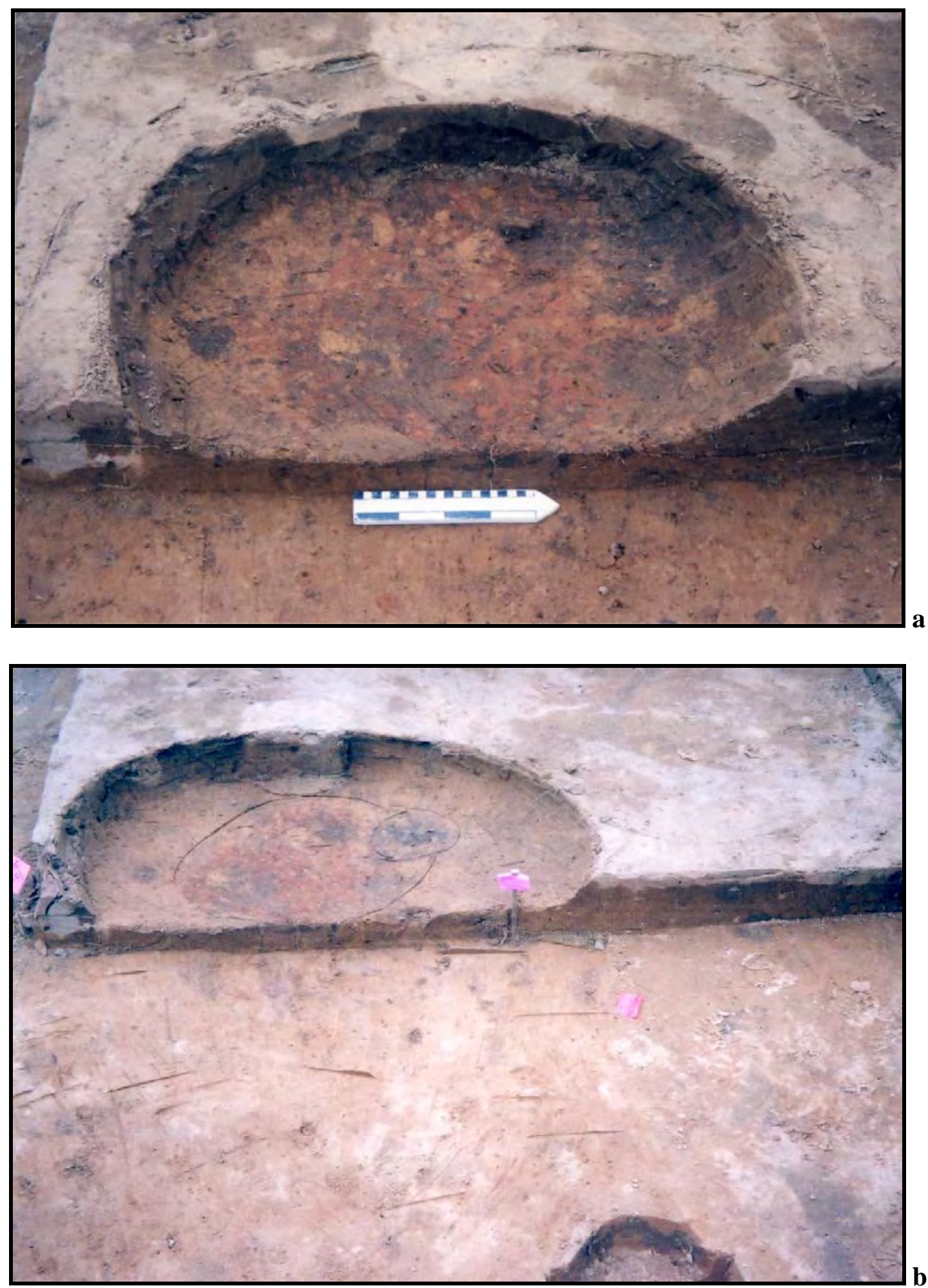

Figure 5-22. Feature 36 with the Organically-Enriched Fill Removed: a, oxidized soil exposed at the base of Feature $36,25-35 \mathrm{~cm}$, looking west; b, below oxidized soil, looking west. 
Upon the removal of these organicallyenriched feature sediments, a large area (52 x $44 \mathrm{~cm})$ of dark red (2.5YR 3/6) oxidized sediments were exposed at $35 \mathrm{~cm}$ bs (Figure 5-23a). The black charcoal-stained fill within Feature 36 surrounded and filled this oxidized basin, and had obviously been raked out of the cooking basin during its use. Four post holes (Features 18, 19, 42, and 43) from the Structure 3 ramada were exposed where they had cut through Feature 36, including cutting through and postdating the oxidized basin (Figure 5-23b).

Feature $37\left(0.109 \mathrm{~m}^{3}\right.$ in volume, and therefore able to hold ca. 3 bushels of plant foods) is a moderately-sized pit within the Structure 1 walls. The pit is basin-shaped, with gently sloping sides and a relatively flat bottom (Figures 5-24 and 5-25a-b), with dark yellowish-brown (10YR 3/6) loamy fine sand fill. A range of artifacts had been discarded in the pit (see Table 5-2), including deer teeth.

Feature 40 is a small basin-shaped pit (ca. $0.017 \mathrm{~m}^{3}$ ) in the outdoor activity area north of Structure 2. It has sloping sides and a rounded bottom, with a dark yellowish-brown (10YR 3/4) loamy fine sand fill. The feature fill contained only a few lithic artifacts and pieces of wood charcoal (see Table 5-2).

Feature 45 is another small basin-shaped pit $\left(0.013 \mathrm{~m}^{3}\right)$. It is situated amidst the post hole stains associated with the Structure 3 ramada, northeast of Structure 1 (see Figure 5-4). The pit had a dark brown (10YR 3/3) loamy fine sand fill, with visible charcoal and bone flecks; flotation samples recovered a few pieces of lithic debris from the feature fill (see Table 5-2).

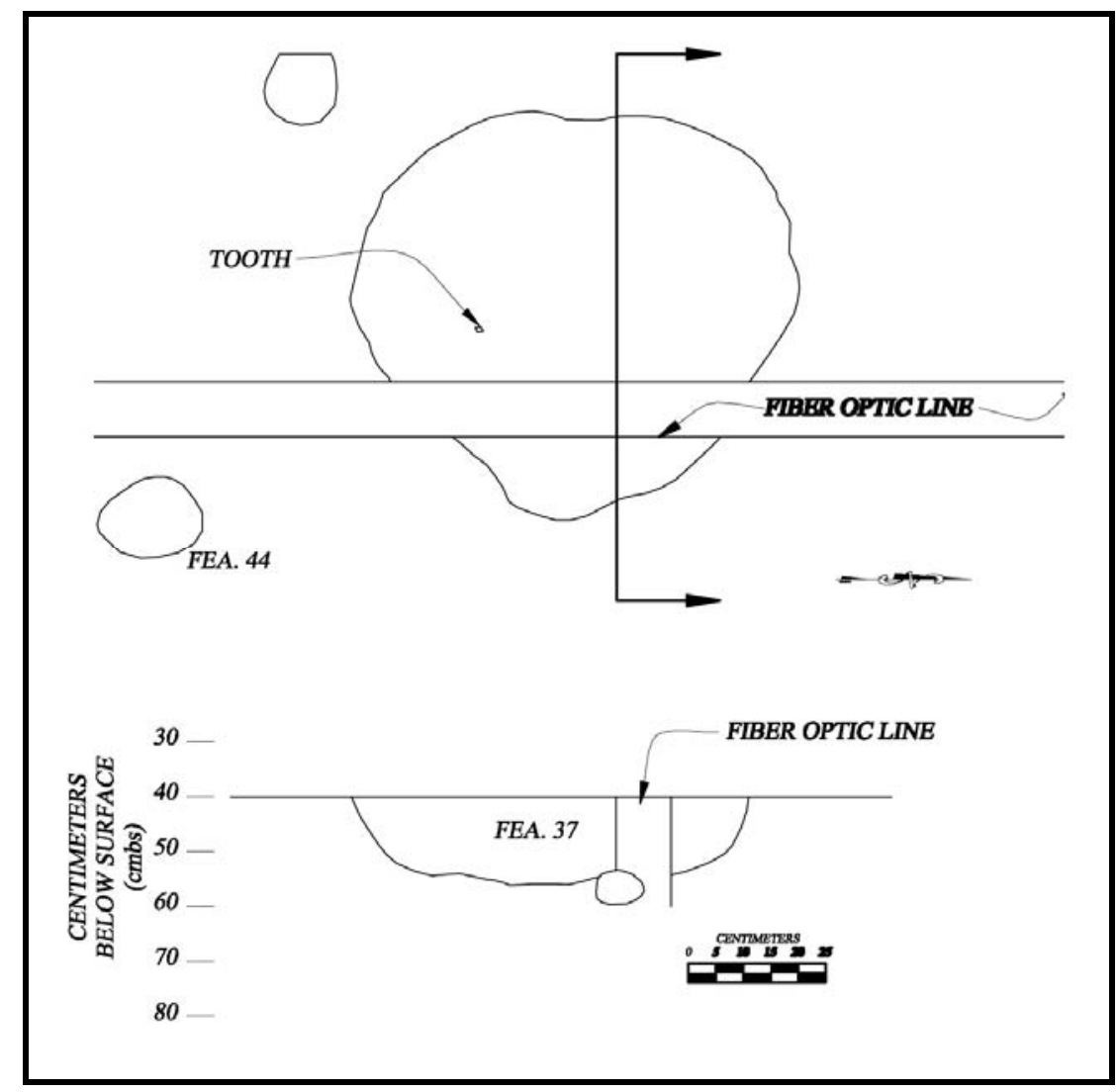

Figure 5-23. Plan and Profile of Feature 37. 

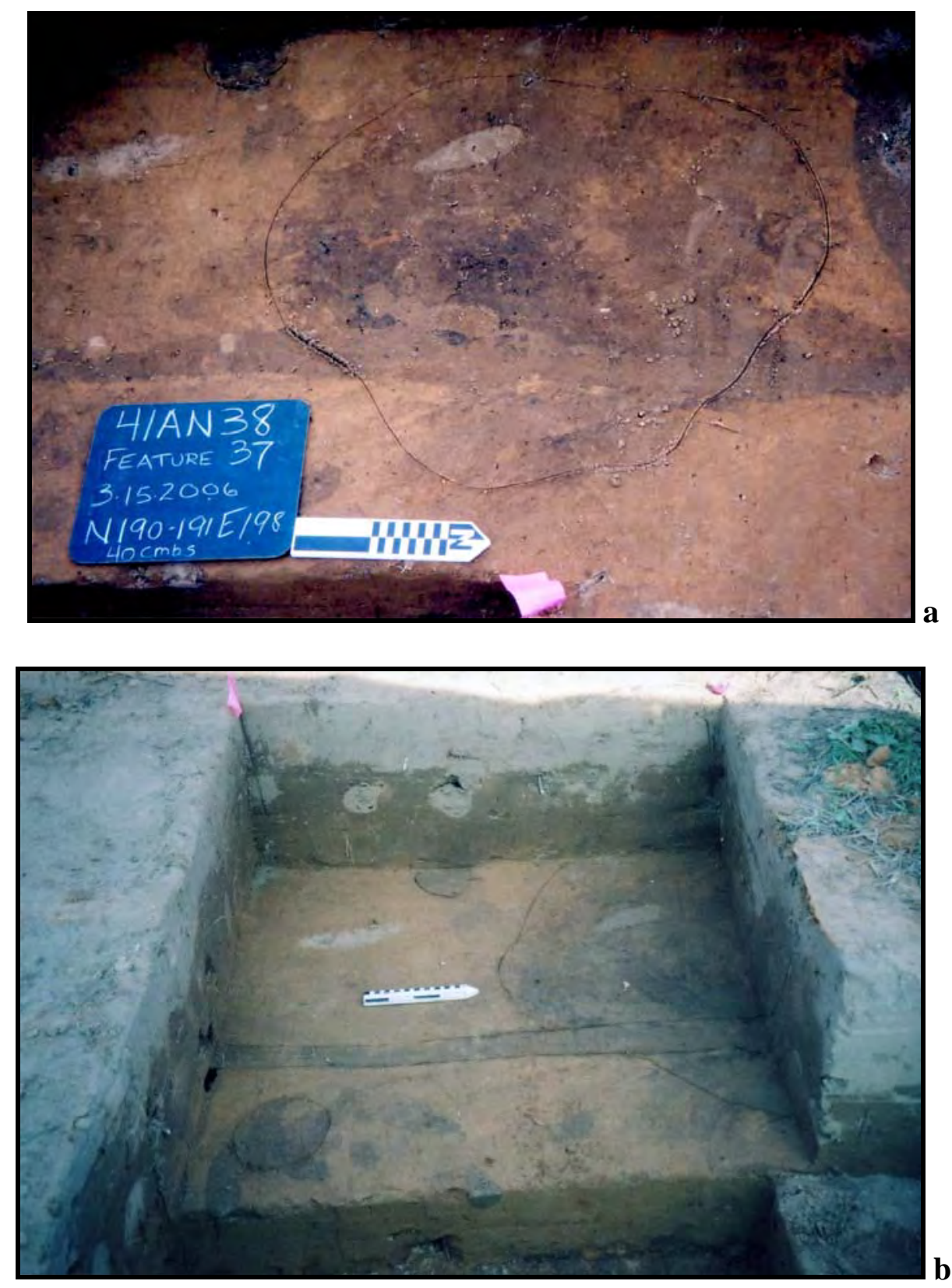

Figure 5-24. Two Views of Feature 37 in Plan: a, close-up, looking west; b, at a distance, looking west. 

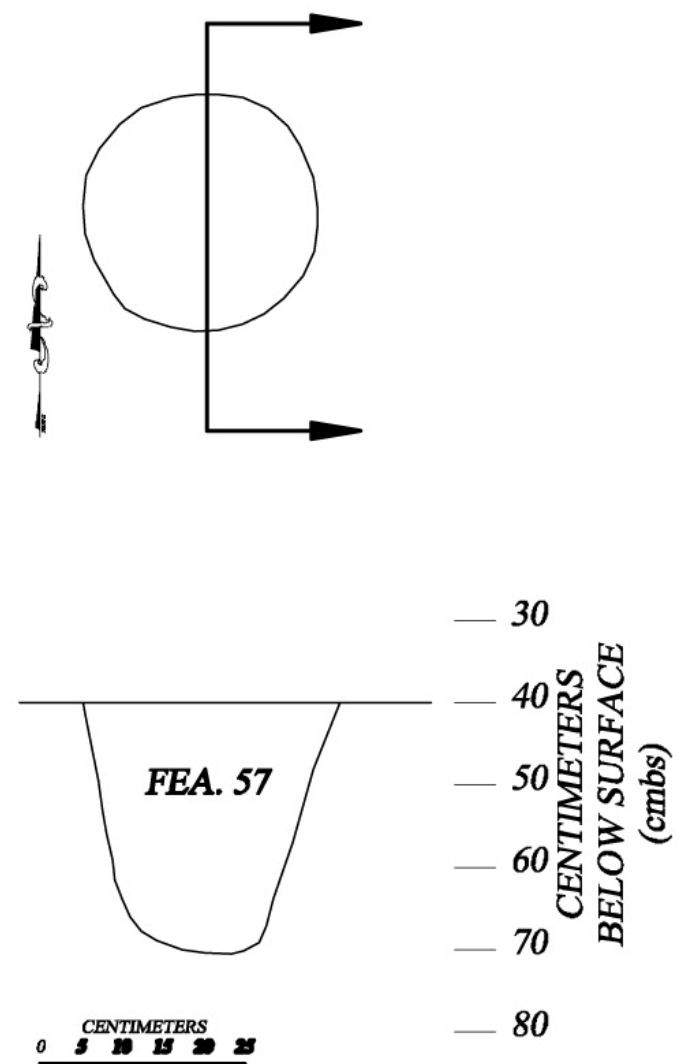

Figure 5-25. Plan and Profile of Feature 57.

Another small pit in the area of the Structure 3 ramada is Feature 57 (Figure 5-26). Its estimated volume is $0.023 \mathrm{~m}^{3}$, not large enough to hold even a bushel of plant foods. The pit is circular in shape, but conical in profile, with relatively straight sides and a gently rounded bottom. Feature fill is a dark brown (10YR 3/3) loamy fine sand, with charcoal flecking. It had a small assortment of ceramic and lithic artifacts, charred plant remains, and animal bone in its fill (see Table 5-2).

Feature 76 is by far the largest and most complex pit feature exposed at the Lang Pasture site. This pit feature-and its sub-pit features 76A, 76B, 76C, and 76D-are situated about $5 \mathrm{~m}$ northeast of Structure 1, and just northeast of the Structure 3 ramada and its associated outdoor activity area.

The pit measures approximately $3.6 \mathrm{~m}$ northsouth by $2.1 \mathrm{~m}$ east-west (Figures 5-27 and 528), and is somewhat oblong in shape. The pit, marked primarily by dark brown (10YR 3/3) charcoal-flecked sediments but with significant pockets of dark yellowish-brown (10YR 3/4 and 10YR 4/6) and strong brown (7.5YR 4/6) fill (especially near the base of the pit), was first well-defined at $40 \mathrm{~cm}$ bs (but was noted at $30 \mathrm{~cm}$ bs in several plan views) — near the contact of Zones II and IIIand extended to $135 \mathrm{~cm}$ bs (Figure 5-29; see also Figure 5-28). The pit cut at least $60 \mathrm{~cm}$ into the red clay B-horizon (see Figure 5-29). 
After the Feature 76 pit was excavated and used presumably for storage purposes, it was abandoned. At the point of abandonment, and before the pit had seen the accumulation of sediments/trash in it, the burial of a child or juvenile (Feature 76D was excavated into the central part of the floor of the pit (Figure 527).

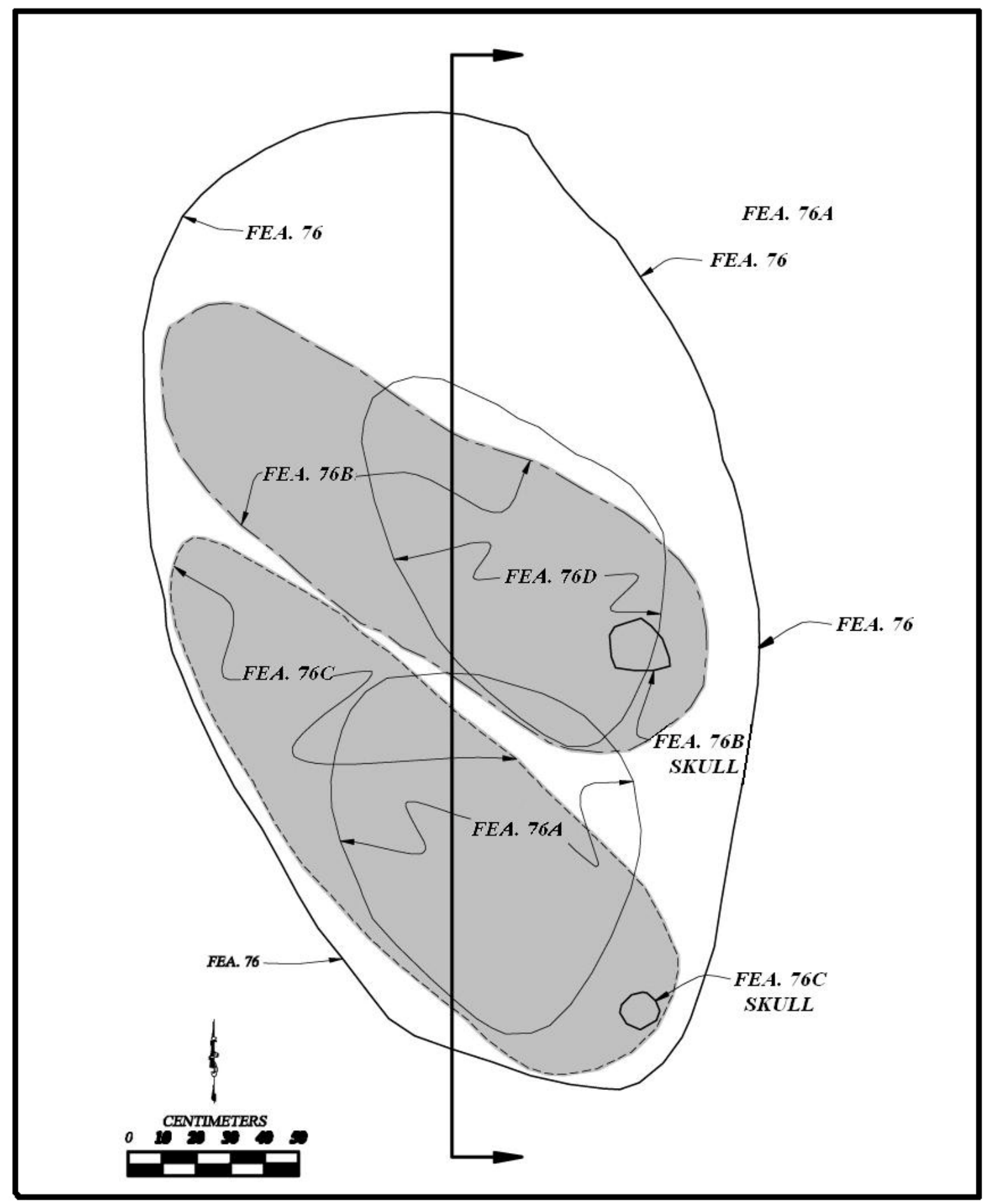

Figure 5-26. Plan of Feature 76 (note Features 76A-76D). 


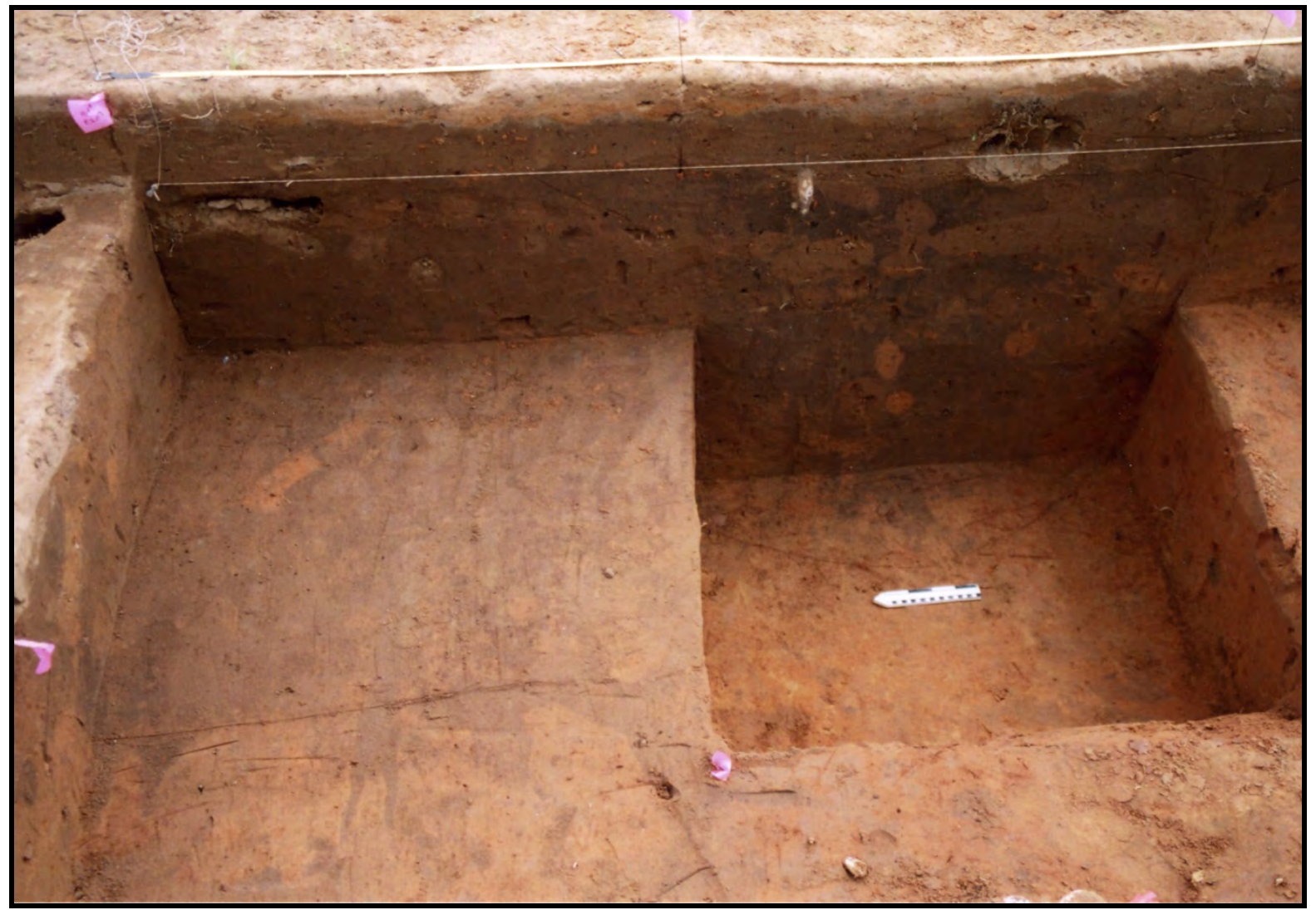

Figure 5-27. Looking East at Feature 76 in Plan and Profile View.

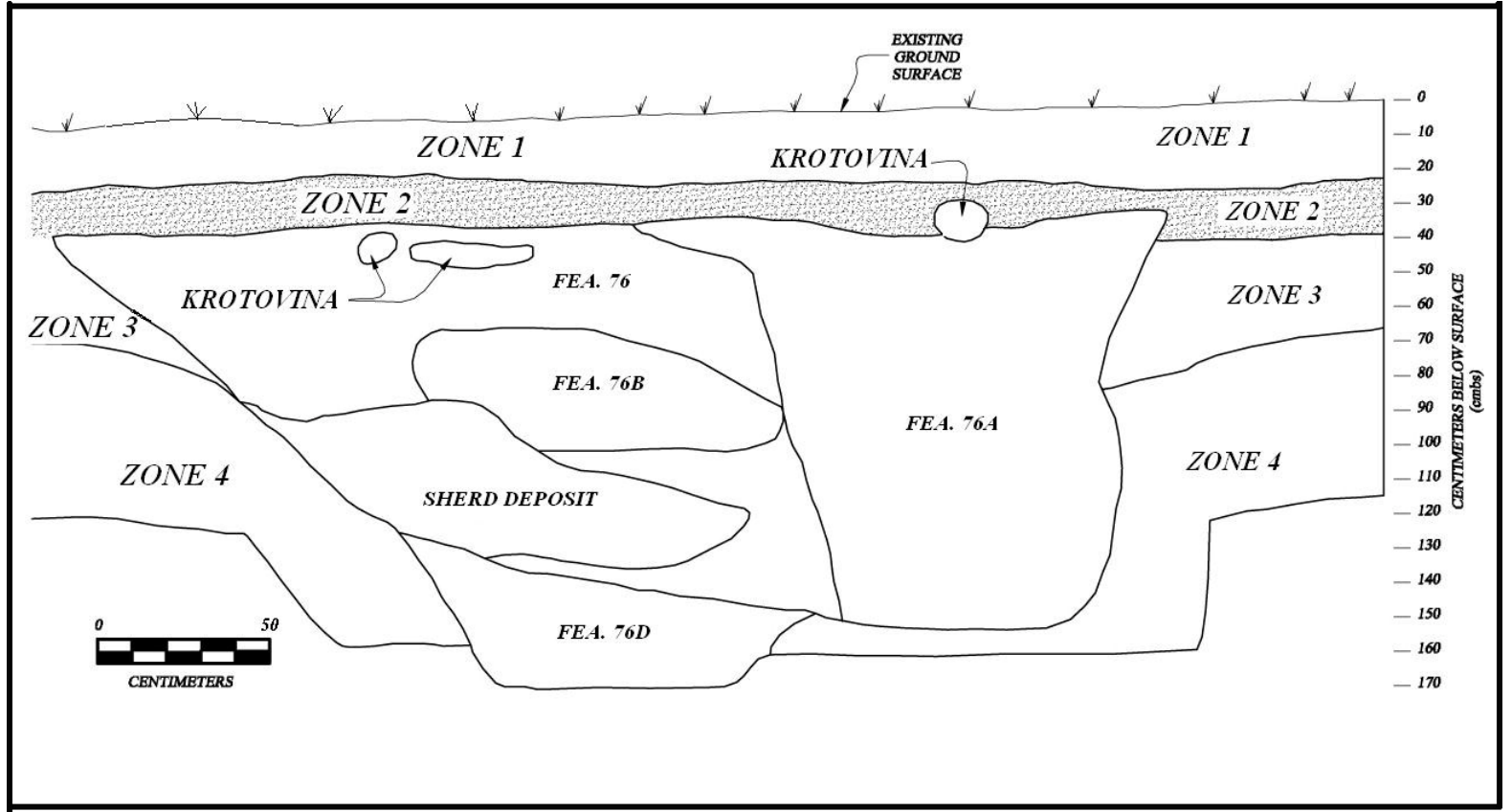

Figure 5-28. Profile of Feature 76 (note Features 76A, 76B, and 76D). 
Sometime later (perhaps only a matter of a few days), some sediments had begun to accumulate in the bottom of the pit (Zone 2E in Figure 5-29), at which point a large ceramic sherd deposit (Zones 2C and 2D) and additional sediments were dumped in the pit, immediately above the Feature 76D burial. Following this, two extended adult burials (Features 76B and 76C) were laid side by side in the floor of Feature 76, with the Feature 76B burial placed to be almost directly above that of the earlier Feature 76D burial (see Figure 5-25); this implies that little time separated the three burials.

A post hole (Feature 83) at the western end of Feature 76B may represent a burial marker post placed by the Caddo. The Feature 76C burial was then nestled into the southern part of Feature 76, with its head at the eastern end of the burial pit. After these mortuary events had been concluded, the pit was filled up. Finally, at an unknown interval after the mortuary episodes, when the Feature 76 pit was full of sediments to ground level, another pit feature (Feature 76A) was excavated into the larger pit, extending to the approximate base of the older pit, and having cut through the earlier Feature 76C burial (see Figures 527 and 5-29).

The estimated volume of Feature 76 is 7.18 $\mathrm{m}^{2}$, large enough to hold more than 200 bushels $(4670 \mathrm{~kg})$ of plant foods. If maize kernels were held in Feature 76, the volume would be sufficient to meet the dietary requirements of 8-9 families for a year, suggesting that it may have been a shared multi-household storage feature. This also suggests that the Lang Pasture site was occupied by multiple Caddo households, the majority of which remain uninvestigated on private property outside the TxDOT ROW.

The pit had steep and straight walls on one side, where the later Feature 76A pit had been cut into it (Figure 5-30a-b), but otherwise its walls are gently sloping, with a relatively flat bottom. Large quantities of artifacts were found in the feature fill, especially ceramic sherds, lithics (including several arrow points), wood charcoal and nutshells, and animal bone (see Table 5-2).

The Feature 76A pit has a very dark grayishbrown (10YR 3/2) loamy fine sand fill, with patches of very dark brown (10YR 2/2) sediments pieces of charcoal, and charcoal flecks. The obvious charcoal staining of Feature 76A clearly contrasts in plan and profile to the earlier and older Feature 76 pit feature into which it had been dug by the Caddo (Figure 5-31a-b).

Feature 76A has an estimated volume of 1.01 $\mathrm{m}^{3}$. The pit feature could have held approximately 28 bushels $(660 \mathrm{~kg})$ of plant foods, sufficient to hold a year's worth of maize for a single household. This feature may have replaced one of the other probable storage pits in use at the site, as underground storage pits were sequentially used and abandoned. New pits used for storage were dug by the Caddo occupants when the old pits were no longer usable-either because they were unable to successfully preserve foods buried in the pits or they were too much trouble to maintain. Excavations of the pit recovered an assortment of fragmentary ceramic and lithic artifacts, charred plant remains, and animal bones, indicative of trash disposal once its probable storage function had ceased.

Feature 79 is one of the larger and deeper pit features identified and excavated at the Lang Pasture site. It is located about $2 \mathrm{~m}$ directly north of the northern wall of Structure 1, and is probably the principal storage feature that was used by the Caddo household that lived there. The pit would have held at least an estimated 26 bushels (600 kg) of plant foods, more than sufficient to feed a family of five for one year if maize contributed $55-60 \%$ of their total diet. 

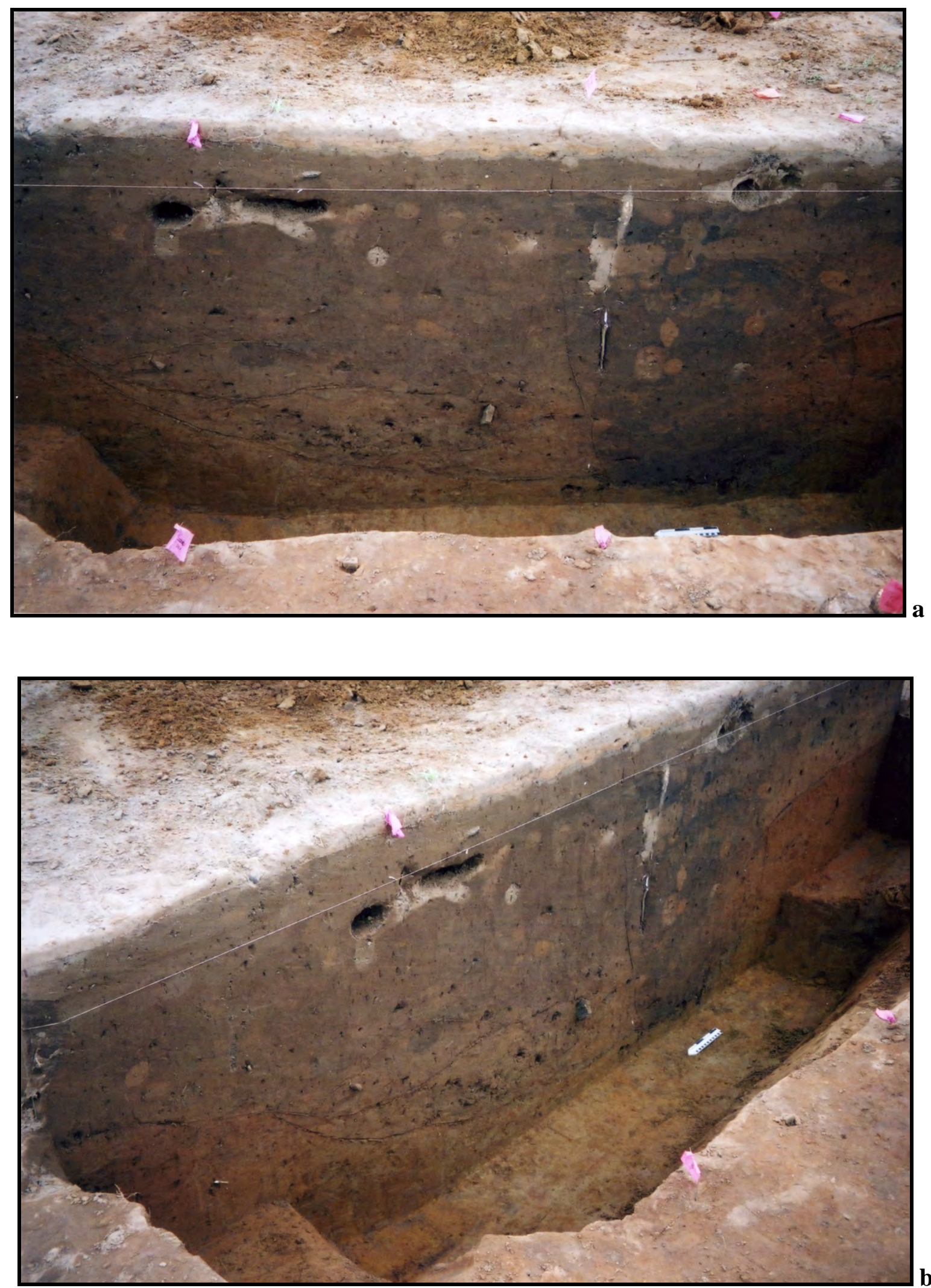

Figure 5-29. Relationship of Feature 76 and Feature 76A in Profile: a, looking east; b, looking southeast. 

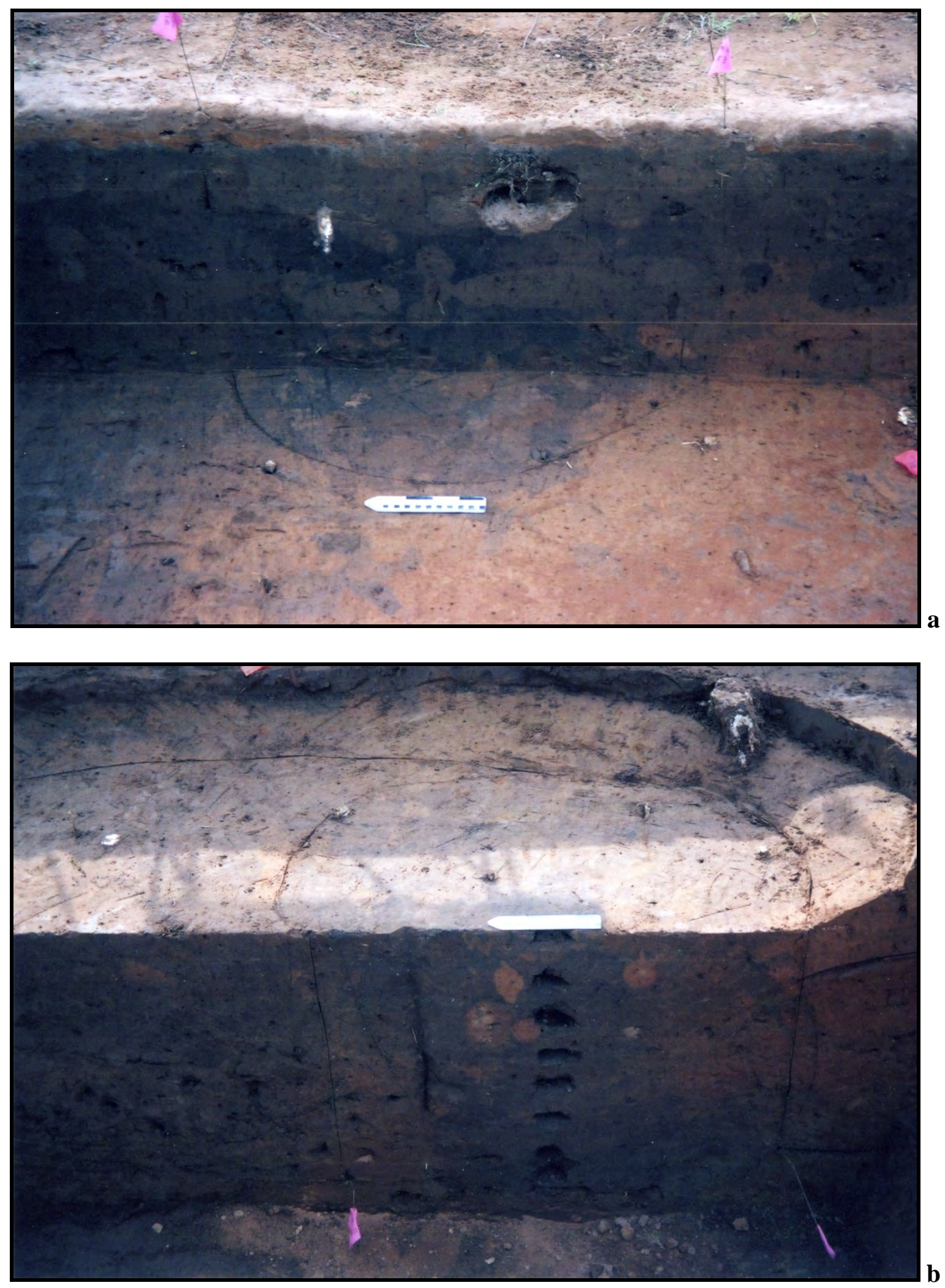

Figure 5-30. Feature 76A: a, in plan, looking east; $b$, in profile, looking east. 
This pit feature had gently sloping sides and a rounded bottom (Figures 5-32 and 5-33a-b). Its fill ranged from a very dark brown (10YR $2 / 2$ ) to a dark brown (10YR 3/3) loamy fine sand, with charcoal flecking. Significant amounts of trash-including ceramic and lithic artifacts, charred plant remains (including nutshells), animal bone, and firecracked rock-were recovered from the feature fill (see Table 5-2).

Feature 81 is a circular pit $\left(0.049 \mathrm{~m}^{3}\right.$ in estimated volume, ca. 1.4 bushels) about $4 \mathrm{~m}$ north of Structure 1, in an area with no other features or pits. In profile, it has relatively straight and deep sides and a flat bottom (Figure 5-34). The charcoal-stained feature fill contained a few ceramic sherds and pieces of lithic debris as well as moderate amounts of charred plant remains and animal bones (see Table 5-2).

Feature 82, a medium-sized pit (ca. $0.134 \mathrm{~m}$ in estimated volume, and thus able to hold ca. 3.8 bushels or $90 \mathrm{~kg}$ of plant foods if it were used for storage) about $1 \mathrm{~m}$ north of Structure 1- and just south of Feature 79. The pit has a flat bottom and gently sloping side walls (Figure 5-35). It has a mottled dark yellowish-brown (10YR 3/6) loamy fine sand fill, with lithic debris and small amounts of charred plant remains and animal bones (see Table 5-2), probably discarded as trash by the Structure 1 inhabitants.

Feature 84 is another pit just north of Structure 1. It is basin-shaped, with sloping sides and a rounded bottom, with an estimated volume of ca. $0.037 \mathrm{~m}^{3}$. It has a dark brown (10YR 3/3) loamy fine sand fill, with charcoal flecks. Flotation samples of the pit fill recovered ceramic sherds, lithic artifacts, a few animal bones, and $20 \mathrm{~g}$ of charred plant remains (see Table 5-2).

Feature 85 is one of three pits (the others are Features 86 and 87) found in a cluster west of the Feature 8 burial, and $10+m$ north of Structure 1.

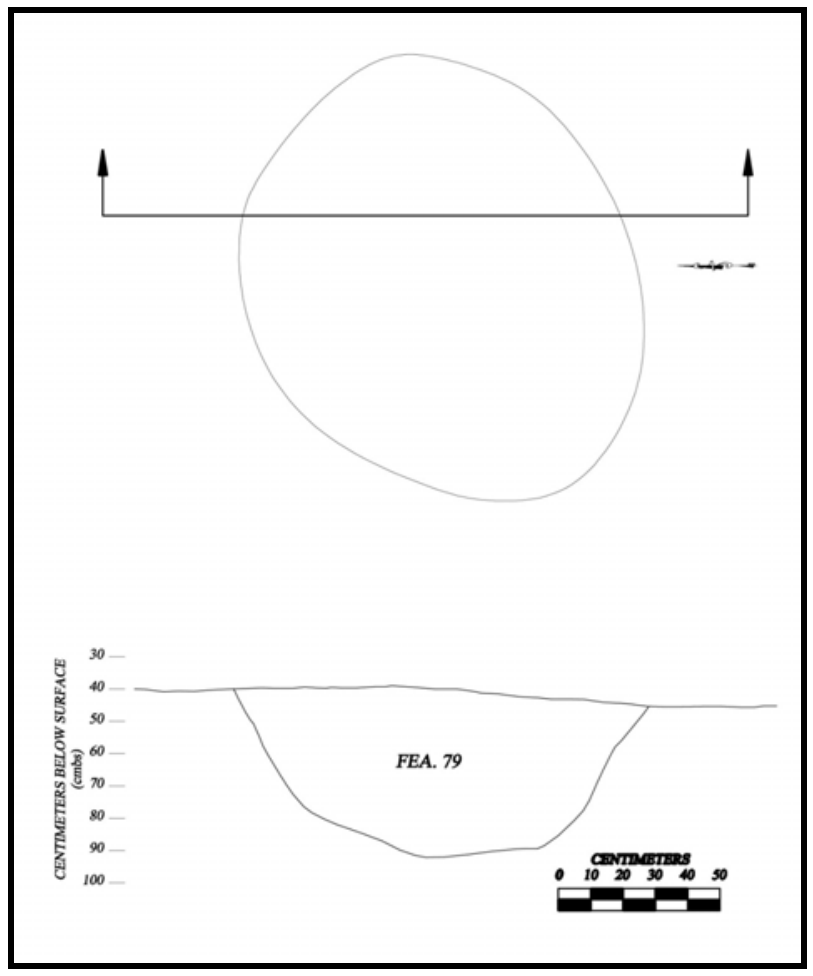

Figure 5-31. Plan and Profile of Feature 79. 

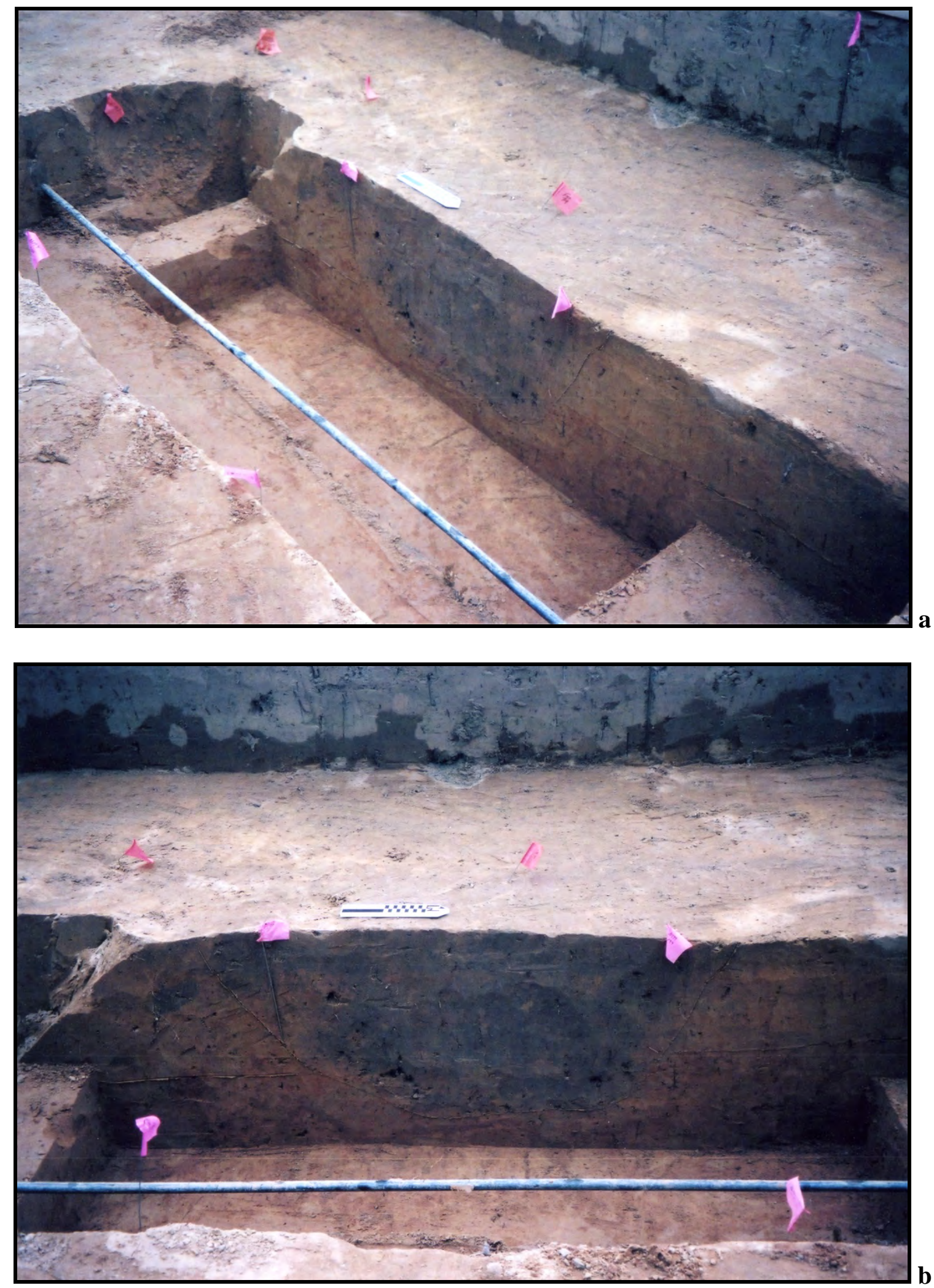

Figure 5-32. Photographs of Feature 79: $a$, in profile, looking southwest; $b$, looking west at profile. 


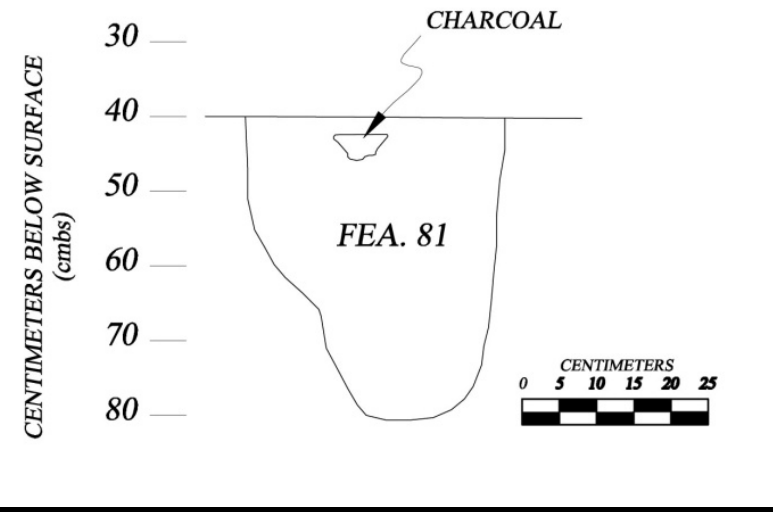

Figure 5-33. Plan and Profile of Feature 81.

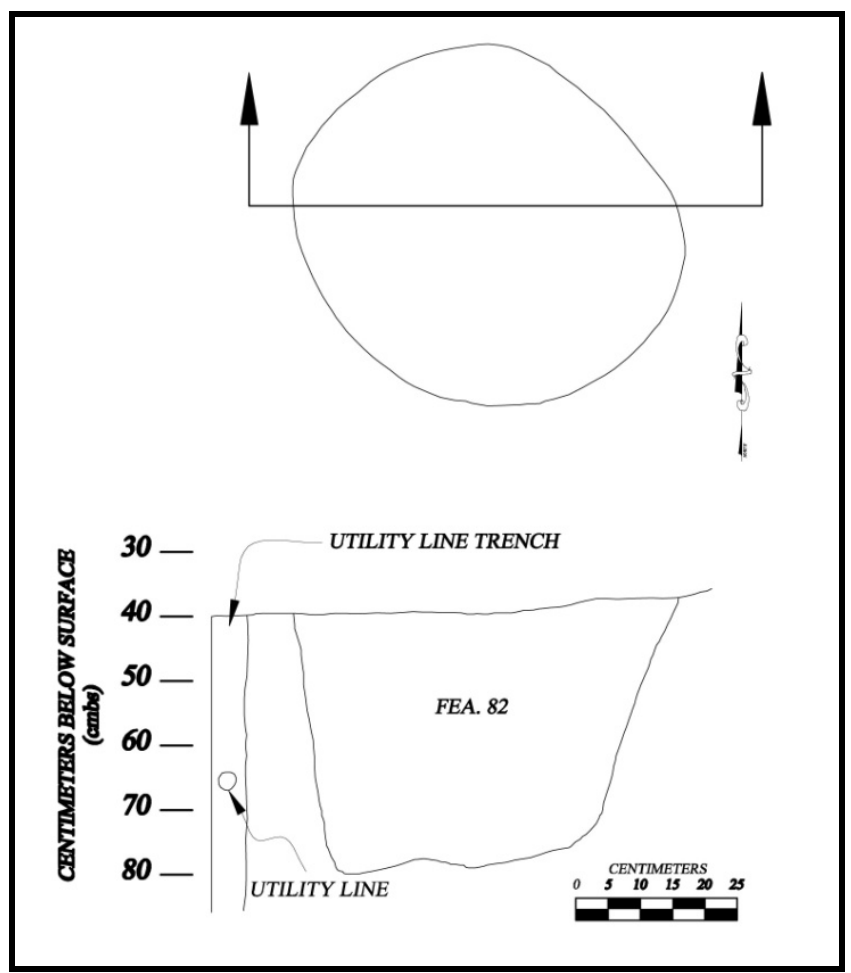

Figure 5-34. Plan and Profile of Feature 82. 


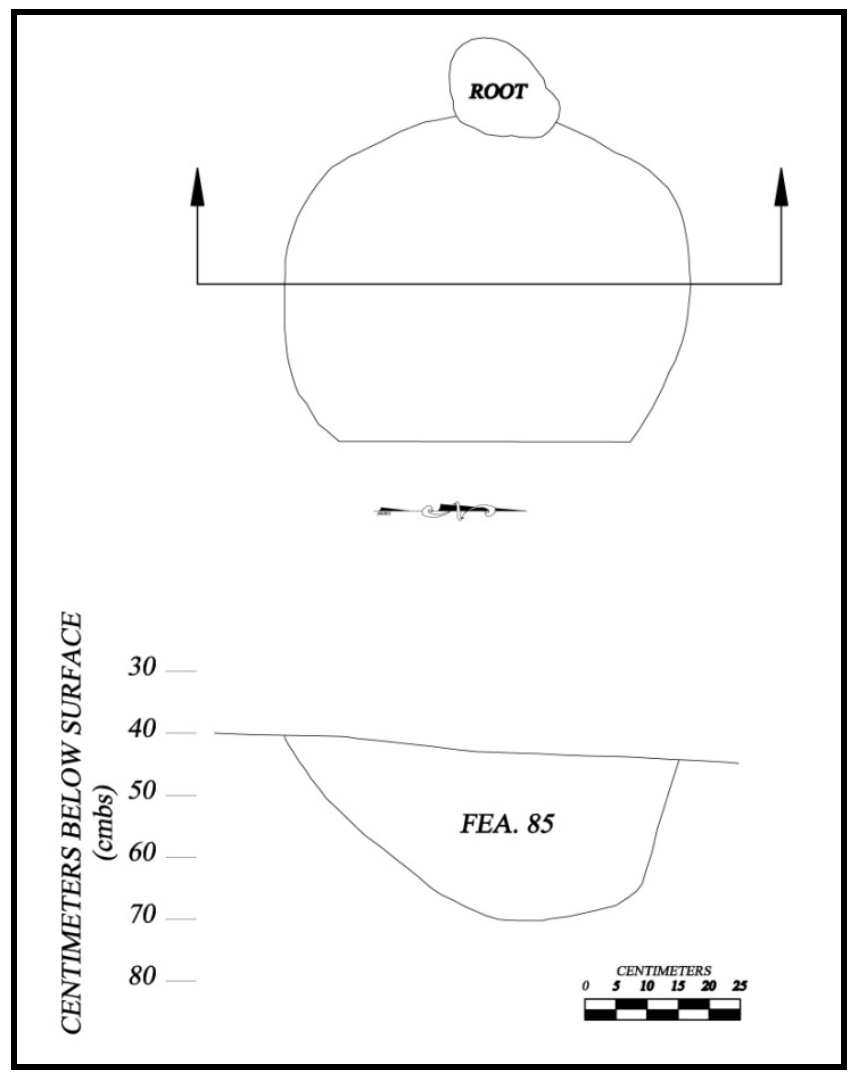

Figure 5-35. Plan and Profile of Feature 85.

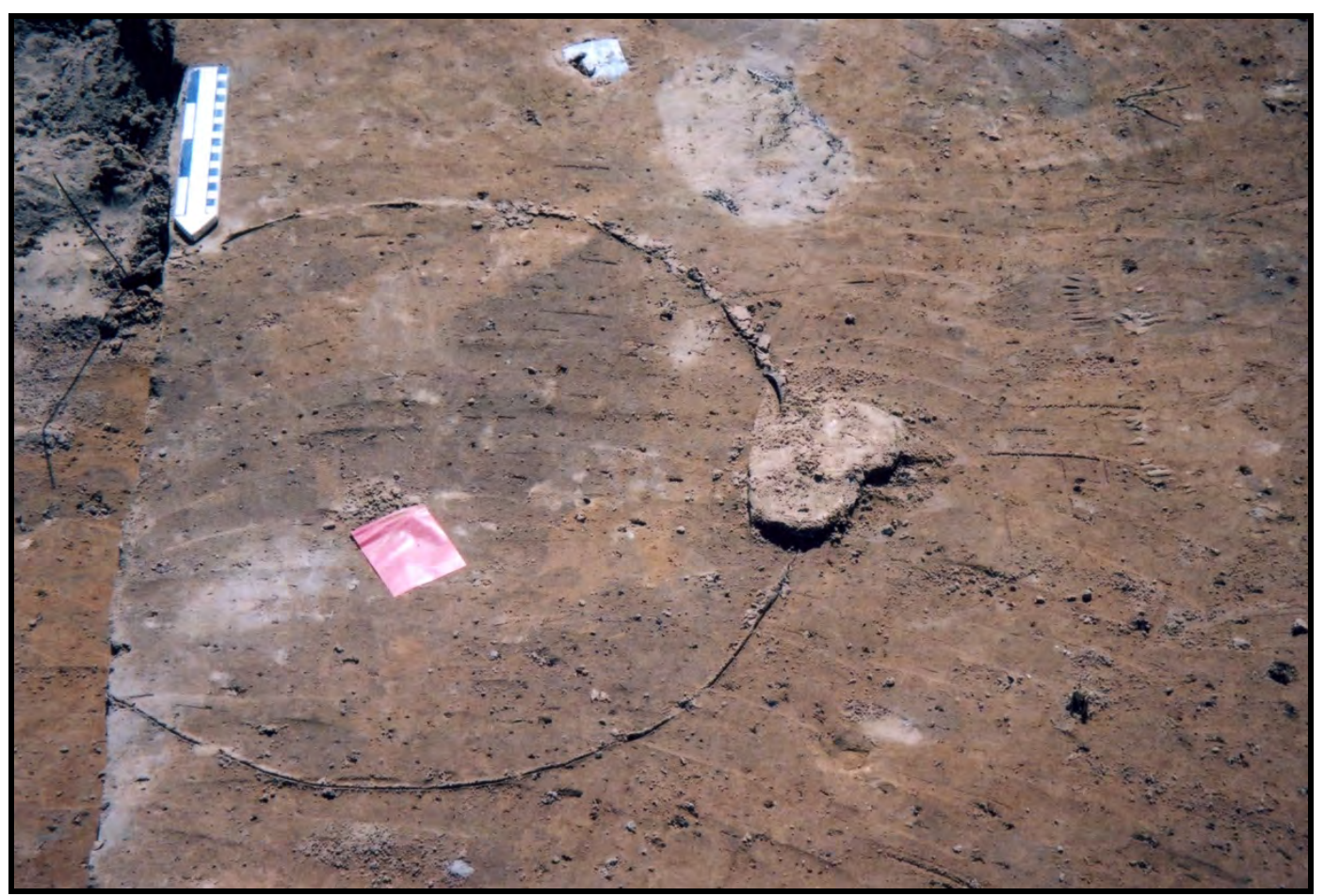

Figure 5-36. Looking South at Feature 85 in Plan View. 
Feature 85 (Figures 5-36 and 5-37) is $65 \times 60$ $\mathrm{cm}$ in size, with an estimated volume of 0.066 $\mathrm{m}^{3}$, or large enough to have held ca. 2 bushels of food stuffs. The pit has sloping sides and a rounded bottom (see Figure 5-36), with a dark brown (10YR 3/3) loamy fine sand fill with charcoal flecking. Only small amounts of ceramics, lithics, charred plant remains, or animal bones were recovered from the flotation of the feature fill (see Table 5-2).

Feature 86 is virtually the same size as Fea. 85 , but it was excavated much deeper (to 86 $\mathrm{cm} \mathrm{bs),} \mathrm{and} \mathrm{consequently} \mathrm{has} \mathrm{a} \mathrm{larger}$ estimated volume: $0.165 \mathrm{~m}^{3}$ or large enough to hold ca. 4.7 bushels (ca. $110 \mathrm{~kg}$ ) of plant foods. The pit is roughly circular, with sloping sides and a rounded bottom (Figure 538 ). The feature fill is a brown (10YR 5/3) loamy fine sand with visible pieces of charcoal and charcoal flecking. Large amounts of wood charcoal $(170 \mathrm{~g})$ were recovered in the flotation of the fill of Feature 86, along with a few pieces of animal bone and lithic artifacts.

Feature 87 is a slightly larger oval-shaped pit feature about $1 \mathrm{~m}$ northeast of Feature 86. Its volume is estimated at ca. $0.071 \mathrm{~m}^{3}$, only large enough to hold about $50 \mathrm{~kg}$ of plant food stuffs. The pit has gently sloping side walls and a rounded bottom (Figure 5-39), with brown (10YR 5/3) loamy fine sand fill. Its artifact content is minimal (see Table 5-2), suggesting only incidental materials ended up in the pit as it was filled and abandoned.

\subsubsection{Smudge Pits}

Smudge pits are small (ca. 20-30 cm in diameter) pit features with distinctive organically-enriched and charcoal-stained sediment fills. Charred corn cobs are often found in smudge pits as well as other organic materials (i.e., pine cones, sweet gum balls, etc.), and it seems likely that they were used as fuels, probably to produce large amounts of smoke to keep the insects away, or for smoking hides (cf. Binford 1967). Trinkley (1995:126) notes that in such pits, "the material was burned in an oxygen-starved environment. As a result, the materials were uniformly carbonized rather than reduced to ash." Smoking fires such as these smudge pits would have helped to keep mosquitoes and gnats away while the Caddo were working outside in areas where foods were being heated and cooked.

A total of four smudge pits are present at the Lang Pasture site (Table 5-8), two in the ramada area by Structure 1 (Fea. 21 and Fea. 38 ), another in the outdoor work/activity area by Structure 2 (Fea. 41), and the third (Fea. 80) north of Fea. 76.

Features 21 and 41 had dark brown (7.5YR 3/3 and 10YR 3/2) charcoal-stained fills, while Feature 38 had a black (10YR 2/1) charcoalstained fill; corn cob fragments were recovered from Features 41 and 80 . These pits are roughly circular to oval in shape (Figures 5-40a, 5-41, and 5-42) with shallow sloping and rounded sides (Figures 5-39b and 5-40).

\subsubsection{Outdoor Hearth}

The one outdoor hearth (Feature 25) is northeast of Structure 1 and near the ramada/elevated work platform (Structure 3). A 2-sigma calibrated radiocarbon date on charred materials in Feature 25 has an age range of AD 1290-1420. 

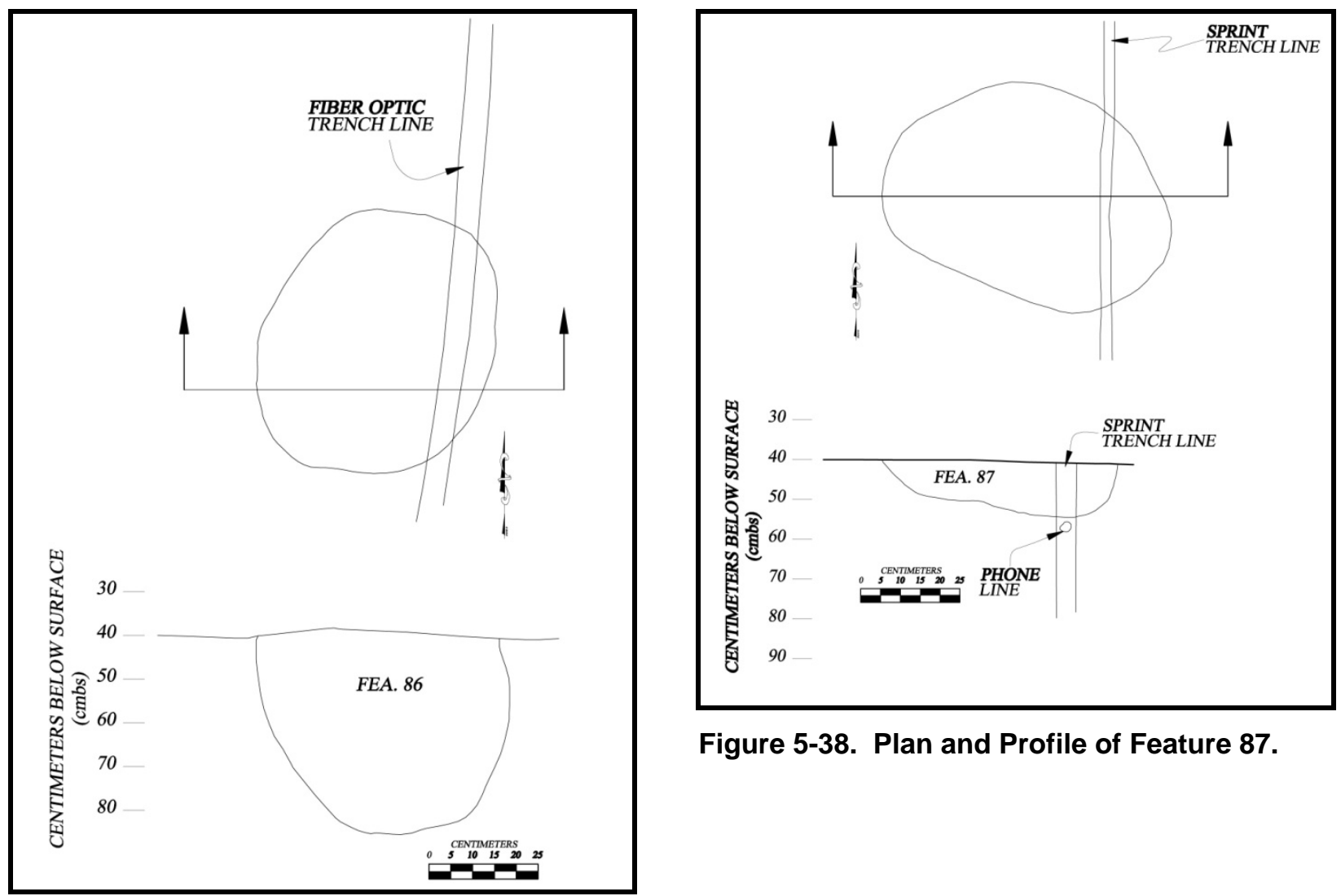

Figure 5-38. Plan and Profile of Feature 87.

Figure 5-37. Plan and Profile of Feature 86.

Table 5-8. Smudge Pits.

\begin{tabular}{cccc}
\hline Feature No. & $\begin{array}{c}\text { Dimensions } \\
(\mathbf{L} \text { x W, in cm) }\end{array}$ & $\begin{array}{c}\text { Depth } \\
(\mathbf{c m} \text { bs) }\end{array}$ & Comments \\
\hline 21 & $30 \times 34$ & $15-35$ & \\
38 & $17 \times 17$ & $27-31$ & \\
41 & $35 \times 31$ & $30-45$ & C14 Date (2 sigma): AD 1290-1420 \\
80 & $29 \times 29$ & $35-45$ &
\end{tabular}



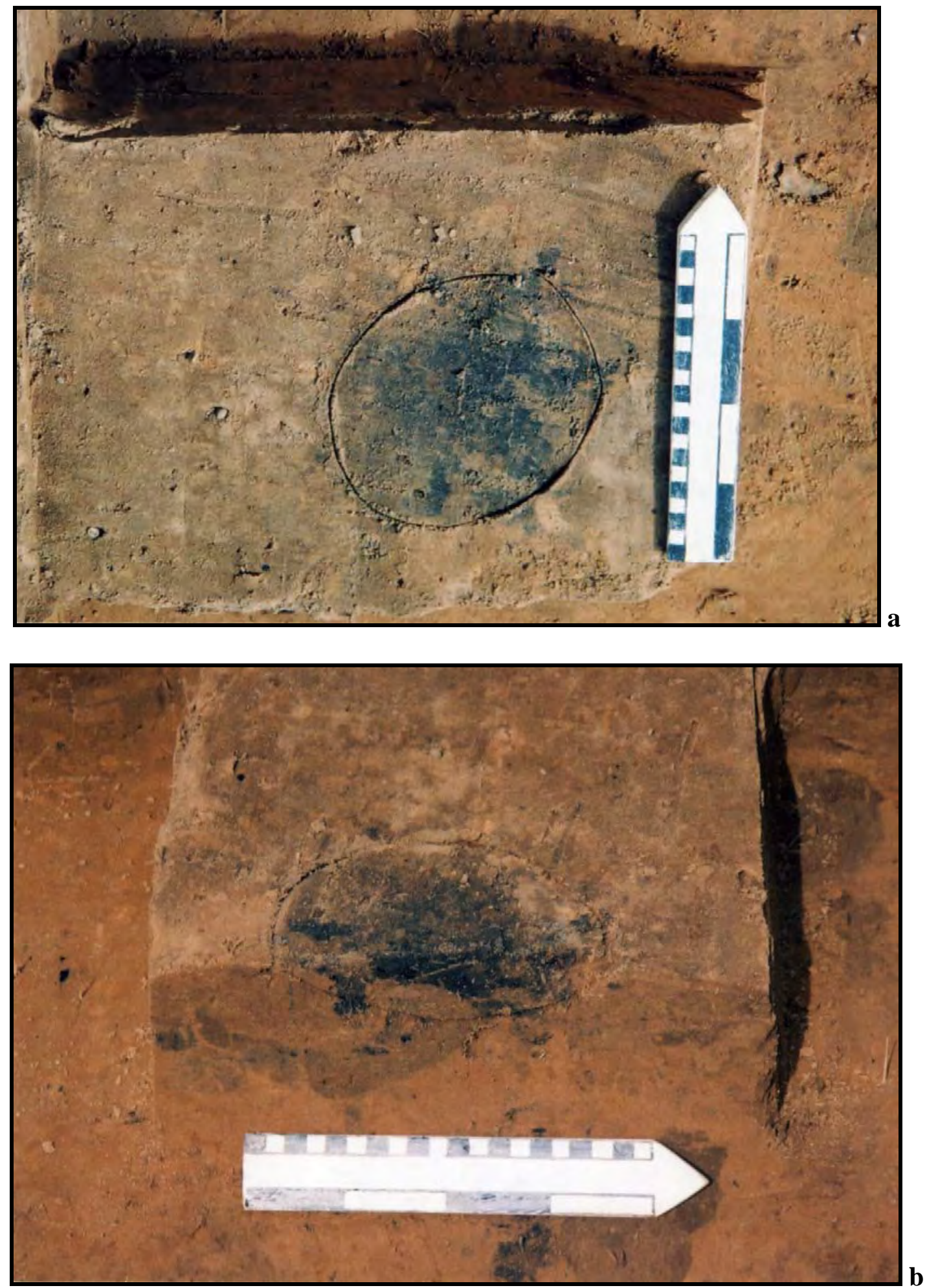

Figure 5-39. Feature 38: a, in Plan View, Looking North; b, in Plan and Profile, Looking West. 


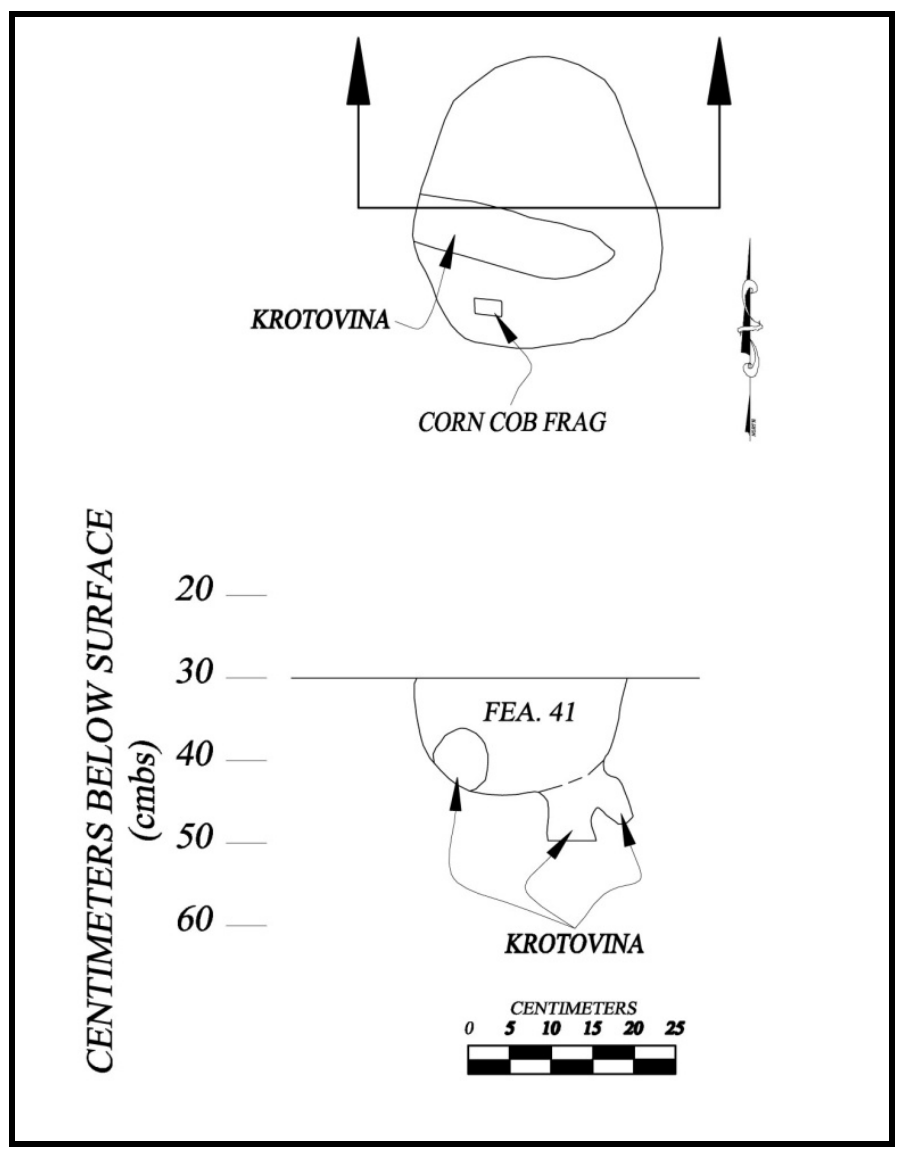

Figure 5-40. Plan and Profile of Feature 41.

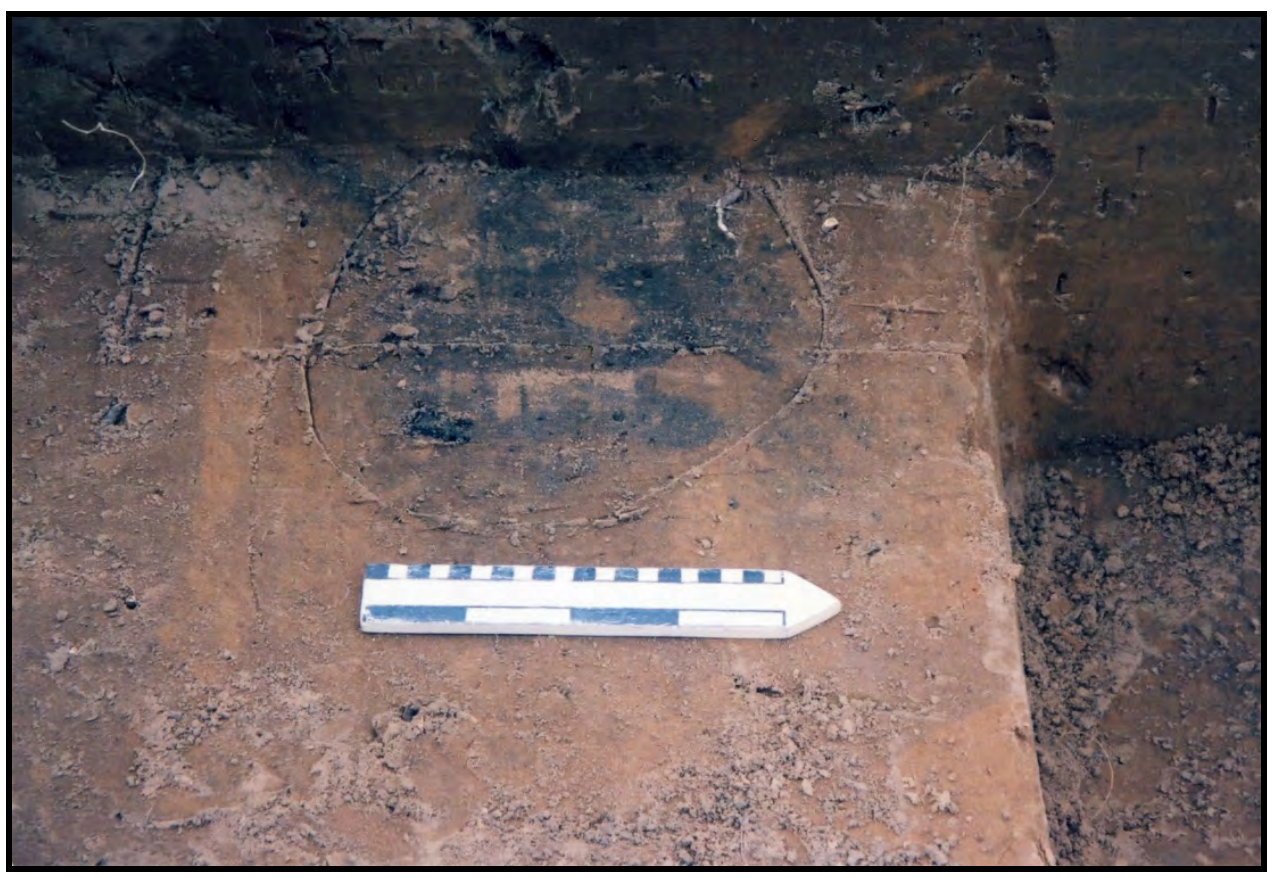

Figure 5-41. Looking West at Feature 41 in Plan View. 
The hearth covers a $70 \times 133 \mathrm{~cm}$ area of ash, oxidized soil, and dark brown sediments; it extends from 20-41 cm bs (Figures 5-43 and 5-44). In profile, the hearth is basin-shaped, with sloping sides and a fairly flat bottom.

When the hearth was first exposed, it was marked by dark brown charcoal-stained sediments and two concentrated pockets of ash (Figure 5-43a), suggesting that the feature had held a high-intensity fire, probably used for outdoor cooking, as there would have been a "constant flow of oxygen to fuel the flames" (Shafer 2003:37). Once the contents of the hearth had been removed, it was apparent that the hearth basin had been exposed to intense heat because the surface of the basin had been oxidized to a dark red color (2.5YR 3/6). Near the center of the exposed basin at $35 \mathrm{~cm}$ bs, was a large black (10YR 2/2) stain, ca. 35 $\mathrm{cm}$ in diameter at exposure (see Figures 5-44 and 5-45b), that resolved itself into a post hole (Feature 74) that reached to $64 \mathrm{~cm}$ bs (see Table 5-5). This post hole apparently postdates the active use of Feature 25, as it would make no practical sense to have a wood post situated inside a hearth that held a high-intensity fire; when the post was dug, it apparently cut through the upper ash deposits, leaving two remaining ash pockets.

There were considerable quantities of animal bone, charred plant remains, lithics, and some mussel shell fragments in the fill of Feature 25 (see Table 5-2). These remains must have been discarded in the hearth during periods of active use in outdoor activities associated with the Structure 1 household occupation.

\subsubsection{Fire-Cracked Rock Concentration}

The one fire-cracked rock concentration (Feature 35) was exposed northeast of
Structure 2 in an apparently associated outdoor work/activity area. The concentration of rocks (Figures 5-46 and 5-47) covered a 40 x $25 \mathrm{~cm}$ oval-shaped area, with top elevations ranging between 16-23 $\mathrm{cm}$ bs and bottom elevations of 25-31 cm bs. There was no evidence of a pit, but the overlapping nature of the rocks and the differences in their top and basal elevations suggest these rocks had become fire-cracked in situ, probably in an instance of hot rock cooking of plant or animal foods.

This is the only feature from the Lang Pasture site that contains fire-cracked rock $(n=17$ pieces) (see Table 5-2). Other artifacts found in association with the fire-cracked rock include a few pieces of lithic debris and wood charcoal from flotation sediments collected around the rocks themselves.

\subsubsection{Fire-Cracked Rock Distribution}

Although only one fire-cracked rock (FCR) feature (Feature 35) was defined during the data recovery excavations at the Lang Pasture site, pieces of FCR were widely distributed across the site (Figure 5-48). There are six notable concentrations of FCR in the block: a small area south of Structure 2; two FCR clusters in and immediately adjacent to Structure 2; a fourth cluster associated with Feature 35 in an outdoor activity work area north of Structure 2; a fifth cluster just east of Structure 1; and a final cluster of FCR from Feature 76, north of the Structure 3 ramada and associated outdoor activity area. Very few pieces of FCR were found within the boundaries of Structure 1 or Structure 3. 


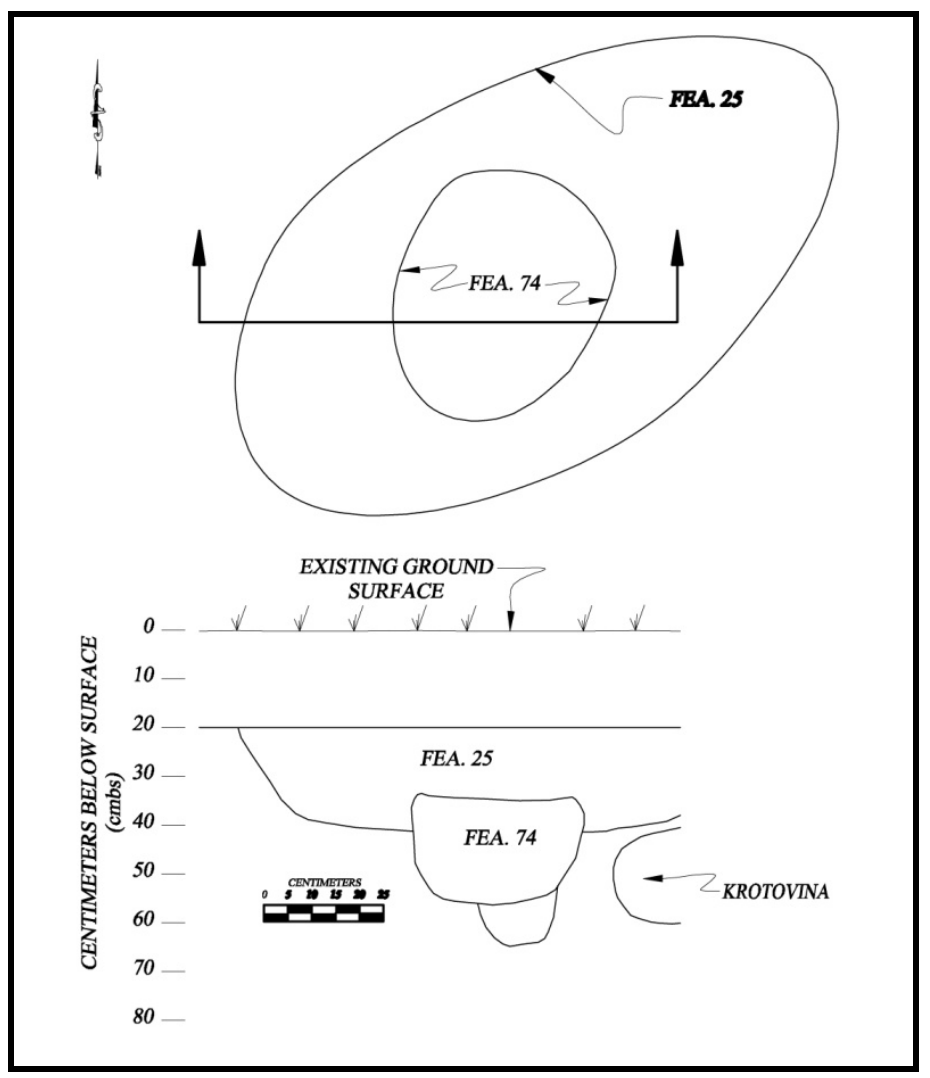

Figure 5-42. Plan and Profile of Feature 25.

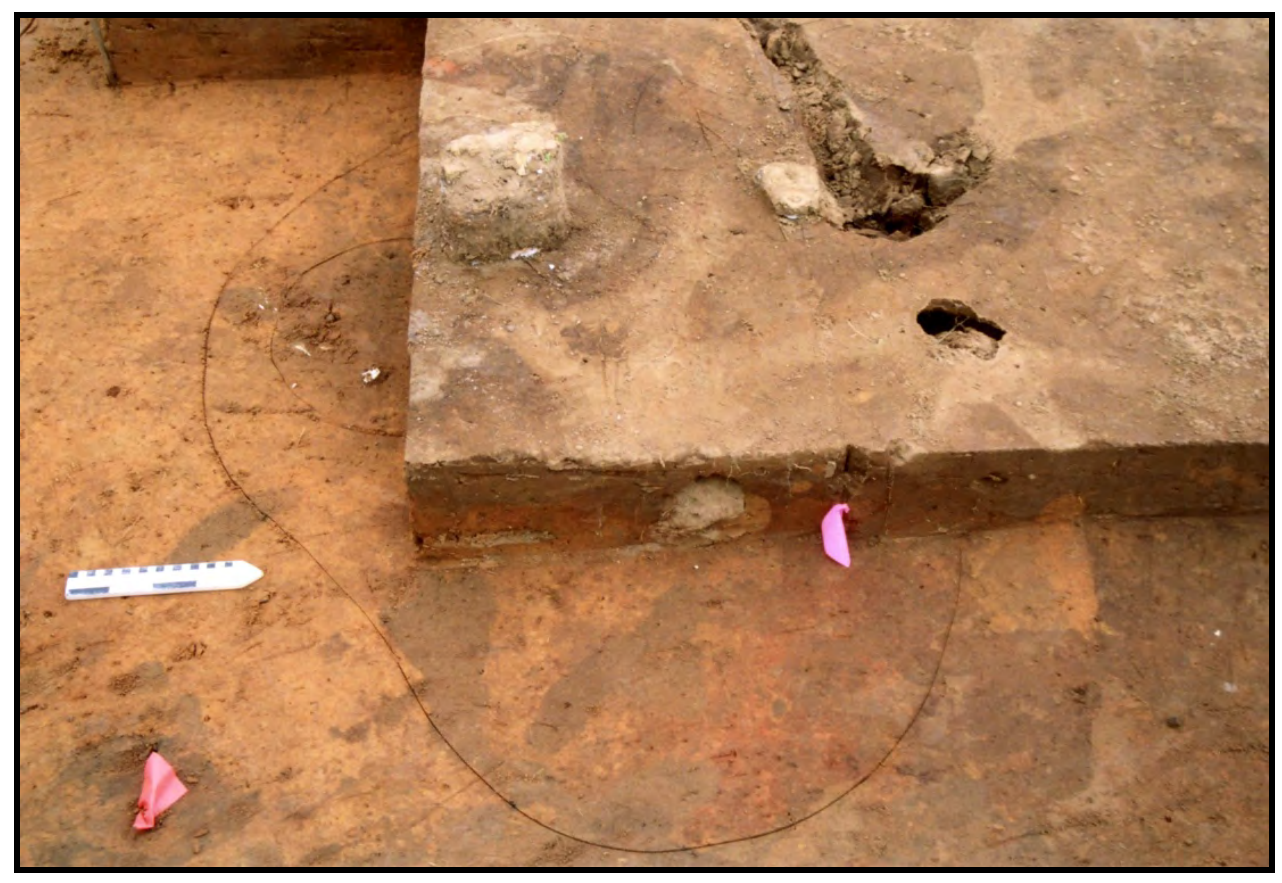

Figure 5-43. Plan of Feature 25, Looking West. 

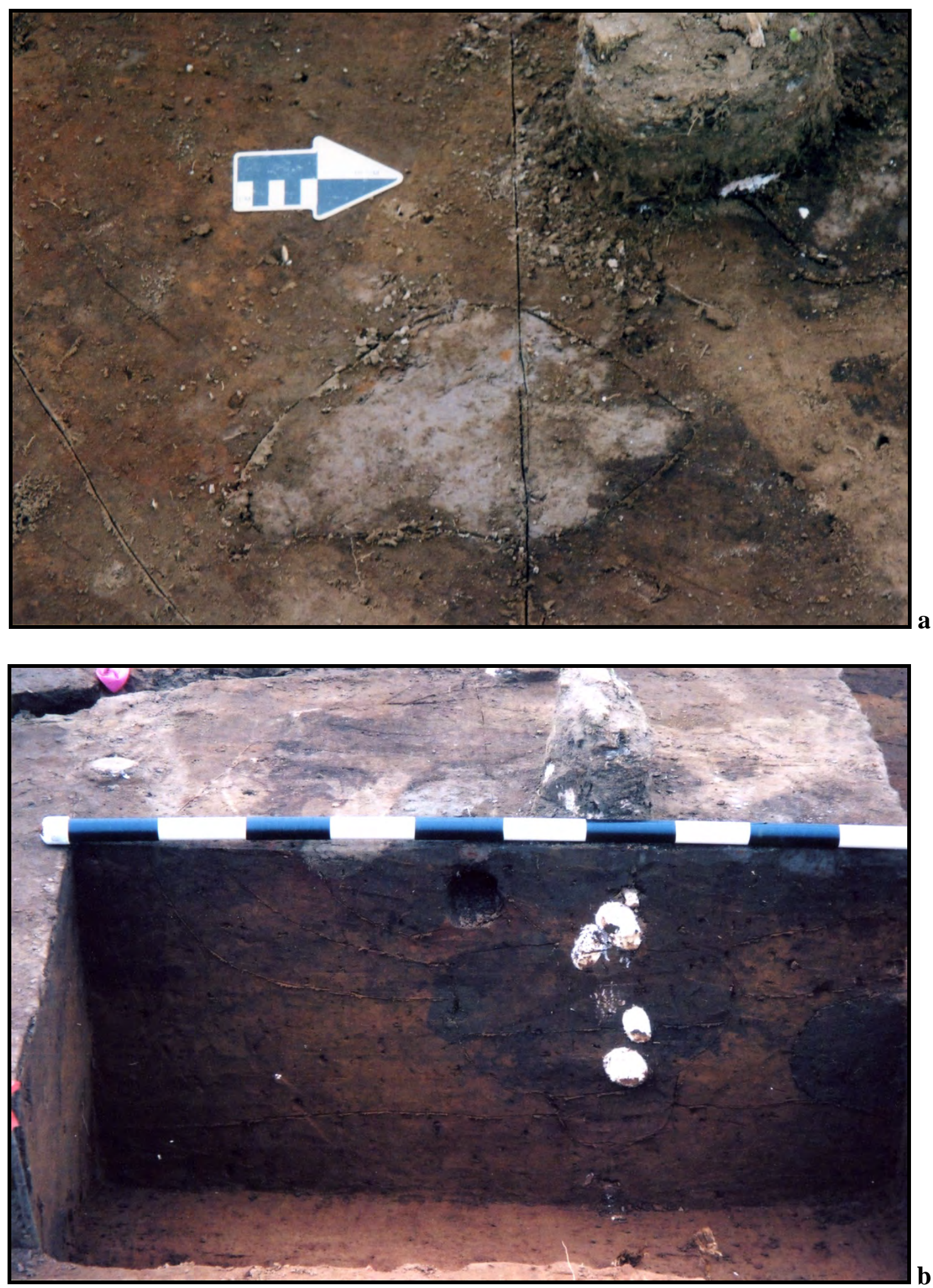

Figure 5-44. Close-up Views of Feature 25: a, area of compact ash, looking west; b; profile, looking north. 


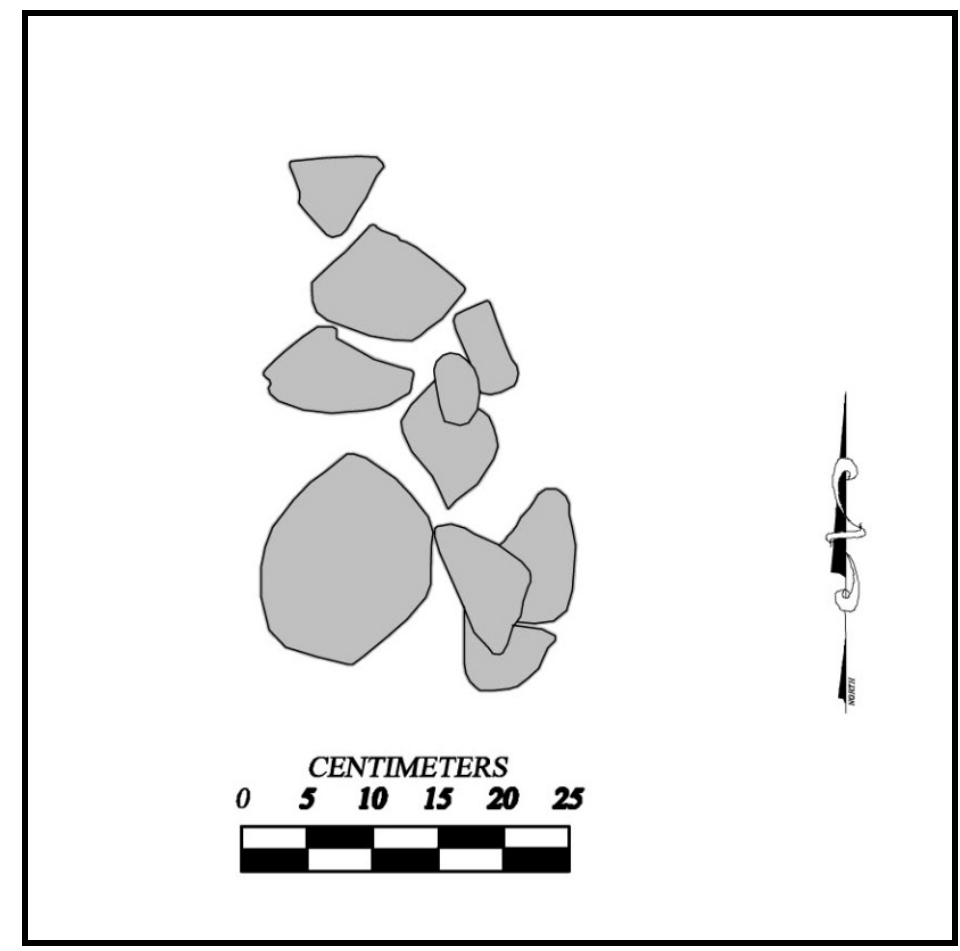

Figure 5-45. Plan of Feature 35.

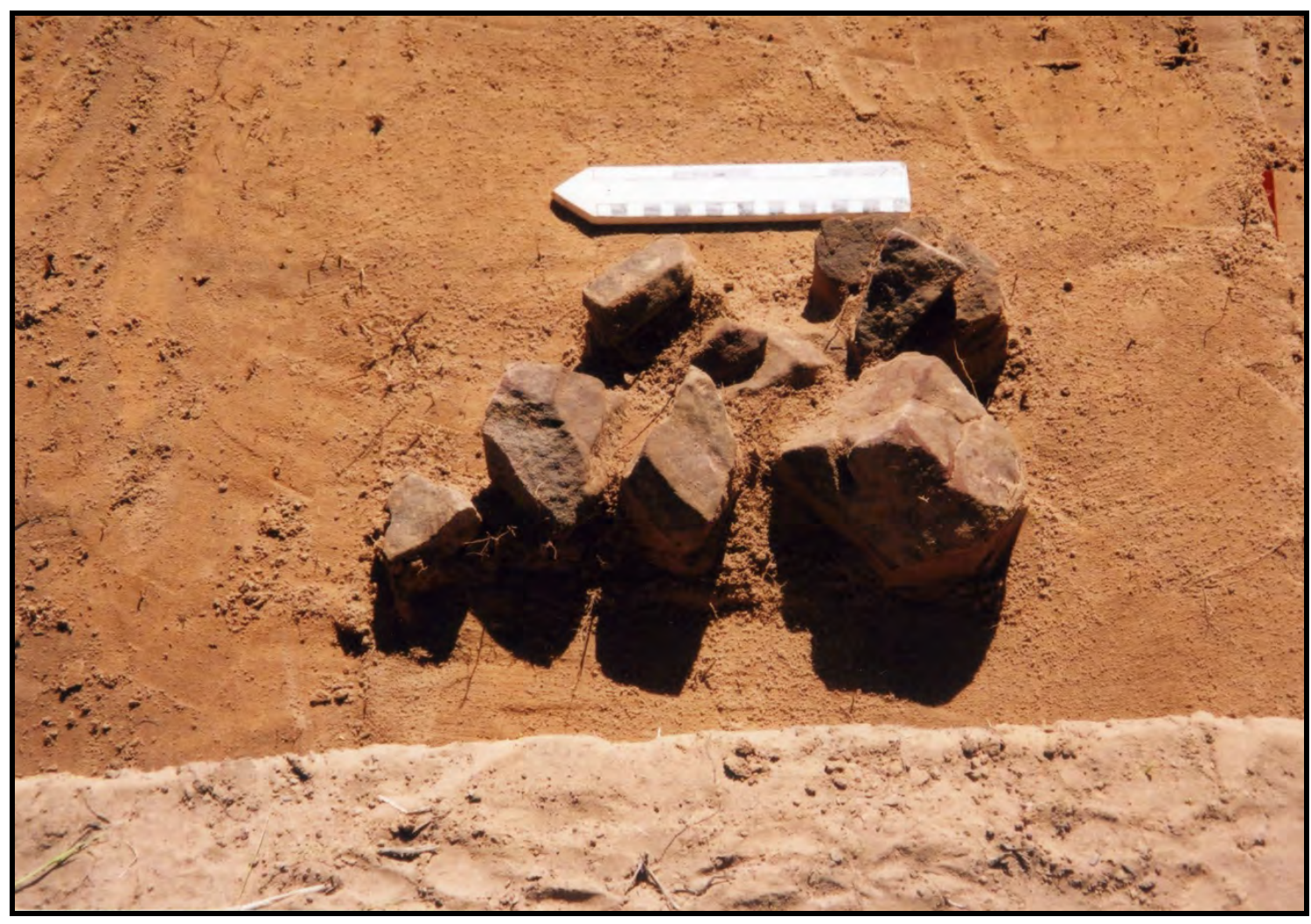

Figure 5-46. Feature 35, Looking East. 


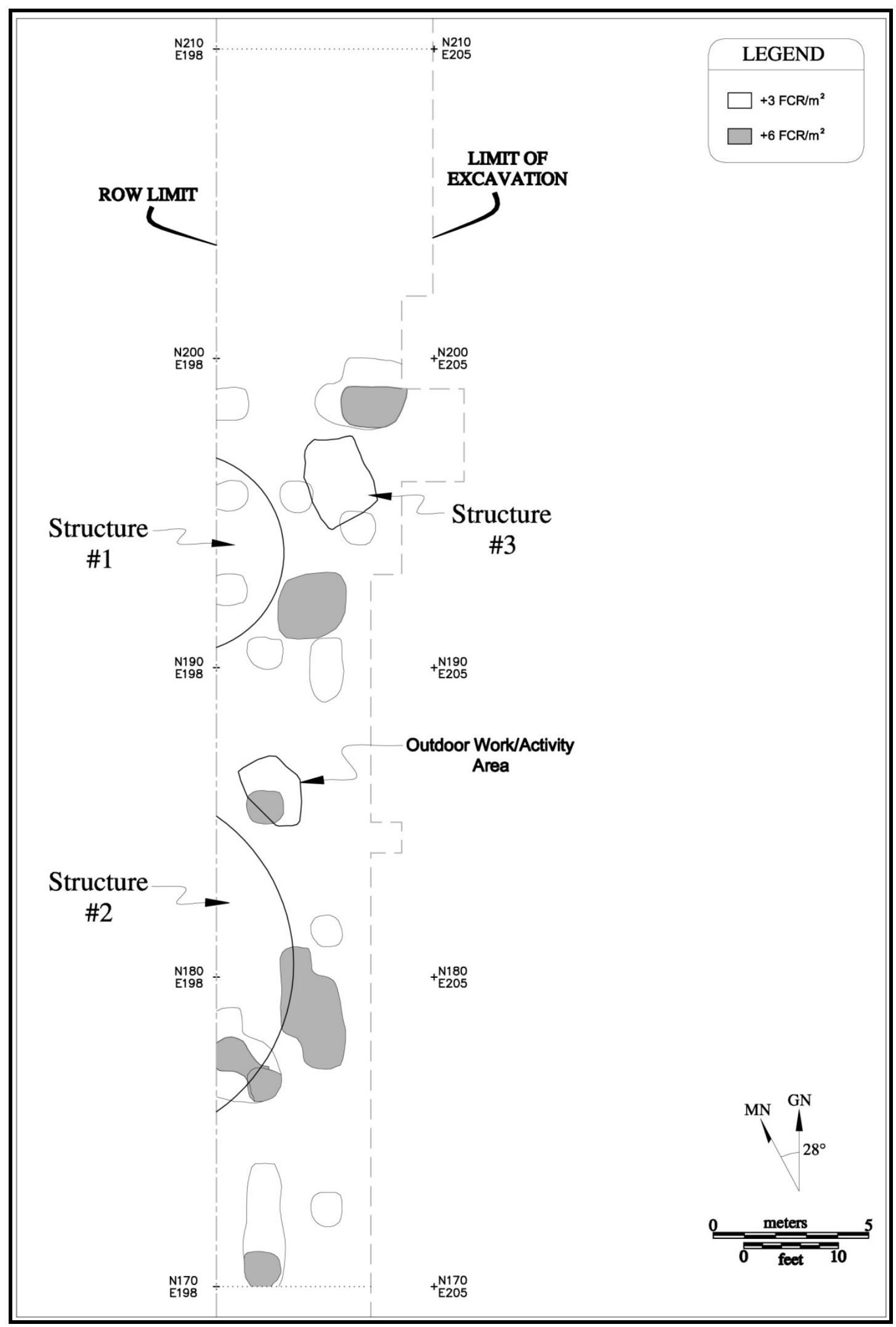

Figure 5-47. Spatial Distribution of Fire-Cracked Rock at the Lang Pasture Site. 
The spatial distribution of FCR suggests that occasional hot rock cooking activities during the prehistoric Caddo occupation at the Lang Pasture site took place primarily in outdoor activity areas in proximity to the three structures. Not all of the FCR found at the Lang Pasture site-perhaps not even half-is a product of Caddo cooking activities because hot rock cooking had primarily been replaced by the extensive use of ceramic vessels for cooking, as the vertical distribution of FCR in the clusters just outside Structures 1 and 2 extend below the depths of the Caddo ceramics found in the same areas (cf. Lohse 2004:Table 3.3). Thus, it is likely that much of the FCR is from various prehistoric occupations (dating from ca. 1200-3000 cal. years B.P.) that predate the principal Caddo occupation at Lang Pasture.

\section{Interpretation of the Domestic Features}

The analysis of the kind and distribution of features within the TXDOT right-of-way at the Lang Pasture site indicates that there are portions of two prehistoric Caddo structures within it, with some portion of the structures extending west onto private property (where they were not investigated). There are no obvious entrances visible along the post hole wall arcs, but the one structure excavated at the A. C. Saunders site (41AN19) has an entrance along its east side (Kleinschmidt 1982). There is also a well-preserved midden deposit on private property, about $10 \mathrm{~m}$ from the right-of-way fence (Perttula et al. 2007).

The spatial proximity of the two domestic Caddo structures and the midden deposit suggests that these features are part of a household compound, much like those identified at the late $17^{\text {th }}$-early $18^{\text {th }}$ century A.D. Deshazo site (Good 1982; Story 1982), the $14^{\text {th }}$ and $15^{\text {th }}$ century A.D. compounds at the Tallow Grove and Beech Ridge sites (Perttula 2008a, ed.), all in the Angelina River basin in East Texas, and the various historic Caddo compounds on farmsteads documented from the 1691 Teran de los Rios map of a Nasoni Caddo village on the Red River (Swanton 1942:Plate 1), the 1867 Reagle drawing of Caddo George Washington's compound (Journal sketch on file, Western History Collections, University of Oklahoma Libraries), and 1868-1872 Soule photographs of Long Hat's camp (or compound) (Swanton 1942:Plate 14). That is, individual structures were grouped together into a small compound arrayed around an open courtyard, with outdoor activity areas and ancillary facilities (i.e., ramadas, granaries, or other sorts of elevated platforms) and shared trash/midden disposal areas (Figure 5-49). The documentation of several large pits north of Structure 1 that may have served as underground storage facilities suggests that above-ground granaries were not at use at the Lang Pasture site during the prehistoric Caddo occupation. Although the full extent of the Lang Pasture site is not known, it is likely that there are several other domestic household compounds on the private property portion of the site.

The two domestic structures appear to be circular, Structure 1 (between N190-196 and E198-199.5) is an estimated $6.8 \mathrm{~m}$ in diameter, with relatively closely-spaced wall post holes. There are post holes inside the wall arc (Features 66, 57, 73) that may be roof or wall support post holes, and there is also one pit feature (Feature 37). The second structure (Structure 2) is less well-defined, with widelyspaced post holes comprising the wall arc. It extends from N175-184 and E198-200, and has an estimated diameter of ca. $9 \mathrm{~m}$. There are two pits (Feature 2 and Feature 29) that may be associated with the use of the structure.

There appear to be at least one small arbor or ramada (i.e., elevated work platform) defined by a number of post holes, with associated outdoor working/cooking areas, situated to the east and northeast of the two house structures. The first and better defined arbor or ramada (Structure 3, at N194-197 E200-202) by Structure 1 is about $2 \times 4 \mathrm{~m}$ in size, and there are pits and smudge pits (Features 20 and 36) and a hearth (Feature 25) under and adjacent to it. 


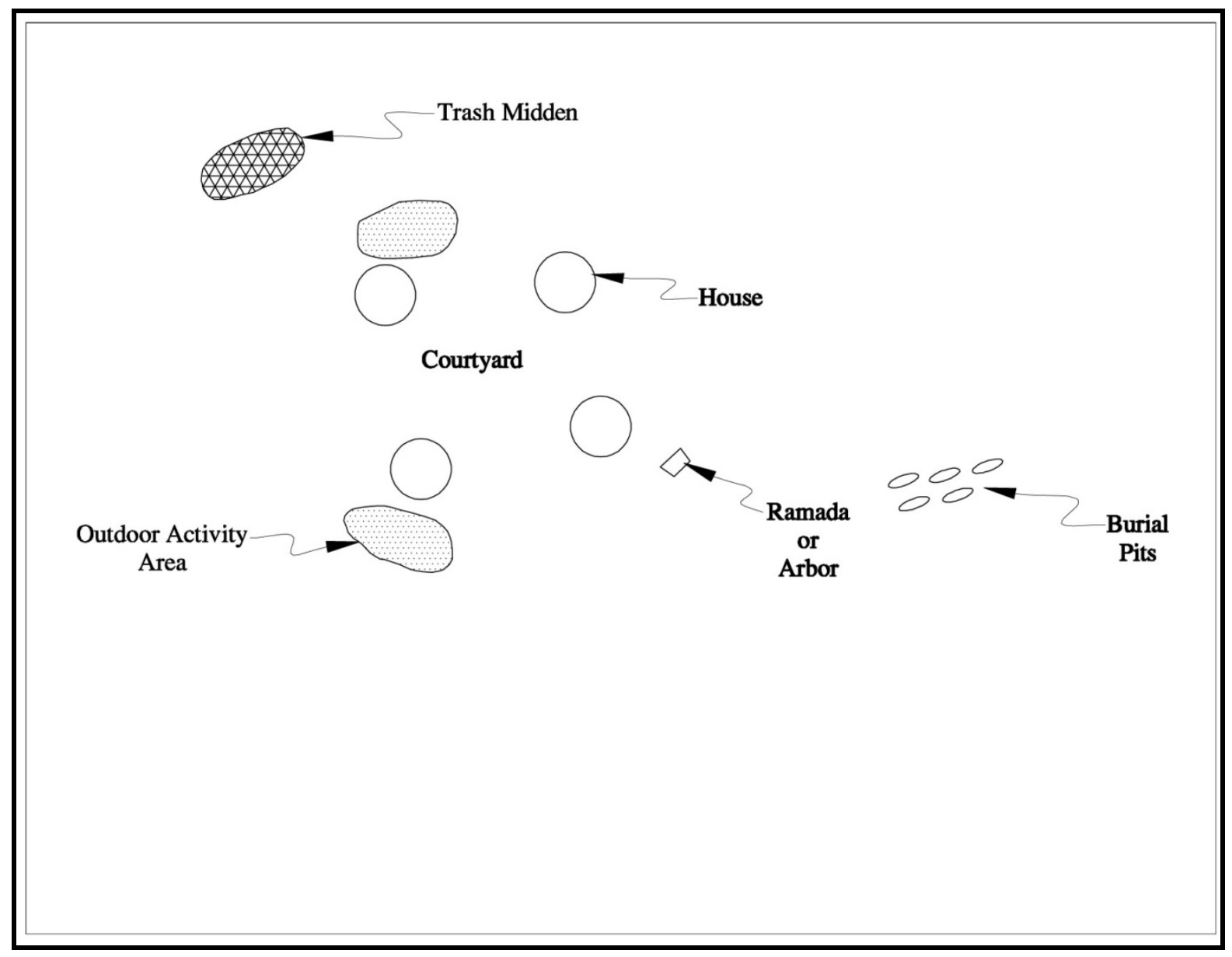

Figure 5-48. Plan of an Idealized Caddo Household in a Rural Community Setting, Including Houses, a Shared Courtyard, Ramada or Arbor, Outdoor Activity Areas, Trash Midden, and Household Cemetery.

Also to the east of this cluster of features is Feature 76, a very large pit feature that also contained three separate burials (Features 76B-D, with four vessels between them, see discussion below). The second outdoor work/activity area, also possibly with an arbor or ramada and other extramural facilities, although the pattern of post holes is far from clear, is at N184 to N186 and E198 to E200, just outside Structure 2. This outdoor activity areas has an associated fire-cracked rock concentration (Feature 35) as well as a few post holes and small pit features probably used for cooking.

\section{Spatial Patterns in Domestic Features and Material Culture Remains}

The spatial patterning of artifacts at the Lang Pasture site provide insights into how different parts of the site may have been used by its Caddo occupants as well as insights in to how Caddo households (structures, courtyards, activity areas, and trash disposal) in the upper Neches River basin of East Texas were spatially organized and arranged. The intrasite spatial data on artifacts and features from the Lang Pasture site, even though they represent only a $40 \times 5$ 5-6 m slice across one habitation area, are the first such spatial data obtained on what surely are the range of 
discrete prehistoric Caddo households in this region.

\section{Ceramics}

The distribution of each kind of ceramic vessel sherd-including decorated sherds, plain body and base sherds, and plain rim sherds - at the Lang Pasture site provides compelling spatial data on the importance of outdoor activity areas for the Caddo households uncovered during the excavations. Most ceramic vessels were apparently broken and discarded in the two outdoor activity areas north and northeast of Structure 1 and north and east of Structure 2 (Figures 5-50-5-52), including being discarded in several large pit features (Features 76 and 79). Certainly the highest density of sherd discard took place around Structure 1.

In the case of Structure 1, only low densities of sherds are found within its walls, consisting primarily of plain sherds. This suggests that the structure floor was swept to gather up broken vessels and vessel fragments that had been previously broken and stored under beds or on storage platforms, possibly because of vessel re-use needs (cf. Arthur 2006:102). These were then stored or dumped in a broad scatter north and east of Structure 1, including the Structure 3 ramada. Decorated sherds were more abundant within the walls of Structure 2 than was the case for the Structure 1 deposits (see Figure 5-50), but this was not the case for either plain sherds or plain rims. The higher densities of decorated sherds in Structure 1 suggest that decorated vessels or re-used vessel sections may have been in use by its Caddo occupants longer in Structure 2 than in Structure 1, or that the intensity of outdoor activity use and sherd discard was less around Structure 2 (perhaps because the occupation was of a shorter duration) than was the case in the northern part of the site. There, outdoor activity areas and features were substantialincluding several large pits-are well-defined. 


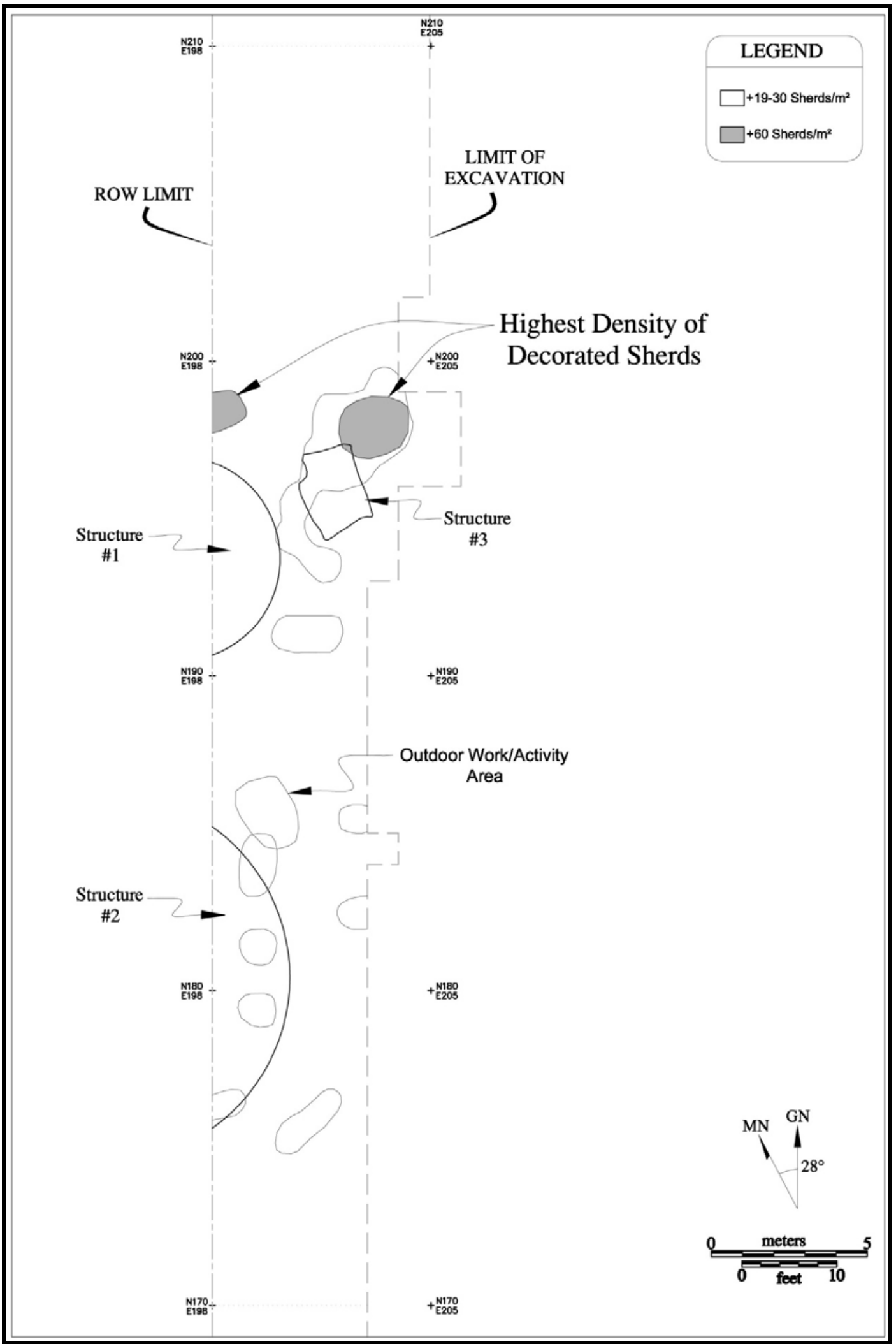

Figure 5-49. Spatial Distribution of Decorated Ceramic Sherds. 


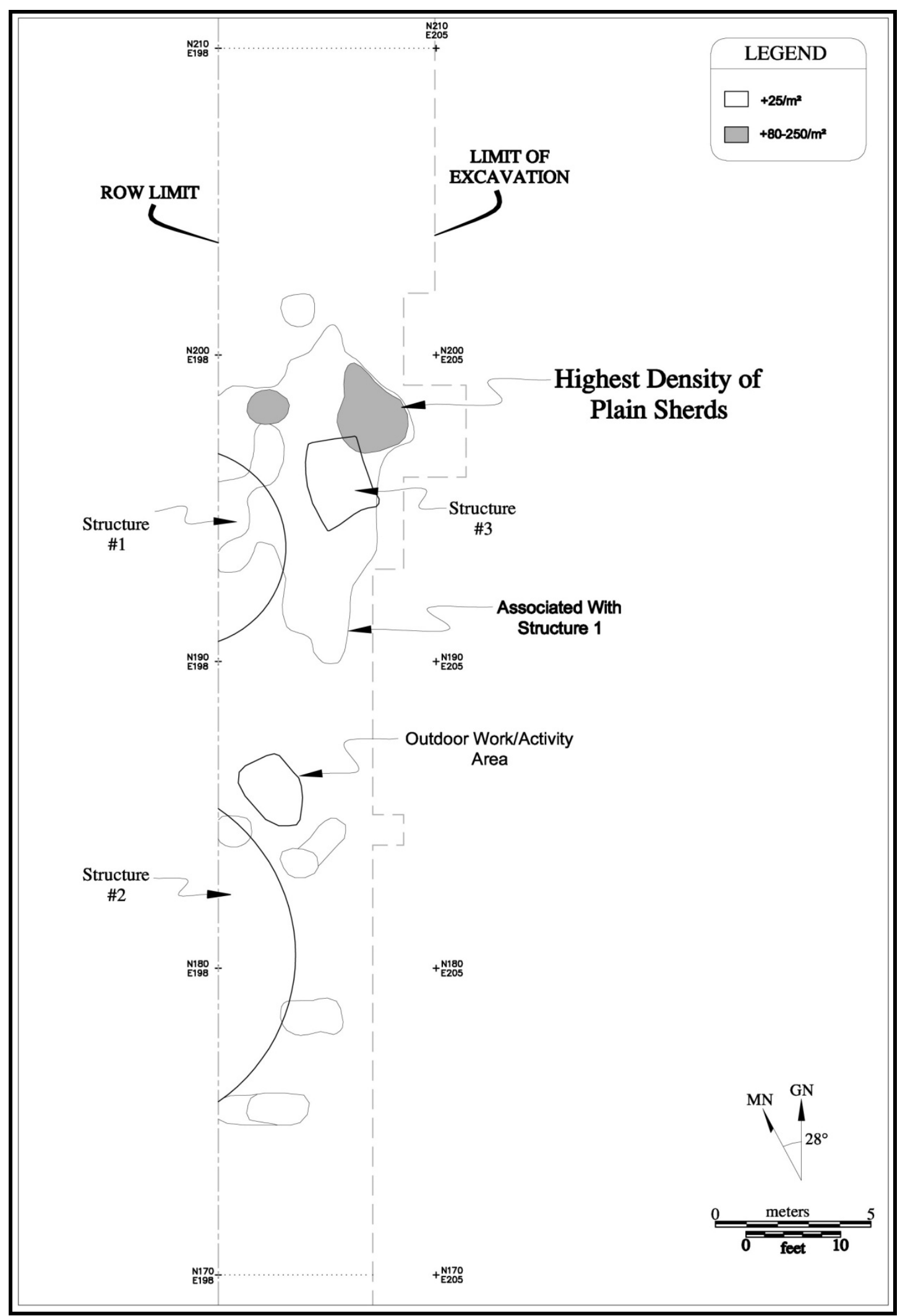

Figure 5-50. Spatial Distribution of Plain Body and Base Sherds. 


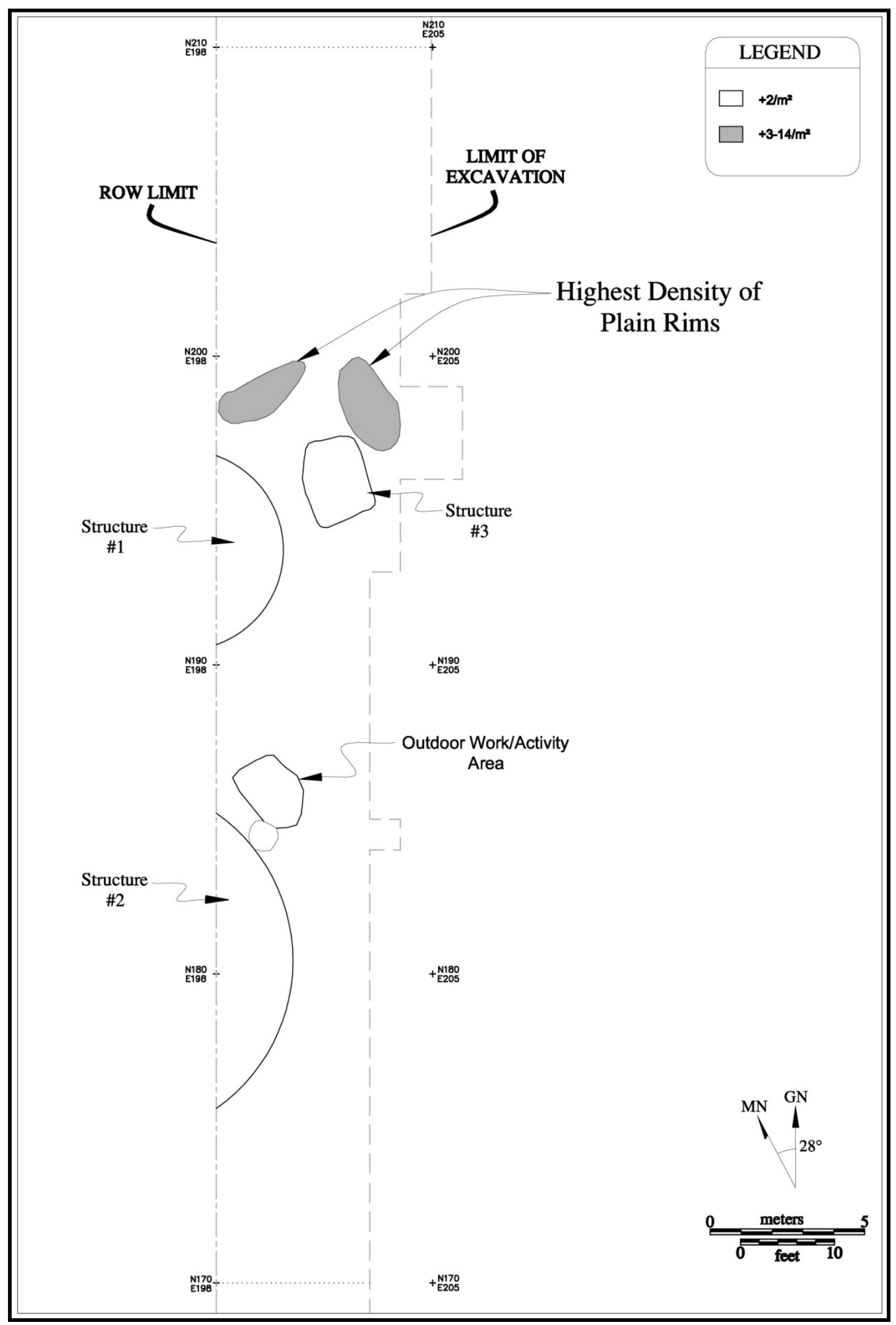

Figure 5-51. Spatial Distribution of Plain Rim Sherds. 


\section{Pipes}

In addition to the ceramic pipes recovered from two burial features (Features 8 and 93) and in the Scrape E work, ceramic pipe sherds are also found in domestic contexts at the Lang Pasture site. Of the 28 pipe sherds (Figure 5-53), only four were recovered within the two domestic structures, with the remainder being widely distributed to the north and northeast of Structure 1 and north and east of Structure 2. The occupants of both structures apparently had and frequently used ceramic pipes.

These sherds from broken pipes ended up being discarded in outdoor activity areas associated with both structures. This is likely because most smoking activities took place outdoors during the course of daily activities outside the houses, whereas the houses were used mainly for sleeping and the storage of foodstuffs and certain domestic material goods.

\section{Burial Features}

To the north of Structure 1, and separated from that structure by at least $10-17 \mathrm{~m}$, are a series of Caddo Indian burials (Features 8, 88,
91, 92, 93, and 94) from an associated family household cemetery. These six burials, each of which contained either one or two individuals (Feature 93), had ceramic vessel $(n=27)$ and elbow pipes $(n=2)$ as associated funerary offerings. The mean number of funerary offerings from these six burials is 4.83 (ranging from 2-10 items) A second set of burials (Features 76B, 76C, and 76D) were placed in Feature 76, a large pit feature, to the east of Structure 1. These burials had four ceramic vessels as the sole funerary offerings, with a mean of only 1.33 funerary offerings per individual (Table 5-9).

In each of the burials at the Lang Pasture site, the deceased Caddo individual was laid out in an extended supine position on the floor of the burial pit, with funerary offerings placed on either one or both sides of the body, but also resting of the burial pit floor. The three burials placed in Feature 76 were oriented northwestsoutheast (see Table 5-9), with the head of the individual at the southeastern end of the burial pit, and facing to the northwest. The other burials are all laid out in an east-west position, in two north-south rows, with the head of the deceased at the eastern end of the burial pit, and thus facing to the west (Figure 5-54). 


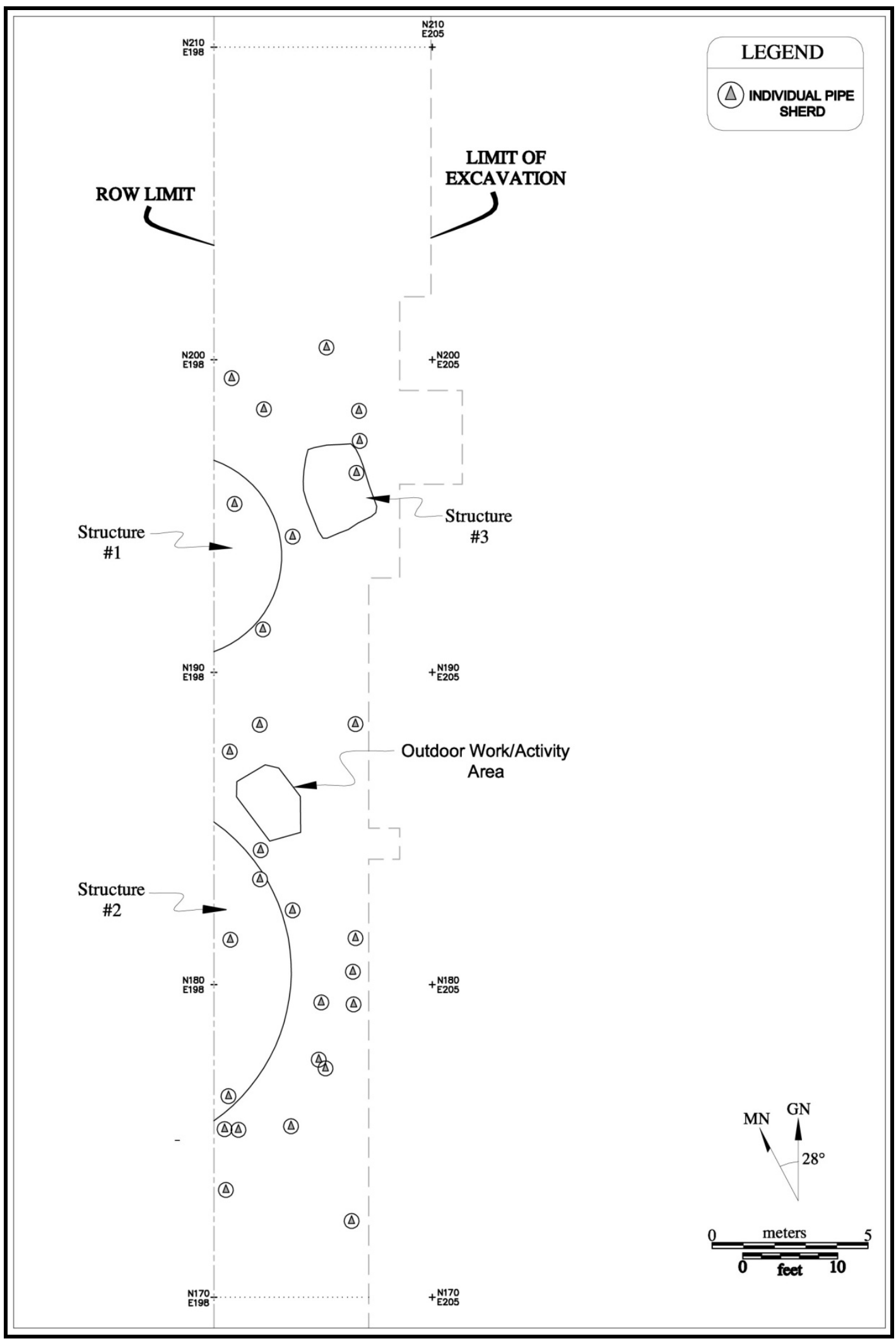

Figure 5-52. Spatial Distribution of Pipe Sherds. 
Table 5-9. Burial Features at the Lang Pasture Site.

\begin{tabular}{|c|c|c|c|c|c|}
\hline Feature & Orientation & $\begin{array}{l}\text { Dimensions } \\
\text { (cm) }\end{array}$ & $\begin{array}{l}\text { Depth } \\
\text { (cm bs) }\end{array}$ & Vessels & Pipes \\
\hline 8 & east-west & $260 \times 130$ & $50-79$ & 7 & 1 \\
\hline $76 \mathrm{~B}$ & $\begin{array}{l}\text { northwest- } \\
\text { southeast }\end{array}$ & $189 \times 64$ & 55-91 & 2 & \\
\hline $76 \mathrm{C}$ & $\begin{array}{l}\text { northwest- } \\
\text { southeast }\end{array}$ & $200 \times 69$ & $60-88$ & 1 & \\
\hline $76 \mathrm{D}$ & $\begin{array}{l}\text { northwest- } \\
\text { southeast }\end{array}$ & $115 \times 63$ & $135-166$ & 1 & \\
\hline 88 & east-west & $320 \times 170$ & $12-31$ & 2 & \\
\hline 91 & east-west & $276 \times 100$ & $7-27$ & 2 & \\
\hline 92 & east-west & $300+\times 110$ & $59-73$ & 2 & \\
\hline $93 *$ & east-west & $312 \times 176$ & $52-80$ & 9 & 1 \\
\hline 94 & east-west & $260 \times 120$ & $51-70$ & 5 & \\
\hline
\end{tabular}

*two individuals were placed in Feature 93

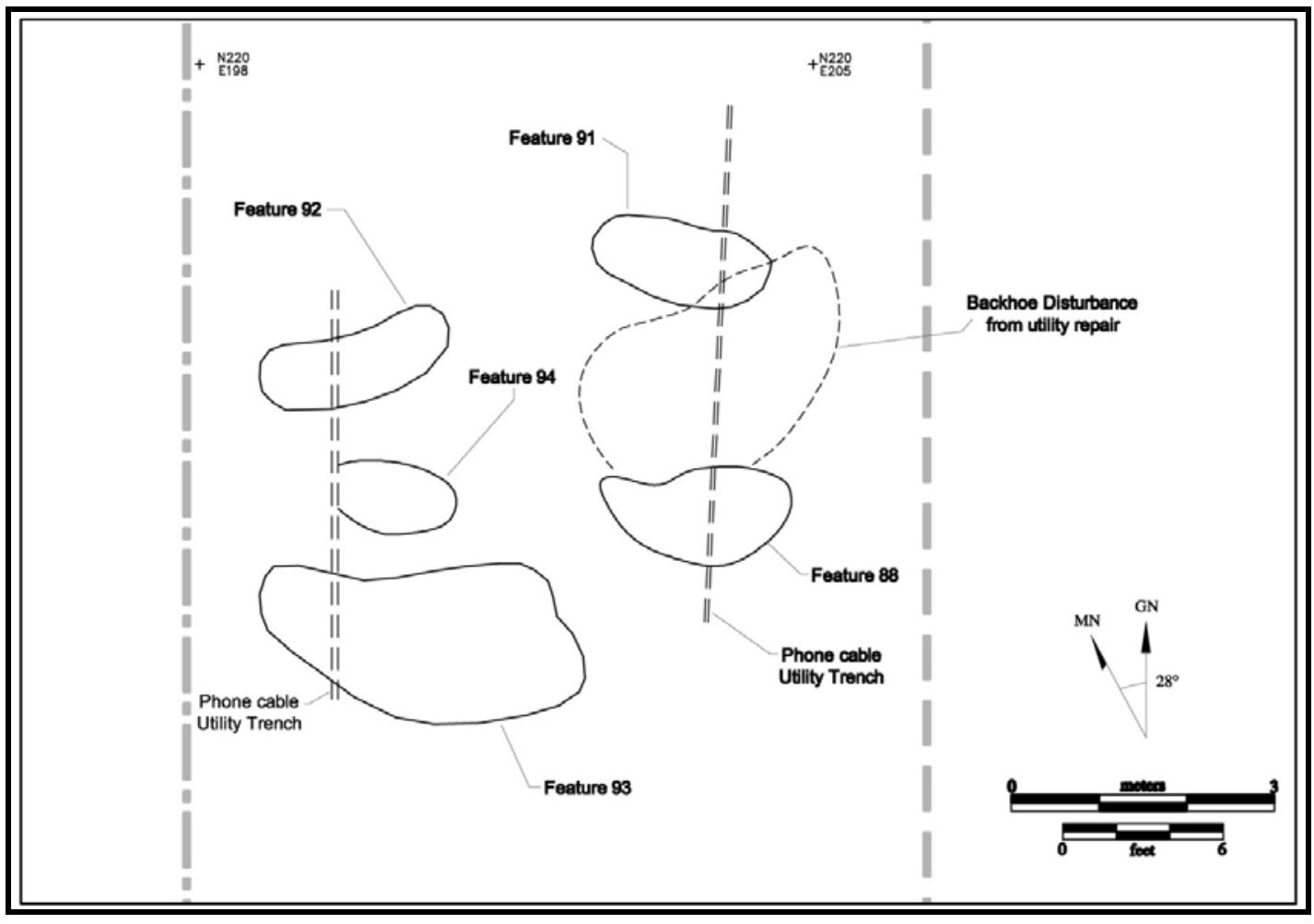

Figure 5-53. Plan of Features 88, 91, 92, 93, and 94. 


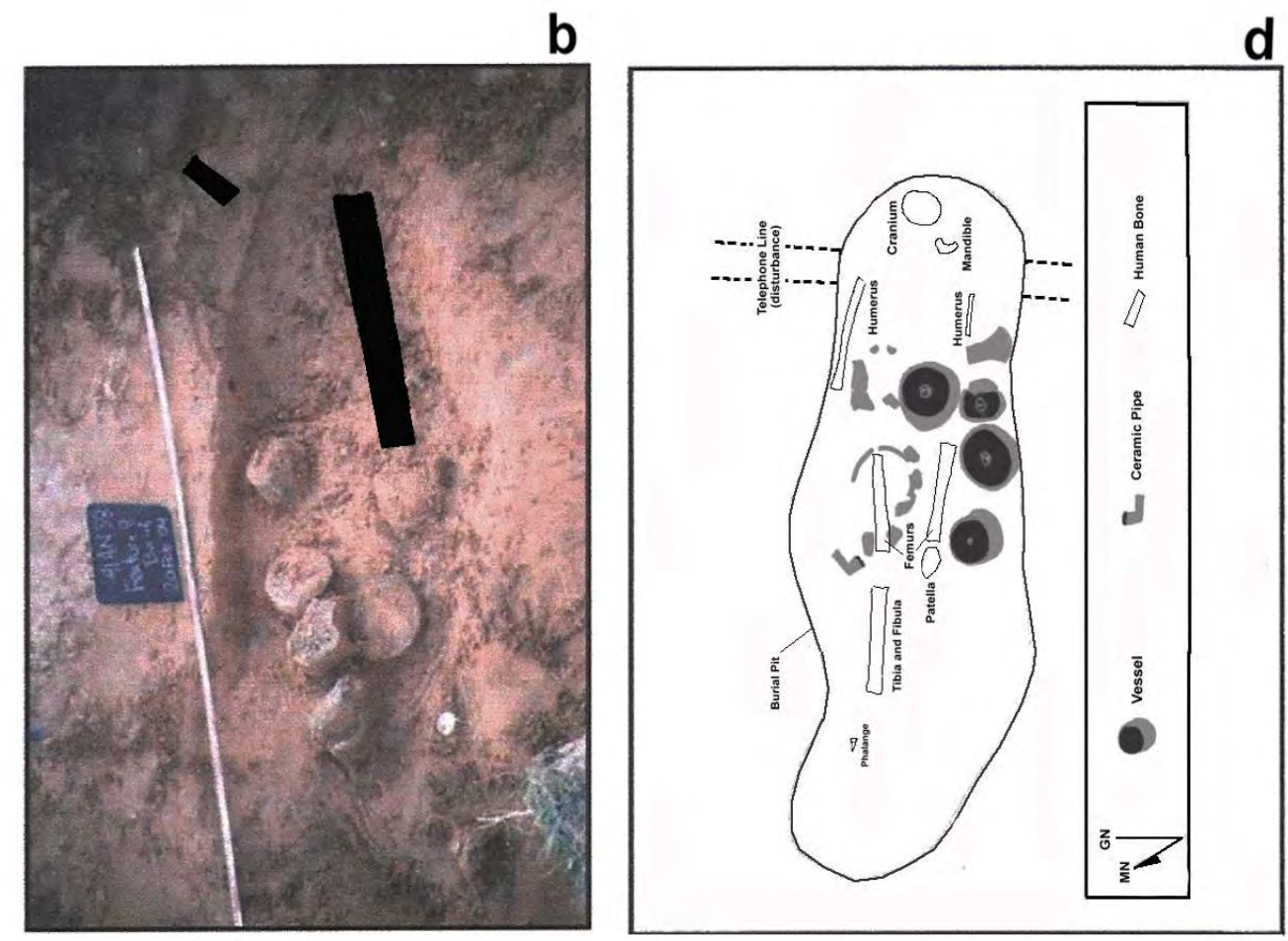

a
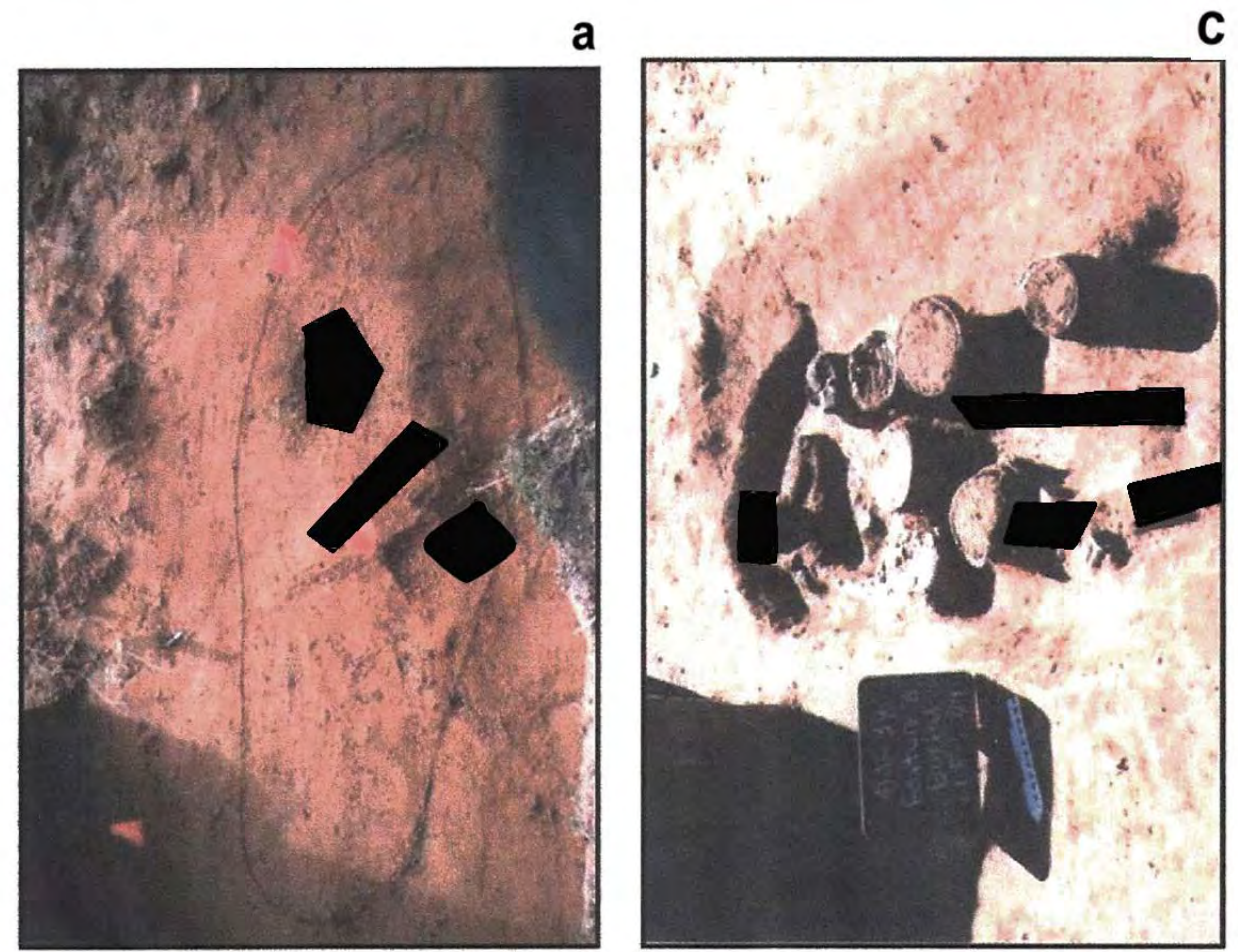

Figure 5-54. Views of Feature 8 During Excavations: a, with the burial pit defined, looking northwest; b, looking south, incompletely exposed; c, fully exposed, looking east; $d$, plan of the Feature 8 burial (after Lohse 2004:Figure 3.13; blacked-out areas cover images of human bones to conform to TXDOT policy to not publish photographs of human remains) 


\section{Feature 8}

This Caddo burial was exposed and excavated during the 2004 testing at the Lang Pasture site (see Lohse 2004:22-25). The Feature 8 burial pit is about 8-9 m north of the suite of Feature 76 burials, $12 \mathrm{~m}$ north of Structure 1, and ca. 6-7 $\mathrm{m}$ south of the other burials in the family household cemetery. The burial had been previously disturbed by installation of a telephone line that cut across the burial pit just below the skull (Figure 5-55b).

The individual was laid out in an extended supine position in a burial pit that was eastwest in orientation (see Figure 5-55a-c). The head was at the eastern end of the pit and faced west, towards the setting sun, and also the direction in which the soul traveled to the Caddi-Ayo (Swanton 1942:205, 210). This east-west orientation in the body is a typical burial practice of upper Neches River basin Caddo peoples (see Chapter 11, this volume).

A number of funerary offerings were placed in the Feature 8 burial pit, including seven ceramic vessels and an elbow pipe. The elbow pipe was placed along the right side of the body, near the upper right leg (see Figure 555d). The seven vessels included four carinated bowls (Vessels 1-3 and 5), a bowl (Vessel 4), a jar (Vessel 6), and a bottle (Vessel 7). The carinated bowls were placed on both sides of the body, above the waist, and one vessel (Poynor Engraved, Vessel 3) was apparently set atop the body. The one bowl was by the right arm, the jar by the lower left leg, and the bottle was placed by the upper left arm (see Figure 5-55d). It is a welldocumented prehistoric mortuary practice among the East Texas Caddo that the water bottles placed in burials are near the head of the grave (cf. Gonzalez 2005:58).

One distinctive feature of the Feature 8 burial pit is a compact area of the burial pit floor at the foot of the grave (see Figure 5-55d). This compact area exhibited signs of oxidation and charcoal flecking, likely because a fire had been placed at the foot of the grave. Gonzalez (2005:59) indicates that for the Caddo "[i]n the old days, when a person died, a fire was lit at the foot of the grave...From the time of death until the person is laid to rest in the grave the fire stays lit for six days until food is taken to the grave."

\section{Feature 76B, 76C, and 76D}

The Feature 76B burial, like Feature 76C, was placed in an extended position inside the Feature 76 (see Figure 5-29) basin. The floor of the burial pit was approximately $44 \mathrm{~cm}$ above the Feature 76D burial pit as well as the original bottom of the Feature 76 basin. Feature 76B was interred in a pit directly above Feature 76D and directly above a discrete sherd deposit (Zones 2C and 2D in Figure 5-28) that covered Feature 76D and provided a platform for the Feature 76B burial.

Based on the size of the burial pit, the Feature $76 \mathrm{~B}$ interment was thought to be that of a Caddo adult. Subsequent analyses by Wilson (see Chapter 10) indicate it was that of a 6-10 year old child. The head was placed at the southeastern part of the burial pit, and would have been facing northwest (Figure 5-56). The Feature $76 \mathrm{~B}$ skull rests almost directly above the skull area of Feature 76D, compelling evidence-along with the other spatial relationships mentioned above- that these two burial features are intimately related, probably because both individuals were from the same family and likely also because both the interments were not separated by much time or many years.

A deeply-set post hole (Feature 83) at the western end of the burial pit (see Figure 5-26) may have been intended to serve as a post marker for this burial.

Two ceramic vessels were placed in the Feature 76B burial pit as funerary offerings, along with the tip of an arrow point. All three offerings were laid just south of the head, above the shoulders. 


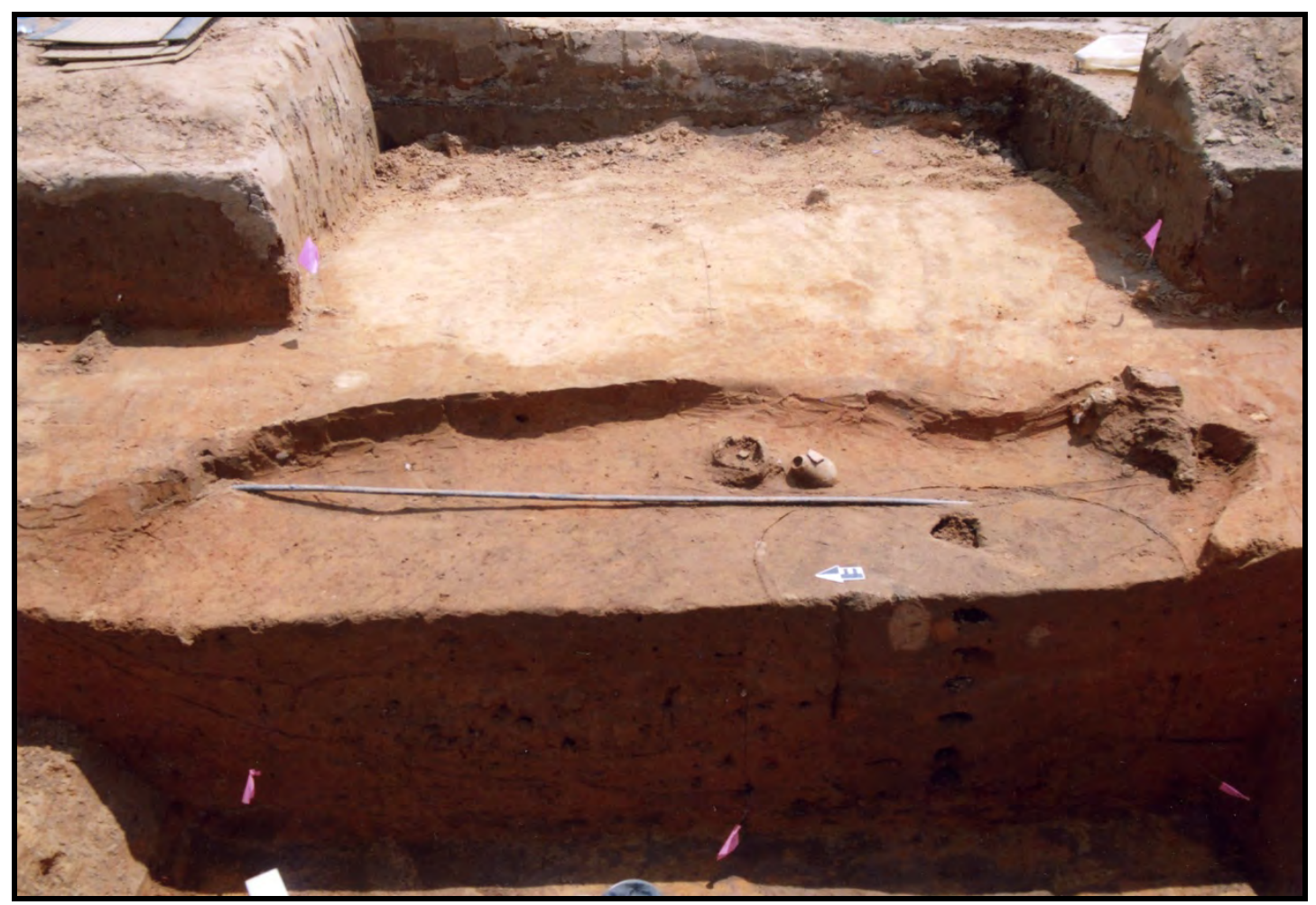

Figure 5-55. Feature 76B Looking East with Feature 76 and Feature 76A Visible in Profile.

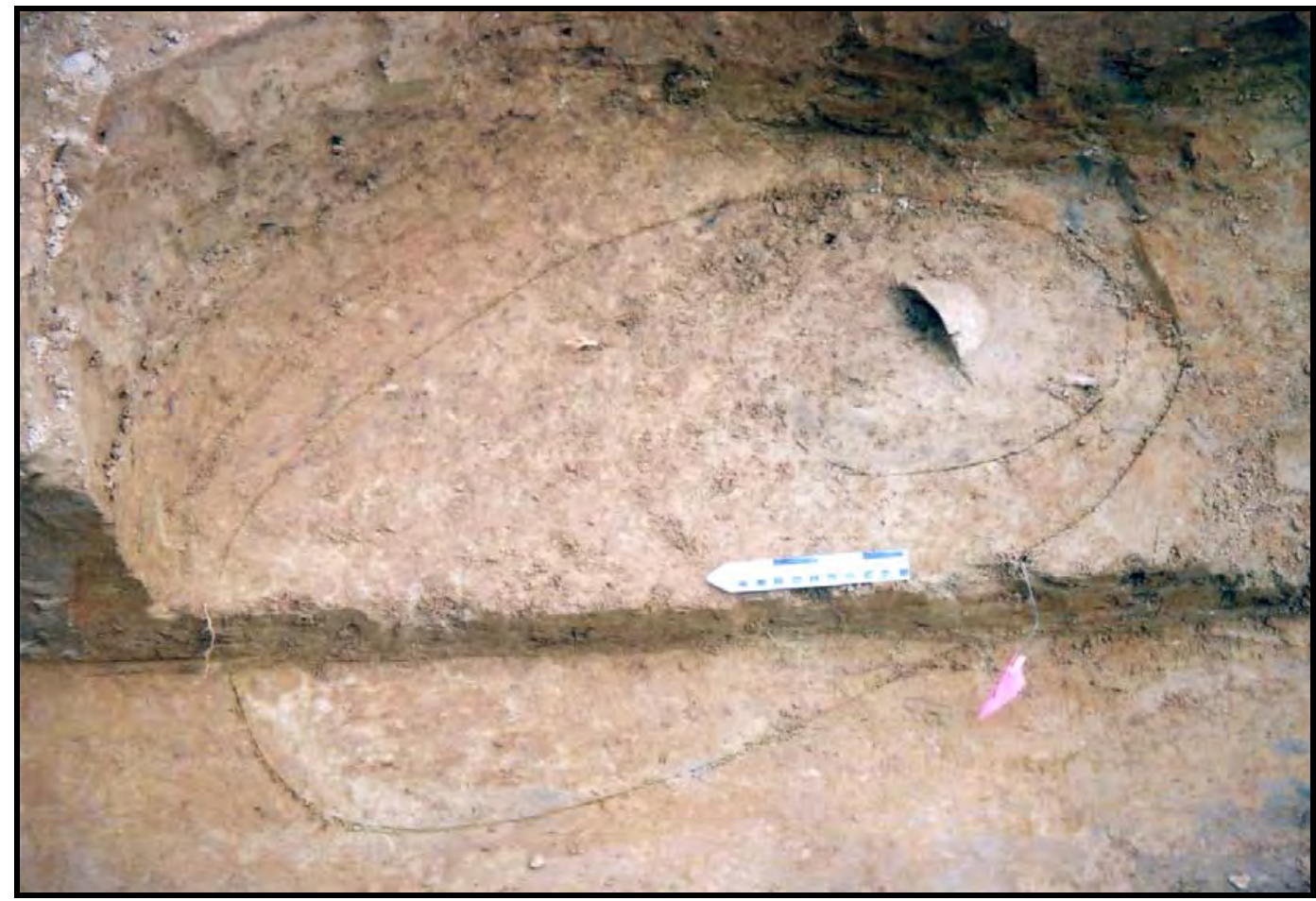

Figure 5-56. View of Feature 76D, Looking East. 
The vessels include a Poynor Plain globular carinated bowl (Vessel 1) and a unique engraved-rocker-stamped seed jar or neckless bottle (Vessel 2, see Chapter 6, this volume). The arrow point lay between the two vessels.

The Feature 76C burial pit was excavated to the immediate south of Feature 76B (see Figure 5-27). The Feature $76 \mathrm{C}$ pit was approximately the same size and same orientation as Feature 76B (see Table 5-9), and it is probable that these two burials, both children (Feature 76C was approximately 8 years old at death), were placed in the larger Feature 76 basin at the same time. Much of Feature 76C was disturbed by the Caddo during their subsequent excavation of the Feature 76A storage pit, which cut through the mid-section of this burial pit. What remains indicates that the deceased was laid on its back in an extended supine position, with the head at the southeastern edge of the burial pit, facing to the northwest.

A single funerary offering was placed in the Feature 76C burial pit. This was a plain, but fragmentary, ceramic bowl nestled to the left of the head, apparently at or immediately above the shoulder area; the two vessels in Feature 76B were placed in that burial pit in the same relationship to the body.

The first burial in the large Feature 76 pit was Feature 76D, which was dug into the floor of the pit feature (Figure 5-57). In the absence of any appreciable bone fragments, the small size of the burial pit (see Table 5-9) suggests that this too was the interment of a Caddo child or juvenile. Wilson's analyses suggest the individual was between 3-12 years of age at death. Associated funerary offerings include a plain bowl (Vessel 1) with a scalloped lip (see Chapter 6, this volume), placed near what would have been the head of the deceased, and a ground stone tool (see Chapter 7, this volume) near the right side of the body near its midsection (see Figure 5-57).
The burial pit itself was a dark red (2.5YR 3/6) sandy clay mottled with strong brown (7.5YR 5/8) sandy clay. It was not clearly recognized as a burial pit until Vessel 1 was discovered (its top was at $132 \mathrm{~cm}$ bs) while cleaning the bottom of Feature 76.

\section{Feature 88}

Feature 88 is the easternmost of the group of five burials at the northern end of the Lang Pasture site (see Figure 5-54). Like Feature 91, the burial pit was quite shallow (see Table 59).

spatially associated burials are laid out in an east-west orientation (see Table 5-9), with the head of the deceased at the eastern end of the burial pit, facing west. Although the Feature 88 burial pit only held one adult individual (Figure 5-58), it is the largest of the burial pits in the cemetery, even larger than the Feature 93 burial pit, into which two adults were laid to rest

The Feature 88 burial pit was also disturbed by the installation of a phone line; the phone line cut across the mid-section of the body (see Figure 5-58a) and bisected one of the ceramic vessel funerary offerings.

Two ceramic vessels were placed in the burial pit with the deceased, a compound vessel or a wide-mouthed bottle with suspension holes (Vessel 1) at and above the right side of the head, and a plain carinated bowl (Vessel 2) along the left side of the body by the waist (see Figure 5-58a). There is no evidence of a fire having been lit in this grave.

\section{Feature 91}

Feature 91 was only shallowly excavated by the Caddo when they interred a deceased adult individual in this burial pit. The tops of the two ceramic vessels placed in the grave (Figure 5-59a-b) were encountered between 7$10 \mathrm{~cm}$ bs. 
The eastern end of Feature 91 was destroyed by a utility line/phone line trench (see Figure 5-59a-b), removing any remnants of the skull or upper body of the deceased, as well as any funerary offerings that may have been placed by or above the head. There were no preserved human remains in the burial pit fill other than a single tooth. The two recovered funerary offerings include a Poynor Engraved compound bowl (Vessel 1) along what would have been the leg area along the right side of the body, and a Poynor Engraved carinated bowl near the waist area, but on the left side of the body (see Figure 5-59a).

\section{Feature 92}

Feature 92 is the northernmost burial in the western row of burials that includes Features 92, 93, and 94 (see Figure 5-54). These western burials were placed in deeper burial pits than Features 88 and 91 in the eastern row of burials (see Table 5-9). Funerary offerings in general-or at least those that were not perishable-were generally more abundant in the western row of burials than in those in the eastern burial row.

This burial pit was bisected by a second phone line (Figure 5-60a-b), and the extreme western or foot portion of the burial pit extends onto private property. Skeletal remains of the Caddo adult placed in this burial pit are poorly preserved, consisting only of the skull and parts of the arms and legs (see Figure 5-60a).

Two funerary offerings were placed with the deceased in Feature 92, both ceramic vessels. The first (Vessel 1) is a small plain bowl by the upper left leg, and the other is a rectangular-shaped plain bowl (Vessel 2) along what would have been the left knee area (see Figure 5-60a). 

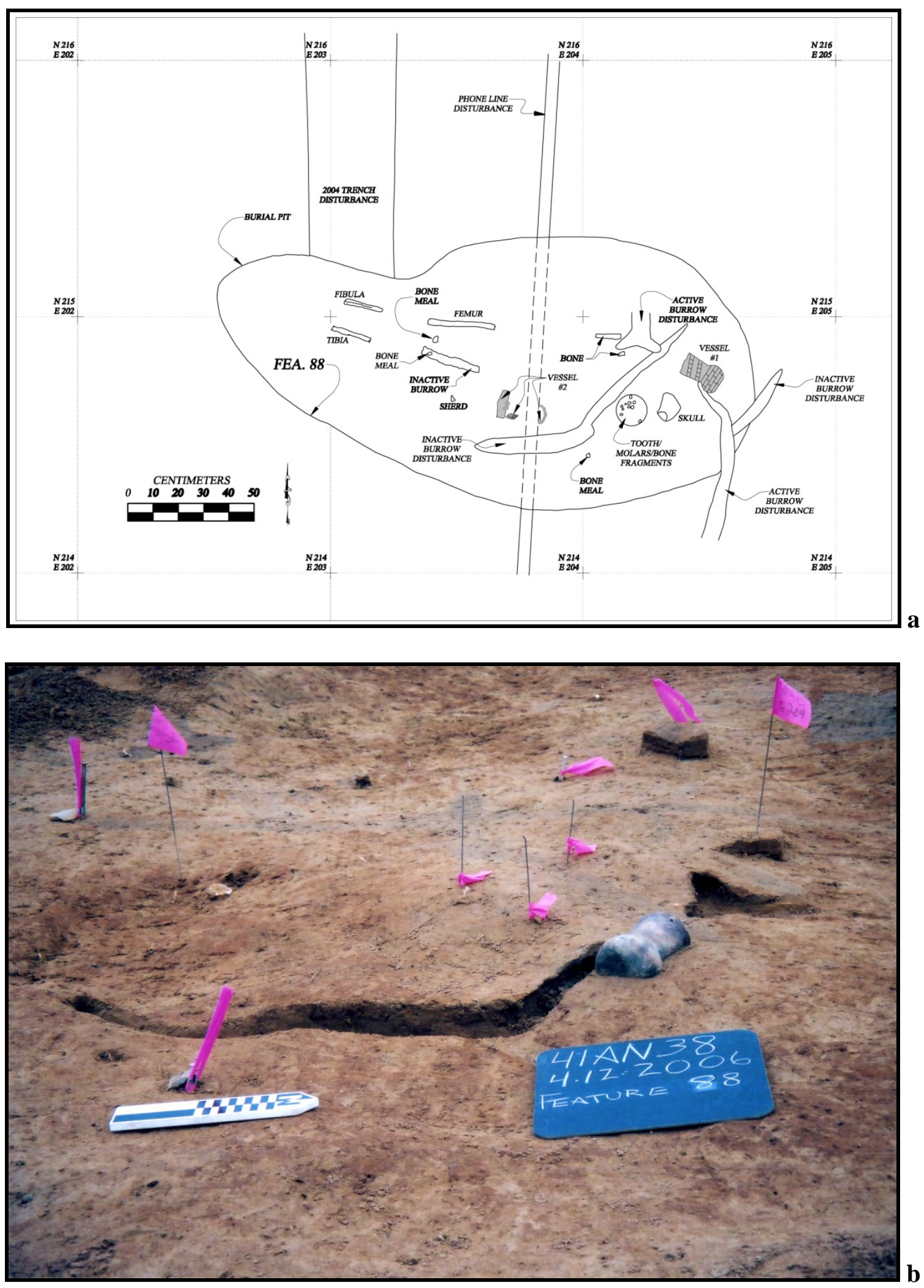

Figure 5-57. Feature 88: a, plan of the burial; b, looking west at Feature 88 near its initial exposure. 

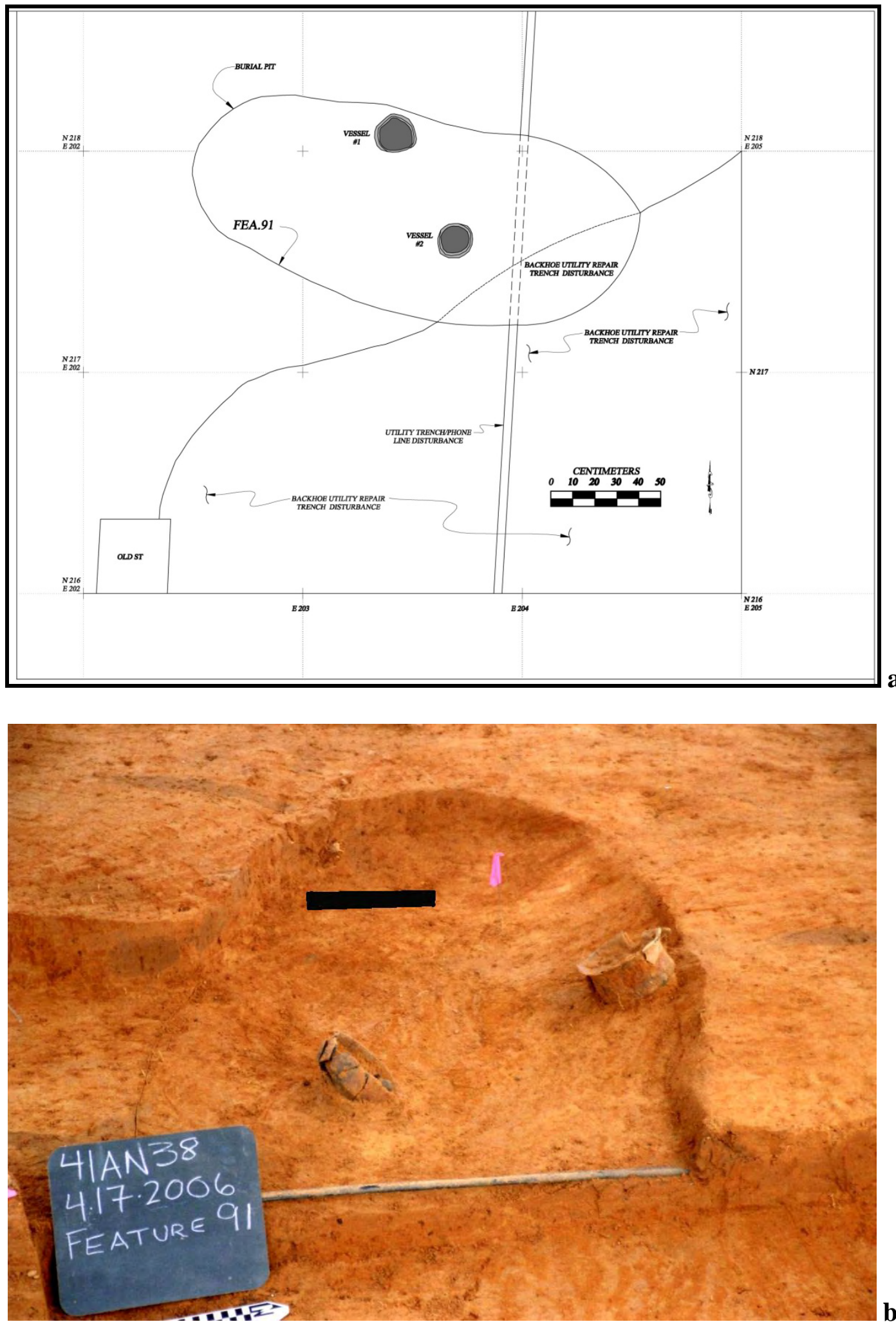

Figure 5-58. Feature 91: a, plan of the burial; b, looking west at Feature 91,

Note: Vessels 1 and 2 (blacked-out area covers image of human bone to conform to TxDOT policy to not publish photographs of human remains). 

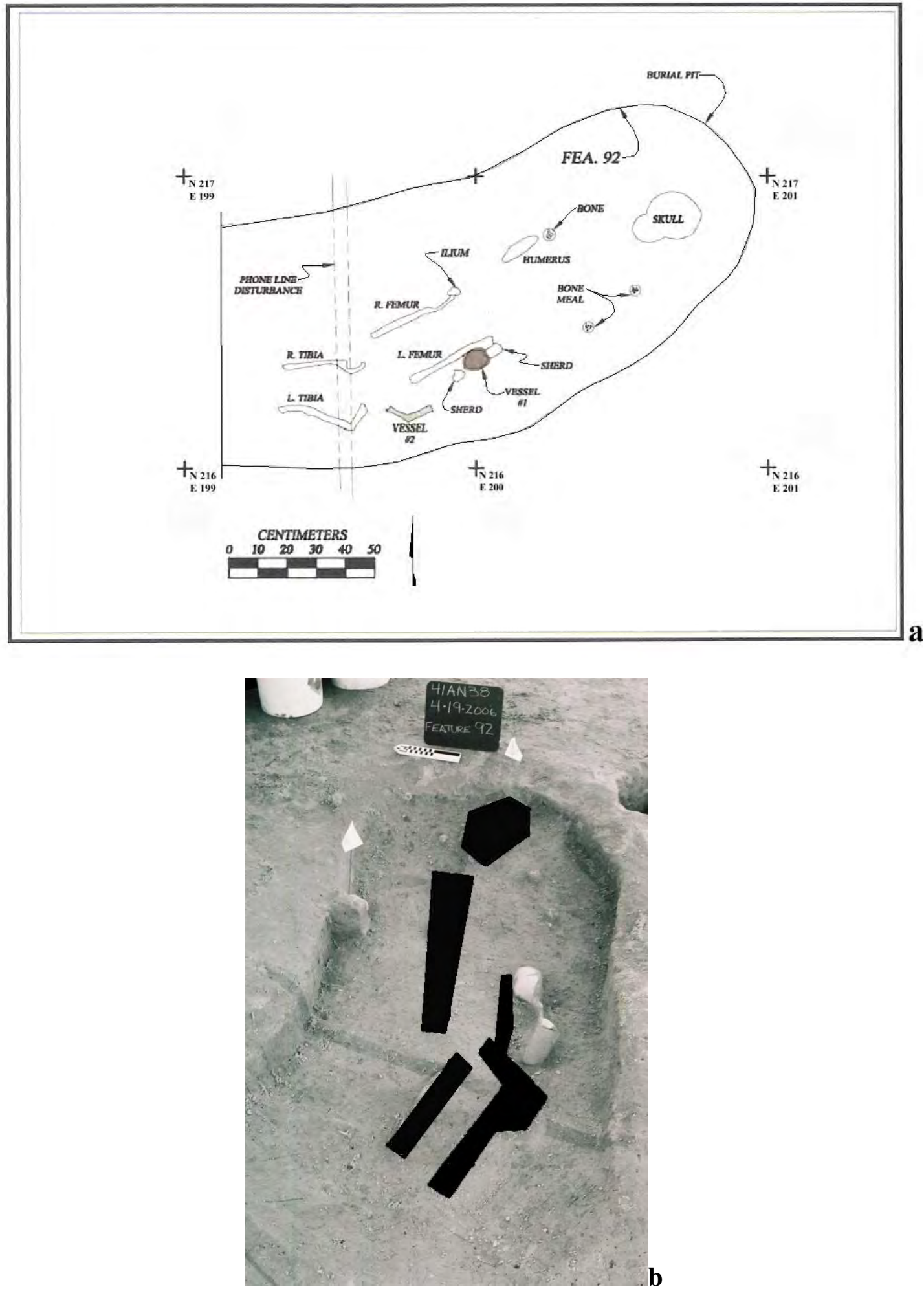

Figure 5-59. Feature 92: a, plan of the burial; b, looking east at Feature 92. Feature 93: (blacked-out areas cover images of human bones to conform to TXDOT policy to not publish photographs of human remains). 
Feature 93 is the most distinctive of the burial features at the Lang Pasture site. First, the fill of the burial pit is a red to reddish-yellow sandy clay mixed with a very gravelly red sandy loam. This particular clay and gravel deposit is not widely distributed on the site. The other distinctive aspect of the burial feature is the fact that it had two deceased adult individuals placed in it (Figure 5-61). A phone line cuts across the western end of the burial pit.

These individuals (A on the north side of the burial pit, and $\mathrm{B}$ on the south side) were placed side by side, about $50 \mathrm{~cm}$ apart, with their heads resting near the eastern end of the burial pit (see Figure 5-63). Preserved skeletal materials included the skulls and the left and right femurs of both burials. There is a darker soil stain associated with Individual A, perhaps the product of decaying organic materials laid on and around the body's midsection (see Figure 5-60d).
Both individuals had associated funerary offerings. Individual $\mathrm{A}$ had four vessels (Vessels 1, 2, 3/4A, and 4B, see Chapter 6, this volume), while Individual $B$ had five vessels placed with it (Vessels 5-9), along with an elbow pipe resting by the right upper leg. In the case of Individual A, one large vessel (a plain bowl, Vessel 4B) was placed above the head, another large vessel (Vessel 3/4A, a Poynor Engraved compound bowl whose fragments were dispersed and intermixed with Vessel 4B) by the right shoulder, and two other vessels (Vessels 1 and 2) near the left leg (see Figure 5-61). These are, respectively, a plain bowl and a small Poynor Engraved carinated bowl. In the case of Individual B, the elbow pipe and a small Poynor Engraved bowl (Vessel 5) were resting along the right leg. Four other vessels (Vessels 6-9) were set a short distance from the left leg, all in a row, and reaching up to the left shoulder area (see Figure 5-60 a, d).

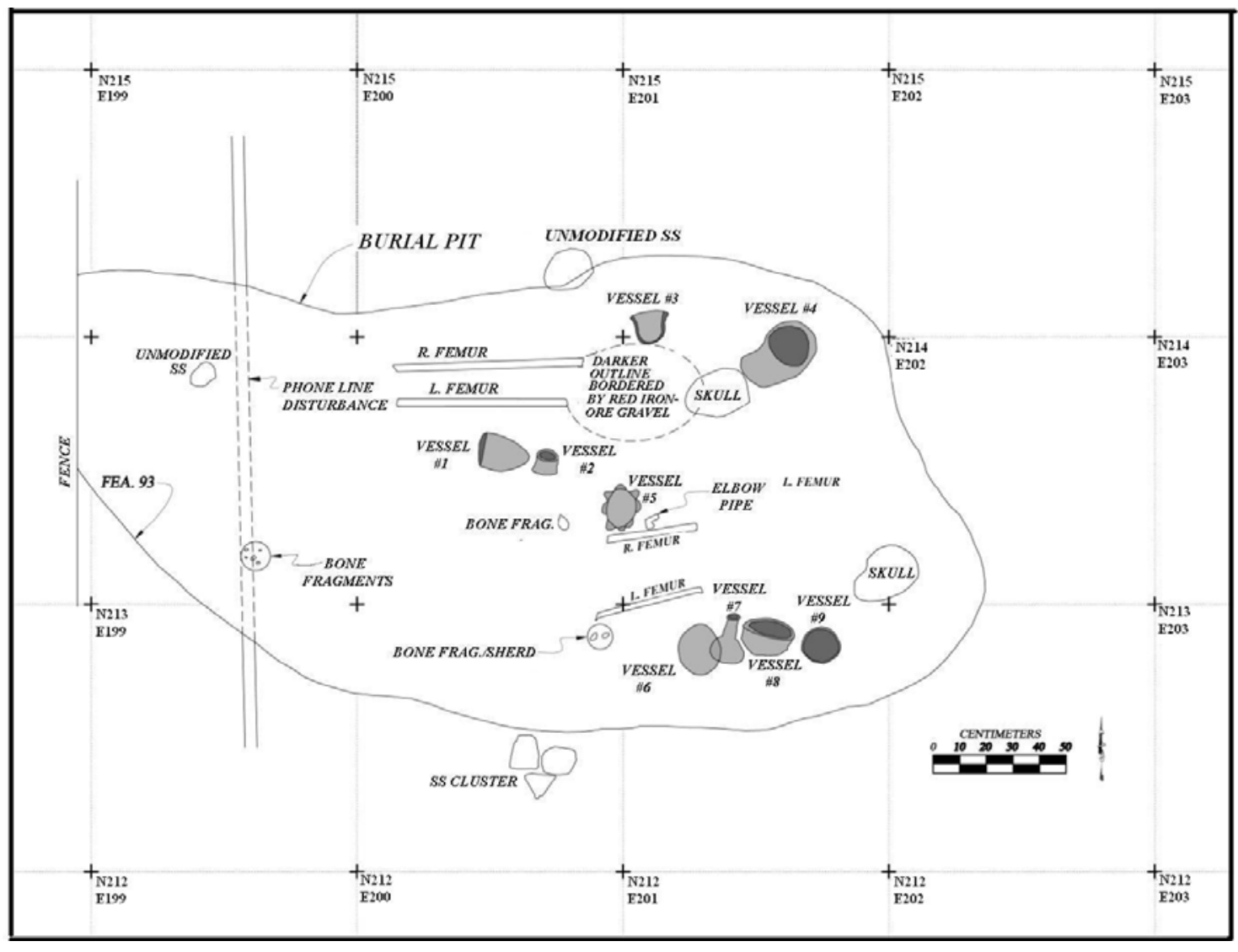

Figure 5-60. Plan View of Feature 93. 

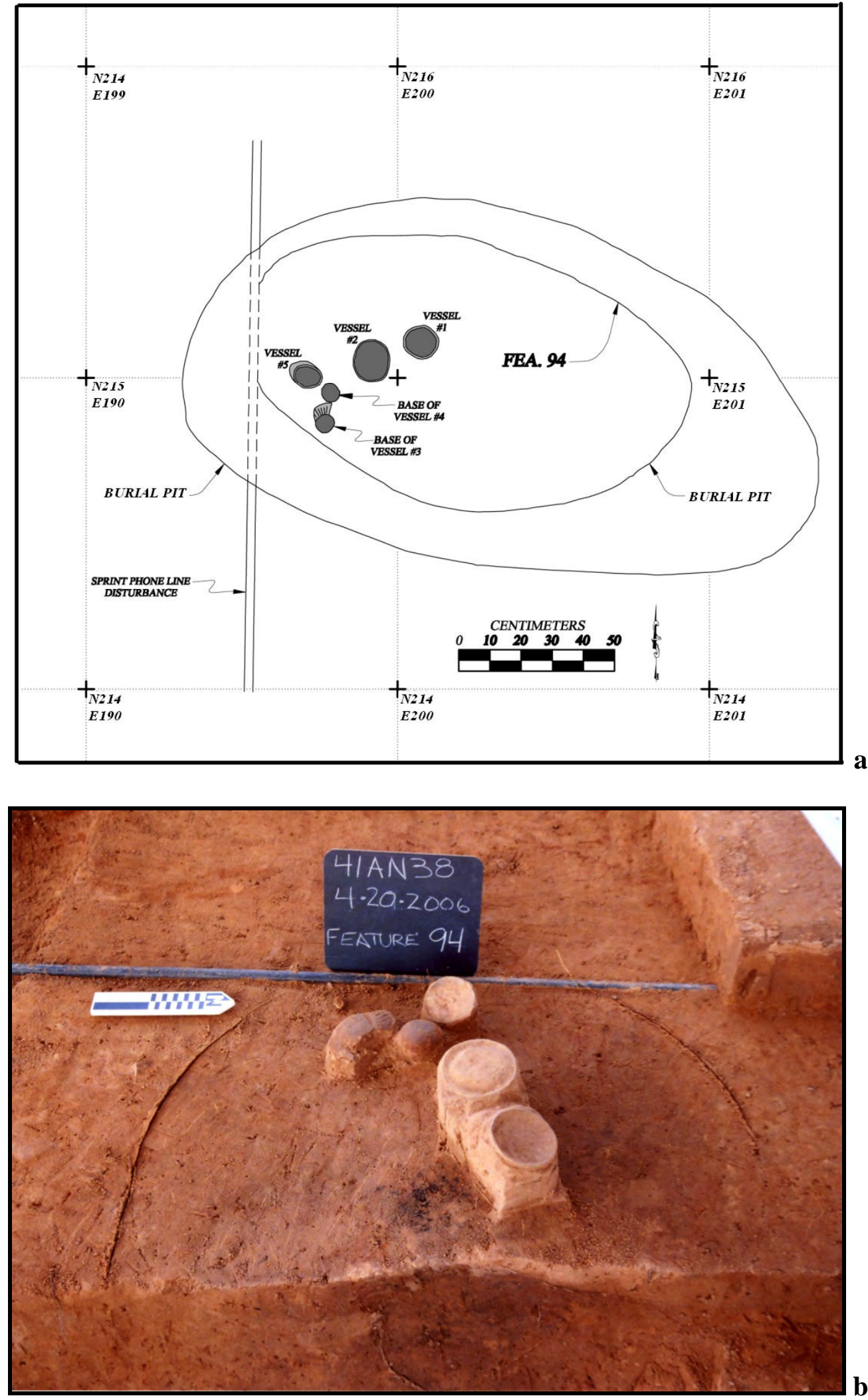

Figure 5-61. Feature 94: a, plan of the burial; b, looking west at Feature 94. 
From west to east these funerary vessels include a plain carinated bowl (Vessel 6), a plain bottle (Vessel 7), another plain carinated bowl (Vessel 8), and a medium-sized Maydelle Incised jar (Vessel 9).

\section{Feature 94}

The last of the prehistoric Caddo burials at the Lang Pasture site is in a pit sandwiched between Feature 92 to the north and Feature 93 to the south (see Figure 5-54). There were no preserved human remains in the burial pit, but there were five ceramic vessel funerary offerings (Figures 5-62a-b and 5-63).

\subsection{RADIOCARBON DATES FROM THE LANG PASTURE SITE (41AN38) AND OTHER UPPER NECHES RIVER BASIN CADDO SITES}

A total of 29 radiocarbon dates have been obtained from a variety of cultural features at the Lang Pasture site (Table 5-10). Five other radiocarbon dates have been obtained from burials at five other upper Neches River Caddo sites, including Emma Owens (41AN21), Fred McKee (41AN32), Pierce Freeman (41AN34), Solon Stanley (41CE3), and A. H. Reagor (41CE15) (Table 5-11).

The funerary offerings were apparently placed along the lower body of the deceased, perhaps along the right leg. In this same area was a 48 x $38 \mathrm{~cm}$ brown (10YR 4/3) and very dark brown (10YR 2/2) charcoal-flecked soil stain that is likely the remnants of a small fire that had been placed on the floor of the burial pit. Vessel 1 (a small plain bowl) rested amidst this stained area, and Vessel 2 (a Poynor Plain globular carinated bowl) had been placed a short distance to the west of Vessel 1 and the charcoal-flecked soil stain. The other three vessels (Vessels 3-5) are in a cluster closer to the foot of the grave. These vessels include a small Killough Pinched bowl (Vessel 3), a small plain carinated bowl (Vessel 4), and a small plain bowl (Vessel 5). 


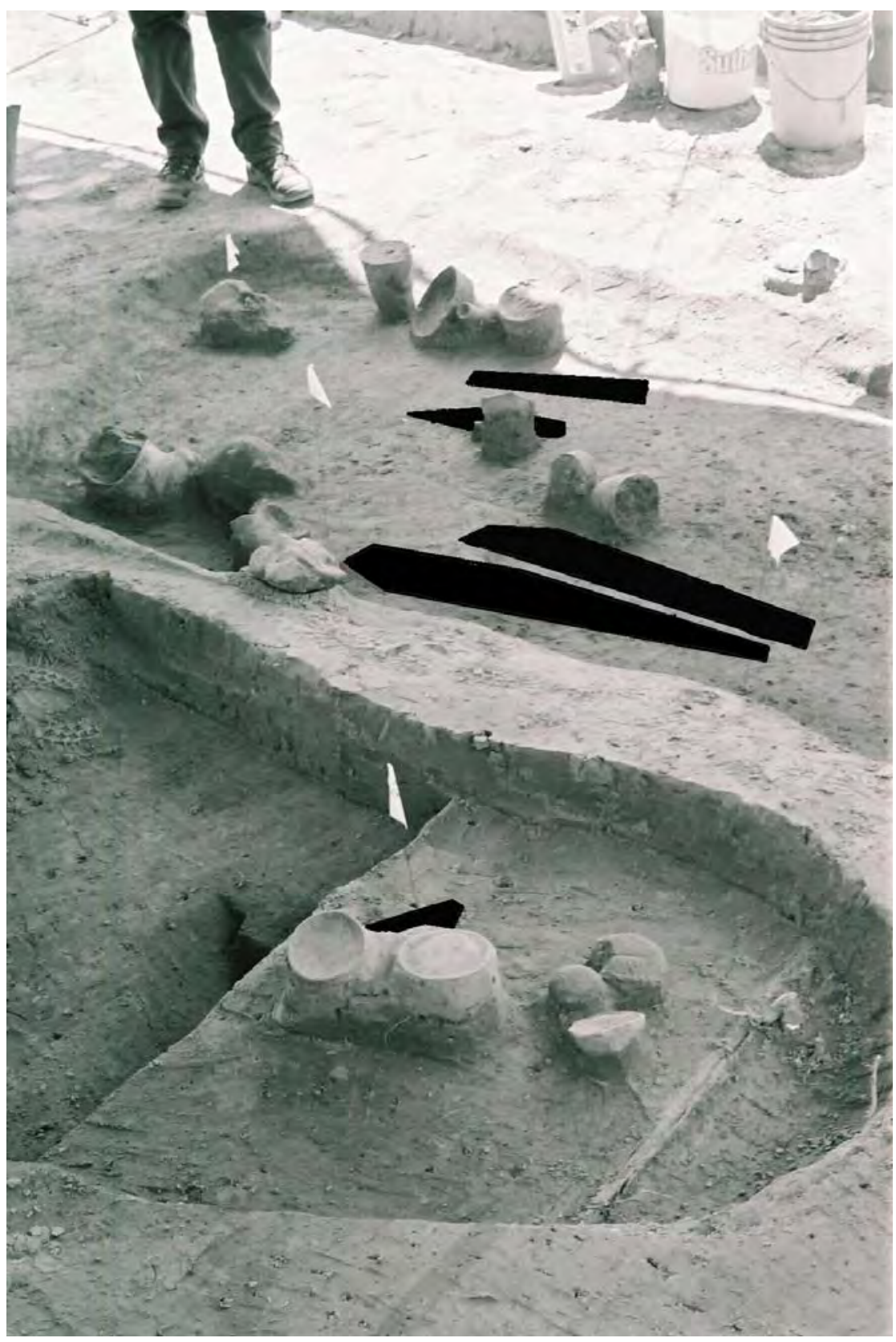

Figure 5-62. Looking Southeast at Feature 93 and Feature 94 (blacked-out areas cover images of human bones to conform to TxDOT policy to not publish photographs of human remains). 
Table 5-10. Radiocarbon Dates from the Lang Pasture Site.

\begin{tabular}{|c|c|c|c|c|c|c|}
\hline $\begin{array}{l}\text { Beta } \\
\text { No. }\end{array}$ & Fea. & $\begin{array}{l}\text { Conventional } \\
\text { Radiocarbon } \\
\text { Age (B.P.) }\end{array}$ & $\begin{array}{l}1 \text { sigma } \\
\text { cal age } \\
\text { (A.D.) }\end{array}$ & $\begin{array}{l}2 \text { sigma } \\
\text { cal age } \\
\text { (A.D.) }\end{array}$ & $\begin{array}{l}\text { cal intercept } \\
\text { (A.D.) }\end{array}$ & $13 C / 12 C$ \\
\hline 236772 & $\begin{array}{l}\text { w/in } \\
\text { Str. } 1\end{array}$ & $600 \pm 40$ & $1300-1400$ & $1290-1420$ & $\begin{array}{l}1320,1350 \\
1390\end{array}$ & -9.5 o/oo* \\
\hline 236773 & 8 & $460 \pm 40$ & $1430-1450$ & $1410-1470$ & 1440 & -16.6 o/oo** \\
\hline 236774 & 16 & $1090 \pm 40$ & $900-1000$ & $880-1020$ & 980 & -23.4 o/oo \\
\hline 236775 & 20 & $610 \pm 40$ & $1300-1400$ & $1290-1420$ & $\begin{array}{l}1320,1350 \\
1390\end{array}$ & -21.4 o/oo \\
\hline 236776 & 20 & $350 \pm 40$ & $\begin{array}{l}1460-1540 \\
1540-1630\end{array}$ & $1450-1650$ & $\begin{array}{l}1500,1600, \\
1610\end{array}$ & -25.5 o/oo \\
\hline 236777 & 25 & $600 \pm 40$ & $1300-1400$ & $1290-1420$ & $\begin{array}{l}\text { 1320, } 1350 \\
1390\end{array}$ & -29.9 o/oo \\
\hline 236778 & 29 & $1290 \pm 40$ & $670-770$ & $660-780$ & 690 & -26.2 o/oo \\
\hline 236779 & 30 & $1060 \pm 40$ & $970-1020$ & 890-1030 & 990 & -21.5 o/oo \\
\hline 236780 & 36 & $490 \pm 40$ & $1420-1440$ & $1400-1450$ & 1430 & -9.7 o/oo* \\
\hline 236781 & 36 & $530 \pm 60$ & $\begin{array}{l}1330-1340 \\
1400-1440\end{array}$ & $1300-1450$ & 1420 & -29.6 o/oo \\
\hline 236782 & 37 & $500 \pm 40$ & $1410-1440$ & $1400-1450$ & 1430 & -25.2 o/oo \\
\hline 236783 & 41 & $610 \pm 40$ & $1300-1400$ & $1290-1420$ & $\begin{array}{l}\text { 1320, } 1350 \\
1390\end{array}$ & -10.2 o/oo* \\
\hline 236784 & 45 & $700 \pm 40$ & $1270-1300$ & $\begin{array}{l}1260-1310 \\
1360-1390\end{array}$ & 1280 & -9.7 o/oo* \\
\hline 236785 & 76 & $560 \pm 40$ & $\begin{array}{l}1320-1350 \\
1390-1420\end{array}$ & $\begin{array}{l}1300-1370 \\
1380-1430\end{array}$ & 1400 & -25.3 o/oo \\
\hline 236786 & 76 & $560 \pm 40$ & $\begin{array}{l}1320-1350 \\
1390-1420\end{array}$ & $\begin{array}{l}1300-1370 \\
1380-1430\end{array}$ & 1400 & -9.2 o/oo* \\
\hline 236787 & 76 & $190 \pm 40$ & $\begin{array}{l}1660-1680 \\
1740-1810 \\
1930-1950\end{array}$ & $\begin{array}{l}1650-1700 \\
1720-1820 \\
1840-1880 \\
1920-1950\end{array}$ & $\begin{array}{l}1670,1780 \\
1800,1950\end{array}$ & -24.6 o/oo \\
\hline 236788 & $76 \mathrm{~A}$ & $850 \pm 40$ & $1160-1230$ & $\begin{array}{l}1050-1090 \\
1130-1140 \\
1140-1260\end{array}$ & 1210 & $-26.1 \mathrm{o} / \mathrm{oo}$ \\
\hline
\end{tabular}


Table 5-10, continued.

\begin{tabular}{|c|c|c|c|c|c|c|}
\hline $\begin{array}{l}\text { Beta } \\
\text { No. }\end{array}$ & Fea. & $\begin{array}{l}\text { Conventional } \\
\text { radiocarbon } \\
\text { age (B.P.) }\end{array}$ & $\begin{array}{l}1 \text { sigma } \\
\text { cal age } \\
\text { (A.D.) }\end{array}$ & $\begin{array}{l}2 \text { sigma } \\
\text { cal age } \\
\text { (A.D.) }\end{array}$ & $\begin{array}{l}\text { cal intercept } \\
\text { (A.D.) }\end{array}$ & 13C/12C \\
\hline 236789 & 79 & $690 \pm 40$ & $1280-1300$ & $\begin{array}{l}1260-1320 \\
1350-1390\end{array}$ & 1290 & -9.2 o/oo* \\
\hline 236790 & 79 & $1420 \pm 40$ & $610-650$ & $570-660$ & 640 & $-25.8 \mathrm{o} / \mathrm{oo}$ \\
\hline 236791 & 82 & $2800 \pm 40$ & $1000-910$ BC & $1040-840$ BC & $930 \mathrm{BC}$ & $-23.9 \mathrm{o} / \mathrm{oo}$ \\
\hline 236792 & 84 & $460 \pm 40$ & $1430-1450$ & $1410-1470$ & 1440 & -10.4 o/oo* \\
\hline 236793 & 85 & $600 \pm 40$ & $\begin{array}{l}1300-1370 \\
1380-1400\end{array}$ & $1290-1420$ & $\begin{array}{l}\text { 1320, 1350, } \\
1390\end{array}$ & -10.4 o/oo* \\
\hline 236794 & 86 & $1830 \pm 50$ & $120-240$ & $\begin{array}{l}70-260 \\
280-330\end{array}$ & 210 & $-24.3 \mathrm{o} / \mathrm{oo}$ \\
\hline 236795 & 86 & $1220 \pm 40$ & $\begin{array}{l}720-740 \\
770-880\end{array}$ & $680-890$ & 780 & $-27.7 \mathrm{o} / \mathrm{oo}$ \\
\hline 239845 & $76 \mathrm{~B}$ & $1190 \pm 40$ & $780-890$ & $\begin{array}{l}710-750 \\
760-900 \\
920-960\end{array}$ & 870 & $-17.4 \mathrm{o} / \mathrm{oo}^{* *}$ \\
\hline 239846 & $76 \mathrm{C}$ & $600 \pm 40$ & $\begin{array}{l}1300-1370 \\
1380-1400\end{array}$ & $1290-1420$ & $\begin{array}{l}\text { 1320, 1350, } \\
1390\end{array}$ & $-15.6 \mathrm{o} / \mathrm{oo}^{* *}$ \\
\hline 239847 & 88 & $250 \pm 50$ & $\begin{array}{l}1640-1670 \\
1780-1790\end{array}$ & $\begin{array}{l}1500-1600 \\
1610-1680 \\
1740-1810 \\
1930-1950\end{array}$ & 1650 & -19.6 o/oo** \\
\hline 239848 & 92 & $180 \pm 40$ & $\begin{array}{l}1660-1690 \\
1730-1810 \\
1930-1950\end{array}$ & $\begin{array}{l}1650-1710 \\
1710-1880 \\
1910-1950\end{array}$ & $\begin{array}{l}\text { 1670, 1770, } \\
1800,1940, \\
1950\end{array}$ & $-18.8 \mathrm{o} / \mathrm{oo} * *$ \\
\hline 239850 & 93, B2 & $540 \pm 40$ & $1400-1430$ & $\begin{array}{l}1310-1360 \\
1390-1440\end{array}$ & 1410 & $-17.6 \mathrm{o} / \mathrm{oo}^{* *}$ \\
\hline
\end{tabular}

*corn

**human bone collagen

These 34 radiocarbon dates from the Lang Pasture site and nearby prehistoric Caddo cemetery sites in the upper Neches River basin constitute the largest assemblage of radiocarbon dates ever obtained from this region (see Perttula 1998; Story 1990). Taken together with the very large assemblage of radiocarbon dates $(n=130)$ from the George C. Davis site (41CE19), downstream in the

middle Neches River basin, they provide the only comprehensive set of calibrated radiocarbon dates from an area that heretofore has had only limited and not necessarily very successful radiocarbon dating. 
Table 5-11. Radiocarbon Dates from Other Upper Neches River Basin Caddo Sites.

\begin{tabular}{lllllll}
\hline Site* & $\begin{array}{l}\text { Beta } \\
\text { No. }\end{array}$ & $\begin{array}{l}\text { Conventional } \\
\text { radiocarbon } \\
\text { age (B.P.) }\end{array}$ & $\begin{array}{l}\text { 1 sigma } \\
\text { cal age } \\
\text { (A.D.) }\end{array}$ & $\begin{array}{l}\text { 2 sigma } \\
\text { cal age } \\
\text { (A.D.) }\end{array}$ & $\begin{array}{l}\text { cal intercept } \\
\text { (A.D.) }\end{array}$ & 13C/12C \\
\hline AN21 & 236796 & $300 \pm 40$ & $\begin{array}{l}1520-1590 \\
1620-1650\end{array}$ & $1470-1660$ & 1640 & -13.1 o/oo** \\
& & & $1470-1640$ & $1450-1650$ & $\begin{array}{l}1520,1590, \\
1620\end{array}$ & -12.0 o/oo** \\
AN32 & 236797 & $340 \pm 40$ & $1450-1500$ & $1440-1540$ & 1460 & -13.8 o/oo** \\
& & & $1600-1610$ & $1540-1630$ & & \\
AN34 & 236798 & $390 \pm 40$ & $1050-1090$ & $1030-1230$ & 1160 & -19.9 o/oo** \\
& & & $1130-1140$ & & & \\
CE3 & 236799 & $890 \pm 40$ & $1140-1210$ & & 1520,1580, & -14.9 o/oo** \\
& & & $1480-1640$ & $1450-1650$ & 1630 & \\
\hline
\end{tabular}

*site numbers preceded by “41”

**human bone collagen

The significance of the 34 radiocarbon dates is two-fold. First, the first 29 calibrated radiocarbon dates (see Table 5-10) help in unraveling and establishing the occupational history of the Lang Pasture site and its various domestic and burial features, when taken together with feature stratigraphic and spatial relationships and associated diagnostic artifacts recovered in these features. Second, the radiocarbon dates on Caddo burials from the Lang Pasture site $(n=6)$ and other upper Neches River basin sites $(n=5)$ demarcate the principal temporal period(s) in which large numbers of Caddo cemeteries were established and used in the region, and generally lend corroboration to the current chronological ordering of Caddo burials based on ceramic vessel offerings (cf. Kleinschmidt 1982; Perttula 2007b) placed with the burials.

\section{The Samples}

All 34 radiocarbon samples-whether wood charcoal, charred hickory (Carya sp.) nutshell, maize, or human remains-were submitted to Beta Analytic, Inc. for analysis (see Appendix B). The results of the analyses by Beta Analytic, Inc. include the measured radiocarbon age of the dated material (in years B.P.); the $13 \mathrm{C} / 12 \mathrm{C}$ ratio used to correct the measured radiocarbon age because of the isotopic fractionation of that material; the resulting conventional radiocarbon age (in years B.P.); and the calibrated age range and calibrated intercepts (following Reimer et al. 2004; Talma and Vogel 1993) of the dated material. The calibrated age ranges are determined at 1 sigma (66\% probability) and 2 sigma ( $95 \%$ probability), and presented as years B.C. or A.D. (see Tables 5-10 and 5-11).

\section{Lang Pasture Site}

Arranged in chronological order (Figure 5-64), the 29 calibrated radiocarbon dates from the Lang Pasture site (see Table 5-10) suggest that the site was occupied from as early as about 1000 B.C. (2 sigma calibrated age range of $1040-840 \mathrm{BC})$ to as late as the mid- $17^{\text {th }}$ century (AD 1650), but that occupation was certainly not continuous. Based strictly on the calibrated radiocarbon age ranges, the first but intermittent occupational episode at the site took place between 1040-840 BC (Feature 82), followed by a 910 year period of abandonment (840 BC to $\mathrm{AD} 70$ ), after which it was 
occupied and used a second time from AD 70330 (Feature 86). The site was again abandoned between AD 330-570 (a 240 year period), followed by a more sustained but still relatively ephemeral use of the site in the $3^{\text {rd }}$ occupational episode from AD 570-1030 $\left(1^{\text {st }}\right.$ Radiocarbon Group, Features 16, 29, 30, 79, and 86). ${ }^{1}$ A third temporal break in the radiocarbon series between AD 1030-1260 (with the exception of an anomalous radiocarbon date from Feature $76 \mathrm{~A})^{2}$ indicates another period of site abandonment. A $2^{\text {nd }}$
Radiocarbon Group of dates from features and burials (Features 8, 20, 25, 36, 37, 41, 45, 76, 76C, 79, 84, 85, and 93) from AD 1260-1470 (at 2 sigma) pertain to the principal prehistoric Caddo occupation of the Lang Pasture site during $\mathrm{a} 4^{\text {th }}$ occupational episode. This occupational episode is represented by Structures 1, 2, and 3, most of the post holes and pit features, and the vast majority of the recovered decorated and plain ceramics distributed within and between these structures and associated features.

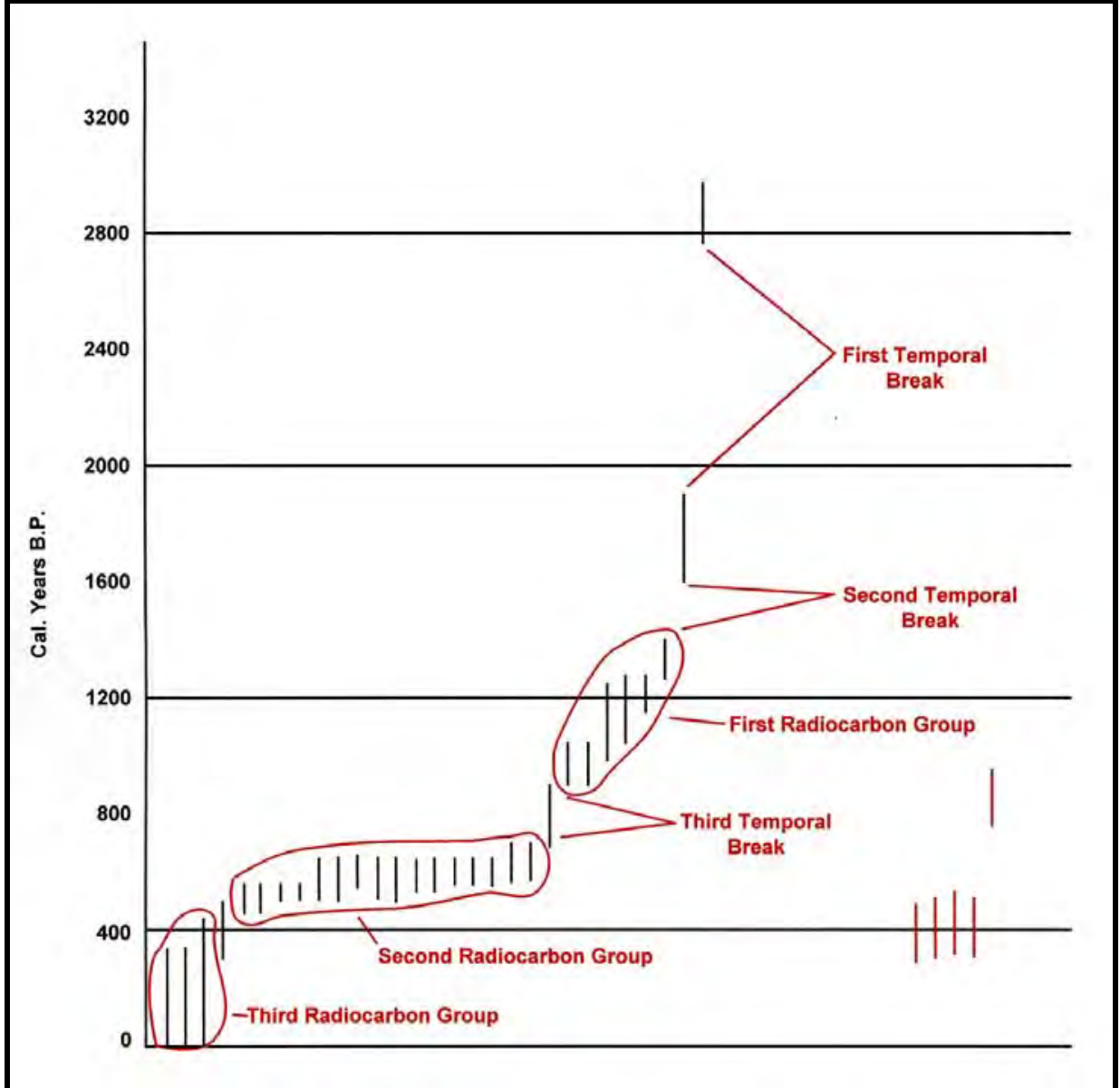

Figure 5-63. Plots of 2 Sigma Calibrated Radiocarbon Age Ranges for the 29 Samples from the Lang Pasture Site (black bars) and Five Samples from Other Upper Neches River Basin Caddo Sites (red bars).

There are four calibrated radiocarbon dates from Lang Pasture features (the $3^{\text {rd }}$ Radiocarbon Group: Feature 20, 76, 88, and $92)^{3}$ that suggest the site was also used sometime after AD 1450. However, given that three of these dates (Feature 76, 88, and 92) have age ranges that reach to $\mathrm{AD} 1950$ and modern times (and hence have been contaminated by modern radiocarbon materials), with intercepts of AD 1770, 1780, 
1800, 1940, and 1950 (Feature 76), among others, lends little if any confidence in any assertion that the Lang Pasture site was used by the Caddo after the $15^{\text {th }}$ century. Thus, the $3^{\text {rd }}$ Radiocarbon Group from the Lang Pasture site (see Figure 5-64) is not thought to represent a coherent group of dates from a $5^{\text {th }}$ and final occupational episode. Instead, it is much more likely_as well as consistent with the number and internal consistency of dates from the $4^{\text {th }}$ occupational episode) - that the Lang Pasture was abandoned in the latter part of the $15^{\text {th }}$ century, certainly by ca. AD 1470 .

\section{The $2^{\text {nd }}$ Radiocarbon Group}

The results of the radiocarbon dating from the Lang Pasture site, although not without its problems (see End Notes 1-3) and its inconsistencies, suggest with some confidence that the principal occupation of the site took place during an occupational episode that took place (at 2 sigma, with a 95\% probability) sometime between AD 1260-1470 (see Figure 5-64 and Table 5-10). An examination of the results of the calibrated radiocarbon dates in the $2^{\text {nd }}$ Radiocarbon Group on maize from nine different contexts in this component (maize within Structure 1, Feature 20, Feature 36, Feature 41, Feature 45, Feature 76, Feature 79, Feature 84, and Feature 85) narrows the likely period of the principal domestic occupation of the site by the Caddo to an 80 year interval between ca. AD 1320-1400, prior to the estimated beginning of the Frankston phase.

The mean calibrated age range of the nine aforementioned 1 sigma maize dates from the Lang Pasture site is AD 1335-1386. The mean calibrated age range of the 2 sigma maize dates is AD 1323-1404; the mean calibrated intercept age for the maize dates is AD 1358. If averaging the age ranges of the calibrated maize dates is a reasonable way to proceedand it is thought to be a reasonable approach because the same kind of plant material is being dated in each case and the dates are also temporally consistent-then the principal domestic occupation at the Lang Pasture site was by Caddo peoples from the first quarter of the $14^{\text {th }}$ century A.D. to the first few years of the $15^{\text {th }}$ century A.D.

\section{Calibrated Dates on Lang Pasture Site Caddo Burials}

Six of the Caddo burials from the Lang Pasture site have calibrated radiocarbon dates (Features 8, 76B, 76C, 88, and 92, and Burial 2 in Feature 93) (see Table 5-10). The calibrated age ranges for these burials as a group are ambiguous, to say the least. Two of the calibrated dates-from Feature 88 and Feature 92-are rejected out of hand because the age ranges extend to modern times, indicating contamination with materials with modern carbon content, with calibrated intercepts ranging almost impossibly from $\mathrm{AD}$ 1650, 1670, 1770, 1800, 1940, and 1950. As the Caddo abandoned the upper Neches River basin by the middle of the $18^{\text {th }}$ century, and none of the decorated vessels found with these two burials (see Chapter 6 , this volume) have the kinds of decorative styles documented on vessels from post-AD 1650 contexts (see Kleinschmidt 1982; Perttula 2007b), the dates are clearly too young and of no real assistance in establishing the age range of the mortuary features at the Lang Pasture site.

Another mortuary feature (Feature 76B) has a 2 sigma calibrated age range on a small sample of human remains of AD 710-960 (see Table 5-10). This calibrated age range appears to be at least 400-700 years too old given the apparent age of the pit feature (AD 13001430) within which it was emplaced, as well as given the age of the adjacent Feature 76C (AD 1290-1420) burial, since both Feature 76B and 76C appear to have been interred at approximately the same time (see Figures 5-27 and 5-29) within the partially filled Feature 76 basin. Another cause for concern about the accuracy of the Feature 76B calibrated date is the placement of a Poynor Plain vessel, a likely Frankston phase ceramic vessel form, as a funerary offering with this burial feature.

With the discarding of the unreliable and apparently inaccurate calibrated radiocarbon dates from Features 76B, 88, and 92, we are 
left with 2 sigma calibrated radiocarbon dates from Feature 8 (AD 1410-1470, with an intercept of $\mathrm{AD}$ 1440), Feature 76C (AD 1290-1420, with intercepts of AD 1320, 1350, and 1390), and Feature 93, Burial 2 (AD 1310-1440, with an intercept of AD 1410). These burials have similar $\mathrm{C} 13 / \mathrm{C} 12$ ratios ($15.6 \%$ to $-17.6 \%$ oo) (see Table 5-10).

Given the mean calibrated age range (at 2 sigma) of AD 1323-1404 for the principal domestic occupation at the Lang Pasture site (see above), and the AD 1290-1420 and AD 1310-1440 age ranges for Features 76C and 93, it appears to be the case that the majority, if not all, of the burials at the site were interred by Caddo peoples during the course of the settlement there. Burial 8, which was by itself (see Figure 5-4) and separated from the Feature 76 burial cluster and the northern burial cluster (Features 88, 91-94), may have been interred shortly after the domestic occupation at the Lang Pasture site had ended, or at least had ended in the portion of the domestic farmstead compound investigated in the TxDOT right-of-way. The site as a whole likely continued to be occupied for some years after the first quarter of the $15^{\text {th }}$ century A.D. (see Perttula et al. 2007).

\section{Other Upper Neches River Basin Sites}

Based on the associated ceramic vessels found with Caddo burials at the Emma Owens (41AN21), Fred McKee (41AN32), Pierce Freeman (41AN34), Solon Stanley (41CE3), and A. H. Reagor (41CE15) sites, these burials were thought to date to either Frankston (ca. A.D. 1400-1650) or Allen phase (ca. A.D. 1650-1800) times (cf. Kleinschmidt 1982; Perttula 2007b). In fact, Kleinschmidt's (1982: Table 19) seriation of mortuary components in the upper Neches River basin indicated that the Emma Owens site cemetery dated to the Allen phase, the cemeteries at the Fred McKee, Pierce Freeman, and A. H. Reagor dated to the Frankston 3 sub-phase (ca. A.D. 1570-1650), and the Solon Stanley cemetery was a Frankston 1 sub-phase (ca. A.D. 14001480) component. Only the Solon Stanley cemetery was thought to be generally contemporaneous with the principal prehistoric Caddo occupation at the Lang Pasture site.

The Emma Owens calibrated radiocarbon age range on burial $G$ from the site (see Cole 1975:120-129) is the youngest of the five assays in this group of other upper Neches River basin sites. It has a calibrated intercept of $\mathrm{AD} 1640$, and a 2 sigma age range of $\mathrm{AD}$ 1470-1660 (see Table 5-11 and Figure 5-64). These results suggest that this burial was interred in the middle of the $17^{\text {th }}$ century, near or at the estimated beginning of the Allen phase.

The discrepancy between the calibrated age ranges of the Emma Owens assay and the ceramic seriation estimates for the age of Allen phase components are attributed to the difficulty in precisely and accurately dating archeological occupations that fall after AD 1500 because of rapid changes in atmospheric ${ }^{14} \mathrm{C}$ levels after this time (Stuiver 1993:67-68). Because the period after AD 1500 is characterized by extreme and short-term atmospheric radiocarbon fluctuations, there are numerous "wiggles" or inversions in current calibration curves. These "wiggles" on the calibration curve create increasingly imprecise calendrical age ranges for dates that fall between AD 1500 and AD 1940, as does the one radiocarbon date from the Emma Owens site. The chronological resolution of the Caddo occupation at the Emma Owens site (based as it is on one calibrated radiocarbon date) is consequently not likely to be particularly precise. This is because of the number of calibration curve intercepts that can occur in post-AD 1500 assays as a result of these "wiggles," and the broader calibrated age ranges around those intercepts that are also characteristic of this part of the calibration curve (Miller 1996:50 and Figure II.13). As Miller (1996:54) has indicated, most calibrated dates that fall after 350 years B.P. (AD 1600) will "span the entire period" between AD 1600 and the present.

The mean age range at 1 sigma for the calibrated radiocarbon dates from the 
Frankston 3 sub-phase burials is AD 15001598 and the mean age range is $\mathrm{AD} 1470$ 1620 at 2 sigma; the mean calibrated intercept is AD 1560. These calibrated dates do overlap with the estimated age of Frankston 3 subphase components in the upper Neches River basin, and moreover, these mean calibrated dates and intercepts indicate that the burials from the Fred McKee, Pierce Freeman, and A. H. Reagor sites are approximately 40 to 80 years older than the Emma Owens Allen phase burial.

The final calibrated radiocarbon date-from the Solon Stanley site-is temporally anomalous and at least 250 years too old given its Frankston 1 sub-phase age based on associated funerary offerings from the burials (see Kleinschmidt 1982; Woolsey 1935a). The 13C/12C stable carbon isotope ratio from the human remains from this site $(-19.9 \%$, indicating a low consumption of maize) is also anomalous if this is purely a Frankston phase cemetery, because the 13C/12C ratios from the other upper Neches River Caddo sites range between $-12.0 \%$ and $-14.9 \%$ (see Table 5-11). These isotope values are consistent with a maize-rich diet (an estimated 47-69\% percent of the diet would have come from maize or other C4 plants). The Solon Stanley site $13 \mathrm{C} / 12 \mathrm{C}$ ratio is also higher than that detected with any of the Lang Pasture site burials (see Table 5-10), as those values range from $-15.6 \%$ oo to $-19.6 \%$ oo.

There is no question that the associated ceramic vessels, arrow points (two Perdiz points) and pipes collected from the Solon Stanley site are from Frankston phase burials, but there is a question about the date on the human remains themselves, since the human remains from the four burials (AK-1 to AK-4) have been commingled at the Texas Archeological Research Laboratory (Diane Wilson, personal communication, 2008). Because of previous disturbances from earlier looting activities before the University of Texas work at the site in November 1935, only one of the burials at the Solon Stanley cemetery still had in situ funerary offerings (burial AK-2), and only two burials (AK-1 and
AK-2) had much in the way of preserved human remains. Burial AK-2 was one of three (AK-2 to AK-4) that was oriented east-west, with the head to the east, a typical Frankston phase burial orientation (see Chapter 11, this volume). Burial AK-1 had no remaining funerary offerings but there were recovered human remains. This burial was unusual if it is a Frankston phase burial, however, in that its orientation was northeast-southwest, with the head to the northeast; this burial orientation direction may represent a chronologically earlier but still rarely used Caddo burial practice, a suggestion that could be verified if it could be established with certainty that the cal AD 1030-1230 radiocarbon age obtained from the human remains at the Solon Stanley site came from burial AK-1 instead of the three more obvious Frankston phase burials. Unfortunately, this does not appear to be feasible with the available information at the Texas Archeological Research Laboratory, including Woolsey's (1935a) sketchy report. Thus, all that can be concluded about the Solon Stanley site calibrated radiocarbon age on the human remains was that some use of the site for burial interment was made by the Caddo between AD 1030-1230, and that at that time, maize was not the principal food resource in one upper Neches River basin Caddo individual's diet.

\section{End Notes}

1. There are conflicting radiocarbon age ranges from both Feature 79 and Feature 86 (see Table 5-10). Those from Feature 79 are separated by more than 600 years, but its contents (including more than 140 Caddo sherds and one Perdiz arrow point) indicates that the later of the two dates (AD 1260-1390, 2 sigma) is most likely the accurate age range. In the case of Feature 86, the 2 sigma calibrated age ranges (AD 70-330 and AD 680-890) are between 560-610 years apart. Its archeological content (Table 5-2) is of no particular use in evaluating its most likely age, other than to conclude that Feature 86 predates the principal Caddo occupation of the Lang Pasture site. 
2. The AD 1050-1260 calibrated age range for charred plant remains from Feature 76A appears to be inaccurate. First, the best two calibrated radiocarbon dates from Feature 76-into which Feature 76A intrudes (see above) - have age ranges of $\mathrm{AD} 1300-1430$. Since Feature 76A intrudes into Feature 76, it must have been dug by the Caddo sometime after AD 1300-1430. The AD 1050-1260 date on charred materials from Feature 76A, if accepted at face value, would imply that the Feature 76A pit was dug prior to Feature 76, which is an impossibility, since the excavation of the larger Feature 76 pit would have destroyed Feature 76A. The plan maps and profiles of the Feature 76 pit complex (see Figures 5-30 and 5-31) clearly indicate that Feature $76 \mathrm{~A}$ postdates the excavation of Feature 76 , but probably not by many years. It is likely that the charred materials submitted for dating from Feature $76 \mathrm{~A}$ represent a combination of plant remains that derived from the $3^{\text {rd }}$ and $4^{\text {th }}$ occupational episodes at the Lang Pasture site.
3. There are two conflicting radiocarbon dates from Feature 20, one falling in the $2^{\text {nd }}$ Radiocarbon Group (AD 1290-1420, 2 sigma, with calibrated intercepts of AD 1320, 1350, and 1390) and the other falling in the $3^{\text {rd }}$ Radiocarbon Group (AD 1450-1650, 2 sigma, with intercepts of AD 1500, 1600, and 1610) (see Table 5-10). The source of the 200+ year discrepancy between the two dates is not known. Similarly, Feature 76 has three calibrated radiocarbon dates, two with identical age ranges (AD 1300-1430, 2 sigma, with AD 1400 intercepts) and a third that ranges from AD 1650-1950 (2 sigma, with intercepts of AD 1670, 1780, 1800, and 1950). The fact that this third calibrated date extends into modern times indicates that the dated material was either contaminated in some unknown respect before it was submitted to Beta Analytic, Inc. or was comprised primarily of modern charred plant remains. In either event, this third calibrated date from Feature 76 is unreliable and archeologically unrealistic. 


\section{CHAPTER 6}

\section{THE CERAMIC ARTIFACTS FROM THE LANG PASTURE SITE (41AN38) AND THE PLACE OF THE SITE WITHIN AN UPPER NECHES RIVER BASIN CADDO CERAMIC TRADITION}

Timothy K. Perttula

\subsection{INTRODUCTION}

The analysis of the recovered ceramic sherds, vessels, and pipes from the Lang Pasture site (41AN38), as well as other generally contemporaneous prehistoric Caddo sites in the upper Neches River basin, emphasizes the acquisition of information on the stylistic and technological character of the prehistoric Caddo ceramic assemblage. Chronology, social relationships, culinary traditions, the context of ceramic manufacture and production, and exchange/interaction between Caddo groups are each to be addressed in this chapter employing the abundant ceramic vessel sherds and sherds recovered from the Lang pasture site during 2006 excavations, with the goal of assessing the place of the Caddo pottery made and used at the Lang Pasture site within the context of upper Neches River basin ceramic traditions and practices.

Certainly a principal research issue includes first refining or bracketing the age and intrasite chronological relationships of the ceramics at the site, starting from the available radiocarbon (Ch. 5, this volume) and TL dates (Appendix C, this volume) from features, and investigating differences and similarities in ceramic decoration and manufacture. Attributes of the ceramics are then employed to establish the occupational history of the site as reconstructed from ceramic stylistic analyses (particularly variation in decorative elements and motifs in both the utility ware and fine ware), and then determining structure and feature relationships through time by defining distinct ceramic assemblages from the southern and northern parts of the Lang Pasture site.

These same stylistic analyses are employed to answer broader questions of the social and cultural affiliation of the post-A.D. 1300 Caddo groups in the upper Neches River basin and the place of the Lang Pasture site within this community of Caddo people, through stylistic and vessel morphological comparisons with collections from other broadly contemporaneous Caddo sites in the local area. These include Texas Archeological Research Laboratory (TARL) collections of sherds and whole vessels from the best known Caddo sites in the local area, building on the comparative analyses already completed by Campbell (1936), Gilmore (1983), and Kleinschmidt (1982): the Mrs. J. M. Cook (41AN1), J. M. Cook Farm (41AN2), Fred McKee (41AN32), Mrs. J. W. Blackburn (41CE4), Omer and Otis Hood (41CE14), E. W. Henry (41CE17), and R. J. Fair (41CE25) sites, and whole vessels from the Vanderpool site (41SM77) in the Buddy Calvin Jones collection (Figure 6-1). We are also concerned with determining the character and frequency of the utility ware vessel forms in any prehistoric Caddo households and components at the site, and how their composition at the assemblage level may be related to (and influenced by) the postulated intensification of maize consumption by Late Caddo groups in northeastern Texas (see SU 9 in Kenmotsu and Perttula 1993:140), as well as differences in culinary and plant food storage traditions. 
The stylistic analysis of the Lang Pasture site ceramics will focus on the definition of recognizable decorative elements in the fine wares (i.e., the engraved and red-slipped vessels, including carinated bowls and bottles) and utility wares (i.e., the coarse-paste decorated vessels), usually cooking or storage jars and simple bowls. These wares are known to have been made and used differently, based on functional, technological, and stylistic analyses on numerous Caddo sherd assemblages in the broader East Texas region, with uses ranging from food service, cooking of food stuffs, as containers for liquids, and for plant food/seed crop storage. The ceramic analysis will be completed in conjunction with formal and technological analyses of vessels and vessel sections (from macroscopic analyses of sherd cross-sections), from the detailed analysis of more than 750 plain and decorated sherds (see Appendix F.1 and F.2), as well as a sample of the plain rim sherds $(n=41)$, emphasizing paste characteristics, non-plastic inclusions, surface treatments, and firing environments of the decorated and plain sherd assemblages. The whole vessels from the Lang Pasture site are examined in similar detail, as are the whole vessels from the mortuary assemblages mentioned above (Appendix F.3 and F.4).

\subsection{ORgANIZATION OF THE CHAPTER}

In this chapter, I will begin with the analysis of the decorated and plain vessel sherds recovered from the Lang Pasture site, leading to a detailed presentation of the fine wares and utility wares in the assemblage as well as the definition of distinct southern and northern ceramic assemblages at the site. These assemblages apparently represent the remains from sequent Caddo occupations between ca. A.D. 1320-1400 (see Chapter 5, this volume). The rim and lip form of the plain rim sherds, as well as the decorated rim sherds, are then discussed, along with a consideration of orifice diameter differences in the vessels from domestic contexts at the site.
Next, I consider important technological attributes of the domestic ceramics, including the use of different tempers, the character of the vessel sherd paste, and firing conditions. These analyses will demonstrate the essential continuity in ceramic manufacture and practice during the course of the Caddo occupation at the Lang Pasture site.

Other ceramic artifacts have been recovered from the Lang Pasture site, including clay elbow pipes from both domestic and mortuary contexts, ornaments, and a possible ear spool. These are also discussed in this chapter, as are the different decorative and temporal styles of clay elbow pipes now documented in the upper Neches River basin.

Due to their great length, Tables 6-1 and 6-17 can be found on the compact disk that is inserted in a sleeve in the back cover of this report. They comprise Appendix G. Additional tabulations of raw ceramic data are also found on the same disk, as are the tables in Appendix F.

Whole vessels placed in graves as funerary offerings are also discussed in Chapter 6, including the vessels from the burials at the Lang Pasture site. The focus is on the (a) shape, size, temper, firing, and decoration of these vessels, which come from a number of nearby cemeteries; (b) the recognition and definition of new Caddo pottery types and varieties in the upper Neches River basin; (c) stylistic and technological changes in the vessels for the period from ca. A.D. 13001650; and (d) comparisons among other Caddo traditions in the kinds and proportions of ceramic vessels placed as mortuary goods with the deceased.

I conclude the chapter with a synthesis of the domestic and mortuary ceramic assemblages from the Lang Pasture site, along with a consideration of the place of this Caddo occupation in the ceramic tradition of practice documented for $14^{\text {th }}$ to mid- $17^{\text {th }}$ century Caddo groups living in the upper Neches River basin. 


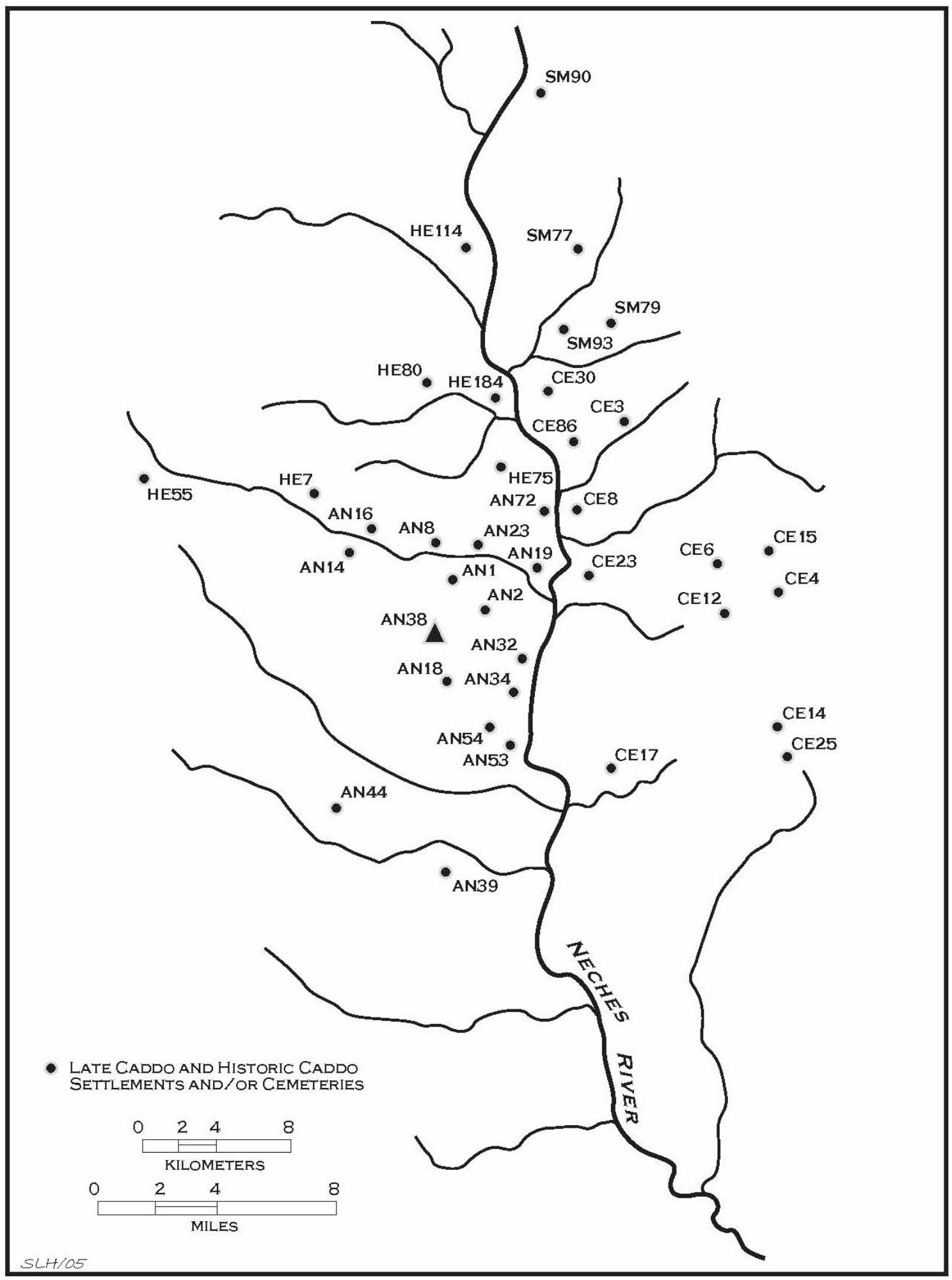

Figure 6-1. Upper Neches River Basin and Caddo Sites Mentioned in the Text. 
The findings of the instrumental neutron activation analysis (see Appendix D, this volume) of sherds from Caddo sites throughout the upper Neches River basin are also reviewed in the synthesis to provide a spatial grounding for these pottery assemblages.

\subsection{METHODS OF ANALYSIS OF THE VESSEL SHERDS}

Detailed analysis of the decorated and plain ceramic sherds from the Lang Pasture site (Appendix F.1 and F.2) is based on differences in temper, type of sherd (i.e., rim, body, or base), rim and lip form (cf. Brown 1996:Figure 2-12), decoration (if present), surface treatment (smoothing, burnishing, or polishing; see Rice 1987), and firing conditions (cf. Teltser 1993). Sherd crosssections were inspected macroscopically and with a 10X hand lens to determine the character of the paste and its inclusions. Determining the firing conditions is based on the identification of the firing core in the sherd cross-sections and the identification of oxidation patterns as defined in Teltser (1993:535-536 and Figure 2a-h; see also Perttula 2005, ed.).

More specifically, the following attributes were employed in the analysis of the ceramics from the Lang Pasture site: (a) temper, the deliberate and indeterminate materials found in the paste (Rice 1987:411), including a variety of tempers (grog or crushed sherds, burned bone, and hematite) and "particulate matters of some size;" (b) although most of the sherds are small and thus from indeterminate vessel forms, where sherds were large enough, vessel form categories that could be identified include open containers (bowls and carinated bowls) and restricted containers, including jars and bottles. Other form attributes include rim profile (outflaring or everted, direct or vertical, and inverted) and lip profile (rounded, flat, or folded to the exterior, among others). Observations on ceramic sherd cross-sections permit consideration of oxidation patterns (Teltser 1993:Figure 2), namely the conditions under which a vessel was fired and then cooled after firing. Finally, wall thickness was recorded in millimeters (mm), using a vernier caliper, along the mid-section of the sherd.

With respect to interior and exterior surface treatment on the sherds, the primary methods of finishing the surface of Caddo vessels includes smoothing, burnishing, and polishing, although a few sherds may still have scraping marks from initial surface treatment work by the potter. Brushing, a popular method of roughening the surface of Middle, Late, and Historic Caddo cooking jars in the Neches/Angelina river basins with stiff bundles of grasses, is considered a decorative treatment here rather than solely a functional surface treatment (cf. Rice 1987:138). A roughened and brushed pot would certainly have been easier to pick up and carry than would an unroughened or smoothed vessel, but because the brushing was applied to be an integral part of the decoration of both rim and body vessel surface, I de-emphasize it as a surface treatment. Smoothing creates "a finer and more regular surface...[and] has a matte rather than a lustrous surface" (Rice 1987:138). Burnishing creates an irregular lustrous finish marked by parallel facets left by the burnishing tool (perhaps a smoothed pebble or bone). A polished surface treatment is marked by a uniform and highly lustrous surface finish, done when the vessel is dry, but without "the pronounced parallel facets produced by burnishing leather-hard clay" (Rice 1987:138).

The application of a hematite-rich clay slip, black after firing in a reducing environment, is another form of surface treatment noted in this assemblage, although it is very rare. The clay slip was typically applied to the vessel exterior or both surfaces, and then was burnished or polished after it was leather-hard or dry; when the vessel was fired, it created a thin red slip. In other instances, a kaolin-rich clay (i.e., white pigment) or a hematite-rich clay (i.e., 
red pigment) was applied as a pigment to engraved ceramic vessels.

Decorative techniques present in the Lang Pasture site ceramic sherd collections include engraving, incising, punctation, brushing, pinching, appliqué, and neck banding, and on certain sherds, combinations of decorative techniques (i.e., brushed-incised and brushedappliqued, or incised-punctated sherds) created the decorative elements and motifs. Engraving was done with a sharp tool when the vessel was either leather-hard or after it was fired, while the other decorative techniques were executed with tools or fingers (incising, punctations, and pinching with wood or bone sticks or dowels), by adding strips of clay to the wet body (appliqué), using frayed sticks or grass stems (brushing) across the vessel surface, or corrugating vessel coils when the vessel was wet or still plastic to create a series of neck bands. Excising is considered a form of engraved decoration, where the clay is deliberately and closely marked/scraped and carved away with a sharp tool, usually to create triangular elements or crescent-shaped elements separating or defining scrolls.

\subsection{DECorated ShERds}

There are 22 different decorative methods identified in the Lang Pasture site ceramics, including appliquéd (alone and in combination with brushed and incised elements), brushed, brushed-incised, brushed-punctated, brushedincised-punctated, engraved (from bowls, carinated bowls, and bottles), engravedbrushed, engraved-punctated, engraved-lip notched, incised incised-punctated, lip notched, neck banded, punctated (including tool, cane, fingernail, or combinations), pinched, pinched-punctated, and red-slipped. Within these general decorative methods, a number of specific ceramic decorative elements are defined that represent distinct kinds of decorations or decorative combinations. These decorative elements, discussed and tabulated in more detail below, are based only on sherds larger than $1.5 \mathrm{~cm}$ in length and width (any sherd smaller than that was considered a sherdlet) from areas with specific intrasite provenience contexts.

Ceramic style elements defined and recognized on sherds and vessels from the Lang Pasture site simply represent one classification of different ways of decorating a vessel by the prehistoric Caddo peoples, and there is general consensus that shared styles are "the result of direct cultural transmission once chance similarity in a context of limited possibilities is excluded" (Dunnell 1978:199). If the decorative elements are truly stylistic in character, they allow the measurement of time as well as interaction between different but contemporaneous groups of people (Lyman et al. 1997:10), along with an assessment of a potter's place within a larger tradition of ceramic practice. Because the lion's share of the ceramics are sherds rather than vessels or sherd vessel groupings, the most accessible stylistic information from the Lang Pasture site are the rim and body decorations (often different on the same vessel), even though differences in Caddo vessel forms through time appear to be stylistic as well. According to Sadie Bedoka, a Caddo-Delaware woman interviewed by historians employed by the Works Progress Administration in the 1930s, "each [Caddo] clan had its own shape to make its pottery. One clan never thought of making anything the same pattern of another clan. You could tell who made the pottery by the shape" (La Vere 1998:92).

I am interested, however, in determining not only the broad trends in changing ceramic styles, but also in exploring more-fine-tuned synchronic and diachronic differences in stylistic composition and diversity between the northern and southern areas at the Lang Pasture site. This dictates a more detailed consideration of ceramic stylistic variability and diversity, focusing on decorative elements (also termed modes). These represent distinct designs or design combinations (i.e., the breakdown of individual decorations within an overall design, as in a hatched triangle, circle, or tick marks) that can be identified on sherds and vessel sections (even if it is only a portion of the element), generally comparable to what 
Schambach et al. (n.d.) term a "recurrent feature of decoration” within each of the major decorative methods (e.g., incising, punctating, engraving, etc.) present in a Caddo ceramic assemblage. The design elements are defined at different levels of association, depending upon variations in the designs (e.g., the number and spacing of engraved lines on a rim), the location of the decoration (e.g., on the rim, body, on the vessel interior, etc.), and the method of decoration (e.g., horizontal vs. vertical brushing).

There are a total of 2588 decorated rim and body sherds from the Lang Pasture site, including the decorated sherds from the 2004 test excavations (see Table 6-1, on CD in back cover).
Approximately $12 \%$ of the decorated sherds are from feature contexts-particularly from Feature 76 (see Table 6-2) —while the remainder are from habitation deposits in and around the two domestic structures and associated extra-mural activity areas situated in the vicinity of the two structures (see Chapter 5, this volume). The majority of the decorated and plain sherds at the Lang Pasture site are from outdoor contexts, where it is likely most cooking and food serving activities took place, as well as trash discard activities.

Table 6-1. Decorated Sherds from the Lang Pasture Site (41AN38). (This table may be found in Appendix $G$ on the $C D$ in the back cover of this report.) 
Table 6-2. Decorated Sherds from Lang Pasture (41AN38) Features.

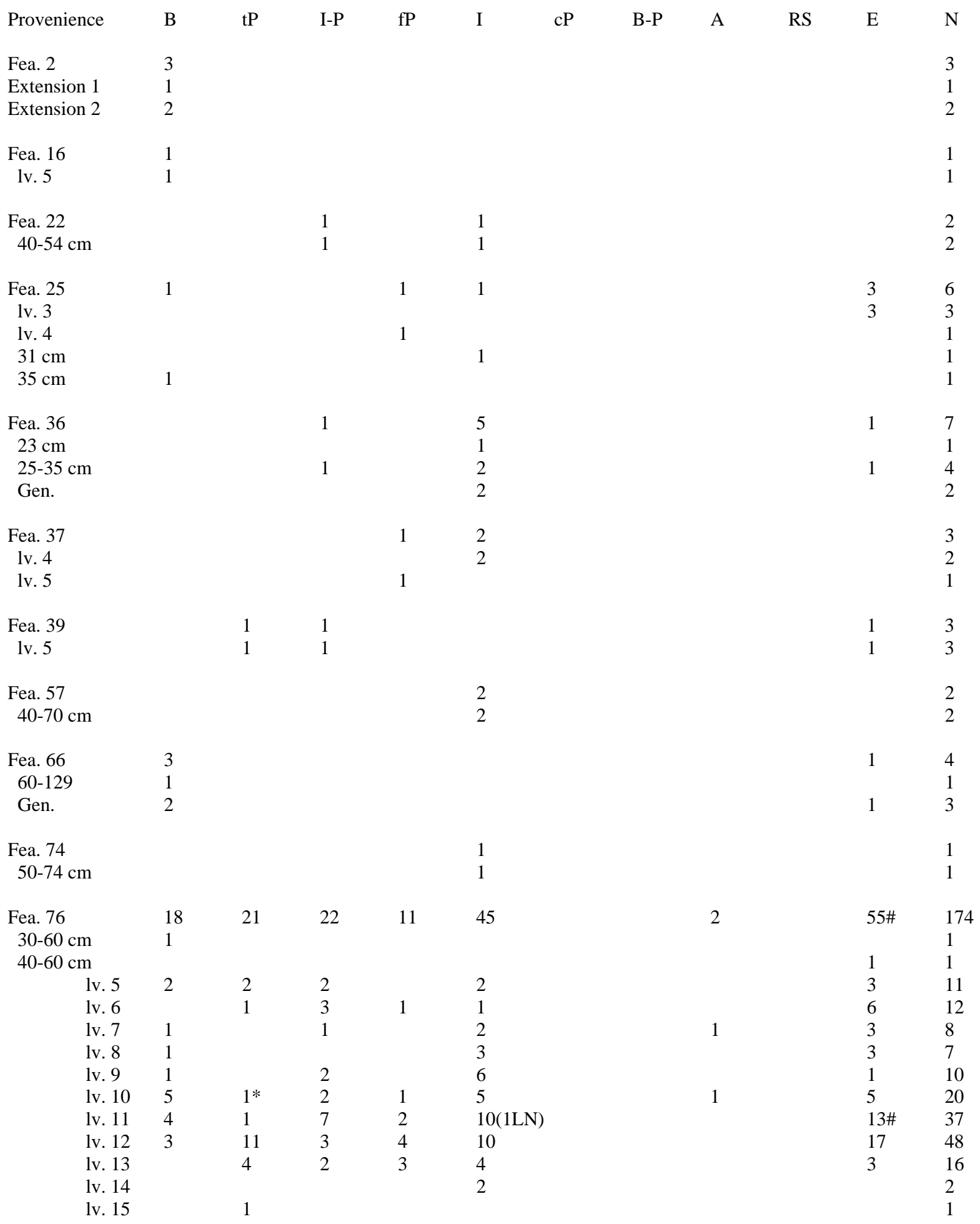


Table 6-2. continued

\begin{tabular}{|c|c|c|c|c|c|c|c|c|c|c|c|}
\hline Provenience & $\mathrm{B}$ & $\mathrm{tP}$ & I-P & $\mathrm{fP}$ & I & $\mathrm{cP}$ & B-P & A & RS & $\mathrm{E}$ & $\mathrm{N}$ \\
\hline Fea. 76A 2 & 2 & 1 & & 5 & & & & & 2 & 12 & \\
\hline lv. 6 & & & & & 1 & & & & & & 1 \\
\hline lv. 10 & & 1 & & & 1 & & & & & & 2 \\
\hline lv. 11 & & 1 & & & & & & & & 1 & 2 \\
\hline lv. 12 & 1 & & 1 & & 1 & & & & & 1 & 4 \\
\hline lv. 15 & 1 & & & & 2 & & & & & & 3 \\
\hline Fea. 76B 2 & 5 & 9 & 6 & 8 & & & & & 7 & 37 & \\
\hline $70-85 \mathrm{~cm}$ & & 4 & 4 & 3 & 3 & & & & & 1 & 15 \\
\hline $75-90 \mathrm{~cm}$ & 2 & 1 & 5 & 3 & 5 & & & & & 5 & 21 \\
\hline lv. 10 & & & & & & & & & & 1 & 1 \\
\hline Fea. 79 & 7 & 7 & 4 & 5 & 8 & & & & 1 & $15 \#$ & 47 \\
\hline lv. 5 & 1 & 1 & & & & & & & & 2 & 4 \\
\hline lv. 6 & 3 & 3 & 2 & 1 & 1 & & & & & $3 \#$ & 13 \\
\hline lv. 7 & 1 & $1^{*}$ & 1 & 1 & 2 & & & & 1 & 2 & 9 \\
\hline lv. 8 & 2 & 1 & & 3 & 2 & & & & & $5 \#$ & 13 \\
\hline lv. 9 & & 1 & 1 & & 3 & & & & & 3 & 8 \\
\hline Fea. 81 & & & & 1 & & & & & & 1 & 2 \\
\hline lv. 5 & & & & 1 & & & & & & & 1 \\
\hline $40-80 \mathrm{~cm}$ & & & & & & & & & & 1 & 1 \\
\hline Fea. 84 & 1 & & & & 1 & & & & & 1 & 3 \\
\hline $40-70 \mathrm{~cm}$ & 1 & & & & 1 & & & & & 1 & 3 \\
\hline Fea. 85 & & 1 & & & & & & & & & 1 \\
\hline lv. 6 & & 1 & & & & & & & & & 1 \\
\hline Fea. 88 & 1 & & & & & & & & & & 1 \\
\hline $23 \mathrm{~cm}$ & 1 & & & & & & & & & & 1 \\
\hline Fea. 91 & & $1^{*}$ & & & & & & & & & 1 \\
\hline Fea. 92 & 2 & & & & & & & & & & 2 \\
\hline Fea. 93 & 1 & & & & & & & & & & 1 \\
\hline Fea. 94 & & & & & & & & & & 1 & 1 \\
\hline Totals & 42 & 38 & 39 & 25 & 79 & 0 & 0 & 2 & 1 & 93 & 319 \\
\hline Percent & 13.2 & 11.9 & 12.2 & 7.9 & 24.8 & 0 & 0 & 0.6 & 0.3 & 29.1 & \\
\hline
\end{tabular}

\#=includes engraved-punctated sherd

$\mathrm{x}=$ pinched sherd; $\mathrm{B}=$ brushed (also includes a few brushed-incised body sherds); $\mathrm{P}=$ tool punctated; $\mathrm{I}-\mathrm{P}=$ incisedpunctated; $\mathrm{fP}=$ =fingernail punctated; $\mathrm{I}=$ incised; $\mathrm{CP}=$ cane punctated; $\mathrm{B}-\mathrm{P}=$ brushed-punctated; $\mathrm{A}=$ appliqued; $\mathrm{RS}=$ redslipped; E=engraved; LN=lip notched 
In addition to the decorated sherds, there are 4,254 plain sherds from the Lang Pasture site, including 442 plain sherds recovered during the 2004 test excavations (Perttula 2004:Table 3.6); these plain sherds from the test excavations were not reanalyzed for this project. Among these many plain sherds are 144 plain rims from numerous plain vessels recovered in the data recovery excavations, as well as 240 base sherds and 3428 plain body sherds from the same excavations.

In general terms, the decorated sherds from domestic contexts at the Lang Pasture site are dominated by utility wares. For the site as a whole, this includes almost $79 \%$ of the decorated sherds from non-feature domestic contexts (see Table 6-1) and $70.6 \%$ of the decorated sherds from features (see Table 62 ); these percentages differ by northern and southern site areas. These sherds are from vessels used for cooking, storage, and probably other culinary activities; they tend to have a coarse paste, thick body walls, have smoothed interior surfaces, and are decorated with wet-paste designs (i.e., decorations were made with tools and fingers prior to the vessel being fired, when the vessel had a wet exterior surface). Fine wares are engraved and redslipped vessels that were used for food service and to hold liquids, as well as for other purposes (effigy vessels). They tend to have fine pastes, with finely crushed tempers, are frequently burnished on interior and/or exterior vessel surfaces (except the bottles, which were burnished on exterior surfaces only), and have relatively thin body walls compared to the utility wares. There are other differences between these two classes of decorated pottery, and these will be discussed below where appropriate.

The plain/decorated sherd ratio (P/DR) of the Lang Pasture ceramic assemblage as a whole is 1.65. Since the $\mathrm{P} / \mathrm{DR}$ ratio appears to be temporally sensitive (see discussion in Chapter 4, this volume; see also Table 4-5), the initial impression of the P/DR value for the Lang Pasture site suggests that the Caddo occupation there took place early in the Frankston phase (i.e., Group III on Table 4-5), about the same time as, or slightly earlier than, the Caddo settlement at the Tomato Patch site (41HE185) at Lake Palestine (cf. Anderson et al. 1974).

As will become apparent in the discussion of the character of the decorated sherds from the Lang Pasture site, the overall P/DR value is misleading because there are considerable differences from the southern to the northern end of the site in the kinds and proportions of decorated sherds, as well as in the relative frequency of plain ware vessels (and in the overall number of plain sherds). This has led to the scrutiny of the intra-site spatial character of the decorated sherd assemblage from Lang Pasture, and the definition of two different but culturally related ceramic assemblages, one of which is thought to be temporally sequent from the other.

\subsection{ASSEMBLAGE DEFINITION AT THE LANG PASTURE SITE BASED ON DECORATED SHERD CHARACTERISTICS}

As alluded to in the previous sections of this chapter, the decorated sherds from the Lang Pasture site appear to derive from two different but related assemblages, a southern (between N170 and N188) and a northern (between N189-209) component/area. In most measures - kinds and proportions of decorated sherds, including utility wares; differences in decorative elements; rim and lip form; frequency of plain vessels; temper use; and firing conditions - these two areas represent temporally and spatially distinctive assemblages of Caddo utility and fine ware ceramic vessel sherds that span the period roughly from ca. A.D. 1320-1400, and perhaps slightly later in time (see discussion of the radiocarbon dates in Chapter 5, this volume). This section of Chapter 6 details the similarities and differences between the two assemblages, which appear to be part of the same regional ceramic tradition, investigates the likely temporal character of these differences (based in large measure on comparisons with other upper Neches River basin sites and the seriation of ceramic sherds 
and vessels, see Anderson et al. 1974; Kleinschmidt 1982; Perttula 2007b), and speculates about changes in the stylistic and technological character of $14^{\text {th }}$ and early $15^{\text {th }}$ century Caddo ceramics in this locale (see Figure 6-1).

The relative proportions of brushed utility ware sherds at the Lang Pasture site are the first clear measure of decorative differences in the ceramics from one end of the site to the other. Brushed sherds comprise no less than $44.7 \%$ and no more than $70.5 \%$ of all the decorated sherds from all units between N170 and N188, at the southern end of the site (see Table 6-1); [interestingly, brushed pottery recovered from a midden (center point estimated at ca. N189 E184) deposit on private property at the site comprises $76 \%$ of the decorated sherds, suggesting the midden accumulated at the end of the southern ceramic component/area occupation (see Perttula et al. 2007)]. Conversely, in none of the units north of N188 do brushed utility ware sherds amount to more than $38.2 \%$ of all the decorated sherds in each unit, and north of N193 (and in units with more than 20 decorated sherds), brushed sherds occur in proportions that range between 12.5-28.3\% (see Table 6-1). Features in the northern area also have relatively low percentages of brushed utility ware sherds (see Table 6-2), amounting to $13.2 \%$ of all the decorated sherds, and can readily be associated with the northern area simply by propinquity. These differences in the proportions of brushed utility wares were the first and principal basis for dividing the decorated ceramics from the Lang Pasture site in spatial terms.

There are other differences in the decorative style of utility ware and fine ware sherds from the two site areas, and these will be explored in more detail below, as will apparent technological differences in use of temper, pastes, and firing conditions. Here, I summarize the main characteristics of the two different ceramic assemblages (Figure 6-2). First, fine wares, especially engraved bottles, are $70 \%$ more common in the northern site component/area than they are in the southern area (Table 6-3). Lip notched, engraved-lip notched, and red-slipped fine ware sherds, although rare overall, are a distinctive feature of the northern area fine ware assemblage.

Utility wares in the northern ceramic component/area are dominated equally by sherds from incised vessels (23.6\%), punctated vessel sherds (17.8\%), especially tool and fingernail punctates, brushed sherds (19.1\%), and vessel sherds with incised-punctated decorations (7.8\%) (see Table 6-3). Sherds with pinching decorations appear to be more common in the northern ceramic component/area

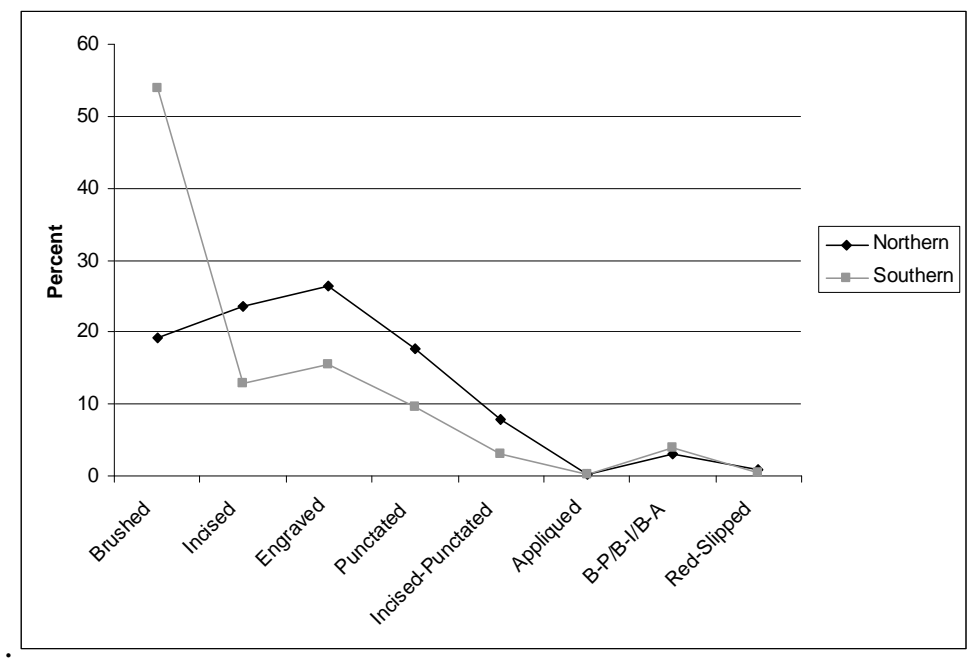

Figure 6-2. Differences in the Proportion of Decorative Methods on Vessel Sherds from the Southern and Northern Areas of the Lang Pasture Site. 


\section{Table 6-3. Frequency of Decorated Utility Ware and Fine Ware Sherds in the Southern and} Northern Areas at the Lang Pasture Site.

\begin{tabular}{|c|c|c|}
\hline Decorative Method & Southern Area* & Northern Area \\
\hline \multicolumn{3}{|l|}{$\underline{\text { Fine wares }}$} \\
\hline Engraved & $12.9 * *$ & 17.5 \\
\hline Engraved, bottle & 2.2 & 8.1 \\
\hline Engraved-brushed & 0.2 & - \\
\hline Engraved-punctated & 0.2 & 0.6 \\
\hline Engraved-lip notched & - & 0.1 \\
\hline Lip notched & - & 0.1 \\
\hline Red-slipped & 0.5 & 0.9 \\
\hline Subtotal & 16.0 & 27.3 \\
\hline \multicolumn{3}{|l|}{$\underline{\text { Utility wares }}$} \\
\hline Brushed & 53.8 & 19.1 \\
\hline Brushed-punctated & 1.5 & 1.9 \\
\hline Brushed-incised & 2.3 & 1.2 \\
\hline Brushed-appliqued & 0.2 & - \\
\hline Brushed-incised-punctated & - & 0.1 \\
\hline Incised-punctated & 3.0 & 7.8 \\
\hline Tool punctated & 7.6 & 12.9 \\
\hline Cane punctated & 0.4 & 0.1 \\
\hline Fingernail punctated & 1.5 & 4.7 \\
\hline Fingernail-tool punctated & - & 0.1 \\
\hline Incised & 12.9 & 23.6 \\
\hline Appliqued & 0.3 & 0.2 \\
\hline Incised-appliqued & - & 0.1 \\
\hline Pinched & 0.2 & 0.6 \\
\hline Pinched-tool punctated & - & 0.1 \\
\hline Neck banded & 0.2 & 0.1 \\
\hline Subtotal & 84.0 & 72.7 \\
\hline Total sherds & 1216 & 1356 \\
\hline \multicolumn{3}{|c|}{$\begin{array}{l}\text { *includes sherds from features in both areas } \\
\text { ** percentage }\end{array}$} \\
\hline \multicolumn{2}{|c|}{$\begin{array}{l}\text { With the increasing frequency of brushed } \\
\text { utility wares in the southern ceramic } \\
\text { component/area, brushed vessel sherds } \\
\text { comprise } 53.8 \% \text { of all the decorated sherds } \\
\text { here (an } 180 \% \text { increase from the northern } \\
\text { ceramic component/area). This one change in } \\
\text { the manufacture and use of one kind of utility } \\
\text { ware led to considerable reductions in } \\
\text { previously important kinds of decorated utility } \\
\text { wares, and a different character to the overall }\end{array}$} & $\begin{array}{l}\text { utility ware assemblage with time: incised } \\
\text { ( } 12.9 \% \text {, a } 45 \% \text { reduction), incised-punctated } \\
\text { ( } 3.0 \% \text {, a } 62 \% \text { reduction), and punctated (9.5\%, } \\
\text { a } 47 \% \text { reduction) (see Table 6-3). In the } \\
\text { northern ceramic component/area, the incised, } \\
\text { punctated, and incised-punctated vessel sherds } \\
\text { account for } 49.2 \% \text { of all the decorated sherds, } \\
\text { whereas in the southern ceramic } \\
\text { component/area, that percentage has decreased } \\
\text { to only } 25.4 \% \text {. }\end{array}$ \\
\hline
\end{tabular}


In addition to these substantial differences in the two areas of the site in both the fine wares and the character of the utility wares used and discarded there, other differences are readily detected in the two assemblages. Plain wares and plain sherds are more abundant in the northern area, both in terms of the overall proportion of plain sherds in each of the assemblages as well as in comparisons of the ratio of plain to decorated rim sherds (Table 64 ). There are simply more plain ware vessels in the northern site area than there are in the southern site area, particularly as measured by the relative proportion of plain rims to decorated rims. The differences in the P/DR ratios between the two areas (1.28 versus 1.99 , see Table 6-4) also corroborate the increased importance of the manufacture, use, and discard of plain ware vessels in the northern part of the site.

From these general comparisons of the compositional differences of the ceramic assemblages from the southern and northern areas of the Lang Pasture site, I turn to a consideration of the decorative elements present in the utility wares and fine wares from both areas. As will become apparent, while there are significant differences in the proportions of certain kinds of utility wares and fine wares within the boundaries of the site area investigated during the data recovery excavations, generally speaking, the wares in both areas share many similar decorative elements and motifs, and in a number of cases, these elements and motifs occur in roughly similar proportions. This suggests that they are part of the same ceramic tradition, and that they are not separated much in time.

\section{Age of the Ceramic Components at the Lang Pasture Site}

Our evaluation of the age of the ceramic component $\mathrm{s}$ at the Lang Pasture site is based on several criteria: (a) the age range of calibrated radiocarbon dates from various contexts; (b) the thermoluminescence (TL) dates obtained on a sample of fine ware and utility ware sherds from both site areas (see James Feathers, Appendix D, this volume), and (c) the general understanding of the age ranges of selected kinds and relative proportions of decorated sherds (especially brushed pottery and varieties of Poynor Engraved) and defined pottery types-as well as the L-shaped elbow pipes-found at Lang Pasture and other prehistoric Caddo ceramic assemblages in the upper Neches River basin.

The radiocarbon dating from the Lang Pasture site suggests that the principal occupation of the site took place (at 2 sigma, calibrated, with a 95\% probability) sometime between $\mathrm{AD}$ 1260-1470. An examination of the results of the calibrated radiocarbon dates on maize from nine different contexts in this component narrows the likely period of the principal domestic occupation of the site by the Caddo to an 80 year interval between ca. AD 13201400 , prior to the estimated beginning of the Frankston phase. The mean calibrated age range of the nine aforementioned 1 sigma maize dates from the Lang Pasture site is AD 1335-1386. The mean calibrated age range of the 2 sigma maize dates is $\mathrm{AD} 1323-1404$; the mean calibrated intercept age for the maize dates is $A D$ 1358. In summary, then, the calibrated radiocarbon dates indicate that the principal domestic occupation at the Lang Pasture site was by Caddo peoples from the first quarter of the $14^{\text {th }}$ century A.D. to the first few years of the $15^{\text {th }}$ century A.D. 


\section{Table 6-4. Other Differences in the Ceramics from the Northern and Southern Areas at the} Lang Pasture Site.

\begin{tabular}{lll} 
Attribute & Southern area & Northern area \\
\hline $\begin{array}{l}\text { Proportion of plain sherds } \\
\text { in the assemblage* }\end{array}$ & $56.1 \%$ & $66.5 \%$ \\
$\begin{array}{l}\text { Plain Rim: Decorated rim** } \\
\text { ratio }\end{array}$ & $1: 2.9$ & $1: 1.9$ \\
$\begin{array}{l}\text { Plain/Decorated } \\
\text { Sherd ratio (P/DR) }\end{array}$ & 1.28 & 1.99 \\
\hline
\end{tabular}

*southern area ( $\mathrm{n}=2772)$; northern area $(\mathrm{n}=4053)$

**southern area, 165 rim sherds, 42 plain (25.4\%); northern area, 294 rim sherds, 102 plain (34.7\%)

Given the mean calibrated age range (at 2 sigma) of AD 1323-1404 for the principal domestic occupation at the Lang Pasture site, and the AD 1290-1420 and AD 1310-1440 age ranges for two of the burial features at the site (Features 76C and 93), it appears that the majority, if not all, of the burials at the site were interred by Caddo peoples during the course of the settlement there. Burial 8, with a 2 sigma calibrated age range of AD 14101470, may have been interred shortly after the domestic occupation at the Lang Pasture site ended, or at least had ended in the portion of the domestic farmstead compound investigated in the TxDOT right-of-way. Based on the proportions of decorated sherds from a midden deposit on private property, the Lang Pasture site as a whole likely continued to be occupied for some years after the first quarter of the $15^{\text {th }}$ century A.D. (see Perttula et al. 2007).

The TL or luminescence dating of ceramics (see Feathers 1997, 2000, 2003) has been applied with some considerable success in a variety of settings - and on different ceramic wares-in North America (Lipo et al. 2005; Dykeman et al. 2002), but since the days of Alpha Analytic (a subsidiary of Beta Analytic) in the early to mid-1980s, there have been no TL dating of Caddo ceramic wares in East Texas. Given the abundance of ceramics of several different kinds and styles at the Lang
Pasture site, the TL dating of decorated sherds recovered in situ at the site was also explored since it is a method "that dates the manufacture and use of...ceramic objects [that] provide a closer relationship between the target event [when a site is occupied] and the dated event [the age determined by the luminescence on a sherd]. Luminescence is particularly well suited for the dating of ceramics since the method measures the time elapsed since vessels were last heated, usually corresponding to manufacture or use" (Lipo et al. 2005:535).

The results of the TL or luminescence dating of 21 decorated sherds (five fine ware sherds and 16 utility ware sherds) ${ }^{1}$ are presented in Appendix C, Table C-6, by James K. Feathers, along with a discussion of the method and procedures followed in obtaining these dates. Due to the vagaries of sampling during the excavations, the requirement by TxDOT that both utility wares and fine wares be sampled in the proportions documented at the Lang Pasture site (see discussion in Chapter 4, this volume), and the necessity that sherds to be submitted for TL dating should be at least 3 $\mathrm{cm}$ in diameter and $5 \mathrm{~mm}$ in thickness (Dykeman et al. 2002:164), 17 of the sherds submitted for TL dating are from the southern ceramic component/area (N170-188), and the other four are from the northern ceramic component/area (N189-209); it is unfortunate 
that additional TL samples were not obtained from the northern area, as it has proven difficult to assess the accuracy of the few TL dates from this part of the site.

In the discussion of these 21 TL dates, I exclude four dates (UW1700, UW1703, UW1713, and UW 1719) from further consideration because of their excessively high percentage error (13.4-22.1\%). This leaves three TL dates from the northern site area and 14 from the southern ceramic component/area. Percentage errors are calculated by "dividing the one sigma error range by the midpoint age of the range" (Lipo et al. 2005:536). Percentage errors of $10 \%$ or less are optimal (Feathers 1997:51; Dykeman et al. 2002:154), and in the case of the Lang Pasture site, the percentage errors for the remaining 17 TL dates ranges from 3.8-11.4\%. Table 6-5 lists these 17 TL dates.

It is apparent from an inspection of Table 6-5 that the TL dates from both ceramic component/areas have a very wide temporal range at 1 sigma, even though the range of TL dates overlap at this sigma: A.D. 1098-1541 from the northern area and A.D. 964-1604 from the southern area. However, given that

the "date" of a ceramic assemblage consists of the sum of deposition events that resulted in the aggregation of sherds into the assemblage. Assemblages, like individual objects, have a temporal range as well as a mean date that is determined by the rate of individual object deposition...The luminescence dating of a single sherd in a ceramic assemblage, therefore, will not necessarily produce an accurate estimate for the assemblage deposition event any more than a single 14C date. Consequently, a large number of luminescence dates is needed to generate the temporal distribution of each assemblage (Lipo et al. 2005:538).

That being said, and factoring in the significant age ranges from both areas, it seems unlikely that the three TL dates from the northern site area do constitute a reasonable sample with which to estimate the age of the ceramics from this part of the Lang Pasture site. As discussed below, however, the 14 TL samples from the southern site area appear tp comprise an adequate TL assemblage for evaluating the temporal distribution of the decorated ceramics.

Averaging the three TL dates from the northern site area produces a mean TL date of A.D. $1299+45$ (A.D. 1254-1344). The mean TL date from the southern site area is A.D. $1377+46$ (A.D. 1331-1423). Both mean TL age ranges overlap with the calibrated radiocarbon dates. Furthermore, the mean dates from both areas overlap between A.D. 1331-1344, which also falls within the estimated age range of the principal Caddo component (A.D. 1320-1400) as determined from the analysis of calibrated radiocarbon dates (coming mainly from the northern site area) from the Lang Pasture site. These mean TL dates also indicate that the ceramics from the northern ceramic component/area are older than those from the southern ceramic component/area, but not significantly older.

What about the TL ages of the different ceramic wares from the Lang Pasture site? Perhaps they can provide insights into establishing the overall age of the assemblages, as"one kind of sherd may often serve as a proxy for the set, and by dating that kind of sherd one is in effect dating the set" (Lipo et al. 2005:539). 
Table 6-5. TL Samples and TL Dates from the Lang Pasture Site.

Lab No. TL Date Description of Pottery Sherd

Northern ceramic component/area

UW1701 A.D. $1145+47$

engraved carinated bowl; hatched ladder, triangle, and semi-circle; early variety of Poynor Engraved

UW1717

A.D. $1233+67$

cross-hatched incised body sherd

UW1718

A.D. $1519+22$

diagonal brushed rim

Southern ceramic component

UW1702

UW1704

UW1705

UW1706

UW1707

UW1708

UW1710

UW1711

UW1712

UW1714

UW1715

UW1716

UW1720

UW1722
A.D. $1474+27$

A.D. $1363 \pm 41$

A.D. $1274 \pm 84$

A.D. $1150 \pm 64$

A.D. $1339 \pm 43$

A.D. $1542+28$

A.D. $1366+45$

A.D. $1474+37$

A.D. $1415+41$

A.D. $1433 \pm 64$

A.D. $1588 \pm 16$

A.D. $1041 \pm 77$

A.D. $1366 \pm 29$

A.D. $1450 \pm 52$ engraved panel, Poynor Engraved, var. Blackburn, body sherd

diagonal engraved rim

parallel brushed body sherd

curvilinear and opposed incised lines, body sherd

diagonal incised rim

parallel brushed body sherd, pinkware

opposed brushed body sherd

tool punctated rows, body sherd

overlapping brushed, body sherd

overlapping brushed, body sherd

parallel brushed body sherd

single straight incised line, body sherd

incised panel, body sherd
The dated incised utility wares from both site areas (see Table 6-5) have a mean TL date of A.D. $1224 \pm 53$. This is unreasonably early given the overall character of the TL dates from the two ceramic components, unless the incised wares as a group are part of an unrecognized ceramic assemblage, which is unlikely given the kinds and numbers of decorated incised sherds in both assemblages (see below). The mean TL dates for the engraved sherds from the southern area (the one Poynor Engraved sherd from the northern site area has an improbable TL date of A.D. 1145) is A.D. $1419 \pm 34$ (see Table 6-5). The brushed sherds from the southern area have a mean TL date of A.D. $1440 \pm 47$; the one TL date from the northern area is A.D. $1519 \pm 22$. The one punctated sherd from the southern area has a TL date of A.D. $1474 \pm 37$.
There is good concordance, then, in the single and mean TL dates from the brushed, engraved, and punctated sherds from the southern part of the Lang Pasture site, as they overlap at 1 sigma. Combining these three classes of pottery as a means to estimate the temporal distribution of the ceramics from this area, at least, the mean TL date is A.D. $1444 \pm$ 39 (A.D. 1405-1483). This suggests that the southern ceramic component/area at the Lang Pasture site dates to the early or sub-phase 1 of the Frankston phase, and probably postdates the Caddo occupation in the northern part of the site (if relying on the calibrated radiocarbon dates) by as little as a generation (or even overlapping by a few years) to as much as 4-5 generations, depending upon the beginning and ending points of either the radiocarbon or TL dates. 
There are a few radiocarbon dates from other upper Neches River basin sites that put these temporal estimates from the Lang Pasture site in context, including dates recently obtained on Caddo burials at the Emma Owens (41AN21), Fred McKee (41AN32), Pierce Freeman (41AN34), and A. H. Reagor (41CE15) sites (see Chapter 5, this volume); a stratified series of dates from a midden deposit at the ALCOA \#1 site (41AN87, see Perttula 2009); and dates on maize from 41HE139 and 41HE343 near Lake Palestine (Cliff et al. 2004). Based on the recovered ceramics, these sites date to either Frankston (ca. A.D. 14001650) or Allen phase (ca. A.D. 1650-1800) times (cf. Kleinschmidt 1982; Perttula 2007b).

The Emma Owens site calibrated radiocarbon age range is the youngest of the assays in this group of upper Neches River basin sites: it has a calibrated intercept of $\mathrm{AD} 1640$, and a 2 sigma age range of AD 1470-1660. This burial was interred in the middle of the $17^{\text {th }}$ century, near or at the estimated beginning of the Allen phase; the ceramics and pipes from the site indicate it does date to the post-A.D. 1650 Allen phase (see Cole 1975). The mean age range at 1 sigma for the calibrated radiocarbon dates from the Frankston 3 (or late Frankston phase) sub-phase burials at the Fred McKee, Pierce Freeman, and A. H. Reagor sites is AD $1500-1598$ and the mean age range is $A D$ $1470-1620$ at 2 sigma; the mean calibrated intercept is $\mathrm{AD}$ 1560. These calibrated dates do overlap with the estimated age of Frankston 3 sub-phase components (ca. A.D. 1570-1650) in the upper Neches River basin, and moreover, these mean calibrated dates and intercepts indicate that the burials from the Fred McKee, Pierce Freeman, and A. H. Reagor sites are approximately 40 to 80 years older than the Emma Owens Allen phase burial.

Calibrated dates from the ALCOA \#1 midden date to the $15^{\text {th }}$ century (Perttula 2009), and have intercepts from samples at the bottom to top in the deposit that range from $\mathrm{AD} 1407$, $\mathrm{AD}$ 1426, and $\mathrm{AD}$ 1470. This is perhaps currently the best dated Frankston phase domestic habitation component in the upper
Neches River basin: the ceramics found here include several varieties of Poynor Engraved and large numbers of brushed utility wares (70\% of the decorated sherds in a sample of more than 400 decorated sherds) (Perttula 2009). Two sigma calibrated age ranges from Frankston phase components at 41HE139 and 41HE343 are A.D. 1320-1480 from the former (and a ceramic assemblage with 17.5\% brushed sherds among the decorated wares, comparable to the northern ceramic/component area at the Lang Pasture site; Cliff et al. 2004), and AD 1440-1640 for the latter site. The last piece of the chronological puzzle is the L-shaped elbow pipes from two of the burial features at the Lang Pasture site. This distinctive form of elbow pipe appears to be the earliest of the elbow pipe forms in East Texas, including the upper Neches River basin (see below). Rogers and Perttula (2004) documented this form of elbow pipe from Late Village contexts at the Oak Hill Village site (41RK214), estimated to date from ca. A.D. 1350-1450, when later decorated elbow pipe forms began to be manufactured in the upper Neches.

In summary, taking all these disparate dates together, we can speak with confidence that Frankston phase sites - and thus the associated Frankston phase ceramics, dominated by Poynor Engraved and much brushed potterydate after ca. A.D. 1400. Furthermore, the considerable amounts of brushed utility wares from the southern ceramic component/area, the occurrence of several varieties of Poynor Engraved (see below), and the mean TL dates on engraved, brushed, and punctated ceramics that range from AD 1405-1483, indicate that the southern ceramic component/area dates to the early part of the Frankston phase, namely sub-phase 1 (cf. Kleinschmidt 1982). The Lshaped elbow pipes as well as the lower frequency of brushed wares in the northern ceramic component/area-as with the ceramics from the White Mule site (41HE166) at Lake Palestine (18.5\%, see Anderson et al. 1974) and 41HE139-but many of the same kinds of engraved fine wares and engraved fine ware decorative elements between the southern and northern areas, are consistent 
with a Caddo occupation that predates ca. A.D. 1400, but not by many years. The calibrated radiocarbon dates from features in the northern area suggest that this Caddo occupation may only be a few generations older in time, and may even have slightly overlapped in time with the occupation in the southern ceramic component/area. Nevertheless, I suggest that the Caddo occupation at the Lang Pasture site, or at least that part in the TxDOT right-of-way, began in the early-mid- $14^{\text {th }}$ century in the northern part of the site, and ended by the last quarter of the $15^{\text {th }}$ century in the southern part of the site.

\section{Decorated Utility Wares}

There are over 2000 utility ware pottery sherds from the southern and northern ceramic component/areas at the Lang Pasture site, including 215 rims (Table 6-6). On the basis solely of the rims, which provide a broader view of the range in decorative styles used on utility wares, ${ }^{2}$ vessels with incised decorative elements are the most common form of utility ware in both areas, comprising 55\% of the rims in the northern area and $38.7 \%$ of the southern area utility ware rims. In both areas, incised rims account for between 22-24\% of all the incised sherds, suggesting vessels were probably decorated in a similar fashion on rim and body in both ceramic components/areas. Decorated vessels with tool punctated, incised-punctated, and brushed rims-in that order-are also common in the northern area, accounting for $17.9 \%, 15 \%$, and $7.1 \%$, respectively of the rims. Between $14-20 \%$ of the tool punctated and incised-punctated sherds in the northern area are rims, compared to only $4 \%$ of the brushed sherds.

Table 6-6. Utility Wares.

\begin{tabular}{|c|c|c|c|c|}
\hline \multirow{2}{*}{ Decorative Method } & \multicolumn{2}{|c|}{ Southern area } & \multicolumn{2}{|c|}{ Northern area } \\
\hline & $\operatorname{Rim}$ & Body & $\operatorname{Rim}$ & Body \\
\hline Brushed & 19 & 635 & 10 & 248 \\
\hline Brushed-Punctated & 5 & 13 & 1 & 25 \\
\hline Brushed-Incised & 3 & 25 & 1 & 15 \\
\hline Brushed-Incised-Punctated & - & - & - & 2 \\
\hline Brushed-Appliqued & - & 2 & - & - \\
\hline Incised-Punctated & 4 & 33 & 21 & 85 \\
\hline Tool Punctated & 11 & 81 & 25 & 150 \\
\hline Tool Punctated-Pinched & - & - & - & 1 \\
\hline Tool-Fingernail Punctated & - & - & - & 1 \\
\hline Cane Punctated & 1 & 4 & - & 2 \\
\hline Fingernail Punctated & - & 18 & 1 & 63 \\
\hline Incised & 29 & 128 & 77 & 243 \\
\hline Appliqued & - & 4 & 1 & 2 \\
\hline Incised-Appliqued & - & - & - & 1 \\
\hline Pinched & - & 3 & 1 & 7 \\
\hline Neck Banded & 3 & - & 2 & - \\
\hline Totals & 75 & 946 & 140 & 845 \\
\hline
\end{tabular}


In the southern area, jars with brushed rims are particularly abundant (25.3\%), even though only $3 \%$ of the brushed sherds are rims, which is one of the distinctive features of the southern area ceramic assemblage. This is followed by vessels with tool punctated (14.7\%), brushed-punctated (6.7\%), and incised-punctated (5.3\%) rim decorations (see Table 6-6). In these categories of decorative method, between $11-28 \%$ of all of the sherds are rims. The proportions of rims among these particular utility wares are not much different between the northern and southern areas (11$20 \%$ ), except for the brushed-punctated sherds. In this decorative method, only $4 \%$ of the brushed-punctated sherds in the northern area are rims, compared to $28 \%$ of these sherds from the southern area.

\section{Brushed}

The brushed sherds from the Lang Pasture site are dominated by body sherds with parallel brushing marks (Table 6-7 and Figure 6-3a, c); although the orientation of these sherds is unknown, it is likely that the brushing was oriented vertically on the body of cooking and storage jars. Rims in both areas tend to have vertical brushing on them $(58 \%$ in the southern area and $40 \%$ in the northern area) (Figure 6-4a), but horizontal, diagonal, and overlapping (only in the northern area) brushed rims are also present in both areas in similar relative proportions.

Occasionally, the bodies of brushed jars have opposed (see Figure 6-4e) or overlapping brushed marks (see Figure 6-3b) instead of vertical/parallel brushing (see Table 6-7). These together comprise $11.4 \%$ of the brushed sherds in the southern area and only a very slightly higher $13.6 \%$ of the northern area brushed sherds.

Overall, brushed vessels in both areas of the Lang Pasture site were decorated in a similar manner on both the rim and vessel body. The only significant difference in the brushed sherds from the southern and northern areas is the absolute proportions of brushed sherds in the utility wares: $26.2 \%$ in the northern area and $64.1 \%$ in the southern area. Clearly, the period after ca. A.D. 1320-1400 and in much of the $15^{\text {th }}$ century A.D. is one where Caddo potters in the upper Neches River basin began to manufacture considerable numbers of brushed jars and jars with brushed vessel bodies.

Table 6-7. Brushed Sherds from the Southern and Northern Areas at the Lang Pasture Site.

\begin{tabular}{|c|c|c|c|c|c|c|}
\hline \multirow{2}{*}{ Decorative element } & \multicolumn{3}{|c|}{ Southern area } & \multicolumn{3}{|c|}{ Northern area } \\
\hline & Rim & Body & $\%$ & Rim & Body & $\%$ \\
\hline parallel brushed & - & 556 & 85.0 & - & 211 & 81.8 \\
\hline opposed brushed & - & 10 & 1.5 & - & 3 & 1.2 \\
\hline overlapping brushed & - & 65 & 9.9 & 1 & 31 & 12.4 \\
\hline vertical brushed & 11 & 3 & 2.1 & 4 & 2 & 2.3 \\
\hline diagonal brushed & 2 & - & 0.3 & 2 & - & 0.8 \\
\hline horizontal brushed & 6 & - & 0.9 & 3 & - & 1.2 \\
\hline horizontal brushed, CB & - & 1 & 0.2 & - & 1 & 0.4 \\
\hline Totals & 19 & 635 & 654 & 10 & 248 & 258 \\
\hline
\end{tabular}

$\mathrm{CB}=$ carinated bowl 


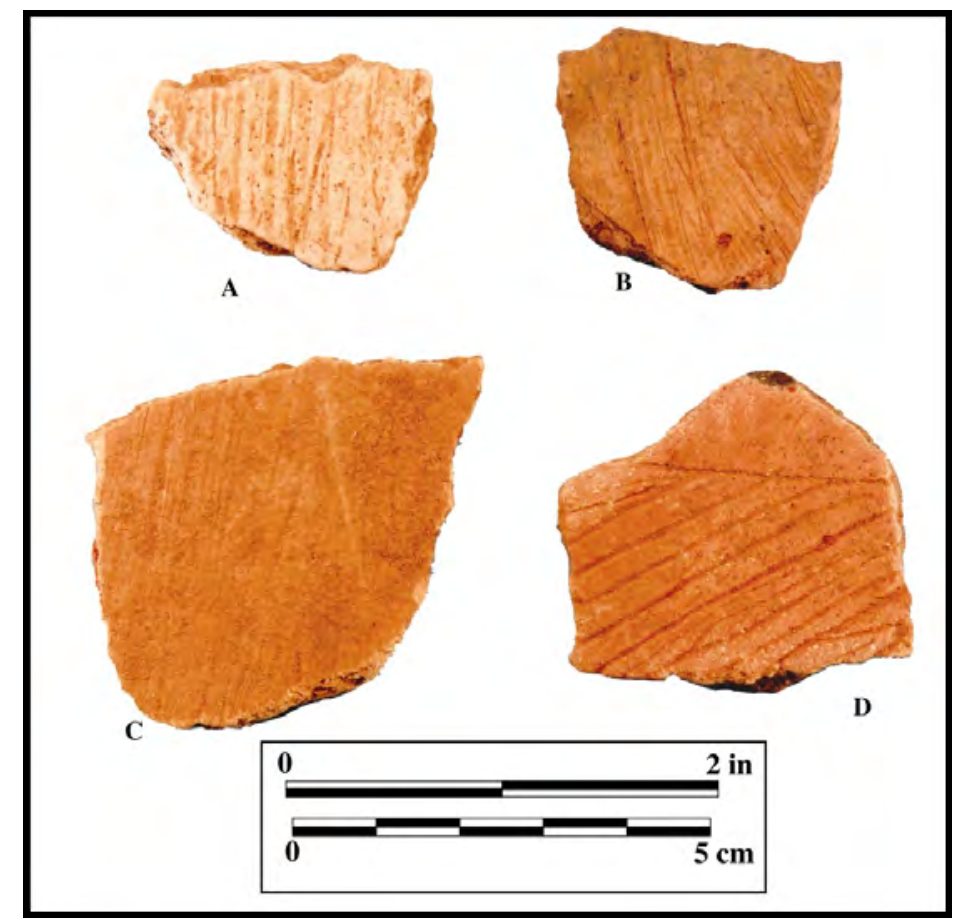

Figure 6-3. Brushed and Engraved Sherds from the Northern Area: a, c, parallel brushed; b, overlapping brushed; d, opposed engraved panel. Provenience: a, N193-198, Feature 66, 60129 cm bs; b, N199 E202, Feature 76, level 10; c, N198 E199, Feature 79, level 5; d, N198 E198, Feature 79, level 8.

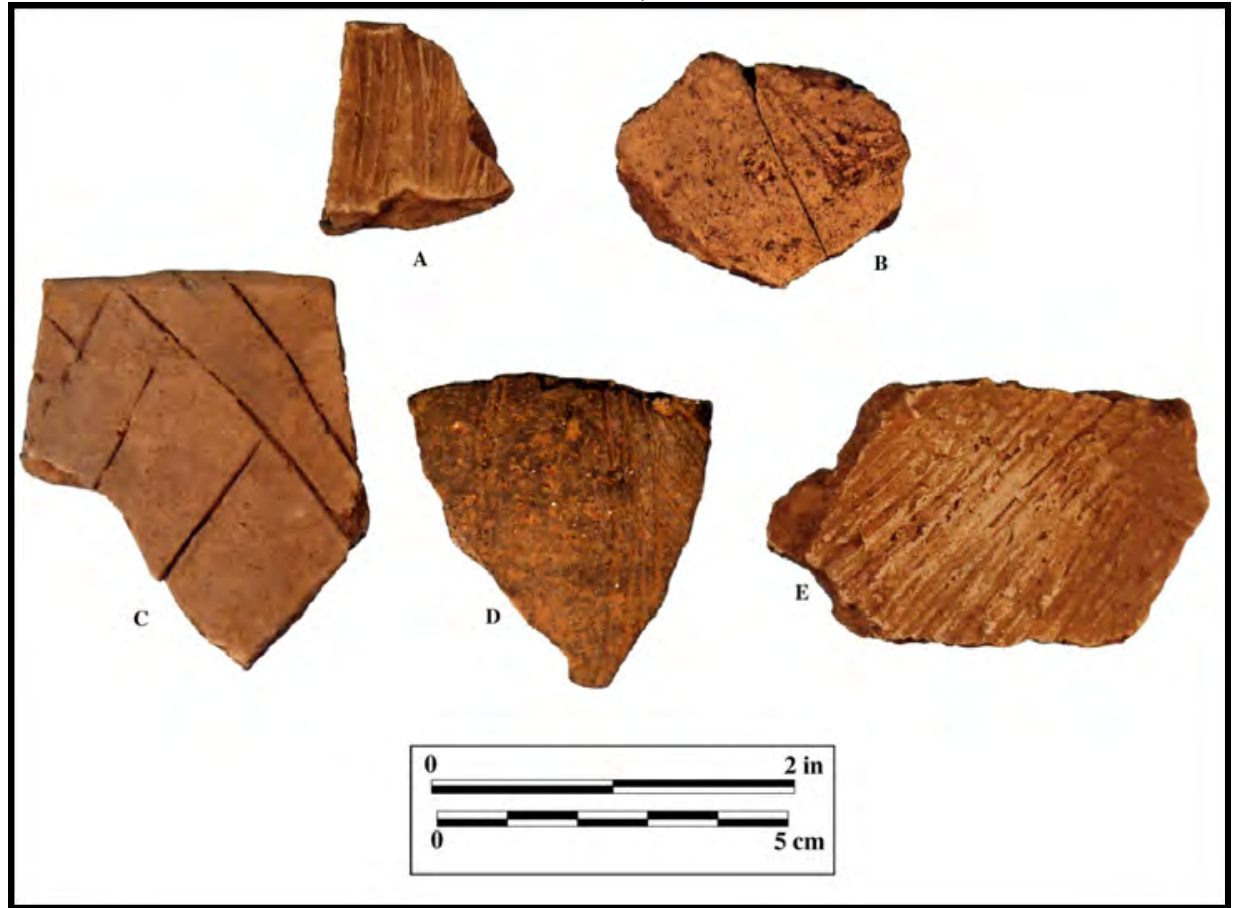

Figure 6-4. Decorated Sherds from the Lang Pasture Area Recovered During the Test Excavations: a, vertical brushed rim; b, hatched engraved triangle element, Poynor Engraved; c, opposed incised rim; d, bottle sherd with engraved panel; e, opposed brushed.

Provenience: a, N181-201, level 2; b, N181 E201, general; c, N191 E201, level 4; d, N178 E200, level 1; e, N181 E200, Iv. 1. 


\section{Brushed-Punctated}

Brushed-punctated decorations on utility ware sherds are rare at the Lang Pasture site in both areas (Table 6-8), accounting for only $1.8 \%$ of the utility wares in the southern area and $2.6 \%$ of the northern area utility wares (see Table 66). These are likely from Bullard

Brushed jars (see Suhm and Jelks 1962:21 and Plate 11a-c, e-f). By far the most common decorative elements are body sherds with parallel brushing marks and at least one row of tool or fingernail punctates pushed through the brushing marks (Figure 6-5f). Brushed and fingernail punctated elements are particularly common in the northern area; the only sherd with large circular punctations is also from this area.

Other differences between the two assemblages in the kinds of brushed-punctated decorations can be discerned. First, vertical brushed sherds with tool punctates either through the brushing or above the brushing (i.e., a row of punctates at the rim-body juncture) are more abundant in the southern area, as are sherds with overlapping brushed marks and tool punctates pushed through the brushing (see Table 6-8).

Table 6-8. Brushed-Punctated Decorative Elements.

\begin{tabular}{|c|c|c|c|c|c|c|}
\hline \multirow{2}{*}{ Decorative element } & \multicolumn{3}{|c|}{ Southern area } & \multicolumn{3}{|c|}{ Northern area } \\
\hline & Rim & Body & $\%$ & Rim & Body & $\%$ \\
\hline $\begin{array}{l}\text { parallel brushed with } \\
\text { fingernail punctates } \\
\text { through the brushing }\end{array}$ & - & 5 & 27.8 & - & 14 & 53.8 \\
\hline $\begin{array}{l}\text { parallel brushed with } \\
\text { tool punctated row } \\
\text { through the brushing }\end{array}$ & - & 5 & 27.8 & - & 10 & 38.5 \\
\hline $\begin{array}{l}\text { vertical brushed with } \\
\text { tool punctated row } \\
\text { through the brushing }\end{array}$ & 1 & - & 5.6 & - & 1 & 3.8 \\
\hline $\begin{array}{l}\text { vertical brushed below } \\
\text { tool punctated row }\end{array}$ & - & 1 & 5.6 & - & - & - \\
\hline $\begin{array}{l}\text { overlapping brushed with } \\
\text { tool punctates } \\
\text { through the brushing }\end{array}$ & - & 1 & 5.6 & - & - & - \\
\hline $\begin{array}{l}\text { horizontal brushed with } \\
\text { circular punctates } \\
\text { through the brushing }\end{array}$ & & & & 1 & - & 3.8 \\
\hline $\begin{array}{l}\text { horizontal brushed with } \\
\text { tool punctates under } \\
\text { lip and through } \\
\text { brushing }\end{array}$ & 1 & - & 5.6 & - & - & - \\
\hline $\begin{array}{l}\text { horizontal brushed with } \\
\text { tool punctates through } \\
\text { brushing }\end{array}$ & 3 & 1 & 22.2 & - & - & - \\
\hline Totals & 5 & 13 & 18 & 1 & 25 & 26 \\
\hline
\end{tabular}


Horizontal brushed sherds with tool punctated elements are much more common in the southern area $(27.8 \%)$ than they are in the northern area (3.8\%). Punctates on these sherds tend to be in rows under the lip, along the mid-point of the rim, and then at the rimbody juncture (see also Figure 6-7a, below), but most commonly pushed through the brushing.

\section{Brushed-Incised}

Brushed-incised sherds represent another rare form of decoration on the Lang Pasture site utility wares (Table 6-9). These sherds account for $2.7 \%$ of the southern area utility wares and $1.6 \%$ of the northern area utility wares (see Table 6-6). Both Maydelle Incised and Bullard Brushed vessels have brushed and/or incised bodies, particularly Maydelle Incised jars (see Suhm and Jelks 1962:103 and Plate 52a, f-g).
The parallel brushed-parallel incised decorative element on vessel bodies is most common at Lang Pasture in both site areas (see Table 6-9). Diagonal, overlapping, and vertical brushed-incised decorative elements on rims/body sherds are more abundant in the southern area $(14.3 \%)$ than they are in the northern area (6.3\%).

\section{Brushed-Incised-Punctated}

Both of the brushed-incised-punctated sherds are from the northern area at the Lang Pasture site. They have parallel brushing marks adjoining a straight incised zone filled with tool punctates. These sherds are likely from Maydelle Incised jars that have vertical brushing on the body and incised triangles or opposed diagonal lines with tool punctations filling the triangles or areas between the incised lines (cf. Suhm and Jelks 1962:103 and Plate 52e-f).

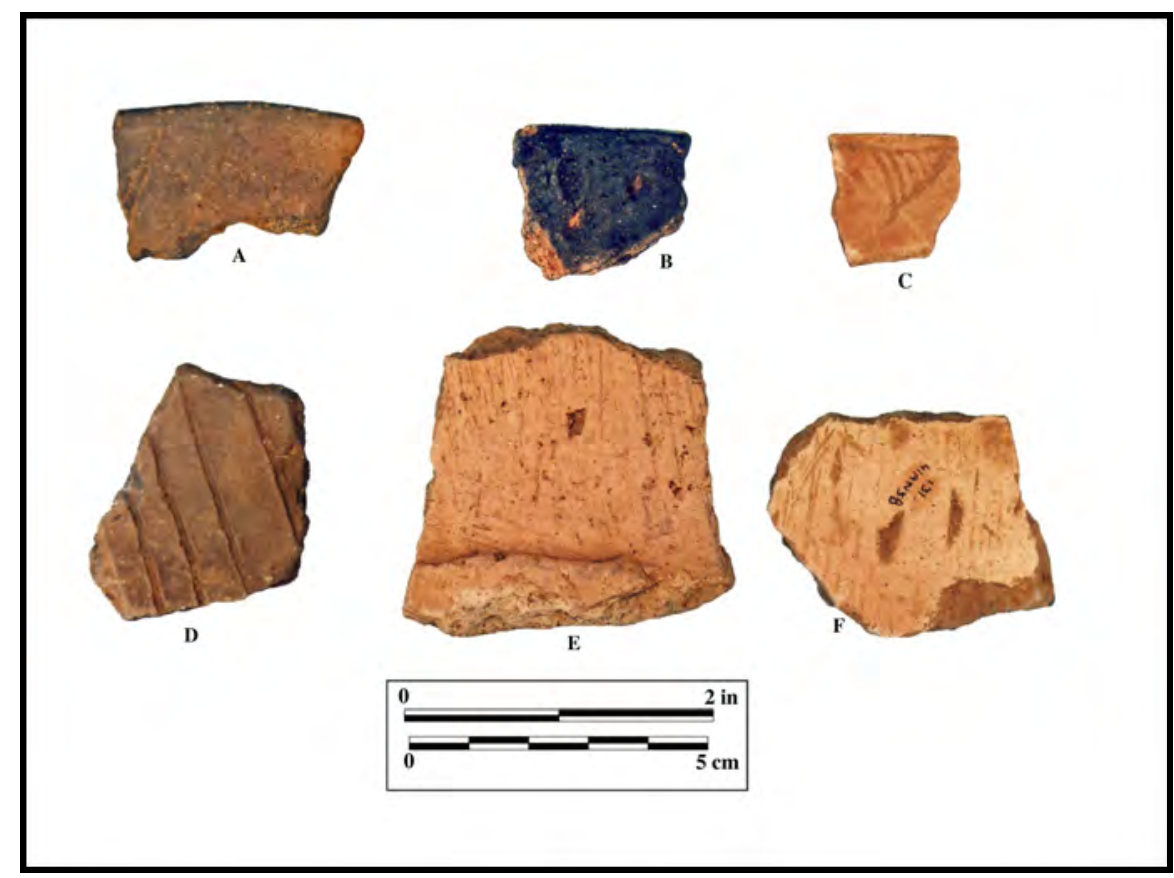

Figure 6-5. Various Decorated Sherds Recovered in the Test Excavations from Both Site Areas: a, diagonal incised rim; b, tool punctated rim; c, Poynor Engraved rim with hatched triangle element; $d$, incised-tool punctated; e, brushed-appliqued; $f$, brushed-fingernail punctated. Provenience: a, N191 E200, level 4; b, N191 E200, level 3; c, N178 E201, level 4; d, N180 E201, level 2; e, N178 E201, level 3; f, N191 E200, level 7. 
Table 6-9. Brushed-Incised Sherds.

\begin{tabular}{|c|c|c|c|c|c|c|}
\hline \multirow[t]{2}{*}{ Decorative Element } & \multicolumn{3}{|c|}{ Southern Area } & \multicolumn{3}{|c|}{ Northern Area } \\
\hline & Rim & Body & $\%$ & Rim & Body & $\%$ \\
\hline $\begin{array}{l}\text { parallel brushed-incised } \\
\text { parallel brushed-incised }\end{array}$ & - & 21 & 75.0 & - & 13 & 81.3 \\
\hline panel & - & - & - & - & 1 & 6.3 \\
\hline $\begin{array}{l}\text { parallel brushed-opposed } \\
\text { incised line }\end{array}$ & - & 2 & 7.1 & - & 1 & 6.3 \\
\hline and opposed brushing & - & 1 & 3.6 & - & - & - \\
\hline diagonal brushed-incised & 1 & - & 3.6 & - & - & - \\
\hline overlapping brushed-incised & - & 1 & 3.6 & - & - & - \\
\hline vertical brushed-incised & 2 & - & 7.1 & 1 & - & 6.3 \\
\hline Totals & 3 & 25 & 28 & 1 & 15 & 16 \\
\hline
\end{tabular}

\section{Brushed-Appliqued}

Two body sherds from different vessels from the southern area have brushed-appliqued decorations. These consist of sherds with parallel (probably vertical or horizontal) and parallel-opposed brushing marks framing either an appliqued fillet (see Figure 6-5e) or an appliqued ridge. These appliqued fillets/ridges likely ran vertically on the vessel body, creating a series of panels filled with brushing.

\section{Incised-Punctated}

A number of utility ware vessels from the Lang Pasture site have incised-punctated decorative elements (Table 6-10). The majority of the incised-punctated decorative elements have straight or geometric incised lines framing punctated zones or rows of punctates (Figure 6-6a-b, see also Figure 65e), particularly notable being the creation of sets of incised triangles filled with tool, fingernail, or cane punctations (Figures 6-7c, h and 6-8a, j). Tool punctated elements were primarily used in the incised-punctated designs in the utility wares in both areas, accounting for $89.2 \%$ of the incised-punctated sherds in the southern area and $92.7 \%$ of the northern area incised-punctated sherds (see Table 6-10). Cane punctated elements were decidedly secondary (5.4-10.8\% by area), and only $1.9 \%$ of the incised-punctated sherds from the northern area have fingernail punctates.

Focusing on the incised-punctated rims, all four from the southern area have incised triangles filled with either tool (see Figure 6$7 \mathrm{~h}$ ) or cane punctates (see Table 6-10). However, only $62 \%$ of the northern area incised-punctated rims (see Figure 6-8a) have this distinctive Maydelle Incised rim decoration. Body and rim sherds with incised triangular elements filled with punctations comprise between $27-33.9 \%$ in the two areas, being more common in the northern area (see Figures 6-7c and 6-8j).

Other rims from the northern area have curvilinear incised zones filled with tool punctates $(19 \%)$ or incised semi-circles filled 
with tool punctates (19\%) (see Figure 6-8b, i). In general, circular, curvilinear, or semicircular incised elements filled with punctates are slightly more popular in the northern area (15.1\%) than they are in the southern area (10.8\%) (see Figure 6-7e).

Additional decorative elements identified in the incised-punctated sherds include those rim and body sherds with horizontal incised lines framing tool punctated rows or zones (1.8$5.4 \%$ of the incised-punctated sherds, being most common in the northern area) (see Table 6-10). Another 36.9-45.9\% have parallel/straight incised lines framing rows or zones of punctations. Incised panels filled with punctations represent $2.7-12.2 \%$ of the incised-punctated sherds, being particularly abundant in the northern area (see Figure 68e). Finally, between $1.9-8.1 \%$ of the incisedpunctated sherds (more from the southern area) from the Lang Pasture site have incised decorative elements situated above a row or zone of tool punctations; the tool punctated rows were likely situated at the rim-body juncture, with either opposed or diagonal incised lines on the rim of utility ware vessels.

Table 6-10. Incised-Punctated Sherds.

\begin{tabular}{|c|c|c|c|c|c|c|}
\hline \multirow[t]{2}{*}{ Decorative element } & \multicolumn{3}{|c|}{ Southern Area } & \multicolumn{3}{|c|}{ Northern Area } \\
\hline & $\operatorname{Rim}$ & Body & $\%$ & $\operatorname{Rim}$ & Body & $\%$ \\
\hline \multicolumn{7}{|l|}{ tool punctated row under lip } \\
\hline and above horizontal lines & - & - & - & 1 & - & 0.9 \\
\hline horizontal and diagonal lines & & & & & & \\
\hline framing tool punctated zone & - & 2 & 5.4 & - & - & - \\
\hline $\begin{array}{l}\text { horizontal and diagonal lines } \\
\text { and triangle el. filled with }\end{array}$ & & & & & & \\
\hline tool punctates & - & - & - & 2 & - & 1.9 \\
\hline $\begin{array}{l}\text { horlzontal line below tool } \\
\text { punctated zone }\end{array}$ & - & - & - & - & 1 & 0.9 \\
\hline \multicolumn{7}{|l|}{ parallel lines framing tool } \\
\hline $\begin{array}{l}\text { punctated zone } \\
\text { straight line framing tool }\end{array}$ & - & 4 & 10.8 & - & 5 & 4.8 \\
\hline $\begin{array}{l}\text { punctated rows/zones } \\
\text { straight incised line framing }\end{array}$ & - & 11 & 29.7 & - & 31 & 29.3 \\
\hline $\begin{array}{l}\text { fingernail punctated zone } \\
\text { straight line framing cane }\end{array}$ & - & - & - & - & 2 & 1.9 \\
\hline punctated rows/zones & - & 2 & 5.4 & - & 1 & 0.9 \\
\hline \\
\hline triangular zone filled with & & & & & & \\
\hline cane punctates & 1 & - & 2.7 & - & 1 & 0.9 \\
\hline $\begin{array}{l}\text { zone filled with tool } \\
\text { punctates }\end{array}$ & - & $1^{*}$ & 2.7 & 10 & 6 & 15.1 \\
\hline \multicolumn{7}{|l|}{ opposed zones filled with } \\
\hline tool punctates & - & 2 & 5.4 & - & - & - \\
\hline diagonal curvilinear zones & & & & & & \\
\hline filled with tool punctates & - & - & - & 1 & - & 0.9 \\
\hline
\end{tabular}


Table 6-10, continued.

\begin{tabular}{|c|c|c|c|c|c|c|}
\hline \multirow[t]{2}{*}{ Decorative Element } & \multicolumn{3}{|c|}{ Southern Area } & \multicolumn{3}{|c|}{ Northern Area } \\
\hline & Rim & Body & $\%$ & Rim & Body & $\%$ \\
\hline circular incised zone & & & & & & \\
\hline $\begin{array}{l}\text { filled with tool punctates } \\
\text { circular incised zone }\end{array}$ & - & 3 & 8.1 & - & 4 & 3.8 \\
\hline $\begin{array}{l}\text { filled with cane punctuates } \\
\text { circular incised zone and } \\
\text { curvilinear panels filled }\end{array}$ & - & 1 & 2.7 & - & - & - \\
\hline $\begin{array}{l}\text { with tool punctates } \\
\text { circular and opposed lines } \\
\text { and triangle el. filled }\end{array}$ & - & - & - & - & 1 & 0.9 \\
\hline $\begin{array}{l}\text { with cane punctates } \\
\text { hatched triangle and circle }\end{array}$ & - & - & - & - & 1 & 0.9 \\
\hline $\begin{array}{l}\text { filled with cane punctuates } \\
\text { semi-circles filled with }\end{array}$ & - & - & - & - & 1 & 0.9 \\
\hline tool punctates & - & - & - & 2 & - & 1.9 \\
\hline $\begin{array}{l}\text { curvilinear zones filled } \\
\text { with tool punctates } \\
\text { opposed lines and panel }\end{array}$ & - & - & - & 2 & 4 & 5.7 \\
\hline filled with tool punctates & - & - & - & - & 2 & 1.9 \\
\hline $\begin{array}{l}\text { incised panel and tool- } \\
\text { punctated filled circle** } \\
\text { incised panel and curvilinear } \\
\text { zone, both filled }\end{array}$ & - & 1 & 2.7 & - & - & - \\
\hline $\begin{array}{l}\text { with tool punctates } \\
\text { straight and semi-circular } \\
\text { panels filled with }\end{array}$ & - & - & - & - & 1 & 0.9 \\
\hline $\begin{array}{l}\text { tool punctates } \\
\text { incised panels filled with }\end{array}$ & - & - & - & - & 1 & 0.9 \\
\hline $\begin{array}{l}\text { tool punctates } \\
\text { incised panel filled with }\end{array}$ & - & - & - & - & 4 & 3.8 \\
\hline $\begin{array}{l}\text { cane punctates } \\
\text { diagonal panel filled }\end{array}$ & - & - & - & - & 1 & 0.9 \\
\hline $\begin{array}{l}\text { with cane punctates } \\
\text { vertical incised panel } \\
\text { filled with incised lines }\end{array}$ & - & - & - & 1 & - & 0.9 \\
\hline $\begin{array}{l}\text { or tool punctates } \\
\text { vertical incised panel }\end{array}$ & - & - & - & - & 1 & 0.9 \\
\hline $\begin{array}{l}\text { filled with tool punctuates } \\
\text { diagonal lines above tool }\end{array}$ & - & - & - & 1 & 1 & 1.9 \\
\hline punctated zone & - & 1 & 2.7 & - & 2 & 1.9 \\
\hline $\begin{array}{l}\text { opposed incised lines above } \\
\text { tool punctated zone/row }\end{array}$ & - & 2 & 5.4 & - & - & - \\
\hline Totals & 4 & 33 & 37 & 21 & 85 & 106 \\
\hline
\end{tabular}




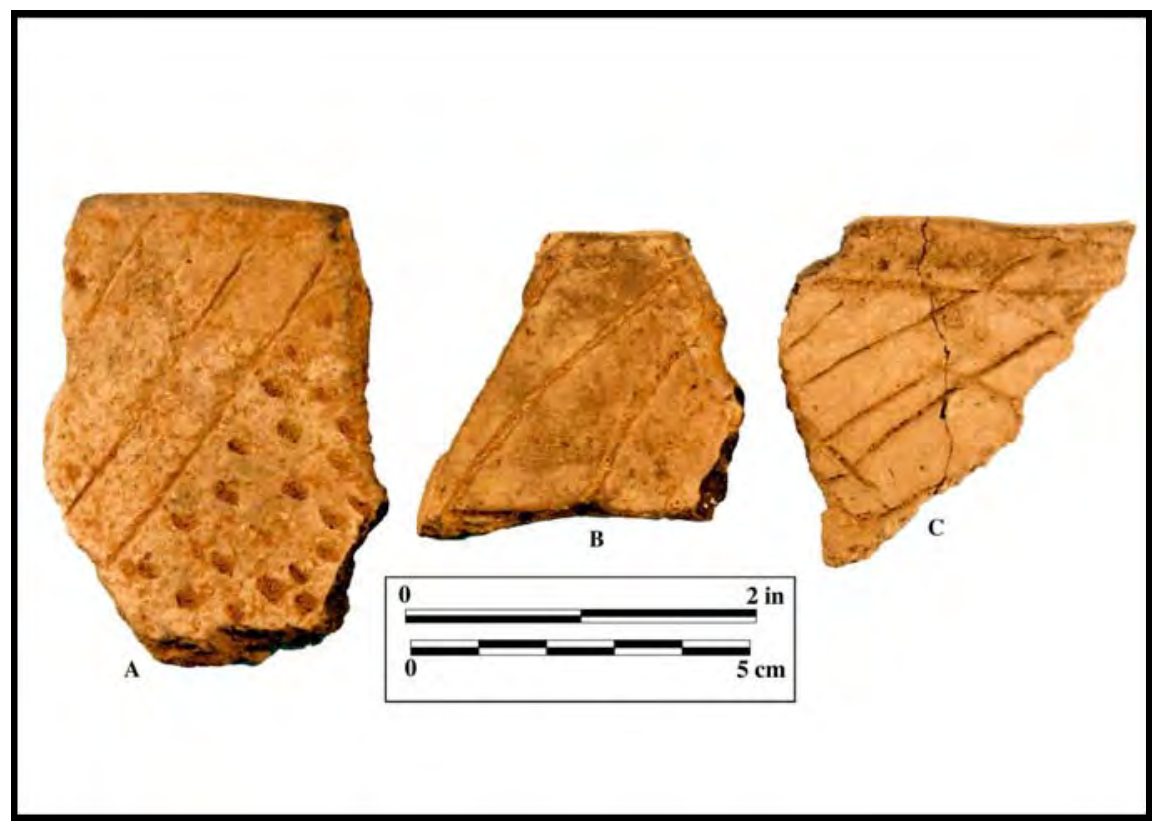

Figure 6-6. Incised-Punctated and Incised Sherds from the Northern Site Area: a-b, incisedtool punctated rims; c, cross-hatched incised rim. Provenience: a, N197 E202, Feature 76, level 9; b, N198 E203, Feature 76, level 13; c, N197.5 E201, Feature 74, 50-74 cm.

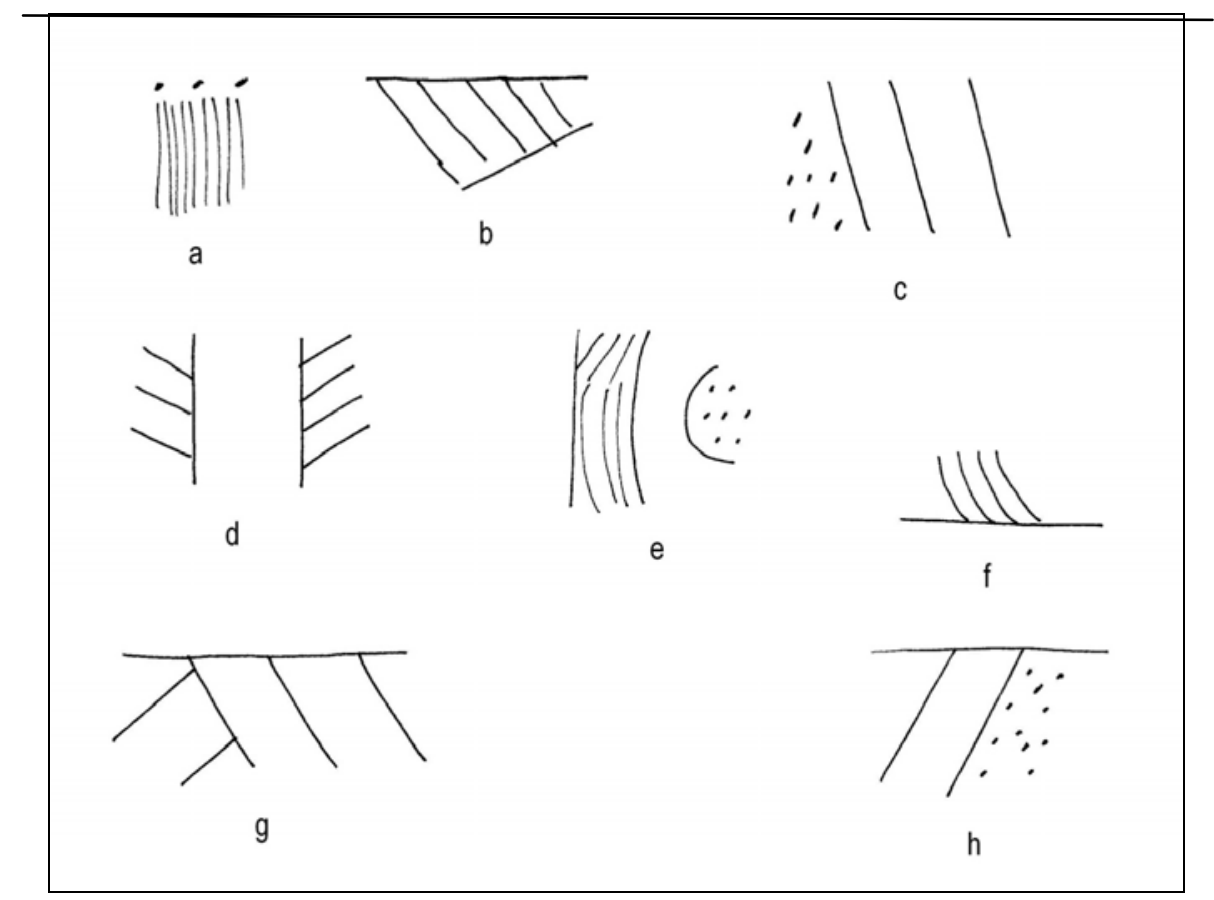

Figure 6-7. Selected Decorative Elements on Utility Wares from the Southern Area of the Site: a, brushed-punctated; b, opposed incised rim; c, incised-tool punctated; d, opposed incised panel; e, incised-punctated, cf. Poynor Engraved decorative element executed in wet paste; $f$, incised triangle, cf. Poynor Engraved decorative element executed in wet paste; g, opposed incised rim; h, incised-tool punctated rim. Provenience: a, N180 E199, level 3, INAA 38-31; b, N183 E201, level 3, INAA 38-44; c, N181 E201, level 3; d, N180 E199, level 4; e, N179 E199, level 4; f, N186 E199, level 3; g, N187 E201, level 2; h, N178 E199, level 1. 


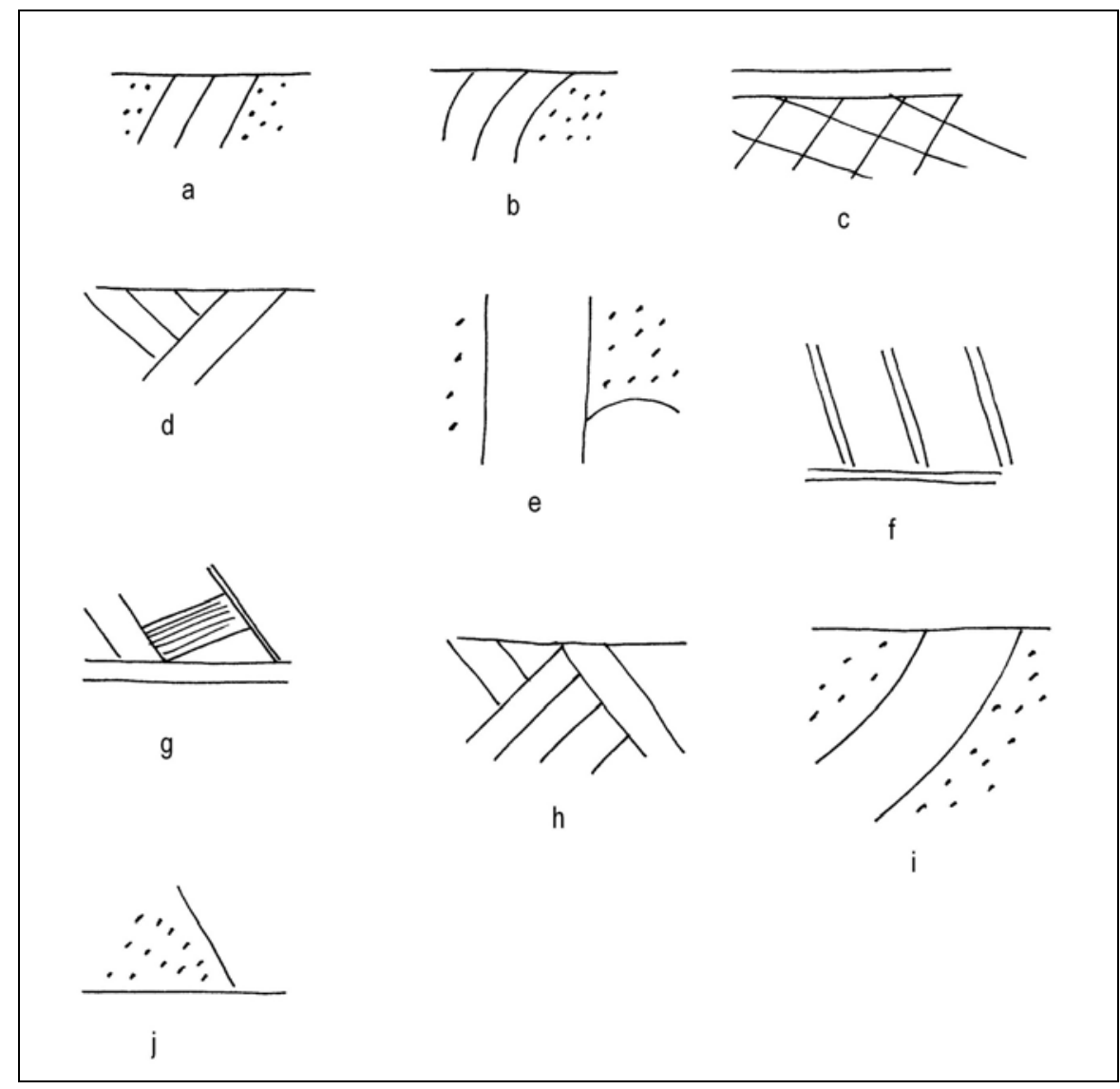

Figure 6-8. Selected Decorative Elements on Utility Wares from the Northern Area of the Site: a-b, i, incised-punctated rim; c, horizontal and cross-hatched incised rim; d, h, opposed incised rim; e, incised panels and tool punctated; f, opposed incised lines; g, horizontaldiagonal incised and hatched triangle, cf. Poynor Engraved executed in wet paste; j, incisedtool punctated. Provenience: a, N197 E202, Feature 76, level 9; b, N198 E203, Feature 76, level 13; c, N197.5 E201, Feature 74, 50-74 cm; d, N199 E200, Feature 76B, level 9; e, N197 E203, Feature 76B, level 8; f, Feature 76, level 9, INAA 38-16; g, Feature 76, INAA 38-17; h, N191 E201, level 4; i, N190 E198, level 3; j, N207 E200, level 3.

\section{Tool Punctated}

Tool punctations were regularly employed as part of several different decorative elements in the Lang Pasture utility wares (Table 6-11), particularly in the northern site where punctated sherds amount to $18.8 \%$ of all the utility wares (see Table 6-6). Most of these consist of rows of tool punctations of various sizes and shapes, either placed in a single row under the lip (see Figure 6-5b), at various places in several rows on the rim (Figure 6-9c and Figure 6-10a), as well as apparently sometimes covering much of the vessel body (Figure 6-10b-d).
Suhm and Jelks (1962:157 and Plate 79) note the considerable diversity in the decoration of utility wares in East Texas Caddo sites, although punctated utility ware in the upper Neches River basin has only the most basic decorative elements (Suhm and Jelks 1962:Plate 79a-b).

In the two site areas at the Lang Pasture site, there are few differences in tool punctated decorative elements, as between $73.1 \%$ (northern area) and 82.6\% (southern area) of the punctated sherds have at least one row, and sometimes many rows, of tool punctates on the rim 
Table 6-11. Tool and Fingernail Punctated Sherds.

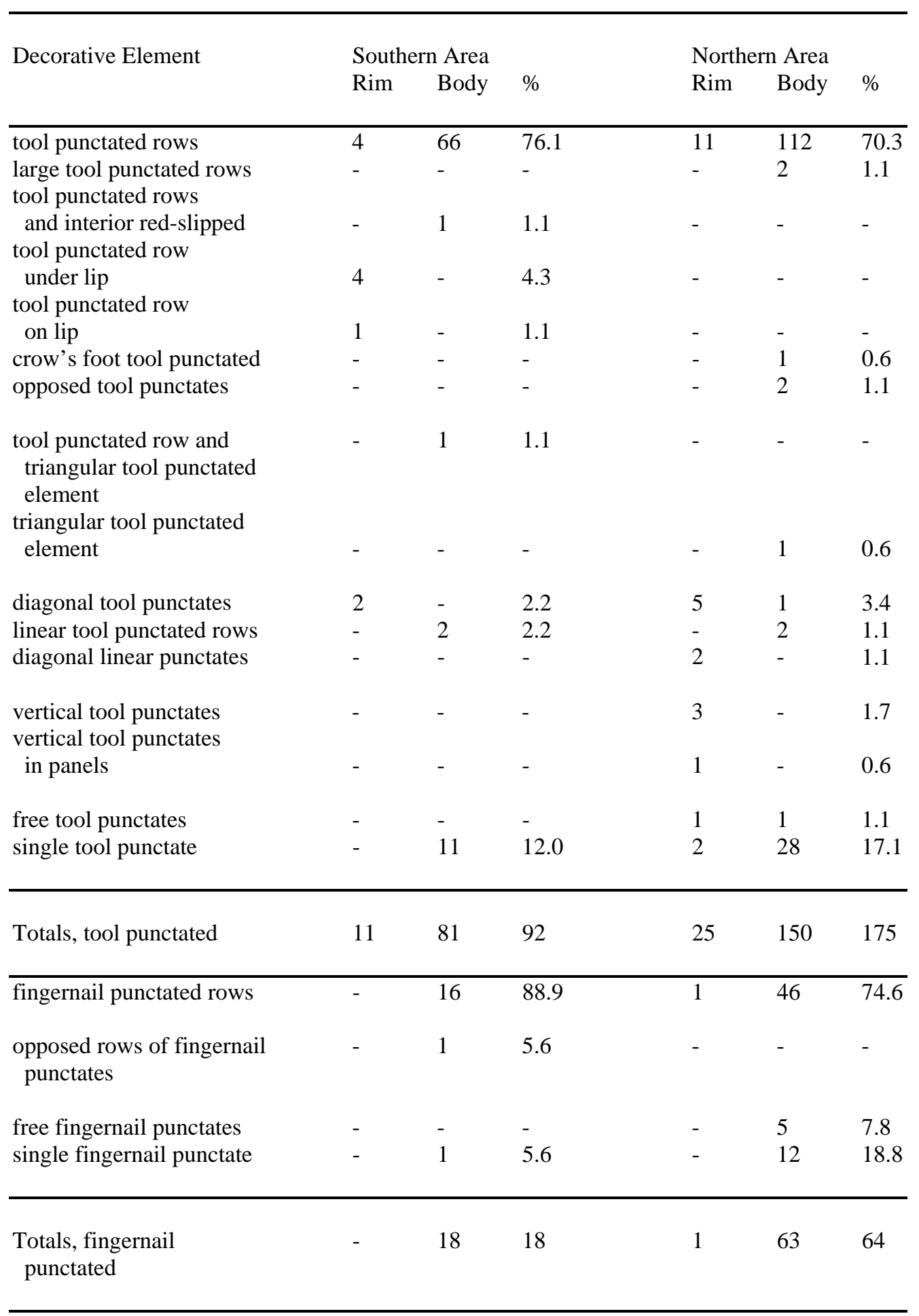




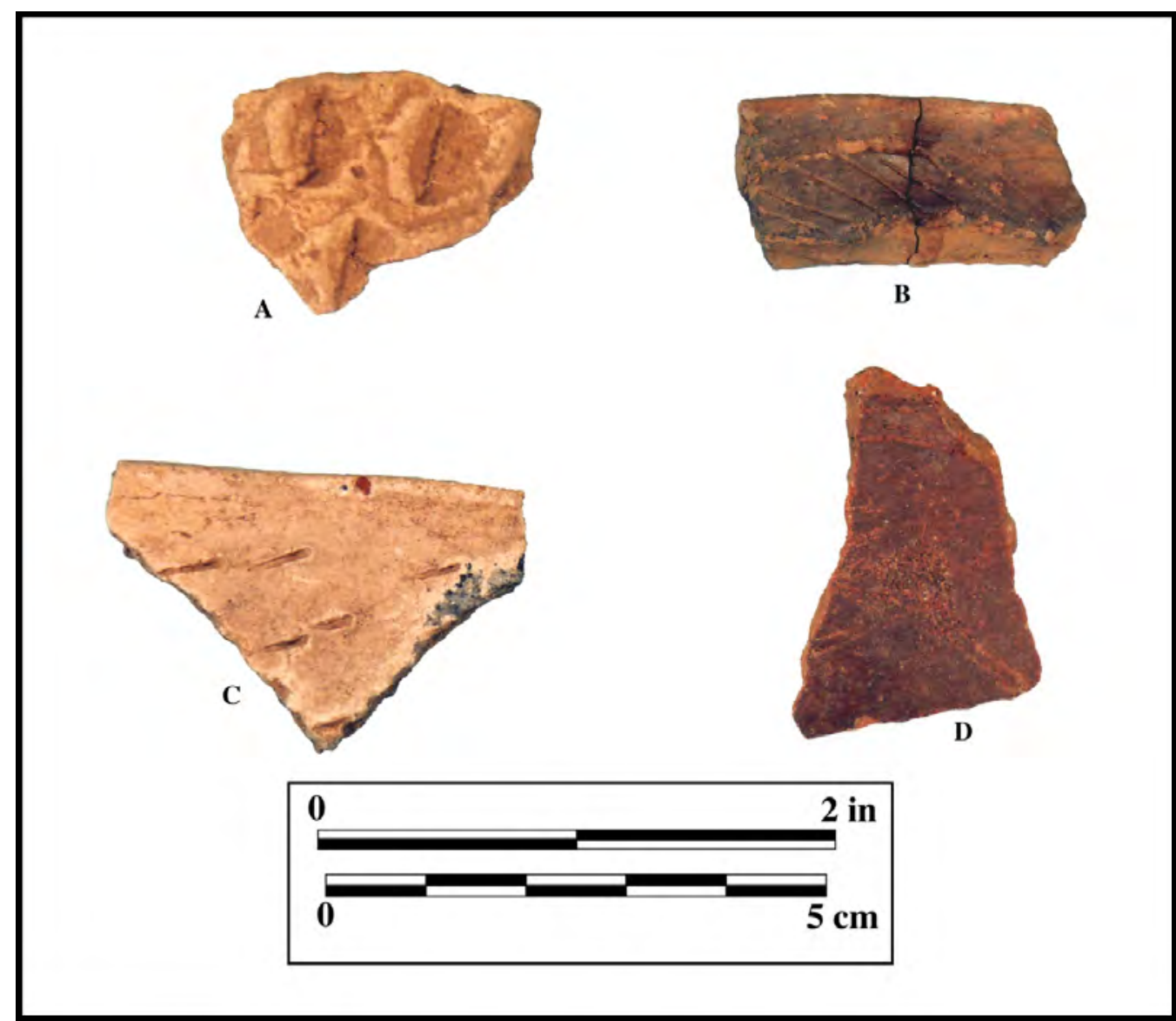

Figure 6-9. Punctated and Engraved Sherds from the Southern Area: a, large tool punctations; b, hatched panel, engraved rim; c, diagonal tool punctated rim; d, hatched engraved triangle. Provenience: a, N180 E200, level 2; b, ST 10, level 2; c, N179 E200, level 3; d, N179 E200, level

(see Figure 6-10a) and/or the body of utility ware vessels (see Table 6-11 and Figures 69a and 6-10c). However, rims with tool punctated rows under the lip (see Figure 6$5 b)$ or on the lip itself are restricted to the southern area. Vertical rows of punctates are restricted to rims from the northern area, while diagonal and linear punctated elements occur in comparable frequencies $\mathbf{( 4 . 4 \%}$ versus $5.6 \%$ ) in both site areas (see Table 611) (see Figure 6-9c).

\section{Tool-Punctated-Pinched}

One body sherd from a Killough Pinched jar in the northern area has tool punctated rows divided by at least one vertical pinched row. The pinching and punctated elements probably covered the entire vessel surface.
4.

\section{Tool-Fingernail Punctated}

One body sherd from the northern area is from a vessel decorated with both tool and fingernail punctations. In this case, the tool punctations were placed in a single row along the rim-body juncture of a cooking jar, while the body of the vessel was covered with rows of fingernail punctations.

\section{Cane Punctated}

The cane punctated sherds from both areas are from vessels covered with rows of cane punctations, with the rows not necessarily confined to the rim. In the southern area, the one cane punctated rim is from a jar with rim peaks. 


\section{Fingernail Punctated}

Given the virtual absence of rims with fingernail punctations (see Table 6-11), it is likely that fingernail punctated decorative elements were most often placed on the body of utility ware vessels (see Figure 6-10b, d), rather than on the rim and body as with tool punctated decorative elements. Fingernail punctated sherds are more abundant in the northern site area utility wares (6.5\%) than they are in the later southern area $(1.8 \%)$ (see Table 6-6).

In most cases from both site, fingernail punctates were placed in straight rows across the exterior surface of utility ware vessels (Figure 6-11b).
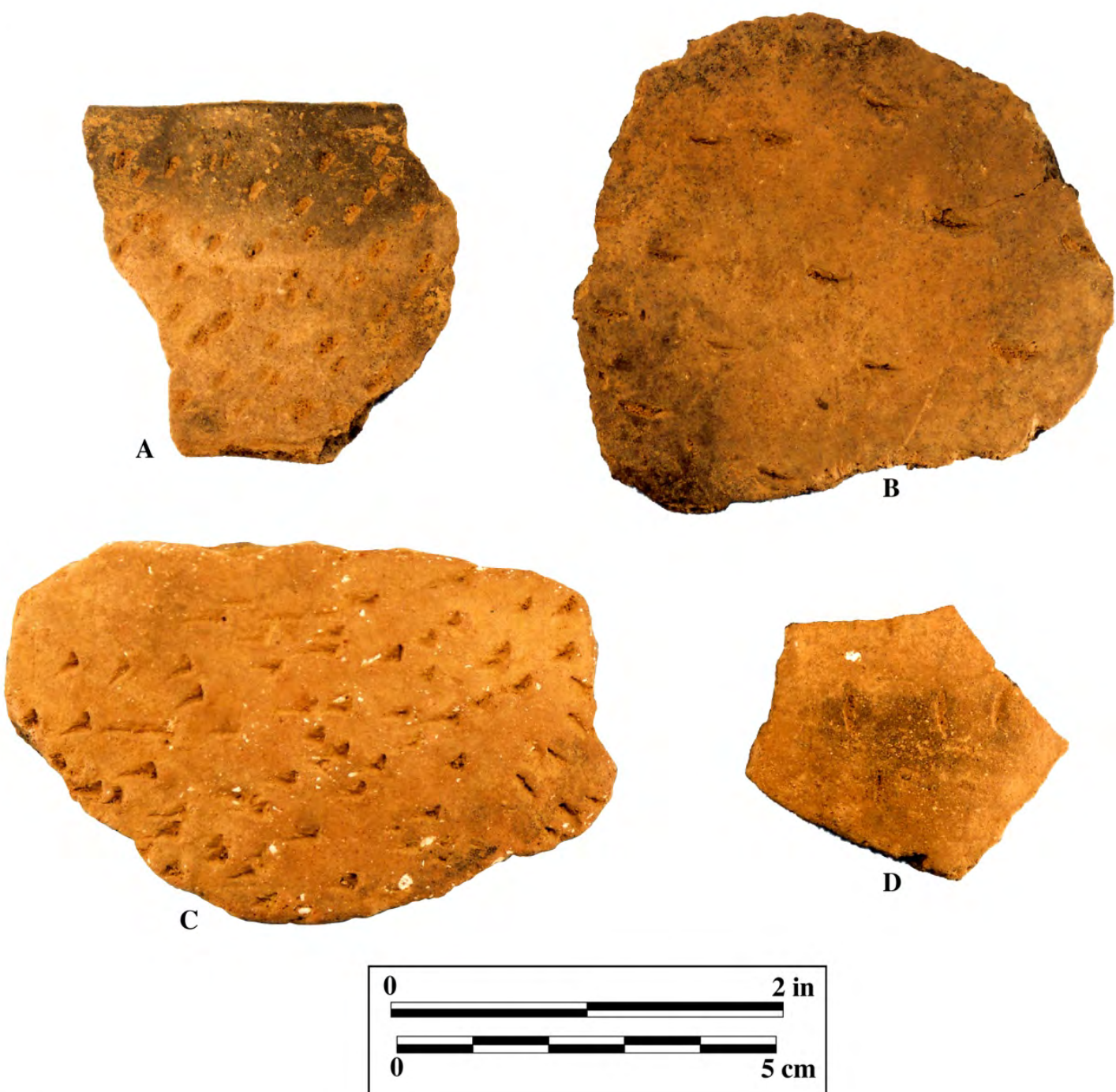

Figure 6-10. Punctated Sherds from the Northern Area: a, c, tool punctated; b, d, fingernail punctated. Provenience: a, N197 E203, Feature 76, level 12; b, N197/198 E200, Feature 81, level 5; c, N197 E203, Feature 76, level 13; d, N198 E199, Feature 79, level 7. 

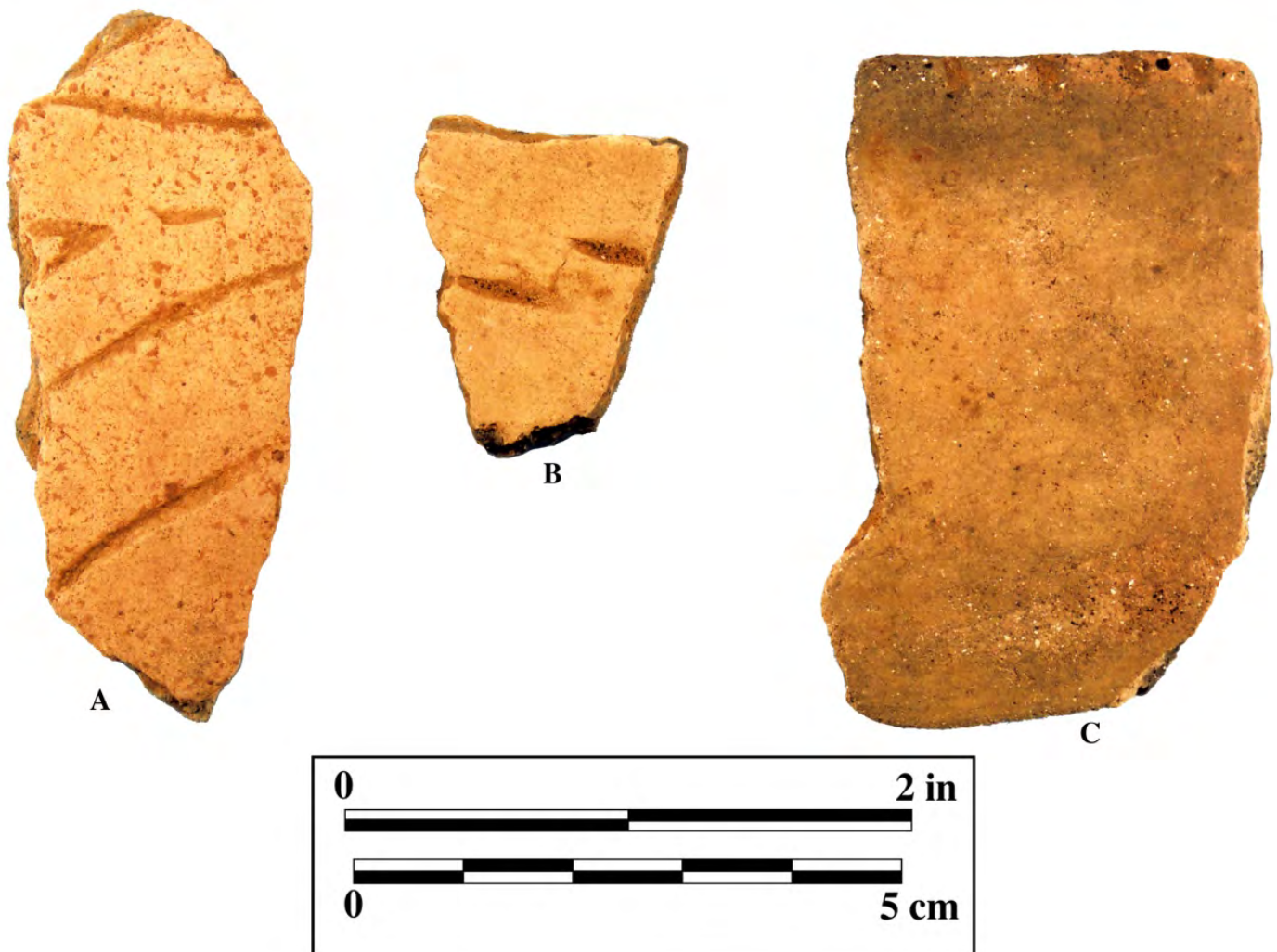

Figure 6-11. Engraved, Lip Notched, and Fingernail Punctated Sherds from the Northern Site Area: a, engraved-punctated bottle sherd; b, fingernail punctated; c, lip notched rim.

Provenience: a, N199 E202, Feature 76, level 5; b, N198 E199, Feature 79, level 8; c, N198 E202, Feature 76, level 11.

There is one example from the southern area where the decorative element is opposed rows of fingernail punctates (see Table 6-11). Randomly or freely-placed fingernail punctated decorative elements are found only on punctated utility wares from the northern site area at the Lang Pasture site.

\section{Incised}

The vast majority of the incised sherds from both areas at the Lang Pasture site have straight line and/or geometric decorative elements (Table 6-12), with little stylistic difference among the incised utility wares between them. Other than single straight or parallel incised lines, the most frequent incised decorative elements include sets of opposed incised lines (Figure 6-12b; see also Figure 6- 4c, Figure 6-7b, g, Figure 6-8d, f, h, 18.8$19.8 \%$ of all the incised sherds by area), where the incised lines are pitched in different directions, sets of diagonal lines (see Figure 65a and Figure 6-12a, 10.2-14.1\%), crosshatched lines (6.4-10.3\%) (see Figure 6-8c and Figure 6-12d), sets of horizontal lines (2.8$3.1 \%$ ), and vertical lines and panels (2.13.8\%) (see Table 6-12 and Figure 6-7d).

Incised utility ware sherds with either curvilinear or circular decorative elements comprise only $1.8-2.8 \%$ of this class of pottery in the Lang Pasture ceramic assemblage (see Table 6-12). The most notable incised pottery from the site are a few sherds from both site areas $(1.2 \%$ in the northern area and 3.1\% in the southern area) that have Poynor Engraved hatched triangle decorative elements (see 
below) that were executed with incised lines (see Figure 6-7f and Figure 6-8g). One rim from the northern area has a horizontal incised line under the lip and a panel filled with crosshatched incised lines (see Figures 6-6c and 68c).

\section{Appliquéd}

Sherds from vessels with appliquéd elements are rare in both the southern and northern ceramic component/areas. In the southern area, four body sherds document the use of appliqued ridges $(n=3)$ or straight appliqued fillets $(n=1)$ as panel dividers on jars. Two of the three appliqued sherds in the northern area also have ridges, not fillets, and a third sherd is a rim from a jar with small nodes at the lip.

\section{Incised-Appliquéd}

A single body sherd (or a sherd from the lower part of the rim) from the northern area has an opposed line incised element on one side of an appliquéd node or short appliqued ridge. This particular sherd is likely from an undefined variety of Maydelle Incised, where two or four appliqued node or ridge elements were added to the rim to separate panels of opposed incised lines.

\section{Pinched}

These pinched rim and body sherds are from Killough Pinched jars (Suhm and Jelks 1962:91 and Plate 46). Most of the pinched sherds have rows of pinching, probably vertically oriented, although horizontal pinched vessels are known (see Suhm and Jelks 1962:Plate 46g). Two of the pinched sherds from the northern area have circular or curvilinear pinched rows, probably part of concentric pinched circle decorative elements, perhaps from Killough Pinched jars with pedestal bases (see Suhm and Jelks 1962:Plate $46 a-c)$.

\section{Neck Banded}

The few neck banded sherds are from La Rue Neck Banded vessels (see Suhm and Jelks 1962:93 and Plate 47). These have horizontal rows on the rim of crimped coils. In the southern area, one of the neck banded rims has a row of tool punctations under the lip and above the first coil, while another has been lightly brushed between the crimped coils. One of the two neck banded rims from the northern area has a row of tool punctates pushed through one of the crimped coils.

\section{Decorated Fine Wares}

Fine ware sherds from the southern and northern ceramic component/areas total 566 sherds, including 100 rims (Table 6-13). The rims are from carinated bowls and bowls that are decorated almost exclusively along a rim panel, or in the case of the lip notched rims, on the lip itself. All of the fine ware rims from the southern area are engraved, with the northern area fine wares having rims from vessels with engraved-punctated, engraved-lip notched, lip notched, and red-slipped decorations. Engraved-brushed sherds from carinated bowls - with an engraved decoration on the rim panel and brushing on the vessel body-are restricted to the southern area fine wares, while the fine wares with lip notching are found only in the northern site area (see Table 6-13). Engraved bottle sherds are more than twice as common in the northern area fine wares by comparison with the decorated fine wares from the southern part of the site. 
Table 6-12. Incised Sherds.

\begin{tabular}{|c|c|c|c|c|c|c|}
\hline \multirow[t]{2}{*}{ Decorative Element } & \multicolumn{3}{|c|}{ Southern Area } & \multicolumn{3}{|c|}{ Northern Area } \\
\hline & Rim & Body & $\%$ & Rim & Body & $\%$ \\
\hline horizontal lines & 3 & - & 1.9 & 1 & - & 0.3 \\
\hline horizontal and diagonal lines & - & 1 & 0.6 & 3 & 2 & 1.6 \\
\hline horizontal and opposed lines & - & - & - & - & 1 & 0.3 \\
\hline horizontal and vertical lines & 1 & - & 0.6 & 1 & - & 0.3 \\
\hline $\begin{array}{l}\text { horizontal and cross-hatched } \\
\text { lines }\end{array}$ & - & - & - & 1 & - & 0.3 \\
\hline $\begin{array}{l}\text { horizontal and hatched } \\
\text { triangle element* }\end{array}$ & - & 4 & 2.5 & - & 2 & 0.6 \\
\hline $\begin{array}{l}\text { horizontal and diagonal lines } \\
\text { and hatched triangle el.* }\end{array}$ & - & - & - & - & 2 & 0.6 \\
\hline hatched triangle element* & 1 & - & 0.6 & - & - & - \\
\hline widely-spaced parallel lines & - & 23 & 14.6 & - & 51 & 15.9 \\
\hline closely-spaced parallel lines & - & 6 & 3.8 & - & 13 & 4.1 \\
\hline parallel lines & - & 8 & 5.1 & - & 5 & 1.6 \\
\hline parallel and opposed lines & - & - & - & - & 1 & 0.3 \\
\hline parallel hatched zones & - & 1 & 0.6 & - & - & - \\
\hline diagonal lines, widely-spaced & 6 & - & 3.8 & - & - & - \\
\hline diagonal lines & 10 & - & 6.4 & 42 & 3 & 14.1 \\
\hline opposed lines & 5 & 26 & 19.8 & 18 & 42 & 18.8 \\
\hline cross-hatched lines & - & 10 & 6.4 & 8 & 24 & 10.0 \\
\hline $\begin{array}{l}\text { cross-hatched, opposed, } \\
\text { and nested triangle el. }\end{array}$ & - & - & - & - & 1 & 0.3 \\
\hline vertical lines & - & - & - & 2 & - & 0.6 \\
\hline vertical panel & 1 & - & 0.6 & 1 & 1 & 0.6 \\
\hline panels with opposed lines & 2 & 3 & 3.2 & - & 3 & 0.9 \\
\hline $\begin{array}{l}\text { widely-spaced curvilinear } \\
\text { lines }\end{array}$ & - & - & - & - & 2 & 0.6 \\
\hline $\begin{array}{l}\text { closely-spaced curvilinear } \\
\text { lines }\end{array}$ & - & 1 & 0.6 & - & - & - \\
\hline $\begin{array}{l}\text { curvilinear and opposed } \\
\text { lines }\end{array}$ & - & 1 & 0.6 & - & - & - \\
\hline $\begin{array}{l}\text { curvilinear and parallel lines } \\
\text { curvilinear, opposed, and }\end{array}$ & - & - & - & - & 1 & 0.3 \\
\hline horizontal lines & - & - & - & - & 1 & 0.3 \\
\hline single curvilinear line & - & 1 & 0.6 & - & 6 & 1.9 \\
\hline hatched circular element & - & - & - & - & 1 & 0.3 \\
\hline single straight line & - & $43^{* *}$ & 27.4 & - & 81 & 25.3 \\
\hline Totals & 29 & 128 & 157 & 77 & 243 & 320 \\
\hline
\end{tabular}

*decorative element is also found on Poynor Engraved vessels from the site; I am tempted to call this group of sherds Poynor Incised, but have resisted the temptation here.

**one with an incised line on the interior vessel sherd surface 


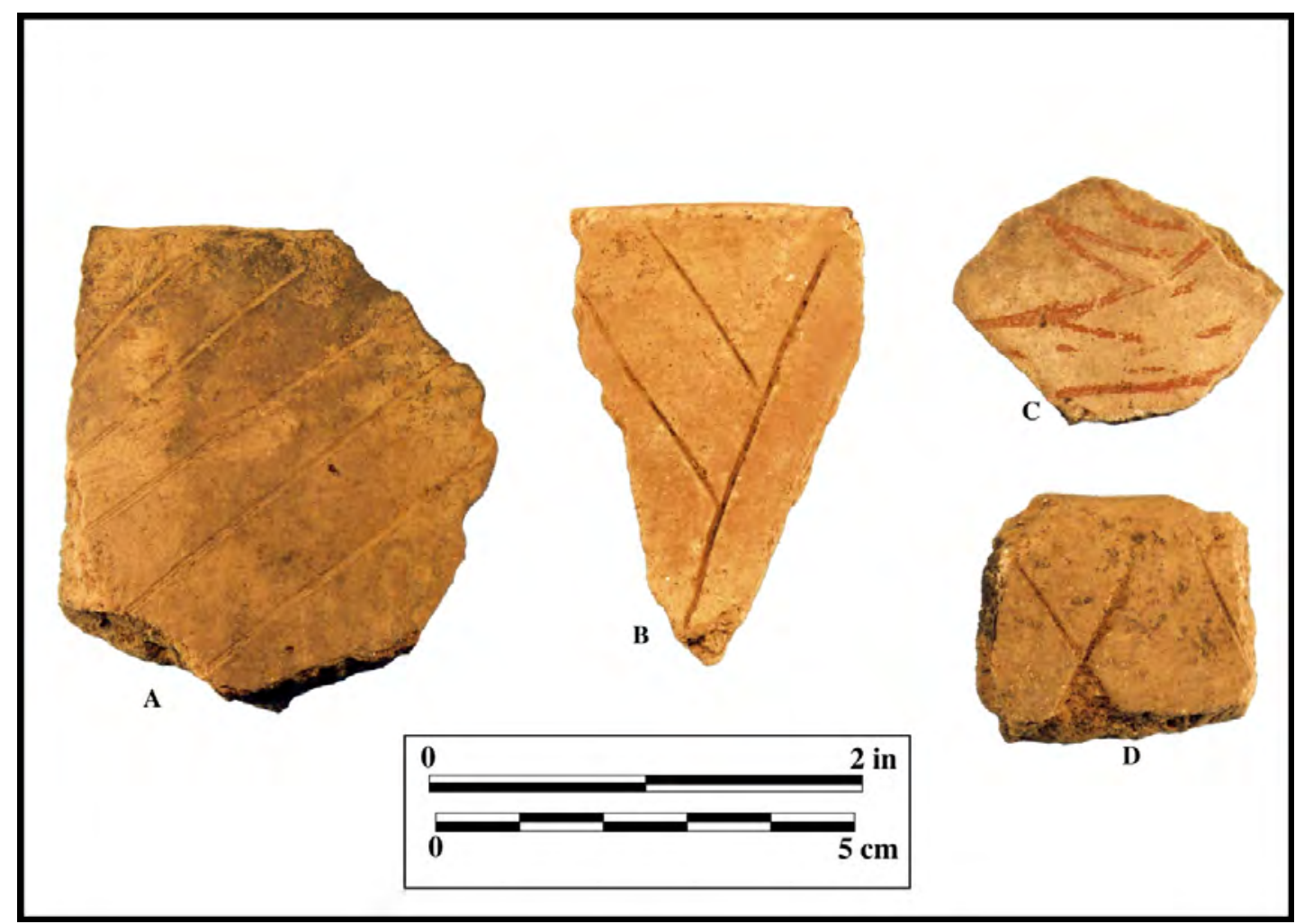

Figure 6-12. Incised and Engraved Sherds from the Northern Part of the Lang Pasture Site: a, diagonal incised rim; b, opposed incised rim; c, engraved bottle sherd; d, horizontal and cross-hatched incised rim. Provenience: a, N196 E201, Feature 36B, level 3; b, N199 E202, Feature 76, level 8; c, N198 E202, Feature 76, level 11; d, N198 E202, Feature 76, level 12.

\section{Engraved Sherds}

The engraved fine wares from bowls and carinated bowls from the Lang Pasture site include 94 rim sherds and 300 body sherds (see Table 6-13). The fine wares have the most diverse range of decorative elements, with geometric designs, the use of panels and zones, hatched triangular and circular elements, opposed lines, curvilinear lines, and ovals-as well as combinations of various elements (Table 6-14)—found primarily on the rim panel of bowls and carinated bowls; in this case, body sherds simply represent the lowermost part of a rim panel, with the lip missing (Figure 6-13b, d-h, j-t and Figure 614a-k, o-s, u-v). A number of these decorative elements feature the use of red or white clay pigments (see discussion below) that had been rubbed in the engraved lines, or in one instance also smeared across the vessel surface.

The northern area engraved carinated bowl and bowl sherds have six principal sets of decorative elements (Table 6-14). These are (1) sets of parallel lines, either closely or widely-spaced, (2) sets of opposed lines (see Figure 6-14f), (3) sets of curvilinear lines, (4) panels that run in various directions that are filled with straight engraved lines (see Figures 6-3d, 6-4d, and 6-9b; see also Figure 6-16c) as well as hatched (see Figure 6-14g, i-j, r) and cross-hatched lines (see Figure 6-14s, u), (5) horizontal lines and hatched triangles (Figure 6-15a-c, see also Figure 6-14b-c, v), and (6) hatched elements, principally triangles (see Figure 6-9d), but also including circles and ladders. 
Table 6-13. Fine Wares.

\begin{tabular}{|c|c|c|c|c|c|c|}
\hline \multirow[t]{2}{*}{ Decorative Method } & \multicolumn{3}{|c|}{ Southern Area } & \multicolumn{3}{|c|}{ Northern Area } \\
\hline & $\operatorname{Rim}$ & Body & $\%$ & $\operatorname{Rim}$ & Body & $\%$ \\
\hline Engraved & 48 & 109 & 80.5 & 46 & 191 & 63.8 \\
\hline Engraved, bottle & - & 27 & 13.8 & - & 111 & 30.0 \\
\hline Engraved-Brushed & - & 3 & 1.5 & - & - & - \\
\hline Engraved-Punctated & - & 2 & 1.0 & 2 & 6 & 2.2 \\
\hline Engraved-Lip Notched & - & - & - & 1 & - & 0.3 \\
\hline Lip Notched & - & - & - & 2 & - & 0.5 \\
\hline Red-slipped & - & 6 & 3.1 & 1 & 11 & 3.2 \\
\hline Totals & 48 & 147 & 195 & 52 & 319 & 371 \\
\hline
\end{tabular}

Table 6-14. Engraved Carinated Bowl and Bowl Fine Wares.

\begin{tabular}{|c|c|c|c|c|c|c|}
\hline \multirow[t]{2}{*}{ Decorative Element } & \multicolumn{3}{|c|}{ Southern Area } & \multicolumn{3}{|c|}{ Northern Area } \\
\hline & $\operatorname{Rim}$ & Body & $\%$ & Rim & Body & $\%$ \\
\hline panel & - & 4 & 2.5 & - & - & - \\
\hline $\begin{array}{l}\text { hatched panel } \\
\text { hatched and curvilinear }\end{array}$ & 1 & 1 & 1.3 & 2 & 3 & 2.1 \\
\hline panels & - & - & - & - & $1 *$ & 0.4 \\
\hline $\begin{array}{l}\text { horizontal and hatched panel } \\
\text { horizontal and curvilinear }\end{array}$ & - & - & - & 1 & - & 0.4 \\
\hline panels & - & - & - & 1 & - & 0.4 \\
\hline horizontal and triangular panel & 1 & - & 0.6 & - & - & - \\
\hline panel with opposed lines & - & - & - & 1 & 7* & 3.4 \\
\hline cross-hatched panel & - & - & - & - & 2 & 0.8 \\
\hline $\begin{array}{l}\text { panels and curvilinear } \\
\text { hatched zone }\end{array}$ & - & - & - & - & 1 & 0.4 \\
\hline $\begin{array}{l}\text { diagonal hatched panel } \\
\text { vertical panel and }\end{array}$ & - & - & - & $1^{*}$ & 1 & 0.8 \\
\hline hatched triangles & - & - & - & 1 & - & 0.4 \\
\hline Subtotal with panels & 2 & 5 & 4.4 & $6^{*}$ & $15^{*}$ & 8.9 \\
\hline cross-hatched zone & - & 2 & 1.3 & - & 3 & 1.3 \\
\hline $\begin{array}{l}\text { horizontal and vertical lines } \\
\text { and cross-hatched zone } \\
\text { horizontal and diagonal } \\
\text { hatched zones and oval-filled }\end{array}$ & 1 & - & 0.6 & - & - & - \\
\hline panels & - & - & - & - & 1 & 0.4 \\
\hline triangular excised zone & - & - & - & - & $2 *$ & 0.8 \\
\hline curvilinear zone & - & - & - & - & 1 & 0.4 \\
\hline $\begin{array}{l}\text { curvilinear hatched zone } \\
\text { curvilinear hatched zone and }\end{array}$ & - & - & - & - & $1 *$ & 0.4 \\
\hline cross-hatched triangular el. & - & - & - & - & 1 & 0.4 \\
\hline Subtotal with engraved zones & 1 & 2 & 1.9 & $\mathbf{0}$ & 9* & 3.8 \\
\hline
\end{tabular}


Table 6-14, continued.

\begin{tabular}{|c|c|c|c|c|c|c|}
\hline \multirow[t]{2}{*}{ Decorative Element } & \multicolumn{3}{|c|}{ Southern Area } & \multicolumn{3}{|c|}{ Northern Area } \\
\hline & Rim & Body & $\%$ & Rim & Body & $\%$ \\
\hline hatched ladders & $1^{*}$ & 2 & 1.9 & - & - & - \\
\hline hatched triangles & 2 & $8^{*}$ & 6.4 & 2 & $9 * *$ & 4.6 \\
\hline $\begin{array}{l}\text { hatched triangle and hatched } \\
\text { semi-circle }\end{array}$ & - & - & - & - & 1 & 0.4 \\
\hline hatched circle & - & - & - & 2* & $1^{*}$ & 1.3 \\
\hline Subtotal with hatched el. & $3^{*}$ & $10 *$ & 8.3 & $4^{*}$ & $11 *$ & 6.3 \\
\hline $\begin{array}{l}\text { horizontal lines and hatched } \\
\text { triangular el. }\end{array}$ & 2 & 7 & 5.7 & 4 & 15 & 8.0 \\
\hline $\begin{array}{l}\text { horizontal lines, hatched } \\
\text { triangles, and cross- }\end{array}$ & & & & & & \\
\hline $\begin{array}{l}\text { hatched circles } \\
\text { horizontal lines and rows }\end{array}$ & - & - & - & - & 1 & 0.4 \\
\hline $\begin{array}{l}\text { of hatched triangles } \\
\text { horizontal lines and cross- }\end{array}$ & - & - & - & - & 2 & 0.8 \\
\hline $\begin{array}{l}\text { hatched triangular el. } \\
\text { horizontal lines, hatched }\end{array}$ & - & - & - & 1 & 1 & 0.8 \\
\hline triangles, and negative ovals & - & 1 & 0.6 & - & - & - \\
\hline $\begin{array}{l}\text { horizontal-diagonal lines and } \\
\text { hatched triangular el. }\end{array}$ & 4 & 1 & 3.2 & - & - & - \\
\hline $\begin{array}{l}\text { horizontal and vertical lines } \\
\text { and hatched triangle el. }\end{array}$ & 1 & 1 & 1.3 & - & - & \\
\hline $\begin{array}{l}\text { Subtotal, horizontal lines } \\
\text { and hatched triangles }\end{array}$ & 7 & 10 & 10.8 & 5 & 19 & 8.0 \\
\hline $\begin{array}{l}\text { horizontal and vertical lines } \\
\text { and hatched semi-circle }\end{array}$ & - & - & - & - & 1 & 0.4 \\
\hline $\begin{array}{l}\text { horizontal lines and semi- } \\
\text { circular hatched zone }\end{array}$ & - & $1 *$ & 0.6 & - & - & 0.4 \\
\hline $\begin{array}{l}\text { horizontal lines and hatched } \\
\text { circle }\end{array}$ & & & & & & \\
\hline $\begin{array}{l}\text { circle } \\
\text { horizontal and curvilinear }\end{array}$ & 1 & - & 0.6 & - & - & - \\
\hline $\begin{array}{l}\text { lines around cross-hatched } \\
\text { circle }\end{array}$ & - & - & - & - & 1 & 0.4 \\
\hline $\begin{array}{l}\text { Subtotal, horizontal and } \\
\text { circle/semi-circle el. }\end{array}$ & 1 & 1* & 1.2 & - & 2 & 0.8 \\
\hline horizontal and curvilinear & & & & & & \\
\hline $\begin{array}{l}\text { lines } \\
\text { horizontal and curvilinear }\end{array}$ & - & - & - & - & $1 *$ & 0.4 \\
\hline $\begin{array}{l}\text { lines, outer line with } \\
\text { triangular tick marks }\end{array}$ & 1 & - & 0.6 & - & - & - \\
\hline $\begin{array}{l}\text { Subtotal, horizontal and } \\
\text { curvilinear lines }\end{array}$ & 1 & - & 0.6 & - & 1 & 0.4 \\
\hline widely-spaced diagonal lines & 3 & - & 1.9 & - & - & - \\
\hline diagonal lines & 1 & 1 & 1.3 & 8 & $1^{*}$ & 3.8 \\
\hline diagonal and vertical lines & 1 & - & 0.6 & - & - & - \\
\hline diagonal and opposed lines & - & 1 & 0.6 & - & - & - \\
\hline
\end{tabular}


Table 6-14, continued.

\begin{tabular}{|c|c|c|c|c|c|c|}
\hline \multirow{2}{*}{ Decorative Element } & \multicolumn{3}{|c|}{ Southern Area } & \multicolumn{3}{|c|}{ Northern Area } \\
\hline & Rim & Body & $\%$ & Rim & Body & $\%$ \\
\hline Subtotal, diagonal lines & 5 & 2 & 4.4 & 8 & $1^{*}$ & 3.8 \\
\hline horizontal lines & 14 & 5 & 12.1 & $9 *$ & $4 *$ & 5.5 \\
\hline $\begin{array}{l}\text { horizontal and diagonal lines } \\
\text { horizontal and diagonal }\end{array}$ & 3 & 2 & 3.2 & - & - & - \\
\hline $\begin{array}{l}\text { lines with small triangular } \\
\text { tick marks }\end{array}$ & - & - & - & 1 & - & 0.4 \\
\hline $\begin{array}{l}\text { horizontal and vertical lines } \\
\text { horizontal and cross-hatched }\end{array}$ & 2 & 1 & 1.9 & - & - & - \\
\hline lines & - & 1 & 0.6 & - & - & - \\
\hline $\begin{array}{l}\text { Subtotal, horizontal and other } \\
\text { geometric el. }\end{array}$ & 5 & 4 & 5.7 & 1 & - & 0.4 \\
\hline closely-spaced parallel lines & - & $8^{*}$ & 5.1 & - & 21 & 8.9 \\
\hline widely-spaced parallel lines & - & 10 & 6.4 & - & 11 & 4.6 \\
\hline $\begin{array}{l}\text { parallel lines } \\
\text { parallel lines with triangular }\end{array}$ & - & 1 & 0.6 & - & 1 & 0.4 \\
\hline tick marks & - & - & - & - & 1 & 0.4 \\
\hline Subtotal, parallel lines & - & $19 *$ & 12.1 & - & 34 & 14.3 \\
\hline $\begin{array}{l}\text { opposed lines } \\
\text { opposed lines with small }\end{array}$ & 1 & 9 & 6.4 & - & $24^{*}$ & 10.1 \\
\hline triangular tick marks & - & 1 & 0.6 & - & 1 & 0.4 \\
\hline Subtotal, opposed lines & 1 & 10 & 7.0 & - & $25^{*}$ & 10.5 \\
\hline cross-hatched lines & - & 1 & 0.6 & - & - & - \\
\hline $\begin{array}{l}\text { vertical lines } \\
\text { vertical lines and hatched }\end{array}$ & 1 & - & 0.6 & - & - & - \\
\hline triangle & 1 & - & 0.6 & - & - & - \\
\hline Subtotal, vertical lines & 2 & - & 1.2 & - & - & - \\
\hline closely-spaced curvilinear & & & & & & \\
\hline $\begin{array}{l}\text { lines } \\
\text { widely-spaced curvilinear }\end{array}$ & - & 3 & 1.9 & - & 8 & 3.4 \\
\hline lines & - & 2 & 1.3 & - & - & - \\
\hline $\begin{array}{l}\text { single broad curvilinear line } \\
\text { curvilinear and diagonal }\end{array}$ & - & 1 & 0.6 & - & - & - \\
\hline opposed lines & - & - & - & 1 & - & 0.4 \\
\hline single curvilinear line & - & 4 & 2.5 & 1 & $11^{* *}$ & 5.1 \\
\hline $\begin{array}{l}\text { vertical curvilinear lines } \\
\text { curvilinear lines and }\end{array}$ & 1 & - & 0.6 & - & - & - \\
\hline $\begin{array}{l}\text { hatched triangles } \\
\text { curvilinear line with }\end{array}$ & - & - & - & - & 2 & 0.8 \\
\hline triangular tick marks & 1 & 1 & 1.3 & - & - & - \\
\hline Subtotal, curvilinear lines & 2 & 11 & 8.2 & 2 & 21 & 9.7 \\
\hline ovals & $4^{*}$ & 3 & 4.5 & 2 & 2 & 1.7 \\
\hline hatched oval & - & 1 & 0.6 & & & \\
\hline $\begin{array}{l}\text { nested triangle and oval } \\
\text { oval, hatched semi-circles }\end{array}$ & - & - & - & 1 & - & 0.4 \\
\hline
\end{tabular}


Table 6-14, continued.

\begin{tabular}{|c|c|c|c|c|c|c|}
\hline \multirow[t]{2}{*}{ Decorative Element } & \multicolumn{3}{|c|}{ Southern Area } & \multicolumn{3}{|c|}{ Northern Area } \\
\hline & $\operatorname{Rim}$ & Body & $\%$ & $\operatorname{Rim}$ & Body & $\%$ \\
\hline and triangles, and & & & & & & \\
\hline horizontal lines & - & - & - & 1 & - & 0.4 \\
\hline Subtotal, ovals & $4^{*}$ & 4 & 5.1 & 4 & 2 & 2.5 \\
\hline circle el. & - & - & - & - & 1 & 0.4 \\
\hline single straight line & - & 22 & 14.0 & - & 37 & 15.6 \\
\hline $\begin{array}{l}\text { Single straight line with } \\
\text { triangular tick marks }\end{array}$ & - & 3* & 1.9 & - & - & - \\
\hline Totals & 48 & 109 & 157 & 46 & 191 & 237 \\
\hline
\end{tabular}

The triangles occur in sets, with different size, and they are presumably pendant from either horizontal, diagonal, or curvilinear lines on rim panels.

The frequency of the horizontal engraved line element (5.5\%) simply is an indication that the carinated bowls and bowls had panels of decoration delimited by horizontal lines that encircled the vessel along the rim. It is possible that some of these horizontal engraved sherds are from effigy vessels, but no effigy heads or tabtails were recovered in the northern area sherds.

Other engraved decorative elements from the northern area feature broader zones filled with hatching, cross-hatching (see Figure 6-14p), or excising, sets of horizontal and curvilinear lines, also probably part of large ovals or circular motifs on rim panels, and ovals (see Figure 6-14d), including small nested ovals (see Figure 6-14i), and large triangular nested ovals (see Figure 6-14o).
Horizontal and circular elements (see Figure 6-14k), and engraved circles are also present in the fine wares, but account for only $1.2 \%$ of the decorated sherds in this part of the site.

Excluding the parallel and horizontal line decorative elements - which presumably framed the rimpanel or are from Hood Engraved effigy vessels--the engraved fine wares in the southern area are dominated by horizontal lines and hatched triangles (see Figures $6-5 \mathrm{c}$ and 6-13e-f, l), and hatched triangles (see Figure 6-4b). Other important elements include sets of curvilinear lines, likely part of oval motifs (Figure 6-13g), opposed lines, and horizontal lines in combination with other geometric elements (i.e., diagonal, vertical, and cross-hatched lines, see Figure 6-13h, p, r) (see Table 6-14). 
<smiles>CCCC1CC1C</smiles>

a

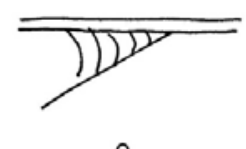

e

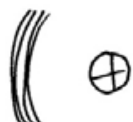

i

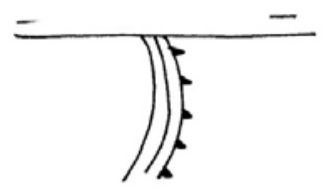

$\mathrm{m}$

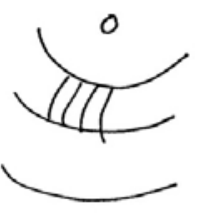

q

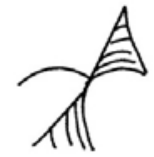

b

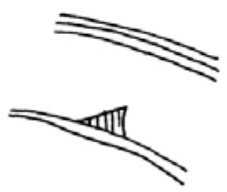

f
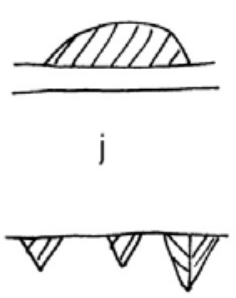

n
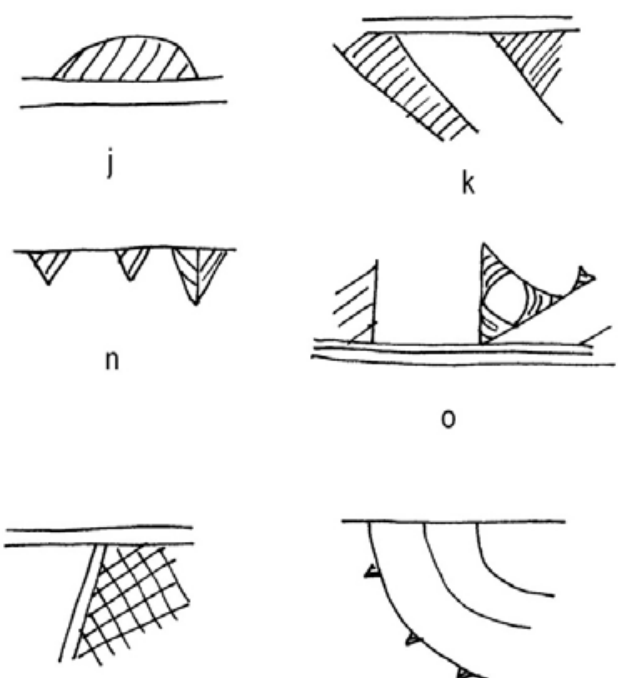

$r$
0

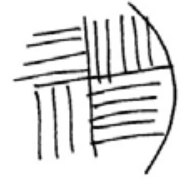

$\mathrm{C}$

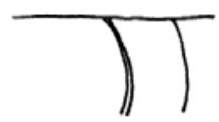

g

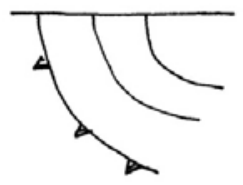

S

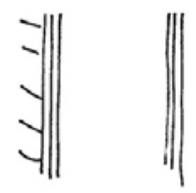

d

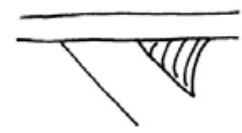

h
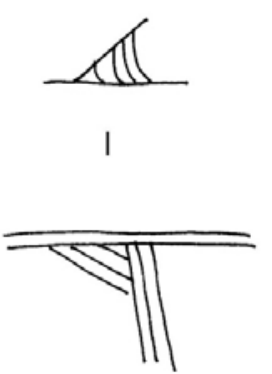

$p$

Figure 6-13. Selected Decorative Elements and Motifs in the Engraved Fine Wares from the southern part of the Lang Pasture site: a, engraved-punctated; b, d-h, j-p, r-t, engraved carinated bowls and bowls; c, i, q, engraved bottles. Provenience: a, N183 E201, level 5, INAA 38-43; b, N176 E199, level 4, INAA 38-35; c, N177 E200, level 2; d, N178 E200, level 1; e, N178 E201, level 4; f, N179 E200, level 4; g, N181 E201, level 3; h, N170 E198, level 4; i, N172 E199, level 4; j, N173 E198, level 4; k, N174 E199, level 4; I, N176 E200, level 3; m, N177 E198, level 3; n, N182 E202, level 3; o, N183 E200, level 3; p, N185 E199, level 4; q, N187 E199, level 5; r, N184 E202, level 3; s, N183 E201, level 6; t, N174 E201, level 5. 


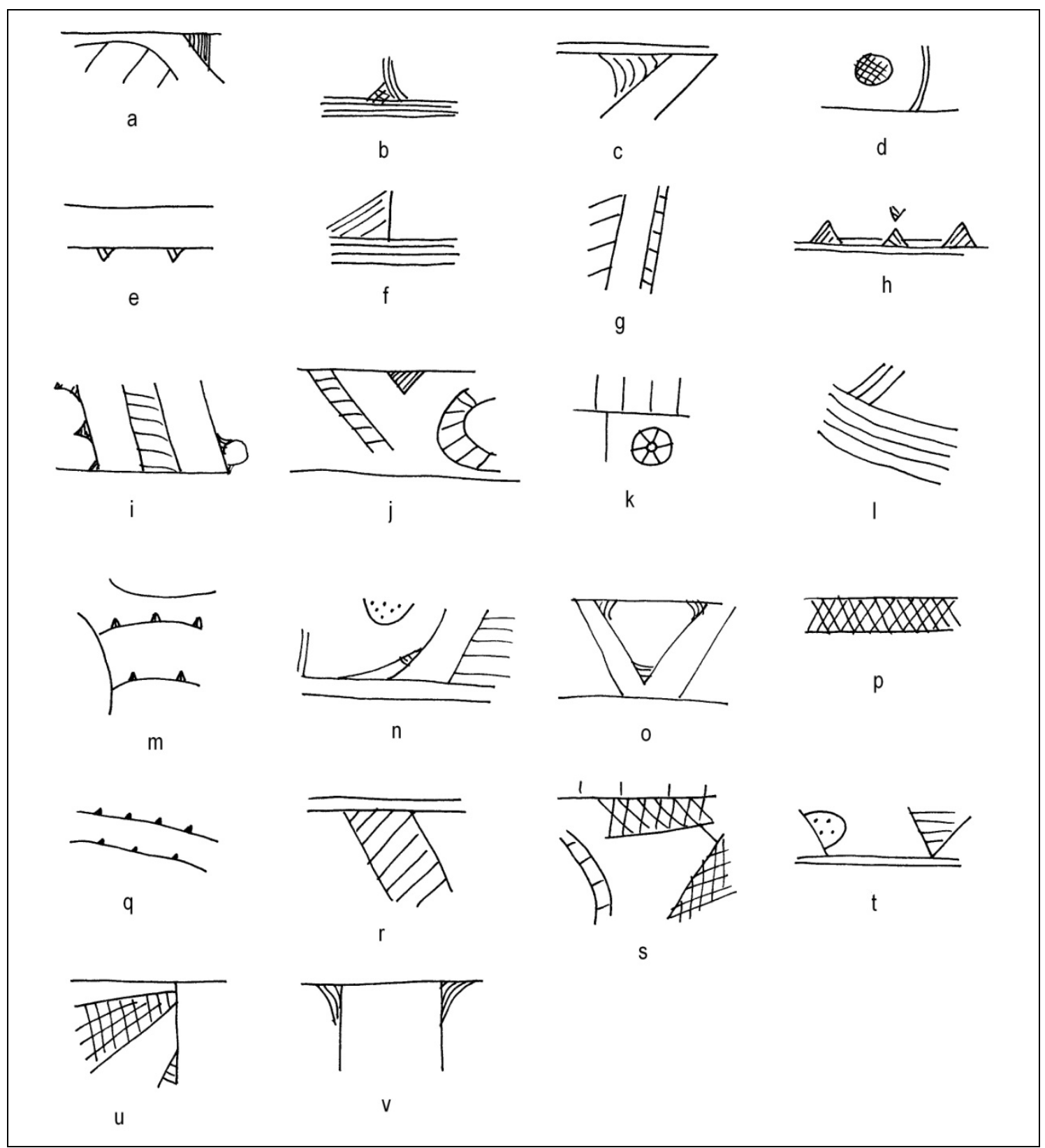

Figure 6-14. Selected Decorative Elements and Motifs in the Engraved Fine Wares from the Northern Part of the Lang Pasture Site: a-k, o-s, u-v, engraved carinated bowls and bowls; I-m, engraved bottles; $n$, t, engraved-punctated. Provenience: a, N198 E202, Feature 76, level 8; b, N197 E202, Feature 76, level 11; c, e, N198-202, Feature 76, level 11; d, N199 E200, Feature 76B, level 9; f, N193 E201, level 2, INAA 38-27; g, N193E202, level 3, INAA 38-29; h, N191 E202, level 1, INAA 38-4; i, N190 E202, level 3,INAA 38-6; j. N199 E202, level 4; k, N190 E200, level 3; I, N193 E199, level 3; m, N193E202, level 5; n, N197 E199, level 2; o, N197 E202, level 5; p, N199 E199, level 2; q,N199 E203, level 3; r, N203 E200, level 2; s, N205 E200, level 1; t, N206 E199, level 1; u,N199 E198, level 3; v, N197 E203, Feature 76B. 


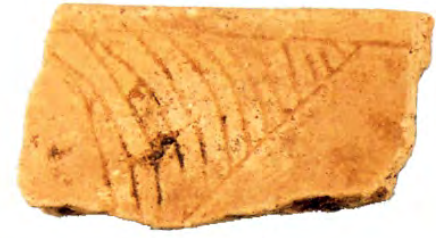

A

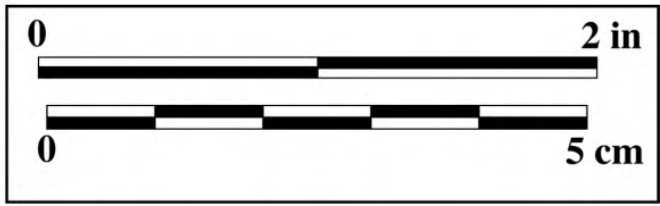

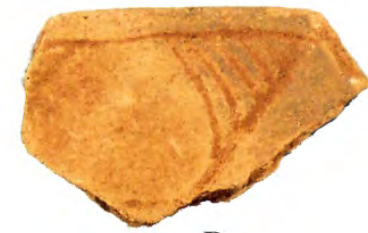

B

Figure 6-15. Poynor Engraved Rims with Hatched Triangle Decorative Elements and/or Panel Dividers. Provenience: a, N197 E203, Feature 76, level 12; b, N198 E202, Feature 76, Level 11; c, N197 E203, Feature 76B, 70-85 cm.

As with the engraved fine wares from the northern area, other decorative elements in the fine wares include panels (see Figure 6-13d, k), zones (see Figure 6-13r), horizontalcircular/semi-circular (see Figure 6-13j), horizontal-curvilinear, occasionally with appended hatched triangles (see Figure 6-13t), and ovals. In some cases, the ovals are formed by the use of other elements, typically hatched triangles, thus forming negative ovals (see Figure 6-13b, o) that are part of a larger rim panel motif. Engraved panels and zones are more common elements in the northern area $(12.7 \%)$ when compared to the southern area (6.3\%), while conversely engraved elements with circles, semi-circles, horizontal and curvilinear lines, and ovals are better represented in the southern area $(10.7 \%)$ than they are in the northern area (7.1\%).

Decorative elements in these engraved fine wares that are unique to the southern area are cross-hatched lines and vertical lines (see Table 6-14). However, these only represent $1.8 \%$ of the engraved carinated bowl and bowl sherds. The vertical lines likely represent rim panel dividers on Poynor Engraved, var.
Blackburn vessels. The cross-hatched engraved vessel sherd is from a typologically unidentified vessel.

In most particulars, these sets of decorative elements in the engraved fine ware carinated bowls and bowls from the northern and southern areas are found on Poynor Engraved vessels in the upper Neches River basin (see Suhm and Jelks 1962:Plate 62a-j), many with hatched triangles of various sizes appended to larger motifs on rim panels. In many cases, the engraved lines are relatively fine and narrow, but "poorly executed, with little contrast between surface colors and the cores exposed by engraving” (Suhm and Jelks 1962:123). The decorations on these engraved vessels feature-either in a singular fashion or in combination-triangular, oval, or circular motifs on rim panels filled in with closely to widely-spaced hatching or cross-hatched lines, usually with appended hatched triangles. The engraved sherds with oval elements on the rim are most likely from Poynor Engraved, var. Cook vessels (see below), and those with geometric lines and geometric lines with appended hatched triangles are from Poynor 
Engraved, var. Blackburn vessels, or any number of unspecified varieties of Poynor Engraved, of which I have identified 22 from the study of whole vessels in the region (see below) and a further five local varieties at the Lang Pasture site (see below).

Larger hatched triangle elements below the lip on one sherd from the southern area indicate it is probably from a Hume Engraved bowl (see Suhm and Jelks 1962:83). The size and hatching on these triangles is comparable to the hatched triangles noted on cylindrical Hume Engraved bottles (see Suhm and Jelks 1962:Plate 42b-c) rather than to the larger and repeatedly hatched triangular elements on carinated bowls and bowls in the assemblage.

Eight sherds from the northern $(\mathrm{n}=3,1.3 \%)$ and southern $(n=5,3.2 \%)$ areas have straight, parallel, curvilinear, or opposed engraved lines with small triangular tick marks (see Figure 6$13 \mathrm{~m}, \mathrm{~s}$ and Figure 6-14q). These are from several different varieties of Patton Engraved (see below; see also Suhm and Jelks 1962:Plate 59), including Patton Engraved, var. Allen and var. Patton. Patton Engraved is the dominant Allen phase (post-A.D. 1650) fine ware in the upper Neches River basin, but is also found in low amounts in ca. A.D. 15601650 Frankston phase sites (see below). As such, these few sherds, along with Patton Engraved sherds from the Lang Pasture midden (see Perttula et al. 2007), constitute evidence for limited use of this part of the site well after the end of the principal prehistoric Caddo occupation in the TxDOT right-of-way area.

\section{Engraved Bottle Sherds}

As mentioned above, engraved bottle sherds are very common in the northern part of the Lang Pasture site, where they account for 30\% of all the fine wares (see Table 6-6). By contrast, only $13.8 \%$ of the fine ware sherds from the southern area are from bottles. Red clay pigments were frequently rubbed in the engraved lines of the bottles, particularly in the northern site area.

Although difficult to characterize by style or motifs, the same range of engraved decorative elements (although in different proportions by site area) are found on both the carinated bowls/bowls and the bottles (Table 6-15, see Table 6-13). Most likely, many of these bottle sherds are from globular Poynor Engraved bottles (see Suhm and Jelks 1962:Plate 63g-j) rather than the elongated bottle form (see Suhm and Jelks 1962:Plate 63a-f), as long vertical decorative motifs as occur on these elongated forms (as they do on Hume Engraved bottles) were not clearly identified in the Lang Pasture bottle sherds. In many cases, particularly bottle sherds with curvilinear lines, parallel lines, diagonal lines, or opposed lines, they cannot be typologically classified.

On post-ca. A.D. 1300 bottles in the upper Neches River basin, the decorative elements and motifs are commonly oriented vertically to follow the shape of the bottle, except on globular bottles-where the designs are oriented horizontally to fit the broader bottle body-and the designs are in consequence unconstrained because they did not need to be confined to a rim panel as is the case with the engraved carinated bowls and bowls. 
Table 6-15. Engraved Bottle Sherds.

\begin{tabular}{|c|c|c|c|c|c|c|}
\hline \multirow[t]{2}{*}{ Decorative eEement } & \multicolumn{3}{|c|}{ Southern Area } & \multicolumn{3}{|c|}{ Northern Area } \\
\hline & Rim & Body & $\%$ & Rim & Body & $\%$ \\
\hline widely-spaced curvilinear & & & & & & \\
\hline $\begin{array}{l}\text { lines } \\
\text { closely-spaced curvilinear }\end{array}$ & - & 1 & 3.7 & - & 5 & 4.5 \\
\hline lines & - & $3^{*}$ & 11.1 & - & $7^{*}$ & 6.3 \\
\hline $\begin{array}{l}\text { opposed curvilinear lines } \\
\text { opposed curvilinear lines }\end{array}$ & - & - & - & - & $11^{*}$ & 10.0 \\
\hline $\begin{array}{l}\text { with hatched triangles } \\
\text { curvilinear lines with }\end{array}$ & - & - & - & - & $3^{*}$ & 2.7 \\
\hline $\begin{array}{l}\text { hatched triangles } \\
\text { curvilinear lines and }\end{array}$ & - & 2 & 7.4 & - & $4^{*}$ & 3.6 \\
\hline $\begin{array}{l}\text { triangle element } \\
\text { curvilinear lines and }\end{array}$ & - & - & - & - & 1 & 0.9 \\
\hline hatched circle & - & - & - & - & $2 *$ & 1.8 \\
\hline $\begin{array}{l}\text { single curvilinear line } \\
\text { horizontal and curvilinear }\end{array}$ & - & 1 & 3.7 & - & $10^{*}$ & 9.0 \\
\hline lines, closely-spaced & - & - & - & - & 1 & 0.9 \\
\hline Subtotal, curvilinear els. & - & $7^{*}$ & 25.9 & - & $43^{*}$ & 39.6 \\
\hline ovals & - & $1 *$ & 3.7 & - & $2 *$ & 1.8 \\
\hline ovals and central circle/cross & - & 2 & 7.4 & - & - & - \\
\hline Subtotal, ovals & - & $3^{*}$ & 11.1 & - & 2* & 1.8 \\
\hline parallel lines, widely-spaced & - & - & - & - & $5 *$ & 4.5 \\
\hline $\begin{array}{l}\text { parallel lines and triangles } \\
\text { parallel lines and hatched }\end{array}$ & - & 1 & 3.7 & - & - & - \\
\hline circles & - & 1 & 3.7 & - & - & - \\
\hline Subtotal, parallel lines & - & 2 & 7.4 & - & $5 *$ & 4.5 \\
\hline panel with horizontal and & & & & & & \\
\hline $\begin{array}{l}\text { vertical lines } \\
\text { parallel panel }\end{array}$ & $\begin{array}{l}- \\
-\end{array}$ & $\begin{array}{l}1 \\
-\end{array}$ & $\begin{array}{l}3.7 \\
-\end{array}$ & $\begin{array}{l}- \\
-\end{array}$ & $\begin{array}{l}1 \\
1\end{array}$ & $\begin{array}{l}0.9 \\
0.9\end{array}$ \\
\hline Subtotal, panels & - & 1 & 3.7 & - & 2 & 1.8 \\
\hline hatched triangles & - & $3^{*}$ & 11.1 & - & $13^{*}$ & 11.7 \\
\hline $\begin{array}{l}\text { hatched triangles and ovals } \\
\text { hatched triangles and }\end{array}$ & - & 1 & 3.7 & - & - & - \\
\hline horizontal lines & - & - & - & - & $10^{*}$ & 9.0 \\
\hline cross-hatched triangle & - & - & - & - & 1 & 0.9 \\
\hline Subtotal, triangle el. & - & $4 *$ & 14.8 & - & $24 *$ & 21.6 \\
\hline hatched circle and panel & - & - & - & - & 1 & 0.9 \\
\hline cross-hatched circle & - & - & - & - & 1 & 0.9 \\
\hline hatched semi-circle & - & - & - & - & $1 *$ & 0.9 \\
\hline circular line & - & - & - & - & 2 & 1.8 \\
\hline $\begin{array}{l}\text { Subtotal, circles and } \\
\text { semi-circles }\end{array}$ & - & - & - & - & $5 *$ & 4.5 \\
\hline hatched zones & - & 3* & 11.1 & - & - & - \\
\hline opposed hatched zones & - & $1^{*}$ & 3.7 & - & - & - \\
\hline diagonal hatched zones & - & - & - & - & $4^{*}$ & 3.6 \\
\hline
\end{tabular}


Table 6-15, continued

\begin{tabular}{|c|c|c|c|c|c|c|}
\hline \multirow[t]{2}{*}{ Decorative Element } & \multicolumn{3}{|c|}{ Southern Area } & \multicolumn{3}{|c|}{ Northern Area } \\
\hline & Rim & Body & $\%$ & Rim & Body & $\%$ \\
\hline curvilinear hatched zone & & & & & & \\
\hline and framed circle & - & 1 & 3.7 & - & - & - \\
\hline Subtotal, hatched zones & - & $5^{*}$ & 18.5 & - & $4^{*}$ & 3.6 \\
\hline curvilinear lines and & & & & & 1 & \\
\hline & & & & & & \\
\hline widely-spaced diagonal lines & - & 2 & 7.4 & - & - & - \\
\hline opposed lines & - & - & - & - & $10 *$ & 9.0 \\
\hline $\begin{array}{l}\text { opposed lines and hatched } \\
\text { triangles }\end{array}$ & - & - & - & - & 3 & 2.7 \\
\hline $\begin{array}{l}\text { opposed lines with triangular } \\
\text { tick marks }\end{array}$ & - & 1 & 3.7 & - & - & - \\
\hline Subtotal, opposed lines & - & 1 & 3.7 & - & $13^{*}$ & 11.7 \\
\hline $\begin{array}{l}\text { single straight line } \\
\text { single straight line with }\end{array}$ & - & 2 & 7.4 & - & $10^{*}$ & 9.0 \\
\hline triangular tick mark & - & - & - & - & 1 & 0.9 \\
\hline Totals & - & 27 & 27 & - & 111 & 100 \\
\hline
\end{tabular}

*includes at least one sherd with red pigment in the engraved lines

Common engraved elements on the bottles from the Lang Pasture site include sets of curvilinear lines, hatched triangles, ovals, hatched circles, hatched zones, circles and semi-circles, and opposed lines (Figure 6-16ab, see also Figure 6-12c, Figure 6-13c, i, q, and Figure 6-14l-m). These are also popular decorative elements on the carinated bowls and bowls (see Table 6-14).

Engraved bottle sherds from the two site areas are distinct from one another with respect to the proportions of different decorative elements (see Table 6-15), although virtually each engraved bottle decorative element is represented in both site areas. That they share many decorative elements, but in slightly different proportions, presumably represents evidence of subtle stylistic changes over time effected by Caddo potters in how bottles were to be decorated, as well as engraved bottle styles preferred by the Lang Pasture community. It is a fact that curvilinear engraved elements (see Figure 6-13i, q, Figure $6-14 \mathrm{~m}$, and Figure 6-16b) are the most common decorative element among the engraved bottle sherds in both site areas, but this particular decorative element is better represented in the northern, and earlier, area decorated bottles (see Table 6-14).

In the northern area, in addition to curvilinear engraved lines as the dominant decorative element, other important engraved elements include hatched triangles (see Figure 6-16a) pendant from other sets of engraved lines, and sets of opposed engraved lines (see Figure 614l); all three elements are more abundant in the northern area bottles than they are in the southern area engraved bottle sherds. These three categories of engraving comprise $73 \%$ of the decorative elements on the northern area bottle sherds (see Table 6-14). The one engraved bottle decoration that appears 
confined to the northern area is circles and semi-circles, with the exception of one large circle filled with a checkerboard zone of hatched squares from the southern area (see Figure 6-13c).

Southern area engraved bottle sherds have four principal decorative elements: sets of curvilinear lines (25.9\%); hatched zones (18.5\%) or panels $(3.7 \%)$, zones or panels being separated depending upon the width and separation of the engraved area from other decorative elements on the bottle; triangular elements, usually hatched (14.8\%); and ovals (11.1\%, see Figure 6-13i). Diagonal engraved lines on bottles (7.4\%) are also more common on the southern area bottles.
Two bottle sherds - one from each site areahave triangular tick marks on either straight or opposed engraved lines. These are from Poynor Engraved bottles (see Suhm and Jelks 1962:Plate 63g).

\section{Engraved-Brushed}

All three of the engraved-brushed sherds are from the southern area of the Lang Pasture site (see Table 6-13). All three are from carinated bowls, with horizontal brushing on the vessel body and either horizontal $(\mathrm{n}=2)$ or horizontaldiagonal $(n=1)$ engraved lines on the rim panel.

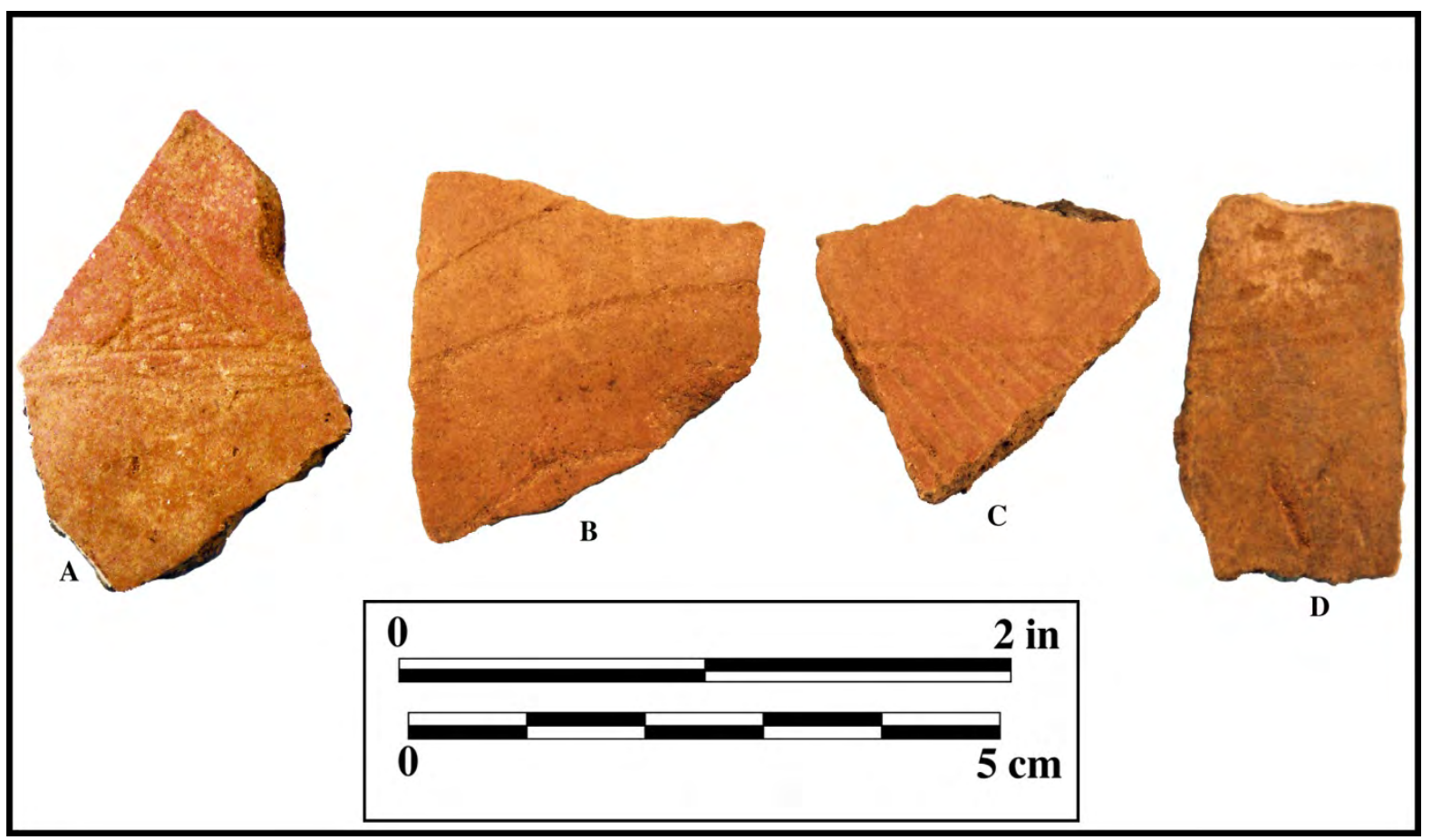

Figure 6-16. Engraved Bottle and Carinated Bowl Sherds: a, horizontal and hatched triangle elements on a bottle; $b$, bottle sherd with curvilinear lines; $c$, hatched panel on a carinated bowl; d, engraved-punctated bottle sherd. Provenience: a, N197 E202, Feature 76, Level 11; b, N196 E201, Feature 39, 40-51 cm; c, N195 E200, Feature 36, 25-35 cm; d, N198 E198, Feature 79, level 8. 


\section{Engraved-Punctated}

Engraved-punctated sherds account for 1.0$2.1 \%$ of the engraved fine wares from the southern and northern parts of the Lang Pasture site (see Table 6-13). These sherds are from several varieties of Poynor Engraved (see Suhm and Jelks 1962:Plate 62g, i) where punctated zones are seen, including Poynor Engraved, var. Blackburn, var. Cook, and var. Lang (see below).

In the southern area, one engraved-punctated sherd has a curvilinear zone filled with small circular punctates (see Figure 6-13a) while the other has an engraved lines framing a zone filled with small circular punctates. One sherd from the northern area has the same decorative element.

Two other engraved-punctated sherds from the northern area are from Poynor Engraved bottles. The first has parallel engraved lines framing a zone of small triangular-shaped punctations (see Figure 6-16d), while the second has an engraved circle filled with tool punctations.

Other northern area engraved-punctated sherds are from carinated bowls. The one rim has horizontal engraved lines, hatched triangular elements, and a circle filled with small circular punctates (see Figure 6-14t), while a second sherd has both the horizontal engraved lines and hatched triangular elements of the rim, as well as diagonal engraved lines creating a panel with a punctate-filled semi-circle (see Figure 6-14n). Another carinated bowl sherd has a design comprised of a hatched engraved panel, and a set of closely-spaced curvilinear lines within the panel that encircle a small punctate-filled circle element (see Suhm and Jelks 1962:Plate 62i). One sherd simply has engraved panels, one of which is filled with small circular punctates.

The last engraved-punctated sherd is a rim from the northern area with opposed diagonal or triangular elements on the rim. These lines have triangular tick or punctated marks on them.

\section{Engraved-Lip Notched}

One rim from the northern area has diagonal engraved lines on the rim panel, and a regular series of notches along the lip itself. A red clay pigment has been rubbed in the engraved decorative element. As will be seen in the discussion of the whole vessels from a series of upper Neches River basin Caddo sites, lip notching was a relatively common lip embellishment on engraved carinated bowls (see below).

\section{Lip Notched}

Two rims from the northern site area have regularly spaced notches cut into the vessel lip (see Table 6-13 and Figure 6-11c). These may be from plain bowls or carinated bowls, or from the upper part of the rim panel of engraved vessels.

\section{Red-Slipped}

The red-slipped sherds from the southern area are from bottles with an exterior red slip $(n=2)$, from bowls or carinated bowls with an interior and exterior red slip $(\mathrm{n}=2)$, or are from bowls $(n=2)$ with only a red slip on the interior vessel surface. Two red-slipped bottle sherds are among the red-slipped sherds from the northern site area, including one that has an interior red-slip on the upper part of the bottle neck. Six other sherds, including one rim, are from carinated bowls with both an interior and exterior red slip. Four other sherds from this area, probably from bowls, are slipped on either the interior $(n=3)$ or exterior $(n=1)$ vessel surfaces.

\section{Use of Pigments}

Both white (Hah ki yo in the Caddo language) kaolin clay and a red (Hatinu in Caddo) hematite-rich clay were used as pigments that were rubbed in the engraved decorations of a number of fine-ware vessels. Red pigments were clearly preferred by the Caddo potters at the Lang Pasture site, particularly as a decorative embellishment on fine ware bottles (Table 6-16), but the pigment was also used on 
an occasional bowl or carinated bowl; in the whole vessels (see below), a red clay pigment was a common feature on Hood Engraved effigy bowls. The white kaolin clay pigment was present on only two engraved sherds from the southern ceramic component/area. In the upper Neches River basin, the white clay pigment was noted primarily on post-A.D. 1650 Patton Engraved vessels (see Campbell 1936).

Pigments were used somewhat more commonly on the engraved fine wares from the northern area $(10.6 \%$ of all the engraved sherds) at the Lang Pasture site. Approximately $5.8 \%$ of the engraved sherds from the southern ceramic component/area have pigments rubbed in the lines of the design.

According to Bobby Gonzalez of the Caddo Nation of Oklahoma (April 2008 personal communication), "the red pigment means life and is very sacred among the Caddo. The red pigment is now used on peyote staffs, and during ritual ceremonies and prayer meetings, the red pigment is painted on and in the ears as well as on the top of the head in the middle of a man's hair line, running from front to back; the women and men paint themselves in the morning when the sun comes up." Vessels or vessel sherds found in domestic contexts with a red pigment likely are from vessels that symbolize life and its sacredness to the Caddo.

The Caddo "also use the red pigment when someone dies. If the deceased is a man we paint them in the middle hair line and on the face on each side of the eyes; if the deceased is a woman, another Caddo woman would paint her under the eyes." It is possible that the red pigment seen on vessels placed in Caddo burials in the upper Neches River basin may have been added to the vessels shortly before they were placed in the grave with the deceased. "The white clay is also very sacred to the Caddo and was used for altars during Caddo peyote meetings. The white clay is used by the Caddo in doctoring people with cuts, burns, stomach problems, and other reasons" (Bobby Gonzalez, April 2008 personal communication). Even today, Caddo home places in Oklahoma have white and red clay altars, and some families still use these colors.

Table 6-16. Use of Pigments on Fine Ware Vessels.

\begin{tabular}{|c|c|c|c|c|}
\hline Fine wares & $\begin{array}{l}\text { Red Pigment } \\
\text { southern }\end{array}$ & northern & $\begin{array}{l}\text { White Pigment } \\
\text { southern }\end{array}$ & northern \\
\hline Engraved Bw/CB & $2.5^{*}$ & 5.9 & 1.3 & . \\
\hline Engraved $\mathrm{Bt}$ & 18.5 & 20.7 & - & . \\
\hline Engraved-brushed CB & - & - & - & . \\
\hline $\begin{array}{l}\text { Engraved- } \\
\text { punctated CB }\end{array}$ & - & - & - & - \\
\hline $\begin{array}{l}\text { Engraved-lip } \\
\text { notched }\end{array}$ & - & 100.0 & - & - \\
\hline Lip notched & - & - & - & . \\
\hline
\end{tabular}

*percentage of engraved sherds with red or white clay pigments $\mathrm{Bw}=$ bowl; $\mathrm{CB}=$ carinated bowl; $\mathrm{Bt}=$ bottle 


\subsection{Plain SHERds}

Detailed comparisons of the plain sherds from the Lang Pasture site are based on the analysis of temper, paste, firing conditions (Teltser 1993; Perttula 2005, ed.), surface treatment, and body wall thickness for a sample of 385 body sherds and 41 plain rim sherds from the data recovery work all areas of the site (Appendix F.2). A total of 4254 plain sherds have been recovered from the Lang Pasture site. This includes 442 plain sherds from the test excavations (see Perttula 2004:Table 3.6), which are not further considered here and have not been subjected to any detailed analyses, and 3,812 plain sherds from the data recovery (see Table 6-17, on CD in back cover). The sample of plain sherds selected for detailed analysis comprises approximately $11.2 \%$ of all the plain sherds in the assemblage recovered in the data recovery work $(n=3812)$. Plain sherd cross-sections were inspected macroscopically and with a $10 \mathrm{X}$ hand lens to determine the character of the paste and its inclusions. Determining the firing conditions, temper, vessel wall thickness, and surface treatment followed the same procedures discussed above for the decorated rim and body sherds.

By area, there are 1293 plain sherds from the southern ceramic component/area, including only $11(0.8 \%)$ from features. By contrast, plain vessel sherds from features in the northern ceramic component area comprise $24.9 \%$ of all the plain sherds $(n=2,516)$ from this part of the site, and $98.3 \%$ of the plain sherds from all the features. As previously mentioned, one of the distinguishing attributes of the ceramic assemblage from the northern ceramic component/area in contrast with the southern ceramic component/area is the abundance of plain wares. This is apparent in the fact that $70.9 \%$ of all the plain rims from the Lang Pasture site are from the northern area.

\section{Plain Rim Sherds}

There are a total of 144 plain rims from undecorated vessels in the Lang Pasture site ceramic assemblage, including the sherds submitted for instrumental neutron activation analysis. Most of them are from the northern ceramic assemblage, particularly from several pit features in this part of the site. Rims from the plain vessels are characterized by the form of the rim and lip, the temper, firing conditions, surface treatment, thickness (in $\mathrm{mm}$ ), and orifice diameter (in $\mathrm{cm}$ ), if they had sufficient curvature (Table 6-18).

Selected plain ware rims are illustrated in Figure 6-17. The majority of the plain ware vessels are from simple bowls or carinated bowls, a few with rim peaks, as well as plain bottles (or at least plain bottle necks).

Table 6-17. Provenience of the Plain Sherds from the Data Recovery Investigations at the Lang Pasture site. (this table may be found in Appendix $G$ on the compact disk in the back cover of this report). 
Table 6-18. Analysis of the Plain Rims from the Lang Pasture Site.

\begin{tabular}{|c|c|c|c|c|c|c|}
\hline Provenience/Level & Rim-Lip & Temper & FC & $\mathrm{ST}$ & $\begin{array}{l}\text { Th } \\
(\mathrm{mm})\end{array}$ & $\begin{array}{l}\mathrm{OD} \\
(\mathrm{cm})\end{array}$ \\
\hline \multicolumn{7}{|c|}{ Southern Component/Assemblage } \\
\hline 171-198, lv. 1 & D-FL & - & - & - & - & 19.0 \\
\hline 171-198, lv. 2 & - Ro & - & - & - & - & - \\
\hline 171-200, lv. 3 & D-FL, ext $\mathrm{f}$ & - & - & - & - & - \\
\hline 172-200, lv. 2 & D-Ro & - & - & - & - & - \\
\hline 172-201, lv. 3 & D-Ro & g-h & - & - & - & - \\
\hline 173-202, lv. 2 & D-FL & - & - & - & - & - \\
\hline 174-202, lv. 3 & D-Ro & - & - & - & - & - \\
\hline 175-198, lv. 4 & D-Ro & - & - & - & - & $10.0^{+}$ \\
\hline 175-198, lv. 5 & - Ro & - & - & - & - & - \\
\hline 175-200, lv. 2 & D-Ro & - & - & - & - & - \\
\hline 176-201, lv. 1 & - Ro & - & - & - & - & - \\
\hline \multirow[t]{2}{*}{ 177-199, lv. 2} & - Ro & - & - & - & - & - \\
\hline & - Ro & - & - & - & - & - \\
\hline 178-199, lv. 5 & $-\mathrm{FL}$ & - & - & - & - & - \\
\hline 179-199, lv. 2 & D-Ro & $\mathrm{b}$ & $\mathrm{F}$ & I SM & 7.1 & $18.0+$ \\
\hline 180-199, lv. 5 & $\begin{array}{l}\text { INV-Ro, } \\
\text { int f }\end{array}$ & g-b & B & - & 7.3 & - \\
\hline 181-199, lv. 5 & $-\mathrm{FL}$ & - & - & - & - & - \\
\hline 181-202, lv. 2 & D-Ro, ext f & - & - & - & - & - \\
\hline 182-201, lv. 4 & - Ro & - & - & - & - & - \\
\hline 183-201, lv. 2 & - Ro & - & - & - & - & 9.0 \\
\hline 184-198, lv. 4 & D-Ro & - & - & - & - & - \\
\hline 184-199, lv. 2 & - Ro & - & - & - & - & - \\
\hline 184-199, lv. 3 & $-F L$ & - & - & - & - & - \\
\hline 184-199, lv. 5 & D-FL & - & - & - & - & 10.0 \\
\hline 184-202, lv. 3 & D-FL & g-b & $\mathrm{C}$ & - & 5.9 & - \\
\hline 185-198, lv. 2 & $-F L$ & - & - & - & - & - \\
\hline 185-201, lv. 1 & D-FL & g & G & E SM & 6.0 & 20.0 \\
\hline 185-202, lv. 3 & -Ro, ext f & - & - & - & - & - \\
\hline 186-198, lv. 3 & - Ro & - & - & - & - & - \\
\hline \multirow[t]{2}{*}{ 186-202, lv. 2} & D-Ro & - & - & - & - & - \\
\hline & D-FL & - & - & - & - & - \\
\hline
\end{tabular}


Table 6-18, continued.

\begin{tabular}{|c|c|c|c|c|c|c|}
\hline Provenience/Level & Rim-Lip & Temper & FC & ST & $\begin{array}{c}\text { Th } \\
(\mathrm{mm})\end{array}$ & $\begin{array}{l}\text { OD } \\
(\mathrm{cm})\end{array}$ \\
\hline 187-200, lv. 3 & $-\mathrm{FL}$ & - & - & - & - & - \\
\hline 187-202, lv. 2 & -Ro & - & - & - & - & - \\
\hline 188-198, lv. 4 & $-F L$ & - & - & - & - & - \\
\hline 188-199, lv. 3 & D-FL, ext f & $g-b$ & B & E SM & 7.2 & 17.0 \\
\hline 188-199, lv. 4 & D-FL & - & - & - & - & - \\
\hline 188-200, lv. 2 & D-INT Bv & g & $\mathrm{F}$ & $\mathrm{I} / \mathrm{E} \mathrm{B}$ & 6.1 & - \\
\hline 188-201, lv. 2 & -Ro & - & - & - & - & - \\
\hline
\end{tabular}

\section{Northern Component/Assemblage}

189-198, lv. 1

189-198, lv. 4

189-199, lv. 2

189-200, lv. 2

190-199, lv. 3

190-200, lv. 2

190-201, lv. 1

191-198, lv. 4

192-202, lv. 2

193-199, lv. 2

193-201, lv. 3

193-202, lv. 5

194-199, lv. 2

194-200, lv. 3

194-200, lv. 4

194-202, lv. 1

194-202, lv. 6

195-199, lv. 3

195-202, lv. 2

195-203, lv. 3

196-198, lv. 1

196-199, lv. 2

196-201, lv. 4

196-202, lv. 3

197-200, lv. 3

198-199, lv. 2

\section{EV-Ro}

D-Ro

$-F L$

-Ro

-Ro, ext $\mathrm{f}$

D-Ro

D-FL

INV-FL

D-FL

D-Ro

D-Ro, ext $f \quad g$

D-FL

-Ro

D-Ro

D-Ro

D-Ro

D-Ro

D-FL

D-FL

D-Ro

-Ro, ext $\mathrm{f}$

D-FL

D-FL

-FL

D-Ro

D-Ro, ext $\mathrm{f}$

INV-Ro

$$
\begin{aligned}
& \text { g } \\
& \text { - } \\
& \text { - } \\
& \text { g }
\end{aligned}
$$

-
g
-
-
-
g-b

$\begin{array}{llll}- & - & - & - \\ \text { A } & \text { E B } & 5.8 & - \\ - & - & - & - \\ - & - & - & -\end{array}$

b-o

B

B

E B/

I SM

6.0

-

7.3

$\begin{array}{lllll}- & - & - & - & - \\ - & - & - & - & 12.0 \\ \text { g } & \text { H } & \text { E SM } & 7.4 & - \\ \text { g } & \text { H } & - & 6.2 & - \\ \text { SP } & \text { B } & \text { E SM } & 6.3 & 16.0\end{array}$

(Woodland, Goose Creek Plain)$$
\begin{array}{llll}
- & - & - & 5.0 \\
\text { F } & \text { E SM } & 5.7 & - \\
- & - & - & -
\end{array}
$$$$
\begin{array}{llll}
- & - & - & - \\
- & - & - & - \\
\text { F } & \text { E SM/ } & 6.8 & 16.0-19.0 \\
& \text { I B }
\end{array}
$$ 
Table 6-18, continued.

\begin{tabular}{|c|c|c|c|c|c|c|}
\hline Provenience/Level & Rim-Lip & Temper & FC & ST & $\begin{array}{l}\text { Th } \\
(\mathrm{mm})\end{array}$ & $\begin{array}{l}\mathrm{OD} \\
(\mathrm{cm})\end{array}$ \\
\hline 198-199, lv. 4 & $\begin{array}{l}\text { D-Ro } \\
\text { scalloped an }\end{array}$ & $\begin{array}{l}\mathrm{g} \\
\text { th. thickened }\end{array}$ & $\bar{G}$ & $\mathrm{I} / \mathrm{ESM}$ & 10.0 & - \\
\hline 198-200, lv. 4 & -FL & - & - & - & - & - \\
\hline 198-201, lv. 5 & D-FL & - & - & - & - & - \\
\hline 198-202, lv. 4 & D-Ro, ext f & - & - & - & - & - \\
\hline 198-202, lv. 7 & D-Ro & g & G & I SM & 8.7 & $11.0+$ \\
\hline 199-198, lv. 4 & $-F L$ & - & - & - & - & - \\
\hline 199-200, lv. 2 & D-Ro & g-b & $\mathrm{H}$ & $\mathrm{I} / \mathrm{ESM}$ & 6.5 & - \\
\hline 199-201, lv. 1 & D-FL & g-h & $\mathrm{F}$ & E SM & 7.5 & 32.0 \\
\hline 199-201, lv. 4 & - Ro & - & - & - & - & - \\
\hline 199-202, lv. 4 & - Ro & - & - & - & - & - \\
\hline 200-199, lv. 1 & D-Ro & - & - & - & - & - \\
\hline 200-200, lv. 2 & D-FL & - & - & - & - & - \\
\hline 200-201, lv. 4 & D-Ro & g-h & I & I SM & 5.7 & $11.0+$ \\
\hline 200-203, lv. 2 & D-Ro & - & - & - & - & - \\
\hline 200-203, lv. 3 & Ev-Ro & $\mathrm{b}$ & - & - & - & $8.0+$ \\
\hline 201-200, lv. 3 & D-Ro & - & - & - & - & - \\
\hline 201-203, lv. 3 & D-Ro (Bt) & - & - & - & - & 5.0 \\
\hline 202-198, lv. 3 & D-FL & - & - & - & - & - \\
\hline 202-200, lv. 4 & D-FL & - & - & - & - & - \\
\hline 202-201, lv. 2 & INV-Ro & - & - & - & - & - \\
\hline 202-203, lv. 1 & $-F L$ & - & - & - & - & - \\
\hline 203-202, lv. 4 & D-Ro & - & - & - & - & - \\
\hline 204-198, lv. 1 & -FL (Bt?) & - & - & - & - & - \\
\hline 204-200, lv. 2 & D-Ro, tp & $\mathrm{g}$ & G & $\mathrm{I} / \mathrm{ESM}$ & 7.3 & 22.0 \\
\hline 204-200, lv. 3 & D-Ro & - & - & - & - & - \\
\hline 205-199, lv. 3 & - Ro & - & - & - & - & - \\
\hline 206-198, lv. 2 & -FL & - & - & - & - & - \\
\hline 206-200, lv. 2 & D-FL & - & - & - & - & - \\
\hline 206-200, lv. 3 & D-Ro & g & G & - & 7.0 & - \\
\hline 207-198, lv. 1 & $-\mathrm{FL}$ & - & - & - & - & - \\
\hline Scrape E & D-Ro & g & B & I SC & 7.8 & 23.0 \\
\hline
\end{tabular}

\section{FEATURES}

\section{Northern Component/Assemblage}

176-199, F. 13, -Ro, ext f 35-79 
Table 6-18, continued.

Provenience/Level $\quad$ Rim-Lip $\quad$ Temper $\quad$ FC $\quad$ ST $\begin{gathered}\text { Th } \\ (\mathrm{mm})\end{gathered} \quad \begin{gathered}\text { OD } \\ (\mathrm{cm})\end{gathered}$

175-199, F.14

D-Ro

g-h

A $\quad$ I SM $\quad 7.6$

Southern Component/Assemblage

197.5-201, F.25, lv. $3 \quad$-Ro

195-201, F.36, 21

D-FL

195-201, F.36, 24

D-RO

g

$\begin{array}{llll}\text { F } & \text { E SM } & 8.1 & 23.0\end{array}$

193-198, F.66

$-F L$

60-120

197-203, F.76, $110-120$

D-Ro

(Bt)

197-203, F.76,

90-100

198-202, F.76,

40-60

198-202, F.76,

70-80

198-202, F.76,

90-100

D-FL

g-b-h

E SM $7.2 \quad 22.0+$

198-202, F.76,

100-110

198-202, F.76,

$110-120$

D-FL

D-Ro

INV-Ro

D-Ro, tp

g

EV-FL

-FL

D-Ro

b-h

g

$\mathrm{F}$

(2.0+

$198-203, F .76$

D-Ro

90-100

198-203, F.76,

100-110

198-203, F.76,

130-140

199-202, F.76,

40-50

199-202, F.76,

70-80

199-202, F.76,

90-100

D-Ro

D-FL

D-INT Bv

$$
\text { g-h }
$$

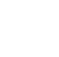

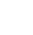

199-202, F.76,

95-100

D-Ro

-Ro

EV-Ro

D-Ro

D-Ro

D-INT Bv

D-FL

199-203, F.76,

40-50

D-Ro

D-Ro

D-FL

D-Ro

D-FL, ext $\mathrm{f}$

g

$\begin{array}{llll}- & - & - & - \\ \mathrm{H} & - & 5.3 & 6.0\end{array}$

$\begin{array}{llll}\mathrm{G} & \mathrm{E} \mathrm{B} / & 6.6 & 22.0\end{array}$

$\begin{array}{llll}\text { F } & \text { I SM } & & \\ \text { E SM } & 8.0 & 22.0\end{array}$

$\begin{array}{llll}\mathrm{F} & \mathrm{ESM} & 8.0 & 22.0 \\ \mathrm{~F} & - & 7.5 & 11-14\end{array}$

$\begin{array}{llll}\mathrm{F} & - & 7.5 & 11-14 \\ - & - & - & 14-19\end{array}$

D-Ro

$\begin{array}{llll}\mathrm{F} \quad & - & 10.3 \quad-\end{array}$

$\begin{array}{llll}- & - & - & - \\ \mathrm{F} & \mathrm{E} \mathrm{B} / & 8.5 & 13.0 \\ & \mathrm{ISM} & & \end{array}$

$\begin{array}{llll} & \text { ISM } & & - \\ - & - & - & - \\ \text { C } & - & - & - \\ \text { B } & - & 6.2 & - \\ - & - & - & 19.0 \\ - & - & - & - \\ - & - & - & 13.0+ \\ \text { G } & \text { E SM } & 6.5 & 15.0 \\ - & - & - & -\end{array}$


Table 6-18, continued.

Provenience/Level

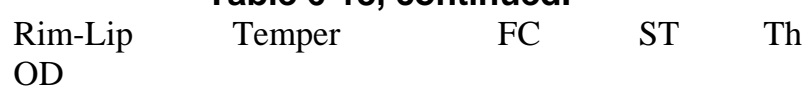

(mm)

$(\mathrm{cm})$

\begin{tabular}{|c|c|c|c|c|c|c|}
\hline $\begin{array}{c}\text { 197-203, F.76A, } \\
29.0\end{array}$ & D-FL & $\mathrm{b}$ & B & - & \multicolumn{2}{|l|}{6.3} \\
\hline \multicolumn{7}{|l|}{$40-50$} \\
\hline \multirow{2}{*}{$\begin{array}{l}\text { 198-203, F.76A, } \\
110-120\end{array}$} & D-INT Bv & - & - & - & - & - \\
\hline & D-FL, CB & g-b & $\mathrm{F}$ & E SM & 7.9 & - \\
\hline \multirow{2}{*}{$\begin{array}{l}\text { 197-203, F.76B, } \\
\text { 70-85 }\end{array}$} & D-Ro & g-h & $\mathrm{F}$ & - & 5.4 & - \\
\hline & D-Ro & - & - & - & - & - \\
\hline \multirow{2}{*}{$\begin{array}{c}\text { 199-200, F.76B } \\
\begin{array}{c}14.0 \\
75-90\end{array}\end{array}$} & D-INT Bv & g & $\mathrm{F}$ & E SM & 7.6 & \\
\hline & with rim peaks & & & & & \\
\hline \multirow{2}{*}{$\begin{array}{c}\text { 199-200, F.76B, } \\
90-100\end{array}$} & D-Ro & - & - & - & - & \\
\hline & & & & & & \\
\hline $\begin{array}{l}\text { 198-198, F.79, } \\
40-50\end{array}$ & D-FL & - & - & - & - & - \\
\hline \multirow{2}{*}{$\begin{array}{l}\text { 198-198, F.79, } \\
60-70\end{array}$} & -Ro & - & - & - & - & - \\
\hline & D-FL & g-h & $\mathrm{F}$ & $\mathrm{E} B /$ & 5.5 & \\
\hline $\begin{array}{c}\text { 198-198, F.79, } \\
18.0\end{array}$ & D-FL & g-h & K & $\begin{array}{l}\text { I SM } \\
\text { I/ESM }\end{array}$ & 6.0 & \\
\hline $70-80$ & & & & & & \\
\hline $80-92$ & $\begin{array}{l}\text { EV-Ro, } \\
\text { rim peaks }\end{array}$ & - & - & - & - & - \\
\hline $\begin{array}{l}\text { 198-199, F.79, } \\
40-50\end{array}$ & -Ro & - & - & - & - & - \\
\hline $\begin{array}{r}\text { 198-199, F.79, } \\
14.0+\end{array}$ & D-FL & - & - & - & - & \\
\hline \multicolumn{7}{|l|}{$60-70$} \\
\hline 215-204, F.88 & $-F L$ & - & - & - & - & - \\
\hline \multicolumn{7}{|c|}{$\begin{array}{l}\text { FC=firing conditions (see Teltser 1993:Figure 2; Perttula 2005: Figure 5-29); ST=surface treatment; } \\
\text { Th=thickness; OD=orifice diameter } \\
\text { D=direct; E=everted; INV=inverted; Ro=rounded; FL=flat; INT Bv=interior beveled; ext. f=exterior } \\
\text { folded; int. f=interior folded; tp=tapered } \\
\text { g=grog; b=bone; h=hematite; o=organics } \\
\text { E B=exterior burnished; E SM=exterior smoothed; INT SM=interior smoothed; INT SC=interior } \\
\text { scraped }\end{array}$} \\
\hline
\end{tabular}




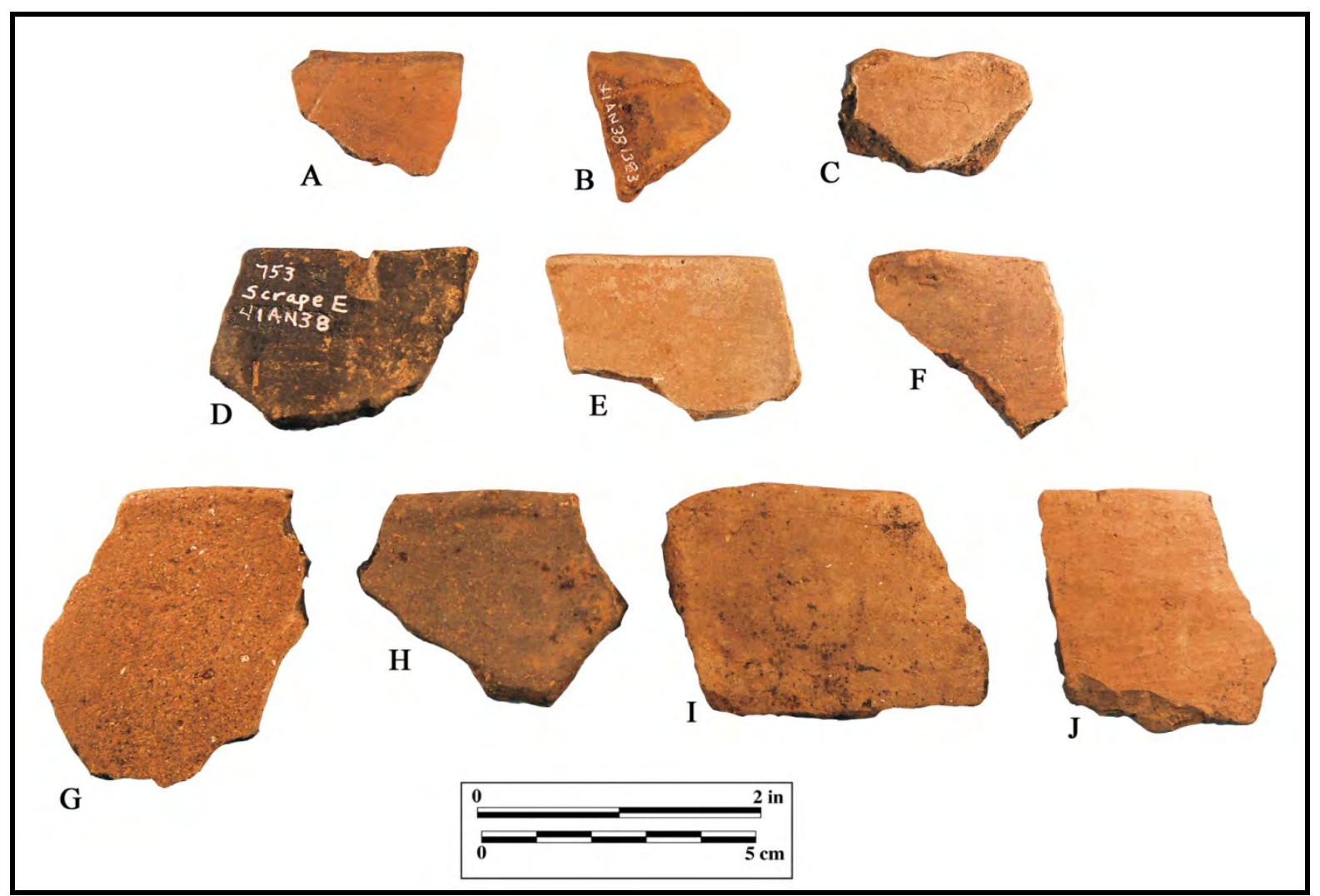

Figure 6-17. Plain Rims from the Lang Pasture Site: a-b, h, direct-interior beveled; c, int. thickened/rim peak; d, i-j, direct-rounded; e, g, direct-flat; f, direct-flat, Redwine mode.

\section{Orifice Diameters of Decorated and Plain Vessel Rim Sherds}

In cases where rim curvatures were sufficient, it was possible to measure the orifice diameter (OD) of a number of plain and decorated rim sherds from both the southern $(\mathrm{n}=31)$ and northern $(\mathrm{n}=71)$ ceramic components/areas at the Lang Pasture site. Measured rims ranged in OD from 5-34 cm (Table 6-19). The orifice diameters of these vessels, used for cooking, food service, and the storage of food stuffs and liquids, provide some indication of the scale of food preparation and food serving in the two different areas of the site. That the vessels from the Lang Pasture site are all hollow wares (i.e., jars, bowls, and carinated bowls), it seems likely that the Caddo diet was based almost entirely on liquid-based foods cooked in jars, including stews, corn and bean dishes, and gruels.
These measurable rims are readily divisible into five size groups: very small (probably bottles), 5-8 cm OD; small, 9-14 cm OD; medium, 15-20 cm OD; large, 21-26 cm OD; and very large, 27-34 cm OD. As discussed below, the vessels used in domestic contexts at the Lang Pasture site are generally much larger than those placed in the burials with the deceased. The mortuary vessels are no larger than $20 \mathrm{~cm}$ in OD (and no larger than 2 liters in volume), and may have been chosen because only one to a few servings of food were necessary on the deceased's journey to the House of the Dead (see Chapter 11, this volume), even though the journey was supposed to last for six days.

In the southern ceramic component/area, plain vessels occur only in the small, medium, and large categories, suggesting that much of the food service was designed for individual or 
small group servings, and thus likely carried out within small social groups, presumably households. All five vessel size groups are represented in the plain ware rims from the northern ceramic component/area. Plain wares in the southern area are predominantly small to medium-sized $(89 \%)$, as they are in the northern area (61\%), but large and very large plain wares account for $25 \%$ of the rims in the northern area but only $11 \%$ in the southern area. It is clear that the full complement of plain wares used by the Lang Pasture Caddo groups are found only in the northern ceramic component/area, and that larger groups or several households were also meant to be served. The large and very large plain bowls could have held between 2-4 liters of food, probably representing at least 4-8 individual servings (cf. Voss 2008:246), while the smaller plain wares may have held only between 0.5-2 liters of food and thus less than four individual servings. Such servings could have included such foods as corn and atole tamales or beans, corn, and pinole (Chapa 1997:149-150).

In both areas, utility wares used for cooking and storage have the same range in size, with small, medium, large, and very large sizes (see Table 6-19), but medium-sized utility vessels are more common (43\%) in the northern area than they are in the southern area (25\%); small utility ware vessels, conversely, are more common in the southern area (50\%; compared to $37 \%$ in the northern ceramic component/area). Large and very large utility ware vessels (with capacities of greater than 4 liters; the actual quantities of food prepared in these vessels would be slightly less, as such vessels would not have been filled to the rim during use) are equally represented in both areas (20-25\%), but most of the very large utility ware vessels are found in the northern site area. In general, the same range in orifice diameters of the utility wares suggest the same range by site area in the quantities of food prepared and food stuffs stored.

The size of these cooking vessels suggest that they were designed to prepare multiple servings of food, perhaps as many as 10 individual servings, depending upon the size of the plain and decorated serving vessels.

Fine ware vessels range from small to very large in both the southern and northern ceramic component/areas (see Table 6-19), but there are significant differences in size group proportions. Small and medium-sized vessels (less than 2 liters in volume) comprise $50 \%$ of the measured rims from the southern area, but $89 \%$ of the fine wares in the northern ceramic component/area. In the southern area, $67 \%$ of the very large vessels (ca. 4-6 liters) are fine wares, compared to $25 \%$ in the northern area. Most of the fine ware serving vessels were designed for more than 2-4 individual servings of food, suggesting that they were designed for use in household contexts, especially in the northern site area. The large and very large serving vessel fine wares would have been used to serve multiple individuals, likely more than 10 individual servings. 
Table 6-19. Rim Orifice Diameters for Rim Sherds in the Southern and Northern Component/Areas.

\begin{tabular}{|c|c|c|c|c|c|c|}
\hline \multirow{2}{*}{$\begin{array}{l}\text { Orifice Diameter } \\
\text { (cm) }\end{array}$} & \multicolumn{3}{|c|}{ Southern Area } & \multicolumn{3}{|c|}{ Northern Area } \\
\hline & PL & UW & FW & PL & UW & FW \\
\hline 5 & - & - & - & 2 & - & - \\
\hline 6 & - & - & - & 1 & - & - \\
\hline 7 & - & - & - & - & - & - \\
\hline 8 & - & - & - & 1 & - & - \\
\hline 9 & 1 & - & - & - & 1 & - \\
\hline 10 & 2 & 1 & 1 & 1 & 3 & - \\
\hline 11 & - & - & - & 2 & 1 & 1 \\
\hline 12 & - & - & - & 1 & 2 & - \\
\hline 13 & - & 3 & 1 & 3 & 5 & 1 \\
\hline 14 & 1 & 2 & 1 & 2 & 1 & 1 \\
\hline 15 & - & - & - & 1 & 3 & 1 \\
\hline 16 & - & 3 & 1 & $2 *$ & 1 & 1 \\
\hline 17 & 1 & - & 1 & 2 & 5 & 1 \\
\hline 18 & 1 & - & - & 2 & 4 & 1 \\
\hline 19 & 1 & - & - & 1 & 2 & - \\
\hline 20 & 1 & - & - & - & - & - \\
\hline 21 & - & - & - & - & 1 & - \\
\hline 22 & - & 1 & - & 4 & 1 & - \\
\hline 23 & 1 & 1 & - & 1 & - & - \\
\hline 24 & - & - & - & - & 1 & - \\
\hline 25 & - & - & 1 & - & 1 & - \\
\hline 26 & - & - & 2 & - & - & - \\
\hline 27 & - & - & - & - & 1 & 1 \\
\hline 28 & - & - & 1 & - & 1 & - \\
\hline 29 & - & - & 1 & 1 & - & - \\
\hline 30 & - & - & - & - & - & - \\
\hline 31 & - & - & - & - & - & - \\
\hline 32 & - & - & - & 1 & - & - \\
\hline 33 & - & 1 & - & - & - & - \\
\hline 34 & - & - & - & - & 1 & - \\
\hline Total & 9 & 12 & 10 & 28 & 35 & 8 \\
\hline
\end{tabular}

PL=Plain; UW=Utility ware; FW=fine ware;

*includes one Goose Creek Plain, var. unspecified bowl sherd.

Overall, when combined, the size of plain, utility ware, and fine ware vessels from the southern and northern ceramic component/ areas is not significantly different (Figure 6-18 and Table 6-20). Caddo potters living in both areas produced vessels of comparable sizes and size proportions, even though there were different preferences (i.e., different food preparation and food serving needs) for vessels of varying sizes from area to area among the three wares.

Given the presumption that the northern ceramic component/area is slightly older than the southern ceramic component/area, there are several notable trends in the vessel rim 
orifice diameter data. First, very small to medium-sized vessels are proportionally more abundant in the older, northern component, although small vessels become more commonly used later in time at the expense of medium-sized vessels. Very small vessels (bottles) - all plain wares-are restricted to the northern area (see Table 6-20). These data suggest that the Caddo living in the northern area made pottery designed for use in cooking and food serving in small social groups, perhaps individual households, and only occasionally were foods prepared and served for larger (i.e., more than 10 individuals) groups of people. Later in time, larger vessels used for food service (fine wares), cooking (utility wares), and storage (utility wares) were more frequently produced and used at the Lang Pasture site. In the southern area of the site, then, the ceramics produced and used by the Caddo were apparently made with the presumption that food preparation and serving needs extended to both household and suprahousehold contexts.

\subsection{RIM AND LIP FORMS FOR DECORATED AND PLAIN VESSELS}

The ceramic vessels made and used at the Lang Pasture site have a wide variety of rim and lip forms. Whether by area or by ceramic ware, direct rims (i.e., rims with a vertical or straight orientation) are the most common form, followed by vessels with everted profiles, with only a few having inverted (i.e. rims with an inward-slanting profile) rims (Table 6-21). A number of rims are beveled on the interior surface of the vessel. The lips on these vessels are most frequently rounded when viewed in profile, but many also have flat lips. Other distinctive lip forms include those where the lip itself has been folded either towards the exterior of the vessel or towards its interior, and several others have tapered, expanded, or scalloped/interior thickened lip forms. Lastly, six of the 441 analyzed rims (1.4\%) have prominent rim peaks.

The rim and lip form data summarized in Table 6-21 from both the southern and northern ceramic component/areas indicate that the same range of forms were used by potters in both areas. These were forms that were obviously considered appropriate to the kinds of vessels being made and used in each areas, and comparisons between the two areas in rim and lip form suggest that there were differences in rim and lip form preferences, and thus presumably, differences in the kinds and proportions of vessels used through time at the Lang Pasture site.

Plain ware rims are more abundant in the northern area $(36.3 \%)$ than in the southern area $(26.3 \%)$, utility ware vessels are equally represented in both areas (45\% and $47.3 \%$, respectively), and fine ware rims are much more common in the southern area (28.8\%) compared to the northern area (16.4\%). 

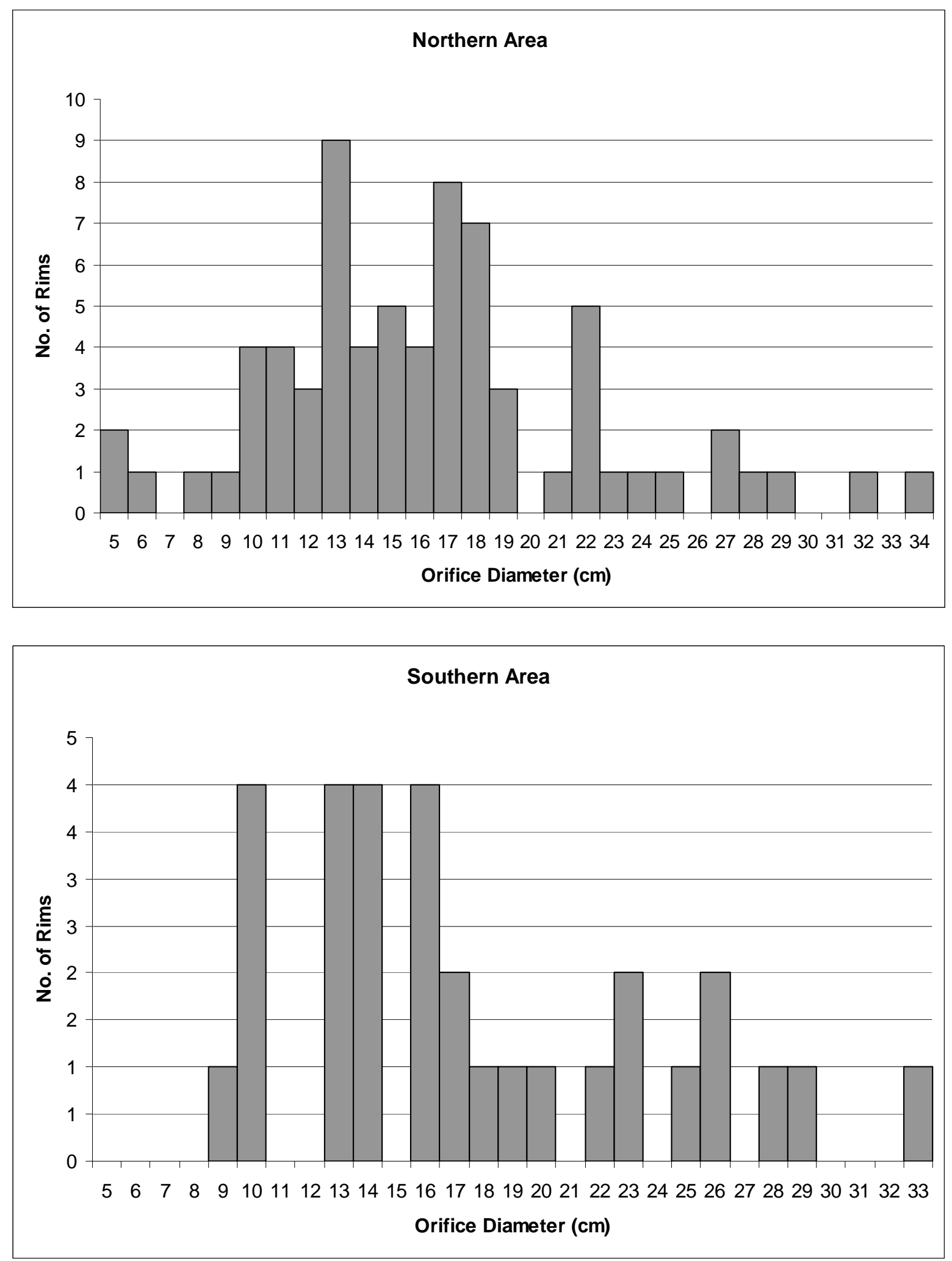

Figure 6-18. Range in Orifice Diameter in Rims from the Southern and Northern Ceramic Component/Areas. 
Table 6-20. Proportions of Vessel Size Classes in the Southern and Northern Areas at the Lang Pasture Site.

\begin{tabular}{lll}
\hline Size Class & Southern area & Northern area \\
\hline very small & $0.0^{*}$ & 5.6 \\
small & 41.9 & 35.2 \\
medium & 29.0 & 38.1 \\
large & 19.4 & 12.7 \\
very large & 9.7 & 8.5 \\
\hline $\mathrm{N}$ & & \\
\hline *percentage & 31 & 71 \\
\hline
\end{tabular}

Table 6-21. Rim and Lip Forms, Southern and Northern Ceramic Component/Areas.

\begin{tabular}{|c|c|c|c|c|c|c|}
\hline \multirow[t]{2}{*}{ Rim-Lip Form } & \multicolumn{3}{|c|}{ Southern Area } & \multicolumn{3}{|c|}{ Northern Area } \\
\hline & PL & UW & FW & PL & UW & FW \\
\hline$\overline{\mathrm{D}-\mathrm{FL}}$ & 7 & 10 & 12 & 25 & 30 & 16 \\
\hline D-FL, ext folded & 2 & - & 2 & 1 & 7 & 2 \\
\hline D-RO & 10 & 20 & $15^{*}$ & 35 & 42 & 13 \\
\hline D-RO, ext folded & 1 & 3 & 1 & 3 & 4 & 2 \\
\hline D-RO, int folded & 1 & - & - & - & - & - \\
\hline $\begin{array}{l}\text { D-RO, scalloped/int. } \\
\text { thickened }\end{array}$ & - & - & - & 1 & - & - \\
\hline D-RO, tapered & - & - & - & 2 & - & - \\
\hline D-INT BV & 1 & 1 & $2^{*}$ & $4^{*}$ & 3 & 3 \\
\hline EV-RO & - & 13 & - & $4^{*}$ & 17 & 1 \\
\hline EV-RO, ext folded & - & 2 & - & - & 4 & - \\
\hline EV-FL & - & 2 & - & 1 & 1 & - \\
\hline INV-RO, ext folded & 1 & - & - & - & - & - \\
\hline INV-FL & - & - & - & 1 & - & - \\
\hline INV-RO & - & - & 8 & 3 & - & - \\
\hline$-\mathrm{RO}$ & 11 & $12^{*}$ & 4 & 9 & 10 & 4 \\
\hline -RO, ext folded & 2 & $2^{*}$ & 1 & 2 & 4 & - \\
\hline RO, expanded lip & - & 1 & - & - & - & - \\
\hline$-F L$ & 6 & 6 & 1 & 11 & 11 & 5 \\
\hline Totals & 42 & 72 & 46 & 102 & 133 & 46 \\
\hline
\end{tabular}

$\mathrm{D}=$ direct; $\mathrm{EV}=$ =verted; INV=inverted; FL=flat; $\mathrm{RO}=$ =rounded; INT BV=interior beveled; PL=plain ware; UW=utility ware; FW=fine ware; *rims with rim peaks 
These rim/lip form differences may be summarized as follows for the form of the rim. First, plain ware vessels strongly tend to have direct rims, regardless of the area, but there is a wider range of rim forms in the plain ware vessels from the northern site area (Table 622 ), suggesting a wider range in plain ware vessel forms in earlier contexts; second, utility ware vessels have a mix of both direct and everted rims from jars, and everted rim jars are more common in the later southern area; and third, direct rims were preferred on the fine ware vessels, with inverted rim fine ware vessels being made and used only in the southern area.

Overall, everted rim vessels comprise 10$10.6 \%$ of the vessel rims from both areas. Inverted rim vessels-bowls and certain carinated bowl forms - only account for $1.4 \%$ of the vessel rims in the northern part of the site, but $5.6 \%$ of the vessel rims in the southern ceramic component/area.

Lip forms are equally as diverse by area. Across the wares, flat lips are more prevalent in the northern area, while rounded lips are more common in the southern ceramic component area (see Table 6-22), especially among the utility wares. Exterior folded lips occur in comparable amounts (10-10.3\%) in both areas, and are a particularly notable form of lip treatment on plain wares (both areas) and utility wares (northern area).

Interior beveled lips are present in both areas, but were apparently were commonly used on vessels (especially fine wares and plain wares) in the northern area. Vessels with rim peaks, although not common in either area, are more frequent in the southern area (on both utility ware and fine ware vessels), while being restricted to two plain ware vessels in the northern area of the Lang Pasture site (see Table 6-22).

\subsection{USE OF TEMPERS}

The Caddo potters that made the pottery vessels that were used and eventually discarded at the Lang Pasture site overwhelmingly preferred to add grog (or crushed sherds) to the vessel paste (Table 623). It was the principal and sole temper added to between $53-61.5 \%$ of the sherds examined in detail from the site, regardless of the site area.

Other important tempers include crushed hematite/ferruginous sandstone fragments and crushed and burned animal bone (Table 6-23). However, these tempers were rarely used by themselves, but were added to the paste of vessels that already had grog temper. By ware, only between $2.5-11 \%$ of the sherds from the southern and northern site areas did not have grog temper. A few sherds have an abundance of charred plant remains and charcoal pieces as aplastics in the paste; these probably represent pieces of charred materials that were in the clay when it was collected, and were never winnowed or cleaned from the clay when it was being worked, or oxidized during firing. 
Table 6-22. Trends and Differences in Rim and Lip Form.

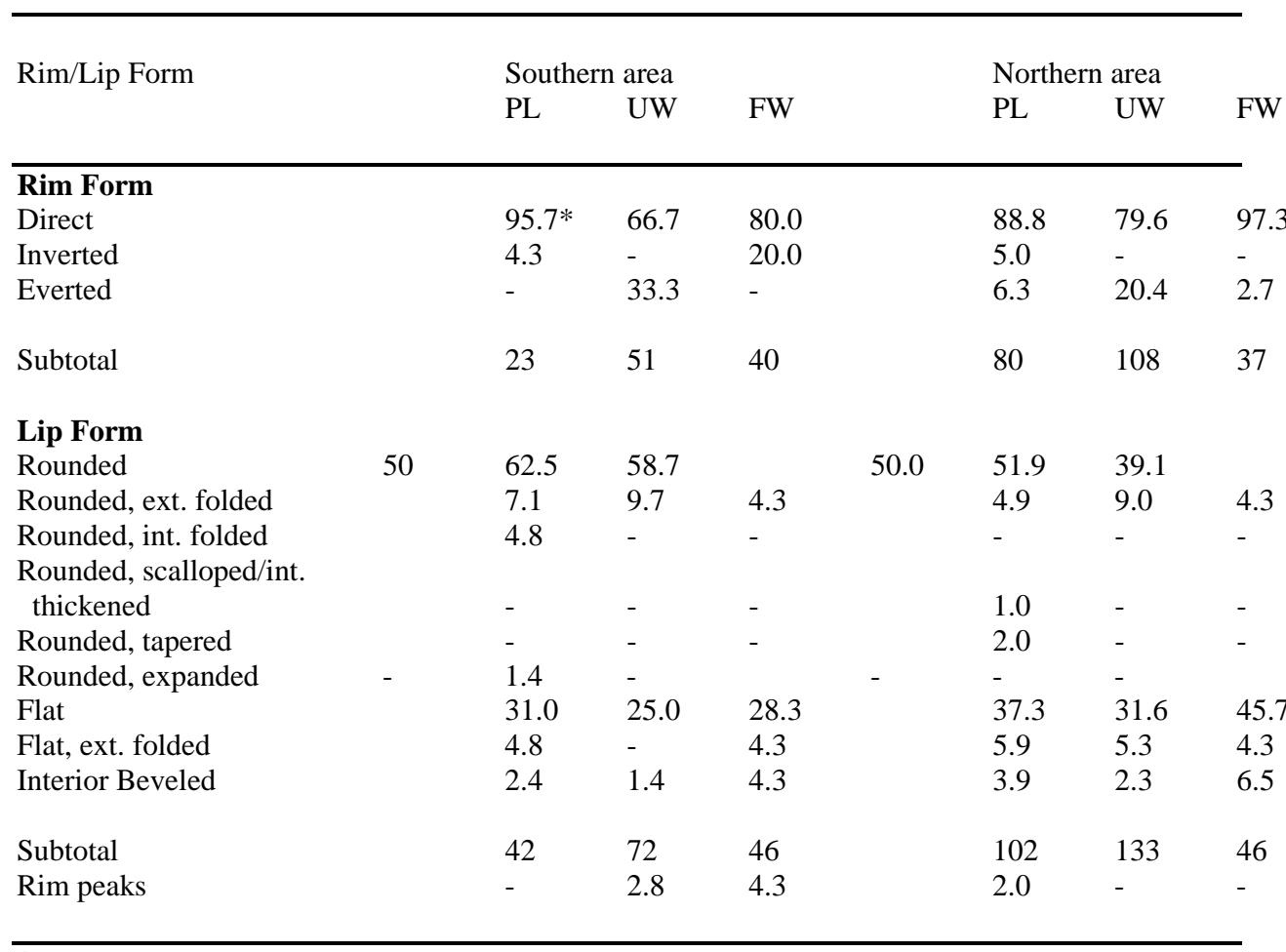

*percentage

Table 6-23. Tempers Used in the Manufacture of Ceramic Vessels.

\begin{tabular}{|c|c|c|c|c|c|c|c|c|}
\hline \multirow[t]{2}{*}{ Temper } & & \multicolumn{4}{|c|}{ Southern Site area } & \multicolumn{3}{|c|}{ Northern Site Area } \\
\hline & & PL & UW & FW & & PL & UW & \\
\hline grog & & $54.0^{*}$ & 56.8 & 53.3 & & 58.8 & 61.5 & \\
\hline grog-hematite & & 16.0 & 28.0 & 17.8 & & 16.3 & 17.9 & \\
\hline grog-hematite-organics & & 0.7 & - & - & & 0.3 & 0.6 & \\
\hline grog-hematite-bone & 1.5 & 1.7 & - & & 2.1 & 2.8 & - & \\
\hline grog-bone & & 13.9 & 11.0 & 8.9 & & 10.4 & 11.2 & \\
\hline grog-bone-organics & 0.7 & - & - & & 0.3 & - & - & \\
\hline grog-organics & & 3.6 & - & 8.9 & & 3.5 & 1.1 & \\
\hline bone & & 4.4 & 0.9 & - & & 3.8 & 3.9 & \\
\hline bone-hematite & & - & 0.9 & - & & 1.4 & - & \\
\hline bone-organics & & - & - & - & & 1.4 & - & \\
\hline hematite & & 1.5 & 0.8 & - & & - & - & \\
\hline hematite-organics & & - & - & - & & 0.3 & - & \\
\hline organics & & - & - & - & & - & - & \\
\hline none & & 3.6 & - & 11.1 & & 1.4 & 1.1 & \\
\hline Totals & & 137 & 118 & 45 & & 289 & 179 & \\
\hline
\end{tabular}

$\mathrm{PL}=$ plain; UW=utility ware; $\mathrm{FW}=$ fine ware *percentage 
The high frequency of grog tempering in the ceramic assemblages, and in each ware, represents a specific attempt on the part of Caddo potters to slow the oxidation process of the ceramic vessels during firing. This would have created darker-colored vessels in a reducing firing environment (or lighter tan, orange, and brown colors in oxidizing environments), while allowing them to be fired longer, and producing a harder ceramic vessel (Rice 1987:354; Teltser 1993:532, 540). Since grog has expansion coefficients comparable to the coefficients of the clay paste most commonly seen in Caddo pottery vessels-especially with the finely crushed grog pieces as seen in the fine wares-this would have contributed further to the ability of fired vessels to withstand heat-related stresses, as well as increasing their flexural strength (Rice 1987:362).

Hematite may have been added to the paste of certain vessels strictly as a matter of personal choice by individual Caddo potters, but it may have served a useful purpose nonetheless. That is, like feldspar (often also found in microscopic quantities in the paste of Caddo vessels, see Perttula 2000), the occurrence of crushed grains of hematite in the paste would have enhanced a vessel's ability to melt and fuse the paste constituents during firing, thus resulting in a dense, hard body, and a reduced vessel porosity (Rice 1987:96). Similarly, the addition of a coarse temper like hematite pieces would have aided a vessel's ability to withstand thermal shock.

Crushed and burned bone may have been added to a vessel's paste for the same reason: namely that crushed and burned bone produces with little effort an angular particle shape whose coarseness and size gave vessels tempered with it the ability to withstand thermal shock (e.g., Whittlesey 2004:287).

Are there any significant differences in the use of temper between the two site areas? The differences, by area and by ceramic ware, are very subtle (Table 6-24). However, the temper data strongly supports the notion that the predominant practice of Caddo potters at the Lang Pasture site was making grog-tempered plain ware, utility ware, and fine ware pottery in both areas and through time.

Grog temper was most abundantly used in the utility wares in both site areas, especially in the southern site area. Conversely, bone tempered ceramics are most common in the plain wares, and least preferred for the manufacture of fine ware vessels, although the differences in proportion are slight. Crushed pieces of hematite are particularly abundant in the utility wares from the southern area as well as in the fine wares from the northern site area (Table 6-24).

Table 6-24. Trends and Differences in the Use of Temper by Site Area and Ceramic Ware.

\begin{tabular}{|c|c|c|c|c|c|c|}
\hline \multirow[t]{2}{*}{ Temper } & \multicolumn{3}{|c|}{ Southern Site Area } & \multicolumn{3}{|c|}{ Northern Site Area } \\
\hline & PL & UW & FW & PL & UW & FW \\
\hline grog & $90.5^{*}$ & 97.5 & 88.9 & 91.7 & 95.0 & 91.6 \\
\hline bone & 20.5 & 14.4 & 8.9 & 19.4 & 17.9 & 12.6 \\
\hline hematite & 19.7 & 31.4 & 17.8 & 20.4 & 21.2 & 23.2 \\
\hline organics & 5.1 & - & 8.9 & 5.9 & 1.7 & 6.3 \\
\hline
\end{tabular}

$\mathrm{PL}=$ plain; UW=utility ware; $\mathrm{FW}=$ fine ware

*percentage; note that percentages do not sum to $100 \%$ in each of the columns because of the use of one or more tempers in the paste of vessel sherds; each instance is tabulated separately 
Finally, vessel sherds with charred organics are confined almost completely to the plain wares and fine wares, suggesting these wares may not have been as well-fired, or fired for a suitable duration to combust any organics in the paste, as were the utility wares from the two site areas.

\subsection{PASTE}

The majority of the vessel sherds from the Lang Pasture site have a clayey to silty paste. Clays used for vessel manufacture were probably gathered from nearby alluvial settings, perhaps along Caddo Creek, but certainly within a short (1-7 km away, at most) distance from the settlement (Arnold 2000:343; Arthur 2006:52), at least as based on recent ethnoarcheological research, so that an inordinate amount of time and energy was not expended by potters in hauling clay back to the site. Arthur (2006:52) points out that potters are likely to select lower quality clays for vessel manufacture than high quality clays if the latter are farther away. To date, the INAA of sherds and clays from East Texas sites and clay sample locales have been unable to pinpoint the locations of clays used for Caddo vessel manufacture.

I assume that the pottery found at the Lang Pasture site-at least the vessel sherds from domestic contexts - was very likely to have been made on site by potters that lived there; this assumption may well be totally incorrect if and when additional chemical analyses of vessel pastes and local clay sources can be conducted, but available chemical analyses of vessel sherds only suggests that the sherds from Lang Pasture (and other sites in the vicinity) were made from local upper Neches River basin clays (see Appendix D; see also Ferguson 2007; Ferguson et al. 2008). Depending upon the area of the site and the type of ware, about 18.4-33.6\% percent of the vessel sherds examined in detail have a sandy paste, suggesting that a naturally sandy clay was occasionally selected by Caddo potters for use in making particular kinds of vessels.

The highest frequency of sandy paste sherds are found in the plain wares from the southern ceramic component/area (Table 6-25), but a sandy clay was also commonly used among the fine wares in both areas. Uniformly, sandy paste clays were not regularly used in the manufacture of utility ware vessels. Overall, however, sandy clays were more frequently selected for vessel manufacture, regardless of the ware, by Caddo potters whose products ended up discarded in the southern ceramic component/area.

Approximately $7.8 \%$ of the plain and decorated sherds analyzed in detail from the Lang Pasture site (see Appendix F.1 and F.2, this volume) are identified as coming from "pinkware" vessels; interestingly, none of the mortuary vessels from the site are pinkware. These pinkware are sherds with a distinctive red (10R 5/8) paste after firing. These vessels were made with a clay with a moderate to high iron content (cf. Cordell 2001:17). Although the source of this clay is not known, I suspect it derives locally from iron-rich Weches Formation outcrops in the southwestern part of Smith County, the northwestern part of Cherokee County, and northeastern Anderson County (see Bureau of Economic Geology 1965).

The pinkware sherds are present in roughly similar amounts in both the southern $(n=30$ sherds) and northern ( $n=39$ sherds) ends of the Lang Pasture site. They are particularly common among the sherds found in the Feature 76 and Feature 79 fill. 
Table 6-25. Sandy Paste Sherds by Ware and Site Area.

Ware

Utility ware

Fine ware

Overall, all wares
Southern site area

(\%)
Northern site area

(\%)

$* \mathrm{~N}=300 ; * * \mathrm{~N}=563$

Pinkware vessels and vessel sherds have been documented in a number of post-A.D. 1400 Caddo ceramic assemblages in the upper Neches River basin (Figure 6-19), as well as a few sites downstream in the middle Neches River basin. In the latter area, this includes a few sherds from the R. F. Wallace site (41CE20) and 41CE47 (Shawn Marceaux, March 2008 personal communication); these may be from vessels made in the upper Neches River basin. In the upper Neches River basin itself, pinkware is present in the sherd assemblages from the Isibel-Gene Donnell site (41AN14, 8\% of the sherds), the Solon Stanley site (41CE3, 8.3\%), and the J. W. Blackburn (41CE4, 1.4\%) sites (see Figure 619).

A number of pinkware vessels have also been identified from prehistoric cemeteries in the upper Neches River basin. Approximately $11.2 \%$ of the 277 vessels analyzed in detail (see below and Appendix F.4) from the Mrs. J. M. Cook (41AN1), Mr. J. M. Cook (41AN2), Fred McKee (41AN32), J. W. Blackburn (41CE4), Omer and Otis Hood (41Ce14), E. W. Henry (41CE17), and R. J. Fair (41CE25) sites have the distinctive iron-rich pinkware paste. This iron-rich clay was used to manufacture both utility ware (i.e., Bullard Brushed, Killough Pinched) and fine ware vessels (Hood Engraved effigy vessels, Hume Engraved, Poynor Engraved), as well as plain bottles and carinated bowls.
The highest proportion of pinkware vessels have been documented at the Fred McKee and J. W. Blackburn sites (Table 6-26), in contexts dating between ca. A.D. 1480-1650 (Frankston phase, subphases 2 and 3). These sitesperhaps closer to the ultimate source of the iron-rich clay-are 4-20 km east of the Lang Pasture site (see Figure 6-19).

\subsection{FIRING CONDITIONS}

The Lang Pasture vessel sherds are from vessels fired in a variety of different ways (Table 6-27), presumably reflecting personal preferences in firing, the desired vessel color, the kind of clays that were used, and the functional and technological requirements of the kinds of vessel forms that were being manufactured at the site. Vessels were fired in an open fire, with the vessels either set atop the fire or nestled in the coals and ash.

Most of the sherds at the Lang Pasture site are from vessels that were fired in a low oxygen or reducing environment, this being particularly the case for all three wares (73.385.9\%) in the northern ceramic component/area. A particular firing method was to fire a vessel in a low oxygen environment, but then pull it from the fire to cool in the open air (see Table 6-27). This left either one or both vessel surfaces a lighter reddish-brown to brown oxidized color, probably a preferred color for plain wares and fine wares, along with occasional vessels that 


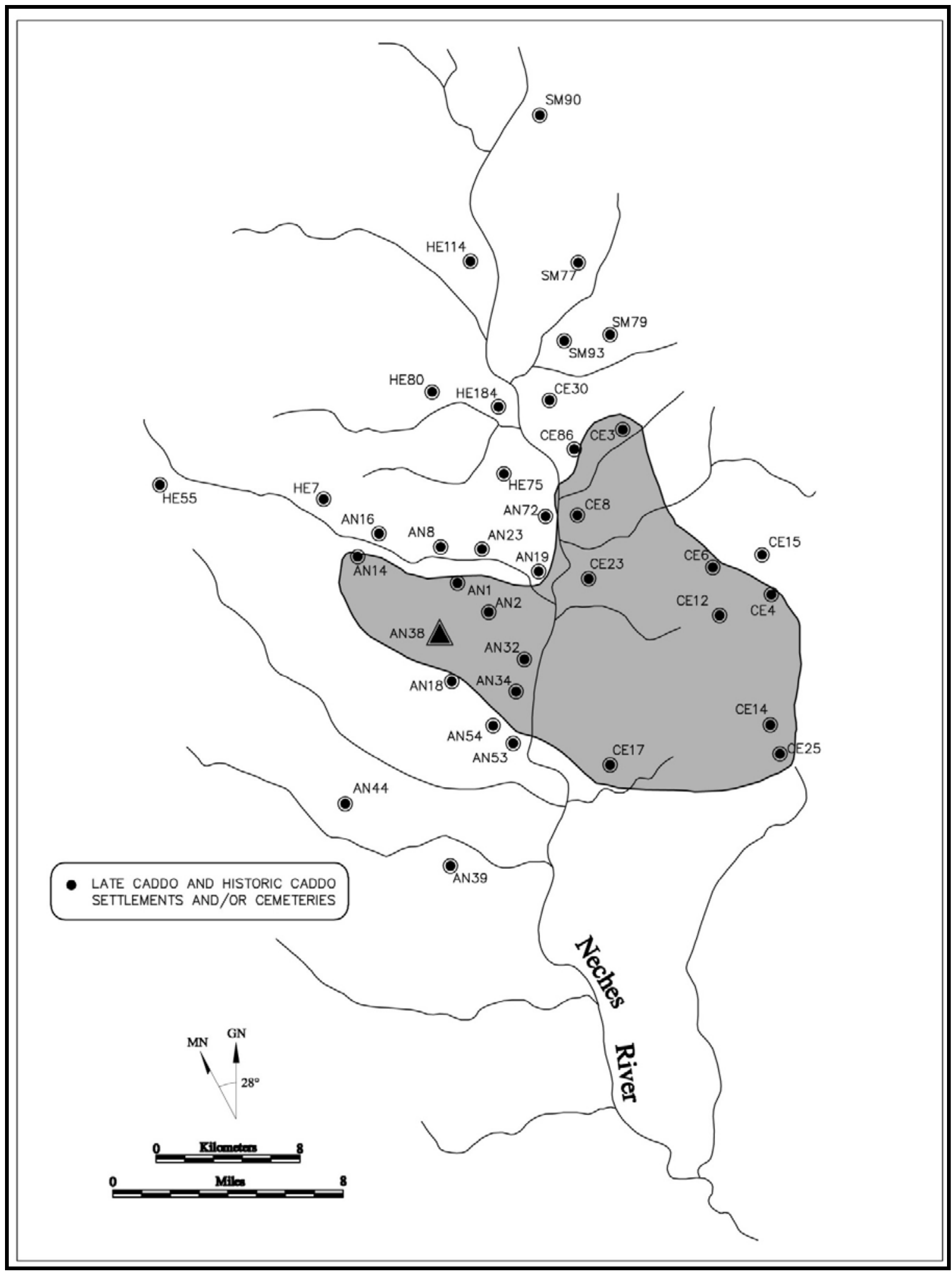

Figure 6-19. Known Distribution of Caddo Sites with Pinkware Vessels and Vessel Sherds. 
were fired to a gray, black, or dark grayishbrown color. Reduced fired sherds are much less common, however, in the sherds from the southern ceramic component/area, especially among the utility wares in this area (see Table 6-27). Conversely, sherds from the southern site area are more likely to be from vessels fired in an oxidizing or incompletely oxidizing environments, again most notably among the utility wares (39.8\%), and less so among the fine wares and plain wares.

In general, there are significant differences in how utility ware, plain ware, and fine ware vessels were fired. Fine ware and plain wares were better made and better fired (at least in terms of regulating the firing temperature), and they were probably fired longer in a low oxygen environment than the utility wares. The Caddo potters exerted more control over the end product of fine ware and plain ware vessel manufacture than they did with the utility wares, primarily to produce a harder ceramic. Firing conditions tend to be more heterogeneous among the utility wares (including the incompletely oxidized vessel sherds), likely the product of the multipurpose nature of these vessel forms, as they were used for cooking pots and storage containers.

Table 6-26. Pinkware Vessels in the Upper Neches River Basin.

$\begin{array}{llll}\text { Site } & \text { No. of } & \text { Proportion of } & \text { Types Represented } \\ & \text { Vessels } & \text { Pinkware Vessels } & \end{array}$

(\%)

\begin{tabular}{|c|c|c|c|}
\hline$\overline{41 \mathrm{AN} 1}$ & 33 & 12.1 & $\begin{array}{l}\text { Poynor Engraved, var. Lang; Hood Engraved; } \\
\text { Killough Pinched }(n=2)\end{array}$ \\
\hline 41AN2 & 17 & 11.8 & Poynor Engraved, var. T; Bullard Brushed \\
\hline 41AN32 & 23 & 39.1 & $\begin{array}{l}\text { Plain bottle; Poynor Engraved, var. P; Poynor } \\
\text { Engraved, var. Freeman }(\mathrm{n}=2) \text {; Poynor Plain; Poynor } \\
\text { Engraved, var. Cook; Brushed-punctated jar }(\mathrm{n}=2) \text {; } \\
\text { Hume Engraved }\end{array}$ \\
\hline 41CE4 & 24 & 20.8 & $\begin{array}{l}\text { Poynor Engraved, var. Hood }(n=2) ; \text { Hume } \\
\text { Engraved ( } n=2) \text {; Hood Engraved }\end{array}$ \\
\hline 41CE14 & 118 & 3.4 & $\begin{array}{l}\text { Poynor Engraved, var. K; Poynor Engraved, var. } \\
\text { Blackburn; Hood Engraved; Killough Pinched; } \\
\text { Poynor Engraved bottle }\end{array}$ \\
\hline 41CE17 & 35 & 8.6 & $\begin{array}{l}\text { Collared bottle; effigy vessel; Poynor Engraved, } \\
\text { var. B }\end{array}$ \\
\hline 41CE25 & 27 & 11.1 & $\begin{array}{l}\text { Poynor Engraved, var. Freeman; Poynor Engraved, } \\
\text { var. Hood }(\mathrm{n}=2)\end{array}$ \\
\hline
\end{tabular}


Table 6-27. Firing Conditions by Site Area and Ceramic Ware.

\begin{tabular}{|c|c|c|c|c|c|c|}
\hline \multirow{2}{*}{ Firing conditions* } & \multicolumn{3}{|c|}{ Southern site area } & \multicolumn{3}{|c|}{ Northern site area } \\
\hline & PL & UW & FW & PL & UW & FW \\
\hline$\overline{\text { Oxidized (A) }}$ & $12.4^{* *}$ & 23.7 & 22.2 & 7.2 & 14.5 & 9.5 \\
\hline Incompletely oxidized (C-E) & 11.7 & 16.1 & 8.9 & 10.5 & 9.5 & 3.2 \\
\hline Reduced (B) & 21.9 & 9.3 & 26.7 & 13.7 & 26.3 & 12.6 \\
\hline $\begin{array}{l}\text { Reduced, cooled in the } \\
\text { open air (F-H) }\end{array}$ & 51.0 & 38.1 & 42.2 & 64.7 & 47.0 & 73.3 \\
\hline $\begin{array}{l}\text { possible smothered firing; } \\
\text { smudging/sooting (I-L) }\end{array}$ & 2.9 & 12.7 & - & 3.9 & 2.8 & - \\
\hline Total & 137 & 118 & 45 & 289 & 179 & 95 \\
\hline
\end{tabular}

As long as the porosity of the utility wares was not excessive, and there was a good balance between clay plasticity and temper constituents, they did not need to be fired for as long a time as the harder fine wares to be quite serviceable vessels without being subject to diminished strength from cumulative thermal fatigue as well as cracks and fractures.

A number of sherds among the plain wares and utility wares in both ceramic components have a distinctive core, with a dark exterior/light exterior cross-section or lighter cores than their surfaces (I-L on Table 6-27). Aten and Bollich (2002:54-55) suggest that vessels with this kind of firing may have been placed in a fire with the "orifice [of the vessel] facing into the fire." Furthermore, the sherds with cores lighter than the surfaces may have come from vessels where "after extended firing that burned off all organics, the fire may have been smothered to cause reduction and darkening of the exterior surface.”

\section{Plain Sandy Paste Ceramic Sherds}

A total of 11 plain sherds (10 body and one rim) from the Lang Pasture site are from Goose Creek Plain, var. unspecified (see Aten 1983; Story 1990a) vessels (Table 6-28). This plain and untempered sandy paste ware is found in East Texas (i.e., south and west of the Sabine River, but concentrated in the middle Neches and Angelina river basins, well downstream and southeast from Lang Pasture) Woodland period or Mossy Grove Culture archeological sites that were occupied from ca. $2400-1200$ B.P. The recovery of a few sherds of this ware at Lang Pasture is additional evidence (beyond dart points, see Chapter 7, this volume) that the site was occupied to a limited extent during this period.

Approximately 64\% of the Goose Creek Plain, var. unspecified sherds from the site are from the northern part of the excavation block (see Table 6-28). Perhaps the transitory Woodland period use of the site was concentrated in this area of the landform. 
Table 6-28. Distribution of Plain Sandy Paste Pottery Sherds.

\begin{tabular}{lc}
\hline & No. of Sherds \\
\hline $180-199$ & 1 \\
$182-199$ & 2 \\
$187-200$ & 1 \\
$194-202$ & 1 \\
$197-198$ & 3 \\
$200-201$ & 1 \\
$204-199$ & 1 \\
$204-202$ & 1 \\
\hline
\end{tabular}

\subsection{PIPE SHERDS}

Ceramic pipes and pipe sherds are common artifacts found in upper Neches River basin Caddo sites, especially those sites occupied after ca. A.D. 1400 (Gilmore 1974; Jackson 1933, 1936; Kleinschmidt 1982). The Lang Pasture site is no exception in that ceramic pipes and pipe sherds are relatively abundant in both domestic and mortuary archeological deposits. The abundance of clay pipes in midden and habitation contexts clearly puts to rest to the assertion by Schambach et al. (1982:121) that "normal farmsteads exhibit an absence of pipes or pipe fragments," and that "pipes denote religious ceremonial activity."

Rather, the prevalence of clay pipes in both domestic and mortuary contexts throughout the upper Neches River basin indicate that the ritual activities associated with pipe smoking-and the smoking of tobacco (see Rafferty and Mann 2005; Winter 2000)—were actually part of daily life and the every-day ceremonies that the Caddo carried out in interacting with the spirits and souls around them. Pipes were probably smoked on a daily basis by adult members of farmsteads and communities-mainly adult males, but not always (see Chapter 11, this volume) - and when the pipes broke, they were discarded in nearby middens. Pipes were made locally for daily use, and for use in mortuary rituals.
A total of two whole pipes and 33 pipe sherds have been recovered from the Lang Pasture site (Table 6-29). The whole pipes are from burials, while the sherds are from broken pipes that were presumably discarded during the period of habitation. All the pipes and pipe sherds are from elbow pipes, a style of ceramic pipe manufacture that began to be popular after ca. A.D. 1350 in East Texas and elsewhere in the Caddo area (see Hoffman 1967: Rogers and Perttula 2004), but are virtually the exclusive form of clay pipe made by the Caddo from the $15^{\text {th }}$ century A.D. on.

The Feature 8 elbow pipe (Figure 6-20a) is plain and tempered with finely crushed bone; the exterior surface retains evidence of burnishing. The pipe has a L-shaped angle between the bowl and the stem, which appears to be the earliest form of elbow pipe in the upper Neches River basin (see below). The pipe bowl is $2.8 \mathrm{~mm}$ thick; bowl height is 32.8 $\mathrm{mm}$; exterior bowl orifice diameter is 27.2 $\mathrm{mm}$; maximum stem length is $39.9 \mathrm{~mm}$; exterior stem diameter is $14.2 \mathrm{~mm}$; and the stem thickness is $3.1 \mathrm{~mm}$.

The Feature 93 elbow pipe (see Figure 6-20b), although fragmentary, is also L-shaped and plain. The bowl is complete, and approximately $50 \%$ of the stem remains; the other half of the stem must have broken off before being placed in the grave. The pipe was tempered with finely crushed grog. The 
exterior surface was well smoothed. There is a thick organic residue inside the bowl.

The bowl on this pipe stands $38.2 \mathrm{~mm}$ in height (slightly larger than the Fea. 8 pipe), and had an orifice diameter of $26.0 \mathrm{~mm}$ at the rim and $20.0 \mathrm{~mm}$ at the juncture with the stem. The bowl and stem are both $3.8 \mathrm{~mm}$ thick. The stem orifice diameter ranges from 15.1-16.0 $\mathrm{mm}$ from the rim to the juncture with the bowl.
The 33 elbow pipe sherds from the domestic areas are from at least 10 different pipes, based on differences in temper, paste, decoration, and bowl/stem orifice diameter. In the southern part of the site (N170-188), the 21 pipe sherds include 13 bowl pieces (Figure 6-21d, g), one stem/bowl fragment (Figure 621b), and seven pipe stems (Figure 6-21a, c, e, f). Four of these had a finely crushed bone temper (19\%), six others had grog temper (29\%), and the others had no obvious temper inclusions.

Table 6-29. Pipe Sherds from the Lang Pasture Site (41AN38).

\begin{tabular}{|c|c|c|}
\hline Provenience & Number & Comments \\
\hline ST 6, lv. 3 & 1 & elbow pipe bowl rim (4 cm OD) \\
\hline 172-202, lv. 3 & 1 & pipe bowl (?) sherd \\
\hline 173-198, lv. 2 & 1 & elbow pipe bowl rim (5 cm OD) \\
\hline 175-198, lv. 5 & 2 & $\begin{array}{l}\text { pipe bowl rim: } 1 \text { plain; } 1 \text { pipe stem decorated with } \\
\text { horizontal engraved lines and a row of tool } \\
\text { punctates ( } 2 \mathrm{~cm} \mathrm{OD)}\end{array}$ \\
\hline 175-200, lv. 4 & 1 & pipe bowl rim sherd \\
\hline 176-198, lv. 3 & 1 & pipe bowl rim sherd \\
\hline 177-201, lv. 1 & 1 & lower pipe bowl* \\
\hline 177-201, lv. 2 & 1 & elbow pipe bowl (3+ cm OD)* \\
\hline 179-201, lv. 3 & 1 & elbow pipe stem sherd, L-shaped pipe form* \\
\hline 179-202, lv. 4 & 1 & elbow pipe bowl rim (5 cm OD) \\
\hline 180-202, lv. 3 & 1 & elbow pipe bowl rim (6 $\mathrm{cm}$ OD) \\
\hline 181-198, lv. 1 & 1 & $\begin{array}{l}\text { elbow pipe bowl with three horizontal engraved } \\
\text { lines near the bowl base }\end{array}$ \\
\hline 181-202, lv. 5 & 1 & pipe stem sherd \\
\hline 182-200, lv. 5 & 1 & pipe stem sherd \\
\hline 183-199, lv. 4 & 1 & elbow pipe bowl rim (4 cm OD) \\
\hline 184-199, lv. 5 & 1 & elbow pipe bowl rim (5 cm OD) \\
\hline 187-198, lv. 2 & 1 & $\begin{array}{l}\text { pipe stem rim, decorated with vertical and diagonal } \\
\text { engraved lines }\end{array}$ \\
\hline 188-199, lv. 4 & 1 & pipe bowl sherd \\
\hline 188-202, lv. 3 & 1 & $\begin{array}{l}\text { elbow pipe stem with } 2 \text { horizontal engraved lines on } \\
\text { the rim }\end{array}$ \\
\hline 191-199, lv. 1 & 1 & pipe stem sherd \\
\hline 194-200, lv. 1 & 1 & pipe stem sherd \\
\hline 195-198, lv. 2 & 1 & elbow pipe bowl sherd \\
\hline 196-202, lv. 1 & 1 & pipe bowl sherd \\
\hline 197-202, lv. 3 & 1 & pipe stem sherd \\
\hline 198-199, lv. 1 & 1 & pipe stem sherd \\
\hline 198-202, F.76, lv. 12 & 1 & pipe stem sherd \\
\hline 199-198, lv. 4 & 1 & elbow pipe bowl rim ( $3 \mathrm{~cm}$ OD) \\
\hline 200-201, lv. 4 & 1 & pipe stem sherd \\
\hline Fea. 8 & 1 & elbow pipe, L-shaped form (2.7 cm OD) \\
\hline Fea. 93 & 1 & elbow pipe, L-shaped, plain (2.6 cm OD) \\
\hline Scrape E & 4 & $\begin{array}{l}3 \text { separate pipe stem rims ( } 2 \mathrm{~cm} \mathrm{OD,} 5 \mathrm{~cm} \mathrm{OD} \text {, and } \\
5 \mathrm{~cm} \text { OD); all three decorated with horizontal } \\
\text { engraved lines on the rim }\end{array}$ \\
\hline
\end{tabular}




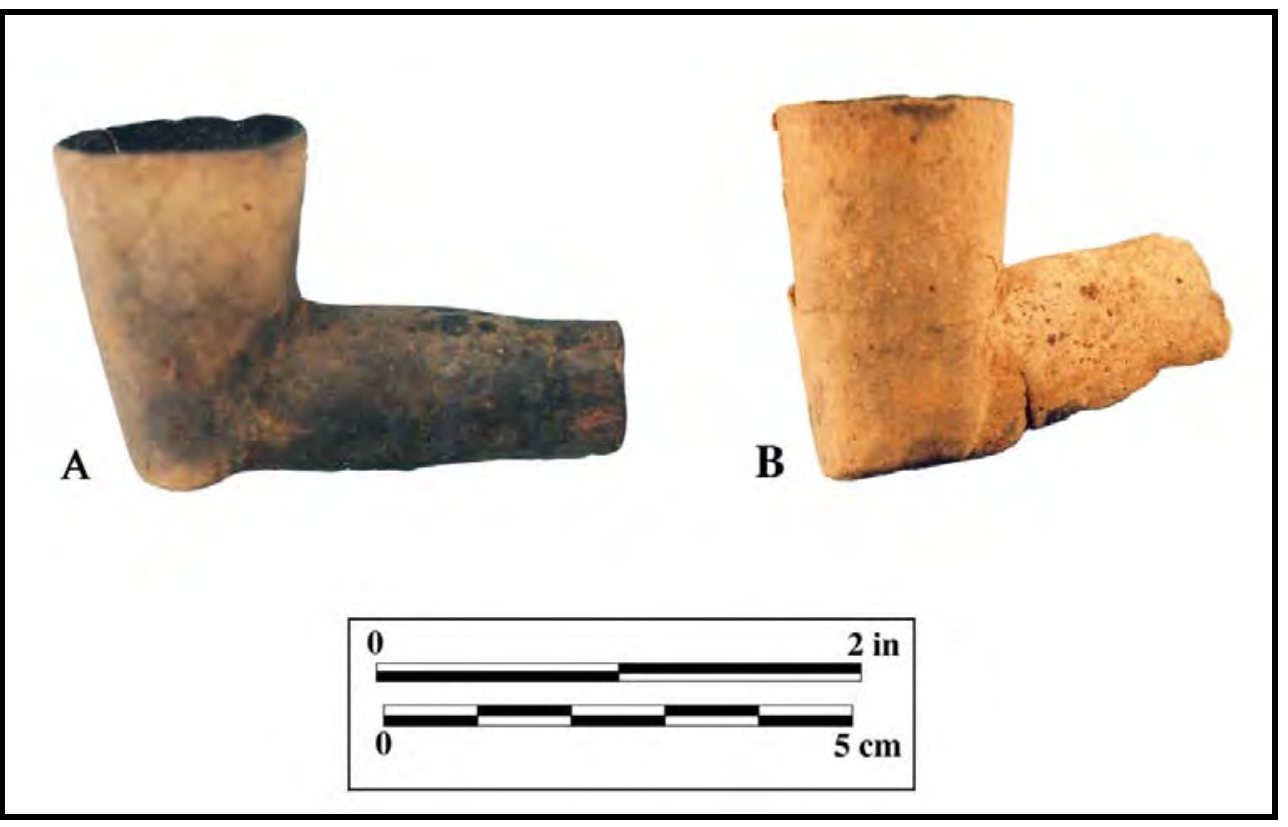

Figure 6-20. Elbow Pipes From Burials: a, Feature 8; b, Feature 93.

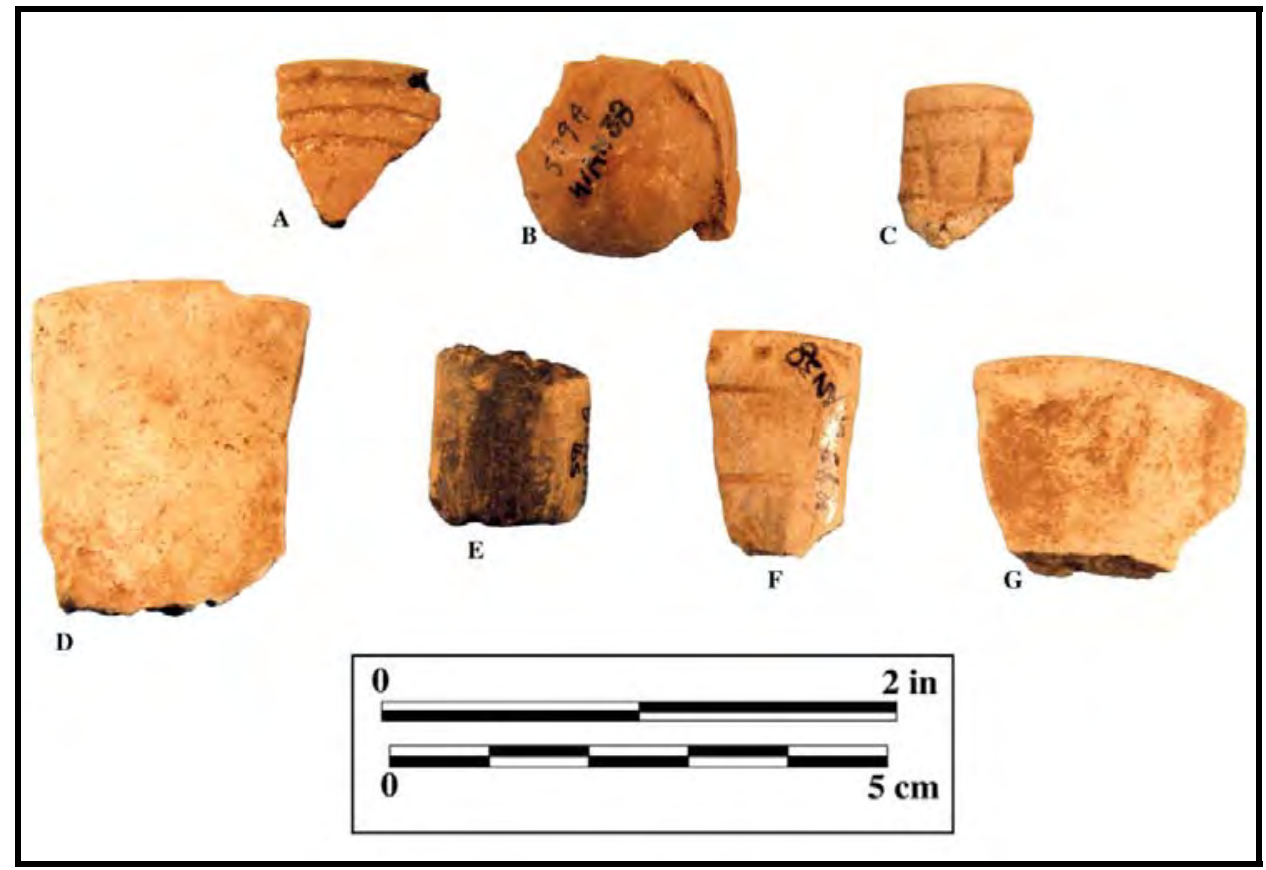

Figure 6-21. Elbow Pipe Sherds from the Southern Area: a-c, engraved stem and bowl sherds; d, g, plain bowl; e, stem; f, engraved-punctated stem. Provenience: a, Scrape E; b, N181 E198, level 1; c, N187 E198, level 2; d, N184 E199, level 5; e, N181 E202, level 5; f, N175 E198, level 5; g, N173 E198, level 2. 


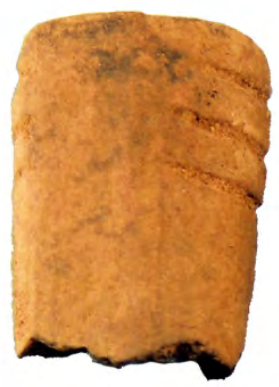

A
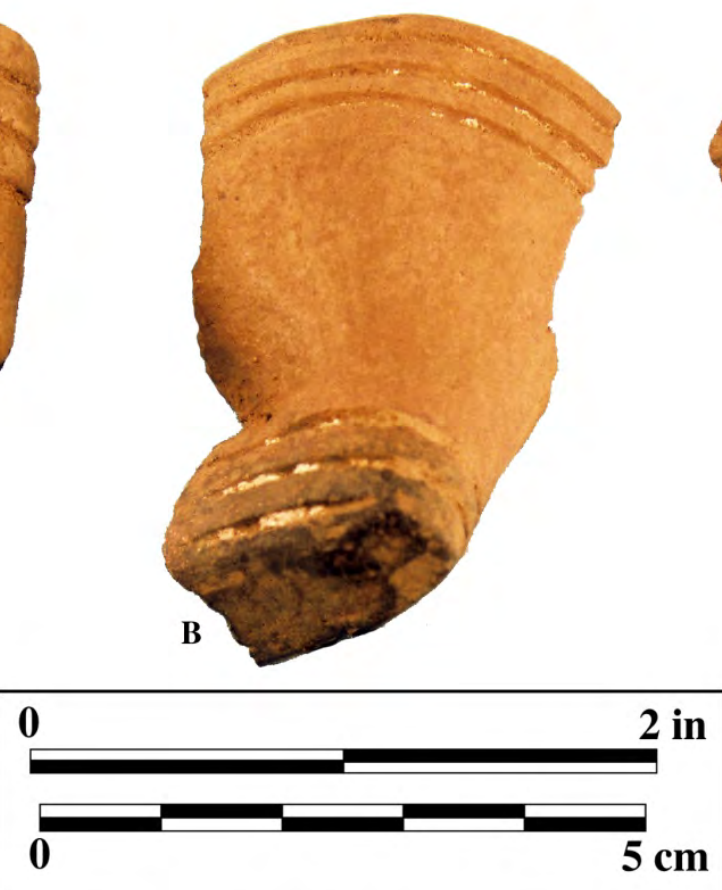

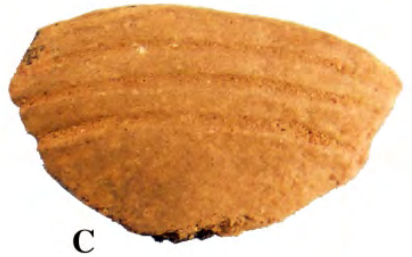

Figure 6-22. Variety B Elbow Pipes from Scrape E at the Southern End of the Lang Pasture Site.

One plain pipe bowl rim had the distinctive pinkware paste previously noted in a number of the vessel sherds from the site (see above). Bowl orifice diameters on the pipes ranged from 3-6 cm. One of the southern area pipes is a fragment from a plain L-shaped elbow pipe form. Four bowls and stems from different pipes have horizontal engraved lines on them (and one has a white kaolin clay pigment rubbed in the engraved lines), and one of these (from Scrape E) also had three horizontal engraved lines on the basal portion of the bowl (Figure 6-22b).

These are Variety B elbow pipe forms in the upper Neches River basin (Figure 6-23). Another stem rim, from a grog-tempered elbow pipe, is decorated with punctated and engraved lines. The design includes a single row of horizontal punctations below the rim and above at least two horizontal engraved lines (see Figure 6-21f).

There are 12 elbow pipe sherds in the northern part (N189-209) of the site, including one pipe stem from Feature 76. These sherds include four bowl pieces and eight stem sherds. Unlike the elbow pipes from the southern part of the site, $67 \%$ of these other pipe sherds are grogtempered (compared to $29 \%$ from the southern site area), and one another has a hematite temper; the remainder have no obvious temper.

These northern site elbow pipes are both plain (probably Var. A L-shaped forms) and engraved. The engraved pipes include one stem with horizontal engraved lines on it (a Var. B form, see Figure 6-23) and a second 
stem with horizontal and opposed lines (Var. C.).

An examination of the clay elbow pipes from mortuary contexts in the upper Neches River basin (see Chapter 11), from cemeteries of known age, indicates the following stylistic and morphological trends (see Figure 6-23):

- the earliest elbow pipes (Var. A) are plain L-shaped forms;

- flaring bowl forms are stylistically sequent, with distal stem knobs; these pipes (Var. B) have three engraved or deep incised lines on the stem and short lines on the lower bowl; some examples have pedestal bases (Figure 6-24a);

- Var. C pipes have engraved/ incised lines on the stem, and lines on the pipe that extend along the entirety of the stem and basal portions of the bowl (Figure 6-24b-c);

- In Var. D pipes, the parallel engraved or incised lines extending along the stem and the lower body are replaced by long rows of small punctations (see Figure 6-23);

- Var. E elbow pipes are the first forms that are completely covered with decoration, in this case curvilinear incised lines; and lastly

- cross-hatched engraved elbow pipes (Var. F).
At the Lang Pasture site, Var. A-C elbow pipe forms are present. The pipes from mortuary contexts are Var. A forms, while all the three forms are present in domestic contexts. In other upper Neches River basin sites of known age (i.e., dating to the Frankston phase, subphase 1-3, and the Allen phase), Var. A pipes are restricted to pre-A.D. 1480 components. Var. B pipes are present in ca. A.D. 1400-1560 cemeteries such as Pierce Freeman (41AN34), Mrs. J. W. Blackburn (41CE4), Omer and Otis Hood (41CE14), cemetery \#1, and John Bragg (41CE23), as well as ceremonial contexts at the A. C. Saunders site (41AN19), while Var. C pipes occur from ca. A.D. 1400-1650. Var. D-F are all apparently post-A.D. 1560 elbow pipe forms as they are present only in Frankston phase, subphase 3, and Allen phase burials at Emma Owens (41AN21), the Fred McKee (41AN32, four examples), E. W. Hackney (41CE6), and Jim P. Allen (41CE12) cemeteries.

Although not present at the Lang pasture site, there are other elbow pipes in the upper Neches River basin that have a variety of incised-punctated decorations (Jackson 1933:75, 78; Gilmore 1974:Table 68; Kleinschmidt 1982). Jackson (1933:75) refers to these as Neches pipes, usually with rows of punctations on the stem, heel, and bowl (see Figure 6-23d; see also Jackson 1936:Plate 28), and rows of raised bands, forming a collar at the stem (Shafer 1981:Figure 9e). These appear to be elbow pipe forms that date from post-A.D. 1480 times, which is corroborated by their absence at the Lang Pasture site. 

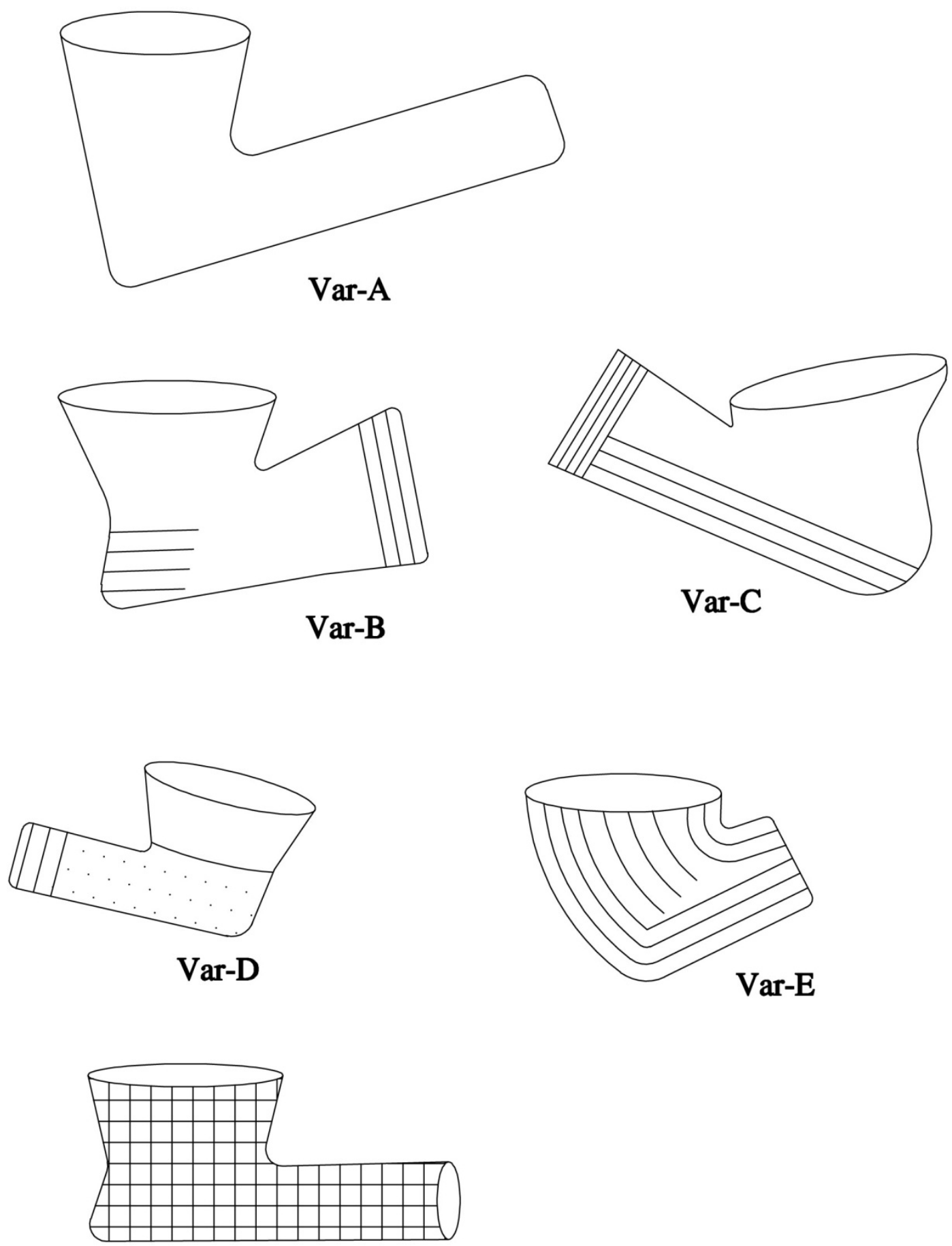

\section{Var-F}

Figure 6-23. Elbow Pipe Varieties A-F in the Upper Neches River Basin. 

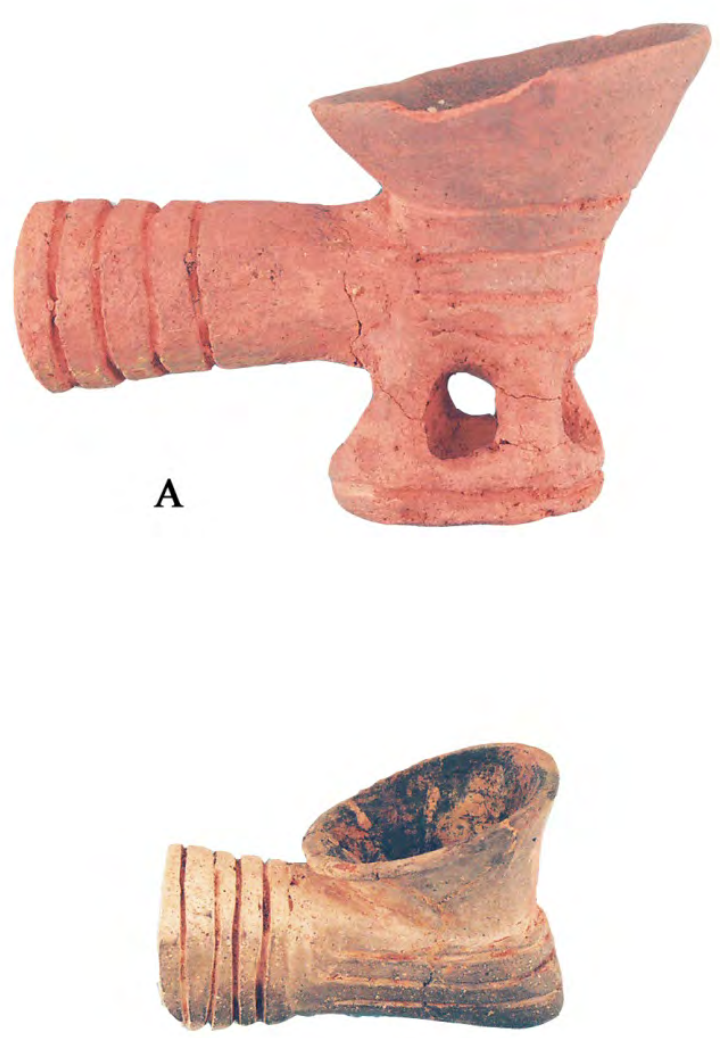

C

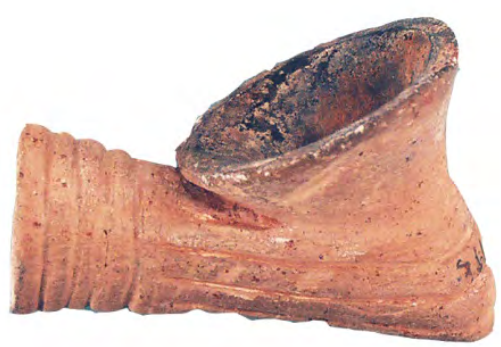

B

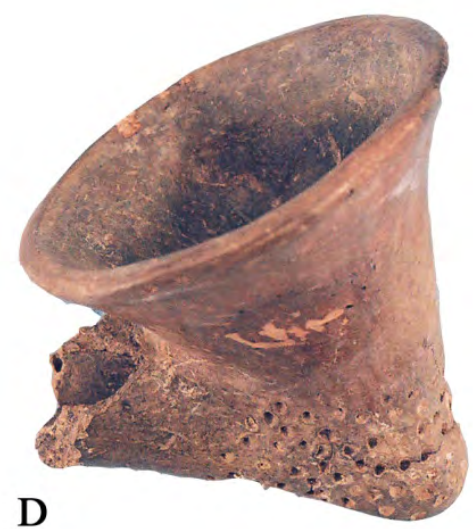

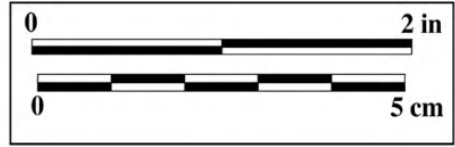

Figure 6-24. Elbow Pipes from the Upper Neches River Basin: a, Var. B. pipe from 41CE3; b, Var. C pipe from 41CE4; c, Var. C. pipe from 41CE25; d, punctated elbow pipe from 41AN32.

\subsection{Other Ceramic Objects FROM THE LANG PASTURE SITE (41AN38)}

There are only a few other ceramic artifacts in the collections from the Lang Pasture site. All are from the northern part of the site (Table 630).

The first of these is a $13.5 \mathrm{~mm}$ wide and thick grog-tempered clay coil or vessel leg/foot support (see Table 6-29), such as are seen on various upper Neches River basin vessels (among them Killough Pinched jars, see below). The fragment is $23.8 \mathrm{~mm}$ in length.

There are also three pieces of burned clay (lacking impressions of plant remains, branches, or sticks) from Features 25, 76, and 79. Two of the pieces are small, but the larger piece from Feature 76 is $43 \times 29.8 \times 16.5 \mathrm{~mm}$ in length, width, and thickness, and may have come from a baked griddle piece or some other culinary facility; this particular piece is grog-tempered. The overall and virtually complete absence of daub and burned clay 
from the Lang Pasture site is notable, and strongly indicates that the structures here were not daub-covered. It is also doubtful that the prehistoric Caddo structures were burned down, which would have increased the likelihood that daub pieces would be preserved. Without burning or exposure to heat, any clay-covered and thatched walls of Caddo structures (i.e., wattle and daubcovered) would have gradually melted away, leaving little to no evidence for the use of clay and thatching to cover the house walls or roof.

It is also possible that Caddo structures in this area did not generally have a wattle and daub covering, and this seems the most reasonable explanation for the general dearth of daub and burned clay at the Lang Pasture site. Fray Casanas in 1691 had noted that "all the [Caddo] tribes towards the north and east [of the Hasinai] live in pueblos. They plant in the same way as the Asinai [Hasinai]. Some have settlements better organized than others, such as the Cadaudachos [Kadohadacho or Cadohadacho], Nasitox [Natchitoches], and others whose houses are located close together and are well plastered" (Hatcher 1927c:287; Swanton 1942:251; brackets added). Large amounts of daub from wall plastered houses on prehistoric and early historic Caddo sites in northeastern Texas tend to be found in parts of the Sabine, Big Cypress, Sulphur River, and Red River basins, but very rarely in sites south of the Sabine River basin. This dichotomy implies differences across the landscape in the construction of houses by the Caddo, as well as their use and eventual abandonment (i.e., deliberate burning of structures). The Lang Pasture Caddo houses tended not to be both wattle and daub-covered.

Two clay spindle whorls (Figure 6-25) were recovered from Feature 76. Spindle whorls are disk-shaped sherds (usually base sherds or thick body sherds) that have a central perforation or hole drilled in them; the central perforations on the two specimens from the site are $10.7-13.0 \mathrm{~mm}$ in diameter. The spindle whorl would have been affixed on a spindle to help maintain its rotary motion during spinning activities. The presence of two spindle whorls at the Lang Pasture site suggests that Caddo women were processing fibers to produce textiles (cf. Alt 1999) there from the $14^{\text {th }}$ to the $15^{\text {th }}$ centuries A.D. Materials that could have been used include animal hair and various vegetable fibers, among them hemp, slippery elm, mulberry, milkweed, and nettle, as well as the bark of trees.

Table 6-30. Other Ceramic Objects from the Lang Pasture Site (41AN38).

\begin{tabular}{lll} 
Provenience & No. & Comments \\
\hline 197-201, F.25, 25-30 & 1 & burned clay $(0.2 \mathrm{~g})$ \\
198-202, F.76, lv. 12 & 2 & 2 spindle whorls, 10.7-13.0 mm in diameter \\
198-203, F. 76, lv. 5 & 1 & large piece of baked clay, no impressions \\
198-199, F.79, lv. 5 & 1 & burned clay $(1.3 \mathrm{~g})$ \\
192-202, lv. 5 & 1 & clay pendant with suspension holes \\
198-201, lv. 2 & 1 & clay plug or stopper; clay ear spool? \\
199-200, lv. 3 & 1 & clay coil or leg/foot vessel support
\end{tabular}




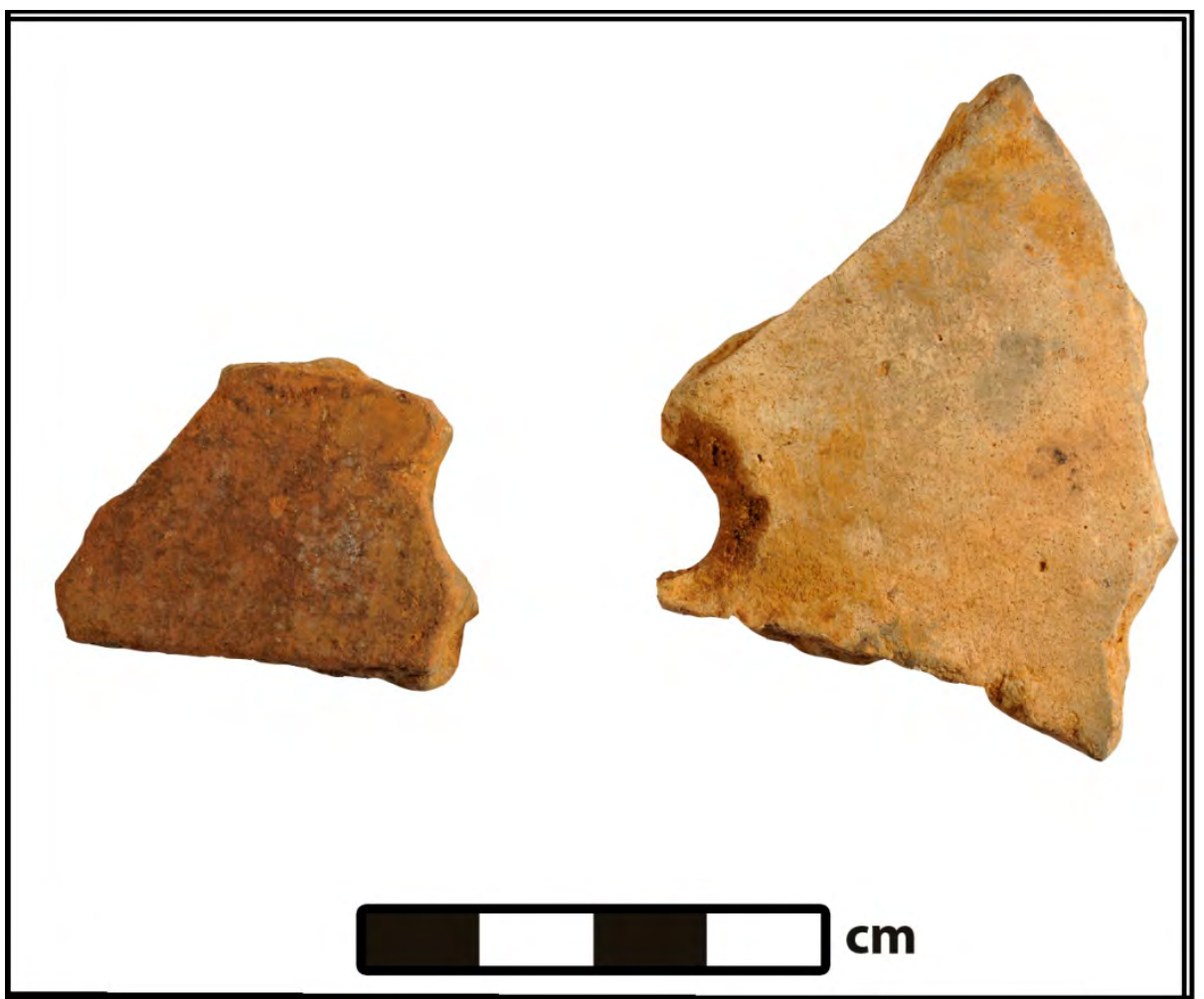

Figure 6-25. Potsherds with Perforations (spindle whorls).

Another clay artifacts (N198 E201) is laminated in cross-section, and has no temper, but is rounded in cross-section $(6.5 \mathrm{~mm}$ in thickness), and smoothed on its exterior surface. The rounded cross-section suggests that this may be part of a clay plug or vessel stopper, or less likely, a fragment of a ceramic ear spool.

The final miscellaneous clay artifact (N192 E202, level 5) is an oval-shaped pendant 29.0 $\mathrm{mm}$ in length and $16.0 \mathrm{~mm}$ in width (Figure 626). The pendant has a $2.0 \mathrm{~mm}$ suspension hole at the narrower end. The pendant was made with a sandy clay, but no obvious temper was added to the paste. One side of the pendant has a fire cloud that must have been produced during the firing of this clay ornament.

\subsection{METHODS OF STUDY OF UPPER NECHES RIVER BASIN CADDO VESSELS}

Because of the number of ceramic vessels in the collections from the Lang Pasture site as well as in generally contemporaneous prehistoric Caddo sites in the upper Neches River basin in the TARL collections that we proposed to study for comparative purposes, we established a documentation protocol to assist in the study of each of the vessels from the different sites. Each of the ceramic vessels in the collections is described and analyzed utilizing a consistent set of morphological, functional, and stylistic attributes modeled after the presentations in Cast et al. (2006); Gadus and Fields (1996); Gonzalez et al. (2005), Perttula et al. (1998, 2008), and Perttula (2005, ed.). The purpose of the documentation is to thoroughly characterize the character of each of the ceramic vessels in the different upper Neches River basin Caddo collections. Appendix F.3 and F.4 provide the 
completed vessel recordation forms (Figure 627) from the Lang Pasture site and seven other prehistoric Caddo sites in the basin, as well as accompanying vessel photographic illustrations.

The following attributes were employed in the ceramic vessel study:

Non-plastics: Deliberate and indeterminate materials in the paste (Rice 1987:411), including a variety of tempers (grog or crushed sherds, bone, hematite, shell, quartz sands, etc.) and "particulate matter of some size." The grog, bone, and hematite non-plastics appear to have been deliberately added to the paste as tempers. The bone used for temper had been burned and calcined, then crushed, before it was added to the paste.
Vessel Form: The principal vessel form categories include open containers (bowls, carinated bowls, and compound bowls) and restricted containers, including jars and bottles (Figure 6-27 a-j)) of several shapes and sizes. As restricted containers, jars allow access by hand, but bottles do not (Brown 1996:335). Another important vessel form, at least in burial contexts, is the effigy bowl (Figure 6-27 k) with a modeled head (usually a bird or duck head) and a tab tail. Occasionally, an effigy vessel will have a broader tab tail that supported a anthropomorphic or zoomorphic tail rider (see Suhm and Jelks 1962:Plate 24k).

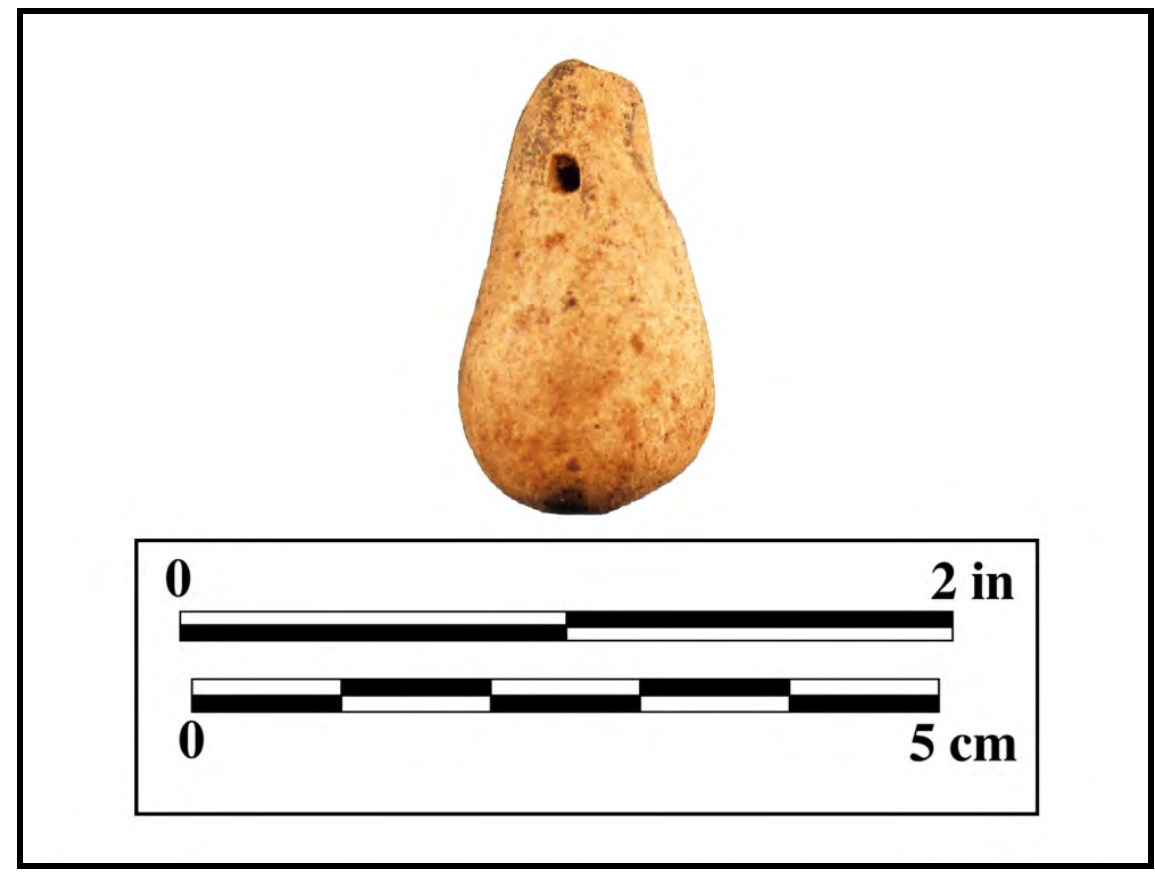

Figure 6-26. Clay Pendant. 

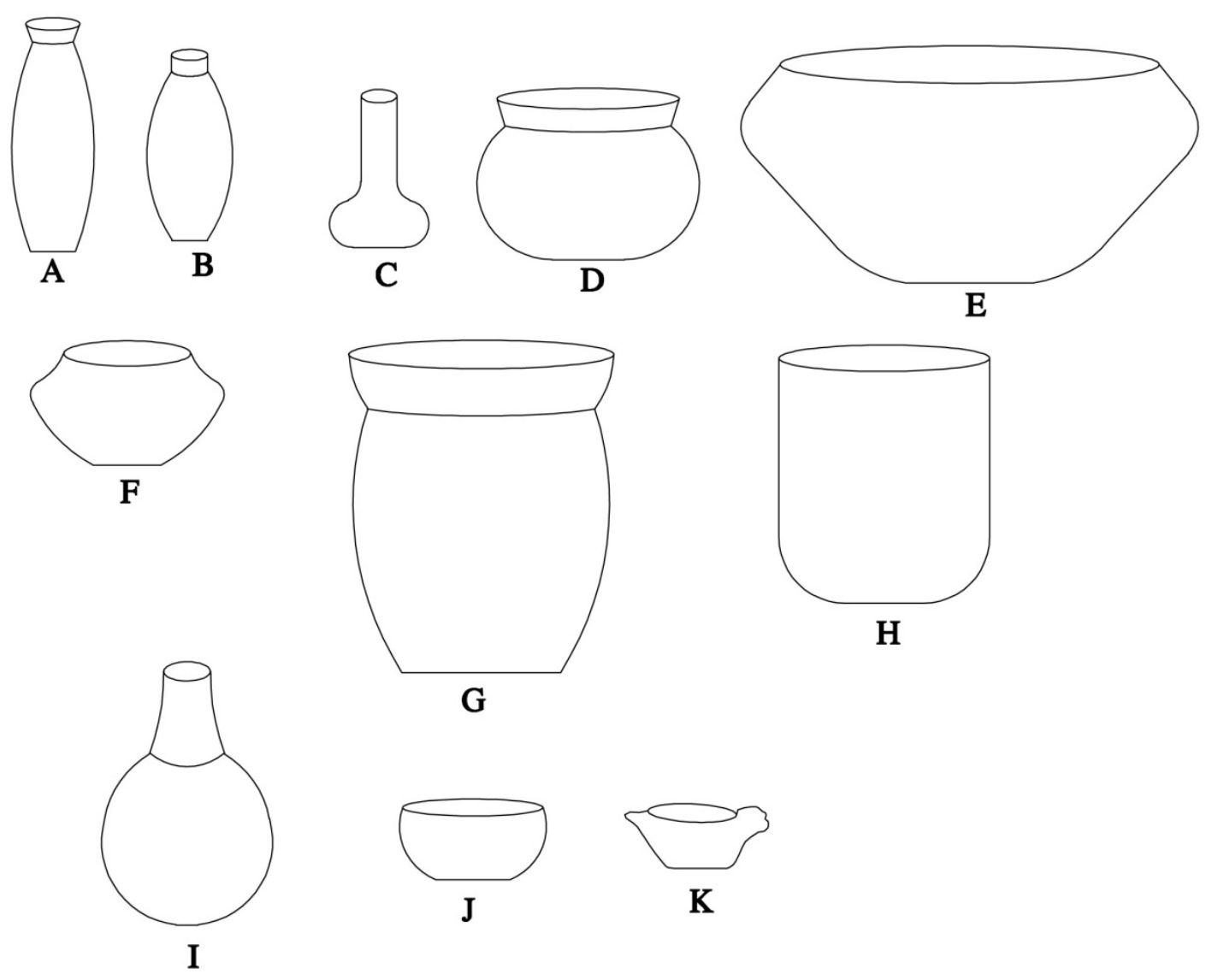

G
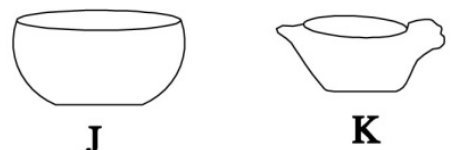

$\mathbf{J}$

Figure 6-27. Upper Neches River Basin Caddo Vessel Forms: a-b, cylindrical bottle with short neck; c, squat-bodied bottle with long neck; d, f, carinated bowl with globular body;

e, inverted rim carinated bowl; g, everted rim jar; h, cylindrical jar; l, globular bottle; j, simple bowl; k, effigy bowl.

Additional form attributes that were recorded on each of the vessels (depending upon their completeness) include the rim profile (outflaring or everted, vertical or standing, and inverted), lip profile (rolled to the exterior, rounded, flat, or thinned), and base shape (flat or rounded).

Core Colors: Observations on ceramic cross-section colors permit consideration of oxidation patterns (Teltser 1993:Figure 2A-H; Perttula 2005, ed.), and thus the conditions under which the vessel was fired and then cooled after firing. Comments are included for these attributes on the presence and location of fire-clouding, sooting or smudging from cooking use (Skibo 1992), and the preservation and location of charred organic remains.

Wall Thickness: Thickness was recorded in millimeters, using a vernier caliper, at the lip, along the rim, at several points along the body, and at the base when possible (only for the vessels that were not complete).

\section{Interior and Exterior Surface} Treatment: The primary methods of finishing the surface of the vessel 
include smoothing, burnishing, and polishing (Rice 1987:138). Brushing is a popular method of roughening the surface (particularly the body) of large and small Middle (ca. A.D. 12001400) and Late Caddo (ca. A.D. 14001680) period cooking jars, but is here considered a decorative treatment rather than solely a functional surface treatment (cf. Rice 1987:138), although not all Caddo ceramic analysts treat brushing as a decorative treatment (cf. Gadus et al. 2006:31). In certain fine ware vessels, brushed bodies accompanied engraved rim panels. Smoothing creates "a finer and more regular surface...[and] has a matte rather than a lustrous finish" (Rice 1987:138). Burnishing, on the other hand, creates an irregular lustrous finish marked by parallel facets left by the burnishing tool (perhaps a pebble or bone). A polished surface treatment is marked by a uniform and highly lustrous surface finish, done when the vessel is dry, but without "the pronounced parallel facets produced by burnishing leatherhard clay" (Rice 1987:138).

The application of a hematite-rich clay slip (Ferring and Perttula 1987), either red or black after firing in an oxidizing or reducing (i.e., low-oxygen) environment, is another form of surface treatment noted in these vessel assemblages, albeit very rarely. The clay slip is more frequently applied on the vessel exterior than on the interior surface, and then was either burnished or polished after it was leather-hard or dry.

Height and Orifice Diameter: These attributes, measured in centimeters, were recorded with a ruler.

\section{Diameter at Bottom of Rim and} Base Diameter: Also recorded in millimeters using a ruler, these attributes permit characterization of the overall contour and shape of the vessel.

Volume: Vessel volume in liters was determined by filling (to within $1 \mathrm{~mm}$ of the lip) the vessel with lentil seeds, then dumping the lentil seeds in containers of known volume. In estimating the volume of vessels with holes, the vessel was first filled with a cloth that conformed to vessel contours, then the lentil seeds were poured into the depression in the cloth to within $1 \mathrm{~mm}$ of the top of the lip. Then they were dumped into containers of known volume. In cases where the vessels were not (or could not) be reconstructed, but measurements of height and orifice diameter were be obtained, volumes were estimated by comparison with known vessel volumes of specific forms (i.e., carinated bowl, jar, bottle, compound bowl, and bowl) in other documented Caddo vessel assemblages.

Decoration: Decorative techniques present in the vessel collections from sites in the upper Neches River Basin of East Texas include engraving and excising, incising, punctating, pinching, lip notching, brushing, neck banding, and appliquéing, and on certain vessels, combinations of decorative techniques (i.e., brushedpunctated) created the decorative elements and motifs. Engraving and lip notching was done with a sharp tool when the vessel was either leather-hard, or after it was fired, while the other decorative techniques were executed with tools (incising and punctation), by adding strips of clay to the wet body (appliqué), by crimping the coils (neck banding), using frayed sticks or grass stems (brushing) dragged across the body surface, or fingernails (certain forms of punctations and pinching), when the 
vessel was wet or still plastic. Excising is considered a form of engraved decoration, where the clay is deliberately and closely marked/scraped and carved away with a sharp tool, usually to create triangular elements (the pendant triangle or small tick marks) or crescent-shaped elements that separate or serve to define scrolls (Suhm and Jelks 1962:Plate 64a-b, f).

Another form of vessel decoration is the use of red (hematite or ochre) or white (kaolin) clay pigments that have been smeared or rubbed into the engraved lines of certain vessels.

Type: The kinds of named ceramic types in the Lang Pasture and TARL collections from the upper Neches River basin follow the work of Suhm and Jelks (1962) and Kleinschmidt (1982), as well as the new types and varieties defined herein (see below).

In the sections that follow, I first discuss the character of the vessels found in mortuary contexts at the Lang Pasture site as well as the mortuary vessels from seven nearby and culturally affiliated prehistoric Caddo cemeteries (see Figure 6-1). Then I use this vessel data to make comparisons of the kinds of decorative motifs and elements found on the different kinds of vessel forms, followed by assemblage-level considerations of vessel form, vessel size, use of temper, and firing conditions, as well as the use of pigments. Lastly, I employ the data from Lang Pasture, the aforementioned seven mortuary sites, along with other upper Neches River basin sites, to examine temporal and spatial trends in Late Caddo and Historic Caddo fine ware pottery types and varieties in the Upper Neches, building on the temporal seriation of vessels and the definition of sub-phases 1-3 by Kleinschmidt (1982) and Perttula (2007b). Here, I also discuss the defined varieties of Poynor Engraved, Hume Engraved, and Patton Engraved - the main fine ware vessels made in the region-as well as provide details on the several new pottery types recognized in the vessel analysis (Fair Plain, Hood Engraved, Hood Plain, Hume Plain, Poynor Plain, and Poynor Brushed).

\subsection{VESSELS FROM MORTUARY CONTEXTS AT THE LANG PASTURE SiTE (41AN38)}

A total of 31 vessels or partial vessel sections were among the funerary offerings placed with the Caddo burials at the Lang Pasture site (see Chapters 5 and 11, this volume; see also Appendix F.3). This includes 10 carinated bowls, 11 bowls, three compound bowls (apparently a rare vessel form in the upper Neches), three jars, and four bottles. One of the more distinctive features of the mortuary vessels from the site is the high frequency of plain vessels (61\%).

Three of the 10 carinated bowls are engraved (Figure 6-28e) with distinctive local varieties of Poynor Engraved: local variety 1, 3, and 4 (Figure 6-29a, c-d). These have rim panels with triangular, semi-circular, and circular decorative elements, sometimes hatched, but in the case of the opposed triangles in local variety 1 (see Figures 6-28e and 6-29a), the three corners of the triangular elements are hatched. Local varieties 1 and 4 match the unnamed but lettered regional varieties $\mathrm{F}$ and $\mathrm{K}$, respectively (see below) of Poynor Engraved.

One other carinated bowl is red-slipped. The other six are plain: one of the plain carinated bowls has a series of rim peaks as a lip embellishment, and another plain carinated bowl from the site is lip notched (see Figure 628b).

One of the three compound bowls is plain (Figure 6-30b). The second, a Poynor Engraved, local variety 2 compound bowl, has stacked engraved triangles and centrally placed circles or sun symbols (see Figure 629b). The third compound bowl is also engraved (Figure 6-30a) —a local variety 5 of 
Poynor Engraved-with semi-circles and hatched triangles in a rim panel divided by vertical and diagonal engraved lines (see Figure 6-29e). Local varieties 2 and 5 of Poynor Engraved are apparently quite rare at other upper Neches River basin Caddo sites, as only a single example of either has been identified from the region, that being a local variety 2 vessel found at a Frankston phase sub-phase 1 site (Rose Daniels, 41AN23).

Two of the 11 bowls from the Lang Pasture site are decorated. These include a Poynor
Engraved, local variety 1 or regional var. F (nested ovals and triangles divided by diagonal cross-hatched ladders, see below) bowl with rim peaks (Figure 6-31c) and a Killough Pinched bowl with scalloped lips. The plain bowls include simple bowls (Figure 6-30a-b) and a triangular-shaped bowl (Figure 6-31d). A number of these plain bowls have either scalloped lips (33\%) or rim peaks (22\%). There are no effigy vessels in this mortuary vessel assemblage. 


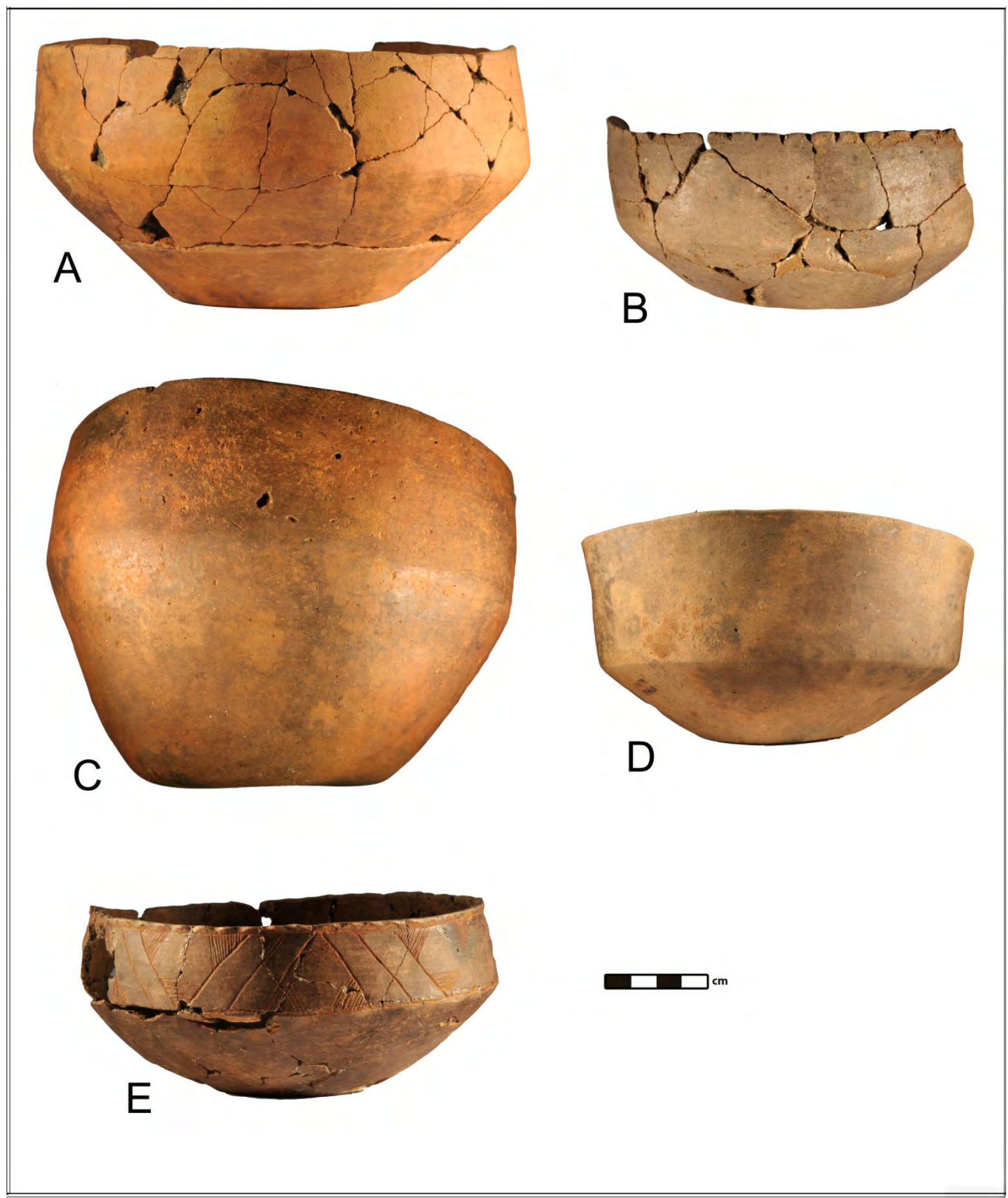

Figure 6-28. Carinated Bowls from the Lang Pasture Site: a-d, plain carinated bowls; e, Poynor Engraved, Var. F. Provenience: a, Feature 8, Vessel 2; b, Feature 8, Vessel 1, scalloped rim; c, Feature 93, Vessel 6; d, Feature 93, Vessel 8; e, Feature 8, Vessel 3. 


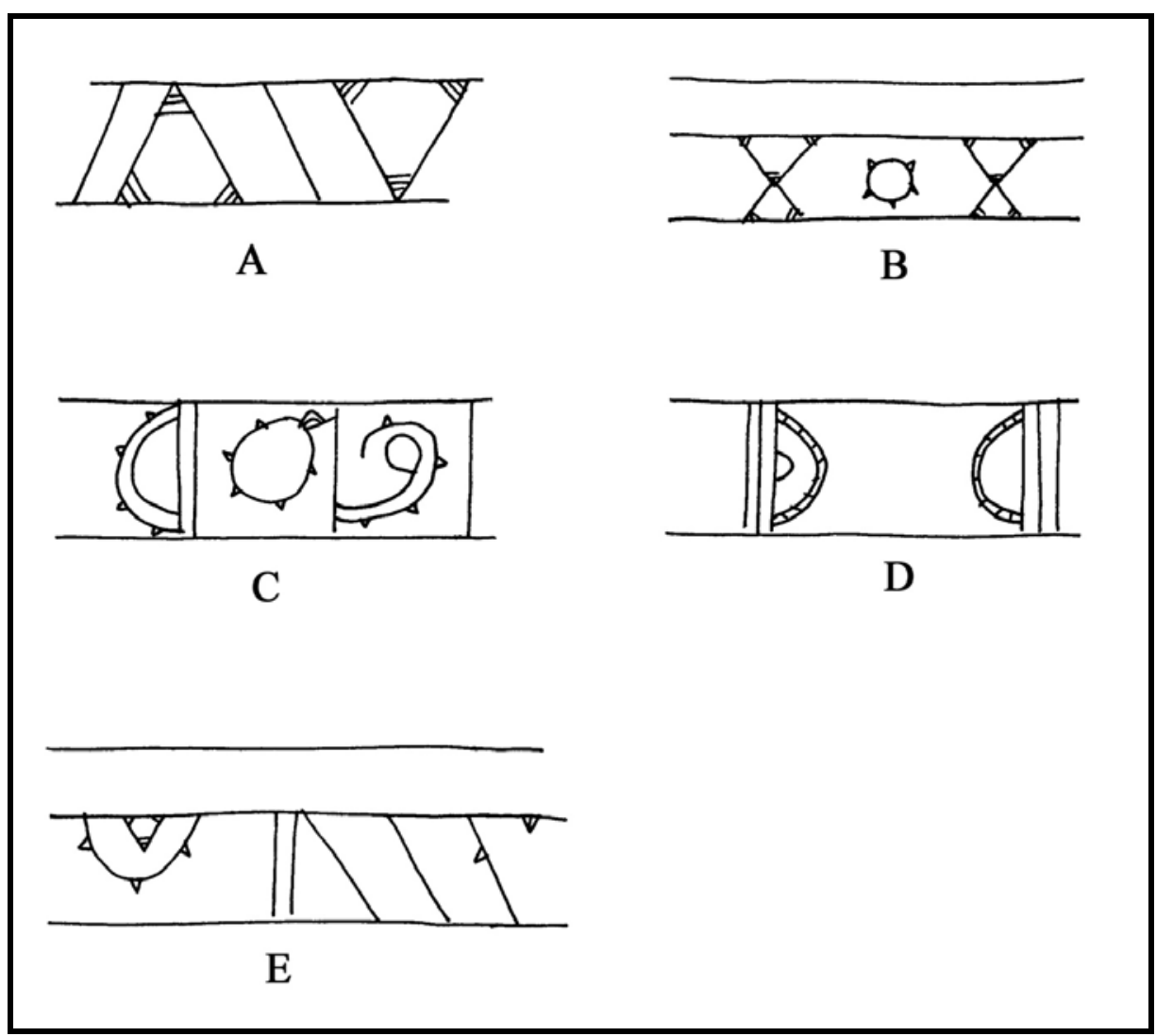

Figure 6-29. Local Varieties (No. 1-5) of Poynor Engraved at the Lang Pasture Site: a, local variety 1 (Feature 8, Vessel 3); b, local variety 2 (Feature 91, Vessel 1); c, local variety 3 (Feature 91, Vessel 2); d, local variety 4 (Feature 93, Vessel 2); e, local variety 5 (Feature 93, Vessel 3/4A).

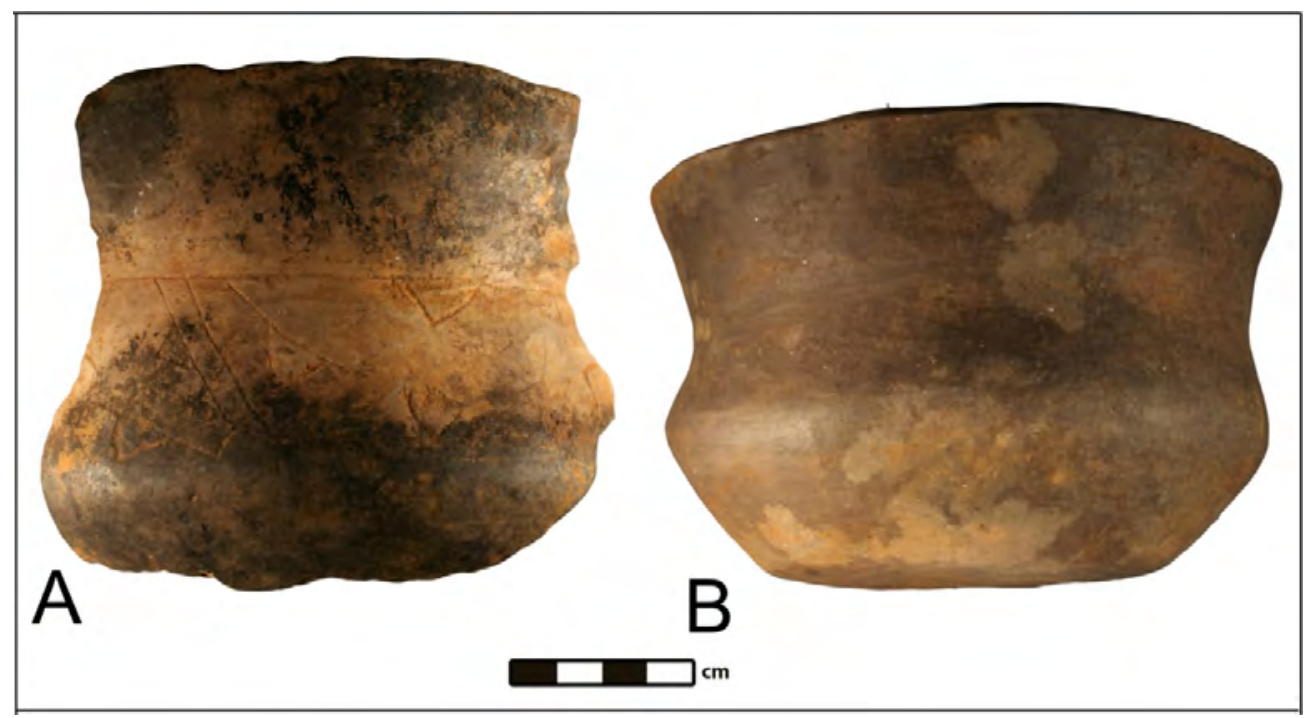

Figure 6-30. Compound Bowls from the Lang Pasture Site: a, Feature 93, Vessel 3/4A, Poynor Engraved, local variety 5; b, Feature 94, Vessel 2, plain. 


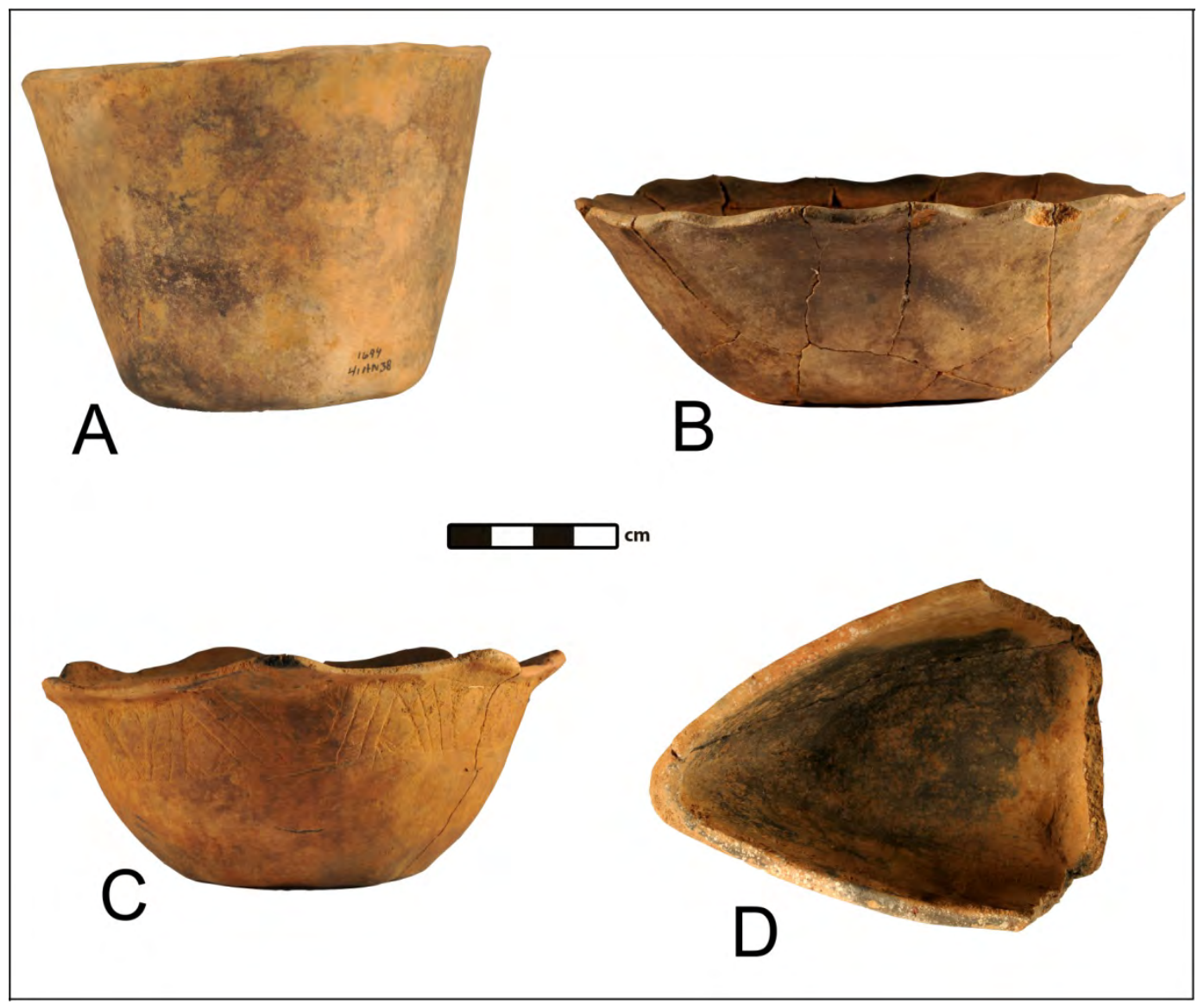

Figure 6-31. Bowls: a, Feature 94, Vessel 1, plain; b, Feature 8, Vessel 4, plain, scalloped rim; c, Feature 93, Vessel 5, Poynor Engraved, Var. F; d, Feature 92, Vessel 2, triangular-shaped bowl.

There are two plain bottles in the Lang Pasture mortuary vessel assemblage, both with relatively long necks and globular bodies (Figure 6-32a-b); the absence of the distinctive short-necked Hume Engraved and Hume Plain bottles (see below), which are a common feature in post-A.D. 1400 mortuary vessel assemblages in the upper Neches, is notable. One of the bottles has a carinated body form (Figure 6-32b).

Two of the jars are Maydelle Incised vessels (Figure 6-33a). One of these has a crosshatched incised motif, while the other has incised triangles filled with tool punctates. The third jar is plain.

Certainly the most unique vessels from the Lang Pasture site are two engraved vessels with suspension holes. The vessel forms themselves-a neckless bottle or seed jar (Figure 6-34a) and a wide-necked bottle or compound vessel (Figure 6-34b)—are unparalleled in other mortuary vessel assemblages from the upper Neches River basin.

The neckless bottle is decorated with a series of diagonal panels decorated with engraved or rocker-stamped elements. The rim has a single row of rocker stamping (see Figure 634a).From top to bottom on the vessel, the diagonal panels begin with a zone of crosshatched engraved pendant triangles inside the panel, followed by a rocker-stamped panel with cross-hatched engraved pendant triangles (14 and 18, respectively) on the outside of the panel. The third diagonal panel is filled with 
rocker stamps (forming triangular areas within the panel) and very small tick-like rocker stamping on either side of the panel. This is followed by a fourth panel that is just like the second in having rocker stamping within the panel (forming triangular areas) and crosshatched engraved pendant triangles on the outside of the panel. The last panel is comprised of two diagonal rows of crosshatched engraved pendant triangles (13 and 15 , respectively), with a row of smaller rocker stamps inside the panel itself.

This engraved-rocker stamped vessel resembles the Garland Engraved type as described by Early (1993:90) in having the roughened rocker-stamped zones and the cross-hatched background or fill elements.
Early (2006 personal communication) indicates that vessels with this shape and decoration may date to ca. A.D. 1400, if not earlier, and are very common in the Hot Spring County, Arkansas area in the Ouachita River valley. This suggests that Vessel 2 from Feature $76 \mathrm{~B}$ is a trade ware from a southwestern Arkansas Caddo group.

The neck of the wide-necked bottle or compound vessel is decorated with horizontal and diagonal hatched engraved zones or narrow panels repeated three times around the neck (see Figure 6-34b). The body has interlocking horizontal scrolls repeated six times around the vessel, as in the Poynor Engraved, var. B examples from the upper Neches River basin (see below).

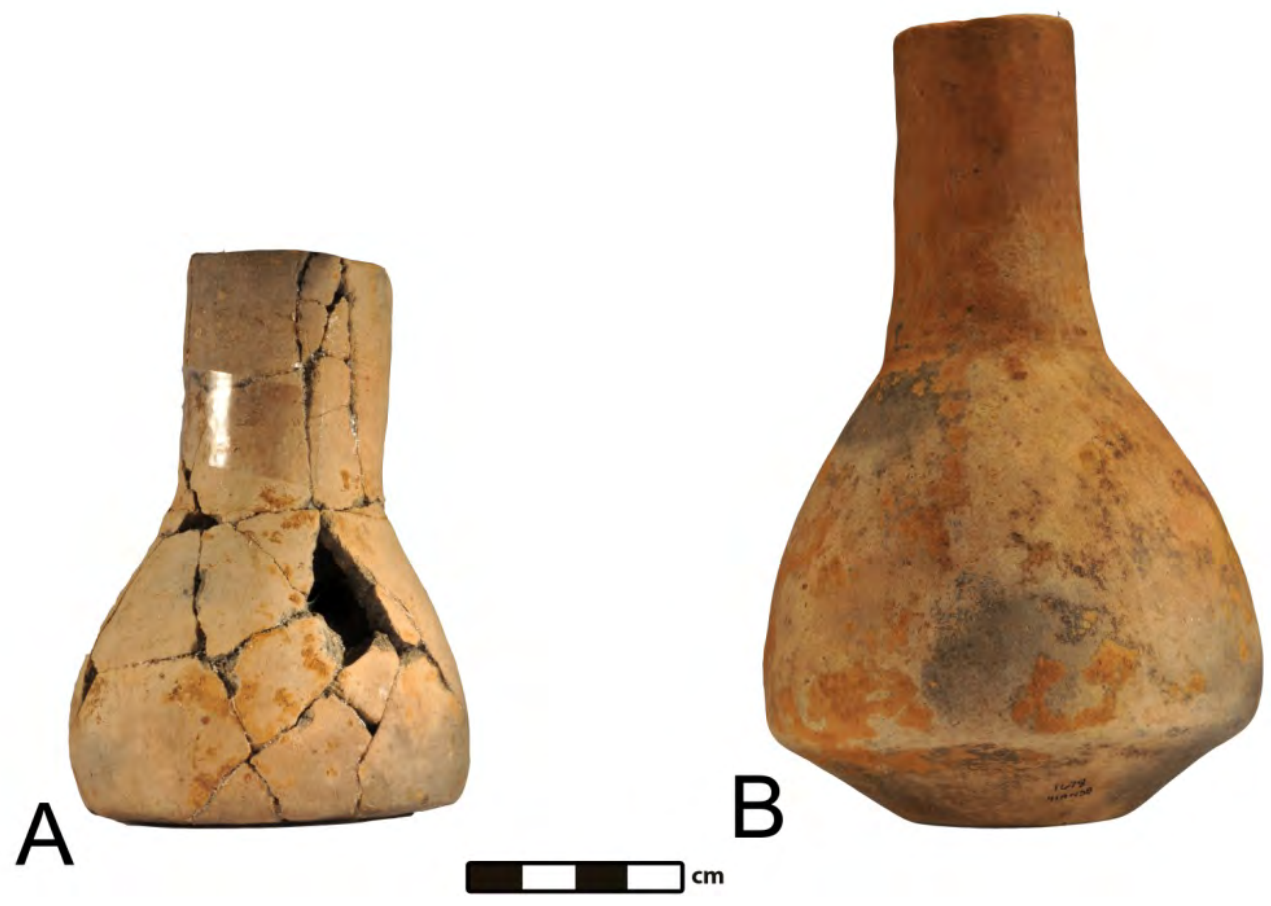

Figure 6-32. Bottles: a, Feature 8, Vessel 7, plain, long neck; b, Feature 93, Vessel 7, plain carinated form, with globular body. 


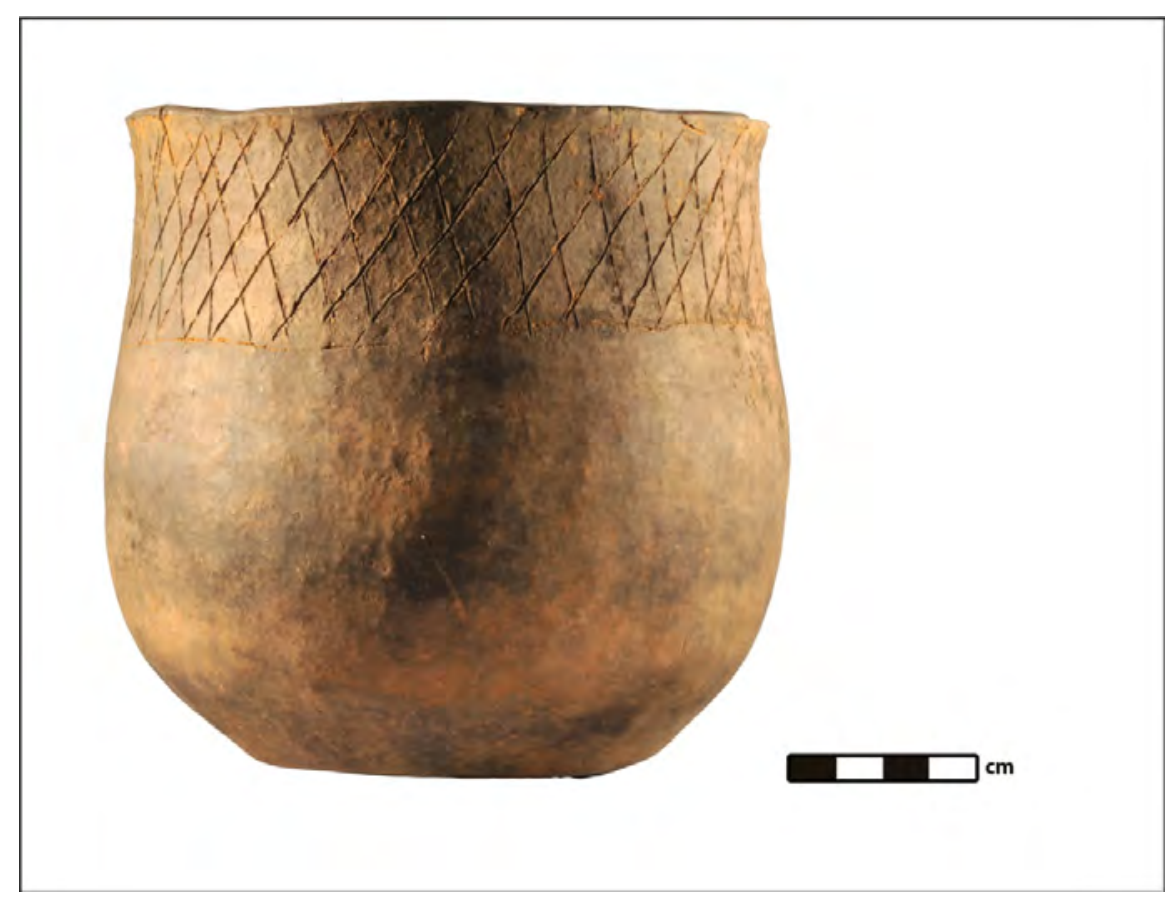

Figure 6-33. Jar: Maydelle Incised. Provenience: Feature 8, Vessel 6.

Another distinctive feature of the mortuary vessels from the Lang Pasture site is their generally small size. Only two of the vessels (6.5\%) have volumes greater than 2 liters (a large bowl and a compound bowl) (Figure 635). Differences in orifice diameter and volumes of the vessel forms in the burials indicate that two different sizes of bottles were in use, as well as a number of small bowls and carinated bowls, several medium-sized carinated and compound bowls, and mediumsized jars. None of these vessels were clearly intended to be used for communal purposes, but were instead designed to hold only a few servings of food for the deceased to use on their journey to the House of the Dead.

\subsection{VESSELS FROM SELECTED UPPER NECHES RIVER BASIN CADDO SITES}

\section{Mrs. J. M. Cook (41AN1)}

The Mrs. J. M. Cook Site was excavated in 1931 by a UT crew (Jackson 1931). All six burials found at this sub-phase 2 Frankston phase (ca. A.D. 1480-1560) cemetery had associated vessels as funerary offerings. A total of 33 vessels are in the TARL collections from the site. They include 11 carinated bowls, one compound bowl, nine jars, eight bowls, and four bottles.

The 11 carinated bowls are all of the Poynor Engraved type, even though there are inverted rim forms (Figure 6-36a), direct rim forms (Figure 6-36b), and globular carinated bowls (Figure 6-36c). Recognized varieties include Poynor Engraved, var. Cook $(\mathrm{n}=4)$, Poynor Engraved, var. Hood 


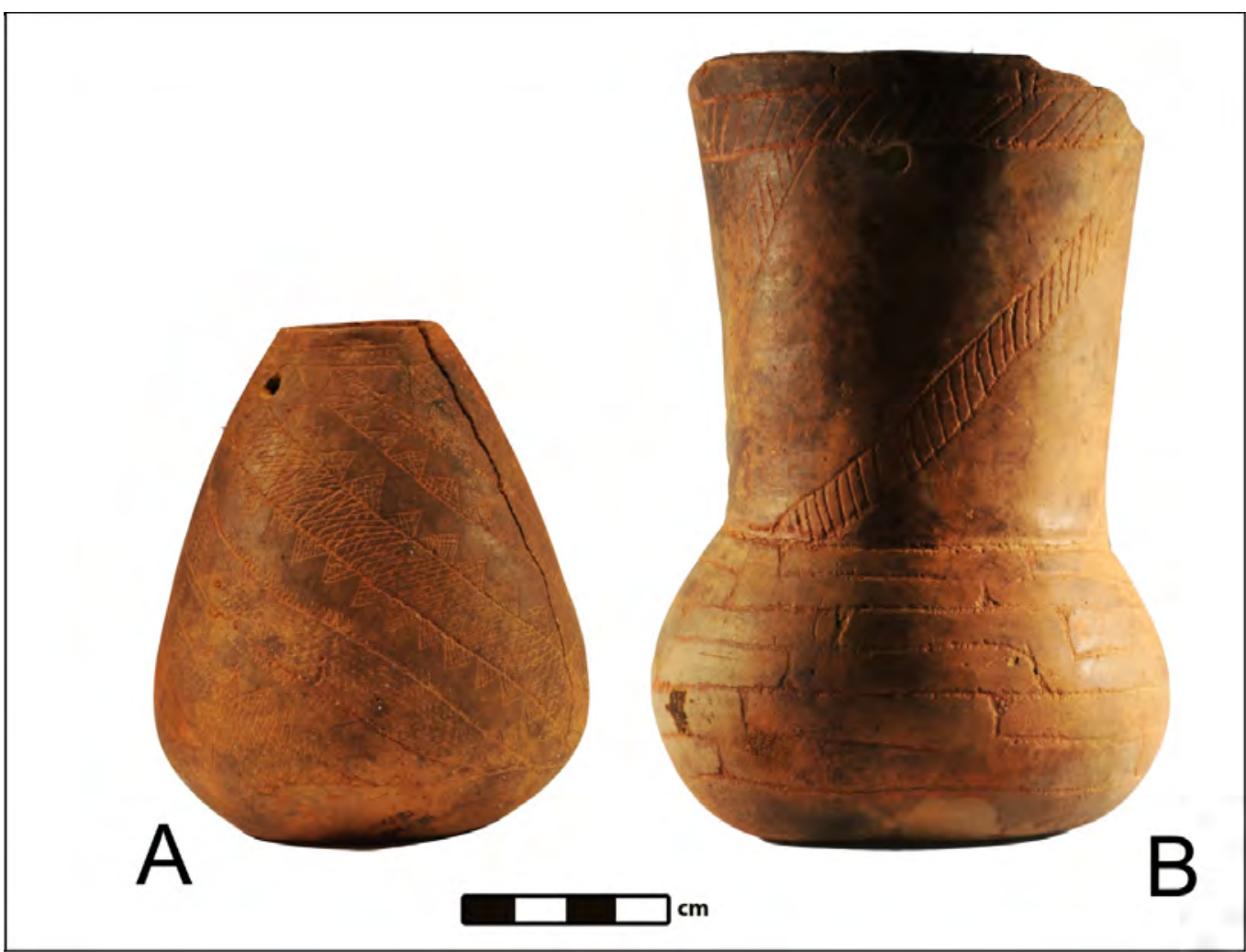

Figure 6-34. Unique Vessels with Suspension Holes: a, Feature 76B, Vessel 2, neckless bottle with engraved, rocker-stamped, and tick mark elements; b, Feature 88, Vessel 1, engraved bottle with wide neck.

( $\mathrm{n}=2$, including one with brushing on its body), Poynor Engraved, var. Blackburn $(\mathrm{n}=3)$, and Poynor Engraved, var. Lang $(\mathrm{n}=1$, with brushing on the body). The last engraved carinated bowl is a Poynor Engraved, var. R vessel, with concentric semi-circles on the rim panel (see below). The one compound bowlwith two distinct panels-has a var. Lang motif on the lower body panel (see Figure 636d). The upper rim panel is plain.

Only one of the bowls in the mortuary assemblage is plain, and this particular vessel has lip tabs. A second bowl is a Killough Pinched rattle bowl with pinching rows covering the entirety of the vessel and the four large rattle nodes (Figure 6-37d). The other bowls have engraved designs.
Three of the engraved bowls from the Mrs. J. M. Cook site are Hood Engraved effigy bowls, including one each of var. Cook, var. Hood (see Figure 6-37b), and var. Allen (see Figure 6-37c) with its zoomorphic tail rider. Two other bowls have Poynor Engraved designs: Poynor Engraved, var. Hood and Poynor Engraved, regional variety Q (hatched nested triangles, see below). The one remaining bowl is a simple bowl with cross-hatched vertical panels and pendant triangles (see Figure 637a). Kleinschmidt (1982) includes this design as Motif 4 for Hume Engraved, although the same elements occur on several different but unnamed varieties of Poynor Engraved recognized in the upper Neches River basin. 


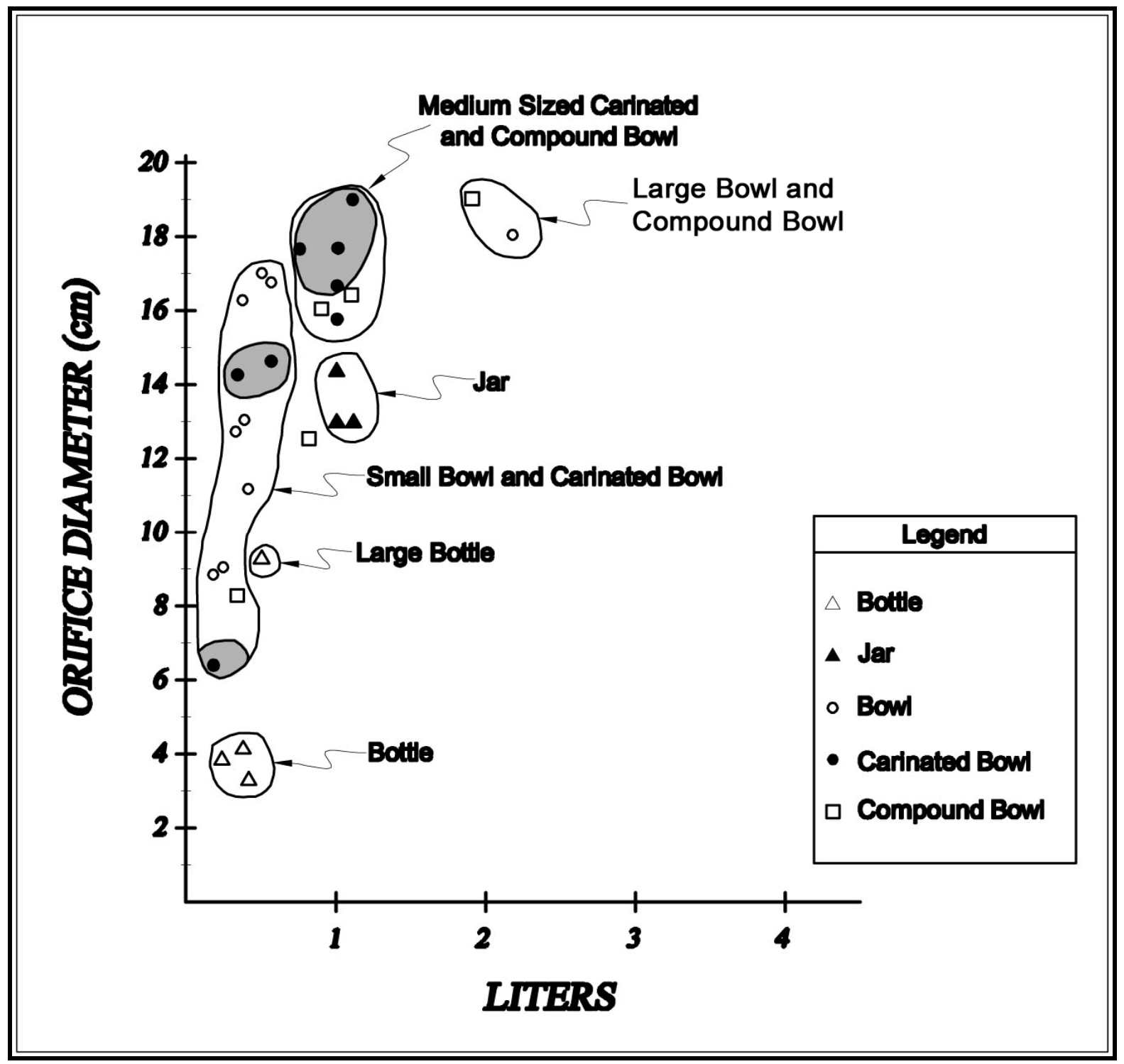

Figure 6-35. Orifice Diameter and Volume of Different Vessel Forms at the Lang Pasture Site.

There are three different bottle forms in the Mrs. J. M. Cook mortuary vessels: (a) a single example of a form with globular body and a short but wide neck (Figure 6-38a), (b) a bottle form $(n=2)$ with an elongated body and a short neck (Figure 6-38b), and (c) one bottle with an elongated neck and a squat body (Figure 638c). The globular-bodied bottle, Hume Engraved, var. unspecified, has vertical engraved panels on the body, and the body- neck juncture is encircled with a row of large hatched pendant triangles (Figure 6-38a). The Fair Engraved bottle with the Fair Plain shape (see Figure 6-38c) has large hatched triangles on the bottle neck (Figure 6-38c). The two other Hume Engraved bottles include one with cross-hatched vertical panels and hatched pendant triangles (Figure 6-38b) and another with broad closely-spaced horizontal engraved lines on the short neck, and the body is plain. 


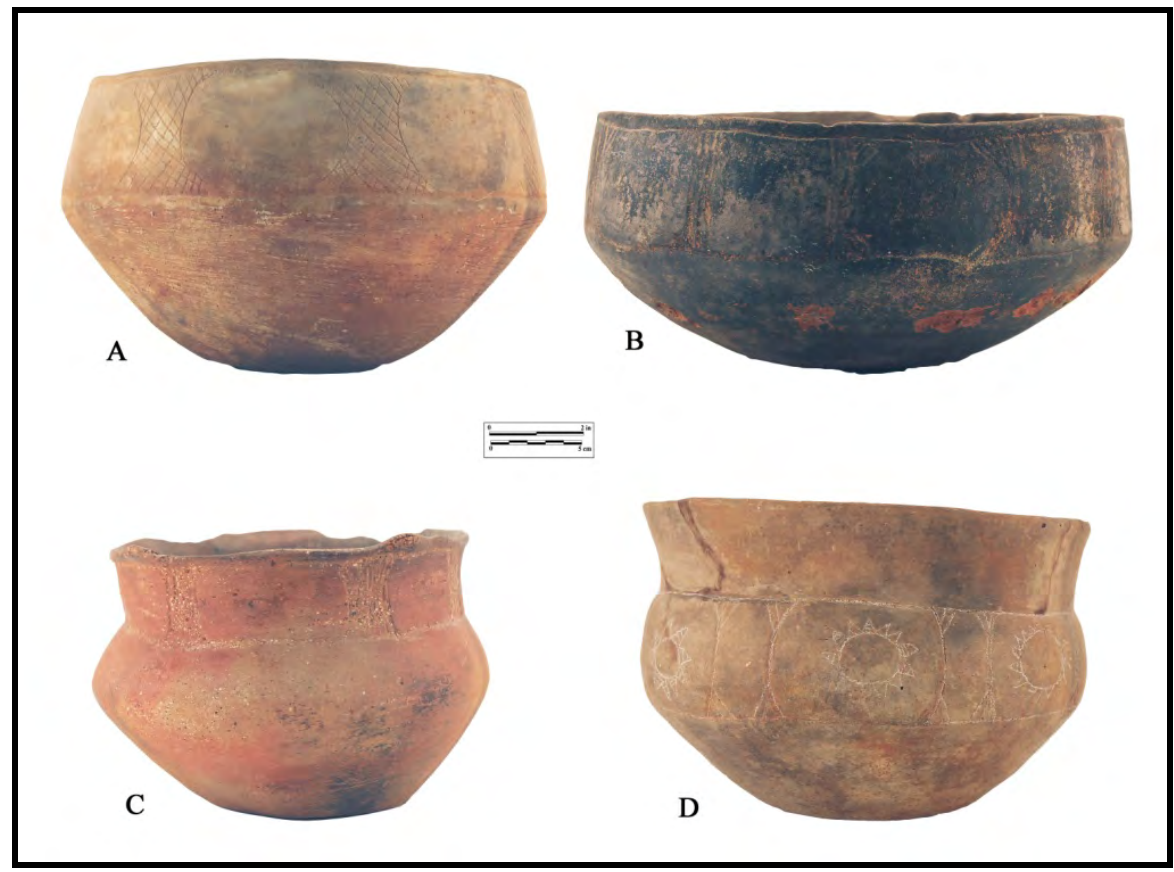

Figure 6-36. Carinated Bowls and Compound Bowls: a, Poynor Engraved, var. Hood; b, Poynor Engraved, var. Blackburn; c, Poyno Engraved, var. Hood, with rim peaks; d, Poynor Engraved, var. Lang compound bowl. Provenience: a, AN1-16; b, AN1-35; c, AN1-2; d, AN1-15.

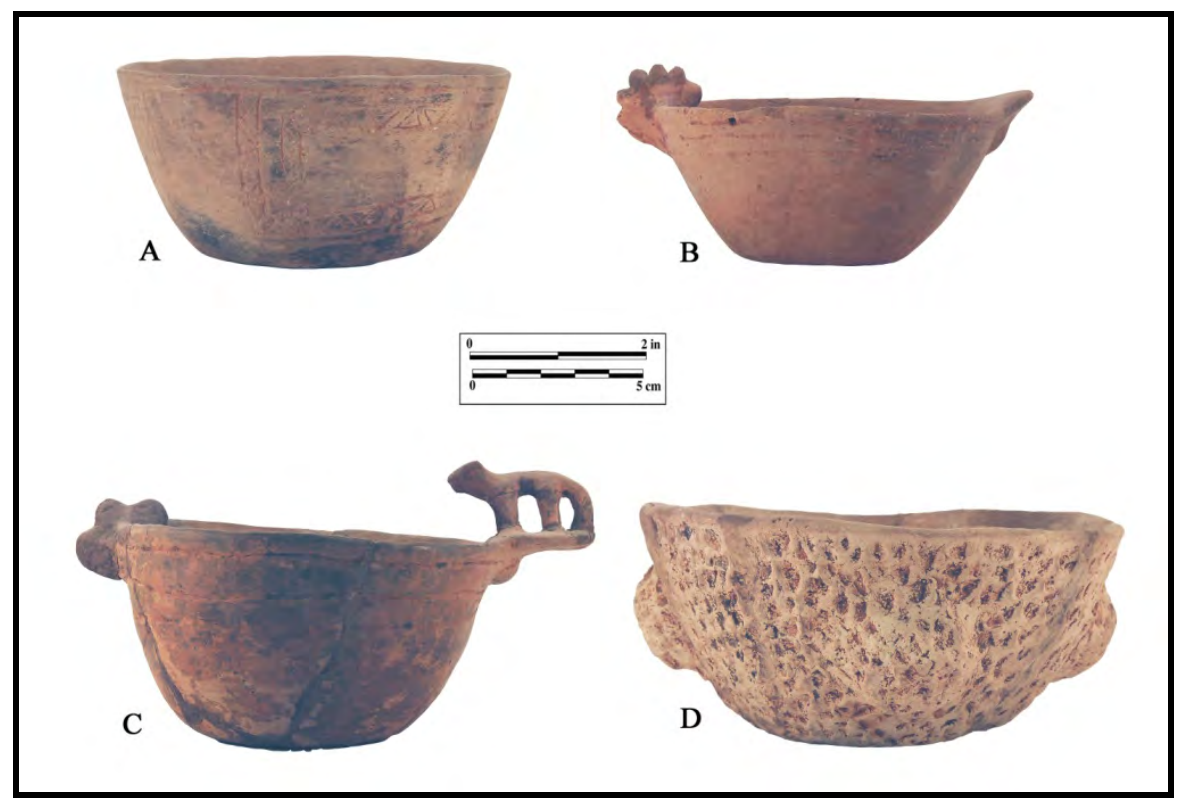

Figure 6-37. Bowls: a, possible Hume Engraved bowl, AN1-31; b, HoodEngraved, var. Hood effigy, AN1-34; c, Hood Engraved, var. Allen, AN1-7; d, Killough Pinched rattle bowl, AN1-6. 
Two of the nine jars, both with lug handles, are plain. Another two are Bullard Brushed jars (Figure 6-39b), one has a neck banded rim and a vertically brushed body (La Rue Neck Banded), and there is an interesting Maydelle Incised jar with a cross-hatched incised rim design (Figure 6-39a). In addition, there are a series of appliqued nodes under the lip and the vessel body is covered with large tool punctations.

The remaining jars $(n=3)$ are Killough Pinched (see Figure 6-38c). These have vertical pinched rows on the rim and pinched concentric circles and spirals covering the vessel body. Two have pinched strap handles and the other has pinched lug handles. The Killough Pinched jars with strap handles also have a substantial pedestal base with four legs; the pedestal base itself is undecorated, but the legs have vertical rows of pinching (see Figure 6-38c).

The full range of vessel sizes and shapes occur in the mortuary vessel assemblage from the Mrs. J. M. Cook site. This includes one size of bottle, a number of medium-sized jars, and small to large bowls (Figure 6-40).

Carinated bowls range from small in size $(<1$ liter), to medium-sized (1-1.5 liters), large
(1.5-3 liters), and one very large carinated bowl ( $>4$ liters). The number of large carinated bowls suggests that communal food service may have been a common part of the burial rituals at the Mrs. J. M. Cook site.

\section{J. M. Cook (41AN2)}

Carinated bowls are well represented in the 17 mortuary vessels from the J. M. Cook site (Jackson 1931); they account for $64.7 \%$ of the vessels. There are also three bowls, two bottles, and a jar in the collection. Vessel and motif seriations (Kleinschmidt 1982; Perttula 2007b, see also below) indicate that this cemetery dates to sub-phase 3 of the Frankston phase.

Only a single plain vessel is amongst the globular and vertical-rimmed carinated bowls from the site. The others are engraved, including Poynor Engraved, var. Freeman $(\mathrm{n}=5$, Figure 6-40b-c); Poynor Engraved, var. Cook (n=2, Figure 6-41a), both with brushed bodies; regional Poynor Engraved, var. $T$ $(n=1$, diagonal engraved with small pendant triangles), and one vessel that has elements of both var. E (scroll and circle) and var. $\mathrm{N}$ (oval and diamond motif). 


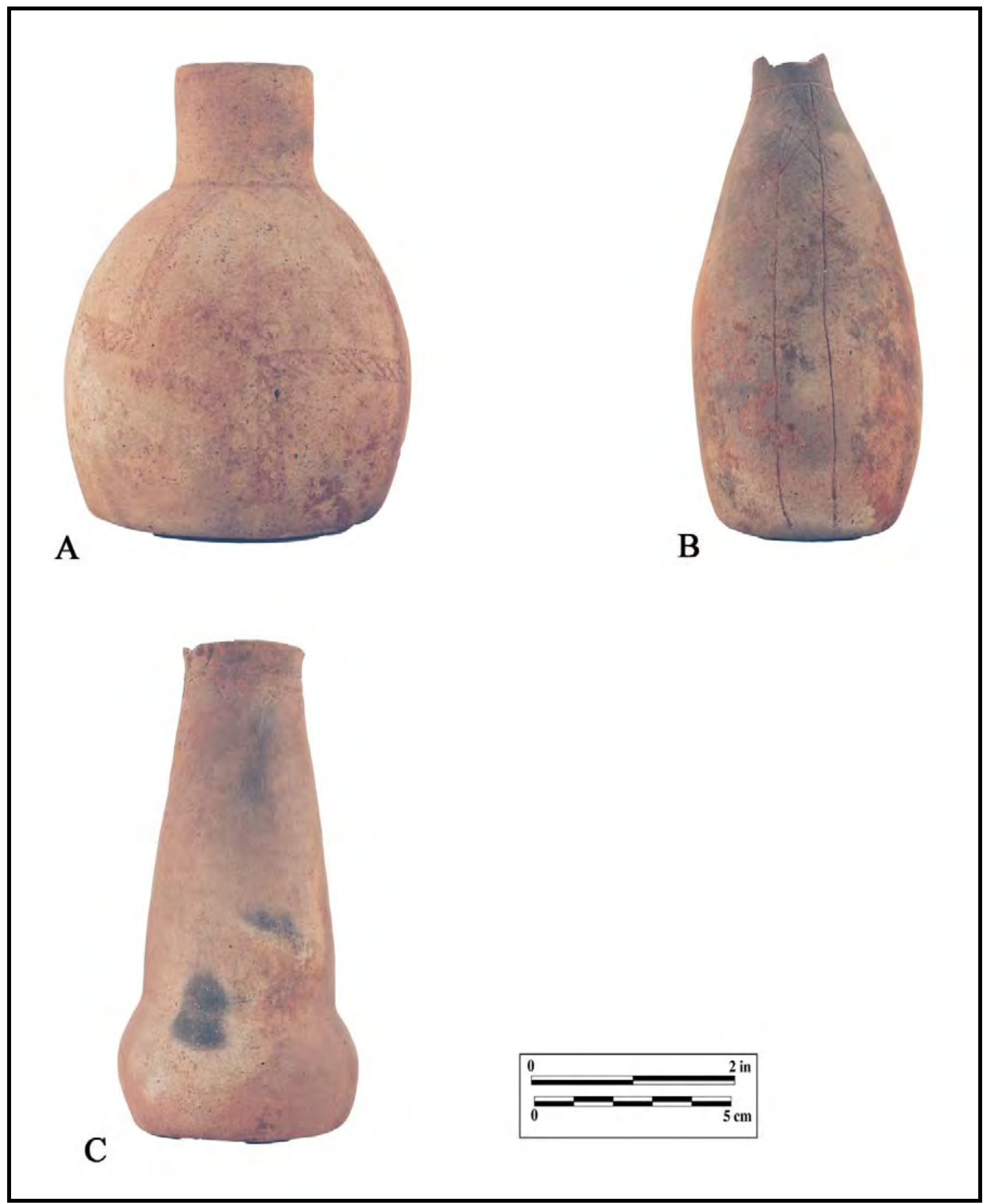

Figure 6-38. Bottles: a, Hume Engraved, var. unspecified globular bottle, AN1-27; b, Hume Engraved, var. unspecified, short-necked bottle, AN1-12; c, Fair Engraved, AN1-28. 


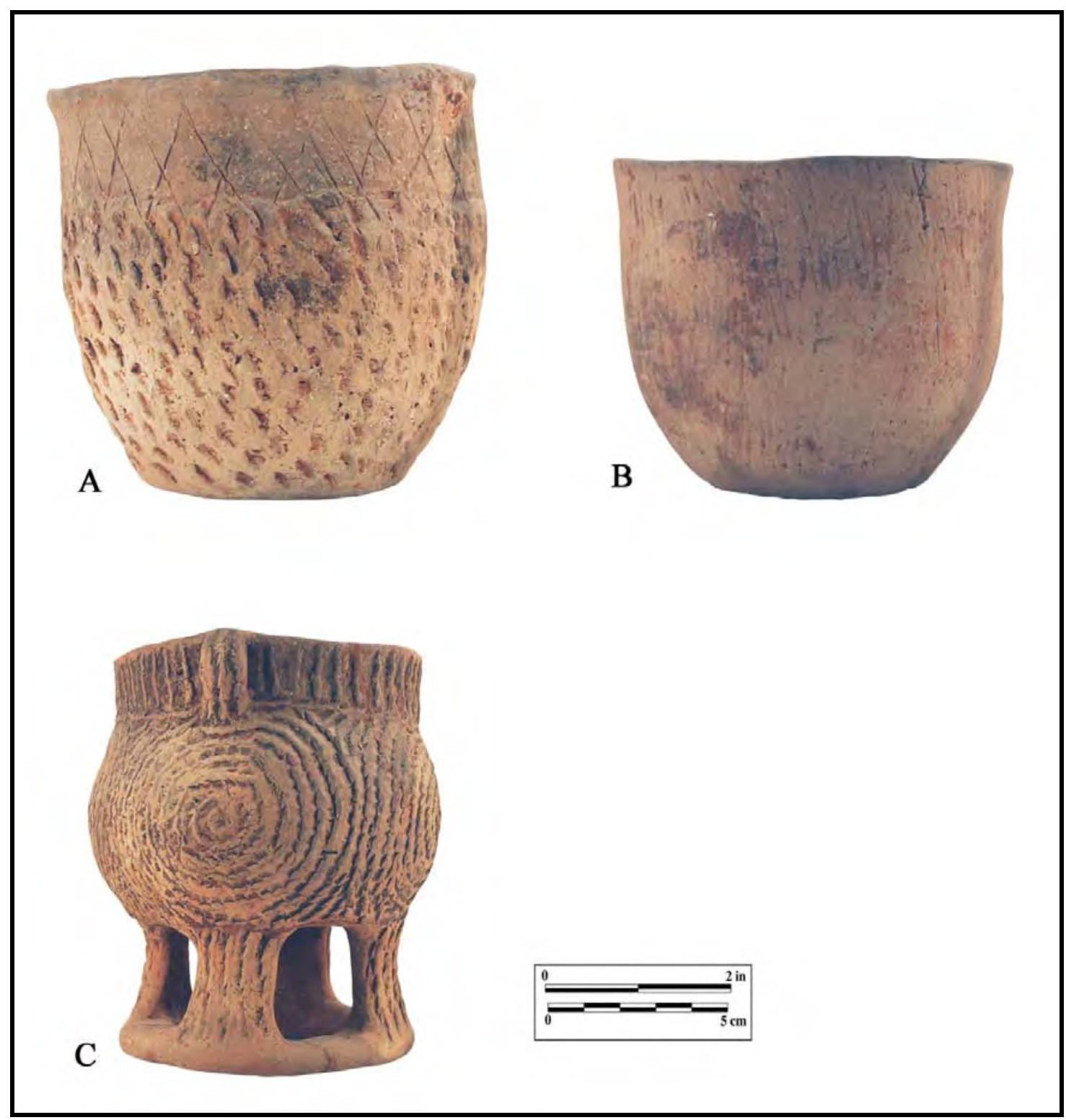

Figure 6-39. Jars: a, Maydelle Incised, AN1-3; b, Bullard Brushed, AN1-37; c, Killough Pinched with a pedestal base, AN1-38.

This particular vessel is also brushed on the body. The last engraved carinated bowl is an unspecified variety of Patton Engraved (Motif 10 in Kleinschmidt [1982]).

One of the bowls is a Hood Engraved, var. unspecified vessel lacking the effigy head or tabtail, both of which have broken off. Another is plain, and the third has brushing on it; this vessel appears to be a cut-down carinated bowl that had brushing on the vessel body. Both bottles have elongated bottles and short necks. One is engraved (Hume Engraved, var. Hume, see Figure 6-41f), but the other is a plain Hume Plain bottle.

The one jar from the J. M. Cook site is the lower brushed portion of a probable broken Bullard Brushed vessel. 


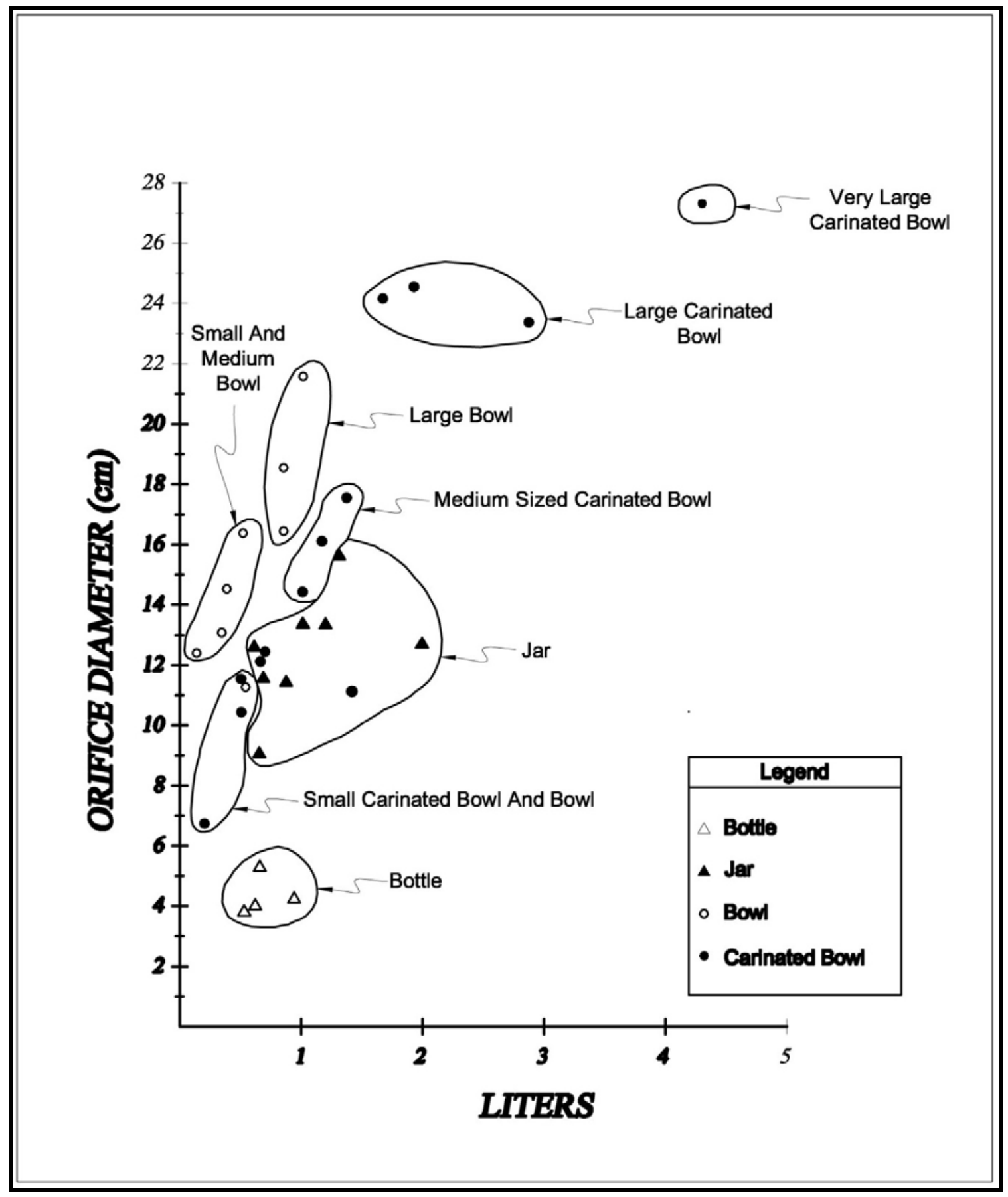

Figure 6-40. Orifice Diameter and Volume of Different Vessel Forms at the Mrs. J. M. Cook Site. 


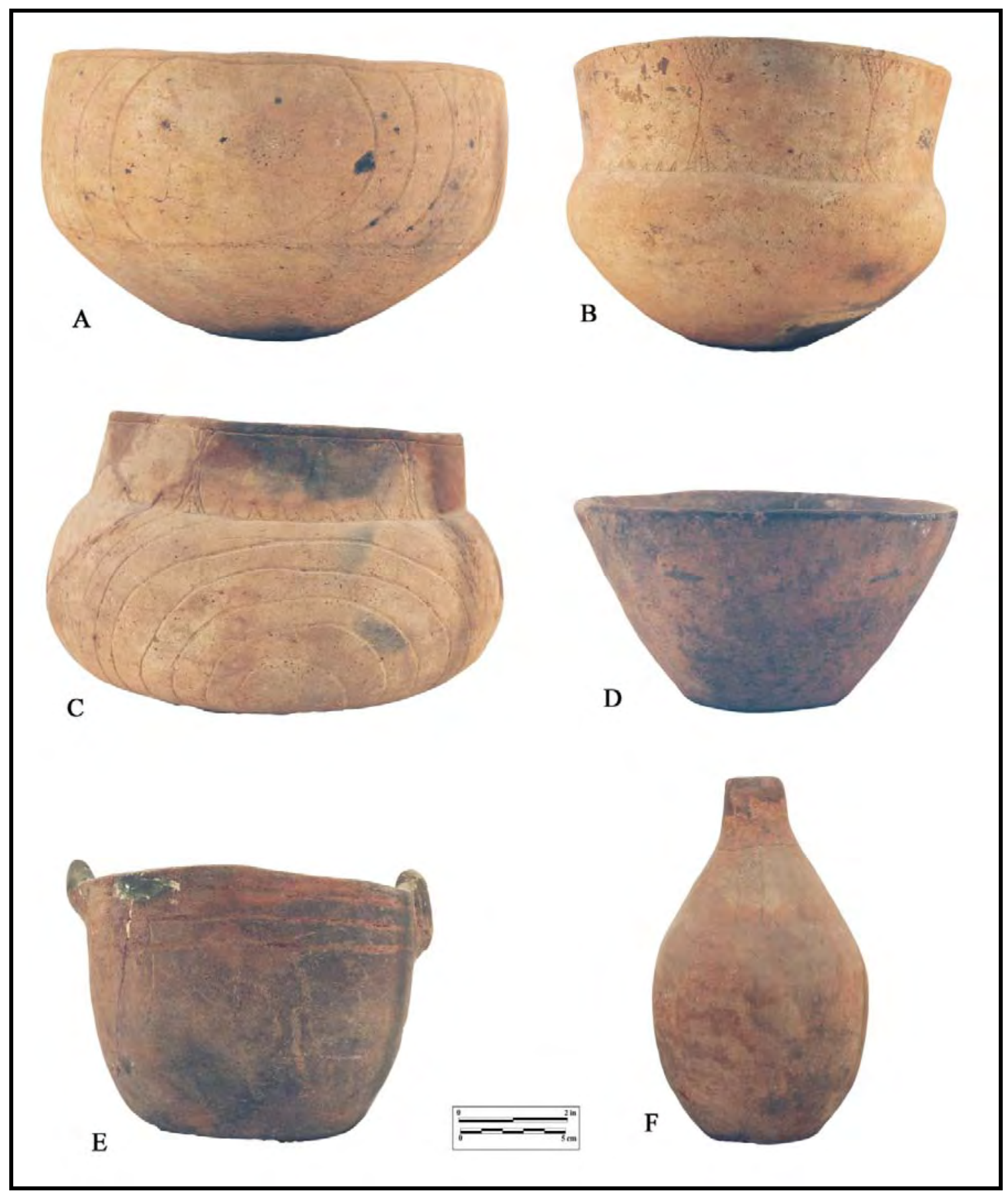

Figure 6-41. Vessels from the J. M. Cook Site: a, Poynor Engraved, var. Cook, AN2-41; b, Poynor Engraved, var. Freeman, AN2-2; c, Poynor Engraved, var. Freeman, AN2-5; d, plain bowl, AN2-56; e, Hood Engraved, var. unspecified effigy bowl, AN2-42; f, Hume Engraved, var. Hume bottle with a short neck, AN2-4. 
There is a wide range in vessel sizes in the $\mathrm{J}$. M. Cook mortuary vessels. A number of the carinated bowls are large (2-4 liters) to very large (6 liters) in volume (Figure 6-42), suggesting some communal use of these serving vessels was intended, but there are also miniature, small, and medium-sized carinated bowls in the assemblage. There is one size of bottle placed in the graves as well as one medium-sized class of bowls (Figure 642).

\section{Fred McKee (41AN32)}

Four prehistoric Caddo burials have been excavated at the Fred McKee site (Woolsey 1935l), another sub-phase 3 Frankston phase cemetery in the upper Neches. The sample of vessels includes 15 carinated bowls, two bowls, three bottles, and three jars.

Two of the carinated bowls are globular Poynor Plain vessels, while the other 13 (both globular and inverted rim forms) have engraved decorations; three of the engraved vessels are also brushed on the body. The
Poynor Engraved vessels from the Fred McKee site include the defined varieties: Poynor Engraved, var. Blackburn $(\mathrm{n}=2)$, Poynor Engraved, var. Cook (n=1, Figure 643b), Poynor Engraved, var. Freeman ( $\mathrm{n}=3$, Figure 6-43c), and Poynor Engraved, var. Hood (n=2, Figure 6-43d). Other regional varieties in the engraved carinated bowls are Poynor Engraved, var. $E(\mathrm{n}=2$, scroll and circle, Figure 6-43a), var. $N(\mathrm{n}=1$, hooked arm and ovals), and var. $P(\mathrm{n}=1$, hooked arm motif).

One of the two bowls from the Fred McKee site is a Hood Engraved, var. unspecified effigy bowl missing its head and tabtails (see Figure 6-43e). The other is a Poynor, var. Hood bowl with small loop handles.

There are two different forms of bottles in the mortuary assemblage. One form, otherwise plain, has a distinct collar at the neck-body juncture, a globular body, and a broad neck (Figure 6-44b). The second form (Hume Engraved, var. unspecified) has an elongated body and a short neck (Figure 6-44a). 


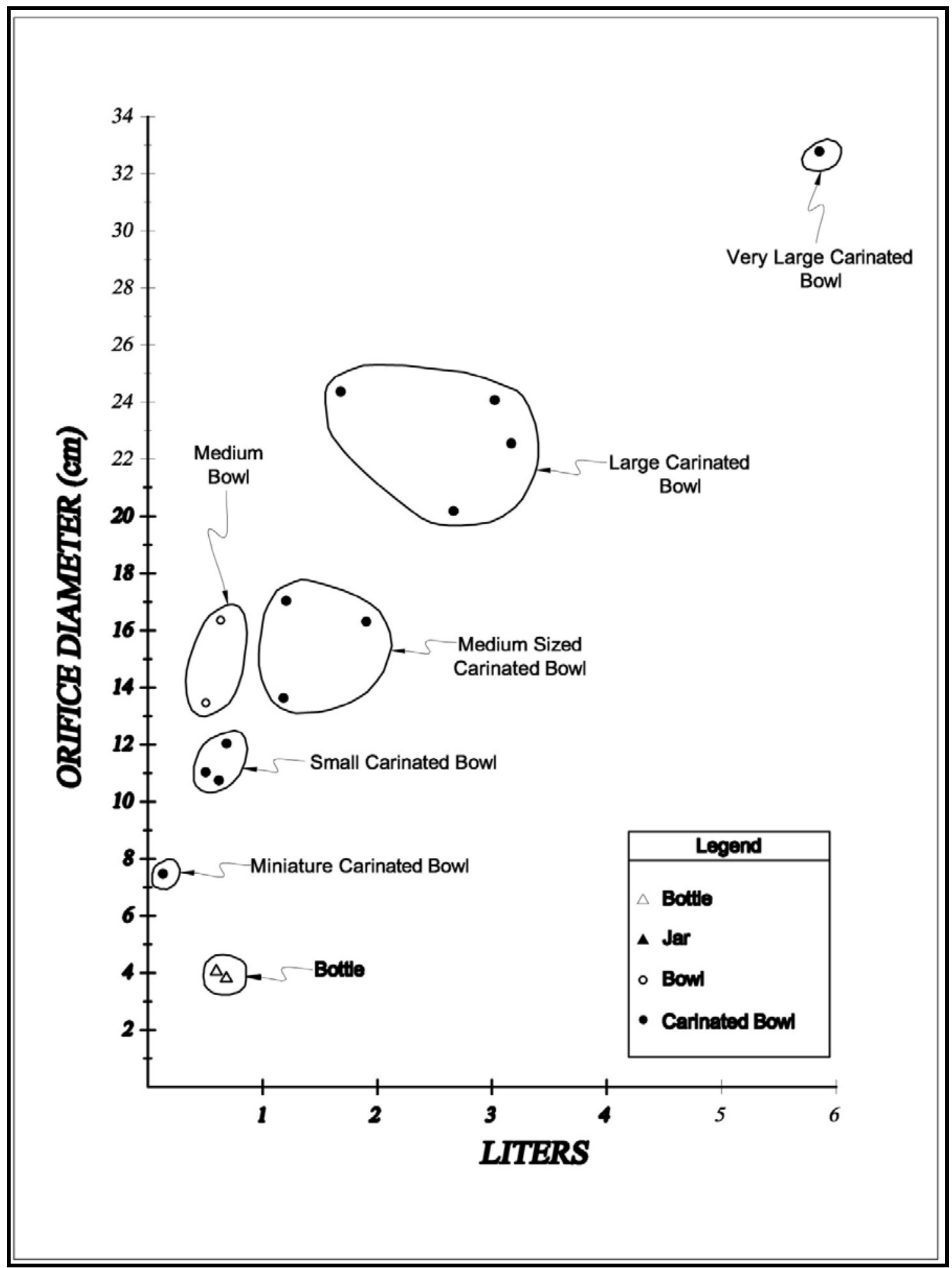

Figure 6-42. Orifice Diameter and Volume of Different Vessel Forms at the J. M. Cook Site. 


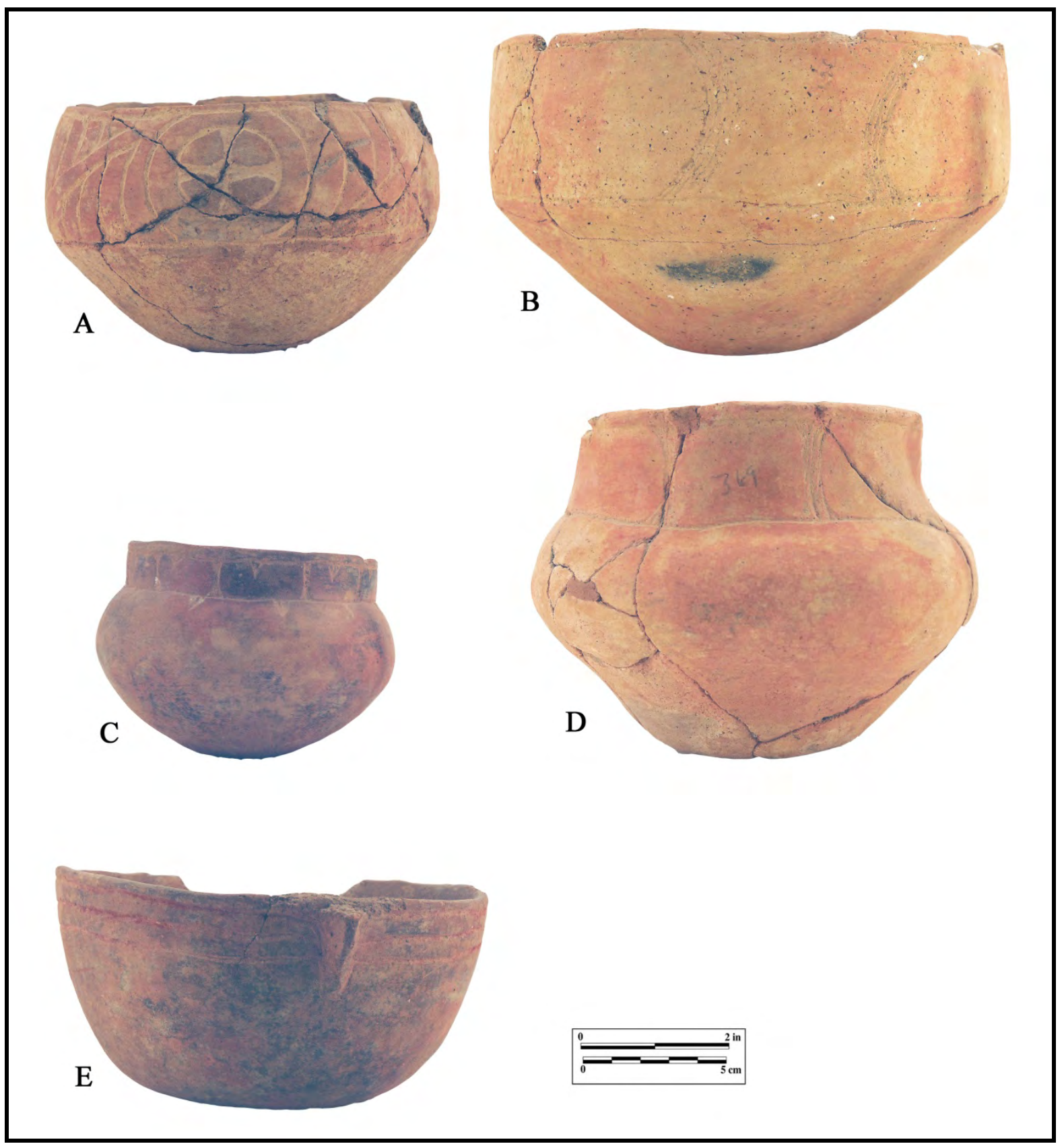

Figure 6-43. Carinated Bowls and Bowls: a, Poynor Engraved, var. E, AN32-28; b, Poynor Engraved, var. Cook, AN32-31; c, Poynor Engraved, var. Freeman, AN32-21; d, Poynor Engraved, var. Hood, AN32-27; e, Hood Engraved, var. unspecified effigy vessel, AN32-6. 


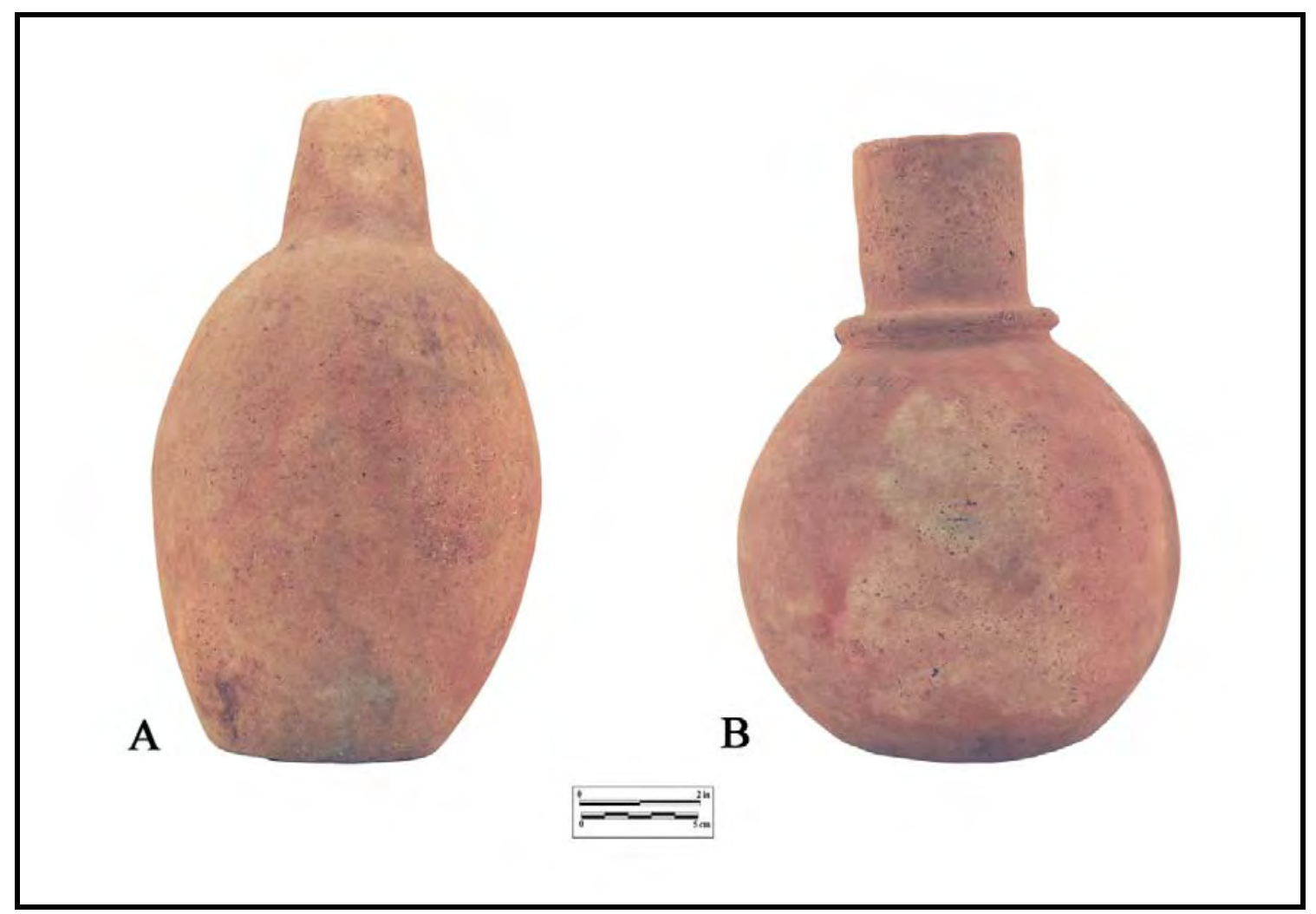

Figure 6-44. Bottles: a, Hume Engraved, var. unspecified bottle with short neck, AN32-2; b, Plain collared bottle with short neck, AN32-3.

Two of the jars have tool punctated rim areas and vertically brushed bodies (Figure 6-45ab). Suhm and Jelks (1962:157 and Plate 79a-b) have previously referred to these particular kinds of decorated vessels as "miscellaneous Caddoan utility pottery.” The third vessel is a Bullard Brushed jar.

A number of the Fred McKee mortuary vessels are large (3-6 liters in volume) or very large in size, especially a number of carinated bowls and a single jar (Figure 6-46). There are also bottles of two different sizes, small and large bowls, medium-sized jars, and small and miniature carinated bowls.

\section{J. W. Blackburn (41CE4)}

The J. W. Blackburn site had six burials in a small cemetery (Woolsey 1935b). The 24 vessels documented during the course of these ceramic analyses include 13 carinated bowls, seven bottles, one bowl, and three jars. Kleinschmidt (1982) considers the cemetery to have been used during sub-phase 2 of the Frankston phase.

Only one of the carinated bowls from the J. W. Blackburn site may be plain, but the rim is missing. The others have engraved motifs on rim panels of inverted and globular carinated bowls (Figure 6-46). Four of these vessels have brushed decorations on vessels, and two of these also have lip notching.

Vessels of the Poynor Engraved, var. Blackburn variety ( $\mathrm{n}=4$, see Figure $6-47 \mathrm{~b}-\mathrm{c}$ ) are the most common at the site, followed by Poynor Engraved, var. Cook $(\mathrm{n}=2$, one of which is brushed on the body) and Poynor Engraved, var. Hood $(\mathrm{n}=3)$. All three of the var. Hood vessels have brushed bodies and two are lip notched (see Figure 6-47a). There are also two var. $C$ Poynor vessels (continuous 
rows of hatched triangles), and one Poynor Engraved, var. $D$ vessel (vertical crosshatched panels) with lip tabs and a brushed body (see Figure 6-47d). Suhm and Jelks (1962:Plate 42f) previously classified this as a Hume Engraved vessel, but the vessel form is decidedly not an elongated short-necked bottle-which I prefer to use as the prototypical form for both Hume Engraved and Hume Plain vessels - and cross-hatched ladders and panels are a common element in three other Poynor Engraved local varieties (var. $F, G$, and $M$, see below).

The one bowl in the J. W. Blackburn vessel assemblage is a Hood Engraved, var. Hood effigy bowl. On this vessel, the bird effigy head is facing inwards towards the other side of the vessel. House (2003:54) suggests that this is a stylized "ventral (belly-upward)" portrayal of the bird.

All of the bottles from the J. W. Blackburn site are elongated bottles with short necks (Figure 6-48a-d). Two are Hume Plain bottles Figure 6-48d), while the other five are Hume Engraved, var. unspecified. Four have vertical engraved elements (panels and ladders) that run down the elongated body (Figure 6-48a-b), while the fifth has two horizontal engraved lines below the neck, with a series of 28 hatched triangles pendant from the lowermost horizontal line (Figure 6-48c).
A

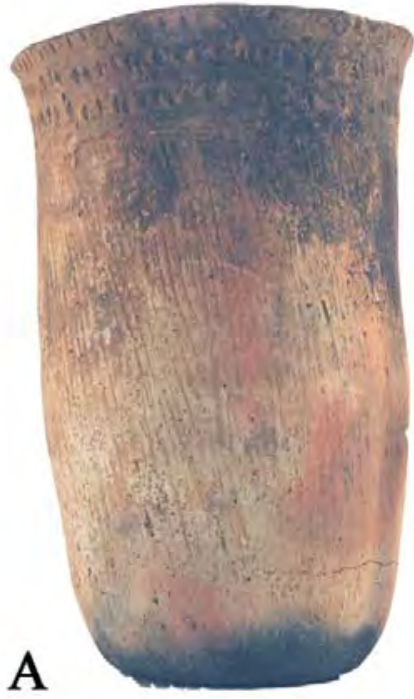

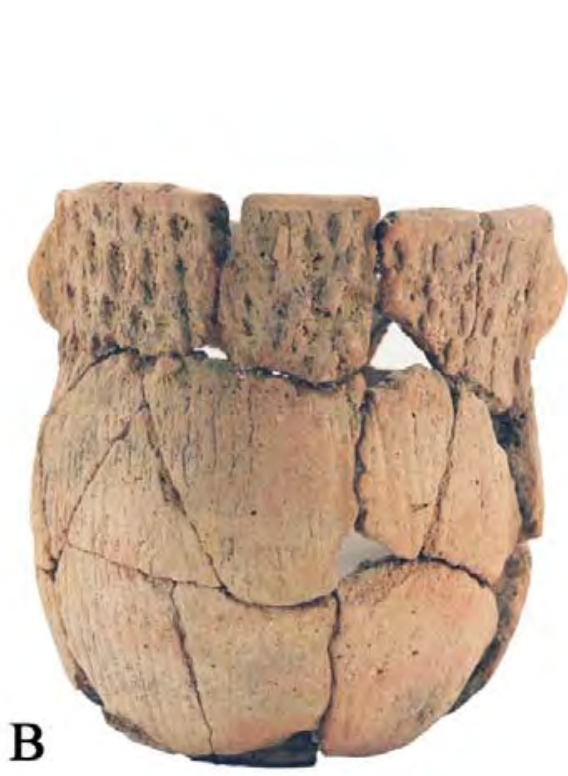

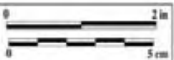

Figure 6-45. Jars: a, Brushed-punctated jar, AN32-32; b, Brushed-punctated jar, AN32-47. 


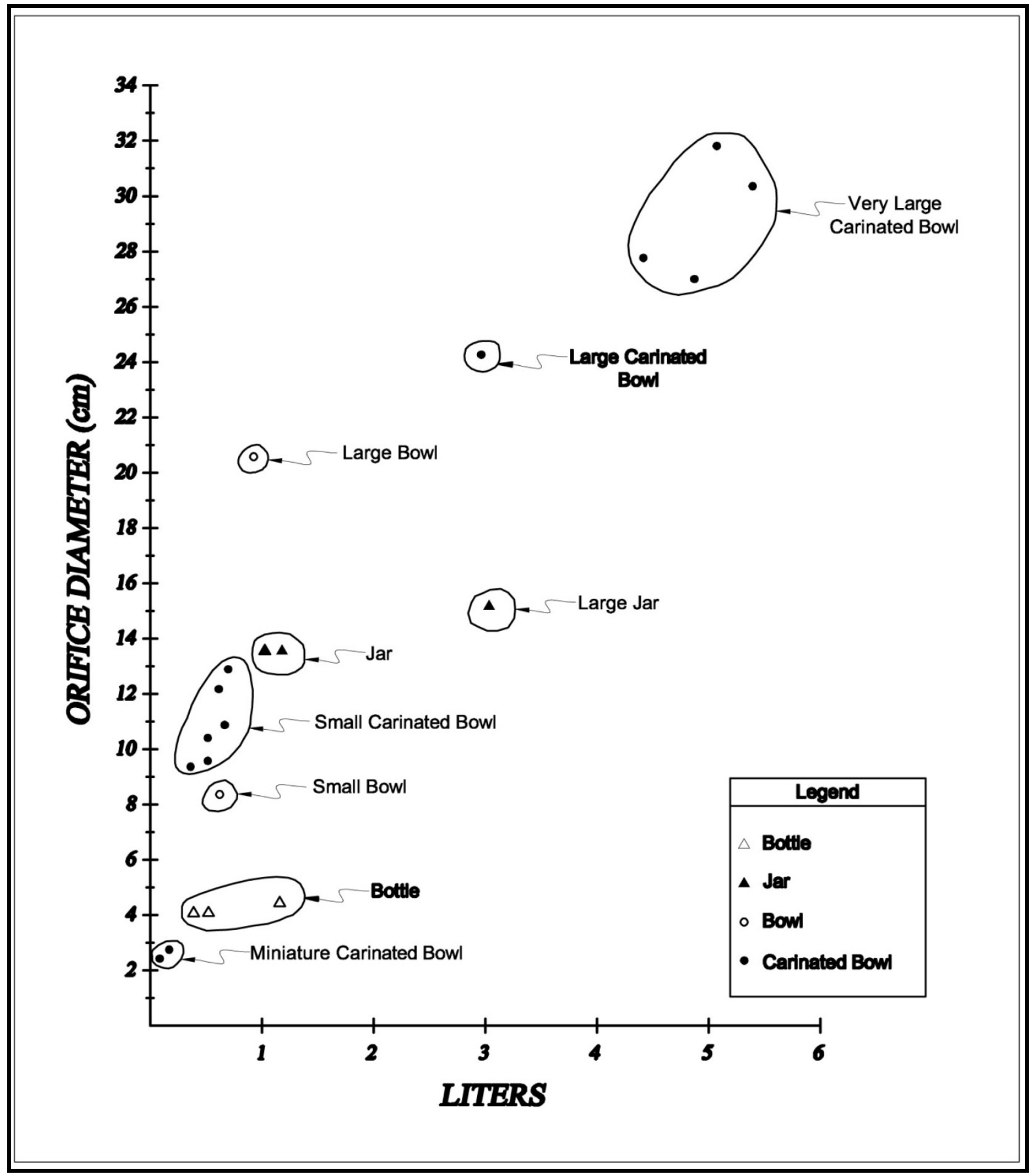

Figure 6-46. Orifice Diameter and Volume of Different Vessel Forms at the Fred McKee Site. 


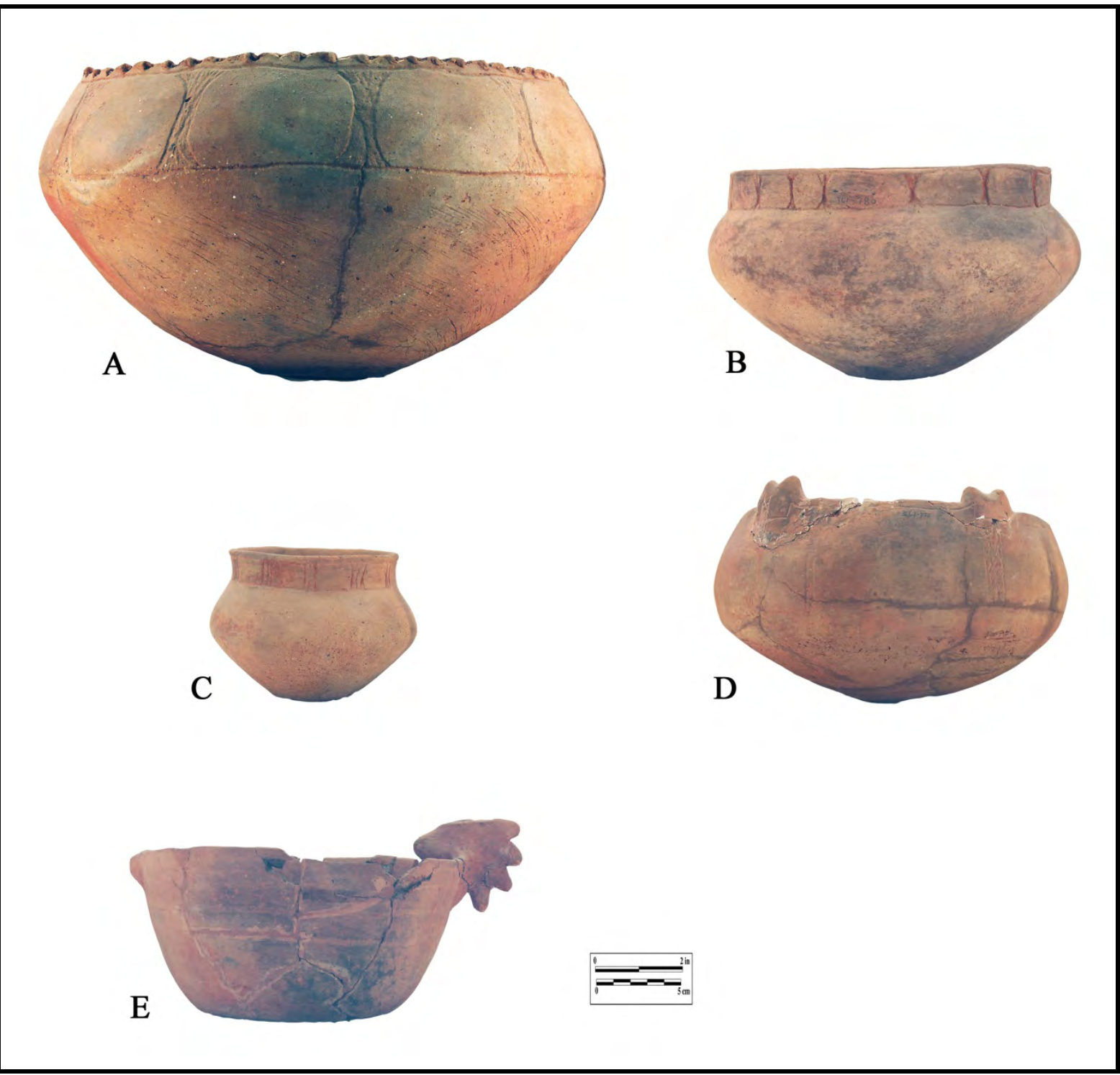

Figure 6-47. Carinated Bowls and Bowls: a, Poynor Engraved, var. Hood, with lip notching and brushed body, CE4-9; b, Poynor Engraved, var. Blackburn, CE4-61; C, Poynor Engraved, var. Blackburn, CE4-54B; d, Poynor Engraved, var. D, CE4-10; e, Hood Engraved, var. Hood effigy bowl, CE4-50. 


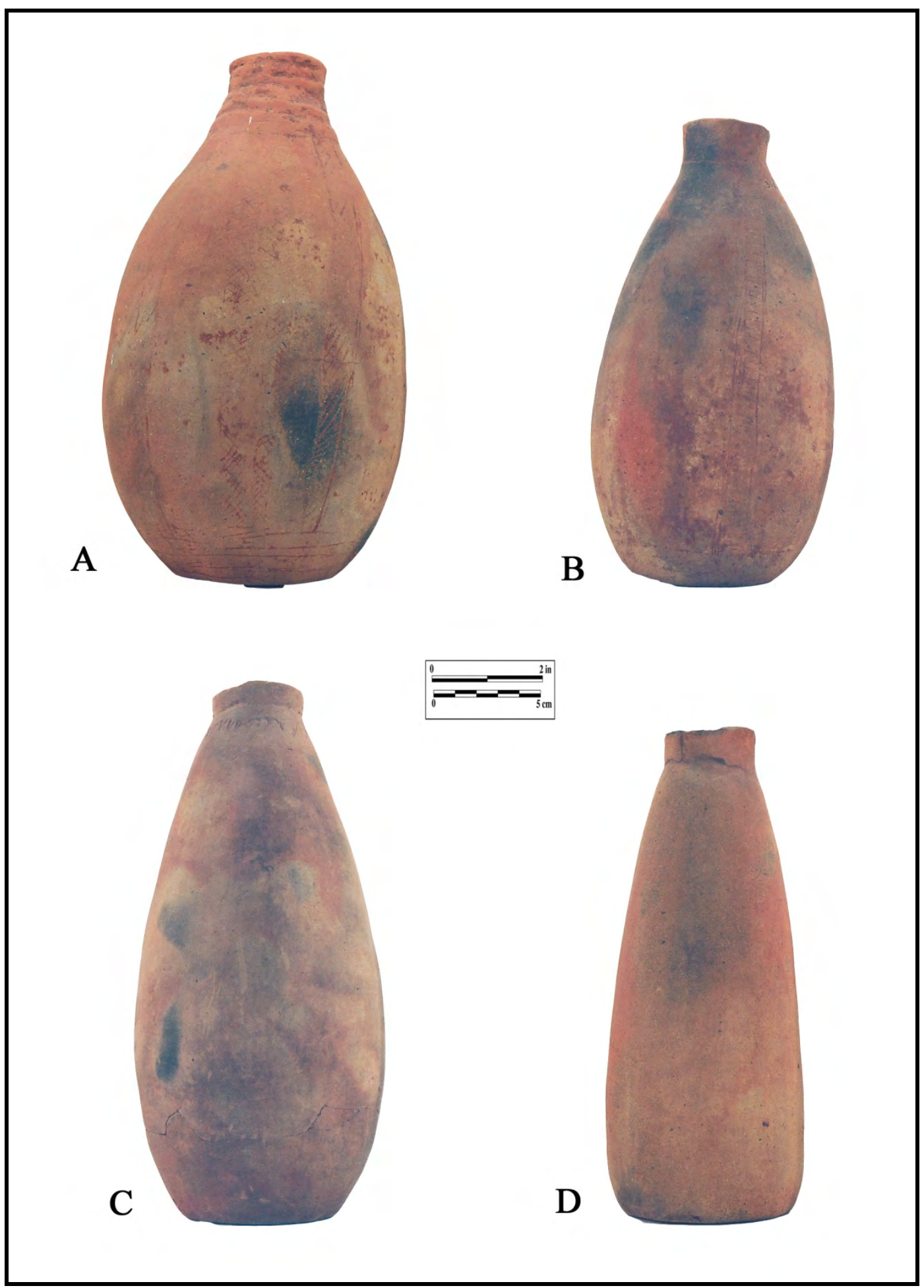

Figure 6-48. Hume Engraved or Hume Plain Bottles: a, short corrugated neck, Hume Engraved, var. unspecified, CE4-1; b, Hume Engraved, var. unspecified, short neck, vertical hatched panels, CE4-53; c, Hume Engraved, var. unspecified, short neck with horizontal engraved lines and pendant triangles, CE4-21; d, Hume Plain, with short neck, CE4-51. 
The three jars are all Killough Pinched vessels with everted rims (Figure 6-49, a-b). These vessels have pinched rows and/or circular pinching decorative elements covering the entire surface of each jar; each jar also has two opposing strap handles. Two of the three Killough Pinched jars have distinctive pedestal or ring bases. Anderson et al. (1974:Figure 3) suggests these distinctive vessels were used to hold body paint or incense, but there is no evidence of such use preserved in these Killough Pinched jars, or similar jars from other upper Neches River basin mortuary vessels.

Based on orifice diameter and volume measurements, there are five different sizes of carinated bowls in the J. W. Blackburn mortuary vessels (Figure 6-50), ranging from miniatures to very large vessels more than 5 liters in volume. There is a single large bowl and three miniature jars, as well as two sizes of bottles (see Figure 6-50).

\section{Omer and Otis Hood (41CE14), Cemeteries \#1 and \#2}

There are two Frankston phase cemeteries on the Omer and Otis Hood site (Woolsey 1935m). Cemetery \#1 had 23 burials (18 of which were dug by a UT crew), and dates to sub-phase 2 of the Frankston phase (Kleinschmidt 1982). Cemetery \#2, an earlier sub-phase 1 burial ground, had only three burials, two excavated by Woolsey and crew. Between the two cemeteries there are 118 vessels in the TARL collections available for analysis, 106 vessels from Cemetery \#1 and 12 vessels from Cemetery \#2.

The Cemetery \#1 vessels include 55 carinated bowls, one compound bowl, 25 bottles, 15 jars, and 10 bowls. Within each of these vessel classes, there are several forms, particularly in the carinated bowls (globular-shaped, inverted rim, direct rim) and bottles (short neck/elongated body, carinated body, beaker-shaped, globularshaped body and a long neck, and widemouth neckless).

Only one of the carinated bowls is plain, and two (cf. Poynor Brushed) are brushed on the vessel body and the rim is plain. The remainder of the carinated bowls have engraved motifs on rim panels. Ten (19\%) of the engraved carinated bowls have lip notching (Figure 6-50a, d), two others have rim peaks, and six (11.5\%) have engraved rim panels and brushed vessel bodies.

In terms of shape, more than half of the carinated bowls $(\mathrm{n}=28)$ from Cemetery \#1 are globular-shaped (see Figure 6-51e-f, h). Another 38\% have inverted rims (see Figure 6-51c-d), while a few others have either direct or slightly everted rim forms (see Figure 6-51a-b).

All the engraved carinated bowls are classified as Poynor Engraved. The following defined varieties of Poynor Engraved are recognized in the Cemetery \#1 vessels: var. Hood $(\mathrm{n}=23,1$ with a pedestal base, 3 lip notched, 2 with a brushed body, and 1 with rim peaks (see Figure 6-51c-d, gh), var. Lang ( $\mathrm{n}=6,1$ lip notched), var. Blackburn ( $\mathrm{n}=6$, see Figure 6-51e-f), var. Cook ( $\mathrm{n}=11,6$ lip notched, 1 with a crimped lip, 3 brushed on the vessel body, and 1 with rim peaks, see Figure 6-51a), one that has both var. Cook (ovals) and var. Blackburn (rectangular panels) elements. Regional varieties of Poynor Engraved in the cemetery vessels include var. $E(\mathrm{n}=2,1$ brushed on the body, scroll and circle, see Figure 6-51b), var. F ( $\mathrm{n}=1$, nested ovals and diagonal cross-hatched panels), and var. $J$ $(\mathrm{n}=1$, rectangular panel and nested circle). 


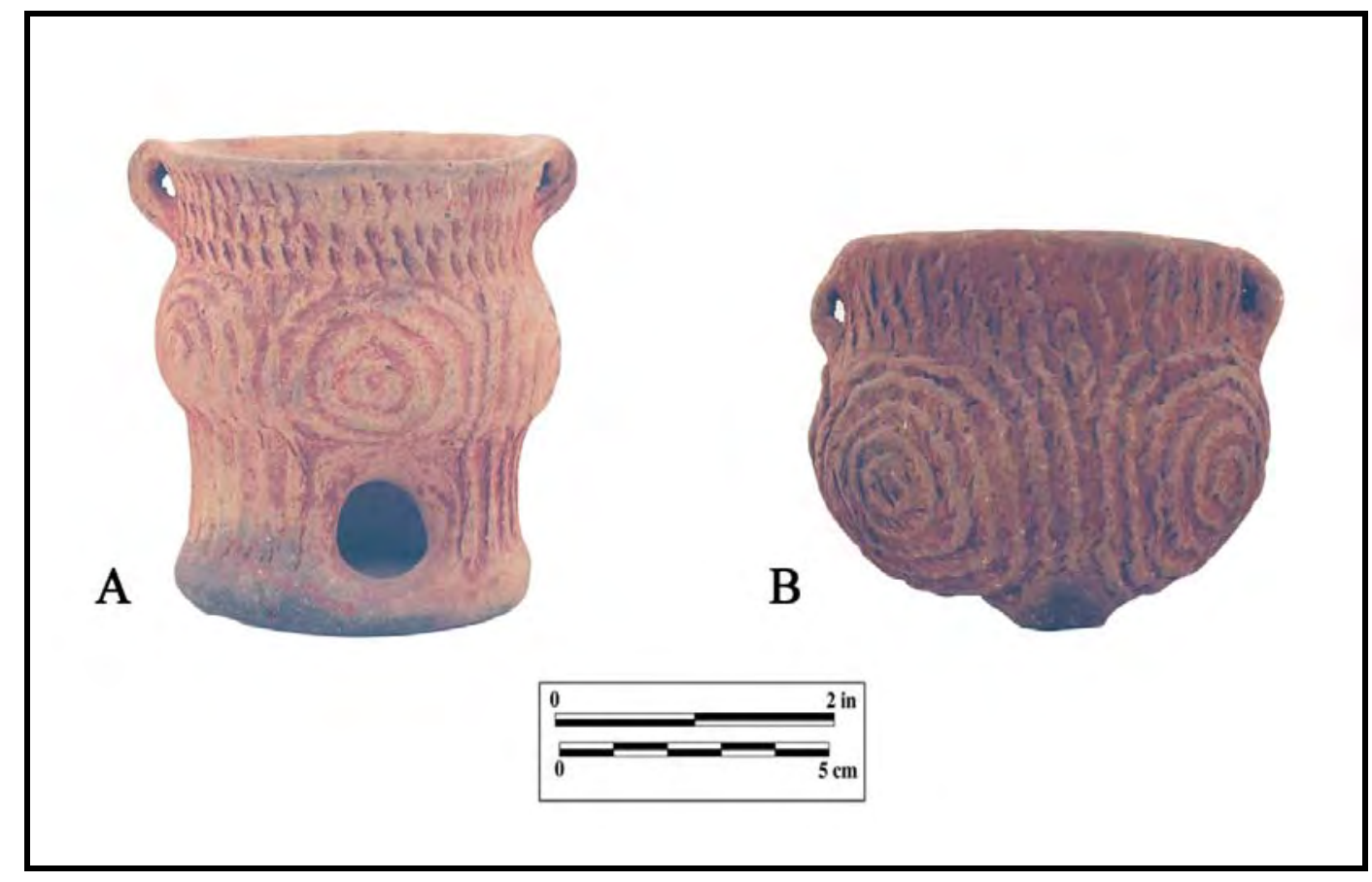

Figure 6-49. Killough Pinched Jars: a, with a pedestal base and two strap handles, CE457; b, jar with a pedestal base and two small strap handles, CE4-60.

Most of the lip-notched Poynor Engraved carinated bowls at Cemetery \#1 are confined to var. Cook (55\%) and var. Hood (13\%) vessels. These same varieties, along with one var. E carinated bowls, are the only varieties with brushed bodies: var. Hood (8.7\%) and var. Cook (27.3\%).

Two of the Poynor Engraved carinated bowls vessels have unique decorative or form attributes. One Poynor Engraved, var. Lang vessel is decorated only on the vessel body, while the rim is plain. The other is a miniature globular carinated bowl with strap handles (since broken off, but the attachment areas still visible), with a var. Hood motif on the rim and engraved (four cross-hatched engraved zones or body dividers), incised (three incised concentric circles), and pinched (one pinched concentric circle) elements on the body (see Figure 6-51h).

The one globular-shaped compound bowl from Cemetery \#1 at the Omer and Otis Hood site is a Poynor Engraved, var. Lang vessel. The var. Lang motif is restricted to the lower or body panel, and the rim is plain. A similar vessel was found in a burial at the Mrs. J. M. Cook site. 


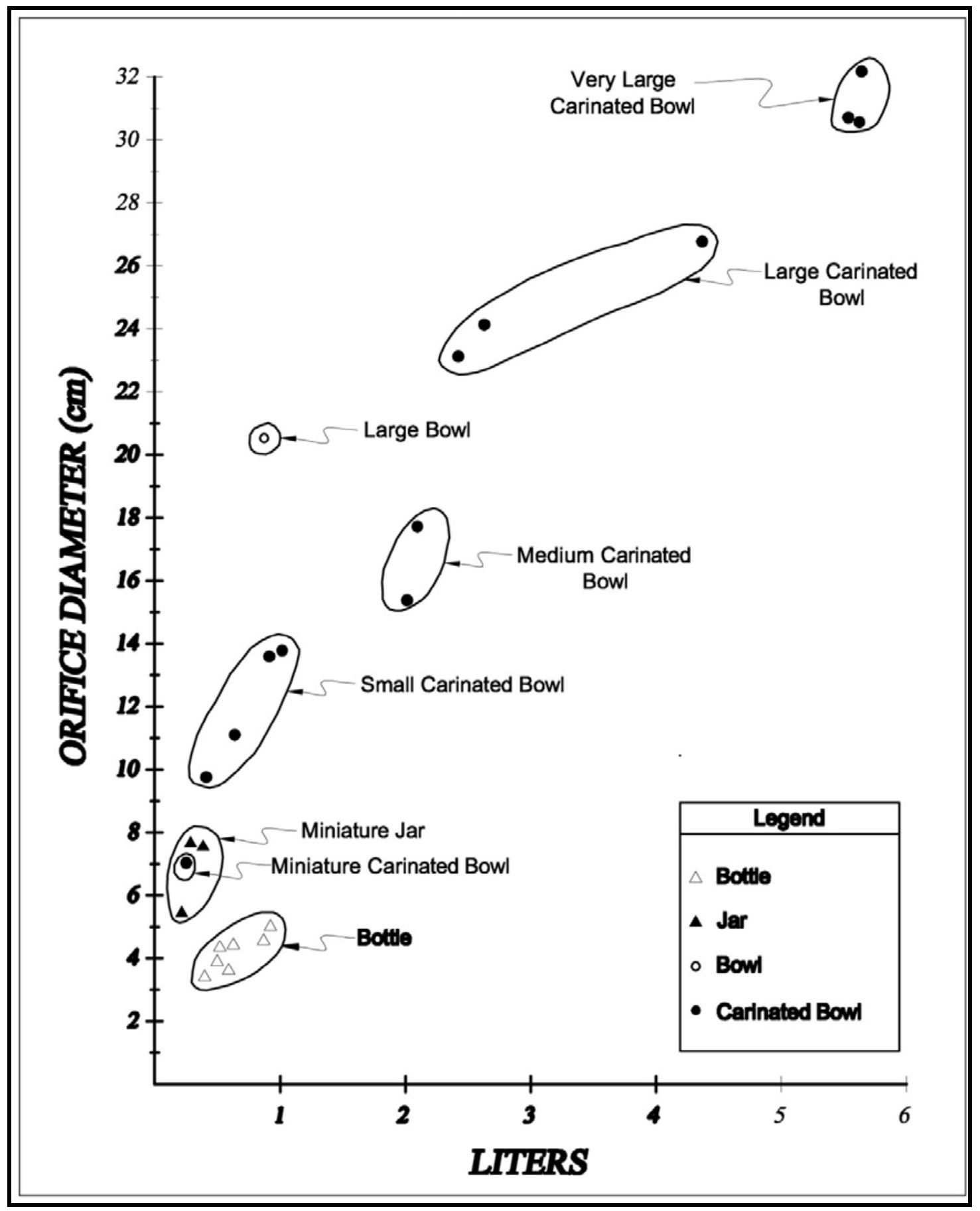

Figure 6-50. Orifice Diameter and Volume of Different Vessel Forms at the J. W. Blackburn Site. 


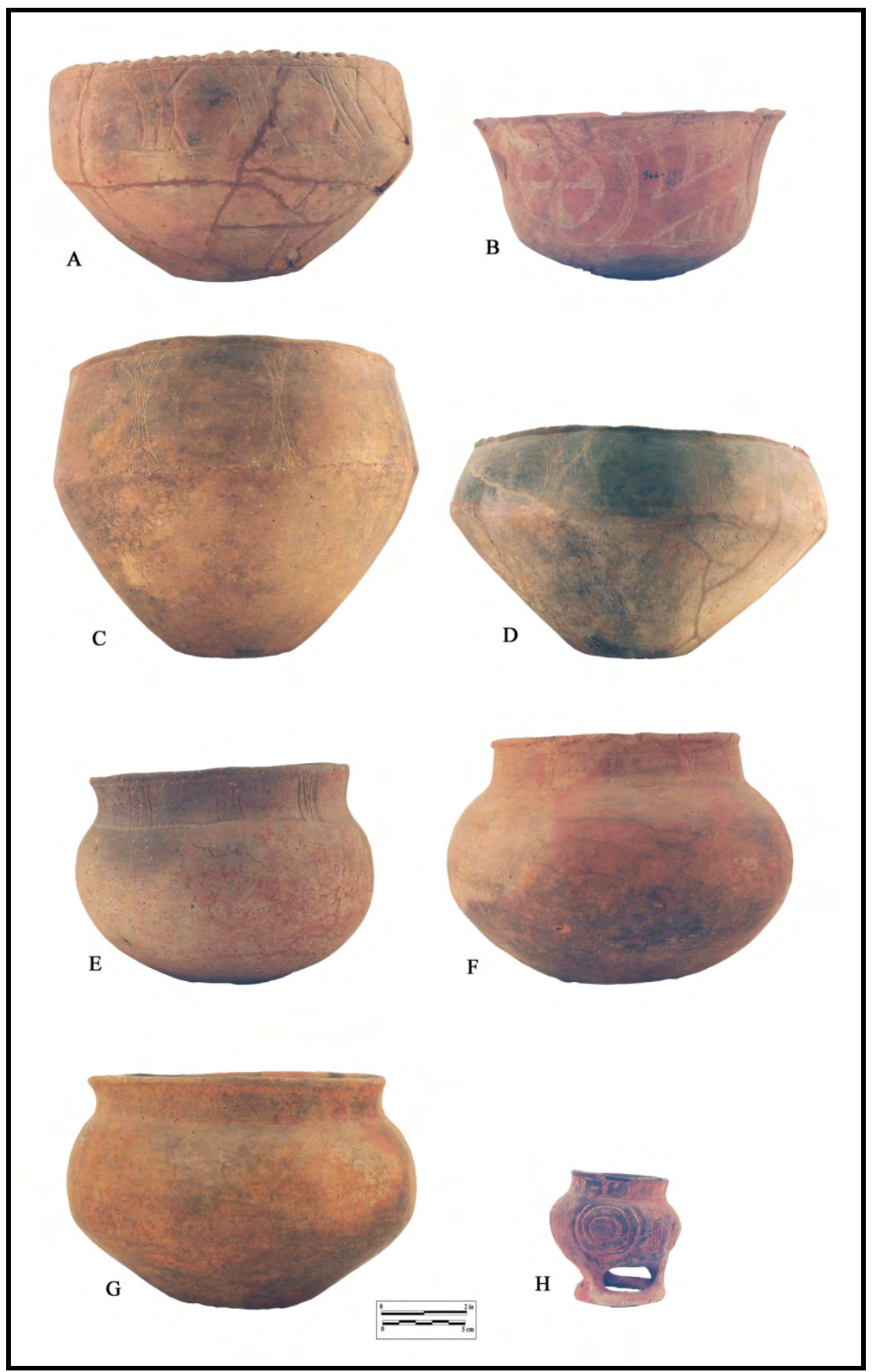

Figure 6-51. Carinated Bowls, Cemetery \#1: a, Poynor Engraved, var. Cook, lip notched, CE14-58; b, Poynor Engraved, var. E, CE14-137; c, Poynor Engraved, var. Hood, CE14-21; d, Poynor Engraved, var. Hood, lip notched and brushed body, CE14-116; e, Poynor Engraved, var. Blackburn, CE14-112; f, Poynor Engraved, var. Blackburn, CE14-54; g, Poynor Engraved, var. Hood, CE1423; h, Poynor Engraved, var. Hood with engraved, incised, and pinched body elements, CE14-101. 
There are seven effigy bowls in Cemetery \#1, all with engraved decorations. The Hood Engraved, var. Hood effigy bowls $(\mathrm{n}=3)$ have broad horizontal engraved lines on the rim (Figure 6-52b), while the Hood Engraved, var. Cook effigy bowl $(\mathrm{n}=1$, Figure 6-52a) has horizontal engraved lines and, under the effigy head and tab tail attachments, hatched pendant triangles. Three others are classified as Hood Engraved, var. unspecified because the appendages have been broken off.

The other bowls include two plain vessels (one a deep bowl and the other with an everted rim), and a brushed bowl with a direct rim.

Five of the bottles are plain. They have elongated bodies and short necks, and can be - negative circles and triangles $(\mathrm{n}=1)$,

- vertical panels and concentric circles $(\mathrm{n}=1)$,

- vertical panels and triangles $(n=1)$,

- vertical panels with crosshatched dividers $(\mathrm{n}=1)$,

- rectangular and vertical panels $(\mathrm{n}=1)$,

- hooked arms and negative circles ( $\mathrm{n}=1$, similar to var. Hood and var. $P$ on carinated bowls), classified as Hume Plain bottles (Figure 653c, e). The other 20 bottles have engraved designs on the vessel body and/or neck.

The two beaker-shaped Poynor Engraved bottles (see Figure 6-53a) includes one with a short neck and engraved panels on the body filled with var. Blackburn panels, and another with circular elements inside vertical panels. Other Poynor Engraved bottles $(n=14)$ primarily have elongated bodies and short necks ( $\mathrm{n}=9$; one has a notched lip), but bottles with wide mouths $(n=1$, see Figure $6-53 d)$, carinated bodies $(\mathrm{n}=1)$, and globular bodies $(\mathrm{n}=3$, see Figure 6-53f-g) are also present in the mortuary assemblage. These vessels are decorated with a diversity of engraved motifs and elements, including:

- $\quad$ negative ovals and circles $(n=1)$,

- sets of horizontal lines on the bottle body $(\mathrm{n}=1)$,

- a var. Hood motif ( $\mathrm{n}=3)$,

- var. $K(\mathrm{n}=2$, semi-circles and nested-circles, some with tick marks), and

- var. Blackburn panels $(\mathrm{n}=1)$ 


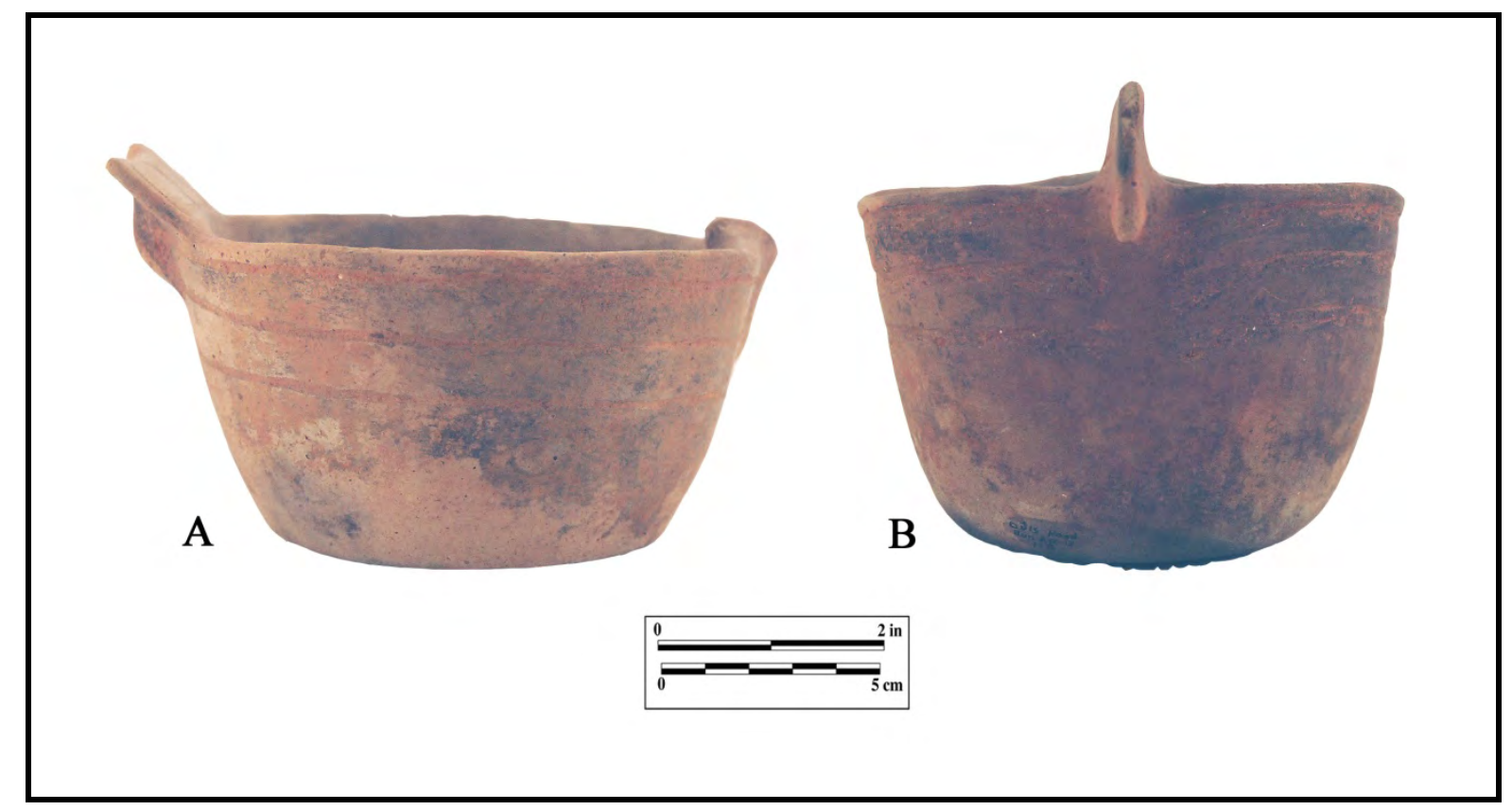

Figure 6-52. Effigy Bowls, Cemetery \#1: a, Hood Engraved, var. Cook, CE14-33; b, Hood Engraved, var. Hood, CE14-118.

Three of the bottles, all with elongated bodies and short necks, are Hume Engraved forms (see Figure 6-53b). One, a Hume Engraved, var. Hume bottle, has vertical cross-hatched panels on the body, and another (var. unspecified) has vertical hatched panels and lines on the body. The third has horizontal engraved licks and pendant hatched triangles on the neck, similar to Hume Engraved, var. Allen, except that this variety as defined from the Jim P. Allen site (41CE12) is more commonly a bowl form rather than a shortnecked bottle. The one remaining bottle is a short-necked form with a series of closelyspaced horizontal lines on the neck, and is probably also a variety of Hume Engraved.
There are both direct (Figure 6-54a-b, d) and everted rim (Figure 6-54c, e-f) jar forms in the mortuary vessel assemblage from Cemetery \#1. The everted rim vessels tend to have either two strap handles or loop handles. Strap handles were either left plain or have short horizontal incised lines on them.

In terms of decorations on the jars, none are plain. Six have punctated designs (see Figure 6-53b, e), either rows of punctations on the rim, or punctated rows on the rim and in concentric arcs covering the vessel body. One jar has punctations on the rim and appliqued triangular elements filled with punctations on the upper vessel body; this vessel has incised strap handles. 
A

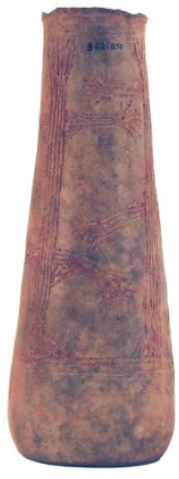

D

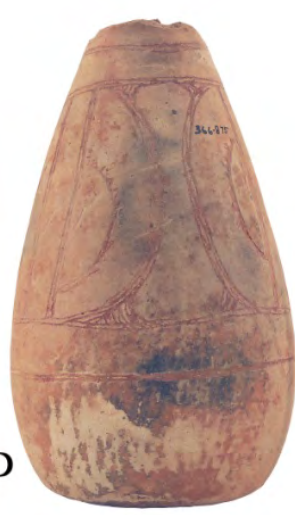

$\mathrm{E}$

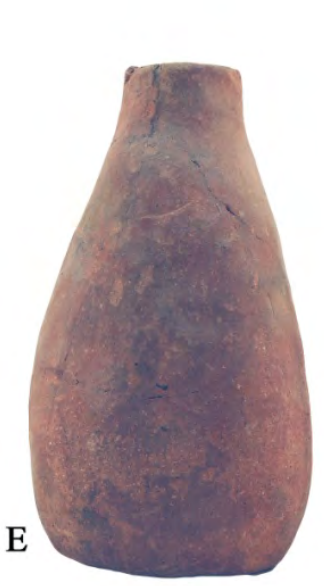

B

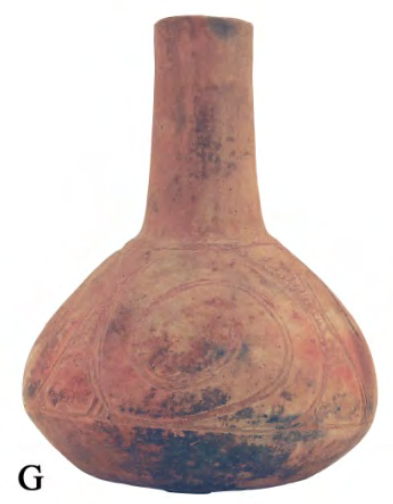

$\mathrm{C}$
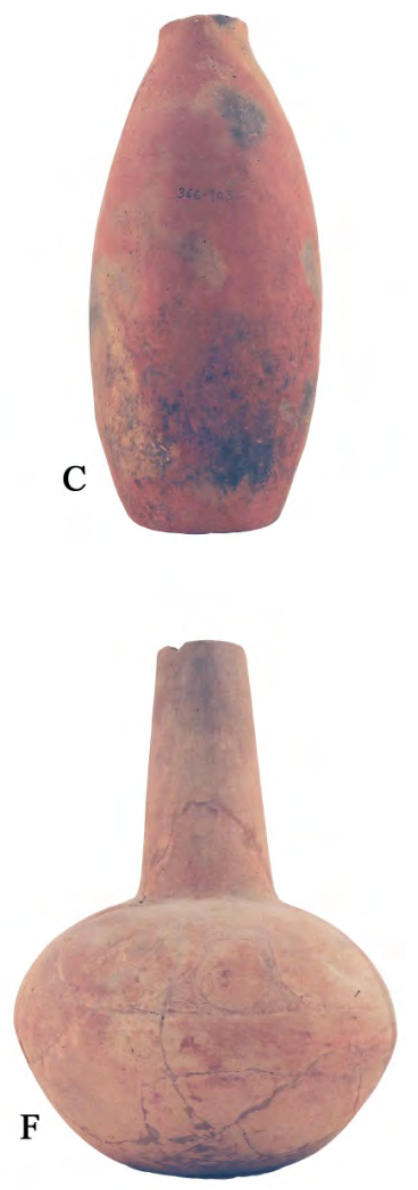

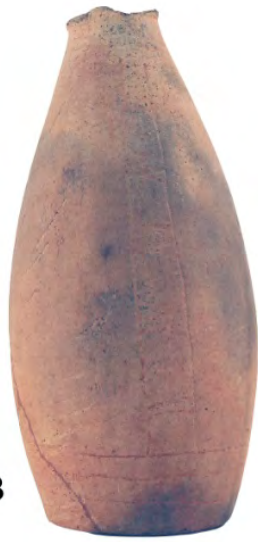

G

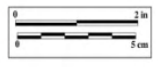

Figure 6-53. Bottles, Cemetery \#1: a, Poynor Engraved short-necked beaker form, CE14-6; b, Hume Engraved, var. Hume, short-necked form, CE1498; c, Hume Plain short-necked form, CE14-56; d, Poynor Engraved wide-mouth neckless bottle, CE14-27; e, Plain short-necked bottle (Hume Plain), CE14-75; f, Poynor Engraved globular bottle, CE14131; g, Poynor Engraved globular bottle, CE14-7. 
There is one Bullard Brushed jar in the collection (see Figure 6-54d), three Maydelle Incised vessels, including one with a vertically brushed body and strap handles (see Figure 6-54a, c), and another probable Maydelle Incised jar (also with strap handles) that has vertical incised lines on the rim and a brushed body. There are also three Killough Pinched jars (see Figure 6-54f), one with strap handles and a pedestal base and another with U-shaped loop handles. These vessels have vertical pinched rows on the rim and concentric pinched rows and hooked arm elements on the body.

The 12 vessels from Cemetery \#2 at the Omer and Otis Hood site include seven carinated bowls, one bowl, two bottles, and two jars. Only one of the carinated bowls is undecorated, while the others, including both inverted rim and globular forms (Figure 6-55a-c), are Poynor Engraved. Varieties represented include var. Cook $(\mathrm{n}=3$, Figure 6-55a-b), including one with sets of lip nodes (Figure 6-55b) and another with rim peaks, var. Hood $(\mathrm{n}=1)$, var. $B(\mathrm{n}=1)$, and var. $F(\mathrm{n}=1$, Figure 6-55c).

The single bowl from this cemetery is a Killough Pinched rattle bowl (see Figure 655e). The vessel is completely covered with pinched rows, as are the four large appliqued nodes or rattles.

The bottle forms from Cemetery \#2 have relatively long necks and globular bottles; one of these has a collar at the junction of the bottle neck and body. Both bottles have Poynor Engraved decorations, including regional var. $E$ (scroll and circle motif) and var. $P$ (hooked arm or scroll motif) (see below).

One of the large everted rim jars from this cemetery has vertical pinching on the rim, a horizontal pinched row at the rim-body juncture, and vertical brushing on the body (see Figure 6-55f). The other has deep pinching on the rim-simulating neck banding - and a brushed body; this may be a local example of a La Rue Neck Banded jar. 


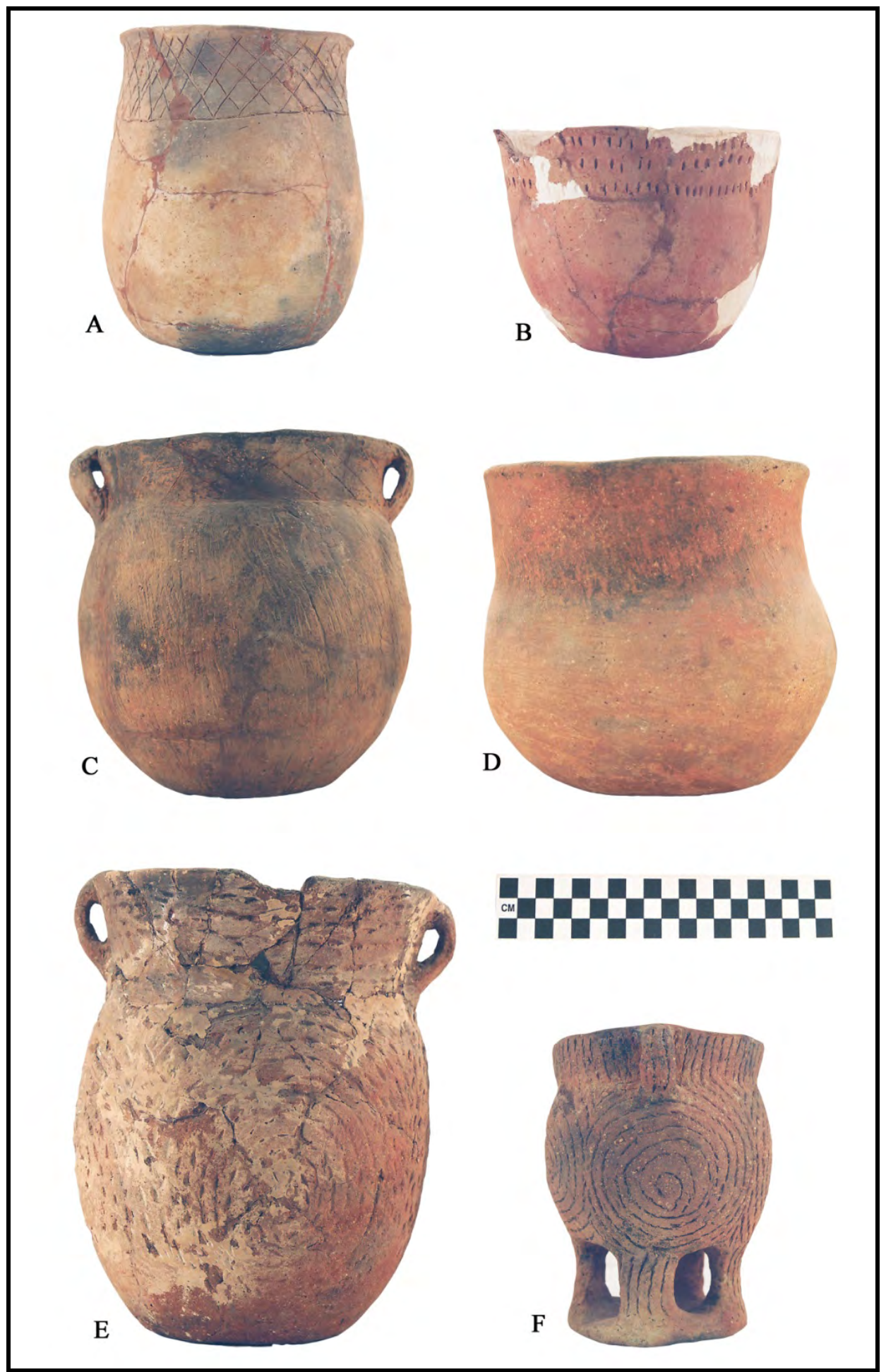

Figure 6-54. Jars, Cemetery \#1: a, Maydelle Incised jar, CE14-29; b, Rim punctated jar, CE14-99; c, Maydelle Incised jar with strap handles, CE14-43; d, Bullard Brushed, CE14-136; e, Punctated jar with strap handles, CE14-17; f, Killough Pinched jar with pedestal base and strap handles, CE14-135. 


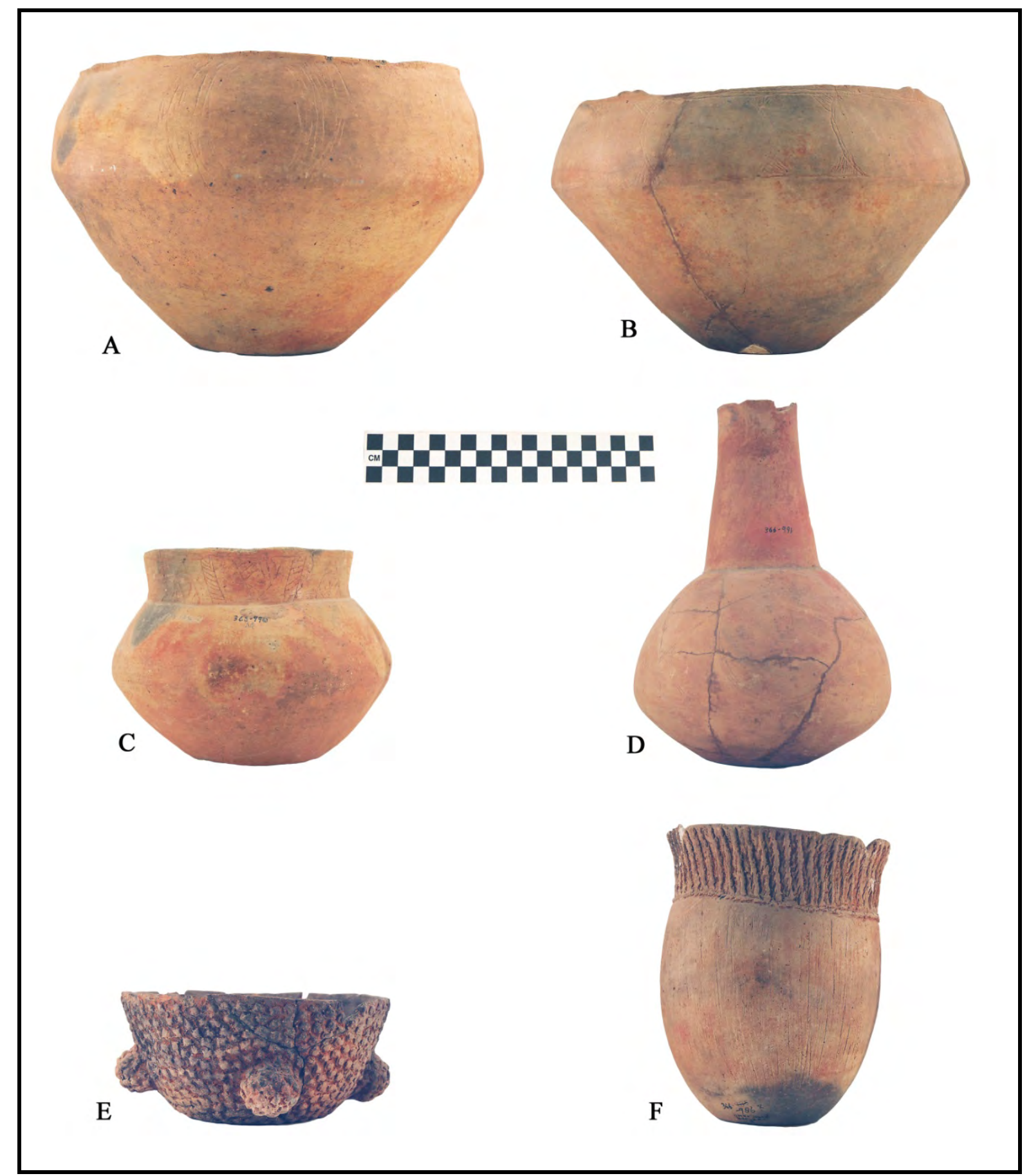

Figure 6-55. Selected Vessels, Cemetery \#2: a, Poynor Engraved, var. Cook carinated bowl, CE14-7; b, Poynor Engraved, var. Cook carinated bowl, CE14-16; c, Poynor Engraved, var. F globular carinated bowl, CE14-12; d, globular Poynor Engraved, var. $E$ bottle, CE14-13; e, Killough Pinched noded and pinched rattle bowl, CE14-10; f, brushed-pinched jar, CE14-8. 


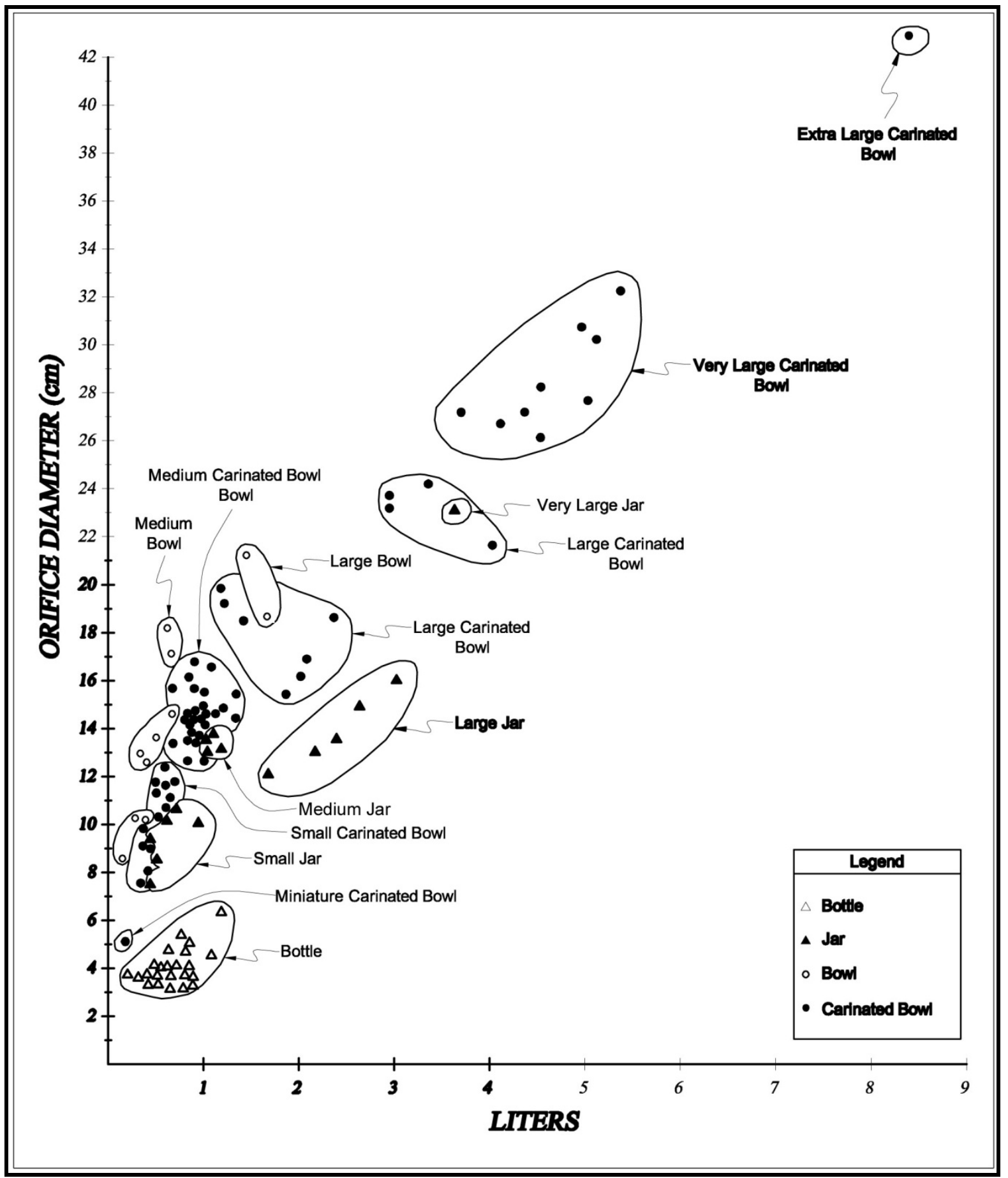

Figure 6-56. Orifice Diameter and Volume of Different Vessel Forms at the Omer and Otis Hood Site, Cemeteries \#1 and \#2. 
There is a wide range and diversity in vessel sizes in the two cemeteries at the Omer and Otis Hood site (Figure 6-56). It has the only extra large ( $>8$ liters) carinated bowl in the suite of upper Neches River mortuary vessel assemblages, a number of very large and large carinated bowls (1.5-6 liters) and jars (2.-3.5 liters), and several large bowls. There are also bottles of two sizes, miniature, small, and medium-sized carinated bowls, jars of smaller sizes, as well as small to medium-sized bowls with volumes ranging from 0.1-0.8 liters (Figure 6-56).

\section{E. W. Henry (41CE17)}

Excavations by Woolsey (1935k) recovered a number of vessels from 11 Frankston phase, sub-phase 1 burials in the E. W. Henry cemetery. We were able to locate and document a total of 35 vessels from mortuary contexts. The 35 vessels include 20 carinated bowls, seven bowls, four bottles, and four jars.

Six of the 20 carinated bowls are plain (30\%). Three of these are globular and round-bodied Poynor Plain carinated bowls (cf. Suhm and Jelks 1962:123 and Plate 62b, j).

The remainder are engraved, with an impressive number of different regional

varieties of Poynor Engraved being represented, as well as a possible Hood Engraved vessel (but lacking the effigy head/tab tail) with broad horizontal engraved lines around the rim. The Poynor Engraved varieties include a globular Poynor Engraved, var. Hood (n=1, Figure 657d) vessel, var. Blackburn $(\mathrm{n}=2)$, var. A $(\mathrm{n}=1$, nested triangles motif), var. $B(\mathrm{n}=2$, interlocking scrolls, Figure 6-57b), var. F $(n=1$, nested ovals and triangles and diagonal cross-hatched ladders, Figure 657c), var. $I(\mathrm{n}=1$, continuous scroll), var. $J$ $(\mathrm{n}=1$, rectangular panel and nested circle, Figure 6-57a), var. $K(\mathrm{n}=1$, semi-circles and nested circles), var. $L \quad(\mathrm{n}=1$, rectangular panel and negative circle), and var. $S(\mathrm{n}=1$, concentric ovals); one other carinated bowl has crudely executed ladders and circles on the rim. 


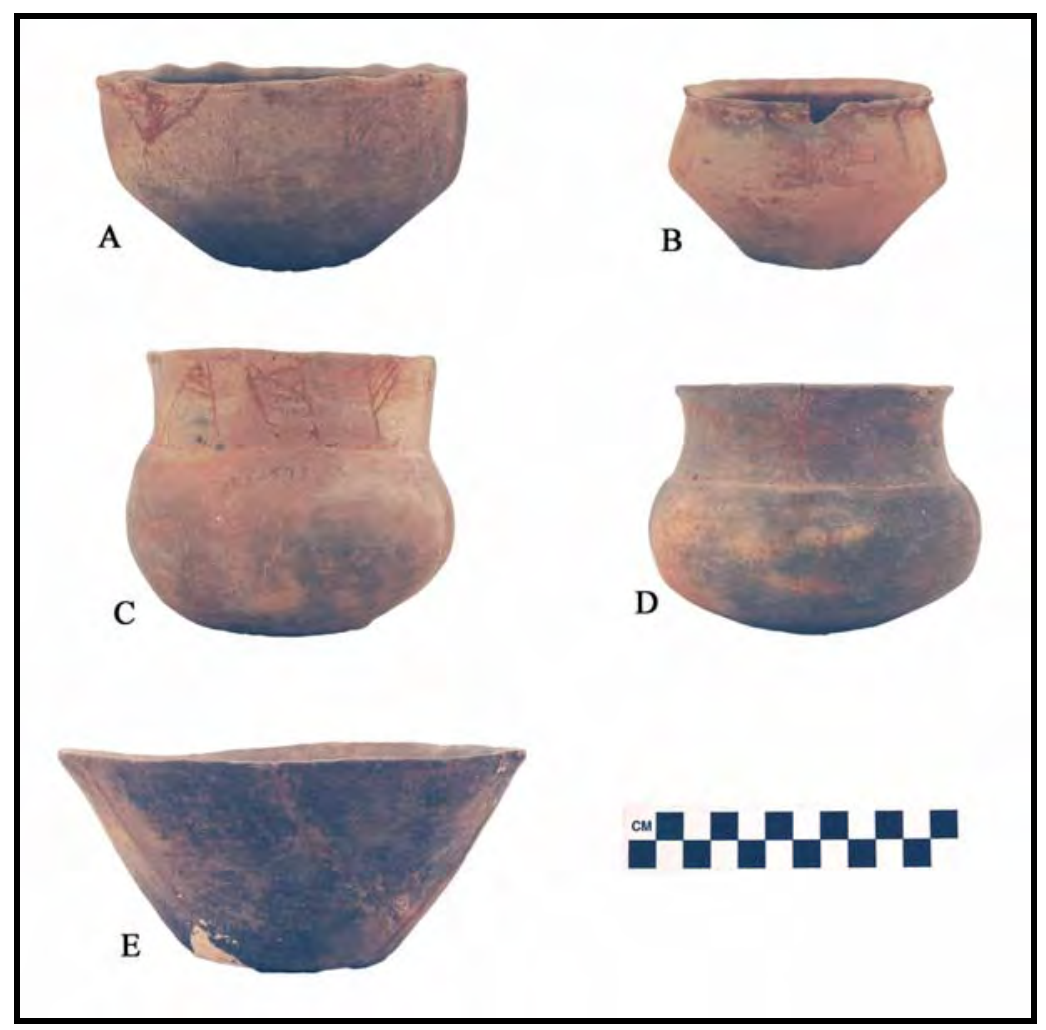

Figure 6-57. Carinated Bowls and Bowls: a, Poynor Engraved, var. J, CE17-34; b, Poynor Engraved, var. B, CE17-30; c, Poynor Engraved, var. F, CE17-29; d, Poynor Engraved, var. Hood, CE17-10; e, Plain bowl, CE17-15.

Three of the E. W. Henry site simple bowls are plain (see Figure 6-57e). The other has incised triangles filled with punctations.

Three of the four bottles from the E. W. Henry site are Poynor Engraved vessels have neck/body collars (Figure 6-58a, c), substantial necks, and globular bodies. The other is an engraved carinated bottle form (Figure 6-58b). Identifiable motifs on the Poynor Engraved bottles include var. $E$ (circle and central cross) and var. $K$ (semicircles and nested ovals) (see below). The carinated bottle, probably also a Poynor Engraved bottle, has a hooked arm or scroll motif (similar to Poynor Engraved, var. P), but with multiple hooked arms covering the vessel body (Figure 6-58b).

Three of the bowls are effigy bowls with bird heads at one end of the vessel and a tabtail at the other, including two Hood
Engraved, var. Hood examples (see Figure 6-58d). The third effigy vessel is plain (Hood Plain).

Two of the medium-sized jars are brushed on the rim and body, and are Bullard Brushed examples; one has a scalloped lip. The others are Maydelle Incised jars, one with incised triangles filled with punctations (Figure 6-59a) and the second with panels on the rim filled with either punctations or short horizontal incised lines (Figure 6-59b).

The mortuary vessels from the E. W. Henry site are almost all small to medium-sized (less than $20 \mathrm{~cm}$ in orifice diameter and less than 2 liters in volume), with only one large jar (3 liters in volume) (Figure 6-60). There is one bottle size, small and medium-sized jars, miniature bowls and carinated bowls (possibly placed in the graves of infants and children), and small to medium-sized bowls 
and carinated bowls. The overall small size of the vessels suggest they were intended for individual use over the course of several days to hold and serve foods.

\section{R. J. Fair (41CE25)}

Twenty-seven vessels were recovered from nine of 10 burials excavated at the R. J. Fair site cemetery (Woolsey 1935i). The R. J. Fair site is a sub-phase 3 (ca. A.D. 15601650) Frankston phase cemetery (see Kleinschmidt 1982; Perttula 2007b).

The 27 vessels are dominated by carinated bowls ( $\mathrm{n}=16,59 \%)$, globular and direct rim forms, and bottles ( $n=10,37 \%)$. There is a single plain jar.

One of the carinated bowls has a plain rim and a brushed body (Figure 6-61b). The others all have engraved designs consistent with defined and regional varieties of either Poynor Engraved $(\mathrm{n}=12)$ or Patton Engraved $(n=3)$. The Poynor Engraved defined varieties from the site include var. Hood ( $\mathrm{n}=6$, Figure 6-61d-e), var. Blackburn $(\mathrm{n}=1)$, and var. Freeman (n=3, Figure 6-61c); one of these vessels has small loop handles. One var. E (scroll and circle) Poynor Engraved vessel (with lip notching and brushing on the body) is also present (Figure 6-61a), along with a small vessel with handles and a pedestal base. This particular vessel has only horizontal engraved lines on the rim-an atypical Poynor Engraved decorative element-but a hooked arm and spiral engraved motif (cf. Poynor Engraved, var. Freeman, see Figure 6-64i, below) on the vessel body. 


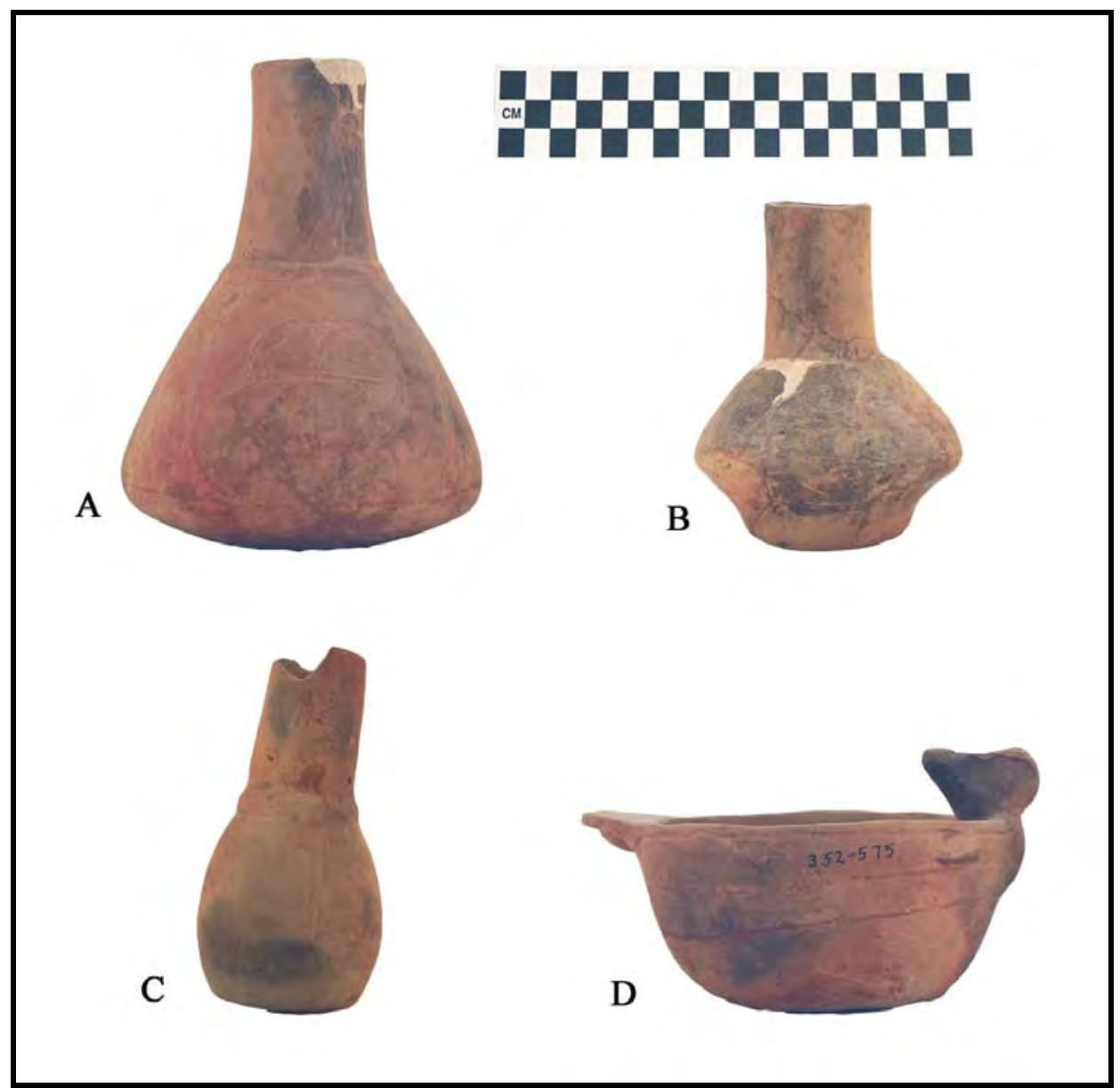

Figure 6-58. Bottles and Effigy Bowls: a, globular and collared Poynor Engraved bottle, CE17-26; b, carinated bottle with hooked arm scroll element, CE17-13; c, collared Poynor Engraved, var. $K$ bottle, CE17-18; d, Hood Engraved, var. Hood effigy bowl, CE17-31.

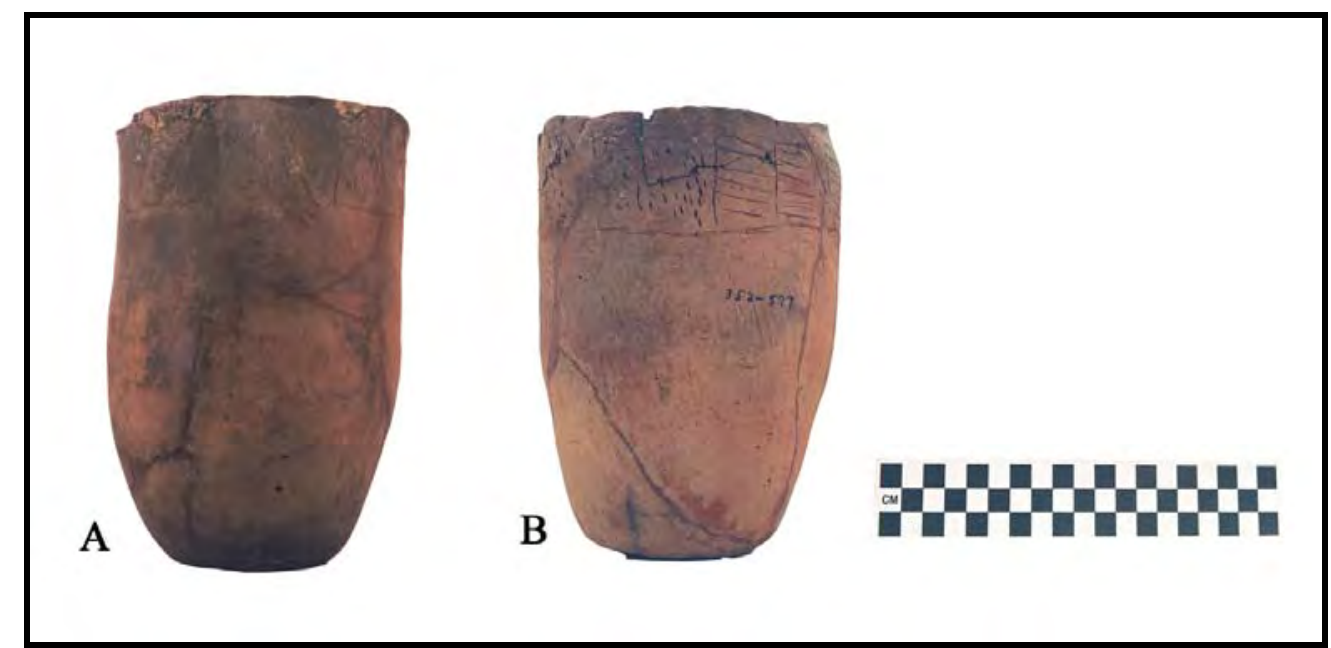

Figure 6-59. Jars: a, Maydelle Incised, CE17-24; b, Maydelle Incised, with incisedpunctated panels on the rim and a brushed body, CE17-33. 


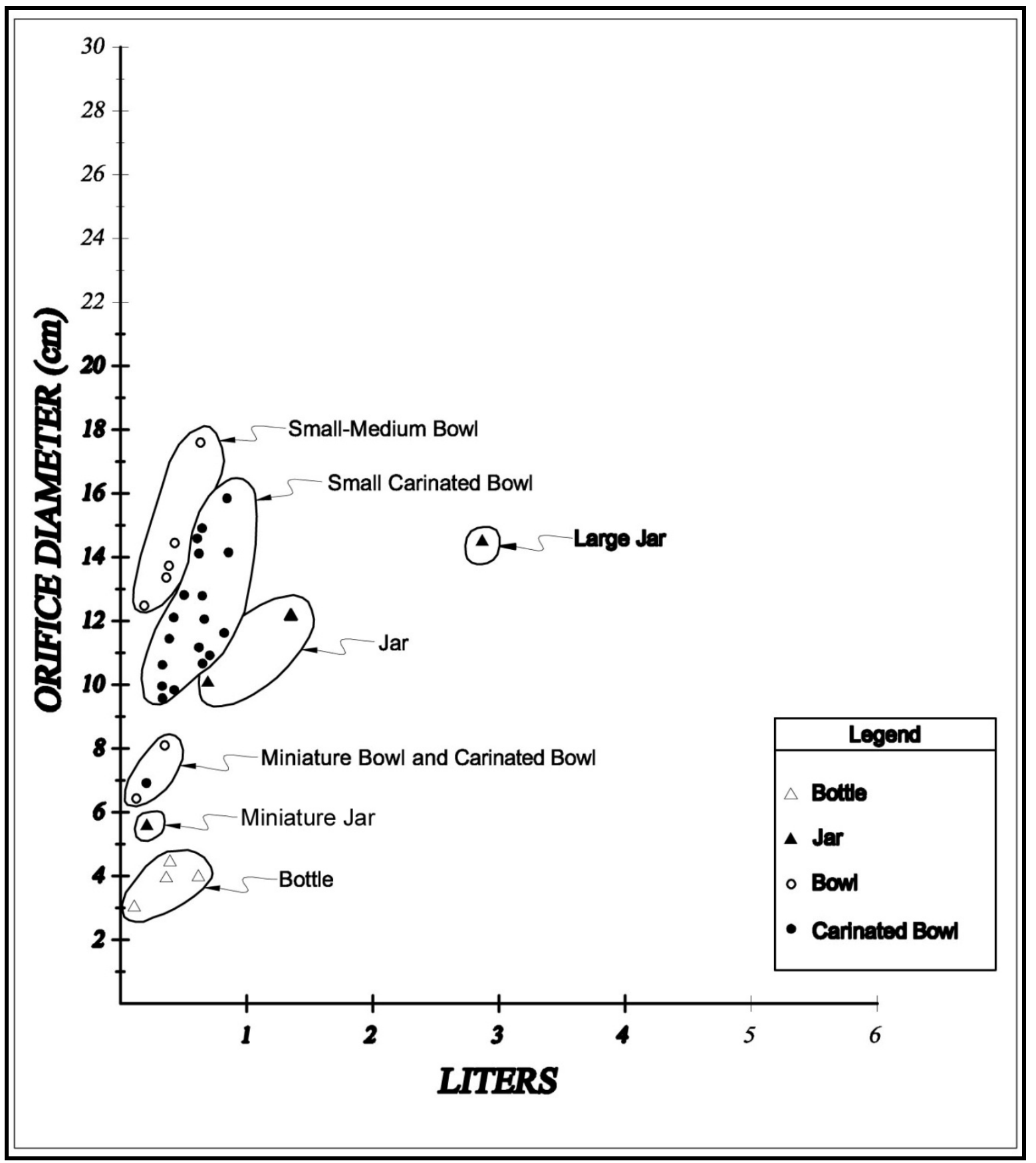

Figure 6-60. Orifice Diameter and Volume of Different Vessel Forms at the E. W. Henry Site. 


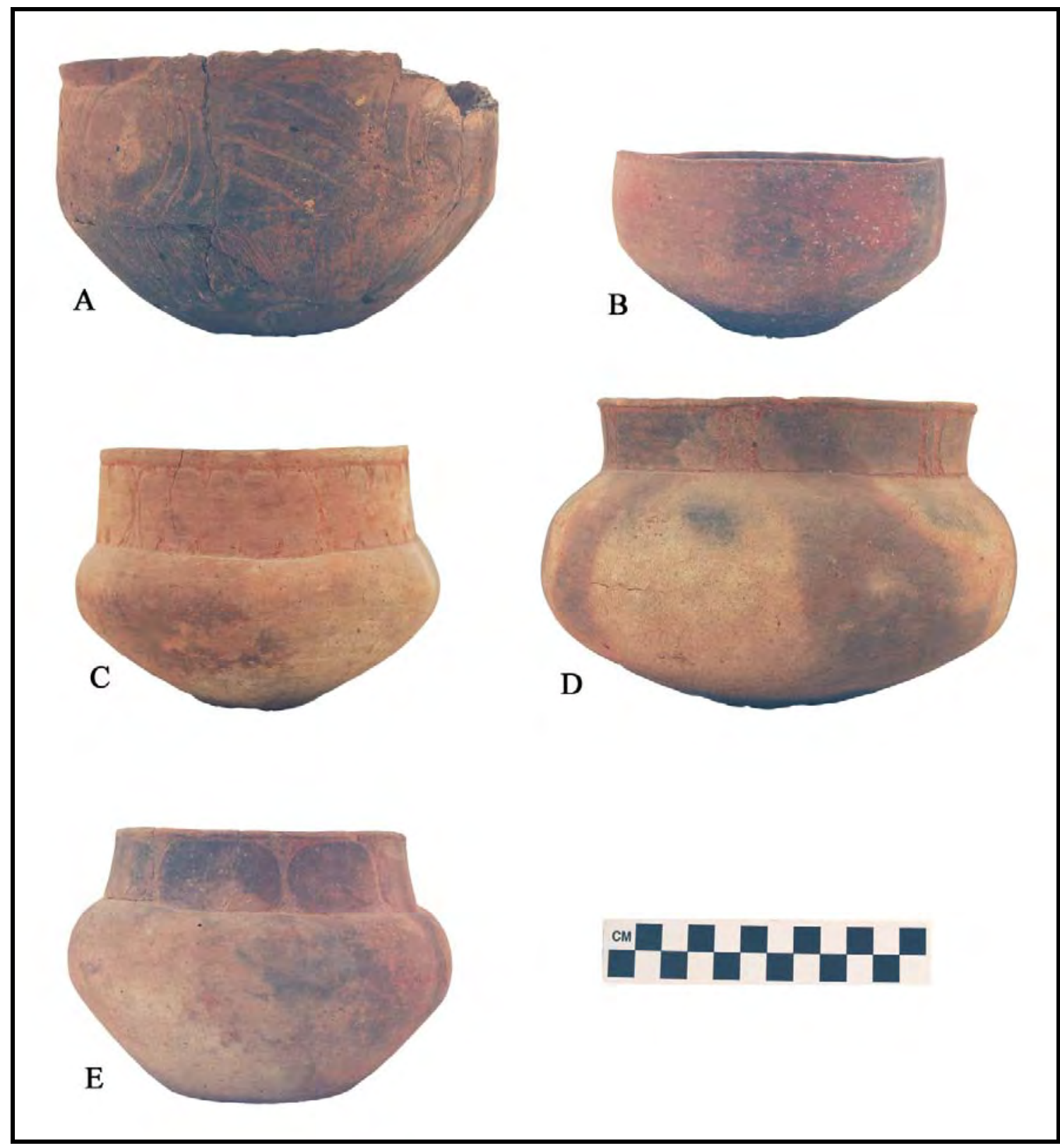

Figure 6-61. Carinated Bowls: a, Poynor Engraved, var. E, CE25-4; b, Brushed carinated bowl, CE25-40; c, Poynor Engraved, var. Freeman, CE25-93; d, Poynor Engraved, var. Hood, CE25-31; e, Poynor Engraved, var. Hood, CE25-32.

The three Patton Engraved vessels include two Patton Engraved, var. Fair carinated bowls (one with loop handles), as well as a Patton Engraved, var. Allen carinated bowl. The frequency of Patton Engraved among the engraved fine wares (20\%) suggest the Caddo cemetery was used near the end of the Frankston phase. In post-A.D. 1650
Allen phase cemeteries in the upper Neches, Patton Engraved vessels comprise almost $70 \%$ of the engraved carinated bowls (Perttula 2007b:Table 1).

The bottles from the R. J. Fair site are a diverse lot. Two are plain Fair Plain bottles with squat globular bodies and elongated 
necks (Figure 6-62a), five are Hume Engraved, var. unspecified bottles with elongated bodies and a short neck (Figure 662c-d) and the sixth is a Hume Engraved globular bottle with a short horizontal engraved neck and a row of hatched pendant triangles at the neck-body juncture (Figure 6-62b). One other bottle is an elongated form with a vertically oriented Poynor Engraved, var. Cook motif on the body. The last bottle is a cut-down body, with a hooked arm scroll, reminiscent of Poynor Engraved, var. $N$ and var. $P$ occasionally seen on engraved carinated bowls.

The R. J. Fair vessels, except for the bottles, are uniformly small in size $(<1.5$ liters) (Figure 6-63), and suitable for a few individual servings. The carinated bowls occur only in miniature, small, and medium sizes. The bottles range from 0.6-1.1 liters in volume.

\section{Comparison of Decorative Motifs and Elements in the Fine Wares}

With the exception of two red-slipped vessels (see Appendix F.5), the fine wares in the vessel collections analyzed in detail (see Appendix F.3 and F.4) from the upper Neches River basin are engraved. The principal engraved fine wares include Poynor Engraved, Hume Engraved, Hood Engraved, and Patton Engraved. Hood Engraved is newly defined herein, while the others were first defined by Suhm and Krieger (1954:306, 336, 342).
On the basis of distinct differences in the style of engraved motifs on each of these fine ware types-differences that are now known to have temporal significance (see below, and probably also have social significance, but this has not been established)-I have defined a series of varieties for each of these types. As with the Caddo ceramic typology in general use, varieties are established following the concepts of Phillips (1958, 1970:24-27; see also discussion of the type-variety system by Read [2007:88-92]) as employed with lower Mississippi Valley ceramics (see Schambach and Miller 1984:112).

Poynor Engraved is by far the most common fine ware type in the upper Neches River basin. Its most distinctive and unifying characteristic, at least in the case of the defined varieties to be discussed in a moment, is the use of rim panels on carinated bowls - or a rim panel decoration turned vertically on bottles (Suhm and Jelks 1954:344; see also Campbell 1936) — that have distinctive dividers, creating central rectangular, oval, negative oval, and semicircular elements. In some cases, there are additional decorative elements within the area created by the dividers, including hatched triangles (so common in the engraved sherds from the Lang Pasture site), pendant triangles, circles, punctate-filled circles, or circles with spurs or ticks. 


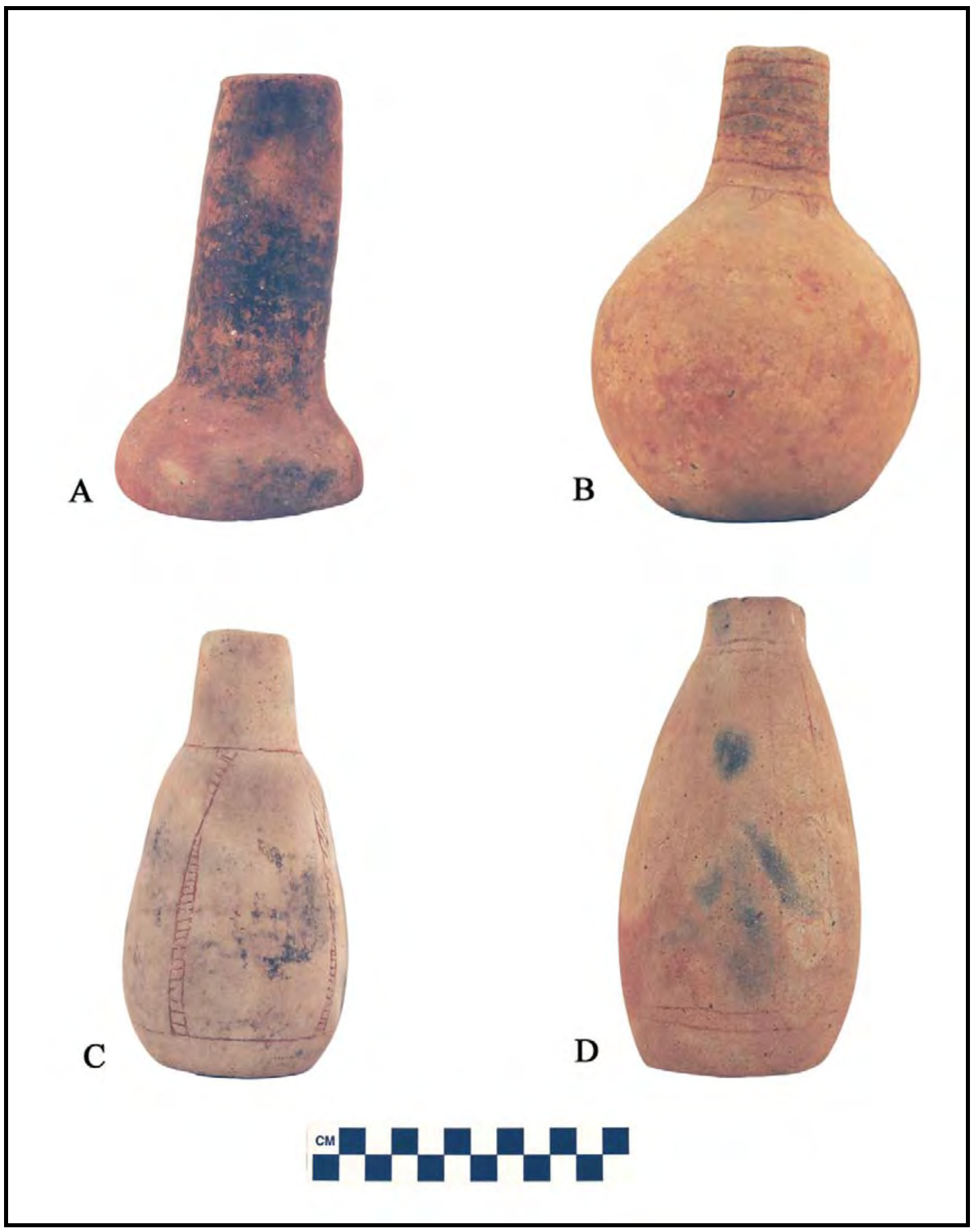

Figure 6-62. Bottles: a, Fair Plain, CE25-1; b, Hume Engraved, var. unspecified, globular bottle, horizontal engraved lines on the neck and pendant triangles, CE25-65; c, Hume Engraved, var. unspecified, short-necked bottle, CE25-39; d, Poynor Engraved, short-necked bottle with vertical var. Cook motif, CE25-17. 


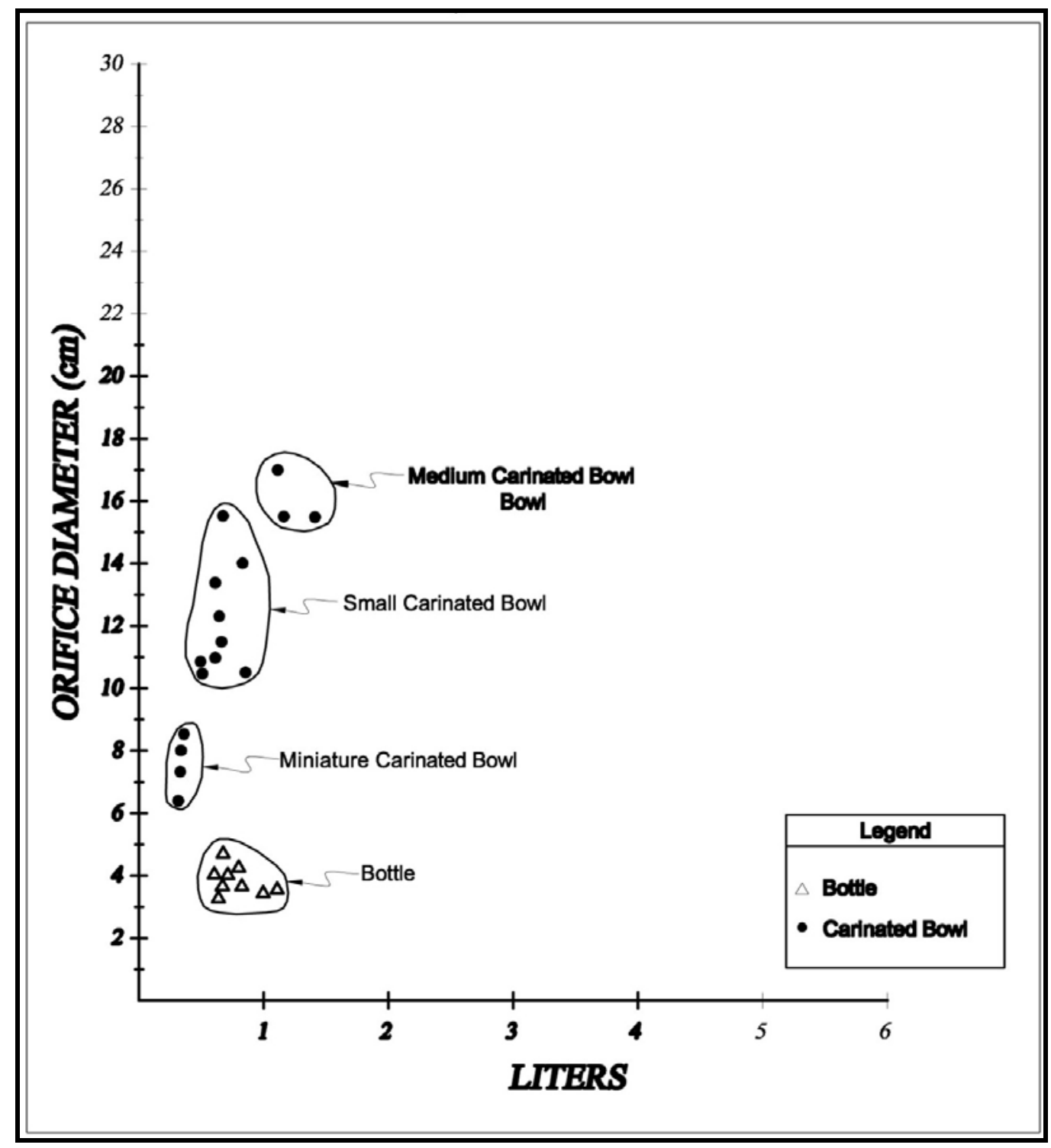

Figure 6-63. Orifice Diameter and Volume of Different Vessel Forms at the R. J. Fair Site.

Poynor Engraved, var. Blackburn has rectangular panels (Figure 6-64a). In some instances, the panels are embellished with hatched triangles at the top and bottom of each panel (Figure 6-64b), or also have small punctate-filled circles within the rectangular panels (Figure 6-64b'). Similar punctate-filled circles are also seen in Poynor Engraved, var. Lang vessels (Figure 6-64g), but they occur always within semicircles. Motifs 13, 14, and 18 for Poynor Engraved (PO) in Kleinschmidt (1982:Figure 19) are consistent with Poynor, var. Blackburn as defined here, as is Var. A in Shafer (1968).

The principal stylistic feature of Poynor Engraved, var. Cook is that it has panels filled with ovals defined by sets of vertically-arcing engraved lines (see Figure 6-64c). Sometimes the ovals have hatched triangle attachments at the top and bottoms of the panel (see Figure 6-64d). Shafer (1968) called this Var. C in his early study of Poynor Engraved, and Motifs 12 and 17 
in Kleinschmidt (1982:Figure 19) represent clear examples of this variety.

Poynor Engraved, var. Hood, is the quintessential and most common Poynor Engraved variety in the upper Neches. It has rim panels divided by sets of hour glassshaped dividers filled with closely-spaced hatched or cross-hatched engraved lines. These hour glass-shaped dividers create a series of negative ovals within the rim panel (see Figure 6-63e). Shafer (19968) combined what I have called Poynor Engraved, var. Cook and var. Hood within his Var. C; Motifs 1, 2, and 21 of Poynor Engraved (PO, see Kleinschmidt 1982:Figure 19) are comparable motifs within this variety.

With Poynor Engraved, var. Lang, the key and defining part of the motif is the small central circle within a series of semi-circles on the rim panel see (Figure 6-64f-g). The small central circle may have spurs or be filled with small punctates. The larger semicircles typically have hatched triangle elements at the top and bottom of the semicircles. Figure 6-63g' may be another example of var. Lang, in that it has a series of repeating semi-circles, attached hatched triangles, and a central element within the larger semi-circle. In this case, however, the central element is not a small circle, but the beginning of a small hooked arm scroll; this particular element is also seen in other less common varieties of Poynor Engraved recognized within the region. Shafer's (1968) Var. B is the same as Poynor Engraved, var. Lang, as are Motifs 4, 27, and 28 (PO) in Kleinschmidt (1982:Figure 19).

The last defined variety of Poynor Engraved is var. Freeman (see Figure 6-64h-i). This variety has hour glass-shaped panel dividers and hatched/excised pendant triangles at the top and bottom of each panel. Some examples of this variety have hooked arm scrolls and concentric circles on the vessel body (see Figure 6-64i), which presages the use of similar motifs in Patton Engraved, var. Freeman, except there the scrolls and concentric circles and rim panels have small triangular tick marks (see below). Shafer (1968) included vessels with these rim motifs in his Var. A, but in our sorting, we restricted var. Freeman to vessels that had hour glass-shaped dividers rather than rectangular panels (as with var. Blackburn) and also had pendant triangles on the rim panel. Kleinschmidt (1982:Figure 20) includes vessels with this engraved rim style in his PP category of Poynor Engraved, vessels with features of both Poynor Engraved and Patton Engraved. PP Motifs 5, 6, and 11 compare favorably to Poynor Engraved, var. Freeman as defined here.

As has been mentioned before, Poynor Engraved is the most common and widespread of the engraved fine wares in the upper Neches River basin. The five defined varieties are found at most of the sites in the vessel database (see Appendix F.5), as well as in sherd assemblages from domestic and mound components (see below; Anderson et al. 1974; Kleinschmidt 1982; Perttula 2009; Perttula and Middlebrook 2009). Poynor Engraved, var. Hood is the most widespread of the defined varieties, followed by Poynor Engraved, var. Blackburn. Poynor Engraved, var. Lang is the least widespread of the defined varieties. It is noteworthy that none of the five defined Poynor Engraved varieties occur in the mortuary assemblage from the Lang Pasture site, and they are not readily identified in the southern and northern area fine ware sherds, although a few probable Poynor Engraved, var. Blackburn and var. Cook sherds were discerned in the southern area (see above). Two other distinguishing characteristics of the decorative elements on Poynor Engraved carinated bowls from the upper Neches are the frequency of brushed bodies on these vessels as well as the use of lip notching, in both sub-phase 2 and sub-phase 3 Frankston phase mortuary contexts. In the sample of vessels from Lang Pasture, none of the engraved carinated bowls have these 
attributes. These attributes are similarly absent from sub-phase 1 Frankston phase mortuary carinated bowls $(n=27)$. By contrast, brushed Poynor Engraved carinated bowls comprise $15-19 \%$ of these vessels, respectively, in the later sub-phases. Lip notched vessels are particularly abundant in ca. A.D. 1480-1560 contexts (15\%), but less so between ca. A.D. 1560-1650 (2.4\%) in the upper Neches.

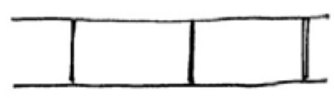

a

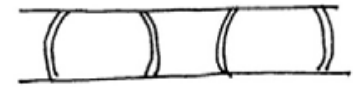

C

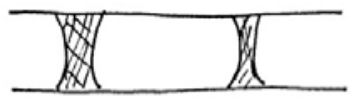

e

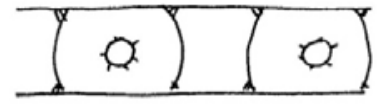

$f$

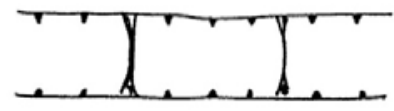

$\mathrm{h}$

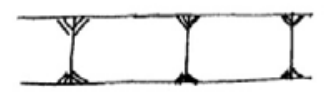

b

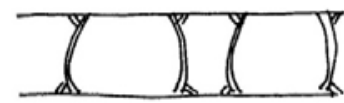

d

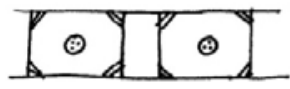

b'

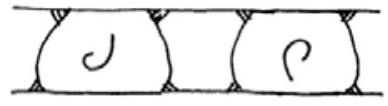

$g^{\prime}$

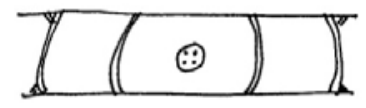

g

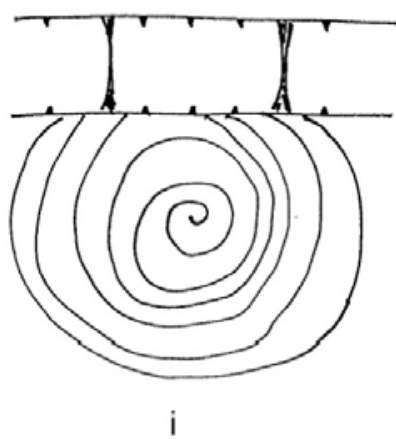

Figure 6-64. Defined Varieties of Poynor Engraved: a-b', var. Blackburn; c-d, var. Cook; e, var. Hood; f-g', var. Lang; h-i, var. Freeman.

As the rim motifs on engraved carinated bowls and compound bowls were being reviewed and quantified from the Lang Pasture site, and by other sites in the upper Neches River basin (which unfortunately
Kleinschmidt [1982] never did with the numerous [ $\mathrm{n}=97$ ] rim motifs he illustrated for both the PO and PP categories of Poynor Engraved), less common rim motifs present at only a few sites (and thus their spatial 
distribution was poorly known) were also defined, referred to here as regional Var. A$T$ (Figure 6-65) of Poynor Engraved. These varieties feature a diverse range and combination of stylistic elements, principal among them nested triangles, nested ovals, and nested circles; scrolls of various sorts; hatched pendant, stacked, and nested triangles; cross-hatched ladders and panels; hooked arms; concentric ovals; and sets of diagonal lines with small pendant triangles.

The most common regional varieties of Poynor Engraved are var. $F$ (nested ovals/triangles and diagonal cross-hatched ladders, also local variety 1 at the Lang Pasture site), var. E (scroll and circle), and var. B (interlocking scrolls) (see Figure 665. Var. F vessels have also been reported from sites in the upper Sabine River that date to the $14^{\text {th }}$ century, including 41 WD518 and the Carlisle site (41WD46, see Perttula et al. 1993), indicating a wider and perhaps earlier distribution to some of these more unique Poynor Engraved styles. ${ }^{3}$ The other regional varieties are represented by vessels from no more than 1-5 sites.

Of significance in this discussion is that $57.2 \%$ of the Poynor Engraved vessels at the Lang Pasture site can be assigned to one of these regional varieties; the other $42.8 \%$ are specific local varieties of Poynor Engraved seen only at Lang Pasture and one or two other sites in the region. In the broader upper Neches River basin mortuary vessel assemblages, these numerous regional varieties-probably representing the product of the work of specific artisans (cf. Read 2007:91) — are most abundant in pre-A.D. 1480 or Frankston phase sub-phase 1 contexts (61.1\%), with a significant drop off in ca. A.D. 1480-1560 (11.7\%) and ca. A.D. 1560-1650 (19.9\%) mortuary contexts. This suggests that prior to A.D. 1480, and reaching back into the early to mid-14th century A.D. when the Lang Pasture site was occupied and distinctive fine ware styles were beginning to be created, the favoring of stylistic innovations and the individual work of specific artisans, were what led to the wide diversity in Poynor Engraved rim motif styles at that time. Innovations and unique artistic expressions began to diminish in favor of stylistic conformity around a certain few rim panel motifs. Although specific archeological and chemical compositional data are not currently available to address the issue, I suspect that after ca. A.D. 1480, specific distinct styles/varieties of Poynor Engraved were not made in each Caddo settlement or community, but instead each style was made by a certain number of artisans living in specific parts of the upper Neches River basin, and the products were then traded and exchanged throughout the region. Examining the near-identical manufacture and decorative style of many of these Poynor Engraved vessels (see Appendix F.4), it is hard to escape the conclusion that a number of them may have been made by the same potter. Either that, or there was a near perfect transmission of information between potters in different communities about certain Poynor Engraved vessel form and decorative styles, which seems improbable given the likelihood of copying errors if many individuals were making these kinds of pottery (cf. Eerkens and Lip 2005, 2007).

There are several defined varieties of Patton Engraved and Hume Engraved (Figure 666); none occur at the Lang Pasture site. Seriation analysis of mortuary vessels (see below) suggest that neither pottery type began to be made until after ca. A.D. 1480 (in the case of Hume Engraved) or after ca. A.D. 1560 (in the case of Patton Engraved). 


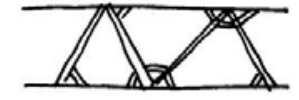

Var. A, Nested

Triangle

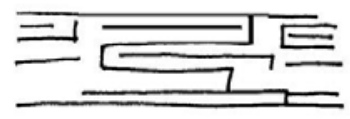

Var. B, Horizontal and Vertical Interlocking Scrolls

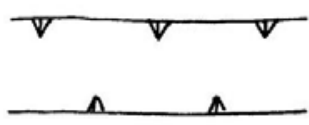

Var. C, Continuous Hatched Triangles

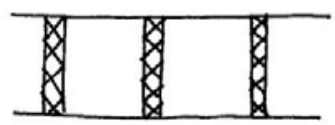

Var. D, Vertical

Cross-Hatched Panels

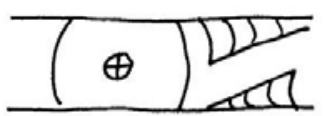

Var. E, Scroll and Circle

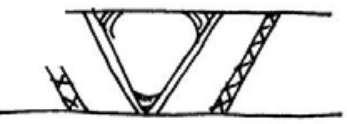

Var. F, Nested Ovals and Diagonal Cross-Hatched Ladders

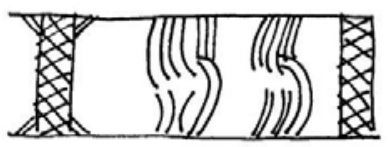

Var. G, Hooked Arm Scrolls and Cross-Hatched Panels

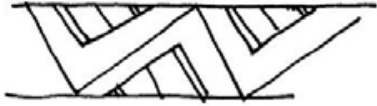

Var. I, Continuous Scroll

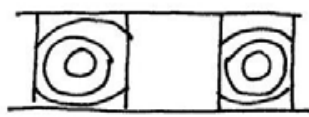

Var. J, Rectangular Panel and Nested Circle

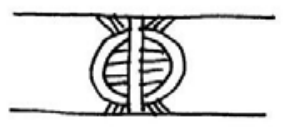

Var. K, Semi-Circle and Nested Circles

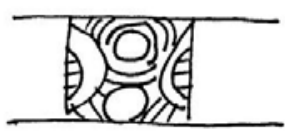

Var. L, Rectangular Panel and Nested Circle

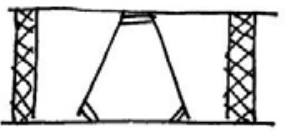

Var. M, Triangle and Cross-Hatched Panel

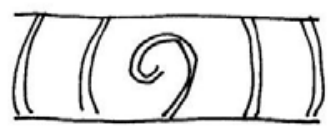

Var. N, Hooked Arm and Oval

Or

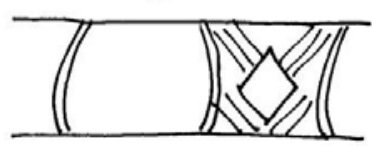

Var. N', Oval and Diamond

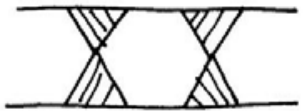

Var. O, Stacked, Hatched Triangles

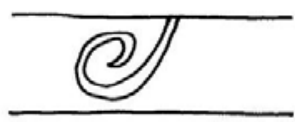

Var. P, Hooked Arm

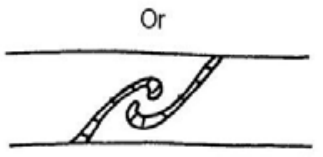

Var. P', Hatched Hooked Arm

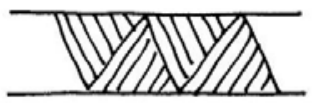

Var. Q, Hatched

Nested Triangles

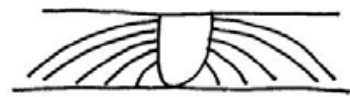

Var. R, Concentric Semi-Circles

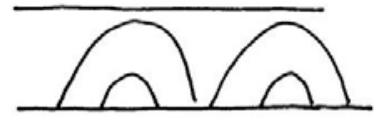

Var. S, Concentric Ovals

Or

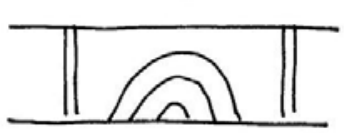

Var. S', Concentric Ovals and Panel

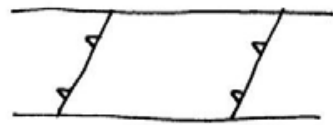

Var. T, Diagonals with Small Pendant Triangles

Figure 6-65. Regional Varieties A-T of Poynor Engraved in the Upper Neches River Basin.

Each of the Patton Engraved varieties (Figure 6-66a-d) feature tick marks as embellishments to: (a) sets of widely-spaced to closely-spaced horizontal engraved lines on vessel rims 


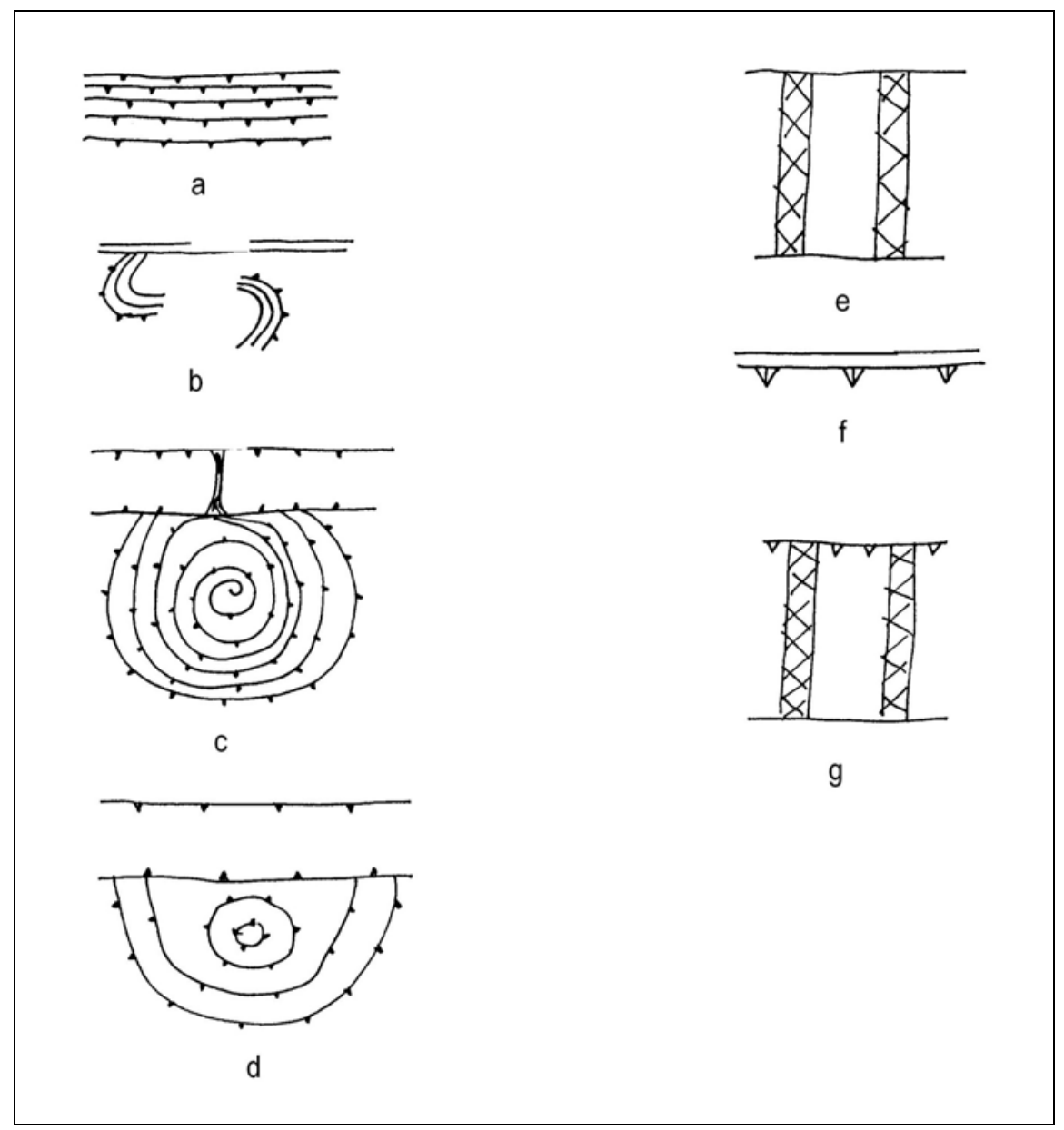

Figure 6-66. Defined Varieties of Patton Engraved and Hume Engraved: a, Patton Engraved, var. Allen; b, Patton Engraved, var. Patton; c, Patton Engraved, var. Freeman; d, Patton Engraved, var. Fair; e, Hume Engraved, var. Hume; f, Hume Engraved, var. Allen; g, Hume Engraved, var. unspecified.

(Patton Engraved, var. Allen, Shafer's [1968] Patton Engraved, Var. B); (b) horizontal and sets of curvilinear lines on the vessel rim (Patton Engraved, var. Patton, Shafer's [1968] Patton Engraved, Var. D), these curvilinear lines, although widely-spaced on Patton Engraved vessels, are reminiscent of the hooked arm element on several Poynor Engraved regional varieties (see Figure 6-65); (c) broad horizontal lines on the rim and semi-circular engraved lines on the vessel body (Patton Engraved, var. Fair, Shafer's [1968] Patton Engraved, Var. C); and (d) rims with hour glass-shaped dividers, small pendant triangles or tick marks on the rim panel engraved lines, and hooked arm/concentric circle elements on the vessel body (Patton Engraved, var. Freeman, Shafer's [1968] Patton Engraved, Var. A, although he also includes Poynor Engraved, var. Freeman vessels within this variety of Patton Engraved).

Hume Engraved vessels are distinctive elongated bottles with short necks (see Figure 6-27a-b). The engraved decorations are a series of vertical panels (usually four) that run from the base of the bottle neck to near the base of the vessel (see Figure 6-66e, g). These panels are commonly filled with cross-hatched lines, but there are examples 
where the panels are filled with diagonal or horizontal hatched lines, or some combination of cross-hatched and hatched panels (see Suhm and Krieger 1954:306). Hume Engraved, var. Hume (see Figure 666e) has sets of cross-hatched vertical panels. Another variety, still unnamed, but present in some numbers at the Jim P. Allen site (41CE12), has cross-hatched vertical panels with a row of hatched pendant triangles along a single horizontal engraved line at the body-neck juncture (see Figure 666g). A slightly different version of this stylistic motif has been documented at the Mrs. J. M. Cook site (41AN1), where in addition to the cross-hatched vertical panels and the hatched pendant triangles along the body-neck juncture, there are additional hatched pendant triangles on the vertical panels themselves. Another unspecified Hume Engraved variety includes two elongated bottles at the J. W. Blackburn site (41CE4) with horizontal engraved lines at the body-neck juncture along with a downward-pointing row of small pendant triangles; there are no vertical panels on these bottles. Lastly, this same motif of horizontal lines and pendant triangles (hatched in this case) - but no vertical panels-occurs on several bowls from 41SM77 and the Richard Patton site (41AN26): I have dubbed this Hume Engraved, var. Allen (see Figure 6-66f).

Hood Engraved effigy vessels are concentrated in post-A.D. 1400 Caddo sites in several parts of the upper Neches River basin (Figure 6-67); no effigy vessels are present at the Lang Pasture site. Seriation analysis suggests that effigy vessels began to be made ca. A.D. 1400, they were most popular as mortuary offerings between ca. A.D. 1400-1480, and then they continued to be made and used through the Allen phase. The three varieties, with Hood Engraved, var. Hood being the most common effigy vessel style, defined here include:

- Hood Engraved, var. Hood: this variety has an effigy head (usually a bird or duck) and tabtails, and broad horizontal engraved lines (usually three lines) on the rim;

- Hood Engraved, var. Cook: these vessels have both an effigy head and tabtails, but in addition to a set of broad horizontal engraved lines, there are also hatched pendant triangle engraved elements;

- Hood Engraved, var. Allen: this variety has an effigy head, tab tails, and a zoomorphic or anthropomorphic tail rider; the bowl rim has broad horizontal engraved lines. Similar kinds of shell-tempered tail-rider effigies are found in Late Mississippian sites in the St. Francis and Memphis areas of the lower Mississippi valley (LMV); Phillips et al. (1951:169) suggested that this effigy vessel form was diffused to the Caddo area from the LMV, but this now seems unlikely.

Hood Engraved, var. Hood vessels are widely distributed in this region, occurring in burial and domestic contexts at a number of sites. Hood Engraved, var. Allen effigy vessels, however, are more concentrated in late Frankston and Allen phase settlements and cemeteries in the Caddo and Flat Creek areas and in the Neches River valley itself (see Figure 6-67) 


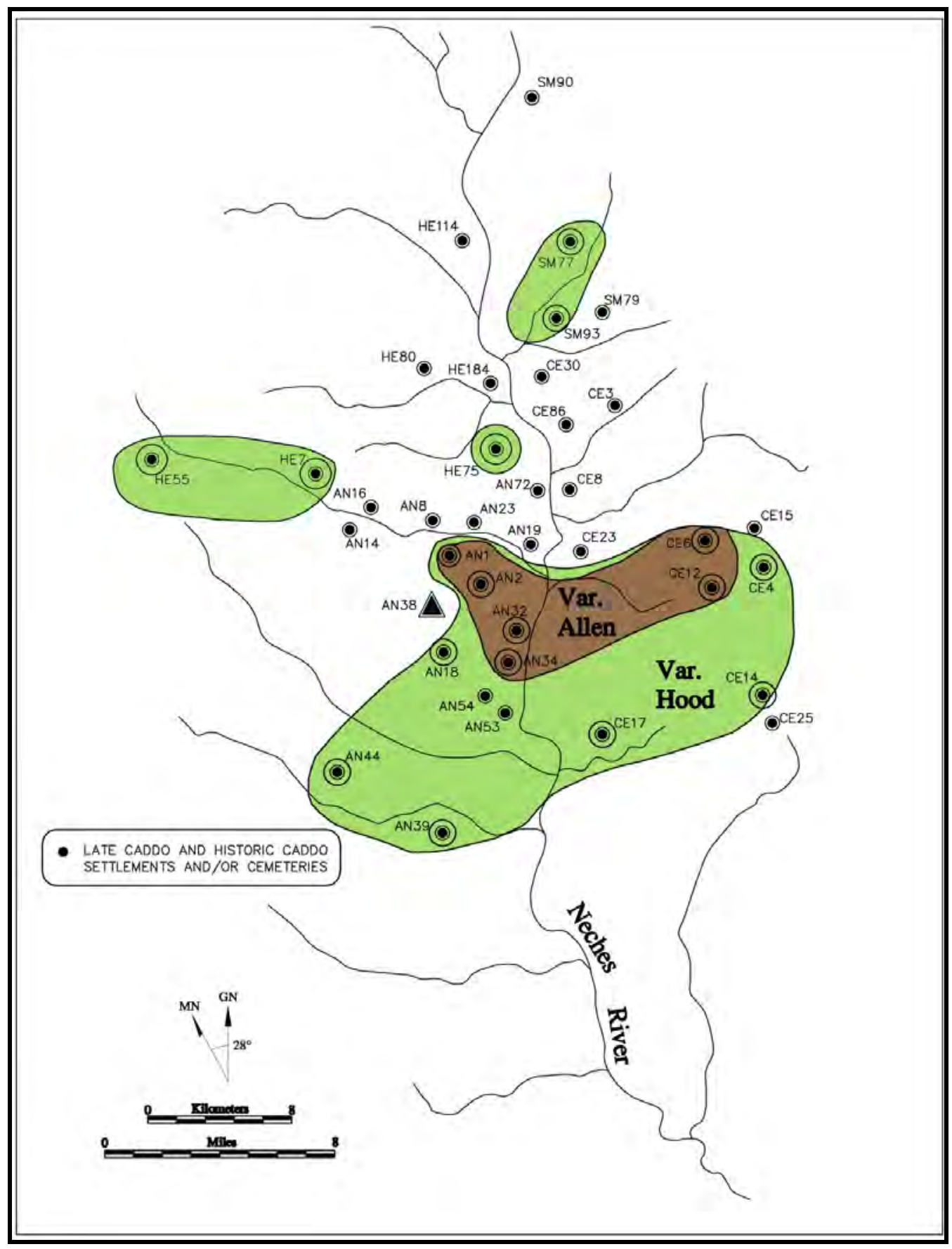

Figure 6-67. Distribution of Hood Engraved Effigy Vessels in the Upper Neches River Basin. 
This latter area probably marks part, if not all, of the territory of a group of early historic Caddo peoples that were living here into the early part of the $18^{\text {th }}$ century.

\section{Decorative Elements in the Utility Wares}

Utility ware vessels are not particularly common mortuary offerings, as engraved fine wares were clearly preferred as grave accompaniments by the Caddo living in the upper Neches River basin. At the Lang Pasture site, only $9.7 \%$ of the funerary vessels were utility wares (see Appendix F.5). In the ceramic vessel data base for the region, numbering 601 vessels (see Appendix F.5), decorated utility wares account for only $14.8 \%$ of the mortuary vessels. Despite the limited number of utility wares $(n=38)$ in the sample of vessels subjected to detailed analysis (see Appendix F.4), the diversity in decorative methods is considerable.

At the Lang Pasture site, the utility wares from mortuary contexts include one Killough Pinched bowl and two Maydelle Incised jars (see above). In the other upper Neches River basin sites, Killough Pinched jars are present only in sub-phase 2 Frankston phase contexts at the Mrs. J. M. Cook, J. W. Blackburn, and Omer and Otis Hood sites. Maydelle Incised vess els are predominant in ca. A.D. 1400-1480 contexts $(42.9 \%$ of the utility wares), diminishing in later burials. What stands out among the utility wares in the apparently later Frankston phase burials in the upper Neches is the frequency of vessels with brushed decorations: $36.8 \%$ of all the utility ware vessels (not including two Maydelle Incised vessels with brushed vessel bodies) in burials are brushed, either on the body (with neck banded, punctated, pinched, or incised-punctated decorations on the rim, $\mathrm{n}=6$ vessels) or brushed on both the rim and body $(n=8)$. None of the Lang Pasture burials have brushed utility wares, and the northern area of the site where the burials were interred also had a relatively low percentage of brushed pottery in domestic contexts.

\section{Comparison of Vessel Form, Size, Temper, and Firing Conditions}

Comparisons between the mortuary vessel assemblages from a number of upper Neches River basin cemetery sites illustrate two notable things: (1) the mortuary vessels from the $14^{\text {th }}$ century to early $15^{\text {th }}$ century A.D. Lang Pasture site are distinctive from the other cemeteries with respect to the relative proportions of the vessel forms that are represented, as well as their size ranges, the tempers that were added to the clay paste, and how the vessels were fired; and (2) the vessels from post-A.D. 1400 Frankston phase sites in the vicinity of Lang Pasture (see Figure 6-1) are more similar to each other than any one assemblage of mortuary vessels are to the Lang Pasture vessel assemblage. These differences are apparently manifestations of important technological changes in the manufacture of Caddo mortuary vessels that occurred around the beginning of the $15^{\text {th }}$ century.

For the purposes of comparison, the vessels from upper Neches cemeteries fall into five basic vessel forms, and with a number of distinctive sub-forms (see Figure 6-26). In the Lang Pasture vessel assemblage, bowls are the most common form (Table 6-31), followed by carinated bowls. In later sub-phase 1 to sub-phase 3 assemblages, carinated bowls are by far the most abundant mortuary offering, accounting for $48.5-62.7 \%$ of all the vessels; this relative proportion peaks during the late Frankston phase (Table 6-31), and likely continues in the Allen phase given the common occurrence of Patton Engraved carinated bowls in graves (see Kleinschmidt 1982; Perttula 2007b). 
Table 6-31. Vessel Forms in Selected Upper Neches River Basin Mortuary Assemblages.

\begin{tabular}{|c|c|c|c|c|c|c|}
\hline Site & Carinated Bowl & Bowl & Bottle & Jar & Compound Bowl & $\mathrm{N}$ \\
\hline \multicolumn{7}{|l|}{ sub-phase 1} \\
\hline CE14, \#2 & 7 & 1 & 2 & 2 & - & 12 \\
\hline CE17 & 20 & 7 & 4 & 4 & - & 35 \\
\hline Subtotal \% & 57.4 & 17.0 & 12.8 & 12.8 & - & 47 \\
\hline \multicolumn{7}{|l|}{ sub-phase 2} \\
\hline AN1 & 11 & 8 & 4 & 9 & 1 & 33 \\
\hline CE4 & 13 & 1 & 7 & 3 & - & 24 \\
\hline CE14, \#1 & 55 & 10 & 25 & 15 & 1 & 106 \\
\hline Subtotal \% & 48.5 & 11.7 & 22.1 & 16.6 & 1.2 & 163 \\
\hline \multicolumn{7}{|l|}{ sub-phase 3} \\
\hline AN2 & 11 & 3 & 2 & 1 & - & 17 \\
\hline AN32 & 15 & 2 & 3 & 3 & - & 23 \\
\hline CE25 & 16 & - & 10 & 1 & - & 27 \\
\hline Subtotal \% & 62.7 & 7.5 & 22.4 & 7.5 & - & 67 \\
\hline AN38 & 10 & 11 & 4 & 3 & 3 & 31 \\
\hline Subtotal \% & 32.3 & 35.5 & 12.9 & 9.7 & 9.7 & \\
\hline
\end{tabular}

Bowls are really only abundant at the Lang Pasture site and the E. W. Henry site, a subphase 1 Frankston phase cemetery; their proportions decrease through the span of the Frankston phase. Short-necked Hume Engraved, Hume Plain, and Poynor Engraved forms and Fair Plain are more common bottle forms from ca. A.D. 1480 on; no short-necked bottles were recovered in the Lang Pasture cemetery. Bottles in general increase in frequency as mortuary offerings after ca. A.D. 1480 as well (see Table 6-31).

Utility ware jars are not particularly common in any of these upper Neches Caddo cemeteries, except perhaps in subphase 2 times (ca. A.D. 1480-1560). Compound bowls are a distinctive vessel offering at the Lang Pasture site (see Table 6-31), while otherwise rarely seen in the upper Neches.
Mortuary vessels in upper Neches River Caddo sites were made in a wide variety of sizes. Surely these vessels held liquids and foodstuffs for the deceased to use on the journey to the House of Death. In most cases, the vessels included with the deceased by his living relatives easily would have held multiple servings of food and liquids (perhaps enough to last for the 6 day journey, see Chapter 11, this volume). Nevertheless, the very large size of some of the carinated bowls (food serving vessels) from the Omer and Otis Hood, J. M. Cook, J. W. Blackburn, and Fred McKee sites-all post-A.D. 1480 Caddo cemeteries-which would have been well-suited for communal food serving, suggests that the vessels may have been intended by the Caddo to serve multiple purposes in mortuary rituals. These could have included use of the vessels in grave-side rituals and daily food offerings by the relatives of the deceased, after which they were placed in the graves as final accompaniment once the "Sixth Day Feast" 
had been concluded (see Gonzalez et al. 2005:57-58). These grave-side practices and changes in mortuary rituals seem to have begun around ca. A.D. 1480. Pre-A.D. 1480 cemeteries in the upper Neches, including Lang Pasture and E. W. Henry, typically have only a range of small to medium-sized vessels (see Figures 6-34 and 6-59), probably destined for individual use.

Carinated bowls fall into miniature, small to medium-sized, large to very large, and extra large sizes (Figure 6-68a), based on overlapping measurements of orifice diameter and estimated volume. The Lang Pasture carinated bowls are small and medium-sized only.

Bowls may be divided into two groups, a small size $(<12 \mathrm{~cm}$ in orifice diameter and $<1$ liter in volume) and a medium to large size (see Figure 6-68b). The Lang Pasture bowls from the burials fall in both size categories.

Lang Pasture jars are small to medium-sized (see Figure 6-68c). In other upper Neches River basin mortuary vessel assemblages, there are also miniature jars (at the J. W. Blackburn and E. W. Henry sites), large jars (at the Omer and Otis Hood, E. W. Henry, and Fred McKee sites), and very large jars at the Omer and Otis Hood site (see Figure 668c).
Large amounts of food stuffs, enough for at least 10 servings, could have been held in these vessels.

Bottles in these Caddo sites tend to have minimal differences in volume, ranging from 0.2-1.2 liters (see Figure 6-68d). However, with the appearance of elongated body/short-necked Hume Engraved and Hume Plain vessels in post-A.D. 1480 contexts, the volume of bottles to hold liquids increased substantially. This trend for increased vessel size and volume after ca. A.D. 1480 is in step with volume size trends seen in the carinated bowls and jars.

As with upper Neches River basin Caddo ceramics in general, the mortuary vessels from the region were predominantly tempered with grog, regardless of the Frankston phase sub-phase to which the vessels can be assigned. Grog is commonly the sole tempering inclusion, but more often than not, was the principal temper in conjunction with smaller amounts of crushed and burned bone and crushed and angular hematite/ferruginous sandstone pieces (Table 6-32). Less than $7 \%$ of the vessels from any of the sites-with the exception of the Lang Pasture site-are tempered solely with aplastics other than grog. 


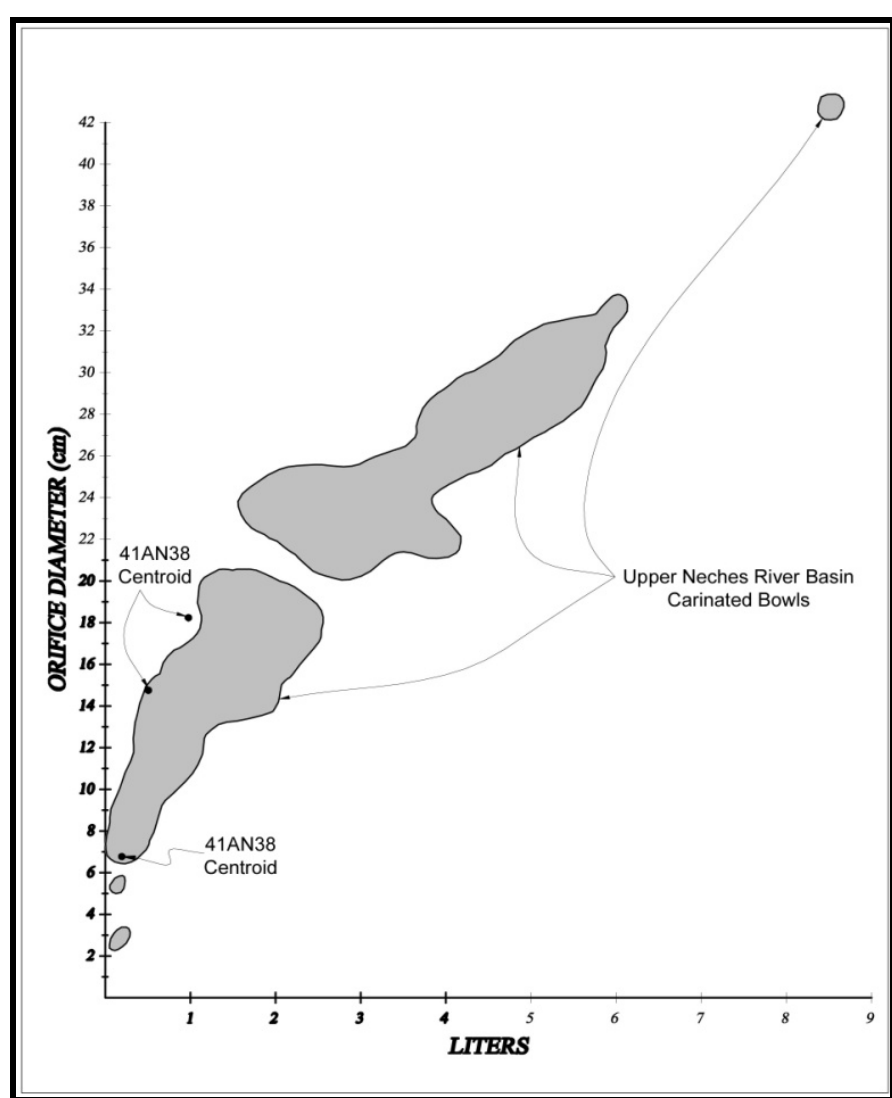

a.

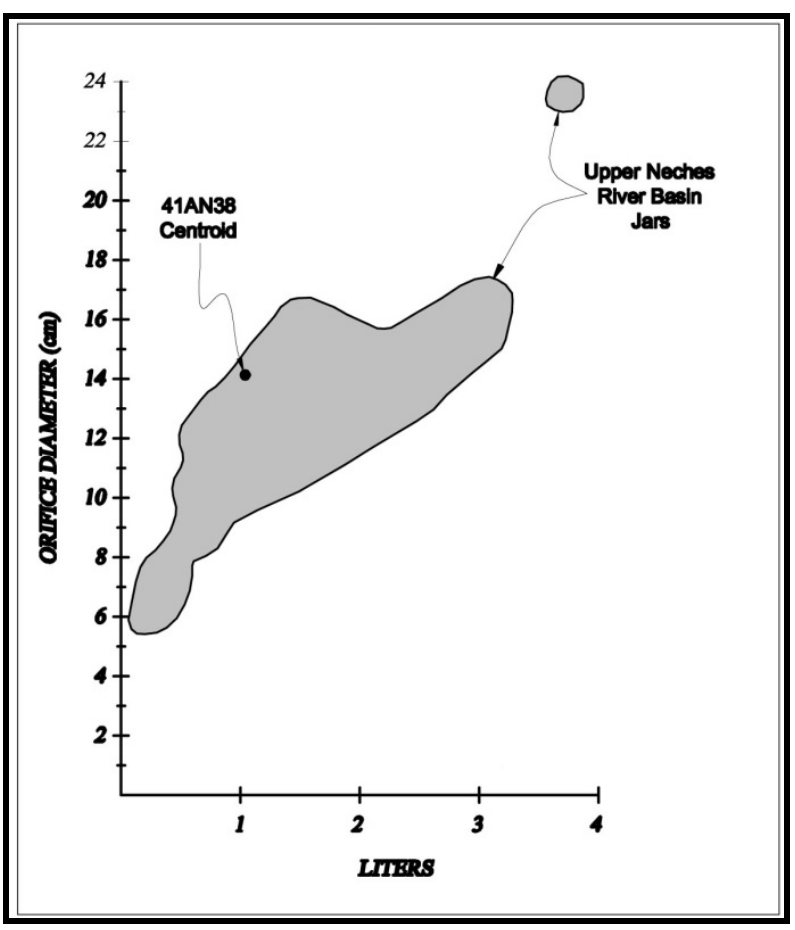

c.

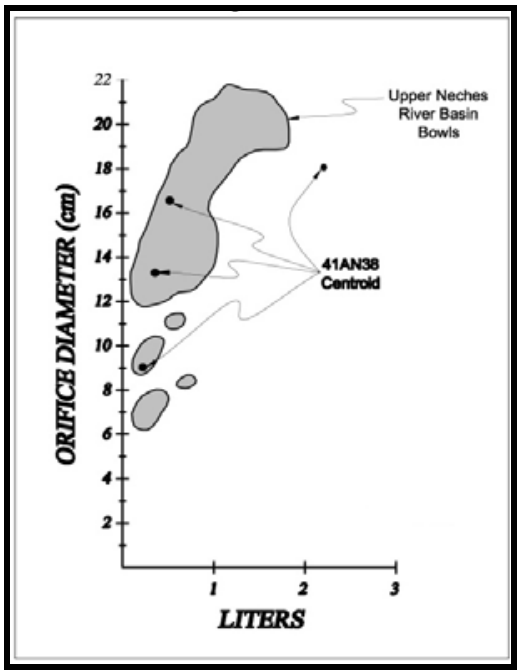

b.
Figure 6-68. Orifice Diameters and Volume (in liters) of Mortuary Vessels in the Upper Neches River Basin: a, carinated bowls; b, bowls; c, jars; d, bottles.

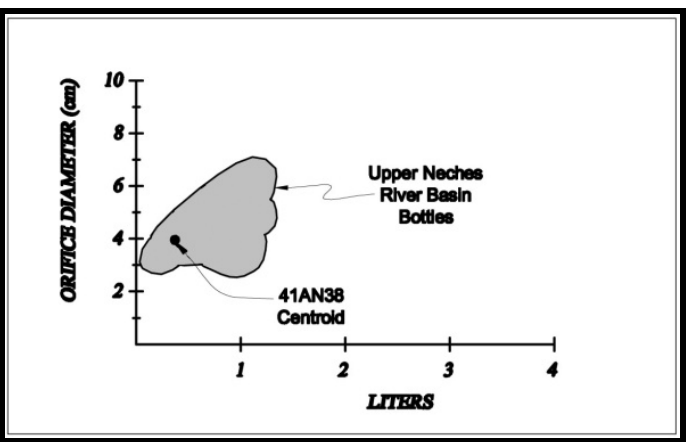

d. 
Table 6-32. Tempers Documented in Mortuary Vessels.

\begin{tabular}{|c|c|c|c|c|c|c|c|c|}
\hline Temper & AN1 & AN2 & AN32 & CE4 & CE14 & CE17 & CE25 & AN38 \\
\hline grog & $48.5^{*}$ & 6.3 & 4.3 & 13.0 & 32.1 & 46.9 & 22.2 & 33.3 \\
\hline grog-hematite & 27.3 & 75.0 & 78.3 & 30.4 & 33.9 & 34.4 & 33.3 & 13.3 \\
\hline $\begin{array}{l}\text { grog-bone } \\
\text { grog-bone- }\end{array}$ & 8.7 & 12.5 & 8.7 & 17.4 & 16.5 & 9.4 & 25.9 & 20.0 \\
\hline $\begin{array}{l}\text { hematite } \\
\text { grog-bone- } \\
\text { hematite- }\end{array}$ & 3.0 & - & 4.3 & 34.8 & 11.1 & 6.3 & 18.5 & 6.7 \\
\hline organics & - & - & - & - & 0.9 & - & - & - \\
\hline bone & - & - & - & - & 0.9 & - & - & 20.0 \\
\hline bone-hematite & - & 6.3 & 4.3 & - & 4.6 & 3.1 & - & 3.3 \\
\hline hematite & 3.0 & - & - & 4.3 & - & - & - & 3.3 \\
\hline$\%$ grog & 97.0 & 93.7 & 95.7 & 95.7 & 94.5 & 96.9 & 100.0 & 73.4 \\
\hline \% bone & 11.7 & 18.8 & 17.3 & 52.2 & 34.0 & 18.8 & 44.4 & 50.0 \\
\hline \% hematite & 33.3 & 81.3 & 86.9 & 68.5 & 50.5 & 43.8 & 51.8 & 26.6 \\
\hline \% sandy paste & - & 12.5 & - & 21.7 & 3.7 & 15.6 & 7.4 & 6.7 \\
\hline
\end{tabular}

*percentage; Note all site numbers are preceded by “41”

The lowest frequency of grog temper (73.4\%) in upper Neches River basin mortuary vessel assemblages is the group of vessels from the Lang Pasture site. In the other sites, which all postdate A.D. 1400, grog is found in $93.7-100 \%$ of the vessels, affirming the predominant practice of employing grog or crushed sherds/fired clay in the manufacture of pottery vessels.

The use of bone temper is very common at the Lang Pasture site (see Table 6-32), matched only by the vessels at the J. W. Blackburn (41CE4) and R. J. Fair (41CE25) sites. Both of these sites date to post-A.D. 1480-1560 contexts, and thus it is apparent that bone temper was a popular temper inclusion used throughout the Frankston phase for vessels placed in burials. Overall, the frequency of bone-tempered pottery in the mortuary vessels ranges from 11.7$52.2 \%$. By comparison, sherds from domestic contexts at a number of these sites (see below), including the Lang Pasture site, are much less likely to have been tempered with bone. For instance, at Lang Pasture, between $8.9-20.5 \%$ of the sherds by site area were tempered with bone, less than half the amount identified in the mortuary vessels. Sherd samples from other upper Neches River sites (see below) tend to have less than $5 \%$ bone-tempered sherds in the assemblages, irrespective of their ages. Because of these dramatic temper differences in domestic vs. mortuary ceramics, vessels placed in mortuary contexts may thus have been made by individual potters solely to accompany the deceased rather than to conform to domestic preferences.

These same differences are apparent in the use of hematite temper in the mortuary vessels. Except for the Lang Pasture site, no less than $33 \%$ of the vessels (from the Mrs. J. M. Cook site, 41AN1) from any one cemetery-and as much as $86.9 \%$ of the vessels (from the Fred McKee site, 41AN32) - had hematite inclusions in the paste (see Table 6-32). The sites with the 
highest proportion of ceramics with hematite tempering are post-A.D. 1480 Caddo cemeteries. The lowest frequencies are in vessels from pre-A.D. 1480 sub-phase 1 Frankston phase cemeteries (see Table 632).

These figures for hematite-tempered pottery represent very substantial use of hematite in upper Neches River Caddo mortuary ceramic contexts, this temper being much less common in domestic vessel sherds where detailed temper analysis has been completed (Shawn Marceaux, March 2008 personal communication). At the Lang Pasture site, however, the use of hematite in vessel sherds from domestic contexts (17.8$31.4 \%$ ) is comparable to that seen in the mortuary vessels; the Henry Lake (41CE324) ceramic sherds from domestic contexts include $22 \%$ with hematite temper (see Perttula and Middlebrook 2009).

No more than $22 \%$ of the vessels from any of the upper Neches River ceramic mortuary assemblages were made using a sandy paste (see Table 6-32). At the Lang Pasture site, between 23-29\% of the sherds from domestic contexts came from vessels with a sandy paste (see Table 6-25), compared to only $6.7 \%$ of the mortuary vessels. Solely on this basis, non-sandy clays were preferred for mortuary vessel manufacture, again highlighting the possibility that mortuary vessels were made in a distinctly different technological manner (or by a different potter than the ones that made vessels for domestic consumption) than vessels that were designed to be used by Caddo families for domestic activities.

The mortuary vessels from the Lang Pasture site were fired almost exclusively in a low oxygen or reducing environment (Table 633). This was also the case with the sherds from vessels used and discarded in domestic contexts at the site (see Table 6-27). Not so with the post-A.D. 1400 Frankston phase mortuary ceramics.

After ca. A.D. 1400, mortuary ceramics were very commonly fired in a high oxygen environment, or were incompletely oxidized. By site, these two methods of firing comprise between $46.7-84.6 \%$ of all the vessels in the post-A.D. 1400 detailed analysis sample (see Table 6-33), very much different than the Lang Pasture vessels.

As a consequence of differences in firing, many of the vessels found in Caddo mortuary contexts have a reddish to reddishbrown color because of high oxygen firing, rather than the darker gray, grayish-brown, or black colors that would have resulted from firing in a reducing environment. However, firing vessels in a reducing environment, but cooling them in the open air-as was done earlier at the Lang Pasture site-would have had a similar effect, at least in terms of the color of the fired pots, since the open air cooling would leave a thin oxidized interior and/or exterior surface. Technologically, if the goal was to produce a vessel of a certain color and durability, it made more sense to fire the pot red-hot in an oxidizing fire, as the Frankston phase Caddo potters did, and thus be able to see when a pottery vessel was done and could be removed from that fire, then it was to gauge the right time to remove a pot from a firing when it was smothered in a bed of coals and ashes. This technological change or firing preference appears to have become part of the upper Neches River ceramic traditionat least with respect to the manufacture of mortuary vessels-after ca. A.D. 1480 to A.D. 1560, during sub-phases 2 and 3 of the Frankston phase. 
Table 6-33. Firing Conditions Observed in Prehistoric Caddo Mortuary Vessels from the Upper Neches River Basin.

\begin{tabular}{|c|c|c|c|c|c|c|c|c|}
\hline $\begin{array}{l}\text { Firing } \\
\text { Condition }\end{array}$ & AN1 & AN2 & AN32 & CE4 & CE14 & CE17 & CE25 & AN38 \\
\hline Oxidizing & $47.6^{*}$ & 70.0 & 52.9 & 76.9 & 46.8 & 40.0 & 71.4 & - \\
\hline $\begin{array}{l}\text { Incompletely } \\
\text { oxidized }\end{array}$ & - & - & 5.9 & 7.7 & 14.5 & 6.7 & - & 7.4 \\
\hline Reduced & 14.3 & 10.0 & 5.9 & 7.7 & 12.9 & 26.7 & - & 15.0 \\
\hline $\begin{array}{l}\text { Reduced, but } \\
\text { cooled in the } \\
\text { open air }\end{array}$ & 38.1 & 20.0 & 35.2 & 7.7 & 25.8 & 26.7 & 28.6 & 75.0 \\
\hline
\end{tabular}

*percentage; note all site numbers are preceded by “41”

\section{Use of Pigments on Vessels}

Of the group of eight sites with vessels discussed above, the lowest percentage of mortuary fine ware vessels with pigment include the J. M. Cook (5.9\% of the vessels have pigment rubbed into the engraved lines), Lang Pasture (6.5\%), and Omer and Otis Hood, cemetery \#2 (8.3\%), sites. Conversely, the highest use of pigment on mortuary vessels is apparent at the $\mathrm{E}$. W. Henry (28.6\%), Fred McKee (21.7\%), and J. W. Blackburn (20.8\%) sites. Pigments were used on carinated bowls, bowls, effigy bowls, and bottles, with the highest frequency of pigment use documented among the bottles from all the sites (29.5\%) as well as the carinated bowls (18.9\%). The percentage of fine ware vessels with pigment in mortuary contexts from the Lang Pasture site $(6.5 \%)$ is little different-at $5.8 \%-10.6 \%$ by area-than that documented in vessel sherds found in the southern and northern site area domestic contexts (see Table 6-16). This suggests that vessels embellished with a clay pigment (in this case, almost invariably a red clay pigment) were used with the same regularity in both domestic and mortuary contexts.

Both red and white clay pigments were used on the upper Neches mortuary vessels. Red pigments were exclusively used on a few bowls and effigy bowls $(9.3 \%$ of these vessels had a pigment), and almost exclusively on bottles (89\% of the bottles had a red pigment in the engraved lines). Among the carinated bowls, almost 27\% had a white clay pigment (with the remainder having a red pigment), particularly the carinated bowls from post-ca. A.D. 1560 Frankston phase cemeteries at the Fred McKee (50\%) and R. J. Fair (100\%) sites.

There is a temporal trend in the use by the Caddo of clay pigments on mortuary vessels (Table 6-34), even though the proportion of pigment use remains very consistent (16.4$16.7 \%$ ) from the early (sub-phase 1 ) to the late (sub-phase 3) Frankston phase. Red clay pigment was almost exclusively preferred on mortuary vessels up to ca. A.D. 1560 (ca. $92.5 \%$ of the vessels have a red clay pigment), but began to be supplanted by a white clay pigment after that time. In subphase 2 contexts, $11 \%$ of the vessels have a white clay pigment, and this increases to $63.6 \%$ in sub-phase 3 times. Six of the seven vessels in sub-phase 3 contexts with white clay pigment are carinated bowls; $67 \%$ of the three vessels in sub-phase 2 burials are on carinated bowls.

This alternating preference for either red or white clay pigments has a resonance that extends beyond simple differences in pigment choice. Lankford (1992) discusses the importance of the use of these two colors 
in social, political, and cosmological dualisms or divisions in Southeastern North American societies, and it is likely that similar dualisms characterized prehistoric Caddo groups living in the upper Neches. In the context of the use of different colors of pigments in mortuary rituals, Lankford's (1992:76-77) suggestion that the two colors symbolize the Lower world of change (red) and the Upper world of order (white) seems apt. It is probable as a means by which to explain the symbolic meaning and use of different pigments on mortuary vessels that cosmological and world views of the Caddo peoples living in the upper Neches began to change after ca. A.D. 1480 (in sub-phase 2), but came to dominate beliefs and mortuary ritual usage after ca. A.D. 1560 and continuing into the Allen phase (i.e., when Patton Engraved vessels have pigments rubbed in the design, it is almost always white $^{4}$ ).

\section{Trends and Varieties in Late Caddo and Historic Caddo Fine Ware Pottery Types in the Upper Neches River Basin}

One of the goals of recent archeological research in the upper Neches River valley in East Texas is to better understand the temporal and stylistic character of the postA.D. 1400/1450 Frankston and Allen phase Caddo ceramic assemblages found in this area.

Table 6-34. Use of Pigments on Mortuary Vessels in the Upper Neches River Basin.

\begin{tabular}{lccc}
$\begin{array}{l}\text { Frankston Phase } \\
\text { Sub-Phase }\end{array}$ & Red Pigment & White Pigment & $\begin{array}{l}\text { Proportion of } \\
\text { Vessels With } \\
\text { Pigment }\end{array}$ \\
\hline sub-phase 1 & 13 & 0 & $16.7 \%$ \\
sub-phase 2 & 24 & 3 & $16.6 \%$ \\
sub-phase 3 & 4 & 7 & $16.4 \%$ \\
\hline
\end{tabular}

From this will hopefully arise a better understanding of the settlement history of Caddo peoples living here, and illuminate the affiliation and occupational history of the Caddo groups that settled the Lang Pasture site.

This research has involved, as discussed above, a detailed examination of 277 vessels from burials on seven sites in the collections at the Texas Archeological Research Laboratory (TARL) and 31 vessels from burials at the Lang Pasture site (Perttula et al. 2007), as well as a review of other vessel data ( $n=323$ vessels) from several other sites and diverse collections, both at TARL, in private collections, and in archeological excavations (see Campbell 1936;
Kleinschmidt 1982; Perttula 2006; Shafer 1981). In total, including the vessels from the Lang Pasture site, I have compiled a data base of 630 vessels from 35 different sites in Anderson, Cherokee, Henderson, and Smith counties, Texas (Table 6-35, see also Appendix F.5).

The basic composition of these Caddo vessel assemblage from upper Neches River burial sites includes fine wares (73.3\%), decorated utility wares (14.9\%), and a significant proportion of plain ware vessels (11.8\%) (see Table 6-35). As previously mentioned, the Lang Pasture mortuary vessels are dominated by plain wares (61.3\%), with a much lower proportion of engraved or red- 
slipped fine wares (25.8\%) placed as funerary offerings in the graves.

The principal fine wares in all these cemeteries are Poynor Engraved bowls and carinated bowls $(n=229,49.6 \%$ of the fine wares), followed by Poynor Engraved bottles of various forms $(n=42,9.1 \%)$, Patton Engraved ( $\mathrm{n}=63,13.4 \%)$, Hood Engraved $(\mathrm{n}=56,12.1 \%)$ effigy ware vessels, and Hume Engraved bottles ( $n=54$, $11.7 \%$ ). Among the utility wares, the major types include Bullard Brushed $(n=21)$, Killough Pinched $(n=20)$, Maydelle Incised $(n=11)$, punctated jars $(n=9)$, and brushedpunctated jars $(n=8)$. Most of the plain wares are simple bowls $(n=29)$, carinated bowls $(n=23)$, and several forms of bottles $(n=16)$. At the Lang Pasture site, the identified types in the mortuary vessel assemblage include Poynor Engraved $(n=7)$ carinated bowls, compound bowls, and a bottle, Maydelle Incised ( $\mathrm{n}=2)$, and Killough Pinched $(\mathrm{n}=1)$, indicating a broad stylistic affiliation and temporal congruity between this cemetery and other excavated Caddo cemeteries in the upper Neches.

For this part of the chapter, I have focused in detail on the fine wares from the ceramic vessel data base, primarily because they are ubiquitous on upper Neches River Caddo sites (they account for $73 \%$ of all the whole vessels in the burials) and because the stylistic diversity in the fine wares is amenable to a more refined consideration of stylistic and temporal changes in these ceramic assemblages, and the chronological and cultural place of the Lang Pasture site. This pursuit includes the recognition of distinct stylistic motifs and elements in the fine wares; the identification of varieties of the fine ware types, especially Poynor Engraved, that have spatial distributions and an adequate site representation (see Figures 6-63 and 6-64); and now the examination of the temporal implications of these varieties. Previous vessel and sherd seriation analyses (Shafer 1968; Kleinschmidt 1982; Perttula 2007b) have already established that Patton
Engraved is the youngest of the fine ware types in the upper Neches River, with Hume Engraved, Hood Engraved, and Poynor Engraved having begun to be made around ca. A.D. 1400 or so. Hume Engraved is most common apparently in post-A.D. 1650 Allen phase contexts, while Poynor Engraved is primarily a Frankston phase (ca. A.D. 14001650) type, with a stylistic tradition that extends back some amount of time before A.D. 1400 (as at the Lang Pasture site and other sites in the upper Neches) and is also found on Caddo sites in the upper Neches that date after ca. A.D. 1650.

Kleinschmidt (1982) reviewed sherd and vessel collections from a number of Frankston phase (ca. A.D. 1400-1650) and Allen phase (ca. A.D. 1650-1800+) sites in the upper Neches River basin (Anderson, Cherokee, Henderson, and Smith counties) and developed a ceramic frequency seriation (see O’Brien and Lyman 1999) of those sites more than 25 years ago (Kleinschmidt 1982: Table 19). That seriation is still useful today, or at least I find it so, because it does seem to provide a good broad measure of the temporal changes in the kinds of decorated ceramic vessels used by these Caddo peoples (or at least used in mortuary rituals), as well as a good measure of the direction of changes in ceramic decorative styles.

To review Kleinschmidt's (1982) work, I first focus on temporal changes in the engraved fine ware vessels as seen in that seriation. The fine wares in question are Poynor Engraved (PO), Patton Engraved, Hume Engraved, and a variety of Poynor Engraved (PP) that shared stylistic elements with Patton Engraved vessels (Kleinschmidt 1982:Figures 19 and 20). In broad strokes, Kleinschmidt (1982) recognized three subphases of the Frankston phase, beginning with sub-phase 1 at ca. A.D. 1400 and ending with sub-phase 3 , followed by the Allen phase (Table 6-36). In the earliest part of the Frankston phase, Poynor Engraved (PO variety) is the exclusive fine ware ceramic. Through time, the PP variety of 
Poynor Engraved, Patton Engraved, and Hume Engraved make their appearance and become more popular, at the expense of the PO variety of Poynor Engraved.

Table 6-35. Ceramic Vessel Database from the Upper Neches River Valley in East Texas. Utility Wares No. of Vessels No. of Sites* Percentage

Killough Pinched

$\begin{array}{lll}20 & 10 & 3.2 \\ 21 & 11 & 3.3 \\ 11 & 7 & 1.8 \\ 9 & 3 & 1.4 \\ 1 & 1 & 0.2 \\ 1 & 1 & 0.2 \\ 5 & 3 & 0.8 \\ 1 & 1 & 0.2 \\ 8 & 4 & 1.3 \\ 1 & 1 & 0.2 \\ 5 & 4 & 0.8 \\ 3 & 2 & 0.5 \\ 2 & 1 & 0.3 \\ 1 & 1 & 0.2 \\ 3 & 2 & 0.5 \\ 1 & 1 & 0.2 \\ 1 & 1 & 0.2 \\ 94 & & \end{array}$

Subtotal

Plain wares

Plain bowl

Plain jar

Plain carinated bowl

Plain bottle

29

6

23

16

74

Subtotal

Fine wares

Simms Engraved, var. Darco

Hume Engraved bottles/bowls

Garland Engraved (?)

Unidentified engraved bottle

Poynor Engraved bottle

Poynor Engraved

Hood Engraved

Taylor Engraved

Patton Engraved

Horizontal engraved bowl

Natchitoches Engraved

Engraved-punctated bowl

Red-slipped bowl

Subtotal

$\begin{array}{lll}3 & 1 & 0.5 \\ 50 / 4 & 19 & 8.6 \\ 1 & 1 & 0.2 \\ 3 & 2 & 0.5 \\ 42 & 15 & 6.7 \\ 229 & 32 & 36.3 \\ 56 & 22 & 8.9 \\ 6 & 5 & 1.0 \\ 63 & 10 & 10.0 \\ 1 & 1 & 0.2 \\ 1 & 1 & 0.2 \\ 1 & 1 & 0.2 \\ 2 & 2 & 0.3 \\ 462 & & 73.3\end{array}$

* sites include 41AN1, 41AN2, 41AN14, 41AN16, 41AN18, 41AN23, 41AN26, 41AN32, 41AN34, 41AN39, 41AN44, 41AN53, 41CE3, 41CE4, 41CE6, 41CE8, 41CE12, 41CE14, 41CE15, 41CE17, 41CE19, 41CE23, 41CE25, 41HE7, 41HE55, 41HE75, 41HE114, 41SM73, 41SM77, 41SM93, 41SM290, 41SM355, Dean site (no trinomial, Smith County), and Smith County Museum (no trinomial)

**globular carinated bowls with brushing as the only form of decoration 
By the end of the Frankston phase (subphase 3), the PO variety of Poynor Engraved only accounts for $46 \%$ of the engraved fine wares, with considerable numbers of Poynor Engraved (PP variety), Patton Engraved, and Hume Engraved vessels (see Table 6-36). Nevertheless, during all three sub-phases of the Frankston phase, Poynor Engraved vessels account for between $70.2-100 \%$ of the total number of sub-phase vessels.
During the later Allen phase, both varieties of Poynor Engraved account for only 27.7\% of the vessels in the seriation. There is a dramatic increase in the popularity of Patton Engraved fine wares-59\%--almost a threefold increase from sub-phase 3 times. Kleinschmidt's seriation further indicates that Hume Engraved vessels also appear to become more common from the time of the Frankston phase to the post-A.D. 1650 Allen phase (see Table 6-36).

Table 6-36. Seriation of Engraved Ceramics in Frankston and Allen Phase Sites, Based on Kleinschmidt (1982:Table 19).

\begin{tabular}{llllll}
\hline Phase & Poynor (PO) & Poynor (PP) & Patton & Hume & No. of \\
Engraved & Engraved & Engr. & Engraved & Vessels \\
\hline
\end{tabular}

A.D. 1400/1450-1650 (Frankston phase)

$\begin{array}{llllll}\text { sub-phase } 1 & 100.0^{*} & 0.0 & 0.0 & 0.0 & 39 \\ \text { sub-phase } 2 & 80.0 & 7.2 & 7.2 & 5.8 & 139 \\ \text { sub-phase } 3 & 46.3 & 23.9 & 22.4 & 7.5 & 67\end{array}$

A.D. $1650-1800+$

$\begin{array}{llllll}\text { Allen } & 6.6 & 21.1 & 59.2 & 13.2 & 76\end{array}$

*percentage; total vessels for all assemblages ( $\mathrm{n}=321)$

+ the ending date of the Allen phase has not been established through archeological means.

Certainly a case can be made that the Allen phase as an archeological unit continues until the late 1830s, when the Hasinai Caddo were removed from East Texas

It is possible to refine the seriation proposed by Kleinschmidt (1982) by focusing in detail on the variation in the style of the engraved rim motifs on the many Poynor Engraved vessels found in the upper Neches, as it is likely that many engraved styles were used by only a few potters in the community and/or were preferred decorations for only a short period of time. Although I have recognized at least 30 Poynor Engraved bowl and carinated bowl rim stylistic motifs-including several from the Lang Pasture site that may be amongst the earliest motifs seen on this fine ware-five new varieties represent more than $73 \%$ of the Poynor Engraved vessels in the upper Neches River basin. These include varieties Blackburn, Cook, Freeman, Hood, and Lang (see Figure 6-64); var. Hood is the most common (see Figure 6-63e) in the upper Neches River vessel sample, accounting for $29.3 \%$ of the Poynor Engraved vessels. Next is Poynor Engraved, var. Cook (15.7\%) and var. Blackburn (12.6\%), then var. Freeman (9.1\%) and var. Lang (6.6\%) (see Figure 6$64)$. 
Some progress has been made in discerning temporal changes in the fine ware varieties beyond the basic distinction between the earlier Poynor Engraved varieties and the later Patton Engraved varieties. The frequency seriation (see Dunnell 1970:308310; O’Brien and Lyman 1999:109-132; Lyman and O'Brien 2006) of the proportions of the different engraved fine ware types and varieties in upper Neches River basin Caddo cemeteries is an appropriate method for inferring the cultural relationship between sites and specific ceramic types and varieties found on those sites because they meet the following conditions necessary for the successful application of the frequency seriation method: "all the groups included in a seriation must be of comparable duration...all the groups in a seriation must belong to the same cultural tradition...[and] all groups in a seriation must come from the same local area” (Dunnell 1970:312-313). Each of these sites and cemeteries were used for short periods of time, based on the number of interments; a number of stylistic, functional, and technological attributes of the fine wares, utility wares, and plain wares indicate that they are from the same Caddo cultural tradition; and all of the sites considered here occur in a ca. $1700 \mathrm{~km}^{2}$ area around the Lang Pasture site (see Figure 6-67).

Our findings are that, firstly, based on a frequency seriation of different decorative motifs on Poynor Engraved vessels from the seven cemeteries discussed above, the earliest sub-phase 1 varieties are var. Cook, var. Blackburn, and var. Hood, as well as regional varieties $A-B, F, I-L$, and $S$ (Table 6-37). Most of these regional varieties are found only in sub-phase 1 contexts. None of the defined varieties of Poynor Engraved are present at the Lang Pasture site, but regional varieties $B, F$, and $K$ are, but in higher proportions at the latter site (Table 6-37). These differing proportions, and the absence of the defined varieties, suggest two things: (a) that the Lang Pasture cemetery-or at least some portion of it-predates the onset of sub-phase 1 of the Frankston phase, and (b) that a number of more stylistically unique varieties of Poynor Engraved had begun to be made in the upper Neches (as well as in the upper Sabine) sometime prior to ca. A. D. 1400.

Secondly, two of these early varieties of Poynor Engraved (var. F and $J$ ) continued to be made in sub-phase 2 times, but in lesser amounts than previously (see Table 6-37). Instead, a number of other regional varieties of Poynor Engraved make their appearance in sub-phase 2 burials, namely var. C-E, $Q$, and $R$ (see Table 6-37). Four of these regional stylistic varieties of Poynor Engraved were made only in sub-phase 2, but var. $E$ became more common in later sub-phase 3 burials. Among the defined varieties of Poynor Engraved, a new variety (var. Lang) makes its first appearance in sub-phase 2 burials; this variety, however, was popular only during sub-phase 2. Var. Hood, Cook, and Blackburn of Poynor Engraved comprise $75.8 \%$ of the sub-phase 2 Poynor Engraved vessels (but only 38.9\% of the sub-phase 1 Poynor Engraved vessels), each variety increasing monotonically in proportion from sub-phase 1 to sub-phase 2 times, and then decreasing in frequency (43.4\%) in sub-phase 3 burials (see Table 6-37). 
Table 6-37. Temporal Sequence of Poynor Engraved Varieties and Other Engraved Fine Wares.

\begin{tabular}{|c|c|c|c|c|}
\hline Type/Variety & $\begin{array}{l}\text { sub-phase } 1 \\
\text { (ca. 1400-1480) }\end{array}$ & $\begin{array}{l}\text { sub-phase } 2 \\
\text { (ca. 1480-1560) }\end{array}$ & $\begin{array}{l}\text { sub-phase } 3 \\
\text { (ca. 1560-1650) }\end{array}$ & \\
\hline \multicolumn{5}{|c|}{ Poynor Engraved varieties } \\
\hline Cook & $16.7 *$ & 21.8 & 6.7 & \\
\hline \multicolumn{5}{|l|}{ Cook or } \\
\hline Var. E & - & - & 3.3 & \\
\hline Blackburn & 11.1 & 16.7 & 10.0 & \\
\hline \multicolumn{5}{|l|}{ Cook/ } \\
\hline Blackburn & - & 1.3 & - & \\
\hline Hood & 11.1 & 37.3 & 26.7 & \\
\hline Lang & - & 11.5 & - & \\
\hline Freeman & - & - & 33.3 & \\
\hline \multicolumn{5}{|c|}{ Regional varieties of Poynor Engraved } \\
\hline Var. A & 5.6 & - & - & \\
\hline Var. B & 16.7 & - & - & $x$ \\
\hline Var. I & 5.6 & - & - & \\
\hline Var. K & 5.6 & - & - & $x$ \\
\hline Var. L & 5.6 & - & - & \\
\hline Var. S & 5.6 & - & - & \\
\hline Var. F & 11.1 & 1.3 & - & $x$ \\
\hline Var. J & 5.6 & 1.3 & - & \\
\hline Var. C & - & 2.6 & - & \\
\hline Var. D & - & 1.3 & - & \\
\hline Var. Q & - & 1.3 & - & \\
\hline Var. R & - & 1.3 & - & \\
\hline Var. E & - & 2.6 & 10.0 & \\
\hline Var. N & - & - & 3.3 & \\
\hline Var. P & - & - & 3.3 & \\
\hline Var. T & - & - & 3.3 & \\
\hline \multicolumn{4}{|l|}{$\overline{\text { No. of }}$} & 7 \\
\hline \multicolumn{4}{|l|}{ Patton } & \\
\hline Engraved & - & - & 37.5 & - \\
\hline \multicolumn{4}{|l|}{ Hume } & \\
\hline \multirow{2}{*}{\multicolumn{4}{|c|}{$\begin{array}{l}\text { Hood } \\
\text { Hoold }\end{array}$}} & - \\
\hline & & & & \\
\hline Engraved & 100.0 & 52.4 & 12.5 & - \\
\hline $\begin{array}{l}\text { No. of } \\
\text { Vessels }\end{array}$ & 3 & 21 & 16 & - \\
\hline
\end{tabular}

*percentage; $\mathrm{X}=$ present in the mortuary vessels from the Lang Pasture site + other Poynor Engraved varieties at the Lang Pasture site include Var. $O$ (Local Variety 2, see Figures 6-29 and 6-64) and Local Varieties 3 and 5 (see Figure 6-29); neither of these varieties are represented in the other seven sets of mortuary vessels 
Thirdly, Poynor Engraved, var. Freeman appears to be the latest variety of the Poynor Engraved type, as it makes its appearance in sub-phase 3 of the Frankston phase, where it is the dominant defined variety (see Table 637). Regional varieties $\mathrm{N}, \mathrm{P}$, and $\mathrm{T}$ are also present only in sub-phase 3 burials, where they account for $10 \%$ of the Poynor Engraved mortuary vessels. This variety of Poynor appears to have developed from the earlier (but still in use in sub-phase 3 times) Poynor Engraved, var. Hood, because they both have hour glass-shaped panel dividers (see Figure 6-63e, h) -none of the other varieties do. What separates var. Hood from var. Freeman are the pendant triangles on the upper and lower parts of the engraved rim panel of the latter.

Lastly, and importantly, in the case of Poynor Engraved, var. Freeman, the simple stylistic decision to add concentric circles and hooked arm elements on the body (see Figure 6-63i) of carinated bowls on this variety, and then the addition of ticked marks to concentric circles on the vessel body (see Figure 6-65c), suggests a clear and not temporally lengthy stylistic link between Poynor Engraved, var. Freeman and Patton Engraved, var. Freeman, and an obvious stylistic and cultural connection between Caddo peoples that archeologists call the Frankston and Allen phases.

This stylistic relationship of concentric circle and hooked arm elements on vessel bodies, embellished by the later addition of ticks on those elements, further suggests that Patton Engraved, var. Freeman is the earliest of the defined Patton Engraved varieties. This variety of Patton Engraved is the dominant one (39.3\%) at the Richard Patton site (41AN26), along with var. Patton (28.6\%), var. Fair (14.3\%), and var. Allen (14.3\%). Based on lower proportions of var. Freeman and var. Patton at the Jim Allen site (41CE12), but higher proportions of var. Allen (41.2\%) and several still unspecified varieties, it is suspected that var.
Allen is a later (and perhaps the latest?) Patton Engraved variety.

Hood Engraved, var. Hood and var. Cook are the earlier effigy forms in the upper Neches (see Table 6-37). Hood Engraved, var. Allen is found in association with Patton Engraved, and is apparently an Allen phase diagnostic, although one burial at the Frankston phase sub-phase 2 Mrs. J. M. Cook site had one of these vessels. This effigy vessel form includes zoomorphic or anthropomorphic tail riders. The other varieties of Hood Engraved have effigy heads and tab tails-as well as horizontal engraved lines as the main rim/body decoration, with var. Cook also having engraved pendant triangle elements-and are found in Frankston phase temporal contexts.

Hume Engraved, var. Allen and var. Hume are found primarily in Allen phase contexts or later (i.e., dating after ca. A.D. 1480) Frankston phase contexts. Hume Engraved bottles are absent from sub-phase 1 burials in the upper Neches (see Table 6-37); no Hume Engraved vessels were in any of the Lang Pasture burials.

\subsection{INTRA-REGIONAL COMPARISONS}

\section{Sherd Assemblages}

Although there are problems with the presentation of the decorated sherds from the Caddo sites and midden deposits excavated at Lake Palestine (Anderson et al. 1974)—as I will discuss momentarily - the sherd assemblages from these sites are substantial. They do provide useful information on the character of the decorated vessels found on domestic Caddo sites in the upper Neches River basin, on sites not far from the Lang Pasture site (see Figure 6-1), and they also comprise foundational sherd data bases anchoring one proposed seriation of Caddo decorated sherd 
assemblages in the region (see Table 4-5, and discussion below).

The decorated sherd data from the Lake Palestine sites cannot be directly or uniformly compared to the information presented here from the Lang Pasture site, as well as that presented from selected sites in the collections at TARL. They cannot be compared directly because of the following problems (see Anderson et al. 1974:10): (1) many different decorative methods represented in the sherds (i.e., incisedpunctated, incised, punctated, appliqued, etc.) from these sites were combined into a single category labeled "wet-paste" decoration; thus it is impossible to compare the proportions of each of the different decorative methods recognized at the Lang Pasture site to these sites; (2) brushed body sherds were kept separate from brushed rims, the latter included in tabulations for "wet-paste" sherds; (3) only [finger]nail punctated sherds are explicitly quantified in the Lake Palestine report; there is no mention of either tool or cane punctated sherds, although such sherds are occasionally illustrated in the report; (4) Anderson et al. (1974) employ an "Other" category to deal with miscellaneous decorated sherds as well as smaller sherds lacking decoration, but no details are presented on what kinds of decorated sherds are included in this category; and (5) the use of bone temper is not consistently specified in Anderson et al. (1974), and in the case of several sites, the percentage of sherds that are bone-tempered cannot be determined.

Nevertheless, the Lake Palestine ceramic assemblages, and those from nearby sites that have been recently analyzed (41CE324, see Perttula and Middlebrook 2009; and 41HE337 in the upper Caddo Creek basin, Bill Young, April 2008, personal communication), especially those that date to Frankston phase times, share several characteristics that make clear the character of an upper Neches River basin Caddo ceramic tradition that was in existence from ca. A.D. 1400 (if not earlier) to the late $17^{\text {th }}$ century (if not later). The decorated and plain sherd assemblages from the following Lake Palestine sites-Tomato Patch (41HE185), Ferguson (41AN67), Woldert (41HE80), Halbert (41AN70), Forest Drive (41HE184), Debro (41CE86), and William Sherman (41CE30)-are (1) almost exclusively grog-tempered; bone-tempered pottery comprises less than 3\% of the sherds, where that information is available; (2) brushed utility ware pottery dominates the decorated sherd assemblages, accounting for between $49-80 \%$ of all the decorated pottery (Figure 6-68 and Table 6-38); (3) fine ware vessel sherds account for less than $10 \%$ of the decorated sherds; (4) wet paste decorations on sherds are also more abundant than fine wares, accounting for between $10.3-42 \%$ of the decorated sherds, by site; (5) fingernail punctated sherds are rare (less than 3\%) at each site; and (6) plain to decorated sherd ratios (P/DR) range from only $0.14-1.50$, with most of the sites having $\mathrm{P} / \mathrm{DR}$ values less than 0.72 . This indicates that Lake Palestine Caddo sites did not have many plain ware vessels. Generally speaking, the lower the P/DR value, the higher the proportion of brushed sherds in the Lake Palestine ceramic assemblages. The engraved fine wares are Poynor Engraved and Hood Engraved.

The majority of the Lake Palestine Frankston phase ceramic assemblages enumerated in Table 6-38 compare favorably to the southern area at the Lang Pasture site, particularly in the proportion of brushed sherds, "wet paste" sherds, and the relatively low frequency of engraved fine wares (see Figure 6-68). Punctated sherds (but including tool, cane, and fingernail) are more abundant at Lang Pasture in this component, but this comparison is equivocal because of the quantification problems already mentioned for the Lake Palestine ceramic assemblages. In any event, it is not untenable to suggest on the basis of the proportions of decorated sherds that the southern ceramic component/area at the 
Lang Pasture site is part of the same ca. A.D. $1400+$ Caddo ceramic tradition in this part of the upper Neches River basin. Of the different sites at Lake Palestine, the earliest Frankston phase Tomato Patch ceramic assemblage most closely resembles the southern ceramic component/area at the Lang Pasture site.

The northern ceramic component/area at the Lang Pasture site stands apart from the Lake Palestine sites in several basic respects (see Figure 6-69). These include a much lower relative frequency of brushed utility wares, considerably more engraved fine wares, and higher proportions of punctated utility wares. It is hard not to draw the conclusion-principally because of the lower frequency of brushed wares as well as the just reviewed stylistic character of the mortuary vessel assemblage - that the northern ceramic component/area at the
Lang Pasture site is part of a Caddo occupation that predates the Frankston phase sites listed in Table 6-38 from Lake Palestine as well as the southern ceramic component/area. In several respects, the northern ceramic component/area at the Lang Pasture site resembles the ceramic assemblage from the White Mule site (41HE166) at Lake Palestine (Anderson et al. 1974:55-57, 59) as well as 41HE139 near Lake Palestine (Cliff et al. 2004). This occupation is dominated by wet-paste decorations on utility wares $(63.6 \%$, see Table 6-38), rather than brushed utility wares - as is also the case in the northern ceramic component/area (53\% wet paste vs. $20 \%$ brushed) — engraved fine wares are well represented (15\%), and fingernail punctated decorated sherds are also comparatively abundant at both White Mule (3\%) and Lang Pasture (4.7\%).

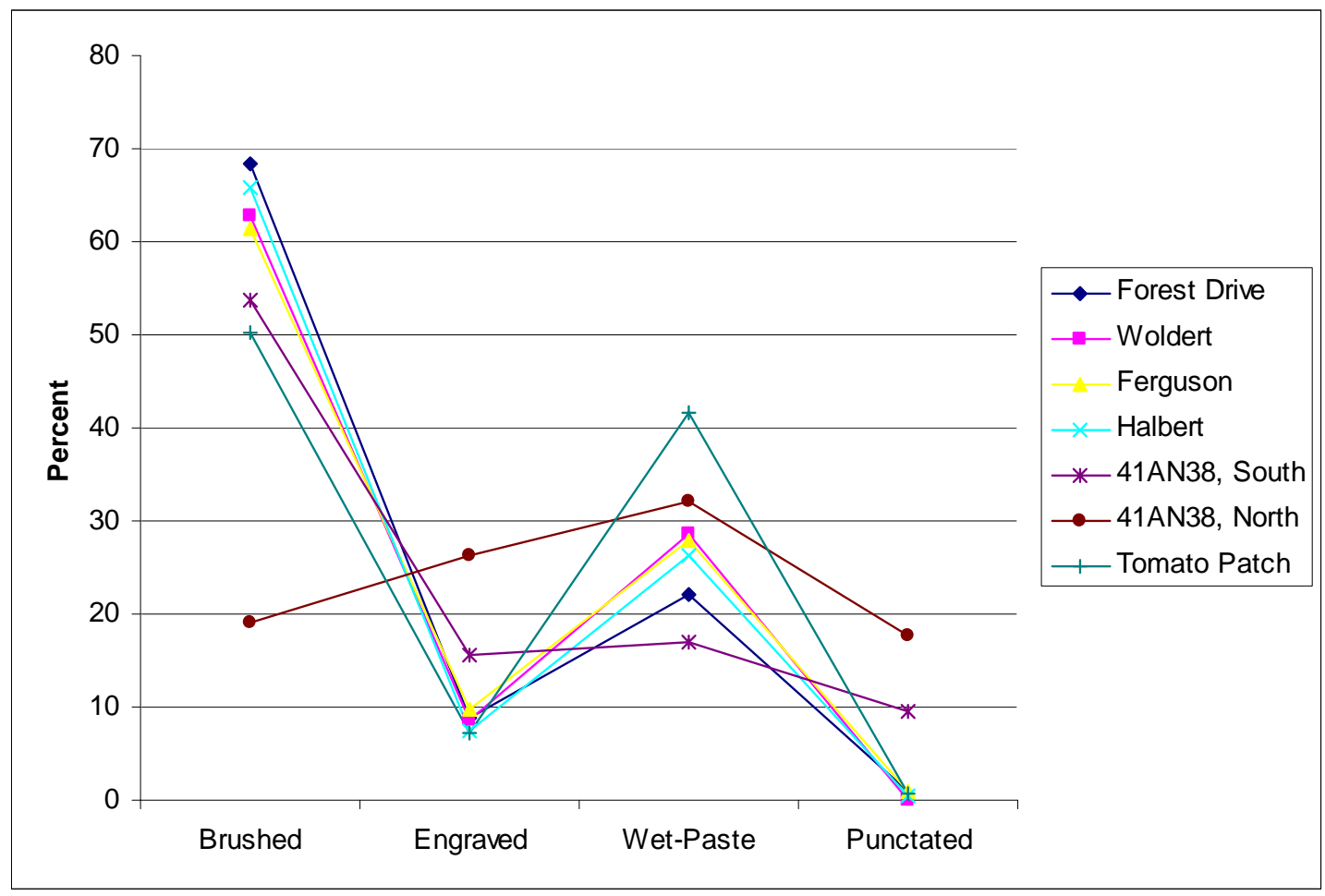

Figure 6-69. Comparison of the Decorated Sherds from the Lake Palestine Sites Amongst Each Other, and to the Northern and Southern areas at the Lang Pasture Site. 
Table 6-38. Decorated Sherd Assemblages from Lake Palestine (based on the Table 45 seriation of Lake Palestine ceramic assemblages).

\begin{tabular}{|c|c|c|c|c|c|}
\hline Sites* & Engraved & Wet-Paste & Brushed & $\begin{array}{l}\text { Fingernail } \\
\text { Punctated }\end{array}$ & P/DR \\
\hline \multicolumn{6}{|c|}{ GROUP I, LATEST FRANKSTON PHASE } \\
\hline Debro & $4.2 * *$ & 10.3 & 80.0 & 2.9 & 0.14 \\
\hline William & 7.6 & 16.2 & 75.8 & 0.4 & 0.44 \\
\hline \multicolumn{6}{|l|}{ Sherman } \\
\hline \multicolumn{6}{|c|}{ GROUP II FRANKSTON PHASE } \\
\hline Forest Drive & 8.9 & 22.0 & 68.3 & 0.9 & 0.56 \\
\hline Woldert & 8.7 & 28.7 & 62.7 & - & 0.72 \\
\hline Ferguson & 9.7 & 27.9 & 61.4 & 1.0 & 0.61 \\
\hline Halbert & 7.5 & 26.2 & 65.8 & 0.5 & 0.70 \\
\hline \multicolumn{6}{|c|}{ GROUP III, EARLIEST FRANKSTON PHASE } \\
\hline Tomato Patch & 7.2 & 41.7 & 50.3 & 0.8 & 1.50 \\
\hline \multicolumn{6}{|c|}{ GROUP IV, pre-A.D. 1400} \\
\hline White Mule & 15.0 & 63.6 & 18.5 & 3.0 & 2.61 \\
\hline
\end{tabular}

What is also interesting about the White Mule occupation is that Poynor Engraved sherds are relatively abundant, at least based on selected sherd illustrations (Anderson et al. 1974:Figure 24a-d, f-i, l); the report mentions that only five Poynor Engraved sherds were identified in the assemblage (Anderson et al. 1974:56), but it was the most common identified fine ware at the site, as it is in the northern ceramic component/area at the Lang Pasture site. Other identified types include Maydelle Incised, Bullard Brushed, and Killough Pinched; these same types are present in the northern ceramic component/area.

Basic analyses of ceramic styles/decorative elements and technology (i.e., the use of grog and bone-tempered pottery vessels) were also completed on available sherd assemblages at TARL from domestic habitation contexts at other prehistoric Caddo sites near to the Lang Pasture site (see Figure 6-1), including Mrs. J. M. Cook (41AN1), J. M. Cook Farm (41AN2), L. Cecil (41AN8), Isibel-Gene Donnell
(41AN14), Rose Daniels (41AN23), Fred McKee (41AN32), Solon Stanley (41CE3), J. W. Blackburn (41CE4), J. M. Snow (41CE8), and E. W. Henry (41CE17). These assemblages are rather small, as they were obtained from only limited investigations by The University of Texas at Austin (UT) during their more concerted work at Caddo cemetery sites; in each instance, habitation debris was noted in general proximity to these cemeteries, and limited excavations as well as surface collections of sherds were conducted by the UT crews. Despite the small size of the decorated sherd samples from individual sites, in aggregate the decorated sherd assemblages from these sites clearly demonstrate that they are part of a distinctive upper Neches River Caddo ceramic tradition dominated by the use of grog (i.e., crushed sherds) temper, brushed utility ware vessels as well as other kinds of decorated utility wares, and an assortment of engraved fine ware sherds, mainly from Poynor Engraved carinated bowls (cf. Suhm and Jelks 1962) (Table 6-39). 
Table 6-39. Summary Characteristics of Vessel Sherd Assemblages from Selected Upper Neches River Basin Caddo Sites.

\begin{tabular}{|c|c|c|c|c|c|c|}
\hline \multirow[b]{2}{*}{ Dec. Method } & \multicolumn{5}{|c|}{ Anderson County sites } & \multirow[b]{2}{*}{ AN32 } \\
\hline & AN1 & AN2 & AN8 & AN14 & AN23 & \\
\hline Brushed & $\mathrm{x}$ & & $\mathrm{x}$ & $\mathrm{x}$ & $\mathrm{x}$ & $\mathrm{x}$ \\
\hline Brushed-Punctated & $\mathrm{x}$ & & $\mathrm{x}$ & & & $\mathrm{x}$ \\
\hline Brushed-Appliqued & & $\mathrm{x}$ & & & & $\mathrm{x}$ \\
\hline Brushed-Incised & $\mathrm{x}$ & & $\mathrm{x}$ & & & \\
\hline Incised-Punctated & & $\mathrm{x}$ & $\mathrm{x}$ & & & \\
\hline Punctated & $\mathrm{x}$ & $\mathrm{x}$ & & & & $\mathrm{x}$ \\
\hline Pinched & $\mathrm{x}$ & & $\mathrm{x}$ & $\mathrm{x}$ & & \\
\hline Incised & $\mathrm{x}$ & $\mathrm{x}$ & $\mathrm{x}$ & $\mathrm{x}$ & & $\mathrm{x}$ \\
\hline Neck banded & $\mathrm{x}$ & $\mathrm{x}$ & $\mathrm{x}$ & & & \\
\hline Plain rim & & & & & & $\mathrm{x}$ \\
\hline Poynor Engraved & $\mathrm{x}$ & $\mathrm{x}$ & $\mathrm{x}$ & $\mathrm{x}$ & $\mathrm{x}$ & $\mathrm{x}$ \\
\hline Patton Engraved & & $\mathrm{x}$ & $\mathrm{x}$ & & & \\
\hline Hume Engraved & & & & & & $\mathrm{x}$ \\
\hline Hood Engraved & $\mathrm{x}$ & & & & & $\mathrm{x}$ \\
\hline other Engraved & $\mathrm{x}$ & $\mathrm{x}$ & $\mathrm{x}$ & $\mathrm{x}$ & $\mathrm{x}$ & $\mathrm{x}$ \\
\hline \multirow[t]{2}{*}{ \% bone temper } & 0 & 0 & 3 & 0 & 0 & 0 \\
\hline & \multicolumn{5}{|c|}{ Cherokee County sites } & \\
\hline Dec. Method & & CE3 & CE4 & CE8 & CE17 & \\
\hline Brushed & & $\mathrm{x}$ & $\mathrm{x}$ & & & \\
\hline Brushed-Punctated & & $\mathrm{x}$ & $\mathrm{x}$ & $\mathrm{x}$ & & \\
\hline Brushed-Appliqued & & & & & & \\
\hline Brushed-Incised & & $\mathrm{x}$ & & & & \\
\hline Incised-Punctated & & & & $\mathrm{x}$ & $\mathrm{x}$ & \\
\hline Punctated & & & & $\mathrm{x}$ & & \\
\hline Pinched & & & & $\mathrm{x}$ & & \\
\hline Incised & & & & $\mathrm{x}$ & & \\
\hline Neck banded & & $\mathrm{x}$ & $\mathrm{x}$ & $\mathrm{x}$ & & \\
\hline Plain rim & & & & & & \\
\hline Poynor Engraved & & & $\mathrm{x}$ & $\mathrm{x}$ & & \\
\hline Patton Engraved & & & $\mathrm{x}$ & $\mathrm{x}$ & $\mathrm{x}$ & \\
\hline Hume Engraved & & & & & & \\
\hline Hood Engraved & & $\mathrm{x}$ & $\mathrm{x}$ & & & \\
\hline other Engraved & & $\mathrm{x}$ & $\mathrm{x}$ & $\mathrm{x}$ & & \\
\hline \% bone temper & & 0 & 0 & 4 & 0 & \\
\hline
\end{tabular}

Note: all site numbers are preceded by " 41 ” 
These sites, as well as the Lang Pasture site, are all south of a possible second and contemporaneous upper Neches River ceramic tradition identified by Woodall (1972) from sites in the upper part of Lake Palestine, in Smith County (north of 41SM79 and 41SM93 on Figure 6-1).

That several of the sites were occupied after ca. A.D. 1650 (or perhaps after ca. A.D. 1560, the onset of sub-phase 3 of the Frankston phase, see Table 6-37) is apparent by the occurrence of Patton Engraved vessel sherds, but the analysis of the vessels from the upper Neches discussed above makes it clear that the style of Patton Engraved evolved from a later variety of Poynor Engraved. Thus, these later sites are still part of the same Caddo ceramic tradition, one that lasted in the upper Neches River basin until sometime in the $18^{\text {th }}$ century A.D., when Caddo groups abandoned the area.

\section{Mrs. J. M. Cook (41AN1)}

There are 68 decorated sherds in the collections from the Mrs. J. M. Cook site, a probable Frankston phase sub-phase 2 Caddo component (at least based on the material goods recovered in the cemetery excavations). Utility wares comprise $60.3 \%$ of the sample, with the fine wares accounting for the remainder (39.7\%), among them a duck head effigy from a Hood Engraved effigy vessel.

Brushed ( $\mathrm{n}=8, \quad 11.8 \%), \quad$ brushed-incised $(\mathrm{n}=3,4.4 \%)$, and brushed-punctated $(\mathrm{n}=11$, 16.2\%) sherds from Bullard Brushed jars are well-represented in the utility wares. Rims have vertical and horizontal brushing marks, while body sherds have both vertical and opposed brushing. Tool or cane punctates were pushed through the brushing marks on brushed-punctated examples from the site. The remainder of the utility wares include La Rue Neck Banded sherds ( $n=6,8.8 \%$ ), four body sherds (5.9\%) with random tool punctations, two (2.9\%) Killough Pinched body sherds, and seven (10.3\%) Maydelle
Incised body sherds, three with crosshatched incised lines.

The duck head effigy appendage from the Mrs. J. M. Cook site is decorated with rows of small tool punctates. The other fine ware sherds (seven rims and 19 body sherds) have engraved designs, and are likely all from Poynor Engraved or Hood Engraved vessels. Three rims are from Poynor Engraved, var. Freeman carinated bowls (a sub-phase 3 diagnostic), three others have opposed engraved lines (probably from Poynor Engraved varieties with triangle, nested triangle, or continuous scroll decorative elements), and the remaining rim has concentric lines (an element noted on several Poynor Engraved varieties) divided by a crudely engraved hatched panel.

The engraved body sherds have hatched triangles $(n=8)$, concentric lines $(n=6)$, or sets of parallel lines $(n=5)$. One of these has tick marks on one of the engraved lines.

\section{J. M. Cook (41AN2)}

Both utility wares $(n=23,56.1 \%)$ and fine wares $(n=18,43.9 \%)$ are well-represented in the decorated sherds from the J. M. Cook site. Vessels recovered from the cemetery at this site suggests it dates to the latter part of the Frankston phase (sub-phase 3, dating after ca. A.D. 1560).

The most common utility ware in the sherd assemblage is La Rue Neck Banded ( $n=7$, $17.1 \%)$, and there are also six body sherds (14.6\%) with fingernail or tool punctates. Seven (17.1\%) Maydelle Incised rim and body sherds have either parallel or opposed incised lines on them, including one that may have a hatched panel decorative element. Another rim has a zone of tool punctates between horizontal incised lines that encircle the upper part of the vessel. Only two of the utility wares are brushed (4.9\%), and both are rims from Bullard Brushed jars with horizontal brushing 
marks; one of these also has an appliqued node on the rim.

Both Poynor Engraved (n=1, 2.4\%), Patton Engraved ( $\mathrm{n}=10,24.4 \%)$ and Hood Engraved $(\mathrm{n}=1)$ sherds have been identified in the J. M. Cook fine wares. The Poynor Engraved rim is a var. Freeman carinated bowl, while the probable Hood Engraved sherd is a rim with a single horizontal line present under the lip. The Patton Engraved sherds have straight or horizontal lines with tick marks on them (Patton Engraved, var. Allen); two of the larger rim sherds are from carinated bowls with brushed bodies, a later Frankston and Allen phase decorative feature in the upper Neches. The remaining fine wares are comprised of six body sherds with either parallel $(n=5,12.2 \%)$ or opposed $(n=1,2.4 \%)$ lines.

\section{Cecil Site (41AN8)}

The L. Cecil site decorated sherd collection includes 108 utility ware and fine ware sherds. Less than 3\% are tempered with bone. The principal kinds of decorated sherds are brushed ( $\mathrm{n}=67,62 \%)$ body and rim sherds, Patton Engraved ( $\mathrm{n}=19,17.6 \%)$ rim and body sherds, and Poynor Engraved $(n=7,6.5 \%)$ rim and body sherds. The predominance of Patton Engraved in the assemblage suggests this site was occupied primarily after ca. A.D. 1650.

The brushed utility wares from the site have horizontal and diagonal brushing on the rim of everted and direct rimmed Bullard Brushed jars, as well as vertical, diagonal, overlapping, and opposed brushing on the vessel body. Two other body sherds have a parallel brushed-incised decoration. The remainder of the utility wares $(n=11,10.2 \%)$ include two rims with diagonal rows of fingernail punctates, a rim with a row of tool punctates below the lip and above a zone of horizontal brushing, a diagonal incised rim, a La Rue Neck Banded rim, and a Maydelle Incised rim with opposed incised lines and tool punctated-filled triangular incised zones. There are five utility ware body sherds: two parallel brushed sherds with a row of tool punctations pushed through the brushing, a Killough Pinched piece, another sherd (probably from a Maydelle Incised jar) with closely-spaced parallel incised lines, and a cross-hatched incised Maydelle Incised body sherd.

Among the fine wares, the Patton Engraved sherds have horizontal rows of engraved lines embellished with small triangular tick marks, probably from Patton Engraved, var. Allen vessels. The Poynor Engraved vessel sherds include two rims with engraved ovals and small hatched triangular elements, either from Poynor Engraved, var. Cook or var. Lang, four other sherds from carinated bowls with negative ovals (Poynor Engraved, var. Hood), and a carinated bowl sherd with broadly spaced horizontal and curvilinear lines; this particular vessel has been brushed on the vessel body. Two other engraved body sherds have either a single straight line or broadly-spaced curvilinear lines (on a carinated bowl).

\section{Isibel-Gene Donnell (41AN14)}

There are 12 decorated sherds in the small collection from the Isibel-Gene Donnell site. Ten (83\%) are from utility ware vessels, among them are eight with brushing on the body, one Killough Pinched rim, and a cross-hatched incised Maydelle Incised body sherd; there also is a portion of a brushed vessel from Burial AG-1 (see Woolsey 1935n) in the sherd collection.

The engraved fine ware sherds from the site are probably both from Poynor Engraved vessels. The first is a portion of a carinated bowl with negative engraved ovals (Poynor Engraved, var. Hood); the body of the vessel has opposed brushing. The second, an engraved body sherd, has concentric lines, probably part of a Poynor Engraved, var. Cook or var. Lang vessel with ovals on rim panels defined by closely-spaced sets of concentric lines. These varieties suggest that 
the Isibel-Gene Donnell site was occupied in sub-phase 2 Frankston phase times.

\section{Rose Daniels Farm (41AN23)}

The 35 decorated sherds from the Rose Daniels Farm site include utility wares $(\mathrm{n}=17,49 \%)$ and fine wares $(\mathrm{n}=18,51 \%)$. The utility wares are dominated by brushed body sherds $(n=16)$, and there is one Killough Pinched body sherd. The fine wares are from Poynor Engraved vessels. Two rims have triangular elements on them, the first with a row of small hatched pendant oval-shaped triangles below the lip, the second a carinated bowl with large hatched nested triangles on the rim panel; several early or sub-phase 1varieties of Poynor Engraved (i.e., var. $A$, var. $F$, and var. $M$ ) have the engraved nested triangle element (see Figure 6-64). Three other sherds have negative engraved ovals (Poynor Engraved, var. Hood), and these also are brushed on the vessel body. Nine others have a hatched triangle element, a common motif in several Poynor Engraved varieties, and the most common engraved decorative element in both the southern and northern areas at the Lang Pasture site. The remaining four engraved body sherds have single or multiple straight or parallel lines on them.

\section{Fred McKee site (41AN32)}

None of the 52 decorated sherds from the Fred McKee site, a sub-phase 3 Frankston phase site based on the apparent age of the cemetery there, are bone-tempered. Decorated utility wares include brushed rim and body sherds ( $n=27,52 \%)$ from Bullard Brushed vessels, and one body sherd (1.9\%) has vertical brushing marks with a vertical row of tool punctates pushed through the brushing. Other utility wares include a punctated rim (1.9\%) with a lug handle and a body sherd with opposed incised lines (1.9\%).

The fine wares include 13 body sherds and nine rims (42\%). Six of the rims have sets of horizontal engraved lines, several with red pigment rubbed in the lines, and these are likely from Hood Engraved, var. unspecified effigy vessels. Two others have either concentric circles (Poynor Engraved, var. Cook) or negative ovals (Poynor Engraved, var. Hood). Another rim from a carinated bowl has cross-hatched vertical panels, probably from a Hume Engraved, var. Hume vessel. Five of the body sherds have Poynor Engraved concentric circle elements, while eight others have sets of parallel engraved lines. The absence of Poynor Engraved, var. Freeman sherds in this domestic collection suggests that the occupation here may have predated sub-phase 3 because this particular variety is the most common Poynor Engraved variety in that sub-phase, and in mortuary contexts at least, is found only during sub-phase 3 times (see Table 6-37).

There are three plains rims in the collection, one from a bowl with an exterior folded lip, another from a jar with a lug handle, and the third plain rim from an effigy vessel. This rim still has a bird effigy head appended to the rim.

\section{Solon Stanley site (41CE3)}

The 60 grog-tempered decorated sherds from the Solon Stanley site (with a cemetery that was apparently established prior to ca. A.D. 1480) are dominated by brushed utility wares $(n=45,75 \%)$. Other utility wares from domestic contexts here include brushedpunctated $(\mathrm{n}=4,6.7 \%)$, brushed-incised $(n=1,1.7 \%)$, and neck banded $(n=4,6.7 \%)$ sherds. In the case of the brushed-punctated sherds, three are decorated with a row of tool punctates (at the rim-body juncture) above vertical brushed jar bodies; another cooking jar sherd has a row of tool punctates pushed through the brushing. The brushedincised body sherd has parallel brushing marks overlain by broad opposed incised lines. The La Rue Neck Banded sherds are from jars with everted rims. The few fine wares $(n=6,10 \%)$ include rim and body 
sherds with horizontal engraved lines, and are likely from Hood Engraved vessels.

\section{J. W. Blackburn (41CE4)}

The grog- and grog-hematite-tempered decorated sherds $(n=75)$ from the J. W. Blackburn site, a subphase 2 Frankston phase component (at least based on the mortuary occupation), are dominated by brushed body sherds (81.3\%). Another brushed body sherd has a row of tool punctates above a zone of horizontal brushing on the vessel body. The other utility ware sherds from the J. W. Blackburn site are two La Rue Neck Banded jar rims.

The fine wares represented in the decorated sherds include one rim with horizontal engraved lines, probably from a Hood Engraved effigy vessel, a Poynor Engraved rim with hatched triangles, probably part of an oval or circular motif, and a third rim with a row of engraved triangles below the lip; the triangles have a red pigment rubbed in the engraved lines. There are also two Patton Engraved rims, indicating some use of the site by the Caddo after ca. A.D. 1560 . Engraved body sherds have parallel lines $(n=2)$ as well as four others from Poynor Engraved vessels. These have either concentric circles or hatched triangle elements.

\section{J. M. Snow (41CE8)}

The J. M. Snow site apparently was occupied late in the Frankston phase and/or early in the Allen phase, given the frequency of Patton Engraved fine ware vessel sherds and Poynor Engraved, var. Freeman vessel sherds in the assemblage of 75 decorated sherds. A most unusual feature of the decorated sherd assemblage from the sitealbeit perhaps affected by the relatively small size of the sample-is the relative rarity of brushed sherds among the utility wares.
The utility wares from the J. M. Snow site include thick-walled, large La Rue Neck Banded jar rim sherds ( $\mathrm{n}=14,18.7 \%)$ and 12 (16\%) brushed-punctated Bullard Brushed jar sherds. These have either vertical or horizontal brushing on the rim and body, with at least one row of tool punctates either above or through the brushing. Two other Maydelle Incised rim and body sherds (2.7\%) have incised triangles filled with tool punctations, while eight additional Maydelle Incised sherds have either diagonal, opposed, or cross-hatched incised decorations on the rim of large jars. Two body sherds $(2.7 \%)$ have rows of tool punctations, and there are also three (4\%) Killough Pinched jar sherds, two with a heavy bone temper.

The fine wares are rather equally divided between Patton Engraved (n=17, 22.7\%) and Poynor Engraved (n=11, 14.7\%) types. The Patton Engraved sherds (11 rims and six body sherds) have horizontal rows of small tick marks or small hatched pendant triangles; one has brushing on the body of a carinated bowl. The Poynor Engraved rims $(\mathrm{n}=4)$ are from Poynor Engraved, var. Freeman vessels. The body sherds include seven with concentric circles, possibly from Poynor Engraved, var. Cook or var. Hood vessels. The other engraved sherds $(n=6$, $8 \%$ ), all body sherds, include a rim with cross-hatched lines (and a white kaolin clay pigment rubbed in the lines), four body sherds with parallel lines, and another body sherd with a cross-hatched engraved ladder or panel.

\section{E. W. Henry site (41CE17)}

Only three decorated sherds (grog-hematitetempered) are in the TARL collection from the E. W. Henry site. The cemetery at the site dates to the early part of the Frankston phase (pre-A.D. 1480), but the habitation area appears to have been occupied sometime after ca. A.D. 1650. 
Two of the decorated sherds are from Patton Engraved bowls, including a rim with a row of tick marks under the lip and a second rim (from a Patton Engraved, var. Allen vessel) with five horizontal engraved lines on it, each with downward-pointing triangular tick marks. The one utility ware sherd from a Maydelle Incised jar has opposed incised triangles around the rim, and each triangular area is filled with rows of tool punctations.

\section{INAA Results}

The results of the INAA results on sherds from the Lang Pasture site and other sites in the upper Neches River basin are presented in detail in Ferguson et al. (Appendix D). As they point out in the concluding section of their contribution, the entire Caddo INAA data base (almost 1000 sherds and a few clay samples) is in the process of re-analysis (see Ferguson 2007; Ferguson et al. 2008). This is being accomplished by changing the scale of analysis (i.e., defining smaller regions within East Texas) and employing K-means analysis and Mahalanobis distances to refine chemical groups within each smaller region.

That reanalysis (including 147 sherd samples from 15 different sites in Region 8 in East Texas, which includes the Lang Pasture site samples and the other sampled sites in the upper Neches River basin, see Ferguson 2007:Figure 1) indicates that approximately $75 \%$ of the analyzed sherds in this region are assigned to a core chemical composition group that clearly represents sherds from vessels made with local but widely available alluvial clays, with the remainder in either two smaller groups (Group 1, 4.8\%, and Group 2, 8.2\%), also apparently from vessels of local manufacture using chemically distinct and geographically isolated clays within the region, or are currently unassigned to a chemical group $(n=17,11.6 \%)$ (Ferguson
2007:Table 5 and Figure 3). This reanalysis has led to a drastic reduction in the percentage of chemically unassigned sherds from this part of East Texas, from over $80 \%$ (see Appendix D) to less than $12 \%$.

Of the unassigned sherds in the upper Neches River basin, three are from the Lang Pasture site (all from utility wares); four are from the J. M. Snow site (brushed utility wares, a Poynor Engraved vessel, and another fine ware with a cross-hatched engraved ladder or panel); one (a brushedpunctated sherd) is from the Fred McKee site; three (all brushed sherds, including one pinkware) are from the Solon Stanley site; and two (a brushed sherd and a Poynor Engraved sherd) are from the samples submitted from the J. W. Blackburn site. Notably, these chemically unassigned sherds are from a localized area east and northeast of the Lang Pasture site, principally on the east side of the Neches River (Figure 6-70). This sort of distribution suggests (1) that a currently poorly documented clay source (possibly a bedrock clay) was used by certain Caddo potters on the east side of the Neches River, 4-20 km from Lang Pasture, and (2) that the unassigned utility wares sherds from the Lang Pasture site may have been made by Caddo potters living primarily on the other side of the river, who traded or exchanged pottery vessels with the Caddo groups living at the Lang Pasture site. ${ }^{6}$ The regional analysis of the chemical compositional make-up of Caddo pottery has the potential to help with the reconstruction of "how people created, modified, or moved items within a particular landscape" (Kantner 2008:54). It is likely that the vast majority of the Caddo pottery made in the upper Neches River basin was produced at the household or community level, and then distributed and used locally, with an unknown quantity of that pottery being made for trade or exchange with neighbors, both near and far-flung. ${ }^{5}$ 


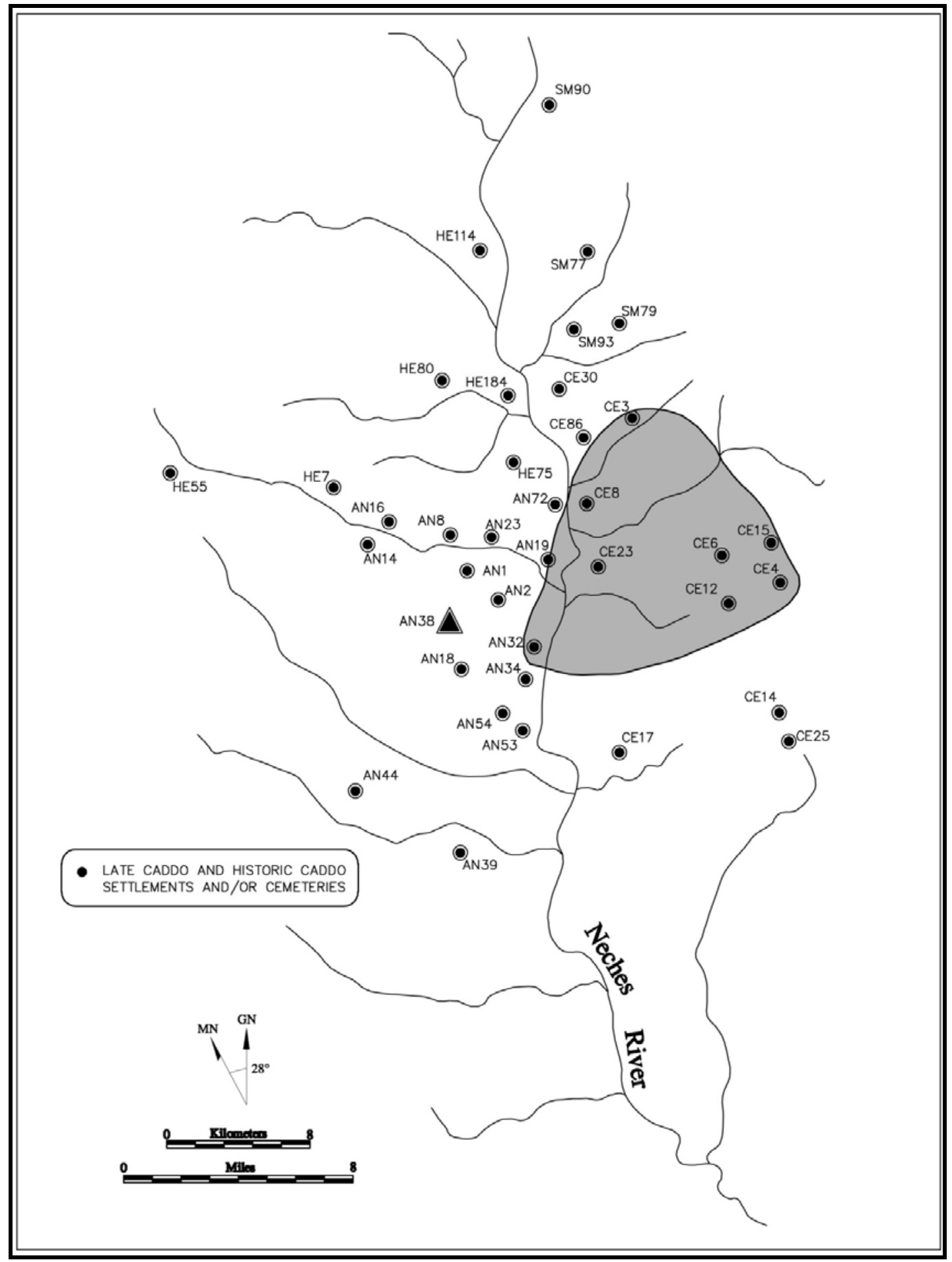

Figure 6-70. The Distribution of Sites with Unassigned INAA Samples in the Upper Neches River Basin. 
However, the INAA database available at present for the upper Neches River basin is not sufficiently robust, because of the apparent chemical homogeneity in locally abundant clays and the still limited number of sites with INAA sherd or clay samples, to establish with certainly the source of clays used by Caddo potters or to link those clays with tempered Caddo pottery vessels and vessel sherds of known styles and temporal ranges. Continued INAA analyses from a range of sites - and on both utility wares and fine wares-will be important in establishing production locales and their spatial scope, as well as delimiting both the kinds of pottery made in each production locale and the extent to which they made have been traded and exchanged amongst neighboring Caddo groups.

Given that quartz sands are a primary constituent of the paste of Caddo pottery from the upper Neches River basin, analytical methods need to be developed and implemented here (following the lead of the important studies that have defined sand composition zones in Hohokam sites in Arizona, cf. Abbott 2003; Harry 2004) through sampling of sands in local clays to identify sand composition zones and sourcespecific pottery types. These analytical methods would include INAA, laser ablation-inductively coupled plasma-mass spectrometry (see Speakman et al. 2007), petrographic analysis of sherd pastes, and electron microprobe analysis of clay and temper types in samples of sherds from well-dated Caddo sites in the region.

\subsection{CONCLUSIONS: UPPER NECHES RIVER BASIN CADDO POTTERY TRADITIONS AND PRACTICES}

At the onset of this analysis of the Caddo ceramic vessel sherds, vessels, and pipes recovered in the data recovery excavations from the Lang Pasture site, the expectation was that these items of material culture were the product of "a single Caddo occupation; that component must not have lasted more than 20-40 years" (Perttula 2004:33). I also speculated, based on the kinds of decorated ceramic sherds and vessels found there during the testing, along with the recovery of a distinctive L-shaped elbow pipe, that "the Caddo occupation may have taken place in the latter part of the $14^{\text {th }}$ century and the early part of the $15^{\text {th }}$ century, on the cusp of what was to become the Late Caddo Frankston phase (ca. A.D. 1400-1650) in this part of the upper Neches River valley" (Perttula 2004:30).

Has this narrative of the ceramic and occupational history of the Lang Pasture site changed, now that there has been continued analysis of new ceramic materials from both domestic household and mortuary contexts, and this analysis has been supplemented with a detailed investigation of vessel assemblages from a number of other upper Neches River? In simple terms: yes and no. In answering this question in the context of summarizing and synthesizing the results of the Lang Pasture ceramic analysis, I am put in mind of a quote from Prudence Rice, a well-known archeological ceramicist. Rice (1996:191) has noted that:

Pottery is a complicated and multifaceted technology, whether past or present, and efforts to oversimplify this complexity and reduce it to a few meager dimensions of variability are a disservice to the field as a whole. "Doing" ceramic analysis has always required of its practioners an enormous tolerance of ambiguity because there is as yet no unifying theory and there are no easy answers. For most of us, that is what keeps it interesting.

This concluding section of Chapter 6 keeps in mind the ambiguity and lack of easy answers. 
The detailed consideration of the style of the decorated fine wares and utility wares recovered at the Lang Pasture site, in conjunction with technological considerations of temper selection, pastes, and means of vessel firing in the different ceramic wares, and a suite of radiocarbon and TL dates (with their own ambiguities) suggests that the prehistoric Caddo occupation at the site began in the first quarter of the $14^{\text {th }}$ century A.D. and ended in the early part of the $15^{\text {th }}$ century. Some of the burials found at the site in a small cemetery were associated with the domestic occupation, while others may be slightly younger in age (and perhaps associated with continued occupation from areas of the site outside of the TxDOT right-of-way, see Perttula et al. 2007), but still having been interred by the first half of the $15^{\text {th }}$ century. Thus, on chronological grounds, the conclusions reached on the basis of the analysis of the ceramics found during test excavations are supported, but with a new sense of intra-site spatial and temporal complexity not previously recognized. One new finding is that there are some substantial intra-site differences in the character of the domestic ceramics, particularly in the proportion of brushed utility wares and plain wares found either in the southern (N170-188) and northern (N189-209) parts of the site. These differences appear to be at least partially grounded in chronological changes in site use from north to south, but in the overall context of the stylistic and technological character of the ceramic assemblage, also reflect the fact that over a short period of time there were significant changes in the proportion of the three wares and in how they were decorated. These changes are embedded in Caddo ceramic assemblages that otherwise share many stylistic and technological practices. These similarities within the southern and northern assemblages at the Lang Pasture site-in conjunction with the associated mortuary vessels-are closely mirrored by the findings from the examination of sherds and vessels from other upper Neches River basin Caddo sites, and led to the formal recognition of a temporally distinctive and spatially coherent Caddo ceramic tradition in this part of East Texas (Figure 6-71).

The temporal framework of this prehistoric Caddo ceramic tradition comes from the seriation of engraved fine ware vessels from mortuary contexts (Kleinschmidt 1982; Perttula 2007b), a more detailed seriation of specific Poynor Engraved rim motifs (see Table 6-37) from a large sample of burial vessels, and extensive radiocarbon and TL dating from the Lang Pasture site and selected other Caddo sites in the upper Neches River basin. This framework includes a ca. A.D. 1320-1400 component at the Lang Pasture site, sub-phase 1 (ca. A.D. 1400-1480), sub-phase 2 (ca. A.D. 14801560), and sub-phase 3 (ca. A.D. 15601650) of the Frankston phase, and the postA.D. 1650 Allen phase. The ceramic tradition probably lasted through the $18^{\text {th }}$ century, but its ending point in the upper Neches River basin has not been established.

The spatial context for this Late Caddo ceramic tradition is a ca. $6600 \mathrm{~km}^{2}$ area of the upper Neches (see Figure 6-70), of which the best-studied part is a $1700 \mathrm{~km}^{2}$ area centered on the Lang Pasture site (see Figure 6-1), a number of small to mediumsized cemeteries, and domestic ceramic assemblages primarily from the Lake Palestine area (cf. Anderson et al. 1974; Kleinschmidt 1982; Perttula and Middlebrook 2009).

This broader upper Neches area is west of a second and broadly contemporaneous Late Caddo ceramic tradition in the Neches, Angelina, and Attoyac river basins that is dominated by bone-tempered brushed pottery and a different suite of engraved fine wares (see Jelks 1965; Story 1982; Middlebrook 1994; Fields 1995). 


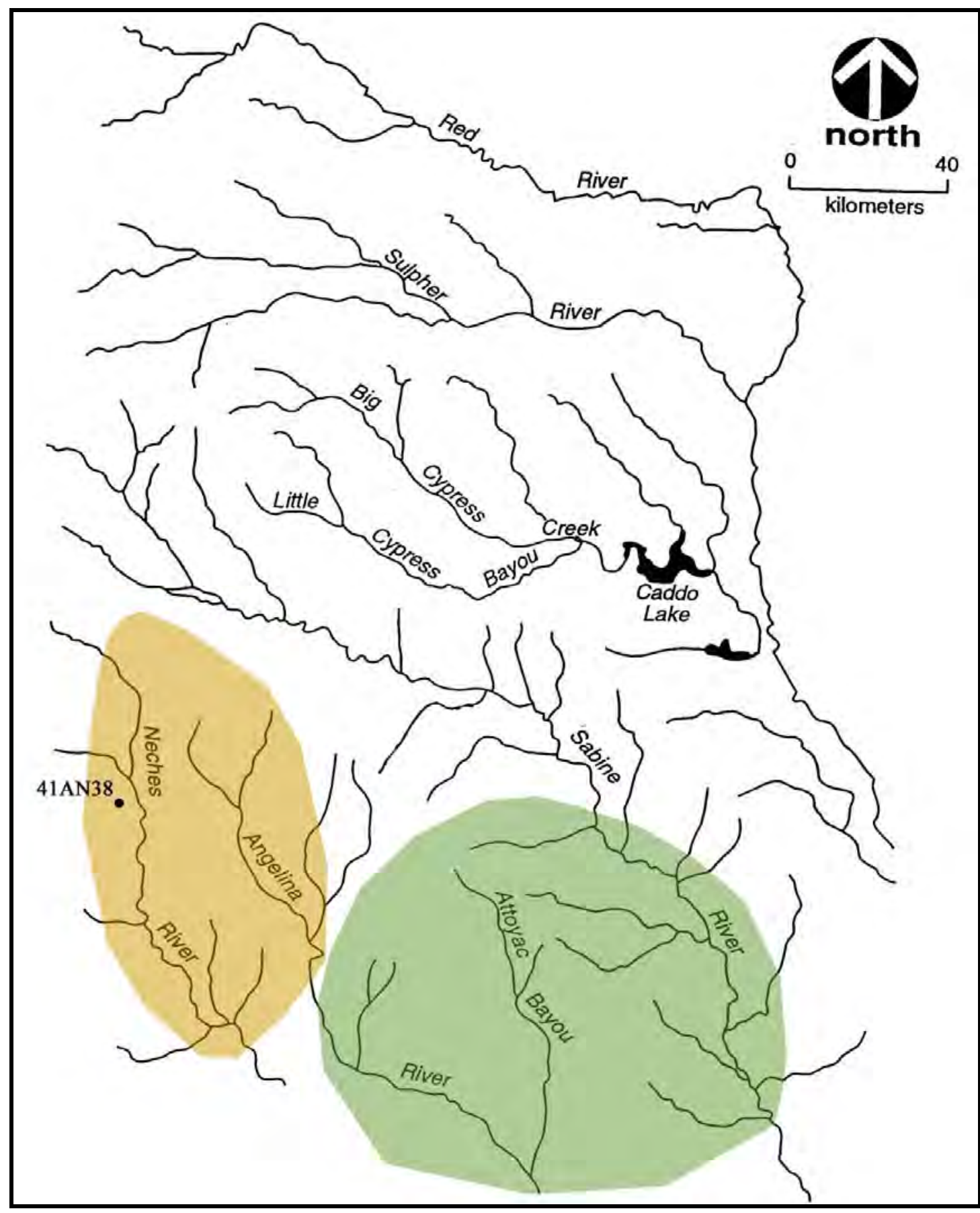

Figure 6-71. Late Caddo Ceramic Traditions in East Texas, South and West of the Sabine River. Frankston Phase Area is on the left, and Bone-Tempered Brushed Tradition is on the right. 


\section{Ceramic Practice}

By ceramic practice, I mean the decorative, technological, and formal attributes of sherds and whole vessels that were chosen and practiced by a potter or group of potters when they made pottery vessels within a distinctive social community or network of socially related individuals (see Eckert 2008:2-3, 10-13). These practices as a whole form the "technical choices [that are] selected in a rich context of tradition, value, alternatives, and compromises" (Rice 1996:140). As Stark (2006:22) puts it, "people reproduce their cultural and social positions through daily practice, that daily practice is structured by basic organizational principles," and that daily practice is expressed through tendencies and trends (habitus) "that develop as a practical solution to a particular demand within the framework of certain environmental and cultural conditions” (Eckert 2008:10).

These choices and tendencies exhibited in the manufacture and decoration of ceramics by potters indicate that the consideration of ceramic practice is an ideal medium for the study of technical systems (the tools and technical capabilities), social interaction, style, and social identity, as well as the dissemination of relevant behaviors between individuals (Chilton 1999:2; van der Leeuw 2002:241; Rogers and Ehrlich 2008). Thus, the particulars of ceramic practice and technical choice that can be identified in a temporally (and socially) related group of aboriginal Caddo sites are a means to recognize socially defined groups that closely interacted, transmitted "knowledge among individuals creating pottery" (McClure 2007:486) as a means of social learning, and this knowledge of manufacture and decoration choices was inherited by other descendant potters in that group. In this context, then, ceramic practices shared or not shared by potters (women in the community) reflect the learning of their craft from other women in the community, and that "patterns in local pottery styles, both technological and decorative, result from potters making different decisions throughout the production process but using a similar set of tools and techniques available to other potters within an area" (Eckert 2008:2).

In what follows, I first summarize the key choices and trends in the character of the domestic ceramics from the Lang Pasture site, followed by the mortuary ceramics from this site. Next, I examine issues of style and social identity and changes in culinary traditions as possible manifestations of changes in ceramic practice that occurred in the upper Neches. The mortuary ceramics from other upper Neches River basin Caddo sites illustrate broad continuities in ceramic practice, particularly in terms of vessel decoration and vessel form, but also demonstrate patterns in technical choices that are very different than what is documented in domestic Caddo ceramic assemblages of the same age and made by the same social group of potters. Finally, I employ the disparate and variable ceramic practice data (i.e., decorative, technological, and formal) discussed at length throughout this chapter-from both domestic and mortuary contexts - to posit the existence of, and sketch the character of, distinctive upper Neches Caddo ceramic tradition.

\section{Domestic Character of the Lang Pasture Caddo Ceramics}

The Caddo ceramics found in domestic, household, contexts at the Lang Pasture site include fine wares (engraved and slipped carinated bowls, bowls, and bottles used for food serving and to hold liquids), utility wares (brushed and wet-paste decorated jars and an occasional bowl used primarily for cooking, but also for storage), and plain wares, including bowls and bottles. There are technological and stylistic differences between the wares, as discussed above, and the Caddo potters that made these vessels clearly had a considerable range in choices and practices in how they were made and 
decorated (cf. van der Leeuw 2002:241-243; Stark 2006:24), although the range of differences were overall rather minor in technical practices, except in the case of certain decorative and stylistic elements. The ubiquity of these wares in every part of the site indicate that they were available to all the Caddo that lived there, and that there was no restricted access to the use of fine wares. These same wares are also found in the mortuary vessel assemblage at the Lang Pasture site, but in very different proportions, with an increased emphasis on fine wares as one of the principal funerary offerings (see Chapter 11, this volume).

Ceramic ethnoarcheological studies (Stark 2003:202-204) over the years have demonstrated that there is a consistent logic and sequence to the production of low-fired hand-made earthenware vessels such as those made and/or used domestically by Caddo peoples at the Lang Pasture site. These steps include, from first to last: (a) procurement of materials such as the clay and temper, as well as fuel; (b) preparation of materials, including the crushing, cleaning, size sorting, or mixing of clays and tempers to prepare the paste; (c) construction of the vessel, beginning with the base, and then building the walls, along with finishing treatments, among them smoothing and burnishing; (d) decoration of the vessel (at least wet-paste utility wares); (e) drying and firing; and (f) post-firing treatments, which in the case of the Lang Pasture fine wares also includes the engraving of certain fine ware vessels, as well as surface burnishing (Stark 1999:Table 3.1; see also Arthur 2006:29-54; Deal 1998:37-51; Tschopik 1941:17-41).

\section{Ceramic Production}

\section{Raw Material}

Clays used for vessel manufacture at the Lang Pasture site were likely gathered from nearby alluvial settings, as suggested by instrumental neutron activation analysis, particularly the more easily processed alluvial clay bodies along Caddo Creek, but certainly within a short (1-7 km away, at most) distance from the settlement. Depending upon the area of the site and the type of ware, about $18.4-33.6 \%$ percent of the vessel sherds have a fine sandy paste, suggesting that a naturally sandy clay was occasionally selected by Caddo potters for use in making particular kinds of vessels, those in which a sandy paste facilitated resistance to thermal shock or mechanical breakage. The presence of sand in the clay paste may, in fact, indicate preferential use of alluvial clays by local potters (at least during the $14^{\text {th }}$ century), rather than the harder-to-process bedrock clay.

Approximately $8 \%$ of the plain and decorated sherds from domestic contexts at the Lang Pasture site came from "pinkware" vessels. These are sherds with a distinctive red paste after firing. These vessels were made with a different and second kind of clay with a moderate-to-high iron content, probably deriving locally from iron-rich Weches Formation outcrops in the southwestern part of Smith County, the northwestern part of Cherokee County, and northeastern Anderson County, 4-20 km from Lang Pasture.

\section{Temper}

Grog, crushed and burned bone, and crushed hematite are the significant tempers used in the locally produced ceramics at the Lang Pasture site. The differences, by area and by ceramic ware, are very subtle in terms of temper use. However, the temper data strongly supports the notion that the predominant practice of Caddo potters at the site, as at other upper Neches River Caddo sites (see Figure 6-70), was in making grogtempered plain ware, utility ware, and fine ware pottery in both areas and through time. It would have been important that sources of grog temper would have been abundant at the site, at least after the first few vessels were broken there, as would the fact that 
including grog in the paste (especially finely crushed pieces) would have helped minimize the likelihood of vessel failure form either mechanical and thermal stress (Steponaitis 1984:94-95, 111). Caddo potters would have discovered the advantages of grog-tempered pastes through trial and error, experience, and learned cultural traditions.

Gamble (2007:198) has suggested that the addition of grog temper to pottery clay reflects more than simply a functional choice for potters. Instead, he interprets the temper choice as 'the inclusion of the ancestors in the next generation of pots." Thus, following this interpretation of temper use, every grog-tempered pot made by a Caddo potter can be construed as a link in an evolving ceramic tradition and a continued reinforcement of social identity.

\section{Methods of Manufacture}

The principal technique used in the manufacture of Lang Pasture and other upper Neches River basin ceramics was the building of vessels using coils, beginning at the flat base and working up the vessel body. Using the coiling method, coils of clay, in the form of ropes, rolls, or fillets, were built up to create the desired size and height of the vessel. Coiling is a technique especially suited to the construction of large, sturdy vessels, such as storage jars (Rice 1987:128), but in the case of the upper Neches Caddo potters, coiling of plastic clays led to the manufacture of a wide variety of vessel forms.

\section{Production Areas}

Production areas are notoriously difficult to discern archeologically (Rice 1987:181). Even in the American Southwest, where preservation of the archeological record is unequalled, Sullivan (1988:23) observed that "hardly any evidence has been recovered regarding the locations where vessels were made and fired...This is unfortunate because information of this sort has strong implications for contemporary research in Southwestern archaeology...For example, reconstructing the organization of a prehistoric settlement necessitates that the presence or absence of different activities be demonstrated as conclusively as possible." The situation is no better in the Caddo area of East Texas.

Sullivan (1988) has suggested several possible correlates of ceramic production that may be present and identifiable in the archeological record, including manos and metates for processing clay and temper; various types of scrapers (stone, bone, and sherd) for scraping and thinning vessel walls; recycled sherds for use as temper or molds; and fire-cracked rock. Production facilities may include basins and hearths. "The most convincing evidence of on-site ceramic production consists of artifacts frequently associated with ceramic manufacture that are found clustered around pottery-making and pottery-firing facilities" (Sullivan 1988:24). Features found at the Lang Pasture site include shallow pit basins and other small features that could have been used in processing materials or in making pots; hearths are also present. Unfortunately, there is nothing associated with any of the pit features or hearths at the Lang Pasture site that suggest their use in ceramic production. The Lang Pasture site ceramic assemblage also contains very little in the way of waste byproducts from ceramic manufacture, such as coil fragments, lumps and balls of clay, clay scraping tools, or stone polishers. The site assemblage has no sherds identified as wasters-pottery damaged during firing (Rye 1981:147). However, wasters may be rare, depending upon the frequency of production, quantities of vessels produced, manufacturing techniques, raw materials, and tempering practices. Waster sherds may also have been used in later firings to protect newly made vessels; sherds used in this manner may not be physically altered to any noticeable degree (Stark 1985:175). Broken 
pottery vessels in Caddo ceramic assemblages were also readily recycled as grog temper, thus further removing any direct evidence of pottery manufacturing failures.

The location of productions areas speaks to the organization of ceramic production. Sullivan (1988:23) notes that "identification of ceramic production loci is crucial for evaluating current models about the complexity of prehistoric Southwestern societies...It has been commonly assumed, for instance, that ceramic manufacture was primarily a household activity...An alternative view suggests that ceramics were made at a few regional centers." While it seems reasonable to believe that ceramic production in the upper Neches River occurred at the individual household level, considering the diversity in vessel forms, sizes, and decorative choices that seem to be apparent even within the southern and northern areas at the Lang Pasture site, it is unknown if this is in fact the case, or if there were more specialized facilities or production locales within the basin itself. Only continued chemical compositional analyses of upper Neches River ceramics and the fine-scale study of vessel forms and distinctive decorative motifs (especially in the mortuary wares) will be able to determine the existence of local vs. regional scales of production of certain kinds of vessels

The sample of rim sherds from the excavated area at the Lang Pasture site $(n=456)$, almost all of which appear to be the broken remnants from separate vessels, suggests that there may have been thousands of vessels used by the Caddo during their occupation here, given the apparent size of the site relative to the proportion that was excavated. With a duration of occupation that lasted at least 80 years-but with an unknown number of households - the number of vessels used by each household during the course of occupation was substantial, perhaps 20-30 vessels at any one time, with different functions, sizes, volumes, and use-lives.

\section{Vessel Form and Function}

The Caddo pottery from domestic contexts at the Lang Pasture site-based on the number of rims from the three different pottery wares found there-is dominated by decorated utility wares, typically jars used for cooking and/or storage activities, and plain wares, generally simple bowls used for food serving along with the fine wares. Overall, almost $48 \%$ of the rims $(n=456)$ are from utility wares, another $31 \%$ are plain wares, and the remaining $22 \%$ are fine wares: carinated bowls, bottles, and some bowl forms. Plain ware rims are more abundant in the northern area (34\%) than in the southern area (25\%); utility ware vessels are equally represented in both areas (46\% and $48 \%$, respectively); and fine ware rims are much more common in the southern area (29\%) compared to the northern area (17\%). For the site as a whole, the utility wares include almost $79 \%$ of all the decorated sherds from non-feature domestic contexts (see Table $6-1$ ) and $70.6 \%$ of the decorated sherds from features.

The rim and lip form data from both the southern and northern ceramic component/ areas indicate that the same range of forms were used by potters in both areas.: carinated bowls, bottles, bowls, and jars These were forms that were obviously considered appropriate by the Caddo to the kinds of vessels being made and used in each areas. The particular shape and form of these vessels is a hallmark of the technology and style of Caddo pottery vessels in the upper Neches, and these shapes and forms would have been immediately recognizable (e.g., Stark 2003:212) to other Caddo as belonging to those of a particular social group, as with the earlier quote from Sadie Bedoka, a Caddo-Delaware woman, that potters from one group could tell those of another simply by different pottery shapes (e.g., La Vere 1998:92). Comparisons 
between the two areas at the Lang Pasture site in rim and lip form suggest that there were minor differences in rim and lip form preferences, and thus presumably, minor differences in the kinds and proportions of vessels used through time at the Lang Pasture site.

Larger jars (with very thick rim and body walls, $>9-10 \mathrm{~mm}$ ) were probably used for short term storage, simply because they would be less easily moved about during cooking, while larger carinated bowls may have been employed in communal food serving; the majority of the serving vessels and cooking jars were in the 1-2 liter range, and thus likely intended for household use. Most of the utility ware jars were used for cooking, based on their form as open containers, as well as the presence of soot deposits, either heavy or light, as well as preserved charred organic remains. Sherds from jars tend to have residues formed on the interior of vessels that are related directly to cooking, as well as soot deposits built up from wood combustion, indicating that vessels were placed over an open fire during use (Hally 1983:9). Bowls may have also been used for serving food, like the carinated bowls, but many of them lacked surface decorative embellishments. Bottle sherds, used for storing and carrying liquids, also were a common utilitarian form made for the use of the site occupants, particularly those Caddo living in the earlier and northern area of the site.

A number of conditions contribute to the longevity or use-live, of a given vessel, including: "(1) basic strength, in terms of wall hardness and thickness, and vessel size, (2) use and reuse frequency and variation, (3) drying and storage practices, (4) opportunity for breakage, especially due to children and animals, (5) the potential for vessel repair [and] (6) the number of vessels in the household inventory" (Deal 1998:168). Smoothed and burnished grogtempered pottery made at Lang Pasture combines strength, thermal shock resistance, resistance to breakage, and low permeability, and, thus, may have lasted for a considerable length of time, especially if the vessels being used were large in size (see Arthur 2006:93). Vessel breakage, by whatever means, nevertheless, occurred with regularity at the Lang Pasture site because they were used on a daily basis, particularly among the cooking vessels, and this resulted in a large accumulation of pottery sherds inside and outside house structures.

Breakage, however, did not always signal the end of use of a vessel (see Arthur 2006:102-120). Deal (1998:108) found in his study of pottery consumption in the Central Maya Highlands that, "The decision to reuse a given vessel for a specific activity was determined by the nature of the surviving portion, such as a rim segment, a large sherd, or a bottomless vessel, rather than by its original value, quality, or morphology." At Lang Pasture, there is no evidence of vessel repair via lacing through holes drilled adjacent to cracks. Where repair was not an option, some vessels could have been recycled. Again, however, there is no evidence in the domestic ceramics from the Lang Pasture site for vessel recycling. It seems to have been easier to either make or obtain new pottery vessels than to recycle broken vessels. The absence of evidence of vessel recycling, mending, and reuse in the Lang Pasture ceramics suggests that there were Caddo potters living at the site or nearby in surrounding households (cf. Arthur 2006:119).

\section{Vessel Size}

Caddo domestic ceramics from the Lang Pasture site are relatively variable in size, ranging from about 0.2 liters to as much as 4-6 liters. There are also several notable trends in the vessel rim orifice diameter data: very small to medium-sized vessels are proportionally more abundant in the older, northern component, although small vessels become more commonly used later in time at the expense of medium-sized vessels. 
Very small vessels (bottles) - all plain wares-are restricted to the northern area (see Table 6-20). These data suggest that the Caddo living in the northern area made pottery designed for use in cooking and food serving in small social groups, perhaps individual households, and only occasionally were foods prepared and served for larger (i.e., more than 10 individuals) groups of people. Later in time, larger vessels used for food service (fine wares), cooking (utility wares), and storage (utility wares) were more frequently produced and used at the Lang Pasture site. In the southern area of the site, then, the ceramics produced and used by the Caddo were apparently made with the presumption that food preparation and serving needs extended to both household and supra-household contexts.

Another aspect of vessel size that can be measured is body wall thickness. The fine ware vessel sherds are consistently from vessels made thinner than the decorated utility ware or plain ware sherds, particularly when measured along the rim. These variations in vessel wall thickness are likely related to functional and technological decisions made by Caddo potters in how these different wares were intended to be used in local Caddo households. The less substantial vessel walls in some of the utility wares would be well suited to the cooking and heating of foods and liquids and, because heat would have been conducted efficiently while heating rapidly, would have contributed to their ability to withstand heatrelated stresses; also, the much thicker utility ware vessels (with rim thicknesses greater than $9 \mathrm{~mm}$ and body wall thicknesses greater than 10-11 mm) would have created stronger and more stable vessels, and would have been well suited for use as long-term storage containers (Rice 1987:227). Fine wares were probably intended for use in the serving of foods and liquids, and thinner and less porous vessel walls would have helped to maintain the temperature of served food and liquids; thinner and lighter vessels would have also contributed to the ease with which serving vessels could be handled, used, and transported.

Another factor that would have influenced vessel body wall thickness would have been the sequence in which a vessel was constructed (Krause 2007:35), of which there are a wide variety of choices available to potters (cf. van der Leeuw 2002:243-256). Vessels constructed from the bottom up, as these Caddo vessels likely were, would tend to have thinner walls moving up the vessel body towards the rim, with the lower portion of the vessel-especially the base, likely made separately, and thus available to serve as a support during later vessel construction-usually significantly thicker than the upper portions of the vessel.

\section{Firing}

The vessel sherds found in domestic contexts were primarily fired in a low oxygen or reducing environment. Reduced or low oxygen fired sherds are less common from the southern ceramic component/area, especially among the utility wares. Conversely, sherds from the southern site area are more likely to be from vessels fired in an oxidizing or incompletely oxidizing environments, again most notably among the utility wares (39.8\%), and less so among the fine wares and plain wares.

Utility ware, plain ware, and fine ware vessels were fired differently from each other. Fine ware and plain wares were better made and better fired (at least in terms of regulating the firing temperature), and they were probably fired longer in a low oxygen environment than the utility wares. The Caddo potters exerted more control over the end product of fine ware and plain ware vessel manufacture than they did with the utility wares, primarily to produce a harder ceramic. Firing conditions tended to be more heterogeneous among the utility wares, likely the product of the multi-purpose 
nature of these vessel forms, as they were used for cooking pots and storage containers. As long as the porosity of the utility wares was not excessive, and there was a good balance between clay plasticity and temper constituents, they did not need to be fired for as long a time as the harder fine wares to be serviceable vessels without being subject to diminished strength from cumulative thermal fatigue as well as cracks and fractures (cf. Steponaitis 1984).

\section{Mortuary Character of the Ceramics from the Lang Pasture Site}

Among the funerary offerings placed with the Caddo burials at the Lang Pasture site are 10 carinated bowls, 11 bowls, three compound bowls (apparently a rare vessel form in the upper Neches), three jars, and four bottles. These are the same vessel forms used in domestic contexts, but with significantly higher numbers of serving vessels in mortuary contexts; this is a practice shared with later upper Neches Caddo groups.

One of the more distinctive features of the mortuary vessels from the site is the high frequency of plain vessels (61\%). The carinated bowls, bowls (with one exception), and bottles, if decorated, have engraved motifs, particularly several distinctive regional and local varieties of Poynor Engraved that appear to have been common only before ca. A.D. 1480. Decorated utility wares from the burials include Maydelle Incised jars and a pinched bowl.

The vessels used in domestic contexts at the Lang Pasture site are generally much larger than those placed in the burials with the deceased, or at least have a wider range in vessel volume, which makes sense when one balances the needs of the living community and household with the needs of the deceased. The mortuary vessels are no larger than $20 \mathrm{~cm}$ in orifice diameter (and no larger than 2 liters in volume), and may have been chosen because at the time of burial interment, the Caddo living there believed that only one to a few servings of food were necessary on the deceased's journey to the House of the Dead.

\section{Local Ceramic Styles and Caddo Social Identity}

There is a general consensus among archeologists that stylistic expressions, and variations in that expression, in material culture, dress, body ornamentation, food practices, etc. can be a measure of social identity. However, the recognition of style in archeological materials is more than "the material correlate" [emphasis in the original] of social affiliation" (Wobst 1999:120). Patterns of style reflect variability in both individual choices as well as social group membership, and therefore the existence and pervasiveness of styles in material culture-our concern here being the existence of local styles of ceramic decoration-reflect the strength of interaction between individuals (individual potters), the form of cultural transmission (i.e., from parent to child; from a teacher to a pupil; from older to younger members of a social group; or between unrelated individuals, see McClure 2007:Table 1), and the ability of styles to be inherited from one generation to the next (O'Brien and Lyman 2003:19). Styles "share a common developmental history and are from the same tradition" (O'Brien and Lyman 2003:19). Style in ceramics as used here simply mean the characteristic patterns of pottery decoration that when applied to the rim and/or body of vessel in certain combinations and elements result in a unique set of visually represented design motifs and attributes. The combinations may be innumerable, as the choice "between certain kinds of design elements on ceramics is not a functional consideration but rather is historically determined and selectively "neutral," because there is no inherent advantage between one element and the next” (Meltzer 2003:140). In actual fact, ceramic practice among Caddo potters in the 
upper Neches dictated the range of acceptable variation (a rather impressive variation at that, particularly among the fine wares) in stylistic choice that were maintained for generations.

One last thing to mention about style: styles are expected to change rapidly, more rapidly than functional forms of tools and pottery vessels (see Rogers and Ehrlich 2008:3418). This interpretation follows from the idea that stylistic traits have a relatively rapid turnover because of their use in generating and reinforcing cultural identity, their selectively neutral character (i.e., stylistic elements have no differential effect on survival), and the potential high variation between individuals and groups in learning and replicating specific shared styles, particularly (in the case of ceramics) if Caddo potters were producing vessels largely independent of one another, that together comprise a ceramic tradition at any one moment in time.

While there are significant differences in the proportions of certain kinds of utility wares and fine wares at the Lang Pasture site, the wares in both areas share many similar decorative elements and stylistic motifs, and in a number of cases, these elements and motifs occur in roughly similar proportions. This suggests that these wares are part of the same ceramic stylistic tradition of practice as well as part of the same Caddo social group; furthermore, they may not be separated much in time. That they share many decorative elements (Table 6-40), but in slightly different proportions, presumably represents evidence of subtle stylistic changes over time effected by Caddo potters in how utility ware and fine ware were to be decorated, as well as the particular styles preferred by the Lang Pasture community.

In the southern area, jars with brushed rims are particularly abundant (25\%). This is followed by vessels with tool punctated (15\%), brushed-punctated (7\%), and incisedpunctated (5\%) rim decorations (see Table 6-6). The proportions of rims among these particular utility wares are not much different between the northern and southern areas (11-20\%), except for the brushedpunctated sherds. In this decorative method, only $4 \%$ of the brushed-punctated sherds in the northern area are rims, compared to $28 \%$ of these sherds from the southern area.

Brushed vessel sherds comprise approximately $54 \%$ of all the decorated sherds in the southern area (an 180\% increase from the northern ceramic component/area). This one change in the manufacture and use of one kind of utility ware-the brushed cooking jar (see below)—led to considerable reductions in previously important kinds of decorated utility wares, and a different character to the overall utility ware assemblage with time, even as the elements of decoration remained consistently in use: incised (13\%, a $45 \%$ reduction from its proportion in the northern area), incised-punctated (3\%, a 62\% reduction), and punctated $(9.5 \%$, a $47 \%$ reduction). 
Table 6-40. Principal Decorative Elements, by Area, in the Lang Pasture Ceramic Sherds.

Southern Area

\section{Utility Ware}

parallel brushed

overlapping brushed

parallel brushed with tool punctates

or fingernail punctates through

the brushing

horizontal brushing with tool punctates through the brushing parallel brushed-incised straight/parallel incised lines framing tool punctated rows or zones

triangle-incised zone filled with tool punctates

tool punctated rows

fingernail punctated rows

parallel incised lines

opposed incised lines

\section{Fine Ware (Carinated bowls and Bowls)}

hatched triangles

horizontal engraved lines and hatched triangles

horizontal engraved lines

parallel engraved lines

-

\section{Fine Ware (Bottles)}

closely-spaced curvilinear engraved

lines

ovals

triangular engraved elements

hatched zones
Northern Area

parallel brushed

overlapping brushed

parallel brushed with tool punctates or fingernail punctates through

the brushing

parallel brushed-incised

straight/parallel incised lines

framing tool punctated rows or zones

diagonal incised lines and triangleincised zone filled with tool punctates

fingernail punctated rows

parallel incised lines

diagonal incised lines

opposed incised lines

cross-hatched incised lines

hatched triangles

horizontal engraved lines and

hatched triangles

parallel engraved lines

opposed engraved lines

curvilinear engraved lines

lip notching

red-slipping

opposed engraved lines

triangular engraved elements

opposed straight lines 
In the northern ceramic component/area, the incised, punctated, and incised-punctated vessel sherds account for $49 \%$ of all the decorated sherds, whereas in the southern ceramic component/area, that percentage has decreased to only 25\%. The emphasis on incised triangles filled with punctations, or the use of geometric incised line designs remained the same (see Table 6-40).

The only significant difference in the brushed sherds from the southern and northern areas is the absolute proportions of brushed sherds in the utility wares: $26 \%$ in the northern area and $64 \%$ in the southern area. Clearly, the period after ca. A.D. 13201400 and in much of the $15^{\text {th }}$ century A.D. is one where Caddo potters in the upper Neches River basin began to manufacture considerable numbers of jars with brushed vessel bodies and rims.

Fine wares, especially engraved bottles, are more common in the northern site component/area than they are in the southern area. Decorative elements on bottles shared in both site areas included sets of curvilinear lines and triangular elements, usually in combination with hatched areas, either triangular, circular, or oval-shaped (see Table 6-40). Many of these bottle sherds are from globular Poynor Engraved bottles (see Suhm and Jelks 1962:Plate 63g-j) rather than the elongated bottle form (see Suhm and Jelks 1962:Plate 63a-f), as long vertical decorative motifs that occur on these elongated forms (as they do on Hume Engraved bottles) were not clearly identified in the Lang Pasture bottle sherds.

The sets of decorative elements in the engraved fine ware carinated bowls and bowls from both site areas are found on Poynor Engraved vessels in the upper Neches River basin (see Suhm and Jelks 1962:Plate 62a-j), many with hatched triangles of various sizes appended to larger motifs on rim panels. The decorations on these engraved vessels feature-either in a singular fashion or in combination- triangular, oval, or circular motifs on rim panels filled in with closely to widelyspaced hatching or cross-hatched lines, usually with appended hatched triangles (see Table 6-40). Horizontal engraved sherds in the southern area may be from Hood Engraved effigy vessels, although no effigy heads were recovered at the Lang Pasture site. Lip notched, engraved-lip notched, and red-slipped fine ware sherds, although rare overall, represent other distinctive stylistic practices used in the decoration of the northern area fine ware assemblage. Sites with Poynor Engraved vessels with similar decorative styles to those from Lang Pasture are found over a ca. $500 \mathrm{~km}^{2}$ area in the central part of the upper Neches, from Caddo Creek on the north and Walnut Creek to the south (Figure 6-72).

\section{Culinary Traditions and Increased Maize Consumption}

The culinary tradition in use at the Lang Pasture site and all other post-A.D. 1300 Caddo sites in the upper Neches River basin was one designed to effectively deal with the processing and cooking of maize, in particular, with other sundry supplements (i.e., beans, deer meat, nut meat and oil) and condiments. That the vessels from the Lang Pasture site are all hollow wares (i.e., jars, bowls, and carinated bowls), and the other studied sites have the same range of vessel forms, it seems likely that the Caddo diet was based almost entirely on liquid-based foods boiled and cooked in jars, including stews, corn and bean dishes, and gruels, as well as the serving and drinking of liquids. It is suspected that Caddo culinary traditions in general were primarily domestic in scale rather than community or communal-based, because of the small to medium size of many of the vessels, although the size of some cooking and serving vessels found in mortuary contexts suggests that communal food practices were also important at certain times in upper Neches River basin Caddo society. 


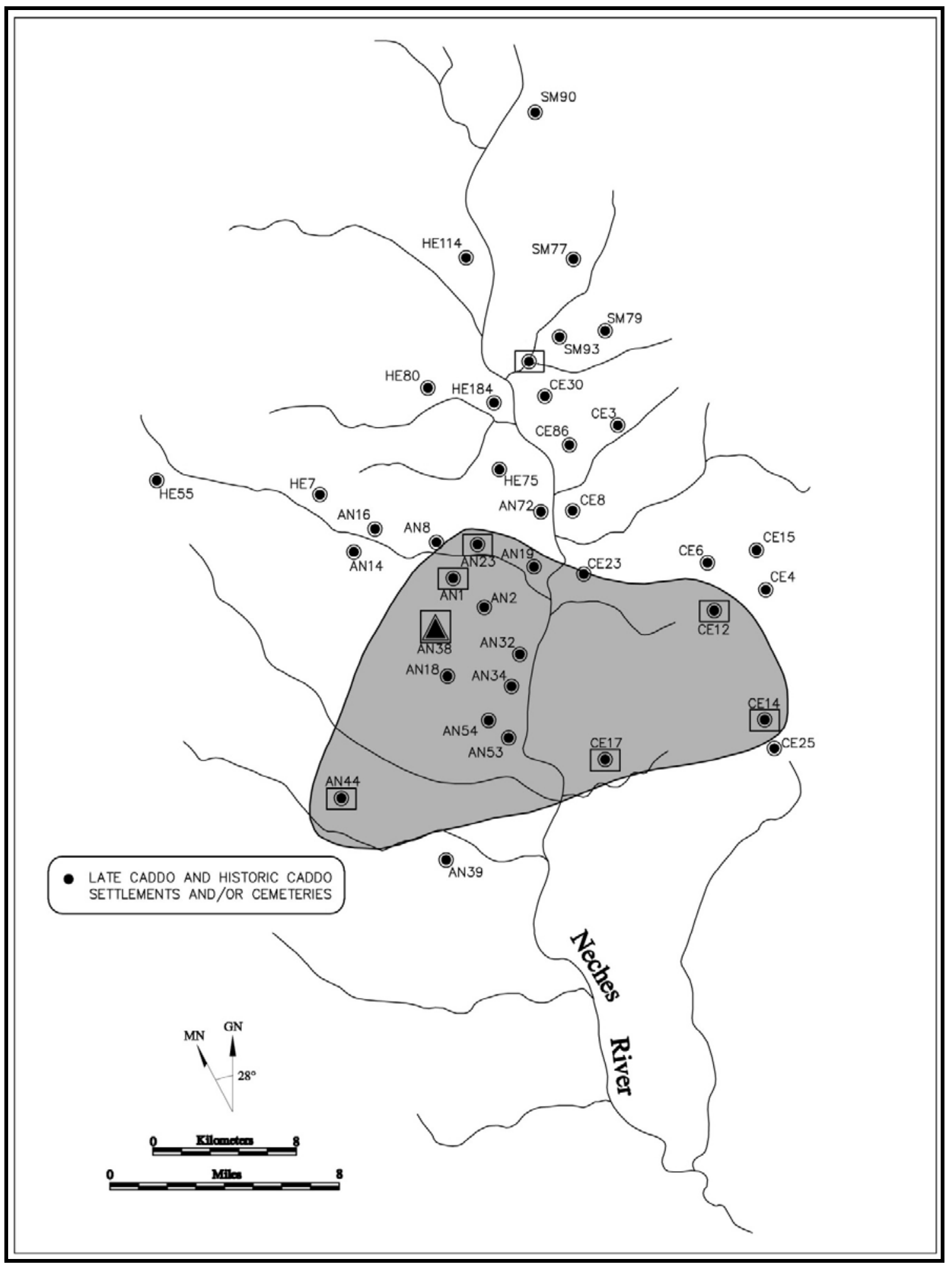

Figure 6-72. Area of the Upper Neches River Basin with Sites Showing the Closest Similarity to the Lang Pasture Site in Poynor Engraved Decorative Motifs. 
Any dietary changes and differences in food consumption by Caddo peoples should have had a significant role in the functional and temporal character of ceramic assemblages in use in the upper Neches River basin, particularly any changes or trends in the character or proportions of cooking jars in Caddo domestic settings. That is, any changes in the kind and proportion of vessel forms that were made and used by the Caddo in cooking imply that there were changes in culinary traditions: changes in the foods that were consumed, and changes in the way that foods were prepared and served (e.g., Mills 1999:100). In other words, increases in agricultural reliance by any Caddo group, in the upper Neches or elsewhere in the Caddo area, ought to be reflected in changes in the character of their cooking wares relative to the remainder of the ceramic assemblage.

I have previously argued that the increasing predominance of utility wares, specifically the number of brushed jars (and the proportion of brushed sherds in the utility wares), after ca. A.D. 1250/1300 in East Texas Caddo sites is a proxy measure of the increasing local intensification in the production and consumption of maize and other cultigens in the diet (Perttula 2001:112). ${ }^{7}$ There was a continual need in an agricultural society to manufacture sufficient numbers of cooking jars that were suitable for the cooking and processing of maize, and these cooking jars were apparently constantly breaking (given the large numbers of cooking jar sherds at Caddo sites) because of thermal stress failures (e.g., Steponaitis 1984:92). It has already been shown by both proportions of rims and proportion of decorated sherds that the Lang Pasture site ceramic assemblage is dominated by utility ware vessels (many of them brushed, at least in the southern area), most of which would have been used for cooking; the Lake Palestine Late Caddo ceramic assemblages reflect this same utility ware dominance in sites occupied after ca. A.D. 1300.

In the absence of any stable isotopic analysis of residues from sherds or vessels (e.g., Beehr and Ambrose 2007) from the upper Neches as a determinant of what foods were actually being cooked among these Caddo societies, stable isotope analyses of Caddo human remains from the region can closely track maize consumption trends and patterns. In fact, it is known from stable carbon isotope data from other parts of the Caddo area, particularly along the Red River (Perttula 2008a:Figure 6), that there were changes in Caddo diet beginning after ca. A.D. 1300, because of the increased consumption of maize. Stable isotope analysis is an integral part of determining maize intensification among the Caddo because it monitors the relative abundance of carbon 13 to carbon $12\left({ }^{13} \mathrm{C} /{ }^{12} \mathrm{C}\right)$ in bone collagen and bioapatite (Pollard et al. 2007:171-172, 180-188). The ratio of ${ }^{13} \mathrm{C} /{ }^{12} \mathrm{C}$ differs between $\mathrm{C}_{3}$ and $\mathrm{C}_{4}$ photosynthetic plant pathways. $\mathrm{C}_{3}$ and $\mathrm{C}_{4}$ plants have different ${ }^{13} \mathrm{C}$ means and ranges with $C_{3}$ plants averaging $-26.7 \pm 2.7 \%$ and $\mathrm{C}_{4}$ plants averaging $-12.5 \pm 1 \%$. These values are passed up the food chain with a fractionation factor of about 5\%. Maize was the primary $\mathrm{C}_{4}$ food source for the Caddo. The stable carbon isotope values on human skeletal remains, specifically on collagen in the bone, should range from a low value of ca. $-21 \%$ value for non-maize-eating populations and a high or $\mathrm{C}_{4}$ enriched value of ca. $-8 \%$ for intensive maize eaters. With respect to general bioapatite values as an indication of maize consumption, given a mean -5 \% spacing between bioapatite and collagen values, a bioapatite value of ca. $16 \%$ would be indicative of a non-maizeeating diet while a value of $-3 \%$ would represent a $100 \% \mathrm{C}_{4}$ or maize diet. 
- $\quad$ Early to Middle Caddo (ca. A.D. 900-1300)

Lee Ellis Farm (41AN56)

George C. Davis (41CE19)

Forest Mound (41CE290)

- $\quad$ Lang Pasture (ca. A.D. 1320-1400+)

- Late Caddo (ca. A.D. 1400-1650), Frankston phase

Pierce Freeman Farm (41AN34)

O. L. Ellis Farm (41AN54)

Solon Stanley Farm (41CE3)

J. W. Blackburn (41CE4)

A. H. Reagor Farm (41CE15)

E. W. Henry Farm (41CE17)

- Historic Caddo (ca. A.D. 1650-1800), Allen phase

Emma Owens Farm (41AN21)

Fred McKee (41AN32)

E. W. Hackney Farm (41CE6)

Jim Allen (41CE12)

Stable carbon isotope analyses of Caddo burials in the upper Neches River basin have been obtained from 14 different sites (see Chapter 10, this volume): The pre-A.D. 1300 Caddo burials in the upper Neches River sample have bioapatite values that fall into two clusters: one between $-10.9 \%$ and $-11.7 \%$ and the other between $-7.6 \%$ and $8.7 \%$.

These same burials have collagen values that range from -15.9 to $-21.8 \%$. The diversity in bioapatite and collagen values at this time is notable, hinting (albeit with very small sample sizes) at a similar diversity in maize consumption by Early Caddo populations in the upper Neches River basin. The lowest maize values (ca. 30-38\% maize in the diet, using bioapatite measurements, and between ca. $10-40 \%$ using the collagen values) are from two Stage II burials from Mound C at the George C. Davis site (see Story 1997) and the Forest Mound site. These burials likely date to the Early Caddo period, from the $10^{\text {th }}$ century A.D. in the case of the George C. Davis burials (Story 1997:60, 64). A later flexed burial (Feature 130), although undated, at the George C. Davis site was found in the vicinity of a large structure (Feature 125) abandoned by the early $12^{\text {th }}$ century A.D. (Story 1997:86). Its bioapatite value indicates this individual may have had a substantial (+55\%) maize diet, but its collagen value of $-18.4 \%$ suggests otherwise; it is unfortunate that a radiocarbon date was not obtained from these remains to better ground the conflicting maize estimations.

The burials from the Lang Pasture site fall into one main group with bioapatite values that range from $-10.8 \%$ o to $-8.7 \%$, with a single outlier (Feature 92) with a bioapatite value of $-6.4 \%$; this latter individual may have had a maize-reliant diet. Collagen values for all the burials range between $15.6 \%$ and $-19.7 \%$, suggesting maize consumption in some individuals topped 
$40 \%$ of the diet. The bioapatite values suggest that among this ca. early $14^{\text {th }}$ to early $15^{\text {th }}$ century Caddo population in the upper Neches River basin, maize consumption was relatively consistent, probably comprising between ca. $40-60 \%$ of the diet. The isotope values partially overlap with the pre-A.D. 1300 Caddo burials, but also evidence a temporal trend in $\mathrm{C}_{4}$ enrichment that continues into the Frankston phase.

In the case of the Frankston phase Caddo burials examined in Wilson's bioarcheological study (Chapter 10, this volume), the bioapatite values for this group fall in one cluster that ranges from $-9.1 \%$ to $-6.7 \%$. Stable carbon isotope values on collagen from the Frankston phase burials range from $-9.7 \%$ to $-14.8 \%$; this range may hint that maize consumption was still diverse at this time. These bioapatite and collagen values in the main do indicate, nevertheless, that these upper Neches River Caddo had a diet based primarily on the consumption of maize, with maize likely contributing an increased ca. $50-70 \%$ of their diet, and maize contributed more to the diet of these Caddo than were documented at either the Lang Pasture site or pre-A.D. 1300 burials in the region. The bioapatite values of the Frankston phase burials from the upper Neches are comparable to, if not also higher in $\mathrm{C}_{4}$, than either Late Caddo burials (-8.0 \%o to $-8.2 \%$ \%) along the Red River in Northeast Texas (see Perttula 2008b:Appendix IX) or northwestern Louisiana (-8 \%o to $-10.3 \%$, see Kelley 1997:Table 44). Both of these populations were maize eaters, with maize probably contributing $50-60 \%$ of the diet.

Bioapatite values for the Historic Caddo burials from the upper Neches River basin also fall in one cluster, with values ranging from $-4.8 \%$ to $-7.4 \%$; collagen values were also more enriched, ranging from only $-12.2 \%$ to $-13.9 \%$. The overall trend in these values when compared to the earlier Frankston phase burial sample indicate that maize consumption had not leveled off by ca. A.D. 1650, but had become even more substantial after that time. The bioapatite values suggest that maize comprised between ca. $65-85 \%$ of the diet for these upper Neches Caddo groups.

The stable carbon isotope data reviewed above from the upper Neches River basin convincingly establishes that there was an increased reliance on maize agriculture after ca. A.D. 1300 - a reliance that never leveled off. This increased consumption of corn, when matched with the contemporaneous increased use of cooking and storage jars (most of them brushed), is one piece of evidence that does not disprove that maize intensification is matched by the increased use of brushed (and other decorated utility ware) cooking vessels in upper Neches culinary traditions. This change in the importance of certain kinds of decorated cooking jars presumably represents the product of individual and group decisions to develop and adopt new strategies of food cooking; this change had functional and stylistic ramifications for the character of the remainder of the ceramic vessel assemblage. This does not mean that there may not be other reasons that account for the increased use of cooking jars (i.e., increase in household size or composition, or an increased incidence of communal feasting, etc.) in upper Neches Caddo social groups, but the evidence of maize intensification is compelling. Locally, then, this change in cuisine and culinary tradition expressed by the ubiquitous utility ware cooking jar (often brushed) appears to have taken place in the latter part of the $14^{\text {th }}$ century and/or early part of the $15^{\text {th }}$ century, about the time of the Caddo occupation of the southern area at the Lang Pasture site. As noted above, the ceramic assemblage from the southern area of the site is dominated by utility wares, particularly brushed utility ware vessels. 


\section{Mortuary Ceramics in the Upper Neches River Basin}

The basic composition of Caddo mortuary vessel assemblages from upper Neches River burial sites includes fine wares (73\%), decorated utility wares (15\%), and a significant proportion of plain ware vessels $(12 \%)$. Th choice of funerary offering is clearly focused on the fine ware serving vessels (and presumably their contents), as it is in all prehistoric and early historic Caddo mortuary vessel assemblages (see Kelley 1997; Perttula 2000).

The principal fine wares in all these cemeteries are Poynor Engraved bowls and carinated bowls (50\% of the fine wares), followed by Poynor Engraved bottles of various forms (9\%), Patton Engraved (13\%), Hood Engraved (12\%) effigy ware vessels, and Hume Engraved bottles (12\%). Among the utility wares, the major types include Bullard Brushed $(n=22 \%$ of the utility wares), Killough Pinched (21\%), Maydelle Incised (12\%), punctated jars (10\%), and brushed-punctated jars (8.5\%). Most of the plain wares are simple bowls (39\% of the plain wares), carinated bowls (31\%), and several forms of bottles (22\%). In upper Neches River basin sites, Killough Pinched jars are present only in sub-phase 2 Frankston phase contexts, while Maydelle Incised vessels are predominant in ca. A.D. 1400-1480 contexts, diminishing in later times. What stands out among the utility wares from mortuary contexts in the upper Neches is the frequency of vessels with brushed decorations: $37 \%$ of all the utility ware vessels are brushed.

The vessels from upper Neches cemeteries fall into five basic vessel forms, and with a number of distinctive sub-forms based on rim and lip treatment, as well as the addition of handles and effigy appendages: carinated bowls, bowls, bottles, jars, and compound bowls. Carinated bowls are by far the most abundant mortuary offering, accounting for $48.5-63 \%$ of all the vessels; this relative proportion peaks during the late (sub-phase 3) Frankston phase, and continues in the Allen phase. Mortuary vessels in upper Neches River Caddo sites were made in a wide variety of sizes. In most cases, the vessels included with the deceased by his living relatives easily would have held multiple servings of food and liquids. There is a clear trend towards the use of very large carinated bowls (food serving vessels) after ca. A.D. 1480-well-suited for communal food serving-suggesting that the vessels may have been intended by the Caddo to meet multiple and changing purposes in mortuary rituals. These could have included use of the vessels in grave-side rituals and daily food offerings by the relatives of the deceased, after which they were placed in the graves as final accompaniment once the "Sixth Day Feast" had been concluded. PreA.D. 1480 cemeteries in the upper Neches have only a range of small to medium-sized vessels, probably destined for individual use.

As was the practice with the manufacture of upper Neches River basin Caddo ceramics that were used in domestic contexts, the mortuary vessels from the region were predominantly tempered with grog, regardless of the Frankston phase sub-phase to which the vessels can be assigned. Grog is commonly the sole tempering inclusion, but more often than not, was the principal temper in conjunction with smaller amounts of crushed and burned bone and crushed and angular hematite pieces. Less than $7 \%$ of the vessels - with the exception of the Lang Pasture site-were tempered solely with aplastics other than grog. Bone temper, however, was a popular temper inclusion used throughout the Frankston phase for vessels placed in burials. Overall, the frequency of bone-tempered pottery in the mortuary vessels ranges from 12-52\%. By comparison, sherds from domestic contexts at these sites, including the Lang Pasture site, are much less likely to have been tempered with bone. For instance, at Lang Pasture, between $9-20.5 \%$ of the sherds by 
site area were tempered with bone, less than half the amount identified in the mortuary vessels. Sherd samples from other upper Neches River sites (see below) tend to have less than $5 \%$ bone-tempered sherds in the assemblages, irrespective of their ages. Because of these dramatic temper differences in domestic vs. mortuary ceramics, vessels placed in mortuary contexts appear to have been made in different ways by individual potters, solely to accompany the deceased rather than to conform to domestic preferences.

Another indication of differences in the character of domestic vs. mortuary ceramic vessels concerns how the vessels were fired. After ca. A.D. 1400, mortuary ceramics were very commonly fired in a high oxygen environment, or were incompletely oxidized. By site, these two methods of firing comprise between $47-85 \%$ of all the vessels in the post-A.D. 1400 detailed analysis sample (see Table 6-33), very much different than the Lang Pasture vessels.

As a consequence of ceramic practice differences in firing, many of the vessels found in Caddo mortuary contexts have a reddish to reddish-brown color because of high oxygen firing, rather than the darker gray, grayish-brown, or black colors that would have resulted from firing in a reducing environment. However, firing vessels in a reducing environment, but cooling them in the open air would have had a similar effect, at least in terms of the color of the fired pots, as the open air cooling would leave a thin oxidized interior and/or exterior surface. Technologically, if the goal was to produce a vessel of a certain color and durability, it seems to have made more sense to fire the pot red-hot in an oxidizing fire, as the Frankston phase Caddo potters chose to do, and thus be able to see when a pottery vessel was done and could be removed from the fire, then it was to gauge the right time to remove a pot from a firing when it was smothered in a bed of coals and ashes. This technological change or firing preference appears to have become part of the upper Neches River ceramic traditionat least with respect to the manufacture of mortuary vessels-after ca. A.D. 1480 to A.D. 1560 (sub-phases 2 and 3 of the Frankston phase).

Both red and white clay pigments were used regularly on upper Neches mortuary vessels. Red pigments were exclusively used on a few bowls and effigy bowls, and almost exclusively on bottles. Among the carinated bowls, about one-quarter had a white clay pigment, particularly the carinated bowls from post-ca. A.D. 1560 Frankston phase cemeteries. White clay pigment began to supplant the red clay pigment after ca. A.D. 1560 on mortuary vessels up to ca. A.D. 1560. The symbolic meaning and use of different pigments on mortuary vessels point to the likelihood that cosmological and world views of the Caddo peoples living in the upper Neches began to change after ca. A.D. 1480, but these new views came to dominate beliefs and mortuary ritual usage after ca. A.D. 1560 and continued into early historic period times.

\section{Upper Neches River Basin Caddo Ceramic Tradition}

The existence of a distinctive prehistoric Caddo ceramic tradition (dating from ca. A.D. 1320-1700) in the upper Neches River basin has been known for many years (cf. Suhm and Krieger 1954; Suhm and Jelks 1962; Shafer 1981; Kleinschmidt 1982; Story and Creel 1982), although not to the extent we are now able to trace and document it, and lies behind the recognition and definition of the Frankston and Allen phases in this region (see Figure 6-70). By ceramic tradition, I mean a single, coherent, community of technological and stylistic practice specific to the Caddo peoples of this area. This tradition is consistent with a broad unity in culture and material culture production, as well as a shared native history, one developed through centuries of intermarriage, trade, transmission of 
learning, and other kinds of reciprocal relationships.

The analysis of the ceramics from the Lang Pasture site (41AN38), as well as sherds and vessels from a number of other broadly contemporaneous and younger Caddo sites in the basin (see Figure 6-1), has considerably refined our understanding of this prehistoric Caddo ceramic tradition. Crucial to this development is the detailed stylistic and technological information that has been obtained on sites with burials and mortuary vessels that were used for short periods of time within this ca. 380 year chronological sequence. Also important to anchoring the beginnings of this ceramic tradition, and laying the framework for tracing stylistic changes in the ceramic fine wares, is the fact that the Lang Pasture site appears to be the earliest of the known sites within this tradition. Grog-tempering is the key component of this ceramic tradition.

Poynor Engraved is by far the most common fine ware type in the upper Neches River basin Caddo ceramic tradition, in both domestic and mortuary contexts. Its most distinctive and unifying characteristic, at least in the case of the defined varieties to be discussed in a moment, is the use of rim panels on carinated bowls (whether with direct or inverted rims or shouldered or globular forms) — or a rim panel decoration turned vertically on bottles - that have distinctive dividers, creating central rectangular, oval, negative oval, and semicircular elements. In some cases, there are additional decorative elements within the area created by the dividers, including hatched triangles, pendant triangles, circles, punctate-filled circles, or circles with spurs or ticks. The five defined varieties of Poynor Engraved are found at most of the sites in the upper Neches, as well as in sherd assemblages from domestic and mound components. Poynor Engraved, var. Hood is the most widespread of the defined varieties, followed by Poynor Engraved, var. Blackburn. Poynor Engraved, var. Lang is the least widespread of the defined varieties. The other varieties are Poynor Engraved, var. Cook and var. Freeman. The analysis of these varieties of Poynor Engraved, in combination with the examination of the later Patton Engraved type, has demonstrated the unbroken stylistic connection between the latest variety of Poynor Engraved-var. Freeman-and the earliest of the distinctive Patton Engraved vessels, namely Patton Engraved, var. Freeman, as well as the earlier stylistic change from Poynor Engraved, var. Hood to var. Freeman (see Figure 6-63).

The earliest site that belongs to this tradition-the Lang Pasture site-has none of these defined Poynor Engraved varieties, but it shares the practice of using grog temper in vessel manufuacture. But there are also a number of regional varieties of Poynor Engraved, some of which are present in the earliest contexts at sites throughout the upper Neches River basin and in widespread $14^{\text {th }}$ century contexts in parts of East Texas. These varieties also feature a diverse range and combination of stylistic elements, principal among them nested triangles, nested ovals, and nested circles; scrolls of various sorts; hatched pendant, stacked, and nested triangles; cross-hatched ladders and panels; hooked arms; concentric ovals; and sets of diagonal lines with small pendant triangles. The most common regional varieties of Poynor Engraved are var. $F$ (nested ovals/triangles and diagonal cross-hatched ladders, also local variety 1 at the Lang Pasture site), var. E (scroll and circle), and var. $B$ (interlocking scrolls). Var. $F$ vessels have also been reported from sites in the upper Sabine River basin that date to the $14^{\text {th }}$ century, indicating a wider and perhaps earlier distribution to some of these more unique Poynor Engraved styles. The other regional varieties are represented by vessels from only a few sites.

More than 57\% of the Poynor Engraved vessels at the Lang Pasture site can be assigned to one of these regional varieties; 
the other $43 \%$ are specific local varieties of Poynor Engraved seen only at Lang Pasture and currently at one or two other sites in the region. In the broader upper Neches River basin mortuary vessel assemblages, these numerous regional varieties are most abundant in pre-A.D. 1480 contexts (61\%), with a significant drop off in ca. A.D. 14801560 (12\%) and ca. A.D. 1560-1650 (20\%) mortuary contexts. This suggests that prior to A.D. 1480, and reaching back into the early to mid- $14^{\text {th }}$ century A.D. when the Lang Pasture site was occupied and distinctive regionally specific fine ware styles were beginning to be created, the favoring of stylistic innovations and the individual work of specific artisans, were what led to the wide diversity or variety in Poynor Engraved rim motif styles at that time. This suggests that pottery learning at this time was primarily between parent and child, usually in independent households (McClure 2007:500 and Table 1).

Innovations and unique artistic expressions with Poynor Engraved vessels eventually began to diminish in favor of stylistic conformity around a certain few rim panel motifs. This uniformity suggests that fewer people were making pottery (or a number of potters from different households were being taught how to make pottery from a prominent teacher, cf. McClure 2007:501), and thus after ca. A.D. 1480, specific distinct styles/varieties of Poynor Engraved may not have been made in each Caddo settlement or community. Instead each style of Poynor Engraved may have made by a certain number of artisans living in specific parts of the upper Neches River basin, and the products were then traded and exchanged throughout the region.

Other important fine wares include Hume Engraved and Patton Engraved, with several defined varieties in the upper Neches, as well as Hood Engraved effigy vessels. Seriation analysis of mortuary vessels suggest that neither of the first two pottery types began to be made until after ca. A.D.
1480 (in the case of Hume Engraved, with their distinctive elongated bodies) or after ca. A.D. 1560 (in the case of Patton Engraved). Hood Engraved effigy vessels began to be made ca. A.D. $1400^{\circ}$, and they were most popular as mortuary offerings between ca. A.D. 1400-1480; they continued to be made and used through the Allen phase. There are three known varieties, with Hood Engraved, var. Hood being the most common effigy vessel style. Hood Engraved, var. Hood vessels occur in burial and domestic contexts at a number of sites. Hood Engraved, var. Allen effigy vessels, however, are more concentrated in late Frankston and Allen phase settlements and cemeteries in the Caddo and Flat Creek areas and in the Neches River valley itself (see Figure 6-67).

Important utility wares include the aforementioned Bullard Brushed, as well as Maydelle Incised, rim punctated jars, and Killough Pinched noded bowls and jars, the latter including exuberant examples with pedestal bases and pinched legs. Plain vessels were an important part of the upper Neches Caddo ceramic tradition, and in addition to simple bowls, other plain wares were made in the same shape as some of the distinctive fine wares, as in the globular carinated bowl form (Poynor Plain) or the elongated body-short-necked bottle form (Hume Plain).

The decorated and plain sherd assemblages from post-A.D. 1400 Lake Palestine domestic sites further illustrate the commonalities of this Late Caddo ceramic tradition. They are (1) almost exclusively grog-tempered; bone-tempered pottery comprises less than 3\% of the sherds; (2) brushed utility ware pottery from Bullard Brushed vessels and other brushed utility ware types dominates the decorated sherd assemblages, accounting for between 49$80 \%$ of all the decorated pottery; (3) fine ware vessel sherds from Poynor Engraved and Hood Engraved vessels account for less than $10 \%$ of the decorated sherds; (4) wet 
paste decorations on sherds from Maydelle Incised vessels and various unnamed utility wares are also more abundant than fine wares, accounting for between $10-42 \%$ of the decorated sherds, by site; (5) fingernail punctated sherds are rare (less than $3 \%$ ) at each site; and (6) plain to decorated sherd ratios (P/DR) range from only 0.14-1.50, with most of the sites having P/DR values less than 0.72. Lake Palestine Caddo sites dating after ca. A.D. 1400 did not have many plain ware vessels.

A final part of the upper Neches River Caddo ceramic tradition was the practice of clay elbow pipe manufacture in various forms and decorative styles. Clay pipes are found in both domestic and mortuary contexts throughout the upper Neches River basin, and pipes were made locally for daily use, as well as for use in mortuary rituals.

Elbow pipes changed in form and decoration through time from a common beginning in the $14^{\text {th }}$ century, beginning with plain Lshaped forms (Var. A elbow pipes), followed by flaring bowl forms with distal stem knobs; these pipes (Var. B) have three engraved or deep incised lines on the stem and short lines on the lower bowl. Var. C pipes have engraved/incised lines on the stem, and lines on the pipe that extend along the entirety of the stem and basal portions of the bowl. In Var. D pipes, the parallel engraved or incised lines extending along the stem and the lower body are replaced by long rows of small punctations. Var. E elbow pipes are the first forms that are completely covered with decoration, in this case curvilinear incised lines, and then later by cross-hatched engraved lines (Var. F elbow pipes). These particular styles of decoration, and combination of decorative elements, on the clay elbow pipes is particular to the upper Neches River basin (cf. Jackson 1933).

Var. A-C elbow pipe forms are present at the Lang Pasture site. The pipes from mortuary contexts are Var. A forms, while all three forms are present in domestic contexts. In other upper Neches River basin sites, Var. A pipes are restricted to pre-A.D. 1480 components. Var. B pipes are present in ca. A.D. 1400-1560 mortuary contexts, as well as $15^{\text {th }}$ century ceremonial contexts at the A. C. Saunders site (41AN19), while Var. C pipes occur from ca. A.D. 14001650. Var. D-F are all apparently post-A.D. 1560 elbow pipe forms in the upper Neches River basin.

\section{End Notes}

1. A total of 23 sherds were submitted for TL dating, but no TL dates were obtained from two of these (UW1709 and UW1721). The first is a pinched body sherd from the southern ceramic component/area, and the second is a parallel brushed body sherd from the southern ceramic component/area.

2. Given the Caddo potter's penchant for decorating pottery vessels with one kind of decoration on the rim, and a different decoration on the vessel body, analysis of the rim decorations do not provide a comprehensive view of the range of decorated utility wares. Categories of decorative methods represented in the utility wares that have only a few or no rims are likely indicative of those decorative methods used only (or primarily) on the vessel body, while those categories with a fair proportion of decorated rims to total sherds are more likely to include vessels decorated in comparable fashion by the same decorative method on both the vessel rim and body.

3. More far-flung examples of decorated Caddo pottery that resemble these early varieties of Poynor Engraved include three vessels from $14^{\text {th }}$ century shaft burials from the Washington Square Mound (41NA49) in the Angelina River basin (Hart 1982:Figure 3-13). These three vessels have rectangular panels with hatched triangles at the corners of each panel, as well as central elements, including circles (as with Poynor Engraved, var. Blackburn, see Figure 6-63b') or 
hooked arm scrolls (as with Poynor Engraved, var. $N$ or $P$, see Figure 6-64). Hatched triangular panels or triangularshaped elements with hatched corners, creating negative ovals, as well as concentric ovals, are elements seen on engraved vessel rims and body sherds from at least three different vessels at the $14^{\text {th }}$ century Bryan Hardy site (41SM55) in the Sabine River basin (Walters and Haskins 2000:Figures 17i-j and 22a-c) and in the $14^{\text {th }}$-early $15^{\text {th }}$ century ceramics from the Redwine site (41SM193) (Walters et al. 1998:Figure 14a). One incised-punctated jar from the site has a nested oval and triangle motif, otherwise comparable to Poynor Engraved, var. $F$ (Walters and Haskins 2000:Figure 19). The well-dated Leaning Rock site (41SM325) in the upper Sabine River basin, with calibrated dates ranging from AD 1280-1420 (and a mean of the calibrated intercepts of AD 1349), has at least one rim with a vertical engraved panel and triangular hatched corners (Walters 2008:30).

4. For example, at the late $17^{\text {th }}$-early $18^{\text {th }}$ century Allen phase Deshazo site (41NA27), only white pigments ( $\mathrm{n}=27$ sherds) were noted on the engraved fine wares (Fields 1995:187-197).

5. Poynor Engraved and/or Patton Engraved sherds from likely upper Neches River Caddo sources have been documented in a number of Central Texas Toyah phase sites (Ricklis and Collins 1994:Figures 142b and 155), north Texas Blackland Prairie sites (Crook 2007:53 and Figure 6; Crook and Hughston 2008), north central Texas prehistoric sites (Bruseth and Martin 1987:Figures 8-2d-e, 8-3c), east central Texas aboriginal sites (Fields 2004:Figure 12.14c, g; Gadus et al. 2002:Figure 50f-g), Spanish mission sites in South Texas (Fox and Tomka 2006:81, Walter 2007:91-93), as well as a ca. A.D. 1450-1684 aboriginal component at the Loma Alta site (41PS15) in the Junta de los Rios area of west Texas (Kelley 1986:83 and Plate IIa). Gregory and
Avery (2007:44) have recovered Patton Engraved at the $18^{\text {th }}$ century Spanish mission at Los Adaes in northwestern Louisiana. Suhm and Krieger (1954:344) have commented that Poynor Engraved "appears to have been the most widely traded Caddoan pottery among tribes living west of the Caddo.”

6. Feathers (Appendix C, this volume) suggests that one of the sherds submitted for TL dating (a parallel brushed body sherd from the southern area), was likely also from a vessel not made at the Lang Pasture site. The radioactivity of this one sherd (UW1721) indicated that it contained unusually high concentrations of $\mathrm{K}$, unlike the other Lang Pasture sherds and accompanying sediment samples submitted as part of the TL dating, and likely came from a vessel made from a different clay source.

7. In a case study from the Oak Hill Village, where paleobotanical remains from feature flotation samples were abundant from three sequential village components, as were brushed pottery sherds, the ubiquity of maize in features closely tracks the proportion of brushed utility wares. In the ca. A.D. 1150-1250 village, the percentage of brushed sherds in the decorated sherd assemblage is $15.3 \%$ and maize ubiquity is $31.6 \%$. In the ca. A.D. $1250-1350$ village, maize ubiquity increases to $50 \%$ and the percentage of brushed sherds is $24.4 \%$. By the time of the late village, dating from ca. A.D. $1350-1450$, maize ubiquity is $96.9 \%$, and brushed sherds comprise $48.7 \%$ of the decorated sherds in this component (Perttula 2001:Table 5).

8. The timing in the appearance of effigy vessels in the upper Neches region is of interest, given previous discussion of how the overall character of the region's ceramic assemblages changed with the increasing prevalence of cooking jars, especially brushed cooking jars, at the time of an increased consumption of maize in the 
Caddo's diet. That finding leads to a question about one possible meaning of the effigy vessels, particularly the very common use of a bird's head appendage on effigy vessels, and a corresponding speculation, following up a review of North American Indian maize myths by Lankford (2008:37). Lankford makes the point that in these myths, maize is commonly described in a "maize-as-a-gift" tradition, as in a gift from a divinity or their emissary; this is the case among the Caddo, for instance (Lankford 2008:Figure 2.1). One of those emissaries is a bird. Perhaps, then, the bird on the effigy bowls made by the upper Neches Caddo is a unique symbolic representation of the bird emissary that brought corn in all its abundance to these Caddo people. 


\section{CHAPTER 7}

\section{LITHIC ANALYLSIS}

Donald G. Hunter

\subsection{INTRODUCTION}

The data recovery excavations at Lang Pasture produced an abundance of lithic artifacts, which include a number of finished tools and a large sample of debitage. A preliminary analysis of the diagnostic lithic artifacts was made, and revealed that the site had multiple occupations beginning in the Early Archaic period and ending in the Late Caddo period. Because of the sandy nature of the local soils and mixing of deposits through bioturbation, other natural processes, and human-related activities, it became apparent that much of the debitage resulting from these multiple occupations had been mixed and was of little value for addressing research questions of interest. This was regarded as especially true of the samples obtained from non-feature contexts. The debitage recovered from selected features was analyzed to determine whether these collections had any research utility, but the following analysis focuses on the diagnostic lithic artifacts.

\subsection{ARTIFACT DESCRIPTIONS}

\section{Arrow Points}

Eighty compete and partial arrow points were identified in the data recovery lithic sample (Table 7-1). Of that number, 30 (37.5 percent) could not be assigned to a particular type because they lacked sortable attributes due to breakage or the stage of manufacture at the time of loss or abandonment, or because diagnostic morphology was not clear present. The remaining $50 \quad$ (62.5 percent) were categorized to one of several previously established types commonly encountered at archeologicalsites in eastern and northcentral Texas. Where arrow points or points resembled a certain type but could not be assigned to that category with any degree of confidence, they were noted as being "similar to" that type (abbreviated as "sim." in the following text and tables).

\section{Steiner Arrow Points}

Steiner arrow points were the most common type recovered during the data recovery excavations. They were represented by 18 examples, accounting for 36 percent of the identified arrow points (Figure 7-1, a-o). They are easily recognized by pronounced or exaggerated serrations or protrusions often placed at irregular intervals along the blade edges, as well as a lack of general symmetry in many instances (cf., Davis 1991:254-255; Turner and Hester 1999:232). Most appear to have been made of local materials, including chert, quartzite, and silicified wood derived from water-worn cobbles, pebbles, or tabular fragments. A relatively high percentage (78 percent) appear to have been heat treated. Metric data relating to the Steiner arrow points in this sample are presented in Table 7-1. As can be seen, roughly 28 percent of the Steiner arrow points were made by means of unifacial work on flakes. Turner and Hester (1999:232) assign the Steiner type to the Late Prehistoric period 


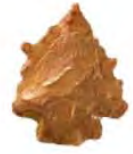

a

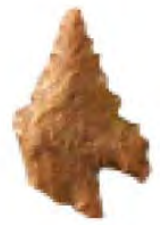

f
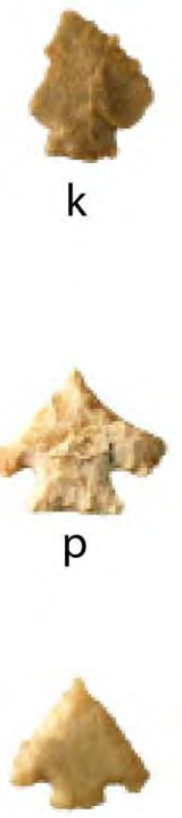

u

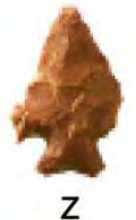

Z

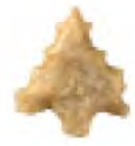

b
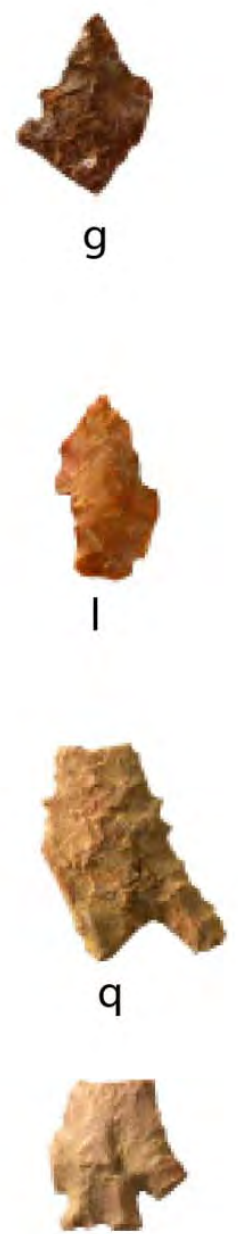

V
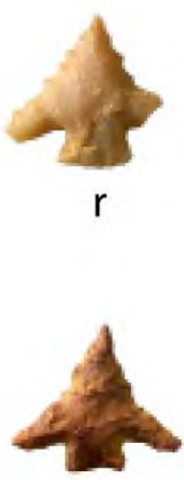

W

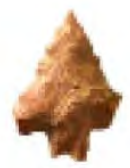

$\mathrm{bb}$

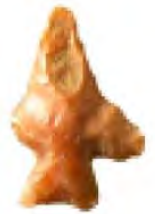

aa

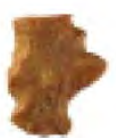

d

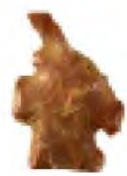

e
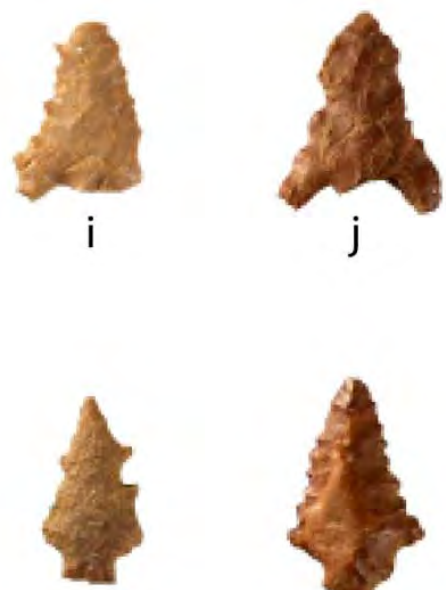

$\mathrm{n}$
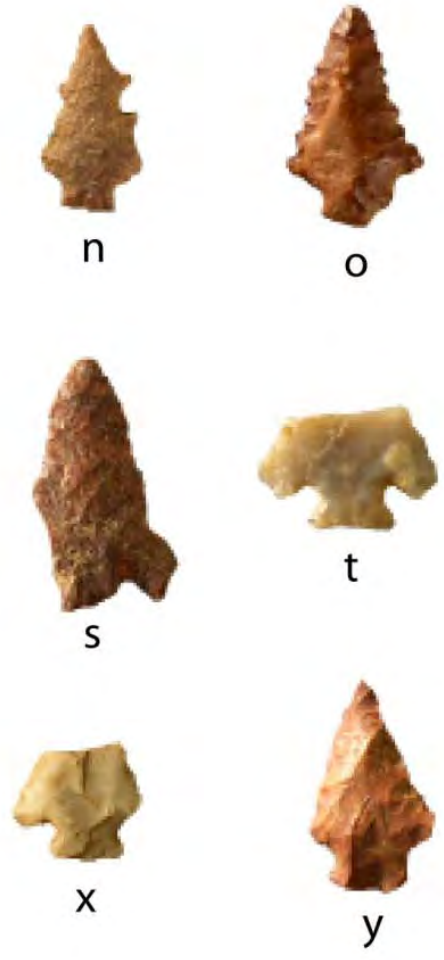

Figure 7-1. Selected Arrow Points from 41AN38: a-o, Steiner; p-u, Catahoula; v-x, probable Catahoula; y-bb, untyped. 
(ca. A.D. 700-1600) and note it as primarily occurring in eastern Texas, where it pertains to the Caddo period. Davis (1991:254) suggests a somewhat more limited chronological position of ca. A.D. 800-1400, a range that would encompass the Formative, Early, and Middle Caddo periods (Perttula 2004a:378). Prewitt (1995:131) shows this type being most commonly reported from sites in east-central Texas.

\section{Perdiz Arrow Points}

Perdiz arrow points $(n=16)$ are the second most common type recovered (see Table 71 ), and account for 32 percent of the identified arrow points (Figure 7-2c-q). This type is characterized by a triangular blade; pronounced barbs; and a relatively long, contracting, and sometimes pointed stem (cf., Suhm and Jelks 1962:283-284; Davis 1991:244-245; Turner and Hester 1999:227). Unlike the Steiner arrow points discussed above, most of the Perdiz in this sample were made of cherts with possible geologic origins in the Edwards Plateau, although Edwards cherts can also be obtained as outwash from Uvalde gravels in East Texas rivers such as the Brazos, Trinity, Navasota, and Neches.
Additionally, only two (13 percent) appear to have been thermally altered. Here, again, metric data relating to the Perdiz arrow points in this collection are presented in Table 7-1. It should be noted that at least 44 percent of the Perdiz arrow points were made by unifacial working of flakes, a substantially greater proportion than the Steiner arrow points described above.

Perdiz arrow points are common at sites in Central and South Texas, and occur in Caddo sites in the Sabine, Cypress, and Neches-Angelina river basins. Turner and Hester (1999:227) suggest a date range of ca. A.D. 1200-1500. Perdiz is the main arrow point diagnostic of the Toyah phase of Central Texas, dated to ca. A.D. 1300-1700 (Prewitt 1985).

\section{Catahoula Arrow Points}

Twelve of the arrow points in this sample, representing 24 percent of the identified total, were classified as the Catahoula type or probable Catahoula (see Table 7-1).

Table 7-1. Metric Data on Typed Arrow Points from the Lang Pasture Site.

\begin{tabular}{lcccc}
\hline Type & Steiner & Catahoula & Perdiz & Bassett \\
\hline Total Sample & $n=18$ & $n=12$ & $n=16$ & $n=2$ \\
Total Complete & $n=7$ & $n=4$ & $n=11$ & $n=2$ \\
& & & $n=11$ & $n=2$ \\
Weight Sample & $n=7$ & $n=4$ & $0.20-1.45$ & $0.20-3.80$ \\
Weight Range (g) & $0.23-0.98$ & $0.27-0.51$ & 0.69 & 0.29 \\
Weight Mean (g) & 0.45 & 0.45 & & $n=11$ \\
& & & & \\
Length Sample & $n=11$ & $n=5$ & $14.8-28.4$ & $14.2-15.0$ \\
Length Range (mm) & $12.4-22.4$ & $12.9-20.6$ & 22.24 & 14.60 \\
Length Mean (mm) & 16.96 & 15.60 & $n=14$ & $n=2$ \\
& & & & \\
Width Sample & $n=10$ & $n=7$ & $8.8-17.2$ & $10.3-11.7$ \\
Width Range (mm) & $9.7-16.7$ & $14.0-18.4$ & 12.35 & 11.0 \\
Width Mean (mm) & 12.53 & 16.78 & $n=7$ & $n=2$ \\
Unifacial (f) & $n=5$ & $n=3$ & $43.75 \%$ & $100.00 \%$ \\
Unifacial (\%) & $27.78 \%$ & $25.00 \%$ & &
\end{tabular}




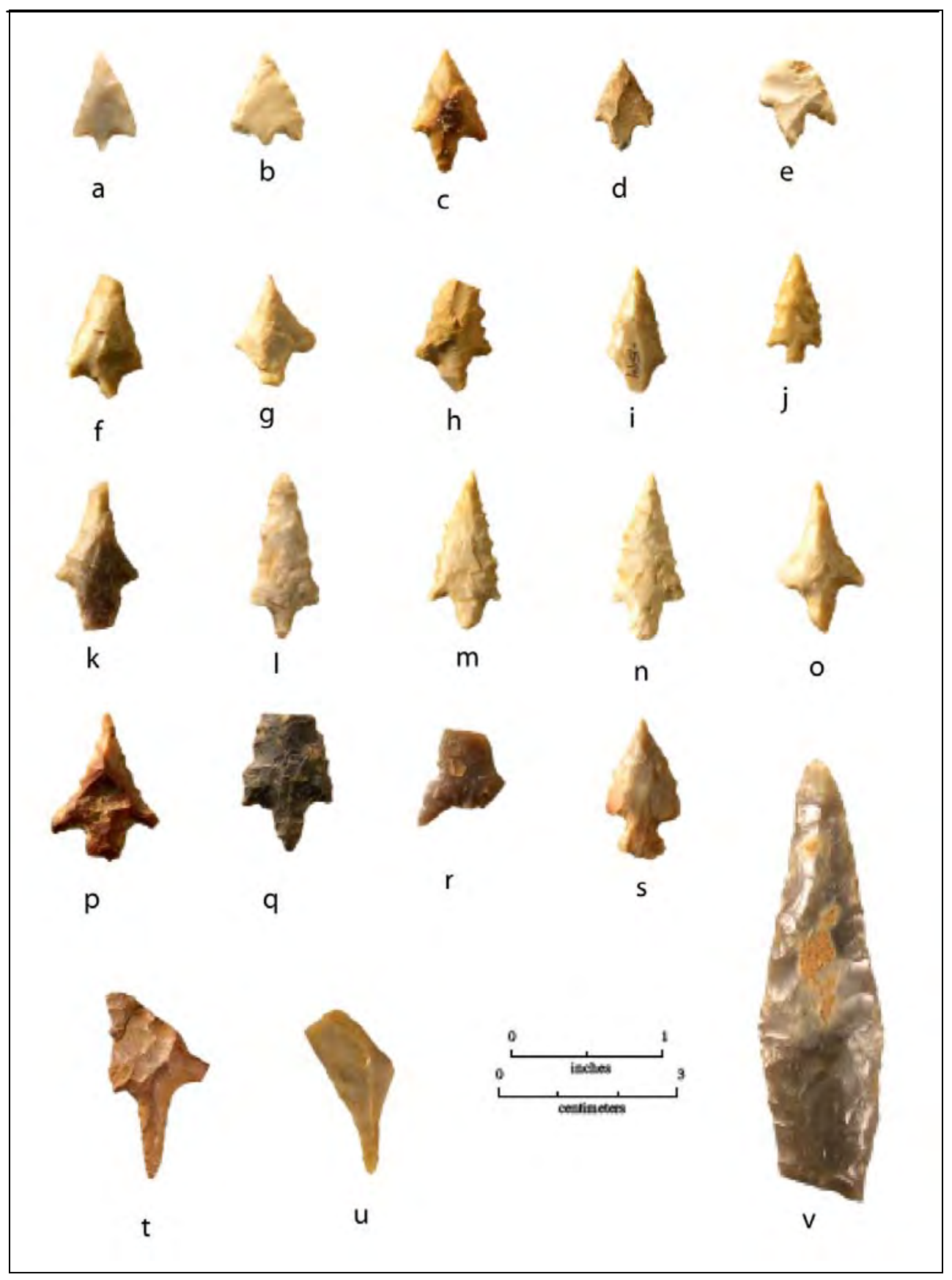

Figure 7-2. Selected Arrow Points and Other Lithic Artifacts Recovered from the Lang Pasture Site (41AN38): a-b, Bassett; c-q, Perdiz; r, s, untyped; t, u, unifacial perforators; $v$, four-beveled biface.

This type (see Figure 7-1p-u) is characterized by its triangular blade; recurved blade edges; prominent barbs with squared ends; and a relatively short, sometimes expanding, stem (cf., Turner and
Hester 1999:206; Davis 1991:202-203; Webb 1981).

Like the Steiner arrow points discussed above, the Catahoula appear to have been 
made primarily of local cherts, quartzites, and silicified woods, with half showing signs of thermal alteration. One Catahoula made of grayish-yellow novaculite is also present in this sample. Several of these arrow points have serrated blade edges resembling, in some respects, the treatment found on some of the Steiner points. Metric data relative to the Catahoula and Steiner arrow points contain similar figures.

The Catahoula points, however, have a somewhat greater average width. Additionally, most of the Catahoula arrow points (75 percent) were not unifacially flaked, which also makes them similar to the Steiner arrow points in this collection.

Catahoula arrow points are normally associated with Coles Creek- and Mississippian-period sites in the Tensas Basin of the Lower Mississippi Valley, where they have been recovered in dated contexts between ca. A.D. 900-1300 (Hunter et al. 1995, 1999). Limited numbers have been found in northwestern Louisiana, several in Formative or Early Caddo Period contexts at Mounds Plantation (Webb and McKinney 1975:Table 3). Catahoula points have also been recovered from sites in East Texas.

\section{Bassett Arrow Points}

Two Bassett arrow points, representing 4 percent of the identified total, were recovered (see Table 7-1 and Figure 7-2a-b). Both are small and feature the triangular blade, pronounced barbs, and small pointed stem characteristic of this type (cf. Suhm and Jelks 1962:265-266; Turner and Hester 1999:201; Davis 1991:194-195). Both were unifacially flaked on flakes, possibly of nonlocal origin (see Table 7-1). The materials include a light gray novaculite and an opaque, white chert.

Bassett arrow points primarily occur at sites in East Texas and adjoining parts of Louisiana. The temporal range in northwestern Louisiana has been given as ca. A.D. 1200-1500 (Webb 1981). In Texas, this type seems to have been in use during the Late Caddo and Historic Caddo periods, with estimated date ranges of ca. A.D. 14001700 (Turner and Hester 1999:201; Davis 1991:194). Apparently, Bassett points were not in use during the early historic period at Caddo sites in Louisiana, based on excavations at the McLelland and Joe Clark sites in Bossier Parish (Kelley 1994).

\section{Other Arrow Points}

Two additional arrow points were recovered that cannot be assigned to established types. The first (Figure 7-2r) has a triangular shape, with a deep concave base, prominent barbs, and distinctive blade notches. One side of the arrow point displays a breakage pattern, commonly referred to as an impact burination. Several Late Caddo sites in the Ouachita Mountain area of west central Arkansas have produced arrow points that appear very similar to the point from the Lang Pasture site. They have the same triangular shape, relatively deep basal concavity, and distinctive blade notches. They were classified as Maud, var. Hopper, arrow points (Early 1988:107-109, 2000:8687).

The second point placed under this heading is made of brown chert (see Figure 7-2s). It has an expanding stem and a rounded base, which makes it similar in appearance to a Bulbar Stemmed (cf., Turner and Hester 1999:203; Davis 1991:198-199). However, that type is common only along the central and southern Texas Gulf coast, far distant from the Lang Pasture site. Because of this, the point is only considered vaguely similar to the type Bulbar Stemmed, a type normally associated with the Late Prehistoric and Historic periods in that general area of Texas (Turner and Hester 1999:203). 


\section{Unclassified Arrow Points}

As noted above, 30 of the arrow points in this collection could not be classified. Most were partial, lacking diagnostic sorting attributes, while others were unfinished. Five of these had attributes similar to Perdiz arrow points, but they could not be sorted as such with any degree of certainty. Four specimens (see Figure 7-1y-bb) have stem shapes similar to Steiner points, but lack the blade-edge serrations/spurs that are distinctive of that type.

\section{Points}

The term "point" is used herein to denote a class of bifacially worked artifacts that have a proximal haft preparation and a pointed distal end. The term "projectile point" implies a specific function-that of the head of a missile, such as a spear, dart, or arrow. Because it is usually impossible to determine the specific use of such artifacts without microscopic analysis and use-wear replication, the latter term, which has this specific functional implication, is avoided. Although some examples of this artifact class might have indeed served as projectile points, many could have also functioned as hafted knives or scraping tools. Thirty-three whole and fragmentary points were classified as belonging to this general artifact category; only 24 (72 percent) were categorized as belonging to a previously identified type. These artifacts are usually be termed "dart points" in the Texas archeologicalliterature (e.g., Turner and Hester 1999).

\section{Andice Points}

Two partial Andice points are in the data recovery sample from the Lang Pasture site (Table 7-2). Both (Figure 7-3h-i) are well made of a light gray chert, possibly derived from the Edwards Plateau. They account for 8 percent of the identified points. One lacks its distal end as well as one barb. The other lacks its stem, one barb, and its distal end.
This type is characterized by its large size, convex blade edges, and deep and narrow basal notches that form a rectangular stem. Its extremely long barbs extend to the base of the point (cf., Prewitt 1983; Turner and Hester 1999:71-72; Davis 1991:26-27). Andice points are typically thin and well made; the extremely large barbs were prone to breakage. Metric data on these two points from the Lang Pasture site are provided in Table 7-2. Andice points are most commonly found in east-central Texas but have been reported southward over large parts of the coastal plain. They date ca. 4050-3050 B.C. (Turner and Hester 1999:71; Davis 1991:26), an interval generally considered to pertain to the Early Archaic in Central Texas (e.g., Prewitt 1985), but more recently (Johnson and Goode 1994; Collins 1995) designated as Middle Archaic, in line with a general time span of ca. 6000-4000 B.P. (cal.) for East Texas (Perttula 2004:9).

\section{Axtell Points}

Axtell is an old type name revitalized by Prewitt and Chandler (1992). This is a small- to medium-sized point with a fairly narrow, triangular blade. The main distinguishing characteristic of this type is its large, bulbous stem formed by shallow corner or side notches. Axtell points occur most frequently in east-central Texas. This type is believed to date to the late part of the Middle Archaic period, from about 30002000 B.C., which would be the early part of the Late Archaic in East Texas It is possible that this point was also in use during the Late Archaic (Prewitt and Chandler 1992; Turner and Hester 1999). Two points in the present sample, representing 8 percent of the identified specimens, were classified as Axtell points (see Figure 7-3a-b and Table 7-2). They were made of brown or brownish gray cherts. No evidence of thermal alteration was noted on either. 


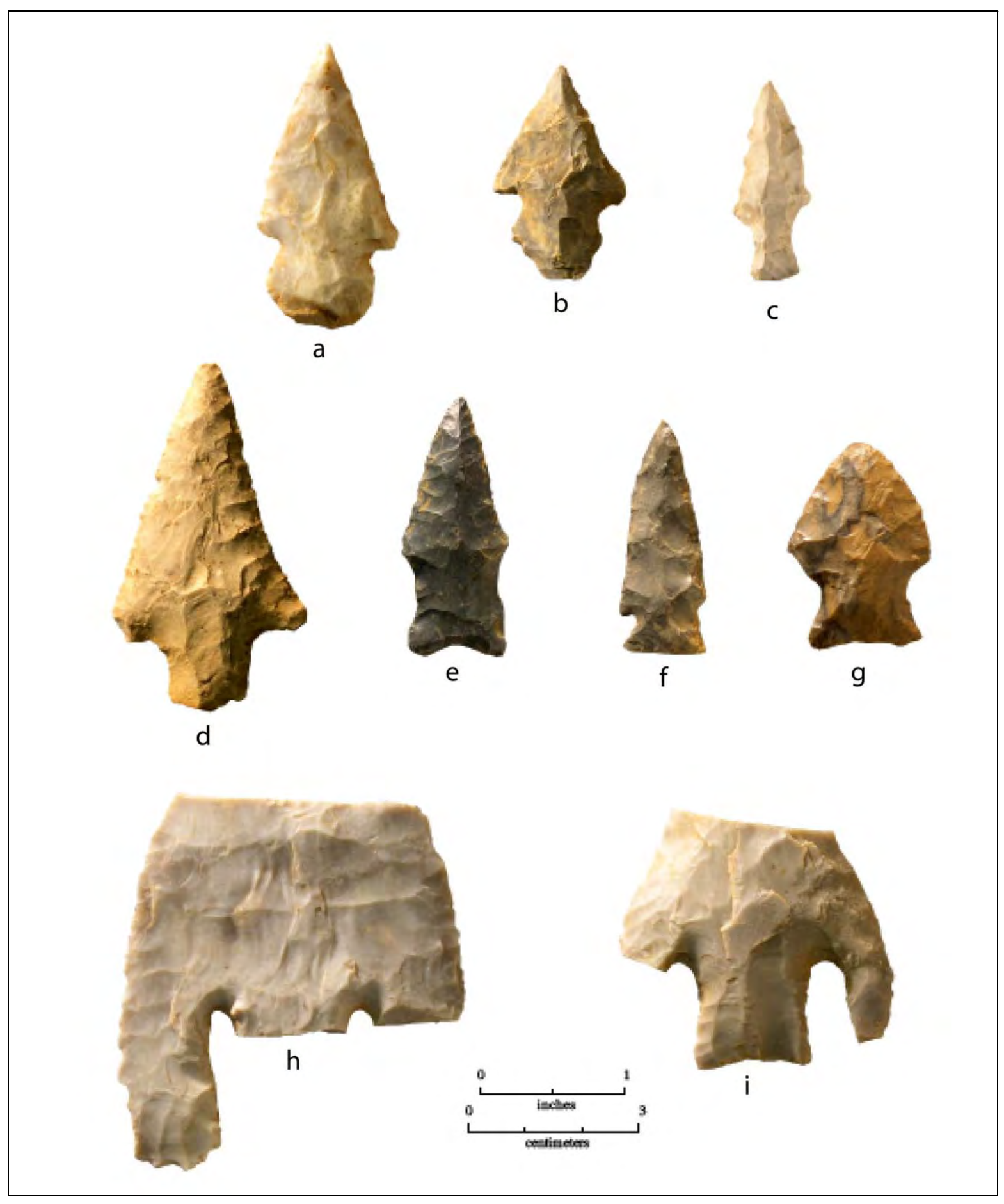

Figure 7-3. Selected Points from the Lang Pasture Site: a-b, Axtell; c, Palmillas; d, Dawson; e, Hoxie; f, Ensor; g, Edgewood; h-i, Andice. 
Table 7-2. Metric Data on Typed Points from the Lang Pasture Site.

\begin{tabular}{|c|c|c|c|c|c|c|c|}
\hline Type & Andice & Axtell & Dawson & Edgewood & \multicolumn{2}{|c|}{ EnsorGaryHoxie } & Palmillas \\
\hline $\begin{array}{l}\text { Total Sample } \\
n=1\end{array}$ & $n=2$ & $n=2$ & $n=2$ & $n=1$ & $n=1$ & $n=8$ & $n=1$ \\
\hline $\begin{array}{l}\text { Total Complete } \\
n=1\end{array}$ & $n=0$ & $n=2$ & $n=2$ & $n=8$ & $n=2$ & $n=2$ & $n=1$ \\
\hline $\begin{array}{l}\text { Weight Sample } \\
n=1\end{array}$ & - & $n=2$ & $n=2$ & $n=1$ & $n=1$ & $n=8$ & $n=1$ \\
\hline $\begin{array}{l}\text { Weight Range (g) } \\
3.70\end{array}$ & - & $4.28-6.44$ & 6.99-9.21 & 5.99 & 3.18 & $1.61-3.0$ & 4.96 \\
\hline $\begin{array}{l}\text { Weight Mean (g) } \\
3.70\end{array}$ & - & 5.36 & 8.1 & 5.99 & 3.18 & 2.18 & - \\
\hline $\begin{array}{l}\text { Length Sample } \\
n=1\end{array}$ & - & $n=2$ & $n=2$ & $n=1$ & $n=1$ & $n=8$ & $n=1$ \\
\hline $\begin{array}{l}\text { Length Range (mm) } \\
44.5\end{array}$ & - & $35.5-47.8$ & $51.2-57.6$ & 34.0 & 38.9 & $21.0-30.5$ & 53.2 \\
\hline $\begin{array}{l}\text { Length Mean (mm) } \\
44.5\end{array}$ & - & 41.65 & 54.4 & 34.0 & 38.9 & 25.45 & 43.2 \\
\hline $\begin{array}{l}\text { Width Sample } \\
n=1\end{array}$ & $n=1$ & $n=2$ & $n=2$ & $n=1$ & $n=1$ & $n=8$ & $n=2$ \\
\hline $\begin{array}{l}\text { Width Range (mm) } \\
17.5\end{array}$ & 56.2 & $22.4-23.9$ & $24.2-33.5$ & 23.5 & 14.6 & $12.0-17.7$ & 17.6 \\
\hline $\begin{array}{l}\text { Width Mean (mm) } \\
17.5\end{array}$ & 5.62 & 23.15 & 28.85 & 23.5 & 14.6 & 15.35 & 17.6 \\
\hline $\begin{array}{l}\text { Unifiacial (f) } \\
n=0\end{array}$ & $n=0$ & $n=0$ & $n=0$ & $n=0$ & $n=0$ & $\mathrm{n}=2$ & $n=0$ \\
\hline Unifacial (\%) & $0.00 \%$ & $0.00 \%$ & $0.00 \%$ & $0.00 \%$ & $0.00 \%$ & $0.00 \%$ & $0.00 \%$ \\
\hline
\end{tabular}

\section{Edgewood Point}

age, dating from ca. 750-300 B.C. Turner and Hester (1999:111) suggest a Transitional Archaic (i.e., ca. A.D. 300-700) temporal placement, a period pertaining to the Woodland period in East Texas.

\section{Ensor Point}

One point, constituting 4 percent of the identified sample, was classified as an Ensor point (see Figure 7-3f and Table 7-2). This type is characterized by a narrow, triangular blade and small corner or side notches that produce a wide expanding stem with a flat base (cf., Suhm and Jelks 1962:189-190; Turner and Hester 1999:114; Davis 1991:76-80). The example from Lang Pasture is small in comparison to most of the as Late Archaic to Transitional Archaic in 
other points in the sample. It is well made and manufactured from a dark gray, almost black, chert presumably of non-local derivation.

Ensor points are common in Central and south-central Texas (Turner and Hester 1999:114; Prewitt 1995:103; Davis 1991). They appear to date to the Late Archaic or Woodland periods with estimated date ranges of ca. 200 B.C.-A.D. 600 (Turner and Hester 1999:114) or ca. 1000 B.C.-A.D. 500 (Davis 1991).

\section{Dawson Points}

According to Turner and Hester (1999:102), this is an East Texas type; they assign it, very roughly, to the "Middle Archaic." Given that these authors generally use Archaic period designations as they have been defined for Central and southern Texas, it is possible that Dawson points fall into the Late Archaic as defined for East Texas (i.e., ca. 4000-2000 years B.P.; see Perttula 2004:9.

One point in the collection (Figure 7-3d) is largely complete and made from a brown chert. Its triangular blade is finely serrated and somewhat asymmetrical, one edge being straight and the other concave. The stem is rectangular with a slightly convex base. Its shoulders are pronounced but not barbed. A second specimen (Figure 7-4o) has distinct but unbarbed shoulders, convex blade edges, and a slightly contracting stem.

\section{Gary Points}

Gary points are primarily found in eastern Texas. Age estimate ranges include Late Archaic to Woodland periods-ca. 2000 B.C.-A.D. 500 (Davis 1991:94) or ca. 2500 B.C.-A.D. 800 (Turner and Hester 1999:123). However, Schambach (1982) dates Gary points ato the period from ca. 500 B.C. to A.D. 700, suggesting that they are best thought of as Woodland period points (see Perttula 2004:9). This is the most numerous of the point types at Lang Pasture $(n=8)$. Several specimens appear to have reworked (and therefore shortened) blade portions (Figure 7-4a-d).

\section{Hoxie Point}

One point, accounting for four percent of the identified sample, is classified as a Hoxie (see Figure 7-3e and Table 7-2). It was made from a dark gray, almost black chert, presumed to be of non-local origin. This is an Early Archaic type, characterized by its long, slender blade, expanding-torectangular stem, weak shoulders, normally concave base, and stem edge grinding (cf., Davis 1991:58-59; Turner and Hester 1999:101). Beveling of the edges and stem occurs on some examples of this type. The point from the Lang Pasture site has ground stem edges and base, but no alternative beveling of the blade. Hoxie points are common in central and south-central Texas. They are thought to date to the latter part of the Early Archaic, ca. 6,000 B.C. (Prewitt 1985; Collins 2004)

Palmillas points have a widespread distribution across the southern half of Texas (Prewitt 1995:125; Turner and Hester 1999:167; Davis 1991:146). They appear to be associated with a date range of ca. 1500 B.C.-500 B.C. (Davis 1991:146), and thus fall into te Late Archaic as defined for East Texas (Perttula 2004:9).

\section{Palmillas Point}

One point, representing 4 percent of the identified total, was classified as a Palmillas point (cf. Suhm and Jelks 1962:229-230; Turner and Hester 1999:167; Davis 1991:146-147) (see Figure 7-3c). It is a relatively narrow point that has wide side notches, an expanding stem, and a rounded base. The point is made of a light gray chert, possibly derived from the Edwards Plateau.It appears to have been resharpened and has hinge stacks on both faces. 


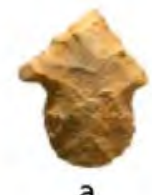

a

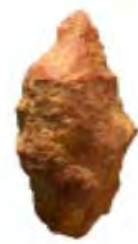

e

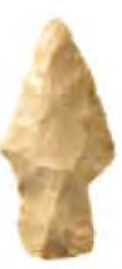

i

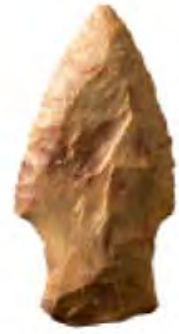

$\mathrm{m}$
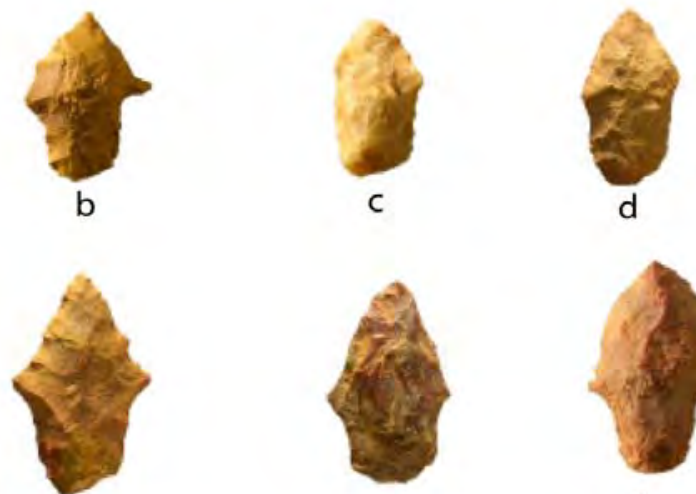

g

f
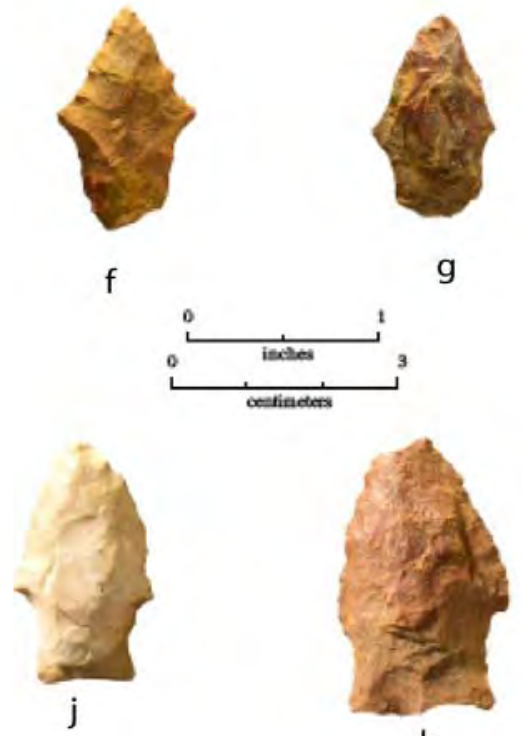

k

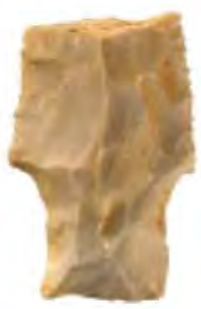

$\mathrm{n}$

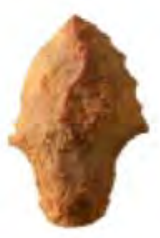

h

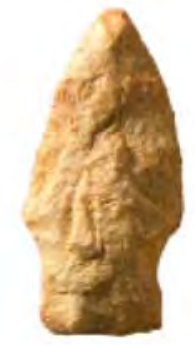

I

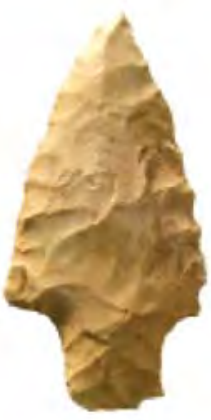

○

Figure 7-4. Selected Points from the Lang Pasture Site: a-h, Gary; j-n, Yarbrough; o, Dawson.

\section{Yarbrough Points}

Six points in the sample ( 25 percent of the identified total) were classified as Yarbrough points (cf. Suhm and Jelks 1962:261-262; Turner and Hester 1999:197; Davis 1991:182-183).
Four are complete, while two are missing the distal ends (see Figure 7-4, i-n and Tables 7-3-7-4). All have relatively narrow, triangular blades; wide, rectangular-toslightly expanding stems; straight-to-slightly convex bases; and weak shoulders formed by broad, shallow side notches. Three were made of light gray chert, perhaps derived from the Edwards Plateau. The remaining 
three were made of thermally altered quartzites and chert.

Yarbrough points most commonly occur in eastern Texas (Davis 1991:182; Prewitt 1995:137; Turner and Hester 1999:196). They probably date to the early part of the Late Archaic as defined in East Texas. Davis (1991:182) suggests a date range for this type of ca. 3000-1000 B.C..

\section{Preforms}

The lithics recovered during the data recovery excavations at the Lang Pasture site included 27 artifacts that have been classified as preforms. Technically, these represent debitage, because they are unfinished items discarded for various reasons. However, they are discussed here with the diagnostic lithic artifacts to facilitate distributional analyses (discussed below) used to identify possible specific use areas within the site. Of the 27, 21 were probably preforms for arrow points, as indicated by their relatively small size, thickness, and general shape, as well as rudimentary stems or barbs on some of the more advanced-stage examples. There is a good deal of variability in this general group. Some were merely flakes that had been trimmed to begin subsequent shaping and thinning. Others had been shaped to the extent of having some of the defining characteristics of arrow points. The remaining six appear to have been for much larger artifacts, such as the dart points described above. Five of these six were broken.

\section{Four-Beveled Biface}

The collection from the Lang Pasture site contains a nearly complete four-beveled biface (cf. Turner and Hester 1999:274-276; Davis 1991:408-409) (see Figure 7-2v). These particular artifacts, sometimes called Harahey Knives (e.g., Johnson 1994) are found in Late Prehistoric and Historic sites throughout Texas and have been commonly found in association with bison kill and processing sites. Age estimates range from ca. A.D. 700-1600 (Davis 1991:408) to ca. A.D. 1300-1750 (Turner and Hester 1999:274). In his Central Texas chronology, Prewitt (1985) assigns this artifact form to the Toyah phase, dating to ca. A.D. 13001700 .

The material is a mottled brown and creamcolored, very fine-grained, chert that was found to fluoresce a strong orange color under ultra-violet light. This strongly suggests that the material is Edwards chert.

\section{Perforators}

Two perforators were recognized in the chipped stone from the Lang Pasture site (see Figure 7-2). Both appear complete and were made from flakes. One was made of a fine-grained thermally altered quartzite; the other was manufactured from a brown chert. Little effort was directed toward shaping these tools. One is merely a long pointed flake that received minimal trimming to form its pointed distal end. The proximal end is considerably wider, evidently to facilitate handling. The other also has an expanding base, the unmodified portion of the parent flake. Somewhat more effort was directed toward shaping its point, which is completely bifacial.

\section{Pitted Stones}

Three pitted stones are in the sample (Figure 7-5a-c). Each is made of a small cobble or tabular fragment of ironstone (ferruginous sandstone), which is locally available. Two of the stones have single pits, the other has one pit on each face.

\section{Palette or Grinding Slab Fragment}

The data recovery sample contains one fairly large tabular fragment of ironstone (see Figure 7-5d). One face has been shaped into a smooth, flat surface. The stone was probably used for shaping implements made 
of bone or wood. There are no grooves on the artifact like those associated with abraders.

\section{Celt Fragment}

The collection from the Lang Pasture site contains one small piece of dark, coarsegrained igneous stone that appears to be a remnant of a ground-stone celt (Figure 7-6). The fragment captures a small part of the bit section, as may be seen in the profile view shown in Figure 7-6. The material is similar to stone found in the St. Francis Mountains of southeastern Missouri, although other source areas possibly exist in the Ouachita Mountain area of western Arkansas, as well, perhaps the most likely source area.

\subsection{DiagnOSTIC ARTIFACT ANALYSIS}

The analysis of diagnostic artifacts from the data recovery excavations at the Lang Pasture site make it possible to make some interpretations concerning the prehistoric occupation of the site. These primarily relate to the number and age of occupations, and also provide some information concerning the distributions of these artifacts across the site.

\section{Number and Age of Occupations}

The diagnostic artifacts in this sample allow some conclusions to be drawn concerning the number and ages of site occupation. Limited use of the site took place during the Early Archaic, as evidenced by the single Hoxie point from the site. Sporadic occupation occurred during the Middle Archaic period, sometime around or after 4000 B.C. This is evidenced by the recovery of two partial Andice points, made of a fine-grained chert, undoubtedly of nonlocal origin.

Several of the point types suggest a slightly more substantial occupation on later Middle Archaic or early Late Archaic time levels, possibly around 3000 B.C. These types include Axtell, Yarbrough, and Palmillas.

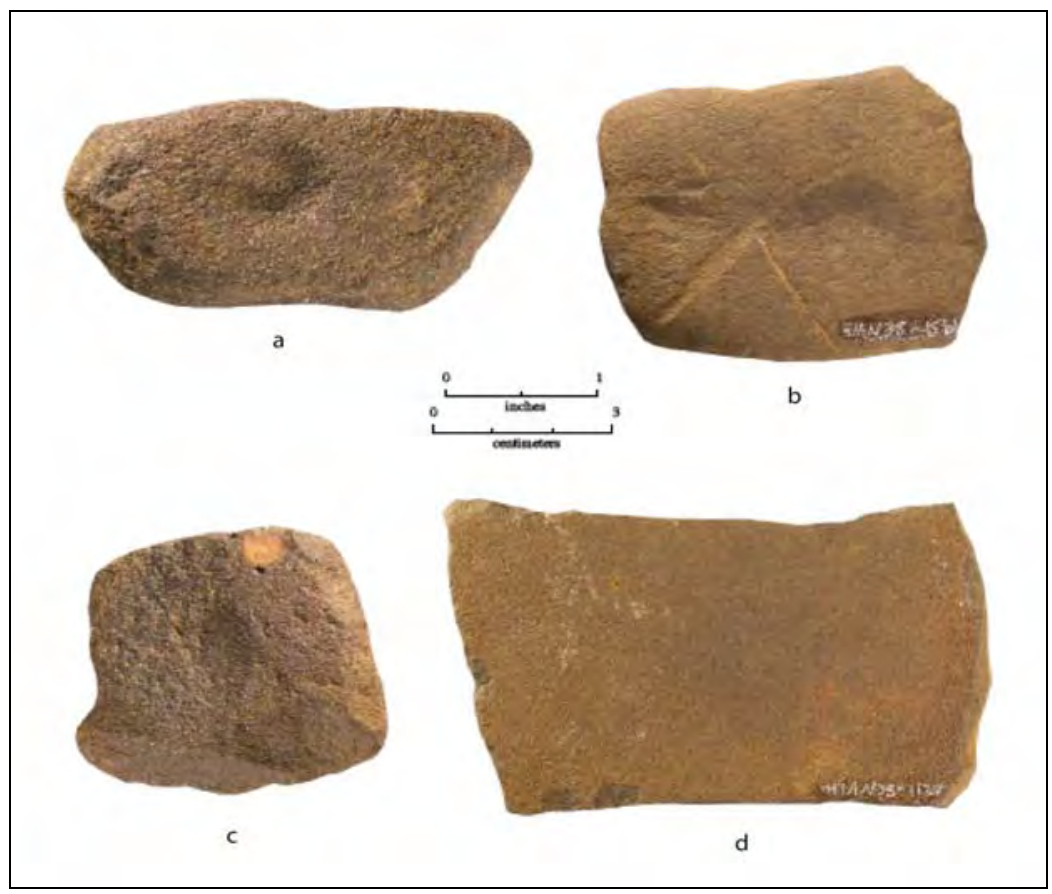

Figure 7-5. Selected Ground-Stone Artifacts from the Lang Pasture Site: a-c, pitted stones; d, palette or grinding slab fragment. 


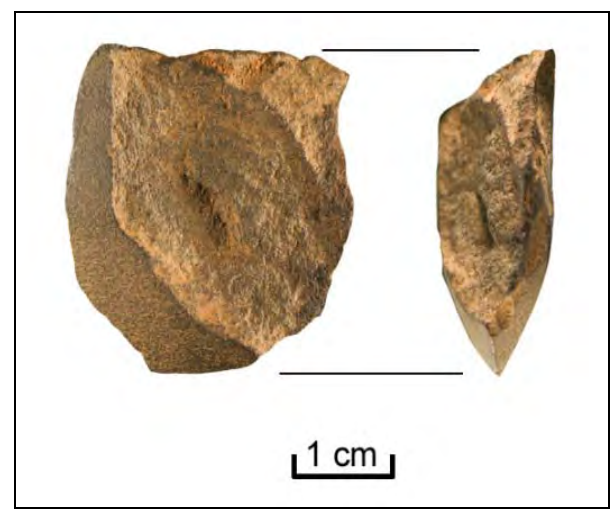

Figure 7-6. Two Views of a Fragment of the Bit Section of a Ground-Stone Celt. The profile view on the right clearly shows the edge of the bit.

There seems to have been a shift towards the use of some local stone at this time, as indicated by several of these points being made of thermally altered pebble cherts and fine-grained quartzites. Sill, some use of imported stone for tools is seen in the occurrence of high quality, light gray (Edwards Plateau?) cherts for making some of the points.

Site occupation seems to have intensified by the middle to latter parts of the Late Archaic period (ca. 1000 B.C.) and lasted, certainly, into the Woodland period. This is suggested by a number of point types, including Ensor, Edgewood, and Gary. Here, too, there seems to have been continued use of local pebble cherts, quartzites, and silicified wood (most thermally altered), in addition to some imported stone. The data at hand suggest that during this general time period, use of Ouachita Mountains novaculite began, albeit on a very limited scale.

It is clear from the shear number of arrow points in the sample that the most substantial occupation of the site occurred on Caddo time levels. The arrow points in this collection have been sorted into four previously established types, including
Bassett, Catahoula, Perdiz, and Steiner. Unfortunately the date ranges for these types have not been precisely delineated. Therefore, it is difficult to ascertain-using the arrow points alone-whether there is one or more Caddo occupations at the site, much less the precise ages of the occupation(s). While the estimated date ranges of some arrow point types seem to overlap in time, several studies have indicated that certain types might be useful for general temporal interpretations. For example, types such as, Scallorn, Catahoula, and Steiner are regarded as being earlier than types such as Perdiz, Maud, and Fresno in north central Texas (Prikryl 1990:Figure 24). Story (1990) maintains that in many parts of eastern and east-central Texas, arrow points with strongly expanded stems, such as Scallorn, Colbert, Homan, or Agee, represent the earliest types. Around A.D. 800 , these begin to be replaced by "forms having slightly expanded or rectangular stems and, on some specimens, elaborations of the blade" (Story 1990:251). These types include Steiner, Catahoula, Friley, Alba, Hayes, and Bonham. According to Story, Perdiz arrow points appear to have been introduced into this region around A.D. 1200 , making them one of the latest types.

Accordingly, the arrow points from the Lang Pasture site could be assigned to early and late groupings, or clusters. The earliest would be composed of the types Catahoula and Steiner. The late cluster would include the Perdiz and Bassett arrow points. Not only do these temporally oriented groupings seem reasonable in light of previous research conducted in the region, but also in regard to other characteristics observed in this sample. First, there was apparently a preference for the use of local stone for making points in the early cluster, as demonstrated by the fact that 74 percent of the stone is thermally altered cherts, quartzites, or silicified wood. In the late cluster, this material category was used for 
only 11 percent of the Bassett and Perdiz arrow points. Furthermore, there seem to have been some technological differences between the two clusters, primarily in the unifacial working of flakes to produce arrow points. In the Bassett/Perdiz cluster, at least 72 percent of the arrow points were made unifacially, as opposed to 35 percent in the Catahoula/Steiner cluster.

With this in mind, it would appear that there are two distinct Caddo occupations at the site represented by the two arrow points groups. The late cluster, composed of Perdiz and Bassett arrow points, would fit the ca. A.D. 1400 Frankston phase date proposed for the Caddo occupation of the site based on the recovered ceramic sherds and vessels, and the majority of the radiocarbon dates. However, most of the classified arrow points (65 percent) appear to date somewhat earlier. How much earlier is impossible to determine at present, because of the lack of precise date ranges for the arrow point types.

It is possible, however, that these clusters have no relation to temporal differences. For example, at Lake Palestine, several Frankston phase sites with possible minor Alto phase or Sanders-like components produced only Perdiz arrow points. Conversely, several of those sites that did not yield Alto or Sanders-like markers had mainly Catahoulas with a good representation of other types, including Friley, Bonham, and Perdiz. Three of the sites, all of which lacked Alto or Sanders ceramic markers, produced only Perdiz arrow points (Anderson et al. 1974:178). The possible temporal implications of these types or clusters is anything but clear and should be a primary research consideration for future archeologicalinvestigations dealing with Caddo developments in this part of Texas.

\section{Horizontal Distributions of Diagnostic Lithics}

One of the tasks undertaken during this analysis involved examining the horizontal distribution of diagnostic lithic artifacts recovered from the hand-excavated units. This was done for several reasons. First, it was undertaken to determine whether temporal markers clustered in different portions of the site. Second, it was done to ascertain whether certain artifacts were associated with particular features or sets of features. Finally, it was hoped that specific activity areas might be defined so that a better understanding of site structure could be obtained. To do this, a base map of the excavation was developed, simply showing the locations of each of the $1 \times 1 \mathrm{~m}$ units (scraped areas were omitted because of limited control in those areas and the relative paucity of artifacts recovered from each). To facilitate a better understanding of site structure, the locations of features were added. On this base map, the probable wall lines of three structures were also shown: Structure 1 being the northernmost, Structure 2 just to the south, and Structure 3 (a possible ramada) being immediately adjacent to Structure 1. Letter symbols were developed for each of the diagnostic artifacts discussed above and simply placed in the corresponding square for the excavation unit from which they were recovered. Counts for diagnostic artifacts recovered during site testing are included for more complete interpretations.

\section{Arrow Points}

The distribution of arrow points within the hand-excavated units is depicted in Figure 77. 


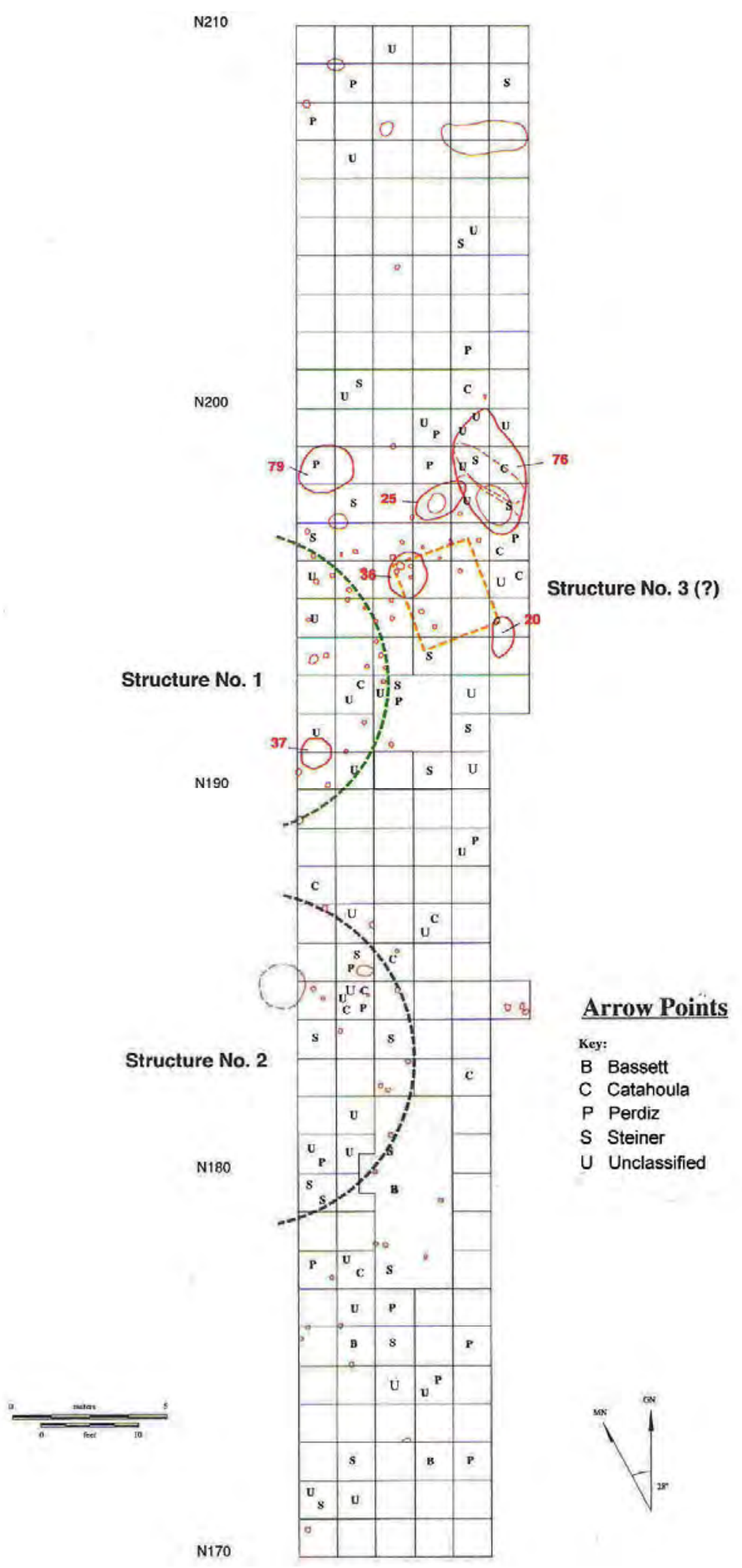

Figure 7-7. Distributions of Typed and Unclassified Arrow Points within the Excavated Area. 
There seems to be a cluster of arrow points in the extreme southern portion of the excavated area, south of the Structure 2 location. This area produced Steiner, Catahoula, Bassett, and Perdiz arrow points. In terms of the arrow point clusters discussed previously, both early $(n=6)$ and late $(n=6)$ groups came from this portion of the site. Another apparent cluster is seen within those units within and around Structure 2 (see Figure 7-7). Whether this represents a concentration distinct from the one previously described is uncertain. Identified types include Steiner, Catahoula, Cuney, and Perdiz. Here, types associated with the early arrow point cluster predominate with 12 being recovered. Later types were limited to three Perdiz and a single Bassett.

Comparatively fewer arrow points were recovered from the excavation units directly associated with Structure 1. Most $(n=6)$ of the arrow points from this area were broken or not finished, precluding them from being classified. Catahoula $(n=1)$, Steiner $(n=2)$, and a single Perdiz point came from this portion of the site. In those units immediately east of the Structure 1 location, three additional Steiner points, one Cuney, a Bassett, and an arrow point similar to a Bulbar Stemmed were also recovered. The two former types are included within the early cluster and if they are spatially related to Structure 2, this could indicate that both houses are about the same age, assuming that the clusters have temporal significance.

A fairly distinct arrow point concentration is seen in and around the Feature 76 locale. Identified types include Perdiz, Catahoula, Steiner, and Cuney. Here again, earlycluster types $(n=7)$ predominate over latecluster types $(n=4)$. This could be interpreted as meaning that the concentration in the Feature 76 area is roughly contemporaneous to those possibly associated with the two structures.

\section{Points}

The distribution of (non-arrow) points recovered from the Lang Pasture site is presented in Figure 7-8. As can be seen, there seems to be a small concentration of Late or Archaic or Woodland types in the Structure 2 vicinity, although the association with that structure is undoubtedly fortuitous. Identified types include, Edgewood $(n=1)$, Ensor $(n=1)$, and Gary $(n=4)$.

A second apparent concentration is in the vicinity of Feature 76 . Six of the points were either fragmentary or unfinished, precluding them from being classified. Six others were identified and included Hoxie $(n=1)$, Gary $(n=2)$, Axtell $(n=1)$, and Yarbrough $(n=2)$. This concentration is somewhat difficult to explain given the fact that a number of arrow points were also recovered from this specific locale. Perhaps the relatively high number of points (mainly Archaic types) reflects the amount of relatively deep excavation done by the Caddo in this area in order to expose and excavated the large pit, Feature 76 . In viewing Figure 7-8, it can be seen that types normally associated with the Early, Middle, and Late Archaic/Woodland periods are scattered over most of the site area sampled by the excavation units.

\section{Preforms}

The distribution of preforms is illustrated in Figure 7-9. Counts are not available for those units excavated during site testing, so those numbers are not shown. What appears to be a slight concentration can be seen within those units associated with Structure 2. Three have been classified as arrow point preforms, while the remainder are too fragmentary to classify.

One definite concentration of preforms, all seemingly intended for arrow points, is seen in the Feature 76 locale. This occurrence cannot be explained with the data at hand. 


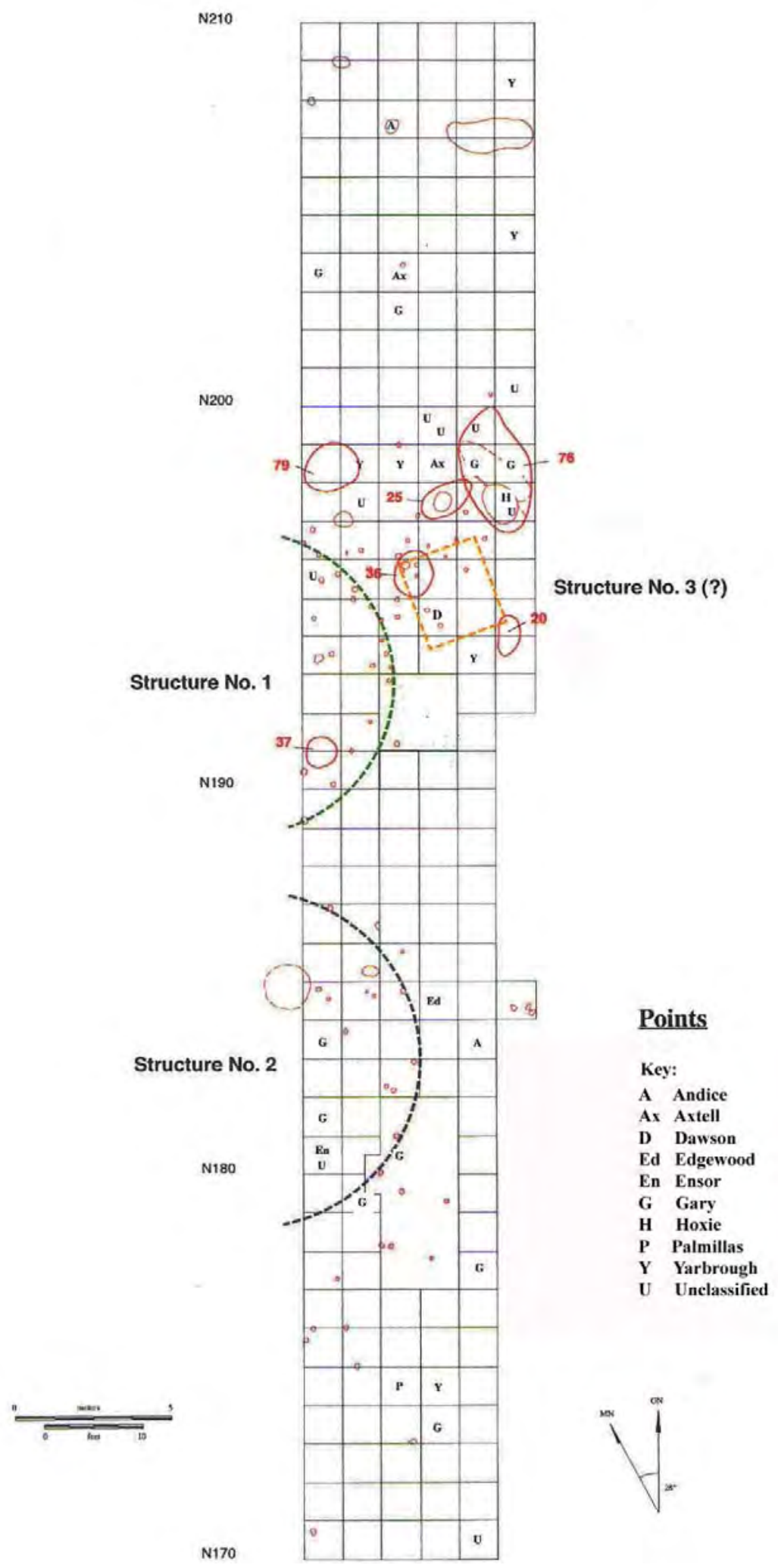

Figure 7-8. Distributions of Dart Points within the Excavations at Lang Pasture. 
As noted above, relatively high frequencies of both dart points and arrow points came from this specific portion of the site

\section{Other Artifacts}

The distributions of the other lithic artifacts are also illustrated in Figure 7-9. Interpretations relating to these categories are even harder to make given the low frequencies in each class. The three pitted stones came from a very limited area of the excavations bounded by the N197 and N201 lines. This seems to indicate a specialized activity locus. Unfortunately, pitted stones are not good temporal markers; it is, therefore, impossible to relate this apparent activity locus to a particular segment of site occupancy.

As noted earlier, only two perforators were recovered during the data recovery excavations. One came from a unit situated within Structure 2. The other was in one of the northern excavation units.

The remaining artifacts under consideration include the possible celt fragment and the four-beveled biface. The former was recovered from Feature 76 in Unit N198E203. An association with a particular segment of site occupancy cannot be made. The four-beveled biface came from a unit just outside the Structure 2 wall line. However, whether that artifact is directly associated with that structure is unknown.

\section{Debitage Analysis}

As mentioned previously, the excavations at the Lang Pasture site produced a large sample of debitage. As used herein, the term debitage refers to all chipped stone that was not completed into a finished tool and the waste products derived from the lithic reduction process. Debitage analysis is usually undertaken for two primary purposes. The first is to examine the actual processes used in making chipped stone tools, while the second is to determine the range of lithic reduction that was being conducted on site. The latter is often useful in interpreting site function. The analytical procedure used in this study places the debitage into one of several categories that can be assumed to be associated wit a particular processual stage in working stone. These categories are defined in Table 7-3.

As noted previously, only a sample of the debitage from the Lang Pasture site was analyzed. The reason for doing so stemmed from the fact that it was impossible to isolate discrete samples that could be associated with a particular segment of site occupancy. The sandy nature of the soils at the site and natural and man-induced disturbances caused cultural deposits to become mixed, thereby eliminating the research potential for much of the debitage obtained from the hand-excavated units. However, it was believed that the debitage in some of the features might be associated with a specific component and could provide some information on the related segment of site occupancy. The following features were selected because they are believed to be associated with the Late Caddo Frankston phase occupation of the site and they appeared little disturbed (for quantities and percentages of debitage from these features, see Table 7-4).

\section{Debitage Samples}

\section{Feature 20}

Feature 20 was interpreted as a mediumsized pit located approximately $3 \mathrm{~m}$ east of Structure 1 near the corner of Structure 3 (see Figure 7-7). Two radiocarbon samples from this feature produced two calibrated 2sigma dates of AD 1290-1420 (calibrated intercepts: AD 1320, 1350, and 1390) and AD 1450-1650 (calibrated intercepts: AD 1500, 1600, and 1610). 


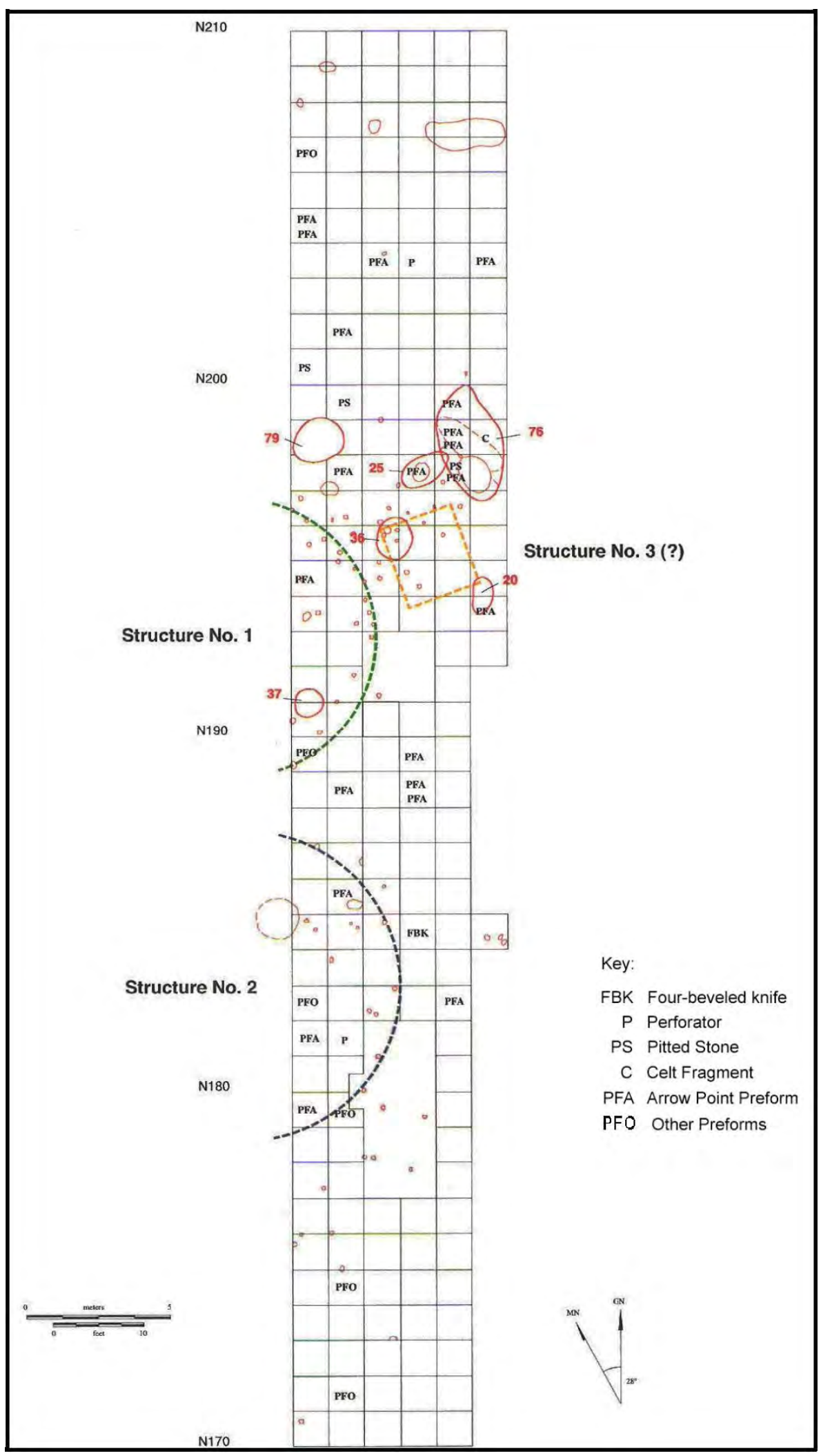

Figure 7-9. Distributions of Miscellaneous Lithic Tools in Lang Pasture Excavations. 
Table 7-3. List of Definitions for Kinds of Debitage from the Lang Pasture Site.

Flakes: Pieces of stone that have been removed from a core, preform, or tool, either by pressure or percussion techniques. Flakes normally have only two faces: (1) a dorsal face, which either bears scars from previous flake removal or cortex and (2) the ventral face. The ventral face is more or less flat to somewhat concave and commonly features a bulb of force, ripples, and radial fissures that result from force passing through the stone when struck from the parent rock.

Primary Flakes: Flakes that have greater than an estimated one-half of the dorsal surface covered by cortex.

Secondary Flakes: Flakes that have less than an estimated one-half of the dorsal surface covered by cortex.

Tertiary Flakes: Flakes that lack cortex and do not have multifaceted platforms or other characteristics of bifacethinning flakes (see below).

Biface-Thinning Flakes: Flakes that lack cortex and display scars on the dorsal surface resulting from previous flake removal. They are distinguished by a distinctive "lipped" or multifaceted platform that was actually a portion of the opposite face of the biface from which they were removed. Biface-thinning flakes are normally associated with latestage reduction in producing bifacial artifacts.

Notching Flakes: Similar to biface-thinning flakes. However, they are characterized by their relatively small size and by their distinctive, concave, proximal ends adjoining an unusually small, multifaceted platform. As the name implies, they are derived from notching artifacts, typically bifaces, for hafting purposes.

Interior Flakes: Flakes that lack cortex and intact striking platform remnants. Most are probably broken tertiary or biface-thinning flakes.

Blades: A "specialized flake with parallel or sub-parallel lateral edges; the length being equal to, or more than, twice the width" that was "associated with a prepared core and blade technique" (Crabtree 1972:42).

Blade Flakes: Resemble blades in terms of length/width ratios, parallel or roughly parallel edges, triangular or trapezoidal cross section, etc. However, they were not produced from specialized cores as indicated by their striking platforms.

Preforms: Represent intermediate stages between cores and finished tools. The division between early stage performs and late stage cores is often subjective. Generally, performs have been thinned substantially more and have assumed more of the general outline of the finished tool. Some performs are derived from flakes.

Unclassified Bifaces: Small fragments of stone bifaces that cannot be categorized to a particular artifact or debitage class.

Blocky Debitage: Angular pieces of stone that lack flake characteristics and typically feature little or no cortex. Larger examples do not appear to be expended cores. The smaller specimens represent what some researchers refer to as "shatter."

Pebble: A rounded water worn nodule of stone measuring between 4 and $64 \mathrm{~mm}$ in diameter (Bates and Jackson 1980:460).

Fractured Pebbles: Pieces of split or broken pebbles. This category includes examples that range from fragments greater than half the pebble to those that are flake size. Regardless of size, all have large amounts of remaining cortex and lack characteristics normally associated with flakes.

Tested Pebbles: Essentially pebbles from which only one or two flakes have been removed. They are believed to represent one of the earliest stages in the lithic reduction process. The removal of these initial flakes would have allowed the knapper to inspect the quality of the stone to determine its suitability for flaking. 


\section{Feature}

No. Flotation Samples

Total Volume (liters)

Sample (frequency)

Density (frequency/liter)

Sample $>1 / 4$-inch (frequency)

Sample $<1 / 4$-inch (frequency)

Materials (frequency)

Chert

Novaculite

Quartzite

Silicified Wood

Thermally-Altered Chert

Thermally-Altered Quartzite

Thermally Altered

Non-Thermally Altered

Form (frequency)

Primary Flakes

Secondary Flakes

Tertiary Flakes

Biface-Thinning Flakes

Notching Flakes

Interior Flakes

Blade Flakes

Blades

Preforms

Unclassified Bifaces

Blocky Debitage

Fractured Pebbles

Tested Pebbles

Table 7-4. Quantities and Percentages of Lithic Materials from Features, Lang Pasture Site.

\section{5}

5
33.0
54

1.64

$15 \quad 27.78 \%$

$39 \quad 72.22 \%$

20

$37.07 \%$

$5.56 \% \quad 14 \quad 14.58 \%$

$\begin{array}{lll}9.26 \% & 6 & 6.25 \%\end{array}$

$7.41 \% \quad 2 \quad 2.08 \%$

$3.70 \% \quad 9 \quad 9.38 \%$

$37.04 \% \quad 31 \quad 32.29 \%$

$54100.00 \% 96 \quad 100.00 \%$

$22 \quad 40.74 \% \quad 40 \quad 41.67 \%$

$59.26 \% \quad 56 \quad 58.33 \%$

$\begin{array}{lcl}0.00 \% & 1 & 1.04 \% \\ 3.70 \% & 5 & 5.21 \% \\ 3.70 \% & 6 & 6.25 \% \\ 14.81 \% & 19 & 19.79 \% \\ 0.00 \% & 2 & 2.08 \% \\ 55.56 \% & 45 & 46.88 \% \\ 0.00 \% & 0 & 0.00 \% \\ 0.00 \% & 0 & 0.00 \% \\ 1.85 \% & 0 & 0.00 \% \\ 0.00 \% & 2 & 2.08 \% \\ 12.96 \% & 9 & 9.38 \% \\ 1.85 \% & 1 & 1.04 \% \\ 0.00 \% & 0 & 0.00 \%\end{array}$

36

3

17.8

81

4.55

$7 \quad 8.64 \%$

$74 \quad 91.36 \%$

$37 \quad 45.68 \%$

$18 \quad 22.22 \%$

$2 \quad 2.47 \%$

$3 \quad 3.70 \%$

$11 \quad 13.58 \%$

$81 \quad 100.00 \%$

$22 \quad 27.16 \%$

$59 \quad 72.84 \%$
$10 \quad 12.35 \%$

76A

4

29.0
31

1.07

1.51

$27.69 \%$

24 92.31\%

$14 \quad 45.16 \%$

$17 \quad 54.84 \%$

$\begin{array}{llcc}7 & 26.92 \% & 13 & 41.94 \% \\ 6 & 23.08 \% & 2 & 6.45 \% \\ 1 & 3.85 \% & 0 & 0.00 \% \\ 0 & 0.00 \% & 2 & 6.45 \% \\ 2 & 7.69 \% & 3 & 9.68 \% \\ \underline{10} & \underline{38.46 \%} & \underline{11} & \underline{35.48 \%} \\ 26 & 100.00 \% & 31 & 100.00 \% \\ 12 & 46.15 \% & 14 & 45.16 \% \\ 14 & 53.85 \% & 17 & 54.84 \%\end{array}$

$1 \quad 1.23 \%$

$6 \quad 7.41 \%$

$4 \quad 4.94 \%$

$24 \quad 29.63 \%$

$0 \quad 0.00 \%$

$29 \quad 35.80 \%$

$0 \quad 0.00 \%$

$0 \quad 0.00 \%$

$0 \quad 0.00 \%$

$1 \quad 1.23 \%$

$9 \quad 11.11 \%$

$0 \quad 0.00 \%$

$0 \quad 0.00 \%$

$\begin{array}{ll}1 & 3.85 \% \\ 1 & 3.85 \% \\ 2 & 7.69 \% \\ 7 & 26.92 \% \\ 0 & 0.00 \% \\ 9 & 34.62 \% \\ 0 & 0.00 \% \\ 0 & 0.00 \% \\ 0 & 0.00 \% \\ 0 & 0.00 \% \\ 2 & 7.69 \% \\ 1 & 3.85 \% \\ 0 & 0.00 \%\end{array}$
$13.23 \%$
$26.45 \%$
$3 \quad 9.68 \%$
$10 \quad 32.26 \%$
o $0.00 \%$
$11 \quad 35.48 \%$
$0 \quad 0.00 \%$
$0 \quad 0.00 \%$
$0 \quad 0.00 \%$
$0 \quad 0.00 \%$
$3 \quad 9.68 \%$
$0 \quad 0.00 \%$
$0 \quad 0.00 \%$

76

$\begin{array}{cl}4 & 10 \\ 29.0 & 80.6 \\ 65 & 143\end{array}$

2.24

1.77

$15 \quad 23.08 \%$

$50 \quad 76.92 \%$

$26 \quad 18.18 \%$

117 81.82\%

$\begin{array}{cccc}27 & 41.54 \% & 74 & 51.75 \% \\ 7 & 10.77 \% & 26 & 18.18 \% \\ 3 & 4.62 \% & 7 & 4.90 \% \\ 1 & 1.54 \% & 3 & 2.10 \% \\ 5 & 7.69 \% & 9 & 6.29 \% \\ \underline{22} & \underline{33.85} \% & \underline{24} & \underline{16.78 \%} \\ 65 & 100.00 \% & 143 & 100.00 \% \\ 27 & 41.54 \% & 33 & 23.08 \% \\ 38 & 58.46 \% & 110 & 76.92 \%\end{array}$

$\begin{array}{cclc}0 & 0.00 \% & 1 & 0.70 \% \\ 0 & 0.00 \% & 14 & 9.79 \% \\ 12 & 18.46 \% & 8 & 5.59 \% \\ 12 & 18.46 \% & 38 & 26.57 \% \\ 1 & 1.54 \% & 0 & 0.00 \% \\ 29 & 44.62 \% & 65 & 45.45 \% \\ 0 & 0.00 \% & 0 & 0.00 \% \\ 0 & 0.00 \% & 1 & 0.70 \% \\ 0 & 0.00 \% & 1 & 0.70 \% \\ 0 & 0.00 \% & 0 & 0.00 \% \\ 9 & 13.85 \% & 8 & 5.59 \% \\ 0 & 0.00 \% & 2 & 1.40 \% \\ 0 & 0.00 \% & 0 & 0.00 \%\end{array}$




\section{Feature}

Fire Spalls

Flakes

Other

Cortical Flakes

Non-Cortical Flakes

Edge-Modified Debitage

Diagnostic Lithics

Table 7-4, continued.

$\underline{3} \quad \underline{5.56} \%$

6 $\quad \underline{6.25} \%$

$54 \quad 100.00 \%$

$96100.00 \%$

$77.78 \%$

$12 \quad 22.22 \%$

$24.76 \%$

$40 \quad 95.24 \%$

\begin{tabular}{ll}
$78 \quad 81.25 \%$ \\
\hline
\end{tabular}

$18 \quad 18.75 \%$

$6 \quad 7.69 \%$

$2 \quad 3.70 \%$

$0 \quad 0.00 \%$

None

None
36

37

$7 \quad 8.64 \%$

81100.00

$64 \quad 79.01 \%$

$17 \quad 20.99 \%$

$7 \quad 10.94 \%$

$57 \quad 89.06 \%$

$1 \quad 1.23 \%$

None
76A

3 $\quad \underline{11.54} \%$

$26 \quad 100.00 \%$

$20 \quad 76.92 \%$

$6 \quad 23.08 \%$

$2 \quad 10.00 \%$

$18 \quad 90.00 \%$

$0 \quad 0.00 \%$

None
76

79 
Feature 20 yielded no diagnostic lithic artifacts; however, one very crude preform possibly intended for a Gary point was in the flotation sample from $50-60 \mathrm{~cm}$. The debitage consisted of 54 pieces of stone obtained from five flotation samples totaling 33.0 liters. This indicated a density of 1.64 pieces of debitage per liter of soil. As a normal part of the lithic analysis, this sample (and all of the other flotation samples) was screened through $1 / 4$ inch wire mesh prior to sorting. Roughly 28 percent of the debitage was greater than $1 / 4$ inch in maximum dimension; whereas, about 72 percent was less than $1 / 4$ inch.

The debitage from Feature 20 included all six of the material types that were common at the site. These include chert, novaculite, quartzite, silicified wood, thermally altered chert, and thermally altered quartzite. Novaculite and thermally altered chert were only present in the less than $1 / 4$ inch sample. Evidence of heat treating was present on 41 percent of the debitage.

Frequencies and percentages of the various debitage categories represented in Feature 20 are presented in Table 7-4. Nothing unusual is seen in the relative frequencies of the various forms. Flakes account for 78 percent of the collection, while other categories comprise 22 percent. Only 5 percent of the flakes had cortex. There were only two pieces of edgemodified debitage in the sample, representing 4 percent of the collection.

\section{Feature 25}

Feature 25 is believed to represent an outdoor hearth, which was situated roughly $3 \mathrm{~m}$ northeast of Structure 1 and about $1 \mathrm{~m}$ north of Structure 3 (see Figure 7-7). A single calibrated radiocarbon date of AD 1290-1420 (2-sigma) with calibrated intercepts of $\mathrm{AD}$ 1320, 1350, 1390 was obtained from Feature 25.

Feature 25 yielded no diagnostic lithic artifacts. All of the debitage (96 pieces) was obtained from 11 flotation samples totaling 80.8 liters. This gave a density of 1.18 pieces of debitage per liter of soil, similar to the density in Feature 20. When screened through $1 / 4$-inch wire mesh, the sample was found to have 22 pieces (23\%) greater than $1 / 4$ inch in maximum dimension and 74 (77\%) less than $1 / 4$ inch.

The debitage in Feature 25 seems fairly typical of the rest of the features in terms of material type. All six major material types were present: chert, novaculite, quartzite, silicified wood, thermally altered chert, and thermally altered quartzite, each represented in both the greater than $1 / 4$ inch and less than $1 / 4$ inch samples. Evidence of heat treating was noted on 42 percent of the collection.

Table 7-4 lists the frequencies and percentages of the various debitage categories in Feature 25. There were two notching flakes in this sample. Both were yellowish-brown novaculite. The maximum widths of the notches were $1.5 \mathrm{~mm}$ and $3.3 \mathrm{~mm}$, suggesting they resulted from arrow point production. Again, nothing is unusual in terms of the various represented types, with one notable exception. There were only six fire-spalled pieces of debitage in the sample, which is extremely low when considering the suggested function of Feature 25 as an outdoor hearth. That is unless the debitage in Feature 25 is intrusive into the feature after its abandonment. Regardless, flakes account for 81 percent of the collection, while other categories comprise 19 percent. Cortex was present on 8 percent of the flakes. There was no edge-modified stone in the sample.

\section{Feature 36}

Feature 36 (see Figure 7-7) was located about $1 \mathrm{~m}$ northeast of Structure 1 and within or immediately adjacent to Structure 3. It was interpreted as either a smudge pit or a hearth. Two radiocarbon samples from Feature 36 produced calibrated 2-sigma dates of AD 1400-1450 (calibrated intercept: AD 1430) 
and AD 1300-1450 (calibrated intercept: AD 1420). There were no diagnostic lithic artifacts in Feature 36.

Most of the debitage (81 pieces) was obtained from three flotation samples totaling 17.8 liters. This resulted in a ratio of 4.55 pieces of debitage per liter, which is substantially greater than any of the other features examined as a part of this analysis. When screened through 1/4-inch hardware cloth, it was found that 9 percent was greater than $1 / 4$ inch in maximum dimension, while 91 percent was less than $1 / 4$ inch. There were eight pieces of debitage from two hand-excavated proveniences in Feature 36. These were eliminated from this analysis because of the small sample size.

The lithic materials present in Feature 36 were fairly typical in comparison to the other features examined. Chert, novaculite, quartzite, silicified wood, thermally altered chert, and thermally altered quartzite were present. Of some interest is the occurrence of an interior flake of dark oolitic chert in the hand-excavated sample. The stone contains numerous white microfossils and has transparent thin edges. It resembles descriptions of Pisgah Ridge chert, which is found in a very limited area of east central Texas near Richland in Navarro County (Banks 1990:52). One noticeable difference in the materials in Feature 36 is the low relative frequency of heat-treated material, only 27 percent. As discussed below, the only feature in which a similar percentage of thermally altered stone occurred was Feature 79.

\section{Feature 37}

Feature 37 was located within the wall lines of Structure 1 in its southeastern quadrant (see Figure 7-6). It was interpreted as a possible food-storage pit. A single calibrated 2-sigma radiocarbon age range of AD 1400-1450 (calibrated intercept: AD 1430) was obtained from Feature 37.

Feature 37 produced no diagnostic lithic artifacts. The debitage sample included 13 pieces of stone from hand-excavated contexts and an additional 26 pieces from two flotation samples totaling 2.5 liters. The flotation samples indicate a density of 1.51 pieces of debitage per liter of soil, which is comparable to most of the other features.

This is very small sample and any generalizations should be considered accordingly. It appears that there is no noticeable difference in the material types, the represented debitage forms, or the percentage of thermally altered stone in this feature. Nor is there anything noteworthy in the handexcavated sample, except a rather large notching flake of black chert that measures 8.3 $\mathrm{mm}$ long and $9.1 \mathrm{~mm}$ wide, larger than what would be expected in arrow point production.

\section{Feature 76A}

Feature $76 \mathrm{~A}$ is a part of the Feature 76 complex located approximately $4 \mathrm{~m}$ northeast of Structure 1 (see Figure 7-6). It was interpreted as a large storage pit. A single radiocarbon sample produced calibrated 2sigma date ranges of AD 1050-1090, 11301140 , and $1140-1260$ with a single calibrated intercept of AD 1210.

Feature 76A produced two diagnostic lithic artifacts. The first was a Hoxie point at a depth of 100-110 cm. The second was a Steiner arrow point (110-120 cm). Additionally, an unclassified biface that appears to have been part of a point perform was recovered between 140-150 cm. These occurrences indicate that (1) the feature contains materials that predate the Caddo occupation(s) of the site and (2) there was mixing of these deposits, both compromising interpretations attempted from the debitage.

The debitage from Feature 76A includes 36 pieces of stone from hand-excavated contexts and 31 more from four flotation samples totaling 29.0 liters. The density of the debitage in the flotation samples was 1.07 pieces per liter of soil, which is comparable to that occurring in most of the other features examined in this study. 
Here, again, nothing in the flotation samples seems unusual as regards types of materials present, represented forms, percentages of thermally altered chert, or the like. The only thing that is of some interest is the high percentage (45 percent) of the sample in the greater than $1 / 4$-inch size category. This could be related to the presence of earlier materials in Feature 76A, if not, in effect, related to the extremely small sample size.

In comparing the hand-excavated debitage from Feature $76 \mathrm{~A}$ to the sample recovered during flotation, nothing out of the ordinary is seen, with the exception of the high relative frequency (46 percent) of cortical flakes. This is substantially higher than any of the other features, including the hand-excavated samples from Features 76 and 79 (discussed below). An explanation for this is impossible with the data at hand. One biface thinning flake in the hand-excavated sample was a dark gray, almost black, chert with numerous white microfossils, possibly another example of Pisgah Ridge chert. Sizes of complete flakes in the hand-excavated sample are provided for additional comparisons.

\section{Feature 76}

Feature 76 was interpreted as a large storage pit that was subsequently used for burials. It was approximately $4 \mathrm{~m}$ northeast of Structure 1 (see Figure 7-6). Two of the radiocarbon samples from Feature 76 produced 2-sigma calibrated date ranges of AD 1300-1370 and AD 1380-1430 (calibrated intercept: AD 1400) and AD 1300-1370 and A.D. 1380-1430 (calibrated intercept: AD 1400). A third radiocarbon date was much later and possibly was contaminated with recent organics.

Feature 76 yielded three diagnostic lithic artifacts. The first was a Perdiz arrow point $(70-80 \mathrm{~cm})$; the second was a Steiner arrow point $(110-120 \mathrm{~cm})$; and the third was a Gary point $(120-130 \mathrm{~cm})$. The latter artifact indicates that some of the debitage in Feature 76 might predate the Caddo occupation(s) of the site.
The debitage from Feature 76 included 149 pieces of stone from hand-excavated contexts and another 65 from four flotation samples totaling 29.0 liters. The density of the lithics in the flotation sample was 2.24 pieces per liter of soil, a figure comparable to most of the other features examined herein. The flotation sample had 23 percent of the debitage in the greater than $1 / 4$-inch size category and 77 percent in the less than $1 / 4$-inch size group.

Nothing seems unusual about the flotation sample in regard to the material types, the amount of thermally altered stone, the represented forms, etc. One interesting observation is the complete lack of cortical flakes. This is obviously related to the small size of the collection, because cortical flakes were present in the hand-excavated debitage.

As noted above, the hand-excavated debitage from Feature 76 included 149 pieces of stone, In comparing the hand-excavated samples from Features 76 and $76 \mathrm{~A}$, there appear to be no notable differences in material types, amounts of thermally altered stone, represented forms, etc. Flake sizes seem comparable also. However, Feature 76 yielded six pieces of dark gray, almost black, chert containing numerous white microfossils (evidently Pisgah Ridge chert) occurring as biface-thinning and interior flakes. Also, Feature 76 produced a very large notching flake that was evidently derived from the production of a biface significantly larger than an arrow point. That notching flake measured $9.0 \mathrm{~mm}$ long and $11.2 \mathrm{~mm}$ wide.

\section{Feature 79}

Feature 79 was interpreted as a large pit. It was located approximately $2 \mathrm{~m}$ north of Structure 1 (see Figure 7-7). One of the two radiocarbon samples from Feature 79 produced a calibrated 2-sigma date range of AD 1260-1320 and AD 1350-1390 (calibrated intercept: AD 1290). The second yielded a calibrated 2-sigma date of AD 570-660 (cal. intercept: AD 640), which seems too early. The first date suggests that Feature 79 might predate many of the other features thought to 
be associated with the Frankston phase occupation of the site. The only diagnostic lithic artifact in Feature 79 was a Perdiz arrow point recovered from $60-70 \mathrm{~cm}$.

Most of the debitage obtained from Feature 79 ( $n=143)$ came from 10 flotation samples totaling 80.6 liters. This indicated a density of 1.77 pieces of stone per liter of soil. Approximately 18 percent of this sample was greater than $1 / 4$-inch in maximum dimension, while 82 percent was less than $1 / 4$-inch.

Nothing unusual is seen in regard to the materials, represented forms, etc. One thing of some interest is the low relative frequency of non-thermally altered material (23 percent) in this sample. This is comparable to Feature 36 (discussed above). As noted above, the hand-excavated samples contained only 36 pieces of debitage. It is somewhat interesting to observe that this collection contained 47 percent heat-treated stone, as opposed to 23 percent in the flotation samples. Possibly, this disparity is related to the small size of the hand-excavated sample.

When comparing the hand-excavated samples from Features 76A, 76, and 79 there are few observable differences in the collections. The number of whole flakes in the hand-excavated sample in Feature 79 was too small to make meaningful comparisons. However, there were a number of complete flakes in the flotation sample. Unfortunately, there are no comparable data sets available to attempt any interpretations. This information is presented here solely to provide data for future studies on Caddo lithic technological developments in this and adjoining parts of Texas.

\section{Interpretations}

The analysis of the debitage collected from selected features at the Lang Pasture site is hampered by several factors. The most notable stems from the fact that the site had multiple occupations beginning in the Early Archaic period and terminating at some point in Caddo times. Although the occupation of the site presumably was not continuous, debitage continued to accumulate as each new group came in and produced chipped stone tools. Natural processes, such as animal burrowing, tree falls, root action, etc. mixed the sandy soils and the materials from these successive occupations over much of the site area. Then, there were the disturbances caused by humans when digging post holes for structures and excavating pits for food storage. Too, if these pits were filled after use, soils from across the site containing earlier artifacts would have been employed, thereby adding to the contamination. This has, to some extent, been seen in the discussions of the features presented above.

The second factor that impedes interpreting the debitage from these features stems from the lack of comparable data sets. The Lang Pasture site is one of a few Late Caddo sites that has been extensively examined in the study area. Additionally, we do not as yet know what earlier Caddo sites in the area look like archaeologically. Ideally, small singlecomponent sites should be located and thoroughly investigated to clearly define the cultural chronology of this region and to delineate discrete artifact and debitage assemblages that can be used for future comparisons.

\subsection{SUMMARY AND CONCLUSIONS}

The analysis of diagnostic lithic artifacts has indicated a number of things concerning site occupancy. First, multiple components are reflected by a number of Early, Middle, and Late Archaic, and Woodland, points. There seems to be some horizontal separation of Archaic materials within the hand-excavated units, with apparent clusters in the northern and southern portion of the excavation. That in the northern part of the site appears somewhat earlier than that in the southern portion of the excavations. A concentration of Archaic points occurred in the Feature 76 area.

A more substantial Caddo-era site utilization is demonstrated by the large number of arrow points in the sample. There seem to be two groups or clusters of arrow points in the 
collection that might have temporal significance. Arrow points classified as Catahoula and Steiner share technological similarities and are probably the earlier of the two groups. Perdiz and Bassett arrow points are interpreted as comprising the later cluster. If these do, in fact, represent two distinct temporal segments of Caddo occupation of the site, recovery frequencies indicate that the earlier was the more substantial, or perhaps that bow and arrow hunting was more intensively practiced during the earlier period. It is impossible to clearly associate one of these two groups with particular features or sets of features on the basis of the lithic artifacts alone.

This work has addressed to various degrees several of the research questions identified in the original data recovery plan. These include age and number of occupations, Caddo tool assemblages, and, to a limited extent, raw material use. It was hoped that a detailed analysis of the artifacts and debitage recovered from the site could be used to address other questions, such as (1) defining specific activity areas within the site, (2) examining the use of informal (i.e., expedient) tools versus formal tools; (3) studying use and acquisition of lithic raw materials, including identification of probable source locations; (4) establishing lithic reduction strategies, and (5) examining site function by comparing the lithic assemblage to contemporary Caddoan sites in the region. This, however, was not possible due to a number of factors, as mentioned above. 


\section{CHAPTER 8}

\section{PLANT REMAINS FROM THE LANG PASTURE SITE (41AN38), ANDERSON COUNTY, TEXAS, AND THE CHARACTER OF CADDO AGRICULTURE IN THE UPPER NECHES RIVER BASIN}

\subsection{INTRODUCTION}

The primary goal of this analysis is to provide botanical data obtained during the data recovery excavations at the Lang Pasture site (41AN38) that will contribute to an understanding of prehistoric Caddo land use and subsistence, specifically the character of Caddo subsistence and agricultural practices at the Lang Pasture site in the upper Neches River basin of East Texas. This study will first describe the macrobotanical remains from the Lang Pasture site and discuss the evidence for plant utilization and plant production (see Table 5-10 for associated radiocarbon dates). The analysis first describes the plants identified in the samples, the context of the plant material and the ubiquity and abundance of the plant resources at the site. The remainder of the chapter discusses the character of prehistoric Caddo agriculture in East Texas, including the paleobotanical findings from the Lang pasture site within this broader context.

\subsection{Methods}

There are two types of samples in the current study: flotation samples and macrobotanical sample. Flotation is a method of recovering organic remains from archeological sediments by using water to separate heavy or soluble inorganic particles from plant parts and small animal bone or other small archeological debris. The material floating to the surface is called the light fraction, and this is caught on a fine-mesh screen or strainer. The material that sinks to the bottom is the heavy fraction and it is also caught on a fine mesh screen (usually about 0.5-0.6 mm bottom mesh size). Most of the soil, including clay and silt, is suspended in water and passes through the screens and is either recycled or discarded. In most cases, only the light fraction is submitted for analysis after the heavy fraction has been examined for plant materials.

Macrobotanical samples are carbonized plant remains that are separated from the rest of the archeological materials by hand. Usually these samples are collected either from an excavator's screen or point collected in-situ. At most open archeological sites, only carbonized plant remains are considered to be potentially a part of the archeological record. In some rare cases certain durable and easily identifiable wood types such as juniper may survive in a partially carbonized state, but only at younger sites in relatively dry conditions. Submerged sites at which deposits have remained in anaerobic conditions often preserve uncarbonized plant remains quite well. Deposits in the current study have been exposed to the elements for a sufficiently lengthy time period that only carbonized plant material is included in the archeological record.

A total of 45 flotation samples were submitted from the Lang Pasture site for the current analysis. Additionally five macrobotanical samples consisting of maize fragments were examined and described for this study (see Chapter 8 appendix). 
The analysis follows standard archeobotanical laboratory procedures. Each sample is passed through a nested set of screens of $4 \mathrm{~mm}, 2$ $\mathrm{mm}, 1 \mathrm{~mm}$, and $0.45 \mathrm{~mm}$ mesh and examined for charred material, which is separated for identification. Plant remains were sorted into three categories: woody fragments, nut fragments, and seed/fruit fragments, including maize parts. Identification of carbonized wood was accomplished by using the snap technique, examining the fragments at 8 to 45 magnifications with a hand lens or a binocular dissecting microscope, and comparing the material to samples in the archeobotanical herbarium. All seed identifications were made using seed manuals and reference collections at Shumla Archeobotanical Services.

Counts and weights from the site sample are presented in tabular format in Appendix $\mathrm{H}$, and in various tables in this chapter. Presence values are presented for woody taxa, for nuts and acorns, and for cultigens. Presence value or ubiquity is defined as the percentage of all analyzed samples, both productive (with seeds) and unproductive (wood charcoal only or no charcoal), in which a particular taxon is present. The presence value does not provide abundance figures, but it does provide a means of determining how widespread a taxon is throughout the samples recovered from a site. Abundance is presented most effectively by weight. Tables that follow include both ubiquity figures and taxon weight in order to best describe and evaluate the occurrence of a taxon.

The nut to wood ratios (i.e., the ratio of nut weight to wood charcoal weight) provide a scale by which to measure changing quantities of nut fragments across a site. These data may have some utility in establishing the nature of subsistence patterns at the Lang Pasture site by comparison with other recently analyzed Caddo paleobotanical assemblages (cf. Bush 2007, 2008; Dering 2008). Nut to wood ratios have been utilized as one line of evidence in the study of other Caddo paleobotanical assemblages in determining the degree to which the landscape has been altered for agriculture, and the degree to which a settlement relies on wild plant resources. However, both the presence values and the nut to wood ratio from a single site are specific to the spatial and temporal framework of that site only, and may not reflect the overall subsistence patterns of the region.

\section{Issues in Identification}

Only charred wood and other plant material is included in the analysis of the paleobotanical remains from the Lang Pasture site, because uncarbonized material is consumed by insects, fungi, and bacteria and does not survive more than a few years in the archeological deposits of open sites. Identifications are made to the most precise taxonomic level possible, given the condition of the plant material. In particular, wood identification is often made to the genus or family level, or in some cases wood is assigned to a type. In the current study, willow/cottonwood, or the Salicaceae type, refers to all wood in the willow family. Rose family refers to several common genera in the study area, including crab-apple, dogwood, and cherry.

\subsection{Results}

Analysis of plant materials recovered from the Lang Pasture site recorded 11 wood types, acorns and hickory nut, maize cupules and kernels, and squash rind. Wood charcoal was the most abundant and frequent of the plant materials. Table 8-1 presents the ubiquity values for the plant remains.

Hickory nut fragments were by far the most frequently occurring and abundant of all the edible plant resources at the Lang Pasture site, occurring in $84.4 \%$ of the flotation samples and in 16 of the 20 features in the study, and weighing a total of $22.7 \mathrm{~g}$. Of the two cultigens recovered from the samples, maize was fairly widespread, occurring in $42.2 \%$ of the flotation samples and in 13 features. The squash rind occurred in three samples from Features 37, 84, and 85. 
Table 8-1. Ubiquity and Total Weight of Plant Taxa Identified in the Flotation Samples.

\begin{tabular}{|c|c|c|c|c|c|}
\hline Taxon & Common & Part & $\begin{array}{l}\text { Samples } \\
\text { Present }\end{array}$ & $\begin{array}{l}\text { Percent } \\
\text { Present }\end{array}$ & $\begin{array}{c}\text { Weight } \\
\text { (g) }\end{array}$ \\
\hline \multicolumn{6}{|c|}{ Wood } \\
\hline $\begin{array}{l}\text { Arundinaria } \\
\text { gigantea }\end{array}$ & Giant Cane & Culm & 2 & $4.4 \%$ & $<.1$ \\
\hline Carya sp. & Hickory & Wood & 5 & $11.1 \%$ & 1.2 \\
\hline Celtis sp. & Hackberry & Wood & 2 & $4.4 \%$ & $<.1$ \\
\hline Indeterminate & NA & Bark & 2 & $4.4 \%$ & 0.4 \\
\hline Indeterminate & NA & Wood & 24 & $53.3 \%$ & 6.4 \\
\hline Juglans nigra & Walnut & Wood & 1 & $2.2 \%$ & $<.1$ \\
\hline $\begin{array}{l}\text { Liquidambar } \\
\text { styraciflua }\end{array}$ & Sweetgum & Wood & 2 & $4.4 \%$ & $<.1$ \\
\hline Pinus sp. & Pine & Wood & 12 & $26.7 \%$ & 2.1 \\
\hline $\begin{array}{l}\text { Platanus } \\
\text { occidentalis }\end{array}$ & Sycamore & Wood & 2 & $4.4 \%$ & 0.1 \\
\hline Quercus sp. & Oak & Wood & 38 & $84.4 \%$ & 29.3 \\
\hline Rosaceae & Rose family & Wood & 1 & $2.2 \%$ & $<.1$ \\
\hline Salicaceae & $\begin{array}{l}\text { Willow/ } \\
\text { Cottonwood }\end{array}$ & Wood & 6 & $13.3 \%$ & 9.3 \\
\hline Ulmus sp. & Elm & Wood & 2 & $4.4 \%$ & $<.1$ \\
\hline \multicolumn{6}{|c|}{ Edible Plants } \\
\hline Quercus sp. & Oak & Acorn & 2 & $4.4 \%$ & $<.1$ \\
\hline Carya sp. & Hickory & Nut & 38 & $84.4 \%$ & 22.7 \\
\hline Cucurbita sp. & Squash & Rind & 3 & $6.7 \%$ & $<.1$ \\
\hline Zea mays & Maize & All & 19 & $42.2 \%$ & 4.5 \\
\hline
\end{tabular}

Oak is the most abundant and widespread wood identified in the flotation samples, accounting for $60 \%$ of the total wood weight. Other wood types include willow/cottonwood, pine, hickory, and indeterminate wood and bark. Pine was the third most common wood type, occurring in over $26 \%$ of the flotation samples. Based on the wood contents of the features at the Lang Pasture site, it is likely that the region was a mixed hardwood/pine woodland with more oak than pine during the Caddo occupation of the area.
In addition to the oak, pine, and hickory noted from the samples, very small quantities of giant cane, hackberry, sweetgum, rose family (cherry, dogwood, crabapple, etc.), and elm wood also were recorded.

Table 8-2 presents the results of all the flotation samples ordered by feature number. Most of the features contained similar contents, that is, oak wood, hickory nut fragments, and 13 of the 20 features contained maize. 
Table 8-2. Plant Materials from Light and Heavy Fractions Ordered by Feature Number and Taxon.

\begin{tabular}{|c|c|c|c|c|c|c|c|c|}
\hline Feature & $\begin{array}{c}\text { Flot } \\
\#\end{array}$ & Lot & Taxon & Common & Part & Count & $\begin{array}{l}\text { Vol } \\
(\mathrm{ml})\end{array}$ & $\begin{array}{l}\text { Wt. } \\
\text { (g) }\end{array}$ \\
\hline 13 & 31 & 1199 & Arundinaria gigantea & Giant Cane & Stem/culm & 1 & -- & $<.1$ \\
\hline 13 & 31 & 1198 & Pinus sp. & Pine & Wood & 7 & -- & $<.1$ \\
\hline 13 & 31 & 1199 & Pinus sp. & Pine & Wood & 10 & -- & $<.1$ \\
\hline 13 & 31 & 1198 & Quercus sp. & Oak & Wood & 5 & -- & $<.1$ \\
\hline 13 & 31 & 1199 & Quercus sp. & Oak & Wood & 22 & -- & 0.1 \\
\hline 13 & 31 & 1199 & Zea mays & Maize & Kernel & 2 & -- & $<.1$ \\
\hline 14 & 45 & 1751 & Carya sp. & Hickory & Nut & 24 & -- & 0.5 \\
\hline 14 & 45 & 1751 & Indeterminate & $\mathrm{NA}$ & Wood & 25 & -- & 0.2 \\
\hline 14 & 45 & 1751 & Pinus sp. & Pine & Wood & 4 & -- & $<.1$ \\
\hline 14 & 45 & 1752 & Pinus sp. & Maize & Kernel & 1 & -- & $<.1$ \\
\hline 14 & 45 & 1751 & Quercus sp. & Oak & Wood & 12 & -- & 0.1 \\
\hline 16 & 32 & 1202 & Carya sp. & Hickory & Nut & 10 & -- & 0.1 \\
\hline 16 & 32 & 1202 & Indeterminate & NA & Wood & 5 & -- & $<.1$ \\
\hline 16 & 32 & 1203 & Indeterminate & NA & Wood & 18 & -- & $<.1$ \\
\hline 16 & 32 & 1202 & Quercus sp. & Oak & Wood & 5 & -- & $<.1$ \\
\hline 20 & 2 & 1210 & Arundinaria gigantea & Giant Cane & Stem/culm & 1 & -- & $<.1$ \\
\hline 20 & 1 & 1208 & Carya sp. & \begin{tabular}{|l|} 
Hickory \\
\end{tabular} & Nut & 2 & -- & $<.1$ \\
\hline 20 & 2 & 1210 & Carya sp. & \begin{tabular}{|l|} 
Hickory \\
\end{tabular} & Nut & 17 & -- & 0.4 \\
\hline 20 & 2 & 1211 & Carya sp. & \begin{tabular}{|l} 
Hickory \\
\end{tabular} & Nut & 1 & -- & $<.1$ \\
\hline 20 & 3 & 1212 & Carya sp. & Hickory & Nut & 10 & -- & 0.1 \\
\hline 20 & 3 & 1213 & Carya sp. & Hickory & Nut & 1 & -- & 0.1 \\
\hline 20 & 1 & 1208 & Indeterminate & NA & Wood & 4 & -- & $<.1$ \\
\hline 20 & 2 & 1210 & Indeterminate & NA & Wood & 6 & -- & $<.1$ \\
\hline 20 & 3 & 1213 & Indeterminate & NA & Wood & 11 & -- & $<.1$ \\
\hline 20 & 3 & 1212 & Juglans nigra & Walnut & Wood & 2 & -- & $<.1$ \\
\hline 20 & 2 & 1210 & $\begin{array}{l}\text { Liquidambar } \\
\text { styraciflua }\end{array}$ & Sweetgum & Wood & 4 & -- & $<.1$ \\
\hline 20 & 1 & 1209 & $\begin{array}{l}\text { No identifiable charred } \\
\text { plant remains }\end{array}$ & -- & -- & -- & -- & - \\
\hline 20 & 3 & 1212 & Quercus sp. & Oak & Wood & 10 & -- & 0.1 \\
\hline 20 & 3 & 1213 & Quercus sp. & Oak & Wood & 7 & -- & $<.1$ \\
\hline 20 & 2 & 1210 & Salicaceae & $\begin{array}{l}\text { Willow/ } \\
\text { Cottonwood }\end{array}$ & Wood & 1 & -- & $<.1$ \\
\hline 20 & 2 & 1210 & Zea mays & Maize & $\begin{array}{l}\text { Cob } \\
\text { segment }\end{array}$ & 1 & -- & $<.1$ \\
\hline 20 & 2 & 1210 & Zea mays & Maize & Cupule & 26 & -- & 0.2 \\
\hline 20 & 2 & 1211 & Zea mays & Maize & Cupule & 5 & -- & $<.1$ \\
\hline 20 & 3 & 1213 & Zea mays & Maize & Cupule & 2 & -- & $<.1$ \\
\hline 25 & 4 & 1230 & Carya sp. & Hickory & Nut & 1 & -- & $<.1$ \\
\hline 25 & 4 & 1231 & Carya sp. & Hickory & Nut & 8 & -- & 0.1 \\
\hline 25 & 5 & 1232 & Carya sp. & Hickory & Nut & 3 & -- & $<.1$ \\
\hline 25 & 6 & 1235 & Carya sp. & Hickory & Nut & 1 & -- & $<.1$ \\
\hline 25 & 7 & 1236 & Carya sp. & Hickory & Nut & 2 & -- & $<.1$ \\
\hline 25 & 7 & 1236 & Carya sp. & Hickory & Wood & 2 & -- & $<.1$ \\
\hline 25 & 8 & 1238 & Carya sp. & Hickory & Nut & 1 & -- & $<.1$ \\
\hline 25 & 9 & 1239 & Carya sp. & Hickory & Nut & 2 & -- & $<.1$ \\
\hline
\end{tabular}


Table 8-2, continued

\begin{tabular}{|c|c|c|c|c|c|c|c|c|}
\hline Feature & $\begin{array}{c}\text { Flot } \\
\#\end{array}$ & Lot & Taxon & Common & Part & Count & $\begin{array}{l}\text { Vol } \\
(\mathrm{ml})\end{array}$ & $\begin{array}{l}\text { Wt. } \\
\text { (g) }\end{array}$ \\
\hline 25 & 4 & 1230 & Indeterminate & NA & $\begin{array}{l}\text { Non-bot } \\
\text { (bone) }\end{array}$ & 2 & -- & $<.1$ \\
\hline 25 & 5 & 1233 & Indeterminate & NA & Wood & 12 & -- & $<.1$ \\
\hline 25 & 6 & 1235 & Indeterminate & $\mathrm{NA}$ & Wood & 17 & -- & $<.1$ \\
\hline 25 & 7 & 1236 & Indeterminate & NA & Wood & 6 & -- & $<.1$ \\
\hline 25 & 7 & 1237 & Indeterminate & NA & Wood & 11 & -- & $<.1$ \\
\hline 25 & 8 & 1238 & Indeterminate & $\mathrm{NA}$ & Wood & 5 & -- & $<.1$ \\
\hline 25 & 9 & 1240 & Indeterminate & NA & Wood & 5 & -- & $<.1$ \\
\hline 25 & 8 & 1238 & $\begin{array}{l}\text { Liquidambar } \\
\text { styraciflua }\end{array}$ & Sweetgum & Wood & 2 & -- & $<.1$ \\
\hline 25 & 6 & 1234 & $\begin{array}{l}\text { No identifiable charred } \\
\text { plant remains }\end{array}$ & -- & -- & -- & -- & - \\
\hline 25 & 4 & 1231 & Quercus sp. & Oak & Acorn & 1 & -- & $<.1$ \\
\hline 25 & 4 & 1230 & Quercus sp. & Oak & Wood & 5 & -- & $<.1$ \\
\hline 25 & 4 & 1231 & Quercus sp. & Oak & Wood & 15 & -- & 0.1 \\
\hline 25 & 5 & 1232 & Quercus sp. & Oak & Wood & 7 & -- & $<.1$ \\
\hline 25 & 7 & 1237 & Quercus sp. & Oak & Wood & 2 & -- & $<.1$ \\
\hline 25 & 9 & 1240 & Quercus sp. & Oak & Wood & 2 & -- & $<.1$ \\
\hline 25 & 4 & 1231 & Rosaceae & Rose family & Wood & 2 & -- & $<.1$ \\
\hline 25 & 4 & 1231 & Ulmus sp. & Elm & Wood & 3 & -- & $<.1$ \\
\hline 25 & 4 & 1231 & Zea mays & Maize & Cupule & 2 & -- & $<.1$ \\
\hline 27 & 33 & 1255 & Carya sp. & \begin{tabular}{|l|} 
Hickory \\
\end{tabular} & Nut & 7 & -- & 0.1 \\
\hline 27 & 33 & 1255 & Pinus sp. & Pine & Wood & 5 & -- & $<.1$ \\
\hline 27 & 33 & 1255 & Quercus sp. & Oak & Wood & 9 & -- & $<.1$ \\
\hline 27 & 33 & 1256 & Quercus sp. & Oak & Wood & 7 & -- & $<.1$ \\
\hline 29 & 34 & 1259 & Carya sp. & \begin{tabular}{|l} 
Hickory \\
\end{tabular} & Nut & 8 & -- & 0.5 \\
\hline 29 & 34 & 1259 & Indeterminate & NA & Wood & $25+$ & 17 & 5.4 \\
\hline 29 & 34 & 1259 & Pinus sp. & Pine & Wood & 20 & -- & 0.7 \\
\hline 29 & 34 & 1260 & Quercus sp. & Oak & Wood & 23 & -- & 1.1 \\
\hline 29 & 34 & 1259 & Salicaceae & $\begin{array}{l}\text { Willow/ } \\
\text { Cottonwood }\end{array}$ & Wood & $25+$ & 28 & 8.9 \\
\hline 36 & 11 & 1278 & Arundinaria gigantea & Giant Cane & Stem & 3 & -- & $<.1$ \\
\hline 36 & 10 & 1275 & Carya sp. & \begin{tabular}{|l|} 
Hickory \\
\end{tabular} & Nut & $25+$ & 7 & 2.3 \\
\hline 36 & 10 & 1276 & Carya sp. & Hickory & Nut & 4 & -- & $<.1$ \\
\hline 36 & 11 & 1277 & Carya sp. & \begin{tabular}{|l} 
Hickory \\
\end{tabular} & Nut & $25+$ & 26 & 10.2 \\
\hline 36 & 11 & 1278 & Carya sp. & \begin{tabular}{|l|} 
Hickory \\
\end{tabular} & Nut & 18 & -- & 0.8 \\
\hline 36 & 12 & 1279 & Carya sp. & Hickory & Nut & 12 & -- & 0.3 \\
\hline 36 & 12 & 1280 & Carya sp. & \begin{tabular}{|l|} 
Hickory \\
\end{tabular} & Nut & 1 & -- & $<.1$ \\
\hline 36 & 11 & 1278 & Indeterminate & NA & Wood & 7 & -- & 0.1 \\
\hline 36 & 12 & 1280 & Indeterminate & NA & Wood & 3 & -- & $<.1$ \\
\hline 36 & 10 & 1275 & Quercus sp. & Oak & Wood & 2 & -- & $<.1$ \\
\hline 36 & 10 & 1276 & Quercus sp. & Oak & Wood & 2 & -- & $<.1$ \\
\hline 36 & 11 & 1277 & Quercus sp. & Oak & Wood & 12 & -- & 0.5 \\
\hline 36 & 12 & 1279 & Quercus sp. & Oak & Wood & 6 & -- & $<.1$ \\
\hline 36 & 11 & 1277 & Salicaceae & \begin{tabular}{|l|} 
Willow/ \\
Cottonwood
\end{tabular} & Wood & 7 & -- & 0.1 \\
\hline
\end{tabular}


Chapter 8: Plant Remains from the Lang Pasture Site (41AN38) Anderson County, Texas, and the Character of Caddo Agriculture in the Upper Neches River Basin

Table 8-2, continued

\begin{tabular}{|c|c|c|c|c|c|c|c|c|}
\hline Feature & $\begin{array}{c}\text { Flot } \\
\#\end{array}$ & Lot & Taxon & Common & Part & Count & $\begin{array}{l}\text { Vol } \\
\text { (ml) }\end{array}$ & $\begin{array}{l}\text { Wt. } \\
\text { (g) }\end{array}$ \\
\hline 36 & 11 & 1278 & Salicaceae & $\begin{array}{l}\text { Willow/ } \\
\text { Cottonwood }\end{array}$ & Wood & 18 & -- & 0.2 \\
\hline 36 & 10 & 1275 & Zea mays & Maize & Cupule & 1 & -- & $<.1$ \\
\hline 36 & 11 & 1277 & Zea mays & Maize & Cupule & 6 & -- & $<.1$ \\
\hline 37 & 35 & 1281 & Carya sp. & Hickory & Nut & $25+$ & 8 & 2.8 \\
\hline 37 & 35 & 1282 & Carya sp. & Hickory & Nut & 23 & -- & 0.8 \\
\hline 37 & 36 & 1283 & Carya sp. & Hickory & Nut & $25+$ & 3 & 0.4 \\
\hline 37 & 45 & 1311 & Cucurbita sp. & Squash & Rind & 3 & -- & $<.1$ \\
\hline 37 & 35 & 1282 & Indeterminate & NA & Bark & 2 & -- & 0.2 \\
\hline 37 & 35 & 1282 & Indeterminate & NA & Wood & 23 & -- & 0.3 \\
\hline 37 & 35 & 1281 & Pinus sp. & Pine & Wood & 22 & -- & 0.4 \\
\hline 37 & 35 & 1281 & Quercus sp. & Oak & Wood & 4 & -- & $<.1$ \\
\hline 37 & 35 & 1282 & Quercus sp. & Oak & Wood & 2 & -- & $<.1$ \\
\hline 37 & 36 & 1283 & Quercus sp. & Oak & Wood & 10 & -- & 0.1 \\
\hline 37 & 36 & 1284 & Quercus sp. & Oak & Wood & 6 & -- & $<.1$ \\
\hline 41 & 14 & 1295 & Indeterminate & $\mathrm{NA}$ & Wood & 6 & -- & $<.1$ \\
\hline 41 & 14 & 1293 & Platanus occidentalis & Sycamore & Wood & 4 & -- & $<.1$ \\
\hline 41 & 13 & 1293 & Quercus sp. & Oak & Wood & 13 & -- & 0.2 \\
\hline 41 & 13 & 1294 & Quercus sp. & Oak & Wood & 4 & -- & 0.1 \\
\hline 41 & 13 & 1293 & Zea mays & Maize & Cupule & 137 & 11 & 2.7 \\
\hline 41 & 13 & 1294 & Zea mays & Maize & Cupule & 45 & -- & 0.2 \\
\hline 41 & 13 & 1293 & Zea mays & Maize & Kernel & 2 & -- & $<.1$ \\
\hline 41 & 14 & 1295 & Zea mays & Maize & Cupule & 29 & -- & 0.2 \\
\hline 41 & 14 & 1296 & Zea mays & Maize & Cupule & 6 & -- & $<.1$ \\
\hline 41 & 14 & 1296 & Zea mays & Maize & Glume & 1 & -- & $<.1$ \\
\hline 41 & 14 & 1295 & Zea mays & Maize & Kernel & 2 & -- & $<.1$ \\
\hline 45 & 37 & 1311 & Carya sp. & Hickory & Nut & 10 & -- & 0.3 \\
\hline 45 & 37 & 1311 & Pinus sp. & Maize & Cupule & 6 & -- & $<.1$ \\
\hline 45 & 37 & 1312 & Pinus sp. & Maize & Cupule & 2 & -- & $<.1$ \\
\hline 45 & 37 & 1311 & Quercus sp. & Oak & Wood & 4 & -- & $<.1$ \\
\hline 76 & 15 & 1369 & Carya sp. & Hickory & Nut & 3 & -- & $<.1$ \\
\hline 76 & 15 & 1370 & Carya sp. & Hickory & Nut & 1 & -- & $<.1$ \\
\hline 76 & 15 & 1370 & Carya sp. & Hickory & Wood & 12 & -- & 0.5 \\
\hline 76 & 16 & 1371 & Carya sp. & Hickory & Nut & 3 & -- & 0.2 \\
\hline 76 & 16 & 1372 & Carya sp. & Hickory & Nut & 1 & -- & $<.1$ \\
\hline 76 & 17 & 1374 & Carya sp. & Hickory & Nut & 1 & -- & $<.1$ \\
\hline 76 & 18 & 1375 & Carya sp. & Hickory & Nut & 3 & -- & 0.1 \\
\hline 76 & 18 & 1375 & Carya sp. & Hickory & Wood & 2 & -- & $<.1$ \\
\hline 76 & 16 & 1372 & Indeterminate & NA & Wood & 20 & -- & 0.1 \\
\hline 76 & 17 & 1373 & Indeterminate & NA & Wood & 1 & -- & $<.1$ \\
\hline 76 & 15 & 1369 & Pinus sp. & Pine & Wood & 10 & -- & 0.1 \\
\hline 76 & 15 & 1370 & Pinus sp. & Pine & Wood & 23 & -- & 0.6 \\
\hline 76 & 16 & 1372 & Pinus sp. & Pine & Wood & 5 & -- & $<.1$ \\
\hline 76 & 15 & 1369 & Quercus sp. & Oak & Wood & 2 & -- & $<.1$ \\
\hline 76 & 17 & 1374 & Quercus sp. & Oak & Wood & 4 & -- & 0.1 \\
\hline
\end{tabular}


Table 8-2, continued

\begin{tabular}{|c|c|c|c|c|c|c|c|c|}
\hline Feature & $\begin{array}{c}\text { Flot } \\
\#\end{array}$ & Lot & Taxon & Common & Part & Count & $\begin{array}{l}\text { Vol } \\
\text { (ml) }\end{array}$ & $\begin{array}{l}\text { Wt. } \\
\text { (g) }\end{array}$ \\
\hline 76 & 18 & 1376 & Quercus sp. & Oak & Wood & 2 & -- & $<.1$ \\
\hline 76 & 15 & 1370 & Salicaceae & $\begin{array}{l}\text { Willow/ } \\
\text { Cottonwood }\end{array}$ & Wood & 4 & -- & $<.1$ \\
\hline 76 & 15 & 1370 & Zea mays & Maize & Cupule & 2 & -- & $<.1$ \\
\hline 76 & 17 & 1374 & Zea mays & Maize & Cupule & 1 & -- & $<.1$ \\
\hline 79 & 21 & 1388 & Carya sp. & Hickory & Nut & 9 & -- & 0.3 \\
\hline 79 & 22 & 1389 & Carya sp. & Hickory & Nut & 8 & -- & 0.1 \\
\hline 79 & 23 & 1391 & Carya sp. & Hickory & Nut & 1 & -- & $<.1$ \\
\hline 79 & 23 & 1392 & Carya sp. & Hickory & Nut & 1 & -- & $<.1$ \\
\hline 79 & 24 & 1393 & Carya sp. & Hickory & Nut & 16 & -- & 0.5 \\
\hline 79 & 25 & 1395 & Carya sp. & Hickory & Nut & 3 & -- & 0.2 \\
\hline 79 & 24 & 1393 & Celtis sp. & Hackberry & Wood & 3 & -- & $<.1$ \\
\hline 79 & 23 & 1391 & Indeterminate & NA & Wood & 7 & -- & 0.1 \\
\hline 79 & 25 & 1396 & Indeterminate & NA & Bark & 13 & -- & 0.2 \\
\hline 79 & 22 & 1389 & Pinus sp. & Pine & Wood & 3 & -- & $<.1$ \\
\hline 79 & 24 & 1393 & Pinus sp. & Pine & Wood & 2 & -- & $<.1$ \\
\hline 79 & 21 & 1387 & Quercus sp. & Oak & Wood & 11 & -- & 0.3 \\
\hline 79 & 22 & 1390 & Quercus sp. & Oak & Acorn & 1 & -- & $<.1$ \\
\hline 79 & 22 & 1389 & Quercus sp. & Oak & Wood & 11 & -- & 0.1 \\
\hline 79 & 22 & 1390 & Quercus sp. & Oak & Wood & 6 & -- & $<.1$ \\
\hline 79 & 23 & 1392 & Quercus sp. & Oak & Wood & 9 & -- & 0.2 \\
\hline 79 & 24 & 1393 & Quercus sp. & Oak & Wood & 22 & -- & 0.8 \\
\hline 79 & 24 & 1394 & Quercus sp. & Oak & Wood & $25+$ & 8 & 1.3 \\
\hline 79 & 25 & 1396 & Quercus sp. & Oak & Wood & 4 & -- & $<.1$ \\
\hline 79 & 21 & 1387 & Zea mays & Maize & Cupule & 3 & -- & $<.1$ \\
\hline 79 & 21 & 1388 & Zea mays & Maize & Cupule & 2 & -- & $<.1$ \\
\hline 79 & 22 & 1389 & Zea mays & Maize & Cupule & 2 & -- & $<.1$ \\
\hline 80 & 38 & 1407 & Carya sp. & Hickory & Nut & 5 & -- & $<.1$ \\
\hline 80 & 38 & 1408 & Indeterminate & NA & Wood & 8 & -- & $<.1$ \\
\hline 80 & 38 & 1407 & Pinus sp. & Pine & Wood & 3 & -- & 0.1 \\
\hline 80 & 38 & 1408 & Pinus sp. & Pine & Wood & 4 & -- & 0.2 \\
\hline 80 & 38 & 1408 & Pinus sp. & Maize & Cupule & 1 & -- & $<.1$ \\
\hline 80 & 38 & 1407 & Quercus sp. & Oak & Wood & $25+$ & 2 & 0.3 \\
\hline 81 & 39 & 1409 & Carya sp. & Hickory & Nut & 3 & -- & $<.1$ \\
\hline 81 & 39 & 1410 & Carya sp. & Hickory & Nut & 4 & -- & 0.1 \\
\hline 81 & 40 & 1411 & Carya sp. & Hickory & Nut & 1 & -- & 0.2 \\
\hline 81 & 40 & 1411 & Celtis sp. & Hackberry & Wood & 2 & -- & $<.1$ \\
\hline 81 & 39 & 1409 & Indeterminate & NA & Wood & 4 & -- & $<.1$ \\
\hline 81 & 40 & 1412 & Indeterminate & NA & Wood & 11 & -- & $<.1$ \\
\hline 81 & 39 & 1410 & Quercus sp. & Oak & Wood & 16 & -- & 0.1 \\
\hline 81 & 40 & 1411 & Quercus sp. & Oak & Wood & 21 & -- & 0.4 \\
\hline 81 & 40 & 1412 & Quercus sp. & Oak & Wood & 8 & -- & $<.1$ \\
\hline 81 & 39 & 1410 & Salicaceae & $\begin{array}{l}\text { Willow/ } \\
\text { Cottonwood }\end{array}$ & Wood & 1 & -- & 0.1 \\
\hline 82 & 41 & 1415 & Carya sp. & Hickory & Nut & $25+$ & 2 & 0.4 \\
\hline 82 & 41 & 1415 & Indeterminate & NA & Wood & 17 & - & $<.1$ \\
\hline
\end{tabular}


Chapter 8: Plant Remains from the Lang Pasture Site (41AN38) Anderson County, Texas, and the Character of Caddo Agriculture in the Upper Neches River Basin

Table 8-2, continued

\begin{tabular}{|c|c|c|c|c|c|c|c|c|}
\hline Feature & $\begin{array}{c}\text { Flot } \\
\#\end{array}$ & Lot & Taxon & Common & Part & Count & $\begin{array}{l}\text { Vol } \\
(\mathrm{ml})\end{array}$ & $\begin{array}{l}\text { Wt. } \\
\text { (g) }\end{array}$ \\
\hline 82 & 41 & 1416 & Indeterminate & NA & Wood & 12 & -- & $<.1$ \\
\hline 82 & 41 & 1415 & Pinus sp. & Maize & Cupule & 1 & -- & $<.1$ \\
\hline 82 & 41 & 1415 & Quercus sp. & Oak & Wood & 5 & -- & $<.1$ \\
\hline 84 & 42 & 1417 & Carya sp. & Hickory & Nut & 12 & -- & 0.2 \\
\hline 84 & 42 & 1417 & Carya sp. & Hickory & Wood & 6 & -- & 0.1 \\
\hline 84 & 42 & 1417 & Cucurbita sp. & Squash & Rind & 2 & -- & $<.1$ \\
\hline 84 & 42 & 1417 & Indeterminate & NA & Wood & 23 & -- & 0.2 \\
\hline 84 & 42 & 1417 & Pinus sp. & Maize & Cupule & 152 & 5 & 1.1 \\
\hline 84 & 42 & 1418 & Pinus sp. & Maize & Cupule & 47 & -- & 0.1 \\
\hline 84 & 42 & 1417 & Pinus sp. & Maize & Glume & 5 & -- & $<.1$ \\
\hline 85 & 44 & 1424 & Cucurbita sp. & Squash & Rind & 2 & -- & $<.1$ \\
\hline 85 & 44 & 1424 & Pinus sp. & Pine & Wood & 2 & -- & $<.1$ \\
\hline 85 & 44 & 1424 & Pinus sp. & Maize & Cupule & 2 & -- & $<.1$ \\
\hline 85 & 44 & 1423 & Quercus sp. & Oak & Wood & 7 & -- & 0.3 \\
\hline 86 & 26 & 1427 & Carya sp. & Hickory & Nut & 3 & -- & 0.1 \\
\hline 86 & 27 & 1429 & Carya sp. & Hickory & Nut & 1 & -- & 0.1 \\
\hline 86 & 28 & 1431 & Carya sp. & Hickory & Nut & 4 & -- & 0.1 \\
\hline 86 & 29 & 1433 & Carya sp. & Hickory & Nut & 4 & -- & 0.2 \\
\hline 86 & 30 & 1435 & Carya sp. & Hickory & Nut & 3 & -- & 0.1 \\
\hline 86 & 26 & 1428 & $\begin{array}{l}\text { No identifiable charred } \\
\text { plant remains }\end{array}$ & -- & -- & -- & -- & -- \\
\hline 86 & 29 & 1434 & $\begin{array}{l}\text { No identifiable charred } \\
\text { plant remains }\end{array}$ & -- & -- & -- & -- & -- \\
\hline 86 & 30 & 1436 & $\begin{array}{l}\text { No identifiable charred } \\
\text { plant remains }\end{array}$ & -- & -- & -- & -- & -- \\
\hline 86 & 26 & 1427 & Platanus occidentalis & Sycamore & Wood & 14 & -- & 0.1 \\
\hline 86 & 26 & 1427 & Quercus sp. & Oak & Wood & $25+$ & 13 & 4.8 \\
\hline 86 & 27 & 1429 & Quercus sp. & Oak & Wood & $25+$ & 10 & 3.8 \\
\hline 86 & 28 & 1431 & Quercus sp. & Oak & Wood & $25+$ & 4 & 1.2 \\
\hline 86 & 29 & 1433 & Quercus sp. & Oak & Wood & $25+$ & 14 & 4.4 \\
\hline 86 & 30 & 1435 & Quercus sp. & Oak & Wood & $25+$ & 10 & 4 \\
\hline 86 & 28 & 1431 & Salicaceae & $\begin{array}{l}\text { Willow/ } \\
\text { Cottonwood }\end{array}$ & Wood & 1 & -- & $<.1$ \\
\hline 86 & 30 & 1435 & Ulmus sp. & Elm & Wood & 3 & -- & $<.1$ \\
\hline $76 \mathrm{~A}$ & 19 & 1378 & Carya sp. & Hickory & Wood & 2 & -- & 0.6 \\
\hline $76 \mathrm{~A}$ & 19 & 1377 & Quercus sp. & Oak & Wood & 1 & -- & 0.2 \\
\hline $76 \mathrm{~A}$ & 20 & 1379 & Quercus sp. & Oak & Wood & $25+$ & 10 & 2.2 \\
\hline $76 \mathrm{~A}$ & 20 & 1380 & Quercus sp. & Oak & Wood & $25+$ & 13 & 2.4 \\
\hline $85(W-1 / 2)$ & 43 & 1421 & Indeterminate & NA & Wood & 13 & -- & $<.1$ \\
\hline $85(W-1 / 2)$ & 43 & 1422 & Indeterminate & NA & Wood & 9 & -- & $<.1$ \\
\hline $85(W-1 / 2)$ & 43 & 1421 & Pinus sp. & Pine & Wood & 6 & -- & $<.1$ \\
\hline $85(\mathrm{~W}-1 / 2)$ & 43 & 1421 & Pinus sp. & Maize & Cupule & 2 & -- & $<.1$ \\
\hline $85(\mathrm{~W}-1 / 2)$ & 43 & 1421 & Quercus sp. & Oak & Wood & 5 & -- & $<.1$ \\
\hline
\end{tabular}


Maize occurrence was limited to only a few kernel or cupule fragments in the flotation samples, however, there were two notable exceptions. Feature 41 contained 222 maize fragments along with a relatively small quantity of oak wood. Several small cob segments from Feature 41 also were submitted as macrobotanical samples. Feature 84 contained 204 maize fragments with hickory nut and hickory wood, and a few squash rind fragments.

Nut fragments, although very widespread, for the most part did not occur in dense concentrations. A few acorn pericarp fragments were recovered from Features 25 and 79. Hickory nut pericarp fragments occurred in most of the features, but only Features 36 and 37 contained large quantities of nut fragments. The implication is that most of the features contain a background scatter of hickory nut fragments.

Table 8-3 presents the results of the macrobotanical samples submitted for analysis. These samples were composed mostly of very small maize cob fragments. Although I can only estimate row counts, most of the cob segments suggest that these samples consisted of 8-10 row cobs. Many of the cupules were comparatively wide, measuring between 5.35-5.65-mm.

Table 8-3. Macrobotanical Samples.

\begin{tabular}{|c|c|c|c|c|c|c|}
\hline Lot & Feature & Taxon & Common & Part & Count & Wt. (g) \\
\hline 795 & 41 & Zea mays & Maize & Cupule & 16 & 0.3 \\
\hline 999 & -- & Zea mays & Maize & $\begin{array}{l}\text { Cob segment, } \\
\text { cupule }\end{array}$ & 27 & 0.7 \\
\hline 1017 & -- & Zea mays & Maize & $\begin{array}{l}\text { Cob segment, } \\
\text { cupule }\end{array}$ & 5 & 0.1 \\
\hline 1667 & 41 & Zea mays & Maize & $\begin{array}{l}\text { Cob segment, } \\
\text { cupule }\end{array}$ & 4 & 0.1 \\
\hline 1668 & 41 & Zea mays & Maize & $\begin{array}{l}\text { Cob segment, } \\
\text { cupule }\end{array}$ & 5 & 0.1 \\
\hline 1668 & 41 & Indeterminate & NA & Wood & 2 & 0.1 \\
\hline
\end{tabular}

\subsection{SUMmARY OF THE PLANT REMAINS FROM THE LANG PASTURE SITE}

Forty-five flotation samples and five macrobotanical samples contained 11 wood types, hickory nuts, acorns, maize, and squash. Hickory nut fragments were the most widespread and abundant of the forest mast remains, but were recovered in large quantities only from Features 36 and 37. Although maize was widespread, remains were thinly scattered through most of the samples with the exception of material from Features 41 and 84. Squash rind occurred in three features. The macrobotanical samples consisted of very small maize cob fragments, too small to reconstruct cob size or cob rows. However, cupule measurements suggest that most of the fragments from Feature 41 were 8 and 10 row types. This does not discount, however, the distinct possibility that higher-number-rowed cobs were present at the site.

The most consistent aspect of the feature paleobotanical descriptions from the Lang Pasture site is the overwhelming ubiquity and abundance of hickory nut fragments recovered in the samples. Hickory nut fragments were present in $84.4 \%$ of the flotation samples, and hickory nut remains outweighed the other plant food resource by a factor of 5:1. 
The ubiquity and relative abundance of hickory nut fragments indicates that the site deposits contain a relatively consistent paleobotanical background of hickory nut fragments. Most of the features, regardless of their original function, were filled or refilled with charred nut fragments. The variety of feature types in which nut fragments are present suggests that they constitute secondary refuse, or trash deposited at some location other than the location of use. Secondary refuse usually consists of larger, more longlasting plant parts such as nut fragments that are often over-represented in archeological deposits. However, the ubiquitous presence of nut fragments at this site also suggests that hickory nut processing was sufficiently intense to have created debris that penetrated virtually every feature at the settlement. Even though hickory nuts are obviously over-represented in the archeological record here, the predominance of nut fragments at this site indicates that hickory nut harvesting and processing must have been an important and repeated activity in the fall, implying that the site was occupied at least during the fall and winter.

Wood charcoal remains indicate that the forest vegetation at the time was probably a mixed hardwood/conifer forest at the Lang Pasture site. The principal overstory trees were pine and oak (see Table 8-1).

Domesticated plants, particularly maize, are widespread and relatively abundant at the Lang Pasture site. Plant production was a major focus of Caddo subsistence at the time of the occupation of the site, based on maize ubiquity of $42 \%$ (see Table $8-1$ ), and it is likely that the agricultural fields for the Caddo peoples living at the Lang Pasture site were located in the nearby stream bottoms or in other settings with arable soils. These fields probably covered no more than an acre per household, and would have been cleared with wood or stone tools to remove brush, weeds, and grasses, as well as dead trees or overhanging limbs (see Swanton 1942:127131). Seeds were planted (probably in two plantings (e.g., Swanton 1942:129) and the fields would then have been carefully tended to protect the crop from small animals and deer. The cultivation of maize, as well as squash, and the collection of hickory nuts and the preparation of hickory nut oil, were the main plant production and processing activities at the site. As the Caddo occupation here appears to have been a permanent one, the paleobotanical record was left by a Caddo group that was moderately invested in agriculture. The stable carbon isotope values from a number of the burial features at the Lang Pasture site (see Wilson, this volume) support the notion that maize was an important part of the diet of these Caddo peoples during the early $14^{\text {th }}$ to mid- $15^{\text {th }}$ centuries A.D..

\subsection{PrEhistoric CADDO AGRICULTURE IN EAST TEXAS}

Ethnographic accounts of Caddo plant utilization (Griffith 1954; Swanton 1942; Rogers and Sabo 2004) indicate that the Caddo peoples living in East Texas and along the Red River in Louisiana grew two varieties of maize, six varieties of beans, squash, sunflower, and tobacco as well as the European introductions of watermelon, peaches, and pomegranates (Swanton 1942:127-134; Blake 1981). While maize, beans, and squash were apparently the mainstays of historic Caddo subsistence, wild plant foods were also collected, including hardwood nuts, seeds, and greens. Like other Southeastern U.S. tribes (see Scarry and Scarry 2005), the Caddo grew crops in small family plots as well as in larger communal fields, storing the harvests in household granaries.

Because floral preservation is generally poor in the acidic soils of the Caddo area, the consideration and interpretation of prehistoric Caddo subsistence until recently rested more on the fortuitous recovery of subsistence remains (primarily maize), and the available ethnographic information compiled by Swanton (1942), than on a systematic study of the Caddo archeological and paleobotanical records themselves. Fortunately, recent research on a number of prehistoric and early 
historic Caddo sites has been directed towards the development of a regional subsistence data base (especially paleobotanical), and to the utilization of techniques such as flotation to maximize the recovery of subsistence remains. Yet, the relative utilization and contribution of domesticates, and models that account for the development of agricultural economies, remain to be fully assessed and evaluated within any one region of the Caddo area. Only by means of the development of a series of regional research efforts, and a focus on the investigation of appropriate archeological resources, can processes of cultural and subsistence change become more evident. Local developmental sequences cannot be generated easily over different parts of the Caddo area, and therefore require supporting data and sufficient temporal control to insure investigation of short and long-term changes in the archeological record.

Story (1981:148) estimated that the contribution of maize to the Caddo diet in prehistoric times was "conservatively to have accounted for at least $30-40 \%$ of the diet."
This would be in line with the current inference that the Caddo had an agricultural subsistence strategy. However, quantifiable data has not been presented to support the estimate, nor is it known if that estimate pertains to the entire sequence of the prehistoric Caddo tradition (in East Texas) or to a particular segment of that lengthy Caddo occupation of the region. Archeological evidence discussed below suggests that it is not until after ca. A.D. 1300 to A.D. 1400 that agricultural subsistence strategies are to be found among the East Texas Caddo, including the Caddo groups that lived at the Lang Pasture site.

\section{Plant Foods Grown and Cultivated by the Caddo Indian Peoples}

With the ever-increasing flotation of sediments from feature fills and trash midden deposits on prehistoric and early historic Caddo sites, it is apparent that there was a wide suite of plant foods were grown and cultivated by Caddo peoples (Table 8-4).

Table 8-4. Plant Foods and Other Plants Grown and Cultivated by the Caddo Indian Peoples as Seen in Various Post-A.D. 800-900 Archeological Sites.

\begin{tabular}{ll}
\hline Cultigens & \\
Maize & Zea mays \\
Common bean & Phaseolus vulgaris \\
Squash/pumpkin & $\begin{array}{l}\text { Cucurbita cf. Pepo } \\
\text { Bottle Gourd }\end{array}$ \\
Watermelon & Citrullus lanatus \\
Starchy Seeds & Chenopodium berlandieri \\
Chenopod & Polygonum erectum \\
Knotweed & Amaranthus hypochrondriacus \\
Amaranth & Phalaris caroliniana \\
Maygrass & Hordium pusillum \\
Little Barley & Panicum sp. \\
Panic grass & \\
Oily Seeds & Iva annua var. macrocarpa \\
Sumpweed & Helianthus annuus var. macrocarpus \\
Sunflower &
\end{tabular}


This includes the important cultigens maize, common bean, and squash, as well as bottle gourd; oily seeds (namely sumpweed and sunflower), and starchy seeds, including chenopod, knotweed, amaranth, maygrass, little barley, and in a few instances in southwestern Arkansas Caddo sites, panic grass (see Powell and Lopinot 2000; Fritz 1993). The same range of plant foods is documented in prehistoric eastern North American sites dating before as well as after ca. A.D. 800/900 (Smith and Cowan 2003:117-122).

Maize is by far the most common cultigen identified on prehistoric and early historic Caddo sites, although its ubiquity varies considerably both spatially and temporally. The types of races of maize grown include Eastern Eight-Row (also known as "Northern Flint”) and Midwestern Twelve-Row, and generally speaking the maize has been grouped with Eastern Complex corn (see discussion in Goldborer [2002:84-85]).

Beans of several different sizes and kinds have been documented in Caddo sites, although they are absent in the Lang Pasture paleobotanical record. Beans are much more commonly recovered in post- $14^{\text {th }}$ century Caddo sites on the Red and Ouachita rivers than they are elsewhere in the Caddo area, including East Texas Caddo sites. Nevertheless, we know that maize, beans, and squash were the principal crops among the Caddo peoples living in East Texas in the late $17^{\text {th }}$ century (Foster 1998:236, 244). Joutel commented in 1687 that the Nasoni Caddo produced large crops of beans, but that the Caddo did "not make much effort in preparing them; for them it suffices to put them in a large pot, without even removing the strings, then they cover the beans with vine leaves until they are almost cooked" (Foster 1998:237).

The squash found on Caddo sites would have been used as edible flesh (cut into strips) and seeds, and would also have been useful as containers. Other cultivated plants of this kind would include the bottle gourd, pumpkin, and various cucurbits.

The chenopod, amaranth, knotweed, sumpweed, and sunflower are clear cultigens that exhibited obvious morphological signs of domestication (i.e., increasing seed size and/or thinner seed coats); these seeds do not occur with regularity on Caddo sites anywhere in the larger Caddo archeological area, however. The maygrass, little barley, and panic grass also appear to have been cultivated, based primarily on their occurrence in large numbers at some sites, but they exhibit no such morphological distinctions. Powell and Lopinot (2000:205) suggest that panic grass may be an element of "the native seed complex” in Arkansas Caddo sites, primarily because it commonly occurs in prehistoric sites in the American Bottom in southwestern Illinois (cf. Johannessen 1984).

\section{Regional and Temporal Diversity in the Importance of Cultivated Plant Foods among the Caddo}

Given the known importance, both prehistorically and in historic times, of the cultigens maize, beans, and squash to the diet of the Caddo peoples, one of the most critical aspects of the plant husbandry system is that these plants were transported and introduced from habitats (probably from the Southwest or even from the eastern United States), where they had been initially incidentally domesticated, into an existing Woodland and Caddo agroecology. Evidence from East Texas and elsewhere suggests that tropical cultigens were introduced independently and sequentially, and that processes of adaptation were gradual. It was not until some 500 to 1000 years after the initial introduction of maize in most areas (see Milner 2004:Figure 62), that it became a staple. Furthermore, while native plants such as sumpweed and sunflower were used for a long time before maize was being grown, it was not until after agriculture based on tropical domesticates developed that these native domesticates received their greatest use. 
At 41HP137 on the Sulphur River, cultivated squash rinds (whether of a native or tropical variety has not been established) were recovered in two features. Calibrated radiocarbon dates from those features range from 154-46 BC and AD 560-652 (see McGregor et al. 1996; Crane 1996:718), namely in Early to Late Woodland times. These remains represent the earliest known evidence for the use of domesticated plants in the southern Caddo area. Other plant species recovered at this site include hickory and acorn nutshells, and a small amount of tuber or rhizome fragments, possibly from the prairie turnip or cf. Pediomelum (Fields et al. 1997:Table 11). Other Woodland-period components in northeastern Texas and northwestern Louisiana are dominated by nutshells, with limited amounts of other kinds of plant remains (Table 8-5). Chenopod seeds were recovered at the Herman Bellew site (41RK222) in the Sabine River basin, but these were not from a domesticated variety.

Current evidence indicates that maize was broadly distributed across much of the eastern U.S. after A.D. 200, and was introduced from the northern Southwest (see Clark and Knoll 2005:Figure 13.2). According to Smith and Cowan (2003:117), "it was only after A.D. 800-900 that this introduced crop took center stage and maize-centered farming appeared across much of the East." Furthermore, "the adoption of maize in eastern North America...was not straightforward, rapid, and uniform across the region, but rather a complex, culturally-variable process" (Smith and Cowan 2003:122).

Table 8-5. Ubiquity Values of Selected Plant Resources from Caddo Sites in Northeastern Texas and Northwestern Louisiana.

Site $\quad$ Time Period N Hickory Acorn Sumpweed Goosefoot Maize

\begin{tabular}{|c|c|c|c|c|c|c|c|}
\hline \multicolumn{8}{|c|}{ Sulphur River Basin } \\
\hline 41HP137 & Woodland & 3 & $100.0^{*}$ & 100.0 & 0.0 & 0.0 & 0.0 \\
\hline Hurricane Hill & Woodland & 42 & 93 & 0.0 & 0.0 & 0.0 & 2.4 \\
\hline Tick & Early Caddo & 7 & 85.7 & 0.0 & 0.0 & 0.0 & 0.0 \\
\hline Spike & Early Caddo & 26 & 69.2 & 3.8 & 0.0 & 3.8 & 0.0 \\
\hline Doctors Creek & Early Caddo & 26 & 100 & 71.4 & 14.3 & 9.5 & 19.1 \\
\hline Thomas & Early Caddo & 41 & 100 & 76.9 & 7.7 & 23.1 & 7.7 \\
\hline Hurricane Hill & Early Caddo & 96 & 89.6 & 0.0 & 0.0 & 0.0 & 14.6 \\
\hline Lawson & Early Caddo & 9 & 100 & 50.0 & 0.0 & 0.0 & 0.0 \\
\hline Spider Knoll & $\begin{array}{l}\text { Early-Middle } \\
\text { Caddo }\end{array}$ & 26 & 61.5 & 0.0 & 11.5 & 0.0 & 7.7 \\
\hline Hurricane Hill & $\begin{array}{l}\text { Middle } \\
\text { Caddo }\end{array}$ & 125 & 92.8 & 0.0 & 0.0 & 0.0 & 9.7 \\
\hline $\begin{array}{l}\text { Peerless } \\
\text { Bottoms }\end{array}$ & Late Caddo & 31 & 100 & 3.2 & 0.0 & 0.0 & 3.2 \\
\hline Earspool & Late Caddo & 58 & 50.0 & 15.5 & 0.0 & 0.0 & 24.1 \\
\hline \multicolumn{8}{|l|}{ Red River Basin } \\
\hline \multirow[t]{3}{*}{ Stallings Ranch } & Woodland & 22 & 90.9 & 22.7 & 0.0 & 0.0 & $4.5^{+}$ \\
\hline & $\begin{array}{l}\text { Formative- } \\
\text { Early Caddo }\end{array}$ & 21 & 95.2 & 28.6 & 0.0 & 0.0 & $4.8^{+}$ \\
\hline & Late Caddo & 3 & 100.0 & 33.3 & 0.0 & 0.0 & 66.7 \\
\hline
\end{tabular}


Chapter 8: Plant Remains from the Lang Pasture Site (41AN38) Anderson County, Texas, and the Character of Caddo Agriculture in the Upper Neches River Basin

Table 8-5, continued.

\begin{tabular}{|c|c|c|c|c|c|c|c|}
\hline Site & Time Period & $\mathrm{N}$ & Hickory & Acorn & Sumpweed & Goosefoot & Maize \\
\hline Ray & $\begin{array}{l}\text { Woodland- } \\
\text { Early Caddo }\end{array}$ & 20 & 55 & 20 & 0.0 & 0.0 & 15.0 \\
\hline Roitsch & $\begin{array}{l}\text { Middle-Late } \\
\text { Caddo }\end{array}$ & 17 & 76.5 & 35.3 & 0.0 & 23.5 & 47.0 \\
\hline \multicolumn{8}{|c|}{ Sabine River Basin } \\
\hline Herman Bellew & Woodland & 25 & 40.0 & 0.0 & 0.0 & 4.0 & 0.0 \\
\hline Spoonbill I & Early Caddo & 2 & 100 & 100 & $50 * *$ & 0.0 & 50.0 \\
\hline Taddlock & Early Caddo & 24 & 100 & 100 & 0.0 & 0.0 & 100 \\
\hline Hudnall-Pirtle & $\begin{array}{l}\text { Early-Middle } \\
\text { Caddo }\end{array}$ & 18 & 61.1 & 55.6 & 0.0 & 0.0 & 44.4 \\
\hline Spoonbill II & Middle Caddo & 4 & 75 & 75 & 0.0 & 25.0 & 100 \\
\hline Oak Hill & Middle Caddo & 175 & 77.7 & 21.1 & 0.0 & 2.3 & 57.7 \\
\hline Nawi haia ina & Middle Caddo & 14 & 85.7 & 1.7 & 0.0 & 0.0 & 21.4 \\
\hline 41HS588 & $\begin{array}{l}\text { Middle-Late } \\
\text { Caddo }\end{array}$ & 19 & 94.7 & 63.2 & 0.0 & 0.0 & 52.6 \\
\hline Burnitt & Late Caddo & 50 & 90 & 58 & 0.0 & 0.0 & 18.0 \\
\hline Steck & Late Caddo & 30 & 100 & 73.0 & 0.0 & 0.0 & 100.0 \\
\hline \multicolumn{8}{|c|}{ Big Cypress Creek Basin } \\
\hline $41 \mathrm{CP} 408$ & Middle Caddo & 9 & 66.6 & 0.0 & 0.0 & 0.0 & 11.1 \\
\hline Pilgrim’s Pride & Late Caddo & 72 & 66.7 & 8.3 & $0 . .0$ & 0.0 & 41.7 \\
\hline Kitchen Branch & Late Caddo & 20 & 95.0 & 60.0 & 0.0 & 0.0 & 45.0 \\
\hline $41 \mathrm{CP} 316$ & Late Caddo & 6 & 83.3 & 0.0 & 0.0 & 0.0 & 33.3 \\
\hline \multicolumn{8}{|c|}{ Neches-Angelina River Basin } \\
\hline 41NA285 & Early Caddo & 31 & 54.8 & 0.0 & 0.0 & 0.0 & 0.0 \\
\hline 41NA231 & Middle Caddo & 30 & 100.0 & 13.3 & 0.0 & 0.0 & 10.0 \\
\hline 41NA242 & Middle Caddo & 23 & 100.0 & 21.7 & 0.0 & 0.0 & 17.4 \\
\hline 41NA235 & Late Caddo & 33 & 72.7 & 3.0 & 0.0 & 0.0 & 6.1 \\
\hline 41AN38 & Late Caddo & 45 & 84.4 & 4.4 & $\mathbf{0 . 0}$ & 0.0 & 42.2 \\
\hline 41CE299 & Late Caddo & 7 & 42.9 & 0.0 & 0.0 & 0.0 & 42.9 \\
\hline \multicolumn{8}{|c|}{ Trinity River Basin } \\
\hline 41FT425 & $\begin{array}{l}\text { A.D. 1200- } \\
1400\end{array}$ & 40 & 97.5 & 37.5 & 0.0 & 0.0 & 15.0 \\
\hline
\end{tabular}

* Percentage; N=no. of flotation samples; ** One seed reported to be Iva annua var. macrocarpa, but the rest are wild type Iva annua; +=may actually be from Late Caddo occupation

Note: Except for Stallings Ranch (Bush 2008) and 41HS588 (Bush 2007), other references are in Perttula (2008a:Table 2) 
The maize introduced into the eastern United States does seem to reflect considerable genetic diversity, both because of the nature of the sources, and gradual environmental and human selection within the area itself (Cutler and Blake 1977:134-135). Ford (1981:15) suggests, therefore, that:

With this range of variation present, it is not necessary to postulate successive introductions of new corn types. As corn was introduced into the northern latitudes, natural and cultural selection favored attributes of rapid germination in cool, moist, soil and quicker maturation for a shorter growing season. There is no reason that the Northern Flint..., which came to dominate the Upper Missouri and Northeast... and which later was introduced into the Mississippi valley and the Southeast, could not have evolved in the Upper Midwest as suggested by a reduction in row number frequencies from 12-and 14-row to 8-row.

At the same time, under less stressful climatic conditions (i.e., longer growing season and minimal threat of frost), row numbers need not decrease or cob sizes increase as part of the evolution of maize (Blake and Cutler 1979). In these areas, including that settled by the Caddo, local selective pressures (including their storability) appear to have led to the maintenance of row and cob size variability in both hard flint and pop races (Midwest-12 row and North American Pop) rather than a reduction in rows like the Eastern Eight Row.

Some of the earliest eight row corn in the Eastern United States was initially identified by Jones (1949) from the George C. Davis (41CE19) corn; the George C. Davis site is located on the middle reaches of the Neches River, downstream about $60 \mathrm{~km}$ from the Lang Pasture site. Dated originally at A.D. $399 \pm 162$ (C-153, corrected, with a 2 sigma calibrated age range of AD 25-434), it was considered to be significant not only in terms of discussions about the cultivation of maize in the Caddo area, but was integral in initial considerations of the development both of the Caddo tradition, and of Mississippian groups in general (Krieger 1948:158; Newell and
Krieger 1949:231). Jones (1949) suggested that the George C. Davis maize resembled the Northern Flint type, and perhaps originated in Highland Guatemala, rather than in North America. This particular date on maize came from a pit (Fea. 31) under the Mound A platform mound at George C. Davis, but has since been discredited because of (1) the early method of radiocarbon analysis (i.e., solid carbon) that tended to produce older than expected radiocarbon ages, and (2) its archeological context (Story 1990:254). That being said, there are a few other more recently obtained calibrated radiocarbon dates on maize from George C. Davis that suggest some use of the plant before A.D. 800: AD 598-787 (also from Fea. 31, along with another calibrated date on maize from this feature of $\mathrm{AD} 1044-1219), \mathrm{AD}$ 251-566 (Fea. 195-137 in one of the village areas), and AD 346-534 (Fea. 195-149 in the same village area as Fea. 195-137). ${ }^{1}$

While the paleobotanical and archeological evidence appeared to go hand in hand, subsequent examination of the Davis site samples and more comprehensive absolute dating (Story and Valastro 1977) indicates that such a temporal affiliation for these corn samples is unlikely. Radiocarbon dates from the George C. Davis site suggest that the Caddo occupation there did not begin prior to A.D. 780 (Story and Valastro 1977:67), or perhaps not until after ca. A.D. 850 (Story 2000). While Galinat (1985) argued that eight row corn spread to the Eastern United States from Northwest Mexico and the Southwest after ca. A.D. 700, the appearance of eight row corn at the George C. Davis site need not imply its dominance even if such an introduction could by demonstrated. Small 10and 12 row maize was apparently the most common kind of maize at George C. Davis and throughout the Caddo area on sites of this time period (see Cutler and Blake 1977, 2001).

The virtual absence of maize remains from a Woodland context in the Caddo area may in part be interpreted as (a) primarily the result of limited data, (b) its still relative unimportance as a crop compared to wild plant and animal 
resources, and (c) perhaps a lack of suitable storage facilities. The oily and starchy seeds, and the gourds, may have been the dominant domesticated crops at that time, but even their level of utilization had yet to intensify prior to the adoption of maize cultivation. In a pre-Caddo-tradition horticultural context, Fritz (1984) suggests that starchy grain crops native to eastern North America were important components of the pre-Mississippian as well as Late Prehistoric diets in the Ozarks as elsewhere. This indigenous husbandry base predated the acquisition of maize, flourished at the time of early, non-intensive maize farming and finally declined in importance as maize became the dominant staple.

The timing of the introduction and adoption of maize as a crop in the Caddo area is not precisely known. Evidence from flotation samples from some sites in East Texas (Table 8-5) suggests it is ubiquitous only after A.D. 950 (Perttula and Bruseth 1983:16). Youngblood (2008:107 and Table 1) asserts that "corn arrived before A.D. 800 as demonstrated by 19 direct dates on cob remains" from East Texas sites such as George C. Davis, Washington Square (41NA49), Oak Hill (41RK214), and Ray (41LR135), but every one of the dates she cited postdates 1010 B.P. (A.D. 940), and thereby refute her own assertion rather convincingly.

Schambach (2002:105) has suggested that "corn horticulture" and/or the gardening of starchy and oily seeds may have been practiced in Woodland period Fourche Maline Culture groups by ca. A.D. 400. He bases this not on any analyses of plant remains from Fourche Maline sites along the Red River, but on the appearance of certain types of stone tools that he thinks may be gardening tools, perhaps hoes. Schambach (2002:106) also argues that corn was present and being used by Fourche Maline groups around A.D. 800, citing the aforementioned early dates from the George C. Davis site, and a single calibrated radiocarbon date on wood charcoal of $\mathrm{AD}$ 690-960 from Feature 2 at the Ray site in the Red River basin (Bruseth 1998:53). (Jeter [2007:176] has made the same mistaken assertion that corn was present in pre-Caddo contexts by relying on this one date.) From these dates, Schambach (2002:106) assumed that late Fourche Maline-Early Caddo groups "added corn gradually to their (still hypothetical) starchy and oily seed horticultural complex, which they almost certainly would have done." He goes on to suggest that corn was introduced to the Caddo area from Late Woodland peoples in the American Bottom, and that the corn may have been an accompaniment of foreign prestige goods exchanged between the American Bottom and Caddo peoples.

What Schambach has overlooked-at least in the case of the putative early corn at the Ray site-is that the corn at the Ray site has been directly dated from two features at the site, including the feature with the $7^{\text {th }}$ to $9^{\text {th }}$ century A.D. calibrated date on wood charcoal, and that it actually dates between AD 1000-1205 (Feature 2) and AD 1045-1220 (Feature 37) (Perttula et al. 2001:207 and Table 11; Fritz 2008:440). It is clear that the corn from the Ray site is from a later Caddo occupation, and has little relevance with regard to the early adoption and use of this cultivated plant by the Woodland ancestors of the Caddo peoples.

The introduction of maize into an existing agroecology based on incidental native crops brought about a change in the scale of aboriginal plant husbandry (e.g., Fritz 1986a). Through time, the relative importance of maize as a crop plant increased as opposed to both native cultigens and wild plant and animal resources. Plant selection was primarily directed towards the production of energy and carbohydrate-rich starchy plant foods, of which maize is most appropriate nutritionally, and in terms of the ability to increase its productivity. The cultivation of maize also increased the agroecological niche for the more successful cultivation of other starchy plant foods. That is, while starchy seeds had been harvested and perhaps grown for several thousand years prior to the introduction of maize, it was not until the human environmental modification associated with corn cultivation became established that 
starchy seeds, and even oily seeds, became domesticates able to take advantage of the agroecological habitat.

The intensified consumption of starchy seeded annuals after ca. 1550 B.P. appears to be confirmed in the paleobotanical record at least in the southwestern Ozarks (Fritz 1986a, 1986b, 1990). Such is not the case in Woodland and prehistoric Caddo sites in northeastern Texas and northwestern Louisiana, where such seeds are absent in Woodland period contexts, and are minimally represented in Early, Middle, and Late Caddo (ca. A.D. 1400-1680) period sites in the Sulphur River, Red River, Neches/Angelina, and Sabine River basins (see Table 8-5).

The most significant aspect of the paleobotanical record for the period between ca. A.D. $850-1400$ is the common appearance of corn in all regions of the Caddo archeological area. Systematically collected paleobotanical assemblages indicate that the introduction and adoption (at least to some extent) of maize by Caddo peoples as a food source was generally accomplished by ca. 1050 B.P. The record of its utilization is sporadic at best prior to 1050 B.P. because only a few paleobotanical assemblages are known in detail before this period of time. Paleobotanical samples from East Texas and the Ozark Highland, based on the systematic recovery of plant remains, has produced evidence of the consumption of corn as early as the $9^{\text {th }}$ century A.D. in Caddo archeological contexts. At the George C. Davis site, pre-mound A (Jones 1949) and Early Village samples from features contained maize from small 8-10 rowed varieties. Quantification of maize remains from village excavations (Jackson 1981; Ford 1997) suggests that maize was more prevalent, however, only by the Late Village (A.D. 1050-1300) occupation at the site. Such a trend in maize has also been documented at the Oak Hill Village (41RK214), where maize ubiquity increased from $31.6 \%$ in the Early Village (ca. A.D. $1150-1250$ ) to $96.9 \%$ in the Late Village (ca. A.D. 1350/1375-1450) (Dering 2004:Table 88 ). The relative abundance of maize was low compared to hardwood nuts throughout the Caddo utilization of this settlement. The general ratio of hardwood nutshells to maize fragments has been used as a measure of the relative importance of wild plant foods versus crops (cf. Scarry and Scarry 2005:267). There is a general scarcity of seeds from these archeological deposits.

The cal. AD 779-955 occupation at the Osborn site (41WD73) in the Upper Sabine Basin contained maize, hickory nuts, and acorn nuts in only a limited number of flotation samples from storage pits. No other domesticates or seeds were recovered from this Formative Caddo (ca. A.D. 800-1000) occupation (see Bruseth and Perttula 1981). Flotation at seven different Caddo components in the Upper Sabine Basin dating between ca. A.D. 800 and A.D. 1350 uniformly contain maize, hickory, and acorn plant remains in paleobotanical samples (see Table 8-5).

After ca. A.D. 900 plant exploitation patterns in the Caddo area are better known. Quantified paleobotanical remains recovered from flotation samples are available from a number of sites dating from the Early Caddo to Late Caddo periods in northeastern Texas and northwestern Louisiana (see Table 8-5). Consequently, there is a better basis for discussion of plant exploitation patterns than in earlier periods.

\section{Utilization of Weeds}

The most important weedy annuals utilized by Caddo groups are the oily and starchy seed complex plants. Oily seeded annuals include sumpweed and sunflower, while maygrass, chenopods, knotweed, and little barley comprise the starchy seed complex. Evidence from elsewhere in the eastern United States indicates that the starchy seeded plants, rich in carbohydrates, began to dominate oily seeds as seed crops at the same time as the widespread utilization of maize (Fritz 2000a, 2000b; Scarry 2003; Gremillion 2004). Furthermore, the relative emphasis on weeds for their seeds (and greens), whether they were oily or starchy, also took place then. In terms of their 
nutritional quality and productive capabilities, the weedy annuals represent a complementary pattern of exploitation to maize since both types of plants are successful colonizers of disturbed habitat. Changes in weedy annuals are expressed phenotypically in both increasing seed size (oily seeds) and number (starchy seeds), in combination with evidence for loss of natural seed dispersal, compactness of seed heads, and the colonization of areas outside their natural habitat.

Fritz (1986a:214-215) pointed out that chenopods, maygrass, and sumpweed domesticates do become scarcer as maize became the most important plant food source, and other domesticates were introduced, including beans and domesticated amaranth. She suggests that "as maize became what would seem to have been the most productive crop, husbandry of the previous staples appears to have become more casual. Introgression from the, by then, probably highly evolved weedy companions may have been permitted to the point that something akin to a gradual reversal of the domestication process went into effect.”

The Caddo paleobotanical record for the utilization of weeds for their seeds is consistent with these general changes in plant exploitation patterns, although the total evidence is considerably more limited outside of the northern Caddo region (e.g., Fritz 1990), as well as outside of the Sulphur River basin in northeastern Texas (see Table 8-5). From quantified paleobotanical assemblages, starchy seeds are present in quantity only after ca. A.D. 1200, although they were probably utilized before that time. Oily seeds dominate the Spoonbill (41WD109) site assemblage dated between cal AD 967-1160. Sumpweed and sunflower from that component comprise more than $65 \%$ of the seeds from weedy annuals present in the assemblage. In the cal AD 1228-1395 component from Spoonbill, Chenopodium sp. and knotweed are the only weedy annuals identified except for one sunflower achene. Measurements on the oily seeds by Crane (1982) indicate that they were non-domesticated varieties of these plants, although Crane (1996) has more recently reported a domesticated variety of Iva annua from Spoonbill.

At Spoonbill, the presence of seeds of morning glory and passionflower from the earliest Caddo component reflects the initial disturbance of the habitat and the natural vegetation for the cultivation of domesticated plants. These plants usually occur in close association with garden plots, old fields, and maize stalks (Crane 1982:87).

In the later occupation at the Oak Hill Village, maize and squash were the only cultigens identified by Dering (2004). As previously mentioned, maize ubiquity increased from $31.6 \%$ to $96.9 \%$ through time, and the "rise in density suggests that maize farming increased during the late [ca. A.D. 1350/1375-1450] occupation” (Dering 2004:332). Seeds of maygrass and cheno-ams were also recovered-although only in the Middle Village (ca. A.D. 1250-1350/1375) occupation-but they may be from wild plants.

\section{Tropical Cultigens}

Tropical cultigens grown by the Caddo peoples include maize, squash, gourds, and beans. Only the latter is not well represented in paleobotanical assemblages, and probably was not grown to much extent before A.D. 1300 , if not slightly later based on paleobotanical remains from Caddo sites in southwestern Arkansas (Perttula 2008a:Table 3 ). Squash and bottle gourd were among the first tropical cultigens used by the aboriginal inhabitants of the eastern United States, and they continued to be cultivated throughout the Mississippian and Historic periods by these peoples (Gremillion 2007:393-394). Like beans, they are poorly represented in paleobotanical assemblages generally, and their representation is probably affected by generally poor preservation conditions on Caddo sites. Squash is very commonly recovered in Early Caddo period contexts at Cooper Reservoir sites, however, with ubiquity ranging from $50-71.4 \%$ at the 
Lawson, Thomas, and Doctors Creek sites (Crane 1996:Table G-1), but is otherwise infrequent in Caddo paleobotanical assemblages from sites in East Texas.

Although the relative abundance of the aforementioned tropical domesticates is generally sporadic, due in large measure to conditions of preservation and probable food preparation and disposal techniques, maize is common in paleobotanical assemblages. Analyses of flotation results from Caddo assemblages, however, indicate that while the utilization of maize was widespread, it was not as intensively used then as it was to become after ca. A.D. 1300-1400 (see Table 8-5). The presence of maize from feature and/or flotation samples discussed rather consistently range between 20-60\%, except in the Sulphur River basin (see Table 8-5), where maize ubiquity is lower. Maize ubiquity in $14^{\text {th }}$ and early $15^{\text {th }}$ century contexts at the Lang Pasture site is $42 \%$.

However, measures of relative abundance commonly employed in paleobotanical research support the general conclusion that maize utilization was not as frequent before ca. A.D. 1300 in an overall sense as was the procurement of a wide range of wild plant foods gathered in a generalized foraging and horticultural economy. The use of these types of abundance measures, while not as reliable as other more direct means of dietary inference such as stable isotopes, does not dispel the fact that in comparably collected, quantified, and analyzed paleobotanical assemblages of the Early and Middle Caddo periods, maize constituted only one of a wide range of plant resources utilized by Caddo peoples.

It does appear to be the case that the use of maize was more intensive in the eastern part of the Caddo area, namely in the Ouachita and Red River basins, as well as the Arkansas River basin, than was the case among Caddo groups living in much of East Texas. This is based on ubiquity measures (Perttula 2008a:Table 3). In Caddo sites of different ages in northeastern Texas, maize ubiquity- with a few exceptions in the Sabine River basin-ranged from only $0-19 \%$ in the Sulphur River basin (with the highest percentage in ca. A.D. 1000-1200 contexts), to $15-47 \%$ in the Red River basin (with the highest percentages in post-A.D. 1300 contexts), to $21-58 \%$ in the Sabine River basin (with the highest percentages after ca. A.D. 1350/1375), and to 6-45\% in the Big Cypress and Neches-Angelina river basins (the highest percentages are in post- $14^{\text {th }}$ century sites, with the exception of several sites in the Attoyac Bayou basin where maize ubiquity is low in later sites [see Perttula 2008b]). By contrast, Caddo sites in the Red and Ouachita river basins in Arkansas and northwestern Louisiana dating after ca. A.D. 1200 have maize ubiquity measures that range from 4094\% (see Perttula 2008a:Table 3). After ca. A.D. 1400, those measures actually range from 58-94\%, all considerably higher than what has been documented to date from northeastern Texas Caddo sites.

Corn remains from Caddo sites are variable in terms of cob size and row numbers, and this is also reflected in median cupule widths between different assemblages. Cupule width of maize may be a good proxy for large kernels, and larger corn yields. That is, "corn varieties with larger cupules will tend to support larger kernels, thus resulting in greater yields” (Diehl 2005:364). In the Ozark Highlands, the earliest directly dated and measured corn (ca. A.D. 750) has the smallest cupule widths $(4.6 \mathrm{~mm})$, while the latest corn (dated after ca. A.D. 1300) have cupule widths that are as large as 8.8-11.5 mm (Fritz 1986a). This supports a trend for larger cupules and kernels over a ca. 600-700 year period. However, it is difficult to discern any temporal trends in cupule width in the Red River (see Blake 1994), Ouachita River (Cutler and Blake 2001), or East Texas Caddo sites. In the Ouachita River basin, cupule widths range from 4.3-6.2 mm, with widths peaking at ca. A.D. 1325-1400. Cupule widths range from 3.2-12.0 mm on Red River Caddo sites, but the largest cupules are reported for the $18^{\text {th }}$ century Caddo maize from Roseborough Lake (Fritz 1986c). In East Texas, the largest cupule 
widths are also reported from a historic Caddo site, in this case the early $19^{\text {th }}$ century Timber Hill site (Goldborer 2002), while the smallest $(3.2 \mathrm{~mm})$ are in Middle Caddo archeological deposits at the Oak Hill Village (Elson et al. 2004). Cupule widths at the Lang Pasture site range from 5.3-5.6 mm.

The very smallest corn (and hence the least productive) documented is from the McGuire's Garden site in the Post Oak Savanna of east-central Texas; this is a nonCaddo site. Here, in contexts dated from ca. A.D. 1290-1410, cupule widths are 2.05-4.65 $\mathrm{mm}$ on cobs and 2.45-3.76 $\mathrm{mm}$ on loose cupules (Dering 2002). Kibler (2005:198, 200) argues that the cultivation of maize was "a short-lived experiment" in this area, and "never played a major role in the overall subsistence.”

Most Caddo corn is from 10, 12 and 14-rowed ears resembling Northern American Pop and Midwest Twelve Row races. These are corn varieties with small cobs and cupules, and longer than wide kernels (Blake and Cutler 1979:53). Archeological samples of maize dating before A.D. 1400 are dominated by 8and 10- rowed varieties (Perttula 2008a:Figure 5). The earliest maize remains in well-studied Caddo plant assemblages with preserved cobs have the highest percentages of 8-rowed corn, amounting to between $29-44 \%$ of the total samples. These assemblages, of course, have the lowest mean row number values. After A.D. 1200 the 10-rowed varieties are most abundant, and remain so until approximately A.D. 1400. The corn grown at that time is commonly ascribed to Midwest Twelve Row, an intermediate form between North American Pop and the Eastern Eight Row races described by Cutler and Blake (2001). The 12 rowed varieties, including some examples of quite small corn (King 1984) from the protohistoric Cedar Grove site (3LA97), are the most common rowed varieties in Caddo assemblages dating after A.D. 1400 (see also Fritz 1986c; Goldborer 2002).

These trends in the evolution of maize present clear evidence for the development of varieties with higher numbers of rows through time in the Caddo area. This points out the basic similarity in maize variation across the Caddo area. Samples from different environmental settings such as the Ouachita Mountains, the Red River and Ouachita River basins, and Arkansas Basin sites, demonstrate that patterns of variation are significant only at the areal scale (Perttula 2008a:Figure 5). These comparisons suggest that the maize varieties grown by the Caddo peoples of different regions were quite similar to one another in character, just as they are to the maize grown in the lower Mississippi Valley (Blake and Cutler 1979).

\section{Late Caddo Plant Use}

The emphasis on the procurement and use of weedy annual nuts and a wide variety of domesticated plants in the Early and Middle Caddo period paleobotanical assemblages is not totally duplicated in the Late Caddo (ca. A.D. 1400-1700) archeological record in East Texas and elsewhere in the Caddo area. Instead the paleobotanical record indicates: (a) a reduction in wild plant food utilization, especially with the weedy annuals, (b) a deemphasis on nuts, and (c) a higher relative abundance of beans, squash, and gourd accompanied by more frequent use of maize. Caddo subsistence remained geographically variable. Our best measure of the importance of maize in the diet of Caddo peoples comes from stable isotope analyses from sites throughout the Caddo area (see Perttula 1996, 2008a; Rogers 1997; Rogers et al. 2003; Rose et al. 1998; Wilson 2008), including the stable carbon and nitrogen values obtained from burials at the Lang Pasture site and other upper Neches River basin Caddo sites.

The stable carbon isotope information from sites in the southern Caddo area indicates that around A.D. 1100-1200, there was a significant increase in the consumption of maize, as marked by C4-enriched samples at that time. Later Caddo samples leveled out and reached a measure of stasis after ca. AD 1250-1300 (Perttula 2008a:Figure 6), although in the upper Neches River basin, isotopic 
values after the $14^{\text {th }}$ century suggest that the importance of maize continued to increase in the Caddo diet (Wilson 2008, see also Wilson, this volume), peaking at ca. A.D. 1650 (during the Allen phase). In the Arkansas River valley of eastern Oklahoma, there was a more gradual increase in the consumption of maize through time (as well as the consumption of bison meat), with the most enriched samples dating after ca. A.D. 1250-1450 (Rogers 1997) and peaking during the Fort Coffee phase.

At the $15^{\text {th }}$ and $16^{\text {th }}$ century Pilgrim's Pride site in the Big Cypress Creek basin (Dering 2005; Perttula 2005), and at other Late Caddo Titus phase sites, maize and beans recovered in feature contexts provide the best evidence for later Caddo agricultural production in East Texas. Notably absent from these Titus phase sites is evidence for the use of oily and starchy seeds of the eastern Agricultural Complex (Fritz 2000a; Scarry 2003). Nevertheless, the abundance of charred nutshells, and a high nut-to-wood ratio (Dering 2005:345), indicated that nut mast collection and processing was also an important part of the subsistence strategy there, more so than at the contemporaneous Lang Pasture site; the nut to wood ratio at the Pilgrim's Pride site was 1.4:1, compared to only $0.5: 1$ at the Lang Pasture site. Dering (2005:345) concluded that the Caddo "clearly relied on maize-based food production as a major source of subsistence, but were not as heavily invested in plant food production as were some of the much larger regional settlements to the north and east in this part of the Caddo archeological area.” The same may be said for Caddo maize-based food production efforts at the Lang Pasture site in the upper Neches River basin.

In the Ouachita River basin, at sites occupied by the Caddo after ca. A.D. 1400, such as Helm (Powell and Lopinot 2000), Hardman (Fritz 1993), Winding Stair (Williams 2000), and Standridge (Early 1988), a wide variety of wild plant and tropical cultigens have been recovered. This includes a heterogeneous mix of maize with from 8-14 rows, starchy seeds, oily seeds, squash/gourds, and beans. Mean maize row numbers increase through time, from 10.2 rows at ca. A.D. $1100-1200$ to 11.2 rows from ca. A.D. 1450-1535. This trend is consistent with the result of environmental and human selection towards many-rowed crops.

The $17^{\text {th }}$ century Joe Clark and McLelland sites along the Red River in northwestern Louisiana had high-rowed maize, beans, squash, cultivated sunflower and sumpweed (Gardner 1997:116), as well as maygrass, and chenopod. None of the seeds of the eastern Agricultural Complex are abundant. Gardner (1997:116) suggests that the thin-testa domesticated chenopod from the two sites represents a cultivated small grain described among the Natchez in the early $18^{\text {th }}$ century. At the Belcher site on the Red River near Shreveport, Louisiana, deposits of charred corn cobs (12-row and 16-row) were found on the floor of $17^{\text {th }}$ century Belcher phase houses, along with persimmon seeds, beans, black walnut, and hickory nuts (Webb 1959:179180).

Beans are abundant in this same set of Late Caddo sites (see Perttula 2008a:Table 3), and the size of the beans are consistent with selection for increasing seed size and plant productivity. Length to width ratios of bean seeds from these sites range from 1.60 for ca. A.D. $1000-1200$ components, and 1.73-1.77 on Caddo sites dating from ca. A.D. 14001600. Beans from historic Indian sites dating after A.D. 1600 are even larger, with ratios of 1.84-1.90 (Blake and Cutler 1982:Table 3). Measurable cotyledons of beans from elsewhere in the Caddo area are limited, but the length/width ratios are consistent with the trends noted in the Ouachita River basin. Beans from the Washington Square Mound site in Nacogdoches County, Texas, dated at ca. A.D. 1250-1420, have length/width ratios of 1.60 (Gennett 1983). Those from an Early to Middle Caddo period context at Beaver Pond Bluffs had length/width ratios of 1.55 (Fritz 1986b:Table 14).

In general, these changes in Late Caddo times regionally may be marked by a reduction in the number of domesticated plants used as staples, with an increasing reliance on one or a 
few species of plants in a specialized subsistence strategy. This focus on one or a few plant species may have resulted in the displacement and/or differing use of other wild and cultivated plants that had previously been important parts of the diet. The selective effects of increasing productivity in these few species resulted in the relative proportional use of these resources at the expense of the displaced resources.

The relative percentage of nutshell remains in Late Caddo period paleobotanical samples ranges between $57-60 \%$ of the total plant food weights, compared to estimates of $87-100 \%$ in previously mentioned Early and Middle Caddo assemblages; at the Lang Pasture site, however, the proportion is ca. $83 \%$ (see Table $8-1$ ), suggesting a continued regular use of hickory nuts. The same types of plant species were harvested by Caddo populations, but the importance of the harvesting was changing through time. Any major increase in maize productivity relative to the potential productivity of wild plant foods-as well as to weedy annuals with a less inherent capacity for productivity increases compared to maize-would mean a reorientation of plant husbandry and associated wild plant foraging activities. Thus, this characteristic of maize would have a positive influence on its fitness. Changes in preparation techniques, storage methods (i.e., a shift to above-ground granaries to save seed for the following year's crop and for maintenance of the food supply for 1-2 years) or harvesting strategies, may also have been critical in Caddo efforts at maize intensification. Archeological evidence from sites in the Red, Sabine, and Big Cypress basins point to a change in some circumstances from below-ground storage pits to above-ground granaries after ca. A.D. 13501450 (Perino 1981; Trubowitz 1984); Rogers and Perttula 2004); the use of below-ground storage pits continued at the Lang Pasture site, however. These granaries are also documented in the ethnohistorical records as the primary means of food storage used by the Caddo peoples.

\subsection{CONCLUSIONS}

The ethnographic and ethnohistorical data on the Caddo utilization of wild and cultivated plant foods is a record of the primary use of maize, beans, and squash (Swanton 1942), including up to six varieties of beans and squash as well as sunflower and tobacco. There is no archeological or paleobotanical evidence of the use of tobacco, which is difficult to recover because of the small size of the seeds. At least two varieties of maize were described by Europeans as grown by the Caddo, but paleobotanical evidence from Late Caddo and Historic period occupations (see Ford 1982; King 1984; Goldborer 2002) suggest that the varieties mentioned by the Europeans actually referred to differences in harvesting strategies rather than to physical differences in the maize itself. Eight-tentwelve- fourteen-and 16-rowed varieties of North American Pop, Midwest 12 Row, and Eastern Eight Row races were present and being cultivated during those periods of time.

Tremendous variability existed among Caddo populations through time and across space in their agricultural practices, their food production success, as well as their absolute dependence upon cultivated foods in the diet. A wide array of cultigens were grownincluding the tropical cultigens corn (kish-sih in Caddo), beans (bah-hey), and pumpkin (coo-nooh-cah-ke-cus-neh) —as well as various oily and starchy seeds, among them chenopods/lambsquarter (bah-ha-tse), sunflower (bah-hun), marsh elder, and maygrass. Hickory and acorn nutshells were also important plant foods. The Caddo also talk of the $e$-ha-si-nai, a wild tuber that was found in northwestern Louisiana and East Texas (Newkumet and Meredith 1988:33). The Caddo believe all these plants are gifts from the earth that "they were to hold and use for their benefit. The two gifts most closely associated with the earth were corn and pumpkin” (Newkumet and Meredith 1988:30).

The available archeological and paleobotanical evidence recovered from Woodland and prehistoric/historic Caddo sites suggest 
that these various cultivated and harvested plants were most intensively used beginning after around A.D. 800/900. A number of them had been grown and used for at least a millennium before that. By A.D. 800/900, the Caddo lived in complex sedentary communities. Intensive food production strategies, however, became most important across almost all of the landscape occupied by the Caddo only after about ca. A.D. $1200 / 1300$. As tropical cultigens became the dominant crops, the other plant foods were much diminished in use and eventually were no longer grown. Such is the case at the Lang Pasture site, where in early $14^{\text {th }}$ to early $15^{\text {th }}$ century A.D. domestic contexts, maize was the most important domesticated plant food as seen in the paleobotanical analyses; stable isotope analyses of Lang Pasture burials provide further confirmation of the relative importance of maize in prehistoric upper Neches River basin Caddo diets.
The Caddo agricultural strategies and economies (based on domesticated plants and various wild plant foods) across the East Texas Caddo area were resilient and flexible, and apparently designed to suit the changing environments and seasons along the western frontier of the eastern Woodlands, and as part of their critical understanding of the rhythms of plant growth. The Caddo believe they came into the world carrying the seeds of corn and pumpkin.

\section{End Note}

1. Youngblood (2008:Table 1) mentions other supposedly early dates on maize from the George C. Davis site, but all of the dates she cited are inexplicably later than 1010 B.P. (A.D. 940). 
Chapter 8: Plant Remains from the Lang Pasture Site (41AN38) Anderson County, Texas, and the Character of Caddo Agriculture in the Upper Neches River Basin

ADDENDUM: LIST OF RECOVERED PLANT REMAINS

\section{WOOD CHARCOAL IN FLOTATION SAMPLES}

\begin{tabular}{|c|c|c|c|c|c|c|c|}
\hline Lot & Feature & Taxon & Common & Part & Count & Vol (ml) & Wt. (g) \\
\hline 1210 & 20 & Arundinaria gigantea & Giant Cane & Stem & 1 & -- & $<.1$ \\
\hline 1278 & 36 & Arundinaria gigantea & Giant Cane & Stem & 3 & -- & $<.1$ \\
\hline 1236 & 25 & Carya sp. & Hickory & Wood & 2 & -- & $<.1$ \\
\hline 1370 & 76 & Carya sp. & Hickory & Wood & 12 & -- & 0.5 \\
\hline 1375 & 76 & Carya sp. & Hickory & Wood & 2 & -- & $<.1$ \\
\hline 1378 & $76 \mathrm{~A}$ & Carya sp. & Hickory & Wood & 2 & -- & 0.6 \\
\hline 1208 & 20 & Indeterminate & NA & Wood & 4 & -- & $<.1$ \\
\hline 1210 & 20 & Indeterminate & NA & Wood & 6 & -- & $<.1$ \\
\hline 1213 & 20 & Indeterminate & NA & Wood & 11 & -- & $<.1$ \\
\hline 1233 & 25 & Indeterminate & NA & Wood & 12 & -- & $<.1$ \\
\hline 1235 & 25 & Indeterminate & NA & Wood & 17 & -- & $<.1$ \\
\hline 1236 & 25 & Indeterminate & NA & Wood & 6 & -- & $<.1$ \\
\hline 1237 & 25 & Indeterminate & NA & Wood & 11 & -- & $<.1$ \\
\hline 1238 & 25 & Indeterminate & NA & Wood & 5 & -- & $<.1$ \\
\hline 1240 & 25 & Indeterminate & NA & Wood & 5 & -- & $<.1$ \\
\hline 1278 & 36 & Indeterminate & NA & Wood & 7 & -- & 0.1 \\
\hline 1280 & 36 & Indeterminate & NA & Wood & 3 & -- & $<.1$ \\
\hline 1295 & 41 & Indeterminate & NA & Wood & 6 & -- & $<.1$ \\
\hline 1372 & 76 & Indeterminate & NA & Wood & 20 & -- & 0.1 \\
\hline 1373 & 76 & Indeterminate & NA & Wood & 1 & -- & $<.1$ \\
\hline 1391 & 79 & Indeterminate & NA & Wood & 7 & -- & 0.1 \\
\hline 1212 & 20 & Juglans nigra & Walnut & Wood & 2 & -- & $<.1$ \\
\hline 1210 & 20 & Liquidambar styraciflua & Sweetgum & Wood & 4 & -- & $<.1$ \\
\hline 1238 & 25 & Liquidambar styraciflua & Sweetgum & Wood & 2 & -- & $<.1$ \\
\hline 1369 & 76 & Pinus sp. & Pine & Wood & 10 & -- & 0.1 \\
\hline 1370 & 76 & Pinus sp. & Pine & Wood & 23 & -- & 0.6 \\
\hline 1372 & 76 & Pinus sp. & Pine & Wood & 5 & -- & $<.1$ \\
\hline 1389 & 79 & Pinus sp. & Pine & Wood & 3 & -- & $<.1$ \\
\hline 1393 & 79 & Pinus sp. & Pine & Wood & 2 & -- & $<.1$ \\
\hline 1427 & 86 & Platanus occidentalis & Sycamore & Wood & 14 & -- & 0.1 \\
\hline 1212 & 20 & Quercus sp. & Oak & Wood & 10 & -- & 0.1 \\
\hline 1213 & 20 & Quercus sp. & Oak & Wood & 7 & -- & $<.1$ \\
\hline 1230 & 25 & Quercus sp. & Oak & Wood & 5 & -- & $<.1$ \\
\hline 1231 & 25 & Quercus sp. & Oak & Wood & 15 & -- & 0.1 \\
\hline 1232 & 25 & Quercus sp. & Oak & Wood & 7 & -- & $<.1$ \\
\hline 1237 & 25 & Quercus sp. & Oak & Wood & 2 & -- & $<.1$ \\
\hline 1240 & 25 & Quercus sp. & Oak & Wood & 2 & -- & $<.1$ \\
\hline 1275 & 36 & Quercus sp. & Oak & Wood & 2 & -- & $<.1$ \\
\hline 1276 & 36 & Quercus sp. & Oak & Wood & 2 & -- & $<.1$ \\
\hline 1277 & 36 & Quercus sp. & Oak & Wood & 12 & -- & 0.5 \\
\hline 1279 & 36 & Quercus sp. & Oak & Wood & 6 & -- & $<.1$ \\
\hline 1293 & 41 & Quercus sp. & Oak & Wood & 13 & -- & 0.2 \\
\hline 1294 & 41 & Quercus sp. & Oak & Wood & 4 & -- & 0.1 \\
\hline 1369 & 76 & Quercus sp. & Oak & Wood & 2 & -- & $<.1$ \\
\hline 1374 & 76 & Quercus sp. & Oak & Wood & 4 & -- & 0.1 \\
\hline 1376 & 76 & Quercus sp. & Oak & Wood & 2 & -- & $<.1$ \\
\hline 1387 & 79 & Quercus sp. & Oak & Wood & 11 & -- & 0.3 \\
\hline
\end{tabular}




\begin{tabular}{|c|c|c|c|c|c|c|c|}
\hline 1389 & 79 & Quercus sp. & Oak & Wood & 11 & -- & 0.1 \\
\hline 1390 & 79 & Quercus sp. & Oak & Wood & 6 & -- & $<.1$ \\
\hline 1392 & 79 & Quercus sp. & Oak & Wood & 9 & -- & 0.2 \\
\hline 1393 & 79 & Quercus sp. & Oak & Wood & 22 & -- & 0.8 \\
\hline 1394 & 79 & Quercus sp. & Oak & Wood & $25+$ & 8 & 1.3 \\
\hline 1396 & 79 & Quercus sp. & Oak & Wood & 4 & -- & $<.1$ \\
\hline 1427 & 86 & Quercus sp. & Oak & Wood & $25+$ & 13 & 4.8 \\
\hline 1429 & 86 & Quercus sp. & Oak & Wood & $25+$ & 10 & 3.8 \\
\hline 1431 & 86 & Quercus sp. & Oak & Wood & $25+$ & 4 & 1.2 \\
\hline 1433 & 86 & Quercus sp. & Oak & Wood & $25+$ & 14 & 4.4 \\
\hline 1435 & 86 & Quercus sp. & Oak & Wood & $25+$ & 10 & 4 \\
\hline 1377 & $76 \mathrm{~A}$ & Quercus sp. & Oak & Wood & 1 & -- & 0.2 \\
\hline 1379 & $76 \mathrm{~A}$ & Quercus sp. & Oak & Wood & $25+$ & 10 & 2.2 \\
\hline 1380 & $76 \mathrm{~A}$ & Quercus sp. & Oak & Wood & $25+$ & 13 & 2.4 \\
\hline 1210 & 20 & Salicaceae & $\begin{array}{l}\text { Willow/ } \\
\text { Cottonwood }\end{array}$ & Wood & 1 & -- & $<.1$ \\
\hline 1277 & 36 & Salicaceae & $\begin{array}{l}\text { Willow/ } \\
\text { Cottonwood }\end{array}$ & Wood & 7 & -- & 0.1 \\
\hline 1278 & 36 & Salicaceae & $\begin{array}{l}\text { Willow/ } \\
\text { Cottonwood }\end{array}$ & Wood & 18 & -- & 0.2 \\
\hline 1370 & 76 & Salicaceae & $\begin{array}{l}\text { Willow/ } \\
\text { Cottonwood }\end{array}$ & Wood & 4 & -- & $<.1$ \\
\hline 1431 & 86 & Salicaceae & $\begin{array}{l}\text { Willow/ } \\
\text { Cottonwood }\end{array}$ & Wood & 1 & -- & $<.1$ \\
\hline 1231 & 25 & Ulmus sp. & Elm & Wood & 3 & -- & $<.1$ \\
\hline 1435 & 86 & Ulmus sp. & Elm & Wood & 3 & -- & $<.1$ \\
\hline
\end{tabular}

\section{NUTSHELL IN FLOTATION SAMPLES}

\begin{tabular}{|c|c|c|c|c|c|c|c|}
\hline Lot & Feature & Taxon & Common & Part & Count & Vol (ml) & Wt. (g) \\
\hline 1231 & 25 & Quercus sp. & Oak & Acorn & 1 & -- & $<.1$ \\
\hline 1390 & 79 & Quercus sp. & Oak & Acorn & 1 & -- & $<.1$ \\
\hline 1208 & 20 & Carya sp. & Hickory & Nut & 2 & -- & $<.1$ \\
\hline 1210 & 20 & Carya sp. & Hickory & Nut & 17 & -- & 0.4 \\
\hline 1211 & 20 & Carya sp. & Hickory & Nut & 1 & -- & $<.1$ \\
\hline 1212 & 20 & Carya sp. & Hickory & Nut & 10 & -- & 0.1 \\
\hline 1213 & 20 & Carya sp. & Hickory & Nut & 1 & -- & 0.1 \\
\hline 1230 & 25 & Carya sp. & Hickory & Nut & 1 & -- & $<.1$ \\
\hline 1231 & 25 & Carya sp. & Hickory & Nut & 8 & -- & 0.1 \\
\hline 1231 & 25 & Carya sp. & Hickory & Nut & 8 & -- & 0.1 \\
\hline 1232 & 25 & Carya sp. & Hickory & Nut & 3 & -- & $<.1$ \\
\hline 1235 & 25 & Carya sp. & Hickory & Nut & 1 & -- & $<.1$ \\
\hline 1236 & 25 & Carya sp. & Hickory & Nut & 2 & -- & $<.1$ \\
\hline 1238 & 25 & Carya sp. & Hickory & Nut & 1 & -- & $<.1$ \\
\hline 1239 & 25 & Carya sp. & Hickory & Nut & 2 & -- & $<.1$ \\
\hline 1275 & 36 & Carya sp. & Hickory & Nut & $25+$ & 7 & 2.3 \\
\hline 1276 & 36 & Carya sp. & Hickory & Nut & 4 & -- & $<.1$ \\
\hline 1277 & 36 & Carya sp. & Hickory & Nut & $25^{+}$ & 26 & 10.2 \\
\hline 1278 & 36 & Carya sp. & Hickory & Nut & 18 & -- & 0.8 \\
\hline 1279 & 36 & Carya sp. & Hickory & Nut & 12 & -- & 0.3 \\
\hline 1280 & 36 & Carya sp. & Hickory & Nut & 1 & -- & $<.1$ \\
\hline 1369 & 76 & Carya sp. & Hickory & Nut & 3 & -- & $<.1$ \\
\hline 1370 & 76 & Carya sp. & Hickory & Nut & 1 & -- & $<.1$ \\
\hline 1371 & 76 & Carya sp. & Hickory & Nut & 3 & -- & 0.2 \\
\hline
\end{tabular}


Chapter 8: Plant Remains from the Lang Pasture Site (41AN38) Anderson County, Texas, and the Character of Caddo Agriculture in the Upper Neches River Basin

\begin{tabular}{|l|l|l|l|l|r|r|c|}
\hline 1372 & 76 & Carya sp. & Hickory & Nut & 1 & -- & $<.1$ \\
\hline 1374 & 76 & Carya sp. & Hickory & Nut & 1 & -- & $<.1$ \\
\hline 1375 & 76 & Carya sp. & Hickory & Nut & 3 & -- & 0.1 \\
\hline 1388 & 79 & Carya sp. & Hickory & Nut & 9 & -- & 0.3 \\
\hline 1389 & 79 & Carya sp. & Hickory & Nut & 8 & -- & 0.1 \\
\hline 1391 & 79 & Carya sp. & Hickory & Nut & 1 & -- & $<.1$ \\
\hline 1392 & 79 & Carya sp. & Hickory & Nut & 1 & -- & $<.1$ \\
\hline 1393 & 79 & Carya sp. & Hickory & Nut & 16 & -- & 0.5 \\
\hline 1395 & 79 & Carya sp. & Hickory & Nut & 3 & -- & 0.2 \\
\hline 1427 & 86 & Carya sp. & Hickory & Nut & 3 & -- & 0.1 \\
\hline 1429 & 86 & Carya sp. & Hickory & Nut & 1 & -- & 0.1 \\
\hline 1431 & 86 & Carya sp. & Hickory & Nut & 4 & -- & 0.1 \\
\hline 1433 & 86 & Carya sp. & Hickory & Nut & 4 & -- & 0.2 \\
\hline 1435 & 86 & Carya sp. & Hickory & Nut & 3 & -- & 0.1 \\
\hline
\end{tabular}

\section{MAIZE IN FLOTATION SAMPLES}

\begin{tabular}{|c|c|c|c|c|c|c|c|}
\hline Lot & Feature & Taxon & Common & Part & Count & $\begin{array}{l}\text { Vol } \\
\text { (ml) }\end{array}$ & $\begin{array}{l}\text { Wt. } \\
\text { (g) }\end{array}$ \\
\hline 1210 & 20 & Zea mays & Maize & Cupule & 26 & -- & 0.2 \\
\hline 1210 & 20 & Zea mays & Maize & Cob segment & 1 & -- & $<.1$ \\
\hline 1211 & 20 & Zea mays & Maize & Cupule & 5 & -- & $<.1$ \\
\hline 1213 & 20 & Zea mays & Maize & Cupule & 2 & -- & $<.1$ \\
\hline 1231 & 25 & Zea mays & Maize & Cupule & 2 & -- & $<.1$ \\
\hline 1275 & 36 & Zea mays & Maize & Cupule & 1 & -- & $<.1$ \\
\hline 1277 & 36 & Zea mays & Maize & Cupule & 6 & -- & $<.1$ \\
\hline 1293 & 41 & Zea mays & Maize & Cupule & 137 & 11 & 2.7 \\
\hline 1293 & 41 & Zea mays & Maize & Kernel & 2 & -- & $<.1$ \\
\hline 1294 & 41 & Zea mays & Maize & Cupule & 45 & -- & 0.2 \\
\hline 1295 & 41 & Zea mays & Maize & Cupule & 29 & -- & 0.2 \\
\hline 1295 & 41 & Zea mays & Maize & Kernel & 2 & -- & $<.1$ \\
\hline 1296 & 41 & Zea mays & Maize & Cupule & 6 & -- & $<.1$ \\
\hline 1296 & 41 & Zea mays & Maize & Glume & 1 & -- & $<.1$ \\
\hline 1370 & 76 & Zea mays & Maize & Cupule & 2 & -- & $<.1$ \\
\hline 1374 & 76 & Zea mays & Maize & Cupule & 1 & -- & $<.1$ \\
\hline 1387 & 79 & Zea mays & Maize & Cupule & 3 & -- & $<.1$ \\
\hline 1388 & 79 & Zea mays & Maize & Cupule & 2 & -- & $<.1$ \\
\hline 1389 & 79 & Zea mays & Maize & Cupule & 2 & -- & $<.1$ \\
\hline
\end{tabular}

\section{MAIZE IN MACROBOTANICAL SAMPLES}

\begin{tabular}{|r|c|l|l|l|l|r|r|}
\hline \multicolumn{1}{|c|}{ Lot } & Feature & Provenience & \multicolumn{1}{|c|}{ Taxon } & \multicolumn{1}{|c|}{ Common } & \multicolumn{1}{|c|}{ Part } & Count & Wt. (g) \\
\hline 795 & 41 & & Zea mays & Maize & Cupule & 0.3 \\
\hline 999 & -- & & Zea mays & Maize & Cob segment, cupule & 0.7 \\
\hline 1017 & -- & & Zea mays & Maize & Cob segment, cupule & 27 & 5 \\
\hline 1667 & 41 & & Zea mays & Maize & Cob segment, cupule & & 0.1 \\
\hline 1668 & 41 & & Zea mays & Maize & Cob segment, cupule & 0.1 \\
\hline 1668 & 41 & & Indeterminate & NA & Wood & 0.1 \\
\hline
\end{tabular}




\section{CHAPTER 9}

\section{FAUNAL REMAINS}

\section{$9.1 \quad$ INTRODUCTION}

The 2006 excavations at the Lang Pasture site (41AN38) yielded a small quantity of vertebrate faunal remains that were generally highly fragmented and poorly preserved. The total sample analyzed consisted of 1,759 specimens, of which 1,016 (57.8 percent) were unidentifiable. This is an exceptionally high percentage of unidentifiable remains, and it is directly related to the poor bone preservation at the site. The 743 identifiable specimens consisted almost entirely of relatively dense mammalian remains.

\subsection{PreVious Research in the REGION}

At present only a handful of sizeable faunal assemblages from Caddo sites in the middle Neches River basin have been reported on. This is partly due to the limited number of excavations that have been undertaken there, but also to the often poor bone preservation found in not only this region, but much of East Texas.

One site in this region that has produced wellpreserved faunal remains is the ALCOA \#1 site (41AN87), a small Frankston phase farmstead or hamlet located about $7 \mathrm{~km}$ northeast of Palestine, Texas on a terrace overlooking Mound Prairie Creek (Amick et al. 1991). Excavations in a thick trash midden at the site yielded an assemblage that included catfish, gar, buffalo fish, frog, box turtle, turkey, a raptor, unidentified large- and medium-sized birds, opossum, cottontail, swamp rabbit, squirrel, raccoon, white-tailed deer, and bison (Amick et al. 1991:14).
Unfortunately, the authors did not quantify their data other than to note that white-tailed deer remains dominated the collection, and that bison was represented by a single element.

Lee Anna Schniebs analyzed a small collection of faunal remains recovered from six shovel tests and a 50 x $50 \mathrm{~cm}$ unit excavated in a midden deposit located in a portion of the Lang Pasture site about $10 \mathrm{~m}$ west of the SH 155 right-of-way. She noted that the bone from this area was fragmented, but "generally well-preserved" (Perttula et al. 2007c:34). Of the 118 specimens recovered, mammals accounted for 95 percent of the number of identified specimens (NISP). The most common mammalian species was whitetailed deer, followed by opossum, and an unidentified species of rabbit. The only other taxa represented were box turtle and an unidentified turtle.

Recently, Schniebs (2007) also reported on another relatively small collection from the Kah-hah-ko-wha site (41CE354) on Flat Creek in northwestern Cherokee County. This assemblage is associated with an Allen phase occupation that dates from the midseventeenth century to the early eighteenth century. A total of 714 specimens were recovered from test excavations in two areas of the site. Mammals accounted for 90 percent of the identified remains, and the most abundant species was white-tailed deer (Schniebs 2007:Table 23). Cottontail, opossum, and squirrel were also present, but in very low frequencies. Reptiles, in this case turtles, made up 9 percent of the NISP. At least two turtle taxa were represented, box 
turtle and the mud-musk turtle family. The only other taxa present were a few unidentified fish remains and a single turkey element. A high percentage of the remains from the Kah-hah-ko-wha site, 78 percent from the site as a whole and 99 percent from one area, were burned, suggesting that preservation bias had a significant effect on this assemblage.

\subsection{Methodology}

The faunal remains analyzed from the Lang Pasture site consisted of material recovered from $1 / 4$-inch screen and from flotation samples. The material from flotation samples came from the heavy fraction, which was collected in window screen.

Identification of the material from the Lang Pasture site was performed by comparing the archeologicalspecimens to elements in the comparative collections of the author, Coastal Environments, Inc., and the Museum of Natural Science at Louisiana State University, Baton Rouge. The analysis involved identification of taxon, element, element symmetry, element portion, and specimen count. Information was also recorded on evidence of burning, butchery, use, and age at death indicators. Bones that were identifiable only to class (e.g. mammal, bird, fish, etc.) were placed into size categories of small, medium, and large, if possible. All of the data were then entered into a spreadsheet program, Microsoft Excel, in order to facilitate manipulation of the information.

\section{Quantification}

Quantification of the faunal remains consisted of one primary figure, NISP, and one secondary figure, the minimum number of individuals (MNI). The limitation of NISP is apparent when attempting to assess the amount of edible portions contributed by each species. For example, if white-tailed deer was represented in one assemblage by five left femora and five right femora and in another assemblage was represented by ten right femora, though the number of specimens in each assemblage would be equal, the number of deer represented, and therefore the amount of available meat, would differ. NISP cannot account for the distinction of individuals of a particular species.

To determine the number of individuals of a species that were present, the most common unit of measure is MNI. MNI is a figure calculated by assessing the minimum number of individual animals represented within an assemblage based on the frequency of specific elements. For example, if there are five right femora and three left femora of a species, the minimum number of individuals that are represented is five. MNI can also take into consideration age or sex differences in the remains.

While MNI overcomes some of the shortcomings of NISP, it has limitations in terms of how accurately it reflects the frequency and dietary importance of certain taxa. One problem is that MNI can be calculated in a number of ways, thus introducing an enormous variable when comparing assemblages analyzed and interpreted by different researchers. Another difficulty is that MNI, which by definition offers a minimum number, often underestimates the true frequency of individuals, especially well-represented ones. Also, MNI does not account for the percentage of the species' skeleton that is present. A species represented by single bone will receive a MNI of one, while another species, represented by every bone in the skeleton, will also receive a MNI of one.

\subsection{Results}

Table 9-1 summarizes the faunal data from the entire site, and Table 9-2 presents data from the flotation samples by feature.

\section{Mammals}

Mammals account for 99.6 percent of the NISP from the site. While they undoubtedly 
Table 9-1. Vertebrate Faunal Remains from the Lang Pasture Site (41AN38).

\begin{tabular}{|c|c|c|c|}
\hline \multirow[b]{2}{*}{ Taxa } & \multicolumn{3}{|c|}{ \% Total } \\
\hline & NISP & NISP & MNI \\
\hline \multicolumn{4}{|l|}{ MAMMALS } \\
\hline \multicolumn{4}{|l|}{ White-tailed deer } \\
\hline Odocoileus virginanus & 64 & $8.61 \%$ & 3 \\
\hline \multicolumn{4}{|l|}{ Dog, coyote or wolf } \\
\hline Canis spp. & 36 & $4.85 \%$ & 1 \\
\hline \multicolumn{4}{|l|}{ Rabbit } \\
\hline Sylvilagus spp. & 4 & $0.54 \%$ & 1 \\
\hline \multicolumn{4}{|l|}{ Cow } \\
\hline Bos taurus & 1 & $0.13 \%$ & 1 \\
\hline \multicolumn{4}{|l|}{ Plains Pocket Gopher } \\
\hline Geomys bursarius & 4 & $0.54 \%$ & 1 \\
\hline Unidentified large mammal & 102 & $13.73 \%$ & \\
\hline Unidentified mammal & 529 & $71.20 \%$ & \\
\hline Total & 740 & $99.60 \%$ & 7 \\
\hline \multicolumn{4}{|l|}{ REPTILES } \\
\hline Unidentified turtle & 3 & $0.40 \%$ & 1 \\
\hline Total & 3 & $0.40 \%$ & 1 \\
\hline UNIDENTIFIED & 1016 & & \\
\hline TOTAL & 1759 & $100.00 \%$ & 8 \\
\hline
\end{tabular}

played an important part in the faunal exploitation strategies of the site's occupants, this exceptionally high percentage is a reflection of preservation bias favoring the remains of larger animals with denser bones. White-tailed deer account for the majority of the mammal remains that are identifiable below the level of class. Most of the deer bone consists of relatively small fragments of dense elements, such as teeth, metapodials, carpals, tarsals and phalanges. However, antler fragments, which are also very dense, are not present, suggesting that they were being curated for tool manufacture. At least three individuals are represented based on right astragali, two adults and a fawn.
Remains of the fawn occurred in two units located immediately south of Structure 1, while the adult remains were much more widely scattered. Most of the features contained no more than a single deer bone, the exceptions being Features 76, 76A, and 79.

The only other mammal represented by more than four specimens is a canid (Canis spp.) represented by 36 mandible and tooth fragments found in the $45-50 \mathrm{~cm}$ level of a single unit near the southern edge of the site. The material was too fragmentary to identify to species level; however, based on the size of the teeth the animal was probably a dog, as they are too small for wolf and too large for coyote. 
Table 9-2. Vertebrate Faunal Remains Recovered from Features at the Lang Pasture

\begin{tabular}{|c|c|c|c|c|c|c|c|c|c|c|c|c|c|c|c|c|c|c|c|c|c|}
\hline \multirow[b]{2}{*}{ Taxa } & \multicolumn{21}{|c|}{ Feature No. } \\
\hline & 13 & 16 & 18 & 20 & 23 & 24 & 25 & 26 & 27 & 28 & 29 & 36 & 37 & 38 & 39 & \multicolumn{2}{|l|}{41} & 44 & \multicolumn{2}{|l|}{45} & 48 \\
\hline MAMMALS & & & & & & & & & & & & & & & & \multicolumn{2}{|c|}{42} & & \multicolumn{2}{|c|}{46} & \\
\hline \multicolumn{22}{|l|}{ White-tailed deer } \\
\hline Odocoileus virginanus & & & & 1 & & & 1 & & & & & & & & & & & & & & \\
\hline \multicolumn{22}{|l|}{ Rabbit } \\
\hline Sylvilagus spp. & & & & & & & 2 & & & & & & & & & & & & & & \\
\hline Unidentified large mammal & & 2 & & & & & 3 & & & & & 7 & & & & & & & & & \\
\hline Unidentified mammal & & & & 4 & & & 40 & & & & & 33 & & & & 2 & & & 1 & & \\
\hline \multicolumn{22}{|l|}{ REPTILES } \\
\hline Unidentified turtle & & & & & & & & & & & & & & & 1 & & & & & & \\
\hline UNIDENTIFIED & 9 & 21 & 17 & 23 & 9 & 3 & 342 & 5 & 6 & 30 & 5 & 62 & 18 & 1 & & 1 & 1 & 4 & 19 & 9 & 2 \\
\hline \multirow[t]{3}{*}{ TOTAL } & 9 & 23 & 17 & 28 & 9 & 3 & 388 & 5 & 6 & 30 & 5 & 102 & 18 & 1 & 1 & 3 & 1 & 4 & 20 & 9 & 2 \\
\hline & \multicolumn{21}{|c|}{ Feature No. } \\
\hline & 51 & 57 & 59 & 61 & 62 & 63 & 66 & 72 & 73 & 74 & 75 & 76 & 76A & 78 & 79 & 80 & 81 & 82 & 84 & 85 & 86 \\
\hline \multicolumn{22}{|l|}{ MAMMALS } \\
\hline \multicolumn{22}{|l|}{ White-tailed deer } \\
\hline Odocoileus virginanus & & & & & & & & & & 1 & & 11 & 3 & & 7 & & & & & & \\
\hline \multicolumn{22}{|l|}{ Rabbit } \\
\hline Sylvilagus spp. & & & & & & & & & & & & & 1 & & & & & & & & \\
\hline Unidentified large mammal & & & & & & & 2 & & & & & 10 & & & 5 & & 1 & & & & \\
\hline Unidentified mammal & & & & & & & & & 2 & & & 57 & 17 & & 22 & & 1 & & & & \\
\hline \multicolumn{22}{|l|}{ REPTILES } \\
\hline Unidentified turtle & & & & & & & & & & & & 1 & & & & & & & & & \\
\hline UNIDENTIFIED & 3 & 1 & 2 & 3 & 2 & 1 & 5 & 2 & & 44 & 7 & 74 & 68 & 3 & 97 & 5 & 54 & 10 & 5 & 7 & 7 \\
\hline TOTAL & 3 & 1 & 2 & 3 & 2 & 1 & 7 & 2 & 2 & 45 & 7 & 153 & 89 & 3 & 131 & 5 & 56 & 10 & 5 & 7 & 7 \\
\hline
\end{tabular}


A small number of rabbit (Sylvilagus spp.) remains were recovered from the excavations. Like much of the faunal material these were highly fragmented and could not be identified to species. All of these remains were recovered in flotation samples from features, two from Feature 25, one from Feature 76A, and one from Feature 79.

Remains of two mammals that represent recent additions to the archeologicaldeposits were also present. These include a single cow (Bos taurus) molar and four cranial elements of Plains Pocket Gopher (Geomys bursarius), all of the latter recovered from a single unit. Gophers have burrowed extensively at the site, and were still active at the time of the excavations.

Unidentified mammal and unidentified large mammal represent the two largest categories of mammalian remains. Most of these remains consisted of small, weathered fragments of long bone shafts or other dense elements. Many of the unidentified large mammal specimens are probably from white-tailed deer, but cannot be confidently identified as such.

\section{Reptiles}

Reptiles are the only other class represented in the faunal remains, and they consist of only three specimens of turtle carapace that could not be identified to genus or species. Interestingly, all of the turtle remains occurred in the area immediately north of Structure 1 . These elements are relatively dense, so their low frequency is probably an accurate reflection of their limited exploitation, rather than preservation bias.

\subsection{SUMMARY}

The collection of faunal remains recovered from the Lang Pasture site is relatively small and poorly preserved. This is largely due to a combination of chemical weathering from the strongly acid soil on which the site is located and gnawing by gophers. Only in a few of the features, particularly two of the hearths, Features 25 and 36, were larger samples of faunal remains recovered. The bone from these contexts is still highly fragmented, and the increased sample size appears to be related to the high percentage of burned bone present there (over 60 percent). Unfortunately the preservation problems encountered in the faunal assemblage recovered from Lang Pasture prevent its use for addressing questions related to subsistence at the site. 


\section{CHAPTER 10}

\section{ANALYSIS OF HUMAN REMAINS FROM THE LANG PASTURE SITE}

Diane Wilson

\subsection{INTRODUCTION}

The study of the Lang Pasture site (41AN38) human remains has two objectives and hopes to test one hypothesis. The first is to provide a written report of an osteological examination conducted on the remains recovered from the Lang Pasture site and human remains housed at the Texas Archeological Research Laboratory (TARL) from 14 Caddo sites in Anderson and neighboring Cherokee counties. The second objective is to provide a synthetic regional review of Caddo bioarchaeology incorporating the new information with bioarchaeological information already published on Caddo human remains from the southern Caddo region. Finally, the data collected here will be used to test the hypothesis that the Caddo from the Lang Pasture site and the rest of the Upper Neches River basin had a diet low in maize and a low rate of infectious disease. The human remains were examined following standard osteological procedures outlined in Buikstra and Ubelaker (1994) and the Texas A\&M University Department of Anthropology Data Collection Forms (Steele et al. 1993). Information gleaned from each burial was recorded in a standard osteological database and provided the information used for the analysis presented here.

The analysis of the recently excavated Lang Pasture human remains and the newly collected data on human remains housed at TARL provide an inventory of the remains recovered from the Upper Neches River Basin, address issues concerning the state of preservation of the remains, the body size and sexual dimorphism of the Caddo from this region, an evaluation of the population's diet and health, and an assessment of their biological affinity to other populations within the region. (Editor's note: Due to their great length, the data tables for this chapterTables 10-1 through 10-24-- are placed on the compact disk, as Appendix $\mathrm{H}$, found in the sleeve in the back cover of this report).

\subsection{INVENTORY}

Establishing an inventory of the individuals in the assemblages and the material representing each individual is the prerequisite to any osteological analysis. The inventory serves as a description of remains present and is useful in assessments of preservation, health, mortuary patterns, bioturbation and other postmortem disturbances, excavation conditions and techniques, and soil conditions.

In addition to the Lang Pasture site, 14 other sites containing human remains are reported on here. Determining the number of burials per site in this region can be problematic due to poor preservation, excavation strategies and the activities of collectors. At the Lang Pasture site the remains of nine individuals were recovered. In addition, machine scrapings produced some human bone fragments. It was not possible to associate these fragments with the nine isolated individuals so their context remains unknown. The number of individuals examined from other sites in the Upper Neches basin ranged from one to 15 . Only the Jim Allen and George C. Davis sites were represented by more than nine individuals. In all, a minimum of 72 individuals were examined for this study. The mean number of individuals examined per site is 4.6. Rose and Burnett (1990) gave a mean of 8.7 individuals per Caddo site from the eastern portion of the Gulf Coastal Plain. This is similar 
to the number of individuals recovered from the Lang Pasture Site.

For this study burials were assigned to time periods following Story's (1990) categories based on radiocarbon dates, archeologicalcontext and associations. Two sites were left out of the temporal analysis: the Lee Ellis site and the Isibell Gene Donnell site could not be placed into a refined time period within the Caddo sequence. For all analyses of sites, dating was done based on the majority of burials. For example, the Lang Pasture site has individuals dated to the Middle and Late Caddo periods, but since a majority dated to the latter part of the Middle Caddo period, it was placed into the Middle Caddo period. All stable isotope analyses were performed on an individual rather than site basis. For all analyses of individuals, burial dates stand. For example, the Formative Caddo period individual from the George C. Davis site remains as an example from the Formative Caddo period rather than being lumped into the Early Caddo period.

\subsection{TAPHONOMY}

The issues most commonly raised when evaluating the taphonomic processes affecting human remains deal with documenting the extent of postmortem degradation and loss of skeletal remains; understanding the processes of destruction and dispersal of bones; and assessing the role of humans as agents causing modification, destruction, and dispersal of human skeletal remains at archeologicalsites.

The human remains in much of the southern portion of the Caddo region in Texas are poorly preserved. Bones can be so degraded as to be recognized only by stains in the soil and burial offerings. Feature 91 from the Lang Pasture site, for example, consisted of one enamel fragment from an unidentifiable tooth, and in another burial, Feature 94, no bones or teeth were preserved. The analysis presented here provides an objective assessment of the state of preservation. Tables 10-1, 10-2, and 10-3 provide summaries of the elements recovered from the sites examined for this report. The tables show that all skeletons are missing skeletal elements and most of the bones present are incomplete. An examination of the skull shows that the interments follow a pattern typical for skeletons buried in the soil. That is, bones of the face are less common and less well preserved than those of the braincase. Bones of the braincase (frontal, parietals, temporals and occipital) have thicker cortices than the thin cortical bone found in the facial bones (e,g., maxilla, palatine and zygomatic). In the postcranium, long bones were more common and recovered in larger fragments than bones of the chest, back, pelvis, hands and feet. No palatines, sternum body, thoracic vertebra 10, eleventh and twelfth ribs, and pubis bones were recovered in the entire Upper Neches River basin sample. One problem with the inventory scoring method was found in the mandible and frontal. In these bones, inventory procedures follow those for bones that have left and right sides because both bones develop from bones with left and right sides into a whole unit. Once the bones have become whole units (adults), they were scored with one completeness score rather than a score for each side. In the computer they are automatically scored as an unsided element, causing some possible confusion as to whether a bone fragment from the mandible or frontal is unsided or could be sided.

The site with the most skeletal elements per person represented was the Emma Owens Farm (41AN21) (Table 10-4). This site only had the remains of one individual. This individual had nearly half of the skeletal elements (47 percent) coded for in the inventory database represented. The one individual from the Isibell-Genen Donnell site had the worst skeletal representation with less than one percent of the skeletal elements present. The Lang Pasture site averaged 7.2 percent of the skeletal elements preserved. This was worse than the average for the entire sample of 12.9 percent. Inventory preservation scores indicate that the Forest Mound site (41CE290) had the best preservation of the elements represented. The combined sample had a mean preservation score of 2.2. The skeletal elements from the one individual represented from the Forest Mound site averaged a score of 1.1 with 1 being the best preservation and 3 being the worst. The worst 
preserved site was the Isibell-Gene Donnell site (41AN14) with a mean score of 3.0. The individuals from the Lang Pasture site had an average preservation score of 2.7, again showing that the site had poor preservation.

The taphonomic processes affecting the Upper Neches River Basin sites are much the same as for other sites from East Texas. As in much of the southern Caddo archeologicalregion the dry and brittle condition of the bones, along with their low organic content can be attributed to acidic soil. In addition, the soil is relatively fine grained which does not impede drainage. Water damage is mainly enhanced when the burial pit and its remains are excavated into a Bt horizon, and the burial pit would hold water during precipitation events. This repeated wetting and with slow rates of drying further intensifies bone destruction through the leaching of organic bone matter into the surrounding matrix. Gill-King (1990) was one of the first to describe this process in the region.

Although geological modification inhibited observation of other forms of surface destruction, root etching was common in the Lang Pasture site. Root etching was observed in all individuals from the Lang Pasture site. Root etching was present in 45 percent of the remaining individuals from the Upper Neches River basin (49 observable individuals). Other forms of biological modification include rodent gnawing in three individuals and insect boring in two individuals from the Lang Pasture site. Rodent gnawing was the second most common biological modification and was observed in 21.3 percent of the remaining Upper Neches River basin population, followed by insect boring which was present in 15 percent of the population (47 observable individuals for both). There was no evidence of human modification of bone in the form of burning or cut marks in the entire Upper Neches River basin sample. Cut marks have been recorded in the Roitsch population (Derrick et al. 2008) but are rare in Caddo sites.

\subsection{DEMOGRAPHY}

The age and sex of individuals from the Lang Pasture site and other Upper Neches River Basin sites were assessed using a variety of techniques (Table 10-5). Individuals were age assessed using one or more of the following: dental formation stage (Moores et al. 1963a, 1963b), dental eruption (Ubelaker 1978), dental wear compared to Texas Red River Caddo (Wilson 1997), external, palatine and internal cranial vault suture closure (Meindl and Lovejoy 1985, Buikstra and Ubelaker 1994), epiphyseal fusion (Baker et al. 2005) and size and features of immature remains (Baker et al. 2005). Sex was determined using one or more of the following techniques: cranial and/or pelvic observations (Krogman 1962; Steele and Bramblett 1988), femoral head circumference (Stewart 1979), femoral midshaft circumference (Black 1978), talus length (Steele 1976) and dental discriminate function formulae (Ditch and Rose 1972).

Table 10-5 provides a summary of age and sex data for the Lang Pasture and comparable Upper Neches River basin human remains. The average age at death for the Lang Pasture Site is 29.3. This is nearly the same average age at death as for sites from the Cooper Lake region at 29.1 years (Wilson and Steele 1997) and the Pine Tree Mound site at 29.6 (Wilson 2008a) and similar to the Mitchell site but higher than the Hatchel site both on the Red River (Lee 1997:163). The Lang Pasture site is lower than the mean for the summary data from the Neches River at 32.5 years presented by Burnett (1990, 1999).

The Upper Neches River basin population examined here has an average age of death of 34.2 years. When the individuals from the Lang Pasture site are included, this average drops to 32.9 years and is nearly identical to Burnett's (1990, 1999) findings. Compared to Burnett's (1990, 1999) summary data from other river basins, the Upper Neches average age at death is higher than other Caddo populations. In looking at Burnett's $(1990,1999)$ data there is a general south to southwestern progression of increasing age at death through the Caddo region in Texas 
which may be the result of differential burial practices, preservation of subadults, or a real increase in longevity.

The average age of death for adults from the Lang Pasture site is high at 42.2 years. This is higher than all other comparable data except from the Pine Tree Mound site (Wilson 2008a) at 41.1, and suggests an absence of young adults in the population. It is higher than at the mound sites of Sanders (35.8) and Mitchell (38.3) (Wilson 1997). The Lang Pasture adult average age at death is also higher than the summary data for the Neches River drainage at 35.9 (Burnett 1990, 1999). The Upper Neches River basin has an adult average age of death of 39.8 without the individuals from the Lang Pasture site and an adult average age at death of 40.0 when they are included. This is higher than summary data for the other river drainages where the Caddo resided on the eastern Gulf Coastal Plain. Only the Cooper Lake population had a higher adult average age at death at 44.6 (Wilson and Steele 1997).

The average age at death did not differ significantly through time. A larger sample is needed to determine if the decreased life expectancy during the Historic period seen in this study will bear out. In the Upper Neches River basin population, the Historic period as represented by the Jim Allen site had an average age of death of 25.8 years. This is an apparent decrease from the Late Caddo period average age of death at 32.1 years, which itself is a slight decrease from the Middle period average of 35.9 years. The Early Caddo period average age of death is nearly the same as the Middle Caddo period at 34.3 years. Adult average ages at death paralleled the site averages. The Historic period mean as represented by the Jim Allen site was approximately five years less than for the other time periods (Early Caddo mean $=40.6$, Middle Caddo mean $=43.8$, Late Caddo period mean $=41.4$, Historic mean $=35.2$ ).

Where demographic data have been provided, males appear to have outlived females throughout the Texas Caddo region. The Lang Pasture site does not follow this pattern, but the Upper Neches River basin does. Based upon the three individuals for whom sex could be determined, females had a higher average age at death at 43.8 years than the male at 40.0 years. The difference between males and females is greater when the entire Upper Neches River basin is examined. Males had an average age of death of 43.7 while females have an average age of death of 33.0. When the individuals from the Lang Pasture site are included the average age of death for females is 34.5 and the average age of death for males is 43.4. Despite a difference of almost nine years, the difference in life expectancy is not statistically significant. A significant difference between male and female average age of death was found in the Cooper Lake population with males averaging 46.6 years compared to 38.4 for females (Wilson and Steele 1997). This is the same pattern with a smaller difference recorded in the Sanders (38.5 years and 35.6 years) and Mitchell (38.3 years and 35.6 years) populations (Wilson 1997). The higher mean age at death for males is common historically and is assumed to be a reflection of higher mortality of adolescent and young adult females due to complications of pregnancy and childbirth.

The adult sex ratio from the Upper Neches River basin is 14 females to 16 males, inclusive of the Lang Pasture Caddo. Throughout the Caddo region in Texas there is a nearly even sex ratio (Table 10-6). It should be noted that Rose (1984) suggested that a sex ratio of more males than females is the norm for Caddo sites, but Derrick et al. (2008), in a review of sites neighboring the Roitsch site, finds females typically outnumber males.

\subsection{BODY SIZE AND SEXUAL DIMORPHISM}

Tables 10-7, 10-8, 10-9, 10-10, and 10-11 provide all measurements recorded during the analysis of the skeletal and dental remains from the Lang Pasture site and the Upper Neches River basin. The relatively poor state of preservation is reflected in the small number of measurements that could be taken. Stature estimates were not possible due to the incomplete nature of the remains from the Upper Neches River basin. 
Since stature estimates were not available, three measurements were chosen to examine the degree of sexual dimorphism: circumference at the nutrient foramen of the tibia, anteriorposterior diameter at the nutrient foramen of the tibia and the transverse diameter of the nutrient foramen of the tibia. Measurements of the tibia were chosen because these bones directly bear body weight and femoral measures were only available for males. Table 10-12 documents these measurements for females and males in the Upper Neches River basin.

Stini (1985) found the range of male/female body size ratios to be between 104 and 111 . Stature estimates for the Caddo fall within this range. Doran's (1975) Caddo sample had a sex ratio of 106 for stature. The Roitsch site has a sex ratio of 103.3 for stature (Derrick et al. 2008). Populations from Sam Kaufman (Butler 1969) had a sex ratio of 106.1 for stature. Based on Loveland's data (1986), the Rowland Clark site population had a sex ratio of 105.4 and the Clark site population had a sex ratio of 108.1. Femoral measures from the Cooper Lake assemblage and tibia measurements presented here are near the upper limit for sexual dimorphism. Taken together, the Caddo had a higher degree of sexual dimorphism in terms of robusticity than stature when compared to other populations. While robusticity and stature are under genetic influence, they are also controlled by the quantity and quality of diet and the health of individuals. Robusticity is also influenced by workloads. While the sample size is small, Table 10-12 shows that the female has a wider tibia than males, males have deeper tibiae that are more robust overall. The difference in shape likely corresponds to a difference in activity patterns and weight bearing.

\subsection{Population AfFinities}

The population affinity of the Caddo is an important topic given the Caddo geographic location between Plains, Mississippian, and Texas hunter-gatherer populations. The Caddo spoke a Caddo language but were culturally similar to Mississippian populations. To date, the most thorough is the study by Lee (1999). Using cranial and dental non-metric traits she showed that the Caddo were a genetically homogenous group with genetic admixture concentrated in the Red River Valley during the A.D. 1200-1600 period and limited both before and after that time period. The Lang Pasture site is located within the time period of greatest population admixture but outside of the geographic region of heterogeneity. Lee (1999) found that populations within the Angelina, Neches, and Neosho rivers and Cypress Creek were closely related with a possible closer link to the Upper Red than Lower Red River populations. The population from the Neches River was found to be homogenous through time based on cranial and dental non-metric features (Lee 1999).

Non-metric traits were recorded using the Texas A\&M University scoring system (Steele et al. 1993) while dental traits were scored using the abbreviated ASU system recommended by Buikstra and Ubelaker (1994). Dental traits were scored using ASU reference plaques. Nonmetric cranial and postcranial traits are presented in Tables 10-13 and 10-14 while dental traits are given in Table 10-15.

The goal of this section was to compare the individuals from the Lang Pasture site to Lee's (1999) findings since these were the only individuals not included in her study. Poor preservation restricted the observations from the Lang Pasture site. Only the absence of a metopic suture was a comparable data point in cranial traits. Lee (1999) found all individuals she examined from her Middle period in the Neches River drainage to lack a metopic suture. While this study re-examined many of the individuals included in Lee's (1999) study, Lee's study was far larger than the present one and a sub-sample of the data set did not produce significant differences in trait observations so her conclusions are assumed to hold for the Upper Neches population examined here.

Dental data from the Lang Pasture site were similarly problematic. Only 10 of the traits scored for in this study were considered significant by Lee (1999). The two traits from the Lang Pasture site that were considered valuable, Carabelli's trait and the Hypocone, in 
Lee's (1999) analysis did not fall outside the pattern she found. Again, the majority of trait scores from the Upper Neches River basin matched Lee's (1999) observations and indicate that the population was congruous with the Caddo living in Texas south and west of the Red River during her Middle period. It is unfortunate that the small number of traits observable from the Lang Pasture population make it impossible to test Lee's (1999) hypothesis that biological distance among the Caddo was more affected by social status than geography.

\subsection{DIET}

Dietary choices are a reflection of cultural norms and the natural environment. A maize-intensive diet is one of the hallmarks of the Caddo archeologicalculture and is used to separate them from hunter-gatherer neighbors and predecessors. To determine what a population ate, most bioarchaeologists focus on dental remains and/or stable isotope analysis on bone. This study uses dental remains and stable isotope analysis to examine foods consumed and processing strategies. Teeth were examined for cariogenesis, dental attrition and abscessing. Reliance on maize provides a sticky carbohydrate-rich dietary source favorable to cariogenic microbial attack. Cariogenesis can, in turn, provide the entry point for infectious organisms to the rest of the body.

One of the important hypotheses the data from the Lang Pasture burial population was proposed to test is Burnett's $(1990,1999)$ idea that the Caddo of the Neches and Pine Forest region did not depend on maize agriculture and that maize carbohydrate consumption was low. She based this assertion in part on the low frequency of dental caries in her sample from the region (Burnett 1990, 1999). Her hypothesis is important because agriculture affects a human population's health not only by changes in diet and nutrition, but also through changes in workloads, settlement patterns, and overall mobility. These changes in turn result in changes in stress, disease and pathogen loads. The Lang Pasture and Upper Neches Caddo populations do not support Burnett's $(1990,1999)$ hypothesis.
Throughout the Americas, increased reliance on maize resulted in increased dental caries. Although Lee (1999) has called into question a direct genetic link between Fourche-Maline populations and the Caddo, the populations who preceded the Caddo and have been assumed to have had a greater reliance on hunting and gathering and had fewer dental caries (Rose et al. 1984; Powell 1985; Burnett 1999) than later Caddo populations. Rose et al. (1998) has shown through data reanalysis and dental microwear studies that increased caries rates indicate an increase in carbohydrate consumption that may be the result of an increase in starchy seed consumption at Fourche Maline and Early Caddo sites. Rose et al. (1998) found regional variability in the adoption of maize prior to the Middle Caddo period as well as ecological variability in maize consumption which, in Texas, was summarized by Burnett's (1990, 1999) summary data that found an increase in caries rates from east to west across vegetation zones.

It is important to remember average ages at death in comparative samples when examining dental disorders. Since the adult average ages at death for the Lang Pasture and Upper Neches River basin are higher than most comparable population sets, dental disorders may be higher than in comparable populations.

\section{Dental attrition}

Dental attrition is not necessarily a disorder but the natural result of occlusal abrasion, the rate of which is influenced by the amount of unprocessed vegetal materials and grit in the diet. Grit is introduced into the diet through associations of dietary items, sand and the use of stone grinding implements. The Caddo used both stone and wooden grinding implements. Dental wear can also result in the introduction of infectious agents and result in abscessing and eventual tooth loss. Colby (1997), in a comparison of Caddo and Texas coastal huntergatherers, found that wear more often leads to dental abscessing than cariogenesis.

Dental wear was assessed using the Smith (1984) technique for the anterior teeth and Scott 
(1979) technique for the posterior teeth. Table 10-16 presents the dental wear scores for all individuals from the Lang Pasture site. Table 1017 provides average dental attrition scores individuals and adults site means for the Upper Neches Caddo population. Comparisons with other populations can be difficult due to a use of non-standardized techniques found in early Caddo bioarchaeological studies. Table 10-18 summarizes available dental attrition scores from other Caddo sites in Texas. In a recent review of this data this author found that age was not a factor in differences in wear patterns among Caddo populations in Texas (Wilson 2008c).

Assuming that maize consumption is directly correlated with decreased attrition because it is a soft food item, and if Burnett's (1990, 1999) hypothesis holds, dental attrition should be considerably less in populations from the Blackland Prairie and the Pineywoods populations should have should have the highest dental attrition scores. Table 10-18 shows that dental wear scores are highest in the Blackland Prairie and this difference was found to be statistically significant (Kruskal-Wallis one-way ANOVA test). This suggests the diet of the Caddo living on the Blackland Prairie was coarser (i.e., contained more seeds and nuts) than those living in the Post Oak Savannah and Pineywoods. It is important to point out that the Blackland Prairie Caddo sites predate the Middle Caddo period.

Differences in dental attrition were also significant through time (Kruskal-Wallis oneway ANOVA). Scores are high prior to the Middle Caddo period (circa A.D. 1200), when they drop. This corresponds to the time when Rose et al. (1998) see a uniform adoption of maize agriculture in Caddo populations outside Texas. Unfortunately, nearly all of the earlier populations from this summary are located in the Blackland Prairie. Both Early Caddo sites from the Pineywoods had low mean dental wear. This suggests that biotic region was important in the temporal trend of food items and processing techniques used by the Caddo.
Dental wear has been shown to decrease with an increase in maize consumption among the Caddo (Burnett 1990, Powell 1985). In this study, using molar wear scores, wear increases very slightly until the Historic period when there is a significant $(p=0.05)$ decrease (Early Caddo period mean $=17.5$, Middle Caddo period mean $=18.4$, Late Caddo period mean $=19.4$, Historic Caddo period mean $=11.9$ ). Molar wear indicates that a shift in diet occurred where coarser items were replaced by soft maize between the Late Caddo and Historic periods. Although anterior wear does not differ through time significantly (Early Caddo mean $=4.0$, Middle Caddo mean $=3.5$, Late Caddo mean $=$ 3.9, Historic Caddo mean $=4.5$ ), it is interesting that anterior wear is greatest during the Historic Caddo period when posterior wear is lowest.

Individual attrition scores for anterior and posterior teeth were examined for differences between females and males in the Upper Neches River basin, including the Lang Pasture site. No significant difference was found. Males averaged 4.8 on their anterior teeth compared to 4.4 for females, while molar wear averaged 17.8 for males and 17.6 for females. The lack of difference between females and males was also found in the Cooper Lake population (Wilson and Steele 1997) and suggests that there was no difference in the coarseness of diets between males and females throughout the Caddo region of Texas.

Although dental wear is expected to be age progressive, it was not found to be progressive in a linear fashion in this study. Dental wear has been shown to be a relatively low predictor of age for the Cooper Lake (Wilson and Steele 1997) and the Sanders and Mitchell (Wilson 1997) populations, but the correlation was even worse in this study. When the Upper Neches River basin site mean Smith (1984) and Scott (1979) scores are compared to the average adult age at death correlations were poor. A Pearson's $\mathrm{R}$ value of 0.24 for the Scott (1979) technique while the Smith (1984) technique produced a Pearson's R value of 0.32. Correlations were similarly poor for the entire Caddo region of Texas as shown in Table 10-18. The Scott (1979) technique yielded a Pearson's R value of 
0.37 and the Smith (1984) technique yielded a Pearson's R value of 0.30 . My study of the Sanders and Mitchell populations suggests that dental wear is stable until age 40 when there was a rise in tooth wear followed by a lack of patterning for those who survive to age 50 (Wilson 1997). This pattern suggests that once enough enamel has been removed from the occlusal surface dentin is exposed and since it is softer than enamel, the exposure of dentin undermines the surviving enamel leading to a faster rate of wear.

\section{Caries}

Age is one of two basic components to consider in examining caries frequency. Caries should be age progressive, but this is not always the case with archeologicalpopulations (Hillson 1979). This was not the case in the Upper Neches River basin population including the Lang Pasture site. In fact, caries are not age progressive among the Caddo from East Texas (Wilson 1997, 2008a, 2008b; Wilson and Steele 1997).

The second factor is diet. A sticky carbohydrate rich diet high in sucrose should produce a relatively high rate of caries. Bacterial Lactobacillus acidophilus and Streptococcus mutans in the mouth convert sucrose (in maize) into an acid that destroys enamel and underlying dentin. A range of 8 to 25 percent carious teeth per individual has been used to identify maize agricultural populations (Turner 1979; Cohen and Armelagos 1984, Powell 1985). The Lang Pasture population actually lies below this rate with only 3.7 percent of the 28 teeth having caries. Another Texas Caddo site that had a comparably low frequency of teeth with caries is Clark (5.6 percent [Loveland 1986]).

In the Caddo region, others have used the caries rate to discriminate maize from non-maize eating populations. Rose and Marks (1985) used a caries of rate of 2.0 per individual to differentiate between high and low carbohydrate diets. More recently Rose et al. (1998) has used caries rates to show variability in the adoption of maize agriculture by the Caddo early in the archeologicalsequence. In this study, the caries rate for the Upper Neches River basin is 4.3 caries per individual, although there is tremendous variability within the region (Table 10-19). The Lang Pasture site has the lowest caries rate, at only 0.2 .

In a recent study, I found that contrary to Burnett's $(1990,1999)$ hypothesis, the frequency of caries in northeastern Texas Caddo sites indicates that maize was a significant part of the diet in all but the Blackland Prairie biotic region (Wilson 2008c). Burnett $(1990,1999)$ gave a caries rate of 2.5 for the Middle Caddo from her summary data and very low rates of 0.5 for the Pineywoods region in which the Lang Pasture and Upper Neches River basin sites lie. In my study, Blackland Prairie Caddo sites had a caries rate of 1.8 compared to 5.4 in the Post Oak Belt and 3.8 in the Pineywoods.

Rose et al. (1998) found variability in caries rates among Caddo living outside Texas prior to ca. A.D. 1100. Perttula (2008), according to analyses of paleobotanical assemblages in East Texas as well as a consideration of stable isotope data, described maize as being less important as a dietary staple until the latter part of the Middle Caddo period, around A.D. 1300. This study found no significant difference in the caries rate through time, although only during the Early and Middle Caddo periods were caries rates below the high carbohydrate threshold. Caries rates were also above the 2.0 rate during the Early Caddo period at the George C. Davis site in the Upper Neches River basin. All Late Caddo period sites and the Historic Caddo period Jim Allen site were above the 2.0 caries rate indicator of a high carbohydrate diet.

In the Caddo paleobotanical assemblages in the Cypress Creek, Neches, and Angelina River basins, maize use peaked sometime during and after the Late Caddo period (Perttula 2008:Table 2). Dental data support Perttula's (2008) findings in the Neches River basin; although variability between sites is present. In the Upper Neches River Basin average caries rates for the Early Caddo period are 7.0, 0.6 during the Middle Caddo period, 6.0 for the Late Caddo period and 4.5 at the Historic Caddo period Jim Allen site. 
Among most modern and archeological populations females have higher caries rates than males. This may be the result of metabolic demands and/or hormones (Hillson 1986; Walker 1986). Females have higher caries rates than males in the Upper Neches River basin. The 10 females have a caries rate of 7.0 compared to 5.8 for the 14 males with dental remains. The difference is not statistically significant in a Chi-square test.

\section{Dental Abscess and Antemortem Loss}

Dental abscess frequency is another indicator of dental health. Colby (1997) hypothesized that caries were causal in abscess formation, so it was expected that the two would co-vary. Among the Caddo they do not and a clear pattern has yet to be established. In this study both periapical and alveolar abscesses were lumped into one category since both can be caused by a number of factors including exposure of the pulp chamber and disease (Ortner and Putschar 1981). Dental abscesses were not found in the Lang Pasture (Table 1020, which can be found in Appendix H) site population but this may be a reflection of the few alveolar margins and maxilla that were preserved. In fact, only one observable alveolar margins was present (Feature 93B1). The frequency of dental abscess is low in the Upper Neches River basin population as a whole with 23 percent of the observable adults affected. A total of seven abscesses were found in four adults. Colby (1997) found significantly more abscesses in the Roitsch population than found in a group of coastal hunter-gatherers. From her findings she suggested that caries are more likely causal than dental attrition in abscess formation. At the Roitsch site, Colby (1997) found 38 percent of the population examined affected by dental abscesses. Burnett (1990, 1999) found abscesses rare throughout the Caddo region of Texas. Wilson (1997) found 31 percent of the Sanders population, but only nine percent of the Mitchell population, affected, but more of the Mitchell population experienced dental caries. Wilson and Steele (1997) found 60 percent of the Cooper Lake population had abscesses. In this study caries did not correlate with abscess frequency $(\mathrm{R}=0.24)$.
Antemortem loss of teeth is typically associated with age, carious destruction, abscess and, most directly, periodontal disease. It is assumed that antemortem loss increases with age. In fact, a Pearson's value of 0.68 on individuals with one or more teeth lost prior to death confirms that there is an association between age and tooth loss in the Upper Neches River basin population. While 532 observations were made, 41 teeth had been lost prior to death resulting in a loss of 7.7 percent. This is lower than the loss reported by Wilson and Steele (1997) for the Cooper Lake region and greater than the rate reported by Burnett $(1990,1999)$ for the eastern portion of the Gulf Coastal Plain.

As in the Cooper Lake population, antemortem tooth loss was higher among males than females in the Upper Neches River basin. There were eleven adults affected by antemortem tooth loss, two of whom were female, eight were male and one was indeterminate. The two females had three teeth lost prior to death while the males had a higher rate of tooth loss with 36 teeth lost prior to death. This may indicate a higher rate of periodontal disease among males and/or is the result of more males living to an older age than females in the Upper Neches River basin.

\section{Stable Isotope Analysis}

Stable isotope analysis is used to examine the trophic level of organisms and the amount of plant matter in the diet from different photosynthetic pathways: $\mathrm{C}_{3}, \mathrm{C}_{4}$ and CAM. In the Caddo region of Northeast Texas, the environment is characterized by plants that use the $\mathrm{C}_{3}$ photosynthetic pathway. Maize can be recognized in stable isotope signatures from the region because it is a $\mathrm{C}_{4}$ plant. The collagen enrichment factor is the difference between the dietary and bone signature for carbon and is approximately $5 \%$. $\mathrm{C}_{3}$ plants have a delta $13 \mathrm{C}$ gelatin signature of $-26.5 \%$ on average, while bone from a $\mathrm{C}_{3}$ plant consumer would have a delta $13 \mathrm{C}$ gelatin value of $-21.5 \%$. $\mathrm{C}_{4}$ plants have a higher delta13C gelatin signature of $12.5 \%$ on average.

Two components of bone are analyzed: collagen and apatite. Collagen values yield the isotopic 
composition of the organic portion of bone while apatite yields the isotopic composition of the mineral portion of bone. The two are believed to have different turnover rates, or rates of replacement, meaning that they reflect different amounts of time in an individual's life (Ambrose 1993). They also reflect different aspects of diet (Ambrose 1993). Carbon collagen has been more commonly sampled than apatite. Ambrose and Norr (1993) and Tieszen and Fagre (1993) have proposed that delta 13C collagen values vary in what they represent based on the amount of protein in the diet of the consumer. For example, in archeologicalpopulations of North American maize agriculturalists, it has been shown that the carbohydrate portion of the diet is seen in delta 13C collagen values because the amount of protein in the diet was relatively low. Apatite is not biased by the amount or source of protein and should be better able to show a small increase in the amount of maize in a given diet. The difference between collagen and apatite isotopic values can be used to determine trophic level. Ambrose (1993) suggested that where the majority of carbohydrates are from a $\mathrm{C}_{4}$ source, such as maize, and the protein is a $\mathrm{C}_{3}$ source in a low protein diet, the difference between delta $13 \mathrm{C}$ values of bone collagen and apatite will be large.

Nitrogen stable isotope signatures represent the amount of nitrogen-fixing plants such as beans, as well as the source and amount of dietary protein (Schoeninger 1989). Nitrogen values are ultimately a result of bacterial fixation or soil nitrates which are passed up the food chain with a 2-3\%o increase per trophic level. Humans in terrestrial-based food webs typically have delta $15 \mathrm{~N}$ values of $6-10 \%$ whereas consumers of fish may have delta $15 \mathrm{~N}$ values that range as high as 15-20\% (Schoeninger and DeNiro 1983). Unlike carbon isotopes, nitrogen stable isotopes also reflect temperature and humidity in the natural environment.

Human bone samples were prepared and processed by Geochron Laboratories. All individuals from the Lang Pasture site were analyzed and 25 individuals from the Upper Neches River basin population housed at TARL were analyzed. In addition, all individuals from
Lang Pasture and five of the individuals from the Upper Neches River Basin population that were sampled for and submitted to Geochron Laboratories were also sent to Beta Analytic, Inc. for radiocarbon dating. These samples produced slightly different results as shown in Table 10-21, suggesting that different processing techniques were used by the different laboratories.

Given the variable caries rates from the Early and Middle Caddo periods in the Upper Neches River basin, it is likely that maize was not uniformly adopted by the Caddo until after the Middle Caddo period in the Neches River Basin. This is consistent with the pattern established by Rose et al. (1998) for other Caddo regions. Paleobotanical evidence shows that maize was present throughout East Texas by the Early Caddo period, but that is was not as important as starchy seeds until later in the archeological sequence (Perttula 2008). If caries rates indicate an increase in carbohydrates but can not distinguish between maize and other carbohydrate sources, then stable isotope analysis provides the only means of determining when and where maize became an important component of the Caddo diet.

In fact, delta 13C collagen values show an increase through time and a Kruskal-Wallis oneway ANOVA test shows the relationship between delta 13C collagen values and time to be statistically significant. There are two large increases in mean values (Table 10-22). The first is between the Formative Caddo period and the Early Caddo period and the second is between the Middle Caddo and Late Caddo periods. These changes suggest that maize was introduced to the Caddo by the Early Caddo period and that an increase in maize and protein consumption took place by the Late Caddo period. While these results are in keeping with the paleobotanical data, more testing is needed since only one individual from the Upper Neches dates to the Formative Caddo period (George C. Davis site, Feature 155).

Delta 13C apatite values show an increase through time from the Early Caddo to Historic Caddo periods. The relationship between delta 
13C apatite and time was statistically significant. Since apatite values indicate the whole diet, it is interesting to note the difference in incremental increase in values between apatite and collagen. Delta 13C apatite values show a large increase between the Early and Middle Caddo periods followed by a steady increase through time. This is interpreted as maize intensification occurring during the Middle Caddo period followed by a further increase in maize consumption during the Late Caddo period.

The difference between collagen and apatite delta $13 \mathrm{C}$ values is believed to represent the amount of protein while delta $15 \mathrm{~N}$ values reflect the protein source. Changes in the difference between delta 13C collagen and apatite values through time and delta $15 \mathrm{~N}$ were not statistically significant. In both values there is a lot of individual variability within the time periods. Mean values indicate that protein consumption was greatest during the Late Caddo period and least during the Formative Caddo period. Protein consumption increased during the Early Caddo period followed by decrease in the Middle Caddo period. Nitrogen isotope values means do not show much difference through time and are consistent with terrestrial based food webs. Nitrogen values are lowest during the Historic Caddo period suggesting the presence of more legumes in the diet.

Despite the difference in antemortem tooth loss and caries rates between the sexes, there were no significant differences in stable isotope results between females and males, showing that the Caddo diet in the Upper Neches River basin did not differ by sex.

The Lang Pasture site testing has added significantly to our understanding of the Caddo diet during a transitional time. Stable isotope studies in the Upper Neches River basin have confirmed that maize was a significant part of the Caddo diet in contrast to Burnett's (1990, 1999) previous bioarcheologicalfindings for the region. Burnett $(1990,1999)$ based her findings on dental data and rates of porotic hyperostosis. Her dental data was limited to the Early Caddo period which stable isotope analysis has shown had maize presence but lacked intensification.
Caries rates do not adequately discriminate amounts of maize consumption in the Upper Neches. For example, the caries rate for the Formative and Early Caddo George C. Davis site is high at 7.0, but delta $13 \mathrm{C}$ collagen and apatite values show that some maize was consumed, but not in the levels seen in the later periods. While delta 13C collagen results for the Upper Neches are similar to those presented by Rose et al. (1998), higher values in both this study and a larger study (Wilson 2008c) during the Early Caddo period suggest that more maize was consumed earlier in Texas than in Caddo regions of Arkansas, Louisiana and Oklahoma. Apatite values show that maize intensification in the Upper Neches River basin occurred during the Middle Caddo period. Unfortunately little stable isotope testing has been performed outside of Texas in the Caddo region from this time period.

\section{Paleopathology}

The second part of the goals established for this study was to determine how common infectious diseases were, how heavy work loads were and whether there were episodes of chronic stress from the lifestyles lead by Caddo in the Upper Neches basin. Specifically this study sought to add to the limited body of information on skeletal health among the Caddo. Rose et al.'s (1998) hypothesis that in regions with a good resource base, agriculture will be adopted later and adaptive health will be better can be tested with the data from the Upper Neches River Basin population. Rose et al. (1989) state that Caddo populations living in the Pineywoods region had the greatest adaptive efficiency compared to populations living further west. This is based in large part on Burnett's (1990, 1999) study of the region, in which she found that the Neches River Caddo had little infectious disease compared to other Caddo populations. Although Burnett's (1990, 1999) sample from the region was small, consisting of nine Caddo individuals whom provided data on infection, she found one individual from the George C. Davis site with evidence of infection. Burnett $(1990,1999)$ had no data on childhood stress for the region. 


\section{Enamel Hypoplasia}

Evidence of childhood stress in the form on enamel hypoplasia in the Lang Pasture population suggests that the population was better adapted to their cultural and natural environment than other Caddo populations. Enamel hypoplasia records a disruption in the formation of enamel on teeth. It may be the best record of fetal, infant and early childhood stress recorded in the human skeleton. Various stressful events can produce enamel defects during the time in which the enamel is being formed, including infectious disease and malnutrition in the mother or child. Genetic factors and trauma may also influence enamel development. The six individuals from Lang Pasture with dental remains had no hypoplasia. Hypoplasias have not been well studied among the Caddo so there is little comparative information. A total of 50 individuals with 575 teeth were examined for enamel hypoplasia from the Upper Neches River basin (Table 10-23). The rate of 12 percent for the Upper Neches River basin as a whole is much lower than seen in the Red River basin (60.2 percent) (Burnett 1990, 1999). The Pine Tree Mound population had a higher incidence with 22.2 percent affected, and Wilson and Steele (1997) found in the Cooper Lake region a higher incidence still (36 percent).

There is a difference in the frequency of individuals affected by enamel hypoplasia through time in the Upper Neches River basin, but larger samples are needed to investigate this pattern further. Hypoplasias are nearly absent until the Historic period. There is one individual from the Early Caddo period George C. Davis site and one from the Late Caddo E. W. Hackney site with hypoplasias. In contrast, four of the nine Historic Caddo period individuals from the Jim Allen site had enamel hypoplasias. During this period there is also evidence of childhood iron deficient anemia in AH-9 from the Jim Allen site. This is the only incidence of cribra orbitalia in the entire Upper Neches population. Taken together, the incidence of enamel hypoplasia and cribra orbitalia suggest a high incidence of childhood stress during the Historic Caddo period.

\section{Infection}

Like enamel hypoplasia, infectious disease may also be influenced by genetic factors, nutritional status, population density of agent and host, behavior and environment. Most infectious agents that affect the skeleton are chronic and debilitating because a certain amount of time is required in the life of the individual for the agent to affect bone. Bone responds to an infection in a limited number of ways causing further challenges to specific diagnoses for paleopathologists. Often only through observing the pattern of bone response throughout a skeleton, can a specific diagnosis be made; thus, preservation has a strong influence over the assessment of infectious disease rates.

Burnett's $(1990,1999)$ data from the region is admittedly limited. While Burnett (1990, 1999) stated that infection rates in the Neches were low, she also hypothesized that infection rates were related to the amount of occupational debris. Wilson (1998) in a study of treponemal infections throughout archeologicalpopulations in Texas, found that population density more than site longevity affected the rate of infectious disease. Based on these hypotheses, the Lang Pasture population would be expected to have a low rate of infection. Unfortunately, the poor preservation of the skeletal remains recovered from the Lang Pasture site makes statements about rates of infection tenuous because the poor preservation results in underreporting of frequencies calculated on a per individual basis. Only one individual from the Lang Pasture site had evidence of infection. Thus, the rate of infection at the Lang Pasture site is 11.1 percent, with no subadult infection and 16.7 percent of the adult population having evidence of infection. In the entire Upper Neches River basin there were only 8 instances of infectious bone, excluding likely scalp infections. (The infection rate rises to 13.9 percent if the two instances of probable scalp infection are included). As previously stated, preservational bias has likely resulted in an underestimate of the actual rate of infection.

While the sample size is slightly larger here $(\mathrm{MNI}=72)$, for the greater Pineywoods region, 
Rose et al. (1998) gave a rate of infection of 18 percent of 57 individuals, a rate higher than that found here. They found the Pineywoods region to have the lowest infection rate for Caddo populations living in the three vegetation zones in Texas. This study confirms their findings. In much of the Upper Neches River basin, population density based on the number of burials per site is relatively low. This matches an expectation of low infection rates with lower population density. Lee (1997) examined two Late Caddo large mound center site populations on the Red River, Hatchel and Mitchell. She found that 31.2 percent of the individuals from Hatchel and 51.6 percent from Mitchell had evidence of infection. In contrast, the Pine Tree Mound population was found to have a low rate of infection at 6.7 percent of the population (Wilson 2008a); however, Wilson (2008a) cautioned that poor preservation may have biased these results. Infection rates at nonmound sites along the Red River in northwestern Louisiana are higher than at Pine Tree Mound, but lower than mound sites on the Red River. At habitation sites such as McLelland (Tiné and Tieszan 1997) the infection rate was 25.0 percent and at Cedar Grove (Rose 1984) the infection rate was 22.2 percent; these sites are two Late Caddo farmsteads in the Red River valley, downstream from the Great Bend. This supports Wilson's (1998) findings that settlement density is directly related to infection rates, but also indicates that geographic location and preservation all play a role in infection rates.

What differs from Rose et al.'s (1998) review of Red River and East Texas Caddo is the temporal trends in infection rates. Rose et al. (1998) found that infection rates peak in the Early Caddo and Historic Caddo periods (25.0 percent each). In this study, infection rates approximately double with each successive time period until the Historic Caddo period when there is only one individual with evidence of infection. During the Early Caddo period 5.9 percent of the 17 individuals were affected; during the Middle Caddo period the rate climbs to 11.4 percent (of 10); in the Late Caddo period 19.2 percent of the 26 individuals had evidence of infection; and 6.7 percent of the 15 from the Historic Caddo period. With the exception of the Historic Caddo period rates, the infection rate parallels increases in maize consumption and likely changes in settlement patterns. The lower rate of infection during the Historic Caddo period warrants further investigation, but may be an indication that individuals died prior to bone involvement from infections, given the approximately 10-year decrease in average age at death.

Of the infections, one was from an Early Caddo period burial, one was from the Middle Caddo period, two were from the Late Caddo period, and one was from the Historic Caddo period. Two are possible cases of osteomyelitis, one from the Late Caddo J. W. Blackburn site (burial AI-1), the other is from F. 93, Burial 2 from the Lang Pasture site. The individual from George C. Davis has non-specific periostitis on the right tibia. The individual from Reagor Farm (burial AJ-1) exhibited endosteal bone formation that was active at the time of death based on the lack of remodeling. Endosteal bone formation indicates a systemic rather than localized infection. There were four "suprainion" depressions. This is recorded as focal bone loss on the occipital above the superior nuchal line that can be described as a shallow depression. Suprinion depressions were recorded on Burial 1 from the O.L. Ellis site, in the two individuals from Fred McKee, and in burial AH-1 from the Jim Allen site. The child from the Fred McKee site is the only child in the Upper Neches River basin population to exhibit signs of infection. The adult from the Fred McKee site and the individual from the Jim Allen site have an unusual pattern of focal bone loss in that it does not show on the occipital but is grouped with the two suprainion depressions because the etiology is the same. These are observed as one and two lesions, one on each parietal just superior and lateral to the lambda. They are suggestive of chronic irritation, presumptively from wearing something on the head in that location. I have seen numerous suprinion depressions among the Caddo and they have been noted in other Caddo populations (Derrick et al. 2008; Derrick and Wilson 1997). They are the result of a localized infection whose source is unknown and may be related to the practice of cranial modeling that produced a localized sore. 
Porotic hyperostosis has been used as an indicator of nutritional stress in the form of irondeficient anemia (El Najjar et al. 1976) and as an indicator of parasite load (Kent 1986). Porotic hyperostosis is found rarely in scurvy, which has not been documented for the Caddo. Observations of porotic hyperostosis are complicated by diagnosis. When diploë are not expanded, porosity may be the result of healed porotic hyperostosis or periosteal reaction to a insect infestation of the scalp, or fungal or bacterial infection of the scalp. It is also possible that a combination of anemia, scalp inflamation and/or scalp infection may have occurred in a given population or individual. Lee (1997) is the only researcher to adequately describe this phenomenon for a given Caddo population. Lee (1997) found 89 percent of the Hatchel population and 56 percent of the Mitchell population had porotic hyperostosis and/or cranial porosity. Porotic hyperostosis and/or cranial porosity was absent in the Lang Pasture population. Burnett $(1990,1999)$ found porotic hyperostosis to be most common in the Blackland Prairie and did not find it in the Pineywoods. Porotic hyperostosis occurred in a high incidence among the Cooper Lake population (18.5 percent) (Wilson and Steele 1997). Three cases (4.3 percent) of porotic hyperostosis were found in two sites from the Upper Neches River basin. This low rate is very different than Lee's (1997) findings and is more consistent with the Rose et al. (1998) findings for the Red River and East Texas. Rose et al. (1998) found that porotic hyperostosis peaked in the Middle Caddo period, but otherwise was fairly consistent at around 8 percent. That was not the case for the Upper Neches where the two sites affected were from the Late Caddo and Historic Caddo periods. The one individual from the Late Caddo period with porotic hyperostosis resulted in a frequency of 3.8 percent, while the frequency for the Historic Caddo period was 13.3 percent.

It is likely that the child from the Fred McKee site with porotic hyperostosis had a scalp infection since the child also has an active infection at the suprainion (depression) and the hypervascularity was found on the superior portion of the occipital and both parietals near the lambda. The two individuals from Jim Allen are more ambiguous. In burial $\mathrm{AH}-1$ the pitting occurs near the (suprainion) depressions on the left parietal. Pitting was concentrated on the occipital just below the lambda adjacent to the three depressions and is therefore believed to be associated with the suprainion depression. In burial AH-7 the well-healed porosity is also located near the lambda but found on the right parietal. There was no evidence of a suprainion depression on this individual. There was, however, an older child from the Jim Allen site with cribra orbitalia, which is caused by iron deficient anemia. The Jim Allen site, therefore, exhibits both infections affecting cranial bones and iron-deficient anemia.

\section{Trauma and Biomechanical Stress}

In most Caddo populations trauma is rare, although Wilson and Steele (1997) reported a very high incidence of trauma in the Cooper Lake population with 9.2 percent of the individuals being affected. The Upper Neches population has a frequency of traumatic injury of 2.9 percent. One individual (Feature 8 burial) from the Lang Pasture site suffered a fractured right tibia. The fracture occurred on the distolateral portion of the diaphysis. It was impossible to determine the extent of the fracture because the medial portion of the diaphysis was missing. The fracture site was extremely well healed indicating that the fracture was set and successfully immobilized. In my experience, the Caddo were adept at setting broken bones. There was one other fracture in the Upper Neches population and one individual with large enthesiopathies. The other fracture was found in the left femur of burial AL1-AL11 from the E. W. Henry Farm site. The break occurred on the lateral aspect at approximately midshaft and was a partial or green stick fracture. Like the individual from Lang Pasture, this individual was completely healed other than the remains of a small bone callous.

Biomechanical stress is seen in the Upper Neches population. One case is suggested by the presence of enthesiopathies on the right femur along the linea aspera and left tibia along 
the soleal line of Feature 163 from the George C. Davis site. Enthesiopahties can result from repeated use or injury from muscle and tendon pulls. In this case, Feature 163 is unusually robust at the muscle attachment sites present. The linea aspera on left femur is enlarged but the surface is too eroded to determine if the injury is bilateral. Likewise, on the right humerus the deltoid attachment site is very pronounced with a sharp edged linear depression suggestive of a muscle tear. Taken together, it appears that Feature 163 led an unusually strenuous life.

Degenerative joint disease is a more common indicator of biomechanical stress in a population. Degenerative joint disease, or arthritis, here refers to degenerative changes in the synovial joints (arthritis) and vertebral column (osteophytosis). Degenerative joint disease is typically the result of repeated stresses from repeated motions through time, but can also result from a single episode injury. As the fluid filled joint capsule breaks down, bone responds by expansion of the surface area with marginal lipping, erosion of the joint surface and finally polishing, eburnation, from direct boneto-bone contact.

Observations of degenerative joint disease are dependent on the preservation of joint surfaces. Due to the cancellous bone that underlies joint surfaces, they are less often preserved than cortical bone diaphyses. None of the individuals from the Lang Pasture site had intact articular surfaces so it was not possible to determine the presence of degenerative joint disease. In the entire Upper Neches River basin population there were only two individuals with degenerative joint disease (7.7 percent). Joint observations were only possible on 26 of the 55 adults. The frequency of degenerative joint disease (arthritis and osteophytosis) in the Upper Neches River basin is much lower than Rose et al. (1998) report for the Red River and East Texas Caddo, excepting during the Middle Caddo period. In their data summary, Rose et al. (1998) find a dramatic peak in arthritis during the Historic Caddo period. The affected individuals in the Upper Neches are from the Late Caddo and Historic Caddo periods, but they are also likely among the older adults in the population who have had longer time over which to accumulate joint stress.

Burial AH-3, an older adult from the Jim Allen site, exhibited both arthritis and osteophytosis. There is osteophytosis and surface porosity of the centrum, superior, and inferior articular facets of preserved cervical vertebrae. Loveland (1994) and Wilson (1994) reported this to be a common location for arthritis among Red River Caddo, where degenerative joint disease is relatively common. The other case of vertebral osteophytosis is in the lumbar vertebrae of a male from the E. W. Henry site (burial AL-3). The individual from the Jim Allen site also had surface porosity at the anterior aspect on the right and left glenoid fossa of the temporomandibular articulation. Degenerative joint disease at the temporomandibular joint was seen in high frequency in the Sam KaufmanRoitsch population with a considerably higher frequency among males (Derrick et al. 2008). While Wilson (1994) found a low incidence of temporomandibular arthritis in the Middle Caddo Sanders site population, she found that male stress loads as evidenced by degenerative joint disease were nearly twice that of females. Derrick et al. (2008) believe that the pattern in the Late Caddo Roitsch-Sam Kaufman population is the result of using the anterior dentition as a tool and that this tool use is part of the sexual division of labor among the Caddo. One individual, Feature 88, from the Lang Pasture site, has an unusual severity of wear on the canine and premolars that is suggestive of use of the teeth for something other than chewing. The left maxillary canine and first premolar exhibit shearing of the lingual cusp and the right mandibular first premolar exhibits shearing of the buccal cusp. Molar wear is comparatively light. Unfortunately the temporomandibular joint in this individual was very fragmentary. Further testing of the hypothesis that some Caddo used their teeth as tools is needed.

Second to dental caries, degenerative joint disease is typically the most common pathological condition seen in Caddo skeletons (Derrick et al. 2008). In the Upper Neches population, fractures were observed on more 
individuals. The low rate of degenerative joint disease is undoubtedly influenced by the poor preservation of joint surfaces in the Upper Neches population. Nearly all joint surfaces present had a preservation score of 3 (Buikstra and Ubelaker 1994), indicating that less than one-third of the surface is present. A more detailed study of degenerative joint disease in the Caddo is clearly necessary to address issues of workload. Yet, a lower rate of degenerative joint disease was reported by Burnett (1990, 1999) for the Pineywoods (2.1 percent) than seen here. Wilson and Steele (1997) reported a rate of 38.9 percent in the Cooper Lake population. Where preservation is better, rates of degenerative joint disease are higher. For example, Loveland (1994) found osteophytosis in 57.7 percent of the males and 46.4 percent of the females from the Sam Kaufman-Bob Williams site sample she analyzed. Likewise, Wilson (1994) found that 78 percent of the Sanders population had some form of degenerative joint disease. At other sites along the Red River with good preservation, Lee (1997) found arthritis in 67 percent of the population from the Hatchel site and 65 percent from the Mitchell site. Derrick et al. (2008) found osteoarthritis in the weight-bearing joints of 43 percent of the adults from the Roitsch site. Another site with a high frequency of arthritis is the McLelland site, where 75 percent of the population were affected (Tiné and Tieszan 1997). The question remains whether the differences represent a difference in preservation or a difference in geographic region and/or time.

\section{Other Conditions}

Three additional pathological conditions were observed. One was the fusion of the second and third cervical vertebrae in a young adult female from the George C. Davis site. No marginal lipping was observed in conjunction with this condition, so it is not scored as degenerative joint disease. Juvenile rheumatoid arthritis can manifest itself in such a way and does affect more females than males. The neural arch and the portion of the centrum that was present were fused. None of the other skeletal remains of this individual were affected. A button osteoma is present on the frontal of a male from the E. W.
Henry site (burial AL-3). This is a common benign lesion. The final condition appears to be a congenital defect as there is no indication of bone growth or remodeling surrounding the lesion. In Burial 97 from Lee Ellis Farm, a significant narrowing of the left auditory canal was present which left a kidney-shaped canal. It is not known if this would have affected the individual's hearing.

The question thus remains, were levels of infection and other indicators of physiological stress lower in populations south of the Red River? It is clear that preservation of human skeletal remains in the region is poor and surface observations are inhibited (Wilson 2008c). Nevertheless, it does appear from the data presented here that childhood stress was significant in the Historic Caddo period. At this time maize intake was at its highest, but is only slightly higher than during the Late Caddo period, so it is likely that childhood health was affected by additional factors. It is intriguing that the highest incidence of porotic hyperostosis occurs during the Historic Caddo period, but, as stated earlier, the meaning of this is somewhat ambiguous. Clearly traumatic injury remained consistent through time. Infection rates exhibit a very different pattern than described for the Caddo from the Red River and East Texas (Rose et al. 1998), with the Upper Neches River basin population showing a steady increase up to the Historic Caddo period when there is a dramatic decrease. It is possible that epidemic diseases were causing death prior to local endemic infections. The Upper Neches River basin skeletal series cannot adequately address the issue of work loads due to its poor preservation, but it does beg for a more specific examination.

\subsection{Cultural Modification}

Cultural modification of the body is an effective form of group identification in human societies and can be useful to archaeologists in reconstructing ethnic and group identity. Cranial modeling is one of the most common forms of body adornment that preserves in hard tissue and is available to archaeologists to study cultural norms of beautification. Cranial modeling was practiced by the Caddo and documented both 
archaeologically (Derrick and Wilson 1997) and ethnohistorically (Swanton 1942). Since cranial modeling occurs early in life when an infant's cranial bones are relatively ductile, cranial modeling reflects the group identification to which the parents or another authority figure wish their child to be perceived as belonging.

Table 10-24 documents the frequency and types of cranial modeling in the Upper Neches River population. Only two of the four cranial modeling styles practiced by the Caddo occurred, and some burials lacked modeling (e.g., Derrick and Wilson 1997). Both annular and tabular styles were observed, indicating that both hard and soft devices were used to produce the desired result. Annular modeling involves the tight circular wrapping of the infant head with soft materials like animal skin or cloth, or the application of removable pads or cords (Rogers 1975). It results in a distinctive conically-shaped head that often had a coronal saddle occurring posterior to the bregma. Tabular forms of modeling are produced by immobilizing the infant head between boards and is differentiated from unintentional flattening of the back of the head cause by a cradleboard. Tabular styles among the Caddo result in a flattened frontal and occipital with expansion of the parietals (Derrick and Wilson 1997).

As in Derrick and Wilson's (1997) study of cranial modeling in the East Texas Caddo, the most common type of modeling among the Upper Neches River Caddo is tabular frontovertico-occipital. Cranial modeling was less common in the Upper Neches River basin than for East Texas Caddo populations as a whole, where 90 percent of the crania were found to be modeled. There were 16 individuals in the Upper Neches for whom observations could be made, 10 of whom had modeled crania (62.5 percent). One individual had cranial modeling but the style could not be determined. Tabular fronto-vertico-occipital is present in seven crania (46.7 percent). Annular parallelo-frontooccipital modeling was observed in two individuals: a male from the Historic period Jim Allen site (Burial AH-3) and a female from the
Lang Pasture site who dates to the early part of the Late Caddo period (F. 93, Burial 2).

There was no difference between males and females in the Upper Neches Caddo in the presence and style of cranial modeling. Because the numbers are small, it is difficult to discern a relationship between cranial modeling and time, although it appears that cranial modeling entered the Caddo region during the Middle Caddo period (Derrick and Wilson 1997). The earliest evidence of cranial modeling in this study is seen in the two individuals from the Lang Pasture site. It is possible that cranial modeling as a practice spread to the Caddo of the Neches River basin somewhat later than in other regions such as the Red River, where cranial modeling was slightly more common than for the region as a whole. It is interesting that cranial modeling is present in the Lang Pasture population at a time when maize intensification has not yet taken place.

In comparing cranial modeling in the Upper Neches River basin with the Red River basin, it is interesting to note that the variety of cranial modeling may correlate with a more heterogenous genetic population than was seen in the Upper Neches (Lee 1999). Unfortunately, the sample size is too small here to test Derrick and Wilson's (1997) finding that mound centers had greater variety in the styles of cranial modeling than other site types. The two mound sites in the studied sample were represented by an individual without cranial modeling and an individual with tabular fronto-vertico-occipital modeling. The results from the Pine Tree Mound site in the Sabine River basin support Derrick and Wilson's (1997) finding. Lee's (1997) research also suggested that mound sites had higher population admixture.

\subsection{SUMMARY AND CONCLUSIONS}

The remains of nine individuals were recovered from the Lang Pasture site. In order to address bioarchaeological issues, the Lang Pasture population was analyzed alongside a minimum of 63 Caddo from the Upper Neches River basin housed at the Texas Archeological Research Laboratory (TARL). This analysis is the largest 
of its kind in a region in which there has been relatively little bioarchaeological study. It provides a needed context for understanding how the Lang Pasture population fits into its temporal and regional circumstance in terms of preservation, adaptive efficiency and health, ethnicity and genetic relationships, and diet. Within the Upper Neches River basin population individual skeletal remains came from the Formative through Historic Caddo periods. Single and multiple interments are represented as are mound burials and non-mound burials. Burials ranged in offerings and presumably status.

The state of preservation was generally poor for the Lang Pasture remains, as was the case for many sites in the Upper Neches River basin. One individual from Lang Pasture, Feature 91, was represented only by enamel fragment from an unidentifiable tooth. The Lang Pasture site has a mean of only 7 percent of the skeleton complete with the best represented individual being only 17 percent represented (Feature 92). The skeletal preservation at the Lang Pasture site is not unlike other southern Caddo sites. The Upper Neches population had a mean representation of 13 percent. Elements were also given a preservation score from 1 to 3 . The individuals from the Lang Pasture site had an average preservation score of 2.7, again indicating poor preservation. The Upper Neches River basin preservation mean is better than observed in the Lang Pasture population, but not by much, at 2.2. Poor bone preservation in the region can be attributed to acidic soils leaching organics from the bone during periods of repeated wetting and slow drying. Because of the poor state of preservation, many metric, nonmetric, and pathological observations could not adequately be made.

The poor preservation made it difficult to address issues of body size and sexual dimorphism. Since stature estimates were not possible, tibial circumferences were used to examine sexual dimorphism in terms of robusticity rather than stature. While robusticity and stature are under genetic influence, they are also controlled by the quantity and quality of diet and the health of individuals. Robusticity scores are also influenced by activity patterns, that is, the degree of muscle use at a given location. Measurements taken here suggest that the Caddo from the Neches River basin fall at the high end of the normal range for humans. The Cooper Lake population had a similar degree of sexual dimorphism in robusticity (Wilson and Steele 1997). This is interpreted as meaning there was a difference in weight bearing and the way the muscles that attach to the tibia were used by males and females, with males bearing the brunt of activities that shaped the lower limb. In a study of the Middle Caddo Sanders site population from the Red River, I found that degenerative joint disease showed higher work loads for males among the Caddo (Wilson 1994). Taken together, there is a suggestion that there was a distinct sexual division of labor among the Caddo and that males experienced greater stress loads than women, but further research on this topic is needed.

The issue of genetic relationships of the Lang Pasture population to nearby populations could not adequately be addressed due to poor preservation. Enlarging the population to the Upper Neches for comparison with Caddo from other regions was possible using non-metric traits. Observations recorded for this study do not differ from Lee's (1999) prior study. Lee (1999) found that populations from the region were relatively homogenous compared to populations from the Red River.

This study disproves Burnett's (1990, 1999) hypothesis that populations south of the Red River and those of the Pineywoods were not reliant on maize agriculture. Burnett (1990, 1999) and Rose et al. (1998) hypothesized that rainfall via vegetation regions influenced the adoption of maize. They hypothesized that maize consumption decreased from the Blackland Prairie to the Pineywoods. This study further adds to a growing body of data that demonstrate higher frequencies of caries in the Pineywoods and Post Oak Savannah than in the Blackland Prairie (Wilson 2008c). Stable isotope analysis shows maize in the diet of all Upper Neches River individuals tested except the Formative Caddo period individual from 
George C. Davis. Both stable isotope and caries rates indicate that maize was a significant part of the Caddo diet at all sites examined by the Late Caddo period.

Rose et al. (1998) found variable caries rates prior to A.D. 1100. This study found caries rates both above and below the threshold of 2.0 prior to the Late Caddo period. For example, the Lang Pasture population has an extremely low caries rate of 0.3 for adults, but the Early Caddo George C. Davis site had a caries rate of 7.0. Stable isotope analysis shows that the delta 13c apatite and collagen values at the two sites are very similar and show that the consumption of carbohydrates other than maize are causing elevated caries rates at some Caddo sites. Perttula (2008), according to analyses of paleobotanical assemblages in East Texas as well as a consideration of stable isotope data, described maize as being less important until the latter part of the Middle Caddo period, around A.D. 1300. This study corroborates his findings as caries rates are consistently greater than 2.0 after the Middle Caddo period. Taken together, dental and stable isotopic data show that maize was an important dietary resource that became a staple for some populations during the Middle Caddo period (Forrest Mound) and during the Late Caddo period for others in the Upper Neches River Basin. From the Late to the Historic Caddo period there was a further dependence on maize.

Stable isotope testing from this study has contributed significantly to our understanding of Caddo diets. Since this study has shown that starchy seeds can elevate caries rates, stable isotope studies are the only direct measure of maize consumption. Delta 13C collagen and apatite values show an increase in maize consumption through time from the Early Caddo to Historic periods. Delta 13C collagen values document two significant increases: the first is between the Woodland period and the Early Caddo period and documents the introduction of maize to the Caddo diet in the Upper Neches; the second is between the Middle Caddo period and the Late Caddo period, when caries rates are uniformly above the high carbohydrate threshold. Delta 13C apatite is regarded as a better indicator of the diet as a whole and is better at showing small increases in maize consumption. It is interesting that apatite values show a significant change between the Early and Middle Caddo periods that signifies intensification of maize agriculture. More testing is required to better refine when maize agricultural intensification occurred within the Middle and Late Caddo periods.

Wear scores from the Upper Neches are relatively stable until the Historic Caddo period. This is the period of highest maize consumption and presumably the softest diet.

Increased sedentism goes hand-in-hand with intensification of maize agriculture. While increased sedentism leads to increased waste at a site, settlement density may be more important in infectious disease rates (Wilson 1998). Agricultural intensification allows for increased settlement density, but does not require it. An increase in the proportion of maize in the diet at the expense of higher quality nutritional items would, like external stress, lower resistance to infection and slow the body's ability to heal from injury. Maize agriculture in the region has been shown to parallel developments outside the Neches River basin with its introduction during the Early Caddo period followed by mixed adoption of the crop until intensification occurred between the Middle and Late Caddo periods. There is a further intensification of maize in the Historic Caddo period that is seen across the Texas Caddo region (Wilson 2008c). In the Upper Neches River basin there is evidence of poor health at this time that was likely associated with cultural stress, increased population density (assumed from number of burials), and malnutrition.

Paleopathological study of the Lang Pasture site and other Upper Neches Caddo human remains was influenced by poor preservation. This raises the question of preservation in the region as a factor in shaping Burnett's (1990, 1999) hypothesis. Site type and settlement density also cannot be ignored. Settlement density as indicated by burial population size is less in the Upper Neches than in other places in the Caddo region. The mean number of burials per site in 
this study was approximately half that found by Rose and Burnett (1990, 1999) for the Caddo region of the eastern Gulf Coastal Plain. Given the distance from the Red River, poor preservation of bone surfaces, and low settlement density, the Upper Neches should have reasonably low infection rates. At 11.113.9 percent for the Upper Neches River basin population, this in fact is the case. Combined with the study of the Pine Tree Mound population from the Sabine River basin (Wilson 2008a) and the Hatchel, Mitchell, Eli Moores sites study (Lee 1997), it does support Burnett's (1990, 1999) hypothesis that infection rates were lower south of the Red River.

What differs from Rose et al.'s (1998) review of Red River and East Texas Caddo is the temporal trends in infection rates. Instead of peaking in the Early Caddo and Historic Caddo periods, infection rates double with each successive time period until the Historic Period when there is no infection. With the exception of the Historic Caddo period, the infection rate parallels increases in maize consumption and likely increasing settlement density. The relatively high incidence of childhood stress during the Historic period coupled with the lack of infection and decreased mean age at death indicates that individuals were succumbing to diseases before bone involvement had time to occur.

Enamel hypoplasia and porotic hyperostosis are the only indicators of adaptive efficiency that are not influenced by poor preservation to the degree of infection, degenerative joint disease and trauma. Rates of enamel hypoplasia are lower in the Upper Neches River basin than elsewhere and support a higher adaptive efficiency in the Pineywoods that may be due to factors other than maize consumption (which is consistent with other Caddo regions in Texas). Rates of enamel hypoplasia also show that there was a significant increase in childhood stress during the Historic Caddo period. This may be the result of epidemic disease and social stress and/or increased maize consumption. Further examination of this is needed both within and outside the Upper Neches.
Porotic hyperostosis was rare in the Upper Neches population. It, unfortunately, has ambiguous meaning among the Caddo. The suprainion depressions show that scalp infection was present among the Caddo of the Upper Neches; however, the case of cribra orbitalia also indicates that iron deficient anemia was present, at least during the Historic period. Porotic hyperostosis is seen only during the Late and Historic Caddo periods in the Upper Neches. Porotic hyperostosis is absent during the Middle Caddo period when Rose et al. (1998) showed a peak for other Caddo from the Red River and East Texas areas.

Unfortunately, this study cannot adequately address issues of workload stress due to poor preservation. It is clear that this is a problem in much of the Caddo region (Rose et al. 1998) and needs further study. Both robusticity of the tibia and the overall picture of pathological conditions related to biomechanical stress suggest that there was a strict division of labor among the Caddo from the Upper Neches and that males bore the brunt of labor stress. Although the number is small, all individuals with fracture, enthesiopathies, and degenerative joint disease are male (excepting the fracture found in the commingled remains from E. W. Henry for whom sex could not be determined).

This study sought to test Burnett's (1990, 1999) hypothesis that peoples inhabiting drainages to the south of the Red River had a greater adaptive efficiency. This study shows that the Upper Neches River population and the Lang Pasture site population had high adaptive efficiency until the Historic Caddo period. This study has already shown that agriculture did not necessarily enter the archeologicalsequence of the Upper Neches later than elsewhere, or that it was practiced with less intensity in the Upper Neches due to a more productive natural resource base than in the Blackland Prairie. A low population density in the Upper Neches may have protected the health that increased maize consumption is often assumed to affect adversely. The Upper Neches Caddo were genetically homogenous, and had a lower population density than was the case in the Red River area. These factors, coupled with 
relatively poor bone preservation, influence observation on health, but it is likely that smaller populations with less admixture had better health and certainly less infectious disease. It is worth investigating whether distance from the Red River has a greater influence over adaptive efficiency than rainfall and corresponding vegetative zones. Using Burnett's $(1990,1999)$ data, settlement density within the Red River was considerably higher than the Caddo average, with a mean of 31.7 individuals per component; it is here that Lee (1999) described the greatest concentration of population admixture, and here where Derrick and Wilson (1997) found the greatest variety of cranial modeling styles within sites. In concert, these factors increase the likelihood of infectious disease through increased population flux, interpersonal contact and increased concentration of waste.
The decreased adaptive efficiency that is seen in the Historic Period may be the result of a small sample size $(\mathrm{n}=15)$ and warrants further investigation both within and outside the Neches River basin. The apparent decreased adaptive efficiency of the Historic period may be the result of a further increase in maize consumption, increased settlement density within sites, and/or external social stress and disease.

Tables 10-1 through 10-24 may be found in Appendix $\mathrm{H}$, located on the compact disk inserted into the back cover of this report. 


\section{CHAPTER 11}

\section{CADDO MORTUARY PRACTICES IN THE UPPER NECHES RIVER BASIN IN EAST TEXAS}

Timothy K. Perttula

\subsection{INTRODUCTION}

Caddo mortuary features from planned cemeteries $^{1}$ have the potential to contribute important information on the social and gender differences as well as religiousphilosophical beliefs that existed among prehistoric Caddo populations that lived in the upper Neches River basin in East Texas. Is there evidence within or between sites in this region of social, gender, and religiousphilosophical differences that may have existed in prehistoric times? The examination of the complexity and character of mortuary behaviors (i.e., the placement and orientation of the deceased; the energy invested in the mortuary rituals; the amounts of grave goods placed with the dead; the kinds of grave goods placed with the dead; and the locale where the dead were buried) can contribute new information on the mortuary treatment of postA.D. 1300 Caddo agricultural communities, beginning with the community of which the Caddo residents of the Lang Pasture site were a part. This examination can be made more compelling by turning our attention to the size and organization of other generally contemporaneous Caddo cemeteries in the upper Neches River basin (see Story and Creel 1982:33) as well as elsewhere in the middle Neches and Angelina river basins (Good 1982; Creel et al. 2005), and building on the basic conclusions from current mortuary information that Caddo groups in these locales lived in "habitation sites [that] were usually not occupied for long periods of time...the population associated with any one settlement was relatively small... and most statuses were not ranked” (Story and Creel 1982:33).

The kinds of funerary objects associated with the interments and the energy invested in burial treatment (i.e., shaft tombs versus individual extended grave pits) provide the information with which to examine the organization of the different prehistoric and early historic Caddo cemeteries by status, rank or political scales, by gender, and with respect to religious-philosophical beliefs (cf. Carr 1995; Cannon 2002, 2005). Information on Caddo burial practices can be illuminated when the sex and age of the individuals (when that is available) is known, as well as would information on the boundaries, sizes (i.e., the number of deceased) and orientation of formal cemetery areas.

Mortuary data from prehistoric Caddo sites in the upper Neches River basin are relatively abundant and competently documented, and well suited for comparative analyses with the burials from the small cemetery at the Lang Pasture site (41AN38). The vast majority of the available mortuary data derives from University of Texas excavations in the 1930s (Jackson 1931, 1933a-b; Pearce 1920; Pearce and Woolsey 1935; Woolsey 1935a-p; see also Cole 1975:337-357; Kleinschmidt 1982). More limited Caddo mortuary data are available from the Attaway site (41HE114; Shafer 1981) and Vanderpool (41SM77) (Anderson 1972:139; Perttula 2006), as well as a few other sites in the Lake Palestine area (Anderson 1972; Anderson et. al 1974; Johnson 1961).

These mortuary data are sufficient to determine the following: (1) the location of cemeteries within sites and in relationship to habitation areas and sources of water, adding a spatial dimension to mortuary practices, since cemeteries are spots on the landscape where 
Caddo groups, "using both the natural and created landscape, construct a setting that gives permanent expression to both identities and relationships" (Goldstein 2006:384); (2) the age of many of the burials (i.e., adult vs. child), and perhaps the sex as well (employing the results of Diane Wilson's analysis of human remains in the Texas Archeological Research Laboratory [TARL] collections from the upper Neches River basin, see Chapter 10, this volume, as well as the results of previous physical anthropological examination); (3) the kind and quantity of grave goods placed in most of the burials, including information on the placement of any goods of non-local origin; and (4) the orientation and internal arrangement of burials within cemeteries. From these data, combined with comparable mortuary data obtained from the analysis of the Lang Pasture site burials, it is possible to evaluate the hypothesis posed by Story and Creel (1982:33) that upper Neches River basin Caddo populations living in this area around and after ca. A.D. 1400 did not have a social hierarchical character, when contemporaneous Caddo groups to the north (among Titus and McCurtain phase groups) or east (Texarkana and Belcher phase Caddo groups living on the Red River) in East Texas, Southwest Arkansas, and Northwest Louisiana) did (see Kelley 1997; Perttula 2004, 2005; Trubowitz 1984; Webb 1959).

\subsection{Perspective on Mortuary PRACTICES}

Cemeteries represent distinctive and socially significant places on the prehistoric Caddo landscape, whether it be the upper Neches River basin after the $14^{\text {th }}$ century A.D. or in the Red River basin in the $17^{\text {th }}$ century. They are places where past Caddo societies created and renewed a sense of place and developed a sense of social memory (e.g., Cannon 2002:193-194; Goldstein 2006:380), leading to an appreciation of the social and spatial dimensions of mortuary practices. Ashmore and Geller (2005:87-88), among others, have noted that burial places are appropriate places for transforming the dead kin through life and death cycles (cf. Silverman 2002:7) and commemorating ancestral continuities through ritual action. Burials, and cemeteries, reflect a continuity of kin and community in their location relative to the inhabited and habitable landscape and in their location relative to other deceased Caddo peoples. Chesson (2001b:110) has noted that:

On a regional scale, the people who buried their dead...followed a particular set of standards in their mortuary rites, forging a sense of similarity between people in [the] region, as well as nurturing a sense of tradition in the treatment of [the] dead. These communities shared a set of principles and local knowledge that instructed them how to treat their dead, where to commemorate them, and the importance of maintaining these practices. This knowledge, and the resulting practices, may reflect a regional identity. [emphasis added]

From this perspective, mortuary practices of the prehistoric Caddo are believed to have been guided by the cultural and social ideas and traditions of the living Caddo people concerning the afterlife as well as the relationship of the living with their ancestors. These ideas and relationships-essentially social ties expressed in shared mortuary rituals-can endure for generations. As detailed in this chapter, shared ritual mortuary practices among the prehistoric Caddo living in the upper Neches River basin lasted as least 250-300 years (10-15 generations). Because these mortuary practices are based on the active beliefs of the living Caddo who laid the deceased in graves in certain sacred areas, with specific burial pit forms and orientations, as well as certain kinds and quantities of grave furniture (cf. Carr 1995:Table III), mortuary practices provide key insights into Caddo cosmology and ideology, particularly beliefs on the afterlife, the nature of the soul, and steps necessary to protect and save the souls of the deceased.

The setting of cemeteries across the upper Neches River basin region is not thought to be haphazard, but should have a spatial and historical context that can be related to 
traditions and beliefs shared by Caddo peoples about universal order and the structure of the cosmos (e.g., Carr 1995:Table XIV; Charles 2005:23-24; Kay and Sabo 2006; Sabo 2008). The demographic dispersion of agricultural Caddo peoples across the upper Neches River basin, and the apparent belief that the dead needed to be kept near to the living, led to the accompanying dispersion of cemetery sites in proximity to habitation areas and settlements. These Caddo households defined their own sense of place and who they were by the unique juxtaposition of the living and the dead in circumscribed areas with larger farming communities. An emphasis on affinity and kinship within and between different households that created these sacred cemetery places was more important to household members than were their broader ties to the larger communities of which they were a part. Although these Caddo shared similar views on social memory and the place of the dead in their lives, it was their households and associated cemeteries (i.e., their ritual space) that were the center of their universe, not the larger and socially more diverse communities.

\subsection{Cemetery ANd Burial Sample}

Not including the Lang Pasture burials, there are 35 roughly contemporaneous prehistoric Caddo cemeteries in the upper Neches River basin, most in Anderson and Cherokee counties, that are the focus of our investigation of the character of Caddo mortuary practices (Figure 11-1 and Table 11-1). The presumed age of these cemeteries as employed throughout this chapter basically follows Kleinschmidt (1982:212-228), whose temporal seriation of cemeteries by Frankston phase sub-phases 1, 2, and 3, and Allen phase contexts has been confirmed by both radiocarbon dating (see Chapter 5, this volume) and the detailed examination of engraved fine ware ceramic vessel funerary offerings from a number of cemetery sites in immediate proximity to the Lang Pasture site (see Chapter 6, this volume). 


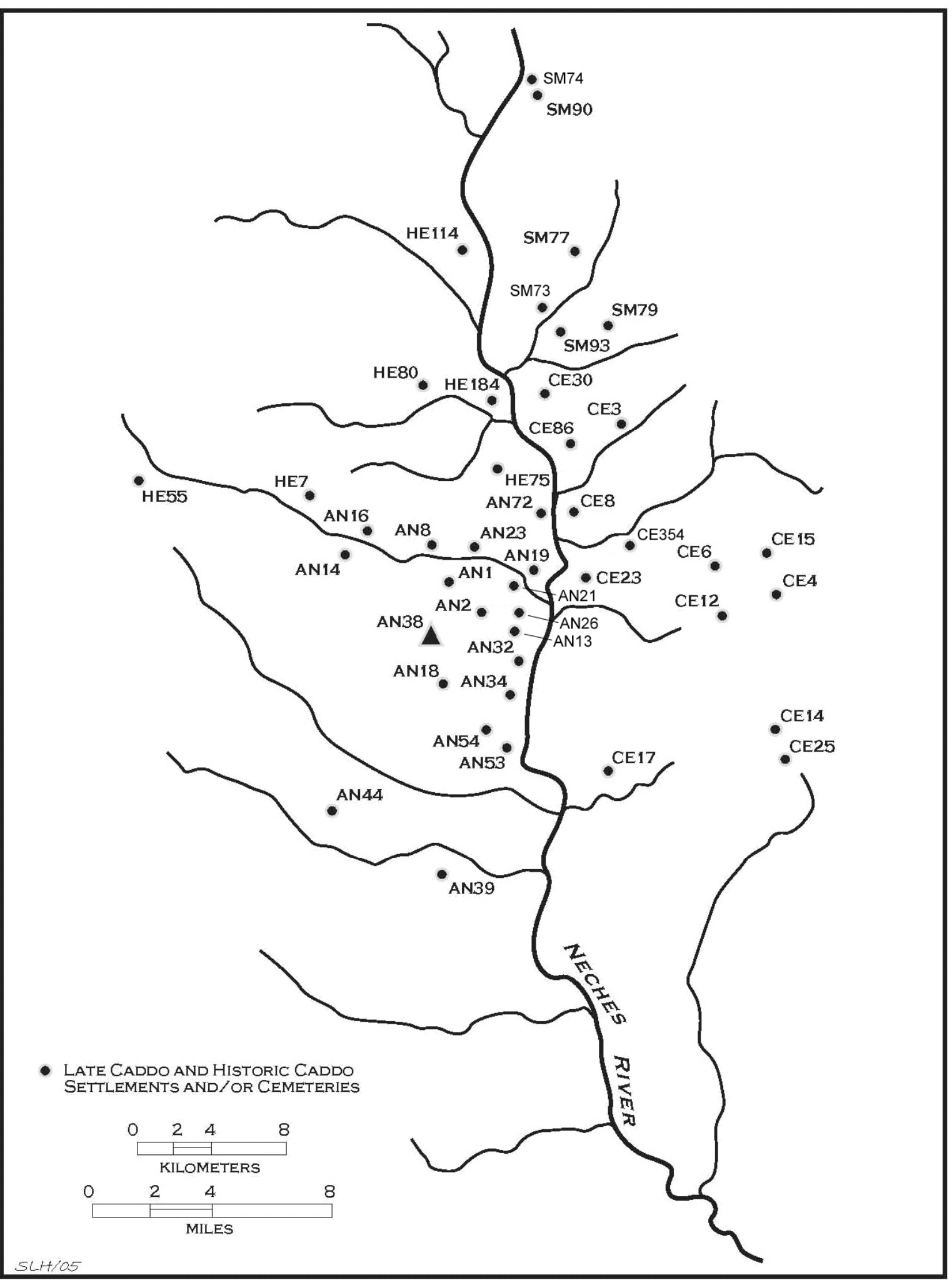

Figure 11-1. Cemetery and Domestic Sites in the Vicinity of the Lang Pasture Site (41AN38) in the Upper Neches River Basin. 
Table 11-1. Upper Neches River Basin Caddo Cemetery Sites.

Site Name and Trinomial No. Orientation Length Width Depth $\quad$ Reference

(m) $\quad(\mathrm{m}) \quad(\mathrm{m})$

(m)

\begin{tabular}{l}
\hline Anderson County \\
Mrs. J. M. Cook (41AN1) \\
J. M. Cook (41AN2) \\
L. Cecil (41AN8) \\
R. L. Jowell (41AN13) \\
Isibel-Gene Donnell (41AN14) \\
Stephenson Farm (41AN16) \\
Rube Beard (41AN18) \\
Emma Owens (41AN21) \\
Rose Daniels (41AN23) \\
Richard Patton (41AN26) \\
Fred McKee (41AN32) \\
Pierce Freeman (41AN34) \\
R. E. Daly (41AN39) \\
Jasper Tucker (41AN44) \\
Ballard Estates (41AN53)
\end{tabular}

Cherokee County

\begin{tabular}{|c|c|c|c|c|c|}
\hline Solon Stanley (41CE3) & 4 & $\begin{array}{l}\text { E-W (3); } \\
\text { NE-SW (1) }\end{array}$ & $1.57-2.41$ & $0.58-0.74$ & $0.30-0.63$ \\
\hline Mrs. J. W. Blackburn (41CE4) & 6 & E-W & $1.83-2.44$ & $0.56-0.89$ & $0.43-1.04$ \\
\hline E. W. Hackney (41CE6) & 2 & E-W & $2.01-2.98$ & $0.81-0.84$ & $0.36-0.50$ \\
\hline J. M. Snow (41CE8) & 1 & ? & ? & ? & ? \\
\hline Jim P. Allen (41CE12) & 19 & E-W & $1.40-2.52$ & $0.38-1.02$ & $0.18-0.61$ \\
\hline \multicolumn{6}{|l|}{ Omer and Otis Hood (41CE14) } \\
\hline \multirow[t]{2}{*}{ Cemetery \#1 } & 23 & E-W (17); & $1.19-2.88$ & $0.46-1.00$ & $0.33-1.32$ \\
\hline & & NE-SW (1) & 1.88 & 1.02 & 1.40 \\
\hline Cemetery \#2 & 3 & E-W & $1.93-2.56$ & $0.86-1.12$ & $0.66-1.04$ \\
\hline A. H. Reagor (41CE15) & 2 & E-W & $1.37-1.83$ & $0.64-0.71$ & $0.28-0.38$ \\
\hline E. W. Henry (41CE17) & 11 & E-W & $1.07-2.08$ & $0.38-0.71$ & $0.20-0.95$ \\
\hline John Bragg (41CE23) & 1 & ? & ? & ? & ? \\
\hline R. J. Fair (41CE25) & 10 & E-W & $1.27-2.10$ & $0.43-0.63$ & $0.33-0.68$ \\
\hline
\end{tabular}

Woolsey 1935a

Woolsey 1935b

Woolsey 1935j;

Cole 1975:101-110

Jackson 1933a:1-4

Woolsey 1935p

Woolsey 1935m

Woolsey $1935 \mathrm{~h}$; Cole 1975:147-151 Woolsey 1935k Jackson 1933b:1-2 Woolsey 1935i

\section{Henderson County}

$\begin{array}{lll}\text { A. S. Mann (41HE7) } & 2 & \text { E-W } \\ \text { L. B. Miller Farm (41HE55) } & 1 & ? \\ \text { DeRossett Farm (41HE75) } & 1 & ? \\ \text { Woldert (41HE80) } & 1 & ? \\ & & \\ \text { Attaway (41HE114) } & 5-7 & \text { E-W }\end{array}$

$\begin{array}{lll}1.22-2.07 & 0.41-0.55 & 0.23-0.55 \\ ? & ? & ? \\ ? & ? & ? \\ ? & ? & ? \\ ? & ? & ?\end{array}$

Smith County

\begin{tabular}{|c|c|c|c|c|c|c|}
\hline Joe Meyers (41SM73) & 6 & WNW-ESE & ? & $?$ & ? & $\begin{array}{l}\text { Anderson 1972:139; } \\
\text { Johnson 1961:219 }\end{array}$ \\
\hline 41SM74 & 2 & ? & ? & ? & ? & Johnson 1961:222 \\
\hline Vanderpool (41SM77) & $7-12$ & $\mathrm{E}-\mathrm{W}$ & $?$ & ? & $?$ & $\begin{array}{l}\text { Anderson 1972:139; } \\
\text { Johnson 1961:224: } \\
\text { Perttula 2006:75-84 }\end{array}$ \\
\hline 41SM90 & 3 & $\mathrm{E}-\mathrm{W}$ & ? & $?$ & $?$ & $\begin{array}{l}\text { Johnson 1961:229- } \\
230\end{array}$ \\
\hline 41SM93 & 4 & E-W & ? & ? & ? & TARL n.d. \\
\hline
\end{tabular}


These 35 cemeteries contained an estimated 167 individuals, ranging from 1 to 23 burials per locale, and with a mean size of less than five individuals per cemetery. Since the investigations of each of the cemetery sites was variable in terms of the extent of excavations, it is doubtful that entire Caddo burial populations were examined or defined archeologically. Thus, the mean number of burials per cemetery is probably a meaningless number since it represents both an amalgamation of sites where only a single burial or a few burials were discovered (cf. Johnson 1961; Shafer 1981)—but excavations were not sufficient to determine if more burials from a cemetery were present-to cases where broad excavations by University of Texas crew apparently were successful in locating all or most graves in certain cemeteries (see Woolsey 1935m, 1935p).

More apt comparisons of mortuary practices can be derived from those examples where burial excavations were intensive and the total number of burials has been reasonably established. In those cases, the largest Caddo cemetery known in the upper Neches River basin has 23 individuals (the Omer and Otis Hood site, cemetery \#1); most have around 10 interments, quite comparable in size and internal complexity in burial treatment and funerary offerings to the nine burials from the Lang pasture cemetery. To the north, among generally contemporaneous Titus phase Caddo groups, a number of the cemeteries there have more than 80 individuals (and as many as 200+, see Perttula [2005:377 and Figure 11$10])$, and large cemeteries with more than 50 individuals are known in Kinsloe phase sites in the middle Sabine River drainage (cf. Jones 1968:157-159). The cultural implications of these differences in cemetery site will be further discussed below.

Documentation on these cemeteries in the upper Neches River basin is available in the records and unpublished manuscripts at TARL as well as Anderson (1972), Anderson et al. (1974), Cole (1975), Johnson (1961), Kleinschmidt (1982), and Shafer (1981). From this information, we examine the questions of whether there are shared mortuary practices that may reflect distinct and shared social, religious, and philosophical beliefs about the dead and the afterlife, as well as whether there is a social hierarchical character to the households within the settlement and the larger community. This is accomplished by comparisons with other Late Caddo family cemeteries with similar information in the upper Neches River basin (see Cole 1975; Kleinschmidt 1982; Shafer 1981; Story and Creel 1982, and reports on file at TARL written in the 1930s), as well as from elite burials in Caddo mound centers (i.e., the George C. Davis site, see Story 2000) or lesser centers. The detailed examinations of ceramic styles and engraved rim motifs on the vessels placed as funerary objects (see Chapter 6, this volume) also provide information that may help to establish if the social affiliations of the household(s) at the sites relate to geographically distinct socio-political groups.

\section{Lang Pasture Site Burials}

There are two distinct groups of Caddo burial interments at the Lang Pasture site. The first group is $10-17 \mathrm{~m}$ north of Structure 1 , and includes six adult burials (Features 8, 88, 91, 92, 93, and 94) - five in two rows and the sixth (Feature 8) somewhat spatially removed from the group-from an associated family household cemetery (see Figure 5-4). These six burials, which contained either one or two individuals (Feature 93), had ceramic vessel $(n=27)$ and elbow pipes $(n=2)$ as associated funerary offerings. A second set of burials (Features 76B, 76C, and 76D) were placed in Feature 76, a large pit feature, to the east a short distance northeast of Structure 1. These burials had only four ceramic vessels as the sole funerary offerings, with a mean of only 1.33 funerary offerings per individual (see Table 5-9). All three individuals were children (see Wilson, Chapter 10, this volume).

In each of the burials at the Lang Pasture site, the deceased Caddo individual was apparently laid out in an extended supine position on the floor of the burial pit, with funerary offerings placed on either one or both sides of the body, 
but also resting on the burial pit floor. The three burials placed in Feature 76 were oriented northwest-southeast (see Table 5-9), with the head of the individual at the southeastern end of the burial pit, and facing to the northwest. The burial pits ranged from $115-200 \mathrm{~cm}$ in length and 63-69 $\mathrm{cm}$ in width; the one smaller grave (Feature 76D) is likely that of a small child, and as previously mentioned, Wilson (Chapter 10, this volume) indicates that the other two Feature 76 burials were those of children. The other burials, all adult Caddo individuals, are laid out in an east-west position, in two north-south rows, with the head of the deceased at the eastern end of the burial pit, and thus facing to the west (see Figure 5-48 and Table 5-9). The burial pits from this second cluster range from $260-312 \mathrm{~cm}$ in length and 100-176 cm in width (see Table 5-9).

There are several distinct and unique characteristics of the Lang Pasture burials, as will become more apparent when the other upper Neches River basin Caddo burials are discussed next. First, three of the burials (Feature 76B-D) were placed within a large and existing pit feature, rather than being placed in burial pits dug from a current ground surface; two (Feature 76B and Feature 76C) were placed side by side; this is a previously undocumented form of burial of Caddo children. Second, the orientation of these burials (northwest-southeast), with the head at the southeastern end of the burial pit, had also not been previously documented in upper Neches River basin Caddo cemeteries. Third, two of these burials (Feature 76B and C) were apparently placed atop an extensive sherd deposit deliberately laid down within the partially filled in Feature 76 basin. Fourth, two of the burials (Feature 8 and Feature 94) had evidence of small fires that had been placed at the foot of the grave. Fifth, one of the graves (Feature 93) had two adults placed in it. Sixth, one of the burials (Feature 93) had a very distinctive red gravelly fill. And last, the burial pits of the first burial group (Features 8, 88, 91-94) are larger in length and width than all but a few of the Caddo burials from the other upper Neches River basin graves (see Table 11-1).

\subsection{MORTUARY RITUALS AND BURIAL FEATURES}

\section{Cemetery Size}

As noted above, the average size of an upper Neches River basin Caddo cemetery is less than five individuals, but with a range from 123 individuals (see Table 11-1). As others have noted, the variation in the size of the cemeteries relate not only to the length of time that they were used by different families and lineages, but also to whether the cemeteries were used by a larger community such as is the case among Titus phase Caddo groups (Perttula 2005:377), or just by extended and kin-related family members. In the case of the upper Neches River basin Caddo, it is suspected that these cemeteries were used only by members of a small number of related settlements that are part of a single community, as populations contributing to each of them must not have been substantial (e.g., Story and Creel 1982:33); they are best considered to be family or multi-family cemeteries. In fact, because of their small size and their intimate spatial relationship with associated settlements, with respect to Frankston and Allen phase cemeteries, Shafer (1981:156) has suggested that "the relative duration of the hamlets (settlements) can be measured by the number of graves in the cemeteries and relative temporal placement of each hamlet can be determined by seriating mortuary assemblages.”

Consider that a community with a population of 100 and a hypothetical mortality or death rate of three percent.per year, a not unreasonable death rate for individuals between 5-50 years of age in a sedentary agricultural population like the Caddo (Chamberlain 2006:25-29 and Figure 3.6), would create a death assemblage of approximately 10 individuals in 3.3 years. Similarly, an extended family or two in a small farmstead compound of approximately 20 people would create a death assemblage of 
10 individuals in only 17 years with a 3\% death rate. These hypothetical computations indicate that only a matter of a few years to a single generation would need to have elapsed for either the occupants of a small Caddo farmstead compound or a small community of related individuals to create nearby cemeteries of the range in size documented in upper Neches River basin Caddo sites.

\section{Burial Orientation}

The vast majority of the upper Neches River Caddo burials were placed singly in pits that were oriented east-west, with the deceased's body placed on their back in an extended, supine position, with the head at the eastern end of the grave, facing west. Sabo (2008:1520) has noted that:

among the Caddo, the western cardinal direction, associated with the setting sun, symbolizes death and the realm of ancestral souls whereas the eastern cardinal direction, associated with the rising sun, symbolizes life and the realm of the living. Eastfacing rituals accordingly would be associated with life-affirming events, such as agricultural ceremonies or community renewal celebrations. West-facing rituals, on the other hand, would logically be associated with life-threatening events, such as hunting, warfare, or funeral rites.

In early $18^{\text {th }}$ century observations of Hasinai Caddo mortuary practices by Fray Espinosa
(Hatcher 1927a:162), he noted that "as soon as the souls leave the body they travel towards the west and from there they rise once more into the air and go close to the presence of the great captain whom they call caddi ayo. From there they go to wait in a house located towards the south, called the House of Death.” For the Caddo, the soul's travel to the west is also associated with the setting of the sun.

There are a few notable exceptions to the eastwest burial orientation in upper Neches River basin Caddo cemeteries. One burial (AL-9) at the E. W. Henry site (41CE17) was placed in an east-west oriented pit (Figure 11-2), but its head was at the western end of the grave and faced to the east (Woolsey 1935k:47). Several others had their heads facing to the southwest (see Table 11-1), while, as previously mentioned, three child burials from the Lang Pasture site faced to the northwest. The orientation of these burials may have been more influenced by the position of the sunset at certain times of the year (i.e., summer and winter solstice) or their position relative to the House of Death in the southwestern sky (Kay and Sabo 2006:32), rather than to beliefs that the soul traveled west on their journey to the House of Death. In any respect, these few exceptional burial treatments do not change the fact that an east-west body orientation was likely primarily due to a near universal belief in the direction of the afterlife and the soul's journey to the afterlife. 


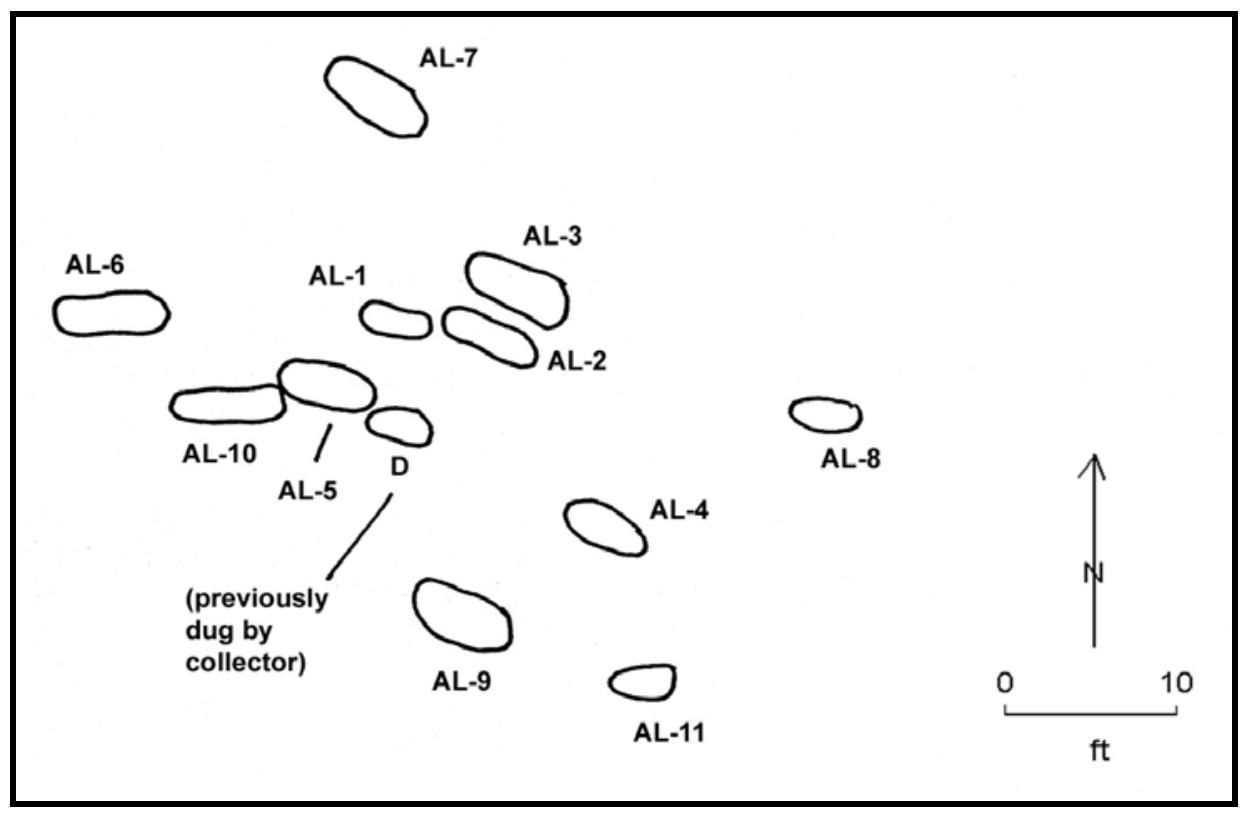

Figure 11-2. Plan of the Caddo Cemetery at the E. W. Henry Site (41CE17).

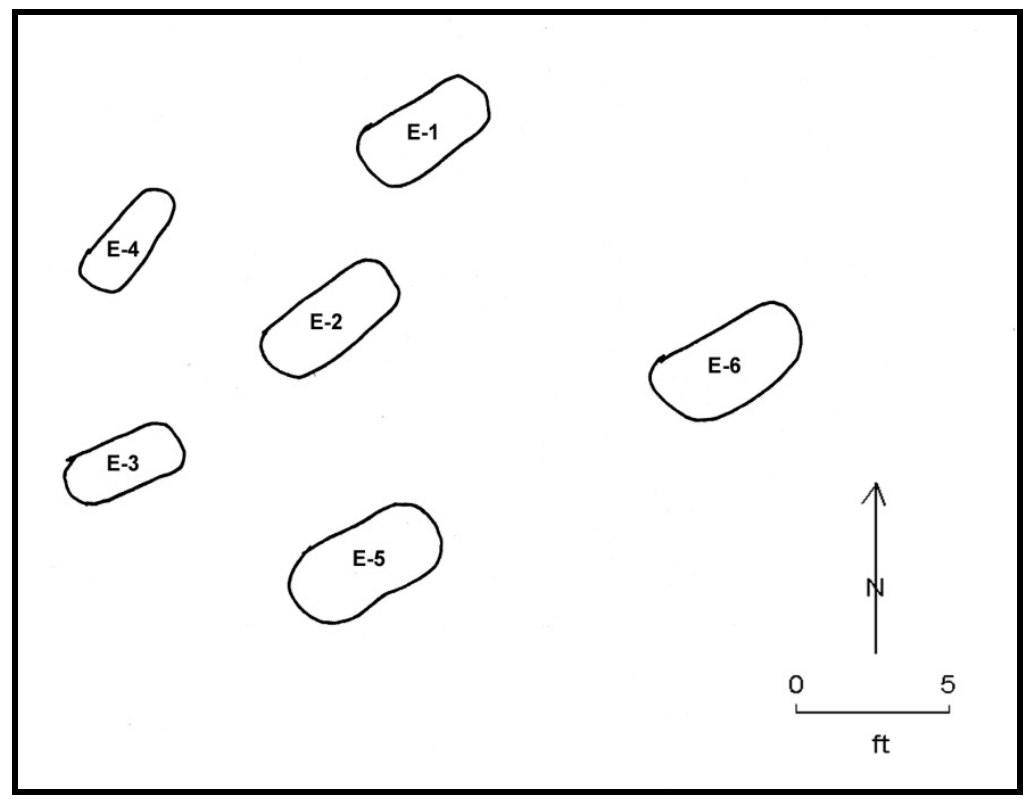

Figure 11-3. Plan of the Caddo Cemetery at the Mrs. J. M. Cook Site (41AN1).

Burials were typically placed in single or multiple rows, either east-west (Figure 11-3) or north-south rows (Figures 11-4, 11-5, and 11-6), with each body separated from the other by ca. $1 \mathrm{~m}$ (Figure 11-7). The rows may have had as many as seven individuals before a second row of burials were added to the interments, although Creel et al. (2005:10 and
Figure 7) have detected through remote sensing a probable single north-south row of Late Caddo or historic Caddo burials at the George C. Davis site that has 12 individuals. Burial pit sizes, funerary offerings, and preserved human remains suggest that the majority of the burials in the family cemeteries are adult males and females. 


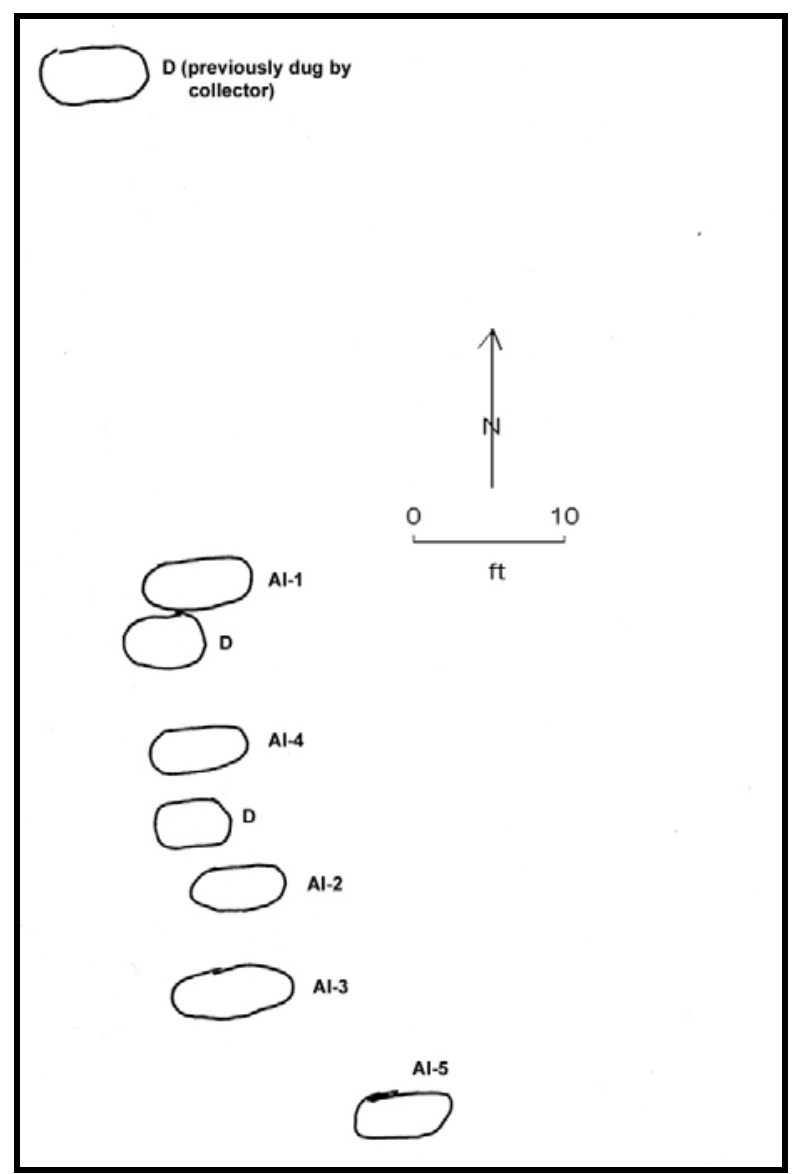

Figure 11-4. The Caddo Cemetery at the Mrs. J. W. Blackburn Site (41CE4).

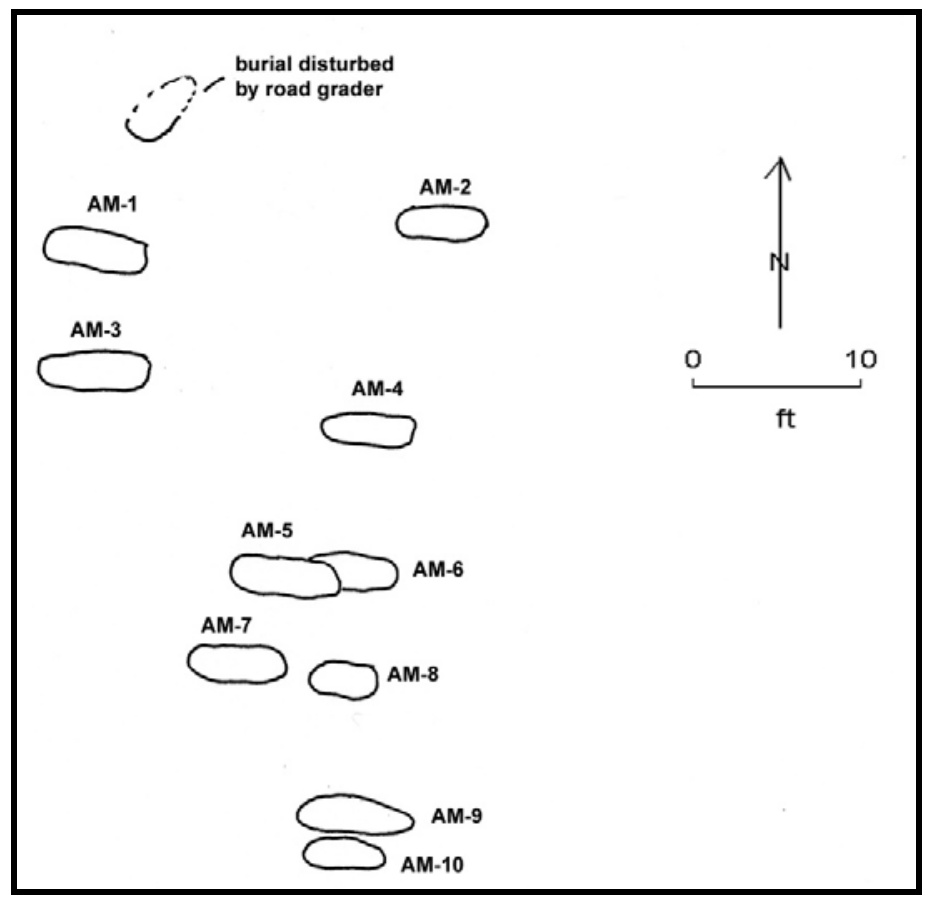

Figure 11-5. Plan of the Caddo Cemetery at the R. J. Fair Site (41CE25). 


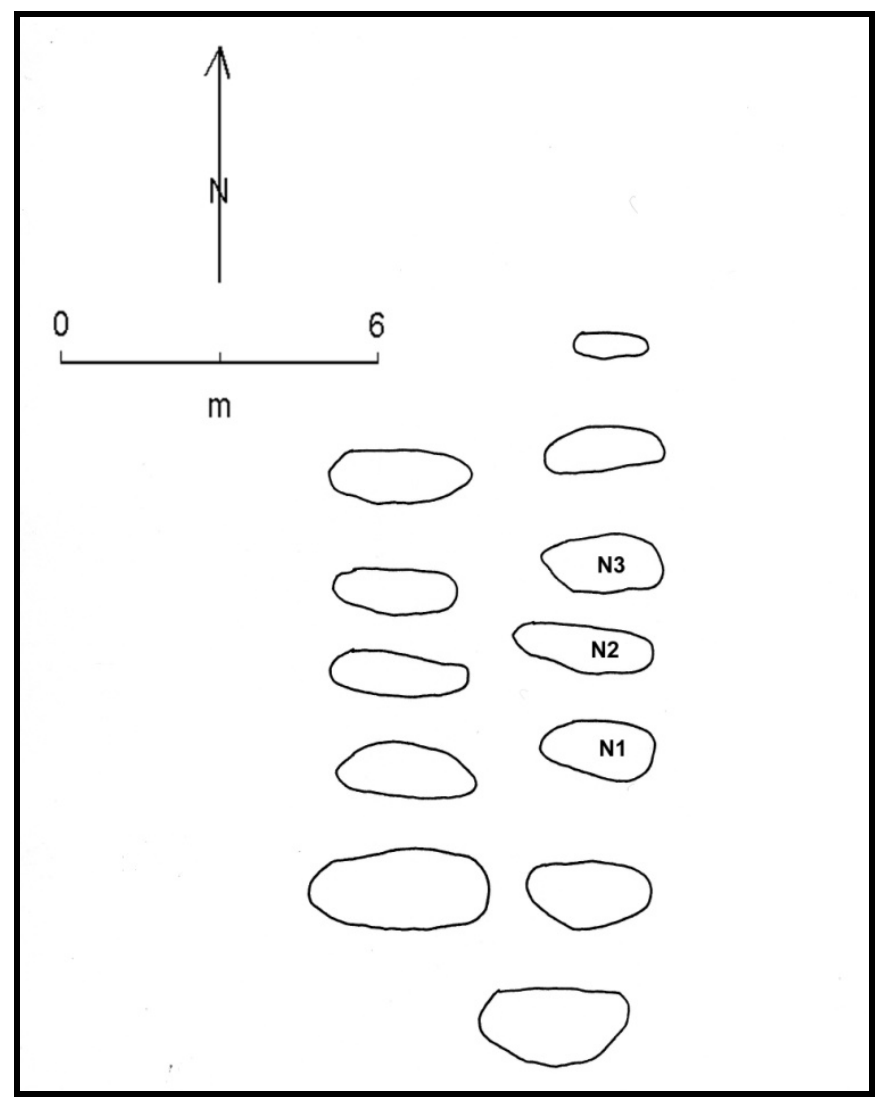

Figure 11-6. The Allen Phase Caddo Cemetery at the Richard Patton Site (41AN26).

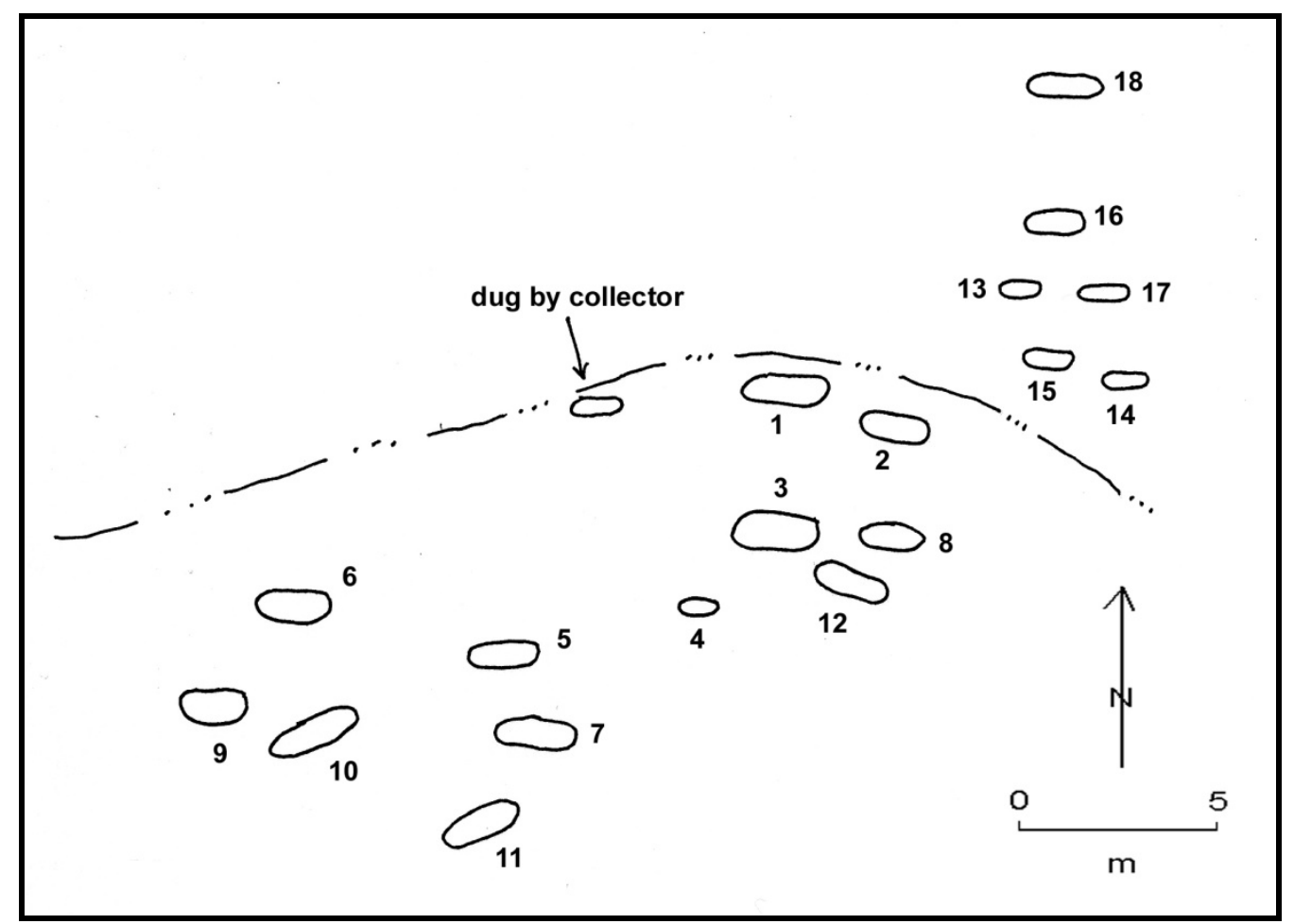

Figure 11-7. Plan of the Large Cemetery at the Jim Allen Site (41CE12). 
Caddo adults and children were buried together in a few of the cemeteries, based at least on the differences in size of the burial pits, rather than on the recovery and study of human skeletal remains because the remains of children rarely tend to be preserved in the sandy burial fills of upper Neches River basin graves. These few instances include two of the four burials at the Fred McKee site (Woolsey 1935l), two of the burials at the Pierce Freeman site (Jackson 1931:3-15), at least two children at the Jim P. Allen site (Woolsey 1935p; Cole [1975:322] suggests that children were buried in a separate section of this cemetery, apart from the adult burials), three children in cemetery \#1 at the Omer and Otis Hood site (Woolsey 1935m), one burial at the A. H. Reagor site (Woolsey 1935h), three children at the E. W. Henry site (Woolsey 1935k), one or two burials from the R. J. Fair site (Woolsey 1935i), and one of two burials at the A. S. Mann site (Woolsey 1935g). Significantly, seven of the eight sites in the upper Neches River basin with child burials placed in cemeteries date only after ca. A.D. 1480 , and $63 \%$ of these sites date after the mid- $16^{\text {th }}$ century. Children also were probably buried in pits under house floors (although this has not been documented in the upper Neches River basin because few Caddo structures have ever been identified or excavated in past archeological investigations), likely while the houses were still occupied by an extended family (cf. Story 1995:241).

There are a few instances where more than one Caddo individual was placed in a burial pit. This includes Feature 93 at the Lang Pasture site and Burial AO-1/AO-2 at the Jasper Tucker site (41AN44, see Woolsey 19350; see Figure 11-1). Anderson (1972:139140) mentions an unidentified site on County Line Creek in Smith County (in the vicinity of 41SM79, see Figure 11-1), about $20 \mathrm{~km}$ to the northeast, where a burial had been excavated by collectors that had three individuals interred in a $3.6 \mathrm{~m}$ wide pit; the size of this tomb as well as the number of individuals placed in it, although not found in a mound, bears some resemblance to the treatment of elite burials in Mound C at the George C. Davis site (Story 1997, 1998) and the Reavely Mound at the Washington Square site (Corbin and Hart 1998) that date prior to ca. A.D. 1300/1400. This particular Smith County burial had an abundance of funerary objects, among them 21 pottery vessels (of Frankston phase types), a celt, and a Jowell knife; the recovery of the Jowell knive suggests this burial feature dates late in the Frankston phase, likely after ca. A.D. 1600, since Jowell knives are relatively common offerings in late $17^{\text {th }}$-mid- $18^{\text {th }}$ century Allen and Kinsloe phase burials (Cole 1975; Jones 1968).

Only rarely did burials in these upper Neches River basin cemeteries intrude or intersect one another (AM-5 and AM-6 at the R. J. Fair site [see Figure 11-5 and Woolsey 1935i] and AQ1 , AQ-6, and AQ-10 in cemetery \#1 at the Omer and Otis Hood site [Woolsey 1935m]). It seems likely that the burials probably had wood post markers or some other form of commemoration at one end of the burial pit to insure that individual burials were kept separate and did not disturb earlier burials in sacred ground. The near absence of intersecting burials also suggests that these cemeteries were not used for long periods of time, as the memory of specific burial locations and rows of burials still remained strong among the living.

\section{Burial Pit Treatment}

In general, there is not much diversity in burial treatment of the deceased in prehistoric Caddo societies in the Upper Neches River basin. This limited diversity in burial treatment is part of the evidence preserved in the mortuary practices that strongly hints that there were not any considerable social organizational differences between affiliated and kin-related farmsteads that created these cemeteries (cf. Carr 1995:157 and Tables XIII and XIV). Carr (1995:Tables XI and XIV) suggests that body treatment, body preparation, and body orientation closely track beliefs about the soul and the afterlife more than they do the social position of the deceased. 
In the upper Neches River basin region, Caddo burials typically were placed in long and relatively narrow pits that were excavated to no more than $50-100 \mathrm{~cm}$ in depth. The fact that the pits tend to be narrow from the head to the foot of the burial suggests that the feet and ankles of the deceased may have been tied together. There was substantial room in the burial pits around the head, shoulders, and upper body of the deceased, probably for the purpose of leaving sufficient room to place food stuffs, ceramic vessels, and other accompanying funerary objects.

Not all Caddo received the same burial treatment and burial pit preparation at death. Several burials, including one at the Lang Pasture site, had a hard-packed gravel burial fill. These others include burial E-6 at the Mrs. J. M. Cook site (Jackson 1931) (see Figure 113) and burial AH-10 at the Jim P. Allen site (41CE12) (Woolsey 1935p:64); here the gravel lens was placed "under the middle part of the skeleton and extending to edge of grave on both sides of the skeleton" (see Figure 11$7)$.

At the Omer and Otis Hood site (41CE14) cemetery \#1, burial AQ-6 had a $51 \mathrm{~cm}$ thick white clay deposit that filled the bottom half of this deep $(1.32 \mathrm{~m})$ burial pit (Woolsey $1935 \mathrm{~m})$. There was a long-term importance of clay in Caddo burial rituals (Gonzalez 2005:57), particularly the washing of the body in red clay. It may be significant that the color white is a counterpoint to red clay (associated with the Other World). Thus, there appears to have been a general symbolic significance for Caddo peoples in the upper Neches River basin with respect to different colors and their cosmological views about the world (cf. Cobb and Drake 2008).

\section{Funerary Offerings}

The kinds, proportions, and absolute number of funerary offerings in upper Neches River basin Caddo sites do not show much evidence among these individuals for differential status or social rank, although there may be gender differences (i.e., artifact associations differ only by age and sex), but a definitive determination of this is hampered by little comprehensive information on the age and sex of the deceased individuals from these excavated cemeteries. It has been assumed in archeological analyses of prehistoric mortuary practices that "the abundance and quality of burial goods equate with status" (Cobb 2003:72). However, this assumption needs reconsideration given the many factors that come into play that can account for the number and kind of funerary offerings placed in the grave by the living (see Chesson 2001a:4-7), particularly since "mortuary rituals are frequently utilized by the living to negotiate, display, mask, or transform actual power or social relations" (Rakita and Buikstra 2005:7).

It does appear to be the case with upper Neches River basin Caddo burials that only a few individuals in these communities had access (either in life or death) to the kinds, numbers, and variety of funerary offerings that have been documented in Caddo cemeteries and individual burial features in mound contexts, in shaft tombs, or in other special mortuary contexts from East Texas where individuals had distinctive exotic and nonlocal funerary offerings. From the available evidence at the Lang Pasture site, none of the burial features appear to be those of individuals of high social status ranking. Nevertheless, there are certain individuals in this region, probably adult males, that are found with high numbers of ceramic vessels and/or arrow point quivers and pipes, as well as a diverse array of other sorts of funerary offerings; these individuals may represent those with a higher social position, likely the heads of different lineages or extended kin groups that resided in nearby farmsteads, and ended up being interred in associated cemeteries amidst their kin relations.

Ethnographic information about East Texas Hasinai Caddo mortuary practices suggest that in a symbolic and material sense the items used by individuals in life, as well as the range of goods needed to accompany the deceased on their journey to the other world (or the 
House of Death), were placed with the deceased in their graves. In 1691, Fray Casanas noted that for the Caddo, "when all the souls are gathered together [in the House of Death] they will enter another world to live anew. For this reason, they bury their dead with all the arms and utensils which each possesses and for several days they carry something to eat to the place where they have buried a person" (Hatcher 1927c:294). Fray Hidalgo in 1716 stated that at death, after the deceased had been bathed, the Caddo "place there something of everything they have to eat as well as buffalo hides... They place there provisions for the journey and other possessions to serve for clothing" (Hatcher 1927b:57). Fray Espinosa made similar observations, namely that the Caddo "provide great quantities of pinole, corn, and other eatables" for the deceased, which they place in the grave (Hatcher 1927a:162). He went on to write that if the deceased was a man, the Caddo "collect his bows and arrows, his knife, and the other things needed in life and, if it be a woman, all her domestic utensils, canisters, grinding instruments, and earthen-ware vessels, because they say the dead will have need of them where they are going" (Hatcher 1927a:162). That these practices were maintained into modern times is indicated by 20th century Caddo ethnographic informants of Parsons (1941:37), who told her that they would "put into the grave whatever they think the deceased should take with her or him, for a woman, cooking utensils, plates, etc., clothing; and for a man, besides clothes and blankets, bow and arrows 'to defend himself on his road if anything bother him'.”
In the upper Neches River basin in later prehistoric times, after ca. A.D. 1300-1400, the Caddo placed a number of different kinds of funerary offerings in the graves of the deceased (Table 11-2). The principal and ubiquitous funerary offering in virtually every grave-regardless of age or sex-were ceramic vessels, including bottles (13\%), bowls and carinated bowls (70\%), and cooking jars (17\%) (Perttula 2000:Table 7). These vessels must have held, at least symbolically, foods and liquid provisions that the deceased would have used to quench their thirst and hunger on their journey to the House of Death. Furthermore, these mortuary assemblages may have been placed in the graves "to mirror a mini-household assemblage envisioned to take care of the needs of that specific individual” (Shafer 1981:175).

Other important funerary offerings in prehistoric Caddo cemeteries include arrow points, usually in quivers, and clay pipes, as both of these kinds of objects are found in at least one burial at each of the better documented cemeteries. Among the less well represented funerary objects are large bifacial and/or beveled knives, chipped and/or ground stone tools, marine shell ornaments (beads and disks), clay pigments or chunks of hematite pigment, animal bone tools or beads, or in the case of Allen phase cemeteries, European trade goods (see Table 11-2). 
Table 11-2. Proportions of Various Kinds of Mortuary Offerings in the Upper Neches Region, by Phase and Sub-phase.

\begin{tabular}{|c|c|c|c|c|c|c|c|c|c|c|}
\hline Site & Ceramic Vessels & Arrow Points & Knives & Stone Tools & $\begin{array}{c}\text { Marine } \\
\text { Shell }\end{array}$ & Ochre/Pigment & $\begin{array}{l}\text { Bone Tool/ } \\
\text { Bone Bead }\end{array}$ & $\begin{array}{l}\text { Trade } \\
\text { Good }\end{array}$ & Clay Pipe & $\begin{array}{l}\text { No. of } \\
\text { Burial }\end{array}$ \\
\hline \multicolumn{11}{|c|}{ Allen Phase } \\
\hline AN21 & $100.0^{*}$ & - & - & 100.0 & 100.0 & - & - & - & 100.0 & 1 \\
\hline AN26 & 100.0 & 66.7 & 66.7 & 33.3 & - & 66.7 & 33.3 & 33.3 & 33.3 & 3 \\
\hline CE6 & 100.0 & 50.0 & 100.0 & - & 100.0 & - & - & - & 50.0 & 2 \\
\hline CE12 & 100.0 & 22.2 & 33.3 & 5.6 & 22.2 & 38.9 & 11.1 & 5.6 & 5.6 & 18 \\
\hline
\end{tabular}

Frankston Phase, Sub-phase $3^{* *}$

$\begin{array}{lc}\text { AN2 } & 100.0 \\ \text { AN32 } & 100.0 \\ \text { AN34 } & 100.0 \\ \text { CE15 } & 100.0 \\ \text { CE25 } & 90.0 \\ \text { HE75 } & 100.0\end{array}$

Frankston Phase, Sub-phase 2

$\begin{array}{lc}\text { AN1 } 1 & 100.0 \\ \text { AN14 } & 100.0 \\ \text { CE3 } & 100.0 \\ \text { CE4 } & 100.0 \\ \text { CE14, \#1 } & 94.4 \\ \text { HE7 } & 100.0 \\ \text { HE114 } & 100.0\end{array}$

$\begin{array}{cccc}50.0 & 50.0 & - & - \\ 25.0 & - & - & - \\ - & - & - & - \\ - & 50.0 & - & - \\ 50.0 & 10.0 & - & - \\ 100.0 & 100.0 & - & 100.0\end{array}$

-
-
-
-
-

-
-
-
-
-
-

$\begin{array}{lcc}- & 50.0 & 2 \\ - & 75.0 & 4 \\ - & 50.0 & 4 \\ - & - & 2 \\ - & 10.0 & 10 \\ - & 100.0 & 1\end{array}$

$\begin{array}{ccc}- & - & - \\ 50.0 & 50.0 & - \\ 100.0 & - & - \\ 60.0 & - & - \\ 33.3 & - & - \\ - & - & - \\ 50.0 & - & -\end{array}$


Bone Tool/

Bone Bead

100.0

100.0

50.0

50.0

$-$

Frankston Phase, Sub-phase 1

\begin{tabular}{|c|c|c|c|c|c|c|c|c|c|c|}
\hline AN44 & 50.0 & 50.0 & - & - & - & - & - & - & 50.0 & 2 \\
\hline AN53 & - & - & - & - & - & - & - & - & - & 1 \\
\hline CE14, \#2 & 100.0 & - & - & - & - & 50.0 & - & - & 50.0 & 2 \\
\hline CE17 & 81.8 & - & - & - & 9.1 & - & - & - & 9.1 & 11 \\
\hline CE23 & 100.0 & 100.0 & - & 100.0 & - & - & - & - & 100.0 & 1 \\
\hline SM90 & 100.0 & 33.3 & - & - & - & - & - & - & 33.3 & 3 \\
\hline SM93 & 75.0 & 25.0 & - & - & - & - & - & - & - & 4 \\
\hline
\end{tabular}

* Proportion of burials from the cemetery that have each kind of funerary offering

** Sub-phase designations follow Kleinschmidt (1982:Table 19) 
Through time, the proportion of burials with ceramic vessel funerary offerings remained remarkably consistent, with vessels placed as offerings in $88-100 \%$ of the known burials (Table 11-3), peaking during the historic Allen phase. It seems likely that beliefs about the provisioning of the dead remained virtually unchanged. Arrow points (16-36.8\% of the burials by phase and sub-phase) and clay pipes (16.7-34.8\% of the burials by phase and subphase) also tend to have been placed as offerings in the same relative proportions in both Frankston and Allen phase contexts, although arrow point and clay pipe offerings were more likely to have been placed in greater quantities and greater relative proportions with Frankston 2 and 3 sub-phase burials (ca. A.D. 1480-1650), particularly those of adult males.

Such is not the case with the other kinds of funerary offerings, namely stone tools, knives, marine shell, pigments, animal bone objects, or European trade goods. Discounting the European trade goods (i.e., glass beads and metal artifacts), which would only have been available to Allen phase Caddo groups, all of these other categories of funerary offerings were only commonly placed in the burials of Caddo individuals in either post-A.D. 1650 Allen phase cemeteries or a few post-A.D. 1560 Frankston phase cemeteries, and not before (see Table 11-3). This fundamental change in the kinds and proportions of funerary offerings placed with the deceased suggests that some differences and changes in mortuary beliefs and practices occurred among the Caddo in the upper Neches River basin around the mid- $16^{\text {th }}$ century and were then maintained through the early part of the $18^{\text {th }}$ century, if not longer.
These temporal, and presumably social, religious, and philosophical, differences in Caddo mortuary practices are also evident if we examine the mean number of funerary offerings per burial in the better documented upper Neches River basin cemeteries, including the two burial groupings at the Lang Pasture site (Table 11-4). The cemeteries sort clearly into two distinct groups: (a) one group from 12 different sites throughout the region that have higher mean numbers of funerary offerings (ranging from at least 7.00-17.34 offerings per burial in each cemetery; and (b) a second group of seven cemeteries in the upper Neches-among them the Lang Pasture burials as well as the Deshazo site (see Good 1982; Story 1995) — with burials that have few funerary offerings.

The principal difference in the funerary offerings between these two groups of prehistoric Caddo cemeteries rests in the numbers and relative proportions of arrow points placed in the graves (see Table 11-4). In the first grouping of cemeteries, arrow points comprise between $30-68 \%$ of the items placed with the deceased, while the majority of the deceased individuals buried in the second group of cemeteries either lack arrow point quiver offerings or they comprise less than $20 \%$ of all the funerary offerings. Pipes and lithic tools are also proportionally more common in the first group of cemetery sites (see Table 11-4).

In the second group of cemeteries, those where burials have lesser amounts of funerary offerings in general, ceramic vessels account for $80-100 \%$ of the funerary offerings (see Table 11-4). Conversely, in the cemeteries dominated by offerings of arrow point quivers, ceramic vessels represent only 33-68\% of the funerary offerings. 
Table 11-3. Summary Comparison of the Kinds and Proportions of Funerary Offerings in Frankston and Allen Phase Cemeteries and the Lang Pasture Site (41AM38).

\begin{tabular}{|c|c|c|c|c|c|c|c|c|c|c|}
\hline Phase/Site & $\begin{array}{c}\text { Ceramic } \\
\text { Vessel }\end{array}$ & $\begin{array}{c}\text { Arrow } \\
\text { Point }\end{array}$ & Knife & $\begin{array}{l}\text { Stone } \\
\text { Tool }\end{array}$ & $\begin{array}{l}\text { Marine } \\
\text { Shell }\end{array}$ & Ochre/Pigment & $\begin{array}{l}\text { Bone Tool/ } \\
\text { Bone Bead }\end{array}$ & Trade Good & $\begin{array}{l}\text { Clay } \\
\text { Pipe }\end{array}$ & $\begin{array}{l}\text { No. of } \\
\text { Burials }\end{array}$ \\
\hline $\begin{array}{l}\text { AN38, Gp. } \\
1^{*}\end{array}$ & 100.0 & - & - & - & - & - & - & - & - & 3 \\
\hline AN38, Gp. 2 & 100.0 & - & - & - & - & - & - & - & 33.3 & 6 \\
\hline Frankston 1 & 88.0 & 16.0 & & 4.0 & 4.0 & 4.0 & - & - & 20.0 & 25 \\
\hline Frankston 2 & 97.4 & 36.8 & 5.3 & 2.6 & - & - & - & - & 23.7 & 38 \\
\hline Frankston 3 & 95.5 & 34.8 & 17.4 & - & 7.7 & - & - & - & 34.8 & 23 \\
\hline Allen Phase & 100.0 & 29.2 & 41.7 & 12.5 & 29.2 & 37.5 & 12.5 & 8.3 & 16.7 & 24 \\
\hline
\end{tabular}

* Group 1: Feature 76B-D burials; Group 2: Features 8, 88, 91-94 
Table 11-4. Mean No. of Funerary Offerings per Burial.

\begin{tabular}{lllllll}
\hline Site & MNI & $\begin{array}{l}\text { Mean No. } \\
\text { of Vessels } \\
\text { per burial }\end{array}$ & $\begin{array}{l}\text { Mean No. } \\
\text { of Arrow points } \\
\text { per burial }\end{array}$ & $\begin{array}{l}\text { Mean No. } \\
\text { of Lithic Tools } \\
\text { per burial }\end{array}$ & $\begin{array}{l}\text { Mean No. } \\
\text { of Pipes } \\
\text { per burial }\end{array}$ & $\begin{array}{l}\text { Mean } \\
\text { Burial } \\
\text { Totals }\end{array}$ \\
\hline 41AN2 & 3 & 5.67 & 10.33 & 0.67 & 0.67 & 17.34 \\
41SM77 & 2 & 5.50 & 7.00 & 1.00 & 0.00 & 13.50 \\
41CE4 & 6 & 5.20 & 6.40 & 0.00 & 0.60 & 12.20 \\
41AN32 & 4 & 6.25 & 2.75 & 0.00 & 0.75 & 9.75 \\
41CE14 & 24 & 6.35 & 2.60 & 0.00 & 0.35 & 9.30 \\
41CE25 & 11 & 2.70 & 6.30 & 0.10 & 0.10 & 9.20 \\
41CE6 & 2 & 4.50 & 3.00 & 1.00 & 0.50 & 9.00 \\
41HE114 & $5-7$ & 3.50 & 4.50 & 0.00 & 0.50 & 8.50 \\
41AN26 & 12 & 3.58 & 2.33 & 1.92 & 0.00 & $7.83+$ \\
41AN44 & 2 & 4.50 & 2.50 & 0.00 & 0.50 & 7.50 \\
41CE12 & 18 & 3.50 & 3.00 & 0.78 & 0.05 & $7.33++$ \\
41SM90 & 3 & 2.67 & 4.00 & 0.00 & 0.33 & 7.00 \\
& & & & & & \\
41CE3 & 4 & 5.25 & 0.50 & 0.00 & 0.25 & 6.00 \\
41AN1 & 6 & 6.00 & 0.00 & 0.00 & 0.00 & 6.00 \\
41AN34 & 4 & 5.00 & 0.00 & 0.00 & 0.50 & 5.50 \\
41AN38, G2* & $\mathbf{7}$ & $\mathbf{3 . 8 6}$ & $\mathbf{0 . 0 0}$ & $\mathbf{0 . 0 0}$ & $\mathbf{0 . 2 9}$ & $\mathbf{4 . 1 5}$ \\
41SM93 & 4 & 3.00 & 0.75 & 0.00 & 0.00 & 3.75 \\
41CE17 & 12 & 3.00 & 0.00 & 0.00 & 0.09 & $3.09+++$ \\
41CE15 & 2 & 2.00 & 0.00 & 0.50 & 0.00 & 2.50 \\
Deshazo & 13 & 1.33 & 0.00 & 0.25 & 0.08 & 1.66 \\
41AN38, G1** & $\mathbf{3}$ & $\mathbf{1 . 3 3}$ & $\mathbf{0 . 0 0}$ & $\mathbf{0 . 0 0}$ & $\mathbf{0 . 0 0}$ & $\mathbf{1 . 3 3}$ \\
\hline & & & & & & \\
\hline
\end{tabular}

MNI=Minimum Number of Individual Burials

*includes Features 8, 88, and 91-94

**includes Features 76B-76D

+does not include bone bead or hematite pieces

++ does not include bison bone, pigment, and marine shell offerings

+++ does not include shell beads

Taking into account the fact that cemeteries contain the burials of both adult men and women, as well as some children, it is likely that this diversity in the absolute quantity and kinds of funerary offerings in upper Neches River basin Caddo sites represent the existence of social differences among the Caddo communities that created and maintained these cemeteries, particularly between adult men and women. These social differences and changes in social relationships between adult men and women also have a temporal character, in that $50 \%$ of the cemeteries with high mean numbers of funerary offerings and arrow point quivers date after ca. A.D. 1560 (and 83\% date after ca. A.D. 1480), when the status of adult men relative to women in their society may have been increasing, while $67 \%$ of the cemeteries with low mean numbers of funerary offerings per burial date before ca. A.D. 1560 (and 50\% date before ca. A.D. 1480). Prior to ca. A.D. 1560 , then, the social position of adult Caddo men and women appears to have been more or less the same within upper Neches River communities. 


\section{Age and Sex Characteristics in Caddo Mortuary Practices}

In a study of a Frankston phase (sub-phase

2) cemetery at the Attaway site (41HE114) on the west side of the Neches River (see Figure 11-1 and Tables 11-1, 11-2, and 114), Shafer (1981:175) suggested that the sexual status of Caddo individuals at this site may have played an important role in the kinds of funerary offerings placed in their graves at death. Specifically, Shafer hypothesized that clay pipes, clusters of arrow points, and celts were characteristic offerings placed with adult males, and that the selection of the kinds of vessels placed in graves was along gender lines.

These types of age and sex relationships with respect to the character of funerary offerings has been well-documented in contemporaneous Titus phase cemeteries (cf. Thurmond 1990; Turner 1992; Perttula 2005) in East Texas, certainly with respect to offerings that are strongly associated with adult males, but also with ceramic vessels used for provisioning of the dead. In Titus phase burials, for instance, bowls were most common in the graves of adolescents and younger children, although they were also placed in the graves of both adult males and females. Cooking jars were more frequent funerary offerings among adult females and adolescents, and children had more jars than did adult males. Compound bowls were particularly common in the graves of younger children, adolescents, and adult females, while carinated bowls were most frequent in the graves of adult males. All burials contained at least a single bottle (Perttula 2005:259, 261). From these differences, it seems likely that the needs of the dead differed in Titus phase societies between adults and children/juveniles. Were there similar age and sex differences in funerary offerings in upper Neches Caddo burials?

The best available mortuary data in the upper Neches River basin on the placement of funerary offerings with Caddo individuals of different age and sex is from a few Allen phase sites (see Cole 1975:176-336), due in large part to the preservation of skeletal remains from these early historic Caddo burials that could be aged and sexed. Cole's findings are as follows: (1) the preponderance of arrow points, chipped stone scraping tools, Jowell and Anderson knives, bison bone tools, and clay pipes were placed with adult males over 20 years of age; and (2) adult males and children tended to have beveled knives and green (glauconite pigments) clay pigments placed with them as funerary offerings. Overall, ceramic vessels, on the other hand, were seemingly uniformly placed with adult males, females, and children (Cole 1975); their needs with respect to the provisioning of foods and liquids were about the same. However, Hood Engraved effigy vessels were a more frequent funerary offering in the graves of adult males, as were Patton Engraved, var. Allen, Simms Engraved, var. Darco, Taylor Engraved, and Hume Engraved, var. Allen fine wares. Other forms of Patton Engraved (var. Fair and var. Freeman) were equally common offerings in the graves of adult men and women, while Patton Engraved, var. Patton vessels, the ultimate Allen phase serving vessel, were equally abundant in the graves of adult men, women, and children.

Additional demographic analyses of upper Neches River basin Caddo skeletal remains by Wilson (Chapter 10, this volume) provide further insights into the treatment of the deceased, and the offerings placed with them, according to their age and sex. Children as well as adults uniformly had funerary offerings placed with them at death. In the case of children and adult females, the principal funerary offerings were ceramic vessels (Table 11-5). Adult females had approximately twice as many funerary offerings as did children, and they had more diverse kinds of offerings. 
Table 11-5. Differences in the Kind and Proportion of Funerary Offerings in Burials of Children and Adults in Upper Neches River Basin Caddo Sites.

\begin{tabular}{|c|c|c|c|c|c|c|c|c|c|}
\hline $\begin{array}{l}\text { Age and/or } \\
\text { Sex (No. of } \\
\text { Individuals) }\end{array}$ & Vessels & Knive & Pipe & $\mathrm{AP}$ & Shell & \multicolumn{2}{|c|}{$\begin{array}{r}\text { Pigment Trade } \\
\text { Goods }\end{array}$} & Tools & Total \\
\hline Children (6)** & $1.83^{*}$ & 0.17 & - & - & - & - & - & - & 2.00 \\
\hline $\begin{array}{l}\text { Adult (sex } \\
\text { unknown) } \\
(14)^{* * *}\end{array}$ & 3.93 & 0.07 & 0.36 & 2.29 & 0.21 & 0.14 & - & - & 7.00 \\
\hline $\begin{array}{l}\text { Adult, poss. } \\
\text { female }(1)^{\wedge}\end{array}$ & 3.00 & - & 1.00 & - & - & - & - & - & 4.00 \\
\hline $\begin{array}{l}\text { Adult, female } \\
\text { (6)\# }\end{array}$ & 3.33 & 0.17 & 0.17 & - & 0.33 & 0.17 & - & - & 4.17 \\
\hline $\begin{array}{l}\text { Adult, male } \\
(6)^{+}\end{array}$ & 4.17 & 0.50 & 0.67 & 6.17 & 12.33 & - & 1.50 & 0.50 & 25.74 \\
\hline $\begin{array}{l}\text { *mean no. of fu } \\
* * 41 \mathrm{AN} 32, \mathrm{~A} \\
* * * 41 \mathrm{AN} 38, \mathrm{~F} \\
\mathrm{AH}-2, \mathrm{AH}-6, \mathrm{~A} \\
\wedge \text { 41AN34, D-2 } \\
\text { \# 41AN32, AP } \\
+41 \mathrm{AN} 32, \mathrm{AP}\end{array}$ & $\begin{array}{l}\text { erary off } \\
2 \text {; } 41 \mathrm{AN} \\
\text { atures } 88 \\
\text { I-8, and } A \\
\text {; } 41 \mathrm{AN} 3 \\
\text {. } 41 \mathrm{AN} 3\end{array}$ & $\begin{array}{l}38, \text { Feat } \\
91,92, \\
\text { H-15 }\end{array}$ & $\begin{array}{l}3, \mathrm{Bu} \\
\text { es } 76\end{array}$ & $\begin{array}{l}; 41 C \\
2 \text {, anc } \\
11 ; 4\end{array}$ & $41 \mathrm{CH}$ & $\begin{array}{l}\text { nd } f \\
\text { AL. }\end{array}$ & L-2, & $3, \mathrm{AI}$ & $\begin{array}{l}\text { AL-5; 41CE12, } \\
\text { 11; 41CE15, AJ-1 } \\
\text { AH-10 }\end{array}$ \\
\hline
\end{tabular}

Adult men had a wealth of funerary offerings placed with them at death (see Table 11-5). In addition to ceramic vessels_-about the same number of vessels as placed with adult females, again equating to similar death provisioning needs among adults - adult Caddo men had large chipped stone knives, other stone or bone tools, clay pipes, arrow points, marine shell ornaments, and European trade goods. Clay pigments were absent in the graves of adult men.

While not extensive (only 19 individuals of known age and sex, see Table 11-5), the demographic and funerary offerings data clearly indicate that the kinds and amounts of funerary offerings placed among upper Neches River Caddo groups, and needed by them in their journey to the House of Death, varied significantly by age and sex. Other than broad similarities in the number of vessels per burial-suggesting that these vessels held sufficient food stuffs for children and adults on their journey, but nothing more-in all other aspects adult men clearly had need in the afterlife of such gender-laden things as stone tools and arrow points, a clay smoking pipe, and ornaments on their journey, while children and adult females did not.

Three gender-laden exceptions are worth noting in the Table 11-5 demographic and funerary offerings data. Adult female or probable adult female burials from the Fred Mckee site (41AN32, AP-3), Pierce Freeman site (41AN34, D-2), and E. W. Hackney site (41CE6, AN-1)_all post-A.D. 1560 Caddo cemeteries-had either clay pipes, marine shell, or large chipped stone knives placed in their graves along with ceramic vessels. Provided that the 
identifications of sex for these burials is accurate, then it appears to be the case that some Caddo women had access to, and used, these material goods in life and then were provided with them as an accompaniment in death.

\section{Notable Interred Individuals}

Based on several attributes, including the number of funerary offerings placed with the dead, ${ }^{2}$ the number of individuals placed in a burial pit, as well as the specific kinds of artifacts included as funerary offerings, all of which bespeak social differences (cf. Carr 1995:169, 179-180, 191), there are several notable interred individuals among the ca. A.D. 1400 to early historic Caddo burials in the upper Neches River basin. These notable interred individuals represent about $5 \%$ of the known Caddo burial population in the region.

These individuals include the following:

Burial F-1 at the J. M. Cook site (41AN2). This adult individual had a very large assortment of funerary offerings $(n=39)$, including five vessels placed around the head and by the left hip, two large chipped stone knives by the left hip and right knee, a large ceramic elbow pipe between the legs and near the feet, and 31 arrow points in quivers by the right knee and between the legs and near the feet (Jackson 1931);

Burial AO-1/AO-2 at the Jasper Tucker site (41AN44). This particular burial had two adult individuals interred together. Also notable is that between the two individuals, a total of six Hood Engraved effigy vessels were among the funerary offerings (Woolsey 1935o:13); effigy vessels are otherwise relatively rare funerary offerings;
Burial AI-3 at the Mrs. J. W. Blackburn site (41CE4) (see Figure 11-4). This adult had a large number of funerary offerings $(n=29)$, including seven vessels placed either by the head, from the waist to the feet, or on the body, one clay pipe by the right foot, and 21 Perdiz arrow points in quivers by the head and the right waist (Woolsey 1935b);

Burial AN-2 at the E. W. Hackney site (41CE6), an Allen phase burial. This adult individual had six ceramic vessels by the head, left shoulder, right arm, and left leg/foot, six arrow points by the skull and at the back of the head; a large knive by the left side of the body; 27 marine shell beads at the waist and left arm (bracelet); and an engraved pipe by the left arm (Woolsey 1935j);

Three adult male individuals at the Jim P. Allen site, another Allen phase cemetery, were buried with impressive amounts of funerary offerings: $\mathrm{AH}-3 \quad(\mathrm{n}=53), \quad \mathrm{AH}-7$ $(\mathrm{n}=60)$, and AH-10 $(\mathrm{n}=24)$ (Woolsey 1935p) (see Figure 11-7). Burial AH-3 (more than 40 years of age at death), situated in the approximate center of the cemetery, had six ceramic vessels by the head, hip, and left leg; a quiver of 27 arrow points by the left side of the head; various lithic tools (two beveled chipped stone knives, a mallet/maul, three scrapers, and a drill, all by the left arm); a clay pipe by the right shoulder; a bison bone by the right arm; and marine shell beads and discs on the neck and chest, and one by an ear; Woolsey (1935p:113) commented that it was the "richest and most valuable burial" at the site. Burial AH-7, about $8 \mathrm{~m}$ southwest of AH-3 (see 
Figure 11-7) had two vessels placed by the head and left foot, a stone knive by the left waist, 33 shell beads on the waist (probably decorating a sash), 22 arrow points, including a quiver of 16 by the right side, along the ribs, and a bison bone tool by the right leg. Burial $\mathrm{AH}-10$, near the western end of the cemetery (see Figure 11-7), had a ceramic bottle placed by the head, mussel shells above the head, seven marine conch shell beads at the waist, eight glass beads at the back of the head and around the deceased's neck, a brass tinkler by the right knee, and four arrow points placed by the left side of the head; and

Burial AQ-9 at the Omer and Otis Hood site (41CE14) had a large number $(n=25)$ of funerary offerings placed with the deceased. This included seven ceramic vessels around the head and shoulders, two arrow point quivers (one by the right hand and the other by the right leg) with a total of 16 arrow points, and two engraved ceramic elbow pipes, placed by the two arrow point quivers (Woolsey 1935m).

Half of these notable interred individuals are from Allen phase contexts, and three of the remaining four individuals are in Frankston sub-phase 2 and sub-phase 3 cemeteries. In other words, it appears that after ca. A.D. 1500, and certainly after ca. A.D. 1560, there were a few Caddo individuals in upper Neches River basin Caddo societies that were recognized as having particularly important social identities above that of others in Caddo communities, probably manifest in leadership roles within specific communities. Where information on age and sex is available, these individuals appear to have been adult males.

\section{Placement of Cemeteries relative to Domestic Habitation areas}

Caddo cemeteries in the upper Neches River basin tend to be situated in proximity to springs, spring-fed tributaries, and small streams, and on the periphery of habitation locales (Figure 11-8). As such, their distribution tends to match closely the distribution of prehistoric Caddo settlements in the basin (see Figure 11-1), wherein domestic abodes are found on elevated landforms along small to medium-sized streams that are tributaries to the Neches River, the principal drainage in the basin, as well as along the Neches River itself. Caddo populations appear to be distributed about equally between these settings, based on the distribution of known post-A.D. 1300/1400 Caddo sites in the region. Tributary streams with notable concentrations of Caddo habitation sites and cemeteries include Caddo Creek - the Lang Pasture site and cemetery is above a small stream in the Caddo Creek drainage-Flat Creek, County Line Creek, Brushy Creek, and Saline Creek. On the Neches River itself, habitation sites and cemeteries are concentrated in the immediate vicinity — both north and southof the A. C. Saunders (41AN19) mound center, but no cemeteries are known at this mound center. It is likely that these settlements and cemeteries represent parts of a distinct political community or constituent group (cf. Story and Creel 1982:33) comprised of interrelated settlements and cemeteries that are centered on a key site distinguished by public architecture (i.e., earthen mounds as temple platforms) and large domestic village areas. 


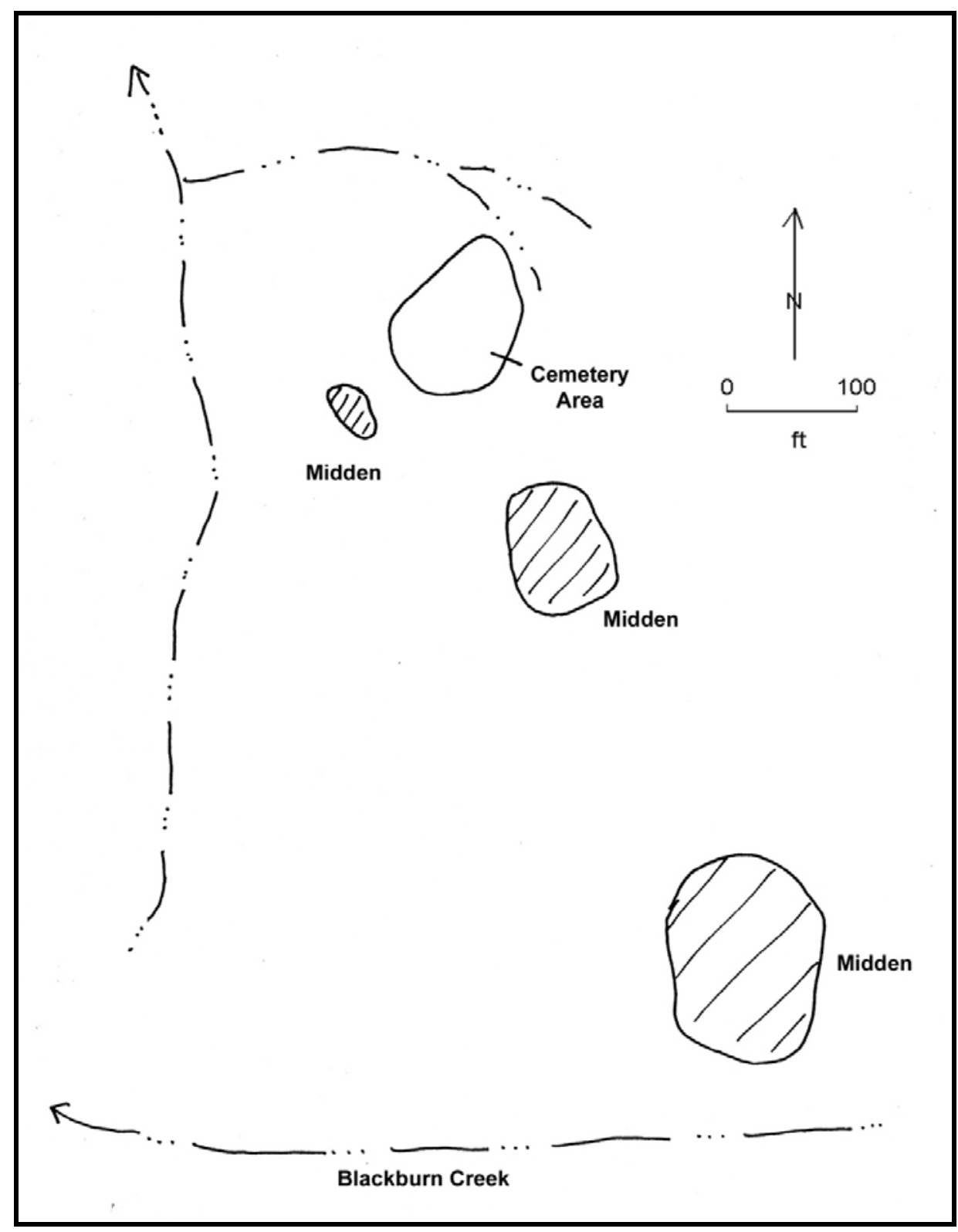

Figure 11-8. The Placement of the Large Cemetery at the Jim Allen Site (41CE12) Relative to Midden and Habitation Areas.

At the local or micro-scale, cemeteries are well-defined and discrete sacred areas set away from habitation debris, structures, and midden deposits. Cemeteries also tend to be placed in settings near freshwater and flowing water, and between the sources of freshwater and habitation areas, regardless of the direction of water from the latter. A good example is the E. W. Henry cemetery
(41CE17, see Figure 11-2), where the "burial place was in almost direct line between the midden and the watering place" (Woolsey 1935k:1). With all things, there are exceptions. In the case of the Frankston phase cemetery at the Pierce Freeman site (41AN34), the cemetery was on a hill slope overlooking a small creek (Poley Creek), and a considerable distance from water 
(Jackson 1931), as was the John Bragg site cemetery (Jackson 1933b). At the Solon Stanley site (41CE3), the cemetery was more than $800 \mathrm{~m}$ from a small tributary to Killough Creek, but unlike most of the other cemetery and habitation sites, here the midden and habitation areas were located between the cemetery and freshwater; Woolsey (1935a:16) commented that "this situation is unusual, as graves are usually between water and campsite." Finally, at the Woldert site (41HE80), a looted burial there was found in a midden deposit, not in a separate cemetery (Anderson et al. 1974:102).

Caddo ancestors and the dead played a role in structuring the lives of the living. Once a cemetery had been created in association with a nearby set of farmsteads and small communities, it imbued the landscape with a duality of life and the hereafter, one that was not readily transgressed. Thus, when the farmsteads or small community was abandoned after a generation or thereabouts and the people moved to another locale within the territory of the community, so to was the cemetery, left to mark the dead in the memory of the living. Rarely was a cemetery returned to or re-used by the these Caddo, and consequently, Caddo cemeteries commonly dot the landscape lived in and shaped by the life and death of upper Neches River Caddo agricultural communities.

\subsection{REgIONAL COMPARISONS IN MORTUARY PRACTICES}

The mortuary practices of the Caddo peoples living in the upper Neches River basin between ca. A.D. 1300 and the early $18^{\text {th }}$ century are in some ways quite comparable to the set of mortuary practices documented among contemporaneous Titus phase Caddo groups in the Sabine and Cypress drainage basins in East Texas (Perttula 2005:370388), as well as with historic Kinsloe phase or Nadaco Caddo groups (cf. Jones 1968:157-159) in the middle reaches of the Sabine River basin (Figure 11-9). In both cases, these groups established formal cemeteries of varying sizes, usually at some distance from habitation or residential areas and not in middens, where rows of individuals - mostly adults - were buried in an extended supine position, with the heads of the deceased facing east. Each of these individuals, whether male or female, was accompanied by an assortment of funerary offerings, generally ceramic vessels, occasional quivers of arrow points, clay pipes, stone tools, ornaments, and pigments. These funerary offerings were placed around the head and shoulders of the deceased, as well as near their feet, and in rows along one or both sides of the body. 


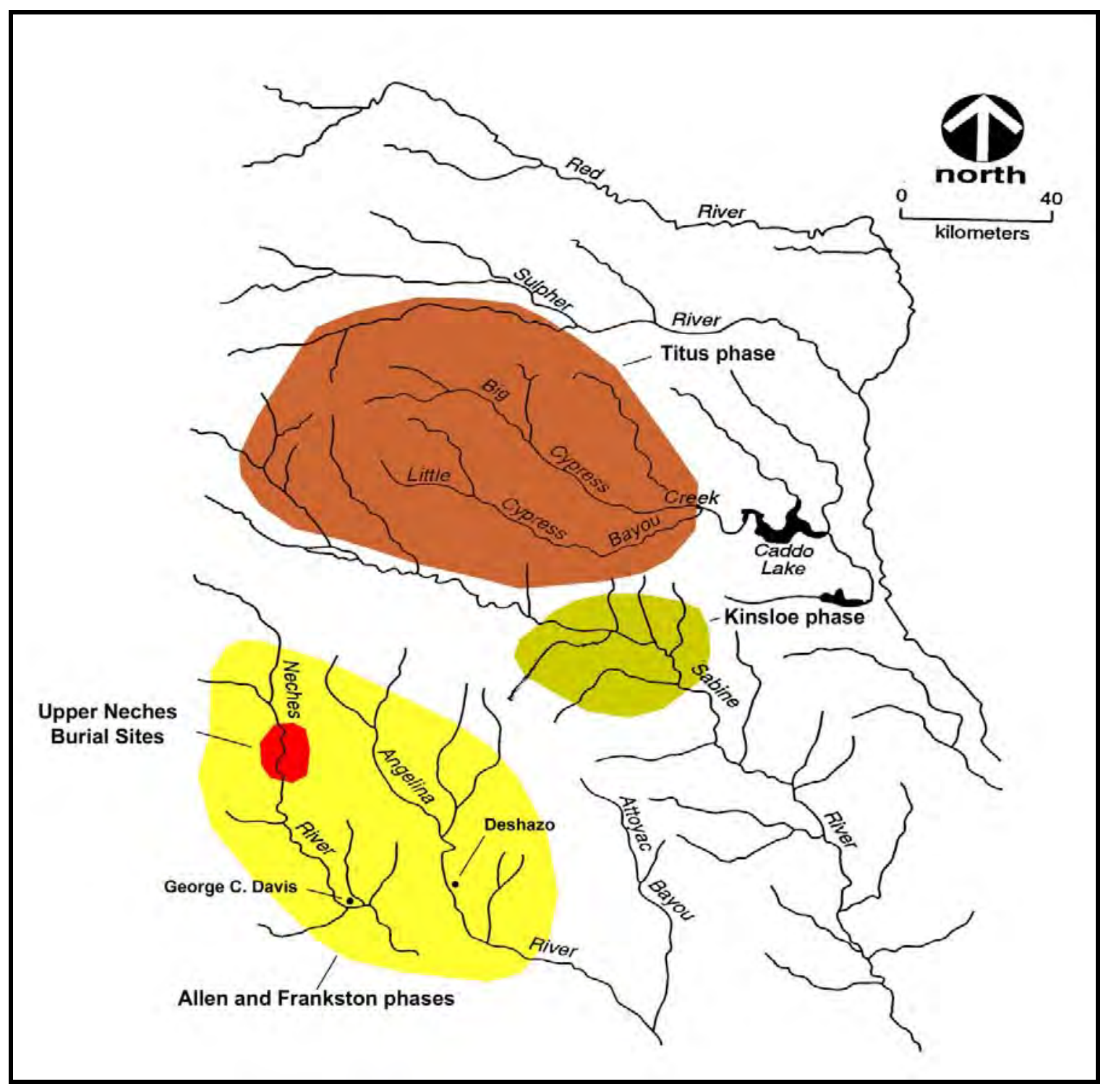

Figure 11-9. East Texas Caddo Areas, Including the Allen and Frankston Phase Territories, the Upper Neches River Basin, the Titus Phase, the Kinsloe Phase, and Selected Sites Mentioned in the Text.

One of the ways in which these Titus and Kinsloe phase cemeteries differ from those of the upper Neches River basin is in their absolute size, with a number of the cemeteries commonly containing more than 50-80 individuals. These are apparently community cemeteries used by discrete political communities for several generations; by contrast, community cemeteries are not known in the upper
Neches. Both Titus and Kinsloe phase Caddo societies also had smaller cemeteries-family plots-near habitation areas and farmsteads, and these cemeteries tended to have had about 10-30 individuals interred in them, about or near the same size as the Caddo family cemeteries in the upper Neches. 
In the vast majority of Titus phase Caddo burials, adults tended to have more funerary offerings placed with them that did children or adolescents, but adult males, adult females, adolescents, and children received different amounts and kinds of grave goods to accompany them on their death journey (Perttula 2000:107; Thurmond 1990:235236). Furthermore, graves of adult men frequently contained clusters or quivers of arrow points, while those of adult females contained polishing stones (probably used in ceramic vessel manufacture) or more diverse numbers and kinds of pottery vessels. Very few of these burials contained supra-local offerings (cf. Brown 1981:29-30) made of exotic or non-local materials.

As with the notable interred individuals identified primarily in post A.D. 1560 Frankston and Allen phase cemeteries, there are a number of burials found in Titus phase cemeteries that are clearly those of important people, typically males, either adult members of the social elite, individual community leaders, or heads of paramount lineages (Perttula 2005:384). They received special treatment at death, including unique and rare artifacts (including large chipped bifacial knives, marine shell ornaments, or other exotic ceramic and lithic artifacts) placed with them in the burial pits, just as they must have had use of these artifacts during their lives. Most of these individuals, members of the social elite, were interred in large community cemeteries or in shaft tombs and burial mounds (Perttula 2005:Table 11-7). Most of the notable social elite burials in Titus phase society date after the early $16^{\text {th }}$ century, and are found in cemeteries dating at late as the early to mid$17^{\text {th }}$ century, if not later. This same heightened sense of temporal changes in the status relationship of certain adult Caddo men is also apparent in the upper Neches during this time, although overall, Titus phase mortuary practices are more complex in their structure and organization than has been documented for Frankston and Allen phase Caddo social groups. This in turn implies that kin-related groups within Titus phase Caddo societies were more socially hierarchical in character, or socio-politically complex (cf. Carr 1995:169, 174) than were upper Neches Caddo groups and communities.

The kinds and quantities of funerary offerings in Kinsloe phase burials closely mirror what has been recognized for post-ca. A.D. 1650 burials and cemeteries in the upper Neches. That is, individuals tended to have placed with them at death not only an assortment of ceramic vessels and arrow point quivers, but also large bifacially chipped knives (Anderson and Jowell types), marine conch shell ornaments, clay pigments, and European trade goods (see Jones 1968). One distinctive feature of Kinsloe phase cemeteries was the checkerboard pattern of burial rows at the Millsey Williamson, Susie Slade, and Brown \#1 sites. In these cemeteries, the burials were also more widely spaced (1-4.5 $\mathrm{m})$ in alternating rows than is the case for either Frankston/Allen or Titus phase interments.

The Deshazo site (41NA27) is perhaps the best-studied Caddo domicile in East Texas (Story 1982, 1995). This site (see Figure 119), on a tributary to the Angelina River, was occupied by a Hasinai Caddo group between ca. A.D. 1686-1714. An associated cemetery with 10 individuals was situated across an unnamed tributary stream from the habitation area. Here, adult individuals were placed in a row that was oriented northeastsouthwest, very different from the upper Neches Caddo, with the heads of the deceased in the southeastern portion of the grave pit, and they faced to the northwest (Figure 11-10). This distinctive orientation suggests that the Caddo living at the Deshazo site may have had different beliefs about the direction in which souls traveled at death, or the location of the House of Death in the sky, than did their upper Neches brethren, and this is one expression about differences in their regional identity. 


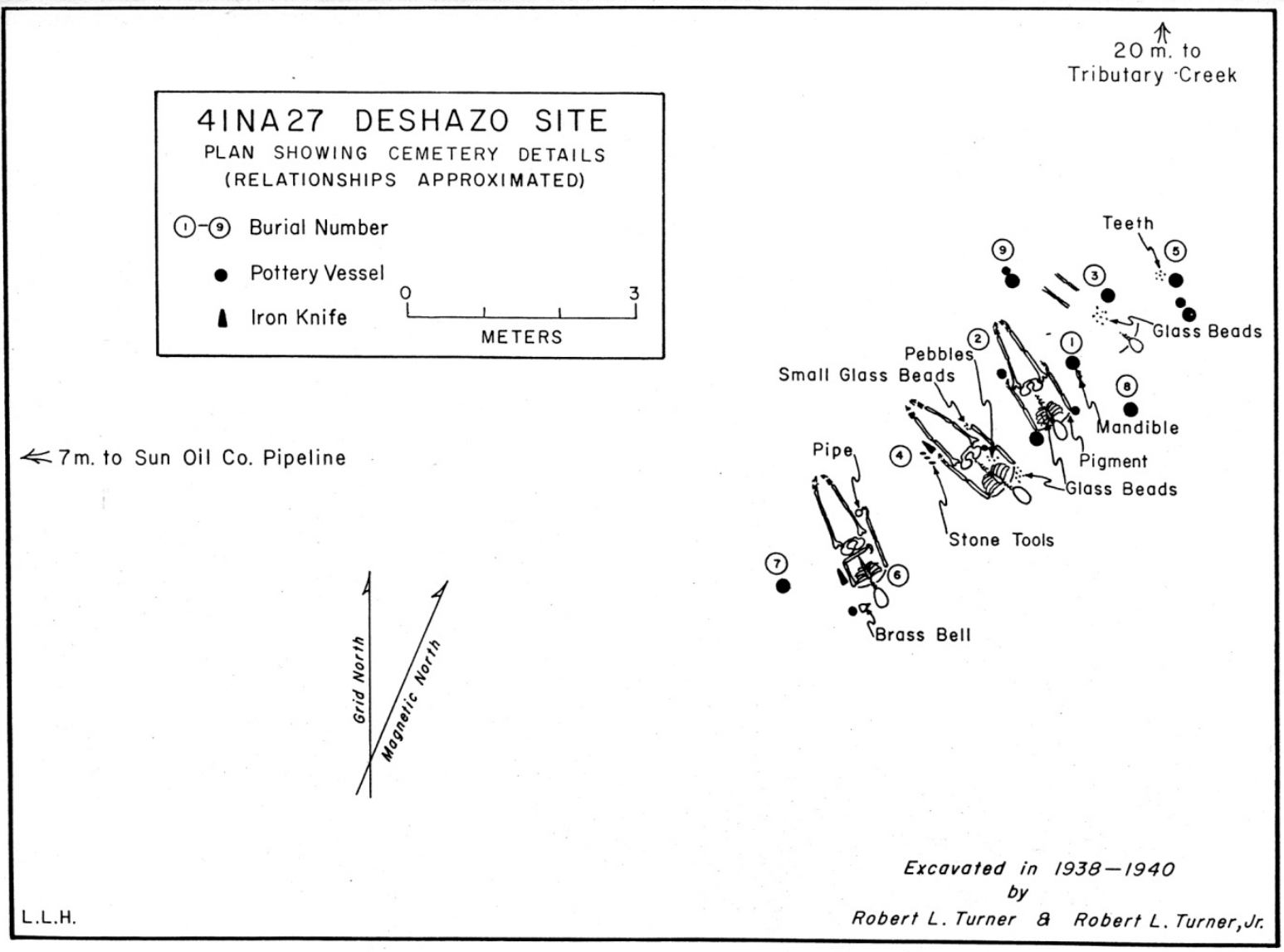

Figure 11-10. Plan of the Cemetery at the Deshazo Site (41NA27) (from Good

1982: Figure 28).

Furthermore, there may be a relationship between this distinctive body orientation and particular mortuary beliefs about both the importance of winter and summer solstices and specific cosmological frames of reference in insuring the "condition of the souls of the dead" (Kay and Sabo 2006:39) here that did not exist in upper Neches Frankston and other Allen phase population mortuary beliefs. The dead buried in the Deshazo cemetery were accompanied by a very limited range and quantity of offerings (see Table 11-4; see also Good 1982; Perttula 1992:Table 15), including one to three ceramic vessels per burial and some amount of European glass trade beads. Story $(1995: 241)$ suggests that the mortuary patterning is the product of a "small, egalitarian” Caddo society with only limited social differences in status by age or sex. It is possible that the greater diversity in the kinds and numbers of funerary offerings in burials at the Deshazo site that have European trade goods may indicate that an individual Caddo's access to these goods enhanced their social importance (Perttula 1992:185); such may also be the situation with certain Kinsloe phase burials and an older adult male (AH-10) at the Richard Allen cemetery in the upper Neches River valley. 


\subsection{SUMMARY AND CONCLUDING COMMENTS}

"Relationships to places may also find expression through the agencies of myth, prayer, music, dance, art, architecture, and, in many communities, recurrent forms of religious and political ritual. This represented and enacted-daily, monthly, seasonally, annuallyplaces and their meanings are continually woven into the fabric of social life, anchoring it to features of the landscape and blanketing it with layers of significance that few can appreciate” (Basso 1996:57)

The prehistoric and early historic Caddo cemeteries found in the upper Neches River basin (a ca. $1700 \mathrm{~km}^{2}$ area, see Figure 11-1) represent the social, material, and religioussymbolic beliefs about death, the soul, and the afterlife among a series of small communities and affiliated farmsteads. The adults and children buried in these cemeteries are believed to have been lineally related, perhaps in some form of corporate descent group or lineage (Goldstein 1980:78). In this sense, then, "to the degree that corporate group rights to use and/or control crucial but restricted resources are attained and/or legitimized by means of lineal descent from the dead (i.e., lineal ties to ancestors), such groups will maintain formal disposal areas for the exclusive disposal of the dead" (Saxe 1970:119). In these situations, the placement of burials in cemeteries (areas used exclusively for the dead) are expected to reflect these lineal relationships, with burials with the same orientation and proximity in rows likely to represent distinctive groups of related individuals. The placement of burials one to another, and the kinds of funerary offerings placed with the dead, are intimately tied to each person's life, their ties to others in the community, and to their social memories within that community, as each deceased person and their material surroundings "become significant in the orientation of persons, both deceased and alive, in relation to their past, present and future" (Hallam and Hockey 2001:190).

At a broader spatial scale, the distribution of Caddo cemeteries across the upper Neches River basin represent the Caddo's past in the landscape, as also do the abandoned farmsteads and farmstead compounds of different communities. The burials themselves, and the consecration of each cemetery as sacred ground, gave each place a long-lasting meaning and cultural significance in everyday life.

The mortuary practices of the prehistoric Caddo communities that lived in the upper Neches River basin of East Texas, as seen at the Lang Pasture site and the many other cemeteries in the region, include the following attributes:

1. The cemeteries and burial places of these Caddo were deliberately kept physically distant from habitation areas, as an act of separating the dead from the living but also in creating a social memory of the deceased in those places; they are often placed near sources of fresh water;

2. The burials are primarily those of single interments, usually adult men and women; children were sometimes buried in cemeteries along with adults (at least after the ca. mid- $16^{\text {th }}$ century), but there are instances both before and after the mid- $16^{\text {th }}$ century where children were buried in spatially distinct groups;

3. The graves are relatively shallow, and are narrowed near the foot end, and the deceased were laid in the graves in an extended supine position, with their arms by their sides;

4. In most cases, the deceased's head was at the eastern end of the grave, and faced west towards the setting sun; in a few cases where burial orientation of a few graves 
was different, as at Lang Pasture (Features 76B-D), this may be evidence of a slightly earlier (i.e., pre-A.D. 1400) form of burial interment, perhaps one associated with the summer and winter solstices. The westwardfacing burial orientation of the Caddo deceased reflects the path in which the souls traveled to their House of Death (e.g., Hatcher 1927a:162), while "east is the direction of life" (Kay and Sabo 2006:32). Kay and Sabo (2006:29, 33) further link this directionality in Caddo mortuary practices with a symbolic relationship between death and winter, death imagery, and concern for the dead, where mortuary rituals represent a physical embodiment of cosmology as expressed in the social order and a specific set of beliefs about life, death, and socially necessary funerary accompaniments;

5. Burials were in rows, with the graves parallel to one another, in either east-west or north-south rows; the burials were typically only 1-2 $\mathrm{m}$ apart in these rows; the graves rarely intersected; prepared grave floors are rare, but when done, consisted of a gravel fill or a white clay;

6. The cemeteries were not used for substantial periods of time by any one farmstead compound or group of related farmsteads, perhaps no longer than 10-30 years at their maximum, based on the range in the size of each cemetery and the number and extent of associated habitation areas;

7. The common occurrence of charcoal in the burial fill of many of the graves suggests that as an important ritual, fire may have been placed in the graves (near the feet) or by the foot of the graves prior to the burial pit being filled; the fires may have been kept for six days (see Parsons 1941:37; Gonzalez 2005:57-59). The use of a controlled and consecrated fire in mortuary ritual was an important symbol for these Caddo people, and "smoke appears to serve as an axis mundi between life and death, or a path to the spirit world” (Kay and Sabo 2006:33);
8. Almost all individuals, whether child or adult, had accompanying offerings, both durable as well as perishable (i.e., food stuffs); the offerings placed with the deceased almost invariably contain an assortment of ceramic pottery vessels, followed by for adult males arrow points (commonly in quivers), clay pipes, chipped stone knives, other kinds of stone tools, marine shell ornaments, pigments, bone tools or beads, and in the case of Allen phase burials, a few European trade goods (see Tables 11-2 and 11-3); pigments were apparently specific offerings associated with adult females; children had the lowest number of funerary offerings as well as the least diverse kinds of offerings. The differences in funerary offerings between children and adults are clearly related to gender and personal identity; Story and Creel (1982:23) reached the same conclusions when they stated that among East Texas Caddo burials "offerings reflected the individual's position in the social organization;" in summary, since a very high proportion of Caddo burials had funerary offerings, it seems likely that the placement of these offerings was a function of both individual wealth and community esteem (cf. Cannon 2005:52), reflecting differences in gender status;

9. The fact that some adult Caddo females had clay pipes and stone tools (large bifacial knives) as funerary offerings suggests that certain adult females participated along with more adult men in both religious rituals associated with smoking (cf. Rafferty and Mann 2005:xiii-xv; Winter 2000:266) as well as activities associated with the specialized butchering of game animals;

10. The offerings were generally placed by the head and shoulders, as well as at the waist and by the hands and feet; in some cases, the offerings appear to have been placed on the body, usually at the hips and on the legs; ceramic bottles were consistently placed near the head; the arrangement and placement of funerary 
offerings reflect particular social meanings to these Caddo groups, as "items take on specific meanings by dint of where they were placed" (Ashmore and Geller 2005:90);

11. The variation in offerings by grave or by cemetery are not substantial, except in the absolute frequency of quivers of arrow points in certain cemeteries (see Table 11-4) north and east of the Lang Pasture site that date to the latter part of the Frankston phase; and

12. Certain adult males in upper Neches River basin Caddo society had a recognized higher social status in life-achieved through accomplishments as hunters, warriors, or diplomats/leaders-that was reflected in their distinctive treatment at death. These social identity or leadership relationships became clearest after ca. A.D. 1560 in the region. Even with their elite social position, these individuals were buried with their families and lineages in family cemeteries, rather than being interred at a social distance with other social elites from related farmsteads and communities.

At the Lang Pasture site, Caddo adult men and women were buried in a spatially discrete cemetery placed ca. 10-20 m distant from habitation and outdoor work areas. The burials of children, on the other hand, were placed together in a large pit feature that may have first been used for storage of food stuffs, until its storage function was discontinued, at which point three child burials were placed in it, and then filled in. As with other upper Neches River basin Caddo cemeteries, the children had only a few funerary offerings placed with them, while the adults had two or three times as many ceramic vessels; two burials-both probably adult men-had clay pipes placed with them at death.
The rarity of double burials in upper Neches River Caddo cemeteries suggests that the double burial (Feature 93, that of an adult male and female) at the Lang Pasture site may represent the interment of notable and important adult individuals in a Caddo community that lived in part of the Caddo Creek basin. Otherwise, the other burials at the site-including those from both groups of burials defined here (see Figures 5-4 and 5-48) - appear to have had an equivalent social position, separated only by age. They were buried by a living community of Caddo peoples that shared similar social beliefs about personal identity and gender, beliefs about the soul's nature, the afterlife, and the soul's journey to the House of Death.

\section{End Notes}

1. A cemetery is a "place where burials of isolated individuals are placed with separate graves relatively soon after death; thus 'cemetery' implies primary burials in individual graves" (Hutchinson and Aragon 2002:42).

2. Based on extensive ethnographic research, the absolute quantity of funerary offerings is apparently a less important reflection of social status of the deceased than are such characteristics as the internal organization of cemeteries, the overall amount of energy expended on a specific interment (i.e., grave construction), as are the form of disposition of the body, the number of different kinds of burial treatments (i.e., in cemeteries, in mounds, in shaft tombs, etc.), the number of persons placed in a grave, and the kinds of funerary offerings found associated with the deceased (Carr 1995:Table XXII). 


\section{CHAPTER 12}

\section{SUMMARY AND SYNTHESIS}

Timothy K. Perttula, with contributions by Robert Cast and Bobby Gonzalez

\subsection{Summary Statement, Site SETTING, AND ARCHEOLOGICAL COMPONENTS AT THE LANG PASTURE SITE}

The Lang Pasture site (41AN38) is a multicomponent prehistoric site situated on an upland ridge and toe slope in the Caney Branch Creek valley in the upper Neches River basin, a few miles south of the community of Frankston, Texas. The principal prehistoric occupation was by ancestors of the modern-day Caddo Nation of Oklahoma some 600 years ago, who established a permanent domestic settlement of indeterminate size and complexity (more than $90 \%$ of the site occurs on private land, and little is known about the archeological deposits there, see Perttula et al. [2007]). A household cemetery with ten burials is part of this prehistoric Caddo settlement.

In modern times, this part of the upper Neches basin is in the Pineywoods physiographic zone (Diggs et al. 2006:Figure 4). The Pineywoods are a generally well-watered part of East Texas characterized by an overstory of shortleaf and loblolly pines and a variety of deciduous hardwoods (including mast-bearing trees) in upland settings as well as a diverse bottomland hardwood community along the major river and creek drainages. The sandy loam and loamy fine sand deposits found in the uplands and creek floodplains would have been amenable to cultivation by the Caddo peoples with hand tools, especially large tracts of land on the west side of the Caney Branch Creek valley and the fine sandy loam floodplain soils immediately east of the Lang Pasture site.

The recovered archeological materials found at the site indicate that this landform was used only lightly and periodically from the Middle Archaic (ca. 6000 years ago) until about A.D. 900, and this is based almost exclusively on the recovery of a series of dart and arrow points of a variety of styles, but little else in the way of identifiable features or clearly discrete or concentrated archeological deposits. OSL dating of sand grains seemed to indicate that the landform was very slowly aggrading beginning about 8000 years ago, and ending around 900 years ago, but that may be too simplistic. Abbott (2010 personal communication). Abbott suggests that "[a]lthough the A-E sequence containing the cultural sequence could represent an eolian veneer of Holocene age, the OSL samples are not consistent with such an interpretation. The character and spread of the single-grain histograms implies that grains were exposed to light at very different times. The fact that the age of grains tends to increase with depth is not a function of progressive burial as much as a probabilistic function of sediment mixing." Radiocarbon dates (from charred plant materials incorporated in the fill of various pit features) indicate relatively ephemeral use (presumably for hunting purposes and tool refurbishing, as well as some hot rock cooking, as little in the way of other associated artifacts or features can be associated with these earlier remains) of the Lang Pasture site around cal 1040-840 BC, AD 70-330, and AD 570-1030. 
When the landform was essentially a stable topographic surface (or whether it had always been a stable surface for thousands of years before the Caddo settlement), it was occupied by a group of Caddo Indians, and was the location of a permanent settlement of Caddo peoples from the first quarter of the $14^{\text {th }}$ century to the early part of the $15^{\text {th }}$ century A.D. Associated with the domestic settlement was a small family cemetery of Caddo peoples that likely resided at the Lang Pasture site. Both radiocarbon dating of non-burial features and thermoluminescence (TL) dating of decorated ceramic sherds support the temporal estimate for the duration of the Caddo occupation, although there are ambiguities in both series (see discussion in Chapters 5 and 6, this volume) of absolute dates. At least one of the nine Caddo burial features (Feature 8) found in the associated family cemetery at the site appears to have been interred shortly after the domestic occupation ended in the portion of the site investigated during this project. Otherwise, the stylistic character of the recovered ceramic vessels, particularly the engraved fine wares, from the burial features indicate that the Lang Pasture burials share stylistic features with both pre-A.D. 1400 and early (ca. A.D. 1400-1450) Frankston phase mortuary ceramics in the upper Neches River basin. Ceramic sherds recovered from a midden on another portion of the Lang Pasture site suggest that domestic activities in other compounds likely continued into the $16^{\text {th }}$ and $17^{\text {th }}$ centuries (Perttula et al. 2007).

The principal prehistoric Caddo component in the investigated portion of the Lang Pasture site included two circular domestic structures (Structures 1 and 2) each inhabited by at least one family. The structures, marked by arcs of post holes, were built of wood, grass, and thatch, and were between 6.8 and $9 \mathrm{~m}$ in diameter. The structures were less than $5 \mathrm{~m}$ apart. No entrances were apparent along the portions of the walls in the project right-of-way, and thus it is likely that the entrances to both structures opened to the west to face the remainder of the Caddo community (now on private property). The two structures are interpreted, based on spatial proximity and a broad similarity in the ceramic material culture found in the excavations, to be part of a household compound, probably one of at least several such compounds that may be preserved at the Lang Pasture site.

Such a compound at Caddo sites in the Neches-Angelina river basins of East Texas would have consisted of a series of domestic structures set around an open courtyard, with outdoor activity areas and ancillary facilities. At Lang Pasture, these outdoor activity areas were marked by pits, smudge pits, and hearths not far removed to either the north or east of the domestic structures; these were also trash disposal areas, based on the broad scatter of broken ceramic vessels and pipe sherds in these same areas. Outdoor storage pits were also found in these areas. Ancillary facilities include at least one small $(2 \times 4 \mathrm{~m})$ arbor or ramada (i.e., elevated work platform) east of Structure 1.

There was also an associated Caddo family household cemetery north and northeast of Structure 1, but physically distant from it. A total of nine burial features (including one feature with two individuals interred in it) were identified and excavated at the Lang Pasture site, and they were found in two distinct groups. Based on the size of the cemetery, it is unlikely that it was in use for any substantial period of time by any one household compound or related group of households, perhaps no longer than 10-30 years.

One group of burials is composed of adults (Features 8, 88, and 91-94) and the other, not far removed from Structure 1, is composed of children (Features 76B, 76C, and 76D). The deceased Caddo adults and children were laid out in extended supine positions, with their heads either facing west (adults) or northwest (children) towards the House of Death and the setting sun, and they were accompanied by a modicum of 
funerary offerings (ceramic vessels and elbow pipes) that would have served as provisioning on the deceased's journey. The mortuary practices evidenced with the Lang Pasture burials are clearly comparable to the practices employed by other Caddo populations that lived in the upper Neches River basin from ca. the $14^{\text {th }}$ century to the early $18^{\text {th }}$ century.

\subsection{DISCUSSION OF RESEARCH DESIGN ISSUES}

This section discusses the archeological findings from the Lang Pasture site archeological, bioarcheological, and paleoenvironmental investigations-as well as broader findings based on the incorporation of analyses of a wide variety of upper Neches River basin Caddo sites (especially mortuary sites and their associated funerary objects) - in light of the research issues and problems developed in the project research design (see Chapter 4, this volume). These research issues include: cultural chronology; paleoenvironmental conditions and human adaptation; Caddo settlement systems and households; subsistence systems; local and extra-local trade and exchange; the material culture of the Caddo peoples living at the Lang Pasture site; mortuary practices; and the health and diet of the Caddo living at the site and in the upper Neches River basin.

\section{Cultural Chronology}

Establishing the Age of the Occupations at the Site, and Arriving at a Better Understanding of the Cultural Chronology of the Local Region

Several lines of evidence were employed in establishing the ages of the various prehistoric occupations at the Lang Pasture site, including the presumed age of temporally diagnostic projectile points (e.g., Davis 1991; Story 1990; Suhm and Jelks 1962; Turner and Hester 1999), seriation of Caddo ceramic stylistic motifs and decorative elements, a series of radiocarbon dates $(n=34)$ on charred plant remains from features, and 21 TL dates on both fine ware and utility ware sherds. The preponderance of the evidence, taken in conjunction with the kinds of material culture remains found in association with those features and in other discrete archeological contexts, indicates that the principal occupation of the site was by a prehistoric Caddo group from the early part of the $14^{\text {th }}$ century A.D. to the early part of the $15^{\text {th }}$ century A.D. It is likely that the Caddo occupation lasted less than that interval, but it is impossible to be more specific given the 1 and 2 standard deviation ranges for both the radiocarbon and TL dates. The earlier uses of the site, as suggested by the range of identified projectile points, extended from the Middle Archaic through the Late Archaic, Woodland, and early Caddo (ca. 1000-900 years ago) periods, but only as a result of sporadic use. Nevertheless, it does appear to be the case that during this broad span of time prior to the establishment of a permanent Caddo settlement in the $14^{\text {th }}$ century A.D., the use of the site was more common in the Late Archaic and Woodland periods (ca. 3000 B.C. to A.D. 800).

The stylistic analysis of plain to decorated sherd ratios, decorative methods, elements, and motifs on ceramic vessel sherds from domestic contexts, in combination with the more detailed consideration of engraved motifs from fine ware vessels placed as funerary offerings in graves, led to the initial conclusion that the Lang Pasture site was occupied early in the Frankston phase (ca. A.D. 1350-1450). More detailed considerations of the decorated ceramics, in combination with radiocarbon and TL dates, have narrowed the age of the principal Caddo occupation at the site to the period from ca. A.D. 1320 to 1400 , or shortly thereafter, with the occupation beginning prior to the Frankston phase, but ending in the early part (sub-phase 1) of the Frankston phase in the southern ceramic/component area. Moreover, subtle differences in the decorative character of the sherd assemblage from the Lang Pasture site resulted in the 
recognition of southern (younger) and northern (older) ceramic components that appear to represent temporally sequent occupations, but occupations where the northern ceramic component is not significantly older than the southern ceramic component/area.

Additional radiocarbon dates on human remains from other Caddo sites in the upper Neches River basin pertain to post-A.D. 1400 occupations during Frankston phase (ca. A.D. 1400-1650) and Allen phase (ca. A.D. 1650-1800) times. In conjunction with seriation analysis of more than 620 mortuary vessels in the region from 35 cemeteries in this region, the earlier analyses by Kleinschmidt (1982), and the results of the radiocarbon analysis, it is possible now to recognize three temporal sub-phases of the Frankston phase: Frankston 1 (ca. A.D. 1400-1480), Frankston 2 (ca. A.D. 14801560), and Frankston 3 (ca. A.D. 15601650). The decorative rim motifs identified on the fine wares in each sub-phase are distinct-and several local varieties are recognized in the Lang Pasture mortuary ceramics that are not well represented at other Caddo cemeteries in the upper Neches River basin-and have temporal implications; five different varieties of the principal fine ware (Poynor Engraved) have been defined as part of this study (see Figure 6-63). None of the defined varieties of Poynor Engraved are present at the Lang Pasture site, although there are several distinctive but unnamed (because of their rarity) regional varieties that are seen at a few other sites in the basin, but not in the frequency with which they are present here. This suggests that the Lang Pasture cemetery began to be used prior to the onset of sub-phase 1 of the Frankston phasewhich is in concordance with radiocarbon dates and the analysis of the domestic ceramic assemblage - and that several stylistically unique varieties of Poynor Engraved began to be made in the upper Neches sometime prior to A.D. 1400.

\section{Paleoenvironmental Conditions and Human Adaptations}

Establishing the Extent to Which the Caddo Population at the Lang Pasture Site and the Surrounding Region Affected Vegetation Patterns

Pollen Assemblage Zone 3 in Core 1 (see Albert, Appendix A, this volume), with calibrated radiocarbon dates that range from AD 1180-1400, contains 10\% ruderals (i.e., Ambrosia and Chenopodiaceae) that may serve as proxies for evidence of humancaused disturbance to the vegetation, such as land clearing, burning, and tree removals. At the time of the Caddo occupation at the Lang Pasture site, the forested overstory was comprised of pine, oak, and hickory, as it is in modern times. Given the low levels of ruderal pollen representation, as well as an absence of evidence for the substantial use of cultivated plants by the Caddo until after that time (as seen in stable isotope analyses of human remains, see Table 10-22), it seems probable that the major changes in the Caddo Creek pollen diagrams reflect local and regional changes in climate, as well as the local effects of natural fires (see Albert 2007), not the effects of Caddo agricultural practices.

\section{Establish If the Agricultural Practices of the Caddo Degraded the Local and Regional Environmental Setting}

Albert's analysis of sedimentation rates from three pollen cores in alluvial deposits along Caddo Creek (Appendix A, this volume) indicate that the highest rates of accumulation (and upland erosion) occur after 3800 B.P. He also notes from one core that these rates of alluvial accumulation actually doubled between cal A.D. 12401340 , immediately preceding the onset of the principal Caddo occupation at the Lang Pasture site. This change in alluvial accumulation appears to correlate with longterm paleoenvironmental and climatic changes, and fluctuating wet and dry cycles 
at that time (as well as before and after), in eastern Texas (see Perttula 2005:Figure 2-4), not to Caddo-induced environmental degradation.

The pollen data obtained by Albert does not support any suggestion that the Caddo groups living in the upper Neches River basin had any long-term effect on the character of the local and regional environment. A similar pollen study from the Sabine River basin did not detect any significant anthropogenic effects of Caddo land use practices (i.e., land clearance and firing) until after ca. A.D. 1560 (Albert 2007). Although stable isotope data on Caddo human remains from the upper Neches indicate that Caddo groups were cultivating domesticated plants such as maize from ca. A.D. 1000, if not earlier, an intensification of maize production did not occur until after ca. A.D. 1400, primarily after the Lang Pasture site was abandoned. The pollen cores from the Caddo Creek have preserved pollen that primarily predates ca. A.D. 1400 , so it is not surprising that any anthropogenic effects of Caddo maize agricultural practices could not be detected. Another factor that may be responsible for the low levels of disturbances that can be attributed to the Caddo is that Caddo settlements, and their associated fields, in the upper Neches were well dispersed and localized, such that an intensive local and regional pollen sampling effort would need to be conducted to identify any evidence of local and regional environmental degradation through the course of the near millennial settlement of the region by Caddo peoples.

\section{Caddo Settlement Systems and Households}

Establishing the Internal Organization of the Caddo Settlement, and How It Differed From Other Dettlements in This Region or Other Parts of the Caddo Area
The archeological exploration of the internal organization of the $14^{\text {th }}$ to early $15^{\text {th }}$ century Caddo settlement at the Lang Pasture site was constrained by the fact that the Texas Department of Transportation-sponsored investigations were confined to a narrow proposed right-of-way (see Figures 1-2 and 5-4) that arbitrarily bisects only a portion of what is clearly a much larger prehistoric Caddo site that extends onto private property; the only information available about the private-property portion of the site is that there is a concentrated midden deposit about $10 \mathrm{~m}$ west of the right-of-way fence (see Perttula et al. 2007). That being said, the combination of extensive block excavations at the Lang Pasture site, in conjunction with machine-aided scraping, of the intact archeological deposits on the upland landform, clearly defined the internal organization of the prehistoric Caddo component on one portion of the site.

The Caddo settlement at the Lang Pasture site includes portions of two circular structures (Structures 1 and 2), probably not contemporaneous based on recovered decorated ceramics (see Chapter 6, this volume), that would have been occupied by one or more families. Associated with each of these structures were outdoor activity areas to one side of the structures (on the side away from the structure entrances?) that were marked by: (1) pits and other features where plants and animal foods were processed and cooked, stone tools were manufactured and resharpened, and pottery vessels were in use and were being cached, as well as (2) concentrations of broken artifacts. Several of the pits are of considerable size and depth, and may have been used initially for below-ground storage of food stuffs (likely plant foods such as hickory nutshells and corn) before they were filled with trash at the time of their abandonment. There is a pattern of post holes about $2 \times 4 \mathrm{~m}$ in size to one side of the northern structure, amidst an outdoor work/activity area (Structure 3, see Figure 549) that is suggested to represent a small 
arbor or ramada (i.e., elevated work platform).

In addition to these domestic features, the final aspect of the Caddo settlement at the Lang Pasture site is two groups of burials. The first group, all children, was buried in a large pit feature (Feature 76) that is apparently associated with the northernmost domestic structure (Structure 1). The adults that lived in this portion of the site were buried in a small cemetery about 10-17 m north of Structure 1 (see Figure 5-4), between the domestic compound and the Caney Branch valley. The small size of the cemetery suggests that the Caddo occupation in this portion of the site was not lengthy or intensive. A population of 20 adults and children living at the site for ca. 40 years, and having a moderate annual death rate (1-3\%) could have had this many deaths.

Although only an apparently small portion of the prehistoric Caddo settlement at the Lang Pasture site has been examined in detail, the arrangement of domestic structures, outdoor work/activity areas and elevated work platform, the presence of a trash midden, and a family or household cemetery (see Figure 5-49), is quite reminiscent of the layout of the few prehistoric and early historic Caddo households that have been examined in any detail (through archeological investigations and/or archaeo-geophysical studies) in rural community settings in the Neches and Angelina river basin in East Texas. This includes household settlements at sites such as Deshazo (41NA27) (Story 1995:239 and Figure 82), J. T. King (41NA15, Walker 2009), Tallow Grove (41NA231, Perttula 2008b:Figure 5-29), and Beech Ridge (41NA242, Perttula 2008b:Figure 5-49). The Deshazo site investigations are the best known with respect to intra-site settlement organization because of the extensive excavations conducted there over the entirety of the site area, but the basic pattern is clear: two concentrations of circular domestic structures at the northern and southern ends of the site, with an open courtyard between them; a dense midden set to one side and somewhat removed spatially from the domestic structures; ramadas or storage racks to one side of the concentration of structures; outdoor hearths (in likely outdoor work/activity areas); and a cemetery for the burial of adults living at the site that is removed from the area of domestic activities of the households living there. The impression we have gained from the archeological investigations at the Lang Pasture site and other contemporaneous and later Caddo settlements is that rural Caddo households dating from ca. the $14^{\text {th }}$ century A.D. to the early $18^{\text {th }}$ century A.D. did not differ substantially from one another with respect to how they were arranged for domestic, outdoor, trash disposal, and mortuary activities, suggesting they were occupied by the same kind and size of households.

\section{Were There Changes Through Time in the Organization of the Settlement?}

If we examine the long-term use of the Lang Pasture site, not just the principal prehistoric $14^{\text {th }}$ to early $15^{\text {th }}$ century A.D. Caddo settlement, the one fundamental change in the use of the site was from a very transitory occupation during Early Archaic, Middle Archaic, Late Archaic, and Woodland times (as based almost exclusively on temporally diagnostic projectile points, in conjunction with radiocarbon dates on charred plant remains that were incorporated in the fill of Caddo pit features) to the establishment of a sedentary household of two or more Caddo families beginning in the early part of the $14^{\text {th }}$ century A.D. Given the vagaries of radiocarbon and TL dating (and the 2-sigma standard deviations of these absolute dates), this Caddo occupation in this one investigated portion of the Lang Pasture site probably did not last more than one or two generations.

Subtle differences in the decorative style of fine-ware and utility-ware ceramics at the Lang Pasture site, as well as radiocarbon and 
TL dates from Caddo features (both domestic and mortuary), suggest that the two domestic structures may not have been contemporaneous, but sequent. Structure 1 (at the northern end of the domestic compound preserved in the project right-ofway) appears to have been the earlier of the two structures, with Structure 2 (at the southern end of the project right-of-way) being slightly younger in age. Despite this apparent non-contemporaneity, there are no significant differences in the character and spatial layout of the domestic features associated with these two different occupational episodes. Indeed, the Caddo occupants of both structures apparently continued to use the one household cemetery for the interment of deceased adults that lived in Structures 1 and 2.

\section{Subsistence Systems}

\section{Establishing the Importance of Plant- Food Production in Caddo Subsistence Strategies at the Site}

The paleobotanical study of the preserved plant remains from flotation samples and macrobotanical samples recovered from features at the Lang Pasture site (see Chapter 8, this volume) indicate that the use of maize was widespread at the site; maize was the principal cultigen, although a domesticated squash was also cultivated. In terms of its ubiquity, maize (probably primarily 8-10 rowed cobs) was present in $42 \%$ of the flotation samples (see Table 8$1)$.

The cultivation of maize, as well as squash, and the collection of hickory nuts and the preparation of hickory nut oil, were the main plant production and processing activities at the Lang Pasture site. As the Caddo occupation here appears to have been a permanent one, the paleobotanical record was left by a Caddo group that was moderately invested in agriculture. The stable carbon isotope values from a number of the burial features at the Lang Pasture site (see Chapter 10, this volume) support the notion that maize was a relatively important part of the diet of these Caddo peoples during the early $14^{\text {th }}$ to mid- $15^{\text {th }}$ centuries A.D., although it became more important in Late and Historic Caddo times (Wilson 2008c). The stable carbon (on bone collagen) isotope values from the Lang Pasture site range from $-21.0 \%$ to $-15.2 \%$ oo with a site average of $-18.1 \%$ oo to $-17.6 \%$ These average stable carbon isotope values indicate that maize comprised between 28-31\% (see the mass balance equations in Schoeninger and Schurr [1998:127]) of the diet of the Lang Pasture Caddo population.

\section{How Did Subsistence Strategies Here Compare to Contemporary Sites in the Region or Other Caddo Regions?}

The available subsistence evidence from the Lang Pasture site indicates that the Caddo group living there relied on a generalized subsistence strategy that was based on a broad-spectrum collection of hickory nuts for the preparation of hickory nut oil, oak mast, the cultivation of maize in local fields, the procurement of a variety of wild animals, including medium-sized prey (deer) and turtle, and undoubtedly other seasonal resources such as seeds, roots/tubers, and greens. The consumption of maize was important, but it was not the mainstay of the Caddo diet here, or in much of the rest of the Caddo area at the time (i.e., ca. A.D. 13201400) (Perttula 2008a; Wilson 2008c). Other cultigens that the Caddo grew included beans and bottle gourd, as well as various starchy and oily seeds, but these cultigens are not present in the Lang Pasture paleobotanical remains; poor preservation probably is a principal contributing factor in the absence of beans and most seeds.

In terms of the ubiquity of maize in East Texas Caddo assemblages, ubiquity values of $42 \%$ (as at Lang Pasture) or higher have been documented only in post-A.D. 1300 assemblages in the Red River basin; postA.D. 1000 Caddo sites in the middle and upper reaches of the Sabine River basin; and 
post-A.D. 1400 Titus phase sites in the Big Cypress Creek basin and Frankston phase sites in the Neches-Angelina River basin (see Table 8-5). Outside of East Texas, it does appear to be the case that the use of maize was more intensive in the eastern part of the Caddo area, namely in the Ouachita and Red River basins, as well as the Arkansas River basin, and that Caddo subsistence strategies had become more specialized. This finding is based on ubiquity measures (Perttula 2008a:Table 3). Caddo sites in the Red and Ouachita river basins in Arkansas and northwestern Louisiana dating after ca. A.D. 1200 have maize ubiquity measures that range from 40 94\% (see Perttula 2008a:Table 3). After ca. A.D. 1400 , those measures actually range from 58-94\%, all considerably higher than what has been documented to date from northeastern Texas Caddo sites.

The stable carbon isotope information from sites in the southern Caddo area indicates that around A.D. 1100-1200, there was a significant increase in the consumption of maize in the Ouachita River basin (i.e., maize contributed an estimated $60 \%$ of the diet in the Caddo population at the Ferguson site [Rose et al. 1998:Table 6-2), as marked by C4-enriched samples at that time. Later Caddo samples in southwest Arkansas and northwest Louisiana sites leveled out and reached a measure of stasis after ca. AD 1250-1300 (Perttula 2008a:Figure 6); isotope values indicate that the contribution of maize to the diet may have been less in East Texas at that time.

In the upper Neches River basin, however, isotopic values after the $14^{\text {th }}$ century suggest that the importance of maize continued to increase in the Caddo diet (Wilson 2008c), peaking at ca. A.D. 1650 (during the Allen phase), and the consumption of maize in the diet of the East Texas Caddo was quite comparable to other Caddo groups in the larger Caddo area. Mean LateCaddo stable isotope values in the upper Neches basin $(-14.380 / 00)$ are not significantly different from Late Caddo contexts at the Belcher
Mound on the Red River $(-15.88 \%$ oo, see Rose et al. 1998:Table 6-2)—perhaps representing only a $10 \%$ difference in maize consumption in the diets of these two populations. Farther afield, in the Arkansas River valley of eastern Oklahoma, there was a more gradual increase in the consumption of maize through time (as well as the consumption of bison meat), with the most enriched samples dating after ca. A.D. 12501450 (Rogers 1997) and peaking during the Late Caddo Fort Coffee phase. By the late $17^{\text {th }}$ century, Caddo diets, as measured by stable carbon isotope data from analyzed human remains, are apparently quite homogeneous and reflect a subsistence strategy based on the production and consumption of maize: mean stable carbon isotope values in the upper Neches river basin are $-13.74 \%$ (see Table 10-22), while two populations from the Red River in southwest Arkansas and northwestern Louisiana have mean values of $-14.11 \%$ and $-13.97 \%$, respectively (Rose et al. 1998:Table 6-2; Tine and Tieszen 1997:Table 43). These values indicate that after ca. A.D. 1650, maize contributed approximately $56-59 \%$ of the diet of these Caddo populations.

\section{Local and Extra-Local Trade and Exchange}

\section{Establishing What Goods Were Obtained Through Trade, and How That Trade Was Organized}

The instrumental neutron activation analysis (INAA) of a large sample of ceramic sherds from the Lang Pasture site and other generally contemporaneous Caddo sites in the upper Neches River basin indicates that the vast majority of ceramic vessels made and used on Caddo sites were produced at the local household and community level and used and distributed on those same local sites. There is no evidence discernible in the INAA database for the specialized production of ceramic vessels, or a concomitant, directed trade and exchange of specific kinds of ceramic vessels within the 
upper Neches River basin or other parts of the Caddo area.

The INAA analysis did identify one chemically distinctive set of ceramic sherds (8.8\% of the analyzed sherds, including both utility ware and fine ware sherds) that may have been made from clays that occur in a localized area east and northeast of the Lang Pasture site, principally on the east side of the Neches River. It does appear that these sherds are from vessels made by Caddo potters living on the other side of the river from Lang Pasture, who then traded or exchanged pottery vessels with the Caddo groups living at Lang Pasture. These INAA data are the best current ceramic evidence for intra-regional exchange of material goods between Caddo households and communities.

Different lithic raw materials in the chipped and ground stone tools at the Lang Pasture site attest to the Caddo very occasionally obtaining, most likely through through trade or exchange rather than logistical/embedded acquisition, completed tools made from nonlocal raw material sources. In the principal Caddo occupation, this principally includes novaculite arrow points $(n=2)$ from either materials available in Red River gravels or Ouachita Mountains sources in southeastern Oklahoma (cf. Banks 1990), as well as a ground stone celt from the same non-local source areas more than 100 miles to the north of the Lang Pasture site. Novaculite is also present in lithic debris samples from Caddo features (11\%), suggesting that novaculite tools were resharpened and maintained during the occupation. Another completed tool (a four-beveled knife) from this component was made on a large piece of Edwards cherts from Central Texas sources. The rarity of chipped and ground stone tools on non-local lithic raw materials indicates that the Caddo tool makers at the site relied on more accessible and locally available resources for tool manufacture, rather than having to trade for suitable materials, since these few non-local raw materials were apparently derived from completed tools, not from cores and bifaces brought to the site for reduction. The local materials were probably collected from Neches River gravel sources (Perttula and Nelson 2007:105). Central Texas pebbles and cobbles that were incorporated in Uvalde gravel sources in the Brazos and Trinity River drainages more than 30 miles to the west to the west were apparently also exploited for lithic raw materials suitable for tool manufacture. These include a wide variety of high-quality cherts, among them Pisgah chert from Trinity River sources (see Banks 1990; McGregor 1993), and the Caddo groups living at Lang Pasture may well have directly procured these raw materials or obtained them from related Caddo communities living between the Neches and Trinity River valleys in exchange for other material goods. The latter scenario seems the most likely given the high frequency of chert flakes in the lithic debris (51\% in flotation samples and $65 \%$ in hand-excavated samples) from analyzed features (see Chapter 7, this volume). Lithic debris samples from a nearby late $17^{\text {th }}$ to early $18^{\text {th }}$ century Allen phase Caddo sites in the upper Neches River basin had even higher proportions of chert raw materials (74\%) (see Perttula and Nelson 2007:Table 19), suggesting this pattern of lithic raw material exchange continued unabated well after the Lang Pasture site was abandoned. In the case of the late $17^{\text {th }}$-early $18^{\text {th }}$ century Caddo groups, they may have had the horse, and thus could have directly obtained needed lithic raw materials during long-distance deer/fur trade trips into the Trinity River valley. The $15^{\text {th }}$ century Caddo living in the upper Neches seem more provincial with respect to longer-distance forays from sedentary farms and villages. 


\section{Material Culture of the Caddo Peoples Living at the Lang Pasture site}

\section{Establishing the Temporal, Cultural, or Functional Variability in the Ceramic Assemblages in the Region}

The analysis of the ceramics from the Lang Pasture site, as well as sherds and vessels from a number of other broadly contemporaneous and younger Caddo sites in the upper Neches River basin, has considerably refined our understanding of the temporal, cultural, and functional character of prehistoric Caddo ceramic assemblages in the region. These sites are part of a culturally recognizable cultural tradition confined to the upper Neches (see Figure 6-70). Crucial to understanding the temporal and cultural development of this ceramic tradition is the detailed stylistic and technological information that has been obtained from Caddo cemetery sites with mortuary vessels that were used for short periods of time within a ca. 380 year chronological sequence (ca. A.D. 13201700), as supported by a large suite of radiocarbon and TL dates from Lang Pasture and other Caddo sites in the upper Neches area (see Chapter 5, this volume, and Feathers, Appendix C, this volume). Also important to anchoring the beginnings of this ceramic tradition, and laying the framework for tracing subsequent stylistic changes in the ceramic fine wares in the region, is the fact that the Lang Pasture site appears to be the earliest of the known sites within this tradition.

Building on the seriation of mortuary vessels proposed by Kleinschmidt (1982), the ceramic analysis of the mortuary vessels focused on the engraved rim motifs on the many Poynor Engraved vessels found in upper Neches River basin Caddo cemeteries, primarily because of the stylistic diversity of this type and its overall abundance in mortuary contexts. More than 30 distinctive Poynor Engraved rim stylistic motifs have now been recognized (see Figures 6-63 and 6-64) in the region-including several from the Lang Pasture site that may be amongst the earliest motifs seen on this fine warebut five new varieties represent more than $73 \%$ of the documented Poynor Engraved vessels in the upper Neches River basin. These include varieties Blackburn, Cook, Freeman, Hood, and Lang; var. Hood is the most common in the upper Neches River vessel sample (29.3\% of the vessels), followed by Poynor Engraved, var. Cook (15.7\%), var. Blackburn (12.6\%), var. Freeman (9.1\%), and var. Lang (6.6\%). The frequency seriation of these different decorative motifs on Poynor Engraved vessels from seven nearby prehistoric Caddo cemeteries - the Mrs. J. M. Cook (41AN1), J. M. Cook (41AN2), Fred McKee (41AN32), J. W. Blackburn (41CE4), Omer and Otis Hood, cemeteries \#1 and \#2 (41CE14), E. W Henry (41CE17), and R. J. Fair (41CE25) sites-indicates that the earliest varieties are var. Cook, var. Blackburn, and var. Hood, as well as regional varieties A-B, F, I-L, and S. Most of these regional varieties are found only in pre-A.D. 1480 contexts. None of the defined varieties of Poynor Engraved are present at the Lang Pasture site, but regional varieties $\mathrm{B}, \mathrm{F}$, and $\mathrm{K}$ are, although in higher proportions here compared to the other cemeteries. These differing proportions, and the absence of the defined varieties, suggests that the Lang Pasture cemetery-or at least some significant portion of it-predates the onset of the Frankston phase at ca. A.D. 1400, and that a number of more stylistically unique varieties of Poynor Engraved had begun to be made in the upper Neches sometime prior to ca. A. D. 1400.

Two of the early varieties of Poynor Engraved (var. F and J) continued to be made between ca. A.D. 1480-1560, but in lesser amounts. Instead, a number of other regional varieties of Poynor Engraved make their appearance at this time, namely var. CE, Q, and R. Four of these regional stylistic varieties of Poynor Engraved were made only during this temporal interval, but var. E became more common in later (ca. A.D. 1560-1650) Frankston phase burials. 
Among the defined varieties of Poynor Engraved, a new variety (var. Lang) makes its first and only appearance in ca. A.D. 1480-1560 burials. Var. Hood, Cook, and Blackburn comprise $75.8 \%$ of the ca. A.D. 1480-1560 Poynor Engraved vessels (but only $38.9 \%$ of the ca. A.D. 1400-1480 Poynor Engraved vessels). Each variety increased monotonically in proportion during ca. A.D. 1400-1480 to ca. A.D. 1480 1560 intervals, and then decreased in frequency in ca. A.D. 1560-1650 burials.

Poynor Engraved, var. Freeman appears to be the latest variety of the Poynor Engraved type in the upper Neches, as it makes its appearance between ca. A.D. 1560-1650, the latter part of the Frankston phase, where it is the dominant defined variety. Regional varieties $\mathrm{N}, \mathrm{P}$, and $\mathrm{T}$ are also present in low proportions only in ca. A.D. 1560-1650 burials. Var. Freeman appears to have developed from the earlier Poynor Engraved, var. Hood, because they both have hour glass-shaped panel dividers and none of the other varieties do. What separates var. Hood from var. Freeman are the pendant triangles on the upper and lower parts of the engraved rim panel of the latter.

In the case of Poynor Engraved, var. Freeman, a simple stylistic decision to add concentric circles and hooked arm elements on the body of carinated bowls, and then the addition of tick marks to concentric circles on the vessel body, suggests a clear and not temporally lengthy stylistic link between Poynor Engraved, var. Freeman and Patton Engraved, var. Freeman, and an obvious stylistic and cultural connection between Caddo peoples and potters that archeologists call the Frankston and Allen phases. This stylistic relationship of concentric circle and hooked arm elements on vessel bodies, embellished by the later addition of ticks on those elements, further suggests that Patton Engraved, var. Freeman is the earliest of the defined Patton Engraved varieties. These stylistic changes took place long after the Lang Pasture site was abandoned.
Hood Engraved, var. Hood and var. Cook are the earliest effigy vessel forms in the upper Neches. Hood Engraved, var. Allen is found in association with Patton Engraved, and is apparently part of Allen phase ceramic assemblages, although one burial at the Frankston phase Mrs. J. M. Cook site (41AN1) had one of these vessels. This effigy vessel form includes zoomorphic or anthropomorphic tail riders. The other varieties of Hood Engraved have effigy heads and tab tails, as well as horizontal engraved lines as the main rim/body decoration, with var. Cook also having engraved pendant triangle elements, and all are found in Frankston phase temporal contexts. Hume Engraved, var. Allen and var. Hume, are found primarily in Allen phase contexts or later (i.e., dating after ca. A.D. 1480) Frankston phase contexts. Hume Engraved bottles are absent from earlier Caddo burials in the upper Neches, and no Hume Engraved vessels were in any of the Lang Pasture burials.

The culinary tradition in use at the Lang Pasture site and all other post-A.D. 1300 Caddo sites in the upper Neches River basin was one designed to effectively deal with the processing and cooking of maize, in particular, with other sundry supplements (i.e., beans, deer meat, nut meat and oil) and condiments. Because the vessels from the Lang Pasture site are hollow wares (i.e., jars, bowls, and carinated bowls), and the other studied sites have the same range of vessel forms, it apparently is the case that the Caddo diet was based almost entirely on liquid-based foods boiled and cooked in jars, including stews, corn and bean dishes, and gruels, as well as the serving and drinking of liquids. It is suspected that Caddo culinary traditions in general were primarily domestic in scale rather than community or communal-based, because of the small to medium size of many of the vessels, although the size of some cooking and serving vessels found in mortuary contexts suggests that communal food practices were also important at certain times in upper Neches River basin Caddo society. 
Poynor Engraved is by far the most common fine ware type in the upper Neches River basin, in both domestic and mortuary contexts. Its most distinctive and unifying characteristic is the use of rim panels on carinated bowls - or a rim panel decoration turned vertically on bottles - that have distinctive dividers, creating central rectangular, oval, negative-oval, and semicircular elements. In some cases, there are additional decorative elements within the area created by the dividers, including hatched triangles, pendant triangles, circles, punctate-filled circles, or circles with spurs or ticks. The five newly defined varieties of Poynor Engraved are found at most of the sites in the upper Neches, as well as in sherd assemblages from domestic and mound components. Poynor Engraved, var. Hood is the most widespread of the defined varieties, followed by Poynor Engraved, var. Blackburn. Poynor Engraved, var. Lang is the least widespread of the defined varieties. The other varieties are Poynor Engraved, var. Cook and var. Freeman. The analysis of these varieties of Poynor Engraved, in combination with the examination of the later Patton Engraved type, has demonstrated the unbroken stylistic connection between the latest variety of Poynor Engraved-var. Freeman-and the earliest of the distinctive Patton Engraved vessels, namely Patton Engraved, var. Freeman, as well as the earlier stylistic change from Poynor Engraved, var. Hood to var. Freeman.

The earliest site that belongs to this tradition-the Lang Pasture site-has none of these defined Poynor Engraved varieties. There are a number of unnamed regional varieties of Poynor Engraved we have recognized, some of which are present in the earliest contexts at sites throughout the upper Neches River basin and in widespread $14^{\text {th }}$ century contexts in adjacent parts of East Texas. These varieties also feature a diverse range and combination of stylistic elements, principal among them are nested triangles, nested ovals, and nested circles; scrolls of various sorts; hatched pendant, stacked, and nested triangles; cross-hatched ladders and panels; hooked arms; concentric ovals; and sets of diagonal lines with small pendant triangles. The most common regional varieties of Poynor Engraved are var. F (nested ovals/triangles and diagonal cross-hatched ladders), var. E (scroll and circle), and var. B (interlocking scrolls). More than $57 \%$ of the Poynor Engraved vessels at the Lang Pasture site can be assigned to one of these regional varieties; the other $43 \%$ are specific local varieties of Poynor Engraved seen only at Lang Pasture and currently at one or two other sites in the region. In the broader upper Neches River basin mortuary vessel assemblages, these numerous regional varieties are most abundant in pre-A.D. 1480 contexts, with a significant drop off in ca. A.D. 1480-1560 and ca. A.D. 1560-1650 mortuary contexts. This suggests that prior to A.D. 1480, and reaching back into the early to mid- $14^{\text {th }}$ century A.D. when the Lang Pasture site was occupied and distinctive regionally specific fine ware styles were beginning to be created, the favoring of stylistic innovations and the individual work of specific artisans were what led to the wide diversity or variety in Poynor Engraved rim motif styles at that time.

Innovations and unique artistic expressions with Poynor Engraved vessels eventually began to diminish in favor of stylistic conformity around a certain few rim panel motifs. This uniformity suggests that fewer people were making pottery, and after ca. A.D. 1480, specific distinct styles/varieties of Poynor Engraved may not have been made in each Caddo settlement or community. Instead, each style of Poynor Engraved may have made by a certain number of artisans living in specific parts of the upper Neches River basin, and the products were then traded and exchanged throughout the region.

Other important fine wares include Hume Engraved and Patton Engraved, with several defined varieties in the upper Neches, as well as Hood Engraved effigy vessels. 
Seriation analysis of mortuary vessels suggest that neither of the first two pottery types began to be made until after ca. A.D. 1480 (in the case of Hume Engraved) or after ca. A.D. 1560 (in the case of Patton Engraved). Hood Engraved effigy vessels began to be made ca. A.D. 1400, and they were most popular as mortuary offerings between ca. A.D. 1400-1480, although they were made and used through the Allen phase. There are three known varieties, with Hood Engraved, var. Hood being the most common effigy vessel style. Hood Engraved, var. Hood vessels occur in burial and domestic contexts at a number of sites. Hood Engraved, var. Allen effigy vessels, however, are more concentrated in late Frankston and Allen phase settlements and cemeteries in the Caddo and Flat Creek areas and in the Neches River valley itself.

Important utility wares include Bullard Brushed, as well as Maydelle Incised, rim punctated jars, and Killough Pinched noded bowls and jars, the latter including exuberant examples with pedestal bases and pinched legs. Plain vessels were an important part of this ceramic tradition through time, and in addition to simple bowls, other plain wares were made in the same shape as some of the distinctive fine wares, as in the globular carinated bowl form (Poynor Plain) or the elongated bodyshort-necked bottle form (Hume Plain).

The decorated and plain sherd assemblages from post-A.D. 1400 domestic sites in the upper Neches (e.g., Anderson et al. 1974) are dominated by brushed utility ware pottery from Bullard Brushed vessels and other brushed utility ware types. Wet paste decorations on sherds from Maydelle Incised vessels and various unnamed utility wares are also a distinctive part of the utility wares in the region. Fine-ware vessel sherds are from Poynor Engraved and Hood Engraved vessels, and they are relatively rare (comprising less than $10 \%$ of the decorated sherds at the Lake Palestine sites). Plain to decorated sherd ratios for these assemblages range from only 0.14-1.50, with most of the sites having values of less than 0.72. Lake Palestine Caddo sites dating after ca. A.D. 1400 did not have many plain ware vessels.

\section{Establishing the Stylistic, Technological, and Functional Character of the Artifact Assemblage on a Caddo Residential Settlement}

Sherds from early $14^{\text {th }}$ to early $15^{\text {th }}$ century domestic contexts at the Lang Pasture site are from plain wares (including carinated bowls, bowls, and bottles), fine wares (i.e., the engraved and red-slipped vessels, including carinated bowls and bottles) and utility wares (i.e., the coarse-paste decorated vessels), usually cooking or storage jars and simple bowls. These wares are known to have been made and used differently, based on functional, technological, and stylistic analyses on numerous Caddo sherd assemblages in the broader East Texas region, with uses ranging from food service, cooking of foodstuffs, containers for liquids, and storage of plant food/seed crops. The ubiquity of these wares in every part of the site indicates that they were available to all the Caddo that lived there, and that there was no restricted access to the use of fine wares. These same wares are also found in the mortuary vessel assemblage at the Lang Pasture site, but in very different proportions, with an increased emphasis on fine wares as one of the principal funerary offerings.

The decorative style of the fine and utility wares in the northern (presumed to be the earliest Caddo occupational episode) and southern (the presumptive later occupational episode) areas at the Lang Pasture site share many similar decorative elements and stylistic motifs, and in a number of cases, these elements and motifs occur in roughly similar proportions. This suggests that these wares are part of the same ceramic stylistic tradition of the same Caddo social group; furthermore, they may not be separated much in time. That they share many decorative elements, but in slightly different 
proportions, presumably represents evidence of subtle stylistic changes over time effected by Caddo potters in how utility ware and fine ware were to be decorated, as well as the particular styles preferred by the Lang Pasture community. Overall, almost $48 \%$ of the rims in the ceramic assemblage are from utility wares, another $31 \%$ are from plain wares, and the remaining $22 \%$ are fine wares (engraved carinated bowls, bottles, and some bowl forms).

Jars with horizontally brushed rims are particularly abundant in the utility wares, followed by vessels with rim decorations consisting of tool-punctated rows, horizontal brushed-tool punctations (with the punctates pushed through the brushing), and triangle incised zones filled with tool punctations. The only significant difference in the brushed sherds from the southern and northern areas at the Lang Pasture site is the absolute proportions of brushed sherds in the utility wares: $26 \%$ in the northern area and $64 \%$ in the southern area. Clearly, the period after ca. A.D. 1320-1400 and in much of the $15^{\text {th }}$ century A.D. is one in which Caddo potters in the upper Neches River basin began to manufacture considerable numbers of jars with brushed vessel bodies and rims. This one change in the manufacture and use of one kind of utility ware-the brushed cooking jar -led to considerable reductions in previously important kinds of decorated utility wares and, with time, a different character to the overall utility ware assemblage, even as the elements of decoration remained consistently in use: incised (parallel, diagonal, opposed, and cross-hatched elements), incised-punctated (straight/parallel incised lines framing tool punctated rows or zones), and punctated (tool and fingernail punctated rows). In the northern ceramic-component/area, the incised, punctated, and incised-punctated vessel sherds account for $49 \%$ of all the decorated sherds, whereas in the southern ceramic component/area, that percentage has decreased to only 25 percent.
Fine wares, especially engraved bottles, are more common in the northern site component/area at the Lang Pasture site. Decorative elements on bottles shared in both site areas included sets of curvilinear lines and triangular elements, usually in combination with hatched areas, either triangular, circular, or oval-shaped. Many of these bottle sherds are from globular Poynor Engraved bottles rather than the elongated bottle form, as long vertical decorative motifs that occur on these elongated forms (as they do on Hume Engraved bottles) were not clearly identified in the Lang Pasture bottle sherds.

The sets of decorative elements in the engraved fine-ware carinated bowls and bowls from both site areas are found on Poynor Engraved vessels in the upper Neches River basin, many with hatched triangles of various sizes appended to larger motifs on rim panels. The decorations on these engraved vessels feature-either in a singular fashion or in combinationtriangular, oval, or circular motifs on rim panels filled in with closely to widelyspaced hatching or cross-hatched lines, usually with appended hatched triangles. Horizontal engraved sherds in the southern area may be from Hood Engraved effigy vessels, although no effigy heads were recovered at the Lang Pasture site. Lipnotched, engraved-lip-notched, and redslipped fine ware sherds, although rare, represent other distinctive stylistic practices used in the decoration of the northern area fine-ware assemblage.

Clays used for vessel manufacture at the Lang Pasture site were likely gathered from nearby alluvial settings, as suggested by instrumental neutron activation analysis, particularly the more easily processed alluvial clay bodies along Caddo Creek, but certainly within a short (1-7 km away, at most) distance from the settlement. Grog, burned and crushed bone, and crushed hematite are the significant tempers used in the locally produced ceramics at the Lang Pasture site. The predominant practice of 
Caddo potters at the site, as at other upper Neches River Caddo sites, was in making grog-tempered plain ware, utility ware, and fine ware pottery in both areas and through time. The principal technique used in the manufacture of Lang Pasture and other upper Neches River basin ceramics was the building of vessels using coils, beginning at the flat base and working up the vessel body. Using the coiling method, coils of clay, in the form of ropes, rolls, or fillets, were built up to create the desired size and height of the vessel.

The sample of rim sherds from the excavated area at the Lang Pasture site $(n=456)$, almost all of which appear to be from separate vessels, suggests that there may have been thousands of vessels used by the Caddo during their occupation of the entire site, given the apparent size of the site relative to the proportion that was excavated. With a duration of occupation that may lasted no more than ca. 80 years in the area excavated for this project, the number of vessels used by each household during the course of occupation was substantial, perhaps 20 -30 vessels at any one time, with different functions, sizes, volumes, and use-lives. Based on the number of rims from the three different pottery wares found in domestic contexts, the vessels in use were dominated by decorated utility wares, typically jars used for cooking and/or storage activities, and plain wares, generally simple bowls used for food serving along with the fine wares. The rim and lip form data from the southern and northern ceramic component/areas indicate that the same range of forms were used by potters in both areas: carinated bowls, bottles, bowls, and jars. These were forms that were considered appropriate by the Caddo for the kinds of vessels being made and used in each area. The particular shape and form of these vessels is a hallmark of the technology and style of Caddo pottery vessels in the upper Neches, and these shapes and forms would have been immediately recognizable to other Caddo as belonging to those of a particular social group.

Vessel orifice data suggest that the Caddo living in the northern area at the Lang Pasture site made pottery designed for use in cooking and food serving in small social groups, perhaps individual households, and only occasionally were foods prepared and served for larger (i.e., more than 10 individuals) groups of people. Later in time, larger vessels used for food service (fine wares), cooking (utility wares), and storage (utility wares) were more frequently produced and used at the site. In the southern area of the site, then, the ceramics produced and used by the Caddo were apparently made with the presumption that food preparation and serving needs extended to both household and supra-household contexts.

Utility-ware, plain-ware, and fine-ware vessels were fired differently from each other. Fine ware and plain wares were better made and better fired (at least in terms of regulating the firing temperature), and they were probably fired longer in a low oxygen environment than the utility wares. The Caddo potters exerted more control over the end product of fine ware and plain ware vessel manufacture than they did with the utility wares, primarily to produce a harder ceramic. Firing conditions tended to be more heterogeneous among the utility wares, likely the product of the multi-purpose nature of these vessel forms, as they were used as cooking pots and storage containers.

The manufacture and use of clay pipes is a distinctive feature of the artifact assemblage at the Lang Pasture site: there were two pipes from mortuary contexts and sherds from at least 10 other pipes that were found in the domestic areas. Pipes were probably smoked on a daily basis by adult members of farmsteads and communities-mainly by adult males - and when the pipes broke, they were discarded in nearby middens. Pipes were made locally for daily use, and for use in mortuary rituals. The pipes and 
pipe sherds are from elbow pipes, a style of ceramic pipe manufacture that began to be popular after ca. A.D. 1350 in East Texas, and are virtually the exclusive form of clay pipe made by the Caddo from the $15^{\text {th }}$ century A.D. on. At the Lang Pasture site there were L-shaped elbow pipes (Var. A) in two burials, the earliest form of elbow pipe in the upper Neches, as well as engraved Var. B and Var. C pipes (see Figure 6-23).

The stylistic character of the few arrow points from the site that can reasonably be associated with the principal Caddo occupation (i.e., Perdiz and Bassett) suggests the shared practice after ca. A.D. 1300 across the upper Neches River basin in the manufacture and form of suitable arrow points. The chipped and ground stone tools found in domestic contexts at Lang Pasture point to hunting activities as well as food processing activities, and there is some evidence of expedient flake tool use for tasks and activities that emphasized the "processing of smaller quantities of resources” (Tomka 2001:208) than would formal knapped tools. These expedient flake tools and perforators would have been used on wood or bone, or to cut and scrape hides and animal parts. The four-beveled knive would have been used for the butchering and processing of medium-sized prey such as deer (see Chapter 9, this volume). The one ground stone celt may have been used in the cutting of timbers for house construction or structure repair.

\section{How the Caddo at the Lang Pasture Site Processed and Cooked Wild and Domesticated Plant Foods and Wild Animal Foods}

The Caddo groups that lived at the Lang Pasture site cooked plant and animal foods almost exclusively in utility ware ceramic jars that were placed in or over a hearth or an open high-intensity fire. Sherds from these ceramic jars have sooting and preserved organic residues from the cooking of plant food stuffs. The virtual absence of ground stone plant processing equipment- nutting stones, grinding slabs, manos, and metates-associated with the principal prehistoric Caddo component further suggests that plant foods were processed using bone and wood tools (i.e., wooden mortars and pestles, bone sickles, see Swanton 1942). One shallowly buried firecracked rock concentration (Feature 36) northeast of Structure 2 (a domestic structure) suggests that occasional hot rock cooking of plant or animal foods (cf. Thoms 2008) took place in Caddo times as well, but this cooking technology had been virtually supplanted early in the Caddo archeological record by the boiling of foodstuffs in ceramic cooking pots.

The distribution of discarded sherds and other artifacts at the site suggest that most of the processing and cooking activities took place outdoors, in activity and work areas near to the domestic structures (see Figure $5-48$, this volume). The one outdoor hearth (Feature 25) is near both Structure 1 (a domestic residence) and Structure 3 (a ramada/elevated work platform). There are also fire-cracked rock concentrations in the outdoor work/activity areas, but the archeological evidence suggests that most of these clusters are the product of occasional hot-rock cooking in Woodland and Late Archaic times in these areas.

\section{Establishing the Kinds of Tools Made and Used During the Principal Caddo Occupation}

The kinds of stone tools made and used at the Lang Pasture site during the early $14^{\text {th }}$ to early $15^{\text {th }}$ century A.D. occupation include arrow points of several forms (most likely the Perdiz and Bassett types), perforators, and edge-modified flakes. Formally retouched flake tools (i.e., scrapers and drills) are conspicuously absent in the chipped stone tool assemblage, and chipped stone tools are not common at the site given the extensive excavations that were conducted there. A concentration of arrow point preforms in the vicinity of Feature 76 indicates, however, that arrow point 
manufacture took place in this specific area during the Caddo occupation. Other tools that were used at the site-but were probably not made there-include one ground stone celt and a four-beveled knive of Edwards chert. With respect to the low number of arrow points that can be reasonably associated with the principal Caddo occupation at the Lang Pasture site (16 Perdiz and two Bassett points), it has been shown in several studies in East Texas that the frequency of arrow points in post-ca. A.D. 1300 contexts is rather low-even on single component sites - and it appears that stone arrow points and tools were not intensively made or used after this time (perhaps as a consequence of less hunting, or greater use of bone or wood tools) (see Perttula and Nelson 2007; Walters 2008). Thus, on a site like Lang Pasture, the numbers of arrow points reflect more than simply occupational intensity but also intensity of tool use, site function, etc., regardless of age, as well as the lower intensity of use/production of chipped stone tools for hunting and hide-processing activities.

The fact that there are more early style arrow points (i.e., pre-A.D. 1200) such as Steiner and Catahoula at the Lang Pasture site than there are arrow points of the Perdiz and Bassett types, but almost no evidence in the more abundant ceramic sherds (and from many of the C14 and TL dates) for a preA.D. 1300 Caddo occupation, suggest a specialized use of the area at that time for Caddo hunting pursuits. This earlier Caddo use must have originated from different households and communities situated elsewhere in the upper Neches River basin, although such sites are far from common (cf. Anderson et al. 1974; Johnson 1961; Story 2000).

\section{Establishing the Manufacturing and Tool Maintenance Activities at the Site}

The best evidence for the manufacture of chipped stone tools at the Lang Pasture site is the 21 arrow point flake preforms and preform fragments recovered in the excavations. Also substantiating the on-site manufacture of chipped stone tools is the number of cortical flakes in the lithic debris assemblage from a series of Caddo pit features (see Chapter 7, this volume). Approximately $17 \%$ of the lithic debris from these features has cortical remnants. This relatively high percentage of cortex in the lithic debris suggests that the Caddo stone knappers reduced pebbles and cobbles of raw material via bifacially flaked cores that had some considerable amount of cortex on them at the time of reduction. The goal of the knapping was to produce flakes of sufficient length and width that would be suitable for arrow point manufacture or for use as sharp-edged expedient flake tools.

\section{Establishing Differences in the Proportion of Local vs. Non-Local Lithic Raw Materials in the Tools and Lithic Debris}

Non-local lithic raw materials are present in the chipped and ground stone tools and chipped stone lithic debris from the Lang Pasture site, but they are not abundant. They include novaculite and metamorphic stone from Ouachita Mountains sources and Central Texas chert from likely Trinity and Brazos River gravel sources. Less than 10\% of the arrow points are clearly made from non-local lithic raw materials (and even some of these are from sources not that far distant), among them a few Perdiz and Bassett arrow points. Local chert, quartzite (primarily heat-treated), and petrified wood were the predominant raw materials used by the Caddo to manufacture tools at the site. More specific analyses of the color and cortex (i.e., proportion that are cortical, have smoothed/roughened or limestone-covered cortex, etc.) of the chert lithic debris would need to be conducted to more specifically sort probable local chert raw materials that were being used and reduced on site versus non-local chert debris that is likely the product of the resharpening of tools made elsewhere. 


\section{Mortuary Practices}

The main purpose of this research effort was to establish if the burials at the Lang Pasture site have evidence for social differences in status or rank, and what were the prevalent forms of mortuary treatment at the site and in the region.

At the Lang Pasture site, Caddo adult men and women were buried in a spatially discrete cemetery placed ca. 10-20 m from habitation and outdoor work areas. The burials of children, on the other hand, were placed together in a large pit feature that may have first been used for storage of food stuffs, until its storage function was discontinued, at which point three child burials were placed in it, and then filled in. As with other upper Neches River basin Caddo cemeteries, the children had only a few funerary offerings placed with them, while the adults had two or three times as many ceramic vessels; two burials-both probably adult men-had clay pipes placed with them at death. Each grave had very similar kinds and amounts of funerary offerings, and the form of burial treatment was also the same, both evidence preserved in the mortuary practices that indicates that there were not any considerable socialorganizational differences between the individuals that were interred at the Lang Pasture site.

The rarity of double burials in upper Neches River Caddo cemeteries suggests that the double burial (Feature 93, that of an adult male and female) at the Lang Pasture site may represent the interment of notable and important adult individuals in a Caddo community that lived in this part of the Caddo Creek basin. Otherwise, the other burials at the site-including those from both adult and children burial groupsappear to have had an equivalent social position, separated only by age. The Caddo burials found throughout the upper Neches were buried by a living community of Caddo peoples that shared similar social beliefs about personal identity and gender, beliefs about the soul's nature, the afterlife, and the soul's journey to the House of Death. These Caddo households defined their own sense of place and who they were by the unique juxtaposition of the living and the dead in circumscribed areas with larger farming communities. An emphasis on affinity and kinship within and between different households that created these sacred cemetery places was more important to household members than were their broader ties to the larger communities of which they were a part. Although these Caddo shared similar views on social memory and the place of the dead in their lives, it was their households and associated cemeteries (i.e., their ritual space) that were the center of their universe, not the larger and socially more diverse communities of which they were a part.

The mortuary practices of the prehistoric Caddo communities that lived in the upper Neches River basin, as seen at the Lang Pasture site and the many other cemeteries in the region, have several significant characteristics. First, the cemeteries and burial places of these Caddo were deliberately kept physically distant from habitation areas, as an act of separating the dead from the living but also in creating a social memory of the deceased in those places; they are often placed near sources of fresh water. The burials are primarily those of single interments, usually adult men and women; children were sometimes buried in cemeteries along with adults, but there are instances where children were buried in spatially distinct groups. The graves are relatively shallow, and are narrowed near the foot end, and the deceased was laid in the grave in an extended supine position, with arms by the sides. In most cases, the deceased's head was at the eastern end of the grave, facing west towards the setting sun; in a few cases where burial orientation of a few graves was different, as at Lang Pasture, this may be evidence of a slightly earlier (i.e., pre-A.D. 1400) form of burial interment, perhaps one associated with the summer and winter solstices. The westward- 
facing burial orientation of the Caddo deceased reflects the path in which the souls traveled to their House of Death. This directionality in upper Neches Caddo mortuary practices is a symbolic relationship between death and winter, death imagery, and concern for the dead, where mortuary rituals represent a physical embodiment of cosmology as expressed in the social order and a specific set of beliefs about life, death, and socially necessary funerary accompaniments. Individual burials were in rows, with the graves parallel to one another, in either east-west or north-south rows; the burials were typically only 1-2 m apart in these rows; the graves rarely intersected; prepared grave floors are rare, but when made, consisted of a gravel fill or a white clay. Finally, the upper Neches River Caddo cemeteries were not used for substantial periods of time by any one farmstead compound or group of related farmsteads, perhaps no longer than 10-30 years at their maximum, based on the range in the size of each cemetery and the number and extent of associated habitation areas.

Almost all individuals, whether child or adult, had accompanying offerings, both durable as well as perishable (i.e., foodstuffs). Funerary offerings were generally placed by the head and shoulders, as well as at the waist and by the hands and feet; in some cases, the offerings appear to have been placed on the body, usually at the hips and on the legs. Ceramic bottles were consistently placed near the head; the arrangement and placement of funerary offerings reflect particular social meanings to these Caddo groups.

The offerings placed with the deceased contain an assortment of pottery vessels, followed by arrow points (commonly in quivers) for adult males, clay pipes, chipped stone knives, other kinds of stone tools, marine shell ornaments, pigments, bone tools or beads, and in the case of Allen phase burials, a few European trade goods. The variations in offerings by grave or by cemetery are not substantial, except in the absolute frequency of quivers of arrow points in certain cemeteries (see Table 11-4) north and east of the Lang Pasture site that date to the later part of the Frankston phase. Pigments were apparently specific offerings associated with adult females; children had the lowest number of funerary offerings as well as the least diverse kinds of offerings. The differences in funerary offerings between children and adults are clearly related to gender and personal identity. Since a very high proportion of Caddo burials had funerary offerings, it seems likely that the placement of these offerings was a function of both individual wealth and community esteem, reflecting differences in gender status, not social status. The fact that some adult Caddo females had clay pipes and stone tools (large bifacial knives) as funerary offerings suggests that certain adult females participated along with more adult men in both religious rituals associated with smoking as well as activities associated with the specialized butchering of game animals.

Certain adult males in upper Neches River basin Caddo society had a recognized higher social status in life-achieved through accomplishments as hunters, warriors, or diplomats/leaders-that was reflected in their distinctive treatment at death. These social identity or leadership relationships became clearest after ca. A.D. 1560 in the region. Even with their elite social position, these individuals were buried with their families and lineages in family cemeteries, rather than being interred at a social distance with other social elites from related farmsteads and communities.

\section{Evaluate the Hypothesis that Caddo Populations in the Area Did Not Have a Social Hierarchical Character as Seen in Mortuary Practices}

The demographic and funerary offerings data from upper Neches River basin Caddo cemeteries clearly indicate that the kinds and amounts of funerary offerings placed among upper Neches River Caddo groups, and needed by them in their journey to the 
House of Death, varied significantly by age and sex. Other than broad similarities in the number of vessels per burial-suggesting that these vessels held sufficient food stuffs for children and adults on their journey, but nothing more-in all other aspects adult men clearly had need in the afterlife of such gender-laden things as stone tools and arrow points, a clay smoking pipe, and ornaments on their journey, while children and adult females did not. After ca. A.D. 1500, and certainly after ca. A.D. 1560, there were a few Caddo individuals in upper Neches River basin who were recognized as having important social identities, probably manifest in leadership roles within specific communities, or as heads of important lineages. These individuals represent about $5 \%$ of the known Caddo burial population in the region. Where information on age and sex is available, these individuals appear to have been adult males. By comparison to contemporaneous Caddo populations in the Big Cypress and Red River basins, mortuary practices are less complex in their structure and organization for Frankston and Allen phase Caddo social groups. This in turn implies that kin-related groups within upper Neches Caddo societies were less socially hierarchical in character or socio-politically complex (cf. Carr 1995:169, 174) than were other East Texas Caddo groups and communities.

Establish the Social Affiliation of the Households at the Site to Geographically Related Socio-Political Groups in the Upper Neches River Basin

The analysis of the decorative motifs in the mortuary ceramics from a large number of upper Neches River basin Caddo sitesincluding the ceramic vessels from the Lang Pasture site-as well as sherd assemblages from domestic contexts-indicate that the Caddo occupants of the Lang Pasture site are socially affiliated at the regional scale with other Caddo communities that had settled over a ca. $5000 \mathrm{~km}^{2}$ area of the upper Neches and upper Angelina River basins (see Figure 6-70). A more detailed consideration of decorative elements in the engraved fine ware vessels, and a comparison with the decorative styles identified at the Lang Pasture site, indicate that the closest social relationships (using ceramic stylistic similarities as a proxy for the closest social relationships and intensity of social interaction) between the Caddo living at the Lang Pasture site are with other Caddo households and communities found over a ca. $500 \mathrm{~km}^{2}$ in the central part of the upper Neches, from Caddo Creek on the north, Walnut Creek to the south, and including sites on both the east and west sides of the Neches River valley (see Figure 6-71).

\section{Health and Diet of the Caddo}

\section{Establishing If the Diet was Adequate, and If Infectious Diseases or Episodes of Chronic Stress Were Common}

Paleopathological evidence gathered in the course of the bioarcheological investigations of the Lang Pasture human remains, and additional analyses of human remains from a series of sites in the upper Neches River basin, has shown that these Caddo population had high adaptive efficiency until after ca. A.D. 1650. Enamel hypoplasia and porotic hyperostosis are the best available indicators of adaptive inefficiency, and their rates of occurrence are lower in the upper Neches River basin than elsewhere in the Caddo area (see Wilson 2008c). Rates of enamel hypoplasia show a significant increase in childhood stress only after ca. A.D. 1650 that may be the result of epidemic disease, social stress, and/or increased maize consumption. Porotic hyperostosis was rare in the upper Neches population, but Rose et al. (1998) has showed a peak for other Caddo populations from the Red River and East Texas. The one case of cribra orbitalia seen in the upper Neches bioarcheological record indicates that iron deficient anemia was present, at least after ca. A.D. 1650. 
It is likely that an overall low, localized, and dispersed Caddo population density in the upper Neches through much of the history of Caddo settlement there (or at least up until ca. A.D. 1650) may have protected the health that increased maize consumption is otherwise assumed to negatively affect. The upper Neches Caddo were genetically homogenous, and with a lower population density than that seen in the middle reaches of the Red River basin. It is probably the case that the lower population density of the Caddo groups living in the upper Neches after ca. A.D. 1200, in combination with minimal population admixture or significant periods of interpersonal contact, had better health conditions and certainly experienced less exposure to infectious diseases than did those Caddo populations living along a major stream such as the Red River, or those populations that lived in the Blackland Prairie (i.e., the upper Sulphur River basin).

\section{Evaluate the Hypothesis That the Caddo Population Living at the Lang Pasture Site Had a Diet with a Relatively Low Dependency on Maize}

Stable isotope studies in the upper Neches River basin, and at the Lang Pasture site, have confirmed that maize was a significant part of the Caddo diet as early as the Middle Caddo period, and that maize consumption significantly increased after ca. A.D. 1400. The stable isotope values from Lang Pasture indicate that, on average, maize comprised between $28-31 \%$ of the diet, although one individual (Feature 76C) had stable isotope values on bone collagen that are consistent with $45-48 \%$ maize consumption. Caddo populations with a low dependency on maize are seen only in pre-A.D. 1000 Caddo burials from the upper Neches River basin and in other Caddo populations of the same age in the Red and Sulphur River basins in southwestern Arkansas and East Texas (Rose et al. 1998; Wilson 2008c). Otherwise, bioarcheological evidence (including stable isotopes, dental caries rates, and dental wear) in the Pineywoods of the upper Neches River basin are consistent with Caddo diets in which maize was important, when the Lang Pasture site was occupied, and that it became an even more important food resource in the region after this site was abandoned.

\section{Establish if Maize Was as Important in the Diet of the Upper Neches River Basin Caddo as it Appears to Be in Other Caddo Populations}

Dental and stable isotopic data clearly indicate that maize was an important dietary resource in the upper Neches River basin beginning during the Middle Caddo period, as it was across much of the Caddo area where such bioarcheological information is available (Perttula 2008:Figure 6; Wilson 2008c). In the upper Neches, moreover, the consumption of maize apparently increased two-fold in the region after ca. A.D. 1400 (the Late Caddo period). Caries rates are uniformly above the high carbohydrate threshold (2.0 caries per individual) beginning in the Middle Caddo period, but increase to more than 4.5 caries per individual during this same time period. Wear scores from the Upper Neches remain relatively stable until after ca. A.D. 1650. This is the period of highest Caddo maize consumption and presumably the softest diet.

The highest bone collagen values for maize in the upper Neches occur during Historic Caddo times (see Table 10-22), as has also been documented in Caddo populations living along the Red River in southwestern Arkansas and northwestern Louisiana (see Rose et al. 1998; Tine and Tieszen 1997). In fact, the stable isotope values in all three areas suggest that maize comprised between $56-59 \%$ of the diet at that time. 


\subsection{The Caddo Nation Perspective ON THE ANALYSIS OF HUMAN REMAINS FROM THE LANG PASTURE SITE (41AN38)}

Robert Cast and Bobby Gonzalez

On January 30, 2007 we visited the Texas Archeological Research Laboratory at The University of Texas at Austin to watch Dr. Diane Wilson perform analysis on human remains excavated from the Lang Pasture site (41AN38), an archeological site in Anderson County, Texas, that was excavated by archeological contractors working for the Texas Department of Transportation (TxDOT). There were nine burials represented at the site, however, only seven individuals were represented in the archeological excavations because human remains were not preserved in all of the burials (see Chapter 10, this volume).

There were some problems with getting to view Dr. Wilson doing the analysis on the remains. First of all, none of the burials or remains had been cleaned or prepared for her to look at. She had assumed that the human remains would have had all the soil matrix removed from them and that they would have been prepared and cleaned for her simply to do her measurements, observations, and analysis; however, this was not the case. Dr. Wilson explained that the soil matrix was attached to a lot of the bone, which was brittle and easily flaked apart. Diane spent most of the week cleaning the human remains. We took this as an opportunity to learn what some of her preliminary observations were regarding the remains and the people living at the Lang Pasture site.

When we are participants in these types of work contracts, as a federally recognized tribal government with a connection to the archeological site and the human remains, these projects are a recognition of our tribal sovereignty. The Caddo Nation has believed for decades that it has been unprofessional for archeologists, anthropologists, and historians to ignore the questions raised by the tribe when doing projects that may concern the living descendants over the life of any given project. Some of the questions raised during a project would be: "Why remove these remains to begin with? Can't they be left in place? If not, where will they be reburied? How long will it take to rebury them?"

With respect to the Caddo Nation and the scientific community we can have a common ground in that we believe there are things to be learned from each other. If we can learn to be equals over the life of a project we can better understand each other. We want to teach our people about the past so future generations will also be aware of the Caddo in Texas and the archeological record left behind there. When we understand more about the types of analysis that are being done, we are more readily able to understand what types of research questions are out there and what new information can be obtained from these analyses.

Because Dr. Wilson had to wash and prepare all the human remains for analysis, we discussed what her analysis would entail and what she had observed so far from the skeletal remains recovered in the excavations and from the cleaning of the remains. She explained that certain diseases that were introduced by the Europeans impacted the Caddo and these can be seen when analyzing the bones. She stated that arthritis is common with Caddo human remains and seems to be prevalent along the back of the neck, and is somewhat of a genetic marker. This prompted us to question whether or not this shows up in the present day Caddo people. We also questioned her about diabetes and if this showed up in the human remains. She stated that none of the Caddo in Texas observed from these archeological contexts had diabetes but that the Caddo developed the disease during historic times. From our discussions with Dr. Wilson, we believe that this type of 
research can in some ways benefit the present day Caddo people and we hope this research will provide a better understanding of our genetic make-up concerning our own health and diet.

Dr. Wilson also discussed different types of cranial modeling that had been seen on Caddo burials in the Caddo Area. We found it interesting that one of the crania at the Lang Pasture site had "banding rings" present on the skull; Dr. Wilson explained that there were four types of cranial modeling among the Caddo in prehistoric and early historic period times. She stated that she did not see any evidence for cranial modeling occurring exclusively among the elite but that cranial modeling was noted in burials throughout the Caddo regardless of status.

Dr. Wilson also stated that there were a lot of charcoal fragments in the burials, on the remains, and throughout the soil matrix. We found this interesting because perhaps this charcoal is related to the fact that the present day Caddo always build a fire near the foot of the grave of the deceased; the prehistoric Caddo may have had similar mortuary practices. This fire burns for six days and is used as a light to help guide the person in the afterlife.

Any type of research question needs to be handled with care and respect when analyzing human remains that we believe to be our ancestors. We have a Repatriation Committee made up of traditional elders that hear requests for analysis from a variety of graduate students and professional archeological contractors doing research in a number of fields related to Caddo archeology. When we, and the Repatriation Committee, hear these requests, we cannot help but learn more about some of the reasons why archeologists and anthropologists do what they do. The Repatriation Committee answers each request on a case-by-case basis. In rare cases they have allowed destructive analysis of human remains when the person doing the research has met with them, presented in detail what they wanted to do, and presented a clear argument to the committee on how the analysis would be beneficial. Meeting with the Repatriation Committee also helps the archeologist and anthropologist know what issues are of concern to the tribe. When this does not happen, we are unaware of the research questions being asked, how they may or may not benefit the tribe, and the archeologists and anthropologists cannot be made aware of any of our questions or concerns regarding their studies. We believe that sharing information is pertinent to a productive relationship and benefits everyone.

To answer some of the questions regarding the analysis of human remains from the Lang Pasture site and our perspective on that analysis, we must first ask the question, "Why were the human remains excavated in the first place?" The Caddo would prefer to have left the remains in place. This however, was not possible because of the highway project and its right-of-way. So, through consultations with TxDOT, it was agreed that the human remains and any funerary objects recovered during the archeological investigations would be professionally documented for reporting purposes. The Federal Highway Administration and TxDOT also agreed with the request of the tribe that the human remains and any funerary objects would be repatriated and reburied as close as possible to the area from which they came. These details are still ongoing and reinterment of the remains and the location of the reinterment will be worked out with further consultation.

The Caddo Nation Preservation Office reviewed the research design for the work and agreed with the overall research design and data recovery plan. With this in mind, we agreed to allow standard identification related to age and gender of the human remains without allowing any destructive analysis of the remains. However, the 
tribal council agreed to isotope analysis in February of 2006, once more details were explained about the analysis.

As observers, we were very pleased with the care and respect that Dr. Wilson showed the remains. However, it was sad to see human remains having to be washed, with the minute bone meal fragments going down the drain of the sink, which we understood could not be prevented. We also realize if a burial has only bone meal left within its context (as did two of the interments in one grave) it will be difficult for archeologists to collect it all. When we have been involved in reburials of human remains it is sometimes devastating to the elders doing the reburial to have to remove the bones from all the packaging. They may ask "Why are we having to take these remains out of plastic bags?" In other words, it is not traditional for them to have to rebury these remains in the first place, or to have to remove them from boxes, cartons, plastic bags, or vials. Observing how these human remains were packaged for transport to the laboratory, we realize bone meal is also often left in the packaging material and then discarded in the trash; this again is something that is not traditional for us. Bone meal is still a part of that individual. Archeologists recognize that from tiny portions of human remains there is the opportunity to extract DNA, obtain chronological dates on the context of the remains, and in a sense, ask questions about where this type of analysis will go in the future and what scientific techniques will be developed to further our understanding of humanity. We also understand the significance of these small fragments of remains for they are our people. How the Caddo people choose to address this issue, however, is a dilemma for us. On the one hand, we would try to collect every single bit of human remains, bone meal and all, for proper reburial. Traditionally, we would never use plastic bags or artificial containers to hold or transport the remains, but would prefer cedar boxes or blankets. We would hope that the archeological community would be more aware of these cultural differences and realize that we have been asked to address certain questions that we never expected that we would have to address. What other groups in Texas have to rebury human remains on a regular basis?

TXDOT understands that we use cedar boxes and blankets to rebury our people. However, when they are removed from the field, archeologists use standard materials to transport the remains. We do prefer cedar boxes and blankets; however, once the remains are put in boxes or blankets they need to be left alone until reburial. We know that the dirt from the fill and every burial along with remains will be reunited with all their individual material that was removed with them, and that is good.

Even though the human remains were examined following standard procedures explained in the report, there are tribal members that may feel this type of research was wrong, unnecessary, and against tribal beliefs and outside of tribal custom. Also, in providing synthetic regional review of Caddo bioarcheology, and incorporating that new information with bioarcheological information already published on Caddo human remains from the Caddo region, bioarcheologists should explain in more detail how this information can help the present day Caddo. We know that the word "Caddoan" as seen in the Chapter $10 \mathrm{draft}$ was used linguistically and lumps in other federally recognized tribes that are different than the Caddo. Terms like these cause confusion among tribes and scholars alike and should be corrected and referred to as just the bioarcheology of the Caddo. This report also seems to be merely more research data for those in the field of bioarcheology and archeology at the expense of our ancestral remains, although this is understandable given the circumstances that our ancestors had to be removed.

However, we are pleased with the establishment of the inventory of the 
individuals from the Lang Pasture site. In understanding the assemblages of the material representing each individual, this can be used as a good tool for the tribe and does chart a way for repatriating the individuals along with any associated materials. The inventory also gives an assessment on the preservation of the human remains, health, mortuary patterns, bioturbation, postmortem disturbances, excavation conditions, and other useful information. The assessment in the report is useful and needed for the tribe to understand what took place during and after the excavations of the human remains and the material representing each individual. This report also indicates the likelihood that more research questions and requests for more specific examinations may be brought forth in the future. It is important for the Caddo Nation to communicate that any expectations for more research relating to the human remains from the Lang Pasture site will be treated independently from this research analysis.

One topic that could use a lot more dialogue and discussion is the bioarcheological information concerning cranial modeling and the different types of cranial modeling used by the Caddo people over time as described in this research. We would like to see a presentation made to the Tribal Council detailing the findings contained in this report along with an explanation of the archeological contents and mortuary contexts excavated from the Lang Pasture site. This would be a good starting point to discuss the various types of cranial modeling and how long this has occurred with the Caddo, to provide a temporal context for when this occurs, and where this occurs on the Caddo cultural landscape. In conclusion, this research has shown that there are many differences between those individual scholars and archeologists who seek answers to their questions about the Caddo and those of the tribe that is impacted with such explorations and requests.

\subsection{CONCLUSIONS}

What began in the winter of 2004 as the Texas Department of Transportationsponsored test excavation of a poorly known prehistoric Caddo site in a right-of-way along SH155 that was proposed for expansion, now referred to as the Lang Pasture site (41AN38), in the upper Neches River basin in East Texas, has now, several years later, resulted in one of the most extensive and archeologically compelling investigations of a Caddo site in this area. The data recovery work completed by a Coastal Environments, Inc. and Archeological \& Environmental Consultants, LLC team in 2006 obtained a wealth of new archeological, bioarchaeological, and paleoenvironmental information about the lives and times of prehistoric ancestors of the Caddo Indian peoples, and has cast a new light on the character and pace of native history of the Caddo in the East Texas region.

The data recovery investigations summarized in this volume have been particularly important for advancing the field of Caddo archeology in several different respects. First, the intensive work completed in domestic habitation contexts at the site resulted in the identification of a well-defined series of features from prehistoric Caddo houses, specialized structures (i.e., granaries or ramadas/arbors), and ancillary outdoor activity areas, such that the character of a rural domestic Caddo household in much of East Texas (or at least the Neches-Angelina River basins) has come into better focus. Second, the exposure and excavation of a Caddo family cemeteryand the attempt to determine the regional context for changes in Caddo diet and health-has led to an understanding of the bioarcheological character of the Caddo people in the upper Neches River basin that is unparalleled anywhere in the larger Caddo archeological area (cf. Wilson 2008c). The bioarcheological information on diet, health, and pathologies obtained during the course of the Lang Pasture site investigations has 
an importance well beyond the local archeological context, because it provides a sweeping view of more than 800 years of Caddo life that will be relevant to understanding different Caddo peoples and groups in other parts of the Caddo world. Thirdly, the Lang Pasture archeological and bioarcheological investigations were done in consultation with the Caddo Nation of Oklahoma, most particularly arising from their permission to conduct the intensive bioarcheological analysis of the Lang Pasture human remains and the human remains from other upper Neches River Caddo sites. That consultation has allowed the Caddo peoples to keep abreast of the bioarcheological approach and findings, and most importantly also provides them an opportunity to communicate their perspectives on the meaning of the findings from these investigations. This is a first for the field of Caddo archeology, and it is a step in the right direction of making room for the Caddo peoples to be full partners in future Caddo archeological and bioarcheological investigations within their traditional homelands.

Fourth, and finally for the purposes of this summary, the identification of the family cemetery at the Lang Pasture site-as well as the associated funerary offerings placed in each of the graves-allowed for the regional consideration of Caddo mortuary practices based on a study of a number of upper Neches River basin Caddo cemeteries, a topic that heretofore had been of limited interest to East Texas Caddo archeologists.
To complement the consideration of mortuary practices, the study of the style, manufacture, and function of mortuary vessels in this region permitted the first examination of issues of style and stylistic change, social identity, and changes in culinary traditions as possible manifestations of changes in ceramic practice that occurred among Caddo groups living in the upper Neches River valley of East Texas between the $14^{\text {th }}$ to $17^{\text {th }}$ centuries A.D.

The mortuary ceramics from upper Neches River basin Caddo sites illustrate broad continuities in ceramic practice, which had been suspected but never fully demonstrated, particularly in terms of vessel decoration and vessel form, but also demonstrate patterns in technical choices that are very different than what is documented in domestic Caddo ceramic assemblages of the same age and made by the same social group of potters. The ceramic practice data (i.e., decorative, technological, and formal) from both domestic and mortuary contexts has been employed to posit the existence of a distinctive upper Neches Caddo tradition of ceramic practice. 


\section{REFERENCES CITED}

Abbott, D. R.

2003 Ceramics, Communities, and Irrigation Management. In Centuries of Decline during the Hohokam Classic Period at Pueblo Grande, edited by D. R. Abbott, pp. 148-165. University of Arizona Press, Tucson.

Ahr, S. W.

1999 A Summary Report on Archeological Investigations at 41CE326: A Late Caddo Burial Site Inadvertently Discovered along US 69 south of Rusk, Cherokee County, Texas. Draft report. Archeological Studies Program, Environmental Affairs Division, Texas Department of Transportation, Austin.

Albert, B. M.

2007 Climate, Fire, and Land-Use History in the Oak-Pine-Hickory Forests of Northeast Texas During the Past 3500 years. Castanea 72(2):81-90.

Alt, S.

1999 Spindle Whorls and Fiber Production at Early Cahokian Settlements. Southeastern Archaeology 18(2):124134.

Ambrose, S. H.

1993 Isotopic Analysis of Paleodiets: Methodological and Interpretive Considerations. In Investigations of Ancient Human Tissue Chemical Analyses in Anthropology, edited by M. K. Stanford, pp. 59-130. Gordon and Breach, Langhorne, Pennsylvania.
Ambrose, S. H. and L. Norr

1993 Experimental Evidence for the Relationship of Carbon Isotope Ratios of Whole Diet and Dietary Protein to Those of Bone Collagen and Carbonate. In Prehistoric Human Bone: Archaeology at the Molecular Level, edited by J. B. Lambert and G. Grupe, pp. 1-37. Springer-Verlag, New York.

Amick, C., E. Furman, T. K. Perttula, J. E. Bruseth, and B. C. Yates

1991 ALCOA \#1 (41AN87): A Frankston Phase Settlement along Mound Prairie Creek, Anderson County, Texas. Caddoan Archeology Newsletter 2 (2):11-15.

Anderson, D. G.

1996a Models of Paleoindian and Early Archaic Settlement in the Lower Southeast. In The Paleoindian and Early Archaic Southeast, edited by D. G. Anderson and K. E. Sassaman, pp. 29-57. University of Alabama Press, Tuscaloosa.

1996b Approaches to Modeling Regional Settlement in the Archaic Period Southeast. In The Archaeology of the Mid-Holocene Southeast, edited by K. E. Sassaman and D. G. Anderson, pp. 157-176. University Press of Florida, Gainesville.

Anderson, D. G., D. W. Stahle, and M. K. Cleaveland

1995 Paleoclimate and the Potential Food Resources of Mississippian Societies: A Case Study from the Savannah River Valley. American Antiquity 60(2):258-286. 
Anderson, D. G., L. O’Steen, and K. E. Sassaman

1996 Environmental and Chronological Considerations. In The Paleoindian and Early Archaic Southeast, edited by D. G. Anderson and K. E. Sassaman, pp. 3-15. University of Alabama Press, Tuscaloosa.

Anderson, K. M.

1972 Prehistoric Settlement of the Upper Neches. Bulletin of the Texas Archeological Society 43:121-197.

Anderson, K. M., K. Gilmore, O. R. McCormick III, and E. P. Morenon

1974 Archaeological Investigations at Lake Palestine, Texas. Contributions in Anthropology No. 11. Department of Anthropology, Southern Methodist University, Dallas.

Arnold, D. E.

2000 Does the Standardization of Ceramic Pastes Really Mean Specialization? Journal of Archaeological Method and Theory 7:333-375.

Arthur, J. W.

2006 Living with Pottery: Ethnoarchaeology among the Gamo of Southwest Ethiopia. The University of Utah Press, Salt Lake City.

Ashmore, W. and P. L. Geller

2005 Social Dimensions of Mortuary Space. In Interacting with the Dead: Perspectives on Mortuary Archaeology for the New Millennium, edited by G. F. M. Rakita, J. E. Buikstra, L. A. Beck, and S. R. Williams, pp. 81-92. University Press of Florida, Gainesville.

Aten, L, E. and C. N. Bollich

2002 Late Holocene Settlement in the Taylor Bayou Drainage Basin: Test Excavations at the Gaulding Site (41JF27), Jefferson County, Texas. Studies in Archeology 40, Texas Archeological Research Laboratory,
The University of Texas at Austin, and Special Publication No. 4, Texas Archeological Society, San Antonio.

Baker, B. J., T. L. Dupras and M. W. Tocheri

2005 The Osteology of Infants and Children. Texas A\&M University Press, College Station.

Banks, L. D.

1990 From Mountain Peaks to Alligator Stomachs: A Review of Lithic Sources in the Trans-Mississippi South, the Southern Plains, and Adjacent Southwest. Memoir \#4. Oklahoma Anthropological Society, Norman.

Basso, K. H.

1996 Wisdom Sits in Places: Notes on a Western Apache Landscape. In Senses of Place, edited by S. Feld and K. H. Basso, pp. 53-90. School of American Research Press, Santa Fe.

Bates, R. L., and J. A. Jackson (editors)

1980 Glossary of Geology. American Geological Institute, Falls Church, Virginia.

Beehr, D. E. and S. H. Ambrose

2007 Were They What They Cooked? Stable Isotopic Analysis of Mississippian Pottery Residues. In The Archaeology of Food and Identity, edited by K. C. Twiss, pp. 171-191. Occasional Paper No. 34. Center for Archaeological Investigations, Southern Illinois University, Carbondale.

Benson, L. V., M. S. Berry, E. A. Jolie, J. D. Spangler, D. W. Stahle, and E. M. Hattori

2007 Possible impacts of early-11th-, middle-12th-, and late-13th-century droughts on western Native Americans and the Mississippian Cahokians. Quaternary Science Reviews 26:336-350. 
Bever, M. R. and D. J. Meltzer

2007 Exploring Variation in Paleoindian Life Ways: The Third Revised Edition of the Texas Clovis Fluted Point Survey. Bulletin of the Texas Archeological Society 78:65-99.

Binford, L. R.

1967 Smudge Pits and Hide Smoking: The Use of Analogy in Archaeological Reasoning. American Antiquity 32(1):1-12.

Black III, T. K.

1978 A new method for assessing the sex of fragmentary skeletal remains: Femoral shaft circumference. American Journal of Physical Anthropology 48:227-232.

Blake, L. W.

1981 Early Acceptance of Watermelon by Indians of the United States. Journal of Ethnobiology 1(2):192-199.

Blake, L. W. and H. C. Cutler

1979 Plant Remains from the Upper Nodena Site (3MS4). The Arkansas Archeologist 20:53-58.

1982 Plant Remains from the King Hill Site (23BN1) and Comparisons with those from the Utz Site. The Missouri Archaeologist 43:86-110.

Bousman, C. B.

1998 Paleoenvironmental Change in Central Texas: The Palynological Evidence. Plains Anthropologist 43(164):201219.

Bousman, C. B., B. W. Baker, and A. C. Kerr 2004 Paleoindian Archeology in Texas. In The Prehistory of Texas, edited by $\mathrm{T}$. K. Perttula, pp. 15-97. Texas A\&M University Press, College Station.

Brown, D. O.

1998 Late Holocene Climates of NorthCentral Texas. Plains Anthropologist 43(164):157-172.
Brown, D., F. Reichenbacher, and S. E. Franson 1998 A Classification of North American Biotic Communities. University of Utah Press, Salt Lake City.

Brown, J. A.

1981 The Search for Rank in Prehistoric Burials. In The Archeology of Death, edited by R. Chapman, I. Kinnes, and K. Randsborg, pp. 25-38. Cambridge University Press, New York.

1996 The Spiro Ceremonial Center: The Archaeology of Arkansas Valley Caddoan Culture in Eastern Oklahoma. 2 Vols. Memoirs No. 29. Museum of Anthropology, University of Michigan, Ann Arbor.

Brown, K. M.

1976 Fused Volcanic Glass from the Manning Formation. Bulletin of the Texas Archeological Society 47:189207.

Bruseth, J. E.

1991 Hudnall-Pirtle (41RK4): An Early Caddoan Mound Complex in Northeast Texas. Caddoan Archeology Newsletter II(3):9-15.

1992 Artifacts of the de Soto Expedition: The Evidence from Texas. Bulletin of the Texas Archeological Society 63:67-97.

1998 The Development of Caddoan Polities along the Middle Red River Valley of Eastern Texas and Oklahoma. In The Native History of the Caddo: Their Place in Southeastern Archeology and Ethnohistory, edited by T. K. Perttula and J. E. Bruseth, pp. 47-68. Studies in Archeology 30. Texas Archeological Research Laboratory, The University of Texas at Austin. 
Bruseth, J. E. and W. A. Martin (editors)

1987 The Bird Point Island and Adams Ranch Sites: Methodological and Theoretical Contributions to North Central Texas Archaeology. Richland Creek Technical Series, Volume II. Archaeology Research Program, Institute for the Study of Earth and Man, Southern Methodist University, Dallas.

Bruseth, J. E. and T. K. Perttula

1981 Prehistoric Settlement Patterns at Lake Fork Reservoir. Texas Antiquities Permit Series No. 2. Archaeology Research Program, Southern Methodist University, Dallas, and Texas Antiquities Committee, Austin.

2006 Archeological Investigations at the Hudnall-Pirtle Site (41RK4): An Early Caddo Mound Center in Northeast Texas. Caddo Archeology Journal 15:57-158.

Buikstra, J. E. and D. H. Ubelaker (editors)

1994 Standards for Data Collection from Human Skeletal Remains: Proceedings of a Seminar at the Field Museum of Natural History Organized by Jonathan Haas. Research Series No. 44. Arkansas Archeological Survey, Fayetteville.

\section{Bureau of Economic Geology}

1965 Geologic Atlas of Texas, Tyler Sheet. Bureau of Economic Geology, The University of Texas at Austin.

1992 Geology of Texas Map. Bureau of Economic Geology, The University of Texas at Austin.

Burnett, B. A.

1990 The Bioarcheological Synthesis of the Gulf Coastal Plain Study Area Part I: The Bioarcheological Synthesis of the Eastern Portion of the Gulf Coastal Plain. In The Archeology and Bioarcheology of the Gulf Coastal
Plain, by D. A. Story, J. A. Guy, B. A. Burnett, M. D. Freeman, J. C. Rose, D. G. Steele, B. W. Olive, and K. J. Reinhard, pp. 385-418. 2 Vols. Research Series No. 38. Arkansas Archeological Survey, Fayetteville.

1999 The Bioarchaeological Synthesis of the Eastern Portion of the Gulf Coastal Plain. In Bioarcheology of the South Central United States, edited by J. C. Rose, pp. 102-132. Research Series No. 55. Arkansas Archeological Survey, Fayetteville.

Bush, L. L.

2007 Macrobotanical Remains from 41HS231 and 41HS588, Two Sites in Sabine Mine Area M, Harrison County, Texas. Macrobotanical Analysis, Manchaca, Texas.

2008 Macrobotanical Remains from the 2005 and 2006 Texas Archeological Society Field Schools at the Gene and Ruth Ann Stallings Site (41LR297). Macobotanical Analysis, Manchaca, Texas.

Butler, B. H.

1969 Analysis of the Human Skeletal Remains. In Investigations at the Sam Kaufman site, Red River County, Texas, edited by S. A. Skinner, R. K. Harris and K. M. Anderson, pp. 115136. Contributions in Anthropology No. $5 . \quad$ Southern Methodist University, Dallas.

Campbell, J. A., with contributions by R. Feit, R. Clark, N. Anderson, and J. A. McClellan

2003 Archeological Survey of State Highway 155 from Frankston to Pert, Anderson County, Texas. Archeology Series \#116. Hicks \& Company, Inc., Austin. 
Cannon, A.

2002 Spatial Narratives of Death, Memory, and Transcendence. In The Space and Place of Death, edited by $\mathrm{H}$. Silverman and D. B. Small, pp. 191199. Archeological Papers No. 11. American Anthropological Association, Washington, D.C.

2005 Gender and Agency in Mortuary Fashion. In Interacting with the Dead: Perspectives on Mortuary Archaeology for the New Millennium, edited by G. F. M. Rakita, J. E. Buikstra, L. A. Beck, and S. R. Williams, pp. 41-65. University Press of Florida, Gainesville.

Carr, C.

1995 Mortuary Practices: Their Social, Philosophical-Religious, Circumstantial, and Physical Determinants. Journal of Archaeological Method and Theory 2(2):105-200.

Cast, R., T. K. Perttula, B. Gonzalez, and B. Nelson

2006 Documentation of Caddo Ceramic Vessels from 41WD60, Wood County, Texas. Historic Preservation program, Caddo Nation of Oklahoma, Binger, Oklahoma.

Chamberlain, A.

2006 Demography in Archaeology. Cambridge Manuals in Archaeology. Cambridge University Press, Cambridge, United Kingdom.

Chapa, J. B.

1997 Texas and Northeastern Mexico, 1630-1690. Edited and with an introduction by W. C. Foster. University of Texas Press, Austin.
Charles, D. K.

2005 The Archaeology of Death as Anthropology. In Interacting with the Dead: Perspectives on Mortuary Archaeology for the New Millennium, edited by G. F. M. Rakita, J. E. Buikstra, L. A. Beck, and S. R. Williams, pp. 15-24. University Press of Florida, Gainesville.

Chesson, M. S.

2001a Social Memory, Identity, and Death: An Introduction. In Social Memory, Identity, and Death: Anthropological Perspectives on Mortuary Rituals, edited by M. S. Chesson, pp. 1-10. Archeological Papers No. 10. American Anthropological Association, Washington, D.C.

2001b Embodied Memories of Place and People: Death and Society in an Early urban Community. In Social Memory, Identity, and Death: Anthropological Perspectives on Mortuary Rituals, edited by M. S. Chesson, pp. 100-113. Archeological Papers No. 10. American Anthropological Association, Washington, D.C.

Chilton, E. S.

1999 Material Meanings and Meaningful Materials: An Introduction. In Material Meanings: Critical Approaches to the Interpretation of Material Culture, edited by E. S. Chilton, pp. 1-6. University of Utah Press, Salt Lake City.

Clark, J. E. and M. Knoll

2005 The American Formative Revisited. In Gulf Coast Archaeology: The Southeastern United States and Mexico, edited by N. M. White, pp. 281-303. University Press of Florida, Gainesville. 
Clark, J. W. and J. E. Ivey

1974 Archaeological and Historical Investigations at Martin Lake, Rusk and Panola Counties, Texas. Research Report 32. Texas Archeological Survey, The University of Texas at Austin.

Cliff, M. B.

1997 The Middle Caddoan Period in the Lower Sulphur River Area. Journal of Northeast Texas Archaeology 9:9-16.

Cliff, M. B. and T. K. Perttula

2002 Results of National Register Investigations Conducted on 41PN175, Panola County, Texas. Archeological Studies Program, Report No. 32. Texas Department of Transportation, Austin.

Cliff, M. B., E. C. Sills, T. K. Perttula, and P. Dering

2004 National Register Testing of Sites 41HE14, 41HE139, and 41HE343 within proposed FM 3506 Right of Way, Henderson County, Texas. Archeological Studies Program, Report No. 60. Environmental Affairs Division, Texas Department of Transportation, Austin.

Cliff, M. B., M. M. Green, S. M. Hunt, D. Shanabrook, and D. E. Peter

1996 Excavations at 41CS151, Area C, White Oak Creek Mitigation Area (WOCMA), Cass County, Texas. White Oak Creek Mitigation Area Archeological Technical Series, Report of Investigations, No. 4. GeoMarine, Inc., Plano.

Cobb, C. R.

2003 Mississippian Chiefdoms: How Complex? Annual Review of Anthropology 32:63-84.
Cobb, C. R. and E. Drake

2008 The Colour of Time: Head Pots and Temporal Convergence. Cambridge Archaeological Journal 18(1):85-93.

Coffee, D. R.

1975 Soil Survey of Anderson County, Texas. United States Department of Agriculture, Soil Conservation Service, in cooperation with the Texas Agricultural Experiment Station.

Cohen, M. N. and G. J. Armelagos

1984 Paleopathology at the Origins of Agriculture. Academic Press, New York.

Colby, G. R.

1997 Analysis of Dental Abscess Formation in a Texas Hunter-Gatherer and a Texas Agricultural Population. Bulletin of the Texas Archeological Society 68:179-190.

Cole, N. M.

1975 Early Historic Caddoan Mortuary Practices in the Upper Neches Drainage, East Texas. Master's thesis, Department of Anthropology, The University of Texas at Austin.

Corbin, J. E.

1998 Reflections on the Early Ceramic Period and the Terminal Archaic in South Central East Texas. Journal of Northeast Texas Archaeology 11:108116.

Corbin, J. E. and J. P. Hart

1998 The Washington Square Mound Site: A Middle Caddo Mound Complex in South Central East Texas. Bulletin of the Texas Archeological Society 69:47-78.

Cordell, A. S.

2001 Continuity and Change in Apalachee Pottery Manufacture: A Technological Comparison of Apalachee-Style and Colono Ware Pottery from French 
Colonial Old Mobile and Mission San Luis de Talimali. Archaeological Monographs No. 9. Center for Archaeological Studies, University of South Alabama, Mobile.

Crabtree, D. E.

1972 An Introduction to Flintworking. Occasional Papers No. 28. Idaho State University Museum, Pocatello.

Crane, C. J.

1982 Plant Utilization at Spoonbill, an Early Caddo Site in Northeast Texas. Midcontinental Journal of Archaeology 7:81-97.

1996 Archaeobotanical Remains. In Archaeological Investigations at Cooper Lake, Delivery Order Numbers 2, 3, \& 4, 1987: Cultural Resource Studies for Cooper Lake, Hopkins and Delta Counties, Texas, by D. E. McGregor, M. M. Green, D. H. Jurney, W. A. Martin, R. W. Moir, and J. W. Saunders, pp. 717-728. Archaeology Research Program, Department of Anthropology, Southern Methodist University, Dallas.

Creel, D. G.

1996 Hatchel-Mitchell Site. In The New Handbook of Texas, Vol. 3, edited by R. Tyler, pp. 504-505. Texas State Historical Association, Austin.

Creel, D., D. Hudler, S. Wilson, C. Schultz, and C. Walker

2005 A Magnetometer Survey of Caddoan Mounds State Historic Site. Technical Report 51. Texas Archeological Research Laboratory, The University of Texas at Austin.

Crook, W. W., III

2007 The Mantooth Site (41COL167): A Mid-size Late Prehistoric Occupation in Collin County, Texas. The Record 55(2):45-57. Dallas Archaeological Society, Dallas.
Crook, W. W., III, and M. D. Hughston

2008 The Late Prehistoric of the East Fork of the Trinity River: Whatever Happened to the Wylie Focus? MS on file with the authors.

Cutler, H. C. and L. W. Blake

1977 Corn from Cahokia Sites. In Explorations into Cahokia Archaeology, edited by M. L. Fowler, pp. 122-137. Bulletin 7. Illinois Archaeological Survey, Urbana.

2001 Plants from Archaeological Sites East of the Rockies. In Plants from the Past, by L. W. Blake and H. C. Cutler, pp. 93-147. University of Alabama Press, Tuscaloosa.

Davis, Dan R., Jr.

1991 Prehistoric Artifacts of the Texas Indians. Pecos Publishing, San Antonio, Texas.

Deal, M.

1998 Pottery Ethnoarchaeology in the Central Maya Highlands. University of Utah Press, Salt Lake City.

Derrick, S. M., G. R. Colby and D. G. Steele

2008 Analysis of Human Remains from the Arnold Roitsch Site (41RR16). In Collected Papers from Past Texas Archeological Society Field Schools, edited by T. K. Perttula, pp. 413-432. Special Publication No. 5. Texas Archeological Society, San Antonio.

Derrick, S. M. and D. E. Wilson

1997 Cranial Modeling as an Ethnic Marker among the Prehistoric Caddo. Bulletin of the Texas Archeological Society 68:139-146.

2001 The Effects of Epidemic Disease on Caddo Demographic Structure. Bulletin of the Texas Archeological Society 72:91-103. 
Dering, J. P.

2002 Plant Remains from 41FT425. In Data Recovery Excavations at the McGuire's Garden Site (41FT425), Jewett Mine, Freestone County, Texas, by E. F. Gadus, J. K. McWilliams, and R. C. Fields, pp. 209-227. Report of Investigations No. 134. Prewitt \& Associates, Inc., Austin.

2004 Archaeobotanical Evidence for Agriculture and Wild Plant Use at 41RK214. In The Oak Hill Village Site (41RK214) Rusk County, Texas, by Robert Rogers and Timothy K. Perttula, pp. 329-336. PBS\&J, Inc. Submitted to TXU Business Services, Dallas.

2005 Plant Remains from Three Late Caddoan Sites in Camp County, Pilgrim's Pride (41CP304), 41CP316, and Shelby Mound (41CP71). In Archeological Investigations at the Pilgrim's Pride Site (41CP304), a Titus Phase Community in the Big Cypress Creek Basin, Camp County, Texas, edited by T. K. Perttula, pp. 325-346. Report of Investigations No. 30. Archeological \& Environmental Consultants, LLC Austin.

2008 Plant Remains from Five Prehistoric Archeological Sites in the Lake Naconiche Area, Nacogdoches County, Texas. In Lake Naconiche Archeology, Nacogdoches County, Texas: Results of the Data Recovery Excavations at Five Prehistoric Archeological Sites, edited by T. K. Perttula. 2 Vols. Report of Investigations No. 60. Archeological \& Environmental Consultants, LLC, Austin.

Descantes, C., R. J. Speakman, and M. D. Glascock

2003 Letter Report to Timothy K. Perttula with enclosed figures and tables. University of Missouri Research
Reactor, Columbia, September 3, 2003. 40 pp.

Diamond, D. D., D. H. Riskind, and S. L. Orzell 1987 A Framework for Plant Community Classification and Conservation in Texas. The Texas Journal of Science 39:203-221.

Dickinson, S. D.

1941 Certain vessels from the Clements Place, an historic Caddo site. Bulletin of the Texas Archeological and Paleontological Society 13:117-132.

Diehl, M. W.

2005 Morphological Observations on Recently Recovered Early Agricultural Period Maize Cob Fragments from Southern Arizona. American Antiquity 70(2):361-375.

Diggs, G. M., Jr., B. L. Lipscomb, M. D. Reed, and R. J. O’Kennon

2006 Illustrated Flora of East Texas, Volume One: Introduction, Pteridophytes, Gymnosperms, and Monocotyledons. Botanical Research Institute of Texas, Fort Worth.

Ditch, L. E. and J. C. Rose

1972 A multivariate dental sexing technique. American Journal of Physical Anthropology 37:61-64.

Doran, G.

1975 The Long Bones of the Texas Indians. Unpublished Masters thesis, Department of Anthropology, University of Texas, Austin.

Duffield, L. F.

1963 The Wolfshead Site: An Archaic-NeoAmerican Site in San Augustine County, Texas. Bulletin of the Texas Archeological Society 34:83-141. 
Duffield, L. F. and E. B. Jelks

1961 The Pearson site: A historic Indian site in Iron Bridge Reservoir, Rains County, Texas. Archaeology Series No. 4. Department of Anthropology, The University of Texas at Austin.

Dunnell, R.C.

1970 Seriation Method and Its Evaluation. American Antiquity 35:305-319.

1978 Style and Function: A Fundamental Dichotomy. American Antiquity 43(2):192-202.

Dykeman, D. D., R. H. Towner, and J. K. Feathers

2002 Correspondence in Tree-Ring Dating and Thermoluminescence Dating: A Protohistoric Navajo Pilot Study. American Antiquity 67(1):145-164.

Early, A. M.

1988 Standridge: Caddoan Settlement in a Mountain Environment. Research Series No. $29 . \quad$ Arkansas Archeological Survey, Fayetteville.

2004 Prehistory of the Western Interior After 500 B.C. In Handbook of North American Indians, Volume 14, Southeast, edited by R. D. Fogelson, pp. 560-573. Smithsonian Institution, Washington, D.C.

Early, A. M. (editor)

1993 Caddoan Saltmakers in the Ouachita Valley: The Hardman Site. Research Series No. 43. Arkansas Archeological Survey, Fayetteville.

2000 Forest Farmsteads: A Millennium of Human Occupation at Winding Stair in the Ouachita Mountains. Research Series No. $57 . \quad$ Arkansas Archeological Survey, Fayetteville.

Eckert, S. L.

2008 Pottery and Practice: The Expression of Identity at Pottery Mound and
Hummingbird Pueblo. University of New Mexico Press, Albuquerque.

Eerkens, J. W. and C. P. Lipo

2005 Cultural transmission, copying errors, and the generation of variation in material culture and the archaeological record. Journal of Anthropological Archaeology 24(4):316-334.

2007 Cultural Transmission Theory and the Archaeological Record: Providing Context to Understanding Variation and Temporal Changes in Material Culture. Journal of Archaeological Research 15(3):239-274.

El-Najjar, M. Y., D. J. Ryan, C. Turner, and B. Lozoff

1976 The Etiology of Porotic Hyperostosis among the Historic and Prehistoric Anasazi Indians of the Southwestern United States. American Journal of Physical Anthropology 44:477-488.

Elson, K. M., C. Smith, and T. K. Perttula 2004 Additional Maize Studies. In The Oak Hill Village (41RK214), Rusk County, Texas, by R. Rogers and T. K. Perttula, pp. 337-344. Document No. 030083. PBS\&J, Austin.

Ewers, J. C.

1973 The Influence of Epidemics on the Indian Populations and Cultures of Texas. Plains Anthropologist 18:104115.

Feathers, J. K.

1997 The Application of Luminescence Dating in American Archaeology. Journal of Archaeological Method and Theory 4:1-66.

2000 Why Luminescence Dating Deserves Wider Application in American Archaeology. In It's About Time, edited by S. Nash, pp. 168-185. University of Utah Press, Salt Lake City. 
2003

Use of Luminescence Dating in Archaeology. Measurement Science and Technology 14:1493-1509.

Ferguson, J. E.

2007 Reanalysis of the Caddo INAA Ceramic database. MS on file, Missouri University Research Reactor, Columbia.

Ferguson, J. E., T. K. Perttula, and M. D. Glascock

2008 Dividing up the Caddo Cultural Landscape: Small-Scale Analysis of a Large Ceramic INAA Database. Poster presented at the 2008 Annual meeting of the Society for American Archaeology, Vancouver, British Columbia.

Ferring, C. R.

1994 McGee Creek in Regional Paleoenvironmental Context. In Past Environments and Prehistory at McGee Creek Reservoir, Atoka County, Oklahoma, edited by C. R. Ferring, pp. 29-43. McGee Creek Archaeological Project Reports, Volume V, Part 4. Institute of Applied Sciences, University of North Texas, Denton.

1995 Middle Holocene Environments, Geology, and Archaeology in the Southern Plains. In Archaeological Geology of the Archaic Period in North America, edited by E. A. Bettis III, pp. 29-43. Special Paper 297. Geological Society of America, Boulder.

Ferring, C. R. and B. C. Yates

1996 Holocene Geoarchaeology and Prehistory of the Ray Roberts Lake Area, North Central Texas. Institute of Applied Sciences, University of North Texas, Denton.

Fields, R. C.

1979 Report on the 1977 University of Texas Field School Archeological
Survey in Houston County, Texas. Department of Anthropology, The University of Texas at Austin.

2004 The Archeology of the Post Oak Savanna of East-Central Texas. In The Prehistory of Texas, edited by T. K. Perttula, pp. 347-369. Texas A\&M University Press, College Station.

Fields, R. C. and S. A. Tomka

1993 Hunter-Gatherer Mobility in Northeast Texas, 10,000-200 B.C. In Archeology in the Eastern Planning Region, Texas: A Planning Document, edited by N. A. Kenmotsu and T. K. Perttula, pp. 69-95. Cultural Resource Management Report 3. Texas Historical Commission, Department of Antiquities Protection, Austin.

Fields, R. C., M. E. Blake, and K. W. Kibler 1997 Synthesis of the Prehistoric and Historic Archeology of Cooper Lake, Delta and Hopkins Counties, Texas. Reports of Investigations No. 104. Prewitt and Associates, Inc., Austin.

Ford, R. I.

1981 Gardening and Farming before A.D. 1000: Patterns of Prehistoric Cultivation North of Mexico. Journal of Ethnobiology 1:6-27.

1982 The Archeobotany of the Deshazo Site. In The Deshazo Site, Nacogdoches County, Texas, Volume 1, edited by D. A. Story, pp. 158-163. Texas Antiquities Permit Series No. 7. Texas Antiquities Committee, Austin.

1997 Preliminary Report on the Plant Remains from the George C. Davis Site, Cherokee County, Texas 19681970 Excavations. Bulletin of the Texas Archeological Society 68:104107. 
Foster, W. C. (editor)

1998 The La Salle Expedition to Texas: The Journal of Henri Joutel 1684-1687. Texas State Historical Association, Austin.

Fox, A. A. and S. A. Tomka

2006 Excavations at Presidio Nuestra Senora de Loreto de la Bahia del Espiritu Santo. Bulletin of the Texas Archeological Society 77:33-159.

Fritz, G. J.

1984 Identification of Cultigen Amaranth and Chenopod from Rockshelter Sites in Northwest Arkansas. American Antiquity 49:558-572.

1986a Prehistoric Ozark Agriculture: The University of Arkansas Rockshelter Collections. Ph.D. dissertation, Department of Anthropology, University of North Carolina, Chapel Hill.

1986b Desiccated Botanical Remains from Three Bluffshelter Sites in the Pine Mountain Project Area, Crawford County, Arkansas. In Contributions to Ozark Prehistory, edited by G. Sabo III, pp. 86-97. Research Series No. 27. Arkansas Archeological Survey, Fayetteville.

1986c Maize. In French-Indian Interaction at an $18^{\text {th }}$ Century Frontier Post: The Roseborough Lake Site, Bowie County, Texas, by K. Gilmore, pp. 131-134. Contributions in Archaeology No. 3. Institute of Applied Sciences, North Texas State University, Denton.

1990 Multiple Pathways to Farming in Precontact Eastern North America. Journal of World Prehistory 4(4):387435.

1993 Archeobotanical Analysis. In Caddoan Saltmakers in the Ouachita Valley: The Hardman Site, edited by
A. M. Early, pp. 159-168. Research Series No. 43. Arkansas Archeological Survey, Fayetteville.

1994 The Value of Archaeological Plant Remains for Paleodietary Reconstruction. In Paleonutrition: The Diet and Health of Prehistoric Americans, edited by K. D. Sobolik, pp. 21-33. Occasional Paper No. 22. Center for Archaeological Investigations, Southern Illinois University at Carbondale.

2000a Native Farming Systems and Ecosystems in the Mississippi River Valley. In Imperfect Balance: Landscape Transformations in the Precolumbian Americas, edited by D. L. Lentz, pp. 225-249. Columbia University Press, New York.

2000b Levels of Native Biodiversity in Eastern North America. In Biodiversity \& North America, edited by P. E. Minnis and W. J. Elisens, pp. 223-247. University of Oklahoma Press, Norman.

2008 Archeobotanical Remains from Five Sites on the Red River, Northeast Texas. In Collected Papers from Past Texas Archeological Society Summer Field Schools, edited by T. K. Perttula, pp. 432-446. Special Publication No. 5. Texas Archeological Society, San Antonio.

Gadus, E. F. and R. C. Fields

1996 Ceramic Vessels from the Pleasure Point Site (41MR63), Marion County, Texas. Technical Report No. 22. Prewitt and Associates, Inc., Austin.

Gadus, E. F., R. C. Fields, C. B. Bousman, S. A. Tomka, and M. A. Howard

1992 Excavations at the Finley Fan Site (41HP159), Cooper Lake Project, Hopkins County, Texas. Reports of Investigations No. 78. Prewitt and Associates, Inc., Austin. 
Gadus, E. F., R. C. Fields, J. K. McWilliams, J. Dockall, and M. C. Wilder

2006 National Register Testing of Seven Prehistoric Sites in the Sabine Mine's Area Q, Harrison County, Texas. Reports of Investigations No. 147. Prewitt \& Associates, Inc., Austin.

Gadus, E. F., J. K. McWilliams, and R. C. Fields 2002 Data Recovery Excavations at the McGuire's Garden Site (41FT425), Jewett Mine, Freestone County, Texas. Reports of Investigations No. 134. Prewitt and Associates, Inc., Austin.

Galan, V., R. Rogers, T. K. Perttula, and E. Skokan Switek

1997 National Register Testing of Seven Sites in the Monticello B-2 Surface Mine, Titus County, Texas. Document No. 971085. Espey, Huston \& Associates, Inc., Austin.

Galinat, W. C.

1985 Domestication and Diffusion of Maize. In Prehistoric Food Production in North America, edited by R. I. Ford, pp. 245-278. Anthropological Papers No. 75. Museum of Anthropology, University of Michigan, Ann Arbor.

Gamble, C.

2007 Origins and Revolutions: Human Identity in Earliest Prehistory. Cambridge University Press, Cambridge.

Gardner, P. S.

1997 Plant Remains. In Two Caddoan Farmsteads in the Red River Valley: The Archeology of the McLelland and Joe Clark Sites, edited by D. B. Kelley, pp. 109-120. Research Series No. 51. Arkansas Archeological Survey, Fayetteville.

Gennett, J. A.

1983 Botanical Remains from Two Archaeological Sites in Texas.
Manuscript on file, Stephen F. Austin University, Nacogdoches, Texas.

Gill-King, $\mathrm{H}$.

1990 Human Skeletal Remains:

Pathological and Dietary/Nutritional Aspects. In The Hurricane Hill Site (41HP106): Excavations at Cooper Lake, Hopkins County, Texas (review draft), by T. K. Perttula, pp. 235-255. Contributions in Archaeology No. 9. Institute of Applied Sciences, University of North Texas, Denton.

Gilmore, K.

1974 Appendix I-Analysis of Pipes. In Archaeological Investigations at Lake Palestine, Texas, by K. M. Anderson, K. Gilmore, O. F. McCormick III, and E. P. Morenon, pp. 192-197. Contributions in Anthropology No. 11. Department of Anthropology, Southern Methodist University, Dallas.

1983 Caddoan Interaction in the Neches Valley, Texas. Reprints in Anthropology, No. 27. J\&L Reprint Company, Lincoln, Nebraska.

$1986 \quad$ French-Indian Interaction at an Early Eighteenth-Century Post: The Roseborough Lake Site, Bowie County, Texas. Contributions in Archaeology No. 5. Institute of Applied Sciences, North Texas State University, Denton.

Girard, J. S.

1994 Investigations at the James Pace Site (16DS268), De Soto Parish, Louisiana. Caddoan Archeology Newsletter V(1):8-16.

1997 Caddoan Settlement in the Red River Floodplain: Perspectives from the Willow Chute Bayou Area, Bossier Parish, Louisiana. Louisiana Archaeology 22:143-162. 
2000

Regional Archaeology Program, Management Unit 1, Eleventh Annual Report. Northwestern State University, Natchitoches.

Goldborer, S. E.

2002 Macrobotanical Evidence of Subsistence at Timber Hill. In Finding Sha'chahdinnih (Timber Hill): The Last Village of the Kadohadacho in the Caddo Homeland, by M. L. Parsons, J. E. Bruseth, J. Bagur, S. E. Goldborer, and C. McCrocklin, pp. 81-86. Archeological Reports Series No. 3. Texas Historical Commission, Austin.

Goldschmidt, W. R.

1935 A Report on the Archeology of Titus County in East Texas. Bulletin of the Texas Archeological and Paleontological Society 7:89-99.

Goldstein, L.

1980 Mississippian Mortuary Practices. Scientific Papers No. 4. Northwestern University Archaeological Program, Kampsville, Illinois.

2006 Mortuary Analysis and Bioarchaeology. In Bioarchaeology: The Contextual Analysis of Human Remains, edited by J. E. Buikstra and L. A. Beck, pp. 375-387. Elsevier and Academic Press, Burlington, Massachusetts.

Gonzalez, B.

2005 Caddo Tribal Religious Burial Ceremonies beyond Archeology. In A Rediscovering of Caddo Heritage: The W. T. Scott Collection at the American Museum of Natural History and Other Caddo Collections from Arkansas and Louisiana, by B. Gonzalez, R. Cast, T. K. Perttula, and B. Nelson, pp. 55-59. Historic Preservation Program, Caddo Nation of Oklahoma, Binger, Oklahoma.
Gonzalez, B., R. Cast, T. K. Perttula, and B. Nelson

2005 A Rediscovering of Caddo Heritage: The W. T. Scott Collection at the American Museum of Natural History and Other Caddo Collections from Arkansas and Louisiana. Historic Preservation Program, Caddo Nation of Oklahoma, Binger, Oklahoma.

Good, C. E.

1982 Analysis of Structures, Burials, and Other Cultural Features. In The Deshazo Site, Nacogdoches County, Texas, Vol. 1, edited by D. A. Story, pp. 51-110. Texas Antiquities Permit Series No. 7. Texas Antiquities Committee, Austin.

Granberry, D. S.

1995 William T. McKenzie Mound. The Record 46(1):1-18. Dallas Archeological Society, Dallas.

Gregory, H. F. and G. Avery

2007 American Indian Pottery from Historic Period Sites in North Louisiana. Journal of Northeast Texas Archaeology 26:33-76.

Gremillion, K. J.

2004 Seed Processing and the Origins of Food Production in Eastern North America. American Antiquity 69 (2):215-233.

Southeast Plants. In Environment, Origins, and Population, edited by $\mathrm{D}$. H. Ubelaker, pp. 388-395. Handbook of North American Indians, Volume 3, W. C. Sturtevant, general editor. Smithsonian Institution, Washington, D.C.

Griffith, W. J.

1954 The Hasinai Indians of East Texas as Seen by Europeans, 1687-1772. Middle American Research Institute, Philological and Documentary Studies, Volume 2, No. 3. Tulane University, New Orleans. 
Guy, J. A.

1990 Previous Archeological Investigations. In The Archeology and Bioarcheology of the Gulf Coastal Plain, by D. A. Story, J. A. Guy, B. A. Burnett, M. D. Freeman, J. C. Rose, D. G. Steele, B. W. Olive, and K. J. Reinhard, pp. 27130. 2 Vols. Research Series No. 38. Arkansas Archeological Survey, Fayetteville.

Hallam, E. and J. Hockey

2001 Death, Memory \& Material Culture. Berg Publishers, Oxford.

Hally, D. J.

1983 Use Alteration of Pottery Vessel Surfaces: An Important Source of Evidence for the Identification of Vessel Function. North American Archaeologist 4(1):3-26.

Hamilton, D. L.

1997 Observations on Caddoan Burial Practices at the Sanders Site (41LR2). Bulletin of the Texas Archeological Society 68:115-134.

Harris, R. K. I. M. Harris, and M. P. Miroir 1980 The Atlanta State Park site in Northeastern Texas. Louisiana Archaeology 6:233-239.

Harry, K. G.

2004 Investigations into Ceramic Technology. In Pots, Potters, and Models: Archaeological Investigations at the SRI Locus of the West Branch Site, Tucson, Arizona, Volume 2: Synthesis and Interpretations, edited by S. M. Whittlesey, pp. 271-281. Technical Series 80. Statistical Research, Inc., Tucson, Arizona.

Hart, J. P.

1982 An Analysis of the Aboriginal Ceramics from the Washington Square Mound Site, Nacogdoches County, Texas. Master's thesis, Northeast Louisiana University, Monroe.
1999 Maize Agriculture Evolution in the Eastern Woodlands of North America: A Darwinian Perspective. Journal of Archaeological Method and Theory 6(2):137-180.

Hatcher, M. A.

1927a Description of the Tejas or Asinai Indians, 1691-1722, Part IV. Southwestern Historical Quarterly 31:150-180.

1927b Description of the Tejas or Asinai Indians, 1691-1722, Part III. Southwestern Historical Quarterly 31:50-62.

1927c Descriptions of the Tejas or Asinai Indians, 1691-1722, Part II: Fray Francisco Casanas de Jesus Maria to the Viceroy of Mexico, August 15, 1691. Southwestern Historical Quarterly 30:283-304.

Hillson, S. W.

1979 Diet and Dental Disease. World Archaeology 11:147-162.

Hoffman, M. P.

1967 Ceramic Pipe Style Chronology along the Red River Drainage in Southwestern Arkansas. The Arkansas Archeologist 8(1):4-14.

Holliday, V. T.

2004 Soils in Archaeological Research. Oxford University Press, Oxford, England.

Holloway, R. G.

1994 Ferndale Bog: A Record of Late Pleistocene-Holocene Climate and Vegetational Change. In Past Environments and Prehistory at McGee Creek Reservoir, Atoka County, Oklahoma, edited by C. R. Ferring, pp. 9-27. McGee Creek Archaeological Project Reports, Volume V, Part 4. Institute of Applied 
Sciences, University of North Texas, Denton.

House, J. H.

2003 Gifts of the Great River: Arkansas Effigy Pottery from the Edwin Curtiss Collection. Peabody Museum Press, Harvard University, Cambridge, Massachusetts.

Hudson, C. M.

1997 Knights of Spain, Warriors of the Sun: Hernando de Soto and the South's Ancient Chiefdoms. University of Georgia Press, Athens.

Hunter, D. G., G. J. Fritz, W. J. Autin, and K. Liu

1995 Manifest East: Cultural Resources Investigations Along Portions of Louisiana Highway 8, Catahoula Parish, Louisiana. Coastal Environments, Inc. Submitted to the Louisiana Department of Transportation and Development.

Hunter, D. G., D. B. Lee, W. J. Autin, C. L. Coxe, and K. M. Roberts

1999 Archaeology Along the Lower Tensas: Cultural Resources Investigations Relating to Items $2 A$ and $2 B$ of the Sicily Island Levee Project, Catahoula Parish, Louisiana. Coastal Environments, Inc. Submitted to the U.S. Army Corps of Engineers, Vicksburg District.

Hutchinson, D. L. and L. V. Aragon

2002 Collective Burials and Community Memories: Interpreting the Placement of the Dead in the Southeastern and Mid-Atlantic United States with Reference to Ethnographic Cases from Indonesia. In The Space and Place of Death, edited by H. Silverman and D. B. Small, pp. 27-54. Archeological Papers No. 11. American Anthropological Association, Washington, D.C.
Jackson, A. T.

1931 Field Notes, Excavations in Anderson County, Texas, 13 October 1931 to 12 November 1931. MS on file Texas Archeological Research Laboratory, The University of Texas at Austin.

1933a John Bragg Farm located in north edge of Village of Cuney, 300 Yards South of Highway No. 40 and 1/2 Mile East of Neches River, Cherokee County, Texas. Excavated September 1, 1933 to September 4, 1933. MS on file Texas Archeological Research Laboratory, The University of Texas at Austin.

1933b J. M. Snow Farm, 4 Miles N.W. of Reese, Cherokee County, Texas, Excavated September 4 to September 9, 1933. MS on file Texas Archeological Research Laboratory, The University of Texas at Austin.

1933c Some Pipes of East Texas. Bulletin of the Texas Archeological and Paleontological Society 5:69-86.

1934 Types of East Texas Pottery. Bulletin of the Texas Archeological and Paleontological Society 6:38-57.

1936 A Perpetual Fire Site. Bulletin of the Texas Archeological and Paleontological Society 8:134-174.

Jackson, J. M.

1981 Floral and Faunal Remains. In Archeological Investigations at the George C. Davis Site, Cherokee County, Texas: Summers of 1979 and 1980, edited by D. A. Story, pp. 347360. Occasional Papers, Vol. 1. Texas Archeological Research Laboratory, The University of Texas at Austin.

Jelks, E. B.

1961 Excavations at Texarkana Reservoir, Sulphur River, Northeastern Texas. River Basin Survey Papers No. 21. Bulletin No. 179. Bureau of American 
Ethnology, Smithsonian Institution, Washington, D.C.

1965 The Archeology of McGee Bend Reservoir. Ph.D. dissertation, Department of Anthropology, The University of Texas at Austin.

Jelks, E. B. (editor)

1967 The Gilbert Site: A Norteno Focus Site in Northeastern Texas. Bulletin of the Texas Archeological Society 37:1248.

Jensen, H. P.

1968 Archaeological Investigations in the Toledo Bend Reservoir, 1966-1967. Archaeology Salvage Project, Southern Methodist University, Dallas.

Jeter, M. D.

2007 The Outer Limits of Plaquemine Culture: A View from the Northerly Borderlands. In Plaquemine Archaeology, edited by M. A. Rees and P. C. Livingood, pp. 161-195. University of Alabama Press, Tuscaloosa.

Jeter, M. D., J. C. Rose, G. I. Williams, Jr., and A. M. Harmon

1989 Archeology and Bioarcheology of the Lower Mississippi Valley and TransMississippi South in Arkansas and Louisiana. Research Series No. 37. Arkansas Archeological Survey, Fayetteville.

Johannessen, S.

1984 Plant Remains from the Edelhart Phase. In The BBB Motor Site, by T. E. Emerson and D. E. Jackson, pp. 169-189. American Bottom Archaeology FAI-270 Reports, Vol. 6. University of Illinois Press, Champaign.
Johnson, L., Jr.

1961 An Archeological Survey of Blackburn Crossing Reservoir on the Upper Neches River. Bulletin of the Texas Archeological Society 31:213238.

1962 The Yarbrough and Miller Sites of Northeastern Texas, with a Preliminary Definition of the La Harpe Aspect. Bulletin of the Texas Archeological Society 32:141-284.

1989

Great Plains Interlopers in the Eastern Woodlands in Late Paleoindian Times: The Evidence from Oklahoma, Texas, and Areas Close By. Report Series No. 36. Office of the State Archeologist, Texas Historical Commission, Austin.

1994 The Life and Times of Toyah-Culture Folk: The Buckhollow Encampment, Site 41KM16, Kimble County, Texas. Office of the State Archeologist, Report No. 28. Texas Department of Transportation and the Texas Historical Commission, Austin.

Jones, B. C.

1968 The Kinsloe Focus: A study of seven historic Caddoan sites in Northeast Texas. Master's thesis, Department of Anthropology, University of Oklahoma, Norman.

Jones, V. H.

1949 Maize from the Davis Site: Its Nature and Interpretation. In The George C. Davis Site, Cherokee County, Texas, by H. P. Newell and A. D. Krieger, pp. 241-249. Memoirs No. 5. Society for American Archaeology and The University of Texas, Menasha, Wisconsin.

Jordan, T. G.

1981 Trails to Texas: Southern Routes of Western Cattle Ranching. University of Nebraska Press, Lincoln. 
Kantner, J.

2008 The Archaeology of Regions: From Discrete Analytical Toolkit to Ubiquitous Spatial Perspective. Journal of Archaeological Research 16(1):37-81.

Kay, M. and G. Sabo III

2006 Mortuary Ritual and Winter Solstice Imagery of the Harlan-Style Charnel House. Southeastern Archaeology 25(1):29-47.

Kelley, D. B. (editor)

1994 The McLelland and Joe Clark Sites: Protohistoric-Historic Caddoan Farmsteads in Southern Bossier Parish, Louisiana. Coastal Environments, Inc. Submitted to the U.S. Army Corps of Engineers, Vicksburg District.

1997 Two Caddoan Farmsteads in the Red River Valley: The Archeology of the McLelland and Joe Clark Sites. Research Series No. 51. Arkansas Archeological Survey, Fayetteville.

Kelley, D. B. and C. L. Coxe

1998 Cultural Resources Survey of Levee Rehabilitation/Restoration Areas along the Red River between Fulton, Arkansas and the Louisiana State Line: Items 4, 5, and 9. Coastal Environments, Inc., Baton Rouge. Submitted to the U.S. Army Corps of Engineers, Vicksburg District.

Kelley, D. B., T. K. Perttula, B. Nelson, D. G. Hunter, B. M Albert, J. A. Kelly, D. E. Wilson 2006 Interim Report on Archaeological Data Recovery at 41AN38, Anderson County, Texas. Coastal Environments, Inc. Submitted to the Texas Department of Transportation, Austin.

Kelley, J. C.

1986 Jumano and Patarabueye: Relations at Junta de los Rios. Anthropological Papers No. 77. Museum of
Anthropology, University of Michigan, Ann Arbor.

Kenmotsu, N. A.

1992 The Mayhew Site: A Possible Hasinai Farmstead, Nacogdoches County, Texas. Bulletin of the Texas Archeological Society 63:135-173.

Kenmotsu, N. A., J. E. Bruseth, and J. E. Corbin 1993 Moscoso and the Route in Texas: A Reconstruction. In The Expedition of Hernando de Soto West of the Mississippi, 1541-1543, edited by G. A. Young and M. P. Hoffman, pp. 106-131. University of Arkansas Press, Fayetteville.

Kenmotsu, N. A., and T. K. Perttula (editors)

1993 Archeology in the Eastern Planning Region, Texas: A Planning Document. Cultural Resource Management Report 3. Department of Antiquities Protection, Texas Historical Commission, Austin.

Kent, S.

1986 The Influence of Sedentism and Aggregation on Porotic Hyperostosis and Anemia: A Case Study. MAN 21:605-636.

Kibler, K. W.

2005 Broader Continental Connections through the Gulf Coastal Plain of Texas. In Gulf Coast Archaeology: The Southeastern United States and Mexico, edited by N. M. White, pp. 197-204. University Press of Florida, Gainesville.

King, F. B.

1984 Plant Remains from the Cedar Grove (3LA97) and Sentell (3LA128) Sites. In Cedar Grove: An Interdisciplinary Investigation of a Late Caddo Farmstead in the Red River Valley, edited by N. L. Trubowitz, pp. 207210. Research Series No. 23. Arkansas Archeological Survey, Fayetteville. 
Kleinschmidt, U. K. W.

1982 Review and Analysis of the A. C. Saunders Site, 41AN19, Anderson County, Texas. Master's thesis, Department of Anthropology, The University of Texas at Austin.

Kotter, S. M., R. Rogers, R. Taylor, K. ReeseTaylor, and W. P. Glander

1993 Archeological Investigations within the Monticello B-2 First Five Year Disturbance Area, Titus County, Texas. Document No. 920013. Espey, Huston \& Associates, Inc., Austin.

Krause, R. A.

2007 A Potter's Tale. In Plains Village Archaeology: Bison-hunting Farmers in the Central and Northern Plains, edited by S. A. Ahler and M. Kay, pp. 32-40. University of Utah Press, Salt Lake City.

Krieger, A. D.

1948 Importance of the "Gilmore Corridor" in Culture Contacts between Middle America and the Eastern United States. Bulletin of the Texas Archeological and Paleontological Society 19:155-178.

Krogman, W. M.

1962 The Human Skeleton in Forensic Medicine. Charles C. Thomas, Springfield Ill.

Lankford, G. E.

1992 Red and White: Some Reflections on Southern Symbolism. Southern Folklore 50(1):53-80.

2008 Looking for Lost Lore: Studies in Folklore, Ethnology, and Iconography. University of Alabama Press, Tuscaloosa.

La Vere, D.

1998 Life Among the Texas Indians: The WPA Narratives. Texas A\&M University Press, College Station.
Lee, C.

1997 Paleopathology of the HatchelMitchell-Moores Sites, Bowie County, Texas. Bulletin of the Texas Archeological Society 68:161-177.

1999 Origins and Interactions of the Caddo: A Study in Dental and Cranial Nonmetric Traits. Master's thesis, Department of Anthropology, Arizona State University, Tempe.

Lewis, G. A.

1987 The Clements Brothers' Farm Site 41CS25. Master's thesis, Department of Anthropology, The University of Texas at Austin.

Lipo, C. P., J. K. Feathers, and R. C. Dunnell

2005 Temporal Data Requirements, Luminescence Dates, and the Resolution of Chronological Structure of Late Prehistoric Deposits in the Central Mississippi Valley. American Antiquity 70(3):527-544.

Lohse, J. C., with contributions by T. K. Perttula and R. A. Ricklis

2004 Interim Report on Archaeological Testing at 41AN38 and 41AN159, Anderson County, Texas. Coastal Environments, Inc., Baton Rouge and Corpus Christi. Submitted to the Texas Department of Transportation, Austin.

2005 National Register Eligibility of the Weaver Creek Site, 41BW692, Bowie County, Texas. Archeological Studies Program, Report No. 69. Texas Department of Transportation, Environmental Affairs Division, Austin, and Coastal Environments, Inc., Baton Rouge and Corpus Christi.

Lonsdale, J. T., and D. J. Crawford

1928 Pseudo-Igneous Rock and Baked Shale from the Burning of Lignite, Freestone County, Texas. In 
Contributions to Geology, 1928. Bulletin No. 2801, pp. 147-158. University of Texas, Austin.

Loveland, C. J.

1986 Human Skeletal Remains from the Clark and Holdeman Sites, Red River County, Texas. Bulletin of the Texas Archeological Society 57:165-182.

1994

Vertebral Anomalies and Degenerative Lesions in the Caddoan Skeletal Population, KaufmanWilliams Site, Red River County, Texas. Bulletin of Texas Archeology 65:161-184.

Lyman, R. L. and M. J. O’Brien

2006 Measuring Time with Artifacts: A History of Methods in American Archaeology. University of Nebraska Press, Lincoln.

Lyman, R. L., M. J. O’Brien, and R. C. Dunnell 1997 The Rise and Fall of Culture History. Plenum Press, New York.

Martin, W. A., T. K. Perttula, N. A. Kenmotsu, L. Roark, J. Wise, J. E. Bruseth, J. Ippolito, V. Hubbard, and W. Kingsborough

1995 Cultural Resource Management Planning for the National Forest and Grasslands in Texas. Cultural Resource Management Report 6. Department of Antiquities Protection, Texas Historical Commission, Austin.

McClure, S. B.

2007 Gender, Technology, and Evolution: Cultural Inheritance Theory and Prehistoric Potters in Valencia, Spain. American Antiquity 72(3):485-508.

McClurkan, B. B., W. T. Field, and J. N. Woodall

1966 Excavations in Toledo Bend Reservoir, 1964-65. Papers of the Texas Archeological Salvage Project, No. 8. Texas Archeological Salvage Project, The University of Texas at Austin.
McGregor, D. E.

1993 Pisgah Ridge Chert Distributions: Evidence for Changing Territorial Size in North Central Texas. Bulletin of the Texas Archeological Society 64:247-267.

1997 Archaeological Investigations at 41HP137. In Archaeological Survey of Cooper Lake, Delivery Order Numbers 2, 3 \& 4, 1987: Cultural Resource Studies for Cooper Lake, Hopkins and Delta Counties, Texas, by D. E. McGregor, M. M. Green, D. H. Jurney, W. A. Martin, R. W. Moir, and J. W. Saunders, pp. 341-361. 2 Vols. Archaeology Research Program, Southern Methodist University, Dallas.

McGregor, D. E., M. M. Green, D. H. Jurney, W. A. Martin, R. W. Moir, and J. W. Saunders 1996 Archaeological Investigations at Cooper Lake, Delivery Order Numbers 2, 3, \& 4, 1987: Cultural Resource Studies for Cooper Lake, Hopkins and Delta Counties, Texas. Archaeology Research Program, Department of Anthropology, Southern Methodist University, Dallas.

Meindl, R.S. and C. O. Lovejoy

1985 Ectocranial Suture Closure: A Revised Method for the Determination of Skeletal Age at Death Based on the Lateral-Anterior Sutures. American Journal of Physical Anthropology 68:57-66.

Meltzer, D. J.

2003 A Study of Style and Function in a Class of Tools. In Style, Function, Transmission: Evolutionary Archaeological Perspectives, edited by M. J. O’Brien and R. L. Lyman, pp. 139-156. University of Utah Press, Salt Lake City.

Middlebrook, T.

1994 An Update of Archaeological Investigations at the Tyson Site 
(41SY92). Journal of Northeast Texas Archaeology 3:1-36.

1997 The Caddoan Occupation of the Attoyac and Angelina River Basins in the Middle Caddoan Period. Journal of Northeast Texas Archaeology 10:36-40.

Middlebrook, T. and T. K. Perttula

1997 The Middle Caddoan Period in East Texas: A Summary of the Findings of the East Texas Caddoan Research Group. Journal of Northeast Texas Archaeology 9:1-8.

Miller, M. R., III

1996 The Chronometric and Relative Chronology Project. Archaeological Technical Report No. 5. Anthropology Research Center, Department of Sociology and Anthropology, University of Texas at El Paso.

Mills, B. J.

1999 Ceramics and the Social Contexts of Food Consumption in the Northern Southwest. In Pottery and People: A Dynamic Interaction, edited by J. M. Skibo and G. M. Feinman, pp. 99-114. University of Utah Press, Salt Lake City.

Milner, G. R.

2004 The Moundbuilders: Ancient Peoples of Eastern North America. Thames \& Hudson, London.

Miroir, M. P., R. K. Harris, J. C. Blaine, and J. McVay

1973 Benard de la Harpe and the Nassonite post. Bulletin of the Texas Archeological Society 44:113-168.

Moore, C. B.

1912 Some Aboriginal Sites on Red River. Journal of the Academy of Natural Sciences of Philadelphia, Volume 14, part 4.
Moores, C. F. A., E. A. Fanning and E. E. Hunt, Jr.

1963a Formation and Resorption of Three Deciduous Teeth in Children. American Journal of Physical Anthropology 21:205-213.

1963b Age Variation of Formation Stages for Ten Permanent Teeth. Journal of Dental Research 42:1490-1502.

Morfi, Fr. J. A. de

1935 History of Texas, 1663-1779. Publications No. 6, edited by C. E. Castaneda. Quivira Society, Santa Fe.

Neff, H. and M. D. Glascock

2000 Compositional Variation in Caddoan and Other Ceramics from Northeastern Texas: Update on Results of Instrumental Neutron Activation Analysis. Missouri University Research Reactor, University of Missouri, Columbia.

Newell, H. P. and A. D. Krieger

1949 The George C. Davis Site, Cherokee County, Texas. Memoirs No. 5. Published jointly by the Society for American Archaeology and the University of Texas, Menasha, Wisconsin.

Newkumet, V. B. and H. L. Meredith

1988 Hasinai: A Traditional History of the Caddo Confederacy. Texas A\&M University Press, College Station.

O’Brien, M. J. and R. L. Lyman

1999 Seriation, Stratigraphy, and Index Fossils: The Backbone of Archaeological Dating. Kluwer Academic/Plenum Publishers, New York.

2003 Style, Function, Transmission: A Introduction. In Style, Function, Transmission: Evolutionary Archaeological Perspectives, edited by M. J. O’Brien and R. L. Lyman, 
pp. 1-32. University of Utah Press, Salt Lake City.

Ortner, D. J. and W. G. J. Putschar

1981 Identification of Pathological

Conditions in Human Skeletal

Remains. Contributions to

Anthropology No. 57. Smithsonian Institution, Washington, D.C.

Parsons, E. C.

$1941 \quad$ Notes on the Caddo. Memoirs No. 57. American Anthropological Association, Menasha, Wisconsin.

Pearce, J. E.

1920 Explorations near Frankston, Texas. MS on file, Texas Archeological Research Laboratory, The University of Texas at Austin.

1932 The Archaeology of East Texas. American Anthropologist 34:670-687.

Pearce, J. E. and A. M. Woolsey

1935 Notes on Field Work, Jasper Tucker Farm, Mrs. Joe Watkins Owner, 9 Miles southwest of Frankston, Anderson County, Texas, November 20 to November 22, 1935. MS on file, Texas Archeological Research Laboratory, The University of Texas at Austin.

Perino, G.

1981 Archeological Investigations at the Roden Site (Mc-215), McCurtain County, Oklahoma. Potsherd Press No. 1, Museum of the Red River, Idabel, Oklahoma.

Perino, G. and W. J. Bennett

1978 Archaeological Investigations at the Mahaffey Site, CH-1, Hugo Reservoir, Choctaw County, Oklahoma. Museum of the Red River, Idabel.

Perttula, T. K.

1984 Patterns of Prehistoric Lithic Raw Material Utilization in the Caddoan Area: The Western Gulf Coastal Plain.
In Prehistoric Chert Exploitation Studies from the Midcontinent, edited by B. M. Butler and E. E. May, pp. 129-148. Occasional Paper No. 2. Center for Archaeological Investigations, Southern Illinois University at Carbondale.

The Paleoindian Archaeological Record in Northeast Texas: Evidence from Avocational Collecting Activities. Current Research in the Pleistocene 6:19-21.

"The Caddo Nation": Archaeological and Ethnohistoric Perspectives. University of Texas Press, Austin.

1993 The Development of Agriculture in Northeast Texas before A.D. 1600. In Archeology in the Eastern Planning Region, Texas: A Planning Document, edited by N. A. Kenmotsu and T. K. Perttula, pp. 121-146. Cultural Resource Management Report 3. Texas Historical Commission, Department of Antiquities Protection, Austin.

1996 Caddoan Area Archaeology Since 1990. Journal of Archaeological Research 4(4):295-348.

1998 A Compendium of Radiocarbon and Oxidizable Carbon Ratio Dates from Archaeological Sites in East Texas, with a Discussion of the Age and Dating of Select Components and Phases. Radiocarbon 39(3):305-341.

2000 Functional and Stylistic Analyses of Ceramic Vessels from Mortuary Features at a $15^{\text {th }}$ and $16^{\text {th }}$ Century Caddo Site in Northeast Texas. Midcontinental Journal of Archaeology 25(1):101-151.

2001 The Analysis of Caddoan Ceramics from Four Sites in Rusk County, Texas. In NRHP Eligibility Testing (41RK107, 41RK240, 41RK242, 
41RK243, 41RK276, and 41RK286) and Additional Testing (41RK243) Investigations within the Oak Hill DIII Mine, Permit No. 46, Rusk County, Texas, by D. L. Sherman, pp. 95-115. Document No. 000237. PBS\&J, Austin.

Archaeological Evidence for the Long-Distance Exchange of Caddo Indian Ceramics in the Southern Plains, Midwest, and Southeastern United States. In Geochemical Evidence for Long-Distance Exchange, edited by M. D. Glascock, pp. 89-107. Bergin and Garvey, Westport, Connecticut.

2004a 41AN38 Ceramics. In Interim Report on Archaeological Testing at 41AN38 and 41AN159, Anderson County, Texas, by J. C. Lohse, with contributions by T. K. Perttula and R. A. Ricklis, pp. 30-44. Coastal Environments, Inc., Baton Rouge and Corpus Christi.

2004b The Prehistoric and Caddoan Archeology of the Northeastern Texas Pineywoods. In The Prehistory of Texas, edited by T. K. Perttula, pp. 370-407. Texas A\&M University Press, College Station.

2004c An Introduction to Texas Prehistoric Archeology. In The Prehistory of Texas, T. K. Perttula, editor, pp. 5-14. Texas A\&M University Press, College Station.

2007a One Attempt at Defining Allen Phase Subclusters. Journal of Northeast Texas Archaeology 26:77-81.

2007b Seriation proposed by Kleinschmidt (1982:Table 19) of Allen phase and Frankston phase Sites in the Upper Neches River Basin. Journal of Northeast Texas Archaeology 26:150153. 2007c Archeological Investigations of the Lang Pasture (41AN38) Midden Deposits on Private Property West of the SH 155 Right-of-Way, Anderson County, Texas. Caddo Archeology Journal 16:27-36.

2008 Caddo Agriculture on the Western Frontier of the Eastern Woodlands. Plains Anthropologist 53(205):79-105.

2009 Frankston Phase Ceramics from the ALCOA \#1 (41AN87) Site, Mound Prairie Creek, Anderson County, Texas. Journal of Northeast Texas Archaeology 29:23-44.

Perttula, T. K. (editor)

1999 The Hurricane Hill Site (41HP106): The Archaeology of a Late Archaic/Early Ceramic and EarlyMiddle Caddoan Settlement in Northeast Texas. 2 Vols. Special Publication No. 4. Friends of Northeast Texas Archaeology, Pittsburg and Austin.

2005 Archeological Investigations at the Pilgrim's Pride Site (41CP304), a Titus Phase Communityr in the Big Cypress Creek Basin. 2 Vols. Report of Investigations No. 30. Archeological \& Environmental Consultants, LLC, Austin, in press.

2008a Lake Naconiche Archeology, Nacogdoches County, Texas: Results of the Data Recovery Excavations at Five Prehistoric Archeological Sites. 2 Vols. Report of Investigations No. 60. Archeological \& Environmental Consultants, LLC, Austin.

2008b The Archeology of the Roitsch Site (41RR16), an Early to Historic Caddo Period Village on the Red River in Northeast Texas. In Collected Papers from Past Texas Archeological Society Summer Field Schools, edited by T. K. Perttula, pp. 313-628. Special 
Publication No. 5. Texas Archeological Society, San Antonio.

Perttula, T. K. and J. E. Bruseth

1983 Early Caddoan Subsistence Strategies, Sabine River Basin, East Texas. Plains Anthropologist 28(99):9-21.

1995 Trade and Exchange in Eastern Texas, 1100 B.C.-A.D. 800. Louisiana Archaeology 17:93-121.

Perttula, T. K., J. E. Bruseth, N. A. Kenmotsu, D. J. Prikryl, W. A. Martin, L. Banks, J. Smith, N. G. Reese, and S. A. Iruegas

2001 Archeological Investigations on the Red River and Tributaries: Summary of the Findings of the 1991 and 1992 Texas Archeological Society Field School in Red River and Lamar Counties, Texas. Bulletin of the Texas Archeological Society 72:250.

Perttula, T. K., R. Cast, B. Gonzalez, and B. Nelson 2008

Documentation of Unassociated and Culturally Unidentifiable Funerary Objects in the U.S. Army Corps of Engineers, Fort Worth District Collections Housed at the Texas Archeological Research Laboratory at The University of Texas at Austin. Historic Preservation Program, Caddo Nation of Oklahoma, Binger, Oklahoma.

Perttula, T. K., R. C. Fields, J. E. Corbin, and N. A. Kenmotsu

1993 The Emergence of Sedentism in the Northeast Texas Archeological Region, ca. 500 B.C. to A.D. 1000. In Archeology in the Eastern Planning Region, Texas: A Planning Document, edited by N. A. Kenmotsu and T. K. Perttula, pp. 97-120. Cultural Resource Management Report 3. Texas Historical Commission, Department of Antiquities Protection, Austin.
Perttula, T. K. and T. Middlebrook

2009 Prehistoric Caddo Ceramics from the Henry Lake Site (41CE324), Cherokee County, Texas. Journal of Northeast Texas Archaeology 29:9-21.

Perttula, T. K. and B. Nelson

2006 Test Excavations at Three Caddo Sites at Mission Tejas State Park, Houston County, Texas. Report of Investigations No. 76. Archeological \& Environmental Consultants, LLC, Austin.

2007 Archeological Survey Investigations and Test Excavations at 41CE354 at the North and South Lake areas of the H.R.C. Cherokee Tree Farm, L. P. Project, Cherokee County, Texas. Report of Investigations No. 80. Archeological \& Environmental Consultants, LLC, Austin.

Perttula, T. K. and R. Rogers

2007 The Evolution of a Caddo Community in Northeastern Texas: The Oak Hill Village Site (41RK214), Rusk County, Texas. American Antiquity 72(1):71-94.

Perttula, T. K. and D. L. Sherman

2008 Data Recovery Investigations at the Ear Spool Site (41TT653), Titus County, Texas. Document No. 070205. PBS\&J, Austin.

Perttula, T. K., B. D. Skiles, and B. C. Yates 1993 The Carlisle Site (41WD46), a Middle Caddoan Occupation on the Sabine River, Wood County, Texas. Notes on Northeast Texas Archaeology 1:34-62.

Perttula, T. K., M. Tate, H. Neff, J. W. Cogswell, M. D. Glascock, E. Skokan, S. Mulholland, R. Rogers, and B. Nelson

1998 Analysis of the Titus Phase Mortuary Assemblage at the Mockingbird Site (“Kahbakayammaahin”), $41 T T 550$. Document No. 970849. PBS\&J, Austin. 
Perttula, T. K., with contributions by D. E. Wilson and M. Walters

2006 A Study of the Buddy Calvin Jones Collection from Northeast Texas Caddo Sites. Special Publication No. 6. Friends of Northeast Texas Archaeology, Austin and Pittsburg.

Phillips, P.

1958 Application of the Wheat-GiffordWasley taxonomy to eastern ceramics. American Antiquity 24:117-130.

1970 Archaeological Survey in the Lower Yazoo Basin, Mississippi, 1949-1955. 2 Parts. Papers of the Peabody Museum of Archaeology and Ethnology, Volume 60. Harvard University, Cambridge, Massachusetts.

Phillips, P., J. A. Ford, and J. B. Griffin

1951 Archaeological Survey in the Lower Mississippi Alluvial Valley, 19401947. Papers of the Peabody Museum of Archaeology and Ethnology, Volume 25. Harvard University, Cambridge, Massachusetts.

Pires-Ferreira, Jane W., and Kent V. Flannery 1976 Ethnographic Models for Formative Exchange. In The Early Mesoamerican Village, edited by Kent V. Flannery, pp. 286-292. Academic Press, New York.

Pollard, M., C. Batt, B. Stern, and S. M. M. Young 2007

Analytical Chemistry in Archaeology. Cambridge University Press, Cambridge.

Powell, G. S. and N. H. Lopinot

2000 Archeological Plant Remains from the Helm Site. In Data Recovery at the Helm Site, 3HS449, Hot Spring County, Arkansas, by R. H. Lafferty III, A. M. Early, M. C. Sierzchula, M. C. Hill, G. S. Powell, N. H. Lopinot, L. S. Cummings, S. L. Scott, S. K. Nash, and T. K. Perttula, pp. 187-229.
MCRA Report 2000-1. MidContinental Research Associates, Lowell, Arkansas.

Powell, M. L.

1985 The Analysis of Dental Wear and Caries for Dietary Reconstruction. In The Analysis of Prehistoric Diets, edited by R. I. Gilbert Jr. and J. H. Mielke, pp. 307-338. Academic Press, Orlando.

Prewitt, E. R.

1983 Andice: An Early Archaic Dart Point Type. La Tierra 10(3):1-6.

1995 Distribution of Typed Projectile Points in Texas. Bulletin of the Texas Archeological Society 66:83-173.

Prewitt, E. R., and C. K. Chandler

1992 Axtell: A Middle Archaic Dart Point Type. La Tierra 19(1):15-20.

Prikryl, Daniel J.

1990 Lower Elm Fork Prehistory. Office of the State Archaeologist Report No. 37. Texas Historical Commission, Austin.

Rafferty, S. M. and R. Mann

2005 Introduction: Smoking Pipes and Culture. In Smoking and Culture: The Archaeology of Tobacco Pipes in Eastern North America, edited by S. Rafferty and R. Mann, pp. xi-xx. The University of Tennessee Press, Knoxville.

Rakita, G. F. M. and J. E. Buikstra

2005 Introduction. In Interacting with the Dead: Perspectives on Mortuary Archaeology for the New Millennium, edited by G. F. M. Rakita, J. E. Buikstra, L. A. Beck, and S. R. Williams, pp. 1-11. University Press of Florida, Gainesville. 
Read, D. W.

2007 Artifact Classification: A Conceptual and Methodological Approach. Left Coast Press, Walnut Creek, California.

Reimer, P., M. Baillie, and E. Bard

2004 Intcal04 Terrestrial Radiocarbon Age Calibration, 0-26 Cal Kyr BP. Radiocarbon 46:1029-1058.

Rice, P. M.

1987 Pottery Analysis: A Sourcebook. University of Chicago Press, Chicago.

1996 Recent Ceramic Analysis: 2. Composition, Production, and Theory. Journal of Archaeological Research 4(3):165-202.

Ricklis, R. A.

2004 The Archeology of the Native American Occupation of Southeast Texas. In The Prehistory of Texas, edited by T. K. Perttula, pp. 181-202. Texas A\&M University Press, College Station.

Ricklis, R. A. (compiler and editor)

2004 Archaeological Testing at 41UR77 on Big Sandy Creek, Upshur County, Texas: An Interim Report. Review draft. Coastal Environments, Inc., Baton Rouge and Corpus Christi.

Ricklis, R. A. and M. B. Collins

1994 Archaic and Late Prehistoric Human Ecology in the Middle Onion Creek Valley, Hays County, Texas. 2 Vols. Studies in Archeology 19. Texas Archeological Research Laboratory, The University of Texas at Austin.

Ricklis, R. A. and T. K. Perttula

2004 Conclusions and Recommendations. In Interim Report on Archaeological Testing at 41AN38 and 41AN159, Anderson County, Texas, by J. C. Lohse, with contributions by T. K. Perttula and R. A. Ricklis, pp. 60-64. Coastal Environments, Inc., Baton Rouge and Corpus Christi.
Rogers, D. S. and P. R. Ehrlich

2008 Natural selection and cultural rates of change. Proceedings of the National Academy of Sciences 105(9):34163420.

Rogers, J. D.

1997 Stable Isotope Analysis and Diet in Eastern Oklahoma. Manuscript on file, Department of Anthropology, National Museum of Natural History, Smithsonian Institution, Washington. D.C.

Rogers, J. D. and G. M. Sabo III

2004 Caddo. In Southeast, Volume 14, Handbook of the North American Indians, edited by R. D. Fogelson, pp. 616-631. Smithsonian Institution, Washington, D.C.

Rogers, R. and T. K. Perttula

2004 The Oak Hill Village (41RK214), Rusk County, Texas. Document No. 030083. PBS\&J, Austin.

Rogers, R., M. A. Nash, and T. K. Perttula 2001 Excavations at the Herman Bellew Site (41RK222), Rusk County, Texas. Document No. 000021. PBS\&J, Austin.

Rogers, R., M. B. Cliff, T. K. Perttula, G. Rutenberg, S. Victor, P. Dering, and $\mathrm{M}$. Malainey

2003 Excavations at the Alex Justiss Site, 41TT13, Titus County, Texas. Archeological Studies Program Report No. 36. Texas Department of Transportation, Austin.

Rogers, S. L.

1975 Artificial Deformation of the Head: New World examples of Ethnic Mutilation and Notes on its Consequences. San Diego Museum Papers No. 8. San Diego Museum of Man, San Diego. 
Rose, J. C.

1984 Bioarchaeology of the Cedar Grove Site. In Cedar Grove: An Interdisciplinary Investigation of a Late Caddo Farmstead in the Red River Valley, edited by N. L. Trubowitz, pp. 227-256. Research Series No. $23 . \quad$ Arkansas Archeological Survey, Fayetteville.

Rose, J. C. and B. Burnett

1990 The Eastern Portion. In The Archeology and Bioarchaeology of the Gulf Coastal Plan: Volume 2, by D. A. Story, J. A. Guy, B. A. Burnett, M. D. Freeman, J. C. Rose, D. G. Steele, B. W. Olive, and K. J. Reinhard, pp. 83-102. Research Series No. 38. Arkansas Archeological Survey, Fayetteville.

Rose, J. C., B. A. Burnett, M. S. Nassaney, and F. M. Blaeuer

1984 Paleopathology and the Origins of Maize Agriculture in the Lower Mississippi Valley and Caddoan Culture Areas. In Paleopathology at the Origins of Agriculture, edited by M. N. Cohen and G. J. Armelagos, pp. 393-425. Academic Press, New York.

Rose, J. C., M. P. Hoffman, B. A. Burnett, A. M. Harmon, and J. E. Barnes

1998 Skeletal Biology of the Prehistoric Caddo. In The Native History of the Caddo: Their Place in Southeastern Archeology and Ethnohistory, edited by T. K. Perttula and J. E. Bruseth, pp. 123-136. Studies in Archeology 30. Texas Archeological Research Laboratory, The University of Texas at Austin.

Rose, J. C. and M. K. Marks

1985 Bioarcheology of the Alexander Site. In The Alexander Site, Conway County, Arkansas, edited by E. T. Hemmings and J. H. House, pp. 79-98. Research Series No. 24. Arkansas Archeological Survey, Fayetteville.
Rose, J. C., D. G. Steele, B. A. Burnett, K. J. Reinhard, and B. W. Olive

1999 Gulf Coastal Plain. In Bioarcheology of the South Central United States, edited by J. C. Rose, pp. 83-132. Research Series No. 55. Arkansas Archeological Survey, Fayetteville.

Rye, O. S.

1981 Pottery Technology: Principles and Reconstruction. Manuals on Archaeology 4. Taraxacum, Washington, D.C.

Sabo, G., III

2008 The Teran Map as a Seventeenth Century Caddo Cosmogram. Chapter 15 In The Archaeology of the Caddo, edited by T. K. Perttula and C. P. Walker. University of Nebraska Press, in press.

Saunders, J. W. and T. Allen

1997 The Archaic Period. Louisiana Archaeology 22:1-30.

Saunders, J. W., R. D. Mandel, R. T. Saucier, E. T. Allen, C. T. Hallmark, J. K. Johnson, E. H. Jackson, C. M. Allen, G. L. Stringer, D. S. Frink, J. K. Feathers, S. Williams, K. J. Gremillion, M. F. Vidrine, and R. Jones

1997 A Mound Complex in Louisiana at 5400-5000 Years before the Present. Science 277:1796-1799.

Saxe, A. A.

1970 Social Dimensions of Mortuary Practices. Ph.D. dissertation, Department of Anthropology, University of Michigan, Ann Arbor.

Scarry, C. M.

2003 Patterns of Wild Plant Utilization in the Prehistoric Eastern Woodlands. In People and Plants in Ancient Eastern North America, edited by P. E. Minnis, pp. 50-104. Smithsonian Books, Washington, D.C. 
Scarry, C. M. and J. F. Scarry

2005 Native American 'Garden Horticulture' in Southeastern North America. World Archaeology 37(2):259-274.

Schambach, F. F.

1982 An Outline of Fourche Maline Culture in Southwest Arkansas. In Arkansas Archeology in Review, edited by N. L. Trubowitz and M. D. Jeter, pp. 132197. Research Series No. 15. Arkansas Archeological Survey, Fayetteville.

1983

The Archeology of the Great Bend Region in Arkansas. In Contributions to the Archeology of the Great Bend Region of the Red River Valley, Southwest Arkansas, edited by F. F. Schambach and F. Rackerby, pp. 1-11. Research Series No. 22. Arkansas Archeological Survey, Fayetteville.

1989 The End of the Trail: The Route of Hernando De Soto's Army Through Southwest Arkansas and East Texas. The Arkansas Archeologist 27/28:933.

1996 Mounds, Embankments, and Ceremonialism in the TransMississippi South. In Mounds, Embankments, and Ceremonialism in the Midsouth, edited by R. C. Mainfort and R. Walling, pp. 36-43. Research Series No. 46. Arkansas Archeological Survey, Fayetteville.

1997 The Development of the Burial Mound Tradition in the Caddo Area. Journal of Northeast Texas Archaeology 9:53-72.

1998 Pre-Caddoan Culture in the TransMississippi South: A Beginning Sequence. Research Series No. 53. Arkansas Archeological Survey, Fayetteville.

2001 Fourche Maline and Its Neighbors: Observations on an Important
2002

Woodland Period Culture of the Trans-Mississippi South. The Arkansas Archeologist 40:21-50.

Fourche Maline: A Woodland Period Culture of the Trans-Mississippi South. In The Woodland Southeast, edited by D. G. Anderson and R. C. Mainfort, Jr., pp. 91-112. University of Alabama Press, Tuscaloosa.

Schambach, F. F., N. L. Trubowitz, F. Rackerby, E. T. Hemmings, W. F. Limp, and J. E. Miller, III

1982 Test Excavations at the Cedar Grove Site (3LA97): A Late Caddo Farmstead in the Great Bend Region, Southwest Arkansas. In Contributions to the Archeology of the Great Bend Region, edited by F. F. Schambach and F. Rackerby, pp. 90-140. Research Series 22. Arkansas Archeological Survey, Fayetteville.

Schambach, F. F., J. C. Weber, and A. M. Early

n.d. Typology and Nomenclature for South Arkansas Ceramics, Part II: The Descriptive Classification. Ms. on file, Arkansas Archeological Survey, Fayetteville.

Schmidly, D. J.

2002 Texas Natural History: A Century of Change. Texas Tech University Press, Lubbock.

Schniebs, LeeAnna

2007 Animal Remains. In Archeological Survey Investigations and Test Excavations at 41CE354 at the North and South Lake Areas of the H.R.C. Cherokee Tree Farm, L.P. Project, Cherokee County, Texas, by Timothy K. Perttula and Bo Nelson, pp. 120124. Archeological and Environmental Consultants, LLC. Report of Investigations No. 80. 
Schoeninger, M. J.

1989 Prehistoric Human Diet. In Chemistry of Prehistoric Human Bone, edited by T. D. Price, pp. 38-67. Cambridge University Press, Cambridge.

Schoeninger, Margaret J. and Michael J. DeNiro 1983 Stable Nitrogen Isotope Ratios of Bone Collagen Reflect Marine and Terrestrial Components of Prehistoric Human Diet. Science 220:1381-1383.

Schoeninger, M. J. and M. R. Schurr

1998 Human Subsistence at Moundville: The Stable-Isotope Data. In Archaeology of the Moundville Chiefdom, edited by V. J. Knight, Jr. and V. P. Steponaitis, pp. 120-132. Smithsonian Institution Press, Washington, D.C.

Schroeder, S.

1999 Maize Productivity in the Eastern Woodlands and Great Plains of North America. American Antiquity 64(2):499-516.

Scott, E. C.

1979 Principal Axis Analysis of Dental Attrition Data. American Journal of Physical Anthropology 51:203-211.

Scott, S. L. and H. E. Jackson

1998 Early Caddo Ritual and Patterns of Animal Use: An Analysis of Faunal Remains from the Crenshaw Site (3MI6), Southwestern Arkansas. The Arkansas Archeologist 37:1-37.

Shafer, H. J.

1968 Toward an Application of the Modified Wheat-Gifford-Wasley

Taxonomy to Fulton Aspect, Frankston and Allen Focus Pottery. MS on file, Texas Archeological Research Laboratory, The University of Texas at Austin.

1981 Archeological Investigations at the Attaway Site, Henderson County, Texas. Bulletin of the Texas Archeological Society 52:147-178.
2003

Mimbres Archaeology at the NAN Ranch Ruin. University of New Mexico Press, Albuquerque.

Sherman, E., D. H. Jurney, P. Wolff, W. Kingsborough, D. Mangum, V. M. Owens, and J. Ippolito

1999 A Report on the Conduct of Pilot Surveys and Archeological Survey Planning on the Angelina, Davy Crockett, Sabine, and Sam Houston National Forests in Texas. National Forests and Grasslands in Texas, U.S. Department of Agriculture, Forest Service, Lufkin.

Silverman, $\mathrm{H}$.

2002 Introduction: The Space and Place of Death. In The Space and Place of Death, edited by H. Silverman and D. B. Small, pp. 1-11. Archeological Papers No. 11. American Anthropological Association, Washington, D.C.

Skibo, J. M.

1992 Pottery Function: A Use-Alteration Perspective. Plenum Press, New York.

Slaughter, B. H. and B. R. Hoover

1965 An Antler Artifact from the Late Pleistocene of Northeastern Texas. American Antiquity 30:351-352.

Smith, B. D. and C. W. Cowan

2003 Domesticated Crop Plants and the Evolution of Food Production Economies in Eastern North America. In People and Plants in Ancient Eastern North America, edited by P. E. Minnis, pp. 105-125. Smithsonian Books, Washington, D.C.

Smith, B. H.

1984 Patterns of Molar Wear in HunterGatherers and Agriculturalists. American Journal of Physical Anthropology 63:39-56. 
Speakman, R. J., M. D. Glascock, R. H. Tykot, C. Descantes, J. J. Thatcher, C. E. Skinner, and K. M. Lienhop

2007 Selected Applications of Laser Ablation Inductively Coupled PlasmaMass Spectrometry to Archaeological Research. In Archaeological Chemistry: Analytical Techniques and Archaeological Interpretation, edited by M. D. Glascock, R. J. Speakman, and R. S. Popelka-Filcoff, pp. 275296. ACS Symposium Series 968. American Chemical Society, Washington, D.C.

Stahle, D. W.

1996 The Hydroclimatic Application of Tree-Ring Chronologies. In Tree Rings, Environment and Humanity: Proceedings of the International Conference, Tucson, Arizona, 17-21 May 1994, edited by J. S. Dean, D. M. Meko, and T. W. Sweetman, pp. 119126. Radiocarbon, Department of Geosciences, The University of Arizona, Tucson.

Stahle, D. W. and M. K. Cleaveland

1988 Texas Drought History Reconstructed and Analyzed from 1698 to 1980. Journal of Climate 1:59-74.

1992 Reconstruction and Analysis of Spring Rainfall over the Southeastern U.S. for the Past 1000 Years. Bulletin of the American Meteorological Society 73:1947-1961.

1993 Southern Oscillation Extreme Reconstructed from Tree Rings of the Sierra Madre Occidental and southern Great Plains. Journal of Climate 6:129-140.

1994 Tree-Ring Reconstructed Rainfall over the Southeastern U.S.A. during the Medieval Warm period and Little Ice Age. Climatic Change 26:194-212.
1995

Texas Paleoclimatic Data from Daily and Millennial Time Scales. In The Changing Climate of Texas: Predictability and Implications for the Future, edited by J. Norwine, J. R. Giardino, G. R. North, and J. B. Valdes, pp. 49-69. GeoBooks, College of Geosciences and Maritime Studies, Texas A\&M University, College Station.

Stahle, D. W., M. K. Cleaveland, and J. G. Hehr 1985 A 450-Year Drought Reconstruction for Arkansas, United States. Nature 316:530-532.

Stark, B. L.

1985 Archaeological Identification of Pottery Production Locations: Ethnoarchaeological and Archaeological Data in Mesoamerica. In Decoding Prehistoric Ceramics, edited by B. A. Nelson, pp. 158-194. Southern Illinois University Press, Carbondale.

Stark, M. T.

1999 Social Dimensions of Technical Choice in Kalinga Ceramic Traditions. In Material Meanings: Critical Approaches to the Interpretation of Material Culture, edited by E. S. Chilton, pp. 24-43. University of Utah Press, Salt Lake City.

2003 Current Issues in Ceramic Ethnoarchaeology. Journal of Archaeological Research 11(3):193242.

2006 Glaze Ware Technology, the Social Lives of Pots, and Communities of Practice in the Late Prehistoric Southwest. In The Social Life of Pots: Glaze Wares and Cultural Dynamics in the Southwest, $A D$ 1250-1680, edited by J. A. Habicht-Mauche, S. L. Eckert, and D. L. Huntley, pp. 17-33. University of Arizona Press, Tucson. 
Steele, D. G.

1976 The estimation of sex on the basis of the talus and calcaneus. American Journal of Physical Anthropology 45:581-88.

Steele, D. G. and C. A. Bramblett

1988 The Anatomy and Biology of the Human Skeleton. Texas A\&M University Press, College Station, Texas.

Steele, D. G., G. R. Colby, B, W, Baker, D. L. Carlson, H. D. Dockall, P. M. Landau, S. K. McCormick, B. W. Olive, J. P. Powell, B. S. Schaffer

1993 Texas A\&M University physical anthropology data form. Unpublished manuscript. Department of Anthropology, Texas A\&M University, College Station.

Steponaitis, V. P.

1984 Technological Studies of Prehistoric Pottery from Alabama: Physical Properties and Vessel Function. In The Many Dimensions of Pottery: Ceramics in Archaeology and Anthropology, edited by S. E. van der Leeuw and A. C. Pritchard, pp. 79122. Universiteit van Amsterdam, Amsterdam.

Stewart, T. D.

1979 Essentials of Forensic Anthropology Especially as Developed in the United States. Charles C. Thomas, Springfield, Illinois.

Stini, W. A.

1985 Growth Rates and Sexual Dimorphism in Evolutionary Perspective. In The Analysis of Prehistoric Diets, edited by R. I. Gilbert, Jr. and J. H. Mielke, pp. 104-155. Academic Press, New York.

Story, D. A.

1981 An Overview of the Archeology of East Texas. Plains Anthropologist 26:139-156.
1990 Cultural History of the Native Americans. In The Archeology and Bioarcheology of the Gulf Coastal Plain, by D. A. Story, J. A. Guy, B. A. Burnett, M. D. Freeman, J. C. Rose, D. G. Steele, B. W. Olive, and K. J. Reinhard, pp. 163-366. 2 Vols. Research Series No. 38. Arkansas Archeological Survey, Fayetteville.

1995 General Summary and Synthesis. In The Deshazo Site, Nacogdoches County, Texas, Volume 2: Artifacts of Native Manufacture, edited by D. A. Story, pp. 233-247. Studies in Archeology 21. Texas Archeological Research Laboratory, The University of Texas at Austin.

1968-1970

Archeological Investigations at the George C. Davis Site, Cherokee County, Texas. Bulletin of the Texas Archeological Society 68:1-113.

1998 The George C. Davis Site: Glimpses into Early Caddoan Symbolism and Ideology. In The Native History of the Caddo: Their Place in Southeastern Archeology and Ethnohistory, edited by T. K. Perttula and J. E. Bruseth, pp. 9-43. Studies in Archeology 30. Texas Archeological Research Laboratory, The University of Texas at Austin.

2000

Introduction. In The George C. Davis Site, Cherokee County, Texas, by H. P. Newell and A. D. Krieger, pp. 1-31. Second edition. Society for American Archaeology, Washington, D.C.

Story, D. A. (editor)

1981 Archeological Investigations at the George C. Davis Site, Cherokee County, Texas: Summers of 1979 and 1980. Occasional Papers No. 1. Texas Archeological Research Laboratory, The University of Texas at Austin. 
1982

The Deshazo Site, Nacogdoches County, Texas, Vol. 1. Texas Antiquities Permit Series No. 7. Texas Antiquities Committee, Austin.

1995

The Deshazo Site, Nacogdoches County, Texas, Volume 2: Artifacts of Native Manufacture. Studies in Archeology 21. Texas Archeological Research Laboratory, The University of Texas at Austin.

Story, D. A. and D. G. Creel

1982 The Cultural Setting. In The Deshazo Site, Nacogdoches County, Texas, Vol. 1, edited by D. A. Story, pp. 20-34. Texas Antiquities Permit Series No. 7. Texas Antiquities Committee, Austin.

Story, D. A. and S. Valastro, Jr.

1977 Radiocarbon Dating and the George C. Davis Site, Texas. Journal of Field Archaeology 4:63-89.

Stuiver, M.

1993 A Note on Single-Year Calibration of the Radiocarbon Time Scale, AD 1510-1954. Radiocarbon 35(1):67-72.

Suhm, D. A. and E. B. Jelks (editors)

1962 Handbook of Texas Archeology: Type Descriptions. Special Publication No. 1, Texas Archeological Society and Bulletin No. 4, Texas Memorial Museum Bulletin 4, Austin.

Suhm, D. A. and A. D. Krieger, with the collaboration of E. B. Jelks

1954 An Introductory Handbook of Texas Archeology. Bulletin of the Texas Archeological Society 25:1-562.

Sullivan, A. P.

1988 Prehistoric Southwestern Ceramic Manufacture: The Limitations of Current Evidence. American Antiquity 53(1):23-35.

Swanton, J. R.

1942 Source Material on the History and Ethnology of the Caddo Indians.
Bulletin 132. Smithsonian Institution, Bureau of American Ethnology, Washington, D.C.

Talma, A. S. and J. C. Vogel

1993 A Simplified Approach to Calibrating C14 Dates. Radiocarbon 35(2):317322.

Thoms, A. V.

2008 The fire stones carry: Ethnographic records and archaeological expectations for hot-rock cookery in western North America. Journal of Anthropological Archaeology 27(4):443-460.

Thurmond, J. P.

1990 Archeology of the Cypress Creek Basin, Northeastern Texas and Northwestern Louisiana. Studies in Archeology 5. Texas Archeological Research Laboratory, The University of Texas at Austin.

Tieszen, Larry L. and T. Fagre

1993 Effects of Diet Quality and Composition on the Isotopic Composition of Respiratory CO2, Bone Collagen, Bioapatite, and Soft Tissues. In Prehistoric Human Bone: Archaeology at the Molecular Level, edited by J. B. Lambert and G. Grupe, pp. 121-155. Springer-Verlag, New York.

Tiné, A. and L. Tieszen

1994 Bioarchaeology. In The McLelland and Joe Clark Sites: Protohistoric and Historic Caddoan Farmsteads in Southern Bossier Parish, Louisiana, edited by D. B. Kelley, pp. 213-238. Report submitted to U.S. Army Corps of Engineers, Vicksburg District.

Tomka, S. A.

2001 The Effect of Processing Requirements on Reduction Strategies and Tool Form: A New Perspective. In Lithic Debitage: Context, Form, Meaning, edited by W. Andrefksy, Jr., 
pp. 207-223. University of Texas Press, Austin.

Trinkley, M.

1995 Plant Resources. In Town Creek Indian Mound: A Native American Legacy, by J. L. Coe, pp. 117-135. University of North Carolina Press, Chapel Hill.

Trubowitz, N. L. (editor)

1984 Cedar Grove: An Interdisciplinary Investigation of a Late Caddo Farmstead in the Red River Valley. Research Series No. 23. Arkansas Archeological Survey, Fayetteville.

Tschopik, H., Jr.

1941 Navajo Pottery Making: An Inquiry into the Affinities of Navaho Painted Pottery. Papers of the Peabody Museum of American Archaeology and Ethnology, Vol. XVII, No. 1. Peabody Museum of American Archaeology and Ethnology, Harvard University, Cambridge, Massachusetts.

Turner, C. G., II

1979 Dental Anthropological Indications of Agriculture Among the Jomon People of Central Japan. American Journal of Physical Anthropology 48:101-106.

Turner, Ellen Sue, and Thomas R. Hester 1999 A Field Guide to Stone Artifacts of Texas Indians. Third edition. Gulf Publishing, Lanham, Maryland.

Turner, R. L.

1992 Prehistoric Mortuary Remains at the Tuck Carpenter Site, Camp County, Texas. Studies in Archeology No. 10. Texas Archeological Research Laboratory, The University of Texas at Austin.
Turner, R. L. and J. E. Smith, with contributions by T. K. Perttula, B. Nelson, M. Walters, and B. Gonzalez

2003 The Harold Williams Site (41CP10) and the Texas Archeological Society Field School of 1967. Bulletin of the Texas Archeological Society 73:1-68.

Ubelaker, D. H.

1978 Human Skeletal Remains: Excavation, Analysis, Interpretation. Taraxacum, Washington, D.C.

van der Leeuw, S.

2002 Giving the Potter a Choice: Conceptual aspects of pottery technique. In Technological Choices: Transformation in Material Cultures since the Neolithic, edited by $\mathrm{P}$. Lemonnier, pp. 238-288. Routledge, London.

Vogel, G.

2002 A Handbook of Soil Descriptions for Archeologists. Technical Paper 11. Arkansas Archeological Survey, Fayetteville.

Voss, B. L.

2008 The Archaeology of Ethnogenesis: Race and Sexuality in Colonial San Francisco. University of California Press, Berkeley.

Walker, C. P.

2009 Archaeo-geophysical Investigations at the J. T. King Site (41NA15): Some Preliminary Results. Paper presented at the $16^{\text {th }}$ East Texas Archeological Conference, Tyler.

Walter, T. L.

2007 Espiritu Santo de Zuniga: A Frontier Mission in South Texas. University of Texas Press, Austin. 
Walters, $\mathrm{M}$.

2008 Life on Jackson Creek, Smith County, Texas: Archeological Investigations of a $14^{\text {th }}$ Century Caddo Domicile at the Leaning Rock Site (41SM325). Caddo Archeology Journal 17:1-119.

Walters, M. and P. Haskins

2000 The Bryan Hardy Site (41SM55), Smith County, Texas. Journal of Northeast Texas Archaeology 12:1-26.

Walters, M., P. Haskins, D. H. Jurney, S. E. Goldborer, and T. K. Perttula

1998 Archaeological Investigations at the Redwine Site (41SM193), Smith County, Texas. Journal of Northeast Texas Archaeology 11:1-38.

Waters, M. R. and T. W. Stafford, Jr.

2007 Redefining the Age of Clovis: Implications for the Peopling of the Americas. Science 315:1122-1126.

Webb, C. H.

1959 The Belcher Mounds, A Stratified Caddoan Site in Caddo Parish, Louisiana. Memoirs No. 16. Society for American Archaeology, Salt Lake City.

1981 Stone Points and Tools of Northwestern Louisiana. Special Publication No. $1 . \quad$ Louisiana Archaeological Society.

1984 The Bellevue Focus: A MarksvilleTroyville Manifestation in Northwestern Louisiana. Louisiana Archaeology 9:251-274.

Webb, C. H. and R. R. McKinney

1975 Mounds Plantation (16CD12), Caddo Parish, Louisiana. Louisiana Archaeology 2:39-127.
Webb, C. H., F. E. Murphey, W. G. Ellis, and H. R. Green

1969 The Resch Site, 41HS16, Harrison County, Texas. Bulletin of the Texas Archeological Society 40:3-106.

Webb, C. H., J. L. Shiner, and E. W. Roberts

1971 The John Pearce Site (16CD56): A San Patrice Site in Caddo Parish, Louisiana. Bulletin of the Texas Archeological Society 42:1-49.

Wedel, M. M.

1978 La Harpe's 1719 Post on the Red River and Nearby Caddo Settlements. Bulletin No. 30. Texas Memorial Museum, Austin.

Weinstein, R. A., D. B. Kelley, and J. W. Saunders (editors)

2003 The Louisiana and Arkansas Expeditions of Clarence Bloomfield Moore. University of Alabama Press, Tuscaloosa.

Whittlesey, S. M.

2004 Ceramic Containers. In Pots, Potters, and Models: Archaeological Investigations at the SRI Locus of the West Branch Site, Tucson, Arizona, Volume 2: Synthesis and Interpretations, edited by S. M. Whittlesey, pp. 283-322. Technical Series 80. Statistical Research, Inc., Tucson, Arizona.

Williams, M. L.

2000 Ethnobotanical Analysis. In Forest Farmsteads: A Millennium of Human Occupation at Winding Stair in the Ouachita Mountains, edited by A. M. Early, pp. 111-122. Research Series 57. Arkansas Archeological Survey, Fayetteville.

Wilson, D.

1994 Division of Labor and Stress Loads at the Sanders Site (41LR2), Lamar County, Texas. Bulletin of the Texas Archeological Society 65:129-160. 
1997 Dental Paleopathology in the Sanders (41LR2) and Mitchell (41BW4) Populations from the Red River Valley, Northeast Texas. Bulletin of the Texas Archeological Society 68:147-160.

1998

The Paleoepidemiology of Treponematosis in Texas. Ph.D. dissertation, Department of Anthropology, The University of Texas at Austin.

2006 Human Remains in the Collection. In A Study of the Buddy Calvin Jones Collection from Northeast Texas Caddo Sites, by T. K. Perttula, pp. 110-133. Special Publication No. 6. Friends of Northeast Texas Archaeology, Pittsburg and Austin.

2008a The Human Remains from 41HS15, the Pine Tree Mound Site, Harrison County, Texas. Report Submitted to Prewitt and Associates, Austin.

2008b Human Remains. In Lake Naconiche Archeology, Nacogdoches County, Texas: Results of the Data Recovery Excavations at Five Prehistoric Archeological Sites, edited by T. K. Perttula. 2 Vols. Report of Investigations No. 60. Archeological \& Environmental Consultants, LLC, Austin.

2008c Bioarchaeological Evidence of Subsistence Strategies among the East Texas Caddo. In The Archaeology of the Caddo, edited by T. K. Perttula and C. P. Walker. University of Nebraska Press, Lincoln, in press.

Wilson, D. and D. G. Steele

1997 Appendix D: Analysis of Human Remains from Cooper Lake. In Synthesis of the Prehistoric and Historic Archaeology of Cooper Lake, Delta and Hopkins Counties, Texas, by R. C. Fields, M. E. Blake and K. W. Kibler, pp. 177-244. Reports of
Investigations, Number 104. Prewitt and Associates, Austin.

Winter, J. C.

2000 From Earth Mother to Snake Woman: The Role of Tobacco in the Evolution of Native American Religious Organization. In Tobacco Use by Native North Americans: Sacred Smoke and Silent Killer, edited by J. C. Winter, pp. 265-304. University of Oklahoma Press, Norman.

Wobst, H. M.

1999 Style in Archaeology or Archaeologists in Style. In Material Meanings: Critical Approaches to the Interpretation of Material Culture, edited by E. S. Chilton, pp. 118-132. University of Utah Press, Salt Lake City.

Woodall, J. N.

1969 Archaeological Excavations in the Toledo Bend Reservoir, 1966. Contributions in Anthropology No. 3. Department of Anthropology, Southern Methodist University, Dallas.

1972 Prehistoric Social Boundaries: An Archeological Model and Test. Bulletin of the Texas Archeological Society 43:101-120.

Woolsey, A. M.

1935a Notes on Field Work, Solon Stanley Farm, 9 Miles Northeast Frankston, Cherokee County, November 5 and 6, 1935. MS on file, Texas Archeological Research Laboratory, The University of Texas at Austin.

1935b Notes on Field Work, Mrs. J. W. Blackburn Farm, 7 1/2 Miles Northwest of Jacksonville, Cherokee County, October 19, 1935 and October 30-November 4, 1935. MS on file, Texas Archeological Research Laboratory, The University of Texas at Austin. 
1935c Notes on Field Work, Ballard Estate, 7 1/2 Mi. south of Frankston, Anderson County, September 30, 1935. MS on file, Texas Archeological Research Laboratory, The University of Texas at Austin.

1935d Notes on Field Work, L. Cecil Farm, 2 1/2 Miles East of Frankston, Anderson County, October 11, 1935. MS on file, Texas Archeological Research Laboratory, The University of Texas at Austin.

1935e Notes on Field Work, Rube Beard Farm, 2 1/2 Miles South of Frankston, Anderson County, October 12, 1935. MS on file, Texas Archeological Research Laboratory, The University of Texas at Austin.

1935f Notes on Field Work De Long Farm [Stephenson Farm], 2 Miles Northwest Frankston, Anderson County, October 17, 1935. MS on file, Texas Archeological Research Laboratory, The University of Texas at Austin.

1935g Notes on Work Done, Henderson County, Texas, Mann Place, October 17, 1935. MS on file, Texas Archeological Research Laboratory, The University of Texas at Austin.

1935h Notes on Field Work, A. H. Reagor Farm, 1 Mile East of Old Larissa, 7 Miles Northwest Jacksonville, Cherokee County, November 4 and 5, 1935. MS on file, Texas Archeological Research Laboratory, The University of Texas at Austin.

1935i Burial Site, R. J. Fair Farm, 2 1/2 Miles Southwest of Jacksonville, Cherokee County, Texas, November 11 to November 16, 1935. MS on file, Texas Archeological Research Laboratory, The University of Texas at Austin. 1935j Notes on Field Work, E. W. Hackney Farm, 9 Miles Northwest Jacksonville, Cherokee County, November 16 to November 19, 1935. MS on file, Texas Archeological Research Laboratory, The University of Texas at Austin.

1935k Notes on Field Work, E. W. Henry Farm, 7 Miles West of Jacksonville, Cherokee County, Texas. MS on file, Texas Archeological Research Laboratory, The University of Texas at Austin.

1935l Fred McKee Farm, 5 Miles Southeast Frankston, Anderson County, November 25 to November 27, 1935. MS on file, Texas Archeological Research Laboratory, The University of Texas at Austin.

1935m Notes on Field Work Omer and Otis Hood Farm, 4 1/2 Miles Northwest Jacksonville, Cherokee County, November 28 to December 7, 1935, Sites No. 1 and 2. MS on file, Texas Archeological Research Laboratory, The University of Texas at Austin.

1935n Notes on Work Done-Anderson County, Texas, Isibel-Gene Donnell Farm, October 14-16, 1935. MS on file, Texas Archeological Research Laboratory, The University of Texas at Austin.

19350 Notes on Field Work, Jim P. Allen Farm $7 \quad 1 / 2 \quad$ Miles Northwest Jacksonville, Cherokee County, October 19-November 4, $1935 . \quad$ MS on file, Texas Archeological Research Laboratory, The University of Texas at Austin.

Wyckoff, D. G. and R. Bartlett

1995 Living on the Edge: Late PleistoceneEarly Holocene Cultural Interactions along the Southeastern WoodlandsPlains Border. In Native American Interactions: Multiscalar Analyses and Interpretations in the Eastern 
Woodlands, edited by M. S. Nassaney and K. E. Sassaman, pp. 27-72. University of Tennessee Press, Knoxville.
Youngblood, D.

2008 The Windfall/Shortfall Model: A Seasonal Theory of Crop Inclusion Based on Analysis of Woodlands Frontier Plant Remains. Plains Anthropologist 53(205):107-120. 


\section{APPENDIX A \\ MIDDLE TO LATE HOLOCENE PALYNOLOGY OF VIBRA-CORES FROM 41AN38 AND CADDO CREEK}

Prepared for:

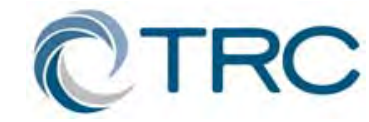

TRC Environmental Corporation 505 East Huntland Drive, Suite 250

Austin, Texas 78752

Prepared by:

Bruce M. Albert

Research Fellow, Department of Geography and Environment, The University of Texas at Austin 



\section{A.1 Introduction}

Site selection for the 41AN38 pollen project in Anderson County, Texas was guided by a desire to locate reduced sediments containing stratigraphically ordinal and well-preserved pollen of significant timedepth reflecting both local (41AN38 site specific) and regional vegetation conditions within a zone of exploitation by site inhabitants and neighboring communities. Such flora would then be used to reconstruct the ecology of human settlement, including a reconstruction of potential food mosaics and regional climate conditions. Moreover, direct and indirect human impact on vegetation through time might also be reconstructed in this East Texas region lacking in pollen data. In this context, possibilities of understanding historic forest ecology of parts of East Texas are also realizable. Moreover, important methodological advances in alluvial palynology are finally achieved in this study, as described in concluding sections.

Pollen cores from site environs and the Caddo Creek valley derive from a narrow strip of post oak savanna after regional vegetation maps (Diggs et al. 2006), although fine mapping systems also locate aspects of blackland prairie vegetation within the valley, depending on the incidence of certain soil types (Bureau of Economic Geology 2000). Immediately to the east of the core sites, a transition of vegetation to a piney-woods mixture is mapped, indicating that a variety of flora might be encountered in pollen stratigraphy of the Caddo Creek region, ranging from floodplain woodlands supporting demanding tree species, to Pinus echinata and Quercus stellata on more acidic uplands, to (little bluestem dominated) grasslands with forbs of the Schizochyrium-Sorgastrum association depending on the presence of local Alfisols.
An importance of soil formations for vegetation in the study region has been noted. To this end, it is observed that a main soil type of the Caddo Creek valley (and of the 41AN38 site locality) is that of the moderately acidic Pickton-Wolfpen series, which is sandy, well drained, and usually developed on moderate slopes (Texas Agricultural Experiment Station 1975, 1979). This formation supports acidophytic woodland, consisting of oak with some pine (as above) and yaupon (Ilex vomitoria). Important particularly to Cores 1 and 3 in the Caddo Creek valley itself is the Nahatche series, described as a loamy soil on poorly drained level ground. Trees of a more demanding sort, including black hickories (Carya texana), as well as numerous oaks (Quercus marilandica, Q. nigra), and $Q$. phellos in increasingly wet areas) occur here.

A further soil formation of importance to the study region is the Trawick series around the boundary of Anderson and Henderson Counties. This is a variegated series of glauconite, sandy marl, loamy sediment, and inter-bedded clayey strata. This supports grassland or savanna vegetation in places, and is generally less acidic than the Pickton and Nahatche. By analogy to defined sugarberry-elm forests of the post-oak savanna in the Middle Brazos valley (Diggs et al. 2006), such alkaline soils can promote a variety of deciduous trees, including species of Ulmus, Celtis, and Fraxinus.

\section{A.2 Field Work}

Three vibra-cores contained within 3-inchdiameter modified irrigation pipe were extracted for dating and pollen analysis from the environs of 41AN38 and the Caddo Creek immediately south of Frankston near the boundary of Anderson and Henderson Counties, Texas. The vibra-corer itself was made by Harry Williams, Professor. of Geography at the University of North Texas, 
from a concrete vibrator and machinedclamp, which is attached to pipe. Thus attached, the apparatus drives such pipe through sediment via vibration. A cutting element with retractable welded plates was attached to the low end of the pipe for sample retention during core extraction, when pipe and sediment core is supported by tripod. The device works well in wet sediments, although limits to coring include drier clays, which are difficult to penetrate via vibration and the sheer weight of the entire apparatus in wet places during sediment core extraction by winch.

Of the three cores, Core 2 derives from a small seep immediately south of the archaeological site, on the western edge of the H-155 ROW. Cores 1 and 3 derive from alluvial accretion deposits in the north and middle parts of the Caddo Creek valley, on the eastern edge of the ROW of H-155, about one mile north of the archaeological site. By topographic context, all cores derive from places of high water table conducive to pollen preservation (reduction limits that biotic activity degrades pollen). An acidic sedimentary matrix is also indicated after reactions of HCL in laboratory work described below (acidic matrices also lower biotic activity). Furthermore, according to topography, deposits at Core 2 are accumulating as colluvium along a transportational slope. In contrast, deposits from Cores 1 and 3 from the small Caddo Creek valley are finer and consist of alluvium. Of these latter, Core 1 lies on the northern alluvial margin (overbank deposit) six meters north of Core 3 , which derives from the middle part of the creek valley.
Due to factors of sorting, sediments from Core 3 are generally coarser than those from Core 1. Both Cores 1 and 2 reach consolidated sediments below alluvium and colluvium respectively. Work at Core 3, however, was limited by constraints of the wetland setting in the absence of a special platform. Here, the base of unconsolidated alluvium was not reached at a depth of 2.75 meters, the logistical limit of coring.

\section{A.2.1 Description of Pollen Core Sediments}

The irrigation pipes containing Cores 1, 2, and 3 were cut open by pneumatic machinery prior to description and sampling. Of these, Core 1 from over-bank deposits was recovered to a depth of 2.95 (or 3.15 after factoring for compression) meters. Sediments here consist mostly of silt with some clay and a minor fraction of fine sand. Most fine sand occurs in the lower part of the core (266-295 cm). Sediments also become finer in three bands, which contain more clay and traces of humus (218-266, 106-160, and 0-90 cm). A grayish-brown hue predominates in this core, suggestive of a reducing situation. Some mottling is also observed in the upper part of the core. Sediments are described in a quartile (0-4) system after Troels-Smith (1955) in Table A-1 below. In this system, trace values of a given sediment type are registered as a plus, while boundaries between sedimentary zones are termed limus, whereby sharper boundaries are registered with high values on a four-point scale. Importantly, all cores are integral (i.e., derive en toto from a single pipe). 
Table A-1. Caddo Creek Core 1 (with 30-cm compression after vibra-coring).

\begin{tabular}{|lllc|}
\hline Cm (boundary) & Granulometry (four-part) & Munsell hue & humus \\
\hline & & & \\
\hline $0-5$ & Clay 1, Silt 3 & $10 \mathrm{yr} 4 / 3$ & trace \\
\hline (Limus 1) & & & \\
\hline $5-90$ & Clay 1, Silt 3 & 10yr5/2+6/3 (mottling) & trace \\
\hline (Limus 1) & & $10 \mathrm{yr} 5 / 2$ & \\
\hline $90-106$ & Silt 4, Sand + & trace \\
\hline (Limus 1) & & $10 \mathrm{yr} 5 / 3$ & \\
\hline $106-160$ & Clay 1, Silt 3 & trace \\
\hline (Limus 1) & & $10 \mathrm{yr} 5 / 2$ & \\
\hline $160-218$ & Silt 4, Sand + & \\
\hline (Limus 1) & & $10 \mathrm{yr} 5 / 3$ & \\
\hline $218-266$ & Clay 1, Silt 3, Sand + & $10 \mathrm{yr} 6 / 4$ & \\
\hline (Limus 1) & & & \\
\hline $266-295$ & Fine sand 2, Silt 2 & \\
\hline
\end{tabular}

Core 2 from a seep south of the archaeological excavations consists of sand and clay, with an increasing proportion of fine sediment to a depth of $92 \mathrm{~cm}$ (or $112 \mathrm{~cm}$ after factoring for compression). Notably, a soil hue suggestive of oxidation appears in deeper sediments. Darker hues, suggestive of reduction, appear only in the upper $24 \mathrm{~cm}$ of the core, along with traces of uncarbonized plants and humus. These sediments are described (after Troels-Smith 1955) in Table A-2.

Table A-2. Caddo Creek Core 2 (with $20 \mathrm{~cm}$ compression after vibra-coring).

\begin{tabular}{|llll|}
\hline Cm (boundary) & Granulometry (four-part) & Munsell hue & humus \\
\hline $0-24$ & Medium sand 4 & $10 \mathrm{yr} 4 / 3$ & trace \\
\hline (Limus 1) & & & \\
\hline $24-36$ & Medium sand 4, Clay + & $10 \mathrm{yr} 5 / 2$ & \\
\hline (Limus 0) & & \\
\hline $36-57$ & Medium sand 4, Clay + & $10 \mathrm{yr} 6 / 3$ \\
\hline (Limus 3) & & \\
\hline $57-66$ & Medium sand 2, Clay 2 & $10 \mathrm{yr} 7 / 4,5 \mathrm{yr} 4 / 6$ \\
\hline (Limus 1) & & \\
\hline $66-88$ & Clay 4, Sand + & $5 \mathrm{yr} 4 / 6,10 \mathrm{yr} 7 / 4$ \\
\hline (Limus 1) & & \\
\hline $88-92$ & Medium sand 4, Clay + & $10 \mathrm{yr} 7 / 1$ \\
\hline
\end{tabular}

Core 3 from mid-channel deposits was recovered to a depth of 2.45 (or 2.75 after factoring for compression) meters. Sediments here are coarser than those in Core 1 and consist mostly of silt and fine sand. Almost pure fine sand occurs in the lower part of the core $(185-245 \mathrm{~cm})$. Sediments also fine in two bands with more clay and traces of humus (73-128 and 33-66 $\mathrm{cm})$.
A light gray hue predominates in this core, suggestive of a reducing situation. Mottling in the upper-most part of the core (5-33 cmbs) is distinctive, and is further suggestive of disturbance. These sediments are described (after Troels-Smith 1955) in Table A-3 below. 
Table A-3. Caddo Creek Core 3 (with $30 \mathrm{~cm}$ compression after vibra-coring)

\begin{tabular}{|c|c|c|c|}
\hline Cm (boundary) & Granulometry (four-part) & Munsell hue & humus \\
\hline $0-5$ & Silt 3 , Fine sand 1 & $10 \mathrm{yr} 4 / 3$ & trace \\
\hline \multicolumn{4}{|l|}{ (Limus 2) } \\
\hline $5-33$ & Silt 3 , Fine sand 1 & 10yr6/2+7/8 (+ mottling) & \\
\hline \multicolumn{4}{|l|}{ (Limus 1) } \\
\hline $33-66$ & Silt 2, Clay 2, Sand + & $10 \mathrm{yr} 5 / 2+6 / 2$ & trace \\
\hline \multicolumn{4}{|l|}{ (Limus 2) } \\
\hline $66-73$ & Silt 3 , Fine sand 1 & $10 \mathrm{yr} 6 / 1+6 / 2$ & \\
\hline \multicolumn{4}{|l|}{ (Limus 2) } \\
\hline $73-128$ & Silt 2, Clay 2, Sand + & $10 \mathrm{yr} 4 / 3+4 / 2$ & trace \\
\hline \multicolumn{4}{|l|}{ (Limus 1) } \\
\hline 128-185 & Silt 3 , Fine sand 1 & $10 \mathrm{yr} 5 / 2+6 / 1$ & trace \\
\hline \multicolumn{4}{|l|}{ (Limus 0) } \\
\hline$\frac{185-212}{(\operatorname{Limus} 0)}$ & Fine sand 3, Silt 1 & $10 \mathrm{yr} 6 / 1$ & \\
\hline \multicolumn{4}{|l|}{ (Limus 0) } \\
\hline
\end{tabular}

\section{A.3 AMS Dating and Rates of Sedimentation}

A total of fourteen AMS samples, principally of bulk sediment, have been assayed from the three pollen cores (Table A-4), although isolated dates are also derived from non-carbonized plants. For example, leafy detritus (D. Hood, pers. comm. 2008) is assayed in the upper part of Core 3 (Beta 239842), where an Atomic age comparable to that of upper bulk sediment (cf. Beta 218312) is obtained. In this case, a non-intrusive deposition is inferred. It is also apparent here that a low-energy setting (indicated in sediments) might reduce the incidence of the introduction of old carbon via erosion and redeposition. Conversely, a single rejected date (Beta 239844) from Core 3 derives from minute and indeterminate plants, and may be rhizomous (i.e., significantly intrusive from above). This assay is more than a millennium too young relative to other dates in Core 3 as well as contextual dates in Core 1 . A reliability check on Beta 239844 is thus made after an assay on bulk sediments from which the minute plant fraction derives (Beta 243084), which produces a contextually rational date about three thousand years older.
Importantly, twelve dates from organic sediment produced rational sequences in all three cores. For example, all bulk sediment dates from Core 3 increase in age with depth. From Core 2, two closely spaced samples produced very close dates in proper sequence. The position of this core in a seep along a gentle transportational slope reinforces the impression that bulk sediments can produce reliable dates in low energy settings. An exception to this rule is a less significant inversion (with 2-Sigma overlap) of dates in the upper part of the over-bank deposit of Caddo Creek (Core 1). These (Beta 218308 and 238499) are quite similar, despite a 40-cm difference in depth, and suggest either a high rate of accumulation with redeposition of up-stream deposits, or else an intrusion of sediment after bio-turbation in this terrestrial setting. A lack of stratigraphic evidence for an unconformity here, along with a mottling of sediment hues support the latter possibility, which is also a more sensible one in terms of topographic context. Thus older date ranges will be used to estimate sedimentation in the upper part of Core 1 (this supposes that Beta 238499 is too young, as opposed to 218308 being too old). 
In general, dates from Core 1 support the mid-channel sequence from Core 3 in that the highest rates of accumulation in the channel are correlated with the entirety of the over-bank deposition (post-3800 BP). Also, highest (pre-Atomic) rates of sedimentation in Core 3 are coeval with the highest rates of over-bank deposition after Core 1 AMS data (to after 800 BP). These correlations indicate that a significant level of erosion and accumulation along the middle channel and over-bank aspects of the Caddo Creek valley region predates the Caddo period (Woodland or Fourche Maline), although such rates double during and after Middle Caddo times (Table A-5).
Local to 41AN38, it is not possible to accurately estimate rates of later sediment accumulation (containing much pollen) on the transportational slope of the seep after the AMS data from Core 2 (this is attempted after relative pollen dating). It is noted, however, that over the long-term, net sedimentation rates are low here $(\sim 1$ cm/century). From Caddo Creek, sedimentation rates are far greater, particularly in Core 1 from the over-bank (3.1-20+ $\mathrm{cm} /$ century), while sedimentation rates are highly variable in Core 3 from the mid-channel deposit (1.4 - 50 cm/ century).

Table A-4. Pollen Core AMS Dates.

\begin{tabular}{|c|c|c|c|c|c|}
\hline $\begin{array}{l}\text { Beta lab } \\
\text { number }\end{array}$ & Material dated & $\begin{array}{l}\text { Core \# and } \\
\text { provenience }\end{array}$ & $\begin{array}{l}\text { Depth } \\
\text { (cmbs) }\end{array}$ & $\begin{array}{l}\text { Radiocarbon age } \\
\text { And error range }\end{array}$ & $\begin{array}{l}\text { Calibrated } \\
\text { age }(2 \Sigma) \mathrm{BP}\end{array}$ \\
\hline 218308 & Bulk sediment & $\begin{array}{l}\text { 1, Caddo } \\
\text { Creek over. }\end{array}$ & $0-5$ & $760+/-40$ & $770-660$ \\
\hline 238499 & Bulk sediment & $\begin{array}{l}\text { 1, Caddo } \\
\text { Creek over. }\end{array}$ & $40-5$ & $640+/-40$ & $670-550$ \\
\hline 238498 & Bulk sediment & $\begin{array}{l}\text { 1, Caddo } \\
\text { Creek over. }\end{array}$ & $140-5$ & $1390+/-40$ & $1350-1270$ \\
\hline 238500 & Bulk sediment & $\begin{array}{l}\text { 1, Caddo } \\
\text { Creek over. }\end{array}$ & $240-5$ & $2000+/-40$ & $2040-1870$ \\
\hline 218309 & Bulk sediment & $\begin{array}{l}\text { 1, Caddo } \\
\text { Creek over. }\end{array}$ & $290-5$ & $3310+/-50$ & $3690-3460$ \\
\hline 218310 & Bulk sediment & $\begin{array}{l}2,41 \mathrm{AN} 38 \\
\text { south seep }\end{array}$ & $54-7$ & $4280+/-50$ & $4980-4830$ \\
\hline 218311 & Bulk sediment & $\begin{array}{l}\text { 2, 41AN38 } \\
\text { south seep }\end{array}$ & $57-60$ & $4350+/-50$ & $5220-4850$ \\
\hline 218312 & Bulk sediment & $\begin{array}{l}\text { 3, Caddo } \\
\text { Creek mid. }\end{array}$ & $0-5$ & Atomic & $\begin{array}{l}\text { (Post-AD } \\
1950)\end{array}$ \\
\hline 239842 & $\begin{array}{l}\text { Herbaceous } \\
\text { detritus }\end{array}$ & $\begin{array}{l}\text { 3, Caddo } \\
\text { Creek mid. }\end{array}$ & $20-25$ & Atomic & $\begin{array}{l}\text { (Post-AD } \\
1950)\end{array}$ \\
\hline 239843 & Bulk sediment & $\begin{array}{l}\text { 3, Caddo } \\
\text { Creek mid. }\end{array}$ & $84-6$ & $1210+/-40$ & $1260-1050$ \\
\hline 239844 & $\begin{array}{l}\text { Indeterminate } \\
\text { detritus }\end{array}$ & $\begin{array}{l}\text { 3, Caddo } \\
\text { Creek mid. }\end{array}$ & $184-6$ & $\begin{array}{l}820+/-50 \\
\text { (rejected) }\end{array}$ & $\begin{array}{l}780-660 \\
\text { (rejected) }\end{array}$ \\
\hline 243084 & Bulk sediment & $\begin{array}{l}\text { 3, Caddo } \\
\text { Creek mid. }\end{array}$ & $184-6$ & $3530+/-40$ & $3910-3700$ \\
\hline 243085 & Bulk sediment & $\begin{array}{l}\text { 3, Caddo } \\
\text { Creek mid. }\end{array}$ & $219-221$ & $5540+/-50$ & $6410-6280$ \\
\hline 218313 & Bulk sediment & $\begin{array}{l}\text { 3, Caddo } \\
\text { Creek mid. }\end{array}$ & $235-240$ & $5890+/-50$ & $6800-6680$ \\
\hline
\end{tabular}


In Core 3, sedimentary boundaries are well defined (Lim. values of 2-3) where higher rates of accumulation occur. In this light, grading boundaries (Lim 0-1) in slowly accumulating sediment in the same core reflect a more continuous if low average rate of accumulation, rather than erosion, which should produce a sharp, not a grading boundary. The same boundary characteristics are also evident in the upper part of Core 1, where other problems of dating arise. A demonstration of a higher sedimentation rate of later alluvia in the creek valley as a whole gives contextual support the chronometry in Table A-5.

Table A-5. Pollen Core Sedimentation Rates and Chronometry.

\begin{tabular}{|c|c|c|c|}
\hline Core & $\begin{array}{c}\text { depth range } \\
\text { (cmbs) }\end{array}$ & $\begin{array}{c}\text { Estimated sedimentation } \\
\text { Rates }\end{array}$ & $\begin{array}{c}\text { Estimated } \\
\text { time-range BP }\end{array}$ \\
\hline 1 & $0-45$ & $>20 \mathrm{~cm} /$ century & (ca. 710+/610) \\
\hline 1 & $45-145$ & $16.7 \mathrm{~cm} /$ century & $1310-710+$ \\
\hline 1 & $145-245$ & $15.5 \mathrm{~cm} /$ century & $1955-1310$ \\
\hline 1 & $245-295$ & $3.1 \mathrm{~cm} /$ century & $3575-1955$ \\
\hline 2 & $0-54$ & $\sim 1 \mathrm{~cm} /$ century & $4905-0$ \\
\hline 2 & $54-7$ & $2.3 \mathrm{~cm} /$ century & $5035-4905$ \\
\hline 3 & $0-25$ & $\sim 50 \mathrm{~cm} /$ century & Atomic age \\
\hline 3 & $25-85$ & $7.5 \mathrm{~cm} /$ century & $1155-$ Atomic \\
\hline 3 & $85-185$ & $3.8 \mathrm{~cm} /$ century & $3805-1155$ \\
\hline 3 & $185-220$ & $1.4 \mathrm{~cm} /$ century & $6345-3805$ \\
\hline 3 & $220-240$ & $5.1 \mathrm{~cm} /$ century & $6345-6740$ \\
\hline & & & \\
\hline
\end{tabular}

\section{A.4 Laboratory Work}

All pollen samples were processed using the HF method (an application of a hot 49\% HF solution followed by a controlled $10 \%$ warm, HCL reduction of silico-flourides), along with a pretreatment of $10 \%$ cold HCL and $10 \%$ hot $\mathrm{KOH}$. Distilled water for cleaning and pure ETOH for dehydration is employed herein. A post-treatment of an acetolysis solution (of sulfuric acid and acedic anhydride) was made after relative cellulose content of sample material. All samples with major clay content are further deflocculated in a $5 \%$ solution of sodium hexa-metaphosphate and filtrated using a tested 8-micron nitex screens in a modified Gilson SS-15 apparatus, prior to chemical reduction. In addition, a Lycopodium tablet, containing 6000 exotic fern spores, issued by the Department of Quaternary Geology, University of Lund in Sweden, was added to all samples towards the calculation of pollen concentration. Samples were then dyed red in saffranine and placed in a substrate of 2000 viscosity silicone oil for purposes of light microscopic work. Notably, an advantage of oil over gelatin pollen preparations lies in the fact that grain expansion common to glycerols is avoided. This is important where the size of grain attributes is a part of taxonomy, for example in Zea pollen identification.

After reduction of pollen samples, light microscope work aimed at achieving statistically significant counts in the order of 200 to 500 grains per sample. Most grains are examined at $\times 400$ magnification, with immersion oil being used for examinations at x1000 magnification. Special emphasis is also given to Zea pollen identification, given its potential importance for detecting prehistoric agricultural episodes and a potential confusion of wild grass with maize pollen. Regarding the latter, modern varieties of Zea average more than 80 microns in diameter, although the pollen 
morphology of prehistoric maize varieties is unknown due to a lack of direct comparative specimens.

Attention to the question comparative ZeaPoaceae morphology includes an examination of type-slide collection from the University of Texas at Austin Herbarium at the Dept. of Geography and Environment and a review of literature (esp. Eubanks 1997 and Dull 2006). In short, it is concluded that there is a potential for a confusion of large wild grass with small maize pollen grains (those under 65 microns dia.). However, given that the average diameter of Teosinte (maize progenitor) pollen is observed to be 79 microns, it is unlikely that ancient maize will produce pollen significantly smaller, as domestication should increase rather than decrease cultigen pollen grain size with cultural selection. This is certainly the case in the Old World, where pollen grains of varieties of (originally cultivated) emmer wheat range from 40 to 50 microns in diameter, increasing to 70 microns in subsequently cultivated bread wheat varieties. Indeed, most pollen grains of modern American maize varieties have diameters ranging from 118 to 122 microns, while pollen of Mexican maize varieties of an "indigenous" characteristic exhibit diameters ranging mostly from 76 to 97 microns. Only statistical outliers of the latter varieties exhibit diameters under 60 microns. In fact, a pollen grain of 58 microns diameter is the smallest maize specimen cited by Eubanks (1997).

There are no established criteria other than measured diameter to distinguish Zea from large Poaceeae, and although early maize pollen is sometimes defined on the basis of grains as small as 50 microns in diameter, these assignments are tenuous (Dull 2006). A need for caution in this respect is also reflected at Caddo Creek, where three Poaceae grains with diameters of 55 to 60 microns occur at 263 and $150 \mathrm{~cm}$ depths in Cores 1 and 3, respectively. These sediments are about 3,000 years old, and predate by many centuries the earliest evidence for maize cultivation in the TransMississippian South (Schambach 2001). These observations support Dull (2006), who limits the definition of Zea to those pollen grains with a minimal long axis of 65 microns.

With regard to the palynological identification of tree species important for human economy, hickory and pecan are usually subsumed under the general Caryatype. However, based upon pollen typeslide examination at the Herbarium, as well as investigations of multiple sequences in South Texas and Mexico (where Carya relates to $C$. illinoensis), pecan pollen exhibits a more robust exine thickening at the pore margin and somewhat larger average grain size vis à vis hickory, although measurements over-lap in these respects. Notably, pollen grains of Carya from Caddo Creek and 41AN38 cores are less robust, and probably derive mostly from hickory rather than pecan trees.

\section{A.5 Pollen Preservation and Concentration}

Subsequent to laboratory work, wellpreserved pollen in high concentrations was found in a great majority of analyzed samples from the Caddo Creek valley (Cores 1 and 3), although layers with low pollen concentrations were found in one sample at $85 \mathrm{~cm}$ depth in Core 1 and in two samples around $100 \mathrm{~cm}$ depth in Core 3. These low grain concentration samples are listed in absolute pollen count tables, but insufficient grains are countable to make such data statistically meaningful. In general, pollen exines in sediment are generally preserved due to a reducing environment promoted by the local water table. Crumpling of pollen grain walls has occurred in these (noncushioned) mineragenic matrices, but this is moderate, allowing for proper identifications in all but a small number of cases. A silicone oil preparation employed above is 
useful here, as this allows for grain rotation under the light microscope, for a complete examination of morphological aspects. More than 40 different pollen types have been distinguished in the examination of about 15,000 grains from the three pollen cores, in which pollen concentration values vary in a somewhat random fashion by a high magnitude.

Table A-6. Cores 1 - 2, Pollen Concentration Values.

\begin{tabular}{|l|l|}
\hline $\begin{array}{l}\text { Core context-depth } \\
\text { below surface (cm) }\end{array}$ & $\begin{array}{l}\text { Pollen grains } \\
\text { per cubic cm }\end{array}$ \\
\hline Caddo Creek over-bank-15 & 28,846 \\
\hline Caddo Creek over-bank-25 & 57,800 \\
\hline Caddo Creek over-bank-30 & 27,900 \\
\hline Caddo Creek over-bank-39 & 20,829 \\
\hline Caddo Creek over-bank-50 & 75,545 \\
\hline Caddo Creek over-bank-106 & 1,433 \\
\hline Caddo Creek over-bank-130 & 8,213 \\
\hline Caddo Creek over-bank-150 & 17,231 \\
\hline Caddo Creek over-bank-200 & 31,125 \\
\hline Caddo Creek over-bank-220 & 12,259 \\
\hline Caddo Creek over-bank-240 & 23,308 \\
\hline Caddo Creek over-bank-263 & 1,508 \\
\hline Caddo Creek over-bank-280 & 4,727 \\
\hline Caddo Creek over-bank-290 & 4,261 \\
\hline Caddo Creek over-bank-295 & 3,172 \\
\hline 41AN38 seep-1 & 5,037 \\
\hline 41AN38 seep-2 & 80,700 \\
\hline 41AN38 seep-3 & 59,500 \\
\hline 41AN38 seep-4 & 6,330 \\
\hline 41AN38 seep-5 & 14,333 \\
\hline 41AN38 seep-7 & 6,420 \\
\hline 41AN38 seep-8 & 12,218 \\
\hline 41AN38 seep-10 & 79,125 \\
\hline 41AN38 seep-12 & 144,000 \\
\hline 41AN38 seep-16 & 342,000 \\
\hline 41AN38 seep-21 & 347,000 \\
\hline & \\
\hline
\end{tabular}

In Core 1 from over-bank deposits of Caddo Creek, pollen concentration values of viable samples range from 1,433 to 75,545 grains per cubic $\mathrm{cm}$. Importantly, these values vary without respect to pollen zones (see below) or relative quantities of degradationresistant Pinus pollen. It is inferred that conditions of initial sedimentation (rather than degradation) modulate pollen concentration values, whereby relative percentage values are not affected in a significant way. Comparative pollen concentration values in Core 3 from the middle part of the channel also vary greatly from sample-to-sample, from 4,395 to 429,000 grains per cubic $\mathrm{cm}$ in absolute terms. A uniformity of non-degradation of pollen is also observed, even in low concentration samples. Although multiple peaks of pollen concentration are further observed here, it is significant that there is no relation of this variation (of two orders of magnitude) in pollen concentration to granulometry, pollen grain diameter, pollen type, or pollen zone definition. Moreover, abrupt variation in concentration from level- 
to-level observed in many close-set samples (e.g., 170/160 and 155/151 cmbs) produces no abrupt change in relative pollen percentages. Rather, pollen representation in close-set samples grades according to longer-term trends, which reflect ecologically rational floral change through time. The data pattern from Cores 1 and 3 from Caddo Creek thus shows that pollen concentration in alluvium is not a necessary indicator of differential representation (sorting), and moreover, major variations of up to two orders of magnitude in such concentration has a negligible influence on relative pollen percentages or zonation.

Conditions for pollen preservation are far worse in Core 2 colluvium, where an oxidation of middle and lower sediments is observed according to Munsell hues. Samples from a depth of $55 \mathrm{~cm}$ (approximate depth of site AMS dates) to surface are analyzed, and virtually no pollen is encountered below a depth of $21 \mathrm{~cm}$.

Table A-7. Core 3, Pollen Concentration Values.

\begin{tabular}{|l|l|}
\hline \multicolumn{1}{|c|}{$\begin{array}{c}\text { Core context and } \\
\text { Depth below surface (cm) }\end{array}$} & $\begin{array}{c}\text { Pollen grains } \\
\text { per cubic cm }\end{array}$ \\
\hline Caddo Creek channel-0 & 56,167 \\
\hline Caddo Creek channel-5 & 164,250 \\
\hline Caddo Creek channel-25 & 5,915 \\
\hline Caddo Creek channel-28 & 28,909 \\
\hline Caddo Creek channel-30 & 50,077 \\
\hline Caddo Creek channel-33 & 5,759 \\
\hline Caddo Creek channel-35 & 7,929 \\
\hline Caddo Creek channel-40 & 5,839 \\
\hline Caddo Creek channel-60 & 4,395 \\
\hline Caddo Creek channel-70 & 28,091 \\
\hline Caddo Creek channel-85 & 18,375 \\
\hline Caddo Creek channel-130 & 17,595 \\
\hline Caddo Creek channel-140 & 8,406 \\
\hline Caddo Creek channel-145 & 7,667 \\
\hline Caddo Creek channel-150 & 14,190 \\
\hline Caddo Creek channel-151 & 4,950 \\
\hline Caddo Creek channel-155 & 141,000 \\
\hline Caddo Creek channel-160 & 13,145 \\
\hline Caddo Creek channel-170 & 132,000 \\
\hline Caddo Creek channel-180 & 429,000 \\
\hline Caddo Creek channel-190 & 274,000 \\
\hline Caddo Creek channel-200 & 38,000 \\
\hline Caddo Creek channel-210 & 28,241 \\
\hline Caddo Creek channel-220 & 23,250 \\
\hline Caddo Creek channel-225 & 242,250 \\
\hline Caddo Creek channel-230 & 74,308 \\
\hline Caddo Creek channel-235 & 106,000 \\
\hline Caddo Creek channel-245 & 33,000 \\
\hline & \\
\hline
\end{tabular}

Given the low-energy setting of the site, which would allow for initial pollen sedimentation, mostly by gravity and air transport (see below), pollen degradation under oxidizing conditions is a likely agent of this absence. However, once conditions for pollen preservation are made effective, very high concentration values are observed, 
with a site maximum of 347,000 grains per cubic cm occurring in the basal viable sample. A secondary peak of 80,700 grains per cubic cm also occurs in upper parts of the core (at $2 \mathrm{cmbs}$ ), below a near surface sample with a minimum of pollen concentration (5,037 grains/cc). Evidently, factors of sedimentation rates might importantly affect the relative concentration of pollen grains (higher mineragenic accumulation rates may produce lower, time-dependent pollen concentration values and vice versa). It is guessed that the hydrology of the seep by 41AN38 has also varied though time, and had a different orientation entirely below the $21 \mathrm{cmbs}$ depth threshold, which seems to mark the starting point of local reduction.

\section{A.6 Pollen Recruitment Dynamics}

After topographic context, it is inferred that pollen from creek valley sediments in Cores 1 and 3 is derived importantly from water transport after flood events and more equitable drainage, ultimately after overland flow from a basin area estimated to extend 145 square kilometers in northern Anderson (inclusive of 41AN38) and southern Henderson Counties, after aerial photographic soil maps (Texas Agricultural Experiment Station 1975, 1979). This inference is supported by a wealth of pollen analog data from bay and lake settings (e.g. Peck 1973, Bonny 1976, 1978, Pennington 1979), which indicate that about 80 to $97 \%$ of pollen is recruited into sediment by water in settings where there are significant inlet channels for a water transport of pollen.

Particular to alluvium, a landmark study based upon a multi-year collection of analog data in multiple fluvial basins in Exeter County, England (Brown et al. 2007), shows that $91 \%$ of pollen in alluvium is recruited into such sediment from high-energy flood events, ultimately from overland flow, with only a minor aspects originating from air deposition or the redeposition of top-set sediments upstream. Moreover, a close match between basin vegetation composition and pollen in alluvium is discerned, along with an effective transport of upland pollen types (e.g., Calluna vulgaris) without major distance decay of the representation of such pollen at downstream sites. The land area of pollen recruitment at such alluvial sites closely corresponds to the shape of the upstream drainage basin. The latter finding indicates an actual empirical superiority of aqueous transport sites over those where airborne deposition of pollen is predominant, in that distance decay relationship of pollen deposition after air transport are exceedingly difficult to define, and varies greatly moreover according to the surface area of lake or peat basins, as well as the relative afforestion of their margins, the trunk and canopy space of which importantly localize site aerodynamics and pollen taphonomy (Tauber 1967, Anderson 1974, Jacobson and Bradshaw 1981). Often, the land area represented by pollen spectra in small wooded basins is greatly over-estimated due a failure to account for such aerodynamic factors, and local pollen flora are thus interpreted to be regional, as has been the case at Boriack Bog, Texas (Bryant and Holloway 1985).

In less temperate regions, a similar match between pollen in alluvium and basin vegetation is inferred by the author according to the criterion of ecologic rationality of pollen spectra in an earlier study from Highway 155 at Big Sandy Creek in Upshur County, Texas (Albert 2007). In the present study, a more stringent test of the reliability of alluvial pollen data will be made after comparative pollen zonation of nearby cores in different alluvial facies, as well as a comparison of percentage values of statistically robust main pollen types in near-coeval samples from such cores (see below).

Pollen Core 2 from the source of a seep by the site of41AN38 is quite different in pollen taphonomic terms vis à vis the Caddo creek cores, in that there is no possibility of 
extensive upstream transport of pollen at the seep. Here a mix of airborne deposition from extra-local flora, gravity deposition by local types, and some overland flow from the transportational slope of the 41AN38 locale is inferred to be operative. As will become apparent below, it is nonetheless interesting that pollen types found at the 41AN38 seep correspond to those found in the valley of Caddo Creek as a whole, not only with respect to actual genera represented, but often also their relative levels of representation. This comparative similarity provides direct empirical support to the inference that pollen in the creek valley cores is significantly derived from overland flow from extra-riparian zones. Differences between the creek and seep pollen flora are minor, and probably reflect local elements of the seep, where Rhus for example is a significant arboreal element, and Asteraceae is somewhat less important amongst herbaceous pollen types.

\section{A.7 Pollen Zonation}

Pollen zonation, for objective, comparative purposes, is done statistically using a stratigraphically constrained incremental sum of squares cluster analysis employing pollen percentage data. This analysis is facilitated by the CONISS program developed by Dr. E.C. Grimm of the Southern Illinois State Museum and COHMAP member. The program measures the dissimilarity of sample clusters in terms of Edwards and Cavalli-Sforza's chord distance. A dendrogram of this distance is plotted on the right-hand side of pollen diagrams as an addendum. For purposes of zonation here, a chord distance of less-than four is required for the grouping of distinctive pollen assemblages in stratigraphic sequence. At present, it is noted that there is a positive relation between time-depth of individual sequences and the number of defined zones. Thus the abbreviated, $21 \mathrm{~cm}$ pollen sequence in Core 2 produces a single pollen zone. In contrast, seven zones are observed in the circa 6,700 year sequence from Core 3, while a circa 3,000 year parallel sequence in Core 1 produces 3 pollen zones according to consistent statistical standards after Grimm (1987). These zones are described on a sequential basis. The dating of individual pollen zones depends principally on AMS data, although stratigraphic data, including that of pollen and sediments types, is also used to infer less-approximate ranges in some cases.

\section{A.8 Pollen Core 1}

Five AMS dates from this core are used to infer the dating of three pollen zones from the over-bank deposit, although an age estimate of the final zone is necessarily more approximate due to date over-lap or inversion of two assays here. Upper dates from the core nonetheless establish a premodern, post-1000 cal. BP age for the termination of major sedimentation, probably around Late Caddo times. Below this zone, a vegetation history sequence of 3,600-year age is observed. Zones defined on the basis of samples separated by multiple centuries (due to low rates of sedimentation) are assigned minimal chronologic ranges only.

Pollen Assemblage Zone 1 (295-263 cmbs), 3575-2535 cal. BP, Quercus, Carya, Asteraceae. Quercus pollen dominates this zone, ranging from 14.4 to $24.8 \%$, while Carya is almost as important, with values ranging from 12.3 to $18.8 \%$. Low to moderate Pinus values occur, ranging from 3.0 to $11.7 \%$. Trace values (ca.1\%) of Ulmus, Celtis, Juglans, Populus, Alnus, and Fraxinus, as well as low values (ca. 2\%) of Salix appear. Tree pollen as a whole averages about $45 \%$ within this zone. 


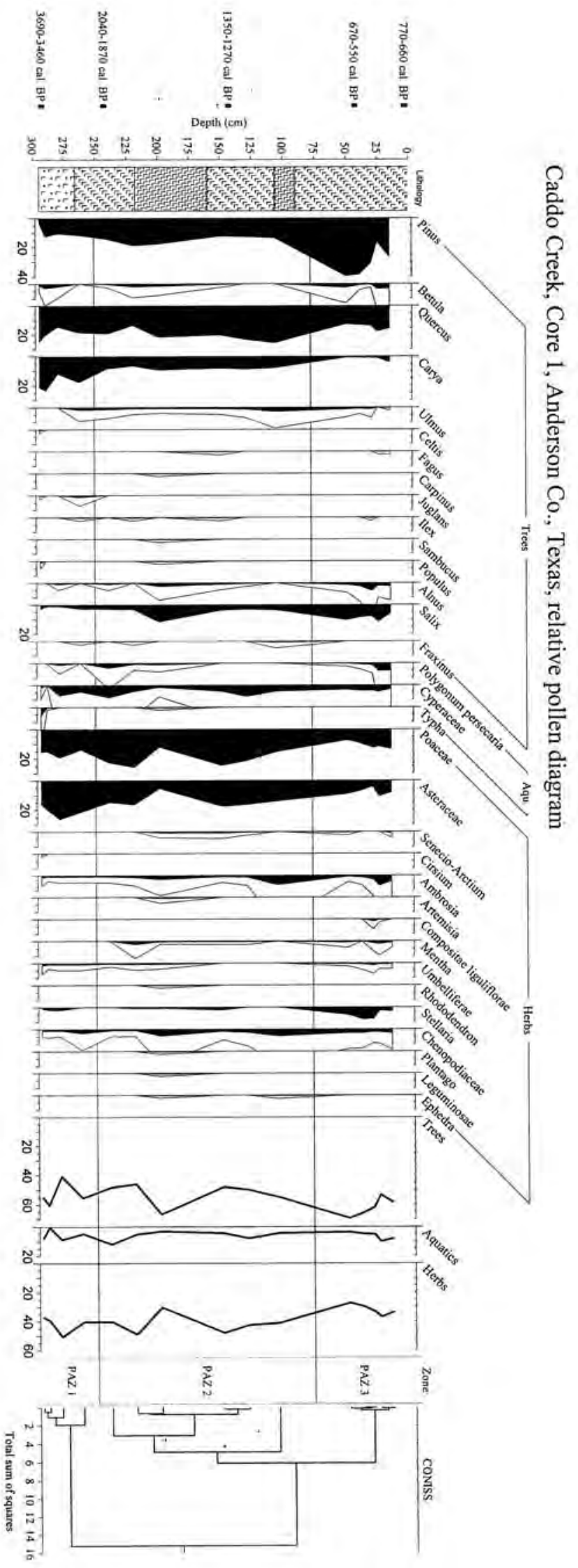


Herbaceous pollen is comprised largely of Asteraceae and Poaceae. These attain maxima of 26.4 and $19.2 \%$ respectively at 280 cmbs. In addition, low but rational values (ca. 1-2\%) of possible ruderal (human disturbance) indicators including Ambrosia and Chenopodiaceae are observed. Minor herbs here include Cirsium, Umbelliferae, and Stellaria. Aquatics are represented by low values of Polygonum persecaria, Cyperaceae, and Typha.

Pollen Assemblage Zone 2 (240-106 cmbs), 1920-1075 cal. BP, Quercus, Pinus, Salix. Quercus pollen dominates this zone, ranging from 12.3 to $25.7 \%$, while Pinus is also important, with values ranging from 12.3 to 18.8\%. Moderate Carya values, ranging from 6.6 to $9.4 \%$, are expressed. Traces of Fagus, Carpinus, Ilex, Sambucus, and Populus are further noted. Alnus and Salix also co-vary, achieving low-to-moderate values, attaining maxima of 2.4 and $11.8 \%$ respectively at 200 cmbs. Tree pollen averages about $55 \%$ in this zone. Herbaceous pollen is comprised largely of Poaceae and Asteraceae. These attain maxima of 25.8 and $16.4 \%$ respectively at 220 cmbs. In addition, a rational representation by ruderal indicators such as Ambrosia and Chenopodiaceae is observed, attaining maxima of 6.5 and $4.7 \%$ in tandem at 106 cmbs. Minor herbs include various composites, Mentha, Umbelliferae, Rhododendron, Stellaria, Plantago, Leguminosae, and Ephedra (a long-distance type). Aquatics are represented by low values of Polygonum persecaria, Cyperaceae, and Typha.

Pollen Assemblage Zone 3 (50-15 cmbs), 750-650 cal. BP, Pinus, Quercus, Salix, Stellaria. Pinus pollen is fluctuating but dominant in zone, and ranges from 16.7 to 39.6\%. Quercus pollen maintains moderate values ranging from 12.8 to $17.8 \%$. Carya declines to only low values (ca. 2\%), while isolates include Fagus and Ilex. Among riparian trees, Alnus generally increases (to a maximum of $5.6 \%$ ), as does Salix (to a maximum of $11.6 \%$ ). Tree pollen as a whole averages about $60 \%$ within this zone. Herbaceous pollen is comprised largely of Poaceae and Asteraceae. These attain maxima of 13.6 and $11.6 \%$ at 15 and 25 cmbs respectively. In addition, a rational representation by ruderal indicators such as Ambrosia and Chenopodiaceae is observed, attaining maxima of 7.0 and $2.8 \%$ in different strata. A significant representation of Stellaria is particular to this zone, attaining a maximum of $7.9 \%$. Minor herbs include composites, Mentha, and Umbelliferae. Aquatics are represented by low values of Polygonum persecaria and Cyperaceae.

\section{A.9 Pollen Core 2}

Two AMS dates from the middle part of this core are used in part to infer the dating of one defined pollen zone from the upper part of the seep deposit by 41AN38. In the main, low sedimentation rates at this site imply a two thousand year time depth of the latter zone; however, a lack of stratigraphic change in the pollen assemblage (statistically clustered into a single, moderately variable zone after CONISS) is suggestive of a shorter time-span, in the order of one thousand years or less after durations of defined pollen assemblage zones in the other, better-dated cores. Further correlations with Cores 1 and 3 are made where Pinus is pollen dominant, Carya values are low (<\%5), and Stellaria is significant, in Zones 3 and 5 respectively. Such relative dating is supportive of a post$1000 \mathrm{cal}$. BP chronologic range of the Core 2 pollen assemblage. Finally, a modern age of the surface sample $(1 \mathrm{cmbs})$ cannot be assumed. It may be important in this respect that not trace of disturbance from adjacent Highway 155 construction is 


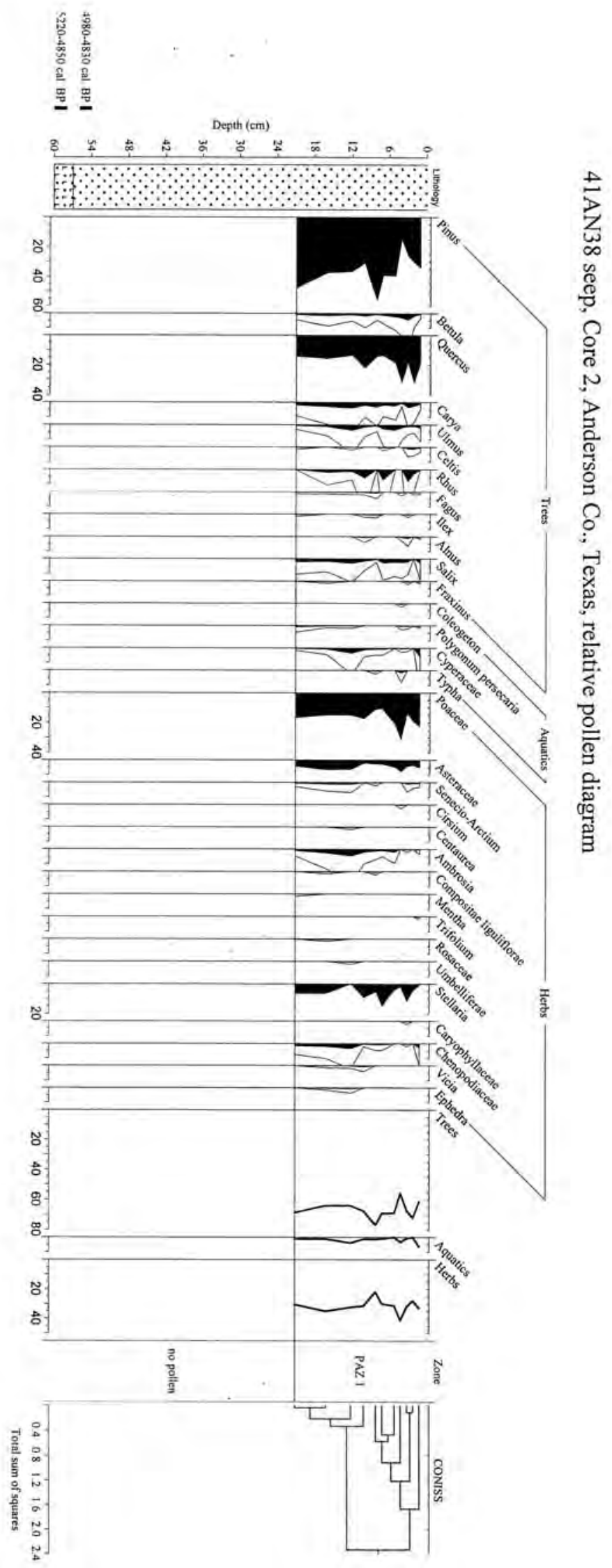




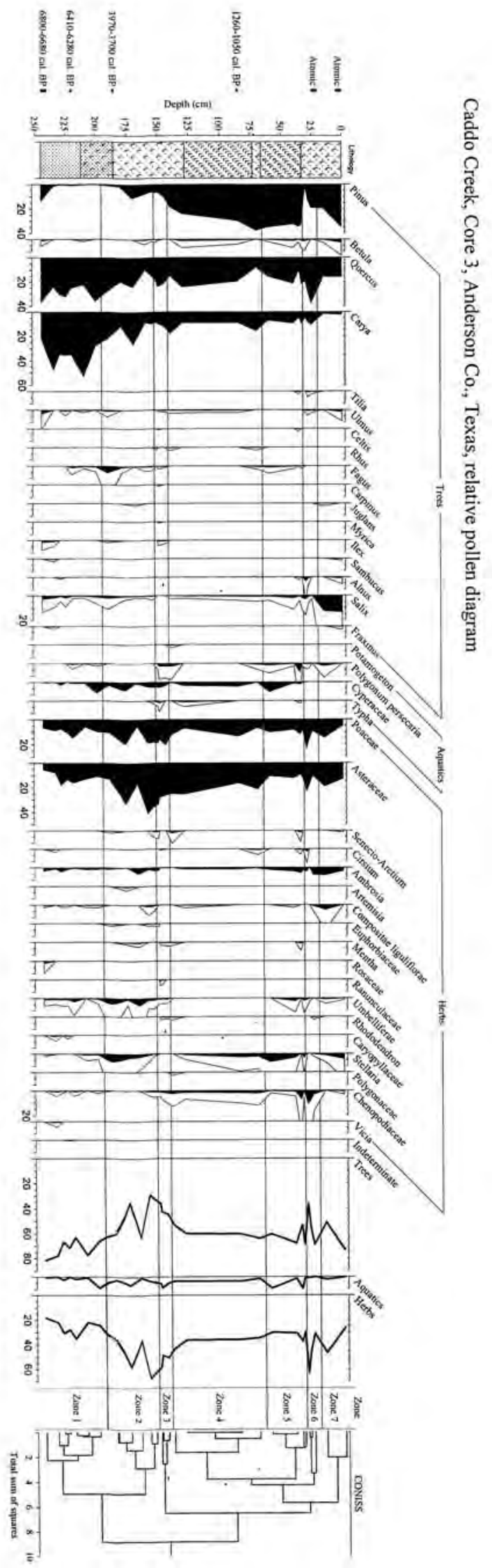


detected in upper samples of Core 2, Zone 1, as is the case in Core 3 (below).

Pollen Assemblage Zone 1 (1-21 cmbs), post-1000 cal. BP (?), Pinus, Quercus, Salix, Poaceae, Stellaria.

This singular pollen assemblage zone exhibits very high values of Pinus (to a maximum of 55.8\%) and high values of Quercus (to a maximum of $31.6 \%$ ). Significant level of Poaceae (to a maximum of $30.7 \%$ ) and Stellaria (to a maximum of $14.5 \%$ ) pollen are also expressed. Only low values (са. 2\%) of Betula, Carya, Ulmus, and Salix occur, although these trees achieve a rational expression. Less continuous are traces of Celtis, Fagus, Ilex, Alnus, and Fraxinus amongst the arboreal pollen types. Finally, a sporadically significant representation by Rhus (to a maximum of $8.0 \%$ ) is noted. Minor herbaceous types are variously represented at the site, and include Asteraceae, the Senecio-Arctium type, Cirsium, Centaurea, Ambrosia, Compositae liguliflorae, Mentha, Trifolium, Rosaceae (not Prunus), Umbelliferae, Caryophyllaceae, Chenopodiaceae, Vicia, and Ephedra (a long-distance type). Of these minor herbs, only composites and chenopods achieve a nearly rational representation. Aquatic pollen types here include low values of Cyperaceae, Typha, Polygonum persecaria, and an isolate of the distinctive Coleogeton-type. Tree pollen averages about $65 \%$ within this zone.

\section{A.10 Pollen Core 3}

Six AMS dates from this core are used to infer the dating of seven pollen zones of the middle channel deposit at Caddo Creek, although an upper disturbed horizon above 33 cmbs is correlated after sedimentary characteristics, with the support of two Atomic age AMS dates, to the period of initial Highway 155 construction around 1940 (Zone 6). In addition to actual dating and sediment mottling due to disturbance, this upper correlation is supported by a coincidence of an absolute maximum of ruderal (human disturbance) pollen indicators (Chenopodiaceae) and forbs (Asteraceae) which would be emphatically promoted by such construction (note such curves in samples at $2.5 \mathrm{~cm}$ increments), as well as inference of a major change of pollen taphonomy, from water to air or gravity deposition, itself caused by this temporary obstruction of drainage. This obstruction of water-flow produces artificial fluctuations in the representation of local floodplain (Quercus+) vs. regional upland (Pinus-Quercus-) pollen types. Inferentially, a resumption of water flow, ultimately from uplands, results in a final rise of Pinus, further enhanced in Atomic times with a development of pine plantations in the region. Below these anthropogenic floral changes, acomplex vegetation historical sequence of 6,700-year time-depth is described (Zones 1-5). Zones defined on the basis of samples separated by multiple centuries (due to low rates of sedimentation) are assigned minimal chronologic ranges.

Pollen Assemblage Zone 1 (245-200 cmbs), 6740-4875 cal. BP (minimally), Carya, Quercus. Carya pollen (52.7\% maximum) dominates this zone, although Quercus is important (37.2\% maximum). Minor arboreal elements further include Pinus, Betula, Ulmus, Fagus, Ilex, Sambucus, Alnus, and Salix. Important herbs include Poaceae (14.7\% maximum) and Asteraceae (18.0\%). Ruderal types here include Ambrosia and Chenopodiaceae, while other minor herbs include Cirsium, Compositae liguliflorae, Rosaceae (not Prunus), Umbelliferae, Caryophyllaceae, Stellaria, and Vicia pollen.

Pollen Assemblage Zone 2 (190-155 cmbs), 4160-3015 cal. BP (minimally), Quercus, Carya, Asteraceae. ). Both Quercus (28.8\% maximum at 190 cmbs, then declining), and Carya pollen (26.5\% maximum at $170 \mathrm{cmbs}$, then declining) dominate this the lower part of zone, which witnesses a rise in Asteraceae to an absolute 
maximum of $41.1 \%$ at 160 cmbs. Pinus exhibits rather low values here. Minor trees further include Betula, Ulmus, Fagus, Juglans, Ilex and Salix. Other important herbs are limited to Poaceae (18.7\% maximum). Ruderal types here include Ambrosia and Chenopodiaceae, while minor herbs include Senecio-Arctium, Artemisia, Compositae liguliflorae, Euphorbiaceae, and Mentha, as well as somewhat higher levels of Umbelliferae and Stellaria pollen.

Pollen Assemblage Zone 3 (151-145 cmbs), 2910-2750 cal. BP (minimally), Quercus, Asteraceae, Carya. Both Quercus (24.4\% maximum), and Asteraceae pollen (33.8\% and declining) dominate this zone. Carya pollen is less significant, and averages about $10 \%$, while amongst other trees, low values of Tilia, Ulmus, Celtis, Rhus, Fagus, Carpinus, Myrica, and Ilex also occur. Other important herbs include Poaceae (20.3\% maximum). Ruderal types achieve a low but rational representation as reflected in Chenopodiaceae, while other minor herbaceous types include Senecio-Arctium, Cirsium, Ranunculaceae, Umbelliferae, and Rhododendron.

Pollen Assemblage Zone 4 (140-70 cmbs), 2620-955 cal. BP, Quercus, Pinus. Both Quercus (24.4\% maximum), and Pinus pollen (rising to $37.9 \%$ ) dominate this zone. Carya pollen is less significant, but achieves minor highs at 140 and $85 \mathrm{cmbs}$ (17.9 and $16.0 \%$ maxima, respectively), while amongst other trees, low values of Ulmus, Celtis, Rhus, Fagus, and Salix occur. Important herbaceous types include Poaceae (13.5\% maximum) and Asteraceae (25.0\% and declining). Ruderal types achieve a low but rational representation after Ambrosia (ca. 1\%) and Chenopodiaceae, which achieves minor highs of 2.6 and $2.4 \%$ at 140 and 85 cmbs, respectively. Minor herbs include Senecio-Arctium, Compositae liguliflorae, Rhododendron, and Polygonaceae.
Pollen Assemblage Zone 5 (60-33 cmbs), 820 cal. BP-Modern, Pinus, Quercus, Stellaria. This zone is dominated by Pinus pollen (34.9\% maximum), with an important representation by Quercus (21.6\% maximum) and Stellaria (6.7\% maximum). Carya undergoes a relative decline $(9.8 \%$ maximum), while amongst other trees, low values of Betula, Tilia, Celtis, Fagus, Alnus, and Salix occur. Important herbaceous types include Poaceae (12.6\% maximum) and Asteraceae (12.4\% maximum). Ruderal types achieve a minor high at 35 $\mathrm{cm}$, including Ambrosia (4.5\%) and Chenopodiaceae (7.2\%). Minor herbs include Cirsium, Compositae liguliflorae, and Umbelliferae.

Pollen Assemblage Zone 6 (30-25 cmbs), ca. $\mathrm{AD}$ 1940, Quercus, Chenopodiaceae, Asteraceae. This zone is dominated by Quercus pollen (rising to $37.8 \%$ ), with an important representation by Chenopodiaceae (10.6\% maximum) and Asteraceae (22.6\% maximum). High values of Poaceae are also evident $(23.0 \%$ maximum). Low values of Betula, Carya, Tilia, Ulmus, Alnus, Salix, Umbelliferae, and Rhododendron further occur.

Pollen Assemblage Zone 7 (0-15 cmbs), Atomic age, Pinus, Quercus, Salix. This zone is dominated by Pinus pollen (rising to $35.0 \%$ at surface), with an important representation by Quercus (16.0\% maximum) and Salix (13.6\% maximum). Low values of Betula, Carya, Celtis, Juglans, Sambucus, Alnus, and Fraxinus also occur. Important herbs include Poaceae (14.6\% maximum) and Asteraceae (19.2\% maximum), with lower pollen values being seen in Ambrosia (6.4\% maximum) and Stellaria (4.2\% maximum). Trace values of Compositae liguliflorae and Umbelliferae finally occur amongst herbs. 
Table A-8. Correlation of Pollen Assemblage Zones in Cores 1-3.

\begin{tabular}{|c|c|c|c|c|c|c|}
\hline $\begin{array}{l}\text { Core } 1 \\
\text { zone }\end{array}$ & $\begin{array}{l}\text { (minimal) } \\
\text { Zonal } \\
\text { time-span }\end{array}$ & $\begin{array}{c}\text { Core } 2 \\
\text { zone }\end{array}$ & $\begin{array}{l}\text { Zonal } \\
\text { time-span }\end{array}$ & $\begin{array}{l}\text { Core } 3 \\
\text { zone }\end{array}$ & $\begin{array}{l}\text { (minimal) } \\
\text { Zonal } \\
\text { time-span }\end{array}$ & $\begin{array}{l}\text { Main zonal } \\
\text { pollen types in } \\
\text { Cores 1-3 }\end{array}$ \\
\hline 一 & 一 & 一 & 一 & PAZ 1 & $\begin{array}{c}(6740-4875 \\
\text { cal. BP) }\end{array}$ & Carya-Quercus \\
\hline PAZ 1A & $\begin{array}{l}\text { 3575-3000 } \\
\text { cal. BP }\end{array}$ & - & - & PAZ 2 & $\begin{array}{l}\text { 4160-3015 } \\
\text { cal. BP }\end{array}$ & $\begin{array}{l}\text { Quercus-Carya } \\
(+) \text {-Asteraceae } \\
(+) \\
\end{array}$ \\
\hline PAZ 1B & $\begin{array}{l}3000-2535 \\
\text { cal BP }\end{array}$ & - & - & PAZ 3 & $\begin{array}{l}\text { 2910-2750 } \\
\text { cal. BP }\end{array}$ & $\begin{array}{l}\text { Quercus-Carya } \\
\text { (-)-Asteraceae (- } \\
\text { ) }\end{array}$ \\
\hline PAZ 2 & $\begin{array}{c}(1920-1075 \\
\text { cal. BP) }\end{array}$ & - & - & PAZ 4 & $\begin{array}{c}\text { 2620-955 } \\
\text { cal. BP }\end{array}$ & Quercus-Pinus \\
\hline PAZ 3 & $\begin{array}{l}\sim 750-650 \\
\text { cal. BP }\end{array}$ & PAZ 1 & $\begin{array}{l}\text { Post-1000 } \\
\text { cal. BP? }\end{array}$ & PAZ 5 & $\begin{array}{l}820 \text { cal. BP- } \\
\text { Modern }\end{array}$ & $\begin{array}{l}\text { Pinus-Quercus- } \\
\text { Stellaria }\end{array}$ \\
\hline- & - & - & - & PAZ 6 & са. 1940 & $\begin{array}{l}\text { Quercus- } \\
\text { Chenopodiaceae- } \\
\text { Asteraceae } \\
\end{array}$ \\
\hline - & - & - & - & PAZ 7 & Atomic age & $\begin{array}{l}\text { Pinus-Quercus- } \\
\text { Salix }\end{array}$ \\
\hline
\end{tabular}

Inter-core correlations are evident from the above, which support a significant chronologic alignment of variation in the main tree and herb pollen types. Identical trends are particularly evident in a general decline of Carya, and a converse rise of Pinus over several millennia. A maximum of forb (Asteraceae and Ambrosia) vegetation is likewise reconstructed in both creek pollen cores during the Fourth Millennium (cal.) BP. After this period, Asteraceae undergoes a continuous decline at Caddo Creek until about 700/800 (cal.) $\mathrm{BP}$, when a minor rise of composites is registered in PAZ 3 in Core 1 and PAZ 5 in Core 3. A minor, secondary rise in Carya also occurs in Core 3 around this time, but this event is not clearly discerned in Core 1 (which is poorly resolved in this aspect). A significant level of Stellaria pollen registration, along with high Pinus levels and generally lower levels of Carya are main traits tentatively aligning pollen zones from the creek sites with the single pollen zone of the seep by 41AN38.

Chronological correlations of the same pollen zonation of the well-dated Cores 1 and 3 in the Caddo Creek valley are a powerful test as to the reliability as well as reproducibility of the alluvial pollen data from lower energy situations. This is particularly true given the statistical characteristics of the CONISS-based cluster analysis, which tends to split rather than lump stratigraphic pollen assemblages zones (Grimm 1987). Apparent chronologic differences in correlated pollen zonal expression in Cores 1 and 3 are evident (Table A-8), but such differences reflect limits of long (multi-century) time increments between samples as imposed by low sedimentation rates. 


\section{A.11 Comparison of Near-Coeval Pollen Samples}

A particularistic comparison of pollen samples from Cores 1 and 3 first depends on the identification of spectra from each core in close chronometric proximity. Comparative pollen spectra of less than 100 years difference in (estimated) age are selected for this purpose. One century is a minimal empirical limit of two-Sigma values after the AMS dating method under ideal conditions. Additional uncertainties as to dating of the upper aspect of Core 1 thus make comparison of these spectra undesirable using this standard. Moreover in Core 3, a break in the pollen sequence around one meter below surface limits comparisons with further parts of Core 1 . More secure comparisons after these criteria are limited to six spectra in Table A-9. In this, pollen types with high base percentages, including Pinus, Quercus, and Carya, Poaceae, and Asteraceae amongst the herbs are considered, as these provide a better statistical basis for comparison. In addition, Salix, a minor tree, is considered, as this may be over-represented on the riparian margin. Finally, Stellaria, a minor herb, is considered, as this is important for a relative dating of Core 2 . A particularistic test of the synchronicity of its relative representation is thus desirable.

A tabulation of major coeval pollen representation levels reveals a highly comparative pattern among the thirty main taxon and spectrum combinations. Twentyseven of these paired values fall within $95 \%$, $1 / 1$ confidence interval as defined by baselevel percentages and absolute pollen counts (Faegri et al. 1989). Exceptions are limited to Asteraceae (which is better represented in Core 3 at 180 and $160 \mathrm{cmbs}$ ) and Pinus (also better represented in Core 3 , at $85 \mathrm{~cm}$ ). Because these are non-local types, and the local pollen of the Salix-type is better represented in Core 1 at the valley margin, it is inferred that such differences reflect higher relative levels of gravity deposition of pollen (never fully airborne nor significantly transported by water) by riparian verge species at the more terrestrial (Core 1) locale.

Along these lines, somewhat higher Quercus levels evident in Core 1 at 106, 280, and 295 $\mathrm{cm}$ depth might reflect a registration of riparian oaks ( $Q$. nigra and $Q$. phellos). Effects of local over-representation due to gravity-deposition by riparian types after terrestrialization are in fact most emphatic within the Core 3 sequence, whereby Salix first becomes an important type in Atomic times (Zone 7). This event is demonstrably after the restriction of water-flow from the highway, which partially dams the drainage of Caddo Creek, giving rise to aquatic communities of Typha domingensis west of the highway (upstream) and telmatic Salix and Quercus nigra to the east (downstream).

Along these lines, it is notable that Stellaria representation, although identical in its trend in both sequences, is consistently if moderately better represented in Core 3 vis à vis Core 1. Stellaria is efficiently transported by wind, and is a regional type as defined in the pollen study from Big Sandy Creek in Upshur County (Albert 2007), where it generally co-varies with Pinus as a favored sub-canopy element of pine woodlands (Bratton 1976). In spite of such minor differences, it is important that the main woodland and grassland types (Pinus, Quercus, Carya, and Poaceae) often achieve a symmetry of representation approaching a 95\%, 2/5 confidence level (values lie within $20 \%$ of each other, after statistical noise). This would further indicate that such types might be used for quantitative ecology studies, including natural history reconstruction. 
Table A-9. Caddo Creek Cores 1/3, Comparison of Coeval Relative Pollen Percentages.

\begin{tabular}{|c|c|c|c|c|c|c|c|c|}
\hline $\begin{array}{l}\text { Depth } \\
\text { cmbs } \\
\text { C. 1/C. } 3\end{array}$ & $\begin{array}{l}\text { Est. age } \\
\text { cal. BP } \\
\text { C. } 1 / \text { C. } 3\end{array}$ & $\begin{array}{l}\mathrm{Pi} \\
(\%) \\
\text { C. 1/C. } 3\end{array}$ & $\begin{array}{l}\text { Quercus } \\
\text { (\%) } \\
\text { C. 1/C. } 3\end{array}$ & $\begin{array}{l}\text { Carya } \\
(\%) \\
\text { C. } 1 / \text { C. } 3\end{array}$ & $\begin{array}{l}\text { Salix } \\
(\%) \\
\text { C. } 1 / \text { C. } 3 \\
\end{array}$ & $\begin{array}{l}\text { Poaceae } \\
\text { (\%) } \\
\text { C. } 1 / \text { C. } 3\end{array}$ & $\begin{array}{l}\text { Aster. } \\
(\%) \\
\text { C. } 1 / \text { C. } 3 \\
\end{array}$ & $\begin{array}{l}\text { Stellaria } \\
(\%) \\
\text { C. } 1 / \text { C. } 3\end{array}$ \\
\hline $295 / 180$ & $3775 / 3675$ & $3.0 / 1.7$ & $24.8 / 19.9$ & $21.3 / 11.9$ & $3.0 / 0.7$ & $15.3 / 19.6$ & $16.3 / 32.9$ & ?/3.5 \\
\hline $290 / 170$ & $3415 / 3410$ & $12.5 / 11.4$ & $20.2 / 24.2$ & $23.5 / 26.5$ & $1.1 / 0.4$ & $15.1 / 5.3$ & $19.9 / 16.7$ & $? / 2.7$ \\
\hline $280 / 160$ & $3090 / 3150$ & $10.6 / 7.9$ & $14.4 / 10.4$ & $12.0 / 8.7$ & $1.0 / 0.4$ & $19.2 / 18.7$ & $26.4 / 41.4$ & $? / 1.2$ \\
\hline $263 / 140$ & $2545 / 2620$ & $11.7 / 18.0$ & $18.7 / 15.0$ & $17.8 / 17.5$ & $2.8 / 0.5$ & $14.0 / 12.0$ & $21.5 / 24.5$ & $0.0 / 0.0$ \\
\hline $106 / 85$ & $1080 / 1155$ & $13.6 / 29.8$ & $25.7 / 19.6$ & $7.9 / 9.0$ & $3.7 / 0.8$ & $15.4 / 13.5$ & $14.0 / 16.3$ & $0.0 / 2.9$ \\
\hline $50 / 60$ & $740 / 820$ & $39.6 / 34.9$ & $12.8 / 15.9$ & $0.9 / 7.1$ & $10.6 / 0.8$ & $7.5 / 10.3$ & $9.3 / 10.7$ & $5.3 / 6.7$ \\
\hline
\end{tabular}

\section{A.12 Natural History}

A natural history of the Caddo Creek valley and 41AN38 environs is made reconstructable by the demonstration of a rational program of dating and pollen data analysis. Pollen data from Cores 1 and 3 Caddo Creek will be considered in tandem, but remarks will be made first regarding the local vegetation situation elucidated in upper aspects of Core 2 from the 41AN38 seep.

As hypothesized above, the pollen zone from Core 2, comprised of eleven viable samples from a depth of $21 \mathrm{~cm}$ to surface, dates principally to the last 1000 years. Probable time-elapse between samples is thus something in the order of one century, while individual $1 \mathrm{~cm}$ thick samples probably relate to pollination over multiple decades. In this time frame, little significant change in vegetation occurs outside of minimally significant oscillations of Pinus vs. Quercus, as well as Poaceae and an occasional appearance of moderate values of Rhus and other local species of trees and herbs. The pollen spectrum in fact is typical of a post-oak savanna type with an admixture of pine (note proximity of this vegetation zone to the east of the site). Also compared to the creek valley sites, much less Asteraceae occurs. A relative poverty of this common forb pollen type is related to a lower influence of prairie vegetation patches atop the Trawick series, which are proximal to the valley but not the archaeological site. It is thought also that
Stellaria is a regional type after its dispersion characteristics and associations with pine-dominated woodlands, which would strengthen its use in relative pollen dating (cf. Albert 2007). Notably, Stellaria is also not common to the archaeological locale today.

A most characteristic prehistoric disturbance pollen taxon defined by the author at the Caddo mound site of 3HE40 (Albert 2004), as well as Mississippian archaeological sites (Peacock and Reese 2003) is the Chenopodiaceae-type. This occurs in most levels in Core 2, but as low values usually ( 0.5-1\%), except in some lower levels, where a maximum value of $3.5 \%$ is registered at 12 cmbs. By depth and logical date, it is tempting to associate this Chenopodiaceae maximum with the 41AN38 Caddo occupation. No definitive cultivation indicators occur here, however (Dull 2006 and Eubanks 1997). It is probable in any event that long-term Caddo impact on the environment is negligible. A singular change in ecology indicated in the pollen data from the 41AN38 seep is reflected, however, in pre-recent $(4 \mathrm{cmbs})$ finds of Coleogeton (false-pondweed). This local aquatic type certainly derives from the seep, and is strongly indicative of an alkaline hydrology (possibly as affected by regional marls). Regardless of moderately acidic conditions read after soil maps, it is likely that local (41AN38) soil conditions were more basic at certain times in the past. 
From Caddo Creek itself, conclusive evidence has been collected indicating a major decline of Carya, in relative pollen terms from $52.7 \%$ before six thousand years ago to only trace values in the early part of the $20^{\text {th }}$ Century. During this same time, a major increase in Pinus from negligible values to about $35 \%$ of total land pollen is also registered. This increase may sometimes be promoted by, but is never significantly negated by climate forcing. Rather, a step-like increase in Pinus endures through the long-term (until artificial transforms in Core 3, Zone 6). This pattern is strongly suggestive of gradual acidification of regional soils commonly inferred in North Hemispheric Holocene bio-stratigraphy (this is a product of increases in precipitation and leaching in Global terms after Ice Ages, which are drier). This is regionally possible due to tendencies of most upland pine species in East Texas to increase local soil ph through needle-fall. As soils acidify, the relative prominence of pine increases, leading to still more localized acidification (cf. Diggs et al. 2006). The present study demonstrates that such acidification is irreversible over Holocene timescales.

Due to generally low levels of ruderal pollen representation as well as an absence of evidence for substantial cultivation, it is probable that other major changes in the Caddo Creek diagrams reflect climate forcing. Most obvious of such changes is the major rise of forbs and grasses in Zone 2, where Asteraceae attains an absolute maximum of $41.1 \%$, and non-tree pollen as a whole forms a majority. After AMS dating, this rise begins a little before four thousand years ago and peaks a little before three thousand years before present. The beginning of the Pinus rise also dates to this upper part of this zone, which further supports an inference of warm and a dry climate, conditions that promote forbs. After pollen response surface data from eastern North America, it seems likely that a summer temperature increase by more than
1 degree Celsius at this time, else there is a decline in effective (non-winter) precipitation in the order of $100 \mathrm{~mm}$ per annum or more (Bartlein et al. 1986), although these are inferences made conservatively, as they based on analog sites lacking major inlet channels (which might affect relative pollen recruitment). Other elements of the Fourth Millennium (cal.) BP include isolated grains in three separate spectra of Euphorbiaceae, a taxon (unproductive of pollen) typical of blackland prairie formations to the west. Although the more common Poaceae grains are less than distinctive with respect to specific morphology, an expansion of little bluestem and Indian grass species is probably reflected in this zone. Close-interval sampling subsequently attests to the empirical reality of a decline in non-tree pollen after three thousand years ago, generally coeval to a major mesic climate phase (Zone 3) at Big Sandy Creek in Upshur County, Texas (Albert 2007). It is likely that wetter conditions here have led to a contraction of grasslands, although this palynological climate signal is overpatterned by a hypothesized pedogenic rise of pine. A secondary decline of non-tree pollen then occurs after 800 years ago. Importantly, this decline is also coeval with a mesic phase (Zone 6) at Big Sandy Creek, and together with the latter data strongly suggests that somewhat cooler or wetter climate conditions prevailed broadly during Late Caddo and post-Contact times (Little Ice Age). Relatively modest (ca. 30\%) nontree pollen values of Euro-American date at Caddo Creek (around $40 \mathrm{cmbs}$ ) further show by way of comparison that prehistoric vegetation was relatively open, with a mosaic of grasslands, woodlands, and savannas. In fact, the extent of grassland a little before three thousand years ago was probably greater than that witnessed in modern times, even after significant EuroAmerican impacts.

Compared to pollen stratigraphy in the Big Sandy Creek valley, that at Caddo Creek 
produces a more complex data pattern involving a wider variety of plant species and genera reacting importantly not only to climate forcing and fire, but also major pedogenic changes which may be characterized as gradual and unidirectional acidification. Since base conditions at Big Sandy Creek are more generally hyperacidic, given a prevalence of highly leached sandy substrates in the valley (with ph values approaching four), it is inferred that the latter sequence is largely insensitive to increasing acidity vectors by 3500 (cal.) BP. The same acidity leads also to a poverty of Carya and high levels of Betula (which remains sensitive to climate changes after moisture requirements). Rather than reflecting principally bi-directional climatic forcing, the 6,700 year pollen sequence at Caddo Creek thus indicates a unidirectional geologic as well as more variable climatic vectors. A richer human subsistence base provided by a more diverse environment densely vegetated at times by highly productive Carya might also allow for different prehistoric (both Caddo and PreCaddo) human interactions with the environment. This cultural ecological history is now considered in a detailed manner, focusing upon anthropogenic indicator horizons in the main valley pollen diagrams.

\section{A.13 Cultural Ecological History}

The valley of Caddo Creek presents a mosaic of vegetation types through history ranging from extensive hickory woodlands to grasslands and oak savannas in the period before 4000 (cal.) BP. Judging from modern vegetation surveys in West Arkansas, it is more likely that woodland conditions promoting hickory are semi-open as opposed to closed canopy (Jurney and Stahle 2004). The West Arkansas data thus affirm the definition by Tharp (1926) of Carya texana and other hickories as midseral species in East Texas, promoted by moderate disturbance. In terms of huntergatherer economy, this earlier epoch is a highly productive one, for hickory is a major food source, producing about 23,000 Kcalories per tree. This is much more than oak (or any other deciduous element, excepting pecan), which produces little more than 1,000 K-calories per tree (Brown 1988), while processing requirements for hickory nuts are also considerably lower than those of acorns (Tull 1999). By virtue of the principle of trophic levels, food resources for Native populations from fauna should be considerably less than that from flora (by a factor of more than ten after calculations by Brown 1988 respecting Aquilla Lake environments of Hill County in North Central Texas). Nonetheless, a presence of grasslands, open woodlands, and forests in valley bottoms would produce a variety of game animals for exploitation, with suitable environments for both bison and deer.

After pollen data, this wide resource base becomes more restrictive during the Fourth Millennium (cal.) BP, when grasses expand and hickories significantly contract. It is important to note that ruderal Chenopodiaceae (which do occur in dry grasslands) does not achieve a rational representation at this time. In fact, Chenopodiaceae in Trans-Mississippian grasslands are often attributable to human disturbance (Schauwecker and MacDonald 2003), rather than a natural condition.

At the beginning of the Third Millennium (cal.) B.P., grasses began a long decline as woodlands became increasingly dominated by pine. Nonetheless, a secondary rise of Carya to $17.9 \%$ at 140 cmbs was accompanied by a high in ruderal Chenopodiaceae of $2.6 \%$, when the latter taxon also first achieved a rational representation. Chenopod values around $1 \%$ continued under arboreal conditions until about 1,000 (cal.) B.P., when tertiary rises of Carya (to 16.0\%) and Chenopodiaceae (to 2.4\%) are evident. Prehistoric maxima of Chenopodiaceae pollen of about two-to-three percent are not 
inordinately lower than a modern maximum (prior to Highway 155 construction) of $7.2 \%$.

This association of a syn-anthropic with higher hickory pollen levels amid increasingly afforested conditions provides support for a syn-anthropic origin of the rational Chenopodiaceae response, which is expressed contrary to primary ecologic bias (this ruderal should increase with grasslands). Its regular representation is due to fact that amongst anthropogenic indicators, chenopods share high levels of pollen production and an efficient airborne distribution of pollen grains (Behre and Kucan 1986). Of course, this also enhances its representation levels on land surfaces subject to surface run-off. An association of this taxon with higher hickory pollen values then not only supports modern observations of Carya ecology (Tharp (1926), but also a hypothesis for an anthropogenic origin of some prehistoric hickory rises, which is posited as a sylvicultural expansion fostered first by Woodland peoples, and then by the Early or Middle Caddo, achieved through an artificial opening of canopy space, ultimately as part of a general adaptive pattern to increase hickory nut yields through moderate disturbance (Delcourt and Delcourt 2004). Indeed, two coeval Carya rises are also observed at Big Sandy Creek in periods of moderate disturbance or recovery from major fires (Albert 2007). Along these lines, a long-term (pedogenic) decline of hickory, a major food source in the Middle Archaic (Story et al. 1990), might induce later peoples to increase its distribution and production through minor clearances, possibly aided by fire setting, which may also further contribute to a rise of pine (Spalt and Reifsnyder 1962).

This hypothesis generally supports models of later Woodland and earlier Caddo subsistence that posit an importance of hickory nut exploitation in many regions of eastern Texas after macro-botanical evidence (Dering 1993 1994). At Hurricane Hill (41HP106) in Hopkins County, Texas for example, hickory comprises about 92\% of finds even in Middle Caddo times, where only one gram of maize and a single squash rind is observed (Goldborer and Pertulla 1999). The Chenopodiaceae pollen type also includes amaranths such as pigweed, which is present at earlier Caddo sites such as Spider Knoll in Delta County (Dering 1994), along with Polygonaceae, considered generally as an anthropogenic indicator (Behre 1981). Notably, a sole pollen grain of this type at Caddo Creek occurs in Woodland times, along with the above Chenopodiaceae maximum.

It has been noted that no Zea is identified in the Caddo Creek valley pollen cores. Direct evidence of cultivation is thus lacking, although it is further noted that by way of comparison, Zea in cores from the Tennessee valley, from regions under considerable Native cultivation, is an uncommon pollen type (Delcourt et al. 1986). Thus less considerable maize cultivation might not register unless a very intensive pollen sampling strategy is adopted. With a view to models of maize cultivation in Late Caddo times, macrobotanical and isotope evidence point to an increased consumption of corn in East Texas (Pertulla 1996, 2008). Particular to Caddo Creek, Chenopodiaceae pollen declines at this time $(<1 \%)$ alongside Carya, although Ambrosia, a syn-anthropic type, achieves a more rational representation in approximate Late Caddo times.

Rather than increasing, syn-anthropic pollen indications thus become more ambiguous after corn cultivation is (thought to be) established. It may be that a greater later Caddo focus on maize production seen in other regions (e.g., Gardner 1997 for Red River valley) need not relate to higher total human impact on the environment. At Caddo Creek, such impacts might actually contract as more economic effort is placed on small garden plots and away from wider 
woodland clearances that are palynologically more visible. A shift in character of minor anthropogenic indicators from less Chenopodiaceae to more Ambrosia might relate to subtle changes in the character of human impacts that are at present difficult to distinguish, due to their low amplitude. A slightly higher amplitude combination of this type is indeed seen in one spectrum from $12 \mathrm{cmbs}$ in Core 2 (middle part of post-1000 cal. BP zone) by 41AN38, which registers $4.5 \%$ Ambrosia and $3.5 \%$ Chenopodiaceae. It seems plausible that this mid-zonal spectrum from the seep reflects a local product of moderate Caddo agricultural impacts that are registered regionally in the better-dated valley cores.

\section{A.14 Conclusions}

A use of pollen data to infer human-plant interactions in the Caddo Creek valley and a seep adjacent to the archaeological site of 41AN38 has met with some success. Given the pioneer nature of the study, it is unsurprising that some major unexpected findings are apparent. Most important of these is a clear documentation of a multimillennial decline of Carya and rise of Pinus that must reflect a gradual acidification of soil substrates in the study region. Very low Pinus values seen in this period are of particular interest in that pine is a productive and extensively transported pollen type. It near-absence in earlier Holocene sediments indicates that the proximity of mixed-pine woodland mapped east of the study region (Diggs et al. 2006 and Bureau of Economic Geology 2000) is at a far remove, and has expanded into its present position over the long-term. After comparisons of growing stock volume and pollen expression from surfaces in the eastern United States ((Delcourt et al. 1984), it is estimated that this early zonal remove of mixed-pine forest is greater than $50 \mathrm{~km}$; in other words, there is a major shift of vegetation belts in the region in the past six thousand years. Altogether, these findings are important for present forestry, as the above would indicate that acidification caused by mono-cultural pine plantations in modernity is irreversible in practical terms.

The quite different environment before four thousand years ago is much more productive for human economy, which in times of decline might adapt to a reduction of resources through an adoption of first sylviculture (by 3,000 cal. B.P. or earlier?) and then agriculture (by 1,200 cal. B.P. or earlier?). A further find of interest is that the prehistoric vegetation landscape of the Caddo Creek valley is relatively open, if not at times more open than the present condition, particularly as forced by a xeric Fourth Millennium B.P. climate. Caddo impact on woodlands and grasslands is moderate, whereby a non-employment of the plow may be a factor (in Old World palynology, the range and magnitude of agricultural indicators is greater due to the use of animal traction, Behre 1981). Moreover, there is no discernable relationship between a more intensive cultivation of maize probable in later Caddo times and a higher registration of synanthropic pollen. In fact, Woodland period impacts inferred to be sylvicultural are as great as those of the early Caddo. Such impacts scarcely affect pollen zonation, which is first determined by pedogenic and then by climatic change.

From a methodological point-of-view, comparisons of pollen zones and individual spectra from alluvium of different aspect and granulometry indicate that, although pollen concentration in alluvium is highly variable, relative pollen recruitment (i.e., percentage data) is insensitive to such differences, in both the present study as well as earlier work sponsored by Texas Department of Transport Environmental Affairs Division at 41UR77, to the northeast (Albert 2007). This would imply that the differential sorting of pollen by size under different water velocities detected in controlled flume experiments (e.g., Brush 
and Brush 1972) is not necessarily operative in real world situations. Indeed, multiple years of observation of actual pollen transported by water in fluvia from Exeter County, England show uniform pollen composition in respective water columns from a range of basins types under different flood stages (Brown et al. 2007).

After analytic experiences of the author, as well as lab- and field-work of Holmes (1990), macro- and micro-topic graphic effects in most slack water alluvial deposits prevent sorting. By the latter, it is meant that the grain and micro-undulation of alluvium acts as a trap unless surfaces are comprised largely of very level fines (clays and fine silts). This catchment prevents an effective sorting of pollen in most alluvial situations. Respecting macro-topographic effects, one can also observe that many depositional environments, including oxbows (e.g. Delcourt et al. 1986; Albert 2007), as well as undulating over-bank deposits of the present study, also act as pollen traps at a larger scale. In such cases, pollen is differentially represented is only if it is already sorted prior to site recruitment, presumably when water flow rates are low (Allen 1965). Along these lines, more sophisticated flume experiments of Holmes (1990) show there is no sorting of pollen in water flows greater than $30 \mathrm{~cm}$ per second, while such sorting is fully effected only at quite low rates of about $5 \mathrm{~cm}$ per second. In real world terms, Holmes finds that these conditions occur most often in sediment-laden embayments and lakes. Even should a small-order drainage exhibit such rates regularly, this would not actually result in differential pollen sorting in sediment, as a great majority $(91+\%)$ is transported by water during flood stage (Brown 2007). The implications of the present and other (laboratory and analog) studies are that properly selected alluvial sites can provide data for environmental study far beyond the limited geographic extent of traditional bog sites. 
Table A-10. Caddo Creek Core 1, Absolute Pollen Counts.

Depth

Tree and shrub pollen

$\begin{array}{lc}\text { Pinus } & 6 \\ \text { Betula } & 8 \\ \text { Quercus } & 39 \\ \text { Carya } & 1 \\ \text { Ulmus } & 1 \\ \text { Celtis } & - \\ \text { Fagus } & 1 \\ \text { Carpinus } & - \\ \text { Juglans } & - \\ \text { Ilex } & - \\ \text { Sambucus } & - \\ \text { Populus } & - \\ \text { Alnus } & 6 \\ \text { Salix } & 15 \\ \text { Fraxinus } & -\end{array}$

Aquatic

Polygonum pers.

Cyperaceae

Typha

Non-tree pollen

Poaceae
Asteraceae
Senecio-Arctium
Cirsium
Ambrosia
Artemisia
Compositae lig.
Mentha
Umbelliferae
Rhododendron
Stellaria
Chenopodiaceae
Plantago
Leguminosae
Ephedra

Total land pollen

Lycopodium (spike)
$15 \mathrm{~cm}$

66

8

39

10

1

1

-

$-$

6

15

- -

13

7

$-$

34

20

2

10

-

$-$

2

2

$-$

7

7

$-$

$-$

-

250

26

43

9

3

1

-

-

-

$-$

5

$-$
$25 \mathrm{~cm}$

$30 \mathrm{~cm}$

$39 \mathrm{~cm}$

46

$-$

30

$67 \quad 90$

12

$30 \quad 31$

22

32

-

-

-

1

-

12

$17 \quad 20$

-

14

12

3

8

2

9$$
\text { - }
$$

30

27

23

28

9

16

18

$-$

$-$

6

-

3

3

17

19

46

- -

$-$

-

259

186

243

15

20

35 
Table A-10, continued.

Depth

$50 \mathrm{~cm}$

$85 \mathrm{~cm}$

$106 \mathrm{~cm}$

$130 \mathrm{~cm}$

Tree and shrub pollen

Pinus

90

Betula

6

Quercus

29

Carya

2

Ulmus

Celtis

Fagus

Carpinus

Juglans

Ilex

Sambucus

Populus

Alnus

3

Salix

Fraxinus

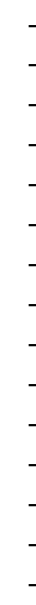

29

28

$-$

55

$-$

$\begin{array}{ll}- & 55 \\ - & 17\end{array}$

51

19

3

$-$

- 6

63

Aquatic pollen

Polygonum pers.
Cyperaceae
Typha

1

Typha

Non-tree pollen

Poaceae
Asteraceae
Senecio-Arctium
Cirsium
Ambrosia
Artemisia
Compositae lig.
Mentha
Umbelliferae
Rhododendron
Stellaria
Chenopodiaceae
Plantago
Leguminosae
Ephedra

Total land pollen

$33 \quad 47$

$30 \quad 36$

$\begin{array}{ll}30 & 1\end{array}$

-

143

- -

- $\quad$ -

$\begin{array}{ll}- & - \\ - & 1\end{array}$

$\begin{array}{ll}- & 1 \\ - & -\end{array}$

$-$

-

10

5

- $\quad-$

6 
Table A-10, continued.

Depth

Tree and shrub pollen

Pinus

Betula

Quercus

Carya

Ulmus

Celtis

Fagus

Carpinus

Juglans

Ilex

Sambucus

Populus

Alnus

Salix

Fraxinus

Aquatic pollen

Polygonum pers.

Cyperaceae

Typha

Non-tree pollen

Poaceae
Asteraceae
Senecio-Arctium
Cirsium
Ambrosia
Artemisia
Compositae lig.
Mentha
Umbelliferae
Rhododendron
Stellaria
Chenopodiaceae
Plantago
Leguminosae
Ephedra

Total land pollen

Lycopodium (spike)
$150 \mathrm{~cm}$

26

1

43

17

2

-

1

-

8

-

9

-

52

37

2

-

2

$-$

$-$

2

1

-

4

3

$-$

$-$

-

224

39
$200 \mathrm{~cm}$

$220 \mathrm{~cm}$

$240 \mathrm{~cm}$

45

4

55

24

2

$-$

-

1

-

-

1

6

30

-

\section{3}

4

$-$

-

31

14

2

$-$

7

2

$-$

1

1

1

2

12

\section{1}

1

1

249

24
2

9

40

4

29

14

2

-

$-$

1

$-$

$-$

7

1

17

-

55

46

29

1

39

17

3

$-$

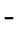

-

-

2

6

-

($$
\text { . }
$$

$35 \quad 30$

- $\quad-$

- $\quad$ -

32

- -

-

5 -

$2 \quad 1$

- -

2 -

22

- -

-

$213 \quad 202$

$51 \quad 26$ 
Table A-10, continued.

Depth

Tree and shrub pollen

Pinus

Betula

Quercus

Carya

Ulmus

Celtis

Fagus

Carpinus

Juglans

Ilex

Sambucus

Populus

Alnus

Salix

Fraxinus

Aquatic pollen

Polygonum pers.

Cyperaceae

Typha

Non-tree pollen

Poaceae

Asteraceae

Senecio-Arctium

Cirsium

Ambrosia

Artemisia

Compositae lig.

Mentha

Umbelliferae

Rhododendron

Stellaria

Chenopodiaceae

Plantago

Leguminosae

Ephedra

Total land pollen

Lycopodium (spike)
$263 \mathrm{~cm}$

$280 \mathrm{~cm}$

$290 \mathrm{~cm}$

$295 \mathrm{~cm}$

25

$-$

40

38

4

-

3

1

$-$

$-$

6

1

10

-

30

46

$-$

$-$

2

$-$

$-$

$-$

2

$-$

$-$

6

$-$

$-$

213

403
22

4

30

25

$-$

$-$

$-$

$-$

$-$

-

2

$-$
$34 \quad 6$

82

$55 \quad 50$

$64 \quad 43$

-

$-$

$-$

$-$

$-$

$-$

$-$

3

$-$

6

4

$-$

12

$\begin{array}{lll}40 & 41 & 31\end{array}$

$55 \quad 54 \quad 33$

$-$

$-$

2

$-$

-

1

- 1

23

- -

$-$

- 1

$2 \quad 3$

-

52

32

- -

$-$

277

203

208

195

192 
Table A-11. Caddo Creek Core 1, Relative Pollen Percentages.

Depth

Tree and shrub pollen

$\begin{array}{ll}\text { Pinus } & 26.4 \\ \text { Betula } & 3.2 \\ \text { Quercus } & 15.6 \\ \text { Carya } & 4.0 \\ \text { Ulmus } & 0.4 \\ \text { Celtis } & - \\ \text { Fagus } & 0.4 \\ \text { Carpinus } & - \\ \text { Juglans } & - \\ \text { Ilex } & - \\ \text { Sambucus } & - \\ \text { Populus } & - \\ \text { Alnus } & 2.4 \\ \text { Salix } & 6.0 \\ \text { Fraxinus } & -\end{array}$

Aquatic pollen

Polygonum pers.
Cyperaceae
Typha

Non-tree pollen

Poaceae
Asteraceae
Senecio-Arctium
Cirsium
Ambrosia
Artemisia
Compositae lig.
Mentha
Umbelliferae
Rhododendron
Stellaria
Chenopodiaceae
Plantago
Leguminosae
Ephedra

Total land pollen Lycopodium (spike)

250

26

Tree and shrub pollen

$\begin{array}{ll}\text { Pinus } & 39.6 \\ \text { Betula } & 2.6 \\ \text { Quercus } & 12.8 \\ \text { Carya } & 0.9 \\ \text { Ulmus } & 1.3 \\ \text { Celtis } & - \\ \text { Fagus } & - \\ \text { Carpinus } & - \\ \text { Juglans } & -\end{array}$

5.2

2.8

13.6

8.0

0.8

$-$

$-$

$-$

0.8

0.8

2.8

2.8

-

-
$25 \mathrm{~cm}$

$30 \mathrm{~cm}$

$39 \mathrm{~cm}$

11.6

10.9

-

7.0

16.7

3.5

17.8

31.0

39.6

0.5

13.9

0.9

0.9

13.3

1.2

1.4

0.9

$-$

-

-

0.5

-

5.6

7.9

2.6

1.9

$-$

1.4

3.7

0.9

4.7

$-$

$12.5 \quad 9.9$

$4.2 \quad 6.9$

- -

$2.8 \quad 1.3$

-

1.4 -

1.4 -

$1.4 \quad 0.9$

-

$\begin{array}{ll}7.9 & 8.2\end{array}$

$1.9 \quad 2.6$

1.9

- -

$-$

$186 \quad 243$

$20 \quad 35$ 
Depth

Ilex

Sambucus

Populus

Alnus

Salix

Fraxinus

Aquatic pollen

Polygonum pers.

Cyperaceae

Typha

Non-tree pollen

Poaceae

Asteraceae

Senecio-Arctium

Cirsium

Ambrosia

Artemisia

Compositae lig.

Mentha

Umbelliferae

Rhododendron

Stellaria

Chenopodiaceae

Plantago

Leguminosae

Ephedra

Total land pollen

Lycopodium (spike)

277

11

0.4

3.1

1.3

10.6

$15 \mathrm{~cm}$

7.5

9.3

0.4

$-$

$-$

$-$

0.9

0.4

5.3

2.6

$-$

$-$

Tree and shrub pollen

$\begin{array}{ll}\text { Pinus } & 12.3 \\ \text { Betula } & 0.5 \\ \text { Quercus } & 20.4 \\ \text { Carya } & 8.1 \\ \text { Ulmus } & 0.9 \\ \text { Celtis } & - \\ \text { Fagus } & 0.5 \\ \text { Carpinus } & - \\ \text { Juglans } & - \\ \text { Ilex } & 0.5 \\ \text { Sambucus } & - \\ \text { Populus } & - \\ \text { Alnus } & 0.9 \\ \text { Salix } & 3.8 \\ \text { Fraxinus } & -\end{array}$

Aquatic pollen

Polygonum pers. Cyperaceae

4.3

Typha
Table A-11, continued.

$30 \mathrm{~cm} \quad 39 \mathrm{~cm}$

0.5

3.2

3.7

0.9

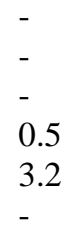

7.8

4.2

$-$

15.4

21.5

16.4

0.5

$-1.4$

6.5

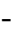

-

$-$

$-$

$-$

4.7

$-$

0.5

224

469

219

80

0.5

$-$

$-$

2.3

$-$

$-$

17.7

18.8

14.4

1.6

1.9

0.5

13.6

6.6

19.3

9.4

8.4

0.8

0.9

1.5

-

$-$

0.4

$-$

$-$

0.4

$-$

2.4

11.8

$-$

-

$-$

-

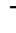

-

3.3

1.0

-

0.5

0.9

3.5

1.2

4.2

8.4

0.4 
Table A-11, continued.

Depth

Non-tree pollen

Poaceae

Asteraceae

Senecio-Arctium

Cirsium

Ambrosia

Artemisia

Compositae lig.

Mentha

Umbelliferae

Rhododendron

Stellaria

Chenopodiaceae

Plantago

Leguminosae

Ephedra

Total land pollen

Lycopodium (spike)

Tree and shrub pollen

$\begin{array}{ll}\text { Pinus } & 11.7 \\ \text { Betula } & - \\ \text { Quercus } & 18.7 \\ \text { Carya } & 17.8 \\ \text { Ulmus } & 1.9 \\ \text { Celtis } & - \\ \text { Fagus } & - \\ \text { Carpinus } & - \\ \text { Juglans } & 1.4 \\ \text { Ilex } & 0.5 \\ \text { Sambucus } & - \\ \text { Populus } & - \\ \text { Alnus } & - \\ \text { Salix } & 2.8 \\ \text { Fraxinus } & 0.5\end{array}$

Aquatic pollen

Polygonum pers.

Cyperaceae

Typha

Non-tree pollen

Poaceae

Asteraceae

Senecio-Arctium

Cirsium

Ambrosia

Artemisia

Compositae lig.

Mentha

Umbelliferae

Rhododendron
$15 \mathrm{~cm}$

24.6

17.5

0.9

0.9

-

0.9

0.5

$-$

1.9

1.4

-

-

224

39

11.7

18.7

17.8

1.9

1.4

0.5

2.8

0.5
25
12.2
5.5
0.8
-
2.8
0.8
-
0.4
0.8
0.4
0.8
4.7
0.4
0.4
0.4

249

24

10.6

1.9

14.4

12.0

$-$

$-$

$-$

-

$-$

-

-

-

1.0

1.0

1.4

7.2

-

19.2

26.4

-

$-$

1.0

$-$

-

-

$-$ $\begin{array}{llll}0.9 & 1.0 & 0.7 & 1.5\end{array}$

$30 \mathrm{~cm}$

$39 \mathrm{~cm}$

25.8

16.4

22.8

14.9

$-$

1.4

1.0

-

$-$

2.3

0.9

$-$

0.9

0.9

$-$

-

-

213

51

202

26

34

3.0

2.9

1.0

$20.2 \quad 24.8$

$23.5 \quad 21.3$

$-$

-

0.5

$-$

-

-

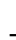

$-$

$-$

$-$

-

$1.1 \quad 3.0$

0.5

$-$

1.0

-

$\begin{array}{ll}- & 2.0\end{array}$

$\begin{array}{ll}0.4 & 5.9\end{array}$

$15.1 \quad 15.3$

$19.9-16.3$

- -

$\begin{array}{ll}- & 0.5\end{array}$

$\begin{array}{ll}0.7 & 1.5\end{array}$

- -

-

$\begin{array}{ll}- & 0.5\end{array}$

$\begin{array}{llll}0.9 & 1.0 & 0.7 & 1.5\end{array}$ 


\begin{tabular}{lllll} 
& \multicolumn{4}{c}{ Table A-11, continued. } \\
Stellaria & - & 1.9 & 1.8 & 1.0 \\
Chenopodiaceae & 2.8 & 1.0 & 1.1 & 1.0 \\
$\quad$ Plantago & - & - & - & - \\
Leguminosae & - & - & - & - \\
Ephedra & - & - & - & - \\
& & & & \\
Total land pollen & 213 & 208 & 277 & 203 \\
Lycopodium (spike) & 403 & 132 & 195 & 192
\end{tabular}

Table A-12. 41AN38 Seep Core 2, Absolute Pollen Counts.

Depth

$1 \mathrm{~cm}$

$2 \mathrm{~cm}$

$3 \mathrm{~cm}$

$4 \mathrm{~cm}$

Tree and shrub pollen

$\begin{array}{ll}\text { Pinus } & 107 \\ \text { Betula } & 2 \\ \text { Quercus } & 59 \\ \text { Carya } & 3 \\ \text { Ulmus } & 7 \\ \text { Celtis } & 2 \\ \text { Rhus } & - \\ \text { Fagus } & 1 \\ \text { Ilex } & - \\ \text { Alnus } & 1 \\ \text { Salix } & 9 \\ \text { Fraxinus } & 1\end{array}$

$\begin{array}{lll}82 & 62 & 29 \\ 5 & 11 & 6 \\ 85 & 44 & 60 \\ 7 & 8 & 1 \\ 3 & 3 & 4 \\ 3 & 3 & - \\ 8 & 19 & - \\ 1 & - & 1 \\ - & 1 & - \\ - & 3 & 1 \\ - & 5 & 5 \\ - & 1 & -\end{array}$

Aquatic pollen

Coleogeton
Polygonum pers.

Cyperaceae 18

Typha

Non-tree pollen

Poaceae
Asteraceae
Senecio-Arctium
Cirsium
Centaurea
Ambrosia
Compositae lig.
Mentha
Trifolium
Rosaceae
Umbelliferae
Stellaria
Caryophyllaceae
Chenopodiaceae
Urtica
Vicia
Ephedra

Total land pollen

Lycopodium (spike)

8

-
-
-

29

60 ( - 
Table A-12, continued.

Depth

Tree and shrub pollen

Pinus
Betula
Quercus
Carya
Ulmus
Celtis
Rhus
Fagus
Ilex
Alnus
Salix
Fraxinus

pollen
Coleogeton
Polygonum pers.
Cyperaceae
Typha

Non-tree pollen

Total land pollen

Lycopodium (spike)

Aquatic pollen

Polygonum pers.

Typha

Poaceae
Asteraceae
Senecio-Arctium
Cirsium
Centaurea
Ambrosia
Compositae lig.
Mentha
Trifolium
Rosaceae
Umbelliferae
Stellaria
Caryophyllaceae
Chenopodiaceae
Urtica
Vicia
Ephedra

$5 \mathrm{~cm}$

85

5

40

5

8

$-$

-

-

-

5

$-$
$7 \mathrm{~cm}$

$8 \mathrm{~cm}$

$10 \mathrm{~cm}$

.

45
215

44

10

-

$-$

4

$-$

-

-

$-$

9

$-$

$-$

$-$

$-$
84

3

29

4

6

1

15

-

$-$

6

6

-
79

5

56

5

4

15

1

1

2

4

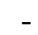


Depth

Tree and shrub pollen

Pinus

Betula

Quercus

Carya

Ulmus

Celtis

Rhus

Fagus

Ilex

Alnus

Salix

Fraxinus

Aquatic pollen

Coleogeton
Polygonum pers.
Cyperaceae
Typha

Non-tree pollen

Poaceae
Asteraceae
Senecio-Arctium
Cirsium
Centaurea
Ambrosia
Compositae lig.
Mentha
Trifolium
Rosaceae
Umbelliferae
Stellaria
Caryophyllaceae
Chenopodiaceae
Urtica
Vicia
Ephedra

Total land pollen

Lycopodium (spike)
$12 \mathrm{~cm}$

106

3

39

11

11

1

4

1

$-$

6

$-$

1

10

$-$

43
18
4
-
1
13
-
-
-
-
1
-
-
10
-
1
-

288

6

\section{Table A-12, continued.}

$16 \mathrm{~cm} \quad 21 \mathrm{~cm}$

$23 \mathrm{~cm}$ 
Table A-12, continued.

Depth

$26 \mathrm{~cm}$

$27 \mathrm{~cm}$

$30 \mathrm{~cm}$

$35 \mathrm{~cm}$

Tree and shrub pollen

Pinus

Betula

Quercus

Carya

Ulmus

Celtis

Rhus

Fagus

Ilex

Alnus

Salix

Fraxinus

Aquatic pollen

Coleogeton

Polygonum pers.

Cyperaceae

Typha

Non-tree pollen

Poaceae

Asteraceae

Senecio-Arctium

Cirsium

Centaurea

Ambrosia

Compositae lig.

Mentha

Trifolium

Rosaceae

Umbelliferae

Stellaria

Caryophyllaceae

Chenopodiaceae

Urtica

Vicia

Ephedra

Total land pollen

Lycopodium (spike)

1
2
3
-
-
-
-
-
-
-
1
-

1

-

-

-

-

$-$ 
Table A-12, continued.

Depth

$40 \mathrm{~cm}$

$45 \mathrm{~cm}$

$50 \mathrm{~cm}$

$55 \mathrm{~cm}$

Tree and shrub pollen

Pinus

Betula

Quercus

Carya

Ulmus

Celtis

Rhus

Fagus

Ilex

Alnus

Salix

Fraxinus

Aquatic pollen

Coleogeton

Polygonum pers.

Cyperaceae

Typha

Non-tree pollen

Poaceae

Asteraceae

Senecio-Arctium

Cirsium

Centaurea

Ambrosia

Compositae lig.

Mentha

Trifolium

Rosaceae

Umbelliferae

Stellaria

Caryophyllaceae

Chenopodiaceae

Urtica

Vicia

Ephedra

Total land pollen

Lycopodium (spike)

100

100

100

100 
Table A-13. 41AN38 Seep Core 2, Relative Pollen Percentages.

Depth

Tree and shrub pollen

$\begin{array}{ll}\text { Pinus } & 34.1 \\ \text { Betula } & 0.6 \\ \text { Quercus } & 18.8 \\ \text { Carya } & 1.0 \\ \text { Ulmus } & 2.2 \\ \text { Celtis } & 0.6 \\ \text { Rhus } & - \\ \text { Fagus } & 0.3 \\ \text { Ilex } & - \\ \text { Alnus } & 0.3 \\ \text { Salix } & 2.9 \\ \text { Fraxinus } & 0.3\end{array}$

Aquatic pollen
$1 \mathrm{~cm}$

34.1

18.8

1.0

2.2

0.6

0.3

0.3

0.3
$2 \mathrm{~cm}$

30.5

1.9

31.6

2.6

1.1

1.1

3.0

0.4

$-$

-

-
$3 \mathrm{~cm}$

$4 \mathrm{~cm}$

26.1

4.6

18.5

3.4

1.3

1.3

8.0

$-$

0.4

1.3

2.1

0.4
15.1

3.1

31.2

0.5

2.1

-

0.5

$-$

0.5

2.6

Non-tree pollen

Poaceae

22.3

19.0

$-$

0.5

Polygonum pers.

0.3

Cyperaceae

5.7

Asteraceae

5.1

Senecio-Arctium

0.6

Cirsium

-

Centaurea

Ambrosia

Compositae lig.

Mentha

Trifolium

Rosaceae

Umbelliferae

Stellaria

Caryophyllaceae

Chenopodiaceae

Urtica

Vicia

Ephedra

Total land pollen

Lycopodium (spike)

314

187

3.7

0.7

0.4

0.5

$\begin{array}{ll}0.4 & 0.5\end{array}$

$-$

-

1.6

0.6

-

$\overline{0} 3$

$-$

1.0

$-$

$-$

0.3

$-$

$-$

$-$

-

$-$

-

-

$-$

4.5

11.3

13.9

30.7

4.2

7.8

1.3

$-$

$\begin{array}{ll}1.3 & 0.5\end{array}$

0.4

$-$

-

-

$-$

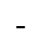

$-$
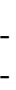

$-$

-

2.1

$-$

0.4

0.4

-

$-$

-

269

238

192

10

12

91

Tree and shrub pollen

Pinus
Betula
Quercus
Carya
Ulmus
Celtis

39.5

1.4

18.6

1.9

2.3

Celtis

3.7

39.3
1.4
13.6
1.9
2.8
0.5

55.8

31.0

$\begin{array}{ll}5 & .9 \\ 14.3 & 2.0\end{array}$

$14.3 \quad 22.0$

$3.1 \quad 2.0$

$\begin{array}{ll}0.9 & 1.6\end{array}$ 
Table A-13, continued.

Depth

Rhus

Fagus

Ilex

Alnus

Salix

Fraxinus

Aquatic pollen

Coleogeton

Polygonum pers.

Cyperaceae

Typha

Non-tree pollen

Poaceae

Asteraceae

Senecio-Arctium

Cirsium

Centaurea

Ambrosia

Compositae lig.

Mentha

Trifolium

Rosaceae

Umbelliferae

Stellaria

Caryophyllaceae

Chenopodiaceae

Urtica

Vicia

Ephedra

Total land pollen

Lycopodium (spike)

Tree and shrub pollen

$\begin{array}{ll}\text { Pinus } & 36.7 \\ \text { Betula } & 1.0 \\ \text { Quercus } & 13.5 \\ \text { Carya } & 3.8 \\ \text { Ulmus } & 3.8 \\ \text { Celtis } & 0.3 \\ \text { Rhus } & 1.4 \\ \text { Fagus } & 0.3 \\ \text { Ilex } & - \\ \text { Alnus } & - \\ \text { Salix } & 3.1 \\ \text { Fraxinus } & -\end{array}$

$\begin{array}{lll}7 \mathrm{~cm} & 8 \mathrm{~cm} & 10 \\ 7.0 & - & 5.9 \\ - & 0.9 & 0.4 \\ - & 0.4 & 0.4 \\ - & - & 0.8 \\ 2.8 & 0.4 & 1.6 \\ - & - & -\end{array}$

0.9

$0.9 \quad 1.2$

0.4

10.7

17.3

$2.7 \quad 2.0$

0.4 -

- -

-

$1.3 \quad 2.0$

0.4 -

- -

-

-

$-$

$\begin{array}{ll}5.4 & 9.0\end{array}$

-

$\begin{array}{ll}0.9 & 0.4\end{array}$

-

$\begin{array}{ll}- & 0.8\end{array}$

-

224

211

$55 \quad 8$ 
Table A-13, continued.

Depth

Aquatic pollen

Coleogeton

Polygonum pers.

Cyperaceae

Typha

Non-tree pollen

Poaceae

Asteraceae

Senecio-Arctium

Cirsium

Centaurea

Ambrosia

Compositae lig.

Mentha

Trifolium

Rosaceae

Umbelliferae

Stellaria

Caryophyllaceae

Chenopodiaceae

Urtica

Vicia

Ephedra

Total land pollen

Lycopodium (spike)
$12 \mathrm{~cm}$

0.3

3.5

-

14.9

6.2

1.4

$-$

4.5

$-$

-

-

$-$

0.3

-

3.5

$-$

0.3

-

288

6
$16 \mathrm{~cm}$

$21 \mathrm{~cm}$

0.3

0.9

0.9

0.3

-

16.6

14.9

4.2

$1.2 \quad 0.6$

- -

$-$

2.6

$-$

0.9

0.3

$\begin{array}{ll}- & 0.3\end{array}$

$-$

0.3

$-$

6.4

6.2

2.0

$-$

1.5

$-$

$-$

0.3

-

$342 \quad 347$

33

Table A-14. Caddo Creek Core 3, Absolute Pollen Counts.

Depth

Tree and shrub pollen

$\begin{array}{lllll}\text { Pinus } & 118 & 43 & 40 & 26 \\ \text { Betula } & 9 & 1 & - & 2 \\ \text { Quercus } & 54 & 35 & 79 & 60 \\ \text { Carya } & 8 & 4 & 22 & 18 \\ \text { Tilia } & - & - & 1 & 2 \\ \text { Ulmus } & 6 & - & 1 & 2 \\ \text { Celtis } & - & - & - & - \\ \text { Rhus } & - & - & - & - \\ \text { Fagus } & - & - & - & - \\ \text { Carpinus } & - & - & - & - \\ \text { Juglans } & - & 1 & - & - \\ \text { Myrica } & - & - & - & - \\ \text { Ilex } & - & - & - & - \\ \text { Sambucus } & 1 & - & - & - \\ \text { Alnus } & 4 & - & - & 3 \\ \text { Salix } & 46 & 28 & 1 & 3 \\ \text { Fraxinus } & 2 & - & - & -\end{array}$

$0 \mathrm{~cm}$

$15 \mathrm{~cm}$

$25 \mathrm{~cm}$

$28 \mathrm{~cm}$ 
Aquatic pollen

Potamogeton

Polygonum pers.

Cyperaceae

Typha

Non-tree pollen

Poaceae

Asteraceae

Senecio-Arctium

Cirsium

Ambrosia

Artemisia

Compositae lig.

Euphorbiaceae

Mentha

Rosaceae

Ranunculaceae

Umbelliferae

Rhododendron

Caryophyllaceae

Stellaria

Polygonaceae

Chenopodiaceae

Vicia

Indeterminate

Total land pollen

Lycopodium (spike)

337

18

Tree and shrub pollen

$\begin{array}{ll}\text { Pinus } & 5 \\ \text { Betula } & 4 \\ \text { Quercus } & 42 \\ \text { Carya } & 11 \\ \text { Tilia } & - \\ \text { Ulmus } & 1 \\ \text { Celtis } & - \\ \text { Rhus } & - \\ \text { Fagus } & - \\ \text { Carpinus } & - \\ \text { Juglans } & - \\ \text { Myrica } & - \\ \text { Ilex } & - \\ \text { Sambucus } & - \\ \text { Alnus } & - \\ \text { Salix } & 8 \\ \text { Fraxinus } & 7\end{array}$

44

1

9

$-$

$-$

$-$

$-$

1

-

14

$-$

2

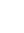

5

42

11

$-$

1

$-$

$-$

-

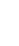

8

7

Aquatic pollen

Potamogeton
Polygonum pers.
Cyperaceae
Typha

\section{Table A-14, continued.}

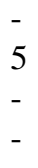

$\begin{array}{ll}- & - \\ - & 2 \\ - & - \\ - & -\end{array}$

$\begin{array}{lll}32 & 20 & 35 \\ 42 & 22 & 39 \\ - & - & - \\ - & - & - \\ 14 & 12 & - \\ - & - & - \\ 9 & 2 & - \\ - & - & - \\ - & - & - \\ - & - & - \\ - & - & - \\ 2 & - & 1 \\ - & 1 & - \\ - & - & - \\ 3 & 1 & - \\ - & - & - \\ - & 7 & 19 \\ - & - & - \\ - & - & - \\ 219 & 209 & 212 \\ 4 & 106 & 22\end{array}$

212

$\begin{array}{lll}71 & 77 & 71\end{array}$

$3 \quad 1 \quad 3$

$\begin{array}{lll}47 & 24 & 47\end{array}$

$21 \quad 11 \quad 21$

- 11

- 1

- 1

- $\quad$ -

$\begin{array}{lll}1 & - & 1\end{array}$

$\begin{array}{lll}1 & - & - \\ - & - & -\end{array}$

$\begin{array}{lll}- & - \\ - & - & -\end{array}$

- -

$\begin{array}{lll}- & - \\ - & -\end{array}$

5

1

25

- $\quad-\quad 5$


Table A-14, continued.

Depth

Non-tree pollen

Poaceae

Asteraceae

Senecio-Arctium

Cirsium

Ambrosia

Artemisia

Compositae lig.

Euphorbiaceae

Mentha

Rosaceae

Ranunculaceae

Umbelliferae

Rhododendron

Caryophyllaceae

Stellaria

Polygonaceae

Chenopodiaceae

Vicia

Indeterminate

Total land pollen

Lycopodium (spike)

Tree and shrub pollen

Pinus
Betula
Quercus
Carya
Tilia
Ulmus
Celtis
Rhus
Fagus
Carpinus
Juglans
Myrica
Ilex
Sambucus
Alnus
Salix
Fraxinus

Aquatic pollen

Potamogeton

Polygonum pers.

Cyperaceae

Typha
$30 \mathrm{~cm}$

50

49

$-$

5

7

$-$

$-$

-

-

$-$

$-$

-

23

-

217

13

88

1

40

18

$-$

-

$-$

3

-

-

$-$

-

$-$

2

$-$

$\begin{array}{lll}33 \mathrm{~cm} & 35 \mathrm{~cm} & 40 \mathrm{~cm} \\ 18 & 27 & 18 \\ 27 & 21 & 27 \\ - & 4 & - \\ - & 2 & - \\ 5 & 10 & 7 \\ - & - & - \\ - & - & 1 \\ - & - & - \\ - & 3 & - \\ - & - & - \\ - & - & - \\ 5 & - & 5 \\ - & - & - \\ - & - & - \\ 7 & - & - \\ - & - & 2 \\ 2 & 16 & \\ - & & - \\ & - & 218 \\ - & - & 112\end{array}$

78

73

17

33

48

22

1

-

-

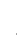

-

-

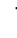

-

2

-

218

7

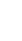


Table A-14, continued.

Depth

Non-tree pollen

Poaceae

Asteraceae

Senecio-Arctium

Cirsium

Ambrosia

Artemisia

Compositae lig.

Euphorbiaceae

Mentha

Rosaceae

Ranunculaceae

Umbelliferae

Rhododendron

Caryophyllaceae

Stellaria

Polygonaceae

Chenopodiaceae

Vicia

Indeterminate

Total land pollen

Lycopodium (spike)

252

172

Tree and shrub pollen

Pinus

Betula

Quercus

Carya

Tilia

Ulmus

Celtis

Rhus

Fagus

Carpinus

Juglans

Myrica

Ilex

Sambucus

Alnus

Salix

Fraxinus

Aquatic pollen

Potamogeton

Polygonum pers.

Cyperaceae

Typha
$60 \mathrm{~cm}$

26

27

$-$

$-$

5

$-$

-

$-$

$-$

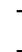

$-$

$-$

17

-

1

$-$

(1)

$70 \mathrm{~cm}$

$85 \mathrm{~cm}$

$100 \mathrm{~cm}$ 
Table 14, continued.

Depth

Non-tree pollen

Poaceae

Asteraceae

Senecio-Arctium

Cirsium

Ambrosia

Artemisia

Compositae lig.

Euphorbiaceae

Mentha

Rosaceae

Ranunculaceae

Rhododendron

Umbelliferae

Caryophyllaceae

Stellaria

Polygonaceae

Chenopodiaceae

Vicia

Indeterminate

Total land pollen

Lycopodium (spike)

Tree and shrub pollen

Pinus
Betula
Quercus
Carya
Tilia
Ulmus
Celtis
Rhus
Fagus
Carpinus
Juglans
Myrica
Ilex
Sambucus
Alnus
Salix
Fraxinus

Aquatic pollen

Potamogeton
Polygonum pers.
Cyperaceae
Typha

$105 \mathrm{~cm}$

1

-

$-$

$-$

1

-

1

-

$-$

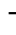

-

-

-

-

-

$-$

$-$

$-$

8

100

30

1

114

46

-

1

-

-

1

-

1

4

-

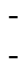

-

$130 \mathrm{~cm}$

$140 \mathrm{~cm}$

$145 \mathrm{~cm}$

1

15

24

70

55

90

-

3

$-$

1

-

-

-

$-$

$-$

$-$

2

-

3

-

217

37

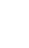

.

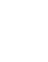


Table A-14, continued.

$$
151 \mathrm{~cm}
$$

$155 \mathrm{~cm}$

$160 \mathrm{~cm}$
Depth

Non-tree pollen

Poaceae

Asteraceae

Senecio-Arctium

Cirsium

Ambrosia

Artemisia

Compositae lig.

Euphorbiaceae

Mentha

Rosaceae

Ranunculaceae

Rhododendron

Umbelliferae

Caryophyllaceae

Stellaria

Polygonaceae

Chenopodiaceae

Vicia

Indeterminate

Total land pollen

Lycopodium (spike)

Tree and shrub pollen

Pinus
Betula
Quercus
Carya
Tilia
Ulmus
Celtis
Rhus
Fagus
Carpinus
Juglans
Myrica
Ilex
Sambucus
Alnus
Salix
Fraxinus

pollen
Potamogeton
Polygonum pers.
Cyperaceae
Typha

Non-tree pollen

Poaceae

Asteraceae

64

70

$-$

$-$

$-$

-

-

1

$-$

$-$

-

1

$-$

Aquatic pollen

Polygonum pers.

Cyperaceae

4

-

$-$

14

44
$150 \mathrm{~cm}$

75

133

-

1

2

$-$

-

$-$

2

5

2

4

2

$-$

6

$-$

$\begin{array}{ll}75 \\ 133 \\ 1 \\ 2 \\ - \\ 2 \\ - \\ 5 \\ 2 & - \\ 2 & - \\ - & -\end{array}$

43

78

$51 \quad 45$

3

-

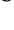

-

1

-

-

2

$-$

-

2

-

231

140

282

6

241

55

$102 \quad 99$

3

$-$

7

3

1

-

-

-

5

$-$

1

3

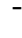

3

77

$30 \quad 5$

57

34

61

64

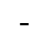

$-$

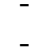

-

3

$-$

$-$

.

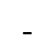

:

$-$

2

$-$

$-$

19

1

56

29

36

99

-

4

1

4

3

2

-

-

$-$

15

2

-

-

1

6

$-$

3

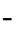

20

$-$
22

25 
Table A-14, continued.

Depth

Senecio-Arctium
Cirsium
Ambrosia
Artemisia
Compositae lig.
Euphorbiaceae
Mentha
Rosaceae
Ranunculaceae
Umbelliferae
Rhododendron
Caryophyllaceae
Stellaria
Polygonaceae
Chenopodiaceae
Vicia
Indeterminate

Total land pollen

Lycopodium (spike)

Tree and shrub pollen

Pinus
Betula
Quercus
Carya
Tilia
Ulmus
Celtis
Rhus
Fagus
Carpinus
Juglans
Myrica
Ilex
Sambucus
Alnus
Salix
Fraxinus

Aquatic pollen

Potamogeton

Polygonum pers.

Cyperaceae

Typha

Non-tree pollen

Poaceae
Asteraceae
Senecio-Arctium
Cirsium
Ambrosia

Poaceae

Senecio-Arctium

Ambrosia
$170 \mathrm{~cm}$

13

-

$-$

2

$-$

16

-

7

-

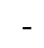

264

6

\section{1}

1

62

144

$-$

1

-

-

1

$-$

-

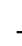

-

-

1
$180 \mathrm{~cm}$

$190 \mathrm{~cm}$

$200 \mathrm{~cm}$

$\begin{array}{ll}1 & - \\ - & -\end{array}$

33

- -

$\begin{array}{ll}- & 1\end{array}$

1

-

-

13

-

18

$-$

-

-

-

274

18

$$
\begin{aligned}
& 3 \\
& - \\
& 1 \\
& - \\
& - \\
& - \\
& - \\
& - \\
& - \\
& - \\
& 2 \\
& - \\
& 1 \\
& - \\
& - \\
& 228
\end{aligned}
$$

3

1

98

$115 \quad 112$

- -

3

-

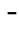

-

-

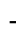

-

$-$

6

- 


\section{Table A-14, continued.}

Depth

Artemisia

Compositae lig.

Euphorbiaceae

Mentha

Rosaceae

Ranunculaceae

Umbelliferae

Rhododendron

Caryophyllaceae

Stellaria

Polygonaceae

Chenopodiaceae

Vicia

Indeterminate

Total land pollen

Lycopodium (spike)
$210 \mathrm{~cm}$

$\overline{1}$

$-$

$-$

$-$

$-$

$-$

$-$

3

$-$

-

$-$

$-$

273

29
$220 \mathrm{~cm}$

$225 \mathrm{~cm}$

$230 \mathrm{~cm}$

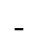

$-$

$-$

$-$

-

6

-

$-$

$-$

2

-

-

217

28

$\begin{array}{ll}- & - \\ 1 & 1 \\ - & - \\ - & - \\ - & - \\ - & - \\ 4 & - \\ - & - \\ 2 & 1 \\ - & - \\ - & - \\ - & -\end{array}$

323

322

13 


\section{Table A-14, continued}

Depth

$235 \mathrm{~cm}$

$245 \mathrm{~cm}$

Tree and shrub pollen

$\begin{array}{lll}\text { Pinus } & 4 & 35 \\ \text { Betula } & - & 3 \\ \text { Quercus } & 52 & 94 \\ \text { Carya } & 101 & 55 \\ \text { Tilia } & - & - \\ \text { Ulmus } & - & 8 \\ \text { Celtis } & - & - \\ \text { Rhus } & - & - \\ \text { Fagus } & - & - \\ \text { Carpinus } & - & - \\ \text { Juglans } & - & - \\ \text { Myrica } & - & - \\ \text { Ilex } & 2 & 4 \\ \text { Sambucus } & 1 & - \\ \text { Alnus } & - & - \\ \text { Salix } & 4 & 7 \\ \text { Fraxinus } & 1 & -\end{array}$

Aquatic pollen

Potamogeton

Polygonum pers.

Cyperaceae

Typha

Non-tree pollen

Poaceae

Asteraceae

$19-16$

Senecio-Arctium

Cirsium

Ambrosia

Artemisia

Compositae lig.

Euphorbiaceae

Mentha

Rosaceae

Ranunculaceae

Rhododendron

Umbelliferae

5

94

55

8

Caryophyllaceae

Stellaria

Polygonaceae

Chenopodiaceae

Vicia

$17-13$

Indeterminate

Total land pollen

212

253

Lycopodium (spike)

6

23 
Table A-15. Caddo Creek Core 3, Relative Pollen Percentages.

Depth

Tree and shrub pollen

$\begin{array}{ll}\text { Pinus } & 35.0 \\ \text { Betula } & 2.7 \\ \text { Quercus } & 16.0 \\ \text { Carya } & 2.4 \\ \text { Tilia } & - \\ \text { Ulmus } & 1.8 \\ \text { Celtis } & - \\ \text { Rhus } & - \\ \text { Fagus } & - \\ \text { Carpinus } & - \\ \text { Juglans } & - \\ \text { Myrica } & - \\ \text { Ilex } & - \\ \text { Sambucus } & 0.3 \\ \text { Alnus } & 1.2 \\ \text { Salix } & 13.6 \\ \text { Fraxinus } & 0.6\end{array}$

Aquatic pollen

Potamogeton

Polygonum pers.

Cyperaceae

Typha

Non-tree pollen

Poaceae

Asteraceae

Senecio-Arctium

Cirsium

Ambrosia

Artemisia

Compositae lig.

Euphorbiaceae

Mentha

Rosaceae

Ranunculaceae

Umbelliferae

Rhododendron

Caryophyllaceae

Stellaria

Polygonaceae

Chenopodiaceae

Vicia

Indeterminate

Total land pollen

Lycopodium (spike)
$0 \mathrm{~cm}$

$15 \mathrm{~cm}$

19.6

0.5

16.0

1.8

$-$

$-$

$-$

$-$

0.5

$-$

$-$

-

12.8

0.6
$25 \mathrm{~cm} \quad 28 \mathrm{~cm}$

$19.1 \quad 12.3$

$\begin{array}{ll}19.1 & 0.9\end{array}$

$\begin{array}{ll}37.8 & 28.3\end{array}$

$10.5 \quad 8.5$

$0.5 \quad 0.9$

$\begin{array}{ll}0.5 & 0.9\end{array}$

-

-

-

-

-

-

- $\quad$ -

$\begin{array}{ll}- & 1.4\end{array}$

$0.5 \quad 1.4$

-
2.3

0.3

5.0

13.1

0.3

2.7

$-$

-

-

$-$

$-$

0.3

$-$

$-$

4.2

$-$

0.6

-

337

18
14.6

19.2

-

6

$-$

4.1

$-$

$-$

-

$\overline{0} .9$

$-$

-

1.4

$-$

$-$

-

219

4
9.6

10.5

-

$-$

5.7

$-$

1.0

$-$

-

-

-

0.5

$-$

0.5

3.

3.

$-$

209

106
16.5

18.4

0.9

$-$

-

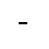

-

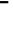

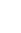

$-$

0.5

-

-

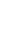

$-$

9.0

212

22 
Table A-15, continued.

Depth

Tree and shrub pollen

$\begin{array}{ll}\text { Pinus } & 2.3 \\ \text { Betula } & 1.8 \\ \text { Quercus } & 19.4 \\ \text { Carya } & 5.1 \\ \text { Tilia } & - \\ \text { Ulmus } & 0.5 \\ \text { Celtis } & - \\ \text { Rhus } & - \\ \text { Fagus } & - \\ \text { Carpinus } & - \\ \text { Juglans } & - \\ \text { Myrica } & - \\ \text { Ilex } & - \\ \text { Sambucus } & - \\ \text { Alnus } & 3.7 \\ \text { Salix } & 3.2 \\ \text { Fraxinus } & -\end{array}$

Aquatic pollen

Potamogeton

Polygonum pers.

Cyperaceae

Typha

Non-tree pollen

Poaceae

Asteraceae

Senecio-Arctium

Cirsium

Ambrosia

Artemisia

Compositae lig.

Euphorbiaceae

Mentha

Rosaceae

Ranunculaceae

Umbelliferae

Rhododendron

Caryophyllaceae

Stellaria

Polygonaceae

Chenopodiaceae

Vicia

Indeterminate

Total land pollen

Lycopodium (spike)
$30 \mathrm{~cm}$

2.3

19.4

5.1

0.5

3.7

3.2

0.9

$-$

-

23.0

22.6

$-$

2.3

3.2

$-$

-

$-$

$-$

$-$

1.4

$-$

-

-

10.6

$-$

217

13
$33 \mathrm{~cm}$

$35 \mathrm{~cm}$

$40 \mathrm{~cm}$

33.0

1.4

21.9

9.8

$-$

$-$

-

0.5

$-$

$-$

$-$

$-$

-

2.3

34.7

32.6

0.5

10.8

5.0

0.5

$-$

0.5

$-$

-

$-$

-

$-$

-

0.5

0.9

2.3

-

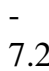

0.5

0.5

7.2

2

0.5

$-$

8.4

12.2

18

12.6

9.5

27

$-$

$-$

2.3

1.8

0.9

4.5

3.2

-

-

-

$-$

$-$

$-$

2.3

$-$

-

3.3

$-$

0.9

-

-

-

1.4

-

$-$

$-$

$-$

-

$-$

7.2

3.2

0.

-

215

222

84

218

112 
Table A-15, continued.

Depth

Tree and shrub pollen

Pinus

Betula

Quercus

Carya

Tilia

Ulmus

Celtis

Rhus

Fagus

Carpinus

Juglans

Myrica

Ilex

Sambucus

Alnus

Salix

Fraxinus

Aquatic pollen

Potamogeton

Polygonum pers.

Cyperaceae

Typha

Non-tree pollen

Poaceae

Asteraceae

Senecio-Arctium

Cirsium

Ambrosia

Artemisia

Compositae lig.

Euphorbiaceae

Mentha

Rosaceae

Ranunculaceae

Umbelliferae

Rhododendron

Caryophyllaceae

Stellaria

Polygonaceae

Chenopodiaceae

Vicia

Indeterminate

Total land pollen

Lycopodium (spike)
$60 \mathrm{~cm}$

34.9

0.4

15.9

7.1

$-$

$-$

-

1.2

-

-

$-$

-

-

0.8

$-$

$-$

1.6

7.9

$-$

10.3

10.7

-

2.0

$-$

-

$-$

-

-

$-$

$-$

$-$

6.7

$-$

0.4

-

$-$

252

172
$70 \mathrm{~cm}$

$85 \mathrm{~cm}$

37.4

29.8

$-$

8.3

0.8

19.6

$16.0 \quad 9.0$

$-$

$\begin{array}{ll}- & 0.4\end{array}$

- $\quad-$

0.5 -

0.5 -

- $\quad-$

- $\quad-$

- $\quad-$

-

-

$-$

1.0

0.8

-

0.4$$
-
$$

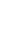$$
\text { - }
$$$$
\text { - }
$$$$
0.8
$$$$
-
$$

$-$

$\begin{array}{ll}0.5 & 3.7\end{array}$

3.7

13.5

$21.4 \quad 16.3$

- -

-

$0.5 \quad-1.2$

- -

-

-

-

-

$-$

-

-

-

$2.4 \quad 2.9$

- $\quad-$

$\begin{array}{ll}- & - \\ 2.4 & 2.0\end{array}$

- $\quad-$

$206 \quad 245$

$22 \quad 40$


Table A-15, continued.

Depth

Tree and shrub pollen

$\begin{array}{ll}\text { Pinus } & 24.0 \\ \text { Betula } & 1.4 \\ \text { Quercus } & 24.4 \\ \text { Carya } & 9.2 \\ \text { Tilia } & - \\ \text { Ulmus } & 0.5 \\ \text { Celtis } & - \\ \text { Rhus } & - \\ \text { Fagus } & - \\ \text { Carpinus } & - \\ \text { Juglans } & - \\ \text { Myrica } & - \\ \text { Ilex } & - \\ \text { Sambucus } & - \\ \text { Alnus } & - \\ \text { Salix } & 0.5 \\ \text { Fraxinus } & -\end{array}$

Aquatic pollen

Potamogeton

Polygonum pers.

Cyperaceae

Typha

Non-tree pollen

Poaceae

Asteraceae

Senecio-Arctium

Cirsium

Ambrosia

Artemisia

Compositae lig.

Euphorbiaceae

Mentha

Rosaceae

Ranunculaceae

Rhododendron

Umbelliferae

Caryophyllaceae

Stellaria

Polygonaceae

Chenopodiaceae

Vicia

Indeterminate

Total land pollen

Lycopodium (spike)

2.8

0.9

6.9

25.3

1.4
$130 \mathrm{~cm}$

$140 \mathrm{~cm}$

$145 \mathrm{~cm}$

6.3

21.4

11.9

0.3

$-$

0.3

$-$

-

0.6

$-$

0.3

$0.5 \quad 0.3$

-

2.3

2.9

2.6

-

12.2

20.3

25.0

26.1

2.0

$-$

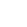

0.3

$-$

$-$

$0.5 \quad 0.6$

$-$

0.5

-

0.9

0.3

$-$

$-$

2.0

$-$

$196 \quad 345$

$70 \quad 135$ 
Table A-15, continued.

Depth

Tree and shrub pollen

$\begin{array}{lc}\text { Pinus } & 6 \\ \text { Betula } & 0 . \\ \text { Quercus } & 2 \\ \text { Carya } & 9 \\ \text { Tilia } & - \\ \text { Ulmus } & 0 \\ \text { Celtis } & 0.2 \\ \text { Rhus } & - \\ \text { Fagus } & 0.4 \\ \text { Carpinus } & 0.2 \\ \text { Juglans } & - \\ \text { Myrica } & 0.2 \\ \text { Ilex } & 0.8 \\ \text { Sambucus } & - \\ \text { Alnus } & - \\ \text { Salix } & - \\ \text { Fraxinus } & -\end{array}$

Aquatic pollen

Potamogeton

Polygonum pers.

Cyperaceae

Typha

6.3

0.2

24.1

9.7

0.2

0.2

$-$

0.4

0.2

0.2

0.8

$-$

-

Non-tree pollen

Poaceae

Asteraceae

15.9

28.1

Senecio-Arctium

Cirsium

Ambrosia

Artemisia

Compositae lig.

Euphorbiaceae

Mentha

Rosaceae

Ranunculaceae

Rhododendron

Umbelliferae

Caryophyllaceae

Stellaria

Polygonaceae

Chenopodiaceae

Vicia

Indeterminate

Total land pollen

Lycopodium (spike)

4.7

$-$

0.2

0.4

$-$

$-$

$-$

0.4

-

1.1

0.4

0.8

0.4

$-$

-

1.3

$-$

473

100
$150 \mathrm{~cm}$

$151 \mathrm{~cm}$

$155 \mathrm{~cm}$

$160 \mathrm{~cm}$

6.9

6.4

7.9

0.4

0.4

0.8

19.5

14.9

10.4

8.7

9.9

8.7

-

-

0.4

-

$-$

-

-

-

-

-

-

-

-

0.7

0.8

-

-

-

$-$

0.7

0.4

-

0.9

3.9

0.9

4.3

3.7

0.4

18.6

18.1

18.7

33.8

36.2

41.1

1.3

1.1

$-$

231

140
-

2.5

1.1

0.4

$-$

-

-

1.8

$-$

0.4

-

1.1

$-$

282

6
-

1.7

1.7

0.4

-

-

1.7

0.8

$-$

241

55 
Table A-15, continued.

Depth

Tree and shrub pollen

Pinus

Betula

Quercus

Carya

Tilia

Ulmus

Celtis

Rhus

Fagus

Carpinus

Juglans

Myrica

Ilex

Sambucus

Alnus

Salix

Fraxinus

Aquatic pollen

Potamogeton

Polygonum pers.

Cyperaceae

Typha

Non-tree pollen

Poaceae

Asteraceae

Senecio-Arctium

Cirsium

Ambrosia

Artemisia

Compositae lig.

Euphorbiaceae

Mentha

Rosaceae

Ranunculaceae

Umbelliferae

Rhododendron

Caryophyllaceae

Stellaria

Polygonaceae

Chenopodiaceae

Vicia

Indeterminate

Total land pollen

Lycopodium (spike)
$170 \mathrm{~cm}$

11.4

24.2

26.5

-

-

-

$-$

0.4

$-$

-

0.4

-

0.8

$-$

5.3

16.7

-

4.9

$-$

$-$

$-$

0.8

$-$

6.1

-

-

2.7

$-$

-

$-$

264

6
$180 \mathrm{~cm}$

$190 \mathrm{~cm}$

$200 \mathrm{~cm}$

1.7

19.9

11.9

$-$

$-$

-

1.0

$-$

-

$-$

$-$

-

0.7

1.1

- 28.1

22.3

36.0

28.1

1.1

$-$

-

5.5

0.9

-

-

0.4

-

$-$

1.3

-

$-$

2.6

0.4

6.6

$-$

19.6

10.6

9.6

32.9

13.1

11.0

-

$-$

$-$

0.7

$-$

$-$

0.3

-

1.0

$-$

3.5

$-$

$-$

$-$

286

0.4

1.

$1.1 \quad 1.3$

$-$

$-$

0.4

0.4

$-$

$-$

4.7

$-$

$-$

6.6

0.9

$-$

$-$

0.4

$-$

$-$

228

2
274

3 
Table A-15, continued.

Depth

Tree and shrub pollen

$\begin{array}{lc}\text { Pinus } & 0.4 \\ \text { Betula } & 0.4 \\ \text { Quercus } & 22.7 \\ \text { Carya } & 52.7 \\ \text { Tilia } & - \\ \text { Ulmus } & 0.4 \\ \text { Celtis } & - \\ \text { Rhus } & - \\ \text { Fagus } & 0.4 \\ \text { Carpinus } & - \\ \text { Juglans } & - \\ \text { Myrica } & - \\ \text { Ilex } & - \\ \text { Sambucus } & - \\ \text { Alnus } & - \\ \text { Salix } & 0.4 \\ \text { Fraxinus } & -\end{array}$

Aquatic pollen

Potamogeton

Polygonum pers.

Cyperaceae

Typha

Non-tree pollen

Poaceae

Asteraceae

Senecio-Arctium

Cirsium

Ambrosia

Artemisia

Compositae lig.

Euphorbiaceae

Mentha

Rosaceae

Ranunculaceae

Umbelliferae

Rhododendron

Caryophyllaceae

Stellaria

Polygonaceae

Chenopodiaceae

Vicia

Indeterminate

Total land pollen

Lycopodium (spike)
$210 \mathrm{~cm}$

0.4

0.4

22.7

52.7

0.4

-

0.4

$-$

-

-

-

0.4

0.4

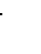

$220 \mathrm{~cm}$

0.9

25.3

35.0

$-$

$-$

-

1.4

-

$-$

-

$-$

$-$

0.5

$-$

0.9

0.9

0.7

-

5.9

13.2

-

$-$

1.5

$-$

0.4

-

$-$

$-$

$-$

-

$-$

$-$

1.1

$-$

$-$

-

273

29

14.7

16.1

$-$

0.5

$-$

217
$225 \mathrm{~cm}$

$230 \mathrm{~cm}$

0.6

0.3

32.5

35.6

30.4

34.8

$-$

0.9

-

-

$-$

$-$

-

-

-

- $\quad 0.3$

$\begin{array}{ll}1.9 & 0.9\end{array}$

$-$

-

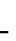

$-$

-

$-$

$-$

3

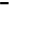

$\begin{array}{ll}- & 2.5\end{array}$

$-$

$-$

7.5

10.5

18.0

13.6

$-$

-

$1.5 \quad 3.4$

$\begin{array}{ll}0.3 & 0.3\end{array}$

- -

-

-

$1.2 \quad 1.2$

- -

0.6 -

$\begin{array}{ll}0.6 & 0.3\end{array}$

-

$\begin{array}{ll}- & 0.3\end{array}$

$-$

0.6

323

322

4

13 
Table A-15, continued.

Depth

Tree and shrub pollen

Pinus
Betula
Quercus
Carya
Tilia
Ulmus
Celtis
Rhus
Fagus
Carpinus
Juglans
Myrica
Ilex
Sambucus
Alnus
Salix
Fraxinus

pollen
Potamogeton
Polygonum pers.
Cyperaceae
Typha

Non-tree pollen

Poaceae

Asteraceae

Senecio-Arctium

Cirsium

Ambrosia

Artemisia

Compositae lig.

Euphorbiaceae

Mentha

Rosaceae

Ranunculaceae

Rhododendron

Umbelliferae

Caryophyllaceae

Stellaria

Polygonaceae

Chenopodiaceae

Vicia

Indeterminate

Total land pollen

Lycopodium (spike)
$235 \mathrm{~cm}$

$245 \mathrm{~cm}$

13.8

1.2

37.2

21.7

3.2

$-$

-

-

$-$

1.6

$-$

$\begin{array}{ll}1.9 & 2.8\end{array}$

0.5 $\begin{array}{ll}- & 0.4\end{array}$

$-$

9.0

6.3

$8.0 \quad 5.1$

- -

$0.5-$

$0.9 \quad 2.8$

-

$\begin{array}{ll}- & 0.4\end{array}$

- -

- $\quad-$

$\begin{array}{ll}- & 2.0\end{array}$

- -

$0.9 \quad 1.2$

0.9 -

$\begin{array}{ll}0.9 & 0.4\end{array}$

-

0.9 -

0.9 -

$212 \quad 253$

623 


\section{References Cited}

Albert, B. M.

2004 Pollen Evidence for Natural Environment and Human Settlement at the Tom Jones Site (3HE40) in Hempstead Co., Southwest Arkansas. Manuscript on file, Arkansas Archaeological Survey, Magnolia.

2007 Climate, Fire, and Land-Use History in the Oak-Pine-Hickory Forests of Northeast Texas during the past 3500 years. Castanea 72 (2):81-90.

Allen, J. R. L.

1965 A Review of the Origin and Characteristics of Recent Alluvial Sediments. Sedimentology. 5:89191.

Anderson, S. T.

1974 Wind Conditions and Pollen Deposition in a Mixed Deciduous Forest. Grana 14: 57-77.

Bartlein, P. J., Prentice, I. C., and T. Webb III

1986 Climatic Response Surfaces from Pollen Data for Some Eastern North American Taxa. Journal of Biogeography. 13:35-57.

Behre, K.E.

1981 The Interpretation of Anthropogenic Indicators in Pollen Diagrams. Pollen et Spores. 23: 225-45

Behre, K.E. and D. Kucan

1986 The Reflection of Archaeologically Known Settlements in Pollen Diagrams at Varying Distances. in Behre, K.E. (ed.) Anthropogenic Indicators in Pollen Diagrams. pp. 95-114. A.A. Balkema, Rotterdam, Netherlands
Bonny, A.P.

1976 Recruitment of Pollen to the Seston and Sediment of Some Lake District Lakes. Journal of Ecology. 64: 859887.

1978 The Effect of Pollen Recruitment Processes on Pollen Distribution over the Sediment Surface of a Small Lake in Cumbria. Journal of Ecology. 66: 385-416

Bratton, S.P.

1976 Resource Division in an Understory Herb Community: Responses to Temporal and Microtopographic effects. American Naturalist 110: 679-693

Brown, A.G., Carpenter, R.G., and D.E. Walling

2007 Monitoring Fluvial Pollen Transport, its Relationship to Catchment Vegetation and Implications for Palaeoenvironmental Studies. Review of Palaeobotany and Palynology 147: 60-76

Brown, D.O.

1988 Prehistoric Subsistence Strategies in Northeastern Central Texas. Bulletin of the Texas Archeological Society 59: 201-244

Brush, G.S. and L.M. Brush

1972 The Transport of Pollen in a Sediment-Laden Channel: A Laboratory Study. American Journal of Science 272: 359-81

Bryant, V.M. and R.G. Holloway

1985 A Late-Quaternary Paleoenvironmental Record of Texas: An Overview of the Pollen Evidence. in Pollen Records of Late-Quaternary North American Sediments, V. M. 
Bryant and H.G. Holloway (eds.) pp. 39-70. American Association of Stratigraphic Palynologists, Dallas, Texas

Bureau of Economic Geology

2000 Vegetation/Cover Types of Texas. University of Texas at Austin, Austin, Texas

Bush, L.L.

2006 Fourche Maline and Caddo Macrobotanical Remains from the 2005 Texas Archeological Society Field School at the Stallings Ranch (41LR297 and 41LR298). manuscript in file: AR Consultants, Dallas, Texas

Delcourt, P.A. and H.R. Delcourt

2004 Prehistoric Native Americans and Ecological Change: Human Ecosystems in Eastern North America Since the Pleistocene. Cambridge University Press, Cambridge, United Kingdom.

Delcourt, P.A., Delcourt, H.R., Cridlebaugh, P.A., and J. Chapman

1986 Holocene Ethnobotanical and Palaeoecological Record of Human Impact on Vegetation in the Little Tennessee River Valley, Tennessee. Quaternary Research. 25: 330-349

Delcourt, P.A., Delcourt, H.R., and T. Webb III

1984 Atlas of Mapped Distributions of Dominance and Modern Pollen Percentages for Important Tree Taxa of Eastern North America. American Association of Stratigraphic Palynologists Contributions Series Number 14. American Association of Stratigraphic Palynologists Foundation, Dallas, Texas

Dering, J.P.

1993 Macrobotanical Analysis of Samples from Four Woodland and
Caddoan Period Sites in the Cooper Lake Area of the Upper Sulphur River. in Excavations at the Tick, Spike, Johns Creek, and Peerless Bottoms Sites, Cooper Lake Project, Delta and Hopkins Counties, Texas. Fields, R.C., Gadus, E.F., Klement, L.W., Bousman, C.B., and J.B. McLerran (eds.), pp. 337-355. Reports of Investigations, Number 91. Prewitt and Associates, Inc., Austin, Texas.

1994 Analysis of the Plant Remains. in Excavations at the Spider Knoll Site, Cooper Lake Project, Delta County, Texas. Fields, R.C., Gadus, E.F., Klement, L.W., and K.M. Gardner (eds.), pp. 162-171. Reports of Investigations, Number 96. Prewitt and Associates, Inc. Austin, Texas

Diggs G.M., Lipscomb, B.L., Reed, M.D., and R.J. O'Kennon

2006 Illustrated Flora of East Texas, Volume One: Introduction, Pteridophytes, Gymnosperms, and Monocotyledons. Sida, Botanical Miscellany, No. 26. Botanical Research Institute of Texas, Fort Worth, Texas

Dull, R.

2006 The Maize Revolution: A View from El Salvador. in Histories of Maize, Staller, JE., Tykot, R.H., and B.F. Benz (eds.), pp. 357-64. Elsevier Academic Press, Boston, Massachusetts

Eubanks, M.

1997 Reevaluation of the Identification of Ancient Maize Pollen from Alabama. American Antiquity 62: 1: 139-45

Faegri, K., Iversen, J., Kaland, P.E. and K. Krzywisnki

1989 Textbook of Pollen Analysis, 3rd ed. Chichester, John Wiley and Sons 
Gardner, P.S.

1997 Plant Remains. in Two Caddoan Farmsteads in The Red River Valley: The Archeology of the McLelland and Joe Clark Sites, Kelley, D.B. (ed.), pp. 109-120. Arkansas Archeological Survey Research Series No. 51. Arkansas Archeological Survey, Fayetteville, Arkansas.

Goldborer, S.E. and T.K. Perttula

1999 Macrobotanical Remains from a Northeast Texas Late Archaic to Middle Caddoan Site: Hurricane Hill (41HP106), Hopkins County. in The Hurricane Hill Site (41HP106): The Archaeology of a Late Archaic/Early Ceramic and EarlyMiddle Caddoan Site in Northeast Texas, Perttula , T.K. (ed.), pp. 365382. Special Publication No. 4. Friends of Northeast Texas Archaeology, Dallas, Texas

Grimm, E.C.

1987 CONISS: A Fortran 77 Program for Stratigraphically Constrained Cluster Analysis by the Method of Incremental Sum of Squares. Computers and Geosciences 13.1: 13-35.

Holmes, P.

1990 Differential Transport of Spores and Pollen- A Laboratory Study. Review of Palaeobotany and Palynology 64: 289-96

Jacobson, G. and R.H.W. Bradshaw

1981 The Selection of Sites for Paleovegetational Studies. Quaternary Research. 16: 80-96

Jurney, D., Stahle, D.W.

2004 Old-Growth Wooded Pasture in the Ozarks. In Upland Oak Ecology Symposium: History, Current Conditions, and Sustainability, Spetich, M. (ed.), pp. 42-52. General Technical Report SRS-73.
USFS Southern Research Station, Asheville, North Carolina.

Peacock, E. and M.C. Reese

2003 A Comparison of Three Methods of Palaeo-environmental Analysis at an Archaeological Site on the Mississippi Black Prairie. In Blackland Prairies of the Gulf Coastal Plain, Peacock, E. and T.S. Schauwecker (eds.), pp. 64-79. University of Alabama Press, Tuscaloosa, Alabama

Peck, R.M.

Pollen Budget Studies in a Small Yorkshire. In Quaternary Plant Ecology, Birks, H.J.B. and R.G. West (eds.), pp. 43-60. Blackwell Scientific Publications, Oxford, United Kingdom.

Pennington, W.

1979 The Origins of Pollen in Lake Sediments: An Enclosed Lake Compared to One Receiving Inflow Streams. New Phytologist 83: 189213

Perttula, T.K.

1996 Caddoan Area Archaeology Since 1990. Journal of Archaeological Research 4(4):295-348

2008 Caddo Agriculture on the Western Frontier of the Eastern Woodlands. Plains Anthropologist 53: 205:77103.

Schambach, F.F.

2001 Fourche Maline and Its Neighbors: Observations on an Important Woodland Period culture of the Trans-Mississippi South. The Arkansas Archeologist 40: 2: 1-50

Schauwecker, T.S. and J. MacDonald

2003 Plant Assemblage Response to Disturbance at a Blackland Prairie Restoration Site in Northeastern Mississippi. In Blackland Prairies 
of the Gulf Coastal Plain, Peacock, $\mathrm{E}$ and T.S. Schauwecker (eds.), pp. 246-53. University of Alabama Press, Tuscaloosa, Alabama

Spalt, K.W. and W.E. Reifsnyder

1962 Bark Characteristics and Fire Resistance: A Literature Survey. Occasional Paper 193, USDA Forest Service, Southern Experimental Research Station.

Story, D.A., Guy, J.A., Burnett, B.A., Freeman, M.D., Rose, J.C., Steele, D.G., Olive, B.W., and K.J. Rheinhard

1990 The Archaeology and Bioarchaeology of the Gulf Coastal Plain. Research Series No. 38, Arkansas Archaeological Survey, Fayetteville, Arkansas.

Tauber, $\mathrm{H}$.

1967 Investigations of the Mode of Pollen Transfer in Forested Areas. Review of Palaeobotany and Palynology 3:277-286.

Tharp, B.C.

1926 The Structure of Texas Vegetation East of the 98th Meridian. University of Texas Bulletin no.
2006. The University of Texas, Austin

Troels-Smith, J.

1955 Characterization of Unconsolidated Sediments. Danmarks Geologiske Undersøgelse, IV Raekke. Copenhagen: National Museum

Tull, D.

1999 Edible and Useful Plants of Texas and the Southwest. University of Texas Press, Austin, Texas

Turner, B.L., Nichols, H., Denny, G., and O. Doron

2003 Atlas of the Vascular Plants of Texas, Volume 1. Sida, Botanical Miscellany, Number 24 Volume 1: Dicots. BRIT Press, Fort Worth, Texas

Texas Agricultural Experiment Station 1975 Soil Survey of Anderson County, Texas. United States Department of Agriculture, Washington D.C.

1979 Soil Survey of Henderson County, Texas. United States Department of Agriculture, Washington D.C. 


\section{APPENDIX B \\ QUARTZ OPTICAL DATING OF SEDIMENT SAMPLES FROM 41AN38}

Prepared for:

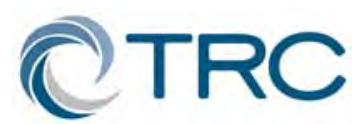

TRC Environmental Corporation

505 East Huntland Drive, Suite 250

Austin, Texas 78752

Prepared by:

Mark D. Bateman

Sheffield Center for International Drylands Research 



\section{B.1 Abstract}

Optical luminescence dating at the single grain level was applied to coarse quartz grains extracted from twenty seven samples taken from two stratigraphic columns from the site 41AN38, Texas. All samples behaved well from an OSL perspective, but analysis of sample replicates indicates they have undergone post-depositional disturbance and/or incomplete sediment resetting prior to burial. Whilst attempts have been made to isolate what may be the burial ages, inconsistencies down profile from this tightly sampled dataset indicate this has not been entirely successful. Thus, best estimates of the sample's burial age range from $610 \pm 40$ years (Shfd07145) to 6,630 \pm 360 years for the first sampled column and $130 \pm 20$ years (Shfd07156) to $7980 \pm 410$ years (Shfd07169). Further analysis of the component related age calculations with other site information is recommended as a possible way to improve the site chronology.

\section{B.2 Introduction}

Twenty seven samples in opaque PVC tubing from site 41AN38 northeast, Texas, USA were submitted for luminescence dating by Dr. David Kelley (Coastal Environments Inc.). All luminescence work was carried out at the Sheffield Centre for International Drylands Research (SCIDR) luminescence laboratory. The samples are assumed not to have been exposed to sunlight during sampling or transportation to the laboratory. Upon arrival, each sample was allocated a Sheffield lab number (Table B-1). This report provides a brief summary of the procedures employed and results obtained for samples.

In order to derive an optically stimulated luminescence (OSL) age both the palaeodose (De - the amount of absorbed dose since the sample was buried) and the dose rate (the estimated radiation flux for the sedimentary bodies) have to be determined. Aitken (1998) gives a detailed explanation of both these parameters. To calculate an age, the palaeodose (expressed in Grays) is divided by the annual dose rate (Grays/yr). An inherent assumption in these age calculations is that the sediment was fully reset or 'bleached' by exposure to sunlight during the last transport event or whilst in situ prior to burial and that no postdepositional sediment disturbance has occurred. As part of this investigation, efforts have been taken to establish if these sediments have been bleached or disturbed by, for example, bioturbation. As the OSL signal measured with a standard aliquot is an average of 2000 grains the true distribution of De values within a sample may be masked. This is of particular significance in heterogeneously dosed samples (e.g. poorly reset/bleached) in which grains with a high De signal will dominated the signal at the expense of grains containing a true burial De. Measurement of the accumulated dose from individual grains obviates this problem. Thus this latter single grain approach was adopted for this study.

\section{B.3 Dose Rate Analysis}

Naturally occurring potassium (K), thorium $(\mathrm{Th})$, rubidium $(\mathrm{Rb})$ and uranium $(\mathrm{U})$ are the main contributors of dose to sedimentary quartz. The concentrations of these elements were determined by inductively coupled plasma mass spectrometry (ICP) at SGS laboratories Ontario Canada (Table B2). Elemental concentrations were converted to annual dose rates using data from Adamiec and Aitken (1998), Marsh et al. (2002), and Aitken (1988). 
Table B-1. Sample Descriptive Data.

\begin{tabular}{|c|c|c|c|c|c|}
\hline Lab No. & $\begin{array}{c}\text { Field } \\
\text { Reference }\end{array}$ & $\begin{array}{l}\text { Latitude } \\
\left({ }^{\circ} \mathrm{N}\right)\end{array}$ & $\begin{array}{l}\text { Longitude } \\
\left({ }^{\circ} \mathrm{W}\right)\end{array}$ & $\begin{array}{l}\text { Altitude } \\
\text { (m) }\end{array}$ & $\begin{array}{l}\text { Sampling Depth } \\
\text { (cm below surface) }\end{array}$ \\
\hline Shfd07143 & 1589 & $32^{\circ} 03^{\prime}$ & $95^{\circ} 52^{\prime}$ & 122 & 5 \\
\hline Shfd07144 & 1590 & $32^{\circ} 03^{\prime}$ & $95^{\circ} 52^{\prime}$ & 122 & 10 \\
\hline Shfd07145 & 1591 & $32^{\circ} 03^{\prime}$ & $95^{\circ} 52^{\prime}$ & 122 & 15 \\
\hline Shfd07146 & 1592 & $32^{\circ} 03^{\prime}$ & $95^{\circ} 52^{\prime}$ & 122 & 20 \\
\hline Shfd07147 & 1593 & $32^{\circ} 03^{\prime}$ & $95^{\circ} 52^{\prime}$ & 122 & 25 \\
\hline Shfd07148 & 1594 & $32^{\circ} 03^{\prime}$ & $95^{\circ} 52^{\prime}$ & 122 & 30 \\
\hline Shfd07149 & 1595 & $32^{\circ} 03^{\prime}$ & $95^{\circ} 52^{\prime}$ & 122 & 35 \\
\hline Shfd07150 & 1596 & $32^{\circ} 03^{\prime}$ & $95^{\circ} 52^{\prime}$ & 122 & 40 \\
\hline Shfd07151 & 1597 & $32^{\circ} 03^{\prime}$ & $95^{\circ} 52^{\prime}$ & 122 & 45 \\
\hline Shfd07152 & 1598 & $32^{\circ} 03^{\prime}$ & $95^{\circ} 52^{\prime}$ & 122 & 50 \\
\hline Shfd07153 & 1599 & $32^{\circ} 03^{\prime}$ & $95^{\circ} 52^{\prime}$ & 122 & 55 \\
\hline Shfd07154 & 1600 & $32^{\circ} 03^{\prime}$ & $95^{\circ} 52^{\prime}$ & 122 & 60 \\
\hline Shfd07155 & 1601 & $32^{\circ} 03^{\prime}$ & $95^{\circ} 52^{\prime}$ & 122 & 65 \\
\hline Shfd07156 & 1602 & $32^{\circ} 03^{\prime}$ & $95^{\circ} 52^{\prime}$ & 122 & 5 \\
\hline Shfd07157 & 1603 & $32^{\circ} 03^{\prime}$ & $95^{\circ} 52^{\prime}$ & 122 & 10 \\
\hline Shfd07158 & 1604 & $32^{\circ} 03^{\prime}$ & $95^{\circ} 52^{\prime}$ & 122 & 15 \\
\hline Shfd07159 & 1605 & $32^{\circ} 03^{\prime}$ & $95^{\circ} 52^{\prime}$ & 122 & 20 \\
\hline Shfd07160 & 1606 & $32^{\circ} 03^{\prime}$ & $95^{\circ} 52^{\prime}$ & 122 & 25 \\
\hline Shfd07161 & 1607 & $32^{\circ} 03^{\prime}$ & $95^{\circ} 52^{\prime}$ & 122 & 30 \\
\hline Shfd07162 & 1608 & $32^{\circ} 03^{\prime}$ & $95^{\circ} 52^{\prime}$ & 122 & 35 \\
\hline Shfd07163 & 1609 & $32^{\circ} 03^{\prime}$ & $95^{\circ} 52^{\prime}$ & 122 & 40 \\
\hline Shfd07164 & 1610 & $32^{\circ} 03^{\prime}$ & $95^{\circ} 52^{\prime}$ & 122 & 45 \\
\hline Shfd07165 & 1611 & $32^{\circ} 03^{\prime}$ & $95^{\circ} 52^{\prime}$ & 122 & 50 \\
\hline Shfd07166 & 1612 & $32^{\circ} 03^{\prime}$ & $95^{\circ} 52^{\prime}$ & 122 & 55 \\
\hline Shfd07167 & 1613 & $32^{\circ} 03^{\prime}$ & $95^{\circ} 52^{\prime}$ & 122 & 60 \\
\hline Shfd07168 & 1614 & $32^{\circ} 03^{\prime}$ & $95^{\circ} 52^{\prime}$ & 122 & 65 \\
\hline Shfd07169 & 1615 & $32^{\circ} 03^{\prime}$ & $95^{\circ} 52^{\prime}$ & 122 & 70 \\
\hline
\end{tabular}

This took into account attenuation factors relating to sediment grain sizes used, density and palaeomoisture. It has been assumed that the samples formed part of a thick homogeneous unit with no gamma contribution (other than from cosmogenic sources) being received by the samples from other unsampled sedimentary units. Attenuation of dose by moisture used the present-day moisture values as measured in the laboratory, with a $\pm 2 \%$ error to incorporate seasonal and longer-term fluctuations in moisture which the samples may have endured since burial (Table B-2). 
Table B-2. Summary of Results - Dosimetry Related Data.

\begin{tabular}{|c|c|c|c|c|c|c|c|}
\hline Lab Code & $\begin{array}{c}\mathbf{U} \\
(\mathrm{PPM})\end{array}$ & $\begin{array}{c}\text { Th } \\
(\mathrm{PPM}) \\
\end{array}$ & Rb (PPM) & $\begin{array}{c}\mathbf{K} \\
(\%)\end{array}$ & $\begin{array}{r}\mathbf{D}_{\text {cosmic }}{ }^{+} \\
\left(\mu \mathrm{Gy} / \mathrm{a}^{-1}\right)\end{array}$ & Moisture (\%) & $\begin{array}{c}\text { Dose rate }^{\dagger}\left(\mu \mathrm{Gy} / \mathrm{a}^{-}\right. \\
\left.{ }^{-}\right)\end{array}$ \\
\hline Shfd07143 & 1.88 & 5.0 & 24.5 & 0.46 & $213 \pm 11$ & 7.4 & $1388 \pm 48$ \\
\hline Shfd07144 & 1.81 & 5.1 & 25.6 & 0.45 & $211 \pm 11$ & 6.0 & $1389 \pm 48$ \\
\hline Shfd07145 & 1.70 & 5.1 & 26.1 & 0.48 & $210 \pm 10$ & 4.3 & $1415 \pm 49$ \\
\hline Shfd07146 & 1.81 & 5.5 & 26.0 & 0.46 & $208 \pm 10$ & 5.0 & $1438 \pm 49$ \\
\hline Shfd07147 & 1.77 & 5.3 & 26.3 & 0.45 & $207 \pm 10$ & 5.6 & $1395 \pm 48$ \\
\hline Shfd07148 & 1.77 & 5.4 & 25.8 & 0.46 & $205 \pm 10$ & 5.2 & $1416 \pm 45$ \\
\hline Shfd07149 & 1.80 & 5.1 & 25.7 & 0.46 & $204 \pm 10$ & 5.6 & $1395 \pm 44$ \\
\hline Shfd07150 & 1.76 & 5.3 & 25.5 & 0.48 & $203 \pm 10$ & 5.8 & $1413 \pm 45$ \\
\hline Shfd07151 & 1.67 & 5.1 & 24.3 & 0.51 & $201 \pm 10$ & 2.7 & $1452 \pm 50$ \\
\hline Shfd07152 & 1.91 & 5.6 & 25.5 & 0.46 & $200 \pm 10$ & 7.8 & $1416 \pm 49$ \\
\hline Shfd07153 & 1.78 & 5.2 & 24.8 & 0.57 & $198 \pm 10$ & 7.0 & $1469 \pm 52$ \\
\hline Shfd07154 & 1.74 & 5.2 & 24.9 & 0.51 & $197 \pm 10$ & 5.2 & $1433 \pm 50$ \\
\hline Shfd07155 & 1.84 & 5.4 & 27.0 & 0.48 & $196 \pm 10$ & 7.1 & $1411 \pm$ \\
\hline Shfd07156 & 1.98 & 5.5 & 24.3 & 0.47 & $213 \pm 11$ & 8.8 & $1430 \pm 49$ \\
\hline Shfd07157 & 2.09 & 5.4 & 24.6 & 0.46 & $211 \pm 11$ & 9.0 & $1435 \pm 50$ \\
\hline Shfd07158 & 2.09 & 5.3 & 24.9 & 0.51 & $210 \pm 10$ & 9.8 & $1458 \pm 51$ \\
\hline Shfd07159 & 2.08 & 5.8 & 25.5 & 0.46 & $208 \pm 10$ & 9.3 & $1451 \pm 50$ \\
\hline Shfd07160 & 2.02 & 5.4 & 27.1 & 0.43 & $207 \pm 10$ & 9.5 & $1381 \pm 48$ \\
\hline Shfd07161 & 1.98 & 5.3 & 27.0 & 0.49 & $205 \pm 10$ & 9.1 & $1423 \pm 45$ \\
\hline Shfd07162 & 2.09 & 5.7 & 27.0 & 0.48 & $204 \pm 10$ & 9.7 & $1454 \pm 46$ \\
\hline Shfd07163 & 2.06 & 5.6 & 27.8 & 0.51 & $203 \pm 10$ & 9.5 & $1469 \pm 47$ \\
\hline Shfd07164 & 2.02 & 5.4 & 25.8 & 0.47 & $201 \pm 10$ & 10.0 & $1403 \pm 49$ \\
\hline Shfd07165 & 2.00 & 5.8 & 27.0 & 0.51 & $200 \pm 10$ & 9.9 & $1459 \pm 51$ \\
\hline Shfd07166 & 1.92 & 5.2 & 25.6 & 0.49 & $198 \pm 10$ & 9.8 & $1385 \pm 48$ \\
\hline Shfd07167 & 1.94 & 5.3 & 25.2 & 0.50 & $197 \pm 10$ & 10.5 & $1393 \pm 48$ \\
\hline Shfd07168 & 2.05 & 5.5 & 25.8 & 0.44 & $196 \pm 10$ & 9.8 & $1387 \pm 48$ \\
\hline Shfd07169 & 2.05 & 5.5 & 28.4 & 0.50 & $194 \pm 10$ & 10.9 & $1421 \pm 50$ \\
\hline
\end{tabular}

+ Cosmic dose is calculated as a linear decay curve at depths below $50 \mathrm{~cm}$. Above this depth, errors in calculation may lead to an under-estimation of the cosmic dose contribution.

${ }^{\dagger}$ Total Dose is attenuated for grain size, density and moisture. 
The contribution to dose rates from cosmic Sources were calculated using the expression published in Prescott and Hutton (1994; Table 2). It should be noted however that as most of the samples were collected from less than $50 \mathrm{~cm}$ from the surface the cosmic dose rate calculation will be an under-estimate as it does no include the soft component (Precott and Hutton 1994). The dose rates calculated are based on analyses of the sediment sampled at the present day. This assumption is only valid if no movement and/or reprecipitation of the four key elements has taken place since sediment burial and the adjacent sediments to those sampled had similar dose rates. Analysis of the ICP data indicates no increase in leachable $\mathrm{K}$ or $\mathrm{U}$ with depth from the two sample columns and the U:Th ratio is within the norm for a natural sample. Further analysis would have to be undertaken to establish whether the latter is true and if radioactive disequilibrium is present in the dose rate.

\section{B.4 Palaeodose Determination}

The samples were prepared under subdued red lighting following the procedure to extract and clean quartz outlined in Bateman and Catt (1996). Prepared aliquots of the samples were taken from within a maximum size range of 125-180 $\mu \mathrm{m}$. Samples then underwent measurements at the single grain level using a Risø TL DA-15 single grain laser luminescence reader with radiation doses administered using a calibrated ${ }^{90}$ strontium beta source. Grains were mounted in $300 \square \mathrm{m}$ pits with 100 pits per $9.6 \mathrm{~mm}$ stainless steel aliquot. A focussed $532 \mathrm{~nm} \quad \mathrm{Nd}: \mathrm{YVO}_{4}$ laser provided the stimulation and luminescence detection was through a Hoya U-340 filter. All samples were analysed using the single aliquot regenerative (SAR) approach (Murray and Wintle 2000), in which an interpolative growth curve is constructed using data derived from repeated measurements of a single aliquot which has been given various laboratory irradiations (Figure B-1). The last irradiation dose replicated the first to check if sensitivity changes cause by repeated measurement of the same aliquot had been correctly monitored and corrected for by the SAR protocol ((known as the recycling ratio).

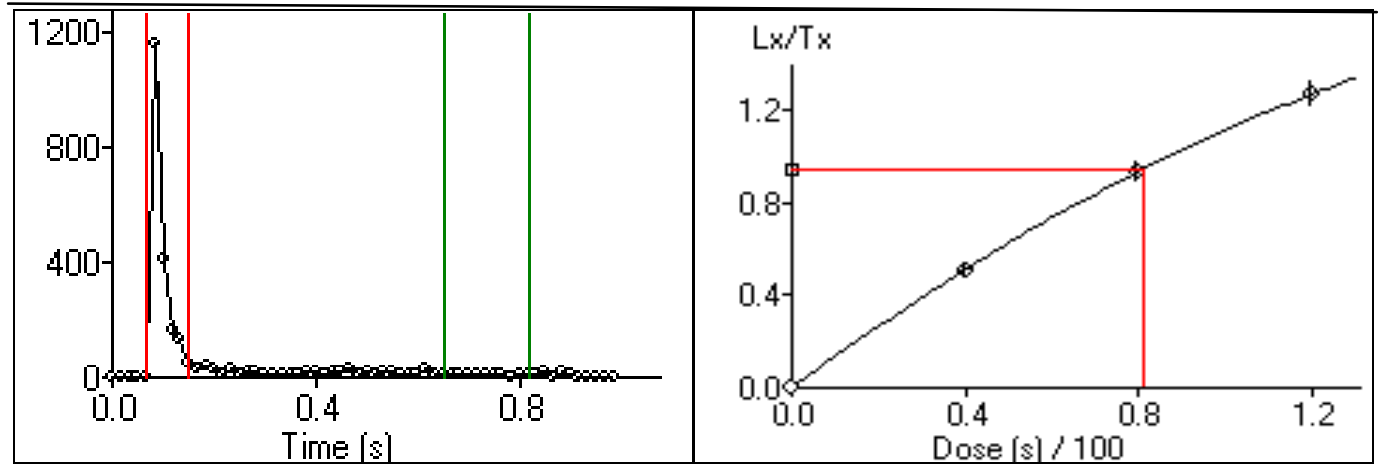

Figure B-1. Examples of Single Grain OSL Data for Sample Shfd07148 (a) OSL Decay of Naturally Acquired Signal and (b) SAR Growth Curves.

Within the SAR protocol a preheat of $240{ }^{\circ} \mathrm{C}$ for 10 seconds prior to OSL measurement was used to remove unstable signal generated by laboratory irradiations. This preheat was derived experimentally using a dose recovery test with a range of preheat temperatures (after Murray and Wintle, 2003). As Figure B-2 shows the $240^{\circ} \mathrm{C}$ for 10 preheat recovers the $40 \mathrm{~s}$ exposure to the laboratory beta radiation source within errors and has recycling ratios within $\pm 10 \%$. 


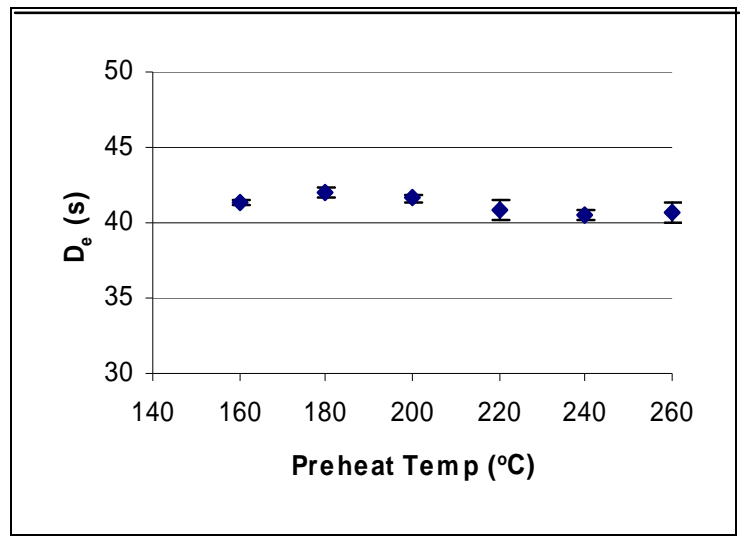

A.

Figure B-2. Results of Dose Recovery Test on Shfd07147Used to Determine Appropriate Preheat for SAR Protocol. (a) Results of different preheat recovering a $40 \mathrm{~s}$ exposure to the laboratory beta radiation source; (b) recycling ratio of different preheats.

With all single grain OSL analysis many grains exhibit insufficient OSL signal to be utilised and/or are too poorly behaved for the De to be accurately measured. De values from individual grains were only accepted where their recycling ratio was $1 \pm 0.20$, they exhibited good growth with dose and the error on the test dose used within the SAR protocol was less than $20 \%$. As Table B-3 shows, for sample Shfd07147 300 grains were measured of which $25 \%$ yielded grains which met these criteria. For sample Shfd07161 of the 400 grains measured $16 \%$ yielded grains which met these criteria. These return rates are high compared to other sites within Texas and further a field (typically $<10 \%$ of grains yield usable data) indicating that the quartz grains from 41AN38 are behaving as good natural dosimeters with relatively high sensitivity to dose.

\section{B.5 Sedimentary Bleaching Behaviour}

The effects of incomplete bleaching of the sediment during the last period of transport or exposure in situ can be profound. Typically, poorly bleached sediments retain

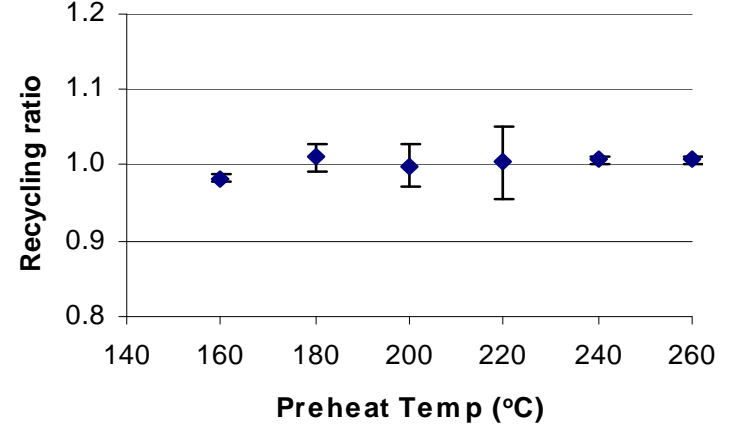

B.

a significant level of residual signal from previous phases of sedimentary cycling, leading to inherent inaccuracies in the calculation of a palaeodose value. By plotting the replicate data for each sample as a probability density function some assessment of whether older or younger material has been included in the sample measurements can be made (Figure 3). In principle a well bleached unpostdepositionally disturbed sample should have replicate palaeodose (De) data which is normally distributed and highly reproducible (See Bateman et al. 2003, Fig 3; Bateman et al 2007a). Where post-depositional disturbance or incomplete bleaching prior to sample burial has occurred skewing of this distribution may occur and/or replicate reproducibility may be lower (Bateman et al 2007a; Bateman et al. 2007b). In the case of poorly bleached material skewing should be evident with a high De tail (e.g. Olley et al. 2004).

As Figure B-3 (and Appendix 1) shows the single grain data distributions all vary and none form a tight normal distribution. 
Table B-3. Summary of Single Grain OSL De Results Including Their Over-Dispersion Values (OD; Galbraith et al. 1999) and a Description and Interpretation of the De Replicate Distributions.

\begin{tabular}{|c|c|c|c|c|c|c|}
\hline Lab Code & $\begin{array}{c}\text { Total No. } \\
\text { Grains } \\
\text { Measured }\end{array}$ & $\begin{array}{l}\text { Usable } \\
\text { Grains }\end{array}$ & $\begin{array}{l}\text { Zero } \\
\text { Grain }^{\ddagger} \\
(\%)\end{array}$ & $\begin{array}{l}\text { OD } \\
(\%)\end{array}$ & De Distribution & Interpretation \\
\hline Shfd07143 & 600 & $19 \%$ & 13 & 410 & Skewed with high De tail, zero grains & Bioturbated (surface, internal) \\
\hline Shfd07144 & 600 & $16 \%$ & 17 & 107 & Skewed with high De tail, zero grains & Bioturbated (surface, internal) \\
\hline Shfd07145 & 400 & $16 \%$ & 53 & 456 & Skewed with high De tail, zero grains & Bioturbated (surface, internal) \\
\hline Shfd07146 & 200 & $32 \%$ & 14 & 92 & Multimodal, high De outliers, zero grains & Bioturbated (surface, internal) \\
\hline Shfd07147 & 300 & $25 \%$ & 8 & 90 & Skewed with high De tail, zero grains & Bioturbated (surface, internal) \\
\hline Shfd07148 & 400 & $18 \%$ & 6 & 77 & Broad multimodal De, zero grains & Bioturbated (surface, internal) \\
\hline Shfd07149 & 300 & $21 \%$ & 27 & 91 & Skewed with high De tail, zero grains & Bioturbated (surface, internal) \\
\hline Shfd07150 & 300 & $27 \%$ & 19 & 79 & Skewed with high De tail, zero grains & Bioturbated (surface, internal) \\
\hline Shfd07151 & 300 & $20 \%$ & 0 & 87 & Broad multimodal De & Bioturbated (internal) \\
\hline Shfd07152 & 300 & $29 \%$ & 1 & 90 & Skewed with high De tail & Bioturbated (internal) \\
\hline Shfd07153 & 300 & $23 \%$ & 4 & 85 & Skewed with high De tail & Bioturbated (internal) \\
\hline Shfd07154 & 400 & $20 \%$ & 1 & 74 & Broad, multimodal, some high outliers & Bioturbated (internal) \\
\hline Shfd07155 & 300 & $17 \%$ & 0 & 70 & Broad, multimodal, some high outliers & Bioturbated (internal) \\
\hline Shfd07156 & 400 & $14 \%$ & 67 & 432 & Dominated by zero grains, some high outliers & Recently bioturbated \\
\hline Shfd07157 & 500 & $13 \%$ & 74 & 422 & Dominated by zero grains, some high outliers & Recently bioturbated \\
\hline Shfd07158 & 400 & $15 \%$ & 55 & 462 & Skewed with high De tail, zero grains & Bioturbated (surface, internal) \\
\hline Shfd07159 & 300 & $22 \%$ & 32 & 442 & Skewed with high De tail, zero grains & Bioturbated (surface, internal) \\
\hline Shfd07160 & 300 & $22 \%$ & 34 & 475 & Skewed with high De tail, zero grains & Bioturbated (surface, internal) \\
\hline Shfd07161 & 400 & $16 \%$ & 2 & 102 & Skewed with high De tail & Bioturbated (internal) \\
\hline Shfd07162 & 300 & $24 \%$ & 0 & 57 & Skewed with high De tail & Bioturbated (internal) \\
\hline Shfd07163 & 300 & $27 \%$ & 0 & 64 & Broad single De peak with De outliers & Partially bioturbated (internal) \\
\hline Shfd07164 & 300 & $19 \%$ & 0 & 58 & Broad single De peak with De outliers & Partially bioturbated (internal) \\
\hline Shfd07165 & 300 & $20 \%$ & 2 & 75 & Broad single De peak with De outliers & Partially bioturbated (internal) \\
\hline Shfd07166 & 300 & $25 \%$ & 1 & 76 & Broad single De peak with De outliers & Partially bioturbated (internal) \\
\hline Shfd07167 & 300 & $18 \%$ & 0 & 171 & Skewed with high De tail & Bioturbated (internal) \\
\hline Shfd07168 & 300 & $21 \%$ & 2 & 151 & Broad single De peak with De outliers & Partially bioturbated (internal) \\
\hline Shfd07169 & 300 & $17 \%$ & 0 & 54 & Broad single De peak with De outliers & Partially bioturbated (internal) \\
\hline
\end{tabular}

${ }^{\mp}$ Zero dose grains counted as those with a De $<0.2$ Gy, error not taken into account.

Note: Zero grains are assumed to indicate recent exhumation to the surface of grains and burial whereas skewing and high De outliers are assumed to indicate internal mixing upward of older grains. 

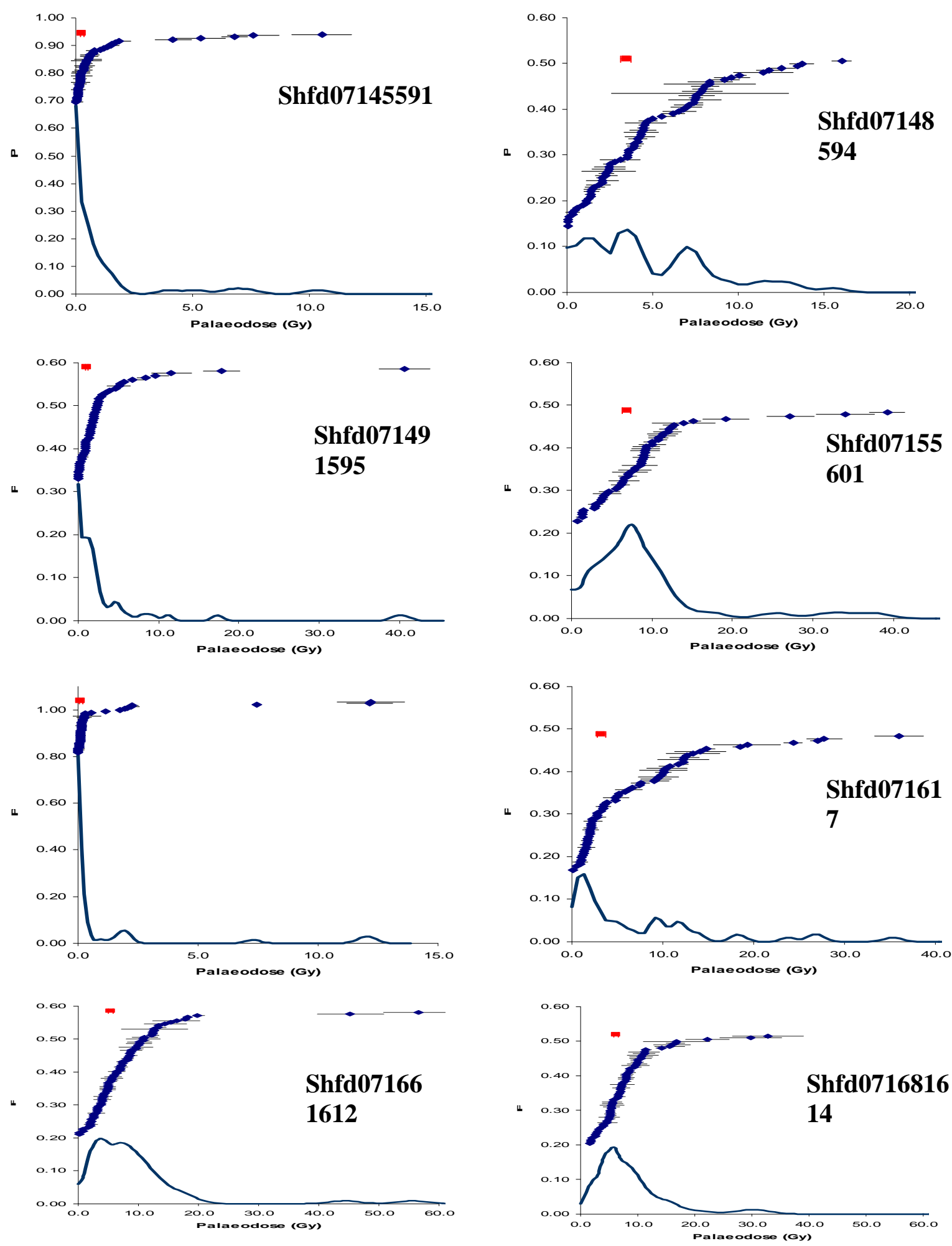

Figure B-3. Examples of Combined Probability Density Functions for Single Grains Showing Degree of Inter-Aliquot Scatter. Also plotted are individual grain De (black) and the unweighted mean De (red). 
For all samples the De distribution is much broader/non-normal than would be expected for a well-bleached undisturbed sediment with OD values in excess of $50 \%$ for all samples (Table B-3; Bateman et al. 2007a). Samples from near the surface clearly have large numbers of zero dosed grains and extremely high OD values (>400\%). Whilst some of the zero-dosed grains may be due to instrumental error it has been argued that where significant numbers of zero dose grains have been measured this is indicative of grains which have recently been exhumed and returned to depth by, for example, bioturbation (see Heimsath 2002; Bateman et al 2007). As Figure 4 demonstrates, the number of zero-dosed grains found decreases with sampled depth as does the scatter represented by OD (Table B-3 above). This conforms to the fact pedogenic overturning and bioturbation are most intense in the uppermost horizons and decrease in intensity with depth (See Bateman et al. 2007b, Fig. 8).

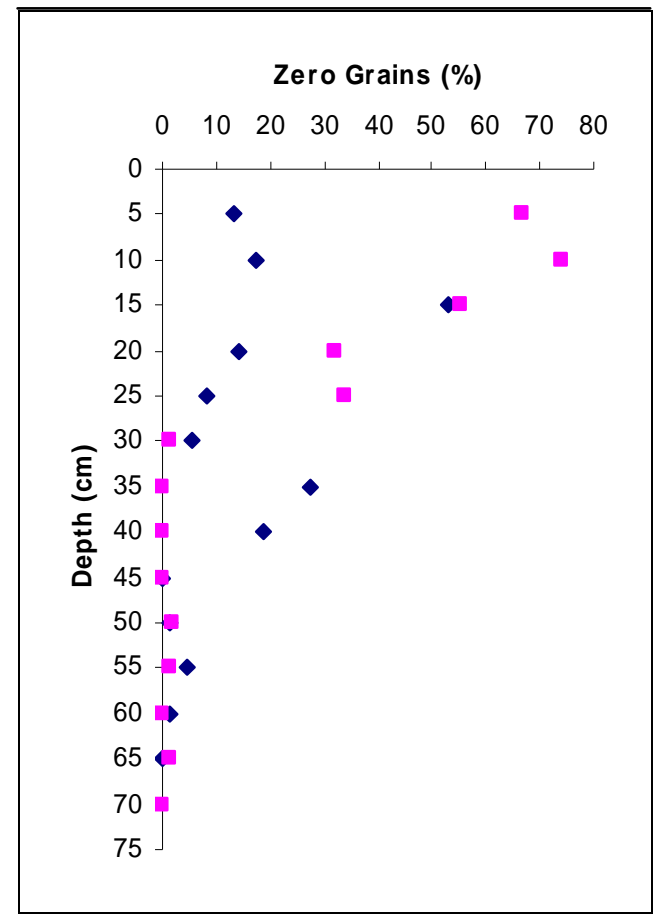

Figure B-4. The Relationship between Zero Dose Grains and Depth (Blue is sample 1589-1601, pink is samples 1602 1615).
There also appears to be a significance difference between the two sampled columns in terms of the amount of this disturbance (Figure B-4), with the column incorporating field samples1602-1615 having much higher levels of zero-dosed grains.

In addition to some samples having a significant zero grain component, all samples also include either multiple peaks and/or are skewed with high De values (Figure B-3, Table B-3).

Two possibilities exist to explain these. Firstly, that this represents incomplete resetting of previously accumulated OSL signal due to incomplete exposure of the sediment to sunlight prior to its reburial. Alternatively, these high De values could represent the movement upward of older sediment into sediments of younger antiquities by post-depositional disturbance. Without other information about the depositional style of the sediments, detailed site stratigraphic and sedimentological/ archaeological evidence, it is impossible to differentiate between these two possibilities using only the OSL data. However this does cause significant difficulties if one is trying to isolate the samples' burial age. Most samples have one dominant De peak reflecting a number of coincident De's from replicate. If peaks related to zero dosed grains are excluded as representing recent bioturbation, and it is assumed that bioturbation has not completely homogenised the sediment (Bateman et al. 2003) then the dominant De peak may represent the true burial age De. As such steps have been made to try and statistically isolate replicates associated only with this dominant peak using the finite mixture model of Galbraith and Green (1990). This model assumes a natural sample dispersion of $15 \%$ for the single grain data (Jacobs et al. 2003). Table B-4 shows the results of the finite mixture modelling and the number of components recognised in each sample. All samples had at least 3 components present. 
Table B-4. Summary of Palaeodoses (De) from Components Identified within Samples by the Finite Mixture Model (Galbraith and Green 1990) and Their Relative Probabilities.

Components highlighted in bold indicate dominant peak (excluding zero grains).

Component representing $<10 \%$ of grains measured have been excluded for clarity.

\begin{tabular}{|c|c|c|c|c|c|c|c|c|}
\hline Lab Code & $\begin{array}{l}\text { Compone } \\
\text { De } \\
\text { (Gy) }\end{array}$ & & $\begin{array}{l}\text { Compone } \\
\text { De } \\
\text { (Gy) }\end{array}$ & & $\begin{array}{l}\text { Compone } \\
\text { De } \\
\text { (Gy) }\end{array}$ & $\begin{array}{l}3 \\
\text { (\%) }\end{array}$ & $\begin{array}{l}\text { Compone } \\
\text { De } \\
\text { (Gy) }\end{array}$ & $\begin{array}{l}4 \\
\text { (\%) }\end{array}$ \\
\hline Shfd07143 & $0.00 \pm 0.00$ & 18 & $1.48 \pm 0.08$ & 35 & $3.79 \pm 0.16$ & 32 & $9.43 \pm 0.57$ & 11 \\
\hline Shfd07144 & $0.00 \pm 0.00$ & 17 & $2.20 \pm 0.11$ & 33 & $4.83 \pm 0.38$ & 16 & $9.92 \pm 0.51$ & 18 \\
\hline Shfd07145 & $0.00 \pm 0.00$ & 56 & $0.87 \pm 0.05$ & 36 & & & & \\
\hline Shfd07146 & $0.00 \pm 0.00$ & 14 & $1.02 \pm 0.10$ & 26 & $3.03 \pm 0.23$ & 24 & $7.76 \pm 0.33$ & 37 \\
\hline Shfd07147 & $0.00 \pm 0.00$ & 12 & $1.30 \pm 0.07$ & 54 & $5.99 \pm 0.26$ & 33 & & \\
\hline Shfd07148 & $1.50 \pm 0.13$ & 25 & $4.04 \pm 0.20$ & 36 & $9.30 \pm 0.39$ & 32 & & \\
\hline Shfd07149 & $0.00 \pm 0.00$ & 29 & $0.84 \pm 0.148$ & 14 & $2.03 \pm 0.13$ & 40 & $6.27 \pm 0.54$ & 14 \\
\hline Shfd07150 & $0.00 \pm 0.00$ & 20 & $1.41 \pm 0.11$ & 32 & $3.91 \pm 0.19$ & 40 & & \\
\hline Shfd07151 & $0.319 \pm 0.08$ & 32 & $1.51 \pm 0.09$ & 32 & $4.02 \pm 0.29$ & 27 & $7.79 \pm 0.44$ & 34 \\
\hline Shfd07152 & $0.00 \pm 0.00$ & 32 & $1.24 \pm 0.08$ & 31 & $3.53 \pm 0.19$ & 39 & $8.79 \pm 0.53$ & 25 \\
\hline Shfd07153 & $1.50 \pm 0.28$ & 21 & $2.99 \pm 0.52$ & 26 & $7.40 \pm 0.35$ & 34 & $18.17 \pm 1.09$ & 14 \\
\hline Shfd07154 & $1.07 \pm 0.10$ & 14 & $4.39 \pm 0.24$ & 39 & $9.50 \pm 0.39$ & 46 & & \\
\hline Shfd07155 & $3.13 \pm 0.24$ & 26 & $9.02 \pm 0.32$ & 66 & & & & \\
\hline Shfd07156 & $0.00 \pm 0.00$ & 53 & $0.18 \pm 0.03$ & 28 & $2.67 \pm 0.18$ & 19 & & \\
\hline Shfd07157 & $0.00 \pm 0.00$ & 63 & $0.20 \pm 0.02$ & 23 & $3.34 \pm 0.19$ & 14 & & \\
\hline Shfd07158 & $0.00 \pm 0.00$ & 45 & $0.09 \pm 0.01$ & 17 & $1.34 \pm 0.09$ & 25 & $5.82 \pm 0.42$ & 13 \\
\hline Shfd07159 & $0.00 \pm 0.00$ & 26 & $0.22 \pm 0.05$ & 16 & $2.00 \pm 0.13$ & 38 & $7.72 \pm 0.59$ & 21 \\
\hline Shfd07160 & $0.00 \pm 0.00$ & 34 & $2.30 \pm 0.11$ & 50 & $11.67 \pm 0.86$ & 11 & & \\
\hline Shfd07161 & $1.65 \pm 0.12$ & 40 & $4.94 \pm 0.39$ & 26 & $15.21 \pm 0.65$ & 34 & & \\
\hline Shfd07162 & $2.25 \pm 0.15$ & 36 & $4.87 \pm 0.24$ & 46 & $9.65 \pm 0.68$ & 18 & & \\
\hline Shfd07163 & $2.54 \pm 0.16$ & 20 & $5.72 \pm 0.29$ & 49 & $10.73 \pm 0.59$ & 28 & & \\
\hline Shfd07164 & $3.65 \pm 0.28$ & 31 & $7.23 \pm 0.30$ & 56 & $19.50 \pm 1.43$ & 13 & & \\
\hline Shfd07165 & $2.09 \pm 0.32$ & 17 & $4.60 \pm 0.45$ & 38 & $9.26 \pm 0.53$ & 39 & & \\
\hline Shfd07166 & $3.02 \pm 0.33$ & 25 & $6.59 \pm 0.58$ & 39 & $13.00 \pm 0.87$ & 27 & & \\
\hline Shfd07167 & $1.78 \pm 0.37$ & 11 & $4.26 \pm 0.31$ & 49 & $13.05 \pm 0.73$ & 38 & & \\
\hline Shfd07168 & $7.37 \pm 0.28$ & 66 & $3.03 \pm 0.30$ & 20 & $18.34 \pm 1.71$ & 13 & & \\
\hline Shfd07169 & $4.29 \pm 0.47$ & 19 & $11.33 \pm 0.42$ & 72 & & & & \\
\hline
\end{tabular}


Table B-5. Ages Calculated from All Components Identified Within Samples by the Finite Mixture Model (Galbraith and Green 1990). Components highlighted in bold indicate ages from dominant peak (excluding zero grain components and those representing less than $10 \%$ of grains measured).

\begin{tabular}{|c|c|c|c|c|c|}
\hline Lab Code & $\begin{array}{c}\text { Component } 1 \\
\text { Age } \\
(\mathrm{Ka})\end{array}$ & $\begin{array}{c}\text { Component } 2 \\
\text { Age } \\
\text { (Ka) }\end{array}$ & $\begin{array}{c}\text { Component } 3 \\
\text { Age } \\
\text { (Ka) }\end{array}$ & $\begin{array}{c}\text { Component } 4 \\
\text { Age } \\
\text { (Ka) }\end{array}$ & $\begin{array}{c}\text { Component } 5 \\
\text { Age } \\
\text { (Ka) }\end{array}$ \\
\hline Shfd07143 & & $1.07 \pm 0.07$ & $2.73 \pm 0.15$ & $6.80 \pm 0.47$ & \\
\hline Shfd07144 & & $1.58 \pm 0.10$ & $3.48 \pm 0.30$ & $7.14 \pm 0.44$ & \\
\hline Shfd07145 & & $0.61 \pm 0.04$ & & & \\
\hline Shfd07146 & & $0.71 \pm 0.07$ & $2.11 \pm 0.18$ & $5.40 \pm 0.29$ & \\
\hline Shfd07147 & & $0.93 \pm 0.06$ & $4.29 \pm 0.24$ & & \\
\hline Shfd07148 & $1.06 \pm 0.10$ & $2.85 \pm 0.17$ & $6.57 \pm 0.35$ & & \\
\hline Shfd07149 & & $0.60 \pm 0.11$ & $1.46 \pm 0.10$ & $4.50 \pm 0.41$ & \\
\hline Shfd07150 & & $1.00 \pm 0.08$ & $2.77 \pm 0.16$ & & \\
\hline Shfd07151 & $0.22 \pm 0.06$ & $1.04 \pm 0.07$ & $2.77 \pm 0.22$ & $5.37 \pm 0.36$ & \\
\hline Shfd07152 & & $0.88 \pm 0.06$ & $2.49 \pm 0.16$ & $6.21 \pm 0.43$ & \\
\hline Shfd07153 & $1.02 \pm 0.19$ & $2.04 \pm 0.36$ & $5.04 \pm 0.30$ & $12.37 \pm 0.86$ & \\
\hline Shfd07154 & $0.75 \pm 0.07$ & $3.06 \pm 0.20$ & $6.63 \pm 0.36$ & & \\
\hline Shfd07155 & $2.22 \pm 0.19$ & $6.39 \pm 0.32$ & $21.78 \pm 2.32$ & & \\
\hline Shfd07156 & & $0.13 \pm 0.02$ & $1.87 \pm 0.14$ & & \\
\hline Shfd07157 & & $0.14 \pm 0.01$ & $2.33 \pm 0.16$ & & \\
\hline Shfd07158 & & $0.06 \pm 0.01$ & $0.92 \pm 0.07$ & $3.99 \pm 0.32$ & \\
\hline Shfd07159 & & $0.15 \pm 0.03$ & $1.38 \pm 0.10$ & $5.32 \pm 0.45$ & \\
\hline Shfd07160 & & $1.66 \pm 0.10$ & $8.45 \pm 0.69$ & & \\
\hline Shfd07161 & $1.16 \pm 0.09$ & $3.47 \pm 0.30$ & $10.69 \pm 0.57$ & & \\
\hline Shfd07162 & $1.55 \pm 0.11$ & $3.35 \pm 0.20$ & $6.64 \pm 0.51$ & & \\
\hline Shfd07163 & $1.73 \pm 0.12$ & $3.89 \pm 0.23$ & $7.31 \pm 0.46$ & & \\
\hline Shfd07164 & $2.60 \pm 0.22$ & $5.15 \pm 0.28$ & $13.90 \pm 1.13$ & & \\
\hline Shfd07165 & $1.43 \pm 0.22$ & $3.15 \pm 0.33$ & $6.35 \pm 0.42$ & & \\
\hline Shfd07166 & $2.18 \pm 0.25$ & $4.76 \pm 0.45$ & $9.38 \pm 0.71$ & & \\
\hline Shfd07167 & $1.28 \pm 0.27$ & $3.06 \pm 0.25$ & $9.37 \pm 0.62$ & & \\
\hline Shfd07168 & $5.31 \pm 0.27$ & $2.18 \pm 0.23$ & $13.22 \pm 1.32$ & & \\
\hline Shfd07169 & $3.02 \pm 0.35$ & $7.98 \pm 0.41$ & & & \\
\hline
\end{tabular}

Table B-6. Final Ages Based on Dominant De Component as Identified within Samples by the Finite Mixture Model (Galbraith and Green 1990).

\begin{tabular}{lcccc}
\hline Lab Code & Field Ref. & Depth & $\begin{array}{c}\mathbf{( c m}) \\
\text { Single Grain } \\
\mathbf{D e}^{*} \\
(\mathrm{~Gy})\end{array}$ & $\begin{array}{c}\text { Single Grain } \\
\text { Age } \\
\text { (yrs) }\end{array}$ \\
\hline Shfd07143 & 1589 & 5 & $1.48 \pm 0.08$ & $\mathbf{1 . 0 7} \pm \mathbf{0 . 0 7}$ \\
Shfd07144 & 1590 & 10 & $2.20 \pm 0.11$ & $\mathbf{1 . 5 8} \pm \mathbf{0 . 1 0}$ \\
Shfd07145 & 1591 & 15 & $0.87 \pm 0.05$ & $\mathbf{0 . 6 1} \pm \mathbf{0 . 0 4}$ \\
Shfd07146 & 1592 & 20 & $7.76 \pm 0.33$ & $\mathbf{5 . 4 0} \pm \mathbf{0 . 2 9}$ \\
Shfd07147 & 1593 & 25 & $1.30 \pm 0.07$ & $\mathbf{0 . 9 3} \pm \mathbf{0 . 0 6}$ \\
Shfd07148 & 1594 & 30 & $4.04 \pm 0.20$ & $\mathbf{2 . 8 5} \pm \mathbf{0 . 1 7}$ \\
Shfd07149 & 1595 & 35 & $2.03 \pm 0.13$ & $\mathbf{1 . 4 6} \pm \mathbf{0 . 1 0}$ \\
Shfd07150 & 1596 & 40 & $3.91 \pm 0.19$ & $\mathbf{2 . 7 7} \pm \mathbf{0 . 1 6}$ \\
Shfd07151 & 1597 & 45 & $7.79 \pm 0.44$ & $\mathbf{5 . 3 7} \pm \mathbf{0 . 3 6}$ \\
Shfd07152 & 1598 & 50 & $3.53 \pm 0.19$ & $\mathbf{2 . 4 9} \pm \mathbf{0 . 1 6}$ \\
Shfd07153 & 1599 & 55 & $7.40 \pm 0.35$ & $\mathbf{5 . 0 4} \pm \mathbf{0 . 3 0}$ \\
Shfd07154 & 1600 & 60 & $9.50 \pm 0.39$ & $\mathbf{6 . 6 3} \pm \mathbf{0 . 3 6}$ \\
Shfd07155 & 1601 & 65 & $9.02 \pm 0.32$ & $\mathbf{6 . 3 9} \pm \mathbf{0 . 3 2}$
\end{tabular}




\begin{tabular}{lcccc}
\multicolumn{5}{c}{ Table B-6, continued } \\
Shfd07156 & 1602 & 5 & $0.18 \pm 0.03$ & $\mathbf{0 . 1 3} \pm \mathbf{0 . 0 2}$ \\
Shfd07157 & 1603 & 10 & $0.20 \pm 0.02$ & $\mathbf{0 . 1 4} \pm \mathbf{0 . 0 1}$ \\
Shfd07158 & 1604 & 15 & $1.34 \pm 0.09$ & $\mathbf{0 . 9 2} \pm \mathbf{0 . 0 7}$ \\
Shfd07159 & 1605 & 20 & $2.00 \pm 0.13$ & $\mathbf{1 . 3 8} \pm \mathbf{0 . 1 0}$ \\
Shfd07160 & 1606 & 25 & $2.30 \pm 0.11$ & $\mathbf{1 . 6 6} \pm \mathbf{0 . 1 0}$ \\
Shfd07161 & 1607 & 30 & $1.65 \pm 0.12$ & $\mathbf{1 . 1 6} \pm \mathbf{0 . 0 9}$ \\
Shfd07162 & 1608 & 35 & $4.87 \pm 0.24$ & $\mathbf{3 . 3 5} \pm \mathbf{0 . 2 0}$ \\
Shfd07163 & 1609 & 40 & $5.72 \pm 0.29$ & $\mathbf{3 . 8 9} \pm \mathbf{0 . 2 3}$ \\
Shfd07164 & 1610 & 45 & $7.23 \pm 0.30$ & $\mathbf{5 . 1 5} \pm \mathbf{0 . 2 8}$ \\
Shfd07165 & 1611 & 50 & $9.26 \pm 0.53$ & $\mathbf{6 . 3 5} \pm \mathbf{0 . 4 2}$ \\
Shfd07166 & 1612 & 55 & $6.59 \pm 0.58$ & $\mathbf{4 . 7 6} \pm \mathbf{0 . 4 5}$ \\
Shfd07167 & 1613 & 60 & $4.26 \pm 0.31$ & $\mathbf{3 . 0 6} \pm \mathbf{0 . 2 5}$ \\
Shfd07168 & 1614 & 65 & $7.37 \pm 0.28$ & $\mathbf{5 . 3 1} \pm \mathbf{0 . 2 7}$ \\
Shfd07169 & 1615 & 70 & $11.33 \pm 0.42$ & $\mathbf{7 . 9 8} \pm \mathbf{0 . 4 1}$ \\
\end{tabular}

Based on dominant De as calculated by finite mixture modelling of De replicates.

Thus from an OSL data perspective postdepositional disturbance of the sediments associated with all the samples cannot be ruled out and careful consideration of this data in relation to other available site information is recommended.

\section{B.6 Age Calculation and Conclusions}

Ages are quoted in years from the present day (2007) and are presented with one sigma confidence intervals which incorporate systematic uncertainties with the dosimetry data, uncertainties with the palaeomoisture content and errors associated with the De determination. Table B-4 shows the ages calculated for all the De component extracted from finite mixture model except those which returned a zero dose value or for which the component represented less than $10 \%$ of the grains measured. Figure B-5 and the summary in Table B-6 and show ages derived only from the dominant De peak. These show multiple age reversals (e.g. Shfd07146 and Shfd07147) and significant age divergences between similar depths from the two columns sampled (e.g. Shfd07149 and Shfd07162).

This suggests that the assumption made that the dominant De peak has retained the true burial age De maybe not valid. As the data stands, there is some hint of increasing antiquity with depth with ages ranging from $610 \pm 40$ years (Shfd07145) to 6,630 \pm 360 years for the first sampled column and $130 \pm$ 20 years (Shfd07156) to $7980 \pm 410$ years (Shfd07169) for the second sampled column. With additional chronological and stratigraphical/archaeological information, combined with using ages above and below as constraining points (assuming the law of super-position) it may be possible to better select the De component which has the true burial age from those calculated in Table B4 (See Bateman et al. 2007). Such approaches have also been developed for radiocarbon using Bayesian statistics (see Ramsey 2000, Ramsey 2007). This further analysis is highly recommended. 
(a) Age (ka)

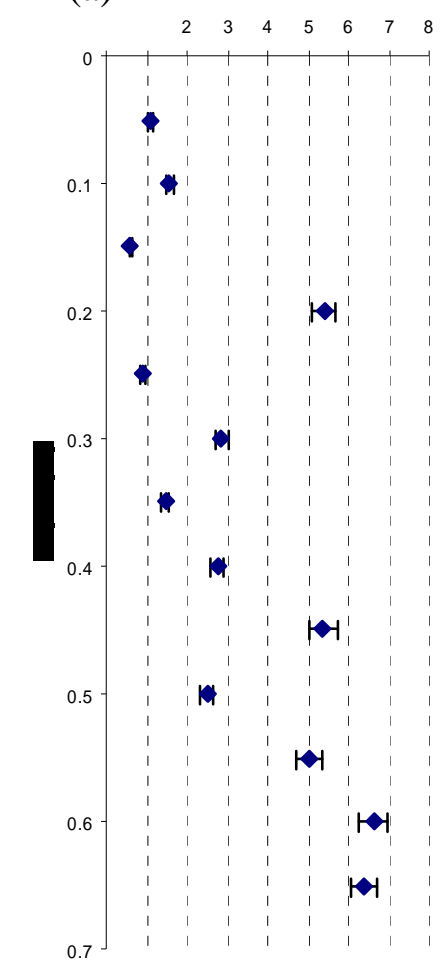

(b)

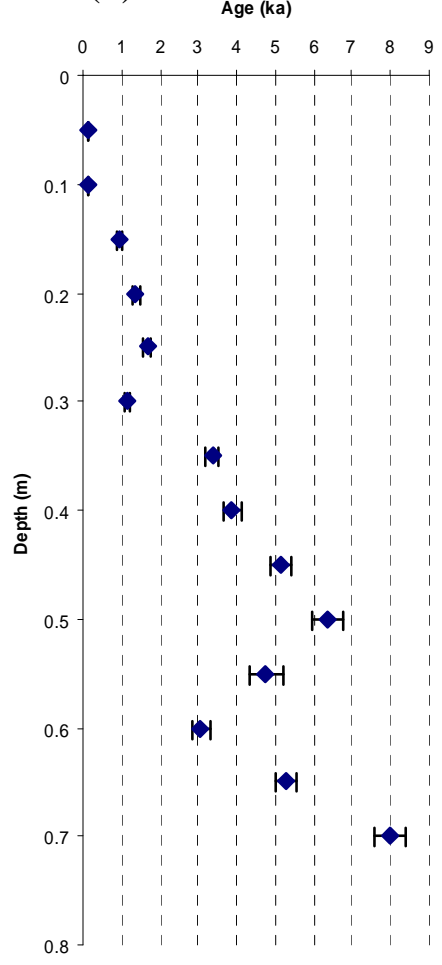

Figure B-5. Showing the Age Depth Relationship with Single Grain OSL Ages Based on the Dominant De Replicate Peak Once Zero Dosed Grains were Excluded. 


\section{References Cited}

Adamiec, G. and M. J. Aitken

1998 Dose-Rate Conversion Factors

Update. Ancient TL 16: 37-50

Aitken, M. J.

1998 An Introduction to Optical Dating: The Dating of Quaternary Sediments by the Use of PhotoStimulated Luminescence. Oxford Science Publication.

Bateman, M. D., C. H. Boulter, A. S. Carr, C. D. Frederick, D Peter, and M. Wilder 2007a Detecting Post-depositional Sediment Disturbance in Sandy Deposits using Optical Luminescence. Quaternary Geochronology 2, 57-64.

Bateman, M. D., C. H. Boulter, A. S. Carr, C. D. Frederick, D. Peter, and M. Wilder 2007b Preserving the Palaeoenvironmental Record in Drylands: Bioturbation and its Significance for Luminescence Derived Chronologies. Sediment Geology, 195, 5-19.

Bateman, M. D., C. D. Frederick, M. K. Jaiswal, and A. K. Singhvi

2003 Investigations into the Potential Effects of Pedoturbation on Luminescence Dating. Quaternary Science Reviews, 22, 1169-1176.

Bateman, M. D. And J. A. Catt

1996 An Absolute Chronology for the Raised Beach Deposits at Sewerby, E. Yorkshire, UK. Journal of Quaternary Science, 11, 389-395.

Duller, G. A. T.

2004 Luminescence dating of Quaternary Sediments: Recent Advances. Journal of Quaternary Science 19: 183-192.
Galbraith, R. F. and Green, P. F.

1990 Estimating the Component Ages in a Finite Mixture. Radiation Measurements, 17: 197-206.

Galbraith, R. F, R. G. Roberts, G. M. Laslett, H. Yoshida, and J. M. Olley 1999 Optical Dating of Single and Multiple Grains of Quartz from Jinmium Rock Shelter, Northern Australia. Part I, Experimental Design and Statistical Models. Archaeometry 41: 339-364.

Heimsath, A. M., J. Chappell, N. A. Spooner, and D. G. Questiaux

2002 Creeping Soil. Geological Society of America 30: 111-114.

Jacobs, Z., A. G. Wintle, and G. A. T. Duller

2003 Optical dating of dune sand from Blombos Cave, South Africa: IMultiple Grain Data. Journal of Human Evolution 44: 599-612.

Marsh, R. E., W. V. Prestwich, W. J. Rink and B. J. Brennan

2002 Monte Carlo Determinations of the Beta Dose Rate to Tooth Enamel. Radiation Measurements 35: 609616.

Murray, A. S. And A. G. Wintle

2000 Luminescence Dating of Quartz Using an Improved Single-Aliquot Regenerative-Dose Protocol. Radiation Measurements 32: 5773. 
Murray, A. S. and A. G. Wintle

2003 The Single Aliquot Regenerative Dose Protocol: Potential for Improvements in Reliability. Radiation Measurements 37: 377381.

Olley, J. M., T. Pietsch, and R. G. Roberts 2004 Optical Dating of Holocene Sediments from a Variety of Geomorphic Settings Using Single Grains of Quartz. Geomorphology 60, 337-358.

Prescott, J. R. and J. T. Hutton

1994 Cosmic Ray Contributions to Dose Rates for Luminescence and ESR
Dating: Large Depths and LongTerm Time Variations. Radiation Measurements, 2/3: 497-500.

Ramsey, B. C.

2007 Deposition Models for Chronological Records, Quaternary Science Reviews, (INTIMATE special issue) in press.

Ramsey, B. C.

2000 Comment on 'The Use of Bayesian Statistics for 14C Dates of Chronologically Ordered Samples: a Critical Analysis. Radiocarbon 42(2): 199-202. 


\section{Addendum: Single Grain Data and Plots for 41AN38, The Lang Pasture Site \\ Sample Specific Data:}

Probability density plot (curve) with ranked single grain De data and probability mean (uppermost point)
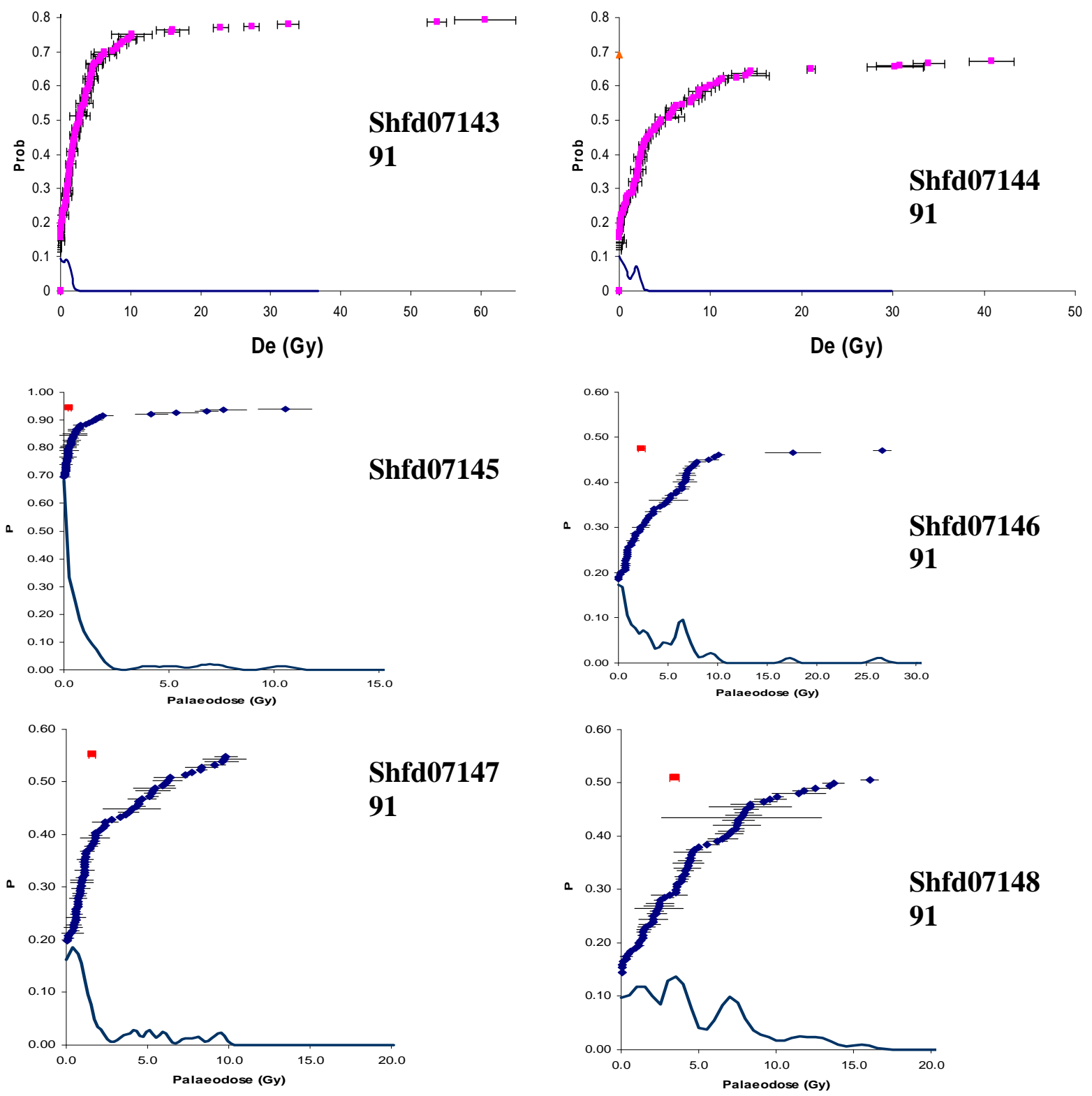

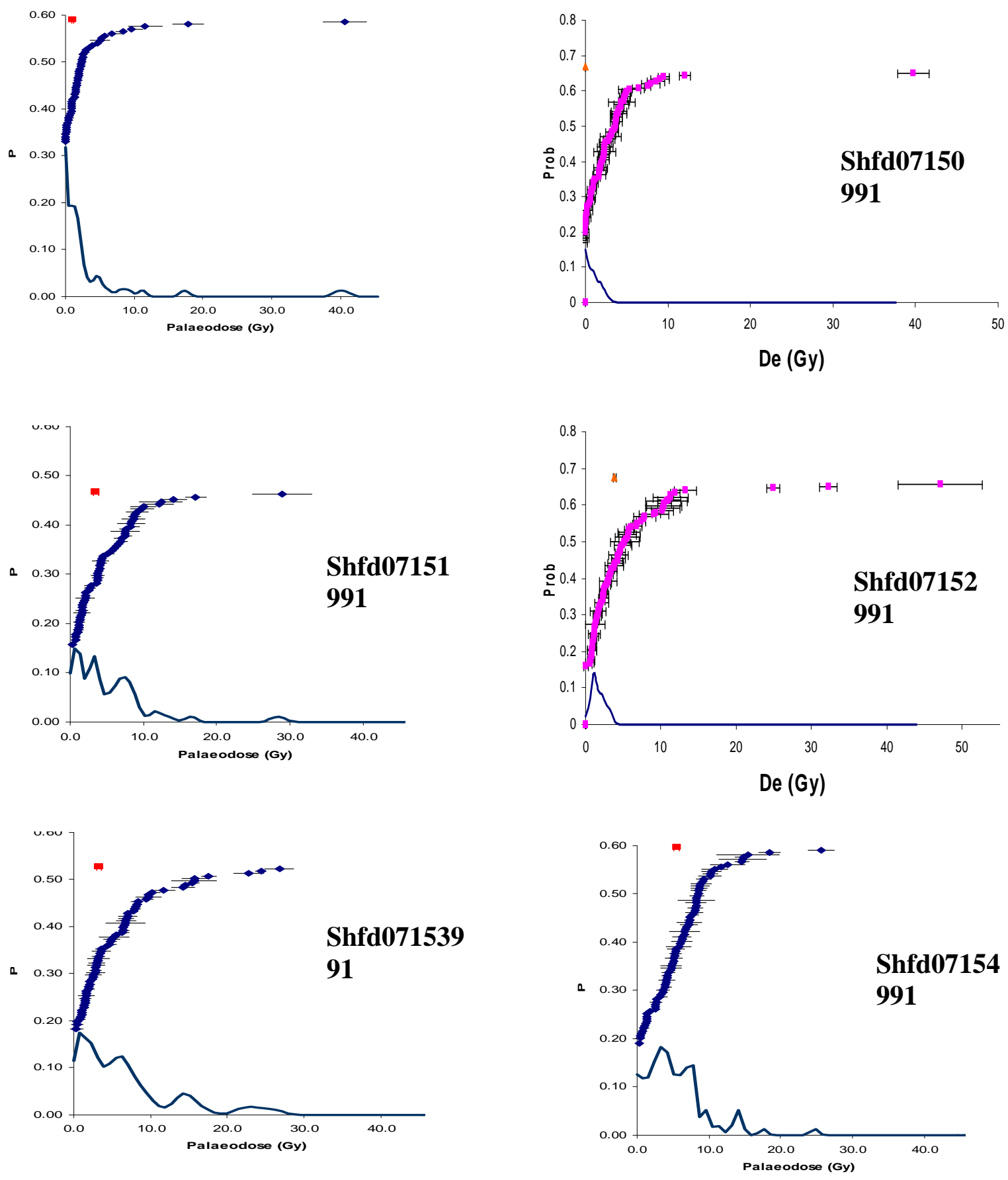

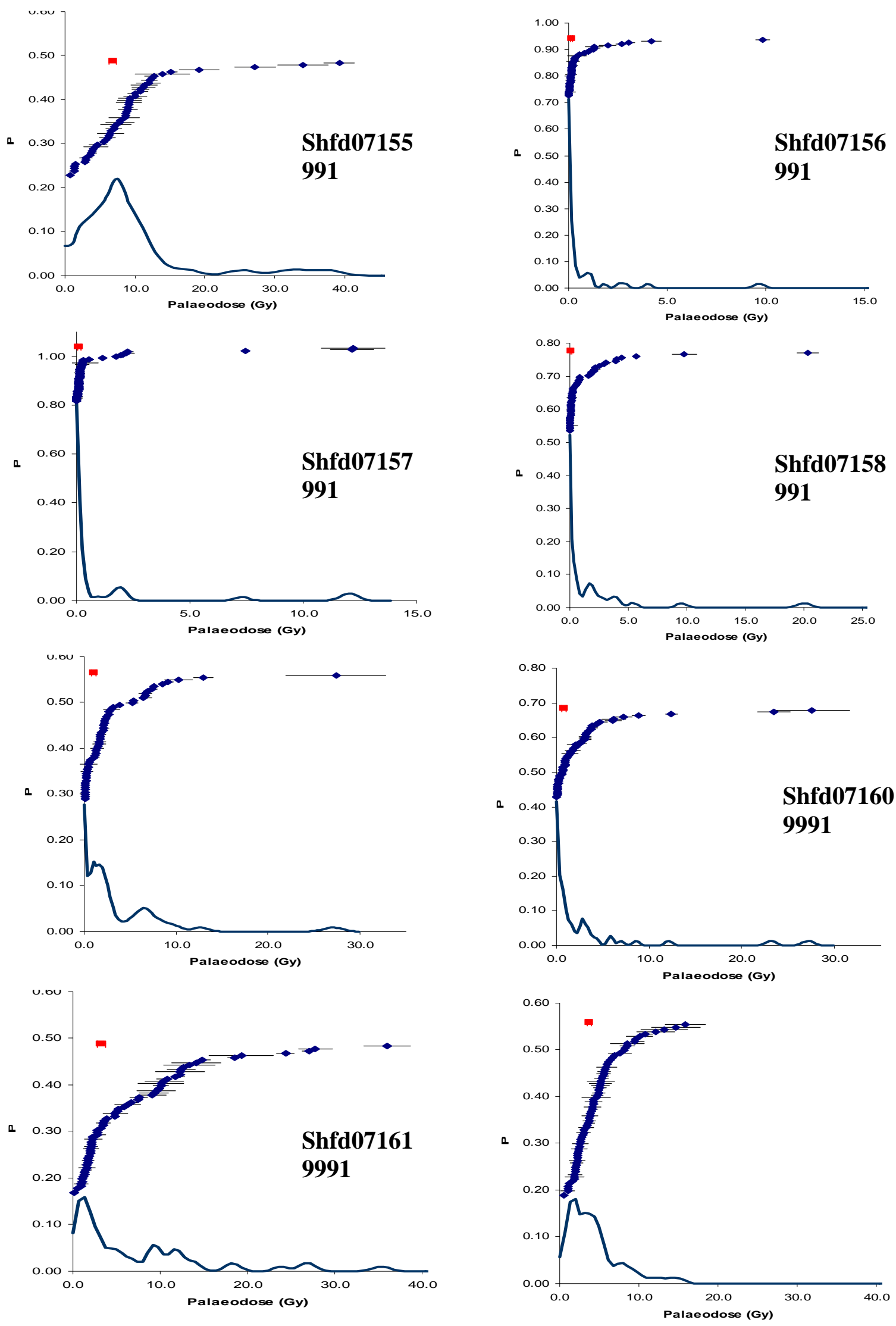

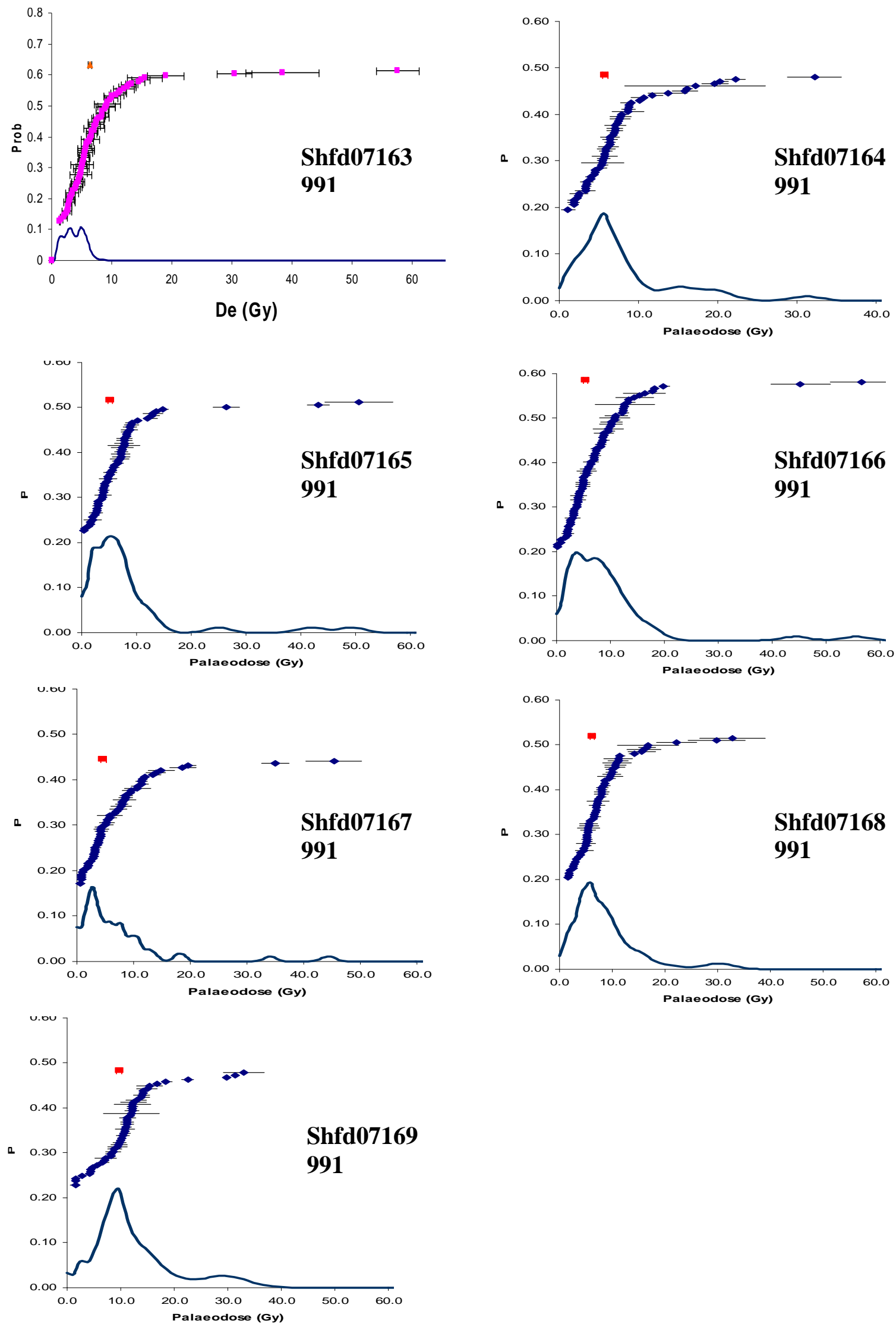


\section{APPENDIX C \\ LUMINESCENCE DATING OF CERAMICS FROM THE LANG PASTURE SITE}

Prepared for:

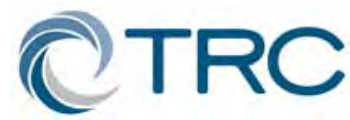

TRC Environmental Corporation

505 East Huntland Drive, Suite 250

Austin, Texas 78752

Prepared by:

James R. Feathers

Luminescence Dating Laboratory

University of Washington 



\section{C.1 INTRODUCTION}

Twenty-three ceramic sherds from site 41AN38 in eastern Texas were submitted for luminescence dating by David B. Kelley of Coastal Environments, Inc. Table C-1 gives the laboratory numbers, sample numbers, provenience, depth and decoration. Laboratory procedures are given in the appendix.

Table C-1. Sample Characteristics.

\begin{tabular}{|c|c|c|c|c|}
\hline UW lab \# & $\begin{array}{c}\text { Sample } \\
\#\end{array}$ & $\begin{array}{c}\text { Site } \\
\text { coordinates }\end{array}$ & $\begin{array}{c}\text { Burial } \\
\text { depth }(\mathrm{cm})\end{array}$ & decoration \\
\hline \multicolumn{5}{|c|}{ Fine wares } \\
\hline UW1700 & 1 & N196 E198 & 21 & Parallel engraved lines, bottle \\
\hline UW1701 & 2 & N199 E202 & 40 & Poynor Engraved carinated bowl rim \\
\hline UW1702 & 3 & N177 E198 & 19 & Poynor Engraved panel \\
\hline UW1703 & 4 & N175 E200 & 28 & $\begin{array}{c}\text { Poynor Engraved carbonated bowl, with } \\
\text { brushing on body }\end{array}$ \\
\hline UW1704 & 5 & N174 E198 & 44 & Diagonal engraved lines on rim \\
\hline \multicolumn{5}{|c|}{ Utility wares } \\
\hline UW1705 & 6 & N176 E199 & 24 & Parallel brushed \\
\hline UW1706 & 7 & N175 E202 & 30 & Curvilinear and opposed incised lines \\
\hline UW1707 & 8 & N181 E199 & 28 & Diagonal incised rim \\
\hline UW1708 & 9 & N176 E199 & 27 & Parallel brushed; pink ware \\
\hline UW1709 & 10 & N180 E202 & 28 & Killough Pinched \\
\hline UW1710 & 11 & N180 E202 & 17 & Opposed brushed \\
\hline UW1711 & 12 & N172 E199 & 22 & Tool punctuated rows \\
\hline UW1712 & 13 & N179 E202 & 26 & Overlapping brushed \\
\hline UW1713 & 14 & N183 E202 & 41 & Parallel brushed \\
\hline UW1714 & 15 & N181 E198 & 21 & Overlapping brushed \\
\hline UW1715 & 16 & N174 E200 & 27 & Parallel brushed \\
\hline UW1716 & 17 & N178 E198 & 32 & Straight incised line \\
\hline UW1717 & 18 & N195 E199 & 24 & Cross-hatched incised llines \\
\hline UW1718 & 19 & N197 E202 & 25 & Diagonal brushed rim \\
\hline UW1719 & 20 & N178 E199 & 21 & Overlapping brushed \\
\hline UW1720 & 21 & N180 E199 & 32 & Incised panels \\
\hline UW1721 & 22 & N180 E199 & 38 & Parallel brushed \\
\hline UW1722 & 23 & N183 E198 & 29 & Parallel brushed \\
\hline
\end{tabular}

Dose rate - Alpha counting, using the pairs techniques, was used to determine $\mathrm{U}$ and $\mathrm{Th}$ contents from the sherds and associated sediments. Flame photometry was employed to measure K contents. While this information, given in Tables C-2 and C-3, can provide current alpha, beta and gamma dose rates, it is accurate only insofar as secular equilibrium can be assumed in the $U$ and Th decay chains and if the associated sediment is an accurate proxy for the environmental dose rate.

The first assumption can be assessed to some degree by comparing beta dose rates determined directly by an independent means, beta counting, with those calculated from the alpha counting/flame photometry results. Disagreement, particularly if $\mathrm{K}$ (a major beta emitter) contents are small (as 
they are for these samples), suggests some disequilibrium between $\mathrm{U}$ and daughter isotopes in the ${ }^{238} \mathrm{U}$ decay chain. Significant disagreement was found only for four sherds. In these four cases the beta counting provides a more accurate measure, assuming that the disequilibrium occurred prior to the deposition of the pottery. (Clays are prone to such disequilibrium and so it probably occurred prior to pottery manufacture.) Other causes of disequilibrium, such as those involving radon or radium daughters, are less likely to be detected by this comparison, but, at least in the case of radon emanation, the state of equilibrium may be relatively constant and therefore not a problem for dose rate measures, such as alpha counting, which measure activities and not concentrations.
The second assumption was not assessed directly by in situ measurements of gamma dose rates, but the radioactivity of all 23 associated sediment samples is remarkably similar (Table C-3). This suggests radioactivity across the site is fairly uniform and the external dose rate is therefore not likely to vary greatly from sherd to sherd. There is also no evidence of increased $U$ activity in any of the sediments, which might occur if $\mathrm{U}$ or Ra may have leached from the pottery.

In sum, the determined dose rates for the pottery and sediments appear to be reasonably accurate and there is no evidence these dose rates have changed markedly through time. Moisture contents were assumed to be $80 \pm 20 \%$ of saturated values for the pottery and $10 \pm 5$ percent for the sediments.

Table C-2. Sherd Radioactivity.

\begin{tabular}{|c|c|c|c|c|c|}
\hline Sample & ${ }^{238} \mathrm{U}(\mathrm{ppm})$ & ${ }^{232} \mathrm{Th}(\mathrm{ppm})$ & $K(\%)$ & \multicolumn{3}{|c|}{ Beta dose rate $(\mathrm{Gy} / \mathrm{ka})$} \\
\cline { 5 - 6 } & & & & $\beta$-counting & $\alpha$-counting/flame photometry \\
\hline UW1700 & $2.73 \pm 0.27$ & $19.82 \pm 1.81$ & $0.98 \pm 0.04$ & $1.55 \pm 0.14$ & $1.72 \pm 0.07$ \\
\hline UW1701 & $3.54 \pm 0.26$ & $11.62 \pm 1.47$ & $0.76 \pm 0.02$ & $1.41 \pm 0.12$ & $1.45 \pm 0.06$ \\
\hline UW1702 & $2.23 \pm 0.25$ & $18.52 \pm 1.87$ & $0.96 \pm 0.01$ & $1.46 \pm 0.12$ & $1.60 \pm 0.06$ \\
\hline UW1703 & $3.02 \pm 0.21$ & $7.82 \pm 1.17$ & $0.91 \pm 0.02$ & $1.56 \pm 0.15$ & $1.39 \pm 0.05$ \\
\hline UW1704 & $3.02 \pm 0.28$ & $17.94 \pm 1.86$ & $0.94 \pm 0.08$ & $1.60 \pm 0.13$ & $1.68 \pm 0.09$ \\
\hline UW1705 & & & $0.79 \pm 0.02$ & & \\
\hline UW1706 & $2.63 \pm 0.17$ & $5.53 \pm 0.87$ & $1.03 \pm 0.01$ & $1.64 \pm 0.14$ & $1.36 \pm 0.04^{*}$ \\
\hline UW1707 & $2.06 \pm 0.14$ & $4.57 \pm 0.72$ & $0.89 \pm 0.01$ & $1.55 \pm 0.16$ & $1.14 \pm 0.03^{*}$ \\
\hline UW1708 & $5.82 \pm 0.36$ & $11.33 \pm 1.53$ & $1.18 \pm 0.03$ & $1.82 \pm 0.15$ & $2.11 \pm 0.07^{*}$ \\
\hline UW1709 & $3.73 \pm 0.24$ & $6.99 \pm 1.13$ & $1.56 \pm 0.03$ & $2.02 \pm 0.27$ & $1.99 \pm 0.05$ \\
\hline UW1710 & $4.48 \pm 0.27$ & $6.85 \pm 1.03$ & $1.27 \pm 0.01$ & $1.91 \pm 0.17$ & $1.86 \pm 0.05$ \\
\hline UW1711 & $3.93 \pm 0.27$ & $10.70 \pm 1.42$ & $0.86 \pm 0.02$ & $1.50 \pm 0.12$ & $1.55 \pm 0.06$ \\
\hline UW1712 & $4.97 \pm 0.30$ & $8.69 \pm 1.17$ & $1.51 \pm 0.03$ & $2.09 \pm 0.18$ & $2.18 \pm 0.06$ \\
\hline UW1713 & $2.70 \pm 0.19$ & $8.13 \pm 1.05$ & $1.21 \pm 0.04$ & $1.72 \pm 0.15$ & $1.58 \pm 0.05$ \\
\hline UW1714 & & & $1.12 \pm 0.01$ & & \\
\hline UW1715 & $3.76 \pm 0.24$ & $7.39 \pm 1.05$ & $0.96 \pm 0.02$ & $1.57 \pm 0.13$ & $1.52 \pm 0.05$ \\
\hline UW1716 & $3.45 \pm 0.28$ & $15.64 \pm 1.61$ & $1.06 \pm 0.01$ & $1.76 \pm 0.14$ & $1.78 \pm 0.06$ \\
\hline UW1717 & $2.71 \pm 0.25$ & $16.50 \pm 1.76$ & $1.04 \pm 0.02$ & $1.70 \pm 0.16$ & $1.68 \pm 0.06$ \\
\hline UW1718 & & & $0.90 \pm 0.03$ & & \\
\hline UW1719 & $2.87 \pm 0.20$ & $7.22 \pm 1.02$ & $1.09 \pm 0.02$ & $1.69 \pm 0.14$ & $1.49 \pm 0.04^{*}$ \\
\hline UW1720 & $3.46 \pm 0.23$ & $7.02 \pm 1.12$ & $1.11 \pm 0.04$ & $1.56 \pm 0.14$ & $1.59 \pm 0.06$ \\
\hline UW1721 & $4.44 \pm 0.29$ & $11.02 \pm 1.34$ & $3.63 \pm 0.03$ & & \\
\hline UW1722 & $3.76 \pm 0.85$ & $13.06 \pm 1.58$ & $1.09 \pm 0.09$ & $1.76 \pm 0.18$ & $1.78 \pm 0.15$ \\
\hline
\end{tabular}

*Significant disagreement in beta dose rate between beta counting and alpha counting/flame photometry 
Table C-3. Sediment Radioactivity.

\begin{tabular}{|c|c|c|c|}
\hline Sample & ${ }^{238} \mathrm{U}(\mathrm{ppm})$ & ${ }^{232} \mathrm{Th}(\mathrm{ppm})$ & $K(\%)$ \\
\hline UW1700 & $2.00 \pm 0.15$ & $7.47 \pm 0.82$ & $0.46 \pm 0.02$ \\
\hline UW1701 & $1.29 \pm 0.14$ & $8.66 \pm 1.19$ & $0.48 \pm 0.02$ \\
\hline UW1702 & $1.27 \pm 0.16$ & $11.05 \pm 1.36$ & $0.44 \pm 0.02$ \\
\hline UW1703 & $1.67 \pm 0.17$ & $9.68 \pm 1.28$ & $0.43 \pm 0.02$ \\
\hline UW1704 & $1.83 \pm 0.19$ & $10.05 \pm 1.31$ & $0.46 \pm 0.01$ \\
\hline UW1705 & $1.78 \pm 0.16$ & $6.56 \pm 1.04$ & $0.43 \pm 0.01$ \\
\hline UW1706 & $1.88 \pm 0.17$ & $8.79 \pm 1.21$ & $0.45 \pm 0.01$ \\
\hline UW1707 & $1.97 \pm 0.17$ & $7.79 \pm 1.14$ & $0.45 \pm 0.01$ \\
\hline UW1708 & $1.62 \pm 0.13$ & $4.60 \pm 0.85$ & $0.45 \pm 0.01$ \\
\hline UW1709 & $1.94 \pm 0.17$ & $7.06 \pm 1.08$ & $0.45 \pm 0.01$ \\
\hline UW1710 & $2.85 \pm 0.20$ & $5.71 \pm 1.00$ & $0.44 \pm 0.02$ \\
\hline UW1711 & & & $0.43 \pm 0.01$ \\
\hline UW1712 & $3.31 \pm 0.20$ & $4.58 \pm 0.83$ & $0.45 \pm 0.01$ \\
\hline UW1713 & & & $0.46 \pm 0.01$ \\
\hline UW1714 & $2.12 \pm 0.17$ & $7.38 \pm 1.00$ & $0.43 \pm 0.01$ \\
\hline UW1715 & & & $0.46 \pm 0.01$ \\
\hline UW1716 & $2.14 \pm 0.17$ & $8.46 \pm 1.10$ & $0.46 \pm 0.01$ \\
\hline UW1717 & $1.76 \pm 0.16$ & $7.97 \pm 1.12$ & $0.46 \pm 0.01$ \\
\hline UW1718 & & & $0.48 \pm 0.01$ \\
\hline UW1719 & & & $0.46 \pm 0.01$ \\
\hline UW1720 & $2.06 \pm 0.17$ & $8.92 \pm 1.03$ & $0.45 \pm 0.02$ \\
\hline UW1721 & & & $0.46 \pm 0.01$ \\
\hline UW1722 & & & $0.39 \pm 0.11$ \\
\hline & & & \\
\hline
\end{tabular}

Cosmic radiation was determined following Prescott and Hutton (1988). It is assumed the current burial depths have not changed more than about $5 \mathrm{~cm}$ through time. Lower average burial depths will increase the ages somewhat by reducing the external dose rate, but the latter constitutes only about $25 \%$ of the total dose rate for most samples, so the problem should not be very significant.

The radioactivity of most of the ceramics does not vary greatly, with one exception, UW1721, which contained unusually high concentrations of $\mathrm{K}$. This ceramic was likely made from a different clay source than the others, possibly representing an import.

Equivalent dose - Equivalent dose was determined both by TL and by combined IRSL/OSL, as described in the appendix
(Table C-4). The TL was measured from relatively short plateau regions (where equivalent dose does not vary with temperature). The plateau extended beyond $340^{\circ} \mathrm{C}$ for only four samples, and on 10 samples it did not exceed $320^{\circ} \mathrm{C}$ (Table C5). This is attributed to the relatively low firing temperature of the pottery. Sensitivity change with heating, however, was minimal, being significant at 2-sigma only for seven samples. Anomalous fading was detected to some degree on all but four sherds (no test was performed on two others). Corrections were applied following Huntley and Lamothe (2001). Fading past the one week storage time after irradiation, however, was not considered significant for many of the samples that did show fading. For these, when computing the age, the uncorrected results were used. 
The purpose of the IR stimulation in the IRSL/OSL measurements is to reduce the feldspar signal, so that the subsequent OSL signal stems largely from quartz. Feldspars are stimulated by IR but quartz is not. However, both minerals respond to the blue stimulation used for OSL. Because feldspars are prone to anomalous fading, removing its signal increases the probability the OSL signal is free from fading. However, because feldspars also respond to blue stimulation, it is not certain that the IR stimulation removes all the feldspar signal, so that the subsequent OSL signal may still contain a fading element. Table $\mathrm{C}-4$ shows that most of the samples did not have a measurable IRSL signal. This suggests that feldspars have only a weak presence. To look at this further, an experiment using pulsed OSL was employed on five samples, UW1705, UW1710, UW1712. UW1717, and UW1722. In normal OSL measurements, the luminescence signal is collected during the stimulation. With pulsed OSL, the luminescence signal is collected after the stimulating light is turned off. It has been found that the time between stimulation and luminescence emission for feldspars is much shorter than it is for quartz, about $5 \mu \mathrm{sec}$ and $30 \mu \mathrm{sec}$ respectively. By setting the pulse for $10 \mu \mathrm{sec}$ off (i.e., luminescence signal not being collected) and $240 \mu s e c$ on, the feldspar signal can be greatly reduced. A fading test using both pulsed and non-pulsed data showed that none of the signals faded, either pulsed or non-pulsed, again suggesting a weak feldspar presence. However, the equivalent dose for pulsed and non-pulsed did differ on all but one sample.
In all but one case, the pulsed equivalent dose was more consistent with the TL results than the non-pulsed, so it was used. The differences in equivalent dose might reflect difference in b-value (to be discussed next), but b-value was not measured using a pulsed signal for any of the samples. Research into pulsed OSL is continuing, but it does seem to produce more consistent results than the non-pulsed data.

Alpha radiation is less efficient at producing luminescence than beta or gamma radiation, so a correction to take this into account must be made. This is done by comparing additive dose slopes using beta and alpha irradiation, the slope ratio called b-value. These values differ among TL, IRSL and OSL (because the measured minerals differ) and are shown in Table C-4. The values for OSL are very typical of pure quartz samples, the exception being the high value for UW1721, a sample that was atypical in its radioactivity as well.

In summary, the OSL signal does not seem to reflect feldspar to a very large degree in these samples, as evidence from the lack of an IR signal in many samples, the typical quartz b-values for OSL, and the lack of evidence for fading of non-pulsed signals. Nevertheless, where it was measured, pulsed OSL did tend to produce results more consistent with TL. 
Table C-4. Equivalent Dose and b-Value.

\begin{tabular}{|c|c|c|c|c|c|c|}
\hline \multirow{2}{*}{ Sample } & \multicolumn{3}{|c|}{ Equivalent dose (Gy) } & \multicolumn{3}{c|}{$b$-value $\left(\mathrm{Gy} \mu \mathrm{m}^{2}\right)$} \\
\cline { 2 - 7 } & TL & IRSL & OSL & TL & IRSL & OSL \\
\hline UW1700 & $1.35 \pm 0.37$ & $11.4 \pm 1.94$ & $2.90 \pm 0.52$ & $1.73 \pm 0.13$ & $0.94 \pm 0.22$ & $0.51 \pm 0.02$ \\
\hline UW1701 & $4.13 \pm 0.36$ & $4.20 \pm 0.76$ & $2.22 \pm 0.10$ & $2.15 \pm 0.19$ & $0.78 \pm 0.21$ & $0.47 \pm 0.02$ \\
\hline UW1702 & $2.73 \pm 0.21$ & $1.82 \pm 0.09$ & $1.56 \pm 0.04$ & $1.59 \pm 0.14$ & - & $0.53 \pm 0.04$ \\
\hline UW1703 & $2.00 \pm 0.13$ & -- & $4.94 \pm 0.54$ & $1.93 \pm 0.25$ & - & $0.46 \pm 0.02$ \\
\hline UW1704 & $2.77 \pm 0.14$ & -- & $1.80 \pm 0.17$ & $1.37 \pm 0.15$ & - & $0.47 \pm 0.02$ \\
\hline UW1705 & $2.00 \pm 0.21$ & -- & $15.3 \pm 3.77$ & $0.68 \pm 0.09$ & - & -- \\
\hline UW1706 & $1.98 \pm 0.16$ & -- & $2.35 \pm 0.12$ & $1.68 \pm 0.16$ & - & $0.45 \pm 0.02$ \\
\hline UW1707 & $1.89 \pm 0.24$ & -- & $1.69 \pm 0.03$ & $1.46 \pm 0.12$ & -- & $0.46 \pm 0.02$ \\
\hline UW1708 & $2.40 \pm 0.23$ & -- & $1.43 \pm 0.03$ & $3.92 \pm 0.44$ & -- & $0.56 \pm 0.04$ \\
\hline UW1709 & -- & & -- & -- & -- & -- \\
\hline UW1710 & $2.25 \pm 0.29$ & -- & $1.95 \pm 0.10$ & $2.17 \pm 0.22$ & -- & -- \\
\hline UW1711 & $2.33 \pm 0.17$ & -- & $1.46 \pm 0.10$ & $1.92 \pm 0.25$ & -- & -- \\
\hline UW1712 & $1.30 \pm 0.16$ & -- & $2.01 \pm 0.10$ & $1.46 \pm 0.11$ & -- & -- \\
\hline UW1713 & $2.93 \pm 0.43$ & -- & $1.44 \pm 0.07$ & $2.22 \pm 0.34$ & -- & $0.48 \pm 0.04$ \\
\hline UW1714 & $2.29 \pm 0.60$ & -- & $1.74 \pm 0.20$ & $1.85 \pm 0.25$ & -- & $0.78 \pm 0.06$ \\
\hline UW1715 & $1.72 \pm 0.10$ & $3.66 \pm 1.19$ & $1.05 \pm 0.01$ & $1.56 \pm 0.12$ & -- & $0.42 \pm 0.01$ \\
\hline UW1716 & $5.67 \pm 0.79$ & $9.34 \pm 1.08$ & $3.04 \pm 0.25$ & $2.47 \pm 0.27$ & $1.61 \pm 0.49$ & $0.61 \pm 0.03$ \\
\hline UW1717 & $3.36 \pm 0.82$ & -- & $2.48 \pm 0.41$ & $1.10 \pm 0.13$ & -- & -- \\
\hline UW1718 & $2.28 \pm 0.31$ & -- & $2.34 \pm 0.49$ & $1.83 \pm 0.15$ & -- & $0.53 \pm 0.02$ \\
\hline UW1719 & $2.97 \pm 0.60$ & -- & $1.85 \pm 0.30$ & $2.15 \pm 0.35$ & -- & $0.67 \pm 0.09$ \\
\hline UW1720 & $2.28 \pm 0.27$ & $3.73 \pm 1.11$ & $1.72 \pm 0.04$ & $0.83 \pm 0.13$ & -- & $0.49 \pm 0.03$ \\
\hline UW1721 & -- & $5.13 \pm 1.71$ & $9.02 \pm 0.80$ & -- & -- & $2.53 \pm 0.93$ \\
\hline UW1722 & $2.66 \pm 0.35$ & $11.7 \pm 3.11$ & $1.73 \pm 0.18$ & $1.96 \pm 0.11$ & -- & -- \\
\hline
\end{tabular}

Table C-5. TL Parameters.

\begin{tabular}{|c|c|c|c|c|}
\hline Sample & TL plateau $\left({ }^{\circ} \mathrm{C}\right.$ ) & fit & Slope ratio & g-value (fading rate) \\
\hline UW1700 & $260-330$ & linear & $1.81 \pm 0.19$ & $13.2 \pm 11.8$ \\
\hline UW1701 & $260-290$ & linear & $1.49 \pm 0.16$ & No fading \\
\hline UW1702 & $250-340$ & quadratic & 1.0 & $7.1 \pm 1.7$ \\
\hline UW1703 & $250-320$ & linear & 1.0 & $7.8 \pm 2.4$ \\
\hline UW1704 & $250-300$ & linear & 1.0 & $12.9 \pm 3.7$ \\
\hline UW1705 & $270-300$ & linear & 1.0 & $15.2 \pm 6.2$ \\
\hline UW1706 & $270-310$ & quadratic & 1.0 & $5.0 \pm 3.4$ \\
\hline UW1707 & $270-340$ & linear & $1.45 \pm 0.16$ & $10.3 \pm 2.8$ \\
\hline UW1708 & $250-290$ & linear & 1.0 & $10.7 \pm 3.1$ \\
\hline UW1709 & -- & linear & -- & -- \\
\hline UW1710 & $260-300$ & linear & $0.85 \pm 0.10$ & $8.1 \pm 4.0$ \\
\hline UW1711 & $270-340$ & quadratic & 1.0 & $6.6 \pm 3.3$ \\
\hline UW1712 & $290-360$ & linear & 1.0 & $10.8 \pm 3.7$ \\
\hline UW1713 & $260-370$ & linear & 1.0 & No fading \\
\hline UW1714 & $260-340$ & quadratic & $0.66 \pm 0.12$ & No test \\
\hline UW1715 & $280-320$ & linear & 1.0 & $10.1 \pm 1.9$ \\
\hline UW1716 & $280-350$ & linear & $0.83 \pm 0.10$ & No test \\
\hline UW1717 & $260-320$ & linear & $1.59 \pm 0.24$ & $6.2 \pm 5.3$ \\
\hline UW1718 & $250-320$ & linear & $1.20 \pm 0.10$ & No fading \\
\hline UW1719 & $270-300$ & linear & 1.0 & No fading \\
\hline UW1720 & $250-350$ & quadratic & 1.0 & $9.2 \pm 3.4$ \\
\hline UW1721 & & linear & & \\
\hline UW1722 & $270-330$ & linear & $1.45 \pm 0.14$ & $8.0 \pm 2.1$ \\
\hline
\end{tabular}


Ages - For most of the samples, the ages calculated from TL and OSL did not significantly differ, so a weighted average was used to estimate the age (Table C-6). Where fading was judged significant, the corrected TL age was used in this calculation. Exceptions are discussed briefly. For UW1703 and UW1705, the OSL produced an unreasonably old age that was significantly greater than the age for TL, so only the TL was used to estimate the age. The cause of the over-estimated OSL is unknown. For UW1713, the ages from TL and OSL differed significantly, but either produced reasonable ages in terms of the ages of other samples. Because there was no reason to prefer one over the other, a simple average was used as the estimate, which explains the high error.

The ages range from $\mathrm{AD} 1041 \pm 77$ to $\mathrm{AD}$ $1588 \pm 16$. It must be remembered that the dates address when the ceramics were last fired to at least $400^{\circ} \mathrm{C}$, probably when they were made. It does not necessarily address the time of occupation.

Table C-6. Ages.

\begin{tabular}{c|cccc}
\hline Sample & Basis for age & Age $(\mathrm{ka})$ & \% error & Calendar age (years $A D)$ \\
\hline UW1700 & OSL/TL* weighted & $0.938 \pm 0.171$ & 18.3 & $1069 \pm 171$ \\
UW1701 & OSL/TL weighted & $0.874 \pm 0.018$ & 5.5 & $1145 \pm 47$ \\
UW1702 & OSL/TL weighted & $0.533 \pm 0.027$ & 5.1 & $1474 \pm 27$ \\
UW1703 & TL* & $0.800 \pm 0.148$ & 18.5 & $1207 \pm 148$ \\
UW1704 & OSL/TL weighted & $0.644 \pm 0.041$ & 6.3 & $1363 \pm 41$ \\
UW1705 & TL & $0.733 \pm 0.84$ & 11.5 & $1274 \pm 84$ \\
UW1706 & OSL/TL* weighted & $0.857 \pm 0.064$ & 7.4 & $1150 \pm 64$ \\
UW1707 & OSL/TL weighted & $0.668 \pm 0.043$ & 6.4 & $1339 \pm 43$ \\
UW1708 & OSL/TL* weighted & $0.465 \pm 0.028$ & 6.0 & $1542 \pm 28$ \\
UW1709 & & & & \\
UW1710 & OSL/TL* weighted & $0.641 \pm 0.045$ & 7.1 & $1366 \pm 45$ \\
UW1711 & OSL/TL weighted & $0.536 \pm 0.037$ & 6.3 & $1474 \pm 37$ \\
UW1712 & OSL/TL* weighted & $0.592 \pm 0.041$ & 7.0 & $1415 \pm 41$ \\
UW1713 & OSL/TL average & $0.660 \pm 0.146$ & 22.1 & $1347 \pm 146$ \\
UW1714 & OSL/TL weighted & $0.575 \pm 0.064$ & 11.1 & $1433 \pm 64$ \\
UW1715 & OSL/TL weighted & $0.419 \pm 0.016$ & 3.8 & $1588 \pm 16$ \\
UW1716 & OSL/TL weighted & $0.967 \pm 0.077$ & 7.9 & $1041 \pm 77$ \\
UW1717 & OSL/TL weighted & $0.775 \pm 0.067$ & 8.6 & $1233 \pm 67$ \\
UW1718 & OSL/TL weighted & $0.489 \pm 0.022$ & 4.6 & $1519 \pm 22$ \\
UW1719 & OSL/TL weighted & $0.683 \pm 0.092$ & 13.5 & $1324 \pm 92$ \\
UW1720 & OSL/TL weighted & $0.641 \pm 0.029$ & 4.5 & $1366 \pm 29$ \\
UW1721 & & & & \\
UW1722 & OSL/TL weighted & $0.557 \pm 0.052$ & 9.4 & $1450 \pm 52$ \\
\hline
\end{tabular}

* TL corrected for anomalous fading 


\section{Addendum: Procedures for Thermoluminescence Analysis of Pottery}

\section{Sample Preparation -- Fine Grain}

The sherd is broken to expose a fresh profile. Material is drilled from the center of the cross-section, more than $2 \mathrm{~mm}$ from either surface, using a tungsten carbide drill tip. The material retrieved is ground gently by a corundum mortar and pestle, treated with $\mathrm{HCl}$, and then settled in acetone for 2 and 20 minutes to separate the 1-8 $\mu \mathrm{m}$ fraction. This is settled onto a maximum of 72 stainless steel discs.

\section{Glow-Outs}

Thermoluminescence is measured by a Daybreak reader using a 9635Q photomultiplier with a Corning 7-59 blue filter, in $\mathrm{N}_{2}$ atmosphere at $1^{\circ} \mathrm{C} / \mathrm{s}$ to $450^{\circ} \mathrm{C}$. A preheat of $240^{\circ} \mathrm{C}$ with no hold time precedes each measurement. Artificial irradiation is given with a ${ }^{241} \mathrm{Am}$ alpha source and a ${ }^{90} \mathrm{Sr}$ beta source, the latter calibrated against a ${ }^{137} \mathrm{Cs}$ gamma source. Discs are stored at room temperature for at least one week after irradiation before glow out. Data are processed by Daybreak TLApplic software.

\section{Fading Test}

Several discs are used to test for anomalous fading. The natural luminescence is first measured by heating to $450^{\circ} \mathrm{C}$. The discs are then given an equal alpha irradiation and stored at room temperature for varied times: 10 min, 2 hours, 1 day, 1 week and 8 weeks. The irradiations are staggered in time so that all of the second glows are performed on the same day. The second glows are normalized by the natural signal and then compared to determine any loss of signal with time (on a log scale). If the sample shows fading and the signal versus time values can be reasonably fit to a logarithmic function, an attempt is made to correct the age following procedures recommended by Huntley and Lamothe (2001).

\section{Equivalent Dose}

The equivalent dose is determined by a combination additive dose and regeneration (Aitken 1985). Additive dose involves administering incremental doses to natural material. A growth curve plotting dose against luminescence can be extrapolated to the dose axis to estimate an equivalent dose, but for pottery this estimate is usually inaccurate because of errors in extrapolation due to nonlinearity. Regeneration involves zeroing natural material by heating to $450^{\circ} \mathrm{C}$ and then rebuilding a growth curve with incremental doses. The problem here is sensitivity change caused by the heating. By constructing both curves, the regeneration curve can be used to define the extrapolated area and can be corrected for sensitivity change by comparing it with the additive dose curve. This works where the shapes of the curves differ only in scale (i.e., the sensitivity change is independent of dose). The curves are combined using the "Australian slide" method in a program developed by David Huntley of Simon Fraser University (Prescott et al. 1993). The equivalent dose is taken as the horizontal distance between the two curves after a scale adjustment for sensitivity change. Where the growth curves are not linear, they are fit to quadratic functions. Dose increments (usually five) are determined so that the maximum additive dose results in a signal about three times that of the natural and the maximum regeneration dose about five times the natural. If the regeneration curve has a significant negative intercept, which is not expected given current understanding, the additive dose intercept is taken as the best, if not fully reliable approximation.

A plateau region is determined by calculating the equivalent dose at temperature increments between $240^{\circ}$ and $450^{\circ} \mathrm{C}$ and determining over which temperature range the values do not differ significantly. This plateau region is compared with a similar one constructed for 
the b-value (alpha efficiency), and the overlap defines the integrated range for final analysis.

\section{Alpha Effectiveness}

Alpha efficiency is determined by comparing additive dose curves using alpha and beta irradiations. The slide program is also used in this regard, taking the scale factor (which is the ratio of the two slopes) as the b-value (Aitken 1985).

\section{Radioactivity}

Radioactivity is measured by alpha counting in conjunction with atomic emission for ${ }^{40} \mathrm{~K}$. Samples for alpha counting are crushed in a mill to flour consistency, packed into plexiglass containers with ZnS:Ag screens, and sealed for one month before counting. The pairs technique is used to separate the $\mathrm{U}$ and Th decay series. For atomic emission measurements, samples are dissolved in HF and other acids and analyzed by a Jenway flame photometer. $\mathrm{K}$ concentrations for each sample are determined by bracketing between standards of known concentration. Conversion to ${ }^{40} \mathrm{~K}$ is by natural atomic abundance. Radioactivity is also measured, as a check, by beta counting, using a Risø low level beta GM multicounter system. About $0.5 \mathrm{~g}$ of crushed sample is placed on each of four plastic sample holders. All are counted for 24 hours. The average is converted to dose rate following BøtterJensen and Mejdahl (1988) and compared with the beta dose rate calculated from the alpha counting and flame photometer results.

Both the sherd and an associated soil sample are measured for radioactivity. Additional soil samples are analyzed where the environment is complex, and gamma contributions determined by gradients (after Aitken 1985: appendix H). Cosmic radiation is determined after Prescott and Hutton (1988). Radioactivity

concentrations are translated into dose rates following Adamiec and Aitken (1998).

\section{Moisture Contents}

Water absorption values for the sherds are determined by comparing the saturated and dried weights. For temperate climates, moisture in the pottery is taken to be $80 \pm 20$ percent of total absorption, unless otherwise indicated by the archaeologist. Again for temperate climates, soil moisture contents are taken from typical moisture retention quantities for different textured soils (Brady 1974: 196), unless otherwise measured. For drier climates, moisture values are determined in consultation with the archaeologist.

\section{Procedures for Optically Stimulated or Infrared Stimulated Luminescence of Fine-Grained Pottery}

Optically stimulated luminescence (OSL) and infrared stimulated luminescence (IRSL) on fine-grain (1-8 $\mu \mathrm{m})$ pottery samples are carried out on single aliquots following procedures adapted from Banerjee et al. (2001) and Roberts and Wintle (2001. Equivalent dose is determined by the singlealiquot regenerative dose (SAR) method (Murray and Wintle 2000).

The SAR method measures the natural signal and the signal from a series of regeneration doses on a single aliquot. The method uses a small test dose to monitor and correct for sensitivity changes brought about by preheating, irradiation or light stimulation. SAR consists of the following steps: 1) preheat, 2) measurement of natural signal (OSL or IRSL), L(1), 3) test dose, 4) cut heat, 5) measurement of test dose signal, $\mathrm{T}(1), 6)$ regeneration dose, 7) preheat, 8) measurement of signal from regeneration, $\mathrm{L}(2)$, 9) test dose, 10) cut heat, 11) measurement of test dose signal, $\mathrm{T}(2), 12)$ repeat of steps 6 through 11 for various regeneration doses. A growth curve is constructed from the L(i)/T(i) ratios and the equivalent dose is found by interpolation of $\mathrm{L}(1) / \mathrm{T}(1)$. Usually a zero regeneration dose and a repeated regeneration dose are employed to insure the procedure is working 
properly. For fine-grained ceramics, a preheat of $240^{\circ} \mathrm{C}$ for $10 \mathrm{~s}$, a test dose of 3.1 $\mathrm{Gy}$, and a cut heat of $200^{\circ} \mathrm{C}$ are currently being used, although these parameters may be modified from sample to sample.

The luminescence, $\mathrm{L}(\mathrm{i})$ and $\mathrm{T}(\mathrm{i})$, is measured on a Risø TL-DA-15 automated reader by a succession of two stimulations: first $100 \mathrm{~s}$ at $125^{\circ} \mathrm{C}$ of IRSL (880nm diodes), and then $100 \mathrm{~s}$ at $125^{\circ} \mathrm{C}$ of OSL (470nm diodes). Detection is through $7.5 \mathrm{~mm}$ of Hoya U340 (ultra-violet) filters. The two stimulations are used to construct IRSL and OSL growth curves, so that two estimations of equivalent dose are available. Anomalous fading usually involves feldspars and only feldspars are sensitive to IRSL stimulation. The rationale for the IRSL stimulation is to remove most of the feldspar signal, so that the subsequent OSL signal is free from anomalous fading. However, feldspar is also sensitive to blue light $(470 \mathrm{~nm})$, and it is possible that IRSL does not remove all the feldspar signal. Some preliminary tests in our laboratory have suggested that the OSL signal does not suffer from fading, but this may be sample specific. The procedure is still undergoing study.
A dose recovery test is performed by first zeroing the sample by exposure to light and then administering a known dose. The SAR protocol is then applied to see if the known dose can be obtained.

Alpha efficiency will surely differ among IRSL, OSL and TL on fine-grained materials. It does differ between coarsegrained feldspar and quartz (Aitken 1985). Research is currently underway in the laboratory to determine how much b-value varies according to stimulation method. Results from several samples from different geographic locations show that OSL b-value is less variable and centers around 0.5. IRSL b-value is more variable and is higher than that for OSL. TL b-value tends to fall between the OSL and IRSL values. We currently are measuring the b-value for IRSL and OSL by adding two alpha regeneration points to the SAR sequence. The slopes of the beta regeneration growth curve and that of the alphas are compared to determine b-value. This procedure is also undergoing study. 


\section{References Cited}

Adamiec, G., and M. J. Aitken

1998 Dose rate Conversion Factors:

Update. Ancient TL 16:37-50.

Aitken, M. J.

1985 Thermoluminescence Dating. Academic Press, London.

Banerjee, D., A. S. Murray, L. BøtterJensen, and A. Lang,

2001 Equivalent Dose Estimation Using a Single Aliquot of Polymineral Fine Grains. Radiation Measurements 33:73-93.

Bøtter-Jensen, L, and V. Mejdahl 1988 Assessment of Beta Dose-Rate Using a GM Multi-Counter System. Nuclear Tracks and Radiation Measurements 14:187-191.

Brady, N. C.

1974 The Nature and Properties of Soils. Macmillan, New York.

Huntley, D. J., and M. Lamothe

2001 Ubiquity of Anomalous Fading in K-feldspars, and Measurement and Correction for it in Optical Fating. Canadian Journal of Earth Sciences 38:1093-1106.

Mejdahl, V.

1983 Feldspar Inclusion Dating of Ceramics and Burnt Stones. PACT 9:351-364.
Murray, A. S., and A. G. Wintle

2000 Luminescence Dating of Quartz Using an Improved Single-Aliquot Regenerative-Dose Protocol. Radiation Measurements 32:57-73.

Prescott, J. R., D. J. Huntley, and J. T. Hutton, J. T.

1993 Estimation of Equivalent Dose in Thermoluminescence Dating - The Australian Slide Method. Ancient TL 11:1-5.

Prescott, J. R., and J. T. Hutton 1988 Cosmic Ray and Gamma Ray Dose Dosimetry for TL and ESR. Nuclear Tracks and Radiation Measurements 14:223-235.

Roberts, H. M., and A. G. Wintle 2001 Equivalent Dose Determinations for Polymineralic Fine-Grains Using the SAR Protocol: Application to a Holocene Sequence of the Chinese Loess Plateau. Quaternary Science Reviews 20:859-863.

For a general review of luminescence dating by the director of this laboratory, see:

Feathers, J. K.

2003 Use of Luminescence Dating in Archaeology. Measurement Science and Technology 14:1493-1509 


\section{APPENDIX D \\ INSTRUMENTAL NEUTRON ACTIVATION ANALYSIS OF CADDO POTTERY FROM TEN SITES IN EASTERN TEXAS}

Prepared for:

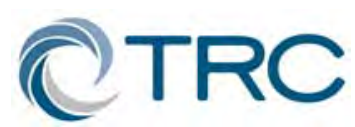

TRC Environmental Corporation 505 East Huntland Drive, Suite 250

Austin, Texas 78752

Prepared for:

Jeffrey R. Ferguson and Michael D. Glascock

Arhaeometry Laboratory, University of Missouri

*All figures in this report are the intellectual property of the authors and should not be reproduced or used elsewhere without their permission. 



\section{D.1 Introduction}

Pottery ( $\mathrm{n}=100$, TKP754-803 and TKP826875) from ten sites in eastern Texas were analyzed by instrumental neutron activation analysis (INAA) at the University of Missouri Research Reactor Center (MURR). Here, we describe sample preparation and analytical techniques used at MURR and report the compositional group membership of the new samples. The Caddo database consists of approximately 900 samples, and ten reference groups. We are currently in the process of reassessing all of the Caddo samples to create more inclusive reference groups, but for the purpose of assigning these samples, the tightly defined reference groups presented in Ferguson and Glascock (2006) are used. To further complicate matters, the samples described in this report are compositionally intermediate between the Smith and Titus Groups, and appear to also come from sites between the areas where most of the members of the Smith and Titus reference groups derive. Rather than blur the boundary between the Titus and Smith groups by including some of the new samples or create a new group with little separation fro other groups, we have decided to describe the sample as unassigned until the reanalysis of the Caddo database is complete.

\section{D.2 Sample Preparation}

Pottery samples were prepared for INAA using procedures standard at MURR. Fragments of about $1 \mathrm{~cm}^{2}$ were removed from each sample and abraded using a silicon carbide burr in order to remove glaze, slip, paint, and adhering soil, thereby reducing the risk of measuring contamination. The samples were washed in deionized water and allowed to dry in the laboratory. Once dry, the individual sherds were ground to powder in an agate mortar to homogenize the samples. Archival samples were retained from each sherd (when possible) for future research.
Two analytical samples were prepared from each source specimen. Portions of approximately $150 \mathrm{mg}$ of powder were weighed into clean, high-density polyethylene vials used for short irradiations at MURR. At the same time, $200 \mathrm{mg}$ of each sample was weighed into clean highpurity quartz vials used for long irradiations. Individual sample weights were recorded to the nearest $0.01 \mathrm{mg}$ using an analytical balance. Both vials were sealed prior to irradiation. Along with the unknown samples, standards made from National Institute of Standards and Technology (NIST) certified standard reference materials of SRM-1633a (coal fly ash) and SRM-688 (basalt rock) were similarly prepared, as were quality control samples (e.g., standards treated as unknowns) of SRM-278 (obsidian rock) and Ohio Red Clay (a standard developed for in-house applications).

\section{D.3 Irradiation and Gamma-Ray Spectroscopy}

Neutron activation analysis of ceramics at MURR, which consists of two irradiations and a total of three gamma counts, constitutes a superset of the procedures used at most other NAA laboratories (Glascock 1992; Neff 1992, 2000). As discussed in detail by Glascock (1992), a short irradiation is carried out through the pneumatic tube irradiation system. Samples in the polyvials are sequentially rradiated, two at a time, for five seconds by a neutron flux of $8 \times 1013 \mathrm{n}$ cm-2 s-1 The 720-second count yields gamma spectra containing peaks for nine short-lived elements aluminum (Al), barium (Ba), calcium (Ca), dysprosium (Dy), potassium (K), manganese $(\mathrm{Mn})$, sodium $(\mathrm{Na})$, titanium (Ti), and vanadium (V). The samples are encapsulated in quartz vials and are subjected to a 24-hour irradiation at a neutron flux of $5 \times 1013 \mathrm{n} \mathrm{cm}-2 \mathrm{~s}-1$. This long irradiation is analogous to the single irradiation utilized at most other laboratories. After the long irradiation, samples decay for seven days, and then are counted for 1,800 seconds (the "middle count") on a high-resolution germanium 
detector coupled to an automatic sample changer. The middle count yields determinations of seven medium half-life elements, namely arsenic (As), lanthanum (La), lutetium (Lu), neodymium (Nd), samarium (Sm), uranium (U), and ytterbium (Yb). After an additional three- or four-week decay, a final count of 8,500 seconds is carried out on each sample. The latter measurement yields the following 17 long half-life elements: cerium (Ce), cobalt (Co), chromium $(\mathrm{Cr})$, cesium $(\mathrm{Cs})$, europium $(\mathrm{Eu})$, iron (Fe), hafnium (Hf), nickel (Ni), rubidium ( $\mathrm{Rb})$, antimony (Sb), scandium (Sc), strontium (Sr), tantalum (Ta), terbium (Tb), thorium (Th), zinc (Zn), and zirconium (Zr).

The element concentration data from the three measurements are tabulated in parts per million using the EXCEL spreadsheet program. Descriptive data for the archaeological samples were appended to the concentration spreadsheet. The data are also stored in a dBASE/FOXPRO database file useful for organizing, sorting, and extracting sample information. The data file enclosed with this report contains the sample database in EXCEL format.

\section{D.4 Interpreting Chemical Data}

The analyses at MURR described previously produced elemental concentration values for 33 elements in most of the analyzed samples. Data for Ni in most samples was below detection limits (as is the norm for most New World ceramic analyses) and was removed from consideration during the statistical analysis. Calcium levels were found to be high enough in approximately five of the specimens to require a calcium correction of the dataset, but all of the comparative Caddo sherds have been calcium corrected, so to maintain a consistent dataset we have corrected the new samples as well. Because calcium has the potential to affect (dilute) the concentrations of other elements in the analysis, all samples were mathematically corrected to compensate for any possible calcium included effects (the data were examined before and after calcium correction and the results were similar). The following mathematical correction was used as it has been proven to be effective in other calciumrich datasets (Cogswell et al. 1998:64; Steponaitis et al. 1988):

$$
e^{\prime}=\frac{10^{6} e}{10^{6}-2.5 c}
$$

where $\mathrm{e}^{\prime}$ is the corrected concentration of a given element in ppm, e is the measured concentration of that element in ppm, and c is the concentration of elemental calcium in ppm. After the calcium correction, statistical analysis was subsequently carried out on base-10 logarithms of concentrations on the remaining 31 elements. Use of $\log$ concentrations rather than raw data compensates for differences in magnitude between the major elements, such as calcium, on one hand and trace elements, such as the rare earth or lanthanide elements (REEs). Transformation to base-10 logarithms also yields a more normal distribution for many trace elements.

Statistical analysis was subsequently carried out on base-10 logarithms of concentrations on the remaining 30 elements. Use of log concentrations rather than raw data compensates for differences in magnitude between the major elements, such as calcium, on one hand and trace elements, such as the rare earth or lanthanide elements (REEs). Transformation to base-10 logarithms also yields a more normal distribution for many trace elements.

The interpretation of compositional data obtained from the analysis of archaeological materials is discussed in detail elsewhere (e.g., Baxter and Buck 2000; Bieber et al. 1976; Bishop and Neff 1989; Glascock 1992; Harbottle 1976; Neff 2000) and will only be summarized here. The main goal of data analysis is to identify distinct homogeneous groups within the analytical database. Based on the provenance postulate of Weigand et al. (1977), different chemical 
groups may be assumed to represent geographically restricted sources. For lithic materials such as obsidian, basalt, and cryptocrystalline silicates (e.g., chert, flint, or jasper), raw material samples are frequently collected from known outcrops or secondary deposits and the compositional data obtained on the samples is used to define the source localities or boundaries. The locations of sources can also be inferred by comparing unknown specimens (i.e., ceramic artifacts) to knowns (i.e., clay samples) or by indirect methods such as the "criterion of abundance" (Bishop et al. 1992) or by arguments based on geological and sedimentological characteristics (e.g., Steponaitis et al. 1996). The ubiquity of ceramic raw materials usually makes it impossible to sample all potential "sources" intensively enough to create groups of knowns to which unknowns can be compared. Lithic sources tend to be more localized and compositionally homogeneous in the case of obsidian or compositionally heterogeneous as is the case for most cherts.

Compositional groups can be viewed as "centers of mass" in the compositional hyperspace described by the measured elemental data. Groups are characterized by the locations of their centroids and the unique relationships (i.e., correlations) between the elements. Decisions about whether to assign a specimen to a particular compositional group are based on the overall probability that the measured concentrations for the specimen could have been obtained from that group.

Initial hypotheses about source-related subgroups in the compositional data can be derived from non-compositional information (e.g., archaeological context, decorative attributes, etc.) or from application of various pattern-recognition technique to the multivariate chemical data. Some of the pattern recognition techniques that have been used to investigate archaeological data sets are cluster analysis (CA), principal components analysis (PCA), and discriminant analysis (DA). Each of the techniques has it own advantages and disadvantages which may depend upon the types and quantity of data available for interpretation.

The variables (measured elements) in archaeological and geological data sets are often correlated and frequently large in number. This makes handling and interpreting patterns within the data difficult. Therefore, it is often useful to transform the original variables into a smaller set of uncorrelated variables in order to make data interpretation easier. Of the abovementioned pattern recognition techniques, PCA is a technique that transforms from the data from the original correlated variables into uncorrelated variables most easily.

PCA creates a new set of reference axes arranged in decreasing order of variance subsumed. The individual PCs are linear combinations of the original variables. The data can be displayed on combinations of the new axes, just as they can be displayed on the original elemental concentration axes. PCA can be used in a pure patternrecognition mode, i.e., to search for subgroups in an undifferentiated data set, or in a more evaluative mode, i.e., to assess the coherence of hypothetical groups suggested by other criteria. Generally, compositional differences between specimens can be expected to be larger for specimens in different groups than for specimens in the same group, and this implies that groups should be detectable as distinct areas of high point density on plots of the first few components.

It is well known that PCA of chemical data is scale dependent (Mardia et al. 1979), and analyses tend to be dominated by those elements or isotopes for which the concentrations are relatively large. As a result, standardization methods are common to most statistical packages. A common approach it to transform the data into logarithms (e.g., base 10). As an initial step in the PCA of most chemical data at MURR, the data are transformed into log 
concentrations to equalize the differences in variance between the major elements such as $\mathrm{Al}, \mathrm{Ca}$ and $\mathrm{Fe}$, on one hand and trace elements, such as the rare-earth elements (REEs), on the other hand. An additional advantage of the transformation is that it appears to produce more nearly normal distributions for the trace elements.

One frequently exploited strength of PCA, discussed by Baxter (1992), Baxter and Buck (2000z), and Neff (1994, 2002), is that it can be applied as a simultaneous $\mathrm{R}$ - and Q-mode technique, with both variables (elements) and objects (individual analyzed samples) displayed on the same set of principal component reference axes. A plot using the first two principal components as axes is usually the best possible twodimensional representation of the correlation or variance-covariance structure within the data set. Small angles between the vectors from the origin to variable coordinates indicate strong positive correlation; angles at 90 degrees indicate no correlation; and angles close to 180 degrees indicate strong negative correlation. Likewise, a plot of sample coordinates on these same axes will be the best two-dimensional representation of Euclidean relations among the samples in log-concentration space (if the PCA was based on the variance-covariance matrix) or standardized log-concentration space (if the PCA was based on the correlation matrix). Displaying both objects and variables on the same plot makes it possible to observe the contributions of specific elements to group separation and to the distinctive shapes of the various groups. Such a plot is commonly referred to as a "biplot" in reference to the simultaneous plotting of objects and variables.

The variable inter-relationships inferred from a biplot can be verified directly by inspecting bivariate elemental concentration plots. [Note that a bivariate plot of elemental concentrations is not a biplot.] Whether a group can be discriminated easily from other groups can be evaluated visually in two dimensions or statistically in multiple dimensions. A metric known as the Mahalanobis distance (or generalized distance) makes it possible to describe the separation between groups or between individual samples and groups on multiple dimensions. The Mahalanobis distance of a specimen from a group centroid (Bieber et al. 1976, Bishop and Neff 1989) is defined by:

$$
\mathrm{D}^{2}{ }_{\mathrm{yX}}=[\mathrm{y}-\mathrm{X}]^{\mathrm{t}} \mathrm{I}_{\mathrm{x}}[\mathrm{y}-\mathrm{X}]
$$

where $\mathrm{y}$ is the $1 \mathrm{x} \mathrm{m}$ array of logged elemental concentrations for the specimen of interest, $\mathrm{X}$ is the $\mathrm{n} \mathrm{x} \mathrm{m}$ data matrix of logged concentrations for the group to which the point is being compared $\mathrm{X}$ being it $1 \mathrm{x} \mathrm{m}$ centroid, and Ix is the inverse of the $\mathrm{m} x \mathrm{~m}$ variance-covariance matrix of group $\mathrm{X}$.

Because Mahalanobis distance takes into account variances and covariances in the multivariate group it is analogous to expressing distance from a univariate mean in standard deviation units. Like standard deviation units, Mahalanobis distances can be converted into probabilities of group membership for individual specimens. For relatively small sample sizes, it is appropriate to base probabilities on Hotelling's T 2 , which is the multivariate extension of the univariate Student's t.

When group sizes are small, Mahalanobis distance-based probabilities can fluctuate dramatically depending upon whether or not each specimen is assumed to be a member of the group to which it is being compared. Harbottle (1976) calls this phenomenon "stretchability" in reference to the tendency of an included specimen to stretch the group in the direction of its own location in elemental concentration space. This problem can be circumvented by cross-validation, that is, by removing each specimen from its presumed group before calculating its own probability of membership (Baxter 1994; Leese and Main 1994). This is a conservative approach to group evaluation that may sometimes exclude true group members. 
Small sample and group sizes place further constraints on the use of Mahalanobis distance: with more elements than samples, the group variance-covariance matrix is singular thus rendering calculation of Ix (and D2 itself) impossible. Therefore, the dimensionality of the groups must somehow be reduced.

One approach would be to eliminate elements considered irrelevant or redundant. The problem with this approach is that the investigator's preconceptions about which elements should be discriminate may not be valid. It also squanders the main advantage of multielement analysis, namely the capability to measure a large number of elements. An alternative approach is to calculate Mahalanobis distances with the scores on principal components extracted from the variance-covariance or correlation matrix for the complete data set. This approach entails only the assumption, entirely reasonable in light of the above discussion of PCA, that most groupseparating differences should be visible on the first several PCs. Unless a data set is extremely complex, containing numerous distinct groups, using enough components to subsume at least $90 \%$ of the total variance in the data can be generally assumed to yield Mahalanobis distances that approximate Mahalanobis distances in full elemental concentration space.

Lastly, Mahalanobis distance calculations are also quite useful for handling missing data (Sayre 1975). When many specimens are analyzed for a large number of elements, it is almost certain that a few element concentrations will be missed for some of the specimens. This occurs most frequently when the concentration for an element is near the detection limit. Rather than eliminate the specimen or the element from consideration, it is possible to substitute a missing value by replacing it with a value that minimizes the Mahalanobis distance for the specimen from the group centroid. Thus, those few specimens which are missing a single concentration value can still be used in group calculations.

\section{D.5 Results and Conclusions}

The primary questions addressed here are 1) How do the new samples fit within the compositional groups structure previously developed for the Caddo region? 2) Are there any apparent differences in the composition of the samples from 41AN38 and those from the other nine sites in this study? Table D-1 displays the group assignments and some descriptive data for the samples.

\section{Compositional Group Structure}

Before discussing the compositional group assignments of the new samples, it is necessary to discuss the current status of the reference groups. The similarity of the clay sources in the Caddo area results in large compositional groups with considerable overlap. In the most recent analysis of Caddo pottery (Ferguson and Glascock 2006) we refined the reference groups to allow for some separation of the groups using Mahalanobis distance calculations. Prior to this reanalysis, the reference groups had grown to the point that there was very little chemical separation. As an unfortunate result of this refinement, approximately half of the Caddo sherds in the database are now unassigned. The reference groups are now reduced to much tighter groups that allow more confident assignment of new samples, however, this results in many new samples not fitting well into existing reference groups. In the following paragraphs we explain why none of the new samples belong in any of the reference groups except for possibly Titus and Smith, but we also explain some of the problems with assigning new samples to these groups.

\section{Comparison with Small Caddo Reference Groups}

The most chemically unique Caddo reference group is the Sandy Paste Group. 
This group has diluted concentrations of most elements, likely resulting from large amounts of sand (although we are not sure if this is due to the use of a sandy clay, or the addition of sand temper). None of the new samples plot well within this group. Another reference group, Rusk, consists of 20 members, and thus also precludes the use of Mahalanobis distance calculations (due to small sample size). Figure D-1 plots the distribution of the new samples relative to the Rusk and Sandy Paste Groups, according to concentrations of chromium and dysprosium. Figure D-2 plots the new samples relative to the very small $(n=5)$ Washington Square reference group. Figures D-3 and D-4 plot the Leaning Rock samples against the Hurricane $1(n=20)$ and Hurricane $2 \quad(n=25)$ reference groups, respectively. Figures D-5 and D-6 plot the samples against the Cypress $1(n=14)$ and Cypress $2(n=16)$ Reference Groups. The Cypress 1 Reference Group is a problematic group because is consistently overlaps with many other reference groups, particularly with Titus. The overlap of Cypress 1 with Titus is the likely reason why there are no plots that completely separate the new samples from Cypress 1. This relationship may become clearer following the reanalysis of the entire Caddoan database that is currently underway.

\section{Comparison with Large Caddo Reference Groups}

The three remaining groups, Titus, Smith, and Red River, are all large enough to permit statistical assessment of group membership using probabilities of group membership calculated from a Mahalanobis distance projection. Figure D-7 is a bivariate plot of the new samples against the Red River reference group. There is little overlap, and the Mahalanobis distance projections shown in Table D-2 support this complete separation from the Red River Group. The highest probability of membership for any of the 100 samples was only $0.021 \%$.
The assessment of the Smith and Titus Groups is where this interpretation gets more complicated. Bivariate elemental plots are quite confusing because the sherds consistently plot right around the intersection of the Smith and Titus ellipses. A plot of Figure D-8 is a good example of this overlap. All other elemental bivariate plots show considerably greater overlap between Titus and Smith, and thus more samples that simultaneously plot in both groups. The probabilities of group membership calculated from the Mahalanobis distance projection shown in Table D-2 was used to identify the samples with a consistent and exclusive connection to one of the reference groups. Using the criteria that the sample must be overwhelmingly associated with only one group, five samples were assigned to the Smith Group, and eleven were assigned to Titus. If these assigned samples are added to the reference groups, and then a new Mahalanobis distance projection conducted, more samples fall into one group or the other, but this leads to problems with the reference groups. The new samples added tend to fall closer to the overlap between the two groups, thus, each round of adding new samples further blurs the distinction between the groups. This fuzzy overlap is the reason the groups were cut back to central clusters in the 2006 (Ferguson and Glascock) report, and it seems counter productive to reduce the separation between the reference groups. As of this report, the eleven samples in Titus and five in Smith have been assigned to the reference group, but not added to the actual reference group. Dr. Perttula has suggested that the samples for this project come from sites in the region between the areas that have produced the bulk of the Titus and Smith samples, and the compositional data presented here agree.

Canonical discriminate analysis can be quite useful in creating separation between groups that do not separate well in elemental bivariate plots. One problem with canonical discriminate analysis is that it requires three identified groups in order to calculate the 
variables. Using the Titus, Smith and Red River groups, the canonical discriminate functions do a good job of isolating the Red River Group and they reveal the overlap with the Smith and Titus Groups (Figure D9). As an additional exploratory test, we treated the new samples as a single compositional group and then calculated the canonical discriminate function of the new samples, Titus, and Smith. Figure D-10 shows how it is possible to isolate the new samples into a separate cluster, but this difference is not sufficient to consider the new samples to be a new group, just an intermediate scatter with some samples closer to Titus and others closer to Smith.

While only $16 \%$ of the samples were assigned to an existing reference group, that is not surprising given the complex relationship with the Titus and Smith Reference Groups outlined above. The remaining samples fall into two broad categories: intermediate and unassigned. These designations are based on the probabilities of group membership listed in Table D-2. Samples are assigned to the intermediate group if that have a reasonable probability of belonging to both the Smith and Titus groups, while the unassigned do not. Some of the unassigned samples may have a slight probability of membership in only one of the groups, but not enough to assign it to the reference group. Figure D-11 shows some predictable, yet interesting, patterns in the data. The samples assigned to the Titus and Smith reference groups pull in opposite directions, and the remaining samples cluster in the middle. The intermediate samples have a tighter cluster inside the distribution of the unknown samples. This separation between the unassigned and unassigned and intermediate samples is not incredible informative except to suggest that some of the unassigned samples might be more likely to be imported than some of the intermediate samples, assuming that the local production is using raw materials that have compositions intermediate between Smith and Titus.

\section{Intersite Comparison}

One of the goals of this project was to determine if there were any systematic differences in the raw materials used in the ceramics found at 41AN38 and the sherds from the other nine sites included in the analysis. Bivariate elemental plots revealed no systematic differences between the two assemblages in any elements, except perhaps aluminum, but the differences were quite small and aluminum is one of the more difficult elements to measure accurately. There are also no significant patterns in the assignments to either the reference groups or to the differences in the intermediate or the unassigned categories. At this point we cannot see any differences in the composition between the samples from 41AN38 and those from the other sites.

\section{D.6 Conclusions}

Of the 100 sherds analyzed for this project, 16 were assigned to either the Titus or Smith reference groups. This low percentage of unassigned specimens is likely the result of the gradual and systematic differences in the chemical composition of the raw materials used in pottery manufacture the Caddo area. Almost all of the new samples appear to have been made of raw material that is compositionally intermediate between those used to make the Titus and the Smith Reference Groups. This analysis contains material from ten different sites, and there appears to be little systematic difference in the materials used at the different sites. This report should be considered preliminary until the reanalysis of the entire Caddoan database, currently underway, is completed.

\section{D.7 Acknowledgments}

We acknowledge Ben Zalaski for his role in preparing the samples for irradiation. This project was supported in part by NSF grant BCS-0504015 to the Archaeometry Laboratory at the University of Missouri Research Reactor. 


\section{References Cited}

Baxter, M. J.

1992 Archaeological Uses of the Biplot-A Neglected Technique? In Computer Applications and Quantitative Methods in Archaeology, 1991, edited by G. Lock and J. Moffett, pp. 141-148.. BAR International Series S577. Tempvs Reparatvm, Archaeological and Historical Associates, Oxford.

1994 Exploratory Multivariate Analysis in Archaeology. Edinburgh University Press, Edinburgh.

Baxter, M. J. and C. E. Buck

2000 Data Handling and Statistical Analysis. In Modern Analytical Methods in Art and Archaeology, edited by E. Ciliberto and G. Spoto, pp. 681-746. John Wiley and Sons, Inc., New York.

Bieber, A. M. Jr., D. W. Brooks, G. Harbottle, and E. V. Sayre

1976 Application of Multivariate Techniques to Analytical Data on Aegean Ceramics. Archaeometry 18:59-74.

Bishop, R. L. and H. Neff

1989 Compositional Data Analysis in Archaeology. In Archaeological Chemistry IV, edited by R. O. Allen, pp. 576-586. Advances in Chemistry Series 220. American Chemical Society, Washington, D.C.
Bishop, R. L., R. L. Rands, and G. R. Holley 1992 Ceramic Compositional Analysis in Archaeological Perspective. In Advances in Archaeological Method and Theory, Vol. 5, edited by M. B. Schiffer, pp. 275330. Academic Press, New York.

Cogswell et al.

1998 Analysis of Shell-Tempered Pottery Replicates: Implications for Provenance Studies. American Antiquity 63:63-72.

Ferguson, J. R. and M. D. Glascock

2006 Instrumental Neutron Activation Analysis of Caddoan Pottery and Clay Samples from Texas and Louisiana. Report prepared for Timothy K. Perttula, September 14.

Glascock, M. D.

1992 Characterization of Archaeological Ceramics at MURR by Neutron Activation Analysis and Multivariate Statistics. In Chemical Characterization of Ceramic Pastes in Archaeology, edited by $H$. Neff, pp. 11-26. Prehistory Press, Madison, Wisconsin.

Harbottle, G.

1976 Activation Analysis in Archaeology. Radiochemistry 3:33-72.

Leese, M. N. and P. L. Main

1994 The Efficient Computation of Unbiased Mahalanobis Distances and Their Interpretation in Archaeometry. Archaeometry 36:307-316. 
2000 Inferences About Prehistoric Ceramics and People in Southeast Missouri: Results of Ceramic Compositional Analysis. American Antiquity 65(1):103-126.

Mardia et al.

1979 Multivariate Analysis. Academic Press, London.

Neff, Hector

1992 Introduction. In Chemical Characterization of Ceramic Pastes in Archaeology, edited by H. Neff, pp. 1-10. Prehistory Press, Madison, Wisconsin.

1994 RQ-Mode Principal Components Analysis of Ceramic Compositional Data. Archaeometry 36:115-130.

2000 Neutron Activation Analysis for Provenance Determination in Archaeology. In Modern Analytical Methods in Art and Archaeology, edited by E. Ciliberto and G. Spoto, pp. 81-134. John Wiley and Sons, Inc., New York.

2002 Quantitative Techniques for Analyzing Ceramic Compositional Data. In Ceramic Source Determination in the Greater Southwest, edited by D. M. Glowacki and H. Neff, pp.15-36. Monograph 44. Cotsen Institute of Archaeology, UCLA, Los Angeles.
Sayre, E. V.

1975 Brookhaven Procedures for Statistical Analyses of Multivariate Archaeometric Data. Report BNL23128. Brookhaven National Laboratory, New York.

Steponaitis, V., M. J. Blackman, and H. Neff 1996 Large-scale Compositional Patterns in the Chemical Composition of Mississippian Pottery. American Antiquity 61:555-572.

Weigand, P. C., G. Harbottle, and E. V. Sayre

1977 Turquoise Sources and Source Analysis: Mesoamerica and the Southwestern U.S.A. In Exchange Systems in Prehistory, edited by $\mathrm{T}$. K. Earle and J. E. Ericson, pp. 15-34. Academic Press, New York. 
Table D-1. Chemical Group Assignments and Descriptive Data for the Pottery Samples.

\begin{tabular}{|c|c|c|c|c|c|c|}
\hline ANID & Group & Alt_id & Site_no & Pr_tmpr & Thickness & Decoration \\
\hline TKP754 & intermed & AN38-1 & 41AN23 & grog & 8.3 & fingernail punct. \\
\hline TKP755 & unassign & AN38-2 & 41AN23 & grog-hematite & 8.8 & parallel brushed \\
\hline TKP756 & unassign & AN38-3 & 41AN23 & grog-hematite & 7.8 & zoned incised \\
\hline TKP757 & intermed & AN38-4 & 41AN23 & grog-bone & 7.4 & horizontal engr. \\
\hline TKP758 & intermed & AN38-5 & 41AN23 & grog-hematite & 8.4 & parallel brushed \\
\hline TKP759 & intermed & AN38-6 & 41AN23 & none visible & 6.6 & hatched engraved \\
\hline TKP760 & intermed & AN38-7 & 41CE3 & grog & 7.4 & parallel incised \\
\hline TKP761 & unassign & AN38-8 & 41CE3 & grog & 5.7 & large tool punctate \\
\hline TKP762 & unassign & AN38-9 & 41CE3 & grog & 7.9 & parallel brushed w \\
\hline TKP763 & intermed & AN38-10 & 41CE3 & grog-hematite & 7.5 & horiz./diag. punct., \\
\hline TKP764 & unassign & AN38-11 & 41CE3 & grog & 7.1 & cross-hatch incised \\
\hline TKP765 & Titus & AN38-12 & 41CE3 & grog & 6.8 & plain rim \\
\hline TKP766 & unassign & AN38-13 & 41AN8 & grog & 8.1 & plain rim \\
\hline TKP767 & Titus & AN38-14 & 41AN8 & grog & 8.4 & parallel brushed \\
\hline TKP768 & intermed & AN38-15 & 41AN8 & grog-hematite & 10.7 & parallel brushed \\
\hline TKP769 & unassign & AN38-16 & 41AN8 & grog & 9.8 & horiz./diag. incis. \\
\hline TKP770 & unassign & AN38-17 & 41AN8 & grog & 7.8 & horiz.diag.incis. \\
\hline TKP771 & unassign & AN38-18 & 41AN8 & grog-bone & 6.7 & fingernail punct. \\
\hline TKP772 & intermed & AN38-19 & 41AN8 & grog & 7.2 & incised-tool punct. \\
\hline TKP773 & intermed & AN38-20 & 41AN8 & grog-hematite & 5.2 & triang. engr. w. red \\
\hline TKP774 & unassign & AN38-21 & 41AN32 & grog & 8.4 & cross-hatched incis. \\
\hline TKP775 & Smith & AN38-22 & 41AN32 & grog & 7.2 & opposed eng. panel \\
\hline TKP776 & unassign & AN38-23 & 41AN32 & grog & 9.2 & brush. incis. \\
\hline TKP777 & unassign & AN38-24 & 41AN32 & grog & 7.9 & parallel brushed \\
\hline TKP778 & unassign & AN38-25 & 41AN32 & grog & 8.6 & vert. brush., punct \\
\hline TKP779 & Titus & AN38-26 & 41AN32 & grog & 7.7 & tool punct. \\
\hline TKP780 & Intermed & AN38-27 & 41CE8 & grog & 7.9 & horiz./triang. eng. \\
\hline TKP781 & unassign & AN38-28 & 41CE8 & grog & 7.5 & crow's foot punct. \\
\hline TKP782 & Titus & AN38-29 & 41CE8 & grog & 6.6 & hatched eng. panel \\
\hline TKP783 & intermed & AN38-30 & 41CE8 & grog-hematite & 7 & vert. incis. \\
\hline TKP784 & unassign & AN38-31 & 41CE8 & grog-hematite & 10.1 & vert. brush., punct. \\
\hline TKP785 & unassign & AN38-32 & 41CE8 & grog & 6.9 & parallel brushed \\
\hline TKP786 & intermed & AN38-33 & 41AN14 & grog & 6.4 & ext. red-slipped \\
\hline TKP787 & intermed & AN38-34 & 41AN14 & grog & 9.6 & single punctate \\
\hline TKP788 & unassign & AN38-35 & 41AN14 & none visible & 7.1 & Poynor Engraved \\
\hline TKP789 & unassign & AN38-36 & 41CE17 & grog-hematite & 8 & overlap. brushed \\
\hline TKP790 & unassign & AN38-37 & 41CE17 & grog & 9.2 & parallel brushed \\
\hline TKP791 & unassign & AN38-38 & 41AN1 & bone-grog & 8.7 & fingernail punct. \\
\hline TKP792 & intermed & AN38-39 & 41AN1 & grog-bone & 8.2 & opposed incised \\
\hline TKP793 & Titus & AN38-40 & 41AN38 & none visible & 5.4 & curvilin. engraved \\
\hline TKP794 & unassign & AN38-41 & 41AN38 & grog-hematite & 11.5 & brushed., incised \\
\hline
\end{tabular}


Table D-1, continued.

\begin{tabular}{|c|c|c|c|c|c|c|}
\hline ANID & Group & Alt_id & Site_no & Pr_tmpr & Thickness & Decoration \\
\hline TKP795 & unassign & AN38-42 & 41AN38 & hematite & 7 & brushed, incised \\
\hline TKP796 & unassign & AN38-43 & 41AN38 & none visible & 7.1 & curv. engraved el. \\
\hline TKP797 & intermed & AN38-44 & 41AN38 & grog-bone & 5.2 & opposed incised \\
\hline TKP798 & Smith & AN38-46 & 41AN38 & grog-hematite & 7.3 & curv. eEngr. line \\
\hline TKP799 & unassign & AN38-45 & 41AN38 & grog & 7.2 & tool punct. rows \\
\hline TKP800 & intermed & AN38-47 & 41AN38 & grog-hematite & 8.4 & parallel brushed \\
\hline TKP801 & unassign & AN38-48 & 41AN38 & hematite & 7.7 & parallel brushed \\
\hline TKP802 & unassign & AN38-49 & 41AN38 & grog-hematite & 8.8 & curv. eng. lines \\
\hline TKP803 & unassign & AN38-50 & 41AN38 & grog & 8.1 & $\begin{array}{l}\text { opposed incised } \\
\text { parallel incised }\end{array}$ \\
\hline TKP826 & intermed & & 41AN38 & grog & & lines \\
\hline TKP827 & unassign & & 41AN38 & grog-hematite & & Poynor Engraved \\
\hline TKP828 & intermed & & 41AN38 & grog-hematite & & Patton Engraved \\
\hline TKP829 & unassign & & 41AN38 & grog-hematite-ol & sanics & Maydelle Incised \\
\hline TKP830 & unassign & & 41AN38 & grog & & parallel brushed \\
\hline TKP831 & unassign & & 41AN38 & bone-hem. Sand & paste & Killough Pinched \\
\hline TKP832 & intermed & & 41AN38 & grog & & parallel brushed \\
\hline TKP833 & unassign & & 41AN38 & grog-hematite & & punctated rows \\
\hline TKP834 & Titus & & 41AN38 & grog & & horizontal brushed \\
\hline TKP835 & Titus & & 41AN38 & grog & & cross-hatched eng. \\
\hline TKP836 & unassign & & 41AN38 & grog & & brush. -punct. row \\
\hline TKP837 & unassign & & 41AN38 & grog-hematite & & Poynor Engraved \\
\hline TKP838 & unassign & & 41AN38 & grog & & Poynor Engraved \\
\hline TKP839 & intermed & & 41AN38 & grog-hematite & & Poynor Engraved \\
\hline TKP840 & unassign & & 41AN38 & grog/sandy paste & & Poynor Engraved \\
\hline TKP841 & unassign & & 41AN38 & grog-hematite & & $\begin{array}{l}\text { broad engraved line } \\
\text { parallel brushed- }\end{array}$ \\
\hline TKP842 & unassign & & 41AN38 & grog & & $\begin{array}{l}\text { tool punctuated } \\
\text { horizontal brushed }\end{array}$ \\
\hline TKP843 & unassign & & 41AN38 & grog & & with node \\
\hline TKP844 & unassign & & 41AN38 & grog & & parallel brushed \\
\hline TKP846 & intermed & & 41AN38 & grog & & parallel brushed \\
\hline TKP847 & unassign & & 41AN38 & grog & & parallel brushed \\
\hline TKP848 & Titus & & 41AN38 & grog-hematite & & horizontal brushed \\
\hline TKP849 & intermed & & 41AN38 & grog & & opposed brushed \\
\hline TKP850 & Titus & & 41AN38 & grog & & Poynor Engraved \\
\hline TKP851 & unassign & & 41AN38 & grog-hematite & & Poynor Engraved \\
\hline TKP852 & Titus & & 41AN38 & grog & & Killough Pinched \\
\hline TKP853 & Intermed & & 41AN38 & grog & & parallel brushed \\
\hline TKP854 & unassign & & 41AN38 & grog & & parallel brushed \\
\hline TKP855 & unassign & & 41AN38 & grog & & parallel brushed \\
\hline TKP856 & Smith & & 41AN38 & grog & & parallel brushed \\
\hline TKP857 & unassign & & 41AN38 & grog & & parallel brushed \\
\hline
\end{tabular}


Table D-1, continued.

\begin{tabular}{|c|c|c|c|c|c|c|}
\hline ANID & Group & Alt_id & Site_no & Pr_tmpr & Thickness & Decoration \\
\hline TKP858 & unassign & & 41AN38 & grog-hematite & & parallel brushed \\
\hline TKP859 & Smith & & 41AN38 & grog & & LaRue Neck Band. \\
\hline TKP860 & unassign & & 41AN38 & $\begin{array}{l}\text { grog } \\
\text { grog/sandy }\end{array}$ & & Poynor Engraved \\
\hline TKP861 & unassign & & 41AN38 & $\begin{array}{l}\text { paste } \\
\text { grog/sandy }\end{array}$ & & eng. hatched ladder \\
\hline TKP862 & unassign & & 41AN38 & paste & & Poynor Engraved \\
\hline TKP863 & unassign & & 41AN38 & grog-hematite & & Poynor Engraved \\
\hline TKP864 & unassign & & 41AN38 & grog & & parallel brushed \\
\hline TKP845 & intermed & & 41AN38 & grog & & parallel brushed \\
\hline
\end{tabular}

Table D-2. Probabilities of Group Membership Based on a Mahalanobis Distance Calculation for Each of the Sherds. Those assigned to a group are highlighted in bold type.

\begin{tabular}{|c|c|c|c|}
\hline ID. NO. & Titus & Smith & Red River \\
\hline TKP754 & 11.282 & 3.757 & 0.000 \\
\hline TKP755 & 0.009 & 0.000 & 0.000 \\
\hline TKP756 & 0.000 & 0.005 & 0.000 \\
\hline TKP757 & 0.361 & 0.768 & 0.000 \\
\hline TKP758 & 0.369 & 0.056 & 0.000 \\
\hline TKP759 & 21.719 & 7.716 & 0.000 \\
\hline TKP760 & 6.305 & 14.562 & 0.000 \\
\hline TKP761 & 0.887 & 0.002 & 0.000 \\
\hline TKP762 & 0.000 & 0.000 & 0.000 \\
\hline TKP763 & 5.059 & 2.462 & 0.000 \\
\hline TKP764 & 0.000 & 0.111 & 0.000 \\
\hline TKP765 & 17.745 & 0.038 & 0.003 \\
\hline TKP766 & 0.000 & 0.001 & 0.000 \\
\hline TKP767 & 10.998 & 0.046 & 0.000 \\
\hline ТКР768 & 18.878 & 2.142 & 0.000 \\
\hline TKP769 & 0.000 & 0.001 & 0.000 \\
\hline TKP770 & 0.000 & 0.055 & 0.000 \\
\hline TKP771 & 0.000 & 0.891 & 0.000 \\
\hline TKP772 & 0.515 & 0.338 & 0.001 \\
\hline TKP773 & 18.014 & 4.554 & 0.001 \\
\hline TKP774 & 0.000 & 0.001 & 0.000 \\
\hline TKP775 & 0.214 & 16.181 & 0.000 \\
\hline TKP776 & 0.000 & 0.004 & 0.000 \\
\hline TKP777 & 0.000 & 0.260 & 0.000 \\
\hline TKP778 & 0.000 & 0.002 & 0.000 \\
\hline TKP779 & 42.514 & 0.044 & 0.004 \\
\hline TKP780 & 1.588 & 9.493 & 0.000 \\
\hline TKP781 & 0.024 & 0.001 & 0.000 \\
\hline TKP782 & 9.998 & 0.002 & 0.000 \\
\hline TKP783 & 0.402 & 1.330 & 0.000 \\
\hline TKP784 & 2.029 & 0.005 & 0.000 \\
\hline TKP785 & 2.317 & 0.001 & 0.000 \\
\hline TKP786 & 26.962 & 2.740 & 0.000 \\
\hline TKP787 & 28.737 & 1.574 & 0.001 \\
\hline TKP788 & 0.073 & 0.066 & 0.000 \\
\hline TKP789 & 0.027 & 0.515 & 0.000 \\
\hline TKP790 & 0.000 & 0.000 & 0.000 \\
\hline TKP791 & 0.000 & 0.044 & 0.000 \\
\hline TKP792 & 1.529 & 0.870 & 0.000 \\
\hline TKP793 & 12.089 & 0.016 & 0.000 \\
\hline TKP794 & 0.006 & 0.025 & 0.000 \\
\hline TKP795 & 0.004 & 0.000 & 0.000 \\
\hline
\end{tabular}


Table D2, continued.

\begin{tabular}{|c|c|c|c|}
\hline ID. NO. & Titus & Smith & Red River \\
\hline TKP796 & 1.500 & 0.018 & 0.000 \\
\hline ТKP797 & 64.006 & 7.514 & 0.005 \\
\hline ТКР798 & 0.001 & 5.789 & 0.000 \\
\hline ТКР799 & 3.503 & 0.005 & 0.000 \\
\hline TKP800 & 84.121 & 3.297 & 0.000 \\
\hline TKP828 & 6.458 & 0.408 & 0.003 \\
\hline ТКР829 & 0.005 & 0.020 & 0.000 \\
\hline TKP801 & 3.524 & 0.009 & 0.000 \\
\hline TKP802 & 0.118 & 0.000 & 0.000 \\
\hline TKP803 & 0.000 & 0.000 & 0.000 \\
\hline TKP826 & 7.630 & 1.076 & 0.000 \\
\hline TKP830 & 0.020 & 0.032 & 0.000 \\
\hline TKP831 & 0.001 & 0.494 & 0.000 \\
\hline TKP832 & 0.202 & 0.111 & 0.000 \\
\hline TKP833 & 0.032 & 0.000 & 0.000 \\
\hline TKP834 & 39.414 & 0.350 & 0.000 \\
\hline TKP835 & 26.151 & 1.821 & 0.000 \\
\hline TKP836 & 0.000 & 0.000 & 0.000 \\
\hline TKP837 & 0.055 & 0.037 & 0.000 \\
\hline TKP838 & 0.002 & 0.001 & 0.000 \\
\hline TKP839 & 1.761 & 3.373 & 0.000 \\
\hline TKP840 & 0.000 & 0.024 & 0.000 \\
\hline TKP841 & 0.000 & 0.019 & 0.000 \\
\hline TKP842 & 0.147 & 0.000 & 0.021 \\
\hline TKP843 & 0.026 & 3.307 & 0.000 \\
\hline TKP844 & 0.000 & 0.002 & 0.000 \\
\hline TKP845 & 3.499 & 1.099 & 0.000 \\
\hline TKP846 & 0.000 & 0.000 & 0.000 \\
\hline TKP847 & 12.515 & 0.437 & 0.000 \\
\hline TKP848 & 6.854 & 2.905 & 0.000 \\
\hline ТКР849 & 51.547 & 0.004 & 0.000 \\
\hline TKP850 & 0.000 & 0.000 & 0.000 \\
\hline TKP851 & 6.540 & 0.058 & 0.000 \\
\hline TKP852 & 0.814 & 2.153 & 0.000 \\
\hline TKP853 & 0.000 & 0.001 & 0.000 \\
\hline TKP854 & 0.000 & 0.000 & 0.000 \\
\hline TKP855 & 0.092 & 28.073 & 0.000 \\
\hline TKP856 & 0.002 & 0.780 & 0.000 \\
\hline TKP857 & 0.000 & 1.093 & 0.000 \\
\hline TKP858 & 0.006 & 6.201 & 0.000 \\
\hline TKP859 & 0.017 & 0.131 & 0.000 \\
\hline TKP860 & 0.000 & 0.082 & 0.000 \\
\hline TKP861 & 0.020 & 0.031 & 0.000 \\
\hline TKP862 & 0.356 & 0.028 & 0.000 \\
\hline TKP863 & 0.000 & 0.042 & 0.000 \\
\hline TKP864 & 0.238 & 0.118 & 0.000 \\
\hline TKP865 & 0.227 & 0.220 & 0.000 \\
\hline TKP866 & 12.329 & 0.041 & 0.000 \\
\hline TKP867 & 0.001 & 0.002 & 0.000 \\
\hline TKP868 & 0.000 & 0.420 & 0.000 \\
\hline TKP869 & 0.266 & 0.000 & 0.000 \\
\hline TKP870 & 0.000 & 9.806 & 0.000 \\
\hline TKP871 & 8.575 & 2.197 & 0.000 \\
\hline TKP872 & 0.000 & 0.075 & 0.000 \\
\hline TKP873 & 0.000 & 1.050 & 0.000 \\
\hline TKP874 & 0.030 & 0.000 & 0.000 \\
\hline TKP875 & 1.854 & 4.947 & 0.004 \\
\hline
\end{tabular}




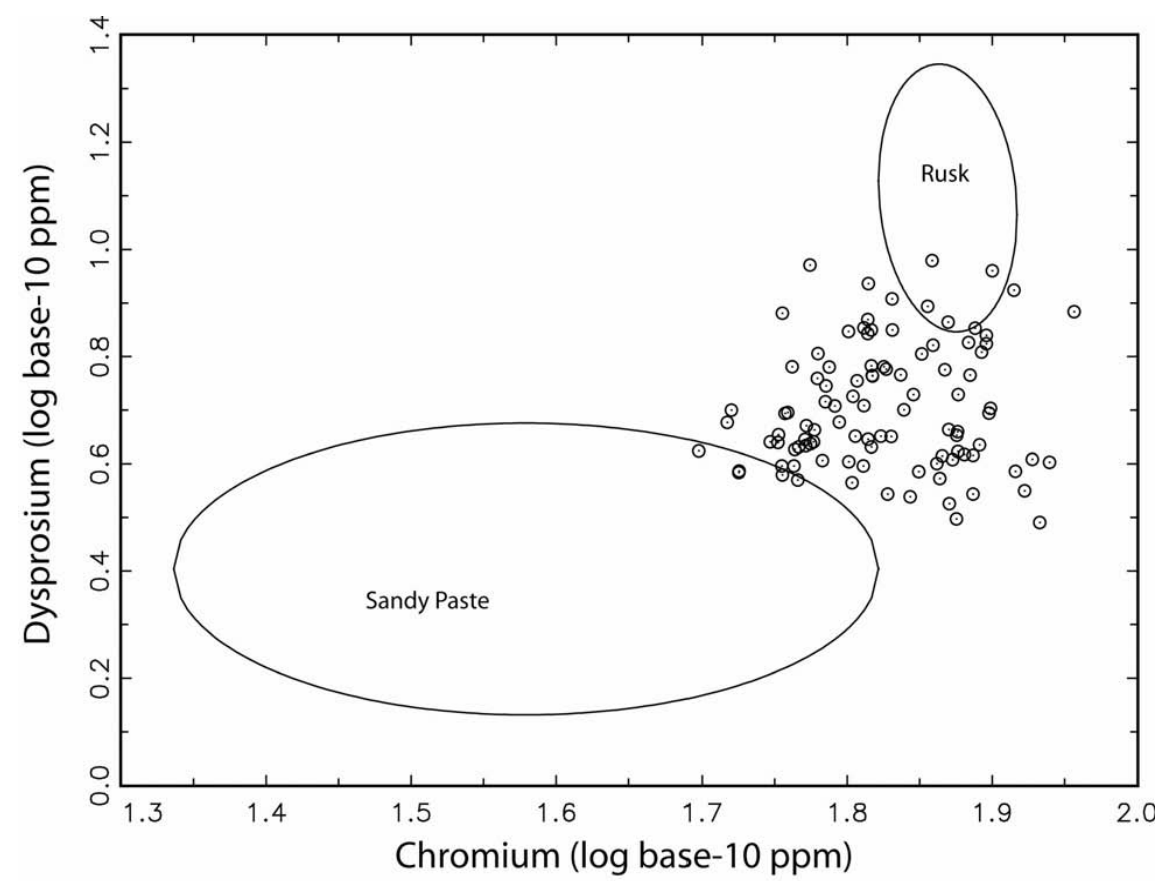

Figure D-1. Bivariate Plot of Chromium and Dysprosium Base-10 Logged ConcentrationsShowing that the New Samples Do Not Match with Either the Rusk or Sandy Paste Reference Groups. Ellipses represent a $90 \%$ confidence level for membership in the group.

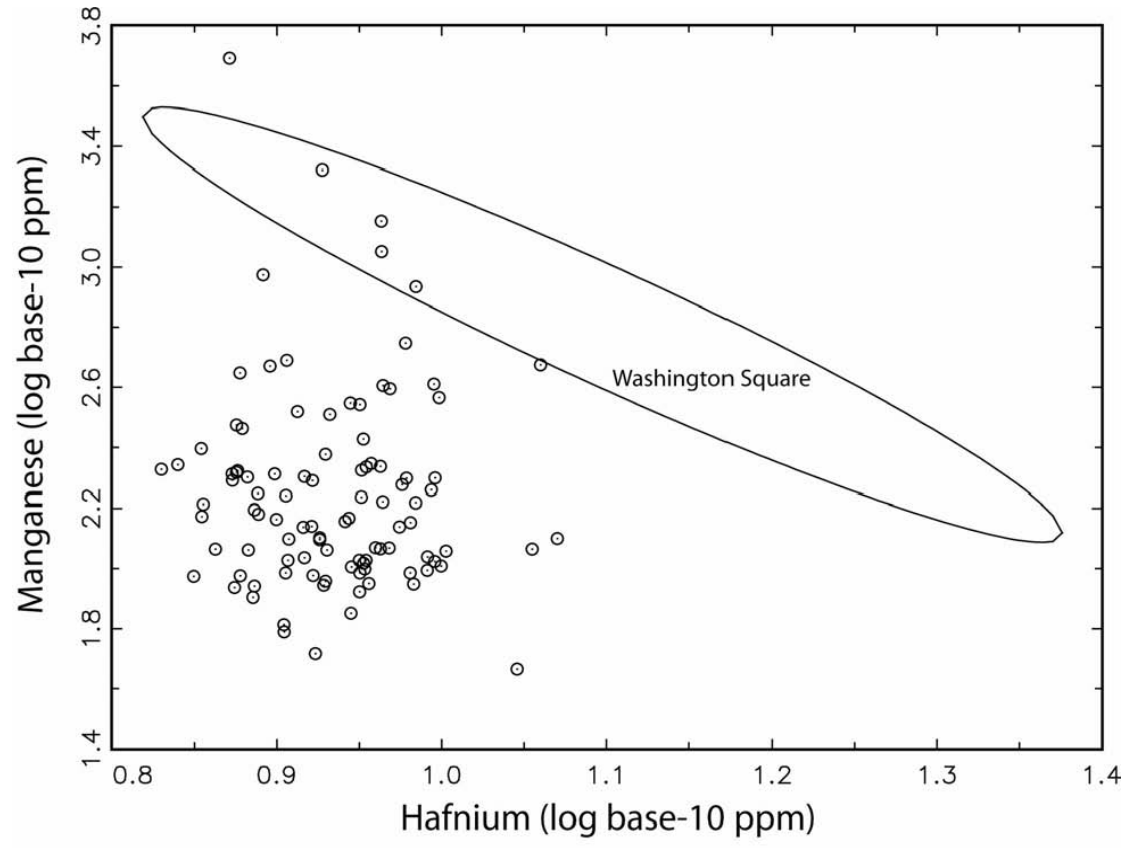

Figure D-2. Bivariate Plot of Hafnium and Magnesium Base-10 Logged ConcentrationsShowing That the New Samples Do Not Match with the Washington Square Reference Group. Ellipses represent a $90 \%$ confidence level for membership in the group. 


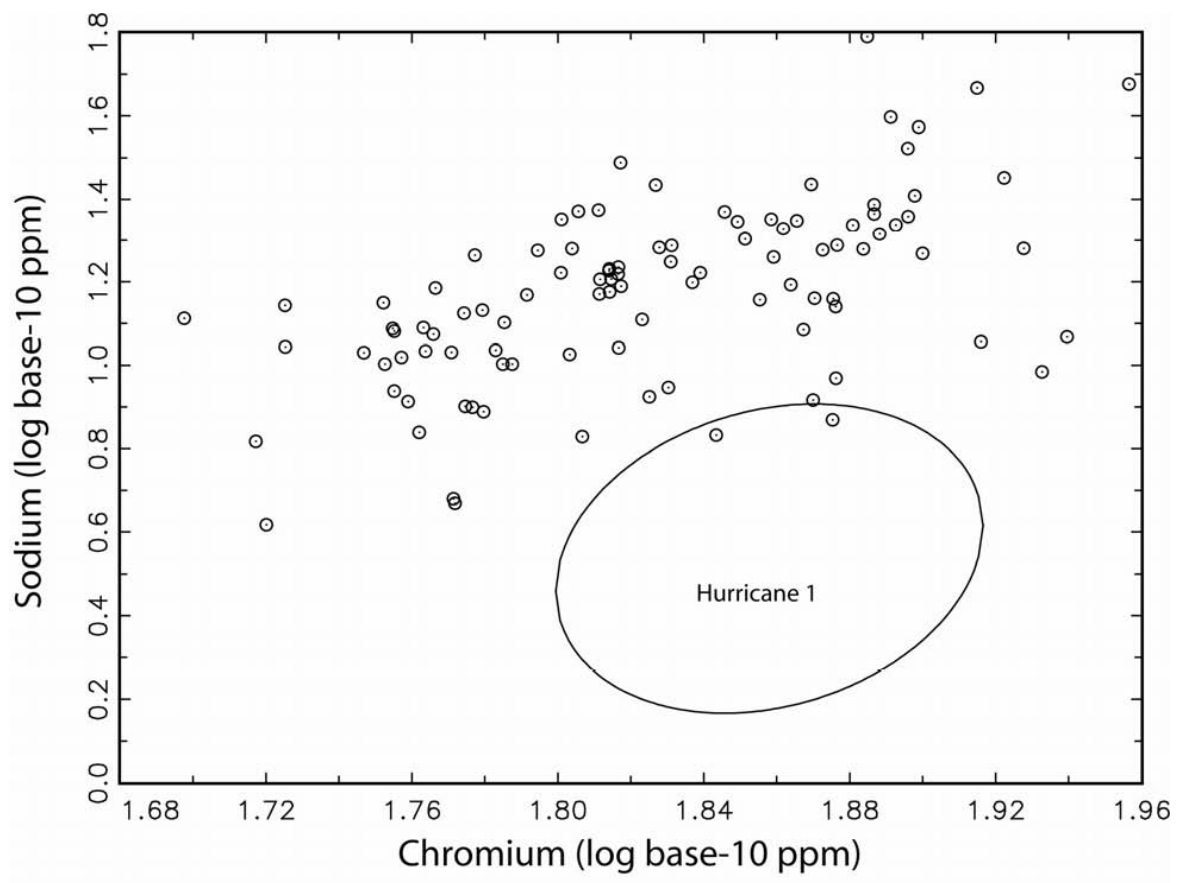

Figure D-3. Bivariate Plot of Sodium and Chromium Base-10 Logged ConcentrationsShowing the Separation from the Hurricane 1 Reference Group. Ellipses represent a $90 \%$ confidence level for membership in the group.

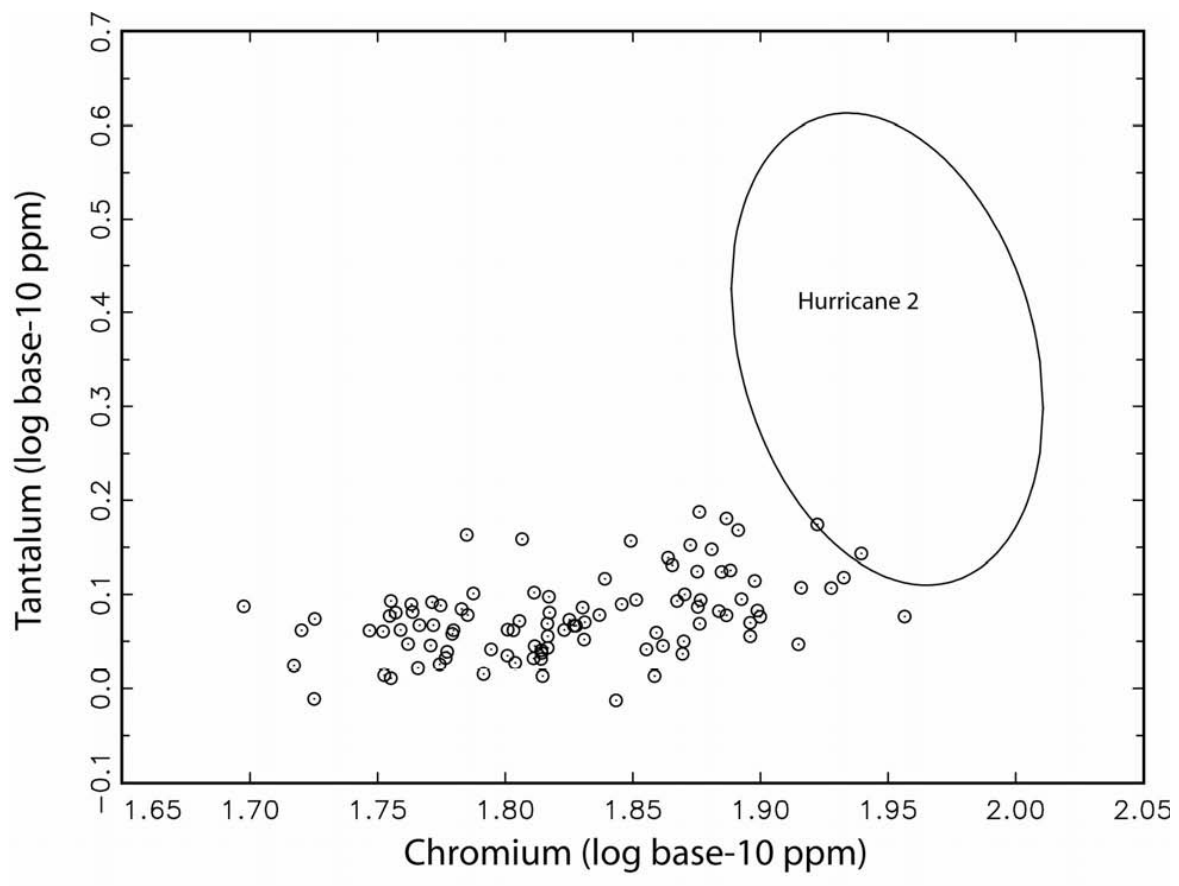

Figure D-4. Bivariate Plot of Chromium and Tantalum Base-10 Logged ConcentrationsShowing the Separation from the Hurricane 2 Reference Group. Ellipses represent a $90 \%$ confidence level for membership in the group. 


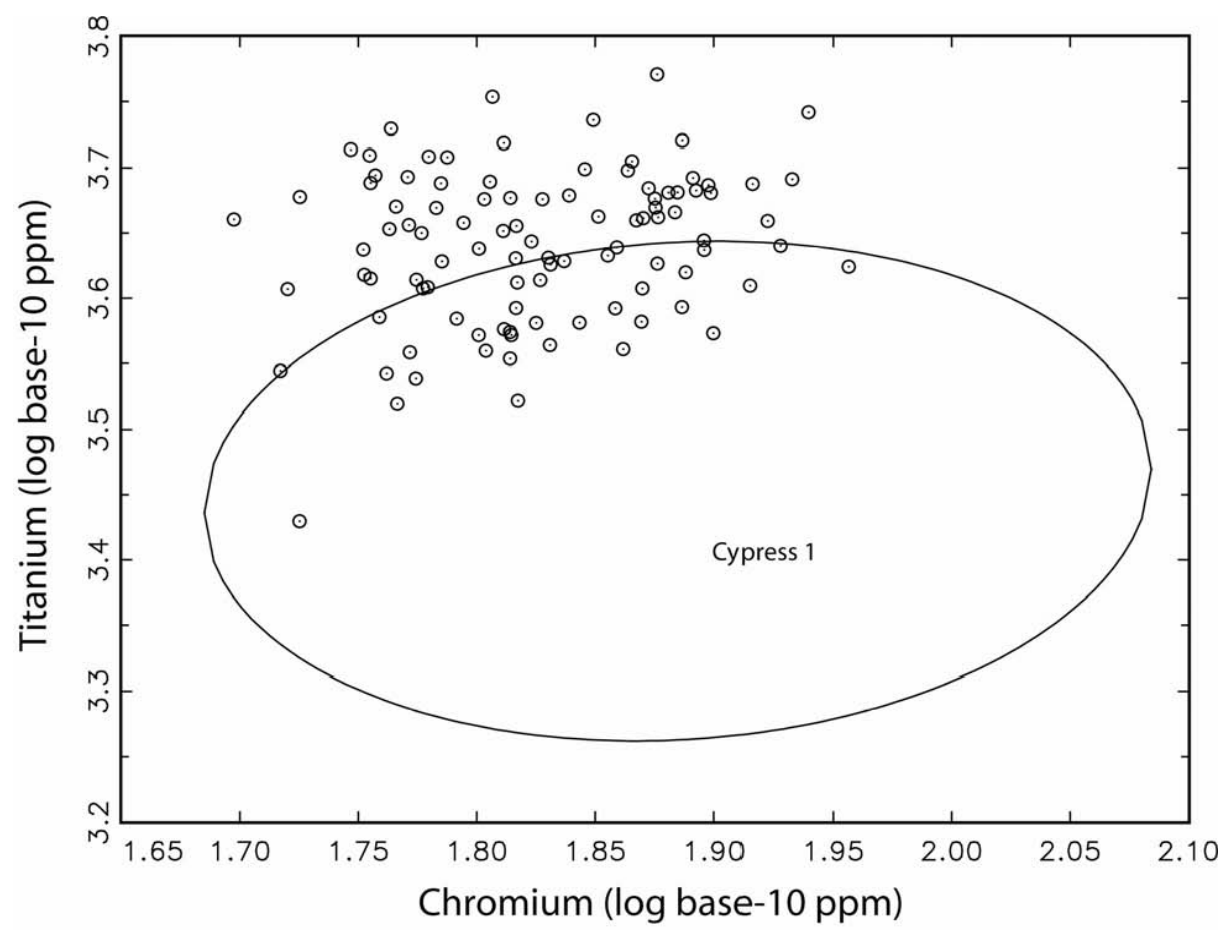

Figure D-5. Bivariate Plot of Chromium and Titanium Base-10 Logged Concentrations Showing the Separation from the Cypress 1 Reference Group. Ellipses represent a 90\% confidence level for membership in the group.

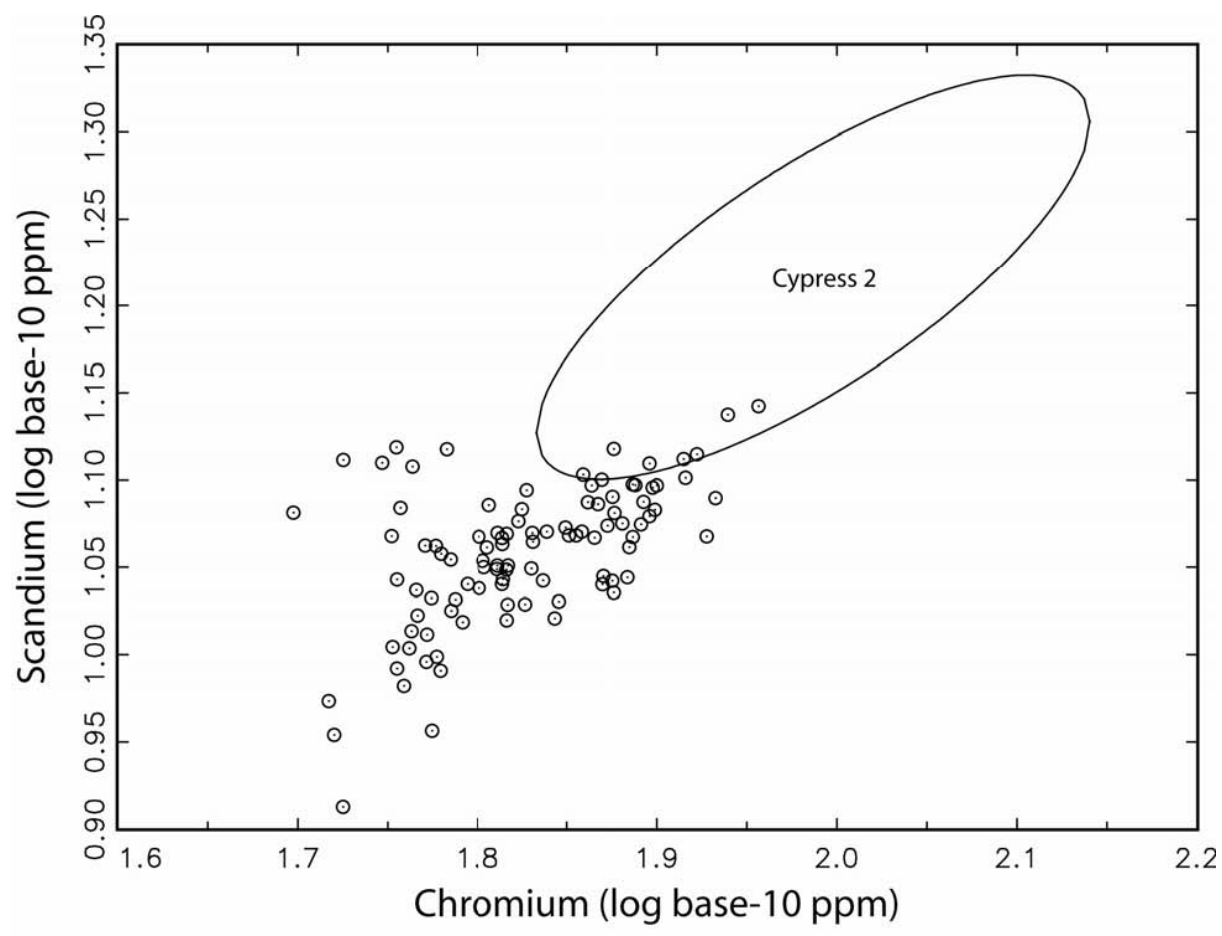

Figure D-6. Bivariate Plot of Chromium and Scandium Base-10 Logged ConcentrationsShowing the Separation from the Cypress 2 Reference Group. Ellipses represent a $90 \%$ confidence level for membership in the group. 


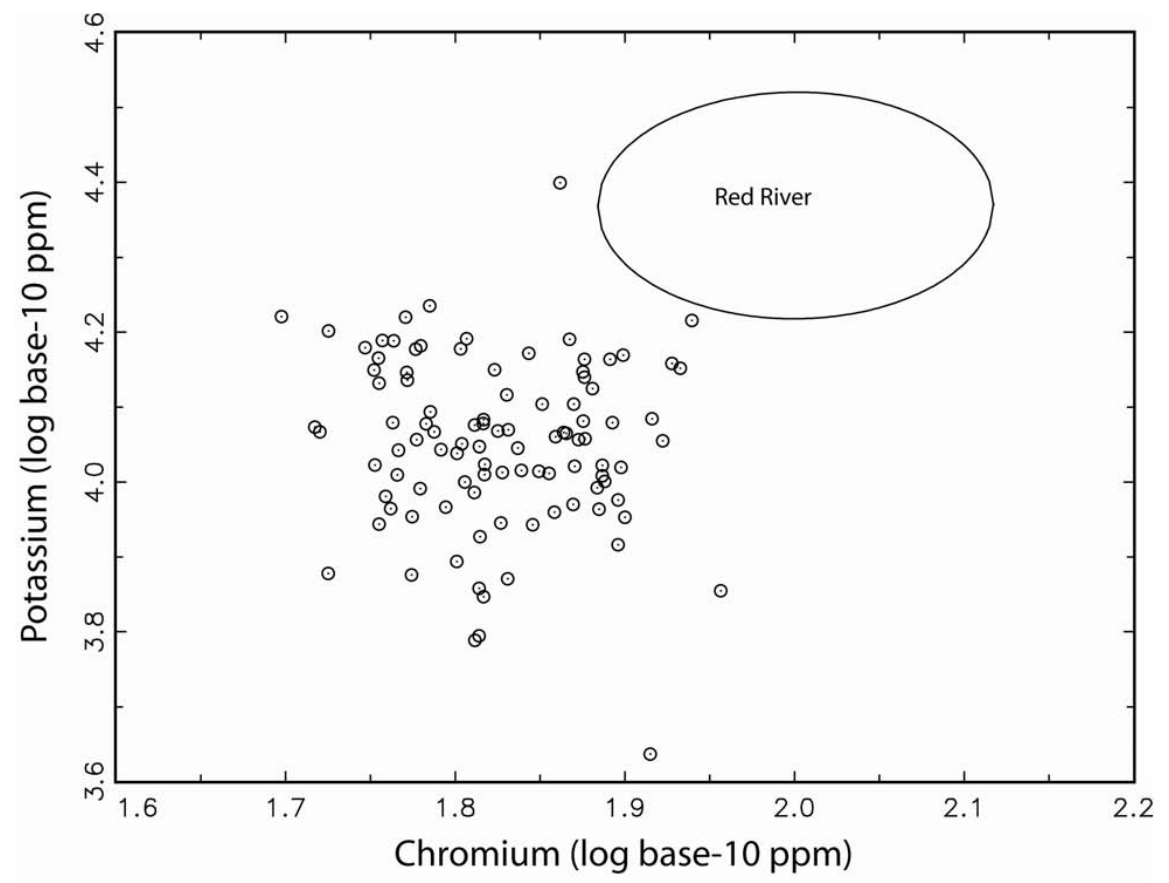

Figure D-7. Bivariate Plot of Chromium and Potassium Base-10 Logged ConcentrationsShowing the Separation from the New Samples from the Red River Compositional Group. Ellipses represent a $90 \%$ confidence level for membership in the group.

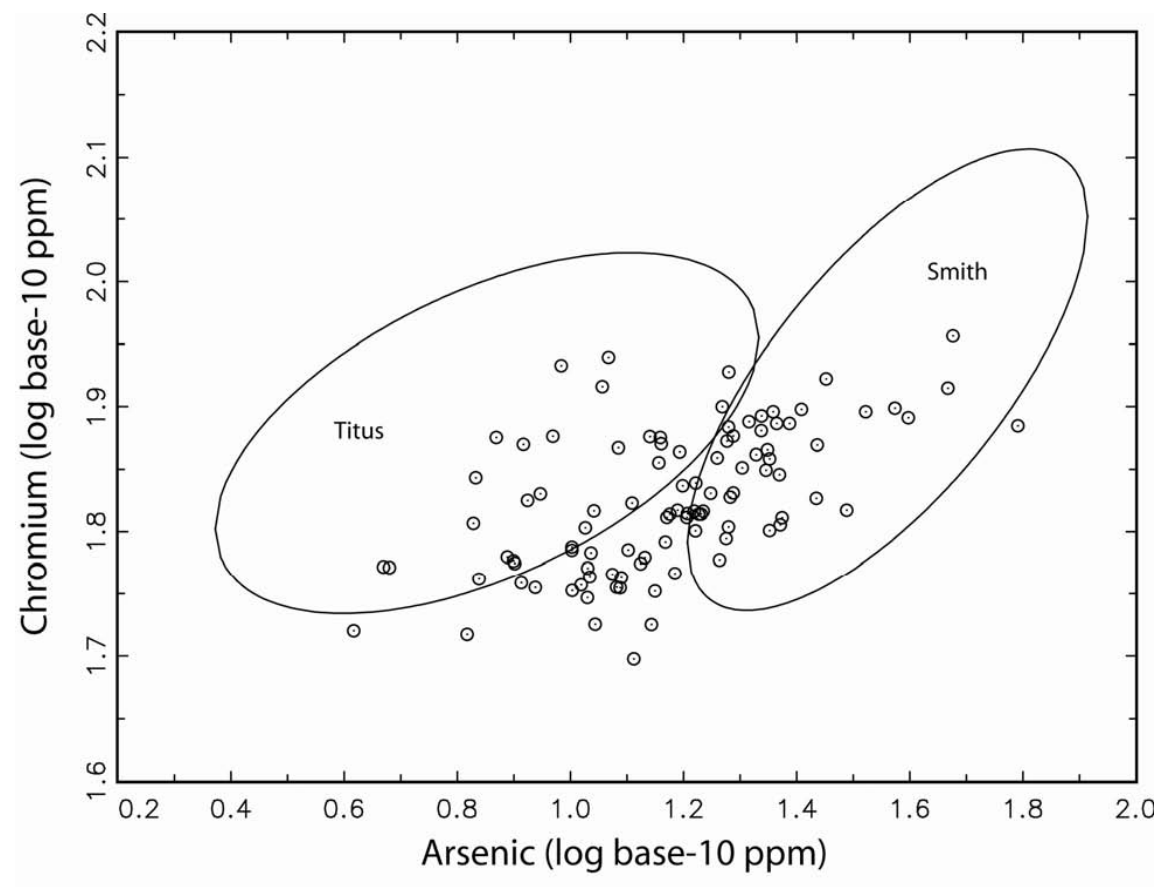

Figure D-8. Bivariate Plot of Arsenic and Chromium Base-10 Logged ConcentrationsShowing the Overlap the New Samples with the Titus and Smith Compositional Groups. Ellipses represent a $90 \%$ confidence level for membership in the group. 


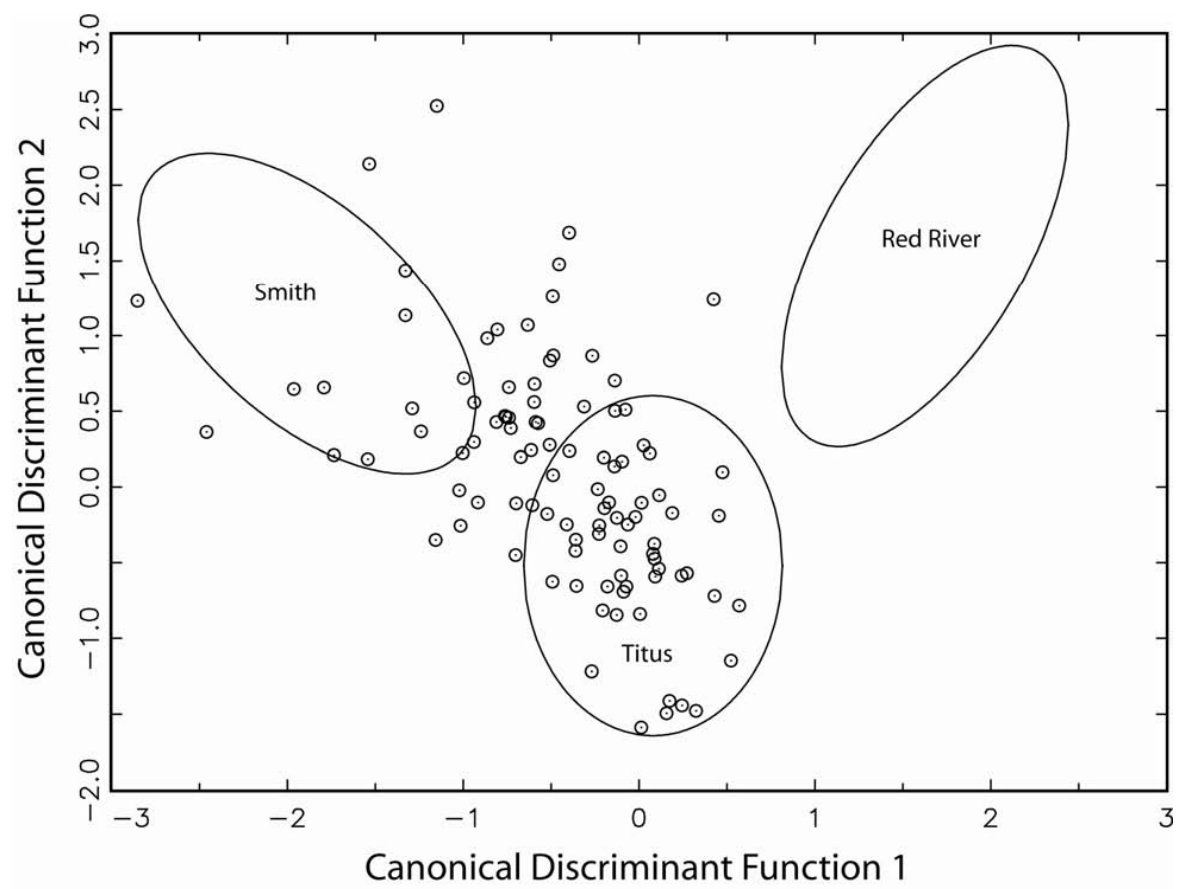

Figure D-9. Biplot of Canonical Discriminant Functions One and Two Showing the Relationship Between the New Samples and the Three Largest Caddoan Reference Groups. Ellipses represent a $90 \%$ confidence level for membership in the group.

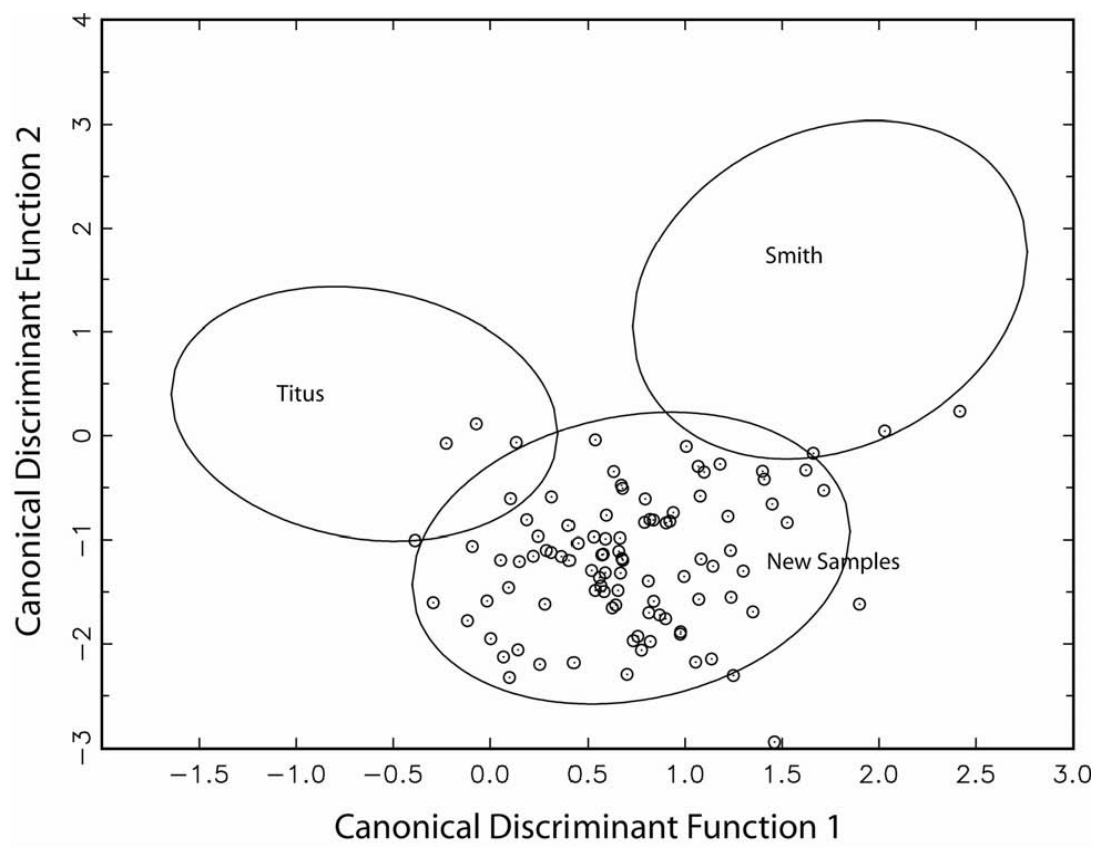

Figure D-10. Biplot of Canonical Discriminant Functions One and Two Showing the Relationship between the New Samples and the Titus and Smith Reference Groups, if the New Samples are Considered a Group. Ellipses represent a $90 \%$ confidence level for membership in the group. 


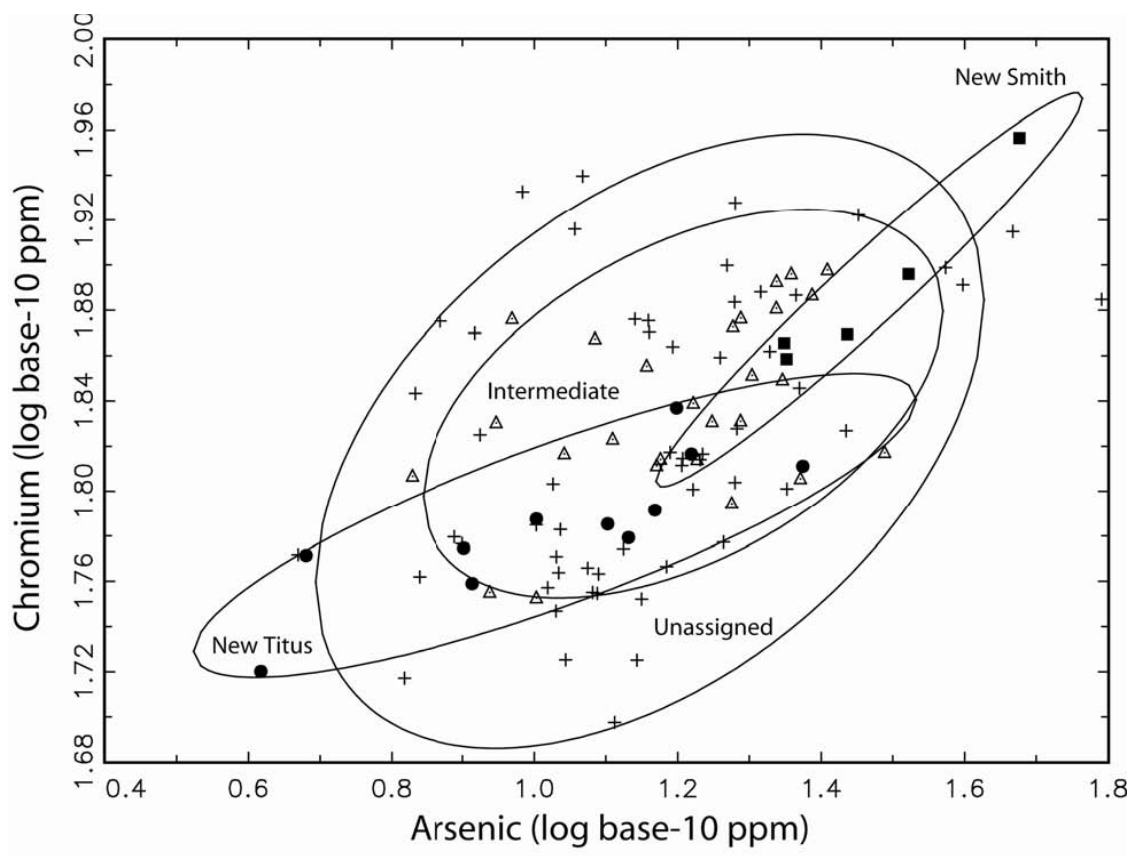

Figure D-11. Bivariate Plot of Arsenic and Chromium Base-10 Logged ConcentrationsShowing the Newly Assigned Members of Smith and Titus as Well as Both the Unassigned and the Intermediate Samples. The intermediate samples are represented

by an open triangle, and the unassigned samples are represented by a "+" symbol. Ellipses represent a $90 \%$ confidence level for membership in the group. 


\section{APPENDIX E \\ TEST EXCAVATIONS AT 41AN159}

Prepared for:

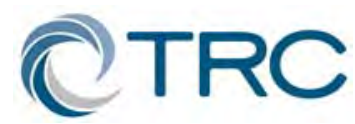

TRC Environmental Corporation

505 East Huntland Drive, Suite 250

Austin, Texas 78752

Prepared by:

Jon C. Lohse, Timothy K. Perttula, and Robert A. Ricklis 



\section{E.1 Introduction}

In late-January and February of 2004, archeologists from Coastal Environments, Inc. (CEI), working under contract to the Texas Department of Transportation (TxDOT), conducted test-level investigations at two sites (41AN38 and 41AN159) in Anderson County, Texas. The sites are located alongside State Highway 155, and will be impacted by scheduled expansion of SH155 from two to four lanes. 41AN38 was initially recorded by TxDOT archeologists in the early 1980s, who recommended the site for testing at that time. 41AN159 was recorded during a survey conducted by Hicks \& Company (under contract to TxDOT) in 2002, at which time the site was recommended for testing based on the recovery of Caddo style ceramic sherds, including several decorated pieces. Hicks \& Company also revisited 41AN38, recovering additional Caddo materials and reconfirming the earlier recommendation.

On the basis of artifact recoveries, both sites were characterized as probable Caddo farmsteads of unknown time periods. The sites were perceived as having potential to make significant contributions to the regional understanding of Caddo prehistory, especially considering the information they were thought to contain regarding residential or domestic activities. The great majority (though not all) of archeological attention given to Caddo sites in East Texas and adjacent regions has been focused on mound sites and cemeteries, leaving questions of regional settlement, subsistence practices, domestic organization (around lines of age, gender, task group, and/or status), and household-scale religious behavior relatively unsettled. Farmsteads, along with communities, have been referred to as one of the "fundamental building blocks of the Caddoan settlement system" (Story 1990a:336), though farmsteads are most frequently overlooked in research efforts (Kelley 1997).

At TxDOT's request, a Research Design and Scope of Work was prepared (Perttula and
Ricklis 2003) outlining work to be conducting in determining whether the sites should be considered eligible for listing to the National Register of Historic Places (NRHP) and warrant further treatment prior to road construction. Important questions to be resolved included whether the sites were farmsteads and whether they were contemporaneously occupied, in which case they could be considered together as part of an integrated regional settlement system. To resolve these questions in determining site NRHP eligibility, the Scope recommended that additional shovel testing be carried out to identify concentrations of buried remains. Hand excavated units would follow to recover an adequate sample of temporally diagnostic decorated ceramic sherds which can be compared with assemblages recovered from nearby Lake Palestine (Anderson et al. 1974) to help seriate site occupations based on percentages of different decorative elements and paste treatments (50-100 decorated sherds were needed and 200+ was considered ideal). Based on the results of the Hicks \& Company survey, it was predicted that at least nine square meters would need to be excavated at 41AN38 and perhaps as many as 22 square meters of excavation were required for 41AN159 to recover 200 decorated sherds. To resolve the first question, the nature of residential site structure, potential features were to be sought by hand excavations and also by mechanically stripping of large sections of overburden. These exposures would ideally reveal cultural features such as postholes, middens, burial or storage pits, and so forth. Such features would be recognizable by discrete patterns of soil discolorations, usually a dark staining. All units, including shovel tests, test units, and mechanically scraped areas, were to be located on topographic maps of the sites that would be prepared using a surveyor's transit.

\section{E.2 Environmental Setting}

Physiographically, the study area lies in what Story et al. (1990) termed the West Gulf Coastal Plain (Figure E-1). Following Fenneman (1938), this section of the Coastal Plain includes the 
Texas-Louisiana border and extends west as far as the Trinity River. Surrounded by more active geologic provinces (such as the Ouachita, Mississippi Valley, and Central Texas sections), the region is characterized by rolling topography, abundant groundwater and numerous rivers, and sandy loam sediments that are often loosely consolidated. The region's sandy soils, while agriculturally productive, are not considered particularly fertile without constant replenishment of nutrients.

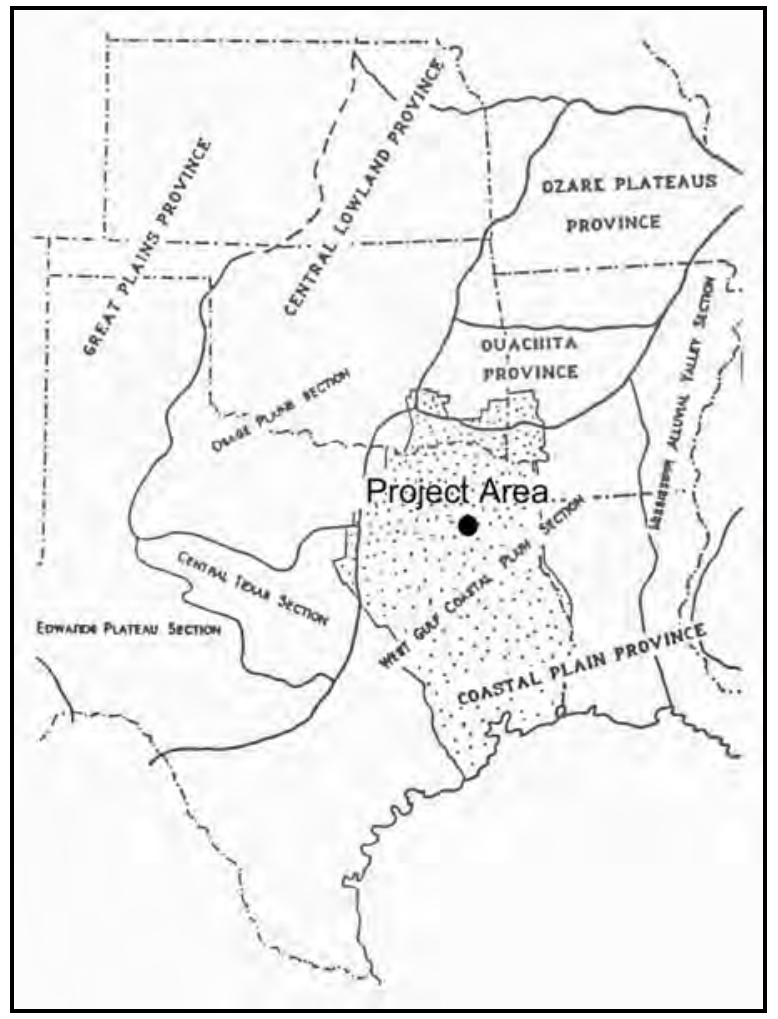

Figure E-1. Location of Project Area with Respect to Physiographic Provinces (after Story 1990b: Figure 4).

Moreover, the loose sediment consolidation can result in serious problems of topsoil loss from erosion and runoff once standing vegetation is cleared, unless the soils are otherwise protected through slope management. Owing to the heavily weathered geologic substratum and the sedimentary nature of much of the region's bedrock, the study area lacks an abundance of raw stone materials well suited for tool-making (coarse petrified wood was commonly used in the absence of finer grained silicious material). Much of the toolstone that is available (including quartzite, petrified wood, and chert nodules) occurs in secondary deposits as river gravels, and is heavily battered and generally small in size.

Vegetation across the project area is presently characterized by a mixture of evergreen and deciduous growth. Pines and hardwoods are present in mixed communities, with species including shortleaf and loblolly pines, oaks, bois d'arc, hickory, redbud, and dogwood among others (see Perttula 1995). This vegetation regime is supported by a fairly mesic or wet climate, including standing ground water and boggy tracts as well as numerous streams, drainages, and river systems (Figure E-2). For the Cypress Creek valley, Thurmond (1981) suggested that the region's late prehistoric archeological record of dense occupations sustained by agricultural production, in sharp contrast to adjacent areas where regional stream flows are more intermittent, is likely to be a direct result of the perennial presence and reliability of water. One result of the region's numerous active stream channels is that drainages and their valleys are frequently filled with alluvial sediments from flood events, reducing their suitability for habitation sites; most of the region's prehistoric settlement (including the two sites discussed in this report) is found on adjacent well drained upland areas. The floodplains, however, also were very important environmental areas for prehistoric inhabitants, and are quite likely to contain wellpreserved paleoenvironmental records of flood events, deforestation, and perhaps agricultural practices reflective of regional occupational sequences. 


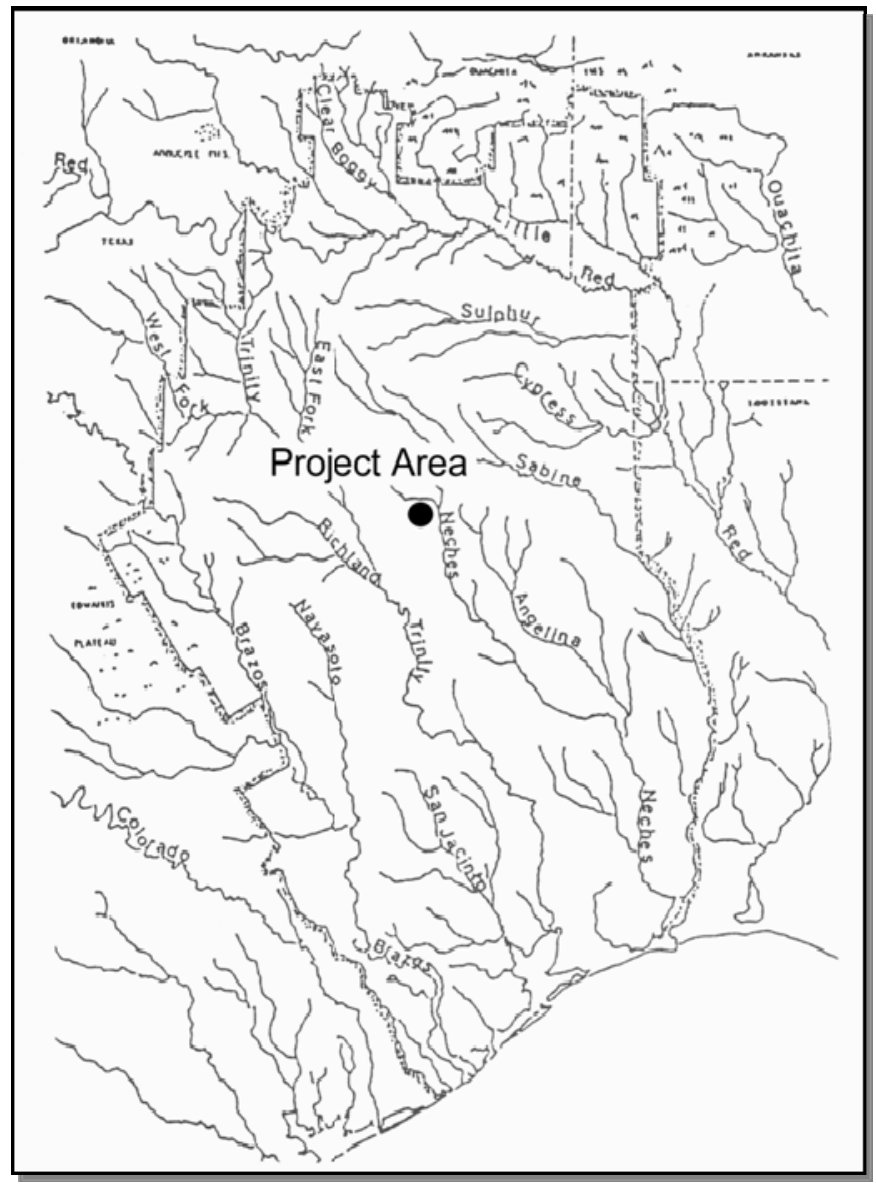

Figure E-2. Location of Project Area in Relation to Important River Drainages.

\section{E.3 Cultural Context}

Sites 41AN38 and 41AN159 are situated in a part of the Neches River valley that is well known as one of the principal areas settled by prehistoric and historic Caddo groups that are identified archeologically as the Frankston (ca. A.D. 1400-1650) and Allen (ca. A.D. 16501750) phases (see Story and Creel 1982:29-32; Kleinschmidt 1982), but much of the relevant archeological work was done in the 1930s and focused on the excavation of cemeteries (see Guy 1990: Table E-3; see also Cole 1975); one such nearby cemetery in the Caney Branch Creek valley is the Mrs. J. M. Cook site (41AN1). Major excavations were also conducted in the early 1930 s at the A. C. Saunders (41AN19) mound center (Jackson 1936; Kleinschmidt 1982), but there was a dearth of work done in habitation deposits (other than occasionally trenching a trash midden deposit). Story (2000:13) has noted that "none of the [Frankston phase] sites...has been extensively investigated nor well dated and much of the information comes from excavations made in the early and middle 1930s.”

In more recent times, archeological work in this part of the upper Neches River basin has taken place at or near Lake Palestine, where a number of primarily Late Caddo Frankston phase sites have been investigated (Anderson et al. 1974; Cliff et al. 2004; Gilmore 1983; Shafer 1981). Here too, however, the work was not specifically directed towards identifying and studying habitation features and the layout of Caddo settlements/households, and it was primarily successful only in the identification of midden deposits and their contents, or in salvaging the contents of a disturbed Late Caddo burial (e.g., Shafer 1981). 
On Caddo habitation sites, "most excavations have been too limited to permit accurate characterization of the settlement size and structure, and sometimes even its history of use" (Story 1990:334). While there have been more extensive archeological investigations of Caddo habitation sites more recently in some parts of northeastern Texas, the fact remains that our understanding of the basic character of prehistoric and early historic Caddo households, settlements, and communities is still poorly known. This is as true for Caddo habitation sites in the upper part of the Neches River basin as it is in any part of northeastern Texas.

The archeological investigations that we proposed to conduct at 41AN38 and 41AN159 were designed to determine if: (a) both sites have archeological deposits that are informative about the nature and character of Caddo households and farmsteads in the upper Neches River basin, and (b) if the plain and decorated ceramics found on the sites can establish if they are part of a related set of households/farmsteads in the Caney Branch Creek valley and the upper Neches River basin.

To investigate the research issue "Caddo settlement systems and households" by focusing on these two Caddo sites of unknown age, we needed to be able to establish their spatial parameters and internal organization (see Kenmotsu and Perttula 1993:137). This included establishing whether there are structures and other kinds of features (especially specialized storage facilities and midden deposits) preserved on the sites, as well as any spatial clusters of ceramic sherds, lithic tools and debris, plant remains, and any preserved animal bones. These spatial data on features and artifacts are key to determining if Caddo households are present at 41AN38 and 41AN159, and if the configuration of household features and activity areas can also be identified during the archeological work. We also hoped to establish their age, hopefully within a 50-100-year span, to either establish the contemporaneity of the two sites or, if they were of different ages, how much older one was than the other so that diachronic changes in household configuration and material culture could be measured in the archeological record.
Since Caddo sites in the upper Neches River basin appear to be part of sedentary, but dispersed settlement systems of agricultural communities, we expected well-preserved individual households or farmsteads to contain evidence of pole-frame structures (thatched with grass)—such as post holes, smudge pits, or central hearth features in the archeological record-that would have been occupied by nuclear or extended families for 10-20 years. There should also be evidence for outdoor activity areas where foods were cooked and plant and animal products were processed; midden deposits from trash disposal and the discard of broken ceramic vessels and stone tools; postholes denoting possible granary structures, ramadas, and arbors; and the presence of burials from small family cemeteries. Furthermore, well-preserved and single component Caddo households/farmsteads should contain artifacts found in various archeological deposits that may be present at 41AN38 and 41AN159 (i.e., residential, storage, and trash midden contexts) that stylistically, technologically, and functionally can be shown to belong together as part of a single isolable component. Should such well-preserved features and archeological deposits be identified at the two sites, then they would have the potential to contribute important information on the prehistoric Caddo archeology of the northeastern Texas region, and would warrant inclusion in the National Register of Historic Places.

\section{E.4 Field Methods}

\section{Site Description}

Site 41AN159 is located at the edge of a formerly forested upland landform overlooking the Caney Branch Creek valley. Caney Branch Creek is a very small tributary of the Neches River, into which it flows approximately 10 kilometers downstream (northeast) from the site. The project area is between three and four kilometers south of the town of Frankston, in an area of rolling topography and perennial drainages fed by seep springs.

The site extends some distance (30 or more meters) inside the SH155 ROW. The area is covered in moderately dense secondary growth; 
Hicks \& Company archeologists described the site as not having been cleared or plowed in at least 50 years (Figure E-3). The site was interpreted as a possible Caddoan farmstead based on the recovery of a small sample of sherds and lithic debris. Most of the site area is located on sloping terrain, though generally flat and level areas are located at the top of the landform; sediment depths in these flat areas varies considerably from only 10 or so centimeters to over $60 \mathrm{~cm}$. A private drive and residence are located to the south of the site (Figure E-4), and Caney Branch Creek runs immediately to the south of the drive.

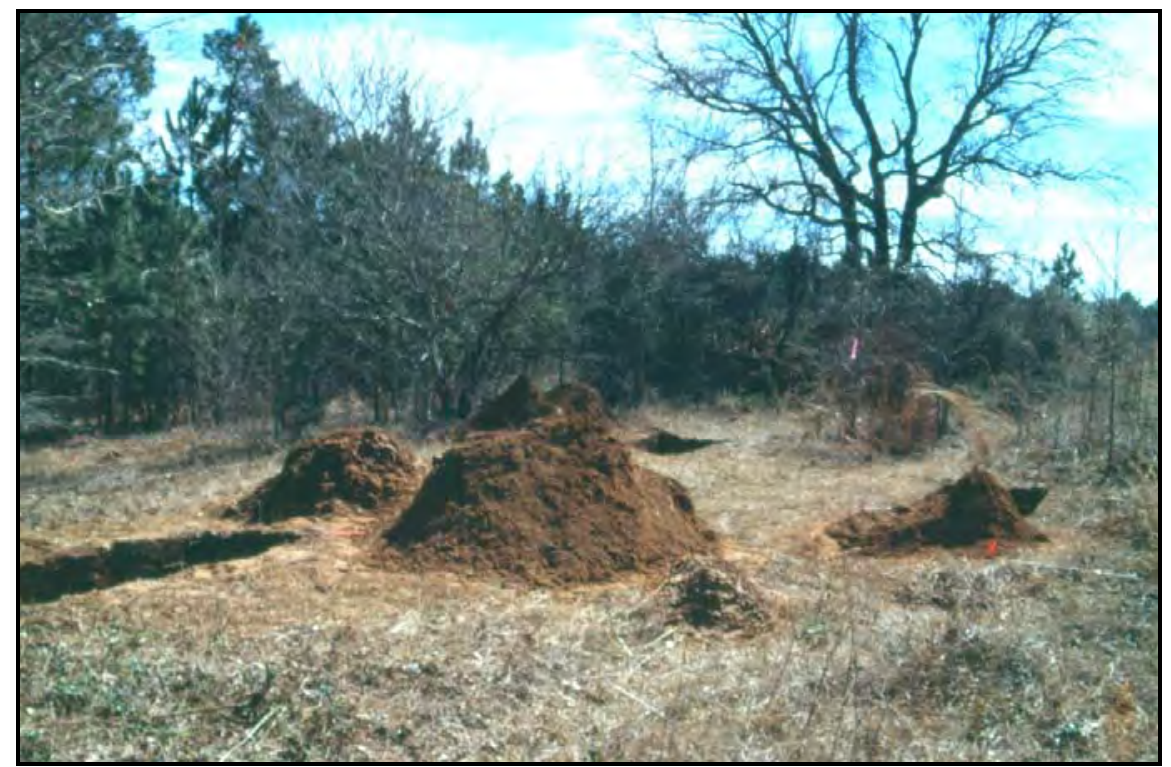

Figure E-3. Overview of 41AN159, Looking Southeast After Excavation of Test Units. Pink ribbon in the tree marks location of one of the Hicks \& Company test units.

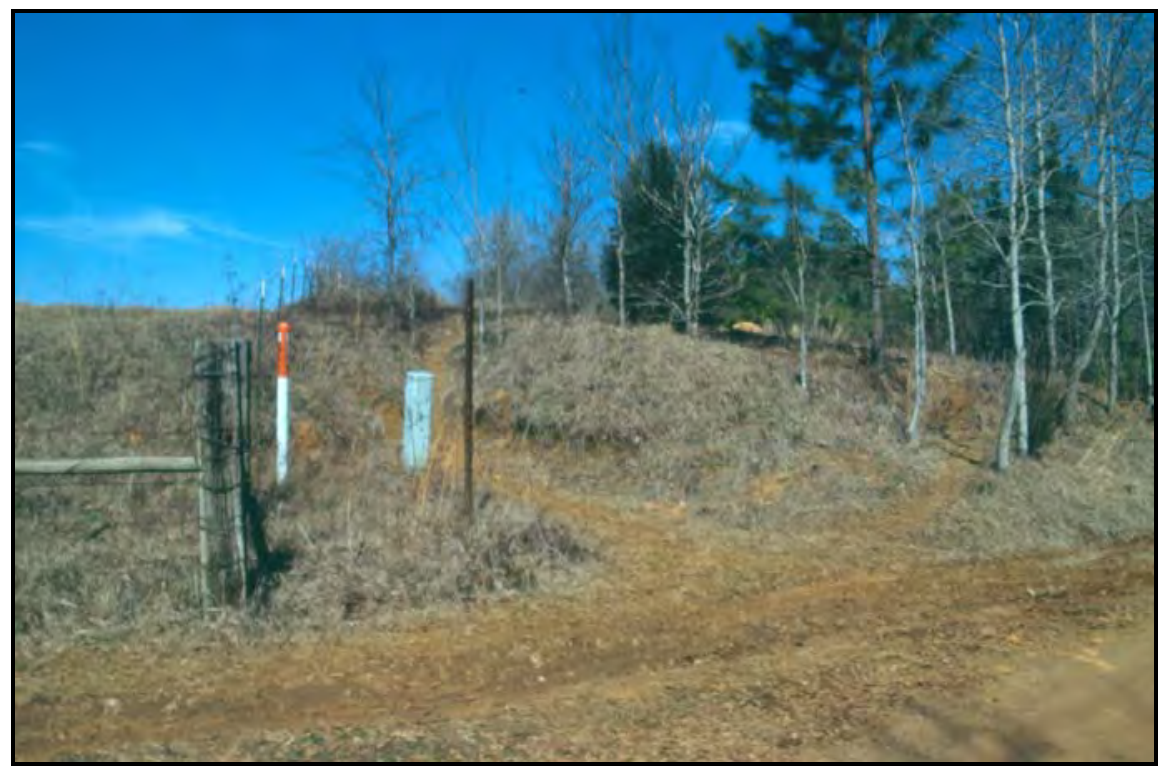

Figure E-4. Southern End of 41AN159, Looking North onto Site across Private Drive. 
Contour plowing, dating to the early 1900s, has heavily impacted sloped areas across the site. The process of contour plowing involves building up linear berms of sediment across slopes to slow or prevent the erosion of topsoil. Soil comes from above and immediately below the berm, involving a substantial amount of sediment dislocation and redeposition. Much of this work was done with either tractors or mule teams drawing plows behind them; depths of impact probably exceeded 40 to 50 centimeters and covered wide horizontal swaths both above and below each berm (Figure E-5).

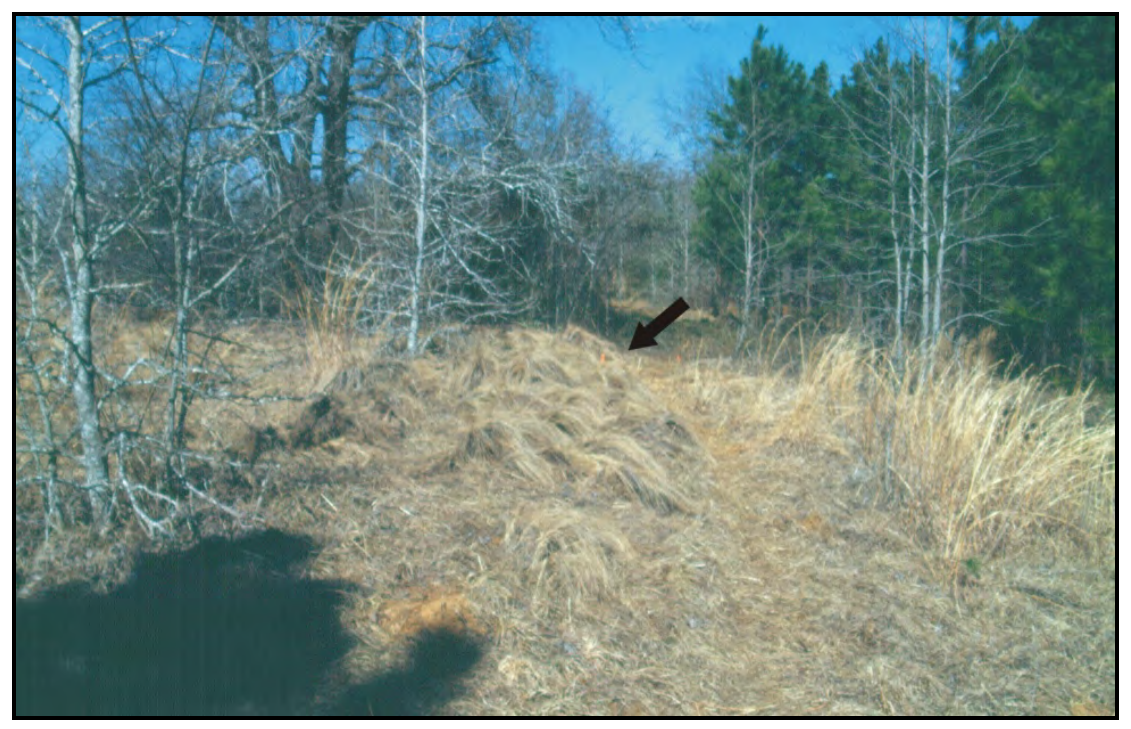

Figure E-5. Contour Terrace at 41AN159 (grass covered berm indicated by arrow), Looking North.

Additional disturbance at the site is from localized erosional drainages; two such features were observed during CEI work (Figure E-6). The same telecom line noted at 41AN38 parallels the fenceline along the western edge of this site as well (visible in Figure E-4). Finally, in some places portions of earthen berms have begun eroding away as a result of continued rainfall and the lack of regular maintenance.

Hicks \& Company archeologists estimated the total site area of 41AN159 within the ROW at approximately 900 square meters, though CEI work recovered artifacts from a somewhat larger area (albeit not in any patterned concentration). In general, it is clear that there has been a considerable amount of sediment displacement and redeposition through a number of processes across the site. Soil depths vary widely from only a few centimeters in upslope areas to well over a meter in downslope settings. Unlike
41AN38, this area appears to have undergone considerable impacts in historic times, both from agricultural landscape modifications and natural erosion.

\section{Methods of Investigation}

The first activity conducted at the site consisted of the preparation of a topographic map onto which all excavation units could be plotted, and that also established control (horizontal and vertical) for documenting artifact recovery and the locations of possible features. An initial baseline was established that paralleled the fence line along the western edge of the site. The fence line was also used as "grid north" for aligning all subsequent hand excavations and overall map orientation; these alignments later were rectified with magnetic north, using a Silva hand-held plate compass. Grid points were established at 1-meter intervals in reference to the site's primary datum point (arbitrarily 
defined as N100E100, elevation 100m). Elevation values were recorded in reference to the site's main datum; these topographic data were entered into a spreadsheet, and then into a computer mapping program (Surfer, version 7.0) capable of rendering the site terrain in a variety of formats, including standard contour maps at nearly any interval as well as wireframe overviews depicting landform geography in three-dimensional views. Unit locations, features, fence lines, terracing and erosional features all are plotted onto contour base maps in a computer drawing program (CorelDraw, version 9.0).

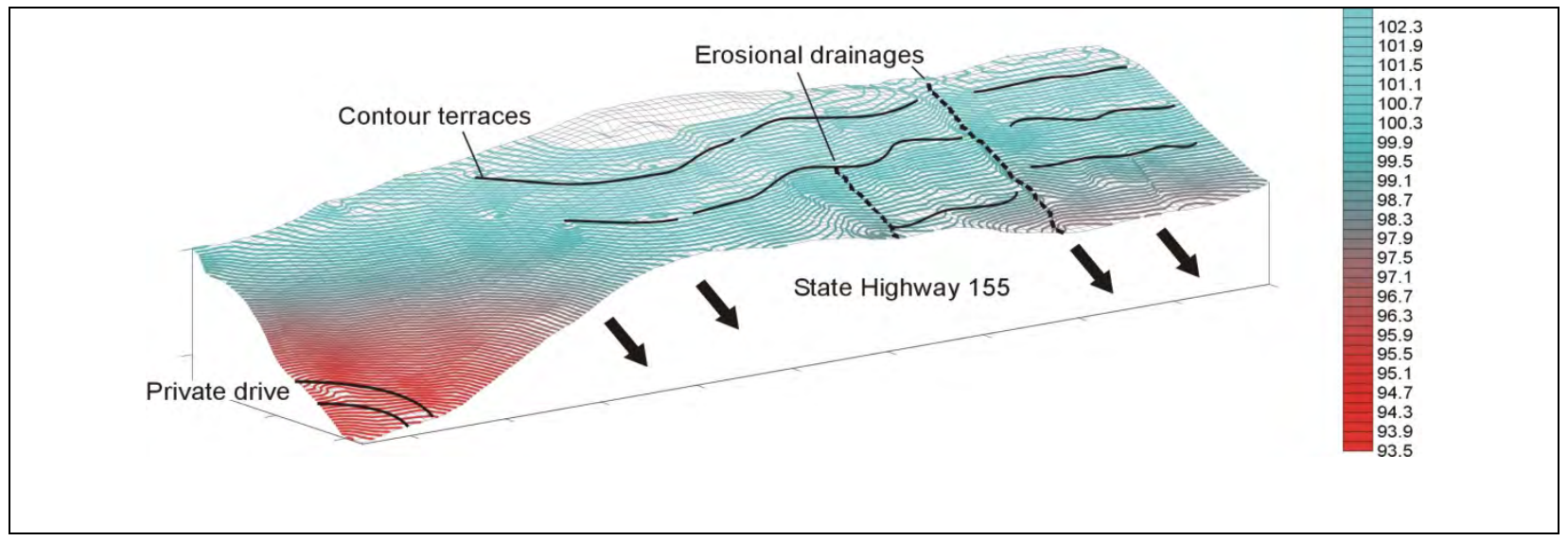

\footnotetext{
Figure E-6. "Wireframe" Overview of 41AN159, Looking to the West/Northwest, Showing Erosional Drainages, Contour Terracing, and the Direction to SH155. Vertical scale is approximately $4 x$ the horizontal scale, total area depicted measures approximately $50 \mathrm{~m} \mathrm{E-W}$ by $190 \mathrm{~m} \mathrm{~N}-\mathrm{S}$.
}

All shovel tests were excavated in 20-cm levels with sediments screened through $1 / 4$ " mesh. Hand-excavated units, consisting of $1-x-2 m$ and $2-x-2 m$ units dug in arbitrary $10-\mathrm{cm}$ vertical levels, were then opened. All sediment from these units was also screened through $1 / 4$ " mesh, with artifacts collected by provenience. A total of 20 square meters (10 1-x-2m units) were hand excavated at 41AN159 spread across the top of the landform (one of the units was placed in a downslope area). Finally, mechanical scraping was conducted in order to remove overburden from large blocks in an effort to expose potential cultural features (post molds, pits, middens, etc.) that would provide detail concerning site structure. A box blade was affixed to a John Deere tractor and pulled across the top of the site in specific areas considered likely for the presence of features. Topsoil was removed to a depth of 20 or so centimeters, the scraped areas closely inspected by hand, and then more soil was scraped. In areas yielding any artifact recovery whatsoever, sediments were shovel skimmed between passes of the tractor so that potential feature outlines were exposed as clearly as possible (Figure E-7). 


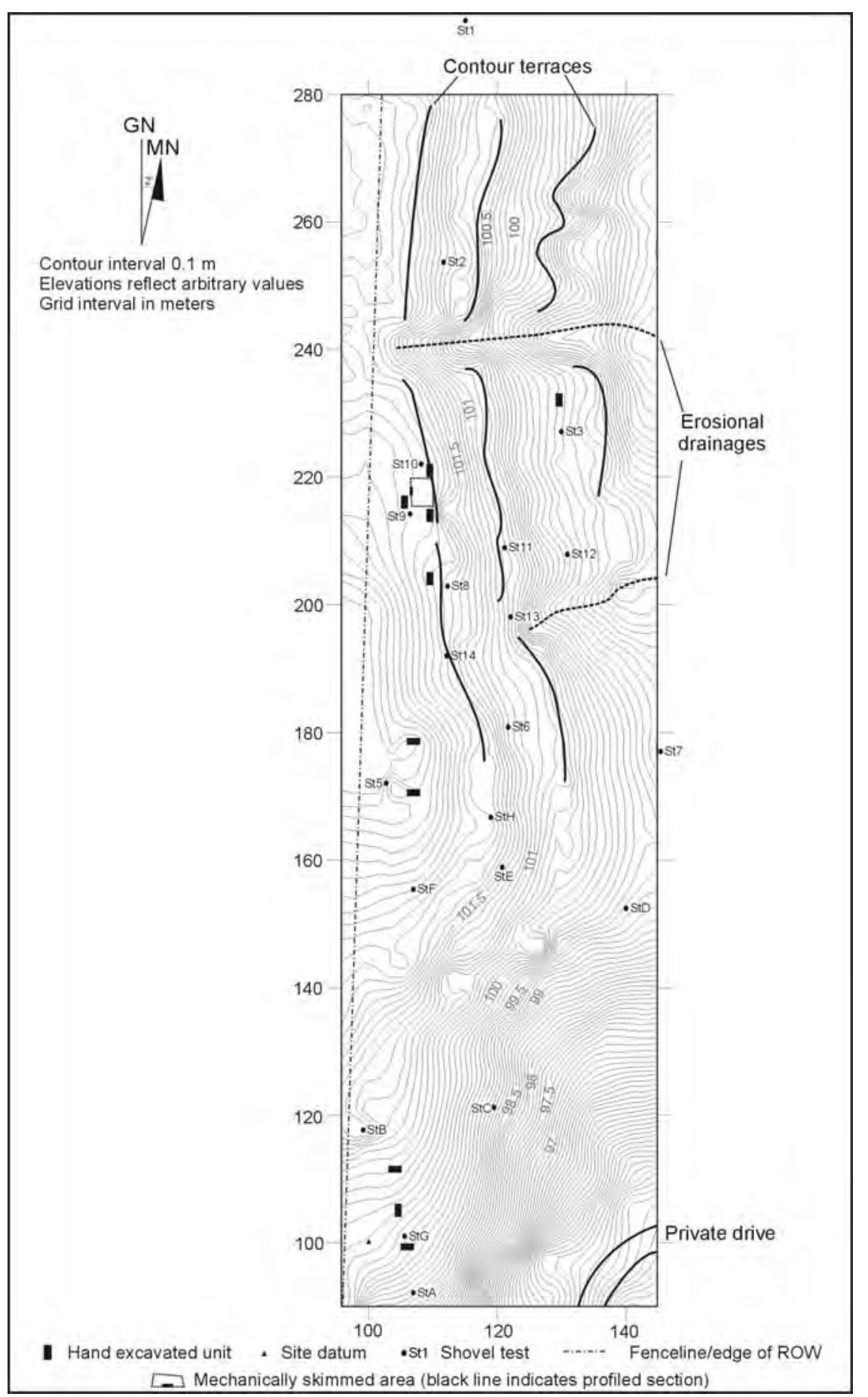

Figure E-7. Topographic Map of 41AN159 with Unit Locations, Fence Line/Edge of ROW, Erosional Features, Contour Terraces, and Private Drive. 


\section{E.5 Excavation Results}

\section{Description of Excavations}

A total of 22 shovel tests were spaced across the 41AN159 site area in an effort to identify concentrations of cultural materials that indicated the presence of intact components or deposits (see Figure E-7). These probes failed to identify any particularly strong or patterned concentrations of artifact material, but rather reflected the diffuse and seemingly disturbed depositional character of the site (Table E-1).

Table E-1. Total Artifact Recovery from Shovel Tests at 41AN159.

\begin{tabular}{|c|c|c|c|}
\hline $\begin{array}{c}\text { Shovel Test } \\
\text { Number }\end{array}$ & Lithics & Ceramics & Other \\
\hline 1 & 0 & 0 & \\
\hline 2 & 2 & 0 & \\
\hline 3 & 0 & 0 & \\
\hline 4 & 1 & 0 & \\
\hline 5 & 5 & 0 & \\
\hline 6 & 1 & 0 & \\
\hline 7 & 3 & 0 & 2 FCR \\
\hline 8 & 4 & 0 & 1 FCR \\
\hline 9 & 7 & 1 & 1 FCR \\
\hline 10 & 3 & 5 & 1 FCR \\
\hline 11 & 6 & 0 & \\
\hline 12 & 0 & 0 & \\
\hline 13 & 1 & 0 & \\
\hline 14 & 0 & 0 & \\
\hline A & 2 & 0 & \\
\hline B & 1 & 0 & \\
\hline C & 1 & 0 & \\
\hline D & 1 & 0 & \\
\hline E & 4 & 0 & \\
\hline F & 0 & 0 & \\
\hline G & 2 & 0 & \\
\hline H & 3 & 0 & \\
\hline
\end{tabular}

Hand excavations, consisting of ten $1-x-2 m$ units, were conducted in areas thought, based on shovel tests results, to have potential for containing intact deposits. Nine units were located in three general areas across the top, flat portion of the site landform; the remaining unit was placed in a downslope setting to test whether colluvial slopewash had buried earlier deposits. Results from the test units indicate a sediment profile across the site that is highly variable. Units ranged in total depth from only $12-15 \mathrm{~cm}$ to over a meter; these varied depths are an accurate reflection of the dramatic impacts from historic agricultural activities and erosion that this site has undergone.

Sediment profile information from all test units showed the site to contain a stratigraphic sequence that was not present in its entirety in all units. The basal stratum was densely compacted sterile clay that probably represented a buried Pleistocene terrace or illuviated $\mathrm{Bt}$ horizon. Lying directly atop this layer was a dark red sandy clay with gravel inclusions. Gravels decreased in frequency upwards through the soil column, suggesting a paleoenvironmental shift from a period of 
erosion following the deposition of the Pleistocene terrace to resumed deposition. The erosional event likely removed early Holocene deposits, causing an unknown amount of time to be unrepresented in the soil profiles. Some units showed a dark staining in the sandy clay some distance (ranging from only a few centimeters to several decimeters) above the sterile clay. We suggest that this dark stratum, where present, corresponded to the period of Caddoan occupation of the area, perhaps reflecting widespread swidden agricultural practices that deposited charcoal and ashy particles across the region, even at sites where habitation did not take place. It is not interpreted as a distinct depositional event. In units where this inferred anthropogenic zone is present, it was separated from the surface by an upper stratum of reddish sandy clay that ranged in thickness depending on the amount of topsoil loss in that immediate vicinity. Important characteristics for overall stratigraphic sequence are gravel size and content; gravels diminished considerably towards the top of the stratigraphic column. A shallow A-horizon overlied the entire site (Figures E-8-E-10).

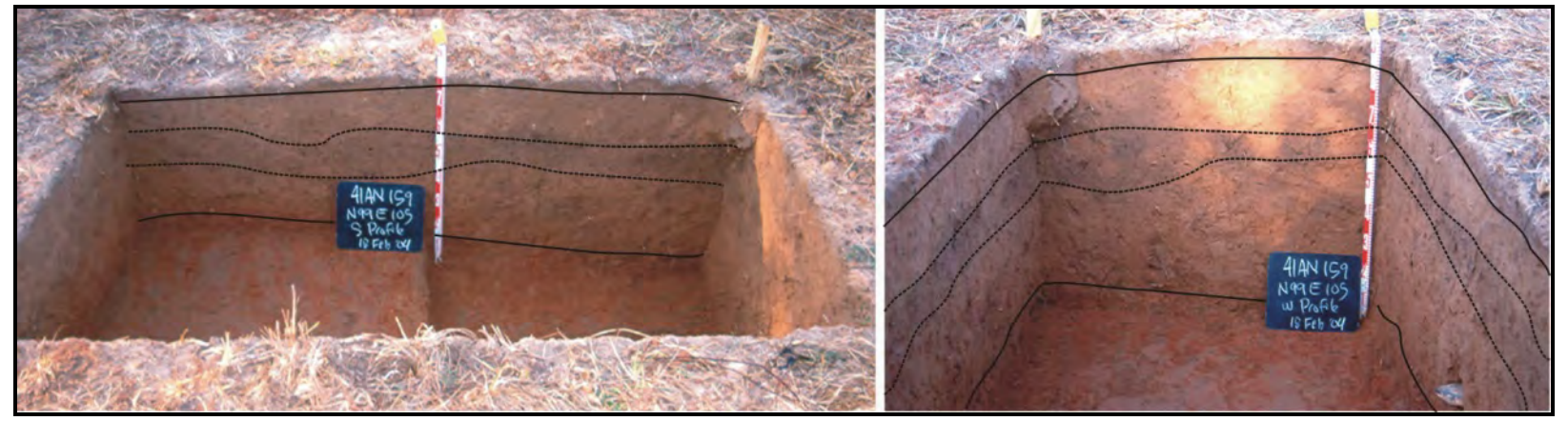

Figure E-8. Profiles of N99E105, South Wall (left) and N99E105, West Wall (Right) Unit Showing Intact, Five-Part Stratigraphy That Characterizes Only Parts of 41AN159. A fire cracked rock is visible in the right sidewall of right frame.

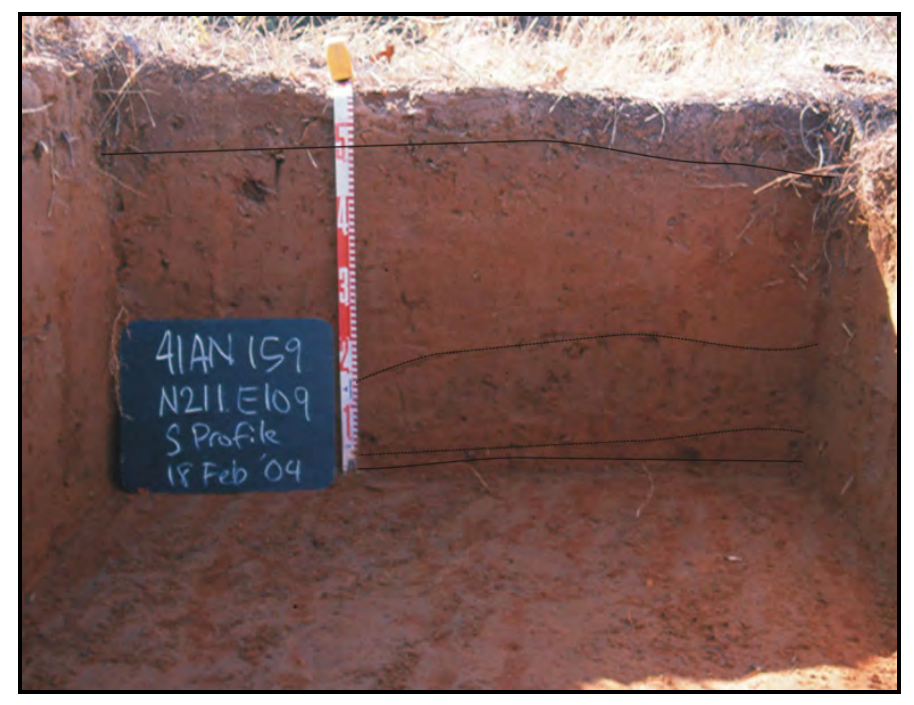

Figure E-9. South Wall Profile of N211E109. Note how close the dark-stained layer is to the basal clay, compared with Figure 8. 


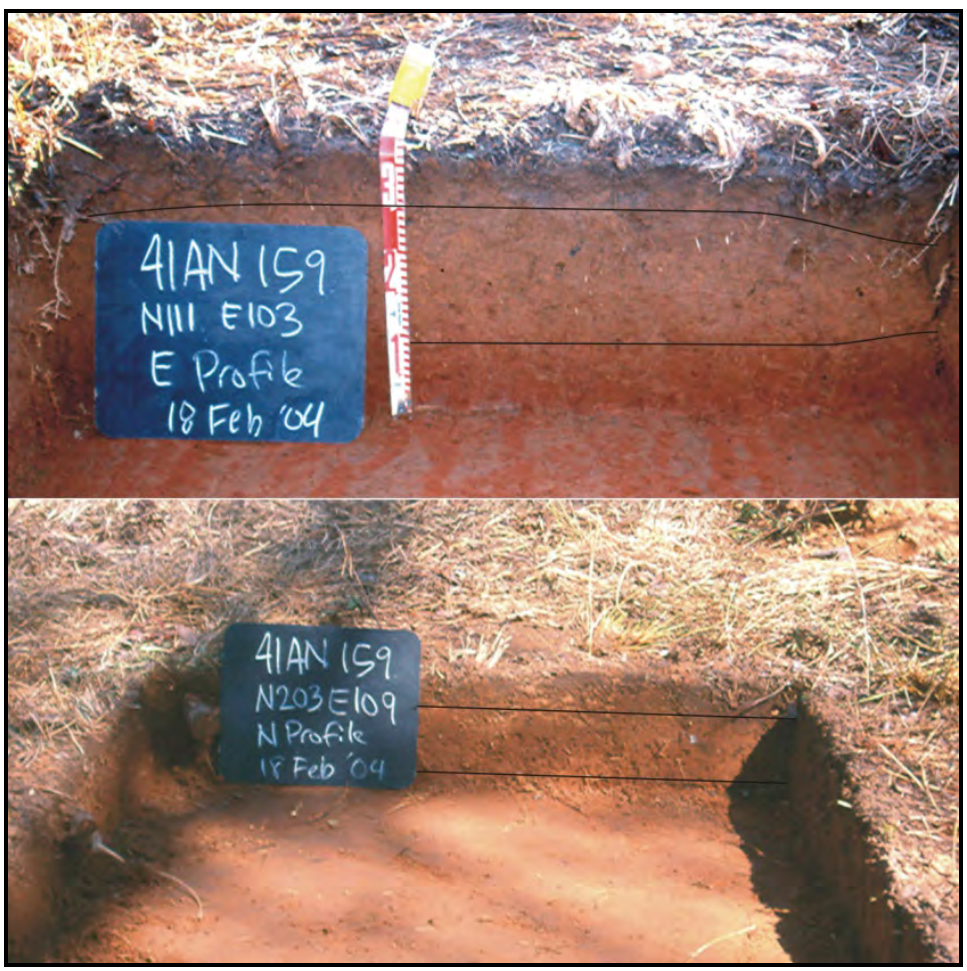

Figure E-10. Profiles of N11E103, East Wall (Top) and N203E109, North Wall (Bottom). Note the absence of the anthropogenic layer, as well as the shallow nature of the deposits.

The southernmost part of the site area was tested by three units (N99E105, N104E104, and N111E103) and was characterized by a steep downward slope in the basal clay toward the south and southeast. The northern of these three units extended only approximately $20 \mathrm{~cm}$ before the basal clay was encountered. In contrast, the southernmost unit, N99E105 was almost $70 \mathrm{~cm}$ deep before it was terminated. Sediments pinched out rather abruptly to the north between the N99 and N111 units. The middle site area was initially probed by Shovel Test 5 , which yielded a total of five pieces of lithic debitage. Two $1 \times 2 m$ units were excavated here (N170E106 and N178E106), though the soil profiles exposed in these units extended only around $30 \mathrm{~cm}$. Two of the Archaic dart points recovered from the site came from these units (see below), although little to no pottery was recovered. Moreover, very few additional artifacts were recovered from these units. The northernmost excavated area was sampled by four 1x2m units (N203E109, N213E109, N215E105, and N220E109), based on the results from Shovel Tests 9 and 10 (see Table E-1). Stratigraphy ranged from approximately $15 \mathrm{~cm}$ deep (see Figure E-10, lower frame) to over $80 \mathrm{~cm}$, including the anthropogenically stained layer. In spite of the potential for ordered deposits to be present, artifact recovery was minimal and is considered indicative of only sparse and infrequent site visitation rather than one or more periods of sustained or intensive occupation.

Unit N231E129 was placed somewhat off the top of the landform, in a downslope area thought to have the potential for containing undisturbed sediments. Controlled excavations continued over a meter, and were even extended to almost two meters in a small probe to define what was thought to be an intrusive feature but which turned out to be the mold of a tap root for a pine tree (Figure E-11). No stratified or isolable components were exposed in this unit. 


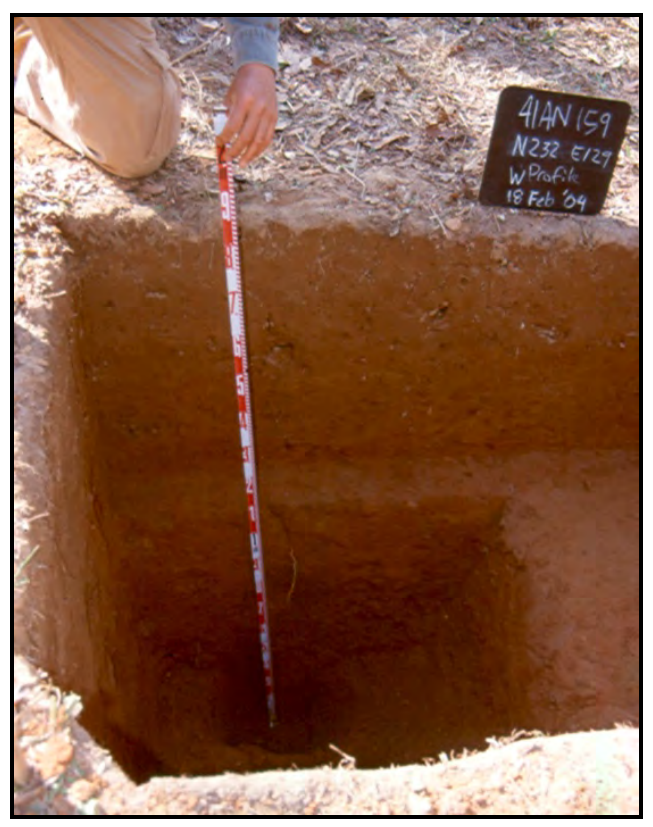

Figure E-11. West Wall Profile of N231E129. Hand held scale is at $1.9 \mathrm{~m}$ from the bottom of excavations.

The last component of excavations at the site included the mechanical scraping of a small area at the north end of the site (see Figure E-7). This work exposed no cultural features (thus, none were documented at the site).

\section{E.6 Artifacts}

\section{Total Artifacts}

Recoveries of lithic debitage, ceramics, and fire cracked rock (FCR) by both count and weight are presented by unit-level in Table E-2. These data reveal the spotty distribution of cultural remains across the site, and indicate that northernmost area, sampled by units N203E109, N213E109, N215E105, and N220E109 held the greatest potential for intact and informationally meaningful deposits.

\section{Projectile Points}

Six projectile points and point fragments were recovered from 41AN159 (Figure E-12, Table E-3); two of these are untypeable distal fragments and a third is an untyped rounded blade with a very short, heavily reworked stem. 


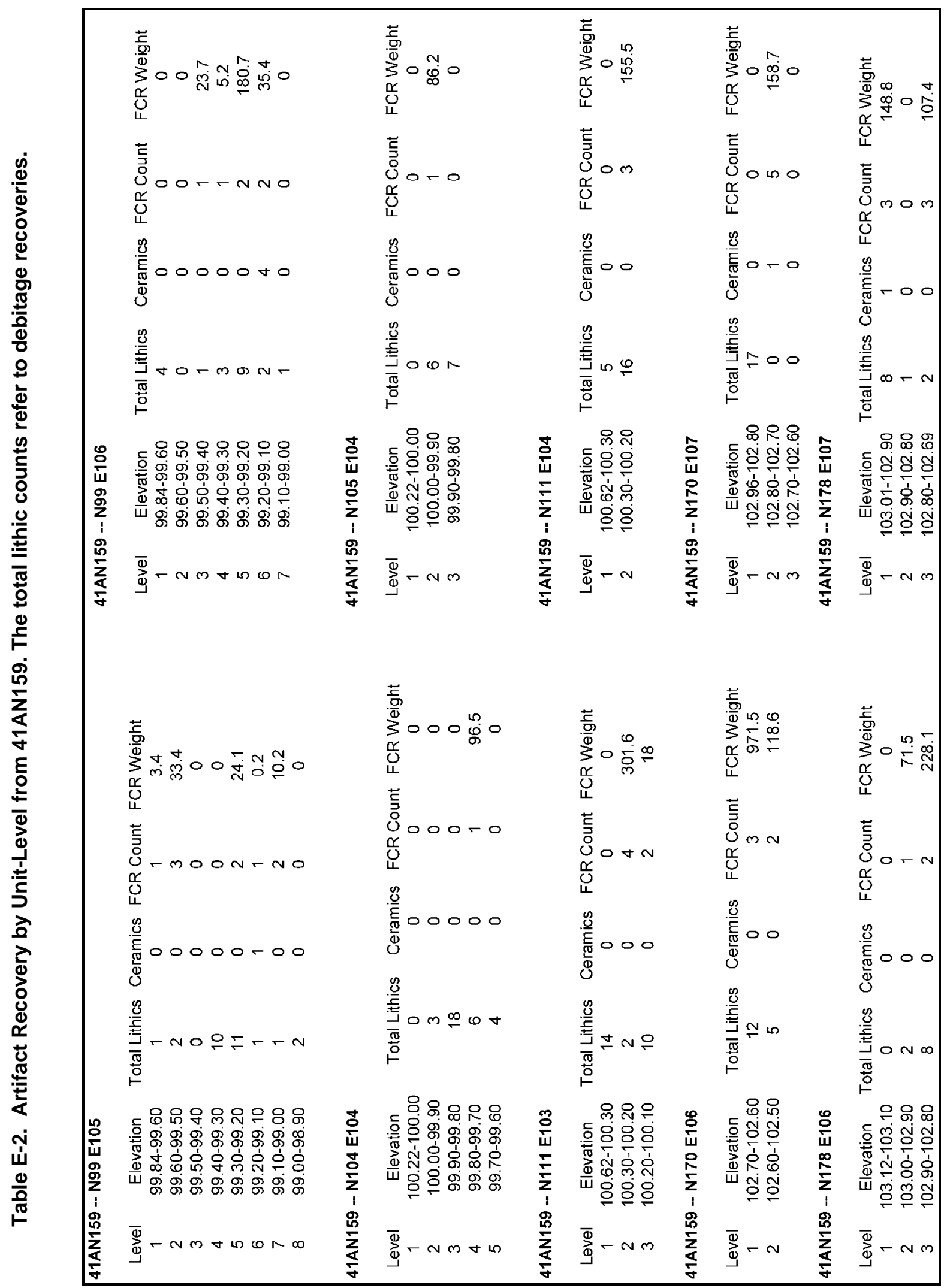




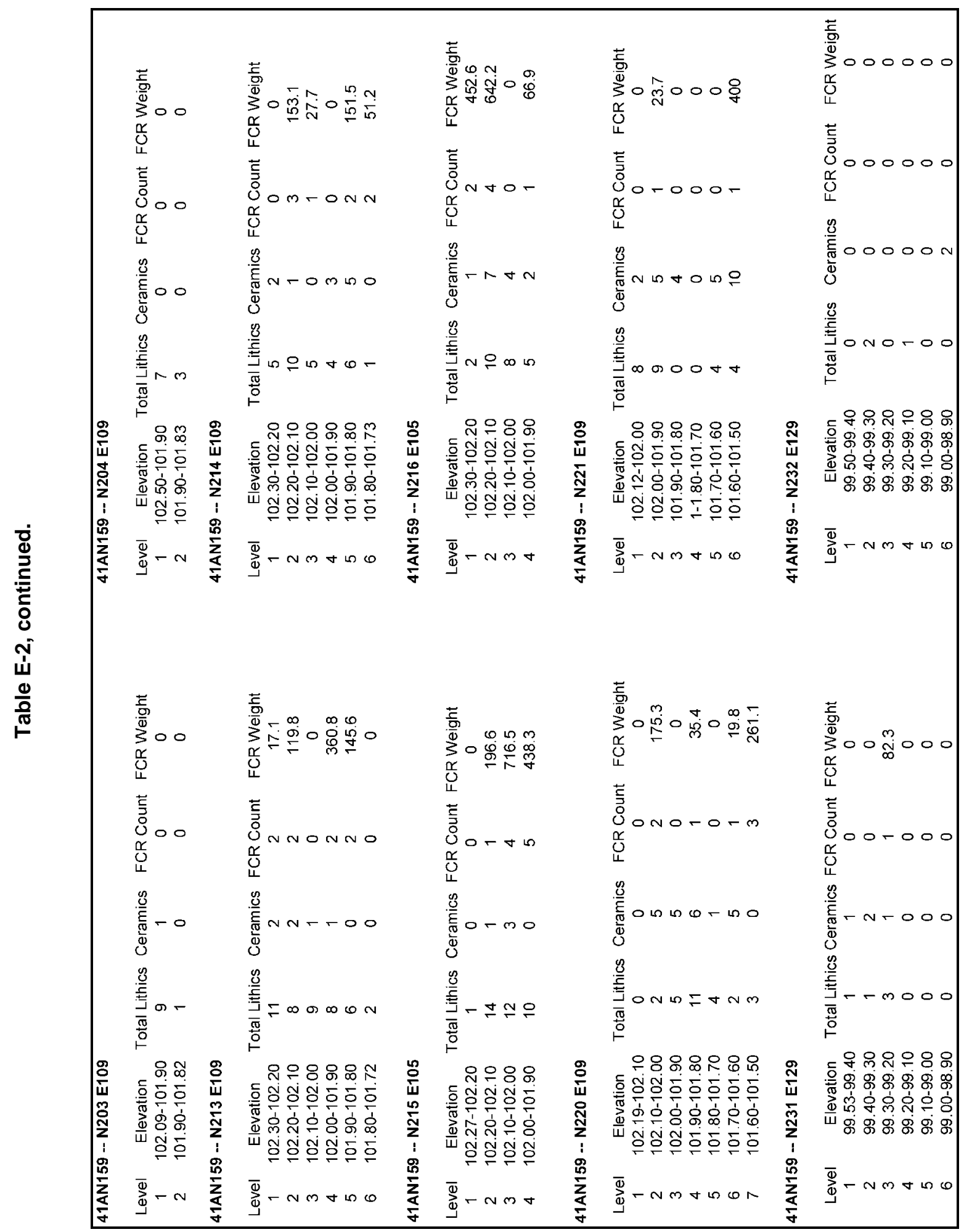


Three types identified include Yarbrough and Trinity dart points, dating from the Middle to Late Archaic (Suhm and Jelks 1962; Turner and Hester 1999), and Catahoula, an arrow point type occurring later in time, generally from A.D.
700 onward. Two of these specimens (Lots 62 and 66) were made from petrified wood. Together, the diagnostic artifacts indicate dispersed periods of site occupation ranging from Middle Archaic times onward.

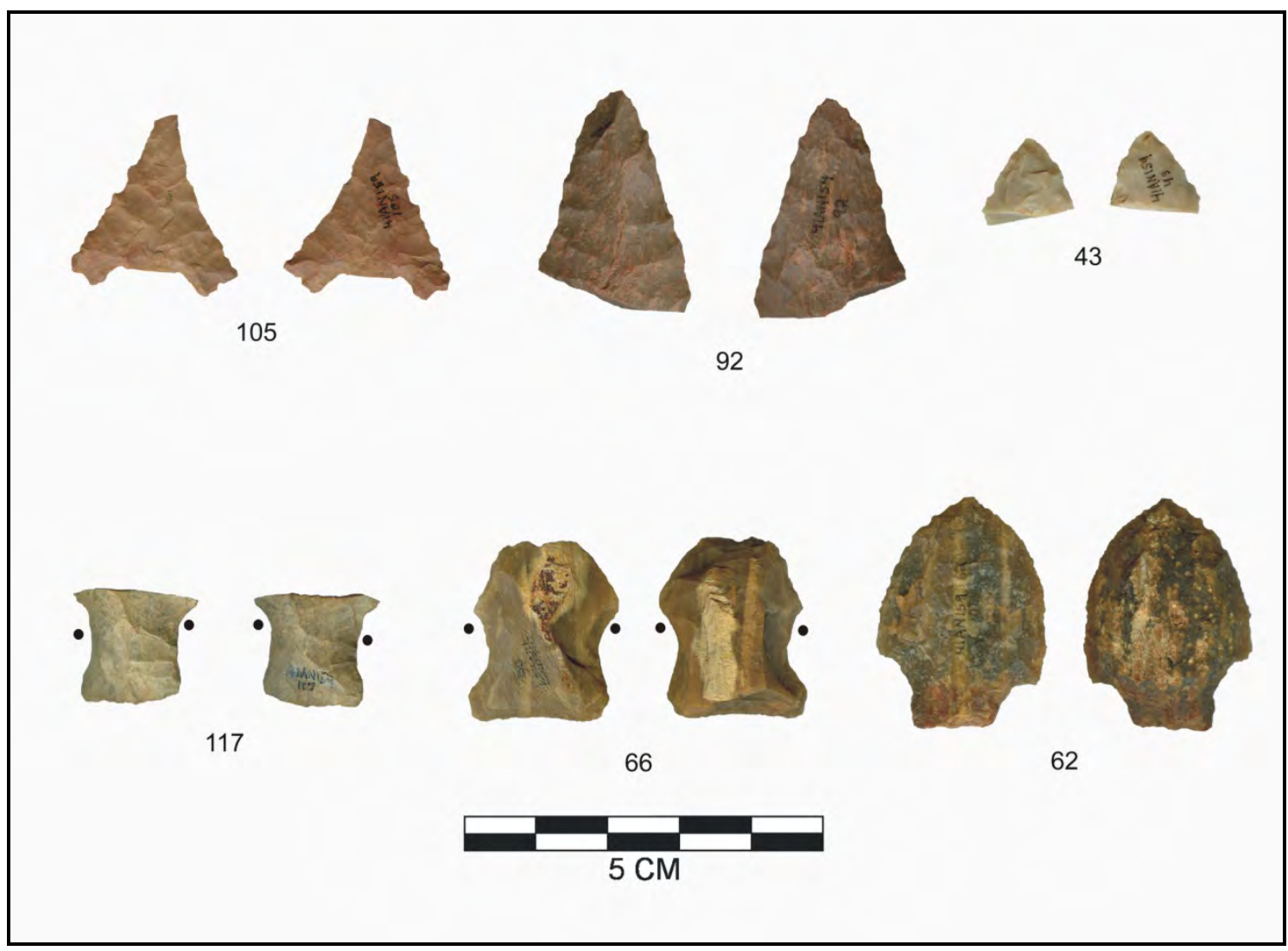

Figure E-12. Projectile Points and Fragments, By Lot Number, Recovered from 41AN159. Black Dots Indicate Edge Grinding.

Table E-3. Projectile Points and Point Fragments from 41AN159.

\begin{tabular}{|c|c|c|c|}
\hline Lot Number & Type & Provenience & Specimen \\
\hline 43 & Unknown & N99E106, Lv. 2 & Distal tip \\
\hline 62 & Unknown & N170E106, Lv. 1 & Blade, stem reworked \\
\hline 66 & Trinity & N170E107, Lv. 3 & Complete, reworked \\
\hline 92 & Unknown & N215E105, Lv. 4 & Distal tip \\
\hline 105 & Catahoula & N221E109, Lv. 3 & Complete except for stem \\
\hline 117 & Yarbrough & N104E104, Lv. 2 & Base \\
\hline
\end{tabular}




\section{Lithic Tools}

Eight non-diagnostic chipped stone tools were recovered from 41AN159 (Table E-4, Figure E13). These include utilized flakes and blades $(n=5)$, a biface fragment (not shown), and a gouge made of petrified wood. This tool is interpreted as a gouge on the basis of its convex bit.

\section{E.7 Ceramics from 41AN159}

By Timothy K. Perttula

There are 101 sherds from the archeological investigations at 41AN159, including 23 decorated rim and body sherds and 78 plain sherds. The distribution of sherds is provided in Table E-5.

Table E-4. Chipped Stone Tools from 41AN159.

\begin{tabular}{|c|c|c|}
\hline Lot Number & Tool Type & Provenience \\
\hline 15 & Retouched/utilized flake & Shovel Test G \\
\hline 28 & Biface frgament & Shovel Test 9, Lv. 2 \\
\hline 41 & Retouched flake, scraper & N99E105, Lv. 7 \\
\hline 70 & Utilized blade fragment & N178E107, Lv. 1 \\
\hline 87 & Utilized blade & N214E109, Lv. 5 \\
\hline 89 & Utilized thinning flake & N216E105, Lv. 2 \\
\hline 94 & Gouge & N220E109, Lv. 2 \\
\hline 97 & Utilized flake & \\
\hline
\end{tabular}

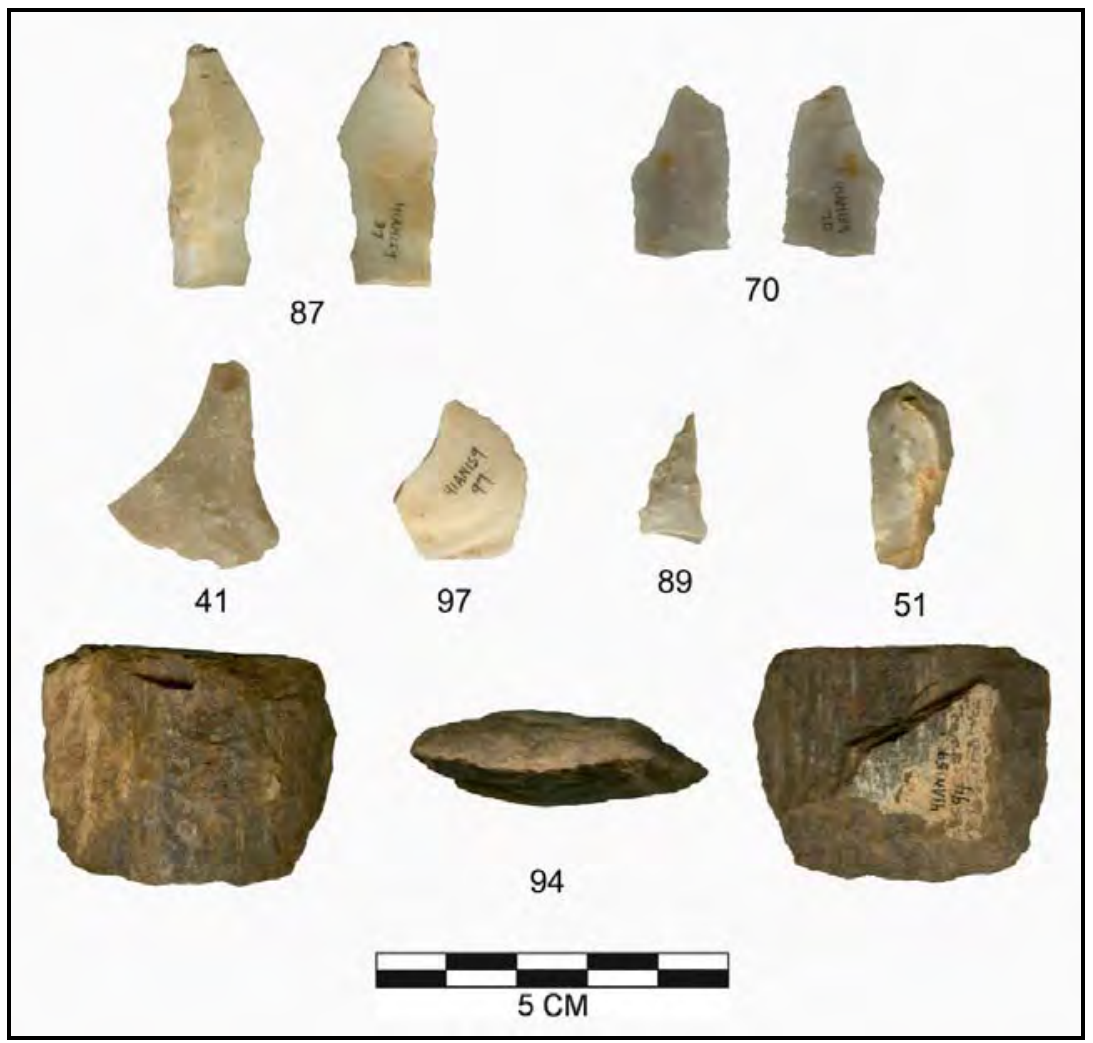

Figure E-13. Non-Diagnostic Chipped Stone Tools Recovered from 41AN159. 
Table E-5. Distribution of Sherds at 41AN159.

\begin{tabular}{|c|c|c|c|c|c|}
\hline Lot No. & Unit/Area & Level & $\begin{array}{c}\text { Number of } \\
\text { Decorated Sherds } \\
\end{array}$ & $\begin{array}{c}\text { Number of } \\
\text { Plain Sherds } \\
\end{array}$ & Total \\
\hline Lot 27 & Shovel Test 9 & 1 & & 1 & 1 \\
\hline Lot 29 & Shovel Test 10 & 1 & & 2 & 2 \\
\hline Lot 30 & Shovel Test 10 & 2 & & 2 & 2 \\
\hline Lot 31 & Shovel Test 10 & 3 & & 1 & 1 \\
\hline Lot 40 & N99 E105 & 6 & & 1 & 1 \\
\hline Lot 47 & N99 E106 & 6 & & 3 & 3 \\
\hline Lot 64B & N170 E107 & 2 & & 1 & 1 \\
\hline Lot 67 & N170 E108 & 1 & & 1 & 1 \\
\hline Lot 70 & N170 E107 & 1 & & 1 & 1 \\
\hline Lot 73 & N203 E109 & 1 & 1 & & 1 \\
\hline Lot 77 & N213 E109 & 1 & & 2 & 2 \\
\hline Lot 78 & N213 E109 & 2 & 1 & 1 & 2 \\
\hline Lot 79 & N213 E109 & 3 & & 1 & 1 \\
\hline Lot 80 & N213 E109 & 4 & & 1 & 1 \\
\hline Lot 83 & N214 E109 & 1 & & 2 & 2 \\
\hline Lot 84 & N214 E109 & 2 & & 1 & 1 \\
\hline Lot 86 & N214 E109 & 4 & & 3 & 3 \\
\hline Lot 87 & N214 E109 & 5 & & 3 & 3 \\
\hline Lot 90 & N215 E105 & 2 & & 1 & 1 \\
\hline Lot 91 & N215 E105 & 3 & 1 & 2 & 3 \\
\hline Lot 93 & N216 E105 & 1 & & 1 & 1 \\
\hline Lot 94 & N216 E105 & 2 & 3 & 4 & 7 \\
\hline Lot 95 & N216 E105 & 3 & 1 & 3 & 4 \\
\hline Lot 96 & N216 E105 & 4 & 1 & 1 & 2 \\
\hline Lot 97 & N220 E109 & 2 & & 5 & 5 \\
\hline Lot 98 & N220 E109 & 3 & 2 & 3 & 5 \\
\hline Lot 99 & N220 E109 & 4 & 3 & $3^{*}$ & 6 \\
\hline Lot 100 & N220 E109 & 5 & & 1 & 1 \\
\hline Lot 101 & N220 E109 & 6 & 1 & 4 & 5 \\
\hline Lot 103 & N221 E109 & 1 & & 2 & 2 \\
\hline Lot 104 & N221 E109 & 2 & & 5 & 5 \\
\hline Lot 105 & N221 E109 & 3 & 1 & 3 & 4 \\
\hline Lot 106 & N221 E109 & 5 & & 5 & 5 \\
\hline Lot 107 & N221 E109 & 6 & 3 & 7 & 10 \\
\hline Lot 108 & N231 E129 & 1 & 1 & & 1 \\
\hline Lot 109 & N231 E129 & 2 & 2 & & 2 \\
\hline Lot 110 & N231 E129 & 3 & & 1 & 1 \\
\hline Lot 116 & N232 E129 & 6 & 2 & & 2 \\
\hline Total & & & 23 & 78 & 101 \\
\hline
\end{tabular}

The plain/decorated sherd ratio (P/DR) for the 41AN159 ceramic assemblage is 3.39. The principal decorative methods represented are incised ( $n=10)$, engraved $(n=5)$, punctated $(n=4)$, and brushed $(n=3)$, with one brushed-incised sherd. The relatively low frequency of brushed sherds (13.0\%), along with the P/DR value of 3.39 suggests that the prehistoric Caddo occupation at 41AN159 dates some time prior to
A.D. 1400 based upon comparisons with nearby Lake Palestine Caddo sites as well as the Broadway site (41SM273) on West Mud Creek (Perttula and Nelson 2004). In the absence of radiocarbon dates, and with only a few Lake Palestine Caddo sites for comparison, I suggest that the Caddo occupation took place perhaps between ca. A.D. 1200-1300. Almost 14\% of the plain and decorated sherds at 41AN159 are 
bone-tempered, which is consistent with a higher use of bone tempering in earlier Caddo ceramic vessels, and provides further support for the speculative chronological placement of the site.

The site is placed in Group IV of the Lake Palestine Caddo ceramic assemblages (Table E6). These sites have fairly low frequencies of brushed sherds (9.7-18.5\%), many sherds with wet paste decorations (i.e., incised, punctated, pinched, appliqued), and a relatively high P/DR; in the case of the latter, that means that more of the surfaces of the vessels made when the Group IV sites were occupied were left undecorated than was the case in later Group I-III Caddo assemblages, where vessels tended to have decorations more often on the rim as well as the body surface

Table E-6. Comparative Sherd Assemblage Data from Lake Palestine Caddo Sites.

\begin{tabular}{|c|c|c|c|c|c|c|}
\hline Site & $\begin{array}{l}\text { No. of Dec. } \\
\text { Sherds }\end{array}$ & \%Brushed & $\begin{array}{l}\text { \%bone- } \\
\text { temper }\end{array}$ & $\begin{array}{l}\text { \%Wet-paste } \\
\text { decorations }\end{array}$ & $\mathrm{P} / \mathrm{DR}$ & $\begin{array}{l}\text { Brushed :Wet } \\
\text { paste ratio }\end{array}$ \\
\hline
\end{tabular}

\begin{tabular}{lllllll}
\hline GROUP I & & & & & & \\
Debro & 311 & 80.0 & $?$ & 10.3 & 0.14 & 7.75 \\
A. C. Saunders & 5805 & 74.5 & 15.5 & 14.1 & 0.21 & 5.30 \\
William Sherman & 525 & 75.8 & $?$ & 16.2 & 0.44 & 4.68 \\
41HE14 & 12 & 83.3 & 0.0 & 16.7 & 0.73 & 5.00
\end{tabular}

\section{GROUP II}

Halbert

Woldert $\quad 1730$

Ferguson $\quad 4116$

\section{GROUP III}

Tomato Patch

41AN38

912

Mitchell, De
49.2

47.1

32.1

\section{GROUP IV}

White Mule

41HE139

41AN159

41SM273, Z3

\section{GROUP V}

Mitchell, A-C

\section{4}

40

23

155
17.5

13.0

10.9

9.7

68.6
65.8
62.7
60.8

2.6

0.0

$<1.0$

\section{9}

26.3

28.8

27.9

$\begin{array}{ll}? & 41.7 \\ 6.7 & 39.5 \\ 0.0 & 33.3\end{array}$

1.5

63.7
$8.1 \quad 65.0$

$13.9 \quad 65.2$

$28.8 \quad 70.0$

$32.3 \quad 73.5$
$0.56 \quad 3.12$

$0.70 \quad 2.51$

$0.72 \quad 2.19$

$0.61 \quad 2.17$
As Perttula and Ricklis (2003) pointed out, Group I-III Caddo sites at Lake Palestine date after ca. A.D. 1400, and appear to be Late Caddo Frankston phase sites.

The 10 incised sherds are from utility ware vessels, and they include the following decorative elements: parallel sets of straight lines $(n=3)$; a rim with horizontal and crosshatched lines ( $n=1$, probably a variety of Dunkin Incised); cross-hatched $(n=1)$; and sets of diagonal lines $(n=1)$, apparently on the vessel body. The other four incised sherds are body sherds with a single straight line of indeterminate orientation. 
There are fingernail ( $n=2)$, tool $(n=1)$, and cane punctated $(n=1)$ rim and body sherds from utility ware vessels. The punctations are in rows, either on the rim or on the rim and vessel body. The few brushed sherds are from cooking jars have parallel brushing marks on the vessel body; the brushed-incised sherd has overlapping incised and brushing marks.

The fine ware sherds from 41AN159 include five engraved sherds. Two from bowls or carinated bowls simply have a single straight line of uncertain orientation, another has a set of parallel lines, and a fourth has a set of vertical engraved lines that may be part of a panel. The last engraved sherd is from a bottle with a set of widely spaced curvilinear engraved lines. Although the sample of engraved sherds is small, none of the decorative elements present resemble motifs and elements seen on Late Caddo Poynor Engraved vessels (Kleinschmidt 1982: Figure 19).

\section{E.8 Definition of Site Components}

As no features were recorded at the site, defining components relies solely on patterns of artifact recovery correlated with soil profiles and temporally diagnostic artifacts. Recovery rates of debitage and FCR in the south area of the site suggest that a thin component is, or was, present ranging from approximately $99.40 \mathrm{~m}$ elevation in N99E105 upwards towards to approximately 100.30 in unit N111E103. The Yarbrough point from Level 2 in N104E104 suggests that this thin component dates to sometime around the Middle to Late Archaic, though ceramics underlie this cultural zone in N99E106. It appears that the stratigraphy and site components in this vicinity are somewhat mixed and perhaps redeposited.

Sediments in the central site area, tested by units N170E106 and N178E106, have been described as thin and deflated. Two Archaic dart points, a Trinity point and one untyped point were recovered from N170E107, from Levels 1 and 3, indicating that there might have been a moderately intensive Archaic period occupation here at one time. However, debitage recovery is minimal and the soil profiles reflect the loss of unknown amounts of topsoil, leaving what deposits remain in an insecure geomorphological context.

The northernmost area of the site, sampled in units N203E109, N213E109, N215E105, and N220E109, shows the most robust artifact recovery from all excavations at 41AN159. However, debitage counts from these units do not reveal cleanly or consistently stratified deposits. The Catahoula point, associated with ceramics and perhaps with Caddo occupation, was recovered from Level 3 of N221E109, although ceramics were also recovered from the bottom of this unit at $101.50 \mathrm{~m}$ elevation. While this sequence is not necessarily out of order, it cannot be directly compared in any sense with the sequences indicated in other parts of the site. Moreover, frequencies of artifact recoveries from these four units appear to show some vertical movement of component materials.

In general, Caddo presence at the site is represented in the ceramic inventory though it is not well defined in the lithic assemblage, which instead more strongly reflects the Archaic period. However, the lack of features or consistent and stratigraphically ordered deposits in any unit are clear indications of severe site disturbance through a number of processes, including deflation, soil redeposition by historic agriculture, and natural erosion. These conclusions are supported by the mapping data and presence of numerous contour terraces across the sloped areas of the site landform. What components are or were present at one time now appear to be severely mixed, conflated, and without stratigraphic integrity.

\section{E.9 Conclusions and Recommendations}

By Robert A. Ricklis and Timothy K. Perttula

As Lohse has discussed above, the testing at 41AN159 revealed evidence of occupation during the Middle-Late Archaic and during some part of the prehistoric Caddo occupation in northeastern Texas. Perttula's analysis of Caddo 
ceramics from the site suggests occupation relatively early in the regional Caddo sequence. However, the subsurface investigations at this site showed the deposits to be significantly disturbed, probably in large part by historic land modification associated with contour terracing that was presumably associated with agricultural activity. Although test units were placed across the site, there was no definable continuity in stratigraphy, and temporally diagnostic materials (such as pottery sherds) were vertically dispersed, suggesting considerable disturbance of the site deposit. Adding to this the relatively low density of artifacts at the site and the absence of any definable subsurface cultural features, it seems clear that stratigraphically isolable components cannot be defined at 41AN159. Given this, the site has little potential to elucidate either cultural chronology or to provide information on synchronic community plan or intra-site activity patterns. Thus, the site holds little potential for meaningful data recovery and is not considered to be eligible for inclusion in the National Register of Historic Places or to merit designation as a State Archeological Landmark. No further archaeological work is recommended at 41AN159. 


\section{References Cited}

Anderson, K. M., K. Gilmore, O. F. McCormick, and E. P. Morenon

1974 Archaeological Investigations at Lake Palestine, Texas. Contributions in Anthropology No. 11. Department of Anthropology, Southern Methodist University, Dallas.

Campbell, T. N.

1934 A Study of Ornamentation in the Pottery of Prehistoric East Texas, with special attention given to designs. Master's thesis, Department of Anthropology, The University of Texas at Austin.

Cliff, M. B., E. C. Sills, T. K. Perttula, and P. Dering

2004 National Register Testing of Sites 41HE14, 41HE139, and 41HE343 within proposed FM 3506 Right of Way, Henderson County, Texas. Archeological Studies Program, Report No. 60. Texas Department of Transportation, Austin.

Fields, R. C.

1995 Analysis of Native-Made Ceramics. In The Deshazo Site, Nacogdoches County, Texas, Volume 2: Artifacts of Native Manufacture, edited by D. A. Story, pp. 173-232. Studies in Archeology 21. Texas Archeological Research Laboratory, The University of Texas at Austin.

Fenneman, N. M.

1936 Physiography of the Eastern United States. McGraw-Hill Book Company, Inc., New York.

Jackson, A. T.

1935 Indian Pipes of East Texas. Bulletin of the Texas Archeological and Paleontological Society 5:47-78.
Kelley, David B.

1997 Introduction. In Two Caddoan Farmsteads in the Red River Valley, edited by David B. Kelley, pp. 1-23. Arkansas Archeological Survey Research Series No. 51, Fayetteville.

Kleinschmidt, U. K. W.

1982 Review and Analysis of the A. C. Saunders Site, 41AN19, Anderson County, Texas. Master's thesis, Department of Anthropology, The University of Texas at Austin.

Perttula, Timothy K.

1995 The Archeology of the Pineywoods and Post Oak Savanna of Northeast Texas. Bulletin of the Texas Archeological Society 66:331-359.

Perttula, T. K.

2000 Functional and Stylistic Analyses of Ceramic Vessels from Mortuary Features at a $15^{\text {th }}$ and $16^{\text {th }}$ Century Caddo Sites in Northeast Texas. Midcontinental Journal of Archaeology 25(1):101-152

Perttula, Timothy K., and Robert A. Ricklis

2003 Research Design and Scope of Work for Test Excavations at $41 \mathrm{AN} 38$ and 41AN159, Anderson County, Texas. Proposal submitted to the Texas Department of Transportation, Austin.

Perttula, T. K. and B. Nelson

2004 Woodland and Caddo Archeology at the Broadway or Kanduts'ah Kuhnihdahahdisa' Site (41SM273) on the City of Tyler-Lake Palestine WTP Project, Smith County, Texas. Report of Investigations No. 50. Archeological and Environmental Consultants, LLC, Austin. 
Rogers, R. and T. K. Perttula

2004 The Oak Hill Village Site (41RK214), Rusk County, Texas. Document No. 030083. PBS\&J, Austin.

Shafer, H. J.

1981 Archeological Investigations at the Attaway Site, Henderson County, Texas. Bulletin of the Texas Archeological Society 52:147-178.

Story, Dee Ann

1990a Culture History of the Native Americans. In The Archeology and Bioarcheology of the Gulf Coastal Plain: Volume 1, by D. A. Story, J. A. Guy, G. A. Burnett, M. D. Freeman, J. C. Rose, D. G. Steele, B. W. Olive, and K. J. Reinhard, pp. 163-366. Arkansas Archaeological Survey Research Series No. 38, Fayetteville.

1990b Environmental Setting. In The Archeology and Bioarcheology of the Gulf Coastal Plain: Volume 1, by D. A. Story, J. A. Guy, G. A. Burnett, M. D. Freeman, J. C. Rose, D. G. Steele, B. W. Olive, and K. J. Reinhard, pp. 5-26. Arkansas Archaeological Survey Research Series No. 38, Fayetteville.

Story, D. A. and D. G. Creel

1981 Cultural Setting. In The Deshazo Site, Nacogdoches County, Texas, Volume 1, edited by D. A. Story, pp. 20-34. Texas Antiquities Permit Series No. 7. Texas Antiquities Committee, Austin.
Story, Dee Ann, Janice A. Guy, Barbara A. Burnett, Martha Doty Freeman, Jerome C. Rose, D. Gentry Steele, Ben W. Olive, and Karl J. Reinhard

1990 The Archeology and Bioarcheology of the Gulf Coastal Plain: Volume 1. Arkansas Archaeological Survey Research Series No. 38, Fayetteville.

Suhm, D. A., and E. B. Jelks, editors

1962 Handbook of Texas Archeology: Type Descriptions. Joint Publication of the Texas Archeological Society (Special Publication no. 1) and the Texas Memorial Museum (Bulletin no. 4), Austin.

Thurmond, J. P.

1981 Archeology of the Cypress Creek Drainage Basin, Northeastern Texas and Northwestern Louisiana. Unpublished Master's thesis, Department of Anthropology, The University of Texas at Austin.

Turner, Ellen Sue, and Thomas R. Hester

1999 A Field Guide to Stone Artifacts of Texas Indians. New edition. Gulf Publishing Company, Houston.

Walters, M., P. Haskins, D. H. Jurney, S. E. Goldborer, and T. K. Perttula

1998 Archaeological Investigations at the Redwine Site (41SM193), Smith County, Texas. Journal of Northeast Texas Archaeology 11:1-38. 


\section{APPENDIX F \\ DETAILED CERAMIC DATA, LANG PASTURE SITE (41AN38) AND OTHER CADDO SITES IN THE UPPER NECHES DRAINAGE BASIN}

Prepared for:

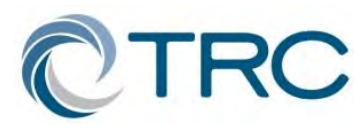

TRC Environmental Corporation 505 East Huntland Drive, Suite 250

Austin, Texas 78752

Prepared by:

Timothy K. Perttula 



\section{Appendix F.1 Detailed Data, Decorated Sherds}

\begin{tabular}{|c|c|c|c|c|c|c|c|}
\hline Provenience/Level & $\begin{array}{l}\text { Sherd } \\
\text { Type }\end{array}$ & Temper & Firing & $\begin{array}{l}\text { Surface } \\
\text { Treatment }\end{array}$ & $\begin{array}{l}\text { Thickness } \\
(\mathrm{mm})\end{array}$ & Paste & Decoration \\
\hline 170-198, lv. 1 & body & grog & $\mathrm{L}$ & I SM & 8.3 & SP & parallel brushed \\
\hline \multirow[t]{2}{*}{ 170-198, lv. 4} & body & grog & A & - & 8.2 & $\mathrm{c}$ & parallel brushed; pinkware \\
\hline & rim & grog & $\mathrm{F}$ & - & 6.0 & $\mathrm{c}$ & $\begin{array}{l}\text { diagonal and triangular engraved el.; D-Ro; } \\
\text { Poynor Engraved; } 26 \mathrm{~cm} \text { OD }\end{array}$ \\
\hline $170-199$, lv. 5 & body & grog & G & I SM & 9.0 & silt & overlapping brushed \\
\hline \multirow{2}{*}{ 170-200, lv. 1} & body & grog-hematite & $\mathrm{K}$ & - & 8.4 & SP & massive applique ridges \\
\hline & body & grog-hematite & $\mathrm{K}$ & - & 10.1 & $\mathrm{SP}$ & parallel brushed \\
\hline 170-200, lv. 2 & body & bone-grog & $\mathrm{G}$ & - & 8.0 & $\mathrm{c}$ & fingernail punctated rows \\
\hline $170-200$, lv. 5 & body & grog-hematite & A & I SM & 7.9 & $\mathrm{c}$ & parallel brushed \\
\hline 171-198, lv. 3 & body & grog-hematite & A & I SM & 10.0 & SP & $\begin{array}{l}\text { horizontal engraved on rim; } \mathrm{CB} \text {; horizontal } \\
\text { brushed on body }\end{array}$ \\
\hline 171-199, lv. 3 & body & grog-organics & G & - & 6.5 & $\mathrm{c}$ & hatched engraved panels; $\mathrm{Bt}$ \\
\hline $171-199$, lv. 5 & body & grog & $\mathrm{K}$ & - & 6.3 & SP & parallel brushed; pinkware \\
\hline 171-200, lv. 4 & body & grog & $\mathrm{B}$ & $\mathrm{I} / \mathrm{E} \mathrm{B}$ & 7.5 & $\mathrm{c}$ & parallel engraved lines \\
\hline $171-200,1 v .5$ & rim & grog & A & I/E SM & 6.7 & $\mathrm{c}$ & $\begin{array}{l}\text { horizontal engraved line; INV-Ro; } 28 \mathrm{~cm} \\
\text { OD; pinkware }\end{array}$ \\
\hline 171-202, lv. 1 & body & grog & $\mathrm{E}$ & I SM & 10.8 & $\mathrm{c}$ & overlapping brushed \\
\hline $172-198$, lv. 5 & body & grog & $\mathrm{K}$ & - & 7.5 & $\mathrm{c}$ & overlapping brushed \\
\hline 172-199, lv. 4 & $\operatorname{rim}$ & grog & A & $\mathrm{I} / \mathrm{E} \mathrm{SM}$ & 6.1 & $\mathrm{c}$ & $\begin{array}{l}\text { horizontal and diagonal engraved lines; } \\
\text { INV-Ro, } 16 \mathrm{~cm} \text { OD }\end{array}$ \\
\hline \multirow[t]{2}{*}{$172-199$, lv. 5} & rim & grog & $\mathrm{B}$ & $\mathrm{I} / \mathrm{E} \mathrm{B}$ & 7.4 & $\mathrm{c}$ & $\begin{array}{l}\text { diagonal and curvilinear engraved lines; } \\
\text { INV-Ro; Bw }\end{array}$ \\
\hline & rim & grog-organics & $\mathrm{B}$ & $\mathrm{I} / \mathrm{E} \mathrm{B}$ & 7.2 & $\mathrm{c}$ & $\begin{array}{l}\text { single broad horizontal engraved line; D-Ro, } \\
\text { with rim peaks; } 13 \mathrm{~cm}+\mathrm{OD}\end{array}$ \\
\hline $172-200$, lv. 5 & body & grog-hematite & $\mathrm{F}$ & - & 11.0 & $\mathrm{SP}$ & parallel brushed \\
\hline 172-201, lv. 4 & body & grog-hematite & $\mathrm{G}$ & I SM & 8.2 & $\mathrm{c}$ & opposed brushed \\
\hline 172-202, lv. 4 & body & grog-hematite & A & I SM & 6.7 & $\mathrm{c}$ & overlapping brushed; pinkware \\
\hline 173-198, lv. 4 & body & grog-organics & $\mathrm{F}$ & $\mathrm{I} / \mathrm{E} \mathrm{B}$ & 6.1 & $\mathrm{c}$ & $\begin{array}{l}\text { horizontal and semi-circular engraved el; } \\
\text { CB; red pigment; brown slip }\end{array}$ \\
\hline 173-199, lv. 5 & body & grog & $\mathrm{H}$ & - & 7.1 & $\mathrm{c}$ & $\begin{array}{l}\text { parallel brushed with tool punctated row } \\
\text { through the brushing }\end{array}$ \\
\hline
\end{tabular}




\begin{tabular}{|c|c|c|c|c|c|c|c|}
\hline Provenience/Level & $\begin{array}{l}\text { Sherd } \\
\text { Type }\end{array}$ & Temper & Firing & $\begin{array}{l}\text { Surface } \\
\text { Treatment }\end{array}$ & $\begin{array}{l}\text { Thickness } \\
(\mathrm{mm})\end{array}$ & Paste & Decoration \\
\hline 173-200, lv. 3 & body & grog & $\mathrm{K}$ & - & 8.8 & $\mathrm{c}$ & overlapping brushed \\
\hline 173-201, lv. 3 & body & grog & A & I SM & 8.4 & $\mathrm{c}$ & parallel brushed; pinkware \\
\hline 173-202, lv. 2 & rim & grog & $\mathrm{F}$ & I/E SM & 6.5 & $\mathrm{c}$ & diagonal incised lines; D-RO, $16 \mathrm{~cm}+\mathrm{OD}$ \\
\hline 173-202, lv. 2 & body & grog & $\mathrm{D}$ & - & 8.1 & silt & parallel brushed \\
\hline 173-202, lv. 3 & body & grog & $\mathrm{H}$ & - & 7.4 & $\mathrm{c}$ & $\begin{array}{l}\text { horizontal and diagonal incised lines above } \\
\text { fingernail punctated rows }\end{array}$ \\
\hline \multirow[t]{2}{*}{ 174-198, lv. 2} & rim & grog & A & I B & 8.4 & $\mathrm{c}$ & horizontal brushed; EV-FL, $10 \mathrm{~cm}+\mathrm{OD}$ \\
\hline & body & grog-bone & $\mathrm{F}$ & - & 8.0 & $\mathrm{c}$ & $\begin{array}{l}\text { diagonal incised lines above tool punctated } \\
\text { rows }\end{array}$ \\
\hline 174-199, lv. 3 & body & grog & $\mathrm{B}$ & I SM & 7.5 & $\mathrm{c}$ & tool punctated rows \\
\hline 174-199, lv. 4 & rim & grog & $\mathrm{F}$ & $\mathrm{I} / \mathrm{E} \mathrm{B}$ & 5.7 & c & hatched engraved panels; D-Ro; red pigment \\
\hline \multicolumn{2}{|c|}{ 175-198, N. Profile body } & grog & $\mathrm{K}$ & I SM & 8.6 & $\mathrm{c}$ & parallel brushed; pinkware \\
\hline 175-198, lv. 3 & body & grog & $\mathrm{G}$ & - & 6.3 & silt & parallel brushed \\
\hline $175-198$, lv. 5 & body & grog & $\mathrm{B}$ & $\mathrm{I} / \mathrm{E} \mathrm{B}$ & 7.1 & $\mathrm{c}$ & cross-hatched engraved zone \\
\hline 175-199, lv. 1 & body & grog-hematite & $\mathrm{C}$ & E SM & 7.3 & c & single broad curvilinear engraved line \\
\hline 175-199, lv. 3 & body & grog-hematite & $\mathrm{K}$ & I SM & 8.4 & c & overlapping brushed \\
\hline 175-200, lv. 2 & body & grog & A & - & 8.9 & $\mathrm{c}$ & parallel brushed \\
\hline 175-200, lv. 3 & body & grog-hematite & G & - & 8.4 & SP & parallel brushed \\
\hline \multicolumn{8}{|c|}{ hematite } \\
\hline 175-201, lv. 5 & body & grog & $\mathrm{F}$ & - & 8.2 & SP & $\begin{array}{l}\text { horizontal brushed with large tool punctates } \\
\text { through the brushing }\end{array}$ \\
\hline 175-202, lv. 2 & body & grog & G & - & 7.2 & silt & tool punctated rows \\
\hline 176-198, lv. 1 & body & grog-bone & A & - & 7.6 & SP & horizontal and diagonal incised lines \\
\hline 176-198, lv. 3 & body & grog-organics & $\mathrm{F}$ & E B & 6.4 & $\mathrm{c}$ & ext. red-slipped; Bt \\
\hline 176-198, lv. 4 & body & grog & $\mathrm{B}$ & I SM & 5.4 & $\mathrm{c}$ & parallel incised lines \\
\hline 176-199, lv. 2 & body & grog & G & - & 9.6 & $\mathrm{c}$ & single large tool punctate \\
\hline \multirow[t]{2}{*}{ 176-198, lv. 5} & body & grog & A & - & $8 ., 1$ & $\mathrm{c}$ & parallel brushed; pinkware \\
\hline & body & grog & $\mathrm{B}$ & - & 6.6 & c & tool punctated rows \\
\hline \multirow[t]{2}{*}{ 176-199, lv. 3} & body & grog & G & - & 6.9 & $\mathrm{c}$ & parallel brushed \\
\hline & body & grog-hematite & $\mathrm{E}$ & - & 9.3 & SP & parallel brushed \\
\hline \multirow[t]{2}{*}{ 176-199, lv. 4} & body & - & B & E B & 7.1 & silt & $\begin{array}{l}\text { engraved ovals and triangular elements; Bt; } \\
\text { Poynor Engraved }\end{array}$ \\
\hline & Body & grog & I & I SM & 11.8 & SP & parallel brushed \\
\hline
\end{tabular}




\begin{tabular}{|c|c|c|c|c|c|c|c|}
\hline Provenience/Level & $\begin{array}{l}\text { Sherd } \\
\text { Type }\end{array}$ & Temper & Firing & $\begin{array}{l}\text { Surface } \\
\text { Treatment }\end{array}$ & $\begin{array}{l}\text { Thickness } \\
(\mathrm{mm})\end{array}$ & Paste & Decoration \\
\hline 176-200, lv. 3 & body & grog & $\mathrm{G}$ & - & 7.7 & $\mathrm{c}$ & parallel brushed \\
\hline $176-200$, lv. 5 & body & grog & A & E B & 5.9 & $\mathrm{c}$ & curvilinear engraved lines; $\mathrm{Bt}$; red pigment \\
\hline 176-201, lv. 6 & body & grog-hematite & A & - & 9.0 & $\mathrm{c}$ & parallel brushed \\
\hline 176-202, lv. 3 & body & grog-hematite & $\mathrm{G}$ & - & 8.6 & $\mathrm{SP}$ & overlapping brushed \\
\hline 177-198, lv. 3 & rim & grog & A & E B & 7.3 & $\mathrm{c}$ & $\begin{array}{l}\text { curvilinear engraved and ticked lines; } \\
\text { Poynor Engraved (PP); INV-Ro }\end{array}$ \\
\hline \multirow{2}{*}{ 177-198, lv. 4} & body & grog-hematite & A & - & 8.0 & $\mathrm{c}$ & overlapping brushed \\
\hline & body & grog & $\mathrm{E}$ & I SM & 6.8 & $\mathrm{c}$ & cane punctated rows \\
\hline 177-199, lv. 1 & body & grog & $\mathrm{C}$ & I SM & 6.8 & $\mathrm{SP}$ & int. red-slipped \\
\hline 177-199, lv. 2 & body & grog-hematite & A & - & 9.3 & $\mathrm{c}$ & $\begin{array}{l}\text { parallel brushed with tool punctated row } \\
\text { through the brushing }\end{array}$ \\
\hline \multirow{2}{*}{ 177-199, lv. 3} & body & grog-bone & $\mathrm{B}$ & I SM & 8.3 & $\mathrm{c}$ & parallel brushed \\
\hline & $\operatorname{rim}$ & grog & $\mathrm{G}$ & I SM & 6.3 & $\mathrm{c}$ & diagonal incised lines; D-Ro \\
\hline 178-198, lv. 1 & body & grog & $\mathrm{B}$ & I SM & 9.0 & $\mathrm{c}$ & parallel brushed \\
\hline \multirow[t]{2}{*}{ 178-198, lv. 3} & body & grog & A & - & 7.5 & $\mathrm{c}$ & parallel brushed \\
\hline & body & grog & $\mathrm{F}$ & - & 5.5 & $\mathrm{c}$ & ext. red-slipped; Bt \\
\hline 178-198, lv. 5 & body & bone-grog & $\mathrm{E}$ & - & 8.7 & $\mathrm{c}$ & fingernail punctates \\
\hline \multirow[t]{2}{*}{ 178-199, lv. 1} & body & grog & A & I SM & 8.2 & $\mathrm{SP}$ & parallel brushed; pinkware \\
\hline & rim & grog & $\mathrm{F}$ & - & 8.0 & $\mathrm{c}$ & $\begin{array}{l}\text { incised triangles filled with tool punctates; } \\
\text { D-Ro }\end{array}$ \\
\hline 178-199, lv. 5 & body & grog-bone & $\mathrm{F}$ & I SM & 8.2 & $\mathrm{c}$ & opposed incised lines \\
\hline 178-200, lv. 1 & body & grog-bone & $\mathrm{B}$ & I SM & 6.3 & $\mathrm{c}$ & engraved panel with hatched lines \\
\hline 178-201, lv. 3 & body & grog-hematite & G & I SM & 10.3 & $\mathrm{c}$ & $\begin{array}{l}\text { parallel and opposed brushed and appliqued } \\
\text { fillet }\end{array}$ \\
\hline 178-202, lv. 1 & body & grog & $\mathrm{C}$ & - & 9.2 & $\mathrm{SP}$ & parallel brushed \\
\hline \multirow[t]{2}{*}{ 178-202, lv. 4} & body & grog-hematite & G & - & 7.7 & $\mathrm{c}$ & horizontal brushing on body; $\mathrm{CB}$ \\
\hline & rim & grog-hematite & $\mathrm{K}$ & I SM & 9.1 & SP & $\begin{array}{l}\text { tool punctated rows; EV-Ro, } 13 \mathrm{~cm} \mathrm{OD;} \\
\text { pinkware }\end{array}$ \\
\hline \multirow[t]{2}{*}{ 179-198, lv. 4} & body & grog-bone & $\mathrm{G}$ & I SM & 7.0 & $\mathrm{c}$ & tool punctated rows \\
\hline & rim & grog & A & E B & 7.3 & $\mathrm{c}$ & $\begin{array}{l}\text { hatched engraved panel; D-FL, } 29 \mathrm{~cm} \text { OD; } \\
\text { pinkware }\end{array}$ \\
\hline
\end{tabular}




\begin{tabular}{|c|c|c|c|c|c|c|c|}
\hline Provenience/Level & $\begin{array}{l}\text { Sherd } \\
\text { Type }\end{array}$ & Temper & Firing & $\begin{array}{l}\text { Surface } \\
\text { Treatment }\end{array}$ & $\begin{array}{l}\text { Thickness } \\
(\mathrm{mm})\end{array}$ & Paste & Decoration \\
\hline 179-199, lv. 3 & rim & grog & $\mathrm{B}$ & I SM & 6.1 & $\mathrm{c}$ & opposed incised lines; D-Ro \\
\hline 179-199, lv. 4 & body & grog-bone & $\mathrm{B}$ & I SM & 7.0 & $\mathrm{c}$ & $\begin{array}{l}\text { incised hatched panel and incised circle } \\
\text { filled with tool punctates }\end{array}$ \\
\hline 179-200, lv. 4 & body & grog & $\mathrm{C}$ & $\mathrm{I} / \mathrm{E} \mathrm{B}$ & 5.8 & SP & $\begin{array}{l}\text { closely-spaced engraved lines and triangular } \\
\text { el.; Poynor Engraved }\end{array}$ \\
\hline 179-202, lv. 4 & body & grog & $\mathrm{K}$ & I SM & 7.7 & SP & parallel brushed \\
\hline 180-198, lv. 1 & body & grog-hematite & $\mathrm{G}$ & - & 7.0 & $\mathrm{SP}$ & incised hatched panels \\
\hline 180-199, lv. 3 & body & grog-hematite & A & I SM & 10.1 & $\mathrm{c}$ & $\begin{array}{l}\text { vertical brushed and tool punctated row } \\
\text { below brushing; pinkware }\end{array}$ \\
\hline & rim & grog & $\mathrm{F}$ & I SM & 9.6 & $\mathrm{SP}$ & vertical brushed; D-Ro; $22 \mathrm{~cm}$ OD \\
\hline 180-199, lv. 5 & rim & grog-hematite & $\mathrm{C}$ & I SM & 7.0 & $\mathrm{c}$ & opposed incised lines; D-Ro \\
\hline $180-200$, lv. 2 & body & grog-hematite & $\mathrm{F}$ & - & 10.6 & $\mathrm{c}$ & large tool punctated rows \\
\hline 180-200, lv. 4 & body & grog & $\mathrm{B}$ & $\mathrm{I} / \mathrm{E} \mathrm{SM}$ & 6.9 & $\mathrm{c}$ & incised panel with hatched lines \\
\hline 181-198, lv. 1 & body & grog-hematite & I & I SM & 8.0 & $\mathrm{c}$ & parallel brushed \\
\hline 181-198, lv. 4 & body & grog-hematite & A & I SM & 11.5 & $\mathrm{c}$ & parallel brushed \\
\hline 181-199, lv. 1 & body & - & $\mathrm{F}$ & $\mathrm{I} / \mathrm{E} \mathrm{B}$ & 5.4 & $\mathrm{c}$ & $\begin{array}{l}\text { closely-spaced curvilinear engraved lines; } \\
\text { Bw }\end{array}$ \\
\hline 181-199, lv. 3 & body & grog & G & I SM & 8.2 & $\mathrm{c}$ & parallel brushed \\
\hline 181-202, lv. 3 & body & grog-hematite & $\mathrm{E}$ & - & 7.6 & $\mathrm{c}$ & parallel brushed \\
\hline 181-202, lv. 4 & body & $\begin{array}{l}\text { grog-bone- } \\
\text { hematite }\end{array}$ & A & - & 7.0 & $\mathrm{SP}$ & parallel brushed-incised \\
\hline $181-202$, lv. 5 & body & grog & $\mathrm{K}$ & I SM & 8.6 & SP & parallel brushed \\
\hline 182-198, lv. 3 & rim & grog-bone & $\mathrm{B}$ & - & 8.8 & $\mathrm{c}$ & $\begin{array}{l}\text { opposed incised lines and triangular tool } \\
\text { punctated-filled zone; D-Ro; } 16 \mathrm{~cm} \text { OD }\end{array}$ \\
\hline 182-198, lv. 4 & body & bone & $\mathrm{B}$ & - & 8.2 & $\mathrm{c}$ & fingernail punctated rows \\
\hline $182-198$, lv. 5 & body & bone-hematite & $\mathrm{C}$ & I SM & 6.5 & $\mathrm{c}$ & tool punctated rows \\
\hline 182-199, lv. 2 & body & grog-hematite & A & - & 9.2 & $\mathrm{c}$ & parallel brushed \\
\hline $182-200$, lv. 5 & body & grog & A & $\mathrm{I} / \mathrm{E} \mathrm{SM}$ & 8.4 & $\begin{array}{l}\mathrm{c} \\
\mathrm{CB}\end{array}$ & triangular engraved el; Poynor Engraved; \\
\hline 182-200, lv. 7 & body & grog-hematite & A & I/E SM & 8.4 & $\mathrm{SP}$ & U-shaped engraved el. \\
\hline 182-201, lv. 2 & body & grog & $\mathrm{E}$ & - & 10.2 & $\mathrm{SP}$ & pinched ridges \\
\hline 182-201, lv. 4 & body & grog & $\mathrm{C}$ & I SM & 8.1 & $\mathrm{c}$ & parallel brushed \\
\hline
\end{tabular}




\begin{tabular}{|c|c|c|c|c|c|c|c|}
\hline Provenience/Level & $\begin{array}{l}\text { Sherd } \\
\text { Type }\end{array}$ & Temper & Firing & $\begin{array}{l}\text { Surface } \\
\text { Treatment }\end{array}$ & $\begin{array}{l}\text { Thickness } \\
(\mathrm{mm})\end{array}$ & Paste & Decoration \\
\hline 182-202, lv. 2 & body & grog-hematite & A & - & 8.3 & $\mathrm{c}$ & parallel brushed \\
\hline \multirow[t]{2}{*}{$182-202$, lv. 3} & body & grog-bone & $\mathrm{F}$ & - & 8.6 & $\mathrm{c}$ & fingernail punctated rows \\
\hline & body & grog & G & E SM & 7.7 & SP & engraved pendant triangles; Hume Engraved \\
\hline 182-202, lv. 4 & body & grog-hematite & $\mathrm{D}$ & - & 7.9 & $\mathrm{c}$ & overlapping brushed \\
\hline \multirow[t]{2}{*}{ 182-202, lv. 5} & body & grog & $\mathrm{B}$ & - & 8.1 & SP & opposed incised lines \\
\hline & rim & grog-hematite & $\mathrm{B}$ & E SM & 6.3 & $\begin{array}{l}\text { SP } \\
\text { Ro }\end{array}$ & horizontal and vertical engraved panels; D- \\
\hline 183-199, lv. 1 & body & grog & A & - & 6.8 & $\mathrm{c}$ & parallel brushed; pinkware \\
\hline 183-199, lv. 4 & body & grog-hematite & $\mathrm{D}$ & I SM & 6.1 & $\mathrm{c}$ & parallel brushed \\
\hline 183-200, lv. 1 & body & grog & $\mathrm{F}$ & - & 7.4 & SP & opposed incised lines \\
\hline 183-200, lv. 3 & body & grog & $\mathrm{G}$ & $\mathrm{I} / \mathrm{E} \mathrm{SM}$ & 7.5 & $\mathrm{c}$ & $\begin{array}{l}\text { engraved hatched panels and triangular el; } \\
\text { Poynor Engraved; CB }\end{array}$ \\
\hline 183-200, lv. 4 & body & grog & $\mathrm{L}$ & - & 8.2 & $\mathrm{c}$ & parallel brushed \\
\hline 183-201, lv. 1 & rim & grog & $\mathrm{F}$ & - & 8.1 & SP & $\begin{array}{l}\text { diagonal engraved with hatched triangular } \\
\text { el; D-FL, ext f, } 10 \mathrm{~cm} \text { OD }\end{array}$ \\
\hline 183-201, lv. 2 & body & grog & $\mathrm{K}$ & I SM & 8.3 & $\mathrm{c}$ & overlapping brushed; pinkware \\
\hline \multirow[t]{2}{*}{ 183-201, lv. 3} & rim & grog-bone & A & - & 5.2 & $\mathrm{c}$ & opposed incised lines; D-FL \\
\hline & body & grog-bone & $\mathrm{G}$ & I SM & 8.8 & $\mathrm{c}$ & $\begin{array}{l}\text { hatched incised triangle el.; cf. Poynor } \\
\text { variety }\end{array}$ \\
\hline 183-201, lv. 5 & body & - & $\mathrm{F}$ & - & 7.1 & SP & $\begin{array}{l}\text { curvilinear engraved lines and circular } \\
\text { punctate-filled zone }\end{array}$ \\
\hline 183-201, lv. 6 & rim & grog & $\mathrm{B}$ & I/E SM & 7.0 & SP & $\begin{array}{l}\text { engraved semi-circles and pendant triangles; } \\
\text { lip notched; Poynor/Patton; D-Ro, } \\
26 \mathrm{~cm}+\text { OD }\end{array}$ \\
\hline 183-202, lv. 2 & body & grog-hematite & $\mathrm{B}$ & - & 6.0 & SP & int./ext. red-slipped \\
\hline 183-202, lv. 3 & body & grog & $\mathrm{B}$ & - & 7.1 & $\mathrm{c}$ & $\begin{array}{l}\text { horizontal engraved lines and pendant } \\
\text { triangles; white pigment }\end{array}$ \\
\hline 183-202, lv. 4 & body & grog & $\mathrm{E}$ & - & 7.9 & $\mathrm{c}$ & parallel brushed \\
\hline 183-202, lv. 5 & body & grog-hematite & $\mathrm{E}$ & - & 8.1 & SP & parallel brushed; pinkware \\
\hline \multirow[t]{2}{*}{ 184-198, lv. 4} & body & grog-hematite & G & E B & 8.8 & $\mathrm{c}$ & curvilinear engraved lines; $\mathrm{Bt}$ \\
\hline & body & grog-hematite & $\mathrm{E}$ & I SM & 8.1 & $\mathrm{c}$ & parallel brushed \\
\hline 184-199, lv. 3 & body & grog & $\mathrm{F}$ & I SM & 6.4 & $\mathrm{c}$ & parallel brushed \\
\hline $184-200$, lv. 1 & body & hematite & A & I SM & 7.7 & SP & parallel brushed \\
\hline 184-201, lv. 1 & body & grog & $\mathrm{G}$ & - & 8.3 & SP & $\begin{array}{l}\text { parallel brushed with fingernail punctates } \\
\text { through the brushing }\end{array}$ \\
\hline 184-201, lv. 4 & body & grog & $\mathrm{G}$ & I SM & 7.5 & $\mathrm{c}$ & parallel brushed \\
\hline
\end{tabular}




\begin{tabular}{|c|c|c|c|c|c|c|c|}
\hline Provenience/Level & $\begin{array}{l}\text { Sherd } \\
\text { Type }\end{array}$ & Temper & Firing & $\begin{array}{l}\text { Surface } \\
\text { Treatment }\end{array}$ & $\begin{array}{l}\text { Thickness } \\
(\mathrm{mm})\end{array}$ & Paste & Decoration \\
\hline 184-202, lv. 4 & rim & grog & $\mathrm{E}$ & I SM & 8.4 & $\mathrm{c}$ & $\begin{array}{l}\text { horizontal brushed; D-Ro, } 13 \mathrm{~cm} \mathrm{OD;} \\
\text { pinkware }\end{array}$ \\
\hline $184-202$, lv. 5 & body & grog-hematite & $\mathrm{F}$ & I SM & 9.6 & SP & parallel brushed \\
\hline 184-203, lv. 2 & body & grog-bone & G & I SM & 7.2 & $\mathrm{c}$ & circular incised, cane-punctated filled zone \\
\hline 185-198, lv. 1 & body & grog & A & - & 9.7 & SP & overlapping brushed \\
\hline 185-198, lv. 4 & body & grog & $\mathrm{A}$ & I SM & 7.6 & $\mathrm{c}$ & parallel brushed-appliqued ridge \\
\hline 185-199, lv. 4 & rim & grog & $\mathrm{G}$ & $\mathrm{I} / \mathrm{E} \mathrm{SM}$ & 6.2 & $\mathrm{c}$ & $\begin{array}{l}\text { diagonal and triangular engraved lines; D- } \\
\text { FL; Poynor Engraved }\end{array}$ \\
\hline 185-200, lv. 1 & body & grog & A & E SM & 6.9 & $\mathrm{c}$ & $\begin{array}{l}\text { straight engraved line with triangular tick } \\
\text { marks (Poynor/Patton Engraved) }\end{array}$ \\
\hline 185-201, lv. 1 & body & grog-hematite & $\mathrm{F}$ & - & 5.9 & SP & triangular engraved elements \\
\hline 185-202, lv. 3 & rim & grog & $\mathrm{C}$ & - & 10.0 & $\mathrm{c}$ & $\begin{array}{l}\text { horizontal brushed with tool punctated rows } \\
\text { through brushing; D-Ro, ext. folded }\end{array}$ \\
\hline 185-202, lv. 4 & body & grog & A & - & 7.1 & $\mathrm{c}$ & parallel brushed \\
\hline \multirow[t]{2}{*}{$185-202$, lv. 5} & body & grog & $\mathrm{H}$ & - & 7.1 & $\mathrm{c}$ & opposed incised lines \\
\hline & rim & grog & A & I SM & 8.6 & $\mathrm{c}$ & neck banded; EV-Ro \\
\hline 186-199, lv. 2 & body & grog & G & $\mathrm{I} / \mathrm{E} \mathrm{B}$ & 6.0 & $\mathrm{c}$ & diagonal and triangular engraved el.; CB \\
\hline 186-199, lv. 3 & body & grog-bone & $\mathrm{G}$ & - & 9.6 & $\mathrm{c}$ & incised triangular el; Poynor variety \\
\hline 186-199, lv. 4 & body & grog & $\mathrm{G}$ & - & 7.2 & $\mathrm{c}$ & $\begin{array}{l}\text { parallel brushed with tool punctations } \\
\text { through the brushing }\end{array}$ \\
\hline $186-200$, lv. 4 & body & grog & $\mathrm{G}$ & - & 6.2 & $\mathrm{c}$ & tool punctated rows \\
\hline $186-201$, lv. 5 & body & grog-bone & $\mathrm{G}$ & - & 7.6 & $\mathrm{c}$ & opposed fingernail punctated rows \\
\hline $186-201$, lv. 6 & body & grog & $\mathrm{F}$ & - & 8.1 & $\mathrm{c}$ & parallel brushed-incised \\
\hline 186-202, lv. 3 & body & grog & $\mathrm{H}$ & - & 7.4 & SP & tool punctated rows \\
\hline 187-198, lv. 3 & body & grog & $\mathrm{G}$ & I SM & 7.4 & $\mathrm{c}$ & parallel brushed-opposed incised lines \\
\hline $187-199$, lv. 3 & body & - & $\mathrm{B}$ & - & 7.4 & SP & triangular engraved el., CB \\
\hline $187-200$, lv. 2 & body & grog & $\mathrm{F}$ & - & 8.2 & $\mathrm{c}$ & $\begin{array}{l}\text { overlapping brushed with tool punctated } \\
\text { rows through the brushing }\end{array}$ \\
\hline 187-200, lv. 4 & body & grog-hematite & A & I SM & 6.3 & $\mathrm{c}$ & parallel brushed \\
\hline \multirow[t]{2}{*}{$187-201$, lv. 2} & body & grog-hematite & A & I SM & 8.0 & $\mathrm{c}$ & overlapping brushed \\
\hline & rim & grog & $\mathrm{G}$ & - & 6.2 & $\begin{array}{l}\text { SP } \\
\text { OD }\end{array}$ & opposed incised lines; D-Ro, ext f; $23 \mathrm{~cm}$ \\
\hline 188-198, lv. 2 & body & grog & $\mathrm{G}$ & - & 7.0 & $\mathrm{c}$ & tool punctated rows \\
\hline $188-198$, lv. 5 & body & grog & A & I SM & 7.3 & $\mathrm{c}$ & fingernail punctated rows \\
\hline
\end{tabular}




\begin{tabular}{|c|c|c|c|c|c|c|c|}
\hline Provenience/Level & $\begin{array}{l}\text { Sherd } \\
\text { Type }\end{array}$ & Temper & Firing & $\begin{array}{l}\text { Surface } \\
\text { Treatment }\end{array}$ & $\begin{array}{l}\text { Thickness } \\
(\mathrm{mm})\end{array}$ & Paste & Decoration \\
\hline 188-199, lv. 3 & body & grog & G & - & 5.5 & $\mathrm{c}$ & $\begin{array}{l}\text { circular incised zone filled with tool } \\
\text { punctates }\end{array}$ \\
\hline 188-200, lv. 2 & rim & grog-hematite & $\mathrm{F}$ & E B & 6.5 & $\mathrm{SP}$ & diagonal engraved lines; D-FL \\
\hline $188-200$, lv. 3 & body & grog-bone & A & I SM & 6.5 & SP & horizontal and vertical engraved lines \\
\hline $188-200$, lv. 5 & body & grog & $\mathrm{E}$ & $\mathrm{I} / \mathrm{E} \mathrm{B}$ & 7.9 & $\mathrm{c}$ & $\begin{array}{l}\text { engraved lines with excised pendant } \\
\text { triangles; Poynor Engraved (PP) }\end{array}$ \\
\hline 188-201, lv. 1 & body & grog & $\mathrm{G}$ & - & 8.3 & $\mathrm{c}$ & $\begin{array}{l}\text { parallel brushed with tool punctated row } \\
\text { through brushing }\end{array}$ \\
\hline 188-201, lv. 3 & rim & grog & $\mathrm{F}$ & $\mathrm{I} / \mathrm{E} \mathrm{SM}$ & 5.8 & $\mathrm{c}$ & hatched engraved triangle; D-Ro \\
\hline 188-201, lv. 4 & body & grog-hematite & $\mathrm{C}$ & I SM & 8.1 & $\mathrm{SP}$ & parallel brushing \\
\hline \multirow[t]{2}{*}{ 189-198, lv. 3} & rim & grog & G & I SM & 6.4 & $\mathrm{c}$ & diagonal incised lines; D-FL \\
\hline & body & grog & G & - & 6.7 & $\mathrm{SP}$ & ext. red-slipped, Bt \\
\hline 189-199, lv. 2 & body & grog & G & E SM & 7.9 & $\mathrm{c}$ & $\begin{array}{l}\text { cross-hatched engraved zone and curvilinear } \\
\text { engraved lines; } \mathrm{Bt}\end{array}$ \\
\hline 189-199, lv. 3 & body & grog & $\mathrm{F}$ & E SM & 6.1 & $\mathrm{c}$ & single broad curvilinear engraved line \\
\hline 189-199, lv. 4 & rim & grog & $\mathrm{B}$ & I SM & 7.0 & $\mathrm{c}$ & $\begin{array}{l}\text { curvilinear incised panel filled with tool } \\
\text { punctations; EV-Ro }\end{array}$ \\
\hline 189-200, lv. 3 & body & grog-hematite & $\mathrm{F}$ & E SM & 6.8 & $\mathrm{c}$ & horizontal and diagonal engraved lines \\
\hline 189-201, lv. 2 & body & grog & $\mathrm{B}$ & I SM & 9.2 & $\mathrm{c}$ & parallel brushed \\
\hline 189-201, lv. 3 & body & grog & $\mathrm{B}$ & E B & 7.2 & $\mathrm{SP}$ & $\begin{array}{l}\text { engraved pendant triangles; Bt; Hume } \\
\text { Engraved }\end{array}$ \\
\hline 189-202, lv. 2 & body & grog & $\mathrm{F}$ & - & 8.2 & $\mathrm{SP}$ & parallel brushed \\
\hline 189-202, lv. 3 & body & grog-hematite & $\mathrm{C}$ & - & 9.4 & $\mathrm{c}$ & parallel brushing \\
\hline 190-198, lv. 1 & body & grog-hematite & G & - & 7.9 & $\mathrm{c}$ & parallel brushed \\
\hline 190-198, lv. 3 & rim & grog-bone & $\mathrm{B}$ & I SM & 8.2 & $\mathrm{c}$ & $\begin{array}{l}\text { diagonal incised panels filled with tool } \\
\text { punctations; EV-FL, } 10 \mathrm{~cm}+\text { OD }\end{array}$ \\
\hline 190-199, lv. 2 & body & grog & $\mathrm{F}$ & - & 5.7 & silt & large tool punctates \\
\hline 190-199, lv. 3 & body & grog & $\mathrm{F}$ & - & 7.9 & $\mathrm{c}$ & $\begin{array}{l}\text { parallel brushed with fingernail punctates } \\
\text { through the brushing }\end{array}$ \\
\hline 190-200, lv. 1 & body & grog & $\mathrm{F}$ & I SM & 5.9 & $\mathrm{c}$ & parallel brushed-incised \\
\hline 190-200, lv. 3 & rim & grog & $\mathrm{L}$ & - & 9.3 & $\mathrm{c}$ & vertical brushed \\
\hline 190-201, lv. 2 & body & grog & A & - & 7.5 & $\mathrm{c}$ & parallel brushed \\
\hline 190-201, lv. 3 & body & grog-organics & $\mathrm{F}$ & - & 7.4 & $\mathrm{c}$ & widely spaced parallel incised lines \\
\hline \multirow[t]{2}{*}{ 190-202, lv. 3} & body & - & $\mathrm{F}$ & I B & 6.6 & $\mathrm{SP}$ & hatched and oval engraved els., CB \\
\hline & body & grog & A & I SM & 8.4 & $\mathrm{c}$ & overlapping brushed \\
\hline
\end{tabular}




\begin{tabular}{|c|c|c|c|c|c|c|c|}
\hline Provenience/Level & $\begin{array}{l}\text { Sherd } \\
\text { Type }\end{array}$ & Temper & Firing & $\begin{array}{l}\text { Surface } \\
\text { Treatment }\end{array}$ & $\begin{array}{l}\text { Thickness } \\
(\mathrm{mm})\end{array}$ & Paste & Decoration \\
\hline 191-199, lv. 1 & body & grog & $\mathrm{B}$ & - & 6.7 & SP & parallel incised lines \\
\hline $191-200$, lv. 3 & rim & grog & $\mathrm{H}$ & - & 6.5 & SP & cross-hatched incised; D-RO, $16 \mathrm{~cm}$ OD \\
\hline 191-201, lv. 4 & rim & grog & $\mathrm{B}$ & I SM & 6.8 & SP & opposed incised lines; D-FL, $19 \mathrm{~cm}+$ OD \\
\hline 191-202, lv. 1 & body & grog-bone & $\mathrm{H}$ & $\mathrm{I} / \mathrm{E} \mathrm{B}$ & 7.4 & $\mathrm{c}$ & $\begin{array}{l}\text { horizontal engraved lines and hatched } \\
\text { triangles; } \mathrm{CB}\end{array}$ \\
\hline 191-202, lv. 2 & body & grog-hematite & $\mathrm{F}$ & - & 10.6 & SP & parallel brushed-incised \\
\hline 192-198, lv. 3 & body & grog-hematite & $\mathrm{L}$ & - & 8.4 & $\mathrm{c}$ & parallel brushed \\
\hline 192-199, lv. 1 & body & grog-hematite & G & - & 8.7 & $\mathrm{c}$ & $\begin{array}{l}\text { parallel brushed with opposed fingernail } \\
\text { punctated rows through brushing }\end{array}$ \\
\hline 192-199, lv. 2 & rim & grog-hematite & $\mathrm{F}$ & - & 5.2 & $\mathrm{c}$ & engraved hatched circular el; D-FL \\
\hline 192-200, lv. 3 & body & grog & $\mathrm{F}$ & $\mathrm{I} / \mathrm{E} \mathrm{SM}$ & 7.0 & SP & opposed engraved lines; red pigment \\
\hline \multirow[t]{2}{*}{ 192-200, lv. 4} & body & grog & A & - & 6.9 & $\mathrm{c}$ & parallel brushed-incised \\
\hline & body & grog & $\mathrm{G}$ & I SM & 6.8 & c & triangular engraved el.; cf. Poynor Engraved \\
\hline 192-202, lv. 4 & body & grog & $\mathrm{K}$ & - & 8.0 & SP & parallel brushed-incised; pinkware \\
\hline 193-198, lv. 2 & body & grog & G & - & 8.6 & $\mathrm{c}$ & $\begin{array}{l}\text { vertical brushing with tool punctated row } \\
\text { within brushing }\end{array}$ \\
\hline 193-198, lv. 2 & body & grog-hematite & $\mathrm{G}$ & E B & 6.7 & $\mathrm{c}$ & curvilinear engraved lines; Bt \\
\hline 193-198, lv. 3 & body & grog-hematite & $\mathrm{E}$ & I SM & 8.1 & $\mathrm{c}$ & horizontal brushed on body, $\mathrm{CB}$ \\
\hline 193-198, lv. 4 & rim & grog-hematite & A & - & 8.6 & $\mathrm{c}$ & diagonal brushed; EV-Ro \\
\hline 193-198, lv. 4 & body & grog & $\mathrm{B}$ & - & 7.7 & $\mathrm{c}$ & tool punctated rows \\
\hline \multirow[t]{2}{*}{ 193-199, lv. 2} & body & grog & $\mathrm{C}$ & I SM & 7.9 & $\mathrm{c}$ & parallel brushed \\
\hline & body & grog-hematite & $\mathrm{F}$ & I SM & 11.0 & SP & overlapping brushed \\
\hline 193-199, lv. 3 & body & grog & $\mathrm{F}$ & E B & 5.4 & $\mathrm{c}$ & multiple curvilinear engraved lines; Bt \\
\hline 193-200, lv. 1 & body & grog & $\mathrm{F}$ & E SM & 4.8 & $\mathrm{c}$ & opposed incised lines \\
\hline \multirow[t]{2}{*}{ 193-201, lv. 2} & body & grog & A & $\mathrm{I} / \mathrm{E} \mathrm{SM}$ & 7.9 & SP & $\begin{array}{l}\text { horizontal and engraved panel; } \mathrm{CB} \text {; } \\
\text { pinkware }\end{array}$ \\
\hline & body & grog & G & - & 7.6 & SP & incised panels filled with tool punctates \\
\hline 193-201, lv. 3 & body & grog-hematite & $\mathrm{F}$ & E B & 7.4 & $\mathrm{c}$ & diagonal engraved lines; $\mathrm{CB}$; red pigment \\
\hline 193-201, lv. 4 & body & grog-bone & $\mathrm{F}$ & - & 5.5 & $\mathrm{c}$ & zoned incised-tool punctated \\
\hline 193-201, lv. 5 & rim & grog-hematite & $\mathrm{F}$ & - & 6.5 & $\mathrm{c}$ & opposed incised lines; D-Ro; $25 \mathrm{~cm}$ OD \\
\hline 193-202, lv. 2 & rim & $\begin{array}{l}\text { grog-hematite- } \\
\text { bone }\end{array}$ & G & I SM & 7.6 & $\mathrm{c}$ & $\begin{array}{l}\text { incised triangle filled with tool punctations; } \\
\text { EV-Ro, ext. folded }\end{array}$ \\
\hline 193-202, lv. 3 & body & grog & $\mathrm{F}$ & E B & 6.6 & SP & hatched engraved ladders; $\mathrm{Bt}$ \\
\hline 193-202, lv. 4 & body & grog & $\mathrm{F}$ & I SM & 7.6 & $\mathrm{c}$ & $\begin{array}{l}\text { parallel brushed with fingernail punctated } \\
\text { rows through brushing }\end{array}$ \\
\hline
\end{tabular}




\begin{tabular}{|c|c|c|c|c|c|c|c|}
\hline Provenience/Level & $\begin{array}{l}\text { Sherd } \\
\text { Type }\end{array}$ & Temper & Firing & $\begin{array}{l}\text { Surface } \\
\text { Treatment }\end{array}$ & $\begin{array}{l}\text { Thickness } \\
(\mathrm{mm})\end{array}$ & Paste & Decoration \\
\hline 193-202, lv. 5 & body & grog & G & - & 8.4 & SP & $\begin{array}{l}\text { curvilinear engraved lines with pendant } \\
\text { triangles; cf. Hume Engraved; Bt }\end{array}$ \\
\hline \multirow[t]{2}{*}{ 193-203, lv. 5} & body & grog & $\mathrm{G}$ & - & 7.5 & $\mathrm{c}$ & tool punctated el. \\
\hline & rim & grog & A & - & 7.1 & SP & horizontal brushed \\
\hline 194-198, lv. 1 & body & grog & $\mathrm{F}$ & - & 8.4 & $\mathrm{c}$ & $\begin{array}{l}\text { parallel brushed with fingernail punctated } \\
\text { rows through brushing }\end{array}$ \\
\hline 194-198, lv. 2 & body & grog & $\mathrm{F}$ & I SM & 8.4 & $\mathrm{c}$ & $\begin{array}{l}\text { parallel brushed and zoned incised-tool } \\
\text { punctated zone }\end{array}$ \\
\hline 194-198, lv. 4 & body & grog & $\mathrm{F}$ & - & 8.0 & $\mathrm{c}$ & $\begin{array}{l}\text { triangular incised el. and incised circle } \\
\text { with small cane punctates; Poynor variety }\end{array}$ \\
\hline 194-199, lv. 3 & rim & grog-bone & $\mathrm{C}$ & - & 5.9 & $\mathrm{SP}$ & lip notched/scalloped; D-FL, ext folded \\
\hline 194-199, lv. 4 & body & bone & $\mathrm{B}$ & - & 7.7 & $\mathrm{c}$ & parallel incised lines \\
\hline 194-200, lv. 1 & body & grog-bone & A & - & 5.2 & $\mathrm{c}$ & tool punctated rows; pinkware \\
\hline \multirow[t]{2}{*}{ 194-200, lv. 2} & body & grog & $\mathrm{F}$ & I SM & 9.2 & $\mathrm{c}$ & $\begin{array}{l}\text { parallel brushed-incised with tool punctated } \\
\text { row through the brushing }\end{array}$ \\
\hline & rim & grog-bone & $\mathrm{F}$ & $\mathrm{I} / \mathrm{E} \mathrm{SM}$ & 5.4 & SP & hatched incised panel; D-INT BV \\
\hline 194-200, lv. 3 & rim & grog-hematite & $\mathrm{F}$ & - & 9.5 & SP & opposed incised lines \\
\hline \multirow[t]{2}{*}{ 194-201, lv. 2} & body & grog-organics & $\mathrm{F}$ & $\mathrm{I} / \mathrm{E} \mathrm{SM}$ & 7.2 & $\mathrm{c}$ & hatched engraved panel \\
\hline & rim & grog-hematite & A & I SM & 6.7 & $\mathrm{c}$ & opposed incised lines; D-Ro; $28 \mathrm{~cm}$ OD \\
\hline 194-201, lv. 4 & rim & grog-hematite & $\mathrm{B}$ & I SM & 6.1 & $\begin{array}{l}\mathrm{c} \\
\mathrm{OD}\end{array}$ & overlapping brushed; EV-Ro, ext f, $17 \mathrm{~cm}$ \\
\hline 194-202, lv. 5 & body & grog & $\mathrm{B}$ & - & 7.4 & SP & opposed incised lines \\
\hline \multirow[t]{2}{*}{ 194-203, lv. 4} & body & grog & $\mathrm{F}$ & - & 8.4 & $\mathrm{c}$ & cross-hatched incised lines \\
\hline & body & grog & $\mathrm{F}$ & I SM & 7.2 & $\mathrm{c}$ & $\begin{array}{l}\text { parallel brushed with fingernail punctated } \\
\text { rows through brushing }\end{array}$ \\
\hline 195-199, lv. 1 & body & grog-bone & $\mathrm{F}$ & - & 8.4 & $\mathrm{c}$ & $\begin{array}{l}\text { parallel brushed with fingernail punctated } \\
\text { rows through brushing }\end{array}$ \\
\hline 195-199, lv. 2 & rim & grog & $\mathrm{F}$ & $\mathrm{I} / \mathrm{E} \mathrm{SM}$ & 5.6 & $\mathrm{c}$ & horizontal engraved; red pigment \\
\hline 195-199, lv. 4 & body & bone-hematite & A & $\mathrm{I} / \mathrm{E} \mathrm{B}$ & 7.5 & $\mathrm{c}$ & horizontal and diagonal engraved; CB \\
\hline 195-200, lv. 1 & body & grog & $\mathrm{B}$ & $\mathrm{I} / \mathrm{E} \mathrm{B}$ & 5.5 & $\mathrm{c}$ & triangular engraved el., Poynor Engraved \\
\hline \multirow[t]{3}{*}{ 195-200, lv. 2} & body & grog & A & - & 7.1 & $\mathrm{c}$ & cross-hatched incised; pinkware \\
\hline & body & grog & $\mathrm{G}$ & I SM & 7.5 & $\mathrm{c}$ & fingernail punctated rows \\
\hline & body & grog-bone & $\mathrm{G}$ & I SM & 7.6 & $\mathrm{c}$ & $\begin{array}{l}\text { parallel brushed with fingernail punctated } \\
\text { rows through brushing }\end{array}$ \\
\hline
\end{tabular}




\begin{tabular}{|c|c|c|c|c|c|c|c|}
\hline Provenience/Level & $\begin{array}{l}\text { Sherd } \\
\text { Type }\end{array}$ & Temper & Firing & $\begin{array}{l}\text { Surface } \\
\text { Treatment }\end{array}$ & $\begin{array}{l}\text { Thickness } \\
(\mathrm{mm})\end{array}$ & Paste & Decoration \\
\hline 195-200, lv. 2 & body & grog-hematite & A & I SM & 9.0 & $\mathrm{c}$ & $\begin{array}{l}\text { curvilinear engraved lines and triangular } \\
\text { elements }\end{array}$ \\
\hline 195-200, lv. 3 & body & $\begin{array}{l}\text { grog-hematite- } \\
\text { organics }\end{array}$ & $\mathrm{F}$ & - & 7.4 & SP & $\begin{array}{l}\text { cross-hatched, opposed, and nested } \\
\text { triangles }\end{array}$ \\
\hline 195-201, lv. 1 & body & grog & $\mathrm{F}$ & E SM & 5.6 & $\mathrm{SP}$ & horizontal engraved lines; red pigment \\
\hline 195-201, lv. 2 & body & grog-bone & $\mathrm{G}$ & - & 8.1 & $\mathrm{c}$ & $\begin{array}{l}\text { triangular incies zone filled with tool } \\
\text { punctates }\end{array}$ \\
\hline 195-201, lv. 3 & body & $\begin{array}{l}\text { grog-hematite- } \\
\text { organics }\end{array}$ & $\mathrm{F}$ & E B & 5.2 & $\mathrm{c}$ & $\begin{array}{l}\text { engraved hatched triangular element and } \\
\text { curvilinear engraved lines; red pigment; } \mathrm{Bt}\end{array}$ \\
\hline 195-201, lv. 4 & body & grog & $\mathrm{F}$ & E SM & 6.6 & SP & curvilinear engraved lines; $\mathrm{Bt}$, red pigment \\
\hline 195-202, lv. 2 & rim & grog & $\mathrm{B}$ & I SM & 6.5 & SP & $\begin{array}{l}\text { incised panels filled with tool punctates; } \\
\text { D-Ro, ext. f, } 15 \mathrm{~cm}\end{array}$ \\
\hline 195-202, lv. 3 & body & grog-hematite & $\mathrm{F}$ & - & 7.8 & $\mathrm{SP}$ & incised panels filled with tool punctates \\
\hline 195-202, lv. 3 & body & grog-hematite & $\mathrm{F}$ & - & 8.0 & $\mathrm{c}$ & $\begin{array}{l}\text { curvilinear incised zones filled with } \\
\text { tool punctates }\end{array}$ \\
\hline 195-203, lv. 3 & body & grog & G & E B & 6.8 & $\mathrm{c}$ & curvilinear engraved lines; $\mathrm{Bt}$ \\
\hline 196-198, lv. 1 & body & grog & $\mathrm{H}$ & I SM & 8.3 & $\mathrm{c}$ & fingernail punctated rows \\
\hline 196-199, lv. 3 & body & grog & $\mathrm{G}$ & E B & 7.7 & $\mathrm{c}$ & ext. red-slipped \\
\hline $196-200$, lv. 5 & body & grog-hematite & $\mathrm{F}$ & I/E SM & 7.2 & $\mathrm{c}$ & $\begin{array}{l}\text { horizontal engraved lines and triangular } \\
\text { engraved el., Poynor Engraved }\end{array}$ \\
\hline 196-201, lv. 1 & body & grog & $\mathrm{F}$ & - & 8.9 & $\mathrm{c}$ & $\begin{array}{l}\text { parallel brushed with fingernail punctates } \\
\text { through the brushing }\end{array}$ \\
\hline \multirow[t]{3}{*}{ 196-201, lv. 2} & body & grog-hematite & $\mathrm{E}$ & - & 8.8 & $\mathrm{c}$ & parallel brushed; pinkware \\
\hline & body & grog & $\mathrm{G}$ & - & 8.1 & $\mathrm{c}$ & parallel brushed \\
\hline & rim & grog & $\mathrm{B}$ & I SM & 6.9 & $\mathrm{c}$ & vertical tool punctated row \\
\hline 196-201, lv. 4 & rim & grog & $\mathrm{G}$ & I SM & 10.2 & $\mathrm{c}$ & neck banded; Ev-Ro \\
\hline 196-202, lv. 1 & body & grog & $\mathrm{F}$ & - & 6.8 & $\mathrm{SP}$ & int. red-slipped \\
\hline 196-202, lv. 3 & body & hematite & A & - & 8.2 & SP & fingernail punctated rows \\
\hline 196-203, lv. 4 & body & grog & G & I/E SM & 6.9 & SP & $\begin{array}{l}\text { horizontal and diagonal engraved; hatched } \\
\text { panel; Poynor Engraved; CB }\end{array}$ \\
\hline 197-198, lv. 4 & body & grog & $\mathrm{F}$ & - & 9.2 & $\mathrm{c}$ & fingernail punctated rows \\
\hline 197-199, lv. 2 & body & grog & $\mathrm{F}$ & $\mathrm{I} / \mathrm{E} \mathrm{B}$ & 6.8 & $\mathrm{c}$ & $\begin{array}{l}\text { curvilinear and hatched panel engraved with } \\
\text { engraved circle filled with small circular } \\
\text { punctates; cf. Poynor Engraved; CB }\end{array}$ \\
\hline 197-199, lv. 3 & body & $\begin{array}{l}\text { grog-bone- } \\
\text { hematite }\end{array}$ & G & I SM & 7.6 & $\mathrm{c}$ & tool punctated and pinched rows \\
\hline
\end{tabular}




\begin{tabular}{|c|c|c|c|c|c|c|c|}
\hline Provenience/Level & $\begin{array}{l}\text { Sherd } \\
\text { Type }\end{array}$ & Temper & Firing & $\begin{array}{l}\text { Surface } \\
\text { Treatment }\end{array}$ & $\begin{array}{l}\text { Thickness } \\
(\mathrm{mm})\end{array}$ & Paste & Decoration \\
\hline $197-200$, lv. 3 & body & grog-hematite & $\mathrm{F}$ & - & 8.6 & SP & parallel incised lines \\
\hline 197-201, lv. 1 & body & grog & G & I SM & 7.9 & $\mathrm{c}$ & horizontal and opposed incised lines \\
\hline 197-201, lv. 6 & body & grog & $\mathrm{H}$ & - & 7.7 & $\mathrm{c}$ & cross-hatched incised lines \\
\hline 197-202, lv. 2 & body & grog-bone & $\mathrm{B}$ & - & 7.4 & $\mathrm{c}$ & curvilinear engraved lines; $\mathrm{Bt}$ \\
\hline 197-202, lv. 4 & body & grog & $\mathrm{F}$ & I SM & 8.1 & $\mathrm{c}$ & curvilinear incised lines \\
\hline \multirow{2}{*}{ 197-202, lv. 5} & body & grog-hematite & $\mathrm{F}$ & I SM & 9.9 & $\mathrm{c}$ & tool punctated rows \\
\hline & rim & grog & $\mathrm{H}$ & - & 7.1 & SP & $\begin{array}{l}\text { diagonal and triangular engraved el.; cf. } \\
\text { Poynor Engraved; D-RO, CB }\end{array}$ \\
\hline 197-203, lv. 3 & body & grog & $\mathrm{B}$ & E B & 7.7 & $\mathrm{c}$ & $\begin{array}{l}\text { curvilinear and triangular engraved els; } \\
\text { Bt; red pigment }\end{array}$ \\
\hline 197-203, lv. 4 & body & grog-hematite & $\mathrm{G}$ & - & 7.9 & SP & tool punctated rows \\
\hline 198-198, lv. 1 & body & grog & $\mathrm{B}$ & I SM & 7.1 & $\mathrm{c}$ & cross-hatched incised lines \\
\hline \multirow[t]{2}{*}{ 198-198, lv. 4} & body & grog & $\mathrm{F}$ & $\mathrm{I} / \mathrm{E} \mathrm{B}$ & 4.7 & $\mathrm{c}$ & closely-spaced engraved lines \\
\hline & rim & grog & $\mathrm{B}$ & I SM & 7.9 & $\begin{array}{l}\mathrm{c} \\
\mathrm{OD}\end{array}$ & cross-hatched incised lines; D-Ro; $19 \mathrm{~cm}$ \\
\hline 198-199, lv. 2 & body & grog & G & E B & 5.9 & $\mathrm{c}$ & curvilinear engraved lines; Bt; red pigment \\
\hline 198-199, lv. 4 & body & grog & $\mathrm{G}$ & E B & 5.6 & SP & engraved hatched panels; red pigment \\
\hline $198-200$, lv. 2 & rim & grog & A & I SM & 6.5 & $\mathrm{c}$ & diagonal incised lines; pinkware \\
\hline 198-201, lv. 1 & body & grog-hematite & A & I SM & 10.3 & $\mathrm{c}$ & overlapping brushed \\
\hline 198-201, lv. 2 & body & grog & $\mathrm{B}$ & $\mathrm{I} / \mathrm{E} \mathrm{B}$ & 9.0 & $\mathrm{c}$ & $\begin{array}{l}\text { engraved panels and triangular elements; } \\
\text { Poynor Engraved; CB }\end{array}$ \\
\hline 198-201, lv. 3 & body & grog & $\mathrm{D}$ & - & 8.1 & $\mathrm{c}$ & parallel brushed \\
\hline 198-201, lv. 4 & body & grog-organics & $\mathrm{H}$ & E B & 5.7 & $\mathrm{c}$ & $\begin{array}{l}\text { curvilinear engraved lines and hatched } \\
\text { circular element, } \mathrm{Bt}\end{array}$ \\
\hline 198-201, lv. 6 & body & grog & $\mathrm{B}$ & E B & 7.3 & $\mathrm{c}$ & curvilinear engraved lines; $\mathrm{Bt}$ \\
\hline 198-202, lv. 3 & body & grog & $\mathrm{H}$ & - & 7.7 & $\mathrm{c}$ & diagonal and horizontal incised lines \\
\hline 198-202, lv. 5 & body & grog-hematite & A & E B & 6.0 & $\mathrm{c}$ & rectilinear engraved lines, $\mathrm{Bt}$ \\
\hline 198-202, lv. 6 & body & grog & $\mathrm{C}$ & - & 6.5 & $\mathrm{c}$ & parallel brushed \\
\hline 198-202, lv. 7 & rim & grog & $\mathrm{D}$ & $\mathrm{I} / \mathrm{E} \mathrm{SM}$ & 7.3 & $\mathrm{c}$ & engraved ovals; Poynor Engraved; D-Ro \\
\hline 198-203, lv. 3 & body & grog & A & - & 9.4 & SP & parallel brushed \\
\hline \multirow[t]{2}{*}{ 198-203, lv. 4} & body & grog & $\mathrm{H}$ & I SM & 8.9 & $\mathrm{c}$ & tool punctated rows \\
\hline & body & grog & $\mathrm{F}$ & I SM & 8.9 & $\mathrm{c}$ & $\begin{array}{l}\text { diagonal incised and tool punctated filled } \\
\text { triangles }\end{array}$ \\
\hline 198-203, lv. 7 & body & grog-bone & $\mathrm{G}$ & E B & 5.1 & $\mathrm{c}$ & opposed engraved lines; $\mathrm{Bt}$ \\
\hline 199-198, lv. 3 & rim & grog-hematite & $\mathrm{G}$ & $\mathrm{I} / \mathrm{E} \mathrm{B}$ & 5.6 & SP & $\begin{array}{l}\text { hatched and cross-hatched engraved } \\
\text { triangular el., D-FL, } 13 \mathrm{~cm}+\text { OD }\end{array}$ \\
\hline
\end{tabular}




\begin{tabular}{|c|c|c|c|c|c|c|c|}
\hline Provenience/Level & $\begin{array}{l}\text { Sherd } \\
\text { Type }\end{array}$ & Temper & Firing & $\begin{array}{l}\text { Surface } \\
\text { Treatment }\end{array}$ & $\begin{array}{l}\text { Thickness } \\
(\mathrm{mm})\end{array}$ & Paste & Decoration \\
\hline 199-198, lv. 4 & body & grog & G & - & 6.5 & SP & curvilinear engraved lines; $\mathrm{Bt}$; red pigment \\
\hline 199-199, lv. 3 & body & grog & $\mathrm{F}$ & I SM & 6.8 & $\mathrm{c}$ & fingernail punctated rows \\
\hline 199-194, lv. 4 & rim & grog-hematite & $\mathrm{F}$ & E SM & - & SP & horizontal hatched engraved panel; -Ro \\
\hline 199-200, lv. 1 & rim & grog & $\mathrm{B}$ & I SM & 6.0 & $\begin{array}{l}\text { SP } \\
\text { OD }\end{array}$ & cross-hatched incised lines; D-Ro, $27 \mathrm{~cm}$ \\
\hline \multirow[t]{2}{*}{ 199-200, lv. 2} & body & grog-bone & $\mathrm{F}$ & E SM & 7.1 & $\mathrm{c}$ & horizontal and vertical engraved lines, $\mathrm{CB}$ \\
\hline & body & bone & $\mathrm{F}$ & - & 8.8 & $\mathrm{c}$ & incised triangular el; Poynor variety \\
\hline 199-200, lv. 4 & body & grog & $\mathrm{B}$ & - & 7.6 & $\mathrm{c}$ & cross-hatched incised lines \\
\hline 199-201, lv. 2 & body & grog & $\mathrm{G}$ & E SM & 6.2 & $\mathrm{c}$ & engraved oval el, Bt \\
\hline \multirow[t]{2}{*}{ 199-201, lv. 3} & body & grog & $\mathrm{G}$ & I SM & 8.0 & $\mathrm{c}$ & overlapping brushed \\
\hline & body & grog & $\mathrm{G}$ & I SM & 6.7 & $\mathrm{c}$ & cross-hatched incised lines \\
\hline 199-201, lv. 4 & body & grog & $\mathrm{F}$ & I SM & 8.3 & $\mathrm{c}$ & diagonal incised lines \\
\hline 199-201, lv. 5 & rim & - & $\mathrm{B}$ & - & 7.1 & SP & diagonal incised lines; EV-Ro, $21 \mathrm{~cm}+\mathrm{OD}$ \\
\hline 199-202, lv. 2 & body & - & $\mathrm{G}$ & E B & 5.9 & $\mathrm{c}$ & engraved triangular elements, $\mathrm{Bt}$ \\
\hline 199-202, lv. 3 & body & grog-hematite & A & - & 10.0 & SP & overlapping brushed \\
\hline 199-202, lv. 5 & body & grog & $\mathrm{F}$ & - & 9.0 & $\mathrm{c}$ & incised triangle filled with tool punctations \\
\hline 199-203, lv. 2 & body & grog & $\mathrm{B}$ & I SM & 6.5 & SP & tool punctated rows \\
\hline 199-203, lv. 3 & body & grog & A & - & 6.9 & SP & $\begin{array}{l}\text { curvilinear engraved lines with triangular } \\
\text { tick marks, Poynor/Patton Engraved }\end{array}$ \\
\hline 200-198, lv. 3 & body & bone-grog & $\mathrm{E}$ & - & 7.0 & $\mathrm{c}$ & engraved triangle element, $\mathrm{Bt}$ \\
\hline 200-199, lv. 3 & body & grog & G & I SM & 5.9 & $\mathrm{c}$ & hatched engraved panel \\
\hline 200-200, lv. 3 & body & bone & $\mathrm{B}$ & I SM & 6.0 & $\mathrm{c}$ & tool punctated row \\
\hline 200-200, lv. 4 & body & grog & $\mathrm{C}$ & - & 6.1 & $\mathrm{c}$ & parallel brushed \\
\hline 200-201, lv. 2 & body & grog & $\mathrm{F}$ & I SM & 9.8 & $\mathrm{c}$ & tool punctated rows \\
\hline 200-201, lv. 4 & body & grog & G & - & 9.6 & $\mathrm{c}$ & parallel brushed \\
\hline $200-202$, lv. 1 & body & grog & $\mathrm{G}$ & - & 7.6 & $\mathrm{c}$ & parallel incised lines \\
\hline 200-202, lv. 3 & rim & grog & $\mathrm{B}$ & I SM & 7.6 & $\mathrm{c}$ & diagonal incised lines; EV-Ro, $22 \mathrm{~cm}+\mathrm{OD}$ \\
\hline \multirow[t]{2}{*}{$200-203$, lv. 3} & body & grog & A & - & 8.4 & $\mathrm{c}$ & parallel brushed, pinkware \\
\hline & body & grog & $\mathrm{A}$ & $\mathrm{I} / \mathrm{E} \mathrm{B}$ & 5.2 & $\mathrm{c}$ & engraved circle, red pigment \\
\hline 201-198, lv. 2 & body & grog-hematite & $\mathrm{F}$ & I SM & 7.7 & $\mathrm{c}$ & fingernail punctated rows \\
\hline 201-198, lv. 3 & body & grog-bone & $\mathrm{F}$ & I SM & 4.9 & $\mathrm{c}$ & $\begin{array}{l}\text { parallel engraved panel filled with small } \\
\text { circular punctations }\end{array}$ \\
\hline 201-198, lv. 4 & body & $\begin{array}{l}\text { grog-bone- } \\
\text { hematite }\end{array}$ & $\mathrm{F}$ & I SM & 6.9 & $\mathrm{c}$ & $\begin{array}{l}\text { parallel incised lines with tool punctated } \\
\text { row below incised lines }\end{array}$ \\
\hline
\end{tabular}




\begin{tabular}{|c|c|c|c|c|c|c|c|}
\hline Provenience/Level & $\begin{array}{l}\text { Sherd } \\
\text { Type }\end{array}$ & Temper & Firing & $\begin{array}{l}\text { Surface } \\
\text { Treatment }\end{array}$ & $\begin{array}{l}\text { Thickness } \\
(\mathrm{mm})\end{array}$ & Paste & Decoration \\
\hline 201-199, lv. 2 & body & grog & $\mathrm{F}$ & I SC & 6.8 & $\mathrm{c}$ & fingernail punctated row \\
\hline 201-200, lv. 4 & body & grog & $\mathrm{E}$ & - & 6.7 & SP & $\begin{array}{l}\text { engraved circle with small circular } \\
\text { punctations within circle; cf. Poynor }\end{array}$ \\
\hline 201-201, lv. 2 & rim & grog-hematite & $\mathrm{C}$ & - & 7.0 & $\mathrm{c}$ & $\begin{array}{l}\text { tool punctated rows below horizontal incised } \\
\text { line, } D-R o, 13 \mathrm{~cm}+\text { OD }\end{array}$ \\
\hline 201-201, lv. 3 & rim & grog & G & I SM & 7.9 & $\mathrm{c}$ & $\begin{array}{l}\text { diagonal opposed incised lines; EV-Ro, } \\
17 \mathrm{~cm}+\text { OD }\end{array}$ \\
\hline 201-202, lv. 2 & body & grog-hematite & G & - & 6.2 & $\mathrm{c}$ & engraved hatched panel \\
\hline 201-202, lv. 4 & body & grog & A & - & 6.7 & $\mathrm{c}$ & opposed brushed; pinkware \\
\hline 201-203, lv. 3 & body & grog & $\mathrm{F}$ & - & 5.9 & $\mathrm{c}$ & $\begin{array}{l}\text { vertical incised panels filled with tool } \\
\text { punctates }\end{array}$ \\
\hline 202-200, lv. 2 & body & grog-hematite & $\mathrm{K}$ & E B & 5.4 & SP & straight engraved line; BT, red pigment \\
\hline 202-200, lv. 4 & body & grog & A & I SM & 7.2 & c & overlapping brushed \\
\hline 202-201, lv. 2 & body & grog & $\mathrm{F}$ & E SM & 7.7 & c & single diagonal engraved line, $\mathrm{Bw}$ \\
\hline 202-203, lv. 4 & body & bone & A & I SM & 6.6 & $\mathrm{c}$ & tool punctated rows \\
\hline $202-204,40 \mathrm{~cm}$ & body & grog-hematite & G & - & 6.8 & $\mathrm{c}$ & engraved hatched panel \\
\hline 203-200, 1v. 3 & body & grog-hematite & A & - & 9.4 & $\mathrm{c}$ & overlapping brushed \\
\hline 203-201, lv. 4 & body & grog-hematite & $\mathrm{B}$ & I SM & 7.2 & $\mathrm{c}$ & fingernail punctated rows \\
\hline 203-202, 1v. 3 & body & grog & A & - & 10.2 & SP & parallel brushed; pinkware \\
\hline 203-202, lv. 4 & body & grog-organics & G & E B & 6.7 & $\mathrm{c}$ & $\begin{array}{l}\text { parallel engraved lines and triangular el; } \\
\mathrm{Bt} \text {, red pigment }\end{array}$ \\
\hline 203-203, lv. 4 & rim & grog & $\mathrm{F}$ & $\mathrm{I} / \mathrm{E} \mathrm{SM}$ & 5.5 & $\mathrm{c}$ & single horizontal engraved line, D-Ro \\
\hline 204-199, lv. 1 & body & grog-hematite & $\mathrm{F}$ & - & 7.5 & SP & $\begin{array}{l}\text { horizontal engraved and circular engraved } \\
\text { el, Poynor Engraved }\end{array}$ \\
\hline 204-200, lv. 1 & body & grog-hematite & $\mathrm{F}$ & - & 7.4 & $\mathrm{c}$ & parallel brushed \\
\hline 204-202, lv. 1 & body & grog-hematite & G & E SM & 6.3 & SP & ext. red-slipped, Bt \\
\hline \multirow[t]{2}{*}{ 204-202, lv. 4} & body & grog-bone & $\mathrm{F}$ & I SM & 7.9 & $\mathrm{c}$ & $\begin{array}{l}\text { parallel brushed with tool punctated rows } \\
\text { through the brushing }\end{array}$ \\
\hline & body & grog & $\mathrm{F}$ & - & 6.6 & $\mathrm{c}$ & $\begin{array}{l}\text { curvilinear and hatched engraved, Bt; red } \\
\text { pigment }\end{array}$ \\
\hline 205-200, lv. 1 & body & - & G & I SM & 9.2 & SP & diagonal tool punctated rows \\
\hline 206-198, lv. 3 & body & grog & $\mathrm{H}$ & - & 8.1 & $\mathrm{c}$ & cross-hatched incised lines \\
\hline 206-199, lv. 1 & body & grog & $\mathrm{F}$ & I/E SM & 6.4 & SP & horizontal and triangular engraved el. and \\
\hline
\end{tabular}




\begin{tabular}{|c|c|c|c|c|c|c|c|}
\hline Provenience/Level & $\begin{array}{l}\text { Sherd } \\
\text { Type }\end{array}$ & Temper & Firing & $\begin{array}{l}\text { Surface } \\
\text { Treatment }\end{array}$ & $\begin{array}{l}\text { Thickness } \\
(\mathrm{mm})\end{array}$ & Paste & Decoration \\
\hline 206-200, lv. 1 & rim & grog & $\mathrm{F}$ & E B/I SM 6.5 & & SP & $\begin{array}{l}\text { engraved circle filled with small } \\
\text { punctations; Poynor Engraved } \\
\text { diagonal engraved lines; lip notched; } \\
\text { D-FL; red pigment }\end{array}$ \\
\hline 206-200, lv. 4 & body & grog-hematite & $\mathrm{K}$ & - & 6.6 & $\mathrm{c}$ & overlapping brushed \\
\hline 207-199, lv. 3 & body & grog-bone & $\mathrm{B}$ & E B & 7.0 & $\mathrm{c}$ & single straight engraved line, $\mathrm{Bt}$ \\
\hline 208-198, lv. 4 & body & grog-bone & G & E B/I SM 6.5 & & $\mathrm{c}$ & int./ext. red-slipped \\
\hline 208-199, lv. 1 & body & grog & $\mathrm{F}$ & I SM & 6.9 & $\mathrm{c}$ & parallel brushed \\
\hline 209-199, lv. 3 & body & bone & $\mathrm{B}$ & I SM & 6.1 & $\mathrm{c}$ & tool punctated rows \\
\hline
\end{tabular}

\section{Features}

\begin{tabular}{|c|c|c|c|c|c|c|c|}
\hline Provenience/Level & $\begin{array}{l}\text { Sherd } \\
\text { Type }\end{array}$ & Temper & Firing & $\begin{array}{l}\text { Surface } \\
\text { Treatment }\end{array}$ & $\begin{array}{l}\text { Thickness (mm) } \\
\text { t }\end{array}$ & Paste & Decoration \\
\hline 197-201, F.25, lv. 3 & body & $\begin{array}{l}\text { grog-bone- } \\
\text { hematite }\end{array}$ & $\mathrm{F}$ & E B & 4.6 & $\mathrm{c}$ & engraved hatched panels, $\mathrm{Bt}$, red pigment \\
\hline 197-201, F.25, lv. 4 & body & grog-bone & G & I SM & 7.0 & $\mathrm{c}$ & fingernail punctated rows \\
\hline \multirow[t]{3}{*}{$\begin{array}{l}195-200, \text { F.36, } \\
25-35 \mathrm{~cm}\end{array}$} & rim & grog & $\mathrm{B}$ & I SM & 7.1 & $\begin{array}{l}\mathrm{c} \\
18 \mathrm{~cm}\end{array}$ & $\begin{array}{l}\text { opposed incised triangles; D-Ro, ext f; } \\
\text { D }\end{array}$ \\
\hline & body & grog & $\mathrm{B}$ & I SM & 7.6 & $\mathrm{c}$ & incised triangles filled with tool punctates \\
\hline & body & grog & $\mathrm{B}$ & $\mathrm{I} / \mathrm{E} \mathrm{B}$ & 7.0 & $\mathrm{c}$ & engraved hatched panel; int./ext red slip \\
\hline $\begin{array}{l}196-201, \text { F.36B } \\
23 \mathrm{~cm}\end{array}$ & rim & grog & $\mathrm{G}$ & I SM & 8.4 & $\mathrm{c}$ & diagonal incised lines, D-Ro, $13 \mathrm{~cm}$ OD \\
\hline \multirow[t]{3}{*}{ 196-201, F.39, lv. 5} & rim & grog & A & - & 6.7 & $\mathrm{c}$ & $\begin{array}{l}\text { triangular incised zone filled with tool } \\
\text { punctates; D-FL, } 11 \mathrm{~cm}+\text { OD }\end{array}$ \\
\hline & body & grog & $\mathrm{G}$ & I SM & 6.4 & silt & tool punctated rows \\
\hline & body & grog-hematite & A & - & 6.7 & $\mathrm{c}$ & curvilinear engraved lines, $\mathrm{Bt}$ \\
\hline 193-198, F.66, & body & grog & A & I SM & 8.4 & $\mathrm{c}$ & parallel brushed \\
\hline $60-129 \mathrm{~cm}$ & body & grog & $\mathrm{B}$ & I SM & 9.7 & $\mathrm{c}$ & parallel brushed \\
\hline 197-201, F.74, & rim & grog-hematite & $\mathrm{G}$ & I SM & 8.0 & $\mathrm{c}$ & cross-hatched lines, D-FL, $34 \mathrm{~cm}$ OD $50-74 \mathrm{~cm}$ \\
\hline
\end{tabular}




\begin{tabular}{|c|c|c|c|c|c|c|c|}
\hline Provenience/Level & $\begin{array}{l}\text { Sherd } \\
\text { Type }\end{array}$ & Temper & Firing & $\begin{array}{l}\text { Surface } \\
\text { Treatmen }\end{array}$ & Thickness (mm) & Paste & Decoration \\
\hline 196-203, F.76, lv. 6 & body & grog & $\mathrm{B}$ & - & 7.5 & SP & incised panels filled with tool punctates \\
\hline 197-202, F.76, lv. 9 & rim & grog & $\mathrm{F}$ & I SM & 7.4 & $\mathrm{c}$ & $\begin{array}{l}\text { incised triangles filled with cane punctates; } \\
\text { EV-Ro }\end{array}$ \\
\hline 197-202, F.76, lv. 11 & body & grog & $\mathrm{G}$ & E B & 5.7 & $\mathrm{c}$ & $\begin{array}{l}\text { horizontal lines and hatched engraved } \\
\text { triangles; } \mathrm{Bt}\end{array}$ \\
\hline 197-202, F.76, lv. 15 & rim & grog & $\mathrm{B}$ & I SM & 5.5 & $\mathrm{c}$ & tool punctated rows; D-FL \\
\hline \multirow[t]{6}{*}{ 197-203, F. 76, lv. 12} & body & grog & $\mathrm{G}$ & I SM & 7.9 & $\mathrm{c}$ & fingernail punctated row \\
\hline & body & grog & G & - & 8.0 & $\mathrm{c}$ & tool punctated row \\
\hline & body & grog-bone & $\mathrm{G}$ & - & 7.0 & $\mathrm{c}$ & parallel incised lines \\
\hline & body & - & $\mathrm{B}$ & E SM & 5.5 & silt & engraved hatched panel \\
\hline & rim & grog & $\mathrm{C}$ & I SM & 7.3 & $\mathrm{SP}$ & diagonal tool punctates; D-Ro, $18 \mathrm{~cm}$ OD \\
\hline & rim & grog-hematite & A & - & 6.5 & SP & $\begin{array}{l}\text { diagonal and triangular engraved lines; } \\
\text { Poynor Engraved, D-Ro, } 17 \mathrm{~cm} \text { OD }\end{array}$ \\
\hline 197-203, F.76, lv. 13 & body & bone & $\mathrm{G}$ & - & 8.4 & $\mathrm{c}$ & tool punctated over body; pinkware \\
\hline 197/198-202, F.76, & body & grog & G & I SM & 9.8 & $\begin{array}{l}\text { c } \\
\text { lv. } 9\end{array}$ & broad horizontal and diagonal incised lines \\
\hline \multirow[t]{2}{*}{ 198-202, F.76, lv. 9} & body & grog & G & E B & 7.8 & $\mathrm{c}$ & $\begin{array}{l}\text { horizontal and diagonal incised lines and } \\
\text { incised diamond, cf. Poynor, CB }\end{array}$ \\
\hline & body & grog & $\mathrm{H}$ & I SM & 8.7 & $\mathrm{c}$ & zoned incised-fingernail punctated row \\
\hline \multirow[t]{3}{*}{ 198-202, F.76, lv. 10} & body & grog & $\mathrm{A}$ & - & 7.4 & $\mathrm{c}$ & parallel brushed; pinkware \\
\hline & body & grog-hematite & G & - & 6.8 & $\mathrm{c}$ & opposed incised lines \\
\hline & body & grog & $\mathrm{G}$ & - & 7.6 & $\mathrm{c}$ & curvilinear engraved lines, $\mathrm{Bt}$ \\
\hline \multirow[t]{10}{*}{ 198-202, F.76, lv. 11} & body & grog-hematite & A & - & 9.7 & $\mathrm{c}$ & parallel brushed \\
\hline & body & grog & $\mathrm{A}$ & - & 7.3 & $\mathrm{c}$ & overlapping brushed; pinkware \\
\hline & body & grog & $\mathrm{C}$ & - & 7.5 & $\mathrm{c}$ & fingernail punctated rows \\
\hline & body & grog & $\mathrm{B}$ & I SM & 7.5 & SP & single straight incised line \\
\hline & body & grog & B & - & 7.5 & SP & cross-hatched incised lines \\
\hline & body & grog & $\mathrm{B}$ & $\mathrm{I} / \mathrm{E} \mathrm{SM}$ & 6.2 & $\mathrm{c}$ & cross-hatched engraved panels \\
\hline & body & - & $\mathrm{G}$ & E SM & 6.9 & SP & curvilinear engraved lines; $\mathrm{Bt}$ \\
\hline & body & grog & G & E B & 6.2 & SP & curvilinear engraved lines, Bt; red pigment \\
\hline & rim & bone & $\mathrm{F}$ & $\mathrm{I} / \mathrm{E} \mathrm{SM}$ & 6.6 & $\mathrm{c}$ & lip notched; D-Ro, $18 \mathrm{~cm} \mathrm{OD}$ \\
\hline & rim & bone-grog & $\mathrm{B}$ & I SM & 6.5 & $\mathrm{c}$ & $\begin{array}{l}\text { incised triangles filled with tool punctates; } \\
\text { D-FL, } 24 \mathrm{~cm} \text { OD }\end{array}$ \\
\hline 198-202, F.76, lv. 12 & body & grog-bone & $\mathrm{B}$ & I SM & 7.6 & $\mathrm{c}$ & $\begin{array}{l}\text { triangular incised zone filled with tool } \\
\text { punctates }\end{array}$ \\
\hline
\end{tabular}




\begin{tabular}{|c|c|c|c|c|c|c|c|}
\hline Provenience/Level & $\begin{array}{l}\text { Sherd } \\
\text { Type }\end{array}$ & Temper & Firing & $\begin{array}{l}\text { Surface } \\
\text { Treatment }\end{array}$ & $\begin{array}{l}\text { Thickness (mm) } \\
\mathrm{t}\end{array}$ & Paste & Decoration \\
\hline & body & grog & $\mathrm{B}$ & I SM & 7.4 & $\mathrm{c}$ & $\begin{array}{l}\text { circular incised zone filled with tool } \\
\text { punctates }\end{array}$ \\
\hline & rim & grog & $\mathrm{B}$ & - & 7.9 & $\mathrm{c}$ & cross-hatched incised lines; D-Ro \\
\hline & body & grog & $\mathrm{F}$ & - & 8.0 & $\mathrm{c}$ & parallel incised lines \\
\hline & body & grog-bone & $\mathrm{B}$ & E SM & 5.4 & $\mathrm{c}$ & tool punctated rows \\
\hline & body & grog-hematite & $\mathrm{E}$ & I SM & 7.7 & $\mathrm{c}$ & fingernail punctated rows \\
\hline & body & grog & $\mathrm{B}$ & $\mathrm{I} / \mathrm{E} \mathrm{B}$ & 5.2 & $\mathrm{c}$ & $\begin{array}{l}\text { triangular elements and engraved oval; cf. } \\
\text { Poynor Engraved; int./ext. red slipped }\end{array}$ \\
\hline & $\begin{array}{l}\text { rim } \\
\text { hematite }\end{array}$ & bone-grog- & $\mathrm{B}$ & - & 7.0 & $\mathrm{c}$ & tool punctated rows; D-Ro, $18 \mathrm{~cm}$ OD \\
\hline \multirow[t]{2}{*}{ 198-202, F.76, lv. 13} & body & grog-hematite & $\mathrm{C}$ & - & 6.8 & $\mathrm{c}$ & fingernail punctated rows \\
\hline & rim & grog & $\mathrm{B}$ & I SM & 6.9 & SP & tool punctated rows; D-Ro \\
\hline 198-203, F.76, lv. 5 & rim & grog & $\mathrm{B}$ & I SM & 6.8 & $\mathrm{c}$ & $\begin{array}{l}\text { incised triangles filled with tool punctates; } \\
\text { D-Ro, ext f; } 13 \mathrm{~cm} \mathrm{OD}\end{array}$ \\
\hline \multirow[t]{3}{*}{ 198-203, F.76, lv. 6} & body & grog-bone & $\mathrm{B}$ & I SM & 6.7 & $\mathrm{c}$ & fingernail punctated \\
\hline & body & bone & $\mathrm{H}$ & I SM & 6.8 & $\mathrm{c}$ & tool punctated rows \\
\hline & $\begin{array}{l}\text { body } \\
\text { organics }\end{array}$ & grog-hematite- & $\mathrm{F}$ & E SM & 6.8 & SP & hatched triangular engraved zone, $\mathrm{Bt}$ \\
\hline 198-203, F.76, lv. 7 & body & grog & $\mathrm{B}$ & I SM & 5.1 & $\mathrm{c}$ & hatched triangular el. $\mathrm{Bt}$ \\
\hline 198-203, F.76, lv. 10 & body & bone & $\mathrm{B}$ & I SM & 6.8 & $\mathrm{c}$ & fingernail punctated rows \\
\hline \multirow[t]{3}{*}{ 198-203, F.76, lv. 11} & rim & bone & $\mathrm{B}$ & I SM & 7.7 & $\mathrm{c}$ & $\begin{array}{l}\text { incised triangular zones filled with tool } \\
\text { punctates; D-FL, ext f, } 22 \mathrm{~cm} \text { OD }\end{array}$ \\
\hline & body & grog & $\mathrm{B}$ & I SM & 7.1 & $\mathrm{c}$ & $\begin{array}{l}\text { incised triangular zone filled with tool } \\
\text { punctates }\end{array}$ \\
\hline & body & grog & $\mathrm{E}$ & - & 6.5 & $\mathrm{c}$ & zoned incised-tool punctated \\
\hline \multirow[t]{2}{*}{ 198-203, F.76, lv. 13} & body & organics $G$ & - & & 7.0 & $\mathrm{c}$ & $\begin{array}{l}\text { horizontal and curvilinear engraved lines } \\
\text { and triangular el., Bt }\end{array}$ \\
\hline & rim & grog-bone & $\mathrm{B}$ & I SM & 7.5 & $\mathrm{c}$ & $\begin{array}{l}\text { curvilinear incised zones filled with tool } \\
\text { punctates; D-FL }\end{array}$ \\
\hline 199-202, F.76, lv. 5 & body & grog-hematite & $\mathrm{F}$ & - & 6.7 & $\mathrm{c}$ & broad curvilinear engraved lines; $\mathrm{Bt}$ \\
\hline 199-202, F.76, lv. 8 & rim & grog-bone & A & I SM & 6.5 & $\mathrm{c}$ & $\begin{array}{l}\text { opposed incised lines; D-FL, } 12 \mathrm{~cm} \mathrm{OD;} \\
\text { pinkware }\end{array}$ \\
\hline 199-202, F.76, lv. 9 & rim & grog & $\mathrm{B}$ & - & 7.9 & $\mathrm{SP}$ & opposed incised lines; D-Ro, $13 \mathrm{~cm}+\mathrm{OD}$ \\
\hline \multirow[t]{3}{*}{ 199-202, F.76, lv. 10} & body & grog & $\mathrm{J}$ & - & 6.3 & silt & overlapping brushed \\
\hline & body & grog & $\mathrm{C}$ & - & 6.5 & $\mathrm{c}$ & parallel brushed \\
\hline & body & grog-hematite & A & $\mathrm{I} / \mathrm{E} \mathrm{B}$ & 5.5 & $\mathrm{c}$ & engraved semi-circle, $\mathrm{CB}$ \\
\hline
\end{tabular}




\begin{tabular}{|c|c|c|c|c|c|c|c|}
\hline Provenience/Level & $\begin{array}{l}\text { Sherd } \\
\text { Type }\end{array}$ & Temper & Firing & $\begin{array}{l}\text { Surface } 1 \\
\text { Treatment }\end{array}$ & Thickness (mm) & Paste & Decoration \\
\hline 197-203, F.76A, lv. 11 & body & grog-hematite & $\mathrm{F}$ & E B & 6.7 & SP & $\begin{array}{l}\text { large engraved semi-circle; Bt, red } \\
\text { pigment }\end{array}$ \\
\hline 197-203, F.76A, lv. 12 & body & grog & $\mathrm{F}$ & - & 7.2 & $\mathrm{c}$ & parallel brushed \\
\hline \multirow{3}{*}{$\begin{array}{l}\text { 197-203, F.76B, } \\
70-85 \mathrm{~cm}\end{array}$} & rim & grog & $\mathrm{G}$ & E SM & 7.0 & $\mathrm{c}$ & engraved vertical panels; D-Ro, $27 \mathrm{~cm}$ OD \\
\hline & body & grog-bone & $\mathrm{B}$ & I SM & 7.3 & $\mathrm{c}$ & fingernail punctated rows \\
\hline & body & grog & $\mathrm{C}$ & I SM & 7.4 & $\mathrm{c}$ & $\begin{array}{l}\text { vertical and semi-circular incised panels } \\
\text { filled with tool punctates }\end{array}$ \\
\hline \multirow[t]{5}{*}{$\begin{array}{l}\text { 199-200, F.76B, } \\
75-90 \mathrm{~cm}\end{array}$} & rim & $\begin{array}{l}\text { grog-bone- } \\
\text { hematite }\end{array}$ & $\mathrm{B}$ & I SM & 10.0 & SP & $\begin{array}{l}\text { incised triangle filled with tool punctates; } \\
\text { EV-Ro, } 17 \mathrm{~cm} \text { OD }\end{array}$ \\
\hline & body & grog-bone & $\mathrm{G}$ & I SM & 7.5 & $\mathrm{c}$ & fingernail punctated rows \\
\hline & body & grog & $\mathrm{H}$ & - & 7.2 & $\mathrm{c}$ & cross-hatched incised lines \\
\hline & body & grog-bone & G & I SM & 6.5 & $\mathrm{c}$ & $\begin{array}{l}\text { incised triangle zones filled with tool } \\
\text { punctates }\end{array}$ \\
\hline & body & grog & $\mathrm{G}$ & E B & 7.6 & $\mathrm{c}$ & $\begin{array}{l}\text { curvilinear engraved lines and small } \\
\text { triangular elements; } \mathrm{Bt} \text {, red pigment }\end{array}$ \\
\hline \multirow[t]{3}{*}{ 198-198, F.79, lv. 6} & body & grog-bone & $\mathrm{F}$ & E SM & 5.0 & $\mathrm{c}$ & opposed incised lines \\
\hline & body & grog & $\mathrm{G}$ & - & 6.5 & $\mathrm{c}$ & tool punctated rows \\
\hline & body & grog & G & E B & 6.6 & $\mathrm{c}$ & $\begin{array}{l}\text { small circular punctates (from engraved- } \\
\text { punctated decoration); } \mathrm{Bt}\end{array}$ \\
\hline \multirow[t]{3}{*}{ 198-198, F.79, lv. 8} & body & grog & $\mathrm{B}$ & E SM & 6.0 & SP & engraved hatched panel \\
\hline & body & grog-organics & $\mathrm{F}$ & - & 8.4 & $\mathrm{c}$ & fingernail punctated rows \\
\hline & body & grog & B & - & 7.0 & $\mathrm{c}$ & tool punctated rows \\
\hline 198-198, F.79, lv. 9 & body & grog & $\mathrm{F}$ & E B & 7.2 & $\mathrm{c}$ & $\begin{array}{l}\text { curvilinear and hatched triangular lines; } \mathrm{Bt} \text {, } \\
\text { red pigment }\end{array}$ \\
\hline 198-199, F.79, lv. 5 & body & grog & $\mathrm{D}$ & I SM & 8.1 & $\mathrm{c}$ & parallel brushed \\
\hline 198-199, F.79, lv. 6 & rim & grog & A & - & 7.1 & $\mathrm{c}$ & fingernail punctated row; D-FL, ext. f \\
\hline \multirow[t]{3}{*}{ 198-199, F.79, lv. 7} & body & grog & B & - & 7.2 & $\mathrm{c}$ & $\begin{array}{l}\text { parallel incised lines with tool punctated } \\
\text { zones on either side of incised lines }\end{array}$ \\
\hline & body & grog & A & - & 7.2 & $\mathrm{c}$ & parallel brushed; pinkware \\
\hline & body & grog & $\mathrm{G}$ & E B/I SM & 7.5 & $\mathrm{c}$ & engraved hatched panel \\
\hline 198-199, F.79, lv. 9 & body & grog & $\mathrm{B}$ & I/E SM & 6.2 & SP & diagonal incised lines \\
\hline 197-198-200, F.81, & body & grog & G & I SM & 6.7 & $\mathrm{c}$ & fingernail punctated rows $47 \mathrm{~cm}$ \\
\hline
\end{tabular}




\begin{tabular}{|c|c|c|c|c|c|c|c|}
\hline Provenience/Level & $\begin{array}{l}\text { Sherd } \\
\text { Type }\end{array}$ & Temper & Firing & $\begin{array}{l}\text { Surface } \mathrm{T} \\
\text { Treatment }\end{array}$ & Thickness $(\mathrm{mm})$ & Paste & Decoration \\
\hline 197-198, F.84, & body & grog & $\mathrm{G}$ & E SM & 6.4 & $\mathrm{c}$ & $\begin{array}{l}\text { hatched triangular element on interior vessel } \\
40-70 \mathrm{~cm}\end{array}$ \\
\hline $215-203$, F. $88,23 \mathrm{~cm}$ & body & grog-hematite & $\mathrm{F}$ & - & 10.7 & $\mathrm{c}$ & parallel brushed \\
\hline Fea. 91 & rim & grog & $\mathrm{B}$ & I SM/I OR & 7.6 & $\mathrm{SP}$ & semi-circular pinched ridge; D-INT BV \\
\hline Fea. 94 & body & grog & $\mathrm{H}$ & I SM & 6.2 & $\mathrm{c}$ & $\begin{array}{l}\text { hatched engraved ladder and engraved } \\
\text { triangle el. }\end{array}$ \\
\hline
\end{tabular}

*hem. $=$ hematite; $\mathrm{SP}=$ sandy paste; $\mathrm{c}=$ clay paste

Firing conditions follow Teltser (1993:Figure 2) and Perttula (2005: Figure 5-30)

Surface Treatment: $\mathrm{E}=$ exterior; $\mathrm{I}=$ interior; $\mathrm{Sm}=$ smoothed; $\mathrm{B}=$ burnished; $\mathrm{SC}=$ scraped; $\mathrm{OR}=$ organic residue

$\mathrm{Bt}=$ bottle; $\mathrm{CB}=$ carinated bowl; $\mathrm{BW}=$ bowl

Rim and Lip Form: $\mathrm{D}=$ direct; $\mathrm{EV}=$ everted; $\mathrm{INV}=$ inverted; $\mathrm{RO}=$ rounded; $\mathrm{FL}=$ flat; ext. $\mathrm{f}=$ exterior folded; $\mathrm{INT} \mathrm{BV}=$ interior beveled

$\mathrm{OD}=$ orifice diameter 


\section{Appendix F.2 Detailed Analysis of Plain Body Sherds from 41AN38}

\begin{tabular}{|c|c|c|c|c|c|c|}
\hline Provenience & Temper* & *Paste & $\begin{array}{l}\text { Firing } \\
\text { Conditions }\end{array}$ & $\begin{array}{l}\text { Surface } \\
\text { Treatment }\end{array}$ & $\begin{array}{l}\text { Thickness } \\
(\mathrm{mm})\end{array}$ & Comments \\
\hline 170-198, lv. 4 & bone & $\mathrm{c}$ & $\mathrm{G}$ & - & 8.4 & \\
\hline 170-200, lv. 2 & $\begin{array}{l}\text { grog- } \\
\text { hematite }\end{array}$ & $\mathrm{c}$ & A & - & 8.8 & pinkware \\
\hline 170-202, lv. 3 & grog & SP & G & - & 9.9 & \\
\hline 171-200, lv. 1 & $\begin{array}{l}\text { grog- } \\
\text { hematite }\end{array}$ & SP & G & E SM & 5.1 & \\
\hline 171-200, lv. 2 & grog & $\mathrm{c}$ & $\mathrm{H}$ & - & 7.1 & Bottle \\
\hline 171-202, 1v. 3 & grog & $\mathrm{c}$ & G & I SM & 7.0 & \\
\hline 172-198, lv. 5 & grog & $\mathrm{c}$ & G & - & 7.4 & \\
\hline 172-199, lv. 4 & grog & SP & $\mathrm{F}$ & $\mathrm{I} / \mathrm{E} \mathrm{SM}$ & 6.6 & \\
\hline 172-200, lv. 2 & $\begin{array}{l}\text { grog- } \\
\text { hematite }\end{array}$ & c & A & E B & 6.7 & \\
\hline 172-201, lv. 1 & grog & SP & $\mathrm{F}$ & $\mathrm{I} / \mathrm{E} \mathrm{SM}$ & 6.4 & \\
\hline 172-202, lv. 2 & grog & SP & G & E SM & 8.0 & \\
\hline 173-198, lv. 2 & $\begin{array}{l}\text { grog- } \\
\text { organics }\end{array}$ & SP & $\mathrm{F}$ & I/E SM & 8.3 & \\
\hline 173-199, lv. 2 & $\begin{array}{l}\text { grog- } \\
\text { hematite }\end{array}$ & c & B & E B & 6.4 & \\
\hline 173-199, lv. 4 & grog & SP & B & - & 6.9 & \\
\hline 174-199, lv. 2 & hem. & SP & $\mathrm{F}$ & I SM & 6.4 & \\
\hline 174-199, lv. 3 & grog & $\mathrm{c}$ & $\mathrm{F}$ & I SM & 8.2 & \\
\hline 174-199, lv. 5 & grog & $\mathrm{c}$ & $\mathrm{D}$ & I SM & 6.7 & pinkware \\
\hline 174-200, lv. 5 & grog & $\mathrm{c}$ & G & E SM & 6.5 & \\
\hline 174-201, lv. 2 & grog & SP & A & I SM & 7.8 & \\
\hline 174-201, lv. 3 & grog & $\mathrm{c}$ & G & E SM & 6.7 & \\
\hline 174-202, lv. 5 & grog & $\mathrm{c}$ & G & - & 7.5 & \\
\hline 175-198, lv. 1 & grog & SP & A & I/E SM & 7.0 & \\
\hline 175-198, lv. 5 & grog & SP & B & E B/I SM & 7.0 & Carinated bowl \\
\hline & grog & $\mathrm{c}$ & G & I/E SM & 7.2 & \\
\hline 175-199, lv. 1 & grog & $\mathrm{c}$ & I & - & 6.6 & \\
\hline 175-199, lv. 2 & grog & $\mathrm{c}$ & A & - & 8.1 & \\
\hline 175-199, lv. 3 & $\begin{array}{l}\text { grog- } \\
\text { hematite }\end{array}$ & $\mathrm{c}$ & A & $\mathrm{I} / \mathrm{E} \mathrm{B}$ & 5.8 & pinkware \\
\hline 175-200, lv. 2 & grog & SP & $\mathrm{F}$ & - & 7.7 & \\
\hline 175-201, lv. 2 & grog & SP & B & - & 7.6 & \\
\hline 175-202, lv. 3 & $\begin{array}{l}\text { grog- } \\
\text { bone }\end{array}$ & $\mathrm{c}$ & G & - & 6.6 & \\
\hline 175-202, lv. 5 & $\begin{array}{l}\text { grog- } \\
\text { hematite }\end{array}$ & c & A & - & 6.6 & \\
\hline 176-198, lv. 3 & grog & $\mathrm{c}$ & $\mathrm{F}$ & - & 6.2 & Bottle \\
\hline 176-199, lv. 2 & grog & $\mathrm{c}$ & $\mathrm{E}$ & - & 7.9 & \\
\hline 176-199, lv. 4 & grog & SP & $\mathrm{H}$ & I SM & 5.4 & \\
\hline 176-200, lv. 3 & $\begin{array}{l}\text { grog- } \\
\text { bone }\end{array}$ & $\mathrm{c}$ & $\mathrm{F}$ & - & 7.2 & Bottle \\
\hline
\end{tabular}




\begin{tabular}{|c|c|c|c|c|c|c|}
\hline Provenience & Temper & *Paste & $\begin{array}{l}\text { Firing } \\
\text { Conditions }\end{array}$ & $\begin{array}{l}\text { Surface } \\
\text { Treatment }\end{array}$ & $\begin{array}{l}\text { Thickness } \\
(\mathrm{mm})\end{array}$ & Comments \\
\hline 176-200, lv. 4 & $\begin{array}{l}\text { grog- } \\
\text { hematite }\end{array}$ & SP & $\mathrm{B}$ & I SM & 7.4 & \\
\hline 176-201, lv. 2 & grog & $\mathrm{c}$ & A & $\mathrm{I} / \mathrm{E} \mathrm{SM}$ & 6.2 & \\
\hline 176-202, lv. 2 & grog & $\mathrm{c}$ & $\mathrm{F}$ & - & 6.6 & \\
\hline 176-202, lv. 3 & $\begin{array}{l}\text { grog- } \\
\text { hematite }\end{array}$ & SP & $\mathrm{F}$ & I SM & 8.8 & \\
\hline 177-198, lv. 5 & $\begin{array}{l}\text { grog- } \\
\text { hematite }\end{array}$ & $\mathrm{c}$ & $\mathrm{B}$ & - & 5.7 & \\
\hline 177-199, lv. 2 & grog & $\mathrm{c}$ & $\mathrm{C}$ & E SM & 7.2 & \\
\hline 177-199, lv. 3 & bone & $\mathrm{c}$ & $\mathrm{D}$ & - & 6.0 & pinkware \\
\hline 177-199, lv. 5 & grog & $\mathrm{c}$ & $\mathrm{F}$ & E B & 5.6 & Bottle \\
\hline 177-200, lv. 2 & $\begin{array}{l}\text { grog- } \\
\text { bone }\end{array}$ & $\mathrm{c}$ & G & - & 8.6 & \\
\hline 178-199, lv. 3 & grog & $\mathrm{c}$ & $\mathrm{C}$ & - & 6.6 & \\
\hline 178-199, lv. 4 & $\begin{array}{l}\text { grog- } \\
\text { hematite }\end{array}$ & c & I & $\mathrm{I} / \mathrm{E} \mathrm{B}$ & 6.3 & \\
\hline 178-202, lv. 5 & grog & SP & $\mathrm{F}$ & - & 8.5 & \\
\hline 179-198, lv. 2 & grog & $\mathrm{c}$ & G & I SM & 7.2 & \\
\hline 179-198, lv. 3 & $\begin{array}{l}\text { grog- } \\
\text { hematite }\end{array}$ & SP & B & - & 7.4 & \\
\hline 179-199, lv. 1 & $\begin{array}{l}\text { grog- } \\
\text { bone- } \\
\text { organics }\end{array}$ & $\mathrm{c}$ & G & E SM & 8.6 & \\
\hline 179-199, lv. 3 & $\begin{array}{l}\text { grog- } \\
\text { organics }\end{array}$ & SP & $\mathrm{C}$ & E B & 7.4 & Bottle \\
\hline 180-198, lv. 3 & grog & $\mathrm{c}$ & $\mathrm{G}$ & - & 7.1 & pinkware \\
\hline 180-198, lv. 5 & $\begin{array}{l}\text { grog- } \\
\text { bone }\end{array}$ & SP & B & $\mathrm{I} / \mathrm{E} \mathrm{B}$ & 7.0 & \\
\hline \multirow[t]{2}{*}{ 180-199, lv. 3} & bone & $\mathrm{c}$ & $\mathrm{F}$ & $\mathrm{I} / \mathrm{E} \mathrm{SM}$ & 6.8 & \\
\hline & grog & c & $\mathrm{F}$ & I SM & 8.7 & \\
\hline 181-198, lv. 3 & none & SP & G & E SM & 5.8 & \\
\hline 181-199, lv. 3 & grog & $\mathrm{c}$ & $\mathrm{E}$ & E B & 4.2 & Bottle \\
\hline 181-202, lv. 2 & grog & $\mathrm{c}$ & G & - & 6.3 & \\
\hline 181-202, lv. 4 & $\begin{array}{l}\text { grog- } \\
\text { bone }\end{array}$ & SP & G & I SM & 7.9 & \\
\hline 182-198, lv. 4 & $\begin{array}{l}\text { grog- } \\
\text { hematite }\end{array}$ & $\mathrm{c}$ & $\mathrm{E}$ & - & 6.8 & pinkware \\
\hline 182-199, lv. 1 & grog & $\mathrm{c}$ & $\mathrm{E}$ & I SM & 8.4 & \\
\hline 182-199, lv. 4 & none & SP & B & I SM & 4.9 & $\begin{array}{l}\text { Goose Creek } \\
\text { Plain, var. } \\
\text { unspecified }\end{array}$ \\
\hline 182-200, lv. 2 & grog & SP & A & I SM & 6.8 & \\
\hline \multirow[t]{2}{*}{ 182-201, lv. 1} & grog & SP & $\mathrm{G}$ & - & 7.0 & \\
\hline & $\begin{array}{l}\text { grog- } \\
\text { hematite } \\
\text { bone }\end{array}$ & c & G & - & 8.1 & \\
\hline
\end{tabular}




\begin{tabular}{|c|c|c|c|c|c|c|}
\hline Provenience & Temper* & *Paste & $\begin{array}{l}\text { Firing } \\
\text { Conditions }\end{array}$ & $\begin{array}{l}\text { Surface } \\
\text { Treatment }\end{array}$ & $\begin{array}{l}\text { Thickness } \\
(\mathrm{mm})\end{array}$ & Comments \\
\hline $182-201$, lv. 2 & $\begin{array}{l}\text { grog- } \\
\text { hematite }\end{array}$ & $\mathrm{c}$ & $\mathrm{G}$ & E SM & 7.7 & Bottle \\
\hline 183-198, lv. 1 & $\begin{array}{l}\text { grog- } \\
\text { organics- } \\
\text { hematite }\end{array}$ & c & $\mathrm{H}$ & - & 6.2 & \\
\hline 183-198, lv. 3 & grog & $\mathrm{c}$ & $\mathrm{F}$ & I/E SM & 6.8 & \\
\hline 183-199, lv. 3 & grog & SP & G & I/E SM & 7.1 & \\
\hline 183-199, lv. 5 & $\begin{array}{l}\text { grog- } \\
\text { bone }\end{array}$ & $\mathrm{c}$ & B & E SM & 6.6 & \\
\hline $183-200$, lv. 5 & $\begin{array}{l}\text { grog- } \\
\text { bone }\end{array}$ & $\mathrm{c}$ & A & E SM & 6.2 & \\
\hline 183-201, lv. 5 & grog & SP & G & I SM & 7.4 & \\
\hline \multirow[t]{2}{*}{$183-202$, lv. 2} & grog & $\mathrm{c}$ & A & I SM & 7.5 & \\
\hline & hem. & $\mathrm{c}$ & $\mathrm{C}$ & - & 6.8 & \\
\hline \multirow[t]{2}{*}{ 184-198, lv. 2} & $\begin{array}{l}\text { grog- } \\
\text { bone }\end{array}$ & $\mathrm{c}$ & $\mathrm{B}$ & E SM & 7.5 & \\
\hline & bone & $\mathrm{c}$ & $\mathrm{G}$ & I SM & 7.5 & \\
\hline 184-198, lv. 5 & grog & SP & $\mathrm{B}$ & - & 6.3 & \\
\hline 184-199, lv. 2 & grog & $\mathrm{c}$ & A & - & 8.3 & pinkware \\
\hline 184-199, lv. 5 & grog & $\mathrm{c}$ & G & E B/I SM & 5.0 & Carinated bowl \\
\hline \multirow[t]{2}{*}{ 184-200, lv. 5} & $\begin{array}{l}\text { grog- } \\
\text { bone }\end{array}$ & $\mathrm{c}$ & $\mathrm{B}$ & I/E SM & 6.9 & \\
\hline & grog & SP & G & I SM & 7.4 & \\
\hline 184-201, lv. 3 & $\begin{array}{l}\text { grog- } \\
\text { hematite- } \\
\text { bone }\end{array}$ & c & G & I/E SM & 5.4 & \\
\hline 184-201, lv. 4 & grog & $\mathrm{c}$ & G & I SM & 7.1 & \\
\hline 184-201, lv. 5 & grog & SP & G & I SM & 5.9 & \\
\hline 184-202, lv. 3 & $\begin{array}{l}\text { grog- } \\
\text { bone }\end{array}$ & $\mathrm{c}$ & G & E SM & 5.5 & \\
\hline \multirow[t]{2}{*}{ 185-198, lv. 4} & grog & SP & $\mathrm{F}$ & - & 6.0 & \\
\hline & bone & $\mathrm{c}$ & $\mathrm{F}$ & I/E SM & 6.4 & \\
\hline 185-199, lv. 5 & $\begin{array}{l}\text { grog- } \\
\text { hematite }\end{array}$ & SP & $\mathrm{C}$ & - & 7.2 & \\
\hline \multirow[t]{2}{*}{ 185-200, lv. 4} & $\begin{array}{l}\text { grog- } \\
\text { bone }\end{array}$ & $\mathrm{c}$ & $\mathrm{E}$ & - & 8.2 & \\
\hline & $\begin{array}{l}\text { grog- } \\
\text { organics }\end{array}$ & c & $\mathrm{F}$ & I/E SM & 5.4 & \\
\hline 185-201, lv. 2 & $\begin{array}{l}\text { grog- } \\
\text { hematite }\end{array}$ & SP & B & - & 8.8 & \\
\hline 185-201, lv. 5 & grog & SP & $\mathrm{F}$ & $\mathrm{I} / \mathrm{E} \mathrm{B}$ & 6.9 & \\
\hline 185-201, lv. 6 & $\begin{array}{l}\text { grog- } \\
\text { hematite }\end{array}$ & c & A & - & 5.4 & \\
\hline 185-202, lv. 5 & grog & $\mathrm{c}$ & $\mathrm{B}$ & I/E SM & 7.4 & Carinated bowl \\
\hline 186-198, lv. 2 & grog & $\mathrm{c}$ & $\mathrm{A}$ & I SM & 8.0 & \\
\hline \multirow[t]{2}{*}{ 186-200, lv. 3} & grog & $\mathrm{c}$ & $\mathrm{F}$ & - & 7.9 & Carinated bowl \\
\hline & grog & SP & B & - & 6.7 & \\
\hline 186-200, lv. 4 & $\begin{array}{l}\text { grog- } \\
\text { bone }\end{array}$ & SP & B & I SM & 8.0 & \\
\hline
\end{tabular}




\begin{tabular}{|c|c|c|c|c|c|c|}
\hline Provenience & Temper* & *Paste & $\begin{array}{l}\text { Firing } \\
\text { Conditions }\end{array}$ & $\begin{array}{l}\text { Surface } \\
\text { Treatment }\end{array}$ & $\begin{array}{l}\text { Thickness } \\
(\mathrm{mm})\end{array}$ & Comments \\
\hline 186-201, lv. 1 & $\begin{array}{l}\text { grog- } \\
\text { hematite }\end{array}$ & c & $\mathrm{F}$ & $\mathrm{I} / \mathrm{E} \mathrm{SM}$ & 7.1 & \\
\hline 186-201, lv. 2 & $\begin{array}{l}\text { grog- } \\
\text { hematite }\end{array}$ & SP & $\mathrm{C}$ & - & 8.8 & \\
\hline 186-201, 1v. 3 & $\begin{array}{l}\text { grog- } \\
\text { bone }\end{array}$ & $\mathrm{c}$ & I & I/E SM & 7.4 & Carinated bowl \\
\hline 186-201, lv. 4 & grog & SP & G & I/E SM & 7.7 & \\
\hline 187-198, lv. 2 & grog & SP & $\mathrm{B}$ & - & 6.0 & \\
\hline 187-198, lv. 5 & grog & $\mathrm{c}$ & $\mathrm{B}$ & - & 5.4 & Bottle \\
\hline 187-199, lv. 2 & grog & $\mathrm{c}$ & $\mathrm{F}$ & - & 8.0 & \\
\hline $187-200$, lv. 4 & - & SP & $\mathrm{B}$ & E SM & 4.5 & \\
\hline 187-201, lv. 3 & $\begin{array}{l}\text { bone- } \\
\text { grog }\end{array}$ & $\mathrm{c}$ & $\mathrm{F}$ & E B & 6.0 & \\
\hline \multirow[t]{2}{*}{ 187-202, lv. 3} & grog & $\mathrm{c}$ & $\mathrm{F}$ & $\mathrm{I} / \mathrm{E} \mathrm{SM}$ & 7.0 & \\
\hline & grog & $\mathrm{c}$ & G & I SM & 7.0 & \\
\hline 188-198, lv. 1 & grog & $\mathrm{c}$ & B & E SM & 6.5 & \\
\hline 188-198, lv. 2 & none & SP & $\mathrm{B}$ & - & 8.2 & \\
\hline 188-199, lv. 2 & grog & $\mathrm{c}$ & $\mathrm{F}$ & - & 6.1 & \\
\hline 188-199, lv. 5 & grog & $\mathrm{c}$ & $\mathrm{C}$ & - & 7.6 & \\
\hline 188-200, lv. 2 & $\begin{array}{l}\text { grog- } \\
\text { hematite }\end{array}$ & $\mathrm{c}$ & $\mathrm{F}$ & I SM & 6.7 & \\
\hline 188-200, lv. 4 & $\begin{array}{l}\text { grog- } \\
\text { hematite }\end{array}$ & $\mathrm{c}$ & $\mathrm{F}$ & - & 7.1 & \\
\hline $188-200$, lv. 5 & grog & $\mathrm{c}$ & G & I SM & 7.7 & \\
\hline 188-201, lv. 3 & $\begin{array}{l}\text { grog- } \\
\text { bone }\end{array}$ & SP & $\mathrm{K}$ & - & 7.3 & \\
\hline 188-201, lv. 5 & grog & SP & B & - & 5.4 & \\
\hline 189-198, lv. 3 & $\begin{array}{l}\text { bone- } \\
\text { organics }\end{array}$ & $\mathrm{c}$ & $\mathrm{G}$ & I SM & 8.2 & \\
\hline 189-199, lv. 2 & $\begin{array}{l}\text { bone- } \\
\text { grog- } \\
\text { hematite }\end{array}$ & $\mathrm{c}$ & $\mathrm{K}$ & E SM & 9.3 & pinkware \\
\hline 189-200, lv. 1 & grog & SP & $\mathrm{B}$ & I SM & 7.5 & \\
\hline 189-200, lv. 2 & bone & $\mathrm{c}$ & $\mathrm{C}$ & - & 6.0 & \\
\hline 189-201, lv. 4 & grog & $\mathrm{c}$ & G & I SM & 7.6 & \\
\hline 189-202, lv. 1 & $\begin{array}{l}\text { bone- } \\
\text { grog }\end{array}$ & SP & G & - & 7.7 & \\
\hline 190-198, lv. 5 & $\begin{array}{l}\text { grog- } \\
\text { hematite }\end{array}$ & c & $\mathrm{C}$ & - & 7.3 & pinkware \\
\hline 190-199, lv. 4 & grog & $\mathrm{c}$ & $\mathrm{G}$ & - & 7.0 & $\begin{array}{l}\text { possibly } \\
\text { refired }\end{array}$ \\
\hline \multirow[t]{2}{*}{ 190-200, lv. 3} & grog & $\mathrm{c}$ & $\mathrm{F}$ & I SM & 7.6 & \\
\hline & $\begin{array}{l}\text { grog- } \\
\text { hematite }\end{array}$ & $\mathrm{c}$ & $\mathrm{K}$ & I SM & 8.6 & \\
\hline 190-201, lv. 1 & $\begin{array}{l}\text { grog- } \\
\text { hematite }\end{array}$ & c & $\mathrm{F}$ & E B & 8.3 & \\
\hline 190-201, lv. 5 & $\begin{array}{l}\text { grog- } \\
\text { bone- } \\
\text { hematite }\end{array}$ & SP & $\mathrm{F}$ & - & 6.2 & \\
\hline
\end{tabular}




\begin{tabular}{|c|c|c|c|c|c|c|}
\hline Provenience & Temper* & *Paste & $\begin{array}{l}\text { Firing } \\
\text { Conditions }\end{array}$ & $\begin{array}{l}\text { Surface } \\
\text { Treatment }\end{array}$ & $\begin{array}{l}\text { Thickness } \\
(\mathrm{mm})\end{array}$ & Comments \\
\hline 190-202, lv. 4 & $\begin{array}{l}\text { grog- } \\
\text { bone }\end{array}$ & $\mathrm{c}$ & B & E B/I SM & 8.0 & \\
\hline \multirow[t]{2}{*}{ 191-198, lv. 4} & grog & $\mathrm{c}$ & $\mathrm{F}$ & - & 7.2 & \\
\hline & grog & $\mathrm{c}$ & $\mathrm{B}$ & - & 5.0 & Bottle \\
\hline 191-199, lv. 2 & $\begin{array}{l}\text { grog- } \\
\text { hematite }\end{array}$ & SP & $\mathrm{C}$ & I/E SM & 6.5 & \\
\hline 191-202, lv. 2 & $\begin{array}{l}\text { grog- } \\
\text { organics }\end{array}$ & c & G & E B & 6.0 & Bottle \\
\hline 192-199, lv. 2 & grog & $\mathrm{c}$ & $\mathrm{G}$ & I SM & 9.0 & \\
\hline 192-199, lv. 4 & $\begin{array}{l}\text { grog- } \\
\text { hematite }\end{array}$ & c & G & I SM & 7.5 & \\
\hline 192-202, lv. 3 & grog & SP & $\mathrm{B}$ & I/E SM & 4.9 & \\
\hline 192-202, lv. 5 & $\begin{array}{l}\text { grog- } \\
\text { hematite }\end{array}$ & $\mathrm{c}$ & $\mathrm{F}$ & E B/ I SM & 9.0 & \\
\hline \multirow[t]{2}{*}{ 193-198, lv. 4} & $\begin{array}{l}\text { grog- } \\
\text { hem. }\end{array}$ & $\mathrm{c}$ & I & E SM & 6.8 & $\begin{array}{l}\text { pinkware; } \\
\text { Carinated bowl }\end{array}$ \\
\hline & $\begin{array}{l}\text { grog- } \\
\text { hematite }\end{array}$ & c & $\mathrm{H}$ & - & 6.2 & Carinated bowl \\
\hline 193-199, lv. 3 & grog & $\mathrm{c}$ & $\mathrm{G}$ & I/E SM & 7.1 & \\
\hline 193-200, lv. 2 & grog & $\mathrm{c}$ & $\mathrm{B}$ & E B & 7.0 & Bottle \\
\hline 193-200, lv. 3 & grog & SP & $\mathrm{B}$ & E SM & 7.4 & \\
\hline 193-200, lv. 4 & $\begin{array}{l}\text { grog- } \\
\text { hematite }\end{array}$ & c & $\mathrm{C}$ & E B & 8.0 & \\
\hline \multirow[t]{2}{*}{ 193-201, lv. 3} & grog & SP & $\mathrm{E}$ & E B/I SM & 6.4 & \\
\hline & $\begin{array}{l}\text { grog- } \\
\text { hematite }\end{array}$ & c & $\mathrm{C}$ & - & 7.9 & pinkware \\
\hline 193-201, lv. 4 & grog & $\mathrm{c}$ & $\mathrm{E}$ & I SM & 7.7 & $\begin{array}{l}\text { int. organic } \\
\text { residue }\end{array}$ \\
\hline \multirow[t]{2}{*}{ 193-201, lv. 5} & grog & $\mathrm{c}$ & $\mathrm{B}$ & I/E SM & 6.5 & \\
\hline & grog & SP & $\mathrm{F}$ & E B & 7.7 & \\
\hline 193-202, lv. 2 & grog & $\mathrm{c}$ & $\mathrm{G}$ & I SM & 8.1 & \\
\hline 193-201, lv. 4 & grog & $\mathrm{c}$ & $\mathrm{G}$ & I/E SM & 7.0 & \\
\hline 193-202, lv. 5 & grog & SP & $\mathrm{F}$ & - & 6.5 & \\
\hline 194-198, lv. 1 & grog & $\mathrm{c}$ & $\mathrm{E}$ & - & 8.8 & pinkware \\
\hline 194-199, lv. 2 & $\begin{array}{l}\text { grog- } \\
\text { organics }\end{array}$ & SP & $\mathrm{B}$ & $\mathrm{I} / \mathrm{E} \mathrm{SM}$ & 6.4 & Globular bowl \\
\hline 194-199, lv. 4 & bone & $\mathrm{c}$ & $\mathrm{G}$ & I SM & 6.1 & \\
\hline 194-200, lv. 4 & $\begin{array}{l}\text { grog- } \\
\text { hematite }\end{array}$ & SP & $\mathrm{B}$ & E SM & 8.6 & \\
\hline \multirow[t]{2}{*}{ 194-201, lv. 3} & grog & SP & $\mathrm{B}$ & I/E SM & 7.7 & \\
\hline & grog & $\mathrm{c}$ & $\mathrm{F}$ & I/E SM & 6.8 & \\
\hline 194-202, lv. 3 & grog & SP & $\mathrm{B}$ & - & 6.9 & Jar \\
\hline 194-202, lv. 4 & grog & $\mathrm{SP}$ & $\mathrm{F}$ & E B/I SM & 7.4 & \\
\hline 195-198, lv. 3 & grog & $\mathrm{c}$ & $\mathrm{F}$ & - & 7.3 & \\
\hline 195-198, lv. 4 & grog & $\mathrm{c}$ & $\mathrm{C}$ & - & 6.2 & \\
\hline 195-199, lv. 2 & $\begin{array}{l}\text { grog- } \\
\text { hematite }\end{array}$ & $\mathrm{c}$ & $\mathrm{B}$ & E SM & 6.6 & \\
\hline
\end{tabular}




\begin{tabular}{|c|c|c|c|c|c|c|}
\hline Provenience & Temper & *Paste & $\begin{array}{l}\text { Firing } \\
\text { Conditions }\end{array}$ & $\begin{array}{l}\text { Surface } \\
\text { Treatment }\end{array}$ & $\begin{array}{l}\text { Thickness } \\
\text { (mm) }\end{array}$ & Comments \\
\hline 195-199, lv. 2 & grog & $\mathrm{c}$ & $\mathrm{B}$ & $\mathrm{I} / \mathrm{E} \mathrm{SM}$ & 6.0 & $\begin{array}{l}\text { ext. organic } \\
\text { residue }\end{array}$ \\
\hline 195-199, lv. 3 & grog & $\mathrm{c}$ & $\mathrm{F}$ & E B/I SM & 6.9 & \\
\hline 195-199, lv. 4 & grog & SP & $\mathrm{H}$ & E SM & 6.7 & \\
\hline \multirow[t]{3}{*}{ 195-200, lv. 2} & grog & SP & $\mathrm{G}$ & E SM & 7.1 & \\
\hline & $\begin{array}{l}\text { grog- } \\
\text { bone }\end{array}$ & $\mathrm{c}$ & G & I SC/E SM & 7.3 & \\
\hline & $\begin{array}{l}\text { grog- } \\
\text { bone }\end{array}$ & $\mathrm{c}$ & $\mathrm{F}$ & - & 8.0 & \\
\hline 195-200, lv. 3 & $\begin{array}{l}\text { grog- } \\
\text { hematite }\end{array}$ & SP & G & E SM & 8.1 & \\
\hline \multirow[t]{2}{*}{ 195-201, lv. 2} & grog & SP & B & I/E SM & 6.7 & $\begin{array}{l}\text { ext. organic } \\
\text { residue }\end{array}$ \\
\hline & $\begin{array}{l}\text { grog- } \\
\text { bone }\end{array}$ & $\mathrm{c}$ & G & - & 7.4 & \\
\hline 195-201, lv. 4 & grog & $\mathrm{c}$ & $\mathrm{F}$ & - & 6.2 & \\
\hline 195-202, lv. 3 & grog & $\mathrm{c}$ & $\mathrm{F}$ & I SM & 7.0 & \\
\hline 195-203, lv. 3 & grog & $\mathrm{c}$ & G & I SM & 8.4 & \\
\hline 195-203, lv. 4 & grog & $\mathrm{c}$ & G & $\mathrm{I} / \mathrm{E} \mathrm{SM}$ & 8.3 & \\
\hline 196-198, lv. 4 & grog & $\mathrm{c}$ & $\mathrm{E}$ & I SM & 7.7 & pinkware \\
\hline 196-199, lv. 4 & grog & $\mathrm{c}$ & $\mathrm{F}$ & E SM & 7.4 & \\
\hline 196-200, lv. 1 & grog & SP & $\mathrm{B}$ & - & 6.9 & \\
\hline \multirow[t]{2}{*}{ 196-200, lv. 2} & grog & $\mathrm{c}$ & A & E B/I SM & 7.0 & pinkware \\
\hline & grog & $\mathrm{c}$ & $\mathrm{F}$ & E SM & 7.9 & \\
\hline 196-201, lv. 1 & grog & SP & G & I SM & 6.4 & \\
\hline \multirow[t]{2}{*}{ 196-201, lv. 2} & grog & $\mathrm{c}$ & $\mathrm{E}$ & I SM & 7.5 & \\
\hline & grog & SP & G & I SM & 6.6 & \\
\hline \multirow[t]{2}{*}{ 196-202, lv. 1} & grog & $\mathrm{c}$ & $\mathrm{C}$ & I SM & 8.4 & pinkware \\
\hline & $\begin{array}{l}\text { grog- } \\
\text { hematite }\end{array}$ & $e^{S P}$ & $\mathrm{E}$ & - & 7.1 & \\
\hline \multirow[t]{2}{*}{ 196-202, lv. 2} & $\begin{array}{l}\text { grog- } \\
\text { organics }\end{array}$ & $\mathrm{c}$ & $\mathrm{H}$ & E SM & 7.2 & \\
\hline & grog & $\mathrm{c}$ & $\mathrm{F}$ & E B/I SM & 6.6 & \\
\hline 196-202, lv. 5 & bone & $\mathrm{c}$ & $\mathrm{G}$ & - & 7.5 & \\
\hline 196-203, lv. 4 & grog & SP & $\mathrm{G}$ & $\mathrm{I} / \mathrm{E} \mathrm{SM}$ & 7.2 & \\
\hline 197-198, lv. 3 & grog & $\mathrm{c}$ & G & I SM & 6.6 & \\
\hline 197-199, lv. 3 & $\begin{array}{l}\text { grog- } \\
\text { hematite }\end{array}$ & $e^{c}$ & $\mathrm{~F}$ & E SM & 7.7 & \\
\hline 197-200, lv. 3 & grog & SP & A & - & 6.0 & \\
\hline 197-200, lv. 4 & $\begin{array}{l}\text { grog- } \\
\text { bone }\end{array}$ & $\mathrm{c}$ & G & - & 7.1 & \\
\hline 197-201, lv. 1 & grog & SP & B & E SM & 7.1 & $\begin{array}{l}\text { ext. organic } \\
\text { residue }\end{array}$ \\
\hline \multirow[t]{3}{*}{ 197-201, lv. 2} & $\begin{array}{l}\text { grog- } \\
\text { bone }\end{array}$ & $\mathrm{c}$ & $\mathrm{G}$ & - & 6.9 & \\
\hline & grog & SP & $\mathrm{G}$ & - & 6.7 & \\
\hline & grog & c & B & E SM & 7.0 & \\
\hline 197-201, lv. 4 & grog & SP & A & E SM & 5.9 & \\
\hline 197-202, lv. 3 & $\begin{array}{l}\text { grog- } \\
\text { hematite }\end{array}$ & $e^{c}$ & G & E SM & 7.0 & \\
\hline 197-202, lv. 4 & grog & SP & $\mathrm{E}$ & I SM & 8.0 & \\
\hline
\end{tabular}




\begin{tabular}{|c|c|c|c|c|c|c|}
\hline Provenience & Temper* & *Paste & $\begin{array}{l}\text { Firing } \\
\text { Conditions }\end{array}$ & $\begin{array}{l}\text { Surface } \\
\text { Treatment }\end{array}$ & $\begin{array}{l}\text { Thickness } \\
(\mathrm{mm})\end{array}$ & Comments \\
\hline \multirow[t]{2}{*}{ 197-202, lv. 4} & $\begin{array}{l}\text { grog- } \\
\text { bone }\end{array}$ & $\mathrm{c}$ & $\mathrm{G}$ & $\mathrm{I} / \mathrm{E} \mathrm{SM}$ & 6.9 & \\
\hline & $\begin{array}{l}\text { grog- } \\
\text { hematite- } \\
\text { bone }\end{array}$ & c & $\mathrm{C}$ & - & 7.3 & \\
\hline 197-202, lv. 6 & $\begin{array}{l}\text { grog- } \\
\text { hematite }\end{array}$ & c & A & E SM & 8.8 & \\
\hline 197-203, lv. 2 & grog & SP & $\mathrm{F}$ & I/E SM & 7.2 & \\
\hline 197-203, lv. 3 & bone & $\mathrm{c}$ & $\mathrm{B}$ & E SM & 7.1 & Bottle neck \\
\hline 197-203, lv. 4 & grog & $\mathrm{c}$ & G & E SM & 9.8 & \\
\hline $197.5-201$, lv. 5 & grog & $\mathrm{c}$ & $\mathrm{G}$ & - & 7.4 & \\
\hline 197.5-201, lv. 6 & $\begin{array}{l}\text { grog- } \\
\text { bone }\end{array}$ & SP & G & - & 8.1 & \\
\hline 198-198, lv. 3 & grog & $\mathrm{c}$ & $\mathrm{F}$ & I SM & 7.2 & \\
\hline 198-198, lv. 4 & $\begin{array}{l}\text { grog- } \\
\text { hematite }\end{array}$ & $\mathrm{c}$ & $\mathrm{F}$ & $\mathrm{I} / \mathrm{E} \mathrm{B}$ & 7.4 & \\
\hline 198-199, lv. 3 & grog & SP & $\mathrm{E}$ & E SM & 7.1 & \\
\hline 198-200, lv. 2 & grog & $\mathrm{c}$ & A & - & 8.8 & \\
\hline 198-200, lv. 3 & grog & $\mathrm{c}$ & $\mathrm{G}$ & I/E SM & 8.2 & \\
\hline 198-202, lv. 4 & grog & $\mathrm{c}$ & $\mathrm{F}$ & E SM & 6.2 & \\
\hline \multirow[t]{2}{*}{ 198-202, lv. 5} & grog & $\mathrm{c}$ & $\mathrm{A}$ & I/E SM & 6.2 & pinkware \\
\hline & grog & $\mathrm{c}$ & $\mathrm{G}$ & E SM & 6.6 & \\
\hline 198-202, lv. 6 & grog & $\mathrm{c}$ & $\mathrm{F}$ & - & 7.0 & \\
\hline 198-203, lv. 2 & $\begin{array}{l}\text { bone- } \\
\text { grog- } \\
\text { organics }\end{array}$ & c & $\mathrm{F}$ & E SM & 7.9 & \\
\hline 198-203, lv. 4 & $\begin{array}{l}\text { grog- } \\
\text { hematite- } \\
\text { bone }\end{array}$ & c & $\mathrm{H}$ & E SM & 6.7 & \\
\hline 199-198, lv. 1 & grog & $\mathrm{c}$ & $\mathrm{F}$ & I/E SM & 6.8 & \\
\hline \multirow[t]{2}{*}{ 199-198, lv. 3} & $\begin{array}{l}\text { grog- } \\
\text { hematite }\end{array}$ & $\mathrm{c}$ & $\mathrm{F}$ & I/E SM & 7.7 & \\
\hline & grog & $\mathrm{c}$ & $\mathrm{C}$ & E B/I SM & 7.2 & pinkware \\
\hline 199-200, lv. 3 & grog & $\mathrm{c}$ & B & $\mathrm{I} / \mathrm{E} \mathrm{B}$ & 5.4 & \\
\hline 199-201, lv. 2 & $\begin{array}{l}\text { grog- } \\
\text { hematite }\end{array}$ & $\mathrm{c}$ & $\mathrm{H}$ & I/E SM & 7.1 & \\
\hline 199-201, lv. 4 & grog & SP & A & I/E SM & 6.2 & pinkware \\
\hline 199-201, lv. 5 & grog & $\mathrm{c}$ & A & I/E SM & 7.0 & pinkware \\
\hline 199-202, lv. 2 & grog & SP & $\mathrm{G}$ & E SM & 7.6 & \\
\hline 199-202, lv. 3 & grog & $\mathrm{c}$ & $\mathrm{B}$ & I/E SM & 7.9 & \\
\hline \multirow[t]{2}{*}{ 199-203, lv. 3} & $\begin{array}{l}\text { grog- } \\
\text { bone }\end{array}$ & $\mathrm{c}$ & G & I SM & 8.2 & \\
\hline & grog & $\mathrm{c}$ & $\mathrm{G}$ & E SM & 8.5 & \\
\hline 199-203, lv. 4 & grog & $\mathrm{c}$ & $\mathrm{G}$ & - & 8.2 & \\
\hline 200-198, lv. 2 & $\begin{array}{l}\text { grog- } \\
\text { bone }\end{array}$ & SP & G & $\mathrm{I} / \mathrm{E} \mathrm{SM}$ & 6.3 & \\
\hline $200-198$, lv. 3 & grog & $\mathrm{c}$ & $\mathrm{H}$ & - & 7.4 & \\
\hline 200-199, lv. 2 & $\begin{array}{l}\text { grog- } \\
\text { Hematite }\end{array}$ & SP & $\mathrm{F}$ & - & 8.1 & \\
\hline
\end{tabular}




\begin{tabular}{|c|c|c|c|c|c|c|}
\hline Provenience & Temper* & *Paste & $\begin{array}{l}\text { Firing } \\
\text { Conditions }\end{array}$ & $\begin{array}{l}\text { Surface } \\
\text { Treatment }\end{array}$ & $\begin{array}{l}\text { Thickness } \\
(\mathrm{mm})\end{array}$ & Comments \\
\hline 200-199, lv. 3 & $\begin{array}{l}\text { grog- } \\
\text { bone }\end{array}$ & $\mathrm{c}$ & I & - & 8.2 & pinkware \\
\hline $200-200$, lv. 1 & bone & $\mathrm{c}$ & $\mathrm{G}$ & $\mathrm{I} / \mathrm{E} \mathrm{SM}$ & 6.3 & \\
\hline \multirow[t]{2}{*}{ 200-200, lv. 3} & grog & $\mathrm{c}$ & $\mathrm{G}$ & I SM & 8.8 & \\
\hline & grog & $\mathrm{c}$ & $\mathrm{E}$ & E SM & 7.7 & $\begin{array}{l}\text { int. organic } \\
\text { residue }\end{array}$ \\
\hline 200-201, lv. 2 & grog & SP & $\mathrm{B}$ & - & 6.8 & \\
\hline 200-201, lv. 4 & grog & $\mathrm{c}$ & $\mathrm{B}$ & $\mathrm{I} / \mathrm{E} \mathrm{SM}$ & 7.0 & \\
\hline \multirow[t]{2}{*}{ 200-202, lv. 4} & $\begin{array}{l}\text { bone- } \\
\text { hematite }\end{array}$ & c & $\mathrm{F}$ & - & 6.6 & \\
\hline & $\begin{array}{l}\text { grog- } \\
\text { organics }\end{array}$ & SP & $\mathrm{E}$ & E SM & 7.4 & \\
\hline 200-203, lv. 2 & bone & SP & G & - & 7.5 & \\
\hline \multirow[t]{3}{*}{ 200-203, lv. 3} & grog & $\mathrm{c}$ & $\mathrm{K}$ & E SM & 7.4 & pinkware \\
\hline & grog & $\mathrm{c}$ & $\mathrm{K}$ & - & 8.6 & \\
\hline & grog & SP & G & - & 6.3 & \\
\hline 201-198, lv. 1 & $\begin{array}{l}\text { grog- } \\
\text { hematite }\end{array}$ & c & $\mathrm{F}$ & - & 8.4 & \\
\hline 201-198, lv. 2 & grog & $\mathrm{c}$ & $\mathrm{C}$ & - & 8.8 & \\
\hline 201-199, lv. 3 & grog & $\mathrm{c}$ & $\mathrm{C}$ & E SM & 9.1 & pinkware \\
\hline 201-199, lv. 4 & grog & $\mathrm{c}$ & G & E SM & 6.2 & \\
\hline $201-200$, lv. 2 & $\begin{array}{l}\text { grog- } \\
\text { bone }\end{array}$ & SP & B & E B & 7.1 & \\
\hline 201-200, lv. 4 & grog & SP & G & - & 7.7 & \\
\hline 201-201, lv. 3 & $\begin{array}{l}\text { grog- } \\
\text { bone }\end{array}$ & $\mathrm{c}$ & G & - & 7.2 & \\
\hline 201-202, lv. 2 & $\begin{array}{l}\text { grog- } \\
\text { hematite }\end{array}$ & c & G & - & 9.0 & \\
\hline 201-202, lv. 3 & grog & $\mathrm{c}$ & A & - & 8.8 & pinkware \\
\hline 201-203, lv. 3 & grog & $\mathrm{c}$ & $\mathrm{G}$ & - & 6.8 & \\
\hline 201-202, lv. 4 & grog & $\mathrm{c}$ & G & I SC & 6.3 & \\
\hline 202-198, lv. 1 & grog & $\mathrm{c}$ & $\mathrm{G}$ & - & 7.2 & \\
\hline $202-198$, lv. 2 & $\begin{array}{l}\text { bone- } \\
\text { organics }\end{array}$ & c & $\mathrm{F}$ & - & 8.9 & Carinated bowl \\
\hline 202-199, lv. 3 & $\begin{array}{l}\text { grog- } \\
\text { bone }\end{array}$ & $\mathrm{c}$ & $\mathrm{H}$ & E SM & 8.2 & \\
\hline 202-199, lv. 4 & grog & $\mathrm{c}$ & G & - & 6.5 & \\
\hline $202-200$, lv. 2 & $\begin{array}{l}\text { grog- } \\
\text { hematite }\end{array}$ & SP & A & I/E SM & 8.2 & \\
\hline 202-200, lv. 4 & $\begin{array}{l}\text { grog- } \\
\text { bone }\end{array}$ & $\mathrm{c}$ & $\mathrm{F}$ & $\mathrm{I} / \mathrm{E} \mathrm{B}$ & 7.5 & \\
\hline 202-202, lv. 4 & grog & SP & $\mathrm{G}$ & - & 7.1 & \\
\hline 203-198, lv. 2 & grog & $\mathrm{c}$ & $\mathrm{F}$ & - & 7.2 & \\
\hline 203-200, lv. 4 & grog & SP & $\mathrm{B}$ & - & 8.4 & \\
\hline 203-201, lv. 2 & grog & SP & $\mathrm{F}$ & - & 6.7 & \\
\hline 204-198, lv. 4 & $\begin{array}{l}\text { grog- } \\
\text { Bone }\end{array}$ & $\mathrm{c}$ & $\mathrm{F}$ & E SM & 8.2 & \\
\hline
\end{tabular}




\begin{tabular}{|c|c|c|c|c|c|c|}
\hline Provenience & Temper* & *Paste & $\begin{array}{l}\text { Firing } \\
\text { Conditions }\end{array}$ & $\begin{array}{l}\text { Surface } \\
\text { Treatment }\end{array}$ & $\begin{array}{l}\text { Thickness } \\
(\mathrm{mm})\end{array}$ & Comments \\
\hline 204-199, lv. 3 & none & SP & $\mathrm{F}$ & E SM & 7.0 & $\begin{array}{l}\text { Goose Creek } \\
\text { Plain, var. } \\
\text { unspecified }\end{array}$ \\
\hline 204-199, lv. 4 & grog & $\mathrm{c}$ & $\mathrm{B}$ & E SM & 6.7 & \\
\hline $204-200$, lv. 3 & $\begin{array}{l}\text { grog- } \\
\text { hematite }\end{array}$ & c & $\mathrm{K}$ & I SM & 7.9 & \\
\hline 205-198, lv. 3 & grog & $\mathrm{c}$ & $\mathrm{G}$ & E SM & 7.2 & \\
\hline 205-199, lv. 1 & $\begin{array}{l}\text { hem.- } \\
\text { organics }\end{array}$ & SP & G & E B & 5.6 & Bottle \\
\hline $205-200$, lv. 3 & $\begin{array}{l}\text { grog- } \\
\text { bone }\end{array}$ & SP & $\mathrm{H}$ & I/E SM & 6.6 & \\
\hline \multirow[t]{2}{*}{ 206-198, lv. 3} & grog & $\mathrm{c}$ & $\mathrm{F}$ & I/E SM & 7.2 & \\
\hline & none & SP & $\mathrm{F}$ & I/E SM & 4.9 & \\
\hline $206-200$, lv. 2 & grog & SP & $\mathrm{F}$ & $\mathrm{I} / \mathrm{E} \mathrm{SM}$ & 8.0 & \\
\hline 207-198, lv. 1 & grog & SP & $\mathrm{G}$ & - & 6.4 & \\
\hline 207-198, lv. 2 & $\begin{array}{l}\text { grog- } \\
\text { hematite }\end{array}$ & $\mathrm{c}$ & $\mathrm{F}$ & - & 7.4 & \\
\hline 207-199, lv. 2 & $\begin{array}{l}\text { grog- } \\
\text { bone }\end{array}$ & $\mathrm{c}$ & $\mathrm{F}$ & - & 7.7 & \\
\hline 207-203, lv. 2 & grog & SP & $\mathrm{F}$ & - & 6.9 & \\
\hline 209-200, lv. 1 & grog & SP & $\mathrm{F}$ & - & 7.6 & \\
\hline F. $25,30-38 \mathrm{~cm}$ & grog & $\mathrm{c}$ & $\mathrm{G}$ & $\mathrm{I} / \mathrm{E} \mathrm{B}$ & 7.1 & \\
\hline F. $36,24 \mathrm{~cm}$ & $\begin{array}{l}\text { grog- } \\
\text { hem. }\end{array}$ & $\mathrm{c}$ & $\mathrm{F}$ & - & 8.0 & \\
\hline F. $36,24 \mathrm{~cm}$ & grog & SP & $\mathrm{F}$ & I/E SM & 7.0 & \\
\hline F. $36,20-25 \mathrm{~cm}$ & $\begin{array}{l}\text { grog- } \\
\text { hem. }\end{array}$ & $\mathrm{c}$ & $\mathrm{F}$ & - & 7.6 & Carinated bowl \\
\hline F.54, 50-66 cm & $\begin{array}{l}\text { grog- } \\
\text { bone }\end{array}$ & SP & $\mathrm{C}$ & E SM & 8.0 & \\
\hline \multirow[t]{2}{*}{ F. $66,60-129$} & $\begin{array}{l}\text { grog- } \\
\text { bone }\end{array}$ & $\mathrm{c}$ & $\mathrm{H}$ & E SM & 8.1 & Carinated bowl \\
\hline & grog & SP & $\mathrm{G}$ & - & 6.6 & \\
\hline \multirow[t]{2}{*}{ F.76, $40-50 \mathrm{~cm}$} & grog & $\mathrm{c}$ & G & E SM & 7.6 & Jar \\
\hline & bone & $\mathrm{c}$ & $\mathrm{A}$ & - & 9.7 & \\
\hline \multirow[t]{2}{*}{ F.76, $50-60 \mathrm{~cm}$} & $\begin{array}{l}\text { bone- } \\
\text { grog }\end{array}$ & $\mathrm{c}$ & $\mathrm{F}$ & $\mathrm{I} / \mathrm{E} \mathrm{SM}$ & 6.6 & \\
\hline & grog & SP & $\mathrm{G}$ & I/E SM & 6.3 & \\
\hline F. $76,40-60 \mathrm{~cm}$ & grog & $\mathrm{c}$ & $\mathrm{A}$ & I SM & 6.7 & pinkware \\
\hline \multirow[t]{2}{*}{ F.76, $60-70 \mathrm{~cm}$} & $\begin{array}{l}\text { grog- } \\
\text { hematite }\end{array}$ & $\mathrm{c}$ & $\mathrm{H}$ & E SM & 6.8 & \\
\hline & $\begin{array}{l}\text { grog- } \\
\text { bone }\end{array}$ & $\mathrm{c}$ & $\mathrm{G}$ & I SM & 6.2 & $\begin{array}{l}\text { int. organic } \\
\text { residue }\end{array}$ \\
\hline F.76, $70-80 \mathrm{~cm}$ & grog & $\mathrm{c}$ & A & - & 7.2 & Bottle \\
\hline F.76, 80-90 cm & grog & $\mathrm{c}$ & $\mathrm{G}$ & E SM & 7.8 & Carinated bowl \\
\hline
\end{tabular}




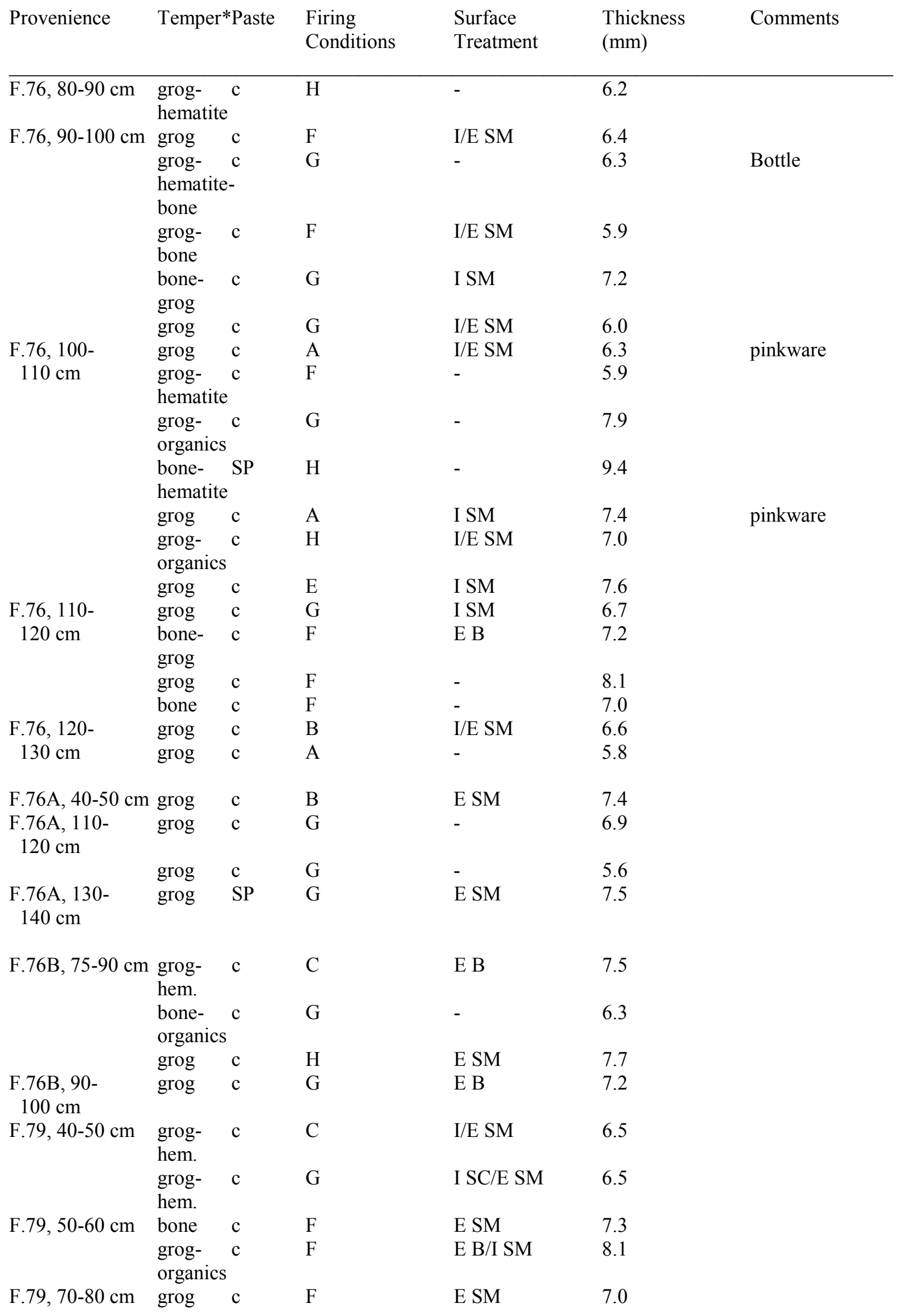




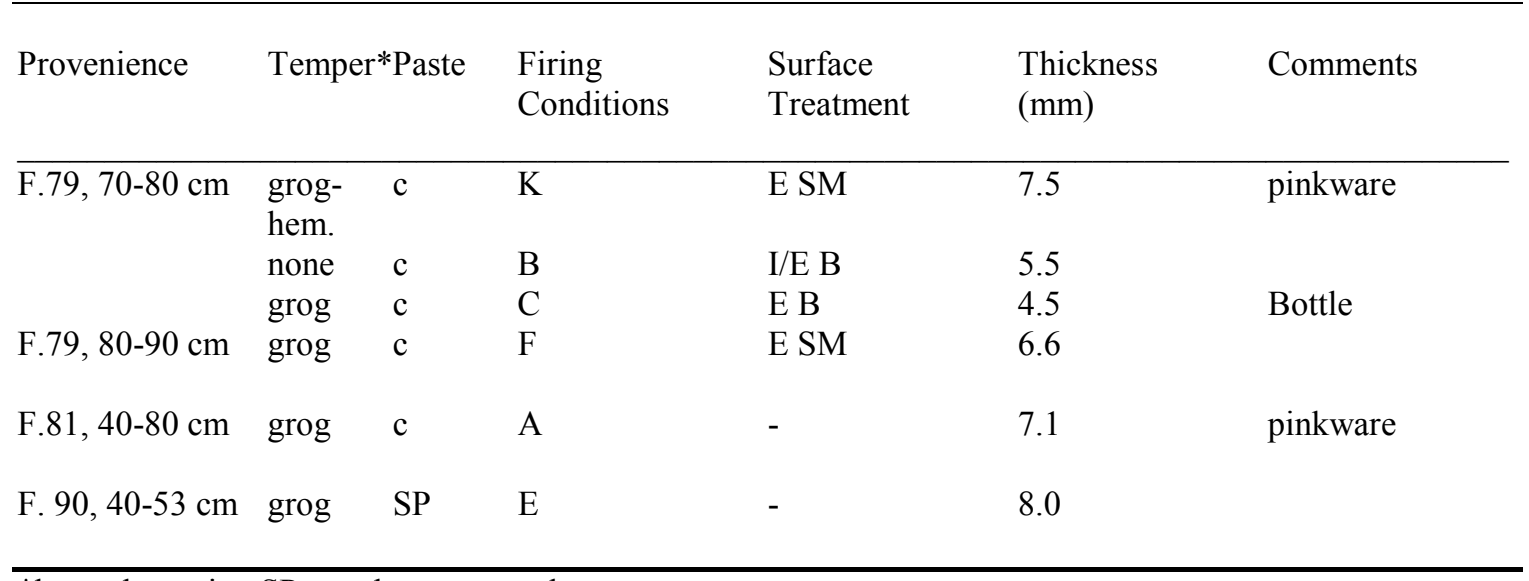

*hem.=hematite; $\mathrm{SP}=$ sandy paste; $\mathrm{c}=$ clay paste

Firing conditions follow Teltser (1993:Figure 2) and Perttula (2005: Figure 5-30)

Surface Treatment: $\mathrm{E}=$ exterior; $\mathrm{I}=$ interior; $\mathrm{Sm}=$ smoothed; $\mathrm{B}=$ burnished; $\mathrm{SC}=$ scraped 


\section{Appendix F.3 Detailed Analysis of Base Sherds from 41AN38}

\begin{tabular}{|c|c|c|c|c|c|c|}
\hline Provenience & Temper & Paste & $\begin{array}{l}\text { Firing } \\
\text { Conditions }\end{array}$ & $\begin{array}{l}\text { Surface } \\
\text { Treatment }\end{array}$ & $\begin{array}{l}\text { Thickness } \\
(\mathrm{mm})\end{array}$ & Comments \\
\hline$\overline{170-199, \text { lv. } 5}$ & grog & $\mathrm{c}$ & $\mathrm{A}$ & - & 11.0 & \\
\hline 171-201, lv. 4 & grog & $\mathrm{c}$ & B & - & 11.6 & \\
\hline $173-200$, lv. 3 & grog & $\mathrm{c}$ & A & - & 9.5 & pinkware \\
\hline 175-200, lv. 4 & $\begin{array}{l}\text { grog- } \\
\text { bone }\end{array}$ & $\mathrm{c}$ & B & - & 10.6 & \\
\hline 178-198, lv. 3 & grog & SP & $\mathrm{F}$ & - & 11.0 & \\
\hline 183-201, lv. 2 & $\begin{array}{l}\text { grog- } \\
\text { hematit }\end{array}$ & c & $\mathrm{E}$ & - & 15.0 & pinkware \\
\hline 187-201, lv. 3 & $\begin{array}{l}\text { grog- } \\
\text { organics }\end{array}$ & $\mathrm{c}$ & $\mathrm{H}$ & - & 13.3 & \\
\hline 188-202, lv. 3 & grog & SP & B & I/E SM & 7.5 & \\
\hline 190-202, lv. 4 & grog & SP & $\mathrm{H}$ & - & 12.5 & \\
\hline 194-200, lv. 3 & grog & $\mathrm{c}$ & G & I SM & 10.0 & pinkware \\
\hline 194-202, lv. 4 & grog & $\mathrm{c}$ & G & - & 9.0 & \\
\hline 194-203, lv. 4 & $\begin{array}{l}\text { grog- } \\
\text { hematit }\end{array}$ & $\mathrm{c}$ & $\mathrm{H}$ & - & 12.0 & \\
\hline 197-200, lv. 1 & $\begin{array}{l}\text { grog- } \\
\text { organics }\end{array}$ & $\mathrm{c}$ & B & - & 9.2 & \\
\hline 198-200, lv. 2 & grog & $\mathrm{c}$ & B & - & 12.8 & \\
\hline 198-203, lv. 2 & $\begin{array}{l}\text { grog- } \\
\text { bone }\end{array}$ & $\mathrm{c}$ & B & $\mathrm{I} / \mathrm{E} \mathrm{SM}$ & 9.9 & \\
\hline 199-201, lv. 3 & grog & $\mathrm{c}$ & $\mathrm{F}$ & E SM & 10.4 & \\
\hline $199-201,69 \mathrm{~cm}$ & $\begin{array}{l}\text { bone- } \\
\text { hematite }\end{array}$ & c & $\mathrm{G}$ & - & 9.0 & bottle \\
\hline 199-202, lv. 3 & grog & $\mathrm{c}$ & G & E SM & 11.9 & \\
\hline 200-202, lv. 2 & $\begin{array}{l}\text { grog- } \\
\text { hematit }\end{array}$ & SP & A & - & 11.0 & \\
\hline 201-203, lv. 4 & grog & $\mathrm{c}$ & $\mathrm{F}$ & - & 11.3 & \\
\hline 202-199, lv. 2 & grog & SP & $\mathrm{F}$ & I SM & 9.7 & \\
\hline 204-198, lv. 3 & grog & $\mathrm{c}$ & $\mathrm{F}$ & E SM & 11.2 & \\
\hline
\end{tabular}




\begin{tabular}{|c|c|c|c|c|c|}
\hline Provenience & Temper*Paste & $\begin{array}{l}\text { Firing } \\
\text { Conditions }\end{array}$ & $\begin{array}{l}\text { Surface } \\
\text { Treatment }\end{array}$ & $\begin{array}{l}\text { Thickness } \\
(\mathrm{mm})\end{array}$ & Comments \\
\hline $214-202, \mathrm{~N} / \mathrm{A}$ & grog & $\mathrm{G}$ & - & 10.2 & \\
\hline F. $16,50-90 \mathrm{~cm}$ & $\begin{array}{l}\text { grog- c } \\
\text { organics }\end{array}$ & G & E SM & 12.6 & \\
\hline F.60, 40-52 cm & $\begin{array}{l}\text { grog- SP } \\
\text { hematite- } \\
\text { organics }\end{array}$ & $\mathrm{F}$ & E SM & 9.4 & \\
\hline F.76, $73 \mathrm{~cm}$ & grog & G & - & 13.5 & \\
\hline $\begin{array}{c}\text { F.76, 110- } \\
120 \mathrm{~cm}\end{array}$ & $\begin{array}{l}\text { grog- c } \\
\text { hematite }\end{array}$ & $\mathrm{H}$ & - & 8.3 & \\
\hline $\begin{array}{l}\text { F.76, 140- } \\
150 \mathrm{~cm}\end{array}$ & grog & $\mathrm{G}$ & I SM & 9.4 & \\
\hline $\begin{array}{l}\text { F.76A, 100- } \\
110 \mathrm{~cm}\end{array}$ & grog & $\mathrm{H}$ & - & 10.7 & \\
\hline Scrape F & grog & B & I/E SM & 8.3 & \\
\hline
\end{tabular}

*SP=sandy paste; $\mathrm{c}=$ clay paste

Firing conditions follow Teltser (1993:Figure 2) and Perttula (2005: Figure 5-30)

Surface Treatment: $\mathrm{E}=$ exterior; $\mathrm{I}=$ interior; $\mathrm{Sm}=$ smoothed; $\mathrm{B}=$ burnished 


\section{REFERENCES CiTED}

Perttula, T. K. (editor)

2005 Archeological Investigations at the Pilgrim's Pride Site (41CP304), a Titus Phase Community in the Big Cypress Creek Basin, Camp County, Texas. 2 Vols. Report of Investigations $\quad$ No. 30 Archeological \& Environmental Consultants, LLC, Austin.
Teltser, P. A.

1993 An Analytic Strategy for Studying Assemblage-Scale Ceramic Variation: A Case Study from Southeast Missouri. American Antiquity 58(3):530-543. 


\section{Appendix F.4 Vessel Recordation Forms for 41AN38}

FEATURE: 8

VESSEL NO.: 1

NON-PLASTICS: grog

VESSEL FORM: Carinated bowl with a notched rim and an interior beveled/thickened lip (Feature 8 Vessel 1)

CORE COLOR: reduced firing

INTERIOR SURFACE COLOR: N/A; fire clouding

EXTERIOR SURFACE COLOR: N/A; fire clouding

WALL THICKNESS: $6.7 \mathrm{~mm}$, rim; $6.5 \mathrm{~mm}$, body; $9.9 \mathrm{~mm}$, base

INTERIOR SURFACE TREATMENT: smoothed and burnished

EXTERIOR SURFACE TREATMENT: smoothed

HEIGHT: $5.85 \mathrm{~cm}$, rim height is $3.35 \mathrm{~cm}$

ORIFICE DIAMETER: $14.3 \mathrm{~cm}$

DIAMETER AT BOTTOM OF RIM OR NECK: $14.2 \mathrm{~cm}$

BASE DIAMETER: $6.5 \mathrm{~cm}$

ESTIMATED VOLUME: 0.3 liters

DECORATION: plain

TYPE: Undetermined plain ware vessel

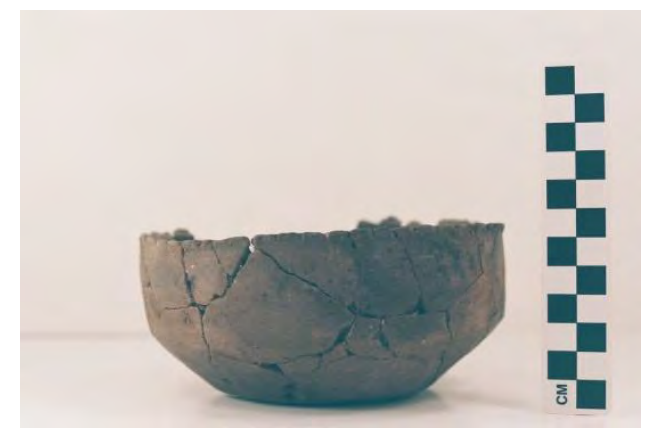

Feature 8 Vessel 1, Plain Carinated Bowl 
FEATURE: 8

VESSEL NO.: 2

NON-PLASTICS: grog-hematite

VESSEL FORM: Carinated bowl with a direct rim and a rounded lip (Feature 8, Vessel 2)

CORE COLOR: fired in a reducing environment

INTERIOR SURFACE COLOR: Not recorded

EXTERIOR SURFACE COLOR: Not recorded

WALL THICKNESS: $6.0 \mathrm{~mm}$, rim; $6.5 \mathrm{~mm}$, body

INTERIOR SURFACE TREATMENT: smoothed

EXTERIOR SURFACE TREATMENT: burnished

HEIGHT: $9.5 \mathrm{~cm}$; rim height, $4.46 \mathrm{~cm}$

ORIFICE DIAMETER: $16.8 \mathrm{~cm}$

DIAMETER AT BOTTOM OF RIM OR NECK: 17.2

BASE DIAMETER: $6.2 \mathrm{~cm}$

ESTIMATED VOLUME: 1.0 liters

DECORATION: plain

TYPE: Undetermined plain ware vessel

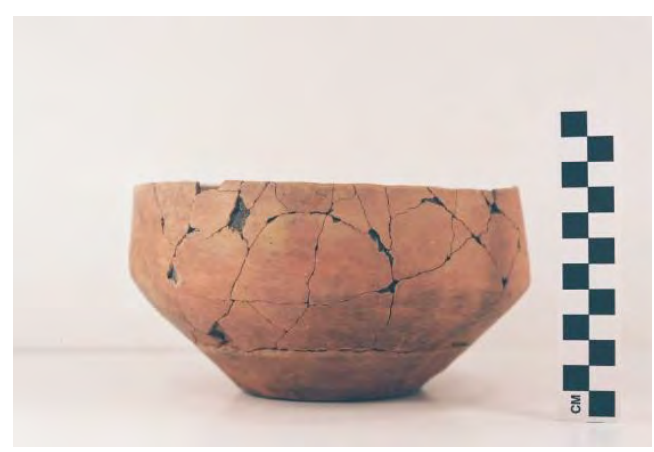

Feature 8, Vessel 2. 
FEATURE: 8

VESSEL NO.: 3

NON-PLASTICS: grog-bone

VESSEL FORM: Carinated bowl with a direct Redwine or pie-crust rim (see Walters 2008) and a rounded lip

CORE COLOR: fired in a reducing environment

INTERIOR SURFACE COLOR: Not recorded

EXTERIOR SURFACE COLOR: Not recorded

WALL THICKNESS: $5.0 \mathrm{~mm}$, rim; $4.1 \mathrm{~mm}$, body

INTERIOR SURFACE TREATMENT: burnished

EXTERIOR SURFACE TREATMENT: burnished

HEIGHT: $9.1 \mathrm{~cm}$; rim height is $3.52 \mathrm{~cm}$

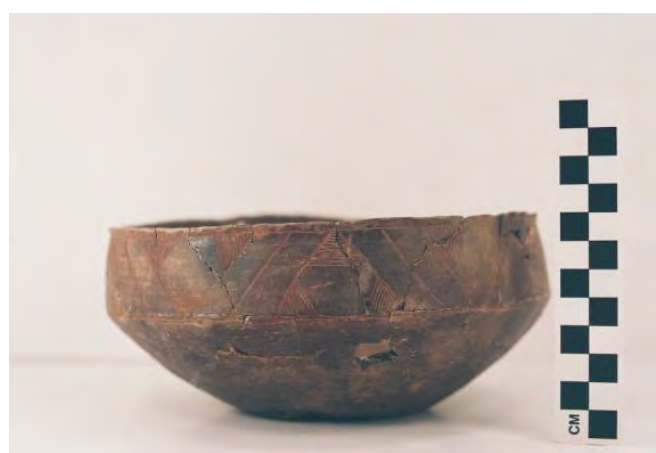

Feature 8, Vessel 3, Poynor Engraved Carinated Bowl

ORIFICE DIAMETER: $17.8 \mathrm{~cm}$

DIAMETER AT BOTTOM OF RIM OR NECK: $18.3 \mathrm{~cm}$

BASE DIAMETER: $6.0 \mathrm{~cm}$

ESTIMATED VOLUME: 1.0 liters

DECORATION: The rim has an engraved motif repeated 10 times around the vessel between upper and lower horizontal engraved lines that encircle the vessel (Feature 8, Vessel 3). The motif is comprised of an engraved triangle with either horizontal or diagonal hatched lines at each of the three corners of the triangle. The points or apex of the triangle rotate from touching the tip of the rim to touching the carination. The triangles are separated from each other by two diagonal engraved lines.

TYPE: Poynor Engraved, var. F 
FEATURE: 8

VESSEL NO.: 4

NON-PLASTICS: grog-bone-hematite

VESSEL FORM: Bowl with an interior thickened and a rounded scalloped lip, probably a

Redwine mode rim (see Walters 2008) (Feature 8, Vessel 4)

CORE COLOR: fired in an reducing environment

INTERIOR SURFACE COLOR: Not recorded

EXTERIOR SURFACE COLOR: Not recorded

WALL THICKNESS: $5.35 \mathrm{~mm}$, rim; $4.7 \mathrm{~mm}$, body

INTERIOR SURFACE TREATMENT: burnished

EXTERIOR SURFACE TREATMENT: burnished

HEIGHT: $5.5 \mathrm{~cm}$; Rim height, $11.0 \mathrm{~mm}$ in non-scalloped sections and $16.5 \mathrm{~mm}$ in scalloped lip sections

ORIFICE DIAMETER: $16.3 \mathrm{~cm}$

DIAMETER AT BOTTOM OF RIM OR NECK: N/A

BASE DIAMETER: $6.0 \mathrm{~cm}$

ESTIMATED VOLUME: 0.35 liters

DECORATION: plain

TYPE: Undetermined plain ware vessel

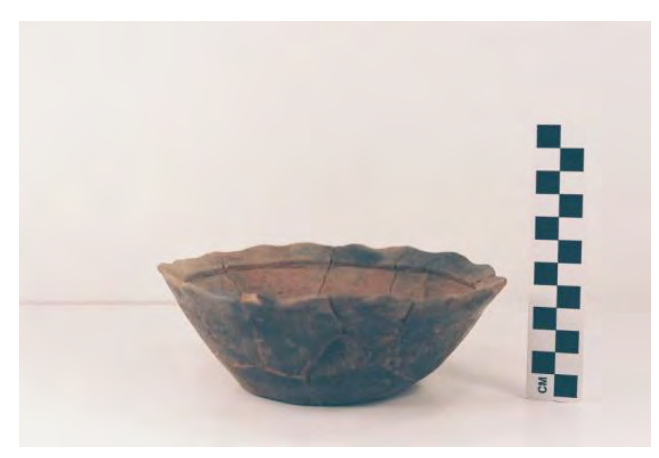

Feature 8, Vessel 4. 
FEATURE: 8

VESSEL NO.: 5

NON-PLASTICS: grog

VESSEL FORM: Carinated bowl with a direct rim and a flat but interior beveled lip (Feature 8, Vessel 5); there are a regular series of small lip nodes that are repeated at $20 \mathrm{~mm}$ intervals around the lip.

CORE COLOR: fired in a reducing environment

INTERIOR SURFACE COLOR: red (2.5YR 5/6)

EXTERIOR SURFACE COLOR: red (2.5YR 5/6)

WALL THICKNESS: $5.1 \mathrm{~mm}$, rim; $5.0 \mathrm{~mm}$, body; $10.5 \mathrm{~mm}$, base

INTERIOR SURFACE TREATMENT: burnished

EXTERIOR SURFACE TREATMENT: burnished

HEIGHT: $6.8 \mathrm{~cm}$; rim height is $3.53 \mathrm{~cm}$

ORIFICE DIAMETER: $17.8 \mathrm{~cm}$

DIAMETER AT BOTTOM OF RIM OR NECK: $17.6 \mathrm{~cm}$

BASE DIAMETER: $5.5 \mathrm{~cm}$

ESTIMATED VOLUME: 0.75 liters

DECORATION: Red-slipped on interior and exterior vessel surfaces

TYPE: Undetermined fine ware and red-slipped vessel

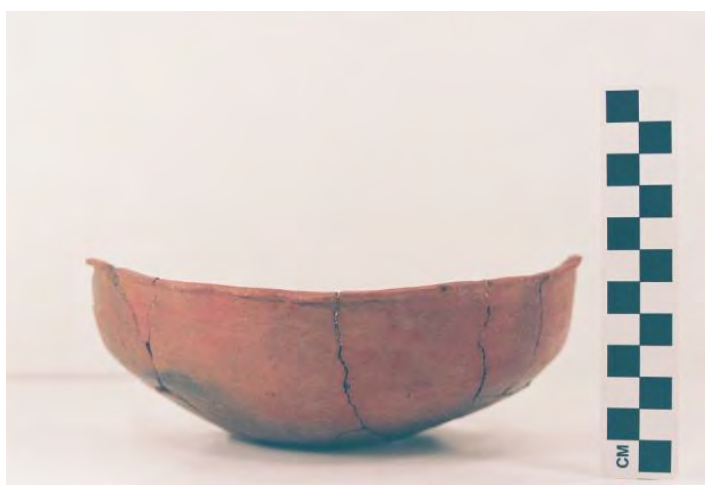

Feature 8, Vessel 5, Red-slipped Carinated Bowl. 
FEATURE: 8

VESSEL NO.: 6

NON-PLASTICS: grog

VESSEL FORM: Jar with a direct rim and a rounded lip

CORE COLOR: fired in a reducing environment

INTERIOR SURFACE COLOR: Not recorded

EXTERIOR SURFACE COLOR: Not recorded

WALL THICKNESS: 4.9-6.0 mm, rim; $6.4 \mathrm{~mm}$, body

INTERIOR SURFACE TREATMENT: smoothed

EXTERIOR SURFACE TREATMENT: smoothed on the lower vessel body; organic residue across the vessel body

HEIGHT: $14.1 \mathrm{~cm}$; rim height, $4.76 \mathrm{~cm}$

ORIFICE DIAMETER: $14.5 \mathrm{~cm}$

DIAMETER AT BOTTOM OF RIM OR NECK: $14.7 \mathrm{~cm}$

BASE DIAMETER: $6.8 \mathrm{~cm}$

ESTIMATED VOLUME: 1.2 liters

DECORATION: Cross-hatched incised lines in a panel on the rim, with a single horizontal incised line along the lower part of the cross-hatched incised motif (Feature 8, Vessel 6).

TYPE: Maydelle Incised

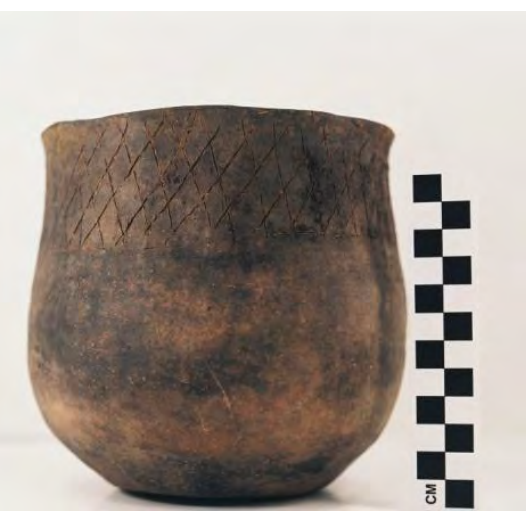

Feature 8, Vessel 6. 
FEATURE: 8

VESSEL NO.: 7

NON-PLASTICS: grog

VESSEL FORM: Bottle with a direct neck and a flat lip (Feature 8, Vessel 7)

CORE COLOR: fired in a reducing environment

INTERIOR SURFACE COLOR: Not recorded

EXTERIOR SURFACE COLOR: Not recorded

WALL THICKNESS: $5.7 \mathrm{~mm}$, rim; $6.5 \mathrm{~mm}$, base

INTERIOR SURFACE TREATMENT: none

EXTERIOR SURFACE TREATMENT: burnished on lower vessel body

HEIGHT: $11.4 \mathrm{~cm}$; neck height, $5.15 \mathrm{~cm}$

ORIFICE DIAMETER: $4.01 \mathrm{~cm}$

DIAMETER AT BOTTOM OF RIM OR NECK: $4.0 \mathrm{~cm}$

BASE DIAMETER: $8.0 \mathrm{~cm}$

ESTIMATED VOLUME: 0.2 liters

DECORATION: plain

TYPE: Undetermined plain ware vessel

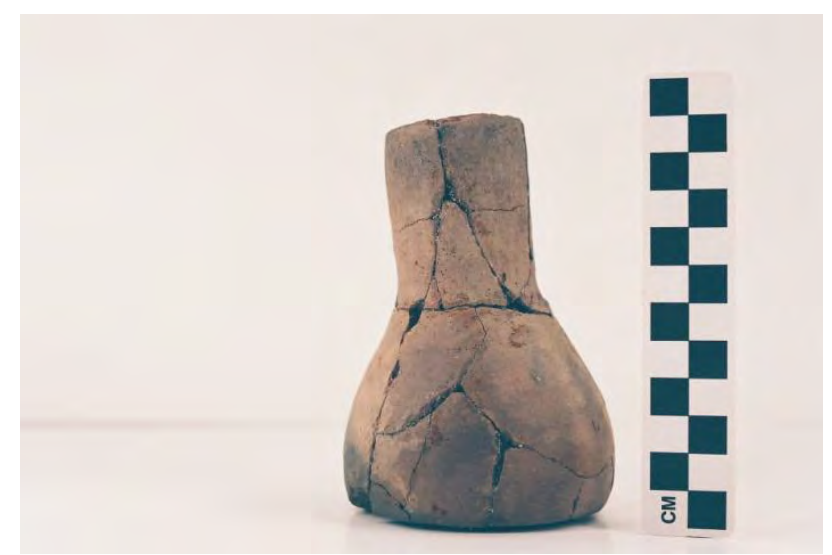

Feature 8, Vessel 7, Plain Bottle. 
FEATURE: 76B, 74-86 cm bs (N199 E203)

VESSEL NO.: 1

NON-PLASTICS: grog-hematite

VESSEL FORM: Globular carinated bowl with an inverted rim (Feature 76B, Vessel 1) and a rounded lip

CORE COLOR: G (fired in a reducing environment, but cooled in the open air, see Teltser 1993:

Figure 2)

INTERIOR SURFACE COLOR: brownish-yellow (10YR 6/6)

EXTERIOR SURFACE COLOR: dark yellowish-brown (10YR 4/4)

WALL THICKNESS: $5.1 \mathrm{~mm}$, rim; $6.1 \mathrm{~mm}$, body

INTERIOR SURFACE TREATMENT: none; fire clouding on base

EXTERIOR SURFACE TREATMENT: none

HEIGHT: $39.2 \mathrm{~mm}$, rim height

ORIFICE DIAMETER: $15.0 \mathrm{~cm}$

DIAMETER AT BOTTOM OF RIM OR NECK: N/A

BASE DIAMETER: N/A

ESTIMATED VOLUME: Undetermined

DECORATION: plain

TYPE: cf. Poynor Plain

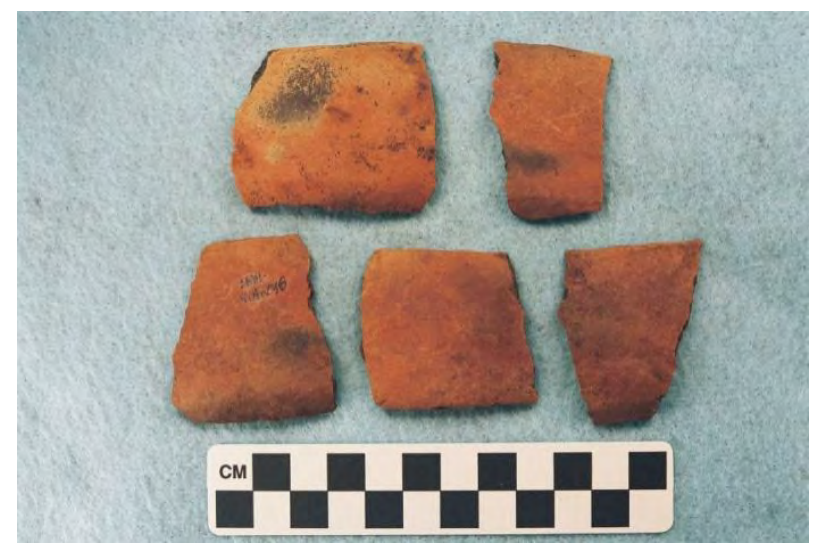

Feature 76B, Vessel 1. 
FEATURE: 76B, 75-89 cm bs (N199 E203)

VESSEL NO.: 2

NON-PLASTICS: bone

VESSEL FORM: Seed jar or neckless bottle with two suspension holes (6.4 $\mathrm{mm}$ in diameter)

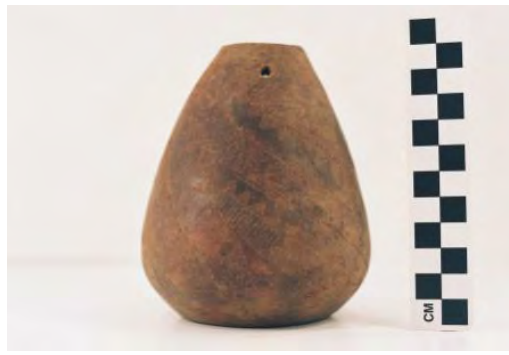

CORE COLOR: Undetermined, but apparently fired in a reducing environment

INTERIOR SURFACE COLOR: Dark brown (7.5YR 3/3)

EXTERIOR SURFACE COLOR: Dark brown (7.5YR 3/3)

WALL THICKNESS: $4.4 \mathrm{~mm}$ at the neck

INTERIOR SURFACE TREATMENT: none

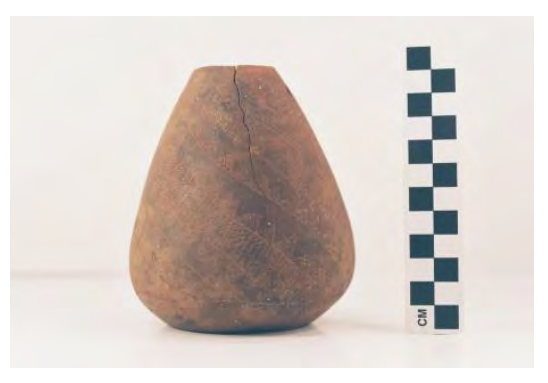

EXTERIOR SURFACE TREATMENT: smoothed

HEIGHT: $11.7 \mathrm{~cm}$

ORIFICE DIAMETER: $3.64 \mathrm{~cm}$ at the neck

DIAMETER AT BOTTOM OF RIM OR NECK: $9.8 \mathrm{~cm}$ near the base

BASE DIAMETER: $6.14 \mathrm{~cm}$

ESTIMATED VOLUME: 0.4 liters

DECORATION: The vessel is decorated with a series of diagonal panels decorated with engraved or rocker-stamped elements. The rim has a single row of rocker stamping.

From top to bottom on the vessel, the diagonal panels begin with a zone of cross-hatched engraved pendant triangles inside the panel, followed by a rocker-stamped panel with crosshatched engraved pendant triangles (14 and 18, respectively) on the outside of the panel. The third diagonal panel is filled with rocker stamps (forming triangular areas within the panel) and very small tick-like rocker stamping on either side of the panel. This is followed by a fourth panel that is just like the second in having rocker stamping within the panel (forming triangular areas) and cross-hatched engraved pendant triangles on the outside of the panel. The last panel is comprised of two diagonal rows of cross-hatched engraved pendant triangles (13 and 15, respectively), with a row of smaller rocker stamps inside the panel itself.

TYPE: Undetermined engraved-rocker stamped vessel; resembles the Garland Engraved type as described by Early (1993:90) in having the roughened rocker-stamped zones and the crosshatched background or fill elements. Early (2006 personal communication) indicates that vessels with this shape and decoration may date to ca. A.D. 1400, if not earlier, and are very common in the Hot Spring County, Arkansas area in the Ouachita River valley. This suggests that Vessel 2 from Feature 76B is a trade ware. Two views of Vessel 2 from Feature 76B: a, view showing suspension holes and decoration; $\mathrm{b}$, view showing decorative elements on vessel rim and body. 
FEATURE: 76C, 66-88 cm bs (N196 E197)

VESSEL NO.: 1

NON-PLASTICS: grog, hematite, and bone, with a sandy paste

VESSEL FORM: Globular bowl, based on sherd profiles and curvature; no rims present (1 base sherd and 51 body sherds) (Feature 76C, Vessel 1)

CORE COLOR: $\mathrm{F}$ (fired in a reducing environment and cooled in the open air)

INTERIOR SURFACE COLOR: strong brown (7.5YR 4/6)

EXTERIOR SURFACE COLOR: brown (10YR 4/3)

WALL THICKNESS: $5.4 \mathrm{~mm}$, body; $6.2 \mathrm{~mm}$, base

INTERIOR SURFACE TREATMENT: none

EXTERIOR SURFACE TREATMENT: none

HEIGHT: Undetermined

ORIFICE DIAMETER: Undetermined

DIAMETER AT BOTTOM OF RIM OR NECK: Undetermined

BASE DIAMETER: Undetermined

ESTIMATED VOLUME: Undetermined

DECORATION: plain

TYPE: Undetermined plain ware vessel

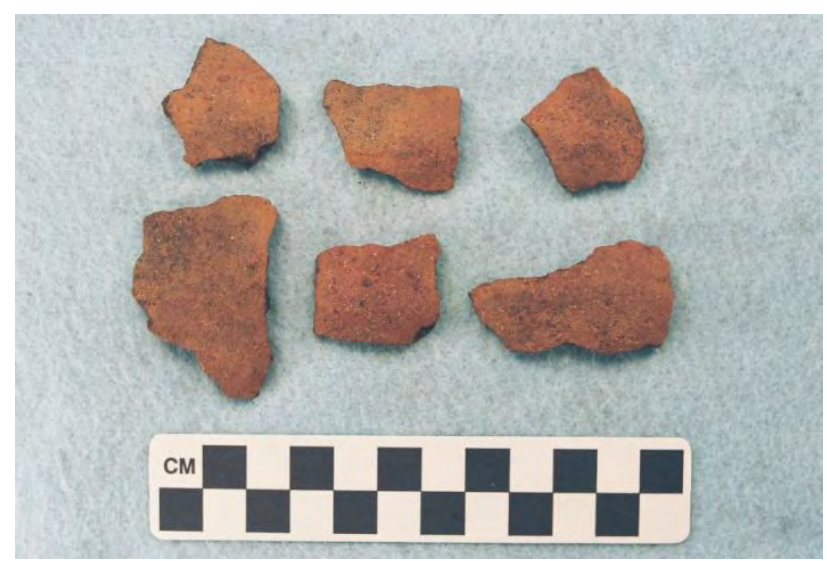

Feature 76C, Vessel 1 Sherds. 
FEATURE: 76D, $162 \mathrm{~cm}$ bs (N198 E203)

VESSEL NO.: 1

NON-PLASTICS: grog

VESSEL FORM: Bowl with a direct rim and a flat, exterior folded and scalloped lip (Feature 76D, Vessel 1)

CORE COLOR: B (fired and cooled in a reducing environment)

INTERIOR SURFACE COLOR: light yellowish-brown (10YR 6/4)

EXTERIOR SURFACE COLOR: brown (7.5YR 5/4); black (10YR 2/1) fire clouds on body and base

WALL THICKNESS: $5.0 \mathrm{~mm}$, rim; $5.6 \mathrm{~mm}$, body; $10.3 \mathrm{~mm}$, base

INTERIOR SURFACE TREATMENT: smoothed

EXTERIOR SURFACE TREATMENT: smoothed to burnished; organic residue on rim; some body erosion

HEIGHT: $7.4 \mathrm{~cm}$

ORIFICE DIAMETER: $17.0 \mathrm{~cm}$

DIAMETER AT BOTTOM OF RIM OR NECK: N/A

BASE DIAMETER: $8.5 \mathrm{~cm}$

ESTIMATED VOLUME: 0.5 liters

DECORATION: plain

TYPE: Undetermined plain ware vessel

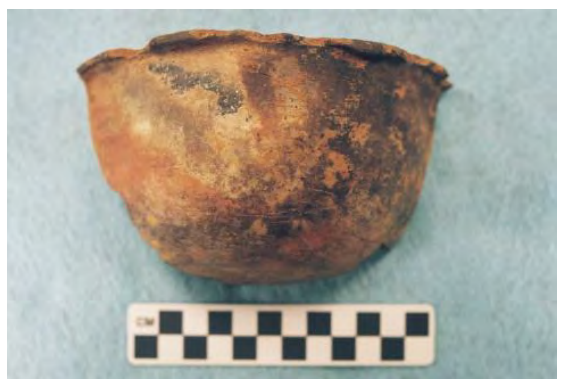

Feature 76D, Vessel 1. 
FEATURE: $88,12 \mathrm{~cm}$ bs (N215 E204)

VESSEL NO.: 1

NON-PLASTICS: grog-bone

VESSEL FORM: Compound vessel or wide-mouthed bottle with a wide neck with a direct rim and a flat lip; two suspension holes (Feature 88, Vessel 1)

CORE COLOR: F (fired in a reducing environment, and cooled in the open air)

INTERIOR SURFACE COLOR: brown (10YR 4/3)

EXTERIOR SURFACE COLOR: brown (7.5YR 5/4), with fire clouds on the neck and base

WALL THICKNESS: $4.6 \mathrm{~mm}$, neck

INTERIOR SURFACE TREATMENT: none

EXTERIOR SURFACE TREATMENT: burnished on neck and body; base is roughened

HEIGHT: $14.85 \mathrm{~cm}$; the neck height is $9.18 \mathrm{~cm}$

ORIFICE DIAMETER: $9.35 \mathrm{~cm}$

DIAMETER AT BOTTOM OF RIM OR NECK: $7.9 \mathrm{~cm}$

BASE DIAMETER: $7.85 \mathrm{~cm}$

ESTIMATED VOLUME: 0.5 liters

DECORATION: The neck of the vessel is decorated with horizontal and diagonal hatched engraved zones or narrow panels repeated three times around the neck. The body has interlocking horizontal scrolls repeated six times around the vessel (Feature 88, Vessel 1), as in the Poynor Engraved, var. B examples from the upper Neches River basin. A red clay pigment has been rubbed in the engraved lines.

TYPE: The design elements (especially those on the body) are reminiscent of several unnamed varieties of Poynor Engraved, including what has been called Poynor Engraved, var. B. The vessel form is unique, however.

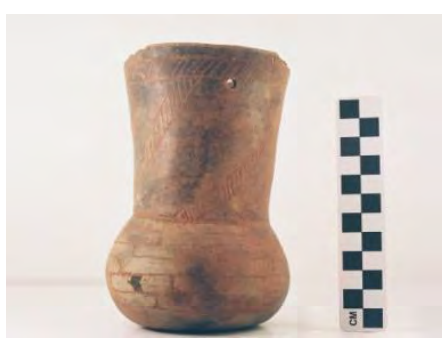

Feature 88, Vessel 1. 
FEATURE: $88,14 \mathrm{~cm}(\mathrm{~N} 215$ E204)

VESSEL NO.: 2

NON-PLASTICS: grog

VESSEL FORM: Carinated bowl with a direct rim and a flat lip; approximately $80 \%$ of the rim is represented (Feature 88, Vessel 2), and approximately $30 \%$ of the vessel.

CORE COLOR: F (fired in a reducing environment, and cooled in the open air)

INTERIOR SURFACE COLOR: dark gray (10YR 4/1)

EXTERIOR SURFACE COLOR: gray (10YR 5/1)

WALL THICKNESS: $5.0 \mathrm{~mm}$, rim; $5.4 \mathrm{~mm}$, body; $8.9 \mathrm{~mm}$, base

INTERIOR SURFACE TREATMENT: smoothed

EXTERIOR SURFACE TREATMENT: smoothed

HEIGHT: N/A; rim height is $3.8 \mathrm{~cm}$

ORIFICE DIAMETER: $17.0 \mathrm{~cm}$

DIAMETER AT BOTTOM OF RIM OR NECK: $17.0 \mathrm{~cm}$

BASE DIAMETER: N/A

ESTIMATED VOLUME: Undetermined

DECORATION: plain

TYPE: Undetermined plain ware vessel

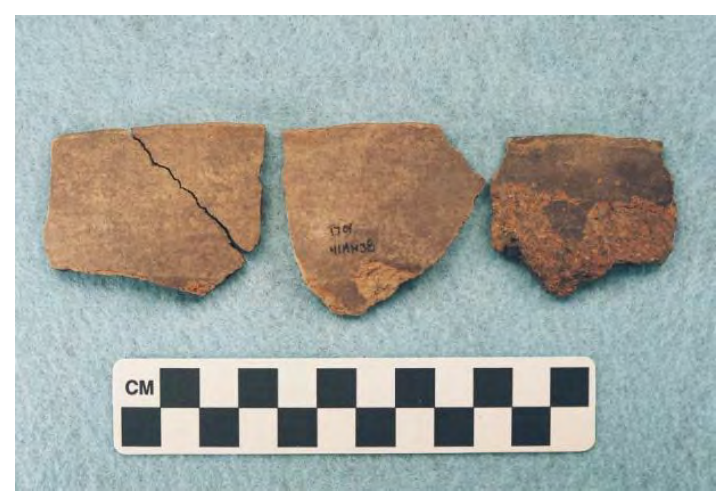

Feature 88, Vessel 2. 
FEATURE: 91, 7-20 cm bs (N218 E203)

VESSEL NO.: 1

NON-PLASTICS: grog

VESSEL FORM: Compound bowl with an everted rim and a flat lip

CORE COLOR: $\mathrm{F}$ (fired in a reducing environment and cooled in the open air)

INTERIOR SURFACE COLOR: strong brown (7.5YR 5/6)

EXTERIOR SURFACE COLOR: brown (7.5YR 5/3)

WALL THICKNESS: $6.4 \mathrm{~mm}$, upper rim panel; $5.9 \mathrm{~mm}$, lower rim panel; $5.7 \mathrm{~mm}$, body; 9.4 $\mathrm{mm}$, base

INTERIOR SURFACE TREATMENT: smoothed, fire clouds

EXTERIOR SURFACE TREATMENT: smoothed, fire clouds

HEIGHT: rim panel height $(7.3 \mathrm{~cm})$ : upper panel height is 2.3 $\mathrm{cm}$, and the lower panel height is $5.0 \mathrm{~cm}$

ORIFICE DIAMETER: $16.0 \mathrm{~cm}$

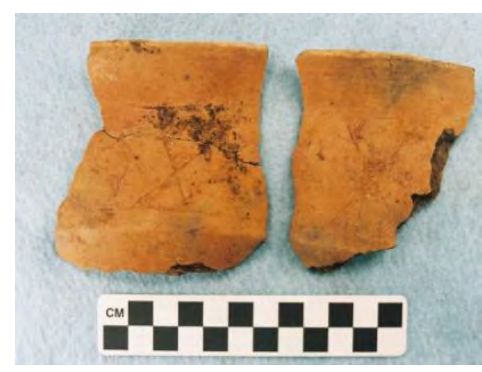

DIAMETER AT BOTTOM OF RIM OR NECK:

Undetermined

Feature 91, Vessel 1.

BASE DIAMETER: $7.4 \mathrm{~cm}$

ESTIMATED VOLUME: 0.9+ liters

DECORATION: The upper panel is plain, while the lower panel has a series of triangular and circular engraved motifs that are repeated seven times around the vessel (Feature 91, Vessel 1). The circles, with small hatched pendant triangles, alternate with the triangular motif, which consists of two triangles that touch at their apex in the central part of the lower panel; the double triangle motif is also seen in examples of Poynor Engraved, var. $\mathrm{O}$ in the upper Neches River basin, but examples have hatched triangles. Four of the engraved triangles have triangular hatched areas at each corner of the larger triangle, while three have negative ovals within the larger triangles, outlined by a series of curvilinear hatched lines at the corner of the larger triangles.

There is also a single engraved triangle on the interior surface of the upper rim panel.

TYPE: Poynor Engraved, variety 2 at $41 \mathrm{AN} 38$. 
FEATURE: 91, 10-25 cm (N217 E203)

VESSEL NO.: 2

NON-PLASTICS: bone

VESSEL FORM: Carinated bowl with a direct rim and a rounded lip

CORE COLOR: $\mathrm{F}$ (fired in a reducing environment and cooled in the open air)

INTERIOR SURFACE COLOR: brown (7.5YR 5/4)

EXTERIOR SURFACE COLOR: yellowish-red (5YR 5/6)

WALL THICKNESS: $6.7 \mathrm{~mm}$, rim panel

INTERIOR SURFACE TREATMENT: smoothed on the rim

EXTERIOR SURFACE TREATMENT: smoothed on the rim and body; fire clouds on lower body and base

HEIGHT: $6.08 \mathrm{~cm}$; rim height is $4.11 \mathrm{~cm}$

ORIFICE DIAMETER: $14.73 \mathrm{~cm}$

DIAMETER AT BOTTOM OF RIM OR NECK: 14.60 $\mathrm{cm}$

BASE DIAMETER: $10.36 \mathrm{~cm}$

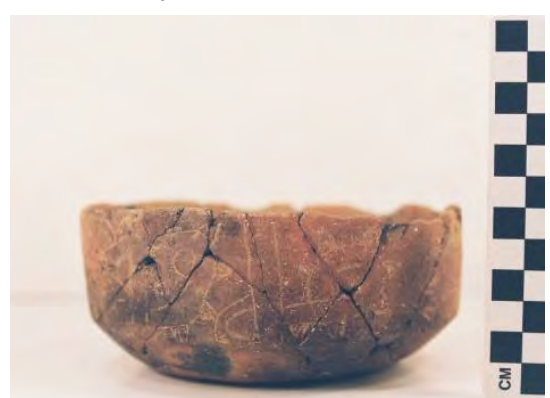

Feature 91, Vessel 2

ESTIMATED VOLUME: 0.55 liters

DECORATION: The rim is divided into six panels by sets of vertical engraved lines. Each panel has unique engraved motifs that feature - in varying combinations - circles or ovals, semi-circles, hooked arm scrolls, pendant triangles, and hatched ovals (Feature 91, Vessel 2). All these elements are commonly featured on upper Neches River Poynor Engraved vessels, but not in the combinations represented on Feature 91, Vessel 2.

Moving from left to right on the vessel, the first panel has two semi-circles, with small hatched pendant triangles on the outer semi-circle. The second panel has a central oval with hatched pendant triangles, as well as two semi-circles, one of which has pendant triangles; there also is a small triangular element with a negative oval opposite the central oval. The third and fourth panels have hooked arm scrolls with hatched pendant triangles. Where they differ is that the third panel has two semi-circles in one corner of the panel, while the fourth panel has three hatched pendant triangles. The fifth panel has two opposed hooked arm scrolls with hatched pendant triangles, a connecting engraved line from one scroll to the other, a hatched negative oval, and semi-circles pendant from the second of the hooked arm scrolls; the outermost semi-circle has hatched pendant triangles. The sixth and last panel has a large semi-circle-with smaller engraved semi-circles within it - and hatched pendant triangles on the outside of the large semicircle (Feature 91, Vessel 2). 
FEATURE: 92, $63 \mathrm{~cm}(\mathrm{~N} 216$ E200)

TYPE: Poynor Engraved vessel, local variety 3 at 41AN38. Feature 91, Vessel 2.

VESSEL NO.: 1

NON-PLASTICS: bone-hematite

VESSEL FORM: Bowl with a direct rim and a rounded lip; two rim peaks or tabs (these are 33 $\mathrm{mm}$ wide and $17.5 \mathrm{~mm}$ in height) (Feature 92, Vessel 1)

CORE COLOR: $\mathrm{G}$ (fired in a reducing environment and cooled in the open air)

INTERIOR SURFACE COLOR: pale brown (10YR 6/3)

EXTERIOR SURFACE COLOR: grayish-brown (10YR 5/2)

WALL THICKNESS: $6.2 \mathrm{~mm}$, rim; $6.2 \mathrm{~mm}$, body; $9.4 \mathrm{~mm}$, base

INTERIOR SURFACE TREATMENT: smoothed; fire clouds

EXTERIOR SURFACE TREATMENT: smoothed; fire clouds on base

HEIGHT: $7.06 \mathrm{~cm}$ (without rim peaks); $8.42 \mathrm{~cm}$ (with rim peaks)

ORIFICE DIAMETER: $17.0 \mathrm{~cm}$

DIAMETER AT BOTTOM OF RIM OR NECK: N/A

BASE DIAMETER: $8.5 \mathrm{~cm}$

ESTIMATED VOLUME: 0.5 liters

DECORATION: plain

TYPE: Undetermined plain ware vessel

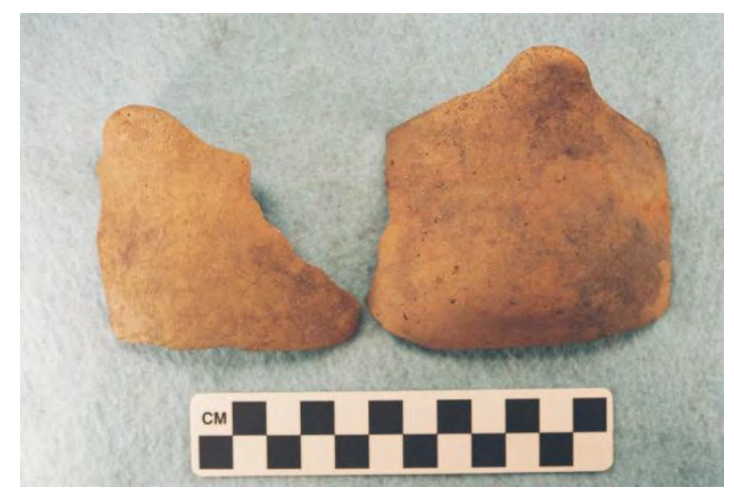

Feature 92, Vessel 1, Rim Sherds.

FEATURE: 92, 59 cm bs (N216 E200) 
VESSEL NO.: 2

NON-PLASTICS: grog-hematite

VESSEL FORM: Rectangular-shaped bowl or small trough with two rim peaks (Feature 92,

Vessel 2, a-b); direct rim and flat lip, except at the rim peaks, where the rim is interior thickened

CORE COLOR: C (incompletely oxidized during firing)

INTERIOR SURFACE COLOR: yellowish-brown (10YR 5/4)

EXTERIOR SURFACE COLOR: brownish-yellow (10YR 6/6)

WALL THICKNESS: $6.2 \mathrm{~mm}$, rim; $5.1 \mathrm{~mm}$, body; $7.1 \mathrm{~mm}$, base

INTERIOR SURFACE TREATMENT: fire clouds on body and base

EXTERIOR SURFACE TREATMENT: poor smoothing

HEIGHT: $5.9 \mathrm{~cm}$

ORIFICE DIAMETER: maximum of $12.9 \mathrm{~cm}$

DIAMETER AT BOTTOM OF RIM OR NECK: N/A

BASE DIAMETER: maximum of $9.6 \mathrm{~cm}$

ESTIMATED VOLUME: 0.3 liters

DECORATION: plain

TYPE: Undetermined plain ware vessel of unique form

a

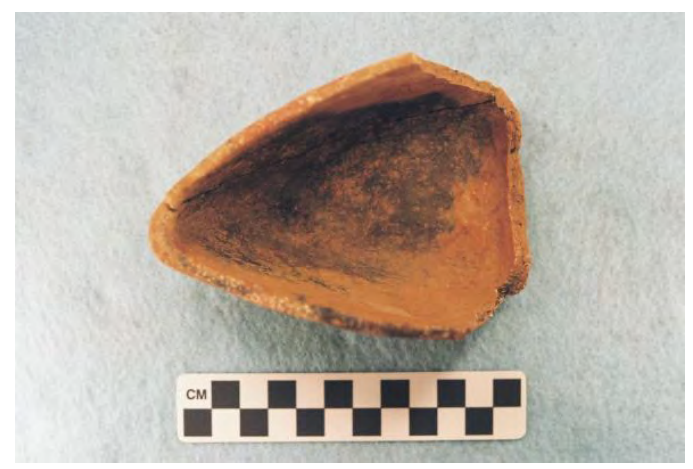

b

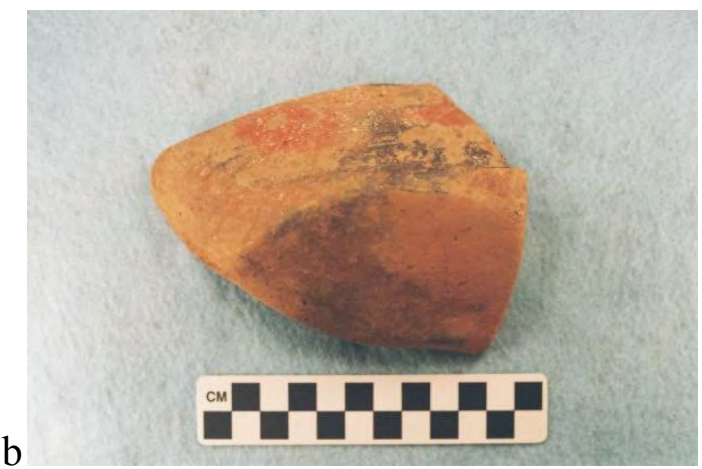

Two Views of Feature 92, Vessel 2: a, looking down on the vessel; b, side and basal view. 
FEATURE: $93,65-75 \mathrm{~cm}$ bs

VESSEL NO.: 1

NON-PLASTICS: bone and grog

VESSEL FORM: Bowl with a direct rim and a flat lip (Feature 93, Vessel 1)

CORE COLOR: $\mathrm{G}$ (fired in a reducing environment but cooled in the open air)

INTERIOR SURFACE COLOR: black (7.5YR 2.5/1)

EXTERIOR SURFACE COLOR: brown (7.5YR 5/4)

WALL THICKNESS: rim, $6.5 \mathrm{~mm}$; mid-body, $7.1 \mathrm{~mm}$; base, $7.2 \mathrm{~mm}$

INTERIOR SURFACE TREATMENT: none

EXTERIOR SURFACE TREATMENT: poorly smoothed; small area of organic residue near rim; fire cloud on rim

HEIGHT: $13.49 \mathrm{~cm}$

ORIFICE DIAMETER: $13.0 \mathrm{~cm}$

DIAMETER AT BOTTOM OF RIM OR NECK: $13.40 \mathrm{~cm}$

BASE DIAMETER: $6.7 \mathrm{~cm}$

ESTIMATED VOLUME: 1.1 liters

DECORATION: Plain

TYPE: Undetermined plain ware vessel

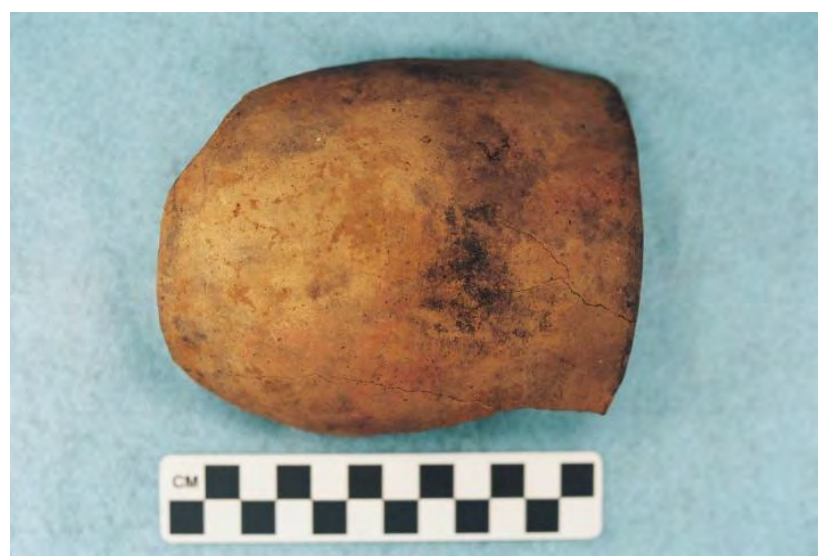

Feature 93, Vessel 1. 
FEATURE: 93

VESSEL NO.: 2

NON-PLASTICS: grog

VESSEL FORM: Globular carinated bowl with broad rim panel (Feature 93, Vessel 2); everted rim and a rounded lip

CORE COLOR: F (fired in a reducing environment and cooled in the open air)

INTERIOR SURFACE COLOR: dark gray (10YR 4/1)

EXTERIOR SURFACE COLOR: pale brown (10YR 6/3)

WALL THICKNESS: $3.6 \mathrm{~mm}$, rim

INTERIOR SURFACE TREATMENT: smoothed on rim; fire cloud on base

EXTERIOR SURFACE TREATMENT: smoothed; fire clouds on the body and base

HEIGHT: $5.69 \mathrm{~cm}$

ORIFICE DIAMETER: $8.40 \mathrm{~cm}$

DIAMETER AT BOTTOM OF RIM OR NECK: $7.6 \mathrm{~cm}$ under the lip; $8.90 \mathrm{~cm}$ at the carination

BASE DIAMETER: $7.35 \mathrm{~cm}$

ESTIMATED VOLUME: 0.3 liters

DECORATION: Seven panels with hatched semi-circular engraved elements; alternate semicircles panels have a smaller but unhatched semi-circle as part of the motif. Each of the panels are divided by three vertical engraved lines, except in one instance where there is a single vertical line and a horizontal hatched ladder. Poynor Engraved, var. $\mathrm{K}$ in the upper Neches River basin sites is comparable to this example from 41AN38.

TYPE: Poynor Engraved, local variety 4.

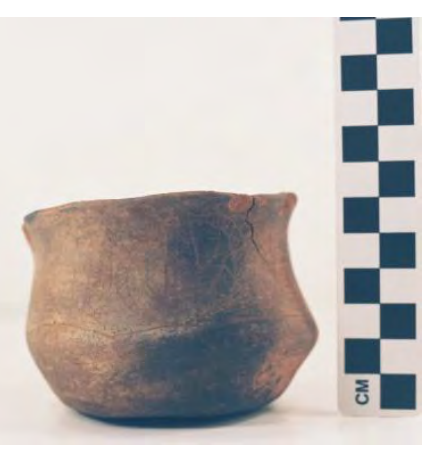

Feature 93, Vessel 2. 
FEATURE: $93,65-71 \mathrm{~cm}$

VESSEL NO.: 3 (also includes Vessel 4A as recognized in the field, which conjoins with Vessel 3)

NON-PLASTICS: grog and bone

VESSEL FORM: Compound bowl with an everted rim and a rounded lip; $47 \%$ of the rim is present (Feature 93, Vessel 3a-b)

CORE COLOR: $\mathrm{G}$ (fired in a reducing environment and cooled in the open air)

INTERIOR SURFACE COLOR: grayish-brown (10YR 5/2) and light brownish-gray (10YR 6/2)

EXTERIOR SURFACE COLOR: yellowish-brown (10YR 5/4) and brown (10YR 5/3)

WALL THICKNESS: upper rim panel, $7.3 \mathrm{~mm}$; lower rim panel, $6.8 \mathrm{~mm}$; lower body, $8.3 \mathrm{~mm}$; base, $9.4 \mathrm{~mm}$

INTERIOR SURFACE TREATMENT: fire cloud on the upper rim panel

EXTERIOR SURFACE TREATMENT: poorly smoothed; organic residue on both rim panels; fire clouds on lower rim panel and base

HEIGHT: $12.7 \mathrm{~cm}$; rim panels height, $8.52 \mathrm{~cm}$; upper panel height, $4.40 \mathrm{~cm}$; lower panel height, $4.12 \mathrm{~cm}$

ORIFICE DIAMETER: $19.0 \mathrm{~cm}$

DIAMETER AT BOTTOM OF RIM OR NECK: N/A

BASE DIAMETER: $7.9 \mathrm{~cm}$, flat disk base (Feature 93, Vessel $3 \mathrm{c}$ )

ESTIMATED VOLUME: 1.9 liters

DECORATION: The upper rim panel is plain (Feature 93, Vessel 3 a-b). The lower rim panel has an engraved design repeated three times around the vessel, defined by upper and lower horizontal engraved lines. This design includes two panels with a semi-circle and small pendant triangles (plain and excised); there is a small triangular element (with hatched corners in one instance) within the semi-circles. These semi-circles are divided by another panel with three engraved diagonal lines, one with a pendant triangle, as well as a hatched pendant triangle suspended from the upper horizontal engraved line on the lower rim panel.

TYPE: Poynor Engraved, local variety 5.

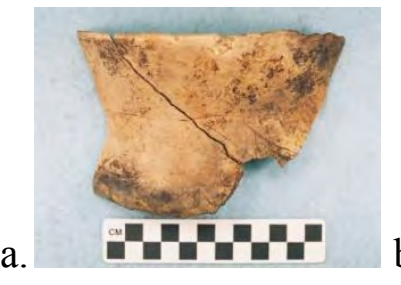

Feature 93, Vessel 3: a-b, upper and low rim panels; c, disk base.

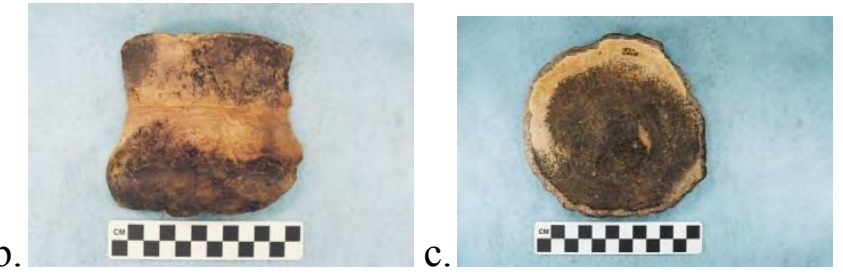


FEATURE: 93

VESSEL NO.: $4 \mathrm{~B}, 66 \%$ of the rim is present

NON-PLASTICS: bone and grog

VESSEL FORM: Bowl with a direct rim and a rounded lip; there is at least one rim peak (20.0 $\mathrm{mm}$ in width), with an interior beveled lip at the rim peak (Vessel 4B, Feature 93)

CORE COLOR: C (incompletely oxidized during firing)

INTERIOR SURFACE COLOR: strong brown (7.5YR 4/6)

EXTERIOR SURFACE COLOR: dark gray $(7.5 Y R$ 4/1)

WALL THICKNESS: $5.6 \mathrm{~mm}$, rim; $11.0 \mathrm{~mm}$ at the rim peak; $5.2 \mathrm{~mm}$, body; $5.6 \mathrm{~mm}$, base

INTERIOR SURFACE TREATMENT: smoothed; fire cloud on base

EXTERIOR SURFACE TREATMENT: smoothed

HEIGHT: estimated at $15.8 \mathrm{~cm}$

ORIFICE DIAMETER: $18.0 \mathrm{~cm}$

DIAMETER AT BOTTOM OF RIM OR NECK: N/A

BASE DIAMETER: $7.9 \mathrm{~cm}$

ESTIMATED VOLUME: $2.2+$ liters

DECORATION: plain

TYPE: Undetermined plain ware vessel

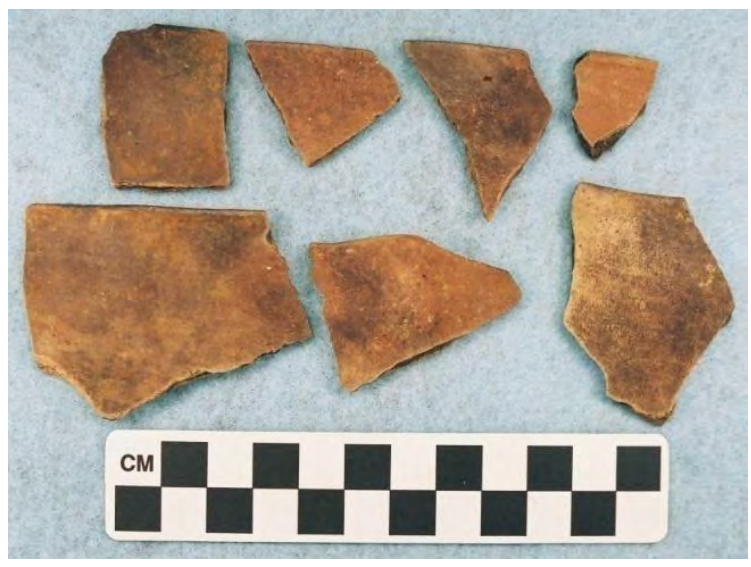

Feature 93, Vessel 4B, Rim Sherds. 
FEATURE: $93,69-72 \mathrm{~cm}$

VESSEL NO.: 5

NON-PLASTICS: grog

VESSEL FORM: Bowl with seven rim peaks (31.5 $\mathrm{mm}$ in width); interior beveled rim

CORE COLOR: Undetermined

INTERIOR SURFACE COLOR: light yellowish-brown (10YR 6/4)

EXTERIOR SURFACE COLOR: dark yellowish-brown (10YR 4/4)

WALL THICKNESS: $3.8 \mathrm{~mm}$, rim

INTERIOR SURFACE TREATMENT: fire clouds on base and body

EXTERIOR SURFACE TREATMENT: smoothed; fire cloud on base

HEIGHT: $5.9 \mathrm{~cm} ; 6.75 \mathrm{~cm}$ at the rim peaks

ORIFICE DIAMETER: $13.0 \mathrm{~cm} ; 13.45 \mathrm{~cm}$ at the rim peaks, as they are angled outward

DIAMETER AT BOTTOM OF RIM OR NECK: N/A

BASE DIAMETER: $6.5 \mathrm{~cm}$

ESTIMATED VOLUME: 0.3 liters

DECORATION: The upper part of the vessel has an engraved motif repeated eight times around the rim, beginning under the rim peaks. Each motif consists of two engraved triangles - one with its apex pointed down and the other with its apex pointing up towards the rim-with hatched corners. The opposed engraved triangles are separated from each other by diagonal hatched ladders or narrow zones.

TYPE: Poynor Engraved, var. F in the upper Neches River basin

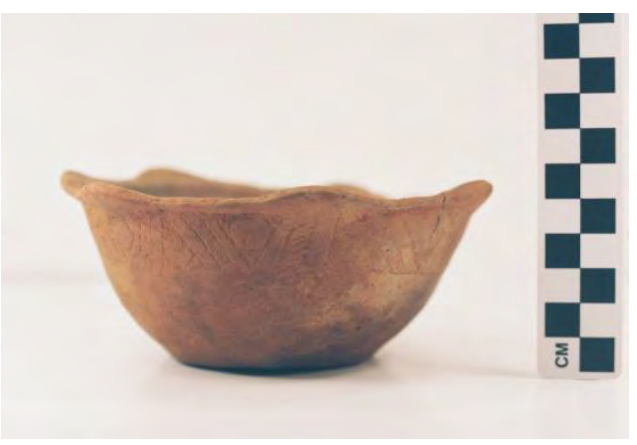

Feature 93, Vessel 5. 
FEATURE: $93,60-74 \mathrm{~cm}$

VESSEL NO.: 6

NON-PLASTICS: grog and bone

VESSEL FORM: Carinated bowl with a direct rim and a flat lip (Feature 93, Vessel 6)

CORE COLOR: F (fired in a reducing environment and cooled in the open air)

INTERIOR SURFACE COLOR: yellowish-red (5YR 4/6)

EXTERIOR SURFACE COLOR: yellowish-red (5YR 4/6)

WALL THICKNESS: rim, $7.4 \mathrm{~mm}$; body, $7.9 \mathrm{~mm}$

INTERIOR SURFACE TREATMENT: smoothed on rim; fire cloud on base

EXTERIOR SURFACE TREATMENT: smoothed on the rim and body; fire cloud on base

HEIGHT: $10.82 \mathrm{~cm}$; rim height, $4.49 \mathrm{~cm}$

ORIFICE DIAMETER: $15.9 \mathrm{~cm}$

DIAMETER AT BOTTOM OF RIM OR NECK: $15.6 \mathrm{~cm}$

BASE DIAMETER: $8.12 \mathrm{~cm}$

ESTIMATED VOLUME: 1.0 liters

DECORATION: plain

TYPE: Undetermined plain ware vessel

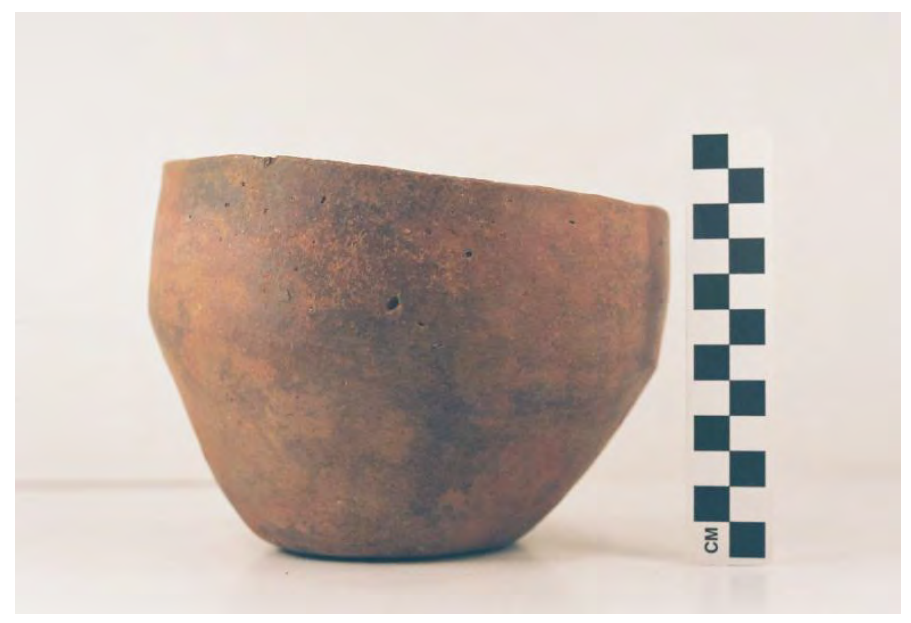

Feature 93, Vessel 6. 
FEATURE: $93,62-78 \mathrm{~cm}$

VESSEL NO.: 7

NON-PLASTICS: grog and hematite

VESSEL FORM: Carinated bottle with a straight neck, direct rim and a flat lip, and a globular body with a carination near the vessel base (Feature 93, Vessel 7)

CORE COLOR: B (fired and cooled in a reducing environment)

INTERIOR SURFACE COLOR: dark yellowish-brown (10YR 4/4)

EXTERIOR SURFACE COLOR: dark yellowish-brown (10YR 4/4)

WALL THICKNESS: $4.9 \mathrm{~mm}$, neck

INTERIOR SURFACE TREATMENT: none

EXTERIOR SURFACE TREATMENT: smoothed in patches; eroded

HEIGHT: $18.9 \mathrm{~cm}$; neck height is $7.7 \mathrm{~cm}$

ORIFICE DIAMETER: $4.35 \mathrm{~cm}$ at the neck

DIAMETER AT BOTTOM OF RIM OR NECK: $11.32 \mathrm{~cm}$ at the widest part of the body (at the body carination)

BASE DIAMETER: $5.3 \mathrm{~cm}$

ESTIMATED VOLUME: 0.4 liters

DECORATION: plain

TYPE: Undetermined plain ware vessel

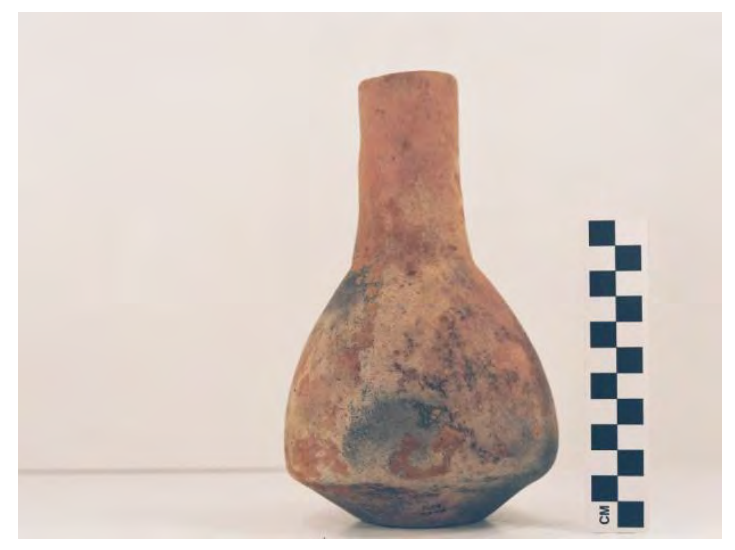

Feature 93, Vessel 7. 
FEATURE: $93,58-77 \mathrm{~cm}$

VESSEL NO.: 8

NON-PLASTICS: hematite; sandy paste

VESSEL FORM: Carinated bowl with a direct rim and a flat lip (Feature 93, Vessel 8)

CORE COLOR: Undetermined

INTERIOR SURFACE COLOR: dark yellowish-brown (10YR 3/4)

EXTERIOR SURFACE COLOR: dark yellowish-brown (10YR 3/4)

WALL THICKNESS: $6.3 \mathrm{~mm}$, rim

INTERIOR SURFACE TREATMENT: scraping and limited smoothing; fire cloud on base EXTERIOR SURFACE TREATMENT: smoothed; organic residue on the rim; fire clouds

HEIGHT: $9.5 \mathrm{~cm}$; rim height, $5.6 \mathrm{~cm}$

ORIFICE DIAMETER: $19.1 \mathrm{~cm}$

DIAMETER AT BOTTOM OF RIM OR NECK: $18.8 \mathrm{~cm}$

BASE DIAMETER: $8.3 \mathrm{~cm}$

ESTIMATED VOLUME: 1.1 liters

DECORATION: plain

TYPE: Undetermined plain ware vessel

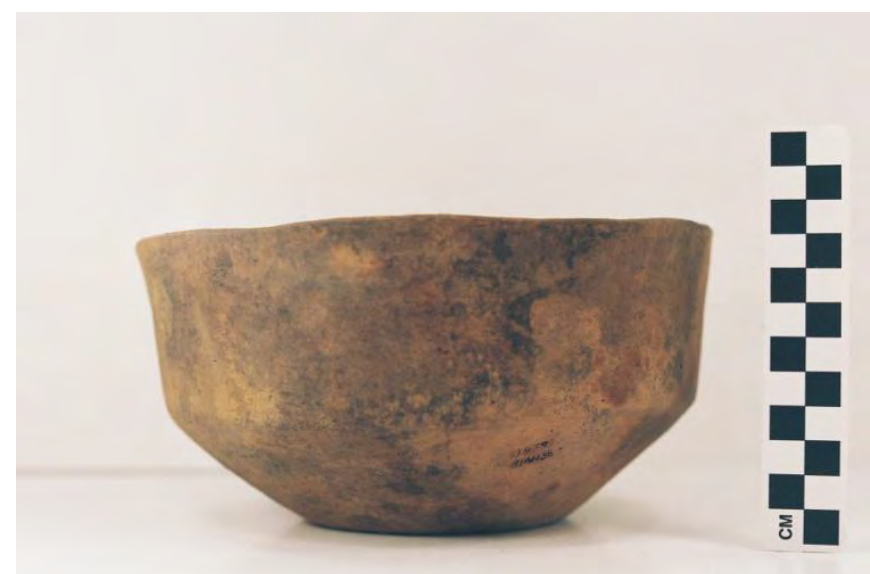

Feature 93, Vessel 8. 
FEATURE: $93,59-73 \mathrm{~cm}$

VESSEL NO.: 9

NON-PLASTICS: grog

VESSEL FORM: Jar with a direct rim and a flat lip

CORE COLOR: $\mathrm{G}$ (fired in a reducing environment and cooled in the open air)

INTERIOR SURFACE COLOR: very dark grayish-brown (10YR 3/2)

EXTERIOR SURFACE COLOR: yellowish-brown (10YR 5/4)

WALL THICKNESS: $7.9 \mathrm{~mm}$, body; $9.4 \mathrm{~mm}$, base

INTERIOR SURFACE TREATMENT: smoothed; organic residue on the rim, fire clouds on the lower body

EXTERIOR SURFACE TREATMENT: smoothed on body; organic residue on body and across the rim; fire cloud on base

HEIGHT: est. $11.8 \mathrm{~cm}$; rim height, $4.6 \mathrm{~cm}$

ORIFICE DIAMETER: $13.0 \mathrm{~cm}$

DIAMETER AT BOTTOM OF RIM OR NECK: N/A

BASE DIAMETER: $6.95 \mathrm{~cm}$

ESTIMATED VOLUME: $1.0+$ liters

DECORATION: The jar is decorated on the rim with incised triangles filled with tool punctations and near vertical incised panels filled with tool punctations (Feature 93, Vessel 9). The near vertical incised panels and incised triangles are divided by a single diagonal incised line, and the bottom of the incised-punctated triangles and panels is defined by a single horizontal incised line.

TYPE: Maydelle Incised

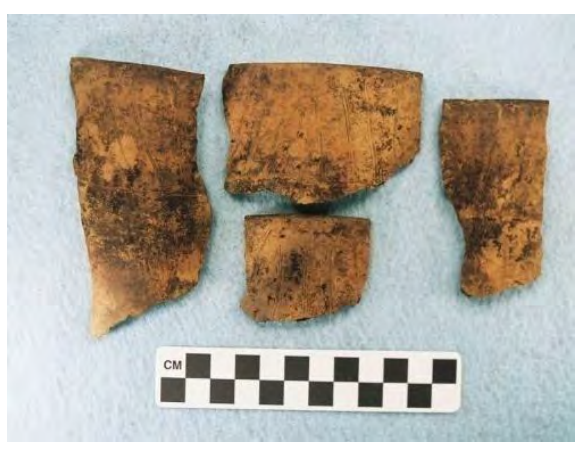

Feature 93, Vessel 9, Rim Sherds. 
FEATURE: 94, 58-68 cm (N215 E200)

VESSEL NO.: 1

NON-PLASTICS: none apparent

VESSEL FORM: Bowl with a direct rim and a rounded lip (Feature 94, Vessel 1)

CORE COLOR: Undetermined

INTERIOR SURFACE COLOR: grayish-brown (10YR 5/2)

EXTERIOR SURFACE COLOR: brown (10YR 4/3)

WALL THICKNESS: 4.9 mm, rim

INTERIOR SURFACE TREATMENT: smoothed; fire clouds on base and rim

EXTERIOR SURFACE TREATMENT: smoothed; fire clouds on base and body

HEIGHT: $8.03 \mathrm{~cm}$

ORIFICE DIAMETER: $11.29 \mathrm{~cm}$

DIAMETER AT BOTTOM OF RIM OR NECK: N/A

BASE DIAMETER: $6.91 \mathrm{~cm}$

ESTIMATED VOLUME: 0.4 liters

DECORATION: plain

TYPE: Undetermined plain ware vessel

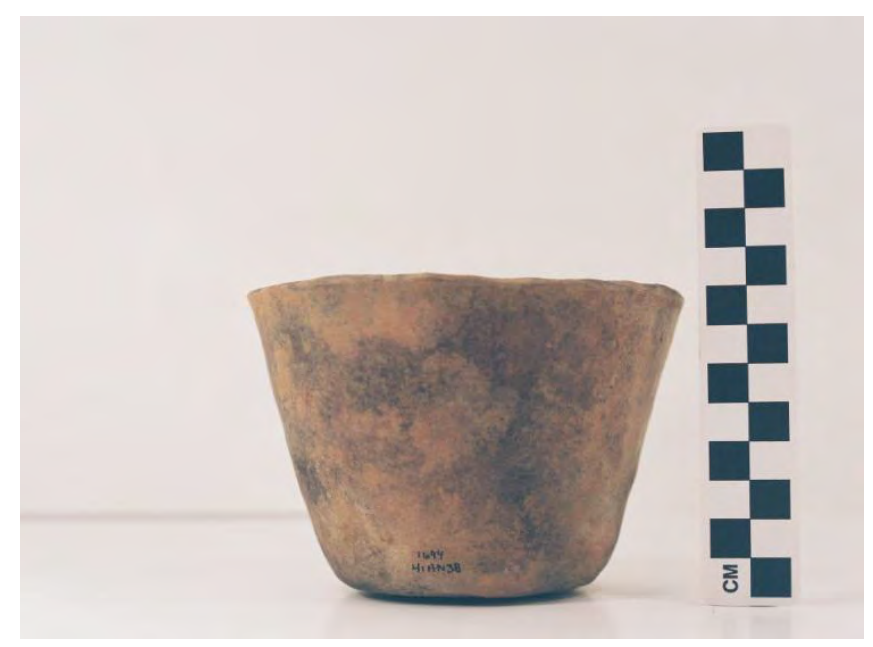

Feature 94, Vessel 1 Bowl. 
FEATURE: $94,59-65 \mathrm{~cm}$

VESSEL NO.: 2

NON-PLASTICS: bone

VESSEL FORM: Compound bowl or globular carinated bowl with an everted rim and a rounded lip (Feature 94, Vessel 2)

CORE COLOR: B (fired and cooled in a low oxygen environment)

INTERIOR SURFACE COLOR: dark grayish-brown (10YR 4/2)

EXTERIOR SURFACE COLOR: very dark grayish-brown (10YR 3/2)

WALL THICKNESS: rim, $4.3 \mathrm{~mm}$; body, $4.2 \mathrm{~mm}$

INTERIOR SURFACE TREATMENT: smoothed on rim

EXTERIOR SURFACE TREATMENT: smoothed

HEIGHT: $7.95 \mathrm{~cm}$

ORIFICE DIAMETER: $12.79 \mathrm{~cm}$

DIAMETER AT BOTTOM OF RIM OR NECK: $10.60 \mathrm{~cm}$ at the upper panel; $12.8 \mathrm{~cm}$ at the lower panel

BASE DIAMETER: $7.32 \mathrm{~cm}$

ESTIMATED VOLUME: 0.8 liters

DECORATION: plain

TYPE: Poynor Plain

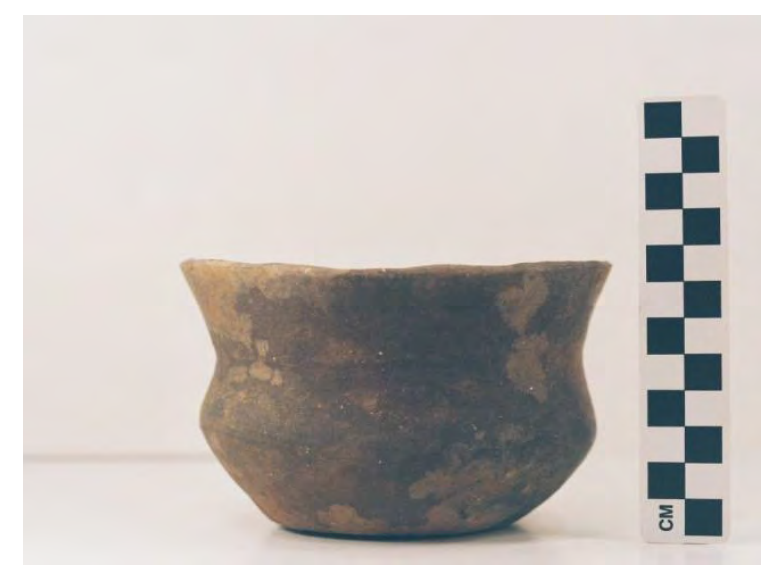

Feature 94, Vessel 2. 
FEATURE: 94, 65-67 cm bs (N215 E200)

VESSEL NO.: 3

NON-PLASTICS: bone and hematite

VESSEL FORM: Bowl with direct rim and a rounded, scalloped lip; the rim is interior thickened and pinched; interior thickened rim height is $16.0 \mathrm{~mm}$

CORE COLOR: $\mathrm{G}$ (fired in a reducing environment and cooled in the open air)

INTERIOR SURFACE COLOR: dark grayish-brown (10YR 4/2)

EXTERIOR SURFACE COLOR: dark gray (10YR 4/1)

WALL THICKNESS: $5.3 \mathrm{~mm}$, rim; $8.8 \mathrm{~mm}$, thickened portion of rim; $7.1 \mathrm{~mm}$, body; $11.8 \mathrm{~mm}$, base

INTERIOR SURFACE TREATMENT: none

EXTERIOR SURFACE TREATMENT: none

HEIGHT: $4.9 \mathrm{~cm}$

ORIFICE DIAMETER: $9.0 \mathrm{~cm}$

DIAMETER AT BOTTOM OF RIM OR NECK: N/A

BASE DIAMETER: $5.3 \mathrm{~cm}$

ESTIMATED VOLUME: 0.2 liters

DECORATION: vertical pinched rows from the rim to the vessel base

TYPE: Killough Pinched

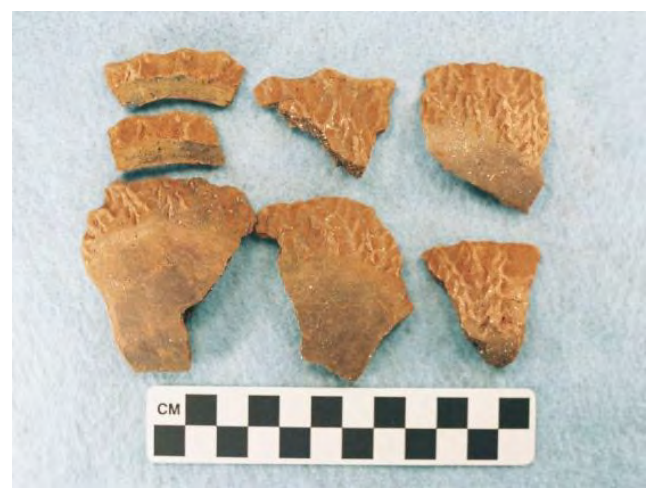

Killough Pinched Rim, Body, and Base Sherds. 
FEATURE: $94,65-69 \mathrm{~cm}$ bs

VESSEL NO.: 4

NON-PLASTICS: bone

VESSEL FORM: Carinated bowl with an inverted rim and a flat lip; one rim peak or vertical tab tail (Feature 94, Vessel 4)

CORE COLOR: $\mathrm{G}$ (fired in a reducing environment, but cooled in the open air)

INTERIOR SURFACE COLOR: dark grayish-brown (10YR 4/2)

EXTERIOR SURFACE COLOR: very dark grayish-brown (10YR 3/2)

WALL THICKNESS: $6.0 \mathrm{~mm}$, rim

INTERIOR SURFACE TREATMENT: scraping marks

EXTERIOR SURFACE TREATMENT: smoothed on rim

HEIGHT: $4.05 \mathrm{~cm} ; 4.65 \mathrm{~cm}$ at rim peaks; rim height, $2.75 \mathrm{~cm}$

ORIFICE DIAMETER: $6.5 \mathrm{~cm}$

DIAMETER AT BOTTOM OF RIM OR NECK: $6.5 \mathrm{~cm}$

BASE DIAMETER: $4.35 \mathrm{~cm}$

ESTIMATED VOLUME: 0.2 liters

DECORATION: plain

TYPE: Undetermined plain ware vessel, possibly an effigy vessel, but with a missing effigy head

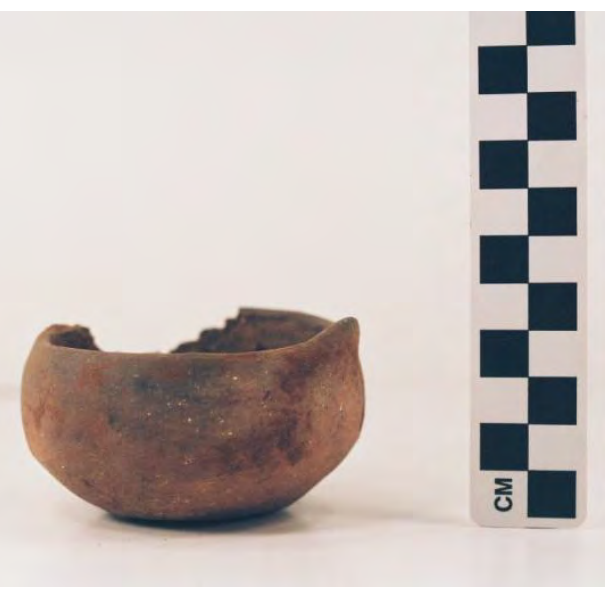




\section{Feature 94, Vessel 4.}

FEATURE: $94,63-70 \mathrm{~cm}$

VESSEL NO.: 5

NON-PLASTICS: bone

VESSEL FORM: Bowl with a direct rim and a flat, but exterior folded, lip

CORE COLOR: F (fired in a reducing environment, but cooled in the open air)

INTERIOR SURFACE COLOR: dark grayish-brown (10YR 4/2)

EXTERIOR SURFACE COLOR: grayish-brown (10YR 5/2)

WALL THICKNESS: $4.7 \mathrm{~mm}$, rim; $6.9 \mathrm{~mm}$, base

INTERIOR SURFACE TREATMENT: none

EXTERIOR SURFACE TREATMENT: poorly smoothed

HEIGHT: $4.6 \mathrm{~cm}$

ORIFICE DIAMETER: $9.0 \mathrm{~cm}$

DIAMETER AT BOTTOM OF RIM OR NECK: N/A

BASE DIAMETER: Undetermined

ESTIMATED VOLUME: 0.2 liters

DECORATION: plain

TYPE: Undetermined plain ware vessel

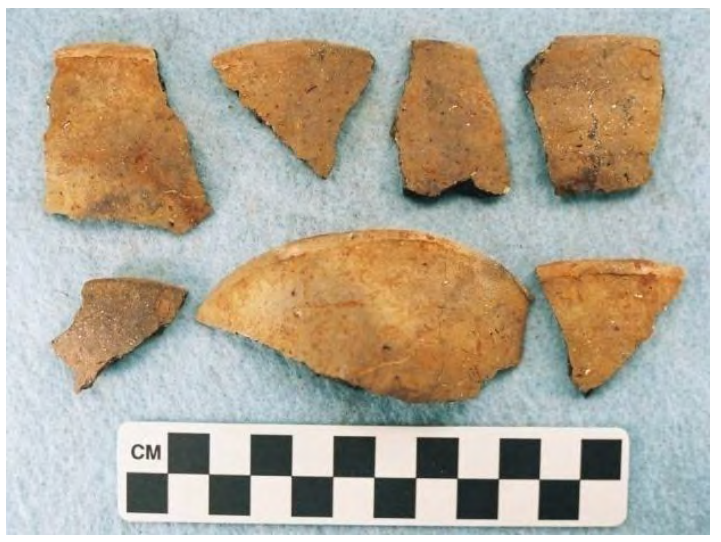

Feature 94, Vessel 5, Rim Sherds. 


\section{References Cited}

Early, A. M. (editor)

1993 Caddoan Saltmakers in the Ouachita Valley: The Hardman Site. Research Series No. 43. Arkansas Archeological Survey, Fayetteville.

Teltser, P. A.

1993 An Analytic Strategy for Studying Assemblage-Scale Ceramic Variation: A Case Study from Southeast Missouri. American Antiquity 58(3):530-543.
Walters, M., with contributions by $\mathrm{T}$. Middlebrook and T. K. Perttula

2008 Redwine or pie-crust rim modes in East Texas Caddo ceramics. MS in preparation. 


\section{Appendix F.5 Vessel Documentation, Caddo Sites in Anderson and Cherokee Counties, Texas, in the upper Neches River Basin}

\section{Mrs. J. M. Cook Site (41AN1)}

SITE NO.: 41AN1

FEATURE: Burial E-1

VESSEL NO.: 41AN1-1

NON-PLASTICS: grog

VESSEL FORM: Miniature carinated bowl with a direct rim and a flat lip

CORE COLOR: A (fired and cooled in an oxidizing environment, following Teltser 1993:Figure 2a-h)

WALL THICKNESS: $4.6 \mathrm{~mm}$, rim

INTERIOR SURFACE TREATMENT: smoothed

EXTERIOR SURFACE TREATMENT: smoothed

HEIGHT: $5.4 \mathrm{~cm}$

ORIFICE DIAMETER: $6.7 \mathrm{~cm}$

DIAMETER AT BOTTOM OF RIM OR NECK: 6.7 $\mathrm{cm}$

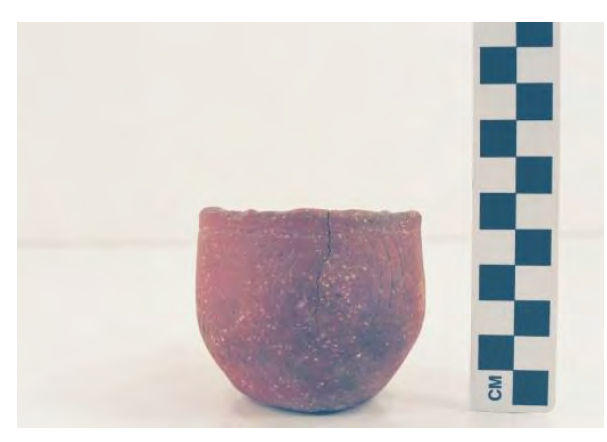

Vessel 41AN1-1.

BASE DIAMETER: $3.9 \mathrm{~cm}$

ESTIMATED VOLUME: 0.2 liters

DECORATION: The vessel has an engraved panel on the rim (Vessel 41AN1-1). Within the panel are four negative ovals. These negative ovals are defined by sets of three closely-spaced vertical curvilinear lines, and they also have triangular hatched areas at the upper and lower ends of the vertical lines.

TYPE: Poynor Engraved, var. Cook 
SITE NO.: 41AN1

FEATURE: Burial E-1

VESSEL NO.: 41AN1-2

NON-PLASTICS: grog and hematite

VESSEL FORM: Globular carinated bowl with a direct to slightly everted rim and a rounded lip, as well as four rim peaks

CORE COLOR: A (fired in an oxidizing environment)

WALL THICKNESS: $6.9 \mathrm{~mm}$

INTERIOR SURFACE TREATMENT: smoothed

EXTERIOR SURFACE TREATMENT: burnished

HEIGHT: $9.0 \mathrm{~cm}$

ORIFICE DIAMETER: $12.0 \mathrm{~cm}$

DIAMETER AT BOTTOM OF RIM OR NECK: $11.68 \mathrm{~cm}$

BASE DIAMETER: $7.2 \mathrm{~cm}$

ESTIMATED VOLUME: 0.65 liters

DECORATION: The rim has an engraved motif composed of six negative ovals. The negative ovals are each defined by two hour glass-shaped excised zones (Vessel 41AN12).

TYPE: Poynor Engraved, var. Hood

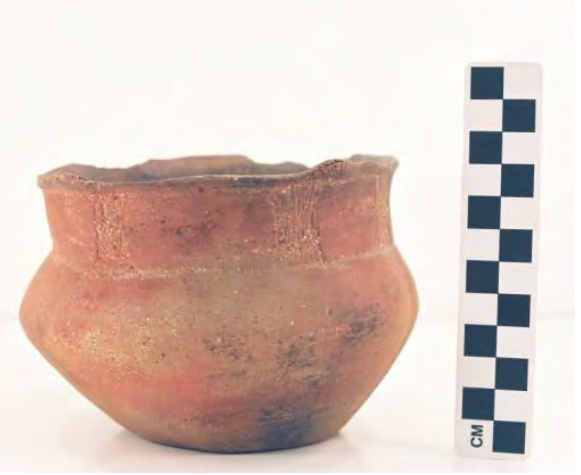

Vessel 41AN1-2. 
SITE NO.: 41AN1

FEATURE: Burial E-1

VESSEL NO.: 41AN1-3

NON-PLASTICS: grog

VESSEL FORM: Jar with a direct rim and a rounded lip

CORE COLOR: Undetermined

WALL THICKNESS: $5.7 \mathrm{~mm}$, rim

INTERIOR SURFACE TREATMENT: smoothed

EXTERIOR SURFACE TREATMENT: none

HEIGHT: $12.0 \mathrm{~cm}$

ORIFICE DIAMETER: $13.2 \mathrm{~cm}$

DIAMETER AT BOTTOM OF RIM OR NECK: $12.3 \mathrm{~cm}$

BASE DIAMETER: $8.6 \mathrm{~cm}$

ESTIMATED VOLUME: 1.0 liters

DECORATION: The rim has a cross-hatched incised motif; there are also two small appliqued nodes on the rim, just under the lip (Vessel 41AN1-3). On the remainder of the vessel, beginning at the rim-body juncture, are vertical rows of large tool punctations. These punctated rows reach to the base of the vessel.

TYPE: possible Maydelle Incised jar

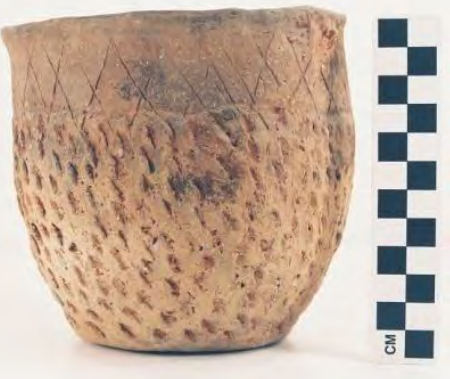

Vessel 41AN1-3. 
SITE NO.: 41AN1

FEATURE: Burial E-1

VESSEL NO.: 41AN1-4

NON-PLASTICS: grog

VESSEL FORM: Carinated bowl with an inverted rim and a rounded lip

CORE COLOR: Undetermined

WALL THICKNESS: $5.5 \mathrm{~mm}$

INTERIOR SURFACE TREATMENT: smoothed

EXTERIOR SURFACE TREATMENT: smoothed

HEIGHT: $7.5 \mathrm{~cm}$

ORIFICE DIAMETER: $11.5 \mathrm{~cm}$

DIAMETER AT BOTTOM OF RIM OR NECK: $12.2 \mathrm{~cm}$

BASE DIAMETER: $7.1 \mathrm{~cm}$

ESTIMATED VOLUME: 0.5 liters

DECORATION: The vessel has a series of four engraved concentric semi-circles on the rim. Each set of concentric semi-circles has five engraved lines (Vessel 41AN1-4). There are also single horizontal engraved lines at the top of the vessel-under the lip - and at the vessel carination.

TYPE: Poynor Engraved, var. $R$ in the upper Neches River basin

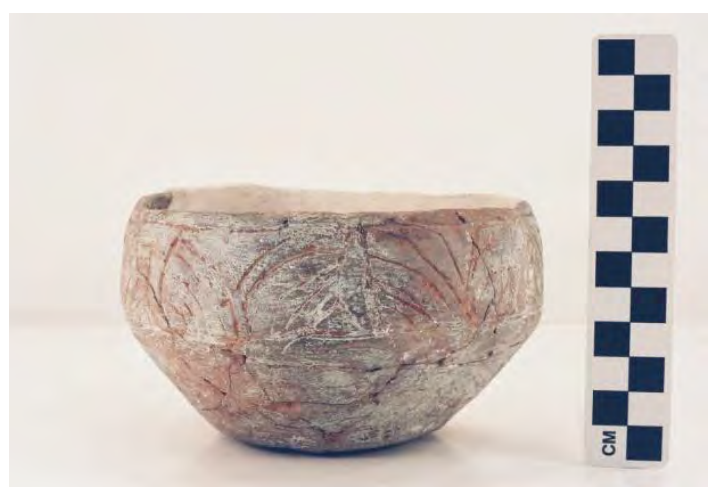

Vessel 41AN1-4. 
SITE NO.: 41AN1

FEATURE: Burial E-1

VESSEL NO.: 41AN1-5

NON-PLASTICS: grog

VESSEL FORM: Carinated bowl with inverted rim and rounded lip

CORE COLOR: $\mathrm{H}$ (fired in a reducing environment but cooled in the open air); pinkware

WALL THICKNESS: $8.0 \mathrm{~mm}$, rim

INTERIOR SURFACE TREATMENT: burnished on the rim, and smoothed on the body

EXTERIOR SURFACE TREATMENT: burnished on the rim

HEIGHT: $14.2 \mathrm{~cm}$

ORIFICE DIAMETER: $23.1 \mathrm{~cm}$

DIAMETER AT BOTTOM OF RIM OR NECK: $23.1 \mathrm{~cm}$

BASE DIAMETER: $9.5 \mathrm{~cm}$

ESTIMATED VOLUME: 2.9 liters

DECORATION: The vessel is engraved on the rim with five negative circles (Vessel 41AN1-5). There are smaller engraved circles at the center of the negative circles, which are defined by four closely-spaced vertical engraved arcs. Five small engraved circles divide each of the negative circles. Portions of the vessel body have diagonal brushing marks.

TYPE: Poynor Engraved, var. Lang

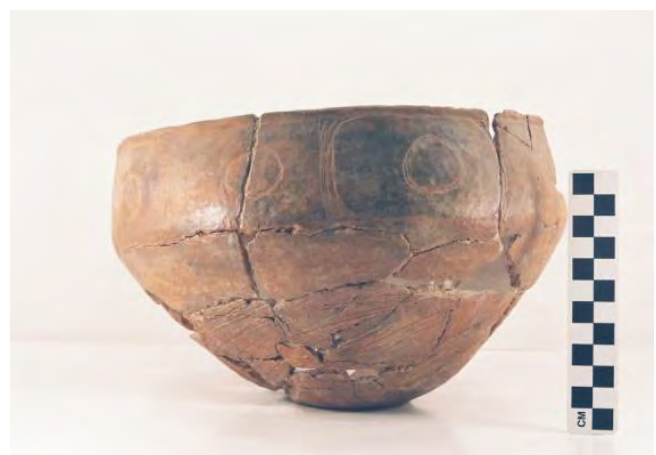

Vessel 41AN1-5. 
SITE NO.: 41AN1

FEATURE: Burial E-1

VESSEL NO.: 41AN1-6

NON-PLASTICS: grog

VESSEL FORM: Rattle bowl with a direct rim and a rounded lip; four attached rattles

CORE COLOR: Undetermined

WALL THICKNESS: $8.2 \mathrm{~mm}$

INTERIOR SURFACE TREATMENT: smoothed

EXTERIOR SURFACE TREATMENT: none

HEIGHT: $11.5 \mathrm{~cm}$

ORIFICE DIAMETER: $21.5 \mathrm{~cm}$

DIAMETER AT BOTTOM OF RIM OR NECK: N/A

BASE DIAMETER: $10.5 \mathrm{~cm}$

ESTIMATED VOLUME: 1.0 liters

DECORATION: The entire vessel rim and body is covered in vertical pinched rows, as are the four attached rattles (Vessel 41AN1-6).

TYPE: Killough Pinched rattle bowl (Suhm and Jelks 1962: Plate 46e).

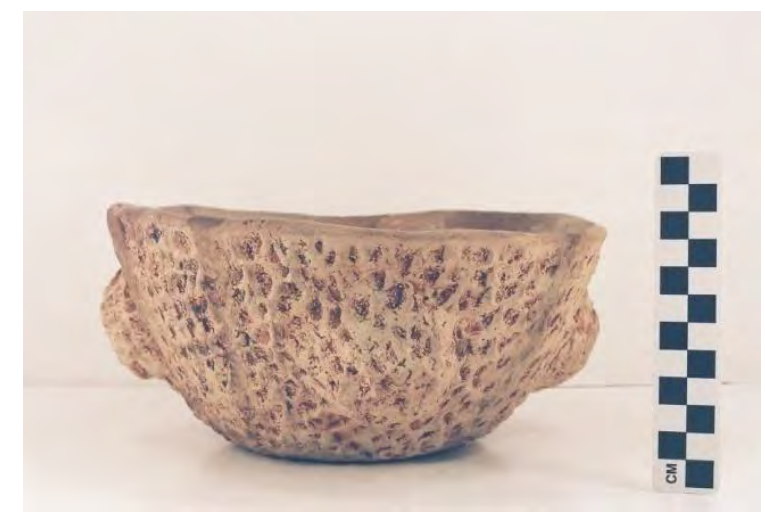

Vessel 41AN1-6. 
SITE NO.: 41AN1

FEATURE: Burial E-2

VESSEL NO.: 41AN1-7

NON-PLASTICS: grog

VESSEL FORM: Effigy bowl with a direct rim and a rounded lip; effigy head (reconstructed bird head) on one side of the vessel and a tail rider (a four-legged animal with a tail) on the opposing side.

CORE COLOR: Undetermined

WALL THICKNESS: $7.8 \mathrm{~mm}$

INTERIOR SURFACE TREATMENT: smoothed

EXTERIOR SURFACE TREATMENT: burnished

HEIGHT: $10.5 \mathrm{~cm}$

ORIFICE DIAMETER: $18.5 \mathrm{~cm}$

DIAMETER AT BOTTOM OF RIM OR NECK: N/A

BASE DIAMETER: $4.0 \mathrm{~cm}$

ESTIMATED VOLUME: 0.8 liters

DECORATION: There are three widely-spaced horizontal engraved lines on the upper part of the vessel (Vessel 41AN1-7).

TYPE: Hood Engraved, var. Allen effigy vessel, previously referred to as an example of a Fulton Aspect effigy bowl (cf. Suhm and Jelks 1962: Plate 24f)

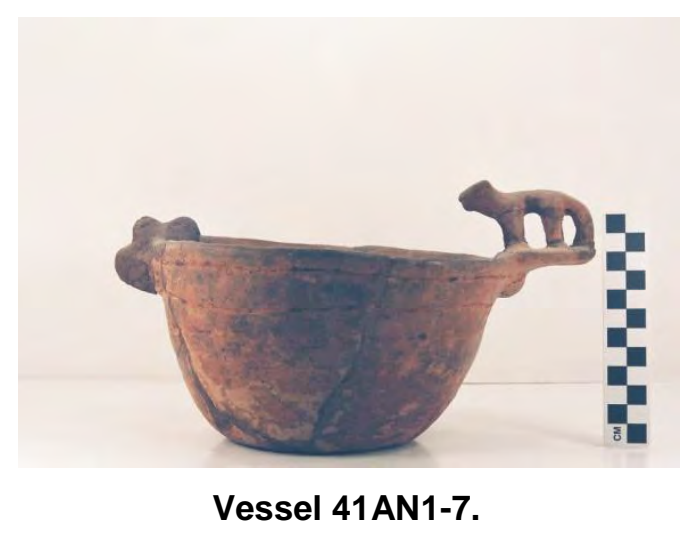


SITE NO.: 41AN1

FEATURE: Burial E-2

VESSEL NO.: 41AN1-8

NON-PLASTICS: grog and hematite

VESSEL FORM: Globular bowl with a direct rim and a rounded lip

CORE COLOR: Undetermined

WALL THICKNESS: $5.4 \mathrm{~mm}$, rim

INTERIOR SURFACE TREATMENT: burnished on rim and smoothed on the body

EXTERIOR SURFACE TREATMENT: burnished

HEIGHT: $11.3 \mathrm{~cm}$

ORIFICE DIAMETER: $16.3 \mathrm{~cm}$

DIAMETER AT BOTTOM OF RIM OR NECK: $15.2 \mathrm{~cm}$

BASE DIAMETER: $7.5 \mathrm{~cm}$

ESTIMATED VOLUME: 0.8 liters

DECORATION: There is an engraved panel (defined by upper and lower horizontal lines) on the upper part or rim of the vessel (Vessel 41AN1-8). The panel is comprised of 36 alternating engraved triangles in six distinct sets. Thirty-one of the engraved triangles have diagonal hatched lines within the triangles, while one set has five triangles with horizontal hatched lines within them.

TYPE: Poynor Engraved, var. $Q$ in the upper Neches River basin

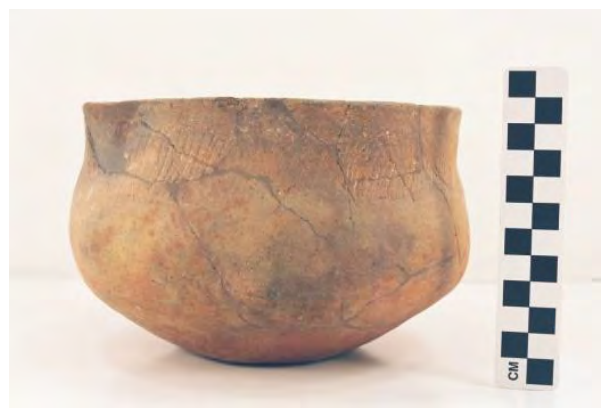

Vessel 41AN1-8. 
SITE NO.: 41AN1

FEATURE: Burial E-2

VESSEL NO.: 41AN1-9

NON-PLASTICS: grog

VESSEL FORM: Globular carinated bowl with a direct rim and a rounded, exterior folded, lip

CORE COLOR: Undetermined

WALL THICKNESS: $5.7 \mathrm{~cm}$

INTERIOR SURFACE TREATMENT: smoothed

EXTERIOR SURFACE TREATMENT: burnished

HEIGHT: $13.0 \mathrm{~cm}$

ORIFICE DIAMETER: $17.5 \mathrm{~cm}$

DIAMETER AT BOTTOM OF RIM OR NECK: $20.0 \mathrm{~cm}$

BASE DIAMETER: $10.0 \mathrm{~cm}$

ESTIMATED VOLUME: 1.4 liters

DECORATION: The engraved panel on the rim (defined by upper and lower horizontal lines) has nine closely-spaced semi-circles or ovals (Vessel 41AN1-9). Each semi-circle or oval is defined by two sets of closely-spaced engraved arcs comprised of three or four lines.

TYPE: Poynor Engraved, var. Cook

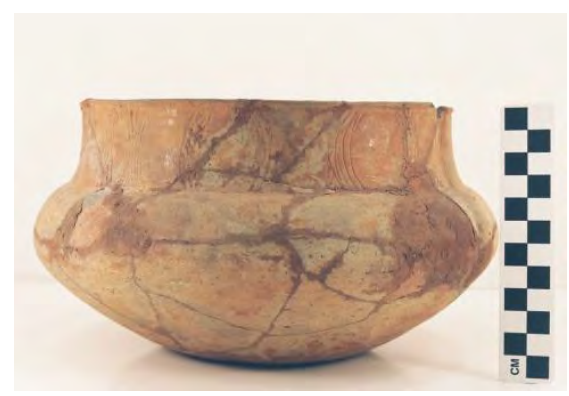

Vessel 41AN1-9. 
SITE NO.: 41AN1

FEATURE: Burial E-2

VESSEL NO.: 41AN1-11

NON-PLASTICS: grog and hematite

VESSEL FORM: Deep Jar with a direct rim and a flat lip, two lug handles $(21 \mathrm{x} 17 \mathrm{~mm}$ in height and width) (Vessel 41AN1-11)

CORE COLOR: A (fired and cooled in a high oxygen environment); pinkware

WALL THICKNESS: $6.3 \mathrm{~mm}$

INTERIOR SURFACE TREATMENT: smoothed; fire clouds

EXTERIOR SURFACE TREATMENT: none

HEIGHT: $15.3 \mathrm{~cm}$

ORIFICE DIAMETER: $13.1 \mathrm{~cm}$

DIAMETER AT BOTTOM OF RIM OR NECK: 13.1

BASE DIAMETER: $8.2 \mathrm{~cm}$

ESTIMATED VOLUME: 1.2 liters

DECORATION: plain

TYPE: Undetermined plain ware vessel

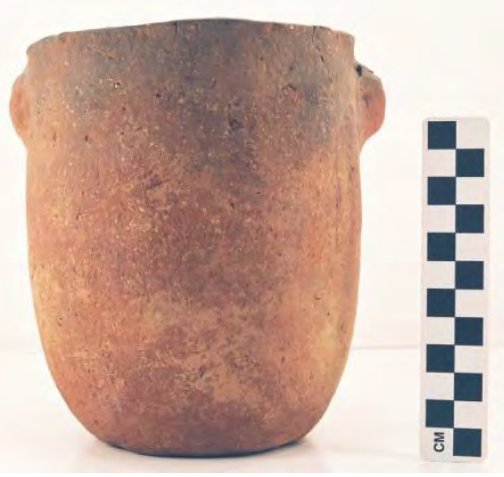

Vessel 41AN1-11. 
SITE NO.: 41AN1

FEATURE: Burial E-3

VESSEL NO.: 41AN1-12

NON-PLASTICS: grog, hematite, and bone

VESSEL FORM: Bottle with a short neck, an elongated body, a direct rim, and a rounded lip

CORE COLOR: B (fired and cooled in a reducing environment)

WALL THICKNESS: $6.7 \mathrm{~mm}$

INTERIOR SURFACE TREATMENT: none

EXTERIOR SURFACE TREATMENT: smoothed

HEIGHT: $26.0 \mathrm{~cm}$

ORIFICE DIAMETER: $4.2 \mathrm{~cm}$

DIAMETER AT BOTTOM OF RIM OR NECK: $11.5 \mathrm{~cm}$ on lower body

BASE DIAMETER: $8.9 \mathrm{~cm}$

ESTIMATED VOLUME: 0.95 liters

DECORATION: The upper body has a row of 10 hatched pendant triangles suspended from a single horizontal engraved line (Vessel 41AN1-12). On the remainder of the body are two vertical panels with two deeply-cut vertical engraved lines. On the first panel, there are a series of small hatched pendant triangles on each vertical engraved line. The second panel has eight hatched pendant triangles and eight small engraved semi-circles on the two vertical engraved lines.

TYPE: Hume Engraved, var. unspecified

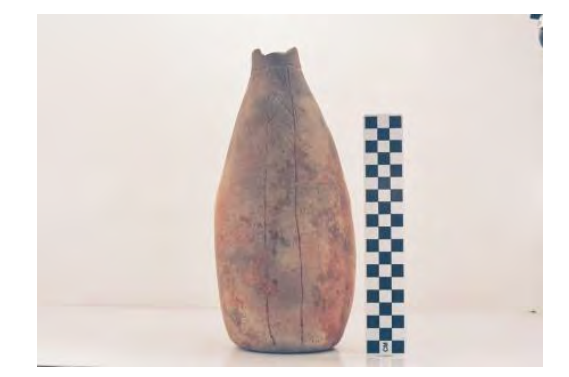

Vessel 41AN1-12, Hume Engraved. 
SITE NO.: 41AN1

FEATURE: Burial E-3

VESSEL NO.: 41AN1-13

NON-PLASTICS: grog

VESSEL FORM: Globular carinated bowl with a short everted rim and a rounded lip

CORE COLOR: A (fired and cooled in an oxidizing environment)

WALL THICKNESS: $7.0 \mathrm{~mm}$, rim-body juncture

INTERIOR SURFACE TREATMENT: burnished

EXTERIOR SURFACE TREATMENT: burnished

HEIGHT: $10.2 \mathrm{~cm}$; rim height, $1.9 \mathrm{~cm}$

ORIFICE DIAMETER: $11.5 \mathrm{~cm}$

DIAMETER AT BOTTOM OF RIM OR NECK: $11.4 \mathrm{~cm}$

BASE DIAMETER: $6.9 \mathrm{~cm}$

ESTIMATED VOLUME: 0.5 liters

DECORATION: The rim has an engraved panel comprised of seven negative rectangles (Vessel 41AN1-13). Each rectangle is defined by hour glass-shaped excised areas. A red clay pigment has been rubbed in the engraved lines.

TYPE: Poynor Engraved, var. Hood

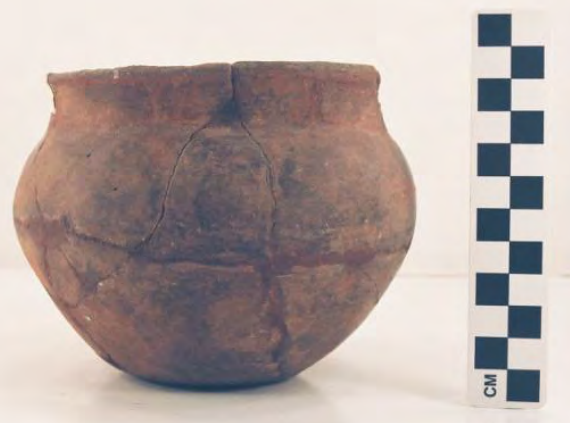

Vessel 41AN1-13. 
SITE NO.: 41AN1

FEATURE: Burial E-3

VESSEL NO.: 41AN1-14

NON-PLASTICS: grog and bone

VESSEL FORM: Bottle with a short neck, a direct rim, and a flat lip

CORE COLOR: B (fired and cooled in a reducing environment)

WALL THICKNESS: $6.0 \mathrm{~mm}$, rim

INTERIOR SURFACE TREATMENT: none

EXTERIOR SURFACE TREATMENT: burnished

HEIGHT: $20.0 \mathrm{~cm}$

ORIFICE DIAMETER: $4.0 \mathrm{~cm}$ at the neck

DIAMETER AT BOTTOM OF RIM OR NECK: $4.8 \mathrm{~cm}$

BASE DIAMETER: $7.7 \mathrm{~cm}$

ESTIMATED VOLUME: 0.6 liters

DECORATION: Five broad horizontal engraved lines on the bottle neck (Vessel 41AN114). A red clay pigment has been rubbed in the engraved lines.

TYPE: Undetermined engraved fine ware bottle, but related to both Poynor and Hume Engraved bottle forms.

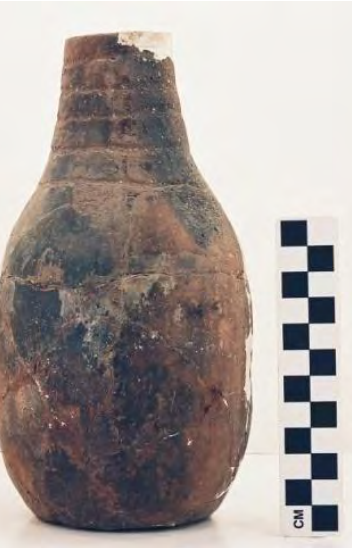

Vessel 41AN1-14. 
SITE NO.: 41AN1

FEATURE: Burial E-3

VESSEL NO.: 41AN1-15

NON-PLASTICS: grog and bone

VESSEL FORM: Compound bowl with a direct rim and a rounded lip

CORE COLOR: Undetermined

WALL THICKNESS: $7.1 \mathrm{~mm}$

INTERIOR SURFACE TREATMENT: none

EXTERIOR SURFACE TREATMENT: none

HEIGHT: $11.0 \mathrm{~cm}$

ORIFICE DIAMETER: $16.0 \mathrm{~cm}$

DIAMETER AT BOTTOM OF RIM OR NECK: $15.8 \mathrm{~cm}$ on the upper panel, $16.6 \mathrm{~cm}$ on the lower panel

BASE DIAMETER: $8.0 \mathrm{~cm}$

ESTIMATED VOLUME: 1.2 liters

DECORATION: The upper rim panel is plain, but the lower rim panel (defined by upper and lower horizontal engraved lines) has seven negative ovals or semi-circles (Vessel 41AN1-15). At the center of each oval or semi-circle are small negative circles defined by seven to 14 hatched triangles. The negative ovals or semi-circles are each divided from the other by two hour glass-shaped engraved elements with hatched triangles at their four corners. There is a white kaolin clay pigment rubbed in the engraved lines.

TYPE: Poynor Engraved, var. Lang

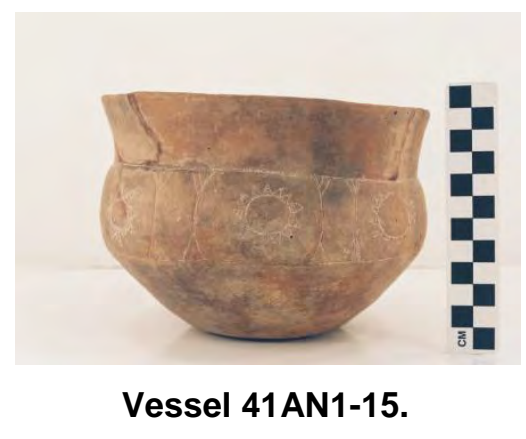


SITE NO.: 41AN1

FEATURE: Burial E-3

VESSEL NO.: 41AN1-16

NON-PLASTICS: grog

VESSEL FORM: Carinated bowl with an inverted rim and a rounded lip

CORE COLOR: A (fired and cooled in an oxidizing environment)

WALL THICKNESS: $7.1 \mathrm{~mm}$

INTERIOR SURFACE TREATMENT: burnished on the rim, smoothed on the body

EXTERIOR SURFACE TREATMENT: burnished

HEIGHT: $17.7 \mathrm{~cm}$

ORIFICE DIAMETER: $27.2 \mathrm{~cm}$

DIAMETER AT BOTTOM OF RIM OR NECK: $28.4 \mathrm{~cm}$

BASE DIAMETER: $9.8 \mathrm{~cm}$

\section{ESTIMATED VOLUME: 4.3 liters}

DECORATION: There is an engraved rim panel defined by upper and lower horizontal engraved lines that encircle the vessel. Within the panel are eight negative ovals defined by cross-hatched hour glass-shaped engraved elements (Vessel 41AN1-116). The vessel body and base has horizontal brushing marks.

TYPE: Poynor Engraved, var. Hood

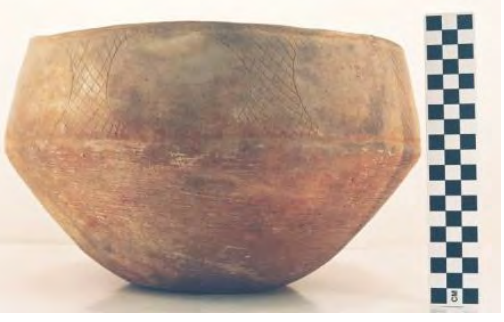

Vessel 41AN1-16, Large Poynor Engraved, var. Hood Carinated Bowl. 
SITE NO.: 41AN1

FEATURE: Burial E-3

VESSEL NO.: 41AN1-17

NON-PLASTICS: grog and bone

VESSEL FORM: Carinated bowl with a slightly everted rim and a rounded lip

CORE COLOR: F (fired in a reducing environment, but cooled in the open air)

WALL THICKNESS: $6.8 \mathrm{~mm}$

INTERIOR SURFACE TREATMENT: smoothed

EXTERIOR SURFACE TREATMENT: burnished

HEIGHT: $13.0 \mathrm{~cm}$

ORIFICE DIAMETER: $24.5 \mathrm{~cm}$

DIAMETER AT BOTTOM OF RIM OR NECK: $23.0 \mathrm{~cm}$

BASE DIAMETER: $8.5 \mathrm{~cm}$

ESTIMATED VOLUME: 1.9 liters

DECORATION: The rim has a panel defined by upper and lower horizontal engraved lines that encircle the vessel. Within the panel are negative rectangular areas defined by two sets of four closely-spaced vertical engraved lines (Vessel 41AN1-17).

TYPE: Poynor Engraved, var. Blackburn

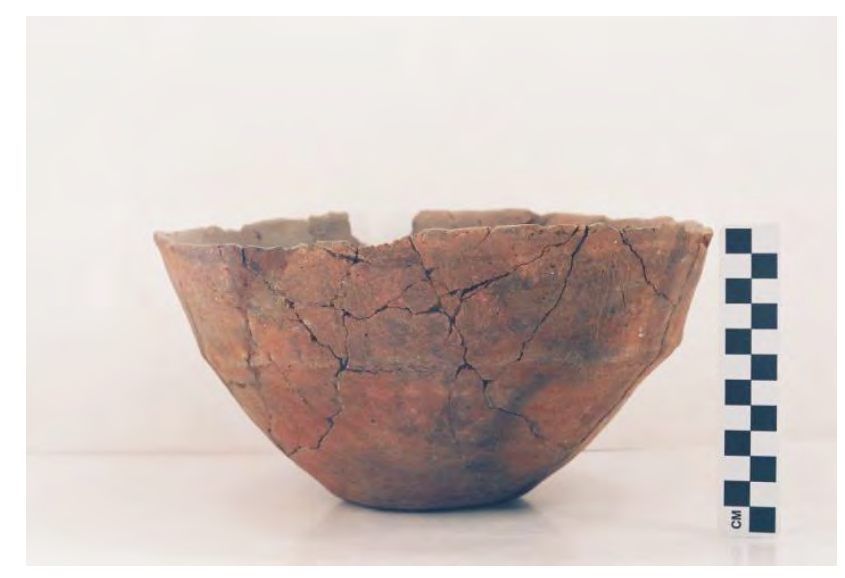

Vessel 41AN1-17. 
SITE NO.: 41AN1

FEATURE: Burial E-3

VESSEL NO.: 41AN1-18

NON-PLASTICS: bone and grog

VESSEL FORM: Small jar with a direct rim and rounded lip; the vessel has two opposed lug handles (10.2 mm wide and $22.2 \mathrm{~mm}$ in height) (Vessel 41AN1-18)

CORE COLOR: $\mathrm{G}$ (fired in a reducing environment and cooled in the open air)

WALL THICKNESS: $7.0 \mathrm{~mm}$

INTERIOR SURFACE TREATMENT: smoothed on rim and upper body

EXTERIOR SURFACE TREATMENT: none

HEIGHT: $8.5 \mathrm{~cm}$

ORIFICE DIAMETER: $12.4 \mathrm{~cm}$

DIAMETER AT BOTTOM OF RIM OR NECK: $12.0 \mathrm{~cm}$

BASE DIAMETER: $6.3 \mathrm{~cm}$

ESTIMATED VOLUME: 0.6 liters

DECORATION: Plain

TYPE: Undetermined plain ware vessel

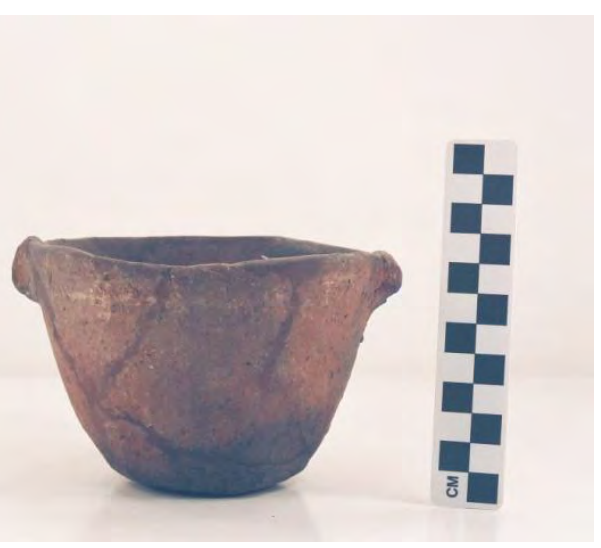

Vessel 41AN1-18. 
SITE NO.: 41AN1

FEATURE: Burial E-3

VESSEL NO.: 41AN1-19

NON-PLASTICS: grog and hematite

VESSEL FORM: Jar with a direct rim and a flat lip

CORE COLOR: A (fired and cooled in a high oxygen environment)

WALL THICKNESS: $6.5 \mathrm{~mm}$

INTERIOR SURFACE TREATMENT: smoothed

EXTERIOR SURFACE TREATMENT: none

HEIGHT: $13.5 \mathrm{~cm}$

ORIFICE DIAMETER: $15.7 \mathrm{~cm}$

DIAMETER AT BOTTOM OF RIM OR NECK: $11.8 \mathrm{~cm}$

BASE DIAMETER: $7.3 \mathrm{~cm}$

ESTIMATED VOLUME: 1.3 liters

DECORATION: The rim has four rows of neck bands (i.e., overhanging, unsmoothed coils), while the vessel body has vertical brushed marks that extend to near the base of the vessel (Vessel 41AN1-19).

TYPE: LaRue Neck Banded

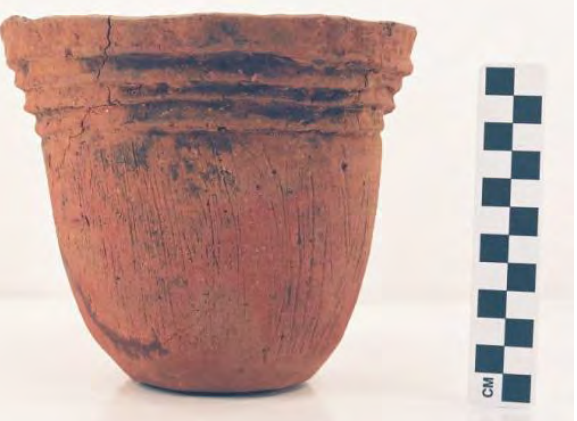

Vessel 41AN1-19. 
SITE NO.: 41AN1

FEATURE: Burial E-4

VESSEL NO.: 41AN1-23

NON-PLASTICS: grog and small amounts of hematite

VESSEL FORM: Effigy bowl with an everted rim and a rounded lip; the effigy head is missing, but there is a $3.4 \mathrm{~cm}$ wide tab tail on one end of the vessel

CORE COLOR: A (fired and cooled in an oxidizing environment); pinkware

WALL THICKNESS: $5.6 \mathrm{~mm}$

INTERIOR SURFACE TREATMENT: burnished

EXTERIOR SURFACE TREATMENT: burnished

HEIGHT: $7.5 \mathrm{~cm}$

ORIFICE DIAMETER: $14.5 \mathrm{~cm}$

DIAMETER AT BOTTOM OF RIM OR NECK: N/A

BASE DIAMETER: $7.0 \mathrm{~cm}$

ESTIMATED VOLUME: 0.4 liters

DECORATION: There is an engraved panel on the rim with upper and lower sets of horizontally hatched pendant triangles (Vessel 41AN1-23). Each set has 12 triangles, with the apex of the upper set pointing downward, and the apex of the lower set pointing upwards. The apex of the two sets of triangles do not touch.

TYPE: Hood Engraved, var. Cook effigy bowl

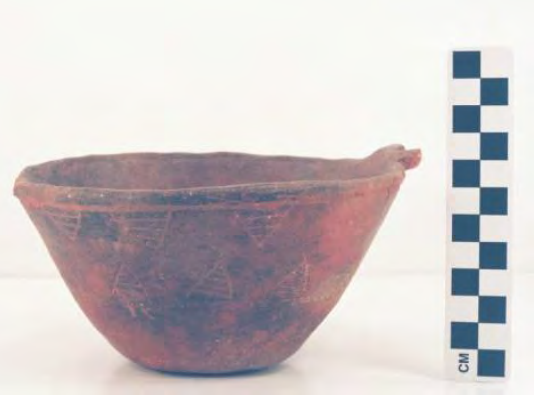

Vessel 41AN1-23, Hood Engraved, var. Cook Effigy. 
SITE NO.: 41AN1

FEATURE: Burial E-4

VESSEL NO.: 41AN1-24

NON-PLASTICS: fine grog

VESSEL FORM: Globular carinated bowl with an everted rim and a rounded, exterior folded, lip

CORE COLOR: G (fired in a reducing environment, and cooled in the open air)

WALL THICKNESS: $3.8 \mathrm{~mm}$

INTERIOR SURFACE TREATMENT: burnished

EXTERIOR SURFACE TREATMENT: burnished

HEIGHT: $8.3 \mathrm{~cm}$

ORIFICE DIAMETER: $10.4 \mathrm{~cm}$

DIAMETER AT BOTTOM OF RIM OR NECK: $9.6 \mathrm{~cm}$

BASE DIAMETER: $6.5 \mathrm{~cm}$

ESTIMATED VOLUME: 0.5 liters

DECORATION: The rim has 11 engraved ovals within a panel defined by upper and lower horizontal engraved lines on the rim (Vessel 41AN1-24). The ovals are defined by only two curvilinear engraved lines, and some of the ovals are divided by a single short vertical engraved line.

TYPE: Poynor Engraved, var. Cook

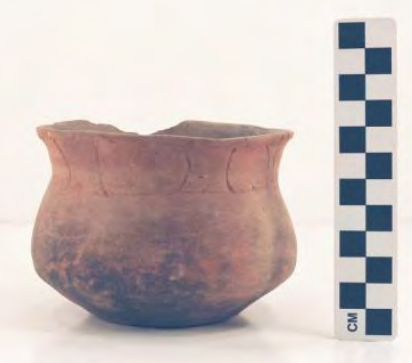

Vessel 41AN1-24. 
SITE NO.: 41AN1

FEATURE: Burial E-4

VESSEL NO.: 41AN1-25

NON-PLASTICS: grog

VESSEL FORM: Jar with an everted rim and a rounded, slightly exterior folded, lip; two lug handles

CORE COLOR: $\mathrm{H}$ (fired in a reducing environment, but cooled in the open air)

WALL THICKNESS: $7.7 \mathrm{~mm}$

INTERIOR SURFACE TREATMENT: smoothed

EXTERIOR SURFACE TREATMENT: none

HEIGHT: $12.0 \mathrm{~cm}$

ORIFICE DIAMETER: $11.25 \mathrm{~cm}$

DIAMETER AT BOTTOM OF RIM OR NECK: $10.6 \mathrm{~cm}$

BASE DIAMETER: $6.0 \mathrm{~cm}$

ESTIMATED VOLUME: 0.8 liters

DECORATION: The rim and lug handles are decorated with vertical rows of pinching (Vessel 41AN1-25). The body has four repeating pinched circles centered under the lugs.

TYPE: Killough Pinched

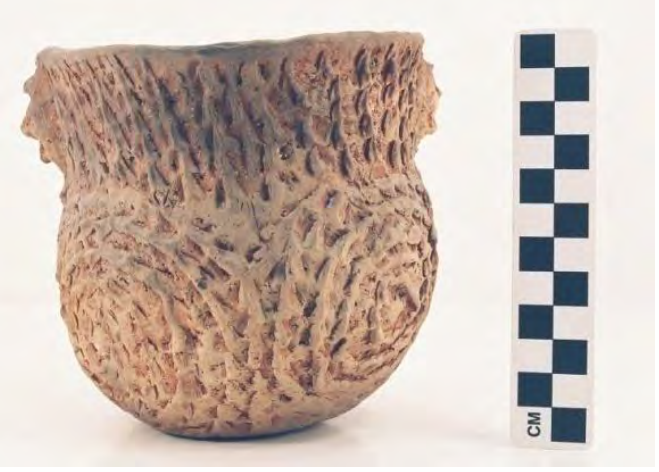

Vessel 41AN1-25, Killough Pinched. 
SITE NO.: 41AN1

FEATURE: Burial E-4

VESSEL NO.: 41AN1-26

NON-PLASTICS: grog and hematite

VESSEL FORM: Carinated bowl with an inverted rim and a rounded lip

CORE COLOR: $\mathrm{H}$ (fired in a reducing environment, but cooled in the open air)

WALL THICKNESS: $6.0 \mathrm{~mm}$, rim

INTERIOR SURFACE TREATMENT: burnished on the rim, smoothed on the body

EXTERIOR SURFACE TREATMENT: burnished on the rim, smoothed on the body

HEIGHT: $11.0 \mathrm{~cm}$

ORIFICE DIAMETER: $14.3 \mathrm{~cm}$

DIAMETER AT BOTTOM OF RIM OR NECK: $14.6 \mathrm{~cm}$

BASE DIAMETER: $6.7 \mathrm{~cm}$

ESTIMATED VOLUME: 1.0 liters

DECORATION: The rim has a panel comprised of four ovals. The ovals are defined by sets of four closely-spaced engraved arcs that extend from upper to lower horizontal engraved lines that encircle the rim (Vessel 41AN1-26). There are four hatched triangular elements on the upper and lower parts of the vertical arcs.

TYPE: Poynor Engraved, var. Cook

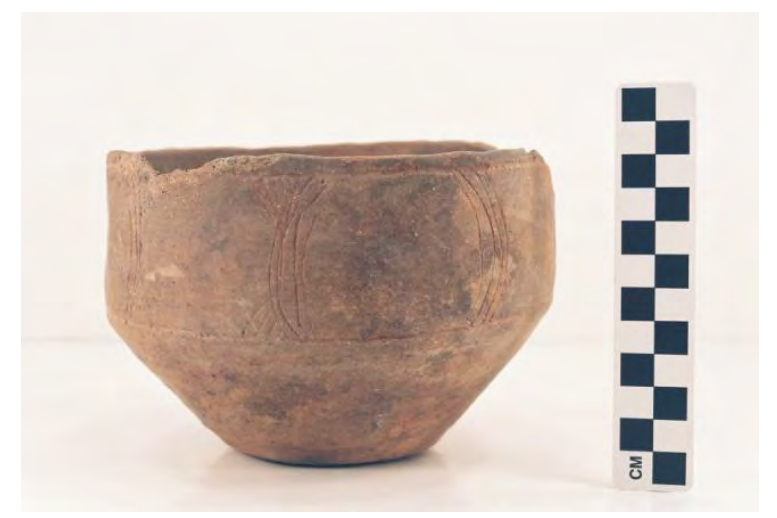

Vessel 41AN1-26, Poynor Engraved, var. Cook. 
SITE NO.: 41AN1

FEATURE: Burial E-5

VESSEL NO.: 41AN1-27

NON-PLASTICS: grog and hematite

VESSEL FORM: Bottle with a short neck, a globular body, a direct rim, and a flat lip

CORE COLOR: Undetermined

WALL THICKNESS: $5.7 \mathrm{~mm}$

INTERIOR SURFACE TREATMENT: none

EXTERIOR SURFACE TREATMENT: smoothed

HEIGHT: $16.0 \mathrm{~cm}$

ORIFICE DIAMETER: $4.0 \mathrm{~cm}$

DIAMETER AT BOTTOM OF RIM OR NECK: $5.3 \mathrm{~cm}$

BASE DIAMETER: $10.0 \mathrm{~cm}$

ESTIMATED VOLUME: 0.65 liters

DECORATION: The body is decorated with two different engraved motifs (Vessel 41AN1-27). There are eight hatched pendant triangles at the upper part of the body, directly under the neck, and three vertically oriented cross-hatched and rectilinear engraved bands (i.e., wide interlocking scrolls) that begin at the body-neck juncture and extend almost to the vessel base.

TYPE: Hume Engraved, var. unspecified

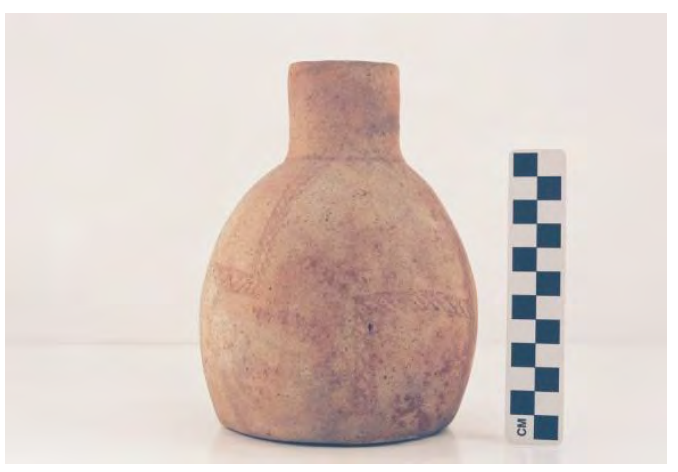

Vessel 41AN1-27. 
SITE NO.: 41AN1

FEATURE: Burial E-5

VESSEL NO.: 41AN1-28

NON-PLASTICS: grog

VESSEL FORM: Bottle with a long neck, with a direct rim and a rounded lip, and a short and squat body/base (i.e., a Fair Plain bottle form)

CORE COLOR: A (fired and cooled in an oxidizing environment)

WALL THICKNESS: $4.1 \mathrm{~mm}$, rim

INTERIOR SURFACE TREATMENT: none

EXTERIOR SURFACE TREATMENT: smoothed

HEIGHT: $17.6 \mathrm{~cm}$

ORIFICE DIAMETER: $4.0 \mathrm{~cm}$ (neck)

DIAMETER AT BOTTOM OF RIM OR NECK: $8.9 \mathrm{~cm}$ on the body

BASE DIAMETER: $7.86 \mathrm{~cm}$

ESTIMATED VOLUME: 0.6 liters

DECORATION: The bottle is decorated only on the neck. There are two horizontal engraved lines near the rim, and the lower engraved line has six hatched pendant triangles (Vessel 41AN1-28).

TYPE: Hume Engraved, var. Allen?

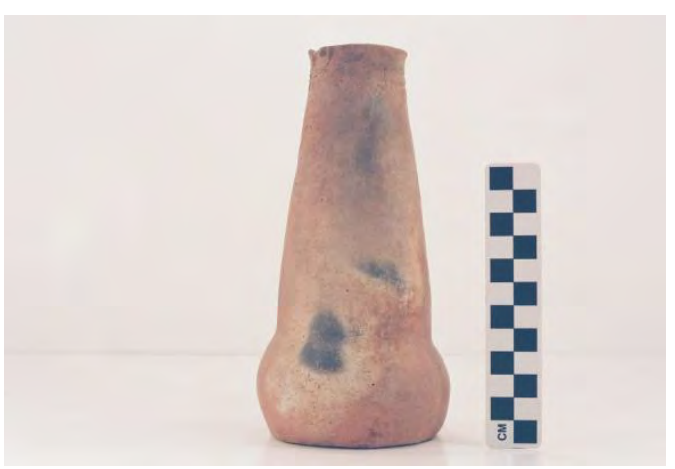

Vessel 41AN1-28, Hume Engraved. 
SITE NO.: 41AN1

FEATURE: Burial E-5

VESSEL NO.: 41AN1-29

NON-PLASTICS: grog

VESSEL FORM: Carinated bowl with a direct rim and a rounded lip

CORE COLOR: B (fired and cooled in a reducing environment)

WALL THICKNESS: $6.3 \mathrm{~mm}$

INTERIOR SURFACE TREATMENT: poorly smoothed

EXTERIOR SURFACE TREATMENT: burnished

HEIGHT: $9.1 \mathrm{~cm}$

ORIFICE DIAMETER: $12.3 \mathrm{~cm}$

DIAMETER AT BOTTOM OF RIM OR NECK: $12.3 \mathrm{~cm}$

BASE DIAMETER: $5.7 \mathrm{~cm}$

ESTIMATED VOLUME: 0.7 liters

DECORATION: The rim has nine engraved panels - all rectangular-set between horizontal engraved lines under the lip and at the carination. The panels are defined by two vertical engraved lines at opposite ends of the rectangle, with triangular hatched areas in each corner (Vessel 41AN1-29).

TYPE: Poynor Engraved, var. Blackburn

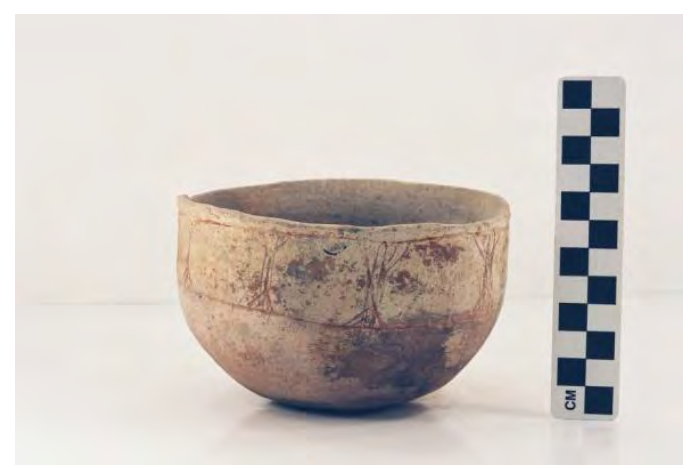

Vessel 41AN1-29. 
SITE NO.: 41AN1

FEATURE: Burial E-5

VESSEL NO.: 41AN1-30

NON-PLASTICS: grog and hematite

VESSEL FORM: Jar with a direct rim and a rounded lip, two strap handles, and four legs on a ring base

CORE COLOR: A (fired and cooled in a high oxygen environment); pinkware

WALL THICKNESS: $5.7 \mathrm{~mm}$

INTERIOR SURFACE TREATMENT: smoothed

EXTERIOR SURFACE TREATMENT: none

HEIGHT: $12.0 \mathrm{~cm}$

ORIFICE DIAMETER: $9.0 \mathrm{~cm}$

DIAMETER AT BOTTOM OF RIM OR NECK: $9.7 \mathrm{~cm}$

BASE DIAMETER: $8.5 \mathrm{~cm}$

ESTIMATED VOLUME: 0.65 liters

DECORATION: Vertical pinched rows on the vessel rim, strap handles, and legs of the ring base, with four sets of circular pinched rows (concentric circles) on the body (Vessel 41AN1-30).

TYPE: Killough Pinched

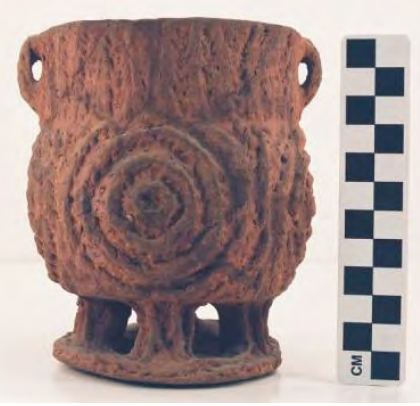

Vessel 41AN1-30, Killough Pinched. 
SITE NO.: 41AN1

FEATURE: Burial E-5

VESSEL NO.: 41AN1-31

NON-PLASTICS: grog and bone

VESSEL FORM: Bowl with a direct rim and a rounded lip

CORE COLOR: Undetermined

WALL THICKNESS: $5.1 \mathrm{~mm}$

INTERIOR SURFACE TREATMENT: smoothed

EXTERIOR SURFACE TREATMENT: burnished

HEIGHT: $7.5 \mathrm{~cm}$

ORIFICE DIAMETER: $16.3 \mathrm{~cm}$

DIAMETER AT BOTTOM OF RIM OR NECK: N/A

BASE DIAMETER: $9.0 \mathrm{~cm}$

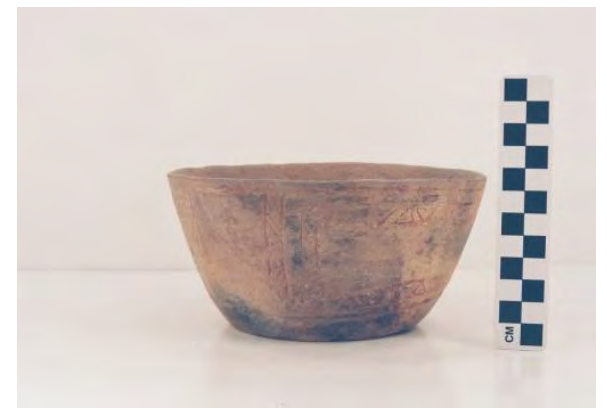

Vessel 41AN1-31.

ESTIMATED VOLUME: 0.5 liters

DECORATION: The rim has an engraved panel set between horizontal lines under the lip and at the vessel carination. There are two distinct motifs comprising the panel, each repeated twice; the panels are divided by a single vertical engraved line with hatched pendant triangles. The first set of panels consists of hatched interlocking horizontal scrolls (Vessel 41AN1-31). The second set of panels has a single hatched and crosshatched interlocking horizontal scroll, and the cross-hatched areas at the end of the scroll - and in a fill element above the scroll - are diamond-shaped, suggesting part of a canebrake rattlesnake body element (Walters 2006: Figure 31).

TYPE: Undetermined engraved vessel; Kleinschmidt (1982) identifies the engraved motif on this vessel as Hume Engraved, Motif 4. 
SITE NO.: 41AN1

FEATURE: Burial E-6

VESSEL NO.: 41AN1-34

NON-PLASTICS: grog and hematite

VESSEL FORM: Effigy bowl with a direct rim and a rounded lip. The effigy (a bird head) is attached to the rim at one end of the vessel and there is a tab tail at the opposite end of the vessel.

CORE COLOR: Undetermined

WALL THICKNESS: $6.3 \mathrm{~mm}$

INTERIOR SURFACE TREATMENT: smoothed

EXTERIOR SURFACE TREATMENT: smoothed

HEIGHT: $6.3 \mathrm{~cm}$

ORIFICE DIAMETER: $13.0 \mathrm{~cm}$

DIAMETER AT BOTTOM OF RIM OR NECK: N/A

BASE DIAMETER: $7.0 \mathrm{~cm}$

ESTIMATED VOLUME: 0.3 liters

DECORATION: Three broad and widely-spaced horizontal engraved lines on the rim (Vessel 41AN1-34); a red clay pigment has been rubbed in the engraved lines.

TYPE: Hood Engraved, var. Hood effigy vessel

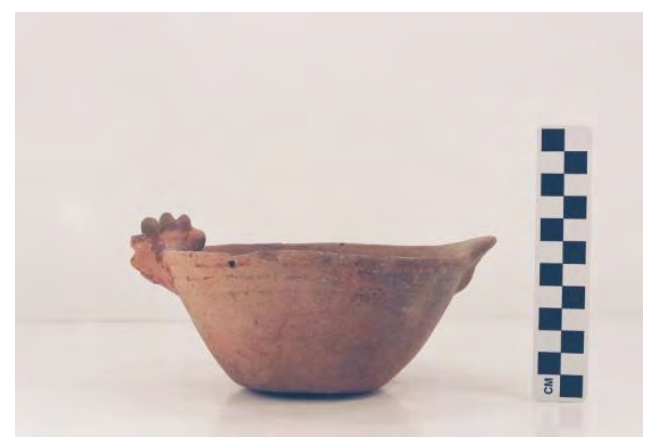

Vessel 41AN1-34. 
SITE NO.: 41AN1

FEATURE: Burial E-6

VESSEL NO.: 41AN1-35

NON-PLASTICS: grog

VESSEL FORM: Carinated bowl with a direct rim and a rounded lip

CORE COLOR: F (fired in a reducing environment and cooled in the open air)

WALL THICKNESS: $6.3 \mathrm{~mm}$

INTERIOR SURFACE TREATMENT: smoothed on the rim

EXTERIOR SURFACE TREATMENT: burnished

HEIGHT: $11.8 \mathrm{~cm}$

ORIFICE DIAMETER: $24.0 \mathrm{~cm}$

DIAMETER AT BOTTOM OF RIM OR NECK: $24.4 \mathrm{~cm}$

BASE DIAMETER: $9.6 \mathrm{~cm}$

\section{ESTIMATED VOLUME: 1.7 liters}

DECORATION: There are seven engraved panels on the rim, and the panels are defined by upper and lower horizontal engraved lines. The panels are large rectangles with hatched triangles at the four corners of the rectangle (Vessel 41AN1-35). Each rectangle is defined by four closely-spaced vertical engraved lines. There is a narrow blank rectangle created by the sets of vertical engraved lines between each of the rectangular panels.

TYPE: Poynor Engraved, var. Blackburn
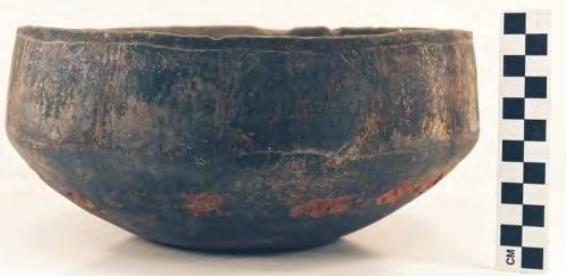

Vessel 41AN1-35, Poynor Engraved, var. Blackburn,. 
SITE NO.: 41AN1

FEATURE: Burial E-6

VESSEL NO.: 41AN1-36

NON-PLASTICS: hematite

VESSEL FORM: Shallow bowl with four lip tabs (Vessel 41AN1-36)

CORE COLOR: Undetermined

WALL THICKNESS: $4.8 \mathrm{~mm}$

INTERIOR SURFACE TREATMENT: none

EXTERIOR SURFACE TREATMENT: none

HEIGHT: $3.0 \mathrm{~cm}$

ORIFICE DIAMETER: $12.2 \mathrm{~cm}$

DIAMETER AT BOTTOM OF RIM OR NECK: N/A

BASE DIAMETER: $6.8 \mathrm{~cm}$

ESTIMATED VOLUME: 0.15 liters

DECORATION: plain

TYPE: Undetermined plain ware vessel

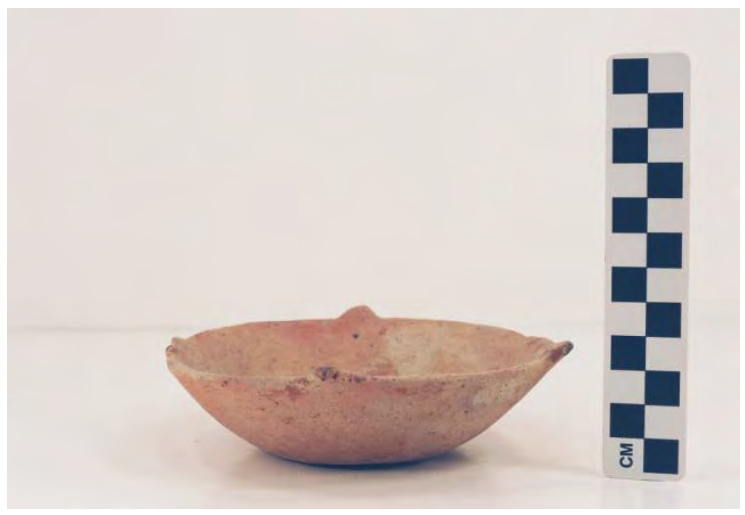

Vessel 41AN1-36. 
SITE NO.: 41AN1

FEATURE: Burial E-6

VESSEL NO.: 41AN1-37

NON-PLASTICS: bone and grog

VESSEL FORM: Jar with a direct rim and a rounded lip

CORE COLOR: $\mathrm{G}$ (fired in a reducing environment and cooled in the open air)

WALL THICKNESS: $6.0 \mathrm{~mm}$

INTERIOR SURFACE TREATMENT: smoothed

EXTERIOR SURFACE TREATMENT: none

HEIGHT: $9.3 \mathrm{~cm}$

ORIFICE DIAMETER: $11.6 \mathrm{~cm}$

DIAMETER AT BOTTOM OF RIM OR NECK: $11.4 \mathrm{~cm}$

BASE DIAMETER: $6.3 \mathrm{~cm}$

ESTIMATED VOLUME: 0.65 liters

DECORATION: vertical brushing from the rim to the vessel base (Vessel 41AN1-37)

TYPE: Bullard Brushed

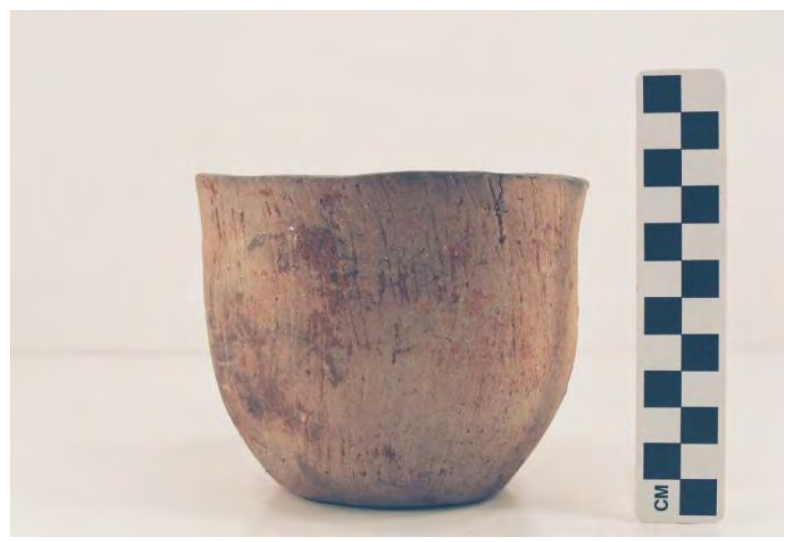

Vessel 41AN1-37. 
SITE NO.: 41AN1

FEATURE: Burial E-6

VESSEL NO.: 41AN1-38

NON-PLASTICS: grog

VESSEL FORM: Jar with a direct rim and a rounded lip, small strap handles, and four legs on a ring base

CORE COLOR: A (fired and cooled in a high oxygen environment); pinkware

WALL THICKNESS: $6.0 \mathrm{~mm}$, rim

INTERIOR SURFACE TREATMENT: smoothed; organic residue

EXTERIOR SURFACE TREATMENT: none

HEIGHT: $17.3 \mathrm{~cm}$

ORIFICE DIAMETER: $12.8 \mathrm{~cm}$

DIAMETER AT BOTTOM OF RIM OR NECK: $12.7 \mathrm{~cm}$

BASE DIAMETER: $13.0 \mathrm{~cm}$ on ring base

ESTIMATED VOLUME: 2.0 liters

DECORATION: Vertical pinching on the vessel rim, four concentric circles comprised of curvilinear pinched rows across the body, and vertical pinching on the strap handles and the ring base legs (Vessel 41AN1-38).

TYPE: Killough Pinched (Suhm and Jelks 1962: Plate 46a)

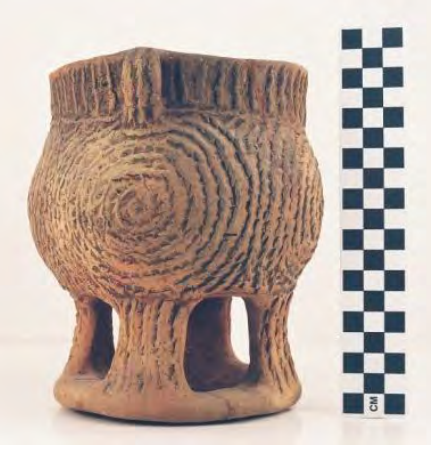

Vessel 41AN1-38, Killough Pinched. 
SITE NO.: 41AN1

FEATURE: Burial E-6

VESSEL NO.: 41AN1-39

NON-PLASTICS: grog

VESSEL FORM: Jar, no rim present

CORE COLOR: Undetermined

WALL THICKNESS: $8.7 \mathrm{~mm}$

INTERIOR SURFACE TREATMENT: smoothed

EXTERIOR SURFACE TREATMENT: none

HEIGHT: Undetermined

ORIFICE DIAMETER: Undetermined

DIAMETER AT BOTTOM OF RIM OR NECK: $15.3 \mathrm{~cm}$

BASE DIAMETER: $7.8 \mathrm{~cm}$

ESTIMATED VOLUME: Undetermined

DECORATION: diagonal brushing marks on vessel body (Vessel 41AN1-39)

TYPE: Bullard Brushed

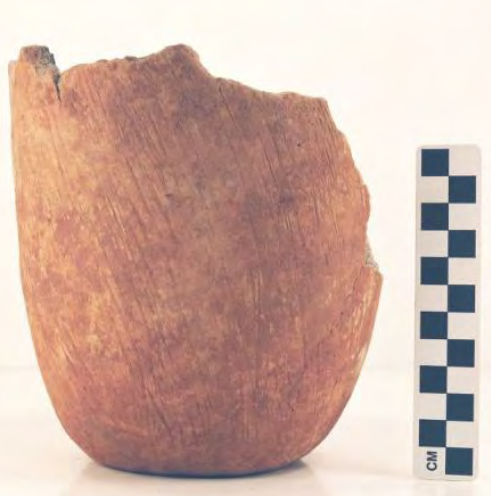

Vessel 41AN1-39, Bullard Brushed. 


\section{J. M. Cook Farm Site (41AN2)}

SITE NO.: 41AN2

FEATURE: Burial F-1

VESSEL NO.: 41AN2-1

NON-PLASTICS: grog and hematite; sandy paste

VESSEL FORM: Globular carinated bowl with a direct rim and a rounded lip

CORE COLOR: Undetermined

WALL THICKNESS: $5.3 \mathrm{~mm}$, rim

INTERIOR SURFACE TREATMENT: smoothed

EXTERIOR SURFACE TREATMENT: smoothed; organic residue on the rim and the lower body

HEIGHT: $10.2 \mathrm{~cm}$

ORIFICE DIAMETER: $12.0 \mathrm{~cm}$

DIAMETER AT BOTTOM OF RIM OR NECK: $10.9 \mathrm{~cm}$

BASE DIAMETER: $4.5 \mathrm{~cm}$

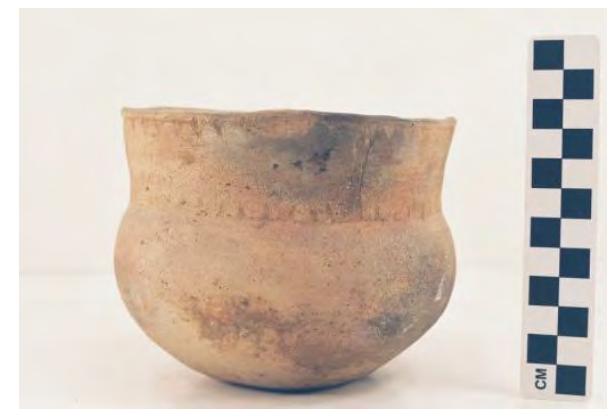

ESTIMATED VOLUME: 0.7 liters

Vessel 41AN2-1.

DECORATION: There are four engraved panels on the rim (defined by upper and lower horizontal engraved lines under the lip and at the carination). They are defined by excised hour glass-shaped zones and 14 small upper and lower pendant triangles within each of the panels (Vessel 41AN2-1).

TYPE: Poynor Engraved, var. Freeman, also a PP variety defined by Kleinschmidt (1982, Motif 6) 
SITE NO.: 41AN2

FEATURE: Burial F-1

VESSEL NO.: 41AN2-2

NON-PLASTICS: grog and hematite; sandy paste

VESSEL FORM: Globular carinated bowl with an everted rim and a rounded lip

CORE COLOR: A (fired and cooled in an oxidizing environment)

WALL THICKNESS: $4.5 \mathrm{~mm}$, rim

INTERIOR SURFACE TREATMENT: smoothed

EXTERIOR SURFACE TREATMENT: none

HEIGHT: $14.9 \mathrm{~cm}$

ORIFICE DIAMETER: $20.4 \mathrm{~cm}$

DIAMETER AT BOTTOM OF RIM OR NECK: $19.8 \mathrm{~cm}$

BASE DIAMETER: $7.0 \mathrm{~cm}$

\section{ESTIMATED VOLUME: 2.7 liters}

DECORATION: There are seven rectangular engraved panels on the rim. Each panel is defined by two vertical engraved lines, and these lines have small cross-hatched pendant triangles at the rim and at the carination. The upper and lower parts of the rectangular panels have large cross-hatched engraved pendant triangles (Vessel 41AN2-2).

TYPE: Poynor Engraved, var. Freeman, also a PP variety of Poynor Engraved as defined by Kleinschmidt (1982, PP variety, Motif 6)

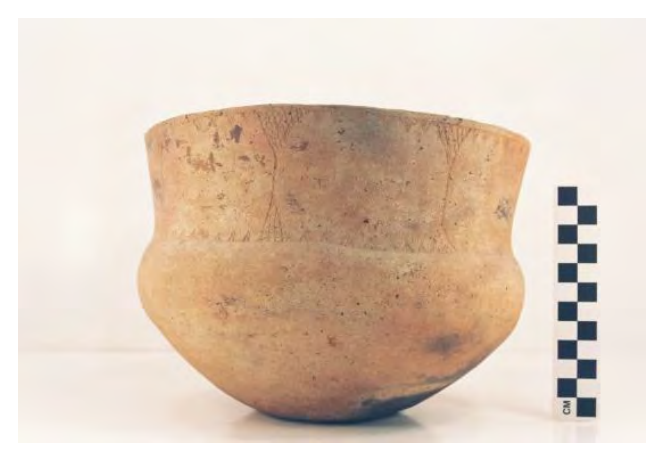

Vessel 41AN2-2. 
SITE NO.: 41AN2

FEATURE: Burial F-1

VESSEL NO.: 41AN2-3

NON-PLASTICS: grog and hematite

VESSEL FORM: Bottle with an elongated body, and a short but a broken neck (Vessel 41AN2-3)

CORE COLOR: A (fired and cooled in a high oxygen environment)

WALL THICKNESS: $5.7 \mathrm{~mm}$, neck

INTERIOR SURFACE TREATMENT: none

EXTERIOR SURFACE TREATMENT: smoothed

HEIGHT: $19.0 \mathrm{~cm}+$

ORIFICE DIAMETER: $4.0 \mathrm{~cm}$ at the neck

DIAMETER AT BOTTOM OF RIM OR NECK: $10.02 \mathrm{~cm}$ on the body

BASE DIAMETER: $7.5 \mathrm{~cm}$

ESTIMATED VOLUME: $0.6+$ liters

DECORATION: plain

TYPE: cf. Hume Plain; a vessel form similar in shape to Hume Engraved bottles, but without any decoration

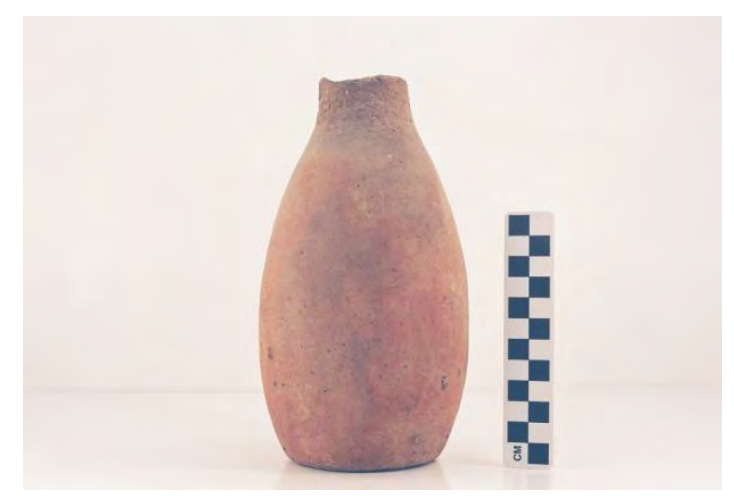

Vessel 41AN2-3, Hume Plain. 
SITE NO.: 41AN2

FEATURE: Burial F-1

VESSEL NO.: 41AN2-4

NON-PLASTICS: grog and hematite

VESSEL FORM: Bottle with a short neck, an elongated body, a direct rim, and a flat lip

CORE COLOR: Undetermined

WALL THICKNESS: 7.9 mm, neck

INTERIOR SURFACE TREATMENT: none

EXTERIOR SURFACE TREATMENT: smoothed

HEIGHT: $25.3 \mathrm{~cm}$

ORIFICE DIAMETER: $4.0 \mathrm{~cm}$ at the neck

DIAMETER AT BOTTOM OF RIM OR NECK: $15.6 \mathrm{~cm}$ on the body

BASE DIAMETER: $6.5 \mathrm{~cm}$

ESTIMATED VOLUME: 0.7 liters

DECORATION: There are four engraved vertical panels on the bottle body. Each panel is filled with cross-hatched engraved elements (Vessel 41AN2-4).

TYPE: Hume Engraved, var. Hume

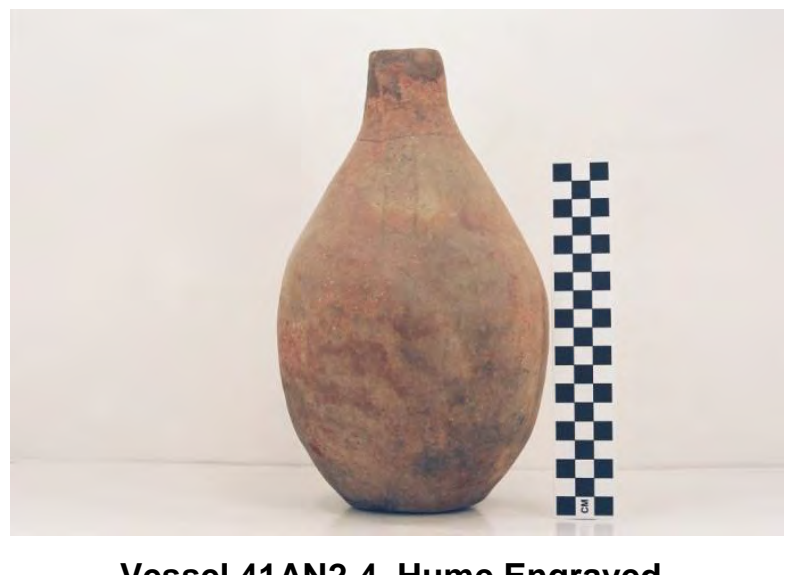

Vessel 41AN2-4, Hume Engraved. 
SITE NO.: 41AN2

FEATURE: Burial F-1

VESSEL NO.: 41AN2-5

NON-PLASTICS: grog and hematite

VESSEL FORM: Globular carinated bowl with a slightly inverted rim and a rounded lip

CORE COLOR: Undetermined

WALL THICKNESS: $7.2 \mathrm{~mm}$, rim

INTERIOR SURFACE TREATMENT: none

EXTERIOR SURFACE TREATMENT: smoothed

HEIGHT: $13.2 \mathrm{~cm}$

ORIFICE DIAMETER: $16.3 \mathrm{~cm}$

DIAMETER AT BOTTOM OF RIM OR NECK: $16.6 \mathrm{~cm}$

BASE DIAMETER: $6.8 \mathrm{~cm}$

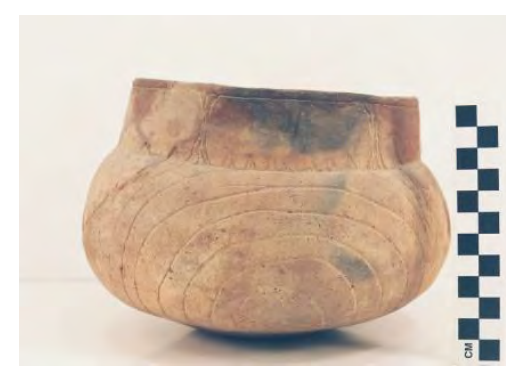

Vessel 41AN2-5.

\section{ESTIMATED VOLUME: 1.9 liters}

DECORATION: The rim has six rectangular-shaped engraved panels defined by excised hour glass-shaped elements (Vessel 41AN2-5). Within each panel, on the upper and lower parts of the rim, are 14 small pendant triangles. On the body are three repeating engraved concentric circle motifs comprised of five separate circular lines. At the center of these concentric circles is a circle and cross motif (Vessel 41AN2-5). This motif is comprised of intersecting horizontal and vertical lines with four excised triangles pendant from these lines where they meet the central circle.

TYPE: Poynor Engraved, PP variety (Kleinschmidt 1982); the rim panel has the Poynor Engraved, var. Freeman motif, but this vessel is not classified as Poynor Engraved, var. Freeman because of the engraved design on the vessel body. Nevertheless, this vessel from the J. M. Cook site is stylistically related to Poynor Engraved, var. Freeman. 
SITE NO.: 41AN2

FEATURE: Burial F-2

VESSEL NO.: 41AN2-40

NON-PLASTICS: none apparent

VESSEL FORM: Globular carinated bowl with a direct rim and a rounded lip

CORE COLOR: A (fired and cooled in an oxidizing environment); pinkware

WALL THICKNESS: $5.7 \mathrm{~mm}$

INTERIOR SURFACE TREATMENT: none

EXTERIOR SURFACE TREATMENT: smoothed

HEIGHT: $8.7 \mathrm{~cm}$

ORIFICE DIAMETER: $10.8 \mathrm{~cm}$

DIAMETER AT BOTTOM OF RIM OR NECK: $10.9 \mathrm{~cm}$

BASE DIAMETER: $6.7 \mathrm{~cm}$

ESTIMATED VOLUME: 0.6 liters

DECORATION: There are 10 diagonal engraved panels repeated around the rim. Each panel has two diagonal engraved lines with hatched pendant triangles (Vessel 41AN240). The panels are enclosed within upper and lower horizontal engraved lines under the lip and at the carination.

TYPE: Poynor Engraved, var. T in the upper Neches River basin

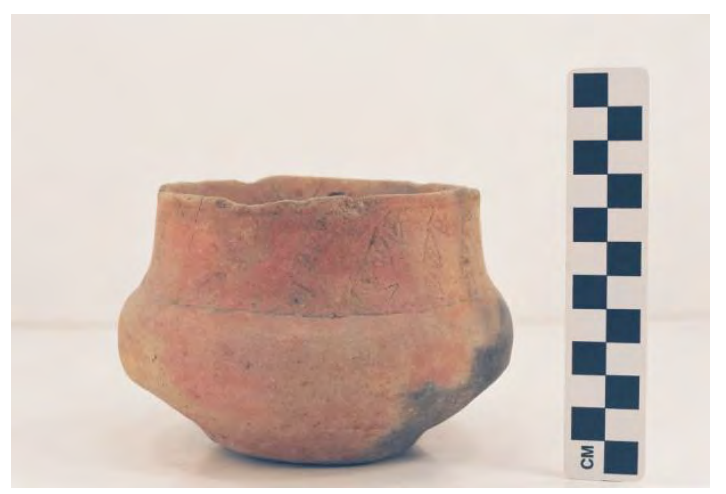

Vessel 41AN2-40. 
SITE NO.: 41AN2

FEATURE: Burial F-2

VESSEL NO.: 41AN2-41

NON-PLASTICS: grog and hematite

VESSEL FORM: Carinated bowl with a direct rim and a rounded lip

CORE COLOR: A (fired and cooled in a high oxygen environment)

WALL THICKNESS: $5.8 \mathrm{~mm}$

INTERIOR SURFACE TREATMENT: smoothed

EXTERIOR SURFACE TREATMENT: burnished

HEIGHT: $14.2 \mathrm{~cm}$

ORIFICE DIAMETER: $24.0 \mathrm{~cm}$

DIAMETER AT BOTTOM OF RIM OR NECK: $23.9 \mathrm{~cm}$

BASE DIAMETER: $8.5 \mathrm{~cm}$

ESTIMATED VOLUME: 3.0 liters

DECORATION: The rim has three engraved ovals. These ovals are comprised of three concentric semi-circular engraved lines, and there are two diagonal engraved lines between each of the negative ovals. The semi-circular lines begin along these diagonal lines. The vessel body has overlapping brushing marks on the body (Vessel 41AN2-41).

TYPE: Poynor Engraved, var. Cook

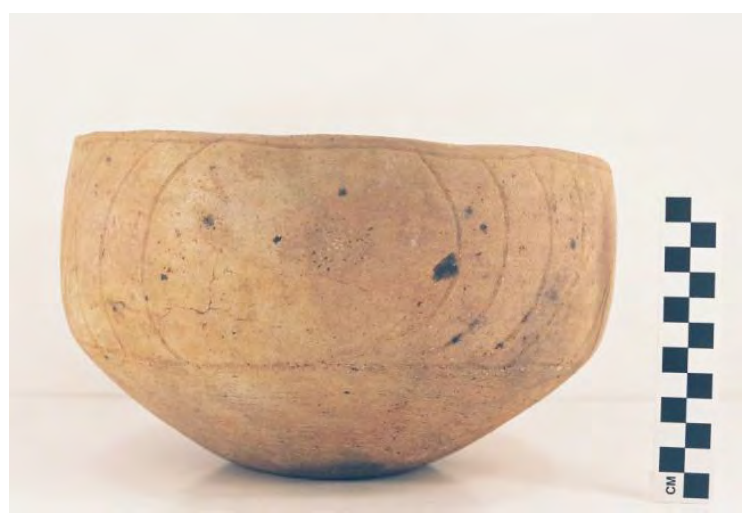

Vessel 41AN2-41. 
SITE NO.: 41AN2

FEATURE: Burial F-2

VESSEL NO.: 41AN2-42

NON-PLASTICS: bone and grog

VESSEL FORM: Bowl with a direct rim and a flat lip; two lip tabs, with the appendage attachment extending onto the rim.

CORE COLOR: Undetermined

WALL THICKNESS: $6.3 \mathrm{~mm}$

INTERIOR SURFACE TREATMENT: smoothed

EXTERIOR SURFACE TREATMENT: smoothed

HEIGHT: $9.0 \mathrm{~cm}$

ORIFICE DIAMETER: $13.5 \mathrm{~cm}$

DIAMETER AT BOTTOM OF RIM OR NECK:

BASE DIAMETER: $8.4 \mathrm{~cm}$

ESTIMATED VOLUME: 0.5 liters

DECORATION: There are three broad and widely-spaced horizontal engraved lines encircling the vessel rim (Vessel 41AN2-42). A red clay pigment has been rubbed into the engraved lines.

TYPE: Hood Engraved, var. unspecified; if an effigy head had been attached to the vessel, it would have been classified as Hood Engraved, var. Hood.

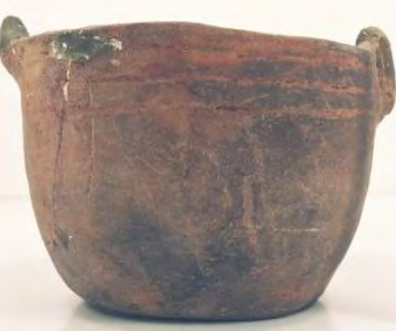

Vessel 41AN2-42. 
SITE NO.: 41AN2

FEATURE: Burial F-2

VESSEL NO.: 41AN2-43

NON-PLASTICS: hematite and bone

VESSEL FORM: Miniature globular carinated bowl with a direct rim and a rounded lip (Vessel 41AN2-43)

CORE COLOR: A (fired and cooled in a high oxygen environment)

WALL THICKNESS: $5.9 \mathrm{~mm}$

INTERIOR SURFACE TREATMENT: none

EXTERIOR SURFACE TREATMENT: none

HEIGHT: $3.5 \mathrm{~cm}$

ORIFICE DIAMETER: $7.5 \mathrm{~cm}$

DIAMETER AT BOTTOM OF RIM OR NECK: N/A

BASE DIAMETER: $4.0 \mathrm{~cm}$

ESTIMATED VOLUME: 0.15 liters

DECORATION: plain

TYPE: Poynor Plain (i.e., the vessel form - globular carinated bowl - is the same as many of the Poynor Engraved vessels, but is undecorated)

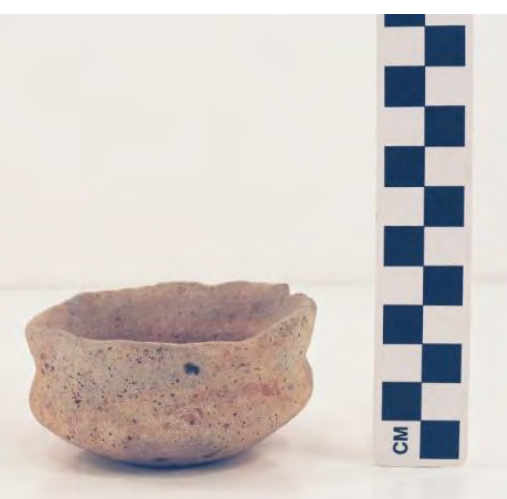

Vessel 41AN2-43, Poynor Plain. 
SITE NO.: 41AN2

FEATURE: Burial F-2

VESSEL NO.: 41AN2-44

NON-PLASTICS: grog and hematite

VESSEL FORM: Carinated bowl with a direct rim and a rounded lip

CORE COLOR: A (fired and cooled in an oxidizing environment)

WALL THICKNESS: $6.5 \mathrm{~mm}$

INTERIOR SURFACE TREATMENT: smoothed

EXTERIOR SURFACE TREATMENT: smoothed

HEIGHT: $19.7 \mathrm{~cm}$

ORIFICE DIAMETER: $32.8 \mathrm{~cm}$

DIAMETER AT BOTTOM OF RIM OR NECK: $33.2 \mathrm{~cm}$

BASE DIAMETER: $7.1 \mathrm{~cm}$

\section{ESTIMATED VOLUME: 5.8 liters}

DECORATION: There are two distinct engraved motifs on the rim of the vessel, each executed two times. The first is an oval with small inward pointing hatched pendant triangles. This alternates with a hooked arm scroll motif with curvilinear and diagonal fill elements that extend to two curvilinear engraved lines that further define the ovals. The body and base of the vessel has overlapping brushed marks (Vessel 41AN2-44).

TYPE: Poynor Engraved, PP variety (Kleinschmidt 1982)

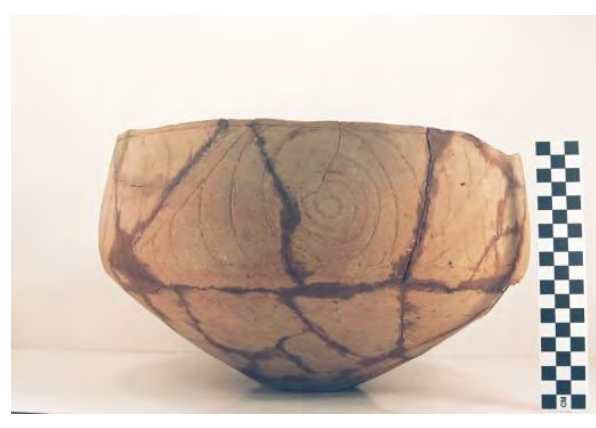

Vessel 41AN2-44. 
SITE NO.: 41AN2

FEATURE: Burial F-2

VESSEL NO.: 41AN2-45

NON-PLASTICS: grog and hematite

VESSEL FORM: Globular carinated bowl with a direct rim and a rounded, exterior folded, lip

CORE COLOR: A (fired and cooled in a high oxygen environment)

WALL THICKNESS: $6.5 \mathrm{~mm}$

INTERIOR SURFACE TREATMENT: smoothed

EXTERIOR SURFACE TREATMENT: smoothed

HEIGHT: $16.4 \mathrm{~cm}$

ORIFICE DIAMETER: $22.5 \mathrm{~cm}$

DIAMETER AT BOTTOM OF RIM OR NECK: $21.5 \mathrm{~cm}$

BASE DIAMETER: $8.0 \mathrm{~cm}$

ESTIMATED VOLUME: 3.2 liters

DECORATION: There are seven rectangular engraved panels around the rim. The panels are defined by two vertical engraved lines with four cross-hatched engraved pendant triangles at the top and bottom of the vertical lines (Vessel 41AN2-45). Within the panels themselves are a series of small upper and lower excised triangles or triangular tick marks. A white kaolin clay pigment is rubbed in the engraved lines.

TYPE: Poynor Engraved, var. Freeman

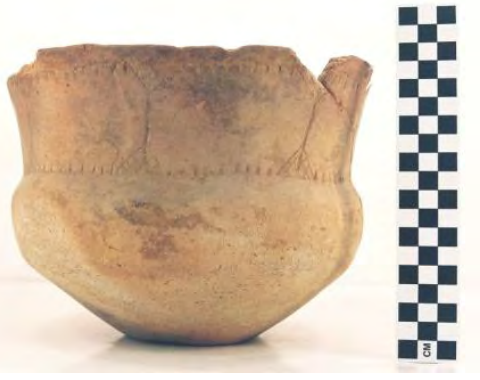

Vessel 41AN2-45. 
SITE NO.: 41AN2

FEATURE: Unknown

VESSEL NO.: 41AN2-51

NON-PLASTICS: grog and hematite

VESSEL FORM: Globular carinated bowl with a direct rim and a rounded lip

CORE COLOR: $\mathrm{G}$ (fired in a reducing environment and cooled in the open air)

WALL THICKNESS: $6.9 \mathrm{~mm}$

INTERIOR SURFACE TREATMENT: smoothed

EXTERIOR SURFACE TREATMENT: smoothed

HEIGHT: $12.0 \mathrm{~cm}$

ORIFICE DIAMETER: $17.0 \mathrm{~cm}$

DIAMETER AT BOTTOM OF RIM OR NECK: $17.2 \mathrm{~cm}$

BASE DIAMETER: $8.3 \mathrm{~cm}$

\section{ESTIMATED VOLUME: 1.2 liters}

DECORATION: The rim has engraved panels defined by hour glass-shaped hatched areas and one row (underneath the rim) of small triangular tick marks (Poynor Engraved, var. Hood rim panel). The body has two series of five concentric circular engraved lines with linear tick marks on the outer three of the circular lines. These circular engraved motifs are divided by a single near-vertical engraved line that ends in large engraved triangles (Vessel 41AN2-51).

TYPE: Patton Engraved, var. Freeman

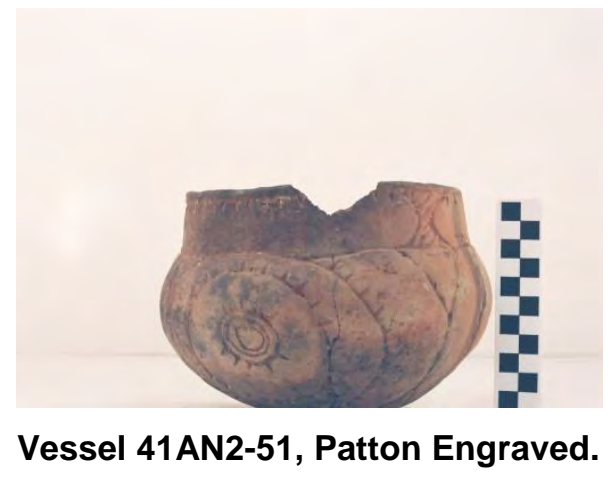


SITE NO.: 41AN2

FEATURE: Unknown

VESSEL NO.: 41AN2-52

NON-PLASTICS: grog and hematite

VESSEL FORM: Bowl with a direct rim and a flat lip; the vessel has a cut-down rim, suggesting this is a vessel recycled from a broken carinated bowl (Vessel 41AN2-52)

CORE COLOR: Undetermined

WALL THICKNESS: $5.4 \mathrm{~mm}$

INTERIOR SURFACE TREATMENT: none

EXTERIOR SURFACE TREATMENT: smoothed

HEIGHT: $11.0 \mathrm{~cm}$ (original vessel would have been taller)

ORIFICE DIAMETER: $24.2 \mathrm{~cm}$

DIAMETER AT BOTTOM OF RIM OR NECK: N/A

BASE DIAMETER: $7.9 \mathrm{~cm}$

ESTIMATED VOLUME: $1.6+$ liters

DECORATION: Overlapping brushing marks on the vessel body; the rim (no longer present) would more than likely have had an engraved motif.

TYPE: probable Poynor Engraved vessel

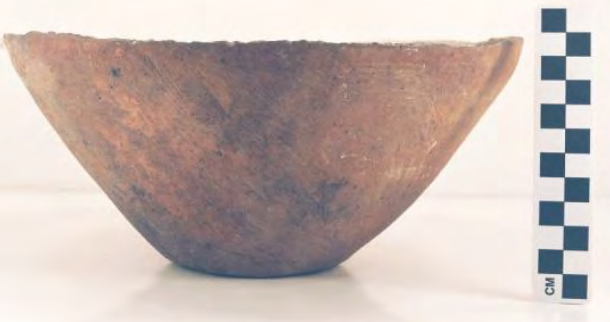

Vessel 41AN2-52. 
SITE NO.: 41AN2

FEATURE: Unknown

VESSEL NO.: 41AN2-53

NON-PLASTICS: grog and bone

VESSEL FORM: Carinated bowl with an inverted rim and a rounded lip

CORE COLOR: B (fired and cooled in a reducing environment)

WALL THICKNESS: $5.8 \mathrm{~mm}$, rim

INTERIOR SURFACE TREATMENT: burnished

EXTERIOR SURFACE TREATMENT: burnished

HEIGHT: $7.3 \mathrm{~cm}$

ORIFICE DIAMETER: $11.0 \mathrm{~cm}$

DIAMETER AT BOTTOM OF RIM OR NECK: $11.4 \mathrm{~cm}$

BASE DIAMETER: $6.0 \mathrm{~cm}$

\section{ESTIMATED VOLUME: 0.5 liters}

DECORATION: There are three engraved ovals in a panel on the rim. Each oval is defined by three closely-spaced curvilinear engraved lines on either side of the oval. The remainder of the panels include another set of three closely-spaced curvilinear engraved lines and two cross-hatched hour glass-shaped dividers. The body of the vessel has horizontal and overlapping brushing marks (Vessel 41AN2-53).

TYPE: Poynor Engraved, var. Cook but with additional var. Hood hour glass-shaped vertical columns

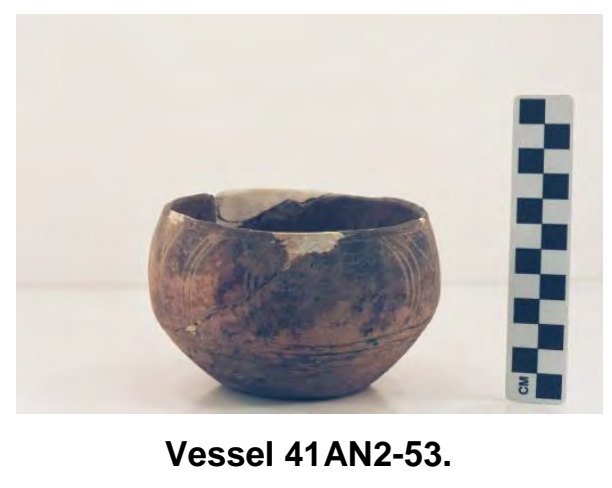


SITE NO.: 41AN2

FEATURE: Unknown

VESSEL NO.: 41AN2-54

NON-PLASTICS: grog and hematite

VESSEL FORM: Globular carinated bowl with a direct rim and a rounded lip (partially reconstructed)

CORE COLOR: Undetermined

WALL THICKNESS: $6.5 \mathrm{~mm}$

INTERIOR SURFACE TREATMENT: smoothed

EXTERIOR SURFACE TREATMENT: smoothed

HEIGHT: $13.0 \mathrm{~cm}$

ORIFICE DIAMETER: $13.5 \mathrm{~cm}$

DIAMETER AT BOTTOM OF RIM OR NECK: $13.4 \mathrm{~cm}$

BASE DIAMETER: $7.5 \mathrm{~cm}$

ESTIMATED VOLUME: 1.2 liters

DECORATION: The rim has upper and lower sets of linear tick marks, the second row (at the carination) pendant from a single horizontal engraved line, and extending onto the vessel body (Vessel 41AN2-54). A single row of tool punctates runs along the central part of the rim.

TYPE: Patton Engraved, Motif 10 (Kleinschmidt 1982)

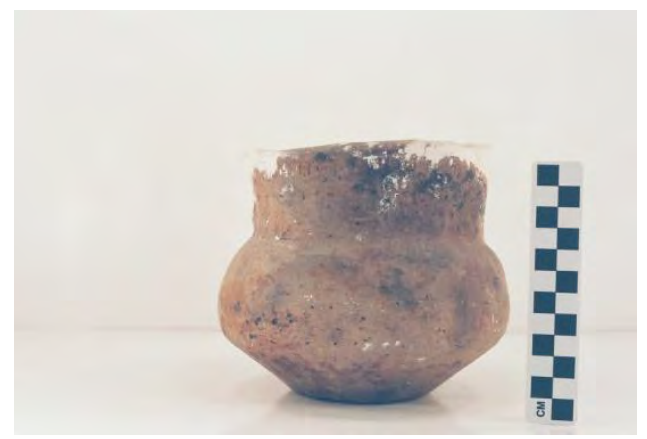

Vessel 41AN2-54. 
SITE NO.: 41AN2

FEATURE: Unknown

VESSEL NO.: 41AN2-55

NON-PLASTICS: grog and hematite

VESSEL FORM: Jar, missing the rim

CORE COLOR: $\mathrm{G}$ (fired in a reducing environment and cooled in the open air); pinkware

WALL THICKNESS: $10.6 \mathrm{~mm}$

INTERIOR SURFACE TREATMENT: none

EXTERIOR SURFACE TREATMENT: none

HEIGHT: Undetermined

ORIFICE DIAMETER: Undetermined

DIAMETER AT BOTTOM OF RIM OR NECK: Undetermined

BASE DIAMETER: $9.5 \mathrm{~cm}$

ESTIMATED VOLUME: Undetermined

DECORATION: diagonal brushing marks on the vessel body (Vessel 41AN2-55)

TYPE: probably Bullard Brushed

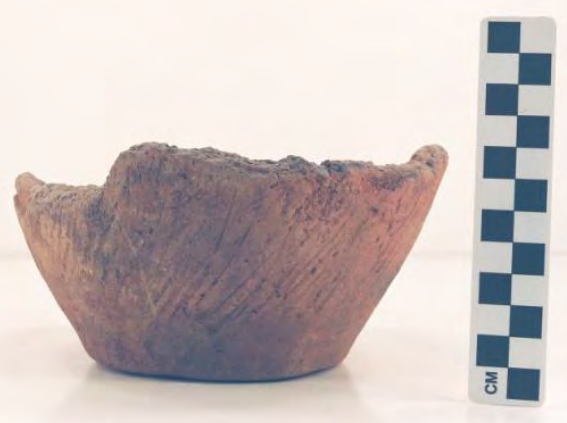

Vessel 41AN2-55. 
SITE NO.: 41AN2

FEATURE: Unknown

VESSEL NO.: 41AN2-56

NON-PLASTICS: grog

VESSEL FORM: Bowl with a direct rim and a rounded lip (Vessel 41AN2-56)

CORE COLOR: Undetermined

WALL THICKNESS: $6.7 \mathrm{~mm}$

INTERIOR SURFACE TREATMENT: smoothed

EXTERIOR SURFACE TREATMENT: roughened

HEIGHT: $8.9 \mathrm{~cm}$

ORIFICE DIAMETER: $16.4 \mathrm{~cm}$

DIAMETER AT BOTTOM OF RIM OR NECK: N/A

BASE DIAMETER: $7.5 \mathrm{~cm}$

ESTIMATED VOLUME: 0.6 liters

DECORATION: plain

TYPE: Undetermined plain ware vessel

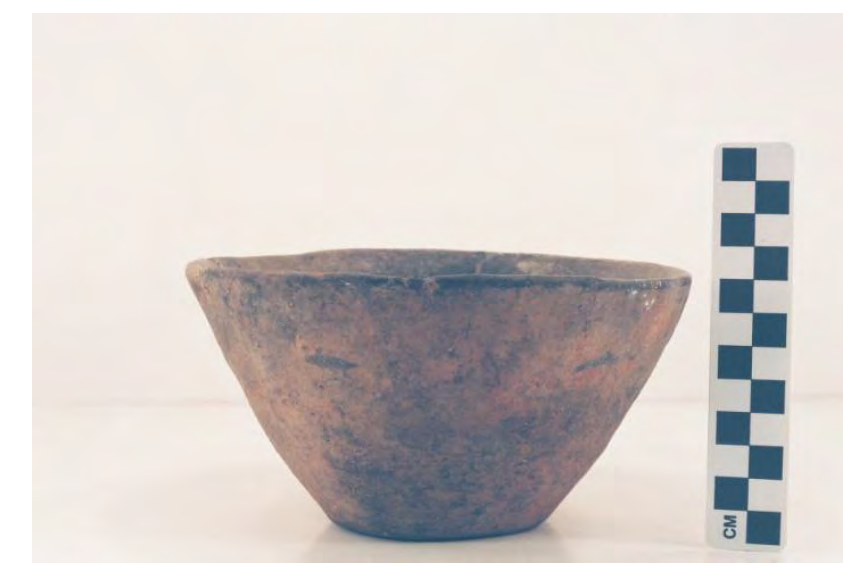

Vessel 41AN2-56. 


\section{Fred McKee Site (41AN32)}

SITE NO.: 41AN32

FEATURE: Burial AP-1

VESSEL NO.: 41AN32-1

NON-PLASTICS: grog and hematite

VESSEL FORM: Carinated bowl with an inverted rim and a rounded lip

CORE COLOR: A (fired and cooled in an oxidizing environment)

WALL THICKNESS: $6.2 \mathrm{~mm}$

INTERIOR SURFACE TREATMENT: smoothed on the rim

EXTERIOR SURFACE TREATMENT: smoothed

HEIGHT: $18.0 \mathrm{~cm}$

ORIFICE DIAMETER: $31.5 \mathrm{~cm}$

DIAMETER AT BOTTOM OF RIM OR NECK: $32.1 \mathrm{~cm}$

BASE DIAMETER: $9.0 \mathrm{~cm}$

ESTIMATED VOLUME: 5.0 liters

DECORATION: There are six rectangular panels on the rim of this vessel, with upper and lower horizontal engraved lines encircling the rim. Each panel is defined by two hour glass-shaped excised areas that extend from the rim to the vessel carination (Vessel 41AN32-1).

TYPE: Poynor Engraved, var. Blackburn

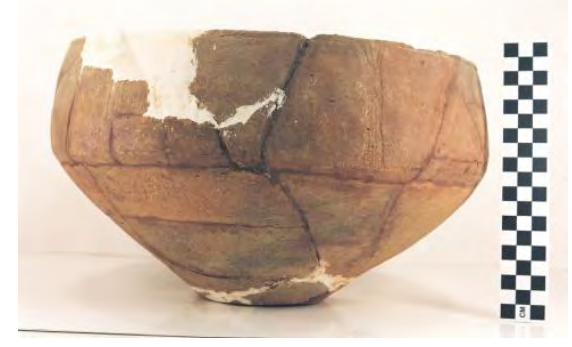

Vessel 41AN32-1, Poynor Engraved, var. Blackburn. 
SITE NO.: 41AN32

FEATURE: Burial AP-1

VESSEL NO.: 41AN32-2

NON-PLASTICS: grog and hematite

VESSEL FORM: Bottle with a short neck, a globular body, a direct rim, and a rounded lip

CORE COLOR: A (fired and cooled in an oxidizing environment)

WALL THICKNESS: $7.9 \mathrm{~mm}$, neck

INTERIOR SURFACE TREATMENT: none

EXTERIOR SURFACE TREATMENT: none

HEIGHT: $30.0 \mathrm{~cm}$

ORIFICE DIAMETER: $4.5 \mathrm{~cm}$

DIAMETER AT BOTTOM OF RIM OR NECK:

BASE DIAMETER: $9.5 \mathrm{~cm}$

ESTIMATED VOLUME: 1.2 liters

DECORATION: The body has four vertical cross-hatched engraved panels that extend from the base of the neck to near the base. There are also hatched pendant triangles on a single horizontal engraved line that encircles the base of the bottle neck (Vessel 41AN322).

TYPE: Hume Engraved, var. unspecified

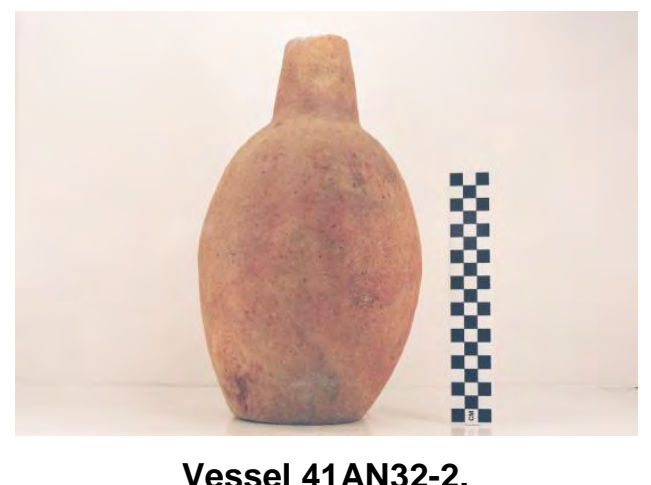

Vessel 41AN32-2. 
SITE NO.: 41AN32

FEATURE: Burial AP-1

VESSEL NO.: 41AN32-3

NON-PLASTICS: grog and hematite

VESSEL FORM: Bottle with a short neck and a distinct collared section at the neck-body juncture (Vessel 41AN32-3); the rim is direct and the lip is flat

CORE COLOR: A (fired and cooled in a high oxygen environment); pinkware

WALL THICKNESS: $5.4 \mathrm{~mm}$

INTERIOR SURFACE TREATMENT: none

EXTERIOR SURFACE TREATMENT: smoothed

HEIGHT: $15.6 \mathrm{~cm}$

ORIFICE DIAMETER: $4.0 \mathrm{~cm}$

DIAMETER AT BOTTOM OF RIM OR NECK: $10.1 \mathrm{~cm}$ on the bottle body

BASE DIAMETER: $6.0 \mathrm{~cm}$

ESTIMATED VOLUME: 0.4 liters

DECORATION: plain

TYPE: Undetermined plain ware vessel

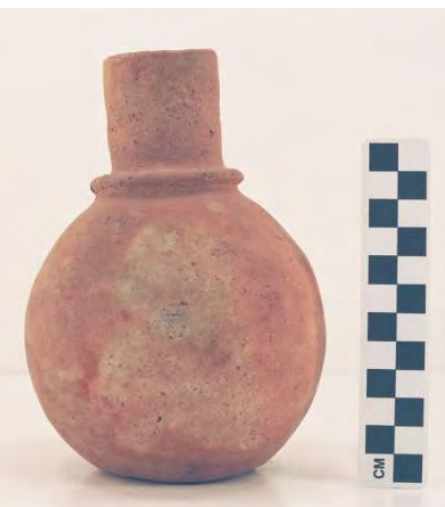

Vessel 41AN32-3. 
SITE NO.: 41AN32

FEATURE: Burial AP-1

VESSEL NO.: 41AN32-4

NON-PLASTICS: grog and hematite

VESSEL FORM: Globular carinated bowl, missing the upper part of the rim

CORE COLOR: $\mathrm{F}$ (fired in a reducing environment and cooled in the open air)

WALL THICKNESS: $5.9 \mathrm{~mm}$

INTERIOR SURFACE TREATMENT: smoothed

EXTERIOR SURFACE TREATMENT: burnished

HEIGHT: Undetermined

ORIFICE DIAMETER: Undetermined

DIAMETER AT BOTTOM OF RIM OR NECK: Undetermined

BASE DIAMETER: $8.0 \mathrm{~cm}$

ESTIMATED VOLUME: Undetermined

DECORATION: The rim has rectangular panels defined by two vertical engraved to excised lines.

TYPE: Poynor Engraved, var. Blackburn 
SITE NO.: 41AN32

FEATURE: Burial AP-1

VESSEL NO.: 41AN32-5

NON-PLASTICS: grog and hematite

VESSEL FORM: Carinated bowl with an inverted rim and a rounded lip

CORE COLOR: A (fired and cooled in an oxidizing environment); pinkware

WALL THICKNESS: $6.2 \mathrm{~mm}$

INTERIOR SURFACE TREATMENT: smoothed

EXTERIOR SURFACE TREATMENT: burnished

HEIGHT: $19.8 \mathrm{~cm}$

ORIFICE DIAMETER: $26.9 \mathrm{~cm}$

DIAMETER AT BOTTOM OF RIM OR NECK: $27.5 \mathrm{~cm}$

BASE DIAMETER: $6.0 \mathrm{~cm}$

\section{ESTIMATED VOLUME: 4.8 liters}

DECORATION: There are four ovals panels comprised of central sets of interlocking curvilinear engraved lines; each interlocking scroll includes two sets of three closelyspaced engraved lines (Vessel 41AN32-5). The oval panels are defined by two closelyspaced vertical curvilinear lines that extend from near the rim to the carination; these sets of curvilinear lines also have one hatched pendant triangles on them. The vessel body has diagonal brushing.

TYPE: Poynor Engraved, var. Cook, but with the addition of the var. P interlocking or hooked arm element in the center of the large ovals.

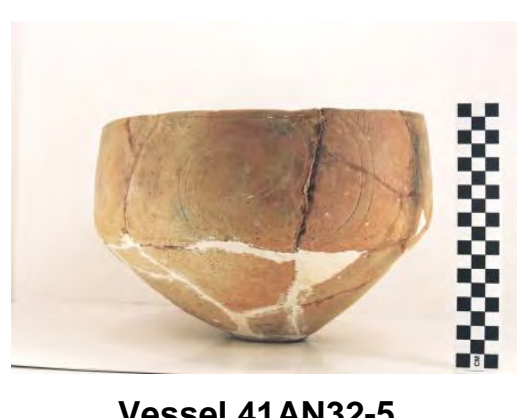

Vessel 41AN32-5. 
SITE NO.: 41AN32

FEATURE: Burial AP-1

VESSEL NO.: 41AN32-6

NON-PLASTICS: grog and hematite

VESSEL FORM: Effigy bowl with a direct rim and a rounded lip, as well as a tab tail; effigy head broken away (Vessel 41AN32-6)

CORE COLOR: $\mathrm{G}$ (fired in a reducing environment and cooled in the open air)

WALL THICKNESS: $7.3 \mathrm{~mm}$

INTERIOR SURFACE TREATMENT: smoothed

EXTERIOR SURFACE TREATMENT: burnished

HEIGHT: $9.4 \mathrm{~cm}$

ORIFICE DIAMETER: $20.4 \mathrm{~cm}$

DIAMETER AT BOTTOM OF RIM OR NECK: N/A

BASE DIAMETER: $11.0 \mathrm{~cm}$

ESTIMATED VOLUME: 0.8 liters

DECORATION: Three widely-spaced and broad horizontal engraved lines on the rim; a red clay pigment was rubbed in the engraved lines (Vessel 41AN32-6)

TYPE: Hood Engraved, var. unspecified effigy vessel

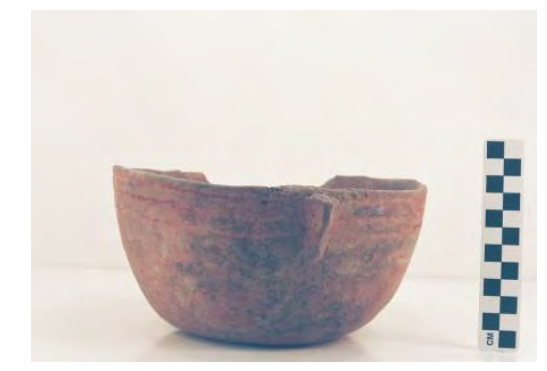

Vessel 41AN32-6, Effigy Vessel. 
SITE NO.: 41AN32

FEATURE: Burial AP-1

VESSEL NO.: 41AN32-7

NON-PLASTICS: hematite, grog, and bone

VESSEL FORM: Globular carinated bowl with a direct rim and a rounded, exterior folded, lip

CORE COLOR: $\mathrm{F}$ (fired in a reducing environment and cooled in the open air)

WALL THICKNESS: $5.4 \mathrm{~mm}$, rim

INTERIOR SURFACE TREATMENT: smoothed

EXTERIOR SURFACE TREATMENT: burnished

HEIGHT: $7.7 \mathrm{~cm}$

ORIFICE DIAMETER: $12.0 \mathrm{~cm}$

DIAMETER AT BOTTOM OF RIM OR NECK: $13.0 \mathrm{~cm}$

BASE DIAMETER: $6.0 \mathrm{~cm}$

ESTIMATED VOLUME: 0.6 liters

DECORATION: There are six engraved panels on the vessel rim. Each panel has upper and lower rows of large hatched pendant triangles, and are defined by cross-hatched hour glass-shaped columns that extend from the rim to the carination (Vessel 41AN32-7). A red clay pigment has been rubbed in the engraved lines.

TYPE: Poynor Engraved, var. Freeman, also previously identified as the PP variety of Poynor Engraved, Motif 5 (Kleinschmidt 1982)

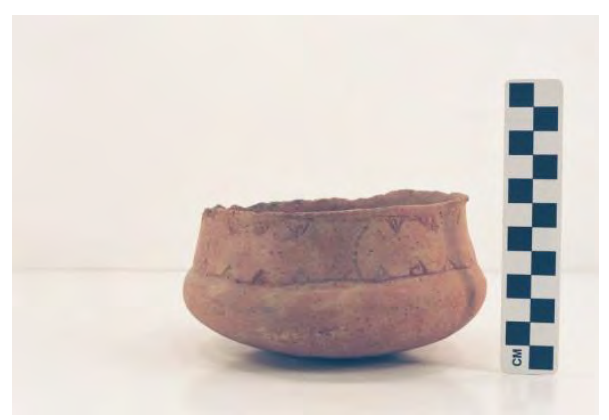

Vessel 41AN32-7. 
SITE NO.: 41AN32

FEATURE: Burial AP-1

VESSEL NO.: 41AN32-8

NON-PLASTICS: grog and hematite

VESSEL FORM: Carinated bowl with an inverted rim and a rounded lip

CORE COLOR: Undetermined

WALL THICKNESS: $6.6 \mathrm{~mm}$

INTERIOR SURFACE TREATMENT: smoothed

EXTERIOR SURFACE TREATMENT: smoothed

HEIGHT: $19.8 \mathrm{~cm}$

ORIFICE DIAMETER: $30.0 \mathrm{~cm}$

DIAMETER AT BOTTOM OF RIM OR NECK: $32.0 \mathrm{~cm}$

BASE DIAMETER: $8.0 \mathrm{~cm}$

\section{ESTIMATED VOLUME: 5.3 liters}

DECORATION: The rim has a curvilinear and interlocking engraved motif that is repeated four times on the vessel rim. The motif includes two sets of three closely-spaced curvilinear lines followed by two interlocking sets of three more closely-spaced engraved lines. There is diagonal brushing on the vessel body (Vessel 41AN32-8).

TYPE: Poynor Engraved, var. Cook with the addition of var. P interlocking engraved lines

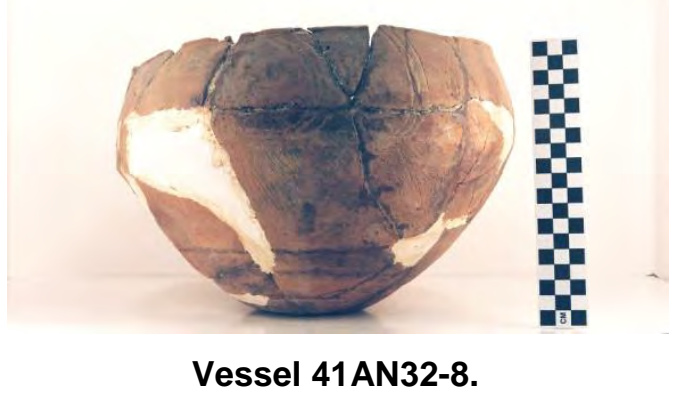


SITE NO.: 41AN32

FEATURE: Burial AP-2

VESSEL NO.: 41AN32-21

NON-PLASTICS: fine grog

VESSEL FORM: Globular carinated bowl with a direct rim and a rounded lip

CORE COLOR: A (fired and cooled in an oxidizing environment); pinkware

WALL THICKNESS: $4.9 \mathrm{~mm}$, rim

INTERIOR SURFACE TREATMENT: smoothed on the rim and upper body

EXTERIOR SURFACE TREATMENT: burnished

HEIGHT: $8.5 \mathrm{~cm}$

ORIFICE DIAMETER: $9.5 \mathrm{~cm}$

DIAMETER AT BOTTOM OF RIM OR NECK: $11.2 \mathrm{~cm}$ on the vessel body

BASE DIAMETER: $4.2 \mathrm{~cm}$

ESTIMATED VOLUME: 0.5 liters

DECORATION: There are 11 rectangular engraved panels on the rim of the vessel. The panels are bounded by upper and lower horizontal engraved lines under the lip and at the carination. Each panel is defined by two hour glass-shaped excised areas, and within the panel there is a single excised pendant triangle that extends from both the upper and lower horizontal lines encircling the rim; the lower pendant triangle is on the upper vessel body (Vessel 41AN32-21). A white kaolin clay pigment has been rubbed in the engraved lines.

TYPE: Poynor Engraved, var. Freeman, also identified as the PP variety of Poynor Engraved, Motif 11 (Kleinschmidt 1982)

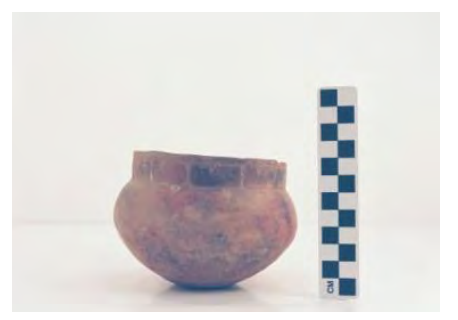

Vessel 41AN32-21. 
SITE NO.: 41AN32

FEATURE: Burial AP-2

VESSEL NO.: 41AN32-22

NON-PLASTICS: grog and hematite

VESSEL FORM: Carinated bowl with an inverted rim and a rounded lip

CORE COLOR: Undetermined

WALL THICKNESS: $4.6 \mathrm{~mm}$, rim

INTERIOR SURFACE TREATMENT: smoothed

EXTERIOR SURFACE TREATMENT: smoothed

HEIGHT: $6.3 \mathrm{~cm}$

ORIFICE DIAMETER: $9.2 \mathrm{~cm}$

DIAMETER AT BOTTOM OF RIM OR NECK: $9.6 \mathrm{~cm}$

BASE DIAMETER: $5.5 \mathrm{~cm}$

ESTIMATED VOLUME: 0.35 liters

DECORATION: The rim has a scroll and circle engraved motif repeated four times around the vessel (Vessel 41AN32-22). A red clay pigment has been rubbed in the engraved lines.

TYPE: Poynor Engraved, var. $E$ in the upper Neches River basin. Another, but less likely possibility is that this vessel is Ripley Engraved (cf. Thurmond 1990: Figure 6), although inverted rim carinated bowls are not a common feature of the Ripley Engraved type.

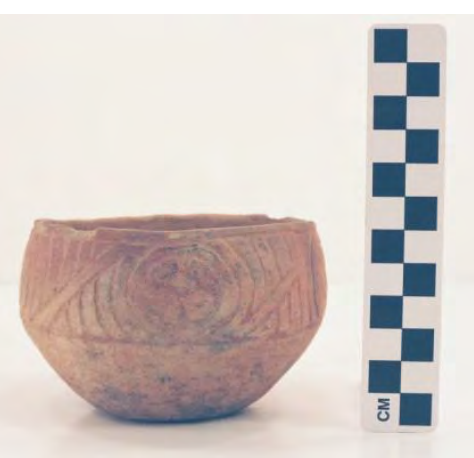

Vessel 41AN32-22. 
SITE NO.: 41AN32

FEATURE: Burial AP-2

VESSEL NO.: 41AN32-23

NON-PLASTICS: grog and hematite

VESSEL FORM: Deep globular bowl with a tall and slightly everted rim, a rounded lip, and with one small loop handle on the rim

CORE COLOR: Undetermined

WALL THICKNESS: $7.0 \mathrm{~mm}$

INTERIOR SURFACE TREATMENT: smoothed on the rim

EXTERIOR SURFACE TREATMENT: burnished

HEIGHT: $10.3 \mathrm{~cm}$

ORIFICE DIAMETER: $8.3 \mathrm{~cm}$

DIAMETER AT BOTTOM OF RIM OR NECK: $8.6 \mathrm{~cm} ; 8.9 \mathrm{~cm}$ on the body

BASE DIAMETER: $7.0 \mathrm{~cm}$

ESTIMATED VOLUME: 0.6 liters

DECORATION: There is an engraved motif repeated four times on the rim. The motif comprises a rectangular panel defined by two excised hour glass-shaped elements (Vessel 41AN32-23).

TYPE: Poynor Engraved, var. Hood

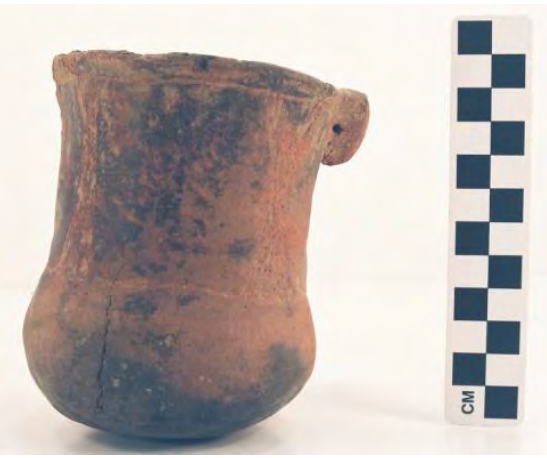

Vessel 41AN32-23. 
SITE NO.: 41AN32

FEATURE: Burial AP-2

VESSEL NO.: 41AN32-24

NON-PLASTICS: grog and hematite

VESSEL FORM: Jar with an everted rim and a rounded lip

CORE COLOR: $\mathrm{G}$ (fired in a reducing environment and cooled in the open air)

WALL THICKNESS: $6.7 \mathrm{~mm}$

INTERIOR SURFACE TREATMENT: smoothed

EXTERIOR SURFACE TREATMENT: none

HEIGHT: $15.2 \mathrm{~cm}$

ORIFICE DIAMETER: $13.5 \mathrm{~cm}$

DIAMETER AT BOTTOM OF RIM OR NECK: $12.9 \mathrm{~cm}$

BASE DIAMETER: $8.7 \mathrm{~cm}$

ESTIMATED VOLUME: 1.2 liters

DECORATION: Diagonal brushing on the rim and vessel body (Vessel 41AN32-24)

TYPE: Bullard Brushed

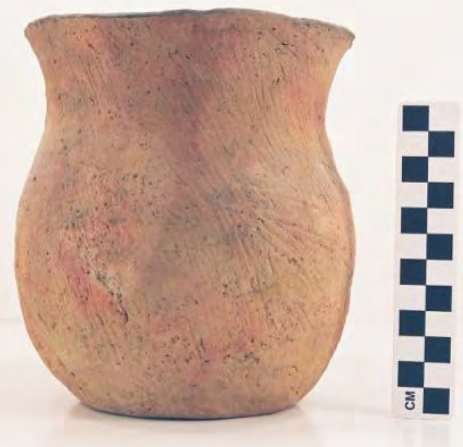

Vessel 41AN32-24, Bullard Brushed. 
SITE NO.: 41AN32

FEATURE: Burial AP-3

VESSEL NO.: 41AN32-26

NON-PLASTICS: grog and hematite

VESSEL FORM: Globular carinated bowl with a direct rim and a rounded lip

CORE COLOR: A (fired and cooled in the open air); pinkware

WALL THICKNESS: $4.8 \mathrm{~mm}$

INTERIOR SURFACE TREATMENT: burnished on the rim

EXTERIOR SURFACE TREATMENT: burnished

HEIGHT: $8.3 \mathrm{~cm}$

ORIFICE DIAMETER: $10.2 \mathrm{~cm}$

DIAMETER AT BOTTOM OF RIM OR NECK: $10.6 \mathrm{~cm}$

BASE DIAMETER: $4.3 \mathrm{~cm}$

ESTIMATED VOLUME: 0.5 liters

DECORATION: The rim of the vessel has an engraved motif in six rectangular panels, defined by single horizontal lines under the lip and at the vessel carination. The panels are defined by two vertical excised areas and sets of four large excised pendant triangles from the upper and lower horizontal engraved lines (Vessel 41AN32-26).

TYPE: Poynor Engraved, var. Freeman

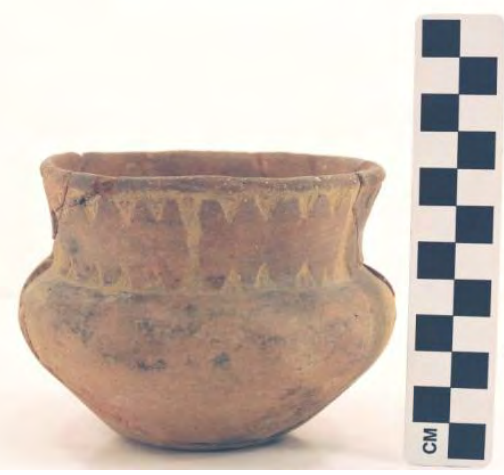

Vessel 41AN32-26. 
SITE NO.: 41AN32

FEATURE: Burial AP-3

VESSEL NO.: 41AN32-27

NON-PLASTICS: grog and hematite

VESSEL FORM: Globular carinated bowl, with a direct rim and a rounded, exterior folded lip

CORE COLOR: F (fired in a reducing environment, but cooled in the open air)

WALL THICKNESS: $4.9 \mathrm{~mm}$

INTERIOR SURFACE TREATMENT: burnished on the rim

EXTERIOR SURFACE TREATMENT: burnished

HEIGHT: $11.3 \mathrm{~cm}$

ORIFICE DIAMETER: $10.8 \mathrm{~cm}$

DIAMETER AT BOTTOM OF RIM OR NECK: $12.9 \mathrm{~cm}$

BASE DIAMETER: $6.8 \mathrm{~cm}$

ESTIMATED VOLUME: 0.7 liters

DECORATION: There are six rectangular engraved panels on the rim (Vessel 41AN3227). Each are defined by horizontal engraved lines under the lip and at the vessel carination as well as by two excised hour glass-shaped elements.

TYPE: Poynor Engraved, var. Hood

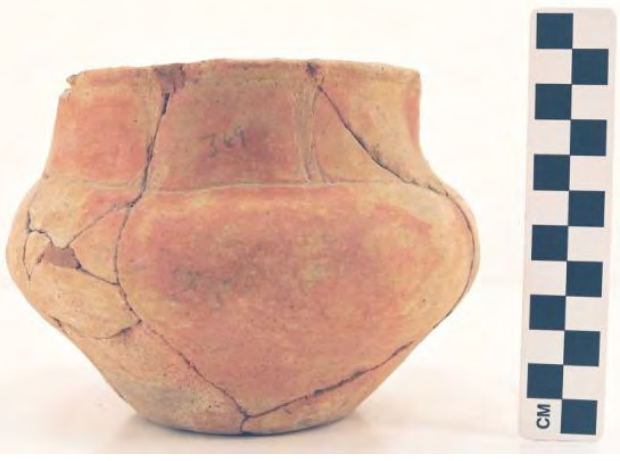

Vessel 41AN32-27. 
SITE NO.: 41AN32

FEATURE: Burial AP-3

VESSEL NO.: 41AN32-28

NON-PLASTICS: grog and hematite

VESSEL FORM: Carinated bowl with an inverted rim and a rounded lip

CORE COLOR: $\mathrm{G}$ (fired in a reducing environment and cooled in the open air)

WALL THICKNESS: $6.2 \mathrm{~mm}$

INTERIOR SURFACE TREATMENT: smoothed on the rim

EXTERIOR SURFACE TREATMENT: burnished

HEIGHT: $9.2 \mathrm{~cm}$

ORIFICE DIAMETER: $12.8 \mathrm{~cm}$

DIAMETER AT BOTTOM OF RIM OR NECK: $13.4 \mathrm{~cm}$

BASE DIAMETER: 5.0

ESTIMATED VOLUME: 0.7 liters

DECORATION: An engraved scroll and circle motif is repeated three times around the rim of the vessel. The circle has intersecting horizontal and vertical engraved lines, with four small excised triangles at the intersection of the lines with the central circle of the motif (Vessel 41AN32-28).

TYPE: Poynor Engraved, var. $E$ in the upper Neches River basin

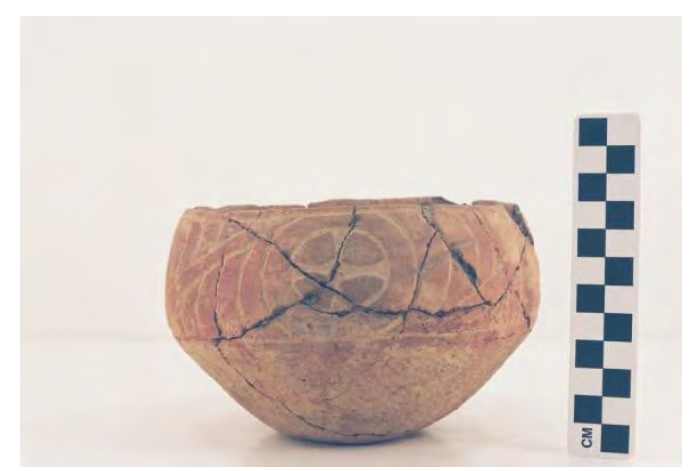

Vessel 41AN32-28. 
SITE NO.: 41AN32

FEATURE: Burial AP-3

VESSEL NO.: 41AN32-29

NON-PLASTICS: grog and hematite

VESSEL FORM: Carinated bowl with an inverted rim and a rounded lip

CORE COLOR: A (fired and cooled in an oxidizing environment)

WALL THICKNESS: $6.9 \mathrm{~mm}$

INTERIOR SURFACE TREATMENT: smoothed

EXTERIOR SURFACE TREATMENT: burnished

HEIGHT: $17.6 \mathrm{~cm}$

ORIFICE DIAMETER: $27.5 \mathrm{~cm}$

DIAMETER AT BOTTOM OF RIM OR NECK: $27.9 \mathrm{~cm}$

BASE DIAMETER: $8.3 \mathrm{~cm}$

ESTIMATED VOLUME: 4.3 liters

DECORATION: The engraved motif on the rim has three very wide negative ovals in a panel (Vessel 41AN32-29). Each panel is defined by two vertical engraved lines that extend from the vessel carination to just under the lip; these vertical lines have crosshatched engraved triangles at the upper and lower parts of the panel.

TYPE: Poynor Engraved, var. Hood

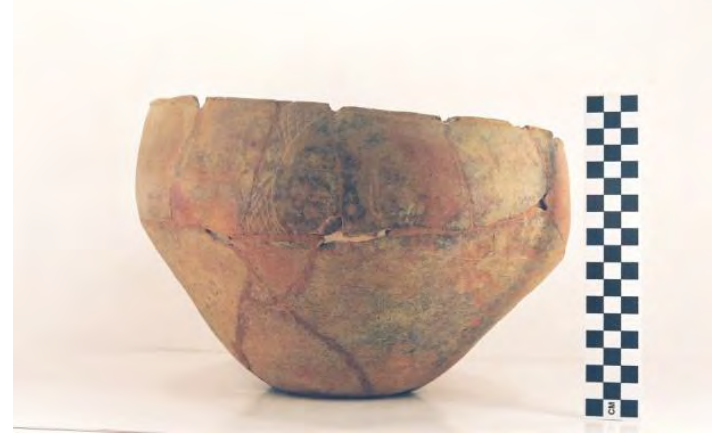

Vessel 41AN32-29. 
SITE NO.: 41AN32

FEATURE: Burial AP-3

VESSEL NO.: 41AN32-30

NON-PLASTICS: grog and hematite

VESSEL FORM: Bottle with a short neck, direct rim, and a flat lip; the vessel has a collared effect or "raised flange" (cf. Suhm and Jelks 1962:Plate 42a) at the base of the neck (Vessel 41AN32-30)

CORE COLOR: A (fired and cooled in a high oxygen environment); pinkware

WALL THICKNESS: $5.9 \mathrm{~mm}$

INTERIOR SURFACE TREATMENT: none

EXTERIOR SURFACE TREATMENT: smoothed

HEIGHT: $18.7 \mathrm{~cm}$

ORIFICE DIAMETER: $4.0 \mathrm{~cm}$ at the neck

DIAMETER AT BOTTOM OF RIM OR NECK: $11.6 \mathrm{~cm}$ on the body

BASE DIAMETER: $6.8 \mathrm{~cm}$

ESTIMATED VOLUME: 0.5 liters

DECORATION: plain

TYPE: cf. Hume Plain. Hume Engraved vessels illustrated by Suhm and Jelks (1962:Plate 42a) also have the distinctive collared neck.

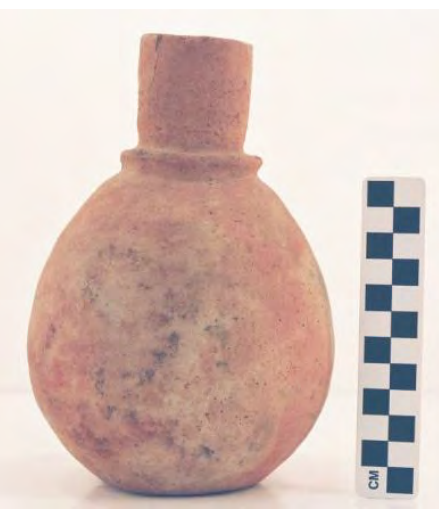

Vessel 41AN32-30. 
SITE NO.: 41AN32

FEATURE: Burial AP-3

VESSEL NO.: 41AN32-31

NON-PLASTICS: bone and hematite

VESSEL FORM: Carinated bowl with a direct rim and a flat lip

CORE COLOR: Undetermined; pinkware

WALL THICKNESS: $7.6 \mathrm{~mm}$

INTERIOR SURFACE TREATMENT: smoothed

EXTERIOR SURFACE TREATMENT: smoothed

HEIGHT: $13.7 \mathrm{~cm}$

ORIFICE DIAMETER: $24.0 \mathrm{~cm}$

DIAMETER AT BOTTOM OF RIM OR NECK: $24.0 \mathrm{~cm}$

BASE DIAMETER: $7.5 \mathrm{~cm}$

ESTIMATED VOLUME: 2.9 liters

DECORATION: The rim has two large ovals defined by two sets (three lines in each set) of closely-spaced curvilinear or arcing engraved lines (Vessel 41 AN32-31). Each oval is divided from the other by an arc of three closely-spaced engraved lines that reach from near the rim to the vessel carination. The ovals are set in a panel defined by upper and lower horizontal engraved lines that encircle the vessel.

TYPE: Poynor Engraved, var. Cook

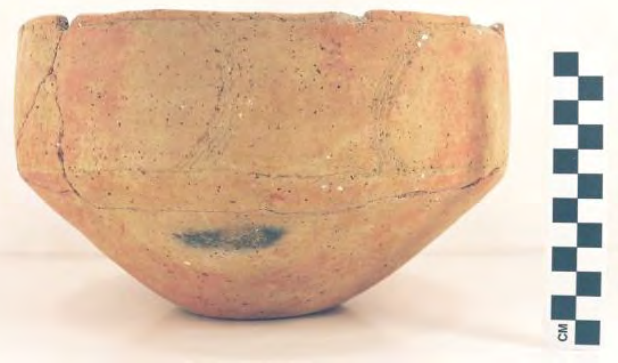

Vessel 41AN32-31. 
SITE NO.: 41AN32

FEATURE: Burial AP-3

VESSEL NO.: 41AN32-32

NON-PLASTICS: grog and hematite

VESSEL FORM: Jar with an elongated body, a direct to slightly everted rim, and a rounded, exterior folded, lip

CORE COLOR: A (fired and cooled in a high oxygen environment); pinkware

WALL THICKNESS: $6.7 \mathrm{~mm}$

INTERIOR SURFACE TREATMENT: smoothed

EXTERIOR SURFACE TREATMENT: none

HEIGHT: $21.7 \mathrm{~cm}$

ORIFICE DIAMETER: $15.0 \mathrm{~cm}$

DIAMETER AT BOTTOM OF RIM OR NECK: $14.6 \mathrm{~cm}$

BASE DIAMETER: $9.0 \mathrm{~cm}$

ESTIMATED VOLUME: 3.0 liters

DECORATION: The rim has three rows of tool punctations beginning immediately below the lip, and the vessel body has vertical brushing marks extending from the rimbody juncture to near the base (Vessel 41AN32-32).

TYPE: Brushed-punctated utility vessel, probably Bullard Brushed

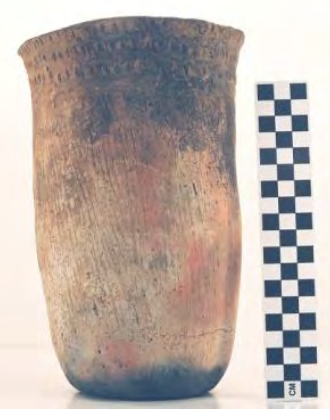

Vessel 41AN32-32. 
SITE NO.: 41AN32

FEATURE: Unknown

VESSEL NO.: 41AN32-46

NON-PLASTICS: grog and bone

VESSEL FORM: Miniature globular carinated bowl, with a missing rim (Vessel 41AN32-46)

CORE COLOR: B (fired and cooled in a low oxygen environment)

WALL THICKNESS: $5.0 \mathrm{~mm}$

INTERIOR SURFACE TREATMENT: none

EXTERIOR SURFACE TREATMENT: burnished

HEIGHT: Undetermined

ORIFICE DIAMETER: $2.8 \mathrm{~cm}$

DIAMETER AT BOTTOM OF RIM OR NECK: $4.4 \mathrm{~cm}$

BASE DIAMETER: $2.5 \mathrm{~cm}$

ESTIMATED VOLUME: Undetermined

DECORATION: plain

TYPE: cf. Poynor Plain

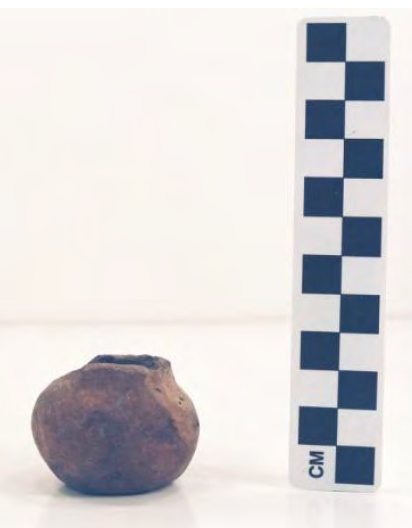

Vessel 41AN32-46. 
SITE NO.: 41AN32

FEATURE: Unknown

VESSEL NO.: 41AN32-47

NON-PLASTICS: grog and hematite

VESSEL FORM: Jar with a direct rim and a rounded, exterior folded lip; two lug handles

CORE COLOR: C (incompletely oxidized during firing); pinkware

WALL THICKNESS: $7.9 \mathrm{~mm}$, body

INTERIOR SURFACE TREATMENT: smoothed

EXTERIOR SURFACE TREATMENT: none

HEIGHT: $12.2 \mathrm{~cm}$

ORIFICE DIAMETER: $13.4 \mathrm{~cm}$

DIAMETER AT BOTTOM OF RIM OR NECK: $13.3 \mathrm{~cm}$

BASE DIAMETER: $7.2 \mathrm{~cm}$

ESTIMATED VOLUME: 1.0 liters

DECORATION: There are three rows of large tool punctations on the rim, only interrupted by the two lug handles. The vessel body has vertical brushing marks (Vessel 41AN32-47).

TYPE: probably Bullard Brushed

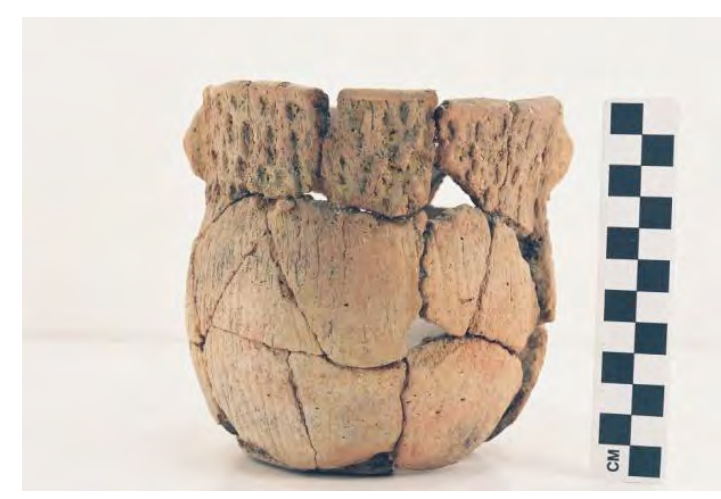

Vessel 41AN32-47. 
SITE NO.: 41AN32

FEATURE: Unknown

VESSEL NO.: 41AN32-Extra-1

NON-PLASTICS: grog and bone

VESSEL FORM: Miniature globular carinated bowl with a direct to slightly everted rim and a rounded lip (Vessel 41AN32-Extra 1); vessel was poorly made and finished.

CORE COLOR: Undetermined

WALL THICKNESS: $3.6 \mathrm{~mm}$

INTERIOR SURFACE TREATMENT: none

EXTERIOR SURFACE TREATMENT: none

HEIGHT: $4.8 \mathrm{~cm}$

ORIFICE DIAMETER: $2.5 \mathrm{~cm}$

DIAMETER AT BOTTOM OF RIM OR NECK: $4.6 \mathrm{~cm}$

BASE DIAMETER: $1.5 \mathrm{~cm}$

ESTIMATED VOLUME: 0.1 liters

DECORATION: plain

TYPE: cf. Poynor Plain

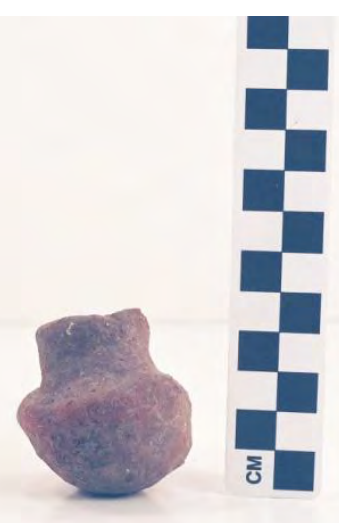

Vessel 41AN32-Extra 1. 
SITE NO.: 41AN32

FEATURE: Unknown

VESSEL NO.: 41AN32-Extra-2

NON-PLASTICS: grog and hematite

VESSEL FORM: Globular carinated bowl, with a direct rim and a rounded, exterior folded lip

CORE COLOR: Undetermined

WALL THICKNESS: Undetermined

INTERIOR SURFACE TREATMENT: burnished

EXTERIOR SURFACE TREATMENT: burnished

HEIGHT: $11.9 \mathrm{~cm}$

ORIFICE DIAMETER: $17.3 \mathrm{~cm}$

DIAMETER AT BOTTOM OF RIM OR NECK: $17.2 \mathrm{~cm}$

BASE DIAMETER: 1.2 liters

ESTIMATED VOLUME: Undetermined

DECORATION: The rim has three horizontal engraved lines with small triangular tick marks, two lines closely-spaced under the lip and the third at the rim-body carination (Vessel 41AN32-Extra 2). The body has four sets of curvilinear engraved lines (four) that end in a hooked arm scroll. There are small triangular tick marks on each of these lines, as well as the one engraved arcing line that separates each of the curvilinear/hooked arm motifs. A white kaolin clay pigment has been rubbed in the engraved lines.

TYPE: Patton Engraved, var. Fair, or Motif 12 (Kleinschmidt 1982)

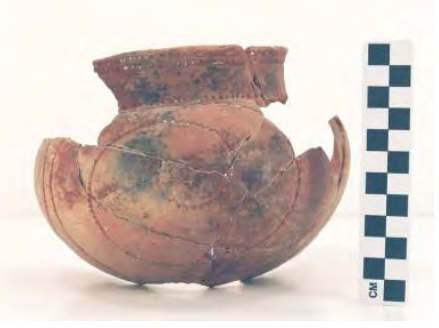

Vessel 41AN32-Extra 2, Patton Engraved. 


\section{Mrs. J. W. Blackburn Site (41CE4)}

SITE NO.: 41CE4

FEATURE: Burial AI-1

VESSEL NO.: 41CE4-1

NON-PLASTICS: none apparent

VESSEL FORM: Bottle with an elongated body and a short neck, direct rim, and a rounded lip

CORE COLOR: A (fired and cooled in a high oxygen environment); pinkware

WALL THICKNESS: $5.7 \mathrm{~mm}$

INTERIOR SURFACE TREATMENT: none

EXTERIOR SURFACE TREATMENT: none

HEIGHT: $27.5 \mathrm{~cm}$

ORIFICE DIAMETER: $5.0 \mathrm{~cm}$, neck

DIAMETER AT BOTTOM OF RIM OR NECK: $13.0 \mathrm{~cm}$ on the vessel body

BASE DIAMETER: $8.0 \mathrm{~cm}$

ESTIMATED VOLUME: 0.9 liters

DECORATION: There are vertical engraved panels that are repeated twice on the vessel body. Each panel includes three wide hatched zones and three narrow hatched zones, with blank areas between them (Vessel 41CE4-1). The rim is eroded but appears to have four horizontal engraved lines on the bottle neck.

TYPE: Hume Engraved, var. unspecified

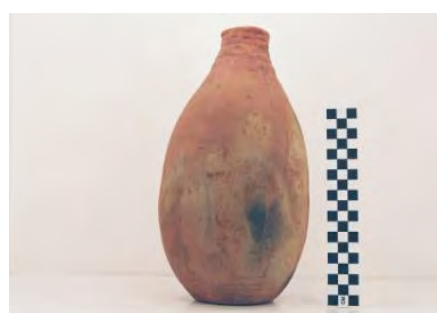

Vessel 41CE4-1. 
SITE NO.: 41CE4

FEATURE: Burial AI-1

VESSEL NO.: 41CE4-4

NON-PLASTICS: grog and hematite

VESSEL FORM: Globular carinated bowl with a direct rim and a rounded, exterior folded, lip

CORE COLOR: Undetermined

WALL THICKNESS: $5.6 \mathrm{~mm}$

INTERIOR SURFACE TREATMENT: smoothed

EXTERIOR SURFACE TREATMENT: none

HEIGHT: $10.7 \mathrm{~cm}$

ORIFICE DIAMETER: $13.5 \mathrm{~cm}$

DIAMETER AT BOTTOM OF RIM OR NECK: $13.5 \mathrm{~cm}$

BASE DIAMETER: $5.4 \mathrm{~cm}$

ESTIMATED VOLUME: 0.9 liters

DECORATION: The rim appears to have 12 rectangular engraved panels, delimited by upper and lower horizontal engraved lines that encircle the vessel (Vessel 41CE4-4). Each panel is defined by two hour glass-shaped excised areas.

TYPE: Poynor Engraved, var. Blackburn
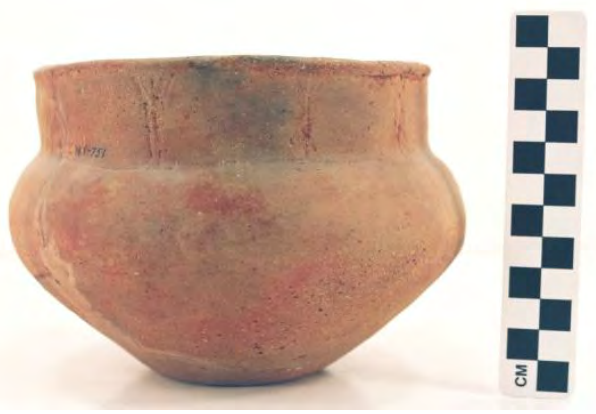

Vessel 41CE4-4, Poynor Engraved, var. Blackburn. 
SITE NO.: 41CE4

FEATURE: Burial AI-1

VESSEL NO.: 41CE4-5

NON-PLASTICS: bone, grog, and hematite; sandy paste

VESSEL FORM: Globular carinated bowl with a direct rim and a rounded lip

CORE COLOR: A (fired and cooled in a high oxygen environment)

WALL THICKNESS: $4.9 \mathrm{~mm}$

INTERIOR SURFACE TREATMENT: none

EXTERIOR SURFACE TREATMENT: none

HEIGHT: $7.0 \mathrm{~cm}$

ORIFICE DIAMETER: $9.8 \mathrm{~cm}$

DIAMETER AT BOTTOM OF RIM OR NECK: $10.3 \mathrm{~cm}$

BASE DIAMETER: $4.2 \mathrm{~cm}$

ESTIMATED VOLUME: 0.4 liters

DECORATION: The vessel has eight engraved rectangular panels enclosed between upper and lower horizontal engraved lines under the lip and at the vessel carination. Each panel is defined by two vertical engraved lines, and there are two sets of small hatched triangles at the top and bottom of each vertical line (Vessel 41CE4-5).

TYPE: Poynor Engraved, var. Blackburn

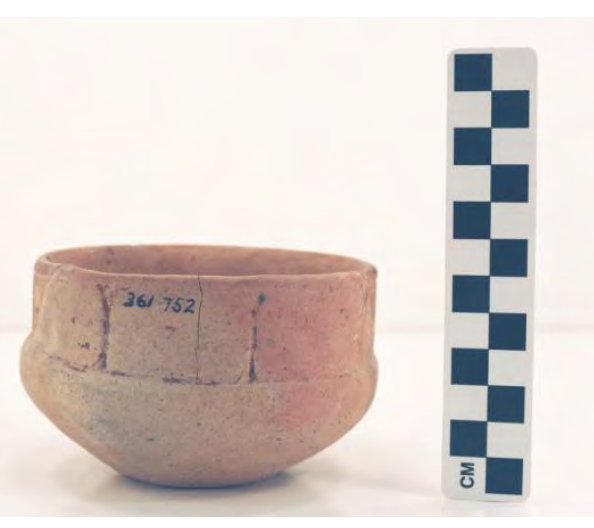

Vessel 41CE4-5. 
SITE NO.: 41CE4

FEATURE: Burial AI-2

VESSEL NO.: 41CE4-9

NON-PLASTICS: grog, hematite, and bone

VESSEL FORM: Carinated bowl with an inverted rim and a rounded lip; the lip is punctated

CORE COLOR: A (fired and cooled in a high oxygen environment); pinkware

WALL THICKNESS: $7.7 \mathrm{~mm}$

INTERIOR SURFACE TREATMENT: burnished

EXTERIOR SURFACE TREATMENT: smoothed

HEIGHT: $19.7 \mathrm{~cm}$

ORIFICE DIAMETER: $32.0 \mathrm{~cm}$

DIAMETER AT BOTTOM OF RIM OR NECK: $35.0 \mathrm{~cm}$

BASE DIAMETER: $6.0 \mathrm{~cm}$

ESTIMATED VOLUME: 5.6 liters

DECORATION: The rim has 10 negative oval engraved panels defined by hour glassshaped excised elements that extend from the rim to the vessel carination. There is a single row of tool punctations on the side of the vessel lip. The vessel body has diagonal brushing marks (Vessel 41CE4-9).

TYPE: Poynor Engraved, var. Hood

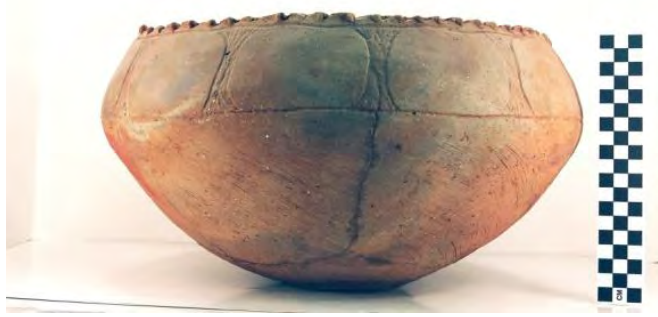

Vessel 41CE4-9. 
SITE NO.: 41CE4

FEATURE: Burial AI-2

VESSEL NO.: 41CE4-10

NON-PLASTICS: grog and hematite

VESSEL FORM: Carinated bowl with an inverted rim and a rounded lip; two sets of conjoined lip tabs

CORE COLOR: Undetermined

WALL THICKNESS: $8.9 \mathrm{~mm}$

INTERIOR SURFACE TREATMENT: smoothed

EXTERIOR SURFACE TREATMENT: burnished

HEIGHT: $13.5 \mathrm{~cm}$

ORIFICE DIAMETER: $24.0 \mathrm{~cm}$

DIAMETER AT BOTTOM OF RIM OR NECK: $26.0 \mathrm{~cm}$

BASE DIAMETER: $8.0 \mathrm{~cm}$

ESTIMATED VOLUME: 2.6 liters

DECORATION: There are vertical cross-hatched engraved panels on the rim, underneath the lip tabs, and three other narrow vertical cross-hatched panels between each of the main vertical panels. The vessel body has overlapping brushing marks (Vessel 41CE4$10)$.

TYPE: Undetermined engraved vessel, but Suhm and Jelks (1962: Plate 42f) classify it as Hume Engraved, apparently because of the vertical engraved panels.

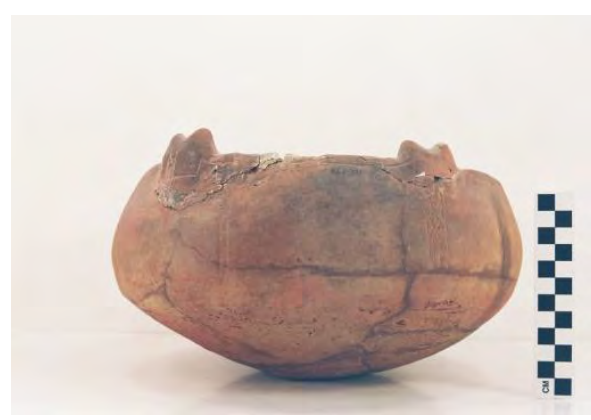

Vessel 41CE4-10. 
SITE NO.: 41CE4

FEATURE: Burial AI-2

VESSEL NO.: 41CE4-11

NON-PLASTICS: grog and hematite

VESSEL FORM: Carinated bowl with an inverted rim and a rounded lip

CORE COLOR: C (incompletely oxidized during firing)

WALL THICKNESS: $6.2 \mathrm{~mm}$, body

INTERIOR SURFACE TREATMENT: none

EXTERIOR SURFACE TREATMENT: smoothed on the rim

HEIGHT: est. 13-14 cm

ORIFICE DIAMETER: $23.0 \mathrm{~cm}$

DIAMETER AT BOTTOM OF RIM OR NECK: $25.0 \mathrm{~cm}$

BASE DIAMETER: $6.5 \mathrm{~cm}$

ESTIMATED VOLUME: est. 2.4 liters

DECORATION: The vessel section represented is the lower portion of a carinated bowl; the body is plain (Vessel 41CE4-11)

TYPE: Undetermined type, probably an engraved fine ware

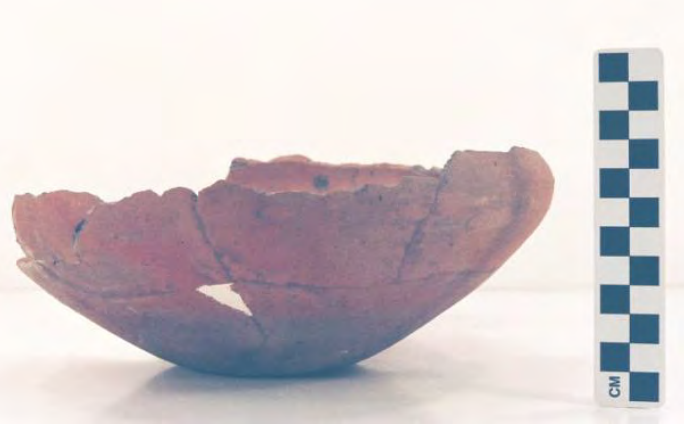

Vessel 41CE4-11. 
SITE NO.: 41CE4

FEATURE: Burial AI-3

VESSEL NO.: 41CE4-20

NON-PLASTICS: grog; sandy paste

VESSEL FORM: Bottle with a short neck, an elongated body, a direct rim, and a rounded lip (Vessel 41CE4-20)

CORE COLOR: A (fired and cooled in the open air)

WALL THICKNESS: $5.1 \mathrm{~mm}$

INTERIOR SURFACE TREATMENT: none

EXTERIOR SURFACE TREATMENT: smoothed

HEIGHT: $17.2 \mathrm{~cm}$

ORIFICE DIAMETER: $3.5 \mathrm{~cm}$ at the neck

DIAMETER AT BOTTOM OF RIM OR NECK: $8.6 \mathrm{~cm}$ on the body

BASE DIAMETER: $6.2 \mathrm{~cm}$

ESTIMATED VOLUME: 0.4 liters

DECORATION: Plain

TYPE: cf. Hume Plain

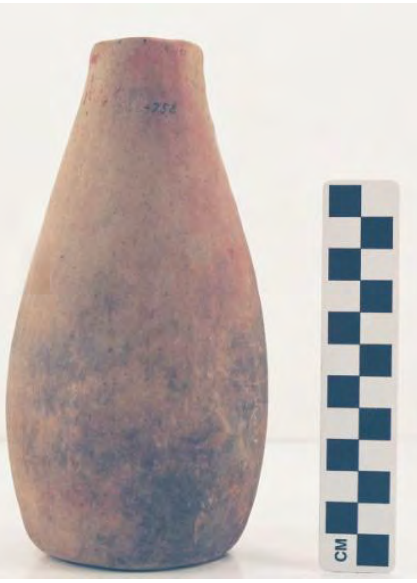

Vessel 41CE4-20. 
SITE NO.: 41CE4

FEATURE: Burial AI-3

VESSEL NO.: 41CE4-21

NON-PLASTICS: hematite; sandy paste

VESSEL FORM: Bottle with a very short neck, an elongated body, a direct rim, and a flat lip

CORE COLOR: A (fired and cooled in a high oxygen environment)

WALL THICKNESS: $7.4 \mathrm{~mm}$

INTERIOR SURFACE TREATMENT: none

EXTERIOR SURFACE TREATMENT: smoothed

HEIGHT: $29.0 \mathrm{~cm}$

ORIFICE DIAMETER: $4.8 \mathrm{~cm}$, neck

DIAMETER AT BOTTOM OF RIM OR NECK: $12.4 \mathrm{~cm}$ on the body

BASE DIAMETER: $8.0 \mathrm{~cm}$

ESTIMATED VOLUME: 0.9 liters

DECORATION: The bottle is decorated only on the rim of the bottle neck. The decoration consists of three horizontal engraved lines, with 25 small pendant triangles on the lowermost horizontal engraved line (Vessel 41CE4-21). A red clay pigment was rubbed in the engraved lines

TYPE: Hume Engraved

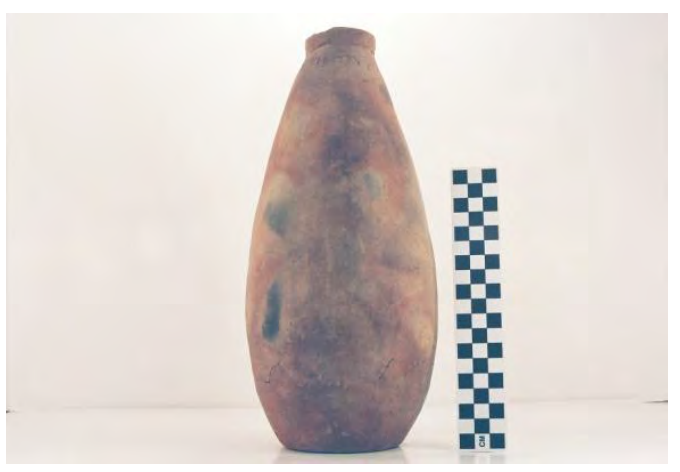

Vessel 41CE4-21, Hume Engraved. 
SITE NO.: 41CE4

FEATURE: Burial AI-3

VESSEL NO.: 41CE4-22

NON-PLASTICS: grog, hematite, and bone; sandy paste

VESSEL FORM: Bottle with a very short neck, an elongated body, a direct rim, and a rounded lip

CORE COLOR: Undetermined

WALL THICKNESS: $6.3 \mathrm{~mm}$, neck

INTERIOR SURFACE TREATMENT: none

EXTERIOR SURFACE TREATMENT: smoothed

HEIGHT: $21.0 \mathrm{~cm}$

ORIFICE DIAMETER: $4.4 \mathrm{~cm}$, neck

DIAMETER AT BOTTOM OF RIM OR NECK: $9.7 \mathrm{~cm}$ on the vessel body

BASE DIAMETER: $6.5 \mathrm{~cm}$

ESTIMATED VOLUME: 0.6 liters

DECORATION: The bottle is decorated only on the vessel body. The decoration consists of two horizontal engraved lines, one at the neck-body juncture, and the second immediately below the neck-body juncture. There are 28 hatched pendant triangles on the second horizontal engraved line (Vessel 41CE4-22). A red clay pigment has been rubbed in the engraved lines.

TYPE: Hume Engraved

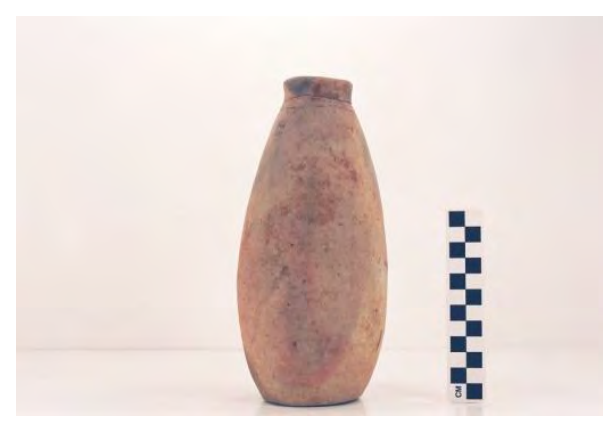

Vessel 41CE4-22. 
SITE NO.: 41CE4

FEATURE: Burial AI-3

VESSEL NO.: 41CE4-23

NON-PLASTICS: grog and bone

VESSEL FORM: Carinated bowl with an inverted rim and a rounded lip

CORE COLOR: A (fired and cooled in the open air); pinkware

WALL THICKNESS: $7.6 \mathrm{~mm}$

INTERIOR SURFACE TREATMENT: burnished

EXTERIOR SURFACE TREATMENT: burnished

HEIGHT: $20.5 \mathrm{~cm}$

ORIFICE DIAMETER: $30.5 \mathrm{~cm}$

DIAMETER AT BOTTOM OF RIM OR NECK: $32.5 \mathrm{~cm}$

BASE DIAMETER: $8.0 \mathrm{~cm}$

ESTIMATED VOLUME: 5.6 liters

DECORATION: There are 10 rectangular engraved panels on the rim between upper and lower horizontal engraved lines under the lip and at the vessel carination. Each panel is defined by two excised hour glass-shaped zones that extend from near the rim to the vessel carination. The lip of the vessel also has regular notching (Vessel 41CE4-23). The vessel body is diagonally brushed.

TYPE: Poynor Engraved, var. Hood

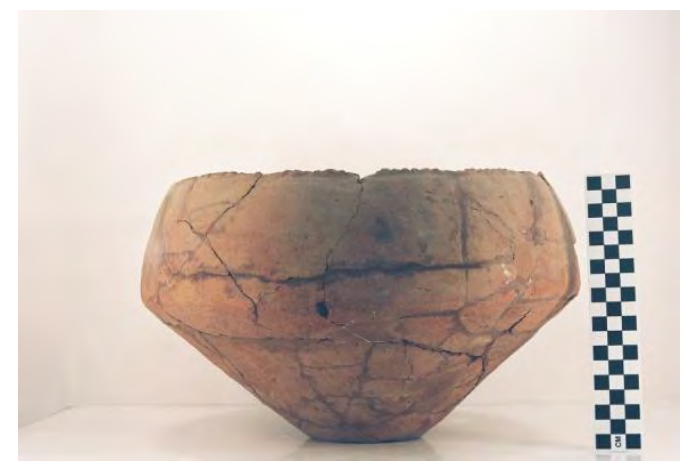

Vessel 41CE4-23. 
SITE NO.: 41CE4

FEATURE: Burial AI-3

VESSEL NO.: 41CE4-24

NON-PLASTICS: grog, bone, and hematite

VESSEL FORM: Globular carinated bowl with a short, direct, rim and a rounded lip

CORE COLOR: A (fired and cooled in a high oxygen environment)

WALL THICKNESS: $6.3 \mathrm{~mm}$

INTERIOR SURFACE TREATMENT: smoothed on the rim

EXTERIOR SURFACE TREATMENT: none

HEIGHT: $14.7 \mathrm{~cm}$

ORIFICE DIAMETER: $15.2 \mathrm{~cm}$

DIAMETER AT BOTTOM OF RIM OR NECK: $15.2 \mathrm{~cm}$

BASE DIAMETER: $7.0 \mathrm{~cm}$

ESTIMATED VOLUME: 2.0 liters

DECORATION: The rim has upper and lower large hatched engraved pendant triangles on the upper rim and at the vessel carination, with the apex of each row of triangles pointing at the other row of pendant triangles (Vessel 41CE4-24).

TYPE: Poynor Engraved, var. $C$ in the upper Neches River basin

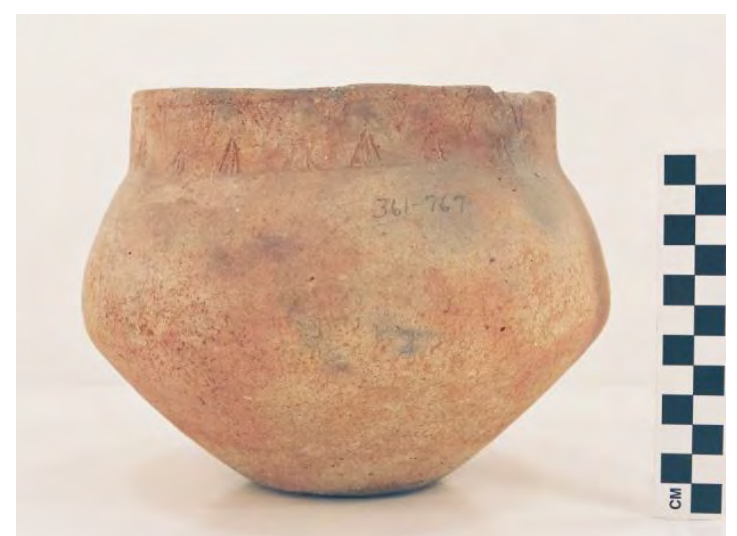

Vessel 41CE4-24. 
SITE NO.: 41CE4

FEATURE: Burial AI-3

VESSEL NO.: 41CE4-25

NON-PLASTICS: grog, bone, and hematite

VESSEL FORM: Carinated bowl with an inverted rim and a rounded lip

CORE COLOR: Undetermined

WALL THICKNESS: $7.9 \mathrm{~mm}$

INTERIOR SURFACE TREATMENT: smoothed

EXTERIOR SURFACE TREATMENT: smoothed

HEIGHT: $17.7 \mathrm{~cm}$

ORIFICE DIAMETER: $26.8 \mathrm{~cm}$

DIAMETER AT BOTTOM OF RIM OR NECK: $28.6 \mathrm{~cm}$

BASE DIAMETER: $8.0 \mathrm{~cm}$

ESTIMATED VOLUME: $4.3 \mathrm{~cm}$

DECORATION: There are eight narrow vertical panels on the vessel rim. Half have nearly vertical engraved arcs of closely-spaced engraved lines, while the others have an arc of closely-spaced engraved lines around a partial oval area containing two sets of short diagonal lines. The vessel body has opposed and diagonal brushing marks (Vessel 41CE4-25).

TYPE: Poynor Engraved, var. Cook?

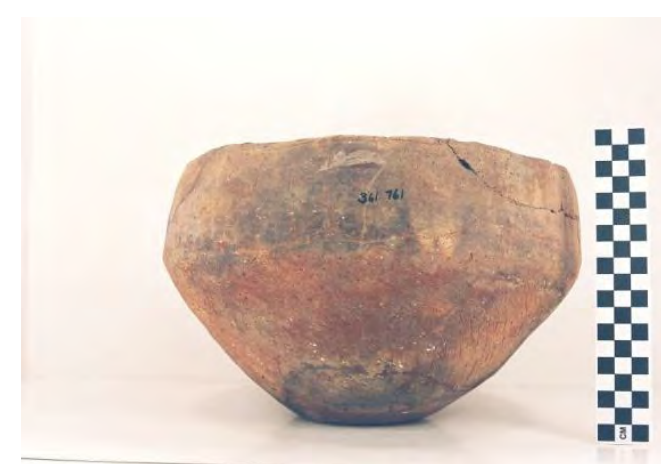

Vessel 41CE4-25. 
SITE NO.: 41CE4

FEATURE: Burial AI-3

VESSEL NO.: 41CE4-26

NON-PLASTICS: grog and hematite

VESSEL FORM: Carinated bowl with an inverted rim and a rounded lip

CORE COLOR: Undetermined

WALL THICKNESS: $6.4 \mathrm{~mm}$

INTERIOR SURFACE TREATMENT: smoothed on the rim

EXTERIOR SURFACE TREATMENT: burnished

HEIGHT: $20.3 \mathrm{~cm}$

ORIFICE DIAMETER: $30.5 \mathrm{~cm}$

DIAMETER AT BOTTOM OF RIM OR NECK: $32.0 \mathrm{~cm}$

BASE DIAMETER: $9.0 \mathrm{~cm}$

\section{ESTIMATED VOLUME: 5.5 liters}

DECORATION: There are eight engraved ovals in a panel on the rim, and the rim is encircled with horizontal engraved lines under the lip and at the vessel carination (Vessel 41CE4-26). The panels are defined by two hour glass-shaped engraved elements that are either excised/hatched or have hatched triangular areas at the top and bottom of the hour glass. The lip also is notched, and the body of the vessel has horizontal brushing marks.

TYPE: Poynor Engraved, var. Hood

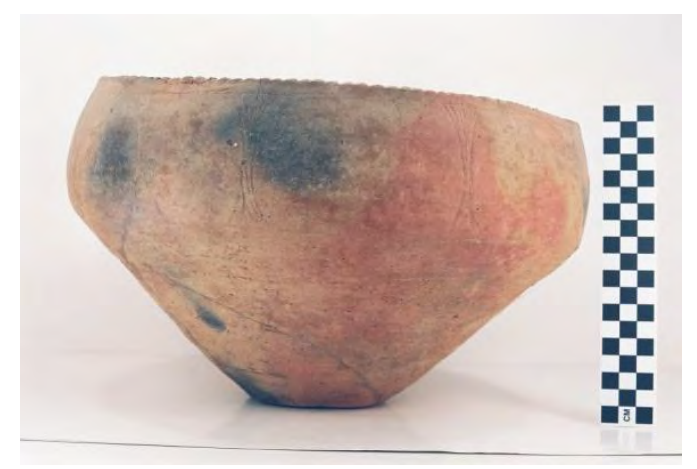

Vessel 41CE4-26. 
SITE NO.: 41CE4

FEATURE: Burial AI-4

VESSEL NO.: 41CE4-50

NON-PLASTICS: grog

VESSEL FORM: Bowl with a direct rim and a rounded lip; bird head effigy at one end of the vessel, and the associated tab tail at the other end has been broken away

CORE COLOR: F (fired in a reducing environment, but cooled in the open air); pinkware

WALL THICKNESS: $6.9 \mathrm{~mm}$

INTERIOR SURFACE TREATMENT: smoothed on the rim

EXTERIOR SURFACE TREATMENT: smoothed

HEIGHT: $10.2 \mathrm{~cm}$

ORIFICE DIAMETER: $20.5 \mathrm{~cm}$

DIAMETER AT BOTTOM OF RIM OR NECK: N/A

BASE DIAMETER: $12.0 \mathrm{~cm}$

ESTIMATED VOLUME: 0.8 liters

DECORATION: Four widely spaced horizontal engraved lines on the upper part of the vessel (Vessel 41CE4-50)

TYPE: Hood Engraved, var. Hood effigy vessel

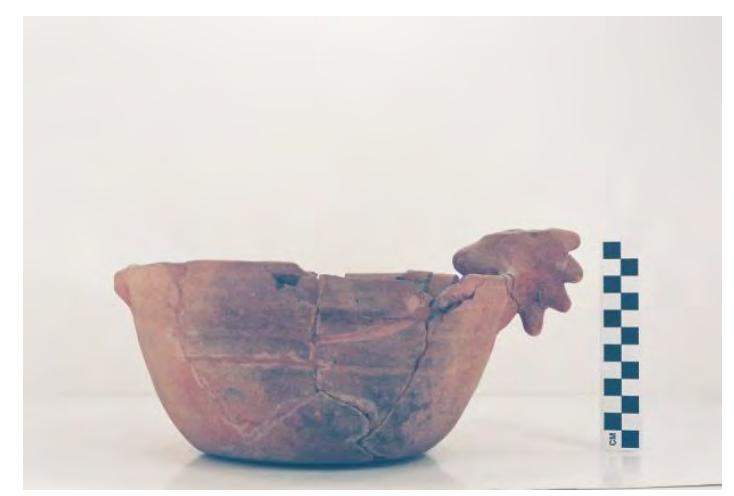

Vessel 41CE4-50. 
SITE NO.: 41CE4

FEATURE: Burial AI-4

VESSEL NO.: 41CE4-51

NON-PLASTICS: grog and hematite

VESSEL FORM: Bottle with a short neck, an elongated body, a direct rim, and a rounded, exterior folded lip (Vessel 41CE4-51)

CORE COLOR: Undetermined

WALL THICKNESS: $5.9 \mathrm{~mm}$

INTERIOR SURFACE TREATMENT: none

EXTERIOR SURFACE TREATMENT: smoothed

HEIGHT: $20.5 \mathrm{~cm}$

ORIFICE DIAMETER:3.7 $\mathrm{cm}$ at the neck

DIAMETER AT BOTTOM OF RIM OR NECK: $7.9 \mathrm{~cm}$ on the vessel body

BASE DIAMETER: $6.9 \mathrm{~cm}$

ESTIMATED VOLUME: 0.6 liters

DECORATION: plain

TYPE: cf. Hume Plain

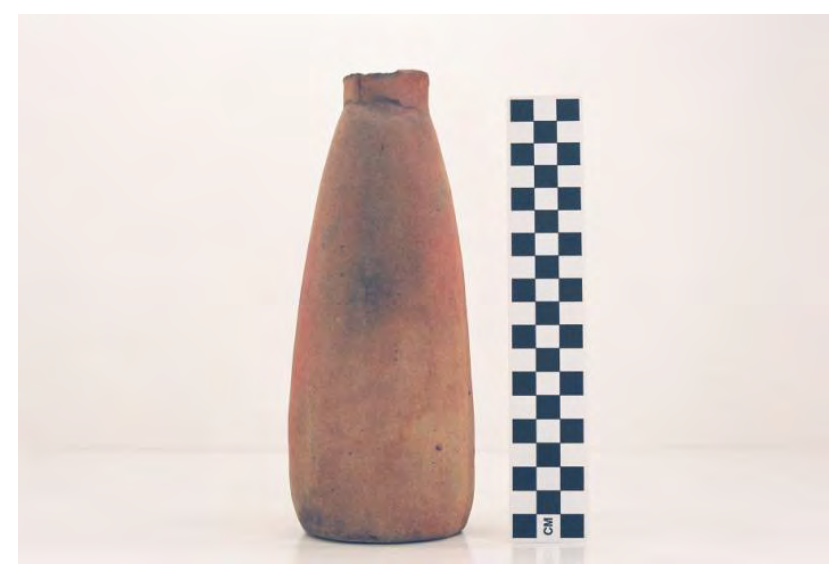

Vessel 41CE4-51. 
SITE NO.: 41CE4

FEATURE: Burial AI-4

VESSEL NO.: 41CE4-53

NON-PLASTICS: grog and hematite

VESSEL FORM: Bottle with a very short neck, an elongated body, a direct rim, and a rounded lip

CORE COLOR: A (fired and cooled in an oxidizing environment); pinkware

WALL THICKNESS: $5.1 \mathrm{~mm}$, neck

INTERIOR SURFACE TREATMENT: none

EXTERIOR SURFACE TREATMENT: smoothed

HEIGHT: $22.5 \mathrm{~cm}$

ORIFICE DIAMETER: $4.3 \mathrm{~cm}$ at the neck

DIAMETER AT BOTTOM OF RIM OR NECK: $11.1 \mathrm{~cm}$ on the vessel body

BASE DIAMETER: $6.8 \mathrm{~cm}$

ESTIMATED VOLUME: 0.6 liters

DECORATION: There are three vertical engraved panels on the vessel body, and single horizontal engraved lines that encircle the vessel at the juncture of the neck and body and the other near the vessel base (Vessel 41CE4-53). At the upper and lower intersection of the vertical panels with the horizontal engraved lines, there are small hatched triangles. A red clay pigment was rubbed in the engraved lines.

TYPE: Hume Engraved, var. unspecified

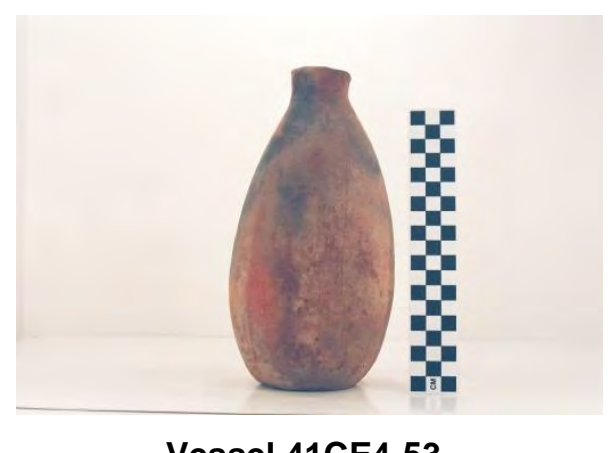

Vessel 41CE4-53. 
SITE NO.: 41CE4

FEATURE: Burial AI-4

VESSEL NO.: 41CE4-54-A

NON-PLASTICS: grog, hematite, and bone

VESSEL FORM: Globular carinated bowl with a direct to slightly everted rim and a rounded lip

CORE COLOR: Undetermined

WALL THICKNESS: $4.8 \mathrm{~mm}$

INTERIOR SURFACE TREATMENT: smoothed

EXTERIOR SURFACE TREATMENT: smoothed

HEIGHT: $11.5 \mathrm{~cm}$

ORIFICE DIAMETER: $13.7 \mathrm{~cm}$

DIAMETER AT BOTTOM OF RIM OR NECK: $13.8 \mathrm{~cm}$

BASE DIAMETER: $6.2 \mathrm{~cm}$

ESTIMATED VOLUME: 1.0 liters

DECORATION: There are seven oval-shaped engraved panels on the vessel rim, delimited by upper and lower (at the carination) horizontal engraved lines. Each panel is defined by two engraved hour glass-shaped elements that are filled with two or three curvilinear lines and a single pendant triangle on the lower horizontal engraved line (Vessel 41CE4-54A). A red clay pigment has been rubbed in the engraved lines.

TYPE: Poynor Engraved, var. Cook

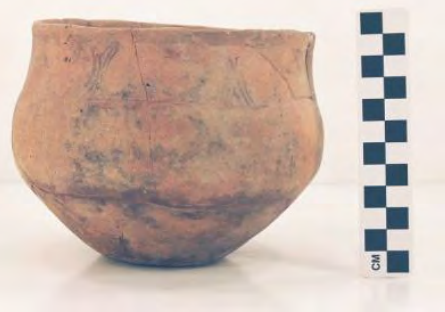

Vessel 41CE4-54A. 
SITE NO.: 41CE4

FEATURE: Burial AI-4

VESSEL NO.: 41CE4-54-B

NON-PLASTICS: grog and hematite

VESSEL FORM: Globular carinated bowl with a direct rim and a rounded lip

CORE COLOR: A (fired and cooled in an oxidizing environment)

WALL THICKNESS: $5.4 \mathrm{~mm}$

INTERIOR SURFACE TREATMENT: smoothed

EXTERIOR SURFACE TREATMENT: smoothed

HEIGHT: $8.8 \mathrm{~cm}$

ORIFICE DIAMETER: $11.0 \mathrm{~mm}$

DIAMETER AT BOTTOM OF RIM OR NECK: $12.8 \mathrm{~cm}$ on the vessel body

BASE DIAMETER: $5.8 \mathrm{~cm}$

ESTIMATED VOLUME: 0.6 liters

DECORATION: There are 11 rectangular engraved panels on the vessel rim. Each panel is defined by two sets of vertical engraved lines, each set comprised of three closelyspaced lines (Vessel 41CE4-54B).

TYPE: Poynor Engraved, var. Blackburn

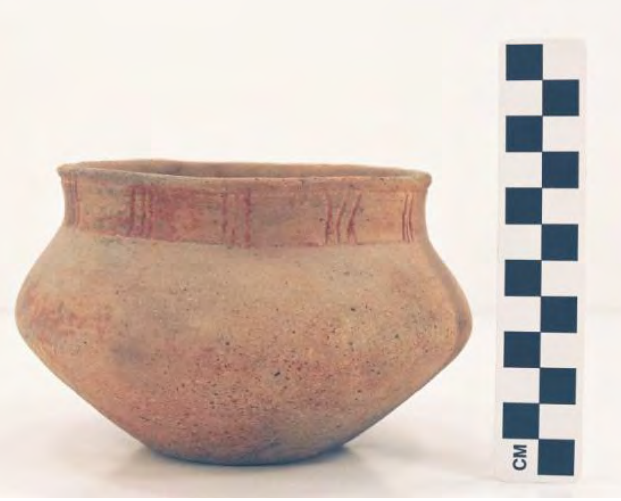

Vessel 41CE4-54B. 
SITE NO.: 41CE4

FEATURE: Burial AI-4

VESSEL NO.: 41CE4-55

NON-PLASTICS: grog, hematite, and bone

VESSEL FORM: Bottle with a very short neck, an elongated body, a direct rim, and a flat lip

CORE COLOR: A (fired and cooled in a high oxygen environment); pinkware

WALL THICKNESS: $6.7 \mathrm{~mm}$

INTERIOR SURFACE TREATMENT: none

EXTERIOR SURFACE TREATMENT: none

HEIGHT: $18.5 \mathrm{~cm}$

ORIFICE DIAMETER: $4.0 \mathrm{~cm}$ at the neck

DIAMETER AT BOTTOM OF RIM OR NECK: $10.3 \mathrm{~cm}$ on the vessel body

BASE DIAMETER: $6.4 \mathrm{~cm}$

ESTIMATED VOLUME: 0.5 liters

DECORATION: There are four vertical cross-hatched engraved panels on the vessel body; the neck is plain (Vessel 41CE4-55)

TYPE: Hume Engraved, var. Hume

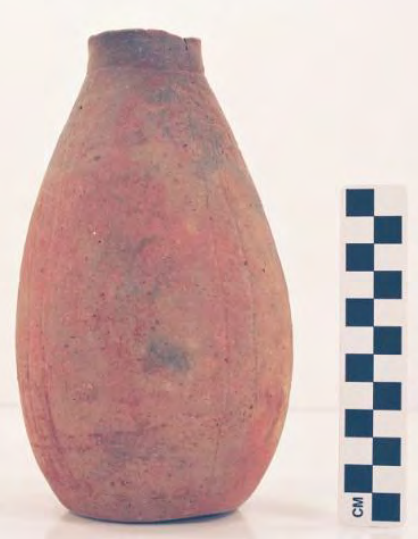

Vessel 41CE4-55. 
SITE NO.: 41CE4

FEATURE: Burial AI-4

VESSEL NO.: 41CE4-56

NON-PLASTICS: grog and bone

VESSEL FORM: Small globular carinated bowl with a direct rim and a rounded lip

CORE COLOR: Undetermined

WALL THICKNESS: $3.7 \mathrm{~mm}$

INTERIOR SURFACE TREATMENT: smoothed on the rim

EXTERIOR SURFACE TREATMENT: smoothed on the rim

HEIGHT: $5.7 \mathrm{~cm}$

ORIFICE DIAMETER: $7.0 \mathrm{~cm}$

DIAMETER AT BOTTOM OF RIM OR NECK: $7.5 \mathrm{~cm}$

BASE DIAMETER: $2.5 \mathrm{~cm}$

ESTIMATED VOLUME: 0.25 liters

DECORATION: The rim has an engraved panel with upper and lower hatched pendant ovals and an occasional engraved pendant triangle. The ovals are hatched with either one or two engraved lines (Vessel 41CE4-56). A red clay pigment has been rubbed in the engraved lines.

TYPE: Poynor Engraved, var. $C$ in the upper Neches River basin? The addition of hatched pendant ovals is what differentiates this vessel from other var. $C$ vessels.

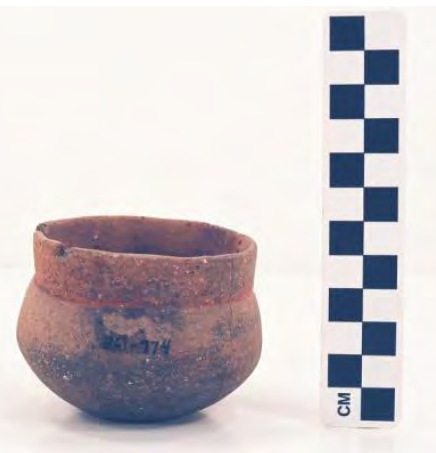

Vessel 41CE4-56. 
SITE NO.: 41CE4

FEATURE: Burial AI-4

VESSEL NO.: 41CE4-57

NON-PLASTICS: bone and grog

VESSEL FORM: Jar with an everted rim and a rounded lip, two strap handles, and a ring base with three legs

CORE COLOR: Undetermined

WALL THICKNESS: $5.1 \mathrm{~mm}$, rim

INTERIOR SURFACE TREATMENT: smoothed

EXTERIOR SURFACE TREATMENT: none

HEIGHT: $8.0 \mathrm{~cm}$

ORIFICE DIAMETER: $7.3 \mathrm{~cm}$

DIAMETER AT BOTTOM OF RIM OR NECK: $7.9 \mathrm{~cm}$ on the vessel body

BASE DIAMETER: $7.0 \mathrm{~cm}$ for the ring base

ESTIMATED VOLUME: 0.35 liters

DECORATION: There are three rows of tool punctations on the rim. The body has five or six concentric circles of pinching that are repeated four times around the vessel, and the ring base legs have six vertical rows of pinching (Vessel 41CE4-57).

TYPE: Killough Pinched

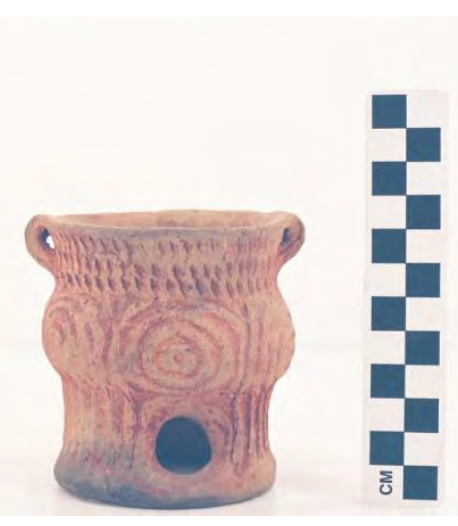

Vessel 41CE4-57, Killough Pinched. 
SITE NO.: 41CE4

FEATURE: Burial AI-5

VESSEL NO.: 41CE4-59

NON-PLASTICS: grog; sandy paste

VESSEL FORM: Jar with a direct rim and a rounded lip. The vessel also has two lug/strap handles formed by punching a hole through the lug handle to create the strap (Vessel 41CE4-59a); the handle was not formed by a separate handle attachment onto the vessel itself.

CORE COLOR: B (fired and cooled in a reducing environment)

WALL THICKNESS: $4.9 \mathrm{~mm}$

INTERIOR SURFACE TREATMENT: smoothed

EXTERIOR SURFACE TREATMENT: none

HEIGHT: $4.8 \mathrm{~cm}$

ORIFICE DIAMETER: $5.6 \mathrm{~cm}$

DIAMETER AT BOTTOM OF RIM OR NECK:

BASE DIAMETER: $4.3 \mathrm{~cm}$

ESTIMATED VOLUME: 0.2 liters

DECORATION: There are five sets of vertical pinched ridges that begin on the vessel rim and extend to the vessel base (Vessel 41CE4-59a-b). Four of the ridges are comprised of three closely-spaced pinched ridges, while the other set has two rows of pinching.

TYPE: Killough Pinched
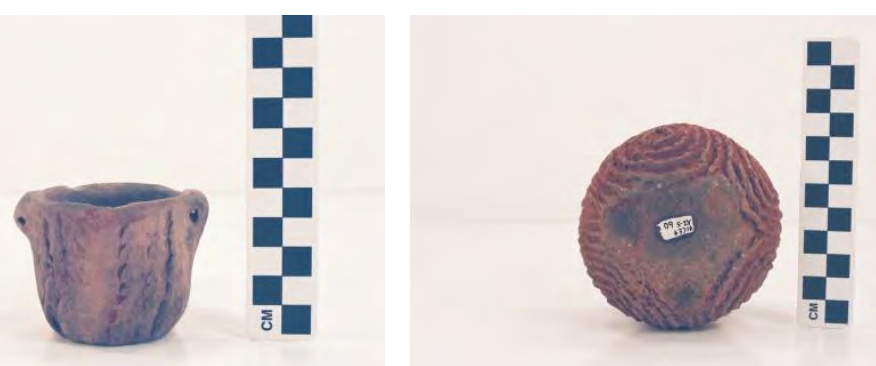

Vessel 41CE4-59:a, side view; b, view of the base and lower body. 
SITE NO.: 41CE4

FEATURE: Burial AI-5

VESSEL NO.: 41CE4-60

NON-PLASTICS: grog and bone

VESSEL FORM: Jar with a direct rim and a rounded lip, two small strap handles, and an area for the attachment of three legs and a ring base; the ring base is missing

CORE COLOR: Undetermined

WALL THICKNESS: $4.6 \mathrm{~mm}$

INTERIOR SURFACE TREATMENT: none

EXTERIOR SURFACE TREATMENT: none

HEIGHT: $6.8 \mathrm{~cm}$; ring base height undetermined

ORIFICE DIAMETER: $7.7 \mathrm{~cm}$

DIAMETER AT BOTTOM OF RIM OR NECK: $8.9 \mathrm{~cm}$

BASE DIAMETER: $4.8 \mathrm{~cm}$

ESTIMATED VOLUME: 0.3 liters

DECORATION: The rim has vertical pinched rows, with four concentric circles of pinching on the vessel body (Vessel 41CE4-60)

TYPE: Killough Pinched

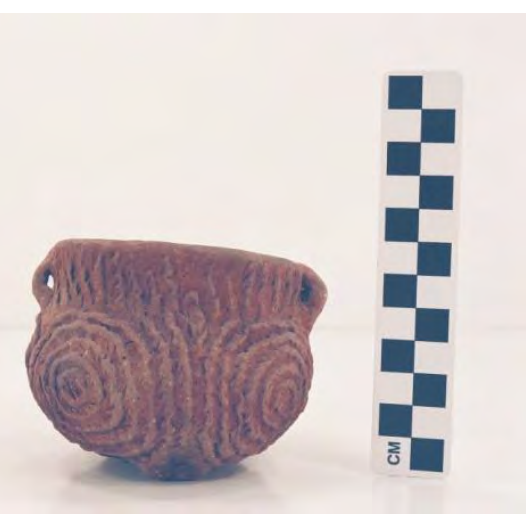

Vessel 41CE4-60. 
SITE NO.: 41CE4

FEATURE: AI-5

VESSEL NO.: 41CE4-61

NON-PLASTICS: grog, bone, and hematite

VESSEL FORM: Globular carinated bowl with a direct rim and a rounded lip

CORE COLOR: Undetermined

WALL THICKNESS: $6.3 \mathrm{~mm}$

INTERIOR SURFACE TREATMENT: smoothed

EXTERIOR SURFACE TREATMENT: smoothed

HEIGHT: $13.4 \mathrm{~cm}$

ORIFICE DIAMETER: $17.6 \mathrm{~cm}$

DIAMETER AT BOTTOM OF RIM OR NECK: $17.6 \mathrm{~cm}$

BASE DIAMETER: $5.5 \mathrm{~cm}$

ESTIMATED VOLUME: 2.1 liters

DECORATION: The rim has 16 rectangular engraved panels. Each panel is defined by upper and lower horizontal engraved lines that encircle the vessel and two vertical lines, one on either side of the panel (Vessel 41CE4-61). The vertical engraved lines have hatched triangles at the top and bottom of the lines where they intersect the encircling horizontal engraved lines.

TYPE: Poynor Engraved, var. Blackburn

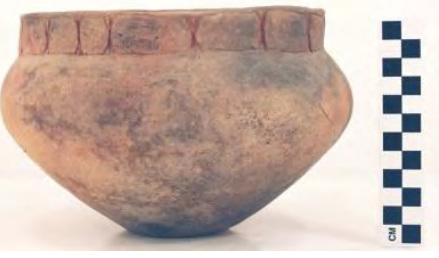

Vessel 41CE4-61. 


\section{Omer and Otis Hood Site (41CE14)}

SITE NO.: 41CE14

FEATURE: Burial AQ-1 (burials with the AQ prefix are from cemetery \#1)

VESSEL NO.: 41CE14-1

NON-PLASTICS: grog and hematite

VESSEL FORM: Bottle with a short neck, a globular body, and direct rim; the lip is broken away

CORE COLOR: F (fired in a reducing environment, but cooled in the open air)

WALL THICKNESS: $5.1 \mathrm{~mm}$

INTERIOR SURFACE TREATMENT: none

EXTERIOR SURFACE TREATMENT: burnished

HEIGHT: $21.5 \mathrm{~cm}+$

ORIFICE DIAMETER: $4.0 \mathrm{~cm}$ at the neck

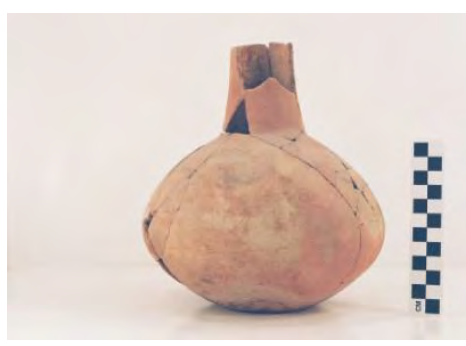

Vessel 41CE14-1.

DIAMETER AT BOTTOM OF RIM OR NECK: $6.4 \mathrm{~cm}$

BASE DIAMETER: $7.5 \mathrm{~cm}$

ESTIMATED VOLUME: $0.6+$ liters

DECORATION: The vessel body is decorated with engraved designs; the design-filled area begins at the base of the bottle neck and extends three-quarters of the way to the vessel base. The first motif, repeated three times, is comprised of hour glass-shaped elements with two (upper and lower) negative circles (Vessel 41CE14-1). The hour glass is filled with hatched lines and small triangular areas. The second motif, also repeated three times, is comprised of three stacked hatched triangles attached to a set of three closely-spaced vertical engraved lines. There is another set of four closely-spaced vertical engraved lines between the stacked triangles motif and the negative circles motif.

TYPE: Poynor Engraved, related to the var. Hood defined on carinated bowls 
SITE NO.: 41CE14

FEATURE: Burial AR-1 (burials with the AR prefix are from cemetery \#2)

VESSEL NO:: 41CE14-2

NON-PLASTICS: grog

VESSEL FORM: Carinated bowl with an inverted rim and a rounded lip (Vessel 41CE14-2)

CORE COLOR: Undetermined

WALL THICKNESS: $4.6 \mathrm{~mm}$

INTERIOR SURFACE TREATMENT: smoothed

EXTERIOR SURFACE TREATMENT: smoothed

HEIGHT: $7.3 \mathrm{~cm}$

ORIFICE DIAMETER: $11.7 \mathrm{~cm}$

DIAMETER AT BOTTOM OF RIM OR NECK: $12.2 \mathrm{~cm}$

BASE DIAMETER: $8.1 \mathrm{~cm}$

ESTIMATED VOLUME: 0.5 liters

DECORATION: plain

TYPE: cf. Poynor Plain

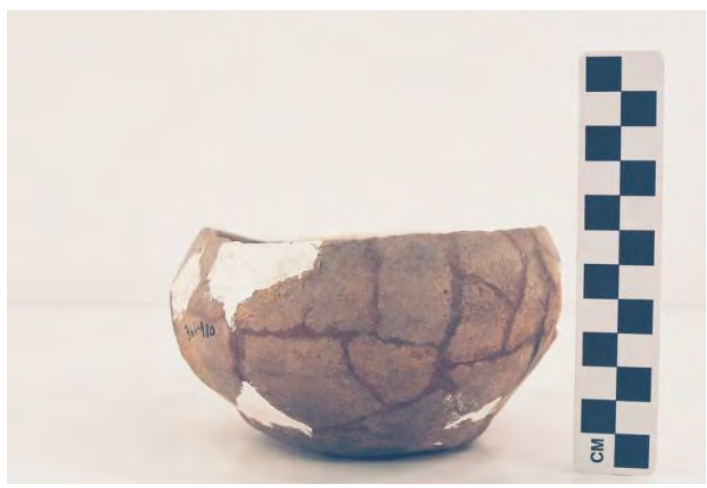

Vessel 41CE14-2, Burial AR-1. 
SITE NO.:41CE14

FEATURE: Burial AQ-1

VESSEL NO.: 41CE14-2

NON-PLASTICS: grog, bone, and hematite

VESSEL FORM: Globular carinated bowl with a direct rim and a rounded lip

CORE COLOR: A (fired and cooled in an oxidizing environment)

WALL THICKNESS: $6.3 \mathrm{~mm}$, rim; $7.1 \mathrm{~mm}$, body

INTERIOR SURFACE TREATMENT: smoothed on the rim

EXTERIOR SURFACE TREATMENT: burnished

HEIGHT: $13.8 \mathrm{~cm}$

ORIFICE DIAMETER: $15.3 \mathrm{~cm}$

DIAMETER AT BOTTOM OF RIM OR NECK: $15.1 \mathrm{~cm}$

BASE DIAMETER: $9.3 \mathrm{~cm}$

ESTIMATED VOLUME: 1.8 liters

DECORATION: The rim has nine engraved negative oval-shaped panels between upper and lower horizontal engraved lines (Vessel 41CE14-2). Each panel is defined by two hour glass-shaped zones filled with five straight and curvilinear engraved lines.

TYPE: Poynor Engraved, var. Hood

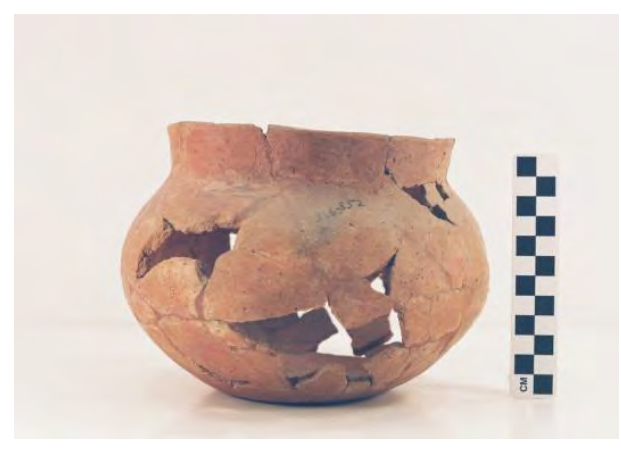

Vessel 41CE14-2, Burial AQ-1. 
SITE NO.: 41CE14

FEATURE: Burial AQ-1

VESSEL NO.: 41CE14-3

NON-PLASTICS: grog

VESSEL FORM: Globular carinated bowl with a direct rim and a rounded lip

CORE COLOR: A (fired and cooled in an oxidizing environment)

WALL THICKNESS: $5.1 \mathrm{~mm}$

INTERIOR SURFACE TREATMENT: smoothed

EXTERIOR SURFACE TREATMENT: burnished

HEIGHT: $10.0 \mathrm{~cm}$

ORIFICE DIAMETER: $13.4 \mathrm{~cm}$

DIAMETER AT BOTTOM OF RIM OR NECK: $14.0 \mathrm{~cm}$

BASE DIAMETER: $8.0 \mathrm{~cm}$

ESTIMATED VOLUME: $0.8 \mathrm{~cm}$

DECORATION: There is a horizontal decorated zone on the vessel body filled with five engraved semi-circles; the rim is plain. Each of these semi-circles has a small central engraved circle partially filled with a few engraved punctates (Vessel 41CE14-3). The semi-circles are divided by engraved hour glass-shaped zones comprised of arcing lines and hatched pendant triangles at the upper and lower ends of the hour glass. In one instance, the semi-circles are divided by only one hour glass, others are divided by two or three hour glass-shaped zones, and two semi-circles are divided by four hour glassshaped zones.

TYPE: Poynor Engraved, var. Lang

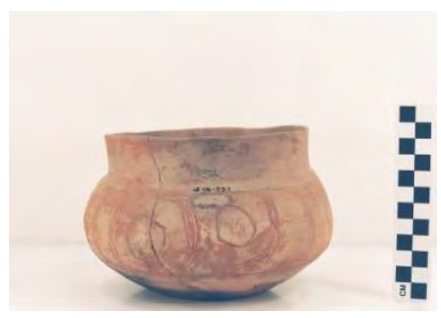

Vessel 41CE14-3. 
SITE NO.: 41CE14

FEATURE: Burial AR-1

VESSEL NO.: 41CE14-4

NON-PLASTICS: grog

VESSEL FORM: Carinated bowl with an everted rim and a rounded, exterior folded lip

CORE COLOR: A (fired and cooled in an oxidizing environment)

WALL THICKNESS: $7.2 \mathrm{~mm}$

INTERIOR SURFACE TREATMENT: burnished

EXTERIOR SURFACE TREATMENT: burnished

HEIGHT: $9.5 \mathrm{~cm}$

ORIFICE DIAMETER: $18.3 \mathrm{~cm}$

DIAMETER AT BOTTOM OF RIM OR NECK: $16.3 \mathrm{~cm}$

BASE DIAMETER: $6.8 \mathrm{~cm}$

ESTIMATED VOLUME: $1.4 \mathrm{~cm}$

DECORATION: The wide rim has continuous vertical and horizontal interlocking engraved scrolls with no central engraved element (Vessel 41CE4-4). Each of the vertical and horizontal engraved scroll elements have hatched triangles, and there are several rectangular elements with either hatched corners or negative circles within them that are defined by hatched zones.

TYPE: Poynor Engraved, var. $B$ in the upper Neches River basin

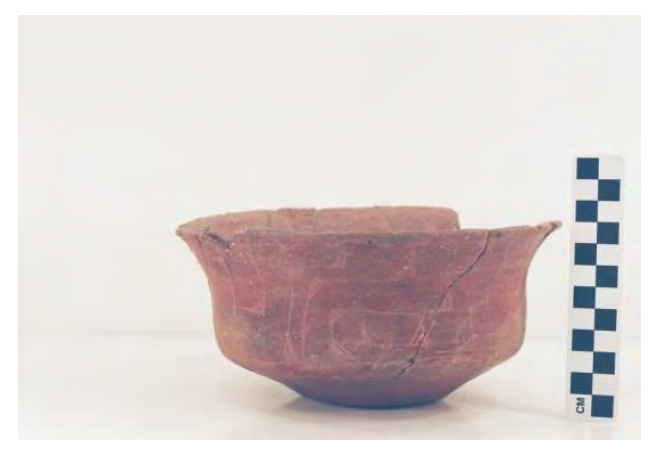

Vessel 41CE4-4, Burial AR-1. 
SITE NO.: 41CE14

FEATURE: Burial AQ-1

VESSEL NO.: 41CE14-4

NON-PLASTICS: none apparent

VESSEL FORM: Globular carinated bowl with a direct rim and a rounded, exterior folded lip

CORE COLOR: C (incompletely oxidized during firing)

WALL THICKNESS: $4.8 \mathrm{~mm}$

INTERIOR SURFACE TREATMENT: burnished

EXTERIOR SURFACE TREATMENT: burnished

HEIGHT: $12.0 \mathrm{~cm}$

ORIFICE DIAMETER: $14.0 \mathrm{~cm}$

DIAMETER AT BOTTOM OF RIM OR NECK: $14.5 \mathrm{~cm}$

BASE DIAMETER: $9.5 \mathrm{~cm}$

ESTIMATED VOLUME: 1.0 liters

DECORATION: The rim has an engraved design comprised of alternating panels of five negative ovals and five rectangles (Vessel 41CE14-4). Each panel is defined by upper and lower horizontal engraved lines that encircle the vessel, and two hour glass-shaped hatched areas that extend from the rim to the vessel carination.

TYPE: Poynor Engraved, var. Hood

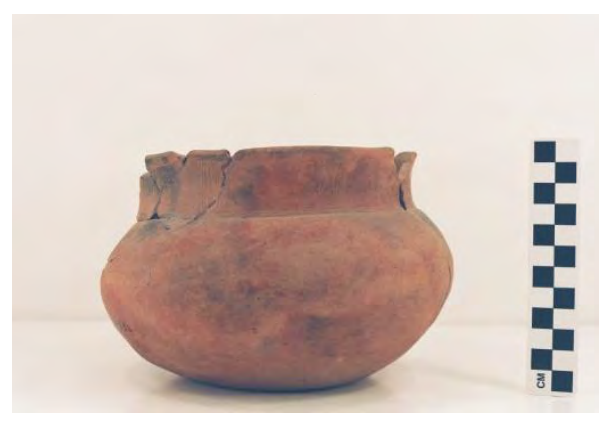

Vessel 41CE14-4, Burial AQ-1. 
SITE NO.: 41CE14

FEATURE: AQ-2

VESSEL NO.: 41CE14-5

NON-PLASTICS: none apparent

VESSEL FORM: Carinated bowl with an inverted rim and a rounded lip

CORE COLOR: C (incompletely oxidized during firing)

WALL THICKNESS: $7.2 \mathrm{~mm}$

INTERIOR SURFACE TREATMENT: smoothed

EXTERIOR SURFACE TREATMENT: burnished

HEIGHT: estimated at $18.0 \mathrm{~cm}$

ORIFICE DIAMETER: $28.0 \mathrm{~cm}$

DIAMETER AT BOTTOM OF RIM OR NECK: $31.5 \mathrm{~cm}$

BASE DIAMETER: $10.0 \mathrm{~cm}$

\section{ESTIMATED VOLUME: 4.5 liters}

DECORATION: The rim has seven engraved semi-circles circles in a panel around the vessel (Vessel 41CE14-5). Each semi-circle is defined by four closely-spaced vertical curvilinear engraved lines on either side of the semi-circle, with two attached hatched pendant triangles. Dividing each semi-circle motif is one set of four closely-spaced vertical curvilinear engraved lines. Within each semi-circle is a small central circle filled with engraved circular punctates.

TYPE: Poynor Engraved, var. Lang

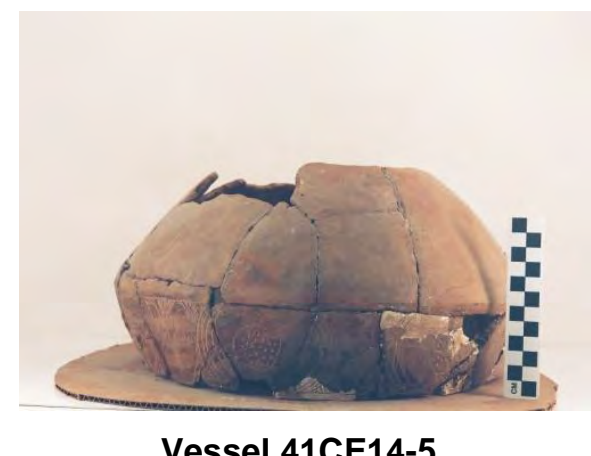


SITE NO.: 41CE14

FEATURE: Burial AQ-2

VESSEL NO.: 41CE14-6

NON-PLASTICS: grog

VESSEL FORM: Short-necked bottle or beaker with a direct rim, an elongated body, and an exterior folded and notched lip

CORE COLOR: F (fired in a reducing environment but cooled in the open air)

WALL THICKNESS: $5.8 \mathrm{~mm}$

INTERIOR SURFACE TREATMENT: none

EXTERIOR SURFACE TREATMENT: burnished

HEIGHT: $20.5 \mathrm{~cm}$

ORIFICE DIAMETER: $3.8 \mathrm{~cm}$, neck

DIAMETER AT BOTTOM OF RIM OR NECK: $4.6 \mathrm{~cm}$

BASE DIAMETER: $6.5 \mathrm{~cm}$

ESTIMATED VOLUME: 0.6 liters

DECORATION: The bottle or beaker has three closely-spaced horizontal engraved lines on the rim and above the vessel base. The remainder of the vessel body has three vertical engraved panels defined by four closely-spaced vertical lines with unique combinations of vertical, horizontal, triangular hatched, and curvilinear sets of engraved lines that extend between the vertical panel dividers (Vessel 41CE14-6, Burial AQ-2). A red clay pigment has been rubbed in the engraved lines.

TYPE: Undetermined engraved fine ware vessel, but likely a Poynor Engraved vessel because of the engraved elements within the vertical panels (cf. Suhm and Jelks 1962).

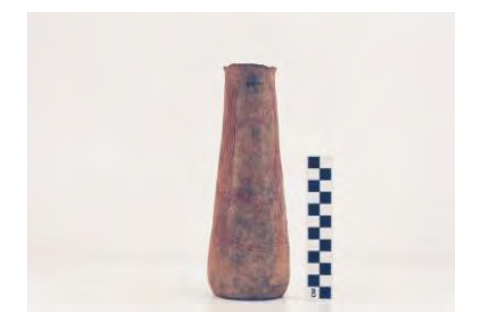

Vessel 41CE14-6, Burial AQ-2. 
SITE NO.: 41CE14

FEATURE: Burial AR-1

VESSEL NO.: 41CE14-6

NON-PLASTICS: grog and hematite

VESSEL FORM: Jar with an everted rim and a rounded lip

CORE COLOR: $\mathrm{G}$ (fired in a reducing environment and cooled in the open air)

WALL THICKNESS: $6.9 \mathrm{~mm}$

INTERIOR SURFACE TREATMENT: smoothed

EXTERIOR SURFACE TREATMENT: none

HEIGHT: $19.5 \mathrm{~cm}$

ORIFICE DIAMETER: $14.9 \mathrm{~cm}$

DIAMETER AT BOTTOM OF RIM OR NECK: $13.3 \mathrm{~cm}$

BASE DIAMETER: $7.5 \mathrm{~cm}$

ESTIMATED VOLUME: 2.6 liters

DECORATION: The rim has six rows of vertical pinching that apparently simulate neck bands. The body has vertical brushing marks (Vessel 41CE14-6, Burial AR-1).

TYPE: cf. LaRue Neck Banded

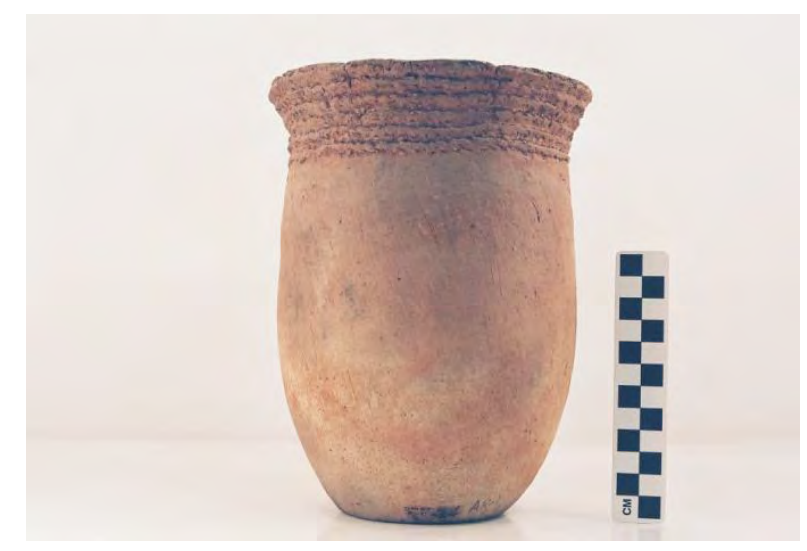

Vessel 41CE14-6, Burial AR-1. 
SITE NO.: 41CE14

FEATURE: Burial AR-1

VESSEL NO.: 41CE14-7

NON-PLASTICS: grog

VESSEL FORM: Carinated bowl with an inverted rim and a rounded, folded out lip

CORE COLOR: B (fired and cooled in a reducing environment)

WALL THICKNESS: $6.9 \mathrm{~mm}$

INTERIOR SURFACE TREATMENT: smoothed

EXTERIOR SURFACE TREATMENT: burnished

HEIGHT: $19.5 \mathrm{~cm}$

ORIFICE DIAMETER: $26.0 \mathrm{~cm}$

DIAMETER AT BOTTOM OF RIM OR NECK: $29.0 \mathrm{~cm}$

BASE DIAMETER: $10.5 \mathrm{~cm}$

ESTIMATED VOLUME: 4.5 liters

DECORATION: The rim has four engraved semi-circles or ovals (Vessel 41CE14-7, Burial AR-1). Each semi-circle or oval is defined by sets of four or five closely-spaced concentric semi-circular lines that extend from the vessel lip to the vessel carination.

TYPE: Poynor Engraved, var. Cook

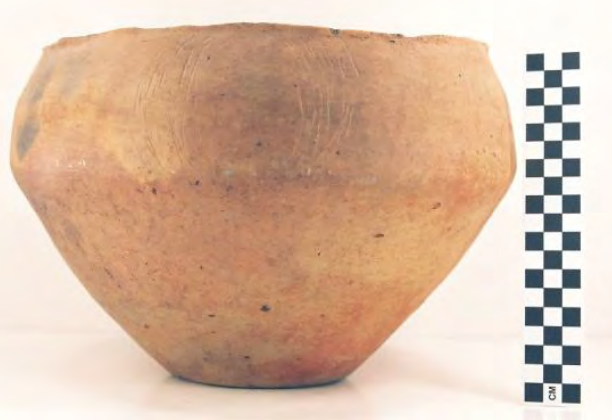

Vessel 41CE14-7, Burial AR-1. 
SITE NO.: 41CE14

FEATURE: Burial AQ-2

VESSEL NO.: 41CE14-7

NON-PLASTICS: grog

VESSEL FORM: Carinated bottle with a long neck, a direct rim, and a rounded lip; there is a very slight collar or flange at the juncture of the neck and bottle body.

CORE COLOR: Undetermined

WALL THICKNESS: $6.2 \mathrm{~mm}$

INTERIOR SURFACE TREATMENT: none

EXTERIOR SURFACE TREATMENT: burnished

HEIGHT: $21.5 \mathrm{~cm}$

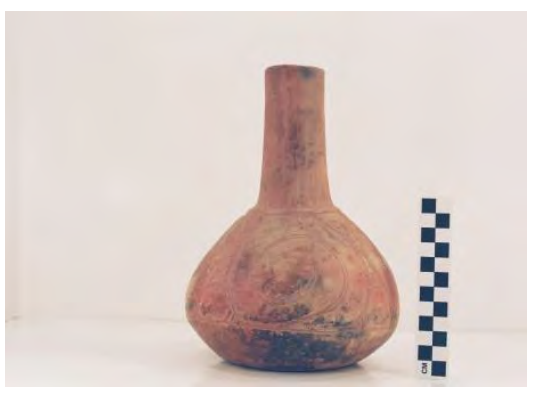

Vessel 41CE14-7, Burial AQ-2.

ORIFICE DIAMETER: $3.7 \mathrm{~cm}$

DIAMETER AT BOTTOM OF RIM OR NECK: $6.1 \mathrm{~cm}$

BASE DIAMETER: $10.5 \mathrm{~cm}$

ESTIMATED VOLUME: 0.9 liters

DECORATION: The engraved motif on the vessel body, repeated four times around the body, includes two separate elements: first, a hooked arm scroll (an element seen on var. $P$ Poynor Engraved carinated bowls) comprised of two closely-spaced curvilinear engraved lines, and second, an hour glass-shaped zone filled with two negative ovals defined by hatched triangles and horizontal hatched lines (Vessel 41CE14-7, Burial AQ2); this general decorative element is also seen on Poynor Engraved, var. Hood carinated bowls. A red clay pigment has been rubbed into the engraved lines.

TYPE: Poynor Engraved 
SITE NO.: 41CE14

FEATURE: Burial AQ-2

VESSEL NO.: 41CE14-8

NON-PLASTICS: grog and hematite

VESSEL FORM: Globular carinated bowl with a slightly everted rim and a rounded lip

CORE COLOR: C (incompletely oxidized during firing)

WALL THICKNESS: $4.9 \mathrm{~mm}$

INTERIOR SURFACE TREATMENT: smoothed

EXTERIOR SURFACE TREATMENT: burnished

HEIGHT: $8.5 \mathrm{~cm}$

ORIFICE DIAMETER: $11.5 \mathrm{~cm}$

DIAMETER AT BOTTOM OF RIM OR NECK: $11.2 \mathrm{~cm}$

BASE DIAMETER: $7.5 \mathrm{~cm}$

ESTIMATED VOLUME: 0.6 liters

DECORATION: The rim is plain, but the vessel body has an engraved design. It is comprised of four semi-circles in a panel delimited by upper and lower horizontal engraved lines that encircle the vessel. Each panel is defined by two sets of three closelyspaced semi-circular lines and a central small circle (Vessel 41CE14-8, Burial AQ-2). Dividing each of the panels are two sets of closely-spaced curvilinear lines, and these sets are repeated three times around the vessel. A red clay pigment has been rubbed in the engraved lines.

TYPE: Poynor Engraved, var. Lang

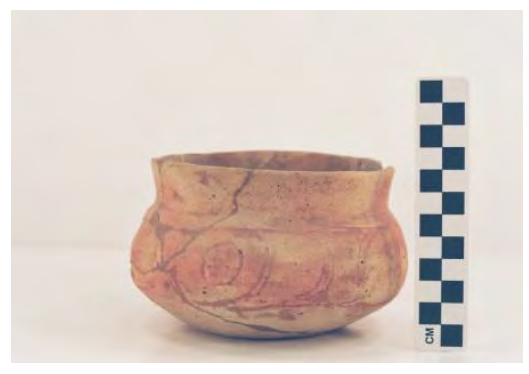

Vessel 41CE14-8, Burial AQ-2. 
SITE NO.: 41CE14

FEATURE: Burial AR-1

VESSEL NO.: 41CE14-8

NON-PLASTICS: grog

VESSEL FORM: Jar with an everted rim and a rounded lip

CORE COLOR: Undetermined

WALL THICKNESS: $5.9 \mathrm{~mm}$

INTERIOR SURFACE TREATMENT: smoothed

EXTERIOR SURFACE TREATMENT: none

HEIGHT: $19.5 \mathrm{~cm}$

ORIFICE DIAMETER: $13.5 \mathrm{~cm}$

DIAMETER AT BOTTOM OF RIM OR NECK: $13.0 \mathrm{~cm}$

BASE DIAMETER: $7.0 \mathrm{~cm}$

ESTIMATED VOLUME: 2.4 liters

DECORATION: The vessel rim has vertical rows of pinched ridges and a single horizontal pinched row at the rim-body juncture (Vessel 41CE14-8, Burial AR-1). The vessel body has vertical brushing marks that extend virtually to the base.

TYPE: Undetermined brushed-pinched utility ware vessel, probably a variety of Killough Pinched

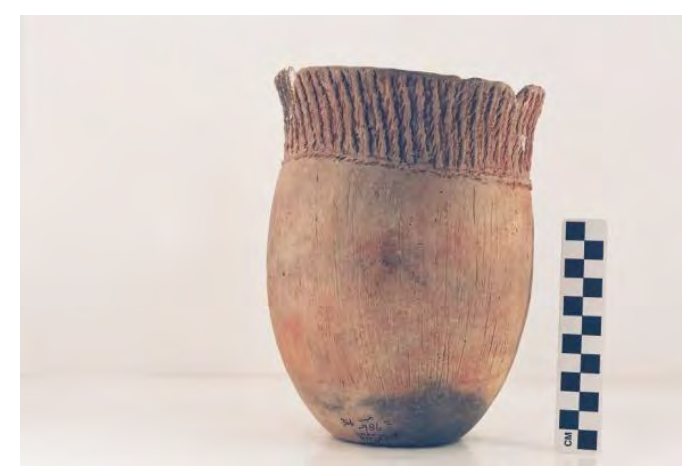

Vessel 41CE14-8, Burial AR-1. 
SITE NO.: 41CE14

FEATURE: Burial AR-1

VESSEL NO.: 41CE14-9

NON-PLASTICS: grog

VESSEL FORM: Carinated bowl with an inverted rim, and a rounded and scalloped lip (defined by eight small and regularly spaced rim peaks)

CORE COLOR: F (fired in a reducing environment and cooled in the open air)

WALL THICKNESS: $6.5 \mathrm{~mm}$, rim; $6.2 \mathrm{~mm}$, body

INTERIOR SURFACE TREATMENT: burnished on the rim and smoothed on the body

EXTERIOR SURFACE TREATMENT: burnished

HEIGHT: $21.8 \mathrm{~cm}$

ORIFICE DIAMETER: $42.5 \mathrm{~cm}$

DIAMETER AT BOTTOM OF RIM OR NECK: $46.5 \mathrm{~cm}$ at the rim-body juncture

BASE DIAMETER: $12.0 \mathrm{~cm}$

ESTIMATED VOLUME: 8.3 liters

DECORATION: There are eight engraved semi-circles in a panel on the rim (Vessel 41CE14-9, Burial AR-1). The panel is defined by single horizontal engraved lines under the lip and at the vessel carination, and each semi-circular motif is defined by two sets of four or five closely-spaced curvilinear lines and two attached triangular hatched areas. The center of the semi-circle is bisected by a vertical set of five closely-spaced engraved lines, and these are aligned so that they fall directly under each rim peak of the scalloped lip.

TYPE: Poynor Engraved, var. Cook

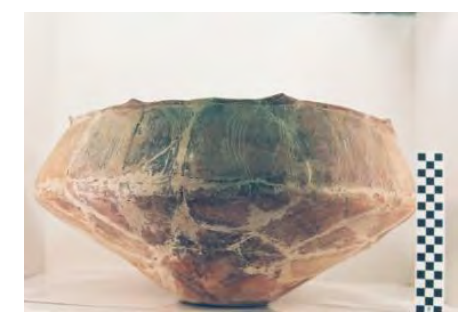

Vessel 41CE14-9, Burial AR-1. 
SITE NO.: 41CE14

FEATURE: Burial AQ-2

VESSEL NO.: 41CE14-9

NON-PLASTICS: grog and hematite

VESSEL FORM: Globular carinated bowl with a slightly everted rim and a rounded lip

CORE COLOR: E (incompletely oxidized during firing)

WALL THICKNESS: $5.6 \mathrm{~mm}$

INTERIOR SURFACE TREATMENT: smoothed

EXTERIOR SURFACE TREATMENT: burnished

HEIGHT: $10.0 \mathrm{~cm}$

ORIFICE DIAMETER: $14.5 \mathrm{~cm}$

DIAMETER AT BOTTOM OF RIM OR NECK: $14.0 \mathrm{~cm}$

BASE DIAMETER: $9.5 \mathrm{~cm}$

ESTIMATED VOLUME: 0.9 liters

DECORATION: The rim of this vessel is plain, but there is an engraved design on the upper vessel body. This design consists of a single panel filled with four engraved semicircles and negative ovals (Vessel 41CE14-9, Burial AQ-2). The semi-circles are defined by four sets of curvilinear engraved lines (in two closely-spaced arcs), and the negative ovals (one between each of the semi-circles) are defined by hour glass-shaped zones filled with curvilinear lines. There is a small engraved circle at the center of each semicircle. A red clay pigment has been rubbed in the engraved lines.

TYPE: Poynor Engraved, var. Lang

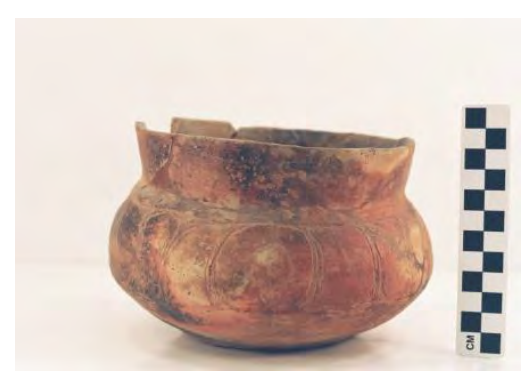

Vessel 41CE14-9, Burial AQ-2. 
SITE NO.: 41CE14

FEATURE: Burial AQ-2

VESSEL NO.: 41CE14-10

NON-PLASTICS: grog

VESSEL FORM: Jar with a direct rim and a rounded lip, and two strap handles

CORE COLOR: Undetermined

WALL THICKNESS: $5.6 \mathrm{~mm}$

INTERIOR SURFACE TREATMENT: none

EXTERIOR SURFACE TREATMENT: none

HEIGHT: $21.5 \mathrm{~cm}$

ORIFICE DIAMETER: $16.0 \mathrm{~cm}$

DIAMETER AT BOTTOM OF RIM OR NECK: $15.5 \mathrm{~cm}$

BASE DIAMETER: $11.0 \mathrm{~cm}$

ESTIMATED VOLUME: 3.0 liters

DECORATION: The rim of this vessel has five rows of horizontal linear tool punctates from the rim to the rim-body juncture; the body is plain. The two strap handles are decorated with short and deep horizontal incised lines (Vessel 41CE14-10, Burial AQ-2).

TYPE: Undetermined punctated utility ware vessel

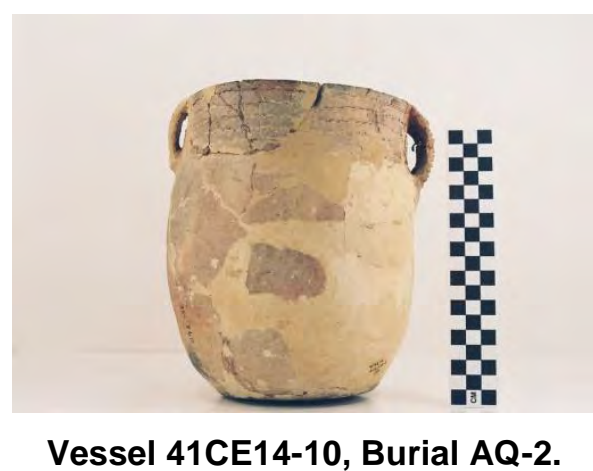


SITE NO.: 41CE14

FEATURE: Burial AR-1

VESSEL NO.: 41CE14-10

NON-PLASTICS: grog

VESSEL FORM: Rattle bowl with an everted rim and a rounded lip; four rattle nodes (3.9 $\mathrm{cm}$ in diameter and $2.0 \mathrm{~cm}$ in height)

CORE COLOR: B (fired and cooled in a reducing environment)

WALL THICKNESS: $5.2 \mathrm{~mm}$

INTERIOR SURFACE TREATMENT: smoothed

EXTERIOR SURFACE TREATMENT: some of the pinching on the vessel has been deliberately smoothed over

HEIGHT: $8.0 \mathrm{~cm}$

ORIFICE DIAMETER: $18.0 \mathrm{~cm}$

DIAMETER AT BOTTOM OF RIM OR NECK: N/A

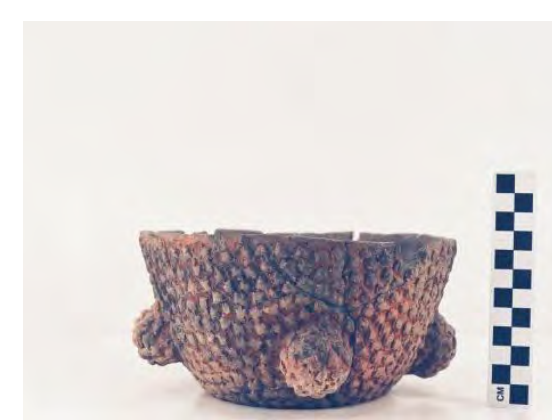

Vessel 41CE14-10.

BASE DIAMETER: $10.0 \mathrm{~cm}$

ESTIMATED VOLUME: 0.6 liters

DECORATION: The vessel is completely covered with rows of pinching, and the four rattle nodes also have a pinched decoration (Vessel 41CE14-10).

TYPE: Killough Pinched (see Suhm and Jelks 1962: Plate 46d) 
SITE NO.: 41CE14

FEATURE: Burial AQ-2

VESSEL NO.: 41CE14-11

NON-PLASTICS: grog

VESSEL FORM: Carinated bowl with an inverted rim and a rounded, exterior folded, lip

CORE COLOR: Undetermined

WALL THICKNESS: $6.3 \mathrm{~mm}$

INTERIOR SURFACE TREATMENT: burnished

EXTERIOR SURFACE TREATMENT: burnished

HEIGHT: $18.0 \mathrm{~cm}$

ORIFICE DIAMETER: $30.5 \mathrm{~cm}$

DIAMETER AT BOTTOM OF RIM OR NECK:

$35.5 \mathrm{~cm}$

BASE DIAMETER: $11.0 \mathrm{~cm}$

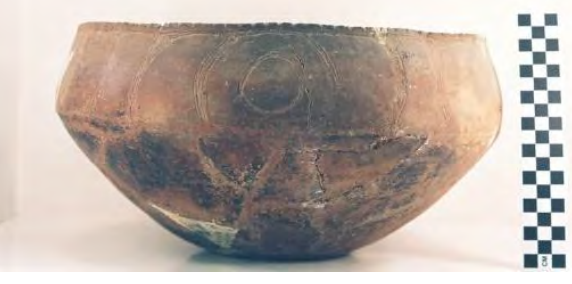

Vessel 41CE14-11.

ESTIMATED VOLUME: 4.9 liters

DECORATION: The vessel rim has a engraved design. There are six semi-circles in a panel defined by upper and lower horizontal engraved lines. Each semi-circle is defined by two sets of closely-spaced vertical curvilinear lines (three or four lines to a set), and there is a smaller central engraved circle within the semi-circles (Vessel 41CE14-11). These smaller circles are either blank or filled with small engraved punctates. In one instance, a small circle is engraved in a rectangular zone that divides each of the semicircles. Otherwise, the semi-circles are divided by two sets of closely-spaced curvilinear lines (three per set) and two triangular hatched zones per set. A red clay pigment has been rubbed into the engraved lines, and the lip is notched.

TYPE: Poynor Engraved, var. Lang 
SITE NO.: 41CE14

FEATURE: Burial AR-2

VESSEL NO.: 41CE14-12

NON-PLASTICS: grog

VESSEL FORM: Globular carinated bowl with a direct rim and a rounded lip; there is a very slight collar at the juncture of the rim and vessel body

CORE COLOR: B (fired and cooled in a reducing environment)

WALL THICKNESS: $5.3 \mathrm{~mm}$

INTERIOR SURFACE TREATMENT: smoothed

EXTERIOR SURFACE TREATMENT: burnished

HEIGHT: $13.5 \mathrm{~cm}$

ORIFICE DIAMETER: $12.5 \mathrm{~cm}$

DIAMETER AT BOTTOM OF RIM OR NECK: $13.0 \mathrm{~cm}$

BASE DIAMETER: $9.0 \mathrm{~cm}$

ESTIMATED VOLUME: 1.0 liters

DECORATION: The vessel is decorated on the rim with hatched engraved triangles and narrow diagonal hatched zones or ladders; there is also a single horizontal engraved line under the lip, but not at the carination (Vessel 41CE14-12). These elements are repeated eight times each around the vessel, with the triangles and hatched zones alternating in pitch across the rim: the apex of the triangles varies from touching the top of the rim to touching the vessel carination, while the hatched zones or ladders are pitched in opposite directions.

TYPE: Poynor Engraved, var. $F$ in the upper Neches River basin

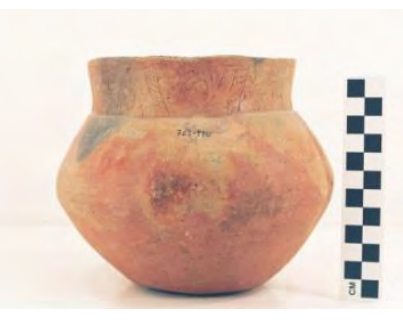

Vessel 41CE14-12. 
SITE NO.: 41CE14

FEATURE: Burial AR-2

VESSEL NO.: 41CE14-13

NON-PLASTICS: none apparent

VESSEL FORM: Bottle with a long neck, a globular body, a direct rim, and a rounded lip

CORE COLOR: Undetermined

WALL THICKNESS: $5.5 \mathrm{~mm}$, rim; $5.1 \mathrm{~mm}$, body

INTERIOR SURFACE TREATMENT: none

EXTERIOR SURFACE TREATMENT: smoothed

HEIGHT: $24.2 \mathrm{~cm}$

ORIFICE DIAMETER: $5.3 \mathrm{~cm}$, neck

DIAMETER AT BOTTOM OF RIM OR NECK: $5.9 \mathrm{~cm}$

BASE DIAMETER: $7.7 \mathrm{~cm}$

ESTIMATED VOLUME: 0.75 liters

DECORATION: The vessel body has a scroll, circle, and negative circle motif that is repeated four times on the vessel (Vessel 41CE14-13). The central circle on the scroll is made up of three concentric circles, and the scroll elements are comprised of 2-3 very closely-spaced lines along the scroll, as fill elements, and in the horizontal engraved lines that define the bottom of the scroll motif. A red clay pigment has been rubbed in the engraved lines.

TYPE: Undetermined engraved fine ware bottle, probably Poynor Engraved based on the concentric circle and scroll elements (also seen as Poynor Engraved, var. E on carinated bowl vessels).

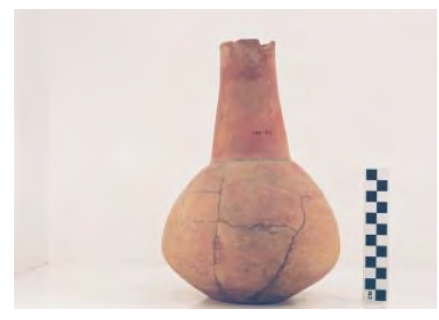

Vessel 41CE14-13. 
SITE NO.: 41CE14

FEATURE: Burial AR-2

VESSEL NO.: 41CE14-14

NON-PLASTICS: grog and hematite

VESSEL FORM: Carinated bowl with an inverted rim and a rounded lip

CORE COLOR: $\mathrm{F}$ (fired in a reducing environment and cooled in the open air)

WALL THICKNESS: $6.2 \mathrm{~mm}$

INTERIOR SURFACE TREATMENT: smoothed

EXTERIOR SURFACE TREATMENT: burnished

HEIGHT: $8.0 \mathrm{~cm}$

ORIFICE DIAMETER: $15.5 \mathrm{~cm}$

DIAMETER AT BOTTOM OF RIM OR NECK: $16.5 \mathrm{~cm}$

BASE DIAMETER: $8.2 \mathrm{~cm}$

ESTIMATED VOLUME: 0.7 liters

DECORATION: The rim has an engraved panel with five negative ovals or semi-circles defined by two hour glass-shaped zones that reach from the top of the rim to the vessel carination. These hour glass-shaped zones include three with hatched triangular corners and a cross-hatched central diamond; three with hatched triangular corners around a negative diamond; and one with hatched corners and small negative ovals (Vessel 41CE14-14).

TYPE: Poynor Engraved, var. Hood

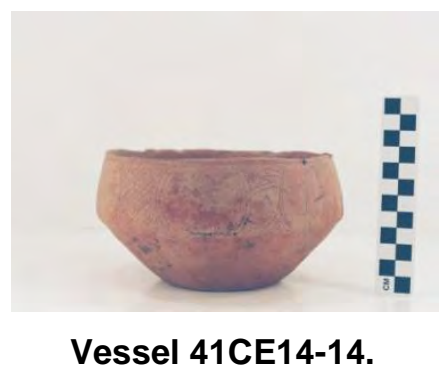


SITE NO.: 41CE14

FEATURE: Burial AR-2

VESSEL NO.: 41CE14-15

NON-PLASTICS: grog and hematite

VESSEL FORM: Bottle with a direct rim and a rounded lip, a globular body, and a slight collar at the neck-body juncture

CORE COLOR: A (fired and cooled in a high oxygen environment)

WALL THICKNESS: $5.7 \mathrm{~mm}$

INTERIOR SURFACE TREATMENT: none

EXTERIOR SURFACE TREATMENT: burnished

HEIGHT: $15.0 \mathrm{~cm}$

ORIFICE DIAMETER: $3.2 \mathrm{~cm}$

DIAMETER AT BOTTOM OF RIM OR NECK: $5.1 \mathrm{~cm}$

BASE DIAMETER: $6.5 \mathrm{~cm}$

ESTIMATED VOLUME: 0.4 liters

DECORATION: The body of the vessel has hooked arm engraved scrolls that are repeated three times. The upper and lower parts of the scroll motif has small crosshatched triangular areas (Vessel 41CE14-15). The hooked arm scroll is also present on Poynor Engraved, var. $P$ carinated bowls in the upper Neches River basin.

TYPE: cf. Poynor Engraved

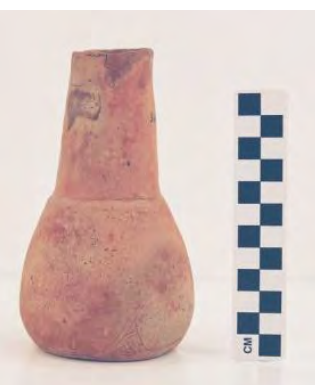

Vessel 41CE14-15. 
SITE NO.: 41CE14

FEATURE: Burial AR-2

VESSEL NO.: 41CE14-16

NON-PLASTICS: none apparent

VESSEL FORM: Carinated bowl with an inverted rim and a rounded lip; there are four lip nodes, formed by two conjoined rim peaks

CORE COLOR: Undetermined

WALL THICKNESS: $5.9 \mathrm{~mm}$

INTERIOR SURFACE TREATMENT: smoothed

EXTERIOR SURFACE TREATMENT: burnished

HEIGHT: $17.5 \mathrm{~cm}$

ORIFICE DIAMETER: $26.5 \mathrm{~cm}$

DIAMETER AT BOTTOM OF RIM OR NECK: $31.5 \mathrm{~cm}$

BASE DIAMETER: $9.0 \mathrm{~cm}$

ESTIMATED VOLUME: 4.1 liters

DECORATION: The vessel rim has an engraved design consisting of a panel filled with seven semi-circles (Vessel 41CE14-16). These semi-circles are formed by two sets (with three closely-spaced lines each) of vertical curvilinear arcing engraved lines. Attached to each of these sets of arcing engraved lines are upper and lower hatched triangles.

TYPE: Poynor Engraved, var. Cook

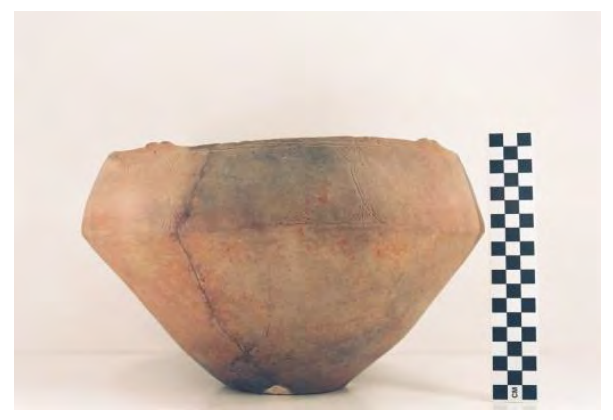

Vessel 41CE14-16. 
SITE NO.: 41CE14

FEATURE: Burial AQ-2

VESSEL NO.: 41CE14-17

NON-PLASTICS: grog and hematite

VESSEL FORM: Jar with an everted rim, a rounded lip, and two strap handles

CORE COLOR: Undetermined

WALL THICKNESS: $6.6 \mathrm{~mm}$

INTERIOR SURFACE TREATMENT: smoothed

EXTERIOR SURFACE TREATMENT: smoothed

HEIGHT: $23.0 \mathrm{~cm}$

ORIFICE DIAMETER: $17.5 \mathrm{~cm}$

DIAMETER AT BOTTOM OF RIM OR NECK: $15.5 \mathrm{~cm}$

BASE DIAMETER: $10.0 \mathrm{~cm}$

ESTIMATED VOLUME: 3.6 liters

DECORATION: The rim has five rows of linear punctations, the bottom row along the rim-body juncture. On the body are four tool punctated concentric circles that extend from the rim-body juncture to not far above the vessel base (Vessel 41CE14-17).

TYPE: Undetermined punctated utility ware vessel

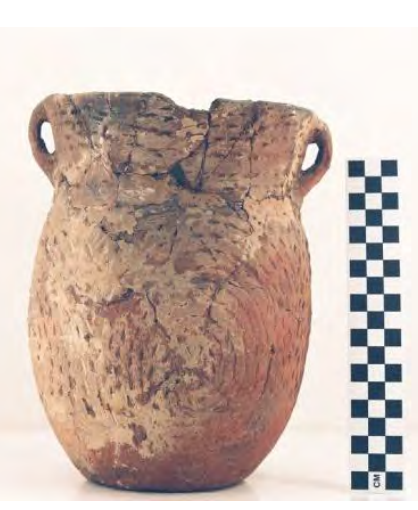

Vessel 41CE14-17. 
SITE NO.: 41CE14

FEATURE: Burial AQ-2

VESSEL NO:: 41CE14-17a

NON-PLASTICS: grog

VESSEL FORM: Bottle with a short neck, elongated body, a slightly everted rim and a rounded, exterior folded lip

CORE COLOR: A (fired and cooled in a high oxygen environment)

WALL THICKNESS: $5.0 \mathrm{~mm}$

INTERIOR SURFACE TREATMENT: none

EXTERIOR SURFACE TREATMENT: burnished

HEIGHT: $18.5 \mathrm{~cm}$

ORIFICE DIAMETER: $4.0 \mathrm{~cm}$

DIAMETER AT BOTTOM OF RIM OR NECK: $4.0 \mathrm{~cm}$

BASE DIAMETER: $7.0 \mathrm{~cm}$

ESTIMATED VOLUME: 0.5 liters

DECORATION: There are three sets of closely-spaced horizontal engraved lines (four lines in each set) on the vessel, one set at the base of the bottle neck, and the other two sets on the upper bottle body (Vessel 41CE14-17a).

TYPE: Undetermined engraved vessel, probably a variety of Hume Engraved because of the dominance of the simple engraved elements, although Suhm and Jelks (1962:Plate 63b) classify it as Poynor Engraved.

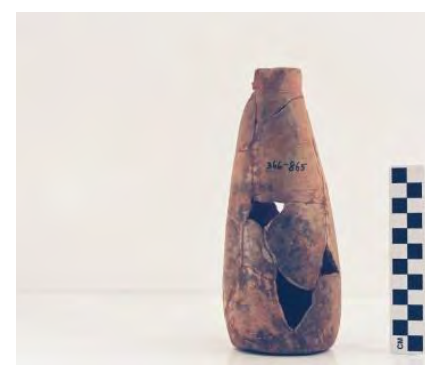

Vessel 41CE14-17a. 
SITE NO.: 41CE14

FEATURE: Burial AQ-3

VESSEL NO.: 41CE14-18

NON-PLASTICS: bone and hematite

VESSEL FORM: Globular carinated bowl with an everted rim and a rounded lip

CORE COLOR: A (fired and cooled in a high oxygen environment)

WALL THICKNESS: $6.5 \mathrm{~mm}$

INTERIOR SURFACE TREATMENT: none

EXTERIOR SURFACE TREATMENT: none

HEIGHT: $14.3 \mathrm{~cm}$

ORIFICE DIAMETER: $16.9 \mathrm{~cm}$

DIAMETER AT BOTTOM OF RIM OR NECK: $16.3 \mathrm{~cm}$

BASE DIAMETER: $7.6 \mathrm{~cm}$

ESTIMATED VOLUME: 2.0 liters

DECORATION: The rim of this vessel has 11 rectangular engraved panels (Vessel 41CE14-18). The top and bottom of the panels are defined by single horizontal engraved lines that encircle the vessel, one under the lip and the other at the vessel carination. The rectangular panels are defined by two sets of closely-spaced vertical engraved lines. Each set has four such engraved lines.

TYPE: Poynor Engraved, var. Blackburn

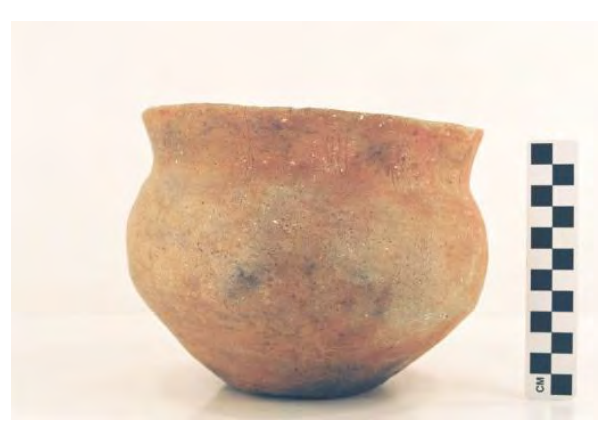

Vessel 41CE14-18. 
SITE NO.: 41CE14

FEATURE: Burial AQ-3

VESSEL NO.: 41CE14-19

NON-PLASTICS: bone and grog

VESSEL FORM: Plain bowl with an everted rim and a rounded lip (Vessel 41CE14-19)

CORE COLOR: A (fired and cooled in a high oxygen environment)

WALL THICKNESS: $9.3 \mathrm{~mm}$

INTERIOR SURFACE TREATMENT: smoothed

EXTERIOR SURFACE TREATMENT: burnished

HEIGHT: $3.5 \mathrm{~cm}$

ORIFICE DIAMETER: $8.5 \mathrm{~cm}$

DIAMETER AT BOTTOM OF RIM OR NECK: N/A

BASE DIAMETER: $5.5 \mathrm{~cm}$

ESTIMATED VOLUME: 0.12 liters

DECORATION: plain

TYPE: Undetermined plain ware vessel

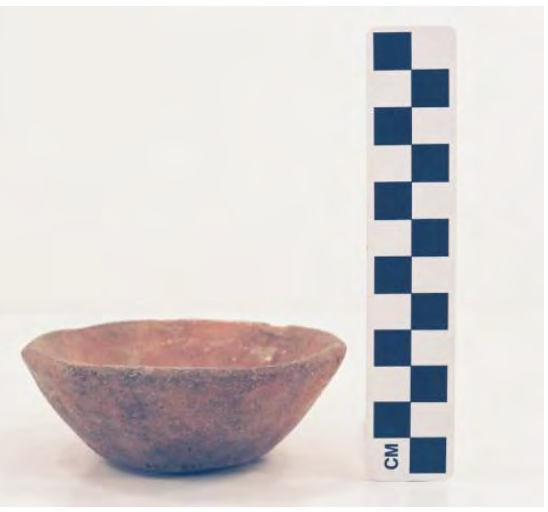

Vessel 41CE14-19. 
SITE NO.: 41CE14

FEATURE: Burial AQ-3

VESSEL NO.: 41CE14-20

NON-PLASTICS: none apparent

VESSEL FORM: Bottle with a short neck, an elongated body, a direct rim, and a rounded, exterior folded lip

CORE COLOR: Undetermined

WALL THICKNESS: $9.0 \mathrm{~mm}$

INTERIOR SURFACE TREATMENT: none

EXTERIOR SURFACE TREATMENT: burnished

HEIGHT: $27.0 \mathrm{~cm}$

ORIFICE DIAMETER: $3.5 \mathrm{~cm}$

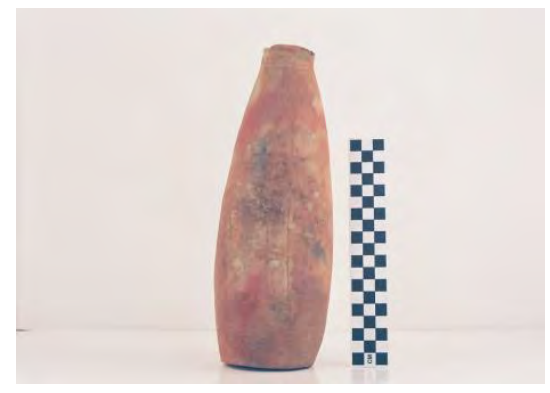

Vessel 41CE14-20, Hume or Poynor Engraved.

DIAMETER AT BOTTOM OF RIM OR NECK: $5.2 \mathrm{~cm}$

BASE DIAMETER: $8.0 \mathrm{~cm}$

ESTIMATED VOLUME: 0.9 liters

DECORATION: The bottle body has an engraved design. There are two sets of horizontal engraved lines on the body, two lines below the bottle neck and three lines near the vessel base. Four engraved vertical panels extend from these two sets of horizontal engraved lines (Vessel 41CE14-20). The panels are filled with either eight (two panels) or nine (two panels) negative circles and ovals, each defined by crosshatched engraved fill zones within the panels.

TYPE: Hume Engraved or Poynor Engraved (in the case of the latter, because of the use of negative circles and ovals in the design) 
SITE NO.: 41CE14

FEATURE: Burial AQ-3

VESSEL NO.: 41CE14-21

NON-PLASTICS: grog, hematite, and bone

VESSEL FORM: Carinated bowl with an inverted rim and a rounded lip

CORE COLOR: Undetermined

WALL THICKNESS: $9.7 \mathrm{~mm}$

INTERIOR SURFACE TREATMENT: burnished

EXTERIOR SURFACE TREATMENT: burnished

HEIGHT: $21.0 \mathrm{~cm}$

ORIFICE DIAMETER: $21.5 \mathrm{~cm}$

DIAMETER AT BOTTOM OF RIM OR NECK: $24.5 \mathrm{~cm}$

BASE DIAMETER: $9.0 \mathrm{~cm}$

ESTIMATED VOLUME: 4.0 liters

DECORATION: The rim has an engraved panel filled with eight ovals or semi-circles (Vessel 41CE14-21). These ovals or semi-circles are defined by hour glass-shaped zones filled with vertical to curvilinear engraved lines. These hour glass-shaped zones extend from near the lip to the vessel carination. A red clay pigment has been rubbed in the engraved lines.

TYPE: Poynor Engraved, var. Hood

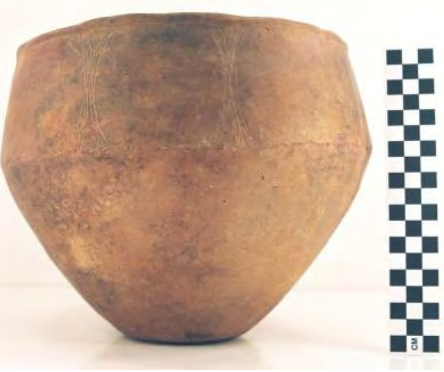

Vessel 41CE14-21. 
SITE NO.: 41CE14

FEATURE: Burial AQ-3

VESSEL NO.: 41CE14-22

NON-PLASTICS: hematite and bone

VESSEL FORM: Globular carinated bowl with a direct rim and a rounded lip

CORE COLOR: A (fired and cooled in an oxidizing environment)

WALL THICKNESS: $5.6 \mathrm{~mm}$

INTERIOR SURFACE TREATMENT: smoothed

EXTERIOR SURFACE TREATMENT: smoothed

HEIGHT: $15.1 \mathrm{~cm}$

ORIFICE DIAMETER: $14.2 \mathrm{~cm}$

DIAMETER AT BOTTOM OF RIM OR NECK: $14.3 \mathrm{~cm}$

BASE DIAMETER: $7.3 \mathrm{~cm}$

ESTIMATED VOLUME: 1.3 liters

DECORATION: The rim has an engraved panel filled with six ovals or semi-circles (Vessel 41CE14-22). These ovals or semi-circles are defined by hour glass-shaped zones filled with vertical to curvilinear engraved lines. These hour glass-shaped zones extend from near the lip to the vessel carination, where there are single horizontal engraved lines.

TYPE: Poynor Engraved, var. Hood

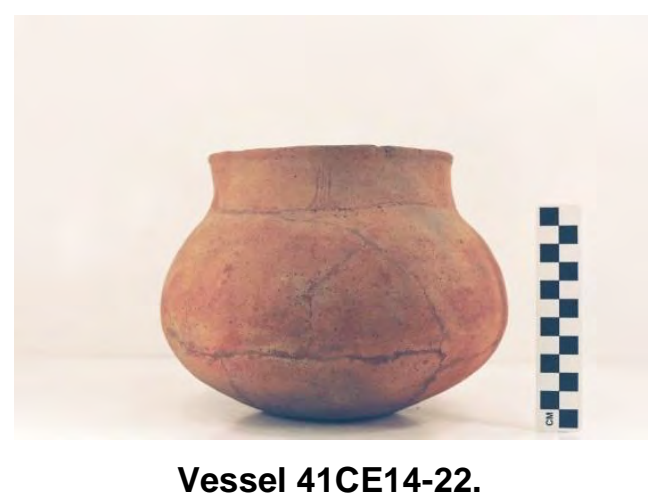


SITE NO.: 41CE14

FEATURE: Burial AQ-3

VESSEL NO.: 41CE14-23

NON-PLASTICS: grog

VESSEL FORM: Globular carinated bowl with a direct rim and a rounded, exterior folded lip

CORE COLOR: Undetermined

WALL THICKNESS: $5.3 \mathrm{~mm}$

INTERIOR SURFACE TREATMENT: smoothed

EXTERIOR SURFACE TREATMENT: burnished

HEIGHT: $10.0 \mathrm{~cm}$; rim height, $1.75 \mathrm{~cm}$

ORIFICE DIAMETER: $12.5 \mathrm{~cm}$

DIAMETER AT BOTTOM OF RIM OR NECK: $12.2 \mathrm{~cm}$

BASE DIAMETER: $7.0 \mathrm{~cm}$

ESTIMATED VOLUME: 0.8 liters

DECORATION: The rim has an engraved panel filled with 17 negative ovals or semicircles. These ovals or semi-circles are defined by hour glass-shaped zones filled with vertical to curvilinear engraved lines (Vessel 41CE14-23). These hour glass-shaped zones extend from near the lip to the vessel carination, where there are single horizontal engraved lines. A red clay pigment has been rubbed in the engraved lines.

TYPE: Poynor Engraved, var. Hood

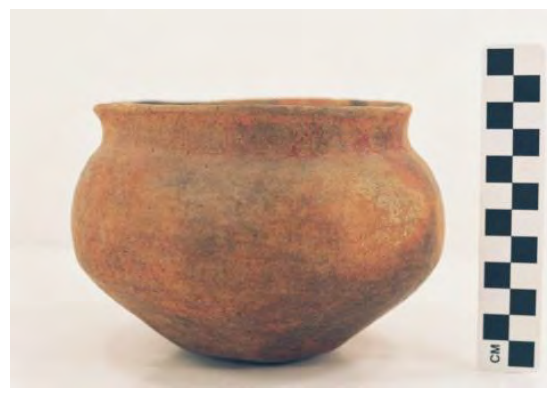

Vessel 41CE14-23. 
SITE NO.: 41CE14

FEATURE: Burial AQ-4

VESSEL NO.: 41CE14-24

NON-PLASTICS: grog and bone

VESSEL FORM: Carinated bottle with a direct rim and a rounded lip

CORE COLOR: E (incompletely oxidized during firing); pinkware

WALL THICKNESS: $4.6 \mathrm{~mm}$

INTERIOR SURFACE TREATMENT: none

EXTERIOR SURFACE TREATMENT: burnished, but badly eroded

HEIGHT: $18.0 \mathrm{~cm}$

ORIFICE DIAMETER: $3.2 \mathrm{~cm}$

DIAMETER AT BOTTOM OF RIM OR NECK: $5.9 \mathrm{~cm}$

BASE DIAMETER: $6.0 \mathrm{~cm}$

ESTIMATED VOLUME: 0.5 liters

DECORATION: The vessel body has an engraved panel filled with closely-spaced sets of hour glass-shaped lines between other sets of hour glass-shaped lines with attached semicircles (Vessel 41CE14-24). The panel begins immediately below the neck-body juncture and extends about midway down the mid-section of the bottle body.

TYPE: Poynor Engraved, var. $K$ in the upper Neches River basin

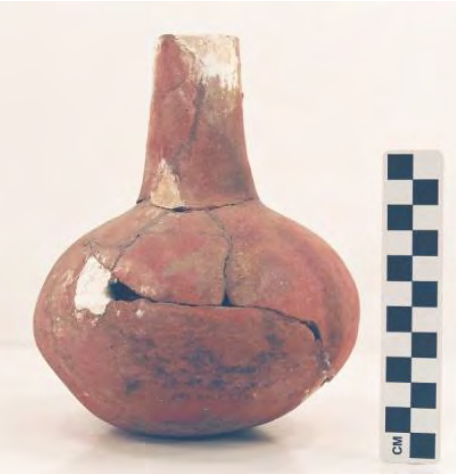

Vessel 41CE14-24. 
SITE NO.: 41CE14

FEATURE: Burial AQ-4

VESSEL NO.: 41CE14-25

NON-PLASTICS: grog

VESSEL FORM: Jar with a slightly everted rim, a rounded lip, and two strap handles

CORE COLOR: Undetermined

WALL THICKNESS: $4.8 \mathrm{~mm}$

INTERIOR SURFACE TREATMENT: smoothed

EXTERIOR SURFACE TREATMENT: none

HEIGHT: $10.5 \mathrm{~cm}$

ORIFICE DIAMETER: $10.1 \mathrm{~cm}$

DIAMETER AT BOTTOM OF RIM OR NECK: $9.5 \mathrm{~cm}$

BASE DIAMETER: $8.5 \mathrm{~cm}$

ESTIMATED VOLUME: 0.6 liters

DECORATION: The rim has vertical rows of linear punctates, probably simulating pinching, while the two strap handles are both decorated with horizontal incised lines (Vessel 41CE14-25). On the body are five punctated concentric circles that have interlocking or hooked arms as their central element.

TYPE: Undetermined punctated utility ware vessel

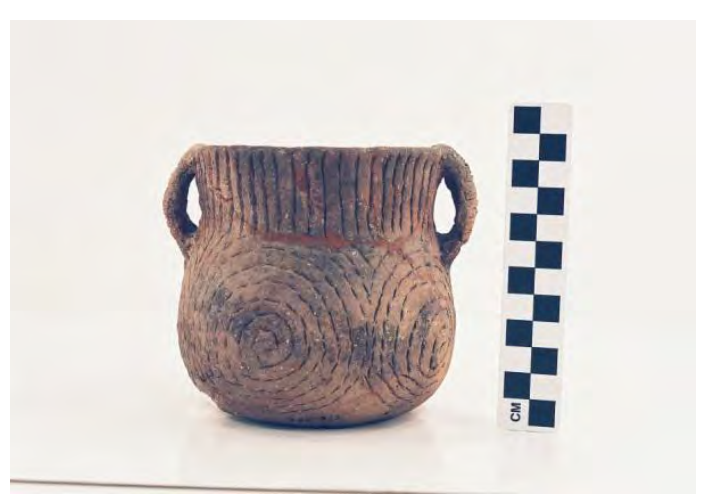

Vessel 41CE14-25. 
SITE NO.: 41CE14

FEATURE: Burial AQ-4

VESSEL NO.: 41CE14-26

NON-PLASTICS: none apparent

VESSEL FORM: Globular carinated bowl with a direct rim and a rounded, exterior folded, lip

CORE COLOR: Undetermined

WALL THICKNESS: $3.9 \mathrm{~mm}$

INTERIOR SURFACE TREATMENT: smoothed

EXTERIOR SURFACE TREATMENT: burnished

HEIGHT: $10.0 \mathrm{~cm}$

ORIFICE DIAMETER: $13.5 \mathrm{~cm}$

DIAMETER AT BOTTOM OF RIM OR NECK: $12.9 \mathrm{~cm}$

BASE DIAMETER: $6.0 \mathrm{~cm}$

ESTIMATED VOLUME: 0.8 liters

DECORATION: The rim of the vessel has an engraved panel filled with ovals (seven across the vessel) alternating with eight rectangular areas. These areas are defined by sets of vertical curvilinear and straight engraved lines around each oval-shaped or rectangular area (Vessel 41CE14-26).

TYPE: Poynor Engraved, var. Hood

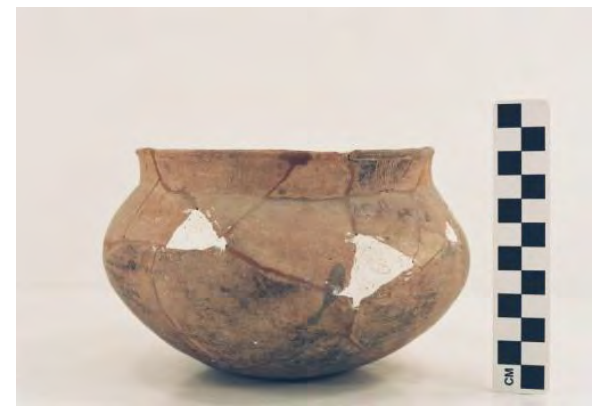

Vessel 41CE14-26. 
SITE NO.: 41CE14

FEATURE: Burial AQ-4

VESSEL NO.: 41CE14-27

NON-PLASTICS: grog

VESSEL FORM: Short-necked bottle with an elongated body; the rim and lip are missing CORE COLOR: C (incompletely oxidized during firing)

WALL THICKNESS: $6.6 \mathrm{~mm}$

INTERIOR SURFACE TREATMENT: none

EXTERIOR SURFACE TREATMENT: burnished

HEIGHT: $24.5+\mathrm{cm}$

ORIFICE DIAMETER: $6.0 \mathrm{~cm}$

DIAMETER AT BOTTOM OF RIM OR NECK: $6.4 \mathrm{~cm}$

BASE DIAMETER: $10.0 \mathrm{~cm}$

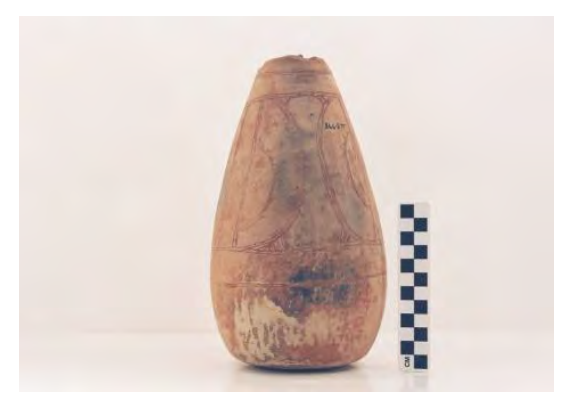

Vessel 41CE-27.

ESTIMATED VOLUME: $1.0+$ liters

DECORATION: There is a set of two closely-spaced horizontal engraved lines on the bottle neck, and three similar sets of horizontal lines on the vessel body. The central engraved motif - on the mid-point of the body - repeated three times, consists of a large engraved semi-circle bisected by two sets of closely-spaced vertical engraved lines (this decorative element is comparable to Poynor Engraved, var. $K$ carinated bowls in the upper Neches River basin); there are hatched triangles at the top and bottom of these larger semi-circles (Vessel 41CE-27). Two smaller semi-circles are pendant from these vertical lines, and each smaller semi-circle has a series of triangular tick marks. A red clay pigment has been rubbed in the engraved lines.

TYPE: Poynor Engraved (see Suhm and Jelks 1962: Plate 63g) 
SITE NO.: 41CE14

FEATURE: Burial AQ-4

VESSEL NO.: 41CE14-28

NON-PLASTICS: bone, hematite, and grog

VESSEL FORM: Globular carinated bowl with a short everted rim and a rounded lip

CORE COLOR: G (fired in a reducing environment and cooled in the open air)

WALL THICKNESS: $3.9 \mathrm{~mm}$

INTERIOR SURFACE TREATMENT: smoothed on the rim

EXTERIOR SURFACE TREATMENT: smoothed

HEIGHT: $8.6 \mathrm{~cm}$

ORIFICE DIAMETER: $13.2 \mathrm{~cm}$

DIAMETER AT BOTTOM OF RIM OR NECK: $12.8 \mathrm{~cm}$

BASE DIAMETER: $4.5 \mathrm{~cm}$

ESTIMATED VOLUME: 0.7 liters

DECORATION: The rim of this vessel has two distinct panels defined by sets of vertical engraved lines. Because the vessel is broken, it is uncertain how many sets of vertical lines comprise each panel, but there are at least five sets in the more complete panel; each set has six closely-spaced vertical engraved lines (Vessel 41CE14-28).

TYPE: Poynor Engraved, var. Blackburn

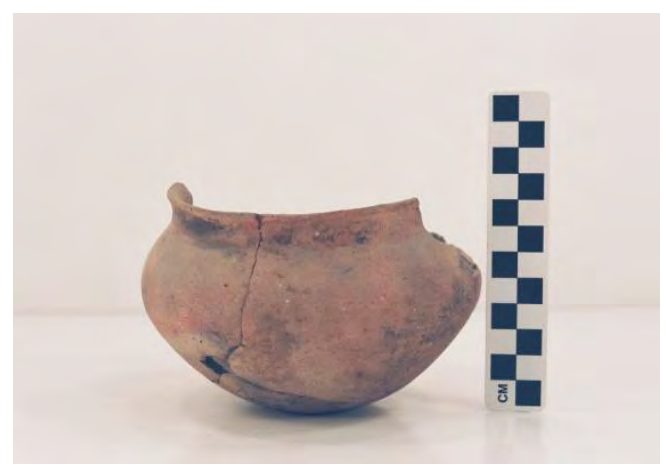

Vessel 41CE14-28. 
SITE NO.: 41CE14

FEATURE: Burial AQ-4

VESSEL NO.: 41CE14-29

NON-PLASTICS: grog

VESSEL FORM: Jar with an everted rim and a rounded, exterior folded lip

CORE COLOR: Undetermined

WALL THICKNESS: $7.0 \mathrm{~mm}$

INTERIOR SURFACE TREATMENT: smoothed

EXTERIOR SURFACE TREATMENT: burnished on the vessel body

HEIGHT: $16.5 \mathrm{~cm}$; rim height, $5.0 \mathrm{~cm}$

ORIFICE DIAMETER: $12.0 \mathrm{~cm}$

DIAMETER AT BOTTOM OF RIM OR NECK: $13.1 \mathrm{~cm}$

BASE DIAMETER: $10.0 \mathrm{~cm}$

ESTIMATED VOLUME: 1.8 liters

DECORATION: Cross-hatched incised lines on the rim (Vessel 41CE14-29)

TYPE: Maydelle Incised

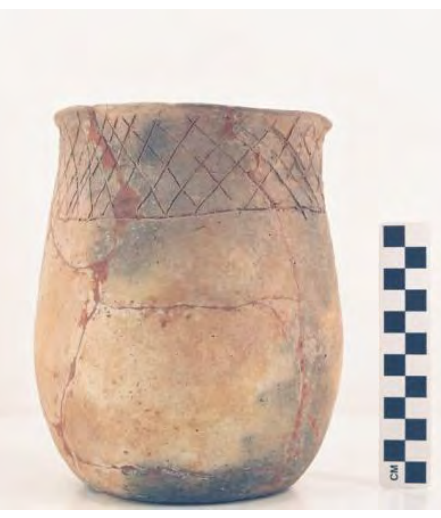

Vessel 41CE14-29. 
SITE NO.: 41CE14

FEATURE: Unknown, but probably Burial AQ-4

VESSEL NO.: 41CE14-30

NON-PLASTICS: bone, grog, and hematite

VESSEL FORM: Globular carinated bowl with a short everted rim and a rounded lip

CORE COLOR: A (fired and cooled in a high oxygen environment)

WALL THICKNESS: $4.6 \mathrm{~mm}$, rim; $3.9 \mathrm{~mm}$, body

INTERIOR SURFACE TREATMENT: burnished

EXTERIOR SURFACE TREATMENT: smoothed

HEIGHT: $7.8 \mathrm{~cm}$

ORIFICE DIAMETER: $11.2 \mathrm{~cm}$

DIAMETER AT BOTTOM OF RIM OR NECK: $12.9 \mathrm{~cm}$ on the vessel body

BASE DIAMETER: $3.9 \mathrm{~cm}$

ESTIMATED VOLUME: 0.5 liters

DECORATION: The vessel rim is broken, but what remains has a series of rectangular engraved panels. These are defined by sets (four or five lines) of closely-spaced vertical engraved lines, one set at least having a hatched triangular area above the vessel carination (Vessel 41CE14-30). One of the rectangular panels is defined by only two vertical engraved lines, and there is a semi-circle or oval within this panel.

TYPE: Poynor Engraved, var. Blackburn

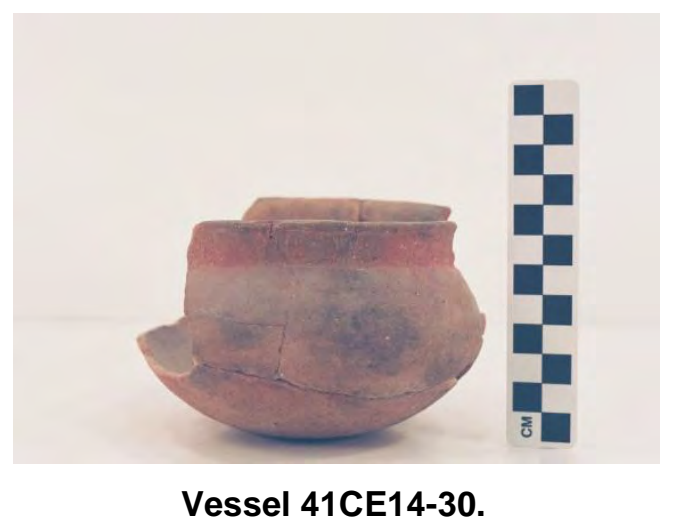


SITE NO.: 41CE14

FEATURE: Burial AQ-4

VESSEL NO.: 41CE14-31

NON-PLASTICS: grog

VESSEL FORM: Globular carinated bowl with a slightly everted rim and a rounded lip

CORE COLOR: A (fired and cooled in a high oxygen environment)

WALL THICKNESS: $4.2 \mathrm{~mm}$

INTERIOR SURFACE TREATMENT: smoothed

EXTERIOR SURFACE TREATMENT: burnished

HEIGHT: $11.5 \mathrm{~cm}$

ORIFICE DIAMETER: $16.5 \mathrm{~cm}$

DIAMETER AT BOTTOM OF RIM OR NECK: $16.0 \mathrm{~cm}$

BASE DIAMETER: $8.5 \mathrm{~cm}$

ESTIMATED VOLUME: 1.1 liters

DECORATION: The rim has a panel defined by upper and lower horizontal engraved lines that encircle the vessel. Within the panel are nine negative oval-shaped areas defined by 10 hour glass-shaped dividers filled with curvilinear engraved lines.

TYPE: Poynor Engraved, var. Hood

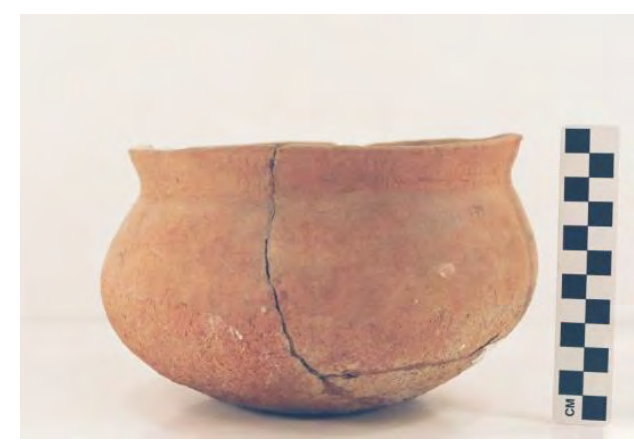


SITE NO.: 41CE14

FEATURE: Burial AQ-5

VESSEL NO.: 41CE14-32

NON-PLASTICS: grog and hematite

VESSEL FORM: Bottle with a short neck, an elongated body, a direct rim, and a rounded lip

CORE COLOR: A (fired and cooled in a high oxygen environment)

WALL THICKNESS: $5.5 \mathrm{~mm}$

INTERIOR SURFACE TREATMENT: none

EXTERIOR SURFACE TREATMENT: burnished

HEIGHT: $17.6 \mathrm{~cm}$

ORIFICE DIAMETER: $4.0 \mathrm{~cm}$, neck

DIAMETER AT BOTTOM OF RIM OR NECK: $9.2 \mathrm{~cm}$ on the body

BASE DIAMETER: $7.4 \mathrm{~cm}$

ESTIMATED VOLUME: 0.5 liters

DECORATION: There are two horizontal engraved lines on the bottle neck, and the body is plain (Vessel 41CE14-32)

TYPE: Undetermined engraved fine ware vessel, but probably Hume Engraved

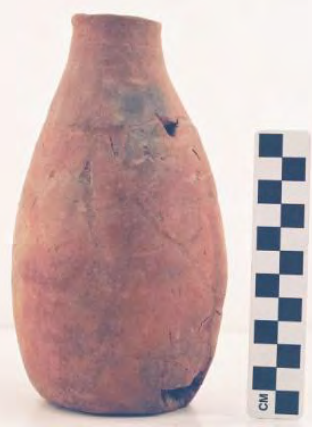

Vessel 41CE14-32, 
SITE NO.: 41CE14

FEATURE: Burial AQ-5

VESSEL NO.: 41CE14-33

NON-PLASTICS: grog, hematite, and bone

VESSEL FORM: Effigy bowl with a direct rim and a rounded lip; the effigy head is missing, but the appendage supporting the head is still attached to one side of the vessel, as is the rear appendage supporting the tab tail.

CORE COLOR: Undetermined

WALL THICKNESS: $5.3 \mathrm{~mm}$

INTERIOR SURFACE TREATMENT: smoothed

EXTERIOR SURFACE TREATMENT: burnished

HEIGHT: $7.0 \mathrm{~cm}$

ORIFICE DIAMETER: $12.5 \mathrm{~cm}$

DIAMETER AT BOTTOM OF RIM OR NECK: N/A

BASE DIAMETER: $9.0 \mathrm{~cm}$

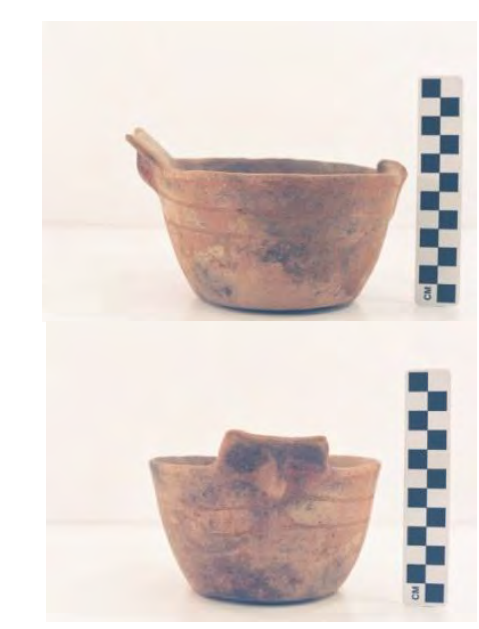

Vessel 41CE14-33: $a$, side view; $b$, view of tab tail appendage.

ESTIMATED VOLUME: 0.4 liters

DECORATION: There are three engraved horizontal lines that encircle the vessel, and either run under the appendages or terminate at them (Vessel 41CE14-33a). Where the horizontal engraved lines intersect the two vessel appendages, there are three sets of hatched pendant triangles jutting out from the appendages (Vessel 41CE14-33b); these pendant triangles on an effigy vessel suggest a typological relationship with Hood Engraved, var. Cook vessels in the upper Neches River basin, although their orientation on the rim is completely different.

TYPE: Hood Engraved, var. unspecified effigy vessel 
SITE NO.: 41CE14

FEATURE: Burial AQ-5

VESSEL NO.: 41CE14-34

NON-PLASTICS: grog, hematite, and bone

VESSEL FORM: Carinated bowl with a direct rim and a rounded, notched lip

CORE COLOR: Undetermined

WALL THICKNESS: $5.7 \mathrm{~mm}$

INTERIOR SURFACE TREATMENT: smoothed

EXTERIOR SURFACE TREATMENT: badly eroded

HEIGHT: $10.0 \mathrm{~cm}$

ORIFICE DIAMETER: $15.5 \mathrm{~cm}$

DIAMETER AT BOTTOM OF RIM OR NECK: $16.0 \mathrm{~cm}$

BASE DIAMETER: $8.5 \mathrm{~cm}$

ESTIMATED VOLUME: 0.9 liters

DECORATION: The rim has an engraved panel filled with ovals defined by two hour glass-shaped engraved columns filled with curvilinear lines and four hatched triangles; the lip is notched (Vessel 41CE14-34).

TYPE: Poynor Engraved, var. Cook

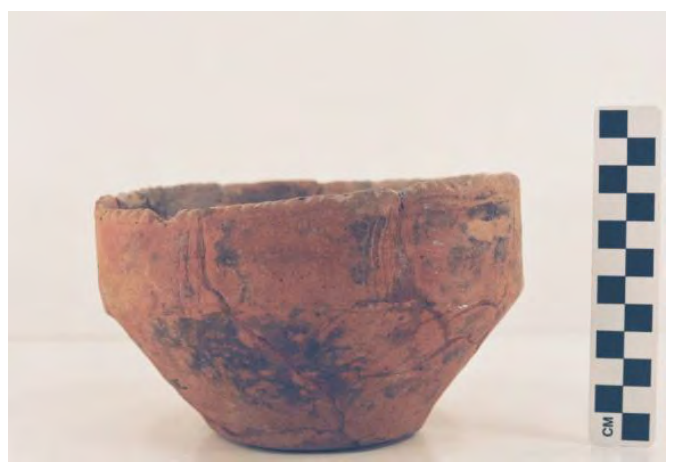

Vessel 41CE14-34. 
SITE NO.: 41CE14

FEATURE: Burial AQ-5

VESSEL NO.: 41CE14-35

NON-PLASTICS: grog and hematite

VESSEL FORM: Carinated bowl with an inverted rim and a rounded lip

CORE COLOR: A (fired and cooled in an oxidizing environment)

WALL THICKNESS: $5.3 \mathrm{~mm}$

INTERIOR SURFACE TREATMENT: smoothed

EXTERIOR SURFACE TREATMENT: burnished

HEIGHT: $7.5 \mathrm{~cm}$

ORIFICE DIAMETER: $9.7 \mathrm{~cm}$

DIAMETER AT BOTTOM OF RIM OR NECK: $13.0 \mathrm{~cm}$

BASE DIAMETER: $6.0 \mathrm{~cm}$

ESTIMATED VOLUME: 0.4 liters

DECORATION: The rim has an engraved panel defined by single horizontal engraved lines at the top and bottom of the rim. Within the panel are 10 oval-shaped areas defined by hour glass-shaped dividers filled with curvilinear engraved lines. Five of the 10 engraved ovals have circles formed by engraved punctates (Vessel 41CE14-35).

TYPE: Poynor Engraved, var. Lang

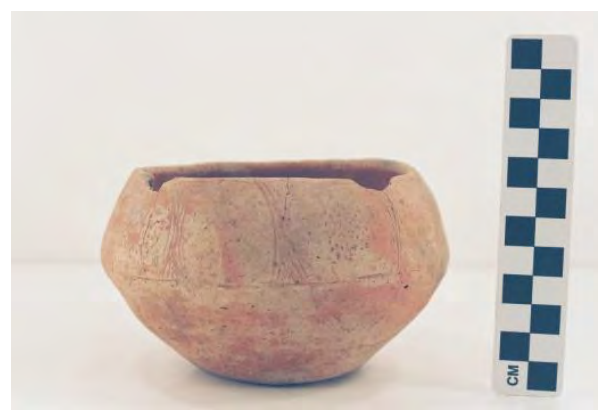

Vessel 41CE14-35. 
SITE NO.: 41CE14

FEATURE: Burial AQ-5

VESSEL NO.: 41CE14-36

NON-PLASTICS: grog, bone, hematite, and organics

VESSEL FORM: Carinated bowl with an inverted rim and a rounded, exterior folded lip

CORE COLOR: Undetermined

WALL THICKNESS: $7.5 \mathrm{~mm}$

INTERIOR SURFACE TREATMENT: smoothed on rim

EXTERIOR SURFACE TREATMENT: none

HEIGHT: $10.6 \mathrm{~cm}$

ORIFICE DIAMETER: $19.6 \mathrm{~cm}$

DIAMETER AT BOTTOM OF RIM OR NECK: $20.2 \mathrm{~cm}$

BASE DIAMETER: $9.5 \mathrm{~cm}$

\section{ESTIMATED VOLUME: 1.2 liters}

DECORATION: The rim has an engraved panel with four ovals defined by two sets (with four lines each) of closely-spaced curvilinear lines that extend from the top of the rim to the vessel carination; the lip is notched. There are two triangular-shaped hatched areas at the top and bottom of the oval, and each oval is separated from the others by a set of four closely-spaced vertical engraved lines (Vessel 41CE14-36).

TYPE: Poynor Engraved, var. Cook

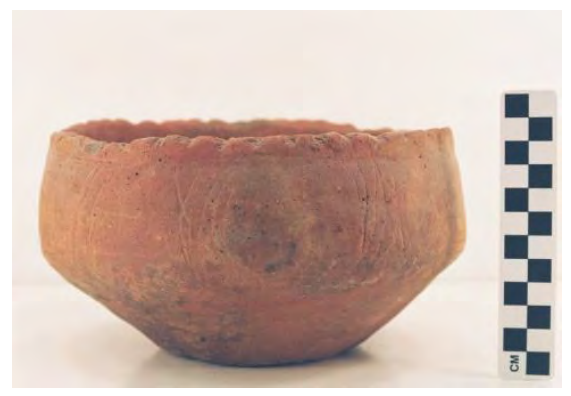

Vessel 41CE14-36. 
SITE NO.: 41CE14

FEATURE: Burial AQ-6

VESSEL NO.: 41CE14-39

NON-PLASTICS: grog and bone; sandy paste

VESSEL FORM: Jar with an everted rim and a rounded lip; two strap handles

CORE COLOR: Undetermined

WALL THICKNESS: $5.1 \mathrm{~mm}$

INTERIOR SURFACE TREATMENT: smoothed

EXTERIOR SURFACE TREATMENT: none

HEIGHT: $7.8 \mathrm{~cm}$

ORIFICE DIAMETER: $9.2 \mathrm{~cm}$

DIAMETER AT BOTTOM OF RIM OR NECK: $8.8 \mathrm{~cm}$

BASE DIAMETER: $6.9 \mathrm{~cm}$

ESTIMATED VOLUME: 0.4 liters

DECORATION: There are five horizontal rows of linear punctates on the rim, and six vertical rows on each of the strap handles. These vertical rows - but composed of eight rows instead of six - of linear punctates continue on the vessel body, extending to the vessel base. These vertical rows of linear punctates divide the jar body into two broad panels filled with 11 rows of horizontal linear punctates as well as (near the vessel base) two rows of vertical linear punctates (Vessel A4.141).

TYPE: Undetermined punctated utility ware vessel

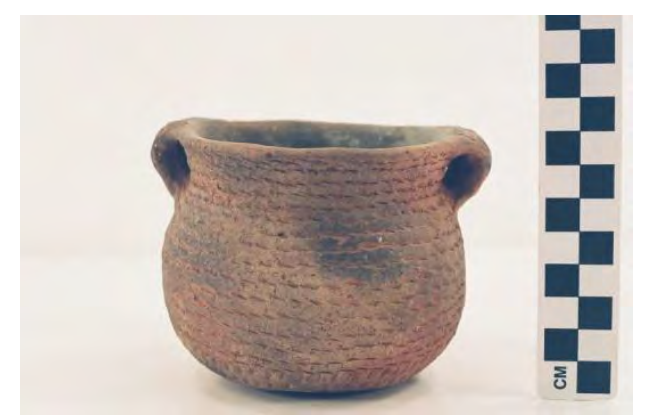

Vessel A4.141. 
SITE NO.: 41CE14

FEATURE: Burial AQ-6

VESSEL NO.: 41CE14-40

NON-PLASTICS: bone

VESSEL FORM: Globular carinated bowl with a direct rim and a rounded lip

CORE COLOR: Undetermined

WALL THICKNESS: $5.1 \mathrm{~mm}$, rim

INTERIOR SURFACE TREATMENT: smoothed on the rim

EXTERIOR SURFACE TREATMENT: burnished

HEIGHT: $11.8 \mathrm{~cm}$

ORIFICE DIAMETER: $13.1 \mathrm{~cm}$

DIAMETER AT BOTTOM OF RIM OR NECK: $13.0 \mathrm{~cm}$

BASE DIAMETER: $7.0 \mathrm{~cm}$

ESTIMATED VOLUME: 0.9 liters

DECORATION: The engraved panel on the rim has 14 negative ovals defined by hour glass-shaped columns filled with very closely-spaced curvilinear engraved lines and excised areas (Vessel 41CE14-40).

TYPE: Poynor Engraved, var. Hood

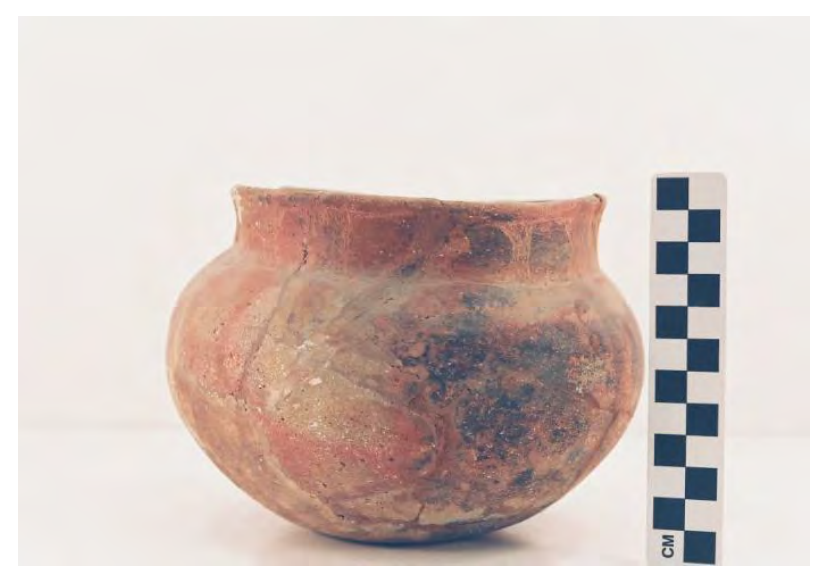

Vessel 41CE14-40. 
SITE NO.: 41CE14

FEATURE: Burial AQ-10

VESSEL NO.: 41CE14-41

NON-PLASTICS: grog and hematite

VESSEL FORM: Bottle with a globular neck, a long straight neck, a direct rim, and a rounded, exterior folded lip

CORE COLOR: A (fired and cooled in a high oxygen environment)

WALL THICKNESS: $5.0 \mathrm{~mm}$

INTERIOR SURFACE TREATMENT: none

EXTERIOR SURFACE TREATMENT: burnished

HEIGHT: $17.5 \mathrm{~cm}$

ORIFICE DIAMETER: $3.5 \mathrm{~cm}$

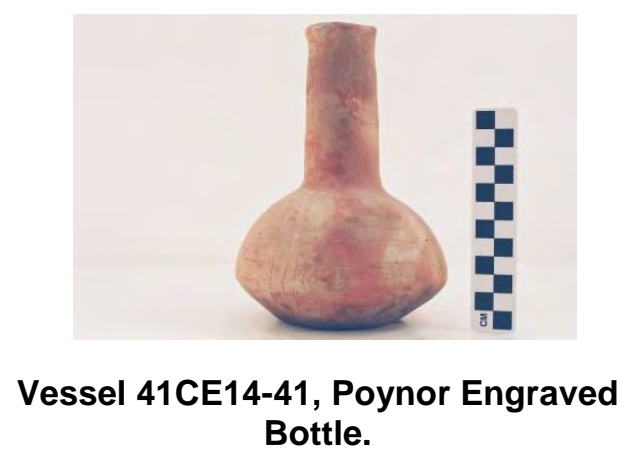

DIAMETER AT BOTTOM OF RIM OR NECK: $5.0 \mathrm{~cm}$

BASE DIAMETER: $7.0 \mathrm{~cm}$

ESTIMATED VOLUME: 0.5 liters

DECORATION: There are four engraved panels on the body of this bottle, each forming two closely-spaced sets (Vessel 41CE14-41). The sets are defined at the top by three horizontal engraved lines that encircle the top of the bottle body, and defined on the sides by two vertical engraved lines. Each panel has vertically-stacked rectangles with hatched triangles at each corner; one panel has three rectangles without hatched triangles and one rectangle with hatched triangles, while its accompanying panel (separated only by a single vertical engraved line) has two rectangles with hatched triangles at the corners that alternate with rectangles without hatched triangles.

TYPE: Poynor Engraved; the engraved rectangles suggest a stylistic relationship between this bottle and Poynor Engraved, var. Blackburn carinated bowls. 
SITE NO.: 41CE14

FEATURE: Burial AQ-6

VESSEL NO.: 41CE14-42

NON-PLASTICS: bone and hematite

VESSEL FORM: Globular carinated bowl with a direct rim and a rounded, exterior folded lip

CORE COLOR: A (fired and cooled in an oxidizing environment)

WALL THICKNESS: $5.5 \mathrm{~mm}$

INTERIOR SURFACE TREATMENT: smoothed on the rim

EXTERIOR SURFACE TREATMENT: smoothed

HEIGHT: $11.4 \mathrm{~cm}$

ORIFICE DIAMETER: $13.4 \mathrm{~cm}$

DIAMETER AT BOTTOM OF RIM OR NECK: $13.4 \mathrm{~cm}$

BASE DIAMETER: $7.0 \mathrm{~cm}$

ESTIMATED VOLUME: $0.9 \mathrm{~cm}$

DECORATION: The rim has an engraved panel filled with 14 negative ovals (Vessel 41CE14-42). In addition to the single horizontal engraved lines at the top and bottom of the rim that delimit the panel, the negative circles are defined by two closely-spaced sets of vertical engraved lines and four pendant hatched triangles at the rim and vessel carination.

TYPE: Poynor Engraved, var. $J$ in the upper Neches River basin

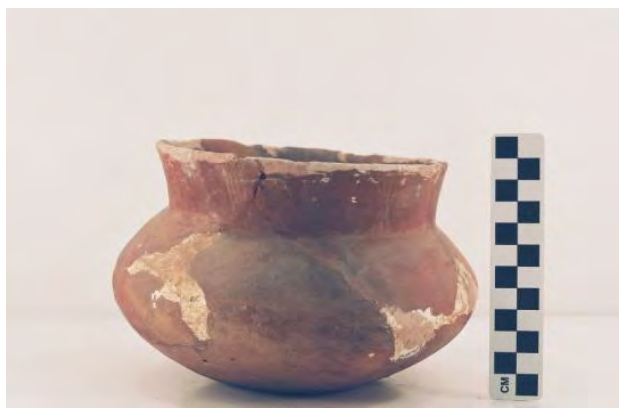

Vessel 41CE14-42. 
SITE NO.: 41CE14

FEATURE: Burial AQ-6

VESSEL NO.: 41CE14-43

NON-PLASTICS: grog

VESSEL FORM: Jar with an everted rim and a rounded lip; two strap handles

CORE COLOR: Undetermined

WALL THICKNESS: $5.5 \mathrm{~mm}$

INTERIOR SURFACE TREATMENT: smoothed

EXTERIOR SURFACE TREATMENT: none

HEIGHT: $16.0 \mathrm{~cm}$

ORIFICE DIAMETER: $13.0 \mathrm{~cm}$

DIAMETER AT BOTTOM OF RIM OR NECK: $13.0 \mathrm{~cm}$

BASE DIAMETER: $8.0 \mathrm{~cm}$

ESTIMATED VOLUME: 1.2 liters

DECORATION: The rim has a cross-hatched incised motif. The vessel body has vertical brushing marks, and the strap handles are plain (Vessel 41CE14-43).

TYPE: Maydelle Incised

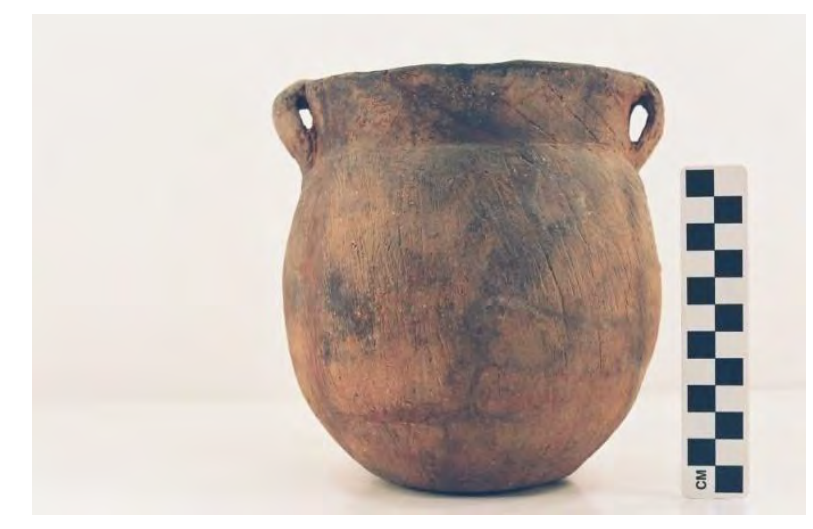

Vessel 41CE14-43. 
SITE NO.: 41CE14

FEATURE: Burial AQ-6

VESSEL NO.: 41CE14-44

NON-PLASTICS: grog

VESSEL FORM: Globular carinated bowl with an everted rim and a rounded lip

CORE COLOR: A (fired and cooled in an oxidizing environment)

WALL THICKNESS: $5.8 \mathrm{~mm}$

INTERIOR SURFACE TREATMENT: none

EXTERIOR SURFACE TREATMENT: none

HEIGHT: $11.5 \mathrm{~cm}$

ORIFICE DIAMETER: $14.5 \mathrm{~cm}$

DIAMETER AT BOTTOM OF RIM OR NECK: $13.5 \mathrm{~cm}$

BASE DIAMETER: $7.5 \mathrm{~cm}$

ESTIMATED VOLUME: 1.0 liters

DECORATION: The rim has an engraved panel filled with five negative ovals that alternate with rectangular areas (Vessel 41CE14-44). The negative ovals are formed by two sets of hour glass-shaped columns filled with vertical and curvilinear engraved lines.

TYPE: Poynor Engraved, var. Hood

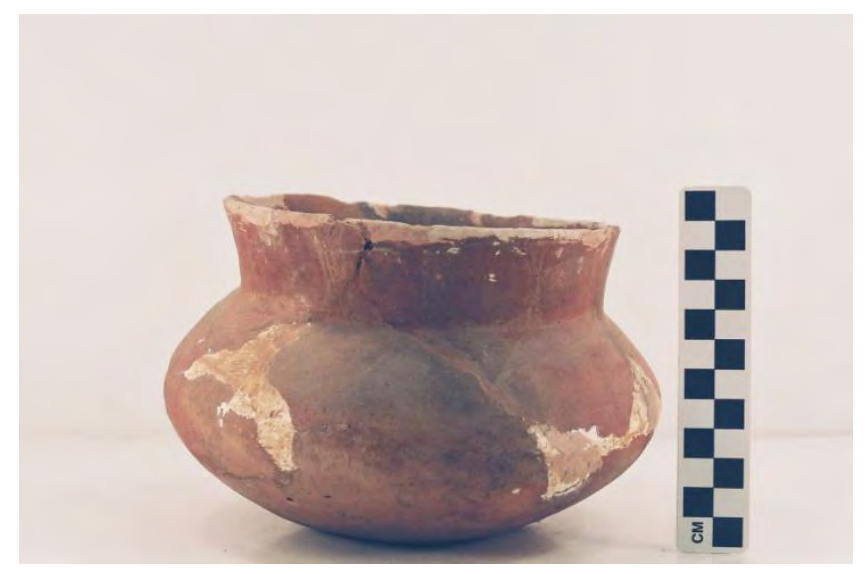

Vessel 41CE14-44. 
SITE NO.: 41CE14

FEATURE: Burial AQ-6

VESSEL NO.: 41CE14-45

NON-PLASTICS: grog and hematite

VESSEL FORM: Carinated bowl with an inverted rim and a rounded, exterior folded, lip CORE COLOR: $\mathrm{G}$ (fired in a reducing environment and cooled in the open air)

WALL THICKNESS: $7.3 \mathrm{~mm}$

INTERIOR SURFACE TREATMENT: smoothed

EXTERIOR SURFACE TREATMENT: burnished

HEIGHT: $20.0 \mathrm{~cm}$

ORIFICE DIAMETER: $27.5 \mathrm{~cm}$

DIAMETER AT BOTTOM OF RIM OR NECK: $31.0 \mathrm{~cm}$

BASE DIAMETER: $10.0 \mathrm{~cm}$

ESTIMATED VOLUME: 5.0 liters

DECORATION: The rim has four engraved ovals with a small circle and cross element at the center of each oval. The ovals are associated with large hatched scroll fill elements that are pendant from either the rim or the vessel carination. The vessel body has vertical brushing marks (Vessel 41CE14-45).

TYPE: Poynor Engraved, var. $E$ in the upper Neches River basin

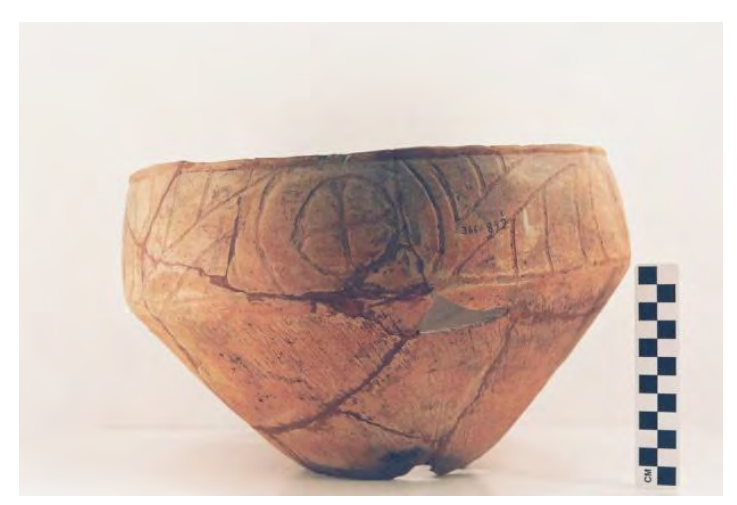

Vessel 41CE14-45. 
SITE NO.: 41CE14

FEATURE: Burial AQ-10

VESSEL NO.: 41CE14-46

NON-PLASTICS: grog and hematite

VESSEL FORM: Carinated bowl with a direct rim and a rounded, exterior folded lip (Vessel 41CE14-46)

CORE COLOR: Undetermined

WALL THICKNESS: $4.9 \mathrm{~mm}$, rim

INTERIOR SURFACE TREATMENT: smoothed on the rim

EXTERIOR SURFACE TREATMENT: burnished

HEIGHT: $10.4 \mathrm{~cm}$

ORIFICE DIAMETER: $15.3 \mathrm{~cm}$

DIAMETER AT BOTTOM OF RIM OR NECK: $15.5 \mathrm{~cm}$

BASE DIAMETER: $7.3 \mathrm{~cm}$

ESTIMATED VOLUME: 1.0 liters

DECORATION: plain

TYPE: cf. Poynor Plain

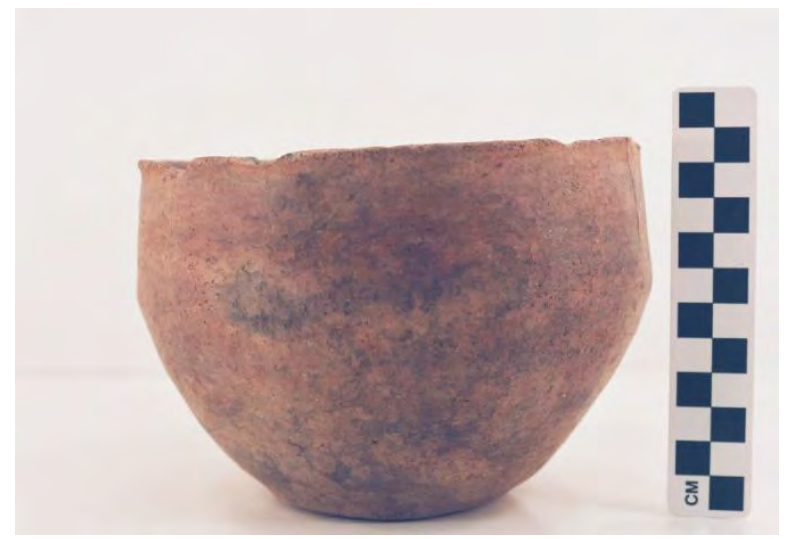

Vessel 41CE14-46. 
SITE NO.: 41CE14

FEATURE: Burial AQ-7

VESSEL NO.: 41CE14-47

NON-PLASTICS: grog

VESSEL FORM: Effigy bowl with a direct rim and a rounded lip; the effigy head has been broken off, but the tab tail appendage remains attached to the rim and the lip (Vessel 41CE14-47)

CORE COLOR: Undetermined

WALL THICKNESS: $6.4 \mathrm{~mm}$

INTERIOR SURFACE TREATMENT: smoothed

EXTERIOR SURFACE TREATMENT: smoothed

HEIGHT: $6.0 \mathrm{~cm}$

ORIFICE DIAMETER: $12.8 \mathrm{~cm}$

DIAMETER AT BOTTOM OF RIM OR NECK: N/A

BASE DIAMETER: $7.9 \mathrm{~cm}$

ESTIMATED VOLUME: 0.3 liters

DECORATION: There are three broad and widely-spaced horizontal engraved lines encircling the upper part of the vessel. The top two horizontal lines dip down in festoons as they proceed under the tab tail appendage, then revert to horizontal lines again.

TYPE: Hood Engraved, var. Hood effigy vessel

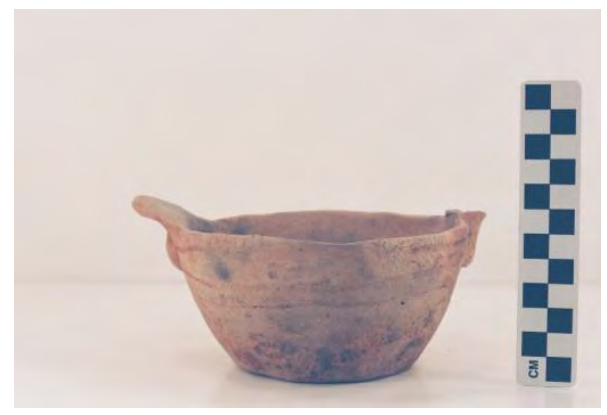

Vessel 41CE14-47. 
SITE NO.: 41CE14

FEATURE: Burial AQ-7

VESSEL NO.: 41CE14-48

NON-PLASTICS: grog

VESSEL FORM: Globular carinated bowl; upper rim and lip missing (Vessel 41CE1448)

CORE COLOR: Undetermined

WALL THICKNESS: $3.9 \mathrm{~mm}$

INTERIOR SURFACE TREATMENT: smoothed

EXTERIOR SURFACE TREATMENT: burnished

HEIGHT: Undetermined

ORIFICE DIAMETER: Undetermined

DIAMETER AT BOTTOM OF RIM OR NECK: $8.0 \mathrm{~cm}$

BASE DIAMETER: Undetermined

ESTIMATED VOLUME: Undetermined

DECORATION: There is a portion of an undetermined engraved panel on the lower part of the remaining vessel rim; the body is plain.

TYPE: Poynor Engraved, var. unspecified

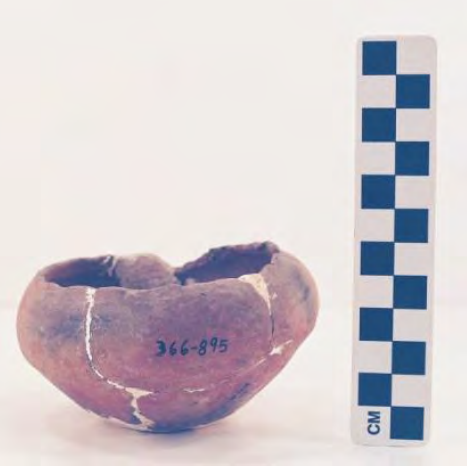

Vessel 41CE14-48. 
SITE NO.: 41CE14

FEATURE: Burial AQ-7

VESSEL NO.: 41CE14-49

NON-PLASTICS: grog and hematite

VESSEL FORM: Carinated bowl with an inverted rim and a rounded lip

CORE COLOR: C (incompletely oxidized during firing)

WALL THICKNESS: $5.5 \mathrm{~mm}$

INTERIOR SURFACE TREATMENT: none

EXTERIOR SURFACE TREATMENT: none

HEIGHT: $7.8 \mathrm{~cm}$

ORIFICE DIAMETER: $9.0 \mathrm{~cm}$

DIAMETER AT BOTTOM OF RIM OR NECK: $9.8 \mathrm{~cm}$

BASE DIAMETER: $6.8 \mathrm{~cm}$

ESTIMATED VOLUME: $0.4 \mathrm{~cm}$

DECORATION: Vertical brushing on the rim and the body (Vessel 41CE14-49)

TYPE: cf. Poynor Brushed

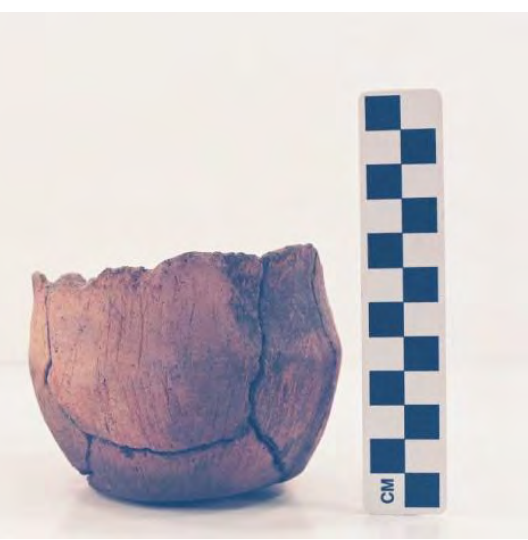

Vessel 41CE14-49. 
SITE NO.: 41CE14

FEATURE: Burial AQ-7

VESSEL NO.: 41CE14-50

NON-PLASTICS: grog and bone

VESSEL FORM: Bottle with a globular body, a straight neck, and a direct rim; the lip is missing

CORE COLOR: Undetermined

WALL THICKNESS: $6.7 \mathrm{~mm}$

INTERIOR SURFACE TREATMENT: none

EXTERIOR SURFACE TREATMENT: none

HEIGHT: $22.5 \mathrm{~cm}+$

ORIFICE DIAMETER: est. $6.0 \mathrm{~cm}$

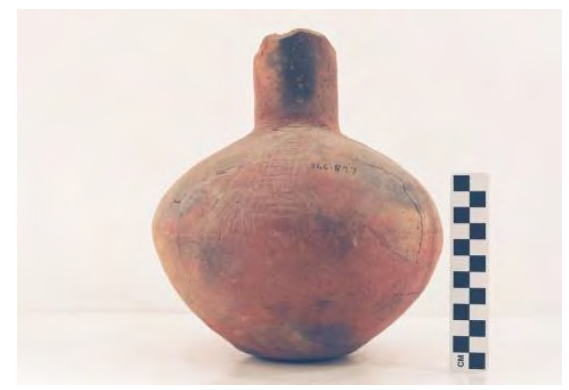

Vessel 41CE14-50.

DIAMETER AT BOTTOM OF RIM OR NECK: $6.0 \mathrm{~cm}$

BASE DIAMETER: $7.5 \mathrm{~cm}$

ESTIMATED VOLUME: 0.7 liters

DECORATION: The body of this vessel has an engraved design. There are three closelyspaced horizontal engraved lines below the bottle neck, and a single horizontal line midway on the vessel body. The body panel has three large hour glass-shaped columns formed by curvilinear engraved lines; the columns are partially filled with cross-hatching (the same engraved element is the primary motif on Poynor Engraved, var. Hood carinated bowls). Between the large hour glass-shaped columns are four smaller hour glass-shaped areas formed only with vertical curvilinear engraved lines (Vessel 41CE1450). A red clay pigment has been rubbed in the engraved lines.

TYPE: Poynor Engraved (see Suhm and Jelks 1962: Plate 63i) 
SITE NO.: 41CE14

FEATURE: Burial AQ-7

VESSEL NO.: 41CE14-51

NON-PLASTICS: grog and hematite

VESSEL FORM: Jar with a direct rim and a rounded lip

CORE COLOR: $\mathrm{G}$ (fired in a reducing environment and cooled in the open air)

WALL THICKNESS: $7.4 \mathrm{~mm}$

INTERIOR SURFACE TREATMENT: smoothed

EXTERIOR SURFACE TREATMENT: none

HEIGHT: $13.0 \mathrm{~cm}$

ORIFICE DIAMETER: $14.4 \mathrm{~cm}$

DIAMETER AT BOTTOM OF RIM OR NECK: $14.4 \mathrm{~cm}$

BASE DIAMETER: $8.5 \mathrm{~cm}$

ESTIMATED VOLUME: 1.1 liters

DECORATION: The rim has widely-spaced and roughly executed cross-hatched incised lines above a single horizontal incised line that encircles the vessel. This decorative motif extends almost three-quarters of the way down the vessel (Vessel 41CE14-51); the remainder of the vessel is plain.

TYPE: Maydelle Incised

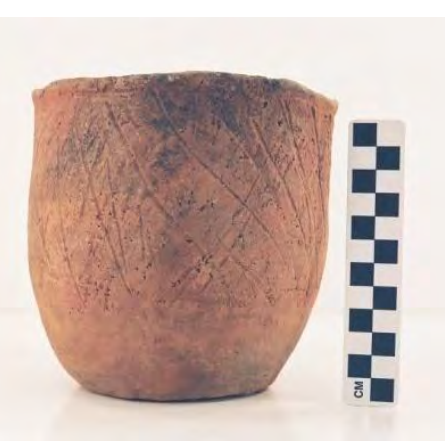

Vessel 41CE14-51. 
SITE NO.: 41CE14

FEATURE: Burial AQ-7

VESSEL NO.: 41CE14-52

NON-PLASTICS: grog and bone

VESSEL FORM: Effigy bowl with a direct rim and a rounded lip; opposing appendages (effigy head and tab tail) are missing (Vessel 41CE14-52)

CORE COLOR: A (fired and cooled in a high oxygen environment)

WALL THICKNESS: $6.4 \mathrm{~mm}$

INTERIOR SURFACE TREATMENT: smoothed

EXTERIOR SURFACE TREATMENT: burnished

HEIGHT: $9.5 \mathrm{~cm}$

ORIFICE DIAMETER: $17.0 \mathrm{~cm}$

DIAMETER AT BOTTOM OF RIM OR NECK: N/A

BASE DIAMETER: $12.0 \mathrm{~cm}$

ESTIMATED VOLUME: 0.65 liters

DECORATION: Three broad and widely-spaced horizontal engraved lines on the vessel rim

TYPE: Hood Engraved, var. unspecified effigy vessel

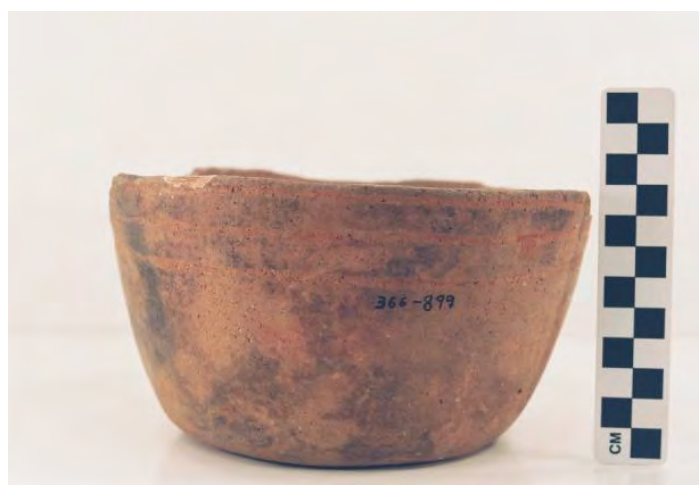

Vessel 41CE14-52. 
SITE NO.: 41CE14

FEATURE: Burial AQ-8

VESSEL NO.: 41CE14-53

NON-PLASTICS: grog and hematite

VESSEL FORM: Carinated bowl with an inverted rim and a rounded base

CORE COLOR: Undetermined

WALL THICKNESS: $4.5 \mathrm{~mm}$

INTERIOR SURFACE TREATMENT: smoothed on the rim

EXTERIOR SURFACE TREATMENT: smoothed

HEIGHT: $7.6 \mathrm{~cm}$

ORIFICE DIAMETER: $7.4 \mathrm{~cm}$

DIAMETER AT BOTTOM OF RIM OR NECK: $9.4 \mathrm{~cm}$

BASE DIAMETER: $5.0 \mathrm{~cm}$

ESTIMATED VOLUME: 0.3 liters

DECORATION: The rim has an engraved panel with seven ovals. The ovals are defined by two sets of four closely-spaced vertical curvilinear lines that extend from upper and lower horizontal engraved lines that encircle the vessel. There are hatched triangular elements adjacent to one side of the central engraved ovals (Vessel 41CE14-53).

TYPE: Poynor Engraved, var. Cook

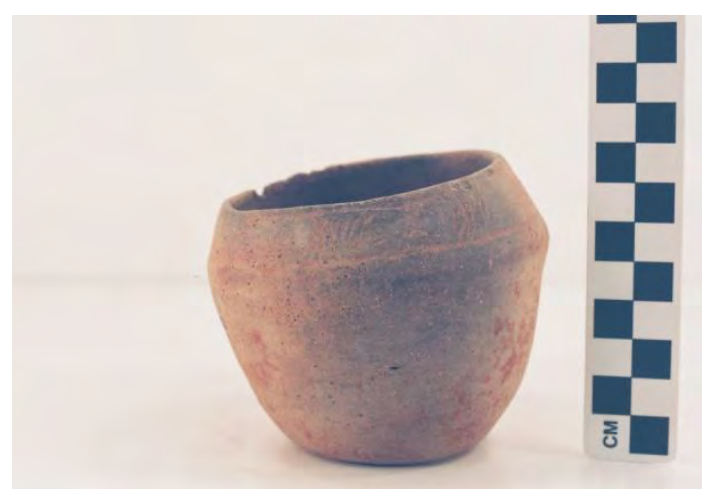

Vessel 41CE14-53. 
SITE NO.: 41CE14

FEATURE: Burial AQ-8

VESSEL NO.: 41CE14-54

NON-PLASTICS: grog and hematite

VESSEL FORM: Globular carinated bowl with a direct rim and a rounded, exterior folded lip

CORE COLOR: Undetermined

WALL THICKNESS: $4.7 \mathrm{~mm}$

INTERIOR SURFACE TREATMENT: smoothed on the rim

EXTERIOR SURFACE TREATMENT: smoothed

HEIGHT: $10.9 \mathrm{~cm}$

ORIFICE DIAMETER: $11.0 \mathrm{~cm}$

DIAMETER AT BOTTOM OF RIM OR NECK: $11.1 \mathrm{~cm}$

BASE DIAMETER: $6.2 \mathrm{~cm}$

ESTIMATED VOLUME: 0.7 liters

DECORATION: The rim has 14 engraved rectangular panels defined by upper and lower horizontal lines and two sets of four closely-spaced vertical engraved lines (Vessel 41CE14-54). A red clay pigment has been rubbed in the engraved lines.

TYPE: Poynor Engraved, var. Blackburn

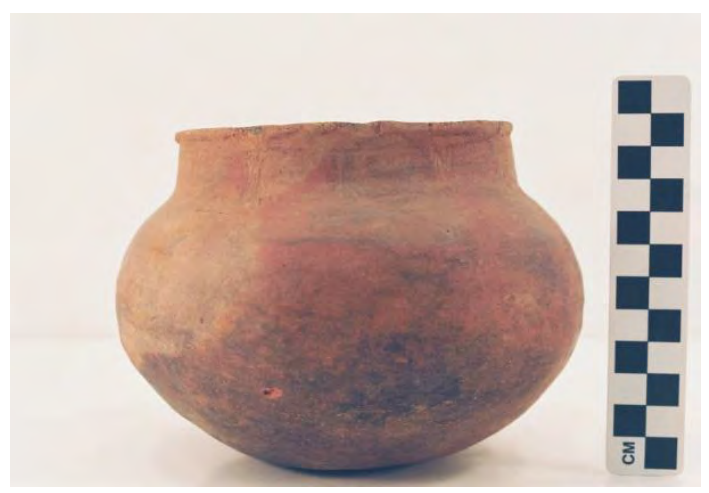

Vessel 41CE14-54. 
SITE NO.: 41CE14

FEATURE: Burial AQ-8

VESSEL NO.: 41CE14-55

NON-PLASTICS: grog and hematite

VESSEL FORM: Globular carinated bowl with an everted rim and a rounded lip

CORE COLOR: Undetermined; pinkware

WALL THICKNESS: $6.1 \mathrm{~mm}$

INTERIOR SURFACE TREATMENT: smoothed on the rim

EXTERIOR SURFACE TREATMENT: smoothed

HEIGHT: $10.5 \mathrm{~cm}$

ORIFICE DIAMETER: $14.1 \mathrm{~cm}$

DIAMETER AT BOTTOM OF RIM OR NECK: $12.1 \mathrm{~cm}$

BASE DIAMETER: $7.0 \mathrm{~cm}$

ESTIMATED VOLUME: 0.9 liters

DECORATION: The rim has 10 engraved rectangular panels defined by upper and lower horizontal lines and two sets of four closely-spaced vertical engraved lines (Vessel 41CE14-55).

TYPE: Poynor Engraved, var. Blackburn

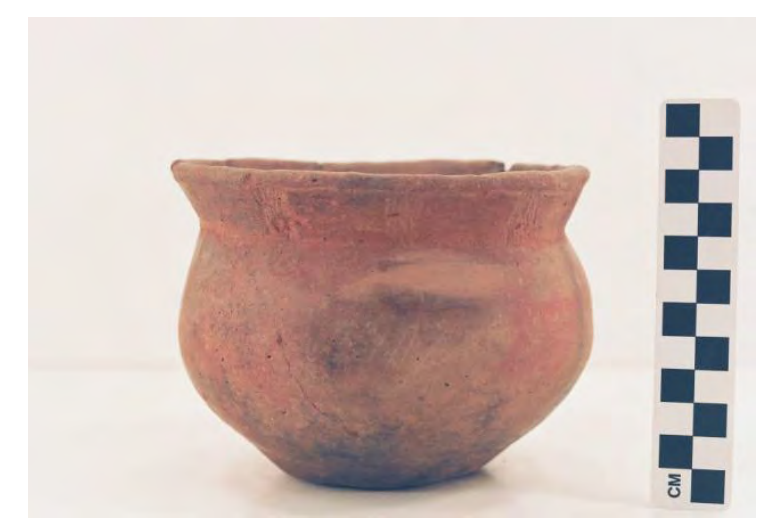

Vessel 41CE14-55. 
SITE NO.: 41CE14

FEATURE: Burial AQ-8

VESSEL NO.: 41CE14-56

NON-PLASTICS: grog and bone

VESSEL FORM: Short-necked bottle with an elongated body, a direct rim, and a rounded lip (Vessel 41CE14-56)

CORE COLOR: A (fired and cooled in a high oxygen environment)

WALL THICKNESS: $5.1 \mathrm{~mm}$

INTERIOR SURFACE TREATMENT: none

EXTERIOR SURFACE TREATMENT: burnished

HEIGHT: $23.0 \mathrm{~cm}$

ORIFICE DIAMETER: $3.1 \mathrm{~cm}$

DIAMETER AT BOTTOM OF RIM OR NECK: $4.4 \mathrm{~cm}$

BASE DIAMETER: $6.5 \mathrm{~cm}$

ESTIMATED VOLUME: 0.6 liters

DECORATION: plain

TYPE: cf. Hume Plain

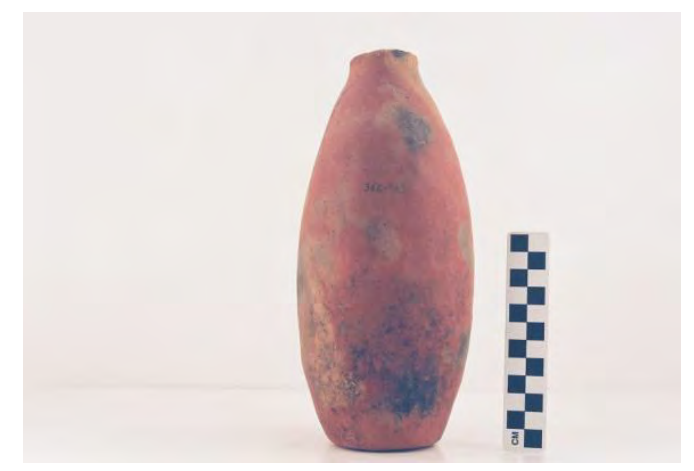

Vessel 41CE14-56. 
SITE NO.: 41CE14

FEATURE: Burial AQ-8

VESSEL NO.: 41CE14-57

NON-PLASTICS: bone, hematite, and grog

VESSEL FORM: Deep bowl with a direct rim and a rounded, exterior folded lip (Vessel 41CE14-57)

CORE COLOR: $\mathrm{G}$ (fired in a reducing environment and cooled in the open air)

WALL THICKNESS: $7.6 \mathrm{~mm}$

INTERIOR SURFACE TREATMENT: smoothed

EXTERIOR SURFACE TREATMENT: none

HEIGHT: $12.4 \mathrm{~cm}$

ORIFICE DIAMETER: $14.5 \mathrm{~cm}$

DIAMETER AT BOTTOM OF RIM OR NECK:

BASE DIAMETER: $7.6 \mathrm{~cm}$

ESTIMATED VOLUME: 0.7 liters

DECORATION: plain

TYPE: Undetermined plain ware vessel

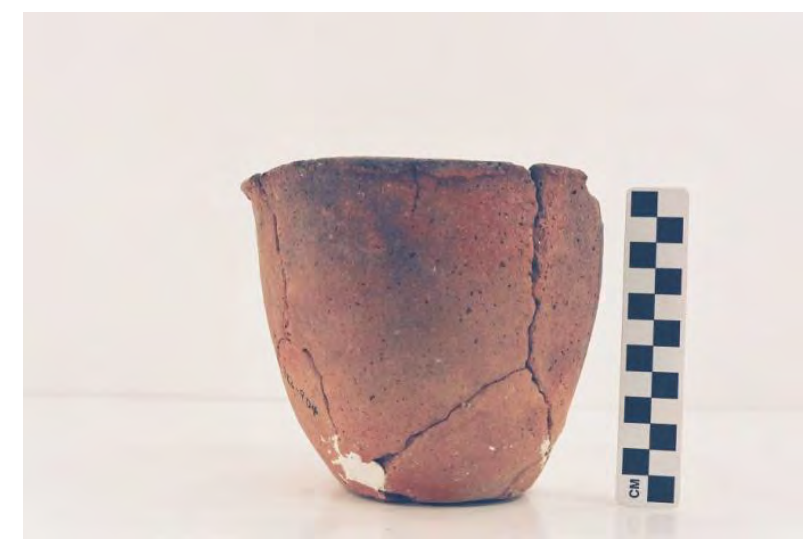

Vessel 41CE14-57. 
SITE NO.: 41CE14

FEATURE: Burial AQ-8

VESSEL NO.: 41CE14-58

NON-PLASTICS: grog and bone

VESSEL FORM: Carinated bowl with a slightly inverted rim and a rounded, notched lip

CORE COLOR: A (fired and cooled in a high oxygen environment)

WALL THICKNESS: $7.0 \mathrm{~mm}$

INTERIOR SURFACE TREATMENT: smoothed

EXTERIOR SURFACE TREATMENT: smoothed

HEIGHT: $14.0 \mathrm{~cm}$

ORIFICE DIAMETER: $23.0 \mathrm{~cm}$

DIAMETER AT BOTTOM OF RIM OR NECK: $25.0 \mathrm{~cm}$

BASE DIAMETER: $9.0 \mathrm{~cm}$

ESTIMATED VOLUME: 2.9 liters

DECORATION: The rim has an engraved panel filled with an irregular assortment of ovals (defined by two sets of closely-spaced vertical curvilinear lines) and rectangles with triangular hatched corners. There are either one or two closely-spaced vertical engraved or curvilinear lines that divide these two different panel elements (Vessel 41CE14-58).

TYPE: Poynor Engraved, var. Cook, with elements of var. Blackburn

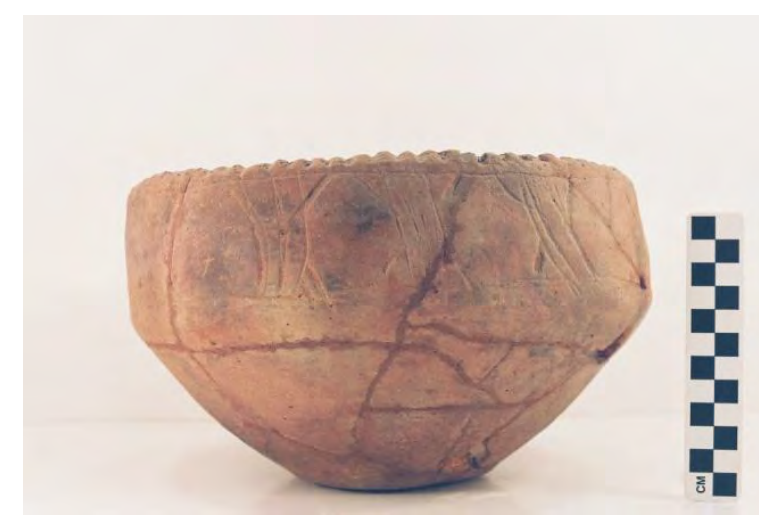

Vessel 41CE14-58. 
SITE NO.: 41CE14

FEATURE: Burial AQ-8

VESSEL NO.: 41CE14-59

NON-PLASTICS: none apparent

VESSEL FORM: Carinated bowl with a direct rim and a rounded lip; the lip is notched

CORE COLOR: A (fired and cooled in a high oxygen environment)

WALL THICKNESS: $5.5 \mathrm{~mm}$

INTERIOR SURFACE TREATMENT: burnished on the rim

EXTERIOR SURFACE TREATMENT: burnished

HEIGHT: $9.0 \mathrm{~cm}$

ORIFICE DIAMETER: $16.6 \mathrm{~cm}$

DIAMETER AT BOTTOM OF RIM OR NECK: $16.6 \mathrm{~cm}$

BASE DIAMETER: $8.4 \mathrm{~cm}$

ESTIMATED VOLUME: 0.9 liters

DECORATION: There are at least seven engraved ovals within the incomplete rim decorative panel. The ovals are formed by two sets of four closely-spaced vertical and curvilinear engraved lines, and there are hatched triangles at the upper corners within the ovals, as well as a hatched triangle pendant attached to the lower end of the closelyspaced curvilinear elements forming one part of the central ovals (Vessel 41CE14-59). A red clay pigment has been rubbed in the engraved lines.

TYPE: Poynor Engraved, var. Cook

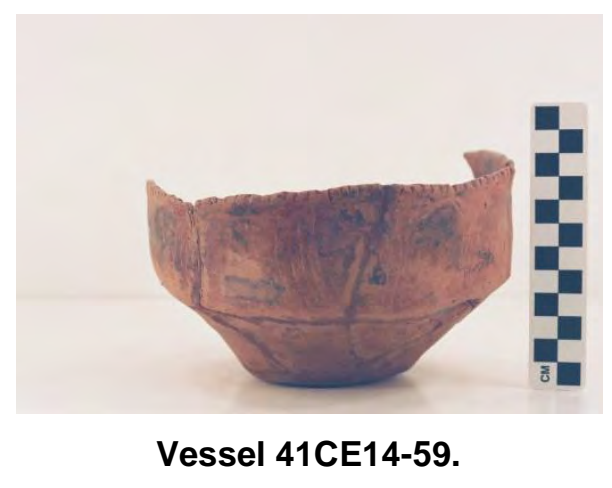


SITE NO.: 41CE14

FEATURE: Burial AQ-9

VESSEL NO.: 41CE14-71

NON-PLASTICS: grog and bone

VESSEL FORM: Globular carinated bowl with a direct rim and a rounded, exterior folded lip

CORE COLOR: Undetermined

WALL THICKNESS: $4.7 \mathrm{~mm}$

INTERIOR SURFACE TREATMENT: smoothed

EXTERIOR SURFACE TREATMENT: burnished

HEIGHT: $9.5 \mathrm{~cm}$

ORIFICE DIAMETER: $10.0 \mathrm{~cm}$

DIAMETER AT BOTTOM OF RIM OR NECK: $11.2 \mathrm{~cm}$

BASE DIAMETER: $7.5 \mathrm{~cm}$

ESTIMATED VOLUME: 0.6 liters

DECORATION: The rim has an engraved panel filled with nine negative ovals defined by nine hour glass-shaped excised areas, one on either side of each negative oval (Vessel 41CE14-71).

TYPE: Poynor Engraved, var. Hood

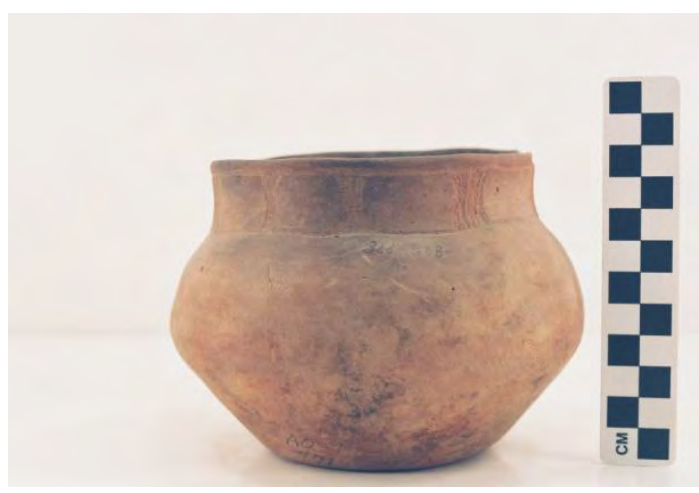

Vessel 41CE14-71. 
SITE NO.: 41CE14

FEATURE: Burial AQ-9

VESSEL NO.: 41CE14-72

NON-PLASTICS: grog and bone

VESSEL FORM: Globular carinated bowl with a direct rim and a rounded, exterior folded lip

CORE COLOR: Undetermined

WALL THICKNESS: $5.5 \mathrm{~mm}$

INTERIOR SURFACE TREATMENT: smoothed

EXTERIOR SURFACE TREATMENT: burnished

HEIGHT: $14.0 \mathrm{~cm}$

ORIFICE DIAMETER: $18.5 \mathrm{~cm}$

DIAMETER AT BOTTOM OF RIM OR NECK: $17.9 \mathrm{~cm}$

BASE DIAMETER: $7.0 \mathrm{~cm}$

ESTIMATED VOLUME: 2.3 liters

DECORATION: The rim has an engraved panel filled with 10 negative ovals defined by 10 hour glass-shaped excised areas, one on each side of the engraved ovals (Vessel 41CE14-72).

TYPE: Poynor Engraved, var. Hood

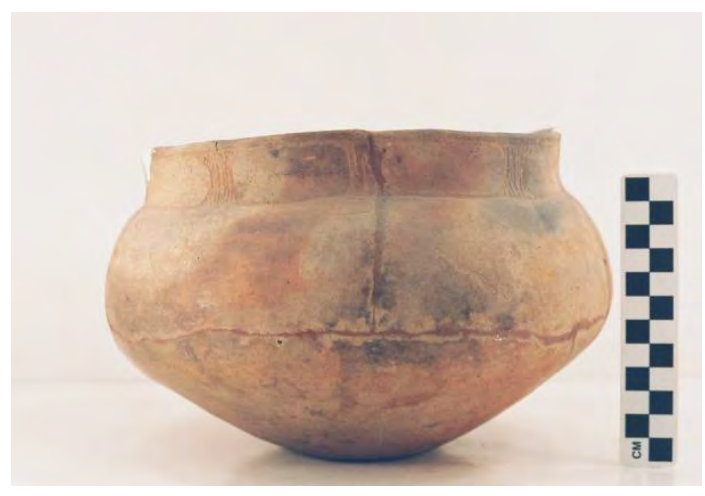

Vessel 41CE14-72. 
SITE NO.: 41CE14

FEATURE: Burial AQ-9

VESSEL NO.: 41CE14-73

NON-PLASTICS: grog and hematite

VESSEL FORM: Bottle with a short neck, an elongated body, a direct rim, and a flat lip

CORE COLOR: Undetermined

WALL THICKNESS: $6.2 \mathrm{~mm}$

INTERIOR SURFACE TREATMENT: none

EXTERIOR SURFACE TREATMENT: burnished

HEIGHT: $22.0 \mathrm{~cm}$

ORIFICE DIAMETER: $4.8 \mathrm{~cm}$

DIAMETER AT BOTTOM OF RIM OR NECK: $9.4 \mathrm{~cm}$ on the body

BASE DIAMETER: $6.9 \mathrm{~cm}$

ESTIMATED VOLUME: 0.6 liters

DECORATION: There are four cross-hatched vertical panels or ladders on the bottle body, beginning at the bottom of the bottle neck. Three of the vertical panels are hatched and the fourth is cross-hatched (Vessel 41CE14-173).

TYPE: Hume Engraved, var. Hume

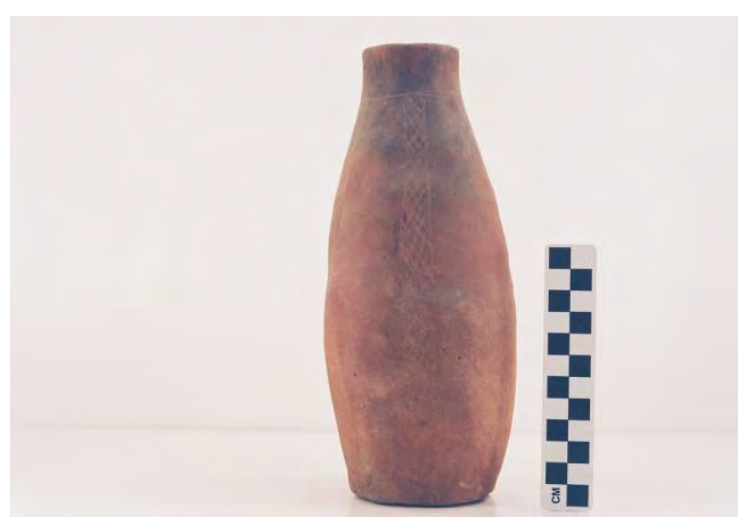

Vessel 41CE14-173. 
SITE NO.: 41CE14

FEATURE: Burial AQ-9

VESSEL NO.: 41CE14-74

NON-PLASTICS: grog and hematite

VESSEL FORM: Vase or beaker with a direct rim and a rounded, exterior folded lip

CORE COLOR: $\mathrm{F}$ (fired in a reducing environment and cooled in the open air)

WALL THICKNESS: $3.9 \mathrm{~mm}$

INTERIOR SURFACE TREATMENT: none

EXTERIOR SURFACE TREATMENT: burnished

HEIGHT: $24.3 \mathrm{~cm}$

ORIFICE DIAMETER: $4.5 \mathrm{~cm}$

DIAMETER AT BOTTOM OF RIM OR NECK: N/A

BASE DIAMETER: $8.5 \mathrm{~cm}$

ESTIMATED VOLUME: 0.8 liters

DECORATION: There are three horizontal engraved lines on the rim and just above the vessel base. Between them, on opposing sides of the vessel, are engraved panels composed of two stacked sets of rectangles with triangular hatched corners (a motif seen on Poynor Engraved, var. Blackburn carinated bowls). These stacked rectangles (four above and five below) are on either side of, and equidistant to, a central engraved circle (Vessel 41CE14-74).

TYPE: Poynor Engraved (see Suhm and Jelks 1962: Plate 63f), probably var. Blackburn

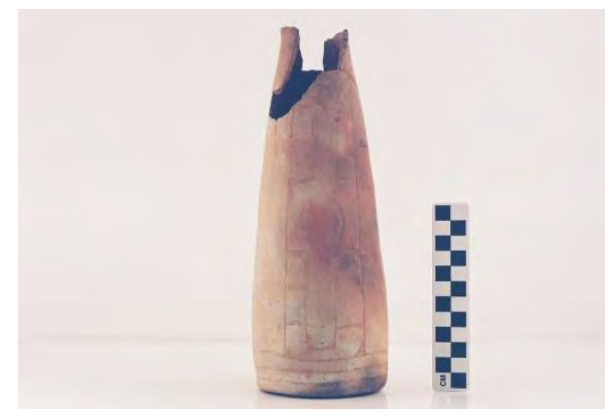

Vessel 41CE14-74. 
SITE NO.: 41CE14

FEATURE: Burial AQ-9

VESSEL NO.: 41CE14-75

NON-PLASTICS: grog and hematite

VESSEL FORM: Bottle with a short neck, an elongated body, a direct rim, and a rounded lip (Vessel 41CE14-75)

CORE COLOR: A (fired and cooled in a high oxygen environment)

WALL THICKNESS: $7.1 \mathrm{~mm}$

INTERIOR SURFACE TREATMENT: none

EXTERIOR SURFACE TREATMENT: smoothed

HEIGHT: $18.4 \mathrm{~cm}$

ORIFICE DIAMETER: $3.7 \mathrm{~cm}$

DIAMETER AT BOTTOM OF RIM OR NECK: N/A

BASE DIAMETER: $8.0 \mathrm{~cm}$

ESTIMATED VOLUME: 0.6 liters

DECORATION: plain

TYPE: cf. Hume Plain

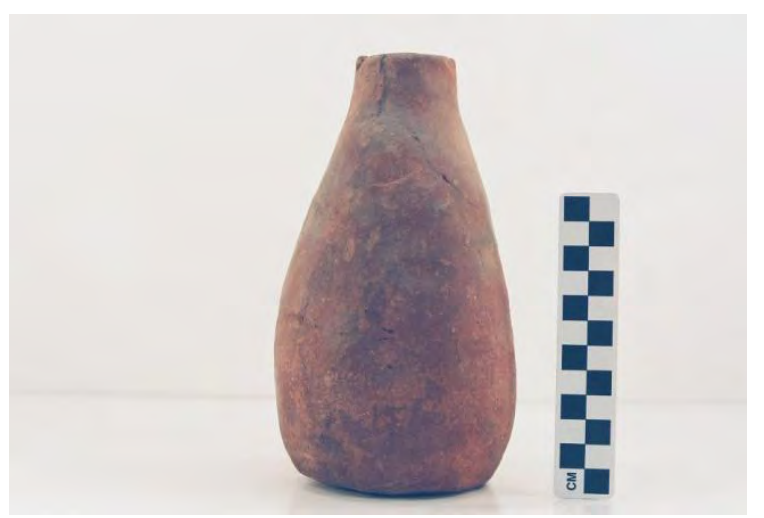

Vessel 41CE14-75. 
SITE NO.: 41CE14

FEATURE: Burial AQ-9

VESSEL NO.: 41CE14-76

NON-PLASTICS: none apparent

VESSEL FORM: Carinated bowl with an inverted rim and a rounded lip; lip notched

CORE COLOR: $\mathrm{G}$ (fired in a reducing environment and cooled in the open air)

WALL THICKNESS: $7.9 \mathrm{~mm}$

INTERIOR SURFACE TREATMENT: burnished on the rim

EXTERIOR SURFACE TREATMENT: burnished on the rim

HEIGHT: $18.6 \mathrm{~cm}$

ORIFICE DIAMETER: $32.0 \mathrm{~cm}$

DIAMETER AT BOTTOM OF RIM OR NECK: $33.2 \mathrm{~cm}$

BASE DIAMETER: $8.4 \mathrm{~cm}$

ESTIMATED VOLUME: 5.3 liters

DECORATION: The rim has an engraved panel filled with four oval-shaped areas defined by two sets of closely-spaced vertical curvilinear lines (six lines per set). Each set of vertical curvilinear engraved lines has two hatched triangular areas at the top and bottom (at the vessel carination) of the panel, two inside each oval-shaped area.

TYPE: Poynor Engraved, var. Cook

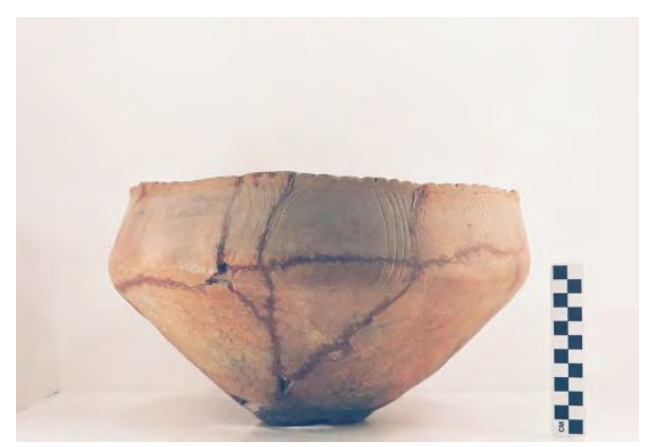

Vessel 41CE14-76, Poynor Engraved. 
SITE NO.: 41CE14

FEATURE: Burial AQ-9

VESSEL NO.: 41CE14-77

NON-PLASTICS: bone, grog, and hematite

VESSEL FORM: Effigy bowl with a direct rim and a rounded lip; the effigy head and tab tail appendages have been broken off the vessel

CORE COLOR: $\mathrm{G}$ (fired in a reducing environment but cooled in the open air)

WALL THICKNESS: $4.9 \mathrm{~mm}$

INTERIOR SURFACE TREATMENT: smoothed

EXTERIOR SURFACE TREATMENT: burnished

HEIGHT: $6.0 \mathrm{~cm}$

ORIFICE DIAMETER: $10.3 \mathrm{~cm}$

DIAMETER AT BOTTOM OF RIM OR NECK: N/A

BASE DIAMETER: $6.2 \mathrm{~cm}$

ESTIMATED VOLUME: 0.25 liters

DECORATION: There are three horizontal engraved lines on the vessel rim. The three lines dip down or festoon below the area of the tab tail appendage attachment, but return to a horizontal orientation on the remainder of the vessel (Vessel 41CE14-77).

TYPE: Hood Engraved, var. Hood effigy bowl

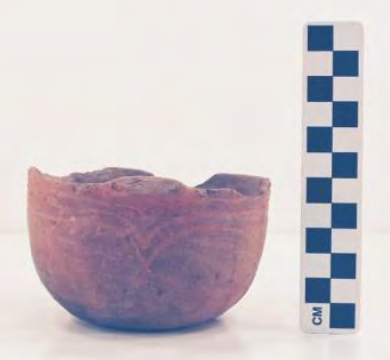

Vessel 41CE14-77. 
SITE NO.: 41CE14

FEATURE: Burial AQ-10

VESSEL NO.: 41CE14-96

NON-PLASTICS: grog

VESSEL FORM: Short-necked bottle with an elongated body, a direct rim, and a rounded lip

CORE COLOR: Undetermined

WALL THICKNESS: $6.1 \mathrm{~mm}$

INTERIOR SURFACE TREATMENT: none

EXTERIOR SURFACE TREATMENT: burnished

HEIGHT: $27.5 \mathrm{~cm}$

ORIFICE DIAMETER: $4.5 \mathrm{~cm}$

DIAMETER AT BOTTOM OF RIM OR NECK: $5.3 \mathrm{~cm}$

BASE DIAMETER: $9.5 \mathrm{~cm}$

ESTIMATED VOLUME: 1.1 liters

DECORATION: The bottle neck has three horizontal engraved lines, and there are two horizontal engraved lines near the vessel base. On the vessel body are four vertical engraved panels with a single vertical engraved line separating each of the panels from the other. Within the larger panels are a series of negative ovals (formed by hatching in the corners of rectangles) and triangular-shaped fill elements also defined by hatched areas in each corner (Vessel 41CE14-96). A white kaolin clay pigment has been rubbed in the engraved lines.

TYPE: Poynor Engraved (see Suhm and Jelks 1962: Plate 63d)

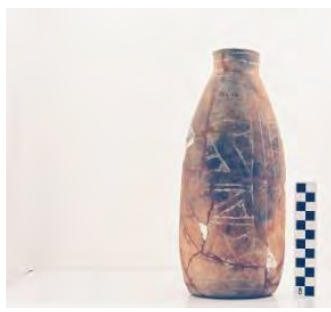

Vessel 41CE14-96. 
SITE NO.: 41CE14

FEATURE: Burial AQ-11

VESSEL NO.: 41CE14-97

NON-PLASTICS: grog and bone

VESSEL FORM: Bottle with an elongated body, and short neck (Vessel 41CE14-97), but with a missing rim and lip

CORE COLOR: A (fired and cooled in a high oxygen environment)

WALL THICKNESS: $7.3 \mathrm{~mm}$

INTERIOR SURFACE TREATMENT: none

EXTERIOR SURFACE TREATMENT: smoothed

HEIGHT: $16.0 \mathrm{~cm}+$

ORIFICE DIAMETER: Undetermined

DIAMETER AT BOTTOM OF RIM OR NECK: $4.7 \mathrm{~cm}$

BASE DIAMETER: $7.5 \mathrm{~cm}$

ESTIMATED VOLUME: $0.5+$ liters

DECORATION: plain

TYPE: cf. Hume Plain

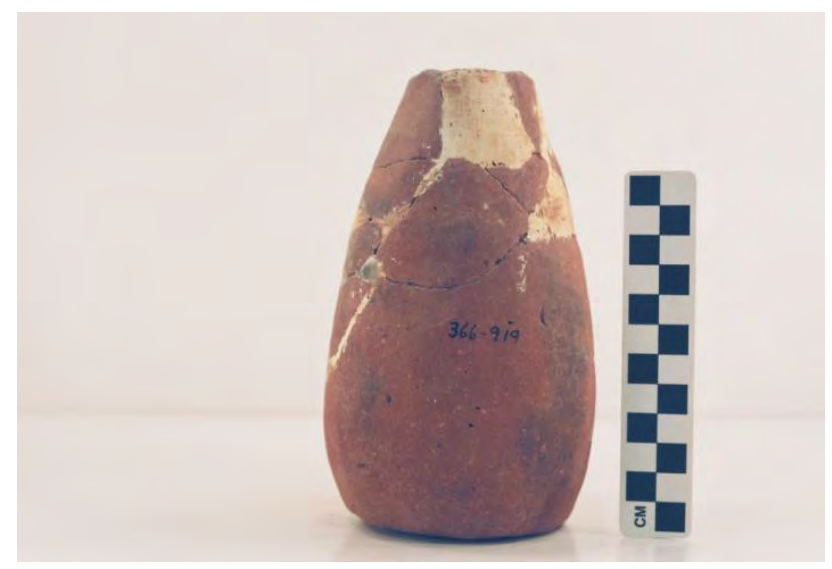

Vessel 41CE14-97. 
SITE NO.: 41CE14

FEATURE: Burial AQ-11

VESSEL NO.: 41CE14-98

NON-PLASTICS: grog and hematite

VESSEL FORM: Short-necked bottle with an elongated body, an inverted rim, and a rounded, exterior folded lip

CORE COLOR: B (fired and cooled in a low oxygen or reducing environment)

WALL THICKNESS: $7.7 \mathrm{~mm}$

INTERIOR SURFACE TREATMENT: none

EXTERIOR SURFACE TREATMENT: burnished

HEIGHT: $25.5 \mathrm{~cm}$

ORIFICE DIAMETER: $3.5 \mathrm{~cm}$

DIAMETER AT BOTTOM OF RIM OR NECK: $4.9 \mathrm{~cm}$

BASE DIAMETER: $9.0 \mathrm{~cm}$

ESTIMATED VOLUME: 0.9 liters

DECORATION: There are three vertical engraved panels on the bottle body, defined by sets of four horizontal engraved lines at the top and bottom of the vessel. Each panel has four horizontal cross-hatched hour glass-shaped dividers such as are seen on Poynor Engraved, var. Hood carinated bowls (Vessel 41CE14-98).

TYPE: Poynor Engraved (Suhm and Jelks 1962: Plate 63e)

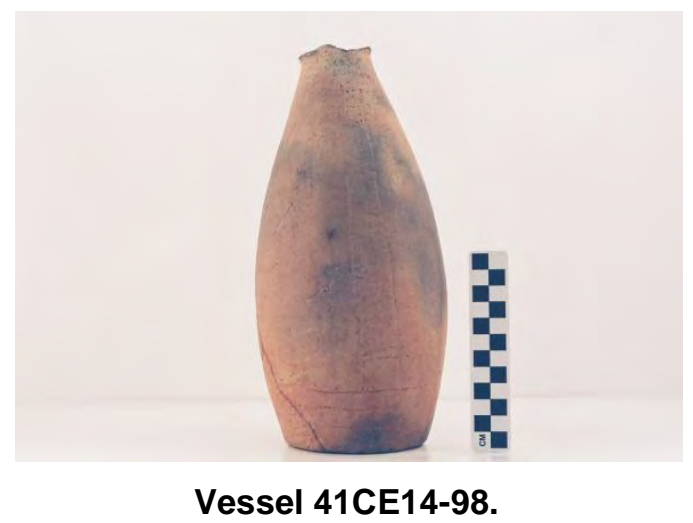


SITE NO.: 41CE14

FEATURE: Burial AQ-11

VESSEL NO.: 41CE14-99

NON-PLASTICS: grog

VESSEL FORM: Jar or deep bowl with a direct rim and a rounded lip

CORE COLOR: $\mathrm{G}$ (fired in a reducing environment and cooled in the open air)

WALL THICKNESS: $4.4 \mathrm{~cm}$

INTERIOR SURFACE TREATMENT: smoothed on the rim

EXTERIOR SURFACE TREATMENT: none

HEIGHT: $9.7 \mathrm{~cm}$

ORIFICE DIAMETER: $13.3 \mathrm{~cm}$

DIAMETER AT BOTTOM OF RIM OR NECK: $13.3 \mathrm{~cm}$

BASE DIAMETER: $6.9 \mathrm{~cm}$

ESTIMATED VOLUME: 0.8 liters

DECORATION: There are three rows of vertically-oriented linear punctates on the vessel rim. The vessel body is plain (Vessel 41CE14-99).

TYPE: Undetermined punctated utility ware vessel

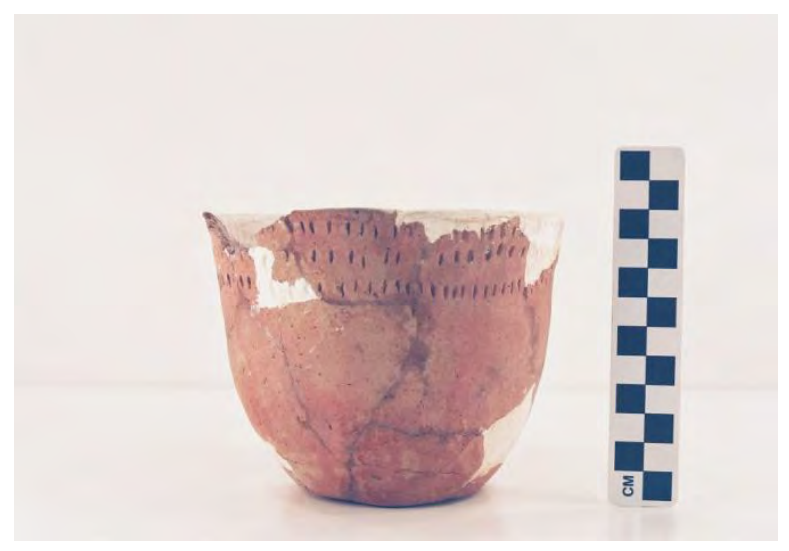

Vessel 41CE14-99. 
SITE NO.: 41CE14

FEATURE: Burial AQ-11

VESSEL NO.: 41CE14-100

NON-PLASTICS: grog

VESSEL FORM: Globular carinated bowl with a direct rim and a rounded, exterior folded lip

CORE COLOR: Undetermined

WALL THICKNESS: $6.5 \mathrm{~mm}$

INTERIOR SURFACE TREATMENT: smoothed

EXTERIOR SURFACE TREATMENT: burnished

HEIGHT: $14.0 \mathrm{~cm}$

ORIFICE DIAMETER: $16.0 \mathrm{~cm}$

DIAMETER AT BOTTOM OF RIM OR NECK: $16.5 \mathrm{~cm}$

BASE DIAMETER: $10.0 \mathrm{~cm}$

ESTIMATED VOLUME: 2.0 liters

DECORATION: The rim has an engraved panel with nine negative ovals defined by two hour glass-shaped columns (there are a total of nine columns around the panel) filled with vertical curvilinear lines (Vessel 41CE14-100.).

TYPE: Poynor Engraved, var. Hood

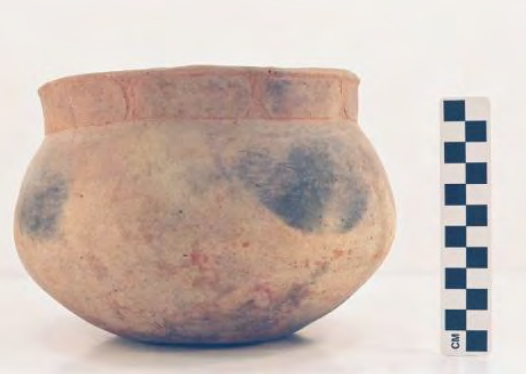

Vessel 41CE14-100. Poynor Engraved, var. Hood, 
SITE NO.: 41CE14

FEATURE: Burial AQ-11

VESSEL NO.: 41CE14-101

NON-PLASTICS: bone and hematite

VESSEL FORM: Miniature globular carinated bowl with direct rim and a rounded, exterior folded lip; attachments for two strap handles; vessel attached to a three-legged ring base

CORE COLOR: Undetermined

WALL THICKNESS: $4.5 \mathrm{~mm}$

INTERIOR SURFACE TREATMENT: smoothed on the rim

EXTERIOR SURFACE TREATMENT: smoothed

HEIGHT: $7.4 \mathrm{~cm}$

ORIFICE DIAMETER: $5.1 \mathrm{~cm}$

DIAMETER AT BOTTOM OF RIM OR NECK: 5.0 $\mathrm{cm}$

BASE DIAMETER: $5.0 \mathrm{~cm}$

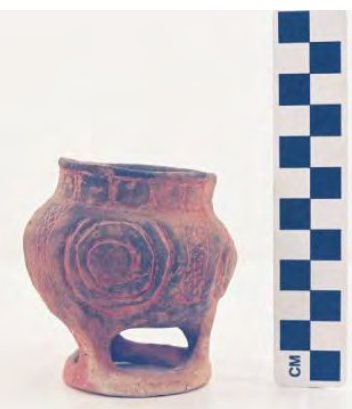

ESTIMATED VOLUME: 0.2 liters

DECORATION: There are 10 engraved negative oval panels on the rim, each defined by two hour glass-shaped zones with small hatched triangles at the upper and lower ends of the vertical lines. On the vessel body there are four rectangular panels that are filled with cross-hatched engraved lines as well as four concentric circles comprised of three incised and one pinched concentric circle (Vessel 41CE14-101); two of the four the concentric circles are directly under the attachments for the strap handles. The strap handles are plain.

TYPE: Poynor Engraved, var. Hood (at least as based on the rim design) 
SITE NO.: 41CE14

FEATURE: Burial AQ-11

VESSEL NO.: 41CE14-102

NON-PLASTICS: bone and hematite

VESSEL FORM: Bowl with a direct rim and a rounded lip

CORE COLOR: E (incompletely oxidized during firing); pinkware

WALL THICKNESS: $7.3 \mathrm{~mm}$

INTERIOR SURFACE TREATMENT: smoothed

EXTERIOR SURFACE TREATMENT: burnished

HEIGHT: $11.5 \mathrm{~cm}$

ORIFICE DIAMETER: $21.0 \mathrm{~cm}$

DIAMETER AT BOTTOM OF RIM OR NECK: N/A

BASE DIAMETER: $12.0 \mathrm{~cm}$

ESTIMATED VOLUME: 1.4 liters

DECORATION: The rim or uppermost part of the vessel has two rectangular panels with three broad horizontal engraved lines within it; the lowermost engraved line has excised pendant triangles (Vessel 41CE14-102). A red clay pigment has been rubbed in the engraved lines.

TYPE: Hood Engraved, var. unspecified

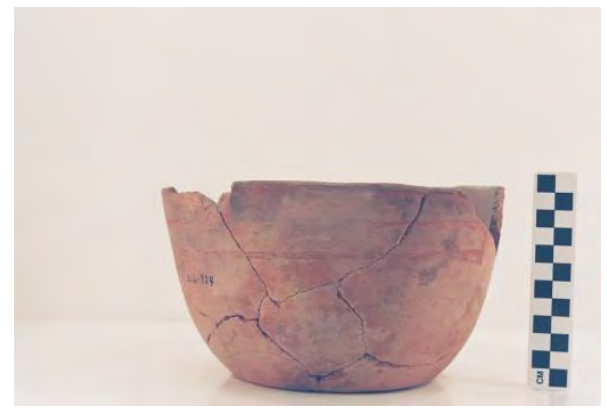

Vessel 41CE14-102. 
SITE NO.: 41CE14

FEATURE: Burial AQ-12

VESSEL NO.: 41CE14-103

NON-PLASTICS: grog, hematite, and bone

VESSEL FORM: Short-necked bottle with an elongated body, a direct rim, and a rounded lip

CORE COLOR: Undetermined

WALL THICKNESS: $6.3 \mathrm{~mm}$

INTERIOR SURFACE TREATMENT: none

EXTERIOR SURFACE TREATMENT: burnished

HEIGHT: $28.0 \mathrm{~cm}$

ORIFICE DIAMETER: $4.0 \mathrm{~cm}$

DIAMETER AT BOTTOM OF RIM OR NECK: $5.6 \mathrm{~cm}$

BASE DIAMETER: $7.0 \mathrm{~cm}$

ESTIMATED VOLUME: 0.8 liters

DECORATION: The bottle neck has two horizontal engraved lines on it. The lowermost engraved line has a series of small hatched pendant triangles (Vessel 41CE14-103). The vessel body is plain.

TYPE: Hume Engraved

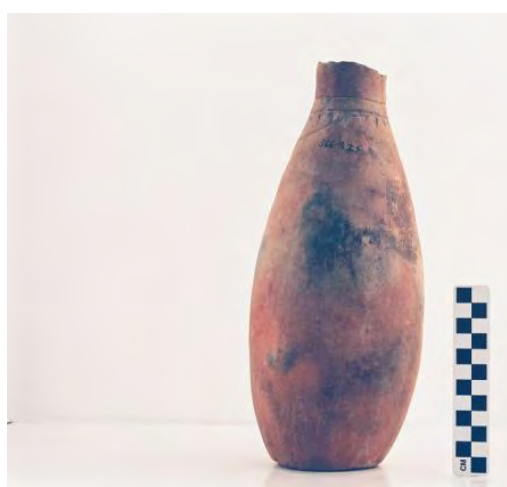

Vessel 41CE14-103. 
SITE NO.: 41CE14

FEATURE: Burial AQ-12

VESSEL NO.: 41CE14-104

NON-PLASTICS: grog and hematite

VESSEL FORM: Short-necked bottle with an elongated body, a direct rim, and a rounded lip

CORE COLOR: A (fired and cooled in a high oxygen environment)

WALL THICKNESS: $9.1 \mathrm{~mm}$

INTERIOR SURFACE TREATMENT: none

EXTERIOR SURFACE TREATMENT: burnished

HEIGHT: $24.5 \mathrm{~cm}$

ORIFICE DIAMETER: $3.1 \mathrm{~cm}$

DIAMETER AT BOTTOM OF RIM OR NECK: $4.9 \mathrm{~cm}$

BASE DIAMETER: $8.0 \mathrm{~cm}$

ESTIMATED VOLUME: 0.8 liters

DECORATION: There are three horizontal engraved lines on the bottle neck, and a second set of five horizontal engraved lines near the vessel base. The body has four vertical panels that extend from the rim to near the vessel base. Each panel has negative ovals defined by two cross-hatched hour glass-shaped columns (Vessel 41CE14-104), a motif seen on Poynor Engraved, var. Hood carinated bowls. Two panels have nine negative ovals, a third has 10 negative ovals, and the last panel has 11 negative ovals.

TYPE: Poynor Engraved

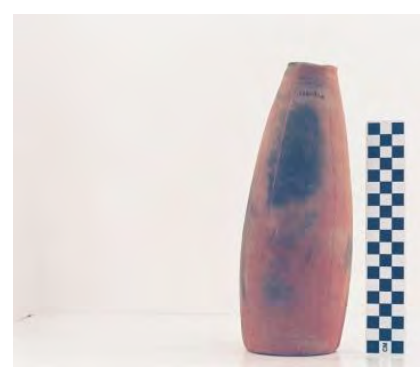

Vessel 41CE14-104. 
SITE NO.: 41CE14

FEATURE: Burial AQ-12

VESSEL NO.: 41CE14-105

NON-PLASTICS: grog and hematite

VESSEL FORM: Short-necked bottle with a somewhat elongated body, a direct rim, and a rounded lip (Vessel 41CE14-105)

CORE COLOR: A (fired and cooled in a high oxygen environment)

WALL THICKNESS: $5.4 \mathrm{~mm}$

INTERIOR SURFACE TREATMENT: none

EXTERIOR SURFACE TREATMENT: none

HEIGHT: $11.0 \mathrm{~cm}$

ORIFICE DIAMETER: $3.8 \mathrm{~cm}$

DIAMETER AT BOTTOM OF RIM OR NECK: $7.6 \mathrm{~cm}$ on the body

BASE DIAMETER: $5.0 \mathrm{~cm}$

ESTIMATED VOLUME: 0.2 liters

DECORATION: plain

TYPE: cf. Hume Plain

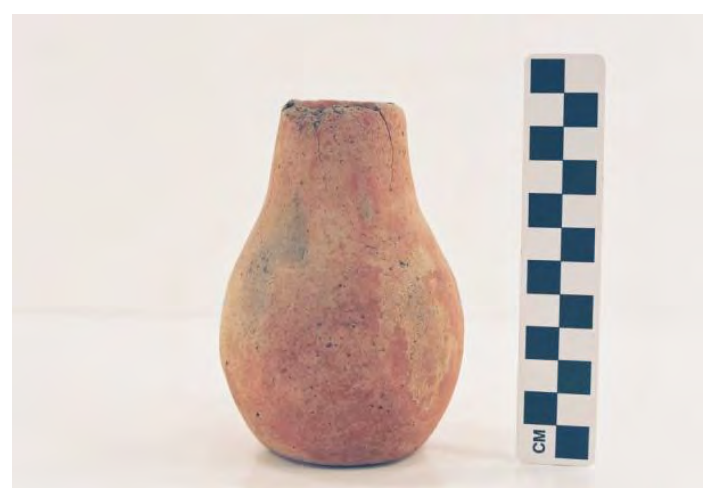

Vessel 41CE14-105. 
SITE NO.: 41CE14

FEATURE: Burial AQ-12

VESSEL NO.: 41CE14-106

NON-PLASTICS: grog and hematite

VESSEL FORM: Jar with a direct rim and a rounded lip; two strap handles

CORE COLOR: Undetermined

WALL THICKNESS: $6.9 \mathrm{~mm}$

INTERIOR SURFACE TREATMENT: smoothed

EXTERIOR SURFACE TREATMENT: none

HEIGHT: $13.2 \mathrm{~cm}$

ORIFICE DIAMETER: $12.7 \mathrm{~cm}$

DIAMETER AT BOTTOM OF RIM OR NECK: $12.8 \mathrm{~cm}$

BASE DIAMETER: $6.2 \mathrm{~cm}$

ESTIMATED VOLUME: 1.0 liters

DECORATION: The rim is decorated with closely-spaced and deeply drawn vertical incised lines, while the body has vertical brushing marks; the strap handle is plain (Vessel 41CE14-106)

TYPE: Undetermined incised-brushed utility ware vessel

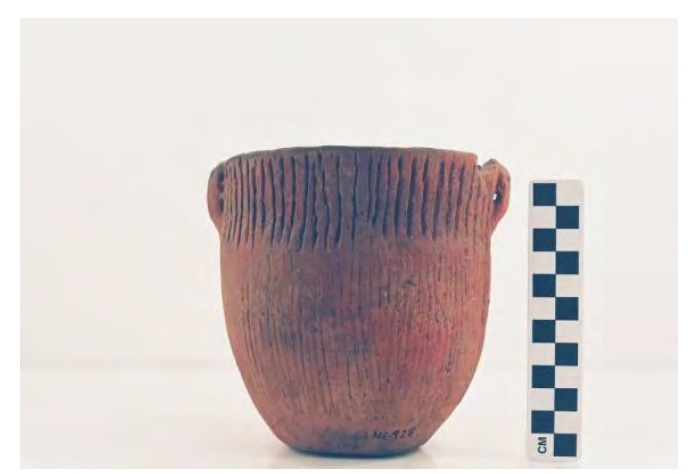

Vessel 41CE14-106. 
SITE NO.: 41CE14

FEATURE: Burial AQ-12

VESSEL NO.: 41CE14-107

NON-PLASTICS: grog and bone

VESSEL FORM: Jar with a direct rim and a rounded, exterior folded, lip

CORE COLOR: A (fired and cooled in an oxidizing environment); pinkware

WALL THICKNESS: $6.0 \mathrm{~mm}$

INTERIOR SURFACE TREATMENT: none

EXTERIOR SURFACE TREATMENT: none

HEIGHT: $9.1 \mathrm{~cm}$

ORIFICE DIAMETER: $8.3 \mathrm{~cm}$

DIAMETER AT BOTTOM OF RIM OR NECK: $8.1 \mathrm{~cm}$

BASE DIAMETER: $5.8 \mathrm{~cm}$

ESTIMATED VOLUME: 0.5 liters

DECORATION: There are four rows of pinching on the rim. On the vessel body are four sets of concentric pinched circles. Each pinched concentric circle is divided by three rows of vertical to diagonal pinched rows (Vessel 41CE14-107.).

TYPE: Killough Pinched

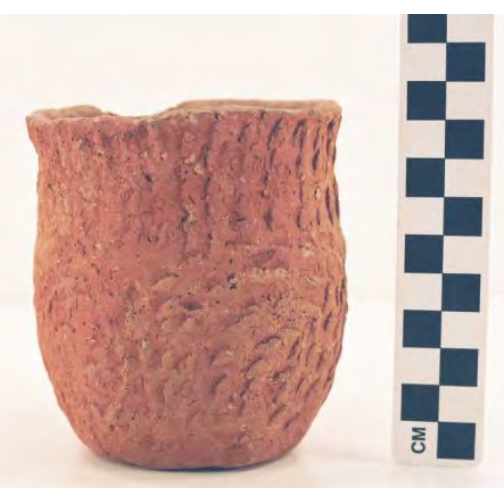

Vessel 41CE14-107. Killough Pinched Jar, 
SITE NO.: 41CE14

FEATURE: Burial AQ-12

VESSEL NO.: 41CE14-108

NON-PLASTICS: grog and bone

VESSEL FORM: Carinated bowl with an inverted rim and a rounded, exterior folded and crimped lip

CORE COLOR: Undetermined

WALL THICKNESS: $7.0 \mathrm{~mm}$

INTERIOR SURFACE TREATMENT: smoothed

EXTERIOR SURFACE TREATMENT: burnished

HEIGHT: $17.5 \mathrm{~cm}$

ORIFICE DIAMETER: $27.0 \mathrm{~cm}$

DIAMETER AT BOTTOM OF RIM OR NECK: $28.2 \mathrm{~cm}$

BASE DIAMETER: $8.5 \mathrm{~cm}$

ESTIMATED VOLUME: 4.3 liters

DECORATION: The rim has an engraved panel filled with four ovals separated by one to three vertical columns of engraved lines (Vessel 41CE14-108). The vessel body has both horizontal and overlapping brushing marks, with the overlapping brushed confined to the lowermost part of the body.

TYPE: Poynor Engraved, var. Cook

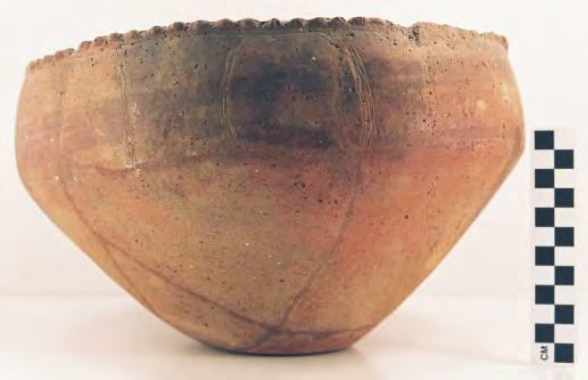

Vessel 41CE14-108. 
SITE NO.: 41CE14

FEATURE: Burial AQ-12

VESSEL NO.: 41CE14-109

NON-PLASTICS: grog and bone

VESSEL FORM: Bowl with a direct rim and a rounded lip; two attached lugs at opposite ends of the vessel

CORE COLOR: Undetermined

WALL THICKNESS: $6.1 \mathrm{~mm}$

INTERIOR SURFACE TREATMENT: smoothed

EXTERIOR SURFACE TREATMENT: burnished

HEIGHT: $7.0 \mathrm{~cm}$

ORIFICE DIAMETER: $10.1 \mathrm{~cm}$

DIAMETER AT BOTTOM OF RIM OR NECK: N/A

BASE DIAMETER: $8.0 \mathrm{~cm}$

ESTIMATED VOLUME: 0.3 liters

DECORATION: Three horizontal engraved lines on the rim that encircle the vessel, except at the appendages, where they are absent (Vessel 41CE14-109).

TYPE: Hood Engraved, var. unspecified, possible effigy vessel

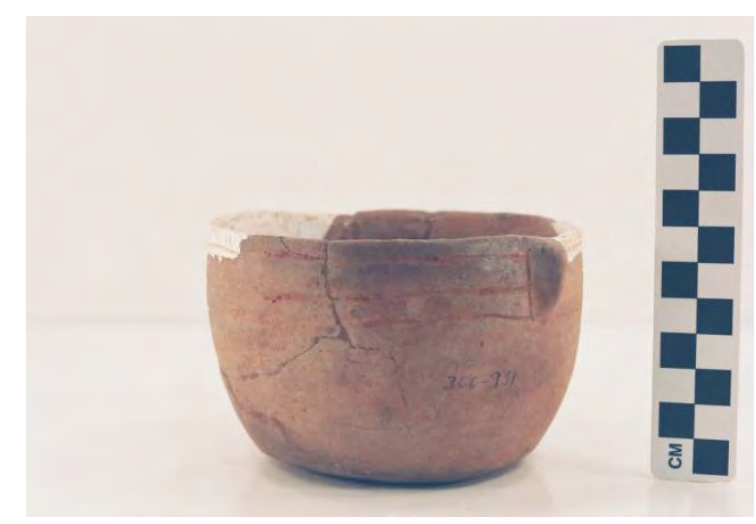

Vessel 41CE14-109. 
SITE NO.: 41CE14

FEATURE: Burial AQ-12

VESSEL NO.: 41CE14-110

NON-PLASTICS: grog and bone

VESSEL FORM: Carinated bowl with an inverted rim and a flat lip

CORE COLOR: Undetermined

WALL THICKNESS: $5.8 \mathrm{~mm}$

INTERIOR SURFACE TREATMENT: smoothed on the rim

EXTERIOR SURFACE TREATMENT: smoothed

HEIGHT: $8.2 \mathrm{~cm}$

ORIFICE DIAMETER: $12.3 \mathrm{~cm}$

DIAMETER AT BOTTOM OF RIM OR NECK: $12.9 \mathrm{~cm}$

BASE DIAMETER: $6.6 \mathrm{~cm}$

ESTIMATED VOLUME: 0.6 liters

DECORATION: The rim has an engraved panel filled with six negative ovals (Vessel 41CE14-110). Each of these ovals are defined by two hour glass-shaped columns filled with vertical and curvilinear engraved lines. The vessel body has both horizontal and diagonal brushing marks.

TYPE: Poynor Engraved, var. Hood

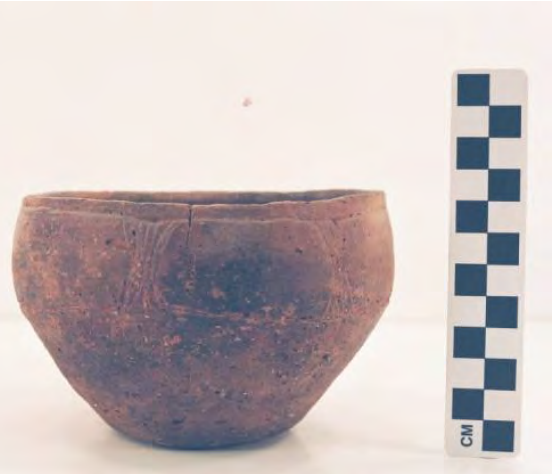

Vessel 41CE14-110. Poynor Engraved, var. Hood, 
SITE NO.: 41CE14

FEATURE: Burial AQ-12

VESSEL NO.: 41CE14-111

NON-PLASTICS: grog, hematite, and bone

VESSEL FORM: Globular carinated bowl with an inverted rim and a rounded, exterior folded lip

CORE COLOR: $\mathrm{F}$ (fired in a reducing environment and cooled in the open air)

WALL THICKNESS: $7.6 \mathrm{~mm}$

INTERIOR SURFACE TREATMENT: smoothed

EXTERIOR SURFACE TREATMENT: burnished

HEIGHT: $7.5 \mathrm{~cm}$

ORIFICE DIAMETER: $9.0 \mathrm{~cm}$

DIAMETER AT BOTTOM OF RIM OR NECK: $10.5 \mathrm{~cm}$

BASE DIAMETER: $5.0 \mathrm{~cm}$

ESTIMATED VOLUME: 0.4 liters

DECORATION: The rim has an engraved panel with 10 negative ovals defined by 10 hour glass-shaped excised areas (Vessel 41CE14-111).

TYPE: Poynor Engraved, var. Hood

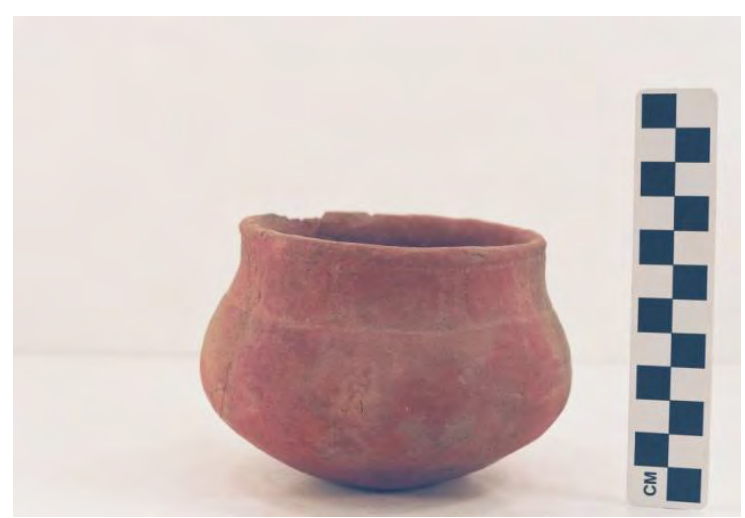

Vessel 41CE14-111. 
SITE NO.: 41CE14

FEATURE: Burial AQ-12

VESSEL NO.: 41CE14-112

NON-PLASTICS: grog

VESSEL FORM: Globular carinated bowl with a slightly everted rim and a rounded lip CORE COLOR: B (fired and cooled in a low oxygen environment)

WALL THICKNESS: $5.3 \mathrm{~mm}$

INTERIOR SURFACE TREATMENT: smoothed

EXTERIOR SURFACE TREATMENT: smoothed

HEIGHT: $9.5 \mathrm{~cm}$

ORIFICE DIAMETER: $10.5 \mathrm{~cm}$

DIAMETER AT BOTTOM OF RIM OR NECK: $11.7 \mathrm{~cm}$

BASE DIAMETER: $6.5 \mathrm{~cm}$

ESTIMATED VOLUME: 0.6 liters

DECORATION: The rim has an engraved design comprised of nine rectangular panels, with single upper and lower horizontal engraved lines encircling the rim. Each rectangular panel is defined by two sets of closely-spaced vertical engraved lines (each set has either four or five vertical lines) (Vessel 41CE14-112.).

TYPE: Poynor Engraved, var. Blackburn

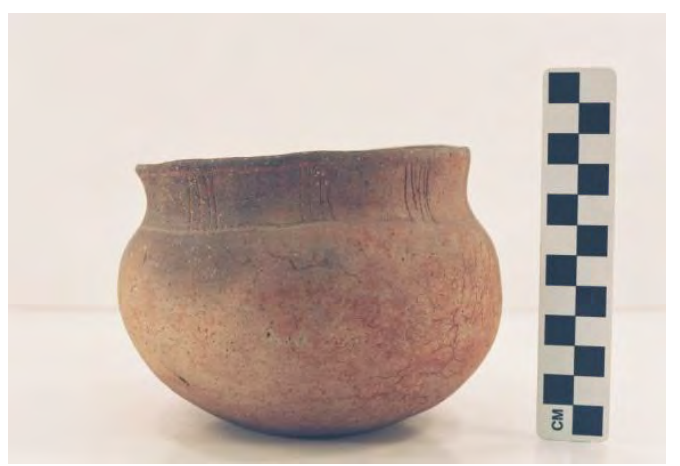

Vessel 41CE14-112. Poynor Engraved, var. Blackburn Carinated Bowl. 
SITE NO.: 41CE14

FEATURE: Burial AQ-12

VESSEL NO.: 41CE14-113

NON-PLASTICS: grog and hematite

VESSEL FORM: Carinated bowl with an inverted rim and a rounded lip

CORE COLOR: A (fired and cooled in a high oxygen environment)

WALL THICKNESS: $6.3 \mathrm{~mm}$

INTERIOR SURFACE TREATMENT: smoothed on the rim

EXTERIOR SURFACE TREATMENT: smoothed

HEIGHT: $9.2 \mathrm{~cm}$

ORIFICE DIAMETER: $14.4 \mathrm{~cm}$

DIAMETER AT BOTTOM OF RIM OR NECK: $15.4 \mathrm{~cm}$

BASE DIAMETER: $7.0 \mathrm{~cm}$

ESTIMATED VOLUME: 0.8 liters

DECORATION: The rim has a panel comprised of nine engraved ovals. Each oval is defined by two sets of three closely-spaced vertical curvilinear engraved lines (Vessel 41CE14-113). There are hatched triangles at each of the four corners of the ovals.

TYPE: Poynor Engraved, var. Cook

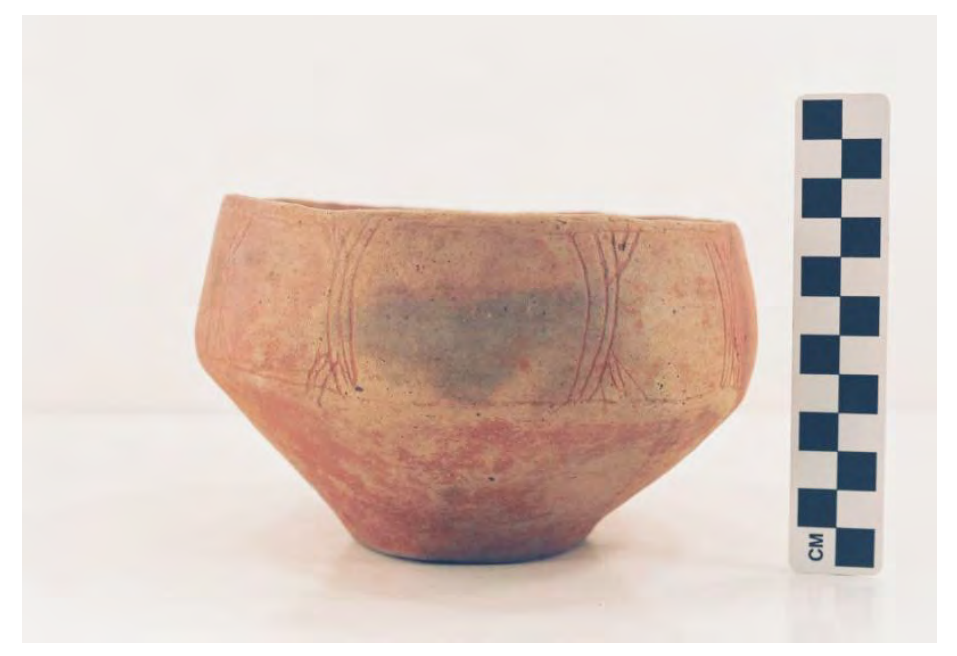

Vessel 41CE14-113. 
SITE NO.: 41CE14

FEATURE: Burial AQ-12

VESSEL NO.: 41CE14-114

NON-PLASTICS: grog

VESSEL FORM: Carinated bowl with an inverted rim and a rounded lip

CORE COLOR: A (fired and cooled in a high oxygen environment)

WALL THICKNESS: $6.4 \mathrm{~mm}$

INTERIOR SURFACE TREATMENT: smoothed on the rim

EXTERIOR SURFACE TREATMENT: smoothed

HEIGHT: $13.7 \mathrm{~cm}$

ORIFICE DIAMETER: $23.5 \mathrm{~cm}$

DIAMETER AT BOTTOM OF RIM OR NECK: $25.9 \mathrm{~cm}$

\section{BASE DIAMETER: $8.5 \mathrm{~cm}$}

\section{ESTIMATED VOLUME: 2.9 liters}

DECORATION: The rim has an engraved panel comprised of four large ovals filled with small punctations. Each oval is defined by two sets of closely-spaced vertical curvilinear engraved lines (two or three lines per set); there are hatched triangles at each outside corner of these vertical lines. The ovals are divided by another set of closely-spaced vertical curvilinear lines (with three closely-spaced lines), and also have hatched triangles at the top and bottom of the rim.

The side of the lip, just above the engraved panel, has a row of tool punctations that encircle the vessel. Finally, the vessel body has horizontal brushing marks (Vessel 41CE14-114).

TYPE: Poynor Engraved, var. Cook, but there are also stylistic affiliations with var. Lang because of the use of punctates in the central ovals.

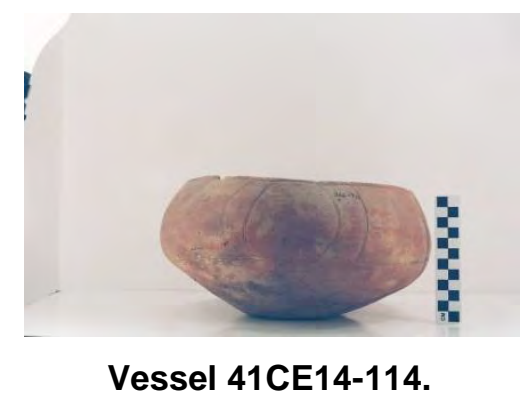


SITE NO.: 41CE14

FEATURE: Burial AQ-13

VESSEL NO.: 41CE14-116

NON-PLASTICS: grog

VESSEL FORM: Carinated bowl with an inverted rim and a rounded lip; lip notched

CORE COLOR: Undetermined

WALL THICKNESS: $7.1 \mathrm{~mm}$

INTERIOR SURFACE TREATMENT: burnished on the rim, smoothed on the body; there is an organic residue on the body

EXTERIOR SURFACE TREATMENT: burnished

HEIGHT: $19.0 \mathrm{~cm}$

ORIFICE DIAMETER: $30.0 \mathrm{~cm}$

DIAMETER AT BOTTOM OF RIM OR NECK: $34.0 \mathrm{~cm}$

BASE DIAMETER: $10.0 \mathrm{~cm}$

ESTIMATED VOLUME: 5.1 liters

DECORATION: The rim has an engraved panel filled with nine large negative ovals (Vessel 41CE14-116). The negative ovals are defined by broad hour glass-shaped zones filled with vertical and curvilinear lines and small hatched triangles. A red clay pigment has been rubbed in the engraved lines. The vessel body has vertical brushing marks.

TYPE: Poynor Engraved, var. Hood

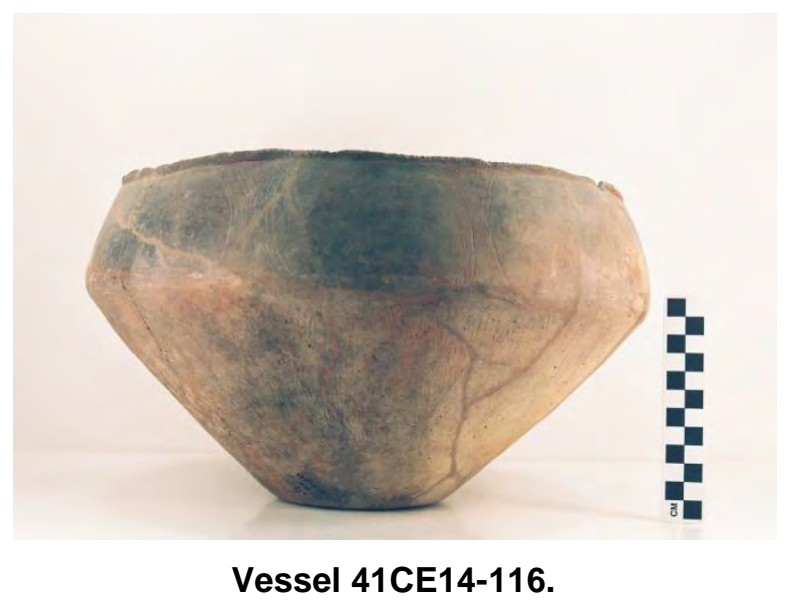


SITE NO.: 41CE14

FEATURE: Burial AQ-13

VESSEL NO.: 41CE14-117

NON-PLASTICS: grog and bone

VESSEL FORM: Globular carinated bowl with a direct rim and a rounded lip

CORE COLOR: Undetermined

WALL THICKNESS: $6.9 \mathrm{~mm}$

INTERIOR SURFACE TREATMENT: smoothed

EXTERIOR SURFACE TREATMENT: smoothed

HEIGHT: $12.3 \mathrm{~cm}$

ORIFICE DIAMETER: $14.5 \mathrm{~cm}$

DIAMETER AT BOTTOM OF RIM OR NECK: $15.0 \mathrm{~cm}$

BASE DIAMETER: $8.5 \mathrm{~cm}$

ESTIMATED VOLUME: 1.1 liters

DECORATION: The engraved rim panel has nine negative ovals defined by vertical hour glassshaped columns filled with vertical and curvilinear lines (Vessel 41CE14-117).

TYPE: Poynor Engraved, var. Hood

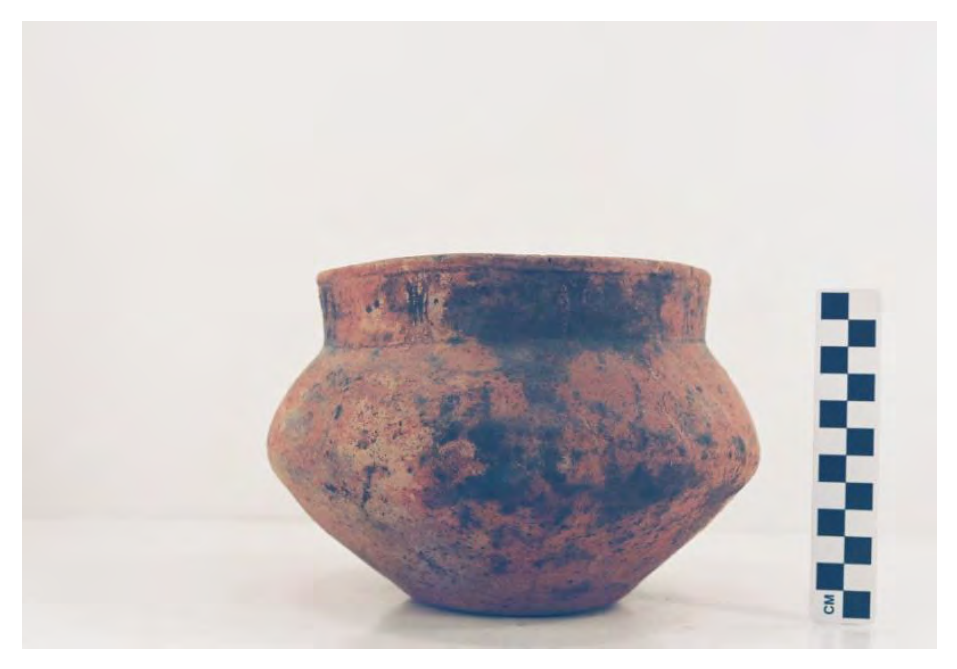

Vessel 41CE14-117. 
SITE NO.: 41CE14

FEATURE: AQ-13

VESSEL NO.: 41CE14-118

NON-PLASTICS: grog, hematite, and bone

VESSEL FORM: Effigy bowl with a direct rim and a rounded lip; bird effigy head appendage and rear tab tail ( $4.5 \mathrm{~cm}$ wide and $2.5 \mathrm{~mm}$ in length out from the bowl lip)

CORE COLOR: Undetermined

WALL THICKNESS: $7.0 \mathrm{~mm}$

INTERIOR SURFACE TREATMENT: smoothed

EXTERIOR SURFACE TREATMENT: burnished

HEIGHT: $8.5 \mathrm{~cm}$

ORIFICE DIAMETER: $13.5 \mathrm{~cm}$

DIAMETER AT BOTTOM OF RIM OR NECK: N/A

BASE DIAMETER: $9.0 \mathrm{~cm}$

ESTIMATED VOLUME: 0.5 liters

DECORATION: The rim of the effigy bowl has three broad horizontal engraved lines. These lines are not continuous, as they are absent under the front effigy head as well as under the rear tab tail. Under these appendages, the lines do not meet, but end in small hatched triangles.

TYPE: Hood Engraved, var. Hood effigy vessel

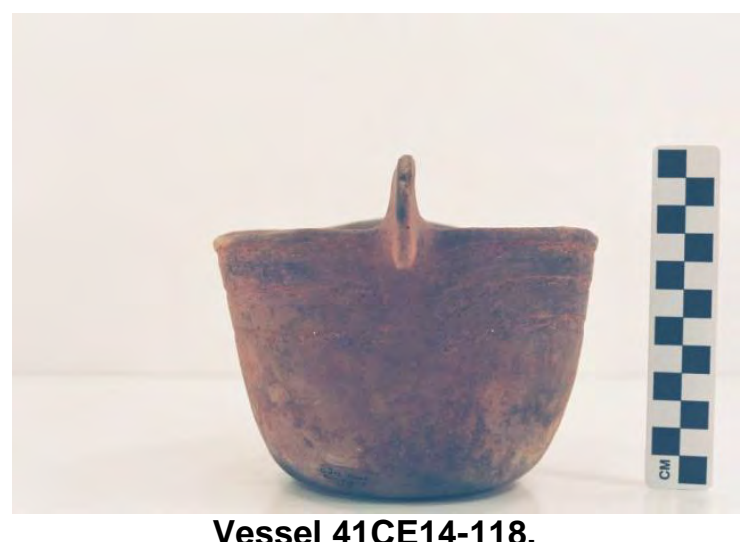

Vessel 41CE14-118. 
SITE NO.: 41CE14

FEATURE: Burial AQ-13

VESSEL NO.: 41CE14-119

NON-PLASTICS: grog; sandy paste

VESSEL FORM: Small jar with a direct rim and a rounded lip; two small strap handles formed by perforating lug handles

CORE COLOR: A (fired and cooled in a high oxygen environment)

WALL THICKNESS: $3.8 \mathrm{~mm}$

INTERIOR SURFACE TREATMENT: smoothed

EXTERIOR SURFACE TREATMENT: none

HEIGHT: $7.8 \mathrm{~cm}$

ORIFICE DIAMETER: $7.5 \mathrm{~cm}$

DIAMETER AT BOTTOM OF RIM OR NECK: $7.5 \mathrm{~cm}$

BASE DIAMETER: $5.0 \mathrm{~cm}$

ESTIMATED VOLUME: 0.4 liters

DECORATION: There are three rows of cane punctations on the rim; the strap handles are plain (Vessel 41CE14-119)

TYPE: Undetermined punctated utility ware vessel

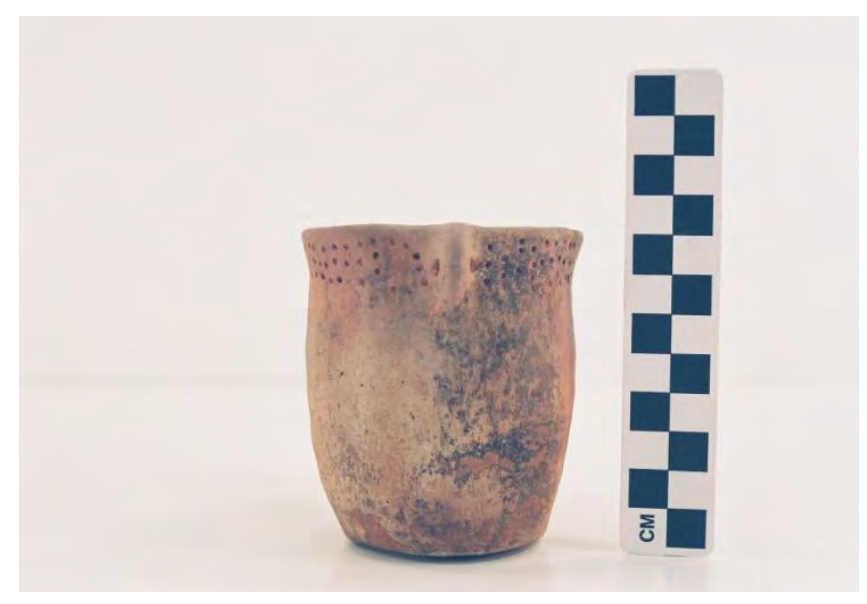

Vessel 41CE14-119, Punctated Jar. 
SITE NO.: 41CE14

FEATURE: Burial AQ-13

VESSEL NO.: 41CE14-120

NON-PLASTICS: grog and hematite

VESSEL FORM: Bowl with a direct rim and a rounded lip

CORE COLOR: Undetermined

WALL THICKNESS: $8.5 \mathrm{~mm}$

INTERIOR SURFACE TREATMENT: smoothed on the rim and upper body

EXTERIOR SURFACE TREATMENT: none

HEIGHT: $12.5 \mathrm{~cm}$

ORIFICE DIAMETER: $18.4 \mathrm{~cm}$

DIAMETER AT BOTTOM OF RIM OR NECK:

BASE DIAMETER: $7.3 \mathrm{~cm}$

ESTIMATED VOLUME: 1.7 liters

DECORATION: The rim and body of the vessel have vertical overlapping brushing marks, extending to near the vessel base (Vessel 41CE14-120).

TYPE: Bullard Brushed

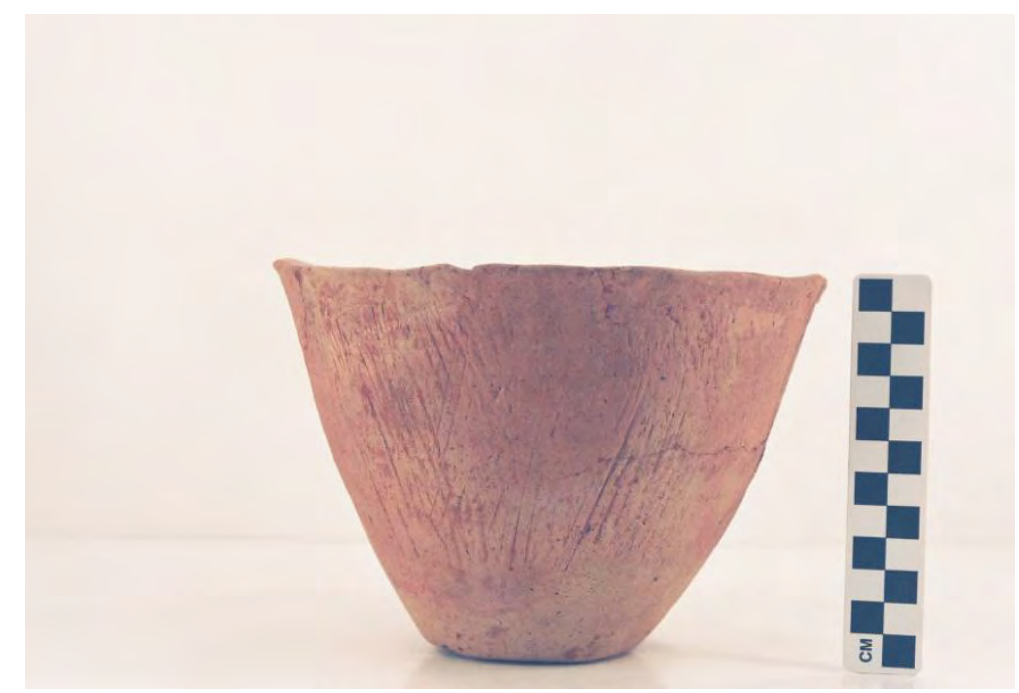

Vessel 41CE14-120. Bullard Brushed. 
SITE NO.: 41CE14

FEATURE: Burial AQ-13

VESSEL NO.: 41CE14-121

NON-PLASTICS: grog and hematite

VESSEL FORM: Beaker with an elongated body, a direct rim and a rounded lip

CORE COLOR: B (fired and cooled in a low oxygen or reducing environment)

WALL THICKNESS: $4.6 \mathrm{~mm}$

INTERIOR SURFACE TREATMENT: none

EXTERIOR SURFACE TREATMENT: burnished

HEIGHT: $19.5 \mathrm{~cm}$

ORIFICE DIAMETER: $4.0 \mathrm{~cm}$

DIAMETER AT BOTTOM OF RIM OR NECK: N/A

BASE DIAMETER: $6.5 \mathrm{~cm}$

\section{ESTIMATED VOLUME: 0.5 liters}

DECORATION: The vessel has a single horizontal engraved line on the rim and three horizontal engraved lines above the base. Between these lines are two vertical engraved panels comprised of vertical and curvilinear lines aligned around a central engraved circle. The vertical engraved lines turn to curvilinear lines around the central circle (Vessel 41CE14-121). A red clay pigment has been rubbed in the engraved lines.

TYPE: Poynor Engraved (Suhm and Jelks 1962: Plate 63c)

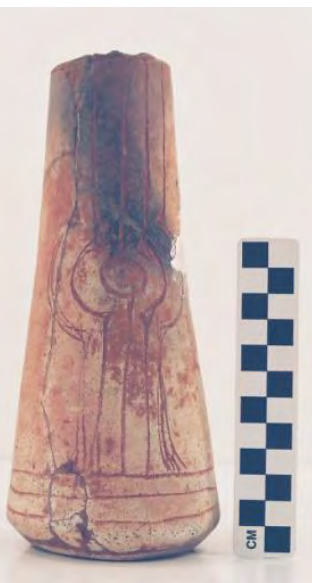

Vessel 41CE14-121. 
SITE NO.: 41CE14

FEATURE: Burial AQ-13

VESSEL NO.: 41CE14-122

NON-PLASTICS: grog, hematite, and bone

VESSEL FORM: Jar with an everted rim, a rounded lip, and plain U-shaped loop handles

CORE COLOR: Undetermined

WALL THICKNESS: $7.2 \mathrm{~mm}$

INTERIOR SURFACE TREATMENT: smoothed

EXTERIOR SURFACE TREATMENT: none

HEIGHT: $10.5 \mathrm{~cm}$

ORIFICE DIAMETER: $10.5 \mathrm{~cm}$

DIAMETER AT BOTTOM OF RIM OR NECK: $11.2 \mathrm{~cm}$

BASE DIAMETER: $8.5 \mathrm{~cm}$

ESTIMATED VOLUME: 0.7 liters

DECORATION: There are two vertical pinched rows on the vessel rim. On the vessel body, there are three vertical rows of pinching set under the two loop handles. These vertical pinched rows divide the body into two panels filled with concentric pinched circles (Vessel 41CE14-122).

TYPE: Killough Pinched (see Suhm and Jelks 1962: Plate 46h)

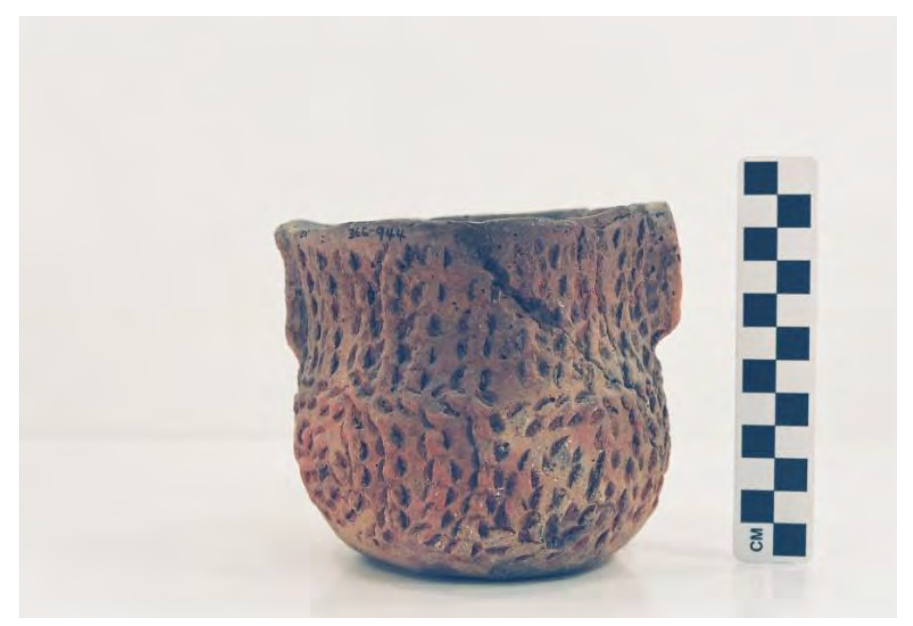

Vessel 41CE14-122, Killough Pinched. 
SITE NO.: 41CE14

FEATURE: Burial AQ-14

VESSEL NO.: 41CE14-123

NON-PLASTICS: grog and bone; sandy paste

VESSEL FORM: Carinated bowl with an inverted rim and a rounded lip

CORE COLOR: Undetermined

WALL THICKNESS: $7.4 \mathrm{~mm}$

INTERIOR SURFACE TREATMENT: smoothed on the rim

EXTERIOR SURFACE TREATMENT: smoothed

HEIGHT: $11.2 \mathrm{~cm}$

ORIFICE DIAMETER: $16.0 \mathrm{~cm}$

DIAMETER AT BOTTOM OF RIM OR NECK: $18.6 \mathrm{~cm}$

BASE DIAMETER: $8.5 \mathrm{~cm}$

ESTIMATED VOLUME: 0.8 liters

DECORATION: The rim has an engraved panel filled with three large ovals (Vessel 41CE14123). Each oval is defined by two sets of closely-spaced curvilinear lines (two lines in each set) that extend from the rim to the vessel carination, as well as hatched triangles at the top and bottom of, but on the outside of, the ovals

TYPE: Poynor Engraved, var. Cook

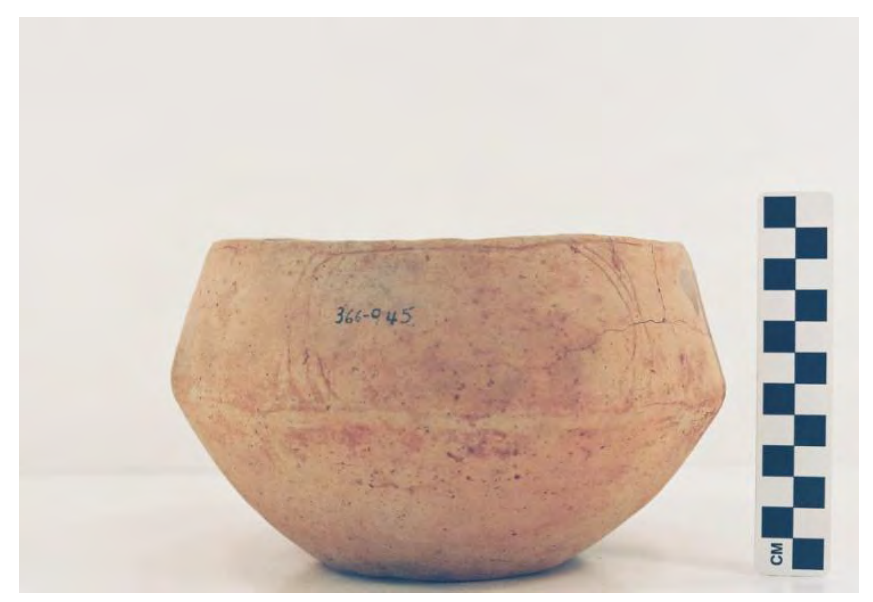

Vessel 41CE14-123. 
SITE NO.: 41CE14

FEATURE: Burial AQ-14

VESSEL NO.: 41CE14-125

NON-PLASTICS: grog and hematite

VESSEL FORM: Bottle with a short neck and an elongated body, a direct rim, and a flat lip

CORE COLOR: Undetermined

WALL THICKNESS: $5.1 \mathrm{~mm}$

INTERIOR SURFACE TREATMENT: none

EXTERIOR SURFACE TREATMENT: none

HEIGHT: $12.0 \mathrm{~cm}$

ORIFICE DIAMETER: $3.5 \mathrm{~cm}$

DIAMETER AT BOTTOM OF RIM OR NECK: $7.4 \mathrm{~cm}$ on the body

BASE DIAMETER: $6.3 \mathrm{~cm}$

ESTIMATED VOLUME: 0.3 liters

DECORATION: The bottle body has an engraved design on it. This consists of single horizontal engraved lines under the neck and just above the base, along with four vertical panels. The panels consist of five closely-spaced vertical engraved lines around a central circle, and these vertical lines extend from the upper and lower horizontal engraved lines. The vertical engraved lines turn to curvilinear lines around the central circle (Vessel 41CE14-125).

TYPE: Poynor Engraved; see also Vessel 41CE14-121

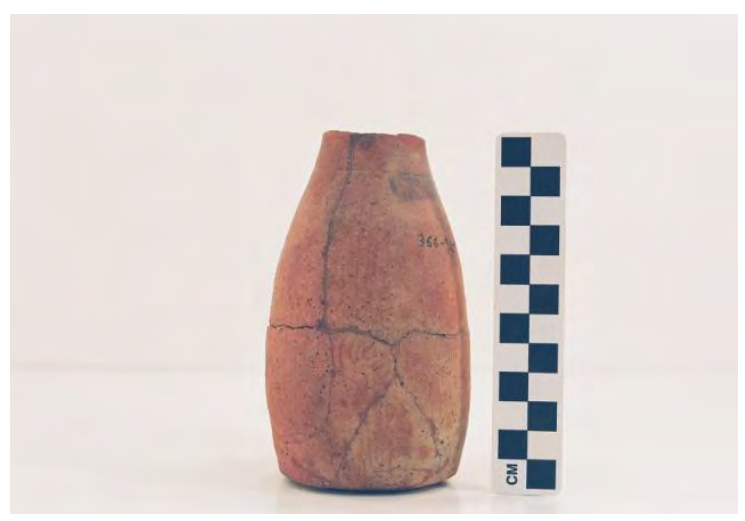

Vessel 41CE14-125. 
SITE NO.: 41CE14

FEATURE: Burial AQ-14

VESSEL NO.: 41CE14-126

NON-PLASTICS: grog

VESSEL FORM: Globular carinated bowl with a direct to slightly everted rim and a rounded lip

CORE COLOR: Undetermined

WALL THICKNESS: $4.7 \mathrm{~mm}$

INTERIOR SURFACE TREATMENT: smoothed on the rim

EXTERIOR SURFACE TREATMENT: burnished

HEIGHT: $10.3 \mathrm{~cm}$

ORIFICE DIAMETER: $14.1 \mathrm{~cm}$

DIAMETER AT BOTTOM OF RIM OR NECK: $13.5 \mathrm{~cm}$

BASE DIAMETER: $7.3 \mathrm{~cm}$

ESTIMATED VOLUME: 0.9 liters

DECORATION: The rim has an engraved panel with seven negative ovals (Vessel 41CE14126). Each negative oval is defined by two hour glass-shaped columns filled with vertical and curvilinear engraved lines.

TYPE: Poynor Engraved, var. Hood

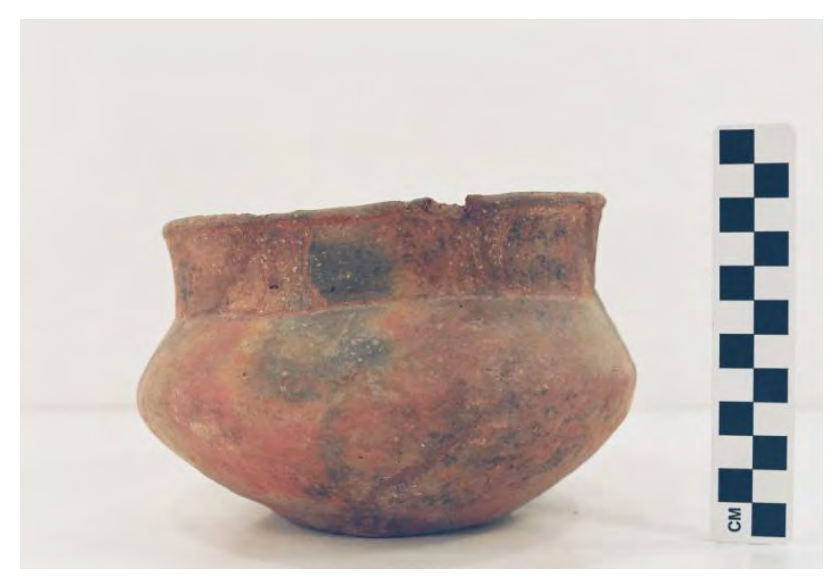

Vessel 41CE14-126. 
SITE NO.: 41CE14

FEATURE: Burial AQ-14

VESSEL NO.: 41CE14-127

NON-PLASTICS: grog

VESSEL FORM: Globular carinated bowl with a direct rim and a rounded, exterior folded lip

CORE COLOR: $\mathrm{G}$ (fired in a reducing environment and cooled in the open air)

WALL THICKNESS: $5.4 \mathrm{~mm}$

INTERIOR SURFACE TREATMENT: smoothed on the rim and body

EXTERIOR SURFACE TREATMENT: burnished

HEIGHT: $9.9 \mathrm{~cm}$

ORIFICE DIAMETER: $14.2 \mathrm{~cm}$

DIAMETER AT BOTTOM OF RIM OR NECK: Undetermined

BASE DIAMETER: $5.6 \mathrm{~cm}$

ESTIMATED VOLUME: 0.8 liters

DECORATION: The rim has an engraved panel filled with seven negative ovals (Vessel 41CE14-127). Each negative oval is defined by two hour glass-shaped columns filled with vertical and curvilinear engraved lines.

TYPE: Poynor Engraved, var. Hood

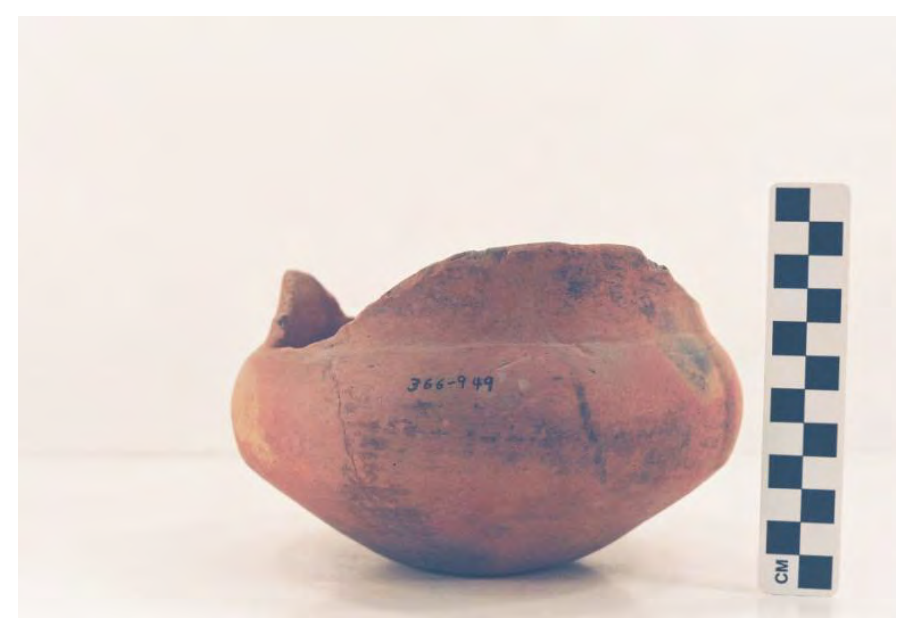

Vessel 41CE14-127. 
SITE NO.: 41CE14

FEATURE: Burial AQ-15

VESSEL NO.: 41CE14-129

NON-PLASTICS: grog

VESSEL FORM: Carinated bowl with an inverted rim, a rounded lip, and four rim peaks

CORE COLOR: A (fired and cooled in a high oxygen environment)

WALL THICKNESS: $4.5 \mathrm{~mm}$

INTERIOR SURFACE TREATMENT: smoothed

EXTERIOR SURFACE TREATMENT: burnished

HEIGHT: $8.0 \mathrm{~cm}$

ORIFICE DIAMETER: $8.0 \mathrm{~cm}$

DIAMETER AT BOTTOM OF RIM OR NECK: $12.2 \mathrm{~cm}$

BASE DIAMETER: $6.0 \mathrm{~cm}$

\section{ESTIMATED VOLUME: 0.4 liters}

DECORATION: The rim has an engraved panel filled with four negative ovals. The negative ovals are defined by two sets of hour glass-shaped columns that are filled with closely-spaced vertical and curvilinear engraved lines (Vessel 41CE14-129). The top and bottom of the panel are defined by single horizontal engraved lines that encircle the vessel. A red clay pigment has been rubbed in the engraved lines.

TYPE: Poynor Engraved, var. Hood

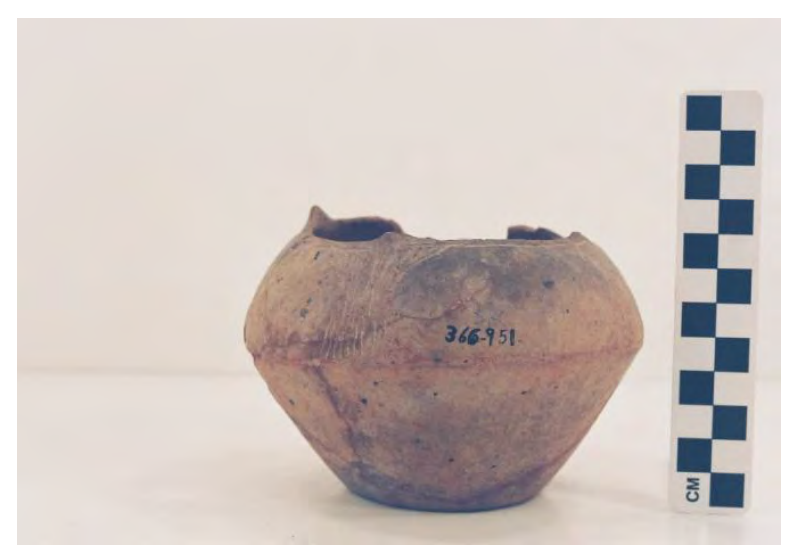

Vessel 41CE14-129. 
SITE NO.: 41CE14

FEATURE: Burial AQ-16

VESSEL NO.: 41CE14-131

NON-PLASTICS: grog and hematite

VESSEL FORM: Bottle with a long tapered neck, globular body, a direct rim, and a rounded lip

CORE COLOR: Undetermined

WALL THICKNESS: $4.4 \mathrm{~mm}$

INTERIOR SURFACE TREATMENT: none

EXTERIOR SURFACE TREATMENT: burnished

HEIGHT: $24.0 \mathrm{~cm}$

ORIFICE DIAMETER: $4.1 \mathrm{~cm}$

DIAMETER AT BOTTOM OF RIM OR NECK: $6.8 \mathrm{~cm}$

BASE DIAMETER: $7.0 \mathrm{~cm}$

ESTIMATED VOLUME: 0.7 liters

DECORATION: The vessel upper body has two large and distinct hour glass-shaped panels on opposite sides of the vessel; the panels are defined by the base of the bottle neck and a single horizontal line at the bottom of the panel. Each panel is comprised of four small negative circles around one large central negative circle (Vessel 41CE14-131). The areas around each of the negative circles has been hatched with closely-spaced engraved lines. A red clay pigment has been rubbed into the engraved lines.

TYPE: Poynor Engraved (Suhm and Jelks 1962:Plate 63j)

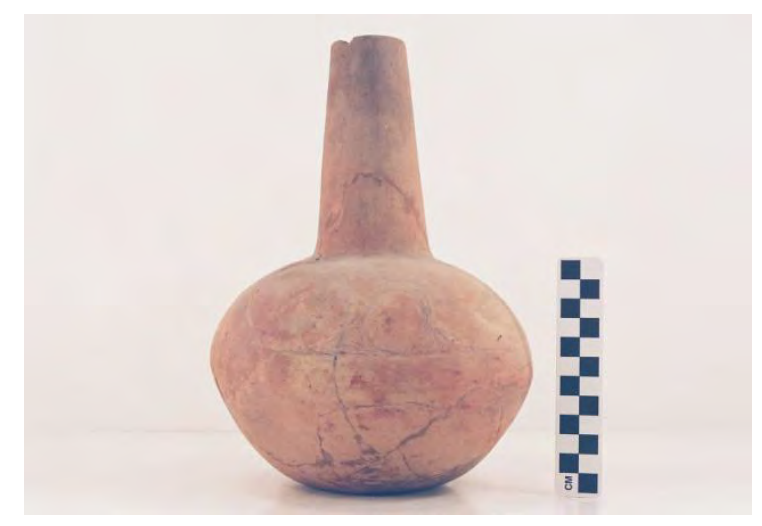

Poynor Engraved Bottle, Vessel 41CE14-131. 
SITE NO.: 41CE14

FEATURE: Burial AQ-16

VESSEL NO.: 41CE14-132

NON-PLASTICS: grog and bone

VESSEL FORM: Carinated bowl with an inverted rim and a rounded lip; lip notched

CORE COLOR: Undetermined

WALL THICKNESS: $5.2 \mathrm{~mm}$

INTERIOR SURFACE TREATMENT: burnished

EXTERIOR SURFACE TREATMENT: burnished

HEIGHT: $9.8 \mathrm{~cm}$

ORIFICE DIAMETER: $14.0 \mathrm{~cm}$

DIAMETER AT BOTTOM OF RIM OR NECK: $15.0 \mathrm{~cm}$

BASE DIAMETER: $7.0 \mathrm{~cm}$

ESTIMATED VOLUME: 0.8 liters

DECORATION: There is an engraved panel on the rim, defined by upper and lower horizontal engraved lines at the rim and the vessel carination. There are 10 negative ovals on the panel, delimited by hour glass-shaped columns filled with vertical and curvilinear engraved lines (Vessel 41CE14-132).

TYPE: Poynor Engraved, var. Hood

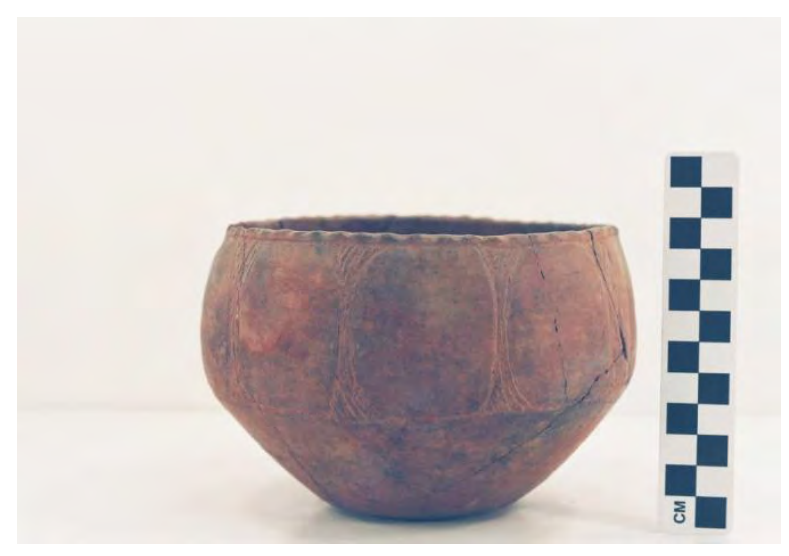

Vessel 41CE14-132. 
SITE NO.: 41CE14

FEATURE: Burial AQ-16

VESSEL NO.: 41CE14-133

NON-PLASTICS: grog and hematite

VESSEL FORM: Bottle with a short neck, an elongated body, a direct but collared rim (see Suhm and Jelks 1962: Plate 42a), and a flat lip (Vessel 41CE14-133)

CORE COLOR: Undetermined

WALL THICKNESS: $5.9 \mathrm{~mm}$

INTERIOR SURFACE TREATMENT: none

EXTERIOR SURFACE TREATMENT: poorly smoothed

HEIGHT: $23.1 \mathrm{~cm}$

ORIFICE DIAMETER: $5.0 \mathrm{~cm}$

DIAMETER AT BOTTOM OF RIM OR NECK: $10.4 \mathrm{~cm}$ on the body near the vessel base

BASE DIAMETER: $8.5 \mathrm{~cm}$

ESTIMATED VOLUME: 0.8 liters

DECORATION: plain

TYPE: cf. Hume Plain

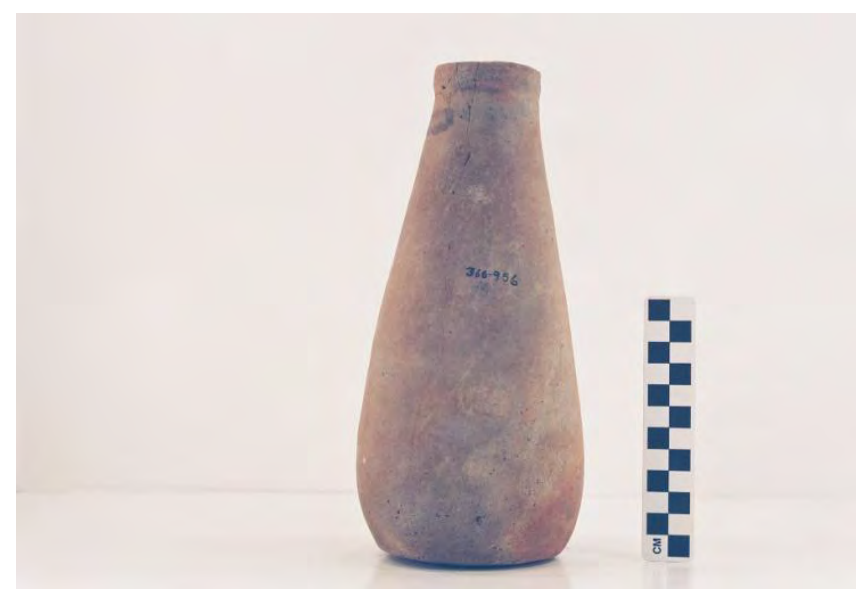

Vessel 41CE14-133, Hume Plain. 
SITE NO.: 41CE14

FEATURE: Burial AQ-16

VESSEL NO.: 41CE14-134

NON-PLASTICS: grog

VESSEL FORM: Globular carinated bowl with a direct rim and a rounded, exterior folded, lip

CORE COLOR: Undetermined

WALL THICKNESS: $4.9 \mathrm{~mm}$

INTERIOR SURFACE TREATMENT: smoothed

EXTERIOR SURFACE TREATMENT: burnished

HEIGHT: $11.8 \mathrm{~cm}$

ORIFICE DIAMETER: $14.5 \mathrm{~cm}$

DIAMETER AT BOTTOM OF RIM OR NECK: $13.5 \mathrm{~cm}$

BASE DIAMETER: $8.9 \mathrm{~cm}$

ESTIMATED VOLUME: 1.0 liters

DECORATION: The rim has an engraved panel filled with seven negative ovals (Vessel 41CE14-134). Each negative oval is defined by two hour glass-shaped columns filled with closely-spaced vertical and curvilinear engraved lines.

TYPE: Poynor Engraved, var. Hood

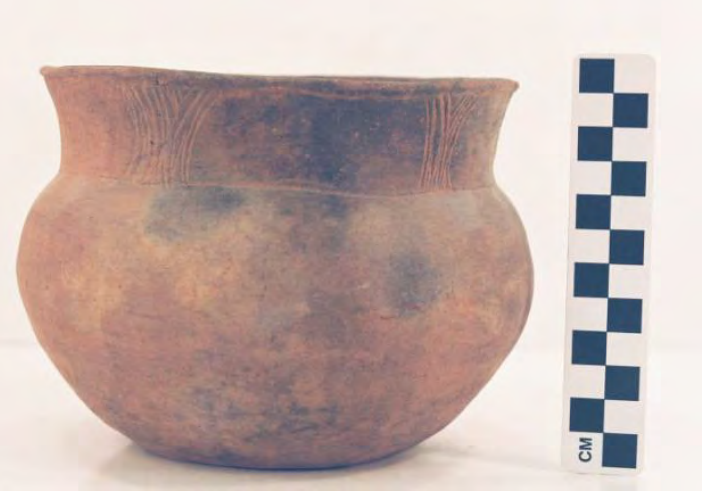

Vessel 41CE14-134. 
SITE NO.: 41CE14

FEATURE: Burial AQ-16

VESSEL NO.: 41CE14-135

NON-PLASTICS: grog

VESSEL FORM: Jar with an everted rim and a flat lip, two strap handles, and a four-legged ring base

CORE COLOR: Undetermined

WALL THICKNESS: $5.5 \mathrm{~mm}$

INTERIOR SURFACE TREATMENT: smoothed

EXTERIOR SURFACE TREATMENT: none

HEIGHT: $14.4 \mathrm{~cm}$

ORIFICE DIAMETER: $10.0 \mathrm{~cm}$

DIAMETER AT BOTTOM OF RIM OR NECK: $9.6 \mathrm{~cm}$

BASE DIAMETER: $8.2 \mathrm{~cm}$ (on the ring base)

ESTIMATED VOLUME: 0.9 liters

DECORATION: The rim has several rows of linear punctates (simulating vertical pinching), and the strap handles have two vertical pinched and punctated rows. The vessel body has four pinched concentric circles, comprised of 10 concentric circles that begin in the center with a hooked arm element (Vessel 41CE14-135). The legs of the ring base each have five rows of vertical linear punctates.

TYPE: Killough Pinched

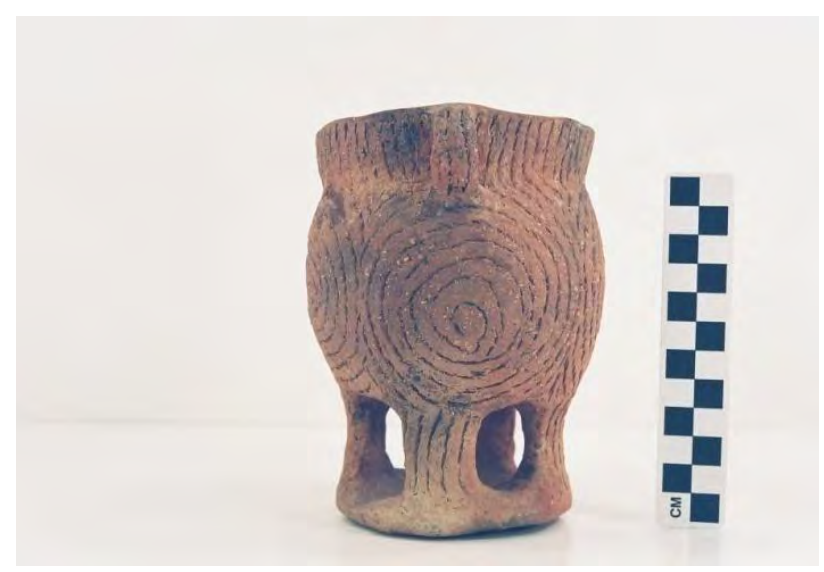

Vessel 41CE14-135. 
SITE NO.: 41CE14

FEATURE: Burial AQ-16

VESSEL NO.: 41CE14-136

NON-PLASTICS: grog and hematite

VESSEL FORM: Globular carinated bowl with a direct rim and a rounded lip

CORE COLOR: Undetermined

WALL THICKNESS: $6.6 \mathrm{~mm}$

INTERIOR SURFACE TREATMENT: smoothed on the body

EXTERIOR SURFACE TREATMENT: none

HEIGHT: $14.7 \mathrm{~cm}$

ORIFICE DIAMETER: $15.2 \mathrm{~cm}$

DIAMETER AT BOTTOM OF RIM OR NECK: $14.9 \mathrm{~cm}$

BASE DIAMETER: $9.5 \mathrm{~cm}$

ESTIMATED VOLUME: 1.3 liters

DECORATION: The rim has vertical brushing marks, while there is horizontal brushing covering the vessel body (Vessel 41CE14-136.).

TYPE: Poynor Brushed

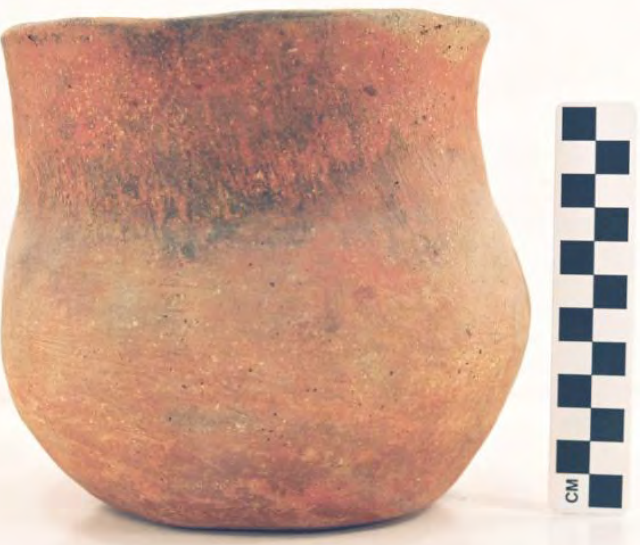

Vessel 41CE14-136, Poynor Brushed. 
SITE NO.: 41CE14

FEATURE: Burial AQ-16

VESSEL NO.: 41CE14-137

NON-PLASTICS: grog and hematite

VESSEL FORM: Carinated bowl with a direct rim and a rounded, exterior folded, lip

CORE COLOR: C (incompletely oxidized during firing)

WALL THICKNESS: $6.8 \mathrm{~mm}$

INTERIOR SURFACE TREATMENT: smoothed

EXTERIOR SURFACE TREATMENT: burnished

HEIGHT: $10.5 \mathrm{~cm}$

ORIFICE DIAMETER: $19.0 \mathrm{~cm}$

DIAMETER AT BOTTOM OF RIM OR NECK: $15.0 \mathrm{~cm}$

BASE DIAMETER: $8.0 \mathrm{~cm}$

ESTIMATED VOLUME: 1.2 liters

DECORATION: The rim has a scroll and circle engraved motif repeated three times around the vessel. Each central circle has an intersecting horizontal and vertical engraved line with hatched triangles. The scroll fill elements are large triangular-shaped engraved areas to either side of the central circle, with three vertical rows of closely-spaced engraved lines (Vessel 41CE14-137).

TYPE: Poynor Engraved, var. $E$ in the upper Neches River basin

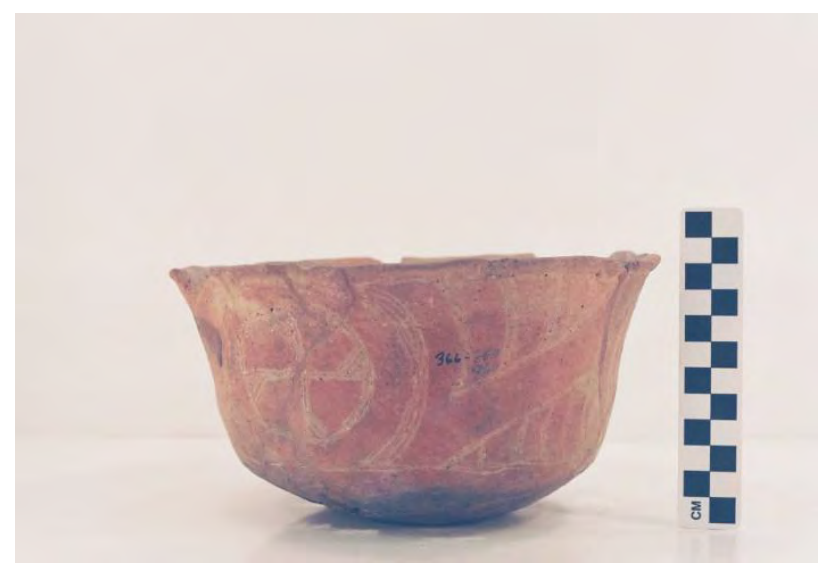

Vessel 41CE14-137. 
SITE NO.: 41CE14

FEATURE: Burial AQ-16

VESSEL NO.: 41CE14-138

NON-PLASTICS:

VESSEL FORM:

CORE COLOR:

WALL THICKNESS:

INTERIOR SURFACE TREATMENT:

EXTERIOR SURFACE TREATMENT:

HEIGHT: $16.4 \mathrm{~cm}$

ORIFICE DIAMETER: $23.3 \mathrm{~cm}$

DIAMETER AT BOTTOM OF RIM OR NECK: $25.5 \mathrm{~cm}$

\section{BASE DIAMETER:}

ESTIMATED VOLUME: 3.4 liters

DECORATION: The rim has nested engraved triangles filled with hatched lines and a negative circle. Separating the nested triangles are narrow diagonal zones filled with cross-hatched engraved lines.

TYPE: Poynor Engraved, var. $F$ in the upper Neches River basin; information provided here is from TARL Ceramic Inventory files. 
SITE NO.: 41CE14

FEATURE: Burial AQ-16

VESSEL NO.: 41CE14-140

NON-PLASTICS: grog and hematite

VESSEL FORM: Jar with a direct rim and a rounded lip

CORE COLOR: B (fired and cooled in a low oxygen environment)

WALL THICKNESS: $6.4 \mathrm{~mm}$

INTERIOR SURFACE TREATMENT: smoothed

EXTERIOR SURFACE TREATMENT: none

HEIGHT: $12.0 \mathrm{~cm}$

ORIFICE DIAMETER: $13.5 \mathrm{~cm}$

DIAMETER AT BOTTOM OF RIM OR NECK: $13.5 \mathrm{~cm}$

BASE DIAMETER: $7.5 \mathrm{~cm}$

ESTIMATED VOLUME: 1.0 liters

DECORATION: Vertical brushing on the rim and the vessel body (Vessel 41CE14-140)

TYPE: Bullard Brushed

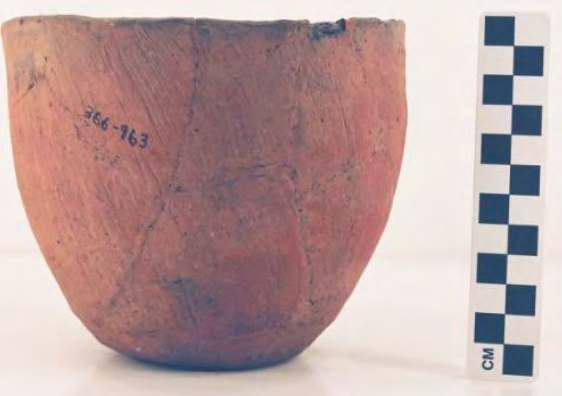

Vessel 41CE14-140. 
SITE NO.: 41CE14

FEATURE: Burial AQ-16

VESSEL NO.: 41CE14-141

NON-PLASTICS: grog and hematite

VESSEL FORM: Carinated bowl with an inverted rim and a rounded lip; lip notched

CORE COLOR: A (fired and cooled in a high oxygen environment)

WALL THICKNESS: $8.3 \mathrm{~mm}$

INTERIOR SURFACE TREATMENT: smoothed

EXTERIOR SURFACE TREATMENT: burnished

HEIGHT: $15.5 \mathrm{~cm}$

ORIFICE DIAMETER: $24.0 \mathrm{~cm}$

DIAMETER AT BOTTOM OF RIM OR NECK: $28.0 \mathrm{~cm}$

BASE DIAMETER: $9.5 \mathrm{~cm}$

ESTIMATED VOLUME: 3.3 liters

DECORATION: In addition to lip notching, the rim has an engraved panel. The panel is filled with nine negative ovals defined by 10 hour glass-shaped columns filled with closely-spaced vertical and curvilinear lines (Vessel 41CE14-141).

TYPE: Poynor Engraved, var. Hood

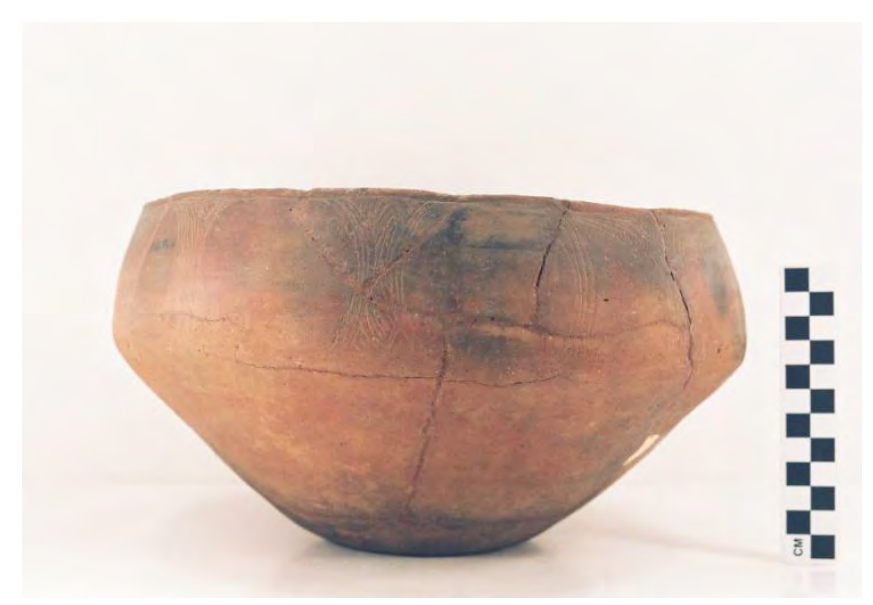

Vessel 41CE14-141. 
SITE NO.: 41CE14

FEATURE: Burial AQ-18

VESSEL NO.: 41CE14-151

NON-PLASTICS: bone and grog

VESSEL FORM: Carinated bowl with an inverted rim and a rounded lip

CORE COLOR: Undetermined

WALL THICKNESS: $6.7 \mathrm{~mm}$

INTERIOR SURFACE TREATMENT: burnished on the rim and smoothed on the body

EXTERIOR SURFACE TREATMENT: burnished

HEIGHT: $9.2 \mathrm{~cm}$

ORIFICE DIAMETER: $11.7 \mathrm{~cm}$

DIAMETER AT BOTTOM OF RIM OR NECK: $13.1 \mathrm{~cm}$

BASE DIAMETER: $7.5 \mathrm{~cm}$

ESTIMATED VOLUME: 0.7 liters

DECORATION: The rim has an engraved panel with 10 diamond-shaped elements. These negative diamonds are defined by two sets of six closely-spaced vertical lines, creating rectangular panels (hence the assignment to var. Blackburn), and four hatched triangles, two attached to each set of vertical engraved lines (Vessel 41CE14-151).

TYPE: Poynor Engraved, var. Blackburn

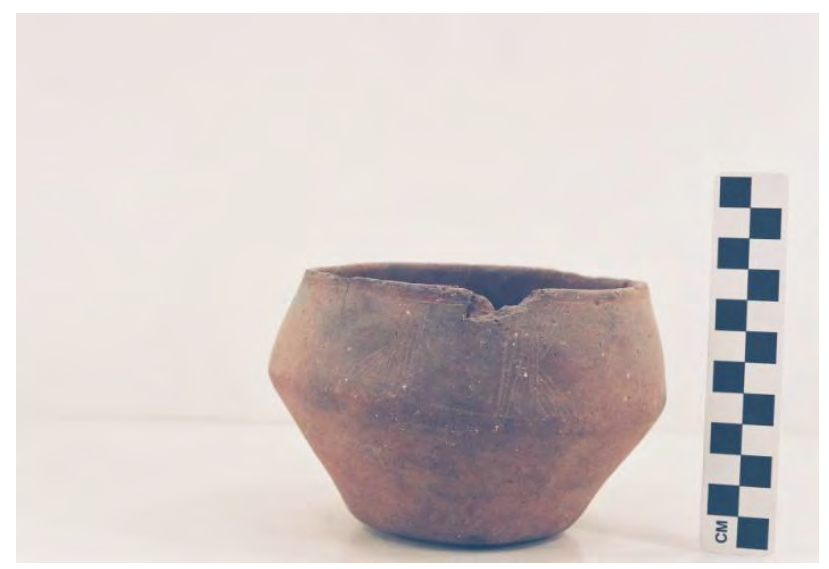

Vessel 41CE14-151. 
SITE NO.: 41CE14

FEATURE: Burial AQ-18

VESSEL NO.: 41CE14-152

NON-PLASTICS: grog and hematite

VESSEL FORM: Carinated bowl with an inverted rim and a rounded lip; six rim peaks

CORE COLOR: B (fired and cooled in a low oxygen environment)

WALL THICKNESS: $5.7 \mathrm{~mm}$

INTERIOR SURFACE TREATMENT: smoothed

EXTERIOR SURFACE TREATMENT: burnished

HEIGHT: $15.5 \mathrm{~cm}$

ORIFICE DIAMETER: $27.0 \mathrm{~cm}$

DIAMETER AT BOTTOM OF RIM OR NECK: $29.5 \mathrm{~cm}$

BASE DIAMETER: $9.0 \mathrm{~cm}$

\section{ESTIMATED VOLUME: 3.7 liters}

DECORATION: The rim has an engraved panel with six ovals (each under a rim peak), defined by three closely-spaced curvilinear lines on either side; one of the ovals has two small circles within it. The area between the engraved ovals are filled with six hour glass-shaped columns. The four corners of each column have hatched triangles as well as a small central engraved oval (Vessel 41CE14-152).

TYPE: Poynor Engraved, var. Cook

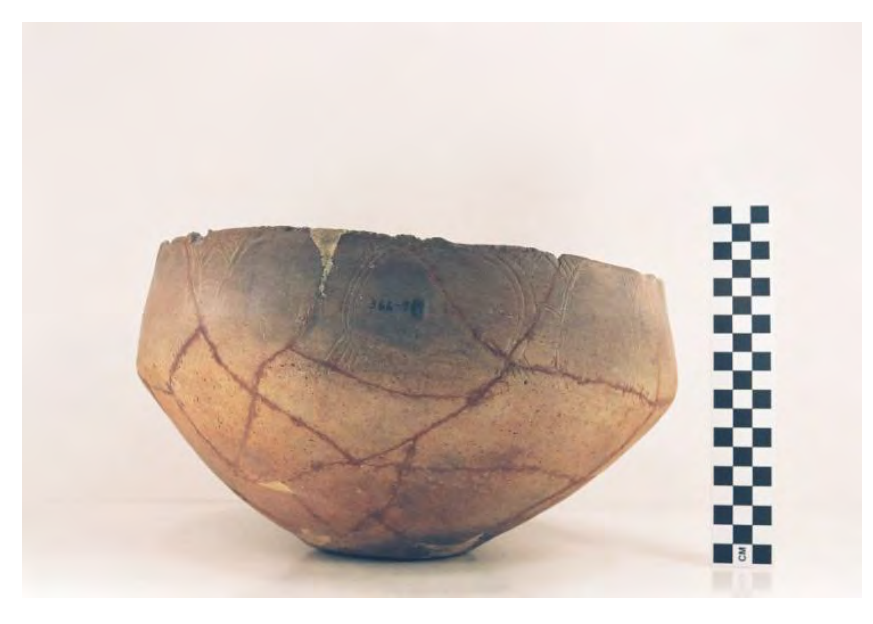

Vessel 41CE14-152. 
SITE NO.: 41CE14

FEATURE: Burial AQ-18

VESSEL NO.: 41CE14-153

NON-PLASTICS: grog and hematite

VESSEL FORM: Jar with an everted rim and a rounded lip; two strap handles

CORE COLOR: $\mathrm{G}$ (fired in a reducing environment and cooled in the open air)

WALL THICKNESS: $5.4 \mathrm{~mm}$, rim

INTERIOR SURFACE TREATMENT: smoothed

EXTERIOR SURFACE TREATMENT: none

HEIGHT: $18.0 \mathrm{~cm}$

ORIFICE DIAMETER: $13.0 \mathrm{~cm}$

DIAMETER AT BOTTOM OF RIM OR NECK: $12.2 \mathrm{~cm}$

BASE DIAMETER: $10.5 \mathrm{~cm}$

ESTIMATED VOLUME: 2.2 liters

DECORATION: The rim has three rows of vertical tool punctations. On the vessel body are four large triangular appliqued ridged areas that begin at the rim-body juncture and the triangle's apex points toward the vessel base. Each appliqued triangle is filled with linear tool punctations. The two strap handles have closely-spaced horizontal incised lines on them (Vessel 41CE14-153).

TYPE: Undetermined appliqued and punctated utility ware vessel

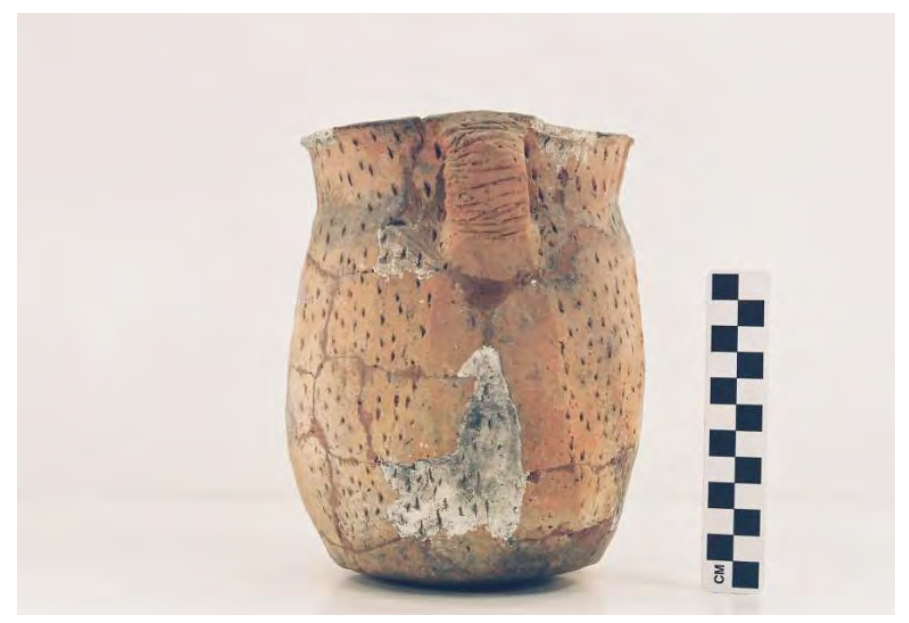

Vessel 41CE14-153. 
SITE NO.: 41CE14

FEATURE: Burial AQ-18

VESSEL NO.: 41CE14-154

NON-PLASTICS: grog and hematite

VESSEL FORM: Globular carinated bowl with a direct rim and a rounded lip

CORE COLOR: Undetermined

WALL THICKNESS: $4.6 \mathrm{~mm}$, rim

INTERIOR SURFACE TREATMENT: smoothed

EXTERIOR SURFACE TREATMENT: smoothed

HEIGHT: $11.3 \mathrm{~cm}$

ORIFICE DIAMETER: $14.6 \mathrm{~cm}$

DIAMETER AT BOTTOM OF RIM OR NECK: $14.4 \mathrm{~cm}$

BASE DIAMETER: $10.7 \mathrm{~cm}$

ESTIMATED VOLUME: 1.0 liters

DECORATION: The rim has an engraved panel filled with four large ovals, each defined by two sets of closely-spaced curvilinear lines (Vessel 41CE14-154.). Two of the ovals have small punctate-filled circles at their centers, and two have small engraved circles only. Dividing each of the engraved ovals are centrally-placed narrow hour glass-shaped columns with triangular hatched and closely-spaced vertical engraved lines. Alternating dividers have small hatched triangles attached to them.

TYPE: Poynor Engraved, var. Lang

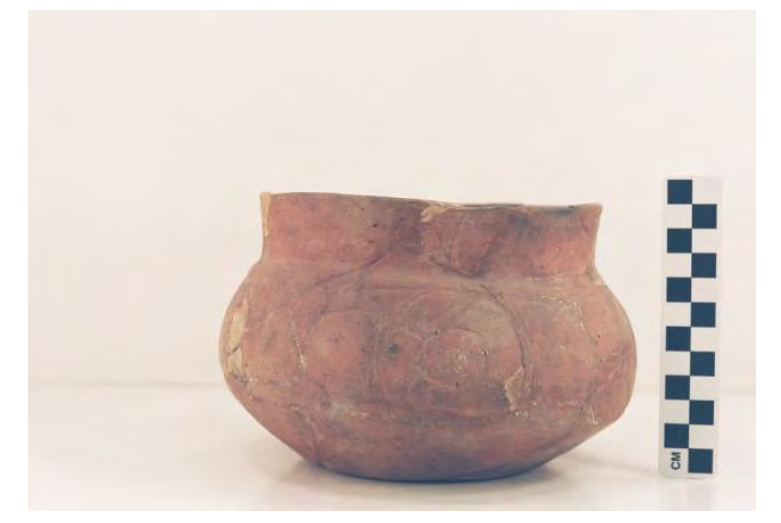

Vessel 41CE14-154, Poynor Engraved, var. Lang. 
SITE NO.: 41CE14

FEATURE: Burial AQ-18

VESSEL NO.: 41CE14-155

NON-PLASTICS: grog; sandy paste

VESSEL FORM: Bottle with a short neck, an elongated body, an everted rim and a rounded lip; there is a slight collar at the base of the bottle neck

CORE COLOR: Undetermined; pinkware

WALL THICKNESS: $4.1 \mathrm{~mm}$

INTERIOR SURFACE TREATMENT: none

EXTERIOR SURFACE TREATMENT: smoothed

HEIGHT: $24.9 \mathrm{~cm}$

ORIFICE DIAMETER: $6.1 \mathrm{~cm}$

DIAMETER AT BOTTOM OF RIM OR NECK: $5.7 \mathrm{~cm}$

BASE DIAMETER: $12.0 \mathrm{~cm}$

ESTIMATED VOLUME: 1.2 liters

DECORATION: The top and bottom of the vessel body has three closely-spaced sets of horizontal engraved lines. These delimit a vertical engraved motif that is repeated three times around the vessel. The motif includes two vertical panels with seven stacked rectangles (reminiscent of var. Blackburn on carinated bowls), five of which have hatched triangles at their corners, and a central panel defined by a central oval and two centrally-placed and closely-spaced vertical engraved lines (Vessel 41CE14-155).

TYPE: Poynor Engraved, var. unspecified

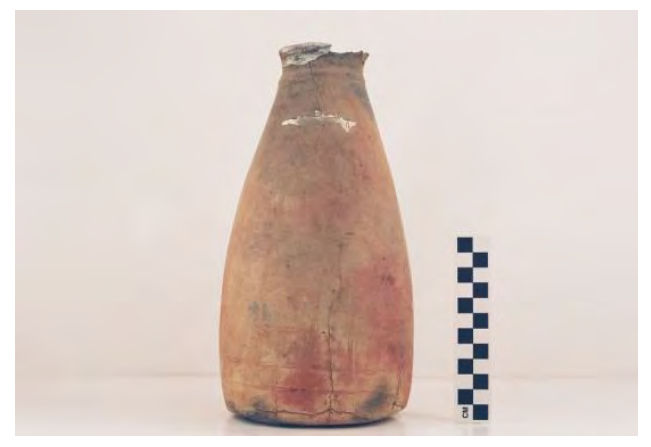

Vessel 41CE14-155. 


\section{E. W. Henry Site (41CE17)}

SITE NO.: $41 \mathrm{CE} 17$

FEATURE: Discovery Grave

VESSEL NO.: 41CE17-1

NON-PLASTICS: grog

VESSEL FORM: Jar with an everted rim and a rounded, scalloped lip

CORE COLOR: Undetermined

WALL THICKNESS: $7.0 \mathrm{~mm}$, rim

INTERIOR SURFACE TREATMENT: smoothed on the rim and the upper body

EXTERIOR SURFACE TREATMENT: smoothed

HEIGHT: $11.0 \mathrm{~cm}$

ORIFICE DIAMETER: $10.0 \mathrm{~cm}$

DIAMETER AT BOTTOM OF RIM OR NECK: $9.4 \mathrm{~cm}$

BASE DIAMETER: $8.8 \mathrm{~cm}$

ESTIMATED VOLUME: 0.7 liters

DECORATION: Faint horizontal brushing marks on the rim and vessel body (Vessel 41CE171)

TYPE: Bullard Brushed

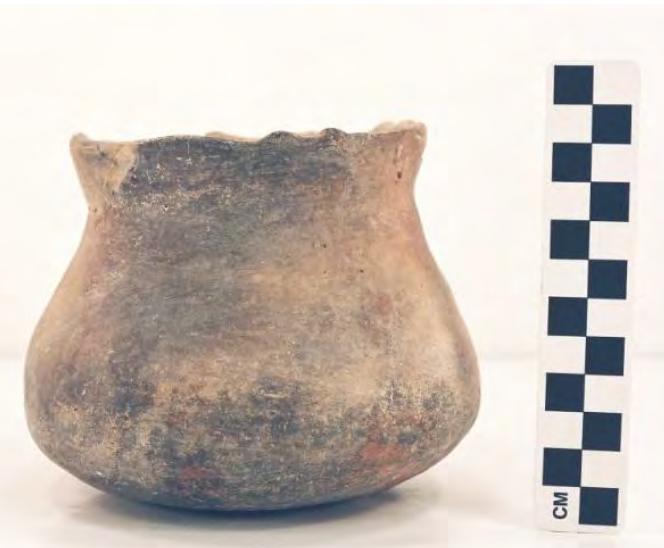

Vessel 41CE17-1. 
SITE NO.: 41CE17

FEATURE: Discovery Grave

VESSEL NO.: 41CE17-2

NON-PLASTICS: grog; sandy paste

VESSEL FORM: Bottle with a broad neck and a collar at the neck-body juncture, a direct rim, and a rounded lip

CORE COLOR: A (fired and cooled in a high oxygen environment); pinkware

WALL THICKNESS: $3.4 \mathrm{~mm}$

INTERIOR SURFACE TREATMENT: none

EXTERIOR SURFACE TREATMENT: smoothed

HEIGHT: $7.6 \mathrm{~cm}$

ORIFICE DIAMETER: $3.0 \mathrm{~cm}$

DIAMETER AT BOTTOM OF RIM OR NECK: $6.1 \mathrm{~cm}$ on the body

BASE DIAMETER: $3.5 \mathrm{~cm}$

ESTIMATED VOLUME: 0.1 liters

DECORATION: There are three vertical engraved panels on the vessel body (Vessel 41CE172 ). Each of the panels has hatched ladders at opposing ends of the panels, as well as two separate sets of two vertical engraved lines. One of these sets has a single pendant engraved triangle, and the other has four hatched pendant triangles.

TYPE: Undetermined engraved bottle, probably an undetermined variety of Hume Engraved because of the vertical panels and the collared neck.

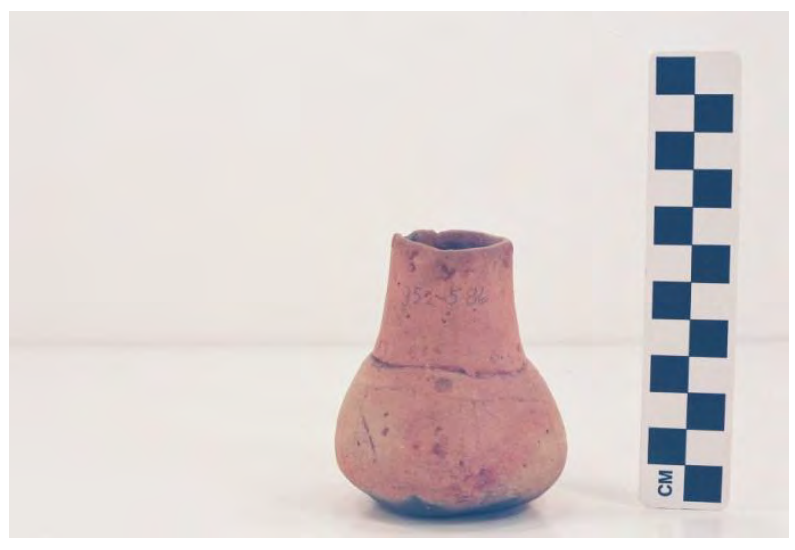

Vessel 41CE17-2. 
SITE NO.: 41CE17

FEATURE: Discovery Grave

VESSEL NO.: 41CE17-3

NON-PLASTICS: grog and hematite

VESSEL FORM: Carinated bowl with an inverted rim and a rounded lip (Vessel 41CE17-3)

CORE COLOR: Undetermined

WALL THICKNESS: $4.4 \mathrm{~mm}$

INTERIOR SURFACE TREATMENT: smoothed on the rim

EXTERIOR SURFACE TREATMENT: smoothed on the rim

HEIGHT: $4.2 \mathrm{~cm}$

ORIFICE DIAMETER: $10.5 \mathrm{~cm}$

DIAMETER AT BOTTOM OF RIM OR NECK: $10.8 \mathrm{~cm}$

BASE DIAMETER: $6.0 \mathrm{~cm}$

ESTIMATED VOLUME: 0.3 liters

DECORATION: plain

TYPE: Poynor Plain vessel

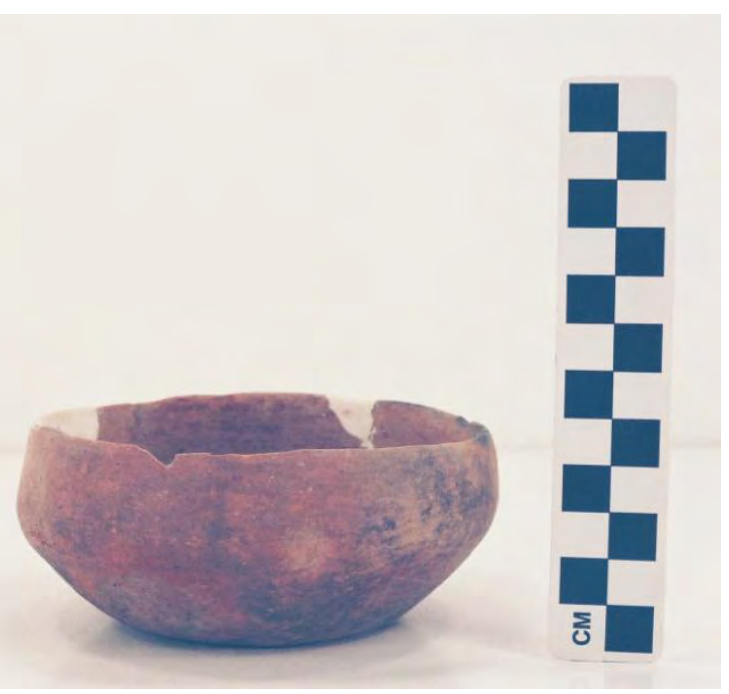

Vessel 41CE17-3. 
SITE NO.: 41CE17

FEATURE: Discovery Grave

VESSEL NO.: 41CE17-4

NON-PLASTICS: grog and hematite

VESSEL FORM: Carinated bowl with an inverted rim and a rounded lip (Vessel 41CE17-4)

CORE COLOR: A (fired and cooled in a high oxygen environment)

WALL THICKNESS: $4.5 \mathrm{~mm}$

INTERIOR SURFACE TREATMENT: smoothed on the rim

EXTERIOR SURFACE TREATMENT: none

HEIGHT: $5.3 \mathrm{~cm}$

ORIFICE DIAMETER: $9.5 \mathrm{~cm}$

DIAMETER AT BOTTOM OF RIM OR NECK: $9.7 \mathrm{~cm}$

BASE DIAMETER: $6.0 \mathrm{~cm}$

ESTIMATED VOLUME: 0.3 liters

DECORATION: plain

TYPE: Poynor Plain ware vessel

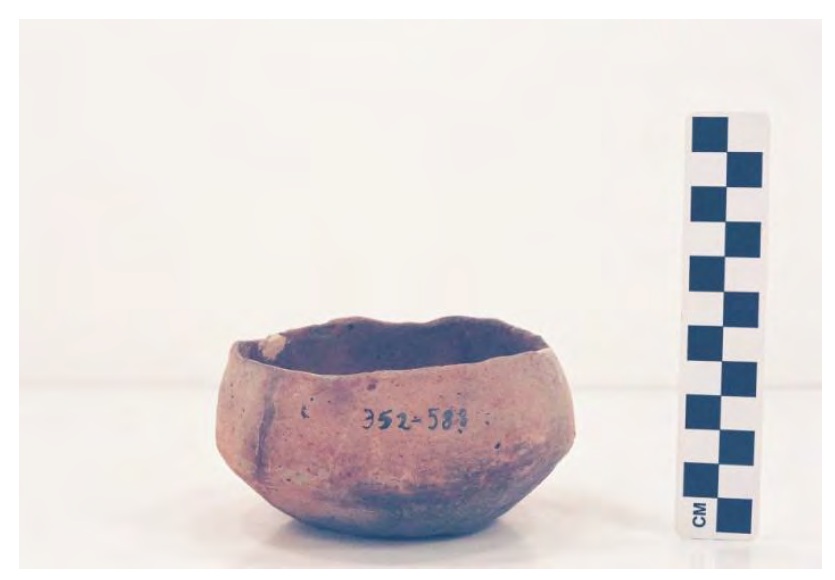

Vessel 41CE17-4. 
SITE NO.: 41CE17

FEATURE: Discovery Grave

VESSEL NO.: 41CE17-5

NON-PLASTICS: bone and grog

VESSEL FORM: Jar with a direct rim and a rounded lip

CORE COLOR: G (fired in a reducing environment and cooled in the open air)

WALL THICKNESS: $5.4 \mathrm{~mm}$

INTERIOR SURFACE TREATMENT: smoothed

EXTERIOR SURFACE TREATMENT: none

HEIGHT: $9.0 \mathrm{~cm}$

ORIFICE DIAMETER: $8.0 \mathrm{~cm}$

DIAMETER AT BOTTOM OF RIM OR NECK: $8.0 \mathrm{~cm}$

BASE DIAMETER: $4.5 \mathrm{~cm}$

ESTIMATED VOLUME: 0.3 liters

DECORATION: The rim of the vessel has incised triangles, half filled with small circular punctates (those with their apex at the rim) and the alternating triangles are defined solely by two opposed incised lines (their apex points towards the vessel base) (Vessel 41CE17-5).

TYPE: Maydelle Incised

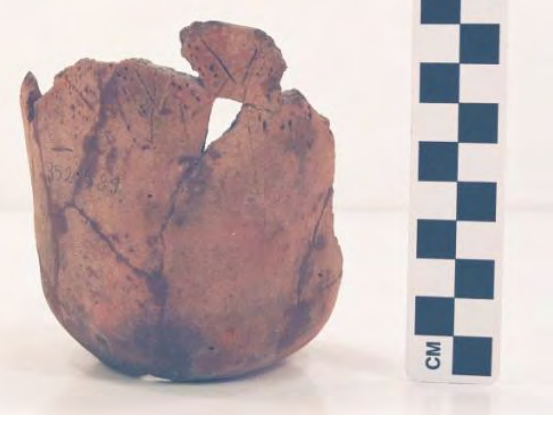

Vessel 41CE17-5. 
SITE NO.: 41CE17

FEATURE: Burial AL-1

VESSEL NO.: 41CE17-6

NON-PLASTICS: grog

VESSEL FORM: Bowl with a direct rim and a rounded, exterior folded, lip (Vessel 41CE17-6)

CORE COLOR: A (fired and cooled in a high oxygen environment)

WALL THICKNESS: $3.7 \mathrm{~mm}$

INTERIOR SURFACE TREATMENT: none

EXTERIOR SURFACE TREATMENT: none

HEIGHT: $3.5 \mathrm{~cm}$

ORIFICE DIAMETER: $6.3 \mathrm{~cm}$

DIAMETER AT BOTTOM OF RIM OR NECK: N/A

BASE DIAMETER: $4.0 \mathrm{~cm}$

ESTIMATED VOLUME: 0.1 liters

DECORATION: plain

TYPE: Undetermined plain ware vessel

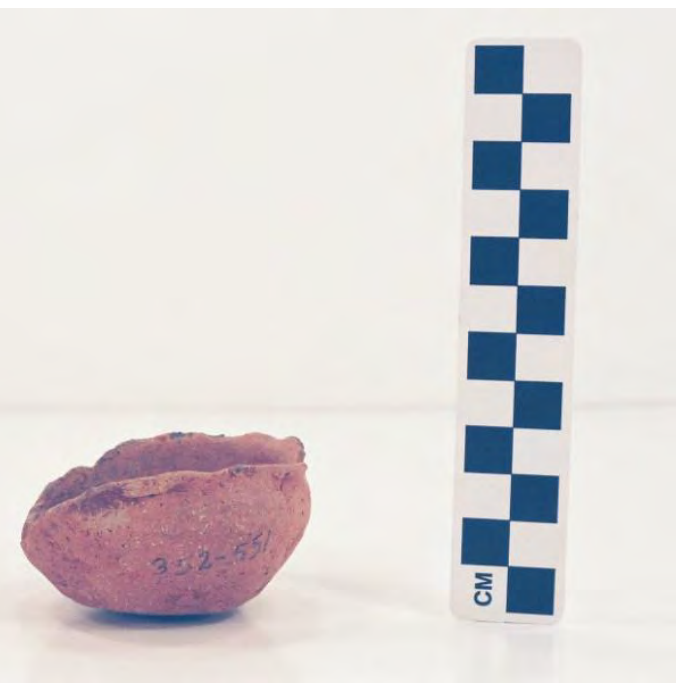

Vessel 41CE17-6. 
SITE NO.: 41CE17

FEATURE: Burial AL-1

VESSEL NO.: 41CE17-7

NON-PLASTICS: grog

VESSEL FORM: Effigy bowl with a direct rim and a rounded lip; there is a curved tab tail at one end of the vessel, but the effigy head has broken away

CORE COLOR: $\mathrm{G}$ (fired in a reducing environment and cooled in the open air)

WALL THICKNESS: $5.0 \mathrm{~mm}$

INTERIOR SURFACE TREATMENT: smoothed

EXTERIOR SURFACE TREATMENT: smoothed

HEIGHT: $6.6 \mathrm{~cm}$

ORIFICE DIAMETER: $13.7 \mathrm{~cm}$

DIAMETER AT BOTTOM OF RIM OR NECK: N/A

BASE DIAMETER: $7.9 \mathrm{~cm}$

ESTIMATED VOLUME: 0.4 liters

DECORATION: The rim has two broadly-spaced horizontal engraved lines that encircle the vessel, except under the tab tail (Vessel 41CE17-7)

TYPE: Hood Engraved, var. Hood effigy bowl

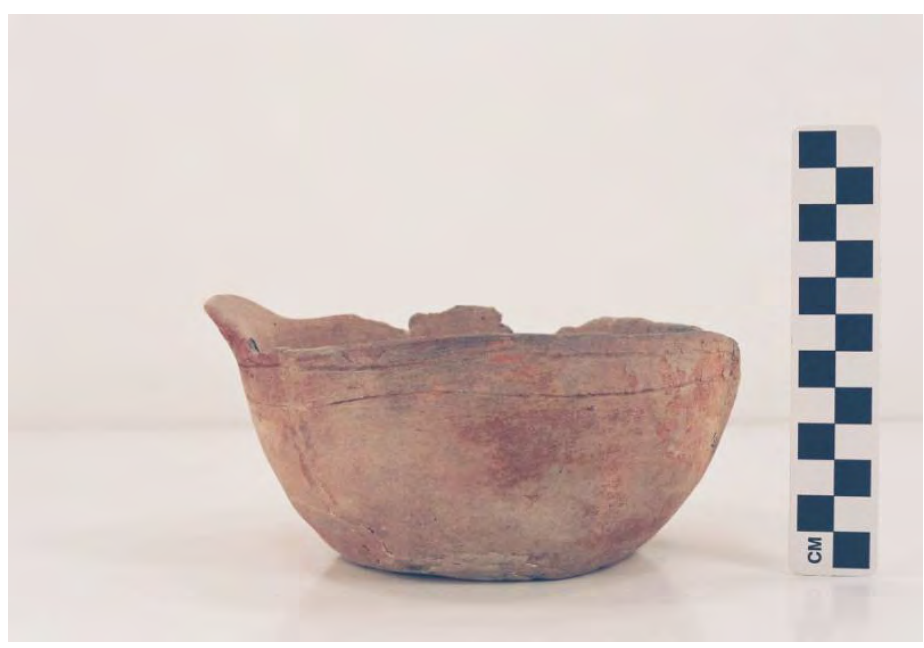

Vessel 41CE17-7. 
SITE NO.: 41CE17

FEATURE: Burial AL-2

VESSEL NO.: 41CE17-9

NON-PLASTICS: bone, grog, and hematite

VESSEL FORM: Carinated bowl with a direct rim and a flat lip (Vessel 41CE17-9)

CORE COLOR: G (fired in a reducing environment and cooled in the open air)

WALL THICKNESS: $5.9 \mathrm{~mm}$, rim

INTERIOR SURFACE TREATMENT: none

EXTERIOR SURFACE TREATMENT: smoothed

HEIGHT: $7.0 \mathrm{~cm}$

ORIFICE DIAMETER: $12.8 \mathrm{~cm}$

DIAMETER AT BOTTOM OF RIM OR NECK: $12.7 \mathrm{~cm}$

BASE DIAMETER: $6.6 \mathrm{~cm}$

ESTIMATED VOLUME: 0.5 liters

DECORATION: plain

TYPE: Undetermined plain ware vessel

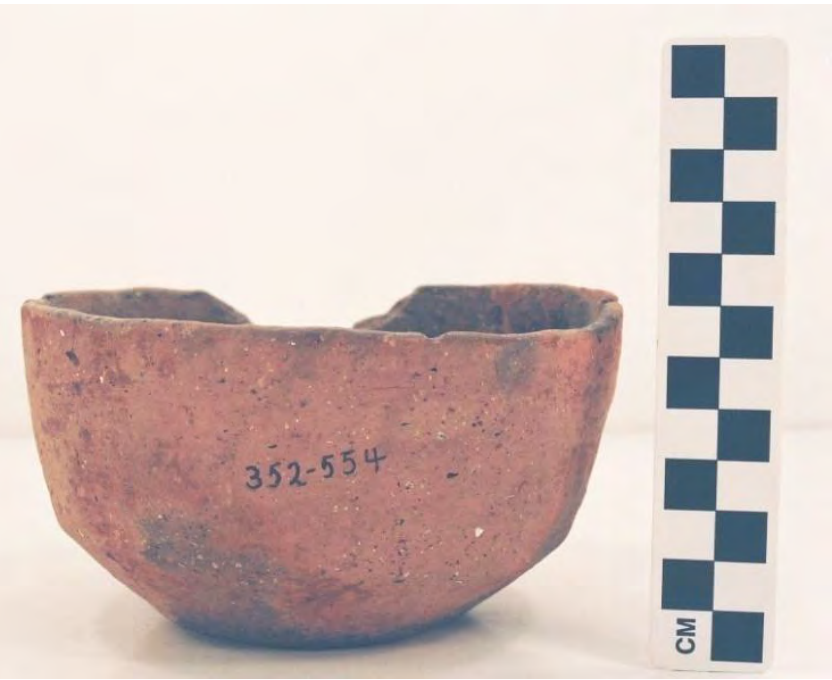

Vessel 41CE17-9. 
SITE NO.: 41CE17

FEATURE: Burial AL-2

VESSEL NO.: 41CE17-10

NON-PLASTICS: none apparent

VESSEL FORM: Globular carinated bowl with a direct rim and a rounded, exterior folded lip

CORE COLOR: Undetermined

WALL THICKNESS: $3.8 \mathrm{~mm}$

INTERIOR SURFACE TREATMENT: smoothed on the rim

EXTERIOR SURFACE TREATMENT: smoothed

HEIGHT: $9.3 \mathrm{~cm}$

ORIFICE DIAMETER: $11.0 \mathrm{~cm}$

DIAMETER AT BOTTOM OF RIM OR NECK: $11.4 \mathrm{~cm}$

BASE DIAMETER: $6.0 \mathrm{~cm}$

ESTIMATED VOLUME: 0.6 liters

DECORATION: The rim has an engraved panel with four large negative ovals (Vessel 41CE1710). The negative ovals are each defined by two broad hour glass-shaped columns filled with closely-spaced vertical and curvilinear engraved lines. A red clay pigment has been rubbed in the engraved lines.

TYPE: Poynor Engraved, var. Hood

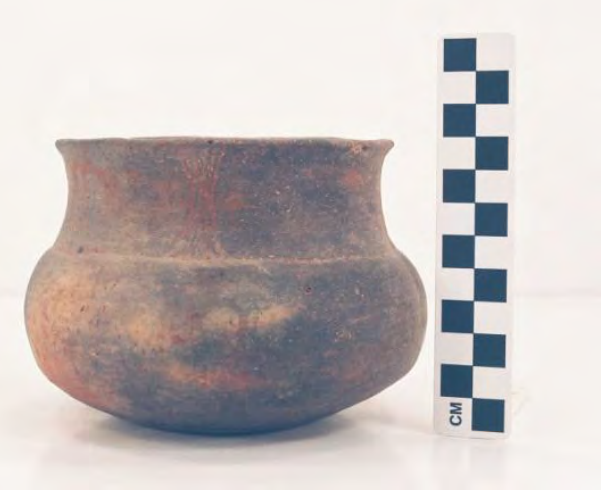

Vessel 41CE17-10. 
SITE NO.: 41CE17

FEATURE: Burial AL-4

VESSEL NO.: 41CE17-12

NON-PLASTICS: grog and hematite

VESSEL FORM: Carinated bowl with a direct rim and a flat lip; two lip tabs on opposing sides of the vessel (Vessel 41CE17-12)

CORE COLOR: A (fired and cooled in a high oxygen environment)

WALL THICKNESS: $5.5 \mathrm{~mm}$, rim

INTERIOR SURFACE TREATMENT: smoothed on the rim

EXTERIOR SURFACE TREATMENT: smoothed

HEIGHT: $4.7 \mathrm{~cm}$

ORIFICE DIAMETER: $9.6 \mathrm{~cm}$

DIAMETER AT BOTTOM OF RIM OR NECK:

BASE DIAMETER: $6.5 \mathrm{~cm}$

ESTIMATED VOLUME: 0.3 liters

DECORATION: plain

TYPE: Undetermined plain ware vessel

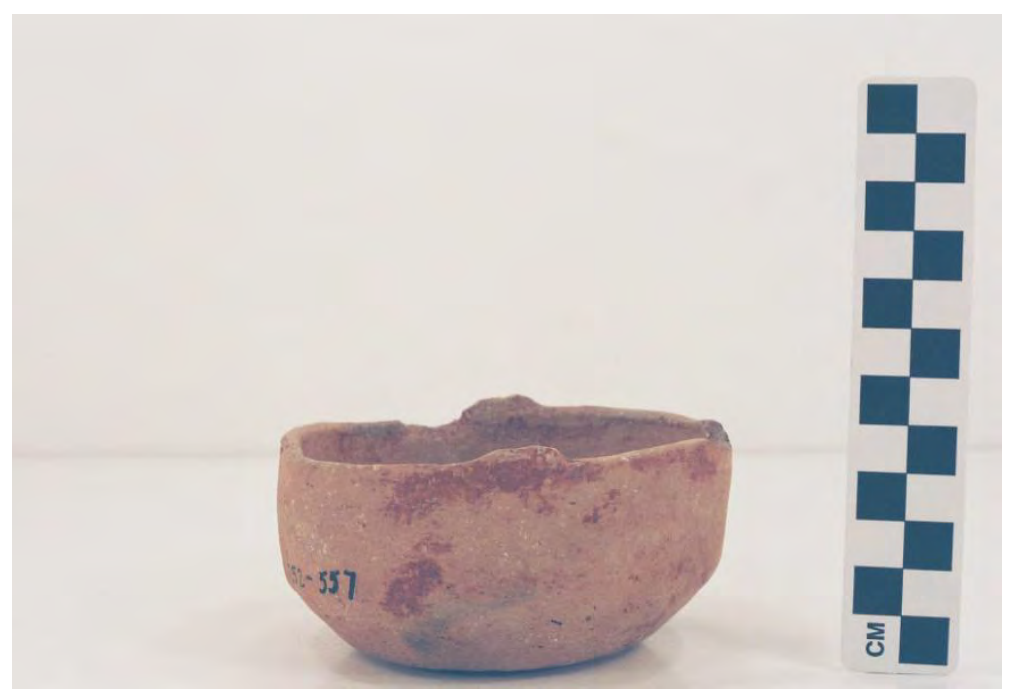

Vessel 41CE17-12. 
SITE NO.: 41CE17

FEATURE: Burial AL-4

VESSEL NO.: 41CE17-13

NON-PLASTICS: grog

VESSEL FORM: Carinated bottle with a direct rim and straight neck; flat lip

CORE COLOR: Undetermined

WALL THICKNESS: $5.0 \mathrm{~mm}$

INTERIOR SURFACE TREATMENT: none

EXTERIOR SURFACE TREATMENT: smoothed

HEIGHT: $14.0 \mathrm{~cm}$

ORIFICE DIAMETER: $4.4 \mathrm{~cm}$

DIAMETER AT BOTTOM OF RIM OR NECK: $10.8 \mathrm{~cm}$ on the vessel body

BASE DIAMETER: $6.5 \mathrm{~cm}$

ESTIMATED VOLUME: 0.4 liters

DECORATION: The vessel body has a series of interlocking and curvilinear scrolls in a panel that extends from the base of the bottle neck to the mid-body, as delimited by single horizontal engraved lines (Vessel 41CE17-13). A red clay pigment has been rubbed into the engraved lines.

TYPE: Taylor Engraved (?), but poorly executed

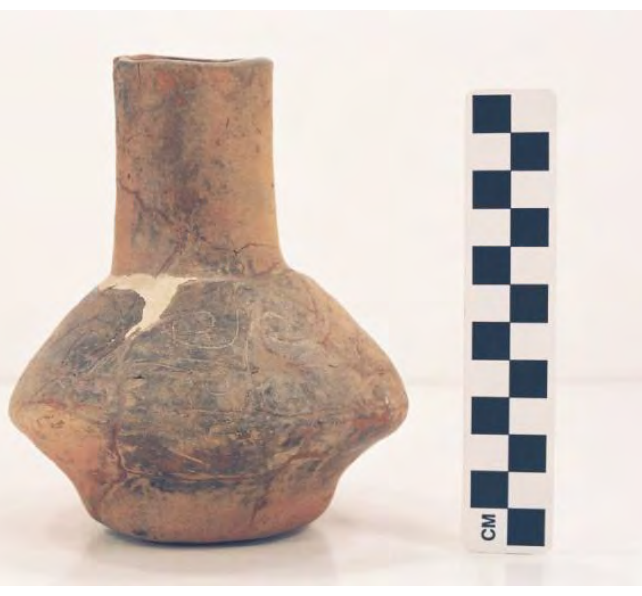

Vessel 41CE17-13. 
SITE NO.: 41CE17

FEATURE: Burial AL-4

VESSEL NO.: 41CE17-14

NON-PLASTICS: bone and grog

VESSEL FORM: Globular carinated bowl with a direct rim and a rounded lip

CORE COLOR: C (incompletely oxidized during firing)

WALL THICKNESS: $5.8 \mathrm{~mm}$, rim; $5.9 \mathrm{~mm}$, body

INTERIOR SURFACE TREATMENT: smoothed

EXTERIOR SURFACE TREATMENT: smoothed

HEIGHT: Undetermined

ORIFICE DIAMETER: $12.3 \mathrm{~cm}$

DIAMETER AT BOTTOM OF RIM OR NECK: $11.8 \mathrm{~cm}$

BASE DIAMETER: Undetermined

ESTIMATED VOLUME: Undetermined

DECORATION: The rim has an engraved panel filled with large hatched and nested triangles whose apex point either towards the rim or towards the vessel carination (Vessel 41CE17-14). Within each hatched triangle is a single negative circle.

TYPE: Poynor Engraved, var. $A$ in the upper Neches River basin

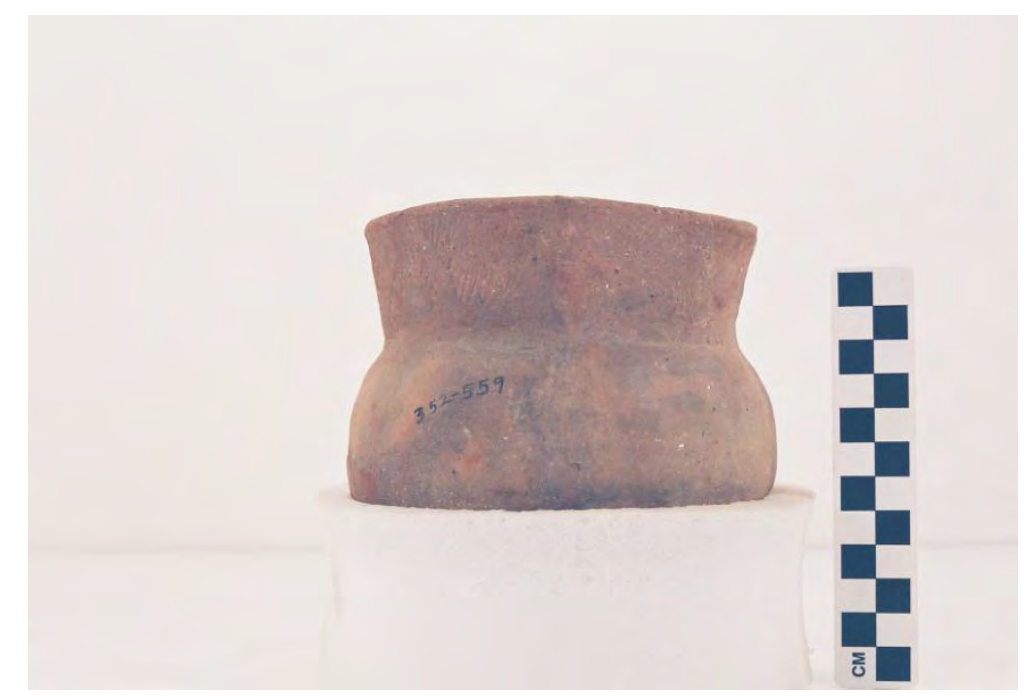

Vessel 41CE17-14. 
SITE NO.: 41CE17

FEATURE: Burial AL-4

VESSEL NO.: 41CE17-15

NON-PLASTICS: none apparent

VESSEL FORM: Bowl with a direct rim and a rounded lip (Vessel 41CE17-15)

CORE COLOR: B (Fired and cooled in a reducing environment)

WALL THICKNESS: $6.7 \mathrm{~mm}$

INTERIOR SURFACE TREATMENT: smoothed

EXTERIOR SURFACE TREATMENT: burnished; organic residue

HEIGHT: $8.0 \mathrm{~cm}$

ORIFICE DIAMETER: $17.5 \mathrm{~cm}$

DIAMETER AT BOTTOM OF RIM OR NECK: N/A

BASE DIAMETER: $7.5 \mathrm{~cm}$

ESTIMATED VOLUME: 0.6 liters

DECORATION: plain

TYPE: Undetermined plain ware vessel

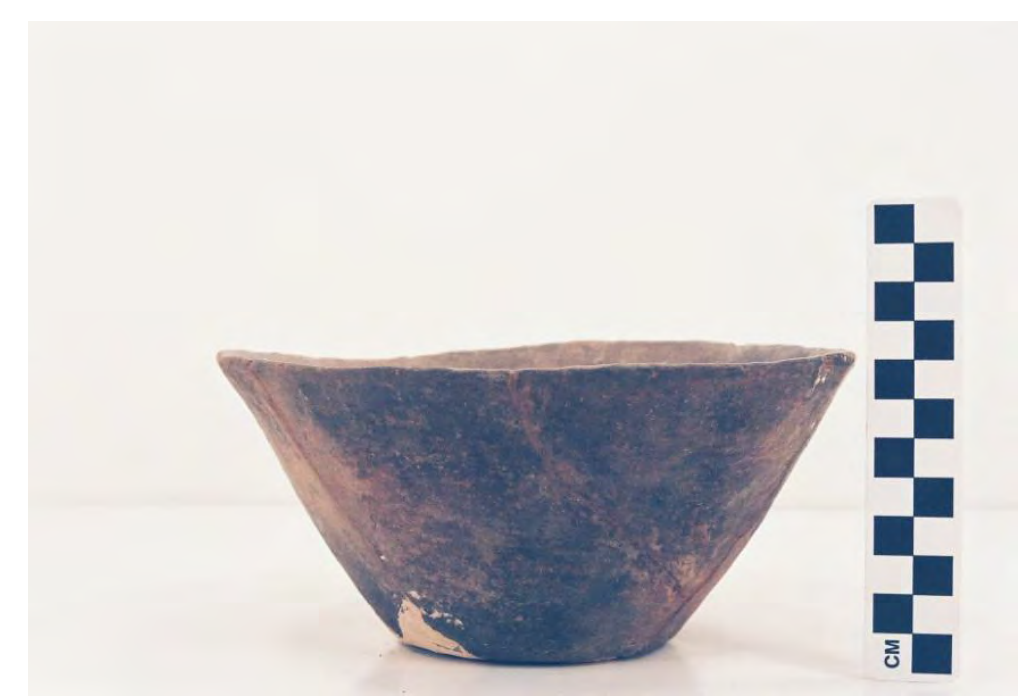

Vessel 41CE17-15. 
SITE NO.: 41CE17

FEATURE: Burial AL-4

VESSEL NO.: 41CE17-16

NON-PLASTICS: grog and hematite

VESSEL FORM: Miniature jar with a direct rim and a rounded lip

CORE COLOR: Undetermined

WALL THICKNESS: $6.7 \mathrm{~mm}$

INTERIOR SURFACE TREATMENT: none

EXTERIOR SURFACE TREATMENT: none

HEIGHT: $5.2 \mathrm{~cm}$

ORIFICE DIAMETER: $5.6 \mathrm{~cm}$

DIAMETER AT BOTTOM OF RIM OR NECK: undetermined

BASE DIAMETER: $4.5 \mathrm{~cm}$

ESTIMATED VOLUME: 0.2 liters

DECORATION: Vertical brushed rim and body (Vessel 41CE17-16)

TYPE: Bullard Brushed

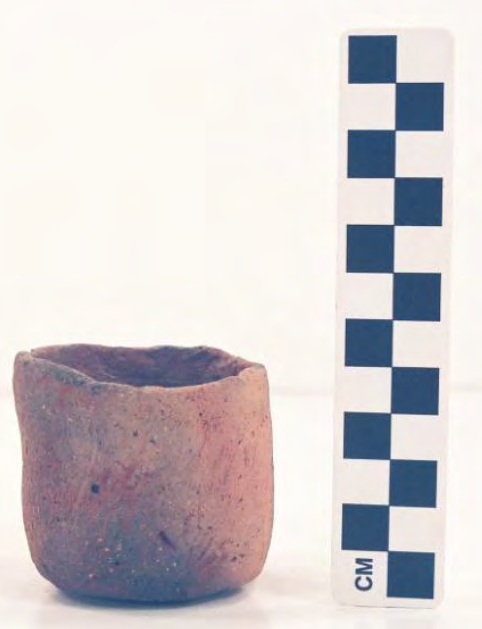

Vessel 41CE17-16. 
SITE NO.: 41CE17

FEATURE: Burial AL-4

VESSEL NO.: 41CE17-17

NON-PLASTICS: bone and hematite

VESSEL FORM: Carinated bowl with a direct rim and a rounded, exterior folded lip

CORE COLOR: A (fired and cooled in a high oxygen environment)

WALL THICKNESS: $4.1 \mathrm{~mm}$

INTERIOR SURFACE TREATMENT: smoothed on the rim

EXTERIOR SURFACE TREATMENT: smoothed

HEIGHT: $5.7 \mathrm{~cm}$

ORIFICE DIAMETER: $12.0 \mathrm{~cm}$

DIAMETER AT BOTTOM OF RIM OR NECK: $11.7 \mathrm{~cm}$

BASE DIAMETER: $6.0 \mathrm{~cm}$

\section{ESTIMATED VOLUME: 0.4 liters}

DECORATION: The rim has a continuous engraved scroll with triangular hatched fill elements above and below the central scroll line. In three instances, a triangular hatched fill element is replaced by an engraved semi-circle that encloses a small hatched triangle. There is a row of tool punctates or incised dashed lines above the engraved scroll and immediately below the lip (Vessel 41CE17-17). A red clay pigment has been rubbed in the engraved lines.

TYPE: Poynor Engraved, var. I in the upper Neches River basin

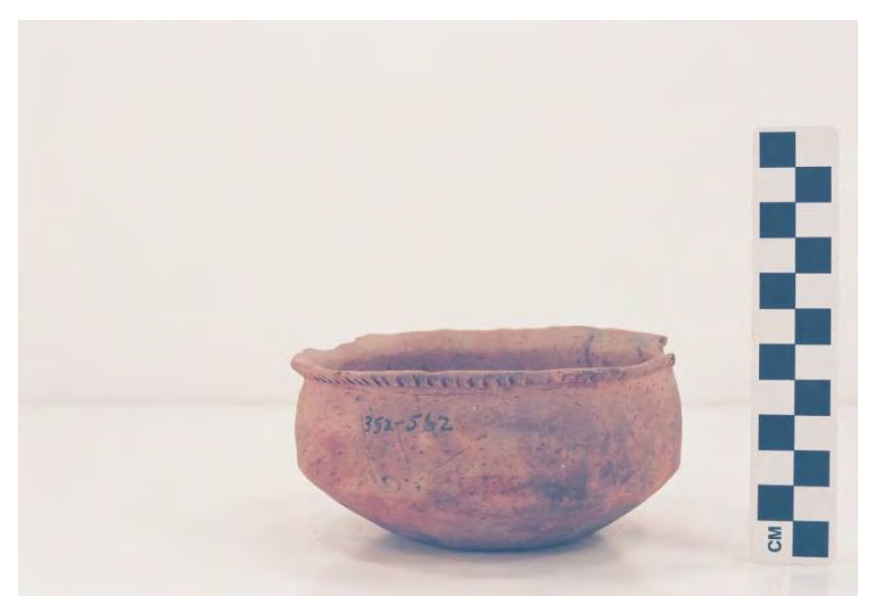

Vessel 41CE17-17. 
SITE NO.: 41CE17

FEATURE: Burial AL-5

VESSEL NO.: 41CE17-18

NON-PLASTICS: grog

VESSEL FORM: Bottle with a direct rim, a flat lip, and a collared neck

CORE COLOR: $\mathrm{F}$ (fired in a reducing environment and cooled in the open air)

WALL THICKNESS: $4.6 \mathrm{~mm}$

INTERIOR SURFACE TREATMENT: none

EXTERIOR SURFACE TREATMENT: poorly smoothed

HEIGHT: $15.2 \mathrm{~cm}$

ORIFICE DIAMETER: $4.0 \mathrm{~cm}$

DIAMETER AT BOTTOM OF RIM OR NECK: $7.9 \mathrm{~cm}$ on the vessel body

BASE DIAMETER: $5.7 \mathrm{~cm}$

ESTIMATED VOLUME: 0.35 liters

DECORATION: The vessel body has six vertical engraved panels (Vessel 41CE17-18). Each panel is comprised of two sets of two vertical engraved lines, with a combination of either hatched triangles and partially hatched semi-circles (as seen on var. $K$ Poynor Engraved carinated bowls in the upper Neches River basin) that are pendant from each of sets of vertical engraved lines. A red clay pigment has been rubbed in the engraved lines.

TYPE: Poynor Engraved bottle

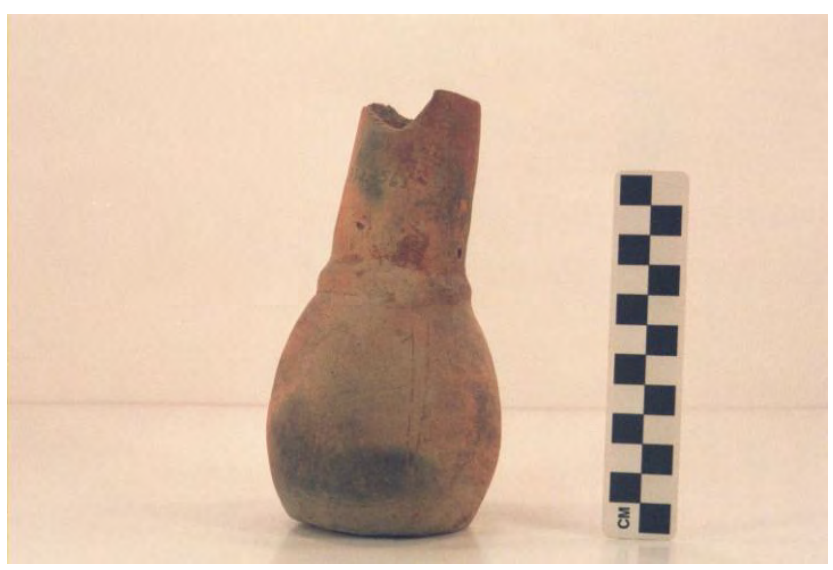

Vessel 41CE17-18. 
SITE NO.: 41CE17

FEATURE: Burial AL-5

VESSEL NO.: 41CE17-19

NON-PLASTICS: grog; sandy paste

VESSEL FORM: Effigy bowl with a direct rim and a rounded lip; there is a bird's head effigy (pointing in towards the bowl) at one end of the rim and a tab tail directly opposite (Vessel 41CE17-19)

CORE COLOR: Undetermined; pinkware

WALL THICKNESS: $4.2 \mathrm{~mm}$

INTERIOR SURFACE TREATMENT: none

EXTERIOR SURFACE TREATMENT: smoothed

HEIGHT: $6.8 \mathrm{~cm}$

ORIFICE DIAMETER: $13.3 \mathrm{~cm}$

DIAMETER AT BOTTOM OF RIM OR NECK: N/A

BASE DIAMETER: $7.3 \mathrm{~cm}$

ESTIMATED VOLUME: 0.4 liters

DECORATION: plain

TYPE: Plain effigy bowl, cf. Hood Plain, var. unspecified

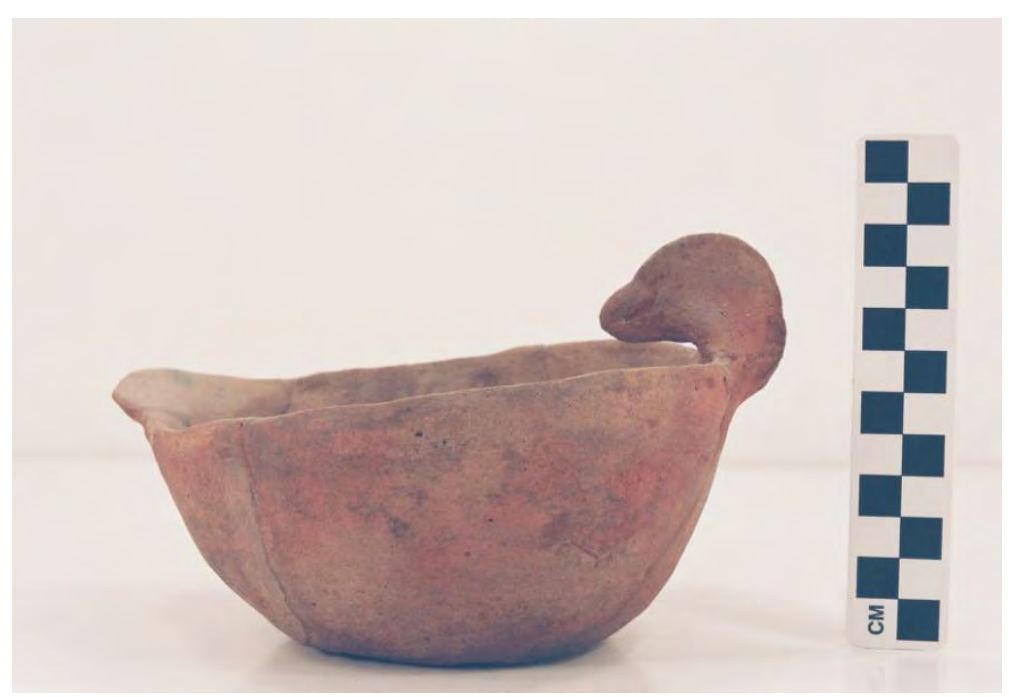

Vessel 41CE17-19. 
SITE NO.: 41CE17

FEATURE: Burial AL-7

VESSEL NO.: 41CE17-21

NON-PLASTICS: grog; sandy paste

VESSEL FORM: Globular carinated bowl with a direct but interior beveled rim and a flat lip

CORE COLOR: Undetermined

WALL THICKNESS: $5.4 \mathrm{~mm}$

INTERIOR SURFACE TREATMENT: smoothed on the rim

EXTERIOR SURFACE TREATMENT: smoothed

HEIGHT: $9.9 \mathrm{~cm}$

ORIFICE DIAMETER: $12.0 \mathrm{~cm}$

DIAMETER AT BOTTOM OF RIM OR NECK: $11.8 \mathrm{~cm}$

BASE DIAMETER: $5.2 \mathrm{~cm}$

ESTIMATED VOLUME: 0.7 liters

DECORATION: The rim has an engraved panel filled with a vertical and semi-circular motif that is repeated six times around the vessel (Vessel 41CE17-21). The motif includes two vertical engraved lines with two opposed pendant semi-circles (one on each vertical line) comprised of two or three separate and increasingly larger semi-circles. The first and innermost semi-circle is filled with horizontal hatched lines. There are two hatched triangles attached the upper and lower ends of the outermost and largest semi-circle. A red clay pigment has been rubbed in the engraved lines.

TYPE: Poynor Engraved, var. $K$ in the upper Neches River basin

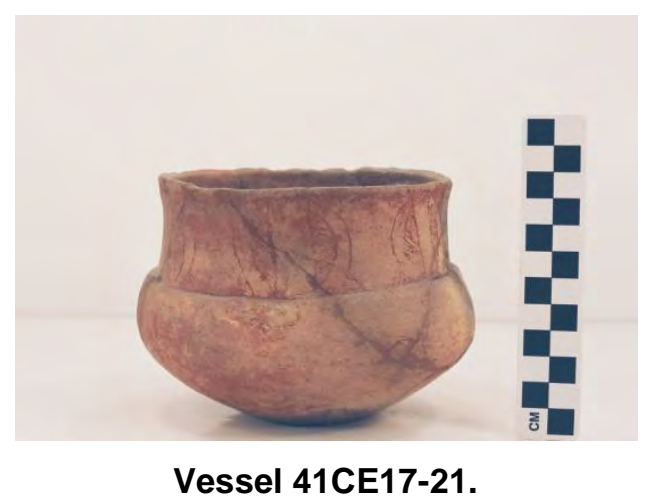


SITE NO.: 41CE17

FEATURE: Burial AL-7

VESSEL NO.: 41CE17-23

NON-PLASTICS: grog; sandy paste

VESSEL FORM: Shallow bowl with a direct rim and a rounded lip (Vessel 41CE17-23)

CORE COLOR: Undetermined

WALL THICKNESS: $5.6 \mathrm{~mm}$, rim

INTERIOR SURFACE TREATMENT: none

EXTERIOR SURFACE TREATMENT: smoothed

HEIGHT: $3.4 \mathrm{~cm}$

ORIFICE DIAMETER: $12.3 \mathrm{~cm}$

DIAMETER AT BOTTOM OF RIM OR NECK: N/A

BASE DIAMETER: $6.2 \mathrm{~cm}$

ESTIMATED VOLUME: 0.2 liters

DECORATION: plain

TYPE: Undetermined plain ware vessel

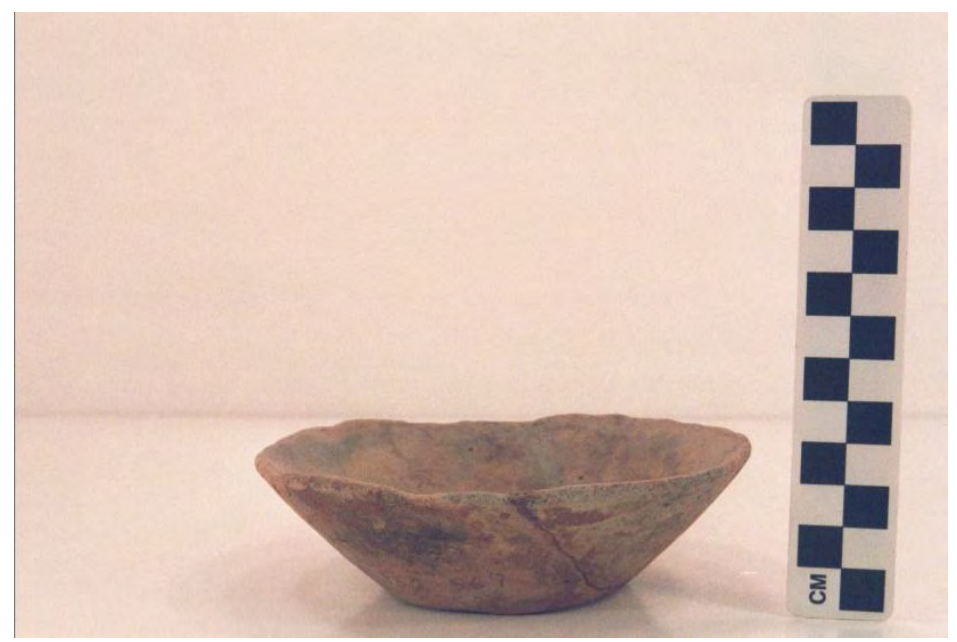

Vessel 41CE17-23. 
SITE NO.: 41CE17

FEATURE: Burial AL-7

VESSEL NO.: 41CE17-24

NON-PLASTICS: grog

VESSEL FORM: Jar with a direct rim and a rounded lip

CORE COLOR: B (fired and cooled in a reducing or low oxygen environment)

WALL THICKNESS: $6.5 \mathrm{~mm}$

INTERIOR SURFACE TREATMENT: smoothed

EXTERIOR SURFACE TREATMENT: smoothed on the lower body

HEIGHT: $21.5 \mathrm{~cm}$

ORIFICE DIAMETER: $14.2 \mathrm{~cm}$

DIAMETER AT BOTTOM OF RIM OR NECK: $14.1 \mathrm{~cm}$

\section{BASE DIAMETER: $7.5 \mathrm{~cm}$}

\section{ESTIMATED VOLUME: 2.8 liters}

DECORATION: The rim has an incised-punctated decoration consisting of seven incised triangles and 14 tool punctated-filled incised triangles, with no open areas on the rim between these two sets of decorated triangles (Vessel 41CE17-24). Each open incised triangle on the rim is followed by two punctate-filled triangles that are back to back, and the apex of each of the triangles alternate across the rim, from the apex touching the rim to the apex pointing towards the vessel base.

TYPE: Maydelle Incised

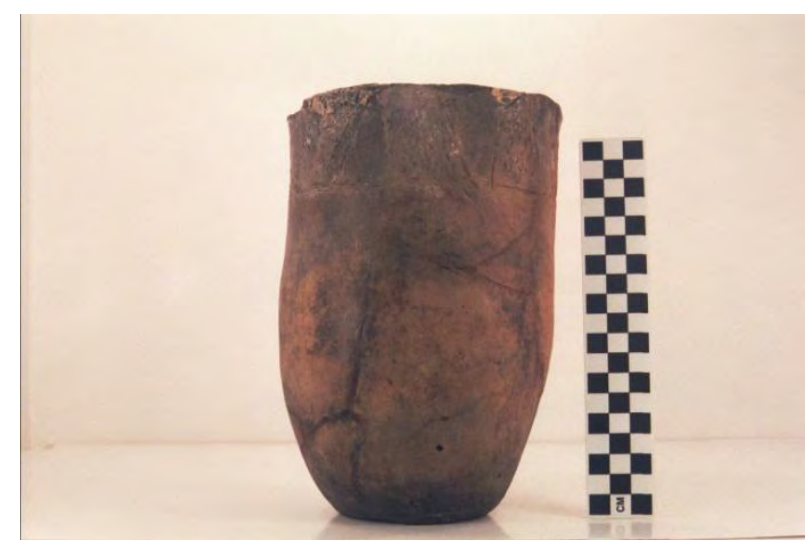

Vessel 41CE17-24, Maydelle Incised. 
SITE NO.: 41CE17

FEATURE: Burial AL-7

VESSEL NO.: 41CE17-25

NON-PLASTICS: grog and hematite

VESSEL FORM: Carinated bowl with a direct rim and rounded lip; two sets of two tab tails on the lip

CORE COLOR: Undetermined

WALL THICKNESS: $5.1 \mathrm{~mm}$

INTERIOR SURFACE TREATMENT: smoothed on the rim

EXTERIOR SURFACE TREATMENT: none

HEIGHT: $6.0 \mathrm{~cm}$

ORIFICE DIAMETER: $11.3 \mathrm{~cm}$

DIAMETER AT BOTTOM OF RIM OR NECK: $11.3 \mathrm{~cm}$

BASE DIAMETER: $6.0 \mathrm{~cm}$

ESTIMATED VOLUME: 0.4 liters

DECORATION: The rim has four rectangular engraved panels defined by two sets of two closely-spaced vertical lines (Vessel 41CE17-25). Within each panel are three concentric semicircles that are attached to the lower (at the carination) horizontal engraved line of the panel.

TYPE: Poynor Engraved, var. $S$ in the upper Neches River basin

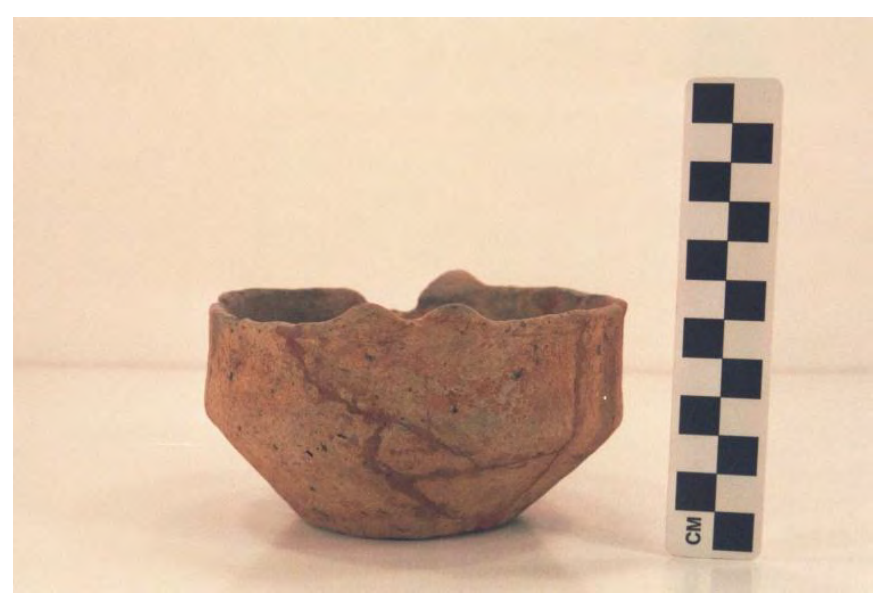

Vessel 41CE17-25. 
SITE NO.: 41CE17

FEATURE: Burial AL-7

VESSEL NO.: 41CE17-26

NON-PLASTICS: grog and bone

VESSEL FORM: Bottle with a globular carinated body, a direct rim and straight neck, a flat lip, and a slight collar at the body-neck juncture

CORE COLOR: Undetermined

WALL THICKNESS: $5.9 \mathrm{~mm}$

INTERIOR SURFACE TREATMENT: none

EXTERIOR SURFACE TREATMENT: burnished

HEIGHT: $20.0 \mathrm{~cm}$

ORIFICE DIAMETER: $4.0 \mathrm{~cm}$

DIAMETER AT BOTTOM OF RIM OR NECK: $6.6 \mathrm{~cm}$

BASE DIAMETER: $7.0 \mathrm{~cm}$

ESTIMATED VOLUME: 0.6 liters

DECORATION: The vessel body has an engraved motif repeated twice around the body, delimited by sets of two horizontal engraved lines at the rim and at the vessel carination. The central part of the motif is a large oval defined by two sets of three closely-spaced vertical curvilinear lines. Within the oval is a central circle with intersecting horizontal and vertical lines and attached hatched triangles (i.e., circle and cross) (Vessel 41CE17-26); this motif is seen on var. E Poynor Engraved carinated bowls in the upper Neches River basin. Separating the two large ovals is a curvilinear engraved zone filled with tool punctations and a second narrow but unfilled oval. A red clay pigment has been rubbed in the engraved lines.

TYPE: Poynor Engraved fine ware bottle

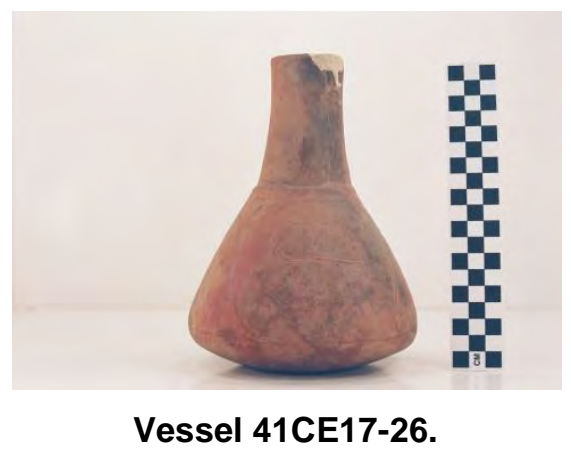


SITE NO.: 41CE17

FEATURE: Burial AL-8

VESSEL NO.: 41CE17-27

NON-PLASTICS: grog and hematite; sandy paste

VESSEL FORM: Globular carinated bowl with a short and inverted rim and a rounded lip (Vessel 41CE17-27)

CORE COLOR: B (fired and cooled in a reducing environment)

WALL THICKNESS: $4.5 \mathrm{~mm}$

INTERIOR SURFACE TREATMENT: none

EXTERIOR SURFACE TREATMENT: none

HEIGHT: $9.0 \mathrm{~cm}$

ORIFICE DIAMETER: $12.7 \mathrm{~cm}$

DIAMETER AT BOTTOM OF RIM OR NECK: $13.3 \mathrm{~cm}$

BASE DIAMETER: $7.0 \mathrm{~cm}$

ESTIMATED VOLUME: 0.7 liters

DECORATION: plain

TYPE: cf. Poynor Plain

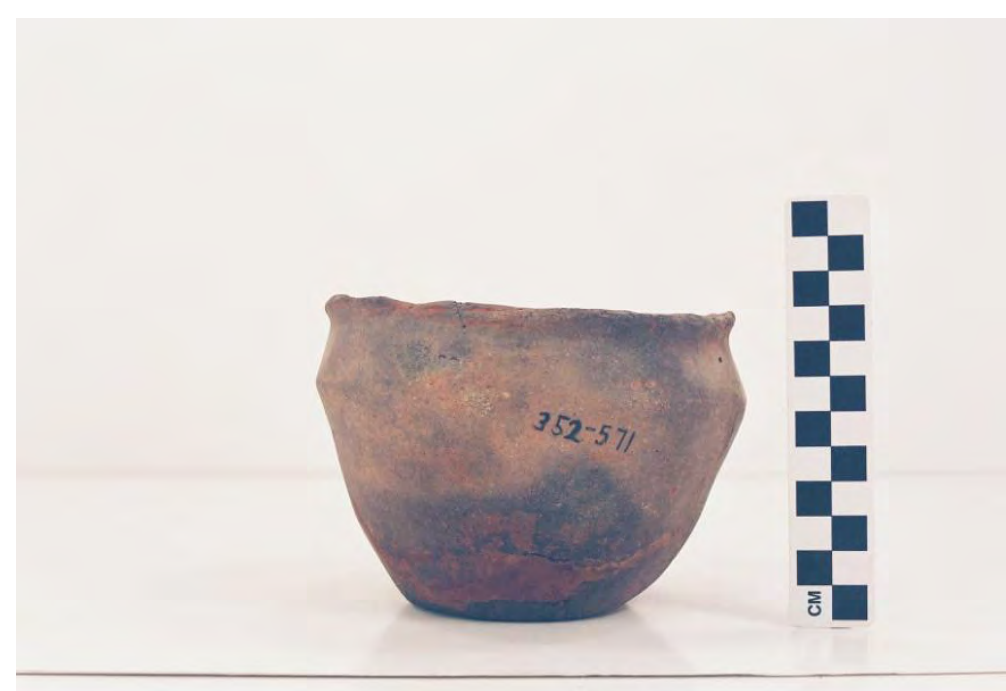

Vessel 41CE17-27. 
SITE NO.: 41CE17

FEATURE: Burial AL-8

VESSEL NO.: 41CE17-28

NON-PLASTICS: grog

VESSEL FORM: Globular carinated bowl with a direct rim and a rounded lip

CORE COLOR: Undetermined

WALL THICKNESS: $4.5 \mathrm{~mm}$

INTERIOR SURFACE TREATMENT: smoothed

EXTERIOR SURFACE TREATMENT: smoothed

HEIGHT: $10.8 \mathrm{~cm}$

ORIFICE DIAMETER: $10.5 \mathrm{~cm}$

DIAMETER AT BOTTOM OF RIM OR NECK:

BASE DIAMETER: $8.0 \mathrm{~cm}$

ESTIMATED VOLUME: 0.7 liters

DECORATION: The rim has two broadly spaced horizontal engraved lines that encircle the vessel (Vessel 41CE17-28)

TYPE: Hood Engraved, var. unspecified

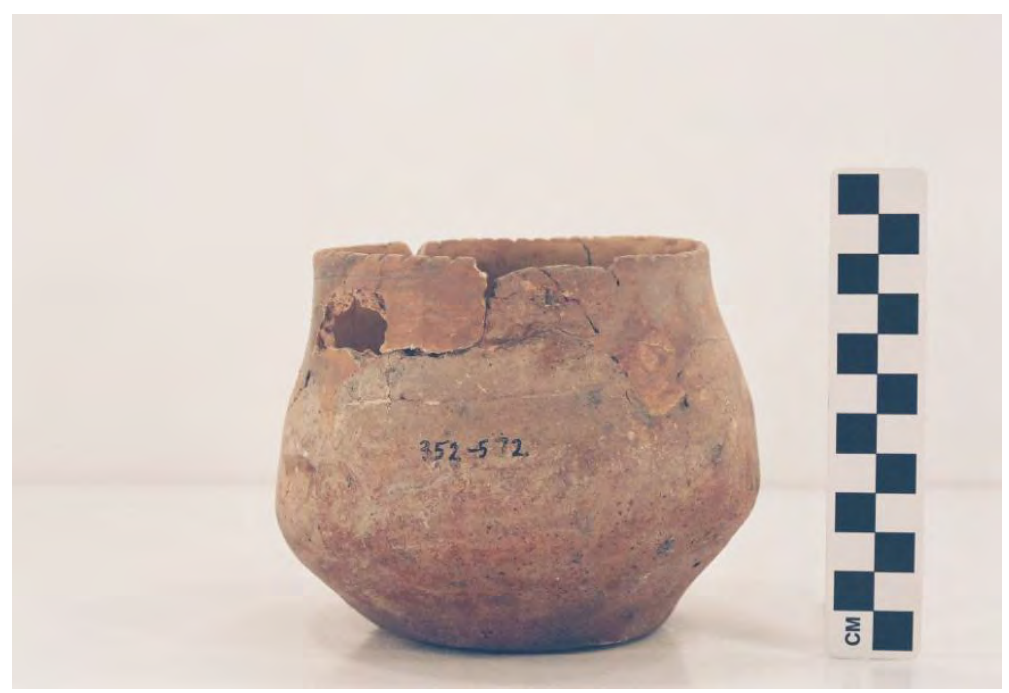

Vessel 41CE17-28. 
SITE NO.: 41CE17

FEATURE: Burial AL-8

VESSEL NO.: 41CE17-29

NON-PLASTICS: grog

VESSEL FORM: Globular carinated bowl with a direct rim and a rounded lip

CORE COLOR: Undetermined

WALL THICKNESS: $5.6 \mathrm{~mm}$

INTERIOR SURFACE TREATMENT: smoothed

EXTERIOR SURFACE TREATMENT: burnished

HEIGHT: $10.0 \mathrm{~cm}$

ORIFICE DIAMETER: $10.6 \mathrm{~cm}$

DIAMETER AT BOTTOM OF RIM OR NECK: $10.7 \mathrm{~cm}$

BASE DIAMETER: $7.0 \mathrm{~cm}$

ESTIMATED VOLUME: 0.6 liters

DECORATION: The rim has an engraved motif consisting of alternating cross-hatched vertical panels (or ladders) and triangles with hatched corners; the apex of each triangle touches the rim. The vertical panels and hatched triangles are pendant from a single horizontal engraved line at the vessel carination (Vessel 41CE17-29).

TYPE: Poynor Engraved, var. F (?) in the upper Neches River basin

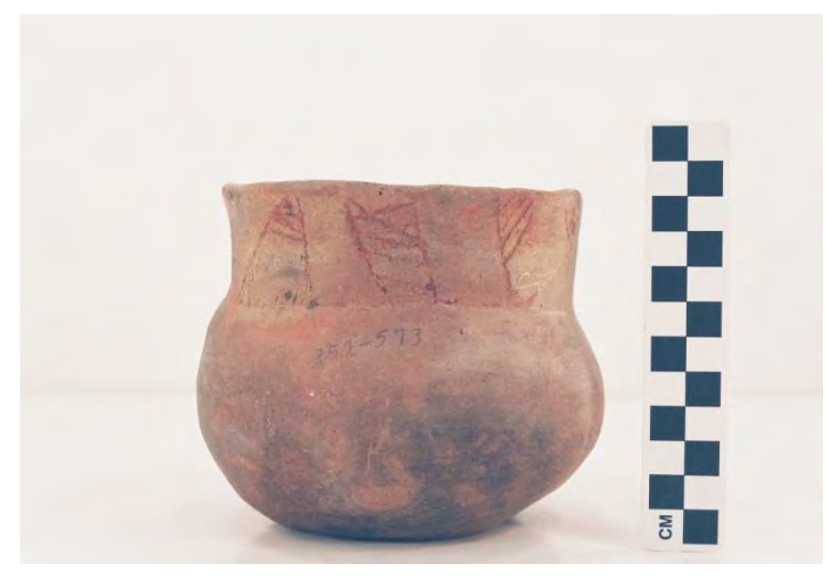

Vessel 41CE17-29. 
SITE NO.: 41CE17

FEATURE: Burial AL-9

VESSEL NO.: 41CE17-30

NON-PLASTICS: grog and hematite

VESSEL FORM: Carinated bowl with an inverted and beveled rim and a rounded, exterior folded lip

CORE COLOR: A (fired and cooled in a high oxygen environment); pinkware

WALL THICKNESS: $5.0 \mathrm{~mm}$

INTERIOR SURFACE TREATMENT: smoothed on the rim

EXTERIOR SURFACE TREATMENT: smoothed

HEIGHT: $6.5 \mathrm{~cm}$

ORIFICE DIAMETER: $9.5 \mathrm{~cm}$

DIAMETER AT BOTTOM OF RIM OR NECK: $10.1 \mathrm{~cm}$ on the body

BASE DIAMETER: $5.0 \mathrm{~cm}$

ESTIMATED VOLUME: 0.4 liters

DECORATION: There are five repeating interlocking horizontal engraved scrolls on the rim (Vessel 41CE17-30). A red clay pigment was rubbed in the engraved lines.

TYPE: Poynor Engraved, var. $B$ in the upper Neches River basin

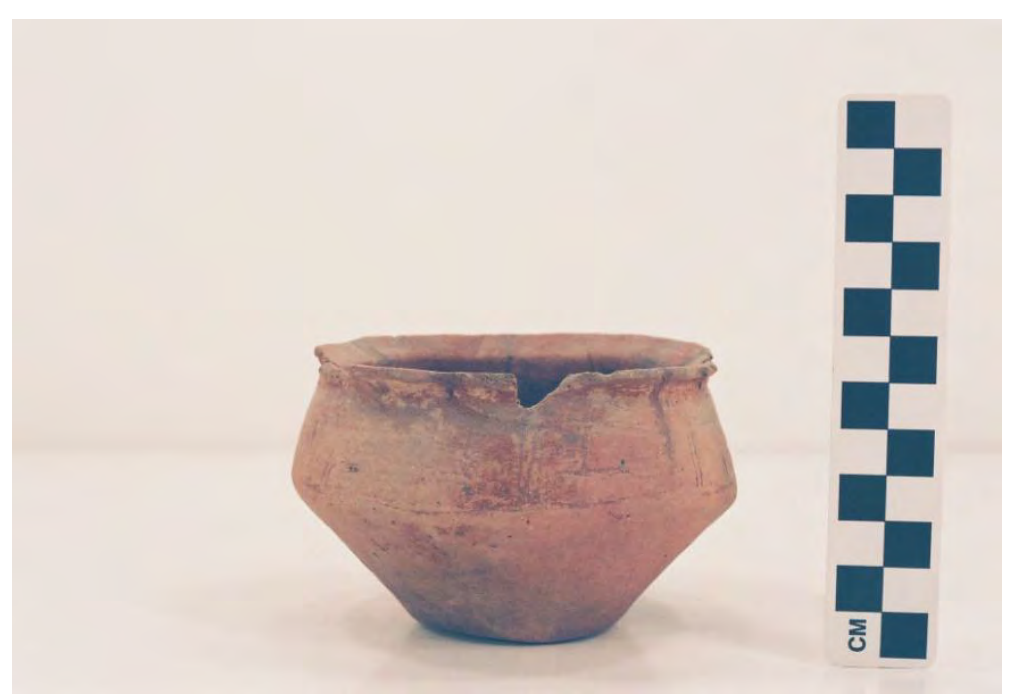

Vessel 41CE17-30. 
SITE NO.: 41CE17

FEATURE: Burial AL-9

VESSEL NO.: 41CE17-31

NON-PLASTICS: grog

VESSEL FORM: Bowl with a direct rim and a flat lip; effigy head appendage (facing inward) and large tab tail and lug appendage at the opposite side of the vessel

CORE COLOR: Undetermined

WALL THICKNESS: $6.2 \mathrm{~mm}$

INTERIOR SURFACE TREATMENT: smoothed

EXTERIOR SURFACE TREATMENT: burnished

HEIGHT: $7.5 \mathrm{~cm}$

ORIFICE DIAMETER: $14.3 \mathrm{~cm}$

DIAMETER AT BOTTOM OF RIM OR NECK: N/A

BASE DIAMETER: $9.5 \mathrm{~cm}$

ESTIMATED VOLUME: 0.4 liters

DECORATION: There are three widely-spaced horizontal engraved lines on the upper part of the vessel (Vessel 41CE17-31)

TYPE: Hood Engraved, var. Hood effigy bowl

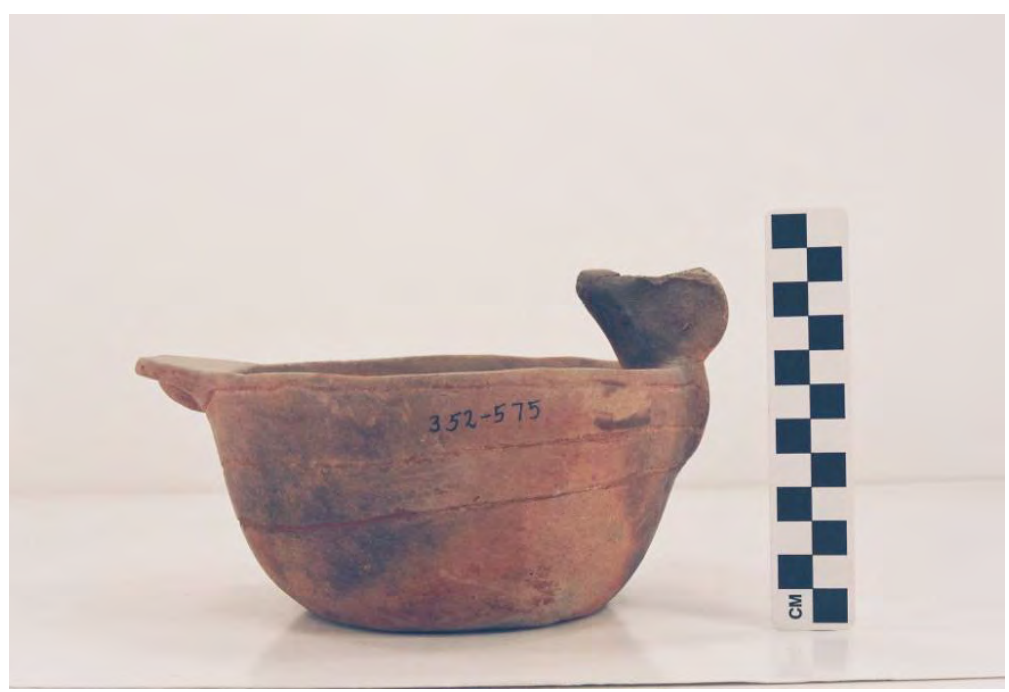

Vessel 41CE17-31. 
SITE NO.: 41CE17

FEATURE: Burial AL-9

VESSEL NO.: 41CE17-32

NON-PLASTICS: grog and hematite

VESSEL FORM: Carinated bowl with a direct rim and a rounded lip

CORE COLOR: Undetermined

WALL THICKNESS: $5.5 \mathrm{~mm}$

INTERIOR SURFACE TREATMENT: smoothed

EXTERIOR SURFACE TREATMENT: burnished

HEIGHT: $7.0 \mathrm{~cm}$

ORIFICE DIAMETER: $14.9 \mathrm{~cm}$

DIAMETER AT BOTTOM OF RIM OR NECK: $14.0 \mathrm{~cm}$

BASE DIAMETER: $8.5 \mathrm{~cm}$

ESTIMATED VOLUME: 0.6 liters

DECORATION: There is an engraved design on the vessel rim. This design consists of rectilinear scrolls, repeated four times, that begin and end with a hooked arm element (Vessel 41CE17-32). A red clay pigment has been rubbed in the engraved lines.

TYPE: Poynor Engraved, var. B (?) in the upper Neches River basin

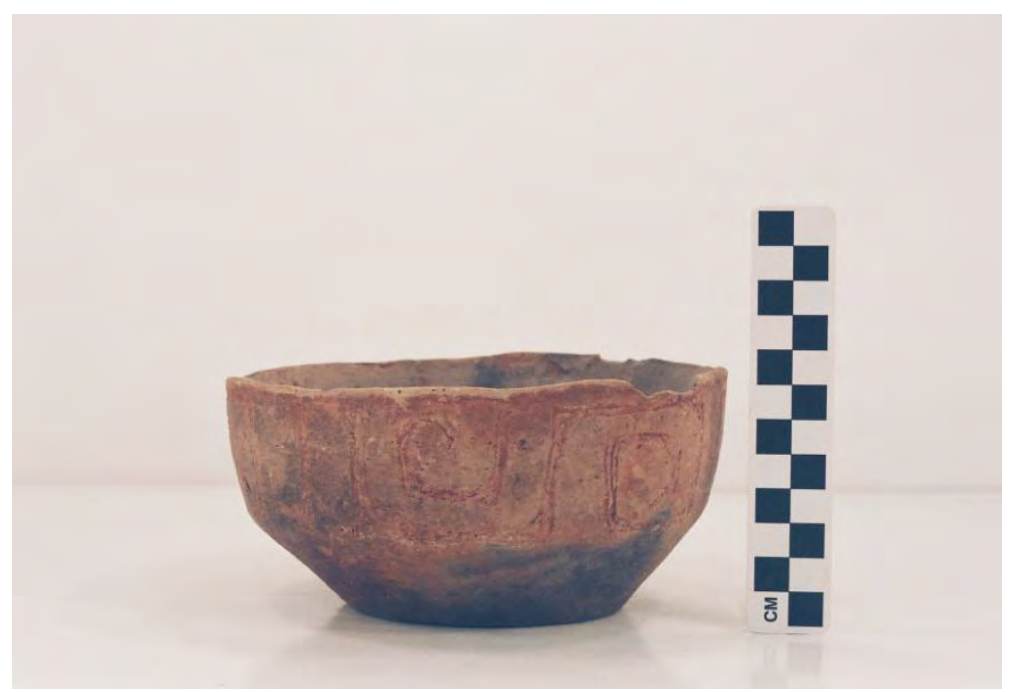

Vessel 41CE17-32. 
SITE NO.: 41CE17

FEATURE: Burial AL-9

VESSEL NO.: 41CE17-33

NON-PLASTICS: grog

VESSEL FORM: Jar with a direct rim and a rounded lip

CORE COLOR: A (fired and cooled in a high oxygen environment)

WALL THICKNESS: $7.5 \mathrm{~mm}$

INTERIOR SURFACE TREATMENT: none

EXTERIOR SURFACE TREATMENT: none

HEIGHT: $17.5 \mathrm{~cm}$

ORIFICE DIAMETER: $12.0 \mathrm{~cm}$

DIAMETER AT BOTTOM OF RIM OR NECK: $12.0 \mathrm{~cm}$

BASE DIAMETER: $7.5 \mathrm{~cm}$

ESTIMATED VOLUME: 1.3 liters

DECORATION: The rim has incised panels filled with either sets of closely-spaced horizontal incised lines or linear punctations. The vessel body has vertical brushing marks (Vessel 41CE17-33).

TYPE: Undetermined utility ware vessel

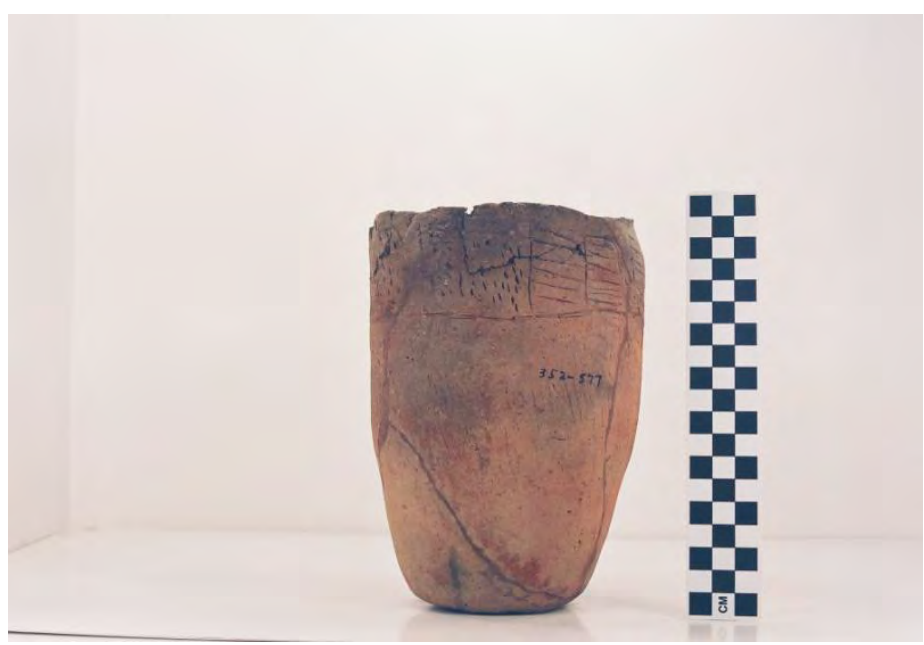

Vessel 41CE17-33. 
SITE NO.: 41CE17

FEATURE: Burial AL-10

VESSEL NO.: 41CE17-34

NON-PLASTICS: grog and hematite

VESSEL FORM: carinated bowl with a direct but interior beveled rim and a rounded, scalloped lip, possibly a Redwine mode rim

CORE COLOR: Undetermined

WALL THICKNESS: $5.6 \mathrm{~mm}$

INTERIOR SURFACE TREATMENT: none

EXTERIOR SURFACE TREATMENT: smoothed on the body

HEIGHT: $7.0 \mathrm{~cm}$

ORIFICE DIAMETER: $14.5 \mathrm{~cm}$

DIAMETER AT BOTTOM OF RIM OR NECK: $14.4 \mathrm{~cm}$

BASE DIAMETER: $6.0 \mathrm{~cm}$

ESTIMATED VOLUME: 0.6 liters

DECORATION: The rim has an engraved panel filled with seven rectangles defined by two vertical engraved lines (Vessel 41CE17-34). Within each rectangle is a central circle surrounded by five concentric semi-circles. A red clay pigment has been rubbed in the engraved lines.

TYPE: Poynor Engraved, var. $J$ in the upper Neches River basin

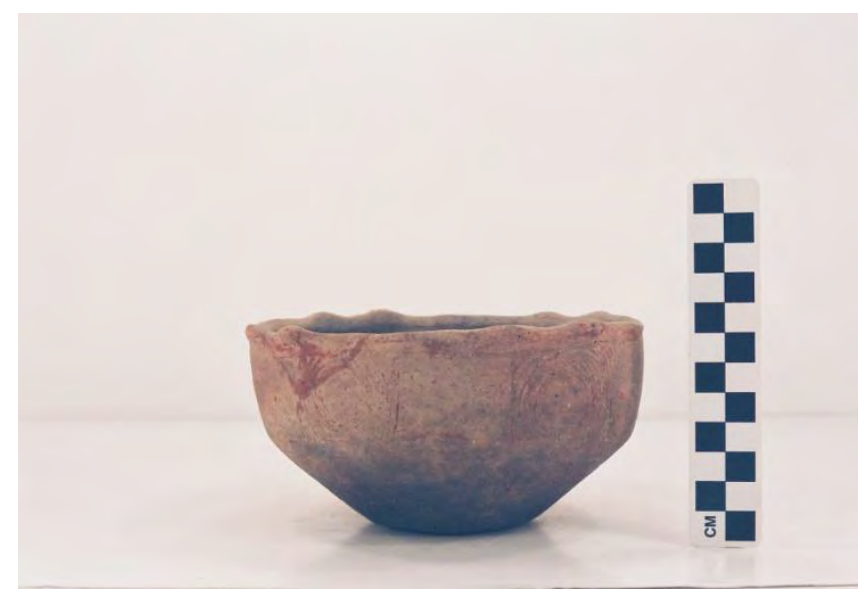

Vessel 41CE17-34. 
SITE NO.: 41CE17

FEATURE: Burial AL-10

VESSEL NO.: 41CE17-35

NON-PLASTICS: grog, hematite, and bone

VESSEL FORM: Globular carinated bowl with a direct rim and a rounded, exterior folded, lip

CORE COLOR: Undetermined

WALL THICKNESS: $4.1 \mathrm{~mm}$

INTERIOR SURFACE TREATMENT: none

EXTERIOR SURFACE TREATMENT: smoothed on the body; the rim is eroded

HEIGHT: $5.5 \mathrm{~cm}$

ORIFICE DIAMETER: $6.8 \mathrm{~cm}$

DIAMETER AT BOTTOM OF RIM OR NECK:

BASE DIAMETER: $5.3 \mathrm{~cm}$

ESTIMATED VOLUME: 0.2 liters

DECORATION: The rim has an engraved panel filled with rectangles; the exact number of rectangles cannot be determined because erosion of the vessel exterior rim surface. Each rectangle is defined by two narrow vertical excised lines (Vessel 41CE17-35).

TYPE: Poynor Engraved, var. Blackburn

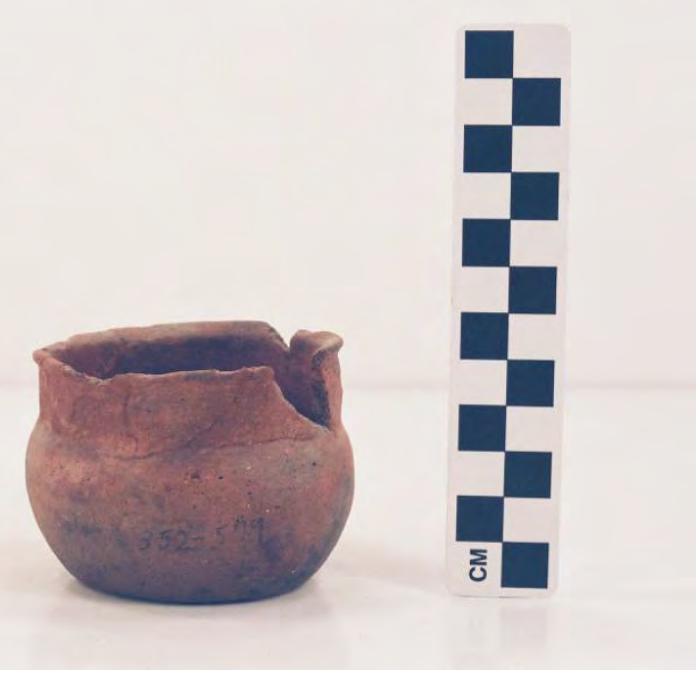

Vessel 41CE17-35. 
SITE NO.: 41CE17

FEATURE: Burial AL-10

VESSEL NO.: 41CE17-36

NON-PLASTICS: none apparent

VESSEL FORM: Globular carinated bowl with a direct rim and a rounded lip

CORE COLOR: Undetermined

WALL THICKNESS: $4.6 \mathrm{~mm}$

INTERIOR SURFACE TREATMENT: smoothed

EXTERIOR SURFACE TREATMENT: burnished

HEIGHT: $12.0 \mathrm{~cm}$

ORIFICE DIAMETER: $11.5 \mathrm{~cm}$

DIAMETER AT BOTTOM OF RIM OR NECK: $12.1 \mathrm{~cm}$

BASE DIAMETER: $7.0 \mathrm{~cm}$

ESTIMATED VOLUME: 0.8 liters

DECORATION: The rim has an engraved panel with six squares. Each square has two hatched semi-circles divided by an hour glass-shaped column with horizontal and curvilinear hatched areas around two small negative circles (Vessel 41CE17-36). A red clay pigment has been rubbed in the engraved lines.

TYPE: Poynor Engraved, var. $L$ in the upper Neches River basin

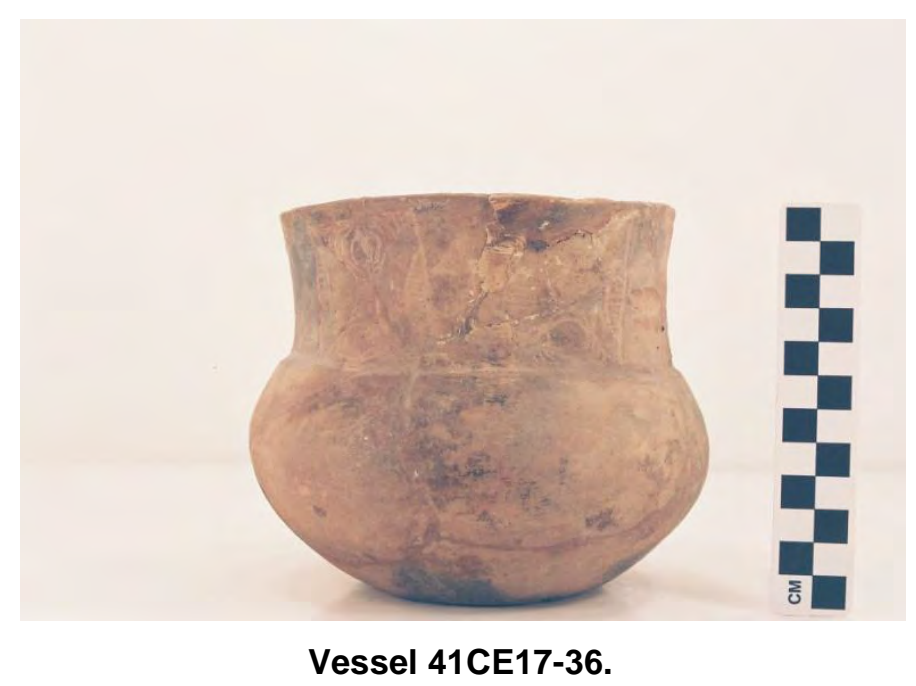


SITE NO.: 41CE17

FEATURE: Burial AL-10

VESSEL NO.: 41CE17-37

NON-PLASTICS: grog and hematite

VESSEL FORM: Carinated bowl with a direct rim and a rounded lip

CORE COLOR: Undetermined

WALL THICKNESS: $6.7 \mathrm{~mm}$

INTERIOR SURFACE TREATMENT: smoothed

EXTERIOR SURFACE TREATMENT: smoothed

HEIGHT: $8.0 \mathrm{~cm}$

ORIFICE DIAMETER: $15.8 \mathrm{~cm}$

DIAMETER AT BOTTOM OF RIM OR NECK: Undetermined

BASE DIAMETER: $8.8 \mathrm{~cm}$

\section{ESTIMATED VOLUME: 0.8 liters}

DECORATION: The rim has an engraved panel with six squares defined by two vertical lines. Three of the squares have small hatched triangles at each corner, along with two joined hatched triangles in the center of the squares (Vessel 41CE17-37); without the central hatched triangles or the negative S-shaped scrolls, the shape of the panels suggest a var. Blackburn classification. The other three squares have a negative S-shaped scroll formed by six hatched triangles, four in the corners of the square and two others in the upper and lower center of each square.

TYPE: Poynor Engraved, var. Blackburn (?)

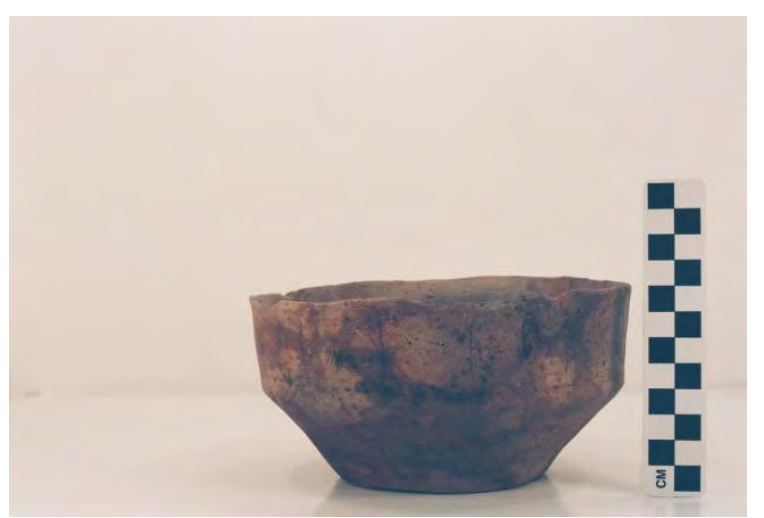

Vessel 41CE17-37. 
SITE NO.: 41CE17

FEATURE: Burial AL-10

VESSEL NO.: 41CE17-38

NON-PLASTICS: grog

VESSEL FORM: carinated bowl with an inverted rim and a rounded lip; rim peaks and/or scalloped lip

CORE COLOR: Undetermined

WALL THICKNESS: $7.2 \mathrm{~mm}$

INTERIOR SURFACE TREATMENT: smoothed

EXTERIOR SURFACE TREATMENT: smoothed

HEIGHT: $9.0 \mathrm{~cm}$

ORIFICE DIAMETER: $14.0 \mathrm{~cm}$

DIAMETER AT BOTTOM OF RIM OR NECK: $14.8 \mathrm{~cm}$

BASE DIAMETER: $6.0 \mathrm{~cm}$

ESTIMATED VOLUME: 0.8 liters

DECORATION: The rim has a series of poorly executed hatched engraved ladders, hatched semicircles, and small circles (Vessel 41CE17-38).

TYPE: Undetermined engraved fine ware vessel

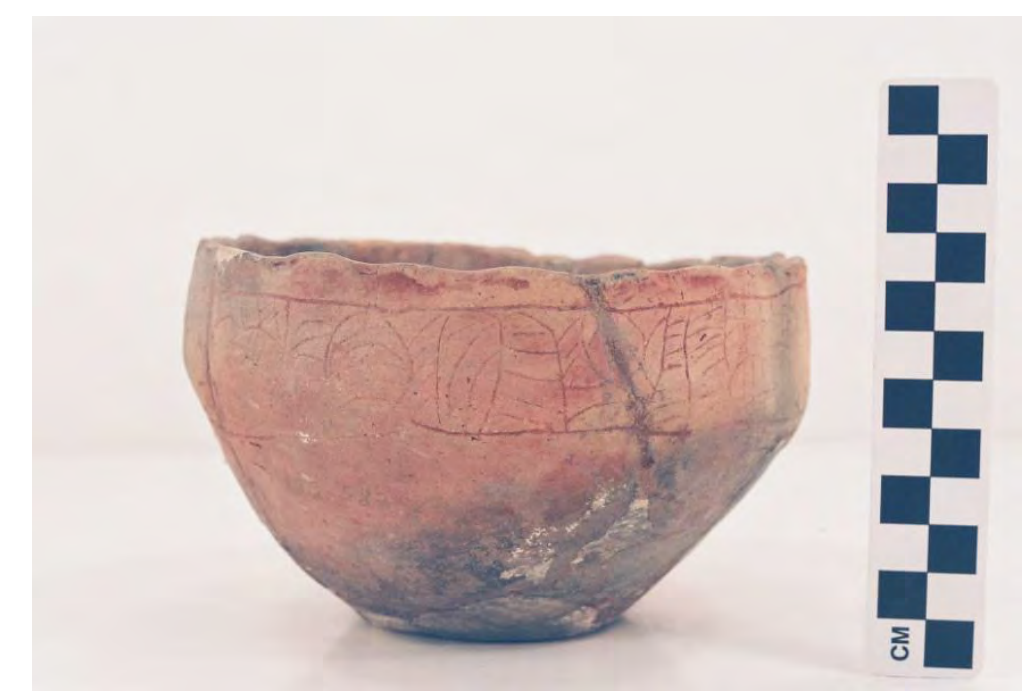

Vessel 41CE17-38. 
SITE NO.: 41CE17

FEATURE: Burial AL-11

VESSEL NO.: 41CE17-40

NON-PLASTICS: grog and hematite

VESSEL FORM: Carinated bowl with a direct rim and a rounded lip (Vessel 41CE17-40)

CORE COLOR: Undetermined

WALL THICKNESS: $4.6 \mathrm{~mm}$

INTERIOR SURFACE TREATMENT: burnished

EXTERIOR SURFACE TREATMENT: burnished

HEIGHT: $6.5 \mathrm{~cm}$

ORIFICE DIAMETER: $14.0 \mathrm{~cm}$

DIAMETER AT BOTTOM OF RIM OR NECK: $13.4 \mathrm{~cm}$

BASE DIAMETER: $7.0 \mathrm{~cm}$

ESTIMATED VOLUME: 0.6 liters

DECORATION: plain

TYPE: Undetermined plain ware vessel

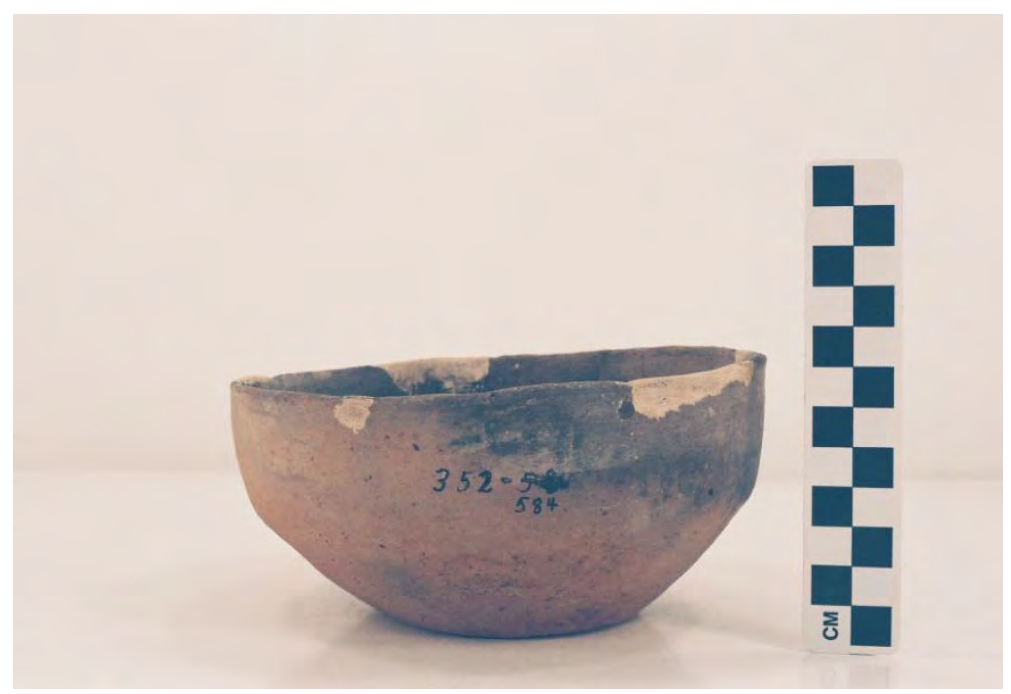

Vessel 41CE17-40, Plain Carinated Bowl. 


\section{R. J. Fair site (41CE25)}

SITE NO.: 41CE25

FEATURE: Burial AM-1

VESSEL NO.: 41CE25-1

NON-PLASTICS: bone and grog

VESSEL FORM: Bottle with a long neck, a short and squat body, a direct rim, and a flat lip (Vessel 41CE25-1)

CORE COLOR: Undetermined

WALL THICKNESS: $7.4 \mathrm{~mm}$

INTERIOR SURFACE TREATMENT: none

EXTERIOR SURFACE TREATMENT: burnished on the neck

HEIGHT: $17.5 \mathrm{~cm}$

ORIFICE DIAMETER: $4.8 \mathrm{~cm}$

DIAMETER AT BOTTOM OF RIM OR NECK: $9.6 \mathrm{~cm}$ on the body

BASE DIAMETER: $9.5 \mathrm{~cm}$

ESTIMATED VOLUME: 0.7 liters

DECORATION: plain

TYPE: cf. Fair Plain bottle

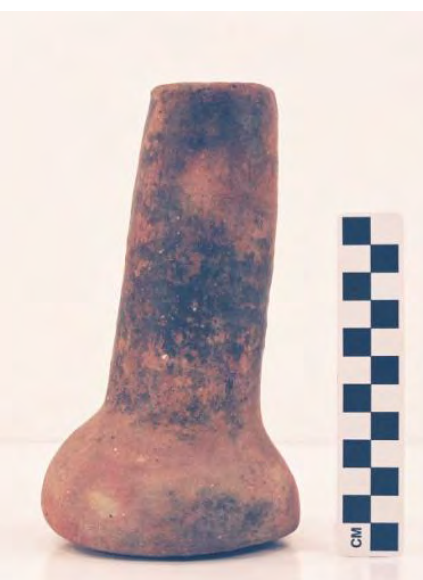

Vessel 41CE25-1. 
SITE NO.: 41CE25

FEATURE: Burial AM-1

VESSEL NO.: 41CE25-2

NON-PLASTICS: grog, hematite, and bone

VESSEL FORM: Short-necked bottle with an elongated body, a direct rim, and a rounded lip

CORE COLOR: Undetermined

WALL THICKNESS: $6.8 \mathrm{~mm}$

INTERIOR SURFACE TREATMENT: none

EXTERIOR SURFACE TREATMENT: burnished

HEIGHT: $25.0 \mathrm{~cm}$

ORIFICE DIAMETER: $3.5 \mathrm{~cm}$

DIAMETER AT BOTTOM OF RIM OR NECK: $6.0 \mathrm{~cm}$

BASE DIAMETER: $9.9 \mathrm{~cm}$

ESTIMATED VOLUME: 1.0 liters

DECORATION: There are four sets of vertical engraved lines (each set with four closely-spaced lines) on the vessel body, attached to sets of horizontal engraved lines at the bottom of the bottle neck and above the base; these have two or three horizontal lines, respectively (Vessel 41CE25$2)$.

TYPE: Hume Engraved, var. unspecified

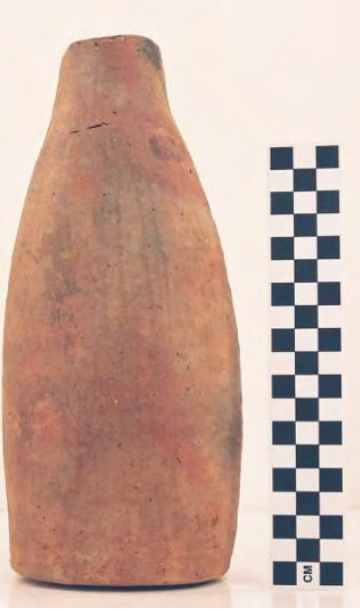

Vessel 41CE25-2, Hume Engraved. 
SITE NO.: 41CE25

FEATURE: Burial AM-1

VESSEL NO.: 41CE25-3

NON-PLASTICS: grog, hematite, and bone

VESSEL FORM: Globular carinated bowl with evidence of attachments at the rim and for a fourlegged ring base, but these attachments have broken away; the diameter of the legs is $2.0 \mathrm{~cm}$

CORE COLOR: A (fired and cooled in a high oxygen environment); pinkware

WALL THICKNESS: $5.5 \mathrm{~cm}$

INTERIOR SURFACE TREATMENT: none

EXTERIOR SURFACE TREATMENT: smoothed

HEIGHT: $8.0 \mathrm{~cm}$

ORIFICE DIAMETER: $12.2 \mathrm{~cm}$

DIAMETER AT BOTTOM OF RIM OR NECK:

BASE DIAMETER: $9.5 \mathrm{~cm}$

ESTIMATED VOLUME: 0.6 liters

DECORATION: The vessel rim has three horizontal engraved lines. The vessel body has four discrete concentric circle motifs, each comprised of six concentric circles (Vessel 41CE25-3).

TYPE: possibly a PP variety of Poynor Engraved as defined by Kleinschmidt (1982) 

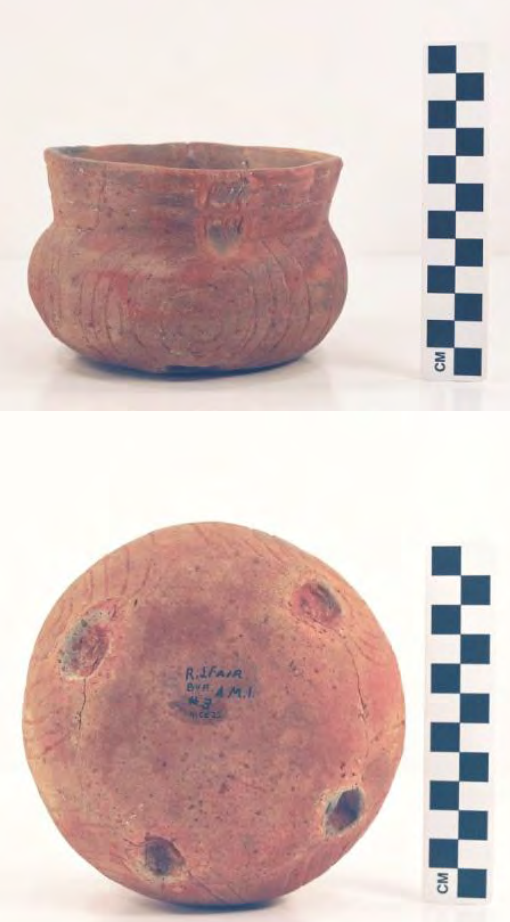

Vessel 41CE25-3: a, side view; b. basal view, showing four attachment areas for fourlegged ring base. 
SITE NO.: 41CE25

FEATURE: Burial AM-1

VESSEL NO.: 41CE25-4

NON-PLASTICS: grog and hematite

VESSEL FORM: Carinated bowl with a direct rim and a rounded, exterior folded lip; lip notched CORE COLOR: Undetermined

WALL THICKNESS: $8.4 \mathrm{~mm}$

INTERIOR SURFACE TREATMENT: smoothed

EXTERIOR SURFACE TREATMENT: smoothed

HEIGHT: $11.0 \mathrm{~cm}$

ORIFICE DIAMETER: $17.0 \mathrm{~cm}$

DIAMETER AT BOTTOM OF RIM OR NECK: $18.0 \mathrm{~cm}$

BASE DIAMETER: $7.0 \mathrm{~cm}$

\section{ESTIMATED VOLUME: 1.1 liters}

DECORATION: The rim has an engraved scroll and circle motif repeated four times around the vessel. The circles are open and the scroll fill elements are triangular hatched areas above and below the central scroll line (Vessel 41CE25-4). The vessel body has vertical brushing marks.

TYPE: Poynor Engraved, var. $E$ in the upper Neches River basin

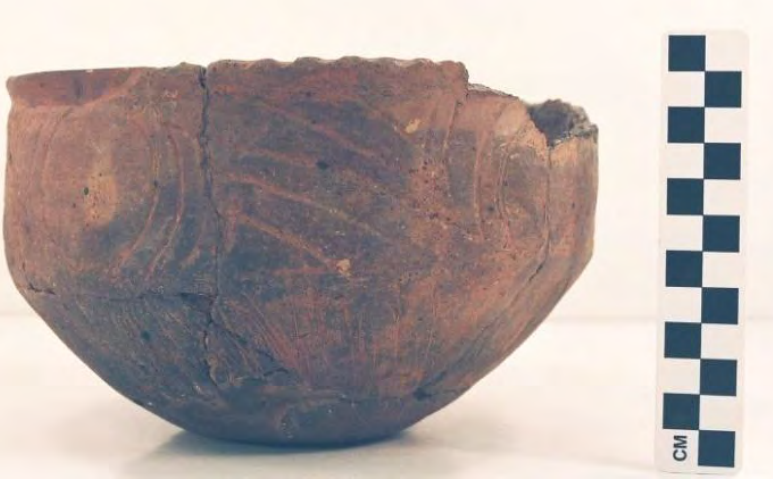

Vessel 41CE25-4. 
SITE NO.: 41CE25

FEATURE: Burial AM-1

VESSEL NO.: 41CE25-5

NON-PLASTICS: grog and hematite

VESSEL FORM: possible broken jar

CORE COLOR: $\mathrm{G}$ (fired in a reducing environment and cooled in the open air)

WALL THICKNESS: $6.7 \mathrm{~mm}$

INTERIOR SURFACE TREATMENT: smoothed

EXTERIOR SURFACE TREATMENT: none, eroded

HEIGHT: Undetermined

ORIFICE DIAMETER: $13.0 \mathrm{~cm}$

DIAMETER AT BOTTOM OF RIM OR NECK: Undetermined

BASE DIAMETER: $6.4 \mathrm{~cm}$

ESTIMATED VOLUME: Undetermined

DECORATION: plain

TYPE: Undetermined plain ware vessel 
SITE NO.: 41CE25

FEATURE: Burial AM-2

VESSEL NO.: 41CE25-17

NON-PLASTICS: grog and hematite

VESSEL FORM: Bottle with a short neck, an elongated body, a direct rim, and a rounded lip

CORE COLOR: Undetermined

WALL THICKNESS: $5.7 \mathrm{~mm}$

INTERIOR SURFACE TREATMENT: none

EXTERIOR SURFACE TREATMENT: burnished

HEIGHT: $19.0 \mathrm{~cm}$

ORIFICE DIAMETER: $3.1 \mathrm{~cm}$

DIAMETER AT BOTTOM OF RIM OR NECK: $5.1 \mathrm{~cm}$

BASE DIAMETER: $7.0 \mathrm{~cm}$

ESTIMATED VOLUME: 0.6 liters

DECORATION: There are two horizontal engraved lines at the base of the bottle neck and three horizontal engraved lines near the vessel base. In between are two vertical engraved panels filled with four widely-spaced hour glass-shaped areas comprised of three lines (two curvilinear and one horizontal) (Vessel 41CE25-17).

TYPE: Poynor Engraved

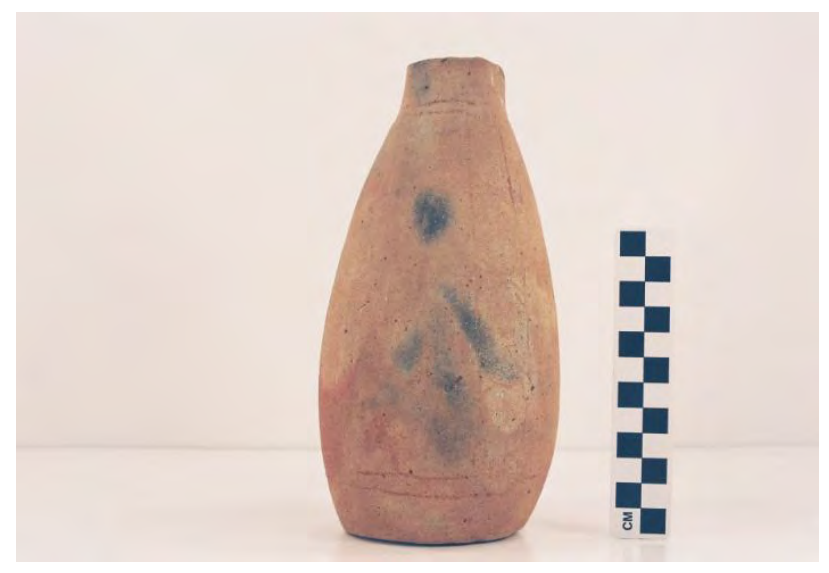

Vessel 41CE25-17, Poynor Engraved. 
SITE NO.: 41CE25

FEATURE: Burial AM-2

VESSEL NO.: 41CE25-18

NON-PLASTICS: grog and bone

VESSEL FORM: Globular carinated bowl with a direct rim and a rounded lip

CORE COLOR: Undetermined

WALL THICKNESS: $4.9 \mathrm{~mm}$

INTERIOR SURFACE TREATMENT: smoothed on the rim

EXTERIOR SURFACE TREATMENT: smoothed

HEIGHT: $10.3 \mathrm{~cm}$

ORIFICE DIAMETER: $13.5 \mathrm{~cm}$

DIAMETER AT BOTTOM OF RIM OR NECK: $13.5 \mathrm{~cm}$

BASE DIAMETER: $6.5 \mathrm{~cm}$

ESTIMATED VOLUME: 0.6 liters

DECORATION: The rim has an engraved panel comprised of seven negative ovals. The ovals are defined by two hour glass-shaped columns filled with closely-spaced vertical and curvilinear engraved lines (Vessel 41CE25-18).

TYPE: Poynor Engraved, var. Hood

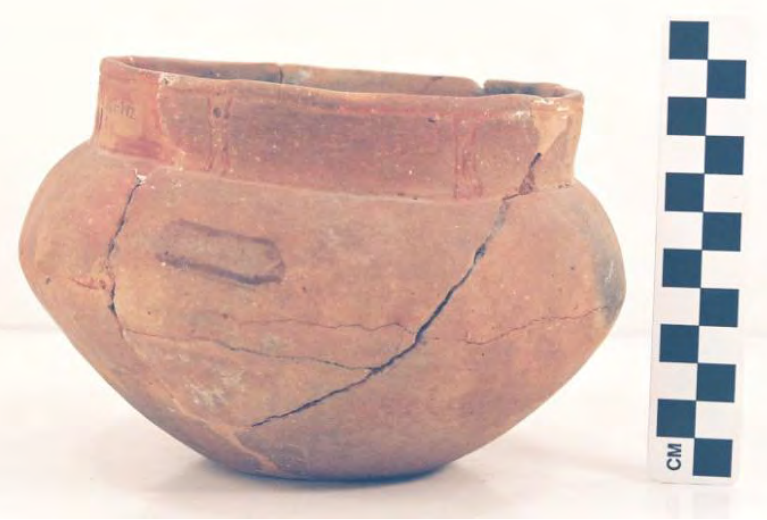

Vessel 41CE25-18. 
SITE NO.: 41CE25

FEATURE: Burial AM-3

VESSEL NO.: 41CE25-29

NON-PLASTICS: grog and bone

VESSEL FORM: Bottle with an elongated neck, a short and squat body, a direct rim, and a rounded lip (Vessel 41CE25-29)

CORE COLOR: Undetermined

WALL THICKNESS: $7.9 \mathrm{~mm}$

INTERIOR SURFACE TREATMENT: none

EXTERIOR SURFACE TREATMENT: burnished

HEIGHT: $17.0 \mathrm{~cm}$

ORIFICE DIAMETER: $3.7 \mathrm{~cm}$

DIAMETER AT BOTTOM OF RIM OR NECK: $6.3 \mathrm{~cm}$

BASE DIAMETER: $11.0 \mathrm{~cm}$

ESTIMATED VOLUME: 0.8 liters

DECORATION: plain

TYPE: cf. Fair Plain bottle

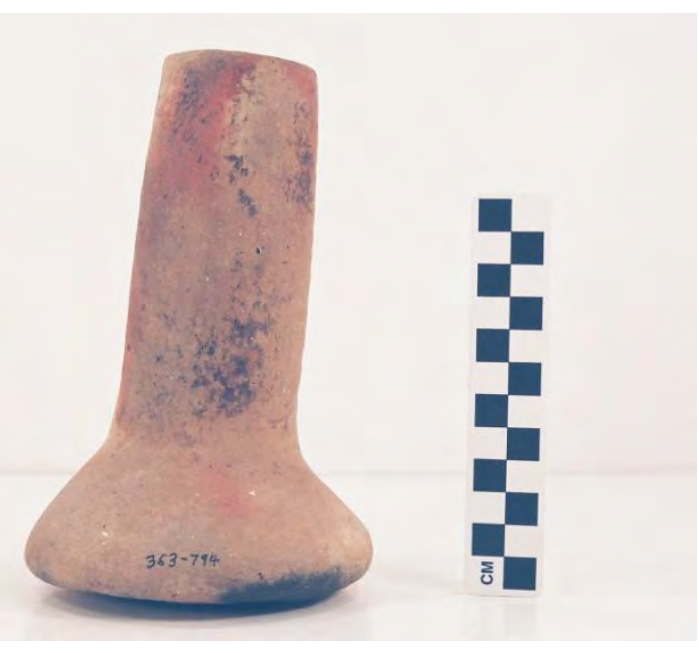

Vessel 41CE25-29. 
SITE NO.: 41CE25

FEATURE: Burial AM-3

VESSEL NO.: 41CE25-30

NON-PLASTICS: grog and bone

VESSEL FORM: Bottle with a short neck, an elongated body, a direct rim, and a rounded lip

CORE COLOR: Undetermined

WALL THICKNESS: $7.0 \mathrm{~mm}$

INTERIOR SURFACE TREATMENT: none

EXTERIOR SURFACE TREATMENT: burnished

HEIGHT: $26.0 \mathrm{~cm}$

ORIFICE DIAMETER: $3.6 \mathrm{~cm}$

DIAMETER AT BOTTOM OF RIM OR NECK: $5.4 \mathrm{~cm}$

BASE DIAMETER: $11.0 \mathrm{~cm}$

\section{ESTIMATED VOLUME: 1.1 liters}

DECORATION: There are three closely-spaced horizontal engraved lines on the short bottle neck and two on the vessel body near the base. There are three vertical engraved panels on the bottle body between these sets of horizontal lines, each comprised of four closely-spaced vertical engraved lines (Vessel 41CE25-30).

TYPE: Hume Engraved, var. unspecified

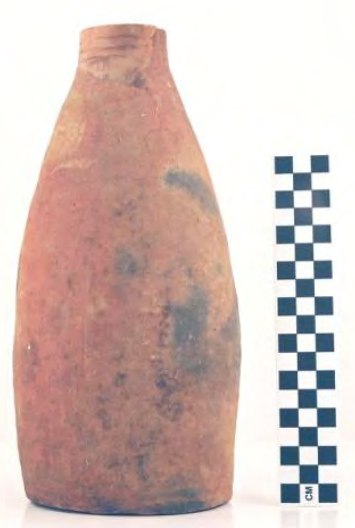

Vessel 41CE25-30. 
SITE NO.: 41CE25

FEATURE: Burial AM-3

VESSEL NO.: 41CE25-31

NON-PLASTICS: grog, hematite, and bone; sandy paste

VESSEL FORM: Globular carinated bowl with a direct rim and a rounded, exterior folded lip

CORE COLOR: Undetermined

WALL THICKNESS: $6.3 \mathrm{~mm}$

INTERIOR SURFACE TREATMENT: smoothed

EXTERIOR SURFACE TREATMENT: burnished

HEIGHT: $12.5 \mathrm{~cm}$

ORIFICE DIAMETER: $15.5 \mathrm{~cm}$

DIAMETER AT BOTTOM OF RIM OR NECK: $15.0 \mathrm{~cm}$

BASE DIAMETER: $8.0 \mathrm{~cm}$

ESTIMATED VOLUME: 1.2 liters

DECORATION: The rim has an engraved panel with seven negative ovals. Each negative oval is defined by two hour glass-shaped columns filled with closely-spaced vertical and curvilinear lines (Vessel 41CE25-31).

TYPE: Poynor Engraved, var. Hood

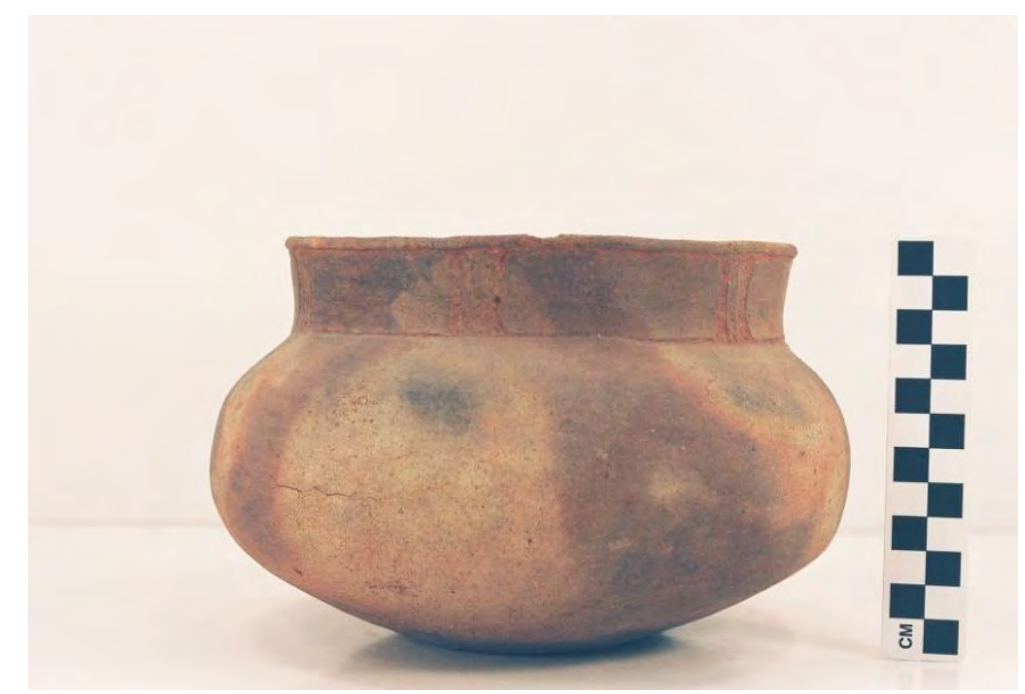

Vessel 41CE25-31. 
SITE NO.: 41CE25

FEATURE: Burial AM-3

VESSEL NO.: 41CE25-32

NON-PLASTICS: grog, hematite, and bone

VESSEL FORM: Globular carinated bowl with a direct rim and a rounded lip

CORE COLOR: A (fired and cooled in a high oxygen environment); pinkware

WALL THICKNESS: $4.5 \mathrm{~mm}$

INTERIOR SURFACE TREATMENT: smoothed on the rim

EXTERIOR SURFACE TREATMENT: smoothed on the rim

HEIGHT: $10.4 \mathrm{~cm}$

ORIFICE DIAMETER: $11.5 \mathrm{~cm}$

DIAMETER AT BOTTOM OF RIM OR NECK: $11.7 \mathrm{~cm}$

BASE DIAMETER: $7.0 \mathrm{~cm}$

ESTIMATED VOLUME: 0.7 liters

DECORATION: The rim has an engraved panel comprised of nine negative ovals. Each oval is defined by two excised hour glass-shaped columns (Vessel 41CE25-32).

TYPE: Poynor Engraved, var. Hood

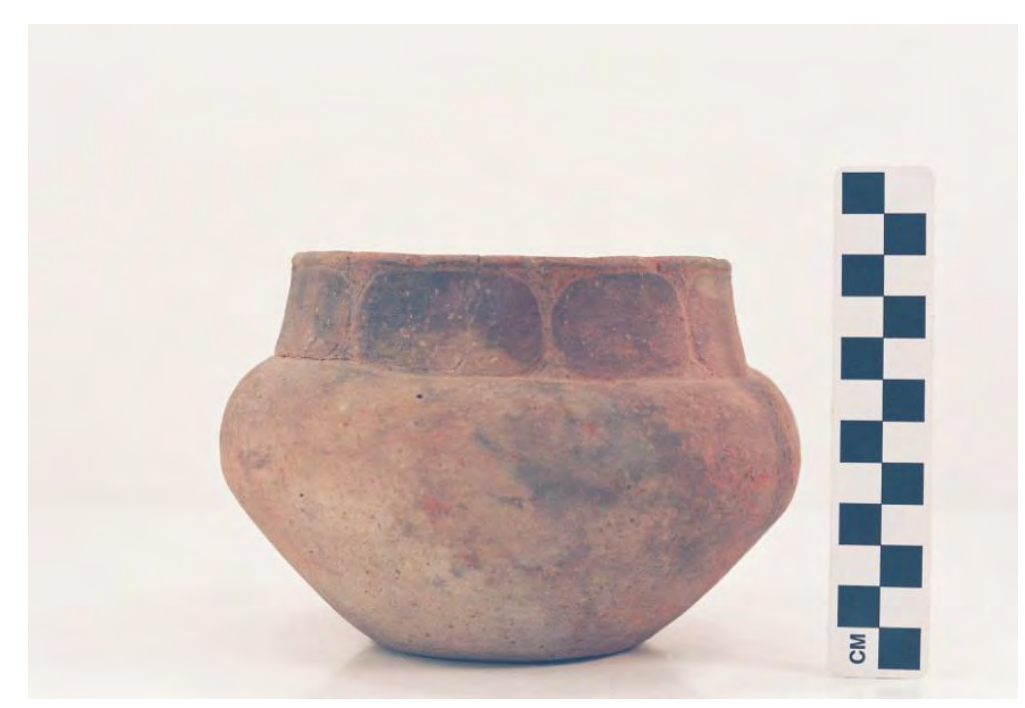

Vessel 41CE25-32. 
SITE NO.: 41CE25

FEATURE: Burial AM-3

VESSEL NO.: 41CE25-33

NON-PLASTICS: grog and hematite

VESSEL FORM: Globular carinated bowl with a direct rim and a rounded lip; two small loop handles

CORE COLOR: Undetermined

WALL THICKNESS: $5.1 \mathrm{~mm}$

INTERIOR SURFACE TREATMENT: smoothed

EXTERIOR SURFACE TREATMENT: smoothed

HEIGHT: $7.0 \mathrm{~cm}$

ORIFICE DIAMETER: $6.4 \mathrm{~cm}$

DIAMETER AT BOTTOM OF RIM OR NECK:

BASE DIAMETER: $4.0 \mathrm{~cm}$

ESTIMATED VOLUME: 0.3 liters

DECORATION: The vessel rim is plain. The vessel body has an engraved concentric circle motif that is repeated twice on the vessel. This motif is comprised of five concentric circles, each of which has small pendant triangles (Vessel 41CE25-33).

TYPE: Poynor Engraved, PP variety (Kleinschmidt 1982)

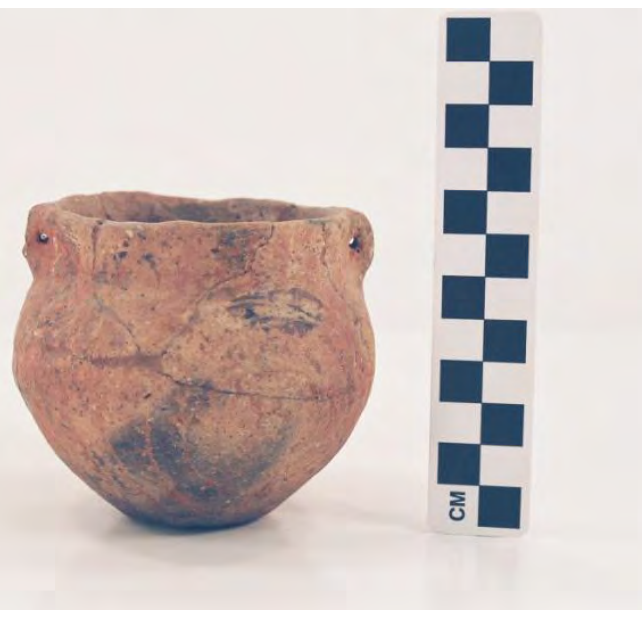

Vessel 41CE25-33. 
SITE NO.: 41CE25

FEATURE: Burial AM-5

VESSEL NO.: 41CE25-35

NON-PLASTICS: grog and hematite

VESSEL FORM: Bottle with a short neck, an elongated body, a direct rim, and a rounded lip

CORE COLOR: Undetermined

WALL THICKNESS: $7.2 \mathrm{~mm}$

INTERIOR SURFACE TREATMENT: none

EXTERIOR SURFACE TREATMENT: burnished

HEIGHT: $24.0 \mathrm{~cm}$

ORIFICE DIAMETER: $3.3 \mathrm{~cm}$

DIAMETER AT BOTTOM OF RIM OR NECK: $4.5 \mathrm{~cm}$

BASE DIAMETER: $7.0 \mathrm{~cm}$

ESTIMATED VOLUME: 0.7 liters

DECORATION: The bottle has four horizontal engraved lines on the vessel rim/neck; the body is plain (Vessel 41CE25-35).

TYPE: cf. Hume Engraved

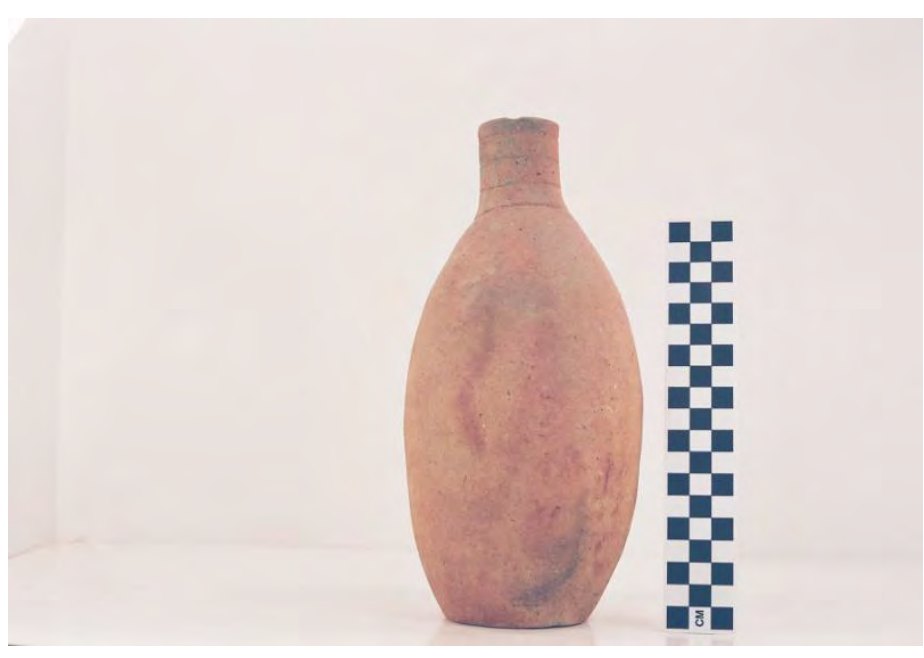

Vessel 41CE25-35. 
SITE NO.: 41CE25

FEATURE: Burial AM-5

VESSEL NO.: 41CE25-36

NON-PLASTICS: grog

VESSEL FORM: Globular carinated bowl with a direct rim and a rounded lip

CORE COLOR: F (fired in a reducing environment and cooled in the open air)

WALL THICKNESS: $5.3 \mathrm{~mm}$

INTERIOR SURFACE TREATMENT: smoothed

EXTERIOR SURFACE TREATMENT: burnished

HEIGHT: $15.5 \mathrm{~cm}$

ORIFICE DIAMETER: $15.5 \mathrm{~cm}$

DIAMETER AT BOTTOM OF RIM OR NECK: $17.5 \mathrm{~cm}$

BASE DIAMETER: $6.5 \mathrm{~cm}$

\section{ESTIMATED VOLUME: 1.4 liters}

DECORATION: The rim has two widely-spaced horizontal engraved lines. Each of the engraved lines has small hatched pendant triangles or triangular tick marks, one line with the triangle apex pointing towards the carination and the other line with the apex of the triangles pointing toward the rim (Vessel 41CE25-36).

TYPE: Patton Engraved, var. Allen

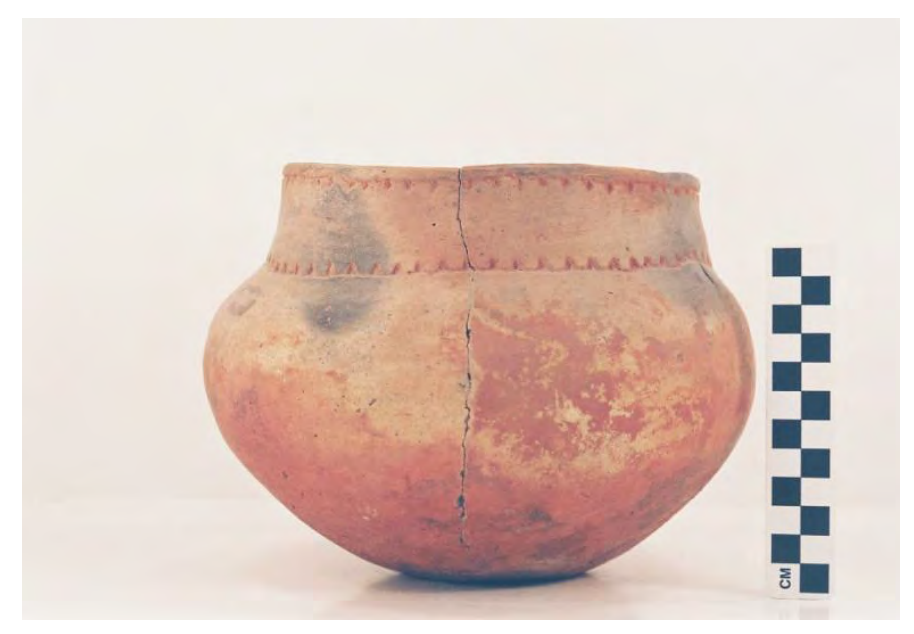

Vessel 41CE25-36. 
SITE NO.: 41CE25

FEATURE: Burial AM-5

VESSEL NO.: 41CE25-37

NON-PLASTICS: grog

VESSEL FORM: Globular carinated bowl with a direct but interior thinned rim and a rounded lip CORE COLOR: Undetermined

WALL THICKNESS: $5.6 \mathrm{~mm}$

INTERIOR SURFACE TREATMENT: smoothed

EXTERIOR SURFACE TREATMENT: burnished

HEIGHT: $8.0 \mathrm{~cm}$

ORIFICE DIAMETER: $10.5 \mathrm{~cm}$

DIAMETER AT BOTTOM OF RIM OR NECK: $10.9 \mathrm{~cm}$

BASE DIAMETER: $5.5 \mathrm{~cm}$

\section{ESTIMATED VOLUME: 0.5 liters}

DECORATION: The rim has an engraved panel with 11 negative ovals each defined by two hour glass-shaped columns filled with closely-spaced vertical and curvilinear lines (Vessel 41CE2537 ). One of the negative ovals also has a single row of excised pendant triangles at the top of the panel.

TYPE: Poynor Engraved, var. Freeman, otherwise defined as a PP variety of Poynor Engraved (Kleinschmidt 1982)

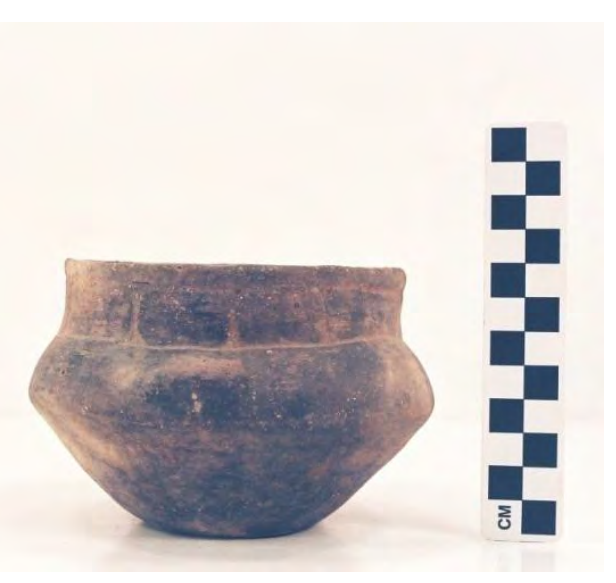

Vessel 41CE25-37. 
SITE NO.: 41CE25

FEATURE: Burial AM-5

VESSEL NO.: 41CE25-38

NON-PLASTICS: grog and hematite

VESSEL FORM: Globular carinated bowl with a direct rim, a rounded lip, and two loop handles

CORE COLOR: Undetermined

WALL THICKNESS: $6.1 \mathrm{~mm}$

INTERIOR SURFACE TREATMENT: smooth

EXTERIOR SURFACE TREATMENT: burnished

HEIGHT: $7.5 \mathrm{~cm}$

ORIFICE DIAMETER: $7.3 \mathrm{~cm}$

DIAMETER AT BOTTOM OF RIM OR NECK: $7.9 \mathrm{~cm}$

BASE DIAMETER: $4.9 \mathrm{~cm}$

ESTIMATED VOLUME: 0.3 liters

DECORATION: The rim has two horizontal engraved lines with pendant triangles. The vessel body has an engraved concentric circle motif that is repeated twice on the vessel. Each concentric circle is comprised of five circles of increasingly larger size (Vessel 41CE25-38).

TYPE: Poynor Engraved, PP variety (see Kleinschmidt 1982)

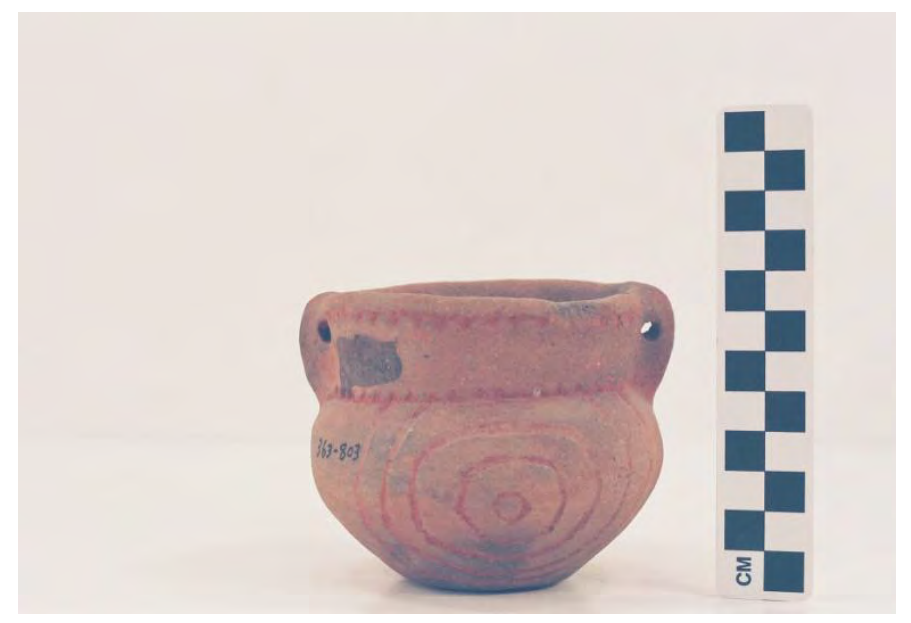

Vessel 41CE25-38. 
SITE NO.: 41CE25

FEATURE: Burial AM-6

VESSEL NO.: 41CE25-39

NON-PLASTICS: grog and hematite; sandy paste

VESSEL FORM: Bottle with a short neck, an elongated body, a direct rim and a flat lip

CORE COLOR: Undetermined

WALL THICKNESS: $6.7 \mathrm{~mm}$

INTERIOR SURFACE TREATMENT: none

EXTERIOR SURFACE TREATMENT: smoothed

HEIGHT: $20.5 \mathrm{~cm}$

ORIFICE DIAMETER: $4.0 \mathrm{~cm}$

DIAMETER AT BOTTOM OF RIM OR NECK: $9.9 \mathrm{~cm}$ on the body

BASE DIAMETER: $7.2 \mathrm{~cm}$

ESTIMATED VOLUME: 0.6 liters

DECORATION: The vessel body has four vertical engraved/hatched panels between single horizontal engraved lines below the bottle neck and above the base. One of the four panels is divided into three parts, including a central hatched semi-circle, while the other three vertical panels are divided into two parts (Vessel 41CE25-39). A white clay pigment has been rubbed in the engraved lines.

TYPE: Hume Engraved

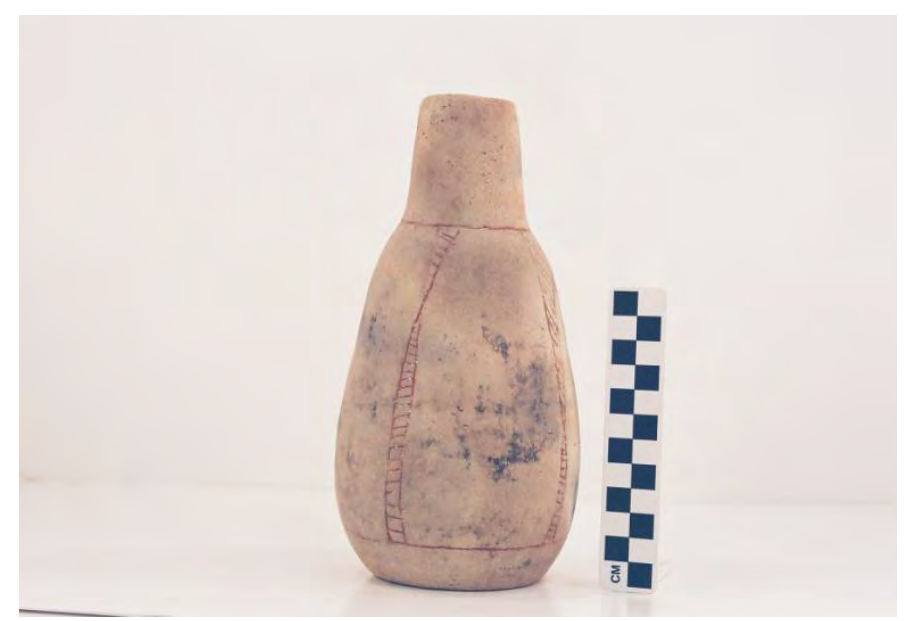

Vessel 41CE25-39. 
SITE NO.: 41CE25

FEATURE: Burial AM-6

VESSEL NO.: 41CE25-40

NON-PLASTICS: grog, hematite, and bone

VESSEL FORM: Carinated bowl with a direct rim and a rounded, exterior folded lip

CORE COLOR: Undetermined

WALL THICKNESS: $7.0 \mathrm{~mm}$

INTERIOR SURFACE TREATMENT: smoothed

EXTERIOR SURFACE TREATMENT: burnished

HEIGHT: $7.0 \mathrm{~cm}$

ORIFICE DIAMETER: $15.5 \mathrm{~cm}$

DIAMETER AT BOTTOM OF RIM OR NECK: $15.1 \mathrm{~cm}$

BASE DIAMETER: $7.0 \mathrm{~cm}$

ESTIMATED VOLUME: 0.7 liters

DECORATION: This vessel has horizontal brushing marks only on the body; the vessel rim is plain (Vessel 41CE25-40)

TYPE: Undetermined utility ware vessel

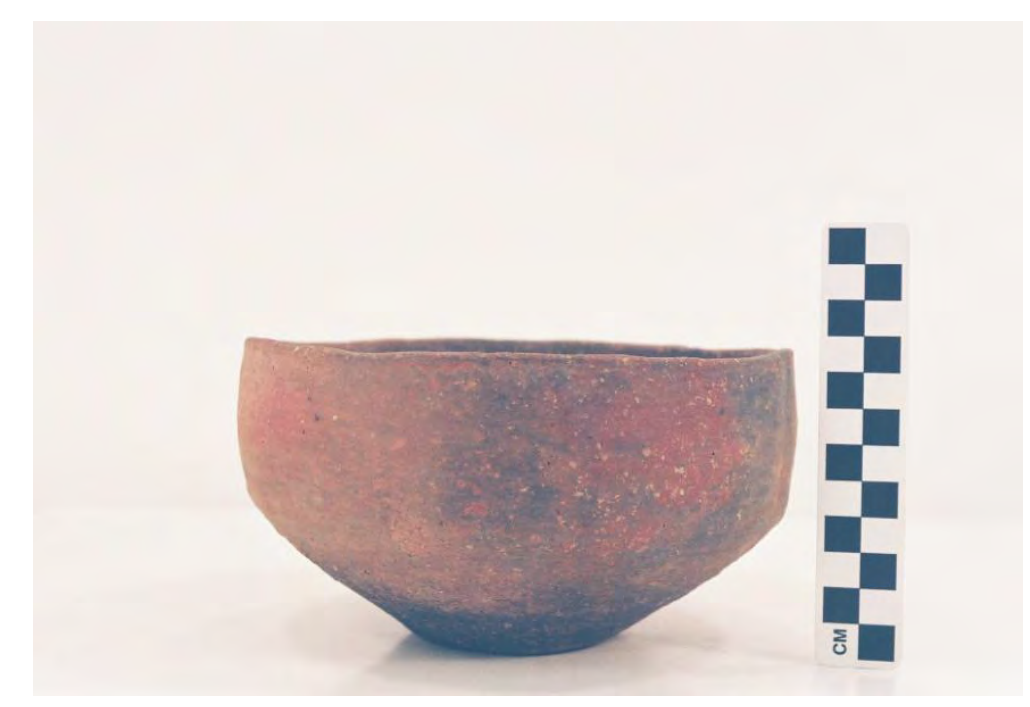

Vessel 41CE25-40. 
SITE NO.: 41CE25

FEATURE: Burial AM-6

VESSEL NO.: 41CE25-41

NON-PLASTICS: grog and hematite

VESSEL FORM: Globular carinated bowl with an inverted rim and a rounded, exterior folded lip

CORE COLOR: A (fired and cooled in a high oxygen environment); pinkware

WALL THICKNESS: $5.6 \mathrm{~mm}$

INTERIOR SURFACE TREATMENT: smoothed

EXTERIOR SURFACE TREATMENT: smoothed

HEIGHT: $6.5 \mathrm{~cm}$

ORIFICE DIAMETER: $8.5 \mathrm{~cm}$

DIAMETER AT BOTTOM OF RIM OR NECK: $10.1 \mathrm{~cm}$

BASE DIAMETER: $4.8 \mathrm{~cm}$

ESTIMATED VOLUME: 0.3 liters

DECORATION: The rim has an engraved panel comprised of negative ovals defined by two hour glass-shaped columns filled with closely-spaced vertical and curvilinear lines (Vessel 41CE2541). The number of negative ovals in the panel cannot be determined because of vessel rim reconstruction.

TYPE: Poynor Engraved, var. Hood

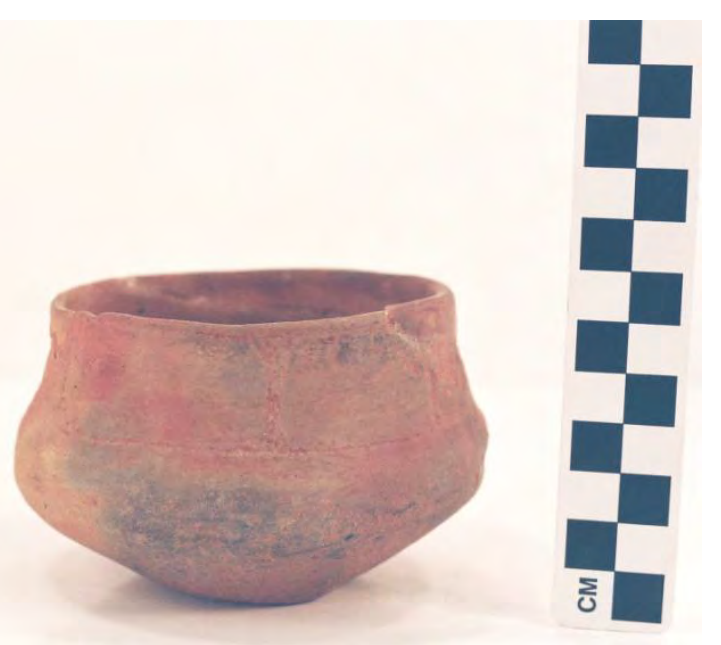

Vessel 41CE25-41. 
SITE NO.: 41CE25

FEATURE: Burial 41AM-7

VESSEL NO.: 41CE25-42

NON-PLASTICS: grog

VESSEL FORM: Globular carinated bowl with a direct rim and a rounded lip

CORE COLOR: Undetermined

WALL THICKNESS: $4.9 \mathrm{~mm}$

INTERIOR SURFACE TREATMENT: burnished

EXTERIOR SURFACE TREATMENT: burnished

HEIGHT: $6.3 \mathrm{~cm}$

ORIFICE DIAMETER: $8.0 \mathrm{~cm}$

DIAMETER AT BOTTOM OF RIM OR NECK: $7.8 \mathrm{~cm}$

BASE DIAMETER: $3.8 \mathrm{~cm}$

ESTIMATED VOLUME: 0.3 liters

DECORATION: The rim has an engraved panel comprised of seven rectangles. Each rectangle is defined by two vertical engraved/excised lines (Vessel 41CE25-42). A white clay pigment has been rubbed into the engraved lines.

TYPE: Poynor Engraved, var. Blackburn

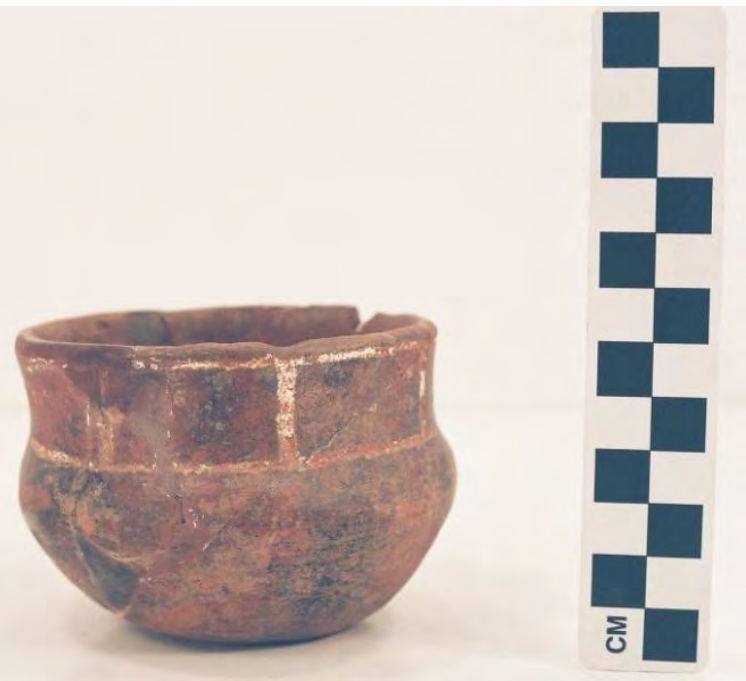

Vessel 41CE25-42. 
SITE NO.: 41CE25

FEATURE: Burial AM-8

VESSEL NO.: 41CE25-60

NON-PLASTICS: grog and bone

VESSEL FORM: Globular carinated bowl with a short and direct rim and a rounded lip

CORE COLOR: Undetermined

WALL THICKNESS: Undetermined

INTERIOR SURFACE TREATMENT: smoothed

EXTERIOR SURFACE TREATMENT: burnished

HEIGHT: $12.0 \mathrm{~cm}$

ORIFICE DIAMETER: $10.5 \mathrm{~cm}$

DIAMETER AT BOTTOM OF RIM OR NECK: $10.5 \mathrm{~cm}$

BASE DIAMETER: $4.0 \mathrm{~cm}$

ESTIMATED VOLUME: 0.8 liters

DECORATION: The rim has two rows of small hatched pendant triangles, with an engraved hooked arm scroll repeated twice on the vessel body. The scroll, with four concentric scroll lines around the central hooked arm element, has small triangular tick marks on each engraved line comprising the scroll (Vessel 41CE25-60).

TYPE: Patton Engraved, var. Patton

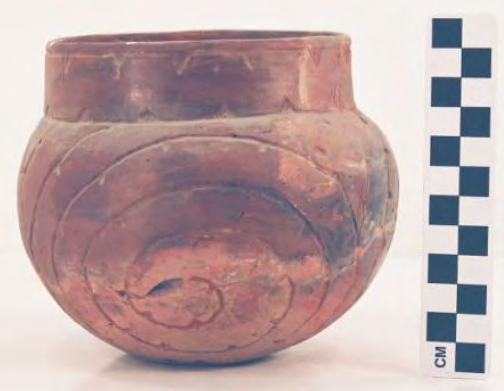

Vessel 41CE25-60. 
SITE NO.: 41CE25

FEATURE: Burial AM-9

VESSEL NO.: 41CE25-62

NON-PLASTICS: grog

VESSEL FORM: Globular carinated bowl with a direct rim and a rounded lip

CORE COLOR: Undetermined

WALL THICKNESS: $5.0 \mathrm{~mm}$

INTERIOR SURFACE TREATMENT: smoothed

EXTERIOR SURFACE TREATMENT: burnished

HEIGHT: $8.0 \mathrm{~cm}$

ORIFICE DIAMETER: $10.7 \mathrm{~cm}$

DIAMETER AT BOTTOM OF RIM OR NECK: $11.0 \mathrm{~cm}$

BASE DIAMETER: $5.1 \mathrm{~cm}$

\section{ESTIMATED VOLUME: 0.5 liters}

DECORATION: The rim has an engraved panel with six negative ovals (Vessel 41CE25-62). Each oval is defined by two hour glass-shaped columns filled with closely-spaced curvilinear and vertical lines. A heavy white kaolin clay pigment has been rubbed into the engraved lines.

TYPE: Poynor Engraved, var. Hood

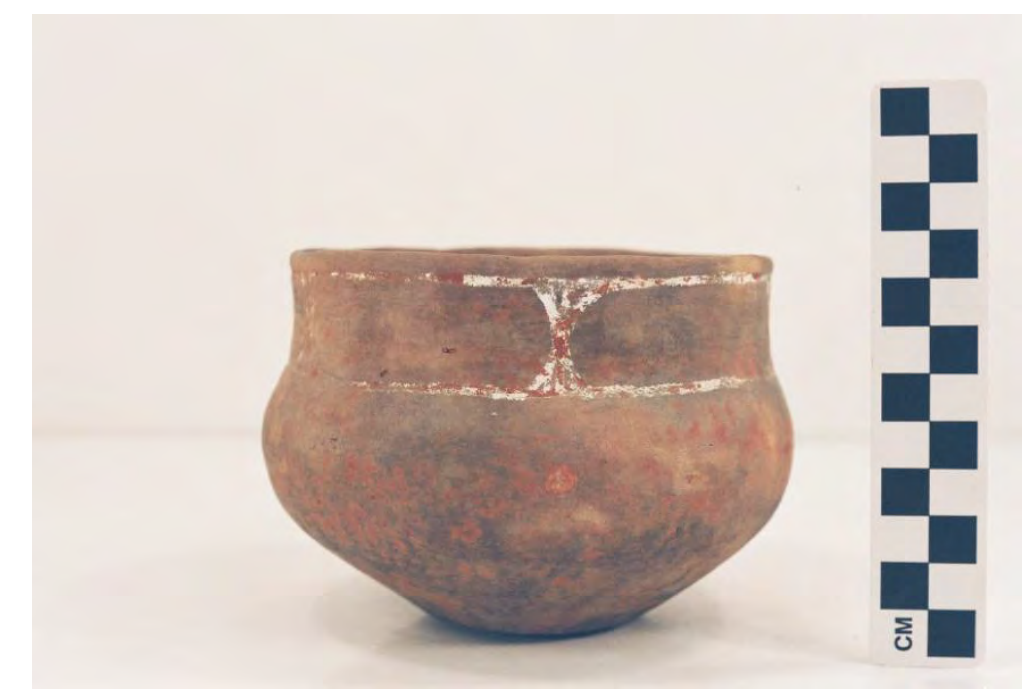

Vessel 41CE25-62. 
SITE NO.: 41CE25

FEATURE: Burial AM-9

VESSEL NO.: 41CE25-63

NON-PLASTICS: grog

VESSEL FORM: Bottle, with its neck cut off and ground/smoothed down

CORE COLOR: Undetermined

WALL THICKNESS: $5.7 \mathrm{~mm}$

INTERIOR SURFACE TREATMENT: smoothed

EXTERIOR SURFACE TREATMENT: smoothed, but badly eroded

HEIGHT: $8.0 \mathrm{~cm}$

ORIFICE DIAMETER: $10.0 \mathrm{~cm}$

DIAMETER AT BOTTOM OF RIM OR NECK: N/A

BASE DIAMETER: $6.5 \mathrm{~cm}$

ESTIMATED VOLUME: ca. $0.2+$ liters

DECORATION: Hooked arm curvilinear scrolls are repeated three times on the vessel body (Vessel 41CE25-63). The hooked arm scroll motif is also seen on Poynor Engraved, var. $P$ carinated bowls in the upper Neches River basin.

TYPE: cf. Taylor Engraved

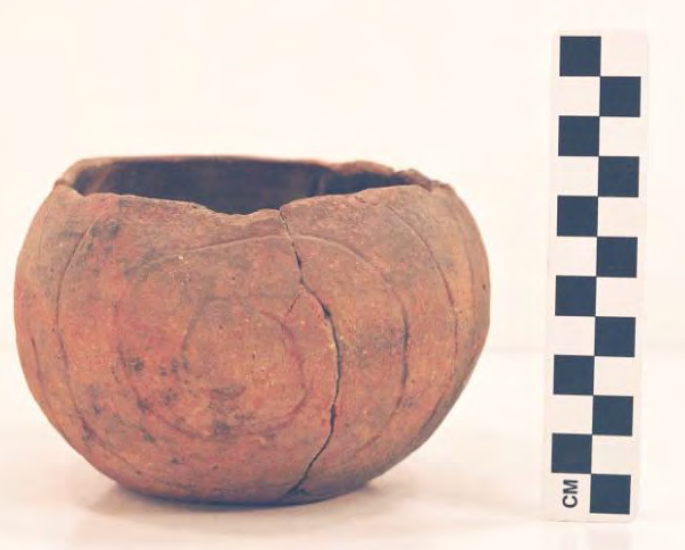

Vessel 41CE25-63. 
SITE NO.: 41CE25

FEATURE: Burial AM-9

VESSEL NO.: 41CE25-64

NON-PLASTICS: grog and bone

VESSEL FORM: Globular carinated bowl with an inverted rim and a rounded lip

CORE COLOR: Undetermined

WALL THICKNESS: $5.8 \mathrm{~mm}$

INTERIOR SURFACE TREATMENT: smoothed

EXTERIOR SURFACE TREATMENT: burnished

HEIGHT: $9.5 \mathrm{~cm}$

ORIFICE DIAMETER: $14.0 \mathrm{~cm}$

DIAMETER AT BOTTOM OF RIM OR NECK: $15.6 \mathrm{~cm}$

BASE DIAMETER: $6.7 \mathrm{~cm}$

ESTIMATED VOLUME: 0.8 liters

DECORATION: The rim has an engraved panel with seven negative ovals. Each negative oval is defined by two hour glass-shaped columns filled with closely-spaced vertical and curvilinear engraved lines (Vessel 41CE25-64).

TYPE: Poynor Engraved, var. Hood

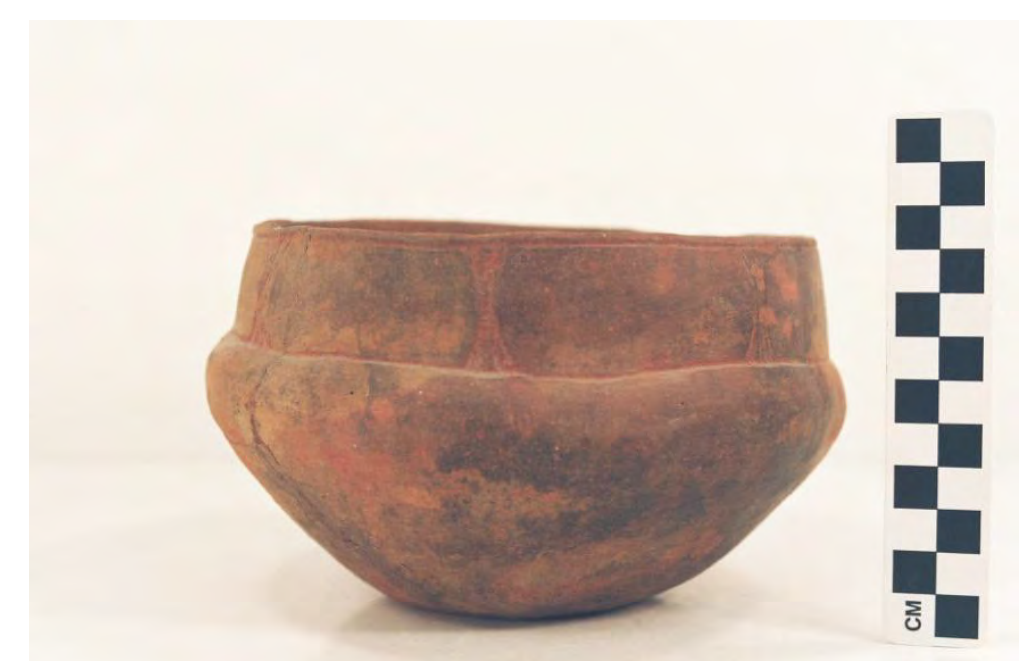

Vessel 41CE25-64. 
SITE NO.: 41CE25

FEATURE: Burial AM-9

VESSEL NO.: 41CE25-65

NON-PLASTICS: grog

VESSEL FORM: Bottle with a short neck, an elongated body, a direct rim, and a rounded lip

CORE COLOR: A (fired and cooled in a high oxygen environment)

WALL THICKNESS: $7.7 \mathrm{~mm}$

INTERIOR SURFACE TREATMENT: none

EXTERIOR SURFACE TREATMENT: smoothed

HEIGHT: $20.0 \mathrm{~cm}$

ORIFICE DIAMETER: $4.0 \mathrm{~cm}$

DIAMETER AT BOTTOM OF RIM OR NECK: $4.2 \mathrm{~cm}$

BASE DIAMETER: $7.5 \mathrm{~cm}$

ESTIMATED VOLUME: 0.6 liters

DECORATION: There are seven closely-spaced horizontal engraved lines on the rim and eight hatched pendant triangles on the upper vessel body (Vessel 41CE25-65)

TYPE: Hume Engraved

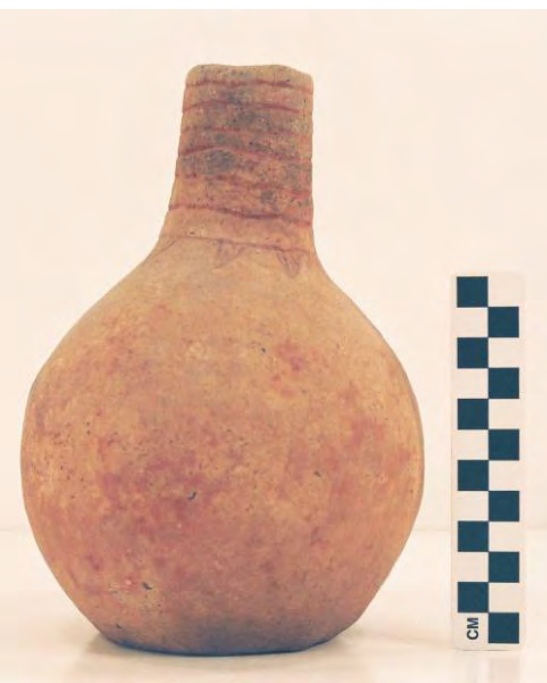

Vessel 41CE25-65, Hume Engraved Bottle, 
SITE NO.: 41CE25

FEATURE: Burial AM-10

VESSEL NO.: 41CE25-92

NON-PLASTICS: grog and hematite

VESSEL FORM: Bottle with a short neck, an elongated body, a direct rim, and a flat lip

CORE COLOR: A (fired and cooled in a high oxygen environment)

WALL THICKNESS: $8.6 \mathrm{~mm}$

INTERIOR SURFACE TREATMENT: none

EXTERIOR SURFACE TREATMENT: smoothed

HEIGHT: $23.7 \mathrm{~cm}$

ORIFICE DIAMETER: $4.0 \mathrm{~cm}$

DIAMETER AT BOTTOM OF RIM OR NECK: $4.1 \mathrm{~cm}$

BASE DIAMETER: $7.3 \mathrm{~cm}$

ESTIMATED VOLUME: 0.7 liters

DECORATION: The bottle neck has three horizontal engraved lines. There are eight pendant triangles at the base of the bottle neck (Vessel 41CE25-92). A red clay pigment has been rubbed in the engraved lines.

TYPE: Hume Engraved

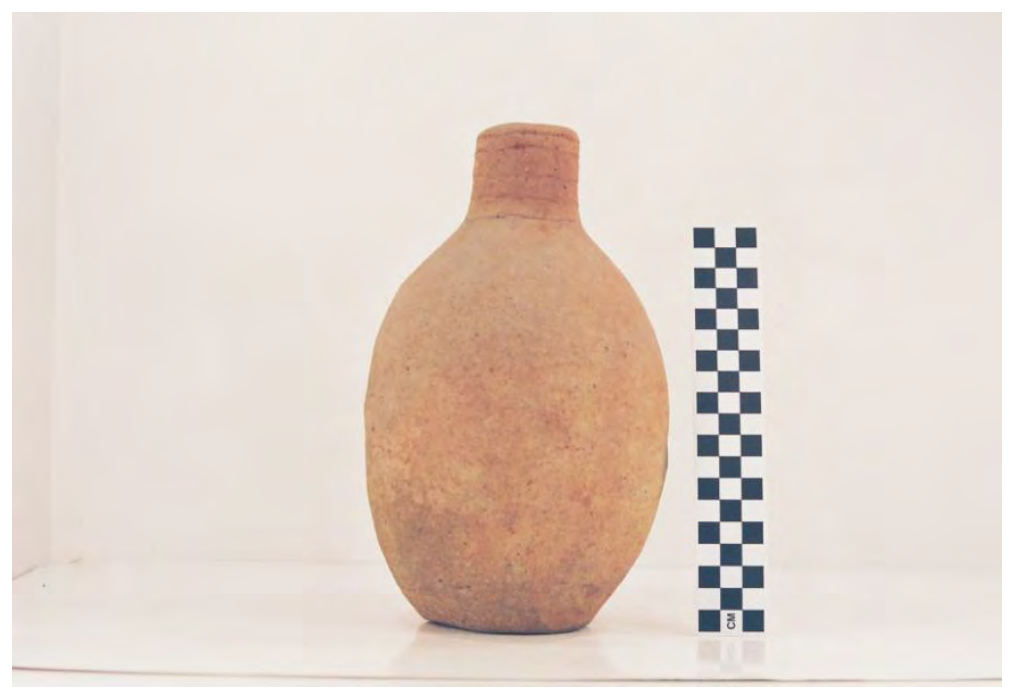

Vessel 41CE25-92. 
SITE NO.: 41CE25-93

FEATURE: Burial AM-10

VESSEL NO.: 41CE25-93

NON-PLASTICS: grog and bone

VESSEL FORM: Globular carinated bowl with a direct rim and a rounded lip

CORE COLOR: Undetermined

WALL THICKNESS: $6.0 \mathrm{~mm}$

INTERIOR SURFACE TREATMENT: smoothed

EXTERIOR SURFACE TREATMENT: burnished

HEIGHT: $9.5 \mathrm{~cm}$

ORIFICE DIAMETER: $11.0 \mathrm{~cm}$

DIAMETER AT BOTTOM OF RIM OR NECK: $11.7 \mathrm{~cm}$

BASE DIAMETER: $5.1 \mathrm{~cm}$

ESTIMATED VOLUME: 0.6 liters

DECORATION: The rim has an engraved panel with five negative ovals defined by two hour glass-shaped columns filled with closely-spaced vertical and curvilinear lines. Each negative oval panel has between nine and 12 hatched pendant triangles on both the upper and lower parts of the panel.

TYPE: Poynor Engraved, var. Freeman

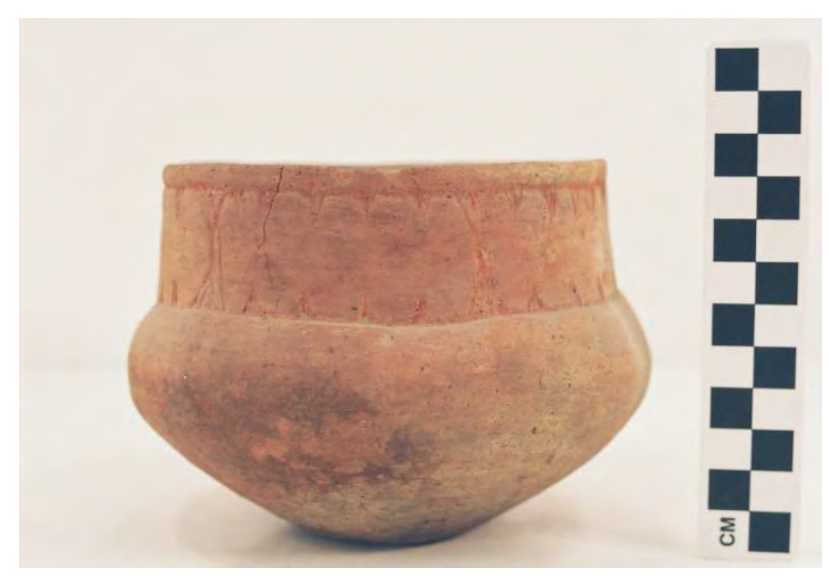

Vessel 41CE25-93, Poynor Engraved. 


\section{References Cited}

Kleinschmidt, U. K. W.

1982 Review and Analysis of the A. C. Saunders Site, 41AN19, Anderson County, Texas. Master's thesis, Department of Anthropology, The University of Texas at Austin.

Suhm, D. A. and E. B. Jelks (editor)

1962 Handbook of Texas Archeology: Type Descriptions. Special Publication No. 1, Texas Archeological Society, and Bulletin No. 4, Texas Memorial Museum, Austin.

Teltser, P. A.

1993 An Analytic Strategy for Studying Assemblage-Scale Ceramic Variation: A Case Study from Southeast Missouri. American Antiquity 58(3):530-543.
Thurmond, J. P.

1990 Archeology of the Cypress Creek Drainage Basin, Northeastern Texas and Northwestern Louisiana. Studies in Archeology No. 5. Texas Archeological Research Laboratory, The University of Texas at Austin.

Walters, $M$.

2006 The Lake Clear (41SM243) Site and Crotalus horridus atricaudatus. Caddo Archeology Journal 15:5-39. 


\section{Appendix F.6 Database of Ceramic Vessels from the Upper Neches River Basin}

\begin{tabular}{|c|c|c|c|c|c|c|c|c|c|c|c|c|c|c|}
\hline \multicolumn{7}{|l|}{ Pottery type } & \multicolumn{8}{|l|}{ Sites } \\
\hline & HE55 & SM77 & SM93 & HE75 & HE7 & AN53 & AN39 & AN23 & CE8 & CE23 & HE114 & CE15 & AN44 & AN18 AN16 \\
\hline \multicolumn{15}{|l|}{ UTILITY WARE } \\
\hline Killough Pinched & 1 & - & 2 & - & - & - & 1 & - & - & 1 & - & - & - & - \\
\hline Bullard Brushed & - & 1 & - & 1 & - & - & - & - & - & 2 & - & - & - & - \\
\hline Maydelle Incised & - & - & - & - & - & - & 1 & - & - & - & 1 & - & - & - \\
\hline Incised-punctated & - & 1 & - & - & - & - & - & - & - & - & - & - & - & - \\
\hline Incised-pinched & - & 1 & - & - & - & - & - & - & - & - & - & - & - & - \\
\hline Rim Punctated & - & - & - & - & 1 & - & - & - & - & - & 2 & - & - & - \\
\hline Punctated-appliqued & - & - & - & - & - & - & - & - & - & - & - & - & - & - \\
\hline Incised jar & - & - & - & - & 1 & - & - & - & - & 2 & - & - & 2 & - \\
\hline Brushed-punctated jar & - & 3 & - & - & - & - & - & - & 1 & - & - & - & - & - \\
\hline Brushed-incised & - & 2 & - & - & - & - & - & - & - & - & - & - & - & - \\
\hline $\begin{array}{l}\text { Brushed-incised- } \\
\text { punctated }\end{array}$ & - & 1 & - & - & - & - & - & - & - & - & - & - & - & - \\
\hline $\begin{array}{l}\text { Brushed-pinched- } \\
\text { appliqued }\end{array}$ & - & 1 & - & - & - & - & - & - & - & - & - & - & - & - \\
\hline Brushed-pinched & - & - & - & - & - & - & - & - & - & - & - & - & - & - \\
\hline Brushed bowl & - & - & - & - & - & - & - & - & - & - & - & 1 & - & - \\
\hline Poynor Brushed & - & 1 & - & - & - & - & - & - & - & - & - & - & - & - \\
\hline Appliqued & - & 1 & - & - & - & - & - & - & - & - & - & - & - & - \\
\hline La Rue Neck Banded & - & - & - & - & - & - & - & - & - & - & - & - & - & - \\
\hline \multicolumn{15}{|l|}{ FINE WARE } \\
\hline $\begin{array}{l}\text { Simms Engraved, } \\
\text { var. Darco }\end{array}$ & - & - & - & - & - & - & - & - & - & - & - & - & - & - \\
\hline Hume Engraved Bt & - & 2 & - & 1 & - & - & - & - & - & - & 1 & - & - & - \\
\hline Hume Engraved Bw & - & 1 & & & & & & & & & & & & \\
\hline UID Engraved Bt & - & 1 & - & - & - & - & - & - & - & & & & & \\
\hline
\end{tabular}




\begin{tabular}{|c|c|c|c|c|c|c|c|c|c|c|c|c|c|c|c|}
\hline \multicolumn{7}{|l|}{ Pottery type } & \multicolumn{9}{|l|}{ Sites } \\
\hline & HE55 & SM77 & SM93 & HE75 & HE7 & AN53 & AN39 & AN23 & CE8 & CE23 & HE114 & CE15 & AN44 & AN18 & AN16 \\
\hline Poynor Engraved Bt & 1 & 8 & - & 1 & 1 & 1 & 2 & - & - & - & 2 & - & 2 & - & - \\
\hline Poynor Engraved & 1 & 12 & 5 & 4 & 2 & 3 & 2 & 1 & - & 2 & 5 & 1 & 1 & 1 & 1 \\
\hline Hood Engraved & 1 & 5 & 4 & 2 & 1 & - & 1 & - & - & - & 8 & - & 6 & 1 & - \\
\hline Taylor Engraved? & - & - & 1 & - & - & - & - & - & - & - & 2 & - & - & - & - \\
\hline Patton Engraved & - & 1 & - & - & - & - & - & - & - & - & - & 1 & - & - & - \\
\hline $\begin{array}{l}\text { Horizontal Engraved } \\
\text { bowl }\end{array}$ & - & - & - & - & - & - & - & - & - & - & - & - & - & - & - \\
\hline $\begin{array}{l}\text { Natchitoches Eng. } \\
\text { Garland Engraved? }\end{array}$ & - & - & - & - & - & - & - & - & - & - & - & - & - & - & - \\
\hline Red-slipped bowl & - & - & - & - & - & - & - & - & - & - & - & - & 1 & - & - \\
\hline Engraved-punctated & - & 1 & - & - & - & - & - & - & - & - & - & - & - & - & - \\
\hline \multicolumn{16}{|l|}{ PLAIN WARE } \\
\hline Plain bowl & - & 1 & 1 & - & 2 & - & - & - & - & 1 & - & - & - & - & - \\
\hline Plain jar & - & 2 & 1 & - & - & - & - & - & - & - & - & - & - & - & - \\
\hline Plain carinated bowl & - & 1 & - & - & - & - & 1 & - & - & - & - & - & - & - & - \\
\hline Plain Bt & - & - & - & - & - & - & - & - & - & - & - & - & - & - & - \\
\hline Totals & 4 & 47 & 14 & 9 & 8 & 4 & 8 & 1 & 1 & 8 & 21 & 3 & 12 & 2 & 1 \\
\hline
\end{tabular}


Pottery type

Sites

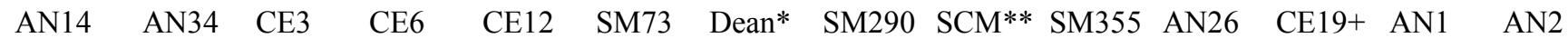

\section{UTILITY WARE}

Killough Pinched

Bullard Brushed

Maydelle Incised

Incised-punctated

Incised-pinched

Rim Punctated

Punctated-appliqued

Incised jar

Brushed-punctated jar

Brushed-incised

Brushed-incised-

punctated

Brushed-pinched-

appliqued

Brushed-pinched

Brushed bowl

Poynor Brushed

Appliqued

La Rue Neck Banded

FINE WARE

Simms Engraved,

var. Darco

Hume Engraved Bt

Hume Engraved Bw

UID Engraved Bt

Poynor Engraved Bt

$\begin{array}{llll}- & - & - & - \\ 2 & - & 4 & - \\ - & - & - & - \\ - & - & - & - \\ - & - & - & - \\ - & - & - & - \\ - & - & - & - \\ - & - & - & - \\ - & 2 & - & - \\ - & - & - & - \\ - & - & - & - \\ - & - & - & - \\ - & - & - & - \\ - & - & - & - \\ - & - & - & - \\ - & - & - & - \\ - & - & - & -\end{array}$

$\begin{array}{llllllllll}- & - & 2 & - & - & 1 & - & - & 4 & - \\ 4 & - & - & - & - & - & - & - & 2 & 1 \\ - & - & - & - & 1 & - & - & - & 1 & - \\ - & - & - & - & - & - & - & - & - & - \\ - & - & - & - & - & - & - & - & - & - \\ - & - & - & - & - & - & - & - & - & - \\ - & - & - & - & - & - & - & - & - & - \\ - & - & - & - & - & - & - & - & - & - \\ - & - & - & - & - & - & - & - & - & - \\ - & - & - & - & - & - & - & - & - & - \\ - & - & - & - & - & - & - & - & - & - \\ & & & & & & - & - & - & - \\ - & - & - & - & - & - & - & - & - & - \\ - & - & - & - & - & - & - & - & - & - \\ 2 & - & - & - & - & - & - & - & - & - \\ 1 & - & - & - & - & - & - & - & - & - \\ - & - & - & - & - & - & - & - & - & - \\ - & - & - & - & - & - & - & - & 1 & -\end{array}$

$\begin{array}{lllll}- & - & - & -\end{array}$

$\begin{array}{llllllll}1 & 1 & 2 & 2 & 13 & 1 & - & 3 \\ - & - & - & - & - & - & - & - \\ - & - & - & - & - & - & - & - \\ 3 & - & - & - & - & - & - & 1\end{array}$


Pottery type

Sites

\begin{tabular}{|c|c|c|c|c|c|c|c|c|c|c|c|c|c|c|}
\hline & AN14 & AN34 & CE3 & CE6 & CE12 & SM73 & Dean* & SM290 & $\mathrm{SCM}^{* *}$ & SM355 & AN26 & CE19+ & AN1 & AN2 \\
\hline Poynor Engraved & 7 & 10 & 13 & - & 9 & 4 & 1 & 21 & - & 1 & - & 14 & 9 & \\
\hline Hood Engraved & - & 1 & - & 1 & 4 & 2 & 1 & 1 & - & - & - & - & 3 & 1 \\
\hline Taylor Engraved? & - & - & - & - & 1 & - & - & - & - & - & - & - & - & - \\
\hline Patton Engraved & - & 3 & - & 4 & 20 & - & - & - & - & - & 28 & 1 & - & 2 \\
\hline $\begin{array}{l}\text { Horizontal Engraved } \\
\text { bowl }\end{array}$ & 1 & - & - & - & - & - & - & - & - & - & - & - & - & - \\
\hline Natchitoches Eng. & - & - & - & 1 & - & - & - & - & - & - & - & - & - & - \\
\hline Garland Engraved? & - & - & - & - & - & - & - & - & - & - & - & - & - & - \\
\hline Red-slipped bowl & - & - & - & - & - & - & - & - & - & - & - & - & - & - \\
\hline Engraved-punctated- & - & - & - & - & - & - & - & - & - & - & - & - & - & - \\
\hline \multicolumn{15}{|l|}{ PLAIN WARE } \\
\hline Plain bowl & - & 1 & 2 & - & - & - & - & - & 1 & - & 3 & - & 1 & 1 \\
\hline Plain jar & - & - & - & - & - & - & - & - & - & - & - & - & 2 & - \\
\hline Plain carinated bowl & - & - & - & - & - & - & - & - & 1 & - & - & - & - & 1 \\
\hline Plain Bt & - & - & - & - & 1 & - & - & 1 & - & - & - & - & - & - \\
\hline Totals & 14 & 18 & 21 & 8 & 58 & 7 & 4 & 8 & 4 & 1 & 35 & 1 & 33 & 17 \\
\hline
\end{tabular}


Pottery type

Sites

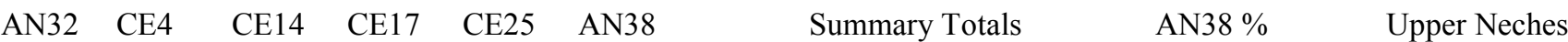

Comparative Sample \%

\begin{tabular}{|c|c|c|c|c|c|c|c|c|c|}
\hline \multicolumn{10}{|l|}{ UTILITY WARE } \\
\hline Killough Pinched & - & 3 & 4 & - & - & 1 & 20 & 3.2 & 3.2 \\
\hline Bullard Brushed & 1 & - & 1 & 2 & - & - & 21 & - & 3.5 \\
\hline Maydelle Incised & - & - & 3 & 2 & - & 2 & 11 & 6.4 & 1.5 \\
\hline Incised-punctated & - & - & - & 1 & - & - & 1 & - & 0.2 \\
\hline Incised-pinched & - & - & - & - & - & - & 1 & - & 0.2 \\
\hline Rim Punctated & - & - & 6 & - & - & - & 9 & - & 1.5 \\
\hline Punctated-appliqued & - & - & 1 & - & - & - & 1 & - & 0.2 \\
\hline Incised jar & - & - & - & - & - & - & 5 & - & 0.8 \\
\hline Brushed-punctated jar & 2 & - & - & - & - & - & 8 & - & 1.3 \\
\hline Brushed-incised & - & - & 1 & - & - & - & 3 & - & 0.5 \\
\hline $\begin{array}{l}\text { Brushed-incised- } \\
\text { punctated }\end{array}$ & - & - & - & - & - & - & 1 & - & 0.2 \\
\hline $\begin{array}{l}\text { Brushed-pinched- } \\
\text { appliqued }\end{array}$ & - & - & - & - & - & - & 1 & - & 0.2 \\
\hline Brushed-pinched & - & - & 2 & - & - & - & 2 & - & 0.3 \\
\hline Brushed bowl & - & - & 1 & - & 1 & - & 5 & - & 0.8 \\
\hline Poynor Brushed & - & - & 2 & - & - & - & 3 & - & 0.5 \\
\hline Appliqued & - & - & - & - & - & - & 1 & - & 0.2 \\
\hline La Rue Neck Banded & - & - & - & - & - & - & 1 & - & 0.2 \\
\hline \multicolumn{10}{|l|}{ FINE WARE } \\
\hline $\begin{array}{l}\text { Simms Engraved, } \\
\text { var. Darco }\end{array}$ & - & - & - & - & - & - & 3 & - & 0.5 \\
\hline Hume Engraved Bt & 1 & 5 & 4 & 1 & 6 & - & 50 & - & 8.3 \\
\hline Hume Engraved Bw & - & 1 & - & - & - & - & 4 & - & 0.7 \\
\hline
\end{tabular}




\begin{tabular}{|c|c|c|c|c|c|c|c|c|c|}
\hline \multirow[t]{2}{*}{ Pottery type } & \multicolumn{8}{|c|}{ Sites } & \multirow[b]{2}{*}{$\begin{array}{c}\text { Upper Neches } \\
\text { Comparative Sample }\end{array}$} \\
\hline & AN32 & CE4 & CE14 & CE17 & CE25 & AN38 & Summary Totals & AN38 \% & \\
\hline UID Engraved Bt & - & - & - & - & - & - & 3 & - & 0.5 \\
\hline Poynor Engraved Bt & - & - & 16 & 2 & 1 & 1 & 42 & 3.2 & 6.8 \\
\hline Poynor Engraved & 13 & 11 & 61 & 13 & 13 & 6 & 229 & 19.4 & 37.2 \\
\hline Hood Engraved & 1 & 1 & 7 & 4 & - & - & 56 & - & 9.3 \\
\hline Taylor Engraved? & - & - & - & 1 & 1 & - & 6 & - & 1.0 \\
\hline Patton Engraved & 1 & - & - & - & 2 & - & 63 & - & 10.5 \\
\hline $\begin{array}{l}\text { Horizontal Engraved } \\
\text { bowl }\end{array}$ & - & - & - & - & - & - & 1 & - & 0.2 \\
\hline Natchitoches Eng. & - & - & - & - & - & - & 1 & - & 0.2 \\
\hline Garland Engraved? & - & - & - & - & - & 1 & 1 & 3.2 & - \\
\hline Red-slipped bowl & - & - & - & - & - & 1 & 2 & 3.2 & 0.2 \\
\hline Engraved-punctated & - & - & - & - & - & - & 1 & - & 0.2 \\
\hline \multicolumn{10}{|l|}{ PLAIN WARE } \\
\hline Plain bowl & - & - & 2 & 3 & - & 9 & 29 & 29.0 & 3.3 \\
\hline Plain jar & - & - & - & - & 1 & - & 6 & - & 1.0 \\
\hline Plain carinated bowl & 2 & 1 & 2 & 6 & - & 8 & 23 & 25.8 & 2.5 \\
\hline Plain Bt & 2 & 2 & 6 & - & 2 & 2 & 16 & 6.5 & 2.3 \\
\hline Totals & 23 & 24 & 119 & 35 & 27 & 31 & 632 & 31 & 601 \\
\hline
\end{tabular}

$\mathrm{Bt}=$ bottle; $\mathrm{Bw}=$ bowl

*personal communication, Mark Walters, October 2007

**Smith County Museum collections

+from Early (2004:Figure 12d) 



\section{APPENDIX G \\ CERAMIC ARTIFACTS FROM THE LANG PASTURE SITE, TABLES FOR CHAPTER 6}

Prepared for:

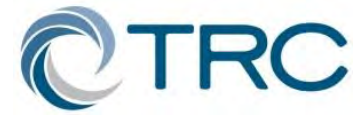

TRC Environmental Corporation

505 East Huntland Drive, Suite 250

Austin, Texas 78752

Prepared by:

Timothy K. Perttula 

Table 6-1. Decorated Sherds from the Lang Pasture Site (41AN38).

\begin{tabular}{|c|c|c|c|c|c|c|c|c|c|c|c|}
\hline Provenience & $\mathrm{B}$ & $\mathrm{tP}$ & I-P & $\mathrm{fP}$ & I & $\mathrm{cP}$ & B-P & $\mathrm{A}$ & RS & $\mathrm{E}$ & $\mathrm{N}$ \\
\hline ST $3,1 v .3$ & 1 & & & & & & & & & & 1 \\
\hline ST 5,1 v. 5 & 1 & & & & & & & & & & 1 \\
\hline ST 5, lv. 11 & 1 & & & & & & & & & & 1 \\
\hline ST 6, lv. 5 & 1 & & & & & & & & & & 1 \\
\hline ST 6,1 lv. 8 & & & & & 1 & & & & & & 1 \\
\hline ST 7, lv. 7 & 1 & & & & & & & & & & 1 \\
\hline ST 8, lv. 6 & & & 1 & & & & & & & & 1 \\
\hline ST 8, lv. 7 & & & & & 1 & & & & & & 1 \\
\hline ST 9, lv. 1 & & & 1 & & & & & & & & 1 \\
\hline ST 9, lv. 2 & 1 & & & & & & & & & & 1 \\
\hline ST 10, lv. 2 & & & & & & & & & & 1 & 1 \\
\hline ST 10, lv. 4 & 2 & 1 & & & 1 & & & & & & 4 \\
\hline ST 11, lv. 4 & 2 & & & & & & & & & & 2 \\
\hline ST 13, lv. 6 & 1 & & & & & & & & & & 1 \\
\hline \multirow[t]{2}{*}{ Subtotal } & 11 & 1 & 2 & 0 & 3 & $\mathbf{0}$ & $\mathbf{0}$ & $\mathbf{0}$ & $\mathbf{0}$ & 1 & 18 \\
\hline & \multicolumn{11}{|c|}{ Southern Component } \\
\hline N170 E198 & 5 & & & & 2 & & & & & 1 & 8 \\
\hline lv. 1 & 1 & & & & & & & & & & 1 \\
\hline lv. 3 & 1 & & & & 1 & & & & & & 2 \\
\hline lv. 4 & 3 & & & & & & & & & 1 & 4 \\
\hline lv. 5 & & & & & 1 & & & & & & 1 \\
\hline N170 E199 & 10 & & & & & & & & & 2 & 12 \\
\hline lv. 2 & 2 & & & & & & & & & & 2 \\
\hline lv. 3 & 2 & & & & & & & & & 1 & 3 \\
\hline lv. 4 & 2 & & & & & & & & & 1 & 3 \\
\hline lv. 5 & 4 & & & & & & & & & & 4 \\
\hline N170 E200 & 11 & 2 & & 1 & 1 & & & 1 & & 1 & 17 \\
\hline lv. 1 & 3 & 2 & & & 1 & & & 1 & & & 7 \\
\hline lv. 2 & 3 & & & 1 & & & & & & & 4 \\
\hline lv. 3 & & & & & & & & & & 1 & 1 \\
\hline lv. 4 & 1 & & & & & & & & & & 1 \\
\hline lv. 5 & 4 & & & & & & & & & & 4 \\
\hline N170 E201 & 4 & & & & & & 1 & & & 1 & 6 \\
\hline lv. 1 & & & & & & & & & & 1 & 1 \\
\hline lv. 3 & 1 & & & & & & & & & & 1 \\
\hline lv. 4 & 2 & & & & & & & & & & 2 \\
\hline lv. 5 & 1 & & & & & & 1 & & & & 2 \\
\hline N170 E202 & & & & 1 & & & & & & & 1 \\
\hline lv. 2 & & & & 1 & & & & & & & 1 \\
\hline N171 E198 & 5 & 1 & & & & & 1 & & & 2 & 9 \\
\hline lv. 2 & 1 & & & & & & 1 & & & & 2 \\
\hline lv. 3 & 3 & 1 & & & & & & & & $1 \mathrm{E}-\mathrm{B}$ & 5 \\
\hline lv. 4 & 1 & & & & & & & & & & 1 \\
\hline lv. 5 & & & & & & & & & & 1 & 1 \\
\hline
\end{tabular}


Table 6-1, continued.

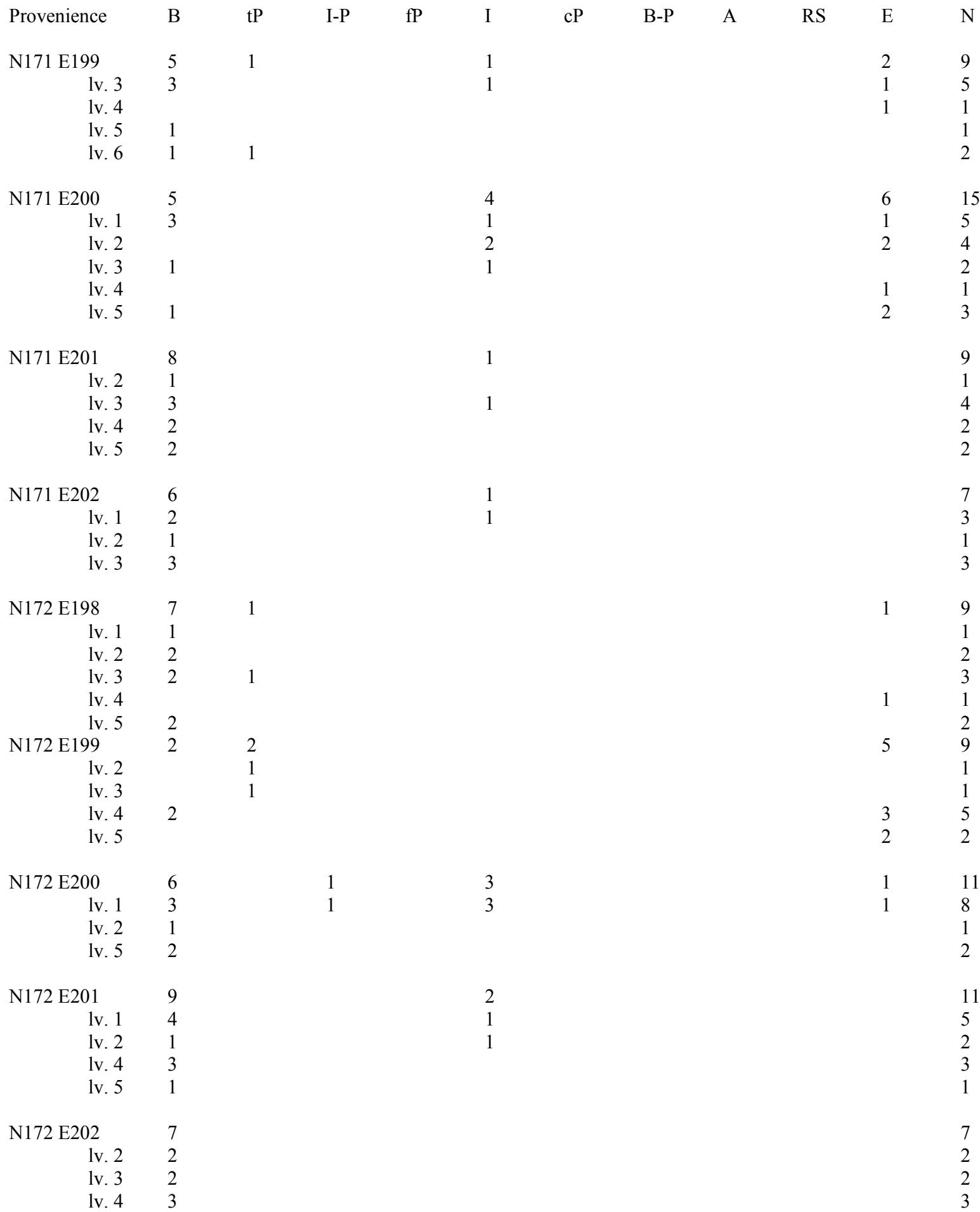


Table 6-1, continued.

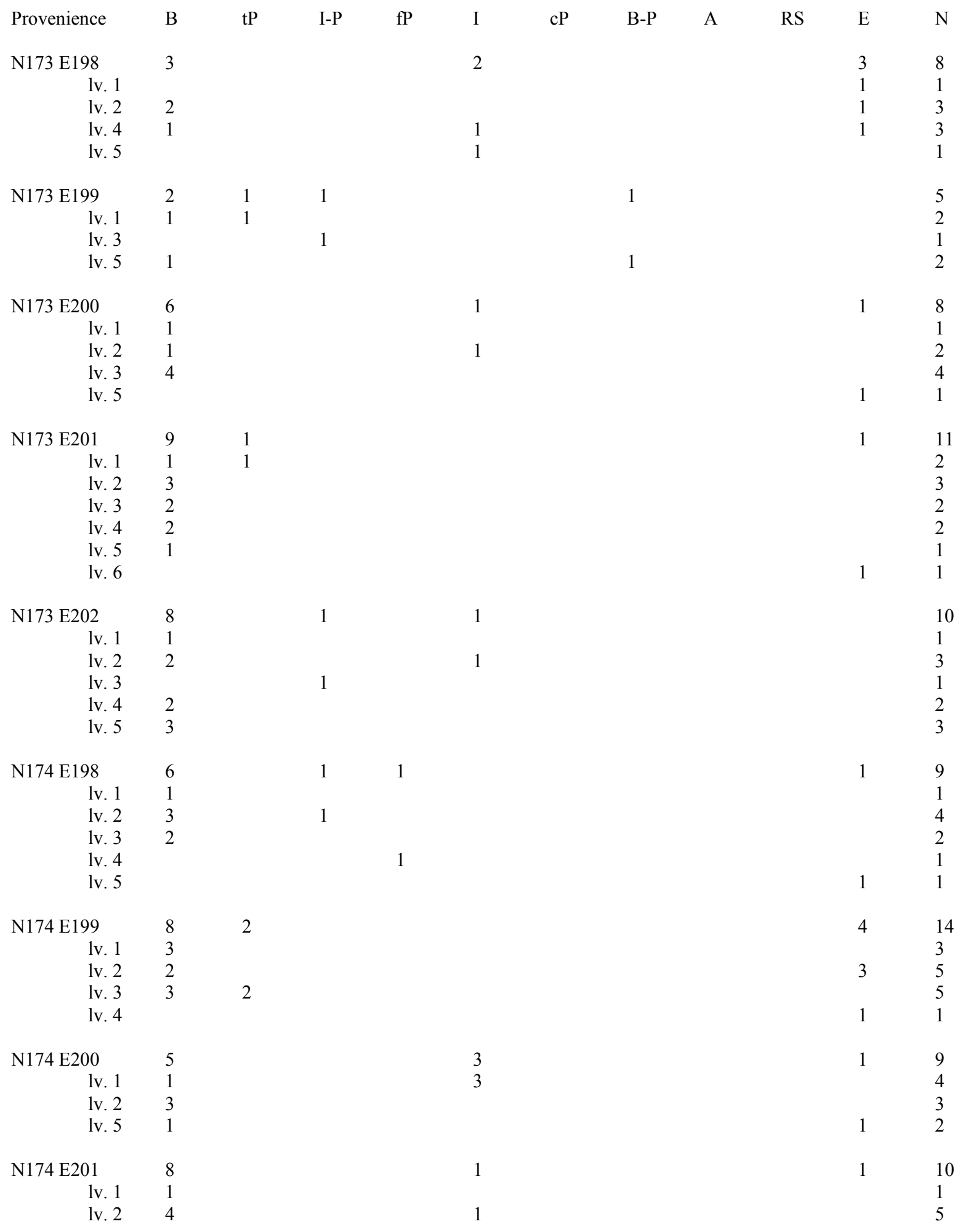


Table 6-1, continued.

$\begin{array}{lllllllllllll}\text { Provenience } & \text { B } & \text { tP } & \text { I-P } & \text { PP } & \text { I } & c P & \text { B-P } & \text { A } & \text { RS } & \text { E } & \text { N }\end{array}$
lv. $3 \quad 1$
lv. $4 \quad 1$
lv. $5 \quad 1$

N174 E202 4

lv. $2 \quad 1$

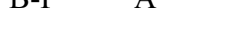

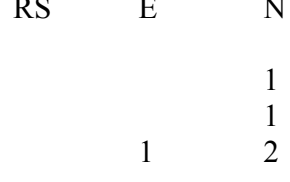

lv. $3 \quad 1$

lv. $4 \quad 1$

lv. $5 \quad 1$

2
2

$\begin{array}{lll}\text { N175 E198 } & 8 & 2\end{array}$

1

lv. $1 \quad 2 \quad 1$

lv. $2 \quad 1$

lv. $3 \quad 1$

lv. $4 \quad 2 \quad 1$

N. Profile

lv. $5 \quad 1$

N175 E199 $\quad 6 \quad 2$

lv. 12

lv. $2 \quad 1$

lv. $3 \quad 3$

N175 E200 $15 \quad 3$

lv. $1 \quad 2$

lv. 23

lv. $3 \quad 3$

lv. $4 \quad 5$

lv. 5

$1 \quad 1$

lv. $1 \quad 1$

lv. $2 \quad 2$

lv. $3 \quad 2$

lv. $4 \quad 2$

lv. 54

N175 E202 2

lv. $1 \quad 1$

lv. 2

lv. $3 \quad 1$

2

$2 \quad 12$

3

1

14

12

$\begin{array}{lllll}\text { N176 E198 } & 11 & 2 & 1 & 5\end{array}$

lv. $1 \quad 1 \quad 1$

lv. $2 \quad 2$

lv. $3 \quad 3$

lv. $4 \quad 1$

lv. 54

1

1

$2 \quad 12$

13

$\begin{array}{ll} & 3 \\ 1 & 6\end{array}$

$1 \quad 21$

2

$1 \quad 5$

1

5
4

1

$2 \quad 17$

1

2

$\begin{array}{ll}1 & 5 \\ 1 & 6\end{array}$

$1 \quad 6$

2

13

$\begin{array}{llll}\text { N176 E199 } & 14 & 1 & 1\end{array}$

lv. $2 \quad 2 \quad 1 \quad 1$

lv. $3 \quad 6$

lv. $4 \quad 6$ 


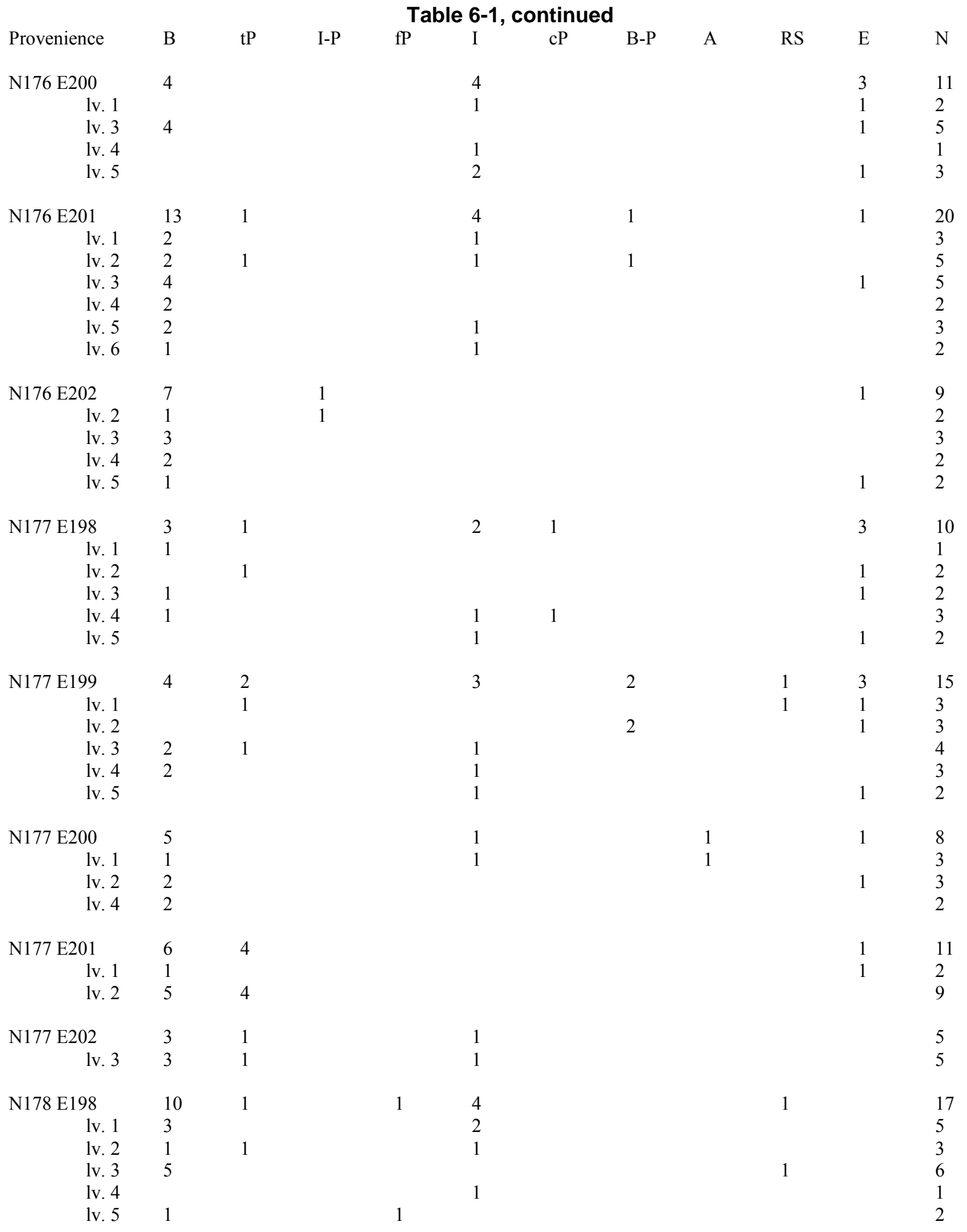


Table 6-1, continued.

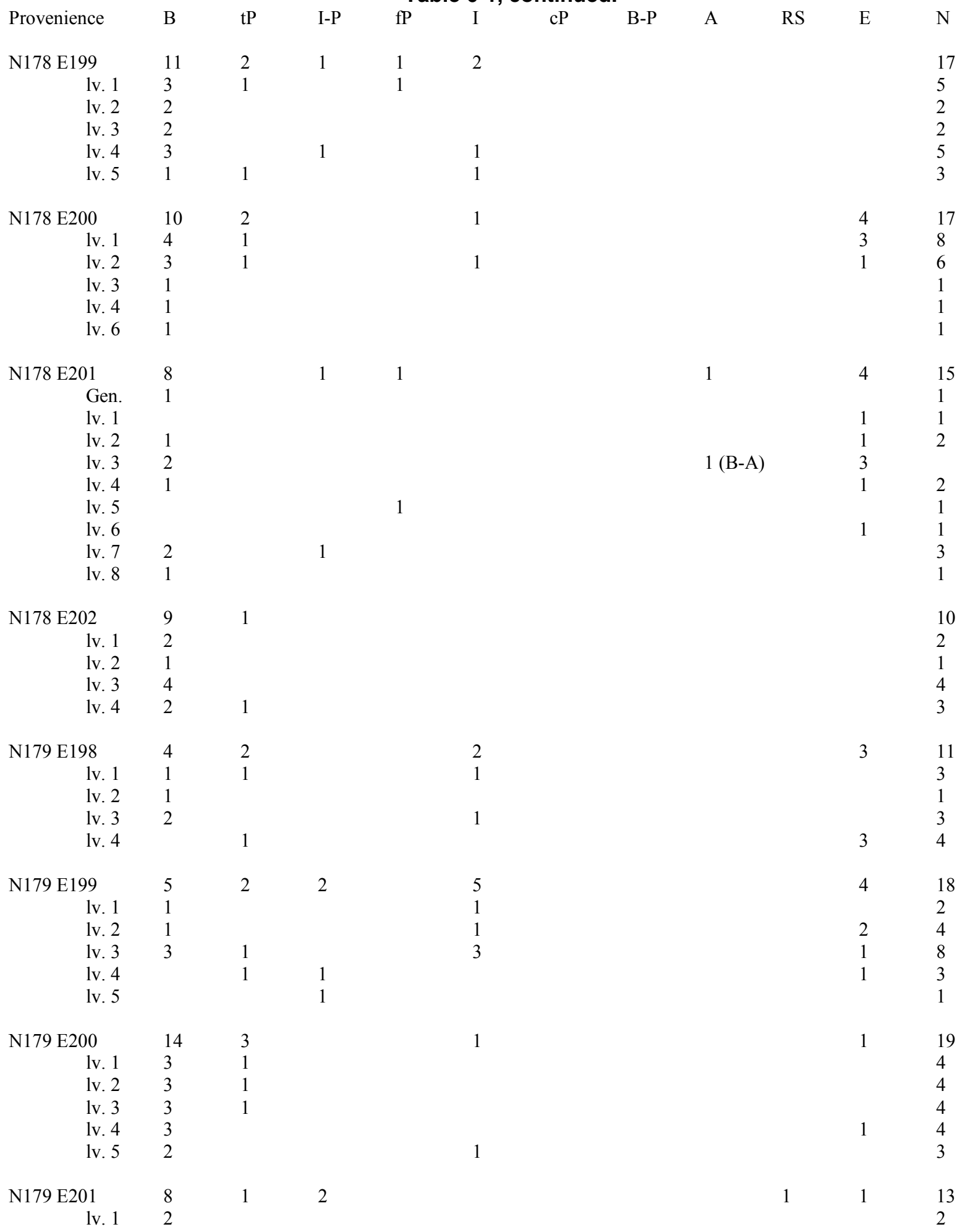




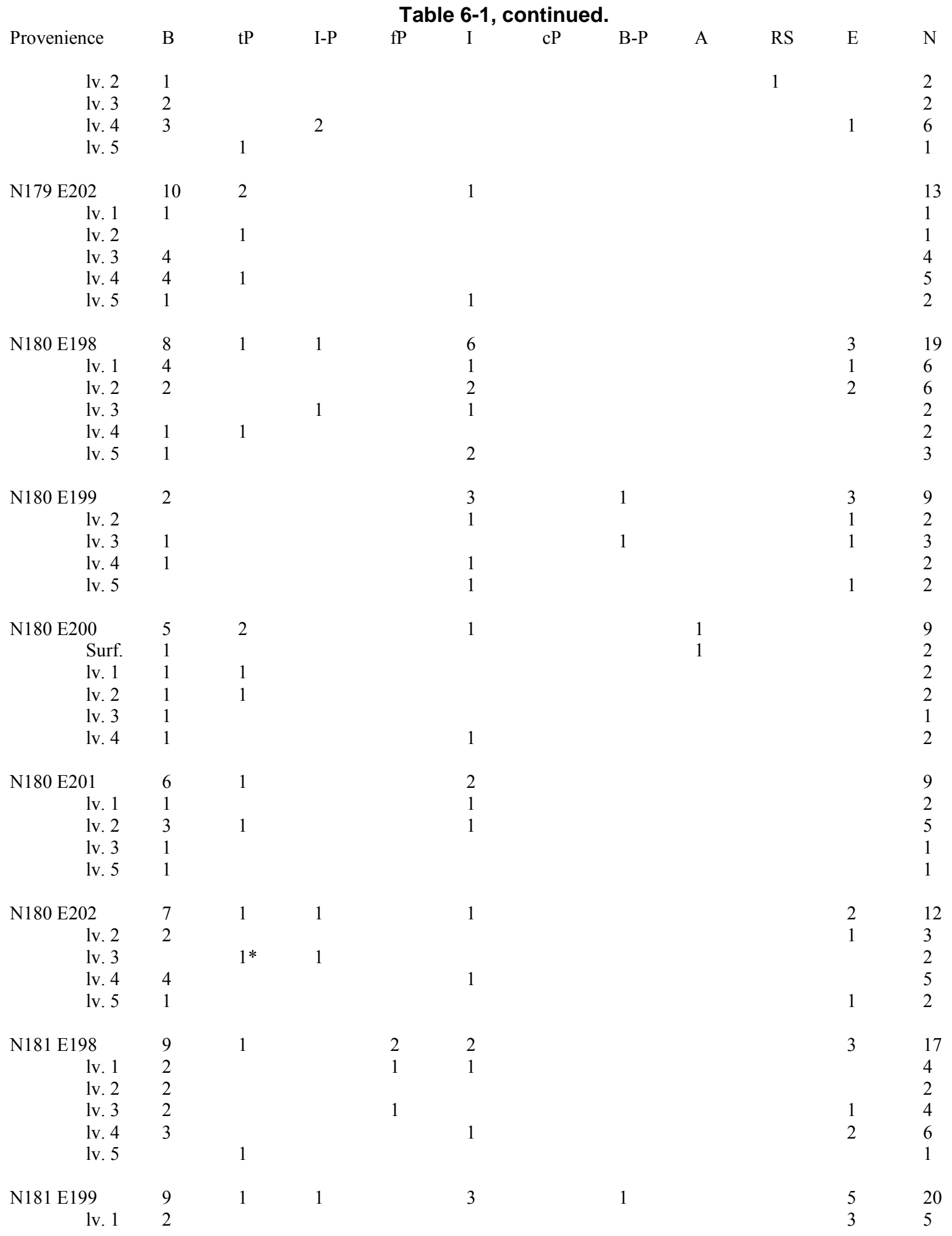


Table 6-1, continued.

$\begin{array}{lllllllllllll}\text { Provenience } & \text { B } & \text { tP } & \text { I-P } & \text { PP } & \text { I } & c P & \text { B-P } & \text { A } & \text { RS } & \text { E } & \text { N }\end{array}$ lv. 2

lv. $3 \quad 4$

1

1

lv. $4 \quad 1$

lv. $5 \quad 2 \quad 1$

N181 E200 $\quad 8$

lv. $1 \quad 3$

lv. 24

lv. $5 \quad 1$

1
1
1

1

$\begin{array}{ll} & 2 \\ & 6 \\ 1 & 3 \\ 1 & 4 \\ & \\ 3 & 13 \\ 1 & 4 \\ 2 & 7 \\ & 2\end{array}$

N181 E201

$\begin{array}{lllll}01 & 9 & 1 & 1 & 4 \\ \text { Surf. } & & & & 2 \\ \text { lv. } 1 & 1 & & & \\ \text { lv. } 2 & 3 & & & \\ \text { lv. } 3 & 3 & 1 & 1 & \\ \text { lv. } 4 & 1 & & & \\ \text { lv. } 5 & 1 & & & \end{array}$

N181 E202 $10 \quad 1$

lv. 1

lv. $2 \quad 2$

lv. $3 \quad 2$

lv. $4 \quad 4$

lv. $5 \quad 2$

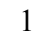

1

$\begin{array}{ll}2 & 17 \\ 1 & 1 \\ & 3 \\ & 3 \\ 1 & 8 \\ & 8 \\ & 1 \\ & 1\end{array}$

N182 E198 6

lv. 12

lv. 2

lv. $3 \quad 3$

lv. $4 \quad 1$

lv. 5

1

$\begin{array}{ll}2 & 13 \\ 1 & 13\end{array}$

$1-1$

$\begin{array}{ll}1 & 2 \\ 1 & 4\end{array}$

2

N182 E199 $11 \quad 1$

lv. $1 \quad 2$

lv. 24

lv. $3 \quad 3$

lv. $4 \quad 1$

1

1

1.. 5

1

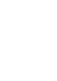

1

$\begin{array}{ll}1 & 14 \\ & 3 \\ 1 & 3 \\ & 4 \\ & 2 \\ & 2\end{array}$

N182 E200 6

lv. $1 \quad 1$

lv. $3 \quad 1$

lv. $5 \quad 2$

lv. $6 \quad 2$

lv. 7

1

$\begin{array}{rrr}\text { N182 E201 } & 8 & 1 * \\ \text { lv. } 1 & & \\ \text { lv. } 2 & 3 & 1 * \\ \text { lv. } 4 & 3 & \\ \text { lv. } 5 & 2 & \\ \text { lv. } 6 & & \end{array}$

4
1
2

1

$1 *$

$1 *$

2

$\begin{array}{ll}2 & 15 \\ 1 & 4 \\ & 4 \\ & 3 \\ & 2 \\ 1 & 2\end{array}$

$\begin{array}{ll}3 & 13 \\ 1 & 3 \\ & 3 \\ 1 & 3 \\ & 2 \\ 1 & 2\end{array}$

$3 \quad 13$

1 


\begin{tabular}{|c|c|c|c|c|c|c|c|c|c|c|c|}
\hline & & & & & $6-$ & htin & & & & & \\
\hline Provenience & $\mathrm{B}$ & $\mathrm{tP}$ & I-P & $\mathrm{fP}$ & I & $\mathrm{cP}$ & B-P & A & RS & $\mathrm{E}$ & $\mathrm{N}$ \\
\hline N182 E202 & 21 & 2 & & 1 & 3 & & & & & 3 & 30 \\
\hline lv. 1 & 2 & & & & & & & & & & 2 \\
\hline lv. 2 & 7 & $1(\mathrm{NB})$ & & & 1 & & & & & & 9 \\
\hline lv. 3 & 5 & & & 1 & & & & & & 1 & 7 \\
\hline lv. 4 & 5 & & & & & & & & & & 5 \\
\hline lv. 5 & 2 & 1 & & & 2 & & & & & 2 & 7 \\
\hline N183 E198 & 3 & 3 & & & & & & & & 3 & 9 \\
\hline lv. 1 & & 2 & & & & & & & & & 2 \\
\hline lv. 3 & 1 & $1(\mathrm{NB})$ & & & & & & & & 2 & 4 \\
\hline lv. 4 & 1 & & & & & & & & & & 1 \\
\hline lv. 5 & 1 & & & & & & & & & 1 & 2 \\
\hline N183 E199 & 16 & $1^{\mathrm{x}}$ & & & 1 & & & & & 4 & 22 \\
\hline lv. 1 & 2 & & & & & & & & & & 2 \\
\hline lv. 2 & 2 & & & & & & & & & & 2 \\
\hline lv. 3 & 5 & & & & & & & & & 1 & 6 \\
\hline lv. 4 & 4 & & & & 1 & & & & & 2 & 7 \\
\hline lv. 5 & 3 & $1 *$ & & & & & & & & 1 & 5 \\
\hline N183 E200 & 8 & & & & 6 & & & & & 4 & 18 \\
\hline lv. 1 & & & & & 1 & & & & & & 1 \\
\hline lv. 2 & 1 & & & & 2 & & & & & 1 & 4 \\
\hline lv. 3 & 2 & & & & 2 & & & & & 1 & 5 \\
\hline lv. 4 & 3 & & & & 1 & & & & & 1 & 5 \\
\hline lv. 5 & 1 & & & & & & & & & 1 & 2 \\
\hline lv. 6 & 1 & & & & & & & & & & 1 \\
\hline N183 E201 & 4 & & & & 2 & & & & & $6 \#$ & 12 \\
\hline lv. 1 & & & & & & & & & & 1 & 1 \\
\hline lv. 2 & 3 & & & & & & & & & 1 & 4 \\
\hline lv. 3 & & & & & 2 & & & & & & 2 \\
\hline lv. 5 & 1 & & & & & & & & & $3 \#$ & 4 \\
\hline lv. 6 & & & & & & & & & & 1 & 1 \\
\hline N183 E202 & 10 & & & & 3 & & 1 & & 1 & 1 & 16 \\
\hline lv. 1 & 3 & & & & 1 & & 1 & & & & 5 \\
\hline lv. 2 & & & & & & & & & 1 & & 1 \\
\hline lv. 3 & 2 & & & & & & & & & 1 & 3 \\
\hline lv. 4 & 2 & & & & 2 & & & & & & 4 \\
\hline lv. 5 & 3 & & & & & & & & & & 3 \\
\hline N184 E198 & 9 & 1 & & & 2 & 2 & & & & 4 & 18 \\
\hline lv. 1 & 1 & & & & 1 & 1 & & & & 1 & 4 \\
\hline lv. 2 & & & & & & 1 & & & & 1 & 2 \\
\hline lv. 3 & 1 & & & & & & & & & & 1 \\
\hline lv. 4 & 6 & 1 & & & 1 & & & & & 1 & 9 \\
\hline lv. 5 & 1 & & & & & & & & & 1 & 2 \\
\hline N184 E199 & 12 & 2 & & 1 & 2 & & & & & 3 & 20 \\
\hline lv. 2 & 6 & & & & 1 & & & & & & 7 \\
\hline lv. 3 & 3 & & & 1 & 1 & & & & & 2 & 7 \\
\hline lv. 4 & 2 & & & & & & & & & & 2 \\
\hline
\end{tabular}


Table 6-1, continued.

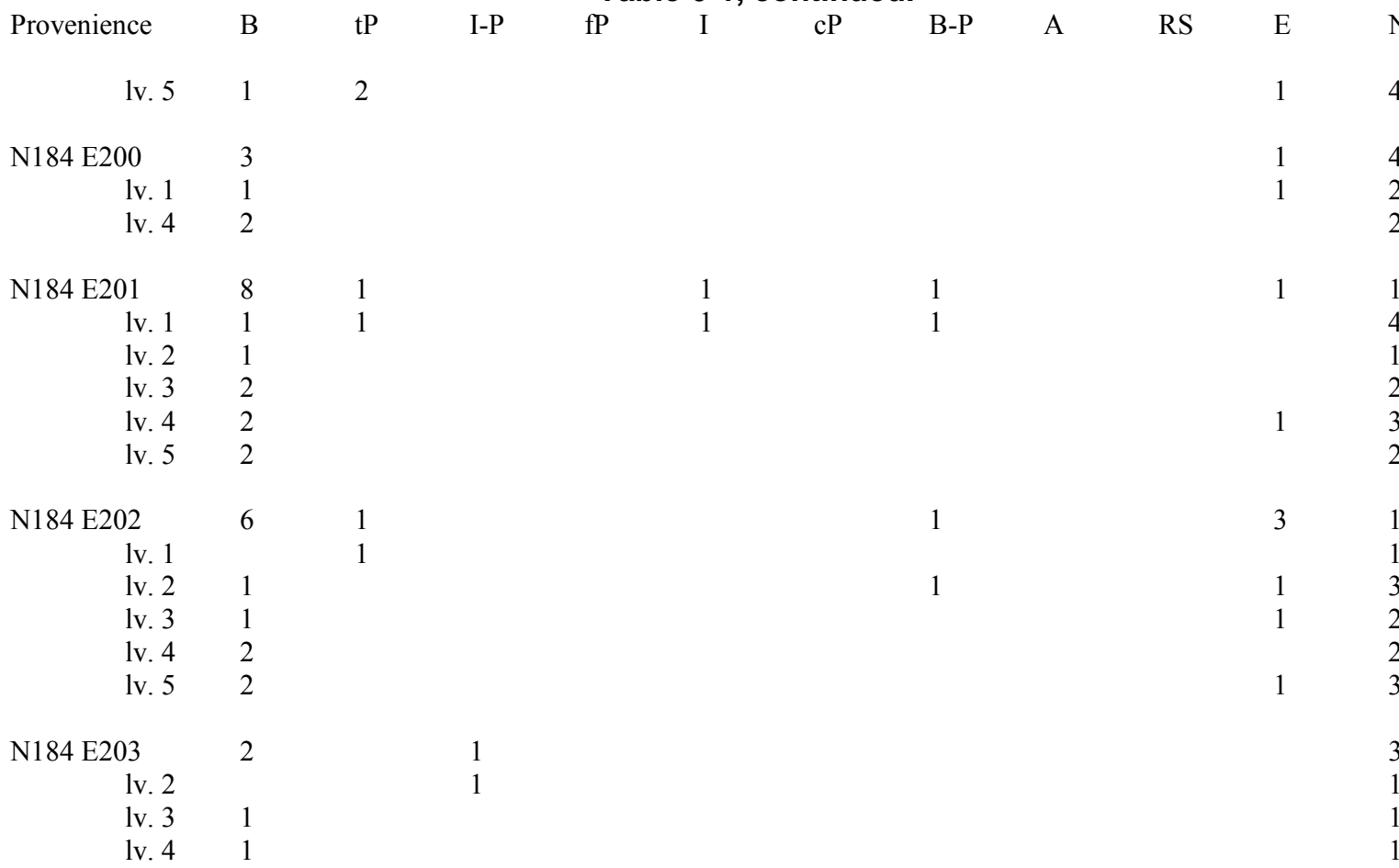

N185 E198 6

lv. $1 \quad 2$

lv. $2 \quad 1$

lv. $4 \quad 2$

lv. $5 \quad 1$

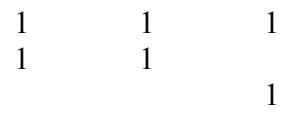

1

$\begin{array}{llll} & & 4 & 14 \\ & & 1 & 5 \\ & & 1 & 3 \\ \text { 1 (B-A) } & 1 & 4 & \\ & & 1 & 2\end{array}$

$\begin{array}{cc}\text { N185 E199 } & 4 \\ \text { lv. } 1 & 1\end{array}$

lv. 2

1

$4 \quad 10$

lv. $4 \quad 2$

lv. $5 \quad 1$

$\begin{array}{ll} & 1 \\ 3 & 2 \\ 1 & 3 \\ & 3\end{array}$

N185 E200 7

lv. $1 \quad 2$

lv. $3 \quad 1$

lv. $4 \quad 4$

1

1

$3 \quad 12$

N185 E201 $6 \quad 6$

lv. $1 \quad 1$

lv. $2 \quad 1$

lv. $3 \quad 3$

lv. 5

lv. $6 \quad 1$

2

$2 \quad 1$

$\begin{array}{lll}1 & 5 & 17\end{array}$

1

1

N185 E202 8

lv. 1

$\begin{array}{lll}3 & 1 & 2\end{array}$

$2 \quad \begin{array}{ll}4 & 23 \\ 1 & 1\end{array}$ 


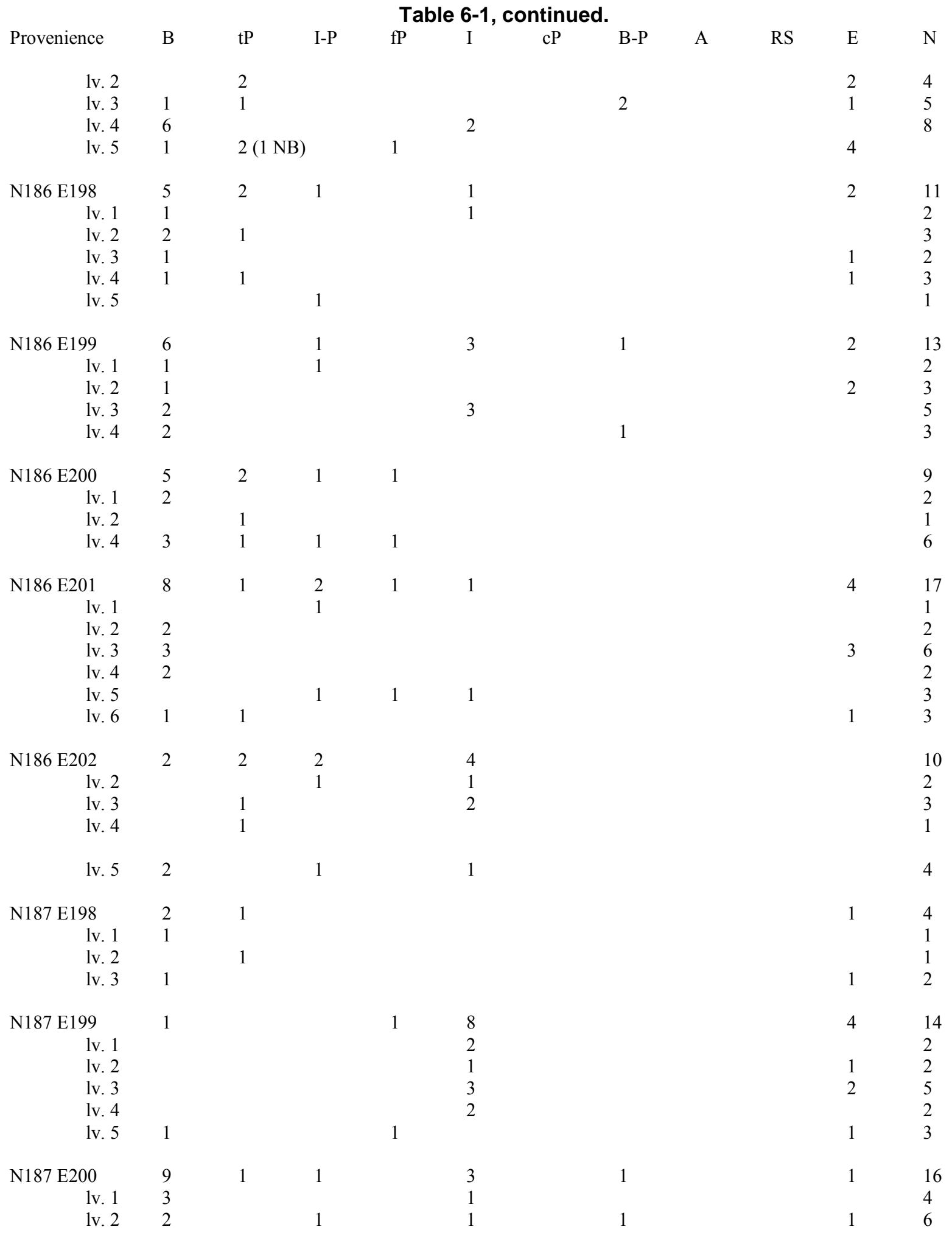


Table 6-1, continued.

$\begin{array}{llllllllllllll}\text { Provenience } & \text { B } & \text { tP } & \text { I-P } & \text { fP } & \text { I } & \text { cP } & \text { B-P } & \text { A } & \text { RS } & \text { E } & \text { N }\end{array}$ $\begin{array}{llllr}\text { lv. } 3 & 3 & 1 & 1 & 5\end{array}$ lv. $4 \quad 1 \quad 1$

N187 E201 $5 \quad 1$

$\begin{array}{lllll}\text { lv. } 1 & 5 & 1 & 1 & 1 \\ \text { lv. } 2 & 4 & 1 & & 1 \\ \text { lv. } 3 & 1 & & 1 & \end{array}$

$2 \quad 10$

N187 E202 $\quad 6 \quad 1$

lv. $1 \quad 1$

lv. $2 \quad 1$

lv. $3 \quad 1 \quad 1$

lv. $4 \quad 3$

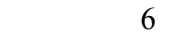

1

$1 \quad 8$

1

2
2

$\begin{array}{llll}\text { N188 E198 } & 2 & 1 & 1\end{array}$

lv. $1 \quad 1$

lv. $2 \quad 1$

lv. $3 \quad 1$

lv. 5

1

$\begin{array}{cc}\text { N188 E199 } & 5 \\ \text { lv. } 1 & 1\end{array}$

lv. 34

lv. 5

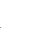

1

$\begin{array}{lll} & & 1 \\ 1 & 1 & 10 \\ & & 1 \\ & 1 & 8 \\ & & 1\end{array}$

$\begin{array}{rrr}\text { N188 E200 } & 5 & 1 \\ \text { lv. } 2 & 3 & \\ \text { lv. } 3 & & \\ \text { lv. } 4 & 1 & 1 \\ \text { lv. } 5 & 1 & \end{array}$

\section{1
3}

N188 E201 6

lv. $1 \quad 1$

2

lv. 2

lv. 3

$\begin{array}{ll}\text { lv. } 4 & 4 \\ \text { lv. } 5 & 1\end{array}$

2

$\begin{array}{rr}\text { N188 E202 } & 5 \\ \text { lv. } 1 & 2 \\ \text { lv. } 2 & 2 \\ \text { lv. } 3 & \\ \text { lv. } 4 & 1\end{array}$

1

1

1
1

$4 \quad 14$

15

14

$\begin{array}{ll}1 & 3 \\ 1 & 2\end{array}$

Iv. $4 \quad 1$

$\begin{array}{cc}\text { N189 E198 } & 3 \\ \text { lv. } 1 & 1 \\ \text { lv. } 2 & 1 \\ \text { lv. } 3 & \\ \text { lv. } 4 & 1\end{array}$

\section{Northern Component}

$4 \quad 15$

2

24

26

$\begin{array}{lllll}2 & 1 & 1 & 3 & 10 \\ 1 & & 1 & 2 & 4 \\ 1 & 1 & 1 & 3 \\ & & & 1 & \\ & & & & \end{array}$




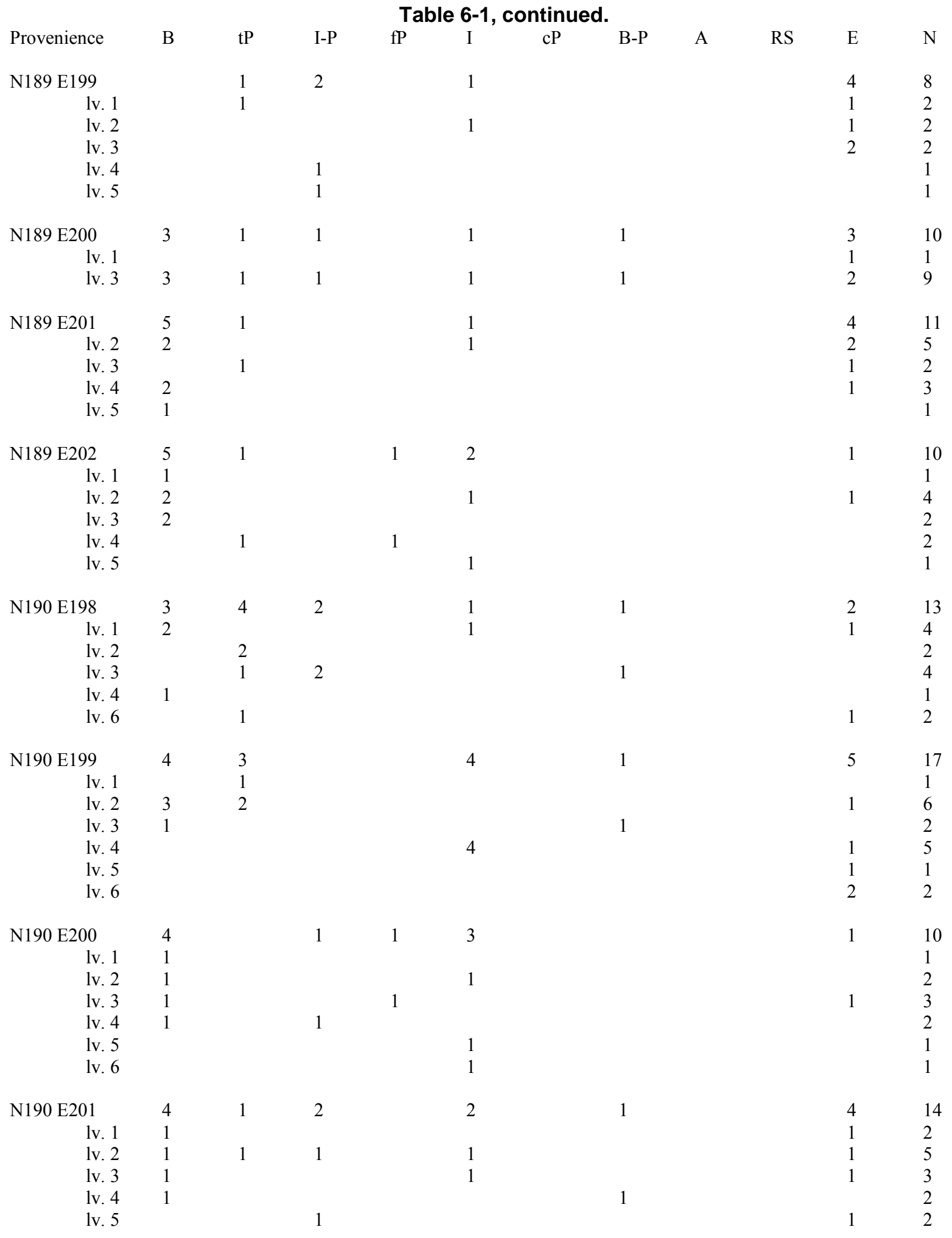


Table 6-1, continued.

\begin{tabular}{|c|c|c|c|c|c|c|c|c|c|c|}
\hline Provenience & B & $\mathrm{tP}$ & I-P & $\mathrm{fP}$ & I & B-P & A & RS & E & $\mathrm{N}$ \\
\hline N190 E202 & 3 & 1 & & & 1 & & & & 4 & 9 \\
\hline lv. 2 & & 1 & & & & & & & 1 & 2 \\
\hline lv. 3 & 2 & & & & & & & & 2 & 4 \\
\hline lv. 4 & 1 & & & & 1 & & & & & 2 \\
\hline lv. 5 & & & & & & & & & 1 & 1 \\
\hline N191 E198 & 4 & 1 & & & 5 & & & & 1 & 11 \\
\hline lv. 1 & 2 & & & & & & & & & 2 \\
\hline lv. 3 & & & & & 1 & & & & 1 & 2 \\
\hline lv. 4 & 1 & & & & 1 & & & & & 2 \\
\hline lv. 5 & 1 & 1 & & & 3 & & & & & 5 \\
\hline N191 E199 & 3 & 2 & & & 2 & & & & 2 & 9 \\
\hline lv. 1 & & & & & 2 & & & & & 2 \\
\hline lv. 2 & & 1 & & & & & & & & 1 \\
\hline lv. 3 & 2 & 1 & & & & & & & 1 & 4 \\
\hline lv. 4 & 1 & & & & & & & & 1 & 2 \\
\hline N191 E200 & 5 & 4 & 2 & 1 & 7 & 1 & & & 2 & 22 \\
\hline lv. 1 & 1 & & & & & & & & & 1 \\
\hline lv. 2 & 2 & 1 & & & 1 & & & & 1 & 5 \\
\hline lv. 3 & & 1 & & & 1 & & & & & 2 \\
\hline lv. 4 & & & 1 & & 2 & & & & & 3 \\
\hline lv. 5 & 1 & & & & 3 & & & & & 4 \\
\hline lv. 6 & 1 & 1 & 1 & & & & & & 1 & 4 \\
\hline lv. 7 & & 1 & & 1 & & 1 & & & & 3 \\
\hline N191 E201 & 13 & 1 & 3 & 2 & 5 & & & & 1 & 25 \\
\hline lv. 1 & 2 & & & & & & & & & 2 \\
\hline lv. 2 & 2 & & & & & & & & & 2 \\
\hline lv. 3 & 2 & & & & 1 & & & & & 3 \\
\hline lv. 4 & 1 & 1 & 1 & 1 & 3 & & & & & 7 \\
\hline lv. 5 & & & 1 & & 1 & & & & & 2 \\
\hline lv. 6 & 3 & & & 1 & & & & & & 4 \\
\hline lv. 7 & 3 & & 1 & & & & & & 1 & 5 \\
\hline N191 E202 & 3 & 1 & & 2 & 1 & & & & $2 \#$ & 9 \\
\hline lv. 1 & & & & & & & & & 1 & 1 \\
\hline lv. 2 & 2 & & & & & & & & $1 \#$ & 3 \\
\hline lv. 3 & & & & 1 & 1 & & & & & 2 \\
\hline lv. 4 & 1 & 1 & & & & & & & & 2 \\
\hline lv. 5 & & & & 1 & & & & & & 1 \\
\hline N192 E198 & 3 & & & & 1 & & & & & 4 \\
\hline lv. 1 & 1 & & & & & & & & & 1 \\
\hline lv. 3 & 1 & & & & 1 & & & & & 2 \\
\hline lv. 4 & 1 & & & & & & & & & 1 \\
\hline N192 E199 & & 1 & & & 1 & 1 & & 1 & 2 & 6 \\
\hline lv. 1 & & & & & & 1 & & & & 1 \\
\hline lv. 2 & & 1 & & & & & & 1 & 2 & 4 \\
\hline lv. 4 & & & & & 1 & & & & & 1 \\
\hline
\end{tabular}




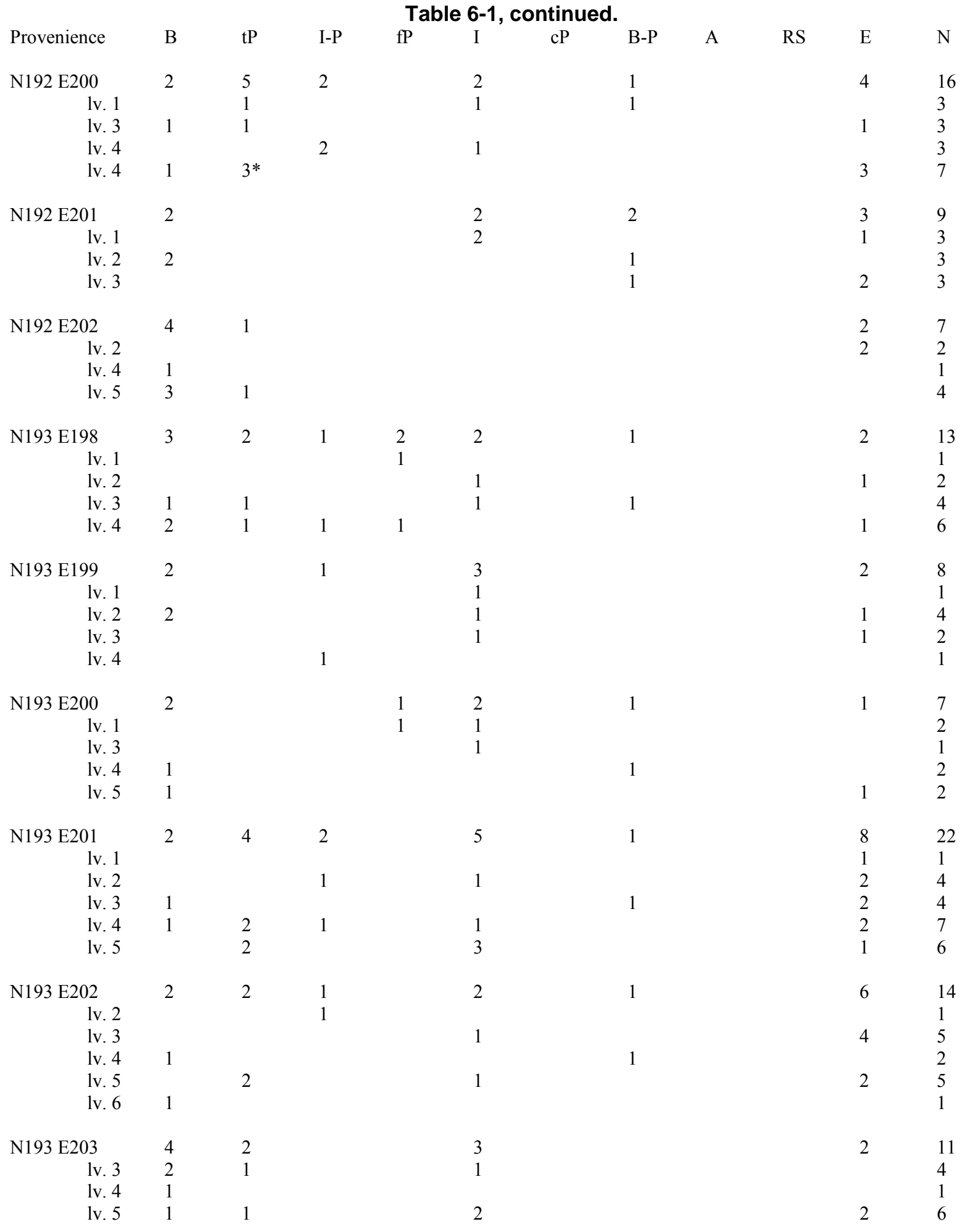


Table 6-1, continued.

\begin{tabular}{|c|c|c|c|c|c|c|c|c|c|}
\hline Provenience & B & $\mathrm{tP}$ & I-P & $\mathrm{fP}$ & I & B-P & A & RS & E \\
\hline N194 E198 & 3 & & 1 & 2 & 2 & 2 & & 1 & 2 \\
\hline lv. 1 & & & & & & 1 & & 1 & \\
\hline lv. 2 & 1 & & & 2 & & 1 & & & 1 \\
\hline lv. 3 & 1 & & & & 2 & & & & 1 \\
\hline lv. 4 & 1 & & 1 & & & & & & \\
\hline
\end{tabular}

N194 E199

lv. 2

lv. 3

lv. 4

$\begin{array}{llll}2 & 1 & 1 & 2\end{array}$

$1(\mathrm{LN})$

N194 E200

lv, 1

lv. 2

lv. 3

lv. 4

1

12

$\begin{array}{lll}2 & 2 & 7\end{array}$

1

1

$\begin{array}{lll}2 & 1 & 4\end{array}$

39

11

$\begin{array}{lllll}\text { N194 E201 } & 2 & 2 & 1 & 8\end{array}$

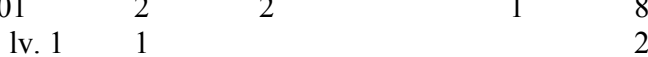

lv. $2 \quad 1 \quad 3$

$\begin{array}{lllll}\text { lv. } 3 & & 1 & 1 & 2 \\ \text { lv. } 4 & 1 & & \end{array}$

$\begin{array}{llllll}\mathrm{N} 194 \mathrm{E} 202 & 2 & 1 & 1 & 1 & 2\end{array}$

$\begin{array}{lllll}\text { lv. } 1 & 1 & 1\end{array}$

lv. 3

lv. $4 \quad 2$

lv. $5 \quad 1$

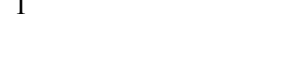

N194 E203

lv. 4

lv. 5

$\begin{array}{ll}1 & 3 \\ 1 & 2 \\ 1 & 1\end{array}$

N195 E198

lv. 1

1v. 3

N195 E199

lv. 1

lv. 2

lv. 3

lv. 4

1

$1(\mathrm{NB})$

$\begin{array}{ccccc}\text { N195 E200 } & 3 & 1 & 1 & 7 \\ \text { lv. 1 } & 1 & & & 2 \\ \text { lv. 2 } & 2 & 1 & 1 & 4 \\ \text { lv. 3 } & & & & 1\end{array}$

2

2

$\begin{array}{lll}1 & 1 & 6 \\ 1 & & 3 \\ & 1 & 3\end{array}$
N195 E201 5
lv. $1 \quad 1$
$\begin{array}{ll}\text { lv. } 2 & 1 \\ \text { lv. } 3 & 2\end{array}$
lv. 4

$\begin{array}{ll}2 & 2 \\ 1 & \\ & 1 \\ & 1 \\ 1 & \end{array}$
1
1

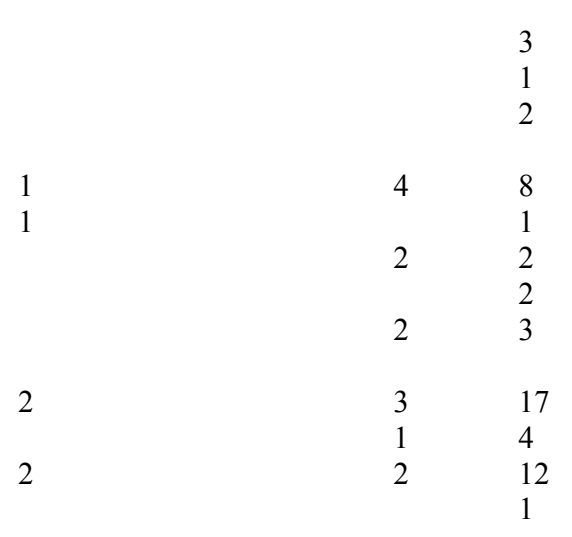




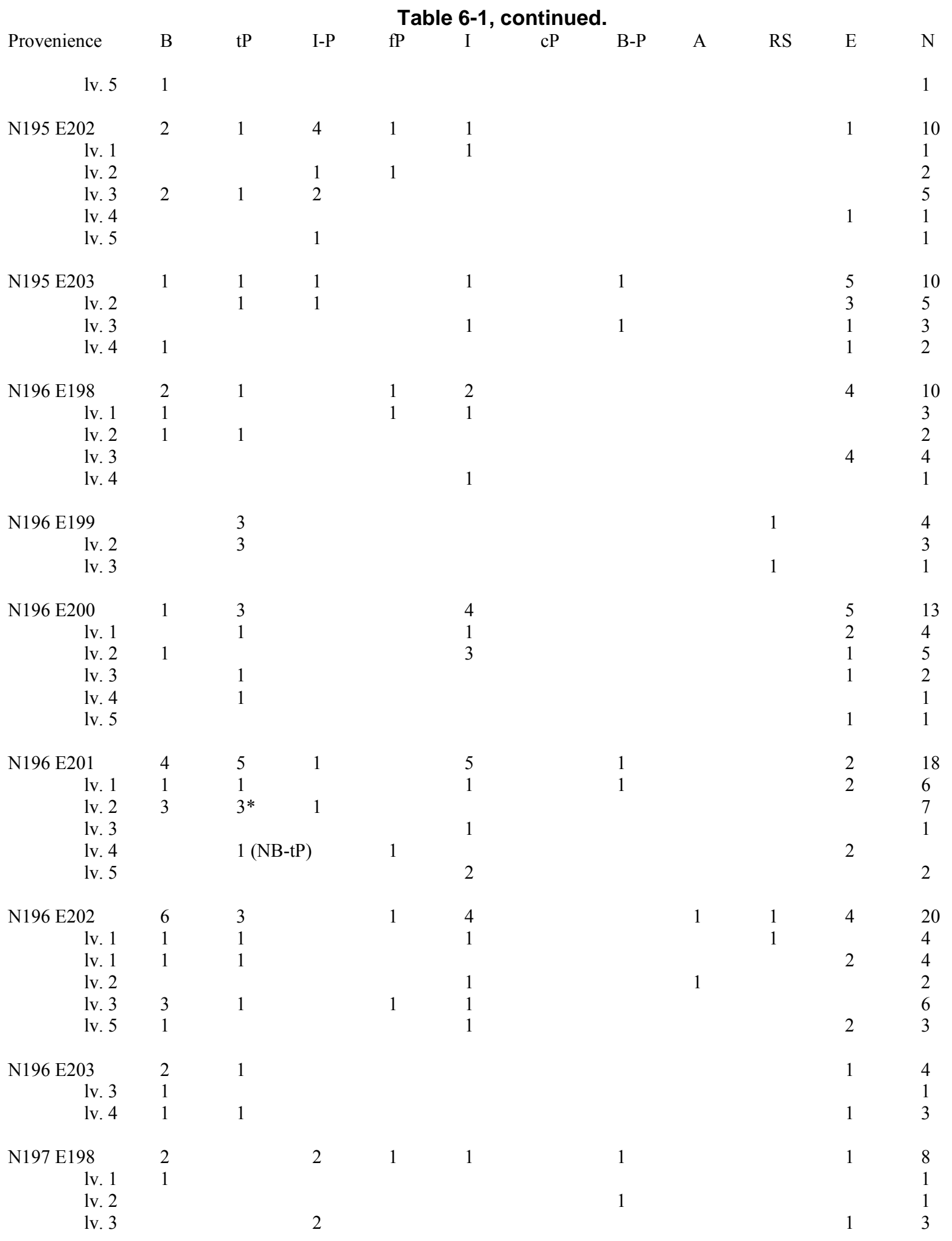


Table 6-1, continued.

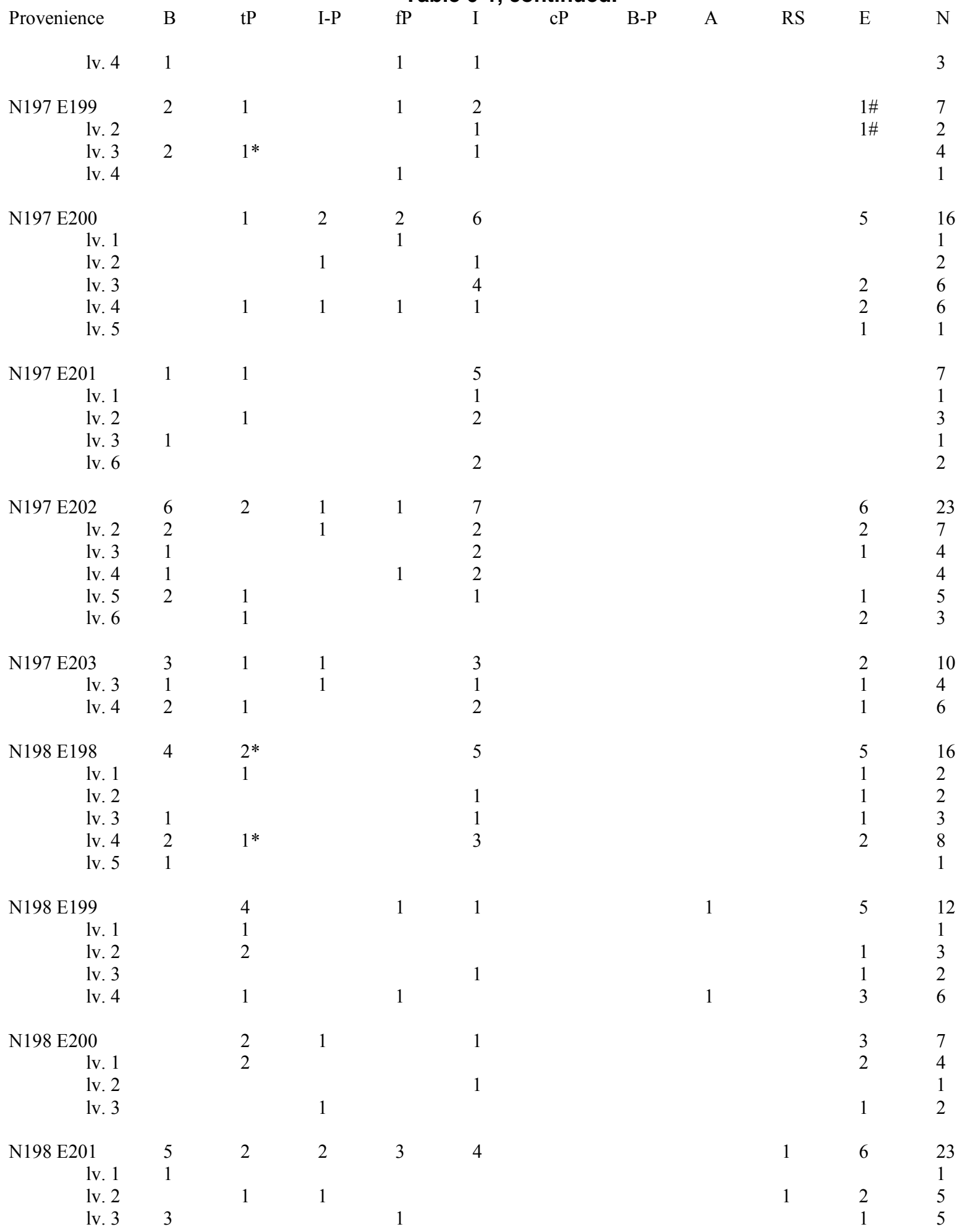




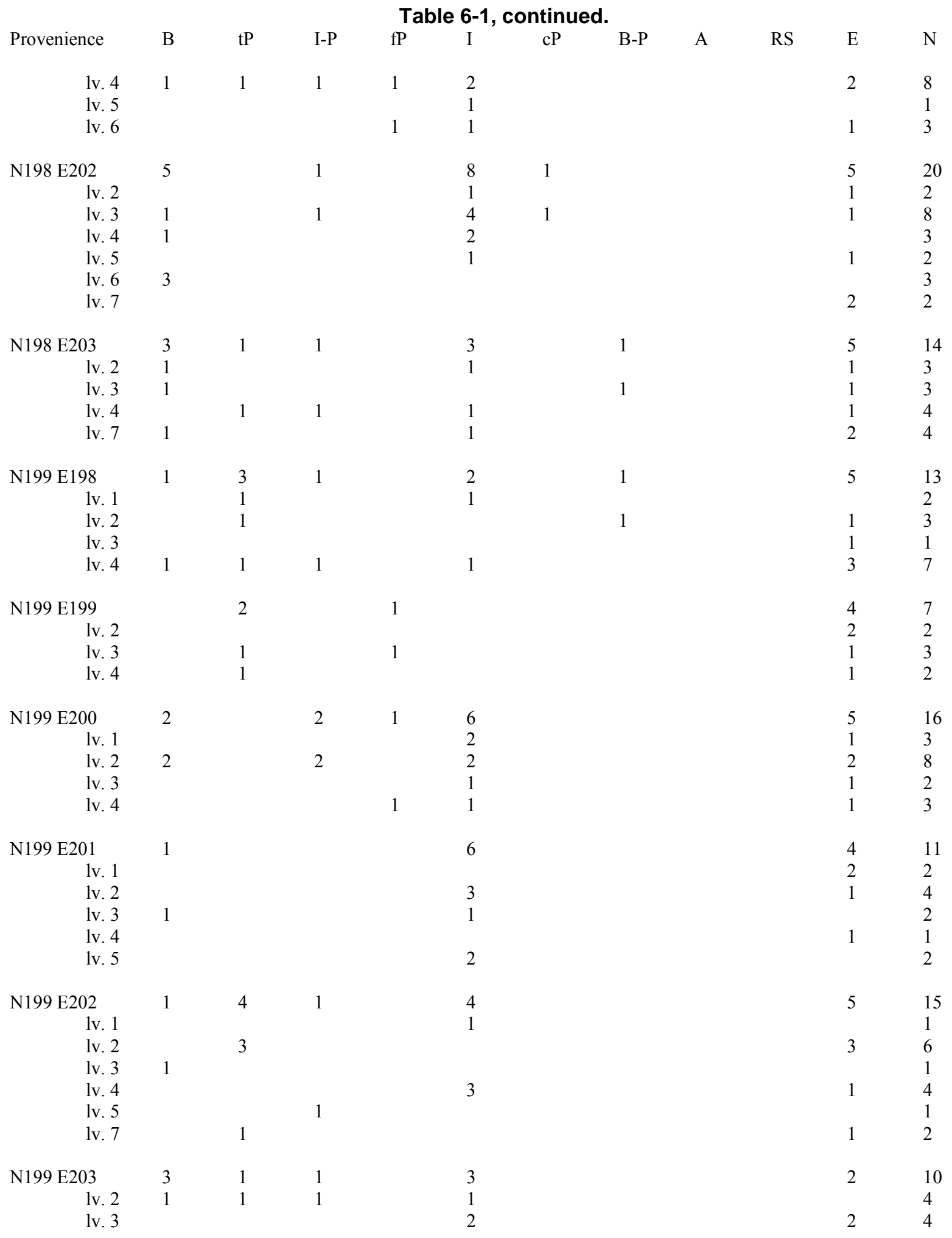


Table 6-1, continued.

$\begin{array}{lllllllllllll}\text { Provenience } & \text { B } & \text { tP } & \text { I-P } & \text { fP } & \text { I } & \text { cP } & \text { B-P } & \text { A } & \text { RS } & \text { E } & \text { N }\end{array}$
lv. $4 \quad 2$

(n) 2

N200 E198 11

lv. 1

lv. $2 \quad 1 \quad 1$

lv. 3

lv. 4

N200 E199 $\quad 1 \quad 3 \quad 1$

lv. $1 \quad 1 \quad 3$

lv. $2 \quad 1 \quad 1$

lv. 3

lv. $4 \quad 1$

$\begin{array}{llll}\text { N200 E200 } & 2 & 4 & 1\end{array}$

lv. 1

lv. 2

lv. 3

lv. $4 \quad 1 \quad 2 * \quad 1$

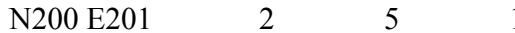

lv. $1 \quad 1$

lv. 2

lv. 3

lv. $4 \quad 2 \quad 1$

N200 E202 22

lv. $1 \quad 2$

lv. $3 \quad 1$

lv. $4 \quad 1$

\section{2}

1

$3 \quad 7$

1

$1-4$

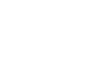




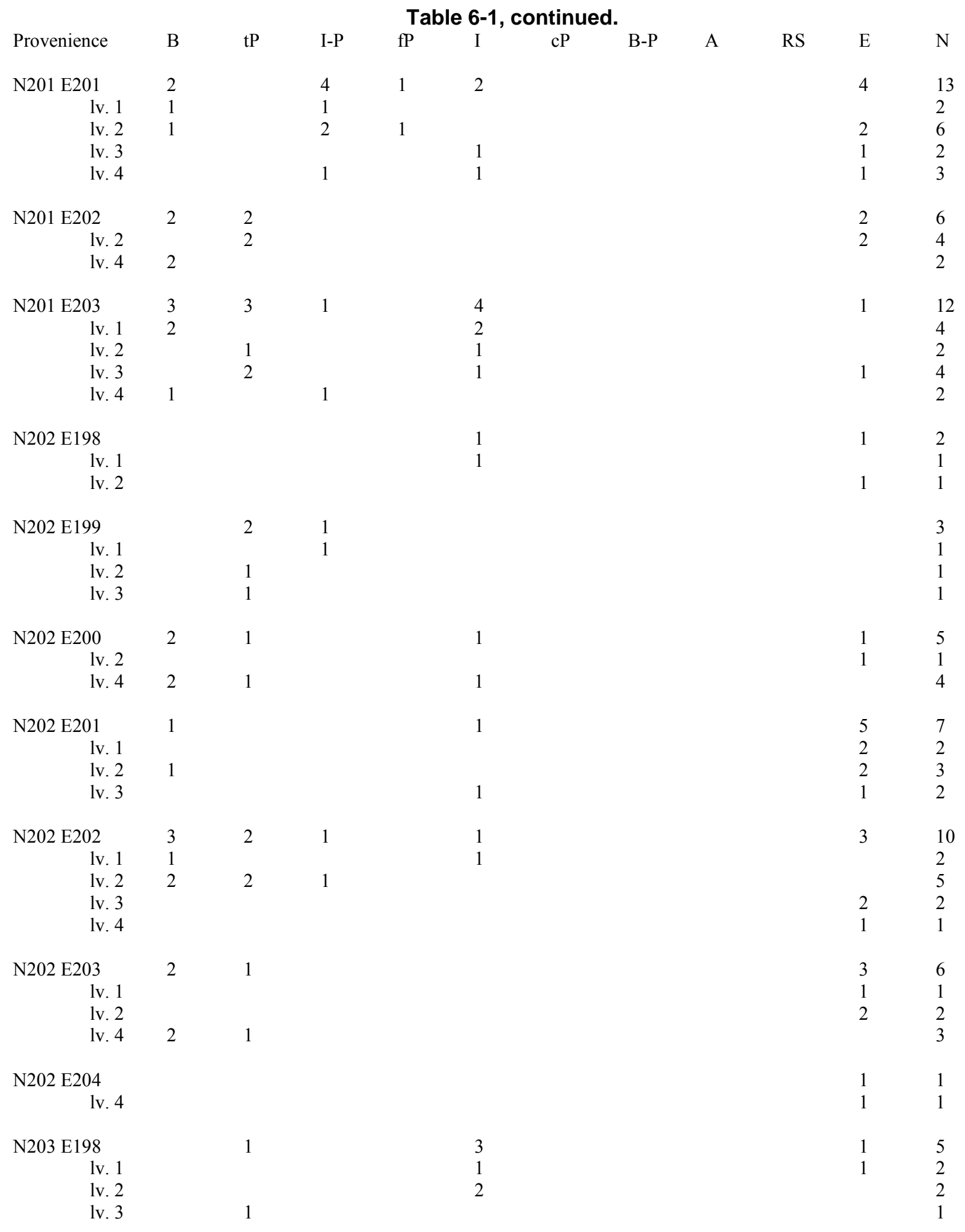


Table 6-1, continued.

\begin{tabular}{|c|c|c|c|c|c|c|c|c|c|c|}
\hline Provenience & B & $\mathrm{tP}$ & I-P & $\mathrm{fP}$ & I & B-P & $\mathrm{A}$ & RS & $\mathrm{E}$ & $\mathrm{N}$ \\
\hline N203 E199 & 1 & 2 & & 1 & 1 & 1 & & & 3 & 9 \\
\hline lv. 1 & 1 & 1 & & & 1 & & & & 1 & 4 \\
\hline lv. 2 & & 1 & & 1 & & 1 & & & 2 & 5 \\
\hline N203 E200 & 1 & & & & & & & & 3 & 4 \\
\hline lv. 1 & & & & & & & & & 1 & 1 \\
\hline lv. 2 & & & & & & & & & 1 & 1 \\
\hline lv. 3 & 1 & & & & & & & & & 1 \\
\hline lv. 4 & & & & & & & & & 1 & 1 \\
\hline N203 E201 & 1 & 1 & & 1 & 3 & 1 & & & & 7 \\
\hline lv. 2 & 1 & 1 & & & 2 & & & & & 4 \\
\hline lv. 4 & & & & 1 & 1 & 1 & & & & 3 \\
\hline N203 E202 & 7 & 2 & & & 2 & & & & 6 & 17 \\
\hline lv. 1 & & & & & & & & & 1 & 1 \\
\hline lv. 2 & & & & & & & & & 2 & 2 \\
\hline lv. 3 & 4 & 1 & & & 2 & & & & 2 & 9 \\
\hline lv. 4 & 3 & 1 & & & & & & & 1 & 5 \\
\hline N203 E203 & 1 & & & & & & & & 3 & 4 \\
\hline lv. 2 & 1 & & & & & & & & & 1 \\
\hline lv. 3 & & & & & & & & & 2 & 2 \\
\hline lv. 4 & & & & & & & & & 1 & 1 \\
\hline N204 E198 & 1 & & & & 2 & & & & & 3 \\
\hline lv. 1 & & & & & 1 & & & & & 1 \\
\hline lv. 2 & & & & & 1 & & & & & 1 \\
\hline lv. 4 & 1 & & & & & & & & & 1 \\
\hline N204 E199 & 2 & & & & 1 & & & & 1 & 4 \\
\hline lv. 1 & & & & & 1 & & & & 1 & 2 \\
\hline lv. 3 & 2 & & & & & & & & & 2 \\
\hline N204 E200 & 2 & 5 & 1 & & 3 & & & & 3 & 14 \\
\hline lv. 1 & 1 & 1 & & & 3 & & & & 1 & 6 \\
\hline lv. 2 & & 1 & & & & & & & 2 & 3 \\
\hline lv. 3 & 1 & 2 & 1 & & & & & & & 4 \\
\hline lv. 4 & & $1^{*}$ & & & & & & & & 1 \\
\hline N204 E202 & & 2 & & & 2 & 1 & & 1 & 1 & 7 \\
\hline lv. 1 & & 1 & & & & & & 1 & & 2 \\
\hline lv. 4 & & 1 & & & 2 & 1 & & & 1 & 5 \\
\hline N205 E198 & & 1 & & & & & & & 3 & 4 \\
\hline lv. 2 & & 1 & & & & & & & 1 & 2 \\
\hline lv. 3 & & & & & & & & & 1 & 1 \\
\hline lv. 4 & & & & & & & & & 1 & 1 \\
\hline N205 E199 & & & & 1 & 1 & & & & 1 & 3 \\
\hline lv. 3 & & & & 1 & 1 & & & & 1 & 3 \\
\hline
\end{tabular}




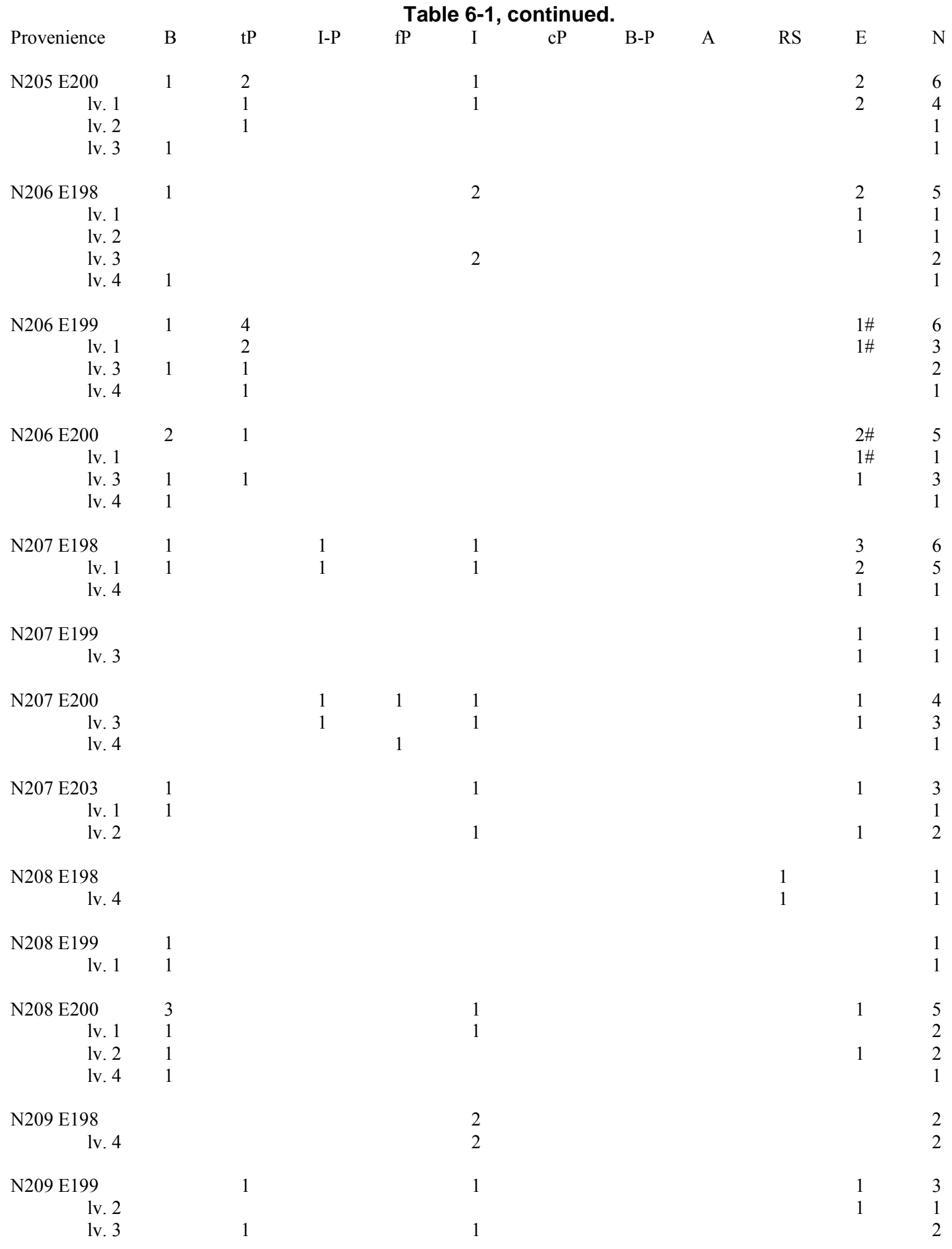




\begin{tabular}{|c|c|c|c|c|c|c|c|c|c|c|c|}
\hline \multirow{2}{*}{ Provenience } & $B$ & $\mathrm{tP}$ & I-P & $\mathrm{fP}$ & $\mathrm{I}$ & $c \mathrm{P}$ & B_P & $\mathrm{A}$ & \multirow{2}{*}{$\mathrm{RS}$} & \multirow{2}{*}{$\mathrm{E}$} & \multirow{2}{*}{$\mathrm{N}$} \\
\hline & & & & & & & & & & & \\
\hline N209 E200 & & & & & & & & & & 1 & 1 \\
\hline lv. 3 & & & & & & & & & & 1 & 1 \\
\hline N209 E203 & 1 & 1 & & & 2 & & & & 1 & & 5 \\
\hline lv. 1 & & & & & 1 & & & & & & 1 \\
\hline lv. 2 & & 1 & & & 1 & & & & & & 2 \\
\hline lv. 3 & 1 & & & & & & & & & & 1 \\
\hline lv. 4 & & & & & & & & & 1 & & 1 \\
\hline Scrape A 1 & & & & & & & & & & & 1 \\
\hline Scrape B 1 & & & & & & & & 1 & & & 2 \\
\hline Scrape C & & & & & & & & & 1 & & 1 \\
\hline Scrape E 15 & & & & 2 & & & & & 2 & & 13 \\
\hline Gen. Surf. & 1 & & & & & & & & & & 1 \\
\hline Gen. Surf/ & 2 & & & & & & & & & & 2 \\
\hline N. profile & 2 & & & & & & & & & & 2 \\
\hline Totals & 917 & 248 & 103 & 60 & 396 & 7 & 46 & 8 & 16 & 468 & 2269 \\
\hline Percent & 40.4 & 10.9 & 4.5 & 2.6 & 17.4 & 0.3 & 2.0 & 0.3 & 0.7 & 20.6 & \\
\hline
\end{tabular}

*pinched; \#=engraved-punctated

$\mathrm{B}=$ brushed (also includes a few brushed-incised body sherds); $\mathrm{tP}=$ tool punctated; $\mathrm{I}-\mathrm{P}=$ incised-punctated; $\mathrm{f}=$ =fingernail punctated; $\mathrm{I}=$ incised; $\mathrm{cP}=$ cane punctated; $\mathrm{B}-\mathrm{P}=$ brushed-punctated; $\mathrm{A}=$ appliqued; $\mathrm{RS}=$ red-slipped; $\mathrm{E}=$ engraved 
Table 6-17. Provenience of the Plain Sherds from the Data Recovery Investigations at the Lang Pasture Site.

\begin{tabular}{|c|c|c|c|c|}
\hline Provenience/Level & Rim & Body & Base & $\mathrm{N}$ \\
\hline UNITS & & SOUT & IPONENT & \\
\hline 170-198, lv. 1 & & 1 & & 1 \\
\hline 170-198, lv. 2 & & 2 & & 2 \\
\hline 170-198, lv. 3 & & 3 & & 3 \\
\hline 170-198, 1v. 4 & & 1 & & 1 \\
\hline 170-198, lv. 5 & & 3 & & 3 \\
\hline Subtotal & 0 & 10 & 0 & 10 \\
\hline 170-199, lv. 1 & & 1 & & 1 \\
\hline 170-199, 1v. 3 & & 3 & & 3 \\
\hline 170-199, lv. 5 & & 2 & 1 & 3 \\
\hline Subtotal & 0 & 6 & 1 & 7 \\
\hline 170-200, lv. 1 & & 3 & 1 & 4 \\
\hline 170-200, lv. 2 & & 6 & 2 & 8 \\
\hline 170-200, 1v. 3 & & 2 & & 2 \\
\hline 170-200, lv. 4 & & 1 & & 1 \\
\hline Subtotal & 0 & 12 & 3 & 15 \\
\hline 170-201, lv. 1 & & 3 & & 3 \\
\hline 170-201, 1v. 2 & & 3 & & 3 \\
\hline 170-201, lv. 4 & & 1 & & 1 \\
\hline 170-201, lv. 5 & & 1 & & 1 \\
\hline Subtotal & 0 & 8 & 0 & 8 \\
\hline $170-202$, lv. 2 & & 1 & & 1 \\
\hline 170-202, lv. 3 & & 2 & & 2 \\
\hline Subtotal & 0 & 3 & 0 & 3 \\
\hline 171-198, lv. 1 & 1 & 1 & & 2 \\
\hline 171-198, lv. 2 & 1 & 3 & 1 & 5 \\
\hline 171-198, 1v. 3 & & 2 & 1 & 3 \\
\hline 171-198, lv. 5 & & & 1 & 1 \\
\hline Subtotal & 2 & 6 & 3 & 11 \\
\hline 171-199, lv. 3 & & 1 & & 1 \\
\hline 171-199, lv. 4 & & 3 & & 3 \\
\hline 171-199, lv. 5 & & 2 & & 2 \\
\hline Subtotal & 0 & 6 & 0 & 6 \\
\hline $171-200$, lv. 1 & & 5 & & 5 \\
\hline 171-200, lv. 2 & & 5 & 1 & 6 \\
\hline $171-200$, lv. 3 & 1 & 1 & & 2 \\
\hline 171-200, lv. 4 & & & 1 & 1 \\
\hline $171-200$, lv. 5 & & 1 & 2 & 3 \\
\hline Subtotal & 1 & 12 & 4 & 17 \\
\hline 171-201, lv. 2 & & 1 & & 1 \\
\hline 171-201, lv. 3 & & 1 & & 1 \\
\hline
\end{tabular}


Table 6-17, continued.

\begin{tabular}{|c|c|c|c|c|}
\hline Provenience/Level & Rim & Body & Base & $\mathrm{N}$ \\
\hline 171-201, lv. 4 & & 1 & 2 & 3 \\
\hline Subtotal & 0 & 3 & 2 & 5 \\
\hline 171-202, lv. 1 & & 3 & & 3 \\
\hline 171-202, lv. 2 & & 4 & & 4 \\
\hline 171-202, lv. 3 & & 2 & & 2 \\
\hline Subtotal & 0 & 9 & 0 & 9 \\
\hline 172-198, lv. 2 & & 2 & & 2 \\
\hline 172-198, lv. 3 & & 2 & & 2 \\
\hline $172-198$, lv. 5 & & 1 & & 1 \\
\hline Subtotal & 0 & 5 & 0 & 5 \\
\hline 172-199, lv. 4 & & 5 & 1 & 6 \\
\hline 172-199, lv. 5 & & & 1 & 1 \\
\hline 172-199, lv. 6 & & 2 & & 2 \\
\hline Subtotal & 0 & 7 & 2 & 9 \\
\hline 172-200, lv. 1 & & 1 & & 1 \\
\hline 172-200, lv. 2 & 1 & 6 & & 7 \\
\hline $172-200$, lv. 3 & & 2 & & 2 \\
\hline 172-200, lv. 4 & & 2 & & 2 \\
\hline $172-200$, lv. 5 & & 3 & & 3 \\
\hline Subtotal & 1 & 14 & 0 & 15 \\
\hline 172-201, lv. 1 & & 4 & & 4 \\
\hline 172-201, lv. 2 & & 1 & & 1 \\
\hline 172-201, lv. 3 & 1 & 4 & 1 & 6 \\
\hline 172-201, lv. 4 & & 3 & 1 & 4 \\
\hline 172-201, lv. 5 & & 2 & & 2 \\
\hline Subtotal & 1 & 14 & 2 & 17 \\
\hline 172-202, lv. 1 & & 1 & & 1 \\
\hline 172-202, lv. 2 & & 1 & & 1 \\
\hline $172-202$, lv. 3 & & 5 & & 5 \\
\hline $172-202,1 v .4$ & & 3 & & 3 \\
\hline Subtotal & 0 & 10 & 0 & 10 \\
\hline 173-198, lv. 1 & & 2 & & 2 \\
\hline 173-198, lv. 2 & & 4 & 1 & 5 \\
\hline 173-198, lv. 3 & & 2 & & 2 \\
\hline 173-198, lv. 5 & & 1 & & 1 \\
\hline Subtotal & 0 & 9 & 1 & 10 \\
\hline 173-199, lv. 2 & & 4 & & 4 \\
\hline 173-199, lv. 3 & & 2 & & 2 \\
\hline 173-199, lv. 4 & & 1 & & 1 \\
\hline $173-199$, lv. 5 & & 1 & & 1 \\
\hline Subtotal & 0 & 8 & 0 & 8 \\
\hline
\end{tabular}

173-200, lv. 1 
Table 6-17, continued.

\begin{tabular}{|c|c|c|c|c|}
\hline Provenience/Level & Rim & Body & Base & $\mathrm{N}$ \\
\hline 173-200, lv. 2 & & 1 & & 1 \\
\hline $173-200$, lv. 3 & & 4 & 1 & 5 \\
\hline $173-200$, lv. 4 & & 2 & & 2 \\
\hline $173-200$, lv. 5 & & 1 & & 1 \\
\hline Subtotal & 0 & 9 & 1 & 10 \\
\hline 173-201, lv. 1 & & 4 & & 4 \\
\hline 173-201, lv. 3 & & 1 & & 1 \\
\hline 173-201, lv. 4 & & 1 & & 1 \\
\hline $173-201$, lv. 5 & & 1 & & 1 \\
\hline Subtotal & 0 & 7 & 0 & 7 \\
\hline 173-202, lv. 1 & & 1 & & 1 \\
\hline 173-202, lv. 2 & 1 & 3 & & 4 \\
\hline 173-202, lv. 4 & & 1 & & 1 \\
\hline $173-202$, lv. 5 & & 1 & & 1 \\
\hline Subtotal & 1 & 6 & 0 & 7 \\
\hline 174-198, lv. 1 & & 2 & & 2 \\
\hline 174-198, lv. 2 & & 5 & 1 & 6 \\
\hline 174-198, lv. 3 & & 1 & & 1 \\
\hline $174-198$, lv. 5 & & 2 & & 2 \\
\hline Subtotal & 0 & 10 & 1 & 11 \\
\hline 174-199, lv. 1 & & 3 & & 3 \\
\hline 174-199, lv. 2 & & 7 & & 7 \\
\hline $174-199$, lv. 3 & & 4 & 1 & 5 \\
\hline 174-199, lv. 4 & & 2 & 1 & 3 \\
\hline $174-199$, lv. 5 & & 3 & & 3 \\
\hline Subtotal & 0 & 19 & 2 & 21 \\
\hline 174-200, lv. 1 & & 4 & & 4 \\
\hline $174-200$, lv. 3 & & 4 & & 4 \\
\hline 174-200, lv. 4 & & 4 & & 4 \\
\hline $174-200$, lv. 5 & & 2 & & 2 \\
\hline Subtotal & 0 & 14 & 0 & 14 \\
\hline 174-201, lv. 1 & & 1 & & 1 \\
\hline 174-201, lv. 2 & & 6 & & 6 \\
\hline 174-201, lv. 3 & & 4 & 1 & 5 \\
\hline 174-201, lv. 4 & & 6 & & 6 \\
\hline 174-201, lv. 6 & & 1 & & 1 \\
\hline Subtotal & 0 & 18 & 1 & 19 \\
\hline 174-202, lv. 2 & & 1 & & 1 \\
\hline 174-202, lv. 3 & 1 & 4 & 1 & 6 \\
\hline 174-202, lv. 4 & & 1 & & 1 \\
\hline 174-202, lv. 5 & & & 1 & 1 \\
\hline Subtotal & 1 & 6 & 2 & 9 \\
\hline 175-198, lv. 1 & & 3 & & 3 \\
\hline
\end{tabular}


Table 6-17, continued.

\begin{tabular}{|c|c|c|c|c|}
\hline Provenience/Level & Rim & Body & Base & $\mathrm{N}$ \\
\hline 175-198, lv. 2 & & 3 & & 3 \\
\hline 175-198, lv. 3 & & 2 & 2 & 4 \\
\hline 175-198, lv. 4 & 1 & 2 & & 3 \\
\hline 175-198, lv. 5 & 1 & 9 & & 10 \\
\hline Subtotal & 2 & 19 & 2 & 23 \\
\hline 175-199, lv. 1 & & 3 & & 3 \\
\hline 175-199, 1v. 2 & & 5 & 2 & 7 \\
\hline 175-199, lv. 3 & & 7 & & 7 \\
\hline 175-199, lv. 4 & & 4 & & 4 \\
\hline 175-199, lv. 5 & & 3 & & 3 \\
\hline Subtotal & 0 & 22 & 2 & 24 \\
\hline 175-200, lv. 1 & & 3 & & 3 \\
\hline 175-200, lv. 2 & 1 & 8 & & 9 \\
\hline 175-200, lv. 3 & & 6 & & 6 \\
\hline $175-200$, lv. 4 & & 7 & 2 & 9 \\
\hline $175-200$, lv. 5 & & 1 & & 1 \\
\hline Subtotal & 1 & 25 & 2 & 28 \\
\hline 175-201, lv. 1 & & 3 & & 3 \\
\hline 175-201, lv. 2 & & 4 & & 4 \\
\hline 175-201, lv. 3 & & 6 & & 6 \\
\hline 175-201, lv. 4 & & 3 & & 3 \\
\hline 175-201, 1v. 5 & & 1 & & 1 \\
\hline 175-201, lv. 6 & & 2 & & 2 \\
\hline Subtotal & 0 & 19 & 0 & 19 \\
\hline 175-202, lv. 1 & & 1 & & 1 \\
\hline 175-202, lv. 2 & & 3 & & 3 \\
\hline 175-202, 1v. 3 & & 4 & & 4 \\
\hline 175-202, lv. 4 & & 1 & 1 & 2 \\
\hline $175-202$, lv. 5 & & 3 & & 3 \\
\hline Subtotal & 0 & 12 & 1 & 13 \\
\hline 176-198, lv. 1 & & & 2 & 2 \\
\hline 176-198, 1v. 2 & & 1 & & 1 \\
\hline 176-198, lv. 3 & & 5 & & 5 \\
\hline 176-198, lv. 4 & & 2 & & 2 \\
\hline 176-198, 1v. 5 & & 5 & & 5 \\
\hline Subtotal & 0 & 13 & 2 & 15 \\
\hline 176-199, lv. 1 & & 5 & & 5 \\
\hline 176-199, 1v. 2 & & 6 & & 6 \\
\hline 176-199, lv. 4 & & 6 & & 6 \\
\hline Subtotal & 0 & 17 & 0 & 17 \\
\hline 176-200, lv. 1 & & 4 & 1 & 5 \\
\hline $176-200$, lv. 2 & & 1 & & 1 \\
\hline 176-200, 1v. 3 & & 3 & & 3 \\
\hline 176-200, lv. 4 & & 3 & & 3 \\
\hline
\end{tabular}


Table 6-17, continued.

\begin{tabular}{|c|c|c|c|c|}
\hline Provenience/Level & Rim & Body & Base & $\mathrm{N}$ \\
\hline 176-200, lv. 5 & & 3 & 1 & 4 \\
\hline Subtotal & 0 & 14 & 2 & 16 \\
\hline 176-201, lv. 1 & 1 & 3 & & 4 \\
\hline 176-201, lv. 2 & & 6 & 1 & 7 \\
\hline 176-201, lv. 3 & & 4 & & 4 \\
\hline $176-201$, lv. 5 & & 2 & & 2 \\
\hline 176-201, lv. 6 & & 5 & 1 & 6 \\
\hline Subtotal & 1 & 20 & 2 & 23 \\
\hline 176-202, lv. 2 & & 4 & & 4 \\
\hline $176-202$, lv. 3 & & 5 & 1 & 6 \\
\hline 176-202, lv. 4 & & 4 & 1 & 5 \\
\hline $176-202$, lv. 5 & & & 1 & 1 \\
\hline Subtotal & 0 & 13 & 3 & 16 \\
\hline 177-198, lv. 1 & & 2 & 2 & 4 \\
\hline 177-199, lv. 2 & & 7 & 1 & 8 \\
\hline 177-198, lv. 3 & & 3 & & 3 \\
\hline 177-198, lv. 4 & & 4 & & 4 \\
\hline 177-198, lv. 5 & & 2 & & 2 \\
\hline Subtotal & 0 & 18 & 3 & 21 \\
\hline 177-199, lv. 2 & 2 & 1 & & 3 \\
\hline 177-199, lv. 3 & & 4 & & 4 \\
\hline 177-199, lv. 4 & & 4 & & 4 \\
\hline $177-199$, lv. 5 & & 3 & & 3 \\
\hline Subtotal & 2 & 12 & 0 & 14 \\
\hline 177-200, lv. 2 & & 1 & 1 & 2 \\
\hline $177-202$, lv. 3 & & 9 & & 9 \\
\hline 177-202, lv. 4 & & 2 & & 2 \\
\hline Subtotal & 0 & 12 & 1 & 13 \\
\hline 178-198, lv. 1 & & 3 & & 3 \\
\hline 178-198, lv. 3 & & 1 & 1 & 2 \\
\hline 178-198, lv. 4 & & 2 & & 2 \\
\hline 178-198, lv. 5 & & 2 & & 2 \\
\hline Subtotal & 0 & 5 & 1 & 6 \\
\hline 178-199, lv. 1 & & 3 & & 3 \\
\hline 178-199, lv. 2 & & 2 & & 2 \\
\hline 178-199, lv. 3 & & 7 & & 7 \\
\hline 178-199, lv. 4 & & 1 & & 1 \\
\hline $178-199$, lv. 5 & 1 & 4 & & 5 \\
\hline Subtotal & 1 & 17 & 0 & 18 \\
\hline 178-202, lv. 2 & & 1 & & 1 \\
\hline $178-202$, lv. 3 & & 8 & & 8 \\
\hline 178-202, lv. 4 & & 6 & & 6 \\
\hline $178-202$, lv. 5 & & 1 & 1 & 2 \\
\hline
\end{tabular}


Table 6-17, continued.

\begin{tabular}{|c|c|c|c|c|}
\hline Provenience/Level & Rim & Body & Base & $\mathrm{N}$ \\
\hline Subtotal & 0 & 16 & 1 & 17 \\
\hline 179-198, lv. 2 & & 3 & & 3 \\
\hline 179-198, lv. 3 & & 1 & & 1 \\
\hline 179-198, 1v. 4 & & 5 & & 5 \\
\hline 179-198, lv. 5 & & 4 & & 4 \\
\hline Subtotal & 0 & 13 & 0 & 13 \\
\hline 179-199, lv. 1 & & 2 & & 2 \\
\hline 179-199, lv. 2 & 1 & 3 & & 4 \\
\hline 179-199, lv. 3 & & 1 & & 1 \\
\hline 179-199, lv. 4 & & 4 & 1 & 5 \\
\hline Subtotal & 1 & 10 & 1 & 12 \\
\hline 179-202, lv. 2 & & 2 & & 2 \\
\hline 179-202, 1v. 3 & & 5 & & 5 \\
\hline 179-202, lv. 4 & & 4 & & 4 \\
\hline 179-202, lv. 5 & & 2 & & 2 \\
\hline Subtotal & 0 & 13 & 0 & 13 \\
\hline 180-198, lv. 1 & & 3 & & 3 \\
\hline 180-198, lv. 2 & & 3 & 1 & 4 \\
\hline 180-198, lv. 3 & & 5 & & 5 \\
\hline 180-198, lv. 4 & & 3 & & 3 \\
\hline $180-198$, lv. 5 & & 3 & & 3 \\
\hline Subtotal & 0 & 17 & 1 & 18 \\
\hline 180-199, lv. 1 & & 1 & & 1 \\
\hline 180-199, 1v. 2 & & 3 & & 3 \\
\hline 180-199, lv. 3 & & 5 & & 5 \\
\hline $180-199$, lv. 4 & & 3 & & 3 \\
\hline $180-199$, lv. 5 & 1 & 2 & & 3 \\
\hline Subtotal & 1 & 14 & 0 & 15 \\
\hline 180-202, lv. 1 & & 1 & & 1 \\
\hline $180-202$, lv. 3 & & 1 & & 1 \\
\hline 180-202, lv. 4 & & 1 & & 1 \\
\hline $180-202$, lv. 5 & & 2 & & 2 \\
\hline Subtotal & 0 & 5 & 0 & 5 \\
\hline 181-198, 1v. 2 & & 4 & 1 & 5 \\
\hline 181-198, lv. 3 & & 6 & 1 & 7 \\
\hline 181-198, lv. 4 & & 4 & & 4 \\
\hline $181-198$, lv. 5 & & 1 & & 1 \\
\hline Subtotal & 0 & 15 & 2 & 17 \\
\hline 181-199, lv. 2 & & 6 & 1 & 7 \\
\hline 181-199, lv. 3 & & 4 & & 4 \\
\hline 181-199, lv. 4 & & 1 & & 1 \\
\hline 181-199, lv. 5 & 1 & 3 & & 4 \\
\hline Subtotal & 1 & 14 & 1 & 16 \\
\hline
\end{tabular}


Table 6-17, continued.

\begin{tabular}{|c|c|c|c|c|}
\hline Provenience/Level & Rim & Body & Base & $\mathrm{N}$ \\
\hline 181-202, lv. 2 & 1 & 5 & & 6 \\
\hline $181-202,1 v .4$ & & 3 & & 3 \\
\hline $181-202$, lv. 5 & & 5 & 1 & 6 \\
\hline Subtotal & 1 & 13 & 1 & 15 \\
\hline 182-198, lv. 1 & & 2 & & 2 \\
\hline 182-198, lv. 2 & & 4 & & 4 \\
\hline 182-198, lv. 3 & & 2 & & 2 \\
\hline 182-198, lv. 4 & & 1 & & 1 \\
\hline $182-198$, lv. 5 & & 4 & 1 & 5 \\
\hline Subtotal & 0 & 13 & 1 & 14 \\
\hline 182-199, lv. 1 & & 2 & 2 & 4 \\
\hline 182-199, lv. 2 & & 1 & 1 & 2 \\
\hline 182-199, lv. 3 & & 6 & & 6 \\
\hline $182-199$, lv. 4 & & 2 & & 2 \\
\hline Subtotal & 0 & 11 & 3 & 14 \\
\hline 182-200, lv. 1 & & 2 & & 2 \\
\hline $182-200$, lv. 2 & & 1 & & 1 \\
\hline $182-200$, lv. 3 & & 2 & & 2 \\
\hline 182-200, lv. 6 & & 2 & & 2 \\
\hline $182-200$, lv. 7 & & 2 & & 2 \\
\hline Subtotal & 0 & 9 & 0 & 9 \\
\hline 182-201, lv. 1 & & 7 & 1 & 8 \\
\hline 182-201, lv. 2 & & 3 & & 3 \\
\hline 182-201, lv. 3 & & 3 & & 3 \\
\hline 182-201, 1v. 4 & 1 & 4 & & 5 \\
\hline 182-201, lv. 5 & & 1 & & 1 \\
\hline Subtotal & 1 & 18 & 1 & 20 \\
\hline 182-202, lv. 1 & & 2 & 1 & 3 \\
\hline 182-202, lv. 2 & & 2 & & 2 \\
\hline $182-202$, lv. 4 & & 6 & 1 & 7 \\
\hline $182-202$, lv. 5 & & 3 & & 3 \\
\hline Subtotal & 0 & 13 & 2 & 15 \\
\hline 183-198, lv. 1 & & 4 & & 4 \\
\hline 183-198, lv. 2 & & 4 & & 4 \\
\hline $183-198$, lv. 3 & & 5 & & 5 \\
\hline 183-198, lv. 4 & & 3 & 1 & 4 \\
\hline $183-198$, lv. 5 & & 2 & & 2 \\
\hline Subtotal & 0 & 18 & 1 & 19 \\
\hline 183-199, lv. 1 & & 3 & & 3 \\
\hline 183-199, lv. 2 & & 3 & 1 & 4 \\
\hline 183-199, lv. 3 & & 5 & 1 & 6 \\
\hline 183-199, lv. 4 & & 4 & & 4 \\
\hline $183-199$, lv. 5 & & 4 & & 4 \\
\hline
\end{tabular}


Table 6-17, continued.

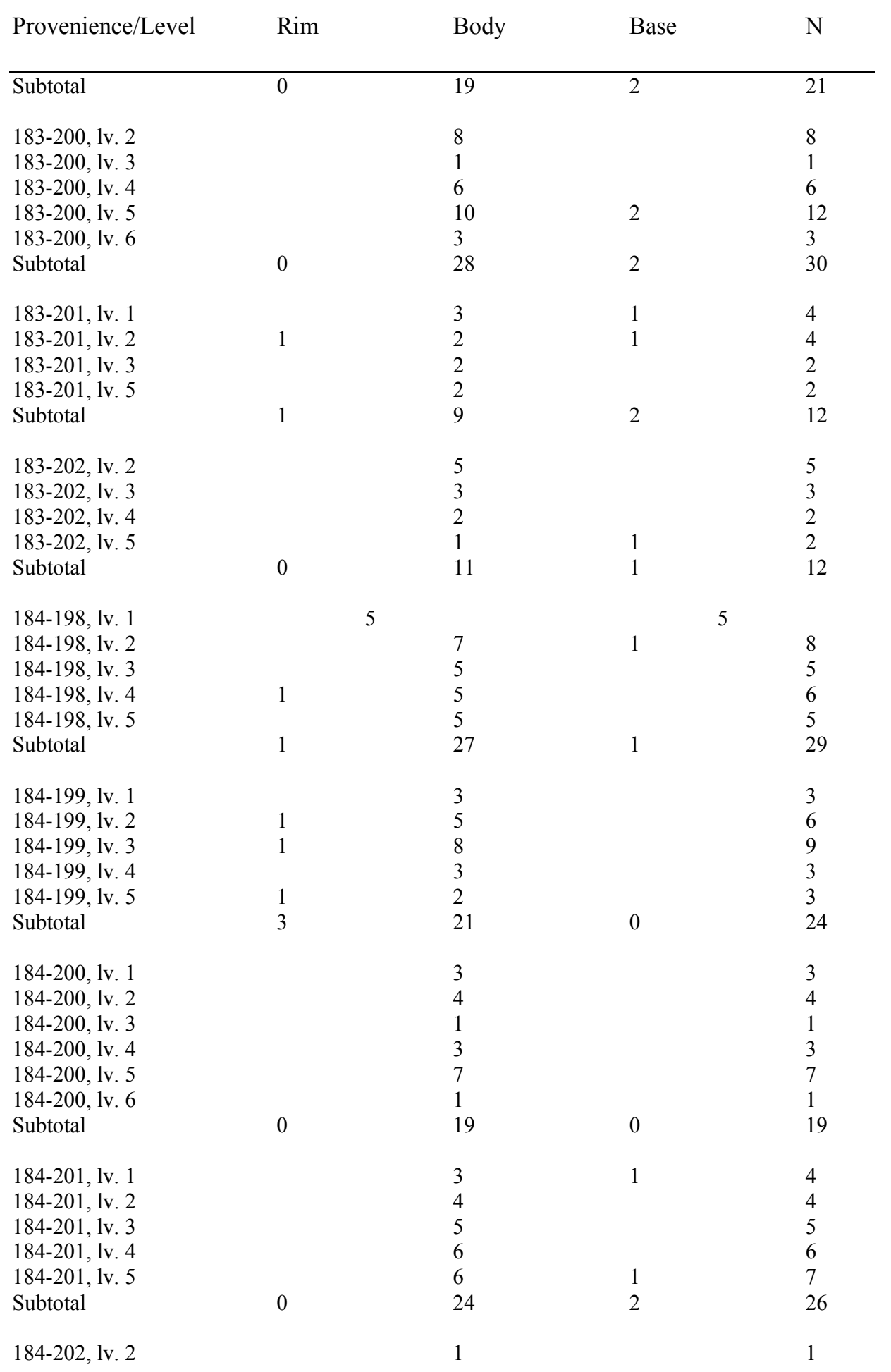

Table 6-17, continued. 


\begin{tabular}{|c|c|c|c|c|}
\hline Provenience/Level & Rim & Body & Base & $\mathrm{N}$ \\
\hline 184-202, lv. 3 & 1 & 3 & & 4 \\
\hline 184-202, lv. 4 & & 2 & 1 & 3 \\
\hline 184-202, lv. 5 & & 1 & & 1 \\
\hline Subtotal & 1 & 7 & 1 & 9 \\
\hline 184-203, lv. 2 & & 2 & & 2 \\
\hline 184-203, lv. 3 & & 4 & & 4 \\
\hline Subtotal & 0 & 6 & 0 & 6 \\
\hline 185-198, lv. 1 & & 1 & & 1 \\
\hline 185-198, lv. 2 & 1 & 5 & 1 & 7 \\
\hline 185-198, lv. 3 & & 5 & 1 & 6 \\
\hline 185-198, lv. 4 & & 4 & & 4 \\
\hline 185-198, lv. 5 & & 5 & & 5 \\
\hline Subtotal & 1 & 20 & 2 & 23 \\
\hline 185-199, lv. 1 & & 1 & & 1 \\
\hline 185-199, lv. 2 & & 2 & & 2 \\
\hline 185-199, lv. 3 & & 3 & & 3 \\
\hline 185-199, lv. 4 & & 2 & & 2 \\
\hline $185-199$, lv. 5 & & 2 & & 2 \\
\hline Subtotal & 0 & 10 & 0 & 10 \\
\hline 185-200, lv. 1 & & 3 & & 3 \\
\hline 185-200, 1v. 2 & & 7 & & 7 \\
\hline $185-200$, lv. 3 & & 2 & & 2 \\
\hline $185-200$, lv. 4 & & 6 & & 6 \\
\hline $185-200$, lv. 5 & & 2 & 1 & 3 \\
\hline $185-200$, lv. 6 & & 1 & & 1 \\
\hline Subtotal & 0 & 21 & 1 & 22 \\
\hline 185-201, lv. 1 & 1 & 3 & & 4 \\
\hline 185-201, lv. 2 & & 5 & & 5 \\
\hline 185-201, lv. 3 & & 4 & & 4 \\
\hline 185-201, lv. 4 & & 5 & & 5 \\
\hline $185-201$, lv. 5 & & 2 & & 2 \\
\hline 185-201, 1v. 6 & & 3 & & 3 \\
\hline Subtotal & 1 & 22 & 0 & 23 \\
\hline 185-202, lv. 2 & & 1 & & 1 \\
\hline $185-202$, lv. 3 & 1 & 4 & & 5 \\
\hline 185-202, lv. 4 & & 6 & 1 & 7 \\
\hline $185-202$, lv. 5 & & 3 & & 3 \\
\hline Subtotal & 1 & 14 & 1 & 16 \\
\hline 186-198, lv. 1 & & 3 & & 3 \\
\hline 186-198, 1v. 2 & & 6 & & 6 \\
\hline 186-198, lv. 3 & 1 & 3 & & 3 \\
\hline 186-198, lv. 4 & & 1 & & 1 \\
\hline Subtotal & 1 & 13 & 0 & 14 \\
\hline
\end{tabular}


Table 6-17, continued.

\begin{tabular}{|c|c|c|c|c|}
\hline Provenience/Level & Rim & Body & Base & $\mathrm{N}$ \\
\hline 186-199, lv. 1 & & 1 & & 1 \\
\hline 186-199, lv. 2 & & 2 & & 2 \\
\hline 186-199, lv. 3 & & 2 & & 2 \\
\hline 186-199, lv. 4 & & 3 & & 3 \\
\hline Subtotal & 0 & 8 & 0 & 8 \\
\hline 186-200, lv. 1 & & 4 & & 4 \\
\hline 186-200, lv. 2 & & 3 & & 3 \\
\hline 186-200, lv. 3 & & 3 & & 3 \\
\hline 186-200, lv. 4 & & 5 & & 5 \\
\hline $186-200$, lv. 5 & & 3 & & 3 \\
\hline 186-200, lv. 6 & & 1 & & 1 \\
\hline Subtotal & 0 & 19 & 0 & 19 \\
\hline 186-201, lv. 1 & & 3 & & 3 \\
\hline 186-201, lv. 2 & & 2 & 2 & 4 \\
\hline 186-201, lv. 3 & & 1 & & 1 \\
\hline 186-201, lv. 4 & & 4 & 1 & 5 \\
\hline 186-201, lv. 5 & & 3 & & 3 \\
\hline $186-201$, lv. 6 & & 4 & & 4 \\
\hline Subtotal & 0 & 17 & 3 & 20 \\
\hline 186-202, lv. 1 & & 2 & & 2 \\
\hline 186-202, lv. 2 & 2 & & & 2 \\
\hline 186-202, lv. 3 & & 1 & & 1 \\
\hline 186-202, lv. 4 & & 1 & 1 & 2 \\
\hline 186-202, lv. 5 & & 2 & & 2 \\
\hline Subtotal & 2 & 6 & 1 & 9 \\
\hline 187-198, lv. 1 & & 3 & & 3 \\
\hline 187-198, lv. 2 & & 4 & & 4 \\
\hline 187-198, lv. 3 & & 5 & & 5 \\
\hline 187-198, lv. 4 & & 4 & & 4 \\
\hline 187-198, lv. 5 & & 2 & & 2 \\
\hline Subtotal & 0 & 18 & 0 & 18 \\
\hline 187-199, lv. 1 & & 2 & 1 & 3 \\
\hline 187-199, lv. 2 & & 3 & & 3 \\
\hline 187-199, lv. 3 & & 4 & & 4 \\
\hline 187-199, lv. 4 & & 1 & 1 & 2 \\
\hline 187-199, lv. 5 & & 2 & & 2 \\
\hline Subtotal & 0 & 12 & 2 & 14 \\
\hline 187-200, lv. 1 & & 5 & 1 & 6 \\
\hline 187-200, lv. 2 & & 4 & & 4 \\
\hline 187-200, lv. 3 & 1 & 2 & & 3 \\
\hline 187-200, lv. 4 & & 4 & & 4 \\
\hline Subtotal & 1 & 15 & 1 & 17 \\
\hline 187-201, lv. 1 & & 4 & & 4 \\
\hline 187-201, lv. 2 & & 3 & & 3 \\
\hline
\end{tabular}


Table 6-17, continued.

\begin{tabular}{|c|c|c|c|c|}
\hline Provenience/Level & Rim & Body & Base & $\mathrm{N}$ \\
\hline$\overline{187-201,1 v .3}$ & & 1 & 1 & 2 \\
\hline 187-201, lv. 4 & & 2 & & 2 \\
\hline $187-201$, lv. 5 & & 1 & & 1 \\
\hline Subtotal & 0 & 11 & 1 & 12 \\
\hline 187-202, lv. 2 & 1 & 3 & & 4 \\
\hline 187-202, lv. 3 & & 6 & & 6 \\
\hline $187-202$, lv. 4 & & 5 & & 5 \\
\hline Subtotal & 1 & 14 & 0 & 15 \\
\hline 188-198, lv. 1 & & 5 & & 5 \\
\hline 188-198, lv. 2 & & 4 & & 4 \\
\hline $188-198$, lv. 3 & & 3 & & 3 \\
\hline $188-198$, lv. 4 & 1 & 1 & & 2 \\
\hline $188-198$, lv. 5 & & 1 & & 1 \\
\hline Subtotal & 1 & 14 & 0 & 15 \\
\hline 188-199, lv. 1 & & 2 & & 2 \\
\hline 188-199, lv. 2 & & 3 & & 3 \\
\hline $188-199$, lv. 3 & 1 & 5 & & 6 \\
\hline 188-199, lv. 4 & 1 & 5 & & 6 \\
\hline $188-199$, lv. 5 & & 4 & & 4 \\
\hline Subtotal & 2 & 19 & 0 & 21 \\
\hline $188-200$, lv. 2 & 1 & 7 & & 8 \\
\hline $188-200$, lv. 3 & & 7 & & 7 \\
\hline $188-200$, lv. 4 & & 4 & & 4 \\
\hline $188-200,1$ v. 5 & & 2 & & 2 \\
\hline Subtotal & 1 & 20 & 0 & 21 \\
\hline 188-201, lv. 1 & & 2 & & 2 \\
\hline $188-201$, lv. 2 & 1 & 4 & & 5 \\
\hline $188-201$, lv. 3 & & 5 & & 5 \\
\hline $188-201$, lv. 4 & & 4 & & 4 \\
\hline $188-201$, lv. 5 & & 4 & 1 & 5 \\
\hline Subtotal & 1 & 19 & 1 & 21 \\
\hline 188-202, lv. 1 & & 2 & 2 & 4 \\
\hline $188-202$, lv. 2 & & 1 & & 1 \\
\hline $188-202$, lv. 3 & & 5 & 1 & 6 \\
\hline $188-202$, lv. 4 & & 2 & & 2 \\
\hline Subtotal & 0 & 10 & 3 & 13 \\
\hline Scrape E & 1 & 1 & & 2 \\
\hline $\begin{array}{l}\text { Subtotal, Southern } \\
\text { Component }\end{array}$ & 39 & 1155 & 88 & 1282 \\
\hline
\end{tabular}


Table 6-17, continued.

\begin{tabular}{|c|c|c|c|c|}
\hline Provenience/Level & Rim & Body & Base & $\mathrm{N}$ \\
\hline & & \multicolumn{3}{|c|}{ NORTHERN COMPONENT } \\
\hline 189-198, lv. 1 & 1 & 2 & & 3 \\
\hline 189-198, lv. 2 & & 1 & & 1 \\
\hline 189-198, lv. 3 & & 7 & & 7 \\
\hline 189-198, lv. 4 & 1 & 1 & & 2 \\
\hline $189-198$, lv. 5 & & 1 & & 1 \\
\hline Subtotal & 2 & 12 & 0 & 14 \\
\hline 189-199, lv. 1 & & 6 & & 6 \\
\hline $189-199$, lv. 2 & 1 & 3 & & 4 \\
\hline $189-199$, lv. 3 & & 3 & & 3 \\
\hline 189-199, lv. 4 & & 1 & & 1 \\
\hline $189-199$, lv. 5 & & 1 & & 1 \\
\hline Subtotal & 1 & 14 & 0 & 15 \\
\hline 189-200, lv. 1 & & 5 & & 5 \\
\hline $189-200$, lv. 2 & 1 & 6 & 1 & 8 \\
\hline $189-200$, lv. 3 & & 1 & & 1 \\
\hline $189-200$, lv. 4 & & 5 & & 5 \\
\hline Subtotal & 1 & 17 & 1 & 19 \\
\hline 189-201, lv. 1 & & 2 & & 2 \\
\hline $189-201$, lv. 2 & & 1 & & 1 \\
\hline 189-201, lv. 3 & & 4 & & 4 \\
\hline $189-201$, lv. 4 & & 3 & 1 & 4 \\
\hline 189-201, lv. 5 & & 1 & & 1 \\
\hline Subtotal & 0 & 11 & 1 & 12 \\
\hline 189-202, lv. 1 & & 1 & & 1 \\
\hline $189-202$, lv. 2 & & 2 & & 2 \\
\hline 189-202, lv. 3 & & 1 & & 1 \\
\hline 189-202, lv. 4 & & 1 & & 1 \\
\hline 189-202, lv. 5 & & 4 & & 4 \\
\hline Subtotal & 0 & 9 & 0 & 9 \\
\hline 190-198, lv. 1 & & 3 & & 3 \\
\hline 190-198, lv. 2 & & 4 & & 4 \\
\hline $190-198$, lv. 3 & & 4 & 1 & 5 \\
\hline 190-198, lv. 4 & & 2 & & 2 \\
\hline $190-198$, lv. 5 & & 3 & & 3 \\
\hline $190-198$, lv. 6 & & 1 & & 1 \\
\hline Subtotal & 0 & 17 & 1 & 18 \\
\hline 190-199, lv. 1 & & 3 & & 3 \\
\hline 190-199, lv. 2 & & 2 & & 2 \\
\hline 190-199, lv. 3 & 1 & 1 & 2 & 4 \\
\hline $190-199$, lv. 4 & & 4 & & 4 \\
\hline 190-199, lv. 5 & & 2 & & 2 \\
\hline Subtotal & 1 & 12 & 2 & 15 \\
\hline
\end{tabular}


Table 6-17, continued.

\begin{tabular}{|c|c|c|c|c|}
\hline Provenience/Level & Rim & Body & Base & $\mathrm{N}$ \\
\hline$\overline{190-200, \text { lv. } 1}$ & & 2 & & 2 \\
\hline 190-200, lv. 2 & 1 & 2 & & 3 \\
\hline $190-200$, lv. 3 & & 4 & 1 & 5 \\
\hline 190-200, lv. 4 & & 3 & 1 & 4 \\
\hline $190-200$, lv. 5 & & 6 & & 6 \\
\hline Subtotal & 1 & 17 & 2 & 20 \\
\hline 190-201, lv. 1 & 1 & 4 & 2 & 7 \\
\hline 190-201, lv. 2 & & 5 & 2 & 7 \\
\hline 190-201, lv. 3 & & 4 & 1 & 5 \\
\hline 190-201, 1v. 4 & & 1 & & 1 \\
\hline 190-201, 1v. 5 & & 5 & & 5 \\
\hline Subtotal & 1 & 19 & 5 & 25 \\
\hline 190-202, lv. 2 & & 2 & & 2 \\
\hline 190-202, lv. 4 & & 2 & 1 & 3 \\
\hline Subtotal & 0 & 4 & 1 & 5 \\
\hline 191-198, lv. 1 & & 5 & & 5 \\
\hline 191-198, lv. 2 & & 4 & & 4 \\
\hline 191-198, lv. 3 & & 5 & & 5 \\
\hline 191-198, lv. 4 & 1 & 4 & 1 & 6 \\
\hline 191-198, lv. 5 & & 4 & & 4 \\
\hline Subtotal & 1 & 22 & 1 & 24 \\
\hline 191-199, lv. 1 & & 1 & & 1 \\
\hline $191-199$, lv. 2 & & 5 & & 5 \\
\hline 191-199, 1v. 3 & & 2 & & 2 \\
\hline 191-199, lv. 4 & & 1 & & 1 \\
\hline Subtotal & 0 & 9 & 0 & 9 \\
\hline 191-202, lv. 1 & & 1 & & 1 \\
\hline 191-202, lv. 2 & & 3 & & 3 \\
\hline 191-202, lv. 3 & & 2 & & 2 \\
\hline 191-202, lv. 4 & & 2 & & 2 \\
\hline Subtotal & 0 & 8 & 0 & 8 \\
\hline 192-198, lv. 1 & & 2 & & 2 \\
\hline 192-198, lv. 2 & & 5 & & 5 \\
\hline 192-198, lv. 3 & & 1 & & 1 \\
\hline 192-198, lv. 4 & & 3 & & 3 \\
\hline Subtotal & 0 & 11 & 0 & 11 \\
\hline 192-199, lv. 1 & & 2 & & 2 \\
\hline 192-199, lv. 2 & & 3 & & 3 \\
\hline 192-199, lv. 4 & & 2 & & 2 \\
\hline Subtotal & 0 & 7 & 0 & 7 \\
\hline 192-202, lv. 1 & & 3 & & 3 \\
\hline 192-202, lv. 2 & 1 & 6 & & 7 \\
\hline 192-202, lv. 3 & & 6 & & 6 \\
\hline
\end{tabular}


Table 6-17, continued.

\begin{tabular}{|c|c|c|c|c|}
\hline Provenience/Level & Rim & Body & Base & $\mathrm{N}$ \\
\hline $192-202$, lv. 4 & & 5 & & 5 \\
\hline 192-202, lv. 5 & & 2 & 1 & 3 \\
\hline Subtotal & 1 & 22 & 1 & 24 \\
\hline 193-198, lv. 1 & & 2 & & 2 \\
\hline 193-198, lv. 2 & & 2 & & 2 \\
\hline 193-198, 1v. 3 & & 6 & & 6 \\
\hline 193-198, lv. 4 & & 5 & & 5 \\
\hline Subtotal & 0 & 15 & 0 & 15 \\
\hline 193-199, lv. 2 & 1 & 3 & & 4 \\
\hline 193-199, lv. 3 & & 7 & & 7 \\
\hline 193-199, 1v. 4 & & 3 & & 3 \\
\hline Subtotal & 1 & 13 & 0 & 14 \\
\hline 193-200, lv. 1 & & 1 & & 1 \\
\hline $193-200$, lv. 2 & & 4 & & 4 \\
\hline 193-200, lv. 3 & & 7 & 1 & 8 \\
\hline 193-200, 1v. 4 & & 6 & 1 & 7 \\
\hline 193-200, lv. 5 & & 4 & & 4 \\
\hline Subtotal & 0 & 22 & 2 & 24 \\
\hline 193-201, lv. 1 & & 3 & & 3 \\
\hline 193-201, lv. 2 & & 2 & & 2 \\
\hline 193-201, lv. 3 & 1 & 5 & 1 & 7 \\
\hline 193-201, lv. 4 & & 4 & & 4 \\
\hline $193-201$, lv. 5 & & 5 & & 5 \\
\hline Subtotal & 1 & 19 & 1 & 21 \\
\hline 193-202, lv. 1 & & 1 & & 1 \\
\hline 193-202, lv. 2 & & 4 & & 4 \\
\hline 193-202, lv. 3 & & 3 & & 3 \\
\hline 193-202, lv. 4 & & 7 & 1 & 8 \\
\hline $193-202$, lv. 5 & 1 & 4 & & 5 \\
\hline 193-202, lv. 6 & & 4 & & 4 \\
\hline Subtotal & 1 & 23 & 1 & 25 \\
\hline 193-203, lv. 2 & & 2 & & 2 \\
\hline 193-203, lv. 3 & & 4 & & 4 \\
\hline 193-203, 1v. 4 & & 9 & & 9 \\
\hline 193-203, lv. 5 & & 5 & & 5 \\
\hline Subtotal & 0 & 20 & 0 & 20 \\
\hline 194-198, lv. 1 & & 4 & & 4 \\
\hline 194-198, lv. 2 & & 3 & & 3 \\
\hline 194-198, lv. 3 & & 4 & & 4 \\
\hline 194-198, lv. 4 & & 2 & & 2 \\
\hline Subtotal & 0 & 13 & 0 & 13 \\
\hline 194-199, lv. 1 & & 4 & 1 & 5 \\
\hline 194-199, lv. 2 & 1 & 6 & 1 & 8 \\
\hline
\end{tabular}


Table 6-17, continued.

\begin{tabular}{|c|c|c|c|c|}
\hline Provenience/Level & Rim & Body & Base & $\mathrm{N}$ \\
\hline 194-199, lv. 3 & & 5 & & 5 \\
\hline 194-199, lv. 4 & & 6 & 2 & 8 \\
\hline Subtotal & 1 & 21 & 4 & 26 \\
\hline 194-200, lv. 1 & & 2 & & 2 \\
\hline 194-200, lv. 2 & & 3 & & 3 \\
\hline 194-200, lv. 3 & 1 & 5 & 3 & 7 \\
\hline 194-200, lv. 4 & 1 & 4 & & 5 \\
\hline Subtotal & 2 & 14 & 3 & 19 \\
\hline 194-201, lv. 1 & & 2 & 1 & 3 \\
\hline 194-201, lv. 2 & & 3 & 1 & 4 \\
\hline 194-201, lv. 3 & & 9 & 1 & 10 \\
\hline 194-201, lv. 4 & & 1 & & 1 \\
\hline Subtotal & 0 & 15 & 3 & 18 \\
\hline 194-202, lv. 1 & 1 & 2 & & 3 \\
\hline 194-202, lv. 2 & & 3 & & 3 \\
\hline 194-202, lv. 3 & & 8 & & 8 \\
\hline 194-202, lv. 4 & & 3 & & 3 \\
\hline 194-202, lv. 5 & & 4 & & 4 \\
\hline $194-202$, lv. 6 & 1 & & & 1 \\
\hline Subtotal & 2 & 20 & 0 & 22 \\
\hline 194-203, lv. 2 & & 1 & 1 & 2 \\
\hline 194-203, lv. 4 & & 7 & 1 & 8 \\
\hline 194-203, lv. 5 & & 1 & & 1 \\
\hline Subtotal & 0 & 9 & 2 & 11 \\
\hline 195-198, lv. 1 & & 6 & & 6 \\
\hline 195-198, lv. 2 & & 8 & 1 & 9 \\
\hline $195-198$, lv. 3 & & 2 & & 2 \\
\hline 195-198, lv. 4 & & 3 & & 3 \\
\hline Subtotal & 0 & 19 & 1 & 20 \\
\hline 195-199, lv. 1 & & 7 & & 7 \\
\hline $195-199$, lv. 2 & & 8 & & 8 \\
\hline 195-199, lv. 3 & 1 & 9 & & 10 \\
\hline $195-199$, lv. 4 & & 4 & 1 & 5 \\
\hline Subtotal & 1 & 28 & 1 & 30 \\
\hline 195-200, lv. 1 & & 3 & & 3 \\
\hline $195-200$, lv. 2 & & 13 & 2 & 15 \\
\hline $195-200,20-25$ & & 6 & & 6 \\
\hline $195-200,21$ & & 1 & & 7 \\
\hline $195-200,25-35$ & & 4 & 1 & 5 \\
\hline $195-200,35-40$ & & 1 & & 1 \\
\hline Subtotal & 0 & 28 & 3 & 31 \\
\hline 195-201, lv. 1 & & 5 & & 5 \\
\hline $195-201$, lv. 2 & & 9 & & 9 \\
\hline
\end{tabular}


Table 6-17, continued.

\begin{tabular}{|c|c|c|c|c|}
\hline Provenience/Level & Rim & Body & Base & $\mathrm{N}$ \\
\hline $195-201,20-25$ & & 6 & & 6 \\
\hline $195-201,25-35$ & & 4 & & 4 \\
\hline Subtotal & 0 & 25 & 0 & 25 \\
\hline 195-202, lv. 1 & & 4 & & 4 \\
\hline 195-202, lv. 2 & 1 & 7 & & 8 \\
\hline 195-202, lv. 3 & & 6 & 3 & 9 \\
\hline 195-202, lv. 4 & & 5 & & 5 \\
\hline 195-202, lv. 5 & & 3 & & 3 \\
\hline Subtotal & 1 & 25 & 3 & 28 \\
\hline 195-203, lv. 2 & & 7 & & 7 \\
\hline 195-203, lv. 3 & 1 & 11 & & 12 \\
\hline 195-203, lv. 4 & & 3 & & 3 \\
\hline Subtotal & 1 & 21 & 0 & 22 \\
\hline 196-198, lv. 1 & 1 & 8 & & 9 \\
\hline 196-198, lv. 2 & & 5 & & 5 \\
\hline 196-198, 1v. 3 & & 8 & & 8 \\
\hline 196-198, lv. 4 & & 6 & & 6 \\
\hline Subtotal & 1 & 27 & 0 & 28 \\
\hline 196-199, lv. 1 & & 5 & & 5 \\
\hline 196-199, lv. 2 & 1 & 4 & & 5 \\
\hline 196-199, lv. 3 & & 3 & & 3 \\
\hline 196-199, lv. 4 & & 5 & & 5 \\
\hline Subtotal & 1 & 17 & 0 & 18 \\
\hline 196-200, lv. 1 & & 10 & 1 & 11 \\
\hline 196-200, 1v. 2 & & 10 & & 10 \\
\hline $196-200,20-25$ & & 3 & & 3 \\
\hline $196-200,25-35$ & & 1 & & 1 \\
\hline $196-200,35-45$ & & 2 & & 2 \\
\hline Subtotal & 0 & 26 & 1 & 27 \\
\hline 196-201, lv. 1 & & 3 & & 3 \\
\hline 196-201, lv. 2 & & 15 & & 15 \\
\hline $196-201,20-25$ & & 2 & & 2 \\
\hline $196-201,25-30$ & & 2 & & 2 \\
\hline $196-201,35-40$ & & 2 & & 2 \\
\hline Subtotal & 0 & 24 & 0 & 24 \\
\hline 196-202, lv. 1 & & 10 & & 10 \\
\hline 196-202, lv. 2 & & 12 & 1 & 13 \\
\hline 196-202, lv. 3 & 2 & 1 & & 3 \\
\hline 196-202, lv. 4 & & 3 & & 3 \\
\hline 196-202, lv. 5 & & 7 & & 7 \\
\hline Subtotal & 2 & 33 & 1 & 36 \\
\hline 196-203, lv. 3 & & 5 & & 5 \\
\hline 196-203, lv. 4 & & 2 & & 2 \\
\hline
\end{tabular}


Table 6-17, continued.

\begin{tabular}{|c|c|c|c|c|}
\hline Provenience/Level & Rim & Body & Base & $\mathrm{N}$ \\
\hline$\overline{\text { Subtotal }}$ & 0 & 7 & 0 & 7 \\
\hline 197-198, 1v. 2 & & 3 & & 3 \\
\hline 197-198, lv. 3 & & 9 & 1 & 10 \\
\hline 197-198, lv. 4 & & 8 & & 8 \\
\hline Subtotal & 0 & 20 & 1 & 21 \\
\hline 197-199, lv. 1 & & 1 & & 1 \\
\hline 197-199, lv. 2 & & 5 & & 5 \\
\hline 197-199, lv. 3 & & 10 & & 10 \\
\hline 197-199, lv. 4 & & 7 & & 7 \\
\hline Subtotal & 0 & 23 & 0 & 23 \\
\hline 197-200, lv. 1 & & 5 & 1 & 6 \\
\hline 197-200, lv. 2 & & 6 & & 6 \\
\hline 197-200, lv. 3 & 1 & 11 & & 12 \\
\hline 197-200, 1v. 4 & & 5 & 1 & 6 \\
\hline Subtotal & 1 & 27 & 2 & 30 \\
\hline 197-201, lv. 1 & & 9 & & 9 \\
\hline 197-201, 1v. 2 & & 6 & 1 & 7 \\
\hline $197-201,20-25$ & & 1 & & 1 \\
\hline $197-201,35-40$ & & 2 & & 2 \\
\hline 197-201, lv. 5 & & 1 & & 1 \\
\hline Subtotal & 0 & 19 & 1 & 20 \\
\hline $197.5-201$, lv. 3 & & 3 & & 3 \\
\hline $197.5-201$, lv. 4 & & 1 & & 1 \\
\hline $197.5-201$, lv. 5 & & 5 & & 5 \\
\hline $197.5-201$, lv. 6 & & 2 & & 2 \\
\hline Subtotal & 0 & 11 & 0 & 11 \\
\hline 197-202, lv. 1 & & 3 & & 3 \\
\hline 197-202, lv. 2 & & 8 & & 8 \\
\hline 197-202, lv. 3 & & 13 & & 13 \\
\hline 197-202, lv. 4 & & 9 & & 9 \\
\hline $197-202$, lv. 5 & & 6 & 1 & 7 \\
\hline 197-202, lv. 6 & & 6 & 2 & 8 \\
\hline Subtotal & 0 & 45 & 3 & 48 \\
\hline 197-203, lv. 2 & & 4 & & 4 \\
\hline 197-203, lv. 3 & & 3 & & 3 \\
\hline 197-203, lv. 4 & & 7 & & 7 \\
\hline Subtotal & 0 & 14 & 0 & 14 \\
\hline 198-198, lv. 1 & & 3 & & 3 \\
\hline 198-198, lv. 2 & & 5 & & 5 \\
\hline 198-198, lv. 3 & & 4 & 1 & 5 \\
\hline 198-198, lv. 4 & & 8 & & 8 \\
\hline $198-198,34$ & & 1 & & 1 \\
\hline Subtotal & 0 & 21 & 1 & 22 \\
\hline
\end{tabular}


Table 6-17, continued.

Provenience/Level

Rim

Body

Base

$\mathrm{N}$

198-199, lv. 1

198-199, lv. 2

198-199, lv. 3

198-199, lv. 4

Subtotal

1

8

1

2

198-200, lv. 1

198-200, lv. 2

198-200, 1v. 3

198-200, lv. 4

Subtotal

198-201, lv. 1

198-201, lv. 2

198-201, lv. 3

198-201, lv. 4

198-201, lv. 5

198-201, lv. 6

Subtotal

1

198-202, lv. 2

198-202, lv. 3

198-202, lv. 4

198-202, 1v. 5 (lot 649)

198-202, lv. 5 (lot 651)

198-202, 1v. 6

198-202, 1v. 7

Subtotal

1

198-203, lv. 2

198-203, lv. 3

198-203, lv. 4

Subtotal

0

$1-20$

199-198, lv. 1 199-198, lv. 2

199-198, lv. 3

$199-198,25 \mathrm{~cm}$

199-198, 1v. 4

Subtotal

1

199-199, lv. 1

199-199, lv. 2

199-199, lv. 3

199-199, 1v. 4

Subtotal

0

199-200, lv. 1

199-200, lv. 2

199-200, 1v. 3

$\begin{array}{ll} & 4 \\ & 7 \\ 1 & 8 \\ 1 & 10 \\ & 30\end{array}$

5

\section{8}

5

$3-11$

$\begin{array}{ll}1 & 7\end{array}$

$4 \quad 25$

126

12

8

8

10

1

145

5

$12-12$

$11-13$

$\begin{array}{lll}5 & 2 & 7\end{array}$

$18-18$

10

61

4

11

2

11

67

129

5

$16-16$

$\begin{array}{lll}29 & 1 & 30\end{array}$

$\begin{array}{llll} & 4 & & 4 \\ & 3 & & 3 \\ & 4 & 4 \\ & 1 & & 1 \\ 1 & 7 & & 8 \\ 1 & 19 & 0 & 20\end{array}$

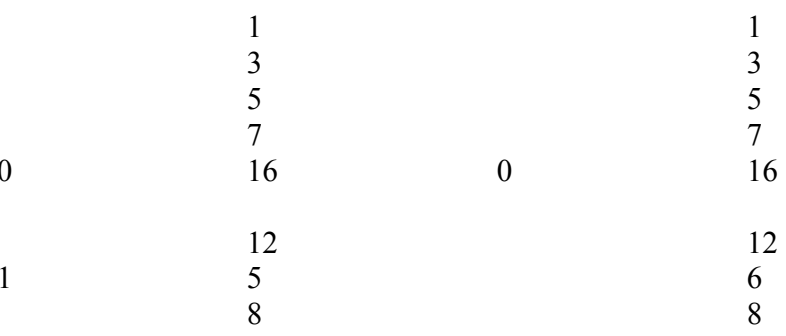


Table 6-17, continued.

\begin{tabular}{|c|c|c|c|c|}
\hline Provenience/Level & Rim & Body & Base & $\mathrm{N}$ \\
\hline 199-200, lv. 4 & & 5 & & 5 \\
\hline Subtotal & 1 & 30 & 0 & 31 \\
\hline 199-201, lv. 1 & 1 & 3 & & 4 \\
\hline 199-201, lv. 2 & & 13 & & 13 \\
\hline 199-201, 1v. 3 & & 5 & 1 & 6 \\
\hline 199-201, 1v. 4 & 1 & 8 & & 9 \\
\hline 199-201, 1v. 5 & & 4 & & 4 \\
\hline $199-201,69 \mathrm{~cm}$ & & 1 & & 1 \\
\hline Subtotal & 2 & 34 & 1 & 37 \\
\hline 199-202, lv. 1 & & 3 & & 3 \\
\hline 199-202, lv. 2 & & 8 & 2 & 10 \\
\hline 199-202, lv. 3 & & 12 & 1 & 13 \\
\hline 199-202, 1v. 4 & 1 & 6 & 1 & 8 \\
\hline 199-202, lv. 5 & & 4 & & 4 \\
\hline 199-202, lv. 7 & & 2 & & 2 \\
\hline Subtotal & 1 & 35 & 4 & 40 \\
\hline 199-203, lv. 2 & & 3 & & 3 \\
\hline 199-203, lv. 3 & & 10 & 1 & 11 \\
\hline 199-203, lv. 4 & & 5 & & 5 \\
\hline Subtotal & 0 & 18 & 1 & 19 \\
\hline 200-198, lv. 1 & & 3 & & 3 \\
\hline 200-198, lv. 2 & & 2 & 1 & 3 \\
\hline 200-198, lv. 3 & & 5 & & 5 \\
\hline 200-198, lv. 4 & & 4 & & 4 \\
\hline Subtotal & 0 & 14 & 1 & 15 \\
\hline 200-199, lv. 1 & 1 & 2 & & 3 \\
\hline $200-199$, lv. 2 & & 4 & & 4 \\
\hline 200-199, lv. 3 & & 2 & & 2 \\
\hline $200-199$, lv. 4 & & 1 & & 1 \\
\hline Subtotal & 1 & 9 & 0 & 10 \\
\hline $200-200$, lv. 1 & & 5 & & 5 \\
\hline $200-200$, lv. 2 & 1 & 2 & & 3 \\
\hline $200-200$, lv. 3 & & 5 & 1 & 6 \\
\hline 200-200, 1v. 4 & & 3 & & 3 \\
\hline Subtotal & 1 & 15 & 1 & 17 \\
\hline 200-201, lv. 1 & & 2 & & 2 \\
\hline $200-201$, lv. 2 & & 9 & & 9 \\
\hline 200-201, lv. 3 & & 9 & & 9 \\
\hline $200-201$, lv. 4 & 1 & 8 & & 9 \\
\hline Subtotal & 1 & 28 & 0 & 29 \\
\hline $200-202$, lv. 1 & & 2 & & 2 \\
\hline 200-202, lv. 2 & & 1 & 1 & 2 \\
\hline $200-202$, lv. 3 & & 7 & 1 & 8 \\
\hline
\end{tabular}


Table 6-17, continued.

\begin{tabular}{|c|c|c|c|c|}
\hline Provenience/Level & Rim & Body & Base & $\mathrm{N}$ \\
\hline $200-202$, lv. 4 & & 3 & & 3 \\
\hline Subtotal & 0 & 13 & 2 & 15 \\
\hline $200-203$, lv. 1 & & 4 & & 4 \\
\hline $200-203$, lv. 2 & 1 & 4 & & 5 \\
\hline $200-203$, lv. 3 & 1 & 3 & 1 & 5 \\
\hline $200-203$, lv. 4 & & & 1 & 1 \\
\hline Subtotal & 2 & 11 & 2 & 15 \\
\hline 201-198, lv. 1 & & 4 & & 4 \\
\hline 201-198, lv. 2 & & 9 & & 9 \\
\hline $201-198$, lv. 3 & & 6 & & 6 \\
\hline $201-198$, lv. 4 & & 2 & & 2 \\
\hline Subtotal & 0 & 21 & 0 & 21 \\
\hline 201-199, lv. 1 & & 2 & 1 & 3 \\
\hline 201-199, 1v. 2 & & 6 & & 6 \\
\hline $201-199$, lv. 3 & & 5 & & 5 \\
\hline $201-199$, lv. 4 & & 7 & & 7 \\
\hline Subtotal & 0 & 20 & 1 & 21 \\
\hline $201-200,1 \mathrm{v} .1$ & & 6 & 2 & 8 \\
\hline $201-200$, lv. 2 & & 3 & 2 & 5 \\
\hline $201-200,1$ v. 3 & 1 & 7 & & 8 \\
\hline $201-200$, lv. 4 & & 4 & & 4 \\
\hline Subtotal & 1 & 20 & 4 & 25 \\
\hline 201-201, lv. 1 & & 4 & & 4 \\
\hline $201-201,1 v .2$ & & 6 & & 6 \\
\hline $201-201$, lv. 3 & & 7 & & 7 \\
\hline Subtotal & 0 & 17 & 0 & 17 \\
\hline 201-202, lv. 1 & & 6 & & 6 \\
\hline $201-202,1 v .2$ & & 5 & 1 & 6 \\
\hline $201-202$, lv. 3 & & 7 & & 7 \\
\hline $201-202,1 \mathrm{v} .4$ & & 3 & 1 & 4 \\
\hline Subtotal & 0 & 21 & 2 & 23 \\
\hline $201-203,1 v .1$ & & 2 & 2 & 4 \\
\hline $201-203$, lv. 2 & & 4 & & 4 \\
\hline $201-203$, lv. 3 & 1 & 3 & & 4 \\
\hline $201-203$, lv. 4 & & 1 & 1 & 2 \\
\hline Subtotal & 1 & 10 & 3 & 14 \\
\hline $202-198$, lv. 1 & & 6 & 1 & 7 \\
\hline $202-198$, lv. 2 & & 4 & & 4 \\
\hline $202-198$, lv. 3 & 1 & 6 & & 7 \\
\hline $202-198$, lv. 4 & & 3 & 1 & 4 \\
\hline Subtotal & 1 & 19 & 2 & 22 \\
\hline
\end{tabular}


Table 6-17, continued.

\begin{tabular}{|c|c|c|c|c|}
\hline Provenience/Level & Rim & Body & Base & $\mathrm{N}$ \\
\hline $202-199$, lv. 1 & & 5 & 1 & 6 \\
\hline 202-199, lv. 2 & & 7 & 2 & 9 \\
\hline 202-199, 1v. 3 & & 2 & 2 & 4 \\
\hline 202-199, lv. 4 & & 3 & & 3 \\
\hline Subtotal & 0 & 17 & 5 & 22 \\
\hline 202-200, lv. 1 & & 2 & 1 & 3 \\
\hline $202-200$, lv. 2 & & 3 & & 3 \\
\hline 202-200, lv. 3 & & 4 & & 4 \\
\hline $202-200$, lv. 4 & 1 & 9 & & 10 \\
\hline Subtotal & 1 & 18 & 1 & 20 \\
\hline 202-201, lv. 1 & & 2 & 1 & 3 \\
\hline 202-201, lv. 2 & 1 & 5 & & 6 \\
\hline 202-201, lv. 3 & & 5 & & 5 \\
\hline Subtotal & 1 & 12 & 1 & 14 \\
\hline 202-202, lv. 1 & & 4 & & 4 \\
\hline 202-202, lv. 2 & & 1 & & 1 \\
\hline $202-202$, lv. 3 & & 1 & & 1 \\
\hline 202-202, lv. 4 & & 5 & & 5 \\
\hline Subtotal & 0 & 11 & 0 & 11 \\
\hline 202-203, lv. 1 & 1 & 1 & & 2 \\
\hline 202-203, lv. 2 & & 4 & & 4 \\
\hline 202-203, lv. 3 & & 4 & & 4 \\
\hline 202-203, lv. 4 & & 1 & & 1 \\
\hline Subtotal & 1 & 10 & 0 & 11 \\
\hline 203-198, lv. 1 & & 5 & & 5 \\
\hline 203-198, 1v. 2 & & 7 & & 7 \\
\hline 203-198, 1v. 3 & & 1 & & 1 \\
\hline 203-198, lv. 4 & & 4 & & 4 \\
\hline Subtotal & 0 & 17 & 0 & 17 \\
\hline 203-199, lv. 2 & & 3 & 1 & 4 \\
\hline 203-199, lv. 3 & & 3 & & 3 \\
\hline $203-199$, lv. 4 & & 2 & & 2 \\
\hline Subtotal & 0 & 8 & 1 & 9 \\
\hline $203-200$, lv. 1 & & 4 & 1 & 5 \\
\hline $203-200$, lv. 2 & & 5 & & 5 \\
\hline $203-200$, lv. 3 & & 3 & & 3 \\
\hline $203-200$, lv. 4 & & 3 & 1 & 4 \\
\hline Subtotal & 0 & 15 & 2 & 17 \\
\hline 203-201, lv. 1 & & 5 & 1 & 6 \\
\hline 203-201, lv. 2 & & 2 & & 2 \\
\hline 203-201, lv. 3 & & 4 & & 4 \\
\hline 203-201, lv. 4 & & 5 & & 5 \\
\hline Subtotal & 0 & 16 & 1 & 17 \\
\hline
\end{tabular}


Table 6-17, continued.

\begin{tabular}{|c|c|c|c|c|}
\hline Provenience/Level & $\operatorname{Rim}$ & Body & Base & $\mathrm{N}$ \\
\hline 203-202, lv. 1 & & 2 & & 2 \\
\hline $203-202$, lv. 2 & & 3 & & 3 \\
\hline $203-202$, lv. 3 & & 1 & & 1 \\
\hline $203-202$, lv. 4 & 1 & 4 & 1 & 6 \\
\hline Subtotal & 1 & 10 & 1 & 12 \\
\hline $203-203$, lv. 2 & & 3 & 1 & 4 \\
\hline 203-203, lv. 3 & & 3 & & 3 \\
\hline $203-203$, lv. 4 & & 1 & & 1 \\
\hline Subtotal & 0 & 7 & 1 & 8 \\
\hline 204-198, lv. 1 & 1 & 5 & & 6 \\
\hline $204-198$, lv. 2 & & 1 & & 1 \\
\hline $204-198$, lv. 3 & & & 1 & 1 \\
\hline $204-198$, lv. 4 & & 3 & & 3 \\
\hline Subtotal & 1 & 9 & 1 & 11 \\
\hline 204-199, lv. 1 & & 3 & & 3 \\
\hline $204-199$, lv. 2 & & 1 & & 1 \\
\hline $204-199$, lv. 3 & & 4 & 1 & 5 \\
\hline 204-199, lv. 4 & & 2 & 1 & 3 \\
\hline Subtotal & 0 & 10 & 2 & 12 \\
\hline $204-200$, lv. 1 & & 2 & & 2 \\
\hline $204-200$, lv. 2 & 1 & 1 & & 2 \\
\hline $204-200$, lv. 3 & 1 & 4 & & 5 \\
\hline $204-200$, lv. 4 & & 2 & & 2 \\
\hline Subtotal & 2 & 9 & 0 & 11 \\
\hline $204-201$, lv. 3 & & 1 & & 1 \\
\hline 204-201, lv. 4 & & 1 & 1 & 2 \\
\hline Subtotal & 0 & 2 & 1 & 3 \\
\hline 204-202, lv. 1 & & 1 & & 1 \\
\hline $204-202$, lv. 2 & & 4 & & 4 \\
\hline $204-202$, lv. 4 & & 3 & & 3 \\
\hline Subtotal & 0 & 8 & 0 & 8 \\
\hline 205-198, lv. 1 & & 5 & & 5 \\
\hline $205-198$, lv. 2 & & 2 & & 2 \\
\hline $205-198$, lv. 3 & & 2 & & 2 \\
\hline $205-198$, lv. 4 & & 2 & & 2 \\
\hline Subtotal & 0 & 11 & 0 & 11 \\
\hline 205-199, lv. 1 & & 3 & & 3 \\
\hline 205-199, lv. 2 & & 3 & & 3 \\
\hline $205-199$, lv. 3 & 1 & 8 & 2 & 11 \\
\hline $205-199$, lv. 4 & & 3 & 1 & 4 \\
\hline Subtotal & 1 & 17 & 3 & 21 \\
\hline
\end{tabular}


Table 6-17, continued.

\begin{tabular}{|c|c|c|c|c|}
\hline Provenience/Level & Rim & Body & Base & $\mathrm{N}$ \\
\hline $205-200$, lv. 1 & & 2 & & 2 \\
\hline 205-200, lv. 2 & & & 1 & 1 \\
\hline $205-200$, lv. 3 & & 4 & & 4 \\
\hline $205-200$, lv. 4 & & 4 & & 4 \\
\hline Subtotal & 0 & 10 & 1 & 11 \\
\hline 206-198, lv. 1 & & 3 & & 3 \\
\hline 206-198, lv. 2 & & 5 & & 5 \\
\hline 206-198, lv. 3 & & 6 & & 6 \\
\hline Subtotal & 0 & 14 & 0 & 14 \\
\hline 206-199, lv. 1 & & & 1 & 1 \\
\hline $206-199$, lv. 2 & 1 & 5 & & 6 \\
\hline 206-199, lv. 3 & & 3 & & 3 \\
\hline Subtotal & 1 & 8 & 1 & 10 \\
\hline 206-200, lv. 1 & & 1 & & 1 \\
\hline $206-200$, lv. 2 & 1 & 3 & & 4 \\
\hline $206-200$, lv. 3 & 1 & & & 1 \\
\hline $206-200$, lv. 4 & & 1 & & 1 \\
\hline Subtotal & 2 & 5 & 0 & 7 \\
\hline 207-198, lv. 1 & 1 & 2 & & 3 \\
\hline $207-198$, lv. 2 & & 6 & & 6 \\
\hline 207-198, lv. 3 & & 2 & & 2 \\
\hline $207-198$, lv. 4 & & 2 & & 2 \\
\hline Subtotal & 1 & 12 & 0 & 13 \\
\hline 207-199, lv. 2 & & 1 & & 1 \\
\hline $207-199$, lv. 3 & & & 1 & 1 \\
\hline $207-199$, lv. 4 & & 2 & 1 & 3 \\
\hline Subtotal & 0 & 3 & 2 & 5 \\
\hline $207-200$, lv. 1 & & 4 & & 4 \\
\hline $207-200$, lv. 2 & & 2 & & 2 \\
\hline $207-200$, lv. 3 & & 2 & & 2 \\
\hline $207-200$, lv. 4 & & 1 & & 1 \\
\hline Subtotal & 0 & 9 & 0 & 9 \\
\hline 207-203, lv. 1 & & 1 & 1 & 2 \\
\hline 207-203, lv. 2 & & 2 & & 2 \\
\hline Subtotal & 0 & 3 & 1 & 4 \\
\hline 208-198, lv. 4 & & 2 & & 2 \\
\hline 208-199, lv. 1 & & 4 & 1 & 5 \\
\hline $208-199$, lv. 2 & & 1 & & 1 \\
\hline $208-199$, lv. 3 & & 1 & & 1 \\
\hline Subtotal & 0 & 6 & 1 & 7 \\
\hline
\end{tabular}


Table 6-17, continued.

\begin{tabular}{|c|c|c|c|c|}
\hline Provenience/Level & Rim & Body & Base & $\mathrm{N}$ \\
\hline 208-200, lv. 2 & & 2 & & 2 \\
\hline $208-200$, lv. 3 & & 1 & & 1 \\
\hline Subtotal & 0 & 3 & 0 & 3 \\
\hline 208-203, lv. 1 & & 2 & & 2 \\
\hline $208-203$, lv. 2 & & 1 & & 1 \\
\hline Subtotal & 0 & 3 & 0 & 3 \\
\hline 209-198, lv. 1 & & 1 & & 1 \\
\hline $209-198$, lv. 2 & & 4 & & 4 \\
\hline Subtotal & 0 & 5 & 0 & 5 \\
\hline 209-200, lv. 1 & & 1 & & 1 \\
\hline 209-200, lv. 2 & & & 1 & 1 \\
\hline Subtotal & 0 & 1 & 1 & 2 \\
\hline 209-203, lv. 1 & & 2 & & 2 \\
\hline 214-202, Scrape F & & 1 & 1 & \\
\hline Scrape F & & 1 & 1 & 2 \\
\hline $\begin{array}{l}\text { Subtotal, Northern } \\
\text { Component Area }\end{array}$ & 56 & 1719 & 113 & 1888 \\
\hline $\begin{array}{l}\text { Subtotal, non-Feature } \\
\text { North/South Areas }\end{array}$ & 95 & 2874 & 201 & 3170 \\
\hline
\end{tabular}

\section{FEATURES}

Provenience/Level

Rim $\quad$ Body $\quad$ Base

176-199, F.13, 35-79

1

175-199, F.14

1

1

2

3

177-199, F.22, 40-54

183-199, F.26, 30-38

186-198, F.41, 40-44

Subtotal, Features

Southern Component/Area
2

$\begin{array}{llll}1 & & 1 \\ 1 & & 1 \\ 8 & 1 & 1\end{array}$


Table 6-17, continued.

\begin{tabular}{|c|c|c|c|c|}
\hline Provenience/Level & Rim & Body & Base & $\mathrm{N}$ \\
\hline & & $\mathrm{RN} \mathrm{COl}$ & FEATURES & \\
\hline 194-202, F.20, 34-36 & & 2 & 1 & 3 \\
\hline 197.5-201, F.25, 20-30 & 1 & 5 & & 6 \\
\hline 197.5-201, F.25, 30-38 & & 1 & & 1 \\
\hline $197.5-201$, F. $25,30-40$ & & 2 & & 2 \\
\hline $197-202$, F. $25,40-50$ & & 1 & & 1 \\
\hline Subtotal, F.25 & 1 & 9 & 0 & 10 \\
\hline 195-200, F.36, 25 & & 1 & & 1 \\
\hline $195-200$, F. $36,25-35$ & & 10 & & 10 \\
\hline 195-201, F.36, 20-25 & & 2 & & 2 \\
\hline 195-201, F.36, 21 & & 1 & & 1 \\
\hline 195-201, F.36, 22 & & 1 & & 1 \\
\hline 195-201, F.36, 24 & 1 & 6 & & 7 \\
\hline $195-201$, F.36, 25-35 & & 2 & & 2 \\
\hline Subtotal, F.36 & 1 & 23 & 0 & 24 \\
\hline 191-198, F.37, 50-60 & & 1 & & 1 \\
\hline 191-199, F.37, 30-40 & & 2 & & 2 \\
\hline Subtotal, F. 37 & 0 & 3 & 0 & 3 \\
\hline 196-201, F.39, 40-51 & & 1 & & 1 \\
\hline 196-200, F.46, 40-50 & & 1 & & 1 \\
\hline 195-199, F.50, 46-50 & & 1 & & 1 \\
\hline 193-200, F.54, 50-60 & & 1 & & 1 \\
\hline 194-201, F.57, 40-70 & & 1 & & 1 \\
\hline 194-195-200, F.60, 40-52 & & & 2 & 2 \\
\hline 193-198, F.66, 60-120 & 1 & 19 & 1 & 21 \\
\hline 195-199, F.69, 40-57 & & 1 & & 1 \\
\hline 197.5-201, F.74, 50-74 & & 2 & & 2 \\
\hline 197-202, F.76, 30-60 & & 5 & & 5 \\
\hline 197-202, F.76, 70-80 & & & 1 & 1 \\
\hline $197-202$, F.76, 90-100 & & 1 & 2 & 3 \\
\hline 197-202, F.76, 100-110 & & 3 & & 3 \\
\hline $197-202$, F.76, $110-120$ & & 1 & & 1 \\
\hline $197-202$, F.76, $140-150$ & & 2 & 1 & 3 \\
\hline 197-202, F.76, Unknown & & 1 & 1 & 2 \\
\hline Subtotal & 0 & 13 & 5 & 18 \\
\hline
\end{tabular}


Table 6-17, continued.

\begin{tabular}{|c|c|c|c|c|}
\hline Provenience/Level & Rim & Body & Base & $\mathrm{N}$ \\
\hline $197-203$, F.76, 40-50 & & 2 & & 2 \\
\hline 197-203, F.76, 50-60 & & 2 & & 2 \\
\hline 197-203, F.76, 90-100 & 2 & & & 2 \\
\hline 197-203, F.76, 100-110 & & 2 & & 2 \\
\hline 197-203, F.76, 110-120 & 3 & 24 & 2 & 29 \\
\hline $197-203$, F.76, $120-130$ & & 3 & & 3 \\
\hline Subtotal & 5 & 33 & 2 & 40 \\
\hline 198-202, F.76, 40-60 & 1 & & & 1 \\
\hline $198-202$, F.76, 50-60 & & 9 & 1 & 10 \\
\hline $198-202$, F.76, 60-70 & & 3 & & 3 \\
\hline 198-202, F.76, 70-80 & 1 & 10 & & 11 \\
\hline 198-202, F.76, 73 & & & 1 & 1 \\
\hline 198-202, F.76, 80-90 & & 13 & & 13 \\
\hline $198-202$, F.76, 90-100 & 2 & 17 & 2 & 21 \\
\hline 198-202, F.76, 100-110 & 4 & 33 & 1 & 38 \\
\hline $198-202$, F.76, 110-120 & 4 & 58 & 1 & 63 \\
\hline $198-202$, F.76, 120-130 & & 26 & 1 & 27 \\
\hline Subtotal & 12 & 169 & 7 & 188 \\
\hline 198-203, F.76, 40-50 & & 6 & & 6 \\
\hline 198-203, F.76, 50-60 & & 11 & 1 & 12 \\
\hline $198-203$, F.76, 60-70 & & 4 & 1 & 5 \\
\hline 198-203, F.76, 90-100 & 1 & 3 & & 4 \\
\hline $198-203$, F.76, 100-110 & 1 & 16 & & 17 \\
\hline 198-203, F.76, 120-130 & & 6 & & 6 \\
\hline 198-203, F.76, 130-140 & 1 & 2 & & 3 \\
\hline Subtotal & 3 & 48 & 2 & 53 \\
\hline 197/198-202, F.76, 70-80 & & 2 & & 2 \\
\hline 197/198-202, F.76, 80-90 & & 1 & & 1 \\
\hline Subtotal & 0 & 3 & 0 & 3 \\
\hline 199-202, F.76, 40-50 & 1 & 9 & 1 & 11 \\
\hline $199-202$, F.76, 50-60 & & 2 & & 2 \\
\hline 199-202, F.76, 60-70 & & 3 & & 3 \\
\hline $199-202$, F.76, 70-80 & 1 & 7 & & 8 \\
\hline 199-202, F.76, 80-90 & & 4 & & 4 \\
\hline 199-202, F.76, 90-100 & 2 & 17 & & 19 \\
\hline $199-202$, F.76, 95-100 & 1 & 2 & 1 & 4 \\
\hline 199-202, F.76, 100-110 & & 3 & 1 & 4 \\
\hline Subtotal & 5 & 47 & 3 & 55 \\
\hline 199-203, F.76, 40-50 & 1 & 1 & & 2 \\
\hline $199-203$, F.76, 60-70 & & 3 & & 3 \\
\hline Subtotal & 1 & 4 & 0 & 5 \\
\hline 197-203, F.76A, 40-50 & 1 & 5 & & 6 \\
\hline $197-203$, F.76A, 50-60 & & 2 & 1 & 3 \\
\hline 197-203, F.76A, 90-100 & & 2 & & 2 \\
\hline 197-203, F.76A, 100-110 & & 1 & 1 & 2 \\
\hline
\end{tabular}


Table 6-17, continued.

\begin{tabular}{|c|c|c|c|c|}
\hline Provenience/Level & Rim & Body & Base & $\mathrm{N}$ \\
\hline 197-203, F.76A, 110-120 & & 3 & & 3 \\
\hline 197-203, F. 76A, 120-130 & & 1 & & 1 \\
\hline 197-203, F.76A, 130-140 & & 4 & 1 & 5 \\
\hline 197-203, F.76A, 140-145 & & 4 & 1 & 5 \\
\hline $197-203$, F.76A, lot $1646 \mathrm{~F}$ & & 2 & & 2 \\
\hline Subtotal & 1 & 22 & 4 & 27 \\
\hline 198-203, F.76A, 60-70 & & 2 & 1 & 3 \\
\hline 198-203, F.76A, 110-120 & 2 & 17 & 2 & 21 \\
\hline Subtotal & 2 & 19 & 3 & 24 \\
\hline 197-203, F.76B, 70-85 & 2 & 4 & & 6 \\
\hline $199-200$, F.76B, $75-90$ & 1 & 20 & 1 & 22 \\
\hline 199-200, F.76B, 90-100 & 1 & 9 & 1 & 11 \\
\hline Subtotal & 4 & 33 & 2 & 39 \\
\hline $198-198$, F.79, 40-50 & 1 & 9 & & 10 \\
\hline $198-198$, F.79, 50-60 & & 1 & 1 & 2 \\
\hline $198-198$, F.79, 60-70 & 2 & 5 & & 7 \\
\hline $198-198$, F.79, $70-80$ & 1 & 4 & 1 & 6 \\
\hline $198-198$, F.79, 80-90 & 1 & 10 & 1 & 12 \\
\hline Subtotal & 5 & 29 & 3 & 37 \\
\hline $198-199$, F.79, 40-50 & 1 & 9 & & 10 \\
\hline $198-199$, F.79, 50-60 & & 12 & 2 & 14 \\
\hline 198-199, F.79, 60-70 & 1 & 7 & & 8 \\
\hline $198-199$, F.79, $70-80$ & & 19 & 1 & 20 \\
\hline $198-199$, F.79, 80-90 & & 4 & & 4 \\
\hline Subtotal & 2 & 51 & 3 & 56 \\
\hline 199-199, F.79, 40-50 & & 1 & & 1 \\
\hline 197/198-200, F.81, 40-80 & & 1 & & 1 \\
\hline 197-199, F.82, 40-80 & & 1 & & 1 \\
\hline 197-198, F.84, 40-70 & & 3 & & 3 \\
\hline $197-198$, F.84, N1/2 & & 1 & & 1 \\
\hline Subtotal & 0 & 4 & 0 & 4 \\
\hline $207-200$, F.85, 40-50 & & 1 & & 1 \\
\hline 215-204, F. 88 & 1 & & & 1 \\
\hline 194-201, F.89, 40-63 & & 1 & & 1 \\
\hline 203-200, F.90, 40-53 & & 2 & & 2 \\
\hline $\begin{array}{l}\text { Subtotal, Features, } \\
\text { Northern Component/Area }\end{array}$ & 44 & 546 & 38 & 628 \\
\hline Subtotal, all Features & 46 & 554 & 39 & 639 \\
\hline$\overline{\text { Grand Total }}$ & 141 & 3428 & 240 & 3809 \\
\hline
\end{tabular}




\section{APPENDIX H \\ ANALYSIS OF HUMAN REMAINS, TABLES FOR CHAPTER 10}

Prepared for:

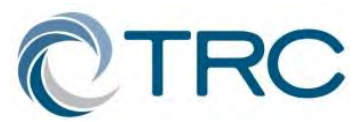

TRC Environmental Corporation

505 East Huntland Drive, Suite 250

Austin, Texas 78752

Prepared by:

Diane Wilson 

Table 10-1. Inventory from the Lang Pasture Site, Burial Features with Skeletal Remains.

\begin{tabular}{|c|c|c|c|c|c|c|c|c|}
\hline Feature No. & 8 & $76 B$ & $76 \mathrm{C}$ & 76D & 88 & 92 & 93 Burial 1 & 93 Burial 2 \\
\hline Frontal & 3 & & & & & $\begin{array}{l}\text { L } 3 \\
\text { R 2 }\end{array}$ & U 3 & U 3 \\
\hline Parietal & U 3 & & U 3 & & L 3 & $\begin{array}{l}\text { L } 2 \\
\text { R } 1\end{array}$ & $\begin{array}{l}\text { L } 3 \\
\text { R } 3\end{array}$ & $\begin{array}{l}\text { L 3 } \\
\text { U 3 } \\
\text { R 3 }\end{array}$ \\
\hline Occipital & 3 & 3 & & & 3 & 2 & 3 & 3 \\
\hline Temporal & $\begin{array}{l}\text { L 3 } \\
\text { R 3 }\end{array}$ & $\begin{array}{l}\text { L } 3 \\
\text { R3 }\end{array}$ & L 3 & & U 3 & $\begin{array}{l}\text { L } 3 \\
\text { R } 2\end{array}$ & $\begin{array}{l}\text { L 3 } \\
\text { R 3 }\end{array}$ & $\begin{array}{l}\text { L 3 } \\
\text { R 3 }\end{array}$ \\
\hline \multicolumn{9}{|l|}{ TMJ } \\
\hline Sphenoid & & & & U 3 & & & & \\
\hline Zygomatic & & & & & & & L 3 & L 3 \\
\hline Maxilla & & & & & & 3 & & \\
\hline \multicolumn{9}{|l|}{ Palatine } \\
\hline Mandible & U3 & & & & & U 3 & $\begin{array}{l}\text { U } 3 \\
\text { R } 2\end{array}$ & U 3 \\
\hline Clavicle & L3 & & & & & & & \\
\hline \multicolumn{9}{|l|}{ Scapula } \\
\hline \multicolumn{9}{|l|}{ Glenoid } \\
\hline \multicolumn{9}{|l|}{ Manubrium } \\
\hline \multicolumn{9}{|l|}{$\begin{array}{l}\text { Sternum } \\
\text { Body }\end{array}$} \\
\hline \multicolumn{9}{|l|}{ C1 } \\
\hline \multicolumn{9}{|l|}{$\mathrm{C2}$} \\
\hline \multicolumn{9}{|l|}{ C3-C6 } \\
\hline \multicolumn{9}{|l|}{ C7 } \\
\hline \multicolumn{9}{|l|}{ T1-T9 } \\
\hline \multicolumn{9}{|l|}{ T10 } \\
\hline \multicolumn{9}{|l|}{ T11 } \\
\hline \multicolumn{9}{|l|}{ T12 } \\
\hline \multicolumn{9}{|l|}{$\mathbf{L 1}$} \\
\hline \multicolumn{9}{|l|}{$\mathbf{L 2}$} \\
\hline \multicolumn{9}{|l|}{$\mathbf{L 3}$} \\
\hline \multicolumn{9}{|l|}{ L4 } \\
\hline \multicolumn{9}{|l|}{$\mathbf{L 5}$} \\
\hline \multicolumn{9}{|l|}{ Sacrum } \\
\hline \multicolumn{9}{|l|}{ Rib 1} \\
\hline \multicolumn{9}{|l|}{ Rib 2} \\
\hline Rib 3-10 & & 3 & & & & & & \\
\hline \multicolumn{9}{|l|}{ Rib 11} \\
\hline \multicolumn{9}{|l|}{ Rib 12} \\
\hline Ilium & & & & & & & & \\
\hline
\end{tabular}


Table 10-1, continued.

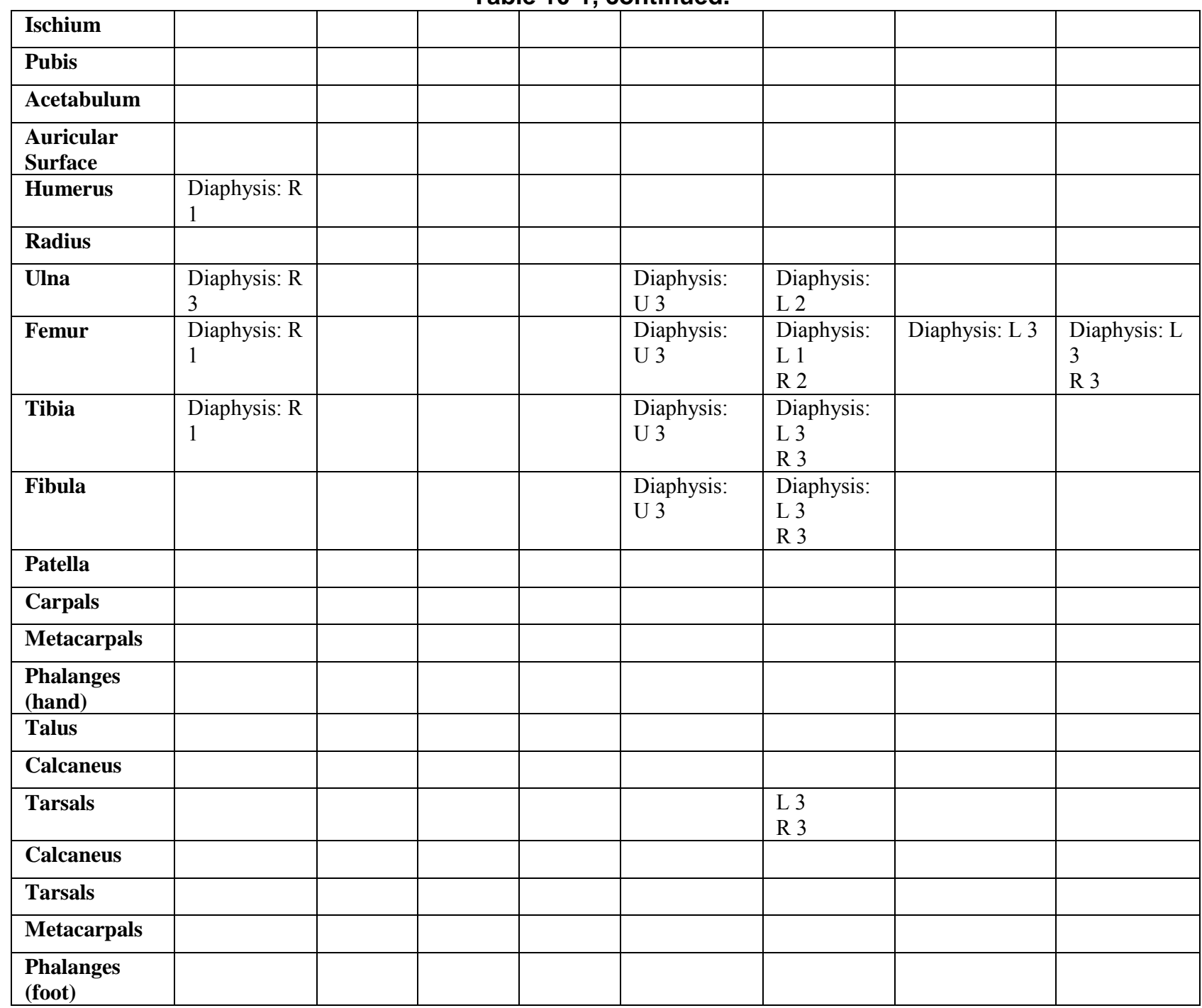

Note: Inventory data follows Buikstra and Ubelacker (1994) with a score of 1 being 75 percent to 100 percent complete, 2 being 25 percent to 75 percent complete and 3 being less than 25 percent complete. Blank spaces indicate a skeletal element was absent. $\quad \mathrm{U}$ indicates unsided element, $\mathrm{L}$ is a left element and $\mathrm{R}$ is a right sided skeletal element. Long bones are scored for proximal and distal epiphyses and diaphyses. 
Table 10-2. Inventory from Area Scrapings from the Lang Pasture Site.

\begin{tabular}{|c|c|c|c|c|c|c|c|c|}
\hline Bone & Side & Segment & Completeness & MNI & Count & Age & Sex & Comment \\
\hline \multicolumn{9}{|c|}{ Area 1} \\
\hline Temporal & $\mathrm{U}$ & petrous & 3 & 1 & 1 & Indet & Indet & $\begin{array}{l}\text { Bag was } \\
\text { labeled } R \text {, but } \\
\text { could not } \\
\text { confirm in lab. }\end{array}$ \\
\hline \multicolumn{9}{|c|}{ Area 2} \\
\hline $\begin{array}{l}\text { Maxillary } \\
\text { P1 }\end{array}$ & $\mathrm{L}$ & crown & 1 & 1 & 2 & $12-35$ & Indet & Root absent \\
\hline $\begin{array}{c}\text { Maxillary } \\
\text { C }\end{array}$ & $\mathrm{L}$ & crown & 1 & 1 & 1 & $12-35$ & Indet & Root absent \\
\hline \multicolumn{9}{|c|}{ Area 3} \\
\hline Ilium & $\mathrm{U}$ & - & 3 & 1 & 1 & Indet & Indet & $\begin{array}{l}\text { Approximately } \\
4 \mathrm{~cm} \text { diameter } \\
\text { mostly } \\
\text { cancellous } \\
\text { fragment }\end{array}$ \\
\hline Tibia & $\mathrm{U}$ & $\begin{array}{c}\text { Diaphysis, } \\
\text { midshaft }\end{array}$ & 3 & 1 & 2 & Indet & Indet & $\begin{array}{l}\text { One fragment } \\
\text { sun bleached }\end{array}$ \\
\hline
\end{tabular}

Notes: Sides are indicated as L for left, R for right and U for unsided. Inventory data follows Buikstra and Ubelacker (1994) with a score of 1 being 75 percent to 100 percent complete, 2 being 25 percent to 75 percent complete and 3 being less than 25 percent complete. MNI is the minimum number of individuals represented by that skeletal element. Indet is indeterminant. Note, also, that Features 91 and 94 are not included in this table due to lack of bone preservation in those features (with the exception of one tooth in Feature 91). 
Table 10-3. Skeletal Inventory from Selected Caddo Sites from Anderson and Cherokee Counties Housed at the Texas Archeological Research Laboratory (TARL).

\begin{tabular}{|c|c|c|c|c|c|c|c|c|c|}
\hline \multicolumn{10}{|c|}{ Anderson County } \\
\hline \multirow[b]{2}{*}{ Fea. No. } & \multirow{2}{*}{$\begin{array}{l}\text { 41AN14 } \\
\text { AG-1 } \\
\end{array}$} & \multirow{2}{*}{$\begin{array}{l}\text { 41AN21 } \\
\text { G-1 }\end{array}$} & \multicolumn{2}{|c|}{ 41AN32 } & \multirow{2}{*}{$\begin{array}{l}\text { 41AN34 } \\
\text { D-2 }\end{array}$} & \multicolumn{3}{|c|}{ 41AN54 } & \multirow{2}{*}{$\begin{array}{l}\text { 41AN56 } \\
97\end{array}$} \\
\hline & & & None & None & & AE-2 & AE-2b & B-1* & \\
\hline Frontal & & U 2 & $\mathrm{U} 1$ & $\mathrm{U} 2$ & & L 2 & & $\mathrm{~L} 2$ & L 2 \\
\hline Parietal & & $\begin{array}{l}\text { L } 2 \\
\text { R } 3\end{array}$ & $\begin{array}{l}\text { L } 1 \\
\text { R } 1\end{array}$ & $\begin{array}{l}\text { L } 2 \\
\text { R } 1\end{array}$ & U 3 & $\begin{array}{l}\text { L } 2 \\
\text { R } 3\end{array}$ & & $\begin{array}{l}\text { L } 3 \\
\text { R 3 }\end{array}$ & U 3 \\
\hline Occipital & & 3 & 2 & 2 & 3 & 3 & & 3 & \\
\hline Temporal & & L 3 & $\begin{array}{l}\text { L } 2 \\
\text { R 3 }\end{array}$ & $\begin{array}{l}\mathrm{L} 1 \\
\mathrm{R} 2 \\
\end{array}$ & L 2 & & R 3 & $\begin{array}{l}\mathrm{L} 2 \\
\mathrm{R} 2\end{array}$ & L 2 \\
\hline TMJ & & L 3 & R 2 & $\begin{array}{l}\text { L } 1 \\
\text { R } 1\end{array}$ & L 2 & & R 1 & $\begin{array}{l}\text { L } 1 \\
\text { R } 2 \\
\end{array}$ & \\
\hline Sphenoid & & & U 3 & & U 3 & & & & U 3 \\
\hline Zygomatic & & & R 3 & & & & & & \\
\hline Maxilla & & & & $\mathrm{U} 1$ & & & & & \\
\hline \multicolumn{10}{|l|}{ Palatine } \\
\hline Mandible & R 3 & $\mathrm{U} 1$ & & $\mathrm{U} 2$ & & & & $\mathrm{U} 2$ & \\
\hline \multicolumn{10}{|l|}{ Condyle } \\
\hline \multicolumn{10}{|l|}{ Clavicle } \\
\hline \multicolumn{10}{|l|}{ Scapula } \\
\hline \multicolumn{10}{|l|}{ Glenoid } \\
\hline \multicolumn{10}{|l|}{ Manubrium } \\
\hline \multicolumn{10}{|l|}{$\begin{array}{l}\text { Sternum } \\
\text { Body }\end{array}$} \\
\hline \multicolumn{10}{|l|}{$\mathrm{C} 1$} \\
\hline \multicolumn{10}{|l|}{$\mathrm{C} 2$} \\
\hline C3-C6 & & & 1 & & & & & & \\
\hline \multicolumn{10}{|l|}{$\mathrm{C} 7$} \\
\hline \multicolumn{10}{|l|}{ T1-T9 } \\
\hline \multicolumn{10}{|l|}{ T10 } \\
\hline \multicolumn{10}{|l|}{ T11 } \\
\hline \multicolumn{10}{|l|}{ T12 } \\
\hline \multicolumn{10}{|l|}{ L1 } \\
\hline \multicolumn{10}{|l|}{ L2 } \\
\hline \multicolumn{10}{|l|}{ L3 } \\
\hline L4 & & & & & & & & & \\
\hline$\overline{L 5}$ & & & & & & & & & \\
\hline Sacrum & & & & & & & & & \\
\hline Rib 1 & & & & & & & & & \\
\hline Rib 2 & & & & & & & & & \\
\hline Rib 3-10 & & & & & & & & & \\
\hline Rib 11 & & & & & & & & & \\
\hline Rib 12 & & & & & & & & & \\
\hline
\end{tabular}


Table 10-3, continued.

\begin{tabular}{|c|c|c|c|c|c|c|c|c|c|}
\hline & 41AN14 & 41AN21 & 41AN & & 41AN34 & 41AN & & & 41AN56 \\
\hline Fea. No. & AG-1 & G-1 & None & None & D-2 & AE-2 & AE-2b & B-1* & 97 \\
\hline Ilium & & $\begin{array}{l}\text { L } 3 \\
\text { R } 3\end{array}$ & & & & & & & \\
\hline Ischium & & R 2 & & & & & & & \\
\hline Pubis & & & & & & & & & \\
\hline Acetabulum & & $\begin{array}{l}\text { L } 3 \\
\text { R } 2\end{array}$ & & & & & & U 3 & \\
\hline $\begin{array}{l}\text { Auricular } \\
\text { Surface }\end{array}$ & & $\begin{array}{l}\text { L } 1 \\
\text { R } 1\end{array}$ & & & & & & & \\
\hline Humerus & & $\begin{array}{l}\text { Diaph.: } \\
\text { L 1 } \\
\text { R 1 }\end{array}$ & & & & & & & \\
\hline Radius & & $\begin{array}{l}\text { Diaph.: } \\
\text { L 2 } \\
\text { R } 2\end{array}$ & & & & & & & \\
\hline Ulna & & $\begin{array}{l}\text { P e: R } 2 \\
\text { Diaph.: } \\
\text { L 1 } \\
\text { R 1 }\end{array}$ & & & & & & & \\
\hline Femur & & $\begin{array}{l}\text { P e: } \\
\text { L } 2 \\
\text { R 2 } \\
\text { Diaph.: } \\
\text { L 1 } \\
\text { R 1 } \\
\text { D e: } \\
\text { L 2 } \\
\text { R 1 }\end{array}$ & & & & & & & \\
\hline Tibia & & $\begin{array}{l}\text { P e: } \\
\text { L } 2 \\
\text { R 1 } \\
\text { Diaph.: } \\
\text { L 1 } \\
\text { R 1 } \\
\text { D e: } \\
\text { L2 } \\
\text { R 2 }\end{array}$ & & & & & & & \\
\hline Fibula & & $\begin{array}{l}\text { Diaph.: } \\
\text { L 1 } \\
\text { R 1 } \\
\text { D e: } \\
\text { L 1 } \\
\text { R 2 }\end{array}$ & & & & & & & \\
\hline Patella & & R 1 & & & & & & & \\
\hline Carpals & & & & & & & & & \\
\hline Metacarpals & & & & & & & & & \\
\hline $\begin{array}{l}\text { Phalanges } \\
\text { (hand) }\end{array}$ & & & & & & & & & \\
\hline Talus & & $\begin{array}{l}\text { L 3 } \\
\text { R 2 }\end{array}$ & & & & & & & \\
\hline Calcaneus & & $\begin{array}{l}\text { L 3 } \\
\text { R 2 }\end{array}$ & & & & & & & \\
\hline
\end{tabular}


Table 10-3, continued.

\begin{tabular}{|c|c|c|c|c|c|c|c|c|c|}
\hline & 41AN14 & 41AN21 & 41AN & & 41AN34 & 41AN & & & 41AN56 \\
\hline Fea. No. & AG-1 & G-1 & None & None & D-2 & AE-2 & AE-2b & B-1* & 97 \\
\hline Calcaneus & & $\begin{array}{l}\text { L 3 } \\
\text { R 2 }\end{array}$ & & & & & & & \\
\hline Tarsals & & $\begin{array}{l}\text { L } 1 \\
\text { R } 1 \\
\end{array}$ & & & & & & & \\
\hline Calcaneus & & & & & & & & & \\
\hline Tarsals & & & & & & & & & \\
\hline Metatarsals & & $\begin{array}{l}\text { U } 3 \\
\text { R } 3\end{array}$ & & & & & & & \\
\hline $\begin{array}{l}\text { Phalanges } \\
\text { (foot) }\end{array}$ & & & & & & & & & \\
\hline Cherokee & unty & & & & & & & & \\
\hline & 41CE3 & 41CE4 & & & & & 41CEC & & 41CE12 \\
\hline $\begin{array}{l}\text { Feature } \\
\text { No. }\end{array}$ & $\begin{array}{l}\text { AK1, 2, } \\
3,4 *\end{array}$ & AI-1 & AI-2 & AI-3 & AI-4 & AI-5 & AN-1 & AN-2 & AH-1* \\
\hline Frontal & $\begin{array}{l}\text { U } 3 \\
\text { R } 2\end{array}$ & R 3 & $\begin{array}{l}\text { U } 3 \\
\text { R 3 }\end{array}$ & U 3 & U 3 & U 3 & U 1 & U 3 & U 3 \\
\hline Parietal & U 3 & $\begin{array}{l}\text { L } 3 \\
\text { U } 3\end{array}$ & $\begin{array}{l}\text { L } 2 \\
\text { R } 2\end{array}$ & U 3 & U 3 & U 3 & $\begin{array}{l}\mathrm{L} 1 \\
\mathrm{R} 2\end{array}$ & $\begin{array}{l}\text { L } 2 \\
\text { R } 2\end{array}$ & $\begin{array}{l}\mathrm{L} 2 \\
\mathrm{U} 3 \\
\mathrm{R} 2\end{array}$ \\
\hline Occipital & 3 & 3 & 2 & 3 & 3 & & & 3 & 3 \\
\hline Temporal & $\begin{array}{l}\mathrm{L} 1 \\
\mathrm{R} 2\end{array}$ & L 3 & $\begin{array}{l}\text { L } 2 \\
\text { R } 2\end{array}$ & $\begin{array}{l}\text { L } 3 \\
\text { R } 2\end{array}$ & $\begin{array}{l}\text { L } 3 \\
\text { R } 3\end{array}$ & $\begin{array}{l}\text { L } 3 \\
\text { R } 3\end{array}$ & $\begin{array}{l}\text { L } 2 \\
\text { U } 3\end{array}$ & $\begin{array}{l}\text { L } 2 \\
\text { R } 2\end{array}$ & $\begin{array}{l}\text { L } 1 \\
\text { U 3 } \\
\text { R } 2\end{array}$ \\
\hline TMJ & & $\begin{array}{l}\text { L } 3 \\
\text { R } 3 \\
\end{array}$ & L 1 & $\begin{array}{l}\mathrm{L} 2 \\
\mathrm{R} 1 \\
\end{array}$ & & $\begin{array}{l}\text { L } 2 \\
\text { R } 1 \\
\end{array}$ & L 3 & R 1 & L 1 \\
\hline Sphenoid & U 3 & & & & & & & & U 2 \\
\hline Zygomatic & & & & & & & L 2 & & \\
\hline Maxilla & $\begin{array}{l}\text { L } 2 \\
\text { U 3 } \\
\text { R 3 }\end{array}$ & & $\begin{array}{l}\text { L } 1 \\
\text { R } 1\end{array}$ & U 3 & & & $\begin{array}{l}\text { L } 1 \\
\text { R } 1\end{array}$ & $\begin{array}{l}\text { L } 1 \\
\text { R } 1\end{array}$ & \\
\hline Palatine & & & & & & & & L 3 & \\
\hline Mandible & $\begin{array}{l}\text { L } 3 \\
\text { R } 2\end{array}$ & & $\begin{array}{l}\text { L } 1 \\
\text { R } 1 \\
\end{array}$ & U 3 & U 3 & U 3 & & $\begin{array}{ll}\text { L } & 1 \\
\text { R } & 1 \\
\end{array}$ & \\
\hline Clavicle & L 2 & U 3 & & & & & & & \\
\hline Scapula & & & & & & & & L 3 & \\
\hline Glenoid & & & & & & & & L 2 & \\
\hline Manubrium & & & & & & & & & \\
\hline $\begin{array}{l}\text { Sternum } \\
\text { Body }\end{array}$ & & & & & & & & & \\
\hline $\mathrm{C} 1$ & 2 & & & 3 & & & & & \\
\hline $\mathrm{C} 2$ & 1 & & 1 & 3 & & & & 2 & \\
\hline C3-C6 & & & 3 & & & & & & \\
\hline C7 & & & & & & & & & \\
\hline T1-T9 & & & & 3 & & & & 3 & \\
\hline T10 & & & & & & & & & \\
\hline
\end{tabular}


Table 10-3, continued.

\begin{tabular}{|c|c|c|c|c|c|c|c|c|c|}
\hline & 41CE3 & 41CE4 & & & & & 41CE6 & & 41CE12 \\
\hline $\begin{array}{l}\text { Feature } \\
\text { No. }\end{array}$ & $\begin{array}{l}\text { AK1, 2, } \\
3,4^{*}\end{array}$ & AI-1 & AI-2 & AI-3 & AI-4 & AI-5 & AN-1 & AN-2 & AH-1* \\
\hline T11 & & & & & & & & 3 & \\
\hline T12 & & & & & & & & 3 & \\
\hline L1 & & & & & & & & 2 & \\
\hline L2 & & & & & & & & 2 & \\
\hline L3 & & & & & & & & 2 & \\
\hline L4 & & & & & & & & 2 & \\
\hline L5 & & & & & & & & 1 & \\
\hline Sacrum & 3 & & 3 & & & & & 3 & \\
\hline Rib 1 & & & & & & & & & \\
\hline Rib 2 & & & & & & & & 3 & \\
\hline Rib 3-10 & & & & & & & & & \\
\hline Rib 11 & & & & & & & & & \\
\hline Rib 12 & & & & & & & & & \\
\hline Ilium & U 3 & & & & & & & U 3 & \\
\hline Ischium & & & L 3 & & & & & & \\
\hline Pubis & & & & & & & & & \\
\hline Acetabulum & & & & & & U 3 & & $\begin{array}{l}\text { L } 3 \\
\text { R } 2\end{array}$ & \\
\hline $\begin{array}{l}\text { Auricular } \\
\text { Surface }\end{array}$ & & & & & & & & L 2 & \\
\hline Humerus & $\begin{array}{l}\mathrm{L} 1 \\
\mathrm{U} 3 \\
\mathrm{R} 2\end{array}$ & & & L 3 & & & $\begin{array}{l}\text { P e: } \\
\text { R } 3 \\
\text { Diaph.: } \\
\text { R 1 } \\
\text { D e: } \\
\text { R } 2\end{array}$ & $\begin{array}{l}\text { P e: } \\
\text { L } 2 \\
\text { Diaph.: } \\
\text { L 1 }\end{array}$ & L 3 \\
\hline Radius & & & & & & & $\begin{array}{l}\text { P e: } \\
\text { R } 3 \\
\text { Diaph.: } \\
\text { R } 2\end{array}$ & & \\
\hline Ulna & & & & U 2 & & & & & \\
\hline Femur & $\begin{array}{l}\text { L } 1 \\
\text { U 3 } \\
\text { R 2 }\end{array}$ & $\begin{array}{l}\text { P e: } \\
\text { L } 3 \\
\text { Diaph.: } \\
\text { L } 2\end{array}$ & $\begin{array}{l}\text { P e: } \\
\text { U } 3 \\
\text { Diaph.: } \\
\text { R } 2\end{array}$ & & & $\begin{array}{l}\text { P e: } \\
\text { U } 3 \\
\text { Diaph.: } \\
\text { U } 3\end{array}$ & & $\begin{array}{l}\text { P e: } \\
\text { L } 2 \\
\text { R } 3 \\
\text { Diaph.: } \\
\text { L 1 } \\
\text { R } 2 \\
\text { D e: } \\
\text { L } 3 \\
\text { R } 2\end{array}$ & $\mathrm{U} 2$ \\
\hline
\end{tabular}


Table 10-3, continued.

\begin{tabular}{|c|c|c|c|c|c|c|c|c|c|}
\hline \multirow{2}{*}{$\begin{array}{l} \\
\text { Feature } \\
\text { No. }\end{array}$} & \multirow{2}{*}{$\begin{array}{l}41 C E 3 \\
\text { AK1, } 2, \\
3,4 * \\
\end{array}$} & \multicolumn{5}{|l|}{ 41CE4 } & \multicolumn{2}{|c|}{ 41CE6 } & \multirow{2}{*}{$\begin{array}{l}\text { 41CE12 } \\
\text { AH-1* }\end{array}$} \\
\hline & & AI-1 & AI-2 & AI-3 & AI-4 & AI-5 & AN-1 & AN-2 & \\
\hline Tibia & $\begin{array}{l}\text { L 2 } \\
\text { U 2 } \\
\text { R } 2\end{array}$ & $\begin{array}{l}\text { Diaph.: } \\
\text { L 2 } \\
\text { R } 3\end{array}$ & & & & & $\begin{array}{l}\text { Diaph.: } \\
\text { L 1 } \\
\text { R } 2 \\
\text { D e: } \\
\text { L 1 } \\
\text { R 1 }\end{array}$ & $\begin{array}{l}\text { Diaph.: } \\
\text { L 1 } \\
\text { R } 2 \\
\text { D e: } \\
\text { U } 2\end{array}$ & \\
\hline Fibula & & & & & & & $\begin{array}{l}\text { Diaph.: } \\
\text { L 1 } \\
\text { R 1 } \\
\text { D e: } \\
\text { L 1 } \\
\text { R } 2\end{array}$ & & \\
\hline \multicolumn{10}{|l|}{ Patella } \\
\hline Carpals & & & & & & & & L 3 & \\
\hline Metacarpals & & & & & & & & L 3 & \\
\hline $\begin{array}{l}\text { Phalanges } \\
\text { (hand) }\end{array}$ & & & & & & & & U 3 & \\
\hline Talus & & & & & & & $\begin{array}{l}\text { L } 1 \\
\text { R } 2 \\
\end{array}$ & $\begin{array}{l}\text { L } 2 \\
\text { R } 2 \\
\end{array}$ & \\
\hline Calcaneus & & & & & & & $\begin{array}{l}\text { L } 1 \\
\text { R } 3 \\
\end{array}$ & $\begin{array}{l}\mathrm{L} 2 \\
\mathrm{R} 3 \\
\end{array}$ & \\
\hline Tarsals & & & & & & & $\begin{array}{l}\text { L } 2 \\
\text { R 3 }\end{array}$ & U 3 & \\
\hline Metatarsals & & & & & & & U 3 & U 3 & \\
\hline $\begin{array}{l}\text { Phalanges } \\
\text { (foot) }\end{array}$ & & & & & & & U 3 & U 3 & \\
\hline & \multicolumn{9}{|c|}{ 41CE12, continued } \\
\hline $\begin{array}{l}\text { Feature } \\
\text { No. }\end{array}$ & AH-2 & AH-3 & AH-5 & AH-6 & AH-7 & AH-8 & AH-9 & AH-10 & AH-11 \\
\hline Frontal & & U 3 & U 3 & & U 3 & & U 3 & U 2 & $\begin{array}{l}\text { L } 1 \\
\text { R } 3 \\
\end{array}$ \\
\hline Parietal & U 3 & $\begin{array}{l}\text { L } 1 \\
\text { R } 2\end{array}$ & $\begin{array}{l}\text { L } 2 \\
\text { R } 2\end{array}$ & $\begin{array}{l}\text { L } 3 \\
\text { R 3 }\end{array}$ & $\begin{array}{l}\text { L } 2 \\
\text { R } 3\end{array}$ & U3 & $\begin{array}{l}\text { U 3 } \\
\text { R 3 }\end{array}$ & $\begin{array}{l}\text { L } 2 \\
\text { R } 2\end{array}$ & $\begin{array}{l}\text { L } 2 \\
\text { R } 2\end{array}$ \\
\hline Occipital & 3 & 2 & 2 & 2 & 2 & 3 & 3 & 2 & 3 \\
\hline Temporal & U 3 & $\begin{array}{l}\mathrm{L} 2 \\
\mathrm{R} 2\end{array}$ & $\begin{array}{l}\text { L } 2 \\
\text { R } 2\end{array}$ & R 2 & $\begin{array}{l}\text { L } 3 \\
\text { R } 2\end{array}$ & U3 & & $\begin{array}{l}\text { L } 3 \\
\text { R 3 }\end{array}$ & \\
\hline TMJ & & $\begin{array}{l}\text { L } 1 \\
\text { R } 1\end{array}$ & $\begin{array}{l}\text { L } 3 \\
\text { R } 1\end{array}$ & R 2 & R 2 & R 2 & & $\begin{array}{l}\text { L } 2 \\
\text { R } 2\end{array}$ & \\
\hline Sphenoid & & $\mathrm{U} 3$ & & & U 3 & & & $\begin{array}{l}\mathrm{L} 2 \\
\mathrm{R} 2 \\
\end{array}$ & \\
\hline Zygomatic & & $\begin{array}{l}\mathrm{L} 2 \\
\mathrm{R} 1\end{array}$ & & & $\mathrm{R} 2$ & & & & L 1 \\
\hline Maxilla & & $\begin{array}{l}\text { L } 3 \\
\text { R } 2 \\
\end{array}$ & & & R 3 & & & $\begin{array}{l}\mathrm{L} 1 \\
\mathrm{R} 2 \\
\end{array}$ & $\begin{array}{l}\mathrm{L} 1 \\
\mathrm{R} 2 \\
\end{array}$ \\
\hline Palatine & & & & & & & & & \\
\hline Mandible & $\begin{array}{l}\text { U } 3 \\
\text { R 3 }\end{array}$ & U 1 & & & R 3 & U 3 & & $\begin{array}{l}\text { L } 2 \\
\text { R } 1\end{array}$ & $\begin{array}{l}\text { L } 1 \\
\text { R } 3\end{array}$ \\
\hline
\end{tabular}


Table 10-3, continued.

\begin{tabular}{|c|c|c|c|c|c|c|c|c|c|}
\hline \multirow{2}{*}{\begin{tabular}{|l|} 
\\
Feature \\
No.
\end{tabular}} & \multicolumn{9}{|c|}{ 41CE12, continued } \\
\hline & AH-2 & AH-3 & AH-5 & AH-6 & AH-7 & AH-8 & AH-9 & AH-10 & AH-11 \\
\hline Clavicle & & R 1 & & & $\begin{array}{l}\text { L } 2 \\
\text { R } 2 \\
\end{array}$ & & & & L 3 \\
\hline Scapula & & U 3 & & & $\begin{array}{l}\text { L } 3 \\
\text { R 3 }\end{array}$ & & R 3 & L 3 & \\
\hline Glenoid & & & & & $\begin{array}{l}\mathrm{L} 2 \\
\mathrm{R} 2\end{array}$ & & & & $\begin{array}{l}\text { L } 2 \\
\text { R } 3\end{array}$ \\
\hline Manubrium & & & & & 3 & & & & \\
\hline \multicolumn{10}{|l|}{$\begin{array}{l}\text { Sternum } \\
\text { Body }\end{array}$} \\
\hline $\mathrm{C} 1$ & & 2 & & & 3 & & & & \\
\hline $\mathrm{C} 2$ & & 1 & & & 3 & & & & \\
\hline C3-C6 & & 3 & 3 & & & & & & 1 \\
\hline $\mathrm{C} 7$ & & 2 & & & & & & & \\
\hline T1-T9 & & 3 & 3 & & 3 & & & & 3 \\
\hline \multicolumn{10}{|l|}{ T10 } \\
\hline \multicolumn{10}{|l|}{ T11 } \\
\hline \multicolumn{10}{|l|}{ T12 } \\
\hline L1 & & & & & 1 & & & & \\
\hline $\mathrm{L} 2$ & & & & & 1 & & & 3 & \\
\hline L3 & & & & & 1 & & & 3 & \\
\hline L4 & & & & & 2 & & & 3 & \\
\hline L5 & & & & & 1 & & & 3 & 3 \\
\hline Sacrum & & & & & 3 & & 3 & 3 & \\
\hline Rib 1 & & R 3 & & & L 3 & & & & \\
\hline Rib 2 & & & & & L 3 & & & & \\
\hline Rib 3-10 & & 3 & & & 3 & & & & \\
\hline \multicolumn{10}{|l|}{ Rib 11} \\
\hline \multicolumn{10}{|l|}{ Rib 12} \\
\hline Ilium & & U 3 & R 3 & & $\begin{array}{l}\text { L } 2 \\
\text { R } 2\end{array}$ & & & $\begin{array}{l}\text { L } 3 \\
\text { R 3 }\end{array}$ & $\begin{array}{ll}\text { L } 1 \\
\text { R } 1\end{array}$ \\
\hline Ischium & & & & & $\begin{array}{l}\text { L } 3 \\
\text { R 3 }\end{array}$ & & U 3 & L 3 & R 3 \\
\hline \multicolumn{10}{|l|}{ Pubis } \\
\hline Acetabulum & & & & & $\begin{array}{l}\text { L } 3 \\
\text { R } 3\end{array}$ & & & $\begin{array}{l}\mathrm{L} 2 \\
\mathrm{R} 2\end{array}$ & $\begin{array}{l}\mathrm{L} 2 \\
\mathrm{R} 2\end{array}$ \\
\hline $\begin{array}{l}\text { Auricular } \\
\text { Surface }\end{array}$ & & & & & $\begin{array}{l}\text { L } 1 \\
\text { R } 1 \\
\end{array}$ & & & & \\
\hline
\end{tabular}


Table 10-3, continued.

\begin{tabular}{|c|c|c|c|c|c|c|c|c|c|}
\hline & \multicolumn{9}{|c|}{ 41CE12, continued } \\
\hline $\begin{array}{l}\text { Feature } \\
\text { No. }\end{array}$ & AH-2 & AH-3 & AH-5 & AH-6 & AH-7 & AH-8 & AH-9 & AH-10 & AH-11 \\
\hline Humerus & & $\begin{array}{l}\text { Diaph.: } \\
\text { R 1 } \\
\text { D e: } \\
\text { L 3 }\end{array}$ & & & $\begin{array}{l}\text { P e: } \\
\text { L } 2 \\
\text { R 2 } \\
\text { Diaph.: } \\
\text { L 1 } \\
\text { R 1 } \\
\text { D e: } \\
\text { L 2 } \\
\text { R 2 }\end{array}$ & & & $\begin{array}{l}\text { Diaph.: } \\
\text { R 1 } \\
\text { D e: } \\
\text { R 1 }\end{array}$ & $\begin{array}{l}\text { Diaph.: } \\
\text { U } 3 \\
\text { D e: } \\
\text { R } 2\end{array}$ \\
\hline Radius & & $\begin{array}{l}\text { Diaph.: } \\
\text { R 1 }\end{array}$ & & & & & & & $\begin{array}{l}\text { Diaph.: } \\
\text { R 1 }\end{array}$ \\
\hline Ulna & & $\begin{array}{l}\text { P e: } \\
\text { R 3 } \\
\text { Diaph.: } \\
\text { U } 3\end{array}$ & & & $\begin{array}{l}\text { P e: } \\
\text { R 2 } \\
\text { Diaph.: } \\
\text { R 2 }\end{array}$ & & $\begin{array}{l}\text { Diaph.: } \\
\text { U } 3\end{array}$ & $\begin{array}{l}\text { P e: } \\
\text { R 3 } \\
\text { Diaph.: } \\
\text { R 3 }\end{array}$ & $\begin{array}{l}\text { Diaph.: } \\
\text { L 1 }\end{array}$ \\
\hline Femur & $\begin{array}{l}\text { Diaph.: } \\
\text { U } 1\end{array}$ & $\begin{array}{l}\text { Diaph.: } \\
\text { L2 } \\
\text { R 1 }\end{array}$ & $\begin{array}{l}\text { Diaph.: } \\
\text { L 1 }\end{array}$ & $\begin{array}{l}\text { Diaph.: } \\
\text { R } 3\end{array}$ & $\begin{array}{l}\text { P e: } \\
\text { L } 1 \\
\text { R 2 } \\
\text { Diaph.: } \\
\text { L 1 } \\
\text { R 1 } \\
\text { D e: } \\
\text { L 2 } \\
\text { R 2 }\end{array}$ & & $\begin{array}{l}\text { P e: } \\
\text { L } 2 \\
\text { R } 2 \\
\text { Diaph.: } \\
\text { L } 2 \\
\text { R } 2\end{array}$ & $\begin{array}{l}\text { P e: } \\
\text { L } 3 \\
\text { R 3 } \\
\text { Diaph.: } \\
\text { L 1 } \\
\text { R 2 } \\
\text { D e: } \\
\text { L 3 } \\
\text { R 3 }\end{array}$ & $\begin{array}{l}\text { P e: } \\
\text { L 1 } \\
\text { R 1 } \\
\text { Diaph.: } \\
\text { L 1 } \\
\text { R 1 } \\
\text { D e: } \\
\text { L 2 } \\
\text { R 2 }\end{array}$ \\
\hline Tibia & & $\begin{array}{l}\text { Diaph.: } \\
\text { R 2 }\end{array}$ & & & $\begin{array}{l}\text { P e: } \\
\text { L 2 } \\
\text { R 2 } \\
\text { Diaph.: } \\
\text { L 1 } \\
\text { R 2 } \\
\text { D e: } \\
\text { R 2 }\end{array}$ & & $\begin{array}{l}\text { P e: } \\
\text { L 2 } \\
\text { Diaph.: } \\
\text { L 1 } \\
\text { R 1 } \\
\text { D e: } \\
\text { L 2 } \\
\text { R } 2\end{array}$ & $\begin{array}{l}\text { Diaph.: } \\
\text { L } 2 \\
\text { R } 1 \\
\text { D e: } \\
\text { L } 2\end{array}$ & $\begin{array}{l}\text { P e: } \\
\text { L } 2 \\
\text { R } 2 \\
\text { Diaph.: } \\
\text { L 2 } \\
\text { R 3 } \\
\text { D e: } \\
\text { L 2 } \\
\text { R 3 }\end{array}$ \\
\hline Fibula & $\begin{array}{l}\text { Diaph.: } \\
\text { L 2 } \\
\text { R } 2\end{array}$ & & & & $\begin{array}{l}\text { Diaph.: } \\
\text { U } 3\end{array}$ & & $\begin{array}{l}\text { Diaph.: } \\
\text { U } 3\end{array}$ & & $\begin{array}{l}\text { Diaph.: } \\
\text { L 2 } \\
\text { R 2 } \\
\text { D e: } \\
\text { L 1 }\end{array}$ \\
\hline Patella & & & & & & & & & \\
\hline Carpals & & & & & & & & & U 3 \\
\hline Metacarpals & & & & & & & & & \\
\hline $\begin{array}{l}\text { Phalanges } \\
\text { (hand) }\end{array}$ & & & & & & & & & \\
\hline Talus & & & & & $\begin{array}{l}\text { L } 2 \\
\text { R } 2\end{array}$ & & & $\begin{array}{l}\text { L } 2 \\
\text { R } 3\end{array}$ & L 2 \\
\hline Calcaneus & & & & & $\begin{array}{l}\text { L } 2 \\
\text { R } 3\end{array}$ & & & & R 2 \\
\hline Tarsals & & & & & & & & & U 3 \\
\hline Metatarsals & & & & & & & & & U 3 \\
\hline
\end{tabular}


Table 10-3, continued.

\begin{tabular}{|c|c|c|c|c|c|c|c|c|c|}
\hline \multirow{2}{*}{\begin{tabular}{|l|} 
\\
Feature \\
No. \\
\end{tabular}} & \multicolumn{9}{|c|}{ 41CE12, continued } \\
\hline & AH-2 & AH-3 & AH-5 & AH-6 & AH-7 & AH-8 & AH-9 & AH-10 & AH-11 \\
\hline \multicolumn{10}{|l|}{$\begin{array}{l}\text { Phalanges } \\
\text { (foot) }\end{array}$} \\
\hline & \multicolumn{2}{|c|}{ 41CE12, continued } & \multicolumn{2}{|c|}{ 41CE15 } & \multicolumn{4}{|l|}{ 41CE17 } & 41CE19 \\
\hline $\begin{array}{l}\text { Feature } \\
\text { No. }\end{array}$ & AH-12 & $\begin{array}{l}\text { Prov. } \\
\text { Unk* }\end{array}$ & AJ-1 & AJ-2* & AL1-11* & AL-2 & AL-3 & AL-7 & F-118 \\
\hline Frontal & & & & U 3 & U 3 & $\mathrm{U} 2$ & $\mathrm{U} 1$ & U 2 & \\
\hline Parietal & U 3 & & U 3 & U 3 & U 3 & $\begin{array}{l}\text { U } 3 \\
\text { R } 2\end{array}$ & $\begin{array}{l}\text { L } 1 \\
\text { R } 1\end{array}$ & $\begin{array}{l}\text { L } 2 \\
\text { R } 3\end{array}$ & \\
\hline Occipital & & & 3 & 2 & 3 & 2 & 2 & 2 & 2 \\
\hline Temporal & U 3 & & & $\begin{array}{l}\text { L } 3 \\
\text { R } 2\end{array}$ & & & $\begin{array}{l}\text { L } 2 \\
\text { R } 2\end{array}$ & $\begin{array}{l}\text { L } 2 \\
\text { R } 3\end{array}$ & \\
\hline TMJ & & & & R 2 & & & $\begin{array}{ll}\text { L } 1 \\
\text { R } 1\end{array}$ & L 1 & \\
\hline \multicolumn{10}{|l|}{ Sphenoid } \\
\hline Zygomatic & & & & & & & $\begin{array}{l}\mathrm{L} 2 \\
\mathrm{R} 2 \\
\end{array}$ & R 2 & \\
\hline Maxilla & U 3 & & & $\begin{array}{l}\text { L } 3 \\
\text { R } 2 \\
\end{array}$ & & & & $\begin{array}{l}\mathrm{L} 2 \\
\mathrm{R} 2 \\
\end{array}$ & \\
\hline \multicolumn{10}{|l|}{ Palatine } \\
\hline Mandible & U 3 & & & $\begin{array}{l}\text { L } 3 \\
\text { R 3 }\end{array}$ & & & U 1 & $\begin{array}{l}\text { L } 3 \\
\text { R 3 }\end{array}$ & R 2 \\
\hline Clavicle & & & & & & & $\begin{array}{l}\text { L } 3 \\
\text { R } 3\end{array}$ & $\begin{array}{l}\text { U } 3 \\
\text { R 3 }\end{array}$ & \\
\hline Scapula & & & & & & & $\begin{array}{l}\text { L } 3 \\
\text { R 3 }\end{array}$ & L 3 & \\
\hline \multicolumn{10}{|l|}{ Glenoid } \\
\hline \multicolumn{10}{|l|}{ Manubrium } \\
\hline \multicolumn{10}{|l|}{$\begin{array}{l}\text { Sternum } \\
\text { Body }\end{array}$} \\
\hline $\mathrm{C} 1$ & & & & & & & 3 & & \\
\hline $\mathrm{C} 2$ & & & & & & & 3 & & 2 \\
\hline C3-C6 & & & & & & & 3 & & \\
\hline \multicolumn{10}{|l|}{$\mathrm{C} 7$} \\
\hline T1-T9 & & & 3 & & & & 3 & & \\
\hline \multicolumn{10}{|l|}{ T10 } \\
\hline \multicolumn{10}{|l|}{ T11 } \\
\hline \multicolumn{10}{|l|}{ T12 } \\
\hline \multicolumn{10}{|l|}{ L1 } \\
\hline \multicolumn{10}{|l|}{ L2 } \\
\hline \multicolumn{10}{|l|}{ L3 } \\
\hline \multicolumn{10}{|l|}{ L4 } \\
\hline \multicolumn{10}{|l|}{ L5 } \\
\hline Sacrum & & 1 & & & & & & & 3 \\
\hline
\end{tabular}


Table 10-3, continued.

\begin{tabular}{|c|c|c|c|c|c|c|c|c|c|}
\hline & 41CE12 & ontinued & 41CE15 & & 41CE17 & & & & 41CE19 \\
\hline $\begin{array}{l}\text { Feature } \\
\text { No. }\end{array}$ & AH-12 & $\begin{array}{l}\text { Prov. } \\
\text { Unk* }\end{array}$ & AJ-1 & AJ-2* & AL1-11* & AL-2 & AL-3 & AL-7 & F-118 \\
\hline Rib 1 & & & & & & & & & \\
\hline Rib 2 & & & & & & & L 3 & & \\
\hline Rib 3-10 & & L 1 & & R 3 & & & U 3 & & \\
\hline Rib 11 & & & & & & & & & \\
\hline Rib 12 & & & & & & & & & \\
\hline Ilium & & & & U 3 & & U 3 & U 3 & U 3 & $\begin{array}{l}\text { L } 3 \\
\text { R } 3\end{array}$ \\
\hline Ischium & & & & & & & & & \\
\hline Pubis & & & & & & & & & \\
\hline Acetabulum & & & & & & & U 3 & U 3 & \\
\hline $\begin{array}{l}\text { Auricular } \\
\text { Surface }\end{array}$ & & & & & & & & & \\
\hline Humerus & & & & & & & $\begin{array}{l}\text { P e: } \\
\text { U } 2 \\
\text { Diaph.: } \\
\text { L } 1 \\
\text { R } 1 \\
\text { D e: } \\
\text { U } 3\end{array}$ & $\begin{array}{l}\text { Diaph.: } \\
\text { U } 3 \\
\text { D e: } \\
\text { U } 3\end{array}$ & \\
\hline Radius & & $\begin{array}{l}\text { Diaph.: } \\
\text { L } 1\end{array}$ & & & & & $\begin{array}{l}\text { Diaph.: } \\
\text { L 2 } \\
\text { R 3 }\end{array}$ & & \\
\hline Ulna & & & & & & & $\begin{array}{l}\text { P e: } \\
\text { L } 3 \\
\text { Diaph.: } \\
\text { L } 2 \\
\text { R 1 }\end{array}$ & $\begin{array}{l}\text { Diaph.: } \\
\text { R 2 }\end{array}$ & \\
\hline Femur & & & $\begin{array}{l}\text { P e: } \\
\text { L } 2 \\
\text { R 2 } \\
\text { Diaph.: } \\
\text { R 2 } \\
\text { D e: } \\
\text { L 2 } \\
\text { R 2 }\end{array}$ & $\begin{array}{l}\text { Diaph.: } \\
\text { L 1 } \\
\text { R } 1\end{array}$ & $\begin{array}{l}\text { Diaph.: } \\
\text { L 1 } \\
\text { R } 1\end{array}$ & $\begin{array}{l}\text { P e: } \\
\text { L } 3 \\
\text { Diaph.: } \\
\text { L 1 } \\
\text { R } 3 \\
\text { D e: } \\
\text { L } 3\end{array}$ & $\begin{array}{l}\text { P e: } \\
\text { L } 3 \\
\text { R 3 } \\
\text { Diaph.: } \\
\text { L 1 } \\
\text { R } 1\end{array}$ & $\begin{array}{l}\text { P e: } \\
\text { L } 3 \\
\text { Diaph.: } \\
\text { L } 3 \\
\text { R } 2 \\
\text { D e: } \\
\text { U } 3\end{array}$ & $\begin{array}{l}\text { P e: } \\
\text { L } 3 \\
\text { R } 3\end{array}$ \\
\hline Tibia & & & $\begin{array}{l}\text { P e: } \\
\text { L } 2 \\
\text { R 2 } \\
\text { Diaph.: } \\
\text { L 2 } \\
\text { R 1 } \\
\text { D e: } \\
\text { L 2 } \\
\text { R 2 }\end{array}$ & $\begin{array}{l}\text { P e: } \\
\text { R } 3\end{array}$ & & & $\begin{array}{l}\text { P e: } \\
\text { U 3 } \\
\text { Diaph.: } \\
\text { L 3 } \\
\text { R } 2\end{array}$ & $\begin{array}{l}\text { Diaph.: } \\
\text { U } 3\end{array}$ & \\
\hline Fibula & & & & & & & & $\begin{array}{l}\text { Diaph.: } \\
\text { U } 3\end{array}$ & \\
\hline Patella & & & L 2 & R 1 & & & U 3 & & \\
\hline Carpals & & & & & & & & & \\
\hline
\end{tabular}


Table 10-3, continued.

\begin{tabular}{|c|c|c|c|c|c|c|c|c|c|}
\hline \multirow{2}{*}{\begin{tabular}{|l|} 
\\
Feature \\
No. \\
\end{tabular}} & \multicolumn{2}{|c|}{ 41CE12, continued } & \multicolumn{2}{|c|}{ 41CE15 } & \multicolumn{4}{|l|}{ 41CE17 } & \multirow{2}{*}{\begin{tabular}{|l|} 
41CE19 \\
F-118 \\
\end{tabular}} \\
\hline & AH-12 & $\begin{array}{l}\text { Prov. } \\
\text { Unk* }\end{array}$ & AJ-1 & AJ-2* & AL1-11* & AL-2 & AL-3 & AL-7 & \\
\hline Metacarpals & & & & & & & $\begin{array}{l}\text { L } 3 \\
\text { U } 3\end{array}$ & & \\
\hline $\begin{array}{l}\text { Phalanges } \\
\text { (hand) }\end{array}$ & & & & & & & U 3 & & \\
\hline Talus & & & $\begin{array}{l}\text { L } 3 \\
\text { R } 2 \\
\end{array}$ & & & & $\begin{array}{l}\text { L } 3 \\
\text { R } 3 \\
\end{array}$ & & \\
\hline Calcaneus & & & U 3 & & & & & & \\
\hline Tarsals & & & & & & & U 3 & & \\
\hline \multicolumn{10}{|l|}{ Metatarsals } \\
\hline \multirow{2}{*}{\multicolumn{10}{|c|}{$\begin{array}{l}\text { Phalanges } \\
\text { (foot) }\end{array}$}} \\
\hline & & & & & & & & & \\
\hline $\begin{array}{l}\text { Feature } \\
\text { No. }\end{array}$ & $\begin{array}{l}\text { F-119, } \\
\text { S1 }\end{array}$ & $\begin{array}{l}\text { F-119, } \\
\text { S2 }\end{array}$ & F-130 & $\begin{array}{l}\text { F-134, } \\
\text { B1 }\end{array}$ & $\begin{array}{l}\text { F-134, } \\
\text { B2 }\end{array}$ & $\begin{array}{l}\text { F-134, } \\
\text { B3 }\end{array}$ & $\begin{array}{l}\text { F-134, } \\
\text { B4 }\end{array}$ & F-155 & F-161 \\
\hline Frontal & $\mathrm{U} 2$ & U 3 & U 1 & R 1 & & & & & \\
\hline Parietal & $\begin{array}{ll}\text { L } 2 \\
\text { R 2 }\end{array}$ & U 3 & & R 1 & & & & & \\
\hline Occipital & 2 & U 3 & & 3 & 3 & & 3 & & \\
\hline Temporal & \begin{tabular}{|l|} 
L 3 \\
R 3 \\
\end{tabular} & $\begin{array}{l}\text { L } 3 \\
\text { R 3 }\end{array}$ & & R 1 & $\mathrm{U} 3$ & & $\mathrm{~L} 2$ & L 3 & \\
\hline TMJ & & $\begin{array}{l}\text { L } 3 \\
\text { R } 2\end{array}$ & & & & & & & \\
\hline \multicolumn{10}{|l|}{ Sphenoid } \\
\hline Zygomatic & & $\begin{array}{l}\text { L } 3 \\
\text { R 1 } \\
\end{array}$ & & R 1 & & & L 1 & & \\
\hline Maxilla & & $\begin{array}{l}\text { L } 3 \\
\text { L } 3 \\
\end{array}$ & & R 3 & & & & $\begin{array}{l}\text { L 3 } \\
\text { R 3 } \\
\end{array}$ & L 3 \\
\hline \multicolumn{10}{|l|}{ Palatine } \\
\hline Mandible & $\mathrm{U} 1$ & $\begin{array}{l}\text { L } 3 \\
\text { R } 2 \\
\end{array}$ & & U 1 & U 3 & U 3 & L 2 & U 3 & $\begin{array}{l}\text { L } 3 \\
\text { R 3 } \\
\end{array}$ \\
\hline Clavicle & & & $\begin{array}{l}\text { L } 3 \\
\text { R } 3 \\
\end{array}$ & & U 3 & & & & \\
\hline \multicolumn{10}{|l|}{ Scapula } \\
\hline \multicolumn{10}{|l|}{ Glenoid } \\
\hline \multicolumn{10}{|l|}{ Manubrium } \\
\hline \multicolumn{10}{|l|}{$\begin{array}{l}\text { Sternum } \\
\text { Body }\end{array}$} \\
\hline $\mathrm{C} 1$ & 2 & & & & & & 1 & & \\
\hline $\mathrm{C} 2$ & 3 & 2 & & & & & 2 & & \\
\hline C3-C6 & 3 & 3 & & & & & 1 & & 1 \\
\hline $\mathrm{C7}$ & & 3 & & & & & & & \\
\hline \multicolumn{10}{|l|}{ T1-T9 } \\
\hline \multicolumn{10}{|l|}{ T10 } \\
\hline T11 & & & & & & & & & \\
\hline
\end{tabular}


Table 10-3, continued.

\begin{tabular}{|c|c|c|c|c|c|c|c|c|c|}
\hline & 41CE1 & ontinued & & & & & & & \\
\hline $\begin{array}{l}\text { Feature } \\
\text { No. }\end{array}$ & $\begin{array}{l}\text { F-119, } \\
\text { S1 }\end{array}$ & $\begin{array}{l}\text { F-119, } \\
\text { S2 }\end{array}$ & F-130 & $\begin{array}{l}\text { F-134, } \\
\text { B1 }\end{array}$ & $\begin{array}{l}\text { F-134, } \\
\text { B2 }\end{array}$ & $\begin{array}{l}\text { F-134, } \\
\text { B3 }\end{array}$ & $\begin{array}{l}\text { F-134, } \\
\text { B4 }\end{array}$ & F-155 & F-161 \\
\hline T12 & & & & & & & & & \\
\hline L1 & & & & & & & & & \\
\hline L2 & & & & & & & & & \\
\hline L3 & & & & & & & & & \\
\hline L4 & & & & & & & & & \\
\hline L5 & & & & & & & & & \\
\hline Sacrum & & & & & & & & & \\
\hline Rib 1 & & & & & & & & & \\
\hline Rib 2 & & & & & & & & & \\
\hline Rib 3-10 & & & & & & & & & \\
\hline Rib 11 & & & & & & & & & \\
\hline Rib 12 & & & & & & & & & \\
\hline Ilium & & & & & & & & & \\
\hline Ischium & & & & & & & & & \\
\hline Pubis & & & & & & & & & \\
\hline Acetabulum & & & & & & & & & \\
\hline $\begin{array}{l}\text { Auricular } \\
\text { Surface }\end{array}$ & & & & & & & & & \\
\hline Humerus & & & & & & & & & \\
\hline Radius & & & & & & & & & \\
\hline Ulna & & & & & & & & & \\
\hline Femur & & & $\begin{array}{l}\text { Diaph.: } \\
\text { L 2 } \\
\text { R 2 }\end{array}$ & & & & & & \\
\hline Tibia & & & $\begin{array}{l}\text { Diaph.: } \\
\text { L } 2 \\
\text { R 3 }\end{array}$ & & & & & & \\
\hline Fibula & & & $\begin{array}{l}\text { Diaph.: } \\
\text { U } 3\end{array}$ & & & & & & \\
\hline Patella & & & & & & & & & \\
\hline Carpals & & & & & & & & & \\
\hline Metacarpals & & & & & & & & & \\
\hline $\begin{array}{l}\text { Phalanges } \\
\text { (hand) }\end{array}$ & & & & & & & & & \\
\hline Talus & & & & & & & & & \\
\hline Calcaneus & & & & & & & & & \\
\hline Tarsals & & & & & & & & & \\
\hline Metatarsals & & & & & & & & & \\
\hline $\begin{array}{l}\text { Phalanges } \\
\text { (foot) }\end{array}$ & & & & & & & & & \\
\hline
\end{tabular}


Table 10-3, continued.

\begin{tabular}{|c|c|c|c|c|c|c|c|}
\hline & $\begin{array}{l}\text { 41CE1 } \\
\text { contin }\end{array}$ & & 41CE290 & & $\begin{array}{l}1 C E 19 \\
\text { continu }\end{array}$ & & 41CE290 \\
\hline $\begin{array}{l}\text { Feature } \\
\text { No. }\end{array}$ & \begin{tabular}{|l|} 
F-163 \\
\end{tabular} & S 1 & $\begin{array}{l}\text { No } \\
\text { burial } \\
\text { number }\end{array}$ & & F-163 & S 1 & $\begin{array}{l}\text { No } \\
\text { burial } \\
\text { number }\end{array}$ \\
\hline Frontal & U 1 & U 2 & $\mathrm{U} 1$ & L5 & & & \\
\hline Parietal & $\begin{array}{ll}\text { L } 1 \\
\text { R } 1\end{array}$ & $\begin{array}{l}\text { L } 2 \\
\text { R } 2\end{array}$ & $\begin{array}{ll}\mathrm{L} & 1 \\
\mathrm{R} & 1\end{array}$ & Sacrum & & & \\
\hline Occipital & 3 & 2 & 1 & Rib 1 & & & \\
\hline Temporal & $\begin{array}{ll}\text { L } 1 \\
\text { R } 1\end{array}$ & $\begin{array}{l}\text { L } 3 \\
\text { R } 3\end{array}$ & $\begin{array}{l}\text { L } 1 \\
\text { R } 2\end{array}$ & Rib 2 & & & \\
\hline TMJ & L 1 & & $\begin{array}{l}\mathrm{L} 1 \\
\mathrm{R} 1\end{array}$ & Rib 3-10 & & & \\
\hline Sphenoid & & & U 3 & Rib 11 & & & \\
\hline Zygomatic & $\begin{array}{ll}\text { L } 1 \\
\text { R } 1\end{array}$ & & L 1 & Rib 12 & & & \\
\hline Maxilla & U 3 & & U 1 & Ilium & & & \\
\hline Palatine & & & & Ischium & & & \\
\hline Mandible & U 1 & U 1 & $\mathrm{U} 2$ & Pubis & & & \\
\hline Clavicle & & & & Acetabulum & & & \\
\hline Scapula & R 3 & & & $\begin{array}{l}\text { Auricular } \\
\text { Surface }\end{array}$ & & & \\
\hline Glenoid & R 3 & & & Humerus & $\begin{array}{l}\text { Diaph.: } \\
\text { R 1 }\end{array}$ & & \\
\hline Manubrium & & & & Radius & & & \\
\hline $\begin{array}{l}\text { Sternum } \\
\text { Body }\end{array}$ & & & & Ulna & & & \\
\hline $\mathrm{C} 1$ & & 2 & & Femur & $\begin{array}{l}\text { Diaph.: } \\
\text { L 2 } \\
\text { R } 2\end{array}$ & & \\
\hline $\mathrm{C} 2$ & & 3 & & Tibia & $\begin{array}{l}\text { Diaph.: } \\
\text { L } 2\end{array}$ & & \\
\hline C3-C6 & & 3 & 2 & Fibula & $\begin{array}{l}\text { Diaph.: } \\
\text { U } 2\end{array}$ & & \\
\hline C7 & & & & Patella & & & \\
\hline T1-T9 & & & 3 & Carpals & & & \\
\hline $\mathrm{T} 10$ & & & & Metacarpals & & & \\
\hline T11 & & & & $\begin{array}{l}\text { Phalanges } \\
\text { (hand) }\end{array}$ & & & \\
\hline T12 & & & & & & & \\
\hline $\mathrm{L} 1$ & & & & & & & \\
\hline L2 & & & & & & & \\
\hline L3 & & & & & & & \\
\hline L4 & & & & & & & \\
\hline
\end{tabular}

Notes: Inventory data follows Buikstra and Ubelacker (1994) with a score of 1 being 75 percent to 100 percent complete, 2 being 25 percent to 75 percent complete and 3 being less than 25 percent complete. Blank spaces indicate a skeletal element was absent. $\mathrm{U}$ indicates unsided element, $\mathrm{L}$ is a left element and $\mathrm{R}$ is a right sided skeletal element. $\mathrm{P}$ e equals proximal epiphysis and $\mathrm{D}$ e equals the distal epiphysis. ${ }^{*}$ Commingled remains. 
Table 10-4. Completeness of Skeletons and Preservation Scores for Burials and Sites.

\begin{tabular}{|c|c|c|c|}
\hline Site & Burial/Feature Number & $\begin{array}{c}\text { Percent Skeletal } \\
\text { Elements Represented }\end{array}$ & $\begin{array}{c}\text { Completeness } \\
\text { Score } \\
\end{array}$ \\
\hline \multirow{7}{*}{$41 \mathrm{AN} 38$} & 8 & 11.3 & 2.0 \\
\hline & $76 \mathrm{~B}$ & 2.7 & 3.0 \\
\hline & $76 \mathrm{C}$ & 2.0 & 3.0 \\
\hline & $76 \mathrm{D}$ & 0.7 & 3.0 \\
\hline & 88 & 6.0 & 3.0 \\
\hline & 92 & 17.3 & 2.4 \\
\hline & 93B1 & 8.0 & 2.8 \\
\hline \multirow[b]{2}{*}{ mean } & 93B2 & 10.0 & 2.7 \\
\hline & & 7.25 & 2.7 \\
\hline 41AN14 & AG-1 & 0.7 & 3.0 \\
\hline 41AN21 & G-1 & 47.0 & 1.6 \\
\hline \multirow[t]{3}{*}{ 41AN32 } & none & 6.7 & 2.0 \\
\hline & none & 6.7 & 1.5 \\
\hline & & 6.7 & 1.8 \\
\hline 41AN34 & D-2 & 2.7 & 2.6 \\
\hline \multirow[t]{3}{*}{ 41AN54 } & $\mathrm{AE}-2$ & 2.7 & 2.5 \\
\hline & $\mathrm{AE}-2 \mathrm{~B}$ & 1.3 & 2 \\
\hline & & 2.0 & 2.2 \\
\hline 41AN56 & 97 & 2.7 & 2.5 \\
\hline \multirow[t]{5}{*}{ 41CE4 } & AI-1 & 12.0 & 2.5 \\
\hline & AI-2 & 13.3 & 1.8 \\
\hline & AI-3 & 9.3 & 2.4 \\
\hline & AI-4 & 4.0 & 3.0 \\
\hline & AI-5 & 6.7 & 2.7 \\
\hline mean & & 9.0 & 2.5 \\
\hline \multirow[t]{3}{*}{ 41CE6 } & AN-1 & 20.7 & 1.8 \\
\hline & AN-2 & 45.3 & 2.0 \\
\hline & & 33.0 & 1.9 \\
\hline \multirow[t]{9}{*}{ 41CE12 } & AH-2 & 5.3 & 2.5 \\
\hline & AH-3 & 30.0 & 1.7 \\
\hline & AH-5 & 9.3 & 1.6 \\
\hline & AH-6 & 4.0 & 2.3 \\
\hline & AH-7 & 52.0 & 2.0 \\
\hline & AH-8 & 3.3 & 2.8 \\
\hline & AH-9 & 13.3 & 2.3 \\
\hline & $\mathrm{AH}-10$ & 32.0 & 2.1 \\
\hline & $\mathrm{AH}-11$ & 40.7 & 1.9 \\
\hline \multirow{2}{*}{ mean } & $\mathrm{AH}-12$ & 2.7 & 3.0 \\
\hline & & 21.4 & 2.5 \\
\hline \multirow[t]{3}{*}{ 41CE15 } & AJ-1 & 13.3 & 2.1 \\
\hline & AJ-2 & 10.0 & 2.5 \\
\hline & & 11.7 & 2.3 \\
\hline \multirow[t]{3}{*}{ 41CE17 } & AL-2 & 8.0 & 2.2 \\
\hline & AL-3 & 45.3 & 2.0 \\
\hline & AL-7 & 20.7 & 2.5 \\
\hline mean & & 24.7 & 2.2 \\
\hline
\end{tabular}


Table 10-4. continued.

\begin{tabular}{|c|c|c|c|}
\hline Site & Burial/Feature Number & $\begin{array}{c}\text { Percent Skeletal } \\
\text { Elements Represented }\end{array}$ & $\begin{array}{l}\text { Completeness } \\
\text { Score }\end{array}$ \\
\hline \multirow[t]{11}{*}{ 41CE19 } & 118 & 5.3 & 2.6 \\
\hline & $119 \mathrm{~S} 1$ & 6.7 & 2.0 \\
\hline & $119 \mathrm{~S} 2$ & 10.7 & 2.5 \\
\hline & 130 & 10.0 & 2.3 \\
\hline & $134 \mathrm{~B} 1$ & 4.7 & 1.6 \\
\hline & $134 \mathrm{~B} 2$ & 2.7 & 3.0 \\
\hline & $134 \mathrm{~B} 3$ & 0.7 & 3.0 \\
\hline & $134 \mathrm{~B} 4$ & 5.3 & 2.0 \\
\hline & 155 & 2.7 & 3.0 \\
\hline & 161 & 3.3 & 3.0 \\
\hline & 163 & 17.3 & 1.7 \\
\hline \multirow{2}{*}{ mean } & S 1 & 6.7 & 2.1 \\
\hline & & 6.3 & 2.4 \\
\hline 41CE290 & none & 9.3 & 1.1 \\
\hline
\end{tabular}

Notes: Preservation scores follow Buikstra and Ubelacker (1994) with a score of 1 being 75 percent to 100 percent complete, 2 being 25 percent to 75 percent complete and 3 being less than 25 percent complete. Only isolated burials are included in this table, comingled remains are excluded. 
Table 10-5. Age and Sex of Individuals from the Upper Neches River Basin.

\begin{tabular}{|c|c|c|c|c|c|}
\hline $\begin{array}{l}\text { Site/Time } \\
\text { Period }\end{array}$ & $\begin{array}{l}\text { Burial } \\
\text { designation }\end{array}$ & Age & Basis for Age Assessment & Sex & $\begin{array}{l}\text { Basis for Sex } \\
\text { Assessment }\end{array}$ \\
\hline $\begin{array}{l}\text { Isibell-Gene } \\
\text { Donnell } \\
\text { 41AN14 } \\
\text { Unknown } \\
\text { Caddo }\end{array}$ & AG-1 & $20-50+$ & $\begin{array}{l}\text { Dental formation stage; dental } \\
\text { wear }\end{array}$ & $\mathrm{I}$ & Lack of diagnostics \\
\hline $\begin{array}{l}\text { Emma Owens } \\
\text { 41AN21 } \\
\text { Late Caddo }\end{array}$ & $\begin{array}{l}\text { G1 } \\
\text { Late Caddo }\end{array}$ & $35-50$ & $\begin{array}{l}\text { Auricular surface; dental } \\
\text { formation stage; dental wear }\end{array}$ & $\mathrm{M}$ & $\begin{array}{l}\text { Cranial morphology; } \\
\text { pelvic morphology; } \\
\text { femoral circumference }\end{array}$ \\
\hline \multirow{2}{*}{$\begin{array}{l}\text { Fred McKee } \\
41 \mathrm{AN} 32 \\
\text { Late Caddo }\end{array}$} & $\begin{array}{l}\text { None, TARL } \\
2100\end{array}$ & $9+/-2$ & $\begin{array}{l}\text { Dental eruption; dental } \\
\text { formation stage }\end{array}$ & I & Age \\
\hline & $\begin{array}{l}\text { None, TARL } \\
2101 \\
\text { Late Caddo }\end{array}$ & $27.5-44$ & $\begin{array}{l}\text { Dental formation stage; dental } \\
\text { wear; ecto- anf endocranial } \\
\text { cranial sutures }\end{array}$ & $\mathrm{F}$ & Cranial morphology \\
\hline $\begin{array}{l}\text { Pierce } \\
\text { Freeman Farm } \\
\text { 41AN34 } \\
\text { Late Caddo }\end{array}$ & $\begin{array}{l}\text { D-2 } \\
\text { Late Caddo }\end{array}$ & $20-50+$ & $\begin{array}{l}\text { Size and thickness of cranial } \\
\text { remains }\end{array}$ & $\mathrm{F}$ & Cranial morphology \\
\hline \multirow{3}{*}{$\begin{array}{l}\text { O.L. Ellis } \\
\text { Farm } \\
\text { 41AN54 } \\
\text { Late Caddo }\end{array}$} & AE-2 & $3-5$ & Size of cranial remains & $\mathrm{I}$ & Age \\
\hline & AE-2B & $20-50+$ & $\begin{array}{l}\text { Size and thickness of cranial } \\
\text { remains }\end{array}$ & I & Lack of diagnostics \\
\hline & B-1 & $\begin{array}{l}\mathrm{MNI}=2 \\
20-50 \\
12-20\end{array}$ & $\begin{array}{l}\text { Ecto- and endocranial sutures } \\
\text { Long bone density }\end{array}$ & $\mathrm{I}$ & Lack of diagnostics \\
\hline $\begin{array}{l}\text { Lee Ellis } \\
\text { Farm } \\
41 \text { AN56 } \\
\text { Unknown } \\
\text { Caddo } \\
\end{array}$ & 97 & $20-50+$ & $\begin{array}{l}\text { Size and thickness of cranial } \\
\text { remains }\end{array}$ & $\mathrm{M}$ & Cranial morphology \\
\hline $\begin{array}{l}\text { Solon Stanley } \\
41 \mathrm{CE} 3 \\
\text { Early Caddo }\end{array}$ & $\begin{array}{l}\text { AK1,2,3,4 } \\
\text { Early Cado }\end{array}$ & $\begin{array}{l}\mathrm{MNI}=5 \\
235-50 \\
120-50+\end{array}$ & $\begin{array}{l}\text { Dental eruption; dental wear; } \\
\text { ectocranial sutures; size and } \\
\text { thickness of cranial remains; } \\
\text { long bone density }\end{array}$ & $\begin{array}{l}2 \mathrm{M} \\
1 \mathrm{~F}\end{array}$ & $\begin{array}{l}\text { Cranial morphology; } \\
\text { femoral circumference }\end{array}$ \\
\hline \multirow{5}{*}{$\begin{array}{l}\text { J.W. } \\
\text { Blackburn } \\
41 \mathrm{CE} 4 \\
\text { Late Caddo }\end{array}$} & AI1 & $20-50+$ & Ecto- and endo cranial sutures & $\mathrm{I}$ & Lack of diagnostics \\
\hline & AI2 & $37-55$ & $\begin{array}{l}\text { Dental eruption; dental } \\
\text { formation stage; dental wear; } \\
\text { palatine and endocranial } \\
\text { sutures }\end{array}$ & $\mathrm{I}$ & Lack of diagnositics \\
\hline & $\mathrm{AI} 3$ & $35-50+$ & Dental formation; dental wear & $\mathrm{I}$ & Lack of diagnostics \\
\hline & AI4 & $20-35$ & Dental formation; dental wear & $\mathrm{I}$ & Lack of diagnostics \\
\hline & AI5 & $20-50$ & $\begin{array}{l}\text { Dental formation stage; dental } \\
\text { wear }\end{array}$ & $\mathrm{I}$ & Lack of diagnostics \\
\hline
\end{tabular}


Table 10-5, continued.

\begin{tabular}{|c|c|c|c|c|c|}
\hline $\begin{array}{l}\text { Site/Time } \\
\text { Period }\end{array}$ & $\begin{array}{l}\text { Burial } \\
\text { designation }\end{array}$ & Age & $\begin{array}{l}\text { Basis for Age } \\
\text { Assessment }\end{array}$ & Sex & $\begin{array}{l}\text { Basis for Sex } \\
\text { Assessment }\end{array}$ \\
\hline \multirow[t]{2}{*}{$\begin{array}{l}\text { E.W. Hackney } \\
\text { 41CE6 } \\
\text { Late Caddo }\end{array}$} & AN1 & $35-50$ & $\begin{array}{l}\text { Dental formation stage; } \\
\text { dental wear; ectocranial } \\
\text { sutures }\end{array}$ & $\mathrm{F}$ & $\begin{array}{l}\text { Cranial morphology; } \\
\text { talus length }\end{array}$ \\
\hline & AN2 & $27.5-44$ & $\begin{array}{l}\text { Dental formation stage; } \\
\text { dental wear; ecto-, } \\
\text { palatine and } \\
\text { endocranial sutures }\end{array}$ & $\mathrm{M}$ & $\begin{array}{l}\text { Cranial morphology; } \\
\text { femoral head diameter; } \\
\text { femoral circumference }\end{array}$ \\
\hline \multirow[t]{13}{*}{$\begin{array}{l}\text { Jim Allen } \\
\text { 41CE12 } \\
\text { Historic }\end{array}$} & AH-1 & $\begin{array}{l}\text { MNI }=3 \\
13-12 \text { (may } \\
\text { be same as } \\
\text { AH-9) } \\
120-50+\end{array}$ & $\begin{array}{l}\text { Epiphyseal fusion; long } \\
\text { bone length and } \\
\text { density; ectocranial } \\
\text { sutures }\end{array}$ & I & Lack of diagnostics \\
\hline & $\mathrm{AH}-2$ & $20-50$ & $\begin{array}{l}\text { Dental formation stage; } \\
\text { dental wear }\end{array}$ & I & Lack of diagnostics \\
\hline & AH-3 & $50+$ & $\begin{array}{l}\text { Dental formation stage; } \\
\text { dental wear; ecto- and } \\
\text { endocranial sutures }\end{array}$ & $\mathrm{M}$ & $\begin{array}{l}\text { Cranial morphology; } \\
\text { femoral circumference }\end{array}$ \\
\hline & AH-5 & $19-44$ & $\begin{array}{l}\text { Ecto- and endocranial } \\
\text { sutures }\end{array}$ & $\mathrm{F}$ & Cranial morphology \\
\hline & AH-6 & $20-50$ & $\begin{array}{l}\text { Ecto- and endocranial } \\
\text { sutures }\end{array}$ & I & Lack of diagnostics \\
\hline & $\mathrm{AH}-7$ & $35-50$ & $\begin{array}{l}\text { Auricular surface; } \\
\text { Dental formation stage; } \\
\text { dental wear; ecto- and } \\
\text { endocranial sutures }\end{array}$ & $\mathrm{M}$ & Cranial morphology \\
\hline & AH-8 & $20-50+$ & Dental wear & I & Lack of diagnostics \\
\hline & $\mathrm{AH}-9$ & $9.5+/-.2$ & $\begin{array}{l}\text { Epiphyseal fusion; } \\
\text { dental formation stage }\end{array}$ & $\mathrm{F}$ & $\begin{array}{l}\text { Dental discriminant } \\
\text { function }\end{array}$ \\
\hline & AH-10 & $35-50+$ & $\begin{array}{l}\text { Auricular surface; } \\
\text { dental formation stage; } \\
\text { dental wear }\end{array}$ & $\mathrm{M}$ & $\begin{array}{l}\text { Cranial morphology; } \\
\text { pelvic morphology }\end{array}$ \\
\hline & AH-11 & $16-22.4$ & $\begin{array}{l}\text { Epiphyseal fusion; } \\
\text { dental formation stage }\end{array}$ & $\mathrm{F}$ & $\begin{array}{l}\text { Cranial morphology; } \\
\text { femoral head diameter }\end{array}$ \\
\hline & AH-12 & $5.2+/-.5$ & $\begin{array}{l}\text { Dental eruption; dental } \\
\text { formation stage }\end{array}$ & I & Age \\
\hline & AH-15 & $16-30$ & $\begin{array}{l}\text { Dental eruption; dental } \\
\text { formation stage; dental } \\
\text { wear }\end{array}$ & I & Lack of diagnostics \\
\hline & Prov unknown & $20-50+$ & Long bone density & $\mathrm{F}$ & Pelvic morphology \\
\hline \multirow{2}{*}{$\begin{array}{l}\text { A.H. Reagor } \\
41 \text { CE15 } \\
\text { Late Caddo }\end{array}$} & $\begin{array}{l}\text { AJ-1 } \\
\text { Late Caddo }\end{array}$ & $20-50+$ & Long bone density & $F$ & Pelvic morphology \\
\hline & AJ-2 & $\begin{array}{l}\mathrm{MNI}=3 \\
20-50+ \\
\text { Birth }-3 \\
7+/-2\end{array}$ & $\begin{array}{l}\text { Dental formation stage; } \\
\text { size and thickness of } \\
\text { cranial remains; } \\
\text { epiphyseal fusion }\end{array}$ & $\begin{array}{l}\text { M (child } 7 \\
+/-2 \text { ) }\end{array}$ & $\begin{array}{l}\text { Dental discriminant } \\
\text { function }\end{array}$ \\
\hline
\end{tabular}


Table 10-5, continued.

\begin{tabular}{|c|c|c|c|c|c|}
\hline $\begin{array}{l}\text { Site/Time } \\
\text { Period }\end{array}$ & $\begin{array}{l}\text { Burial } \\
\text { designation }\end{array}$ & Age & $\begin{array}{l}\text { Basis for Age } \\
\text { Assessment }\end{array}$ & Sex & $\begin{array}{l}\text { Basis for Sex } \\
\text { Assessment }\end{array}$ \\
\hline \multirow[t]{4}{*}{$\begin{array}{l}\text { E.W. Henry } \\
41 \mathrm{CE} 17 \\
\text { Late Caddo }\end{array}$} & AL1-AL11 & $\begin{array}{l}\text { MN1 } 1=4 \\
20-50+ \\
2: 12-19 \\
1: 6-8\end{array}$ & $\begin{array}{l}\text { Long bone length; } \\
\text { dental eruption; dental } \\
\text { formation stage; dental } \\
\text { wear; thickness of } \\
\text { cranial remains }\end{array}$ & I & Age; lack of diagnostics \\
\hline & AL2 & $35-50$ & Ectocranial sutures & $\mathrm{I}$ & Lack diagnostics \\
\hline & AL3 & $48-50+$ & $\begin{array}{l}\text { Dental formation stage; } \\
\text { dental wear; ecto- and } \\
\text { endocranial sutures }\end{array}$ & $\mathrm{M}$ & $\begin{array}{l}\text { Cranial morphology; } \\
\text { femoral head diameter }\end{array}$ \\
\hline & AL7 & $35-50+$ & $\begin{array}{l}\text { Dental formation stage; } \\
\text { dental wear; ectocranial } \\
\text { sutures }\end{array}$ & $\mathrm{M}$ & Cranial morphology \\
\hline \multirow{12}{*}{$\begin{array}{l}\text { George C. } \\
\text { Davis } \\
41 \mathrm{CE} 19 \\
\text { Early Caddo }\end{array}$} & $\begin{array}{l}\text { F. } 118 \\
\text { Middle Caddo }\end{array}$ & $20-35$ & $\begin{array}{l}\text { Dental formation stage; } \\
\text { dental wear }\end{array}$ & $\mathrm{M}$ & $\begin{array}{l}\text { Cranial morphology; } \\
\text { dental discriminant } \\
\text { function }\end{array}$ \\
\hline & $\begin{array}{l}\text { F. } 119 \mathrm{~S} 1 \\
\text { Formative Caddo }\end{array}$ & (prob.) $50+$ & $\begin{array}{l}\text { Dental formation stage; } \\
\text { dental wear; ecto- and } \\
\text { endocranial sutures }\end{array}$ & $\mathrm{M}$ & $\begin{array}{l}\text { Cranial morphology; } \\
\text { dental discriminant } \\
\text { function }\end{array}$ \\
\hline & $\begin{array}{l}\text { F. } 119 \mathrm{~S} 2 \\
\text { Formative Caddo }\end{array}$ & $20-50$ & $\begin{array}{l}\text { Dental formation stage; } \\
\text { dental wear }\end{array}$ & I & Lack of diagnostics \\
\hline & F. 130 & $35-50+$ & $\begin{array}{l}\text { Dental formation stage; } \\
\text { dental wear }\end{array}$ & $\mathrm{F}$ & Cranial morphology \\
\hline & $\begin{array}{l}\text { F. } 134 \text { B1 } \\
\text { Formative - Early } \\
\text { Caddo }\end{array}$ & $20-35$ & $\begin{array}{l}\text { Dental eruption; dental } \\
\text { wear }\end{array}$ & $\mathrm{F}$ & Cranial morphology \\
\hline & $\begin{array}{l}\text { F. 134 B2 } \\
\text { Formative - Early } \\
\text { Caddo }\end{array}$ & $15+/-3$ & $\begin{array}{l}\text { Dental formation stage; } \\
\text { dental wear }\end{array}$ & $\mathrm{I}$ & Age \\
\hline & $\begin{array}{l}\text { F. } 134 \text { B3 } \\
\text { Formative - Early } \\
\text { Caddo }\end{array}$ & $15-25$ & $\begin{array}{l}\text { Dental formation stage; } \\
\text { dental wear }\end{array}$ & $\mathrm{M}$ & $\begin{array}{l}\text { Dental discriminant } \\
\text { function }\end{array}$ \\
\hline & $\begin{array}{l}\text { F. } 134 \text { B4 } \\
\text { Formative - Early } \\
\text { Caddo }\end{array}$ & $20-35$ & $\begin{array}{l}\text { Dental eruption; dental } \\
\text { formation stage; dental } \\
\text { wear }\end{array}$ & $\mathrm{F}$ & Cranial morphology \\
\hline & $\begin{array}{l}\text { F. } 134 \text { B5 } \\
\text { Formative - Early } \\
\text { Caddo }\end{array}$ & $20-50$ & $\begin{array}{l}\text { Dental formation stage; } \\
\text { dental wear }\end{array}$ & I & Lack of diagnostics \\
\hline & $\begin{array}{l}\text { F. } 134 \text { B7 } \\
\text { Formative - Early } \\
\text { Caddo }\end{array}$ & $0.7-1.2 \mathrm{yrs}$ & Dental formation stage & I & Age \\
\hline & $\begin{array}{l}\text { F. } 134 \text { B8 } \\
\text { Formative - Early } \\
\text { Caddo }\end{array}$ & $20-50$ & $\begin{array}{l}\text { Dental formation stage; } \\
\text { dental wear }\end{array}$ & $\mathrm{F}$ & $\begin{array}{l}\text { Dental discriminant } \\
\text { function }\end{array}$ \\
\hline & $\begin{array}{l}\text { F. } 155 \\
\text { Formative Caddo }\end{array}$ & $20-35$ & $\begin{array}{l}\text { Dental eruption; dental } \\
\text { formation stage; dental } \\
\text { wear }\end{array}$ & $\mathrm{M}$ & $\begin{array}{l}\text { Dental discriminant } \\
\text { function }\end{array}$ \\
\hline
\end{tabular}


Table 10-5, continued.

\begin{tabular}{|c|c|c|c|c|c|}
\hline $\begin{array}{l}\text { Site/Time } \\
\text { Period }\end{array}$ & $\begin{array}{l}\text { Burial } \\
\text { designation }\end{array}$ & Age & $\begin{array}{l}\text { Basis for Age } \\
\text { Assessment }\end{array}$ & Sex & $\begin{array}{l}\text { Basis for Sex } \\
\text { Assessment }\end{array}$ \\
\hline & $\begin{array}{l}\text { F. } 161 \\
\text { Formative Caddo }\end{array}$ & $20-50$ & $\begin{array}{l}\text { Dental formation stage; } \\
\text { dental wear }\end{array}$ & I & Lack of diagnostics \\
\hline & F. 163 & $35-50+$ & $\begin{array}{l}\text { Dental formation stage; } \\
\text { dental wear; ecto- and } \\
\text { endocranial sutures }\end{array}$ & $\mathrm{M}$ & Cranial morphology \\
\hline $\begin{array}{l}\text { Forest Mound } \\
41 \text { CE290 } \\
\text { Middle Caddo }\end{array}$ & None, TARL 2172 & $35-50$ & $\begin{array}{l}\text { Dental formation stage; } \\
\text { dental wear; ecto-, } \\
\text { palatine and } \\
\text { endocranial sutures }\end{array}$ & $\mathrm{M}$ & Cranial morphology \\
\hline \multirow[t]{9}{*}{$\begin{array}{l}41 \mathrm{AN} 38 \\
\text { Lang Pasture } \\
\text { Middle Caddo }\end{array}$} & $\begin{array}{l}\text { F. } 8 \\
\text { Middle to Early } \\
\text { Late Caddo }\end{array}$ & $20-50+$ & $\begin{array}{l}\text { Long bone size and } \\
\text { density }\end{array}$ & $\mathrm{M}$ & Femoral circumference \\
\hline & F. 76B & $6-10+/-2.5$ & Dental formation stage & I & $\begin{array}{l}\text { Dental discriminant } \\
\text { function }\end{array}$ \\
\hline & $\begin{array}{l}\text { F. 76C } \\
\text { Middle to Early } \\
\text { Late Caddo }\end{array}$ & $8+/-2$ & Dental formation stage & $\mathrm{I}$ & Age \\
\hline & F. 76D & (poss.) $3-12$ & Cranial bone density & I & Lack diagnostics \\
\hline & F. 88 & $20-50+$ & $\begin{array}{l}\text { Dental formation stage; } \\
\text { dental wear }\end{array}$ & I & Lack of diagnostics \\
\hline & F. 91 & I & Lack of diagnostics & I & Lack of diagnostics \\
\hline & F. 92 & $27-50+$ & $\begin{array}{l}\text { Dental formation stage; } \\
\text { dental wear }\end{array}$ & I & Lack of diagnostics \\
\hline & $\begin{array}{l}\text { F. } 93 \text { B1 } \\
\text { Middle to Early } \\
\text { Late Caddo }\end{array}$ & $50+$ & $\begin{array}{l}\text { Dental formation stage; } \\
\text { dental wear; ectocranial } \\
\text { sutures }\end{array}$ & $\mathrm{F}$ & Cranial morphology \\
\hline & $\begin{array}{l}\text { F. } 93 \text { B2 } \\
\text { Middle to Early } \\
\text { Late Caddo }\end{array}$ & $20-35$ & $\begin{array}{l}\text { Dental formation stage; } \\
\text { dental wear }\end{array}$ & F & Cranial morphology \\
\hline
\end{tabular}

Notes: I means indeterminate; $\mathrm{F}$ means female and $\mathrm{M}$ means male. When time periods are presented with individual burial numbers, it indicates age is based on radiocarbon dating. Note, also, that Features 91 and 94 are not included in this table due to lack of bone preservation in those features (except for a tooth in Feature 91). 
Table 10-6. Sex Ratios from Various Caddo Archaeological Samples.

\begin{tabular}{|c|c|c|c|c|c|}
\hline Sample & $\begin{array}{c}\text { No. of } \\
\text { Females }\end{array}$ & $\begin{array}{c}\% \\
\text { Females }\end{array}$ & $\begin{array}{l}\text { No. of } \\
\text { Males }\end{array}$ & $\begin{array}{c}\% \\
\text { Males }\end{array}$ & Source \\
\hline Lang Pasture Site (41AN38) & 2 & 67.0 & 1 & 33.0 & this study \\
\hline $\begin{array}{l}\text { Upper Neches River Basin } \\
\text { (exclusive of Lang Pasture) }\end{array}$ & 12 & 44.0 & 15 & 56.0 & this study \\
\hline Sanders (41LR2) & 21 & 54.0 & 18 & 46.0 & Wilson (1997) \\
\hline Hatchel (41BW3) & 6 & 66.7 & 3 & 33.3 & Lee (1997) \\
\hline Mitchell (41BW4) & 21 & 45.6 & 25 & 54.4 & Lee (1997) \\
\hline Moores (41BW2) & 1 & 50.0 & 1 & 50.0 & Lee (1997) \\
\hline $\begin{array}{l}\text { Williams Portion of Kaufman- } \\
\text { Williams site }\end{array}$ & 26 & 48.1 & 28 & 51.9 & Loveland (1994) \\
\hline Roitsch (41RR16) & 12 & 57.0 & 9 & 43.0 & Derrick et al. (2008) \\
\hline Henry Spencer & 1 & 50.0 & 1 & 50.0 & Wilson (2006) \\
\hline Lake Palastine & 0 & 0.0 & 3 & 100.0 & Wilson (2006) \\
\hline Gregg Site 20 & 0 & 0.0 & 1 & 0.0 & Wilson (2006) \\
\hline Roitsch*(41RR16) & 0 & 0.0 & 1 & 100.0 & Wilson (2006) \\
\hline Holdeman (41RR11) & 4 & 29.0 & 10 & 71.0 & Loveland (1986) \\
\hline Clark (41RR77) & 10 & 56.0 & 8 & 44.0 & Loveland (1986) \\
\hline Alex Justiss (41TT13) & 2 & 100.0 & 0 & 0.0 & Rogers et al. (2003) \\
\hline Pine Tree Mound (41HS15) & 4 & 44.0 & 5 & 56.0 & Wilson (2008a) \\
\hline Beech Ridge (41NA242) & 0 & 0.0 & 1 & 100.0 & Wilson (2008b) \\
\hline Boyette (41NA285) & 1 & 100.0 & 0 & 0.0 & Wilson (2008b) \\
\hline Cedar Grove (3LA97) & 3 & 33.3 & 6 & 66.7 & Rose (1984) \\
\hline McLelland (16BO236) & 2 & 40.0 & 3 & 60.0 & $\begin{array}{l}\text { (Tiné and Tieszan } \\
\text { 1997) }\end{array}$ \\
\hline Cooper Lake & 14 & 46.6 & 16 & 53.3 & $\begin{array}{l}\text { Wilson and Steele } \\
\text { (1997) }\end{array}$ \\
\hline Red River & 107 & 48.2 & 115 & 51.8 & Burnett $(1990,1999)$ \\
\hline Sulphur River & 10 & 67.0 & 5 & 33.0 & Burnett $(1990,1999)$ \\
\hline $\begin{array}{l}\text { Cypress Creek \& Upper } \\
\text { Sabine }\end{array}$ & 12 & 57.1 & 9 & 42.9 & Burnett $(1990,1999)$ \\
\hline Middle Sabine & 5 & 26.3 & 14 & 73.7 & Burnett $(1990,1999)$ \\
\hline Neches River & 6 & 75.0 & 2 & 25.0 & Burnett $(1990,1999)$ \\
\hline $\begin{array}{l}\text { Texas TARL (exclusive of } \\
\text { Upper Neches River sites) }\end{array}$ & 72 & 51.0 & 68 & 49.0 & Wilson (1998) \\
\hline Total & 354 & 49.0 & 368 & 51.0 & \\
\hline
\end{tabular}

Notes: The total excludes known individuals who were double counted from Hatchel, Mitchell and Moores which are housed at TARL. It is not known how many individuals from Burnett's (1999) data are from TARL, but her Sulphur River data has been reduced to reflect those re-examined in the Cooper Lake study. 
Table 10-7. Cranial Masurements for Adults from the Upper Neches River Basin.

\begin{tabular}{|c|c|c|c|c|c|c|c|c|c|}
\hline & 41AN21 & 41AN32 & 41CE1 & & 41CE17 & 41CE1 & & & 41CE290 \\
\hline & G1 & None & AH-3 & AH-7 & AL3 & $\begin{array}{l}\text { F } 119 \\
\text { S1 }\end{array}$ & F 163 & S 1 & None \\
\hline $\begin{array}{l}\text { Cranial } \\
\text { length }\end{array}$ & & & 195 & & & & & & \\
\hline $\begin{array}{l}\text { Cranial } \\
\text { height }\end{array}$ & & 135 & 194 & & & & & & \\
\hline $\begin{array}{l}\text { Cranial } \\
\text { breadth }\end{array}$ & & & & & 139 & & & & 137 \\
\hline $\begin{array}{l}\text { Maximum } \\
\text { frontal } \\
\text { breadth }\end{array}$ & & & & & 114 & & & & 95 \\
\hline $\begin{array}{l}\text { Biauricular } \\
\text { breadth }\end{array}$ & & 111 & & & & & & & \\
\hline $\begin{array}{l}\text { Porion- } \\
\text { lambda }\end{array}$ & & 111.5 & & & 119 & & & & 121 \\
\hline $\begin{array}{l}\text { Orbit height } \\
\text { - right }\end{array}$ & & 32.6 & & & & & & & \\
\hline $\begin{array}{l}\text { Mastoid } \\
\text { length - left }\end{array}$ & & & & & & & 29 & & \\
\hline $\begin{array}{l}\text { Mastoid } \\
\text { length -right }\end{array}$ & & & & 23 & & & & & \\
\hline $\begin{array}{l}\text { Mastoid } \\
\text { width - left }\end{array}$ & & & 30.2 & & & & & & \\
\hline $\begin{array}{l}\text { Mastoid } \\
\text { width - right }\end{array}$ & & & & 15.3 & & & & & \\
\hline $\begin{array}{l}\text { Foramen } \\
\text { magnum } \\
\text { length }\end{array}$ & & 31.4 & & & & & & & \\
\hline $\begin{array}{l}\text { Foramen } \\
\text { magnum } \\
\text { breadth }\end{array}$ & & 28.6 & & & & & & & \\
\hline $\begin{array}{l}\text { Mandibular } \\
\text { corpus } \\
\text { height - left }\end{array}$ & & 27 & & & 30.9 & 24.6 & & 24.6 & 27.9 \\
\hline $\begin{array}{l}\text { Mandibular } \\
\text { corpus } \\
\text { height - } \\
\text { right }\end{array}$ & 32 & $\begin{array}{c}23.7 \\
\text { (antemortem } \\
\text { loss of M1) }\end{array}$ & & & 28.2 & & 35.6 & & 27.9 \\
\hline $\begin{array}{l}\text { Mandibular } \\
\text { corpus } \\
\text { breadth - } \\
\text { left } \\
\end{array}$ & & 14.4 & & & 16.4 & & & & 15 \\
\hline $\begin{array}{l}\text { Mandibular } \\
\text { corpus } \\
\text { breadth - } \\
\text { right }\end{array}$ & 15.7 & 14.1 & & & 16.4 & & & & 15.2 \\
\hline $\begin{array}{l}\text { Bimental } \\
\text { foramina } \\
\text { chord }\end{array}$ & & 50 & & & 49 & & & & \\
\hline
\end{tabular}


Table 10-7, continued.

\begin{tabular}{|c|c|c|c|c|c|c|c|c|c|}
\hline & \multirow{2}{*}{$\begin{array}{l}\text { 41AN21 } \\
\text { G1 }\end{array}$} & \multirow{2}{*}{$\begin{array}{l}\text { 41AN32 } \\
\text { None }\end{array}$} & \multicolumn{2}{|c|}{ 41CE12 } & \multirow{2}{*}{$\begin{array}{l}\text { 41CE17 } \\
\text { AL3 }\end{array}$} & \multicolumn{3}{|c|}{ 41CE19 } & \multirow{2}{*}{$\begin{array}{l}\text { 41CE290 } \\
\text { None }\end{array}$} \\
\hline & & & AH-3 & AH-7 & & $\begin{array}{l}\text { F } 119 \\
\text { S1 }\end{array}$ & F 163 & S 1 & \\
\hline $\begin{array}{l}\text { Minimum } \\
\text { ramus } \\
\text { breadth - } \\
\text { right }\end{array}$ & & 30.9 & & & & & & & \\
\hline $\begin{array}{l}\text { Maximum } \\
\text { ramus } \\
\text { breadth - } \\
\text { right }\end{array}$ & & 38.2 & & & & & & & \\
\hline $\begin{array}{l}\text { Coronoid } \\
\text { height - } \\
\text { right }\end{array}$ & & 62.9 & & & 76.5 & & & & \\
\hline $\begin{array}{l}\text { Bigonial } \\
\text { breadth }\end{array}$ & & & 94.6 & & & & & & \\
\hline & & & & & & & & & \\
\hline
\end{tabular}

Notes: Measures are in millimeters. 
Table 10-8. Adult Postcranial Measurements.

\begin{tabular}{|c|c|c|c|c|c|c|c|c|c|}
\hline & \multirow{2}{*}{$\begin{array}{l}\text { 41AN38 } \\
\text { F. } 8\end{array}$} & \multirow{2}{*}{$\begin{array}{l}\text { 41AN21 } \\
\text { G1 }\end{array}$} & \multicolumn{2}{|c|}{ 41CE6 } & \multicolumn{4}{|c|}{ 41CE12 } & \multirow{2}{*}{$\begin{array}{l}\text { 41CE19 } \\
\text { F. } 163\end{array}$} \\
\hline & & & AN1 & AN2 & AH-3 & AH-7 & $\begin{array}{l}\text { AH- } \\
11\end{array}$ & $\begin{array}{l}\text { Prov. } \\
\text { unknown }\end{array}$ & \\
\hline \multicolumn{10}{|l|}{ Humerus } \\
\hline Segment 3 & & & $12.9 \mathrm{R}$ & $15.5 \mathrm{~L}$ & & & & & \\
\hline $\begin{array}{l}\text { Middle } \\
\text { circumference }\end{array}$ & & & & $66 \mathrm{~L}$ & & $62 \mathrm{~L}$ & & & \\
\hline $\begin{array}{l}\text { Maximum } \\
\text { diameter at } \\
\text { midshaft }\end{array}$ & & & & $21.9 \mathrm{~L}$ & & $20.9 \mathrm{~L}$ & & & \\
\hline $\begin{array}{l}\text { Minimum } \\
\text { diameter at } \\
\text { midshaft }\end{array}$ & & & & 19.4 & & $16.5 \mathrm{~L}$ & & & \\
\hline $\begin{array}{l}\text { Minimum } \\
\text { circumference }\end{array}$ & & & & & & $61 \mathrm{~L}$ & & & \\
\hline \multicolumn{10}{|l|}{ Radius } \\
\hline $\begin{array}{l}\text { Middle } \\
\text { circumference }\end{array}$ & & & & & & & & $38 \mathrm{~L}$ & \\
\hline $\begin{array}{l}\text { Anterior- } \\
\text { posterior } \\
\text { diameter at } \\
\text { midshaft } \\
\end{array}$ & & & & & & & & $12.1 \mathrm{~L}$ & \\
\hline $\begin{array}{l}\text { Transverse } \\
\text { diameter at } \\
\text { midshaft }\end{array}$ & & & & & & & & $11.8 \mathrm{~L}$ & \\
\hline $\begin{array}{l}\text { Minimum } \\
\text { circumference }\end{array}$ & & & & & & & & $34 \mathrm{~L}$ & \\
\hline $\begin{array}{l}\text { Minimum } \\
\text { diameter }\end{array}$ & & & & & & & & $9.5 \mathrm{~L}$ & \\
\hline \multicolumn{10}{|l|}{ Clavicle } \\
\hline $\begin{array}{l}\text { Middle } \\
\text { circumference }\end{array}$ & & & & & $35 \mathrm{R}$ & & & & \\
\hline $\begin{array}{l}\text { Anterior- } \\
\text { posterior } \\
\text { diameter at } \\
\text { midshaft }\end{array}$ & & & & & $11.9 \mathrm{R}$ & & & & \\
\hline $\begin{array}{l}\text { Vertical diameter } \\
\text { at midshaft }\end{array}$ & & & & & $10.7 \mathrm{R}$ & & & & \\
\hline \multicolumn{10}{|l|}{ Os coxa } \\
\hline $\begin{array}{l}\text { Acetabular } \\
\text { diameter }\end{array}$ & & & & & & & $49.5 \mathrm{R}$ & & \\
\hline \multicolumn{10}{|l|}{ Femur } \\
\hline $\begin{array}{l}\text { Midshaft } \\
\text { circumference }\end{array}$ & $84 \mathrm{~L}$ & $\begin{array}{l}96 \mathrm{~L} \\
93 \mathrm{R} \\
\end{array}$ & & $91 \mathrm{R}$ & $88 \mathrm{R}$ & & & & \\
\hline $\begin{array}{l}\text { Anterior- } \\
\text { posterior } \\
\text { diameter }\end{array}$ & & $\begin{array}{c}31 \mathrm{~L} \\
33.5 \mathrm{R}\end{array}$ & & $33.4 \mathrm{R}$ & $28.9 \mathrm{R}$ & & & & \\
\hline $\begin{array}{l}\text { Transverse } \\
\text { diameter }\end{array}$ & & $\begin{array}{l}29.7 \mathrm{~L} \\
26.8 \mathrm{R} \\
\end{array}$ & & $24.5 \mathrm{R}$ & $25.6 \mathrm{R}$ & & & & \\
\hline $\begin{array}{l}\text { Anterior } \\
\text { subtrochanteric } \\
\text { diameter }\end{array}$ & & & & $25.7 \mathrm{~L}$ & & & & & \\
\hline
\end{tabular}


Table 10-8, continued.

\begin{tabular}{|c|c|c|c|c|c|}
\hline $\begin{array}{l}\text { Transverse } \\
\text { subtrochanteric } \\
\text { diameter } \\
\end{array}$ & & & $32.8 \mathrm{~L}$ & & \\
\hline $\begin{array}{l}\text { Maximum head } \\
\text { diameter }\end{array}$ & & & $48 \mathrm{~L}$ & & \\
\hline $\begin{array}{l}\text { Minimum vertical } \\
\text { diameter }\end{array}$ & & & $33.2 \mathrm{~L}$ & & \\
\hline \multicolumn{6}{|l|}{ Tibia } \\
\hline $\begin{array}{l}\text { Midshaft } \\
\text { circumference }\end{array}$ & $89 \mathrm{~L}$ & & & & \\
\hline $\begin{array}{l}\text { Circumference at } \\
\text { nutrient foramen }\end{array}$ & $\begin{array}{l}97 \mathrm{~L} \\
96 \mathrm{R}\end{array}$ & & $\begin{array}{l}95 \mathrm{~L} \\
99 \mathrm{R}\end{array}$ & $88 \mathrm{R}$ & $101 \mathrm{~L}$ \\
\hline $\begin{array}{l}\text { Minimum } \\
\text { circumference }\end{array}$ & $\begin{array}{l}80 \mathrm{~L} \\
79 \mathrm{R}\end{array}$ & & $84 \mathrm{~L}$ & & \\
\hline $\begin{array}{l}\text { Anterior-posterior } \\
\text { diameter (nutrient } \\
\text { foramen) }\end{array}$ & $\begin{array}{l}36.7 \mathrm{~L} \\
35.6 \mathrm{R}\end{array}$ & & $\begin{array}{c}38 \mathrm{~L} \\
41.4 \mathrm{R}\end{array}$ & $30.7 \mathrm{R}$ & $39.4 \mathrm{~L}$ \\
\hline $\begin{array}{l}\text { Transverse } \\
\text { diameter (nutrient } \\
\text { foramen) }\end{array}$ & $\begin{array}{l}24.3 \mathrm{~L} \\
23.9 \mathrm{R}\end{array}$ & & $\begin{array}{l}21.3 \mathrm{~L} \\
21.5 \mathrm{R}\end{array}$ & $23.9 \mathrm{R}$ & $22.9 \mathrm{~L}$ \\
\hline $\begin{array}{l}\text { Position nutrient } \\
\text { foramen }\end{array}$ & & & & $97.4 \mathrm{R}$ & \\
\hline \multicolumn{6}{|l|}{ Talus } \\
\hline Maximum length & & 52 & & & \\
\hline
\end{tabular}

Notes: Measurements given are in millimeters. Sides are indicated by $\mathrm{L}$ for left and $\mathrm{R}$ for right.

Table 10-9. Subadult Cranial Measurements in Millimeters.

\begin{tabular}{|l|l|}
\hline & 41AN32 \\
\hline Squamous width & 105.1 \\
\hline length & $39.8 \mathrm{~L}$ \\
\hline Width of arc & $31 \mathrm{~L}$ \\
\hline Length & $95.9 \mathrm{R}$ \\
\hline
\end{tabular}

Note: Sides are indicated by $\mathrm{L}$ for left and $\mathrm{R}$ for right. 
Table 10-10. Dental Measurements in Millimeters on Permanent Dentition.

\begin{tabular}{|c|c|c|c|c|c|c|c|c|c|}
\hline & \multicolumn{5}{|c|}{ 41AN38 } & \multirow{2}{*}{$\begin{array}{l}\text { 41AN14 } \\
\text { AG-1 }\end{array}$} & \multirow{2}{*}{$\begin{array}{l}\text { 41AN21 } \\
\text { G-1 }\end{array}$} & \multirow{2}{*}{$\begin{array}{l}\text { 41AN32 } \\
\text { NONE } \\
(\text { TARL 2100) }\end{array}$} \\
\hline & & $\begin{array}{l}\text { F. } \\
76 B\end{array}$ & $\begin{array}{l}\text { F. } \\
76 \mathrm{C}\end{array}$ & $\begin{array}{l}\text { F. } \\
92\end{array}$ & $\begin{array}{l}\text { F. } 93 \\
\text { B1 }\end{array}$ & $\begin{array}{l}\text { F. } 93 \\
\text { B2 }\end{array}$ & & & \\
\hline \multicolumn{10}{|l|}{ Tooth } \\
\hline \multicolumn{10}{|c|}{ Maxillary } \\
\hline \multirow[t]{6}{*}{ RM3 } & $\begin{array}{l}\text { Crown } \\
\text { Mesio-distal }\end{array}$ & & & & & & & 10.0 & \\
\hline & $\begin{array}{l}\text { Crown Bucco- } \\
\text { lingual }\end{array}$ & & & & & & & 11.6 & \\
\hline & Crown height & & & & & & & & \\
\hline & $\begin{array}{l}\text { Cervical } \\
\text { Mesio-distal }\end{array}$ & & & & & & & 8.3 & \\
\hline & $\begin{array}{l}\text { Cervical } \\
\text { Bucco-lingual }\end{array}$ & & & & & & & 10.8 & \\
\hline & Root length & & & & & & & 15.5 & \\
\hline \multirow[t]{6}{*}{ RM2 } & $\begin{array}{l}\text { Crown } \\
\text { Mesio-distal }\end{array}$ & & 8.8 & & & 11.1 & & & \\
\hline & $\begin{array}{l}\text { Crown Bucco- } \\
\text { lingual }\end{array}$ & & 9.8 & & & 12.2 & & & \\
\hline & Crown height & & & & & & & & \\
\hline & $\begin{array}{l}\text { Cervical } \\
\text { Mesio-distal }\end{array}$ & & & 9.9 & & & & & \\
\hline & $\begin{array}{l}\text { Cervical } \\
\text { Bucco-lingual }\end{array}$ & & & 14.1 & & & & & \\
\hline & Root length & & & & & & & & \\
\hline \multirow[t]{5}{*}{ RM1 } & $\begin{array}{l}\text { Crown } \\
\text { Mesio-distal }\end{array}$ & & & & & & & 11.0 & 11.3 \\
\hline & $\begin{array}{l}\text { Crown Bucco- } \\
\text { lingual }\end{array}$ & & & & & & & & 11.2 \\
\hline & Crown height & & & & & & & & \\
\hline & $\begin{array}{l}\text { Cervical } \\
\text { Mesio-distal }\end{array}$ & & & & & & & 8.4 & \\
\hline & $\begin{array}{l}\text { Cervical } \\
\text { Bucco-lingual }\end{array}$ & & & & & & & 10.8 & \\
\hline
\end{tabular}


Table 10-10, continued.

\begin{tabular}{|c|c|c|c|c|c|c|c|c|c|}
\hline & & \multicolumn{5}{|c|}{ 41AN38 } & \multirow{2}{*}{$\begin{array}{l}\text { 41AN14 } \\
\text { AG-1 }\end{array}$} & \multirow{2}{*}{$\begin{array}{l}\text { 41AN21 } \\
\text { G-1 }\end{array}$} & \multirow{2}{*}{$\begin{array}{l}\text { 41AN32 } \\
\text { NONE (TARL } \\
2100 \text { ) }\end{array}$} \\
\hline & & $\begin{array}{l}\text { F. } \\
76 B\end{array}$ & $\begin{array}{l}\text { F. } \\
76 C\end{array}$ & $\begin{array}{l}\text { F. } \\
92\end{array}$ & $\begin{array}{l}\text { F. } 93 \\
\text { B1 }\end{array}$ & $\begin{array}{l}\text { F. 93 } \\
\text { B2 }\end{array}$ & & & \\
\hline & Root length & & & & & & & & \\
\hline \multirow[t]{6}{*}{$\mathrm{RP} 2$} & $\begin{array}{l}\text { Crown } \\
\text { Mesio-distal }\end{array}$ & & & & & & & 6.8 & \\
\hline & $\begin{array}{l}\text { Crown Bucco- } \\
\text { lingual }\end{array}$ & & & & & & & 9.4 & \\
\hline & Crown height & & & & & & & & \\
\hline & $\begin{array}{l}\text { Cervical Mesio- } \\
\text { distal }\end{array}$ & & & & & & & 5.0 & \\
\hline & $\begin{array}{l}\text { Cervical Bucco- } \\
\text { lingual }\end{array}$ & & & & & & & 8.2 & \\
\hline & Root length & & & & & & & 16.3 & \\
\hline \multirow[t]{6}{*}{ RP1 } & $\begin{array}{l}\text { Crown } \\
\text { Mesio-distal }\end{array}$ & & & & & & & & \\
\hline & $\begin{array}{l}\text { Crown Bucco- } \\
\text { lingual }\end{array}$ & & & & & & & & \\
\hline & Crown height & & & & & & & & \\
\hline & $\begin{array}{l}\text { Cervical Mesio- } \\
\text { distal }\end{array}$ & & & & & & & 4.9 & \\
\hline & $\begin{array}{l}\text { Cervical Bucco- } \\
\text { lingual }\end{array}$ & & & & & & & 7.8 & \\
\hline & Root length & & & & & & & & \\
\hline \multirow[t]{5}{*}{$\mathrm{RC}$} & $\begin{array}{l}\text { Crown } \\
\text { Mesio-distal }\end{array}$ & 7.5 & & & & & & 8.8 & \\
\hline & $\begin{array}{l}\text { Crown Bucco- } \\
\text { lingual }\end{array}$ & 5.5 & & & & & & 8.9 & \\
\hline & Crown height & & & & & & & & \\
\hline & $\begin{array}{l}\text { Cervical Mesio- } \\
\text { distal }\end{array}$ & & & & & & & 6.5 & \\
\hline & $\begin{array}{l}\text { Cervical Bucco- } \\
\text { lingual }\end{array}$ & & & & & & & 8.2 & \\
\hline
\end{tabular}


Table 10-10, continued.

\begin{tabular}{|c|c|c|c|c|c|c|c|c|c|}
\hline & \multicolumn{5}{|c|}{ 41AN38 } & \multirow{2}{*}{$\begin{array}{l}\text { 41AN14 } \\
\text { AG-1 }\end{array}$} & \multirow{2}{*}{$\begin{array}{l}\text { 41AN21 } \\
\text { G-1 }\end{array}$} & \multirow{2}{*}{$\begin{array}{l}\text { 41AN32 } \\
\text { NONE (TARL } \\
2100 \text { ) } \\
\end{array}$} \\
\hline & & $\begin{array}{l}\text { F. } \\
76 B\end{array}$ & $\begin{array}{l}\text { F. } \\
76 C\end{array}$ & $\begin{array}{l}\text { F. } \\
92\end{array}$ & $\begin{array}{l}\text { F. } 93 \\
\text { B1 }\end{array}$ & $\begin{array}{l}\text { F. } 93 \\
\text { B2 }\end{array}$ & & & \\
\hline & Root length & & & & & & & & \\
\hline \multirow[t]{6}{*}{ RI2 } & $\begin{array}{l}\text { Crown } \\
\text { Mesio-distal }\end{array}$ & & & & & & & & \\
\hline & $\begin{array}{l}\text { Crown Bucco- } \\
\text { lingual }\end{array}$ & & & & & & & & \\
\hline & Crown height & & & & & & & & \\
\hline & $\begin{array}{l}\text { Cervical Mesio- } \\
\text { distal }\end{array}$ & & & & & & & & \\
\hline & $\begin{array}{l}\text { Cervical Bucco- } \\
\text { lingual }\end{array}$ & & & & & & & & \\
\hline & Root length & & & & & & & & \\
\hline \multirow[t]{6}{*}{ RI1 } & $\begin{array}{l}\text { Crown } \\
\text { Mesio-distal }\end{array}$ & 9.3 & & & & & & & \\
\hline & $\begin{array}{l}\text { Crown Bucco- } \\
\text { lingual }\end{array}$ & 6.5 & & & & & & & \\
\hline & Crown height & & & & & & & & \\
\hline & $\begin{array}{l}\text { Cervical Mesio- } \\
\text { distal }\end{array}$ & & & & & & & & \\
\hline & $\begin{array}{l}\text { Cervical Bucco- } \\
\text { lingual }\end{array}$ & & & & & & & & \\
\hline & Root length & & & & & & & & \\
\hline \multirow[t]{5}{*}{ LI1 } & $\begin{array}{l}\text { Crown } \\
\text { Mesio-distal }\end{array}$ & & & & & & & & \\
\hline & $\begin{array}{l}\text { Crown Bucco- } \\
\text { lingual }\end{array}$ & & & & & & & & \\
\hline & Crown height & & & & & & & & \\
\hline & $\begin{array}{l}\text { Cervical Mesio- } \\
\text { distal }\end{array}$ & & & & & & & & \\
\hline & $\begin{array}{l}\text { Cervical Bucco- } \\
\text { lingual }\end{array}$ & & & & & & & & \\
\hline
\end{tabular}


Table 10-10, continued.

\begin{tabular}{|c|c|c|c|c|c|c|c|c|c|}
\hline & \multicolumn{5}{|c|}{ 41AN38 } & \multirow{2}{*}{$\begin{array}{l}\text { 41AN14 } \\
\text { AG-1 }\end{array}$} & \multirow{2}{*}{$\begin{array}{l}\text { 41AN21 } \\
\text { G-1 }\end{array}$} & \multirow{2}{*}{$\begin{array}{l}\text { 41AN32 } \\
\text { NONE (TARL } \\
\text { 2100) } \\
\end{array}$} \\
\hline & & $\begin{array}{l}\text { F. } \\
76 B\end{array}$ & $\begin{array}{l}\text { F. } \\
76 \mathrm{C}\end{array}$ & $\begin{array}{l}\text { F. } \\
92\end{array}$ & $\begin{array}{l}\text { F. } 93 \\
\text { B1 }\end{array}$ & $\begin{array}{l}\text { F. } 93 \\
\text { B2 }\end{array}$ & & & \\
\hline & Root length & & & & & & & & \\
\hline \multirow[t]{6}{*}{ LI2 } & $\begin{array}{l}\text { Crown } \\
\text { Mesio-distal }\end{array}$ & & & & & & & & \\
\hline & $\begin{array}{l}\text { Crown Bucco- } \\
\text { lingual }\end{array}$ & & & & & & & & \\
\hline & Crown height & & & & & & & & \\
\hline & $\begin{array}{l}\text { Cervical Mesio- } \\
\text { distal }\end{array}$ & & & & & & & & \\
\hline & $\begin{array}{l}\text { Cervical Bucco- } \\
\text { lingual }\end{array}$ & & & & & & & & \\
\hline & Root length & & & & & & & & \\
\hline \multirow[t]{6}{*}{ LC } & $\begin{array}{l}\text { Crown } \\
\text { Mesio-distal }\end{array}$ & & & & & & & 8.7 & \\
\hline & $\begin{array}{l}\text { Crown Bucco- } \\
\text { lingual }\end{array}$ & & & & & & & 8.8 & \\
\hline & Crown height & & & & & & & & \\
\hline & $\begin{array}{l}\text { Cervical Mesio- } \\
\text { distal }\end{array}$ & & & & & & & 6.7 & \\
\hline & $\begin{array}{l}\text { Cervical Bucco- } \\
\text { lingual }\end{array}$ & & & & & & & & \\
\hline & Root length & & & & & & & & \\
\hline \multirow[t]{5}{*}{ LP1 } & $\begin{array}{l}\text { Crown } \\
\text { Mesio-distal }\end{array}$ & 8.4 & & & & & & & \\
\hline & $\begin{array}{l}\text { Crown Bucco- } \\
\text { lingual }\end{array}$ & 9.9 & & & & & & 9.1 & \\
\hline & Crown height & & & & & & & & \\
\hline & $\begin{array}{l}\text { Cervical Mesio- } \\
\text { distal }\end{array}$ & & & & & & & 4.8 & \\
\hline & $\begin{array}{l}\text { Cervical Bucco- } \\
\text { lingual }\end{array}$ & & & & & & & 7.9 & \\
\hline
\end{tabular}


Table 10-10, continued.

\begin{tabular}{|c|c|c|c|c|c|c|c|c|c|}
\hline & \multicolumn{5}{|c|}{ 41AN38 } & \multirow{2}{*}{$\begin{array}{l}\text { 41AN14 } \\
\text { AG-1 }\end{array}$} & \multirow{2}{*}{$\begin{array}{l}\text { 41AN21 } \\
\text { G-1 }\end{array}$} & \multirow{2}{*}{$\begin{array}{l}\text { 41AN32 } \\
\text { NONE (TARL } \\
\text { 2100) }\end{array}$} \\
\hline & & $\begin{array}{l}\text { F. } \\
76 B\end{array}$ & $\begin{array}{l}\text { F. } \\
76 C\end{array}$ & $\begin{array}{l}\text { F. } \\
92\end{array}$ & $\begin{array}{l}\text { F. } 93 \\
\text { B1 }\end{array}$ & $\begin{array}{l}\text { F. } 93 \\
\text { B2 }\end{array}$ & & & \\
\hline & Root length & & & & & & & 16.5 & \\
\hline \multirow[t]{6}{*}{ LP2 } & $\begin{array}{l}\text { Crown } \\
\text { Mesio-distal }\end{array}$ & & & & & & & 7.4 & \\
\hline & $\begin{array}{l}\text { Crown Bucco- } \\
\text { lingual }\end{array}$ & & & & & & & 8.9 & \\
\hline & Crown height & & & & & & & & \\
\hline & $\begin{array}{l}\text { Cervical Mesio- } \\
\text { distal }\end{array}$ & & & & & & & 5.0 & \\
\hline & $\begin{array}{l}\text { Cervical Bucco- } \\
\text { lingual }\end{array}$ & & & & & & & 7.7 & \\
\hline & Root length & & & & & & & & \\
\hline \multirow[t]{6}{*}{ LM1 } & $\begin{array}{l}\text { Crown } \\
\text { Mesio-distal }\end{array}$ & & 11.7 & & & & 12.0 & & 10.9 \\
\hline & $\begin{array}{l}\text { Crown Bucco- } \\
\text { lingual }\end{array}$ & & 11.1 & & & & 11.1 & & 11.3 \\
\hline & Crown height & & & & & & & & \\
\hline & $\begin{array}{l}\text { Cervical Mesio- } \\
\text { distal }\end{array}$ & & & & & & & 7.7 & \\
\hline & $\begin{array}{l}\text { Cervical Bucco- } \\
\text { lingual }\end{array}$ & & & & & & & 11.3 & \\
\hline & Root length & & & & & & & & \\
\hline \multirow[t]{5}{*}{ LM2 } & $\begin{array}{l}\text { Crown } \\
\text { Mesio-distal }\end{array}$ & & & & & & & 9.8 & \\
\hline & $\begin{array}{l}\text { Crown Bucco- } \\
\text { lingual }\end{array}$ & & & & & & & 10.3 & \\
\hline & Crown height & & & & & & & & \\
\hline & $\begin{array}{l}\text { Cervical Mesio- } \\
\text { distal }\end{array}$ & & & & 7.7 & & & 7.6 & \\
\hline & $\begin{array}{l}\text { Cervical Bucco- } \\
\text { lingual }\end{array}$ & & & & & & & 10.8 & \\
\hline
\end{tabular}


Table 10-10, continued.

\begin{tabular}{|c|c|c|c|c|c|c|c|c|c|}
\hline & \multicolumn{5}{|c|}{ 41AN38 } & \multirow{2}{*}{$\begin{array}{l}\text { 41AN14 } \\
\text { AG-1 }\end{array}$} & \multirow{2}{*}{$\begin{array}{l}\text { 41AN21 } \\
\text { G-1 }\end{array}$} & \multirow{2}{*}{$\begin{array}{l}\text { 41AN32 } \\
\text { NONE (TARL } \\
2100) \\
\end{array}$} \\
\hline & & $\begin{array}{l}\text { F. } \\
76 B\end{array}$ & $\begin{array}{l}\text { F. } \\
76 C\end{array}$ & $\begin{array}{l}\text { F. } \\
92\end{array}$ & $\begin{array}{l}\text { F. } 93 \\
\text { B1 }\end{array}$ & $\begin{array}{l}\text { F. } 93 \\
\text { B2 }\end{array}$ & & & \\
\hline & Root length & & & & & & & & \\
\hline \multirow[t]{6}{*}{ LM3 } & $\begin{array}{l}\text { Crown } \\
\text { Mesio-distal }\end{array}$ & & & & & & & & \\
\hline & $\begin{array}{l}\text { Crown Bucco- } \\
\text { lingual }\end{array}$ & & & & & & & & \\
\hline & Crown height & & & & & & & & \\
\hline & $\begin{array}{l}\text { Cervical Mesio- } \\
\text { distal }\end{array}$ & & & & & & & & \\
\hline & $\begin{array}{l}\text { Cervical Bucco- } \\
\text { lingual }\end{array}$ & & & & & & & & \\
\hline & Root length & & & & & & & & \\
\hline \multicolumn{10}{|c|}{ Mandibular } \\
\hline \multirow[t]{6}{*}{ LM3 } & $\begin{array}{l}\text { Crown } \\
\text { Mesio-distal }\end{array}$ & & & & & & & & \\
\hline & $\begin{array}{l}\text { Crown Bucco- } \\
\text { lingual }\end{array}$ & & & & & & & & \\
\hline & Crown height & & & & & & & & \\
\hline & $\begin{array}{l}\text { Cervical Mesio- } \\
\text { distal }\end{array}$ & & & & 10.2 & & & & \\
\hline & $\begin{array}{l}\text { Cervical Bucco- } \\
\text { lingual }\end{array}$ & & & & 9.3 & & & & \\
\hline & Root length & & & & & & & & \\
\hline \multirow[t]{5}{*}{ LM2 } & $\begin{array}{l}\text { Crown } \\
\text { Mesio-distal }\end{array}$ & & & & & & & & \\
\hline & $\begin{array}{l}\text { Crown Bucco- } \\
\text { lingual }\end{array}$ & & & & & & & & \\
\hline & Crown height & & & & & & & & \\
\hline & $\begin{array}{l}\text { Cervical Mesio- } \\
\text { distal }\end{array}$ & & & & & & & & \\
\hline & $\begin{array}{l}\text { Cervical Bucco- } \\
\text { lingual }\end{array}$ & & & & & & & & \\
\hline
\end{tabular}


Table 10-10, continued.

\begin{tabular}{|c|c|c|c|c|c|c|c|c|c|}
\hline & \multicolumn{5}{|c|}{ 41AN38 } & \multirow{2}{*}{$\begin{array}{l}\text { 41AN14 } \\
\text { AG-1 }\end{array}$} & \multirow{2}{*}{$\begin{array}{l}\text { 41AN21 } \\
\text { G-1 }\end{array}$} & \multirow{2}{*}{$\begin{array}{l}\text { 41AN32 } \\
\text { NONE (TARL } \\
2100)\end{array}$} \\
\hline & & $\begin{array}{l}\text { F. } \\
76 B\end{array}$ & $\begin{array}{l}\text { F. } \\
76 C\end{array}$ & $\begin{array}{l}\text { F. } \\
92\end{array}$ & $\begin{array}{l}\text { F. } 93 \\
\text { B1 }\end{array}$ & $\begin{array}{l}\text { F. } 93 \\
\text { B2 }\end{array}$ & & & \\
\hline & Root length & & & & & & & & \\
\hline \multirow[t]{6}{*}{ LM1 } & $\begin{array}{l}\text { Crown } \\
\text { Mesio-distal }\end{array}$ & & & & & & & 11.8 & 11.7 \\
\hline & $\begin{array}{l}\text { Crown Bucco- } \\
\text { lingual }\end{array}$ & & & & & & & 11.1 & 10.8 \\
\hline & Crown height & & & & & & & & \\
\hline & $\begin{array}{l}\text { Cervical Mesio- } \\
\text { distal }\end{array}$ & & & & & & & 9.4 & \\
\hline & $\begin{array}{l}\text { Cervical Bucco- } \\
\text { lingual }\end{array}$ & & & & & & & & \\
\hline & Root length & & & & & & & & \\
\hline \multirow[t]{6}{*}{ LP2 } & $\begin{array}{l}\text { Crown } \\
\text { Mesio-distal }\end{array}$ & & & & & & & & \\
\hline & $\begin{array}{l}\text { Crown Bucco- } \\
\text { lingual }\end{array}$ & & & & & & & & \\
\hline & Crown height & & & & & & & & \\
\hline & $\begin{array}{l}\text { Cervical Mesio- } \\
\text { distal }\end{array}$ & & & & & & & & \\
\hline & $\begin{array}{l}\text { Cervical Bucco- } \\
\text { lingual }\end{array}$ & & & & & & & 4.7 & \\
\hline & Root length & & & & & & & 7.0 & \\
\hline \multirow[t]{5}{*}{ LP1 } & $\begin{array}{l}\text { Crown } \\
\text { Mesio-distal }\end{array}$ & & & & & & & & \\
\hline & $\begin{array}{l}\text { Crown Bucco- } \\
\text { lingual }\end{array}$ & & & & & & & & \\
\hline & Crown height & & & & & & & & \\
\hline & $\begin{array}{l}\text { Cervical Mesio- } \\
\text { distal }\end{array}$ & & & & & & & & \\
\hline & $\begin{array}{l}\text { Cervical Bucco- } \\
\text { lingual }\end{array}$ & & & & & & & & \\
\hline
\end{tabular}


Table 10-10, continued.

\begin{tabular}{|c|c|c|c|c|c|c|c|c|c|}
\hline & \multicolumn{5}{|c|}{ 41AN38 } & \multirow{2}{*}{$\begin{array}{l}\text { 41AN14 } \\
\text { AG-1 }\end{array}$} & \multirow{2}{*}{$\begin{array}{l}\text { 41AN21 } \\
\text { G-1 }\end{array}$} & \multirow{2}{*}{$\begin{array}{l}\text { 41AN32 } \\
\text { NONE (TARL } \\
2100) \\
\end{array}$} \\
\hline & & $\begin{array}{l}\text { F. } \\
76 B\end{array}$ & $\begin{array}{l}\text { F. } \\
76 C\end{array}$ & $\begin{array}{l}\text { F. } \\
92\end{array}$ & $\begin{array}{l}\text { F. } 93 \\
\text { B1 }\end{array}$ & $\begin{array}{l}\text { F.93 } \\
\text { B2 }\end{array}$ & & & \\
\hline & Root length & & & & & & & & \\
\hline \multirow[t]{6}{*}{ LC } & $\begin{array}{l}\text { Crown } \\
\text { Mesio-distal }\end{array}$ & 8.4 & & & & & & & \\
\hline & $\begin{array}{l}\text { Crown Bucco- } \\
\text { lingual }\end{array}$ & 8.0 & & & & & & & \\
\hline & Crown height & & & & & & & & \\
\hline & $\begin{array}{l}\text { Cervical Mesio- } \\
\text { distal }\end{array}$ & & & & & & & & \\
\hline & $\begin{array}{l}\text { Cervical Bucco- } \\
\text { lingual }\end{array}$ & & & & & & & & \\
\hline & Root length & & & & & & & & \\
\hline \multirow[t]{6}{*}{ LI2 } & $\begin{array}{l}\text { Crown } \\
\text { Mesio-distal }\end{array}$ & & & & & & & & 7.1 \\
\hline & $\begin{array}{l}\text { Crown Bucco- } \\
\text { lingual }\end{array}$ & & & & & & & & 5.7 \\
\hline & Crown height & & & & & & & & 8.8 \\
\hline & $\begin{array}{l}\text { Cervical Mesio- } \\
\text { distal }\end{array}$ & & & & & & & & \\
\hline & $\begin{array}{l}\text { Cervical Bucco- } \\
\text { lingual }\end{array}$ & & & & & & & & \\
\hline & Root length & & & & & & & & \\
\hline \multirow[t]{5}{*}{ LI1 } & $\begin{array}{l}\text { Crown } \\
\text { Mesio-distal }\end{array}$ & & & & & & & & 5.6 \\
\hline & $\begin{array}{l}\text { Crown Bucco- } \\
\text { lingual }\end{array}$ & & & & & & & & \\
\hline & Crown height & & & & & & & & \\
\hline & $\begin{array}{l}\text { Cervical Mesio- } \\
\text { distal }\end{array}$ & & & & & & & & \\
\hline & $\begin{array}{l}\text { Cervical Bucco- } \\
\text { lingual }\end{array}$ & & & & & & & & \\
\hline
\end{tabular}


Table 10-10, continued.

\begin{tabular}{|c|c|c|c|c|c|c|c|c|c|}
\hline & \multicolumn{5}{|c|}{ 41AN38 } & \multirow{2}{*}{\begin{tabular}{|l|} 
41AN14 \\
AG-1 \\
\end{tabular}} & \multirow{2}{*}{$\begin{array}{l}\text { 41AN21 } \\
\text { G-1 }\end{array}$} & \multirow{2}{*}{$\begin{array}{l}\text { 41AN32 } \\
\text { NONE } \\
\text { (TARL } \\
2100 \text { ) } \\
\end{array}$} \\
\hline & & $\begin{array}{l}\text { F. } \\
76 B\end{array}$ & $\begin{array}{l}F . \\
76 C\end{array}$ & $\begin{array}{l}\text { F. } \\
92\end{array}$ & $\begin{array}{l}\text { F. } 93 \\
\text { B1 }\end{array}$ & $\begin{array}{l}\text { F. } 93 \\
\text { B2 }\end{array}$ & & & \\
\hline & Root length & & & & & & & & \\
\hline \multirow[t]{6}{*}{ RI1 } & $\begin{array}{l}\text { Crown } \\
\text { Mesio-distal }\end{array}$ & & & & & & & & \\
\hline & $\begin{array}{l}\text { Crown Bucco- } \\
\text { lingual }\end{array}$ & & & & & & & & \\
\hline & Crown height & & & & & & & & \\
\hline & $\begin{array}{l}\text { Cervical Mesio- } \\
\text { distal }\end{array}$ & & & & & & & & \\
\hline & $\begin{array}{l}\text { Cervical Bucco- } \\
\text { lingual }\end{array}$ & & & & & & & & \\
\hline & Root length & & & & & & & & \\
\hline \multirow[t]{6}{*}{ RI2 } & $\begin{array}{l}\text { Crown } \\
\text { Mesio-distal }\end{array}$ & & & & & & & & \\
\hline & $\begin{array}{l}\text { Crown Bucco- } \\
\text { lingual }\end{array}$ & & & & & & & 6.0 & \\
\hline & Crown height & & & & & & & & \\
\hline & $\begin{array}{l}\text { Cervical Mesio- } \\
\text { distal }\end{array}$ & & & & & & & 4.1 & \\
\hline & $\begin{array}{l}\text { Cervical Bucco- } \\
\text { lingual }\end{array}$ & & & & & & & 5.8 & \\
\hline & Root length & & & & & & & & \\
\hline \multirow[t]{6}{*}{$\mathrm{RC}$} & $\begin{array}{l}\text { Crown } \\
\text { Mesio-distal }\end{array}$ & & & & & & & & \\
\hline & $\begin{array}{l}\text { Crown Bucco- } \\
\text { lingual }\end{array}$ & & & & & & & & \\
\hline & Crown height & & & & & & & & \\
\hline & $\begin{array}{l}\text { Cervical Mesio- } \\
\text { distal }\end{array}$ & & & & & & & & \\
\hline & $\begin{array}{l}\text { Cervical Bucco- } \\
\text { lingual }\end{array}$ & & & & & & & & \\
\hline & Root length & & & & & & & & \\
\hline
\end{tabular}


Table 10-10, continued.

\begin{tabular}{|c|c|c|c|c|c|c|c|c|c|}
\hline & \multicolumn{5}{|c|}{ 41AN38 } & \multirow{2}{*}{$\begin{array}{l}\text { 41AN14 } \\
\text { AG-1 }\end{array}$} & \multirow{2}{*}{$\begin{array}{l}\text { 41AN21 } \\
\text { G-1 }\end{array}$} & \multirow{2}{*}{$\begin{array}{l}\text { 41AN32 } \\
\text { NONE (TARL } \\
2100 \text { ) }\end{array}$} \\
\hline & & $\begin{array}{l}\text { F. } \\
76 B \\
\end{array}$ & $\begin{array}{l}\text { F. } \\
76 \mathrm{C}\end{array}$ & $\begin{array}{l}\text { F. } \\
92\end{array}$ & $\begin{array}{l}\text { F. } 93 \\
\text { B1 }\end{array}$ & $\begin{array}{l}\text { F. 93 } \\
\text { B2 }\end{array}$ & & & \\
\hline \multirow[t]{6}{*}{ RP1 } & $\begin{array}{l}\text { Crown } \\
\text { Mesio-distal }\end{array}$ & & & & & & 6.9 & & \\
\hline & $\begin{array}{l}\text { Crown Bucco- } \\
\text { lingual }\end{array}$ & & & & & & 8.4 & & \\
\hline & Crown height & & & & & & & & \\
\hline & $\begin{array}{l}\text { Cervical Mesio- } \\
\text { distal }\end{array}$ & & & & & & 4.9 & & \\
\hline & $\begin{array}{l}\text { Cervical Bucco- } \\
\text { lingual }\end{array}$ & & & & & & & & \\
\hline & Root length & & & & & & & & \\
\hline \multirow[t]{6}{*}{ RP2 } & $\begin{array}{l}\text { Crown } \\
\text { Mesio-distal }\end{array}$ & & 6.9 & & & & 7.0 & & \\
\hline & $\begin{array}{l}\text { Crown Bucco- } \\
\text { lingual }\end{array}$ & & 8.2 & & & & 8.6 & & \\
\hline & Crown height & & & & & & & & \\
\hline & $\begin{array}{l}\text { Cervical Mesio- } \\
\text { distal }\end{array}$ & & & & & & 5.3 & 4.9 & \\
\hline & $\begin{array}{l}\text { Cervical Bucco- } \\
\text { lingual }\end{array}$ & & & & & & 7.3 & 7.1 & \\
\hline & Root length & & & & & & & & \\
\hline \multirow[t]{6}{*}{ RM1 } & $\begin{array}{l}\text { Crown } \\
\text { Mesio-distal }\end{array}$ & 12.7 & & & & & & 10.8 & 11.7 \\
\hline & $\begin{array}{l}\text { Crown Bucco- } \\
\text { lingual }\end{array}$ & 11.6 & & & & & & & 10.6 \\
\hline & Crown height & & & & & & & & \\
\hline & $\begin{array}{l}\text { Cervical Mesio- } \\
\text { distal }\end{array}$ & & & & & & & & \\
\hline & $\begin{array}{l}\text { Cervical Bucco- } \\
\text { lingual }\end{array}$ & & & & & & & & \\
\hline & Root length & & & & & & & & \\
\hline \multirow[t]{6}{*}{ RM2 } & $\begin{array}{l}\text { Crown } \\
\text { Mesio-distal }\end{array}$ & & & & & & & 9.8 & \\
\hline & $\begin{array}{l}\text { Crown Bucco- } \\
\text { lingual }\end{array}$ & & & & & & & & \\
\hline & Crown height & & & & & & & & \\
\hline & $\begin{array}{l}\text { Cervical Mesio- } \\
\text { distal }\end{array}$ & & & & & & & & \\
\hline & $\begin{array}{l}\text { Cervical Bucco- } \\
\text { lingual }\end{array}$ & & & & 9.0 & & & & \\
\hline & Root length & & & & & & & & \\
\hline \multirow[t]{5}{*}{ RM3 } & $\begin{array}{l}\text { Crown } \\
\text { Mesio-distal }\end{array}$ & & & & & & & 9.6 & \\
\hline & $\begin{array}{l}\text { Crown Bucco- } \\
\text { lingual }\end{array}$ & & & & & & & & \\
\hline & Crown height & & & & & & & & \\
\hline & $\begin{array}{l}\text { Cervical Mesio- } \\
\text { distal }\end{array}$ & & & & & & & & \\
\hline & $\begin{array}{l}\text { Cervical Bucco- } \\
\text { lingual }\end{array}$ & & & & & & & & \\
\hline
\end{tabular}


Archeological Investigations at the Lang Pasture Site (41AN38) in the Upper Neches River Basin of East Texas Texas Department of Transportation

\begin{tabular}{|l|l|l|l|l|l|l|l|l|l|}
\hline \multirow{2}{*}{ RM3 } & Root length & & & & & & & & \\
\hline & $\begin{array}{l}\text { Crown } \\
\text { Mesio-distal }\end{array}$ & & & & & & 8.8 & & \\
\cline { 2 - 9 } & $\begin{array}{l}\text { Crown Bucco- } \\
\text { lingual }\end{array}$ & & & & & & 9.5 & & \\
\hline & Crown height & & & & & & & & \\
\hline
\end{tabular}


Table 10-10, continued.

\begin{tabular}{|c|c|c|c|c|c|c|c|c|c|}
\hline & \multirow{2}{*}{$\begin{array}{l}\text { 41AN32 } \\
\text { NONE (TARL } \\
\text { 2101) } \\
\end{array}$} & \multicolumn{5}{|c|}{$41 \mathrm{CE} 4$} & \multicolumn{2}{|c|}{ 41CE6 } \\
\hline & & & $\begin{array}{l}\text { AI- } \\
1\end{array}$ & $\begin{array}{l}\text { AI- } \\
2\end{array}$ & $\begin{array}{l}\text { AI- } \\
3\end{array}$ & $\begin{array}{l}\text { AI- } \\
4\end{array}$ & $\begin{array}{l}\text { AI- } \\
5\end{array}$ & $\begin{array}{l}\text { AN- } \\
1\end{array}$ & $\begin{array}{l}\text { AN- } \\
2\end{array}$ \\
\hline & Cervical Mesio-distal & & 8.8 & 6.8 & & & 6.9 & & \\
\hline & $\begin{array}{l}\text { Cervical Bucco- } \\
\text { lingual }\end{array}$ & 9.4 & 9.6 & 10.2 & & & 8.2 & & \\
\hline & Root length & & 13.4 & 14.5 & & & 9.3 & & \\
\hline RM2 & $\begin{array}{l}\text { Crown } \\
\text { Mesio-distal }\end{array}$ & & & & & & & & \\
\hline & Crown Bucco-lingual & 11.4 & & & & & & & \\
\hline & Crown height & & & & & & & & \\
\hline & Cervical Mesio-distal & 7.8 & & 7.7 & 8.6 & & & 6.8 & \\
\hline & $\begin{array}{l}\text { Cervical Bucco- } \\
\text { lingual }\end{array}$ & 10.5 & & 11.0 & 10.8 & & & 10.5 & \\
\hline & Root length & & & & & & & 14.0 & \\
\hline RM1 & $\begin{array}{l}\text { Crown } \\
\text { Mesio-distal }\end{array}$ & & & & & & & & \\
\hline & Crown Bucco-lingual & & & & & & & & \\
\hline & Crown height & & & & & & & & \\
\hline & Cervical Mesio-distal & & & & 9.3 & & 6.5 & & \\
\hline & $\begin{array}{l}\text { Cervical Bucco- } \\
\text { lingual }\end{array}$ & & & & 12.4 & & 8.5 & & \\
\hline & Root length & & & 11.3 & & & 11.5 & & \\
\hline RP2 & $\begin{array}{l}\text { Crown } \\
\text { Mesio-distal }\end{array}$ & & & & & & & & \\
\hline & Crown Bucco-lingual & & & & & & & & \\
\hline & Crown height & & & & & & & & \\
\hline & Cervical Mesio-distal & & & & & & & & \\
\hline & $\begin{array}{l}\text { Cervical Bucco- } \\
\text { lingual }\end{array}$ & & & & & & & & \\
\hline & Root length & & & 17.5 & & & & & 13.2 \\
\hline
\end{tabular}


Table 10-10, continued.

\begin{tabular}{|c|c|c|c|c|c|c|c|c|c|}
\hline & \multirow{2}{*}{$\begin{array}{l}\text { 41AN32 } \\
\text { NONE (TARL } \\
\text { 2101) } \\
\end{array}$} & \multicolumn{5}{|c|}{ 41CE4 } & \multicolumn{2}{|c|}{ 41CE6 } \\
\hline & & & $\begin{array}{l}\text { AI- } \\
1\end{array}$ & $\begin{array}{l}\text { AI- } \\
2\end{array}$ & $\begin{array}{l}\text { AI- } \\
\mathbf{3}\end{array}$ & $\begin{array}{l}\text { AI- } \\
4\end{array}$ & $\begin{array}{l}\text { AI- } \\
5\end{array}$ & $\begin{array}{l}\text { AN- } \\
1\end{array}$ & $\begin{array}{l}\text { AN- } \\
2\end{array}$ \\
\hline \multirow[t]{6}{*}{ RP1 } & $\begin{array}{l}\text { Crown } \\
\text { Mesio-distal }\end{array}$ & & & & & & & & \\
\hline & Crown Bucco-lingual & & & & & & & & \\
\hline & Crown height & & & & & & & & \\
\hline & Cervical Mesio-distal & & & 5.1 & & & & & \\
\hline & $\begin{array}{l}\text { Cervical Bucco- } \\
\text { lingual }\end{array}$ & & & 8.6 & & & & & \\
\hline & Root length & & & & & & & & \\
\hline \multirow[t]{6}{*}{$\mathrm{RC}$} & $\begin{array}{l}\text { Crown } \\
\text { Mesio-distal }\end{array}$ & & & & & & & & \\
\hline & Crown Bucco-lingual & & & & & & & & \\
\hline & Crown height & & & & & & & & \\
\hline & Cervical Mesio-distal & & & 6.3 & & & & 5.7 & \\
\hline & $\begin{array}{l}\text { Cervical Bucco- } \\
\text { lingual }\end{array}$ & & & & & & & 8.0 & \\
\hline & Root length & & & & & & & 16.3 & \\
\hline \multirow[t]{6}{*}{ RI2 } & $\begin{array}{l}\text { Crown } \\
\text { Mesio-distal }\end{array}$ & 7.2 & & & & & & & \\
\hline & Crown Bucco-lingual & 6.2 & & & & & & & \\
\hline & Crown height & & & & & & & & \\
\hline & Cervical Mesio-distal & 5.2 & & & & & & & 5.1 \\
\hline & $\begin{array}{l}\text { Cervical Bucco- } \\
\text { lingual }\end{array}$ & 5.7 & & & & & & & 6.2 \\
\hline & Root length & & & & & & & & \\
\hline \multirow[t]{6}{*}{ RI1 } & $\begin{array}{l}\text { Crown } \\
\text { Mesio-distal }\end{array}$ & & & & & & & & \\
\hline & Crown Bucco-lingual & & & & & & & & \\
\hline & Crown height & & & & & & & & \\
\hline & Cervical Mesio-distal & & & & & & & & 6.9 \\
\hline & $\begin{array}{l}\text { Cervical Bucco- } \\
\text { lingual }\end{array}$ & & & & & & & & 6.5 \\
\hline & Root length & & & & & & & & \\
\hline \multirow[t]{6}{*}{ LI1 } & $\begin{array}{l}\text { Crown } \\
\text { Mesio-distal }\end{array}$ & & & & & & & & \\
\hline & Crown Bucco-lingual & & & & & & & & \\
\hline & Crown height & & & & & & & & \\
\hline & Cervical Mesio-distal & & & & & & & & 6.4 \\
\hline & $\begin{array}{l}\text { Cervical Bucco- } \\
\text { lingual }\end{array}$ & & & & & & & & 7.0 \\
\hline & Root length & & & & & & & & 13.6 \\
\hline \multirow[t]{5}{*}{ LI2 } & $\begin{array}{l}\text { Crown } \\
\text { Mesio-distal }\end{array}$ & & & & & & & & \\
\hline & Crown Bucco-lingual & & & & & & & & \\
\hline & Crown height & & & & & & & & \\
\hline & Cervical Mesio-distal & & & & & & & & \\
\hline & $\begin{array}{l}\text { Cervical Bucco- } \\
\text { lingual }\end{array}$ & & & & & & & & \\
\hline
\end{tabular}


Table 10-10, continued.

\begin{tabular}{|c|c|c|c|c|c|c|c|c|c|}
\hline & \multirow{2}{*}{$\begin{array}{l}\text { 41AN32 } \\
\text { NONE (TARL } \\
\text { 2101) } \\
\end{array}$} & \multicolumn{5}{|c|}{ 41CE4 } & \multicolumn{2}{|c|}{ 41CE6 } \\
\hline & & & \multirow[t]{2}{*}{$\begin{array}{l}\text { AI- } \\
1\end{array}$} & \multirow[t]{2}{*}{$\begin{array}{l}\text { AI- } \\
2\end{array}$} & \multirow[t]{2}{*}{$\begin{array}{l}\text { AI- } \\
3\end{array}$} & \multirow[t]{2}{*}{$\begin{array}{l}\text { AI- } \\
4 \\
\end{array}$} & \multirow[t]{2}{*}{$\begin{array}{l}\text { AI- } \\
5\end{array}$} & \multirow[t]{2}{*}{$\begin{array}{l}\text { AN- } \\
1\end{array}$} & \multirow[t]{2}{*}{$\begin{array}{l}\text { AN- } \\
2\end{array}$} \\
\hline \multirow[t]{6}{*}{$\mathrm{LC}$} & $\begin{array}{l}\text { Crown } \\
\text { Mesio-distal }\end{array}$ & 7.8 & & & & & & & \\
\hline & Crown Bucco-lingual & 7.8 & & & & & & & \\
\hline & Crown height & & & & & & & & \\
\hline & Cervical Mesio-distal & 7.2 & & & & & & & 9.0 \\
\hline & $\begin{array}{l}\text { Cervical Bucco- } \\
\text { lingual }\end{array}$ & & & & & & & 7.5 & 5.8 \\
\hline & Root length & & & & & & & 15.8 & \\
\hline \multirow[t]{6}{*}{ LP1 } & $\begin{array}{l}\text { Crown } \\
\text { Mesio-distal }\end{array}$ & & & & & & & & \\
\hline & Crown Bucco-lingual & & & & & & & & \\
\hline & Crown height & & & & & & & & \\
\hline & Cervical Mesio-distal & & & & & & & & \\
\hline & $\begin{array}{l}\text { Cervical Bucco- } \\
\text { lingual }\end{array}$ & & & & & & & & \\
\hline & Root length & & & & & & & & 14.3 \\
\hline \multirow[t]{6}{*}{ LP2 } & $\begin{array}{l}\text { Crown } \\
\text { Mesio-distal }\end{array}$ & & & & & & & & \\
\hline & Crown Bucco-lingual & & & & & & & & \\
\hline & Crown height & & & & & & & & \\
\hline & Cervical Mesio-distal & & & & 5.7 & & & & 5.4 \\
\hline & $\begin{array}{l}\text { Cervical Bucco- } \\
\text { lingual }\end{array}$ & & & & & & & & 7.3 \\
\hline & Root length & & & & & & & & \\
\hline \multirow[t]{6}{*}{ LM1 } & $\begin{array}{l}\text { Crown } \\
\text { Mesio-distal }\end{array}$ & & & & & & & & \\
\hline & Crown Bucco-lingual & & & & & & & & \\
\hline & Crown height & & & & & & & & \\
\hline & Cervical Mesio-distal & & & & & & & & \\
\hline & $\begin{array}{l}\text { Cervical Bucco- } \\
\text { lingual }\end{array}$ & & & & 11.8 & & & & \\
\hline & Root length & & & 12.9 & & & & & \\
\hline \multirow[t]{6}{*}{ LM2 } & $\begin{array}{l}\text { Crown } \\
\text { Mesio-distal }\end{array}$ & & & & & & & & \\
\hline & Crown Bucco-lingual & 10.9 & & & & & & & \\
\hline & Crown height & & & & & & & & \\
\hline & Cervical Mesio-distal & & & & 8.6 & 8.7 & & 6.8 & \\
\hline & $\begin{array}{l}\text { Cervical Bucco- } \\
\text { lingual }\end{array}$ & 9.4 & & & 10.6 & 11.5 & & 10.1 & \\
\hline & Root length & & & & & & & & \\
\hline \multirow[t]{6}{*}{ LM3 } & $\begin{array}{l}\text { Crown } \\
\text { Mesio-distal }\end{array}$ & & & & & & & & \\
\hline & Crown Bucco-lingual & & & & & & & & \\
\hline & Crown height & & & & & & & & \\
\hline & Cervical Mesio-distal & & & & & & & 6.2 & 6.2 \\
\hline & $\begin{array}{l}\text { Cervical Bucco- } \\
\text { lingual }\end{array}$ & & & 10.0 & & 11.0 & & 8.5 & 10.2 \\
\hline & Root length & & & & & & & 11.6 & \\
\hline
\end{tabular}


Table 10-10. continued.

\begin{tabular}{|c|c|c|c|c|c|c|c|c|c|}
\hline & \multirow{2}{*}{$\begin{array}{l}\text { 41AN32 } \\
\text { NONE (TARL } \\
\text { 2101) } \\
\end{array}$} & \multicolumn{5}{|c|}{ 41CE4 } & \multicolumn{2}{|c|}{ 41CE6 } \\
\hline & & & $\begin{array}{l}\text { AI- } \\
1\end{array}$ & $\begin{array}{l}\text { AI- } \\
2\end{array}$ & $\begin{array}{l}\text { AI- } \\
3\end{array}$ & $\begin{array}{l}\text { AI- } \\
4\end{array}$ & $\begin{array}{l}\text { AI- } \\
5\end{array}$ & $\begin{array}{l}\mathrm{AN}- \\
1\end{array}$ & $\begin{array}{l}\text { AN- } \\
2\end{array}$ \\
\hline \multirow[t]{6}{*}{ LM3 } & $\begin{array}{l}\text { Crown } \\
\text { Mesio-distal }\end{array}$ & & & & & 10.0 & & & \\
\hline & Crown Bucco-lingual & & & & & 10.0 & & & \\
\hline & Crown height & & & & & 8.0 & & & \\
\hline & Cervical Mesio-distal & & & 11.0 & & 8.8 & & & \\
\hline & $\begin{array}{l}\text { Cervical Bucco- } \\
\text { lingual }\end{array}$ & & & & & 11.6 & & & \\
\hline & Root length & & & & & & & & \\
\hline \multirow[t]{6}{*}{ LM2 } & $\begin{array}{l}\text { Crown } \\
\text { Mesio-distal }\end{array}$ & & & & & & & & \\
\hline & Crown Bucco-lingual & 11.0 & & & & & & & \\
\hline & Crown height & & & & & & & & \\
\hline & Cervical Mesio-distal & & & & 10.5 & 10.7 & & & \\
\hline & $\begin{array}{l}\text { Cervical Bucco- } \\
\text { lingual }\end{array}$ & 9.2 & & & 9.7 & 10.6 & & & 9.2 \\
\hline & Root length & & & & 15.3 & & & & \\
\hline \multirow[t]{6}{*}{ LM1 } & $\begin{array}{l}\text { Crown } \\
\text { Mesio-distal }\end{array}$ & & & & & & 10.1 & & \\
\hline & Crown Bucco-lingual & 11.8 & & & & & 9.9 & & \\
\hline & Crown height & & & & & & & & \\
\hline & Cervical Mesio-distal & & & & & 10.9 & 8.2 & & \\
\hline & $\begin{array}{l}\text { Cervical Bucco- } \\
\text { lingual }\end{array}$ & & & & & 10.5 & 7.9 & & \\
\hline & Root length & & & & & & & & \\
\hline \multirow[t]{6}{*}{ LP2 } & $\begin{array}{l}\text { Crown } \\
\text { Mesio-distal }\end{array}$ & & & & & & & & \\
\hline & Crown Bucco-lingual & & & & & & & & \\
\hline & Crown height & & & & & & & & \\
\hline & Cervical Mesio-distal & & & & & & & & \\
\hline & $\begin{array}{l}\text { Cervical Bucco- } \\
\text { lingual }\end{array}$ & & & & & & & & \\
\hline & Root length & & & & & & & & \\
\hline \multirow[t]{6}{*}{ LP1 } & $\begin{array}{l}\text { Crown } \\
\text { Mesio-distal }\end{array}$ & & & & & & & & \\
\hline & Crown Bucco-lingual & & & & & & & & \\
\hline & Crown height & & & & & & & & \\
\hline & Cervical Mesio-distal & & & & & & & & \\
\hline & $\begin{array}{l}\text { Cervical Bucco- } \\
\text { lingual }\end{array}$ & & & & & & & & \\
\hline & Root length & & & & & & & & \\
\hline \multirow[t]{6}{*}{$\mathrm{LC}$} & $\begin{array}{l}\text { Crown } \\
\text { Mesio-distal }\end{array}$ & 7.5 & & & & & & & \\
\hline & Crown Bucco-lingual & 7.9 & & & & & & & \\
\hline & Crown height & & & & & & & & \\
\hline & Cervical Mesio-distal & & & & & & & & \\
\hline & $\begin{array}{l}\text { Cervical Bucco- } \\
\text { lingual }\end{array}$ & & & & & & & & \\
\hline & Root length & & & & & & & & \\
\hline
\end{tabular}


Table 10-10, continued.

\begin{tabular}{|c|c|c|c|c|c|c|c|c|c|}
\hline & \multirow{2}{*}{$\begin{array}{l}\text { 41AN32 } \\
\text { NONE (TARL } \\
\text { 2101) }\end{array}$} & \multicolumn{5}{|c|}{ 41CE4 } & \multicolumn{2}{|c|}{ 41CE6 } \\
\hline & & & $\begin{array}{l}\text { AI- } \\
1\end{array}$ & $\begin{array}{l}\text { AI- } \\
2\end{array}$ & $\begin{array}{l}\text { AI- } \\
3\end{array}$ & $\begin{array}{l}\text { AI- } \\
4\end{array}$ & $\begin{array}{l}\text { AI- } \\
5\end{array}$ & $\begin{array}{l}\text { AN- } \\
1\end{array}$ & $\begin{array}{l}\text { AN- } \\
2\end{array}$ \\
\hline \multirow[t]{6}{*}{ LI2 } & $\begin{array}{l}\text { Crown } \\
\text { Mesio-distal }\end{array}$ & & & & & & & & \\
\hline & Crown Bucco-lingual & 6.4 & & & & & & & \\
\hline & Crown height & & & & & & & & \\
\hline & Cervical Mesio-distal & & & & & & & & \\
\hline & $\begin{array}{l}\text { Cervical Bucco- } \\
\text { lingual }\end{array}$ & & & & & & & & \\
\hline & Root length & & & & & & & & \\
\hline \multirow[t]{6}{*}{ LI1 } & $\begin{array}{l}\text { Crown } \\
\text { Mesio-distal }\end{array}$ & & & & & & & & \\
\hline & Crown Bucco-lingual & & & & & & & & \\
\hline & Crown height & & & & & & & & \\
\hline & Cervical Mesio-distal & & & & & & & & \\
\hline & $\begin{array}{l}\text { Cervical Bucco- } \\
\text { lingual }\end{array}$ & & & & & & & & \\
\hline & Root length & & & & & & & & \\
\hline \multirow[t]{6}{*}{ RI1 } & $\begin{array}{l}\text { Crown } \\
\text { Mesio-distal }\end{array}$ & 5.9 & & & & & & & \\
\hline & Crown Bucco-lingual & 5.9 & & & & & & & \\
\hline & Crown height & & & & & & & & \\
\hline & Cervical Mesio-distal & & & & & & & & 3.9 \\
\hline & $\begin{array}{l}\text { Cervical Bucco- } \\
\text { lingual }\end{array}$ & & & & & & & & 5.3 \\
\hline & Root length & & & & & & & & \\
\hline \multirow[t]{6}{*}{ RI2 } & $\begin{array}{l}\text { Crown } \\
\text { Mesio-distal }\end{array}$ & & & & & & & & \\
\hline & Crown Bucco-lingual & & & & & & & & \\
\hline & Crown height & & & & & & & & \\
\hline & Cervical Mesio-distal & & & & & & & & 4.0 \\
\hline & $\begin{array}{l}\text { Cervical Bucco- } \\
\text { lingual }\end{array}$ & & & & & & & & 6.2 \\
\hline & Root length & & & & & & & & \\
\hline \multirow[t]{6}{*}{$\mathrm{RC}$} & $\begin{array}{l}\text { Crown } \\
\text { Mesio-distal }\end{array}$ & 7.5 & & & & & & & \\
\hline & Crown Bucco-lingual & 7.6 & & & & & & & \\
\hline & Crown height & & & & & & & & \\
\hline & Cervical Mesio-distal & & & & & & & 5.2 & \\
\hline & $\begin{array}{l}\text { Cervical Bucco- } \\
\text { lingual }\end{array}$ & & & & & & & 8.3 & \\
\hline & Root length & & & & & & & 18.6 & \\
\hline \multirow[t]{6}{*}{ RP1 } & $\begin{array}{l}\text { Crown } \\
\text { Mesio-distal }\end{array}$ & 7.3 & & & & & & & \\
\hline & Crown Bucco-lingual & 7.8 & & & & & & & \\
\hline & Crown height & & & & & & & & \\
\hline & Cervical Mesio-distal & & & & & & & 4.9 & \\
\hline & $\begin{array}{l}\text { Cervical Bucco- } \\
\text { lingual }\end{array}$ & & & & & & & 7.0 & \\
\hline & Root length & & & & & & & & \\
\hline
\end{tabular}


Table 10-10, continued.

\begin{tabular}{|c|c|c|c|c|c|c|c|c|c|}
\hline & \multirow{2}{*}{$\begin{array}{l}\text { 41AN32 } \\
\text { NONE (TARL } \\
\text { 2101) } \\
\end{array}$} & \multicolumn{5}{|c|}{ 41CE4 } & \multicolumn{2}{|c|}{ 41CE6 } \\
\hline & & & $\begin{array}{l}\text { AI- } \\
1\end{array}$ & $\begin{array}{l}\text { AI- } \\
2\end{array}$ & $\begin{array}{l}\text { AI- } \\
3\end{array}$ & $\begin{array}{l}\text { AI- } \\
4\end{array}$ & $\begin{array}{l}\text { AI- } \\
5\end{array}$ & $\begin{array}{l}\text { AN- } \\
1\end{array}$ & $\begin{array}{l}\text { AN- } \\
2\end{array}$ \\
\hline \multirow[t]{3}{*}{ RP1 } & Cervical Mesio-distal & & & & & & & 4.9 & \\
\hline & $\begin{array}{l}\text { Cervical Bucco- } \\
\text { lingual }\end{array}$ & & & & & & & 7.0 & \\
\hline & Root length & & & & & & & & \\
\hline \multirow[t]{6}{*}{$\mathrm{RP} 2$} & $\begin{array}{l}\text { Crown } \\
\text { Mesio-distal }\end{array}$ & & & & & & & & \\
\hline & Crown Bucco-lingual & & & & & & & & \\
\hline & Crown height & & & & & & & & \\
\hline & Cervical Mesio-distal & & & & & & & & 5.0 \\
\hline & $\begin{array}{l}\text { Cervical Bucco- } \\
\text { lingual }\end{array}$ & & & & & & & & 7.4 \\
\hline & Root length & & & & & & & & 14.7 \\
\hline \multirow[t]{6}{*}{ RM1 } & $\begin{array}{l}\text { Crown } \\
\text { Mesio-distal }\end{array}$ & & & & & & & & \\
\hline & Crown Bucco-lingual & 11.0 & & & & & & & \\
\hline & Crown height & & & & & & & & \\
\hline & Cervical Mesio-distal & & & & & & & & \\
\hline & $\begin{array}{l}\text { Cervical Bucco- } \\
\text { lingual }\end{array}$ & 9.4 & & & & & & & \\
\hline & Root length & & & & & & & & \\
\hline \multirow[t]{6}{*}{ RM2 } & $\begin{array}{l}\text { Crown } \\
\text { Mesio-distal }\end{array}$ & & & & & & & & \\
\hline & Crown Bucco-lingual & & & & & & & & \\
\hline & Crown height & & & & & & & & \\
\hline & Cervical Mesio-distal & & & & & & & & \\
\hline & $\begin{array}{l}\text { Cervical Bucco- } \\
\text { lingual }\end{array}$ & & & & & & & & \\
\hline & Root length & & & & & & & & \\
\hline \multirow[t]{6}{*}{ RM3 } & $\begin{array}{l}\text { Crown } \\
\text { Mesio-distal }\end{array}$ & & & & & & & & \\
\hline & Crown Bucco-lingual & & & & & & & & \\
\hline & Crown height & & & & & & & & \\
\hline & Cervical Mesio-distal & & & & & & & & 9.1 \\
\hline & $\begin{array}{l}\text { Cervical Bucco- } \\
\text { lingual }\end{array}$ & & & & & & & & 9.5 \\
\hline & Root length & & & & & & & & \\
\hline
\end{tabular}


Table 10-10, continued.

\begin{tabular}{|c|c|c|c|c|c|c|c|c|c|}
\hline & \multicolumn{8}{|c|}{ 41CE12 } \\
\hline & & AH-2 & AH-3 & AH-7 & AH-9 & AH-10 & AH-11 & AH-12 & AH-15 \\
\hline \multicolumn{10}{|c|}{ Tooth } \\
\hline \multicolumn{10}{|c|}{ Maxillary } \\
\hline \multirow[t]{6}{*}{ RM3 } & $\begin{array}{l}\text { Crown } \\
\text { Mesio-distal }\end{array}$ & & & & & & & & \\
\hline & Crown Bucco-lingual & & & & & & & & \\
\hline & Crown height & & & & & & & & \\
\hline & Cervical Mesio-distal & & & & & & & & \\
\hline & Cervical Bucco-lingual & & & & & & & & \\
\hline & Root length & & & & & & & & \\
\hline \multirow[t]{6}{*}{ RM2 } & $\begin{array}{l}\text { Crown } \\
\text { Mesio-distal }\end{array}$ & & & & 9.1 & & & & \\
\hline & Crown Bucco-lingual & & & & 10.2 & & & & \\
\hline & Crown height & & & & & & & & \\
\hline & Cervical Mesio-distal & & & & & & & & \\
\hline & Cervical Bucco-lingual & 9.9 & & & & & & & \\
\hline & Root length & 14.6 & & & & & & & \\
\hline \multirow[t]{6}{*}{ RM1 } & $\begin{array}{l}\text { Crown } \\
\text { Mesio-distal }\end{array}$ & & & & & & & 11.1 & \\
\hline & Crown Bucco-lingual & & & & & & & 11.2 & \\
\hline & Crown height & & & & & & & 8.0 & \\
\hline & Cervical Mesio-distal & & & & & & & 8.9 & \\
\hline & Cervical Bucco-lingual & & & 11.3 & & & & 10.7 & \\
\hline & Root length & & & 13.8 & & & & & \\
\hline \multirow[t]{6}{*}{$\mathrm{RP} 2$} & $\begin{array}{l}\text { Crown } \\
\text { Mesio-distal }\end{array}$ & & & & & & & & \\
\hline & Crown Bucco-lingual & & & & & & & & \\
\hline & Crown height & & & & & & & & \\
\hline & Cervical Mesio-distal & & & & & & & & \\
\hline & Cervical Bucco-lingual & & & & & & & & \\
\hline & Root length & & & & & & & & \\
\hline \multirow[t]{7}{*}{ RP1 } & $\begin{array}{l}\text { Crown } \\
\text { Mesio-distal }\end{array}$ & & & & 7.1 & & & 7.0 & \\
\hline & Crown Bucco-lingual & & & & 9.2 & & 10.1 & 8.7 & \\
\hline & Crown Bucco-lingual & & & & 10.2 & & & & \\
\hline & Crown height & & & & & & & & \\
\hline & Cervical Mesio-distal & & & & & & & & \\
\hline & Cervical Bucco-lingual & 9.9 & & & & & & & \\
\hline & Root length & 14.6 & & & & & & & \\
\hline \multirow[t]{6}{*}{ RM1 } & $\begin{array}{l}\text { Crown } \\
\text { Mesio-distal }\end{array}$ & & & & & & & 11.1 & \\
\hline & Crown Bucco-lingual & & & & & & & 11.2 & \\
\hline & Crown height & & & & & & & 8.0 & \\
\hline & Cervical Mesio-distal & & & & & & & 8.9 & \\
\hline & Cervical Bucco-lingual & & & 11.3 & & & & 10.7 & \\
\hline & Root length & & & 13.8 & & & & & \\
\hline
\end{tabular}


Table 10-10, continued.

\begin{tabular}{|c|c|c|c|c|c|c|c|c|c|}
\hline & \multicolumn{8}{|c|}{ 41CE12 } \\
\hline & & AH-2 & AH-3 & AH-7 & AH-9 & AH-10 & AH-11 & AH-12 & AH-15 \\
\hline \multirow[t]{6}{*}{ RP2 } & $\begin{array}{l}\text { Crown } \\
\text { Mesio-distal }\end{array}$ & & & & & & & & \\
\hline & Crown Bucco-lingual & & & & & & & & \\
\hline & Crown height & & & & & & & & \\
\hline & Cervical Mesio-distal & & & & & & & & \\
\hline & Cervical Bucco-lingual & & & & & & & & \\
\hline & Root length & & & & & & & & \\
\hline \multirow[t]{4}{*}{ RP1 } & $\begin{array}{l}\text { Crown } \\
\text { Mesio-distal }\end{array}$ & & & & 7.1 & & & 7.0 & \\
\hline & Crown Bucco-lingual & & & & 9.2 & & 10.1 & 8.7 & \\
\hline & Cervical Bucco-lingual & 9.9 & & & & & & & \\
\hline & Root length & 14.6 & & & & & & & \\
\hline \multirow[t]{6}{*}{ RM1 } & $\begin{array}{l}\text { Crown } \\
\text { Mesio-distal }\end{array}$ & & & & & & & 11.1 & \\
\hline & Crown Bucco-lingual & & & & & & & 11.2 & \\
\hline & Crown height & & & & & & & 8.0 & \\
\hline & Cervical Mesio-distal & & & & & & & 8.9 & \\
\hline & Cervical Bucco-lingual & & & 11.3 & & & & 10.7 & \\
\hline & Root length & & & 13.8 & & & & & \\
\hline \multirow[t]{6}{*}{ RP2 } & $\begin{array}{l}\text { Crown } \\
\text { Mesio-distal }\end{array}$ & & & & & & & & \\
\hline & Crown Bucco-lingual & & & & & & & & \\
\hline & Crown height & & & & & & & & \\
\hline & Cervical Mesio-distal & & & & & & & & \\
\hline & Cervical Bucco-lingual & & & & & & & & \\
\hline & Root length & & & & & & & & \\
\hline \multirow[t]{6}{*}{ RP1 } & $\begin{array}{l}\text { Crown } \\
\text { Mesio-distal }\end{array}$ & & & & 7.1 & & & 7.0 & \\
\hline & Crown Bucco-lingual & & & & 9.2 & & 10.1 & 8.7 & \\
\hline & Crown height & & & & 9.0 & & & & \\
\hline & Cervical Mesio-distal & & & & & & 5.1 & & \\
\hline & Cervical Bucco-lingual & & & 8.3 & & 9.0 & 9.1 & & \\
\hline & Root length & & & & & & 15.4 & & \\
\hline \multirow[t]{6}{*}{$\mathrm{RC}$} & $\begin{array}{l}\text { Crown } \\
\text { Mesio-distal }\end{array}$ & & & & & & & & \\
\hline & Crown Bucco-lingual & & & & & & 9.0 & & \\
\hline & Crown height & & & & & & & & \\
\hline & Cervical Mesio-distal & & & & & & & & \\
\hline & Cervical Bucco-lingual & & & & & 8.4 & & & \\
\hline & Root length & & & & & & & & \\
\hline \multirow[t]{6}{*}{ RI2 } & $\begin{array}{l}\text { Crown } \\
\text { Mesio-distal }\end{array}$ & & & & & & & & 7.9 \\
\hline & Crown Bucco-lingual & & & & & & 7.2 & & \\
\hline & Crown height & & & & & & & & \\
\hline & Cervical Mesio-distal & & & & & 5.5 & & & \\
\hline & Cervical Bucco-lingual & & & & & 5.1 & & & \\
\hline & Root length & & & & & & & & \\
\hline \multirow[t]{3}{*}{ RI1 } & Crown Mesio-distal & & & & & & & & \\
\hline & Crown Bucco-lingual & & & & & & 7.1 & & \\
\hline & Crown height & & & & & & & & \\
\hline
\end{tabular}


Table 10-10. continued.

\begin{tabular}{|c|c|c|c|c|c|c|c|c|c|}
\hline & \multicolumn{8}{|c|}{ 41CE12 } \\
\hline & & AH-2 & AH-3 & AH-7 & AH-9 & AH-10 & AH-11 & AH-12 & AH-15 \\
\hline \multirow[t]{3}{*}{ RI1 } & Cervical Mesio-distal & & & & & & & & \\
\hline & Cervical Bucco-lingual & & & & & & & & \\
\hline & Root length & & & & & 14.5 & & & \\
\hline \multirow[t]{6}{*}{ LI1 } & $\begin{array}{l}\text { Crown } \\
\text { Mesio-distal }\end{array}$ & & & & 7.4 & & & & \\
\hline & Crown Bucco-lingual & & & & 8.5 & & 7.1 & & \\
\hline & Crown height & & & & & & & & \\
\hline & Cervical Mesio-distal & & & & 6.6 & & & & \\
\hline & Cervical Bucco-lingual & & & & 7.5 & 6.6 & 6.6 & & \\
\hline & Root length & & & & & & & & \\
\hline \multirow[t]{6}{*}{ LI2 } & $\begin{array}{l}\text { Crown } \\
\text { Mesio-distal }\end{array}$ & & & & 6.4 & & & & \\
\hline & Crown Bucco-lingual & & & & 6.3 & & 7.1 & & \\
\hline & Crown height & & & & & & & & \\
\hline & Cervical Mesio-distal & & 4.6 & & 5.7 & 5.7 & & & \\
\hline & Cervical Bucco-lingual & & 6.3 & & 6.2 & & & & \\
\hline & Root length & & & & & & & & \\
\hline \multirow[t]{6}{*}{$\mathrm{LC}$} & $\begin{array}{l}\text { Crown } \\
\text { Mesio-distal }\end{array}$ & & & & 8.6 & & & & \\
\hline & Crown Bucco-lingual & & & & 7.8 & & 8.9 & & \\
\hline & Crown height & & & & 10.5 & & & & \\
\hline & Cervical Mesio-distal & & & & 6.5 & 6.1 & & & \\
\hline & Cervical Bucco-lingual & & & & & 8.3 & & & \\
\hline & Root length & & & & & & & & \\
\hline \multirow[t]{6}{*}{ LP1 } & $\begin{array}{l}\text { Crown } \\
\text { Mesio-distal }\end{array}$ & & & & 7.0 & & & & \\
\hline & Crown Bucco-lingual & & & & 9.2 & & 10.2 & & \\
\hline & Crown height & & & & 9.3 & & & & \\
\hline & Cervical Mesio-distal & & & & 5.2 & & & & \\
\hline & Cervical Bucco-lingual & 6.8 & & & 8.1 & & & & \\
\hline & Root length & 11.7 & & & & & & & \\
\hline \multirow[t]{6}{*}{ LP2 } & $\begin{array}{l}\text { Crown } \\
\text { Mesio-distal }\end{array}$ & & & & & & & & 7.7 \\
\hline & Crown Bucco-lingual & & & & 7.8 & & 9.8 & & \\
\hline & Crown height & & & & 7.9 & & & & \\
\hline & Cervical Mesio-distal & 6.0 & & & & & & & \\
\hline & Cervical Bucco-lingual & 8.6 & & & & 8.3 & & & \\
\hline & Root length & & & & & & & & \\
\hline \multirow[t]{6}{*}{ LM1 } & $\begin{array}{l}\text { Crown } \\
\text { Mesio-distal }\end{array}$ & & & & & & & 11.3 & \\
\hline & Crown Bucco-lingual & & & & 11.9 & & 12.2 & 11.2 & \\
\hline & Crown height & & & & & & & 7.7 & \\
\hline & Cervical Mesio-distal & & 8.8 & & & & & & \\
\hline & Cervical Bucco-lingual & & 12.4 & & & & & & \\
\hline & Root length & & 13.8 & & 10.6 & & & & \\
\hline
\end{tabular}


Table 10-10, continued.

\begin{tabular}{|c|c|c|c|c|c|c|c|c|c|}
\hline & \multicolumn{8}{|c|}{ 41CE12 } \\
\hline & & AH-2 & AH-3 & AH-7 & AH-9 & AH-10 & AH-11 & AH-12 & AH-15 \\
\hline \multirow[t]{6}{*}{ LM2 } & Crown Mesio-distal & & & & 10.3 & & & & \\
\hline & Crown Bucco-lingual & & & & 11.2 & & 12.1 & & \\
\hline & Crown height & & & & 7.8 & & & & \\
\hline & Cervical Mesio-distal & 11.0 & & & & 12.2 & & & \\
\hline & Cervical Bucco-lingual & & & & 10.7 & & & & \\
\hline & Root length & & & & & 12.4 & & & \\
\hline \multirow[t]{6}{*}{ LM3 } & Crown Mesio-distal & & & & & & & & \\
\hline & Crown Bucco-lingual & & & & & & 10.5 & & \\
\hline & Crown height & & & & & & & & \\
\hline & Cervical Mesio-distal & 7.9 & & & & & & & \\
\hline & Cervical Bucco-lingual & 10.3 & & & & & 9.6 & & \\
\hline & Root length & & & & & & & & \\
\hline \multicolumn{10}{|c|}{ Mandibular } \\
\hline \multirow[t]{6}{*}{ LM3 } & Crown Mesio-distal & & & & & & & & \\
\hline & Crown Bucco-lingual & & & & & & & & \\
\hline & Crown height & & & & & & & & \\
\hline & Cervical Mesio-distal & 10.2 & & & & & & & \\
\hline & Cervical Bucco-lingual & 11.4 & & & & & & & \\
\hline & Root length & 14.1 & & & & & & & \\
\hline \multirow[t]{6}{*}{ LM2 } & Crown Mesio-distal & & & & 10.5 & & & & \\
\hline & Crown Bucco-lingual & & & & 10.2 & & & & \\
\hline & Crown height & & & & 7.9 & & & & \\
\hline & Cervical Mesio-distal & & & & 9.9 & & & & \\
\hline & Cervical Bucco-lingual & & & & & & & & \\
\hline & Root length & & & & & & & & \\
\hline \multirow[t]{6}{*}{ LM1 } & Crown Mesio-distal & & & & & & & 11.8 & \\
\hline & Crown Bucco-lingual & & & & 11.1 & & & 10.5 & \\
\hline & Crown height & & & & & & & 6.9 & \\
\hline & Cervical Mesio-distal & & & & 10.1 & & & 10.1 & \\
\hline & Cervical Bucco-lingual & & & & & & & 9.2 & \\
\hline & Root length & & & & & & & & \\
\hline \multirow[t]{6}{*}{ LP2 } & Crown Mesio-distal & & & & & & & & 7.7 \\
\hline & Crown Bucco-lingual & & & & & & 8.5 & & 7.7 \\
\hline & Crown height & & & & & & & & \\
\hline & Cervical Mesio-distal & & & & & & & & \\
\hline & Cervical Bucco-lingual & & & & & & & & \\
\hline & Root length & & & & & & & & \\
\hline \multirow[t]{6}{*}{ LP1 } & Crown Mesio-distal & & & & 8.5 & & & & \\
\hline & Crown Bucco-lingual & & & & 7.6 & & & & \\
\hline & Crown height & & & & & & & & \\
\hline & Cervical Mesio-distal & & & & 5.1 & 5.4 & & & \\
\hline & Cervical Bucco-lingual & & & & 7.4 & & & & \\
\hline & Root length & & & & 14.4 & & & & \\
\hline
\end{tabular}


Table 10-10, continued.

\begin{tabular}{|c|c|c|c|c|c|c|c|c|c|}
\hline & \multicolumn{8}{|c|}{ 41CE12 } \\
\hline & & AH-2 & AH-3 & AH-7 & AH-9 & AH-10 & AH-11 & AH-12 & AH-15 \\
\hline \multirow[t]{6}{*}{$\mathrm{LC}$} & $\begin{array}{l}\text { Crown } \\
\text { Mesio-distal }\end{array}$ & & & & 6.6 & & & 6.8 & \\
\hline & Crown Bucco-lingual & & & & & & 8.4 & & \\
\hline & Crown height & & & & & & & & \\
\hline & Cervical Mesio-distal & & & & 6.1 & 5.6 & & & \\
\hline & Cervical Bucco-lingual & & & & 8.1 & 7.7 & & & \\
\hline & Root length & & & & & & & & \\
\hline \multirow[t]{6}{*}{ LI2 } & $\begin{array}{l}\text { Crown } \\
\text { Mesio-distal }\end{array}$ & & & & 5.9 & & & 6.0 & \\
\hline & Crown Bucco-lingual & & & & 5.8 & & 6.4 & 5.4 & \\
\hline & Crown height & & & & & & & & \\
\hline & Cervical Mesio-distal & & & & 4.0 & & & & \\
\hline & Cervical Bucco-lingual & & & & 6.3 & & & & \\
\hline & Root length & & & & & & & & \\
\hline \multirow[t]{6}{*}{ LI1 } & $\begin{array}{l}\text { Crown } \\
\text { Mesio-distal }\end{array}$ & & & & & & & & \\
\hline & Crown Bucco-lingual & & & & & & 5.7 & & \\
\hline & Crown height & & & & & & & & \\
\hline & Cervical Mesio-distal & & & & & 3.8 & & & \\
\hline & Cervical Bucco-lingual & & & & & & & & \\
\hline & Root length & & & & & & & & \\
\hline \multirow[t]{6}{*}{ RI1 } & $\begin{array}{l}\text { Crown } \\
\text { Mesio-distal }\end{array}$ & & & & & & & & \\
\hline & Crown Bucco-lingual & & & & & & 5.4 & & \\
\hline & Crown height & & & & & & & & \\
\hline & Cervical Mesio-distal & & & & & & & & \\
\hline & Cervical Bucco-lingual & & 5.6 & & & & & & \\
\hline & Root length & & & & & & & & \\
\hline \multirow[t]{6}{*}{ RI2 } & $\begin{array}{l}\text { Crown } \\
\text { Mesio-distal }\end{array}$ & & & & & & & & \\
\hline & Crown Bucco-lingual & & & & & & 6.0 & & \\
\hline & Crown height & & & & & & & & \\
\hline & Cervical Mesio-distal & & & & & 4.0 & & & \\
\hline & Cervical Bucco-lingual & & & & & & & & \\
\hline & Root length & & & & & & & & \\
\hline \multirow[t]{6}{*}{$\mathrm{RC}$} & $\begin{array}{l}\text { Crown } \\
\text { Mesio-distal }\end{array}$ & & & & 6.8 & & & 7.1 & 7.2 \\
\hline & Crown Bucco-lingual & & & & 6.5 & & & 6.2 & \\
\hline & Crown height & & & & & & & & \\
\hline & Cervical Mesio-distal & & & & & & & & \\
\hline & Cervical Bucco-lingual & & & & & & & & \\
\hline & Root length & & & & & & & & \\
\hline
\end{tabular}


Table 10-10, continued.

\begin{tabular}{|c|c|c|c|c|c|c|c|c|c|}
\hline & \multicolumn{8}{|c|}{ 41CE12 } \\
\hline & & AH-2 & AH-3 & AH-7 & AH-9 & AH-10 & AH-11 & AH-12 & AH-15 \\
\hline \multirow[t]{6}{*}{ RP1 } & $\begin{array}{l}\text { Crown } \\
\text { Mesio-distal }\end{array}$ & & & & 6.2 & & & & 7.3 \\
\hline & Crown Bucco-lingual & & & & 7.4 & & & & 7.4 \\
\hline & Crown height & & & & 9.0 & & & & \\
\hline & Cervical Mesio-distal & & & 4.9 & 5.4 & & & & \\
\hline & Cervical Bucco-lingual & & & 7.1 & 7.3 & & & & \\
\hline & Root length & & & & & & & & \\
\hline \multirow[t]{6}{*}{ RP2 } & $\begin{array}{l}\text { Crown } \\
\text { Mesio-distal }\end{array}$ & & & & 8.1 & & 7.9 & & 7.4 \\
\hline & Crown Bucco-lingual & & & & 7.0 & & 8.6 & & 8.1 \\
\hline & Crown height & & & & 8.2 & & & & \\
\hline & Cervical Mesio-distal & & & & 6.1 & & 6.3 & & \\
\hline & Cervical Bucco-lingual & & & & 7.9 & & 7.2 & & \\
\hline & Root length & & & & & & & & \\
\hline \multirow[t]{6}{*}{ RM1 } & $\begin{array}{l}\text { Crown } \\
\text { Mesio-distal }\end{array}$ & & & & 10.6 & & & 11.7 & \\
\hline & Crown Bucco-lingual & & & & 10.9 & & & 10.7 & \\
\hline & Crown height & & & & & & & 8.5 & \\
\hline & Cervical Mesio-distal & & & & 10.3 & & & 9.9 & \\
\hline & Cervical Bucco-lingual & & & 9.3 & 10.3 & & & 8.9 & \\
\hline & Root length & & & & 14.5 & & & & \\
\hline \multirow[t]{6}{*}{ RM2 } & $\begin{array}{l}\text { Crown } \\
\text { Mesio-distal }\end{array}$ & & & & 10.9 & & & & \\
\hline & Crown Bucco-lingual & & & & 10.2 & & & & \\
\hline & Crown height & & & & 8.0 & & & & \\
\hline & Cervical Mesio-distal & 9.8 & & & 9.8 & & & & \\
\hline & Cervical Bucco-lingual & 9.6 & & & 10.1 & & & & \\
\hline & Root length & & & & & & & & \\
\hline \multirow[t]{6}{*}{ RM3 } & $\begin{array}{l}\text { Crown } \\
\text { Mesio-distal }\end{array}$ & & & & & & & & \\
\hline & Crown Bucco-lingual & & & & & & & & \\
\hline & Crown height & & & & & & & & \\
\hline & Cervical Mesio-distal & 10.7 & & & & & & & \\
\hline & Cervical Bucco-lingual & 9.6 & & & & & & & \\
\hline & Root length & & & & & & & & \\
\hline
\end{tabular}


Table 10-10, continued.

\begin{tabular}{|c|c|c|c|c|c|c|c|c|c|}
\hline & \multirow{2}{*}{$\begin{array}{l}\text { 41CE15 } \\
\text { AJ-2 }\end{array}$} & \multirow{2}{*}{$\begin{array}{l}\text { 41CE17 } \\
\text { AL-3 }\end{array}$} & \multicolumn{6}{|c|}{ 41CE19 } \\
\hline & & & & \multirow[t]{2}{*}{$\begin{array}{l}\text { F. } \\
118\end{array}$} & \multirow[t]{2}{*}{$\begin{array}{l}\text { F. } 119 \\
\text { S1 }\end{array}$} & \multirow[t]{2}{*}{$\begin{array}{l}\text { F. } \\
130\end{array}$} & \multirow[t]{2}{*}{$\begin{array}{l}\text { F. } 134 \\
\text { B2 }\end{array}$} & \multirow[t]{2}{*}{$\begin{array}{l}\text { F. } 134 \\
\text { B3 } \\
\end{array}$} & \multirow[t]{2}{*}{$\begin{array}{l}\text { F. } 134 \\
\text { B4 } \\
\end{array}$} \\
\hline \multicolumn{4}{|l|}{ Tooth } & & & & & & \\
\hline \multicolumn{10}{|l|}{ Maxillary } \\
\hline \multirow[t]{6}{*}{ RM3 } & $\begin{array}{l}\text { Crown } \\
\text { Mesio-distal }\end{array}$ & & & & 8.2 & & 8.2 & 8.7 & \\
\hline & $\begin{array}{l}\text { Crown Bucco- } \\
\text { lingual }\end{array}$ & & & & 9.7 & & 10.2 & 11.7 & \\
\hline & Crown height & & & & & & & 6.8 & \\
\hline & $\begin{array}{l}\text { Cervical Mesio- } \\
\text { distal }\end{array}$ & & & & 5.9 & & & & \\
\hline & $\begin{array}{l}\text { Cervical Bucco- } \\
\text { lingual }\end{array}$ & & & & 8.6 & & & & \\
\hline & Root length & & & & 13.2 & & & & \\
\hline \multirow[t]{6}{*}{ RM2 } & $\begin{array}{l}\text { Crown } \\
\text { Mesio-distal }\end{array}$ & & & & 10.5 & & 10.6 & 11.7 & \\
\hline & $\begin{array}{l}\text { Crown Bucco- } \\
\text { lingual }\end{array}$ & & & 12.9 & 11.9 & & 11.7 & 13.3 & \\
\hline & Crown height & & & & & & & & \\
\hline & $\begin{array}{l}\text { Cervical Mesio- } \\
\text { distal }\end{array}$ & & & 8.3 & 8.8 & & & & \\
\hline & $\begin{array}{l}\text { Cervical Bucco- } \\
\text { lingual }\end{array}$ & & & & & & & & \\
\hline & Root length & & & & & & & & \\
\hline \multirow[t]{6}{*}{ RM1 } & $\begin{array}{l}\text { Crown } \\
\text { Mesio-distal }\end{array}$ & & & 10.9 & 10.8 & & & & \\
\hline & $\begin{array}{l}\text { Crown Bucco- } \\
\text { lingual }\end{array}$ & 11.7 & & 12.8 & & & & & \\
\hline & Crown height & & & & & & & 11.7 & \\
\hline & $\begin{array}{l}\text { Cervical Mesio- } \\
\text { distal }\end{array}$ & & & & 8.1 & & & & \\
\hline & $\begin{array}{l}\text { Cervical Bucco- } \\
\text { lingual }\end{array}$ & & & & 11.7 & & & & \\
\hline & Root length & & & & & & & & \\
\hline \multirow[t]{5}{*}{ RP2 } & $\begin{array}{l}\text { Crown } \\
\text { Mesio-distal }\end{array}$ & & & & & & 6.9 & 7.0 & \\
\hline & $\begin{array}{l}\text { Crown Bucco- } \\
\text { lingual }\end{array}$ & & & 10.6 & & & 9.1 & 10.6 & \\
\hline & Crown height & & & & & & & & \\
\hline & $\begin{array}{l}\text { Cervical Mesio- } \\
\text { distal }\end{array}$ & & & & & & & 5.2 & \\
\hline & $\begin{array}{l}\text { Cervical Bucco- } \\
\text { lingual }\end{array}$ & & 9.9 & & & 7.1 & & 9.2 & \\
\hline
\end{tabular}


Table 10-10, continued.

\begin{tabular}{|c|c|c|c|c|c|c|c|c|c|}
\hline & \multirow{2}{*}{$\begin{array}{l}41 \mathrm{CE} \\
15 \\
\text { AJ-2 }\end{array}$} & \multirow{2}{*}{$\begin{array}{l}41 C E \\
17 \\
\text { AL-3 }\end{array}$} & \multicolumn{6}{|c|}{ 41CE19 } \\
\hline & & & & $\begin{array}{l}\text { F. } \\
118\end{array}$ & $\begin{array}{l}\text { F. } 119 \\
\text { S1 }\end{array}$ & $\begin{array}{l}\text { F. } \\
130\end{array}$ & $\begin{array}{l}\text { F. } 134 \\
\text { B2 }\end{array}$ & $\begin{array}{l}\text { F. } 134 \\
\text { B3 }\end{array}$ & $\begin{array}{l}\text { F. } 134 \\
\text { B4 }\end{array}$ \\
\hline & Root length & & & & & & & & \\
\hline \multirow[t]{6}{*}{ RP1 } & $\begin{array}{l}\text { Crown } \\
\text { Mesio-distal }\end{array}$ & 7.6 & & & 7.6 & & 7.1 & 7.2 & 7.6 \\
\hline & Crown Bucco-lingual & 9.9 & & & 10.3 & & 8.8 & 10.5 & 9.6 \\
\hline & Crown height & 8.7 & & & & & & & \\
\hline & Cervical Mesio-distal & & & & & & & & \\
\hline & $\begin{array}{l}\text { Cervical Bucco- } \\
\text { lingual }\end{array}$ & & 8.9 & & & & & & \\
\hline & Root length & & 16.4 & & & & & & 13.9 \\
\hline \multirow[t]{6}{*}{$\mathrm{RC}$} & $\begin{array}{l}\text { Crown } \\
\text { Mesio-distal }\end{array}$ & 8.8 & & & 8.5 & & 8.3 & 7.7 & 8.0 \\
\hline & Crown Bucco-lingual & 8.9 & & 9.9 & 8.7 & & & 9.4 & 8.5 \\
\hline & Crown height & 11.4 & & & & & & & \\
\hline & Cervical Mesio-distal & 5.8 & & & & & & & \\
\hline & $\begin{array}{l}\text { Cervical Bucco- } \\
\text { lingual }\end{array}$ & 8.1 & & & & & & & \\
\hline & Root length & & 18.7 & & & & & & \\
\hline \multirow[t]{6}{*}{ RI2 } & $\begin{array}{l}\text { Crown } \\
\text { Mesio-distal }\end{array}$ & & & & 7.8 & & 7.2 & & \\
\hline & Crown Bucco-lingual & & & & 6.9 & & & & \\
\hline & Crown height & & & & & & & & \\
\hline & Cervical Mesio-distal & & & & 5.3 & & & & \\
\hline & $\begin{array}{l}\text { Cervical Bucco- } \\
\text { lingual }\end{array}$ & & & & & & & & \\
\hline & Root length & & & & & & & & \\
\hline \multirow[t]{6}{*}{ RI1 } & $\begin{array}{l}\text { Crown } \\
\text { Mesio-distal }\end{array}$ & 8.9 & & & 8.6 & & & & \\
\hline & Crown Bucco-lingual & 9.0 & & 8.3 & 7.9 & & & & \\
\hline & Crown height & 12.5 & & & & & & 6.8 & \\
\hline & Cervical Mesio-distal & & & 6.3 & 5.6 & & & & \\
\hline & $\begin{array}{l}\text { Cervical Bucco- } \\
\text { lingual }\end{array}$ & & & 7.2 & 6.7 & & & & \\
\hline & Root length & & 13.2 & & & & & & \\
\hline \multirow[t]{6}{*}{ LI1 } & $\begin{array}{l}\text { Crown } \\
\text { Mesio-distal }\end{array}$ & 9.2 & & & 8.5 & & & & \\
\hline & Crown Bucco-lingual & 6.8 & & & 8.1 & & & & \\
\hline & Crown height & 12.3 & & & & & & & \\
\hline & Cervical Mesio-distal & & & & 6.0 & & & & \\
\hline & $\begin{array}{l}\text { Cervical Bucco- } \\
\text { lingual }\end{array}$ & & & & & & & & \\
\hline & Root length & & & & & & & & \\
\hline \multirow[t]{3}{*}{ LI2 } & $\begin{array}{l}\text { Crown } \\
\text { Mesio-distal }\end{array}$ & 7.5 & & 8.2 & & & & & \\
\hline & Crown Bucco-lingual & 6.3 & & 7.1 & 7.1 & & & & \\
\hline & Crown height & 10.6 & & & & & & & \\
\hline
\end{tabular}


Table 10-10, continued.

\begin{tabular}{|c|c|c|c|c|c|c|c|c|c|}
\hline & \multirow{3}{*}{$\begin{array}{l}\text { 41CE15 } \\
\text { AJ-2 }\end{array}$} & \multirow{3}{*}{$\begin{array}{l}\text { 41CE17 } \\
\text { AL-3 }\end{array}$} & \multicolumn{6}{|c|}{ 41CE19 } \\
\hline & & & & $\begin{array}{l}\text { F. } \\
118\end{array}$ & $\begin{array}{l}\text { F. } \\
119\end{array}$ & $\begin{array}{l}\text { F. } \\
130\end{array}$ & $\begin{array}{l}\text { F. } 134 \\
\text { B2 }\end{array}$ & $\begin{array}{l}\text { F. } 134 \\
\text { B3 }\end{array}$ & $\begin{array}{l}\text { F. } 134 \\
\text { B4 }\end{array}$ \\
\hline \multirow{3}{*}{$\mathrm{LI} 2$} & Cervical Mesio-distal & & & & S1 & & & & \\
\hline & $\begin{array}{l}\text { Cervical Bucco- } \\
\text { lingual }\end{array}$ & & & & 6.2 & & & & \\
\hline & Root length & & & & 14.3 & & & & 17.6 \\
\hline \multirow[t]{6}{*}{ LC } & $\begin{array}{l}\text { Crown } \\
\text { Mesio-distal }\end{array}$ & & & 8.5 & 8.4 & & & & \\
\hline & Crown Bucco-lingual & & & 9.7 & 9.1 & & & & \\
\hline & Crown height & & & & & & & & \\
\hline & Cervical Mesio-distal & & & & & & & & \\
\hline & $\begin{array}{l}\text { Cervical Bucco- } \\
\text { lingual }\end{array}$ & & & & & & & & \\
\hline & Root length & & 19.5 & & 17.6 & & & & \\
\hline \multirow[t]{6}{*}{ LP1 } & $\begin{array}{l}\text { Crown } \\
\text { Mesio-distal }\end{array}$ & & & $\begin{array}{l}10 . \\
8\end{array}$ & 7.6 & & & & 7.0 \\
\hline & Crown Bucco-lingual & & & & & & 8.6 & & 9.6 \\
\hline & Crown height & & & & & & & 10.1 & \\
\hline & Cervical Mesio-distal & & & & & & & & \\
\hline & $\begin{array}{l}\text { Cervical Bucco- } \\
\text { lingual }\end{array}$ & & & & & & & & \\
\hline & Root length & & & & & & & & \\
\hline \multirow[t]{6}{*}{ LP2 } & $\begin{array}{l}\text { Crown } \\
\text { Mesio-distal }\end{array}$ & & & 7.7 & 7.8 & & 7.2 & & 6.6 \\
\hline & Crown Bucco-lingual & & & $\begin{array}{l}10 . \\
3\end{array}$ & 10.8 & & 9.2 & & 9.4 \\
\hline & Crown height & & & & & & & & \\
\hline & Cervical Mesio-distal & & & & 5.5 & & & & \\
\hline & $\begin{array}{l}\text { Cervical Bucco- } \\
\text { lingual }\end{array}$ & & & & & & & & \\
\hline & Root length & & & & & & & & \\
\hline \multirow[t]{6}{*}{ LM1 } & $\begin{array}{l}\text { Crown } \\
\text { Mesio-distal }\end{array}$ & & & $\begin{array}{l}10 . \\
9\end{array}$ & & & & 10.0 & \\
\hline & Crown Bucco-lingual & & & $\begin{array}{l}12 . \\
6\end{array}$ & & & & 12.2 & \\
\hline & Crown height & & & & & & & & \\
\hline & Cervical Mesio-distal & & & & 9.9 & & & & \\
\hline & $\begin{array}{l}\text { Cervical Bucco- } \\
\text { lingual }\end{array}$ & & 12.5 & & 12.6 & & & & \\
\hline & Root length & & 12.6 & & 11.7 & & & & 11.3 \\
\hline \multirow[t]{6}{*}{ LM2 } & $\begin{array}{l}\text { Crown } \\
\text { Mesio-distal }\end{array}$ & & & & & & 10.2 & 12.2 & \\
\hline & Crown Bucco-lingual & & & & & & 11.9 & 13.4 & 11.2 \\
\hline & Crown height & & & & & & & & \\
\hline & Cervical Mesio-distal & & & 8.6 & & & & 8.5 & \\
\hline & $\begin{array}{l}\text { Cervical Bucco- } \\
\text { lingual }\end{array}$ & & & 9.5 & & & & & \\
\hline & Root length & & & & & & & & 13.8 \\
\hline
\end{tabular}


Table 10-10, continued.

\begin{tabular}{|c|c|c|c|c|c|c|c|c|c|}
\hline & \multirow{2}{*}{$\begin{array}{l}\text { 41CE15 } \\
\text { AJ-2 }\end{array}$} & \multirow{2}{*}{$\begin{array}{l}\text { 41CE17 } \\
\text { AL-3 }\end{array}$} & \multicolumn{6}{|c|}{ 41CE19 } \\
\hline & & & & $\begin{array}{l}\text { F. } \\
118\end{array}$ & $\begin{array}{l}\text { F. } 119 \\
\text { S1 }\end{array}$ & $\begin{array}{l}\text { F. } \\
130\end{array}$ & $\begin{array}{l}\text { F. } 134 \\
\text { B2 }\end{array}$ & $\begin{array}{l}\text { F. } 134 \\
\text { B3 }\end{array}$ & $\begin{array}{l}\text { F. } 134 \\
\text { B4 }\end{array}$ \\
\hline \multirow[t]{6}{*}{ LM3 } & $\begin{array}{l}\text { Crown } \\
\text { Mesio-distal }\end{array}$ & & & & & 9.6 & 8.2 & 7.7 & \\
\hline & $\begin{array}{l}\text { Crown Bucco- } \\
\text { lingual }\end{array}$ & & & & 10.6 & 10.3 & 10.5 & 10.6 & \\
\hline & Crown height & & & & & & & & \\
\hline & $\begin{array}{l}\text { Cervical Mesio- } \\
\text { distal }\end{array}$ & & & & 7.1 & & & & \\
\hline & $\begin{array}{l}\text { Cervical Bucco- } \\
\text { lingual }\end{array}$ & & & & 10.4 & & & & \\
\hline & Root length & & & & 10.6 & & & & 12.2 \\
\hline \multicolumn{10}{|c|}{ Mandibular } \\
\hline \multirow[t]{6}{*}{ LM3 } & $\begin{array}{l}\text { Crown } \\
\text { Mesio-distal }\end{array}$ & & & & & & 11.4 & 11.5 & 11.8 \\
\hline & $\begin{array}{l}\text { Crown Bucco- } \\
\text { lingual }\end{array}$ & & & & & & 11.0 & 11.1 & 11.8 \\
\hline & Crown height & & & & & & 6.2 & 7.7 & \\
\hline & $\begin{array}{l}\text { Cervical Mesio- } \\
\text { distal }\end{array}$ & & & & & & & & \\
\hline & $\begin{array}{l}\text { Cervical Bucco- } \\
\text { lingual }\end{array}$ & & & & & & & 9.4 & \\
\hline & Root length & & & & & & & & 9.6 \\
\hline \multirow[t]{6}{*}{ LM2 } & $\begin{array}{l}\text { Crown } \\
\text { Mesio-distal }\end{array}$ & 11.5 & & & & & 11.4 & 12.3 & 11.0 \\
\hline & $\begin{array}{l}\text { Crown Bucco- } \\
\text { lingual }\end{array}$ & 10.1 & & & & & 10.8 & 11.8 & 10.5 \\
\hline & Crown height & & & & & & & & \\
\hline & $\begin{array}{l}\text { Cervical Mesio- } \\
\text { distal }\end{array}$ & & & & & & & 9.7 & 9.6 \\
\hline & $\begin{array}{l}\text { Cervical Bucco- } \\
\text { lingual }\end{array}$ & & & & & & & 10.0 & 9.5 \\
\hline & Root length & & & & & & & & \\
\hline \multirow[t]{6}{*}{ LM1 } & $\begin{array}{l}\text { Crown } \\
\text { Mesio-distal }\end{array}$ & & & & & & 11.9 & & \\
\hline & $\begin{array}{l}\text { Crown Bucco- } \\
\text { lingual }\end{array}$ & & & & & & 11.2 & & \\
\hline & Crown height & 7.3 & & & & & & & \\
\hline & $\begin{array}{l}\text { Cervical Mesio- } \\
\text { distal }\end{array}$ & & & & & & & 9.2 & 10.4 \\
\hline & $\begin{array}{l}\text { Cervical Bucco- } \\
\text { lingual }\end{array}$ & & & & & & & & 9.8 \\
\hline & Root length & & & & & & & & 13.1 \\
\hline
\end{tabular}


Table 10-10, continued.

\begin{tabular}{|c|c|c|c|c|c|c|c|c|c|}
\hline & \multirow{2}{*}{$\begin{array}{l}\text { 41CE15 } \\
\text { AJ-2 }\end{array}$} & \multirow{2}{*}{$\begin{array}{l}\text { 41CE17 } \\
\text { AL-3 }\end{array}$} & \multicolumn{6}{|c|}{ 41CE19 } \\
\hline & & & & $\begin{array}{l}\text { F. } \\
118\end{array}$ & $\begin{array}{l}\text { F. } 119 \\
\text { S1 }\end{array}$ & $\begin{array}{l}\text { F. } \\
130\end{array}$ & $\begin{array}{l}\text { F. } 134 \\
\text { B2 }\end{array}$ & $\begin{array}{l}\text { F. } 134 \\
\text { B3 }\end{array}$ & $\begin{array}{l}\text { F. } 134 \\
\text { B4 }\end{array}$ \\
\hline \multirow[t]{6}{*}{ LP2 } & $\begin{array}{l}\text { Crown } \\
\text { Mesio-distal }\end{array}$ & & & & & & 7.1 & 7.3 & \\
\hline & Crown Bucco-lingual & & & & 9.6 & & 7.0 & 9.3 & \\
\hline & Crown height & & & & & & & & \\
\hline & Cervical Mesio-distal & & 5.4 & & & & & 5.5 & \\
\hline & Cervical Bucco-lingual & & 8.1 & & & & & 8.0 & \\
\hline & Root length & & 16.9 & & & & & & \\
\hline \multirow[t]{6}{*}{ LP1 } & $\begin{array}{l}\text { Crown } \\
\text { Mesio-distal }\end{array}$ & & & & & & 7.4 & 7.2 & \\
\hline & Crown Bucco-lingual & & & & 9.1 & & 8.1 & 8.9 & \\
\hline & Crown height & & & & & & & & \\
\hline & Cervical Mesio-distal & & & & & & & 5.2 & \\
\hline & Cervical Bucco-lingual & & & & & & & 7.5 & \\
\hline & Root length & & & & & & & 16.5 & 15.2 \\
\hline \multirow[t]{6}{*}{ LC } & $\begin{array}{l}\text { Crown } \\
\text { Mesio-distal }\end{array}$ & & & & & & 7.1 & 6.7 & \\
\hline & Crown Bucco-lingual & 7.7 & & 9.2 & & & & 8.5 & \\
\hline & Crown height & & & & & & & & \\
\hline & Cervical Mesio-distal & & & & & & & 5.4 & \\
\hline & Cervical Bucco-lingual & & & & & & & 8.3 & \\
\hline & Root length & & & & & & & & \\
\hline \multirow[t]{6}{*}{ LI2 } & $\begin{array}{l}\text { Crown } \\
\text { Mesio-distal }\end{array}$ & 6.8 & & & & & & & \\
\hline & Crown Bucco-lingual & & & & & & & & \\
\hline & Crown height & & & & & & & & \\
\hline & Cervical Mesio-distal & 3.8 & & & & & & & \\
\hline & Cervical Bucco-lingual & & & & & & & & \\
\hline & Root length & & & & & & & & \\
\hline \multirow[t]{6}{*}{ LI1 } & $\begin{array}{l}\text { Crown } \\
\text { Mesio-distal }\end{array}$ & & & & & & & & \\
\hline & Crown Bucco-lingual & & & & & & & & \\
\hline & Crown height & & & & & & & & \\
\hline & Cervical Mesio-distal & & & & & & & & \\
\hline & Cervical Bucco-lingual & & & & & & & & \\
\hline & Root length & & & & & & & & \\
\hline \multirow[t]{6}{*}{ RI1 } & $\begin{array}{l}\text { Crown } \\
\text { Mesio-distal }\end{array}$ & & & & & & & & \\
\hline & Crown Bucco-lingual & & & & & & & & \\
\hline & Crown height & & & & & & & & \\
\hline & Cervical Mesio-distal & & & & & & & & \\
\hline & Cervical Bucco-lingual & & & & & & & & \\
\hline & Root length & & & & & & & & \\
\hline
\end{tabular}


Table 10-10, continued.

\begin{tabular}{|c|c|c|c|c|c|c|c|c|c|}
\hline & \multirow{2}{*}{$\begin{array}{l}\text { 41CE15 } \\
\text { AJ-2 }\end{array}$} & \multirow{2}{*}{$\begin{array}{l}\text { 41CE17 } \\
\text { AL-3 }\end{array}$} & \multicolumn{6}{|c|}{ 41CE19 } \\
\hline & & & & $\begin{array}{l}\text { F. } \\
118\end{array}$ & $\begin{array}{l}\text { F. } \\
119 \\
\text { S1 }\end{array}$ & $\begin{array}{l}\text { F. } \\
130\end{array}$ & $\begin{array}{l}\text { F.134 } \\
\text { B2 }\end{array}$ & $\begin{array}{l}\text { F. } 134 \\
\text { B3 }\end{array}$ & $\begin{array}{l}\text { F. } 134 \\
\text { B4 }\end{array}$ \\
\hline \multirow[t]{6}{*}{ RI2 } & $\begin{array}{l}\text { Crown } \\
\text { Mesio-distal }\end{array}$ & 6.8 & & & & & & & \\
\hline & Crown Bucco-lingual & & & & & & & & \\
\hline & Crown height & 10.4 & & & & & & & \\
\hline & Cervical Mesio-distal & 3.7 & & & & & & & \\
\hline & $\begin{array}{l}\text { Cervical Bucco- } \\
\text { lingual }\end{array}$ & & & & & & & & \\
\hline & Root length & & & & & & & & \\
\hline \multirow[t]{6}{*}{$\mathrm{RC}$} & $\begin{array}{l}\text { Crown } \\
\text { Mesio-distal }\end{array}$ & & & & & & & 6.9 & \\
\hline & Crown Bucco-lingual & & & & & & & 8.7 & \\
\hline & Crown height & & & & & & & & \\
\hline & Cervical Mesio-distal & & & & & & & & \\
\hline & $\begin{array}{l}\text { Cervical Bucco- } \\
\text { lingual }\end{array}$ & & & & & & & & 8.3 \\
\hline & Root length & & & & & & & & 17.8 \\
\hline \multirow[t]{6}{*}{$\begin{array}{l}\mathrm{RP} \\
1\end{array}$} & $\begin{array}{l}\text { Crown } \\
\text { Mesio-distal }\end{array}$ & & & & & & 6.9 & 7.0 & \\
\hline & Crown Bucco-lingual & & & 9.4 & & & 8.4 & 8.6 & 8.9 \\
\hline & Crown height & & & & & & & & \\
\hline & Cervical Mesio-distal & & & & & & & & 4.9 \\
\hline & $\begin{array}{l}\text { Cervical Bucco- } \\
\text { lingual }\end{array}$ & & & & & & & & \\
\hline & Root length & & & & & & & & 15.6 \\
\hline \multirow[t]{6}{*}{$\begin{array}{l}\mathrm{RP} \\
2\end{array}$} & $\begin{array}{l}\text { Crown } \\
\text { Mesio-distal }\end{array}$ & & & 7.5 & & & & 7.5 & 7.0 \\
\hline & Crown Bucco-lingual & & & & & & & 9.8 & 8.7 \\
\hline & Crown height & & & & & & & & \\
\hline & Cervical Mesio-distal & & & & & & & & \\
\hline & $\begin{array}{l}\text { Cervical Bucco- } \\
\text { lingual }\end{array}$ & & & & & & & & 7.7 \\
\hline & Root length & & & & & & & & \\
\hline \multirow[t]{6}{*}{$\begin{array}{l}\mathrm{RM} \\
1\end{array}$} & $\begin{array}{l}\text { Crown } \\
\text { Mesio-distal }\end{array}$ & & & & & & 11.6 & & 11.4 \\
\hline & Crown Bucco-lingual & 10.7 & & & & & 11.6 & & 10.9 \\
\hline & Crown height & 7.6 & & & & & & & \\
\hline & Cervical Mesio-distal & & & & & & & & \\
\hline & $\begin{array}{l}\text { Cervical Bucco- } \\
\text { lingual }\end{array}$ & & & & & & & & \\
\hline & Root length & & & & & & & & 14.1 \\
\hline \multirow[t]{3}{*}{$\begin{array}{l}\mathrm{RM} \\
2\end{array}$} & $\begin{array}{l}\text { Crown } \\
\text { Mesio-distal }\end{array}$ & & & & & & 11.3 & 12.4 & 11.1 \\
\hline & Crown Bucco-lingual & & & & & & 10.5 & 11.7 & 11.6 \\
\hline & Crown height & & & & & & 6.6 & & \\
\hline
\end{tabular}


Table 10-10, continued.

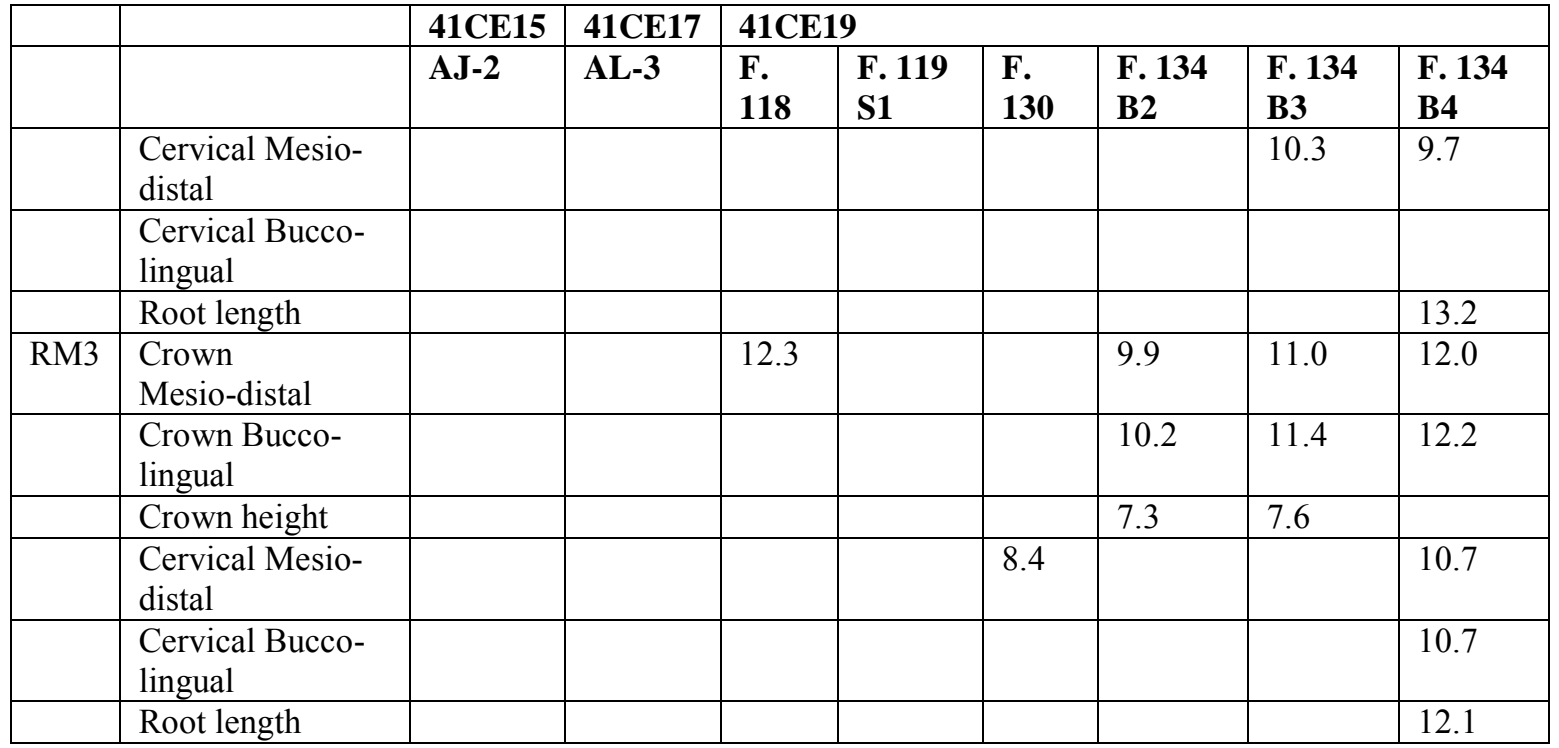


Table 10-10, continued.

\begin{tabular}{|c|c|c|c|c|c|c|}
\hline & \multicolumn{4}{|c|}{ 41CE19 cont. } & \multirow{2}{*}{$\begin{array}{l}\text { 41CE290 } \\
\text { NONE }\end{array}$} \\
\hline & & F. 134 B5 & F. 134 B8 & F. 155 & F. 161 & \\
\hline \multicolumn{7}{|c|}{ Tooth } \\
\hline \multicolumn{7}{|c|}{ Maxillary } \\
\hline \multirow[t]{6}{*}{ RM3 } & $\begin{array}{l}\text { Crown } \\
\text { Mesio-distal }\end{array}$ & & & 8.6 & & 9.4 \\
\hline & Crown Bucco-lingual & & & 11.0 & & 11.7 \\
\hline & Crown height & & & & & 8.3 \\
\hline & Cervical Mesio-distal & & & & & \\
\hline & Cervical Bucco-lingual & & & & & \\
\hline & Root length & & & & & \\
\hline \multirow[t]{6}{*}{ RM2 } & $\begin{array}{l}\text { Crown } \\
\text { Mesio-distal }\end{array}$ & & & 10.2 & & \\
\hline & & & & & & \\
\hline & & & & & & \\
\hline & Cervical Mesio-distal & & & & & \\
\hline & Cervical Bucco-lingual & & & & & \\
\hline & Root length & & & & & \\
\hline \multirow[t]{6}{*}{$\mathrm{RP} 2$} & $\begin{array}{l}\text { Crown } \\
\text { Mesio-distal }\end{array}$ & 10.5 & & & & \\
\hline & Crown Bucco-lingual & 10.7 & & 9.8 & & \\
\hline & Crown height & & & & & \\
\hline & Cervical Mesio-distal & & & & & \\
\hline & Cervical Bucco-lingual & & & & & \\
\hline & Root length & & & & & \\
\hline \multirow[t]{6}{*}{ RP1 } & $\begin{array}{l}\text { Crown } \\
\text { Mesio-distal }\end{array}$ & & & 7.2 & & \\
\hline & Crown Bucco-lingual & & & 9.9 & & \\
\hline & Crown height & & & & & \\
\hline & Cervical Mesio-distal & & & & & \\
\hline & Cervical Bucco-lingual & & & & & \\
\hline & Root length & & & & & \\
\hline \multirow[t]{6}{*}{$\mathrm{RC}$} & $\begin{array}{l}\text { Crown } \\
\text { Mesio-distal }\end{array}$ & & 7.4 & & & \\
\hline & Crown Bucco-lingual & & 8.5 & & & \\
\hline & Crown height & & & & & \\
\hline & Cervical Mesio-distal & & & & & \\
\hline & Cervical Bucco-lingual & & & & & \\
\hline & Root length & & & & & \\
\hline \multirow[t]{6}{*}{ RI2 } & $\begin{array}{l}\text { Crown } \\
\text { Mesio-distal }\end{array}$ & & & & & \\
\hline & Crown Bucco-lingual & & & & & \\
\hline & Crown height & & & & & \\
\hline & Cervical Mesio-distal & & & & & \\
\hline & Cervical Bucco-lingual & & & & & \\
\hline & Root length & & & & & \\
\hline
\end{tabular}


Table 10-10. continued.

\begin{tabular}{|c|c|c|c|c|c|c|}
\hline & \multicolumn{4}{|c|}{ 41CE19 cont. } & \multirow{2}{*}{$\begin{array}{l}\text { 41CE290 } \\
\text { NONE }\end{array}$} \\
\hline & & F. 134 B5 & F. 134 B8 & F. 155 & F. 161 & \\
\hline \multirow[t]{6}{*}{ RI1 } & Crown Mesio-distal & & & 8.9 & & \\
\hline & Crown Bucco-lingual & & & 8.0 & & 8.2 \\
\hline & Crown height & & & & & \\
\hline & Cervical Mesio-distal & & & & & \\
\hline & Cervical Bucco-lingual & & & & & \\
\hline & Root length & & & & & \\
\hline \multirow[t]{6}{*}{ LI1 } & $\begin{array}{l}\text { Crown } \\
\text { Mesio-distal }\end{array}$ & & & & & \\
\hline & Crown Bucco-lingual & & & & & \\
\hline & Crown height & & & & & \\
\hline & Cervical Mesio-distal & & & & & \\
\hline & Cervical Bucco-lingual & & & & & \\
\hline & Root length & & & & & \\
\hline \multirow[t]{6}{*}{ LI2 } & $\begin{array}{l}\text { Crown } \\
\text { Mesio-distal }\end{array}$ & & & 7.3 & & \\
\hline & Crown Bucco-lingual & & & & & \\
\hline & Crown height & & & & & \\
\hline & Cervical Mesio-distal & & & & & \\
\hline & Cervical Bucco-lingual & & & & & \\
\hline & Root length & & & & & \\
\hline \multirow[t]{6}{*}{$\mathrm{LC}$} & $\begin{array}{l}\text { Crown } \\
\text { Mesio-distal }\end{array}$ & & 7.6 & 8.4 & 8.4 & \\
\hline & Crown Bucco-lingual & & 8.5 & 9.6 & 8.6 & \\
\hline & Crown height & & & & & \\
\hline & Cervical Mesio-distal & & & & & \\
\hline & Cervical Bucco-lingual & & & & & \\
\hline & Root length & & & & & \\
\hline \multirow[t]{6}{*}{ LP1 } & $\begin{array}{l}\text { Crown } \\
\text { Mesio-distal }\end{array}$ & & & & 7.1 & \\
\hline & Crown Bucco-lingual & & & 10.1 & & \\
\hline & Crown height & & & & & \\
\hline & Cervical Mesio-distal & & & & & \\
\hline & Cervical Bucco-lingual & & & & & \\
\hline & Root length & & & & & \\
\hline \multirow[t]{6}{*}{ LP2 } & $\begin{array}{l}\text { Crown } \\
\text { Mesio-distal }\end{array}$ & & 6.7 & 7.4 & & 6.9 \\
\hline & Crown Bucco-lingual & & 9.1 & & & 10.1 \\
\hline & Crown height & & & & & \\
\hline & Cervical Mesio-distal & & & & & \\
\hline & Cervical Bucco-lingual & & & & & \\
\hline & Root length & & & & & \\
\hline \multirow[t]{6}{*}{ LM1 } & $\begin{array}{l}\text { Crown } \\
\text { Mesio-distal }\end{array}$ & & 9.7 & 10.4 & 10.5 & \\
\hline & Crown Bucco-lingual & & 11.3 & 11.9 & 11.8 & \\
\hline & Crown height & & & & & \\
\hline & Cervical Mesio-distal & & & & & \\
\hline & Cervical Bucco-lingual & & & & & \\
\hline & Root length & & & & & \\
\hline
\end{tabular}


Table 10-10, continued.

\begin{tabular}{|c|c|c|c|c|c|c|}
\hline & \multicolumn{4}{|c|}{ 41CE19 cont. } & \multirow{2}{*}{$\begin{array}{l}\text { 41CE290 } \\
\text { NONE }\end{array}$} \\
\hline & & F. 134 B5 & F. 134 B8 & F. 155 & F. 161 & \\
\hline \multirow[t]{6}{*}{ LM2 } & $\begin{array}{l}\text { Crown } \\
\text { Mesio-distal }\end{array}$ & & & & 10.3 & \\
\hline & Crown Bucco-lingual & & & 11.6 & 11.8 & 12.1 \\
\hline & Crown height & & & & & \\
\hline & Cervical Mesio-distal & & & & & \\
\hline & Cervical Bucco-lingual & & & & & \\
\hline & Root length & & & & & 9.4 \\
\hline \multirow[t]{6}{*}{ LM3 } & $\begin{array}{l}\text { Crown } \\
\text { Mesio-distal }\end{array}$ & & 8.0 & & 9.2 & \\
\hline & Crown Bucco-lingual & & 10.9 & 10.3 & & \\
\hline & Crown height & & & & & \\
\hline & Cervical Mesio-distal & & & & & \\
\hline & Cervical Bucco-lingual & & & & & \\
\hline & Root length & & & & & \\
\hline \multirow[t]{6}{*}{ LM3 } & $\begin{array}{l}\text { Crown } \\
\text { Mesio-distal }\end{array}$ & & & 10.7 & & \\
\hline & Crown Bucco-lingual & & & 10.5 & & \\
\hline & Crown height & & & & & \\
\hline & Cervical Mesio-distal & & & & & \\
\hline & Cervical Bucco-lingual & & & & & \\
\hline & Root length & & & & & \\
\hline \multirow[t]{6}{*}{ LM2 } & $\begin{array}{l}\text { Crown } \\
\text { Mesio-distal }\end{array}$ & & & 11.0 & & \\
\hline & Crown Bucco-lingual & & & 10.2 & & 11.4 \\
\hline & Crown height & & & & & \\
\hline & Cervical Mesio-distal & & & & & \\
\hline & Cervical Bucco-lingual & & & & & \\
\hline & Root length & & & & & \\
\hline \multirow[t]{6}{*}{ LM1 } & $\begin{array}{l}\text { Crown } \\
\text { Mesio-distal }\end{array}$ & & & & & \\
\hline & Crown Bucco-lingual & & & & & \\
\hline & Crown height & & & & & \\
\hline & Cervical Mesio-distal & & & & & \\
\hline & Cervical Bucco-lingual & & & & & \\
\hline & Root length & & & & & \\
\hline \multirow[t]{6}{*}{ LP2 } & $\begin{array}{l}\text { Crown } \\
\text { Mesio-distal }\end{array}$ & 6.4 & & & & \\
\hline & Crown Bucco-lingual & 7.9 & & & & 8.9 \\
\hline & Crown height & & & & & \\
\hline & Cervical Mesio-distal & & & & & \\
\hline & Cervical Bucco-lingual & & & & & \\
\hline & Root length & & & & & \\
\hline
\end{tabular}


Table 10-10, continued.

\begin{tabular}{|c|c|c|c|c|c|c|}
\hline & & \multicolumn{4}{|c|}{$41 \mathrm{CE} 19$ cont. } & \multirow{2}{*}{$\begin{array}{l}\text { 41CE290 } \\
\text { NONE } \\
\end{array}$} \\
\hline & & F. 134 B5 & F. 134 B8 & F. 155 & F. 161 & \\
\hline \multirow[t]{6}{*}{ LP1 } & $\begin{array}{l}\text { Crown } \\
\text { Mesio-distal }\end{array}$ & & 6.6 & & & \\
\hline & Crown Bucco-lingual & & & & & 8.6 \\
\hline & Crown height & & & & & \\
\hline & Cervical Mesio-distal & & & & & \\
\hline & Cervical Bucco-lingual & & & & & \\
\hline & Root length & & & & & \\
\hline \multirow[t]{6}{*}{$\mathrm{LC}$} & $\begin{array}{l}\text { Crown } \\
\text { Mesio-distal }\end{array}$ & & & & & \\
\hline & Crown Bucco-lingual & & & & & 8.0 \\
\hline & Crown height & & & & & \\
\hline & Cervical Mesio-distal & & & & & \\
\hline & Cervical Bucco-lingual & & & & & \\
\hline & Root length & & & & & \\
\hline \multirow[t]{6}{*}{ LI2 } & $\begin{array}{l}\text { Crown } \\
\text { Mesio-distal }\end{array}$ & & & & & \\
\hline & Crown Bucco-lingual & & & & & \\
\hline & Crown height & & & & & \\
\hline & Cervical Mesio-distal & & & & & \\
\hline & Cervical Bucco-lingual & & & & & \\
\hline & Root length & & & & & \\
\hline \multirow[t]{6}{*}{ LI1 } & $\begin{array}{l}\text { Crown } \\
\text { Mesio-distal }\end{array}$ & & & & & \\
\hline & Crown Bucco-lingual & & & & & \\
\hline & Crown height & & & & & \\
\hline & Cervical Mesio-distal & & & & & \\
\hline & Cervical Bucco-lingual & & & & & \\
\hline & Root length & & & & & \\
\hline \multirow[t]{6}{*}{ RI1 } & $\begin{array}{l}\text { Crown } \\
\text { Mesio-distal }\end{array}$ & & & & & \\
\hline & Crown Bucco-lingual & & & & & \\
\hline & Crown height & & & & & \\
\hline & Cervical Mesio-distal & & & & & \\
\hline & Cervical Bucco-lingual & & & & & \\
\hline & Root length & & & & & \\
\hline \multirow[t]{6}{*}{ RI2 } & $\begin{array}{l}\text { Crown } \\
\text { Mesio-distal }\end{array}$ & & & & & \\
\hline & Crown Bucco-lingual & & & & & \\
\hline & Crown height & & & & & \\
\hline & Cervical Mesio-distal & & & & & \\
\hline & Cervical Bucco-lingual & & & & & \\
\hline & Root length & & & & & \\
\hline
\end{tabular}


Table 10-10, continued.

\begin{tabular}{|c|c|c|c|c|c|c|}
\hline & \multicolumn{4}{|c|}{$41 C E 19$ cont. } & \multirow{2}{*}{$\begin{array}{l}\text { 41CE290 } \\
\text { NONE }\end{array}$} \\
\hline & & F. 134 B5 & F. 134 B8 & F. 155 & F. 161 & \\
\hline \multirow[t]{6}{*}{$\mathrm{RC}$} & $\begin{array}{l}\text { Crown } \\
\text { Mesio-distal }\end{array}$ & & & & & \\
\hline & Crown Bucco-lingual & & & & & \\
\hline & Crown height & & & & & \\
\hline & Cervical Mesio-distal & & & & & \\
\hline & Cervical Bucco-lingual & & & & & \\
\hline & Root length & & & & & \\
\hline \multirow[t]{6}{*}{ RP1 } & $\begin{array}{l}\text { Crown } \\
\text { Mesio-distal }\end{array}$ & & & & & \\
\hline & Crown Bucco-lingual & & & & & \\
\hline & Crown height & & & & & \\
\hline & Cervical Mesio-distal & & & & & \\
\hline & Cervical Bucco-lingual & & & & & \\
\hline & Root length & & & & & \\
\hline \multirow[t]{6}{*}{ RP2 } & $\begin{array}{l}\text { Crown } \\
\text { Mesio-distal }\end{array}$ & & & & & \\
\hline & Crown Bucco-lingual & & 7.7 & & & \\
\hline & Crown height & & & & & \\
\hline & Cervical Mesio-distal & & & & & \\
\hline & Cervical Bucco-lingual & & & & & \\
\hline & Root length & & & & & \\
\hline \multirow[t]{6}{*}{ RM1 } & $\begin{array}{l}\text { Crown } \\
\text { Mesio-distal }\end{array}$ & & & & & \\
\hline & Crown Bucco-lingual & & & & & \\
\hline & Crown height & & & & & \\
\hline & Cervical Mesio-distal & & & & & \\
\hline & Cervical Bucco-lingual & & & & & \\
\hline & Root length & & & & & \\
\hline \multirow[t]{6}{*}{ RM2 } & $\begin{array}{l}\text { Crown } \\
\text { Mesio-distal }\end{array}$ & & & & 11.8 & \\
\hline & Crown Bucco-lingual & & & & 11.3 & \\
\hline & Crown height & & & & & \\
\hline & Cervical Mesio-distal & & & & & \\
\hline & Cervical Bucco-lingual & & & & 9.8 & \\
\hline & Root length & & & & & \\
\hline \multirow[t]{6}{*}{ RM3 } & $\begin{array}{l}\text { Crown } \\
\text { Mesio-distal }\end{array}$ & & & & 11.2 & \\
\hline & Crown Bucco-lingual & & & 10.6 & 11.2 & \\
\hline & Crown height & & & & & \\
\hline & Cervical Mesio-distal & & & & 9.4 & \\
\hline & Cervical Bucco-lingual & & & & 8.9 & \\
\hline & Root length & & & & & \\
\hline
\end{tabular}

Notes: Many measurements were not possible due to attrition. Comingled remains are not included in this table. 
Table 10-11. Dental Measurements in Millimeters on Deciduous Dentition.

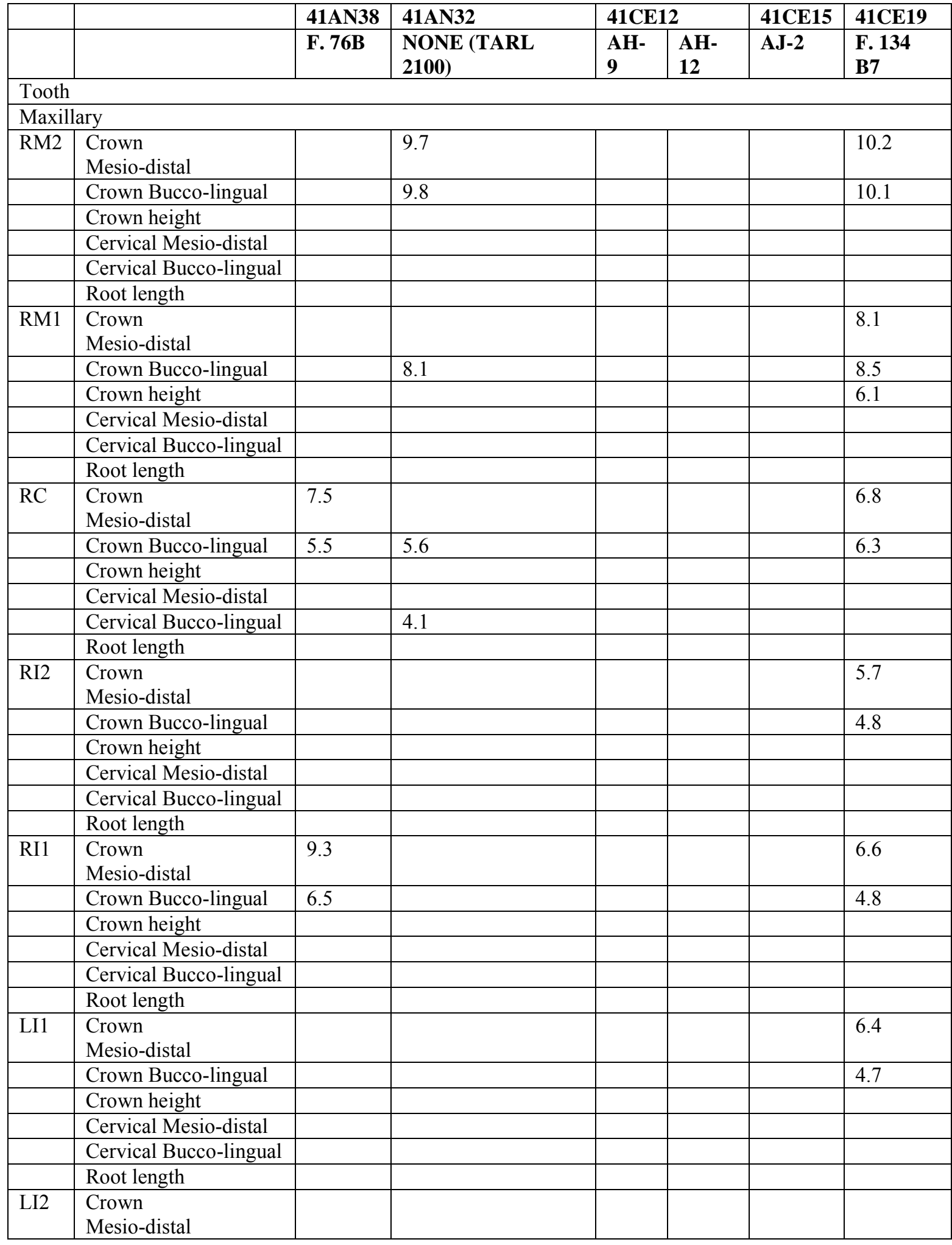


Table 10-11, continued.

\begin{tabular}{|c|c|c|c|c|c|c|c|}
\hline & & 41AN38 & 41AN32 & $41 \mathrm{CI}$ & & 41CE15 & 41CE19 \\
\hline & & F. 76B & $\begin{array}{l}\text { NONE (TARL } \\
2100)\end{array}$ & $\begin{array}{l}\text { AH- } \\
9\end{array}$ & $\begin{array}{l}\text { AH- } \\
12\end{array}$ & AJ-2 & $\begin{array}{l}\text { F. } 134 \\
\text { B7 }\end{array}$ \\
\hline & Crown Bucco-lingual & & & & & & \\
\hline & Crown height & & & & & & \\
\hline & Cervical Mesio-distal & & & & & & \\
\hline & Cervical Bucco-lingual & & & & & & \\
\hline & Root length & & & & & & \\
\hline LC & $\begin{array}{l}\text { Crown } \\
\text { Mesio-distal }\end{array}$ & & & & & & \\
\hline & Crown Bucco-lingual & & & & & & \\
\hline & Crown height & & & & & & \\
\hline & Cervical Mesio-distal & & & & & & \\
\hline & Cervical Bucco-lingual & & & & & & \\
\hline & Root length & & & & & & \\
\hline LM1 & $\begin{array}{l}\text { Crown } \\
\text { Mesio-distal }\end{array}$ & & 7.1 & & & & 8.2 \\
\hline & Crown Bucco-lingual & & 7.9 & & & & 8.5 \\
\hline & Crown height & & & & & & \\
\hline & Cervical Mesio-distal & & & & & & \\
\hline & Cervical Bucco-lingual & & 6.9 & & & & \\
\hline & Root length & & & & & & \\
\hline LM2 & $\begin{array}{l}\text { Crown } \\
\text { Mesio-distal }\end{array}$ & & & & & & 10.2 \\
\hline & Crown Bucco-lingual & & 9.8 & & & & 10.2 \\
\hline & Crown height & & & & & & \\
\hline & Cervical Mesio-distal & & & & & & \\
\hline & Cervical Bucco-lingual & & & & & & \\
\hline & Root length & & & & & & \\
\hline Mand & lar & & & & & & \\
\hline LM2 & $\begin{array}{l}\text { Crown } \\
\text { Mesio-distal }\end{array}$ & & & & & & 10.6 \\
\hline & Crown Bucco-lingual & & 8.9 & & & & 9.2 \\
\hline & Crown height & & & & & & \\
\hline & Cervical Mesio-distal & & & & & & \\
\hline & Cervical Bucco-lingual & & & & & & \\
\hline & Root length & & & & & & \\
\hline LM1 & $\begin{array}{l}\text { Crown } \\
\text { Mesio-distal }\end{array}$ & & & & & & 8.7 \\
\hline & Crown Bucco-lingual & & 6.9 & & & & 6.8 \\
\hline & Crown height & & & & & & \\
\hline & Cervical Mesio-distal & & & & & & \\
\hline & Cervical Bucco-lingual & & & 4.7 & & 7.7 & \\
\hline & Root length & & & & & & \\
\hline$\overline{\mathrm{LC}}$ & $\begin{array}{l}\text { Crown } \\
\text { Mesio-distal }\end{array}$ & 8.4 & & & & & 5.9 \\
\hline & Crown Bucco-lingual & 8.0 & & & & & 6.4 \\
\hline & Crown height & & & & & & \\
\hline & Cervical Mesio-distal & & & & & & \\
\hline & Cervical Bucco-lingual & & & & & & \\
\hline & Root length & & & & & & \\
\hline
\end{tabular}


Table 10-11, continued.

\begin{tabular}{|c|c|c|c|c|c|c|c|}
\hline & & 41AN38 & 41AN32 & $41 \mathrm{CE}$ & & 41CE15 & 41CE19 \\
\hline & & F. 76B & $\begin{array}{l}\text { NONE (TARL } \\
\text { 2100) }\end{array}$ & $\begin{array}{l}\text { AH- } \\
9 \\
\end{array}$ & $\begin{array}{l}\text { AH- } \\
12 \\
\end{array}$ & AJ-2 & $\begin{array}{l}\text { F. } 134 \\
\text { B7 }\end{array}$ \\
\hline $\mathrm{LI} 2$ & $\begin{array}{l}\text { Crown } \\
\text { Mesio-distal }\end{array}$ & & & & & & 4.4 \\
\hline & Crown Bucco-lingual & & & & & & \\
\hline & Crown height & & & & & & \\
\hline & Cervical Mesio-distal & & & & & & \\
\hline & $\begin{array}{l}\text { Cervical Bucco- } \\
\text { lingual }\end{array}$ & & & & & & \\
\hline & Root length & & & & & & \\
\hline LI1 & $\begin{array}{l}\text { Crown } \\
\text { Mesio-distal }\end{array}$ & & & & & & 5.7 \\
\hline & Crown Bucco-lingual & & & & & & 3.7 \\
\hline & Crown height & & & & & & \\
\hline & Cervical Mesio-distal & & & & & & \\
\hline & $\begin{array}{l}\text { Cervical Bucco- } \\
\text { lingual }\end{array}$ & & & & & & \\
\hline & Root length & & & & & & \\
\hline RI1 & $\begin{array}{l}\text { Crown } \\
\text { Mesio-distal }\end{array}$ & & & & & & 5.7 \\
\hline & Crown Bucco-lingual & & & & & & \\
\hline & Crown height & & & & & & \\
\hline & Cervical Mesio-distal & & & & & & \\
\hline & $\begin{array}{l}\text { Cervical Bucco- } \\
\text { lingual }\end{array}$ & & & & & & \\
\hline & Root length & & & & & & \\
\hline RI2 & $\begin{array}{l}\text { Crown } \\
\text { Mesio-distal }\end{array}$ & & & & & & \\
\hline & Crown Bucco-lingual & & & & & & \\
\hline & Crown height & & & & & & \\
\hline & Cervical Mesio-distal & & & & & & \\
\hline & $\begin{array}{l}\text { Cervical Bucco- } \\
\text { lingual }\end{array}$ & & & & & & \\
\hline & Root length & & & & & & \\
\hline $\mathrm{RC}$ & $\begin{array}{l}\text { Crown } \\
\text { Mesio-distal }\end{array}$ & & & & & & 6.1 \\
\hline & Crown Bucco-lingual & & & & & & 5.7 \\
\hline & Crown height & & & & & & \\
\hline & Cervical Mesio-distal & & & & & & \\
\hline & $\begin{array}{l}\text { Cervical Bucco- } \\
\text { lingual }\end{array}$ & & & & & & \\
\hline & Root length & & & & & & \\
\hline RM1 & $\begin{array}{l}\text { Crown } \\
\text { Mesio-distal }\end{array}$ & 12.7 & & & & & 8.7 \\
\hline & Crown Bucco-lingual & 11.6 & 9.1 & & & & 6.8 \\
\hline & Crown height & & & & & & \\
\hline
\end{tabular}


Table 10-11, continued.

\begin{tabular}{|l|l|l|l|l|l|l|l|}
\hline & & 41AN38 & 41AN32 & 41CE12 & 41CE15 & 41CE19 \\
\hline & F. 76B & $\begin{array}{l}\text { NONE (TARL } \\
\mathbf{2 1 0 0}\end{array}$ & $\begin{array}{l}\text { AH- } \\
\mathbf{9}\end{array}$ & $\begin{array}{l}\text { AH- } \\
\mathbf{1 2}\end{array}$ & $\begin{array}{l}\text { AJ-2 } \\
\text { F. 134 } \\
\text { B7 }\end{array}$ \\
\hline & Cervical Mesio-distal & & & & 6.0 & & \\
\hline & $\begin{array}{l}\text { Cervical Bucco- } \\
\text { lingual }\end{array}$ & & & & 7.3 & 7.4 & \\
\hline & Root length & & & & & & \\
\hline RM2 & $\begin{array}{l}\text { Crown } \\
\text { Mesio-distal }\end{array}$ & 11.4 & & & & & 10.5 \\
\hline & Crown Bucco-lingual & 10.8 & 6.9 & & & & 9.3 \\
\hline & Crown height & & & & & & \\
\hline & Cervical Mesio-distal & & 5.4 & & 7.7 & & \\
\hline $\begin{array}{l}\text { Cervical Bucco- } \\
\text { lingual }\end{array}$ & & 5.1 & & 7.1 & & \\
\hline & Root length & & & & & & \\
\hline
\end{tabular}

Notes: Commingled materials are not included in this table.

Table 10-12. Sexual Dimorphism in the Tibia.

\begin{tabular}{|l|l|l|l|}
\hline & Male & Female & Male/Female Ratio \\
\hline Circumference at nutrient & 97 & 88 & 110.9 \\
foramen of the tibia & 96 & & \\
mean & 95 & & \\
& 99 & & \\
\hline Anterior-posterior & 101 & & \\
diameter at the nutrient & 36.7 & 30.7 & 124.4 \\
foramen of the tibia & 35.6 & & \\
& 41.4 & & \\
mean & 39.4 & & \\
\hline Transverse diameter at the & $\mathbf{3 8 . 2}$ & & \\
nutrient foramen of the & 23.3 & 23.9 & \\
tibia & 21.3 & & \\
& 21.5 & & \\
mean & 22.9 & & \\
\hline
\end{tabular}

Note: Measurements are in millimeters. 
Table 10-13. Cranial Nonmetric Traits.

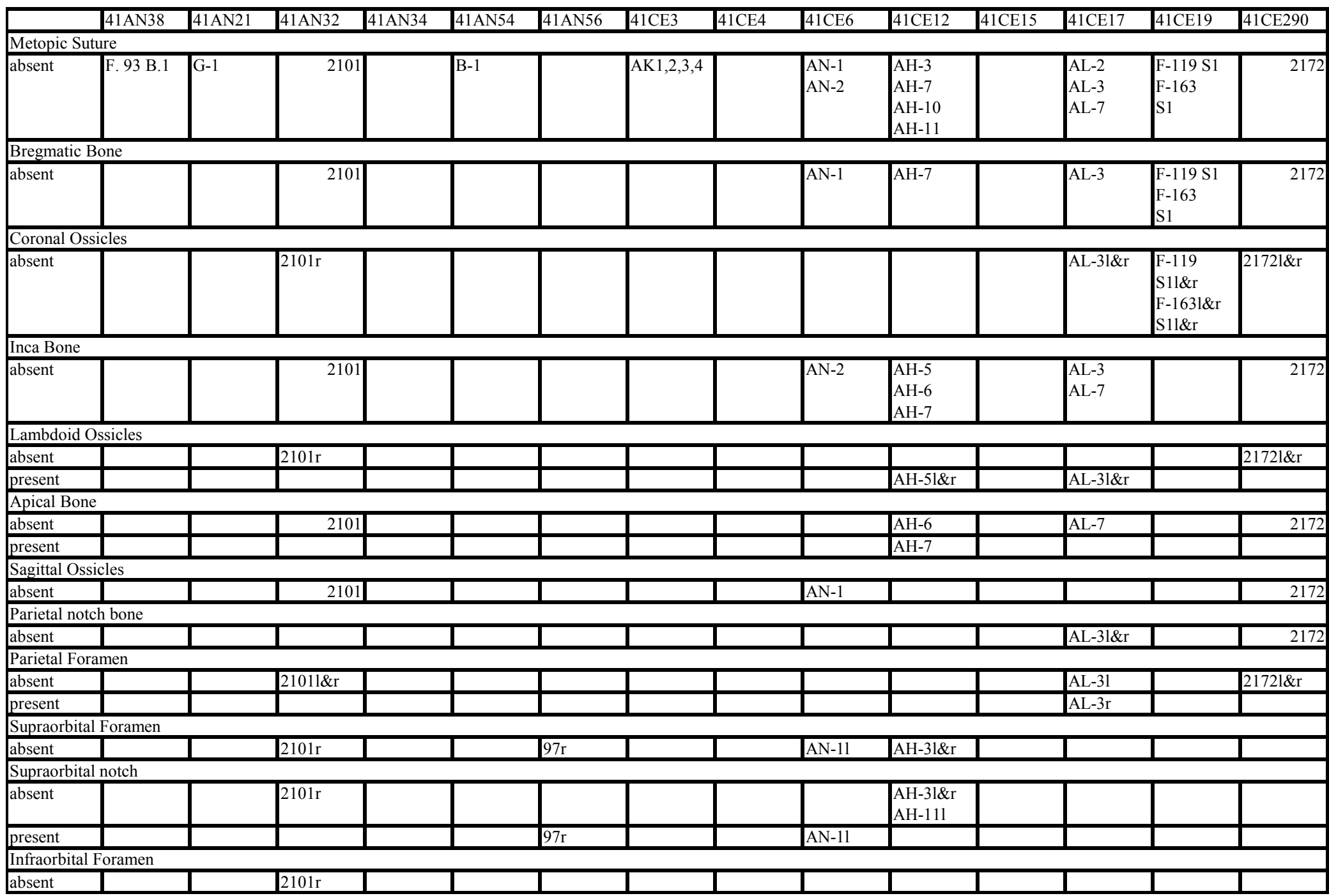


Table 10-13, continued.

\begin{tabular}{|c|c|c|c|c|c|c|c|c|c|c|c|c|c|c|}
\hline 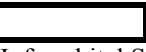 & 41AN38 & 41AN21 & $41 \mathrm{AN} 32$ & $41 \mathrm{AN} 34$ & 41AN54 & $41 \mathrm{AN} 56$ & $41 \mathrm{CE} 3$ & $41 \mathrm{CE} 4$ & 141CE6 & 41CE12 & $41 \mathrm{CE} 15$ & $141 \mathrm{CE} 17$ & 141CE19 & 141CE290 \\
\hline \multicolumn{15}{|c|}{ Infraorbital Suture } \\
\hline absent & & & $2101 \mathrm{r}$ & & & & & & & & & & & \\
\hline \multicolumn{15}{|c|}{ Zygomatic Foramen } \\
\hline 1 large & & I & $21011 \& \mathrm{r}$ & I & & I & & & AN-11 & & & & J-119 S21 & 21721 \\
\hline \multicolumn{15}{|c|}{ Mastoid Foramen Locus } \\
\hline Temporal & & & & $\mathrm{L}$ & & L & & & & & & $\mathrm{AL}-31$ & & 21721 \\
\hline Sutural & & & $2101 \mathrm{r}$ & & & & & & & & & & & \\
\hline \multicolumn{15}{|c|}{ Mastoid Foramen number } \\
\hline & & & & & & & & & & & & & & 21721 \\
\hline & & & $2101 \mathrm{r}$ & & & & & & & & & & & \\
\hline & & & & & & & & & & & & AL-31 & & \\
\hline \multirow{2}{*}{\multicolumn{15}{|c|}{ Supramastoid Crest }} \\
\hline absent & & & & & & 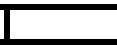 & & & & AH-6r & & & & \\
\hline $\begin{array}{l}\text { present, } \\
\text { gracile }\end{array}$ & & & $2101 \mathrm{r}$ & & $\mathrm{AE}-2 \mathrm{Br}$ & 971 & & & & $\begin{array}{l}\text { AH-31\&r } \\
\text { AH-5r }\end{array}$ & & $\begin{array}{l}\text { AL-31 } \\
\text { AL-71 } \\
\end{array}$ & & \\
\hline $\begin{array}{l}\text { present, } \\
\text { intermediate }\end{array}$ & & & 21011 & & & & & & $\mathrm{AN}-2 \mathrm{r}$ & & & & & 21721 \\
\hline $\begin{array}{l}\text { present, } \\
\text { robust }\end{array}$ & & & & & & & & & & & & & F-1631 & $2172 \mathrm{r}$ \\
\hline \multicolumn{15}{|c|}{ Suprameatal Pit } \\
\hline absent & & G-11 & & D-21 & & & & & & $\begin{array}{l}\text { AH-5l\&r } \\
\text { AH-6r }\end{array}$ & & AL-71 & & T21721\&r \\
\hline present & & & $21011 \& \mathrm{r}$ & & $\mathrm{AE}-2 \mathrm{Br}$ & 971 & & & AN-21\&r & $\begin{array}{l}\text { AH-31\&r } \\
\text { AH-7r }\end{array}$ & & AL-31\&r & F-1631 & \\
\hline \multicolumn{15}{|c|}{\begin{tabular}{|l|} 
Occipito-mastoid ossicles \\
\end{tabular}} \\
\hline absent & & & & L & & I & & & & & & AL-31\&r & & T21721 \\
\hline \multicolumn{15}{|c|}{ Auditory Exostosis } \\
\hline absent & & & 21011 & D-21 & B-11\&r & 971 & & AI-5I\&r & AN-21\&r & \begin{tabular}{|l} 
AH-31\&r \\
AH-51\&r \\
AH-6r \\
AH-71\&r
\end{tabular} & & AL-31\&r & & 21721\&r \\
\hline \multicolumn{15}{|c|}{ Tympanic Dehiscence } \\
\hline absent & & & 21011\&r & D-2l & & 971 & & \begin{tabular}{|l} 
AI-21 \\
AI-51\&r
\end{tabular} & & & & \begin{tabular}{|l} 
AL-31\&r \\
AL-71
\end{tabular} & \begin{tabular}{|l}
$\mathrm{F}-119$ \\
$\mathrm{~S} 21 \& \mathrm{r}$
\end{tabular} & 21721\&r \\
\hline small & & & & & B-11\&r & & & & & & & & & \\
\hline $\begin{array}{l}\text { Major part } \\
\text { of meatus } \\
\text { floor } \\
\text { missing }\end{array}$ & & & & & & & & & & AH-51\&r & & & & \\
\hline
\end{tabular}


Table 10-13, continued.

\begin{tabular}{|c|c|c|c|c|c|c|c|c|c|c|c|c|c|c|}
\hline & T1AN38 & 141AN21 & T1AN32 & 141AN34 & 4 41AN54 & 411AN56 & $\longdiv { 4 1 \mathrm { CE } 3 }$ & $41 \mathrm{CE} 4$ & T41CE6 & ד1CE12 & ד1CE15 & T41CE17 & 41CE19 & 141CE290 \\
\hline \multirow{2}{*}{\multicolumn{15}{|c|}{ Accessory Lesser Palatine Foramen }} \\
\hline & & & & & & & I & 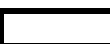 & L & 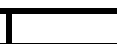 & 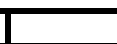 & 1 & 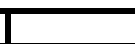 & $2172 \mathrm{r}$ \\
\hline \multicolumn{15}{|c|}{ Maxillary Torus } \\
\hline$\overline{\text { absent }}$ & & & & & & & & $\mathrm{AI}-2 \mathrm{r}$ & AN-11\&r & $\begin{array}{l}\mathrm{AH}-91 \\
\mathrm{AH}-111\end{array}$ & & & & $2172 \mathrm{r}$ \\
\hline $\begin{array}{l}\text { small bony } \\
\text { nodules }\end{array}$ & & & $21011 \& r$ & & & & $\mathrm{AK} 1,2,3,41$ & AI-2l & & & & & & 21721 \\
\hline $\begin{array}{l}\text { Large } \\
\text { protrusions }\end{array}$ & & & & & & & & & $\mathrm{AN}-2 \mathrm{r}$ & $\mathrm{AH}-3 \mathrm{r}$ & & & & \\
\hline Precondylar & Tubercle & & & & & & & & & & & & & \\
\hline absent & & & \multicolumn{2}{|c|}{\begin{tabular}{l|l|}
2101 & $\mathrm{D}-2$ \\
\end{tabular}} & & & & & & 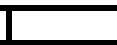 & & 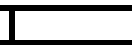 & & \\
\hline \multicolumn{15}{|c|}{ Double Occipital Condyle } \\
\hline absent & & & $21011 \& r$ & $\mathrm{D}-21 \& \mathrm{r}$ & & & $\mathrm{AK} 1,2,3,4 \mathrm{r}$ & & & & & & F-134 B41 & \\
\hline $\mathrm{AK} 1,2,3,41$ & & & & & & & AK1,2,3,41 & & & & & & & \\
\hline \multicolumn{15}{|c|}{$\frac{\text { avision }}{\text { Postcondylar Foramen }}$} \\
\hline absent & & & 21011 & $\mathrm{D}-21 \& \mathrm{r}$ & & & $\mathrm{AK} 1,2,3,4 \mathrm{r}$ & & & & & & & \\
\hline present & & & $2101 \mathrm{r}$ & & & & & & & & & & & \\
\hline \multicolumn{15}{|c|}{ Occipital Foramen } \\
\hline absent & & & $\overline{210}$ & & & & & & & & & 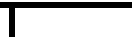 & & \\
\hline \multicolumn{15}{|c|}{ Pharyngeal Fossa } \\
\hline \multicolumn{15}{|l|}{$\begin{array}{l}\text { Medium (2- } \\
4 \mathrm{~mm} \text { deep) }\end{array}$} \\
\hline \multicolumn{15}{|c|}{ Bifurcated Hypoglossal Canal } \\
\hline absent & & T & $21011 \& \mathrm{r}$ & $\mathrm{D}-21 \& \mathrm{r}$ & & & & & & & & & & \\
\hline \multicolumn{15}{|c|}{ Superior Sagittal Sulcus Direction } \\
\hline right & & & & & & & & & & \begin{tabular}{|l|}
$\mathrm{AH}-3$ \\
$\mathrm{AH}-7$
\end{tabular} & & & & \\
\hline$\overline{\text { left }}$ & & & & & & & & & & \begin{tabular}{|l}
$\mathrm{AH}-5$ \\
$\mathrm{AH}-6$
\end{tabular} & & \begin{tabular}{|l} 
AL-2 \\
AL-3
\end{tabular} & & \\
\hline bifurcation & & $\mathrm{G}-1$ & & & & & & & & 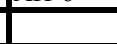 & & 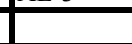 & & \\
\hline \multicolumn{15}{|c|}{ Mandible Torus } \\
\hline absent & & & & & & & & AI-21\&r & AN-21\&r & $\mathrm{AH}-111$ & & ए & & \\
\hline trace & & & & & & & & & & $\begin{array}{l}\mathrm{AH}-3 \mathrm{r} \\
\mathrm{AH}-7 \mathrm{r}\end{array}$ & & & F-119 S2r & \\
\hline moderate & & G-1r & $21011 \& r$ & & & & & & & $\begin{array}{l}\mathrm{AH}-31 \\
\mathrm{AH}-91 \\
\mathrm{AH}-10 \mathrm{r}\end{array}$ & & AL-31\&r & $F-163 r$ & \\
\hline
\end{tabular}


Table 10-13, continued.

\begin{tabular}{|c|c|c|c|c|c|c|c|c|c|c|c|c|c|c|}
\hline & $41 \mathrm{AN} 38$ & $41 \mathrm{AN} 21$ & $41 \mathrm{AN} 32$ & 41AN34 & $41 \mathrm{AN} 54$ & 41AN56 & $141 \mathrm{CE} 3$ & $41 \mathrm{CE} 4$ & $41 \mathrm{CE} 6$ & $41 \mathrm{CE} 12$ & $41 \mathrm{CE} 15$ & $41 \mathrm{CE} 17$ & 41CE19 & $41 \mathrm{CE} 290$ \\
\hline extreme & & & & & & & & & & & & & \begin{tabular}{|l|} 
F-119 \\
S11\&r \\
F-1611 \\
S11\&r \\
\end{tabular} & \\
\hline \multicolumn{15}{|l|}{ Mental } \\
\hline & & & $21011 \& r$ & & & & & AI-2l & AN-21\&r & $\begin{array}{l}\text { AH31\&r } \\
\text { AH-7r } \\
\text { AH-10r }\end{array}$ & & $\begin{array}{l}\text { AL-31\&r } \\
\text { AL-7r }\end{array}$ & $\begin{array}{l}\text { F-119 } \\
\text { S11\&r } \\
\text { F-119 S2r } \\
\text { S11\&r }\end{array}$ & \\
\hline & & G-1r & & & & & & & & $\mathrm{AH}-91$ & & & F-1631 & \\
\hline \multicolumn{15}{|l|}{ Mylohyoid } \\
\hline partial & & & & & & & & & & AH-111 & & & \begin{tabular}{|l} 
F-119 S1r \\
F-134 B41 \\
S11\&r \\
\end{tabular} & \\
\hline complete & & & & & & & & & & & & AL-31\&r & & \\
\hline mandibular & & & & & & & & & & & & AL-31\&r & $\begin{array}{l}\text { F-119 S1r } \\
\text { F-134 B4l }\end{array}$ & \\
\hline canal & & & & & & & & & & $\mathrm{AH}-111$ & & & & \\
\hline \multicolumn{15}{|l|}{\begin{tabular}{|l} 
Genial \\
\end{tabular}} \\
\hline absent & & & & & & & & & & & & & F-119 S2 & \\
\hline & & & & & B-1 & & & & & & & & $\begin{array}{l}\text { F-119 S1 } \\
\text { S1 }\end{array}$ & \\
\hline & & G-1 & 2101 & & & & \begin{tabular}{|l} 
AK1,2,3,4 \\
AK1,2,3,4
\end{tabular} & AI-2 & AN-2 & \begin{tabular}{|l|}
$\mathrm{AH}-3$ \\
$\mathrm{AH}-11$ \\
\end{tabular} & & $\begin{array}{l}\text { AL-3 } \\
\text { AL-7 } \\
\end{array}$ & & 2172 \\
\hline 3 & & & & & & & & & & \begin{tabular}{|l|}
$\mathrm{AH}-9$ \\
$\mathrm{AH}-10$
\end{tabular} & & & & \\
\hline small ridge & & & & & B-1 & & $\mathrm{AK} 1,2,3,4$ & $\mathrm{AI}-2$ & & $\mathrm{AH}-10$ & & & & \\
\hline large ridge & & & 2101 & & & & & & $\sqrt{\mathrm{AN}-2}$ & $\begin{array}{l}\mathrm{AH}-3 \\
\mathrm{AH}-11\end{array}$ & & AL-3 & & \\
\hline small spine & & & & & & & $\mathrm{AK} 1,2,3,4$ & & & & & AL-7 & \begin{tabular}{|l|}
$\begin{array}{l}\text { F-119 S1 } \\
\text { S1 }\end{array}$ \\
\end{tabular} & 2172 \\
\hline large spine & & & & & & & & & & $\mathrm{AH}-9$ & & & & \\
\hline
\end{tabular}

Notes: Nonmetric traits recorded following the TAMU system, where 0 indicates trait absence and gradations follow Steele et al. 1993. Traits are scored on adults only, but both single and comingled burials are included. Only individuals and traits for which observations in the study population could be made are listed in the table above. On traits that are scored for side, $r$ indicates right and 1 indicates left. TARL numbers are given when no burial numbers are present. 
Table 10-14. Postcranial Nonmetric Traits.

\begin{tabular}{|c|c|c|c|c|c|c|c|c|c|c|c|c|c|}
\hline & $41 \mathrm{AN} 38$ & 141AN21 & $141 \mathrm{AN} 32$ & 141AN34 & 41AN54 & 141AN56 & $41 \mathrm{CE} 3$ & $41 \mathrm{CE} 4$ & $41 \mathrm{CE} 6$ & 141CE12 & $141 \mathrm{CE} 15$ & $41 \mathrm{CE} 17$ & $41 \mathrm{CE} 19$ \\
\hline \multicolumn{14}{|c|}{ CLAVICLE } \\
\hline \multicolumn{14}{|c|}{ Rhomboid fossa } \\
\hline absent & & & & & & & & & & $\mathrm{AH}-3 \mathrm{r}$ & & & \\
\hline \multicolumn{14}{|c|}{ Subclavian facet } \\
\hline present & & & & & & & & & & $\begin{array}{l}\text { AH-3r } \\
\text { AH-71 }\end{array}$ & & & \\
\hline \multicolumn{14}{|c|}{ Supraclavicular nerve } \\
\hline absent & & & & & & & & & & $\mathrm{AH}-3 \mathrm{r}$ & & & \\
\hline \multicolumn{14}{|c|}{ SCAPULA } \\
\hline \multicolumn{14}{|c|}{ Superscapular foramen } \\
\hline Slight notc & & & & & & & & & & $\mathrm{AH}-111$ & & & \\
\hline \multicolumn{14}{|c|}{ HUMERUS } \\
\hline \multicolumn{14}{|c|}{ Septal aperture } \\
\hline absent & & & & & & & & & $\begin{array}{l}\text { AN-1r } \\
\text { AN-21 }\end{array}$ & AH-71\&r & & & \\
\hline \multicolumn{14}{|c|}{ Pectoralis major and teres major impression } \\
\hline absent & & & & & & & & & & & & JAL-3r & \\
\hline present & & & & & & & & & & $\mathrm{AH}-71 \& \mathrm{r}$ & & AL-31 & \\
\hline \multicolumn{14}{|l|}{ ULNA } \\
\hline \multicolumn{14}{|c|}{ Trochlear notch form } \\
\hline \multicolumn{14}{|l|}{$\begin{array}{l}\text { partially } \\
\text { separate }\end{array}$} \\
\hline separate & & & & & & & & & & $\mathrm{AH}-7 \mathrm{r}$ & & & \\
\hline \multicolumn{14}{|l|}{ FEMUR } \\
\hline \multicolumn{14}{|c|}{ Third trochanter } \\
\hline absent & F. $8 \mathrm{r}$ & & & & & & & & & & & & \\
\hline \multicolumn{14}{|c|}{ Femoral neck depression } \\
\hline absent & & & & & & & & & & $\mathrm{AH}-7 \mathrm{r}$ & & & \\
\hline \multicolumn{14}{|c|}{ Hypertrochanteric Fossa } \\
\hline absent & & G-11\&r & & & & & & & & & & & \\
\hline present & F. $8 \mathrm{r}$ & & & & & & & & & $\mathrm{AH}-71 \& \mathrm{r}$ & & & \\
\hline \multicolumn{14}{|c|}{ Trochanteric spicules } \\
\hline absent & & & & & & & & & & $\mathrm{AAH}-71$ & & & \\
\hline smooth & & G-1r & & & & & & & & AH-7r & & & \\
\hline tubercle & F. $8 \mathrm{r}$ & & & & & & & & & & & & \\
\hline
\end{tabular}


Table 10-14, continued.

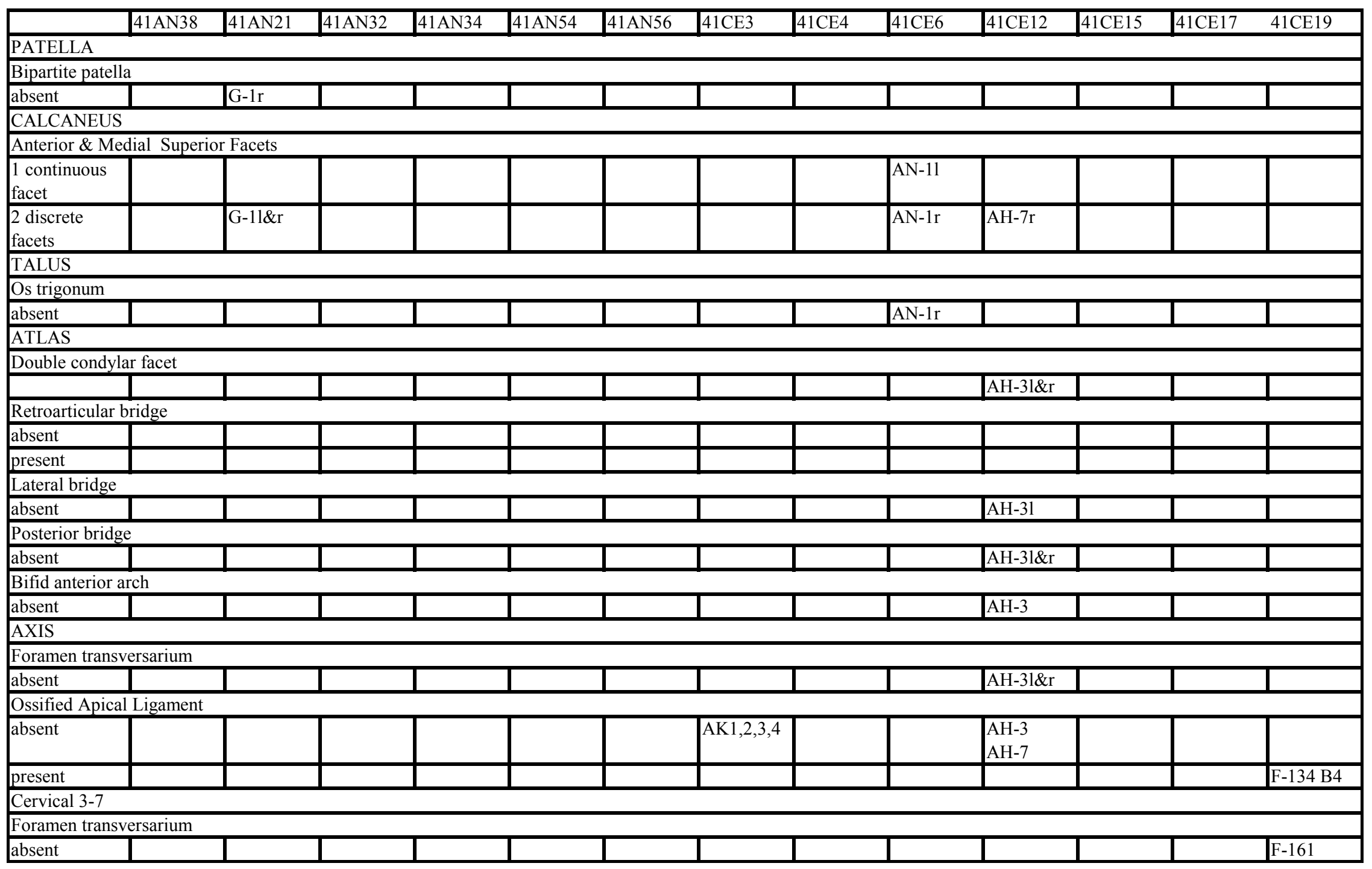


Table 10-14, continued.

\begin{tabular}{|c|c|c|c|c|c|c|c|c|c|c|c|c|c|}
\hline & 41AN38 & $41 \mathrm{AN} 21$ & $41 \mathrm{AN} 32$ & 41AN34 & 41AN54 & $41 \mathrm{AN} 56$ & $41 \mathrm{CE} 3$ & $41 \mathrm{CE} 4$ & $41 \mathrm{CE} 6$ & $41 \mathrm{CE} 12$ & $41 \mathrm{CE} 15$ & $41 \mathrm{CE} 17$ & $41 \mathrm{CE} 19$ \\
\hline \multicolumn{14}{|c|}{ SACRUM } \\
\hline \multicolumn{14}{|c|}{ Lumbo-sacrilization } \\
\hline absent & & & & & & & & & & \begin{tabular}{|l} 
Prov. \\
unknown
\end{tabular} & & & \\
\hline \multicolumn{14}{|c|}{ Sacral hiatus } \\
\hline absent & & & & & & & & & & \begin{tabular}{|l} 
Prov. \\
unknown
\end{tabular} & & & \\
\hline \multicolumn{14}{|c|}{\begin{tabular}{|l|l} 
Spina \\
bifida/sacral 1 \\
\end{tabular}} \\
\hline absent & & & & & & & & & & \begin{tabular}{|l}
$\begin{array}{l}\text { Prov. } \\
\text { unknown }\end{array}$ \\
\end{tabular} & & & \\
\hline \multicolumn{14}{|c|}{ OS COXA } \\
\hline \multicolumn{14}{|c|}{ Preauricular Sulcus } \\
\hline absent & & & & & & & & & & AH-101\&r & & & \\
\hline present & & G-11\&r & & & & & & & & $\begin{array}{l}\mathrm{AH}-71 \& \mathrm{r} \\
\mathrm{AH}-111\end{array}$ & $\widehat{\mathrm{AJ}-1}$ & & \\
\hline \multicolumn{14}{|c|}{ Accessory sacral facets } \\
\hline absent & & & & & & & & & & $\begin{array}{l}\text { AH-71\&r } \\
\text { AH-111\&r }\end{array}$ & & & \\
\hline \multicolumn{14}{|c|}{ Acetabular crease } \\
\hline absent & & & & & & & & & & AH-101\&r & & & \\
\hline present & & & & & & & & & & $\begin{array}{l}\mathrm{AH}-71 \& \mathrm{r} \\
\mathrm{AH}-111 \& \mathrm{r}\end{array}$ & & & \\
\hline
\end{tabular}

Notes: Nonmetric traits recorded following the TAMU system, where 0 indicates trait absence and gradations follow Steele et al. 1993. Only traits for which observations in the study population could be made are listed in the table above. On traits that are scored for side, $\mathrm{r}$ indicates right, 1 indicates 1 . 
Table 10-15. Dental Nonmetric Traits.

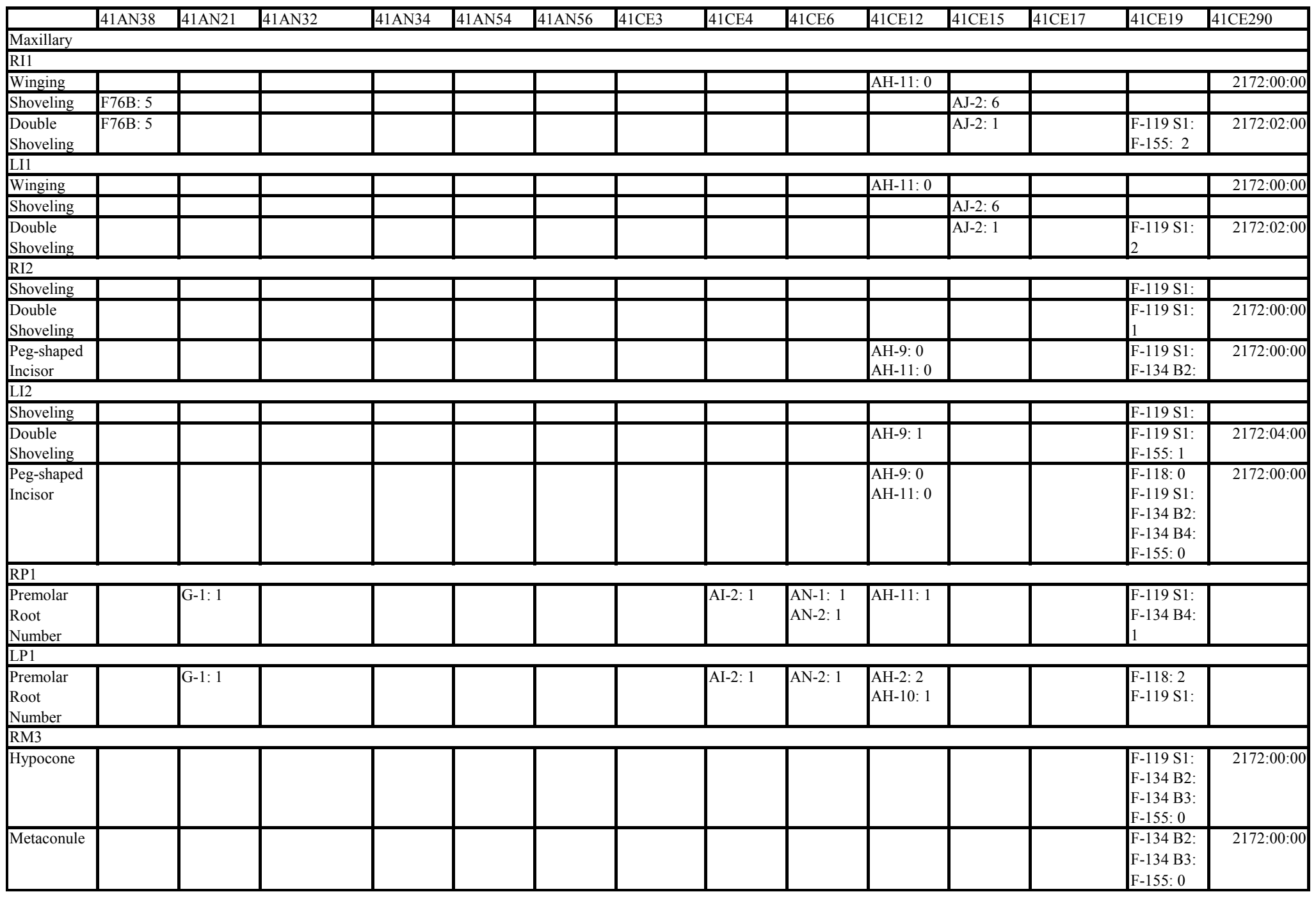


Table 10-15, continued.

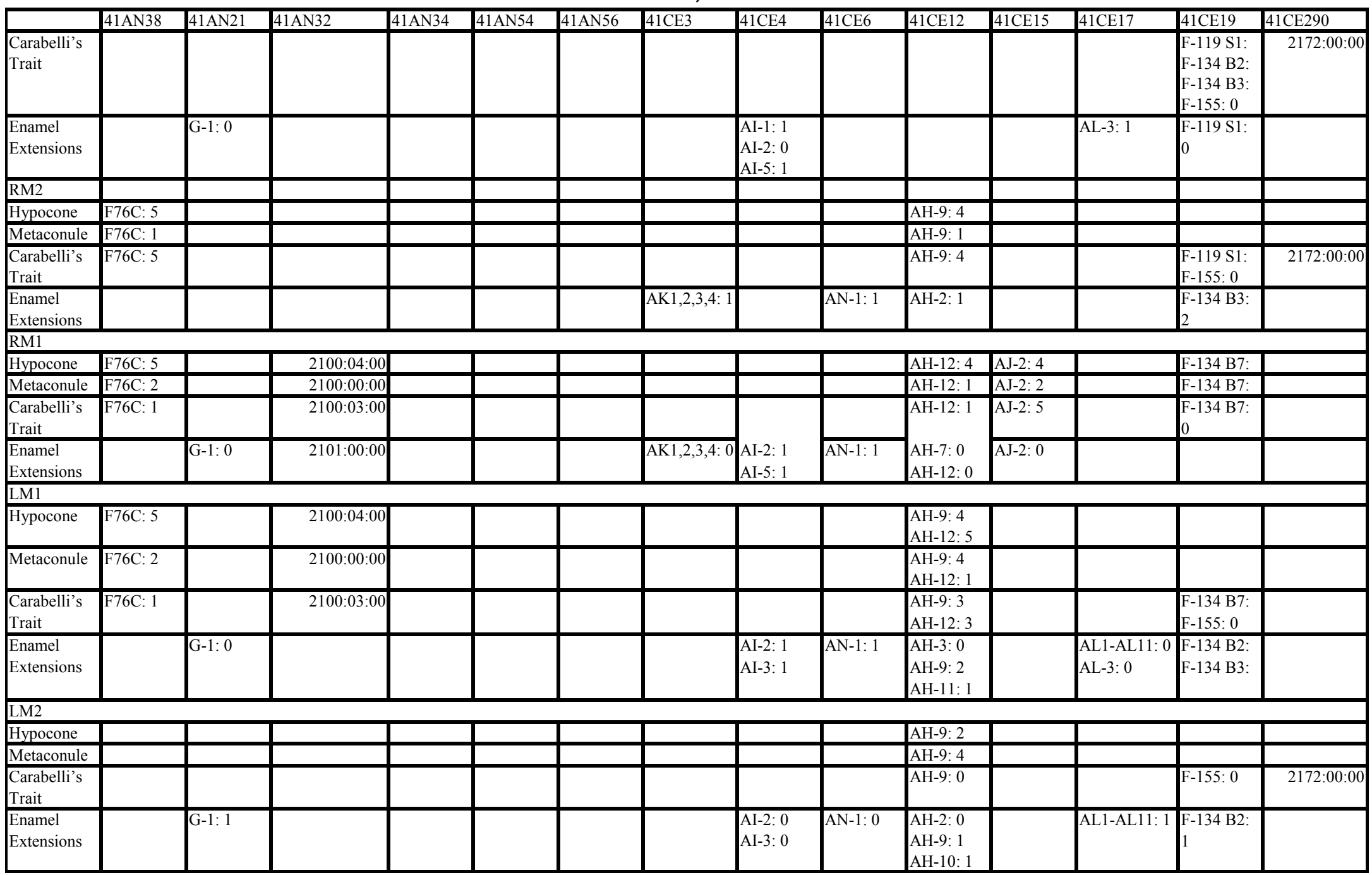


Table 10-15, continued.

\begin{tabular}{|c|c|c|c|c|c|c|c|c|c|c|c|c|c|c|}
\hline & 41AN38 & 41AN21 & 41AN32 & 41AN34 & 41AN54 & 41AN56 & $41 \mathrm{CE} 3$ & प11CE4 & प11CE6 & प1CE12 & 41CE15 & $41 \mathrm{CE} 17$ & प1CE19 & प1CE290 \\
\hline \multicolumn{15}{|l|}{ LM3 } \\
\hline Hypocone & & & & & & & & & & & & & $\begin{array}{l}\text { F-134 B2: } \\
\text { F-134 B3: } \\
\text { F-155: }\end{array}$ & \\
\hline Metaconule & & & & & & & & & & & & & F-134 B2: & \\
\hline \begin{tabular}{|l|} 
Carabelli's \\
Trait
\end{tabular} & & & & & & & & & & AH-11: 1 & & & $\begin{array}{l}\text { F-119 S1: } \\
\text { F-134 B2: } \\
\text { F-134 B3: } \\
\text { F-155:0: }\end{array}$ & \\
\hline \begin{tabular}{|l} 
Enamel \\
Extensions
\end{tabular} & & & & & & & & AI-2: 0 & AN-1:0 & $\begin{array}{l}\text { AH-2: 1 } \\
\text { AH-10: } 1\end{array}$ & & & $\begin{array}{l}\text { F-119 S1: } \\
\text { F-134 B3: }\end{array}$ & \\
\hline \multirow{2}{*}{\multicolumn{15}{|c|}{ Mandibular }} \\
\hline & & & & & & & & & & & & & & \\
\hline \begin{tabular}{|l|} 
Premolar \\
Root \\
Number
\end{tabular} & & & & & & & & & & AH-9: 1 & & AL-3: 1 & $\begin{array}{l}\text { F-134 B4: } \\
1\end{array}$ & \\
\hline$\overline{\mathrm{LP1}}$ & & & & & & & & & & & & & & \\
\hline \begin{tabular}{|l} 
Premolar \\
Root \\
Number
\end{tabular} & & & & & & & & AI-2: 1 & |AN-2: 1 & AH-9: 1 & & & $\begin{array}{l}\text { F-118: 1 } \\
\text { F-134 B3: } \\
1\end{array}$ & \\
\hline LM3 & & & & & & & & & & & & & & \\
\hline \begin{tabular}{|l|}
$\begin{array}{l}\text { Groove } \\
\text { Pattern }\end{array}$ \\
Patter
\end{tabular} & & & & & & & & AI-4:y & & $\begin{array}{l}\text { AH-2:y } \\
\text { AH-11:y }\end{array}$ & & AL1-AL11:y & $\begin{array}{l}\text { F-134 B2: } \\
\text { F-134 B3: } \\
\text { F-134 B4: } \\
\text { F-155-+ }\end{array}$ & \\
\hline \begin{tabular}{|l|l|} 
Cusp \\
Number
\end{tabular} & & & & & & & & & & AH-11: 4 & & AL1-AL11: 6 & $\begin{array}{l}\text { F-134 B2: } \\
\text { F-134 B3: } \\
\text { F-134 B4: } \\
\text { F-155: } 4\end{array}$ & \\
\hline Protostylid & & & & & & & & & & AH-11: 4 & & AL1-AL11: 1 & $\begin{array}{l}\text { F-134 B2: } \\
\text { F-134 B3: } \\
\text { F-134 B4: } \\
\text { F-155: } 7\end{array}$ & \\
\hline Casp 5 & & & & & & & & & & AH-11: 0 & & AL1-AL11: 5 & $\begin{array}{l}\text { F-134 B2: } \\
\text { F-134 B3: } \\
\text { F-134 B4: } \\
\text { F-155: } 0\end{array}$ & \\
\hline Cusp 6 & & & & & & & & & & AH-11: 0 & & AL1-AL11: 5 & $\begin{array}{l}\text { F-134 B2: } \\
\text { F-134 B3: } \\
\text { F-134 B4: } \\
\text { F-155: } 0\end{array}$ & \\
\hline
\end{tabular}


Table 10-15, continued.

\begin{tabular}{|c|c|c|c|c|c|c|c|c|c|c|c|c|c|c|}
\hline & J1AN38 & 41AN21 & 41AN32 & 41AN34 & 41 AN54 & 41 AN56 & $41 \mathrm{CE} 3$ & $\longdiv { 4 1 \mathrm { CE } 4 }$ & $41 \mathrm{CE} 6$ & 41CE12 & 41CE15 & $41 \mathrm{CE} 17$ & 41CE19 & $\longdiv { 4 1 C E 2 9 0 }$ \\
\hline Cusp 7 & & & & & & & & & & AH-11: 1 & & AL1-AL11: 0 & \begin{tabular}{|l} 
F-134 B2: \\
F-134 B3: \\
F-134 B4: \\
F-155: 0
\end{tabular} & \\
\hline $\begin{array}{l}\text { Molar Root } \\
\text { Number }\end{array}$ & & & & & & & AK1,2,3,4:2 & & & AH-2: 2 & & & $\begin{array}{l}\text { F-134 B4: } \\
2\end{array}$ & \\
\hline \multicolumn{15}{|l|}{$\overline{\text { LM2 }}$} \\
\hline $\begin{array}{l}\begin{array}{l}\text { Groove } \\
\text { Pattern }\end{array} \\
\text { Pats }\end{array}$ & & & 2101: + & & & & & AI-4: $y$ & & \begin{tabular}{|l|} 
AH-9: + \\
AH-11:y \\
AH-15:
\end{tabular} & & & $\begin{array}{l}\text { F-134 B2: } \\
\text { F-134 B3: } \\
\text { F-155: }\end{array}$ & \\
\hline $\begin{array}{l}\text { Uusp } \\
\text { Number }\end{array}$ & & & & & & & & & & AH-9: 4 & & & $\mathrm{~F}-155: 3$ & \\
\hline Protostylid & & & & & & & & & & AH-9: 1 & & & $\begin{array}{l}\text { F-134 B3: } \\
\text { F-155: } 1\end{array}$ & \\
\hline Cusp 5 & & & & & & & & & & AH-9: 0 & & & F-155:0 & \\
\hline Cusp 6 & & & & & & & & & & AH-9: 0 & & & F-155:0 & \\
\hline \begin{tabular}{|l|} 
Cusp 7 \\
\end{tabular} & & & & & & & & & & AH-9: 0 & & & F-155:0 & \\
\hline \begin{tabular}{|l} 
Molar Root \\
Number
\end{tabular} & & & & & & & \begin{tabular}{|l|}
$\mathrm{AK} 1,2,3,4: 2$ \\
$\mathrm{AK} 1,23,4: 2$
\end{tabular} & AI-3:2 & & AH-10: 2 & & & $\begin{array}{l}\text { F-134 B4: } \\
1\end{array}$ & \\
\hline \multicolumn{15}{|l|}{$\overline{\text { LM1 }}$} \\
\hline $\begin{array}{l}\begin{array}{l}\text { Groove } \\
\text { Pattern }\end{array} \\
\end{array}$ & & & \begin{tabular}{|l}
$2100: y$ \\
$2101: y$
\end{tabular} & & & & & & & $\begin{array}{l}\text { AH-9: y } \\
\text { AH-12:y } \\
\text { AH-15:y }\end{array}$ & AJ-2:- & & $\begin{array}{l}\text { F-134 B7: } \\
\text { F-155:y }\end{array}$ & \\
\hline $\begin{array}{l}\text { Cusp } \\
\text { Number }\end{array}$ & & & & & & & & & & AH-12: 6 & AJ-2: 6 & & $\begin{array}{l}\text { F-134 B7: } \\
\text { F-155: } 5\end{array}$ & \\
\hline Protostylid & & G-1: 1 & & & & & & & & AH-12: 1 & $A \mathrm{~S}-2=0$ & & F-134 B7: & \\
\hline Cusp 5 & & & & & & & & & & AH-12:0 & AJ-2:2:2 & & F-134 B7: & \\
\hline $\begin{array}{l}\text { Cusp } 6 \\
\end{array}$ & & & & & & & & & & AH-12: 0 & AJ $-2: 5$ & & F-134 B7: & \\
\hline Cusp 7 & & & & & & & & & & AH-12:0 & $A \mathrm{AJ}-2=0$ & & F-134 B7: & \\
\hline \begin{tabular}{|l|} 
Molar Root \\
Number
\end{tabular} & & & & & & & & AI-5: 2 & & & & & \begin{tabular}{|l} 
F-134 B4: \\
2
\end{tabular} & \\
\hline \multicolumn{15}{|l|}{ RM1 } \\
\hline $\begin{array}{l}\text { Groove } \\
\text { Pattem }\end{array}$ & & & $\begin{array}{l}2100: y \\
2101:+\end{array}$ & & & & & & & $\begin{array}{l}\text { AH-9: y } \\
\text { AH-12:y }\end{array}$ & $\mathrm{AJ}-2=\mathrm{y}$ & & & \\
\hline \begin{tabular}{|l|} 
Cusp \\
Number
\end{tabular} & & & $2100: 6$ & & & & & & & AH-12: 6 & AJ-2: 6 & & & \\
\hline Protostylid & & G-1: 1 & & & & & & & & AH-12: 1 & & & & \\
\hline Cusp 5 & & & & & & & & & & AH-12:0 & $\mathrm{AJ}-2: 3$ & & & \\
\hline Cusp 6 & & & & & & & & & & AH-12:0 & AJ-2:2 & & & \\
\hline Cusp 7 & & & $2100=00$ & & & & & & & AH-12:0 & $A \mathrm{~J}-2: 0$ & & & \\
\hline $\begin{array}{l}\text { Molar Root } \\
\text { Number }\end{array}$ & & & & & & & & & & AH-9: 2 & & & \begin{tabular}{|l} 
F-134 B4: \\
2
\end{tabular} & \\
\hline
\end{tabular}


Table 10-15, continued.

\begin{tabular}{|c|c|c|c|c|c|c|c|c|c|c|c|c|c|c|}
\hline & 41AN38 & 41AN21 & T1AN32 & J1AN34 & 141AN54 & 41AN56 & प11CE3 & 141CE4 & प41CE6 & T41CE12 & T1CE15 & T1CE17 & T1CE19 & T1CE290 \\
\hline \multicolumn{15}{|l|}{ RM2 } \\
\hline $\begin{array}{l}\text { Groove } \\
\text { Pattern }\end{array}$ & & & & & & & & & & $\begin{array}{l}\text { AH-2: y } \\
\text { AH-9:y }\end{array}$ & & & & \\
\hline $\begin{array}{l}\text { Cusp } \\
\text { Number }\end{array}$ & & & & & & & & & & AH-9: 5 & & & & \\
\hline Protostylid & & G-1: 1 & & & & & & & & AH-9: 0 & & & F-134 B3: & \\
\hline Cusp 5 & & & & & & & & & & AH-9: 2 & & & & \\
\hline Cusp 6 & & & & & & & & & & AH-9: 2 & & & & \\
\hline Cusp 7 & & & & & & & & & & AH-9: 0 & & & & \\
\hline $\begin{array}{l}\text { Molar Root } \\
\text { Number }\end{array}$ & & & & & & & & & & $\begin{array}{l}\text { AH-2: } 2 \\
\text { AH-9: } 2\end{array}$ & & & $\begin{array}{l}\text { F-134 B4: } \\
1\end{array}$ & \\
\hline \multicolumn{15}{|l|}{\begin{tabular}{|l} 
RM3 \\
\end{tabular}} \\
\hline $\begin{array}{l}\text { Groove } \\
\text { Pattern }\end{array}$ & & G-1:y & & & & & & & & $\begin{array}{l}\text { AH-2: y } \\
\text { AH-7: y }\end{array}$ & & AL1-AL11: $\mathrm{x}$ & $\begin{array}{l}\text { F-134 B2: } \\
\text { F-134 B3: } \\
\text { F-134 B4: }\end{array}$ & \\
\hline $\begin{array}{l}\text { Cusp } \\
\text { Number }\end{array}$ & & & & & & & & & & & & AL1-AL11: 6 & $\begin{array}{l}\text { F-134 B2: } \\
\text { F-134 B3: } \\
\text { F-134 B4: }\end{array}$ & \\
\hline Protostylid & & G-1: 0 & & & & & & & & & & AL1-AL11: 1 & $\begin{array}{l}\text { F-134 B2: } \\
\text { F-134 B3: }\end{array}$ & \\
\hline Cusp 5 & & & & & & & & & & & & AL1-AL11: 3 & $\begin{array}{l}\text { F-134 B2: } \\
\text { F-134 B3: } \\
\text { F-134 B4: }\end{array}$ & \\
\hline Cusp 6 & & & & & & & & & & & & AL1-AL11: 4 & $\begin{array}{l}\text { F-134 B2: } \\
\text { F-134 B3: } \\
\text { F-134 B4: }\end{array}$ & \\
\hline Cusp 7 & & & & & & & & & & & & AL1-AL11:0 & $\begin{array}{l}\text { F-134 B2: } \\
\text { F-134 B3: } \\
\text { F-134 B4: }\end{array}$ & \\
\hline $\begin{array}{l}\text { Molar Root } \\
\text { Number }\end{array}$ & & & & & & & & & AN-2: 1 & AH-2: 2 & & & $\begin{array}{l}\text { F-134 B4: } \\
2\end{array}$ & \\
\hline
\end{tabular}

Notes: Traits recorded in accordance with the primary list presented by Buikstra and Ubelaker (1994). Traits were recorded following Turner et al. (1991) using the standard reference plaques. Numbers following burial designation indicate feature designation as described in Tumer et al. (1991). Where burial designations were not available, TARL numbers are used. 
Table 10-16. Dental Wear Scores following Scott (1979) for Molars and Smith (1984) for Premolars, Canines and Incisors.

\begin{tabular}{|c|c|c|c|c|c|c|c|}
\hline 41AN38 & F. 76B & F. 76C & F. 88 & F.92 & F.93B1 & F. 93B2 & Site average \\
\hline \multicolumn{8}{|l|}{ Maxillary } \\
\hline \multicolumn{8}{|l|}{ RM3 } \\
\hline RM2 & & 4 & & 31 & & 14 & 16.3 \\
\hline RM1 & & 4 & & & & & 4.0 \\
\hline \multicolumn{8}{|l|}{ RP2 } \\
\hline \multicolumn{8}{|l|}{ RP1 } \\
\hline $\mathrm{RC}$ & 1 & 1 & & & & & 1.0 \\
\hline \multicolumn{8}{|l|}{ RI2 } \\
\hline RI1 & 1 & & 4 & & & & 2.5 \\
\hline \multicolumn{8}{|l|}{ LI1 } \\
\hline \multicolumn{8}{|l|}{ LI2 } \\
\hline LC & & & 4 & & & & 4.0 \\
\hline LP1 & 1 & & 5 & & & & 3.0 \\
\hline LP2 & & & 3 & & & & 3.0 \\
\hline LM1 & & 4 & 12 & & & & 8.0 \\
\hline LM2 & & & 14 & & 20 & & 17.0 \\
\hline LM3 & & & 14 & & 27 & & 20.5 \\
\hline \multicolumn{8}{|c|}{ Mandibular } \\
\hline LM3 & & & & & 21 & & 21.0 \\
\hline \multicolumn{8}{|l|}{ LM2 } \\
\hline \multicolumn{8}{|l|}{ LM1 } \\
\hline \multicolumn{8}{|l|}{ LP2 } \\
\hline \multicolumn{8}{|l|}{ LP1 } \\
\hline $\mathrm{LC}$ & 1 & & & & & & 1.0 \\
\hline \multicolumn{8}{|l|}{ LI2 } \\
\hline \multicolumn{8}{|l|}{ LI1 } \\
\hline \multicolumn{8}{|l|}{ RI1 } \\
\hline \multicolumn{8}{|l|}{ RI2 } \\
\hline \multicolumn{8}{|l|}{$\mathrm{RC}$} \\
\hline RP1 & 1 & & 3 & & & & 2.0 \\
\hline RP2 & 1 & 1 & & & & & 1.0 \\
\hline RM1 & 4 & & & & & & 4.0 \\
\hline RM2 & & & & & 19 & & 19.0 \\
\hline \multicolumn{8}{|l|}{ RM3 } \\
\hline Age & $6-10+/-2.5$ & $8+/-2$ & $20-50+$ & $27-50+$ & $50+$ & $20-35$ & \\
\hline $\begin{array}{l}\text { Average } \\
\text { anterior }\end{array}$ & 1.0 & 1.0 & 3.8 & & & & $\begin{array}{l}2.1^{*} \\
3.8\end{array}$ \\
\hline $\begin{array}{l}\text { Average } \\
\text { posterior }\end{array}$ & 4.0 & 4.0 & 13.3 & 31.0 & 21.8 & 14.0 & $\begin{array}{l}14.5^{*} \\
21.5\end{array}$ \\
\hline
\end{tabular}

Notes: Scott's (1979) is a scale of 4 - 40, Smith's (1984) is a scale of 1- 8. Averages are given for the whole population as indicated by an asterisk $(*)$ and adults, who are here defined by being placed in an age category beginning with 20 years or more. 
Table 10-17. Dental Wear Scores following Scott (1979) for Molars and Smith (1984) for Premolars, Canines and Incisors.

\begin{tabular}{|c|c|c|c|}
\hline Site/Time Period & Burial Number & Average Anterior Wear & Average Posterior Wear \\
\hline $\begin{array}{l}\text { 41AN14 } \\
\text { Unknown Caddo }\end{array}$ & AG-1 & 3.0 & 24.0 \\
\hline $\begin{array}{l}\text { 41AN21 } \\
\text { Late Caddo }\end{array}$ & G-1 & 4.1 & 20.4 \\
\hline \multirow{3}{*}{$\begin{array}{l}\text { 41AN32 } \\
\text { Late Caddo }\end{array}$} & None TARL 2100 & 1.0 & 11.3 \\
\hline & None TARL 2101 & 3.2 & 16.8 \\
\hline & Adult average & 3.2 & 16.8 \\
\hline $\begin{array}{l}\text { 41CE3 } \\
\text { Early Caddo }\end{array}$ & AK $1,2,3,4$ & 4.7 & 16.9 \\
\hline \multirow{5}{*}{$\begin{array}{l}41 \mathrm{CE} 4 \\
\text { Late Caddo }\end{array}$} & $\mathrm{AI}-2$ & 3.6 & 19.9 \\
\hline & AI-3 & 2.5 & 24.7 \\
\hline & AI-4 & & 13.4 \\
\hline & AI-5 & & 21.7 \\
\hline & Adult average & 3.0 & 19.9 \\
\hline \multirow{3}{*}{$\begin{array}{l}\text { 41CE6 } \\
\text { Late Caddo }\end{array}$} & $\mathrm{AN}-1$ & 5.0 & 19.2 \\
\hline & AN-2 & 4.6 & 22.0 \\
\hline & Adult average & 4.8 & 20.6 \\
\hline \multirow{10}{*}{$\begin{array}{l}41 \mathrm{CE} 12 \\
\text { Historic }\end{array}$} & $\mathrm{AH}-2$ & 3.0 & 17.0 \\
\hline & AH-3 & 7.5 & \\
\hline & AH-7 & 4.0 & 14.0 \\
\hline & AH-8 & 4.0 & \\
\hline & AH-9 & 1.9 & 7.0 \\
\hline & AH-10 & 5.3 & 15.5 \\
\hline & AH-11 & 3.8 & 12.0 \\
\hline & $\mathrm{AH}-12$ & 1.0 & 4.0 \\
\hline & AH-15 & 1.6 & 13.3 \\
\hline & Adult average & 4.2 & 15.0 \\
\hline $\begin{array}{l}\text { 41CE15 } \\
\text { Late Caddo }\end{array}$ & AJ-2 & 1.0 & 5.2 \\
\hline \multirow{4}{*}{$\begin{array}{l}41 \mathrm{CE} 17 \\
\text { Late Caddo }\end{array}$} & AL1-11 & 1.5 & 12.2 \\
\hline & AL-3 & 7.7 & 23.2 \\
\hline & AL-7 & 5.9 & \\
\hline & Adult average & 6.8 & 23.2 \\
\hline \multirow{14}{*}{$\begin{array}{l}\text { 41CE19 } \\
\text { Early Caddo }\end{array}$} & F. 118 & 2.1 & 12.5 \\
\hline & F. 119S1 & 2.7 & 13.0 \\
\hline & F. 119S2 & 3.2 & 15.2 \\
\hline & F. 130 & 6.3 & 27.8 \\
\hline & F. 134B1 & 4.0 & 17.8 \\
\hline & F. 134B2 & 2.7 & 10.3 \\
\hline & F. 134B3 & 3.1 & 10.7 \\
\hline & F. 134B4 & 4.3 & 14.0 \\
\hline & F. 134B5 & 3.0 & 22.0 \\
\hline & F. 134B8 & 4.1 & 15.4 \\
\hline & F. 155 & 5.4 & 12.2 \\
\hline & F. 161 & 3.8 & 17.2 \\
\hline & F. 163 & 6.9 & 34.0 \\
\hline & Adult average & 4.1 & 17.7 \\
\hline $\begin{array}{l}\text { 41CE290 } \\
\text { Middle Caddo }\end{array}$ & None TARL 2172 & 3.3 & 17.8 \\
\hline
\end{tabular}

Notes: Scott's (1979) is a scale of $4-40$, Smith's (1984) is a scale of 1- 8. Averages are given for the whole population as indicated by an asterisk $\left(^{*}\right)$ and adults, who are here defined by being placed in an age category beginning with 20 years or more. Time periods follow those defined by Story (1990). 
Table 10-18. Average Wear Scores, Adults ( $>19$ yrs. of age) from Caddo Sites in Texas.

\begin{tabular}{|c|c|c|}
\hline Site/Time Period & $\begin{array}{c}\text { Ave. wear using Smith } \\
(1984)\end{array}$ & $\begin{array}{l}\text { Ave. wear using Scott } \\
(1979)\end{array}$ \\
\hline $\begin{array}{l}\text { 41DT1 } \\
\text { Manton Miller } \\
\text { Woodland/Early Caddo }\end{array}$ & 7.8 & 39 \\
\hline $\begin{array}{l}\text { 41DT6 } \\
\text { Tick } \\
\text { Woodland/Early Caddo }\end{array}$ & 7 & 30.5 \\
\hline $\begin{array}{l}\text { 41DT16 } \\
\text { Spike } \\
\text { Early Caddo }\end{array}$ & 4.3 & \\
\hline $\begin{array}{l}\text { 41DT80 } \\
\text { Thomas } \\
\text { Early Caddo }\end{array}$ & 6.9 & 34.7 \\
\hline $\begin{array}{l}41 \mathrm{DT} 124 \\
\text { Doctors Creek } \\
\text { Early Caddo }\end{array}$ & 4.6 & 15.1 \\
\hline $\begin{array}{l}41 \mathrm{HP} 78 \\
\text { Lawson } \\
\text { Woodland/Early Caddo }\end{array}$ & & 21.7 \\
\hline $\begin{array}{l}41 \mathrm{HP} 102 \\
\text { Arnold } \\
\text { Early Caddo }\end{array}$ & 6.3 & 24.6 \\
\hline $\begin{array}{l}41 \mathrm{HP} 105 \\
\text { Cox } \\
\text { Woodland/Early Caddo }\end{array}$ & 6.7 & 35.8 \\
\hline $\begin{array}{l}\text { 41HP106 } \\
\text { Hurricane Hill } \\
\text { Woodland }\end{array}$ & 5 & 27.9 \\
\hline Average & 6.1 & 28.7 \\
\hline $\begin{array}{l}\text { 41RR16 } \\
\text { Roitsch } \\
\text { Late Caddo } \\
\text { (Derrick et al. 2008) }\end{array}$ & 4.2 & 14.4 \\
\hline $\begin{array}{l}\text { 41LR2 } \\
\text { Sanders } \\
\text { Middle Caddo (Wilson 1997) }\end{array}$ & & 16.5 \\
\hline $\begin{array}{l}\text { 41MR63 } \\
\text { Pleasure Point } \\
\text { Unknown Caddo } \\
\text { (Wilson and Steele 1996) }\end{array}$ & 4 & \\
\hline Average & 4.1 & 15.4 \\
\hline $\begin{array}{l}\text { 41CP71 } \\
\text { Shelby Mound } \\
\text { Late Caddo } \\
\text { (Wilson 2004) }\end{array}$ & 4 & 16.8 \\
\hline $\begin{array}{l}41 \mathrm{HS} 269 \\
\text { C D Marsh } \\
\text { Late Caddo } \\
\text { (Wilson 2006) }\end{array}$ & & 18 \\
\hline
\end{tabular}




\begin{tabular}{|l|l|l|}
\hline $\begin{array}{l}41 \text { R315 } \\
\text { Henry Spencer } \\
\text { Late Caddo } \\
\text { (Wilson 2006) }\end{array}$ & 16.5 \\
\hline $\begin{array}{l}\text { 41NA231 } \\
\text { Tallow Grove } \\
\text { Middle Caddo } \\
\text { (Wilson 2008c) }\end{array}$ & 2.9 & 9.9 \\
\hline $\begin{array}{l}\text { 41NA242 } \\
\text { Beech Ridge } \\
\text { Middle Caddo } \\
\text { (Wilson 2008c) }\end{array}$ & 6.0 & 16.2 \\
\hline $\begin{array}{l}41 \text { BW4 Mitchell } \\
\text { Late } \\
\text { (Wilson 1997) }\end{array}$ & 14.4 \\
\hline $\begin{array}{l}\text { Average including Lang } \\
\text { Pasture and Upper Neches } \\
\text { River Basin sites }\end{array}$ & 4.1 & 18.0 \\
\hline
\end{tabular}

Notes: Wear scores follow Smith (1984) for anterior teeth and Scott (1979) for molars. Time periods follow Story (1990).

Table 10-19. Caries Rates for Sites in the Upper Neches River Basin.

\begin{tabular}{|l|l|l|l|}
\hline Site & Time period & $\begin{array}{l}\text { Caries per person } \\
\text { (Caries rate) }\end{array}$ & $\begin{array}{l}\text { Number of individuals } \\
\text { with teeth }\end{array}$ \\
\hline 41NA14 & Unknown Caddo & 2.0 & 1 \\
\hline 41AN21 & Late Caddo & 3.0 & 1 \\
\hline 41AN32 & Late Caddo & 6.5 & 2 \\
\hline 41CE4 & Late Caddo & 3.0 & 4 \\
\hline 41CE6 & Late Caddo & 13.0 & 2 \\
\hline 41CE12 & Historic & 4.5 & 9 \\
\hline 41CE17 & Late Caddo & 4.5 & 2 \\
\hline 41CE19 & Early Caddo & 7.0 & 14 \\
\hline 41CE290 & Middle Caddo & 1.0 & 1 \\
\hline 41AN38 & Middle Caddo & 0.2 & 6 \\
& & $0.3^{*}$ & $3 *$ \\
\hline
\end{tabular}

Notes: Comingled remains were excluded from analysis of caries rates.

*Adults. 
Table 10-20. Summary of Adult Dental Data from the Upper Neches River Basin.

\begin{tabular}{|c|c|c|c|c|c|}
\hline Site/Time Period & Burial Number & Teeth Present & $\begin{array}{c}\text { Antemortem } \\
\text { Tooth Loss }\end{array}$ & Caries & Abscess \\
\hline $\begin{array}{l}\text { 41AN14 } \\
\text { Unknown Caddo }\end{array}$ & AG-1 & 4 & 0 & 2 & - \\
\hline $\begin{array}{l}\text { 41AN21 } \\
\text { Late Caddo }\end{array}$ & G-1 & 17 & 0 & 3 & - \\
\hline $\begin{array}{l}1 \mathrm{AN} 32 \\
\text { Late Caddo }\end{array}$ & None TARL 2101 & 16 & 2 & 9 & 0 \\
\hline \multirow{4}{*}{$\begin{array}{l}41 \mathrm{CE} 4 \\
\text { Late Caddo }\end{array}$} & AI-2 & 20 & 0 & 2 & 0 \\
\hline & AI-3 & 8 & 2 & 4 & 0 \\
\hline & AI-4 & 5 & 0 & 5 & - \\
\hline & AI-5 & 3 & 0 & 1 & - \\
\hline \multirow{2}{*}{$\begin{array}{l}\text { 41CE6 } \\
\text { Late Caddo }\end{array}$} & AN-1 & 13 & 0 & 8 & 0 \\
\hline & AN-2 & 23 & 2 & 18 & 0 \\
\hline \multirow{7}{*}{$\begin{array}{l}1 \mathrm{CE} 12 \\
\text { Historic }\end{array}$} & AH-2 & 11 & 0 & 5 & - \\
\hline & AH-3 & 10 & 11 & 10 & 3 \\
\hline & AH-7 & 6 & 2 & 2 & 0 \\
\hline & AH-8 & 1 & 0 & 0 & - \\
\hline & AH-10 & 19 & 6 & 7 & 0 \\
\hline & AH-11 & 22 & 0 & 11 & 0 \\
\hline & AH-15 & 15 & 0 & 4 & - \\
\hline \multirow{2}{*}{$\begin{array}{l}41 \mathrm{CE} 17 \\
\text { Late Caddo }\end{array}$} & AL-3 & 20 & 4 & 8 & 2 \\
\hline & AL-7 & 9 & 2 & 1 & - \\
\hline \multirow{12}{*}{$\begin{array}{l}\text { 41CE19 } \\
\text { Early Caddo }\end{array}$} & F. 118 & 26 & 0 & 0 & - \\
\hline & F. 119S1 & 24 & 5 & 16 & - \\
\hline & F. 119S2 & 17 & 0 & 7 & 1 \\
\hline & F. 130 & 26 & 1 & 6 & 1 \\
\hline & F. 134B1 & 20 & 0 & 10 & 0 \\
\hline & F. 134B3 & 25 & 0 & 5 & - \\
\hline & F. 134B4 & 25 & 0 & 14 & 0 \\
\hline & F. 134B5 & 3 & 0 & 0 & - \\
\hline & F. 134B8 & 17 & 0 & 7 & - \\
\hline & F. 155 & 20 & 0 & 3 & - \\
\hline & F. 161 & 9 & 0 & 4 & - \\
\hline & F. 163 & 26 & 4 & 5 & 0 \\
\hline $\begin{array}{l}\text { 41CE290 } \\
\text { Middle Caddo }\end{array}$ & None TARL 2172 & 26 & 0 & 3 & 0 \\
\hline \multirow{4}{*}{$\begin{array}{l}\text { 41AN38 } \\
\text { Middle Caddo }\end{array}$} & F. 88 & 8 & 0 & 0 & - \\
\hline & F. 92 & 1 & 0 & 0 & - \\
\hline & F. 93B1 & 5 & 0 & 0 & 0 \\
\hline & F. 93B2 & 1 & 0 & 1 & - \\
\hline
\end{tabular}

Notes: A - indicates no observations were possible. 
Table 10-21. Stable Isotope Results from the Lang Pasture Site and the Upper Neches River Basin Population.

\begin{tabular}{|c|c|c|c|c|c|}
\hline Site/ Burial No. & Time & $\begin{array}{c}\text { 13C } \\
\text { Gelatin }\end{array}$ & $\begin{array}{c}\text { 13C } \\
\text { Apatite }\end{array}$ & Difference & 15N Gelatin \\
\hline $\begin{array}{l}\text { 41AN38 } \\
\text { Lang Pasture 76D }\end{array}$ & $\begin{array}{l}\text { (Late) Middle } \\
\text { Caddo }\end{array}$ & -18.1 & -9.3 & 8.8 & \\
\hline $\begin{array}{l}\text { 41AN38 } \\
\text { Lang Pasture } 92\end{array}$ & Middle-Late Caddo & $\begin{array}{l}-21.0 \\
-18.8\end{array}$ & -6.4 & 14.6 & \\
\hline $\begin{array}{l}\text { 41AN38 } \\
\text { Lang Pasture 93B1 }\end{array}$ & (Early) Late Caddo & -18.7 & -10.2 & 8.5 & \\
\hline $\begin{array}{l}\text { 41AN38 } \\
\text { Lang Pasture 76C }\end{array}$ & $\begin{array}{l}\text { (Late) Middle } \\
\text { Caddo }\end{array}$ & $\begin{array}{l}-15.2 \\
-15.6\end{array}$ & -10.8 & 4.4 & 6.7 \\
\hline $\begin{array}{l}\text { 41AN38 } \\
\text { Lang Pasture 93B2 }\end{array}$ & (Early) Late Caddo & $\begin{array}{l}-19.5 \\
-17.6\end{array}$ & -9.7 & 9.8 & \\
\hline $\begin{array}{l}\text { 41AN38 } \\
\text { Lang Pasture } 8\end{array}$ & (Early) Late Caddo & $\begin{array}{l}-15.6 \\
-16.6\end{array}$ & -9.2 & 6.4 & 9.7 \\
\hline $\begin{array}{l}41 \mathrm{AN} 38 \\
\text { Lang Pasture } 88\end{array}$ & Middle-Late Caddo & $\begin{array}{l}-19.7 \\
-19.6\end{array}$ & -8.7 & 11 & \\
\hline $\begin{array}{l}\text { 41AN38 } \\
\text { Lang Pasture 76B }\end{array}$ & Middle Caddo & $\begin{array}{l}-17.1 \\
-17.4\end{array}$ & -10.3 & 6.8 & 7.2 \\
\hline $\begin{array}{l}\text { 41AN38 } \\
\text { Lang Pasture Site } \\
\text { Average }\end{array}$ & Middle-Late Caddo & $\begin{array}{l}-18.1 \\
-17.6\end{array}$ & -9.3 & 8.8 & 7.9 \\
\hline $\begin{array}{l}\text { 41CE19 } \\
\text { George C. Davis } \\
\text { 119S1 }\end{array}$ & Early-Middle Caddo & -18.9 & -11.7 & 7.2 & 8.7 \\
\hline $\begin{array}{l}\text { 41CE19 } \\
\text { George C. Davis } 155\end{array}$ & Formative Caddo & -21.8 & -11.1 & 10.7 & \\
\hline $\begin{array}{l}\text { 41CE19 } \\
\text { George C. Davis } 130\end{array}$ & Early-Middle Caddo & -18.4 & -8.7 & 9.7 & \\
\hline $\begin{array}{l}\text { 41CE19 } \\
\text { George C. Davis Site } \\
\text { Average }\end{array}$ & Early Caddo & -19.7 & -10.5 & 9.2 & 8.7 \\
\hline $\begin{array}{l}\text { 41CE12 } \\
\text { Jim Allen AH-3 }\end{array}$ & $\begin{array}{l}\text { Historic } \\
\text { Caddo }\end{array}$ & -14.5 & -7.3 & 7.2 & 4.7 \\
\hline $\begin{array}{l}\text { 41CE12 } \\
\text { Jim Allen } \mathrm{AH}-11\end{array}$ & Historic Caddo & -13.1 & -7.8 & 5.3 & 9.3 \\
\hline $\begin{array}{l}\text { 41CE12 } \\
\text { Jim Allen AH-10 }\end{array}$ & Historic Caddo & -13.7 & -5.7 & 8 & 2.9 \\
\hline
\end{tabular}


Table 10-21, continued.

\begin{tabular}{|c|c|c|c|c|c|}
\hline Site/ Burial No. & Time & 13C Gelatin & 13C Apatite & Difference & 15N Gelatin \\
\hline $\begin{array}{l}41 \mathrm{CE} 12 \\
\text { Jim Allen AH-6 }\end{array}$ & Historic Caddo & -13.3 & -8.3 & 5 & 11.0 \\
\hline $\begin{array}{l}41 \mathrm{CE} 12 \\
\text { Jim Allen AH-12 }\end{array}$ & Historic Caddo & -14.8 & -9.9 & 4.9 & 1.6 \\
\hline $\begin{array}{l}41 \mathrm{CE} 12 \\
\text { Jim Allen AH-5 }\end{array}$ & Historic Caddo & -13.9 & -6.1 & 7.8 & 4.2 \\
\hline $\begin{array}{l}41 \mathrm{CE} 12 \\
\text { Jim Allen AH-7 }\end{array}$ & Historic Caddo & -12.9 & -6.8 & 6.1 & 12.7 \\
\hline $\begin{array}{l}\text { 41CE12 } \\
\text { Jim Allen Site Average }\end{array}$ & Historic Caddo & -13.7 & -7.4 & 6.3 & 6.6 \\
\hline $\begin{array}{l}\text { 41AN21 (Emma) Owens } \\
\text { Farm G-1 }\end{array}$ & Late Caddo & $\begin{array}{l}-13.9 \\
13.1\end{array}$ & -6.8 & 7.1 & 6.3 \\
\hline $\begin{array}{l}41 \mathrm{CE} 6 \\
\text { E. W. Hackney AN-1 }\end{array}$ & Late Caddo & -12.8 & -6.7 & 6.1 & 2.8 \\
\hline $\begin{array}{l}41 \mathrm{CE} 6 \\
\text { E. W. Hackney AN-2 }\end{array}$ & Late Caddo & & -7.4 & & 8.9 \\
\hline $\begin{array}{l}\text { 41CE6 } \\
\text { E. W. Hackney Site } \\
\text { Average }\end{array}$ & Late Caddo & -12.8 & -7.0 & 6.1 & 5.9 \\
\hline $\begin{array}{l}\text { 41AN56 } \\
\text { Lee Ellis Farm }\end{array}$ & Early-Late Caddo & & -7.6 & & 12.4 \\
\hline $\begin{array}{l}41 \mathrm{CE} 4 \\
\text { J. W. Blackburn AI-3 }\end{array}$ & Late Caddo & & -7.7 & & \\
\hline $\begin{array}{l}41 \mathrm{CE} 4 \\
\text { J. W. Blackburn AI-2 }\end{array}$ & Late Caddo & -9.7 & -7.6 & 2.1 & \\
\hline $\begin{array}{l}41 \mathrm{CE} 4 \\
\text { J. W. Blackburn Site } \\
\text { Average }\end{array}$ & Late Caddo & -9.7 & -7.7 & 2.1 & \\
\hline $\begin{array}{l}\text { 41AN54 } \\
\text { O. L. Ellis Farm }\end{array}$ & Late Caddo & & -8.1 & & 13.7 \\
\hline $\begin{array}{l}\text { 41AN54 } \\
\text { O. L. Ellis Farm AE-2-B }\end{array}$ & Late Caddo & & -7.4 & & 12.4 \\
\hline $\begin{array}{l}\text { 41AN54 } \\
\text { O. L. Ellis Farm Site Ave. }\end{array}$ & Late Caddo & & -7.8 & & 13.0 \\
\hline
\end{tabular}


Table 10-21, continued.

\begin{tabular}{|c|c|c|c|c|c|}
\hline Site/ Burial No. & Time & 13C Gelatin & 13C Apatite & Difference & 15N Gelatin \\
\hline $\begin{array}{l}41 \mathrm{CE} 3 \\
\text { Solon Stanley Farm } \\
\text { AK1,2,3+4 }\end{array}$ & Early Caddo & $\begin{array}{l}-19.3 \\
-19.9\end{array}$ & -14.6 & 4.8 & 10.9 \\
\hline $\begin{array}{l}\text { 41CE290 } \\
\text { Forest Mound }\end{array}$ & Middle Caddo & -15.9 & -10.9 & 5 & 11.5 \\
\hline $\begin{array}{l}41 \mathrm{CE} 17 \\
\text { E. W. Henry Farm AL-2 }\end{array}$ & Late Caddo & -13.3 & -12.1 & 1.2 & \\
\hline $\begin{array}{l}\text { 41AN32 } \\
\text { Fred McKee }\end{array}$ & Late Caddo & $\begin{array}{l}-12.2 \\
-12.0\end{array}$ & -4.8 & 7.4 & 10.4 \\
\hline $\begin{array}{l}41 \mathrm{CE} 15 \\
\text { A.H. Reagor Farm AJ-1 }\end{array}$ & Late Caddo & -14.9 & & & 10.8 \\
\hline $\begin{array}{l}41 \mathrm{CE} 15 \\
\text { A.H. Reagor Farm AJ-2 }\end{array}$ & Late Caddo & -13.3 & -6.7 & 6.6 & \\
\hline $\begin{array}{l}41 \mathrm{CE} 15 \\
\text { A.H. Reagor Farm Site } \\
\text { Average }\end{array}$ & Late Caddo & -14.1 & -6.7 & 6.6 & 10.8 \\
\hline $\begin{array}{l}\text { 41AN34 } \\
\text { Pierce Freeman Farm D-2 }\end{array}$ & Late Caddo & $\begin{array}{l}-14.8 \\
-13.8\end{array}$ & -9.1 & 5.7 & 13.2 \\
\hline
\end{tabular}

Notes: Where two results are given, the second value is from Beta Analytic, Inc.; all other results are from samples processed by Geochron Laboratories.

Table 10-22. Mean Isotope Values Through Time.

\begin{tabular}{|l|c|c|c|c|}
\hline Time Period & Delta 13C collagen & Delta 13C apatite & Difference & Delta 15N \\
\hline Formative & -21.80 & -11.10 & 10.70 & - \\
\hline Early Caddo & -18.87 & -11.67 & 7.20 & 9.8 \\
\hline Middle Caddo & -17.83 & -9.40 & 8.43 & 8.5 \\
\hline Late Caddo & -14.38 & -8.11 & 6.09 & 9.8 \\
\hline Historic & -13.74 & -7.41 & 6.33 & 6.6 \\
\hline
\end{tabular}


Table 10-23. Frequency of Enamel Hypoplasia in the Upper Neches River Basin.

\begin{tabular}{|l|c|c|}
\hline Site & $\begin{array}{c}\text { Enamel Hypoplasia } \\
\text { (\% of individuals affected) }\end{array}$ & $\begin{array}{c}\text { Enamel Hypoplasia } \\
\text { (\% of teeth) }\end{array}$ \\
\hline 41AN38 & 0 & 0 \\
\hline 41AN14 & 0 & 0 \\
\hline 41AN21 & 0 & 0 \\
\hline 41AN32 & 0 & 0 \\
\hline 41CE3 & 0 & 0 \\
\hline 41CE4 & 0 & 0 \\
\hline 41CE6 & 50 & 20.7 \\
\hline 41CE12 & 44.4 & 28.3 \\
\hline 41CE17 & 0 & 0 \\
\hline 41CE19 & 7.1 & 0.9 \\
\hline 41CE290 & 0 & 0 \\
\hline Upper Neches River total & 12 & 6.3 \\
\hline
\end{tabular}

Table 10-24. Cranial Modeling Styles in the Upper Neches River Basin Where Observations Were Possible.

\begin{tabular}{|l|l|l|l|}
\hline Site & Feature & Sex & Style \\
\hline 41 AN38 & F. 93B1 & Female & Annular Parallelo-fronto-occipital \\
\cline { 2 - 4 } & F. 93B2 & Female & Unmodeled \\
\hline \multirow{4}{*}{41 AN32 } & None TARL 2100 & Indeterminate & Tabular Fronto-vertico-occipital \\
\cline { 2 - 4 } & None TARL 2101 & Female & Slight, style indeterminate \\
\hline 41 AN54 & AE-2B & Indeterminate & Unmodeled \\
\hline 41 CE3 & AK1,2,3,4 & $\begin{array}{l}\text { 2 Males } \\
\text { Female } \\
\text { (MNI=3) }\end{array}$ & Unmodeled \\
\hline 41 CE6 & AN-1 & Female & Tabular Fronto-vertico-occipital \\
\cline { 2 - 4 } & AN-2 & Male & Unmodeled \\
\hline 41 CE12 & AH-1 & $\begin{array}{l}\text { Indeterminate } \\
\text { (MNI=3) }\end{array}$ & Tabular Fronto-vertico-occipital \\
\cline { 2 - 4 } & AH-3 & Male & Annular Parallelo-fronto-occipital \\
\cline { 2 - 4 } & AH-5 & Female & Tabular Fronto-vertico-occipital \\
\cline { 2 - 4 } & AH-11 & Female & Tabular Fronto-vertico-occipital \\
\hline 41 CE17 & AL1-AL11 & $\begin{array}{l}\text { Indeterminate } \\
\text { (MNI=4) }\end{array}$ & Unmodeled \\
\cline { 2 - 4 } & AL-3 & Male & Tabular Fronto-vertico-occipital \\
\hline 41 CE19 & F. 163 & Male & Unmodeled \\
\hline 41 CE290 & None TARL 2172 & Male & Tabular Fronto-vertico-occipital \\
\hline
\end{tabular}




\section{APPENDIX I \\ INNA RESULTS ON A NATURAL CLAY SAMPLE FROM 41AN38}

Prepared for:

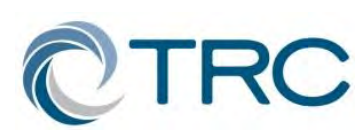

TRC Environmental Corporation

505 East Huntland Drive, Suite 250

Austin, Texas 78752

Prepared by:

Robert A. Ricklis 

The accompanying table shows the proportional representation of trace elements in a sample of raw clay obtained by Waldo Troell (TxDOT) from the Lang Pasture Site, 41AN38 on October 1, 2007. The sample was excavated, using a hand-held shovel, from clay that lay beneath the fine sand on the southeast side of the site, along the roadcut embankment that sloped down toward Caney Creek. The fist-sized sample was sent by Troell to Dr. Leslie C. Cecil (Stephen F. Austin State University), who forwarded it for analysis to Dr. Jeffrey R.
Ferguson Senior Research Specialist, University of Missouri Research Reactor Archaeometry Group (Waldo Troell, personal communication, 1/18/2008).

The results of the analysis are presented here for the sake of availability to researchers conducting studies of clay chemistry with the goals of elucidating patterns of clay extraction by prehistoric peoples in the Texas region and identifying possible patterns of mobility among these peoples and/or transport across the landscape of their ceramic products.

Table I-1. INAA Results on a Natural Clay Sample

\begin{tabular}{|c|c|c|c|c|c|c|}
\hline anid & long rdf & long date & As & La & Lu & Nd \\
SAF001 & EAR2 & 06-Jan-08 & 43.6150 & 26.1139 & 0.3395 & 20.4915 \\
\hline
\end{tabular}

\begin{tabular}{|c|c|c|c|c|c|c|}
\hline $\mathbf{S m}$ & $\mathbf{U}$ & $\mathbf{Y b}$ & $\mathbf{C e}$ & $\mathbf{C o}$ & $\mathbf{C r}$ & $\mathbf{C s}$ \\
4.0464 & 3.4132 & 2.0992 & 55.4584 & 7.9762 & 70.0627 & 4.3096 \\
\hline
\end{tabular}

\begin{tabular}{|c|c|c|c|c|c|c|}
\hline $\begin{array}{c}\mathbf{E u} \\
0.7091 \\
\end{array}$ & $\begin{array}{c}\text { Fe } \\
67580.6\end{array}$ & $\begin{array}{c}\text { Hf } \\
10.1357 \\
\end{array}$ & $\begin{array}{c}\mathbf{N i} \\
0.00\end{array}$ & $\begin{array}{c}\mathbf{R b} \\
74.89 \\
\end{array}$ & \begin{tabular}{c}
\multicolumn{1}{c}{$\mathbf{S b}$} \\
1.2812 \\
\end{tabular} & $\begin{array}{c}\text { Sc } \\
9.0082\end{array}$ \\
\hline $\begin{array}{c}\mathbf{S r} \\
0.00\end{array}$ & $\begin{array}{c}\mathbf{T a} \\
0.8506\end{array}$ & $\begin{array}{c}\mathbf{T b} \\
0.4664\end{array}$ & $\begin{array}{c}\text { Th } \\
11.9591\end{array}$ & $\begin{array}{c}\mathbf{Z n} \\
71.25\end{array}$ & $\begin{array}{c}\mathbf{Z r} \\
255.32\end{array}$ & $\begin{array}{c}\text { sanid } \\
\text { SFA001 }\end{array}$ \\
\hline
\end{tabular}

\begin{tabular}{|c|c|c|c|c|c|c|}
\hline short rdf & short date & Al & Ba & Ca & Dy & K \\
EMC2-S & $18-J a n-08$ & 54500.2 & 251.5 & 1155.4 & 3.6689 & 5915.8 \\
\hline
\end{tabular}

\begin{tabular}{|c|c|c|c|}
\hline $\mathbf{M n}$ & $\mathbf{N a}$ & $\mathbf{T i}$ & $\mathbf{V}$ \\
71.61 & 354.3 & 2671.3 & 159.99 \\
\hline
\end{tabular}


